

\section{REVISTA BRASILEIRA DE POLÍTICAS PÚBLICAS}

\section{BRAZILIAN JOURNAL OF PUBLIC POLICY}

\section{Editores responsáveis por essa edição:}

Editores especiais

Profs. Dres. Patrícia Perrone Campos Mello e Sérgio Nojiri

Editores gerais

Profs. Dres. Marcelo Dias Varella e Ivette Esis Villarroel

Com o apoio e parceria da:

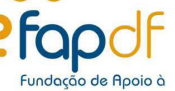

Fundaçoo de Apoio à

ISSN 2236-1677 


\section{REVISTA BRASILEIRA DE POLÍTICAS PÚBLICAS \\ Brazilian Journal of Public Policy}

Programa de Mestrado e Doutorado em Direito do UniCEUB

Centro Universitário de Brasília

Reitor

Getúlio Américo Moreira Lopes

Presidente do Conselho Editorial do UniCEUB

Elizabeth Regina Lopes Manzur

Diretor do ICPD

João Herculino de Souza Lopes Filho

Coordenador do Programa de Mestrado e Doutorado e Editor

Marcelo Dias Varella

\section{Linha editorial}

"A Revista Brasileira de Políticas Públicas é um periódico acadêmico da área jurídica que tem como finalidade constituir instrumento de veiculação de trabalhos científicos e doutrinários que abordem questões jurídicas da contemporaneidade e, ainda, aspectos da interação entre Direito e Políticas Públicas. Direciona, portanto, seu objeto de interesse a questões referentes a governabilidade, integração, participação cidadã, desenvolvimento e outros temas envolvendo o Estado, a Sociedade e o Direito.

Sendo assim, a proposta de linha editorial a ser seguida pela Revista Brasileira de Políticas Públicas é apresentada a partir de duas áreas fundamentais, que se subdividem:

I) Democracia, Políticas de Estado e de Governo e seus aspectos jurídicos: tendências do Direito Constitucional e do Direito Administrativo; teoria das políticas públicas; sistema de governo; sistema eleitoral e cidadania; sistema de partidos e reforma constitucional

II) Políticas Públicas de desenvolvimento econômico e social e suas interfaces com o Direito: políticas de desenvolvimento econômico e produção local/regional, desenvolvimento sustentável e meio-ambiente, desenvolvimento humano e planejamento da ação governamental".

\section{CONSELHO EDITORIAL}

Marie-Pierre Lafranchi, Université d'Aix-en-Provence, Faculté de droit et de science politique, Provence-Alpes-Côte d'Azur, França Frederico Augusto Barbosa, Centro Universitário de Brasília, Programa de Mestrado e Doutorado em Direito, Brasília/DF, Brasil Gilberto Bercovici, Universidade de São Paulo, Faculdade de Direito, Departamento de Direito Econômico-Financeiro, São Paulo/SP, Brasil João Maurício Adeodato, Universidade Federal de Pernambuco, Centro de Ciências Jurídicas, Departamento de Teoria Geral do Direito e do Direito Privado, Recife/PE, Brasil

José Adercio Leite Sampaio, Escola Superior Dom Helder Câmara, Escola de Direito, Belo Horizonte/MG, Brasil

José Heder Benatti, Universidade Federal do Pará, Instituto de Ciências Jurídicas, Belém/PA, Brasil

\section{EDITOR}

Marcelo D. Varella, Centro Universitário de Brasília, Programa de Mestrado e Doutorado em Direito, Brasília/DF, Brasil

\section{EDITORA ADJUNTA}

Ivette Esis Villarroel, Centro Universitário de Brasília, Revista Brasileira de Políticas Públicas, Brasília/DF, Brasil

\section{EQUIPE TÉCNICA}

Yuri Valente do Nascimento, Centro Universitário de Brasília, Revista Brasileira de Políticas Públicas, Brasília/DF, Brasil

Aline Assunção Santos, Centro Universitário de Brasília, Revista Brasileira de Políticas Públicas, Brasília/DF, Brasil

Com o apio da FAP/DF. Processo: 00193.00000304/2018-58, Edital 09/2017.

\section{Layout capa}

Departamento de Comunicação / ACC UniCEUB

\section{Diagramação}

S2 Books

\section{Disponível em:}

http://www.rbpp.uniceub.br

\section{Circulação}

Acesso aberto e gratuito

Matérias assinadas são de exclusiva responsabilidade dos autores.

Citação parcial permitida com referência à fonte. 
Revista Brasileira de Políticas Públicas / Programa de Mestrado e Doutorado em Direito do UniCEUB. - vol. 8, n. 2 (ago. 2018) - . Brasília : UniCEUB, 2011

Quadrimestral.

ISSN 2236-1677

Disponível também on-line: www.rbpp.uniceub.br

1. Direito. 2. Políticas Públicas. I. Programa de Mestrado e Doutorado em Direito do UniCEUB

CDU $34+338.26$

Ficha catalográfica elaborada pela Biblioteca Reitor João Herculino 


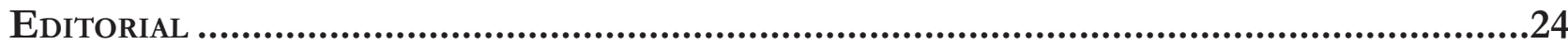

O Direito na fronteira da razão: Psicologia, neurociência e economia comportamental................... 24 Patrícia Perrone Campos Mello e Sergio Nojiri

I. NeURodireito: COGNIÇão, EMOÇÃo, JUÍZOS MORAIS E CIÊNCIA ..........................................26

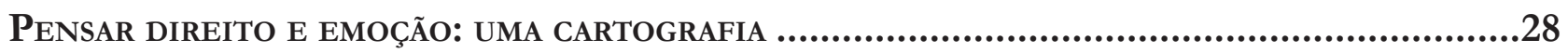
Nevita Maria Pessoa de Aquino Franca Luna

1. A recusa inicial das emoções na tradição do pensamento jurídico ................................................ 29

2. Topos jurídico: breve percurso da união entre direito e emoção ......................................................31

3. Os sentimentos nos domínios do direito ....................................................................................... 34

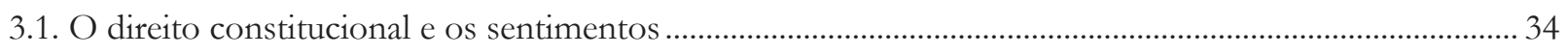

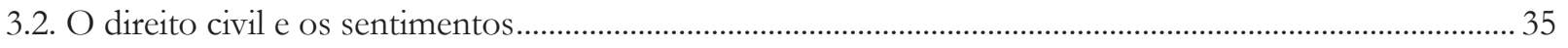

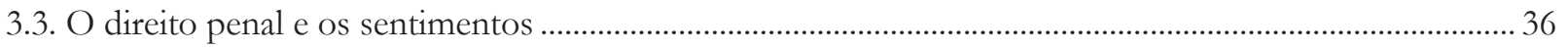

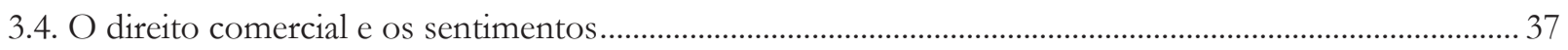

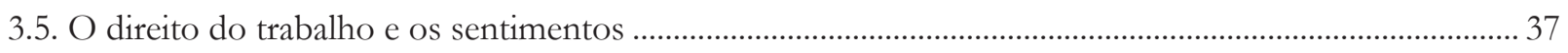

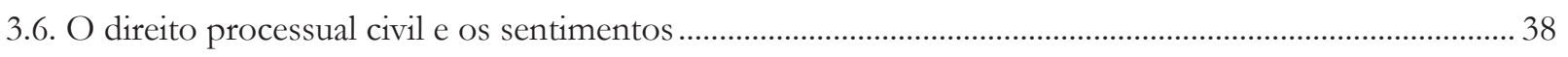

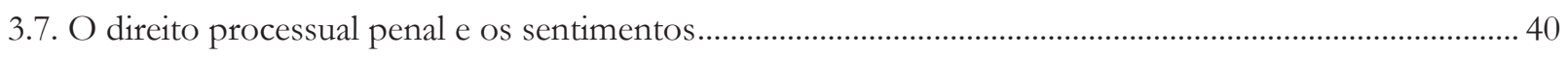

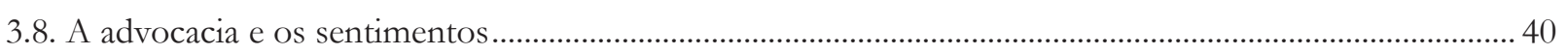

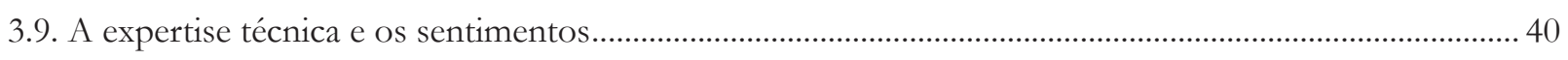

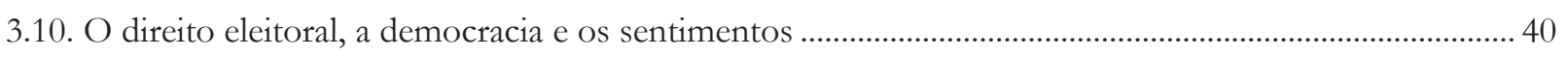

4. A vítima e o reconhecimento de suas emoções na legislação brasileira ............................................41

4.1. O crescimento dos direitos das vítimas ........................................................................................................ 42

4.2. A sofrimento da vítima: uma perspectiva empática .......................................................................................... 43

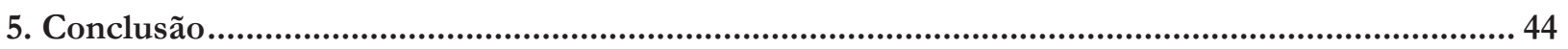

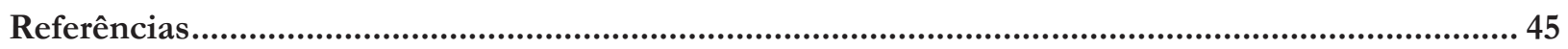

NeURodireito: O INÍCIO, O FIM E O MEIO .........................................................................49

Carlos Marden e Leonardo Martins Wykrota

1. Introdução: o senso comum jurídico na zona de risco ...................................................................50

2. O início: o modelo ideal da dinâmica jurídica e a articulação de elementos que esse modelo

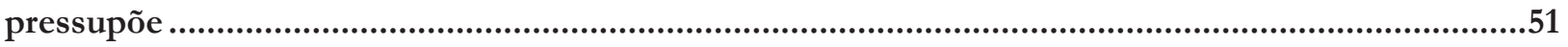

3. O fim: a desarticulação do modelo ideal ……............................................................................. 52

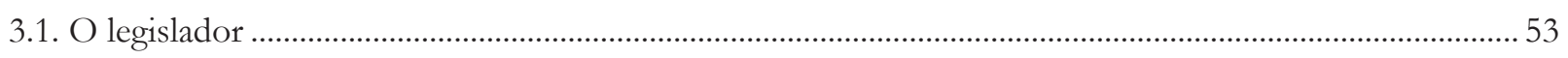

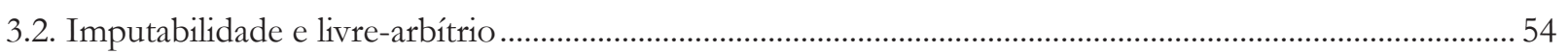




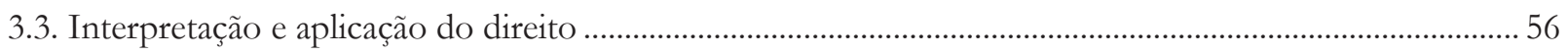

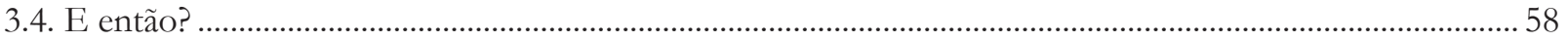

4. O meio: reconstruindo o modelo da dinâmica jurídica...................................................................59

5. Considerações finais: um caminho chamado Neurodireito...........................................................661

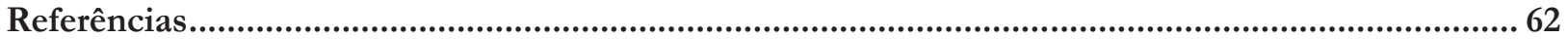

ENSAIO JURÍdico SOBRE A RACIONALIDADE HUMANA: MAIORES, CAPAZES E IRRACIONAIS ...........65 André Perin Schmidt Neto e Eugênio Facchini Neto

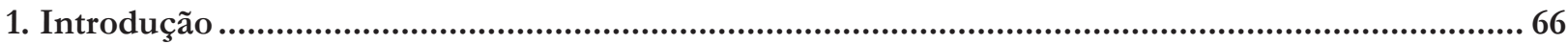

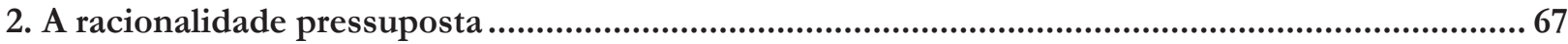

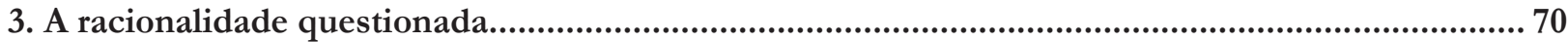

4. A racionalidade, segundo a psicologia comportamental .............................................................. 72

5. A racionalidade, segundo a economia comportamental ................................................................. 73

6. Impactos de um livre-arbítrio relativizado na vida de relação e no Direito ..................................... 82

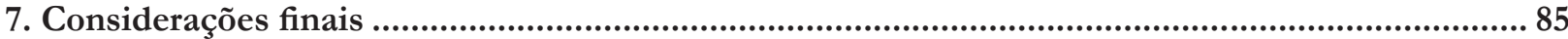

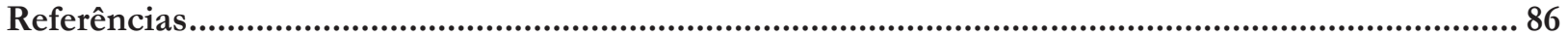

DiVERGÊNCIAS DE PRINCÍPIO: ARGUMENTOS JURÍDICOS E MORAIS EM UM CENÁRIO DE

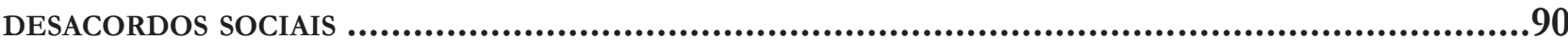

André Matos de Almeida Oliveira, Pâmela de Rezende Côrtes e Leonardo Martins Wykrota

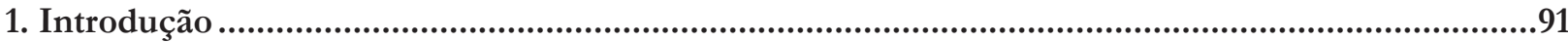

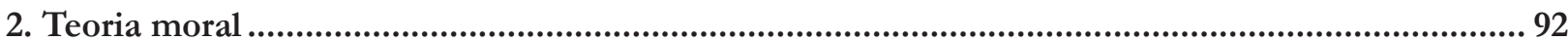

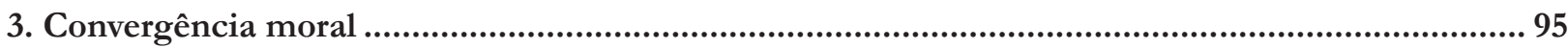

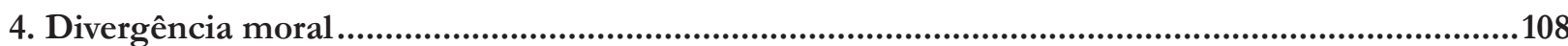

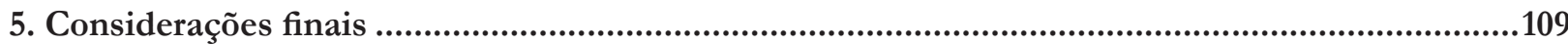

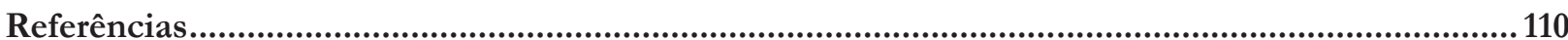

\section{CONSILIÊNCIA E A POSSIBILIDADE DO NEURODIREITO: DA DESCONFIANÇA À RECONCILIAÇÃO}

DISCIPLINAR ............................................................................................ 117

Thaís de Bessa Gontijo de Oliveira e Renato César Cardoso

2. As origens da desconfiança disciplinar: o divórcio entre as duas culturas .................................123

3. A reconciliação disciplinar: rumo à consiliência.........................................................................127

4. Neuroética e neurodireito: a busca pelas borboletas da alma .................................................134

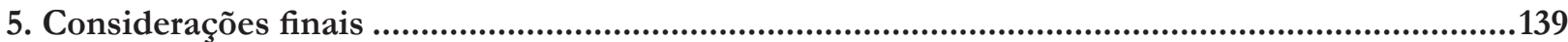

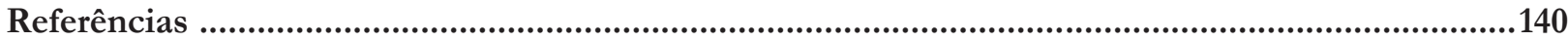

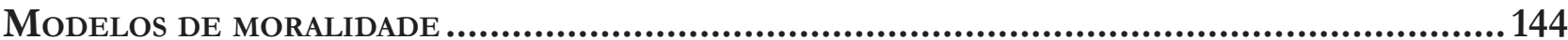

Molly J. Crockett

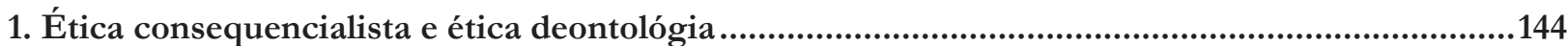

2. Avaliação baseada em modelo (model-based) e sem modelo (model-free)..................................145 


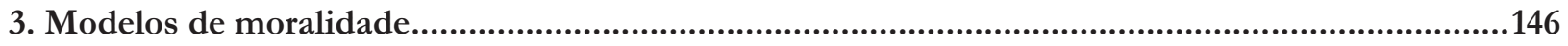

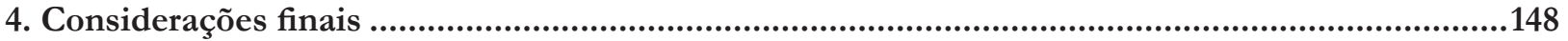

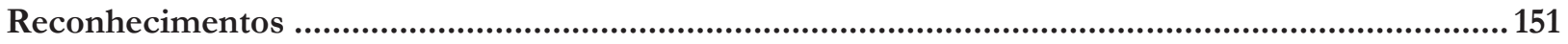

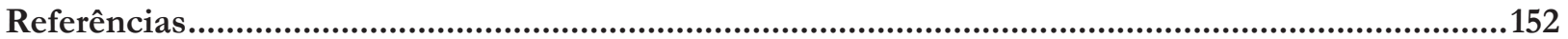

A INFELIZ BUSCA POR FELICIDADE NO DIREITO ................................................... 154

Úrsula Simões da Costa Cunha Vasconcellost, Noel Struchiner e Ivar Hannikainen

1. Introdução

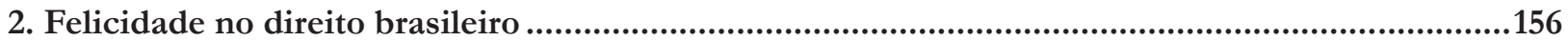

3. Contribuições da filosofia experimental ....................................................................................158

3.1. Diferença entre "felicidade" e "infelicidade" (Philips, Misenheimer, Knobe, 2011) ................................ 159

3.2. São os estados psicológicos e não o julgamento moral que afetam a atribuição de felicidade? (Phillips,

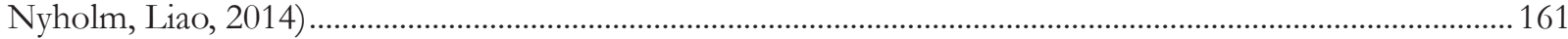

4. Conceito ordinário de felicidade no cenário brasileiro...................................................................162

4.1. Replicação do estudo acerca do conceito ordinário de felicidade: estrutura e fundamentos ................... 162

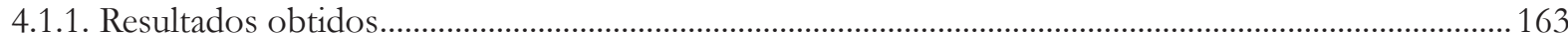

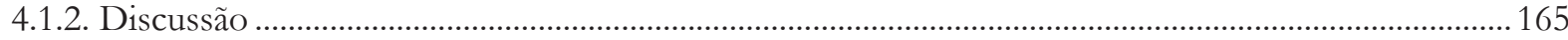

4.2. Aplicação do direito à felicidade: estrutura e fundamentos........................................................................... 166

5. Considerações finais ....................................................................................................................169

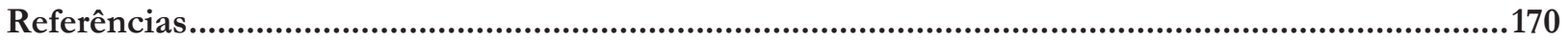

Apêndice A - Vinhetas utilizadas para a realização do estudo de replicação (Item “4.1”) ...............172

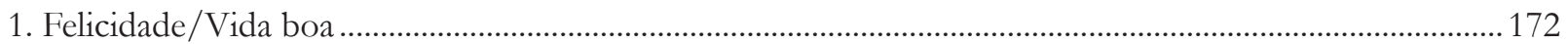

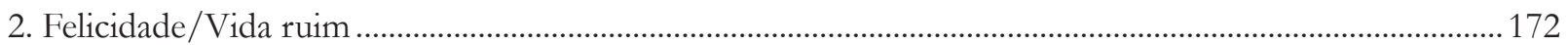

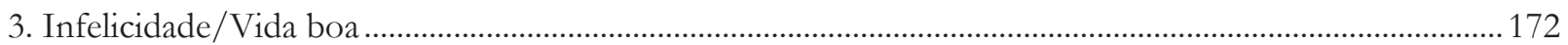

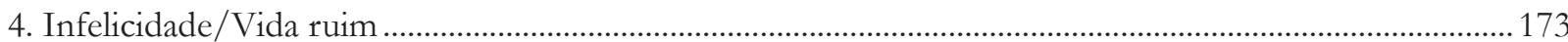

Apêndice B - Vinhetas utilizadas para a realização do estudo envolvendo a aplicação do direito à

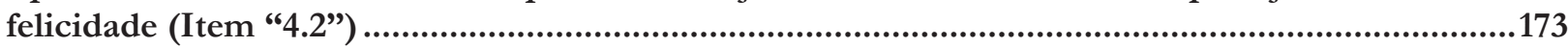

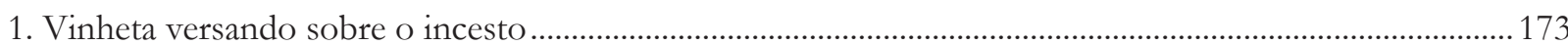

2. Vinheta versando sobre o casamento homoafetivo ……….......................................................................... 174

3. Tabela para descrever a capacidade de pessoas se manterem felizes em certos tipos de relacionamento 175

4. Tabela para indicar o quanto apropriado se considera certos tipos de relacionamento................................176

Além da liberdade: PERSPECTIVAs EM NiETZSCHE.......................................................... 178 Lucas Costa de Oliveira

1. Introdução

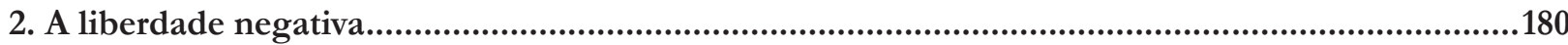

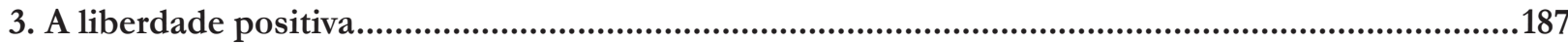

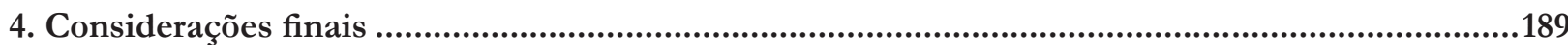

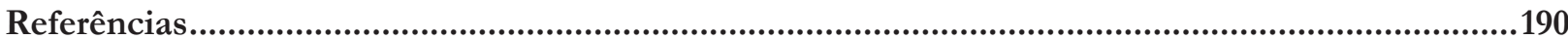




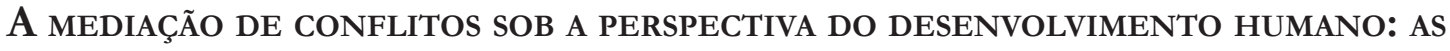
CONTRIBUiÇÕES DA PSICOLOGIA POSITIVA

Simone de Biazzi Ávila Batista da Silveira e Deise Brião Ferraz

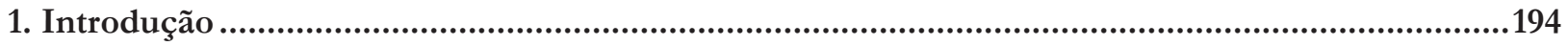

2. Compreendendo a família como lugar de desenvolvimento humano...........................................195

3. Compreendendo a noção de conflito ….........................................................................................198

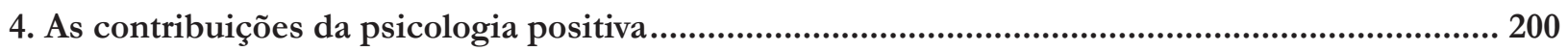

5. A mediação como forma alternativa de tratamento de conflitos ............................................... 203

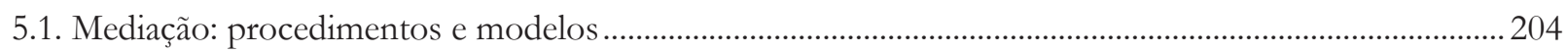

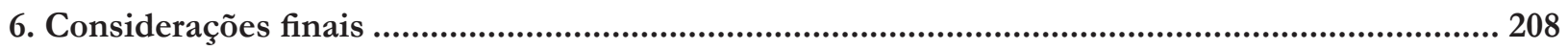

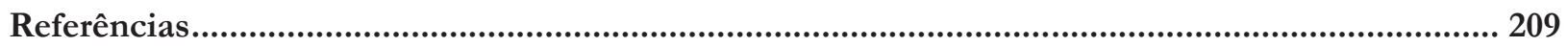

Neuroimagiologia E AVALIAÇÃo de RESPONSABILIDADE ................................................ 213

Nicole A. Vincent

1. Christopher Simmons assassina Shirley Crook …......................................................................214

2. Idade, capacidades mentais e três problemas associados a avaliações comportamentais individualizadas de responsabilidade ..........................................................................................214

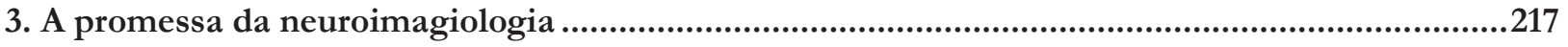

4. Alguns problemas associados à abordagem neuroimagiológica ....................................................219

5. Breves respostas aos problemas identificados na seção anterior ................................................. 222

6. A falácia modal e a neuroimagiologia funcional ....................................................................... 223

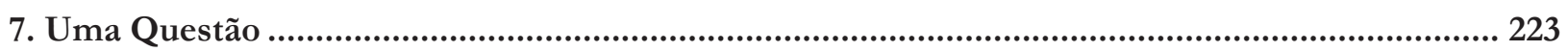

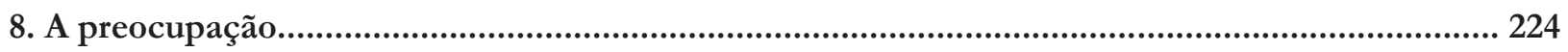

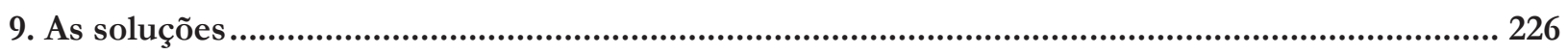

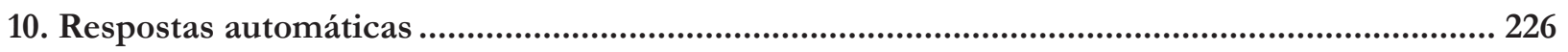

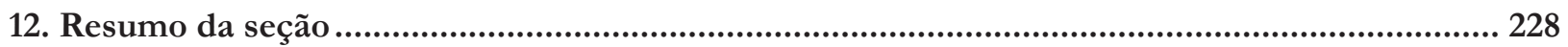

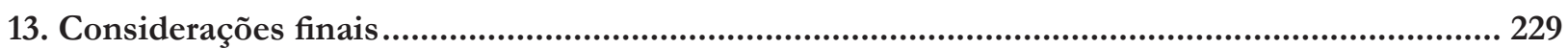

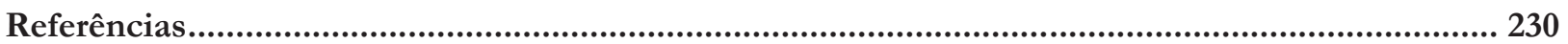

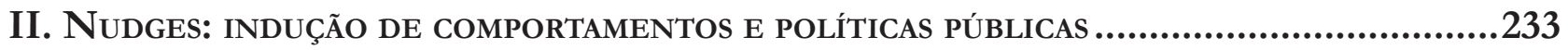

ANÁliSE CRÍTICA DA ORIENTAÇÃo DE CIDADÃOS COMO MÉTODO PARA OTIMIZAR DECISÕES PÚBLICAS POR MEIO DA TÉCNICA NUDGE.............................................................235

Luciana Cristina Souza, Karen Tobias França Ramos e Sônia Carolina Romão Viana Perdigão

1. Introdução

2. Nudge: a proposta de Cass R. Sunstein e Richard H. Thaler.................................................. 238

3. Possibilidade de aplicação da técnica de nudge à democracia brasileira....................................241

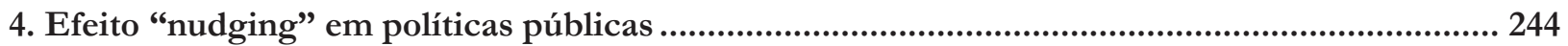

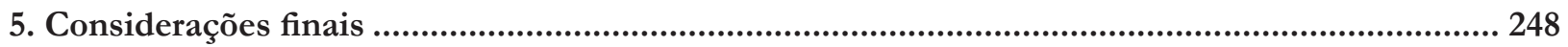


Políticas públicas e o DeVer de monitoramento: “LeVAndo os Direitos A SÉRio" 252 Ana Paula de Barcellos

1. Introdução: normas e decisões judiciais e seus limites: Direitos fundamentais e políticas públicas.

2. Monitoramento das políticas públicas em matéria de direitos fundamentais ............................ 256

3. Dever de monitoramento: levando os direitos à sério e outras razões .........................................261

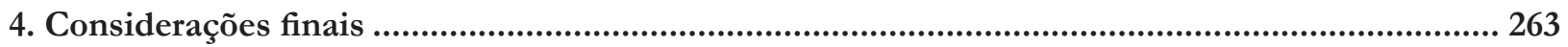

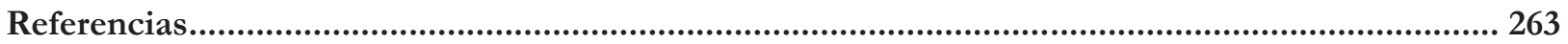

Nudges E POLÍticas PÚblicas: UM MECANISMO DE COMBATE AO TRABALHO EM CONDIÇÃo ANÁLOGA À DE ESCRAVO .............................................................................267

Amanda Carolina Souza Silva, Débhora Renata Nunes Rodrigues e Saul Duarte Tibaldi

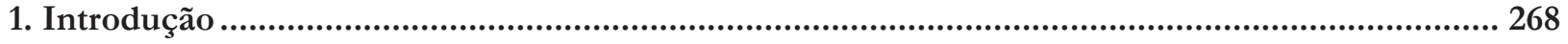

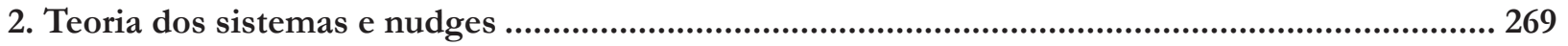

2.1. Breve introdução à teoria dos sistemas de Niklas Luhmann.......................................................................... 269

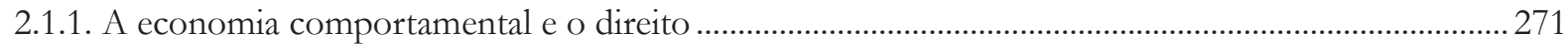

2.2. Nudges, arquitetura de escolhas e políticas públicas......................................................................................273

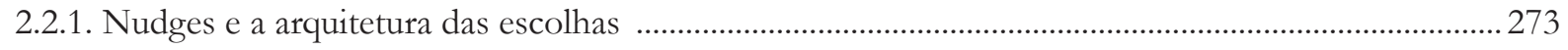

2.2.2. Nudges e políticas públicas ..............................................................................................................2 274

3. A relação entre o trabalho e a promoção da dignidade humana .................................................... 276

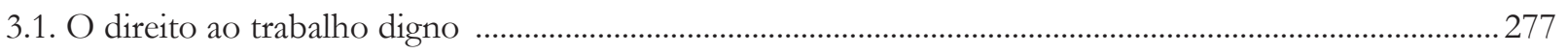

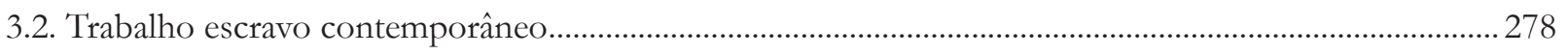

4. Aplicação de nudges no combate ao trabalhado em condição análogo à de escravo................... 280

4.1. Análise da eficácia da lista suja como desestimulo à utilização do trabalho escravo contemporâneo ... 280

4.2. O impacto da Lei $n^{\circ}$ 14.946/2013 (Lei Bezerra) para a proteção do trabalhador ..................................... 281

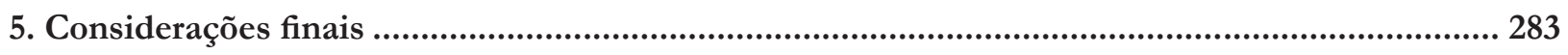

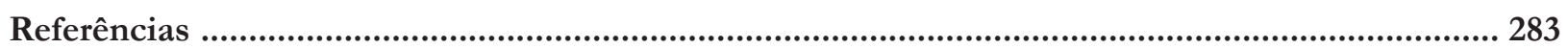

\section{REDUZINDO A TRIBUTAÇÃo COGNITIVA: LIÇÕES COMPORTAMENTAIS PARA A DIMINUIÇÃO DOS}

EFEITOS PSICOLÓGICOS ADVERSOS DA POBREZA.........................................................288 Leandro Novais e Silva, Luiz Felipe Drummond Teixeira, Gabriel Salgueiro Soares e Otávio Augusto Andrade Santos

1. Introdução.....

2. A crítica da economia comportamental: lições preliminares .........................................................291

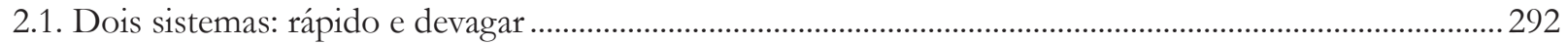

2.2. A teoria dos prospectos e os descontos intertemporais hiperbólicos.........................................................293

2.2.1. Decisões sob risco: a ascensão da Teoria dos Prospectos...................................................................... 293

2.2.2. Anomalias em escolhas intertemporais: descontos hiperbólicos .......................................................... 297 
3. Efeitos psicologicamente adversos da pobreza........................................................................... 302

3.1. A pobreza, os descontos intertemporais e a opção pelo caminho mais seguro .......................................... 303

3.2. Pobreza, esgotamento e funções cognitivas: uma abordagem holística necessária .................................... 306

4. Reduzindo a tributação cognitiva: a opção pelos nudges .............................................................. 308

4.1. O PRONATEC: uma abordagem comportamental .................................................................................. 312

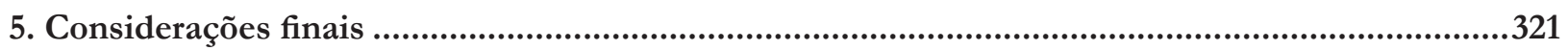

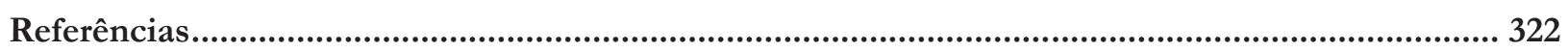

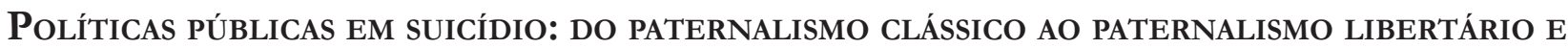

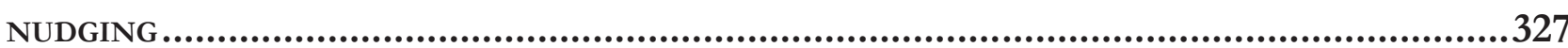

Davi de Paiva Costa Tangerino, Gabriel Cabral e Henrique Olive

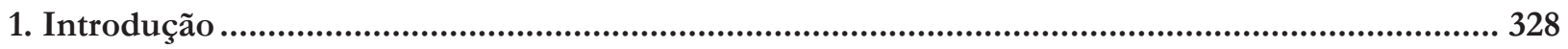

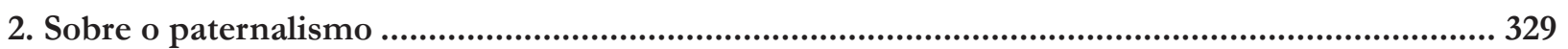

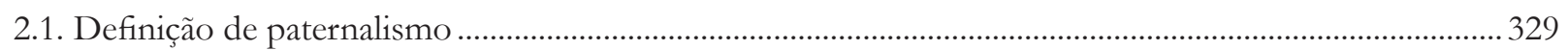

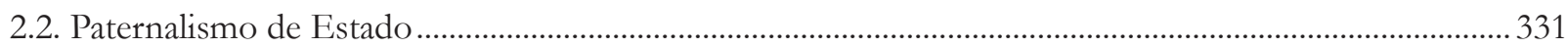

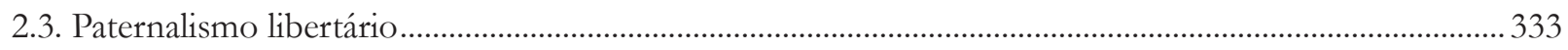

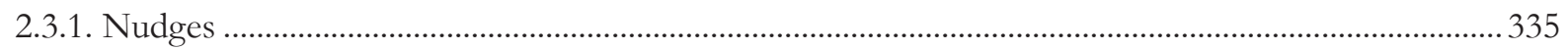

3. Características do suicídio no Brasil em perspectiva com a realidade mundial ........................... 338

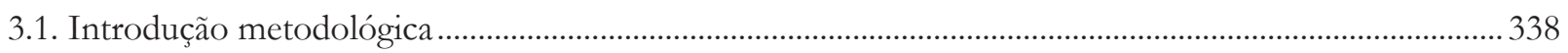

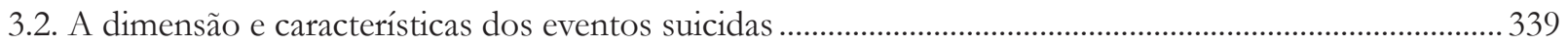

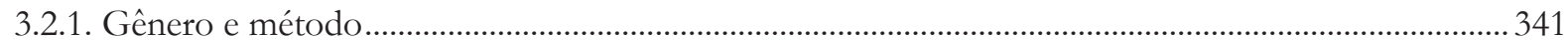

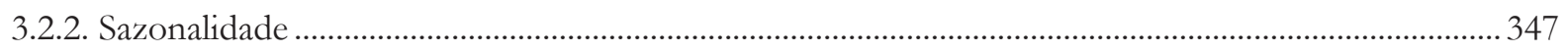

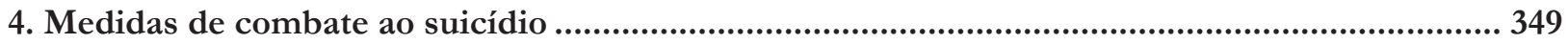

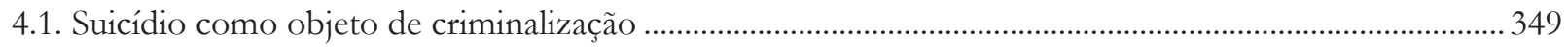

4.2. Suicídio como objeto de políticas públicas não criminalizantes ………………………................................ 351

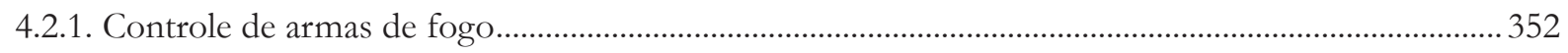

4.2.2. Limitações à livre-circulação de pessoas em hotspots .......................................................................... 353

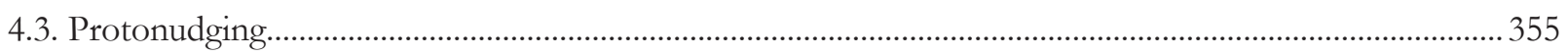

5. Considerações finais: pelo desenvolvimento do método de nudges para políticas públicas de

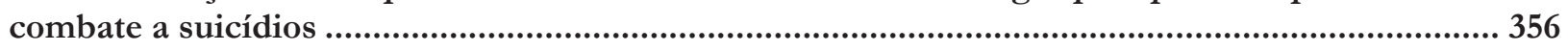

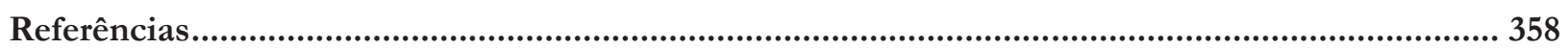

Nudges COMO POLÍtica PÚblica PARA AUMENTAR O ESCASSO NÚMERO DE DOADORES DE ÓRGÃos

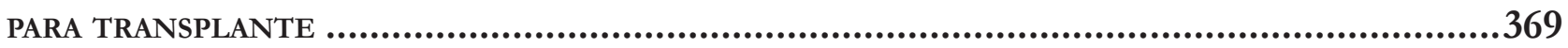

Roberta Marina Cioatto e Adriana de Alencar Gomes Pinheiro

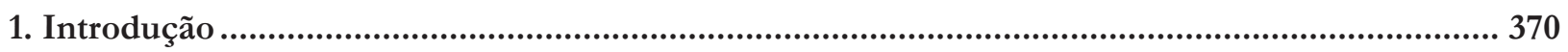

2. Uma breve contextualização sobre doações de órgãos e transplantes...........................................371

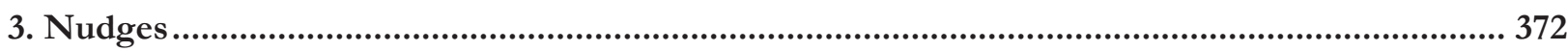


4. Nudges e doações de órgãos para transplantes ........................................................................... 375

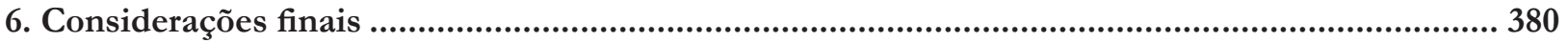

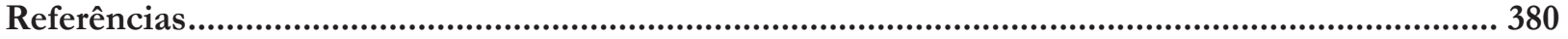

OS PROGRAMAS DE INTEGRIDADE PARA CONTRATAÇÃO COM A ADMINISTRAÇÃO PÚBLICA ESTADUAL: NUDGE OU OBRIGAÇÃO LEGAL? UM OLHAR SOBRE AS DUAS PERSPECTIVAS ............................386

Cíntia Muniz Rebouças de Alencar Araripe e Raquel Cavalcanti Ramos Machado

1. Introdução

2. Teoria do nudge na adoção de programas de integridade por empresas que projetam contratos com a Administração Pública.

3. A exigência legal de programas de integridade pública para a contratação com a Administração

Pública estadual: um olhar sobre a sua constitucionalidade e oportunidade 393

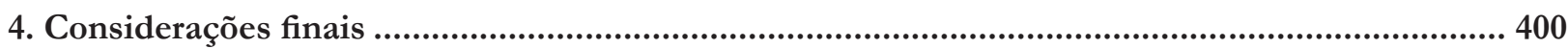

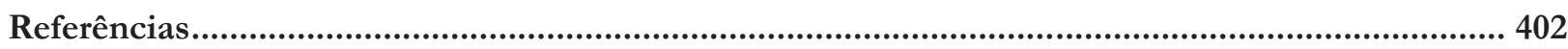

Paternalismo libertário e proteção Jurídica do Ambiente: POR QUe Proteger o AMBIENTE TAMBÉM DEVE SER PROTEGER AS LIBERDADES? .........................................406 Mariana Carvalho Victor Coelho e Patryck de Araujo Ayala

1. Introdução. 407

2. Os desafios da proteção da natureza no antropoceno. 408

2.1. Proteger a natureza ou proteger os negócios de sempre?. 409

2.2. Proteger a natureza deve fazer parte dos negócios de sempre.

3. A proteção jurídica da natureza no Estado de Direito: objetivos, tarefas e um pouco mais 411

3.1. Uma justificativa teórico-constitucional da proteção da natureza

3.2. A consideração de um princípio estruturante de sustentabilidade e o Estado como agente colaborador.

3.3. Nudge, paternalismo libertário e arquiteto de escolhas: porque nudge não pode eliminar liberdades.. 417

3.4. O Estado como arquiteto de escolhas: até que ponto a influência exercida para um objetivo de sustentabilidade é considerada ética?.

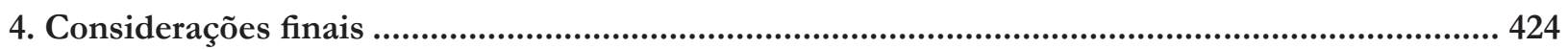

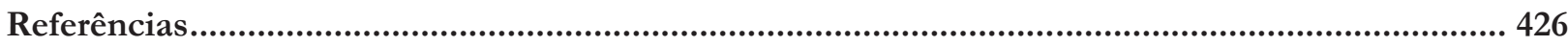

Políticas públicas baseadas em eVIDÊNCIAS COMPORTAMENTAIS: REFLEXões A PaRTIR do Projeto de Lei 488/2017 do Senado

Pâmela de Rezende Côrtes, André Matos de Almeida Oliveira e Fabiano Teodoro de Rezende Lara

1. Introdução

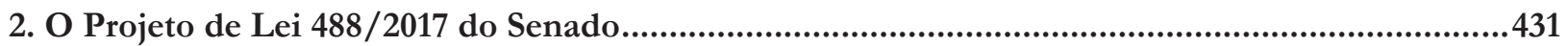

3. Políticas públicas baseadas em evidências............................................................................. 436

3.1. O movimento de análise de políticas públicas e de políticas públicas baseadas em evidências no Brasil e o PLS 488/2017. 
4.1. O uso de evidências comportamentais nas políticas públicas no Brasil à luz do PLS 488/2017

4.2. Aplicando evidências comportamentais a propostas de políticas públicas: análise de duas recomendações do PLS 488/2017. 446

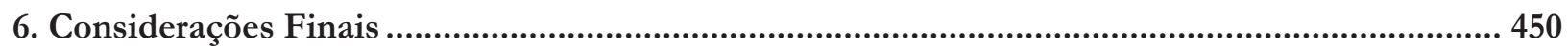

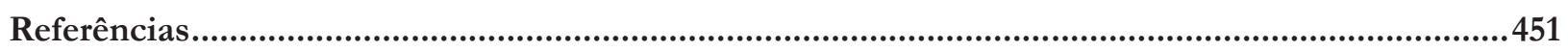

III. ECONOMIA COMPORTAMENTAL: VIESES COGNITIVOS E POLÍTICAS PÚBLICAS ......................455

ECONOMIA COMPORTAMENTAL E DIREITO: A RACIONALIDADE EM MUDANÇA.........................457 Marcia Carla Pereira Ribeiro e Victor Hugo Domingues

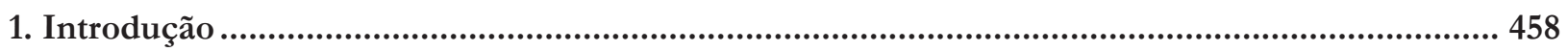

2. A economia comportamental como ponto de partida............................................................ 459

2.1. O Behaviorismo: Passado, Presente e Futuro ....................................................................................................... 459

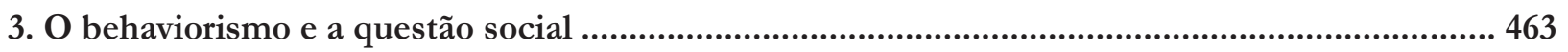

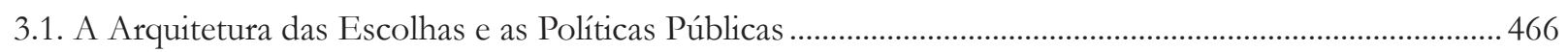

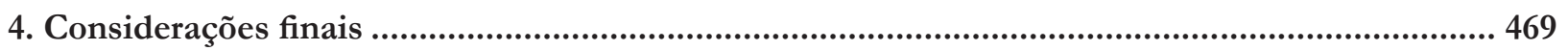

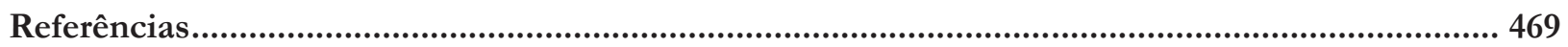

VIESES COGNITIVOS E DESENHO DE POLÍtICAS PÚBLICAS..................................................473

Benjamin Miranda Tabak e Pedro Henrique Rincon Amaral

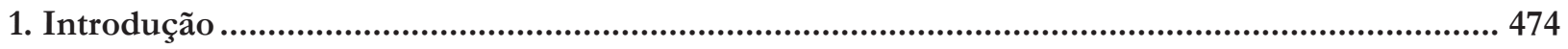

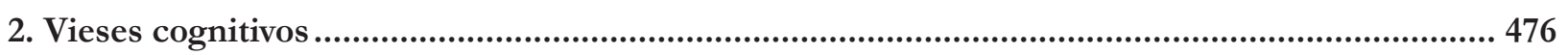

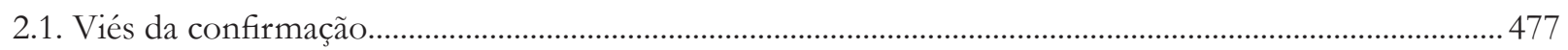

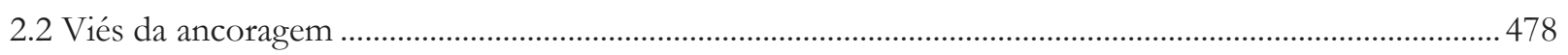

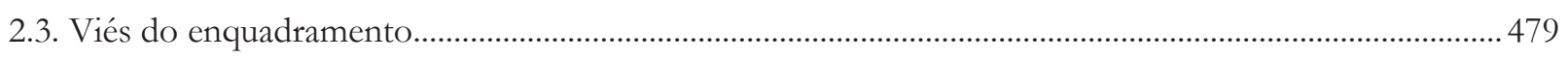

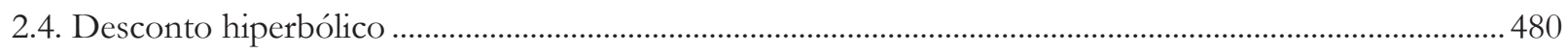

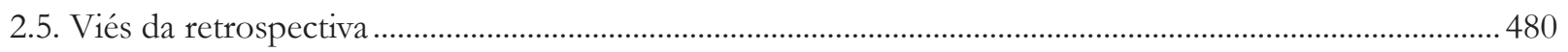

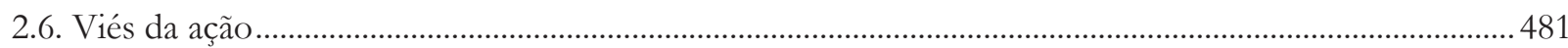

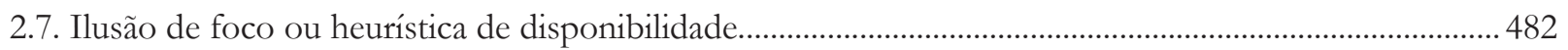

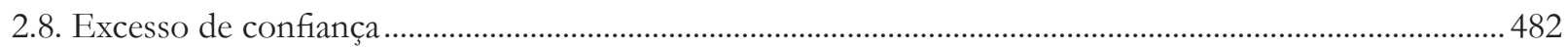

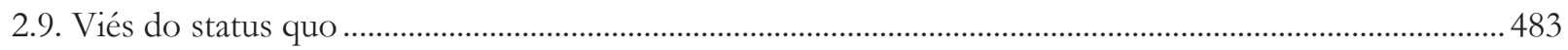

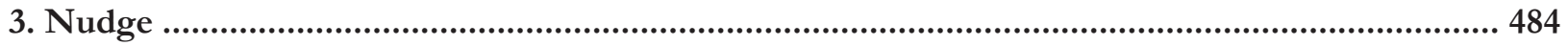

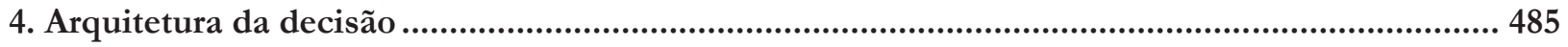

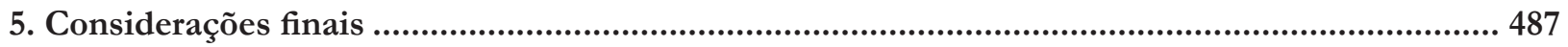

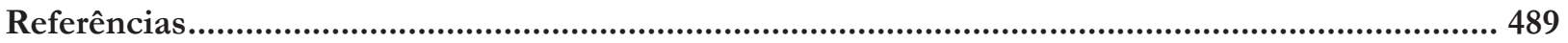

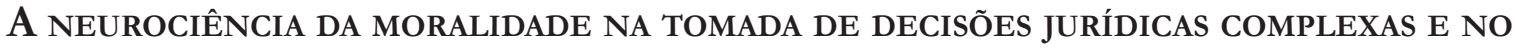
DESENHO DE POLÍTICAS PÚBLICAS ...................................................................493

Erik Navarro Wolkart

1. Introdução. 


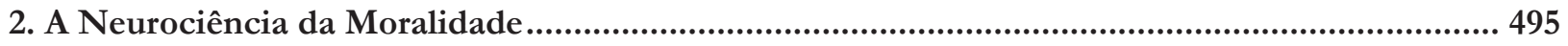

3. Explicando as traições do sistema 1: a troleologia de Joshua Greene.......................................... 498

4. A raiz biológica dos instintos transformada em imperativo categórico kantiano (a teoria da miopia modular)

5. Pragmatismo profundo e políticas públicas: como debater questões difíceis, passíveis de regulação pelo direito

6. Considerações finais .........................................................................................................................519

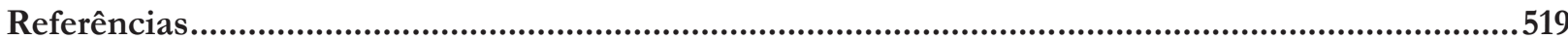

DESVIO DE CARÁTER OU SIMPLESMENTE HUMANO? ECONOMIA COMPORTAMENTAL APLICADA AO COMPORTAMENTO DESONESTO

Diana Orghian, Gabriel Cabral, André Pinto e Alessandra Fontana

1. Introdução 525

2. Economia comportamental: uma base teórica diferente para fundamentar ações práticas contra a corrupção

3. Uma bússola moral quebrada: fatores cognitivos............................................................. 529

4. Ajudando o indivíduo honesto a continuar honesto: fatores contextuais .................................. 533

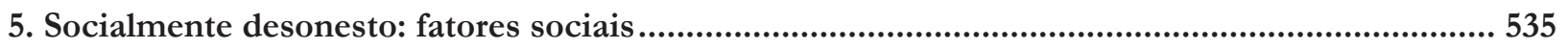

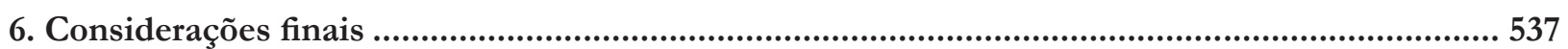

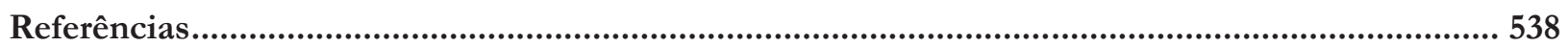

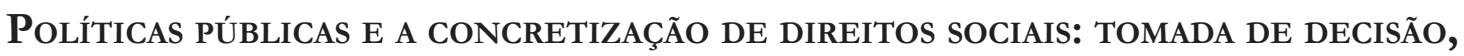
ARQUITETURA DE ESCOLHAS E EFETIVIDADE

Ana Elizabeth Neirão Reymão e Ricardo dos Santos Caçapietra

1. Introdução.....

2. Políticas públicas e direitos sociais: uma breve introdução 545

3. Modelos de análise de políticas públicas ..................................................................................... 548

3.1. Ciclo das políticas públicas ……………………....................................................................................... 548

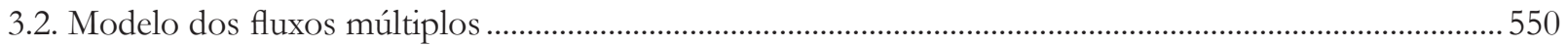

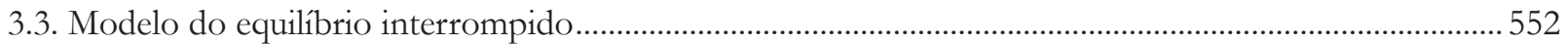

3.4. Coalizões de defesa (ou coligações de interesse) ........................................................................................... 554

4. Tomada de decisão individual e arquitetura de escolhas ............................................................. 556

5. Experimento aleatório controlado (EAC) …................................................................................560

6. Insights comportamentais em políticas públicas que tratam de direitos sociais ......................... 562

7. Considerações finais ....................................................................................................................... 564

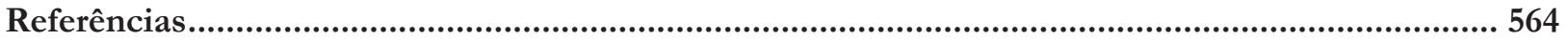

BEHAVIORAL ECONOMICS E DIREITO DO CONSUMIDOR: NOVAS PERSPECTIVAS PARA O ENFRENTAMENTO DO SUPERENDIVIDAMENTO 
1. Introdução

2. As heurísticas, os vieses e a Teoria dos Prospectos: a afirmação da Behavioral Economics .........571

2.1. O funcionamento do pensamento humano diante da tomada de decisões complexas. 578

3. Diálogos entre o direito e a economia comportamental: por que é importante compreender a forma como o consumidor se comporta no mercado de crédito?

3.1. A análise econômico-comportamental do direito

4. Por que proteger o consumidor no Brasil em face dos problemas comportamentais, se vivemos em uma economia de mercado? 586

5. Principais heurísticas e vieses que podem ser relacionados ao superendividamento .591

6. Considerações finais 594

Referências 595

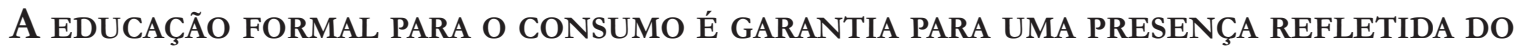
CONSUMIDOR NO MERCADO? UMA ANÁLISE COM BASE NA BEHAVIORAL LAW AND ECONOMICS (ECONOMIA COMPORTAMENTAL)

Marcia Carla Pereira Ribeiro e Edson Mitsuo Tiujo

1. Introdução

2. O direito básico à educação para o consumo como garantia de proteção ao consumidor, diante das práticas comerciais e das políticas econômicas indutoras do consumo

3. Os postulados da economia comportamental em uma comparação com a Teoria Econômica Clássica

4. Heurísticas e vieses: as distorções neurocognitivas nas tomadas de decisões dos consumidores607

5. A educação formal e inicial para o consumo pela ótica da economia comportamental garante a presença refletida do consumidor no mercado?.

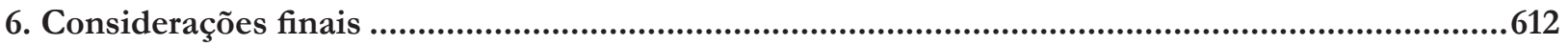

Referências..

LIBET, DETERMINISMO E CONSUMO: AS INFLUÊNCIAS DO MARKETING E A RELEVÂNCIA DA DELIBERAÇÃo CONSCIENTE NA SUPERAÇÃO CONDICIONAL DE HÁBITOS DE CONSUMO PERIGOSOS616 Émilien Vilas Boas Reis e Leonardo Cordeiro de Gusmão

1. Introdução. 617

2. O experimento de Benjamin Libet e algumas reflexões

3. O comportamento do consumidor perante os estímulos ao seu inconsciente e a sua capacidade de autodeterminação consciente. 624

3.1. Marketing, neurociência e os estímulos ao inconsciente do consumidor à luz dos direitos fundamentais.. 625

3.2. A relevância da deliberação consciente na superação condicional de hábitos de consumo perigosos.. 631

4. Considerações finais 635

Referências 637 
1. Introdução.

2. Algumas notas sobre epistemologia jurídica

3. Neurociência e economia comportamental .... 646

3.1. Economia comportamental e extrafiscalidade. 647

4. Reflexos no âmbito da extrafiscalidade tributária ........................................................................ 653

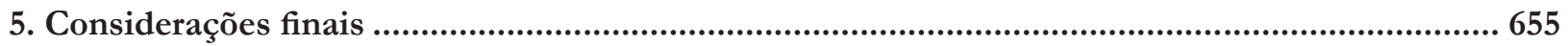

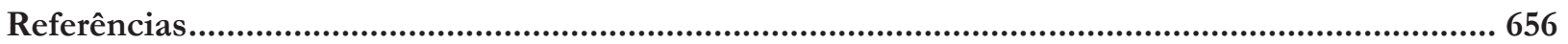

IV. Comportamento Judicial: INFLUÊnCIA DE FATORES EXTRAjurídicos .......................660

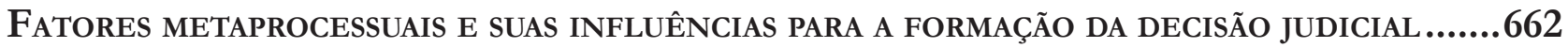
Rogério Roberto Gonçalves de Abreu, Lúcio Grassi de Gouveia e Virgínia Colares

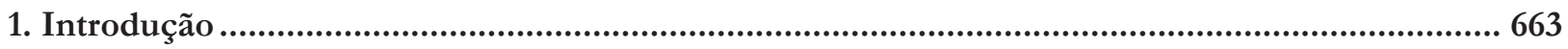

2. O inconsciente como insumo na decisão dita racional............................................................... 665

2.1. O inconsciente freudiano: um marco teórico ...............................................................................................667

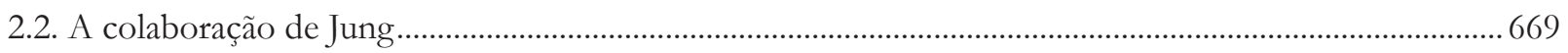

2.3. A decisão judicial como produto (in) consciente do trabalho do julgador................................................ 671

2.4. A neutralidade judicial como mito e o inconsciente do julgador.................................................................. 672

3. Fatores metaprocessuais específicos e a constatação empírica de sua influência na tomada de

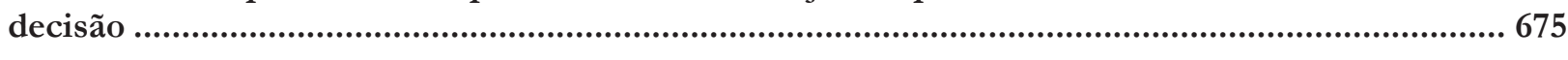

3.1. Inclinações implícitas do julgador............................................................................................................... 675

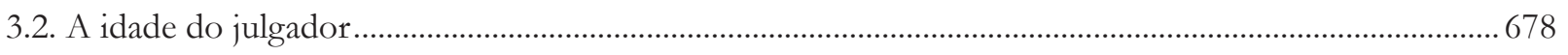

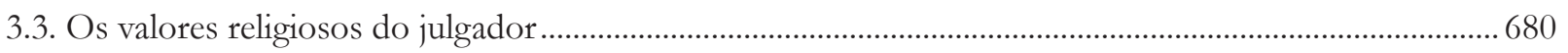

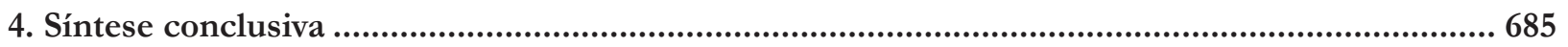

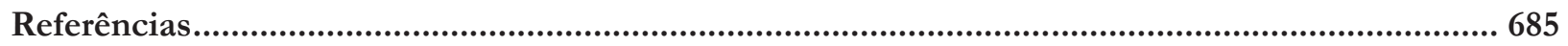

“A VIDA COMO ELA É": COMPORTAMENTO ESTRATÉGICO NAS CORTES..................................689

Patrícia Perrone Campos Mello

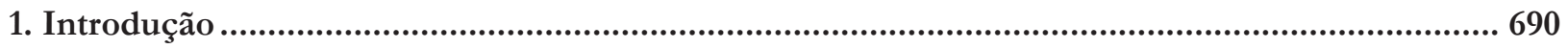

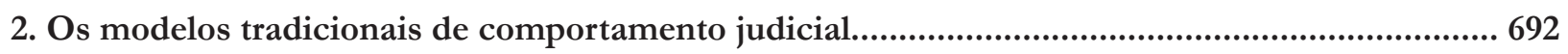

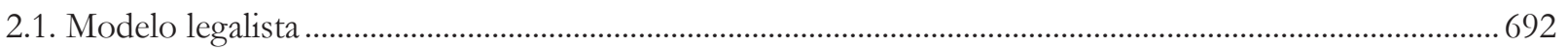

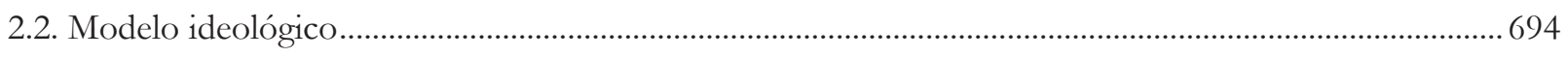

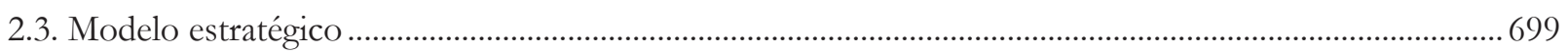

3. O modelo estratégico: dimensões interna e externa ....................................................................701

3.1. Modelo estratégico interno: o caso Craig v. Boren ……………................................................................. 702

3.2. Modelo estratégico externo: Marbury v. Madison...................................................................................... 704

4. O modelo estratégico no Supremo Tribunal Federal ........................................................... 705 
4.1. Atuação estratégica com base em decisões procedimentais ............................................................................ 706

4.2. Atuação estratégica com base em decisões substantivas ................................................................................. 709

5. Considerações finais .....................................................................................................................713

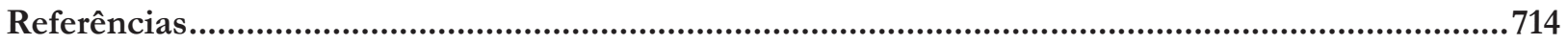

A Composição do ÓRGÃo Colegiado E SEUS EFEITOS NA TOMADA DE DECISÃo....................720 André Garcia Leão Reis Valadares

1. Introdução 721

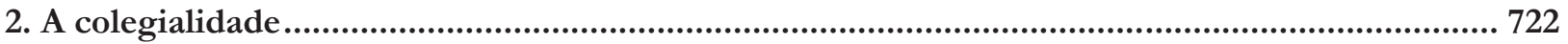

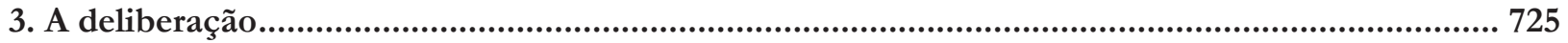

4. A composição do órgão colegiado e a tomada de decisão ............................................................. 730

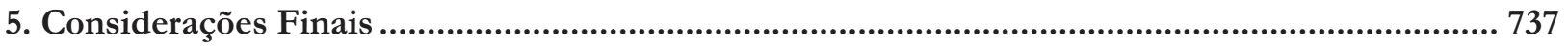

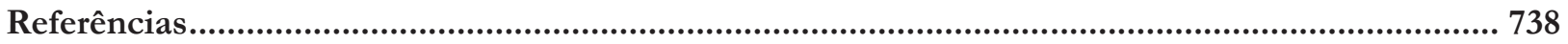

Das 11 ilhas ao centro do arquipélago: os superpoderes do Presidente do STF DURANTE O RECESSO JUDICIAL E FÉRIAS ................................................................. 741

José Mário Wanderley Gomes Neto e Flávia Danielle Santiago Lima

1. Introdução: quem preside o Brasil?

2. Desenhos institucionais e modelos estratégicos: relevância para a compreensão das cortes no

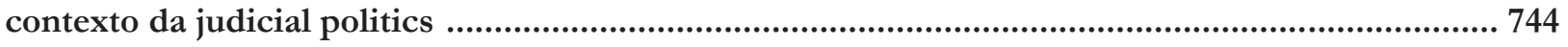

3. O centro do arquipélago no recesso: o Super Presidente do STF ............................................... 747

4. Decidir ou não decidir? Exploração de casos e dinâmica estratégica. .......................................... 750

5. Considerações finais: as repercussões da concentração de poder decisório do Ministro Presidente nos períodos de recesso e de férias judiciais....................................................................................... 752

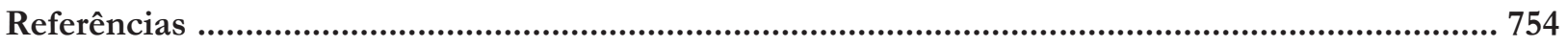

RAZÃo, EMOÇÃo E DELIBERAÇão: AS ADEQUAÇõES REgIMENTAIS Do SUPERIOR TribunAL DE JUSTIÇA PARA A FORMAÇÃo DE PRECEDENTES EFICAZES ............................................758

Peter Panutto e Lana Olivi Chaim

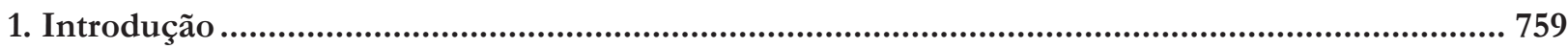

2. Razão e emoção na produção decisória individual ..................................................................... 760

3. A plena deliberação colegiada como garantia da legitimidade da Corte................................... 763

4. As adequações regimentais pelo Superior Tribunal de Justiça para a formação de precedentes

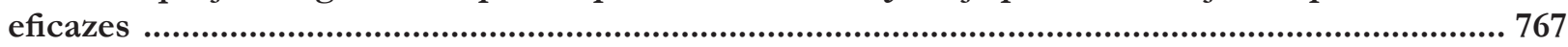

4.1. Da organização da manifestação dos membros dos colegiados no STJ …………………………………... 768

4.2. Do pedido de vista, dos ministros ausentes e da desvalorização do confronto de argumentos.............. 770

4.3. Do recurso especial representativo da controvérsia........................................................................................ 771

4.4. Dos fundamentos determinantes dos precedentes decorrentes de incidente de assunção de competência

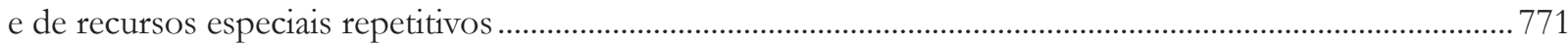

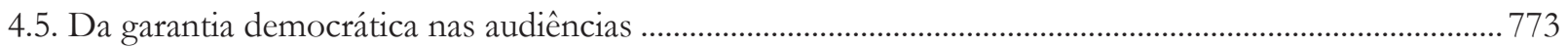




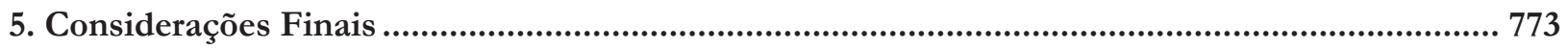

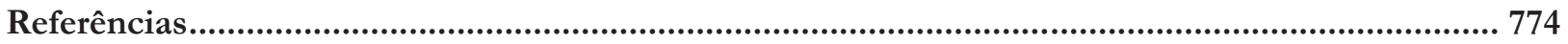

Heurística de ANCORAGEM E FIXAÇÃo de DANOS MORAIS EM JUIZADOS ESPECIAIS Cíveis No Rio

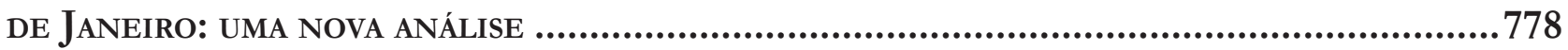

Fernando Leal e Leandro Molhano Ribeiro

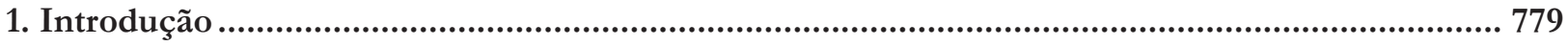

1.1. Teorias normativas e limites reais para a tomada de decisão.......................................................................... 779

1.2. Propósito do trabalho e colocação do problema de pesquisa …………………………………………….... 782

1.3. Hipótese, metodologia e conclusões da primeira análise …………………………………............................ 784

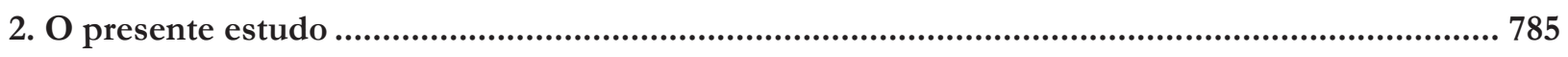

2.1. Os dados dos I e II Juizados Especiais Cíveis da Regional Barra da Tijuca e a definição dos processos a

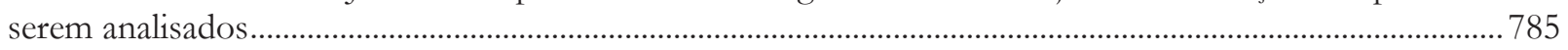

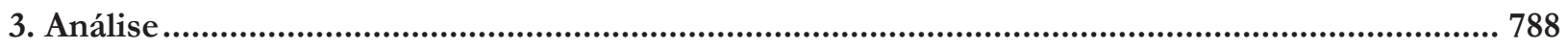

3.1. Valores pedidos e valores deferidos: análise com todos os processos ....................................................... 789

3.2. Valores pedidos e valores deferidos: análise das áreas de telecomunicações, varejo, bancos e setor aéreo.. 794

4. Considerações finais 797

Referências.

LA PROTECCIÓN DE LOS DERECHOS POLÍTICOS FRENTE A LAS FUNCIONES DISCIPLINARIAS

DE LAS AUTORIDADES ADMINISTRATIVAS: SUBSIDIARIEDAD Y DEFERENCIA EN EL SISTEMA INTERAMERICANO DE DERECHOS HUMANOS........................................................... 801

Jorge Ernesto Roa Roa

1. Introducción

2. Los derechos políticos protegidos por la $\mathrm{CADH}$ frente a las funciones disciplinarias de las

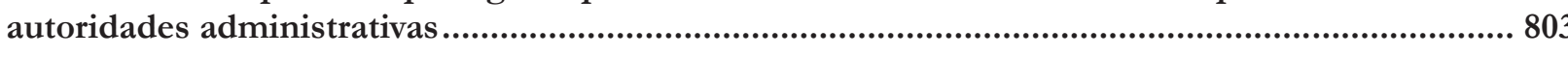

2.1. La profundización de la antinomia por la vía de la jurisprudencia constitucional ..................................... 804

2.2. La complejidad de la antinomia: el fracaso de la interpretación conforme y del principio pro persona807

3. La deferencia y el principio de subsidiariedad en el Sistema Interamericano de Protección de los

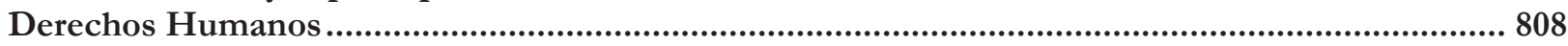

3.1. El previo agotamiento de los recursos internos: reglas, excepciones y carga de la prueba ..................... 810

3.2. La mal denominada fórmula de la cuarta instancia ...................................................................................... 812

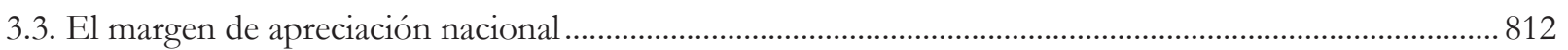

3.4. Enfoques de deferencia como alternativa al margen de apreciación nacional............................................ 816

4. Una interpretación compatible de la $\mathrm{CADH}$ con las funciones disciplinarias de las autoridades administrativas bajo el enfoque de la deferencia y la aplicación del derecho convencional ..............817

4.1. Las condiciones de la interpretación compatible: derechos políticos y garantías judiciales .818

4.2. A modo de conclusión. Las ventajas de la interpretación compatible: diálogo, deferencia, legitimidad y

eficacia no contenciosa del sistema interamericano

Bibliografía 
Como os Juízes decidem os CASOS DE ESTUPRo? ANALISANDo SENTENÇAS SOB A PERSPECTIVA DE VIESES E ESTEREÓTIPOS DE GÊNERO ...................................................................826 Gabriela Perissinotto de Almeida e Sérgio Nojiri

1. Introdução

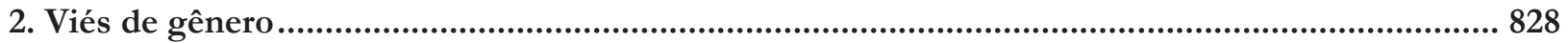

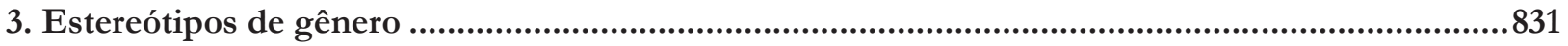

4. Como os juízes decidem os casos de estupro ................................................................................... 834

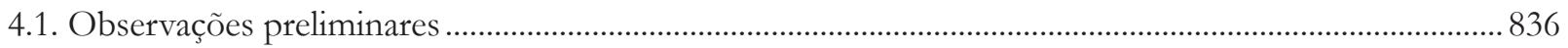

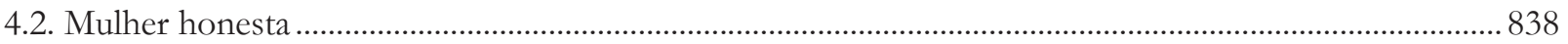

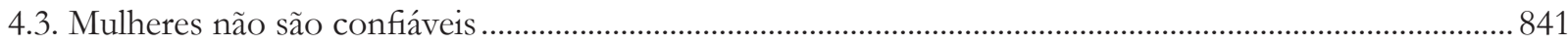

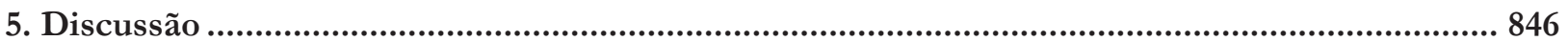

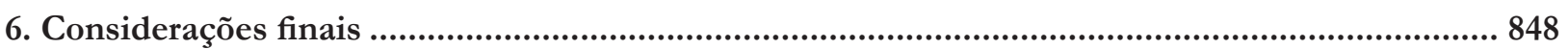

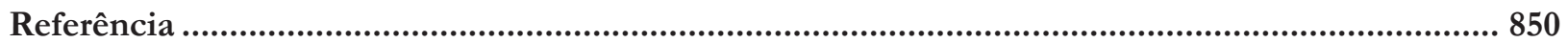

GÊNERO E COMPORTAMENTO JUDICIAL NO SUPREMO TRIBUNAL FEDERAL: OS MINISTROS CONFIAM MENOS EM RELATORAS MULHERES? ................................................................855

Juliana Cesario Alvim Gomes, Rafaela Nogueira e Diego Werneck Arguelhes

1. Introdução

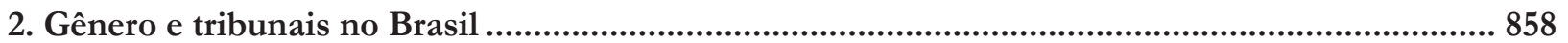

3. Gênero, colegialidade e julgamento no Supremo Tribunal Federal........................................... 860

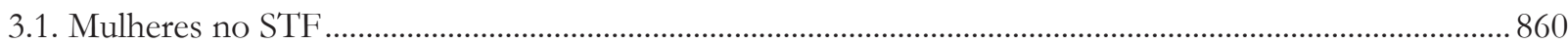

3.2. Gênero e o papel do relator no processo decisório do STF............................................................................. 862

3.2.1. Votos vencidos e confiança no relator ............................................................................................... 863

3.2.2. Interrompendo deliberações: pedidos de vista e confiança na opinião do relator .............................. 865

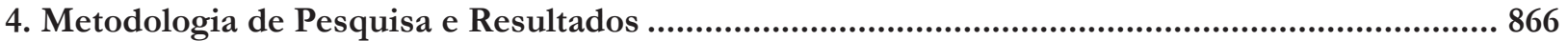

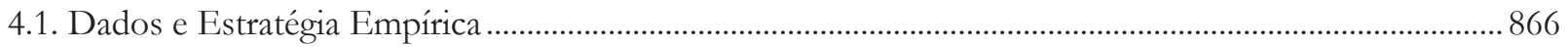

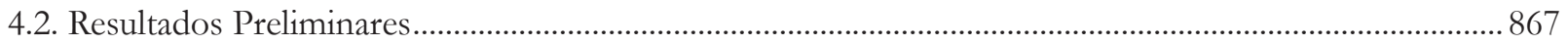

5. Estereótipo de gênero e discussão dos resultados .......................................................................... 869

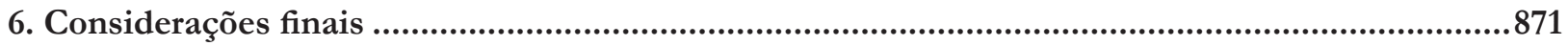

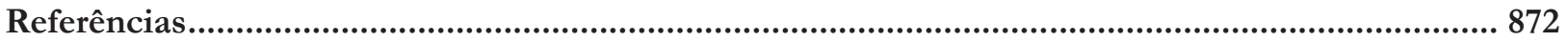

Hércules, Hermes e a pequena sereia: Uma reflexão sobre estereótipos de gêNero, SUbPRESENTAÇ̃̃o DAS MULHERES NOS TRIBUNAIS E (I)LEGITIMIDAdE DEMOCRÁtiCA DO PODER

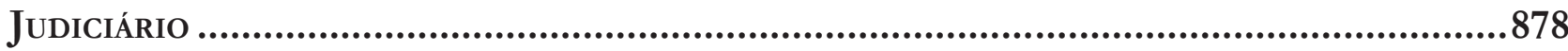
Jane Reis Gonçalves Pereira e Renan Medeiros de Oliveira

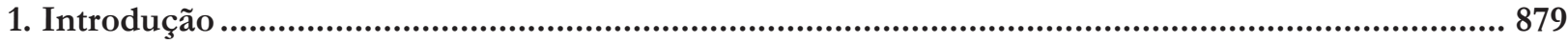

2. A dicotomia público-privado e os estereótipos de gênero na construção do juiz ideal.................881 
2.1. A dicotomia público-privado na teoria feminista......

2.2. A dimensão de gênero na construção da figura do juiz ideal .............................................................. 884

3. A baixa representatividade de gênero nas cúpulas do Judiciário e na Justiça Federal ................ 888

4. Os dilemas da representação e por que diversidade importa ..............................................898

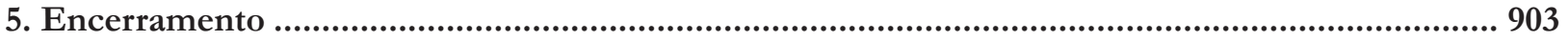

Referências.................................................................................................................. 904

Prisão cautelar de gestantes: análise do fundamento filosófico da decisão do Habeas CoRPUS N. 143.641 ......................................................................................... 912

Artur César Souza e Giovania Tatibana de Souza

1. Introdução. 913

2. Os fundamentos aparentes e expressamente consignados na decisão proferida no Habeas Corpus

n. 143.641 913

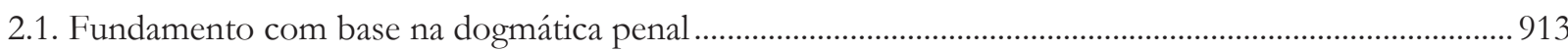

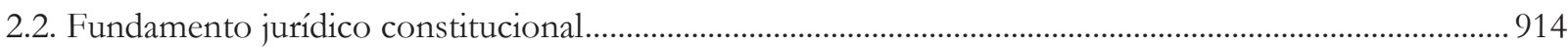

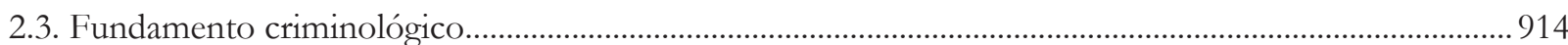

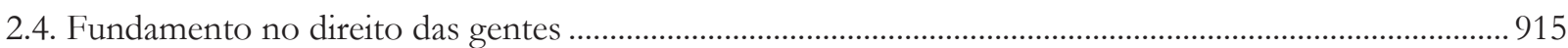

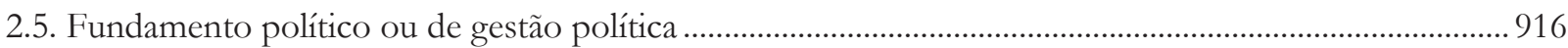

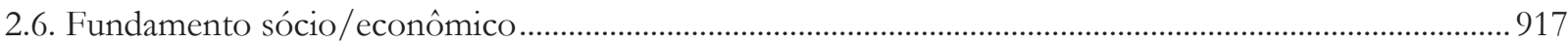

3. Fundamento ético-filosófico ................................................................................917

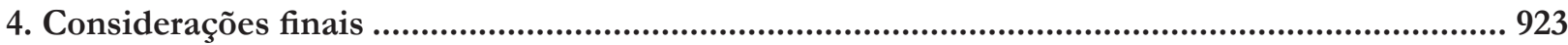

Referências........................................................................................................................ 923

VI. NeURodireito APLiCAdo AO DiREITO E AO PRoCESSO PENAL...........................................926

CÉREBRos QUE PUNEM: UMA REVISÃo CRÍTICA DA NEUROCIÊNCIA DA PUNIÇÃo ........................928

Ricardo de Lins e Horta

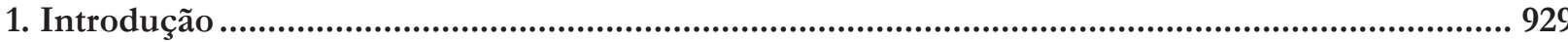

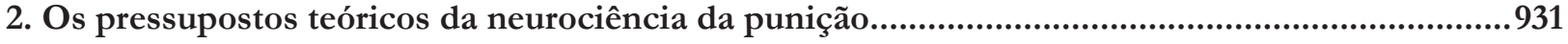

3. Os resultados da neurociência da punição .......................................................................................... 933

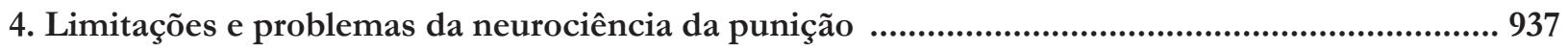

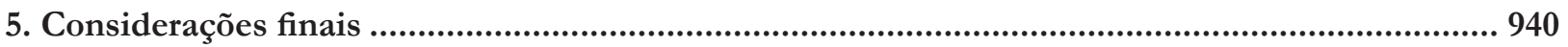

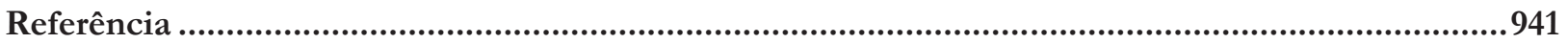

A INTUIÇÃo do DOLO EM DiREITO PENAL: CORRELATOS NEURAis DA TEORIA DA MENTE, RACIOCÍNIO INDUTIVO E A GARANTIA DA CONVICÇÃO JUSTIFICADA............................................946 Thiago Dias de Matos Diniz e Renato César Cardoso

1. Introdução

2. $\mathrm{O}$ modelo intuicionista social

3. Os correlatos neurais da atribuição de estados mentais 
4. Cognição moral e Teoria da Mente.............................................................................................. 952

5. A base psicológica-intuitiva do dolo eventual ............................................................................. 954

6. A relevância do histórico do agente na atribuição de intenção e reprovabilidade moral da

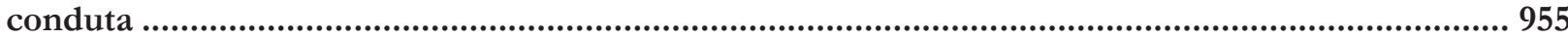

7. Breves considerações sobre os desafios empíricos da prova do dolo........................................... 956

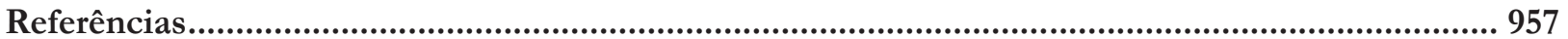

As COMUNIDADES EPISTÊMICAS PENAIS E A PRODUÇÃo LEGISLATIVA EM MATÉRIA CRIMINAL..... 961 Stéphane Enguéléguélé

1. Introdução 961

2. Comunidades epistêmicas: produção teórica e definição de processos de reação penal .............. 964

2.1. A formação das comunidades epistêmicas penais.......................................................................................... 966

3. Modos de organização e estratégias de influência das comunidades epistêmicas penais........... 970

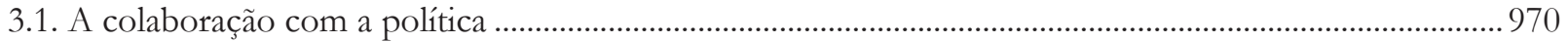

3.2. A estruturação das mobilizações e dos confrontos políticos em torno de questões criminais................ 973

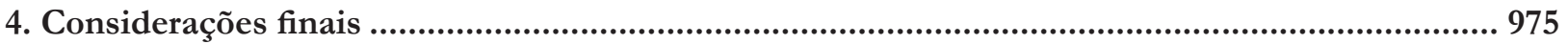

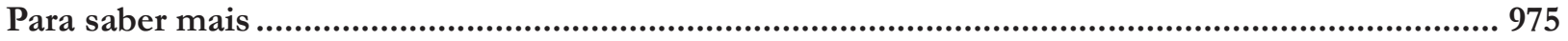

Em português ……................................................................................................................................... 976

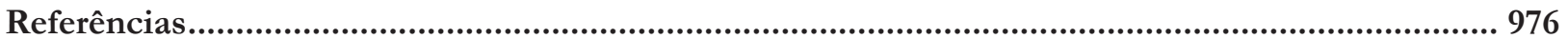

DELINQUÊNCIA JUVENIL: RELAÇÕES ENTRE DESENVOLVIMENTO, FUNÇÕES EXECUTIVAS E

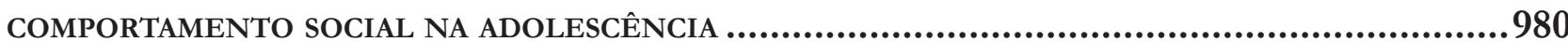

André Vilela Komatsu, Rafaelle CS Costa e Marina Rezende Bazon

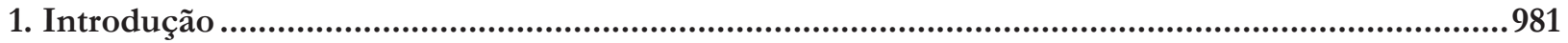

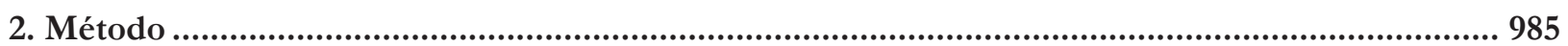

3. Funções Executivas e Comportamentos Delituosos ............................................................... 985

4. Implicações do conhecimento sobre as FEs em intervenções em delinquência juvenil ............. 990

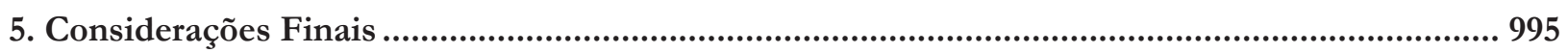

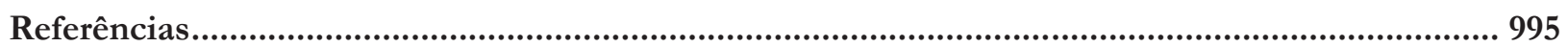

LÍMITES TEMPORALES A LAS PENAS PRIVATIVAS DE LIBERTAD ATENDIENDO AL DESARROLLO

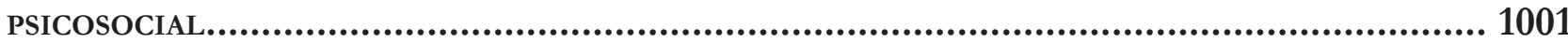
Silvio Cuneo

1. Introducción 1002

2. Interrogantes en torno a la cadena perpetua y a la extensión de las penas privativas de la libertad.

3. Compatibilidad entre la cadena perpetua (u otras penas privativas de libertad excesivamente largas) y las teorías sobre el fin de la pena

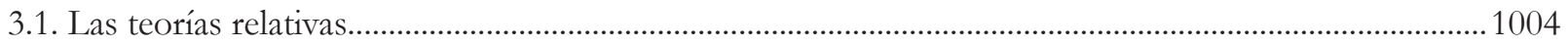

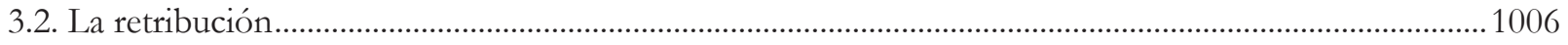




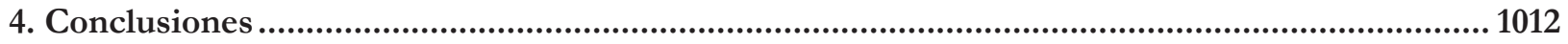

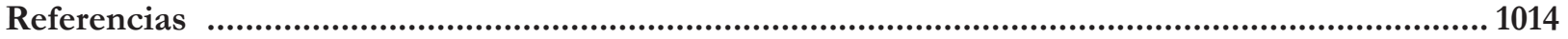

Neurolaw E AS PERSPECTIVAS PARA UMA ANÁlise ObJETIVA do COMPORTAMENTO

SUGESTIONADO: REPERCUSSÃO DAS FALSAS MEMÓRIAS NA ESFERA PENAL.............................. 1017

Mariana Dionísio de Andrade, Marina Andrade Cartaxo e Rafael Gonçalves Mota

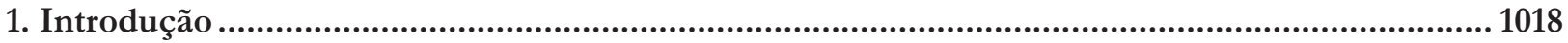

2. Neurolaw: relação entre neurociência e a psicologia do testemunho.......................................... 1019

3. O problema da empatia sobre o comportamento da testemunha.............................................. 1021

4. Quando o depoimento pode prejudicar o processo: testemunha sugestionável ........................1022

5. Repercussões das falsas memórias para a esfera penal: o caso da escola de educação infantil

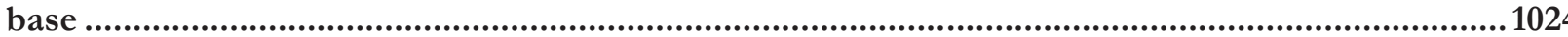

6. Análise de dados: identificando a implantação de falsas memórias em decisões monocráticas no âmbito do superior tribunal de justiça ..........................................................................................1028

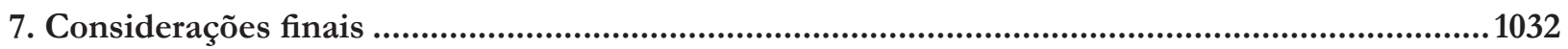

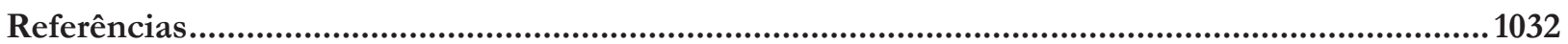

A FALIBILIDAdE DA MEMÓRIA NOS RELATOS TESTEMUNHAis: IMPLiCAÇÕES DAS FALSAS MEMÓRIAS NO CONTEXTO DOS CRIMES CONTRA A DIGNIDADE SEXUAL ....................................... 1036 Caroline Navas Viana

1. Introdução 1037

2. Da prova testemunhal como meio de prova 1037

3. Dos crimes contra a dignidade sexual: sua materialidade e comprovação 1039

4. Desmistificando o funcionamento da memória ......................................................................... 1041

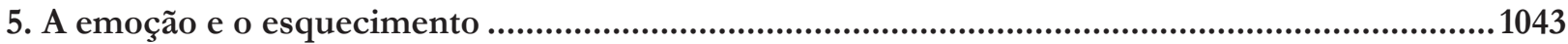

6. Da formação das falsas memórias ................................................................................................1044

7. Os experimentos de Elizabeth Loftus .......................................................................................1045

8. A prova testemunhal como meio isolado de prova .........................................................................1046

9. Do reconhecimento pessoal conduzido sem a observância das formalidades legais...................1047

10. Tempo de colheita da prova testemunhal: do transcurso do tempo..........................................1049

11. Repetição das entrevistas: da prova testemunhal como elemento probatório irrepetível ........... 1051

12. Subjetivismo do julgador: a imparcialidade e neutralidade do julgador ....................................1052

13. Considerações finais ................................................................................................................1053

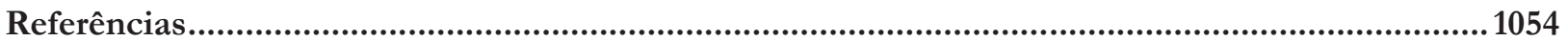

A (IR)REPETIBILIDADE DA PROVA PENAL DEPENDENTE DA MEMÓRIA: UMA DISCUSSÃo COM BASE NA PSICOLOGIA DO TESTEMUNHO.

William Weber Cecconello, Gustavo Noronha de Avila e Lilian Milnitsky Stein

1. Introdução

2. Capacidades e limites da memória humana..... 
3. Repetibilidade da prova penal dependente da memória ............................................................. 1064

4. Políticas públicas para uma prova antecipada ….........................................................................1065

5. Considerações finais .......................................................................................................................1069

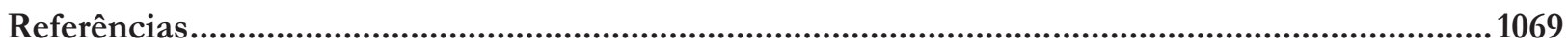

Normas Editoriais................................................................................. 1074

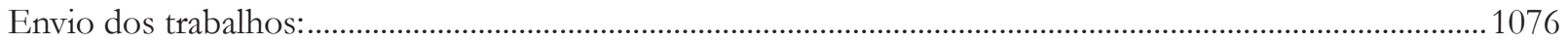




\section{REVISTA BRASILEIRA DE POLÍTICAS PÚBLICAS BRAZILIAN JOURNAL OF PUBLIC POLICY}

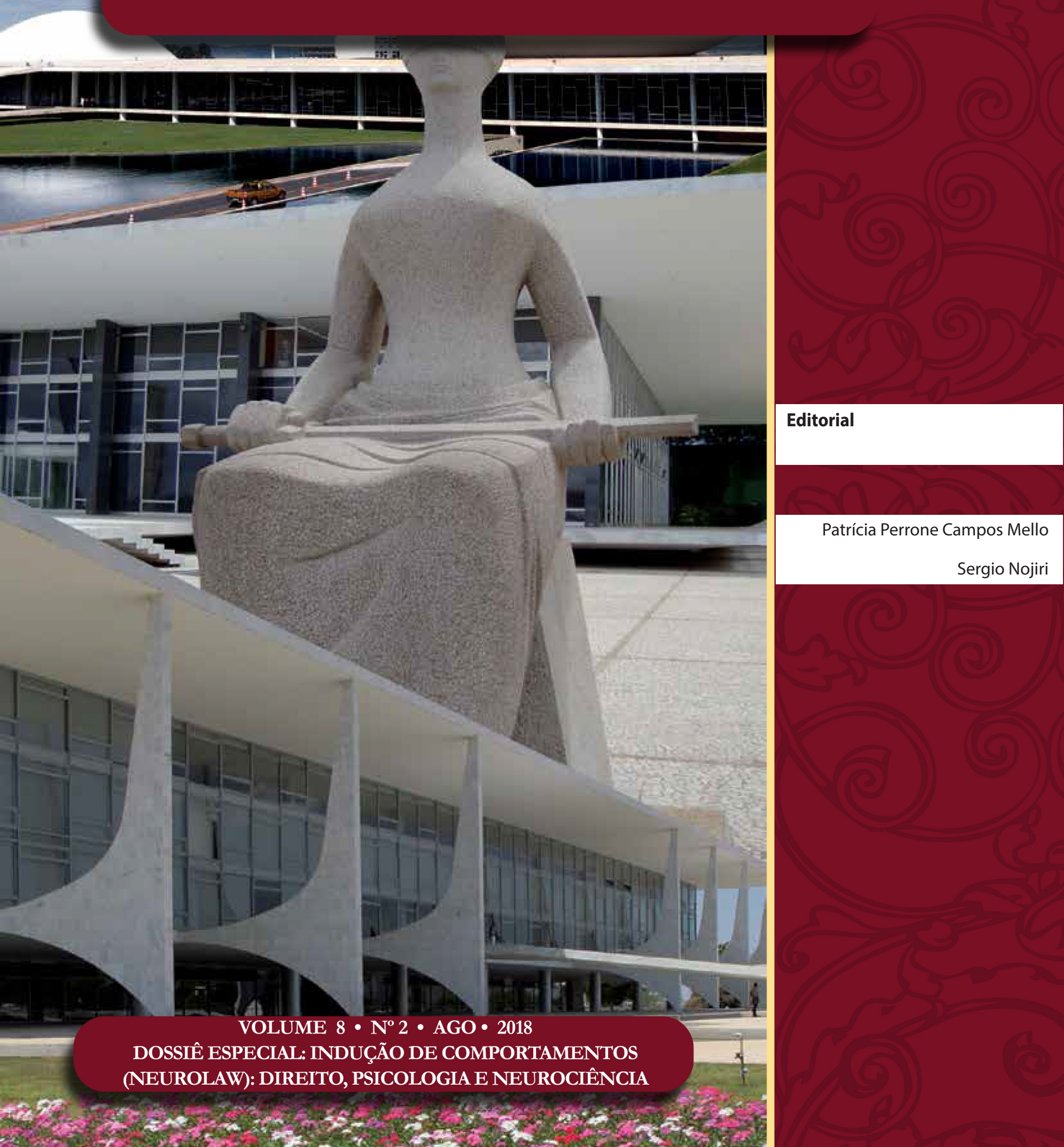




\section{Editorial}

\section{O Direito na fronteira da RazÃo: Psicologia, neurociênCia e ECONOMIA COMPORTAMENTAL}

Há, no campo das ciências cognitivas, um amplo consenso de que nossos padrões de pensamento e comportamento não são governados unicamente pela razão. Decisões, que acreditamos originarem-se de um raciocínio meticuloso, neutro e lógico, podem, na verdade, ser conduzidas por estruturas de pensamento imprevisíveis, muitas vezes não identificáveis no nível da consciência. Inúmeras evidências experimentais têm indicado que nossos pensamentos são compostos por um complexo sistema de juízos inconscientes. Os psicólogos, nesse sentido, há tempos estudam os chamados “atalhos mentais" (vieses e heurísticas), que propiciam um julgamento, na maior parte das vezes rápido e eficiente, mas que também podem criar ilusões cognitivas que produzem resultados equivocados e tendenciosos.

Tudo isso está se tornando lugar-comum em várias áreas do conhecimento. Tomemos o exemplo da economia. A ideia de que temos preferências estáveis e racionais e de que calculamos cuidadosamente o custo-benefício de nossas ações está sob suspeição. A título ilustrativo, desde que os insights da psicologia foram aplicados por Daniel Kahneman e Richard Thaler (para citar dois ganhadores do Prêmio Nobel) ao estudo de problemas econômicos, alguns conceitos clássicos, como o de "utilidade" (ou "teoria da utilidade esperada"), foram colocados em risco. A abordagem interdisciplinar entre a psicologia e a economia gerou toda uma literatura sobre nudges, framing e preços-âncora, que se mostra cada vez mais rica e duradoura.

Apesar disso, no campo do direito, ainda é frequente a alusão à noção de juízes neutros e imparciais e a operadores do direito plenamente racionais e livres de preconceitos, em franca contradição com as pesquisas mais recentes das ciências cognitivas.

Em um contexto no qual as faculdades de direito ainda se valem de uma metodologia de ensino segundo a qual conhecer o direito é conhecer os códigos, as leis e a Constituição, a Revista Brasileira de Políticas Públicas, de forma pioneira, abre espaço para artigos científicos que partem de um pressuposto diverso, no qual sentimentos, intuições e ideologias políticas influenciam diretamente o direito, especialmente o processo de tomada de decisões judiciais. Centenas de pesquisas científicas têm demonstrado que, ao tomarmos decisões, ficamos sujeitos a ilusões cognitivas. Outras tantas nos mostram que nossa racionalidade é limitada e que não somos só razão, mas também emoção. Assim, este parece ser o momento apropriado para pensarmos o direito não mais como um mero conjunto de regras e princípios, mas a partir de uma abordagem ampla e interdisciplinar, que considere o que outras áreas do conhecimento como a neurociência e a psicologia já sabem: todos nós, como seres humanos, somos falíveis, somos produto de nossa cultura, etnia, nacionalidade, condição socioeconômica, gênero, sexo e ideologia; somos vulneráveis a vieses, preconceitos e emoções, negativas e positivas. 
Recebemos por volta de uma centena de artigos em resposta à chamada para este dossiê temático - uma adesão inédita, que surpreendeu a todos. Os editores da revista, os coordenadores do dossiê e os pareceristas trabalharam intensamente, por meses, para selecionar os artigos desta edição. Admitimos recursos, recomendamos ajustes e o resultado final desse processo rigoroso está expresso no presente volume, cuja extensão se justifica pela qualidade dos trabalhos e pela diversidade dos temas que abordam. Mais que oportuna, portanto, a edição do dossiê temático Indução de comportamentos (Neurolaw): Direito, Psicologia e Neurociência. Trata-se de uma reunião de textos jurídicos rica e criteriosa, que aborda o direito a partir de uma visão interdisciplinar, e coloca o processo de deliberação em perspectiva mental e comportamental direcionada à resolução de conflitos sociais. A intersecção entre direito, psicologia e neurociência é mais do que a sobreposição de três conjuntos. É a tentativa de colocar luz sobre os fatores que determinam padrões decisórios que vão além do direito. Trata-se, portanto, nesta obra, de um tema transversal de grande importância: da formulação de políticas públicas à aplicação da lei penal, da proteção do consumidor à igualdade de gênero, não podemos prescidir de uma compreensão adequada dos caminhos pelos quais realmente passa a cognição humana.

Com essas palavras, desejamos aos leitores da Revista Brasileira de Politicas Públicas uma prazerosa viagem ao encontro da sua própria, inevitável e misteriosa irracionalidade.

Patrícia Perrone Campos Mello

Sergio Nojiri 


\section{NEURODIREITO: COGNIÇÃO, EMOÇÃO, JUIZZOS MORAIS E CIÊNCIA}




\title{
Pensar direito e emoção: uma cartografia*
}

\section{Thinking law and emotion: a cartography}

\author{
Nevita Maria Pessoa de Aquino Franca Luna**
}

Mais les juristes? Qui oserait prétendre, un seul instant, que les juristes rêvent? Que ces êtres froids, calculateurs, qui rédigent des lois, des règlements, des contrats, sont des rêveurs impénitents?

\section{Resumo}

O objetivo do artigo é, através de um breve percurso histórico, mapear ${ }^{2}$ o espaço da emoção no direito. De início, mostraremos a recusa dos elementos emocionais no campo jurídico; em seguida, elencamos as influências das emoções em algumas matérias do direito; e, por último, examinamos a tomada de poder da vítima como sujeito de direito na esfera penal. A metodologia utilizada foi a pesquisa bibliográfica em livros e artigos nacionais e estrangeiros. Concluímos que, apesar da aparente rejeição das emoções no campo jurídico, elas estão presentes em quase todas as suas áreas e são fundamentais, pois nada que é humano pode ser estranho ao jurista. O estudo é original porque, além de multidisciplinar, reúne elementos pouco conhecidos na área e existem escassas pesquisas sobre a relação entre direito e emoção.

Palavras-chaves: Direito. Sentimento. Razão. Legislação. Vítima.

* Recebido em 30/01/2018

Aprovado em 26/03/2018

** Doutorado em Direito pela Universidade Federal de Pernambuco (UFPE), na linha de Pragmatismo Jurídico, com estágio de pesquisa na Université Laval (Canadá). Possui Graduação e Mestrado em Filosofia pela Universidade Federal da Paraíba (UFPB). É advogada e professora de Filosofia do Direito e Hermenêutica Jurídica, em cursos de Graduação em Direito. Email:nevitafranca@gmail.com.

Pesquisa financiada pela Coordenação de Aperfeiçoamento de Pessoal de Nível Superior (CAPES).

\section{Abstract}

The objective of the article is, through a brief history, map the space of emotion in the law. Initially, we will show the rejection of emotional elements in the legal field; then we list the influences of emotions on some matters of law; and, lastly, we examine the victim's takeover as a subject of law in the criminal sphere. The methodology used was the bibliographical research in national and foreign books and articles. We conclude that, despite the apparent rejection of emotions in the legal field, they are present in almost all their areas and are fundamental, since nothing that is human may be foreign to the jurist. The study is original because, in addition to multidisciplinary, there is little research on the conflicting relationship between law and emotion.

Key-words: Law. Feeling. Reason. Legislation. Victim.

EDELMAN, Bernard. Quand les juristes inventent le réel. Paris: Hermann, 2007.

2 A expressão "cartografia" é bastante utilizada pelo Professor Gustavo Just da Costa e Silva, docente da Universidade Federal de Pernambuco, em seus cursos e aulas, assumindo aqui o significado de "mapeamento", pois neste artigo iremos localizar o lugar das emoções no direito. 


\section{A RECUSA INICIAL DAS EMOÇõES NA TRADIÇÃO DO PENSAMENTO JURÍDICO}

O tema direito e emoção é inabitual, quase improvável. Isso se explica porque os "movimentos do coração" ${ }^{3}$ talvez tenham sido abandonados do direito pelo projeto iluminista ${ }^{4}$, para serem tratados mais frequentemente pela psicologia e pelas letras. Nestas, eles têm um lugar de destaque e inspiram a literatura, o teatro, a poesia e as artes em geral. Mas por que os juristas se interessaram pouco pelas emoções? Porque elas lhes parecem completamente estranhas ao direito, uma vez que o modelo padrão de educação jurídica trata a interpretação da lei como uma ciência, o raciocínio legal como um processo puramente dedutivo e a emoção como inimiga da razão.

Para retomar a célebre distinção kantiana, enquanto o remorso é o instrumento de que se serve a moral para combater a transgressão de um ponto de vista de foro interno, é por meio dos atos físicos que o direito reprime, de um ponto de vista externo, os comportamentos violentos. Segundo Kant, ainda, o centro das condutas morais e, notadamente, as jurídicas provém unicamente da racionalidade humana. Assim, somente o homem, ser racional, é capaz de fazer leis que fundam e orientam suas ações. O filósofo ensina que, apesar de suas necessidades primitivas (paixões e inclinações naturais), o indivíduo racional é capaz de se determinar com base na autonomia da vontade e seguir o que preconiza o imperativo categórico: agir por dever. A lei oriunda da razão é a única condição possível de constituição dos princípios de justiça e de realização da liberdade. O direito não se refere, portanto, ao universo íntimo do ser humano, aquele dos sentimentos. Incapaz de penetrar nos corações, o direito toma a forma de um discurso racional, frio e rígido.

Nesse modelo tradicional, as emoções são individuais, arbitrárias, inanalisáveis e, ultimamente, uma ameaça ao próprio funcionamento do sistema jurídico. Elas são, nas palavras de Fiss, inconsistentes com muitas normas que governam e legitimam o poder judicial ${ }^{5}$ e tal postura é ainda muito difundida no direito. Até recentemente, os juristas diziam que o conhecimento de outras disciplinas era irrelevante para o direito e que o sistema jurídico é e deve ser um sistema autônomo de pensamento, que basta a si mesmo. ${ }^{6}$

O instrumento de trabalho do jurista, por muitos séculos, foi apenas o texto, de modo que tal atitude contribuiu para perpetuar um sistema antiquado, apesar de todas as evidências contradizerem sua exatidão. O professor Bjarne Melkevik bem traduz esse apego do jurista ao texto ao afirmar que "um jurista trabalha com textos e estes são para ele meros instrumentos de trabalho. [...] Isso significa que, da mesma maneira que um carpinteiro trabalha com um martelo, uma serra, uma furadeira, etc. [...], o jurista trabalha com textos".

Já para os adeptos do positivismo legalista, o direito não passa de um conjunto de normas e regras estatais, coercitivas, de organização social. Todavia, filiamo-nos à lição do professor Paulo Ferreira da Cunha ${ }^{8}$, para quem tal definição é errônea ao se observar a realidade. Segundo o professor Cunha, há um direito que não é nem regra, nem norma, como o costume, o contrato, a jurisprudência e a doutrina. Há um direito que também não é estatal, como o direito internacional, dos organismos interestatais, da União Europeia, das autarquias, etc. Há também um direito que não é coercitivo, como o direito internacional clássico. E, finalmente, a regulamentação estatal pode ser feita por várias outras formas não-jurídicas, tais como a religião, a moral, o convívio social, a etiqueta etc. Mas os positivistas não se preocuparam muito com a imperfeição desta definição, pois o importante para os adeptos dessa corrente é a prática totalmente dependente dos textos legais.

3 CORNU, Gérard. Vocabulaire juridique. 7. ed. França: Puf; Quadriage, 2005.

4 MAIA, Alexandre da. O direito subjetivo como imagem: da invisibilização dos paradoxos na teoria dos sistemas à interação e às situações comunicativas na pragmática normativo- comunicacional de Tercio Sampaio Ferraz Júnior. In: ADEODATO, João Maurício; BITTAR, Eduardo C. B. (Org.). Filosofia e teoria geral do direito: estudos em homenagem a Tercio Sampaio Ferraz Junior por seu septuagésimo aniversário. São Paulo: Quartier Latin, 2010. p. 166.

5 FISS, Owen M. Reason in all its splendor. Brooklyn Law Review, v. 56, p. 789-804, 1990.

6 LANGDELL, C. C. A selection of cases on the law contracts. Boston: Little Brown, 1871.

7 MELKEVIK, Bjarne. Épistemlogie juridique et dejà-droit. Paris: Buenos Books International, 2014. p. 57-58.

8 CUNHA, Paulo Ferreira da. Droit et récit. Québec: Presses de l’Université Laval, 2003. p. 12. (Collection Dikè). 
O direito não é um sistema fechado em si mesmo, que se organiza em virtude de seu aparato conceitual, ou seja, da coerência interna de suas estruturas, conceitos, princípios e formas; a ordem jurídica está sempre relacionada ao objeto material a que ela visa'. E qualquer atitude formalista contra essa ideia está em desacordo com o crescente consenso em outras disciplinas, segundo o qual as emoções estão profundamente interligadas com o raciocínio jurídico, pois, quando normas ou decisões estão baseadas em noções sem fundamentos ou erradas de como as pessoas se comportam, a justiça pode ser comprometida.

A tradicional suposição de que os juristas não devem transitar no terreno das emoções tem trazido grandes lacunas ao conhecimento dos atores do direito, incluindo promotores, advogados, defensores públicos e legisladores, pois, apesar de eles estudarem bastante, seus conhecimentos raramente se concentram em suas emoções e, menos ainda, nas emoções coletivas. Como Terry Maroney ${ }^{10}$ discutiu em sua pesquisa, a emoção dos juízes recebe cada vez menos atenção porque, na maioria das vezes, eles são vistos como praticantes da razão pura, isenta de emoção. Além disso, a afiada dicotomia razão versus paixão embaça a questão acerca de como os argumentos persuadem ${ }^{11}$, e a crença em que a emoção não desempenha um bom papel no raciocínio jurídico teve ainda um poderoso, e às vezes pernicioso, efeito na educação dos juristas. ${ }^{12}$

Para um bom número de pessoas, a justiça é frequentemente percebida como fria, implacável e cega, bem distante das tormentosas paixões humanas e o direito serve para cristalizar as emoções humanas no ordenamento social, restringindo-as e, às vezes, aniquilando-as. Nesse sentido, Carlos Maximiliano, ao discorrer sobre a aplicação viciosa do direito, afirma que:

[...] toda inclinação simpática, ou antipática, enfraquece a capacidade de intelecto para reconhecer a verdade, torna-o parcialmente cego. A ausência de paixão constitui um pré-requisito de todo o pensamento científico. Em verdade, o trabalho do intérprete pode ser viciado, não só pelas causas apontadas, como também por qualquer prevenção, ou simpatia, que o domine, sem ele o perceber talvez, relativamente a parte, por sua classe social, profissão, nacionalidade ou residência, ideias religiosas e políticas. ${ }^{13}$

Ao investigar suas características, tudo parece opor o direito às emoções. O direito é objetivo, a emoção é subjetiva; o direito é controlador, a emoção é insubordinada; o direito é ordem, a emoção é confusão ${ }^{14}$. O direito, sobretudo, revela o espírito da lógica e da razão; já as emoções dependem do coração, o qual tem "razões que a própria razão desconhece" ${ }^{15}$. Como se observa, o pensamento moderno e, particularmente, o pensamento jurídico, ao longo de sua história privilegiou a razão em detrimento das emoções. Isso se explica também porque a razão sempre esteve calcada na invariabilidade, eternidade e origem divina, ao passo que as emoções foram retratadas como manifestações de caráter inconstante e enganoso.

Logo, os juristas deram pouca atenção às emoções e desconfiaram delas, porque, segundo o senso comum, elas desviam o homem da reta razão. O legislador que legisla com emoção perde de vista o interesse público; o juiz que julga com seus sentimentos afasta-se da objetividade e imparcialidade. "Quando um sentimento é exagerado", dizia Gustave le Bon, "a faculdade de raciocinar desaparece". ${ }^{16}$

Por isso, as emoções foram tratadas como perigosas para os juristas e mantidas à distância dos tribunais e das faculdades de direito. Esse narcisismo da razão, inerente ao mundo jurídico, excessivamente apegado

9 MOOR, Pierre. Perméabilités du systeme juridique: essais sur le droit de l'état de droit. Québec: Presses de l'Université Laval, 2016. p. 93. (Collection Dikè).

10 MARONEY, T. A. Law and emotion: a proposed taxonomy of an emerging field. Law and Human Behavior, v. 30, n. 2, p. 119142, 2006.

11 BANDES, Susan; SALERNO, J. Emotion, proof and prejudice: the cognitive science of gruesome photos and victim impact statements. State Law Jornal, Arizona, v. 46, p. 1003-1056, 2014.

12 BANDES, Susan. Repression and denial in criminal lawyering. Buffalo Criminal Law Review, n. 9, p. 339-389, 2006.

13 MAXIMILIANO, Carlos. Hermenêutica e aplicação do direito. 10. ed. Rio de Janeiro: Forense, 1988. p. 103.

14 ZWEIG, Stefan. La confusion des sentiments. Paris: Le livre de Poche, 1992.

15 PASCAL, Blaise. Pensées, article IV, des moyens de croire. Paris: Garnier, 1964. (Ed. Brunschvicg, n. 277).

16 LE BON, Gustave. Hier e demain: pensées brèves. Paris: Flammarion, 1918. p. 12. 
à lógica formal e ao racionalismo, jamais permitiu a emergência de conteúdos que agregassem princípios, valores e conceitos oriundos de campos menos ortodoxos, como aquele no qual se situam os sentimentos humanos.

Assim, a maioria das perspectivas contemporâneas de abordagem normativa do direito e da postura dos seus operadores têm demonstrado não dar a devida atenção à influência das emoções na constituição dos ordenamentos normativos, nem, tampouco, levar em conta a influência de experiências sensoriais nos processos de tomada de decisão jurídica. No entanto, os juristas não têm razão para se distanciar das emoções ou acusá-las de ameaçar a racionalidade, pois se elas forem adequadamente limitadas e filtradas, elas podem oferecer uma orientação insubstituível para o raciocínio jurídico. Ademais, as emoções não devem ser afastadas do direito, porque fazem parte da própria natureza humana: o direito é feito pelos homens e para os homens.

Os teóricos do direito e os jus-filósofos ao elaborarem seus conceitos de interpretação e aplicação das leis, de argumentação e racionalidade jurídica, acabam se afastando do mundo empírico e dos elementos que caracterizam a dimensão sensorial do humano. Eles tendem a criar, paralelamente ao universo real, um universo ideal, um modelo abstrato que obedece à sua própria lógica e constitui um instrumento de medida imparcial para regular as oposições dos interesses do mundo real.

Nessa perspectiva, a concepção de homem é a de um ser dessubstancializado e dessensibilizado, a fim de melhor enquadrá-lo aos estatutos legais. O indivíduo não vive; sua condição humana é apenas para existir dentro de certas regras e relações jurídicas limitadas. O indivíduo que o direito considera deve ser, antes de tudo, contido de suas paixões, freado de seus impulsos para seu próprio bem e da sociedade.

Todavia, essa postura epistemológica tradicional é hoje abalada por um desejo de individualização, de reconhecimento do sujeito na sua singularidade, que se manifesta por um pedido de valorização dos sentimentos no direito. A satisfação desse pedido importaria uma nova vocação para o direito: concorrer para o desenvolvimento - florescimento - do indivíduo. Esse movimento apreende a pessoa humana não mais apenas como um ser dotado de razão, mas igualmente capaz de emoções.

Em outros termos, trata-se de restituir ao sujeito uma profundidade que o direito lhe teria privado. É possível observar nesta valorização contemporânea do florescimento da pessoa humana um declínio dos valores e das instituições coletivas para mobilizar a adesão dos indivíduos para participar indiretamente da construção da personalidade.

A personalização do ser que se assiste hoje, portanto, pode ser interpretada como o produto de uma recusa à homogeneidade implícita pela generalidade das normas e dos modelos sociais. Esta rejeição toma a forma da insaciável demanda por originalidade, singularidade e integração no direito dos sentimentos de cada um.

\section{TOPOS JURÍDICO: BREVE PERCURSO DA UNIÃO ENTRE DIREITO E EMOÇÃO}

O Professor Paulo Ferreira da Cunha ensina que uma das querelas que ainda marca o universo dos juristas é a disputa entre aqueles que concebem o direito como um pensamento quase matemático, ou seja, geométrico, rigoroso, dedutivista, racionalista, em síntese, os adeptos do pensamento sistemático, e aqueles que consideram o discurso jurídico como algo muito mais complexo, permeável à argumentação, aos lugares comuns, aos mitos, com raízes no imaginário e no subconsciente. Este pensamento que analisa quais são as ideias-forças que empurram a lógica (bastante sentimental, mas de um sentimento escondido) do direito é chamado de um "pensamento tópico". ${ }^{17}$

17 CUNHA, Paulo Ferreira da. Droit et récit. Québec: Presses de l’Université Laval, 2003. p. 16. (Collection Dikè). 
Em outras palavras, uma opinião a priori nos conduz a olhar o direito como um instrumento radicalmente estranho ao universo das emoções. Destinado a enquadrar o comportamento dos indivíduos no seio da coletividade, o direito ignora as manifestações mais profundas da alma humana, e apenas a dimensão objetivamente perceptível de sua existência é suscetível de ser levada em consideração, pela ordem jurídica, como fato gerador de sanção. Essa valorização da razão acabou por desconsiderar o valor da vida afetiva do sujeito (paixões, emoções, afetos, sentimentos, pulsões), na medida em que esta passou a ser considerada como um obstáculo à sua ação livre e consciente.

Porém, nenhum indivíduo pode ser definido apenas por sua capacidade de usar a razão. O homo é sapiens, mas, antes disso, ele sempre foi sentiens, pois, do ponto de vista de nossa origem natural, o sentimento antecede todas as nossas demais faculdades, incluindo o pensamento. O direito, apesar de se apoiar em argumentos e métodos intelectualistas, é uma disciplina que leva em consideração essencialmente as emoções, as paixões e os sentimentos.

A própria etimologia da palavra sentença nos remete à relevância e à autoridade do sentimento no âmbito da juridicidade, pois o ato final de um processo jurídico se dá através da declaração do que sente o juiz, ou seja, mediante a sentença, termo cuja origem se encontra no latim, sententia, sentiendo, gerúndio do verbo sentire, que significa sentir.

Filósofos, juristas, romancistas e sociólogos abordaram desde a antiguidade essa intrínseca afinidade entre o direito e a afetividade. Na Retórica ${ }^{18}$, Aristóteles afirma que, para decidir, há quatro poderes da alma que exercem influência ao longo do processo: percepção; emoção; desejo e razão. Toda decisão depende da percepção sensível dos cinco sentidos do que se passa; decidir é sempre em um determinado contexto. Aristóteles também expôs, na Política, que é o sentimento de justiça o que serve para distinguir o homem do animal, uma vez que o senso do justo e do injusto, do bem e do mal, são específicos do ser humano:

a característica especifica do homem em comparação com os outros animais é que somente ele tem o sentimento do bem e do mal, do justo e do injusto e de outras qualidades morais, e é a comunidade de seres com tal sentimento que constitui a família e a cidade. ${ }^{19}$

Cesare Beccaria, em Dos delitos e das penas ${ }^{20}$, sustentou que "toda lei que não for estabelecida sobre essa base [os sentimentos] encontrará sempre uma resistência à qual será constrangida a ceder. [...] Consultemos, pois, o coração humano; acharemos nele os princípios fundamentais do direito de punir".

Barbey d'Aurevilly ${ }^{21}$, literata francês do século XIX, numa obra intitulada Le bonheur dans le crime, apresentou uma íntima relação dos sentimentos com o direito penal.

Rudolf von Jhering, em $A$ luta pelo direito ${ }^{22}$, afirmou que a natureza e a importância do direito se revelam quando o homem é atingido em seu direito, em sua personalidade, e aparece sob a forma de enfermidade moral: “aqueles que não tiveram ocasião de medir pessoalmente esta dor não sabem o que é o direito, ainda que tenham em sua cabeça todo o Corpus Juris; e isto por que não é a razão, mas o sentimento que pode resolver esta questão". Posteriormente, Jhering pronunciou, perante a tradicional Wiener Juristische Gesellschaft, a sua conferência Sobre o Nascimento do Sentimento Jurídico ${ }^{23}$.

Émile Durkheim dialogou com o direito e o sentimento, principalmente, com o denominado sentimento coletivo, na obra As regras do método sociológico:

Com efeito, para que os sentimentos coletivos protegidos pelo direito penal de um povo, num momento

18 ARISTÓTELES. Retórica. Trad. Manuel Alexandre Júnior. Lisboa: Imprensa Nacional, Casa da Moeda, 2005.

19 ARISTÓTELES. Política. Trad. Mário da Gama Kury. Brasília: Universidade de Brasília, 1985. v. 1, 1253b.

20 BECCARIA, Cesare. Dos delitos e das penas. Ed. Eletrônica Ridendo Castigat Mores. Disponível em: < http://www.ebooksbrasil. $\mathrm{org} />$. Acesso em: 10 set. 2014. p. 25.

21 BARBEY D’AUREVILLY, Jules. Le bonbeur dans le crime. Paris: Maxi Livre, 2001.

22 JHERING, Rudolf von. A luta pelo direito. Trad. Ivo de Paula. São Paulo: Pillares, 2009. p. 42-43.

23 JHERING, Rudolf von. Sobre el nacimiento del sentimiento jurídico. Madrid: Trotta, 2008. 
determinado de sua história, consigam penetrar nas consciências que lhes eram então fechadas ou ter mais influência lá onde não tinham bastante, é preciso que eles adquiram uma intensidade superior à que possuíam até então. É preciso que a comunidade como um todo os sinta com mais ardor; pois eles não podem obter de outra fonte a força maior que lhes permite impor-se aos indivíduos que até então lhes eram mais refratários. ${ }^{24}$

John Rawls, em Uma teoria da justiça ${ }^{25}$, explica que os sentimentos morais são os elementos motivadores dos comportamentos humanos e da coesão social.

É preciso recordar, ainda, que Tobias Barreto, o grande escritor e jurista brasileiro, em meados do século XIX, já afirmava que "o direito não é só uma coisa que se conhece, é também uma coisa que se sente". 26

Na mesma linha, Pierre de Tourtoulon afirmou que "a tendência do direito é expressar sentimentos de simpatia ou, pelo menos, de indiferença simpática e desejo de viver em paz e harmonia com o próximo". ${ }^{27}$

O jus filósofo argentino Luís Alberto Warat também desvelou as máscaras do óbvio, mostrando que no âmbito da teoria do direito as certezas e verdades transmitidas pela dogmática jurídica não passam de construções retórico-ideológicas. Em $A$ ciência jurídica e seus dois maridos ${ }^{28}$, ele propôs a volta ao mundo de Dona Flor, famosa personagem de Jorge Amado, como a heroína da ambivalência e metáfora para a realização da conjunção positiva entre os desejos, os afetos e as leis. Seus dois maridos apontam para a ambiguidade da vida, da qual não pode se esquivar o direito. Vadinho é o marido que volta da morte para temperar com a vitalidade e a mobilidade de Eros a realidade unívoca, tediosa e insossa de Diké, vivida por Flor com o legalista Teodoro.

No entanto, a inserção na filosofia jurídica de algumas posições irracionalistas seguindo os caminhos de Nietzsche, Bergson e outros, foi praticamente ilustrativa, ainda que tenha servido para sublinhar as inconsequências da dogmática jurídica conceitualista. ${ }^{29}$

Apenas no início do século XX, o movimento Realista afirmou que a insularidade do sistema jurídico blindou-o contra as influências políticas, psicológicas e sociais que ajudam a moldar o raciocínio e as instituições legais ${ }^{30}$. Apesar de parecer evidente que a teoria e a prática jurídicas são influenciadas pelas forças sociais e políticas, esta visão foi fortemente resistida até a década de 1980 e, no final do século XX, particularmente no despertar do influente movimento do Direito \& Economia - que utiliza a teoria econômica para analisar o direito e prever situações regidas pelas leis -, os juristas começaram a olhar em direção a outras disciplinas para compreender o funcionamento do sistema jurídico.

Além disso, teóricos do feminismo e críticos do racismo foram montando poderosos desafios à ideia de que o raciocínio jurídico é algo desprovido de valor. Esses desenvolvimentos coincidiram com uma nova visão das emoções nos campos da psicologia, neurociência, sociologia e filosofia. E, nesse cenário, o estudo do papel da emoção no direito finalmente ganhou um ponto de apoio. O princípio orientador do campo do direito e emoção é que o direito não deve confiar em suposições não testadas ou inexatas sobre o funcionamento das emoções, mas deve fazer escolhas e projetar as instituições à luz dos melhores conhecimentos disponíveis.

24 DURKHEIM, Émile. As regras do método sociológico. Trad. Paulo Neves. 3. ed. São Paulo: M. Fontes, 2007. p. 68-69.

25 RAWLS, John. A theory of justice. Cambridge: Harvard University Press, 2003.

26 BARRETO, Tobias. Introdução ao estudo do direito. São Paulo: Landy, 2001, p. 38.

27 Tradução livre: "The tendency of the law is to express sentiments of sympathy, or, at least, of sympathetic indifference, and the desire to live in peace and harmony with one's neighbor" (TOURTOULON, Pierre de. Philosophy in the development of law. Trad. Martha McC. Read. Nova Iorque: A.M. Kelly, 1969. p. 136)

28 WARAT, Luís Alberto. A ciência jurídica e seus dois maridos. Santa Cruz do Sul: Faculdades Integradas de Santa Cruz do Sul, 1985.

29 VERDÚ, Pablo Lucas. O sentimento constitucional: aproximação ao estudo do sentir constitucional como modo de integração política. Trad. Agassiz Almeida Filho. Rio de Janeiro: Forense, 2004. p. 3.

30 LLEWELLYN, K. Jurisprudence: realism in theory and practice. Chicago: University of Chicago Press, 1962. 


\section{Os SENTIMENTOS NOS DOMÍNIOS DO DIREITO}

"Iram ou furiam non novit jus": o direito não conhece a cólera ou a fúria, assumidas aqui como protótipos emocionais. Isso significa que o direito não conhece nada além dele mesmo. Em uma definição necessariamente circular ou redundante, toda tentativa de definição do direito (seja brutal ou sofisticada), acaba sempre por agregar o adjetivo "jurídico" para qualificá-la”. Ao se estabelecer a lei, a regra, a sanção, a autoridade, o bem comum, o monopólio da violência, o Estado etc., é necessário especificar "que eles sejam juridicamente fundados". Com efeito, uma verdadeira tautologia faz parte da definição do direito, de modo que, para descrevê-lo convincentemente é preciso se instalar nele, auto-referenciá-lo.

Isso mostra que, na teoria jurídica, o papel das emoções usualmente é desprivilegiado e, em geral, o direito só aparece como a última ferramenta contra as paixões humanas. A proteção do pródigo contra os ímpetos que levam à dilapidação de seus bens, ou a defesa contra as paixões dos adolescentes que desejam se casar sem consentimento dos pais, são meros exemplos de como a história jurídica tentou arrefecer nossos sentimentos.

Em outra hipótese, a audição da palavra "emoção" em um contexto jurídico nos leva logo a pensar no crime passional e na cena de um marido enganado, influenciado pelas emoções (cólera, ciúmes etc.), que pega uma arma e persegue o amante que escapará por uma janela ou pelo telhado. No entanto, ao refletir sobre o lugar dos sentimentos no direito, é possível identificar elementos dessa intersecção em quase todos os seus domínios, como a infância, a família, a pena, o trabalho, o consumo, o processo.

Todavia, de acordo com Popovici ${ }^{32}$, o comportamento social decorrente do amor enseja consequências jurídicas variadas e o direito não regula apenas algumas instituições diretamente ligadas ao amor, como o casamento, mas impõe aos indivíduos um certo número de obrigações ou lhes confere um certo número de direitos, em nome da moral, da ordem pública ou mesmo da proteção dos interesses privados. Nesse sentido, certas manifestações de amor são permitidas, como a união estável; outras são coibidas, como o incesto; e outras são simplesmente toleradas como o concubinato e o adultério.

Enfim, os grandes sentimentos dos homens e mulheres - o amor, o ódio, o ciúme, a deslealdade, o luto - quando são transformados em fatos jurídicos, podem desembocar nos aparatos jurisdicionais. Por isso, vejamos alguns exemplos - não exaustivos - da influência dos sentimentos em alguns ramos do direito.

\subsection{O direito constitucional e os sentimentos}

No campo constitucional, as emoções são tuteladas quando o ordenamento jurídico resguarda a vida privada ou refuta a tortura, o discurso do ódio, o bullying, o racismo, a homofobia etc.

Em um caso específico, em 2012, o Supremo Tribunal Federal (STF), guardião da Constituição, inovou ${ }^{33}$ no acórdão da Arguição de Descumprimento de Preceito Fundamental no. 54/DF, em que a Confederação Nacional dos Trabalhadores na Saúde (CNTS) pleiteava a declaração de inconstitucionalidade na interpretação de interrupção de gravidez de feto anencéfalo como conduta tipificada nos artigos 124, 126 e 128, incisos I e II, do Código Penal.

Neste episódio, o STF tinha de discutir, no mérito, um assunto delicado no que diz respeito ao direito constitucional à vida, a possibilidade, ou não, da antecipação terapêutica do parto de fetos diagnosticados

31 PAPAUX, Alain. Un droit sans émotions. Iram non novit jus: esquisse des rapports entre sciences et droit. REVUE Européenne des Sciences Sociales [on line], v. 47, n. 144, p. 105-119, 2009. Disponível em: <http://ress.revues.org/70>. Acesso em: 10 out. 2017. p. 106-107.

32 POPOVICI, Adrian; PARIZEAU-POPOVICI, Micheline. L'amour et la loi. Montréal: Éditions du Jour, 1971. p. 9-10.

33 LUNA, Nevita Maria Pessoa de Aquino Franca. O pragmatismo jurídico aproximando Thêmis e Eros: o sentimento do Supremo tribunal federal na ADPF 54/DF. Revista de Direito Brasileira, Florianópolis, ano 5. v. 2, p. 216-238, 2015. 
com anencefalia (prática identificada por alguns juízes como o crime de aborto), bem como garantir tal direito sem a apresentação de requerimento judicial.

Como se observou em diversas passagens, a questão dos sentimentos foi amplamente abordada: ora os sentimentos dos próprios Ministros e da sociedade, ora os sentimentos da gestante, da família e do feto. E, ao fim do julgamento, a Corte reconheceu, em votos divergentes, a situação difícil em que se encontrava, e foi possível constatar que ela não se manteve apática às questões sentimentais.

Verificou-se que os Ministros apegaram-se à sensibilidade, sem abandonar a razão, para decidir o caso, demonstrando que o discurso jurídico não é, e não pode ser construído como mera subsunção, com base apenas na ideia de incidência automática e infalível da norma jurídica. O próprio Ministro Cezar Peluso, apesar do voto divergente da maioria, enfatizou que a decisão de cada magistrado ultrapassa a frieza da norma e "envolve a formação, a cultura, o modo de ver, o modo de ser de cada magistrado, de cada homem e de cada mulher, que está atrás de cada toga". ${ }^{34}$

\section{2. $O$ direito civil e os sentimentos}

As emoções no direito civil estão presentes de forma abundante nos temas referentes às doações, contratos, danos morais, adoção, alienação parental, uniões estáveis, reconhecimento de famílias homoafetivas etc. Aqui, o direito figura como um prolongamento das paixões humanas, em especial, das paixões amorosas, quando disciplina o casamento e elenca os deveres dos cônjuges para a sua manutenção (como: fidelidade, vida em comum, mútua assistência, sustento dos filhos e respeito, segundo o artigo 1.566 do Código Civil).

Ainda no direito de família, o direito regulamenta o comportamento social em caso de ausência ou desaparição dos sentimentos, como o divórcio, a separação de corpos (medida protetiva), o abandono afetivo do pai com sua prole, o dano emocional do cônjuge infiel ou do noivo que desfaz o matrimônio no altar.

No domínio das liberalidades, o direito (cf. artigos 550, 555 e 557 do Código Civil brasileiro) assegura, em certa medida, a sanção dos sentimentos pouco honráveis do autor da liberalidade ou daquele que a recebe. Quando o donatário, longe de responder à generosidade do doador através de um certo reconhecimento de sua parte (a gratidão), o direito prevê que ele seja destituído do bem. Inclusive, certas legislações - tais como os códigos brasileiro e alemão $0^{35}$ - preveem a revogação da doação quando a ingratidão é produzida não somente em relação ao donatário, mas também em relação aos seus próximos.

No direito das obrigações, os sentimentos igualmente não são ignorados, e atribui-se um papel de destaque à psicologia e à sociologia. Assim, consequências práticas importantes podem ser deduzidas de investigações psicológicas que estudam a estrutura contratual. Por exemplo, é possível dizer que nos dias atuais a sedução operada pela publicidade de massa se constitui um vício de consentimento nas relações com os consumidores.

No campo contratual, ainda, pode-se opor a vontade ao sentimento, destacando no direito o declínio do papel da vontade e a progressão do papel do sentimento (deslealdade). No entanto, quando o direito considera a vontade, o que importa menos não é a essência da vontade, mas sua exteriorização. Ou seja, o elemento primário do contrato é a lealdade, manifestada através da boa-fé do contratante, mais do que sua vontade propriamente dita. Por isso, todas as vezes que essa vontade não se manifestar fiel aos objetivos intimamente perseguidos, se diz que houve vício, mais precisamente: vício do consentimento.

Ademais, os sentimentos no direito civil também aparecem de forma considerável nas questões relativas

34 BRASIL. Supremo Tribunal Federal. Arguição de descumprimento de preceito fundamental 54 / DF. Requerente: Confederação Nacional dos Trabalhadores na Saúde - CNTS. Intimado: Presidente da República. Relator: Min. Marco Aurélio. Brasília, DF, 2012. p. 375.

35 MECHRI, Farouk. Le sentiment d'affection \& le droit de la famille. Tunis: Éditions Latrach, 2015. p. 9. 
ao "preço da dor", isto é, no que tange à reparação dos danos morais, violações aos sentimentos íntimos juridicamente tutelados.

\subsection{O direito penal e os sentimentos}

As paixões são a trama da ciência penal. Aqui, os sentimentos exibem toda a sua realidade trágica, em estado de crise. Nas sociedades pós-modernas, os crimes passionais se multiplicam e são largamente midiatizados. Qualquer que seja o rigor da lei, os tribunais - sobretudo o júri popular - levam em consideração os motivos que determinaram os dramas passionais.

O homicídio pode ser movido não somente pela paixão, mas também pela piedade: é o caso do homicídio a pedido, quando o agente mata para atenuar o sofrimento da vítima. São exemplos, a eutanásia (tratada como "homicídio qualificado" no Código Penal Brasileiro, pois ainda não foi expressamente tipificada) e o auxílio ao suicídio (art. 122, CP).

Segundo a tese do positivista Ferri que preceitua a impunidade desse ato, o homicídio a pedido não deve ser punido em virtude da máxima de Ulpiano: Volenti et consentienti non fit injuria. Em outras palavras, o direito de morrer que um indivíduo pode exercer sobre ele mesmo, pode se estender a outra pessoa, com o seu consentimento $^{36}$. Ao contrário, os escolásticos não admitem essa doutrina, porque reprovam o suicídio por várias razões. A primeira delas é o amor que todos os indivíduos devem ter uns com os outros, velando pela própria conservação. A segunda é que a existência é um dom de Deus, de modo que só Ele é o mestre da morte e da vida.

É possível exonerar de toda sanção penal as pessoas que matam o próximo por compaixão? A priori, não, pois o móbile é indiferente, e a conduta de matar a pedido é tipificada como ato de auxílio ou provocação ao suicídio. Nem a súplica do enfermo, nem o seu consentimento, constituem justificativas ou excusas legais para retirar do "homicídio por piedade" seu caráter de infração penal. Na maioria das legislações (tais como os códigos penais da Holanda, Noruega, Polônia, Dinamarca, Itália, Rússia e Líbano ${ }^{37}$ ), esses dois elementos (piedade e consentimento) não têm nenhuma influência para o estabelecimento da culpabilidade, apenas para a moderação no pronunciamento da pena.

Uma exceção é o novo Código Penal do Uruguai que, em seu art. 37, foi mais longe e inovou ao permitir ao juiz excluir de qualquer pena o autor do homicídio cometido por motivo de piedade: "Art. 37. Del homicidio piadoso. Los Jueces tienen la facultad de exonerar de castigo al sujeto de antecedentes honorables, autor de un homicidio, efectuado por móviles de piedad, mediante súplicas reiteradas de la víctima". ${ }^{38}$

Em nome do sentimento de afeição familiar, o Código Penal brasileiro assegura a isenção de pena para quem comete um crime em prejuízo dos ascendentes ou descendentes; esposo ou esposa, mesmo divorciados; irmãos ou irmãs, legítimos ou ilegítimos; tios e sobrinhos, com quem o agente coabita (arts. 181 e 182 do $\mathrm{CP}$ ). Na mesma ordem de ideias, o direito francês e o direito otomano também preveem a impunidade absoluta para resguardar o sentimento de afeição familiar ${ }^{39}$. No entanto, a consideração da afeição familiar presumida entre parentes se opõe contra aqueles que cometem roubo ou extorsão, para que sejam julgados penalmente, em nome do abuso de confiança.

Ademais, a proteção da honra (arts. 138 a 145 do CP), do sentimento religioso (art. 208 do CP), do res-

36 Essa tese é combatida com o argumento segundo o qual a pessoa humana não dispõe de sua vida, pois esta não é um interesse privado, mas público. Cf. LEGROS, Bérengère. La douleur comme fondement de l'euthanasie. In: DURAND, Bernard; POIRIER, Jean; ROYER, Jean-Pierre (Org). La douleur et le droit. Paris: Presses Universitaires de France, 1997. p. 389-410.

37 MECHRI, Farouk. Le sentiment d'affection do le droit de la famille. Tunis: Éditions Latrach, 2015. p. 8.

38 URUGUAI. Código Penal. Disponível em: <http://www.wipo.int/wipolex/en/text.jsp?file_id=196342>. Acesso em: 4 out. 2017.

39 MECHRI, Farouk. Le sentiment d'affection \& le droit de la famille. Tunis: Éditions Latrach, 2015. p. 8-9. 
peito aos mortos (art. 209 a 212 do CP) são amostras que o direito reprime alguns comportamentos que vilipendiam a dimensão sentimental das vítimas.

Quanto à sanção, não se pode esquecer que quando o réu é tomado por uma "violenta emoção" sua pena será atenuada, ou seja, quando alguém mata durante um episódio de raiva, geralmente é culpado por um crime menos grave do que quando mata em um estado de ânimo sem exaltação. Com efeito, a emoção é causa de diminuição de pena em algumas circunstâncias previstas no Código Penal, como nos crimes de homicídio simples (art.121 parágrafo $1^{\circ}$ ) e de lesão corporal (art.129 parágrafo $4^{\circ}$ ), e ainda constitui atenuante genérica (art. 65, inciso III, alínea “c” do CP). Por último, os critérios de dosimetria e fixação da pena (art. 59 do CP) são subjetivos, não estando imunes aos sentimentos do juiz e da sociedade.

\subsection{O direito comercial e os sentimentos}

O direito comercial não escapa da influência dos sentimentos, e duas matérias aparecem para exemplificar o assunto. A primeira delas é a concorrência desleal lato sensu, ou seja, quando o empresário utiliza práticas ilícitas para angariar clientela, prejudicando seus concorrentes, sendo que para sua configuração pouco importa os resultados obtidos com a deslealdade e sim os meios que foram empregados para a consecução do fim da atividade empresarial que é, além dos lucros, os clientes. A segunda prática que atenta contra os sentimentos de boa fé e lealdade são as dívidas delituosas do falido, conhecida como fraude contra credores, ou seja, quando o devedor dilapida seu patrimônio tornando-se insolvente, com a intenção deliberada de não pagar suas dívidas.

\subsection{O direito do trabalho e os sentimentos}

Três categorias de sentimentos podem ser encontradas no domínio do direito do trabalho: a fidelidade; a lealdade e o amor.

O artigo 482, alínea “c”, da Consolidação das Leis do Trabalho dispõe sobre o dever de fidelidade, através da não-concorrência nas transações rotineiras, ao fixar que a "negociação habitual por conta própria ou alheia sem permissão do empregador, e quando constituir ato de concorrência à empresa para a qual trabalha o empregado, ou for prejudicial ao serviço" constitui justa causa para a rescisão do contrato pelo empregador. Nesse sentido, o dever de fidelidade do empregado pode dar lugar a um pacto convencional (cláusula da não-concorrência), através do qual o empregador procura assegurar a proteção de seus interesses, principalmente, após a saída do empregado, ao limitar o direito deste de lhe fazer concorrência. Constitucionalmente, é livre o exercício de qualquer trabalho, ofício ou profissão, atendidas as qualificações profissionais (art. $5^{\circ}$, XIII, CF). Porém, não há direitos absolutos, de modo que se o trabalhador tem o direito constitucional quanto à sua liberdade de dispor da sua força de trabalho, o empregador, por seu turno, tem o direito de resguardar sua propriedade, seus inventos, seus segredos comerciais etc.

A lealdade está presente nas obrigações do empregado previstas no contrato de trabalho e na relativização do poder de fiscalização do empregador. A lealdade é uma atitude psicológica, um comportamento ético, uma regra de vida social, que revela mais da moral que do direito. Na verdade, a lealdade está impregnada no direito através do princípio da boa-fé, cuja função é estabelecer um padrão ético de conduta para as partes nas relações obrigacionais. A realização do trabalho deve acontecer em um universo de confiança mútuo. $\mathrm{O}$ empregado deve obedecer às instruções recebidas e manter o respeito escrupuloso às ordens. Em consequência, ele deve se abster de todo ato que seja prejudicial ao seu empregador, devendo consagrar todo o tempo de trabalho previsto a serviço da empresa. A obrigação de lealdade inclui ainda que o empregado, informado de um certo número de práticas, procedimentos ou segredos de fabricação da empresa, não os revele, sob pena de incorrer no crime de violação de segredo profissional, previsto no art. 154 do Código Penal. 
No mesmo espírito, a obrigação de lealdade proíbe o empregado de receber, sem o consentimento de seu empregador, presentes ou comissões de terceiros, seja em pecúnia ou in natura, para fazer ou se abster de um ato relevante de sua função, sob pena de incorrer no crime de corrupção passiva, previsto no art. 317 do Código Penal.

Nos cargos em comissão ou de gerência, a situação é diferente, porque o empregador investe uma confiança maior à medida que o empregado ascende na hierarquia dos quadros da empresa. Os mais altos cargos se beneficiam de uma delegação de poder, de modo que os empregados são tomados por um dever de lealdade reforçado que induz à exclusão de todo desacordo fundamental entre as orientações gerais da empresa, definidas pelo empregador, e suas opiniões pessoais. Com efeito, uma divergência de apreciação no que tange às orientações estratégicas da empresa pode ensejar uma crise de confiança e macular o sentimento recíproco necessário ao bom andamento da empresa.

Convém sublinhar, também, que se a execução do contrato de trabalho implica a lealdade do empregado, é porque a relação de trabalho deve se executar em um clima de confiança. Mas isso só pode ser plenamente atendido se uma obrigação de lealdade pesar também sobre o empregador cuja consequência é a limitação do direito que ele tem de fiscalizar a atividade de seus empregados. O direito de fiscalização decorre do poder hierárquico; no entanto, certos meios de monitoramento devem ser proscritos, por terem um efeito negativo e contribuírem para quebrar o clima de confiança necessária entre as partes. Trata-se, notadamente, dos meios de investigação que atentam contra a dignidade humana, como a revista íntima, a gravação de palavras ou imagens realizadas sem a ciência do empregado, o desprezo pelo sigilo de sua vida privada, a coleta de informações pessoais em redes sociais. Todo excesso no monitoramento das atividades laborais poderá ensejar indenização por dano moral, por ofender o princípio constitucional da inviolabilidade à intimidade, à vida privada, à honra e à imagem das pessoas.

Para os empregados, a mistura de amor e trabalho pode ser sinônimo de conflito, invasão da vida privada no âmbito profissional, ou ainda uma enredada dificuldade quando o casal briga ou se divorcia. Para os empregadores, a existência de relações amorosas no trabalho perturba a concentração dos colaboradores, criando tensões e exigindo às vezes modificações no organograma da empresa para separar os amantes do passado. Quanto à jurisprudência, esta tem se mostrado hostil às cláusulas de celibato em contratos de trabalho ou regulamentos internos, em nome do respeito à liberdade amorosa ou matrimonial dos empregados.

\subsection{0 direito processual civil e os sentimentos}

O Código de Processo Civil é seguramente aquele que, nas instituições que regulamenta, faz as maiores considerações oriundas da psicologia das partes. Afinal, não é surpresa que todo processo constitui um combate no qual dois adversários se afrontam, movidos pela vontade de vencer. A conduta no processo civil pertence, sobretudo, às partes, por isso o legislador foi levado a se preocupar com a psicologia dos adversários, perscrutar seu estado de espírito, desmascarar suas intenções escusas e desvendar os móbiles de seu comportamento.

Se a habilidade é permitida, a malícia e a má-fé devem ser banidas. No conjunto de ações processuais das partes que apresentam perigos, podemos classificar, a título exemplificativo, três tipos de atores: o temerário; o malicioso e o perverso.

Malicioso: aquele que deduzir pretensão ou defesa contra texto expresso de lei ou fato incontroverso; alterar a verdade dos fatos; usar do processo para conseguir objetivo ilegal; ou opuser resistência injustificada ao andamento do processo (art. 80, I, II, III e IV, do Código de Processo Civil).

Temerário: aquele que proceder de modo temerário em qualquer incidente ou ato do processo (art. 80, V, do Código de Processo Civil). 
Perverso: aquele que provocar incidente manifestamente infundado; ou interpuser recurso com intuito manifestamente protelatório (art. 80, VI, do Código de Processo Civil).

Com efeito, para produzir um resultado de intimidação e prevenção, coibir manifestações perigosas do comportamento psicológico das partes e restituir o respeito e a lealdade à regra jurídica, o art. 81 do Código de Processo Civil estabeleceu a multa e a indenização por perdas e danos ao litigante de má-fé.

Outro exemplo da importância dos sentimentos diz respeito à impossibilidade moral da prova pré-constituída. Se a maioria dos contratos são executados sem incidentes relativos à existência ou ao conteúdo da convenção, isso se deve principalmente à prévia redação de um escrito que torna vãs as eventuais contestações sobre o documento. A esta produção antecipada dá-se o nome de "prova pré-constituída" (arts. 381 a 383 do Código de Processo Civil). Todavia, nem sempre é suficiente afirmar a indispensabilidade de uma prova pré-constituída: é necessário que ela seja possível, pois a experiência demonstra que, às vezes, certas circunstâncias não tornam possível a prova escrita. A impossibilidade moral resulta de obstáculos não externos, mas internos às partes do ato jurídico. A redação de um contrato, apesar de facilmente realizável no plano material, vai de encontro aos reflexos psicológicos. Um juiz deve, portanto, considerar esses reflexos e ponderar que eles constituem um empecilho para pré-constituir a prova escrita. Notadamente, deve-se reputar que a confiança nascida no seio da afecção ao seio da familia é um obstáculo à pré-constituição de uma prova, pois a intimidade dos corações impede as formalidades da prova.

O sentimento de afeição familiar não obriga, mas conduz naturalmente à confiança: uma mãe não exige a assinatura de seu filho, nem um marido de sua esposa. O inverso seria uma marca de desconfiança incompatível com a vida e os afetos familiares. Assim, a jurisprudência deve aplicar a noção de impossibilidade de prova pré-constituída no domínio das relações familiares, assim como os tribunais devem reconhecer a inviabilidade moral para se estabelecer por escrito contratos firmados entre pais e filhos, irmãos e irmãs, primos, avós e netos. Quanto às relações entre cônjuges, é admissível que exista uma impossibilidade moral de exigir um escrito; no entanto, o juiz não se limitar a constatar a relação matrimonial entre os contratantes. Aqui, entendemos que é preciso explicitar as circunstâncias particulares das quais decorre a pretendida impossibilidade, pois a prova do contrato entre esposos deve ser feita por escrito.

$\mathrm{Na}$ mesma ordem de ideias, questiona-se se a impossibilidade moral pode ser apresentada em contratos entre concubinos ou companheiros. Recusando-se adentrar no plano moral da defesa da família legítima, as cortes europeias têm admitido que os laços de afeição que unem um casal podem justificar a impossibilidade legal da prova escrita ${ }^{40}$. No entanto, para os cônjuges, o simples fato da união, sem outras circunstâncias, não constitui uma impossibilidade moral.

Outros exemplos da importância das emoções presentes no Código de Processo Civil são a suspeição e o impedimento. Os casos de impedimento são mais graves e têm, como consequência, a proibição do juiz de atuar no processo. Impedimento é objeção ou matéria de ordem pública não sujeita à preclusão. Os atos praticados são nulos, e cabe ação rescisória contra decisão proferida pelo juiz impedido (artigo 966, II, CPC/2015). Já nos casos de suspeição, o juiz poderá atuar no processo se não for arguida sua suspeição no prazo legal. Não cabe ação rescisória, e a invalidação dos atos processuais depende da prova do prejuízo causado à parte, já que os atos processuais realizados pelo juiz suspeito podem ser ratificados pelo juiz substituto. Caso haja interesses pessoais (jurisdição tendenciosa), o magistrado fica impossibilitado de agir judicialmente, pois é sabido que não há a possibilidade da separação completa da vida pessoal e profissional do juiz.

40 MECHRI, Farouk. Le sentiment d'affection \& le droit de la famille. Tunis: Éditions Latrach, 2015, p.15. 


\subsection{O direito processual penal e os sentimentos}

No processo penal, também é possível reconhecer sentimentos bastante heterogêneos em seus atores:

Figura 1 - Sentimentos dos principais atores jurídicos

\begin{tabular}{l|l}
\hline Sentimentos do acusado & O ciúme, a ira, a ambição, a cobiça, a ganância \\
Sentimentos da vítima & A vingança, o rancor, a injustiça, o ódio, o perdão \\
Sentimentos do juiz & A justiça, a lealdade, a imparcialidade \\
Sentimentos dos jurados & A incompreensão, a justiça, o medo \\
Sentimentos do público & A consternação, o horror, a insegurança, o temor, a perplexidade \\
\hline
\end{tabular}

Fonte: SAUTEL, 2014, p. 2.

\subsection{A advocacia e os sentimentos}

A advocacia desperta uma série de questões sentimentais. O relacionamento com clientes pode levantar questões de lealdade, empatia, raiva, frustração e tristeza. Os advogados de defesa de crimes dolosos devem atender a medos, passar confiança em circunstâncias difíceis, bem como lidar com suas próprias emoções quando um cliente é condenado ou executado ${ }^{41}$; já os promotores devem lidar com emoções das vítimas e de suas famílias, bem como com a raiva da comunidade ${ }^{42}$. Estas são apenas algumas emoções evocadas pela advocacia, no entanto, a maioria das faculdades e dos profissionais da área parte do pressuposto de que seus instrumentos de trabalho são puramente cognitivos.

\subsection{A expertise técnica e os sentimentos}

Na construção do trabalho de argumentação necessária à elaboração de uma decisão judiciária, frequentemente, o juiz se confronta com uma questão cuja resposta não é de ordem jurídica, mas oriunda de uma disciplina científica ou técnica que lhe é estranha. Nesse caso, ele deve apelar aos conhecimentos de um especialista competente, para que a intervenção da ciência seja um instrumento primordial na busca da objetividade necessária à produção dos elementos de convicção do juiz. ${ }^{43}$

Neste domínio, os sentimentos são tomados como "dados jurídicos" da palavra sagrada do expert científico, isto é, do perito judicial ou do assistente técnico. Tratam-se de profissionais especializados no campo das emoções (psicólogos, psiquiatras, psicanalistas, neurofisiologistas) que são convocados para contribuir com a verdade dos fatos, elaborando laudos, munidos de objetividade, em investigações ou processos judicias, com vista a auxiliar os juízes na solução do caso concreto. No direito de família, são comuns estudos psicossociais para analisar as condições emocionais e sociais de genitores que pleiteiam a guarda de filhos menores. No direito previdenciário, é imprescindível o lado psicológico para instruir pedidos de aposentadoria por invalidez, aplicável para doenças psíquicas dentre as quais se incluem a depressão. No direito do trabalho, laudos psicológicos também são requisitados em casos de assédio moral no emprego. Esses são apenas alguns exemplos do tratamento "científico" que as emoções recebem no direito.

\subsection{O direito eleitoral, a democracia e os sentimentos}

Ainda resta uma vantagem a creditar aos sentimentos: o fato de eles fornecerem uma energia essencial e necessária às democracias. Enquanto a devoção ao regime democrático leva o cidadão a votar ou ser votado,

41 SCHEFFER, S. Fighting for their lives: inside the experience of capital defense attorneys. Nashville: Vanderbilt University Press, 2013.

42 BANDES, Susan. Loyalty to one's convictions: the prosecutor and tunnel vision. Howard Law Journal, p. 475-494, 2006.

43 TRIMAILLE, Gilles. L'expertise médico-légale: confiscation et traduction de la douleur. In: DURAND, Bernard; POIRIER, Jean; ROYER, Jean-Pierre (Org). La douleur et le droit. Paris: Presses Universitaires de France, 1997. p. 489-500. 
são as emoções e os interesses pessoais que alimentam os partidos e as facções necessárias para o debate político no país.

As emoções são imprescindíveis para reforçar o contraditório e engendrar os desacordos inevitáveis, sem os quais uma democracia representativa liberal perderia seu objeto. As emoções desempenham um relevante papel na formação dos laços entre cidadão-partido-programas-de-governo-eleitos. A atenção levada pelos cidadãos aos problemas sociais, ao país e aos partidos é o cimento que permite ao espaço político se estruturar e se orientar. Enquanto os sentimentos são consagrados apenas em nível local, individual; os partidos desempenham o papel de catalizadores das emoções, permitindo a um eleitorado mais vasto formar relações com pessoas até o momento desconhecidas. Esses laços, reforçados indubitavelmente pela corrida eleitoral e por outros interesses particulares, são fortes o suficiente para que várias distâncias (geográficas, sociais, econômicas, religiosas etc.) sejam cruzadas, mobilizando o eleitorado em favor das vastas propostas lançadas pelos partidos.

Não se espera da população que ela tenha um comportamento racional em suas ações políticas; ao contrário, o sistema representativo e os mecanismos institucionais permitem que os desejos do povo se desenvolvam tanto quanto as ações do governo, em direção ao bem público e à justiça e, ao mesmo tempo, opondo-se à corrupção e às injustiças. O exercício da cidadania implica, assim, um importante equilíbrio entre razão e paixão: as duas estão intimamente ligadas e exercem uma ação recíproca uma sobre a outra. É preciso, no entanto, vencer os preconceitos, a fim de preservar a justiça e o bem comum, para que a parcialidade inscrita no coração das emoções seja neutralizada por um bom uso da razão, permitindo a emergência da objetividade. Como diz Hobbes, "não faças aos outros o que não consideras razoável que seja feito por outrem a ti mesmo" "44. Ao aplicar essa regra, cada indivíduo deverá sopesar suas próprias ações e as do outro, de modo que suas paixões e seu egoísmo não acrescentem nada ao peso obtido. Com efeito, as emoções devem ensejar uma parcialidade que vá ao encontro das exigências da razão, a qual comanda a igualdade de todos, sem favor ou desfavor, pois a justiça não nos permite conceder benefícios àqueles que amamos e privar os que odiamos, simplesmente em razão de nossas relações pessoais.

\section{A vítIMA E O RECONHECIMENTO de SUAS EMOÇõES NA LEGISLAÇÃo bRASILEIRA}

Historicamente ignoradas do processo penal, as vítimas são agora atores imprescindíveis. Nossa época se afigura como a do reconhecimento das vítimas. Até a segunda metade do século XX, um espaço mínimo era ocupado pela vítima nas sociedades ocidentais, tanto em relação aos sistemas de regulação jurídicos, quanto à consciência coletiva. E, assim, a vítima foi, durante muito tempo, mantida à distância do processo, porque toda agressão contra uma pessoa era considerada como uma violação contra a sociedade e a autoridade do Estado, e não somente como um ato de violência sofrido por alguém. Todavia, hoje, a vítima ocupa um assento de destaque na cena jurídica e social, e a sua notoriedade é o resultado da ação conjunta de vários acontecimentos no debate criminal e social. Além disso, a nova atenção concedida à vítima se desenvolveu em um contexto social de valorização das emoções.

Com o término da Segunda Guerra Mundial, surgiram vários fenômenos sociais que contribuíram para o aparecimento da categoria jurídica e social de "vítima", em decorrência do sofrimento impingido ao povo judeu. A tomada de consciência dos crimes tenebrosos perpetrados e seus milhões de padecedores deram origem à emergência de uma sensibilidade pelo sofrimento da vítima. No contexto de desenvolvimento de uma política do Estado-providência, sistemas de indenizações e serviços públicos e privados de ajuda foram criados para auxiliar as pessoas afetadas. Ademais, uma série de movimentos de direitos civis nasceram glo-

44 HOBBES, Thomas. Leviatã ou matéria, forma e poder de um estado eclesiástico e civil. Trad.: João Paulo Monteiro e Maria Beatriz Nizza da Silva. São Paulo: Abril Cultural, 1974. p. 92. 
balmente para a proteção dos direitos das vítimas e de suas necessidades em matéria de assistência, tornando-se porta-vozes de todos aqueles que são julgados vítimas da sociedade, tais como: o movimento feminista, a batalha contra o racismo, a proteção da infância e do idoso, a luta contra a discriminação sexual. Por último, de maneira geral, o interesse pela vítima é a nova preocupação para o risco e a segurança. A exigência de se precaver contra o risco característico de nossa sociedade contemporânea contribuiu para impulsionar a vítima na cena do discurso da segurança, pois os testemunhos de sofrimento, transmitidos e destacados pelos políticos e pelos meios de comunicação, através da instrumentalização de imagens puras e inocentes, ajudaram a difundir, na sociedade, o sentimento segundo o qual cada um é uma vítima em potencial.

\subsection{O crescimento dos direitos das vítimas}

De simples testemunha e instrumento da máquina judiciária, a vítima se tornou um protagonista do processo penal cujas necessidades são cada vez mais consideradas. As vítimas deixaram de ser meros provedores de provas a quem a justiça não dava qualquer importância especial para se beneficiarem, por exemplo, de direitos no processo penal com vistas à proteção de sua personalidade, tais como as audiências fechadas em segredo de justiça, a possibilidade de não se confrontar com o agressor, ou de não testemunhar sobre fatos que concernem à esfera privada. Como consequência, elas passaram a não mais relutar em denunciar a agressão, por medo da experiência judicial e do risco associado à vitimização secundária. Essa hesitação era compreensível, pois, em regra, as vítimas que denunciavam seus ofensores eram alvo de novas experiências negativas e traumatizantes, em decorrência da falta de proteção, de assistência, de informação, e até mesmo de outras agressões em função do percurso judiciário.

Após a década de oitenta, os direitos das vítimas foram consideravelmente reforçados, tanto do ponto de vista de sua posição no sistema penal, como em relação às políticas de ajuda em numerosos países, para tornar a experiência judiciária menos traumatizante. O movimento para a melhoria dos direitos das vítimas começou nos anos oitenta e se concretizou através da implementação de legislações nacionais e instrumentos normativos internacionais que definiram tais direitos. O primeiro texto internacional a reconhecer a ajuda às vítimas através de princípios gerais foi a "Declaração de Princípios Básicos de Justiça Relativo às Vítimas da Criminalidade e de Abuso de Poder", das Nações Unidas em 1985. Este texto abriu a porta para o desenvolvimento da ajuda às vitimas e da extensão de seus direitos no plano nacional, com a edição dos seguintes documentos:

- Lei de Crimes Hediondos: Lei Federal no 8.072/1990;

- Estatuto da Criança e Adolescente: Lei Federal no 8.069/1990;

- Lei da Tortura: Lei Federal n ${ }^{\circ}$ 9.455/1997;

- Multa reparatória do Código de Trânsito: Lei Federal no 9.503/1997;

- Composição civil dos danos da Lei de Juizados Especiais Criminais: Lei Federal no 9.099/1995;

- Estatuto do Idoso: Lei Federal no 10.741/2003;

- Lei contra a discriminação por orientação sexual: Lei do Estado de Pernambuco no $12.876 / 2005$ e a Lei do Estado da Paraíba no ${ }^{\circ}$ 7.309/2003;

- Lei da Maria da Penha: Lei Federal no 11.340/2006;

- Alterações no Código de Processo Penal: Lei Federal no. 11.690/2008;

- Lei contra a discriminação racial: Lei 12.228, de 20/07/2010;

- Lei contra a discriminação do portador do vírus HIV: Lei Federal no 12.984/2014; 
- Lei contra a discriminação do portador de deficiência: Lei Federal no 13.146/2015.

\subsection{A sofrimento da vítima: uma perspectiva empática}

As sensibilidades contemporâneas são fortemente dominadas pelos sofrimentos exprimidos pelas vítimas. Esta é onipresente, tanto no discurso social cotidiano, como na regulação dos comportamentos sociais. Em um mundo em que o individualismo é exacerbado, este fenômeno acompanha o crescimento das subjetividades, ou seja, vemos uma valorização dos sentimentos e emoções individuais. O sujeito se tornou o elemento dominante dos debates políticos e intelectuais. E o interesse de reintegrar a vítima em sua individualidade agredida, ao reconhecer sua subjetividade e sua personalidade individual ultrapassa a simples reprovação oficial do ato criminoso sofrido. Nessa perspectiva, a violência é vista como uma verdadeira negação do sujeito-vítima. Ela destrói as referências subjetivas até a completa despersonalização. O sofrimento se tornou um caractere incontestável inerente à condição de vítima. Se o lugar das emoções no direito está geralmente submetida a certas limitações, com vistas a evitar sua intrusão no raciocínio jurídico, elas parecem invadir as políticas penais, pois o medo do crime e a indignação pública face à violência são destacados para justificar um endurecimento das respostas penais contra a delinquência.

A inversão considerável da vítima no cenário do crime é um dos sinais marcantes da transformação das relações entre os cidadãos e o Estado. A jurisdição penal tende, cada vez mais, a ser avaliada pelo critério da satisfação da vítima como consumidora da justiça. Com efeito, a justiça vem sendo compreendida como uma instância de reconhecimento do sofrimento da vítima expresso pela vítima. A compaixão pelo sofrimento e seu reconhecimento tornaram-se os principais motores das respostas políticas.

A necessidade do legislador de levar em consideração o sofrimento da vítima é cada vez mais valorizado pelas instituições nacionais e internacionais que recomendam a adoção de medidas nesse sentido. O Código de Processo Penal teve sua redação alterada em 2008 para fazer cumprir o princípio da dignidade da pessoa humana em relação ao ofendido, em especial o art. 201, $\iint 5^{\circ}$ e $6^{\circ}$ e o art. 217, segundo os quais:

Art. 201, \5 $5^{\circ}$ Se o juiz entender necessário, poderá encaminhar o ofendido para atendimento multidisciplinar, especialmente nas áreas psicossocial, de assistência jurídica e de saúde, a expensas do ofensor ou do Estado.

Art. 201, \ $6^{\circ} \mathrm{O}$ juiz tomará as providências necessárias à preservação da intimidade, vida privada, honra e imagem do ofendido, podendo, inclusive, determinar o segredo de justiça em relação aos dados, depoimentos e outras informações constantes dos autos a seu respeito para evitar sua exposição aos meios de comunicação.

Art. 217. Se o juiz verificar que a presença do réu poderá causar humilhação, temor, ou sério constrangimento à testemunha ou ao ofendido, de modo que prejudique a verdade do depoimento, fará a inquirição por videoconferência e, somente na impossibilidade dessa forma, determinará a retirada do réu, prosseguindo na inquirição, com a presença do seu defensor.

Ou seja, não se trata unicamente de proteger os interesses das vítimas no âmbito do processo penal em sentido estrito, mas sobretudo tomar medidas necessárias para assistir as vítimas ao longo da experiência judiciária, com vistas a atenuar o sofrimento delas. A evolução da noção jurídica de vítima no Brasil testemunha, assim, esta tendência, ainda que de maneira bem menos explícita. Segundo a jurisprudência do Supremo Tribunal Federal, a determinação do estatuto de vítima se apresenta ainda muito mais dependente das consequências diretas da infração sobre a vítima, do que da gravidade da infração.

No entanto, o discurso legislativo e político atual em matéria de vítima não deve se contentar unicamente em fazer referência à necessidade de fornecer diferentes formas de apoio - psicológico, social, jurídico, etc -, mas incluir, explicitamente, disposições penais que façam referência a conceitos tais como "vitimização secundária" ou "necessidade de ser compreendido", pois só assim a justiça poderá se aproximar do sofrimento das vítimas. 
Entendemos que as vítimas, expostas a uma experiência penal, devem se beneficiar de três categorias de direitos fundamentais: o direito ao reconhecimento, ao acompanhamento e à reparação. $O$ reconhecimento engloba o fato de considerar a vítima como indivíduo detentor de uma personalidade própria. Nesse sentido, a escuta e a empatia são indispensáveis para que se sinta reconhecida, e a despersonificação da vítima pelos atores penais deve ser evitada. Escutar não se restringe apenas a coletar provas da culpabilidade do autor, mas também reconhecer o caractere central e doloroso da narrativa. O acompanhamento supõe que a vítima seja não apenas entendida, mas sobretudo acreditada. Aqui, a investigação da verdade é essencial e a vítima deve ser informada de toda a evolução de seu caso no curso do processo penal. Ademais, a proteção da vítima do risco de vitimização secundária por parte do ofensor é fundamental. Por fim, a reparação compreende a indenização material, mas ainda o aspecto simbólico da restauração da vítima através de sua participação na implementação da justiça.

As três categorias de direitos fundamentais às vítimas não concernem ao domínio processual estrito senso. Elas dizem respeito ao aspecto emocional e subjetivo. Isso nos leva a admitir que a perspectiva empática orienta o estudo concernente às vítimas. Com efeito, a relação da vítima com a justiça não é mais descrita em termos puramente processuais, mas em termos de satisfação de necessidades emocionais, tais como: apoio; escuta e reconhecimento; com vistas a ajudá-la a ultrapassar as consequências emocionais da agressão. Ou seja, dizer sua história, ser entendida, fornecer elementos para a resolução do caso, obter respostas, conhecer a verdade, ser testemunha do remorso de seu agressor e viver uma experiência de justiça através de sua reintegração ao tecido social são formas de contribuir para amortizar o luto emocional pós-agressão e devolver sua humanidade.

\section{Conclusão}

Por todo o exposto, percebe-se que o direito é tanto uma questão de sentimento como de racionalidade; entretanto, ele foi concebido para julgar esse fenômeno emocional do modo mais racional possível. A prova disso é que o direito romano foi declarado como a "ratio scripta". Com São Tomás de Aquino, as descrições da lei eterna e da lei positiva medievais ressaltavam a razão, distanciando-se das correntes voluntaristas (Duns Scoto, Guilherme de Ockham). O processo de racionalização e consequente formalização do direito, em todos os seus domínios, foi crescendo cada vez mais, conforme se avançava em direção ao Estado moderno e contemporâneo ${ }^{45}$.

Assim, se todo o direito está construído por causa do homem, há de se tomar este como razão e emoção, como ser que pensa e que sente, como racionalidade fundada sobre sentimento.

Tal aproximação com os sentimentos nos permitiu mostrar que o direito, longe de ser uma simples técnica de normatização, é um tecido de ficções que dizem o sentido e o valor da vida em sociedade ${ }^{46}$. É verdade que hoje assistimos a um incremento tecnicista e reducionista, que resulta na perda da dimensão simbólica do direito, mas ignorar a dimensão emocional leva o jurista a renunciar os valores e a reduzir a ciência do direito à mera categoria de pura técnica procedimental e formal. Afinal, o pensamento simbólico é aquele que reúne aquilo que está desaparecido, que recria o laço social ${ }^{47}$, que favorece a correspondência, no sentido da interação entre os elementos, às vezes, antagonistas, mas complementares. O direito, além da função de diferenciação que ele assegura através de suas proibições, é também aquilo que permite religar os elementos díspares. Na verdade, o direito tem, no seu tecido, em especial, duas espécies de linhass ${ }^{48}$ a linha-limite e a

45 VERDÚ, Pablo Lucas. O sentimento constitucional: aproximação ao estudo do sentir constitucional como modo de integração política. Trad. Agassiz Almeida Filho. Rio de Janeiro: Forense, 2004. p. 1.

46 OST, François. Le temps du droit. Paris: Odile Jacob, 1999. p. 13.

47 SUPIOT, Alain. Tisser le lien social. Paris: Maison des sciences de l'homme, 2004.

48 FRANCA FILHO, Marcílio Toscano. Sobre a linha: o código de Epitário Pessoa, o tema da fronteira e o direito internacional 
linha-laço. A linha-limite é aquela que traça uma fronteira, que preserva da violência e da indiferenciação; mas é a linha-laço a que une uma comunidade. Esse duplo movimento de separação-ligação é próprio do direito, como também é o que caracteriza as emoções.

Por isso, é urgente reapropriarmo-nos das paixões, pois elas correm o risco de serem instrumentalizadas, deturpadas e monopolizadas pelas forças do terror e da barbárie que pretendem suprimir o futuro ${ }^{49}$.

Nossa perspectiva é uma forma de lucidez que reconhece e aceita plenamente a lógica contraditória, o antagonismo, o conflito e a heteronomia do outro, pois é, na coexistência dos opostos, na sua própria tensão, que a existência humana ganha sentido. A lógica da ambivalência, da contraposição, mostra que da coexistência dos opostos pode nascer o novo: o aspecto efervescente, heterogêneo e barroco das paixões está em correlação com o caráter vivo, dinâmico e labiríntico ${ }^{50}$ do direito.

\section{REFERÊNCIAS}

ARISTÓTELES. Política. Trad. Mário da Gama Kury. Brasília: Universidade de Brasília, 1985. v. 1, 1253b.

ARISTÓTELES. Retórica. Trad. Manuel Alexandre Júnior. Lisboa: Imprensa Nacional, Casa da Moeda, 2005.

BANDES, Susan. Loyalty to one's convictions: the prosecutor and tunnel vision. Howard Law Journal, p. 475-494, 2006.

BANDES, Susan. Repression and denial in criminal lawyering. Buffalo Criminal Law Review, n. 9, p. 339-389, 2006.

BANDES, Susan; SALERNO, J. Emotion, proof and prejudice: the cognitive science of gruesome photos and victim impact statements. State Law Jornal, Arizona, v. 46, p. 1003-1056, 2014.

BARBEY D'AUREVILLY, Jules. Le bonheur dans le crime. Paris: Maxi Livre, 2001.

BARRETO, Tobias. Introdução ao estudo do direito. São Paulo: Landy, 2001.

BECCARIA, Cesare. Dos delitos e das penas. Ed. Eletrônica Ridendo Castigat Mores. Disponível em: <http:// www.ebooksbrasil.org/>. Acesso em: 10 set. 2014.

BRASIL. Supremo Tribunal Federal. Arguição de descumprimento de preceito fundamental 54 / DF. Requerente: Confederação Nacional dos Trabalhadores na Saúde - CNTS. Intimado: Presidente da República. Relator: Min. Marco Aurélio. Brasília, DF, 2012.

CORNU, Gérard. Vocabulaire juridique. 7. ed. França: Puf; Quadriage, 2005.

CUNHA, Paulo Ferreira da. Droit et récit. Québec: Presses de l'Université Laval, 2003. (Collection Dikè).

DURKHEIM, Émile. As regras do método sociologico. Trad. Paulo Neves. 3. ed. São Paulo: M. Fontes, 2007.

EDELMAN, Bernard. Quand les juristes inventent le réel. Paris: Hermann, 2007.

FISS, Owen M. Reason in all its splendor. Brooklyn Law Review, v. 56, p. 789-804, 1990.

dos espaços. In: FRANCA FILHO, Marcílio Toscano; MIALHE, Jorge; JOB, Ulisses. Epitácio Pessoa e a codificação do direito internacional. Porto Alegre: S. A. Fabris Editor, 2013. p. 327-352.

49 JUNG, Carl Gustav. Aspects du drame contemporain. Genève: Georg \& Cie, 1948.

50 "No direito, os arabescos labirínticos de textos legais são incapazes de dar soluções ao caso concreto: só o uso da retórica condicionado pela experiência do sublime é capaz de integrar definitivamente esses arabescos à realidade“. FRANCA FILHO, Marcílio Toscano; MAIA, M. L. Direito, ópera e a mentalidade barroca: contradições, paradoxos e diálogos. In: COLÓQUIO INTERNACIONAL DE DIREITO E LITERATURA - CIDIL: justiça, poder e corrupção., 5., 2017, Uberaba - MG. Anais... Porto Alegre: Rede Brasileira de Direito e Literatura - RDL, 2017. v. 2. p. 592-618. p. 617. 
FRANCA FILHO, Marcílio Toscano. Sobre a linha: o código de Epitário Pessoa, o tema da fronteira e o direito internacional dos espaços. In: FRANCA FILHO, Marcílio Toscano; MIALHE, Jorge; JOB, Ulisses. Epitácio Pessoa e a codificação do direito internacional. Porto Alegre: S. A. Fabris Editor, 2013.

FRANCA FILHO, Marcílio Toscano; MAIA, M. L. Direito, ópera e a mentalidade barroca: contradições, paradoxos e diálogos. In: COLÓQUIO INTERNACIONAL DE DIREITO E LITERATURA - CIDIL: justiça, poder e corrupção., 5., 2017, Uberaba - MG. Anais... Porto Alegre: Rede Brasileira de Direito e Literatura - RDL, 2017. v. 2. p. 592-618.

HOBBES, Thomas. Leviatã ou matéria, forma e poder de um estado eclesiástico e civil. Trad.: João Paulo Monteiro e Maria Beatriz Nizza da Silva. São Paulo: Abril Cultural, 1974.

JHERING, Rudolf von. A luta pelo direito. Trad. Ivo de Paula. São Paulo: Pillares, 2009.

JHERING, Rudolf von. Sobre el nacimiento del sentimiento jurídico. Madrid: Trotta, 2008.

JUNG, Carl Gustav. Aspects du drame contemporain. Genève: Georg \& Cie, 1948.

LANGDELL, C. C. A selection of cases on the law contracts. Boston: Little Brown, 1871.

LE BON, Gustave. Hier e demain: pensées brèves. Paris: Flammarion, 1918.

LEGROS, Bérengère. La douleur comme fondement de l'euthanasie. In: DURAND, Bernard; POIRIER, Jean; ROYER, Jean-Pierre (Org). La douleur et le droit. Paris: Presses Universitaires de France, 1997.

LLEWELLYN, K. Jurisprudence: realism in theory and practice. Chicago: University of Chicago Press, 1962.

LUNA, Nevita Maria Pessoa de Aquino Franca. O pragmatismo jurídico aproximando Thêmis e Eros: o sentimento do Supremo tribunal federal na ADPF 54/DF. Revista de Direito Brasileira, Florianópolis, ano 5. v. 2, p. 216-238, 2015.

MAIA, Alexandre da. O direito subjetivo como imagem: da invisibilização dos paradoxos na teoria dos sistemas à interação e às situações comunicativas na pragmática normativo- comunicacional de Tercio Sampaio Ferraz Júnior. In: ADEODATO, João Maurício; BITTAR, Eduardo C. B. (Org.). Filosofia e teoria geral do direito: estudos em homenagem a Tercio Sampaio Ferraz Junior por seu septuagésimo aniversário. São Paulo: Quartier Latin, 2010.

MARONEY, T. A. Law and emotion: a proposed taxonomy of an emerging field. Law and Human Behavior, v. 30, n. 2, p. 119-142, 2006.

MAXIMILIANO, Carlos. Hermenêutica e aplicação do direito. 10. ed. Rio de Janeiro: Forense, 1988.

MECHRI, Farouk. Le sentiment d'affection \&o le droit de la famille. Tunis: Éditions Latrach, 2015.

MELKEVIK, Bjarne. Épistemlogie juridique et dejà-droit. Paris: Buenos Books International, 2014.

MOOR, Pierre. Perméabilités du systeme juridique: essais sur le droit de l'état de droit. Québec: Presses de l’Université Laval, 2016. (Collection Dikè).

OST, François. Le temps du droit. Paris: Odile Jacob, 1999.

PAPAUX, Alain. Un droit sans émotions. Iram non novit jus: esquisse des rapports entre sciences et droit. REVUE Européenne des Sciences Sociales [on line], v. 47, n. 144, p. 105-119, 2009. Disponível em: <http://ress. revues.org/70>. Acesso em: 10 out. 2017.

PASCAL, Blaise. Pensées, article IV, des moyens de croire. Paris: Garnier, 1964. (Ed. Brunschvicg, n. 277).

POPOVICI, Adrian; PARIZEAU-POPOVICI, Micheline. L'amour et la loi. Montréal: Éditions du Jour, 1971. RAWLS, John. A theory of justice. Cambridge: Harvard University Press, 2003. 
SAUTEL, Oliver. Le droit répressif, un droit sans sentiments? Disponível em: $<$ http:/ / halshs.archives-ouvertes.fr/ halshs-00755911>. Acesso em: 11 set. 2014.

SCHEFFER, S. Fighting for their lives: inside the experience of capital defense attorneys. Nashville: Vanderbilt University Press, 2013.

SUPIOT, Alain. Tisser le lien social. Paris: Maison des sciences de l'homme, 2004.

TOURTOULON, Pierre de. Philosophy in the development of law. Trad. Martha McC. Read. Nova Iorque: A.M. Kelly, 1969.

TRIMAILLE, Gilles. L'expertise médico-légale: confiscation et traduction de la douleur. In: DURAND, Bernard; POIRIER, Jean; ROYER, Jean-Pierre (Org). La douleur et le droit. Paris: Presses Universitaires de France, 1997.

URUGUAI. Código Penal. Disponível em: <http://www.wipo.int/wipolex/en/text.jsp?file_id=196342>. Acesso em: 4 out. 2017.

VERDÚ, Pablo Lucas. O sentimento constitucional: aproximação ao estudo do sentir constitucional como modo de integração política. Trad. Agassiz Almeida Filho. Rio de Janeiro: Forense, 2004.

VERDÚ, Pablo Lucas. O sentimento constitucional: aproximação ao estudo do sentir constitucional como modo de integração política. Trad. Agassiz Almeida Filho. Rio de Janeiro: Forense, 2004.

WARAT, Luís Alberto. A ciência jurídica e seus dois maridos. Santa Cruz do Sul: Faculdades Integradas de Santa Cruz do Sul, 1985.

ZWEIG, Stefan. La confusion des sentiments. Paris: Le livre de Poche, 1992. 


\section{REVISTA BRASILEIRA DE POLÍTICAS PÚBLICAS BRAZILIAN JOURNAL OF PUBLIC POLICY}

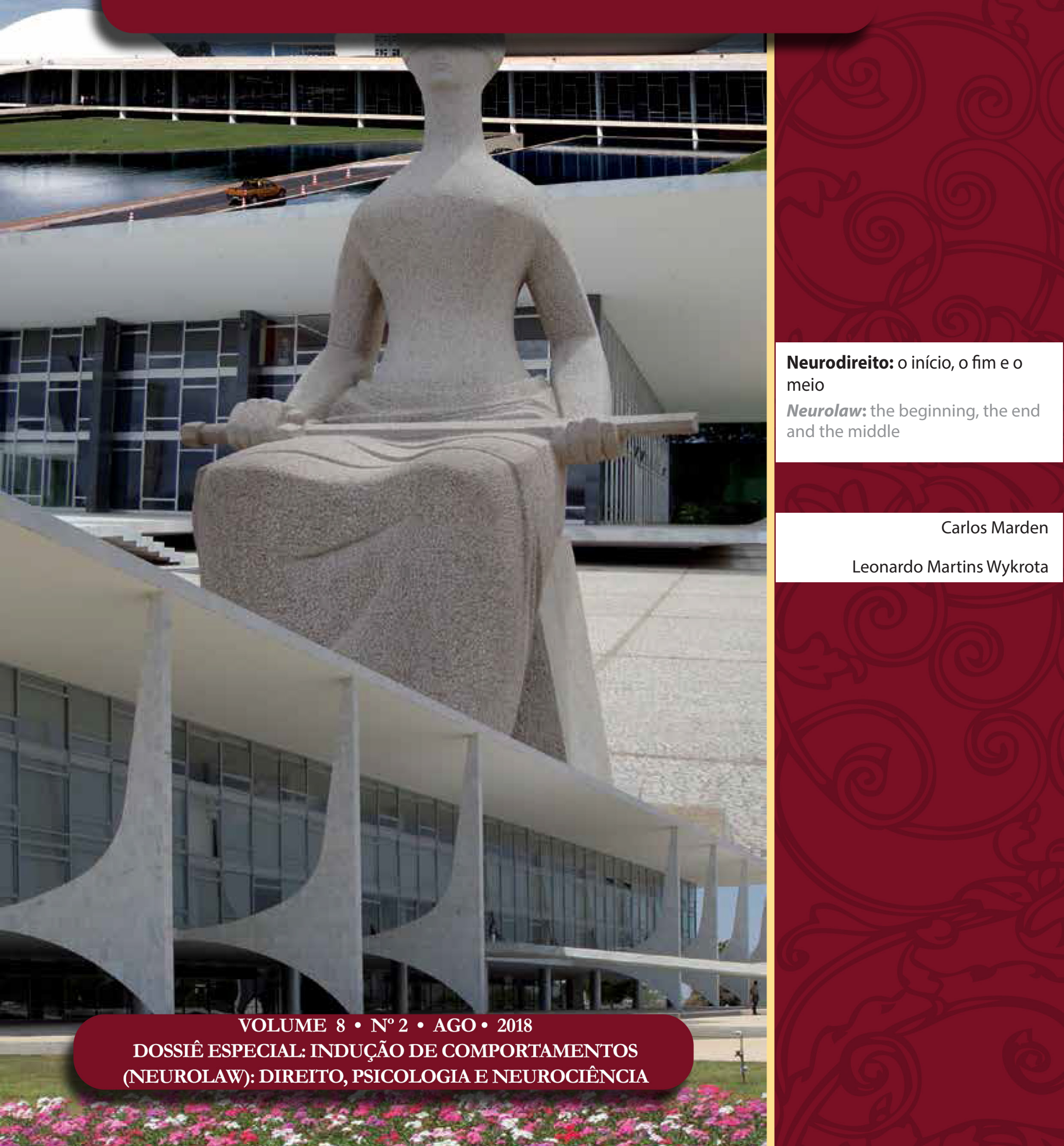




\title{
Neurodireito: o início, o fim e o meio*
}

\section{Neurolaw: the beginning, the end and the middle}

\author{
Carlos Marden** \\ Leonardo Martins Wykrota*** \\ "A consciência que se tem de um motivo envolve uma ilusão - o intelecto totalmente o \\ primeiro e o único mentiroso" (Friedrich Nietzsche).
}

\section{Resumo}

O presente trabalho analisa os impactos de algumas descobertas importantes das neurociências e da Psicologia Comportamental para o Direito, partindo de ideias consideradas intuitivas e consolidadas no campo teórico, mas que, ainda, não têm um reflexo prático muito bem definido. Na sequência, o texto mostra como essas descobertas abrem margem para questionamento de muitas das crenças sobre as quais se funda o pensamento jurídico-sistemático. A tese central defendida no texto é a de que o conjunto dessas ideias pode ser sistematizado sob o rótulo de Neurodireito e ser tratado como uma área interdisciplinar do conhecimento jurídico, por sua vez, capaz de emprestar um instrumental mais adequado para lidar com a complexidade do fenômeno jurídico em geral. Para isso, mediante um estudo bibliográfico, procura mostrar que o Neurodireito oferece maior sofisticação ao sistema jurídico, ajudando a pensar melhor sua dinâmica de funcionamento. Há, assim, um convite à interlocução com essa nova interface, que só tende a se intensificar e a exigir adaptações cada vez mais significativas. Este trabalho é uma reflexão inicial a respeito de como tornar isso possível.

Palavras-chave: Neurociência. Psicologia comportamental. Teoria geral do direito. Teoria da decisão.

* Recebido em 31/05/2018 Aprovado em 24/07/2018

** Procurador Federal. Especialista em Direito Processual Civil e Mestre em Ordem Jurídica Constitucional pela Universidade Federal do Ceará. Doutor em Direito Processual pela Pontifícia Universidade Católica de Minas Gerais. Pós-doutor em Estado, Democracia e Constituição pela Universidade do Vale do Rio dos Sinos. Professor do Programa de Pós-Graduação em Direito do Centro Universitário Christus. E-mail: carlosmardencc@hotmail.com.

*** Advogado. Mestre em Direito Processual e Doutor em Direito Público pela Pontifícia Universidade Católica de Minas Gerais. E-mail: leonardo@vlf.adv.br

\section{Abstract}

The present work aims to analyze the impacts that recent discoveries of Neuroscience bring to Legal Science. To do so, it is initially intended to explain how the study of law is organized from some ideas that are intuitive and considered as consolidated, although in practice they do not prove as functional as in theory. In the sequence, it is intended to present some of the recent advances of Neuroscience and Behavioral Psychology, in order to show how they alow to question many of the beliefs on which Legal Science is founded. As a development, through a bibliographic study it will be supported the thesis that it is possible to improve Legal Science from the discoveries of Neuroscience, opening up a whole field of investigation called Neurolaw. Finally, some comments will be made as to how the Neurolaw 
allows the increase of the level of complexity with which Legal Science is able to deal, leaving behind old beliefs previously unquestioned.

Keywords: Neuroscience. Behavioral psicology. General theory of law. Theory of decision. Neurolaw.

\section{INTRODUÇãO: O SENSO COMUM JURÍDICO NA ZONA DE RISCO}

Em termos evolutivos, pode-se apostar que o direito é a ferramenta mais avançada encontrada por nossa espécie para regular o comportamento em grupo (juntamente com religião e moral). Historicamente, não há superpopulação humana sem um sistema jurídico sólido, que garanta um mínimo de segurança e previsibilidade nas relações sociais. ${ }^{1}$ Porém, o aumento da população nas mais diversas sociedades urbanas e a sofisticação das relações sociais que ali se desenvolvem pressiona essa ferramenta de coesão a fornecer soluções para a complexidade que resulta desse adensamento populacional e das novas tecnologias que permeiam as relações sociais atuais. ${ }^{2}$ Mas, se de um lado vive-se na expectativa de que o Ordenamento Jurídico ajude a absorver, estabilizar e reduzir essa complexidade; ${ }^{3}$ de outro, não raro, o funcionamento do Direito, ainda, é pensado e ensinado segundo um "tipo ideal" que pode ser assim simplificado: (a) "o legislador" procurar regular o comportamento em sociedade valorando condutas humanas por meio de normas jurídicas que edita; (b) a sociedade estaria plenamente consciente da valoração de cada conduta (como proibida, permitida ou obrigatória); (c) o indivíduo, como regra, é livre para decidir observar ou não a norma; e (d) em caso de (ameaça de) descumprimento, o Poder Judiciário pode ser acionado para restabelecer o status quo. ${ }^{4}$

Está implícito nesse esquema convencional que o ser humano (tanto o que legisla quanto o que interpreta e aplica a norma) é "racional" (dotado de livre-arbítrio) e "neutro" (capaz de afastar vieses cognitivos). Muito embora Filosofia e Teoria do Direito já tenham colocado em xeque as visões tradicionais da racionalidade e neutralidade de padrões iluministas há algum tempo, ${ }^{5}$ os recentes avanços da psicologia comportamental e das neurociências ${ }^{6}$ elevaram essa crítica a outro patamar. Perguntas sobre a regulação de conduta em face da forma como os seres humanos reagem a incentivos; o grau de racionalidade das decisões humanas; ou até que ponto os seres humanos podem ser responsabilizados por suas condutas; e sobre os tipos de vieses aos quais estão submetidos os juízes na hora de decidir, apresentam respostas bem mais atraentes e profundas que as teorias jurídicas tradicionais, além de terem suporte empírico mais vasto. Essas respostas, entretanto,

1 Uma explicação detalhada sobre o direito como ferramenta de coesão social pode ser encontrada em WYKROTA, Leonardo Martins. Direito constitucional contemporâneo e análise institucional do judiciário: um diálogo à luz da neurociência, da teoria da evolução e do pragmatismo. 2017. Tese (Doutorado) - Pontifícia Universidade Católica de Minas Gerais, Belo Horizonte, 2017. Frans de Waal também aponta que em toda sociedade (grande ou pequena) verifica-se que os seres humanos só conseguem conviver com a ajuda de intermediários (como o Poder Judiciário), vez que a harmonização de interesses díspares precisa ser institucionalizada. (WAAL, Franz de. Eu, primata: por que somos como somos. São Paulo: Companhia das Letras, 2007. p. 198-199).

2 O vetusto contrato de compra e venda, os títulos de crédito tradicionais, para ficar apenas nesses exemplos, mostram como o Ordenamento Jurídico precisa se renovar para regular fenômenos importantes como a Internet e as transações bancárias on-line, já consolidadas em nosso tempo.

3 MORIN, Edgar. Introdução ao pensamento complexo. Porto Alegre: Sulina, 2011. Nessa ótica, instituições jurídicas consagradas (como o contrato, por exemplo), são uma garantia de estabilização das relações sociais, sobre as quais novas relações são constituídas e assim por diante, sempre com a tendência de incremento no nível de complexidade.

4 Em uma simplificação propositada para atender aos fins deste trabalho, esse é o esquema ordinário de funcionamento do Direito: um Ordenamento Jurídico oriundo de um Parlamento eleito democraticamente, oferecido aos cidadãos que lhe devem conformação e resguardado por um corpo de terceiros imparciais que decide a respeito de sua interpretação/aplicação (BOBBIO, Norberto. Teoria geral do direito. São Paulo: Martins Fontes, 2010).

5 Sobre o tema, vale conferir: CRUZ, Álvaro Ricardo de Souza; DUARTE Bernardo Augusto Ferreira. Além do positivismo jurídico. Belo Horizonte: Arraes, 2013; e CRUZ, Álvaro Ricardo de Souza. A resposta correta: incursões jurídicas e filosóficas sobre as teorias da justiça. Belo Horizonte: Arraes, 2011.

6 Uma concepção exata do que seria "Neurociência" está longe do consenso. O melhor é a designação plural, pois são várias "neurociências" (CHURCHLAND, Patricia Smith. Neurophilosophy: toward a unified science of the mind-brain. Cambridge, Mass: MIT Press, 1989). 
mostram que o senso comum jurídico vem operando em uma verdadeira zona de risco, por assumir premissas que, quando não se provam falsas, seriam no mínimo questionáveis, como se verá mais adiante. Também mostram que um novo campo interdisciplinar se descortina para atuar com a complexidade das relações sociais e do próprio fenômeno jurídico, o Neurodireito.

Para evidenciar essa circunstância, primeiramente, será analisada essa estrutura de premissas básicas do senso comum jurídico, entendendo como ela se organiza em torno da suposição de que haverá uma ponderação racional na criação, interpretação e aplicação do comando normativo. Posteriormente, apresentar-se-ão alguns dos avanços das neurociências nas últimas décadas frente à complexidade do ser humano. Como fechamento, mostrar-se-á que o Neurodireito, nos moldes concebidos nesse texto, possibilita uma releitura do Direito, a partir das contribuições de outros ramos do conhecimento psicológico-comportamental e neurocognitivo. Esclareça-se, porém, que não se trata de "superar" o Direito que é tão familiar, mas de ampliar o diálogo com outras áreas do conhecimento ligadas ao comportamento humano, em busca de uma melhor sintonia entre a valoração de conduta e a condição humana daquele que interpreta e aplica o direito.

\section{O INÍCIO: O MODELO IDEAL DA DINÂMICA JURíDICA E A ARTICULAÇão DE ELEMENTOS QUE ESSE MODELO PRESSUPÕE}

No sistema jurídico brasileiro, pelo menos desde meados do Século XX, quando Miguel Reale Jr. ganhou notoriedade internacional com sua Teoria Tridimensional do Direito, passou-se a explicar o fenômeno jurídico numa dinâmica em que o legislador valora os fatos humanos e traduz essa valoração na norma jurídica, que os classifica como sendo obrigatórios, permitidos ou proibidos. ${ }^{7}$ Está implícita nessa dinâmica a noção de que o regulamento das condutas seria convergente (em prol da construção de uma sociedade ideal). É evidente que a realidade política se mostra muito distante disso, ainda assim, se pode assumir, como um modelo ideal de tipo weberiano, que legisladores estariam preocupados em construir um design social mais adequado para as condutas de determinada sociedade que, sem o reforço das normas legisladas, não se implementaria. $^{8}$

Tal edifício jurídico-normativo é feito sob a premissa de que cada ser humano tem capacidade não apenas de compreender o conteúdo da norma, como também de dimensionar a sanção correspondente ao respectivo descumprimento e de decidir, livremente, qual postura deve ser adotada. ${ }^{9}$ Essas ideias se articulam em uma conexão a priori muito coerente: o povo elege seus representantes e estes se reúnem para deliberar a respeito de como devem valorar as diversas condutas; posteriormente, as decisões são traduzidas em normas jurídicas de observância obrigatória quando em vigor; cabendo aos destinatários dessas mesmas normas avaliar qual conduta adotar, respondendo (civil e criminalmente) por eventuais desvios ${ }^{10}$.

A responsabilização, nessa trilha, se dá por meio do processo judicial, uma tecnologia que, via de regra, desloca a resolução de conflitos para um terceiro que se supõe imparcial (em regra, o Estado). ${ }^{11}$ Essa im-

7 REALE, Miguel. Lições preliminares de direito. São Paulo: Saraiva, 2002. Segundo o jurista brasileiro, havia um falso dilema entre a Teoria Normativista e a Teoria Realista (que se propunham a explicar isoladamente o fenômeno jurídico), pois tanto as normas quanto os fatos eram dimensões do Direito, conectados por meio de outro elemento: o valor.

8 SCHAUER, Frederick. The force of law. Cambridge: Harvard University Press, 2015.

9 Não é por acaso, portanto, que a regra geral prevista no artigo 927 do Código Civil diz que "aquele que, por ato ilícito, causar dando a outrem, fica obrigado a repará-lo". Este artigo é sintomático sobre o aspecto que destacamos da dinâmica jurídica: uma determinada conduta que é considerada ilícita pelo legislador e que, mesmo assim, foi adotada pelo agente, fazendo com que se estabeleça a sua responsabilidade. A mesma lógica, também, se reproduz no artigo 13 do Código Penal, o qual estabelece que "o resultado, que depende da existência do crime, somente é imputável a quem lhe deu causa”. Ou seja: existe um agente que deliberadamente praticou o ato criminoso e que pode ser por ele responsabilizado.

10 SUXBERGER, Antonio Henrique Graciano; LIMA, José Wilson Ferreira. O processo penal e a engenharia de controle da política criminal. Rev. Bras. Polít. Públicas (Online), Brasília, v. 7, n. 1, p. 286-303, 2017.

11 Robert Alexy, por exemplo, vai explicar que, apesar de não serem eleitos, os magistrados têm uma legitimidade discursiva (em 
parcialidade, por sua vez, funciona como pressuposto de validade para a formação do liame entre a fundamentação e as provas produzidas em um determinado caso. ${ }^{12}$ Claramente, esse tipo de dinâmica aposta em um magistrado capaz de valorar racionalmente a prova colhida no processo, ${ }^{13}$ tomando-a como base para a construção de uma decisão adequadamente fundamentada ${ }^{14}$.

Essa aposta acentuada na racionalidade do julgador (não raro pressuposta dentro de padrões iluministas, isso é, livre de suas condicionantes biológicas), há muito levanta suspeitas. A realidade tem sido rica em exemplos nos quais nem sempre se obtêm conclusões contundentes sobre a resposta de um determinado problema jurídico. Há casos em que várias respostas parecem adequadas a um mesmo conjunto de fatos. ${ }^{15}$ Para lidar com isso, a doutrina ou coloca o problema na conta da discricionariedade ou tenta se valer de artifícios como as metáforas do Juiz Hércules ${ }^{16}$ ou do Juiz Iolau ${ }^{17}$, ou de esquemas lógicos-ponderativos, ao modo de Robert Alexy, em busca de uma resposta adequada ao caso concreto.

Embora as correntes que costumam encampar esses artifícios muitas vezes percebam as inconsistências da dinâmica jurídica ideal que aqui se apresenta, intuindo que seus elementos (um órgão legislativo e suas normas; os destinatários dessa mesma norma; e aquele que atua para garantir a adequada interpretação e aplicação do direito) nem sempre estão articulados em sintonia, elas deixam de avançar no diagnóstico e em soluções mais concretas para lidar com o problema. É a essa falta de sintonia que se dedica o próximo tópico.

\section{O FIM: A DESARTICULAÇÃO DO MODELO IDEAL}

Nas últimas décadas, estudos da Psicologia Comportamental ganharam notoriedade na Economia e em outras áreas. ${ }^{18}$ Aliada a esses estudos, a introdução da ressonância magnética funcional ${ }^{19}$ também ajudou a

alternativa à legitimidade representativa do Poder Legislativo e do Poder Executivo), consistente na sua capacidade de construir decisões racionais com base em argumentação jurídica. ALEXY, Robert. Constitucionalismo discursivo. Porto Alegre: Livraria do Advogado, 2007. Já André Cordeiro Leal, por sua vez, vai destacar a importância de que a fundamentação da decisão seja diretamente conectada com um contraditório (entendido como direito de efetiva influência das partes), requisito essencial para que o processo guarde compatibilidade com o paradigma do Estado Democrático de Direito (LEAL, André Cordeiro. O contraditório e a fundamentaşão das decisões. Belo Horizonte: Mandamentos, 2002).

12 A esse respeito, Michele Taruffo observa que: "A narrativa dos fatos construída pelo juiz compõe-se, por conseguinte, de um conjunto ordenado de enunciados fáticos, tendo cada um deles obtido, das provas disponíveis, racionalmente valoradas, uma confirmação probatória suficientemente forte. Nessa situação haverá razões válidas para sustentar-se que, no contexto do processo, tais enunciados possam ser considerados verdadeiros" (TARUFFO, Michele. Uma simples verdade: o juiz e a construção dos fatos. São Paulo: Marcial Pons, 2012. p. 257).

13 BELTRÁN, Jordi Ferrer. La valoración racional de la prueba. Madri: Marcial Pons, 2007.

14 Falando sobre a fundamentação da decisão, Galvão adota, exatamente, a premissa da racionalidade objetiva ao afirmar que: "tradicionalmente concebida como elemento garantidor do controle da atividade decisória, por facilitar a sua correspondência e adequação à noção de legalidade (juridicidade), passa-se, atualmente, a concebê-la e/ou compreendê-la, em todos os âmbitos decisórios estatais, como uma exigência de racionalidade jurídica de cunho objetivo, conformadora de um adequado iter ou processo de fixação dos entendimentos e razões que serão expostos na decisão final a ser tomada". GALVÃO, Ciro di Benatti. Ativismo judicial: o contexto de sua compreensão para a construção de decisões judiciais racionais. Revista Brasileira de Políticas Públicas, Brasília, v. 5, Número Especial, p. 88-99, 2015.

15 Basta pensarmos na legalização do aborto, na destinação de embriões e no casamento homoafetivo, para ficarmos, apenas, nos exemplos mais polêmicos, os quais têm suscitados embates acalorados nas cortes constitucionais mundo afora.

16 DWORKIN, Ronald. Levando os direitos a sério. São Paulo: WMF Martins Fontes, 2010.

17 NEVES, Marcelo. Entre Hidra e Hércules: princípios e regras constitucionais. São Paulo: WMF Martins Fontes, 2014.

18 Em 2002, Daniel Kahneman foi vencedor do "Prêmio Nobel de Economia", por seus estudos a respeito da tomada racional de decisão (tecnicamente falando, não existe Nobel de Economia, já que, ao instituir o prêmio, Alfred Nobel criou, originalmente, apenas, cinco categorias: Física, Química, Medicina, Literatura e Paz, que são os prêmios entregues desde 1901). O que se convencionou chamar de Prêmio Nobel de Economia começou a ser entregue, apenas, em 1969 e na verdade se trata do Prêmio do Banco da Suécia para Ciências Econômicas em Memória de Alfred Nobel.

19 A ressonância magnética funcional (FMRI, do inglês Functional Magnetic Ressonance Imaging) é uma nova tecnologia que permite ver o cérebro em funcionamento durante os testes realizados, tornando possível a comparação de quais áreas do cérebro 
entender melhor o que se passa dentro do cérebro humano. De lá para cá, diversas ciências cognitivas e as novas tecnologias se somaram para explicar o comportamento humano, apresentando conclusões que contrariam muito do que se presumia sobre o funcionamento do cérebro e sua influência no cotidiano. ${ }^{20}$ Como se verá a seguir, essas conclusões também mostram o final da história: a desarticulação entre os elementos do modelo ideal do qual se falou e a necessidade de que ele seja definitivamente repensado.

\subsection{O legislador}

A revisão do modelo começa já com a atividade legislativa, cuja engrenagem supõe três peças básicas: (a) a capacidade de o legislador valorar adequadamente condutas humanas; (b) que os destinatários das normas efetivamente se percebam como tais (o que costumamos chamar de legitimidade substantiva das normas); e que (c) essas mesmas normas sejam efetivas, no sentido de realmente influenciarem pessoas a adotar as condutas desejadas. E, mais uma vez, é a racionalidade de nossa consciência o que dá suporte ao funcionamento dessa engrenagem.

Porém, como bem coloca Sam Harris, "[a] partir do momento em que admitimos que a consciência é o contexto que dá sentido a qualquer discussão sobre valores, precisamos também admitir que há fatos a serem descobertos sobre como a capacidade dos seres conscientes pode mudar" ${ }^{21}$. O que esse neurocientista mostra é que o bem-estar humano e animal é um fenômeno natural e, como tal, pode ser objeto da ciência, ou seja, a valoração moral pode ser examinada em termos científicos. Tradicionalmente, a ciência era avessa a se imiscuir em aspectos morais (quase sempre relegados ao campo religioso), mas a existência de fatos relevantes sobre a forma de funcionamento da moralidade humana aponta para conclusões interessantes no campo legislativo.

Um importante exemplo que a Psicologia Comportamental oferece e que revela - em termos técnicos — a falta de sintonia das engrenagens do mecanismo legislativo é a chamada cascata de disponibilidade (availability cascade). O termo foi cunhado por Cass Sunstein e Timur Kuran em 1999, para designar a transposição de vieses convencionais para políticas públicas e mostra que a importância de uma ideia está ligada, em geral, à sua frequência de disponibilidade, isso é, à quantidade de vezes que é apresentada e à facilidade com que é possível se recordar dela. ${ }^{22}$ Essa ideia revela que a importância de determinado assunto pode ser fabricada, aumentando-se ou diminuindo-se sua exposição ao público. ${ }^{23}$

Outra contribuição no campo da moralidade política e, por consequência, da produção legislativa diz respeito à constatação de que toda a argumentação moral está longe do modelo racional que se costuma supor aplicável a uma ponderação sobre quais valores devem prevalecer em determinada sociedade. A ponderação moral racional, ao que parece, segue o caminho inverso, em vez de se escolher um valor com base em determinadas justificativas ou argumentos morais racionais que pesem em favor daquela escolha, são as intuições morais de que já se dispõe que determinam os juízos no campo moral. Como mostram Jonathan Haidt ${ }^{24} \mathrm{e}$ Joshua Greene $e^{25}$, o argumento moral não passa de uma preferência intuitiva que sempre (para Haidt) e quase sempre (para Greene) é meramente ratificada por alguma justificativa que a racionalidade oferece.

são utilizadas (com maior ou menos intensidade) em várias situações específicas.

20 DAMÁSIO, Antônio R. E o cérebro criou o homem. São Paulo: Companhia das Letras, 2011.

21 HARRIS, Sam. A paisagem moral: como a ciência pode determinar os valores humanos. São Paulo: Companhia das Letras, 2013. p. 47.

22 KURAN, Timur; SUNSTEIN, Cass. Availability cascades and risk regulation. University of Chicago Public Law \& Legal Theory Working Paper, n. 181, 2007.

23 Essa distorção pela gerada pela disponibilidade do evento é também mencionada em KAHNEMAN, Daniel. Rápido e devagar: duas formas de pensar. Rio de Janeiro: Objetiva, 2012. p. 181.

24 HAIDT, Jonathan. The righteous mind: why good people are divided by politics and religion. New York: Knopf Doubleday Publishing Group, 2012.

25 GREENE, Joshua. Moral tribes: emotion, reason and the gap between us and them. New York: The Penguin Press, 2014. 
Ao que parece, o adágio "política e religião não se discute" tem raízes bem mais profundas do que se poderia supor. Sob essa perspectiva, o debate legislativo do qual resulta a infusão de valores morais nas normas jurídicas pode não passar de uma disputa nada racional por preferências intuitivas. Isso, também, revela que o discurso político em favor de determinadas diretrizes ou plano de governo, como já se pode intuir do cenário político atual, tem pouca ou nenhuma relevância para as preferências por cada partido.

Não bastasse a dificuldade em valorar as condutas e em fazer com que elas sejam bem aceitas pelos destinatários, o legislador, ainda, encontra outro grande desafio, qual seja o de conseguir estimular as pessoas a, efetivamente, agir conforme o esperado. Esse tipo de direcionamento pode parecer simples, mas não é. Às vezes a norma criada, mesmo óbvia, pode acabar tendo efeito contrário ao que dela se espera. ${ }^{26}$ Uma das grandes contribuições da psicologia comportamental e das neurociências está em usar os vieses que temos a favor de um design da escolha, o chamado paternalismo libertário, de Cass Sunstein e Richard Thaler, sistematizado em torno da ideia de nudge. ${ }^{27}$

Tirar vantagem da nossa arquitetura mental nas escolhas públicas é a ideia central por trás da noção de nudge, que batiza a teoria de Sunstein e Thaler. Há casos em que o Estado pretende determinada conduta, mas as soluções tradicionais implicam ou a obrigação dessa conduta (o que poderia ferir a ideia de liberdade individual típica do discurso libertário norte-americano) ou a imposição de uma sanção (que, muitas vezes, não resolve o problema). Pense-se na hipótese em que o Estado pretende aumentar o número de doadores de órgãos. A solução tradicional seria tornar obrigatória a doação (ferindo a liberdade individual, perspectiva libertária). Aparentemente, tanto faz o legislador determinar que o cidadão seja ou não doador (escolha padrão), desde que permita a esse mesmo cidadão trocar sua opção a qualquer momento. A neurociência e a psicologia comportamental mostram, porém, que a escolha padrão tem um custo psicológico para ser desfeita. Sunstein e Thaler defendem que o design da escolha pública deve observar essa e outras circunstâncias de nosso comportamento. No exemplo dos doadores, o design adequado seria colocar os cidadãos, inicialmente, como doadores (opt-in), permitindo que optem pelo status contrário de não doador (opt-out) a qualquer momento. O simples fato de se colocar a condição de doador como opt-in já implicaria aumento das doações justamente pelo custo psicológico de se alterar a escolha padrão.

Além disso, como se pode perceber, com base em Haidt e Greene, a lógica da valoração de condutas será tanto melhor quanto mais privilegie o pluralismo, já que as pessoas não comungam dos mesmos valores. ${ }^{28}$ Nessa trilha, pode-se supor com melhor lastro empírico que uma norma terá maior possibilidade de ser cumprida, voluntariamente, pelos destinatários se as pessoas têm a percepção de que tiveram a oportunidade de participar de sua confecção. ${ }^{29}$ Além dos temas afetos ao legislativo e à escolha pública, o Neurodireito, também, trava amplo debate no campo da racionalidade jurídica, no qual os temas do livre-arbítrio e da imputabilidade apresentam grande destaque, como se verá adiante.

\subsection{Imputabilidade e livre-arbítrio}

Outra dissintonia dos elementos do modelo ideal da dinâmica jurídica ideal apresentada é a presunção de que as normas oriundas do Parlamento se dirigem a sujeitos que podem compreender e decidir, com

26 Uma escola nos Estados Unidos pretendia coibir o atraso dos pais em relação ao horário de buscar os filhos depois das aulas e, para tanto, decidiu instituir uma multa por atraso. Surpreendentemente, entretanto, o número de atrasos aumentou. Os pais que se sentiam moralmente pressionados a buscar os filhos no horário, com a instituição da multa, passaram a se sentir "no direito de atrasar", já que estavam "pagando" pela falta. (THALER, Richard H.; SUNSTEIN, Cass R. Nudge: o empurrão pra escolha certa. Rio de Janeiro: Campus-Elsevier, 2008).

27 THALER, Richard H.; SUNSTEIN, Cass R. Nudge: o empurrão pra escolha certa. Rio de Janeiro: Campus-Elsevier, 2008.

28 WRIGHT, Robert. O animal moral: por que somos como somos: a nova ciência da psicologia evolucionista. Rio de Janeiro: Elsevier, 2006.

29 OSANVALLON, Pierre. La legitimidad democrática: imparcialidad, reflexividad y proximidad. Barcelona: Paidós, 2010. 
racionalidade impecável — o que os economistas chamam de hiperracionalidade ou de bomo economicus ${ }^{30}$ —, tanto o comando que lhes é dirigido quanto a sanção atrelada ao seu descumprimento. O pressuposto desse fundamento é a liberdade de escolha estribada no livre-arbítrio (aqui entendido como racionalidade livre de condicionantes biológicas). Em virtude do corte epistemológico do presente trabalho, porém, a abordagem limitar-se-á a algumas objeções sem aprofundar nas questões filosóficas do livre-arbítrio.

A primeira objeção decorre de estudos indicando que a maioria da atividade cerebral e determinada por nossa biologia (e vários dos seus processos) se dá em um plano que se pode chamar de inconsciente ${ }^{31}$ ou subliminar ${ }^{32}$. A questão está longe de ter um ponto final, pois a Neurociência, ainda, não é capaz de explicar, detalhadamente, o mecanismo decisório, muito menos a consciência como um todo. Porém, parece claro que a racionalidade humana é determinada por sua biologia. ${ }^{33}$

Nessa linha, David Eagleman, ${ }^{34}$ dentre outros, ${ }^{35}$ defende que as decisões seriam tomadas antes de serem apropriadas pela consciência, de modo que a escolha seria apenas uma ilusão. ${ }^{36} \mathrm{~A}$ decisão, primeiramente, seria determinada por aspectos biológicos (uma disputa de circuitos cerebrais pelo controle da ação humana) e, em seguida, apareceria à mente consciente como o produto de uma justificativa que parece livre e original, mas que apenas ratifica uma decisão já tomada. ${ }^{37}$ Em síntese, decisões seriam tomadas num plano inconsciente (que Eagleman chamam de Incógnito), mas emergiriam para seus “autores” como uma escolha racional da consciência. Logo, tais escolhas são ditadas por essas condicionantes biológicas. ${ }^{38}$

Outra objeção é corolário desse determinismo e diz respeito à imputação. Como explicam Joshua Greene e Jonathan Cohen:

Free will, as we ordinarily understand it, is an illusion generated by our cognitive architecture. Retributivist notions of criminal responsibility ultimately depend on this illusion, and, if we are lucky, they will give way to consequentialist ones, thus radically transforming our approach to criminal justice ${ }^{39}$

30 Uma metáfora que economistas usam no estudo das ações econômicas do homem, abstraindo-o das dimensões culturais do comportamento humano (moral, ética, religião, política etc.) e concentrando na racionalização maximizadora de proveitos dos indivíduos para o consumo e a produção (KAHNEMAN, Daniel. Rápido e devagar: duas formas de pensar. Rio de Janeiro: Objetiva, 2012. p. 352).

31 O termo consciência, ainda, está em disputa no campo das neurociências. No presente trabalho, usamos o termo "consciente" para designar a atividade reflexiva que se dá conta (se apropria) de determinado evento.

32 MLODINOW, Leonard. Subliminar. Rio de Janeiro: Zahar, 2013.

33 GREENE, Joshua; COHEN, Jonathan. For law, neuroscience changes nothing and everything. Philosofical Transactions of the Royal Society of London. Series B, Biological Sciences 359, n. 1451, 2004.

34 EAGLEMAN, David. Incógnito: as vidas secretas do cérebro. Rio de Janeiro: Rocco, 2012.

35 GREENE, Joshua; COHEN, Jonathan. For law, neuroscience changes nothing and everything. Philosofical Transactions of the Royal Society of London. Series B, Biological Sciences 359, n. 1451, 2004.

36 O neurocientista é categórico ao afirmar que “apesar de nossas esperanças e intuições sobre o livre-arbítrio, atualmente não há argumentos que determinem convincentemente a sua existência" (EAGLEMAN, David. Incógnito: as vidas secretas do cérebro. Rio de Janeiro: Rocco, 2012, p. 182.)

37 O experimento que ele desenvolve é apresentar fotos de mulheres a um grupo de homens, perguntando qual delas eles escolheriam como a mais bela. As escolhas são as mais variadas, pelas mais variadas justificativas. A todos escapa, porém, que as modelos nas fotos escolhidas como "as mais belas" são, em verdade, aquelas que têm a pupila dilatada. É essa circunstância, portanto, que impele o Incógnito a escolher, mas cada um acredita que houve a "escolha" por outro critério qualquer (sorriso, cor do cabelo, semelhança com a namorada, etc.).

38 Para exemplificar, David Eagleman vai narrar o caso de Charles Whitman, um pacato escoteiro e estudante de engenharia que uma noite matou a mulher e a mãe, sem qualquer motivo aparente. No dia seguinte, foi à Universidade do Texas (em Austin), subiu na torre de observação e começou a atirar indiscriminadamente, matando 13 (treze) pessoas e feriando 33 (trinta e três), até que ele próprio fosse morto pela polícia. Ao tentar investigar as causas do massacre, a polícia foi à casa do atirador, onde encontrou um bilhete, no qual Charles Whitman se diz vítima de perturbações mentais que lhe têm causado pensamentos irracionais nos últimos tempos. Em face disso, pede que seja realizada uma autópsia no seu corpo. Atendendo ao pedido do atirador, foi realizada a autópsia, na qual se revelou que ele tinha um pequeno tumor cerebral (do tamanho de uma moeda) que estava pressionando a sua amídala: uma glândula que tem relação direta com o medo e com a agressividade. Em virtude de uma anomalia, a anatomia do cérebro do estudante tinha mudado, provocando mudança na sua personalidade. Seria possível dizer que ele agiu livremente? Caso ele tivesse sobrevivido, seria razoável responsabilizá-lo pelos seus atos? E se uma cirurgia simples fosse capaz de remover o tumor e devolverlhe sua personalidade pacata? (EAGLEMAN, David. Cérebro: uma biografia. Rio de Janeiro: Rocco, 2017. p. 27-28).

39 Em tradução dos próprios autores: "O livre-arbítrio, como nós ordinariamente o entendemos, é uma ilusão criada pela nos- 
Ou seja, se todas as condutas são determinadas pela biologia, há uma dissintonia evidente no sistema jurídico que imputa responsabilidade às pessoas imaginando que suas decisões são livres (em sentido oposto à determinação imposta pela biologia). ${ }^{40}$ Seria necessário, portanto, que o sistema jurídico revisse a noção de culpabilidade (elemento volitivo), para seguir, apenas, com a repressão a uma conduta objetivamente considerada, como defendem tais autores.

\subsection{Interpretação e aplicação do direito}

Também a atividade judicial e a própria existência do Poder Judiciário se escora na duvidosa premissa de que os processos serão decididos por um terceiro que seja não apenas imparcial, mas também racional. ${ }^{41}$ Porém, a suposição de que a interpretação/aplicação da lei seja feita de maneira especialmente racional é contestada pelo experimento conduzido por Shai Dazinger, na Universidade de Tel-Aviv, que ficou conhecido como "Os Juízes de Israel". O estudo mostrou que a racionalidade dos juízes era severamente afetada por questões completamente estranhas aos elementos de prova existentes no processo. ${ }^{42}$ Outra pesquisa polêmica revelou que juízes americanos (geralmente republicanos), quando tiveram filhas do sexo feminino, acabaram mudando a postura em julgamentos que envolviam mulheres em algum momento de suas carreiras, inclinando-se mais para decisões qualificadas como feministas pelos pesquisadores; enquanto juízes que tinham filhos do sexo masculino não mudavam de postura. ${ }^{43} \mathrm{Em}$ suma, a atividade judicante — centro das atenções quando se trata de interpretar e aplicar o direito - supõe (dentro da engrenagem apresentada) um decisor (magistrado ou árbitro) racional e "neutro" (tecnicamente, imparcial). Essa racionalidade presumida ${ }^{44}$ entretanto, tem sua estatura questionada pela Psicologia Comportamental na noção de viés.

Daniel Kahneman ${ }^{45}$, dentre outros, mostram que o ato de decidir é viciado por uma série de vieses cognitivos que fazem duvidar da (hiper)racionalidade pressuposta pelo legislador. Há inúmeros exemplos desses vieses, mas, para entendê-los, é preciso compreender, antes, a metáfora explicativa ${ }^{46}$ dos sistemas cerebrais S1 e S2, raiz comum dos estudos de Kahnemann. S1 é uma espécie de "piloto automático" usado largamente para tarefas repetidas muitas vezes (como trocar a marcha de um carro, para quem já dirige há muito tempo) —é

sa arquitetura cognitiva. Mas as noções retributivistas de responsabilidade criminal definitivamente dependem dessa ilusão e, se tivermos sorte, elas darão lugar a noções consequencialistas, transformando radicalmente nossa abordagem de justiça criminal". GREENE, Joshua; COHEN, Jonathan. For law, neuroscience changes nothing and everything. Philosofical Transactions of the Royal Society of London. Series B, Biological Sciences 359, n. 1451, 2004. p. 1784.

40 "We can recognize that freewill, as conceptualized by the folk psychology system, is an illusion and structure our society accordingly by rejecting retributivist legal principles that derive their intuitive force from this illusion". Em tradução dos próprios autores: "Nós podemos reconhecer que o livre-arbítrio, como conceituado no sistema da psicologia popular, é uma ilusão e estruturar a sociedade de acordo com isso, rejeitando os princípios legais retributivistas que derivam sua força intuitiva dessa ilusão". GREENE, Joshua; COHEN, Jonathan. For law, neuroscience changes nothing and everything. Philosofical Transactions of the Royal Society of London. Series B, Biological Sciences 359, n. 1451, 2004. p. 1776.

41 JORGE NETO, Nagibe de Melo. Abrindo a caixa preta: por que a justiça não funciona no Brasil? Salvador: JusPODIVM, 2018. 42 Durante 10 (dez) meses, o estudo acompanhou o trabalho de 08 (oito) juízes que trabalhavam analisando a concessão de liberdade condicional e chegou à surpreendente conclusão que as chances de o criminoso ser libertado flutuavam de acordo com a fome do magistrado. No decorrer da manhã, as chances estatisticamente diminuíam, voltando a atingir seu nível máximo após o almoço, para tornar a cair ao longo da tarde. Ou seja, ao longo da sessão e com o passar do tempo da volta do intervalo, os níveis de concessão de condicional caiam bruscamente e as denegações da condicional, por serem a "decisão padrão" (default) e, portanto, menos custosa cognitivamente falando, predominavam. KAHNEMAN, Daniel. Rápido e devagar: duas formas de pensar. Rio de Janeiro: Objetiva, 2012.

43 GLYNN, Adam; MAYA, Sen. Identifying judicial empathy: does having daughters cause judges to rule for women's issues?. American Journal of Political Science, v. 59, n. 1, p. 37-54, 2015.

44 Não havendo distorção grave na capacidade (como seria o caso de um juiz senil, por exemplo), presume-se que o decisor seja racional.

45 KAHNEMAN, Daniel. Rápido e devagar: duas formas de pensar. Rio de Janeiro: Objetiva, 2012.

46 Trata-se de uma explicação metafórica porque Kahneman (2012) não apresenta um correlato físico específico desses sistemas na anatomia cerebral. Apenas separa, operacionalmente, o cérebro em dois sistemas distintos no propósito e na forma de funcionar, por razões evolutivas, mas que se inter-relacionam no dia a dia: um deles rápido, intuitivo, automático, que gera pouco esforço cognitivo, chamado de "Sistema 1" (S1); outro, mais lento, deliberativo, custoso, chamado de "Sistema 2" (S2). 
ele que permite chegar a um destino até mesmo sem se dar conta do percurso (quando o trajeto é já muito conhecido) ou abotoar uma camisa sem olhar para os botões como normalmente faz um adulto —; enfim, é "quem", geralmente, cuida de tarefas que são interpretadas pelo cérebro como um procedimento padronizado ou de situações repentinas de risco ou de fortes emoções, nas quais o tempo de resposta é decisivo. S2 é o responsável pelo raciocínio mais elaborado usado quando alguém faz uma conta matemática complexa, planeja uma viagem custosa, pensa sobre um argumento em uma discussão, por exemplo, ou mesmo quando faz, nas primeiras vezes, tarefas que, ainda, não automatizou (como aprender a dirigir).

Agora que se apresentou S1 e S2, pode-se trazer alguns exemplos de vieses. O esgotamento do ego (ego depletion), para começar, é o viés provocado pelo alto gasto energético para um esforço de vontade ou autocontrole, que são atividades cansativas para S2, exatamente como acontece no exemplo mencionado anteriormente dos juízes israelenses — nesse exemplo, o "esgotamento do ego" é o que justifica o regresso à tomada de decisões-padrão. Há, também, o priming ou viés associativo, bem sintetizado no brocardo "a primeira impressão é a que fica". É o que explica - por exemplo, porque a ordem na qual um candidato apresenta suas qualidades ou seus defeitos pode influir na escolha por uma vaga de emprego ou mesmo na avaliação preliminar da confiabilidade de uma pessoa. ${ }^{47}$ Já o viés confirmatório (confirmation bias) designa a tendência confirmatória que existe para as intuições e respostas imediatas de que já se dispõe, o que, talvez, ajudaria a explicar o baixo índice de sucesso de embargos de declaração e das retratações em agravo de instrumento, nos quais o próprio juiz precisaria rever aquilo que decidiu (também sugere a prudência de que não se deve dispensar o duplo grau de jurisdição sem grande circunspecção). ${ }^{48}$

What you see is all there is ("WYSIATI") é o viés pelo qual se desconsidera, olimpicamente, a existência de coisas que escapam à primeira percepção. ${ }^{49} \mathrm{O}$ brocardo o que não está nos autos, não está no mundo serve de analogia nesse caso (o que não está disponível à atenção, em regra, não está sendo processado no plano consciente); ou seja, a atenção interfere, também, em percepção, intuições e avaliações. Há, ainda, a ancoragem (anchoring), que é o viés pelo qual S1 adere ou ancora o raciocínio em referências que são apresentadas previamente, mas sem uma aparente ligação com a ação a ser adotada na sequência, ou seja, é o viés que explica por que se adere a uma referência meramente indicativa para uma avaliação posterior. Por exemplo, em um experimento, juízes alemães, com uma média de mais de 15 anos de experiência em tribunais, liam a mesma descrição de um furto de lojas, que teria sido feito por uma mulher, e, então, jogavam dados que estavam adulterados para resultarem sempre em combinações que somassem 3 ou 9 e, posteriormente, eram perguntados se sentenciariam essa mulher em números de meses maiores ou menores que os números dos dados; os juízes que viam o número 3 sentenciavam a mulher em 5 meses e os que viam o número 9 sentenciavam a mulher em 8 meses, de modo que a referência prévia dos dados lançados pelos juízes ancorava a decisão para cima ou para baixo. ${ }^{50}$

Os estudos em torno dos vieses, também, conferem novos contornos à preocupação com o debiasing (desenviesamento). ${ }^{51}$ Trata-se de um grande desafio para a funcionalidade da dinâmica jurídica: eliminar e/ ou minimizar os impactos que os vieses têm sobre as tomadas de decisão. Efetivamente, a partir do momento em que os vieses são identificados (e percebe-se a sua importância prática), abre-se em paralelo a discussão a respeito de saber se é possível se prevenir contra a sua ocorrência ou pelo menos identificá-los num momento posterior. Isso acontece porque elaborar uma lista dos vieses cognitivos identificados é, apenas, o

47 KAHNEMAN, Daniel. Rápido e devagar: duas formas de pensar. Rio de Janeiro: Objetiva, 2012. p. 69.

48 KAHNEMAN, Daniel. Rápido e devagar: duas formas de pensar. Rio de Janeiro: Objetiva, 2012. p. 106.

49 Em geral, é esse viés o que permite a trapaça de S1 sobre S2, e também o que costuma sustentar a carreira de mágicos ilusionistas. O que justificaria a ausência de pleonasmo no brocardo mineiro "olhe para você ver" (ou, no regionalismo típico: ói p’ocê vê!); olhar é um gesto mecânico de pôr a vista sobre algo, mas é a atenção que "vê", de modo que podemos "olhar sem ver" — de onde decorreria a sabedoria do Matuto de "ter olhos de ver" (Muito provavelmente, só aquele que tem "olhos de ver" saberia distinguir entre a pirita (ouro "de tolo") e o próprio ouro).

50 KAHNEMAN, Daniel. Rápido e devagar: duas formas de pensar. Rio de Janeiro: Objetiva, 2012. p. 160-161.

51 JOLLS, Christine; SUNSTEIN, Cass R. Debiasing through Law. The Journal of Legal Studies, v. 35, n. 1, p. 199-242, 2006. 
primeiro passo para viabilizar a interação entre Direito e Neurociência. A verdadeira busca pela construção de um Neurodireito exige que se pesquise a respeito de como lidar com as complexidades identificadas.

Outro importante reflexo desses estudos é ajudar a questionar a noção — igualmente já antevista por inúmeros filósofos e teóricos do direito - de que determinado texto de norma jurídica tenha um sentido "em si" (previamente escolhido pelo legislador e plenamente passível de ser reconhecido por um magistrado devidamente preparado). Avanços decorrentes da Teoria da Linguagem (e confirmados pela Neurociência) revelam, claramente, que as coisas que compõem o mundo sensível não têm sentido "em si". As viradas linguísticas (a primeira, abolindo a separação total entre sujeito e objeto e, a segunda, demonstrando que os sentidos são construídos mediante consenso) trazem revelações que foram amplamente confirmadas pelos estudos no campo das Ciências Cognitivas. ${ }^{52}$

Além dessas questões, a arquitetura cerebral mostra um sistema de visão e memória bem diferente da concepção de senso comum (de que a visão seria uma espécie de câmera e o cérebro um tipo de "disco rígido", no qual são registradas as imagens "filmadas"). Muitos estudos envolvendo testemunhas chegam a uma conclusão semelhante, quando constatam que elas são capazes de narrar fatos que não aconteceram e de reconhecer pessoas que não são culpadas por um delito ${ }^{53}$. Como diz Leonard Mlodinow ${ }^{54}$, "é raro haver provas do que realmente aconteceu, por isso, na maioria dos casos, nunca saberemos o quanto de nossas lembranças são realmente precisas".

Neste ponto do trabalho, é importante ressaltar que não se trata de pessoas que estejam mentindo e/ou de pessoas com a capacidade cognitiva prejudicada. Quando instadas a apresentar a explicação para determinados eventos, pessoas plenamente capazes e sinceras tendem a, simplesmente, criar narrativas que sejam capazes de organizar todos os fatos em um cenário coerente. ${ }^{55}$ Os seres humanos fazem isso consigo mesmo o tempo todo em um fenômeno chamado de autoengano ${ }^{56}$.

\subsection{E então?}

A essa altura, parece claro que as contribuições da Neurociência tocam a diversos aspectos da dinâmica jurídica. Seja na valoração das condutas, na confecção das normas, na repercussão dos estímulos, na decisão sobre como agir, na investigação dos fatos, na interpretação normativa ou na aplicação da lei, toda a sistemática de funcionamento do Direito merece uma releitura com base nos estudos acumulados ao longo das últimas décadas (e citados exemplificativamente neste tópico).

A soma dessas constatações deixa como legado um senso jurídico convencional desarticulado em suas premissas. Ainda assim, já se pode arriscar que o fim inevitável do aprofundamento dessa jornada de conhecimento de nosso cérebro é a releitura de virtualmente todos os campos que lidam com o comportamento humano. E não haverá de ser diferente com o Direito, dada a sua característica de ciência tipicamente cultural. Ainda é cedo, porém, para dizer quando exatamente os avanços futuros no conhecimento do cérebro levarão a esse fim. Enquanto não se chega ao final dessa história, porém, resta saber como lidar com o meio dela, incorporando e operacionalizando os conceitos vistos acima. O próximo tópico apresenta essa questão.

52 PINKER, Steven. Como a mente funciona. São Paulo: Companhia das Letras, 1998.

53 MLODINOW, Leonard. Subliminar. Rio de Janeiro: Zahar, 2013.

54 MLODINOW, Leonard. Subliminar. Rio de Janeiro: Zahar, 2013. p. 68.

$55 \mathrm{O}$ ato de criar narrativas imaginadas pode até mesmo ser um processo que constitui uma vantagem evolutiva. Como explica Yuval Noah Harari, "a capacidade de criar uma realidade imaginada com palavras possibilitou que um grande número de estranhos coopere de maneira eficaz". Mas e quando essas narrativas são utilizadas como provas num processo? (HARARI, Yuval Noah. Sapiens: uma breve história da humanidade. Porto Alegre: L\&PM, 2015. p. 41.)

56 GIANNETTI, Eduardo. Autoengano. São Paulo: Companhia das Letras, 2005. 


\section{O MEIO: RECONSTRUINDO O MODELO DA DINÂMICA JURÍDICA}

Ao longo do texto, apresentou-se um modelo ideal (típico do senso comum jurídico), no qual o Direito se organiza em torno da valoração das condutas por meio de normas jurídicas, cuja observância (ou não), interpretação e aplicação seria racional. Com base nas contribuições da Psicologia Comportamental e da Neurociência, observou-se que o status dessa racionalidade pode ser questionado com linguajar técnico próprio para isso. Demonstrou-se que esse modelo de tipo ideal e sua narrativa conveniente não passam de uma engrenagem desarranjada, que precisa de revisão. ${ }^{57}$

Porém, esse desarranjo não justifica que se descarte a ferramenta. Parece razoável afirmar que todas as sociedades precisam do Estado, ${ }^{58}$ e este, por sua vez, precisa do Direito (ainda que disfarçado em forma de Estado religioso). Bem ou mal, o ser humano evoluiu de forma a se coordenar em sociedade por meio do direito (sistemas morais e religiosos são incapazes sozinhos de sustentar sociedades superpovoadas como as atuais). É conveniente, portanto, a criação de um ramo interdisciplinar que possa ajudar a ajustar as engrenagens do Direito a essas novas premissas que foram expostas. Esse seria um passo importante no amadurecimento dos sistemas jurídicos (no lugar de simplesmente se aferrar às propostas combalidas de interpretação clássica, fechando os olhos para a complexidade do fenômeno jurídico e das relações sociais que os cercam).

O Neurodireito, segundo se entende, cumpriria exatamente esse papel. Trata-se de disciplina que teria objetivo de reunir estudos das mais diversas áreas neurocogtivas e comportamentais que auxiliem a rever os fundamentos e parte da dinâmica jurídica. Uma disciplina que fomentasse uma linha mais operacional para lidar com as complexidades do fenômeno jurídico que já não podem mais ser ignoradas, como o determinismo, vieses cognitivos e design da escolha pública, para citar apenas poucos exemplos. Mas, praticamente todas as áreas que se debruçam sobre o fenômeno jurídico podem ser sofisticadas a partir do diálogo com o Neurodireito.

Nessa linha, há pelos menos 03 (três) pontos bastante sensíveis: a) como a valoração de condutas pode produzir normas que, efetivamente, estimulem seus destinatários a agir de determinada maneira?; b) em que medida é possível se falar em um livre arbítrio que permita atribuir responsabilidades diversas aos agentes que não atendem aos comandos legais?; e c) existem formas de incrementar o grau de racionalidade da decisão judicial? São essas as questões que serão enfrentadas no presente tópico.

Em relação ao primeiro questionamento, as objeções ao modelo ideal feitas pela Neurociência mostram que não existe uma saída mágica para resolver o problema da regulação de condutas, especialmente em razão da pluralidade de valores que devem ser consagrados e/ou suprimidos, os quais nem sempre refletirão os valores dos destinatários da norma. A opção de convencimento pela decisão da maioria, mesmo sendo o mecanismo que ordinariamente prevalece em sistemas democráticos, não é garantia de que a minoria irá acatá-10 ${ }^{59}$. Ainda assim, a atual configuração dos processos legislativos no Estado Democrático de Direito (de modelo ocidental) é considerada como a mais eficiente até agora, embora se reconheça a sua limitação em cumprir as promessas democráticas. ${ }^{60}$ Esse modelo, como visto, pode ser aprimorado pelas alternativas

57 CRUZ, Álvaro Ricardo de Souza; WYKROTA, Leonardo Martins. Nos corredores do direito. In: CRUZ, Álvaro Ricardo de Souza (Org.). (O) outro (e) (o) direito. Belo Horizonte: Arraes, 2015.

58 NOZICK, Robert. Anarquia, Estado e utopia. São Paulo: WMF Martins Fontes, 2011.

59 Nesse sentido, Matheus Passos Silva chama atenção para o fato de que "apesar da contínua ampliação do direito ao sufrágio - o que permite o entendimento de que cada vez mais e mais cidadãos passaram a ter a possibilidade de intervir nos rumos do Estado —, o que se percebe, na atualidade, é que ocorre um verdadeiro descontentamento do cidadão com a política de maneira geral. Em maior ou menor grau, os cidadãos têm vindo a rechaçar "a política", ou a "classe política", como sendo algo que, a cada dia, parece deixar de ser um "mal necessário" para se transformar em verdadeiro incômodo na vida cotidiana". SILVA, Matheus Passos. Uma perspectiva comparada acerca da (não) efetividade da democracia local no Brasil e em Portugal. Rev. Bras. Polít. Públicas (Online), Brasília, v. 6, n. 2, p. 11-28, 2016.

60 MARDEN, Carlos. Democracia sitiada. In: MORAIS, Jose Luis Bolzan de; SARAIVA, Bruno Cozza (Org.). Estado \& Constituição. Florianópolis: Empório do Direito, 2016. 
comportamentais que a proposta de nudge (por exemplo) oferece.

O simples fato de se chamar a atenção do destinatário das normas para a capacidade institucional daqueles que a editam já pode ser uma vantagem. Nesse sentido, o minimalismo de Sunstein e Vermeule, por exemplo, defende o afastamento tanto do Poder Judiciário quanto do Poder Legislativo de questões regulatórias ${ }^{61}$. Para eles, deveria caber exclusivamente às agências reguladoras a edição de determinadas normas de caráter técnico (p. ex. qual quantidade de conservante o Estado se deve admitir nos alimentos? Ou qual o nível de agrotóxico deve ser tolerado?). Nem o Poder Legislativo, nem o Poder Judiciário, por exemplo, teriam capacidade institucional para decidir sobre essas questões. E essa "incapacidade" resultaria, justamente, de vieses decisórios, como mostram os autores. Claro que essa é uma teoria em disputa, e o simples fato de encontrar amparo neurocientífico não mostra que as conclusões estariam corretas. As agências podem ser cooptadas pelo setor privado e, nesse caso, seriam tão ou mais incapazes de decidir sobre a melhor opção para a sociedade quanto o próprio judiciário. O que se põe em evidência, entretanto, é a necessidade de se levar em conta estudos empíricos no lugar de simplesmente presumir que a engrenagem deva funcionar segundo um tipo ideal que já se viu falido.

Em relação ao segundo questionamento, já se adiantou a objeção ao livre arbítrio. Ela não implica, contudo, o descarte do sistema penal (assumindo-se a inimputabilidade geral, já que não haveria, propriamente, "escolha da conduta delituosa"). Um sistema criminal que levasse em conta as contribuições teóricas da Neurociência deveria abrir mão de trabalhar com o conceito de responsabilidade pelos atos passados e se colocar como consequencialista, de maneira que as penas/punições deveriam levar em conta, principalmente, as possibilidades de mudança de comportamento e/ou de o agente cometer novo ato ilícito. No mesmo sentido, David Eagleman" ${ }^{62}$ afirma que "não pode fazer sentido que a culpabilidade seja determinada pelos limites da tecnologia atual", e que nem todos, talvez, sejam igualmente 'livres' para fazer escolhas socialmente corretas. $^{63}$ A partir de tal constatação (e seguindo a linha de Joshua Greene e Jonathan Cohen), o autor sustenta que está equivocada a política criminal baseada na imputabilidade vinculada à ilusão do livre-arbítrio.

Pleitear uma total superação do conceito de responsabilidade/imputabilidade pode parecer uma solução muito radical e estar muito distante da atual realidade. Afinal, a dinâmica jurídica opera inserida em um contexto social ${ }^{64}$ e nem sempre existem condições sociais que permitam que o Direito incorpore, abruptamente, as contribuições científicas. Entretanto, a incapacidade de absorver novas descobertas e promover grandes rupturas não deve ser motivo para ignorar o conhecimento oriundo da pesquisa científica. Ainda que não se possa implementar um sistema totalmente prospectivo, haverá um significativo ganho sistêmico ao incorporar o tratamento biológico da questão ${ }^{65}$.

Por fim, a influência dos vieses cognitivos agrava uma cultura jurídica que nutre um forte desprezo pelo contraditório e pela fundamentação da decisão. O que esperar de um processo no qual um magistrado de raciocínio enviesado (como todas as outras pessoas) decide com base em provas que não são confiáveis, aplicando uma lei que não tem interpretação objetiva? Certamente, é uma pergunta delicada e que exige uma pequena mudança de perspectiva, pois existe um equívoco em se questionar a utilidade do processo a partir da resolução de conflito. No Estado Democrático de Direito, o processo não deve ser visto, apenas, como um instrumento para resolver conflitos (embora eventualmente o faça), mas sim como uma tecnologia de aplicação do Ordenamento Jurídico. A aplicação da norma pode se dar de inúmeras maneiras (inclusive de forma espontânea), mas o processo tem a peculiaridade de fazer isso assegurando aos envolvidos o contraditório e a ampla defesa, em um devido processo legal público, mediante o qual (em tempo razoável) um

61 SUNSTEIN, Cass R.; VERMEULE, Adrian. Interpretation and institutions. Michigan Law Review, v. 101, n. 4, p. 885-951, 2003.

62 EAGLEMAN, David. Incógnito: as vidas secretas do cérebro. Rio de Janeiro: Rocco, 2012. p. 169.

63 EAGLEMAN, David. Incógnito: as vidas secretas do cérebro. Rio de Janeiro: Rocco, 2012. p. 189.

64 LUHMANN, Niklas. Sociologia do direito. Rio de Janeiro: Tempo Brasileiro, 1997.

65 Não é à toa que os números mostram que o tratamento repressivo nem sempre é efetivo no Direito Penal. SACHSIDA, Adolfo; MENDONÇA, Mário Jorge Cardoso de; MOREIRA, Tito Belchior Silva. O impacto de diferentes tipos de repressão legal sobre as taxas de homicídio entre os estados brasileiros. Revista Brasileira de Políticas Públicas, Brasília, v. 5, n. 2, p. 99-112, 2015. 
terceiro imparcial julgará de maneira fundamentada. ${ }^{66}$

Esses poucos exemplos que foram escolhidos e as breves reflexões que foram apresentadas são uma forma didática de introduzir aquilo que se pretende chamar de Neurodireito. Uma visão realista da dinâmica jurídica exige que (na medida do possível) sejam abandonadas as ilusões que cercam a operacionalidade do Ordenamento Jurídico, especialmente no que diz respeito às peculiaridades de seus agentes, enquanto seres humanos racionais. Embora pareça ser impossível (mesmo em longo prazo) imaginar uma Ciência Jurídica capaz de incorporar todas as complexidades dos seres humanos, há um inegável ganho sistêmico em incorporar tantas complexidades quantas for possível. Este parece ser o objetivo do Neurodireito: sofisticar a dinâmica jurídica mediante incorporação das descobertas da Neurociência.

\section{Considerações finais: um caminho chamado Neurodireito}

Um século depois do surgimento da Psicologia Comportamental e décadas depois da instrumentalização da Neurociência, nenhuma área do conhecimento pode simplesmente ignorar as contribuições teóricas que se acumularam. Tal afirmação é especialmente verdade para as ciências que lidam diretamente com o comportamento humano e adquire uma relevância exponencial quando se trata do Direito. Em todo e qualquer momento, o fenômeno jurídico tem a sua dinâmica criada, operacionalizada e dirigida a seres humanos, motivo pelo qual não faz qualquer sentido organizar o sistema sem levar em conta a complexidade dos indivíduos. E, se ainda se sabe muito pouco da mente e se está longe de entendê-la por completo ${ }^{67}$, isso já é o suficiente para não permitir que o Direito continue a operar como o fazia no Século XIX.

Numa primeira impressão, pode ser que o contato com as ideias aqui reunidas (sob o rótulo de Neurodireito em geral e algumas conquistas da Neurociência em particular) suscitem certo sentimento de "terra arrasada", especialmente pela ruptura com os modelos tradicionais de racionalidade e neutralidade de padrões iluministas (ainda encampados no senso comum jurídico). Não se trata, porém, de abraçar a completa irracionalidade do agir humano, para descrer completamente do modelo jurídico, mas sim de encontrar formas de entender melhor e lidar operacionalmente com essa irracionalidade.

O Século XXI já conta com uma quantidade imensa de conhecimento acumulado no campo da Neurociência, desafiando o Direito a se adaptar às novas descobertas. Pensar em termos de Neurodireito é reconhecer a complexidade da mente humana e tentar trabalhar com a forma como ela afeta o comportamento das pessoas. Se, por um lado, estão em xeque uma série de credos há muito cultuados pelo Direito; por outro, $o$ Neurodireito desponta como um novo instrumental para aprimorar as engrenagens do modelo jurídico. Como esclarece Richard Posner, ${ }^{68}$ incursões teóricas com esse propósito "consistem em métodos que nos permitem contornar nossas tendências irracionais, nunca em mecanismos por meio dos quais podemos nos livrar delas".

Longe de comprometer a credibilidade do Direito, aprende-se a enxergar e enfrentar novas complexidades antes ignoradas. O importante é ajudar a desentrincheirar doutrinas de tipo ideal que, por conveniência de seus seguidores (que já se sabe ser justificável pelo viés confirmatório que vimos), simplesmente ignoram as amplas possibilidades de diálogo para as quais se abre Neurodireito abre. Trata-se de nova ferramenta para ajudar na busca pelo que Horgan chama de epifania reducionista, na qual cada uma das ciências deve oferecer instrumentos para ajudar o ser humano a apreender, reduzir e, logo após, introduzir novas comple-

66 O ganho sistêmico (e o próprio motivo de existir) do processo não está na aplicação da norma (coisas que muitas vezes ele até dificulta), mas sim em fazer com que essa aplicação seja submetida ao devido processo constitucional. MARDEN, Carlos. A ražóvel duração do processo: o fenômeno temporal e o modelo constitucional de processo. Curitiba: Juruá, 2015.

67 HORGAN, John. A mente desconhecida: por que a ciência não consegue replicar, medicar e explicar o cérebro humano. São Paulo: Companhia das Letras, 2002.

68 POSNER, Richard. Fronteiras da teoria do direito. São Paulo: WMF Martins Fontes, 2011. p. 372. 
xidades em determinados sistemas ${ }^{69}$. Enquanto sistema de regulação de condutas, o Direito não pode abrir mão de incorporar, progressivamente, os conhecimentos que as outras ciências produzem para sofisticar a compreensão sobre o seu principal objeto de estudo: o comportamento humano.

O Neurodireito se apresenta como sendo o caminho mais provável de oferecer ao sistema jurídico a sofisticação que ele precisa impor à sua dinâmica de funcionamento, de maneira que é preciso que os juristas se acostumem a lidar com essa interlocução que tende a se intensificar e a exigir adaptações cada vez mais significativas. Este trabalho é uma reflexão inicial a respeito de como tornar isso possível.

\section{REFERÊNCIAS}

ALEXY, Robert. Constitucionalismo discursivo. Porto Alegre: Livraria do Advogado, 2007.

BELTRÁN, Jordi Ferrer. La valoración racional de la prueba. Madri: Marcial Pons, 2007.

BOBBIO, Norberto. Teoria geral do direito. São Paulo: Martins Fontes, 2010.

BRASIL. Código Civil: Lei 10.406, de 10 de janeiro de 2002. São Paulo: Revista dos Tribunais, 2002.

BRASIL. Decreto-Lei 2.848, de 7 de dezembro de 1940. Código Penal. Disponível em: < http://www.planalto. gov.br/ccivil_03/decreto-lei/Del2848compilado.htm>. Acesso em: 20 maio 2018.

CHURCHLAND, Patricia Smith. Neurophilosophy: toward a unified science of the mind-brain. Cambridge, Mass: MIT Press, 1989.

CRUZ, Álvaro Ricardo de Souza. A resposta correta: incursões jurídicas e filosóficas sobre as teorias da justiça. Belo Horizonte: Arraes, 2011.

CRUZ, Álvaro Ricardo de Souza; DUARTE Bernardo Augusto Ferreira. Além do positivismo jurídico. Belo Horizonte: Arraes, 2013.

CRUZ, Álvaro Ricardo de Souza; WYKROTA, Leonardo Martins. Nos corredores do direito. In: CRUZ, Álvaro Ricardo de Souza (Org.). (O) outro (e) (o) direito. Belo Horizonte: Arraes, 2015.

DAMÁSIO, Antônio R. E o cérebro criou o homem. São Paulo: Companhia das Letras, 2011.

DEL VECCIO, Giorgio. Lições de filosofia do direito. Coimbra: Armênio Amado, 1979.

DWORKIN, Ronald. Levando os direitos a sério. São Paulo: WMF Martins Fontes, 2010.

EAGLEMAN, David. Cérebro: uma biografia. Rio de Janeiro: Rocco, 2017.

EAGLEMAN, David. Incógnito: as vidas secretas do cérebro. Rio de Janeiro: Rocco, 2012.

GALVÃO, Ciro di Benatti. Ativismo judicial: o contexto de sua compreensão para a construção de decisões judiciais racionais. Revista Brasileira de Políticas Públicas, Brasília, v. 5, Número Especial, p. 88-99, 2015.

GIANNETTI, Eduardo. Autoengano. São Paulo: Companhia das Letras, 2005.

GREENE, Joshua; COHEN, Jonathan. For law, neuroscience changes nothing and everything. Philosofical Transactions of the Royal Society of London. Series B, Biological Sciences 359, n. 1451, 2004.

HARARI, Yuval Noah. Sapiens: uma breve história da humanidade. Porto Alegre: L\&PM, 2015.

HARRIS, Sam. A paisagem moral: como a ciência pode determinar os valores humanos. São Paulo: Companhia das Letras, 2013.

69 HORGAN, John. A mente desconhecida: por que a ciência não consegue replicar, medicar e explicar o cérebro humano. São Paulo: Companhia das Letras, 2002. 
HORGAN, John. A mente desconhecida: por que a ciência não consegue replicar, medicar e explicar o cérebro humano. São Paulo: Companhia das Letras, 2002.

JOLLS, Christine; SUNSTEIN, Cass R. Debiasing through law. The Journal of Legal Studies, v. 35, n. 1, p. 199-242, 2006.

JORGE NETO, Nagibe de Melo. Abrindo a caixa preta: por que a justiça não funciona no Brasil? Salvador: JusPODIVM, 2018.

KAHNEMAN, Daniel. Rápido e devagar: duas formas de pensar. Rio de Janeiro: Objetiva, 2012.

KURAN, Timur; SUNSTEIN, Cass. Availability cascades and risk regulation. University of Chicago Public Law \& Legal Theory Working Paper, n. 181, 2007.

LEAL, André Cordeiro. O contraditório e a fundamentação das decisões. Belo Horizonte: Mandamentos, 2002.

LUHMANN, Niklas. Sociologia do direito. Rio de Janeiro: Tempo Brasileiro, 1997.

MARDEN, Carlos. A raz̧oável duração do processo: o fenômeno temporal e o modelo constitucional de processo. Curitiba: Juruá, 2015.

MARDEN, Carlos. Democracia sitiada. In: MORAIS, Jose Luis Bolzan de; SARAIVA, Bruno Cozza (Org.). Estado \& Constituição. Florianópolis: Empório do Direito, 2016.

MLODINOW, Leonard. Subliminar. Rio de Janeiro: Zahar, 2013.

MORIN, Edgar. Introdução ao pensamento complexo. Porto Alegre: Sulina, 2011.

NEVES, Marcelo. Entre Hidra e Hércules: princípios e regras constitucionais. São Paulo: WMF Martins Fontes, 2014.

NOZICK, Robert. Anarquia, Estado e utopia. São Paulo: WMF Martins Fontes, 2011.

PINKER, Steven. Como a mente funciona. São Paulo: Companhia das Letras, 1998.

POSNER, Richard. Fronteiras da teoria do direito. São Paulo: WMF Martins Fontes, 2011.

REALE, Miguel. Lições preliminares de direito. São Paulo: Saraiva, 2002.

ROSANVALLON, Pierre. La legitimidad democrática: imparcialidad, reflexividad y proximidad. Barcelona: Paidós, 2010.

SACHSIDA, Adolfo; MENDONÇA, Mário Jorge Cardoso de; MOREIRA, Tito Belchior Silva. O impacto de diferentes tipos de repressão legal sobre as taxas de homicídio entre os estados brasileiros. Revista Brasileira de Políticas Públicas, Brasília, v. 5, n. 2, p. 99-12, 2015.

SCHAUER, Frederick. The force of law. Cambridge: Harvard University Press, 2015.

SILVA, Matheus Passos. Uma perspectiva comparada acerca da (não) efetividade da democracia local no Brasil e em Portugal. Revista Brasileira de Políticas Públicas, Brasília, v. 6, n. 2, p. 11-28, 2016.

SUXBERGER, Antonio Henrique Graciano; LIMA, José Wilson Ferreira. O processo penal e a engenharia de controle da política criminal. Revista Brasileira de Políticas Públicas, Brasília, v. 7, n. 1, p. 286-303, 2017.

TARUFFO, Michele. Uma simples verdade: o juiz e a construção dos fatos. São Paulo: Marcial Pons, 2012.

THALER, Richard H.; SUNSTEIN, Cass R. Nudge: o empurrão pra escolha certa. Rio de Janeiro: CampusElsevier, 2008.

WAAL, Franz de. Eu, primata: por que somos como somos. São Paulo: Companhia das Letras, 2007.

WRIGHT, Robert. O animal moral: por que somos como somos: a nova ciência da psicologia evolucionista. Rio de Janeiro: Elsevier, 2006. 


\section{REVISTA BRASILEIRA DE POLÍTICAS PÚBLICAS BRAZILIAN JOURNAL OF PUBLIC POLICY}

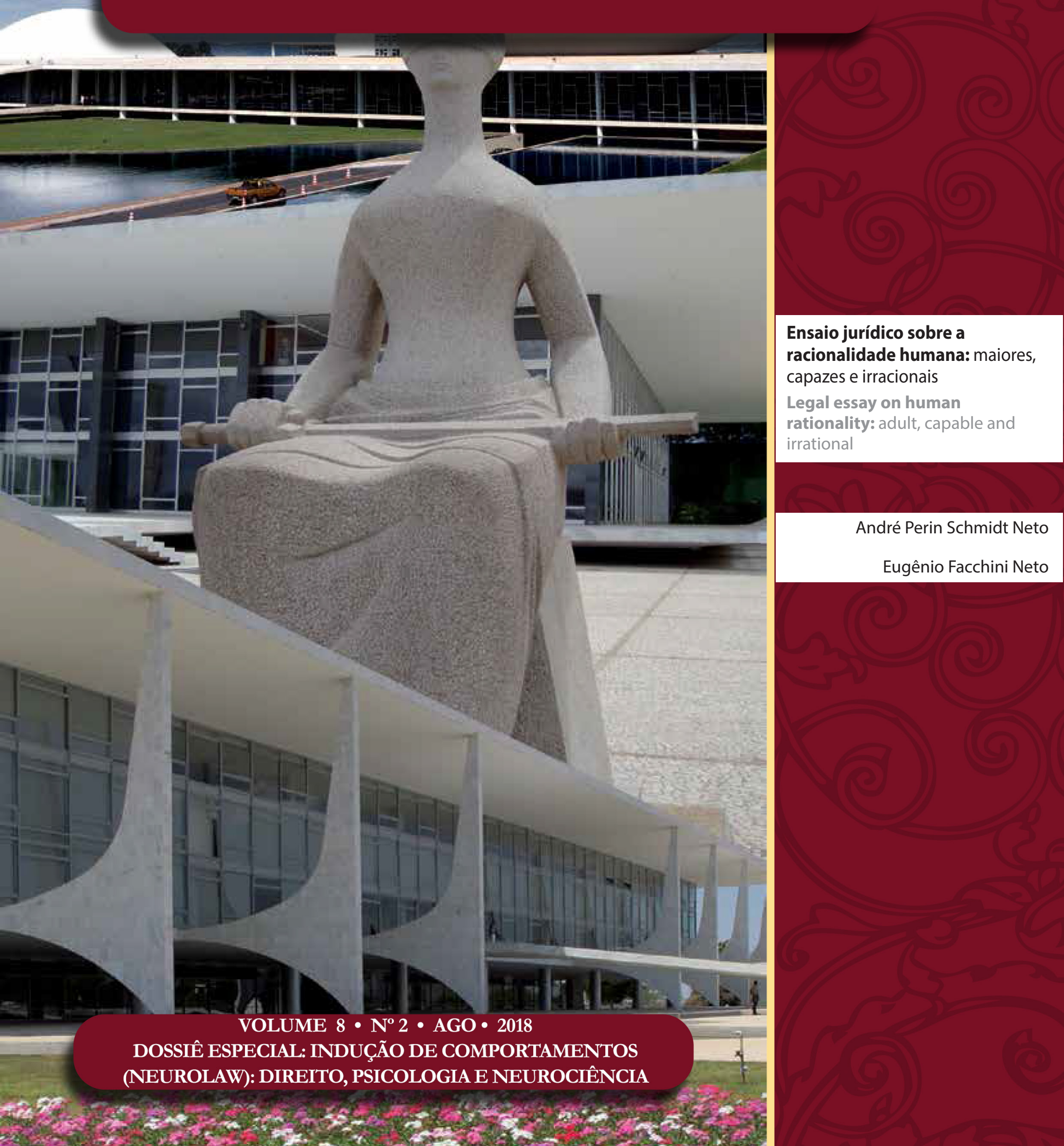




\title{
Ensaio jurídico sobre a racionalidade humana: maiores, capazes e irracionais*
}

\section{Legal essay on human rationality: adult, capable and irrational}

\author{
André Perin Schmidt Neto** \\ Eugênio Facchini Neto***
}

Dizem que o homem é um animal racional. Tenho procurado a vida toda alguma evidência dessa afirmação. (Bertrand Russell)

* Recebido em 31/05/2018 Aprovado em 29/07/2018

** Doutor em Direito Comparado (Università Degli Studi di Firenze/Itália), Mestre em Direito Civil (Faculdade de Direito da Universidade de São Paulo - USP). Professor Titular dos Cursos de Graduação, Mestrado e Doutorado em Direito da PUC/RS. Professor e ex-diretor da Escola Superior da Magistratura/AJURIS. Desembargador do Tribunal de Justiça do Estado do Rio Grande do Sul/Brasil. E-mail: facchini@tirs.jus.br

*** Pós-doutor (Università degli Studio di Salerno/Itália). Doutor, Mestre, bolsista CAPES e especialista em Direito do Consumidor e Direitos Fundamentais (Universidade Federal do Rio Grande do Sul - UFRGS). Professor da Pontifícia Universidade Católica do Rio Grande do Sul (PUC/RS) onde coordena o Grupo de Estudos "Superendividamento: crédito e sociedade de consumo" e da Universidade do Vale do Rio dos Sinos (UNISINOS). Professor da Pós-Graduação Lato Sensu da UFRGS, PUCRS, UNISINOS, UNIRITTER, URI. Professor da Escola Superior da Magistratura/AJURIS, onde é pós-graduado. Membro da Comissão Especial de Defesa do Consumidor da Ordem dos Advogados do Brasil. Autor de livros e artigos jurídicos. Advogado em Porto Alegre/RS. E-mail: andre.schmidt.adv@ gmail.com

\section{Resumo}

$\mathrm{O}$ artigo discute o acerto da pressuposição de que pessoas maiores e capazes sempre agem livremente e realizam escolhas racionais, sendo, portanto, juridicamente responsáveis pelos seus comportamentos. O tema da racionalidade humana é revisitado com base nas noções científicas provenientes da psicologia comportamental e da economia comportamental. Insights oriundos dessas áreas demonstram como os processos psicológicos de tomada de decisão são complexos e nem sempre racionais. Processos mentais denominados de ajustamento, ancoragem, disponibilidade e representatividade são inconscientemente utilizados quando tomamos decisões. Características humanas como o superotimismo e a aversão a perdas, também, estão presentes. O resultado da conjunção desses fatores é que tomamos decisões que nem sempre passam pelo teste da racionalidade. Seres humanos são influenciáveis e sugestionáveis. Dominando determinadas técnicas, agentes econômicos induzem consumidores e outras pessoas vulneráveis a tomarem decisões que nem sempre consultam seus próprios interesses. Embora a ciência jurídica não possa prescindir do pressuposto da liberdade com responsabilidade, ligando consequências jurídicas a condutas aparentemente livres e desejadas, não pode o Direito desconhecer a fragilidade da base sobre a qual se assentam alguns institutos jurídicos, especialmente no campo da responsabilidade contratual e extracontratual. $\mathrm{O}$ artigo conclui apontando alguns efeitos jurídicos possíveis do reconhecimento desse déficit de racionalidade humana. A originalidade do artigo consiste em chamar a atenção dos juristas para os potenciais efeitos jurídicos da irracionalidade do agir humano, visando ampliar a proteção jurídica da pessoa humana. Utilizou-se o método dialético, lançando-se mão de pesquisa bibliográfica básica, visando sua aplicação, com abordagem qualitativa.

Palavras-chave: Psicologia e economia comportamentais. Irracionalidade humana. Efeitos jurídicos. 


\section{Abstract}

The article discusses the accuracy of the assumption that grown-up and capable people always act freely and make rational choices and are therefore legally responsible for their behavior. The theme of human rationality is revisited based on scientific notions from other areas of knowledge, especially behavioral psychology and behavioral economics. Insights from these areas demonstrate how psychological processes of decision making are complex and not always rational. Mental processes called adjustment, anchoring, availability, and representativeness are unconsciously used when making decisions. Human characteristics such as super-optimism and loss-aversion are also present. The result of the conjunction of these factors is that we make decisions that do not always pass the test of rationality. Human beings are influential and suggestible. By mastering certain techniques, economic agents induce consumers and other vulnerable people to make decisions that do not always consult their own interests. Although legal science can not give-away the presupposition of freedom with responsibility, linking legal consequences to seemingly free and desired conduct, law can not ignore the fragility of the basis on which some legal institutes are based, especially in the field of contractual and extracontractual liability. The article concludes by pointing out some possible legal effects of the recognition of this deficit of human rationality. The originality of the article is to draw the attention of jurists to the potential legal effects of the irrationality of human action, aiming to broaden the legal protection of the human person. The dialectical method was used in a bibliographic research, with a qualitative approach.

Keywords: Psychology and behavioral economics. Human irrationality. Legal effects.

\section{INTRODUÇÃo}

A pressuposição básica que subjaz aos mais variados institutos jurídicos consiste na premissa de que o ser humano maior e capaz caracteriza-se por sua liberdade e racionalidade. Como tal, é livre para escolher entre condutas a adotar. A escolha entre as diversas alternativas é fruto de uma reflexão racional. A consequência lógica é que ele pode ser responsabilizado pelo resultado de suas condutas, a ele podendo ser imputados os efeitos previstos em lei para cada segmento jurídico. Isso é válido para o direito penal, para o direito contratual, para a responsabilidade civil extracontratual, para o direito de família, e para os demais ramos do direito em que o comportamento de uma pessoa é relevante para a produção de efeitos jurídicos. Assim, por exemplo, no direito penal, toda a ideia de incriminação funda-se na percepção de que seres humanos têm a liberdade para praticar ou não um tipo penal. A infração penal, voluntariamente praticada, por ser reprovável, acarreta a sanção penal correspondente. Quem não tem imputabilidade não responde penalmente por seus atos. Igualmente não sofre juízo de reprovabilidade penal quem age sob coação irresistível. No direito contratual, só pessoas capazes, livres de qualquer coação, podem assumir obrigações negociais. Assumindo livremente determinada obrigação, fica-se obrigado a cumprir fielmente o que foi pactuado, oriundo de vontade externada - pacta sunt servanda. Classicamente, somente atos culposos (ou seja, voluntários ou negligentemente praticados) acarretavam a responsabilidade aquiliana de alguém. Somente por exceção - e em tempos mais recentes — se admitiu a responsabilidade objetiva de pessoas físicas, desconsiderando-se sua percepção anímica.

A própria noção de democracia se assenta nessa pressuposição: partidos e candidatos se apresentam ao eleitor com suas propostas; devidamente informado sobre elas, o eleitor racionalmente escolheria entre um deles, de forma livre; uma vez eleito, o agente político usaria o poder que lhe é inerente para fazer escolhas entre várias opções de políticas públicas ou de alternativas legislativas. Essas escolhas, feitas por seu representante político, igualmente vinculam e obrigam o cidadão.

O presente artigo, embora reconhecendo que tal pressuposição é imprescindível para a convivência 
jurídica em sociedades civilizadas, questiona os limites da ideia de que os seres humanos sempre tomam decisões livres e racionais.

Após analisar a forma clássica como a racionalidade e o livre-arbítrio ingressou nos institutos jurídicos, passando a constituir noção pressuposta e não mais discutida, sendo considerada inerente a qualquer manifestação de vontade de pessoas maiores e capazes, o artigo questiona o alcance de tal noção, com base nas contribuições oriundas de outras áreas do saber, como a psicologia comportamental e a economia comportamental. Na última parte do artigo, os autores discutem alguns impactos dessa relativização do livre-arbítrio no mundo jurídico, apontando determinados efeitos.

Quanto aos aspectos metodológicos, trata-se de uma pesquisa que vai da básica à aplicada, com abordagem qualitativa, sendo usado o método dialético ${ }^{1}$. No que se refere ao procedimento, utiliza-se a pesquisa bibliográfica.

\section{A racionalidade pREsSUPosta}

"Há momentos em que os homens são donos de seu fado. Não é dos astros, caro Brutus, a culpa, mas de nós mesmos, se nos rebaixamos ao papel de instrumentos". (Shakespeare, Júlio César, Ato 1, Cena II) ${ }^{2}$

Escrevendo em pleno humanismo renascentista era natural que Shakespeare colocasse na boca de seus personagens palavras representativas de noções correntes naquele período histórico. Vivia ele num período em que o homem, libertando-se do jugo de uma estreita visão religiosa de mundo, acreditava ser dono de seu destino, capaz de, pela razão, explicar o mundo e seus fenômenos. Já na época dos antigos romanos e, anteriormente, dos gregos, era relativamente corrente a ideia de que os homens eram quase que joguetes do destino, manipulado pelos humores dos deuses. Hoje, sabemos que os insondáveis mistérios do inconsciente comandam parte de nossas condutas - e impactam nossos destinos —; às vezes, a outra parte é comandada por estratégias de publicidade e marketing que, conhecedoras dos mecanismos anímicos do sugestionamento, influenciam nossos comportamentos. Parece que migramos de um determinismo comandado por deuses brincalhões, passamos por um livre-arbítrio consentido pelo Deus cristão, e chegamos, segundo alguns, a um determinismo identificado pela deusa-ciência: a mente comandada pelo inconsciente; comportamentos comandados por marqueteiros, publicitários, youtubers e diversos outros formadores de opiniões.

Ao contrário dos outros animais, que agem por instinto, o ser humano é o único ser capaz de tomar decisões racionais. ${ }^{3}$ Essa é a premissa sobre a qual foi construída a civilização tal qual a conhecemos. Após

1 "Método dialético (Hegel, G.): empregado em pesquisa qualitativa, considera que os fatos não podem ser considerados fora de um contexto social; as contradições se transcendem dando origem a novas contradições que requerem soluções" - segundo ALMEIDA, Mauricio B. Noções básicas sobre metodologia de pesquisa científica. Disponível em: <http://mba.eci.ufmg.br/downloads/ metodologia.pdf>. Acesso em: 21 jul. 2018. No caso em tela, parte-se de pressuposição (tese) de que o homem é um ser racional e que, portanto, é capaz de tomar as decisões que melhor consultam seus reais interesses para, na sequência, se questionar (antítese) os fundamentos de tal pressuposição, indicando pesquisas que apontam para aspectos irracionais do comportamento humano, tentando-se, ao final (síntese), verificar como é possível a manutenção de tantos institutos jurídicos que pressupõe a racionalidade humana, com a tutela cada vez mais imprescindível de um ser humano que se revela cada vez mais vulnerável.

2 Trata-se da fala de Cássio, dirigida a Brutus, procurando convencê-lo a agir, para evitar que César se proclamasse Imperador e colocasse fim à República Romana. SHAKESPEARE, William. Júlio César. 2000. p. 18-19. Disponível em: < http://www.ebooksbrasil.org/eLibris/cesar.html>.

3 La rationalisation n'est pas un phénomène propre uniquement à l'epoque moderne, bien qu'il ait pris des proportions considérables depuis l'apparition des sciences expérimentales et mathématisables au lendemain immédiat de la Renaissance. La rationalité ne représent pas non plus un phénomène propre au droit, elle s'est développée dans l'ensemble des activités humaines. (Em tradução livre: A racionalização não é um fenômeno específico da era moderna, embora tenha tomado proporções consideráveis, desde o surgimento das ciências experimentais e matematizáveis subseqüentes ao Renascimento. A racionalidade não representa mais um fenômeno próprio do direito, pois tem se desenvolvido em todas as áreas humanas). CHARDIN, Nicole. Le contrat de consommation de crédit et l'autonomie de la volonté. Paris: LGDJ, 1988. p. 173. 
ter saído das cavernas e, aos poucos, se organizado, liberando tempo para reflexões além das necessidades imediatas de garantir a sobrevivência física, o bomo sapiens questionou-se sobre suas diferenças frente aos demais animais. A diferença mais evidente parecia ser a inteligência humana, vista como capacidade de refletir e tomar decisões, alterando o meio ambiente e nele introduzindo inovações ${ }^{4}$. Os demais animais eram vistos como seres vivos que apenas reproduziam padrões instintivos, meramente reagindo a estímulos externos, incapazes de terem ações proativas. Inteligência, portanto, seria o fator distintivo.

Todavia, muito tempo teve que passar para que o homem moderno percebesse que os animais, também, possuem inteligência, ainda que em níveis diversos e inferiores à dos humanos (ao menos na concepção vulgar de inteligência). Pensou-se, assim, que a afetividade pudesse ser o fator discriminatório ${ }^{5}$. Sob esse novo enfoque, seres humanos seriam a única espécie de animal capaz de estabelecer genuínas trocas afetivas, de amar e de sentir empatia (entendida como capacidade de mentalmente colocar-se no lugar de seu semelhante). Contudo, observações mais atentas do reino animal revelam que, também, os animais são capazes de estabelecer vínculos afetivos, tanto entre si como com seres humanos. Aliás, os vínculos afetivos que alguns seres humanos criam com seus animais domésticos, certamente, superam em intensidade os vínculos afetivos que certas pessoas nutrem para com outros seres humanos. Não por acaso surgiu, nas últimas décadas, um grande número de juristas envolvidos com a criação e desenvolvimento de um "direito dos animais". Correntes internas dividem-se entre ver nos animais objetos que não são coisas (posição adotada recentemente pela legislação portuguesa - Estatuto Jurídico dos Animais, entrado em vigor em $1^{\circ}$ de maio de 2017 —, reconhecendo-os como seres vivos dotados de sensibilidade, autonomizando-os face a pessoas e coisas), e, portanto, merecedores de especial proteção jurídica, até correntes que identificam os animais como sujeitos não humanos ${ }^{6}{ }^{7}$

Rousseau lançou, então, a ideia de que a diferença entre seres humanos e os demais animais residiria não na inteligência e nem na afetividade — comuns a humanos e a animais, embora em graus diversos — mas sim na perfectibilidade, ou seja, na capacidade exclusiva dos seres humanos de pensar no futuro, de projetar-se, de melhorar-se, de aperfeiçoar-se ou até mesmo de tomar decisões que o prejudicam e podem até ameaçar sua existência pessoal ${ }^{8}$. Os demais animais, ao contrário, seriam incapazes de refletir sobre o futuro, de per-

4 HARARI, Yuval Noah. Sapiens: uma breve história da humanidade. Tradução Janaína Marcoantonio. 19. ed. Porto Alegre: L\&PM, 2017.

5 A ideia foi avançada por René Descartes. Sobre sua contribuição sobre o tema, comparada com a distinção aristotélica (baseada na capacidade humana de raciocinar) que a precedeu e com a ideia rousseauniana de perfectibilidade (ligada à liberdade) que a sucedeu, v. FERRY, Luc. Aprender a viver: filosofia para os novos tempos. Tradução Véra Lucia dos Reis. Rio de Janeiro: Objetiva, 2006. Capítulo 2, especialmente o item denominado "Três consequências maiores da nova definição das diferenças entre animalidade e humanidade: os homens, únicos seres portadores de história, de igual dignidade e de inquietação moral”.

6 Não é recente o reconhecimento que os animais têm direito a proteção especial, diferenciando-se das coisas. Se alguém chuta seu balde e o destrói, tal atitude é irrelevante para o Direito. Todavia, não pode fazer o mesmo com um cachorro, mesmo que lhe pertença. Em 27/01/1978 a UNESCO/ONU aprovou a Declaração Universal dos Direitos dos Animais, cujo preâmbulo inicia com o "considerando" que todo o animal possui direitos. Seu artigo $1^{\circ}$ reza que "Todos os animais nascem iguais diante da vida e têm o mesmo direito à existência", e o art. $2^{\circ}$ estabelece que “a) Cada animal tem direito ao respeito; b) O homem, enquanto espécie animal, não pode atribuir-se o direito de exterminar os outros animais, ou explorá-los, violando esse direito. Ele tem o dever de colocar a sua consciência a serviço dos outros animais; c) Cada animal tem direito à consideração, à cura e à proteção do homem.” 7 Mais de um habeas-corpus já foi concedido a macacos, por exemplo. Notícia de O Globo, de 05/04/2017, por exemplo, noticia a concessão, na Argentina, de habeas corpus para que a chimpanzé Cecília fosse liberada de zoológico argentino, onde vivia há 19 anos, a fim de ser transferido a um santuário natural no Brasil - Santuário dos Grandes Primatas, de Sorocaba (https://oglobo.globo. $\mathrm{com} /$ sociedade/sustentabilidade/chimpanze-argentina-consegue-habeas-corpus-para-ir-para-santuario-brasileiro-21162673). Em 25 de abril de 2015, a justiça nova-iorquina concedeu liminar em habeas corpus a dois chimpanzés, Hercules e Leo, visando garantirlhes a libertação do laboratório da Universidade Stony Brook, onde viviam confinados. O habeas fora impetrado por advogados da ONG The Nonbuman Rights Project. A liminar foi revogada no dia seguinte, mas permitiu-se que o processo prosseguisse (https:// www.conjur.com.br/2015-abr-25/justica-eua-reconhece-status-pessoa-chimpanzes-dia). A Argentina tem sido pioneira quanto a esse aspecto, pois em 2014 a fêmea de orangotango Sandra já fora beneficiada por uma decisão judicial muito semelhante àquela que favoreceu Cecília, segundo notícia da Folha de São Paulo, edição digital (artigo de Reinaldo José Lopes, de 05/04/2017 - http:/ / www1.folha.uol.com.br/ambiente/2017/04/1873046-habeas-corpus-de-primata-e-fruto-de-decadas-de-articulacao-politica.shtml). 8 Rousseau assim expressa esse raciocínio: "Não vejo em todo animal senão uma máquina engenhosa, à qual a natureza deu sentidos para prover-se, ela mesma, e para se preservar, até certo ponto, de tudo o que tende a destruí-la ou perturbá-la. Percebo precisa- 
der-se em devaneios sobre o que serão num tempo, o futuro, processo reflexivo, esse, que é inerente apenas ao ser humano. Filhotes e jovens animais não ficam angustiados sobre o que os espera no futuro. Apenas reagem ao presente, agindo instintivamente, reproduzindo padrões de comportamento de sua espécie. Se escassear a caça em seu território, um leão — embora rei dos animais - morrerá de fome, mas não pensará em tornar-se herbívoro ou de comer frutos ou tubérculos que estejam disponíveis. Iguanas, golfinhos e gaviões provavelmente adotam os mesmos comportamentos que seus ancestrais há mil anos. Daqui a mil anos, seus descendentes (se os 'superiores' seres humanos permitirem sua sobrevivência) provavelmente repetirão os mesmos padrões de comportamento. O mesmo não ocorre com os seres humanos, que procuram se 'reinventar', mudando comportamentos, formas de convivência, formas de produção, profissões, alteram valores, modificam formas de convivência social e política, transformam arranjos familiares etc.

Outra forma de expressar a perfectibilidade rousseauniana é por meio da concepção do ser humano como ser-liberdade, sendo a liberdade a verdadeira característica humana. O ser humano é o único ser vivo que tem capacidade de projetar e projetar-se. Seus atos, como dito, diferentemente dos atos dos animais, não são reações, mas sim implementação de projetos.

A liberdade faz da pessoa um ser projetivo, criativo, responsável, dinâmico, em contínuo movimento, moldando sua personalidade por meio do tempo. Essa liberdade pode ser vista como ontológica (existente no mundo interior - portanto, ilimitada e absoluta) e como fenomênica (ocorrente no mundo exterior - e, portanto, limitada, relativa e condicionada tanto por fatores do mundo exterior quanto do mundo interior). ${ }^{9}$

A primeira, por ser absoluta e ilimitada, é irrelevante para o Direito. Este se interessa pela segunda, ou seja, pelo projeto de vida que se efetiva por meio de atos ou condutas, já que o Direito somente se preocupa com condutas humanas intersubjetivadas.

A liberdade se fenomenaliza (a raiz grega da palavra fenômeno significa "o que se mostra", "o que aparece no mundo") por meio de atos, condutas, comportamentos do ser humano, sendo dessa exteriorização que se ocupa o Direito.

De certa forma, essa liberdade, que caracterizaria o ser humano, representa aquilo que a pessoa decide ser e fazer "em" sua vida e "com" sua vida. Trata-se do "dasein" (o 'ser aí") heideggeriano, que compreende o ser humano como um "ser projetante". Ou, segundo Jaspers, o projeto de vida do homem permite a ele "chegar a ser o que pode e quer ser".

Tanto no campo da moral como no da religião, bem como na filosofia e no Direito, essas ideias desembocaram na conhecida concepção de "livre-arbítrio", isto é, a liberdade de agir conforme nossa vontade, com a resultante responsabilidade pelos efeitos de nossas escolhas.

Desde Aristóteles a noção de autodeterminação é a base da convivência humana, pois partimos dessa liberdade para recompensar e responsabilizar pessoas em virtude de suas atitudes livremente tomadas.

Para justificar a importância central do homem, $\operatorname{Kant}^{10}$ criou a ideia de dignidade da pessoa humana que o diferenciaria dos demais entes naturais. Afirmava ele que o animal está submetido às leis naturais e necessárias de causa e efeito, porque reagiam, unicamente, por instinto, enquanto o homem pode ultrapassar sua

mente as mesmas coisas na máquina humana, com a diferença de que só a natureza faz tudo nas operações do animal, ao passo que o homem concorre para as suas na qualidade de agente livre. Um escolhe ou rejeita por instinto, o outro por um ato de liberdade, o que faz com que o animal não possa afastar-se da regra que lhe é prescrita, mesmo quando lhe fosse vantajoso fazê-lo, e que o homem dela se afaste frequentemente em seu prejuízo." ROUSSEAU, Jean-Jacques. Discurso sobre a origem da desigualdade. Tradução Maria Lacerda de Moura. Ed. Ridendo castigat mores, 2001. p. 54 e 55. Sobre o impacto dessas ideias, v. a obra de Luc Ferry, já referida, bem como COMTE-SPONVILLE, André. Dicionário filosófico. Tradução Eduardo Brandão. São Paulo: Martins Fontes, 2003.

9 A respeito dessas esferas da liberdade e do profundo significado da liberdade humana enquanto signo distintivo dos demais animais consulte-se SESSAREGO, Carlos Fernández. Trascendencia y reparación del "daño al proyecto de vida" en el umbral del siglo XXI. In: HERNÁNDEZ, Carlos Arturo et al (Org.). La Responsabilidad Civil. Bogotá: Universidad Libre, 2014. (Tendencias Contemporáneas del Derecho, v.19). p. 355.

10 KANT, Immanuel. Crítica da razão pura. Tradução Lucimar A. Coghi Anselmi, Fulvio Lubisco. 3. ed. São Paulo: Ícone, 2011. 
condição natural ascendendo a uma "segunda natureza". ${ }^{11}$ Assim, o ser humano poderia, por seu intelecto, superar a natureza. Essa superioridade humana que torna os homens capazes de livremente controlar e modificar a própria natureza conferiria dignidade ao homem.

O conhecimento de algumas reações naturais — transmitido pela linguagem ${ }^{12}$ de geração a geração — fez evoluir nosso intelecto, permitindo-nos fazer determinadas previsões. Usamos a razão para, com base na memória, analisar os dados colhidos pelos sentidos e buscar uma explicação para as causas, conforme já alertava o Princípio da Razão Suficiente de Leibniz, o qual afirmava ser este um comportamento inerente à racionalidade humana. ${ }^{13}$

Embora alguns filósofos tenham apresentado boas reflexões questionando a premissa da autodeterminação - como Spinoza ${ }^{14}$, Schoppenhauer ${ }^{15}$, Nietzsche ${ }^{16}$ e mais recentemente Deleuze ${ }^{17}$ 一, o fato é que esta sempre prevaleceu e sempre contou com muitos adeptos, tal como Sartre e seu existencialismo: "O homem está condenado a ser livre.”18

Essas ideias, que surgiram, inicialmente, no campo da religião e da filosofia, posteriormente, migraram para o Direito que, como foi dito acima, funda boa parte de seus institutos na equação liberdade-responsabilidade. Ainda que se trate de noção essencial para a operacionalidade de tais institutos, a noção de racionalidade e livre-arbítrio vem sendo cada vez mais questionada. É o que se passa a analisar.

\section{A racionalidade Questionada}

Nossa capacidade de compreender e prever o futuro realmente é muito superior à dos outros animais. Mas será tão desenvolvida quanto imaginamos?

Ao menos desde Kant a racionalidade das escolhas humanas tem sido contestada ${ }^{19}$, em razão da percepção do peso dos mais variados fatores capazes de influenciar o processo de tomada de decisão.

Sem dúvida o ser humano é o animal mais bem sucedido em sua capacidade de adaptar o meio às suas necessidades, em vez de se adaptar ao meio, como ocorre com as demais espécies, segundo o darwiniano princípio da evolução biológica. ${ }^{20}$ Faz isso movido por sua vontade. Essa vontade, na esteira do pensamento de Arthur Schopenhauer, antecede até mesmo a cognição: "este intelecto é o secundário, o posterius do organismo e, enquanto mera função cerebral, condicionado por este. A vontade, por outro lado, é primária, é o prius do organismo, sendo este condicionado por ela." ${ }^{21}$

Também Nietzsche critica o apego fanático à lógica racional: “a 'razão’ é a causa de falsificarmos o tes-

11 RABENHORST, Eduardo Ramalho. O valor da pessoa humana e o valor da natureza. In: MELGARÉ, Plínio; ALMEIDA FILHO, Agassiz. (Org.). Dignidade da pessoa humana: fundamentos e critérios interpretativos. São Paulo: Malheiros, 2010. p. 30.

12 WITTGENSTEIN, Ludwig. Investigações filosóficas. Tradução Marcos G. Montagnoli e Emmanuel Carneiro Leão. 9. ed. Petrópolis: Vozes; Bragança Paulista: Editora Universitária São Francisco, 2014.

13 KANT, Immanuel. Crítica da razão pura. Tradução Lucimar A. Coghi Anselmi, Fulvio Lubisco. 3. ed. São Paulo: Ícone, 2011. p. 190-194.

14 SPINOZA, Benedictus de. Ética. Tradução Thomaz Tadeu. 2. ed. Belo Horizonte: Autêntica, 2013. p. 36.

15 SCHOPENHAUER, Arthur. O mundo como vontade e representação. São Paulo: Saraiva, 2001. SCHOPENHAUER, Arthur. Sobre a vontade na natureza. Tradução Gabriel V. Silva. Porto Alegre: L\&PM, 2013.

16 NIETZSCHE, Friederich. Assim falou Zaratustra. Tradução Carlos Duarte e Anna Duarte. São Paulo: Martin Claret, 2012. NIETZSCHE, Friederich. Crepúsculo dos ídolos. Tradução Paulo César de Souza. São Paulo: Companhia das letras, 2006.

17 DELEUZE, Gilles. Diferença e repetição. Tradução Luiz Orlandi e Roberto Machado. Lisboa: Relógio d’Água, 2000.

18 SARTRE, Jean-Paul. O existencialismo é um bumanismo. Tradução João Batista Kreuch. 3. ed. Petrópolis: Vozes, 2014. p. 24.

19 KANT, Immanuel. Crítica da razão pura. Tradução Lucimar A. Coghi Anselmi, Fulvio Lubisco. 3. ed. São Paulo: Ícone, 2011. p. 211-214.

20 DARWIN, Charles. A origem das espécies por meio da seleção natural. Tradução André Campos Mesquita. São Paulo: Escala, 2009.

21 SCHOPENHAUER, Arthur. Sobre a vontade na natureza. Tradução Gabriel V. Silva. Porto Alegre: L\&PM, 2013. p. 66. 
temunho dos sentidos. [...] Nós possuímos ciência, hoje, exatamente na medida em que resolvemos aceitar o testemunho dos sentidos"22.

Com base no que sentimos, estabelecemos uma lógica relacionada àquilo que a memória apresenta como causas e consequências. A partir desse mecanismo, reproduzimos atitudes que reconhecemos nos outros indivíduos. Por isso um bebê tenta bater palmas ao ver um adulto fazendo o mesmo. Nesse diapasão, o ser humano define quem ele é, imitando características que ele deseja possuir e aperfeiçoando-as à sua maneira (adequando-as). Não apenas seres humanos fazem isso, diria Pavlov. Em animais não humanos, porém, chamamos isso de instinto.

A propósito, é explorando essa característica humana que os publicitários promovem um produto associando-o a um personagem famoso, ressaltando que "fulano" possui aquele produto e, por isso, "você" também deve desejá-lo. "A necessidade de imitação que o consumidor sente é esse desejo infantil, que por vezes racionalizamos com afirmações do estilo "eu mereço". Num nível patológico, consumimos para evitar "o sentimento torturante de estar à margem da existência." 23 O chamado "consumo conspícuo" 24 demonstra que o comportamento humano atende mais a estímulos externos do que a uma vontade independente. ${ }^{25}$

Exemplo disso são os indivíduos absolutamente racionais que, no entanto, gastam fortunas em um produto. Pagam pelo símbolo ${ }^{26}$ que o produto representa naquela sociedade, ${ }^{27}$ agindo tal qual o bebê que reconhece determinado símbolo e o repete. Não chega a ser um comportamento irracional, pois tem uma lógica e um propósito: ser identificado por aqueles que comungam dos mesmos valores. ${ }^{28}$ Todavia, tampouco tal comportamento pode ser tido como realmente livre e autônomo.

22 NIETZSCHE, Friederich. Crepúsculo dos ídolos. Tradução Paulo César de Souza. São Paulo: Companhia das letras, 2006. p. 26.

23 DEBORD, Guy. A sociedade do espetáculo. Tradução Estela dos Santos Abreu. Rio de Janeiro: Contraponto, 1997. p. 140-141.

24 VEBLEN, Thorstein B. A teoria da classe ociosa: um estudo econômico das instituições. São Paulo: Pioneira, 1965.

25 Para um aprofundamento do tema, remete-se ao capítulo "Racionalidade humana", da obra de SCHMIDT NETO, André Perin. Contratos na sociedade de consumo: vontade e confiança. São Paulo: Revista dos Tribunais, 2016. p.123/156.

26 O vocábulo "símbolo" tem sua origem etimológica nas expressões gregas sym (juntar, unir) e balein (em direção a um objetivo, uma meta). Na Grécia antiga, representava o ato de unir dois pedaços de uma moeda partida quando da separação de duas pessoas. Assim, quando uma delas pretendia mandar uma mensagem para a outra, remetia sua metade pelo mensageiro para que o remetente confirmasse a autoria do recado juntando as duas metades da moeda. Desse modo, em termos psicanalíticos, a palavra passou a significar a união de algo conhecido (consciente) a algo desconhecido (inconsciente). "Assim, o símbolo sempre contém um aspecto irracional e tem um enorme poder de mobilização. Podemos perceber o símbolo em formas concretas, como bandeiras, slogans e hinos (...)" - RAMOS, Denise Gimenez; MACHADO JUNIOR, Pericles Pinheiro. Individuação e subjetivação: os conceitos junguianos de inconsciente coletivo e arquétipo mostram o caráter universal das imagens e dinâmicas do inconsciente que representam modos de estruturação da subjetividade no processo de individuação. In: PINTO, Manuel da Costa (Org.). O livro de ouro da psicanálise: o pensamento de Freud, Jung, Melanie Kein, Lacan, Winnicott e outros. 2. ed. Rio de Janeiro: Ediouro, 2007. p. 185. Isso se aplica ao objeto do consumo que, nesta sociedade de consumidores representa, mais do que sua utilidade, a identidade de quem o adquire. 27 LLOSA, Mario Vargas. A civilização do espetáculo: uma radiografia do nosso tempo e da nossa cultura. Tradução Ivone Benedetti. Rio de Janeiro: Objetiva, 2013. p. 20.

28 “'Minha mãe é professora de uma escola primária', disse Corinne a uma entrevistadora, 'e quando ela pergunta aos meninos o que eles querem ser quando crescer, eles respondem: 'Não sei, só quero ser famoso'.' Nesses sonhos 'ser famoso' não significa nada mais (mas também nada menos!) do que aparecer nas primeiras páginas de milhares de revistas e em milhões de telas, ser visto, notado, comentado e, portanto, presumivelmente desejado por muitos — assim como sapatos, saias ou acessórios exibidos nas revistas luxuosas e nas telas de TV, e por isso vistos, notados, comentados, desejados... 'Há mais coisas na vida além da mídia', observa Germaine Greer, 'mas não muito... Na era da informação, a invisibilidade é equivalente à morte." BAUMAN, Zygmunt. Vida para o consumo: a transformação das pessoas em mercadorias. Tradução Carlos Alberto Medeiros. Rio de Janeiro: Zahar, 2008. p. 21. Experimentos demonstram que a maioria das pessoas das classes mais abastadas raramente dirigem o olhar para pessoas que ocupam papéis sociais tidos como subalternos, como faxineiros, encarregados de limpeza, garis, mendigos, etc, criando nesses uma exasperante 'síndrome da invisibilidade'. Para alguns estudiosos da criminalidade, esse sentimento por vezes está na origem inconsciente de alguns tipos de crime, como o assalto à mão armada: quando o criminoso aponta a arma para a cabeça de sua vítima, não há como esta não reconhecer a existência e toda a visibilidade do ser "que está" assaltante. Esse termo ganhou notoriedade com o experimento feito por Fernando Braga da Costa, ao elaborar sua pesquisa de graduação na USP, em psicologia social, ocasião em que se vestiu de gari no campus universitário e foi trabalhar com os mesmos. Vestido de gari, percebeu que jamais era reconhecido por seus colegas e professores - porque jamais dirigiam o olhar para ele, embora cruzando pelos mesmos espaços -, embora rapidamente identificado pelas mesmas pessoas quando trajado "normalmente". Seu impressionante experimento foi posteriormente convertido em livro - COSTA, Fernando Braga da. Homens invisiveis: relatos de uma humilhação social. São Paulo: Globo, 2004. 
A racionalidade do agir humano, já questionada filosoficamente, passou, também, a sofrer intensos e consistentes ataques provenientes de outras áreas científicas, como a psicologia, tema do próximo item.

\section{A RACIONALIDADE, SEGUNDO A PSICOLOGIA COMPORTAMENTAL}

O estudo do comportamento humano e seu condicionamento ganhou impulso com a psicologia comportamental e ciências afins, que cresceram muito, após o surgimento das ideias de condicionamento decorrentes das experiências com cães, realizadas por Ivan Pavlov.

Em conhecido experimento, ao estudar a produção de saliva em cachorros expostos a diferentes alimentos, o filósofo soviético percebeu que, com o tempo, não mais apenas apresentação da comida aos cães lhes causava salivação, mas também o som dos passos dos funcionários que se dirigiam ao canil para alimentá-los. Passou, então, a alimentar os cães sempre ao som de uma determinada campainha, e após repetidas vezes, a salivação, que seria uma reação que deveria ocorrer, apenas, quando o alimento era colocado em sua boca para facilitar a digestão, passou a ocorrer com o simples som daquela mesma campainha. Assim, os animais ofereciam respostas comportamentais ao meio, como reflexos incondicionados, fruto da repetição (experiências resgatadas pela memória), sendo possível criar ou remover respostas fisiológicas e psicológicas em animais e, extensivamente, também em seres humanos.

Na construção do Behaviorismo, Thorndike trouxe contribuições importantes em seus estudos com gatos. Descreveu o comportamento dos felinos submetidos a testes em jaulas denominadas "caixas-de-problemas". "As portas de alguma destas caixas só podiam ser abertas puxando-se um cordão ou um nó, que estavam no interior, ou mediante pressão sobre uma alavanca. $\mathrm{O}$ animal em experiência, habitualmente faminto, tinha de libertar-se da prisão em que fora colocado." ${ }^{29}$ Depois de submetidas várias vezes ao mesmo teste, as cobaias passavam a demonstrar mais eficiência para a solução do problema, demonstrando a aprendizagem por experiência dos animais. "Pouco a pouco, de uma a outra experiência, tornavam-se cada vez mais objetivados os movimentos do animal: todos os movimentos desnecessários são refreados. Sobra apenas um grupo de movimentos que conduzem ao êxito." ${ }^{30}$

As experiências com animais foram superadas pelo behaviorismo, que se distinguiu por estudar o que se passava na mente dos testados e não apenas seus movimentos e reações externamente visíveis. O behaviorismo proposto por John Broadus Watson, em 1913, com a publicação do artigo "Psychology as the Behaviorist Views It", e que depois ganhou diversos desdobramentos, passou a afirmar que o ser humano aprende, essencialmente, por meio da imitação, da observação e da reprodução dos comportamentos dos outros, e que nossas ações são meras respostas ao ambiente externo. Críticas como as da psicologia da Gestalt — que acusaram o behaviorismo de estudar comportamentos isolados ignorando o todo — têm transformado esses estudos. ${ }^{31}$

As pesquisas mais atuais confirmam as limitações à racionalidade pura. Hoje a psicologia cognitiva busca responder como o homem compreende o mundo e de que modo reage a ele, buscando adaptá-lo a si e às suas necessidades. Conforme a psicologia, somos o reflexo de nossas experiências, notadamente as vividas durante nosso período de formação. Assim, uma ação realizada na infância pode provocar uma reação (personalidade) na vida adulta, levando-nos a ter determinado comportamento, comprometendo sua racionalidade.

29 PUCHKIN, V. N. Heurística: a ciência do pensamento criador. Tradução Vera Neverova. Rio de Janeiro: Zahar Editores, 1969. p. 25.

30 PUCHKIN, V. N. Heurística: a ciência do pensamento criador. Tradução Vera Neverova. Rio de Janeiro: Zahar Editores, 1969. p. 25.

31 STARnBERG, Robert J. Psicologia cognitiva. Tradução Anna Maria Dalle Luche e Roberto Galman. São Paulo: Cangage Learning, 2010. p. 8-9. 
Por outro lado, temos a tendência de avaliar comportamentos alheios com base em nossos próprios estados mentais. Essa tendência foi comprovada por uma pesquisa que consistiu em solicitar a pessoas que assistissem um filme no qual formas simples, como triângulos e quadrados, moviam-se aleatoriamente na tela. Quando perguntados sobre o que haviam visto, a maioria das pessoas atribuiu motivos e intenções às formas inanimadas, comportamento que demonstra a tendência natural das pessoas em tentar explicar o comportamento alheio com base em estados mentais e desejos próprios, comprovando que tais explicações não são necessariamente precisas. É quase inevitável não ligar experiências sensoriais a estados mentais ${ }^{32}$, ignorando, também, que decisões e julgamentos são influenciados por fatores sociais e culturais. ${ }^{33}$

Na sociedade de consumo, o conhecimento dos mecanismos por meio dos quais tomamos decisões serve, também, à manipulação do comportamento alheio, na busca de resultados econômicos. Esses aportes da psicologia cognitiva "ingressaram na Ciência Econômica, gerando um sub-ramo denominado de Economia Comportamental” ${ }^{34}$, tema do próximo item.

\section{A RACIONALIDADE, SEgundo a ECONOMIA COMPORTAMENTAL}

De algumas décadas para cá, um ramo da economia, denominada de economia comportamental, vem chamando atenção por mostrar como o ser humano é influenciável e principalmente pelas aplicações práticas que tal conhecimento permite. Seu foco principal recai sobre os limites da racionalidade dos agentes econômicos. Tal ramo do saber incorpora insights da psicologia, neurociência e Teoria Microeconômica.

Essa nova ciência possibilita visões esclarecedoras e desmistificadoras. Estudos nessa área tendem a crescer e a chamar cada vez mais a atenção, pois já haviam rendido dois prêmios Nobel, para Herbert Simon, em 1978 e Daniel Kahneman ${ }^{35}$, em 2002. Em 2017 o economista Richard Thaler igualmente recebeu o Prêmio Nobel de Ciências Econômicas exatamente pelas suas contribuições à economia comportamental e por, pioneiramente, ter descrito como as pessoas são previsivelmente irracionais em suas condutas ${ }^{36}$, principalmente econômicas. Tais achados interessam ao mercado, sempre ávido de informações que possam ser utilizadas

32 O experimento foi extraído de COMMONS, Michael Lamport; MILLER, Patrice Marie. Folk psychology and the law: why behavioral science needs to replace folk psychology. Revista Brasileira de Estudos Políticos, Belo Horizonte, n. 96, p. 10, jul./dez. 2007. Referidos autores mencionam que a noção de livre-arbítrio consiste na crença de que somos absolutamente independentes, sendo que tal noção decorre da filosofia, da religião e do direito ocidentais- op. cit., p. 12.

33 Percepção essa que não é nada recente, já que Descartes há cerca de quatro séculos já havia advertido que "[...] tendo reconhecido que os que têm sentimentos muito contrários aos nossos nem por isso são bárbaros nem selvagens, mas que muitos usam, tanto ou mais do que nós, a razão; e tendo considerado o quanto um mesmo homem, com seu mesmo espírito, criado desde a infância entre franceses ou alemães, torna-se diferente do que seria se tivesse vivido sempre entre chineses ou canibais, e de que maneira, até nas modas de nossas roupas, a mesma coisa que nos agradou dez anos atrás, e que nos agradará talvez daqui dez anos, nos parece agora extravagante ou ridícula: de modo que é bem mais o costume e o exemplo que nos persuadem do que qualquer conhecimento certo, e que, no entanto, a pluralidade das vozes não é uma prova que valha para as verdades um pouco difíceis de descobrir, porque é bem mais provável que um homem sozinho as encontre do que um povo inteiro; [...]" DESCARTES, René. Discurso do método. Tradução Paulo Neves. Porto Alegre: L\&PM, 2013. p. 47-48.

34 OLSSON, Gustavo André. Análise econômica do direito penal e teoria sistêmica. Curitiba: Juruá, 2014. p. 168.

35 Em livro mais recente, Thinking, Fast and Slow ("Pensando, rápido e devagar", publicado em português pela Editora Objetiva, em 2012), Daniel Kahneman, defende a tese de que grande parte das nossas decisões são puramente emocionais, mesmo quando acreditamos que estamos tomando decisões racionais, baseadas em dados concretos. Isso explica, por exemplo, por que as pessoas criam empatia por um político apenas pela sua fisionomia (é um fato que candidatos ou candidatas bonitos/as tendem a ganhar um número razoável de votos apenas pela sua beleza, independentemente de suas qualidades políticas, apesar dessas serem, obviamente, o único fator relevante para a ocupação de um cargo público), ou porque professores tendem a dar melhores notas a alunos que já se destacam (apesar da intuitiva percepção de que nem sempre um bom aluno tem necessariamente elevado desempenho em todas as tarefas e avaliações a que se submete).

36 "People respond to incentives, although not necessarily in ways that are predictable or manifest. Therefore, one of the most powerful laws in the universe is the law of unintended consequences" (em tradução livre: pessoas respondem a incentivos, embora não necessariamente de forma previsível ou manifesta. Portanto, uma das mais poderosas leis no universo é a lei das consequências não intencionais) - LEVITT, Steven D.; DUBNER, Stephen J. Super Freakonomics. New York: HarperCollins Publishers, 2009. p.14. 
para aumentar a venda de seus produtos. Quanto mais supérfluos forem os produtos e serviços que se queiram lançar no mercado, maior é a habilidade necessária para vendê-los ao público. Qualquer informação útil para aumentar as chances de colocação de produtos ou serviços no mercado, é sempre muito bem-vinda.

Sobre seus achados, diz-se que:

Agregando elementos de Psicologia, a Economia comportamental busca descrever um ser humano mais real e concreto e, o que é o principal, o seu comportamento econômico. Considerando que as decisões humanas são sempre econômicas (no sentido de que o ser humano faz sempre ponderações de custo-benefício em seu processo de tomada de decisão), a Economia Comportamental (EC) parte do pressuposto de que as decisões humanas são sempre racionais, embora seja limitada tal racionalidade.

A EC descreve a dificuldade humana com a tomada de decisões intertemporais, assim definidas aquelas para as quais se faz um pequeno sacrifício hoje, à espera de um benefício maior no futuro. Descreve, igualmente, o chamado superotimismo humano, ou a crença dos indivíduos de que eles são mais propensos ao acontecimento de boas coisas em suas vidas que nas dos outros. Comprova, empiricamente, a afirmação de que, por vezes, as escolhas dos seres humanos baseiam-se em compulsões, ódio, paixões, vícios e não representam, exatamente, uma expressão de escolha livre. Confirmam o caráter limitado da força de vontade humana. Demonstram que os seres humanos costumam selecionar, em ter as opções possíveis, os argumentos que confirmam aquilo que eles previamente desejavam como conclusão. ${ }^{37}$

Alguns temas são recorrentes nos estudos da economia comportamental, como a heurística, segundo a qual seres humanos tomam a esmagadora maioria de suas decisões usando atalhos mentais, ou, então, fazendo uso de estereótipos que representam verdadeiros paradigmas emocionais mentais, servindo de filtros para a compreensão da realidade e moldando nossas reações aos eventos a que somos expostos. Outro tema privilegiado de estudo são as ineficiências do mercado, em razão de tomadas de decisão não racionais. Voltaremos a alguns desses aspectos no próximo item.

Com o provocante título "O livre-arbítrio não existe, dizem neurocientistas", a revista Veja $a^{38}$ publicou reportagem cujo subtítulo afirma que "Novas pesquisas sugerem que o que cremos ser escolhas conscientes são decisões automáticas tomadas pelo cérebro. $\mathrm{O}$ homem não seria, assim, mais do que um computador de carne".

No texto, afirma-se que "o exército dos deterministas ganhou um reforço de peso: o dos neurocientistas." Segundo estes, o livre-arbítrio não é mais que uma ilusão, conclusão a que chegam com base em um vasto arsenal de dados, colhidos por meio de testes que monitoram o funcionamento do cérebro:

Mais rápido que o pensamento - Experimentos que vêm sendo realizados por cientistas há anos conseguiram mapear a existência de atividade cerebral antes que a pessoa tivesse consciência do que iria fazer. Ou seja, o cérebro já sabia o que seria feito, mas a pessoa ainda não. Seríamos como computadores de carne - e nossa consciência, não mais do que a tela do monitor. Um dos primeiros trabalhos que ajudaram a colocar o livre-arbítrio em suspensão foi realizado em 2008. O psicólogo Benjamin Libet, em um experimento hoje considerado clássico, mostrou que uma região do cérebro envolvida em coordenar a atividade motora apresentava atividade elétrica uma fração de segundos antes dos voluntários tomarem uma decisão — no caso, apertar um botão. Estudos posteriores corroboraram a tese de Libet, de que a

37 OLIVEIRA, Amanda Flávio de; MOURA, Walter José Faiad de. É preciso proteger o fumante de si mesmo?. Revista Científica Virtual da Escola Superior da Advocacia da OAB-SP, n. 17, inverno 2014. Edição especial: Direito e Tabaco. São Paulo: OAB/SP, 2014. p. 162/163. Dentro da mesma linha, refere Isabella Henriques que o mote da sociedade de consumo é o pensar no momento atual, no prazer imediato, pois é uma sociedade que prima pelo imediatismo, sem lembrar o passado ou preocupar-se com o futuro. E prossegue: "A ideia é curta agora tudo o que é possível, pois você é merecedor desse prazer. Essa ideia é muito eficaz porquanto o ser humano reconhece a sua condição de mortalidade. Por isso mensagens que induzem a esse prazer imediato são facilmente absorvidas, ainda que no caso de promoção de produtos notoriamente conhecidos por seus potenciais danos à saúde, inclusive com risco de morte, como são o tabaco e o álcool. A ideia aqui é: se eu vou morrer mesmo, que ao menos seja desfrutando algo que acredito me dê prazer e me faça feliz" - HENRIQUES, Isabella. "Controle do Tabaco X Controle do Álcool: Convergências e Diferenciações Necessárias. In: HENRIQUES, Isabella. Controle do tabaco x controle do álcool: convergências e diferenciações necessárias. In: HOMSI, Clarissa Menezes (Coord.). Controle do tabaco e o ordenamento jurídico brasileiro. Rio de Janeiro: Lúmen Juris, 2011. p. 249.

38 Artigo escrito por Aretha Yarak, publicado em 06/05/2016, disponível em https://veja.abril.com.br/ciencia/o-livre-arbitrionao-existe-dizem-neurocientistas/ acesso em 25/05.2018. 
atividade cerebral precede e determina uma escolha consciente.

Um deles foi publicado no periódico científico PLoS ONE, em junho de 2011, com resultados impactantes. O pesquisador Stefan Bode e sua equipe realizaram exames de ressonância magnética em 12 voluntários, todos entre 22 e 29 anos de idade. Assim como o experimento de Libet, a tarefa era apertar um botão, com a mão direita ou a esquerda. Resultado: os pesquisadores conseguiram prever qual seria a decisão tomada pelos voluntários sete segundos antes deles tomarem consciência do que faziam.

No mesmo texto, refere-se que, para a neurociência, a mente é um produto do cérebro. Ou seja, como o cérebro já decidiu o que fazer, é preciso explicar a decisão. "É aí que entra a nossa consciência. Ela também é um produto da atividade cerebral, que surge para dar coerência às nossas ações no mundo. O cérebro toma a decisão por conta própria e ainda convence seu 'dono' que o responsável foi ele.”

Tal como os indivíduos, as massas (grupos de seres) têm suas reações próprias, ainda menos comprometidas com a razão, comportando-se como rebanho ${ }^{39}$.

A respeito de nossa capacidade de, às vezes, ingenuamente agir como membros de rebanho, não é nova a sua constatação, como se percebe da leitura de texto originariamente escrito há quase cem anos:

O espírito da época, tal como se nos revela, é, muito frequentemente, apenas o espírito do grupo em que os acidentes do nascimento, da educação, da ocupação ou da companhia nos colocaram. Nenhum esforço ou revolução do espírito removerá totalmente e para sempre o império dessas fidelidades subconscientes. 'As nossas crenças e opiniões', diz James Harvey Robinson ("The Still Small Voice of the Herd", 32 Political Science Quarterly 315), 'assim como os nossos padrões de procedimento, vem-nos insensivelmente como produto da nossa convivência com outros homens, não como resultado da nossa experiência pessoal e das inferências que nós próprios tiramos, individualmente, das nossas próprias observações. Somos constantemente mal induzidos pela nossa extraordinária faculdade de racionalização - isto é, de imaginar argumentos plausíveis para aceitar aquilo que nos é imposto pelas tradições do grupo a que pertencemos. Somos abjetamente crédulos por natureza e aceitamos instintivamente as sentenças do grupo. [....]; estamos sempre de novo ouvindo a vozinha tranquila do rebanho e prontos a defender e justificar suas instruções e conselhos, aceitando-os como maduros resultados do nosso próprio raciocínio ${ }^{40}$.

E esse comportamento de massas promove decisões da maioria que têm grande relevância para as nações. Esses mesmos seres manipuláveis decidem conjuntamente, desde a moda até os governantes. Não se descarta a presença de alguma racionalidade nesse processo de tomada de decisões. A questão consiste em saber o quanto ela é limitada diante das forças naturais, considerando-se que somos parte dessa natureza e algumas de nossas atitudes correspondem mais a reações a determinadas substâncias que compõem nosso corpo (e cérebro) e a nossas experiências, do que fruto amadurecido de nossas reflexões racionais e conscientes.

Essa noção de que o ser humano controla suas atitudes é tão forte que o próprio indivíduo que se comporta movido pelo inconsciente, quando perguntado, pode acreditar que, efetivamente, quis algo. Não temos plena consciência de que reagimos ao nosso inconsciente.

O Direito deve reconhecer que a vontade, enquanto tentativa de mudar o futuro pela tomada de decisões, não pode ser tida como o único fator a ser considerado, porque, em certas situações, ela pode ter sido induzida por quem detém o conhecimento de ciências que analisam padrões comportamentais.

O modelo econômico clássico baseia-se na ideia singela de que é da natureza humana tomar decisões

39 Bauman comenta essa transição afirmando que a sociedade líquido-moderna de consumidores tende a substituir o grupo (coordenado, onde cada membro assume uma função) pelo enxame (aglomerado de indivíduos que apenas segue a maioria) - BAUMAN, Zygmunt. Vida para o consumo: a transformação das pessoas em mercadorias. Tradução Carlos Alberto Medeiros. Rio de Janeiro: Zahar, 2008. p. 99-101.

40 CARDOZO, Benjamin Nathan. The nature of the judicial process. In: A NATUREZA do processo e a evolução do Direito. Revista AJURIS, p. 156, 1978. 
certas para nós mesmos. O exemplo clássico é comparar quem compra uma gravata para dar de presente a alguém - corre o risco dessa pessoa não estar necessitando de gravatas, ou não gostar da cor ou da estampa - e de alguém que vai comprar uma gravata para si - certamente só comprará se estiver necessitado e escolherá cores e estampas de sua predileção. Todavia, amplas pesquisas têm demonstrado a influência de diversos fatores irracionais que nos afetam a cada decisão, desde o subconsciente até fatores externos que nos induzem a não seguir a plena racionalidade. ${ }^{41}$ Como bem demonstra Dan Ariely, "nossos comportamentos irracionais não são aleatórios nem destituídos de sentido. São sistemáticos e, já que o repetimos incessantemente, previsíveis." ${ }^{42}$ Os novos estudos econômicos já passaram a levar em conta tais fatores comportamentais.

Enquanto os estudos jurídicos comumente partem da ideia de que é papel do Direito a análise sob a perspectiva do "mundo do dever ser", pautando o que é certo e errado, a Economia é capaz de abstrair as implicações da moral, atendo-se ao "mundo do ser". Como já foi dito, "o moralismo representa a forma como as pessoas gostariam que o mundo funcionasse, enquanto a economia representa a forma como ele realmente funciona." ${ }^{43}$

O Direito deve regular a Economia e, para isso, deve partir da premissa de que nem sempre os consumidores são plenamente racionais em suas escolhas.

Modern legal scholars frequently and increasingly base their analyses not on neoclassical economics' assumption of rationality, but on the assumption that individuals are subject to a number of systematic behavioral biases. This assumption is itself grounded largely in a substantial experimental literature documenting bounded rationality, errors in judgment, and non-standard preferences. ${ }^{44}$

Um dos autores a fazer tal análise é Cass R. Sunstein ${ }^{45}$, que baseia sua coletânea de artigos na ideia da "bounded rationality", inicialmente introduzida por Herber Simon, que nada mais é do que a noção de que "human cognitive abilities are not infinite", limitação que decorre do fato de que "we have limited computational skills and seriously flawed memories". ${ }^{6}$

Para lidar com tais limitações biológicas, bem como com as de tempo, adotamos atalhos mentais e regras de decisão que permitem que façamos escolhas. ${ }^{47}$ Mesmo com esses recursos, e muitas vezes por causa deles,

41 "Concluo, portanto, que a lógica deve ser ministrada nas escolas com o propósito de ensinar as pessoas a não raciocinar. Porque, se raciocinarem, certamente o farão de forma equivocada.” RUSSELL, Bertrand. Ensaios céticos. Tradução Marisa Motta. Porto Alegre: L\&PM Editores, 2014. p. 93.

42 ARIELY, Dan. Previsivelmente irracional: como as situações do dia-a-dia influenciam as nossas decisões. Tradução Jussara Simões. Rio de Janeiro: Elsevier, 2008. p. 7.

43 LEVITT, Steven. D.; DUBNER, Stephen J. Freakonomics: o lado oculto de tudo que nos afeta. Tradução Regina Lyra. Rio de Janeiro: Elsevier, 2007. p. 13.

44 Em tradução livre: "Juristas modernos cada vez mais freqüentemente baseiam suas análises não no pressuposto da racionalidade da economia neoclássica, mas no pressuposto de que os indivíduos estão sujeitos a uma série de tendências comportamentais sistemáticas. Esta própria suposição é fundamentada, em grande parte, por uma considerável literatura experimental documentando a racionalidade limitada, os erros de julgamento e as preferências fora do padrão" - WRIGHT, Joshua D. Behavioral Law and Economics, paternalism, and consumer contracts: an empirical perspective. NYU Journal of Law \& Liberty, v. 2, n. 3, p. 470-511, 2007. p. 471.

45 SUNSTEIN, Cass R. Behavioral law and economics. New York: Cambridge University, 2000.

46 Em tradução livre: "A cognição humana não é infinita" e "Nós temos habilidades computacionais limitadas e uma memória com graves falhas" - JOLLS, Christine et. al. A behavioral approach to law and economics. In: SUNSTEIN, Cass R. Behavioral Law and economics. New York: Cambridge University, 2000. p. 14.

47 Exemplificativamente, executivos muito ocupados processam extraordinariamente grandes quantidades de informação ao tomarem decisões e decidem quais assuntos merecem mais tempo e atenção. Esse processamento deve ser necessariamente simplificado, às vezes supersimplificado (simplista), para tornar as informações gerenciáveis, de modo a não permitir que o executivo seja esmagado por dados e paralisado pela ambigüidade. É o que pondera LANGEVOORT, Donald C. Organized Illusions: a behavioral theory of why corporations mislead stock market investors (and cause others social harms) In: SUNSTEIN, Cass R. Behavioral law and economics. New York: Cambridge University, 2000. p. 147. Levitt e Dubner citam Einstein para referir que "é preciso enxergar tudo o mais simplesmente possível", pois "por mais gratos que sejamos aos complexos processos que geraram tanta tecnologia e progresso, também ficamos tontos com sua atordoante proliferação. É fácil deixar-se seduzir pela complexidade; mas também há virtudes na simplicidade" LEVITT, Steven D.; DUBNER, Stephen J. Pense como um Freak. Tradução Clóvis Marques. Rio de Janeiro: 
o real comportamento humano destoa daquele padrão ideal pregado pelo modelo da racionalidade ilimitada, que pressupõe que todos ajam de acordo com o que, para a maioria, parece ser o mais benéfico para o agente e o mais correto para o todo. ${ }^{48}$ Ocorre que "human beings often take actions that they know to be in conflict with their own long-term interests". ${ }^{49}$

Nicole Chardin ${ }^{50}$, estudiosa das limitações à autonomia privada e ao autocontrole, explica que a autonomia da vontade é um princípio político oriundo de uma construção filosófica. Aponta ela as limitações à capacidade de manifestação volitiva racional, notadamente em uma sociedade como a atual em que há uma abismal diferença informacional entre as pessoas, tanto físicas quanto jurídicas, afirmando que indivíduos são levados a contratar induzidos por fatores externos enquanto creem estar agindo com autodeterminação. A vontade só estaria presente quando não há automatismo, nem simples impulso (ato reflexo, impensado) e nem influência de fatores externos.

Nem sempre, porém, dispomos de tempo e informações para as reflexões necessárias ao processo de tomada de decisão racional:

Diante de situações nas quais o custo de uma decisão exata é elevado em relação aos benefícios imediatos esperados, as pessoas costumam fazer uma "avaliação subjetiva de probabilidade" usando atalhos mentais para decidir por aproximação. Estes atalhos mentais são denominados na doutrina econômica como heurísticas. Esta forma de agir pode denotar uma conduta racional de simplificação, como exposto acima, ou pode ter como causa o fato de que as pessoas não possuem a informação ou o treinamento necessário para decidir da forma correta. ${ }^{51}$

Em muitos casos, as certezas que servem de premissa para a decisão ou não estão corretas, ou estão incompletas.

Segundo Maule e Hodgkinson (2002), o ponto de partida para as teorias sobre julgamento e tomada de decisão é o fato de que as pessoas têm capacidade limitada para o trabalho mental. Para lidar com um mundo complexo e marcado por rápidas mudanças, as pessoas desenvolveram modos simples de raciocinar. No que tange ao julgamento e tomada de decisão, as heurísticas assumem o papel de simplificar o processamento cognitivo que envolve julgar alternativas sob incerteza. ${ }^{52}$

O processo de tomada de decisões é fruto de avaliação das alternativas, com base em processos mentais denominados de ajustamento, ancoragem, disponibilidade e representatividade.

O "ajustamento" insuficiente decorre das imperfeições próprias da recuperação de informações. Exemplificativamente, "em algumas situações, a facilidade com que um determinado fato é lembrado ou imaginado pelo indivíduo pode determinar uma hiper ou subestimação da probabilidade ou frequência desse evento ocorrer. Dessa forma, as pessoas julgam essa probabilidade pela facilidade de evocar exemplos em suas memórias. ${ }^{" 53}$ Essas probabilidades subjetivas têm função determinante nas tomadas de decisão, uma vez que as pessoas costumam valer-se das heurísticas em detrimento das reais leis da probabilidade.

A “ancoragem" baseia-se na noção de meio-termo, ${ }^{54}$ pois, em uma decisão, partimos de dois extremos que

Record, 2014. p. 96.

48 JOLLS, Christine et. al. A behavioral approach to law and economics. In: SUNSTEIN, Cass R. Behavioral Law and economics. New York: Cambridge University, 2000. p. 14.

49 "Os seres humanos muitas vezes praticam ações que sabem estar em conflito com seus próprios interesses a longo prazo" (Tradução do autor) JOLLS, Christine et. al. A behavioral approach to law and economics. In: SUNSTEIN, Cass R. Behavioral Law and economics. New York: Cambridge University, 2000. p. 15.

50 CHARDIN, Nicole. Le contrat de consommation de crédit et l'autonomie de la volonté. Paris: LGDJ, 1988. p. 37.

51 FLORES FILHO, Edgar Gastón Jacobs; RIBEIRO, Rita de Cássia. Racionalidade limitada do consumidor e assimetria de informação. Economic Analysis of Law Review, v. 3, n. 1. p. 109-121, jan./jun. 2012. p. 110.

52 TONETTO, Leandro Miletto et al. O papel das heurísticas no julgamento e na tomada de decisão sob incerteza. Estudos de Psicologia, Campinas, v. 23, n. 2, p. 182-183, abr./jun. 2006.

53 TONETTO, Leandro Miletto et al. O papel das heurísticas no julgamento e na tomada de decisão sob incerteza. Estudos de Psicologia, Campinas, v. 23, n. 2, p. 184, abr./jun. 2006.

54 No segundo capítulo de seu livro, Dan Ariely explica o modo pelo qual se manipula facilmente a lei da oferta e da procura 
consideramos prováveis e optamos pelo que mais se aproxime de nossa informação âncora ${ }^{55}$, isto é, um valor que julgamos indicar o norte para a opção "correta". ${ }^{56}$

Isso se deve muito à aversão a extremos que é intrínseca aos indivíduos. Considere-se o seguinte exemplo: um comerciante tem alguns televisores de 30' que custariam $\mathrm{R} \$ 300,00$; muitos televisores de 40’ que custariam $\mathrm{R} \$ 500,00$ e alguns televisores de 50', que custariam $\mathrm{R} \$ 700,00$. Em condições normais, cada consumidor escolheria o modelo que lhe convém, considerando, também, os respectivos preços. Um comerciante conhecedor dos mecanismos que comandam o processo de tomada de decisão e que pretenda desovar o estoque de televisores de 40' colocaria estes a venda pelo preço que lhe corresponde $(\mathrm{R} \$ 500,00)$ e colocaria ao lado o televisor de 30’ ao preço de $\mathrm{R} \$ 400,00$ e o televisor de 50 ’ ao preço de $\mathrm{R} \$ 1.000,00$. Comparativamente aos outros, o televisor de 40' tornar-se-ia uma pechincha na cabeça do consumidor (é só um pouco mais caro que um modelo de tamanho menor e muito mais barato que um modelo de tamanho um pouco maior), embora tivesse ele pagando simplesmente o preço real do bem. Talvez ele nem precisasse de um televisor, mas é possível que venha a achar a oferta irresistível.

Isso ocorre porque, quando o sujeito raciocina a respeito de algo novo, instintivamente passa a compará-lo a algo semelhante, conforme as categorias já conhecidas. “A ‘âncora’ é o elemento já ‘conhecido’ que passa a influenciar o novo." ${ }^{57}$ Após o estouro da bolha imobiliária, em 2008, com as terríveis consequências para o setor securitário e bancário ${ }^{58}$, o governo norte-americano (Bush) interveio, injetando recursos bilionários nesses setores, para evitar sua quebra e alastramento para outros setores da economia. Pouco tempo depois, o povo americano, estarrecido, tomou conhecimento que parte desses recursos públicos estavam sendo usados para pagar salários e bônus milionários aos C.E.O.s dessas mesmas empresas, cujos montantes cresceram 32\% de 2009 para 2010. Em 2010, já no governo Obama, aprovou-se a lei Lei Dodd-Frank, reformando o sistema financeiro. Uma de suas disposições obrigava as empresas a divulgarem os salários e bônus de seus executivos. A ideia era que o constrangimento pelo recebimento de beneficiados custeados pelo contribuinte poderia contribuir para diminuir o valor das benesses. Todavia, o contrário aconteceu. Embora cada um deles estivesse satisfeito com seus salários, ao saberem que executivos atuando em empresas concorrentes do mesmo porte estavam ganhando benefícios maiores do que os seus, exigiram uma certa equiparação. Ou seja, em vez de se nivelar por baixo, nivelou-se por cima. Em valores absolutos, cada um estava satisfeito com os milionários salários que recebiam. Mas no momento em que tomaram conhecimento de uma "âncora" com a qual puderam comparar seus vencimentos (valores relativos), passaram a achar pouco o que ganhavam.

A “disponibilidade" é a capacidade de evocar exemplos em nossa memória ${ }^{59}$ para servirem ao ajustamento, com os fatos posteriores. Nos dizeres de Sternberg, é a "presença de informação armazenada na memória de longo prazo" . ${ }^{60}$ Assim, o que já aconteceu com (ou próximo a) alguém tende a ter um nível de ancoragem exagerado quando do cálculo de probabilidade.

criando valores âncora que induzem consumidores a crer no alto valor de um determinado produto. ARIELY, Dan. Previsivelmente irracional: como as situações do dia-a-dia influenciam as nossas decisões. Tradução Jussara Simões. Rio de Janeiro: Elsevier, 2008. p. 19-39.

55 Muitas vezes as pessoas fazem julgamentos de probabilidade, com base em um valor inicial, ou "âncora”, para o qual fazem ajustes insuficientes - SUNSTEIN, Cass R. Behavioral law and economics. New York: Cambridge University, 2000. p. 5.

56 STARnBERG, Robert J. Psicologia cognitiva. Tradução Anna Maria Dalle Luche e Roberto Galman. São Paulo: Cangage Learning, 2010. p. 441.

57 OLSSON, Gustavo André. Análise econômica do direito penal e teoria sistêmica. Curitiba: Juruá, 2014. p. 174.

58 Segundo a Revista Exame, edição de 06/06/2011, “juntas, as 25 maiores instituições de Wall Street viram os lucros sair de 80 bilhões de dólares em 2006 para um prejuízo de 10 bilhões de dólares em 2008. Durante esse período, a remuneração nessas mesmas 25 empresas permaneceu inalterada" - disponível em https://exame.abril.com.br/revista-exame/tudo-como-antes-nos-salariosdos-executivos-americanos/2/, acesso em 25.05.2018.

59 As pessoas tendem a pensar que os riscos são mais graves quando um incidente prontamente é lembrado pela mente ou está 'disponível' - SUNSTEIN, Cass R. Behavioral law and economics. New York: Cambridge University, 2000. p. 5.

60 STARNBERG, Robert J. Psicologia cognitiva. Tradução Anna Maria Dalle Luche e Roberto Galman. São Paulo: Cangage Learning, 2010. p. 521. 
A disponibilidade é um dos fenômenos mais frequentes das heurísticas. Assim, se pedirmos para um grupo de pessoas estimar o grau de violência de sua cidade, por exemplo, muito provavelmente, as pessoas que já tiverem sido assaltadas, que já passaram por algum evento relacionado à violência urbana ou mesmo que tenham assistido a uma reportagem televisiva sobre o assunto irão avaliar o risco de agressão como sendo mais intenso do que aquelas que não tiveram nenhum tipo de experiência negativa nesse sentido. ${ }^{61}$

Desse modo, a proximidade de um evento tende a supervalorizar a recorrência deste. "Um erro judicial que o afete vai minar sua fé no sistema de justiça mais do que um incidente similar sobre o qual você tenha lido num jornal." ${ }^{62}$

Já a "representatividade" baseia-se na sensação de que tudo o que é similar trará resultados próximos. Um acontecimento passado é tido como uma pista sobre o que pode ocorrer no futuro.

Um exemplo de uso incorreto desse meio ocorre quando se deixa de observar se aquilo que causa a similitude é objetivamente irrelevante. Assim, quando alguém ganha um pequeno prêmio em uma rifa, tende a se considerar com sorte, partindo para um jogo de loteria com prêmios maiores, crendo que sua probabilidade de êxito esteja em alta diante do ganho anterior. A verdade é que, matematicamente, a cada jogo suas chances recomeçam sem qualquer influência do jogo anterior, por mais que ambos sejam jogos de azar bastante próximos.

Outro fator importante é a sensação de otimismo ${ }^{63}$ intrínseca ao ser humano, ${ }^{64}$ o que o leva a falsas percepções da realidade e à tomada de decisões desfavoráveis aos seus interesses. ${ }^{65}$

Em estudo sobre a falência, Ron Harris e Einat Albin definem o otimismo como "a crença que as pessoas tem que eventos negativos da vida, que poderiam influenciar sua capacidade de pagar o empréstimo, não acontecerão com eles" ${ }^{\prime 6}$.

A ponderação entre o benefício momentâneo e o risco de fracasso futuro é feita de modo inexato, avaliando sua suscetibilidade ao risco por meio do otimismo. Esse comportamento é intrínseco ao ser humano que, segundo Kilborn, age de acordo com três fatores: frequência, novidade e importância. Por isso, se, recentemente, houve a queda de um avião, ainda que os riscos sejam os mesmos — ou até menores já que a atenção daqueles que trabalham no setor será redobrada —, as pessoas tendem a não se utilizar desse meio de transporte por um tempo. E não há argumento racional — tal como comprovar, matematicamente, que a proporção de acidentes fatais no trânsito é maior — que altere o comportamento daquele indivíduo. Somente quando os meios de comunicação e as pessoas de seu convívio deixarem de comentar o assunto, sua avaliação do risco mudará.

A proximidade do evento danoso, também, é fator que muda o comportamento, como apontado pela "disponibilidade". Portanto, enquanto não chegar ao seu conhecimento a ocorrência de um evento negativo

61 TONETTO, Leandro Miletto et al. O papel das heurísticas no julgamento e na tomada de decisão sob incerteza. Estudos de Psicologia, Campinas, v. 23, n. 2, p.185, abr./jun. 2006.

62 KAHNEMAN, Daniel. Rápido e devagar: duas formas de pensar. Rio de Janeiro: Objetiva, 2012. p. 167.

63 LANGEVOORT, Donald C. Organized Illusions: a behavioral theory of why corporations mislead stock market investors (and cause others social harms) In: SUNSTEIN, Cass R. Behavioral law and economics. New York: Cambridge University, 2000. p. 149. 64 Lúcida a constatação de Spinoza: "por natureza, somos constituídos de maneira a acreditarmos facilmente nas coisas que esperamos e, dificilmente, nas que tememos, e a estimá-las, respectivamente, acima ou abaixo do justo. É essa a origem das superstições que, em toda parte, afligem os homens" - SPINOZA, Benedictus de. Ética. Tradução Thomaz Tadeu. 2. ed. Belo Horizonte: Autêntica, 2013. p. 130.

65 Consumidores, por exemplo, consistentemente subestimam seu endividamento futuro devido a uma miscelânea de tendências comportamentais, tais como autocontrole imperfeito, descontos hiperbólicos, empréstimos parcelados, e sistematicamente subestimam a probabilidade de consequências negativas (por exemplo, a incapacidade de pagar suas dívidas) - WRIGHT, Joshua D. Behavioral Law and Economics, paternalism, and consumer contracts: an empirical perspective. NYU Journal of Law \& Liberty, v. 2, n. 3, p. 475, 2007.

66 HARRIS, Ron; ALBIN, Einat. Bankruptcy in light of manipulation in credit advertising: personal bankruptcy in the 21 st Century: emerging trends and new challenges. Theoretical Inquires in Law, p.7, july 2006. Disponível em: < http://www.westlaw.com>. 
próximo, subestimará o risco de sua ocorrência. Assim, ainda que diariamente a imprensa noticie o aumento no número de acidentes envolvendo motocicletas, enquanto um determinado motociclista não se envolver em um acidente ou não presenciar um, não considerará os riscos que seu meio de transporte possui.

No que tange ao consumo, somos bombardeados muito mais por informações a favor da compra do que contra. De um lado, pingam notícias sobre crises de liquidez, aumento dos níveis de insolvência e casos de dramas pessoais de quem não consegue superar suas dívidas. Por outro lado, há uma publicidade torrencial que procura nos convencer que podemos pagar determinado produto em suaves prestações, a começar em data muito distante, ou de que lucraremos com liquidações imperdíveis, mesmo que não tenhamos reais necessidades daquele produto.

Enfim, os indivíduos supervalorizam benefícios e riscos imediatos e desvalorizam benefícios e riscos futuros. Ambos os sentimentos estão presentes em uma compra a prazo, pois se obtém a vantagem imediata (compre agora) com um custo futuro (pague depois). Faz-se necessária enorme força de vontade para abandonar uma atividade de risco que traz prazeres imediatos. ${ }^{67}$

Também as influências sociais interferem na tomada de decisão, pois os sujeitos costumam se apegar a informações de outros indivíduos a quem consideram confiáveis, sem maiores verificações sobre a informação em si. A contemporânea influência dos youtubers sobre boa parte da população jovem, especialmente a de menor escolaridade, é um fenômeno que comprova essa percepção.

As rotinas são hábitos conscientes praticados pelos sujeitos na busca por previsibilidade. Há uma natural tendência à repetição de atitudes, mesmo que estas não sejam tão benéficas. Assim, por exemplo, vamos supor que alguém adote um determinado trajeto para ir de casa ao trabalho levando em conta, apenas, a beleza do caminho, em detrimento de outras formas de chegar ao mesmo destino de modo mais rápido. Após muito tempo repetindo o mesmo percurso, se um dia esse indivíduo se atrasar e precisar chegar o mais rápido possível ao trabalho, provavelmente, fará o mesmo percurso de sempre mudando, apenas, a velocidade empregada no deslocamento, em vez de adotar um dos outros caminhos mais curtos. Nesse diapasão, por receio de fugir ao conhecido, pessoas seguem caminhos mais tortuosos em vez daqueles que seriam os mais benéficos para a sua finalidade.

Essa atitude também pode ser vista no meio empresarial, quando empreendedores que repetem certas práticas por muitos anos negam-se a mudá-las, apesar de racionalmente perceber que novas práticas poderiam trazer ainda mais benefícios. A resistência a mudanças (noção do "sempre fiz assim") acarreta apego a padrões que se transformam em dogmas absolutamente irracionais.

O modo como somos vítimas de estereótipos, também, é um indicador de irracionalidades:

O estereótipo é um modo de categorizar informações, na esperança de prever sensações. O cérebro não pode partir da estaca zero a cada nova situação. Ele precisa partir de algo que já tenha visto, por isso, os estereótipos não são intrinsecamente maus. Eles são atalhos em nossa eterna tentativa de compreender ambientes complicados. É por isso que temos a expectativa de que o idoso irá precisar de ajuda para usar o computador ou que o aluno de Harvard é inteligente. ${ }^{68}$

Assim, pressupomos certas características de alguém com base, unicamente, em indicadores externos altamente falíveis. Quanto mais interagimos com os indivíduos e percebemos suas características singulares, mais abandonamos os estereótipos ${ }^{69}$, fruto de suposições oriundas de nossa tendência em categorizar e classificar tudo.

67 KILBORN, Jason. Comportamentos econômicos, superendividamento; estudo comparativo da insolvência do consumidor: buscando as causas e avaliando soluções. In: MARQUES, Cláudia Lima; CAVALLAZZI, Rosângela Lunardelli (Coord.). Direitos do consumidor endividado: superendividamento e crédito. São Paulo: Revista dos Tribunais, 2006. p. 67-78.

68 ARIELY, Dan. Previsivelmente irracional: como as situações do dia-a-dia influenciam as nossas decisões. Tradução Jussara Simões. Rio de Janeiro: Elsevier, 2008. p. 135.

69 MLODINOW, Leonard. Subliminar: como o inconsciente influencia nossas vidas. Tradução Claudio Carina. Rio de Janeiro: Zahar, 2013. p. 190. 
Por outro lado, apesar da busca racional pela verdade objetiva ${ }^{70}$, nosso cérebro distorce os fatos sem que percebamos, para chegar às conclusões que pretendemos. Investigamos, observamos, reunimos evidências e descobrimos padrões, mas ao mesmo tempo o cérebro, para raciocinar, busca antigas conclusões visando analisar os dados colhidos. Essa investigação é permanente, por isso colocamos à prova nossas conclusões, comparando-as com novos dados. Isso significa que o cérebro pode partir de evidências e chegar a conclusões, ou chegar a conclusões e buscar evidências que as comprovem. Ocorre que tal raciocínio esquece a natural propensão de ignorar ou menosprezar o que não se quer ver, assim, há uma tendência em nos agarrarmos a certas conclusões que nos parecem importantes e buscamos argumentos para comprová-las. Portanto, o "pensamento humano tende de forma consciente a partir da crença para a evidência, não vice-versa." ${ }^{71}$ Leonard Mlodinow, citando Johathan Haidt, afirma que "há duas maneiras de chegar à verdade: a maneira do cientista e a do advogado. A mente humana foi projetada para ser tanto cientista quanto advogado, tanto um buscador consciente da verdade objetiva quanto um advogado inconsciente e apaixonado por aquilo em que quer acreditar. [...] Podemos dizer que o cérebro é um bom cientista, mas é um advogado absolutamente brilhante." 72

Dificilmente alguma heurística estará baseada em uma racionalidade perfeita, pois as pessoas físicas nunca conseguirão abstrair fatores emocionais que limitam a decisão racional. Não se trata de concluir que o consumidor toma decisões irracionais. Elas são dotadas de uma certa racionalidade, porque obedecem a uma lógica. A questão central é que essa lógica é previsível e passível de identificação e manipulação por quem detém as informações sobre como tudo isso se processa. Independentemente da escolha do consumidor ser ou não racional, as decisões dos fornecedores, ao adotarem as técnicas de vendas, sempre serão mais pensadas do que a do consumidor que cotidianamente contrata com base em heurísticas, isso é, por meio de uma lógica facilmente identificável por aqueles que buscam meios eficientes de provocar o consumo. A assimetria de informação ${ }^{73}$ permite que aquele que vende selecione as informações que serão repassadas àquele que compra, fornecendo uma proposta em um formato que provoque a decisão de assumir a obrigação.

Merece, também, atenção o que cientistas chamam do mecanismo mental denominado "aversão à perda". Trata-se de um hábito mental que nos conduz a evitar decisões que impliquem perdas. Diante de possibilidades de perdas e ganhos, o cérebro se concentra, automaticamente, muito mais na perda, do que no ganho. Assim, diante da hipótese de uma perda imediata, mas com maior ganho compensatório posterior, frente a outra que apresente um ganho posterior inferior, mas sem a perda inicial, o cérebro tenderia a evitar a perda imediata, ainda que, no resultado final, a primeira opção fosse racionalmente mais vantajosa. Poderíamos pensar que isso nos levaria, portanto, a gastar menos. Todavia, outra tendência, já apontada, é aquela que nos leva a supervalorizar ganhos imediatos, em detrimento de despesas futuras. O cartão de crédito é, nesse caso, o instrumento perfeito para estimular um consumo irresponsável. ${ }^{74}$

É claro que esses achados não significam que a noção de livre-arbítrio não tenha mais valor ou sentido. Tal noção é imprescindível para a manutenção da convivência social, pois o mundo, tal como o conhecemos, entraria em colapso se, a partir desses achados, pudéssemos impunemente matar ou roubar com base no argumento simplista que 'meu cérebro mandou fazer isso ${ }^{75}$, ou se pudéssemos simplesmente desistir de

70 TARUFFO, Michele. Uma simples verdade: o juiz e a construção dos fatos. Tradução Vitor de Paula Ramos. Madri: Marcial Pons, 2012. STRECK, Lenio Luiz. Verdade e consenso. Rio de Janeiro: Lumen Juris, 2009.

71 MLODINOW, Leonard. Subliminar: como o inconsciente influencia nossas vidas. Tradução Claudio Carina. Rio de Janeiro: Zahar, 2013. p. 237.

72 MLODINOW, Leonard. Subliminar: como o inconsciente influencia nossas vidas. Tradução Claudio Carina. Rio de Janeiro: Zahar, 2013. p. 237.

73 ZYLBERSZTAJN, Décio; SZTAJN, Rachel. (Org.). Direito e economia: análise econômica do direito e das organizações. Rio de Janeiro: Elsevier, 2005. p. 121-130.

74 RAMOS, Fabiana D’Andrea. Superendividamento maior é problema do mercado de crédito, não do consumidor. 2017. Disponível em: $<$ https://www.conjur.com.br/2017-ago-16/garantias-consumo-superendividamento-maior-problema-mercado-credito-nao-consumidor>. Acesso em: 28 maio 2018

75 Seria como absolver Meursault, a personagem principal de "O estrangeiro", romance do absurdo, de Albert Camus, que com- 
nossos compromissos contratuais, alegando que nosso nível real de consciência sobre o ato praticado era muito reduzido.

Todavia, se é verdade que a relativização do livre-arbítrio não significa, necessariamente, um afrouxamento da responsabilização civil e penal que está vinculada às nossas condutas, também é verdade que esses novos conhecimentos necessariamente devem ser levados em conta para uma nova interpretação da noção do voluntarismo - a ideia de que assumimos responsabilidades, contratuais e extracontratuais, em razão de nossas vontades livremente manifestadas, lícita ou ilicitamente.

Passa-se a analisar, então, algumas das aplicações dessas noções e como elas impactam nosso cotidiano e quais as possíveis respostas do Direito ao fenômeno.

\section{IMPACtOS DE UM LIVRE-ARBítRIO RELATIVIZADO NA VIDA DE RELAÇÃo E No DiREITO}

Usando suas habilidades — inatas ou desenvolvidas — o homem manipula e controla o meio circundante para obter aquilo que almeja. Hoje, sua meta é vender, pois a sociedade capitalista em que vivemos autoalimenta-se do ciclo de produção - consumo de bens e serviços. O pleno emprego depende do consumo. Estimulando-se este, garante-se aquele. Sabe-se hoje que aromas, sons, cores e luzes hipnotizam o consumidor, que é levado a consumir por fatores que em nada se relacionam com a racionalidade da escolha. Assim, por exemplo, carros esportivos remetem ao aroma de borracha, carros de luxo, ao de couro. ${ }^{76}$

É evidente que não há como impedir o uso do conhecimento sobre processos anímicos do consumidor e sobre as limitações cognitivas que o tornam suscetível a induções e sugestionamentos. Uma das soluções para esse impasse, portanto, consiste em considerar o mínimo possível as manifestações volitivas dos consumidores que lhes sejam prejudiciais, notadamente quando a sua vontade se limita à aceitação de condições desfavoráveis previamente fixadas pelo fornecedor em contratos de adesão ${ }^{77}$, interpretando-se com generosidade o conceito e extensão de cláusulas abusivas. O simples fato de alguém ter assinado um contrato não significa que, efetivamente, tenha tomado conhecimento efetivo de todas as suas cláusulas e estivesse consciente de suas implicações jurídicas. A manifestação de uma vontade concordante, em muitas situações, deve ser vista, apenas, como uma ficção jurídica necessária para transformar aquele contato social num negócio produtor de efeitos jurídicos — criação de deveres para ambas as partes. Quando, posteriormente, se percebe que alguns desses deveres são altamente gravosos para a parte vulnerável — normalmente o consumidor —, não há como simplesmente se afirmar que se está diante de um contrato e que, portanto, pacta sunt servanda. Compreende-se, melhor, assim, o alcance e necessidade de conceitos e institutos como o das cláusulas abusivas, no CDC, lesão e estado de perigo, no CC, bem como a possibilidade da atuação equitativa do juiz (v.g., art. 413 do CC).

Uma aplicação evidente dessas ideias está consagrada no art. 49 do CDC, que reza:

Art. 49. O consumidor pode desistir do contrato, no prazo de 7 dias a contar de sua assinatura ou do ato de recebimento do produto ou serviço, sempre que a contratação de fornecimento de produtos e serviços ocorrer fora do estabelecimento comercial, especialmente por telefone ou a domić́lio.

Parágrafo único. Se o consumidor exercitar o direito de arrependimento previsto neste artigo, os valores eventualmente pagos, a qualquer título, durante o prazo de reflexão, serão devolvidos, de imediato, monetariamente atualizados.

ete um homicídio absolutamente imotivado, induzido pelo calor e pela forte luz do sol da praia onde caminhava juntamente com a vítima, sem que fosse expressão de um querer consciente.

76 PEREIRA, Camila; TODESCHINI, Marcos. Anatomia do consumo. Revista Veja, São Paulo, 17 dez. 2008. Disponível em: <http://veja.abril.com.br/171208/p_090.shtml>. Acesso em: 16 jan. 2009.

77 WRIGHT, Joshua D. Behavioral Law and economics, paternalism, and consumer contracts: an empirical perspective. NYU Journal of Law \& Liberty, v. 2, n. 3, p. 493, 2007. 
Esse "prazo de reflexão" revela a percepção, do legislador, de que o consumidor muitas vezes compra por impulso, sendo suscetível a sugestionamentos. Se vínculos jurídicos obrigatórios devem decorrer de manifestação de vontades efetivamente conscientes, entende-se que o próprio legislador, antevendo situações em que essa reflexão consciente possa não inexistir, autorize a desistência do contrato, no exercício de um verdadeiro direito de arrependimento. Se, por um lado, é necessária a permanente preocupação com a estabilidade das relações jurídicas, por outro, é igualmente necessário que o legislador e o juiz estejam igualmente atentos aos reais interesses da parte vulnerável das relações jurídicas — não só consumidores —, protegendo-a de certas práticas negociais prejudiciais aos seus verdadeiros interesses, mas protegendo-a até mesmo de sua própria fraqueza humana. Uma interpretação generosa da exceção prevista no art. 49 do CDC, portanto, impõe-se.

Ainda na seara do consumidor, há já algumas décadas vem se intensificando a preocupação com o fenômeno do "superendividamento", ou seja, a assunção de obrigações superiores à capacidade de pagamento do devedor. No Brasil, Pesquisa de Endividamento e Inadimplência do Consumidor (Peic), apurada pela Confederação Nacional do Comércio, Bens, Serviços e Turismo (CNC) revelou que, em julho de 2017, $57,1 \%$ das famílias brasileiras estão endividadas; $24,2 \%$ estão com contas atrasadas e $9,4 \%$ não terão condições de pagar. ${ }^{78}$

O fenômeno exige uma reflexão profunda especialmente sobre as formas de concessão de crédito, especialmente por meio do mecanismo do crédito consignado. Esse mecanismo, em si interessante, com mais rápida concessão de crédito, com juros mais baratos, tornou-se uma das principais razões desse superendividamento. Uma oferta agressiva de tal tipo de crédito, especialmente a idosos aposentados, fez com que muitas vezes toda a família (filhos, netos) passasse a consumir mais do que o razoável e necessário, usando essa via. ${ }^{79}$

O fenômeno do superendividamento é tão preocupante que o próprio Poder Judiciário dele tomou consciência e procurou reagir, regulando formas de auxilio para quem se encontra em tal situação e procura sair dela. O Judiciário gaúcho (em iniciativa que também está presente em outros judiciários nacionais) institucionalizou a questão, constando do seu site oficial a seguinte página:

Superendividamento do Consumidor

\section{PRÁTICA DO TRATAMENTO DAS SITUAÇÕES DE SUPERENDIVIDAMENTO DOS CONSUMIDORES}

A reflexão e a tranquilidade do consumidor na avaliação da compatibilidade da dívida com a sua renda, antes de contraí-la é elemento determinante para evitar seu endividamento excessivo, também chamado de superendividamento. Este ocorre quando o consumidor gasta mais do que ganha ou quando sofre uma diminuição de seus rendimentos e passa a ter dificuldades de pagar as dívidas sem prejudicar as despesas de sobrevivência da família tais como aluguel, condomínio, alimentação, saúde, educação e transporte. Nesse caso, o prazer imediato da compra é substituído por restrições no orçamento familiar, sensação de frustração e até mesmo depressão. Este fenômeno já foi identificado e tutelado pela legislação em diversos países. Na vanguarda estão

78 RAMOS, Fabiana D'Andrea. Superendividamento maior é problema do mercado de crédito, não do consumidor. 2017. Disponível em: $<$ https://www.conjur.com.br/2017-ago-16/garantias-consumo-superendividamento-maior-problema-mercado-credito-nao-consumidor>. Acesso em: 28 maio 2018.Compartilhar

79 O fenômeno vem sendo objeto de muitas decisões judiciais, servindo de exemplo a seguinte: "AGRAVO DE INSTRUMENTO. SUPERENDIVIDAMENTO. Irresignação com o deferimento da antecipação dos efeitos da tutela que limitou os descontos ao percentual de $30 \%$ dos vencimentos brutos, excetuadas as verbas previdenciárias, os tributos obrigatórios e as pensões alimentícias, com determinação para expedição de ofício ao Órgão Pagador, a teor da súmula no 144 deste Tribunal. A decisão que limita o percentual de descontos a 30\% está amparada em súmula de jurisprudência predominante deste E. Tribunal de Justiça $\left(\mathbb{N}^{\circ} 295\right.$. "Na hipótese de superendividamento decorrente de empréstimos obtidos de instituições financeiras diversas, a totalidade dos descontos incidentes em conta-corrente não poderá ser superior a 30\% do salário do devedor.”). Como o autor é servidor público estadual e figuram no polo passivo da ação originária oito instituições financeiras é necessária a expedição de ofício ao órgão Pagador para que seja garantida a efetivação da medida. Aplicabilidade do art. 461, do CPC. Precedentes jurisprudenciais. RECURSO CONHECIDO. SEGUIMENTO NEGADO. (TJ-RJ - AI 00010336420168190000 , Data de publicação: 25/01/2016). 
países como França, Alemanha, Dinamarca, Suécia, Estados Unidos da América, entre outros. A falta de tutela legal a disciplinar medidas de atenuação ou de solução desta e a recorrente procura dos consumidores ao Poder Judiciário, através de ações revisionais no intuito de amenizar as consequências deste fenômeno de exclusão social, inspiraram a criação e a instalação de Projeto-piloto no Poder Judiciário do Rio Grande do Sul, hoje institucionalizado no Art. 1040 A da CNJ (Consolidação Normativa Judicial).

A prática é gratuita, independe da presença de advogado e viabiliza a renegociação conjunta das dívidas do consumidor e seus credores em único ato, de acordo com o orçamento familiar do superendividado. Para tanto, o requerente dispõe de um formulário padrão, onde declara dados pessoais sobre a renda e a extensão das despesas familiares, bem como a quantidade de credores, individualização destes e dados atinentes a cada uma das dívidas. $\mathrm{Na}$ oportunidade da entrega deste formulário, o consumidor já é notificado da data da audiência de renegociação. Os credores recebem cartas-convite com a advertência da necessidade de comparecimento com carta de preposição e poderes para conciliar.

Uma tentativa de despertar no consumidor a consciência de quanto pode estar sendo prejudicado em um negócio que envolva concessão de crédito foi albergada no art. 52 do CDC, verbis:

Art. 52. No fornecimento de produtos ou serviços que envolva outorga de crédito ou concessão de financiamento ao consumidor, o fornecedor deverá, entre outros requisitos, informá-lo prévia e adequadamente sobre:

I - preço do produto ou serviço em moeda corrente nacional;

II - montante dos juros de mora e da taxa efetiva anual de juros;

III - acréscimos legalmente previstos;

IV - número e periodicidade das prestações;

$\mathrm{V}$ - soma total a pagar, com e sem financiamento.

Preocupação do legislador também é notada na vedação prevista no art. 39, IV, do CDC:

Art. 39. É vedado ao fornecedor de produtos ou serviços, dentre outras práticas abusivas (Redação dada pela Lei no 8.884, de 11.6.1994) :

IV - prevalecer-se da fraqueza ou ignorância do consumidor, tendo em vista sua idade, saúde, conhecimento ou condição social, para impingir-lhe seus produtos ou serviços;

Outra importante aplicação da constatação da fragilidade da noção de livre-arbítrio encontra-se na potencial responsabilidade da indústria do fumo pelos danos causados aos fumantes. ${ }^{80}$ Nos Estados Unidos, o famoso relatório de 1964 do Surgeon General (Ministério da Saúde americano) tornou público que, do ponto de vista científico, era absolutamente incontroverso que o tabaco fazia muito mal à saúde ${ }^{81}$. Buscando neutralizar o impacto de tal relatório, a indústria tabagista procurou apoiar-se no mecanismo psicológico da racionalização e da negação utilizados pelos fumantes, como deixa claro memorando interno expedido pelo então Vice-Presidente Executivo da Philip Morris: "No futuro, devemos dar respostas que ofereçam aos fumantes uma muleta psicológica, uma racionalização para continuar fumando". Entre as 'muletas' e 'racionalizações' propostas constavam questões de teor médico, como 'mais pesquisas são necessárias' e 'existem contradições' e ‘discrepâncias'. ${ }^{82}$

80 Especificamente sobre esse tema, remete-se o leitor a FACCHINI NETO, Eugênio. A relatividade do livre-arbítrio e a responsabilização da indústria do fumo: a desconstrução de um mito. Revista de Derecho Privado, Bogota, v. 31, p. 189-225, 2016.

81 Referido relatório teve um grande impacto na opinião pública norte-americana. Uma pesquisa de opinião realizada em 1958 demonstrou que, apenas, $44 \%$ dos norte-americanos acreditavam que fumar causava câncer, ao passo que tal percentual subiu para $78 \%$ em outra pesquisa realizada em 1968, sobre o mesmo tema, segundo informação colhida no artigo "The Reports of the Surgeon General - The 1964 Report on Smoking and Health”, publicado no site da National Library of Medicine, https://profiles.nlm. nih.gov/ps/retrieve/Narrative/NN/p-nid/60, acessado em 31.07.2016.

82 Informação contida no item 636 da sentença de 1672 páginas proferida pela juíza Gladys Kessler, na ação judicial movida pelos Estados Unidos contra as 11 indústrias fumageiras em atividade nos Estados Unidos (conhecida como United States v. Philip Morris et al.), proposta em 1999, julgada em primeiro grau em 2006 (já com trânsito em julgado) - Disponível em http://publichealthlawcenter.org/sites/default/files/resources/doj-final-opinion.pdf , acesso em 25.05.2018. 
Ou seja, a indústria do fumo, de forma deliberada e consciente, usou de todos os recursos psicológicos disponíveis para 'vender' seu produto, buscando quebrar as barreiras de uma saudável liberdade de escolha, neutralizando informações de que tal produto seria maléfico e fornecendo falsas 'muletas' para neutralizar os alertas cada vez mais abundantes e inequívocos provindos do meio científico.

A Economia Comportamental traz bons insights para esse debate:

[...] os seres humanos costumam selecionar, em tendo as opções possíveis, os argumentos que confirmam aquilo que eles previamente desejavam como conclusão.

[...] É de se reconhecer, por outro lado, que as seguintes afirmações são reconhecidamente corriqueiras entre os próprios fumantes: 'conheço alguém que fumou desde os 12 anos, hoje tem 90 e está bem' (utilizando um caso excepcional para confirmar a ideia que lhe convém, em detrimento de inúmeras pesquisas sérias que comprovam ser essa circunstância rara e que a grande maioria dos fumantes morre mal e prematuramente em razão do tabaco); 'fumo porque quero, paro quando quiser' (desconsiderando o caráter de vício do tabagismo e o fato de que a suposta 'escolha' que ele faz cotidianamente está longe de representar exercício de livre-arbítrio); 'quero parar de fumar, mas, só hoje, estou estressado, vou acender mais um cigarro' (comprovando a necessidade humana de satisfações instantâneas, em detrimento de maiores recompensas futuras); entre tantos outros exemplos possíveis" ${ }^{\prime 3}$.

O argumento do livre-arbítrio, costumeiramente invocado pela indústria do fumo, nas ações que buscam responsabilizá-la pelos danos à saúde dos fumantes, no sentido de que esses estão conscientes dos males que o fumo causa à saúde e, portanto, livremente decidiram fumar, revela-se, portanto, muito frágil, à luz daquilo que hoje se sabe sobre como o cérebro efetivamente funciona e sobre as formas como se pode influenciar comportamentos.

Pelas limitações inerentes a um artigo doutrinário, não há como aqui abordar todos os efeitos jurídicos ligados à constatação do déficit de racionalidade muitas vezes presente no processo de tomada de decisões, como as questões ligadas às revisões de cláusulas contratuais, proteção do idoso, na condição de sujeito hipervulnerável etc.

\section{Considerações finais}

O objetivo do presente trabalho foi demonstrar que, embora boa parte das instituições jurídicas se assente no pressuposto de que a pessoa humana é um ser racional, agindo livremente e conscientemente tomando decisões que geram efeitos jurídicos, os achados da psicologia comportamental e os desenvolvimentos da economia comportamental apontam para a constatação de que aquela pressuposição não pode ser tida como inabalável.

Os mecanismos psicológicos do processo de tomada de decisão revelam toda a fragilidade do ser humano e a sua dificuldade, muitas vezes, de tomar decisões efetivamente racionais. Determinadas escolhas que fazemos não são as que mais consultam nossos próprios interesses. Quem domina os achados das ciências que estudam o comportamento humano e o processo de tomada de decisão dos seres humanos pode, facilmente, influenciar comportamentos e induzir condutas.

Ainda que a necessidade da estabilidade das relações jurídicas exija que se possa confiar nas declarações de vontade 'livremente' emitidas, também um imperativo de justiça impõe que se deva proteger pessoas que, inconscientemente, foram levadas a praticar determinados atos, acreditando que estes eram fruto de sua vontade, quando, na verdade, foram induzidas a certos comportamentos.

Indicamos alguns desses casos e a resposta do direito aos mesmos, sem a pretensão de esgotá-los. Mas

83 OLIVEIRA, Amanda Flávio de; MOURA, Walter José Faiad de. É preciso proteger o fumante de si mesmo?. Revista Científica Virtual da Escola Superior da Advocacia da OAB-SP, São Paulo, n. 17, p. 162-163, inverno 2014. Edição especial: Direito e Tabaco. 
acreditamos que os casos brevemente referidos neste artigo são suficientes para demonstrar a necessidade de não se levar tão a sério o dogma do pacta sunt servanda, se quisermos realmente levar a sério a proteção da pessoa humana, percebida em toda sua fragilidade.

\section{REFERÊNCIAS}

ARIELY, Dan. Previsivelmente irracional: como as situações do dia-a-dia influenciam as nossas decisões. Tradução Jussara Simões. Rio de Janeiro: Elsevier, 2008.

BAUMAN, Zygmunt. Vida para o consumo: a transformação das pessoas em mercadorias. Tradução Carlos Alberto Medeiros. Rio de Janeiro: Zahar, 2008.

CARDOZO, Benjamin Nathan. The nature of the judicial process. In: A NATUREZA do processo e a evolução do Direito. Revista AJURIS, 1978.

CHARDIN, Nicole. Le contrat de consommation de crédit et l'autonomie de la volonté. Paris: LGDJ, 1988.

COMMONS, Michael Lamport; MILLER, Patrice Marie. Folk psychology and the law: why behavioral science needs to replace folk psychology. Revista Brasileira de Estudos Políticos, Belo Horizonte, n. 96, p. 7-30, jul./dez. 2007.

COMTE-SPONVILLE, André. Dicionário filosófico. Tradução Eduardo Brandão. São Paulo: Martins Fontes, 2003.

COSTA, Fernando Braga da. Homens invisiveis: relatos de uma humilhação social. São Paulo: Globo, 2004.

DARWIN, Charles. A origem das espécies por meio da seleção natural. Tradução André Campos Mesquita. São Paulo: Escala, 2009.

DEBORD, Guy. A sociedade do espetáculo. Tradução Estela dos Santos Abreu. Rio de Janeiro: Contraponto, 1997.

DESCARTES, René. Discurso do método. Tradução Paulo Neves. Porto Alegre: L\&PM, 2013.

DELEUZE, Gilles. Diferença e repetição. Tradução Luiz Orlandi e Roberto Machado. Lisboa: Relógio d’Água, 2000.

FACCHINI NETO, Eugênio. A relatividade do livre-arbítrio e a responsabilização da indústria do fumo: a desconstrução de um mito. Revista de Derecho Privado, Bogota, v. 31, p. 189-225, 2016.

SESSAREGO, Carlos Fernández. Trascendencia y reparación del "daño al proyecto de vida" en el umbral del siglo XXI. In: HERNÁNDEZ, Carlos Arturo et al (Org.). La Responsabilidad Civil. Bogotá: Universidad Libre, 2014. (Tendencias Contemporáneas del Derecho, v.19)

FERRY, Luc. Aprender a viver: filosofia para os novos tempos. Tradução Véra Lucia dos Reis. Rio de Janeiro: Objetiva, 2006.

FLORES FILHO, Edgar Gastón Jacobs; RIBEIRO, Rita de Cássia. Racionalidade limitada do consumidor e assimetria de informação. Economic Analysis of Law Review, v. 3, n. 1. p. 109-121, jan./jun. 2012.

HARARI, Yuval Noah. Sapiens: uma breve história da humanidade. Tradução Janaína Marcoantonio. 19. ed. Porto Alegre: L\&PM, 2017.

HARRIS, Ron; ALBIN, Einat. Bankruptcy in light of manipulation in credit advertising: personal bankruptcy in the $21^{\text {st }}$ Century: emerging trends and new challenges. Theoretical Inquires in Law, july 2006. Disponível em: $<$ http://www.westlaw.com>. 
HENRIQUES, Isabella. Controle do tabaco x controle do álcool: convergências e diferenciações necessárias. In: HOMSI, Clarissa Menezes (Coord.). Controle do tabaco e o ordenamento jurídico brasileiro. Rio de Janeiro: Lúmen Juris, 2011.

JOLLS, Christine et. al. A behavioral approach to law and economics. In: SUNSTEIN, Cass R. Behavioral Law and economics. New York: Cambridge University, 2000.

KAHNEMAN, Daniel. Rápido e devagar. duas formas de pensar. Rio de Janeiro: Objetiva, 2012.

KILBORN, Jason. Comportamentos econômicos, superendividamento; estudo comparativo da insolvência do consumidor: buscando as causas e avaliando soluções. In: MARQUES, Cláudia Lima; CAVALLAZZI, Rosângela Lunardelli (Coord.). Direitos do consumidor endividado: superendividamento e crédito. São Paulo: Revista dos Tribunais, 2006.

KANT, Immanuel. Crítica da razão pura. Tradução Lucimar A. Coghi Anselmi, Fulvio Lubisco. 3. ed. São Paulo: Ícone, 2011.

LANGEVOORT, Donald C. Organized Illusions: a behavioral theory of why corporations mislead stock market investors (and cause others social harms) In: SUNSTEIN, Cass R. Behavioral law and economics. New York: Cambridge University, 2000.

LEVITT, Steven. D.; DUBNER, Stephen J. Freakonomics: o lado oculto de tudo que nos afeta. Tradução Regina Lyra. Rio de Janeiro: Elsevier, 2007.

LEVITT, Steven D.; DUBNER, Stephen J. Super Freakonomics. New York: HarperCollins Publishers, 2009.

LEVITT, Steven D.; DUBNER, Stephen J. Pense como um Freak. Tradução Clóvis Marques. Rio de Janeiro: Record, 2014.

MLODINOW, Leonard. Subliminar: como o inconsciente influencia nossas vidas. Tradução Claudio Carina. Rio de Janeiro: Zahar, 2013.

NIETZSCHE, Friederich. Assim falou Zaratustra. Tradução Carlos Duarte e Anna Duarte. São Paulo: Martin Claret, 2012.

NIETZSCHE, Friederich. Crepúsculo dos idolos. Tradução Paulo César de Souza. São Paulo: Companhia das letras, 2006.

OLIVEIRA, Amanda Flávio de; MOURA, Walter José Faiad de. É preciso proteger o fumante de si mesmo?. Revista Cientifica Virtual da Escola Superior da Advocacia da OAB-SP, São Paulo, n. 17, inverno 2014. Edição especial: Direito e Tabaco.

OLSSON, Gustavo André. Análise econômica do direito penal e teoria sistêmica. Curitiba: Juruá, 2014.

PEREIRA, Camila; TODESCHINI, Marcos. Anatomia do consumo. Revista Veja, São Paulo, 17 dez. 2008. Disponível em: <http://veja.abril.com.br/171208/p_090.shtml>. Acesso em: 16 jan. 2009.

PINTO, Manuel da Costa (Org.). O Livro de ouro da psicanálise: o pensamento de Freud, Jung, Melanie Kein, Lacan, Winnicott e outros. 2. ed. Rio de Janeiro: Ediouro, 2007.

PUCHKIN, V. N. Heurística: a ciência do pensamento criador. Tradução Vera Neverova. Rio de Janeiro: Zahar Editores, 1969.

RABENHORST, Eduardo Ramalho. O valor da pessoa humana e o valor da natureza. In: MELGARÉ, Plínio; ALMEIDA FILHO, Agassiz. (Org.). Dignidade da pessoa bumana: fundamentos e critérios interpretativos. São Paulo: Malheiros, 2010.

RAMOS, Denise Gimenez; MACHADO JUNIOR, Pericles Pinheiro. Individuação e subjetivação: os conceitos junguianos de inconsciente coletivo e arquétipo mostram o caráter universal das imagens e dinâmicas 
do inconsciente que representam modos de estruturação da subjetividade no processo de individuação. In: PINTO, Manuel da Costa (Org.). O livro de ouro da psicanálise: o pensamento de Freud, Jung, Melanie Kein, Lacan, Winnicott e outros. 2. ed. Rio de Janeiro: Ediouro, 2007.

RAMOS, Fabiana D’Andrea. Superendividamento maior é problema do mercado de crédito, não do consumidor. 2017. Disponível em: <https://www.conjur.com.br/2017-ago-16/garantias-consumo-superendividamento-maior-problema-mercado-credito-nao-consumidor>. Acesso em: 28 maio 2018.

ROUSSEAU, Jean-Jacques. Discurso sobre a origem da desigualdade. Tradução Maria Lacerda de Moura. 2001.

RUSSELL, Bertrand. Ensaios céticos. Tradução Marisa Motta. Porto Alegre: L\&PM Editores, 2014.

SARTRE, Jean-Paul. O existencialismo é um humanismo. Tradução João Batista Kreuch. 3. ed. Petrópolis: Vozes, 2014.

SCHMIDT NETO, André Perin. Contratos na sociedade de consumo: vontade e confiança. São Paulo: Revista dos Tribunais, 2016.

SCHOPENHAUER, Arthur. O mundo como vontade e representação. São Paulo: Saraiva, 2001.

SCHOPENHAUER, Arthur. Sobre a vontade na natureza. Tradução Gabriel V. Silva. Porto Alegre: L\&PM, 2013.

SHAKESPEARE, William. Júlio César. 2000. Disponível em: < http://www.ebooksbrasil.org/eLibris/cesar. html>.

SPINOZA, Benedictus de. Ética. Tradução Thomaz Tadeu. 2. ed. Belo Horizonte: Autêntica, 2013.

STARNBERG, Robert J. Psicologia cognitiva. Tradução Anna Maria Dalle Luche e Roberto Galman. São Paulo: Cangage Learning, 2010.

SUNSTEIN, Cass R. Behavioral law and economics. New York: Cambridge University, 2000.

TARUFFO, Michele. Uma simples verdade: o juiz e a construção dos fatos. Tradução Vitor de Paula Ramos. Madri: Marcial Pons, 2012.

STRECK, Lenio Luiz. Verdade e consenso. Rio de Janeiro: Lumen Juris, 2009.

TONETTO, Leandro Miletto et al. O papel das heurísticas no julgamento e na tomada de decisão sob incerteza. Estudos de Psicologia, Campinas, v. 23, n. 2, abr./jun. 2006.

LLOSA, Mario Vargas. A civilização do espetáculo: uma radiografia do nosso tempo e da nossa cultura. Tradução Ivone Benedetti. Rio de Janeiro: Objetiva, 2013.

VEBLEN, Thorstein B. A teoria da classe ociosa: um estudo econômico das instituições. São Paulo: Pioneira, 1965.

WITTGENSTEIN, Ludwig. Investigações filosóficas. Tradução Marcos G. Montagnoli e Emmanuel Carneiro Leão. 9. ed. Petrópolis: Vozes; Bragança Paulista: Editora Universitária São Francisco, 2014.

WRIGHT, Joshua D. Behavioral Law and economics, paternalism, and consumer contracts: an empirical perspective. NYU Journal of Law \& Liberty, v. 2, n. 3, p. 470-511, 2007.

YARAK, Aretha. O livre-arbítrio não existe, dizem neurocientistas. Revista Veja. Disponível em: <https:// veja.abril.com.br/ciencia/o-livre-arbitrio-nao-existe-dizem-neurocientistas/>. Acesso em: 26 maio 2018.

ZYLBERSZTAJN, Décio; SZTAJN, Rachel. (Org.). Direito e economia: análise econômica do direito e das organizações. Rio de Janeiro: Elsevier, 2005. 


\section{REVISTA BRASILEIRA DE POLÍTICAS PÚBLICAS BRAZILIAN JOURNAL OF PUBLIC POLICY}

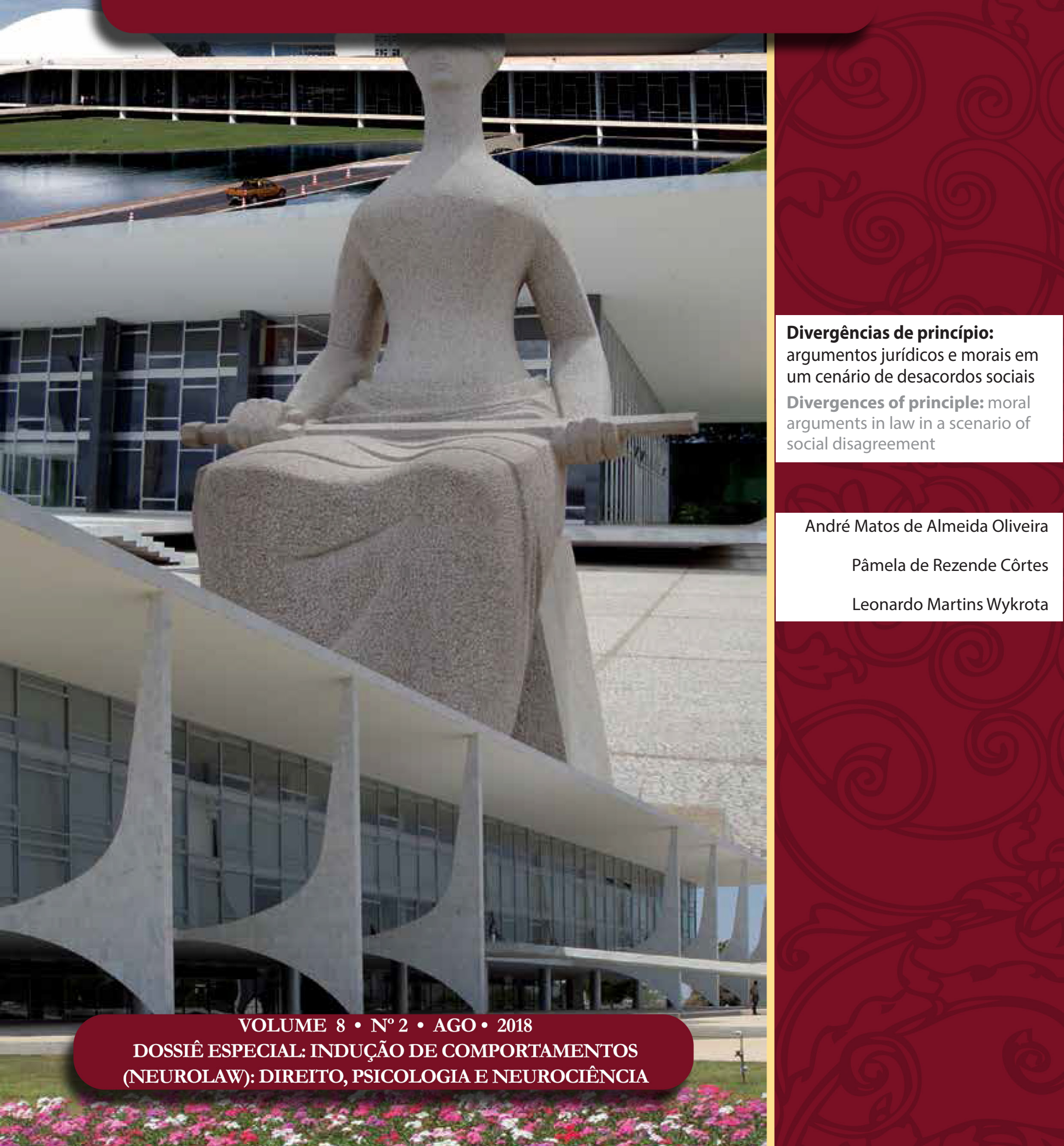




\section{Divergências de princípio: argumentos jurídicos e morais em um cenário de desacordos sociais*}

\section{Divergences of principle: moral arguments in law in a scenario of social disagreement}

* Recebido em 31/05/2018 Aprovado em 17/07/2018

** Mestrando em Direito pela UFMG e bolsista CAPES. Monitor do Grupo de Estudos em Neuroética e Neurodireito da UFMG. Graduado em Direito pela UFMG.

E-mail: andrematosalmeida@hotmail.com

*** Doutoranda em Direito pela UFMG, bolsista CAPES. Mestra em Direito e Graduada em Ciências do Estado pela UFMG. Coordenadora do Projeto de Extensão em Políticas Públicas Baseadas em Evidências. E-mail: pamela. recortes@gmail.com

Doutor em Direito pela PUC/MG. Mestre em Direito pela PUC/MG. MBA em Direito da Economia e da Empresa pela FGV. Advogado. E-mail: leonardo@vlf.adv.br
André Matos de Almeida Oliveira**

Pâmela de Rezende Côrtes***

Leonardo Martins Wykrota****

\section{Resumo}

O objetivo deste artigo é analisar possíveis problemas do uso de argumentos morais no direito, em especial numa pressuposição comum de teóricos: de que argumentos morais podem gerar convergência e consenso. Este pressuposto é o que chamaremos de "ideia de convergência". Dividiremos nossa análise em algumas partes. $\mathrm{Na}$ primeira, mostraremos como teorias morais têm ganhado proeminência no direito atualmente, sendo defendidas e usadas em teorias filosóficas, manuais de doutrina e na jurisprudência. A seguir, mostraremos que uma parte central do uso de teorias morais no direito envolve a ideia de convergência. $\mathrm{Na}$ terceira parte do artigo, a mais substancial, passaremos a uma análise das evidências empíricas sobre os julgamentos morais humanos em áreas como a neurociência, a psicologia e a ciência política. Nossa revisão se focará em três linhas majoritárias de pesquisa: (i) estudos sobre correlatos neurais nas respostas a dilemas morais; (ii) estudos sobre polarização e influência afetiva do grupo na formação de ideologias; (iii) modelo social-intuicionista dos julgamentos morais humanos. Concluiremos que, em relação à visão geral que se forma dessa análise, temos motivos para descartar, em muitos casos, a ideia de convergência, substituindo-a pela oposta, de que julgamentos morais tendem a criar divergências entre pessoas de grupos diferentes. Essa conclusão é especialmente relevante para teóricos e aplicadores do direito, já que uma das funções centrais das instituições jurídicas é resolver e evitar conflitos sociais. Essa função pode ser ameaçada com a aplicação de argumentos morais em casos controversos, o que justifica repensar o papel da moralidade no direito.

Palavras-chave: Teorias morais. Consenso moral. Trolleyology. Modelo social-intuicionista.

\section{Abstract}

This paper aims to analyze one problem with the use of moral arguments in law, especially one in a common presupposition of theorists: that moral arguments can generate convergence and consensus. This assumption 
is what we shall call "convergence idea". We will divide our analysis into some parts. In the first, we shall show how moral theories have gained prominence in law, being defended and used in philosophical theories, doctrinal manuals and jurisprudence. Next, we shall show that a central part of the use of moral theories in law involves the idea of convergence. In the third part, the most substantial of the paper, we shall turn to an analysis of the empirical evidence on human moral judgments in areas such as neuroscience, psychology, and political science. Our review shall be focused on three main lines of research: (i) studies on neural correlates in responses to moral dilemmas; (ii) studies on polarization and affective influence of the group in the formation of ideologies; (iii) the social-intuitionist model of human moral judgments. We shall conclude from this general this analysis that we have reason to dismiss the idea of convergence, replacing it with the opposite, that moral judgments tend to create disagreements between people from different groups. This conclusion is especially relevant for law theorists and public officials, since one of the central functions of legal institutions is to resolve and avoid social conflicts. This function can be threatened by the application of moral arguments in controversial cases, and this justifies rethinking the role of morality in law.

Keywords: Moral theories. Moral consensus. Trolleyology. Social-intuitionist model.

\section{INTRODUÇÃo}

Nosso objetivo neste artigo é apresentar um possível problema decorrente do uso de discursos morais no direito. O problema é que uma premissa central que permeia o uso de argumentos morais no direito (e em geral) pode estar incorreta. Nós chamaremos essa premissa de "ideia da convergência": a noção, implícita ou explicitamente adotada em teorias morais, de que, tendo em vista alguns argumentos suficientemente convincentes numa direção - e que as pessoas são racionais —, com tempo suficiente, elas serão convencidas da razoabilidade da posição defendida com os melhores argumentos.

Mas, para alcançar essa conclusão, devemos, primeiramente, ter uma boa ideia de como a moralidade funciona na realidade. Então, outro objetivo deste trabalho é fazer uma análise interdisciplinar e empírica do comportamento moral humano, usando informações provenientes de áreas diversas, como a psicologia, a neurociência, a economia comportamental e a ciência política.

Podemos, então, organizar os objetivos deste artigo da seguinte forma: primeiramente, mostraremos como argumentos morais são bastante difundidos no direito. Em seguida, explicaremos porque a tese da convergência é uma concepção central para teorias morais e argumentos morais, incluindo (e especialmente) quando aplicados no direito. Posteriormente, faremos uma revisão das pesquisas científicas desse tópico, focando em três linhas principais: (1) a trolleyology, baseada nos experimentos do trolley, feitos por Joshua Greene e outros; (2) o modelo afetivo dos grupos ideológicos, desenvolvido por cientistas políticos e sociais como Shanto Iyengar; (3) o modelo social-intuicionista, defendido com destaque pelo psicólogo Jonathan Haidt.

Finalmente, na última seção do artigo, abordaremos as consequências dessas pesquisas para o direito. Argumentaremos que as evidências apresentadas sugerem que a "ideia da convergência" não é apenas incorreta, mas que, em muitos casos, deve ser substituída pela ideia oposta, de divergência moral. Isso significa que, às vezes, os argumentos morais tendem a exacerbar os desacordos e a polarização política, não a mitigá-los. Concluiremos que, se advogados e outros profissionais do direito - especialmente os juízes — querem evitar o aumento de divergência ideológica em tempos de polarização política, então devem repensar o uso de argumentos morais no direito.

Acreditamos que o tema tratado neste artigo é notoriamente relevante para as discussões jurídicas contemporâneas. É importante que nós — os cidadãos — saibamos quando os profissionais do direito estão usando ou não as melhores estratégias argumentativas e interpretativas disponíveis para decidir casos com- 
plicados. Assim, se ficar demonstrado que os argumentos morais amplificam as divisões políticas, e se nós e os profissionais do direito quisermos evitar essa amplificação, então será preciso modificar a forma como algumas decisões são justificadas. Essa conclusão é ainda mais relevante para os casos difíceis (hard cases), aqueles para os quais os juízes não têm soluções "fáceis", além de serem casos relevantes socialmente e sobre matérias que exigem mais do poder argumentativo e interpretativo do juiz.

Outra razão para relevância dessa discussão é o uso de pesquisas empíricas para informar a análise da moralidade no direito. Acreditamos que teorias do direito meramente abstratas (no sentido de não vinculadas à realidade cotidiana) devem ter seu uso minorado, e que já é tempo de ampliar o uso de análises empiricamente orientadas no direito.

\section{TEORIA MORAL}

Os argumentos morais se tornaram uma parte central dos debates jurídicos e políticos em tempos recentes. Arthur Kaufmann afirma que, no lado jurídico da questão, o crescimento da importância da Teoria Moral foi impulsionado por reações aos sistemas políticos desastrosos que se proliferaram na Europa na metade do século passado ${ }^{1}$. A intenção geral era abolir a arbitrariedade moral, impondo um centro rígido de prescrições morais que se irradiariam para todo ou para a maior parte de nosso sistema jurídico, o que contribuiria para prevenir grandes corrupções sistêmicas.

Essa nova ideia sobre a função dos sistemas jurídicos se espalhou, acompanhada de justificativas de todos os tipos, para países não-Europeus, incluindo, notavelmente, os Estados Unidos e o Brasil. Nos Estados Unidos, esse novo ideal é bem representado nas obras de Ronald Dworkin², um dos filósofos do direito famosos de nossa época.

Dworkin exerce uma grande influência sobre juristas brasileiros. É famoso por suas críticas ao positivismo, e por sustentar a tese de que os padrões normativos do direito são de dois tipos: regras e princípios. Dworkin afirma que os últimos têm uma importância crítica para o direito, especialmente quando se devem resolver os "bard cases", e, inquestionavelmente, para ele, os princípios morais são constituídos por conceitos morais: “Eu chamo de 'princípio' um padrão que deve ser observado, não porque ele avançará ou assegurará uma situação econômica, política ou social considerada como desejável, mas porque ele é um requerimento da justiça ou da equidade ou de alguma outra dimensão da moralidade ${ }^{3}$."

Em tempos recentes, a confiança de Dworkin na relação necessária entre direito e moralidade parece ter aumentado. Em "Justice for Hedgehogs", ele sustenta que todos os empreendimentos normativos humanos são parte e manifestação de um só valor unificador e abstrato:

Nós construímos uma concepção de direito [...] encontrando uma justificação dessas práticas em uma rede maior e integrada de valores políticos. Nós construímos uma teoria do direito, isto é, da mesma forma que construímos uma teoria dos outros valores políticos - da igualdade, da liberdade e da democracia. [...] Nós desfizemos agora a imagem antiga que considera o direito e a moralidade como dois sistemas separados e depois busca ou nega, infrutiferamente, as interconexões entre eles. Nós substituímos isso por imagem de um sistema: nós agora tratamos o direito como parte da moralidade política. ${ }^{4}$

1 KAUFMANN, Arthur. Filosofia do direito. Lisboa: Fundação Calouste Gulbenkian, 1997. Também cf. ALEXY, Robert. Conceito e validade do direito. Tradução Gercélia Batista de Oliveira Mendes. São Paulo: WMF M. Fontes, 2009.

2 DWORKIN, R. M. Taking rights seriously. Cambridge, Mass.: Harvard University Press, 1978.

3 DWORKIN, R. M. Taking rights seriously. Cambridge, Mass.: Harvard University Press, 1978, p. 22. Tradução de: "I call a 'principle' a standard that is to be observed, not because it will advance or secure an economic, political, or social situation deemed desirable, but because it is a requirement of justice or fairness or some other dimension of morality."

4 DWORKIN, Ronald. Justice for hedgehogs. Harvard University Press, 2011, p. 405. Tradução de: "We construct a conception of law $[. .$.$] by finding a justification of those practices in a larger integrated network of political value. We construct a theory of law,$ 
Outros teóricos do direito influentes no Brasil são os autores alemães Jürgen Habermas e Robert Alexy. Ambos os autores também favorecem a combinação do direito e da moral. Habermas usa sua Teoria da Ação Comunicativa como uma forma de sintetizar conceitos contemporâneos como direito, moralidade e democracia: "O que antes podia ser juntado coerentemente nos conceitos da filosofia hegeliana agora demanda uma abordagem pluralista que combina as perspectivas da teoria moral, da teoria social, da teoria jurídica e da sociologia e da história do direito" ${ }^{5}$. Apesar de ele não aceitar a visão radical da subordinação do direito à moralidade, Habermas ainda vê uma relação de complementariedade entre ambos ${ }^{6}$.

Alexy inclui como parte de sua definição do direito a afirmação "não positivista" de que ele deve evitar injustiças extremas. Essa é uma afirmação normativa sobre a conexão entre direito e moralidade. As injustiças extremas são um critério para limitar tanto a consideração do sistema jurídico como um todo quanto a de normas jurídicas isoladas. Para Alexy, então, "os princípios, mesmo quando eles não podem ser identificados como princípios jurídicos de acordo com o critério de validade da constituição, se tornam componentes do direito, assim como outros argumentos normativos"?.

Na profissão jurídica brasileira, parece que esse novo ideal ganhou força também, de forma que, atualmente, ele parece estar firmemente entrincheirado nas teorias da maior parte de nossos pesquisadores, e até nas decisões de boa parte de nossos juízes ${ }^{89}$.

Podemos ter um rápido senso de seu poder ao pesquisar o conteúdo de manuais de direito bem-sucedidos no país. Tomando o Direito Constitucional como exemplo, vemos que uma lista dos manuais mais populares deve incluir: o livro de Gilmar Ferreira Mendes (Ministro do STF) e Paulo Gustavo Gonet Branco ${ }^{10}$; o de Pedro Lenza ${ }^{11}$; o de Bernardo Gonçalves Fernandes ${ }^{12}$; e o de Luís Roberto Barroso ${ }^{13}$ (também Ministro do STF), entre outros (a maior parte dos livros costuma se chamar "Curso de Direito Constitucional", com poucas variações).

Em todos esses livros citados, podemos encontrar algum tipo de validação para o uso de fundamentações teórico-morais na análise do Direito Constitucional. No livro de Mendes e Branco, eles dizem que a Constituição adota direitos fundamentais que têm uma raiz ético-política ${ }^{14}$. Fernandes explicitamente defende uma abordagem procedimentalista moral para a Constituição, baseada em teorias como a de Habermas, José Gomes Canotilho, Menelick de Carvalho Netto, etc. ${ }^{15}$ E, nos livros de Lenza e de Barroso, vemos que

that is, in the same way that we construct a theory of other political values - of equality, liberty, and democracy. [...] We have now scrapped the old picture that counts law and morality as two separate systems and then seeks or denies, fruitlessly, interconnections between them. We have replaced this with a one- system picture: we now treat law as a part of political morality."

5 HABERMAS, Jürgen. Between facts and norms: contributions to a discourse theory of law and democracy. Cambridge: MIT, 1996. p. 10. Tradução de: "What could once be coherently embraced in the concepts of Hegelian philosophy now demands a pluralistic approach that combines the perspectives of moral theory, social theory, legal theory, and the sociology and history of law"

6 HABERMAS, Jürgen. Between facts and norms: contributions to a discourse theory of law and democracy. Cambridge: MIT, 1996. p. 447.

7 ALEXY, Robert. The argument from injustice: a reply to legal positivism. Oxford: Clarendon Press, 2002. p. 129. Tradução de: "principles, even when they cannot be identified as legal principles according to the validity criteria of the constitution, as well as other normative arguments justifying the decision become components of the law".

8 BARROSO, Luís Roberto. A razão sem voto: o Supremo Tribunal Federal e o governo da maioria. Revista Brasileira de Politicas Públicas, Brasília, v. 5, Número Especial, p. 23-50, 2015.

9 BRUM, Guilherme Valle. Juspositivismo, discricionariedade e controle judicial de políticas públicas no direito brasileiro. Revista Brasileira de Políticas Públicas, Brasília, v. 10, n. 1, p. 391-404, 2013.

10 MENDES, Gilmar Ferreira; BRANCO, Paulo Gustavo Gonet. Curso de Direito Constitucional. 7. ed. rev. e atual. São Paulo: Saraiva, 2012.

11 LENZA, Pedro. Direito constitucional esquematizado. 14. ed. rev. atual. e ampl. São Paulo: Saraiva, 2010.

12 FERNANDES, Bernardo Gonçalves; PEDRO, Flávio Quinaud. Curso de Direito Constitucional. 3. ed. Rio de Janeiro: Lumen Juris, 2011.

13 BARROSO, Luis Roberto. Curso de Direito Constitucional. 5. ed. São Paulo: Saraiva, 2012.

14 MENDES, Gilmar Ferreira; BRANCO, Paulo Gustavo Gonet. Curso de Direito Constitucional. 7. ed. rev. e atual. São Paulo: Saraiva, 2012. capítulo 3.

15 FERNANDES, Bernardo Gonçalves; PEDRO, Flávio Quinaud. Curso de Direito Constitucional. 3. ed. Rio de Janeiro: Lumen Juris, 2011. cap. 1. 
uma das fontes fundamentais para o assim chamado "neoconstitucionalismo" é a aproximação entre direito e ética, efetuada especialmente pela tradição filosófica pós-positivista, liderada por autores como Dworkin e Alexy ${ }^{16}$.

O mesmo padrão pode ser visto nas decisões judiciais de cortes brasileiras. Podemos ter uma amostra do uso disseminado de argumentos e teorias morais entre juízes fazendo algumas pesquisas rápidas em indexadores de decisões judiciais. Se procurarmos termos como "leitura moral" (um termo popularizado por Dworkin) no site de pesquisa "Jusbrasil", encontraremos quase cinquenta resultados, que incluem usos pelo STF, pelo TST e por outros tribunais. Podemos, também, elencar diversas frases moralmente carregadas encontradas, como: "Nesse sentido, o pós-positivismo não ignora o direito legislado, no entanto também não abandona os ideais de justiça, por meio de uma leitura moral do direito." ${ }^{17}$; "É necessário fazer leitura moral do direito, prestigiando a teoria da justiça, fortemente influenciada pelos direitos fundamentais." ${ }^{18} \mathrm{E}$ :

$\mathrm{Na}$ esteira da doutrina do jusfilósofo americano Ronald Dworkin, a incorporação moral de valores transcendentais pelo direito está baseada num ideal de igualdade e eqüidade. [...] Daí advogar Dworkin uma leitura moral da Constituição, 'que coloque a moralidade política no coração do direito constitucional.' Tal concepção pressupõe que o aplicador do direito assuma uma postura ativa e construtiva, caracterizada pelo esforço de interpretar um sistema de princípios como um todo coerente e harmônico dotado de integridade. ${ }^{19}$

Podemos encontrar, também, um número significativo de resultados pesquisando por termos como "teorias de justiça" (2.548 resultados) e "princípios morais" (2.506 resultados), com o mesmo padrão de frases citáveis. Pesquisas para "Dworkin", "Habermas" e "Alexy" retornam, respectivamente, 3.517, 1.442 e 5.946 resultados. Isso confirma que esses autores certamente estão entre os mais citados das decisões judiciais no Brasil. É evidente que estamos falando de apenas uma fração, uma pequena amostra, do uso de teorias e argumentos morais por juízes brasileiros, mas elas servem para ilustrar o ponto.

É possível fazer uma análise mais qualitativa também. O STF vem tradicionalmente usando argumentos morais em suas decisões e, como é previsível, o uso é mais comum nos chamados "hard cases".

Podemos considerar a famosa decisão que garantiu às mulheres grávidas o direito de interromper a gestação de fetos anencéfalos (ADPF 54). Tratava-se de um caso difícil e polêmico, fronteiriço à discussão jurídica da permissibilidade ou não do aborto ${ }^{20}$. Lendo-o, podemos encontrar o amplo uso de termos teórico-morais, como referências à defesa de Alexy da dimensão ética dos princípios ${ }^{21}$ e à leitura moral da Constituição de Dworkin"22. Além disso, a ideia de "dignidade humana", que fica na fronteira entre o jurídico e o moral, é usada múltiplas vezes na decisão.

É possível observar, por outro lado, que os juízes também estavam agudamente conscientes da polarização moral que as questões do aborto geram e, então, em vários momentos, eles afirmavam não estar pretendendo fazer julgamentos morais no caso. Em uma situação, a ideia de minimalismo judicial de Sunstein é citada com aprovação: é dito que a decisão judicial será minimalista neste sentido ${ }^{23}$.

No entanto, essa pretensa acomodação entre, por um lado, teorias abstratas, morais, hercúleas (como as

16 LENZA, Pedro. Direito Constitucional esquematizado. 14. ed., rev. atual. e ampl. São Paulo: Saraiva, 2010. cap. 1.

17 BRASIL. Tribunal Superior do Trabalho. Agravo de Instrumento n¹603009420075080016. 2a Turma. Publicação DEJT 07/12/2017. Julgamento 5 de Dezembro de 2017. Relator: José Roberto Freire Pimenta.

18 BRASIL. Tribunal de Justiça de Mato Grosso do Sul - TJ-MS - APL: 00339098420048120001 MS 0033909-84.2004.8.12.0001, Relator: Juiz Vilson Bertelli, Data de Julgamento: 28/08/2013, 2a Câmara Cível, Data de Publicação: 28/08/2013.

19 BRASIL. Tribunal Regional Federal da $3^{a}$ Região - TRF-3 - RI: 00005722920134036321 SP, Relator: Juiz(a) Federal Kyu Soon Lee, Data de Julgamento: 30/06/2017, 5 Turma Recursal de São Paulo, Data de Publicação: e-DJF3 Judicial DATA: 13/07/2017.

20 PIRES, Terezinha Inês Teles. A legitimação do aborto à luz dos pressupostos do estado democrático de direito. Revista Brasileira de Politicas Públicas, Brasília, v. 3, n. 2, p. 363-390, 2013.

21 ADPF 54, p. 125; p. 142-43; notas 44-45.

22 ADPF 54, p. 165.

23 SUNSTEIN, Cass R. Incompletely theorized agreements. Harvard Law Review, v. 108, n. 7, p. 1733-1772, 1995. 
de Alexy e de Dworkin) e, por outro, teorias pragmáticas, formalistas e restritivas (como a de Sunstein) não parece funcionar bem. De fato, Sunstein diz que o juiz minimalista tem um perfil que é quase exatamente o oposto do outro perfil, que ele chama de heroico, que vê como uma conquista (não uma ameaça) a possibilidade de fazer grandes mudanças em nosso sistema judicial, se isso for necessário para estabelecer os princípios sociais morais corretos e para impor a justiça ${ }^{24}$. Posteriormente, Sunstein afirma que, para criar o perfil do juiz heroico inspirou-se, exatamente, em Dworkin.

Parece, então, que, ao decidir o hard case, o STF ficou preso no conflito interno de seguir o perfil do juiz heroico ou de seguir, por razões de prudência, o perfil minimalista. O mesmo parece acontecer em outros casos polêmicos, como o da "marcha da maconha" e o da união homoafetiva. Esse é precisamente o dilema que uma visão teórico-moral do direito pode causar, mas retornaremos a essa questão posteriormente.

É importante, contudo, deixar claro que não estamos criticando as decisões judiciais que enumeramos. Pelo contrário, em casos como o da ADPF 54 concordamos enfaticamente com a decisão da corte. Nesta seção, tivemos o objetivo de destacar o uso difundido de argumentos e teorias morais no direito. Acreditamos que essa afirmação está, agora, bem estabelecida. Cabe passar à questão da convergência.

\section{Convergência moral}

Está claro que, no novo paradigma do pós-positivismo, teorias morais são largamente usadas por nossos juristas. Outro aspecto da adoção dessas teorias é a pressuposição de que elas podem convencer outras pessoas - se esse não fosse o caso, a mera tentativa de argumentar com outras pessoas não faria sentido. Mas a questão não é tão trivial quanto parece, porque, se a expandirmos um pouco — se incluirmos a crença paralela de que as pessoas podem ser racionais ao analisar argumentos — isso pode nos levar à conclusão mais global de que teorias morais, se bem embasadas, podem direcionar todos os membros da sociedade (ou uma grande parte deles) a um consenso. Chamaremos essa visão de "ideia da convergência".

A ideia da convergência deve ter um papel central se o objetivo é aplicar teorias morais ao direito. O direito, especialmente quando representado pelo judiciário, tem a importante função de resolver conflitos sociais. Se teorias morais podem ajudar os juízes com isso, sendo ferramentas argumentativas que levam à convergência e ao acordo, especialmente em hard cases, então certamente a integração entre direito e moralidade defendida por pós-positivistas ofereceria uma grande vantagem ao sistema jurídico.

Isso explica o motivo de pós-positivistas contemporâneos tenderem a colocar a ideia de convergência no centro de suas teorias. Dworkin, por exemplo, coloca grande peso no processo de convergência moral. Isso fica imediatamente claro se considerarmos seu herói idealizado, o "juiz Hércules”, que, por um processo de argumentação e raciocínio, pode encontrar a resposta correta para casos difíceis, mas isso também está visível em sua teoria política ${ }^{25}$.

Dworkin defende que o consenso é importante para uma comunidade, mas tem que surgir acompanhado de um esforço argumentativo. Para Stephen Guest: “O principal ponto de Dworkin é que o consenso de uma comunidade na moralidade é mais profundo do que a descrição de superfície sobre o que as pessoas de fato, em um certo tempo e humor, pensam ou sentem ${ }^{26}$.

Em um diálogo com Rawls (outro com fortes posições convergentistas), também podemos observar que a ideia de Dworkin de um consenso argumentativo fundamenta sua teoria liberal (abrangente):

24 SUNSTEIN, Cass R. Constitutional Personae. The Supreme Court Review, v. 2013, n. 1, p. 433-460, 2014.

25 DWORKIN, Ronald. Law's empire. Harvard University Press, 1986, p. 239.

26 GUEST, Stephen. Ronald Dworkin. Stanford University Press, 2012, p. 126. Tradução livre de: "Dworkin's chief point is that a community consensus on morality runs deeper than a surface description of what people in fact, at a certain time and in a certain mood, think or feel. Any sensible conception of consensus exists at the level of reason or conviction and crosses surface differences." 
Dworkin denomina sua versão continuada do liberalismo de 'igualdade política'. Ele diz que, para estabelecer com sucesso um liberalismo desse tipo, ele terá que mostrar que ele tem um apelo visionário, a possibilidade de que ele será capaz de atrair apoio na forma de um consenso, e que este será suficientemente bem justificado para fornecer o que ele chama de "força categórica ${ }^{27}$

Dworkin baseia a força categórica de sua visão liberal não em um contrato social hipotético (como Rawls), mas nos aspectos interpretativos de conceitos como "liberdade", "igualdade" e "comunidade", que podem unificar a ética e a moralidade ${ }^{28}$. É claro que, com sua abordagem interpretativa, Dworkin não está baseando sua teoria em um consenso real, mas na possibilidade do consenso, dadas nossas práticas sociais e argumentos - o que é suficiente para estabelecer que Dworkin é um forte defensor da ideia de convergência em posições morais e que ela tem um importante papel em sua teoria.

Habermas tem uma preocupação similar com o consenso, que, talvez, exerça um papel ainda mais importante em sua teoria. O que fundamenta sua Teoria Discursiva da Moral, do Direito e da Política é o "Princípio Discursivo", que diz: "apenas são válidas aquelas normas de ação em relação às quais todas as pessoas poderiam concordar em discursos racionais" ${ }^{29}$. Fica claro, então, que a Teoria Normativa de Habermas abraça o ideal da convergência.

Para Alexy, a questão é um pouco mais complexa. Alexy critica a suposição de Dworkin de que é possível chegar a uma resposta correta em todos os casos, incluindo os difíceis, pelo sopesamento de princípios. Essa dificuldade surge porque:

Somente se um consenso fosse sempre garantido na aplicação de normas nós poderíamos defender a possibilidade de alcançar uma 'única resposta correta'. Desde, no entanto, que esse consenso para cada decisão iria exigir tempo e informação ilimitados, ilimitada claridade linguística conceitual, ilimitada capacidade e disposição de troca de papéis entre indivíduos e, finalmente, proteção ilimitada contra preconceitos, ele poderá ser atingido apenas aproximadamente. Por essa razão, na opinião de Alexy, a tese da 'única resposta correta' não é correta. ${ }^{30}$

Mas essa crítica de Alexy pode estar incorreta por confundir o sentido em que Dworkin emprega a ideia de "única resposta correta" (single right answer). Como diz Juliano Benvindo, esse conceito não se refere à "contretização factual de uma única resposta correta em cada caso"; é, antes disso, um ideal, que muito dificilmente será completado algum dia (se o for, estará encerrada a necessidade de interpretação, por exemplo):

É evidente que a 'única resposta correta' não implicaria nem a necessidade de um total consenso factual sobre certo tema e nem a conclusão de que, na realidade, um caso não poderia ter respostas distintas. A 'única resposta correta' é, ao contrário, uma premissa contrafactual em tensão com essa realidade cheia de desacordos e pontos de vista. ${ }^{31}$

27 GUEST, Stephen. Ronald Dworkin. Stanford University Press, 2012. p. 214-15. Tradução de: "Dworkin calls his own continuity version of liberalism 'political equality'. He says that in order to succeed in establishing a liberalism of this kind he will have to show that it has a visionary appeal, the possibility that it will be able to attract support in the form of a consensus, and that it will be sufficiently well justified to provide what he calls 'categorical force'."

28 FURQUIM, Lillian de Toni. O liberalismo abrangente de Ronald Dworkin. 2010. Tese (Doutorado) - Faculdade de História, Letras e Ciências Humanas, Universidade de São Paulo, 2010. p. 20.

29 HABERMAS, Jürgen. Between facts and norms: contributions to a discourse theory of law and democracy. Cambridge: MIT, 1996, p. 107. Tradução de: "Just those action norms are valid to which all possibly affected persons could agree as participants in rational discourses".

30 BENVINDO, Juliano Zaiden. On the limits of constitutional adjudication: deconstructing balancing and judicial activism. Springer Science \& Business Media, 2010. p. 321. Tradução de: "Only if a consensus were always guaranteed in the application of norms could we defend the possibility of achieving the 'single right answer'. Since, nonetheless, this consensus for each decision would require unlimited time and information, unlimited conceptual linguistic clarity, unlimited capacity and disposition to the exchange of roles among individuals, and, finally, unlimited protection against prejudices, it could only be reached approximately. For this reason, in Alexy's opinion, the thesis of the 'single right answer' is not correct."

31 BENVINDO, Juliano Zaiden. On the limits of constitutional adjudication: deconstructing balancing and judicial activism. Springer Science \& Business Media, 2010. p. 321. Tradução de: "factual concretization of the single right answer in each case. [...] It is evident [...] that the 'single right answer' would imply neither the need for a total factual consensus on a certain subject matter nor the conclusion that, in reality, a case could not have distinct responses. The 'single right answer' is rather a counterfactual premise in tension with this reality full of disagreements and points of view." 
Mais importante que isso, porém, é o fato de que a própria Teoria de Alexy parece se apoiar nessa noção de possibilidade ideal de consenso. Do contrário, não seria possível desenvolver uma teoria ética (moral) e jurídica discursiva-racional. É necessário que se abra a possibilidade de convergência ao consenso no diálogo pluralista ético que Alexy propõe, senão não teríamos motivos para pensar que a Teoria Discursiva tem vantagens, por exemplo, sobre uma teoria moral monológica como a kantiana. Como Herget diz:

Alexy diz que as pessoas no discurso frequentemente têm interesses conflitantes que devem ser sopesados. Por sopesamento, ele presumivelmente quer dizer que as partes participantes estão dispostas a se acomodar em uma posição que reconheça parte dos interesses de ambos. Já que não há padrões objetivos para medir esse 'sopesamento', isso se torna essencialmente uma questão de acordo. Um indivíduo tentando reconciliar monologicamente os interesses dos outros não tem nenhuma diretriz racional e, portanto, não pode entrar em um ou formular um acordo. Portanto, de acordo com Alexy, o discurso é necessário para fornecer a oportunidade de acordos nesse tipo de situação. ${ }^{32}$

Então, a Teoria de Alexy também precisa se apoiar num ideal de convergência racional sobre questões morais para fazer sua parte discursiva e de balanço de razões entrar em ação.

Vemos, portanto, que os autores dos quais estamos tratando como influentes no direito brasileiro partilham do ideal de que existe uma propensão à convergência na argumentação moral dos cidadãos.

Essa característica valorização do consenso por teóricos liberais não passou despercebida - e sem críticas - por outros autores. No influente livro "Law and Disagrement" 33, Jeremy Waldron critica essas pressuposições em teorias como a de Rawls e de Dworkin (é evidente que essas críticas podem se aplicar igualmente a outros autores, como Habermas e Alexy). Waldron acredita que teóricos do direito e da política devem parar de ver os desacordos como marginais ao direito e, ao contrário, começar a tratá-los como partes integrais de nossos sistemas políticos. Para ele, uma boa teoria social tem que funcionar dentro dos desacordos. Além disso, as teorias morais são irrelevantes, não farão nada para mudar esse cenário — mesmo se algo como um realismo moral for verdadeiro:

Juízes diferentes alcançarão resultados diferentes mesmo quando todos eles se enxergarem como buscando a resposta correta, e nada sobre a ontologia das respostas corretas dá a qualquer um deles razão para pensar que sua visão é mais correta do que qualquer outra.

No final, é o desacordo moral, não a subjetividade moral, que dá origem a nossas preocupações sobre a moralização judicial. E, já que os realistas [morais] não têm quase nada de interesse para dizer sobre a resolução dos desacordos morais, eles não têm nada a oferecer para amenizar essas preocupações. ${ }^{34}$

Por agora, não precisamos entrar na discussão sobre a utilidade normativa e ontológica da moralidade no direito. Basta compartilharmos com Waldron a conclusão de que teóricos do direito e da política utilizam amplamente argumentos morais sob o pressuposto de que eles abrirão o espaço para a diminuição dos desacordos.

Cabe passar a uma avaliação empírica das relações entre moralidade e desacordo.

32 HERGET, James E. Contemporary German legal philosophy. University of Pennsylvania Press, 1996. p. 57-58. Tradução de: “Alexy says that persons in the discourse often have conflicting interests that must be balanced. By balancing, he presumably means that the parties concerned are willing to settle on a position that recognizes part of the interests of both. Since there are no objective standards by which to measure this 'balancing', it becomes essentially a matter of reasonable compromise. One individual monologically attempting to reconcile the competing interests of others has no rational guideline and therefore cannot enter into or formulate a compromise. Therefore, according to Alexy, the discourse is necessary in order to furnish the opportunity for compromise in this kind of situation."

33 WALDRON, Jeremy. Law and disagreement. Oxford: OUP, 1999.

34 WALDRON, Jeremy. Law and disagreement. OUP Oxford, 1999. p. 187. Tradução de: "Different judges will reach different results even when they all take themselves to be pursuing the right answer, and nothing about the ontology of right answers gives any of them reason for thinking his own view is any more correct than any other.

In the end it is moral disagreement, not moral subjectivity, that gives rise to our worries about judicial moralizing. And since realists have almost nothing of interest to say about the resolution of moral disagreement, they have nothing to offer to allay those concerns." 
1 Quem pode ser convencido por argumentos morais?

Para tentar compreender se os argumentos morais podem convencer alguém, apresentaremos três teorias que lidam com os desacordos: em primeiro lugar, os estudos em neurociência sobre as reações emocionais a decisões em casos de dilema morais. Posteriormente, passaremos à ideia da influência das relações afetivas do grupo para a polarização ideológica. Por fim, apresentaremos o modelo social-intuicionista do comportamento moral humano.

\section{a. Trolleyology}

O dilema trolley é um clássico experimento mental, que teve origem na filosofia — foi proposto pela filósofa Philippa Foot ${ }^{35}$ e analisado a fundo por outros, como Peter Unger $^{36}$ e Judith Jarvis Thomsom ${ }^{37}$ mas se espalhou para outras áreas de investigação. O que faz esse dilema ser peculiar é o fato de ele colocar em evidência conflitos internos de nossas intuições morais. Para perceber como isso acontece, podemos considerar a primeira formulação do problema:

(a) Um bonde (trolley) está desgovernado em uma estrada. Se continuar seu caminho, ele atropelará cinco pessoas que foram amarradas aos trilhos por algum agente maléfico. É possível, porém, apertar um botão que mudará o percurso do bonde, mandando-o para outro trilho. Mas nesse trilho, por azar, há uma pessoa, também atada. Deve-se apertar o botão?

O dilema resulta de nossa necessidade de saber se a escolha de sacrificar uma pessoa para salvar cinco é justificada. Há algo como um conflito entre intuições, sendo algumas mais utilitárias, de maximização de resultado (privilegiando então a vida de cinco contra a vida de um), e outras mais deontológicas, ou kantianas (que nos levam a crer que é errado sacrificar uma vida inocente, não importando os fins pretendidos). Nessa versão original do dilema, a grande maioria das pessoas tende a responder que apertaria o botão para salvar desviar o bonde - o que nos permite intuir que as intuições utilitárias prevalecem sobre as intuições deontológicas ${ }^{38}$.

Cabe levar em conta uma variação do dilema, proposta por Judith Jarvis Thomson, chamado footbridge dilemma (dilema da passarela) ${ }^{39}$ :

(a) Como anteriormente, um bonde está desgovernado em uma estrada e atropelará cinco pessoas se nada for feito. Porém, considere agora que você esteja observando a situação de uma passarela, logo acima dos trilhos. Você sabe que pode parar o bonde se atirar algo muito pesado na frente dele. Imediatamente, você percebe que a seu lado está um homem muito gordo. Então, a única maneira de parar o bonde é empurrando este homem muito gordo da passarela, sacrificando-o para que as cinco pessoas sobrevivam. $\mathrm{O}$ que você deve fazer?

Em relação a essa variação, a grande maioria das pessoas decide que não empurraria o homem, o que nos leva a entender que as intuições mais deontológicas prevalecem sobre as utilitárias. Mas, filosoficamente, isso é um pouco desconcertante, porque, em termos lógicos e morais, o resultado de ambos os dilemas parece ser o mesmo: a possibilidade de salvar cinco pessoas sacrificando uma. Se a situação é a mesma, por que as pessoas tendem a decidir de forma diferente?

Várias explicações foram propostas para dar conta das mudanças de julgamento nos dois casos. Uma das mais famosas baseia-se na ideia de que não devemos usar as pessoas como meros meios, mas como fins em si mesmas, muito relacionada a uma das formulações do imperativo categórico kantiano: "Age de tal forma

35 FOOT, Philippa. The Problem of Abortion and the Doctrine of the Double Effect. In: Virtues and Vices. Oxford: Basil Blackwell, 1978.

36 UNGER, Peter K. Living high and letting die: our illusion of innocence. Oxford University Press, USA, 1996.

37 THOMSON, Judith Jarvis. Killing, letting die, and the trolley problem. The Monist, v. 59, n. 2, p. 204-217, 1976.

38 GREENE, Joshua D. et al. An fMRI investigation of emotional engagement in moral judgment. Science, v. 293, n. 5537, p. 2105-2108, 2001.

39 THOMSON, Judith Jarvis. The trolley problem. The Yale Law Journal, v. 94, n. 6, p. 1395-1415, 1985. 
que uses a humanidade, tanto na tua pessoa, como na pessoa de qualquer outro, sempre e ao mesmo tempo como fim e nunca simplesmente como meio" ${ }^{40}$. As pessoas decidem diferentemente nos casos apresentados acima, a explicação prossegue, porque, no dilema original (a), a pessoa sacrificada não está sendo usada como meio: sua morte é uma mera decorrência indesejada da tomada de decisão; no caso da passarela (b), por outro lado, pede-se que o agente use o homem gordo meramente como um meio para parar o bonde, o que não consideramos como moralmente aceitável.

Não avaliaremos se essa explicação é moralmente convincente ou não. É possível, por outro lado, colocá-la em teste com mais uma variação do dilema:

(a) Como anteriormente, um bonde está desgovernado em uma estrada e atropelará cinco pessoas se nada for feito. E, como no caso (a), é possível apertar um botão que desviará o bonde para um trilho diferente. No entanto, esse segundo trilho é circular, fará o bonde fazer um loop e voltar novamente ao trilho principal, mais uma vez em direção às cinco pessoas. Há um homem gordo no segundo trilho e, se o botão para desviar o bonde for apertado, o bonde vai atropelar o homem gordo e parará antes de fazer o loop e voltar ao trilho principal. Deve-se apertar o botão para que o bonde atropele o homem gordo, salvando-se cinco pessoas? ${ }^{41}$

Nesse caso, as respostas das pessoas tendem a se aproximar mais das respostas ao dilema (a), ao invés de às do dilema (b), mas mesmo assim a impressão que se tem é que o homem gordo é mais uma vez usado como mero meio. Então, a hipótese meios-fins kantiana não é suficiente para explicar as diferenças de juízos morais das pessoas.

Diante desse impasse, no início dos anos 2000, Joshua Greene, psicólogo experimental, filósofo e neurocientista, acompanhado pelo neurocientista Joshua Cohen e outros pesquisadores, tentou dar um tom mais experimental à análise dos dilemas trolley ${ }^{42}$. A nova ideia foi aplicar as perguntas do dilema enquanto os pacientes passavam por exames de um aparelho de Imagem por Ressonância Magnética Funcional (fMRI). O $f M R I$ detecta variações de concentração sanguínea em regiões do cérebro, possibilitando ao pesquisador saber, em tempo real, quais regiões do cérebro do participante estão mais ativas no momento do experimento.

A intenção de Greene, Cohen e outros, ao utilizar o $f M R I$, era saber se existiria algum padrão na ativação cerebral dos participantes do experimento - e, em especial, se esse padrão se correlacionava com as respostas diferentes dadas aos casos, como em (a) e (b), por exemplo.

Depois de uma série de testes, confirmou-se que realmente era possível detectar um padrão de ativação. Para casos que eles chamaram de "impessoais", como o dilema (a), os participantes ativavam mais as partes do córtex pré-frontal dorsolateral (DLPFC), associadas ao que se chama de "controle cognitivo": a capacidade humana de responder a regras mais abstratas e de inibir impulsos emocionais no sentido contrário, favorecendo um raciocínio mais "lógico"43.

Para casos mais "pessoais", como o dilema (b), os participantes, por outro lado, tendiam a ativar em conjunto com o DLPFC outras regiões, mais associadas a respostas emocionais de reações a medo e raiva, por exemplo, como o córtex pré-frontal ventromedial (VMPFC) e a amídala.

Greene, Cohen e os outros perceberam que esses resultados se encaixavam perfeitamente com os tipos de respostas dadas aos experimentos ${ }^{44}$. Em casos como o (a), a resposta mais utilitária parece ser guiada por uma comparação com uma regra (como a análise custo-benefício) e a resposta tende a ser menos emocional. Em casos como (b), parece que as emoções entram em ação com mais força e bloqueiam o raciocínio

40 KANT, Immanuel; QUINTELA, Paulo. Fundamentação da metafísica dos costumes. Lisboa: Edições 70, 1995. p. 69.

41 COSTA, Michael J. Another trip on the trolley. The Southern journal of philosophy, v. 25, n. 4, p. 461-466, 1987.

42 GREENE, Joshua D. et al. An fMRI investigation of emotional engagement in moral judgment. Science, v. 293, n. 5537, p. 2105-2108, 2001.

43 GREENE, Joshua D. et al. An fMRI investigation of emotional engagement in moral judgment. Science, v. 293, n. 5537, p. 2105-2108, 2001. p. 2107.

44 GREENE, Joshua. Moral tribes: emotion, reason, and the gap between us and them. Penguin, 2014. p. 121. 
abstrato utilitário em favor de uma resposta mais "gutural" (de um gut feeling). Para fortalecer ainda mais essa ideia, percebeu-se que as pessoas (a minoria) que davam respostas mais utilitárias aos casos pessoais, como o (b), eram precisamente as que ativavam menos o VMPFC e a amídala ${ }^{45}$.

Depois desses estudos iniciais de Greene, Cohen e outros, originou-se uma longa série de estudos experimentais para os casos trolley, que foi denominada trolleyology (trolleologia, em tradução livre) ${ }^{46}$. Essas pesquisas são importantes porque replicam e aprofundam diversos aspectos da pesquisa original, trazendo novas e importantes descobertas para a psicologia moral.

Mendez e outros pesquisadores ${ }^{47}$ fizeram um estudo em pacientes com demência frontotemporal (FTD), uma condição neurológica degenerativa que atinge, entre outras regiões do cérebro, o VMPFC. Os pesquisadores aplicaram as versões pessoais e impessoais do dilema trolley a três grupos, um composto pelos pacientes com FTD, outro composto por pacientes com Alzheimer e um terceiro composto por pessoas saudáveis. Para os casos impessoais, como o (a), a resposta dos três grupos foi praticamente a mesma: em todos, grande parte das pessoas escolheram a saída utilitária. Para os casos pessoais, como o (b), por outro lado, houve divergências. Os pacientes com Alzheimer e as pessoas saudáveis deram respostas parecidas, com mais ou menos $20 \%$ das pessoas se recusando a dar a resposta utilitária. No grupo dos pacientes com FTD, por outro lado, quase $60 \%$ das pessoas deram a resposta utilitária, o que é uma confirmação da hipótese de que o VMPFC gera respostas emocionais que bloqueiam o raciocínio utilitário.

As pesquisas sobre processos de tomada de decisão moral com pacientes com danos neurológicos devem muito ao pioneirismo do neurocientista português António Damásio. As pesquisas de Damásio, de fato, serviram como inspiração para boa parte de desenho experimental de Greene, especialmente nas partes que ligam o VMPFC ao comportamento moral emocional ${ }^{48}$.

Na década de 1990, Damásio publicou "O erro de Descartes" ${ }^{49}$ um influente livro sobre a neurociência das emoções e do raciocínio moral humano. Um dos focos dos estudos de Damásio é Phineas Gage ${ }^{50}$, um americano do século XIX que sofreu sérios danos cerebrais em um acidente na construção de uma ferrovia. No acidente, uma explosão fez com que uma barra de ferro atravessasse a cabeça de Gage, entrando pela maçã do rosto e saindo pelo topo da cabeça. Impressionantemente, pouco tempo depois da lesão Gage estava consciente e não parecia mostrar maiores sequelas. As mudanças só foram detectadas tempos depois, quando amigos e pessoas próximas perceberam que Gage passou por uma radical transformação de caráter. Visto antes como uma pessoa responsável, diligente e conscienciosa, Gage passou a ter comportamentos impulsivos, muitas vezes imorais, e a demonstrar uma incomum fraqueza de vontade. Seus familiares e amigos passaram a dizer que "Gage não era mais Gage".

Para Damásio, a melhor explicação neurológica ao caso de Gage é que ele sofreu danos no VMPFC no acidente, o que retirou dele a capacidade de usar feedbacks emocionais para se comportar moralmente e tomar decisões importantes para o futuro ${ }^{51}$. A tese de Damásio é de que as emoções possuem um papel essencial no raciocínio humano. Elas são "marcadores", ou seja, funcionam como um mapa que, por meio de pequenas (ou grandes) ativações, guiam nossa cognição em direção a respostas adequadas para os estímulos ambientais e para o planejamento futuro. Sem esses marcadores, nossa cognição "sobrecarrega", por ser,

45 GREENE, Joshua. Moral tribes: emotion, reason, and the gap between us and them. Penguin, 2014, p. 122.

46 GREENE, Joshua. Moral tribes: emotion, reason, and the gap between us and them. Penguin, 2014, p. 124.

47 MENDEZ, Mario F; ANDERSON, Eric; SHAPIRA, Jill S. An investigation of moral judgement in frontotemporal dementia. Cognitive and behavioral neurology, v. 18, n. 4, p. 193-197, 2005.

48 GREENE, Joshua. Moral tribes: emotion, reason, and the gap between us and them. Penguin, 2014, p. 117-118.

49 DAMÁSIO, António R. O erro de Descartes: emoção, razão e o cérebro humano. 2. ed. São Paulo: Companhia das Letras, 2005.

50 DAMÁSIO, António R. O erro de Descartes: emoção, razão e o cérebro humano. 2. ed. São Paulo: Companhia das Letras, 2005. cap. 1 .

51 DAMÁSIO, António R. O erro de Descartes: emoção, razão e o cérebro humano. 2. ed. São Paulo: Companhia das Letras, 2005. cap. 2. 
por si só, incapaz de criar referenciais para a tomada de decisão $0^{52}$.

Em seu laboratório, Damásio vem realizando estudos em pacientes atuais que sofrem os mesmos problemas corticais que Gage, por causas como pequenos AVCs ou outros acidentes. Um desses experimentos, de fato, envolve precisamente a aplicação dos dilemas trolley. Damásio e outros, em um experimento liderado por Koenigs e Young ${ }^{53}$, aplicaram os cenários de dilema moral a grupos de pacientes com danos no VMPFC e a grupos com pacientes saudáveis. A conclusão do estudo foi que:

Pacientes com dano focal bilateral ao córtex pré-frontal ventromedial (VMPC) produzem um padrão anormalmente "utilitário" de julgamentos sobre dilemas morais que colocam considerações convincentes de bem-estar contra comportamentos altamente emocionalmente aversivos. Em contrates, os julgamentos dos pacientes do VMPC eram normais para outras classes de dilemas morais. Esses resultados indicam que, para um conjunto selecionado de dilemas morais, o VMPC é crítico para julgamentos normais de certo e errado. Esses resultados indicam um papel necessário das emoções na geração desses julgamentos. ${ }^{54}$

Em outro estudo, o mesmo grupo de pesquisadores encontrou outras "anormalidades" nos julgamentos morais de pacientes com danos no VMPFC. Esses pacientes davam menos peso moral a casos narrados de tentativas de agressão (como uma tentativa de homicídio) ${ }^{55}$. De fato, inúmeros estudos detectam "anormalidades morais" em pacientes com baixa atividade no VMPFC. Por exemplo, Koenigs e outros perceberam que psicopatas com baixa ansiedade tendiam a dar respostas mais utilitárias aos casos pessoais, enquanto psicopatas com alta ansiedade tinha os mesmos padrões de resposta das pessoas normais ${ }^{56}$.

Além disso, essas "anormalidades" podem ser induzidas por simples alterações ambientais. Valdesolo e DeSteno ${ }^{57}$ fizeram experimentos em que passavam vídeos de comédia de cinco minutos para um grupo de participantes e vídeos de temas neutros para outros. Eles perceberam que, enquanto participantes que viram os vídeos neutros deram respostas semelhantes às que as pessoas dão normalmente, os participantes que assistiram aos vídeos de comédia tenderam a dar respostas mais utilitaristas nos casos pessoais. Isso aconteceu, provavelmente, porque as pessoas que assistiram aos vídeos de comédia estavam mais relaxadas, e, então, ficaram com o VMPFC momentaneamente menos ativo. Com o VMPFC menos ativo, não houve intrusões emocionais que levam as pessoas a sentir os gut feelings da situação do dilema pessoal, e então o raciocínio utilitário ficou desimpedido. Eles concluem:

Alguém poderia esperar que o último árbitro da escolha ética para esses dilemas residiria nas habilidades e motivações do indivíduo para fazer uma análise controlada. No entanto, o modelo de processo dual dos julgamentos morais aqui proposto sugere outra rota não examinada pela qual a escolha pode ser influenciada: a sensitividade contextual do afeto. Estados afetivos se portam como sinais informacionais momentâneos sobre o ambiente e são determinados multiplamente. Consequentemente, fatores ambientais separados de quaisquer violações morais potenciais podem influenciar o afeto no momento do julgamento. ${ }^{58}$

52 DAMÁSIO, António R. O erro de Descartes: emoção, razão e o cérebro humano. 2. ed. São Paulo: Companhia das Letras, 2005. cap. 8.

53 KOENIGS, Michael et al. Damage to the prefrontal cortex increases utilitarian moral judgements. Nature, v. 446, n. 7138, p. 908, 2007.

54 KOENIGS, Michael et al. Damage to the prefrontal cortex increases utilitarian moral judgements. Nature, v. 446, n. 7138, p. 908, 2007. p. 908. Tradução de: "Patients with focal bilateral damage to the ventromedial prefrontal cortex (VMPC) [...] produce an abnormally 'utilitarian' pattern of judgements on moral dilemmas that pit compelling considerations of aggregate welfare against highly emotionally aversive behaviors [...]. In contrast, the VMPC patients' judgements were normal in other classes of moral dilemmas. These findings indicate that, for a selective set of moral dilemmas, the VMPC is critical for normal judgements of right and wrong. The findings support a necessary role for emotion in the generation of those judgements."

55 YOUNG, Liane et al. Damage to ventromedial prefrontal cortex impairs judgment of harmful intent. Neuron, v. 65, n. 6, p. 845-851, 2010.

56 KOENIGS, Michael et al. Utilitarian moral judgment in psychopathy. Social cognitive and affective neuroscience, v. 7, n. 6, p. 708-714, 2011.

57 VALDESOLO, Piercarlo; DESTENO, David. Manipulations of emotional context shape moral judgment. Psychological ScienceCambridge, v. 17, n. 6, p. 476, 2006.

58 VALDESOLO, Piercarlo; DESTENO, David. Manipulations of emotional context shape moral judgment. Psychological Science- 
Em um estudo posterior, Strohminger e outros ${ }^{59}$ chegaram a resultados parecidos, que indicavam que a indução de emoções como a alegria e o humor tendia a fazer com que as pessoas dessem respostas mais utilitárias aos dilemas do trolley. Mas eles também perceberam que nem toda emoção positiva tem esse efeito. De fato, emoções como o assombro (awe) causaram reações anti-utilitárias nos participantes do experimento.

Outra forma de induzir "anormalidades" morais é a manipulação hormonal. Crockett e outros ${ }^{60}$ aplicaram citalopram - um medicamento que aumenta temporariamente a concentração de serotonina no organismo, um hormônio relacionado ao afeto e a comportamentos pró-social —, em participantes que deveriam responder aos dilemas do trolley. Os participantes passaram a dar respostas menos utilitárias nos casos em que eram narrados a possibilidade de dano físico os aspectos emocionais da situação ficavam mais salientes. Os autores acreditam que isso foi um efeito da serotonina, que, por incentivar comportamentos mais pró-socais, deixou as pessoas mais intolerantes e emocionalmente reativas a cenários de danos físicos.

Curiosamente, em outro estudo, Perkins e outros ${ }^{61}$ produziram o efeito inverso, aplicando outra droga, lorazepam, um ansiolítico. Eles perceberam que, quanto maior era a dose da droga, mais propensos os participantes do experimento ficavam a dar respostas utilitaristas, o que sugere, mais uma vez, que o relaxamento desativa reações cognitivas emocionais que podem ter um efeito inibidor no raciocínio abstrato utilitário.

Há muitos outros experimentos que mostram que fatores arbitrários podem influenciar as reações emocionais, e, consequentemente, os julgamentos morais das pessoas em dilemas trolley. De fato, parece que as possibilidades de manipulação são infindáveis: é possível alterar as reações emocionais das pessoas por meio de estímulos visuais ${ }^{62}$; fazendo-as realizar alguma atividade paralela (que cause sobrecarga cognitiva); ${ }^{63}$; removendo pressões temporais e encorajando a deliberação ${ }^{64}$; fazendo-as resolver problemas matemáticos difíceis ${ }^{65}$; etc ${ }^{66}$.

O ponto que quisemos estabelecer aqui é que nossos juízos morais são largamente influenciados por nossas emoções e não é possível, de fato, separar radicalmente razão e emoção, especialmente em questões moralmente controversas, como os dilemas morais. Ambos estão ligados e diversas influências emocionais podem influenciar o raciocínio moral e, consequentemente, o julgamento moral final.

Parece claro, com a linha experimental da trolleyology, que essas conclusões estão bem-estabelecidas.

Nosso próximo passo é estudar o processo de polarização ideológica. No item seguinte (4.2), veremos que a polarização e o acirramento dos desacordos são eminentemente um processo de grupo. No último item desta parte (4.3), faremos a síntese tanto das características emocionais do discurso moral quanto da influência do grupo no processo de polarização, utilizando a abordagem mais integrativa do modelo social-intuicionista.

Cambridge, v. 17, n. 6, p. 476, 2006, p. 476. Tradução de: "One might expect that the ultimate arbiter of ethical choice for such dilemmas would reside in individuals' abilities and motivations to engage in controlled analysis. However, the proposed dual-process model of moral judgment suggests another unexamined route by which choice might be influenced: contextual sensitivity of affect. Affective states stand as momentary informational signals regarding the environment and are multiply determined. Consequently, environmental factors separate from any potential moral violations might influence affect at the time of judgment."

59 STROHMINGER, Nina; LEWIS, Richard L.; MEYER, David E. Divergent effects of different positive emotions on moral judgment. Cognition, v. 119, n. 2, p. 295-300, 2011.

60 CROCKETT, Molly J. et al. Serotonin selectively influences moral judgment and behavior through effects on harm aversion. Proceedings of the National Academy of Sciences, v. 107, n. 40, p. 17433-17438, 2010.

61 PERKINS, Adam M. et al. A dose of ruthlessness: Interpersonal moral judgment is hardened by the anti-anxiety drug lorazepam. Journal of Experimental Psychology, General, v. 142, n. 3, p. 612, 2013.

62 AMIT, Elinor; GREENE, Joshua D. You see, the ends don't justify the means: Visual imagery and moral judgment. Psychological science, v. 23, n. 8, p. 861-868, 2012.

63 GREENE, Joshua D. et al. Cognitive load selectively interferes with utilitarian moral judgment. Cognition, v. 107, n. 3, p. 11441154, 2008.

64 SUTER, Renata S.; HERTWIG, Ralph. Time and moral judgment. Cognition, v. 119, n. 3, p. 454-458, 2011.

65 FREDERICK, Shane. Cognitive reflection and decision making. Journal of Economic perspectives, v. 19, n. 4, p. 25-42, 2005.

66 Para citações de outros experimentos, cf. GREENE, Joshua. Moral tribes: emotion, reason, and the gap between us and them. Penguin, 2014. cap. 4. 


\section{a. Afeto do Grupo (Group Affect)}

Cientistas políticos normalmente estudam os desacordos e a polarização por meio das ideologias, mas recentemente uma nova abordagem vem sendo defendida, uma que se preocupa mais com as disposições de comportamento das pessoas ${ }^{67}$. Nessa visão, o que afeta a polarização não é o fato de as pessoas estarem defendendo ideologias mais extremas, alinhadas com o lado esquerdo ou direito do espectro ideológico. Antes, a polarização aumenta quando membros de um grupo político têm uma predisposição a pensar e a se comportar negativamente em relação aos membros dos grupos políticos rivais. A polarização, nesse caso, seria um efeito das dinâmicas afetivas do grupo político ${ }^{68}$. As posições ideológicas defendidas por um membro de um grupo seriam mais uma consequência do afeto grupal do que sua causa.

Quanto mais o grupo reforça uma atitude negativa em relação às pessoas de fora do grupo (out-group) maior é a associação negativa que um membro do grupo faz com o membro do grupo rival ${ }^{69}$. O reforço negativo do grupo pode funcionar tanto consciente quanto inconscientemente.

Os Testes de Associação Implícita (Implicit Association Tests - IAT) exemplificam como os mecanismos inconscientes entram em ação em nossos julgamentos ${ }^{70}$. Os $I A T$ são desenhados para detectar a força com que as pessoas fazem associações automáticas entre conceitos na memória. São famosos os resultados que revelam que as pessoas têm associações negativas automáticas com, por exemplo, negros, mulheres, homossexuais e até idosos, apesar de conscientemente grande parte delas negar (provavelmente com sinceridade) que tenha qualquer disposição preconceituosa ${ }^{71}$. O mais provável é que essas associações negativas são estabelecidas, reforçadas e externalizadas inconscientemente, por mecanismos de grupo que as pessoas não notam.

Usando essas ideias como ponto de partida, Shanto Iyengar ${ }^{72}$, professor de ciência política, e outros mostram que a correlação entre preferência partidária e posições ideológicas é fraca nos Estados Unidos ${ }^{73}$. Em análises de regressão, eles concluem que a correlação entre a opinião das pessoas sobre temas polêmicos e sua posição partidária é ou inexistente ou fraca ${ }^{74}$. E, continuam eles, isso faz sentido, porque os americanos, em média, têm dificuldade de identificar com clareza a posição que seus partidos preferidos ocupam em escalas de problemas ${ }^{75}$. Por outro lado, há evidências mais fortes de que a exposição a propagandas negativas sobre o outro partido (out-group) realmente influencia a opinião das pessoas dentro do grupo (in-group), fazendo com que elas tenham uma visão mais negativa dos de fora ${ }^{76}$. Esse resultado reforça ainda mais a ideia de que o determinante na polarização é a forma como o grupo (partidário) influencia as relações afetivas de seus membros, e não a ideologia.

Pesquisas anteriores estabelecem que a polarização é, essencialmente, um processo de grupo ${ }^{77}$. Sabe-se,

67 IYENGAR, Shanto; SOOD, Gaurav; LELKES, Yphtach. Affect, not ideology a social identity perspective on polarization. Public opinion quarterly, v. 76, n. 3, p. 405-431, 2012.

68 IYENGAR, Shanto; SOOD, Gaurav; LELKES, Yphtach. Affect, not ideology a social identity perspective on polarization. Public opinion quarterly, v. 76, n. 3, p. 405-431, 2012.

69 TAJFEL, Henri (Ed.). Social identity and intergroup relations. Cambridge: Cambridge University Press, 2010.

70 GREENWALD, Anthony G.; MCGHEE, Debbie E.; SCHWARTZ, Jordan LK. Measuring individual differences in implicit cognition: the implicit association test. Journal of personality and social psychology, v. 74, n. 6, p. 1464, 1998.

71 MCCONNELL, Allen R.; LEIBOLD, Jill M. Relations among the Implicit Association Test, discriminatory behavior, and explicit measures of racial attitudes. Journal of experimental Social psychology, v. 37, n. 5, p. 435-442, 2001.

72 IYENGAR, Shanto; SOOD, Gaurav; LELKES, Yphtach. Affect, not ideology a social identity perspective on polarization. Public opinion quarterly, v. 76, n. 3, p. 405-431, 2012.

73 Infelizmente, não encontramos dados sobre o tema no Brasil.

74 IYENGAR, Shanto; SOOD, Gaurav; LELKES, Yphtach. Affect, not ideology a social identity perspective on polarization. Public opinion quarterly, v. 76, n. 3, p. 405-431, 2012, p. 19.

75 IYENGAR, Shanto; SOOD, Gaurav; LELKES, Yphtach. Affect, not ideology a social identity perspective on polarization. Public opinion quarterly, v. 76, n. 3, p. 405-431, 2012, p. 20.

76 IYENGAR, Shanto; SOOD, Gaurav; LELKES, Yphtach. Affect, not ideology a social identity perspective on polarization. Public opinion quarterly, v. 76, n. 3, p. 405-431, 2012. p. 23.

77 Para mais evidências, cf. SPEARS, Russell; LEA, Martin; LEE, Stephen. De-individuation and group polarization in computer- 
por exemplo, que ela é mais potente quando os membros têm um forte senso de identidade de grupo ${ }^{78}$, o que também gera um efeito inverso: membros de um grupo tendem a ser influenciados menos por argumentos vindos de pessoas pertencentes a outros grupos, mesmo que os argumentos sejam os mesmos ou até melhores do que os apresentados pelos pares do grupo ${ }^{79}$.

Dentro do grupo, a polarização acontece por vários motivos. Um deles a preocupação com reputação: pessoas querem ser percebidas favoravelmente pelos membros de seu grupo e, por isso, tenderão a ajustar seu comportamento no sentido das posições dominantes do grupo ${ }^{80}$. Noelle-Neumann diz que é desse mecanismo que surgem as "espirais de silêncio", a tendência de pessoas com visões socialmente minoritárias se silenciarem, até que a visão desapareça com o tempo ${ }^{81}$. Além disso, há uma relação entre confiança (vinda da corroboração dos pares sobre uma opinião) e extremismo no grupo: quanto mais confiante as pessoas estão de que a posição de grupo é a correta, maior será a tendência de elas irem a extremos, e de considerar que os membros de outros grupos, com posições diferentes, não só estão errados, mas errados de formas condenáveis, que são não só pessoas com opiniões diferentes, mas inimigas ${ }^{82}$.

Por fim, outro mecanismo fundamental da polarização é o de argumentos em grupo e de disponibilidade de informação. Temos a intuição simples de que as pessoas buscam ser convencidas por argumentos, especialmente argumentos de pessoas com as quais se identificam. Mas um grupo político de pessoas com opiniões iguais vai ter um número desproporcionalmente alto de argumentos a favor da posição que o grupo prefere e números desproporcionalmente baixos de argumentos contrários. Por esse motivo, as consequências das discussões em grupo vão ser que as pessoas naturalmente se movam mais em direção ao que o grupo preferia inicialmente, num processo que se retroalimenta.

Há ampla evidência desse processo em ação ${ }^{83}$. Em vários experimentos, viu-se que, depois da deliberação, pessoas do grupo terminavam com opiniões mais extremas do que tinham começado. Nos Estados Unidos, um experimento em Colorado colocou um grupo conservador e um grupo liberal para discutir internamente questões polêmicas, tipicamente relacionadas a partidos, como aborto, ações afirmativas, etc. Antes das discussões, vários membros dos dois grupos tinham opiniões moderadas sobre o tema. Mas, após a discussão, os dois grupos de moveram mais para os extremos. Além disso, os grupos se tornaram mais homogêneos, reprimindo tendências à diversidade ${ }^{84}$.

Há experimentos em que grupos moderadamente feministas se tornaram mais fortemente feministas após a discussão ${ }^{85}$; em que, após discussão, cidadãos que já eram críticos às políticas de um país visto como rival se tornaram ainda mais críticos ${ }^{86}$; em que brancos predispostos a ser racistas, após discussão, tenderam a dar respostas mais negativas à questão de se o racismo dos brancos era responsável pela atual situação dos negros nas cidades americanas ${ }^{87}$; e em que brancos predispostos a não ser racistas, após discussão, tenderam

mediated communication. British Journal of Social Psychology, v. 29, n. 2, p. 121-134, 1990; ABRAMS, Dominic et al. Knowing what to think by knowing who you are: Self-categorization and the nature of norm formation, conformity and group polarization. British Journal of Social Psychology, v. 29, n. 2, p. 97-119, 1990; e TURNER, John C. et al. Rediscovering the social group: a self-categorization theory. Basil Blackwell, 1987.

78 SUNSTEIN, Cass R. Republic: divided democracy in the age of social media. Princeton: Princeton University Press, 2017. p. 75.

79 SUNSTEIN, Cass R. Republic: divided democracy in the age of social media. Princeton: Princeton University Press, 2017. p. 75.

80 SUNSTEIN, Cass R. Republic: divided democracy in the age of social media. Princeton: Princeton University Press, 2017, p. 74,

81 NOELLE-NEUMANN, Elisabeth. The spiral of silence: public opinion, our social skin. Chicago: University of Chicago Press, 1993.

82 BARON, Robert S. et al. Social corroboration and opinion extremity. Journal of Experimental Social Psychology, v. 32, n. 6, p. $537-$ 560, 1996.

83 Para exposição sistemática dos experimentos que estamos citando, cf. SUNSTEIN, Cass R. \# Republic. Divided Democracy in the Age of Social Media. Princeton University Press, 2017, p. 70.

84 SCHKADE, David et al. What Happened on Deliberation Day? California Law Review 95, n. 3, p. 915-40, 2007.

85 MYERS, David G. Discussion-induced attitude polarization. Human Relations, v. 28, n. 8, p. 699-714, 1975.

86 BROWN, Roger. Social Psychology. 2nd ed. New York: Free Press, 1986, p. 224.

87 MYERS, David G.; BISHOP, George D. Enhancement of dominant attitudes in group discussion. Journal of Personality and Social Psychology, v. 20, n. 3, p. 386, 1971. 
a dar respostas mais positivas à mesma questão ${ }^{88}$. Nos Estados Unidos, juízes apontados por republicanos têm tendência mais marcantemente conservadoras quando deliberam em painéis compostos somente por juízes apontados por republicanos. Juízes apontados por democratas apresentam tendências mais liberais ${ }^{89}$.

Assim, a ideia de raciocínio em grupo é central para a polarização. Tanto que normalmente se define polarização como: a tendência de as pessoas, após deliberação, se moverem a um ponto mais extremo, na direção à qual o grupo já estava inicialmente inclinado a se mover $^{90}$. Com isso em mente, podemos voltar à moral e às emoções.

\section{Modelo social-intuicionista (Social-intuitionist model)}

Para sintetizar o que se discutiu nesta seção, devemos investigar, por fim, a influência dos julgamentos morais nos desacordos e na polarização.

Usaremos, para isso, o modelo social-intuicionista (social-intuitionist model) do comportamento e das intuições morais, desenvolvido especialmente por Haidt ${ }^{91}$. O modelo social-intuicionista parte de duas premissas fundamentais. A primeira é de que os julgamentos morais são mais produtos de nossas intuições do que de nosso raciocínio ${ }^{92}$. Ou seja, ao contrário do que se pensa no senso comum (incluído o senso comum filosófico, se podemos falar assim), o que realmente acontece é que, primeiramente, temos uma intuição (gut feeling) de que algo é moralmente errado e só depois buscamos razões para justificar nosso sentimento.

Mas isso não quer dizer que nossos julgamentos morais não mudam ${ }^{93}$. Pelo contrário, e é aí que entra a segunda premissa fundamental do modelo: a de que nossos julgamentos morais mudam, mas, na grande maioria das vezes, por causa da influência do grupo a que pertencemos, tanto por meramente sermos expostos à opinião moral dos membros do grupo quanto propriamente pelos argumentos que eles fornecem a favor de suas posições (esse é o aspecto social do modelo social-intuicionista) ${ }^{94}$. Ou seja, nesse modelo, tendemos muito mais a mudar de opinião por influência do grupo do que por reflexão particular.

Há diversas evidências para isso. Na década de 90, Haidt, Koller e Dias ${ }^{95}$ fizeram um estudo sobre valores morais. A ideia era criar histórias fictícias de violações a tabus morais, mas em que não houvesse danos aparentes (por exemplo: uma família come o cachorro de estimação depois que ele foi atropelado por um carro; ou: um homem usa a carcaça de um frango para masturbação, depois cozinha e come o frango, etc.). No meio do caminho, eles notaram um fenômeno estranho: a maior parte das pessoas chegava muito rapidamente ao julgamento moral, mas tinha alguma dificuldade de encontrar as razões para justificar sua reprovação. Os argumentos que invocavam normalmente eram ruins e gentilmente refutados pelo cientista. Quando isso acontecia, as pessoas não mudavam de opinião, continuando a defender sua posição, mas sem conseguir encontrar razões para isso, às vezes confessando sua dificuldade e sorrindo embaraçosamente. Haidt chama esse estado de incapacidade de justificar sua posição de moral dumbfounding (estupefação moral). O moral dumbfounding foi confirmado por replicações ${ }^{96}$ e é uma evidência para o intuicionismo moral humano.

88 MYERS, David G.; BISHOP, George D. Enhancement of dominant attitudes in group discussion. Journal of Personality and Social Psychology, v. 20, n. 3, p. 386, 1971.

89 SUNSTEIN, Cass R. et al. Are judges political?: an empirical analysis of the federal judiciary. Brookings Institution Press, 2007.

90 SUNSTEIN, Cass R. Republic divided democracy in the age of social media. Princeton University Press, 2017. p. 69.

91 HAIDT, Jonathan; HERSH, Matthew A. Sexual morality: the cultures and emotions of conservatives and liberals. Journal of Applied Social Psychology, v. 31, n. 1, p. 191-221, 2001.

92 HAIDT, Jonathan; HERSH, Matthew A. Sexual morality: the cultures and emotions of conservatives and liberals. Journal of Applied Social Psychology, v. 31, n. 1, p. 191-221, 2001. p. 818-19.

93 BLOOM, Paul. How do morals change? Nature, v. 464, n. 7288, p. 490-490, 2010.

94 HAIDT, Jonathan; BJORKLUND, Fredrik. Social intuitionists answer six questions about morality. In: SINNOTT-ARMSTRONG, Walter (Ed.). Moral psychology: the cognitive science of morality: intuition and diversity. Mit Press, 2008. v. 2 p. $190-93$.

95 HAIDT, J.; KOLLER, S. H.; DIAS, M. G. Affect, culture, and morality, or is it wrong to eat your dog? Journal of Personality and Social Psychology, v. 65, p. 613-628, 1993.

96 HAIDT, J.; BJORKLUND, F.; MURPHY, S. Moral dumbfounding: when intuition finds no reason. Unpublished manuscript, University of Virginia, 2000; HAIDT, Jonathan; HERSH, Matthew A. Sexual morality: the cultures and emotions of conservatives and liberals. Journal of Applied Social Psychology, v. 31, n. 1, p. 191-221, 2001. 
Em outro estudo, Wheatley e Haidt ${ }^{97}$ hipnotizaram sujeitos para sentir flashs de nojo com palavras neutras (como "often" e "take"). Eles separaram dois grupos para ler histórias fictícias envolvendo questões morais, um lendo as palavras modificadas e outro não. Eles repararam que as pessoas com o flash de nojo tendiam a ser mais severas em sua condenação moral. A seguir, eles adicionaram uma nova história, em que não havia nenhuma transgressão moral aparente. Mesmo assim, nos grupos em que havia as palavras modificadas, parte das pessoas continuava a condenar a ação dos personagens da história, mesmo sem nenhum motivo aparente ${ }^{98}$.

Schnall, Haidt, Clore e Jordan ${ }^{99}$ também estimularam flashs de nojo por razões irrelevantes nas pessoas, mas manipulando o ambiente. Eles pediam para as pessoas fazerem julgamentos morais enquanto estavam sentados em frente a uma mesa limpa ou em frente a uma mesa suja com restos de guardanapos de lanches de fast food (que, assume-se, ativariam flashs de baixo nível de nojo). Os resultados mostraram que pessoas que pontuavam alto na escala de "consciência privada corporal" tendiam a fazer julgamentos morais mais severos na segunda situação.

O modelo social-intuicionista sintetiza bem as ideias de Greene e de Damásio, porque, nos casos do trolley, remete as mudanças nos julgamentos morais das pessoas às suas diferentes reações intuitivas. Ele ainda dá mais peso aos fatores intuitivos do que esses autores dão, porque diz que a intuição "vem primeiro" e o raciocínio consciente "só depois" advogada (chegando primeiro à conclusão e depois buscando as razões para defendê-la) do que como juíza (buscando primeiro as razões e depois chegando a conclusão).

O modelo social-intuicionista também se adequa confortavelmente à ideia dos dois sistemas cognitivos, desenvolvida na economia comportamental e capitaneada por Kahneman e Tversky, em seus estudos basilares da área ${ }^{101}$. O sistema 1 seria o das decisões rápidas, automáticas, menos custosas, mais determinadas por emoções. O sistema 2 seria o das decisões mais demoradas, raciocinadas, custosas e passo a passo. Note-se que a diferença não é entre razão e emoção (os dois sistemas têm razões e emoções), mas entre dois tipos de cognições. Haidt ${ }^{102}$ admite que, no seu modelo, as intuições morais podem em larga medida ser rastreadas ao sistema 1 e o raciocínio post hoc de justificação, ao sistema $2^{103}$.

Também devemos reparar na semelhança do modelo social intuicionista da moral com os modelos explicativos da polarização que apresentamos acima. Ambos enfatizam a importância da deliberação em grupo para influenciar as opiniões e o comportamento das pessoas.

Essa semelhança não é fortuita. A polarização é um processo afetivo que funciona no nível do grupo. Vimos que a reputação, a confiança e os argumentos públicos são os mecanismos grupais que levam à polarização. Mas não tínhamos visto como a polarização funciona no nível do indivíduo, em sua parte cognitiva. É exatamente essa lacuna que o modelo social-intuicionista preenche. Ele liga o individual e o social, explicando o funcionamento da maquinaria cognitiva que faz os seres humanos polarizarem. E mostra que essa maquinaria é movida à moralidade. Os julgamentos morais estariam no centro do processo de polarização. Não seriam indiferentes, tampouco (como muitos filósofos defendem) uma forma de barrar a polarização e

97 WHEATLEY, Thalia; HAIDT, Jonathan. Hypnotic disgust makes moral judgments more severe. Psychological science, v. 16, n. 10, p. 780-784, 2005.

98 HAIDT, Jonathan; BJORKLUND, Fredrik. Social intuitionists answer six questions about morality. In: SINNOTT-ARMSTRONG, Walter (Ed.). Moral psychology: the cognitive science of morality: intuition and diversity. Mit Press, 2008. v. 2, p. 199.

99 SCHNALL, S.; HAIDT, Jonathan; CLORE, G. Irrelevant disgust makes moral judgment more severe, for those who listen to their bodies. Unpublished manuscript, University of Virginia, Charlottesville, VA, 2005.

100 HAIDT, Jonathan. The righteous mind: why good people are divided by politics and religion. Vintage, 2012. cap. 2.

101 KAHNEMAN, Daniel. Rápido e devagar: duas formas de pensar. Rio de Janeiro: Objetiva, 2012; KAHNEMAN, Daniel; SLOVIC, Paul; TVERSKY, Amos. Judgment under uncertainty. Cambridge University Press, 1982; GILOVICH, Thomas; GRIFFIN, Dale; KAHNEMAN, Daniel (Ed.). Heuristics and biases: the psychology of intuitive judgment. Cambridge university press, 2002.

102 KAHNEMAN, Daniel. Rápido e devagar: duas formas de pensar. Rio de Janeiro: Objetiva, 2012. cap. 2, nota 47.

103 Greene também desenvolveu uma metáfora diferente. GREENE, Joshua. Moral tribes: emotion, reason, and the gap between us and them. Penguin, 2014. cap. 5. 
chegar a consensos. Seria seu combustível.

Haidt enxerga isso. Nas partes finais de seu livro de 2012, The Righteous Mind ${ }^{104}$, ele reconhece que a situação atual de guerra cultural (culture war) nos Estados Unidos em grande medida decorre dos conflitos morais entre as pessoas ${ }^{105}$. O livro é escrito para divulgar, de forma didática, os três pontos fundamentais de sua pesquisa: intuicionismo, influência social do grupo (que compõem o modelo social-intuicionista) e "fundações morais" 106 . Um dos lemas do livro é que a moralidade "nos liga e nos cega" (morality binds and blinds), especialmente pelo mecanismo de pressão do grupo ${ }^{107}$.

A conexão entre a teoria social-intuicionista e o modelo das "fundações morais" é direta. Em uma sociedade (como a americana ou a brasileira), as pessoas tendem a formar diferentes grupos morais porque, entre outras razões, elas respondem a diferentes premissas morais e são sensíveis a diferentes "fatos morais". Haidt chama a fonte desses princípios e sensibilidades de "fundações morais" (moral foundations) ${ }^{108}$. Nos Estados Unidos, onde há maior disponibilidade de dados, a clara divisão entre liberais e conservadores está ancorada na predominância da sensibilidade moral dos liberais a questões envolvendo cuidado (care) e justiça (fairness), contraposta à sensibilidade predominante dos conservadores a questões envolvendo autoridade (authority), lealdade (loyalty) e pureza (purity) $)^{109}$. Consideramos que essa divisão de matrizes morais também se aplica, em linhas gerais, à divisão política e moral no Brasil entre direita e esquerda ${ }^{11011}$.

O modelo indica que os conservadores também têm alguma sensibilidade moral a cuidado e justiça, mas a sensibilidade não é tão forte quanto a dos liberais; por outro lado, os liberais tendem a dar quase nenhuma importância às fundações de autoridade, lealdade e pureza ${ }^{112}$. De fato, os liberais às vezes veem com aprovação algumas transgressões a esses últimos valores (argumentando moralmente, na maior parte das vezes, que essas transgressões ajudarão a aumentar o escopo dos valores das fundações de cuidado e justiça). Essa é uma das razões de os conservadores considerarem a ideologia liberal como uma ameaça aos valores centrais, de sustentação, da comunidade, e os liberais como pecadores que pretendem, sem nenhuma razão aparente, violar os princípios (e a história) sagrados de um indivíduo ou de uma nação ${ }^{113}$. Os liberais, por sua vez, frequentemente se verão incapacitados de entender como os conservadores podem ser tão ferrenhamente opostos a avanços sociais, como os da promoção da igualdade política entre cidadãos e o fim da pobreza, por exemplo. O liberal, não sendo capaz de ver a interação mais complexa de valores que passam pela mente conservadora, provavelmente atribuirá esse antagonismo à má-fé (temperada, às vezes, com maldade) ou à ignorância das reais condições sociais do mundo (temperada, às vezes, com estupidez) $)^{114}$.

Em virtude de os liberais quase não conseguirem conceber as premissas morais dos argumentos dos conservadores, eles tenderão a dialogar mais frequentemente com pessoas que compartilham suas premissas. E vice-versa. Esse foco no próprio grupo (in-group), provavelmente dará origem às dinâmicas afetivas de polarização e desacordo de que já falamos acima ${ }^{115}$. A proliferação de mídias sociais online que usam algoritmos

104 HAIDT, Jonathan. The righteous mind: why good people are divided by politics and religion. Vintage, 2012,

105 HAIDT, Jonathan. The righteous mind: why good people are divided by politics and religion. Vintage, 2012. cap. 12.

106 HAIDT, Jonathan. The righteous mind: why good people are divided by politics and religion. Vintage, 2012, p. 14.

107 HAIDT, Jonathan. The righteous mind: why good people are divided by politics and religion. Vintage, 2012, p. 187.

108 HAIDT, Jonathan. The righteous mind: why good people are divided by politics and religion. Vintage, 2012. p. 146-48

109 GRAHAM, Jesse et al. Moral foundations theory: the pragmatic validity of moral pluralism. In: Advances in experimental social psychology. Academic Press, 2013. p. 55-130.

110 HAIDT, Jonathan. The righteous mind: why good people are divided by politics and religion. Vintage, 2012, cap. 6.

111 CÔRTES, Pâmela de Rezende; CARDOSO, Renato César. Por que nos unimos a grupos ideológicos?: explicações evolucionistas para as discordâncias políticas. Dissertação (mestrado) - Faculdade de Direito. Universidade Federal de Minas Gerais. 2016. Disponível em: <http://hdl.handle.net/1843/BUBD-AYVNHH>. Acesso em: 21 maio 2018.

112 GRAHAM, Jesse; HAIDT, Jonathan; NOSEK, Brian A. Liberals and conservatives rely on different sets of moral foundations. Journal of personality and social psychology, v. 96, n. 5, p. 1029, 2009.

113 HAIDT, Jonathan. The righteous mind: why good people are divided by politics and religion. Vintage, 2012. cap. 7.

114 HAIDT, Jonathan; GRAHAM, Jesse. When morality opposes justice: conservatives have moral intuitions that liberals may not recognize. Social Justice Research, v. 20, n. 1, p. 98-116, 2007.

115 HAIDT, Jonathan. The righteous mind: why good people are divided by politics and religion. Vintage, 2012. cap. 12. 
que direcionam os indivíduos a interagir com pessoas que têm opiniões similares provavelmente acelerará esse processo de polarização, dando espaço para discursos mais extremos ${ }^{116117}$.

No Brasil, podemos ver com clareza a polarização da direita e da esquerda política ${ }^{118119}$. Em relação à direita, ela pode ser representada pela radicalização dos discursos de segurança pública, contra a corrupção e a violência - muitas vezes responsabilizando os governos de esquerda passados pelo crescimento desses crimes $^{120121122}$. Em relação à esquerda, podemos apontar o aumento e a agressividade do policiamento de discursos considerados preconceituosos, bem como a reação a políticas, geralmente propostas pela direita, que são consideradas como medidas de autoritarismo, supressão a direitos de minorias ou perseguição política à esquerda ${ }^{123124}$. Processos similares, para ambos os lados, podem ser observados nos Estados Unidos e em outros países ${ }^{125}$.

\section{DivergênCIA MORAL}

As evidências que apontamos na seção anterior indicam fortemente que o raciocínio moral humano está muito ligado a ativações emocionais, à influência do grupo e, consequentemente, ao processo de aumento de discordâncias sociais arraigadas sobre valores fundamentais e aumento da polarização.

Essas evidências lançam bastante dúvida sobre o modelo de convergência moral que vários teóricos do direito, da moral e da política vêm aceitando, como vimos, e nos dá razão para substituí-lo, de fato, por um modelo de divergência moral, especialmente quando alguns requisitos são cumpridos, como: (a) as questões morais serem socialmente polarizadas e (b) as questões morais serem emocionalmente salientes.

Saliência emocional e polarização são características muito comuns aos hard cases, o que, mais uma vez nos indica que, ao contrário do que se sustenta, usar argumentos e princípios morais nesses casos pode ser ainda mais socialmente contraproducente. As chances desse tipo de argumento aumentar as divergências sociais são consideravelmente maiores.

Cabe notar que essas críticas aos modelos que pressupõem a convergência moral provavelmente não são — e nem pretendem ser — refutativas. Estamos cientes, por exemplo, de que esses modelos em boa medida são montados precisamente como formas de avaliações contrafactuais das condições não-ideais em vigor

116 SUNSTEIN, Cass R. Republic divided democracy in the age of social media. Princeton University Press, 2017. cap. 1, cap. 3.

117 NAPOLITANO, Carlo José; STROPPA, Tatiana. O Supremo Tribunal Federal e o discurso de ódio nas redes sociais: exercício de direito versus limites à liberdade de expressão. Revista Brasileira de Políticas Públicas, Brasília, v. 7, n. 3, p. 313-332, 2017.

118 POLARIZAÇÃO política nas redes. O Globo. Disponível em <http://infograficos.oglobo.globo.com/brasil/fgv-pronunciamento-dilma.html>. Acesso em: 16 nov. 2017.

119 FELLET, João. Brasil caminha para polarização similar à dos EUA, diz pesquisador. BBC Brasil, 28 mar. 2016. Disponível em: <http://www.bbc.com/portuguese/noticias/2016/03/160327_polarizacao_eua_pesquisador_jf_if>. Acesso em: 16 nov. 2017.

120 VIOLÊNCIA no Brasil aumentou na gestão PT, mostra relatório do Ipea. PSDB, Notícias, 05 jun. 2017. Disponível em: <http://www.psdb.org.br/acompanhe/noticias/violencia-no-brasil-aumentou-na-gestao-pt-mostra-relatorio-do-ipea/>. Acesso em: 30 maio 2018.

121 NOBLAT, Ricardo. A corrupção revolucionária do PT. Blog Noblat. Veja: São Paulo, 05 maio 2018. Disponível em: < https://veja.abril.com.br/blog/noblat/a-corrupcao-revolucionaria-do-pt/>. Acesso em: 30 maio 2018.

122 AZEVEDO, Reinaldo. Os dados vergonhosos da violência: homicídios voltam a superar marca dos 50 mil; SP segue com a mais baixa taxa (confiável) de mortes; violência na Bahia, maior estado governado pelo PT, continua alarmante. Blog Reinaldo Azevedo, Veja. São Paulo, 16 fev. 2017. Disponível em: < https://veja.abril.com.br/blog/reinaldo/os-dados-vergonhosos-da-violencia-homicidios-voltam-a-superar-marca-dos-50-mil-sp-segue-com-a-mais-baixa-taxa-confiavel-de-mortes-violencia-na-bahiamaior-estado-governado-pelo-pt-continua-alarmante/>. Acesso em: 30 maio 2018.

123 OLIVA, Thiago Dias. Minorias sexuais e os limites da liberdade de expressão: o discurso de ódio e a segregação social dos indivíduos LGBT no Brasil. Curitiba: Juruá, 2015.

124 RIBEIRO, Djalma. O impeachment e a onda de autoritarismo. Opinião, Carta Capital, São Paulo, 11 maio 2016. Disponível em: <https://www.cartacapital.com.br/sociedade/impeachment-e-a-onda-de-autoritarismo/>. Acesso em: 30 maio 2018.

125 SUNSTEIN, Cass R. Republic divided democracy in the age of social media. Princeton University Press, 2017. cap. 3. 
em nossas sociedades, ou seja, que eles são, intencionalmente, normativamente $i d e a i s$ em diversos aspectos.

No entanto, abre-se margem para mudanças. Acreditamos que as críticas devem estimular reformas significativas nas teorias desses autores, porque, apesar de não haver problemas em um modelo ter alguma dose de idealidade, há problemas em ele prever tendências sociais que são precisamente opostas às que se observam na análise empírica. Quando isso acontece, a chance de o modelo ideal, ao ser aplicado, causar distorções e consequências institucionais indesejáveis é muito mais alta - e esse é um erro grave.

O risco é mais grave ainda quando as instituições que estão sendo tratadas são jurídicas, tanto porque elas já têm uma função primordial de resolução e prevenção de conflitos quanto porque elas assumiram, no período histórico contemporâneo, a função ainda mais salutar de garantir direitos individuais e sociais. O direito, portanto, principalmente por esses dois motivos, deve ter especial adequação social.

Evidentemente, essas preocupações suscitam discussões normativas. Alguns autores já perceberam que o uso da moral no direito pode gerar defeitos sistêmicos e distorções e procuram alternativas, ou ao menos complementos, ao uso de teorias morais. Dois planos de ação parecem ser mais comuns: um que, em vista desses problemas, busca diminuir a atuação dos tomadores de decisão e outro que, ao contrário, objetiva ampliar sua atuação.

Os que objetivam restringir o papel dos tomadores de decisão jurídica buscam criar teorias do direito mais formalistas, minimalistas, anti-teóricas e detalhistas. Exemplo de autores que seguem essa linha são Cass Sunstein e Adrian Vermeule ${ }^{126}$, que acreditam que é vantajoso que juízes decidam questões judiciais, inclusive as difíceis, por meio de "acordos incompletamente teorizados", uma ilustração do minimalismo judicial.

Autores como Richard Posner ${ }^{127}$, por outro lado, acreditam que essa restrição é impossível: a discricionariedade do juiz é inescapável ${ }^{128}$. Temos, antes, que aceitá-la, pensando em formas de otimização das decisões judiciais, do que tentar suprimi-la infrutiferamente ou mascará-la por trás de argumentações morais pretensamente imparciais. Posner acredita que o melhor método para decidir bem frente a essa abertura argumentativa é o pragmatismo judicial: a preocupação do juiz com as consequências práticas de sua decisão, preferencialmente utilizando evidências empíricas para se informar.

Estas, entre outras, são opções plausíveis para melhorar o processo de justificação e tomada de decisão no direito. Além disso, vale ressaltar, mais uma vez, que não excluímos a moral do direito. Acreditamos que, se teorias morais forem retrabalhadas, levando em consideração os fatores que apontamos acima, elas continuarão a ter um papel importante, sem repetir o problema dos desacordos sociais. Mas não é objetivo, aqui, entrar nas discussões normativas. Apontamos, apenas, que Waldron ${ }^{129}$ parece ter razão quando diz que qualquer teoria moral, política e jurídica tem de ser criada prevendo desacordos sociais arraigados. Ela tem de funcionar bem inserida nesse contexto de alta pluralidade de visões e com ameaça de polarização. Resta direcionarmos nossos esforços teóricos futuros para a criação de teorias que satisfaçam essas condições.

\section{Considerações finais}

O objetivo deste artigo foi discutir o uso da moral do direito, mais precisamente quando acompanhado pela ideia de convergência moral: de que as pessoas, quando racionam o suficiente os melhores argumentos

126 SUNSTEIN, Cass R.; VERMEULE, Adrian. Interpretation and institutions. Michigan Law Review, v. 101, n. 4, p. 885-951, 2003; SUNSTEIN, Cass R. Incompletely theorized agreements. Harvard Law Review, v. 108, n. 7, p. 1733-1772, 1995.

127 POSNER, Richard A. A problemática da teoria moral e jurídica. Tradução Marcelo Brandão Cipolla. São Paulo: M. Fontes, 2012; POSNER, Richard A. How judges think. Harvard University Press, 2008.

128 Referência

129 WALDRON, Jeremy. Law and disagreement. Oxford: OUP, 1999. 
do assunto, chegarão a uma mesma conclusão consensual.

Na primeira parte do texto, mostramos que o uso da moral no direito brasileiro é comum, contando com justificações teórico-filosóficas, doutrinárias e jurisprudenciais. Vimos, a seguir, que esses usos, especialmente quando justificados teoricamente, pressupõem centralmente a ideia de que os agentes racionais envolvidos nas discussões morais poderão convergir ao consenso. Os autores consideram que essa pressuposição é em alguma medida contrafática e ideal, mas não tão distantes da realidade, já que podem ser utilizadas por nossas instituições jurídicas sem maiores problemas.

A seguir, passamos a uma análise empírica sobre a hipótese da capacidade da moralidade de gerar convergências. Analisamos, majoritariamente, três abordagens empíricas da moral, que passagem por campos como a neurociência, a psicologia social, a psicologia mora e a ciência política: (a) os estudos em trolleyology; (b) os estudos da afetividade do grupo e polarização; e (c) o modelo social-intuicionista.

Essas revisões nos levam a concluir, respectivamente, que:

(a) Emoções têm um papel fundamental nos julgamentos morais humanos; essas emoções têm correlatos neurais bem examinados, que, ao serem manipulados, causam alterações emocionais (e, consequentemente, morais) significativas nas pessoas; razões e emoções não podem ser separadas na cognição humana, especialmente nas avaliações morais.

(b) A polarização é um processo de grupo; seu funcionamento e composição no grupo são compreendidos teoricamente, assim como os mecanismos grupais que tendem a aumentá-la ou diminuí-la; a ideologia das pessoas, ao contrário do que costuma se pensar, é muito mais um produto das pressões afetivas do grupo do que de considerações argumentativas individuais.

(c) O modelo social-intuicionista integra os aspectos emocionais do julgamento emocional com a influência que a pressão do grupo pode exercer nas crenças morais das pessoas; nesse modelo, intuições são mais importantes do que as razões para os julgamentos morais: intuições vêm primeiro, razões vêm somente depois, largamente com a função de corroborar o que foi estabelecido pela intuição; julgamentos morais são instrumentais para o aumento da discordância entre grupos e o consequente aumento da polarização social.

Com base nesses resultados, chegamos à conclusão de que a ideia de convergência moral é, para muitos casos, incorreta. Ela deve ser substituída por uma suposição de divergência moral, especialmente quando há fatores como a polarização social e a saliência emocional dos casos em questão.

Encerramos afirmando que essa conclusão tem especial relevância para o direito, que tem a função de resolver conflitos e garantir direitos.

Nossa expectativa é que nossa pesquisa contribua para a discussão sobre o papel da moral no direito e, mais genericamente, sobre as melhores formas de fundamentar o processo de decisão de atores no direito. Também esperamos que o estudo contribua para a disseminação e a discussão aprofundada de pesquisas empíricas. A interdisciplinaridade, especialmente (mas não só) com as ciências, parece-nos uma valiosa alternativa para a análise e a resolução de problemas no direito.

\section{REFERÊNCIAS}

ABRAMS, Dominic et al. Knowing what to think by knowing who you are: self-categorization and the nature of norm formation, conformity and group polarization. British Journal of Social Psychology, v. 29, n. 2, p. 97-119, 1990.

ALEXY, Robert. Conceito e validade do direito. Tradução Gercélia Batista de Oliveira Mendes. São Paulo: WMF M. Fontes, 2009. 
ALEXY, Robert. The argument from injustice: a reply to legal positivism. Oxford: Clarendon Press, 2002.

AMIT, Elinor; GREENE, Joshua D. You see, the ends don't justify the means: visual imagery and moral judgment. Psychological science, v. 23, n. 8, p. 861-868, 2012.

AZEVEDO, Reinaldo. Os dados vergonhosos da violência: homicídios voltam a superar marca dos 50 mil; SP segue com a mais baixa taxa (confiável) de mortes; violência na Bahia, maior estado governado pelo PT, continua alarmante. Blog Reinaldo Azevedo. Veja. São Paulo, 16 fev. 2017. Disponível em: < https://veja. abril.com.br/blog/reinaldo/os-dados-vergonhosos-da-violencia-homicidios-voltam-a-superar-marca-dos50-mil-sp-segue-com-a-mais-baixa-taxa-confiavel-de-mortes-violencia-na-bahia-maior-estado-governadopelo-pt-continua-alarmante/>. Acesso em: 30 maio 2018.

BARON, Robert S. et al. Social corroboration and opinion extremity. Journal of Experimental Social Psychology, v. 32, n. 6, p. 537-560, 1996.

BARROSO, Luís Roberto. A razão sem voto: o Supremo Tribunal Federal e o governo da maioria. Revista Brasileira de Políticas Públicas, Brasília, v. 5, Número Especial, p. 23-50, 2015.

BARROSO, Luis Roberto. Curso de Direito Constitucional. 5. ed. São Paulo: Saraiva, 2012.

BENVINDO, Juliano Zaiden. On the limits of constitutional adjudication: deconstructing balancing and judicial activism. Springer Science \& Business Media, 2010.

BLOOM, Paul. How do morals change?. Nature, v. 464, n. 7288, p. 490-490, 2010.

BOHMAN, James; REHG, William. Jürgen Habermas. In: ZALTA, Edward N. (Ed.). The Stanford Encyclopedia of Philosophy, 2017, sec. 3.4. Disponível em: < https://plato.stanford.edu/archives/fall2017/entries/ habermas/>. Acesso em: 30 maio 2018.

BRASIL. Tribunal de Justiça de Mato Grosso do Sul - TJ-MS - APL: 00339098420048120001 MS 0033909 84.2004.8.12.0001. Relator: Juiz Vilson Bertelli, Data de Julgamento: 28/08/2013, $2^{\text {a }}$ Câmara Cível, Data de Publicação: 28/08/2013.

BRASIL. Tribunal Regional Federal da $3^{a}$ Região - TRF-3 - RI: 00005722920134036321 SP, Relator: Juiz(a) Federal Kyu Soon Lee, Data de Julgamento: 30/06/2017, $5^{\text {a }}$ Turma Recursal de São Paulo, Data de Publicação: e-DJF3 Judicial DATA: 13/07/2017.

BRASIL. Tribunal Superior do Trabalho. Agravo de Instrumento n¹603009420075080016. 2a Turma. Publicação DEJT 07/12/2017. Julgamento 5 de Dezembro de 2017. Relator José Roberto Freire Pimenta.

BROWN, Roger. Social Psychology. 2. ed. New York: Free Press, 1986.

BRUM, Guilherme Valle. Juspositivismo, discricionariedade e controle judicial de políticas públicas no direito brasileiro. Revista Brasileira de Políticas Públicas, Brasília, v. 10, n. 1, 2013 p. 391-404.

COOKE, Maeve. Habermas and consensus. European Journal of Philosophy, v. 1, n. 3, p. 247-267, 1993.

CÔRTES, Pâmela de Rezende; CARDOSO, Renato César. Por que nos unimos a grupos ideológicos?: explicações evolucionistas para as discordâncias políticas. Dissertação (mestrado) - Faculdade de Direito. Universidade Federal de Minas Gerais, 2016. Disponível em: < http://hdl.handle.net/1843/BUBD-AYVNHH>. Acesso em: 21 maio 2018.

COSTA, Michael J. Another trip on the trolley. The Southern journal of philosophy, v. 25, n. 4, p. 461-466, 1987.

CROCKETT, Molly J. et al. Serotonin selectively influences moral judgment and behavior through effects on harm aversion. Proceedings of the National Academy of Sciences, v. 107, n. 40, p. 17433-17438, 2010.

DAMÁSIO, António R. O erro de Descartes: emoção, razão e o cérebro humano. 2. ed. São Paulo: Companhia das Letras, 2005. 
DWORKIN, Ronald. Justice for hedgehogs. Cambridge: Harvard University Press, 2011.

DWORKIN, Ronald. Law's empire. Cambridge: Harvard University Press, 1986

DWORKIN, Ronald. Taking rights seriously. Cambridge: Harvard University Press, 1978.

FELLET, João. Brasil caminha para polarização similar à dos EUA, diz pesquisador. BBC Brasil, 28 mar. 2016. Disponível em: <http://www.bbc.com/portuguese/noticias/2016/03/160327_polarizacao_eua_pesquisador_jf_if $>$. Acesso em: 16 nov. 2017.

FERNANDES, Bernardo Gonçalves; PEDRO, Flávio Quinaud. Curso de Direito Constitucional. 3. ed. Rio de Janeiro: Lumen Juris, 2011.

FGV/DAPP. Polarização política nas redes. O Globo. Disponível em: <http://infograficos.oglobo.globo. com/brasil/fgv-pronunciamento-dilma.html>. Acesso em: 16 nov. 2017.

FOOT, Philippa. The problem of abortion and the doctrine of the double effect. In: VIRTUES and vices. Oxford: Basil Blackwell, 1978.

FREDERICK, Shane. Cognitive reflection and decision making. Journal of Economic perspectives, v. 19, n. 4, p. 25-42, 2005.

FURQUIM, Lillian de Toni. O liberalismo abrangente de Ronald Dworkin. 2010. Tese (Doutorado) - Faculdade de História, Letras e Ciências Humanas. Universidade de São Paulo (USP), 2010.

GILOVICH, Thomas; GRIFFIN, Dale; KAHNEMAN, Daniel (Ed.). Heuristics and biases: the psychology of intuitive judgment. Cambridge: Cambridge University Press, 2002.

GRAHAM, Jesse et al. Moral foundations theory: the pragmatic validity of moral pluralism. In: $A D V A N$ CES in experimental social psychology. Academic Press, 2013. p. 55-130.

GRAHAM, Jesse; HAIDT, Jonathan; NOSEK, Brian A. Liberals and conservatives rely on different sets of moral foundations. Journal of personality and social psychology, v. 96, n. 5, p. 1029, 2009.

GREENE, Joshua D. et al. An fMRI investigation of emotional engagement in moral judgment. Science, v. 293, n. 5537, p. 2105-2108, 2001.

GREENE, Joshua D. et al. Cognitive load selectively interferes with utilitarian moral judgment. Cognition, v. 107, n. 3, p. 1144-1154, 2008.

GREENE, Joshua. Moral tribes: emotion, reason, and the gap between us and them. Penguin, 2014.

GREENWALD, Anthony G.; MCGHEE, Debbie E.; SCHWARTZ, Jordan LK. Measuring individual differences in implicit cognition: the implicit association test. Journal of personality and social psychology, v. 74, n. 6, p. 1464, 1998.

GUEST, Stephen. Ronald Dworkin. 3. ed. Stanford: Stanford University Press, 2012.

HABERMAS, Jürgen. Between facts and norms: contributions to a discourse theory of law and democracy. Cambridge: MIT, 1996.

HAIDT, J.; BJORKLUND, F.; MURPHY, S. Moral dumbfounding: when intuition finds no reason. Unpublished manuscript. Charlottesville: University of Virginia, 2000.

HAIDT, J.; KOLLER, S. H.; DIAS, M. G. Affect, culture, and morality, or is it wrong to eat your dog? Journal of Personality and Social Psychology, v. 65, p. 613-628, 1993.

HAIDT, Jonathan. The righteous mind: why good people are divided by politics and religion. Vintage, 2012.

HAIDT, Jonathan; BJORKLUND, Fredrik. Social intuitionists answer six questions about morality. In: SINNOTT-ARMSTRONG, Walter (Ed.). Moral psychology: the cognitive science of morality: intuition and 
diversity. Mit Press, 2008. v. 2, p.

HAIDT, Jonathan; GRAHAM, Jesse. When morality opposes justice: conservatives have moral intuitions that liberals may not recognize. Social Justice Research, v. 20, n. 1, p. 98-116, 2007.

HAIDT, Jonathan; HERSH, Matthew A. Sexual morality: the cultures and emotions of conservatives and liberals. Journal of Applied Social Psychology, v. 31, n. 1, p. 191-221, 2001.

HERGET, James E. Contemporary German legal philosophy. University of Pennsylvania Press, 1996.

IYENGAR, Shanto; SOOD, Gaurav; LELKES, Yphtach. Affect, not ideology a social identity perspective on polarization. Public opinion quarterly, v. 76, n. 3, p. 405-431, 2012.

KAHNEMAN, Daniel. Rápido e devagar: duas formas de pensar . Rio de Janeiro: Objetiva, 2012.

KAHNEMAN, Daniel; SLOVIC, Paul; TVERSKY, Amos. Judgment under uncertainty. Cambridge: Cambridge University Press, 1982.

KANT, Immanuel. Fundamentação da metafísica dos costumes. Tradução Paulo Quintela. Lisboa: Edições 70, 1995.

KAUFMANN, Arthur. Filosofia do direito. Lisboa: Fundação Calouste Gulbenkian, 1997.

KOENIGS, Michael et al. Damage to the prefrontal cortex increases utilitarian moral judgements. Nature, v. 446, n. 7138, p. 908, 2007.

KOENIGS, Michael et al. Utilitarian moral judgment in psychopathy. Social cognitive and affective neuroscience, v. 7, n. 6, p. 708-714, 2011.

LENZA, Pedro. Direito constitucional esquematizado. 14. ed. rev. atual. e ampl. São Paulo: Saraiva, 2010.

MCCONNELL, Allen R.; LEIBOLD, Jill M. Relations among the Implicit Association Test, discriminatory behavior, and explicit measures of racial attitudes. Journal of experimental Social psychology, v. 37, n. 5, p. 435442, 2001.

MENDES, Gilmar Ferreira; BRANCO, Paulo Gustavo Gonet. Curso de Direito Constitucional. 7. ed. rev. e atual. São Paulo: Saraiva; Brasília: Instituto Brasiliense de Direito Público, 2012.

MENDEZ, Mario F.; ANDERSON, Eric; SHAPIRA, Jill S. An investigation of moral judgement in frontotemporal dementia. Cognitive and behavioral neurology, v. 18, n. 4, p. 193-197, 2005.

MYERS, David G. Discussion-induced attitude polarization. Human Relations, v. 28, n. 8, p. 699-714, 1975.

MYERS, David G.; BISHOP, George D. Enhancement of dominant attitudes in group discussion. Journal of Personality and Social Psychology, v. 20, n. 3, p. 386, 1971.

NAPOLITANO, Carlo José; STROPPA, Tatiana. O Supremo Tribunal Federal e o discurso de ódio nas redes sociais: exercício de direito versus limites à liberdade de expressão. Revista Brasileira de Políticas Públicas, Brasília, v. 7, n. 3, 2017.

NOBLAT, Ricardo. A corrupção revolucionária do PT. Blog Noblat. Veja. São Paulo, 05 maio 2018. Disponível em: <https://veja.abril.com.br/blog/noblat/a-corrupcao-revolucionaria-do-pt/>. Acesso em: 30 maio 2018.

NOELLE-NEUMANN, Elisabeth. The spiral of silence: public opinion, our social skin. Chicago: University of Chicago Press, 1993.

OLIVA, Thiago Dias. Minorias sexuais e os limites da liberdade de expressão: o discurso de ódio e a segregação social dos indivíduos LGBT no Brasil. Curitiba: Juruá, 2015.

PERKINS, Adam M. et al. A dose of ruthlessness: interpersonal moral judgment is hardened by the anti- 
anxiety drug lorazepam. Journal of Experimental Psychology, General, v. 142, n. 3, p. 612, 2013.

PIRES, Terezinha Inês Teles. A legitimação do aborto à luz dos pressupostos do estado democrático de direito. Revista Brasileira de Politicas Públicas, Brasília, v. 3, n. 2, p. 363-390, 2013.

POSNER, Richard A. A problemática da teoria moral e jurídica. Tradução Marcelo Brandão Cipolla. São Paulo: M. Fontes, 2012.

POSNER, Richard A. How judges think. Harvard University Press, 2008.

VIOLÊNCIA no Brasil aumentou na gestão PT, mostra relatório do Ipea. PSDB, Notícias, 05 jun. 2017. Disponível em: <http://www.psdb.org.br/acompanhe/noticias/violencia-no-brasil-aumentou-na-gestaopt-mostra-relatorio-do-ipea/>. Acesso em: 30 maio 2018.

RIBEIRO, Djalma. O impeachment e a onda de autoritarismo. Opinião, Carta Capital, São Paulo, 11 maio 2016. Disponível em: <https://www.cartacapital.com.br/sociedade/impeachment-e-a-onda-de-autoritarismo/>. Acesso em: 30 maio 2018.

SCHKADE, David et al. What Happened on Deliberation Day? California Law Review 95, n. 3, p. 915-40, 2007.

SCHNALL, S.; HAIDT, Jonathan; CLORE, G. Irrelevant disgust makes moral judgment more severe, for those who listen to their bodies. Unpublished manuscript. Charlottesville: University of Virginia, 2005.

SPEARS, Russell; LEA, Martin; LEE, Stephen. De-individuation and group polarization in computer-mediated communication. British Journal of Social Psychology, v. 29, n. 2, p. 121-134, 1990.

STROHMINGER, Nina; LEWIS, Richard L.; MEYER, David E. Divergent effects of different positive emotions on moral judgment. Cognition, v. 119, n. 2, p. 295-300, 2011.

SUNSTEIN, Cass R. Republic: divided democracy in the age of social media. Princeton University Press, 2017.

SUNSTEIN, Cass R. 'Partyism’Now Trumps Racism. Bloomberg View, v. 22, 2014.

SUNSTEIN, Cass R. Constitutional Personae. The Supreme Court Review, v. 2013, n. 1, p. 433-460, 2014.

SUNSTEIN, Cass R. et al. Are judges political? an empirical analysis of the federal judiciary. Brookings Institution Press, 2007.

SUNSTEIN, Cass R. Incompletely theorized agreements. Harvard Law Review, v. 108, n. 7, p. 1733-1772, 1995.

SUNSTEIN, Cass R.; VERMEULE, Adrian. Interpretation and institutions. Michigan Law Review, v. 101, n. 4, p. 885-951, 2003.

SUTER, Renata S.; HERTWIG, Ralph. Time and moral judgment. Cognition, v. 119, n. 3, p. 454-458, 2011.

TAJFEL, Henri (Ed.). Social identity and intergroup relations. Cambridge: Cambridge University Press, 2010.

THOMSON, Judith Jarvis. Killing, letting die, and the trolley problem. The Monist, v. 59, n. 2, p. 204-217, 1976.

THOMSON, Judith Jarvis. The trolley problem. The Yale Law Journal, v. 94, n. 6, p. 1395-1415, 1985.

TURNER, John C. et al. Rediscovering the social group: a self-categorization theory. Basil Blackwell, 1987.

UNGER, Peter K. Living high and letting die: our illusion of innocence. Oxford: Oxford University Press, 1996.

VALDESOLO, Piercarlo; DESTENO, David. Manipulations of emotional context shape moral judgment. Psychological Science - Cambridge, v. 17, n. 6, p. 476, 2006. 
WALDRON, Jeremy. Law and disagreement. Oxford: OUP, 1999.

WHEATLEY, Thalia; HAIDT, Jonathan. Hypnotic disgust makes moral judgments more severe. Psychological science, v. 16, n. 10, p. 780-784, 2005.

YOUNG, Liane et al. Damage to ventromedial prefrontal cortex impairs judgment of harmful intent. Neuron, v. 65, n. 6, p. 845-851, 2010. 


\section{REVISTA BRASILEIRA DE POLÍTICAS PÚBLICAS BRAZILIAN JOURNAL OF PUBLIC POLICY}

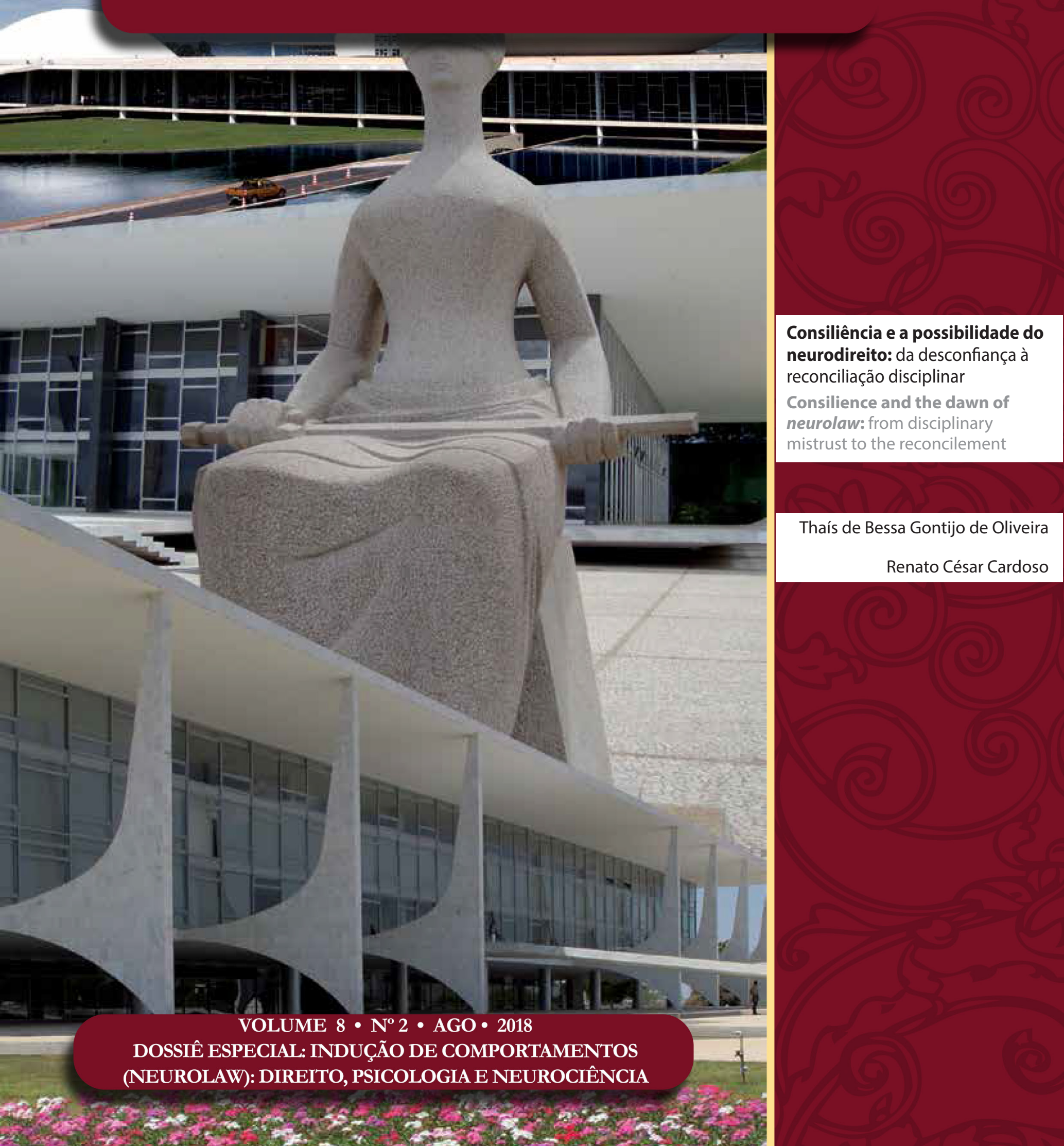




\title{
Consiliência e a possibilidade do neurodireito: da desconfiança à reconciliação disciplinar*
}

\section{Consilience and the dawn of neurolaw: from disciplinary mistrust to the reconcilement}

\author{
Thaís de Bessa Gontijo de Oliveira** \\ Renato César Cardoso***
}

\section{Resumo}

$\mathrm{O}$ artigo tem por objetivo revisitar a origem do afastamento disciplinar que ocorre entre as Ciências Naturais, Ciências Sociais e Humanidades, revisitando obras clássicas sobre a matéria em Língua Inglesa no século XX (em especial, a polêmica palestra de Percy Snow e, na mesma linha, a posterior controvérsia Wilson/Lewontin). O afastamento disciplinar levou ao atual modelo de hiperespecialização que, embora tenha impulsionado um notável avanço em cada uma das disciplinas, teve como consequência a fragmentação do próprio conhecimento e a perda da coerência entre cada uma dessas partes. Esse modelo revela sinais de esgotamento, já que não é capaz de enfrentar questões filosóficas fundamentais, nem de apresentar soluções satisfatórias para os grandes problemas humanos contemporâneos. Nesse contexto, apresenta-se a Consiliência, que propõe a recuperação da coerência entre todos os ramos do conhecimento, tanto na tarefa de conhecer nossa própria humanidade, quanto na tarefa de apresentar respostas a esses grandes problemas. Como conclusão, percebeu-se que, para o Direito, esse movimento de aproximação pode ter consequências disruptivas, já que as explicações das Ciências Cognitivas para o comportamento humano podem desafiar noções fundamentais com as quais o Direito opera. Equacionar tudo isso é a tarefa que se atribui ao Neurodireito. A originalidade do artigo reside na recuperação das origens para o afastamento disciplinar, e as razões para sua superação, sempre dentro do contexto do Direito. Essa revisão evidenciou a tarefa de tornar todo esse conhecimento coerente, ou consiliente. Em relação às das Ciências Jurídicas, essa é a tarefa do Neurodireito.

Palavras-chave: Neurodireito. Neuroética. Consiliência.

\section{Abstract}

*** Professor Associado e Coordenador do Curso de Ciências do Estado da Faculdade de Direito da Universidade Federal de Minas Gerais. Professor do Programa de Mestrado e Doutorado em Direito, bem como do Programa de Mestrado em Neurociências, da Universidade Federal de Minas Gerais. Pós-Doutorado em Filosofia pela Universidade de Barcelona

(2014). E-mail: renatoccardoso@hotmail.com

** Doutorado em Direito pela Universidade (2014). Especialização em Direito ConstituDemocrático, realizada em parceria com a Universidade de Coimbra (Portugal) (2012) Bacharel em Direito (2008). Membro do Grupo (GENe). Advogada. E-mail: thais.bgo@gmail. com
The paper aims to revisit the origin of the disciplinary gap that occurs between Natural Sciences, Social Sciences and Humanities, by revisiting classic literature in English language tradition throughout the XX century (in particular, the provocative lecture by Percy Snow and, in the same tradition, the subsequent Wilson/Lewontin controversy). This departure led to the current model of hyper-specialization which, although it has promoted 
a remarkable advance in each one of the disciplines, had as a consequence the fragmentation of the own knowledge and the loss of the coherence between each one of these parts. This model shows signs of exhaustion, since it is not able to face fundamental philosophical questions, nor to present satisfactory solutions to the great human problems of contemporaries. In this context, we present Consilience, which proposes the recovery of coherence between all branches of knowledge, both in the task of knowing our own humanity and in the task of presenting answers to these great problems. As a conclusion, it has been realized that, for the Law, this movement of approximation can have disruptive consequences, since the explanations of the Cognitive Sciences for the human behavior can defy fundamental notions with which the Law operates. To equate all this is the task that is attributed to the Neuro-Right. The originality of the article lies in the recovery of the origins for the disciplinary removal, and the reasons for its overcoming, always within the context of the Law. This revision brought light to the task of making all this knowledge coherent, or consilient. Within Legal Sciences, this is the task belongs to Neurolaw.

Key-words: Neurolaw. Neuroethics. Consilience.

\section{INTRODUÇão}

O curso de Graduação em Direito equipa o futuro bacharel com técnicas sofisticadas, que deveriam torna-lo apto a operar os procedimentos jurídicos (técnicas de processo, por exemplo), como também deveriam capacitá-lo a lidar de forma mais qualificada com os conflitos sociais decorrentes da interação social, mesmo aqueles que claramente possuam uma conotação moral. No entanto, o curso de Direito, como vários outros cursos das Ciências Sociais e das Humanidades, não dá continuidade aos estudos em Ciências Naturais que o estudante iniciou em sua formação fundamental (ou o faz timidamente).

Não obstante, parece quase inevitável que o futuro bacharel em Direito seja colocado em situações em que deverá navegar de forma competente pelos conhecimentos e contribuições das Ciências Naturais. Indicativo disso, por exemplo, é a crescente importância da prova científica nos processos judiciais, com mais e mais cientistas sendo chamados como testemunhas. Nas audiências públicas realizadas no âmbito de processos de grande repercussão geral, apresentam-se especialistas das mais variadas formações, muitos deles cientistas que vêm trazer evidências para melhor esclarecimento dos fatos. ${ }^{1}$ Vale lembrar que a Lei n. 13.105/2015, o novo Código de Processo Civil, faculta ao juiz e ao relator do processo, considerando a relevância da matéria, a especificidade do tema objeto da demanda ou a repercussão social da controvérsia, solicitar ou admitir a participação de pessoa natural ou jurídica, órgão ou entidade especializada, com representatividade adequada, no prazo de 15 (quinze) dias de sua intimação (art. 138) - o amicus curiae, e que essa pessoa tantas vezes contribuirá no processo justamente com conhecimentos científicos oriundos das Ciências Naturais.

Destaca-se o verbo "solicitar", empregado no dispositivo legal, justamente porque ele antecipa um estado de perplexidade que pode acometer o juiz diante de fatos controversos, sobre os quais será obrigado a decidir. Esse dispositivo constitui uma autorização legal para que o juiz reconheça sua incompetência (o sentido de imperícia) diante dos fatos, e solicite especialistas para aclararem as questões.

Assim, cada vez mais, os processos jurídicos atribuem voz à Ciência, personificada no cientista. No entanto, invariavelmente, a decisão é da autoridade decisória, que deve digerir a informação científica e entre-

1 São exemplos recentes: a audiência pública que discutiu o bloqueio judicial do aplicativo WhatsApp e Marco Civil da Internet, tratado na Ação Direta de Inconstitucionalidade (ADI) 5527, cuja relatora é a ministra Rosa Weber, e na Arguição de Descumprimento de Preceito Fundamental (ADPF) 403; audiência pública que discute aspectos técnicos da coleta de DNA aplicada à investigação forense no âmbito do Recurso Extraordinário 973.837; audiências pública sobre o novo Código Florestal, no âmbito das ações Diretas de Inconstitucionalidade 4901, 4902, 4903 e 4937, para citar algumas das últimas. Em todas eles, foram discutidas questões técnicas, sobre as quais a vasta maioria dos juízes não terá qualquer domínio técnico. 
gar um produto (uma decisão judicial ou administrativa, uma lei, ou uma política pública).

Embora frequentemente sejam obrigados a interagir, é preciso destacar que os processos jurídicos e os processos científicos possuem vocação diferente, sendo diversa, também, a forma como um e de outro chegam ao seu resultado desejado. Além disso, nessas vocações, existem tensões verdadeiras entre os valores e objetivos de cada uma dessas empreitadas, tensões que não devem ser ignoradas. ${ }^{2}$ Assim, as Ciências são investigativas ao passo que o Direito ${ }^{3}$ ainda é, em nossa cultura legal, adversarial. As Ciências buscam princípios gerais, enquanto o Direito se foca em casos particulares (essa característica pertence mais claramente ao common law, ${ }^{4}$ sistema de origem dos autores). As Ciências são uma empreitada amplamente falsificável, ao passo que o Direito está preocupado com alcançar uma resolução rápida e definitiva. As Ciências procuram inovação, enquanto os sistemas jurídicos se estabilizam em precedentes. A investigação científica é informal, baseada em problemas, pragmática, enquanto o procedimento jurídico se fia em regras e procedimentos formais. Por fim, as aspirações da ciência são essencialmente teóricas, enquanto que o Direito é inevitavelmente atraído pela política. Dessas considerações é possível perceber que as Ciências e o Direito lidam com a verdade de forma bastante diferente.

Não só no contexto judicial, o bacharel em Direito poderá ter problemas para lidar com provas científicas nos processos. Embora a produção normativa (como elaboração de leis) ou o delineamento de políticas públicas sejam atribuições, respectivamente, dos membros do Poder Legislativo e Poder Executivo, também nesses procedimentos os bacharéis em Direito participam (seja por meio de assessorias ou por meio de pareceres jurídicos formulados pelas Procuradorias). Quais tratamentos médicos e remédios devem ser oferecidos amplamente à população pelos Sistema Único de Saúde? Quais empreendimentos poluidores devem ser autorizados a operar, e com quais contrapartidas? Quando deve se iniciar a alfabetização de crianças na rede pública, ou o ensino de língua estrangeira, e com qual abordagem? Todas essas decisões devem ser informadas por conhecimentos técnico-científicos específicos, que não são (e nem individualmente devem ser) oferecidos ao estudante de Direito.

Mais ainda: considerando o Princípio na Inafastabilidade da Jurisdição (art. 5, XXXV, CR), todas essas questões podem ser levadas a conhecimento do Poder Judiciário. ${ }^{5}$ Nesse caso, o Poder Judiciário será instado

2 HAACK, Susan. Irreconcilable Differences? The troubles marriage of science and Law. In: HAACK, Susan. Evidence Matters: science, proof, and truth in Law. New York: Cambridge University Press, 2014. p. 78-103. p. 79.

3 Para a proposta deste artigo, considera-se o Direito enquanto técnica, o Direito aprendido e realizado nos processos judiciais, administrativos e legislativos; por outro lado, em relação ao paradigma Ciências Jurídicas, Epistemologia Jurídica, Filosofia Jurídica e Antropologia Jurídica, é possível que as críticas de Haack não sejam aplicáveis, ou sejam não sejam tão marcantes.

4 Segundo Michele Taruffo, os termos tradicionais pelos quais se descrevem e se distinguem os modelos de civil law e common law não mais são aceitáveis, já que a realidade normativa de cada um desses sistemas foi modificada e continua destinada a transformações profundas ainda a porvir. Existem, ainda, diferenças, embora essas diferenças não sejam mais tão acentuadas, tampouco podem ser adequadamente descritas pelos modelos tradicionais. Segundo o autor: "Las transformaciones que se han verificado, y que en muchos aspectos están todavía en curso en numerosos ordenamientos, han provocado una clara fragmentación de los viejos esquemas y han dado lugar a múltiples fenómenos de "recomposición" del derecho procesal a través del complejo juego de interferencias entre sistemas diversos, circulaciones de modelos y trasplantes de instituciones de la naturaleza más variada. (...) Lo único que se puede afirmar de un modo relativamente seguro es que los habituales y cómodos modelos descriptivos, que pretendían representar esquemáticamente las características fundamentales de los procesos de common law y de civil law, aparecen claramente superados y no resultan ya utilizables como instrumentos de conocimiento y descripción de varios ordenamientos." ((TARUFFO, Michelle. El proceso civil de "civil law": aspectos fundamentales. Ius et Praxis, Talca, v. 12, n. 1, p. 69-94, 2006. Disponível em: $<$ https://scielo.conicyt.cl/scielo.php?script=sci_arttext\&pid=S0718-00122006000100004>. Acesso em: 14 set. 2016.).

5 O problema é tamanho que já foi objeto de edição especial da Revista Brasileira de Políticas Públicas (v. 5, n. 2, 2015, Edição Especial - Ativismo Judicial), em que discute os méritos e deméritos daquilo que hoje convencionou-se chamar de ativismo judicial. De especial interesse sobre a matéria, destaca-se: COELHO, Inocêncio Mártires. Apontamentos para um debate sobre o ativismo judicial. Revista Brasileira de Políticas Públicas, v. 5, n. 2, 2015, Edição Especial - Ativismo Judicial, p. 3-22. Disponível em: <https:// www.publicacoesacademicas.uniceub.br/RBPP/article/view/3157/pdf > . Acesso em: 24 jul. 2018; PETER, Christine Oliveira. Do ativismo judicial ao ativismo constitucional no Estado de direitos fundamentais. Revista Brasileira de Políticas Públicas, v. 5, n. 2, 2015, Edição Especial - Ativismo Judicial, p. 64-87. Disponível em: <https://www.publicacoesacademicas.uniceub.br/RBPP/article/ view/3094/pdf>. Acesso em: 24 jul. 2018; GALVÃO, Ciro di Benatti. Ativismo judicial: o contexto de sua compreensão para a construção de decisões judiciais racionais. Revista Brasileira de Políticas Públicas, v. 5, n. 2, 2015, Edição Especial - Ativismo Judicial, p. 89-99. Disponível em: <https://www.publicacoesacademicas.uniceub.br/RBPP/article/view/3101/pdf>. Acesso em: 24 jul. 2018. 
a tomar decisões políticas, inclusive para impor medidas concretas ao Poder Executivo e Poder Legislativo, em matérias que podem demandar conhecimento técnico extraordinário.

Embora todas as questões acima sejam da maior importância, a proposta deste artigo é outra: enfatiza-se uma outra ordem de conhecimento que deveria ser navegada com competência por juristas, que tem como fio condutor o comportamento humano. É preciso perceber que o objeto de estudo do Direito não são as leis propriamente ditas. Da mesma forma, o objeto de Estudo da Economia não são transações econômicas, tampouco o objeto de estudo das Neurociências não são neurônios. Em última instância, todas essas disciplinas se ocupam do comportamento humano, que perfazem hoje as Ciências Cognitivas.

As Ciências Cognitivas são um ramo do conhecimento resultante das contribuições de vários outros, como a Psicologia, Neurociência, Linguística, Filosofia, Antropologia, Biologia Evolucionista, Educação, Ciências da Computação, Inteligência Artificial e Etologia, cada uma delas com seu foco e sua metodologia, em constante aprimoramento dentro de cada campo disciplinar específico, e nem sempre em concordância um com o outro. ${ }^{6}$ Neste artigo, é defendida a ideia de que o Direito — ou as Ciências Jurídicas — deve ingressar nessa construção.

No âmbito das Neurociências, da Psicologia Evolucionista e da Economia, foram feitos alguns avanços notáveis com o objetivo de compreender o comportamento humano, muitos deles contraintuitivos e com significativos potenciais disruptivos. Mais do que isso, esses avanços ampliaram, também, a capacidade preditiva dessas disciplinas. Acredita-se que o Direito se beneficiaria de incorporar esses conhecimentos às suas práticas e reflexões. Acredita-se, ainda, que são palpáveis as contribuições que o Direito pode dar, já que a história do Direito se confunde com a própria história da humanidade. Entretanto, esse tipo de proposta possui pressupostos desconhecidos pela maior parte dos juristas.

Não se está acusando todos os juristas de analfabetismo científico, ${ }^{7}$ mas apenas afirmando que a navegação competente nessas disciplinas ocorre atualmente por mérito, talento ou circunstâncias particulares de cada profissional, quando poderia não ser assim. Os próprios cursos poderiam oferecer essa formação de forma consistente e sistemática, com muito benefício.

Assim, existe um vasto corpo de conhecimento acumulado sobre a própria espécie humana estudada enquanto uma espécie do mundo dos seres vivos, que esclarece quais os comportamentos realmente são tipicamente humanos, e quais são meras fantasias. Esse conhecimento passa despercebido pela maioria dos juristas. Frans de Waal, um dos mais influentes primatologista da atualidade, adverte que

[e]studantes de direito, economia e política não possuem as ferramentas necessárias para ver sua própria sociedade com qualquer objetividade. Com o que eles vão compará-la? Eles raramente, se é que alguma vez, consultaram o vasto conhecimento sobre comportamento humano acumulado na antropologia, psicologia, biologia ou neurociência. A resposta curta derivada dessas disciplinas é que somos animais de grupo: altamente cooperativos, sensíveis a injustiça, algumas vezes belicistas, mas na maior parte das vezes pacíficos. Uma sociedade que ignora essas tendências não pode ser ótima. É verdade, somos também animais movidos por incentivos, focados em status, território e segurança alimentar, de modo

6 WILSON, Robert A.; KEIL, Frank C. Preface. In: WILSON, Robert A.; KEIL, Frank C. (Ed.). The MIT encyclopedia of the cognitive sciences. Cambridge, Massachusetts (EUA); London, England: Massachusetts Institute of Technology, 1999. p. 13-14.

7 Essa dificuldade com as Ciências Naturais não é, evidentemente, uma exclusividade das Ciências Jurídicas. Muito pelo contrário. O conhecimento científico tantas vezes desafia, de forma ameaçadora, noções de mundo geral. Steven Sloman e Philip Fernbach explicam que o crescimento do movimento de pais que se recusam a vacinar seus filhos pode ser listado como um exemplo de como a sociedade muitas vezes lida mal com o conhecimento científico e os avanços dele decorrentes. Essa resistência não pode ser atribuída exclusivamente à baixa escolaridade dos pais, ou à vulnerabilidade socioeconômica, pois está documentando que, em uma comunidade de alto padrão socioeconômico do Colorado, por exemplo, $10 \%$ dos pais se recusam a vacinar. A ideia de deliberadamente expor um filho a doenças graves pode parecer absolutamente aversiva e, no entanto, as vacinas permanecem sendo uma das descobertas mais importantes da Medicina contemporânea. Acredita-se que o movimento anti-vacina contribuiu para o retorno do sarampo, uma doença que estava erradicada nos EUA no começo dos anos 2000. Com o aumento do número de crianças que não são vacinadas, esse número subiu para 600 em 2014. (SLOMAN, Steven; FERNBACH, Philip. The knowledge illusion: why we never think alone. New York: Riverhead Books, 2017. p. 155-157). 
que qualquer sociedade que ignore essas tendências também não pode ser ótima. Existe um lado tanto social quanto egoísta em nossa espécie. ${ }^{8}$

Assim, o comportamento de nossa espécie pode ser conhecido e estudado conforme a metodologia das Ciências Naturais (alguns desses traços de comportamento estão listados por De Waal, no trecho transcrito acima), embora as Ciências Sociais e Humanidades não o façam, preferindo a introspecção e revelação individual. Esse isolamento disciplinar rendeu críticas severas ao conhecimento produzido pelas Ciências Sociais e Humanidades, em particular aos modelos éticos e morais apresentados pela Filosofia, enfatizando sua baixa capacidade preditiva. Nesse sentido, Edward O. Wilson destacou:

Não é de se admirar, então, que a ética seja a mais publicamente contestada de todas as empreitadas filosóficas. Ou que a ciência política, que na base é principalmente o estudo da ética aplicada, é tão frequentemente problemática. Nenhuma delas é instruída por qualquer coisa que seja reconhecível como uma teoria autêntica nas ciências naturais. Tanto a ética quanto a ciência política não possuem um fundamento de conhecimento verificável da natureza humana suficiente para produzir previsões de causa e efeito e julgamentos sólidos com base neles. Certamente será prudente prestar mais atenção às profundidades do comportamento ético. O maior vazio no conhecimento em tal empreendimento é a biologia dos sentimentos morais. ${ }^{9}$

Wilson destaca, ainda, que o sucesso de um código moral depende da sua capacidade de interpretar com sabedoria esses sentimentos morais; para tanto, é necessário que os autores dos sistemas morais saibam como o cérebro funciona, além de como a mente se desenvolve. ${ }^{10}$ Para o autor, o sucesso da Ética dependeria de sua capacidade de prever com precisão as consequências de determinadas ações em oposição às outras, especialmente no caso de ambiguidade moral. A empreitada consiliente tem a esperança de que, "ao explorar as raízes biológicas do comportamento moral e explicar suas origens e vieses no substrato material, devemos ser capazes de moldar um consenso ético mais sábio e duradouro do que antes". ${ }^{11}$ Para isso, há de se frisar, é necessário aprofundar a fluência dos intelectuais das Ciências Sociais e Humanidades nos conhecimentos acumulados pelas Ciências Naturais.

Ignorar esse treinamento científico é sintomático de uma desconfiança disciplinar, e algumas causas desse afastamento são exploradas na próxima seção. Ao final, pretende-se que fique claro como os motivos da ruptura perderam importância, e mais do que isto, que existem bons motivos para trabalhar por uma reconciliação na construção de modelos éticos e morais, bem como em modelos jurídicos, com ênfase no que Wilson chamou de sentimentos morais. ${ }^{12}$ Existe uma necessidade de aproximar o Direito dessas disciplinas, levando as Ciências Jurídicas para esse movimento que veio a ser conhecido como Consiliência, e será me-

8 WAAL, Frans de. The age of empathy: nature lessons for a kinder society. New York: Harmony Books; Crown Publishing, 2009. p. 4-5, (Tradução nossa, grifo nosso). No original: "Students of law, economics, and politics lack the tools to look at their own society with any objectivity. What are they going to compare it with? They rarely, if ever, consult the vast knowledge of human behavior accumulated in anthropology, psychology, biology, or neuroscience. The short answer derived from the latter disciplines is that we are group animals: highly cooperative, sensitive to injustice, sometimes warmongering, but mostly peace loving. A society that ignores these tendencies can't be optimal. True, we are also incentive-driven animals, focused on status, territory, and food security, so that any society that ignores those tendencies can't be optimal, either. There is both a social and a selfish side to our species."

9 WILSON, Edward Osborne. Consilience: the unity of knowledge. New York: Vintage Books, 1999. p. 278-279, (Tradução nossa, grifo nosso). No original: "Little wonder, then, that ethics is the most publicly contested of all philosophical enterprises. Or that political science, which at foundation is primarily the study of applied ethics, is so frequently problematic. Neither is informed by anything that would be recognizable as authentic theory in the natural sciences. Both ethics and political science lack a foundation of verifiable knowledge of human nature sufficient to produce cause-and-effect predictions and sound judgments based on them. Surely it will be prudent to pay closer attention to the deep springs of ethical behavior. The greatest void in knowledge in such a venture is the biology of the moral sentiments".

10 WILSON, Edward Osborne. Consilience: the unity of knowledge. New York: Vintage Books, 1999. p. 262.

11 WILSON, Edward Osborne. Consilience: the unity of knowledge. New York: Vintage Books, 1999. p. 262, tradução dos autores. No original: “"'by exploring the biological roots of moral behavior, and explaining their material origins and biases, we should be able to fashion a wiser and more enduring ethical consensus than has gone before".

12 A expressão sentimentos morais é conceitualmente problemática, e foi empregada por autores com sentidos diferentes. Aqui a referência é ao emprego dado pelos filósofos iluministas, ou seja, predisposições hereditárias no desenvolvimento mental (WILSON, WILSON, Edward Osborne. Consilience: the unity of knowledge. New York: Vintage Books, 1999. p. 262). 
lhor explicado adiante. Pretende-se mostrar que esse movimento não implica perda do rigor técnico típico da disciplina, nem seu esvaziamento. Significa, ao contrário, incluí-la em um debate mais amplo, do qual se pode esperar no mínimo um aprimoramento das soluções jurídicas que as instituições podem oferecer.

Apenas para ilustrar desde logo o quão promissor e proveitoso pode ser esse diálogo, um bom exemplo diz respeito à pena de banimento e seus efeitos sociais. Novamente, com De Waal, ${ }^{13}$ já se sabe que o ser humano é por natureza uma criatura intensamente social, cuja sanidade e felicidade depende da interação com outros indivíduos; por isso mesmo, a não ser a pena de morte, o banimento é a punição mais extrema que pode ser aplicada a alguém. O corpo humano e a mente humana não foram projetados para uma vida solitária. Na ausência de companhia humana, a pessoa se torna irremediavelmente deprimida, e sua saúde física se deteriora.

Nesse contexto, David Eagleman ${ }^{14}$ recupera o relato de um preso chamado Robert Luke, que cumpriu pena em Alcatraz, uma prisão de segurança máxima localizada em uma ilha na cidade de São Francisco (Califórnia, EUA), hoje desativada. Como punição por destruir sua cela, Luke foi enviado para a solitária por 29 dias. Essa solitária consistia de um buraco de $3 \mathrm{M}$ por 3M, em que nenhuma luz entrava: um buraco sem qualquer estímulo sensorial de luz ou som. Luke relata: "O Fosso negro era um lugar ruim. Alguns caras não aguentariam aquilo. Quero dizer, eles estavam lá e em alguns dias eles estavam batendo a cabeça na parede. Você não sabia como agiria quando entrasse lá. Você não queria descobrir". ${ }^{15}$ Apesar de privados de estímulos sensoriais, alguns presos relatam ricas experiências visuais, cuja sensação de realidade em muito supera o mero devaneio. Luke, por exemplo, relata que viajava, e em uma dessas viagens, lembra-se de empinar pipas, como se aquilo realmente estivesse acontecendo. Um outro preso relata ver um ponto de luz que se expandiu até se tornar uma televisão, que ele assistia durante o confinamento. ${ }^{16}$

Esse exemplo é colocado para ilustrar o seguinte ponto: a forma como se administra a pena impacta o apenado de maneiras diferentes. Esses dois presos relatam mecanismos mentais para fugir ao desespero do isolamento sensorial da solitária, embora tantos outros presos não consigam desenvolver tais mecanismos para lidar com situação tão adversa. Depois de cumprida a pena, essas pessoas retornam ao convívio social e a sociedade espera que se comportem como membros responsáveis, civilizados e produtivos — numa palavra: reabilitados. Essa expectativa social não tem como se realizar: é improvável que uma pessoa já em conflito com a lei, tratada desumanamente por longo período, retorne à sociedade serenamente. ${ }^{17}$ Após ser submetida a tal tratamento, é simplesmente infundada essa expectativa de que essa pessoa não reincidirá. É a isso que De Waal se refere quanto às "ferramentas necessárias para ver sua própria sociedade com qualquer objetividade". ${ }^{18}$ Algumas expectativas não se realizam porque ignoram-se traços básicos da espécie humana - a nossa espécie. Quando se incorporam conhecimentos desse arsenal, acredita-se que o resultado seja o aprimoramento das próprias técnicas jurídicas colocadas em prática atualmente.

Até este ponto do artigo, tratou-se muito da necessidade que o jurista enfrentará de operar com competência os conhecimentos produzidos por outras áreas do conhecimento. No entanto, uma outra perspectiva, complementar, é também necessária.

13 WAAL, Frans de. The age of empathy: nature lessons for a kinder society. New York: Harmony Books; Crown Publishing, 2009. p. 6. 14 EAGLEMAN, David. The brain: the story of you. New York: Pantheon Books, 2015. p. 49-51.

15 EAGLEMAN, David. The brain: the story of you. New York: Pantheon Books, 2015. p. 51, tradução dos autores. No original: "The dark Hole was a bad place. Some guys couldn't take that. I mean, they were in there and in a couple of days they were banging their head on the wall. You didn't know how you would act when you got in there. You didn't want to find out."

16 EAGLEMAN, David. The brain: the story of you. New York: Pantheon Books, 2015. p. 51.

17 Não se desconhece aqui a ampla discussão a respeito da função da pena: o caráter retributivo, o caráter pedagógico, e o caráter de reabilitação. Colocar um apenado em uma solitária como a de Alcatraz pode servir às finalidades retributivas e pedagógicas, para aqueles que se filiam a essas correntes. No entanto, entre os que defendem o caráter reabilitativo, considerando essas descobertas, não pode apostar nesse sistema, mesmo inspirado em métodos de recondicionamento de comportamento. Uma reflexão superficial aponta no sentido de que, se o ser humano é necessariamente social, é na recuperação de laços sociais, ou formação de novos laços que os programas de reabilitação devem se focar.

18 WAAL, Frans de. The age of empathy: nature lessons for a kinder society. New York: Harmony Books; Crown Publishing, 2009 . p. 5. 
O jurista italiano Sabino Cassese já anotou como o estudo do Direito não é monopólio dos juristas. Também o estudam a Filosofia, a História, a Sociologia, as Ciências Políticas, Antropologia, Linguística. ${ }^{19}$ Quando outras disciplinas se interessam pelo Direito, levantam-se interrogações às quais os juristas deveriam se atentar, também para saber se podem respondê-las com suas armas tradicionais (os métodos tradicionais de estudo jurídico). O autor oferece o exemplo da análise econômica do Direito, em que a Economia que se ocupa da análise econômica das normas e dos sistemas jurídicos, com seus custos diretos e indiretos, inclusive com a forma como esses custos são conhecidos e divididos, bem como com possíveis externalidades. No contexto analisado por Cassese, o Direito faria bem ao considerar o olhar de outras disciplinas sobre seu objeto de estudo.

É preciso, no entanto, ampliar o diagnóstico de Cassese. As disciplinas mencionadas compartilham com o Direito, em larga medida, o gosto pela forma dissertativa de se expressar, e pelo método fortemente influenciado pela revelação individual, o que favorece o intercâmbio de ideias entre elas. Entretanto, não são apenas elas que voltam o olhar para o Direito. $\mathrm{Na}$ atualidade, também as Ciências Cognitivas se interessam pelo Direito. Questões ontológicas como “O que é o Direito?” e "O que é a Justiça” tomam novos contornos quando se encaram as origens biológicas do comportamento humano.

Soma-se a isso a existência de problemas de ordem prática que jamais serão resolvidos dentro das fronteiras seguras de qualquer campo do conhecimento, cuja solução adequada só aparecerá do diálogo. Nem ao menos pode-se dizer que esses problemas são recentes. Problemas relativos à questão ambiental, além dos desafios que a convivência urbana oferece (como garantir fornecimento de serviços públicos básicos, a locomoção das pessoas, o manejo de resíduos), tudo isso não será resolvido por uma especialidade isolada. Nem qualquer pessoa será capaz de dominar com competência todos os conhecimentos necessários para isso.

Por que, então, o distanciamento disciplinar continua tão intenso? Por que os acadêmicos defendem de forma tão aguerrida seus objetos de estudo de ingerências de outras áreas? A próxima seção é justamente uma tentativa de compreender as origens desse distanciamento que levou ao atual estágio de isolamento. A seção seguinte tem por objetivo mostrar os esforços teóricos — e a urgência — da reconciliação. Por fim, o ponto de chegada dessa reflexão é apresentado na terceira seção, e culmina na consolidação da Neuroética e do Neurodireito, em seus desdobramentos e consequências.

\section{As ORIGENS DA DESCONFIANÇA DISCIPLINAR: O DIVÓRCIO ENTRE AS DUAS CULTURAS}

A ideia de duas culturas, surdas entre si, é uma das apresentações mais influentes no debate sobre afastamento disciplinar tal como atualmente colocado. Essa metáfora foi apresentada por Percy Snow, em famosa palestra ministrada em 1959 no âmbito das Rede Lectures de Cambridge ${ }^{20}$ intitulada "As duas culturas e a revolução científica" (The two cultures and the scientific revolution). As ideias ali apresentadas causaram grande controvérsia, como é da natureza dessas palestras anuais organizadas por grandes universidades, em que um intelectual de destaque é convidado para palestrar.

Na verdade, "As duas culturas" traz muitas provocações: em 1959, era revolucionário questionar diretamente "como" (e não "se") os países ricos deveriam ajudar os países pobres, como alimentar toda a população do planeta e quais eram as esperanças para a humanidade que o futuro reservava; ${ }^{21}$ há, ainda, provocações sobre os privilégios e alienação da aristocracia inglesa educada nas universidades; por fim, foi

19 CASSESE, Sabino. La sonrinsa del gato, o de los métodos de estudio del Derecho Público. In: CASSESE, Sabino. Derecho Administrativo: historia y futuro. Sevilla (España): Global Law Press; Instituto Nacional de Administración Pública, 2014b. Capítulo 20. p. 385-397.

20 Esse ciclo de palestras acontece há séculos, com alguns intervalos temporais.

21 COLLINI, Stefan. Introduction. In: SNOW, Charles Percy. The two cultures. Cambridge: Cambridge University Press, 1998. p. 7- 21. p. 8. 
apresentada a questão do afastamento disciplinar entre as duas culturas, identificadas por Snow como a ciência de um lado e a formação clássica (que enfatizava literatura e filosofia, também chamada cultura literária [literary culture]) de outro. Nesse último aspecto, as reflexões de Snow continuam particularmente provocativas, até porque a polarização e suas consequências são um debate longe de estar superado.

Assim, Snow denuncia o afastamento entre aqueles que chamou de intelectuais literários e os cientistas naturais (entre eles, com maior destaque, os físicos) — integrantes, cada qual, de uma entre as duas culturas. Desde já é preciso reconhecer que Snow ignorou o campo crescente das Ciências Sociais, o que também é motivo para críticas.

O isolamento disciplinar denunciado por Snow não é, todavia, um fenômeno adstrito à sua época, e uma breve incursão histórica pode auxiliar a compreender o cenário em que o autor se manifesta. Segundo Stefan Collini, o divórcio entre as Humanidades, de um lado, e as Ciências Naturais, de outro, tem suas origens no século XIX.22 Antes disso, essa discussão fazia pouco sentido, ainda que já houvesse alguma divisão disciplinar desde as origens do pensamento ocidental na Grécia. Isso porque, durante a Idade Média e Renascença, o objeto de estudo dos filósofos, também, incluía a natureza e o mundo material (não havia uma distinção clara do profissional cientista $^{23}$ ). Apenas no século XVII, no que depois foi conhecido como a Revolução Científica (donde a segunda parte do título da palestra), os estudos do mundo natural pelos "filósofos naturais" forjaram novos parâmetros para aquisição de conhecimento genuíno, avocando para si uma autoridade cultural especial, com a mecânica celestial e método experimental newtoniano. ${ }^{24} \mathrm{Ou}$ seja, até quase o final do século XVII, não existiam os princípios e procedimentos do método científico que hoje consideram-se como lugar comum: a experimentação, a publicação e publicização de resultados, a descrição detalhada de métodos, a replicação, a revisão de ideias por pares, nada disso ocorria antes da revolução científica. ${ }^{25}$ Antes disso, o que se chama hoje de conhecimento científico avançava como avança ainda hoje o conhecimento filosófico: por meio da revelação individual, especulação teórica e insights visionários. ${ }^{26}$ Inclusive, o próprio Thomas Hobbes (1588-1679) expressou preocupações em relação a decisões tomadas em coletividade, por comitês, que ele considerava como pouco confiáveis e passíveis de manipulações. Nessa toada, ele suspeitava particularmente da elite que dominava o establishment científico.

Após a revolução científica, tamanho se tornou o prestígio desse ramo do conhecimento, e, ao longo do século XVIII, foi lançada uma busca pelo "Newton das Ciências Morais". Paralelamente a esse fortalecimento do prestígio das Ciências, o Romantismo do século XVII e XVIII lançava as sementes para a desconfiança quanto ao método experimental (o método científico em sua concepção), que era visto por esse movimento como uma possível uma ameaça à cultura e à empatia, bem como à crença religiosa e à devoção sincera. Para os românticos, a Ciência era incapaz de desvendar o que as pessoas intimamente sentem, o que só poderia ser expresso por meio das artes criativas. Mais do que isso, a fé cega nas ciências amesquinharia o potencial humano. ${ }^{27}$

Não obstante, retornando às origens da separação, é curioso apontar, ainda, como, apenas no século XIX, a palavra "ciência" se fechou em torno do estudo do mundo material, as chamadas ciências físicas ou naturais. Noutras palavras, essa distinção, que hoje é lugar comum, corriqueiro e evidente, aparece, apenas,

22 COLLINI, Stefan. Introduction. In: SNOW, Charles Percy. The two cultures. Cambridge: Cambridge University Press, 1998. p. 7- 21. p. 9.

23 Inclusive, foi somente em 1830 que a Associação Britânica para o Avanço das Ciências passou a denominar aqueles que buscam conhecimento sobre o mundo material de cientistas, em uma palavra inspirada em artista (COLLINI, 1998, p. 11).

24 COLLINI, Stefan. Introduction. In: SNOW, Charles Percy. The two cultures. Cambridge: Cambridge University Press, 1998. p. 7- 21. p. 10.

25 BRANDT, Anthony; EAGLEMAN, David. The runaway species: how human creativity remakes the world. New York: Catapult, 2017. p. 110.

26 BRANDT, Anthony; EAGLEMAN, David. The runaway species: how human creativity remakes the world. New York: Catapult, 2017. p. 110.

27 WILSON, Edward Osborne. The meaning of buman existence. New York: Liveright Publishing Corporation, 2014. p. 39. 
num momento recente da história.

Assim, por quase duzentos anos, as ciências e as humanidades trilharam caminhos separados. ${ }^{28}$

Em "As duas culturas", o objetivo da palestra era, a princípio, denunciar que toda a vida intelectual da sociedade ocidental estava progressivamente se dividindo em dois grupos polarizados (dos cientistas e dos intelectuais literários), o que levou a um cenário de mútua desconfiança. ${ }^{29}$

Esse cenário era causa de um retardo nos esforços de corrigir grandes problemas do mundo (esforços que, para o autor, pesavam inevitavelmente sobre os países mais ricos), entre os quais a fome e a mortalidade infantil, compromisso inafastável dos países ricos. Não por outro motivo Snow quase intitulou sua palestra como "Os ricos e os pobres" ("The Rich and the Poor") antes de optar por "As Duas Culturas". ${ }^{30}$ Assim divididas, cada cultura, por ser apenas representante da metade do todo, seria inevitavelmente pobre.

Mesmo que existam ignorâncias dos dois lados, o que a princípio significaria uma culpa repartida, Snow promove um ataque feroz aos intelectuais literários, como se pesasse sobre eles a maior parte da responsabilidade pelo isolamento disciplinar e, consequentemente, pelo atraso em resolver os problemas do mundo.

Em relação aos cientistas, Snow adverte que sua falta de interesse pela literatura da cultura tradicional e pelas grandes obras de arte (como os livros de Charles Dickens) faz com que a compreensão imaginativa desses cientistas seja diminuída. ${ }^{31}$ No entanto, o autor acusa essa mesma literatura de ser misteriosa, inacessível e desinteressante, de modo que a ignorância dos cientistas seria quase compreensível e desculpável.

Por outro lado, a abordagem de Snow, quanto à ignorância dos intelectuais literários, é mais severa: não saber a segunda lei da termodinâmica, ou conceitos como massa e aceleração, parece-lhe absolutamente imperdoável. Snow chega a relatar espanto sobre como a arte não assimilou as descobertas científicas, e como as poucas tentativas de empregar poeticamente palavras científicas (como refração ou luz polarizada) o fazem equivocadamente. ${ }^{32}$ Soma-se a isso a acusação de que os intelectuais literários não se importariam com o mundo, ao contrário dos cientistas, que nutririam um interesse maior pelo aspecto social que a maior parte das pessoas. ${ }^{33}$

No entanto, além de injusta, essa crítica de Snow às artes criativas está equivocada. A Arte frequentemente incorpora as descobertas científicas às suas representações, num movimento em que a Arte move a Ciência e a Ciência inspira a Arte. ${ }^{34}$

O pintor Vincent Van Gogh, em seus quadros Noite Estrelada (1889), Estrada com Cipreste e Estrela (1890) e Campo de Trigo com Corvos (1890), representou com precisão matemática o fenômeno físico chamado de turbulência. ${ }^{35} \mathrm{O}$ padrão de luminescência empregado pelo pintor nessas telas transmite a essência desse fenômeno físico. Ainda desafiadora na atualidade, a teoria contemporânea sobre a turbulência foi modelada em data posterior ao desenvolvimento das telas, em 1940, pelo cientista soviético Andrei Kolmogorov. Não obstante, a distribuição dos padrões de luz e sombra nas telas distribuem-se conforme o modelo matemático de Kolmogorov para a turbulência. Curiosamente, todos os quadros mencionados foram desenvolvidos durante prolongados períodos de agitação psicótica, ao passo que outros quadros, de períodos

28 WILSON, Edward Osborne. The meaning of human existence. New York: Liveright Publishing Corporation, 2014. p. 39.

29 SNOW, Charles Percy. The two cultures. Cambridge: Cambridge University Press, 1998. p. 3.

30 SNOW, Charles Percy. The two cultures. Cambridge: Cambridge University Press, 1998. p. 79.

31 SNOW, Charles Percy. The two cultures. Cambridge: Cambridge University Press, 1998. p. 13-14.

32 SNOW, Charles Percy. The two cultures. Cambridge: Cambridge University Press, 1998. p. 16.

33 SNOW, Charles Percy. The two cultures. Cambridge: Cambridge University Press, 1998. p. 13.

34 BRANDT, Anthony; EAGLEMAN, David. The runaway species: how human creativity remakes the world. New York: Catapult, 2017.

35 ARAGÓN, J. L. et al. Turbulent luminance in impassioned van Gogh paintings. Journal of Mathematical Imaging and Vision, v. 30 , n. 3, mar. 2008, p. 275-283. Disponível em: <https://link.springer.com/article/10.1007/s10851-007-0055-0>. Acesso em: 20 fev. 2018. BALL, Philip. The disturbed artist intuited the deep forms of fluid flow. Nature, 7 jul. 2006. Disponível em: <https://www. nature.com/news/2006/060703/full/news060703-17.html>. Acesso em: 20 fev. 2018. 
mais calmos, não seguem o padrão matemático, ainda que o padrão estético das pinceladas seja semelhante.

Noutro exemplo, o premiado escritor de ficção norte-americano Neil Gaiman mostra que o sucesso da Ciência e Tecnologia pode estar diretamente implicado no protagonismo das Humanidades, em específico da literatura de ficção. ${ }^{36} \mathrm{O}$ autor relata que, durante muito tempo, a China desencorajou a publicação e o gosto por literatura de ficção científica, e dificultou a realização de convenções sobre esse ramo literário. Em 2007, no entanto, a política oficial mudou, e vários autores estrangeiros desse gênero (inclusive o próprio Gaiman) foram convidados a visitar o país para suscitar o gosto por esse tipo de arte. Durante essa convenção, Gaiman perguntou a um oficial do partido comunista o porquê da mudança, e recebeu a curiosa resposta:

Ah, você sabe que por anos estamos fazendo coisas maravilhosas. Nós fazemos seus iPods. Nós fazemos telefones. Nós fazemos essas coisas melhor que qualquer outra pessoa, mas nós não inventamos nenhuma dessas ideias. Vocês nos trazem coisas e nós as fazemos. Então nós visitamos os Estados Unidos e conversamos com pessoas na Microsoft, na Google, na Apple, e nós fizemos a elas muitas perguntas sobre elas mesmas, àquelas pessoas trabalhando lá. E nós descobrimos que todas elas leram ficção científica quando elas eram adolescentes. Então nós pensamos que talvez isso seja uma coisa boa. ${ }^{37}$

Gaiman, então, questiona: Para que serve a imaginação? Por que as pessoas escrevem histórias de ficção? Escrever importa de alguma coisa? Por que importa? Considerando essa experiência de Gaiman, é possível especular que está nas Humanidades um importante impulso para que a Ciência e a Tecnologia se movam. Conclusão semelhante é defendida por Anthony Brandt (que é músico) e David Eagleman (que é neurocientista) em obra de coautoria: ${ }^{38}$ o cerne do pensamento criativo que move a Humanidade está neste ir e vir de ideias, na troca constante entre as Ciências e as Humanidades.

Na proposta deste artigo, amplia-se o questionamento: para que serve a Filosofia? Ou a Filosofia do Direito? A resposta para essa pergunta será desenvolvida mais adiante. Não obstante, já se adianta que, embora a Filosofia e a Filosofia do Direito sejam ainda hoje culpadas de muitos dos vícios apontados por Snow, outras acusações eram injustas então, e permanecem injustas atualmente. Assim, neste trabalho, acredita-se que certamente existe um lugar de protagonismo e importância reservado a elas, num processo de reconciliação disciplinar.

Entre muitas tarefas, coube à Filosofia questionar, também, a versão idealizada de cientista apresentada por Snow, em um ramo que veio a ser conhecido como Filosofia da Ciência. Questiona-se a ideia de que as Ciências sejam intrinsecamente dotadas de objetividade, imparcialidade e neutralidade, e que os cientistas sejam pessoas dotadas de autoridade moral diferenciada. ${ }^{39}$ Certamente, nem todos os cientistas se importam com questões sociais, tampouco se guiam por rígidos padrões morais (as contribuições da História da Ciência e da Filosofia da Ciência desmistificaram por completo essas ilusões). São, também, fruto da Ciência e do desenvolvimento tecnológico empreitadas que concederam à humanidade nada além de dor e miséria, e exemplos são fartos (a bomba atômica, as lobotomias, vírus criados em laboratório, e até mesmo para o aquecimento global a Ciência contribuiu).

É evidente que Snow se preocupa com os problemas práticos do mundo (identificados por ele, constrito

36 GAIMAN, Neil. The pornography of genre, of the genre of pornography. In: GAIMAN, Neil. The view from the cheap seats: selected nonfiction. New York (EUA): William Morrow; HarperCollins Publishers, 2016. p. 39-. p. 41.

37 GAIMAN, Neil. The pornography of genre, of the genre of pornography. In: GAIMAN, Neil. The view from the cheap seats: selected nonfiction. New York (EUA): William Morrow; HarperCollins Publishers, 2016. p. 41. (Tradução nossa). No original: “'Oh, you know for years we've been making wonderful things. We make your iPods. We make phones. We make them better than anybody else, but we don't come up with any of these ideas. You bring us things and the we make them. So we went on a tour of America talking to people at Microsoft, at Google, at Apple, and we asked them a lot of questions about themselves, just the people working there. And we discovered that they all read science fiction when they were teenagers. So we think maybe it's a good thing"

38 BRANDT, Anthony; EAGLEMAN, David. The runaway species: how human creativity remakes the world. New York: Catapult, 2017.

39 LACEY, Hugh. 2. ed. São Paulo: Editora 34, 2008. LACEY, Hugh. Valores e atividade científica 2. São Paulo: Editora 34, 2010. 
por aquele momento histórico, com um holocausto nuclear, a superpopulação mundial e a desigualdade entre ricos e pobres, com ênfase no último, que estaria se agravando) e com a urgência de abordá-los para solucioná-los. Para o autor, o isolamento disciplinar, em qualquer forma, é deletério para a realização desses objetivos. Se os problemas do mundo agravados pelo isolamento disciplinar não se superam apenas com reformas educacionais, não é possível solucioná-los sem tais reformas:

A educação não é a solução integral para este problema [a desigualdade]: mas sem a educação, o Ocidente não pode sequer começar a lidar. Todas as setas apontam para a mesma direção. Fechar a lacuna entre nossas culturas é uma necessidade no sentido intelectual mais abstrato, assim como no mais prático. Quando esses dois sentidos se separam, nenhuma sociedade é capaz de pensar com sabedoria. Em prol da vida intelectual, em prol do perigo específico deste país [Inglaterra], em prol da sociedade ocidental que vive precariamente rica entre os pobres, em prol dos pobres que não precisam ser pobres se houver inteligência no mundo, é obrigatório para nós [ingleses], para os americanos e para todo o Ocidente olhar para a nossa educação com novos olhos. ${ }^{40}$

Analisando "As Duas Culturas" em retrospecto, fica claro que a esperança depositada por Snow na Ciência e na Tecnologia como panaceia para o mundo não foi realizada. A Ciência sozinha não foi (e continua não sendo) capaz de acabar por si só com a fome, a mortalidade infantil, nem garantir melhores condições de vida para aqueles que nascem em condições desfavoráveis. A atualidade dessa missão permanece.

Não obstante, as críticas a Snow não o desmerecem. O fato de que, 60 anos depois, ainda faz sentido discutir a cisão entre as duas culturas mostra o amplo alcance dessas ideias. A divisão disciplinar é um fenômeno que assombra todo o mundo ocidental, e nutriu ao longo dos anos rivalidade e desconfiança nefastas entre os cientistas e os intelectuais literários. Sua crítica, nesse aspecto, ainda permanece atual, já que o processo de especialização denunciado por ele continuou e se acentuou. A reconciliação ainda não foi totalmente alcançada, e a necessidade de reformas educacionais que superem noções fragmentadas do conhecimento sem perda de rigor metodológico ainda não foi contemplada.

Numa leitura atualizada, o ataque aos intelectuais foi bastante injusto (em comparação, todas as faltas imputadas por Snow aos cientistas foram transgressões pequenas, quase desculpáveis). Uma análise mais atual, talvez, deva trilhar um caminho mais equilibrado em que o isolamento seja resultado da conduta dos dois lados, como posteriormente o fez Edward Osborne Wilson, intelectual ainda vivo e atuante, cujo trabalho será abordado na próxima seção, na influente obra Consiliência.

\section{A RECONCILIAÇÃo disCIPLINAR: RUMO À CONSILIÊNCIA}

$\mathrm{Na}$ seção anterior, procurou-se mostrar como o isolamento disciplinar a respeito do que Snow denominou "as duas culturas" (cientistas de um lado, e intelectuais literários de outro) foi resultado de um processo crescente de especialização que precedeu o próprio Snow, alimentado por uma postura adotada por cada uma das duas culturas de desconfiança em relação à outra. Um dos méritos de Snow é atribuir a responsabilidade pelo isolamento aos dois lados, ainda que sua crítica seja mais severa em relação aos intelectuais literários. Além disso, Snow destacou que o isolamento disciplinar causa problemas para o mundo ou, no mínimo, atrasa os esforços de encontrar soluções para os grandes problemas da humanidade (em particular, a pobreza, e toda sorte de miséria dela decorrente). Para o autor, a cultura ocidental, fracionada em duas

40 SNOW, Charles Percy. The two cultures. Cambridge: Cambridge University Press, 1998. p. 50. (Tradução nossa). No original: "Education isn't the total solution to this problem [gab between rich and poor]: but without education the West can't even begin to cope. All the arrows point the same way. Closing the gap between our cultures is a necessity in the most abstract intellectual sense, as well as in the most practical. When those two senses have grown apart, then no society is going to be able to think with wisdom. For the sake of the intellectual life, for the sake of this country's special danger, for the sake of the western society living precariously rich among the poor, for the sake of the poor who needn't be poor if there is intelligence in the world, it is obligatory for us and the Americans and the whole West to look at our education with fresh eyes." 
culturas, deve ser novamente reunida, ainda que essa reunião não venha sem angústia.

Na trilha do pensamento de Snow, Edward Osborne Wilson defendeu a unificação do conhecimento - a síntese - em um movimento que batizou de Consiliência. ${ }^{41} \mathrm{~A}$ ideia de Consiliência liga-se à ideia de coerência, no sentido de que o conhecimento é único e não se pode admitir que as duas culturas se contradigam. É preciso tornar todo esse conhecimento coerente, ou consiliente. Essa premissa valeria para todas as aventuras intelectuais humanas, inclusive a Ética, e, também, o Direito. Assim, por exemplo, quando se estuda a moralidade humana, é preciso que todas as disciplinas que se ocupam do assunto — Filosofia, Psicologia, Biologia — caminhem para chegar a fundamentos explicativos comuns. Este seria o caminho para a unificação do conhecimento. Assim, a contribuição de Wilson é mais robusta que a de Snow, no sentido de que o primeiro oferece ferramentas concretas para a integração, ou seja, um programa de pesquisa, ao passo que o segundo permanece no diagnóstico crítico. Essa proposição, no entanto, possui implicações polêmicas e encontrou (e encontra ainda) muita resistência.

Isso porque essa proposta desafia algumas concepções fundamentais a sociedade ocidental desenvolveu sobre si mesma. Na verdade, a Ciência há muito vem atacando ilusões humanas de que somos particularmente especiais ou divinos.

Na formulação já conhecida de Sigmund Freud, as três grandes revoluções científicas deflagraram três golpes contra o ingênuo amor que a humanidade nutre por si mesma; noutras palavras, as revoluções científicas quebraram os pedestais da arrogância cósmica do ser humano.

A primeira revolução científica foi promovida por Copérnico, quando a humanidade se deparou como fato de que não é o centro do universo. A segunda, foi a descoberta por Darwin da Teoria da Evolução, que roubou do homem a crença de ter sido especialmente desenhado para um propósito divino, e o colocou como descendente do mundo animal. A terceira, seria a própria descoberta de Freud sobre o inconsciente, que desafiaria a noção humana sobre sua racionalidade.

É curioso perceber que essa formulação de Freud fornece um novo critério para identificar uma revolução científica, qual seja, a capacidade de subverter convicções que a humanidade vaidosamente nutre sobre si mesma. ${ }^{42}$

Gould explica que o golpe copernicano parece não mais provocar angústias existenciais, ou seja, parece que as pessoas se acostumaram à ideia de que vivem um pedaço de rocha orbitando uma galáxia entre muitas. No caso da revolução darwiniana (e aqui Gould desconsidera a enorme quantidade de pessoas que rejeita a Teoria da Evolução por completo, com as quais não se pode sequer dialogar), embora as pessoas já aceitem a ideia de que descendem do mundo animal, a internalização do significado desse fato ainda não foi alcançada, de modo que a revolução darwiniana (no sentido que Freud a explicou) permanece incompleta. Esse significado que ainda se encontra disperso é: os seres humanos não são o ponto de chegada predestinado de um progresso evolutivo determinado, mas sim um refluxo cósmico tardio e fortuito; caso o processo evolutivo tivesse num novo começo, dificilmente a espécie humana, tal como a entendemos hoje, emergiria do processo. ${ }^{43}$

Quando se aceita a segunda revolução científica (a revolução darwiniana), aceita-se, também, a proposta de se estudar o ser humano (e todas as suas experiências e atividades) dentro da mesma metodologia empregada no estudo de todas os outros fenômenos naturais. Essa é a proposta da Consiliência, que, no entanto,

41 WILSON, Edward Osborne. Consilience: the unity of knowledge. New York: Vintage Books, 1999. p. 8.

42 GOULD, Jay Stephen. Can we complete Darwin's Revolution? In: GOULD, Jay Stephen. Dinosaur in a haysack: reflections in natural history. Cambridge (Massachusetts, USA); London (England): The Belknap Press of Harvard University Press, 2011. p. 325-334. p. 325.

43 GOULD, Jay Stephen. Can we complete Darwin's Revolution? In: GOULD, Jay Stephen. Dinosaur in a haysack: reflections in natural history. Cambridge (Massachusetts, USA); London (England): The Belknap Press of Harvard University Press, 2011. p. 325-334. p. 327. 
está cercada de controvérsias.

O que se chama neste artigo de Consiliência decorre de um programa de pesquisa sistematizado por Edward Osborne Wilson, um norte-americano, cientista de formação, formado em Biologia e especializado em Entomologia (o estudo das formigas), e trilha a linha de ataque darwiniana. Em 1975 publicou o livro "Sociobiology: The New Synthesis", ${ }^{44}$ por meio do qual sugeriu que a seleção natural teria também moldado o comportamento dos animais, inclusive dos seres humanos.

Nas palavras do próprio Wilson, a Sociobiologia é “o estudo sistemático das bases biológicas para o comportamento social”. ${ }^{45}$ No entanto, essa formulação sumária esconde a amplitude da proposta: a Sociobiologia, enquanto programa de pesquisa, propunha a síntese entre estudos experimentais e teóricos sobre demografia animal, biologia de populações, comunicação, comportamentos de grupo, a relação de parentalidade e agressão, desde os animais invertebrados, passando por pássaros, mamíferos e finalmente pelos seres humanos, convergindo os desenvolvimentos da Teoria da Evolução, Ecologia e Genética no sentido de construir um enquadramento teórico evolucionista mais rigoroso para o estudo do comportamento dos animais, inclusive os seres humanos. ${ }^{46}$

No que diz respeito aos outros animais (abelhas, formigas, ratos), o programa foi bem-sucedido, ${ }^{47} \mathrm{em}-$ bora hoje seja mais comum encontrar referência a esse ramo do conhecimento como Ecologia Comportamental (behavioural ecology).

No entanto, Wilson teve a audácia de sugerir, no capítulo final do livro, que a seleção natural também influenciou o comportamento humano. Wilson defendeu a ideia (polêmica ainda hoje) de natureza humana, e que essa natureza ofereceria limites para o desenvolvimento humano (pondo limites às próprias possibilidades da razão). Para tanto, Wilson fez referência expressa à Ética, e empregou os modelos racionalistas de justiça (John Rawls) e de desenvolvimento humano (Lawrence Kohlberg), com os quais estava bem familiarizado (já que os três eram professores da Universidade de Harvard à época), para construir seu argumento:

Filósofos da Ética intuem os cânones deontológicos da moralidade, consultando os centros emotivos do seu próprio sistema hipotalâmico-límbico. Isto também é verdade para os [psicólogos] desenvolvimentistas [tais como Kohlberg], mesmo quando eles estão sendo o mais severamente objetivos que conseguem. Somente quando se interpretar a atividade dos centros emotivos como uma adaptação biológica, podese decifrar o significado desses cânones. ${ }^{48}$

Wilson previu que o estudo da ética seria "biologizado", numa abordagem conjunta entre Filosofia, Biologia e Evolução, que batizou primeiro de Sociobiologia e posteriormente chamou de "Consiliência" (Consilience).

Essa ideia é particularmente aversiva quando se considera que parcela significativa da sociedade norte-americana ainda acredita no criacionismo. Em 2006, ${ }^{49}$ foi feita uma pesquisa em que adultos deveriam dizer se a seguinte afirmativa era verdadeira, falsa ou se não sabiam: "Seres humanos, tal como os conhecemos,

44 WILSON, Edward Osborne. Sociobiology: the abridged edition. $7^{\text {th }}$ printing. Cambridge (MA, EUA); London (England); Belknap Press; Harvard University Press, 1998.

45 WILSON, Edward Osborne. Sociobiology: the new synthesis. Cambridge (MA): Harvard University Press, 1975. p. 4. (Tradução nossa). No original: "the systematic study of the biological basis of all social behavior".

46 LALAND, Kevin N.; BROWN, Gillian R. Sense and nonsense: evolutionary perspectives on human behaviour. Oxford: Oxford University Press, 2002. p. 72.

47 LALAND, Kevin N.; BROWN, Gillian R. Sense and nonsense: evolutionary perspectives on human behaviour. Oxford: Oxford University Press, 2002. JOYCE, Richard. The evolution of morality. Paperback edition. Cambridge (Massachusetts, USA); London (England): MIT Press, 2007. p. 4.

48 WILSON apud HAIDT, Jonathan. The righteous mind: why good people are divided by politics and religion. New York: Vintage Books, 2012. p. 38. (Tradução nossa). No original: "Ethical philosophers intuit the deontological canons of morality by consulting the emotive centers of their own hypothalamic-limbic system. This is also true of the developmentalists [such as Kohlberg], even when they are being their most severely objective. Only by interpreting the activity of the emotive centers as a biological adaptation can the meaning of the canons be deciphered".

49 COYNE, Jerry A. Why evolution is true. New York: Penguin Books, 2010. 
se desenvolveram a partir de espécies mais primitivas de animais" (essa é uma das conclusões da Teoria da Evolução, e contrapõe-se diretamente ao criacionismo). Apenas 40\% dos norte-americanos responderam que a afirmativa está correta (em 1985, eram apenas 5\%). No estudo de 2006, Alemanha e Reino Unido apresentaram resultados semelhantes. Ou seja, em 1975, quando Sociobiologia foi publicado, a ideia era absolutamente herética.

Pela audácia de tentar explicar traços do comportamento humano pelas mesmas leis que se aplicam ao reino animal (a propósito, a seleção natural aplica-se a todos os seres vivos), Wilson foi publicamente hostilizado e ostracizado, chamado de fascista, racista e acusado de endossar o genocídio. ${ }^{50}$ Em 1979, durante uma conferência científica, logo antes de uma palestra, um grupo de manifestantes tomou o palco, proferiu xingamentos a Wilson e jogou nele um jarro de água gelada. ${ }^{51}$

A proposta não enfrentou resistência apenas daqueles sem treinamento nas Ciências Biológicas. Embora seja possível acusar alguns críticos (principalmente antropólogos, psicólogos e sociólogos) de nada entenderem de Biologia (de modo que a controvérsia poderia ser explicada por um desconhecimento disciplinar), alguns dos críticos mais vocais e atuantes da Sociobiologia eram também biólogos, inclusive professores vinculados à mesma universidade de Wilson (Harvard). Talvez os mais notórios entre os críticos sejam Richard Lewontin e Stephen Jay Gould, autoridades em Biologia Evolucionista. ${ }^{52}$

Instalou-se, então, uma controvérsia entre Wilson e Lewontin. Posteriormente, Wilson reconheceu que Lewontin foi um adversário respeitável, e que é provável que os ataques deflagrados contra Sociobiologia contribuíram, significativamente, para que a ideia ganhasse atenção. ${ }^{53}$ Não obstante, à medida que a controvérsia se acirrou, muitos foram os ataques pessoais recebidos pelos dois: Wilson era acusado de estar motivado por preconceitos pessoais, e Lewontin, pela ideologia marxista. No entanto, é possível que os estranhamentos entre eles tenham um pano de fundo diverso, não a política ou preconceitos, mas uma postura diante da própria Ciência: se, por um lado, Wilson aprecia o desafio de grandes problemas, procurando o cenário mais amplo e constantemente trabalhando pelo avanço da Ciência por meio do desenvolvimento de novas teorias e sínteses, Lewontin, por outro, adota uma postura muito mais cautelosa, suspeitando de afirmativas arrebatadoras e de especulações sem suporte, bastante atento ao fato de que os argumentos biológicos são sujeitos a manipulação. ${ }^{54}$

A controvérsia entre ambos ilustra como cientistas respeitáveis apresentam posturas diferentes em relação à própria Ciência e à forma como se faz Ciência. Mais ainda, essa diversidade de posturas, em constante interação, evita que a cautela excessiva ou o arrojamento intrépido sejam obstáculo ao desenvolvimento científico.

Em relação à Sociobiologia, somente na década de 1980 e posteriormente a esta, na década de 1990, essas ideias foram recuperadas e novos experimentos foram realizados procurando encontrar justamente as continuidades entre a mente humana e a mente dos demais animais. É possível afirmar que a Sociobiologia é, ainda, um programa de pesquisa em desenvolvimento; no entanto, em virtude da reputação negativa atrelada ao nome, muitos pesquisadores preferem outras denominações: Ecologia do Comportamento Humano (Human Behavioural Ecology), Psicologia Evolucionista (Evolutionary Psychology), Memética (Memetics) e Coevolução Gene-Cultura (Gene-culture Coevolution), que o tempo consolida como programas de pesquisa autônomos,

50 HAIDT, Jonathan. The righteous mind: why good people are divided by politics and religion. New York: Vintage Books, 2012. p. 38.

51 LALAND, Kevin N.; BROWN, Gillian R. Sense and nonsense: evolutionary perspectives on human behaviour. Oxford: Oxford University Press, 2002. p. 89-90.

52 LALAND, Kevin N.; BROWN, Gillian R. Sense and nonsense: evolutionary perspectives on human behaviour. Oxford: Oxford University Press, 2002. p. 91.

53 LALAND, Kevin N.; BROWN, Gillian R. Sense and nonsense: evolutionary perspectives on human behaviour. Oxford: Oxford University Press, 2002. p. 90.

54 LALAND, Kevin N.; BROWN, Gillian R. Sense and nonsense: evolutionary perspectives on human behaviour. Oxford: Oxford University Press, 2002. p. 91. 
ainda que tenham, todos eles, origem na Sociobiologia. ${ }^{55}$

Retomando as discussões epistemológicas em relação à possibilidade de uma síntese do conhecimento, Wilson publica em 1988 um novo trabalho, intitulado "Consiliência: a unidade do conhecimento" (Consilience: the unity of knowledge), ${ }^{56}$ uma versão bem mais elaborada do ponto polêmico defendido no último capítulo do Sociobiologia. ${ }^{57}$

O princípio defendido no livro de 1998 se funda na possibilidade da unidade do conhecimento e na possibilidade da Consiliência, e implica a hipótese de que cada processo mental possui um substrato físico consistente com as Ciências Naturais. A mente tem um papel de destaque nesse programa de pesquisa por uma razão simultaneamente simples e desconfortavelmente profunda: "tudo que já sabemos e podemos vir a saber sobre a existência é criado lá". ${ }^{58}$ Nesse contexto, quase todos os cientistas e filósofos contemporâneos concordam que a mente, composta por processos conscientes e racionais, é o cérebro em funcionamento. "Mente" não é um conceito incontroverso. Até a década de 1970, era de fato um conceito tão fugidio que cientistas o deixavam para a Filosofia. No entanto, para Wilson, ele deve ser melhor trabalhado na juntura entre Biologia e Psicologia, cuja vanguarda trabalha hoje dentro da alcunha Ciências Cognitivas (abrigo de neurobiólogos, psicólogos cognitivos e filósofos). ${ }^{60}$ É um campo que ainda não se consolidou, e os intelectuais que se enveredam por ele assumem mais riscos do que aqueles abrigados em programas de pesquisa consolidados.

Se o conhecimento começou num ramo comum, o que causou esse distanciamento? No diagnóstico, Wilson faz coro ao diagnóstico de Snow: a hiperespecialização da elite educada está na raiz do problema. ${ }^{61}$ No texto de 1998, Wilson trafega pelas contribuições de cada uma das duas culturas (com o mérito de considerar também o campo já bastante consolidado das Ciências Sociais, praticamente ausente em As Duas Culturas).

Não obstante, assim como em Snow, percebe-se que as críticas de Wilson aos intelectuais das Humanidades são severas, talvez até mais severas do que aquelas destinadas aos cientistas naturais. Referindo-se às correntes de pensamento mais estudadas da atualidade (teoria crítica, funcionalismo, historicismo, anti-historicismo, estruturalismo, pós-estruturalismo, marxismo e teoria psicanalítica), Wilson afirma:

Cada uma dessas empreitadas contribuiu com algo para entender a condição humana. Os melhores dos insights, se reunidos, explicam o amplo alcance do comportamento social, pelo menos no mesmo sentido elementar que os mitos pré-literários da criação explicam o universo, isto é, com convicção e certa consistência interna. Mas nunca - eu não acho que essa é uma palavra muito forte - os cientistas sociais foram capazes de ancorar suas narrativas nas realidades físicas da biologia humana e da psicologia, embora elas estejam certamente lá e não em algum plano astral do qual a cultura surgiu. ${ }^{62}$

55 LALAND, Kevin N.; BROWN, Gillian R. Sense and nonsense: evolutionary perspectives on human behaviour. Oxford: Oxford University Press, 2002. p. 106-107.

56 WILSON, Edward Osborne. Consilience: the unity of knowledge. Paperback edition. New York: Vintage Books, 1999. Publicado no Brasil pela editora Campus, também em 1998. A obra consultada neste artigo é o original em inglês, publicado em 1999 , com as traduções dos autores.

57 No intervalo entre a publicação de Sociobiologia (1975) e o Consiliência (1988), o debate em relação à possibilidade de a Biologia explicar o comportamento humano continuou, e algumas formulações originais de Wilson apresentadas na Sociobiologia foram reformuladas, decorrentes da resposta aos críticos, principalmente para incluir o papel da cultura, embora seja importante frisar que Wilson nunca defendeu um determinismo genético cego (e as várias críticas nesse sentido foram injustas).

58 WILSON, Edward Osborne. Consilience: the unity of knowledge. New York: Vintage Books, 1999. p. 105 (Tradução nossa). No original: "Everything that we know and can ever know about existence is created there".

59 WILSON, Edward Osborne. Consilience: the unity of knowledge. New York: Vintage Books, 1999. p. 108-109.

60 WILSON, Edward Osborne. Consilience: the unity of knowledge. New York: Vintage Books, 1999. p. 108.

61 WILSON, Edward Osborne. Consilience: the unity of knowledge. New York: Vintage Books, 1999. p. 137.

62 WILSON, Edward Osborne. Consilience: the unity of knowledge. New York: Vintage Books, 1999. p. 199. (Tradução nossa). No original: "Each of these enterprises has contributed something to understanding the human condition. The best of the insights, if pieced together, explain the broad sweep of social behavior, at least in the same elementary sense that preliterate creation myths explain the universe, that is, with conviction and a certain internal consistency. But never- I do not think that too strong a wordhave social scientists been able to embed their narratives in the physical realities of human biology and psychology, even though it 
Abordando especificamente a Ética, Wilson questiona: seriam os preceitos éticos (como a justiça ou os direitos humanos) independentes da experiência humana ou são invenções humanas? Para o autor, "O raciocínio moral (...) é em qualquer nível intrinsicamente consiliente com as ciências naturais", ${ }^{63}$ e defende, portanto, a necessidade de colocar as Humanidades na trilha da busca pela realidade objetiva, abandonando o método da revelação individual. ${ }^{64}$

Tais críticas focam fortemente nas contribuições destas do passado até o momento atual (em particular, apontam como fracassados os modelos descritivos e explicativos propostos), reservando, não obstante, um tom otimista ao papel que esses ramos do conhecimento podem exercer no futuro, caso adotem um paradigma consiliente.

Esse movimento convergente, na visão de Wilson, já começou, impulsionado por quatro pontes que levam as Ciências Naturais a se aproximarem das Ciências Sociais. ${ }^{65} \mathrm{~A}$ primeira é o florescer das Neurociências Cognitivas (ou Ciências do Cérebro), em que se analisa o substrato físico da atividade mental e se procura resolver os mistérios do pensamento consciente. A segunda é a Genética Comportamental Humana, que busca a base hereditária para essa atividade mental, inclusive a influência genética no seu desenvolvimento. A terceira ponte é a disciplina de Biologia Evolutiva (Evolutionary Biology), desenvolvimento híbrido da Sociobiologia, em que os pesquisadores procuram explicar as origens hereditárias do comportamento social. A última ponte são as Ciências Ambientais, que procuram entender como a psicologia e comportamento da espécie humana foram (ou podem ter sido) influenciados pelo meio ambiente.

Tudo isso pauta o caminho para uma abordagem empirista dos problemas éticos (abandonando a abordagem transcendentalista predominantemente adotada pela Filosofia até a contemporaneidade).

Essa abordagem seria a única consistente com a consiliência, tal como defendida por Wilson. Tal abordagem é baseada naquilo que esses autores chamam de sentimentos morais, entendidos como instintos morais tais como definidos pelas ciências comportamentais modernas, derivados de normas epigenéticas, vieses hereditários no desenvolvimento mental, normalmente condicionados pela emoção, que influencia conceitos e decisões feitos com base nesses sentimentos. ${ }^{66}$ Para ele, filósofos que se dedicam ao estudo da Ética devem dedicar-se à origem evolutiva desses sentimentos morais, e ao funcionamento material do cérebro humano. ${ }^{67}$ Em nenhum outro campo das Humanidades, a união com as ciências naturais seria mais urgente e necessária, já que o estudo dessas qualidades distintivas e vitais da espécie humana permanece como um quadrante vazio no mapa científico. ${ }^{68} \mathrm{O}$ caminho apontado pelo autor para preencher esse vazio foca nos seguintes tópicos: ${ }^{69}$

a) a definição desses sentimentos morais, em que se busca sua descrição precisa por meio da psicologia experimental, seguida pela análise dos processos neurais e endócrinos que subjazem essa resposta;

b) a genética desses sentimentos morais, em que se busca a medida da heritabilidade de processos psicológicos e fisiológicos do comportamento ético e, se for possível, da identificação dos genes que participam dessa manifestação;

c) o desenvolvimento desses sentimentos morais como um produto de interação entre genes e o ambiente, na linha das pesquisas já desenvolvidas pela Psicologia e pela Antropologia, com foco simultaneamente nas histórias dos sistemas éticos como parte da emergência de diferentes culturas, e o desenvolvimento

is surely there and not some astral plane from which culture has arisen".

63 WILSON, Edward Osborne. Consilience: the unity of knowledge. New York: Vintage Books, 1999. p. 260. (Tradução nossa).

No original: "Moral reasoning (...) is at every level intrinsically consilient with the natural sciences".

64 WILSON, Edward Osborne. Consilience: the unity of knowledge. New York: Vintage Books, 1999. p. 7.

65 WILSON, Edward Osborne. Consilience: the unity of knowledge. New York: Vintage Books, 1999. p. $208-209$.

66 WILSON, Edward Osborne. Consilience: the unity of knowledge. New York: Vintage Books, 1999. p. 275.

67 WILSON, Edward Osborne. Consilience: the unity of knowledge. New York: Vintage Books, 1999. p. 277.

68 WILSON, Edward Osborne. Consilience: the unity of knowledge. New York: Vintage Books, 1999. p. 277-278.

69 WILSON, Edward Osborne. Consilience: the unity of knowledge. New York: Vintage Books, 1999. p. 279. 
cognitivo de indivíduos que vivem em variadas culturas;

d) a profunda história desses sentimentos morais, em que se pretende descobrir porque esses sentimentos existem, na presunção desenvolvida por Wilson (e endossada neste artigo) de que esses sentimentos representam um ganho no sucesso de sobrevivência e reprodução desde os períodos da pré-história (quando eles primeiro se manifestaram).

Está-se, portanto, diante de abordagens rivais para a Ética: transcendentalismo (predominante na Filosofia) versus empirismo (defendida por Wilson e endossada neste artigo).

No entanto, é preciso esclarecer que essa proposta não pode ser considerada como ciência em si mesma. A possibilidade de integrar as Ciências Naturais e os demais ramos de conhecimento é melhor descrita como uma visão de mundo metafísica, impossível de ser provada por princípios ou fundada em testes empíricos. A aposta na Consiliência deriva de uma extrapolação do sucesso das Ciências Naturais, cujo maior teste será levar com eficiência seus métodos para as Ciências Sociais e Humanidades. Sua promessa, se bem-sucedida, é a compreensão da condição humana com um grau mais elevado de certeza. ${ }^{70}$

Em uma colocação quase poética, Wilson afirma que o século XXI delineará sua própria versão da batalha pela alma dos homens: a escolha entre transcendentalismo e o empirismo. A Ética ou permanecerá na expressão da Teologia e da Filosofia (onde atualmente se encontra) ou se se voltará para uma análise material baseada na Ciência. Nesse embate, prevalecerá a visão de mundo que se mostrar correta, ou que seja, mais amplamente percebida como correta. ${ }^{71}$

A Neuroética e o Neurodireito são apostas na abordagem empirista, defendida neste artigo. Defende-se, na linha da Consiliência, que a Ética e o Direito estudam o comportamento humano, que pode ser compreendido e explicado conforme as mesmas premissas com base nas quais são compreendidos e explicados todos os demais fenômenos da natureza. Em larga medida, isso significa estudar o cérebro humano, origem de toda experiência humana.

Essas abordagens não expressam exemplos de tecnicismo, ou de naturalismo cego. $\mathrm{Na}$ verdade, existe nela uma certa beleza, uma certa poesia.

Em suas memórias, Santiago Ramón y Cajal recorda que: “[c]omo o entomologista em busca de borboletas de cores vivas, minha atenção caçava, no jardim das flores da matéria cinzenta, células com formas delicadas e elegantes, as misteriosas borboletas da alma, cujas asas batendo podem algum dia — quem sabe? — esclarecer o segredo da vida mental".72

Esse esclarecimento que buscava o médico espanhol, pioneiro da Medicina e considerado um dos pais da Neurociência moderna, aos poucos vai sendo alcançado. Se o cérebro humano realmente é o objeto mais complexo do universo, o esclarecimento abrangente, ainda, está longe de ser alcançado, embora cada nova descoberta nos aproxime dele - cada nova descoberta nos aproxima de compreendermos a nós mesmos.

É preciso reconhecer que essa trajetória, ao mesmo tempo em que abre novas possibilidades de reflexão, abala algumas convicções que a humanidade tem sobre si mesma, o que pode ser fonte de enorme angústia. Essa é a realização da revolução darwiniana.

Não obstante, novamente com De Waal, se as ferramentas que viabilizam uma melhor compreensão do mundo estão à disposição, melhor conhecê-las e empregá-las. Nesse contexto, tem-se a Neuroética e o Neurodireito.

70 WILSON, Edward Osborne. Consilience: the unity of knowledge. New York: Vintage Books, 1999. p. 9.

71 WILSON, Edward Osborne. Consilience: the unity of knowledge. New York: Vintage Books, 1999. p. 262.

72 RAMÓN Y CAJAL, Santiago. Recollections of my life. [...]: MIT Press, 1989. p. 363-364, tradução dos autores. No original: "Like the entomologist in pursuit of brightly colored butterflies, my attention hunted, in the flower garden of the gray matter, cells with delicate and elegant forms, the mysterious butterflies of the soul, the beatings of whose wings may some day—who knows? — clarify the secret of mental life." 


\section{NeUroÉtica e neUROdireito: a busca Pelas borboletas da ALMA}

Em 1953, cientistas consideravam o DNA uma molécula estúpida, também excessivamente simples e monotonamente repetitiva para ser a raiz da vida; em uma avaliação similar, Descartes acreditava que o cérebro era um órgão excessivamente simples e gelatinoso para ser substrato material do pensamento. ${ }^{73}$ Foi apenas nas últimas décadas que a complexidade do cérebro se tornou clara, e muitos hoje o consideram como o objeto mais complexo do universo. ${ }^{74}$ Se o cérebro é de fato o substrato material para a vida mental — as borboletas da alma -, então, é inevitável o interesse por ele por parte de qualquer ramo do conhecimento que se ocupe da cognição humana, que orienta o comportamento humano, inclusive o Direito.

O processo de tomada de decisão é uma das atividades mais importantes do Direito. Embora se preocupe com o conhecimento abstrato, o Direito, geralmente, se preocupa mais com a solução para problemas particulares. ${ }^{75} \mathrm{~A}$ respeito dessa questão, as decisões judiciais são o produto da atividade jurídica que mais recebe destaque no Curso de Direito, tendo em vista que grande parte dos profissionais da área contribuirá para sua construção (embora os juristas frequentemente participem também dos processos que levam à formulação de uma norma jurídica, a produção de uma decisão administrativa ou delineamento de uma política pública). Boa parte da literatura jurídica voltada para a questão da tomada de decisão procura assegurar sua legitimidade, normalmente na tentativa de garantir que elas sejam decisões racionais, o que possui dois problemas. Mesmo que fosse possível garantir a racionalidade de uma decisão, isso não é garantia de sua qualidade. Mais grave que isso, essa racionalidade buscada parece impossível de se garantir, já que se conhece hoje uma série de vieses e fatores emocionais que influenciam a tomada de decisão e impedem a tomada de decisões puramente racionais. ${ }^{76}$

Já se mencionou acima a reflexão de Cassese ${ }^{77}$ acerca do olhar de outras disciplinas sobre o objeto de Estudo do Direito (como a Filosofia, a História, a Sociologia, as Ciências Políticas, Antropologia, Linguística, com seus métodos de estudo próprios). Segundo o autor, uma revolução antiformalista e realista, capitaneada por autores norte-americanos, eliminou os limites artificiais entre as Ciências Jurídicas e as ciências que se interessam pelo Direito. Nesse processo, os receios de que os métodos tradicionais de estudo jurídico se tornassem inúteis mostraram-se infundados: os métodos se completam. Na tarefa de convencer, o jurista-advogado deve recorrer aos métodos tradicionais, como também aos métodos novos. Cassese defende então:

Assim, não é necessário entender a divisão do trabalho científico no sentido de deixar a análise política do direito para os estudantes de ciência política e economia do direito aos economistas. Uma divisão desse tipo acabaria criando novamente barreiras acadêmicas após o devido reconhecimento de valores recíprocos. Se, como Popper lembrou, não se estudam matérias ou objetos, mas sim problemas, e estes são perseguidos além das divisões das disciplinas, o problema será então fixar o método. Serão as perguntas que guiam o método. ${ }^{78}$

73 HILTS, Philip J. Memory's Ghost: The nature of memory and the strange tale of Mr. M. New York (EUA): Touchstone Books; Simon \& Schuster, 1996. p. 73.

74 WILSON, Edward Osborne. The meaning of human existence. New York: Liveright Publishing Corporation, 2014. HILTS, Philip J. Memory's Ghost. the nature of memory and the strange tale of Mr. M. New York (EUA): Touchstone Books; Simon \& Schuster, 1996.

75 GOODENOUGH; Oliver R.; PREHN. Kristin. A neuroscientific approach to normative judgment in law and justice. Philosophical Transactions of the Royal Society B: Biological Sciences. v. 359, n. 1451, p.1709-1726, 29 nov. 2004. Disponível em: <https://www.ncbi.nlm.nih.gov/pmc/articles/PMC1693459/>. Acesso em: 2 maio 2018. DOI: 10.1098/rstb.2004.1552.

76 Obras paradigmáticas nesse sentido: KAHNEMAN, Daniel; SLOVIC, Paul; TVERSKY, Amos. Judgment under uncertainty: heuristics and biases. Cambridge; New York, NY: Cambridge University Press, c1982. KAHNEMAN, Daniel; TVERSKY, Amos. Choices, values, and frames. New York: Russell sage Foundation; Cambridge, UK: Cambridge University Press, 2000. KAHNEMAN, Daniel. Thinking, fast and slow. New York: Farrar, Straus and Giraux, 2011.

77 CASSESE, Sabino. La sonrinsa del gato, o de los métodos de estudio del Derecho Público. In: Derecho Administrativo: historia y futuro. Sevilla (España): Global Law Press; Instituto Nacional de Administración Pública, 2014b. Cap. 20. p. $385-397$.

78 CASSESE, Sabino. La sonrinsa del gato, o de los métodos de estudio del Derecho Público. In: ___ Derecho Administrativo: historia y futuro. Sevilla (España): Global Law Press; Instituto Nacional de Administración Pública, 2014b. Capítulo Vigésimo, p. 
Com isso, percebe-se que, também, entre os juristas, há os que já se alertaram para os problemas decorrentes da defesa excessiva de limites artificiais epistemológicos, e percebem como esses limites empobrecem o conhecimento produzido. Soluções jurídicas propostas dentro do isolamento disciplinar são mais frágeis. Não obstante, o diálogo proposto por Cassese envolve disciplinas que, tal como o Direito, prestigiam o método monográfico, em que o diálogo parece mais evidente, e foca-se muito na tarefa de habilitar o jurista-advogado a convencer.

O que se propõe neste artigo vai um pouco mais além da tarefa de equipar o jurista-advogado de técnicas para convencer: na tarefa de conhecer o Direito, também é necessário aliar os métodos tradicionais do Direito aos métodos novos, métodos das Ciências Naturais.

Muitos juristas se questionam se essa empreitada é viável ou conveniente,$^{79}$ adotando uma postura desconfiada e cautelosa semelhante àquela de Lewontin diante da Sociobiologia. Enquanto isso, outras disciplinas voltam seus olhares para o fenômeno jurídico, com o objetivo de investigá-los conforme seus próprios métodos. O interesse de outras áreas do conhecimento pelo Direito, notavelmente as Ciências Cognitivas, ${ }^{80}$ é crescente e implica consequências potencialmente disruptivas.

A Ética já é objeto de pesquisa dessa maneira. Abordagens neurocientíficas sobre a cognição moral, sobre como ocorrem os julgamentos normativos, ${ }^{81}$ já são uma realidade. Mas não só.

O neurocientista David Eagleman dedica um capítulo de seu livro Incognito ${ }^{82}$ à reflexão sobre o sistema de atribuição de culpa no Direito Penal: para o autor, o Direito Penal atual é muito focado na necessidade de punir, baseado na ideia de que um criminoso poderia ter optado por outra conduta. Quando o sistema penal verifica que a pessoa era incapaz de agir de outra maneira, não existe punição. Uma abordagem mais adequada deveria preocupar-se com a probabilidade de um criminoso voltar a cometer crimes, adotando-se uma abordagem muito mais personalizada do que se faz hoje. Segundo o autor, no futuro, seria possível basear a punição na neuroplasticidade individual (capacidade de alterar os circuitos cerebrais): alguns indivíduos são mais responsivos às abordagens clássicas de condicionamento (por exemplo, a punição e a recompensa), ao passo que outros são refratários a mudanças (por várias circunstâncias pelas quais não possuem qualquer culpa, como distúrbios como psicopatia, sociopatia, mal desenvolvimento cerebral etc.). Em resumo, deve-se partir do pressuposto de que todos os criminosos eram incapazes de agir de outra maneira, para forcar-se no futuro: é possível alterar esse comportamento. As intervenções estatais para alterar esse comportamento devem ser diferentes para cada caso, ou correm o risco de serem inúteis.

385-397. P. 397, tradução dos autores. No original: “Así, pues, no es necesario entender la división del trabajo científico en el sentido de dejar el análisis politológico del Derecho a los estudiosos de las ciencias políticas y el económico del Derecho a los economistas. Una división de este tipo acabaría por crear de nuevo barreras académicas tras el debido reconocimiento de los valores recíprocos. $\mathrm{Si}$, como recordaba Popper, no se estudian materias o objetos, sino problemas, y éstos se persiguen más allá de las divisiones de las disciplinas, el problema será entonces fijar el método. Serán las preguntas las que orienten el método”.

79 Para reflexões mais cautelosas, conferir: MORSE, Stephen. Avoiding Irrational NeuroLaw Exuberance: A Plea for Neuromodesty. Law, Innovation and Technology, v. 3, n. 2, 2011, p. 209-228. Disponível em: <https://www.tandfonline.com/doi/abs/10.5235/17 5799611798204932?journalCode=rlit20>. Acesso em: 24 jul. 2018. DOI: 10.5235/175799611798204932; MORSE, Stephen J. New neuroscience, old problems: legal implications of brain science. Cerebrum, v. 6, n. 4, Fall 2004, p. 81-90. Disponível em: < https:// www.ncbi.nlm.nih.gov/pubmed/15986539>. Acesso em: 24 jul. 2018.

80 Ciências Cognitivas é o ramo do conhecimento resultante das contribuições de vários outros, como a Psicologia, Neurociência, Linguística, Filosofia, Antropologia, Biologia Evolucionista, Educação, Ciências da Computação, Inteligência Artificial e Etologia, cada uma delas com seu foco e sua metodologia, em constante aprimoramento dentro de cada campo disciplinar específico, e nem sempre em concordância um com o outro (WILSON, Robert A.; KEIL, Frank C. Preface. In: WILSON, Robert A.; KEIL, Frank C. (Ed.). The MIT encyclopedia of the cognitive sciences. Cambridge, Massachusetts (EUA); London, England: Massachusetts Institute of Technology, 1999. p. 13-14.).

81 Toma-se de empréstimo a descrição contempla uma descrição inclusiva dos muitos sabores que os humanos encontram entre as coisas que devem ser feitas e aquelas que não devem ser feitas, particularmente no contexto social de interação com outros seres humanos (GOODENOUGH; Oliver R.; PREHN. Kristin. A neuroscientific approach to normative judgment in law and justice. Philosophical Transactions of the Royal Society B: Biological Sciences. v. 359, n. 1451, p.1709-1726, 29 nov. 2005. Disponível em: < https://www.ncbi.nlm.nih.gov/pmc/articles/PMC1693459/>. Acesso em: 2 maio 2018. DOI: 10.1098/rstb.2004.1552.).

82 EAGLEMAN, David. Incognito: the Secret Lives of the Brain. New York: Pantheon, 2011. 151-192. 
Mais ainda, Eagleman relata que estatísticas e cálculos atuariais possuem maior valor preditivo para informar quais pessoas são mais prováveis de cometer novos crimes, em comparação com intuições das pessoas envolvidas no processo penal, sejam juízes ou técnicos (psiquiatras, agentes penitenciários etc.). $\mathrm{O}$ autor reconta uma pesquisa feita com condenados por crimes sexuais: perguntou-se a psiquiatras e outros profissionais envolvidos na concessão de liberdade provisória qual seria a chance de um determinado condenado reincidir, para descobrir-se que a precisão da previsão desses profissionais não possuía qualquer valor preditivo. Esperava-se que as intuições dessas pessoas, acostumadas a lidar com esse tipo de situação, seria orientação segura para informar a decisão, mas isso não foi observado. Assim, passou-se a testar a abordagem atuarial. ${ }^{83}$ Confrontando-se o valor preditivo das intuições dos profissionais envolvidos no processo de concessão de liberdade provisória e os números da abordagem atuarial, os números mostraram-se mais confiáveis.

Mais além, em livro dedicado à Inteligência Artificial (AI), Russel e Norvig ${ }^{84}$ apresentam reflexão similar: já em 1955, havia estudos mostrando como algoritmos de aprendizagem estatística simples apresentavam previsões mais confiáveis para a reincidência criminal do que os especialistas. Os autores, então, refletem como os computadores podem apresentar desempenho melhor que humanos em inúmeras tarefas, inclusive quando se esperaria que fosse necessário grande compreensão e discernimento humano.

$\mathrm{Na}$ tarefa de prever a reincidência criminal, Eagleman especula que, quando os dados da neurociência puderem ser incorporados a essa análise, o valor preditivo dela será ainda melhor.

Outro exemplo dessa natureza são as reflexões da psicóloga Lisa Barrett ${ }^{85}$ sobre a relação entre direito e emoções, apresentadas em um capítulo de seu How emotions are made, dedicado inteiramente a essa questão. A pergunta “como se dá o processo de dizer o direito?” é abordada pela perspectiva de compreender os processos mentais de tomada de decisão (o substrato material desse processo), atualmente em investigação pelas Ciências Cognitivas. A autora pretende demonstrar o quão enviesada pode ser a percepção de juízes e também dos jurados, para colocar em cheque o sistema de júri (amplamente adotado no sistema judiciário norte-americano, muito mais do que no brasileiro) como um todo, questionando se não seria mais apropriado abandoná-lo por completo.

Percebe-se, por meio de trabalhos dessa natureza, como processos decisórios competentes não decorrem exclusivamente de análises racionais, solapando teorias tradicionais de decisão dentro dos processos jurídicos; a cognição emocional competente (para empregar a terminologia oriunda da dicotomia clássica razão versus emoção) é fundamental para a funcionalidade de qualquer pessoa. Assim, esses autores formulam críticas contundentes à orientação de lugar comum no Direito, de que o decisor deve colocar suas emoções de lado para que produza uma decisão racional (partindo da tradição de que emoção e razão são entidades diferentes, quase rivais); entretanto, pensar (no sentido de pensar racionalmente) e sentir não são processos distintos no cérebro. ${ }^{86}$

Isso traz algumas implicações importantes. A primeira é: a autoridade que diz o direito é inexoravelmente um ser humano, cuja resposta emocional competente é elemento imprescindível para que se entregue uma decisão jurídica adequada. Em termos muitos simples, também o juiz é gente. Ainda com Lisa Barrett:

83 Essa abordagem leva em conta informações sobre o condenado tais como: o condenado manteve um relacionamento estável por mais de um ano? Sofreu abuso sexual quando criança? Apresenta vício em drogas? Mostrou remorso? Apresentou interesses sexuais desviantes? Etc.

84 RUSSELL, Stuart J.; NORVIG, Peter. Artificial Intelligence: a modern approach. 3. ed. Harlow (Essex, England): Pearson Education Limited, 2016. p. 1022.

85 BARRETT, Lisa Feldman. How emotions are made: the secret life of the brain. Boston; New York: Houghton Mifflin Harcourt, 2017. Chapter 11, p. 219-251.

86 BARRETT, Lisa Feldman. How emotions are made: the secret life of the brain. Boston; New York: Houghton Mifflin Harcourt, 2017. p. 220. 
Para além do manifesto da ciência afetiva, ${ }^{87}$ também temos o antigo mito do juiz neutro, que é tanto propagado quanto questionado por membros da Suprema Corte dos EUA e por outros juristas. Acadêmicos podem debater em periódicos jurídicos sobre o valor da emoção na ação judicial, mas a anatomia do cérebro humano torna implausível para qualquer ser humano, incluindo um juiz, escapar da influência da interocepção ${ }^{88}$ e do afeto no processo de tomada de decisões. Emoções não são nem o inimigo nem um luxo, mas uma fonte de sabedoria. Os juízes não precisam revelar suas emoções (assim como os terapeutas aprendem a não fazê-lo), mas devem estar cientes delas e usá-las explicitamente com o melhor de suas habilidades. ${ }^{89}$

Tais considerações revelam que o Direito será não apenas intoleravelmente árido quando desconsidera esses processos cognitivos emocionais, mas também possivelmente inócuo.

Esse tipo de pesquisa explora processos cognitivos de forma geral, e aplica as conclusões ao Direito.

Por exemplo, existe um experimento bastante conhecido que procurou descobrir se existem diferenças nos correlatos mentais manifestados quando as pessoas pensam sobre os dilemas do bondinho (conhecidos na literatura de língua inglesa como trolley problems). ${ }^{90}$ Nele, apresentam-se aos participantes variações de dois cenários distintos. No primeiro cenário, descreve-se uma situação em que há cinco pessoas no trilho por onde o bonde passará, e, então, dá-se ao participante a opção acionar uma alavanca que altera o rumo do bonde para um trilho onde está apenas uma pessoa - caso a alavanca seja acionada, essa única pessoa morrerá e as outras cinco serão salvas. O segundo cenário é bastante semelhante, com a diferença de que, para salvar as cinco pessoas, o sujeito está em cima de uma ponte ao lado de outra pessoa; se o sujeito empurra essa pessoa para os trilhos, o trem para; como consequência, essa pessoa morre e as cinco outras se salvam. A maioria das pessoas responde que acionaria a alavanca no primeiro cenário, mas não empurraria a outra pessoa no segundo cenário, ainda que a matemática nos dois casos seja a mesma: por meio de uma ação, sacrifica-se uma pessoa para salvar cinco outras.

Os autores perceberam que os correlatos mentais acionados em cada um dos dois cenários são diferentes. Quando é necessário empurrar uma outra pessoa, o teste mostra uma resposta mais emocional. Esse tipo de estudo possui consequências relevantes para o Direito, que lida, frequentemente, com problemas moralizados. No entanto, a pesquisa não explora especificamente contextos jurídicos, mas sim contextos morais. Assim, pesquisas dessa natureza se ocupam de problemas ético-filosóficos.

Um modelo diferente de teste pode ser concebido empregando contextos jurídicos: é conhecida das Ciências Jurídicas a tensão entre aplicar a letra fria da lei ou fazer justiça (em sua apresentação contemporâ-

87 As chamadas Ciências Afetivas surgem na trilha das Ciências Cognitivas, com objetivo de estudar de forma interdisciplinar as emoções, temperamento, preferências, atitudes, valores e estresse (BARRETT, Lisa Feldman; GROSS, James J. The Emerging Field of Affective Science. Portal Eletrônico da Association for the Psychological Science, Observer, 30 de setembro de 2013. Disponível em: <https://www.psychologicalscience.org/observer/the-emerging-field-of-affective-science>. Acesso em: 07 dez. 2017.)

88 Interocepção (Interoception) é a representação que o cérebro produz de todas as sensações produzidas pelos órgão e tecidos internos, os hormônios que circulam no corpo e seu sistema imunológico. A todo tempo, existe uma percepção do que ocorre com uma pessoa, se o coração está batendo, se ela respira, se o estômago está cheio. Tudo isso gera a atividade interoceptiva que produz espectros de sentimentos básicos que vão do agradável ao desagradável, do calmo ao agitado, e mesmo o sentimento de estar neutro (BARRETT, Lisa Feldman. How emotions are made: the secret life of the brain. Boston; New York: Houghton Mifflin Harcourt, 2017. p. 56).

89 BARRETT, Lisa Feldman. How emotions are made: the secret life of the brain. Boston; New York: Houghton Mifflin Harcourt, 2017. p. 246, grifos acrescidos, tradução dos autores. No original: "Beyond the affective science manifesto, we also have the longstanding myth of the dispassionate judge, which is both propagated and questioned by members of the U.S. Supreme Court and other legal experts. Scholars may debate in legal journals about the value of emotion in judicial action, but the anatomy of the human brain makes it implausible for any human, including a judge, to escape the influence of interoception and affect when making decisions. Emotions are neither the enemy nor a luxury but a source of wisdom. Judges need not reveal their emotions (just as therapists learn not to), but they must be aware of them and explicitly use them to the best of their ability."

90 GREENE, Joshua D. et al. An fMRI Investigation of emotional engagement in moral judgment. Science, Report, v. 293 , n. 5537, p 2105-2108, 14 set. 2001. Disponível em: <science.sciencemag.org/content/293/5537/2105>. Acesso em: 02 maio 2018. DOI: $10.1126 /$ science.1062872. GREENE, Joshua. Moral tribes: emotion, reason, and the gap between us and them. New York: Penguin, 2013. 
nea, trata-se discussão entre Positivismo Jurídico e Neoconstitucionalismo). Segundo Oliver Goodenough e Kristin Prehn, o Direito é, a sua própria maneira, uma ciência investigativa que inquire sobre a natureza do comportamento humanos: o clássico processo legal que busca articular a paisagem mental sobre questões de certo e errado com um mundo baseado em regras representa um exercício intelectual rigoroso, que ocorre cada vez que uma controvérsia jurídica é levada ao Judiciário. Esse processo opõe a tendência de se resolver os problemas com base em intuições sobre certo/errado e a necessidade de se aplicar a lei. Existe, portanto, uma tensão entre lei/justiça material que pode servir de ponto de partida para testes empíricos, tal como a tensão entre razão-emoção serviu de ponto de partida para pesquisas sobre problemas ético-filosóficos, ${ }^{91}$ embora Stephen Morse alerte que praticamente não existem estudos que exploram especificamente dilemas jurídicos. $^{92}$

Diante disso, vê-se como as contribuições das Ciências Cognitivas são relevantes para as Ciências Jurídicas. Para autores como Morse, ${ }^{33}$ as neurociências são apenas o mais novo ramo da Ciência que o Direito deve acomodar (antes dela, tiveram a mesma pretensão a Genética, o Behaviorismo e outras empreitadas científicas com pretensão de apresentar explicações determinísticas para o comportamento humano). Para autores dessa linha, essas descobertas não são suficientemente disruptivas, e, em alguma medida, esse avanço científico é, apenas, mais um que as Ciências Jurídicas tiveram que responder. ${ }^{94}$

Joshua Green e Jonathan Cohen, ${ }^{95}$ por outro lado, entendem que a Neurociência tem o potencial de alterar a forma como as pessoas pensam sobre a agência humana e a responsabilidade jurídica. A ideia de que a ação humana é determinada por leis físicas não é novidade na Filosofia; no entanto, esses argumentos, estruturados com base, apenas, na lógica e na abstração, não são persuasivos o suficiente para suplantar nossa experiência de primeira pessoa de que somos livres e racionais. As demonstrações físicas apresentadas pelas Neurociências, por outro lado, são muito mais atraentes: o que a Neurociência faz é esclarecer o "quando", "onde" e "como" dos processos mecânicos que causam o comportamento humano. O potencial persuasivo desse tipo de esclarecimento, acompanhado de previsões confiáveis, pode finalmente persuadir as pessoas a abandonar noções sobre comportamento amplamente aceitas e que, no entanto, não mais se sustentam. Quando essas intuições forem alteradas, o Direito seguirá a mesma trilha.

É nesse contexto que surge o Neurodireito, na trilha do que vem sendo desenvolvido no âmbito da Neuroética.

A Neuroética amadureceu como campo de conhecimento nos anos 2000, e subdivide-se em torno de dois grandes eixos: o primeiro é a ética da neurociência e o segundo é a neurociência da ética. ${ }^{96} \mathrm{O}$ primeiro é irmão do que se chama Bioética, e preocupa-se com questões éticas relativas à realização dos estudos (v.g.

91 GOODENOUGH; Oliver R.; PREHN. Kristin. A neuroscientific approach to normative judgment in law and justice. Philosophical Transactions of the Royal Society B: Biological Sciences. v. 359, n. 1451, p.1709-1726, 29 nov. 2005. Disponível em: < https://www.ncbi.nlm.nih.gov/pmc/articles/PMC1693459/>. Acesso em: 2 maio 2018. DOI: 10.1098/rstb.2004.1552.

92 Para reflexões mais cautelosas, conferir: MORSE, Stephen. Avoiding Irrational NeuroLaw Exuberance: A Plea for Neuromodesty. Law, Innovation and Technology, v. 3, n. 2, 2011, p. 209-228. Disponível em: <https://www.tandfonline.com/doi/abs/10.523 5/175799611798204932?journalCode=rlit20>. Acesso em: 24 jul. 2018. DOI: 10.5235/175799611798204932.

93 Para reflexões mais cautelosas, conferir: MORSE, Stephen. Avoiding Irrational NeuroLaw Exuberance: A Plea for Neuromodesty. Law, Innovation and Technology, v. 3, n. 2, 2011, p. 209-228. Disponível em: < https://www.tandfonline.com/doi/abs/10.5235/17 5799611798204932?journalCode=rlit20>. Acesso em: 24 jul. 2018. DOI: 10.5235/175799611798204932; MORSE, Stephen J. New neuroscience, old problems: legal implications of brain science. Cerebrum, v. 6, n. 4, Fall 2004, p. 81-90. Disponível em: <https:// www.ncbi.nlm.nih.gov/pubmed/15986539>. Acesso em: 24 jul. 2018.

94 MORSE, Stephen. New neuroscience, old problems: legal implications of brain science. Cerebrum, v. 6, n. 4, p. 81-90, 01 out. 2004. Disponível em: <http://www.dana.org/Cerebrum/Default.aspx?id=39169>. Acesso em: 02 maio 2018.

95 GREENE, J.; COHEN, J. For the law, neuroscience changes nothing and everything. Philosophical Transactions of the Royal Society B: Biological Sciences. v. 359, n. 1451, nov. 2004, p. 1775-1785. Disponível em: < https://www.ncbi.nlm.nih.gov/pmc/articles/ PMC1693457/>. Acesso em: 02 maio 2018. DOI: 10.1098/rstb.2004.1546.

96 ROSKIES, Adina. Neuroethics for the new millenium. Neuron, v. 35, 3 jul. 2002, p. 21-23. Disponível em: <http://ac.els-cdn. com/S0896627302007638/1-s2.0-S0896627302007638-main.pdf?_tid=70263d0a-eab4-11e5-bd39-00000aacb35f\&acdnat=145804 9820_44ea706aaa9daf995136e443aa3955db>. Acesso em: 15 mar. 2015. 
a que tipo de danos os sujeitos que se submetem a um determinado estudo estão submetidos?), bem como com os desdobramentos do conhecimento produzido (v.g é correto o emprego da ressonância magnética funcional para detectar mentiras no processo judicial?). Já a neurociência da ética investiga noções fundamentais da ética (v.g. livre-arbítrio, autocontrole, identidade, intencionalidade) na perspectiva das funções cerebrais. Cada um dos pensamentos de uma pessoa (sua compreensão do mundo, seu planejamento, seus julgamentos morais) manifesta-se, fisiologicamente, no cérebro. Essas manifestações podem ser estudadas por eletroencefalogramas e ressonâncias magnéticas funcionais, por meio das quais pode-se observar qual parte do cérebro ativa quando determinada função é demandada (fazer contas, planejar para o futuro, fazer julgamentos morais). Com isso, é possível saber se a parte do cérebro demandada é uma estrutura mais recente na evolução dos animais (como o córtex pré-frontal) ou se a estrutura é mais antiga, que administra funções básicas (como a amígdala cerebelosa, integrante do sistema límbico, responsável entre outros pelo sentimento de medo).

O mesmo ocorre no Neurodireito. Por um lado, as Ciências Jurídicas podem lidar com as Ciências Cognitivas preservando seus fundamentos, focando em problemas operacionais, como é avaliar o valor probatório e informativo desse conhecimento. Por outro lado, quando as Ciências Cognitivas investigam as noções fundamentais do Direito, os efeitos podem provocar uma alteração profunda: responsabilidade, racionalidade, verdade real estão no cerne do Direito. São exatamente essas noções que as Ciências Cognitivas desafiam. Dentro da Consiliência, essas noções não podem estar em discordância com as noções desenvolvidas por outras áreas.

Todo esse arsenal de conhecimento abre a "caixa preta" que é a mente humana. Ao ignorar essas contribuições, enfrentando os problemas jurídicos por meio de um paradigma de isolamento disciplinar, a consequência é arriscar que as soluções propostas nasçam impossíveis e irrelevantes. Para evitar esse desfecho para os problemas jurídicos, defende-se neste artigo a abordagem consiliente.

No entanto, nesse contexto, é conveniente a advertência de Renato César Cardoso:97 "em relação à consiliência, é mais fácil falar que fazer. É preciso heroísmo para abraçar um admirável mundo novo, para abandoar a zona de conforto das humanidades e se aventurar pelo terreno bruto das ciências naturais". Não obstante, é preciso fazê-lo: "o conhecimento não deve ter limites ou fronteiras".

\section{Considerações finais}

O artigo propôs uma reflexão epistemológica, ou seja, sobre como se pesquisa e se reflete o fenômeno jurídico, no objetivo de conhecê-lo. Foram exploradas as origens da fragmentação disciplinar que levou não só ao atual cenário de hiperespecialização, como também à mútua desconfiança. Esse processo provoca também a fragmentação do próprio conhecimento, em que muitos fragmentos (isoladamente desenvolvidos) simplesmente deixaram de encaixar-se com os demais.

É preciso reconhecer, não obstante, que esse processo levou a um monstruoso acúmulo de conhecimento nas mais variadas áreas do conhecimento. Diante desse resultado, não é possível falar-se em fracasso desse modelo, mas sim em seu esgotamento. Assim, o modelo da hiperespecialização gera atualmente aprofundamento isolado e, consequentemente, incoerências, quando, na verdade, o desafio contemporâneo é de unir para tornar todo esse conhecimento coerente e consistente, ou, no tempo empregado neste artigo, consiliente.

97 CARDOSO, Renato César. XXVI World Congress of Philosophy of Law and Social Philosophy. In: GALUPPO, Marcelo et al. (Ed). Human Rights, Rule of Law and the Contemporary Social Challenges in Complex Societies. Proceedings of the XXVI World Congress of Philosophy of Law and Social Philosophy of the Internationale Vereinigunf für Rechts- und Sozialphilosophie. Belo Horizonte: Initia Vida, 2015. p. 2454. 
No entanto, o próprio Wilson já reflete que essa integração entre as Ciências Naturais e os demais ramos de conhecimento não pode ser considerada ela mesma como ciência. Trata-se, na verdade, de uma visão de mundo metafísica, impossível de ser provada por princípios ou fundada em testes empíricos. A aposta na Consiliência deriva de uma extrapolação do sucesso das Ciências Naturais, cujo maior teste será levar com eficiência seus métodos para as Ciências Sociais e Humanidades. Sua promessa, se bem-sucedida, é a compreensão da condição humana com um grau mais elevado de certeza.

Após feito um possível diagnóstico das causas que levam à fragmentação disciplinar, percebe-se que essas circunstâncias estão superadas. Acredita-se que essa tarefa de procurar a síntese do conhecimento (alinhando-se os institutos jurídicos ao que se sabe do comportamento humano pela pesquisa desenvolvida dentro das Ciências Cognitivas), dentro das Ciências Jurídicas, será atribuída ao Neurodireito. Se as consequências desse alinhamento causarão uma quebra radical de paradigma ou se importarão em aprimoramentos tangenciais das técnicas jurídicas, isso será definido nos futuros trabalhos desenvolvidos dentro desse programa de pesquisa.

Por um lado, juristas como Stephen Morse defendem que as Neurociências são, apenas, a última novidade científica, e que não alteram de forma substancial os métodos jurídicos. Por outro, Greene e Cohen afirmaram que, para o Direito, as Neurociências podem não mudar nada, mas pode ser que mudem tudo: antigas discussões travadas com base em argumentos abstratos e áridos são revisitadas agora com esclarecimentos sobre os processos mecânicos que causam o comportamento, de grande potencial persuasivo.

Assim, noções centrais das Ciências Jurídicas podem ser questionadas com base nesse novo programa de pesquisa (e já estão sendo, mesmo que não por juristas). Para o Direito, isso pode significar leis, políticas públicas e decisões administrativas e judiciais, em suma, um sistema jurídico mais alinhado com a realidade, bem como a possibilidade maior de que as providências determinadas pelas normas jurídicas produzam os efeitos desejados. É uma grande promessa que, acredita-se, vale os riscos.

\section{REFERÊNCIAS}

ARAGÓN, J. L. et al. Turbulent luminance in impassioned van Gogh paintings. Journal of Mathematical Imaging and Vision, v. 30, n. 3, mar. 2008, p. 275-283. Disponível em: <https://link.springer.com/article/10.1007/ s10851-007-0055-0>. Acesso em: 20 fev. 2018.

BALL, Philip. The disturbed artist intuited the deep forms of fluid flow. Nature, 7 jul. 2006. Disponível em: <https://www.nature.com/news/2006/060703/full/news060703-17.html>. Acesso em: 20 fev. 2018.

BARRETT, Lisa Feldman. How emotions are made: the secret life of the brain. Boston; New York: Houghton Mifflin Harcourt, 2017. Chapter 11, p. 219-251.

BARRETT, Lisa Feldman; GROSS, James J. The Emerging Field of Affective Science. Portal Eletrônico da Association for the Psychological Science, Observer, 30 de setembro de 2013. Disponível em: < https://www.psychologicalscience.org/observer/the-emerging-field-of-affective-science>. Acesso em: 07 dez. 2017.

BRANDT, Anthony; EAGLEMAN, David. The runaway species: how human creativity remakes the world. New York: Catapult, 2017.

CARDOSO, Renato César. XXVI World Congress of Philosophy of Law and Social Philosophy. In: GALUPPO, Marcelo et al. (Ed). Human Rights, Rule of Law and the Contemporary Social Challenges in Complex Societies. Proceedings of the XXVI World Congress of Philosophy of Law and Social Philosophy of the Internationale Vereinigunf für Rechts- und Sozialphilosophie. Belo Horizonte: Initia Vida, 2015. p. 2454.

CASSESE, Sabino. La sonrinsa del gato, o de los métodos de estudio del Derecho Público. In: CASSESE, 
Sabino. Derecho Administrativo: historia y futuro. Sevilla (España): Global Law Press; Instituto Nacional de Administración Pública, 2014. Cap. 20, p. 385-397.

COELHO, Inocêncio Mártires. Apontamentos para um debate sobre o ativismo judicial. Revista Brasileira de Políticas Públicas, v. 5, n. 2, 2015, Edição Especial - Ativismo Judicial, p. 3-22. Disponível em: <https://www. publicacoesacademicas.uniceub.br/RBPP/article/view/3157/pdf>. Acesso em: 24 jul. 2018.

COLLINI, Stefan. Introduction. In: SNOW, Charles Percy. The two cultures. Cambridge: Cambridge University Press, 1998. p. 7- 21.

COYNE, Jerry A. Why evolution is true. New York: Penguin Books, 2010.

EAGLEMAN, David. Incognito: the secret lives of the brain. New York: Pantheon, 2011.

EAGLEMAN, David. The brain: the story of you. New York: Pantheon Books, 2015.

GAIMAN, Neil. The pornography of genre, of the genre of pornography. In: GAIMAN, Neil. The view from the cheap seats: selected nonfiction. New York (EUA): William Morrow; HarperCollins Publishers, 2016.

GALVÃO, Ciro di Benatti. Ativismo judicial: o contexto de sua compreensão para a construção de decisões judiciais racionais. Revista Brasileira de Políticas Públicas, v. 5, n. 2, 2015, Edição Especial - Ativismo Judicial, p. 89-99. Disponível em: <https://www.publicacoesacademicas.uniceub.br/RBPP/article/view/3101/pdf>. Acesso em: 24 jul. 2018.

GOODENOUGH; Oliver R.; PREHN. Kristin. A neuroscientific approach to normative judgment in law and justice. Philosophical Transactions of the Royal Society B: Biological Sciences. v. 359, n. 1451, p.1709-1726, 29 nov. 2004. Disponível em: <https://www.ncbi.nlm.nih.gov/pmc/articles/PMC1693459/>. Acesso em: 2 maio 2018. DOI: $10.1098 /$ rstb.2004.1552.

GOULD, Jay Stephen. Can we complete Darwin's Revolution? In: GOULD, Jay Stephen. Dinosaur in a baysack: reflections in natural history. Cambridge (Massachusetts, USA); London (England): The Belknap Press of Harvard University Press, 2011. p. 325-334.

GREENE, Joshua D. et al. An FMRI Investigation of emotional engagement in moral judgment. Science, Report, v. 293, n. 5537, p 2105-2108, 14 set. 2001. Disponível em: <science.sciencemag.org/content $/ 293 / 5537 / 2105>$. Acesso em: 02 maio 2018. DOI: 10.1126/science.1062872. G

GREENE, Joshua. Moral tribes: emotion, reason, and the gap between us and them. New York: Penguin, 2013.

GREENE, Joshua; Cohen Jonathan. For the law, neuroscience changes nothing and everything. Philosophical Transactions of the Royal Society B: Biological Sciences. v. 359, n. 1451, nov. 2004, p. 1775-1785. Disponível em: <https://www.ncbi.nlm.nih.gov/pmc/articles/PMC1693457/>. Acesso em: 02 maio 2018. DOI: 10.1098/ rstb.2004.1546.

HAACK, Susan. Irreconcilable Differences? The troubles marriage of science and Law. In: HAACK, Susan. Evidence Matters: science, proof, and truth in Law. New York: Cambridge University Press, 2014. p. 78-103.

HAIDT, Jonathan. The righteous mind: why good people are divided by politics and religion. New York: Vintage Books, 2012.

HILTS, Philip J. Memory's Ghost: the nature of memory and the strange tale of Mr. M. New York (EUA): Touchstone Books; Simon \& Schuster, 1996.

KAHNEMAN, Daniel. Thinking, fast and slow. New York: Farrar, Straus and Giraux, 2011.

KAHNEMAN, Daniel; SLOVIC, Paul; TVERSKY, Amos. Judgment under uncertainty: heuristics and biases. Cambridge; New York, NY: Cambridge University Press, 1982. 
KAHNEMAN, Daniel; TVERSKY, Amos. Choices, values, and frames. New York: Russell sage Foundation; Cambridge, UK: Cambridge University Press, 2000.

LACEY, Hugh. Valores e atividade cientifica 1. 2. ed. São Paulo: Editora 34, 2008.

LACEY, Hugh. Valores e atividade cientifica 2. São Paulo: Editora 34, 2010.

LALAND, Kevin N.; BROWN, Gillian R. Sense and nonsense: evolutionary perspectives on human behaviour. Oxford: Oxford University Press, 2002.

MORSE, Stephen J. New neuroscience, old problems: legal implications of brain science. Cerebrum, v. 6, n. 4, Fall 2004, p. 81-90. Disponível em: <https://www.ncbi.nlm.nih.gov/pubmed/15986539>. Acesso em: 24 jul. 2018.

MORSE, Stephen. Avoiding Irrational NeuroLaw Exuberance: a Plea for Neuromodesty. Law, Innovation and Technology, v. 3, n. 2, 2011, p. 209-228. Disponível em: < https://www.tandfonline.com/doi/abs/10.5235/1 75799611798204932 ?journalCode $=$ rlit20> . Acesso em: 24 jul. 2018. DOI: 10.5235/175799611798204932.

PETER, Christine Oliveira. Do ativismo judicial ao ativismo constitucional no Estado de direitos fundamentais. Revista Brasileira de Políticas Públicas, v. 5, n. 2, 2015, Edição Especial - Ativismo Judicial, p. 64-87. Disponível em: < https://www.publicacoesacademicas.uniceub.br/RBPP/article/view/3094/pdf>. Acesso em: 24 jul. 2018.

RAMÓN Y CAJAL, Santiago. Recollections of my life. [S.1.]: MIT Press, 1989.

ROSKIES, Adina. Neuroethics for the new millenium. Neuron, v. 35, 3 jul. 2002, p. 21-23. Disponível em: <http://ac.els-cdn.com/S0896627302007638/1-s2.0-S0896627302007638-main.pdf?_tid=70263d0aeab4-11e5-bd39-00000aacb35f\&acdnat=1458049820_44ea706aaa9daf995136e443aa3955db>. Acesso em: 15 mar. 2015.

RUSSELL, Stuart J.; NORVIG, Peter. Artificial Intelligence: a modern approach. 3. ed. Harlow (Essex, England): Pearson Education Limited, 2016.

SLOMAN, Steven; FERNBACH, Philip. The knowledge illusion: why we never think alone. New York: Riverhead Books, 2017.

SNOW, Charles Percy. The two cultures. Cambridge: Cambridge University Press, 1998.

TARUFFO, Michelle. El proceso civil de "civil law": aspectos fundamentales. Ius et Praxis, Talca, v. 12, n. 1, p. 69-94, 2006. Disponível em: <https://scielo.conicyt.cl/scielo.php?script=sci_arttext\&pid =S0718-00122006000100004>. Acesso em: 14 set. 2016 .

WAAL, Frans de. The age of empathy: nature lessons for a kinder society. New York: Harmony Books; Crown Publishing, 2009.

WILSON, Edward Osborne. Consilience: the unity of knowledge. New York: Vintage Books, 1999.

WILSON, Edward Osborne. Sociobiology: the abridged edition. $7^{\text {th }}$ printing. Cambridge (MA, EUA); London (England); Belknap Press; Harvard University Press, 1998.

WILSON, Edward Osborne. The meaning of human existence. New York: Liveright Publishing Corporation, 2014.

WILSON, Robert A.; KEIL, Frank C. Preface. In: WILSON, Robert A.; KEIL, Frank C. (Ed.). The MIT encyclopedia of the cognitive sciences. Cambridge, Massachusetts (EUA); London, England: Massachusetts Institute of Technology, 1999. p. 13-14. 


\section{REVISTA BRASILEIRA DE POLÍTICAS PÚBLICAS BRAZILIAN JOURNAL OF PUBLIC POLICY}

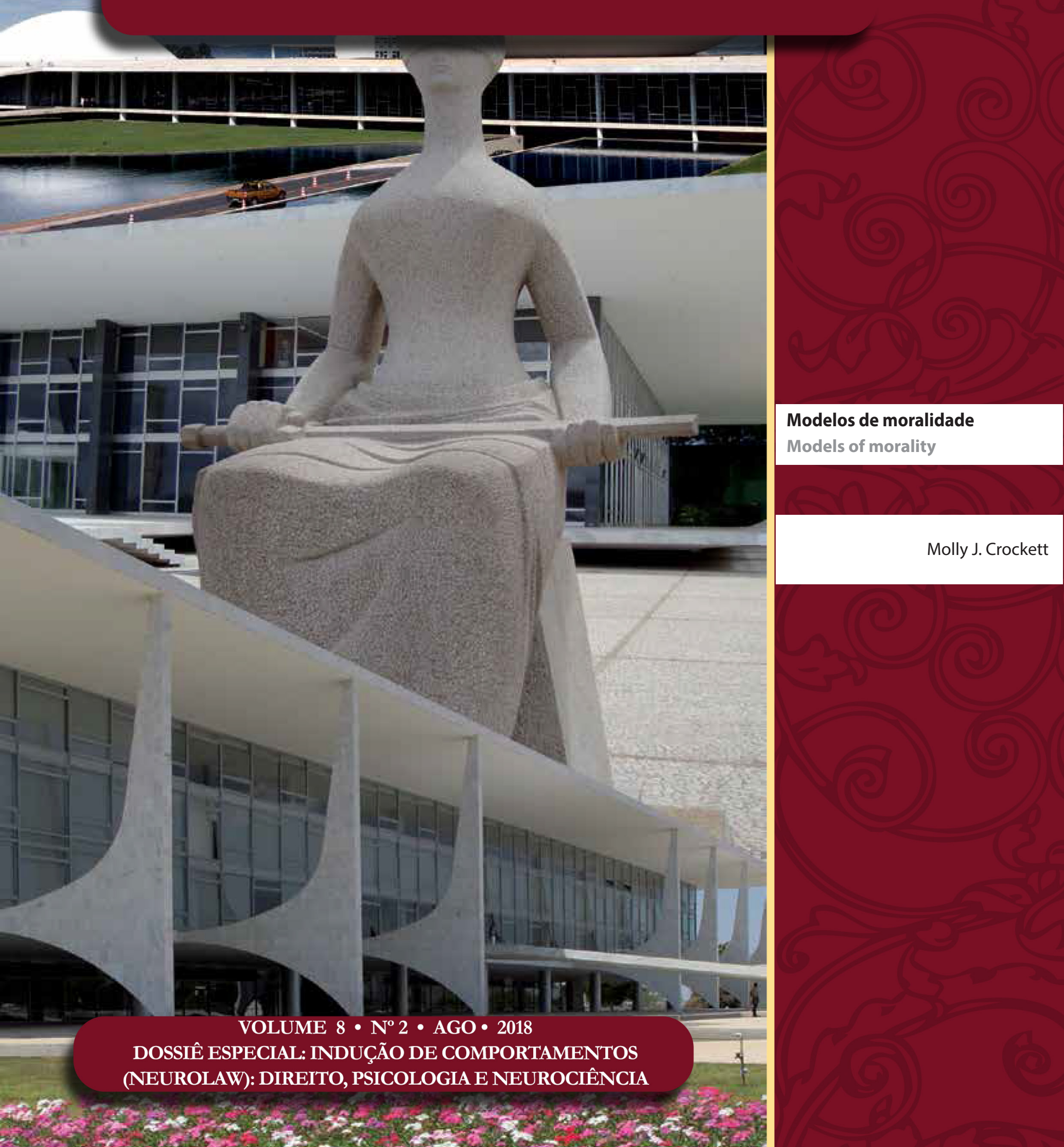




\section{Models of morality}

Molly J. Crockett ${ }^{* * * * *}$

\section{Resumo}

Os dilemas morais geram conflitos entre duas tradições: a consequencialista, que avalia ações baseadas em seus resultados, e a deontológica, que avalia as ações em si. Elas se assemelham de forma marcante a duas distintas estruturas de decisão: um sistema baseado em modelos que seleciona ações fundadas em inferências acerca de suas consequências; e um sistema livre de modelos que seleciona ações com base em seu histórico de incentivos. Aqui, considero como esses sistemas, juntamente com um sistema pavloviano que responde reflexivamente a recompensas e punições, podem iluminar enigmas na psicologia moral.

Palavras-chave: Moralidade; Dilemas morais; Ética consequencialista e ética deontológia; Sistema pavloviano; Tomada de decisão.

\section{Abstract}

Moral dilemmas engender conflicts between two traditions: consequentialism, which evaluates actions based on their outcomes, and deontology, which evaluates actions themselves. These strikingly resemble two distinct decision-making architectures: a model-based system that selects actions based on inferences about their consequences; and a model-free system that selects actions based on their reinforcement history. Here, I consider how these systems, along with a Pavlovian system that responds reflexively to rewards and punishments, can illuminate puzzles in moral psychology.

** Assistant Professor of Psychology at Yale University and a Distinguished Research Fellow at the Oxford Centre for Neuroethics. Prior to joining Yale, Dr Crockett was a faculty member at the University of Oxford's Department of Experimental Psychology and a Fellow of Jesus College. She holds a BSc in Neuroscience from UCLA and a PhD in Experimental Psychology from the University of Cambridge and completed a Wellcome Trust Postdoctoral Fellowship with economists and neuroscientists at the University of Zürich and University College London.

*** Artigo publicado: CROCKETT, Molly, Models of Morality, IN: Trends in Cognitive Sciences, Vol. 17, No. 8, p. 363-366, Julho 2013. Tradução realizada pelo Grupo de Estudos em Direito, Psicologia e Neurociência da Faculdade de Direito de Ribeirão Preto da USP, liderado pelo Prof. Dr. Sérgio Nojiri.
Keywords: Morality; Moral dilemmas; consequentialism ethic and deontology ethic; Pavlovian system; decision making.

\section{1. ÉtICA CONSEQUenCIalista e Ética deONTOLógia}

É moralmente permitido matar uma pessoa para salvar outras cinco? Dilemas morais como esse causam conflitos entre duas principais tradições da ética normativa. $\mathrm{O}$ consequencialismo julga a aceitabilidade das ações com base em seus resultados e, portanto, apoia matar um para salvar cinco; ceteris paribus, cinco vidas são melhores do que uma. Em contrapartida, a deontologia julga a aceitabilidade das ações de acordo com um conjunto de regras; certas ações (por exemplo, matar) são absolutamente erradas, independentemente de suas consequências. 
Recentes pesquisas têm mostrado que manipulações experimentais podem influenciar os julgamentos das pessoas em direção ao consequencialismo ou a deontologia, sugerindo que essas perspectivas possuem bases neurais distintas ${ }^{1}$. Um relato influente dessas descobertas postula que os julgamentos deontológicos resultam de processos emocionais automáticos, enquanto que os julgamentos consequenciais resultam de processos cognitivos controlados ${ }^{2}$. Outros argumentam que esta abordagem de processo dual é computacionalmente insuficiente e não pode explicar como cenários hipotéticos são transformados em representações mentais de ações e resultados ${ }^{3}$. A gramática moral universal oferece uma teoria computacional de transformação de problemas, mas carece de uma descrição mecanicista plausível, neurobiologicamente, de como os valores são atribuídos às representações mentais de ações e resultados, e como esses valores são integrados de forma a produzir um julgamento final, consequencialista ou deontológico.

\section{Avaliação baseada em modelo (MOdel-based) e Sem modelo (MOdel-Free)}

Os avanços recentes na neurociência oferecem uma nova perspectiva. Avaliações de ações e resultados são orientadas por sistemas de decisão distintos que são psicológica e neurologicamente dissociáveis ${ }^{4}$. O sistema baseado em modelo gera uma árvore de decisões voltadas para o futuro que representa as contingências entre ações e resultados e os valores desses resultados. Ele avalia as ações pesquisando a árvore e determinando quais sequências de ação provavelmente produzirão os melhores resultados. De qualquer maneira, a pesquisa de árvores baseada em modelo é computacionalmente cara e pode tornar-se inutilizável quando as árvores de decisão são excessivamente ramificadas.

O sistema computacionalmente simples e sem modelo não depende de um modelo voltado para o futuro. Em vez disso, avalia ações com base em seus valores anteriormente apreendidos em contextos específicos (situações): boas conjugações de situações são aquelas que produziram resultados desejáveis no passado (por exemplo, abrir a porta), enquanto que as conjugações de situações ruins são aquelas que produziram resultados indesejáveis no passado (por exemplo, empurrar uma pessoa). Como o sistema sem modelo não tem acesso às atuais relações entre ação e resultado, ele é retrospectivo ao invés de prospectivo e pode dar recomendações satisfatórias em situações nas quais as ações tradicionalmente boas conduzem a resultados indesejáveis, ou vice-versa 5 .

Um terceiro sistema, o Pavloviano, promove uma abordagem reflexiva automática e respostas aos estímulos apetitivos e aversivos, respectivamente ${ }^{6}$. Vieses pavlovianos podem influenciar comportamentos guiados por avaliações baseadas em modelo e sem modelo: por exemplo, na transferência aversiva Pavloviana para Instrumental (Pavlovian-to-instrumental), as previsões aversivas podem reprimir as ações instrumentais?. Os vieses pavlovianos podem também influenciar as próprias avaliações baseadas em modelos: procurar

1 GREENE, Joshua D. The cognitive neuroscience of moral judgment. The cognitive neurosciences, v. 4, p. 1-48, 2009.

2 GREENE, Joshua D. The cognitive neurscience of moral judgment. The cognitive neurosciences, v. 4, p. 1-48, 2009.

3 MIKHAIL, John. Universal moral grammar: theory, evidence and the future. Trends in cognitive sciences, v. 11, n. 4, p. 143-152, 2007.

4 BALLEINE, Bernard W.; O’DOHERTY, John P. Human and rodent homologies in action control: corticostriatal determinants of goal-directed and habitual action. Neuropsychopharmacology, v. 35, n. 1, p. 48, 2010; HUYS, Quentin J. M. et al. Disentangling the roles of approach, activation and valence in instrumental and pavlovian responding. PLoS computational biology, v. 7, n. 4, p. e1002028, 2011; WUNDERLICH, Klaus; DAYAN, Peter; DOLAN, Raymond J. Mapping value based planning and extensively trained choice in the human brain. Nature neuroscience, v. 15, n. 5, p. 786, 2012; DAYAN, P. How to set the switches on this thing. Curr. Opin. Neurobiol. v. 22, 2012, p. 1068-1074.

5 BALLEINE, Bernard W.; O’DOHERTY, John P. Human and rodent homologies in action control: corticostriatal determinants of goal-directed and habitual action. Neuropsychopharmacology, v. 35, n. 1, p. 48, 2010; DAYAN P. How to set the switches on this thing. Curr. Opin. Neurobiol. v. 22, 2012, p. 1068-1074.

6 DAYAN P. How to set the switches on this thing. Curr. Opin. Neurobiol. v. 22, 2012, p. 1068-1074.

7 HUYS, Quentin J. M. et al. Disentangling the roles of approach, activation and valence in instrumental and pavlovian responding. PLoS computational biology, v. 7, n. 4, p. e1002028, 2011. 
uma árvore de decisão pode ser caracterizado como um conjunto de ações internas que podem ser suprimidas por previsões aversivas ${ }^{8}$. Isso equivale a uma "poda" da árvore de decisão, em que a busca de árvores baseada em modelo é reduzida quando um resultado aversivo é encontrado?.

Há evidências substanciais de que sistemas baseados em modelos, sem modelos e pavlovianos estão levemente situados em circuitos cerebrais parcialmente distintos, embora os resultados comportamentais provavelmente reflitam sua influência combinada ${ }^{10}$, e evidências recentes sugerem que certas regiões integram avaliações baseadas em modelo e sem modelo ${ }^{11}$. Esses sistemas geralmente chegam a conclusões semelhantes sobre a melhor ação a ser tomada, mas às vezes os resultados divergem. Compreender como esses conflitos são resolvidos é um tópico ativo da pesquisa ${ }^{12}$.

\section{Modelos DE MORALIDADE}

De modo superficial, o consequencialismo e a deontologia parecem se projetar diretamente para sistemas baseados em modelos e sem modelos, respectivamente. As abordagens consequencialistas e baseadas em modelos avaliam as ações com base em seus resultados, enquanto as abordagens deontológicas e sem modelos avaliam as próprias ações. No entanto, uma análise mais profunda revela que os julgamentos deontológicos provavelmente surgem devido a uma sofisticada interação entre sistemas.

Pense no seguinte problema. No clássico dilema do bonde, um bonde está fora de controle, nos trilhos, em direção a cinco trabalhadores, que irão morrer caso você não faça nada. Você e um homem grande estão de pé em uma passarela acima dos trilhos. Em uma variante deste dilema (alçapão), você pode virar uma alavanca que liberará um alçapão, derrubando o homem grande nos trilhos, onde seu corpo irá parar o bonde. É moralmente permissível virar a alavanca, matar o homem, e salvar os cinco trabalhadores? Em outra variante (empurrão), você pode empurrar o homem grande da passarela para os trilhos, onde novamente seu corpo irá parar o bonde. É moralmente permissível empurrar o homem, matá-lo, e salvar os cinco trabalhadores? Curiosamente, quando as pessoas comuns são confrontadas com esses dilemas, elas são muito menos propensas a aceitar prejudicar uma pessoa para salvar cinco nos casos em que o dano envolve o contato físico com a vítima (como empurrar) do que nos casos em que o dano não envolve contato físico (como liberar um alçapão ${ }^{13}$, mesmo que esses casos tenham resultados idênticos.

Compreender como diferentes sistemas de decisão avaliam ações e consequências pode trazer uma luz ao problema da divergência entre o empurrão e o alçapão (Box 1). Em consonância com as explicações da gramática moral universal ${ }^{14}$, proponho que o sistema baseado em modelo transforma cenários hipotéticos em uma descrição estrutural de ações e consequências (por exemplo, uma árvore de decisões). Ao examinar a árvore, o sistema baseado em modelo avalia todas as consequências possíveis e recomenda a ação que leva ao melhor resultado.

8 DAYAN P. How to set the switches on this thing. Curr. Opin. Neurobiol. v. 22, 2012, p. 1068-1074.

9 HUYS, Quentin J. M. et al. Disentangling the roles of approach, activation and valence in instrumental and pavlovian responding. PLoS computational biology, v. 7, n. 4, p. e1002028, 2011.

10 BALLEINE, Bernard W.; O'DOHERTY, John P. Human and rodent homologies in action control: corticostriatal determinants of goal-directed and habitual action. Neuropsychopharmacology, v. 35, n. 1, p. 48, 2010; HUYS, Quentin J. M. et al. Disentangling the roles of approach, activation and valence in instrumental and pavlovian responding. PLoS computational biology, v. 7, n. 4, p. e1002028, 2011; WUNDERLICH, Klaus; DAYAN, Peter; DOLAN, Raymond J. Mapping value based planning and extensively trained choice in the human brain. Nature neuroscience, v. 15, n. 5, p. 786, 2012.

11 DAW, Nathaniel D. et al. Model-based influences on humans' choices and striatal prediction errors. Neuron, v. 69, n. 6, p. 12041215, 2011.

12 DAYAN P. How to set the switches on this thing. Curr. Opin. Neurobiol. v. 22, 2012, p. 1068-1074.

13 GREENE, Joshua D. The cognitive neuroscience of moral judgment. The cognitive neurosciences, v. 4, p. 1-48, 2009; MIKHAIL, John. Universal moral grammar: theory, evidence and the future. Trends in cognitive sciences, v. 11, n. 4, p. 143-152, 2007.

14 MIKHAIL, John. Universal moral grammar: theory, evidence and the future. Trends in cognitive sciences, v. 11, n. 4, p. 143-152, 2007. 
Simultaneamente, o sistema sem modelo avalia ações contextualizadas, atribuindo valores negativos a pares de ação estatal com histórico de reforço negativo (por exemplo, empurrar pessoas) ${ }^{15}$. Uma questão importante é como o sistema sem modelo pode avaliar ações que nunca foram realizadas diretamente (por exemplo, atos violentos). Uma possibilidade é que os valores de ação sejam compreendidos através da observação: um estudo recente mostrou que o aprendizado por observação sem modelo envolve estruturas neurais semelhantes ao do aprendizado experimental sem modelo ${ }^{16}$. Alternativamente, o sistema baseado em modelo poderia treinar o sistema sem modelo através de simulações off-line $e^{17}$.

Finalmente, o sistema pavloviano pode responder às previsões de sistemas baseados em modelo de resultados aversivos (derivados do enredo textual e representados na árvore de decisão) ou, alternativamente, aos valores aversivos sem modelo atribuídos às ações descritas. Cada sistema "vota" em sua ação preferida, e as escolhas são um produto de sua influência combinada. Podemos explicar a diferença de julgamentos para os casos de empurrão e alçapão considerando que empurrar uma pessoa e virar uma alavanca diferem em termos de suas histórias de reforçamento (reinforcement histories) e de resultados próximos esperados, o que, por sua vez, influencia os "votos" dos sistemas sem modelo e pavlovianos (Box 1).

Considere uma segunda característica do julgamento moral: as pessoas prontamente distinguem entre danos causados para a obtenção do fim desejado, e um dano que ocorre como um efeito colateral previsível (Box 2). Essa distinção pode ser vista contrastando o caso do alçapão (descrito acima) com o seguinte caso do trilho alternativo: novamente, um bonde está vindo descontrolado pelos trilhos em direção a cinco trabalhadores, que morrerão caso você não faça nada. Você pode virar uma alavanca que desviará o bonde para uma via de trilhos alternativa, onde um homem grande está parado. É moralmente permissível virar a alavanca, matando o homem grande para salvar os cinco trabalhadores? Apesar de os resultados serem os mesmos, as pessoas consideram que virar a alavanca no caso do alçapão é pior do que no caso do trilho alternativo. Por quê?

No caso do alçapão, o homem grande é usado como um meio: seu corpo serve de instrumento para parar o bonde, evitando que ele atinja os cinco trabalhadores. No caso dos trilhos alternativos, a morte do homem grande é um efeito colateral previsível da ação realizada para salvar os cinco trabalhadores. A estrutura da árvore de decisões é crítica aqui; a distinção entre meios e efeitos colaterais previsíveis pode surgir da poda pavloviana da árvore de decisões (Box 2) ${ }^{18}$.

Visto que as neurobiologias do sistema baseado em modelo, sem modelo e pavloviano são razoavelmente bem delineadas, o panorama atual oferece uma parca explicação para descobertas anteriores. Por exemplo, o córtex pré-frontal medial ( $\mathrm{mPFC}$ ) parece exercer um papel na integração de avaliações do sistema de decisões baseadas em modelo e sem modelo ${ }^{19}$. A proposta de que avaliações de sistema sem modelo contribuem para julgamentos deontológicos, junto com a possibilidade de que o mPFC incorpore valores não baseados em modelo em julgamentos morais, pode explicar duas robustas descobertas na ciência: que casos de contato físico, como o do empurrão, normalmente associados a julgamentos deontológicos, ativam o mPFC ${ }^{20}$; e que pacientes com lesões no mPFC mostram uma tendência menor para julgamentos deontológicos nos

15 CUSHMAN, Fiery et al. Simulating murder: the aversion to harmful action. Emotion, v. 12, n. 1, p. 2, 2012; BLAIR, Robert James Richard. A cognitive developmental approach to morality: Investigating the psychopath. Cognition, v. 57, n. 1, p. 1-29, 1995

16 LILJEHOLM, Mimi; MOLLOY, Ciara J.; O’DOHERTY, John P. Dissociable brain systems mediate vicarious learning of stimulus-response and action-outcome contingencies. Journal of Neuroscience, v. 32, n. 29, p. 9878-9886, 2012.

17 DAYAN P. How to set the switches on this thing. Curr. Opin. Neurobiol. v. 22, 2012, p. p. 1068-1074.

18 HUYS, Quentin J. M. et al. Disentangling the roles of approach, activation and valence in instrumental and pavlovian responding. PLoS computational biology, v. 7, n. 4, p. e1002028, 2011.

19 BALLEINE, Bernard W.; O'DOHERTY, John P. Human and rodent homologies in action control: corticostriatal determinants of goal-directed and habitual action. Neuropsychopharmacology, v. 35, n. 1, p. 48, 2010. WUNDERLICH, Klaus; DAYAN, Peter; DOLAN, Raymond J. Mapping value based planning and extensively trained choice in the human brain. Nature neuroscience, v. 15 , n. 5, p. 786, 2012.

20 GREENE, Joshua D. The cognitive neuroscience of moral judgment. The cognitive neurosciences, v. 4, p. 1-48, 2009. 
mesmos $\operatorname{casos}^{21}$. Previsões pavlovianas aversivas já foram relacionadas ao funcionamento da serotonina ${ }^{22}$; se tais previsões exercem um papel fundamental nos julgamentos deontológicos, aprimorar o funcionamento da serotonina pode melhorar os julgamentos deontológicos, o que já foi, de fato, demonstrado. Finalmente, há evidência de que o stress pode mudar o controle do sistema baseado em modelo para o sistema sem modelo $^{23}$. Minha investigação sugere que o stress deve, de modo similar, promover o julgamento deontológico, como recentemente divulgado ${ }^{24}$.

\section{Considerações finais}

Um benefício dos multiplos sistemas de decisão é que cada um deles apresenta vantagens em determinadas situações. O sistema baseado em modelo é ótimo para decisões simples. No entanto, quando a árvore de decisões é muito extensa e sua busca se torna computacionalmente inadministrável, mecanismos pavlovianos ou não-baseados em modelo fornecem heurísticas úteis. Talvez os múltiplos sistemas éticos existam pelos mesmos motivos. O consequencialismo fornece um panorama flexível para maximizar o bem e minimizar o mal, mas em face dos resultados incertos ou ambíguos que são comumente encontrados em dilemas do mundo real, as regras deontológicas nos ajudam a evitar problemas. A questão que permanece é a de saber se modelos normativos de tomada de decisão podem moldar éticas normativas.

\section{Box 1: Explicando a aversão a danos físicos}

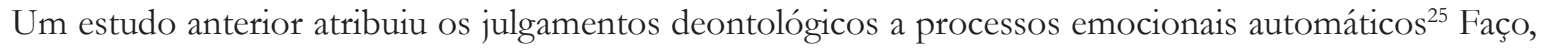
aqui, a distinção entre mecanismos racionais sem modelo (mas retreináveis) e mecanismos pavlovianos fixos e ecologicamente racionais, os quais influenciam julgamentos relativos à deontologia em casos em que o dano envolve contato físico.

O sistema não-baseado em modelo avalia ações contextualizadas com base em sua história de reforçamento. As crianças pequenas aprendem através da experiência que as ações que machucam outros fisicamente (por exemplo, bater, empurrar) tem como consequência resultados aversivos (por exemplo, punições, sinais de ansiedade ${ }^{26}$ ). Simultaneamente, os pais e a sociedade ensinam verbalmente as crianças que é proibido causar danos físicos, alertando sobre as consequências das transgressões. A experiência e a instrução, juntas, permitem que o sistema sem modelo associe valores negativos às ações físicas prejudiciais às pessoas, como em uma classe de algoritmos (chamada Dyna), que complementam o aprendizado experimental de tentativa e erro com o aprendizado hipotético de tentativa e erro ${ }^{27}$. Importante ressaltar que o último método, pelo qual o sistema sem modelo pode ser retreinado por simulações baseadas em modelo, fornece uma via pela qual julgamentos tradicionalmente deontológicos podem ser adaptados a mudanças no ambiente que são detectadas por mecanismos baseados em modelo.

21 KOENIGS, Michael et al. Damage to the prefrontal cortex increases utilitarian moral judgements. Nature, v. 446, n. 7138, p. 908, 2007.

22 HUYS, Quentin J. M. et al. Disentangling the roles of approach, activation and valence in instrumental and pavlovian responding. PLoS computational biology, v. 7, n. 4, p. e1002028, 2011.

HUYS, Quentin J. M. et al. Bonsai trees in your head: how the Pavlovian system sculpts goal-directed choices by pruning decision trees. PLoS computational biology, v. 8, n. 3, p. e1002410, 2012.

23 SCHWABE, Lars; WOLF, Oliver T. Stress and multiple memory systems: from 'thinking'to 'doing'. Trends in cognitive sciences, v. 17, n. 2, p. 60-68, 2013.

24 YOUSSEF, Farid F. et al. Stress alters personal moral decision making. Psychoneuroendocrinology, v. 37, n. 4, p. 491-498, 2012.

25 GREENE, Joshua D. The cognitive neuroscience of moral judgment. The cognitive neurosciences, v. 4, p. 1-48, 2009.

26 CUSHMAN, Fiery et al. Simulating murder: the aversion to harmful action. Emotion, v. 12, n. 1, p. 2, 2012; BLAIR, Robert

James Richard. A cognitive developmental approach to morality: Investigating the psychopath. Cognition, v. 57, n. 1, p. 1-29, 1995.

27 DAYAN P. How to set the switches on this thing. Curr. Opin. Neurobiol. v. 22, 2012, p. 1068-1074. 
Por outro lado, o sistema pavloviano libera respostas para previsões da valência dos estímulos (valenced stimuli) ${ }^{28}$; enquanto os valores do estímulo podem ser aprendidos, tendências pavlovianas para aproximar (afastar) estímulos apetitivos (aversivos) são fixos, como reflexos. Para as previsões aversivas, um tipo de resposta pavloviana é a supressão comportamental; essa resposta é ecologicamente racional no sentido de que deixar de agir é geralmente uma boa estratégia quando algumas ações podem produzir resultados aversivos $^{29}$. Previsões aversivas inseridas em dilemas morais poderiam ativar processos pavlovianos que não propiciam respostas ativas, levando a julgamentos caracteristicamente deontológicos. Ações danosas que envolvem contato físico podem gerar previsões aversivas particularmente fortes (por exemplo, expressões de medo, gritos, lesão).

As abordagens computacionais para a tomada de decisões respondem por escolhas, somando valores de ação baseados em modelo, sem modelo e pavloviano e, em seguida, convertem esses valores em probabilidades de ação usando uma função softmax ${ }^{3031}$, tratando essencialmente os três sistemas como especialistas independentes, cada um dos quais "vota" na ação preferida. As diferenças nas histórias de reforçamento de ação estatal (que influenciam os valores livres de modelo) e as previsões aversivas (que influenciam os valores pavlovianos) podem resultar em mais "votos" para a inatividade no cenário de impulso (figura ID) do que no cenário da trapaça (Figura IC), levando a uma maior proporção de julgamentos deontológicos no primeiro do que no último.

28 A valência (valence) é um termo da psicologia muito utilizado na discussão das emoções. Um evento, objeto ou situação pode ter uma atração intrínseca atrativa, "boa" (valência positiva) ou aversiva, "má" (valência negativa).

29 HUYS, Quentin J. M. et al. Disentangling the roles of approach, activation and valence in instrumental and pavlovian responding. PLOS computational biology, v. 7, n. 4, p. e1002028, 2011.

30 A função Softmax calcula a distribuição de probabilidades de um evento em 'n' diferentes eventos. De modo geral, esta função calculará as probabilidades de cada classe alvo em todas as classes alvo possíveis. Depois, as probabilidades calculadas serão úteis para determinar a classe alvo para as entradas fornecidas.

31 HUYS, Quentin J. M. et al. Disentangling the roles of approach, activation and valence in instrumental and pavlovian responding. PLoS computational biology, v. 7, n. 4, p. e1002028, 2011; DAYAN P. How to set the switches on this thing. Curr. Opin. Neurobiol. v. 22, 2012, p. p. 1068-1074; HUYS, Quentin J. M. et al. Bonsai trees in your head: how the Pavlovian system sculpts goaldirected choices by pruning decision trees. PLOS computational biology, v. 8, n. 3, p. e1002410, 2012. 
(A) Cenário com alçapão (sem contato)

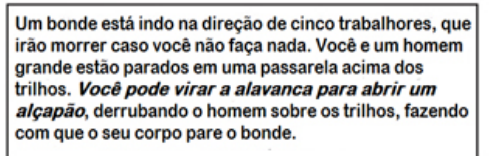

É aceitável virar a alavanca?
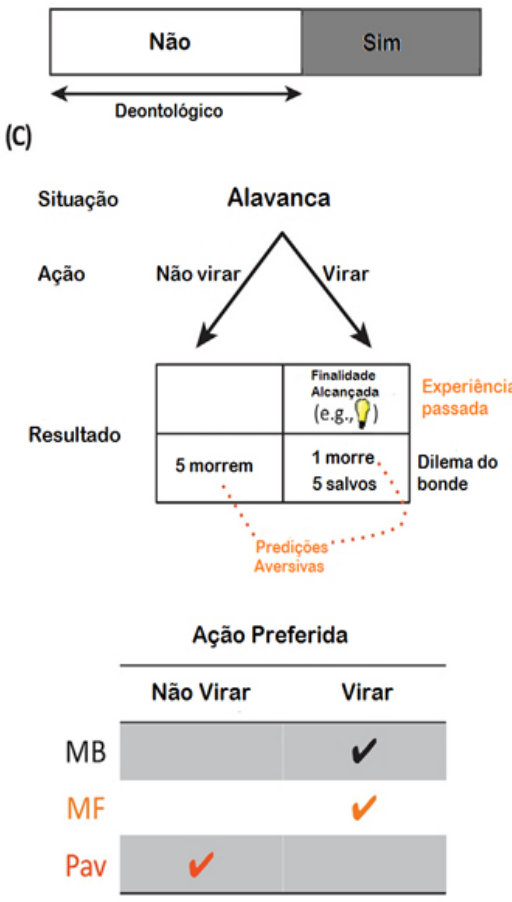

(B) Cenário com empurrão( contato )

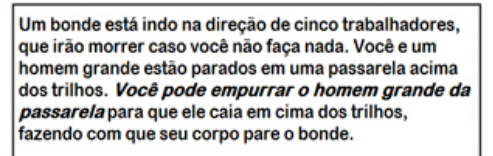
passarela para que ele caia em cima dos trilho

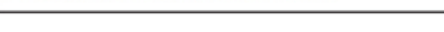

É aceitável empurrar o homem?

(D)
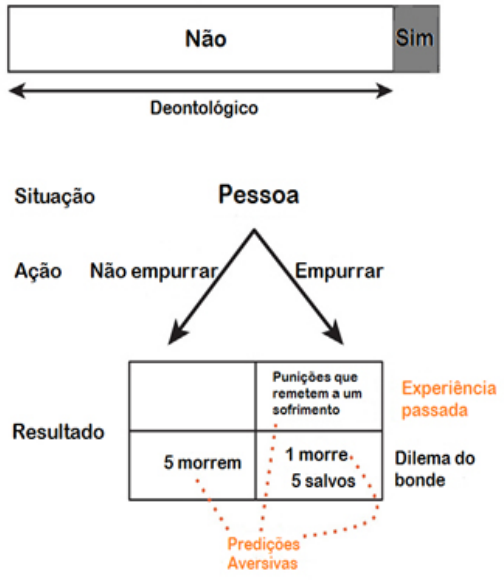

Ação Preferida

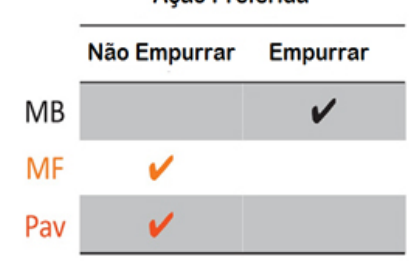

Figura I. (A, B) Exemplo de cenários do bonde e padrões de julgamento típicos (dados adaptados de John Mikhail ${ }^{32}$ ). (C, D) Diagramas que mapeiam links entre estados, ações e resultados, e tabelas que descrevem as ações preferenciais dos sistemas baseados em modelo (MB), sem modelo (MF) e Pavloviano (Pav).

\section{Box 2. Explicando a diferença entre meios/efeitos colaterais}

Construir e pesquisar por meio de uma árvore de decisão pode ser entendido como um conjunto de ações internas que podem ser suscetíveis aos vieses pavlovianos ${ }^{33}$. Um exemplo é a combinação que leva a estados aversivos, ou uma poda da árvore de decisão ${ }^{34}$. Essa poda é pavloviana, na medida em que é evocada reflexivamente por estados aversivos e persiste mesmo quando contraproducente, impedindo a busca de recompensas que se escondem por detrás de estados aversivos ${ }^{35}$.

Uma séria diferença entre os casos de meios e efeitos colaterais é a posição de dano na árvore de decisão, que tem consequências para a avaliação da ação diante da poda. Considere que a avaliação da ação baseada em modelo integra os resultados de todos os ramos da árvore de decisão, e que a poda pavloviana de ramos que contém consequências aversivas resulta em uma ponderação reduzida de todos os resultados de um ramo podado. Em casos de efeitos colaterais, a poda resulta em um valor maior de 'virar o interruptor' reduzindo o

32 MIKHAIL, John. Universal moral grammar: Theory, evidence and the future. Trends in cognitive sciences, v. 11, n. 4, p. 143152, 2007.

33 DAYAN P. How to set the switches on this thing. Curr. Opin. Neurobiol. v. 22, 2012, p. 1068-1074.

34 HUYS, Quentin J. M. et al. Bonsai trees in your head: how the Pavlovian system sculpts goal-directed choices by pruning decision trees. PLoS computational biology, v. 8, n. 3, p. e1002410, 2012.

35 HUYS, Quentin J. M. et al. Bonsai trees in your head: how the Pavlovian system sculpts goal-directed choices by pruning decision trees. PLoS computational biology, v. 8, n. 3, p. e1002410, 2012. 
peso do resultado aversivo de matar alguém (compare os painéis esquerdo e direito na figura IC). Para salvar os cinco indivíduos, o efeito colateral da morte é incidental, de modo que pode ser podada com segurança, preservando a contribuição de salvar cinco relativamente ao valor geral da ação. No entanto, este tipo de amnésia seletiva para efeitos colaterais negativos não é possível em casos significativos. Aqui, porque o resultado aversivo de matar um é necessário para obter o resultado positivo de salvar cinco, podar o resultado aversivo necessariamente também esconde o resultado positivo. Assim, nos casos de meios, embora a poda reduz o peso do resultado negativo de matar um (assim como em casos de efeitos colaterais), ele também reduz o peso do resultado positivo de salvar cinco (compare os painéis esquerdo e direito na Figura ID). A divergência de julgamentos entre os meios e os casos de efeitos colaterais pode ser explicada pela possibilidade de que, em face da poda, o resultado positivo da economia de cinco contribua menos fortemente para o valor geral da ação nos casos (em que é eliminada) em comparação para evitar casos (em que não é).

(A) Cenário com desvio (efeito colateral)

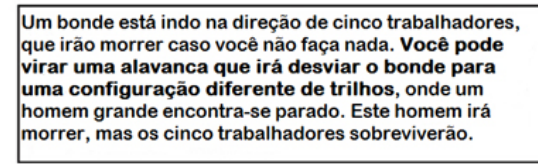

É aceitável virar a alavanca?

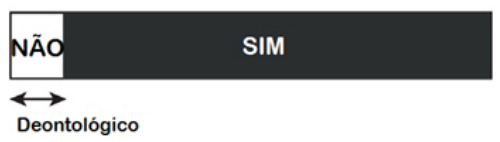

(C)

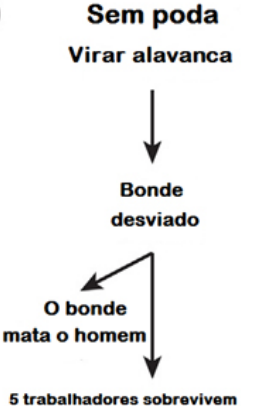

Poda

Virar alavanca
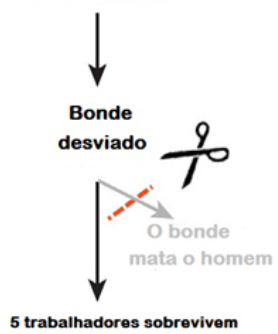

$\begin{aligned} \text { Não podada } V_{\text {virar }} & =V_{(5 \text { vidas })}+V_{(1 \text { morte })} \\ \text { Podada } V_{\text {virar }} & =V_{(5 \text { vidas })}+V_{(1 \text { morto })}\end{aligned}$
(B) Cenário com alçapão (meios)

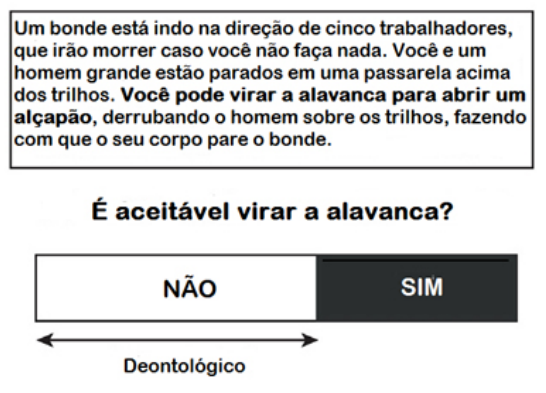

(D)
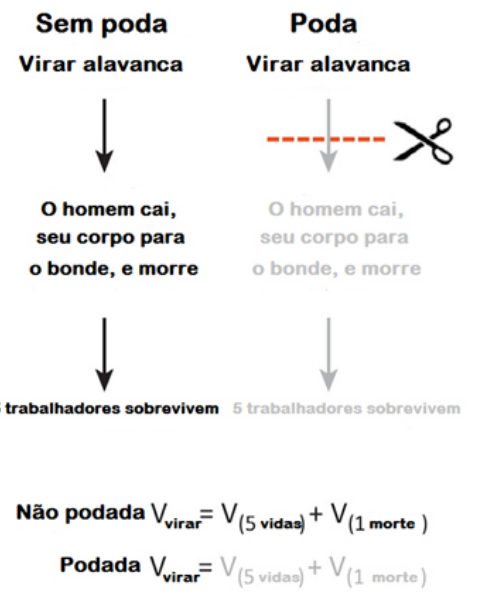

Figura I. (A, B) Exemplo de cenários do bonde e padrões de julgamento típicos (dados adaptados de John Mikhail $\left.{ }^{36}\right)$. (C, D) Árvores de decisão que representam ações e resultados. A poda ocorre no primeiro desfecho aversivo encontrado. $O$ valor geral para virar a alavanca (Vflip) é calculado adicionando valores de todos os ramos da árvore: o valor positivo de salvar cinco indivíduos ( $V$ (5 vidas)) e o valor negativo de matar um indivíduo ( $V$ (1 morte).

\section{Reconhecimentos}

Este trabalho foi apoiado pelo Wellcome Trust. Agradeço a Peter Dayan, Ray Dolan, Quentin Huys, Michael Moutoussis, Francesco Rigoli, Justin Chumbley e Jenifer Siegel pelas perspicazes discussões e comentários.

36 MIKHAIL, John. Universal moral grammar: Theory, evidence and the future. Trends in cognitive sciences, v. 11, n. 4, p. 143$152,2007$. 


\section{REFERÊNCIAS}

GREENE, Joshua D. The cognitive neuroscience of moral judgment. The cognitive neurosciences, v. 4, p. 1-48, 2009.

MIKHAIL, John. Universal moral grammar: theory, evidence and the future. Trends in cognitive sciences, v. 11, n. 4, p. 143-152, 2007.

BALLEINE, Bernard W.; O’DOHERTY, John P. Human and rodent homologies in action control: corticostriatal determinants of goal-directed and habitual action. Neuropsychopharmacology, v. 35, n. 1, p. 48, 2010.

HUYS, Quentin J. M. et al. Disentangling the roles of approach, activation and valence in instrumental and pavlovian responding. PLoS computational biology, v. 7, n. 4, p. e1002028, 2011.

WUNDERLICH, Klaus; DAYAN, Peter; DOLAN, Raymond J. Mapping value based planning and extensively trained choice in the human brain. Nature neuroscience, v. 15, n. 5, p. 786, 2012.

DAYAN P. How to set the switches on this thing. Curr. Opin. Neurobiol. v. 22, 2012, p. 1068-1074.

HUYS, Quentin J. M. et al. Bonsai trees in your head: how the Pavlovian system sculpts goal-directed choices by pruning decision trees. PLoS computational biology, v. 8, n. 3, p. e1002410, 2012.

DAW, Nathaniel D. et al. Model-based influences on humans' choices and striatal prediction errors. Neuron, v. 69 , n. 6, p. 1204-1215, 2011.

CUSHMAN, Fiery et al. Simulating murder: the aversion to harmful action. Emotion, v. 12, n. 1, p. 2, 2012.

BLAIR, Robert James Richard. A cognitive developmental approach to morality: investigating the psychopath. Cognition, v. 57, n. 1, p. 1-29, 1995.

LILJEHOLM, Mimi; MOLLOY, Ciara J.; O’DOHERTY, John P. Dissociable brain systems mediate vicarious learning of stimulus-response and action-outcome contingencies. Journal of Neuroscience, v. 32, n. 29, p. 9878-9886, 2012.

KOENIGS, Michael et al. Damage to the prefrontal cortex increases utilitarian moral judgements. Nature, v. 446, n. 7138, p. 908, 2007.

CROCKETT, Molly J. et al. Serotonin selectively influences moral judgment and behavior through effects on harm aversion. Proceedings of the National Academy of Sciences, v. 107, n. 40, p. 17433-17438, 2010.

SCHWABE, Lars; WOLF, Oliver T. Stress and multiple memory systems: from 'thinking'to 'doing'. Trends in cognitive sciences, v. 17, n. 2, p. 60-68, 2013.

YOUSSEF, Farid F. et al. Stress alters personal moral decision making. Psychoneuroendocrinology, v. 37, n. 4, p. 491-498, 2012. 


\section{REVISTA BRASILEIRA DE POLÍTICAS PÚBLICAS BRAZILIAN JOURNAL OF PUBLIC POLICY}

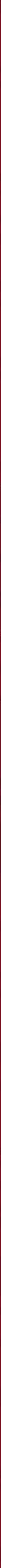




\section{The unhappiness of the pursuit of happiness by the law}

\author{
Úrsula Simões da Costa Cunha Vasconcellost** \\ Noel Struchiner*** \\ Ivar Hannikainen****
}

\title{
Resumo
}

Apesar da ausência de previsão expressa na Constituição, o posicionamento que vem ganhando destaque entre os juristas é o de que o direito à felicidade está implícito em nosso ordenamento, já tendo, inclusive, sido invocado por ministros do Supremo Tribunal Federal (STF) para a resolução de casos emblemáticos. Sendo assim, torna-se importante compreender o conceito de felicidade. Pesquisas empíricas recentes — na contramão do usualmente defendido por psicólogos e alguns filósofos que estudam o tema — têm revelado que, quando um indivíduo avalia a felicidade de outro, são tipicamente levados em consideração tanto elementos descritivos (e.g. se o sujeito apresenta emoções positivas e satisfação com sua vida) quanto normativos (e.g. se o sujeito leva uma vida moralmente boa). No presente artigo, apresentamos os resultados de dois experimentos que apontam que tanto o conceito de "felicidade" quanto, por extensão, o "direito à felicidade", também dependem de valorações descritivas e normativas. Por fim, discutimos algumas implicações e riscos advindos do uso de um conceito moralmente carregado, como é a felicidade, na prática judicial.

Palavras-chave: Direito à felicidade. Felicidade. Psicologia experimental e direito. Filosofia experimental e direito.

* Recebido em 26/05/2018 Aprovado em 29/06/2018

Este artigo contou com o apoio financeiro da FAPERJ e do CNPq

** Bacharel em Direito pela UFRJ. Mestre em Teoria do Estado e Direito Constitucional pela PUC-Rio.

E-mail: ursula.vasconcellos@gmail.com

*** Professor do Programa de Pós-Graduação em Direito da PUC-Rio. Cientista do Nosso Estado (FAPERJ). Bolsista de Produtividade em Pesquisa do Conselho Nacional de Desenvolvimento Científico e Tecnológico (CNPq). E-mail: noel@puc-rio.br

**** Professor do Programa de Pós-Graduação em Direito da PUC-Rio. Pesquisador do núcleo multidisciplinar Legalite, em conjunção com o Departamento de Informática da PUCRio. E-mail: ivar@puc-rio.br

\section{Abstract}

Although not explicit in the Constitution, the view that citizens' right to happiness is protected by the Brazilian law has recently gained traction among legal scholars and actors. Federal Supreme Court (STF) Justices have invoked the right to happiness in emblematic cases. Therefore, the understanding of the concept of happiness becomes crucial. Meanwhile, recent empirical work - on the contrary of what psychologists and some philosophers have usually defend - has revealed that, when reasoning about others' happiness, we typically consider both descriptive elements (i.e., whether the target displays positive emotions and reports life satisfaction) and normative elements (i.e., whether the target's behavior is considered morally good). In the present paper, we summarize the results of two experiments that demonstrate that the Portuguese-language concept of happiness ('felicidade') and, by extension, the right to happiness also depend on both descriptive 
and normative evaluations. Finally, we discuss some implications and risks stemming from the use of a morally-laden concept such as happiness in judicial practice.

Keywords: Right to happiness. Happiness. Experimental psychology and law. Experimental philosophy and law.

\section{INTRODUÇÃO}

O tema da felicidade vem recebendo grande atenção nas últimas décadas ${ }^{1}$, assumindo papel de destaque em diversas áreas acadêmicas². Isso não tem sido diferente no âmbito do direito, que vem, recentemente, incorporando esses novos estudos à sua realidade — ainda que de maneira bastante tímida, sobretudo no que diz respeito ao cenário brasileiro ${ }^{3}$. Pretende-se evidenciar a relação entre o direito e os estudos da felicidade $^{4}$, em especial os resultados trazidos por novas pesquisas da área da filosofia experimental. Busca-se demonstrar que a forma como os indivíduos aplicam o conceito pode ter repercussões normativas importantes na esfera jurídica.

Uma das evidências da relevância da discussão no direito brasileiro foi a apresentação, em 2010, de duas Propostas de Emenda à Constituição ${ }^{5}$ (PEC) que tiveram como finalidade posicionar o direito à busca da felicidade dentro do rol de direitos fundamentais. Apesar de ambas terem sido arquivadas em virtude do final da legislatura, o assunto continua relevante, tendo em vista que doutrinadores e aplicadores do direito brasileiro vêm entendendo que o direito à felicidade é um princípio implícito no nosso ordenamento jurídico. O que se percebe é um otimismo generalizado. É difícil encontrar um estudioso do direito que seja contrário à sua positivação e aplicação. Afinal, quem não quer ser feliz ou não concorda com a promoção da felicidade?

Contudo, apesar de a incorporação, explícita ou implícita, do conceito de felicidade ao direito aparentar, a priori, ser extremamente benéfica para o ordenamento jurídico, percebe-se que a avaliação acerca da sua aplicação prática exige muito mais esforço do que uma análise descuidada pode levar a crer. Pretende-se demonstrar ao longo deste artigo que, além de o conceito de felicidade ser extremamente complexo, as

1 A atenção é tamanha que foi criado um ramo da psicologia que estuda, de maneira central, a temática da felicidade: a "Psicologia Positiva" (conhecida como "positive psychology"), popularizada por Martin Seligman. A psicologia positiva tem como objetivo compreender como os indivíduos podem, cada vez mais, maximizar sua felicidade.

2 Nesse sentido que Kahneman, em um Ted Talk sobre a felicidade, afirmou que: "todo mundo fala sobre felicidade hoje em dia. Eu pedi para que contassem o número de livros publicados nos últimos cinco anos com "felicidade" no título, mas eles desistiram ao chegar em 40, e havia mais. Há uma onda de interesse em felicidade entre os pesquisadores". Em: KAHNEMAN, Daniel. Daniel Kabneman: the riddle of experience vs. memory, 2010. Disponível em:<https://www.ted.com/talks/daniel_kahneman_the_riddle_of_experience_vs_memory?language=em>. Acesso em: 20 maio 2018.

3 Alguns trabalhos sobre o direito e a felicidade incluem: POSNER, Eric; SUNSTEIN, Cass (Ed.). Law and happiness. Chicago: The University of Chicago, 2010; BRONSTEEN, John; BUCCAFUSCO, Christopher; MASUR, Jonathan. Happiness and the law. Chicago: The University of Chicago Press, 2015; e BAGARIC, Mirko; MCCONVILL, James. Goodbye justice, hello happiness: wilcoming positive psychology to the law. Deakin Law Review, v. 10, n. 1, 2005. No Brasil esses estudos são ainda mais raros. Temos: STRUCHINER, Noel; VASCONCELLOS, Úrsula. Direito e felicidade: algumas implicações da teoria comportamental. In: FORTES, Pedro; CAMPOS, Ricardo; BARBOSA, Samuel. (Org.). Teorias contemporâneas do direito: o direito e as incertezas normativas. Curitiba: Juruá, 2016. v. 1. p. 259-278; e LEAL, Saul Tourinho. Direito à felicidade. Rio de Janeiro: C\&C Criações e Textos, 2014 (apesar de, nesse último, as novas descobertas sobre a felicidade apenas aparecerem de maneira marginal — são 11 páginas de um total de 586). Nota-se que todos os estudos são bastante recentes.

4 Destaca-se o alto grau de interdisciplinaridade nos estudos envolvendo a felicidade: "Nas pesquisas atuais sobre a felicidade, em contraste com outras áreas das ciências sociais, a integração entre disciplinas normalmente vai tão longe ao ponto de não ser possível identificar se uma contribuição específica se deve a um economista, um psicólogo, um sociólogo ou um cientista político". No original: "In current happiness research, in contrast with other areas of the social sciences, the integration among disciplines often goes so far that it is not possible to identify whether a particular contribution is due to an economist, a psychologist, a sociologist, or a political scientist". Em: FREY, Bruno. Happiness: a revolution in economics. Massachusetts: MIT Press, 2008. p. 14.

5 As PECs foram as de n. 19 de 2010 e n. 513 de 2010, propostas, respectivamente, pelo Senador Cristóvam Buarque e pela Deputada Federal Manuela D’Ávila. 
intuições que o cercam são muito mais controversas do que aparentam, trazendo implicações preocupantes para a sustentação de sua aplicação direta no âmbito do direito.

Muitos especialistas se dedicam à discussão teórica sobre o conceito de felicidade, havendo uma grande cisão entre as concepções oferecidas por psicólogos e filósofos que estudam o tema. Contudo, nossa preocupação central não é com a concepção dos especialistas nesse debate teórico, mas sim com a dos não especialistas - concepção essa que chamaremos de "ordinária". Isso porque os destinatários do direito são juristas e não juristas que, apesar de (normalmente) não acompanharem de perto o debate teórico sobre o conceito de felicidade, terão que, eventualmente, manejá-lo ${ }^{6}$. Sendo assim, investigar a compreensão e a utilização do conceito de felicidade por esses indivíduos é fundamental para concluir se a sua recepção pelo direito deve (ou não) ser promovida.

Para revelar a concepção ordinária de felicidade será utilizada a metodologia da filosofia experimental ${ }^{7}$, que busca unir a investigação filosófica tradicional aos métodos de investigação empírica mais tradicionalmente associados à área das ciências cognitivas e sociais. A ideia é, a partir da compreensão do significado ordinário de "felicidade", verificar as possíveis implicações da sua utilização no âmbito do direito. Trabalha-se com a hipótese de que, tendo em vista o seu componente valorativo, a maior parte das pessoas emprega o conceito de felicidade de maneira bastante variável, o que pode trazer resultados preocupantes para a tomada de decisão judicial.

O artigo adota o seguinte percurso: inicialmente será apresentado, brevemente, o estado da arte da discussão sobre a felicidade no direito brasileiro. Em seguida, serão expostos alguns estudos recentes da filosofia experimental, com o intuito de demonstrar o entendimento ordinário desse conceito. Com o objetivo de verificar as implicações da utilização da felicidade no âmbito do direito, na sequência, serão retratados dois estudos experimentais desenvolvidos no Núcleo de Estudos sobre Razão, Direito e Sentimentos Morais (NERDS) ${ }^{8}$. O artigo, então, concluirá com a ideia de que, talvez, a positivação do direito à felicidade não seja tão benéfica para o ordenamento jurídico como pode parecer em um primeiro momento.

\section{Felicidade no direito brasileiro}

A felicidade vem, há alguns anos, ganhando destaque expressivo dentro do universo jurídico brasileiro. O destaque é tamanho que foram apresentadas, em 2010, duas PECs ${ }^{9}$ com o objetivo de incluir o direito à busca pela felicidade no artigo $6^{\circ}$ da nossa Constituição ${ }^{10}$. Destaca-se que a tendência de positivação da

6 É importante ressaltar que, no âmbito do direito, o julgamento sobre a felicidade se dará por um terceiro, que avaliará a felicidade de outro. Justamente por isso, não estamos preocupados em descobrir o que "verdadeiramente" torna alguém feliz, mas sim o que os indivíduos, de maneira geral, levam em consideração quando consideram alguém "feliz". É nesse ponto que entra a preocupação do artigo com o conceito ordinário.

7 A filosofia experimental estuda as intuições por meio da utilização dos mecanismos das ciências sociais e cognitivas, por considerá-los mais adequados para se chegar às intuições dos indivíduos em geral - e não apenas às do próprio filósofo. Esses mecanismos, além de permitirem um maior acesso às intuições relevantes, também auxiliam no entendimento dos mecanismos psicológicos que são responsáveis por elas. Em: ALEXANDER, Joshua. Experimental philosophy: an introduction. Cambridge: Polity Press, 2012 . p. 2. A filosofia experimental permite uma complementação das abordagens tradicionais da filosofia, funcionando, nos termos colocados por Knobe e Nichols, como uma ferramenta a mais na caixa de ferramentas do filósofo. Em: KNOBE, Joshua; NICHOLS, Shaun. An experimental philosophy manifesto. In: KNOBE, Joshua; NICHOLS, Shaun (Org.). Experimental philosophy. New York: Oxford University Press, 2008. Para uma análise ampla e introdutória sobre a Filosofia Experimental, sugere-se a leitura dos dois trabalhos mencionados nesta nota.

8 Trata-se de um grupo de pesquisa desenvolvido no âmbito da PUC-Rio, cadastrado no CNPq e coordenado por Noel Struchiner. 9 Consultar nota 9.

10 O texto sugerido por ambas foi exatamente o mesmo, de maneira que, em caso de aprovação de alguma delas, o art. $6^{\circ}$ da Constituição passaria a ser redigido da seguinte forma: "Art. $6^{\circ}$ São direitos sociais, essenciais à busca da felicidade, a educação, a saúde, a alimentação, o trabalho, a moradia, o lazer, a segurança, a previdência social, a proteção à maternidade e à infância, a assistência aos desamparados, na forma desta Constituição". 
felicidade não é exclusivamente brasileira, como apontado na própria justificativa das PECs. Para apoiar a inserção do direito à felicidade no rol de direitos fundamentais, as propostas elencam três países que adotaram a felicidade como cláusula constitucional: o Reino de Butão ${ }^{11}$, o Japão e a Coreia do Sul.

Apesar de ambas as propostas terem sido arquivadas ${ }^{12}$, o direito à felicidade continua ganhando relevância no cenário brasileiro. O posicionamento que vem se destacando dentre os juristas pátrios é o de que o direito à felicidade está implícito em nosso ordenamento jurídico, sendo considerado por alguns uma decorrência direta do princípio da dignidade da pessoa humana, previsto no art. $1^{\circ}$ da Carta Magna ${ }^{13}$. Outros entendem que sequer é necessário derivá-lo do princípio da dignidade da pessoa humana, de maneira que seu reconhecimento se dá com base em análise do ordenamento jurídico como um todo. Nessa linha de entendimento encontra-se Saul Tourinho Leal, que afirma que o direito à felicidade extrai seu fundamento com base nos "diversos poros presentes na Constituição", que são "capazes de absorver os projetos individuais de felicidade, bem como de ampliar a felicidade coletiva"14_-15.

A defesa de um direito à felicidade implícito na Constituição, também, vem se dando por aplicadores do direito. Desde o início do século, a felicidade vem sendo invocada em decisões judiciais ${ }^{16}$. A decisão mais paradigmática de aplicação do direito à felicidade no contexto brasileiro foi a proferida pelo ministro Celso de Mello na ADI n. ${ }^{\circ} 4.277$, em que se objetivou submeter o art. 1.723 do Código Civil brasileiro ${ }^{17}$ à técnica da interpretação conforme à constituição, com o intuito de equiparar a união estável entre indivíduos do mesmo sexo àquela entre um homem e uma mulher. Utilizando o direito à busca pela felicidade como um de seus fundamentos, o ministro Celso de Mello entendeu que deveriam ser cessados quaisquer obstáculos à qualificação da união civil homossexual como uma entidade familiar ${ }^{18}$, como se pode ver no trecho a seguir:

Reconheço que o direito à busca da felicidade - que se mostra gravemente comprometido, quando o Congresso Nacional, influenciado por correntes majoritárias, omite-se na formulação de medidas destinadas a assegurar, a grupos minoritários, a fruição de direitos fundamentais — representa derivação do princípio da dignidade da pessoa humana, qualificando-se como um dos mais significativos postulados constitucionais implícitos.

Outro exemplo bastante relevante de utilização da ideia de felicidade no fundamento de uma decisão judicial é encontrado no julgamento do Recurso Extraordinário n. ${ }^{\circ}$ 898.450, de relatoria do ministro Luiz

11 Destaca, no Reino de Butão, a utilização do Índice Nacional de Felicidade como indicador social.

12 Ambas as propostas foram arquivadas devido ao fim da legislatura, tendo a PEC n. 513 de 2010 sido arquivada em 31/01/2015, nos termos do art. 105 do Regimento Interno da Câmara de Deputados, e a PEC n. ${ }^{\circ} 19$ de 2010 em 26/12/2014, nos termos do art. 332 do Regimento Interno do Senado Federal.

13 Como exemplo pode-se citar Maria Berenice Dias. Ver: DIAS, Maria Berenice. Direito fundamental à felicidade. Revista Interdisciplinar de Direito da Faculdade de Direito de Valença, v. 8, p. 201-205, 2010.

14 LEAL, Saul Tourinho. Direito à felicidade. Rio de Janeiro: C\&C Criações e Textos, 2014. p. 223.

15 Direcionando o seu texto às possíveis críticas que poderiam derivar da aplicação de um direito à felicidade, Saul Tourinho afirma não acreditar "que seja dever do Estado criar a sua própria pauta de felicidade baseada nos padrões morais das autoridades". Ele chega a afirmar que isso seria um "voluntarismo incompatível com as premissas [...] defendidas". Na mesma linha, o autor afirma que "não há sustentação na afirmação de que falar de felicidade, aliada ao direito, corresponde a navegar num oceano moral, ou no direito natural”. Em: LEAL, Saul Tourinho. Direito à felicidade. Rio de Janeiro: C\&C Criações e Textos, 2014. p. 572 e 284. Mas será que, de fato, não há sustentação nessa afirmação? É justamente esse ponto que vamos discutir por meio dos experimentos apresentados nos itens seguintes.

16 E.g. BRASIL. Supremo Tribunal Federal. ADI n. ${ }^{\circ} 3.300$, Relator Ministro Celso de Mello; Supremo Tribunal Federal, RE n. ${ }^{\circ}$ 477.554; Superior Tribunal de Justiça, AREsp n. ${ }^{\circ}$ 578.562, Relator Ministro Napoleão Nunes Maia Filho; Superior Tribunal de Justiça, REsp n. ${ }^{\circ}$ 1428849, Relator Ministro Moura Ribeiro; Tribunal de Justiça do Rio de Janeiro, Agravo de Instrumento n. ${ }^{\circ}$ 0062505-37.2014.8.19.0000, Desembargador Antônio Carlos dos Santos Bitencourt; Tribunal de Justiça do Rio de Janeiro, Apelação n. ${ }^{\circ}$ 0033507-63.2013.8.19.0204, Desembargador Bernardo Moreira Garcez Neto.

17 Art. 1.723. É reconhecida como entidade familiar a união estável entre o homem e a mulher, configurada na convivência pública, contínua e duradoura e estabelecida com o objetivo de constituição de família. $\$ 1^{\circ} \mathrm{A}$ união estável não se constituirá se ocorrerem os impedimentos do art. 1.521; não se aplicando a incidência do inciso VI no caso de a pessoa casada se achar separada de fato ou judicialmente. $₫ 2^{\circ}$ As causas suspensivas do art. 1.523 não impedirão a caracterização da união estável.

18 O direito à busca da felicidade teve um destaque bastante notável na decisão do referido ministro, que chegou a dedicar um tópico inteiro do seu voto à sua discussão. 
Fux. A ação versava sobre a possibilidade de se impedir que um candidato concorresse a um cargo ou emprego público em virtude da existência de tatuagens em seu corpo. Em seu voto, Fux chegou à conclusão de que editais de concurso público não podem, em regra, estabelecer restrições a pessoas com tatuagens. Para tanto, chegou a afirmar que incumbe ao Estado a missão de preservar e incentivar, no mais alto grau, "a máxima de que cada um é feliz à sua maneira”. Destacou, ainda, que o Poder Judiciário tem um importante papel nessa missão.

\section{Contribuições da filosofia experimental}

Pode-se dizer, de uma maneira bastante geral, que as teorias que disputam o conceito de felicidade se dividem em dois grandes grupos: descritivas e valorativas ${ }^{19}{ }^{20}$. No primeiro grupo, enquadram-se aquelas segundo as quais a felicidade se refere a um estado psicológico, de maneira que se confundiria com a posse de determinados estados mentais positivos. No segundo grupo, enquadram-se aquelas que defendem que a felicidade é uma questão de "boa vida", o que envolveria uma espécie de avaliação moral. De acordo com as teorias descritivas, uma máquina que tem a capacidade de acessar determinadas ondas cerebrais que identificam estados mentais positivos seria — por si somente — capaz de revelar se alguém é ou não feliz. Já no âmbito das teorias valorativas, essa máquina — por mais precisa que fosse — jamais seria o suficiente para a realização da avaliação de felicidade de um indivíduo. Seria necessário algo mais, um passo além.

Contudo, nossa preocupação neste artigo não está centrada no conceito de felicidade segundo especialistas no assunto, mas sim no conceito ordinário. Isso porque, no âmbito do direito, além de podemos presumir que aqueles que farão uso do conceito não possuem qualquer tipo de expertise teórica sobre o assunto, o conceito de felicidade ainda não possui um contorno nítido ${ }^{21}{ }^{22}$. Daí surgem as seguintes indagações: qual será a concepção teórica vindicada pelos não especialistas? E quais são as consequências disso para a prática do direito?

Tradicionalmente, os pesquisadores que se debruçaram sobre pesquisas acerca do entendimento ordinário do conceito de felicidade o consideravam puramente descritivo ${ }^{23}$. É seguindo essa linha que Haybron afirma: "deve estar patentemente claro que a maior parte das conversas ordinárias sobre felicidade, mesmo

19 Essas categorias são as mesmas utilizadas em: PHILLIPS, Jonathan; NYHOLM, Sven; LIAO, Shen-yi. The good in happiness. In: Oxford studies in experimental philosophy. Oxford: Oxford University Press, 2014. v. 1.

20 Cumpre destacar que essa divisão em duas categorias extremas tem o objetivo de facilitar o entendimento acerca das teorias envolvendo o conceito de felicidade. Há uma série de teorias que transitam entre ambos os polos, de maneira que consideram tanto o aspecto descritivo quanto o valorativo (ainda que um de maneira predominante em relação ao outro).

21 Deve ficar claro que a afirmação feita não é no sentido de que operadores do direito não devem fazer uso de conceitos manejados por especialistas de outras áreas. Mas sim que, na medida em que for possível, deve-se tentar entender como esses conceitos complexos (como é o caso da felicidade) são de fato utilizados na prática judicial, em uma tentativa de estreitar a relação entre o direito e a realidade. A possibilidade de fazer isso é justamente uma das grandes contribuições da Filosofia Experimental.

22 Destacamos que o contorno sequer é nítido no âmbito dos estudos provenientes da Filosofia e da Psicologia, em que há estudiosos que se dedicam integralmente ao estudo do conceito. Apenas a título exemplificativo: enquanto alguns pesquisadores entendem que para que se atinja a verdadeira felicidade é necessário possuir os elementos da virtude (e.g. FOOT, Philippa. Natural goodness. New York: Oxford University Press, 2001), outros entendem que isso não é necessário, bastando que o indivíduo possua estados mentais positivos (e.g. KAHNEMAN, Daniel. Experienced utility and objective happiness: a moment-based approach. In: Choices, values and frames. New York: Cambridge University Press and the Russell Sage Foundation, 2000). Há, ainda, quem entenda que os estados mentais positivos são necessários, mas não suficientes. Isso porque eles precisam derivar, especificamente, não de atividades sensoriais, mas sim de atitudes derivadas de um estado de consciência (e.g. FELDMAN, Fred. What is this thing called happiness? New York: Oxford University Press, 2010). Há, ainda, aqueles que entendem que a felicidade exige um sentimento de satisfação em relação à própria vida (e.g. SUIKKANEN, Jussi. An improved whole life satisfaction theory of happiness. International Journal of Well-being, v. 1, n. 1, 2011; PETERSON, Christopher; PARK, Nansook; SELIGMAN, Martin. Orientations to happiness and life satisfaction: the full life versus the empty life. Journal of Happiness Studies, 2005).

23 E.g. GILBERT, Dan. Stumbling on happiness. New York: Vintage Books, 2006; HAYBRON, Daniel. The pursuit of unhappiness: the elusive psychology of well-being. New York: Oxford University Press, 2010; e FELDMAN, Fred. What is this thing called happiness? New York: Oxford University Press, 2010. 
nos casos de gravidade considerável, não diz respeito ao bem-estar em si, mas a um conceito amplamente, se não totalmente, psicológico" ${ }^{24}$.

Contudo, pesquisas mais recentes e bastante minuciosas no âmbito da filosofia experimental vêm demonstrando que o conceito ordinário de felicidade não é apenas descritivo, mas também valorativo ${ }^{25}$. Esse duplo enfoque fica evidenciado em uma pesquisa empírica realizada por Phillips, Misenheimer e Knobe ${ }^{26}$, em 2011, que evidencia que a felicidade pode ser compreendida como um conceito que serve para detectar estados mentais particulares (enfoque descritivo) e, ao mesmo tempo, realizar julgamentos morais (enfoque valorativo). Nesse sentido, os autores afirmam:

[...] quando as pessoas avaliam se determinado agente é verdadeiramente 'feliz' [...], elas não estão meramente tentando entender se esse agente tem um tipo específico de estado mental. Eles também estão preocupados, de maneira central, com a valoração do próprio agente ${ }^{27}$.

Assim, os autores revelam que os julgamentos acerca da felicidade concedem grande espaço, na vida prática, para a realização de julgamentos morais particulares. As descobertas iniciais dos autores são posteriormente reforçadas em uma série de novos estudos ${ }^{28}$ que, além de responder a possíveis objeções ao estudo anterior, chegam a novas e instigantes conclusões. Com o objetivo de esclarecer o que as pessoas ordinárias vêm entendendo por felicidade, serão apresentados, a seguir, os estudos desenvolvidos por Phillips, Misenheimer e Knobe, em 2011, e por Phillips, Nyholm e Liao, em 2014.

\subsection{Diferença entre "felicidade" e "infelicidade" (Philips, Misenheimer, Knobe, 2011) ${ }^{29}$}

Este estudo teve como objetivo verificar se os conceitos de "felicidade" e "infelicidade" apresentavam diferenças relevantes no momento da sua utilização prática ${ }^{30}$. Os autores concluíram que há, de fato, uma diferença: enquanto o julgamento valorativo afeta a uso de um dos conceitos, ele não apresenta qualquer influência sobre o outro. A utilização do par "felicidade vs. infelicidade" partiu de um estudo realizado por $\mathrm{Nyholm}^{31}$, no qual se identificou que as intuições das pessoas sobre um agente ser verdadeiramente feliz são afetadas pela sua compreensão acerca de o agente estar vivendo uma vida moralmente boa. Assim, os autores desenvolveram a hipótese de que, enquanto isso seria verdade para o conceito de felicidade, este não aconteceria em relação ao conceito de infelicidade.

Com o intuito de comprovar a hipótese, os autores desenvolveram um estudo experimental, envolvendo

24 Tradução livre. No original: "It should be patently clear that much ordinary talk about happiness, even in matters of considerable gravity, concerns not well-being itself but a largely if not wholly psychological concept". Em: HAYBRON, Daniel. The pursuit of unhappiness: the elusive psychology of well-being. New York: Oxford University Press, 2010. p. 31.

25 Ver: PHILLIPS, Johnathan et al. True happiness: the role of morality in the folk concept of happiness. Journal of Experimental Psychology: General, v. 146, n. 2, p. 165-181, feb. 2017. PHILLIPS, Jonathan; NYHOLM, Sven; LIAO, Shen-yi. The good in happiness. In: Oxford studies in experimental philosophy. Oxford: Oxford University Press, 2014. v. 1.; e PHILLIPS, Jonathan; MISENHEIMER, Luke; KNOBE, Joshua. The ordinary concept of happiness. Emotion Review, California, Sage Publications USA, v. 3, n. 3. 2011. 26 PHILLIPS, Jonathan; MISENHEIMER, Luke; KNOBE, Joshua. The ordinary concept of happiness. Emotion Review, v. 3 , n. 3. California, Sage Publications USA, 2011.

27 Tradução livre. No original: 'when people are wondering whether a given agent is truly 'bappy' or 'in love,' they are not merely trying to figure out whether this agent has a particular sort of mental state. They are also concerned in a central way with evaluating the agent herself'. Em: PHILLIPS, Jonathan; MISENHEIMER, Luke; KNOBE, Joshua. The ordinary concept of happiness. Emotion Review, California, Sage Publications USA, v. 3, n. 3, 2011. p. 320.

28 PHILLIPS, Johnathan et al. True happiness: the role of morality in the folk concept of happiness. Journal of Experimental Psychology: General, v. 146, n. 2, p. 165-181, feb. 2017. e PHILLIPS, Jonathan; NYHOLM, Sven; LIAO, Shen-yi. The good in happiness. In: Oxford Studies in Experimental Philosophy. Oxford: Oxford University Press, 2014. v. 1.

29 PHILLIPS, Jonathan; MISENHEIMER, Luke; KNOBE, Joshua. The ordinary concept of happiness. Emotion Review, California, Sage Publications USA, v. 3, n. 3, 2011.

30 Além do par "felicidade/infelicidade", os autores também analisaram os pares "love/lust" e "valuing/thinking good". No original: "happiness" vs. "unhappiness", "love" vs. "lust" e "valuing" vs. "thinking good".

31 Infelizmente, o trabalho em que esse estudo foi apresentado não foi divulgado, motivo pelo qual ele não se encontra nas referências ao final deste artigo. 
participantes selecionados de maneira aleatória. Cada participante recebeu uma de quatro vinhetas sobre uma mulher chamada Maria. Em um par de vinhetas, Maria era descrita como tendo os estados psicológicos associados à felicidade, enquanto no outro par Maria era descrita como possuindo os estados psicológicos associados à infelicidade. A diferença entre as vinhetas de cada par era que em um caso ela vivia uma vida normalmente considerada moralmente boa ${ }^{32}$, enquanto no outro, uma vida normalmente considerada moralmente ruim ${ }^{33}$. A partir da leitura da vinheta, os participantes deveriam avaliar, em uma escala de 1 a 7 , o grau com o qual concordavam que Maria era "feliz" (ou "infeliz", dependendo da vinheta que haviam recebido).

Fluxograma 1 - Maria na condição de felicidade psicológica

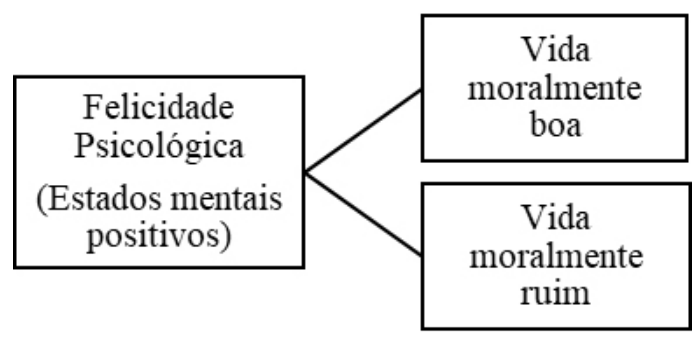

Fluxograma 2 - Maria na condição de infelicidade psicológica

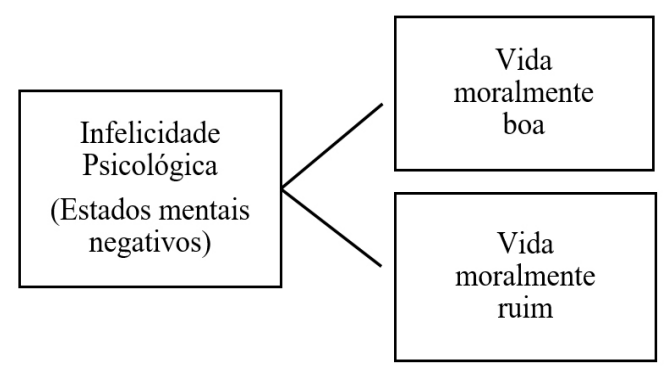

O resultado do estudo corroborou aquilo que havia sido previsto por Nyholm: os julgamentos de valor integram, de maneira crucial, o conceito ordinário de felicidade. Na condição de felicidade psicológica (estados mentais positivos), enquanto Maria tinha uma vida moralmente boa, a média da avaliação da sua felicidade foi de 6,4; ao passo que quando sua vida era moralmente ruim a média da avaliação de felicidade foi de 3,5. A diferença foi bastante significativa: 2,9 pontos.

Além disso, os autores confirmaram a hipótese da sua pesquisa: há, de fato, uma diferença no papel dos julgamentos valorativos na avaliação de felicidade e de infelicidade. $\mathrm{Na}$ condição de infelicidade, a diferença entre as médias da atribuição de infelicidade na vida moralmente boa e na vida moralmente ruim não foi sequer significativa: no primeiro caso, a média da avaliação da infelicidade de Maria foi de 3,1 pontos; ao passo que, no segundo caso, a média da avaliação da infelicidade de Maria foi de 2,9 pontos. O julgamento valorativo em relação à vida de Maria não teve qualquer efeito na avaliação do quanto ela era infeliz. Enquanto a atribuição de felicidade carrega um julgamento moral, a de infelicidade não segue esse mesmo padrão. Este estudo, por si só, traz fortes indícios de que a avaliação moral tem um importante papel no julgamento ordinário de felicidade.

32 Maria é considerada uma pessoa cuidadosa, com uma ótima família e amizades e projetos de vida significativos.

33 Maria é descrita como uma pessoa desinteressada, sem amizades verdadeiras. Seus objetivos de vida não vão além do desejo de sair para festas e conseguir um status social mais alto. 


\subsection{São os estados psicológicos e não o julgamento moral que afetam a atribuição de felicidade? (Phillips, Nyholm, Liao, 2014) ${ }^{34}$}

Em função de uma objeção feita ao estudo anterior, realizou-se um novo experimento. O argumento da objeção foi o de que o julgamento valorativo, na realidade, não teria influenciado, diretamente, a análise sobre se Maria era feliz/infeliz. A valoração teria, apenas, influenciado os participantes a atribuírem um determinado estado psicológico à Maria. Ou seja: os participantes, a partir de seus próprios julgamentos morais, estariam desprezando os estados mentais atribuídos, explicitamente, no desenho experimental, e atribuindo os estados mentais mais compatíveis com seus respectivos julgamentos. Seria, então, com base nesses supostos estados mentais que seria avaliada a felicidade. Para ficar claro:

Fluxograma 3 - Objeção: Influência de estados mentais específicos no julgamento de infelicidade

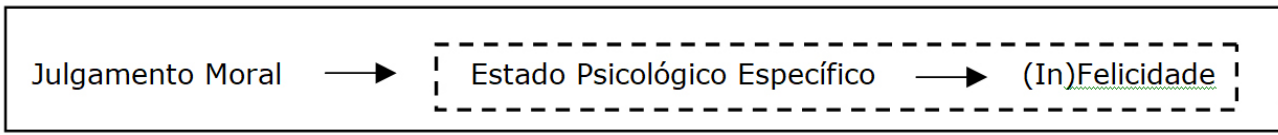

Seria dizer o seguinte: Maria, na condição "vida (moralmente) ruim", experimentava estados mentais distintos daqueles da "vida (moralmente) boa". Seriam esses supostos estados mentais os responsáveis pela atribuição de felicidade.

Nesse novo estudo, os participantes leram uma única vinheta sobre um agente que experimentava, simultaneamente, estados mentais positivos e negativos. Ao utilizar a mesma vinheta, os autores eliminaram a possibilidade de suscitar estados psicológicos díspares nos participantes em decorrência da descrição do caso. A estratégia para descrever um cenário passível de despertar valores morais distintos sem haver a necessidade da utilização de vinhetas diferentes foi a utilização de um caso moralmente controvertido.

A vinheta descrevia Bruce, um indivíduo homossexual, que começou a sair com Andrew (o que despertou estados mentais positivos em Bruce, já que ele sonhava em encontrar um parceiro para ter um relacionamento duradouro), mesmo estando em conflito com a sua crença religiosa e ocasionalmente sentindo culpa por estar em um relacionamento homoafetivo (despertando, assim, estados psicológicos negativos em Bruce). Contudo, na maior parte do tempo, Bruce não se sentia culpado, e, quando ele se sentia, se lembrava de que não havia motivos para tal, já que ele gostava tanto de Andrew quanto do estilo de vida que estava levando.

Solicitou-se, então, que os participantes avaliassem (em uma escala de 1 a 7) o quanto concordavam com três questões: (i) "Bruce é feliz?"; (ii) "Quanta angústia ${ }^{35}$ Bruce sente?”; e (iii) "Você acha que o estilo de vida de Bruce é imoral?”. A pergunta sobre a angústia foi acrescentada para avaliar o estado psicológico que os participantes assumiriam que Bruce estaria enfrentando, com o objetivo de verificar a sua relação (ou não) com as atribuições de imoralidade e de felicidade.

Nesse estudo, os julgamentos de moralidade foram altamente correlacionados com os julgamentos de felicidade. Participantes que achavam que Bruce levava uma vida imoral consideraram-no, significativamente, menos feliz (a média das respostas foi de 3.83) do que aqueles que não achavam sua vida imoral, apesar de a vinheta descrever a contradição com a sua religião (a média de respostas foi de 5,02). Apesar do julgamento de angústia, também, ter apresentado uma correlação com a atribuição de felicidade (ainda que menos significativa do que a correlação desta com a imoralidade), os resultados do estudo evidenciaram que a angústia e a imoralidade afetaram o julgamento de felicidade de maneira independente: não houve qualquer correlação entre ambos. Isso significa que os participantes não consideraram Bruce mais ou menos angustiado em virtude da concepção moral que tinham dele.

34 PHILLIPS, Jonathan; NYHOLM, Sven; LIAO, Shen-yi. The good in happiness. In: Oxford studies in experimental philosophy. Oxford: Oxford University Press, 2014. v. 1.

35 A palavra utilizada no artigo original, em inglês, é "distress". Optou-se pela sua tradução como "angústia". 
Se a objeção levantada no início estivesse correta, o estudo corroboraria a posição assumida pela maior parte dos psicólogos - de que o conceito ordinário é puramente (ou quase) descritivo. Isso porque a causa direta da atribuição de felicidade seria o estado psicológico do agente, que atuaria como um intermediário fazendo a ligação entre o julgamento moral e a julgamento de felicidade. Contudo, isso não aconteceu. $\mathrm{O}$ que significa que o gráfico correto é o que segue abaixo, que evidencia o papel independente da moralidade na atribuição de felicidade, sem a necessidade da atuação de um estado psicológico como intermediário.

Fluxograma 4 - Como o julgamento moral influencia o julgamento de infelicidade

\begin{tabular}{ll}
$\stackrel{\text { Julgamento Moral }}{\text { Estados Psicológicos }}$ Felicidade \\
\hline
\end{tabular}

Os autores afirmam que esse estudo auxiliou, ainda, na descoberta de que a atribuição de felicidade leva em consideração o julgamento moral pessoal do avaliador, que se sobrepõe àquele da pessoa a quem está sendo atribuída a felicidade (Maria ou Bruce). Como todos os participantes leram a mesma vinheta, na qual Bruce vivia uma vida que ele mesmo aprovava, o resultado permitiu afirmar que a relevância no julgamento de felicidade por parte dos participantes se deu, na verdade, em virtude de suas próprias avaliações sobre a moralidade da vida de Bruce. Isso porque se os julgamentos levassem em conta o julgamento do próprio Bruce, o consenso seria por considerar Bruce feliz, o que não aconteceu.

\section{Conceito ordinário de fELICIDADE No CENÁRIo bRASILEIRO}

Com base nas descobertas descritas no item anterior, foram desenvolvidos dois estudos experimentais no âmbito do NERDS, que serão aprofundados nos subitens a seguir. O primeiro teve como objetivo verificar se o julgamento de felicidade/infelicidade variaria, assim como o julgamento de happiness/unhappiness, de acordo com o julgamento moral dos sujeitos. Quer dizer, se a avaliação dos participantes acerca da felicidade de determinado agente variaria de acordo com sua própria concepção acerca de o agente estar vivendo uma vida moralmente boa ou uma vida moralmente ruim. Para tanto, optou-se por fazer uma replicação do estudo realizado por Philips, Misenheimer e Knobe, em 2011, descrito no item “3.1” acima.

O segundo experimento teve como objetivo investigar se a influência do julgamento moral na atribuição de felicidade em contextos que não são de tomada de decisão jurídica se manteria em um cenário de tomada de decisão desse tipo. O estudo consistiu na elaboração de uma vinheta que contemplava uma situação que poderia vir a ser enfrentada por juízes de direito envolvendo a aplicação do direito à busca da felicidade. Optou-se por retratar um casal homossexual e um casal incestuoso que teriam entrado na justiça para solicitar, com base no direito à busca da felicidade, uma autorização para a celebração do seu casamento. Ao final, perguntava-se aos participantes se o pedido das partes deveria ou não ser concedido. Ao mesmo tempo, os indivíduos deveriam responder a um segundo questionário que permitiria analisar quais tipos de relacionamento entendiam como moralmente apropriados e quais tipos de relacionamento acreditavam ser capazes de trazer felicidade aos indivíduos envolvidos. O propósito foi identificar o quanto a decisão acerca da felicidade de outros indivíduos seria afetada pela concepção moral da pessoa que realizou o julgamento.

\subsection{Replicação do estudo acerca do conceito ordinário de felicidade: estrutura e fundamentos}

Da mesma maneira que o estudo realizado por Philips, Misenheimer e Knobe, descrito no item "3.1" acima, nosso estudo contou com quatro vinhetas distintas. As vinhetas utilizadas foram idênticas àquelas utilizadas pelos referidos autores, com a diferença de que foram traduzidas para o português. Um par de 
vinhetas fazia referência ao conceito de 'felicidade psicológica', enquanto o outro par fazia referência ao conceito de 'infelicidade psicológica'. Dentro de cada par de vinhetas (serão chamados de "condições"), uma descrevia uma vida moralmente ruim e a outra descrevia uma vida moralmente boa. As quatro vinhetas estão expostas integralmente no Apêndice 1, e são representadas pelos Fluxogramas 1 e 2.

Cada participante recebeu, aleatoriamente, uma única vinheta. Após sua leitura, pedia-se que respondessem, em uma escala de 1 (discordo muito) a 7 (concordo muito), às seguintes perguntas:

(1) quando recebiam a vinheta na condição de felicidade psicológica:

a) "Você acha que Maria é feliz?"; e

b) "Comparado às outras pessoas, você acha que Maria tem uma vida boa?"

(2) quando recebiam a vinheta na condição de infelicidade psicológica:

a) "Você acha que Maria é infeliz?"; e

b) "Comparado às outras pessoas, você acha que Maria tem uma vida boa?"

A primeira hipótese dessa replicação, assim como no estudo original, se traduziu na afirmação de que a avaliação moral acerca da vida do sujeito descrita na vinheta afetaria o julgamento sobre a sua felicidade. Também se esperava que essa diferença não aparecesse no conceito de infelicidade. A segunda hipótese consistiu na influência da avaliação moral no julgamento de felicidade - no caso de confirmação da primeira hipótese - seria também identificada em operadores do direito. Afinal, profissionais do direito não recebem qualquer tipo de treinamento especial nas discussões teóricas sobre felicidade, não demonstrando qualquer tipo de expertise no assunto. Sendo assim, supôs-se que as considerações dos juízes seriam as mesmas dos não especialistas em geral.

\subsubsection{Resultados obtidos}

O estudo contou com um total de 79 participantes, dos quais 41 receberam a condição que envolvia a felicidade psicológica (destes 21 receberam a descrição de Maria como vivendo uma vida moralmente boa, e 20 como vivendo uma vida moralmente ruim), e 38 receberam a condição que envolvia a infelicidade psicológica (destes 19 receberam a descrição de Maria como vivendo uma vida moralmente boa, e 19 como vivendo uma vida moralmente ruim).

$\mathrm{Na}$ condição de felicidade psicológica, os participantes que receberam a descrição moralmente boa da vida de Maria avaliaram-na com uma média de felicidade de 6,29. Já no caso da vida moralmente ruim, a média das respostas foi de 3,55. Na condição de infelicidade psicológica, os participantes que receberam a condição de vida moralmente boa tiveram uma média de respostas de 2,32 , enquanto os que receberam a condição de vida ruim tiveram uma média de respostas de 2,11 . Segue o gráfico ilustrando os resultados obtidos: 
Gráfico 1 - Resultados da pergunta: “Você acha que Maria é feliz?” e "Você acha que Maria é infeliz?”

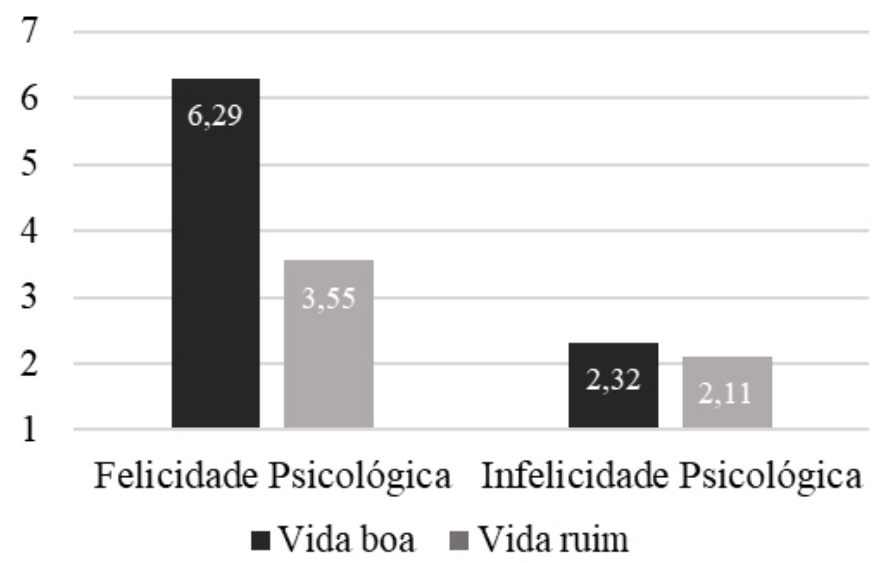

Notou-se que a avaliação sobre a felicidade variou, significativamente, entre as condições de vida boa e de vida ruim, mas a avaliação sobre a infelicidade não ${ }^{36}$.

Posteriormente, dividiram-se os participantes em grupos de acordo com a sua especialidade: (i) profissionais do direito; e (ii) outros. O objetivo foi verificar se o contato com a área do direito mitigava o papel da avaliação moral no julgamento de felicidade.

Gráfico 2 - Resultados da replicação com a divisão entre profissionais do direito e não profissionais do direito

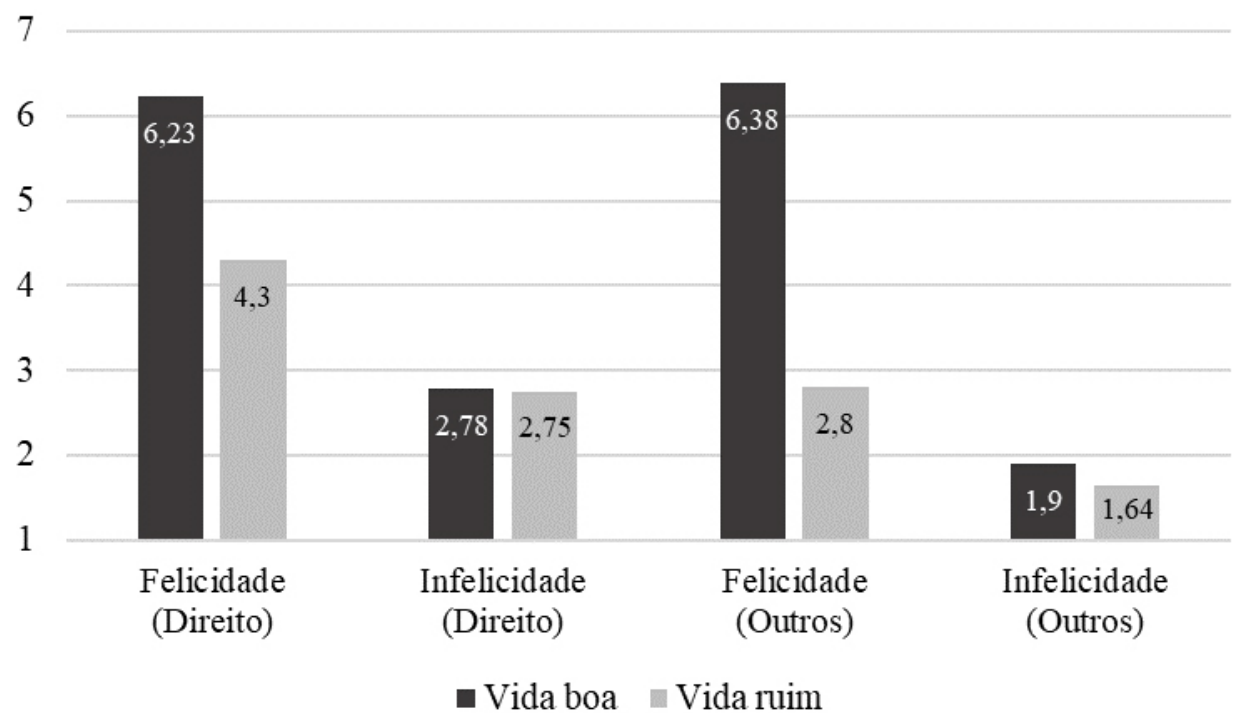

Não foi encontrada uma diferença significativa nos efeitos da condição (felicidade psicológica ou infelicidade psicológica) nos grupos de juristas e não juristas. Em ambos os grupos, os efeitos da interação entre a avaliação moral e o julgamento de felicidade foram significativos ${ }^{37}$. É interessante notar, porém, que essa diferença foi menor no caso dos juristas ${ }^{38}$. Enquanto no caso das pessoas que não eram operadoras do direito a diferença

36 Dois $t$-tests independentes foram realizados: o primeiro $(\mathrm{n}=39, \mathrm{p}<0,001, \mathrm{~d}=1.52)$ indicou uma diferença significativa entre as médias de felicidade atribuída à Maria na condição de vida boa $(6,9)$ e na condição de vida ruim $(3,55)$; o segundo $(\mathrm{n}=36, \mathrm{p}=$ $0,68, \mathrm{~d}=0,13)$ indicou a inexistência de diferença entre as médias de infelicidade atribuídas a Maria.

37 Para verificar isso, foi realizada uma análise de variância (ANOVA), que mostrou efeitos significativos para ambas as interações entre grupo (juristas e não-juristas) e condição (felicidade e infelicidade) (juristas: $\mathrm{F}(1,33)=3.99, \mathrm{p}=.054$; não juristas: $\mathrm{F}(1,35)=$ $11.13, \mathrm{p}=.002)$.

38 T-tests indicaram $\mathrm{d}=1,86$ para leigos e $\mathrm{d}=1.18$ para juristas. 
das médias na avaliação de felicidade entre a vida moralmente boa e a vida moralmente ruim foi de 3,58, a diferença entre os operadores do direito foi de 1,93. Já em relação à vinheta sobre a infelicidade, as diferenças foram igualmente irrelevantes estatisticamente: enquanto no caso dos operadores do direito a diferença foi de 0,03 , no caso daqueles que não tinham qualquer expertise no âmbito do direito a diferença foi de 0,26.

\subsubsection{Discussão}

Os resultados obtidos demonstram que o conceito ordinário de felicidade é muito mais complexo e controvertido do que pode parecer em um primeiro momento. Como Phillips et al. colocaram, "a felicidade ordinária parece ser uma questão de possuir estados psicológicos positivos que são normativamente corretos de se experimentar" ${ }^{39}$. Por se tratar de um conceito que possui um componente valorativo, ele é bastante variável nos casos concretos. O componente valorativo foi corroborado pela replicação, que evidenciou mais uma vez que as atribuições de felicidade não dependem, apenas, da presença de estados mentais positivos, mas também da existência de uma vida que seja considerada moralmente boa. Assim restou comprovada a primeira hipótese.

Inicialmente, a replicação do experimento permitiu afastar uma possível objeção linguística à utilização da pesquisa sobre a felicidade ordinária ${ }^{40}$ no contexto brasileiro. O estudo deixou claro que o padrão encontrado por Philips et al. ${ }^{41}$ em relação ao conceito de happiness se repete com o conceito, em Língua Portuguesa, de felicidade. Os resultados evidenciam que o papel da avaliação moral na atribuição de felicidade, tanto em Língua Portuguesa quanto em Língua Inglesa, se mantém de grande relevância.

De acordo com a segunda hipótese, os operadores do direito — incluindo os juízes estariam tão sujeitos à influência da avaliação moral quanto àqueles sem contato com a área jurídica. Isso porque o currículo do bacharel em direito é composto quase que exclusivamente por disciplinas dogmáticas, raramente se debruçando sobre análises mais rigorosas do raciocínio que poderiam ser melhor trabalhadas por disciplinas como lógica jurídica, teoria da argumentação, psicologia, entre outras que, quando ocupam algum espaço no rol de disciplinas das faculdades de direito, fazem isso de forma excessivamente tímida. Não é diferente com os juízes de direito, que se encontram exatamente no mesmo contexto: apesar de passarem por um intenso preparo técnico para exercerem sua função, não há qualquer tipo de treino para evitar as influências de valores morais na sua tomada de decisão ${ }^{42}$.

Seguindo o previsto, a análise dos resultados da replicação de acordo com a área de especialidade (direito ou não) de cada participante permitiu a tomada de um passo além do estudo original: pessoas que têm uma base jurídica são também suscetíveis à influência da avaliação moral no julgamento de felicidade. Contudo, não se pode deixar de notar que foi encontrada uma discrepância na diferença entre as médias da avaliação de felicidade na vida moralmente boa e na vida moralmente ruim entre os operadores do direito e os demais: enquanto entre os primeiros a diferença foi de 1,93 pontos, a diferença entre os últimos foi de 3,58 pontos. Contudo, essa informação deve ser interpretada com cautela. Isso porque os participantes que eram

39 Tradução livre. No original: "Ordinary happiness seems to be a matter of possessing positive psychological states that are normatively right to experience, given the life one understands one-self to be living”. Em: PHILLIPS, Jonathan; NYHOLM, Sven; LIAO, Shen-yi. The good in happiness. In: Oxford studies in experimental philosophy. Oxford: Oxford University Press, 2014. v. 1. p. 32. 40 PHILLIPS, Johnathan et al. True happiness: the role of morality in the folk concept of happiness. Journal of Experimental Psychology: General, v. 146, n. 2, p. 165-181, feb. 2017.; PHILLIPS, Jonathan; NYHOLM, Sven; LIAO, Shen-yi. The good in happiness. In: Oxford studies in experimental philosophy. Oxford: Oxford University Press, 2014. v. 1.; PHILLIPS, Jonathan; MISENHEIMER, Luke; KNOBE, Joshua. The ordinary concept of happiness. Emotion Review, v. 3, n. 3. California, Sage Publications USA, 2011.

41 PHILLIPS, Jonathan; MISENHEIMER, Luke; KNOBE, Joshua. The ordinary concept of happiness. Emotion Review, California: Sage Publications USA, v. 3, n. 3, 2011.

42 STRUCHINER, Noel; VASCONCELLOS, Úrsula. Direito e felicidade: algumas implicações da teoria comportamental. In: FORTES, Pedro; CAMPOS, Ricardo; BARBOSA, Samuel. (Org.). Teorias contemporâneas do direito: o direito e as incertezas normativas. Curitiba: Juruá, 2016. v. 1. p. 259-278. 
da área do direito apresentaram um nível de estudo mais elevado do que aqueles que não eram ${ }^{43}$. Assim, fica aberta a possibilidade de que o responsável pela minoração da influência das considerações valorativas na atribuição de felicidade seja o grau de escolaridade dos participantes. O mais importante, contudo, é levar em consideração que os operadores do direito são, também, suscetíveis à influência da avaliação moral no julgamento de felicidade.

Essas descobertas sobre o conceito ordinário de felicidade deixam espaço para que sejam levantadas questões importantes para o direito: será que juízes, administradores e legisladores, ao utilizarem o conceito de felicidade no exercício das suas funções, realizam ações baseadas em seus julgamentos morais particulares? Em qual medida isso pode afetar, negativamente, o ordenamento jurídico? Se a resposta para a primeira pergunta é positiva, o direito à felicidade pode trazer consequências alarmantes para o direito.

\subsection{Aplicação do direito à felicidade: estrutura e fundamentos ${ }^{44}$}

Esse estudo consistiu na apresentação, a cada participante, de uma de duas vinhetas que relatavam um caso juridicamente relevante. Ambas traziam a situação de um casal que tinha o objetivo de contrair o matrimônio, mas cujo pedido havia sido recusado pelo cartório. Enquanto um dos casos versava sobre um casal incestuoso, formado por pai e filha que haviam se apaixonado antes de saberem sobre sua relação familiar, o outro versava sobre um casal homoafetivo.

A estratégia deste estudo consistiu na utilização de um caso moralmente controvertido, capaz de suscitar respostas morais e jurídicas variadas por parte dos participantes. Optou-se pelos relacionamentos incestuoso e homoafetivo. Enquanto o primeiro seria mais controvertido, o último seria menos — em virtude de sua aceitação cada vez maior por parte da população. Para evitar que fosse feita a associação entre o caso concreto apresentado e as normas previstas no ordenamento jurídico brasileiro ${ }^{45}$, ambas as vinhetas foram situadas em um "País P", no qual não havia qualquer previsão legal em relação ao casamento homoafetivo nem tampouco quanto ao casamento incestuoso.

Trabalhou-se com a hipótese de que a autorização (ou não) para a celebração do casamento variaria segundo a concepção moral de cada participante. Tendo em vista a maior reprovabilidade moral do relacionamento incestuoso, esperou-se que os participantes tendessem a conceder menos a autorização para a celebração desse tipo de casamento. Ou seja, as pessoas que consideravam o relacionamento moralmente errado tenderiam a não conceder a autorização para o casamento, enquanto as pessoas que não consideravam o relacionamento moralmente errado tenderiam à solução oposta.

Os participantes, após lerem as vinhetas (encontram-se integralmente expostas no Apêndice 2), responderam às seguintes perguntas:

(1) No caso de incesto:

Você, como juiz de Direito, decidiria a favor do pedido de Aline e Pedro?

(Respostas: sim/não)

Você acredita que Aline e Pedro podem ser verdadeiramente felizes em um relacionamento amoroso?

43 Os operadores do direito apresentaram uma taxa de escolaridade significativamente maior do que aqueles que não eram do Direito $(\mathrm{z}=-4.19, \mathrm{p}<.0001, \mathrm{p}($ ed(law $)>\operatorname{ed}($ other $))=.77)$.

44 Destaca-se que, diferentemente do Estudo apresentado no item "4.1", este foi desenvolvido, originalmente, no âmbito do NERDS.

45 No ordenamento jurídico brasileiro, é vedada a qualquer autoridade competente a recusa da celebração do casamento civil entre pessoas do mesmo sexo, desde a edição da Resolução n. ${ }^{\circ}$ 175, de 14 de maio de 2013 pelo Conselho Nacional de Justiça. Já o casamento incestuoso é vedado legalmente nos termos do artigo 1.521 do Código Civil, apesar de não haver a criminalização do relacionamento incestuoso em si. 
(Respostas: Definitivamente sim / Provavelmente sim / Talvez sim ou talvez não / Provavelmente não / Definitivamente não)

(2) No caso do casal homoafetivo:

(i) Você, como juiz de direito, decidiria a favor do pedido de Thiago e Marcelo?

(Respostas: sim/não)

(ii) Você acredita que Thiago e Marcelo podem ser verdadeiramente felizes em um relacionamento amoroso?

(Respostas: Definitivamente sim / Provavelmente sim / Talvez sim ou talvez não / Provavelmente não / Definitivamente não)

Para saber a posição moral dos participantes sobre cada tipo de relacionamento, pedimos que estes avaliassem, em uma escala de 5 pontos, o quanto acreditavam que duas pessoas seriam capazes de se manter felizes em uma série de cinco tipos de relacionamentos (homoafetivo, aberto, incestuoso, à distância e poliafetivo), que apareciam em ordem aleatória (está exposta no Apêndice 2). A inserção de outras modalidades de relacionamento - além daquelas elencadas na vinheta - teve como objetivo evitar que os participantes fizessem uma associação direta com a história que acabava de ser retratada na vinheta. Além disso, também pedimos que os participantes avaliassem, na mesma escala de 5 pontos, o quanto consideravam cada um dos cinco tipos de relacionamento acima elencados 'apropriado'. Optou-se por utilizar o termo apropriado para evitar que os participantes sentissem receio de utilizar a palavra 'moral', já que os dois expressariam a mesma ideia: o quanto aprovavam ou desaprovavam o tipo de relacionamento. Pretendeu-se analisar, então, a correlação entre a concessão da autorização para o casamento, o quanto os participantes consideravam o tipo de relacionamento em pauta apropriado e o quanto os participantes consideravam que as pessoas seriam capazes de se manter felizes no tipo específico de relacionamento descrito.

\subsubsection{Resultados obtidos}

Os resultados obtidos foram, novamente, bastante relevantes. Um total de 114 pessoas responderam ao questionário ${ }^{46}$. Em relação a estas, 63 responderam à vinheta que versava sobre o casal homoafetivo, Thiago e Marcelo; e 51 responderam à vinheta sobre o casal incestuoso, Pedro e Aline. A respeito dos que receberam a primeira vinheta, 56 concederiam o pedido para Thiago e Marcelo; enquanto, em relação aos que receberam a segunda vinheta, 36 concederiam o pedido para Pedro e Aline. Como esperávamos, a porcentagem de participantes que autorizariam o casamento incestuoso (67\%) foi menor do que a porcentagem dos participantes que autorizariam o casamento homoafetivo $(84 \%)^{47}$.

A diferença nas respostas à pergunta jurídica (ou seja, conceder ou não a autorização para o casamento) entre os casais homossexual e incestuoso foi explicada não apenas por diferenças na atribuição de felicidade, mas também — e de maneira ainda mais significativa — pela avaliação moral particular do participante acerca do tipo de relacionamento ${ }^{48}$. Quer dizer, quanto menos apropriado se considerava o relacionamento, menor era a chance de o participante conceder a autorização.

\footnotetext{
46 Não fizemos a separação entre juristas e não juristas porque muitas pessoas que responderam ao questionário não o completaram até o final, tornando o número de respostas à pergunta que identificava juristas e não-juristas insuficiente para uma análise com qualquer resultado significativo.

47 Essa diferença é estatisticamente significativa: $\chi^{2}(1, \mathrm{~N}=114)=4.75, \mathrm{p}<0.05$.

48 A análise demonstrou que a avaliação moral, em relação ao tipo de relacionamento, parece fazer mais diferença na concessão ou não da autorização para a celebração do casamento do que a avaliação da felicidade dos indivíduos retratados na vinheta. Foi construído um modelo de mediação dupla para avaliar quais fatores indiretos poderiam estar mediando a influência do caso (casal homoafetivo versus incestuoso) sobre a concessão do pedido. Esse modelo revelou que tanto a atribuição de felicidade (coeficiente do efeito indireto $=0,129)$ quanto a avaliação moral do tipo de relacionamento (coeficiente do efeito indireto $=0,313)$ influem na resposta dada ao caso jurídico, explicando a diferença entre ambos. T-tests independentes mostraram que a diferença entre casos na atribuição de felicidade é menor $(\mathrm{d}=1,12)$ do que a diferença na avaliação moral $(\mathrm{d}=1,58)$.
} 
Abaixo seguem os gráficos com os resultados das perguntas sobre o quão apropriado cada tipo de relacionamento era considerado, e o quanto se achava que indivíduos eram capazes de se manter felizes nesses tipos de relacionamento. Descartamos da análise a resposta em relação aos outros tipos de relacionamento (à distância, aberto e poliafetivo), tendo em vista que apenas os utilizamos com o objetivo de tirar o foco do participante da vinheta que acabava de ser respondida.

Gráfico 3 - Pergunta sobre o julgamento moral dos relacionamentos homoafetivo e incestuoso

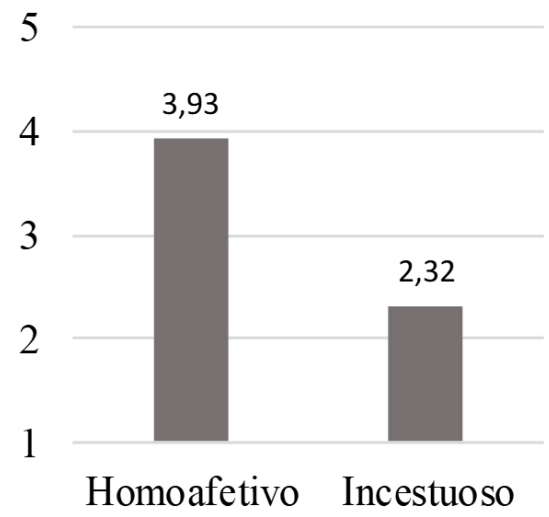

O quão apropriado você considera o tipo de relacionamento a seguir?

Gráfico 2 - Resultados da replicação com a divisão entre profissionais do direito e não profissionais do direito

Você acredita que duas pessoas são capazes de se manter felizes nos seguintes tipos de relacionamento?

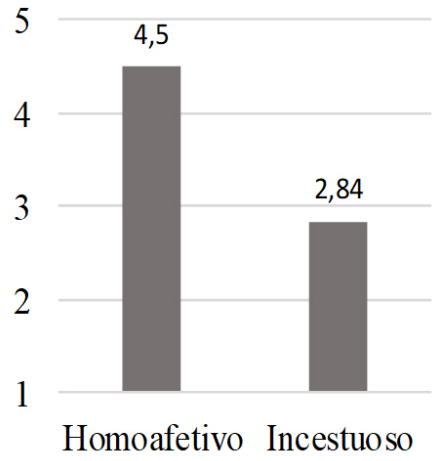

É possível notar que, além dos valores das respostas de ambas as perguntas terem sido semelhantes, a diferença entre as médias de avaliação também foi bastante parecida em ambas as perguntas. Enquanto a diferença nas médias de avaliação entre ambos os tipos de casamento na pergunta sobre o quanto os participantes consideravam-no apropriado foi de 1,61, a diferença na pergunta sobre o quanto os participantes acreditavam que indivíduos são capazes de se manter felizes no relacionamento foi de 1,66. A análise estatística desses resultados ${ }^{49}$ indica um alto grau de correlação entre o quanto os participantes consideravam o tipo de relacionamento mais ou menos apropriado e o quanto eles consideravam indivíduos capazes de se manter felizes nesse mesmo tipo de relacionamento.

\subsubsection{Discussão}

Os resultados deste último estudo sugerem que, assim como em situações que não envolvem tomadas

49 A correlação entre o quanto os participantes consideravam o tipo de relacionamento apropriado e o quanto eles consideravam indivíduos capazes de se manter felizes nesse mesmo tipo de relacionamento foi bastante significativa tanto nas respostas envolvendo incesto $(r=0.72, \mathrm{p}<0,001)$ quanto nas respostas envolvendo o relacionamento homoafetivo $(r=0.60, \mathrm{p}<0,001)$. 
de decisão jurídica, os julgamentos de felicidade são igualmente influenciados por avaliações morais quando em contextos decisórios jurídicos. Apesar de não ter restringido os participantes do estudo a profissionais do direito e, em particular, a juízes, acredita-se que não há qualquer indício de que nesses casos o resultado do estudo seria diferente. Como demonstrado no estudo de replicação, os indivíduos que têm conhecimento na área do direito apresentaram o mesmo padrão de resposta que os demais. Além disso, como também discutimos, não há razões para crer que o estudo do direito mitigue o efeito da influência da avaliação moral na utilização do conceito de felicidade. Pode-se dizer, portanto, que há fortes indicativos de que a utilização do conceito de felicidade no âmbito da aplicação do direito à busca pela felicidade variaria da mesma forma que a atribuição ordinária desse mesmo conceito.

A existência de dois componentes na atribuição (descritivo e valorativo) de felicidade pode trazer ao direito resultados indesejáveis, dentre os quais o desrespeito à segurança jurídica: devido à variedade de concepções morais de diferentes juízes, podem surgir decisões opostas em casos juridicamente semelhantes. Como o experimento demonstrou, se é proposta uma ação no País P com o objetivo de celebrar um casamento incestuoso, seria tão plausível um juiz conceder o pedido quanto não o conceder (na ausência de determinação legal mais específica). E essa diferença estaria longe de ser explicada por um julgamento objetivo. A grande questão é que o conceito de felicidade, como Isaiah Berlin bem colocou, "é tão poroso que há pouca interpretação que ele pareça ser capaz de resistir"50.

Esses resultados levantam questionamentos e reflexões bastante pertinentes e relevantes à realidade jurídica. Isso porque os autores e juristas, quando fazem a defesa de um direito à felicidade, parecem não levar em conta seu conceito ordinário. Saul Tourinho, autor do único livro no Brasil sobre direito e felicidade, afirma que falar em direito à felicidade não implica "navegar em um oceano moral" ${ }^{1}$. Contudo, as pesquisas empíricas tratadas neste artigo sugerem justamente o contrário: a inclusão do conceito de felicidade no direito, na prática, implica avaliações morais por parte dos responsáveis pelas decisões jurídicas. O que não faltam são bases teóricas e empíricas que permitem que essa afirmação seja feita.

Contudo, é importante ficar claro que a afirmação que se faz neste capítulo não é a de que, necessariamente - em todos os casos concretos —, o direito à felicidade será impactado, negativamente, por julgamentos morais, ou tampouco que a influência dos julgamentos morais em relação à utilização do conceito de felicidade não pode ser mitigada por meio de mecanismos projetados, especificamente, para tal finalidade (essas são questões para novos debates e estudos futuros). O que está se afirmando é que o julgamento ordinário de felicidade é, de fato, impactado, significativamente, por considerações de cunho moral; e isso constitui um fato que não pode ser ignorado.

\section{Considerações finais}

Embora a discussão sobre a felicidade tenha ganhado certo destaque no âmbito jurídico, os estudos que foram discutidos raramente são levados em consideração. Nesse contexto, este artigo tem como objetivo contribuir para que essa lacuna comece a ser preenchida. Pretendeu-se, utilizando o instrumental teórico da filosofia experimental, estreitar a relação entre o direito e a realidade ao incorporar aos estudos jurídicos algumas descobertas recentes envolvendo o conceito de felicidade.

As pesquisas realizadas com base na filosofia experimental trouxeram descobertas alarmantes para aqueles que defendem a positivação de um direito à felicidade. Verificou-se que o conceito ordinário de felicidade, quando aplicado para julgar a felicidade de terceiros, além de capturar estados psicológicos, também cede

50 Tradução livre. No original: "so porous that there is little interpretation that it seems to resist". Em: BERLIN, Isaiah. Liberty: incorporating four concepts of liberty. New York: Oxford University Press, 1969. p. 168.

51 LEAL, Saul Tourinho. Direito à felicidade. Rio de Janeiro: C\&C Criações e Textos, 2014. p. 284. 
espaço para a realização de julgamentos morais sobre a vida do agente. E isso não é diferente em relação aos operadores do direito, como foi demonstrado no estudo de replicação realizado. Embora já fosse suficientemente relevante descobrir que a avaliação de felicidade envolve conceitos morais, a questão ganha ainda maior relevo quando se revela que as concepções sobre uma vida moralmente boa/moralmente ruim são cruciais, também, para a tomada de decisões jurídicas com base na felicidade.

Positivar o direito à felicidade, portanto, pode trazer resultados indesejáveis para o direito, dentre os quais o desrespeito à segurança jurídica. Isso porque, devido à variedade de concepções morais de diferentes juízes, podem surgir decisões opostas em casos juridicamente semelhantes. Além disso, as decisões ficam sujeitas aos erros que todos estamos dispostos a incorrer quando realizamos julgamentos morais.

Assim, as decisões afastam-se, de maneira imperceptível e involuntária, da objetividade e imparcialidade que muitos assumem que deveriam revestir as decisões judiciais. As evidências apontam que separar o julgamento subjetivo e objetivo de felicidade não é tão simples quanto parece ser (se é que é possível). Justamente por isso, se há motivos para que haja preocupação em relação à aplicação, por juízes e outros tomadores de decisão no campo do direito, de suas respectivas bússolas morais pessoais no momento de decidir, é preciso adotar uma postura alarmada em relação à incorporação do conceito de felicidade no direito. Ainda que se entenda que o direito à felicidade deve ser garantido, os estudos apresentados continuam de grande valia. Isso porque é importante compreender que o direito tem a pretensão de prescrever condutas para indivíduos reais. Para que isso possa acontecer, é necessário que ele conheça a estrutura cognitiva dos agentes que ele pretende regular ${ }^{52}$. As pesquisas da filosofia experimental citadas neste artigo nos permitem compreender melhor como os indivíduos utilizam o conceito de felicidade. Sendo os resultados destes estudos úteis para a otimização do direito, não nos parece adequado simplesmente ignorá-los. Esses novos conhecimentos, conforme coloca Bronsteen, Buccafusco e Masur, precisam ser aplicados de maneira a aprimorar o direito e o entendimento da relação que este possui com a realidade ${ }^{53}$.

Não se buscou com este trabalho minimizar a importância da felicidade - muito pelo contrário, teve-se como objetivo demonstrar sua grande complexidade. Reconhece-se que a busca da felicidade é uma das mais importantes, se não a mais importante empreitada da humanidade. Contudo, sabendo que seria ingenuidade acreditar que a mera inserção da palavra "felicidade" na Constituição, de forma explícita ou implícita, garantiria a sua consagração na prática ${ }^{54}$, não vale a pena assumir os riscos da produção de resultados possivelmente desastrosos para o sistema jurídico.

\section{REFERÊNCIAS}

ALEXANDER, Joshua. Experimental philosophy: an introduction. Cambridge: Polity Press, 2012.

BAGARIC, Mirko; MCCONVILL, James. Goodbye justice, hello happiness: wilcoming positive psychology to the law. Deakin Law Review, v. 10, n. 1, 2005.

BERLIN, Isaiah. Liberty: incorporating four concepts of liberty. New York: Oxford University Press, 1969.

BRASIL. Supremo Tribunal Federal. ADI n. 3.300, Relator Ministro Celso de Mello; Supremo Tribunal Federal, RE n. ${ }^{\circ}$ 477.554; Superior Tribunal de Justiça, AREsp n. ${ }^{\circ}$ 578.562, Relator Ministro Napoleão Nunes

52 STRUCHINER, Noel; CHRISMANN, Pedro. Aspectos filosóficos e psicológicos das punições: reunindo algumas peças do quebra-cabeça. Caderno CRH, Salvador, v. 25, n. 2, p. 133-150, 2012.

53 BRONSTEEN, John; BUCCAFUSCO, Christopher; MASUR, Jonathan. Happiness and the Law. Chicago, The University of Chicago Press, 2015.

54 STRUCHINER, Noel; VASCONCELLOS, Úrsula. Direito e felicidade: algumas implicações da teoria comportamental. In: FORTES, Pedro; CAMPOS, Ricardo; BARBOSA, Samuel (Org.). Teorias contemporâneas do direito: o direito e as incertezas normativas. Curitiba: Juruá, 2016. v. 1. p. 259-278. 
Maia Filho; Superior Tribunal de Justiça, REsp n. ${ }^{\circ}$ 1428849, Relator Ministro Moura Ribeiro; Tribunal de Justiça do Rio de Janeiro, Agravo de Instrumento n. ${ }^{\circ}$ 0062505-37.2014.8.19.0000, Desembargador Antônio Carlos dos Santos Bitencourt; Tribunal de Justiça do Rio de Janeiro, Apelação n. ${ }^{\circ}$ 0033507-63.2013.8.19.0204, Desembargador Bernardo Moreira Garcez Neto.

BRONSTEEN, John; BUCCAFUSCO, Christopher; MASUR, Jonathan. Happiness and the law. Chicago: The University of Chicago Press, 2015.

DIAS, Maria Berenice. Direito fundamental à felicidade. Revista Interdisciplinar de Direito da Faculdade de Direito de Valença, v. 8, p. 201-205, 2010.

FELDMAN, Fred. What is this thing called happiness? New York: Oxford University Press, 2010.

FOOT, Philippa. Natural goodness. New York: Oxford University Press, 2001.

FREY, Bruno. Happiness: a revolution in economics. Massachusetts: MIT Press, 2008.

GILBERT, Dan. Stumbling on happiness. New York: Vintage Books, 2006.

HAYBRON, Daniel. Happiness. The stanford encyclopedia of philosophy. Ed. Edward N. Zalta. 2011. Disponível em: <https://plato.stanford.edu/archives/fall2011/entries /happiness/>.

HAYBRON, Daniel. The pursuit of unhappiness: the elusive psychology of well-being. New York: Oxford University Press, 2010.

HAYBRON, Daniel. The pursuit of unhappiness: the elusive psychology of well-being. New York: Oxford University Press, 2010.

KAHNEMAN, Daniel. Daniel Kahneman: the riddle of experience vs. memory, 2010. Disponível em:<https:// www.ted.com/talks/daniel_kahneman_the_riddle_of_experience_vs_memory?language $=\mathrm{em}>$. Acesso em: 20 maio 2018.

KAHNEMAN, Daniel. Experienced utility and objective happiness: a moment-based approach. In: Choices, values and frames. New York: Cambridge University Press and the Russell Sage Foundation, 2000.

KNOBE, Joshua; NICHOLS, Shaun. An experimental philosophy manifesto. In: (Org.). Experimental philosophy. New York: Oxford University Press, 2008.

LEAL, Saul Tourinho. Direito à felicidade. Rio de Janeiro: C\&C Criações e Textos, 2014.

PETERSON, Christopher; PARK, Nansook; SELIGMAN, Martin. Orientations to happiness and life satisfaction: the full life versus the empty life. Journal of Happiness Studies, 2005.

PHILLIPS, Johnathan et al. True happiness: the role of morality in the folk concept of happiness. Journal of Experimental Psychology: General, v. 146, n. 2, p. 165-181, Feb. 2017.

PHILLIPS, Jonathan; MISENHEIMER, Luke; KNOBE, Joshua. The ordinary concept of happiness. Emotion Review, California, Sage Publications USA, v. 3, n. 3. 2011.

PHILLIPS, Jonathan; NYHOLM, Sven; LIAO, Shen-yi. The good in happiness. In: Oxford studies in experimental philosophy. Oxford: Oxford University Press, 2014. v. 1.

POSNER, Eric; SUNSTEIN, Cass (Ed.). Law and happiness. Chicago: The University of Chicago, 2010.

STRUCHINER, Noel; CHRISMANN, Pedro. Aspectos filosóficos e psicológicos das punições: reunindo algumas peças do quebra-cabeça. Caderno CRH, Salvador, v. 25, n. 2, p. 133-150, 2012.

STRUCHINER, Noel; VASCONCELLOS, Úrsula. Direito e felicidade: algumas implicações da teoria comportamental. In: FORTES, Pedro; CAMPOS, Ricardo; BARBOSA, Samuel. (Org.). Teorias contemporâneas do direito: o direito e as incertezas normativas. Curitiba: Juruá, 2016. v. 1. 
SUIKKANEN, Jussi. An improved whole life satisfaction theory of happiness. International Journal of Wellbeing, v. 1, n. 1, 2011.

\section{Apêndice A - Vinhetas utilizadas para a Realização do estudo de Replicação (Item "4.1")}

\section{Felicidade/Vida boa}

Maria é mãe de três crianças que a amam verdadeiramente. Elas, inclusive, não conseguem se imaginar tendo uma mãe melhor. Maria geralmente está ocupada cuidando dos seus filhos. Ela frequentemente se encontra correndo de um aniversário para outro, e está sempre indo comprar algumas verduras ou materiais escolares. Enquanto Maria se preocupa com seus filhos, ela ocasionalmente consegue um tempinho para encontrar seus amigos. Quase toda noite ela acaba se dedicando a algum projeto para o dia seguinte ou planejando algo para o futuro dos seus filhos. Diariamente, Maria costuma se sentir empolgada e aproveitar as atividades que faz. Quando ela reflete sobre sua vida, ela também se sente ótima. Ela não consegue pensar em nada no mundo que preferiria estar fazendo e sente que o sucesso que ela vem tendo em sua vida vale, definitivamente, quaisquer sacrifícios que ela tenha feito.

Perguntas:

"Você acha que Maria é feliz?"

"Comparado às outras pessoas, você acha que Maria tem uma vida boa?"

\section{Felicidade/Vida ruim}

Maria quer viver a vida de uma celebridade em Los Angeles. Ela inclusive vem tentando marcar encontros com pessoas famosas. Maria normalmente está ocupada tentando se tornar popular. Ela frequentemente se encontra correndo de uma festa para outra, e está sempre tentando conseguir bebidas alcóolicas ou vestidos. Maria se preocupa tanto em se tornar popular que ela não se importa mais em ser honesta ou gentil com seus antigos amigos, a não ser que eles conheçam alguém famoso. No fim de quase todas as noites ela acaba bêbada ou usando algum tipo de droga, exatamente como as pessoas famosas as quais ela quer ser igual. Diariamente, Maria costuma se sentir empolgada e aproveitar as atividades que faz. Quando ela reflete sobre sua vida, ela também se sente ótima. Ela não consegue pensar em nada no mundo que preferiria estar fazendo e sente que o sucesso que ela vem tendo em sua vida vale, definitivamente, quaisquer sacrifícios que ela tenha feito. Quando Maria conta ao seu melhor amigo que ela se sente dessa forma, ele fica confuso e pergunta: "Do que você está falando?".

Perguntas:

"Você acha que Maria é feliz?"

"Comparado às outras pessoas, você acha que Maria tem uma vida boa?"

\section{Infelicidade/Vida boa}

Maria é mãe de três crianças que a amam verdadeiramente. Elas, inclusive, não conseguem se imaginar tendo uma mãe melhor. Maria geralmente está ocupada cuidando dos seus filhos. Ela frequentemente se encontra correndo de um aniversário para outro, e está sempre indo comprar algumas verduras ou materiais 
escolares. Enquanto Maria se preocupa com seus filhos, ela ocasionalmente consegue um tempinho para encontrar seus amigos. Quase toda noite ela acaba se dedicando a algum projeto para o dia seguinte ou planejando algo para o futuro dos seus filhos. Mas quando Maria reflete sobre sua vida, ela se sente muito mal. Ela não consegue parar de pensar no fato de que as pessoas com as quais ela mais se importa estão sempre mentindo para ela. Ela se sente ainda pior quando começa a pensar que as pessoas que ela mais ama provavelmente preferem drogas a ela.

Perguntas:

"Você acha que Maria é feliz?"

"Comparado às outras pessoas, você acha que Maria tem uma vida boa?"

\section{Infelicidade/Vida ruim}

Maria quer viver a vida de uma celebridade em Los Angeles. Ela inclusive vem tentando marcar encontros com pessoas famosas. Maria normalmente está ocupada tentando se tornar popular. Ela frequentemente se encontra correndo de uma festa para outra, e está sempre tentando conseguir bebidas alcóolicas ou vestidos. Maria se preocupa tanto em se tornar popular que ela não se importa mais em ser honesta ou gentil com seus antigos amigos, a não ser que eles conheçam alguém famoso. No fim de quase todas as noites ela acaba bêbada ou usando algum tipo de droga, exatamente como as pessoas famosas as quais ela quer ser igual. Mas quando Maria reflete sobre sua vida, ela se sente muito mal. Ela não consegue parar de pensar no fato de que as pessoas com as quais ela mais se importa estão sempre mentindo para ela. Ela se sente ainda pior quando começa a pensar que as pessoas que ela mais ama provavelmente preferem drogas a ela.

Perguntas:

"Você acha que Maria é feliz?"

"Comparado às outras pessoas, você acha que Maria tem uma vida boa?"

\section{Apêndice B - Vinhetas utilizadas para a realização do estudo envolvendo a aplicação DO DIREITO À FELICIDADE (ITEM “4.2")}

\section{Vinheta versando sobre o incesto}

Aline, enquanto estava passeando na praça perto de sua casa no País P, conheceu Pedro, 18 anos mais velho do que ela. Aline sofria de um quadro severo de depressão por ter se sentido negligenciada durante toda sua vida. Aline, que enquanto criança havia sido criada apenas por sua mãe, se viu completamente abandonada quando, com apenas 8 anos, sua mãe decidiu sair de casa para se aventurar pelo mundo deixando-a aos cuidados dos seus avós maternos. Justamente por isso, Aline, até então, nunca havia se apegado a pessoa alguma, quanto mais se apaixonado. Contudo, quando conheceu Pedro, apenas com uma troca de olhares, estava certa de que havia encontrado o amor da sua vida. Pedro se sentia exatamente da mesma forma. Ambos cultivaram, durante 5 anos, um relacionamento muito saudável e respeitoso, que deixou ambos realizados. Findo esse período, decidiram se casar. Aline, certa de que esse era um momento único na sua vida, decidida a deixar de lado a mágoa que sentia em relação à sua mãe, convidou-a para o seu casamento. No dia da cerimônia, contudo, houve uma grande descoberta, que Aline ou Pedro sequer podiam imaginar: a mãe de Aline reconheceu Pedro como o seu namorado de adolescência, que a havia abandonado grávida. Pedro era o pai de Aline. Tendo sido feita a revelação, o juiz de paz se recusou a celebrar o casamento de 
ambos, com base na alegação de que um ascendente e o seu descendente jamais poderiam constituir um vínculo matrimonial. Alegou ser impossível tanto com base nas leis de Deus, quanto com base nas leis civis. Contudo, a legislação do País P não faz qualquer previsão acerca do casamento celebrado entre ascendente e descendente. Segue o único artigo que dispõe sobre o casamento no País P:

Art. 8. O casamento se realiza no momento em que o homem e a mulher manifestam, perante o juiz, a sua vontade de estabelecer vínculo conjugal, e o juiz os declara casados.

Pedro e Aline, mesmo sabendo serem pai e filha, decidem que querem contrair o matrimônio. Eles reconhecem que, apesar da revelação feita pela mãe de Aline, nada os fará mais felizes e completos. Por esse motivo, ingressam com uma ação na justiça, objetivando obter uma autorização para a celebração do casamento. Sua fundamentação se dá exclusivamente com base no artigo 40 da Constituição do País P, que consagra a todos os cidadãos do País $\mathrm{P}$ o direito à busca da felicidade, ao prever que todos os indivíduos do país têm o direito a perseguir e viver uma vida feliz. Eles destacam, na petição, que não há qualquer dispositivo que pró́ba, expressamente, o casamento entre ascendente e descendente. Cabe destacar que o incesto é um assunto bastante controvertido tanto dentro quanto fora do Poder Judiciário do País P, havendo uma clara divisão entre os juízes que decidem de forma favorável e os que decidem de forma contrária à sua autorização.

Perguntas:

"Você, como juiz de Direito, decidiria a favor do pedido de Aline e Pedro?"

(Respostas: sim/não)

9ii) "Você acredita que Aline e Pedro podem ser verdadeiramente felizes em um relacionamento amoroso?"

(Respostas: Definitivamente sim / Provavelmente sim / Talvez sim ou talvez não / Provavelmente não / Definitivamente não)

\section{Vinheta versando sobre o casamento homoafetivo}

No País P, Thiago sofria de um quadro severo de depressão por ter se sentido negligenciado durante toda sua vida. Thiago, que enquanto criança havia sido criado apenas por sua mãe, se viu completamente abandonado quando, com apenas 8 anos, sua mãe decidiu sair de casa para se aventurar pelo mundo deixando-o aos cuidados dos seus avós. Justamente por isso, Thiago, até então, nunca havia se apegado a pessoa alguma, quanto mais se apaixonado. Contudo, quando conheceu Marcelo, apenas com uma troca de olhares, estava certo de que havia encontrado o amor da sua vida. Marcelo se sentia exatamente da mesma forma. Ambos cultivaram, durante 5 anos, um relacionamento muito saudável e respeitoso, que deixou ambos realizados. Estando certos de desejarem passar o resto das suas vidas juntos, eles pretendem oficializar sua união. Contudo, chegando ao cartório, a funcionária se recusou a celebrar o casamento de ambos, com base na alegação de que dois homens jamais poderiam constituir um vínculo matrimonial. Alegou ser impossível tanto com base nas leis de Deus, quanto com base nas leis civis. Contudo, a legislação do País P apenas prevê expressamente o casamento entre um homem e uma mulher, não fazendo qualquer previsão acerca do casamento celebrado entre dois homens. Segue o único artigo que dispõe sobre o casamento no País P:

Art. 8. O casamento se realiza no momento em que o homem e a mulher manifestam, perante o juiz, a sua vontade de estabelecer vínculo conjugal, e o juiz os declara casados.

Sabendo que essa união é de grande relevância para ambos, Thiago e Marcelo ingressam com uma ação na justiça, objetivando obter uma autorização para a celebração do casamento. Sua fundamentação se dá exclusivamente com base no artigo 40 da Constituição do País P, que consagra a todos os cidadãos do País $\mathrm{P}$ o direito à busca da felicidade, ao prever que todos os indivíduos do país têm o direito a perseguir e viver 
uma vida feliz. Eles destacam, na petição, que não há qualquer dispositivo que proíba, expressamente, o casamento entre indivíduos do mesmo sexo. Cabe destacar que o casamento homoafetivo é um assunto bastante controvertido tanto dentro quanto fora do Poder Judiciário do País P, havendo uma clara divisão entre os juízes que decidem de forma favorável e os que decidem de forma contrária à sua celebração.

Perguntas:

(i) "Você, como juiz de direito, decidiria a favor do pedido de Thiago e Marcelo?"

(Respostas: sim/não)

(ii) "Você acredita que Thiago e Marcelo podem ser verdadeiramente felizes em um relacionamento amoroso?"

(Respostas: Definitivamente sim / Provavelmente sim / Talvez sim ou talvez não / Provavelmente não / Definitivamente não)

\section{Tabela para descrever a capacidade de pessoas se manterem felizes em certos tipos de relacionamento}

Pergunta: você acredita que duas pessoas são capazes de se manterem felizes nos seguintes tipos de relacionamento?

\begin{tabular}{|c|c|c|c|c|c|}
\hline & $\begin{array}{l}\text { Definitivamente } \\
\text { sim }\end{array}$ & $\begin{array}{l}\text { Provavelmente } \\
\text { sim }\end{array}$ & Talvez & $\begin{array}{l}\text { Provavelmente } \\
\text { não }\end{array}$ & $\begin{array}{l}\text { Definitivamente } \\
\text { não }\end{array}$ \\
\hline $\begin{array}{l}\text { Homoafetivo } \\
\text { (relacionamento } \\
\text { entre duas pessoas } \\
\text { do mesmo sexo) }\end{array}$ & & & & & \\
\hline $\begin{array}{l}\text { Aberto } \\
\text { (relacionamento } \\
\text { em que ambos os } \\
\text { parceiros concor- } \\
\text { dam que o outro } \\
\text { pode ter relações } \\
\text { afetivas/sexuais } \\
\text { com terceiros } \\
\text { sem que isso seja } \\
\text { considerado uma } \\
\text { traição) }\end{array}$ & & & & & \\
\hline $\begin{array}{l}\text { Incestuoso } \\
\text { (relacionamento } \\
\text { entre parentes } \\
\text { próximos, incluin- } \\
\text { do entre ascenden- } \\
\text { te e descendente) }\end{array}$ & & & & & \\
\hline À distância & & & & & \\
\hline
\end{tabular}




\begin{tabular}{|l|l|l|l|l|}
\hline Poliafetivo & & & & \\
(relacionamento & & & & \\
entre três ou mais & & & & \\
indivíduos, em que & & & & \\
cada indivíduo se & & & & \\
relaciona com to- & & & & \\
dos os demais) & & & & \\
\hline
\end{tabular}

\section{Tabela para indicar o quanto apropriado se considera certos tipos de relacionamento}

Pergunta: indique o quão apropriado você considera cada tipo de relacionamento a seguir:

\begin{tabular}{|l|l|l|l|l|l|}
\hline & $\begin{array}{l}\text { Muito } \\
\text { apropriado }\end{array}$ & $\begin{array}{l}\text { Razoavelmente } \\
\text { apropriado }\end{array}$ & $\begin{array}{l}\text { Nem apropria- } \\
\text { do nem inapro- } \\
\text { priado }\end{array}$ & $\begin{array}{l}\text { Razoavelmente } \\
\text { inapropriado }\end{array}$ & $\begin{array}{l}\text { Muito } \\
\text { inapropriado }\end{array}$ \\
\hline Homoafetivo & & & & & \\
\hline Aberto & & & & & \\
\hline Incestuoso & & & & & \\
\hline À distância & & & & & \\
\hline Poliafetivo & & & & & \\
\hline
\end{tabular}




\section{REVISTA BRASILEIRA DE POLÍTICAS PÚBLICAS BRAZILIAN JOURNAL OF PUBLIC POLICY}

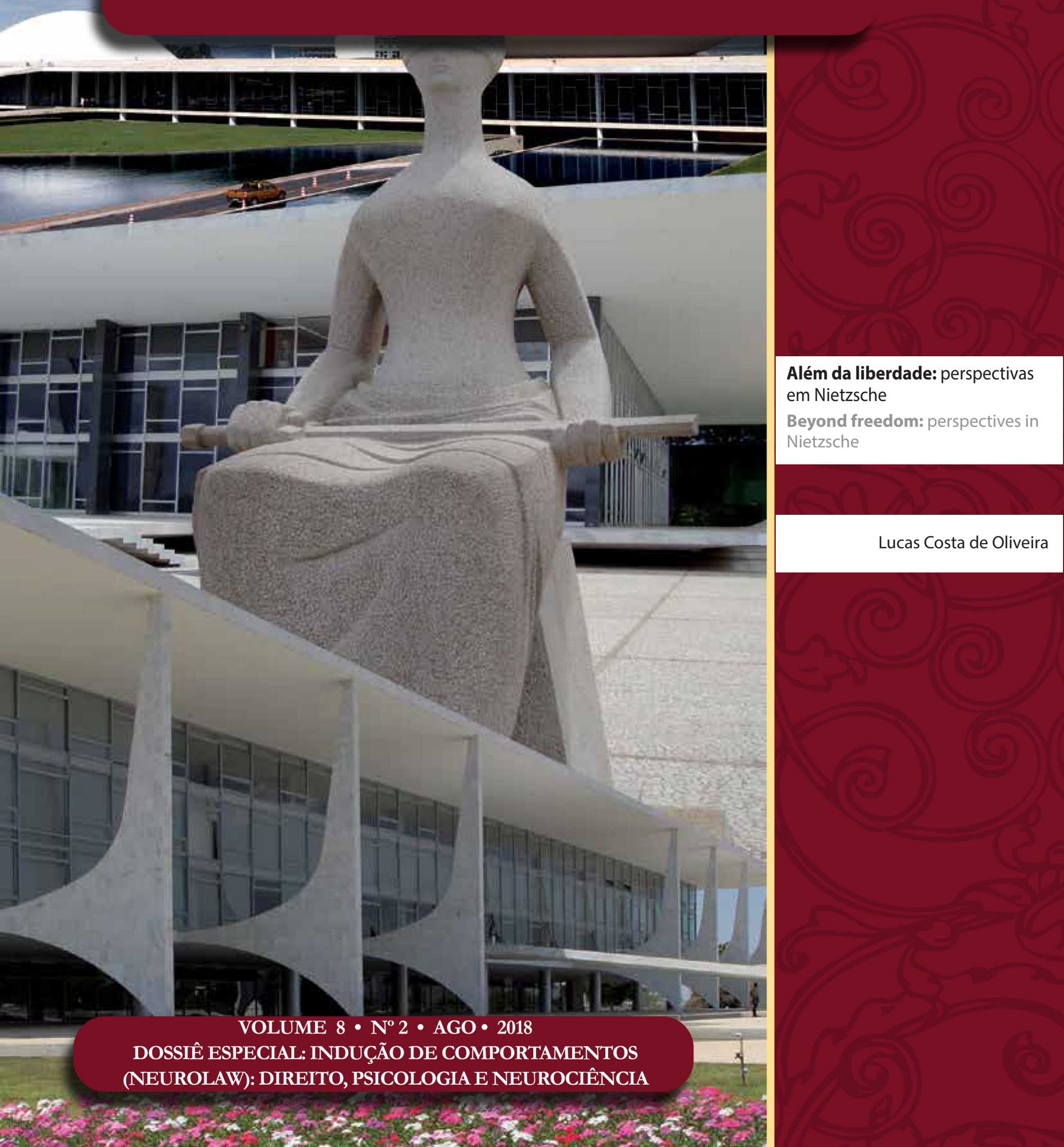




\section{Além da liberdade: perspectivas em Nietzsche*}

\section{Beyond freedom: perspectives in Nietzsche}

Lucas Costa de Oliveira**

Não é o menor atrativo de uma teoria o ser confutável: precisamente por isso atrai os cérebros mais requintados. Parece-me que a teoria, cem vezes refutada, do "livre-arbítrio", só subsiste em virtude de tal atrativo: sempre chega alguém de novo que se sente como força bastante para refutá-la. ${ }^{1}$

\section{Resumo}

O presente artigo pretende analisar a temática da liberdade em relação ao pensamento de Friedrich Nietzsche. Partindo do seu perspectivismo epistemológico, busca-se apresentar duas concepções de liberdade encontradas na obra do filósofo: a liberdade negativa e a liberdade positiva. A primeira é aquela fundada no transcendente, no ressentimento dos fracos contra a moralidade dos fortes; absorvida e difundida pelos sacerdotes em seu desejo de punição e de julgamento. A segunda é a liberdade artística ou criadora, relacionada com o projeto mais amplo de transvaloração dos valores, visando a uma moralidade afirmativa da vida. Assim, a hipótese defendida neste artigo é a de que Nietzsche busca desenvolver uma ideia de liberdade para além do conceito de "liberdade" estabelecido até então: um modelo de liberdade que eleve os homens às alturas, que possibilite uma vida afirmativa. Ao final, os principais argumentos desenvolvidos são retomados para confirmar a hipótese levantada.

Palavras-chave: Liberdade. Livre-arbítrio. Determinism. Nietzsche. Perspectivismo.

\section{Abstract}

The present paper intends to analyze the thematic of freedom in the thought of Friedrich Nietzsche. From his epistemological perspectivism, it is presented two conceptions of freedom found in his philosophical work: the negative freedom and the positive freedom. The first is the one founded in the transcendent, in the resentment of the weak against the morality of the strong; absorbed and spread by the priests in their desires of punishment and judgement. The second is the artistic or creative freedom, related with the broader project of transvaluation of values, aiming an affirmative morality of life. Thus, the hypothesis defended in this paper is that Nietzsche seeks to develop an idea of freedom beyond the concept of "freedom" established until then: a model of freedom that elevates the men to the

1 NIETZSCHE, Friedrich. Além do bem e do mal. Rio de Janeiro: Vozes, 2012. p.31.

** Doutorando em Direito pela UFMG. Mestre em Direito Privado pela PUC Minas. Graduado em Direito pela UFOP. Professor Adjunto de Direito Civil na UNIPAC, campus Mariana.

E-mail: lucascoliveira01@gmail.com
* Recebido em 20/03/2018 Aprovado em 13/04/2018 
heights, that enables an affirmative view of life. In the end, the main arguments developed are resumed to confirm the hypothesis initially presented.

Keywords: Freedom. Free will. Determinism. Nietzsche. Perspectivism.

\section{INTRODUÇÃo}

A investigação de tópicos específicos no pensamento de Friedrich Nietzsche é sempre uma tarefa árdua. A dificuldade emerge devido ao caráter deliberadamente antissistemático de sua abordagem filosófica, subvertendo o tratamento canônico ao qual temas tradicionais eram analisados. ${ }^{2}$ Desse modo, "uma imagem significativa é que a filosofia de Nietzsche assemelha-se a um quebra-cabeça filosófico onde uma visão global se mostra improvável ou até impossível num todo coerente, mas vai se desvelando num lento processo de compreensão em temas tão constantes que pareceria até uma monotonia". ${ }^{3}$

Essa característica possui estreita relação com a orientação epistemológica adotada pelo filósofo, conhecida como perspectivismo — doutrina que afirma não haver fatos, mas apenas interpretações. É possível indicar como principais fontes do perspectivismo: a dissolução da ideia de substância e a suspeita dirigida à cristalização semântica da linguagem. Pela primeira, entende-se que não existem fatos puros, empíricos ou racionais, mas apenas apropriações humanas de tais fatos; ao passo que pela segunda, entende-se que a crença na existência de fatos ou evidências ocorre no âmbito do uso da linguagem. ${ }^{4}$ Nesse sentido, importante é o seguinte aforismo apresentado por Nietzsche em "A gaia ciência", primeira menção expressa do termo "perspectivismo" em sua obra: ${ }^{5}$

Todas as nossas ações, no fundo, são pessoais de maneira incomparável, únicas, ilimitadamente individuais, não há dúvida; mas tão logo as traduzimos para a consciência, não parecem mais sê-lo... Este é o verdadeiro fenomenalismo e perspectivismo, como $e$ o entendo: a natureza da consciência animal ocasiona que o mundo de que podemos nos tornar conscientes seja só um mundo generalizado, vulgarizado que tudo o que se torna consciente por isso mesmo torna-se raso, ralo, relativamente tolo, geral, signo, marca de rebanho, que a todo tornar-se consciente está relacionada uma grande, radical corrupção, falsificação, superficialização e generalização. ${ }^{6}$

Essa breve contextualização é importante para evidenciar que os escritos de Nietzsche são repletos de posições divergentes, inconsistências e contradições - sejam estas aparentes ou não. Todavia, mesmo com objeções relacionadas à "falta de coerência sistêmica do pensamento nietzschiano, avesso a toda lógica", faz-se necessário "buscar uma coesão possível dentro dos seus paradoxos e antagonismos".?

Tendo em vista as variadas perspectivas desenvolvidas por Nietzsche a respeito da liberdade, ${ }^{8}$ o presente

2 PIMENTA, Olímpio. Raz̃ão e conbecimento em Descartes e Nietəsche. Belo Horizonte: UFMG, 2000. p.71

3 ALVES, Luiz Filipe Araújo. A ideia de justiça em Niețşche: ou a justiça para além da ideia. 2016. Tese (Doutorado) - Faculdade de Direito, Universidade Federal de Minas Gerais, Belo Horizonte, 2016. p. 36.

4 PIMENTA, Olímpio. Razão e conbecimento em Descartes e Nietżsche. Belo Horizonte: UFMG, 2000. p.74-77. No mesmo sentido: “o Perspectivismo não é a contemplação parcial de um objeto verdadeiro. O Perspectivismo não é um ponto de vista da realidade, seja a partir propriamente do real, ou do transcendental. Pelo contrário, 'dizer que todo conhecimento é perspectivo significa negar que as coisas tenham uma essência, já que não há uma vontade divina para criá-la, um olhar divino para contemplá-la, uma inteligência divina para pensá-la”'. ALVES, Luiz Filipe Araújo. A ideia de justiça em Nietşsche: ou a justiça para além da ideia. 2016. Tese (Doutorado) - Faculdade de Direito, Universidade Federal de Minas Gerais, Belo Horizonte, 2016. p. 43.

5 ALVES, Luiz Filipe Araújo. A ideia de justiça em Nieţşche: ou a justiça para além da ideia. 2016. Tese (Doutorado) - Faculdade de Direito, Universidade Federal de Minas Gerais, Belo Horizonte, 2016. p. 46.

6 NIETZSCHE, Friedrich. A gaia ciência: do "gênio da espécie". Tradução de Paulo César de Souza. São Paulo: Cia das Letras, 2001. p. 247-250.

7 ALVES, Luiz Filipe Araújo. A ideia de justiça em Nietæșche: ou a justiça para além da ideia. Tese (Doutorado) - Faculdade de Direito, Universidade Federal de Minas Gerais, 2016. p. 37.

8 ANDERSON, Lanier R. Nietssche on autonomy: the Oxford handbook of Nietzsche. Oxford: Oxford University Press, 2013. p. 567-605. No artigo mencionado, Lanier Anderson apresenta um panorama geral das variadas concepções sobre liberdade e autono- 
artigo busca analisar duas posições mais radicais em seu pensamento: a negação da liberdade e a afirmação da liberdade. ${ }^{9}$ Partindo da sua filosofia a marteladas, Nietzsche pretende desconstruir conceitos tradicionais e metafísicos com base na genealogia dos valores. Ao demonstrar que a origem da ideia de liberdade é o ressentimento com a vida e o instinto-de-querer-punir-e-julgar, entende que não existe livre-arbítrio, ou mesmo vontade — tudo é necessário e determinado. É nessa perspectiva que se fala em uma liberdade negativa. Mas sua tarefa não se exaure nesse ponto: também propõe uma transvaloração dos valores, sempre em busca de uma moralidade mais elevada que possibilite a cada um se tornar quem é. Nessa perspectiva, fala-se em uma liberdade afirmativa ou artística.

Em razão dos argumentos até aqui apresentados, é possível afirmar que a proposta de Nietzsche envolve o desenvolvimento de uma ideia de liberdade para além da "liberdade". Explica-se: por mais que exista uma investigação genealógica a respeito da liberdade, buscando sua origem e fundamentos, descontruindo a noção de uma causa sui, o propósito central da filosofia nietzschiana é a transvaloração dos valores, a criação de novos valores superiores criados pelas próprias pessoas em uma postura afirmativa da vida:

[...] ao invés de procurar estabelecer alguma 'lei universal' ou 'imperativo categórico', nos 'limitemos' a algo completamente diferente, ao mesmo tempo menos 'egoísta' e mais importante: 'a criação das nossas próprias novas tábuas de valores sobre o que é bom', como 'seres humanos que são novos, únicos, incomparáveis, que se dão as próprias leis, que criam a si próprios' e, então, 'tornam-se aqueles que são.'10

Esse será, portanto, o caminho a ser percorrido por este breve artigo: da genealogia à transvaloração dos valores; da liberdade negativa à liberdade positiva, da liberdade para além da "liberdade".

\section{A LiBerdade NEgATiva}

O estudo sobre a liberdade negativa sob a perspectiva nietzschiana passa por dois pontos centrais: a análise genealógica da liberdade moral e a crítica das noções da linguagem moral. Ao analisar esses tópicos, será possível identificar as fontes do conceito de liberdade e a finalidade pretendida por aqueles que se apropriaram dessa ideia. Além da análise genealógica, Nietzsche também realiza uma contundente crítica a diversas noções da linguagem moral, como liberdade, livre-arbítrio, subjetividade, causalidade, substancialidade, vontade e outras, com o intuito de demonstrar a fragilidade desses conceitos, típicos de uma moralidade de rebanho, preparando o terreno para sua tarefa posterior de transvaloração dos valores.

Ao realizar uma dedicada investigação sobre a genealogia da liberdade no pensamento de Nietzsche, Miguel Barrenechea apresenta os principais aspectos que fundamentam o surgimento da ideia de liberdade. O referido conceito somente pode ser pensado com base em uma doutrina transcendente, fundada no além. Assim, o conceito de livre-arbítrio passa a ser utilizado pelos discursos morais e religiosos como forma de consolidar o poder sacerdotal no controle do rebanho. Contudo, é o ressentimento da casta sacerdotal, adeptos de uma moralidade fraca, direcionada ao ódio contra a vida terrena em razão de sua impotência de viver uma vida afirmativa, que vai atribuir uma concepção repressiva ao termo. Nesse sentido, a liberdade se torna um mecanismo que tem como objetivo primário o controle, o castigo e a punição. A análise genealógica da liberdade é central para o desenvolvimento dos argumentos posteriores, portanto, cada elemento será analisado de maneira mais atenta. ${ }^{11}$

mia desenvolvidas por Nietzsche e seus intérpretes (e.g. autonomia como autodeterminação espontânea; autonomia como um ideal ético; autonomia como fonte de normatividade; autonomia como uma modelo hierárquico de interpretações etc).

9 BARRENECHEA, Miguel Angel. Nietzsche e a liberdade. 2. ed. Rio de Janeiro: 7 Letras, 2008.

10 SCHACHT, Richard.Nietzsche. The arguments of the philosophers. London: Routledge, 2002. p. 466, (Tradução nossa): “[...] in place of seeking to establish some 'universal law' or 'categorical imperative', we 'limit ourselves' to something quite different, at once less 'selfish' and more important: 'to the creation of our own new tables of what is good' as 'buman beings who are new, unique, incomparable, who give themselves laws, who create themselves' and so 'become those we are".'

11 BARRENECHEA, Miguel Angel. Nietzsche e a liberdade. 2. ed. Rio de Janeiro: 7 Letras, 2008. p. 15. 
Como já mencionado, somente é possível atribuir prêmios e castigos ao homem se este possui liberdade: "será mister, para esta estratégia diretiva, que os homens acreditem na liberdade, para serem responsabilizados, julgados e castigados, pois um indivíduo completamente determinado pelas forças naturais não poderia ser imputado pelo resultado das suas ações". ${ }^{12}$ Todavia, para que um indivíduo acredite na liberdade, faz-se necessário que também acredite na existência de uma substância ou essência distinta das demais presentes na natureza, rompendo com a determinação causada pelas forças naturais. Desse modo, "a condição fundamental para afirmar a liberdade humana consiste na existência do 'além', de um mundo transcendente ao qual o homem livre estaria vinculado". ${ }^{13}$ Se homem é dotado de uma essência transcendente e divina, pode ser considerado livre e autônomo, pode manifestar uma vontade causada exclusivamente pelo seu próprio arbítrio, pode dominar e controlar todos os seus impulsos animais. Essa ideia fica clara no seguinte aforismo de "O anticristo":

Noutros tempos concedia-se ao homem o «livre-arbítrio» como um dote de um mundo superior; hoje, até a vontade lhe retirámos, na medida em que não se pode ser mais entendida no sentido de um atributo. $\mathrm{O}$ antigo termo «vontade» já só serve para designar uma resultante, uma espécie de reacção individual que necessariamente se segue a um conjunto de excitações concordantes ou contraditórias - a vontade já não «age» nem «agita»... Outrora via-se na consciência do homem, no seu «espírito», a prova da sua origem superior, da sua divindade; para aperfeiçoar o homem aconselhavam-no, à semelhança da tartaruga, a recolher seus sentidos em si mesmo, a suprimir as relações com o mundo terrestre, a desprender-se do seu «invólucro mortal»: então não ficaria dele senão o essencial, o «espírito puro». ${ }^{14}$

Nietzsche imputa Sócrates como o precursor de uma racionalidade pura em detrimento dos valores naturais, concepção que seria mais tarde desenvolvida por Platão em sua defesa de um mundo inteligível. Assim, a verdadeira liberdade somente poderia ser alcançada no afastamento do mundo sensível, das vicissitudes, pulsões e desejos que habitam o corpo humano e escravizam o indivíduo. ${ }^{15}$ A negação do terreno e a ascensão ao transcendente: esse seria o único caminho para atingir a liberdade. Sem sombra de dúvidas, Nietzsche vai proferir diversos ataques a essa dualidade, à preponderância de um mundo inteligível sobre o mundo terreno e à própria existência de um além: "Que sentido têm aqueles conceitos mentirosos, os conceitos auxiliares, de moral, 'alma', 'espírito', 'livre-arbítrio', 'Deus', senão o de arruinar fisiologicamente a humanidade?" ${ }^{16}$ Não obstante, a tarefa de desconstruir esses conceitos ficará para um segundo momento. Por ora, cabe salientar que o primeiro aspecto da genealogia moral da liberdade consiste na sua fundamentação e crença no além.

Em "A genealogia da moral" são apresentadas maneiras divergentes e antinômicas de valoração moral: uma é nascida da força, promove uma postura afirmativa da vida terrena, permite a manifestação dos instintos e pulsões, sendo identificada na imagem de uma ave de rapina; enquanto a outra é oriunda da fraqueza, busca um ideal ascético, incentiva a negação da vida terrena em prol de um mundo transcendente, impõe obstáculos aos desejos e impulsos animais, sendo identificada na imagem de um cordeiro. ${ }^{17}$ Essa dualidade valorativa pode ser observada no seguinte trecho: "Que os cordeiros tenham horror às aves de rapina, compreende-se; mas não é uma razão para querer mal às aves de rapina que arrebataram os cordeirinhos." ${ }^{18}$

Ressentidos com a força moral dos demais (aristocratas), os fracos (sacerdotes) vão utilizar de artifícios para inverter os valores: o bom passa a ser referente a uma moralidade doente, que nega e condena a vida,

12 BARRENECHEA, Miguel Angel. Nietzsche e a liberdade. 2. ed. Rio de Janeiro: 7 Letras, 2008. p. 20.

13 BARRENECHEA, Miguel Angel. Nietzsche e a liberdade. 2. ed. Rio de Janeiro: 7 Letras, 2008. p. 28.

14 NIETZSCHE, Friedrich. O anticristo: ensaio de uma crítica do cristianismo. Tradução de Pedro Delfim Pinto dos Santos. Lis-

boa: Guimarães Editores, 1997. p. 32-33.

15 BARRENECHEA, Miguel Angel. Nietzsche e a liberdade. 2. ed. Rio de Janeiro: 7 Letras, 2008. p. 30-31.

16 NIETZSCHE, Friedrich. Ecce homo: como alguém se torna o que é. Aurora. Tradução de Paulo César de Souza. São Paulo: Cia das Letras, 2001. p. 80.

17 BARRENECHEA, Miguel Angel. Nietəsche e a liberdade. 2. ed. Rio de Janeiro: 7 Letras, 2008. p. 33.

18 NIETZSCHE, Friedrich. A genealogia da moral: dissertação primeira. Tradução de Mário Ferreira dos Santos. Rio de Janeiro: Vozes, 2013. p. 48. 
enquanto a moralidade forte e afirmativa passa a ser o mau: "Os fracos, os doentes não perdoam este excesso de saúde, de excelência e de felicidade, por isso instauram, movidos pelo ressentimento, uma inversão de valores: o que é bom para o forte será mau para o fraco ${ }^{\prime \prime} .{ }^{19}$ Mas essa inversão de valores não é suficiente, posto que nenhuma eficácia teria o estabelecimento de novos valores, se não fosse concebível ao indivíduo a escolha entre ser bom ou mau. Portanto, a liberdade se torna um instrumento indispensável a ser utilizado por todos os ressentidos, pregando a possibilidade de ser bom ou mau, de ser diferente do que se é. Por meio desses dois artifícios, quais sejam, a inversão dos valores morais e a defesa do livre-arbítrio, os fracos conseguem dominar os mais fortes:

Esta classe de homem na realidade necessita crer num "sujeito neutro" dotado de livre arbítrio; é um instinto de conservação pessoa, de afirmação de si mesmo porque toda mentira tende a justificar-se. $\mathrm{O}$ sujeito, ou mais popularmente a alma, foi até aqui o artifício de fé mais inquebrantável, porque permitia a grande maioria dos mortais, aos fracos e oprimidos, esta sublime automentira de ter a fraqueza por liberdade, a necessidade por mérito. ${ }^{20}$

Nesse cenário envolto a sentimentos de ódio e vingança contra a realidade, o sacerdote será a figura de maior destaque, uma vez que será o responsável por difundir essa moralidade enfraquecida e por condenar a vida terrena e seus desdobramentos, tornando-se o representante e o incentivador de todos os fracos e ressentidos. Interessante é o fato de o sacerdote ser, paradoxalmente, um afirmador da existência, pois, ao estabelecer um ideal ascético, salvará os fracos que já não possuem a força necessária para viver uma vida que não é saudável, forte e bela: "o padre, ao instaurar um ideal ascético, salvará muitos homens da autodestruição, já que a vontade humana não resiste ao vazio, preferindo ainda "querer o nada a nada querer". ${ }^{21}$ Contudo, o preço a ser pago pelo prolongamento da existência dos fracos será a manutenção de uma moralidade de rebanho, dissipando a expectativa de ideais mais elevados: "a manutenção das doenças será o preço que os crentes devem pagar para ter uma sobrevida". ${ }^{22}$

Outro aspecto defendido pelos sacerdotes será a aproximação entre liberdade e pecado, na medida em que ambos são instrumentos para culpabilizar e responsabilizar os homens pelos seus atos: "as noções de liberdade e pecado estão profundamente articuladas, cumprindo um papel essencial na estratégia de dominação, nas sociedades sacerdotais, que usa estas noções como 'instrumentos de tortura', 'sistemas de crueldade' para garantir a sua autoridade". ${ }^{23}$

A crença no além e em uma natureza humana transcendente, o ressentimento dos fracos contra aqueles que possuem uma moralidade forte e afirmativa, bem como a apropriação e a difusão dessa moralidade inversa pelo poder sacerdotal, vão dar origem a uma base sólida para relacionar a ideia de liberdade com o instinto de querer punir e julgar. Em último grau, a liberdade é pensada como uma forma de justificar o castigo e a punição - afinal, apenas os detentores de uma vontade livre podem ser culpados, uma vez que do absoluto acaso ou do determinismo radical não emergiria nenhum tipo de responsabilidade. ${ }^{24}$

Erro da vontade livre. - Hoje já não temos mais nenhuma compaixão pelo conceito de "vontade-livre": sabemos muito bem o que ele é - o mais suspeito artifício dos teólogos que existe; um artifício que tem por objetivo fazer com que a humanidade se torne "responsável" à moda dos teólogos, isto é, que visa fazer com que a bumanidade seja dependente deles. Eu ofereço aqui apenas a psicologia de toda e

19 BARRENECHEA, Miguel Angel. Nietzsche e a liberdade. 2. ed. Rio de Janeiro: 7 Letras, 2008. p. 33.

20 NIETZSCHE, Friedrich. A genealogia da moral: dissertação primeira. Tradução de Mário Ferreira dos Santos. Rio de Janeiro: Vozes, 2013. p. 49.

21 BARRENECHEA, Miguel Angel. Nietssche e a liberdade. 2. ed. Rio de Janeiro: 7 Letras, 2008. p. 37.

22 BARRENECHEA, Miguel Angel. Nietzsche e a liberdade. 2. ed. Rio de Janeiro: 7 Letras, 2008. p. 38.

23 BARRENECHEA, Miguel Angel. Nietzsche e a liberdade. 2. ed. Rio de Janeiro: 7 Letras, 2008. p. 39.

24 Ao menos no contexto em que Nietzsche escrevera sua obra. Hoje, a partir dos avanços da neurociência, torna-se cada vez mais imperativo buscar outros tipos de fundamentação para a responsabilidade ética e jurídica. O espaço para a existência do livrearbítrio fica cada vez mais restrito em face de um ambiente que se comprova cada vez mais causado e determinado por fatores internos (biológicos, químicos) e externos (sociais). Para uma compreensão geral desse novo contexto. EAGLEMAN, David. Incógnito: as vidas secretas do cérebro. Tradução de Ryta Vinagre. Rio de Janeiro: Rocco, 2012. 
qualquer atribuição de responsabilidade. — Onde quer que as responsabilidades sejam procuradas, aí costuma entrar em ação o instinto do querer punir e julgar. Despiu-se o vir-a-ser de sua inocência, quando se reconduziram os diversos modos de ser à vontade, às intenções, aos atos de responsabilidade. A doutrina da vontade é inventada essencialmente em função das punições, isto é, em função do quererestabelecer-a-culpa. ${ }^{25}$

Desse modo, por meio da análise genealógica da liberdade, percebe-se que esta somente existe para justificar uma moralidade de rebanho (liberdade para ser escravo) e qualquer tentativa frustrada será condenada com severas punições, afinal, o sujeito é um ser transcendente — ou, ao menos, é o que pregam os sacerdotes. Não obstante, Nietzsche não vai se contentar em apresentar a genealogia do valor "liberdade", passando a proferir poderosos ataques a todos esses valores sedimentados. Qual seria o valor dos valores?

Partindo das bases de sua formação acadêmica, Nietzsche realiza uma rigorosa análise filológica dos conceitos que fundamentam a existência da liberdade ou, de maneira mais específica, do livre-arbítrio. Palavras como "sujeito", "substância", "causalidade" e "vontade" são entendidas como indispensáveis para a sustentação da ideia de liberdade. A crítica nietzschiana é abrangente e abarca a linguagem moral como um todo, uma vez que seria uma linguagem preconceituosa, superficial e antropomorfizada. ${ }^{26} \mathrm{O}$ perspectivismo epistemológico reforça essa crítica, na medida em que a linguagem moral estabelece determinados fatos como verdades absolutas, utilizando-se de uma vasta rede conceitual-ontológica para confirmar sua proposição. Seria esse o caso da liberdade: admite-se como uma verdade incontestável, mas necessita-se de uma variedade de conceitos ontológicos, tais como substância, vontade e causalidade, para validar sua força moral. O filósofo das marteladas vai rechaçar cada um desses conceitos, até chegar na própria refutação do conceito de liberdade em seu sentido negativo.

Nos limites deste artigo, o estudo da vontade e da causalidade se apresentam indispensáveis para a confirmação ou contestação do livre-arbítrio. O que é o querer, afinal? Existe algo capaz de surgir ex nibilo, iniciando uma nova e independente cadeia de causalidade ou, por outro lado, tudo é necessário e determinado por uma cadeia de causalidade antecedente?

Rimos daquele que saiu de seu aposento no minuto em que o Sol deixa o dele, e diz: "Eu quero que o Sol se ponha"; e daquele que não pode parar uma roda e diz: "Eu quero que ela rode"; e daquele que no ringue de luta é derrubado e diz: "Estou aqui deitado, mas eu quero estar aqui deitado". No entanto, apesar de toda a risada, agimos de maneira diferente de algum desses três, quando usamos a expressão "eu quero"? 27

A resposta de Brian Leiter é indiscutível: não haveria diferença alguma. Reconhecido por sua interpretação contrária a qualquer defesa da vontade e do livre-arbítrio no pensamento de Nietzsche, Leiter entende que o filósofo prussiano é responsável por antecipar e apresentar argumentos contundentes em favor do incompatibilismo não libertário - posição que defende a incompatibilidade entre livre-arbítrio e determinismo. No caso, a versão não libertária argumenta pela preponderância do determinismo sobre o livre-arbítrio. ${ }^{28}$

$\mathrm{O}$ argumento apresentado por Leiter sobre a teoria da vontade nietzschiana parte de uma fenomenologia da vontade, apresentada no aforismo 19 da obra "Para além do bem e do mal":

Em primeiro lugar, toda vontade compreende uma pluralidade de sensações, quer dizer, a sensação de

25 NIETZSCHE, Friedrich. Crepúsculo dos ídolos: ou como filosofar com o martelo: os quatro grandes erros. Tradução de Marco Antonio Casa Nova. Rio de Janeiro: Relume Dumará, 2000. p. 48-49.

26 BARRENECHEA, Miguel Angel. Nietsssche e a liberdade. 2. ed. Rio de Janeiro: 7 Letras, 2008. (Passim).

27 NIETZSCHE, Friedrich. Aurora: reflexões sobre os preconceitos morais: aforismo 124. Tradução de Paulo César de Souza. São Paulo: Companhia das Letras, 2004. p. 95.

28 LEITER, Brian. Nietzsche's theory of the Will. In: GEMES, Ken; MAY, Simon (Ed.). Nietzsche on freedom and autonomy. Oxford: Oxford University Press, 2009.

LEITER, Brian. The paradox of fatalism and self-creation in Nietzsche. In: RICHARDSON, John; LEITER, Brian (Ed.). Nietzsche. Oxford: Oxford University Press, 2001. 
um estado do qual se quer afastar, e a de um estado no qual se quer encontrar, a própria sensação desse "de onde" e desse "para onde" e ainda mais, uma sensação muscular, a qual, sem agitar "braços e pernas", por uma espécie de costume, torna-se ativa enquanto "queremos". E não só deve reconhecer-se como ingrediente da vontade o sentir, e um sentir múltiplo, mas também o pensar: em todo ato de vontade há um pensamento dominante, e não se acredite que possa separar-se do "querer" este pensamento, pois então não ficaria da vontade. Em terceiro lugar, a vontade não é só um complexo de sensações e pensamento, mas também uma emoção, e precisamente a de mandar. O que se chama de livre-arbítrio é essencialmente a emoção de superioridade a respeito de quem deva obedecer [...]. Um homem que quer manda a alguma coisa dentro de si mesmo, a qual obedece, ou ao menos, ele acredita que obedece. ${ }^{29}$

A tese levantada a partir do referido aforismo é a de que existe uma experiência da vontade, ou seja, as pessoas normalmente se sentem e agem como se tivessem exercitando uma vontade livre. Nietzsche deixa evidente seu ponto de vista ao afirmar que toda vontade decorre de uma pluralidade de sensações, somada a um pensamento dominante e um sentimento de superioridade — esta seria a fenomenologia da vontade. ${ }^{30}$ Exemplifica-se: quando alguém sente fome e pensa se deve buscar algo para comer, tem-se uma sensação de um estado do qual se quer afastar (a fome); uma sensação de um estado no qual se quer encontrar (a saciedade); uma sensação muscular (movimentar-se em busca de comida); um pensamento dominante ou comandante ("eu quero comer algo"); e, por fim, uma emoção ou sentimento de que foi esse pensamento que causou todos esses complexos sentimentos e movimentos corporais. ${ }^{31}$

Para descontruir a fenomenologia da vontade, Nietzsche vai concentrar seus esforços no ataque à noção de pensamento dominante, ${ }^{32}$ pois afirma que “um pensamento vem quando 'ele' quer, não quando 'eu' quero; de tal maneira, que seria falsear a verdade do fato assegurar que o sujeito 'eu' é a condição do predicado 'penso", ${ }^{33}$ Desse modo, (1) se o pensamento não é causado por um sujeito, surgindo quando bem entender; (2) se o pensamento comandante é parte indissociável da fenomenologia da vontade; (3) logo, a vontade não pode ser causada por um sujeito. Ou seja: "do fato de que existe pensamento, não se segue que [...] algum sujeito ou agente está realizando o pensamento e, então, não se segue que o 'Eu’ existe”. ${ }^{34}$ Novamente, retorna-se ao perspectivismo epistemológico de Nietzsche, contrapondo-se à epistemologia cartesiana, principalmente em relação a um sujeito que pensa e, portanto, existe. Também é retomado o ataque mais amplo à linguagem moral, especialmente à categoria do "sujeito" — criada apenas para reforçar a ideia da liberdade como mecanismo para a responsabilização das pessoas.

Qual seria, portanto, a verdadeira gênese da ação humana? Brian Leiter entende que tanto a ação, quanto a vontade humana são primariamente causadas por uma "Doutrina dos Tipos", segundo a qual "toda pessoa possui uma constituição psicofísica fixa que a marca como um particular 'tipo' de pessoa. Chame os relevantes fatos psicofísicos de 'tipos-fatos". ${ }^{35}$ Em outras palavras, essa proposição afirma que cada ser possui certas características psicológicas, psíquicas e físicas que são imutáveis e únicas, constituindo o tipo de pessoa que ela é. Assim, essas características pessoais seriam as responsáveis por dar origem à ação humana, sendo a vontade consciente apenas um efeito secundário dessa doutrina.

Uma outra maneira de entender as alegações acima mencionadas é trabalhar a ideia de que a vontade,

29 NIETZSCHE, Friedrich. Além do bem e do mal. Rio de Janeiro: Vozes, 2012. p.32.

30 LEITER, Brian. Nietzsche's theory of the Will. In: GEMES, Ken; MAY, Simon (Ed.). Nietzsche on freedom and autonomy. Oxford: Oxford University Press, 2009. p. 107-108.

31 Exemplo pensado com base em LEITER, Brian. LEITER, Brian. Nietzsche's theory of the Will. In: GEMES, Ken; MAY, Simon (Ed.). Nietzsche on freedom and autonomy. Oxford: Oxford University Press, 2009. p. 109.

32 LEITER, Brian. Nietzsche's theory of the Will. In: GEMES, Ken; MAY, Simon (Ed.). Nietssche on freedom and autonomy. Oxford: Oxford University Press, 2009. p. 112.

33 NIETZSCHE, Friedrich. Além do bem e do mal. Rio de Janeiro: Vozes, 2012. p. 30.

34 LEITER, Brian. Nietzsche's theory of the Will. In: GEMES, Ken; MAY, Simon (Ed.). Nietzsche on freedom and autonomy. Oxford: Oxford University Press, 2009. p. 112.

35 LEITER, Brian. The paradox of fatalism and self-creation in Nietzsche. In: RICHARDSON, John; LEITER, Brian (Ed.). Nietzsche. Oxford: Oxford University Press, 2001. p. 294. Tradução nossa: "Each person has a fixed psyco-physical constitution, which marks him or her as particular 'type' of person. Call the relevant psyco-physical facts here 'type-facts'. 
entendida como um estado mental consciente, é, simplesmente, um epifenômeno, incapaz de causar uma ação por si só. Isso "significa que apesar de os acontecimentos mentais, estados de consciência e experiência existirem, não têm em si mesmos poderes causais, nem produzem efeitos no mundo físico". ${ }^{36}$ Dessa maneira, partindo da concepção de que toda ocorrência de estados mentais pode, em princípio, ser causada somente por estados físicos, ${ }^{37}$ a vontade seria secundária no processo do comportamento humano, haja vista que somente as características psicofísicas seriam responsáveis pela agência. Elucidativo é o exemplo apresentado por Brian Leiter, segundo o qual o epifenomenismo consistiria em um jogo de videogame em que a pessoa se sente no comando das ações por meio do controle, quando, na verdade, o console está apenas rodando um programa pré-determinado. Assim como o controle no caso mencionado é uma ilusão, a vontade seria uma ilusão de comando das ações que seriam causadas por características psicofísicas inerentes a cada pessoa. Trata-se da mesma noção apresentada por Nietzsche em aforismo já mencionado: o sol se põe, mas a pessoa diz "eu quero que ele ponha", ou o lutador é nocauteado e diz "eu quero estar aqui deitado".38

Interessante notar, realizando uma breve digressão, que essa concepção trabalhada por Nietzsche está sendo confirmada por diversos estudos empíricos na área da neurociência. Para ficar restrito a um único caso, cita-se a pesquisa de Benjamin Libet a respeito do livre-arbítrio ou de uma vontade consciente. O experimento ocorreu da seguinte maneira: foi pedido aos voluntários para que apertassem um botão quando sentissem vontade de realizar tal ato, e que prestassem atenção à localização do ponteiro do relógio no momento em que estivessem conscientes do desejo de agir. ${ }^{39} \mathrm{Em}$ todo o experimento, foi monitorada a carga elétrica presente no cérebro, desse modo, seria possível identificar (1) o início da elevação da carga elétrica no cérebro, chamada por Libet de "potencial de prontidão"; (2) o início da consciência da vontade de realizar o ato; e (3) a realização do ato em si. A conclusão foi assustadora: os atos voluntários foram precedidos por uma mudança elétrica específica no cérebro que se iniciava 550 milissegundos antes da ação. Além disso, o sujeito se tornava consciente da intenção de agir de 350-400 milissegundos depois que a mudança elétrica havia se iniciado, mas 200 milissegundos antes da ação. Ou seja: o processo de volição era iniciado de maneira inconsciente e somente depois as pessoas se tornavam conscientes - logo, a vontade seria um epifenômeno. ${ }^{40}$

Caminhando para o desfecho do tópico, é importante mais uma vez ressaltar que Nietzsche realiza uma robusta crítica não somente contra a vontade e o livre-arbítrio, mas contra a utilização da linguagem moral como um todo. Em "Crepúsculo dos Ídolos", quando escreve sobre os quatro grandes erros, o primeiro a ser mencionado é a confusão entre causa e consequência, para depois contestar a própria ideia de causalidade: "sempre se acreditou saber o que é uma causa: mas de onde retiramos nosso saber, mais exatamente, nossa crença neste saber? Do âmbito dos célebres 'fatos internos': dos quais nenhum se mostrou até aqui como factual." Em "Humano, demasiado humano" novamente rechaça o livre-arbítrio e a responsabilidade, ambos decorrentes da fábula da liberdade inteligível: "a história dos sentimentos morais é a história de um erro, o erro da responsabilidade, que se baseia no erro do livre-arbítrio". ${ }^{2}$ Ao longo do livro, defende com veemência a tese de que tudo é necessário:

Junto à cachoeira. - À vista de uma cachoeira, acreditamos ver nas inúmeras curvas, serpenteios, quebras de ondas, o arbítrio da vontade e do gosto; mas tudo é necessário, cada movimento é matematicamente cal-

36 BLACKBRURN, Simon. Dicionário Oxford de filosofia: epifenomenismo. Tradução de Desidério Murcio et al. Rio de Janeiro: J. Zahar, 1997. p. 119.

37 AUDI, Robert. The Cambridge dictionary of philosophy: epiphenomenalism. Cambridge, Cambridge University Press, 1999 . p. 685.

38 NIETZSCHE, Friedrich. Aurora: reflexões sobre os preconceitos morais: aforismo 124. Tradução de Paulo César de Souza.

São Paulo: Cia das Letras, 2004. p. 95.

39 Libet criou um modelo de relógio diferente do usual em razão da necessidade de indicar milissegundos. O relógio girava a uma velocidade 25 vezes superior à de um relógio comum e cada marca de "segundo" no perímetro era equivalente a 40 milissegundos.

40 LIBET, Benjamim. Do we have free will? the Oxford handbook of free will. Oxford: Oxford University Press, 2002. Passim.

41 NIETZSCHE, Friedrich. Crepúsculo dos ídolos: ou como filosofar com o martelo: os quatro grandes erros. Tradução de Marco Antonio Casa Nova. Rio de Janeiro: Relume Dumará, 2000. p. 43.

42 NIETZSCHE, Friedrich. Humano, demasiado bumano: um livro para espíritos livres. Tradução de Paulo César de Souza. São Paulo: Cia das Letras, 2000. p. 48. 
culável. Assim também com as ações humanas; deveríamos poder calcular previamente cada ação isolada, se fôssemos oniscientes, e o mesmo modo cada avanço do conhecimento, cada erro, cada maldade. É certo que mesmo aquele que age se prende à ilusão do livre-arbítrio; se num instante a roda do mundo parasse, e existisse uma inteligência onisciente, calculadora, a fim de aproveitar essa pausa, ela poderia relatar o futuro de cada ser até as mais remotas eras vindouras, indicando cada trilha por onde essa roda passará. A ilusão acerca de si mesmo daquele que age, a suposição do livre-arbítrio, é parte desse mecanismo que seria calculado. ${ }^{43}$

Em face de tudo o que foi argumentado ao longo desse tópico, pode-se reconhecer que Nietzsche é certamente contrário à ideia de liberdade, livre-arbítrio, vontade e subjetividade, o que poderia levar ao entendimento de que o filósofo seria partidário de um incompatibilismo determinista, conforme interpretado por Brian Leiter. Contudo, trata-se de uma tarefa bastante árdua enquadrar a filosofia de Nietzsche no debate contemporâneo sobre o livre-arbítrio com suas categorias sistemáticas e estritas, tais como o incompatibilismo libertário, o incompatibilismo determinista e as diversas proposições derivadas do compatibilismo entre livre-arbítrio e determinismo. Isso ocorre em razão do ataque generalizado à linguagem moral, aos conceitos pré-estabelecidos, preconceituosos e antropomorfizados. Assim, sustenta-se, no presente artigo, que a tarefa nietzschiana consiste em, antes de mais nada, descontruir todas essas concepções morais estabelecidas de maneira ontológica para, em um segundo momento, construir novos e superiores valores para além do homem. Desse modo, enquadrar Nietzsche como um determinista radical, ou mesmo como um fatalista, é continuar trabalhando com o conceito de causalidade que o filósofo pretende abrir mão. É nesse sentido que se defende a tese de que a sua ideia principal é trabalhar com uma noção de liberdade positiva, artística, auto criadora. É o que parece ser argumentado no seguinte aforismo de "Além do bem e do mal":

A causa sui é a mais formosa autocontradição que foi até agora pensada, é uma espécie de estupro da lógica, é algo contra a natureza; mas o desmedido orgulho do homem chegou a envolver-se profunda e terrivelmente nessa coisa sem sentido. O desejo da "liberdade da vontade" no sentido superlativo metafísico que infelizmente ainda reina hoje nos cérebros semidoutos; o desejo de atribuir a si mesmo toda a responsabilidade de seus próprios atos, desobrigando a Deus, o mundo, os antepassados, o acaso, a sociedade, em última análise, é apenas o desejo de ser causa sui e de levantar-se a si mesmo pelos cabelos, com audácia mais que muchauseana, do pântano do nada até a existência das coisas. E se alguém se adverte da simplicidade camponesa do famoso conceito "livre-arbítrio", e o cancela de seu cérebro, eu lhe rogaria que avançasse seu "esclarecimento" um passo mais e que cancelasse também em sua cabeça o conceito oposto e idiota à "vontade livre": penso na "vontade não livre" que não passa de um abuso de causa e efeito. Não se cometa o erro de considerar causa e efeito como objetos, como acontece aos naturalistas e aos que "naturalizam" no pensamento, segundo o método dos cretinos mecanicistas, que predominam, e querem que a causa e empuxe até produzir um "efeito". É mister servir-se da "causa e do efeito", como de puros conceitos, isto é, como ficções convencionais para designar e compreender, não para "esclarecer". No in se não há "nexos causais", não há "necessidades", não há "determinismo psicológico"; ali o efeito não é uma consequência da "causa"; ali não manda nenhuma "lei". Nós, nós somente, inventamos a causa, as sucessões, a relatividade, a necessidade, o número, a lei, a liberdade, o motivo, o fim; e se misturamos às coisas reais este mundo de signos, como "em si", continuamos fazendo mitologia, como sempre fizemos; A vontade determinada é mitologia; na vida real existem apenas vontades débeis [vontades fortes ou fracas]. ${ }^{44}$

Em síntese, Nietzsche propugna pelo abandono da ideia metafísica de livre-arbítrio, de uma causa em si mesmo, na medida em que se trata do simples desejo de atribuir a responsabilidade de todos os seus atos a si próprio - uma concepção simplista e sem sentido. Por outro lado, também defende o descarte da ideia de uma vontade não livre, pois entende que a utilização dos conceitos de causa e efeito para esclarecer e explicar as ações humanas não passa de uma mera ficção — afinal, não existe nexo causal, necessidade ou determinismo. Assim, o referido aforismo dá sequência à investida nietzschiana contra a linguagem moral como um todo. Por essa razão, entende-se que o projeto primordial de Nietzsche não consiste em discutir se a vontade

43 NIETZSCHE, Friedrich. Humano, demasiado bumano: um livro para espíritos livres. Tradução de Paulo César de Souza. São Paulo: Cia das Letras, 2000. p. 81.

44 NIETZSCHE, Friedrich. Além do bem e do mal. Rio de Janeiro: Vozes, 2012. p. 35-36. 
é livre ou determinada, uma vez que ambas seriam mitologias da linguagem moral, mas em sustentar apenas a existência de vontades fortes ou fracas, sendo a primeira aquela que surge do ímpeto artístico, do poder de autocriação, da liberdade positiva.

\section{A LIBERDADE POSITIVA}

Friedrich Nietzsche adota uma postura agressiva contra a moralidade e sua linguagem fundada em ideais ascéticos e enfraquecedores da existência. A desconstrução da moralidade implementada a duras marteladas epistemológicas, genealógicas e filológicas acaba por definhar diversos conceitos consolidados no vocabulário moral humano: livre-arbítrio; vontade; causalidade e subjetividade são apenas alguns exemplos de noções que passaram a ser questionadas, colocando-se em evidência suas contradições, origens e finalidades.

Certamente, o livre-arbítrio é um dos conceitos morais mais contestados por Nietzsche, muito em razão da sua estreita relação com o transcendente, com o poder sacerdotal e o desejo de julgar e punir. Não obstante, a investida contra a moral não ocorre somente para "retirar do homem os seus grilhões, mas muito mais para obrigá-lo a ascender a uma posição superior sob uma carga mais forte". " ${ }^{5}$ Assim, a negação da liberdade é apenas o primeiro passo de uma tarefa muito mais ampla e importante, denominada de transvaloração dos valores: a defesa de uma liberdade positiva, afirmativa, criativa, artística.

A questão da liberdade positiva é trabalhada em diversos momentos da sua obra — basta pensar na reiterada referência aos espíritos livres:

[...] pode-se imaginar um prazer e força na autodeterminação, uma liberdade da vontade, em que um espírito se despede de toda a crença, todo desejo de certeza, treinado que é em se equilibrar sobre tênues cordas e possibilidades e em dançar até mesmo à beira de abismos. Um tal espírito seria o espirito livre por excelência. ${ }^{46}$

Contudo, em "Assim falou Zaratustra", a liberdade artística ganha seus principais contornos. Após o anúncio da morte de Deus, os homens devem permanecer fiéis à terra, devem reassumir a sua condição criadora de novos valores, devem alcançar o além-do-homem. Nesse contexto, Miguel Barrenechea sintetiza os três momentos do arbítrio humano em face da tradição idealista:

(1) sujeição total à metafísica, à moral e à religião (liberdade servil ou momento do camelo); (2) rejeição dos valores da tradição, ruptura das velhas tábuas (liberdade negativa ou "liberdade de", no momento do leão) e (3) criação lúdica de valores novos (liberdade positiva ou "liberdade para", momento da criança). ${ }^{47}$

A transição da "liberdade de", em direção à "liberdade para", é essencial para a compreensão da liberdade positiva. A partir dessa transição, fica claro que o mais importante não é a libertação dos grilhões, dos jugos, das amarras morais - mas o que cada um vai realizar com essa liberdade. A liberdade para buscar valores superiores e afirmativos é o que importa: "Livre de que? Que importa isso a Zaratustra! Mas claramente deve teu olho informar-me: livre para que? Podes dar a ti mesmo o teu mal e o teu bem e suspender a tua vontade por cima de ti como uma lei? Podes ser o teu próprio juiz e vingador da tua lei?" 48

Para que o homem consiga exercer essa "liberdade para", faz-se mister a transvaloração daquele conceito de liberdade negativa, atrelado ao além, oriundo de um ressentimento dos enfraquecidos que será absorvido e difundido na figura do sacerdote em sua busca pela responsabilização e punição de todos aqueles que se

45 JASPERS, Karl. Introdução à filosofia de Friedrich Nietæssche. Tradução de Marco Antônio Casanova. Rio de Janeiro: Forense Universitária, 2015. p. 191.

46 NIETZSCHE, Friedrich. A gaia ciência: os crentes e a necessidade de crer. Tradução de Paulo César de Souza. São Paulo: Companhia das Letras, 2001. 241p.

47 BARRENECHEA, Miguel Angel. Nietæssche e a liberdade. 2. ed. Rio de Janeiro: 7 Letras, 2008. p. 88.

48 NIETZSCHE, Friedrich. Assim falou Zaratustra: um livro para todos e para ninguém: primeira parte: do caminho do criador. Tradução de Mário da Silva. Rio de Janeiro: Civilização Brasileira, 1998. p. 89. 
desviam da moralidade servil. É nesse contexto que se fala que a liberdade se torna criação; o dever se torna natureza; a graça e redenção do pecado se tornam inocência do devir. ${ }^{49}$

Desse modo, a inocência do devir é também uma noção indispensável para compreender a superação da moral, da culpabilidade e da responsabilização, pois somente por meio dessa inocência que se perde a vergonha de si mesmo, que se fornece a maior de todas a coragens e liberdades. ${ }^{50} \mathrm{Na}$ interpretação de Luiz Filipe Alves,

[...] o devir carece de maldade ou bondade, ele está além do bem e do mal. Todavia, o homem sempre quis ver algo de moral na vida e, pode-se acrescentar, na natureza. Para Nietzsche o devir não é ele mesmo maculado, ele é por si sem nenhuma causalidade e finalidade. Porém, os mestres não conseguem compreender a Inocência do Devir, já que sempre tentaram dar uma causa e finalidade moral para vida. ${ }^{51}$

Poder-se-ia alegar que a inocência do devir levaria a humanidade ao caos, uma vez que cada indivíduo teria sua própria tábua de valores, cada existência teria seu próprio caminhar, inexistindo culpa e responsabilidade - uma travessia para além do bem e do mal. Tal ideia, contudo, é equivocada, uma vez não se tratar de um individualismo egoístico ou relativismo moral em que tudo é permitido. É nesse momento deve entrar em cena a liberdade artística, pois a inocência do devir demanda um criador à sua altura:

O que a sabedoria afirmativa aspira a mostrar é justamente que um mundo assim concebido resulta num espetáculo que demanda atores à sua altura. Não é por não dispormos de um fundamento de última instância para nossas decisões que estamos fadados à anarquia ou à desolação. A responsabilidade que emerge então é a que se exige de um criador, capaz de sustentar a partir de si mesmo os compromissos que firmou. ${ }^{52}$

Corrobora ainda para a perspectiva ética da liberdade, a doutrina do eterno-retorno: "querer algo mais uma vez e por mais incontáveis vezes". No conhecido aforismo de "A gaia ciência" é narrada a história de um demônio que aparece furtivamente e diz: "Esta vida, como você a está vivendo e já viveu, você terá de viver uma vez e por incontáveis vezes; e nada haverá de novo nela, mas cada dor e cada prazer e cada suspiro e pensamento". E, em sequência, indaga qual seria a reação externada: "Você não se prostraria e rangeria os dentes e amaldiçoaria o demônio que assim o falou? Ou [...] lhe responderia: "Você é um deus e jamais ouvi coisa tão divina!". ${ }^{53}$ Dessa maneira, a ideia que Nietzsche pretende manifestar é a de que o criador deve suportar o maior dos pesos: o peso da vida que escolheu viver.

A criação "é a mais elevada exigência, o ser propriamente dito, o fundamento de todo o fazer essencial". Criar é estimar, pois somente o criador sabe o que é bom e mau; criar é aniquilar, pois somente a partir da destruição que surge a criação; criar é alcançar o ser propriamente dito, pois apenas na criação há liberdade. ${ }^{54}$ Karl Jaspers afirma que o homem deve ser compreendido como um ser que produz a si mesmo, seja porque avalia e cria novos valores, ou porque se coloca em relação consigo mesmo, avaliando, iludindo e configurando sua existência, ou porque possui a capacidade de movimento na própria essência, no sentido de uma possibilidade existencial que se realiza no devir de se chegar a ser o que é. A interpretação de Jaspers fica clara na seguinte passagem:

O homem que produz a si mesmo: o fato de o homem não ser apenas um ser mutável, mas um ser que se autoproduz, o fato de ele ser livre, é nesse ponto que Nietzsche insiste. Sua crítica à moral quer

49 JASPERS, Karl. Introdução à filosofia de Friedrich Nietæssche. Tradução de Marco Antônio Casanova. Rio de Janeiro: Forense Universitária, 2015. p. 191-192.

50 JASPERS, Karl. Introdução à filosofia de Friedrich Nietz̧sche. Tradução de Marco Antônio Casanova. Rio de Janeiro: Forense Universitária, 2015. p. 207.

51 ALVES, Luiz Filipe Araújo. A ideia de justiça em Nietz̧sche: ou a justiça para além da ideia. Tese (Doutorado) - Faculdade de Direito, Universidade Federal de Minas Gerais, 2016. p. 106.

52 PIMENTA, Olímpio. Livro de filosofia: ensaios. Belo Horizonte: Tessitura, 2006. p. 25-26.

53 NIETZSCHE, Friedrich. A gaia ciência: o maior dos pesos. Tradução de Paulo César de Souza. São Paulo: Cia das Letras, 2001. p. 362.

54 JASPERS, Karl. Introdução à filosofia de Friedrich Nieţssche. Tradução de Marco Antônio Casanova. Rio de Janeiro: Forense Universitária, 2015. p. 208-209. 
possibilitar precisamente esse ser livre uma vez mais. Mas ele tem seu sentido próprio. A liberdade da autoprodução não é outra coisa senão criação. ${ }^{55}$

Ainda, para que o homem consiga criar para além dele mesmo, faz-se necessária a apropriação da sua vontade de poder, pois "somente desse modo poderá realizar aquilo que, por meio dele, constitui o fervoroso desejo de vida: superar-se a si mesma, rompendo a camisa-de-força em que a encerrou a moderna civilização ocidental - a rigidez da autoconservaģao a qualquer custo." ${ }^{56}$ A vontade de poder consiste no próprio devir, na afirmação do necessário, no elemento condutor da vida. ${ }^{57}$ Nietzsche trabalha a vontade de poder nessa perspectiva na seguinte passagem de Zaratustra: "Não o rio é o vosso perigo e o fim do vosso bem e do mal, ó os mais sábio dentre os sábios, mas aquela mesma vontade, a vontade de poder — a inesgotável e geradora fonte de viver"; ou ainda: "Onde encontrei vida, encontrei vontade de poder". ${ }^{58}$

Muito ainda poderia ser dito sobre a liberdade positiva, contudo, nos limites da pesquisa, foram apresentados os temas necessários para uma compreensão geral do argumento proposto. Finaliza-se o tópico com um aforismo de "A gaia ciência" em que são expostos de maneira sintética alguns dos principais tópicos abordados até aqui:

Nós, porém, queremos nos tornar aqueles que somos — os novos, únicos, incomparáveis, que dão leis a si mesmo! E para isso temos de nos tornar os melhores aprendizes e descobridores de tudo o que é normativo e necessário no mundo: temos de ser físicos, para podermos ser criadores neste sentido enquanto até agora todos os ideais e valorações foram construídos com base na ignorância da física ou em contradição a ela. Portanto: Viva a física! E viva sobretudo o que ela nos compele —nossa retidão! ${ }^{59}$

\section{Considerações finais}

Ao longo do artigo, buscou-se investigar a temática da liberdade no pensamento de Friedrich Nietzsche - objetivo nada simples, muito em razão do caráter antissistemático de sua obra e de seu perspectivismo epistemológico. Assim, o primeiro tópico analisado foi justamente o perspectivismo, questão fundamental para contextualizar e evidenciar a maneira nietzschiana de produção do conhecimento. A dissolução da substância e a suspeita à cristalização semântica da linguagem, entendidas como fontes do perspectivismo, percorrem todo o artigo com diferentes abordagens e facilita o entendimento do tema proposto. Desse modo, entender a maneira que Nietzsche estrutura o seu pensamento é central para a compreensão da "liberdade".

Trabalhou-se a ideia de liberdade no contexto nietzschiano sob duas perspectivas divergentes e radicais: a liberdade negativa ou negação da liberdade e a liberdade positiva ou afirmação da liberdade. A partir da liberdade negativa, realizou-se uma análise genealógica desse conceito, além de uma investigação da linguagem moral estabelecida para reforçar e validar seu uso. A genealogia dos valores demonstrou que o surgimento da liberdade possui alguns marcos centrais: (1) o fundamento no transcendente ou além; (2) o ressentimento dos fracos contra a moralidade dos fortes; (3) a apropriação e difusão da noção de liberdade pelo pode sacerdotal como forma de dominação; (4) o instinto de querer punir e julgar e do querer estabelecer a culpa. No combate contra a linguagem moral, Nietzsche realiza poderosos ataques contra a liberdade,

55 JASPERS, Karl. Introdução à filosofia de Friedrich Nietz̧sche. Tradução de Marco Antônio Casanova. Rio de Janeiro: Forense Universitária, 2015. p. 211.

56 GIACOIA JÚNIOR, Oswaldo. Nietz̧sche. São Paulo: Publifolha, 2000. p. 59.

57 ALVES, Luiz Filipe Araújo. A ideia de justiça em Nieţ̧sche: ou a justiça para além da ideia. Tese (Doutorado) - Faculdade de Direito, Universidade Federal de Minas Gerais, 2016. Passim.

58 NIETZSCHE, Friedrich. Assim falou Zaratustra: um livro para todos e para ninguém: segunda parte: do superar a si mesmo. Tradução de Mário da Silva. Rio de Janeiro: Civilização Brasileira, 1998. p. 144-146.

59 NIETZSCHE, Friedrich. A gaia ciência: viva a física! Tradução de Paulo César de Souza. São Paulo: Companhia das Letras, 2001. p. 224-225. 
o livre-arbítrio, o sujeito, a vontade e a própria causalidade. Nesse ponto é possível identificar com clareza como filosofar com o martelo.

Todavia, sua tarefa não se extingue na destruição da moralidade de rebanho, pois seu principal objetivo é implementar a transvaloração dos valores. Nesse sentido, a liberdade positiva se mostra indispensável, pois significa autocriação e afirmação da vida. Para Nietzsche, não importa tanto a "liberdade de", mas a "liberdade para"; não basta estar livre das antigas amarras morais, mas a criação de novos e superiores valores. O devir inocente demanda criadores à altura, capazes de sustentar os compromissos que foram firmados com base na vontade de potência. Mais que isso, a inocência do devir demanda o amor por aquilo que foi criado (amor fati), pois a doutrina do eterno retorno impõe o querer algo uma vez e por mais incontáveis vezes.

Após essa breve síntese, reafirma-se a tese inicial de que o projeto central da filosofia afirmativa de Nietzsche consiste na transvaloração dos valores, na destruição da liberdade negativa seguida da construção da liberdade positiva. Assim, a filosofia nietzschiana aspira um conceito de liberdade sem transcendência, um conceito afirmativo, artístico, criativo: uma liberdade para além da "liberdade".

\section{REFERÊNCIAS}

ALVES, Luiz Filipe Araújo. A ideia de justiça em Nietșsche: ou a justiça para além da ideia. Tese (Doutorado) Faculdade de Direito, Universidade Federal de Minas Gerais, 2016.

ANDERSON, Lanier R. Nietssche on autonomy: the Oxford handbook of Nietzsche. Oxford: Oxford University Press, 2013.

AUDI, Robert. The Cambridge dictionary of philosophy: epiphenomenalism. Cambridge: Cambridge University Press, 1999.

BARRENECHEA, Miguel Angel. Nietzsche e a liberdade. 2. ed. Rio de Janeiro: 7 Letras, 2008.

BLACKBRURN, Simon. Dicionário Oxford de filosofia: epifenomenismo. Tradução de Desidério Murcio et al. Rio de Janeiro: J. Zahar, 1997.

EAGLEMAN, David. Incógnito: as vidas secretas do cérebro. Tradução de Ryta Vinagre. Rio de Janeiro: Rocco, 2012.

GEMES, Ken. Nietzsche on free will, autonomy and the sovereign individual. In: GEMES, Ken; MAY, Simon (Ed.). Nietasche on freedom and autonomy. Oxford: Oxford University Press, 2009.

GIACOIA JÚNIOR, Oswaldo. Entre servo e livre-arbítrio. In: MARTINS, André (Org.). O mais potente dos afetos: Spinoza e Nietzsche. São Paulo: M. Fontes, 2009.

GIACOIA JÚNIOR, Oswaldo. Nietzsche $x$ Kant: uma disputa permanente a respeito de liberdade, autonomia e dever. Rio de Janeiro: Casa do Saber, 2012.

GIACOIA JÚNIOR, Oswaldo. Nietzsche. São Paulo: Publifolha, 2000.

JASPERS, Karl. Introdução à filosofia de Friedrich Nietșsche. Tradução de Marco Antônio Casanova. Rio de Janeiro: Forense Universitária, 2015.

LEITER, Brian. Nietzsche's theory of the Will. In: GEMES, Ken; MAY, Simon (Ed.). Nietzsche on freedom and autonomy. Oxford: Oxford University Press, 2009.

LEITER, Brian. The paradox of fatalism and self-creation in Nietzsche. In: RICHARDSON, John; LEITER, Brian (Ed.). Nietzsche. Oxford: Oxford University Press, 2001.

LIBET, Benjamim. Do we have free will? the Oxford handbook of free will. Edited by Robert Kane. Oxford: 
Oxford University Press, 2002.

MELO, Eduardo Rezende. Nietz̧sche e a justiça: crítica e transvaloração. São Paulo: Perspectiva, 2004.

NIETZSCHE, Friedrich. A gaia ciência: do gênio da espécie. Tradução de Paulo César de Souza. São Paulo: Cia das Letras, 2001.

NIETZSCHE, Friedrich. A genealogia da moral: dissertação primeira. Tradução de Mário Ferreira dos Santos. Rio de Janeiro: Vozes, 2013.

NIETZSCHE, Friedrich. Além do bem e do mal. Rio de Janeiro: Vozes, 2012.

NIETZSCHE, Friedrich. Assim falou Zaratustra: um livro para todos e para ninguém: primeira parte: do caminho do criador. Tradução de Mário da Silva. Rio de Janeiro: Civilização Brasileira, 1998.

NIETZSCHE, Friedrich. Aurora: reflexões sobre os preconceitos morais: aforismo 124. Tradução de Paulo César de Souza. São Paulo: Cia das Letras, 2004.

NIETZSCHE, Friedrich. Crepúsculo dos ídolos: ou como filosofar com o martelo: os quatro grandes erros. Tradução de Marco Antonio Casa Nova. Rio de Janeiro: Relume Dumará, 2000.

NIETZSCHE, Friedrich. Ecce homo: como alguém se torna o que é. Aurora. Tradução de Paulo César de Souza. São Paulo: Cia das Letras, 2001.

NIETZSCHE, Friedrich. Humano, demasiado bumano: um livro para espíritos livres. Tradução de Paulo César de Souza. São Paulo: Cia das Letras, 2000.

NIETZSCHE, Friedrich. O anticristo: ensaio de uma crítica do cristianismo. Tradução de Pedro Delfim Pinto dos Santos. Lisboa: Guimarães Editores, 1997.

PIMENTA, Olímpio. Livro de filosofia: ensaios. Belo Horizonte: Tessitura, 2006.

PIMENTA, Olímpio. Razão e conbecimento em Descartes e Nietzsche. Belo Horizonte: UFMG, 2000.

SCHACHT, Richard.Nietzsche. The arguments of the philosophers. London: Routledge, 2002. 


\section{A mediação de conflitos sob a perspectiva do desenvolvimento humano: as contribuições da psicologia positiva*}

\author{
The mediation of conflicts under the \\ perspective of human development: the \\ contributions of positive psychology
}

\author{
Simone de Biazzi Ávila Batista da Silveira** \\ Deise Brião Ferraz ${ }^{* * *}$
}

\section{Resumo}

Com o objetivo de verificar a hipótese de que existe um enfoque pedagógico/educativo na mediação familiar, buscou-se analisar as aproximações existentes entre as dinâmicas de mediação de conflitos com a abordagem Bioecológica do Desenvolvimento Humano e a Psicologia Positiva, numa perspectiva transformadora, bem como observar como as famílias podem ser impactadas por esses processos. A metodologia foi construída tendo como olhar a abordagem Bioecológica do Desenvolvimento Humano que situa os fenômenos estudados dentro de um contexto ecológico, numa abordagem sistêmica, o que lhe conferiu notável originalidade em relação a outros estudos da temática que não utilizaram essa abordagem. Os resultados obtidos apontaram que os processos educativos estão presentes nos procedimentos de mediação familiar, no ambiente físico onde se processa, na linguagem utilizada, na abordagem pessoal, bem como na condução dos processos, estando adequada ao tempo do conflito. No tocante aos impactos produzidos nas famílias, observou-se a necessidade que estas ainda carregam de uma autoridade que lhes garanta certezas jurídicas, bem como as dificuldades do estabelecimento de autonomia para suas próprias decisões, tudo isto fruto de uma construção histórico-social que estabeleceu como parâmetros de condução de conflitos a litigiosidade e adversariedade resultantes da judicialização dos conflitos como forma de resolução predominante na sociedade atual. Foi observado, no entanto, que a mediação contribui para a construção de um importante caminho no sentido da autonomia, estando afinada com os reclamos de uma ação transformadora.

Palavras-chave: Mediação de conflitos. Desenvolvimento humano. Psicologia positiva.

\section{Abstract}

In order to verify the hypothesis that there is a pedagogical / educational approach in family mediation, we sought to analyze the existing approaches between the dynamics of conflict mediation with the Bioecological approa-
*** Mestranda em Direito e Justiça Social na Universidade Federal do Rio Grande. Advogada. E-mail: deisebferraz@gmail.com
* Recebido em 11/05/2018

** Doutora e Mestre em Educação Ambiental pela Universidade Federal do Rio Grande (FURG). Professora Adjunta da Faculdade de Direito da FURG. Coordenadora do Centro de Referência em Apoio as Famílias (CRAF). Advogada. E-mail: simonedebiazzi@gmail.com 
ch of Human Development and Positive Psychology, in a transformative perspective, as well how families can be impacted by these processes. The methodology was constructed with a view to the Bioecological Approach of Human Development that places the studied phenomena within an ecological context, in a systemic approach, which gave it remarkable originality in relation to other studies of the theme that did not use this approach. The results showed that the educational processes are present in the procedures of family mediation, in the physical environment where it is processed, in the language used, in the personal approach, as well as in the conduction of the processes, being adequate to the time of the conflict. Regarding the impacts produced in the families, it was observed the necessity that they still carry of an authority that guarantees them certainties juridical, as well as the difficulties of the establishment of autonomy for its own decisions, all this fruit of a social-historical construction that established as the parameters for conducting conflicts the litigiousness and adversity resulting from the judicialization of conflicts as a predominant resolution in today's society. It was observed, however, that mediation contributes to building an important path towards autonomy, being in tune with the demands of transformative action

Keywords: Conflict mediation. Human development. Positive psychology.

\section{INTRODUÇÃo}

As relações familiares, tão importantes para o desenvolvimento humano, são alvo de inúmeras influências de contextos nos quais se formam e com os quais interagem. Com efeito, o desenvolvimento das famílias pode sofrer influências dos mais diversos ambientes, desde os mais distais aos mais proximais. Tornar essas influências condições saudáveis ou prejudiciais para o bem-estar dos indivíduos integrantes depende de como se processam as interações do grupo familiar com os demais contextos do entorno social.

Cabe destacar que, desde o início da trajetória de judicialização dos conflitos, com as dificuldades presentes no acesso aos serviços públicos de assistência judiciária, por meio das defensorias públicas, as famílias eram submetidas a longas filas de espera que representavam inúmeros sacrifícios para obter uma resposta judicial aos seus reclames, respostas estas que, raramente, eram compreendidas e quase sempre insatisfatórias. Outrossim, como integrantes de uma camada menos favorecida em vários aspectos, as famílias não eram bem recepcionadas no ambiente judiciário, onde os profissionais, ainda, demonstravam uma concepção naturalizada de família, deixando vir à tona posicionamentos preconceituosos que aumentavam o espectro de desproteção no atendimento oferecido.

O litígio proveniente da judicialização dos conflitos familiares, baseado no sistema adversarial que compõe as estratégias judiciais de enfrentamento de conflitos, se apresentou como um importante resultado que representava nocividade para as interações familiares, muitas vezes causando a interrupção definitiva dos processos proximais entre os integrantes das famílias. Assim, tem-se que outras formas de enfrentamento das questões familiares poderiam compor ambientes mais protetores às relações familiares.

Estas e tantas outras reflexões conduziram a pensar em outros caminhos que pudessem contribuir para um atendimento mais humanizado e onde se pudesse estabelecer maneiras de colaborar para que as relações familiares fossem protegidas, ainda que diante de situações conflituosas. E é nesse terreno que a mediação de conflitos ganha espaço, fundamentada em procedimentos cuja lógica se afasta do ganhar-perder, permitindo aproximações importantes dessa dinâmica com a abordagem Biecológica do Desenvolvimento Humano e com a Psicologia Positiva.

Nesse sentido, o objetivo do presente estudo é compreender os processos da mediação familiar com vistas a analisar os aspectos pedagógico/educativo dessa intervenção e refletir sobre o impacto dessa prática nas relações/interações de famílias em situação de conflito que tenham optado pela resolução de conflito por meio da mediação. Do ponto de vista teórico, pretende-se investigar as aproximações entre as dinâmicas 
de mediação com a abordagem Bioecológica do Desenvolvimento Humano e com a Psicologia Positiva, numa perspectiva transformadora.

Para uma divisão adequada dos pontos a serem enfrentados, optar-se-á por tratar, inicialmente, das noções da importância da família como contexto de desenvolvimento humano, partindo de uma compreensão de que essas relações familiares estão inseridas em um contexto social repleto de incertezas e inseguranças e que necessitam de políticas públicas sérias e comprometidas com o desenvolvimento sadio das mesmas. Num segundo momento, abordar-se-á o conflito como um processo, bem como as vicissitudes próprias do mesmo quando ocorrem no ambiente familiar. Em seguida, serão analisadas as contribuições da Psicologia Positiva nesse contexto, partindo-se da ideia de que a condução dos conflitos familiares pode se dar de diversas formas, enfocando a condução judicial e apresentando a mediação como outra ou "a" possibilidade de condução dialógica e educativa.

A metodologia foi construída tendo como substrato teórico a abordagem Bioecológica do Desenvolvimento Humano que situa os fenômenos estudados dentro de um contexto ecológico, numa abordagem sistêmica. Trata-se de discussão da maior importância, considerando que muito tem se falado em mediação de conflitos, apenas, sob o ponto de vista procedimental e pouco se tem estudado a respeito de seu potencial emancipador no seio das famílias sob a perspectiva do acolhimento e da proteção, sendo, ainda, o enfoque Bioecológico utilizado neste artigo pioneiro na discussão da temática.

\section{Compreendendo a família como lugar de desenvolvimento humano}

Os modelos de desenvolvimento apresentados por Bronfenbrenner ${ }^{1}$ - Ecológico e Bioecológico dão ênfase à complexidade e poder dos processos proximais definidos como as interações entre organismo-ambiente, progressivamente mais complexas ao longo do ciclo da vida ${ }^{2}$. Portanto, tais modelos podem ser ideais para auxiliar na compreensão das questões referentes à cooperação, à construção de saídas e soluções que, também, contemplam as complexidades de uma proposta atualizada de conflito.

O aprimoramento individual, nesse modelo, é importante, mas é imprescindível a existência de esforços concomitantes para o aprimoramento social. São instâncias que se complementam e se inter-relacionam. Somente por meio da interação reciprocamente equilibrada destas se pode desenvolver novas ecologias. Como modelo contemporâneo de influência na Psicologia, a Ecologia e a Bioecologia do Desenvolvimento Humano de Urie Bronfenbrenner constituem referências obrigatórias aos interessados no tema. Privilegiando o contexto e as interações entre o organismo e o ambiente. Não interessa a essa abordagem tão somente os indivíduos e os ambientes imediatos nos quais estes se encontram. É importante considerar, também, as interações das pessoas com os ambientes mais distantes nos quais, muitas vezes, nem participam diretamente, bem como as interações ambientais, tema do presente estudo.

$\mathrm{Na}$ abordagem ecológica do desenvolvimento humano, Bronfrenbrenner ${ }^{3}$ destaca que não importa o ambiente como se apresenta objetivamente, mas sim conforme ele é percebido pelas pessoas. Aduz o referido autor que o desenvolvimento humano se dá por meio de processos de interações recíprocas entre os ambientes e as características da pessoa em desenvolvimento. O ambiente é composto por contextos ecológicos, desde os mais proximais aos mais distais, situados no espaço/tempo social e historicamente determinado. $\mathrm{O}$ ambiente ecológico, portanto, seria concebido como uma série de estruturas encaixadas,

1 BRONFENBRENNER, U. A ecologia do desenvolvimento bumano: experimentos naturais e planejados. Porto Alegre: Artes Médicas, 1996.

2 BRONFENBRENNER, U.; MORRIS, P. The ecology of developmental processes. In: DAMON, W. (Org.). Handbook of child psychology. New York: John Wiley Sons, 1998. v. 1. p. 569-664.

3 BRONFENBRENNER, U. The ecology of human development. Cambridge, MA: Harvard University Press, 1979; BRONFENBRENNER, U. A ecologia do desenvolvimento humano: experimentos naturais e planejados. Porto Alegre: Artes Médicas, 1996. 
uma dentro da outra, como um conjunto de bonecas russas. No nível mais interno, está o ambiente imediato contendo a pessoa em desenvolvimento, que inclui a família, na maioria dos casos. Os ambientes por onde transitam os indivíduos são analisados em sistemas que se completam e se inter-relacionam que são: o microssistema, o mesossistema, o exossistema e o macrossistema.

O microssistema é o sistema ecológico mais próximo e compreende um conjunto de relações entre a pessoa em desenvolvimento e seu ambiente mais imediato. O mesossistema é constituído pelas interações entre dois ou mais ambientes nos quais a pessoa participa ativamente, constituindo, portanto, um sistema de microssistemas. Ele é formado ou ampliado sempre que a pessoa entra em um novo ambiente. O exossistema se refere a ambientes nos quais a pessoa em desenvolvimento não participa ativamente, mas em que ocorrem eventos que afetam ou que são afetados pelo que acontece no ambiente no qual essa pessoa está inserida. Finalmente, o macrossistema se refere a consistências, na forma e conteúdo de sistemas de ordem inferior (micro, meso e exo) que existem ou poderiam existir, no nível da subcultura ou da cultura como um todo, juntamente a qualquer sistema de crenças ou ideologias subjacentes a essas consistências ${ }^{4}$.

Assim, a Ecologia do Desenvolvimento Humano contempla a observação dos fenômenos naturais sob uma ótica interacionista, que privilegia ações e as interações provenientes das ações, que buscam transformações sociais baseadas na cooperação e no entendimento de que nada funciona de forma isolada, que somos um todo funcionando dinamicamente ${ }^{5}$.

Nesse sentido, famílias são microssistemas nos quais se pode e se deve cultuar a solidariedade. A solidariedade é um princípio que tem origem em vínculos afetivos, de conteúdo ético e que compreende as dimensões humanas de fraternidade e reciprocidade. Para Dias ${ }^{6}$, a pessoa somente pode dizer que existe, quando coexiste. A autora menciona que o princípio da solidariedade tem assento na Constituição Federal, que, em seu preâmbulo, assegura a todos uma sociedade fraterna, estando prevista, ainda, na imposição aos pais de assistência aos filhos (artigo 2272) e o dever de amparo às pessoas idosas (artigo 2303), consagrando, dessa forma, na via legal, o princípio da solidariedade e sugerindo acentuar reciprocidade na relação pais-filhos. Mas mencionar direitos e deveres não é tão eficaz para a transformação da sociedade quanto à propositura de modelos que, efetivamente, movam afetividades, no sentir de oportunizar que as pessoas se sintam comprometidas com princípios de solidariedade e cooperação.

Macedo $^{7}$ aponta que a famillia, do ponto de vista das ciências sociais e humanas, é um dos "organizadores da sociedade", definindo estilos de vida, situando e legitimando o indivíduo no seu espaço social. A autora menciona que, para a Psicologia, a família é revestida de uma importância capital, já que constitui o primeiro ambiente onde se desenvolve a personalidade de cada pessoa, sendo vista como o espaço psicossocial primordial, "protótipo das relações a serem estabelecidas com o mundo". ${ }^{8}$

E, é este o sentido da presente pesquisa, o de pensar a família como um importante contexto e situá-la como elemento social para o qual devem se voltar as políticas públicas, instrumentalizando-a por meio de processos educativos que oportunizem autonomia para que consigam dar conta de, sobrevivendo às rápidas mudanças da atual sociedade, servir de suporte para a transformação social de construir relações reais solidárias com as pessoas e contextos.

Ao referenciar a noção de senso comum de familia, no entanto, há certo consenso nas ideias de refúgio

4 BRONFENBRENNER, U. A ecologia do desenvolvimento bumano: experimentos naturais e planejados. Porto Alegre: Artes Médicas, 1996. 5 JULIANO, M. C.; YUNES, M. A. M. A abordagem bioecológica de desenvolvimento humano: conceitos fundamentais e interfaces com a educação ambiental. In: OLIVEIRA, Márcio Vieira; CORRÊA, Luciara Bilhalva (Org.). Tecendo a educação ambiental a partir de olhares coletivos. Porto Alegre: Evangraf, 2009. v. 1. p. 109-119.

6 DIAS, M. B. Manual de Direito das Famílias. 8. ed. São Paulo: Revista dos Tribunais, 2011.

7 MACEDO, R. M. A família do ponto de vista psicológico: lugar seguro para crescer? Cadernos de Pesquisa, São Paulo, n. 91 , p.62-68, nov. 1994.

8 MACEDO, R. M. A família do ponto de vista psicológico: lugar seguro para crescer? Cadernos de Pesquisa, São Paulo, n. 91, p.6268, nov. 1994. p. 63. 
seguro, de ambiente ideal para retornar após as lutas cotidianas ${ }^{9}$. Essa sensação faz parte de uma sociedade que, fundamentada mais em idealização do que em realidade, potencializa um forte sentimento de nostalgia em relação ao passado. Remonta-se, assim, a um passado "imaginário" onde as famílias eram felizes, mais bem "estruturadas" e "ajustadas". Walsh ${ }^{10}$ menciona a nostalgia da família do passado como melhor do que as famílias contemporâneas.

Existe, portanto, um ideal de família posto no imaginário social e, em virtude dessa mitificação, muitas vezes, não se discutem as precariedades existentes no ambiente familiar, tampouco as possibilidades e potencialidades presentes nesse microssistema e que podem representar importantes fatores de desenvolvimento humano, a depender dos estímulos e investimentos psicossociais nesta instituição. Além disso, há a importante questão de que os componentes da família "vivida" passam a idealizar suas relações em modelos pré-estabelecidos, aceitando os rótulos de "incompletas" e "desestruturadas", que podem gerar sentimentos de incompetência entre os membros.

Conceituar familias, no entanto, não é tarefa fácil. Talvez seja tarefa até mesmo dispensável, porquanto suas significações podem ser bastante diversas, dependendo do contexto onde se inserem. O que se tem em vista, no presente trabalho, não é o interesse em conceituar famílias, mas, sobretudo, em expor, ainda que de forma incompleta ou sucinta, a importância destas como grupos promotores de sobrevivência, socialização e desenvolvimento dos indivíduos e, por via de consequência, a influência desses aspectos para a formação de uma sociedade ecologicamente equilibrada. A utilização do termo "famílias" firma o entendimento de que acreditamos na existência de muitas formas e configurações familiares, numa visão plural, que contempla os mais diversos arranjos vivenciais.

Rodrigo e Palácios ${ }^{12}$ apontam que a família é um cenário de construção de pessoas adultas, de autoestima e de bem-estar psicológico. É um lugar onde se aprende a enfrentar desafios e assumir responsabilidades e compromissos. Representa, para os autores, um contexto de desenvolvimento e realização pessoal dos adultos e é cenário de encontro intergeracional. Além de formar uma rede de apoio social, para os filhos, a família tem a função de assegurar a sobrevivência dos mesmos, seu crescimento, socialização e proporcionar um clima de afeto que possibilite estímulos para os seus relacionamentos com o ambiente físico e social. Nesse compasso, a função educacional das famílias se destaca.

O modelo Ecológico teve novas formulações e acréscimos em 1998, quando Bronfenbrenner criticou a si mesmo e sua teoria Ecológica pelo excesso de ênfase nos contextos em detrimento das características das pessoas em desenvolvimento ${ }^{13}$. A partir dessa crítica, é proposto o modelo Bioecológico que estuda com mais detalhes as características biopsicológicas da pessoa em desenvolvimento e os processos proximais. Sem negar quaisquer dos pressupostos do modelo Ecológico original, são acrescidas informações e abertos novos horizontes, admitindo-se que as interações, por exemplo, não se restringem, somente, a pessoas, mas envolvem objetos e símbolos. Estes se apresentam nos diferentes contextos, além de enfatizar as características biopsicológicas das pessoas como importantes para serem estudadas e pesquisadas. Em síntese, o modelo Bioecológico compreende o desenvolvimento humano em quatro aspectos inter-relacionados: $\mathrm{O}$ processo, a pessoa, o contexto e o tempo.

O processo é construto fundamental do modelo Bioecológico. Os processos se dão por meio da presença de objetos, atividades, ou outras pessoas, em especial, e essas relações orientam o desenvolvimento

9 MACEDO, R. M. A família do ponto de vista psicológico: lugar seguro para crescer? Cadernos de Pesquisa, São Paulo, n. 91, p.6268, nov. 1994.

10 WALSH, F. Fortalecendo a resiliência familiar. São Paulo: Roca, 2005.

11 SZYMANSKI, H. Teoria e "teorias de famílias". In: CARVALHO, M. do C. B. de (Org.). A família contemporânea em debate. São Paulo: EDUC/ Cortez, 1995. p.23-27.; SZYMANSKI, H. Significados de família. In: LOCH, G. M.; YUNES, M. A. M. (Orgs.). A família que se pensa e a família que se vive. Rio Grande: FURG, 1998.

12 RODRIGO, M. J.; PALACIOS, J. Família e desarrollo bumano. Madrid: Alianza Editorial, 1998.

13 BRONFENBRENNER, U.; MORRIS, P. The ecology of developmental processes. In: DAMON, W. (Org.). Handbook of child psychology. New York: John Wiley Sons, 1998. v. 1. p. 569-664. 
humano ${ }^{14}$. Os processos proximais podem produzir efeitos de competência - aquisição e desenvolvimento de conhecimentos, habilidades e capacidades para conduzir e direcionar seu próprio comportamento, ou efeitos de disfunção - manifestação recorrente de dificuldade em manter o controle e a integração do comportamento em diferentes domínios do desenvolvimento ${ }^{15}$.

O segundo componente do modelo, a pessoa, envolve tanto características biopsicológicas como aquelas construídas na interação com o ambiente. O desenvolvimento está relacionado com a estabilidade e as mudanças nas características da pessoa durante o ciclo vital. Tais características são, ao mesmo tempo, produtoras e produto do desenvolvimento.

Narvaz e Koller ${ }^{16}$ reforçam os três grupos de características da pessoa que atuam no desenvolvimento e influenciam os processos proximais, denominados de força, recursos e demandas. A força refere-se às disposições comportamentais ativas que tanto podem desenvolver os processos proximais ou colocar obstáculos e até impedimentos para que tais processos ocorram. Os recursos envolvem deficiências e competências psicológicas que influenciam o efetivo funcionamento dos processos proximais nos diferentes estágios de desenvolvimento. A demanda, por fim, são atributos capazes de estimular ou desencorajar reações do ambiente social, favorecendo ou não o estabelecimento dos processos.

O contexto compreende a interação dos quatro níveis ambientais já referidos - micro, meso, exo e macrossistema - que formam o meio ambiente ecológico. É importante mencionar que é no contexto dos microssistemas que operam os processos proximais, produzindo e sustentando o desenvolvimento. E o tempo permite examinar a influência das mudanças que ocorrem ao longo da vida sobre o desenvolvimento humano. A análise do tempo deve focalizar a pessoa em relação aos acontecimentos presentes em sua vida, desde os mais próximos até os mais distais, incluindo os eventos importantes na vida da pessoa, bem a diversidade de transições históricas.

Nessa esteira, uma das questões que ainda necessita de um suporte adequado, que contemple as diversidades familiares existentes e que sirvam de efetivo apoio ao desenvolvimento saudável aos seus membros, diz respeito às políticas de enfrentamento de conflitos familiares, que reforçam e estimulam o entendimento de que somente o confronto judicial poderá servir para "solucionar" os problemas interpessoais. Sob um aspecto macrossistêmico, a cultura vigente, ainda, reforça o entendimento de que a justiça e suas tecnologias dão conta de resolver todos os problemas, e o imaginário social acaba sendo influenciado por esta abordagem.

Não é raro encontrarmos programas de televisão que mostram os conflitos familiares como verdadeiros espetáculos. Além disso, as questões podem ser resolvidas com exames de DNA, ou com investigações profícuas, que acontecem, somente, na televisão, no mundo show. E essas fórmulas "vendidas" diariamente podem representar risco para relações que necessitam de uma atenção mais protetora, para o efeito de preservar vínculos que, estando ou não ligados por laços consanguíneos, merecem um cuidado mais acurado. Por representarem importantes contextos de convivência e socialização, as relações familiares necessitam de estímulos aos processos de manutenção e/ou criação de laços de afetividade e compromisso e estes poderão ser (re)construídos ou rompidos, a depender de como as adversidades serão conduzidas

\section{Compreendendo a noção de Conflito}

Os conflitos fazem parte dos relacionamentos entre todos os indivíduos e isto se dá em virtude da di-

14 BRONFENBRENNER, U.; MORRIS, P. The ecology of developmental processes. In: DAMON, W. (Org.). Handbook of child psychology. New York: John Wiley Sons, 1998. v. 1. p. 569-664.

15 BRONFENBRENNER, U. The ecology of buman development. Cambridge, MA: Harvard University Press, 1979.

16 NARVAZ, M.G.; KOLLER, S.H. O modelo bioecológico de desenvolvimento humano. In: KOLLER, S. H. (Org.) Ecologia do desenvolvimento humano. São Paulo: Casa do Psicólogo, 2004. p. 55-69. p. 55. 
versidade, dos pontos de vista diferentes sobre os mesmos assuntos, ou seja, os diferentes hábitos, comportamentos, costumes, valores e crenças. Para Bobbio \& Pasquino ${ }^{17}$, conflito é “[...] uma forma de interação entre indivíduos, grupos, organizações e coletividades que implica choques para o acesso à distribuição de bens escassos". Pode ser definido, outrossim, como um processo ou estado em que duas ou mais pessoas divergem em razão de metas, interesses ou objetivos individuais percebidos como mutuamente incompatíveis ${ }^{18}$.

Marodin e Breitman ${ }^{19}$ abordam o conflito inerente aos processos de desenvolvimento humano como dinâmico, como parte da vida e que pode tornar-se saudável ou doentio de conformidade como for conduzido. Aduzem as autoras que o conflito pode ser: no indivíduo, denominado intrapsíquico; entre indivíduos, interpessoal e entre grupos, intergrupal. Para o presente estudo, o foco é o conflito interpessoal, ou seja, os conflitos existentes entre pessoas.

Para Gergen ${ }^{20}$ o conflito possui uma natureza endêmica e devemos nos ocupar em evitar que o antagonismo constante não possa produzir agressões, opressões e, na sua manifestação extrema, genocídios. Para o autor o principal, desafio para o nosso século é conseguirmos continuar a viver juntos. No entanto, tomando o diálogo como base dos conflitos, aposta no diálogo como “[...] nossa melhor opção para tratar de realidades conflitantes". ${ }^{21}$

$\mathrm{Na}$ procura de resolução dos conflitos interpessoais, e que abrange a relação com o outro - alteridade - quanto maior a abrangência das possibilidades, mais valorizada será a pessoa em seu contexto já que é em virtude da complexidade das relações humanas que o conflito se manifesta. De acordo com as interações vivenciadas nessas relações, a situação de conflito pode se tornar um fator de crescimento ou de paralisação dos indivíduos ${ }^{22}$.

O entendimento adotado neste artigo refere-se ao fato de que o conflito não pode ser entendido como uma entidade, como um estado fático imutável, mas como um processo interacional fundamental da vida humana, como parte dos eventos de inter-relação, e, principalmente, como elemento gerador de mudanças, negativas ou positivas, a depender do enfoque que for dado ao mesmo.

Compreende-se que, como processos, os conflitos devem ser conduzidos. Esta é a compreensão de enfrentamento dos tomada como mais correta - a condução destes de forma a propiciar contornos saudáveis para todos os envolvidos. Acolhe-se o dito por Bobbio e Pasquini ${ }^{23}$, para quem raramente se suprime um conflito, ou se eliminam as causas, tensões ou contrastes que o geraram. Ademais, o conflito em si é potencialmente transformativo: se bem conduzido pelas pessoas, pode desenvolver e integrar as capacidades de força individual e empatia pelos outros ${ }^{24}$.

Os conflitos familiares possuem peculiaridades importantes e que merecem destaque, pois a abordagem inadequada destes pode representar risco para as relações entre seus membros. Com efeito, os conflitos familiares não são simplesmente a discordância acerca de algum tema, ou ainda não são somente conflitos de

17 BOBBIO, N.; PASQUINO, G. Dicionário de política. 12. ed. Brasília: Universidade de Brasília, 2004.

18 YARN, D. E. Dictionary of Conflict Resolution. São Francisco: Ed. Jossey-Bass Inc., 1999. p. 113.

19 MARODIN, M.; BREITMAN, S. A prática moderna da mediação: integração entre psicologia e direito. In: ZIMERMAN, D.; COLTRO, A.C.M. (Orgs.). Aspectos psicológicos na prática jurídica. Campinas Ed. Milennium, 2008. p. 335-343.

20 GERGEN, K. J. Rumo a um vocabulário do diálogo transformador. In: SCHNITMAN, D. F.; LIT'TLEJOHN, S., (Orgs). Novos paradigmas em mediação. Porto Alegre, Artmed, 1999. p. 29-45.

21 GERGEN, K. J. Rumo a um vocabulário do diálogo transformador. In: SCHNITMAN, D. F.; LITTLEJOHN, S. (Orgs). Novos paradigmas em mediação. Porto Alegre, Artmed, 1999. p. 30.

22 MARODIN, M.; BREITMAN, S. A prática moderna da mediação: integração entre psicologia e direito. In ZIMERMAN, D.; COLTRO, A.C.M. (Orgs.). Aspectos psicológicos na prática jurídica. Campinas Ed. Milennium, 2008. p. 500.

23 BOBBIO, N.; PASQUINO, G. Dicionário de política. 12. ed. Brasília: Universidade de Brasília, 2004.

24 FOLGER, J. P.; BUSH, R. A. B. Mediação transformativa e intervenção de terceiros: as marcas registradas de um profissional transformador. In: SCHNITMAN, D. F.; LITTLEJOHN, S. (Orgs). Novos paradigmas em mediação. Porto Alegre: Artmed, 1999. p. 85-100. 
direitos, mas são essencialmente afetivos, psicológicos, relacionais, antecedidos e precedidos por sofrimento. No que tange à condução das disputas familiares e a observação dos aspectos emocionais para sua resolução, tem-se a questão da manutenção/preservação dos vínculos. E o vínculo, que pode ser considerado uma união ou ligação entre pessoas.

Conforme já referido, ao longo do ciclo da vida familiar, as crises, apesar de representarem momentos de instabilidade, podem ser molas propulsoras de crescimento, impulsionando as famílias a atingirem o que Falcke e Wagner ${ }^{25}$ denominam "estados maturacionais mais evoluídos". Para as autoras, a crise familiar

[...] frente à ruptura e instabilidade temporária que ocasiona no sistema familiar, cria, por conseguinte, uma necessidade de reorganização das inter-relações e uma descoberta de novas regras de funcionamento familiar ${ }^{26}$.

Isto não quer dizer que, sempre que exista crise na família, ocorrerá, "naturalmente", uma mudança positiva nas relações e que favorece a saúde no meio familiar. No entanto, em havendo uma efetiva transformação positiva na condução dos conflitos, os resultados podem ser promissoramente saudáveis.

Portanto, maior é a importância de uma abordagem multifacetada, em que se contemplem os mais diversos aspectos das situações e, fundamentalmente, em que se possa oferecer o apoio da forma mais abrangente possível. Além disso, abordar a noção de que o conflito é gerador de transformação, e que deve ser conduzido nesse sentido, pode ser muito importante para que se destaquem desse processo os aspectos de saúde, de otimismo, e que podem produzir bem-estar para as pessoas, sob a perspectiva da Psicologia Positiva.

\section{As CONTRIBUIÇÕES DA PSICOLOGIA POSITIVA}

A Psicologia Positiva é um movimento que vem se fortalecendo e que trata do estudo das experiências positivas subjetivas, dos traços positivos do ser humano e de como as instituições e ambientes podem contribuir para ressaltar esses aspectos, para romper com as abordagens do desenvolvimento focadas em patologias. Estuda fatores e processos que conduzam a otimização do desenvolvimento humano, com foco nas forças, para solidificar as competências pessoais como forma de potencializar o bem-estar. Abre espaço, portanto, para estudar as habilidades positivas do ser humano, redirecionando o enfoque, antes dado a patologia, para a promoção da qualidade de vida. ${ }^{27}$.

$\operatorname{Seligman}^{28}$, ao rever a teoria da felicidade autêntica ${ }^{29}$, passa a falar em bem-estar como um construto com vários elementos a contribuir para sua formação e diz que é o bem-estar, não a felicidade, o tema central da Psicologia Positiva. Seligman elenca cinco elementos que formam o bem-estar, quais sejam: 1) a emoção positiva que inclui a felicidade e a satisfação com a vida, e é representada pela sensação de "vida agradável"; 2) o engajamento; 3) o sentido - "pertencer e servir a algo que se acredita ser maior do que eu"30; 4) a realização, em sua forma momentânea e a "vida realizadora", em sua forma ampliada" e 5) relacionamentos positivos. ${ }^{31}$

25 FALCKE, D.; WAGNER, A. A dinâmica familiar e o fenômeno da transgeracionalidade: definição de conceitos. In: WAGNER, A. (Org.). Como se perpetua a família? A transmissão dos modelos familiares. Porto Alegre: EDIPUCRS, 2005. p. 25-43. p. 43.

26 FALCKE, D.; WAGNER, A. A dinâmica familiar e o fenômeno da transgeracionalidade: definição de conceitos. In: WAGNER, A. (Org.). Como se perpetua a família? a transmissão dos modelos familiares. Porto Alegre: EDIPUCRS, 2005. p. 25-43. p. 43.

27 SELIGMAN, M. Felicidade autêntica: usando a nova psicologia positiva para a realização permanente. Rio de Janeiro: Objetiva, $2004 . ;$ SELIGMAN, M. Florescer: uma nova compreensão sobre a natureza da felicidade e do bem-estar. Rio de Janeiro: Objetiva, 2011.

28 SELIGMAN, M. Florescer: uma nova compreensão sobre a natureza da felicidade e do bem-estar. Rio de Janeiro: Objetiva, 2011.

29 SELIGMAN, M. Felicidade autêntica: usando a nova psicologia positiva para a realização permanente. Rio de Janeiro: Objetiva, 2004.

30 SELIGMAN, M. Florescer: uma nova compreensão sobre a natureza da felicidade e do bem-estar. Rio de Janeiro: Objetiva, 2011. p. 28.

31 SELIGMAN, M. Florescer: uma nova compreensão sobre a natureza da felicidade e do bem-estar. Rio de Janeiro: Objetiva, 
As forças e virtudes pessoais passam a ser o suporte de todos os cinco elementos, que devem ter como propriedade contribuir para a formação do bem-estar e as pessoas os buscam por eles próprios, sendo definidos e mensurados independentemente dos demais elementos. A teoria do bem-estar é plural no método, bem como na substância: a emoção positiva é uma variável subjetiva, definida por aquilo que se pensa e sente. O engajamento, o sentido, os relacionamentos e a realização têm componentes subjetivos e objetivos, já que se pode acreditar que tem engajamento, sentido, bons relacionamentos e alta realização e, ainda assim, é possível estar errado ou até iludido. A conclusão é que o bem-estar não pode existir, apenas, para o indivíduo: ele é uma combinação de sentir-se bem e efetivamente ter sentido, bons relacionamentos e realização. O modo como se escolhe a trajetória de vida é maximizando todos esses cinco elementos.

A partir da compreensão de que a amplificação dos aspectos positivos pode resultar em maiores possibilidades de superar adversidades, a Psicologia Positiva aprecia as capacidades, motivações e potencialidades das pessoas como produtoras de desenvolvimento saudável e uma das bases é o conceito de resiliência, que, na Psicologia, é utilizado para se referir aos processos que explicam o enfrentamento e a superação de crises e adversidades ${ }^{32}$.

Rutter $^{33}$ define resiliência como uma variação individual em resposta ao risco e afirma que os mesmos estressores podem ser experienciados de maneira diferente por diferentes pessoas. Assim, a resiliência não pode ser vista como um atributo fixo do indivíduo, mas é necessário dar ao conceito um toque de relatividade, podendo ser entendido como processos que envolvem condições ambientais e variações individuais. Não se fala, portanto, em indivíduos "resilientes" e "não resilientes", devendo a noção de resiliência ser entendida como possibilidades presentes no cotidiano das pessoas ou grupos, como processos complexos e dinâmicos, dependentes das interações entre os indivíduos e entre estes e o ambiente, numa perspectiva ecológica de desenvolvimento humano ${ }^{34}$.

A resiliência, portanto, implica o enfrentamento de uma situação de risco, e se apresenta como um processo psicológico dinâmico, que surge com base na interação entre as características individuais o contexto social. O processo de resiliência se opera na presença de situações de risco, produzindo resultados que podem auxiliar as pessoas a enfrentarem e superarem adversidades e problemas na vida. Resiliência refere-se a um conjunto de processos de vida que possibilitam o enfrentamento de situações de sofrimento com consequente fortalecimento, transformação pessoal e superação das adversidades.

Deve se ressaltar, no entanto, que falar em mecanismos de proteção e risco implica abordar processos que são influenciados por diversos fatores que interagem ao longo do tempo, alterando a trajetória das pessoas, podendo o resultado dessas interações apresentar impacto no desenvolvimento destas. A compreensão do conceito, portanto, se torna possível quando se pensa em resiliência como um processo interativo entre as adversidades e os fatores/mecanismos de proteção que sejam próprios dos sujeitos ou externos a eles, bem como pelas competências que esses sujeitos possam desenvolver ao longo da vida e que possam auxiliar a obtenção de sucesso diante dos desafios e crises próprias da vida.

Nesse sentido, estudar processos de resiliência em famílias vulnerabilizadas pelo conflito, apresenta-se como forma de compreender o papel desempenhado, efetivamente, pelos ambientes de enfrentamento das crises, enquanto estruturas que podem sustentar mecanismos de proteção e desenvolver interações significativas e oportunizadoras de desenvolvimento humano.

Mecanismos de proteção seriam aqueles processos de incremento à resiliência e de inibição do impacto

2011. p. 30.

32 YUNES, M. A. M.; SZYMANSKI, H. Resiliência: noção, conceitos afins e considerações críticas. In: TAVARES, J. (Org.) Resiliência e educação. São Paulo: Cortez, 2001. p. 13-42.

33 RUTTER, M. Psychosocial resilience and protetive mechanisms. American Journal of Orthopsychiatry, Washington, v.57, n. 3, p. 316-331, 1987.

34 YUNES, M. A. M.; GARCIA, N. M.; ALBUQUERQUE, B. de M. Monoparentalidade, pobreza e resiliência: entre as crenças dos profissionais e as possibilidades da convivência familiar. Reflexão \& Crítica, Porto Alegre, v. 20, n.3, 2007. 
do risco e que tanto podem estar ligados às características pessoais como a fatores externos, ambientais. $\mathrm{O}$ contexto e o sistema familiar podem afetar a adaptação do indivíduo, diminuindo ou exacerbando o impacto dos processos de risco. Para Rutter ${ }^{35}$, os quatro principais mecanismos que colaboram para a ocorrência de processos de proteção são: redução do impacto de riscos, ou seja, alterar a exposição da pessoa à situação estressora; redução das reações negativas em cadeia que sucedem a situação de risco na qual a pessoa é exposta; o estabelecimento e manutenção da autoestima, por meio de relações de apego seguras e incondicionais.

A resiliência se processa por meio da criação de oportunidades para os pontos de virada, que “[...] são processos que podem modificar os rumos de uma trajetória, tornando o indivíduo adaptado ou desadaptado durante seu ciclo de vida" ${ }^{36}$. O conceito de resiliência familiar, que interessa ao presente trabalho, encontra-se muito bem explicitado nas palavras de Walsh, que expõe:

O termo resiliência familiar refere-se aos processos de enfrentamento à adaptação na família como uma unidade funcional. Uma perspectiva sistêmica nos permite compreender como os processos familiares intervêm no estresse e permitem a família superar a crise e enfrentar dificuldades prolongadas... A maneira como uma família enfrenta e lida com uma experiência difícil, resiste ao estresse, se reorganiza de modo eficiente e segue a vida influenciará a adaptação imediata e a longo prazo de todos os membros da família e a própria sobrevivência e o bem-estar da unidade familiar. ${ }^{37}$

Para o presente trabalho, é importante abordar resiliência familiar para identificar e fortalecer processos interacionais que permitam às famílias resistir aos desafios desorganizadores da vida e renascer a partir deles. Uma visão de resiliência familiar "[...] muda a perspectiva de se encarar as famílias em situação de angústia como defeituosas, para encará-las como desafiadas, ratificando o seu potencial para o reparo e o crescimento". ${ }^{38}$ Para a autora, tanto a força individual como a força familiar podem ser forjadas por esforços cooperativos, para lidar com as crises.

Todas essas questões referentes à resiliência são importantes para o presente estudo. Assim como as interações negativas podem ter efeito destrutivo para o desenvolvimento humano, também as experiências de sucesso no enfrentamento das crises na família podem representar o aumento da confiança necessária para enfrentar o cotidiano, que se apresenta cada vez mais complexo e representa verdadeiro desafio, principalmente para as famílias em situação de pobreza.

A perspectiva está fundamentada no deixar de olhar os desajustes e falhas dos indivíduos e grupos, para acreditar e valorizar as suas competências, suas possibilidades e potencialidades intelectuais, afetivas, sociais e culturais. A resiliência é um conceito otimista que auxilia na desconstrução de crenças pessimistas sobre populações que vivem situações de risco e de extrema vulnerabilidade social e ambiental, na contramão de um pensamento que é socialmente dominante.

Pensar essas famílias com os óculos da resiliência pode representar possibilidades de reconhecimento de estratégias e habilidades pensadas com base em suas reais necessidades e das suas próprias vivências. Desenvolver, portanto, mecanismos que auxiliem a reduzir os riscos e as vulnerabilidades das famílias em situação de conflito é medida que se impõe dentro da ótica da criação de políticas sérias, pautadas por medidas subjetivas e objetivas de bem-estar, aumentando o que Seligman chama de "florescimento na vida das pessoas e no planeta" ${ }^{39}$.

35 RUTTER, M. Resilience: some conceptual considerations. Journal of Adolescent Health, n.14, p. 626- 631, 1993.

36 YUNES, M. A. M. A questão triplamente controvertida da resiliencia em famílias de baixa renda. 2001. 166 f. Tese (Doutorado em Psicologia) - Pontifícia Universidade Católica de São Paulo, São Paulo, 2001. p. 28.

37 WALSH, F. Fortalecendo a resiliência familiar. São Paulo: Roca, 2005. p. 14.

38 WALSH, F. Fortalecendo a resiliência familiar. São Paulo: Roca, 2005. p. 3.

39 SELIGMAN, M. Florescer: uma nova compreensão sobre a natureza da felicidade e do bem-estar. Rio de Janeiro: Objetiva, 2011. p. 37. 


\section{A MEDIAÇÃO COMO FORMA ALTERNATIVA DE TRATAMENTO DE CONFLITOS}

O presente item visa estabelecer algumas discussões acerca do litígio judicial e suas influências nas relações familiares, e, inobstante seja o entendimento adotado neste artigo, relativo à nocividade presente no ambiente judiciário para o fortalecimento de tais relações, cumpre que se faça uma ressalva no que diz respeito à ordem jurídica como orientadora das relações interpessoais, para que não se incida na compreensão de que este trabalho possa ser avesso ao direito. Ao contrário, compreende-se a ordem jurídica como fundamental para que exista uma sociedade equilibrada e onde sejam previstos os parâmetros mínimos de convivência humana. Sob essa perspectiva, algumas reflexões sobre o ambiente judiciário e seus reflexos nas relações familiares são apresentadas a seguir.

Em uma sociedade que idolatra o espetáculo, o ambiente judiciário pode ser representado como um grande palco, e segundo Santos:

[...] os processos judiciais tiveram sempre o potencial de se transformarem em dramas. Trata-se, porém, de um teatro para um auditório muito selecto, um teatro de culto profissional. Hoje, os meios de comunicação social, sobretudo a televisão, transformam esse teatro de culto num teatro de boulevard, espectáculo como entretenimento segundo uma linguagem directa e acessível a grandes massas. ${ }^{40}$

O autor adverte que a espetacularização do judiciário pode representar perigo para a legitimidade social e política da justiça, por vários motivos, a saber: 1. Pelo excesso de informação, já que é transmitida uma dimensão totalizante dos fatos, o que pode estigmatizar grupos ou classes sociais; 2. Pela sofisticação do escândalo, o que acarreta rupturas entre a realidade e a opinião pública; 3. Pela múltipla penalização dos envolvidos, que são julgados, também, pela audiência; 4. Pela característica de espetáculo, que produz sentimentos contraditórios na comunidade, absolutizando ou trivializando a justiça; 5. Pela banalização da violência; 6. Pela transformação do público em tribunal de opinião e 7. Pelo uso da linguagem, nem sempre adequada à racionalidade jurídica ${ }^{41}$.

Nessa esteira, a transformação do judiciário numa forma de entretenimento pode trazer falsas percepções do verdadeiro papel deste na ordem social, pois, para além do quadro ritual que media a realidade com o julgamento, o processo é o enraizamento principal do direito na vida. O indivíduo que não esteja integrado numa esfera jurídica está ameaçado da violência pura. O papel da justiça é procurar a "distância correta" ${ }^{2}$ entre os sujeitos de direito.

Quando o conflito atinge uma intensidade incontrolável pelos dispositivos da regulação social, o Judiciário se apresenta como um terreno de entendimento e uma linguagem comum: a do direito. Assim, fica possível que as palavras voltem a ter significado, já que lhes é atribuído um sentido sem ambiguidades, o que possibilita que as partes voltem a dialogar.

O conflito familiar, quando levado ao Judiciário, adquire contornos que nem sempre são saudáveis ao desenvolvimento das relações. Para Santos a característica principal da adjudicação judicial está na criação de "[...] dicotomias drásticas entre ganhadores e perdedores, mas só depois de aturados e prolongados procedimentos de contraditório e provas convincentes" "43. As situações passam a ser relacionadas a conceitos de crise e são enfrentadas como eventos prejudiciais e desagradáveis. Estabelece-se como prioridade a "resolução" do conflito, buscando-se o caminho do enfrentamento, da disputa, ou seja, a determinação de um perdedor e de um ganhador. As posições tornam-se rígidas e não se busca a negociação, uma vez que ceder

40 SANTOS, B. S. Os tribunais e as novas tecnologias de comunicação e informação. Sociologias, Porto Alegre, n. 13, p. 82-109, jan./jun. 2005. p. 99.

41 SANTOS, B. S. Os tribunais e as novas tecnologias de comunicação e informação. Sociologias, Porto Alegre, n. 13, p. 82-109, jan./jun. 2005.

42 GARAPON, A. Bem julgar: ensaio sobre o ritual judiciário. Lisboa: Instituto Piaget, 1997. p. 92.

43 SANTOS, B. S. Os tribunais e as novas tecnologias de comunicação e informação. Sociologias, Porto Alegre, n. 13, p. 82-109, jan./jun. 2005. p. 99. 
implica "[...] desistir em favor do outro"

Quando o conflito é judicializado, existe uma série de procedimentos formais e cronológicos que devem ser observados pelos disputantes e que passamos a expor de forma simplificada: uma vez que a pessoa pretenda resolver suas questões com base em um processo judicial, a primeira providência a ser tomada é a procura por um advogado, já que a legislação exige que os pleitos judiciais sejam feitos por meio de procuradores legalmente habilitados. Estando devidamente representada pelo advogado, deverá expor seu pedido e suas razões de pedir por meio de uma petição inicial, devidamente instruída com os documentos considerados indispensáveis à propositura da ação.

O processo judicial faz a abordagem do conflito como se este fosse um fenômeno jurídico, tratando, exclusivamente, daqueles interesses que são juridicamente tutelados e mais, daqueles interesses que foram levados ao judiciário por meio dos petitórios. Dessa sorte, exclui aspectos do conflito que podem ser tão importantes quanto aqueles judicializados, ou, em alguns casos, até mais relevantes do que eles. Falar, por exemplo, de pensão alimentícia, guarda e visitação, definindo valores, responsabilidades e datas para uma família que não consiga estabelecer vínculos positivos, pode auxiliar pouco, ou quase nada, para que sejam (re)construídos laços significativos entre seus integrantes.

Aliado a todos esses fatores, ocorre, com frequência, no Judiciário, a naturalização das relações familiares, que são vistas como inadequadas ao "modelo" a ser seguido. Isso pode conduzir a discursos normativos que influenciam não somente a maneira de conduzir os processos por parte dos profissionais, mas, sobretudo, a aceitação da população atendida que se entende como anormal ou patológica por não prescrever esses preceitos pré-estabelecidos. Isto pode aumentar, significativamente, o estigma da judicialização de suas desavenças.

Este seria um dos fatores que interferem sobremaneira na condução do litígio, e que, uma vez não elaborado de forma saudável por todos os atores envolvidos, poderá representar fator a se somar na sensação de incompetência das famílias e contribuir para a manutenção das teorias que permeiam o imaginário social de "desestruturação" como causador de aumento de conflitos familiares.

A mediação vem sendo apontada como uma nova forma de condução de conflitos familiares, tendo em vista que já existe o entendimento de que a má gestão, quando da jurisdicionalização do conflito, pode ocasionar grandes danos psicológicos à família, e provocar prejuízos emocionais que podem se estender pela vida toda ${ }^{45}$.

Não se busca tão somente o acesso à Justiça, representado pela garantia de que as demandas serão levadas ao Judiciário, mas, sobretudo, o efetivo acesso ao Judiciário, no sentido de incluir os usuários do sistema e que se encontram à margem deste, e, sob o prisma da autocomposição, estimular, difundir e educar as pessoas a melhor resolver conflitos por meio de ações comunicativas.

\subsection{Mediação: procedimentos e modelos}

A mediação é um processo que, por meio da ajuda de uma pessoa neutra e imparcial (o mediador), estimula pessoas a dialogarem e a cooperarem para resolver um determinado problema. É, portanto, mais que um método para conduzir os conflitos: é uma forma que visa também evitar eventuais conflitos no futuro, já que um de seus objetivos é criar um clima de cooperação entre as pessoas. Para Haunes e Marodin:

[...] é um processo no qual uma terceira pessoa, o mediador, auxilia os participantes na resolução de uma disputa. O acordo final resolve o problema com uma solução mutuamente aceitável e será estruturada

44 WALSH, F. Fortalecendo a resiliência familiar. São Paulo: Roca, 2005. p. 117.

45 ROSA, C. P. da R. Mediação: uma nova alternativa de tratamento dos conflitos familiares. In: Ambito Jurídico, 2009. Disponível em: <http://www.ambito-juridico.com.br/site/?n_link=revista_artigos_leitura\&artigo_id=6116\&revista_caderno=14>. Acesso em: 26 jun. 2018 
de modo a manter a continuidade das relações das pessoas envolvidas no conflito. ${ }^{46}$

Para Breitman e Porto:

A mediação é um processo orientado a conferir às pessoas nele envolvidas a autoria de suas próprias decisões, convidando-as à reflexão e ampliando alternativas. É um processo não adversarial dirigido à desconstrução dos impasses que imobilizam a negociação, transformando um contexto de confronto em contexto colaborativo. É um processo confidencial e voluntário no qual um terceiro imparcial facilita a negociação entre duas ou mais partes onde um acordo mutuamente aceitável pode ser um dos desfechos possíveis. ${ }^{47}$

O processo de mediação difere de outros meios de resolução de conflitos extrajudiciais, e não pode se confundir com reconciliação, conciliação ou terapias. Na reconciliação, a pessoa que realiza a intervenção entre as pessoas em conflito visa restabelecer seus vínculos, não considerando os interesses individuais ${ }^{48}$. $\mathrm{Na}$ conciliação, o conciliador não se limita a distinguir questões e trabalhar para que as partes fiquem em equilíbrio. Ele adentra o mérito da questão e trabalha para convencer as partes do que, segundo seu julgamento, é a melhor solução dentro das normas legais. Já a terapia adentra os aspectos psicológicos do conflito e trabalha coma conscientização das partes, com relação a seu comportamento, para que contribuam para a concretização da disputa.

A Mediação, por seu turno, dá à condução da disputa ou conflito, supremacia a vontade das pessoas envolvidas no mesmo, privilegiando a vontade, responsabilidade e compromisso dos envolvidos. Por isto, estimula o diálogo para possibilitar, por meio de um mediador, que as pessoas em conflito consigam encontrar pontos comuns de interesses, e a partir deles construam soluções para os seus impasses. Nesse diapasão, é salutar e possível que se mencione também que "[...] a definição de mediação também se enquadra como espaço de criatividade pessoal e social, um acesso à cidadania. A mediação encontra-se num plano que aproxima, sem confundir, e distingue, sem separar." ${ }^{\prime 4}$.

É um instrumento que busca desvendar o interesse escondido na posição de cada uma das pessoas envolvidas no conflito, e encaminhá-las na direção de um acordo. O entendimento de interesse é diferente do entendimento de posição: posição é aquilo que está expresso, enquanto interesse refere-se ao que está, na maioria das vezes, oculto pela posição do indivíduo. Por exemplo: uma mãe pode se posicionar contrária à visitação do filho pelo pai porque entende que este não cuida de forma adequada a criança. Portanto, a posição é contrária à visitação, mas o interesse envolvido é a segurança do filho, não sendo seu desejo que o pai não conviva com a criança.

$\mathrm{Na}$ mediação o caminho para superar a dicotomia do conflito está na escuta atenta das partes. A chave que abrirá as portas para conhecer e reconhecer os interesses e os meios de chegar ao acordo para que eles sejam alcançados, respeitando o interesse dos que estão em conflito, reside na escuta atenta e no diálogo aberto. O trabalho de escuta das posições das pessoas em conflito e da descoberta do que está contido em seu discurso é o mais importante a ser feito pelo mediador no primeiro momento.

A mediação - desconsiderando as posições e baseando-se nos interesses das pessoas - busca o diálogo e resgata o importante papel delas próprias encontrarem o melhor caminho para conduzir seus problemas. A busca inicia pela comunicação e atuação concreta em prol do reconhecimento da responsabilidade de cada um por sua atitude e consequente mudança de comportamento de forma consciente.

Esse processo ajuda na inclusão social de todos que acabam por perceber o papel importante que têm na luta para fazer valer os seus próprios direitos.

A mediação possui algumas características peculiares que orientam a atividade dos mediadores e sua rela-

46 HAYNES, J. M; MARODIN, M. Fundamentos da mediação familiar. Porto Alegre: Artes Médicas, 1996. p. 11.

47 BREITMAN, S.; PORTO, A. C. Mediação familiar: uma intervenção em busca da paz. Porto Alegre: Criação Humana, 2001. p. 46

48 SERPA, M. N. Mediação de família. Belo Horizonte: Del Rey, 1999.

49 BARBOSA, Á. A. Relação de respeito. Boletim IBDFAM, n. 38, ano 6, p. 7, maio-jun. 2006. p. 7. 
ção com as partes em conflito: a "voluntariedade" e a "liberdade das partes" imperam porquanto a mediação é voluntária e as pessoas têm a liberdade de escolher esse método como forma de lidar com seu conflito. E, uma vez que tomem conhecimento de como funciona a mediação, têm a liberdade de tomar a decisão que melhor lhes convier no decorrer do processo, inclusive, optar por sua continuidade ou não.

O processo de mediação é realizado num ambiente de "privacidade" para que as partes possam estar livres de constrangimentos para se manifestarem. As pessoas em conflito e o mediador fazem um acordo escrito de "confidencialidade" entre si, oportunizando um clima de confiança e respeito, necessário ao diálogo franco e necessário às negociações, sendo relevante, portanto, a confiança e a privacidade.

$\mathrm{Na}$ mediação, as pessoas são auxiliadas por um terceiro, o mediador, que agindo com "imparcialidade" não pode tomar partido por qualquer uma das pessoas em conflito. Ele mantém, assim, equidistância com as pessoas envolvidas não podendo demonstrar, sequer, maior ou menor simpatia por eles ou suas pretensões, preservando a confiança de ambos. Comparada ao processo judicial, a mediação apresenta um procedimento que prima mais pela "informalidade" e valorização da "oralidade", pois a maioria das intervenções é feita por meio do diálogo, somente reduzindo a termo o acordo, se as pessoas, assim, desejarem.

A mediação busca a reaproximação das partes com "imediatidade", diferentemente do processo judicial tradicional em que o acordo é buscado numa fase adiantada da lide. Ademais, para a mediação, não basta, apenas, a redação de um acordo, ou a busca por este. Ainda que as partes se ajustem sobre a situação em conflito ou não, o processo de mediação visa que os envolvidos consigam recompor o relacionamento ao nível de digna relação humana.

Por meio da "autocomposição", o acordo é obtido pelas próprias pessoas em conflito auxiliadas pelo mediador. O mediador não pode decidir pelas pessoas envolvidas no conflito; a elas é que cabe a responsabilidade das escolhas por deterem "autonomia” de decisão. $\mathrm{O}$ mediador não dá sequer sugestões, apenas conduz o diálogo para o caminho da negociação e do acordo. Dessa maneira, possibilita-se aos conflitantes que "[...] recuperem reflexivamente seu próprio poder, promovendo a reciclagem de seus recursos e a criação de novas possibilidades.". ${ }^{50}$

Finalmente, na mediação busca-se estimular um espírito colaborador entre as partes. Não se determina que uma parte seja perdedora e a outra ganhadora, mas que ambas possam ceder um pouco, se necessário, e ganharem de alguma forma. E amenizar ressentimentos entre as pessoas para evitar outros conflitos potenciais e estimular a convivência pacífica.

O Processo inicia-se com uma entrevista (pré-mediação), em que as pessoas descrevem a controvérsia e expõem as suas expectativas, sendo esclarecidas sobre o processo da mediação, seus procedimentos e suas técnicas. Nessa fase do atendimento, é ressaltado que a condução do conflito se processa mediante o diálogo e os acertos das próprias pessoas envolvidas, sem que haja qualquer imposição do mediador, e explicado como funciona o processo. Como o princípio que rege a mediação é o da voluntariedade, esse procedimento inicial é fundamental para o sucesso de todo o processo.

Ao coletar os detalhes do conflito, o mediador verifica se o caso é passível de mediação, já que existem casos, como os de violência, em que não é possível a utilização desse método de resolução, uma vez que, nesses casos, não está presente um dos elementos fundamentais para a mediação, qual seja, o equilíbrio de poder.

Assim, o mediador recebe o consentimento das partes para que possa dar continuidade ao processo, momento em que as pessoas deliberam se adotarão ou não a mediação para a condução de suas controvérsias. Uma vez que decidam continuar com o processo, assinam o Termo de Mediação, onde estabelecem as regras para o procedimento, como a extensão do sigilo, os compromissos de cordialidade e colaboração, e outros

50 SCHNITMAN, D. F. Novos paradigmas em resolução de conflitos. In: SHNITMAN, D. F.; LITTLEJOHN, S. (Orgs). Novos paradigmas em mediação. Porto Alegre: Artmed, 1999. p. 21. 
itens que julgarem necessários.

Numa fase intermediária, ou de mediação propriamente dita, o mediador identifica as posições e interesses dos envolvidos, concedendo oportunidade igual para que eles possam se manifestar levantando as questões que entendem ser a causa do conflito. O mediador aplica a sua capacidade em definir a situação partindo das informações obtidas, resumindo-as e tornando-as compreensíveis, por meio de uma linguagem clara e simples, para os envolvidos. E começa, juntamente a estes, a redefinir o problema e gerar opções de solução ressaltando os aspectos positivos citados pelas pessoas - valorizando-os no mesmo nível - e selecionando, sempre em colaboração, as alternativas que se apresentem mais viáveis à solução do conflito.

A última fase da mediação é marcada pela negociação das pessoas e redação final do acordo a ser firmado entre elas mediante um instrumento particular. Assim, após a identificação das posições e interesses, da redefinição do problema, da seleção das alternativas viáveis e do consenso dos envolvidos, o mediador redige um termo contendo o que as pessoas ajustaram na mediação.

Esta é, em síntese, a forma de condução dos conflitos por meio da mediação. Existem variados enfoques teórico-práticos sobre a mediação e que podem alterar a maneira pela qual a mediação é conduzida, conforme a abordagem que se dê ao procedimento. Os principais modelos de mediação são o Modelo Tradicional, ou Modelo de Satisfação, ou Modelo de Acordo, baseado na escola de negociação da Universidade de Harvard, e o modelo Transformativo, idealizado por Robert Bush e Joseph Folger.

Barusch Bush e Folger ${ }^{51}$ abordam a mediação transformativa, sustentando que devem ser considerados como objetivos da autocomposição o empoderamento das pessoas, que, uma vez educadas sobre as técnicas da negociação, possam, cada vez mais, por seus próprios esforços, conduzir seus conflitos no futuro. Assim, transformando a relação por meio do reconhecimento mútuo de interesses e sentimentos, as pessoas adquirem uma real aproximação e, com isso, empaticamente humanizam suas relações e os conflitos dela decorrentes.

A mediação, portanto, se apresenta como uma prática que se centra na mudança de uma cultura que se fundamenta na transferência da responsabilidade de conduzir os conflitos pessoais, para apontar caminhos que podem representar o desenvolvimento de competências próprias no enfrentamento dessas questões. Essa lógica está afinada com a elaboração de novas epistemologias que possibilitam o que Morin ${ }^{52}$ chama de "reforma do pensamento", trazendo propostas de mudanças de hábitos e de atitudes que desenvolvem nas pessoas a capacidade de avaliar e de participar, ativamente, da condução da própria história e, por conseguinte, da construção ativa de uma sociedade mais equilibrada.

Com efeito, é utilizada uma linguagem simples, sem expressões jurídicas e complicadas, aproximando as pessoas do entendimento do processo e facilitando para que as decisões sejam tomadas de forma consciente e responsável. O aspecto educativo do falar de forma simples está justamente no fato de que, dessa maneira, as interações são estabelecidas, de forma direta, sem delimitarem-se espaços de poder e prestígio, que poderiam retirar do procedimento o caráter de igualdade, informalidade e espontaneidade necessárias à abertura do diálogo.

As pessoas são recebidas sempre pelo mediador - aquele que conduzirá a sessão - e, encaminhadas para a sala de mediação, tomando-se sempre o cuidado para que fiquem dispostas lado a lado nas cadeiras em torno da mesa. Embora esta seja redonda, ainda assim existe a possibilidade de as pessoas ficarem frente a frente, atitude que pode servir de elemento incentivador de uma postura de enfrentamento. Esse cuidado está fundamentado na ideia de que espaço possui uma "pedagocididade indiscutível”.53.

51 BUSH, R. Baruch; FOLGER, J. The promise of mediation: responding to conflict through empowerment and recognition. São Francisco: Ed. Jossey-Bass, 1994.

52 MORIN, E. Complexidade e transdisciplinaridade: a reforma da universidade e do ensino fundamental. Natal: UFRN, 2000.

53 FREIRE, P. Pedagogia da autonomia: saberes necessários à prática educativa. Rio de Janeiro: Paz e Terra, 2011. p. 45. 
Azevedo adverte que o mediador deve ter o máximo cuidado com as questões ambientais, preparando o ambiente onde será realizada a sessão de mediação, atentando para a iluminação, temperatura, privacidade, entre tantos outros itens. $\mathrm{O}$ autor expõe essa intencionalidade, referindo que a forma como as pessoas irão se localizar durante a sessão de mediação “[...] transmite muito mais informações do que se possa inicialmente imaginar" ${ }^{\prime 5}$. Assim, o autor alerta para que o posicionamento das pessoas seja realizado de maneira que todos consigam ver o ouvir uns aos outros, preferencialmente que sejam colocados em posições não antagônicas, evitando sentimentos de rivalidade ou polarização.

\section{Considerações finais}

Diante de todo o exposto, compreende-se que os movimentos iniciados na mediação podem contribuir decisivamente para os processos proximais essenciais para o desenvolvimento humano fundamentados na ideia de ressaltar os aspectos saudáveis das relações, comportando a tese de que a mediação familiar é uma intervenção educativa ambiental que pode contribuir, de forma decisiva, para o processo educativo de novas identidades pessoais e sociais. Sendo o diálogo o orientador dos processos de interação entre os membros das famílias em conflito. Essa forma insubstituível de comunicação pode não somente diminuir as barreiras de interlocução que possam impedir ou dificultar o desenvolvimento dos envolvidos, como potencializar a formação de sujeitos autônomos. Assim, compreendendo-se capazes de resolver suas próprias questões, participar, ativamente, das resoluções das questões comunitárias, sempre por meio da alteridade, diálogo, compromisso, responsabilidade e respeito à natureza da qual fazem parte, os indivíduos protagonistas dos processos podem contribuir para a formação de uma sociedade mais justa e igualitária.

As ideias expostas neste artigo possuem forte identificação com o que Freire entende como uma pedagogia para a autonomia, que não se faz a partir de um ponto de vista absoluto e nem discrimina raças ou opções políticas. Parte da articulação entre a teoria e a prática, sem representar puro ativismo ou simplesmente elucubrações teóricas.

Por meio da abordagem Bioecológica do Desenvolvimento Humano, foi possível dar à pesquisa um olhar sistêmico, o que oportunizou que fossem observadas conexões importantes da mediação familiar, já que esta parte do pressuposto de que o diálogo funciona como construtor de relações interpessoais. Além disso, verificou-se que existe uma pedagogia implícita nas ações do mediador, que possui intencionalidades com contornos bem definidos e que visam, sobretudo, potencializar a autonomia das pessoas em conflito para que estas se tornem protagonistas de seus destinos. Além disso, ao abordar o conflito de forma positiva, a mediação contempla a condução dos conflitos com foco nos aspectos saudáveis das interações: reciprocidade, equilíbrio de poder e afeto o que afasta a noção de patologia que se encontra implícita no senso comum acerca das famílias pobres.

Por conseguinte, o olhar Ecológico, também, foi crucial para a percepção dos impactos do processo de mediação nas relações familiares, deixando ver que estas ainda estão bastante atreladas aos processos tradicionais, que ainda necessitam de uma autoridade que lhes garanta certezas, numa clara demonstração de que vivem o risco social com nuances de dependência imaginária e nociva ao empoderamento e à autonomia.

Tudo isto aponta para a necessidade da implementação de políticas públicas voltadas para o empoderamento e resiliência das famílias em situação de conflito, tendo na mediação essas possibilidades. No entanto, uma política pública focada em processos de mediação deve ser estruturada de forma permanente e dissociada de outros espaços cuja simbologia possa trazer confusão quanto aos seus objetivos e fundamentos transformativos. O que se entende é a necessidade de incorporar a mediação familiar como outra forma de conduzir conflitos, e não como auxiliar ou alternativa, contemplando, na autonomia da política pública, um

54 AZEVEDO, A. G. Manual de mediação judicial. Brasília/DF: Ministério da Justiça e Programa das Nações Unidas, 2009. p. 88. 
indício de que esta é uma maneira séria e adequada de enfrentamento de adversidades.

A mediação familiar, nesse contexto, poderá se constituir como espaço democrático de decisão, trabalhando com a figura do mediador de forma distinta da figura do juiz, que se posiciona em local superior às partes. Trazer a noção de que, ao se encontrar no meio das pessoas, partilhando de um espaço comum e participativo, voltado para a construção do consenso, não faz do mediador uma figura menos importante, mas, ao contrário, traz a compreensão da figura deste como a do educador, do colaborador, que não intervém no conflito, mas oferece às pessoas a liberdade para tratá-lo, ajudando-as a desdramatizá-lo.

Assim, deixa-se a compreensão de que a mediação se revela como uma prática educativa, que transcende campos de conhecimento estanques e papéis profissionais. Por isso, política e ética, e que se destina a formação do ser humano, cada vez mais humano, como afirmou Bronfenbrenner. O entendimento assentado refere-se ao fato de que a mediação pode, sim, ser elaborada de maneira a capturar o potencial transformativo dos conflitos, atendendo a perspectiva relacional da sociedade, representando, outrossim, possibilidades de formação para o fortalecimento das relações saudáveis e a autonomia, revelando-se um verdadeiro processo educativo ambiental.

\section{REFERÊNCIAS}

AZEVEDO, A.G. Manual de mediação judicial. Brasília: Ministério da Justiça e Programa das Nações Unidas, 2009

BARBOSA, Á. A. Relação de respeito. Boletim IBDFAM, n. 38, ano. 6, p. 7, maio/jun. 2006.

BOBBIO, N.; PASQUINO, G. Dicionário de política. 12. ed. Brasilia: Universidade de Brasília, 2004.

BREITMAN, S.; PORTO, A. C. Mediação familiar: uma intervenção em busca da paz. Porto Alegre: Criação Humana, 2001.

BRONFENBRENNER, U. A ecologia do desenvolvimento bumano: experimentos naturais e planejados. Porto Alegre: Artes Médicas, 1996.

BRONFENBRENNER, U. Bioecologia do desenvolvimento humano: tornando os seres humanos mais humanos. Porto Alegre: Artmed, 2011

BRONFENBRENNER, U. The ecology of human development. Cambridge: Harvard University Press, 1979.

BRONFENBRENNER, U.; MORRIS, P. The ecology of developmental processes. In: DAMON, W. (Org.). Handbook of child psychology. New York: John Wiley Sons, 1998. v. 1. p. 569-664.

BUSH, R. Baruch; FOLGER, J. The promise of mediation: responding to conflict through empowerment and recognition. São Francisco: Jossey-Bass, 1994.

CARVALHO, I. M. M. de; ALMEIDA, P. H. de. Família e proteção social. Perspectiva, São Paulo, v. 17, n. 2, 2003.

DIAS, M.B. Manual de direito das famílias. 8. ed. São Paulo: Revista dos Tribunais, 2011.

FALCKE, D.; WAGNER, A. A dinâmica familiar e o fenômeno da transgeracionalidade: definição de conceitos. In: WAGNER, A. (Org.). Como se perpetua a família?: a transmissão dos modelos familiares. Porto Alegre: EDIPUCRS, 2005. p. 25-43.

FOLGER, J. P.; BUSH, R. A. B. Mediação transformativa e intervenção de terceiros: as marcas registradas de um profissional transformador. In: SCHNITMAN, D. F.; LITTLEJOHN, S. (Orgs). Novos paradigmas em mediação. Porto Alegre: Artmed, 1999. p. 85-100.

FREIRE, P. Pedagogia da autonomia: saberes necessários à prática educativa. Rio de Janeiro: Paz e Terra, 2011. 
GARAPON, A. Bem julgar: ensaio sobre o ritual judiciário. Lisboa: Instituto Piaget, 1997.

GERGEN, K. J. Rumo a um vocabulário do diálogo transformador. In: SCHNITMAN, D. F.; LITTLEJOHN, S. (Orgs.). Novos paradigmas em mediação. Porto Alegre: Artmed, 1999. p. 29-45.

HAYNES, J. M.; MARODIN, M. Fundamentos da mediação familiar. Porto Alegre: Artes Médicas, 1996.

JULIANO, M. C.; YUNES, M. A. M. A abordagem bioecológica de desenvolvimento humano: conceitos fundamentais e interfaces com a educação ambiental. In: OLIVEIRA, M. V.; CORRÊA, B. L. (Orgs.). Tecendo a educação ambiental a partir de olhares coletivos. Porto Alegre: Evangraf, 2009.

MACEDO, R. M. A família do ponto de vista psicológico: lugar seguro para crescer? Cadernos de Pesquisa, São Paulo, n. 91, p. 62-68, nov. 1994.

MARODIN, M.; BREITMAN, S. A prática moderna da mediação: integração entre psicologia e direito. In: ZIMERMAN, D.; COLTRO, A. C. M. (Orgs.) Aspectos psicológicos na prática jurídica. Campinas: Milennium, 2008. p. 335-343.

MARTINS, E.; SZYMANSKI, H. A abordagem ecológica de Urie Bronfenbrenner em estudos com famílias. Estudos e Pesquisas em Psicologia, n. 1, p. 63-78, 2004.

MORIN, E. Complexidade e transdisciplinaridade: a reforma da universidade e do ensino fundamental. Natal: UFRN, 2000.

NARVAZ, M. G.; KOLLER, S. H. O modelo bioecológico de desenvolvimento humano. In: KOLLER, S. H. (Org.). Ecologia do desenvolvimento humano. São Paulo: Casa do Psicólogo, 2004. p. 51-66.

RODRIGO, M. J.; PALACIOS, J. Família e desarrollo bumano. Madrid: Alianza Editorial, 1998.

ROSA, C. P. da R. Mediação: uma nova alternativa de tratamento dos conflitos familiares. In: Ámbito Jurídico, 2009. Disponível em: <http://www.ambito-juridico.com.br/site/?n_link=revista_artigos_leitura\&artigo_ $\mathrm{id}=6116 \&$ revista_caderno $=14>$.

RUTTER, M. Psychosocial resilience and protetive mechanisms. American Journal of Orthopsychiatry, Washington, v. 57, n. 3, p. 316-331, 1987.

RUTTER, M. Resilience: some conceptual considerations. Journal of Adolescent Health, n. 14, p. 626- 631, 1993.

SANTOS, B. S. Os tribunais e as novas tecnologias de comunicação e informação. Sociologias, Porto Alegre, n. 13, p. 82-109, jan./jun. 2005.

SCHNITMAN, D. F. Novos paradigmas em resolução de conflitos. In: SHNITMAN, D. F.; LITTLEJOHN, S. (Orgs). Novos paradigmas em mediação. Porto Alegre: Artmed, 1999.

SELIGMAN, M. Felicidade autêntica: usando a nova psicologia positiva para a realização permanente. Rio de Janeiro: Objetiva, 2004.

SELIGMAN, M. Florescer: uma nova compreensão sobre a natureza da felicidade e do bem-estar. Rio de Janeiro: Objetiva, 2011.

SERPA, M. N. Mediação de família. Belo Horizonte: Del Rey, 1999.

SZYMANSKI, H. Significados de família. In: LOCH, G. M.; YUNES, M. A. M. (Orgs.). A família que se pensa e a familia que se vive. Rio Grande: FURG, 1998.

SZYMANSKI, H. Teoria e "teorias de famílias". In: CARVALHO, M. do C. B. de (Org.). A família contemporânea em debate. São Paulo: EDUC/Cortez, 1995. p. 23-27.

WALSH, F. Fortalecendo a resiliência familiar. São Paulo: Roca, 2005. 
YARN, D. E. Dictionary of conflict resolution. São Francisco: Jossey-Bass Inc., 1999.

YUNES, M. A. M. A questão triplamente controvertida da resiliência em famílias de baixa renda. 2001. $166 \mathrm{f}$. Tese (Doutorado em Psicologia) - Pontifícia Universidade Católica de São Paulo, São Paulo, 2001.

YUNES, M. A. M.; GARCIA, N. M.; ALBUQUERQUE, B. de M. Monoparentalidade, pobreza e resiliência: entre as crenças dos profissionais e as possibilidades da convivência familiar. Reflexão \& Crítica, Porto Alegre, v. 20, n. $3,2007$.

YUNES, M. A. M.; SZYMANSKI, H. Resiliência: noção, conceitos afins e considerações críticas. In: TAVARES, J. (Org.) Resiliência e educação. São Paulo: Cortez, 2001. p. 13-42. 


\section{REVISTA BRASILEIRA DE POLÍTICAS PÚBLICAS BRAZILIAN JOURNAL OF PUBLIC POLICY}

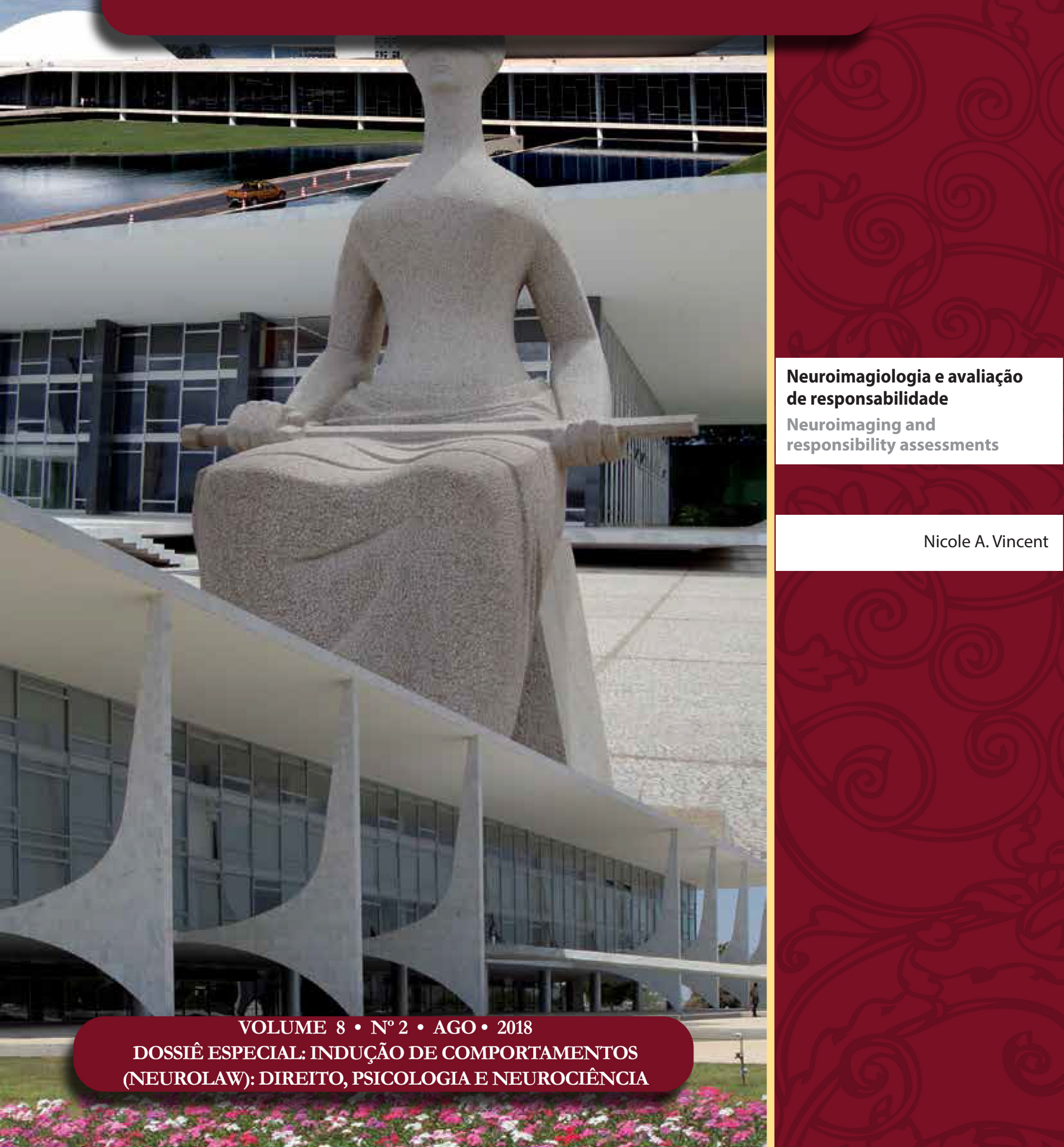




\section{Neuroimagiologia e avaliação de responsabilidade*}

\section{Neuroimaging and responsibility assessments}

Nicole A. Vincent ${ }^{* * * * *}$

* Artigo convidado.

** In mid-2007 I obtained my $\mathrm{PhD}$ in philosophy of tort law from the University of Adelaide in South Australia, with a dissertation entitled "Responsibility, Compensation and Accident Law Reform". From late 2007 until early 2016 I was affiliated with the Philosophy Section at Technische Universiteit Delft in The Netherlands. Initially, as a postdoc working on Dr Gert-Jan Lokhorst's neurolaw research project entitled "The Brain and The Law"; and then as chief investigator of the international research project "Enhancing Responsibility: the effects of cognitive enhancement on moral and legal responsibility". From February 2011 until July 2013 I was a research fellow in the Department of Philosophy at Macquarie University in Sydney, Australia working on a project entitled "Reappraising the Capacitarian Foundation of Neurolaw". From August 2013 until December 2016 I was an Associate Professor of Philosophy, Law, and Neuroscience at Georgia State University in Atlanta, GA, USA. In 2018 I joined the Faculty of Transdisciplinary Innovation at University of Technology Sydney (UTS) as Senior Lecturer. I am also an Honorary Fellow in the Department of Philosophy at Macquarie University, and an Affiliate Member of its Centre for Agency, Values and Ethics.

*** Artigo publicado: VINCENT, Nicole A. Neuroimaging and Responsibility Assessments. Neuroethics, v. 4, n. 1, p. 35-49, abr. 2011. Tradução realizada pelo Grupo de Estudos em Direito, Psicologia e Neurociência da Faculdade de Direito de Ribeirão Preto da USP, liderado pelo Prof. Dr. Sérgio Nojiri.

\section{Resumo}

Poderiam evidências da neuroimagiologia nos ajudar a avaliar o grau de responsabilidade de uma pessoa por um crime que sabemos que ela cometeu? Este ensaio defende uma resposta afirmativa a essa questão. Uma série de típicas objeções a essa abordagem de alta tecnologia de avaliação da responsabilidade das pessoas é considerada e, depois, colocada de lado, mas também trago à luz e, em seguida, rejeito uma objeção original - uma objeção que somente é encontrada quando uma neuroimagem funcional (em vez de estrutural) é usada para aferir a responsabilidade das pessoas.

Palavras-chave: Responsabilidade moral. Responsabilidade legal. Concepção capacitário-teorética da responsabilidade. Teoria capacitária da responsabilidade. Capacidade mental. Capacidade de responsabilidade. Neuroimagiologia. Ressonância magnética funcional por imagem (fMRI). Falácia modal. Funções automáticas. Teoria para a melhor explicação. Caso Roper v. Simmons (2005).

\section{Abstract}

Could neuroimaging evidence help us to assess the degree of a person's responsibility for a crime which we know that they committed? This essay defends an affirmative answer to this question. A range of standard objections to this high-tech approach to assessing people's responsibility is considered and then set aside, but I also bring to light and then reject a novel objection - an objection which is only encountered when functional (rather than structural) neuroimaging is used to assess people's responsibility.

Keywords: Moral responsibility. Legal responsibility. Capacity-theoretic conception of responsibility. Capacitarian theory of responsibility. Mental capacity. Capacity responsibility. Neuroimaging fMRI. Modal fallacy. Automatic functions. Theory to the best explanation. Roper v. Simmons (2005). 


\section{Christopher Simmons assassina Shirley Crook $^{1}$}

Nas primeiras horas da manhã do dia nove de setembro de 1993, no Condado de St. Louis, Missouri, Christopher Simmons, de 17 anos, e seu amigo mais novo, Charles Benjamin, arrombaram a residência da senhora Shirley Crook, que naquele momento estava dormindo. Simmons e Benjamin roubaram sua casa e amarraram os braços e pernas da mulher, agora acordada, com cabos elétricos e tiras de couro, cobriram seu rosto com uma toalha e fita adesiva, colocaram-na atrás de sua própria minivan, e dirigiram próximo ao parque Castlewood State, onde Simmons a atirou do alto de uma ponte ferroviária, correnteza abaixo do rio Meramec. Horas depois, o corpo da senhora Crook, já sem vida, foi retirado do rio por pescadores, e o perito médico determinou que a causa de sua morte fora afogamento.

Que Christopher Simmons matou Shirley Crook não está em questão. Seu papel no crime foi claramente estabelecido nas investigações que se seguiram e essas investigações revelaram também a natureza premeditada do crime (testemunhas afirmaram que Simmons havia falado, durante algum tempo, sobre sua vontade de roubar e assassinar alguém) e o fato de que, imediatamente depois, ele não sentiu remorso ou culpa, mas, sim, orgulho e um sentimento de realização (mais tarde, naquele mesmo dia na escola, ele se gabou aos amigos sobre o assassinato que havia acabado de cometer).

\section{IDADE, CAPACIDADES MENTAIS E TRÊS PROBLEMAS ASSOCIADOS A AVALIAÇÕES COMPORTAMENTAIS INDIVIDUALIZADAS DE RESPONSABILIDADE}

No entanto, embora não haja dúvida de que Christopher Simmons matou Shirley Crook, ainda podemos, legitimamente, questionar se ele é inteiramente responsável por aquilo que fez. A primeira consideração que lhe atenua a atribuição de total responsabilidade por esse crime ${ }^{2}$ é relacionada à idade - pelo menos em algumas definições, Simmons ainda era menor quando cometeu o crime, e visto que, normalmente, supomos que menores não são plenamente responsáveis pelo que fazem por conta de sua imaturidade, nós podemos, portanto, também ser tentados pela sugestão de que Simmons também não foi totalmente responsável pelo seu crime. Todavia, muitos assuntos complicam a questão e talvez o mais relevante seja o fato de que, quando cometeu o crime, Simmons era um adolescente aproximando-se da fase adulta, o que porventura sugere uma importante ausência de analogia entre ele e outros menores que pesa contra o tratar como se fosse uma criança mais nova. É certo, porém, que a idade é um guia muito impreciso para determinar quão matura a pessoa realmente é - alguns indivíduos se tornam maduros muito mais rapidamente que outros - assim,

1 Esse resumo do caso é compilado de várias fontes, e eu forneço essa única citação com vistas a evitar muitas citações repetitivas. ROPER, Donald P. Roper v. Simmons. Superintendent, Potosi Correctional Center, Petitioner v. Christopher Simmons. 2005. Disponível em: <http://laws.findlaw.com/us/543/551.html>. Acesso em: 09 out. 2009; HERNDON, J.; WAXMAN, S. P. Brief for respondent. In: ROPER; SIMMONS. St. Louis, MO: i-xiv, 1-50, 1a-21a, 2004; ABA-1. Christopher Simmons-Jwvenile Death Penalty. Disponível em: <http://www.abanet.org/crimjust/juvjus/simmons.html>. Acesso em: 21 out. 2008; WIKIPEDIA. "Roper v. Simmons". Disponível em: <http://en.wikipedia.org/ wiki/Roper_v._Simmons>. Acesso em: 21 out. 2008.

2 Quando eu falo de "atribuição de responsabilidade por seu crime", minha preocupação é com o que pode ser chamado de responsabilidade pelo resultado (i.e. quais os estados das coisas que ele provocou; PERRY, Stephen R. Loss, agency, and responsibility for outcomes: three conceptions of corrective justice. Philosophy of law, v. 6, p. 546-559, 2000. p. 555, não ao que Christopher Kutz e H.L.A. Hart se referem como liability responsability. i.e. o que deveríamos fazer com ele-, como deveríamos tratá-lo-, como deveríamos responsabilizá-lo, ou até como ele deveria assumir a responsabilidade pelo seu crime; HART, Herbert L. A. Postscript: responsibility and retribution. In: Punishment and responsibility. 2. ed. Oxford: Oxford Scholarship Online, 1968. p. 211; KUTZ, C. Chapter 14: Responsibility. In: COLEMAN, J.; SHAPIRO, S. Jurisprudence and philosophy of law. Oxford: Oxford University Press, 2004. p. 548-587. p. 549. Para evitar equívocos, é crucial manter uma distinção clara entre os muito diferentes sentidos do termo "responsabilidade", ou o que eu, em outro lugar, me refiro como os muito diferentes "conceitos de responsabilidade" VINCENT, N. Responsibility, compensation and accident law reform. Tese (Doutorado) - University of Adelaide, Adelaide, 2006. < http:/ / digital.library. adelaide.edu.au/dspace/handle/2440/39507>. Acesso em: 11 set. 2008, vários dos quais são brevemente mencionados na próxima nota de rodapé. 
se a responsabilidade é de fato uma função da maturidade, então a lei talvez devesse avaliar individualmente a responsabilidade das pessoas - quando tudo isso está em jogo (quão severamente Simmons será punido) nós certamente deveríamos buscar uma maior exatidão e precisão!

Uma maneira de avaliar individualmente a responsabilidade das pessoas pode-se parecer com o seguinte. Partindo da suposição de que a responsabilidade dos indivíduos é uma função de coisas tais como suas capacidades cognitiva e volitiva - i.e. sua capacidade para realizar julgamentos morais sólidos e sua capacidade de exercitar um autocontrole apropriado ${ }^{3}$, respectivamente - nós poderíamos tentar medir quão responsável uma pessoa é por meio da utilização da seguinte abordagem comportamental; por exemplo, poderíamos colocá-los perante tarefas que envolvam julgamentos morais e desafios de autocontrole, observar quão bem se saem e, presumivelmente, quanto melhores forem os resultados obtidos nesses testes, maiores serão suas capacidades cognitiva e volitiva. Alternativamente, poderíamos conversar com outros que conhecem bem tais pessoas - por exemplo, sua família, amigos, vizinhos, professores e colegas - no esforço de construir uma exata imagem de suas capacidades cognitiva e volitiva a partir desses relatos biográficos.

Pelo uso dessa abordagem comportamental, estaríamos tentando determinar não apenas se a pessoa sob avaliação pode faz̧er juízos morais e se controlar, mas também se ela pode realizar julgamentos morais sólidos e se pode controlar-se de maneira apropriada. Afinal, o que importa para a responsabilidade é não só fazer alguns juízos morais, mas, sim, que seus julgamentos morais sejam sólidos, sensatos, e, conforme aponta Susan Wolf, para que isso aconteça, um agente deve ser “capaz de 'rastrear' o Verdadeiro e o Bom em seus juízos valorativos" . Uma maneira de conceber o argumento que Wolf está construindo aqui é que, além dos requisitos formais de como a razão dos indivíduos deve operar a fim de ser válida, há também requisitos substantivos sobre o conteúdo das premissas, das quais uma ou mais razões formam os pressupostos básicos que informam seu julgamento moral - ou o que Neil Levy se refere como "conhecimento moral" que essas questões substantivas também influenciam se os diferentes processos de raciocínio sem falhas do indivíduo serão suficientes para lhe conceder o status de um agente moral responsável. Similarmente, o que é relevante para a responsabilidade não é apenas que o sujeito seja capaz de se controlar de algum modo, mas que possa se controlar da maneira correta - uma forma de colocar essa questão é que as ações do indivíduo devem se expressar a partir de um mecanismo que seja moderadamente sensível às razões ${ }^{6}$. Nesse sentido,

3 Eu sugiro essas capacidades particulares por causa daquilo que me parece uma relação óbvia entre maturidade e responsabilidade - provavelmente, isto é, pelo menos parte da razão pela qual a maturidade está destinada a ser relevante para a responsabilidade - mas também devido à proeminência dessas duas condições mentais (ou outras condições próximas) na literatura relevante. FISCHER, J. M.; RAVIZZA, M. Responsibility and control: a theory of moral responsibility. Cambridge: CUP, 1998. p. 240-259; DENNETT, D. C. On giving libertarians what they say they want. In: ARNOLD, N. S.; BENDITT, T. M.; GRAHAM, G. Philosophy then and now. Malden: Blackwell, 1998. p. 119-130; WOLF, S. Sanity and the metaphysics of responsibility. In: SHOEMAN, F. Responsibility, character and the emotions: New Essays in moral psychology. New York: Cambridge University Press, 1987. p. 46-62; WOLF, S. The reason view. In: EKSTROM, L. W. Agency and responsibility: essays on the metaphysics of freedom. Boulder: Westview, 2001. p. 205-226; SAPOLSKY, R. M. The frontal cortex and the criminal justice system. Philosophical Transactions of the Royal Society of. London, n. 359, p. 1787-1796, 2004; ROSKIES, A. Neuroscientific challenges to free will and responsibility. Trends in Cognitive Sciences, v. 10, n. 9, p. 419-423, 2006; MORSE, S. J. Brain overclaim syndrome and criminal responsibility: A diagnostic note. Obio State Journal of Criminal Law, n. 3, p. 397-412, 2006a; CHURCHLAND, P. S. The big questions: do we have free will. New Scientist, n. 2.578, p. 42-45, nov. 2006. p. 42-45. Entretanto, conforme argumento em outro lugar - e acredito que os outros concordariam neste ponto. GLANNON, W. Neurobiology, neuroimaging, and free will. Midwest Studies in Philosophy, n. 29, p. 68-82, 2005. p. 71; MORSE, S. J. Moral and legal responsibility and the new neuroscience. In: ILLES, J. (Ed.) Neuroetbics: defining the issues in theory, practice, and policy. Oxford: Oxford University Press, 2006b, p. 33-50. p. 38-39, - a responsabilidade não depende apenas de fatos sobre a capacidade mental das pessoas (sua capacidade de responsabilidade), uma vez que, no mínimo, isso provavelmente também dependa de coisas tais como o modo que elas agiram e se houve uma ligação entre sua ação e a consequência daquilo que elas foram alegadamente responsáveis (sua responsabilidade causal), se na ação, da maneira que praticaram, elas violaram as responsabilidades de seus papéis, e muitas outras coisas mais, como se são responsáveis pelo fato de que agora lhe faltam aquelas capacidades mentais VINCENT, N. Responsibility, dysfunction and capacity. Neuroethics, v. 1, n. 3, p. 199-204, 2008. p. 202-203.

4 WOLF, S. The reason view. In: EKSTROM, L. W. Agency and responsibility: essays on the metaphysics of freedom. Boulder: Westview, 2001. p. 205-226. p. 211. Veja também: WOLF, S. Sanity and the metaphysics of responsibility. In: SHOEMAN, F. Responsibility, character and the emotions: New Essays in moral psychology. New York: Cambridge University Press, 1987. p. 46-62.

5 LEVY, N. The responsibility of the psychopath revisited. Philosophy, Psychiatry \& Psychology, v. 14, n. 2, p. 129-138, 2007.

6 FISCHER, J. M.; RAVIZZA, M. Responsibility and control: a theory of moral responsibility. Cambridge: CUP, 1998. p. 240-259. Al- 
o que tal abordagem comportamental tentaria fazer é determinar se a pessoa que está sendo testada é capaz de elaborar juízos morais sólidos (e.g. se ela consegue dar os tipos de respostas corretas a questões morais e se pode justificar, apropriadamente, tais respostas) e se ela pode controlar a si própria de maneira apropriada (e.g. se consegue resistir a tentações de fazer aquilo que acha que deveria resistir).

No entanto, vejo pelo menos três problemas com o uso dessa abordagem comportamental para a avaliação individual da responsabilidade pessoal. A respeito da primeira sugestão (i.e. aplicação de testes), dado que o resultado de um teste como esse pode, eventualmente, influenciar quão severamente será punida a pessoa, os indivíduos teriam toda a razão para fingir que suas capacidades são muito inferiores do que realmente são - i.e. eles teriam toda a razão para, intencionalmente, reprovar em tais testes, dando as mais ridículas respostas para as tarefas de julgamento moral e cedendo até mesmo à mais fraca das tentações, a fim de fazer parecer que suas capacidades cognitiva e volitiva são severamente retardadas. No que se refere à segunda sugestão (i.e. conversar com pessoas que os conhecem), dado que suas famílias e amigos podem querer defendê-los e que seus inimigos podem desejar vê-los perecerem, se aquilo que queremos é um método exato, preciso e imparcial de aferir a responsabilidade da pessoa, então essa não seria a melhor alternativa, uma vez que há, simplesmente, muita oportunidade, a todos, para mentir sobre como a pessoa, cuja responsabilidade está sendo avaliada, realmente é.

Mais importante, porém - e esse ponto, em bases puramente filosóficas, conta contra essas duas sugestões - estritamente falando, tais testes são, na verdade, incapazes de revelar qualquer coisa sobre quais capacidades a pessoa não possui (sobre aquilo que ela não é capaz de fazer). O mero fato de que alguém sempre tenha agido mal - independentemente de se isso é algo que nós averiguamos a partir de testes ou de relatos que outros contam sobre os indivíduos e, independentemente de se isso se relaciona ao seu julgamento moral ou ao seu autocontrole - pode simplesmente mostrar que tais sujeitos são preguiçosos ao invés de incapacitados - i.e. que não fazem o juízo moral correto em vez de não são capazes de formulá-los, ou não se controlam no lugar de não são capaz̨es de se controlarem. Bernadette McShery, por exemplo, também aponta que "é impossível elaborar um teste objetivamente verificável para determinar quando um acusado não seria capaz de controlar a si próprio e quando ele simplesmente não o faria" , e Robert Sapolsky destaca esse mesmo ponto, chamando atenção para as dificuldades associadas com "a distinção entre um impulso irresistivel e um que é, em qualquer medida, resistível, mas que não foi resistido"s.

Meu ponto é que mesmo se os relatos de terceiros revelaram que, desde criança, Christopher Simmons sempre teve um mal comportamento, isto não teria necessariamente mostrado que ele não poderia distinguir o certo do errado ou que ele não seria capaz de agir de outra forma - conforme todos nós sabemos, crianças, com frequência, se comportam deliberadamente mal e, assim, tais relatos são perfeitamente compatíveis com a possibilidade de que Simmons sempre deteve tais capacidades, mas que ele simplesmente não as usou. Alternativamente, mesmo se repetidos testes comportamentais mostrassem que Christopher Simmons constantemente realizava juízos morais errados e que constantemente cedia até mesmo à mais fraca das tentações, isso não necessariamente mostra que ele não é capaz de distinguir o certo do errado ou que não tenha a capacidade de autocontrolar-se, uma vez que esse comportamento pode também ser explicado pela hipótese alternativa de que ele simplesmente não usa as capacidades que, pelo que sabemos, ele, na verdade, possui; talvez a razão pela qual ele aja impulsivamente e pela qual não resista a tentações seja devida à sua preguiça

ternativamente, veja FISCHER, J. M. Reply: the free will revolution. Philosophical Explorations, v. 8, n. 2, p. 145-156, 2005. Ou uma das MCKENNA, M. Assessing reasons-responsive compatibilism. International Journal of Philosophical Studies, v. 8, n. 1, p. 89-124, 2000; MCKENNA, M. Book review: Fischer and Ravizza's "Responsibility and control”. The Journal of Philosophy, v. 98, n. 2, p. 93-100, 2001; MCKENNA, M. Reasons reactivity and incompatibilist intuitions. Philosophical Explorations, v. 8, n. 2, p. 131-143, 2005, para resumos das posições de Fischer e Ravizza.

7 MCSHERRY, B. Criminal responsibility, 'Fleeting' states of mental impairment, and the power of self-control. International Journal of Law and Psychiatry, n. 27, p. 224-257, 2004. p. 188, grifo nosso.

8 SAPOLSKY, R. M. The frontal cortex and the criminal justice system. Philosophical Transactions of the Royal Society of. London, n. 359, p. 1787-1796, 2004. p. 1790, grifo nosso. 
(i.e. pode ser que ele, simplesmente, não se esforce o bastante).

Esse terceiro problema é um caso da tão chamada falácia modal na qual determinados tipos de conclusões sobre o que é possivel são invalidamente derivadas de premissas sobre o que é real-nesse caso, observações acerca daquilo que não ocorre (sobre o comportamento de uma pessoa) são erroneamente tomadas para acarretar conclusões a respeito do que não é possível ocorrer (sobre sua incapacidade). Algumas conclusões acerca do que é possivel podem ser válidas e puramente derivadas de premissas sobre aquilo que é real - por exemplo, o fato de que está chovendo implica que é possivel que esteja chovendo. Todavia, no caso em questão, o que nós temos é algo muito parecido com isso: o fato de que não está chovendo implica que não épossivel que esteja chovendo; e este último tipo de derivação de uma conclusão sobre o que é possível a partir de uma alegação sobre o que é real é, evidentemente, inválida. Desse modo, muito além do fato de que a pessoa está sendo testada e que os outros que nos falam sobre ela podem enganar e mentir, essa falácia modal representa um sério problema filosófico para a utilização de tais abordagens comportamentais na avaliação individual da responsabilidade das pessoas.

Assim, por, pelo menos, esses três motivos - i.e. (1) porque as pessoas podem fingir que suas capacidades cognitiva e volitiva estão prejudicadas quando, de fato, estão completamente intactas, (2) porque relatos biográficos realizados por outras pessoas, de como alguém é, podem ser imprecisos e, (3) devido à falácia modal que foi acima descrita - considero insatisfatórias tais avaliações comportamentais de responsabilidade.

\section{A PROMESSA dA NeURoimagiologia}

Entretanto, a neuroimagiologia parece nos oferecer uma melhor solução - uma maneira altamente tecnológica de avaliar individualmente a responsabilidade das pessoas que não esbarra nesses três problemas - tornando possível inspecionar diretamente o cérebro dos indivíduos e evitar o filtro dos próprios planos e de outras pessoas. Ampla e esquematicamente falando e novamente trabalhando ainda sob o anterior pressuposto de que a responsabilidade de um sujeito é determinada, em parte e dentre outras coisas, através de quais capacidades de responsabilidade relevantes ele possui, a neuroimagiologia poderia conseguir ajudar, em primeiro lugar, a revelar quais mecanismos cerebrais, precisamente, são exigidos para a atuação moral responsável e, então, nos ajudar a checar se um específico indivíduo, cuja responsabilidade necessita de avaliação individual, possui aqueles mecanismos cerebrais. A ideia básica aqui é simples: para ser um agente moral responsável, deve-se ter as capacidades mentais corretas, mas, uma vez que as capacidades mentais estão implementadas nos mecanismos cerebrais (no hardware cerebral), para ser um agente moral responsável deve-se ter os mecanismos cerebrais corretos, e isso - i.e. se a pessoa, cuja responsabilidade está sob avaliação, tem aqueles mecanismos cerebrais - é precisamente a razão pela qual a neuroimagiologia seria utilizada nessa abordagem de alta tecnologia para a avaliação individualizada de responsabilidade?

Algo semelhante já está sendo feito na literatura sobre cognição moral, em que pesquisadores, primeiramente, tentam revelar quais partes do cérebro são usadas em uma variedade de tipos de tarefas sobre julgamentos morais e essa informação pode então ser utilizada na tentativa de esclarecer por que indivíduos específicos elaboram juízos morais estranhos ${ }^{10}$. Similarmente, é concebível que a neuroimagiologia poderia também ser utilizada para estudar a base neural da responsabilidade moral para determinar qual "núcleo co-

9 Estou trabalhando aqui sob a presunção de que nossas capacidades mentais estão implementadas em nossos cérebros, embora essa presunção possa talvez ser contestada por (1) dualistas, (2) aqueles que afirmam que outras partes do sistema nervoso também têm um papel importante e pelos (3) proponentes das hipóteses da mente estendida.

10 GREENE, J.; HAIDT, J. How (and where) does moral judgment work. Trends in Cognitive Sciences, v. 6, n. 12, p. 517-523, 2002; ou a compilação de artigos apresentada por GERRANS, P.; KENNET'T, J. Introduction: is cognitive penetrability the mark of the moral. Philosophical Explorations, v. 9, n. 1, p. 3-12, 2006. 
mum de capacidades mentais [uma] pessoa deve ter para ser um agente moral responsável ou competente"11 e, assim, usar esse conhecimento para nos ajudar a avaliar, individualmente, a responsabilidade de pessoas específicas, checando se elas têm, ou não, aquelas capacidades, com exceção de que, aqui, nossos interesses seriam um tanto mais amplos do que eles são na área da cognição moral, mesmo porque a responsabilidade moral depende da capacidade não apenas volitiva como também cognitiva. Embora, atualmente, não esteja precisamente claro quais capacidades mentais são exigidas para a atuação moral responsável - por exemplo, se uma capacidade para racionalidade é tudo que é exigido ${ }^{12}$, ou se se deve também ter as capacidades emocionais/afetivas corretas ${ }^{13}$, ou talvez até mesmo alguma capacidade mais detalhada que será futuramente revelada por estudos de neuroimagem ${ }^{14}$ - presumivelmente, com a ajuda da neuroimagiologia, no futuro, descobriremos, precisamente, quais capacidades possuem um papel indispensável na atuação moral competente.

Que a neuroimagiologia poderia ser utilizada para nos ajudar a avaliar individualmente a responsabilidade das pessoas, mais ou menos nesta forma, não é uma sugestão original. Walter Glannon, por exemplo, escreve que "a ressonância magnética funcional por imagem (fMRI) pode expor a estrutura e a função de regiões do cérebro que regulam nossa capacidade para regular os impulsos"15, e sugere que uma "imagem de fMRI exibindo uma atividade metabólica significantemente reduzida... nessa parte do cérebro, poderia absolver [uma pessoa] de [uma] acusação de responsabilidade com base em... que nela faltou [uma relevante] capacidade" ${ }^{16}$. Da mesma forma, Adrian Raine e Yaling Yang sintetizam um crescente corpo de dados empíricos que mostra significativas diferenças estruturais e funcionais entre o cérebro de indivíduos normais quando comparados a cérebros de "populações delinquentes, criminosas, violentas e psicopatas" e, no final do estudo, eles sugerem que embora "[p]sicopatas possam não ser... insanos... se neles falta a capacidade para sentir o que é moral devido a deficiências neurobiológicas além de seu controle, [então eles provavelmente não são] inteiramente responsáveis pelo seu comportamento criminoso"17.

As vantagens da abordagem neuroimagiológica para a avaliação individualizada de responsabilidade do indivíduo sobre as abordagens comportamentais anteriormente delineadas podem ser brevemente sintetizadas. Em primeiro lugar, nessa abordagem não há espaço para enganos e mentiras que corrompem a validade dos nossos resultados, porque nossos resultados não dependem da veracidade de alguém - i.e. essa abordagem não é capaz de ser enganada por alguém que intencionalmente é reprovado nos testes de julgamento moral e autocontrole e sua validade não depende da precisão de relatos biográficos realizados por terceiros do indivíduo cuja responsabilidade necessita ser especificamente avaliada. Em segundo lugar, na medida em que os mecanismos presentes em nossos cérebros - i.e., o "hardware" dos nossos cérebros - determinam nossas capacidades mentais ${ }^{18}$, e mais além, na medida em que a neuroimagiologia nos fornece uma visão direta de nossos cérebros ${ }^{19}$, a abordagem neuroimagiológica nos habilita a visualizar diretamente quais as capacidades mentais que uma pessoa realmente tem e, assim, é também imune ao problema da falácia modal que atormenta as abordagens comportamentais descritas ${ }^{20}$.

11 VINCENT, N. Responsibility, dysfunction and capacity. Neuroethics, v. 1, n. 3, p. 199-204, 2008. p. 202.

12 MORSE, S. J. Moral and legal responsibility and the new neuroscience. In: ILLES, J. (Ed.) Neuroethics: defining the issues in theory, practice, and policy. Oxford: Oxford University Press, 2006b, p. 33-50.

13 GREENE, J.et. al. The neural bases of cognitive conflict and control in moral judgment. Neuron, n. 44, p. 389-400, 2004.

14 MATTHEWS, S. Failed agency and the insanity defence. International Journal of Law and Psychiatry, n. 27, p. 413-424, 2004.

15 GLANNON, W. Neurobiology, neuroimaging, and free will. Midwest Studies in Philosophy, n. 29, p. 68-82, 2005. p. 68.

16 GLANNON, W. Neurobiology, neuroimaging, and free will. Midwest Studies in Philosophy, n. 29, p. 68-82, 2005. p. 75.

17 RAINE, A.; YANG, Y. Neural foundations to moral reasoning and antisocial behavior. Social Cognitive and Affective Neuroscience, v. 1, n. 3, p. 203-213, 2006.

18 Comento sobre algumas das limitações por trás desse pressuposto na nota 5 acima.

19 Eu discuto esse ponto, em detalhes, abaixo - veja nota 9 e o texto circundante, bem como a seção abaixo intitulada "Breves Respostas aos Problemas Identificados na Seção Anterior".

20 Discuto uma complicação nesse último ponto - uma complicação que se aplica ao uso da tecnologia de neuroimagem funcional nesse contexto - na seção abaixo intitulada "A Falácia Modal e a Neuroimagem Funcional". 


\section{Alguns problemas associados à abordagem neuroimagiológica}

Naturalmente, ninguém está insinuando que essa promissora solução de alta tecnologia para a avaliação individualizada da responsabilidade das pessoas seja uma "bala de prata" que responderá a todas as nossas questões pertinentes ou que seria completamente livre de problemas.

Glannon, por exemplo, menciona uma longa lista de advertências, incluindo: (1) nem todas as pessoas com anormalidades cerebrais cometem crimes e por isso nós não deveríamos concluir, em qualquer caso, que a anormalidade cerebral observada em um indivíduo particular é o que o levou a cometer o crime ${ }^{21}$; (2) nenhum escaneamento do cérebro realizado após o evento pode estabelecer com algum grau de certeza qual o estado que o cérebro da pessoa estava no momento em que cometeu o crime e esse aspecto temporal pode também limitar nossa capacidade em determinar se é legítimo atribuir responsabilidade a alguém por um crime que sabemos que ele cometeu ${ }^{22}$; (3) imagens de fMRI e de outras tecnologias atuais de neuroimagem funcional não são imagens diretas da atividade cerebral, mas representações, inseridas em uma teoria, dos resultados de análises estatísticas sobre dados relacionados à atividade metabólica no cérebro reunidos em ambientes altamente controlados, quando sujeitos respondem a perguntas muitas vezes artificiais e cuidadosamente trabalhadas ${ }^{2324}$; e, (4) que a responsabilidade é uma noção normativa "que reflete convenções sociais e expectativas acerca de como as pessoas podem ou devem agir" e não apenas conclusões empíricas sobre as capacidades mentais de uma pessoa e, assim, não deveríamos esperar que a neuroimagiologia forneça respostas a todas as questões relevantes que devem ser respondidas para averiguar a responsabilidade de um sujeito $^{25}$. Por outro lado, Raine e Yang apontam que nosso "entendimento da base neural para a tomada de decisões morais está, claramente, ainda engatinhando", e que "fatores sociais de risco" certamente devem ter um papel na disposição dos indivíduos a determinados tipos de comportamento ${ }^{26}-$ i.e. eles também estão cautelosos sobre o quanto a neuroimagiologia pode revolucionar as avaliações individualizadas de responsabilidade.

Comentários similares e preocupações relacionadas sobre a extensão na qual a neuroimagiologia pode revolucionar avaliações individualizadas de responsabilidade são também expressados por outros ou, então, estão implícitos naquilo que eles têm a dizer. Da mesma forma, como Glannon, Stephen Morse também assinala que atribuições de responsabilidade dependem tanto de "questões normativas morais, políticas, sociais e ultimamente constitucionais sobre as quais a ciência comportamental e a neurociência devem... se calar" ${ }^{27}$, como em fatos empíricos sobre o cérebro das pessoas. Ele argumenta, por exemplo, que apenas

21 GLANNON, W. Neurobiology, neuroimaging, and free will. Midwest Studies in Philosophy, n. 29, p. 68-82, 2005 . p. 77.

22 GLANNON, W. Neurobiology, neuroimaging, and free will. Midwest Studies in Philosophy, n. 29, p. 68-82, 2005. p. 80.

23 GLANNON, W. Neurobiology, neuroimaging, and free will. Midwest Studies in Philosophy, n. 29, p. 68-82, 2005. p. 80-1

24 Uma varredura por fMRI, de forma alguma é uma imagem direta da atividade neural, uma vez que apenas revela alterações do nível de oxigenação do sangue no cérebro e, assim, inferências devem ser realizadas a partir de observações sobre alterações de oxigenação sanguínea para afirmar sobre quais partes do cérebro estão sendo usadas, mas ainda um grande número de pressuposições necessitam ser reconhecidas para que essas inferências possam ser aceitas. Além disso, imagens de fMRI revelam áreas do cérebro que estão associadas à performance daquela tarefa; mas embora a associação possa indicar que aquelas partes do cérebro constituam/implementem (parcial ou totalmente) a sua respectiva função ou que, de alguma outra forma, elas apoiam aquela função, pode ser também que aquelas partes do cérebro ativam-se como uma consequência (i.e. como efeitos ao invés de causas ou componentes) do desempenho daquela função. Esses e muitos outros pontos - i.e. isso tudo nos alerta para o fato de que as modernas técnicas de neuroimagem ainda são incipientes, que elas são ainda uma ciência inexata e, nesse sentido, que nós devemos exercitar um saudável grau de ceticismo ou, pelo menos, cautela, sobre quais conclusões tiramos a partir dos dados recolhidos mediante a utilização dessas técnicas - são também levantados em outro lugar (por exemplo, veja GOODENOUGH, O. R.; PREHN, K. A neuroscientific approach to normative judgment in law and justice. In: ZEKI, S.; GOODENOUGH, O. R. Law \& the brain. New York: Oxford University Press, 2004; EASTMAN, N.; CAMPBELL, C. Neuroscience and legal determination of criminal responsibility. Nature Reviews Neuroscience, n. 7, p. 311-318, abr. 2006; MOBBS, D. et. al. Law, responsibility, and the brain. PLoS Biology, v. 5, n. 4, p. 693-700, 2007; LOGOTHETIS, N. K. What we can do and what we cannot do with fMRI. Nature, n. 453, p. 869-878, jun. 2008.

25 GLANNON, W. Neurobiology, neuroimaging, and free will. Midwest Studies in Philosophy, n. 29, p. 68-82, 2005. p. 80-81.

26 RAINE, A.; YANG, Y. Neural foundations to moral reasoning and antisocial behavior. Social Cognitive and Affective Neuroscience, v. 1, n. 3, p. 203-213, 2006. p. 211.

27 MORSE, S. J. Moral and legal responsibility and the new neuroscience. In: ILLES, J. (Ed.) Neuroethics: defining the issues in 
a lei pode dizer de forma precisa qual limiar de capacidade é suficiente para uma pessoa passar no teste de "racionalidade mínima" e, assim, ser considerada um agente responsável; e, de um modo semelhante, que somente ela pode determinar quanta coação é demais para qualquer um suportar e, dessa forma, que é um assunto para aqueles que trabalham com o direito e não para os neurocientistas decidirem quanta coação deve estar presente antes que a responsabilidade de um indivíduo se torne comprometida ${ }^{28}$. Além disso, no que diz respeito à aplicação de punição para aqueles que já foram considerados responsáveis por alguma situação, isso também é, pelo menos parcialmente, uma questão normativa, pois apenas a lei está em posição de determinar qual é e qual não é o grau apropriado de punição para uma dada violação criminal - por exemplo, se a punição retributiva apropriada para uma dada ofensa deve ser algumas palavras duras, um puxão de orelha, uma multa, prisão, dez chibatadas, vinte chibatadas ou, talvez, até mesmo uma execução. Segundo a explicação de Morse, as práticas legais de responsabilidade são sobre fixação de normas e não apenas sobre apuração de fatos e essa é uma importante razão pela qual a neuroimagiologia não é capaz de responder todas as questões relevantes que devem ser respondidas para determinar a extensão da responsabilidade por algo que foi realizado.

A lista de dúvidas e problemas que limitam a medida na qual as modernas técnicas de neuroimagem podem revolucionar como avaliamos individualmente a responsabilidade das pessoas não termina aqui. Em primeiro lugar, dada a plasticidade neural - i.e. o fato de que a mesma função pode ser implementada nos cérebros de diferentes pessoas por caminhos radicalmente diversos - nós não deveríamos apressadamente concluir que alguém carece de particulares capacidades apenas porque não possui o(s) mecanismo(s) cerebrais afins, uma vez que essas capacidades podem ser implementadas em seu cérebro por caminhos muitos diferentes do que esperamos.

Em segundo lugar, conforme eu aponto em outra ocasião ${ }^{29}$, embora escaneamentos cerebrais possam revelar que alguém carece de uma capacidade que é requerida para a atuação moral responsável, se tivermos razão para acreditar que ele seja responsável por aquela incapacidade ${ }^{30}$, então, o mero fato de que, agora, ele tem essa incapacidade não necessariamente o escusará de culpa. Um motorista bêbado que causa um acidente de carro não pode, por exemplo, se eximir da culpa citando o fato de que carecia de capacidade para dirigir com segurança e, desse modo, que não era razoável esperarmos que ele, a princípio, dirigisse com segurança, à luz dessa incapacidade. Pelo contrário, uma vez que ele é responsável pela sua própria incapacidade normalmente pensaríamos que, por isso mesmo, ele não tem o direito de mencionar tal incapacidade como um fator excludente de responsabilidade e, de fato, podemos até mesmo pensar pior dele por fazer algo que comprometeu sua capacidade de ser um agente responsável. Dessa maneira, se alguém é responsável por sua incapacidade atual, então o mero fato de que agora ele tem essa incapacidade não necessariamente o eximirá de culpa, uma vez que, geralmente, apenas incapacidades pelas quais não somos responsáveis podem ter o papel escusatório.

Em terceiro lugar, e de um modo semelhante, embora um escaneamento neuroimagiológico possa revelar que uma pessoa carece de capacidade mental pertinente à responsabilidade, o mero fato dela possuir essa incapacidade não necessariamente a escusará de culpa se tivermos bons motivos para supor que ela devesse ter evitado se colocar em uma situação na qual sua incapacidade constituiria um problema. Por exemplo, embora um motorista que atropele um pedestre, como consequência do aparecimento súbito de um ataque epilético, possa ter tido pouco ou nenhum controle de seu carro, dado o surgimento do ataque epilético, ele

theory, practice, and policy. Oxford: Oxford University Press, 2006b, p. 33-50. p. 48.

28 MORSE, S. J. Moral and legal responsibility and the new neuroscience. In: ILLES, J. (Ed.) Neuroetbics: defining the issues in theory, practice, and policy. Oxford: Oxford University Press, 2006b, p. 33-50. p. 38

29 VINCENT, N. Responsibility, dysfunction and capacity. Neuroethics, v. 1, n. 3, p. 199-204, 2008. p. 202.

30 No que se segue, eu menciono apenas um caminho no qual alguém pode chegar a ser responsável por sua incapacidade - a saber, por fazer algo que, temporária ou permanentemente, diminua suas capacidades (e.g. ficar embriagado) - entretanto, pode haver também outras maneiras - por exemplo, alguém pode ser responsável por sua incapacidade se, negligentemente, não conseguir desenvolvê-la. 
ainda pode, mesmo assim, ser responsável pelas lesões e danos que causar se tivermos boas razões para supor que ele não deveria, em primeiro lugar, ter sentado atrás do volante de seu carro ${ }^{31}$. Se é ou não razoável para tais pessoas dirigir automóveis, isso depende de muitas coisas ${ }^{33}$, no entanto, isso não deve distrair-nos agora, porque o ponto que está sendo formulado no presente é apenas que o mero fato de que alguém carece de uma dada capacidade não necessariamente a exime de culpa, especialmente quando ela sabia da sua incapacidade e podia, razoavelmente, ser esperado que tomasse as medidas necessária para prevenir aquela incapacidade de se tornar um problema.

Uma razão final pela qual podemos não estar preparados para eximir de culpa uma pessoa por algo que ela tenha feito, apesar de que apenas o fez por causa da falta de alguma importante capacidade mental relevante à responsabilidade é porque a falta daquela capacidade pode ser vista como evidência para a sua maldade e, dessa forma, para a sua loucura e, assim, para sua responsabilidade reduzida. Marga Reimer ${ }^{34}$, por exemplo, aponta que a evidência derivada de estudos neuroimagiológicos que revela os fundamentos da psicopatia - por exemplo, dados de James Blair ${ }^{35}[38,39]$ que mostram que a amígdala dos psicopatas funciona muito diferentemente da amígdala de não psicopatas - é compatível com duas interpretações radicalmente diferentes, cada uma das quais tem ramificações completamente diversas para a nossa avaliação da responsabilidade de psicopatas. Segundo uma interpretação, o fato de que a amígdala dos psicopatas funciona diferentemente da amígdala das pessoas normais (e, portanto, que talvez por conta desse perfil funcional diverso eles carecem da capacidade para verdadeiramente perceber que machucar as pessoas é errado) é evidência para a sua loucura - i.e. que eles sofrem de um tipo de déficit, distúrbio ou doença mental que os exime de suas responsabilidades. Entretanto, em uma outra interpretação, tais escaneamentos fornecem conclusivas evidências para a maldade do psicopata - por exemplo, podemos imaginar alguém dizendo alguma coisa semelhante a isso: "Basta dar uma olhada naqueles escaneamentos! Viu? Não é de admirar que os psicopatas ajam daquela forma. Seus cérebros estão conectados para não responder ao sofrimento das outras pessoas. No nível mais básico, eles estão conectados para serem indivíduos perversos que não se preocupam com os outros." Agora, o ponto de Reimer não é que a última interpretação seja preferível à primeira, mas simplesmente que tais dados são neutros entre essas duas interpretações ${ }^{36}$. Contudo, isso parece ser precisamente o ponto central da objeção de Heidi Maibom do uso de evidências de neuroimagem para inocentar psicopatas (e presumivelmente outros que igualmente tenham reduzidas suas capacidades relevantes à responsabilidade) de sua responsabilidade quando ela escreve que "não podemos... simplesmente perdoar pessoas por serem más"37. O ponto de Maibom, aqui, parece ser que o fato de que alguém carece de uma capacidade que é requerida para a atuação moral responsável não é motivo para escusá-lo de culpa, muito pelo contrário, é mais um motivo para condená-lo até mais duramente, uma vez que com tais dados neuroimagiológicos em mãos podemos agora ter a conclusiva evidência de que ele é uma pessoa má.

31 EASTMAN, N.; CAMPBELL, C. Neuroscience and legal determination of criminal responsibility. Nature Reviews Neuroscience, n. 7, p. 311-318, abr. 2006. p. 316; TALLIS, R. Why blame me? It was all my brain's fault: the dubious rise of 'neurolaw'. The Times, 24 de outubro de 2007.

32 Stephen Morse desenvolve um argumento semelhante quando nos pede para considerar um indivíduo que tende a explodir em acessos incontroláveis e violentos de raiva quando acha que alguém está olhando para ele de forma estranha - sobre tal pessoa, Morse diz o seguinte: "Se você sabe que você é desse jeito, talvez seja melhor não frequentar bares". MORSE, S. J. Session 1: neuroscience, brain, and Behavior VI: Neuroscience and the Law, 2004. Disponível em: <http://www.bioethics.gov/transcripts/ sep04/ session1.html>. Acesso em: 28 nov. 2007.

33 É concebível que, em algumas situações, uma pessoa possa ser moralmente justificada em expor os outros usuários da estrada ao risco de que ela sofrerá um repentino acesso epilético e causará um acidente viário - por exemplo, talvez esse seja o caso se o risco do início de um ataque epilético for suficientemente pequeno, se o custo, nessa ocasião, de não dirigir for muito grande (e.g. ela precisa levar sua criança mortalmente doente ao hospital) e se nenhuma opção melhor estiver disponível.

34 REIMER, M. Psychopathy without (the language of) disorder. Neuroethics, v. 1, n. 3, p. 185-198, 2008. p. $185-198$.

35 BLAIR, R. J. R. Aggression, psychopathy and free will from a cognitive neuroscience perspective. Behavioral Sciences and the Law, n. 25, p. 321-331, 2007.

36 REIMER, M. Psychopathy without (the language of) disorder. Neuroethics, v. 1, n. 3, p. 185-198, 2008. 191-192.

37 MAIBOM, H. L. The mad, the bad, and the psychopath. Neuroetbics, v. 1, n. 3, p. 167-184, 2008. p. 168. 


\section{BREVES RESPOStAS AOS PROBLEMAS IDENTIFICADOS NA SEÇÃo ANTERIOR}

A seção anterior listou dez preocupações e problemas com a sugestão de que a neuroimagiologia pode nos ajudar a avaliar individualmente a responsabilidade dos indivíduos: (1) que nem todas as pessoas com cérebros anormais cometem crimes; (2) que nosso entendimento de como trabalha o cérebro humano é ainda muito rudimentar; (3) que a plasticidade cerebral pode tornar difícil diagnosticar quais capacidades cada um possui; (4) que problemas metodológicos e tecnológicos com técnicas atuais de neuroimagem lançam dúvidas sobre a utilidade de dados neuroimagiológicos; (5) que não podemos retroceder no tempo e checar quais capacidades uma pessoa tinha no momento em que cometeu seu crime; (6) que evidências neuroimagiológicas da incapacidade de um indivíduo podem, na verdade, condená-lo até mais duramente ao invés de eximi-lo de culpa; (7) que fatores sociais, e não apenas deficiências neurológicas, também têm algum papel na determinação de nosso comportamento; (8) que avaliações de responsabilidade também dependem, em parte, de presunções normativas que são, pelo menos parcialmente, independentes do que a neurociência cognitiva nos diz acerca da mente humana; (9) que as pessoas podem ser responsáveis por sua própria incapacidade e, desse modo, que elas podem ser responsáveis por aquilo que fazem por conta disso; e (10) que as pessoas que sabem de suas próprias incapacidades podem ser responsáveis pelo que fazem se falharem em evitar situações nas quais aquelas incapacidades possam se tornar um problema.

Essa não é uma lista trivial de problemas. No entanto, ao mesmo tempo, não acho que nenhum deles também seja um obstáculo, uma vez que, com o tempo, alguns desses problemas serão superados através de avanços científicos e tecnológicos e outros, igualmente, se aplicarão à abordagem comportamental que foi discutida acima e, assim, tais problemas não são capazes de nos fornecer um motivo para preferir a abordagem comportamental à abordagem neuroimagiológica - i.e. não ficaremos para trás se adotarmos a abordagem neuroimagiológica em vez de utilizarmos apenas a abordagem comportamental ${ }^{38}$. Os primeiros três itens, por exemplo, irão esperançosamente desaparecer dessa lista na medida em que adquirimos uma melhor compreensão de como o cérebro humano funciona e, de qualquer forma, dadas as causas do comportamento humano que estão localizadas no cérebro, há um bom motivo para se supor que, a longo prazo, entre as melhores explicações científicas para o comportamento humano certamente estarão aquelas que são informadas pela pesquisa proveniente do campo da neurociência cognitiva ${ }^{39}$. Quanto ao quarto item, embora as técnicas atuais de neuroimagem ainda estejam engatinhando, dado o histórico da ciência e da tecnologia - i.e. seus constantes avanços - podemos provável e seguramente presumir que melhores técnicas eventualmente surgirão, as quais não sofrerão nenhuma dessas deficiências. O quinto item aflige a abordagem neuroimagiológica em uma medida não maior da que aflige a abordagem comportamental - i.e. aqueles que desejam avaliar a responsabilidade de um indivíduo por meio de testes comportamentais também não são capazes de voltar no tempo para checar qual o estado que o cérebro daquele sujeito estava no preciso momento em que cometeu o crime - e por isso esse não é um problema específico com a abordagem neuroimagiológica. E, além do fato de que os últimos quatro itens nessa lista também se aplicam igualmente à abordagem comportamental da mesma forma que à abordagem neuroimagiológica, esses itens são meramente uma reafirmação mais detalhada de uma alegação que tenho insistentemente feito ao longo deste ensaio e a qual eu não contesto - a saber, que a responsabilidade não apenas depende de capacidades mentais; entretanto, contrariamente ao que Morse tem a dizer sobre esse assunto (veja a nota 10 acima), isso não implica que a neuroimagem seja irrelevante para avaliações de responsabilidade, mas apenas que evidências neuroimagiológicas têm utilidade limitada (i.e. apenas resolve parte do quebra-cabeça), uma vez que outras

38 Talvez se a abordagem neuroimagiológica fosse mais propensa a sofrer esses problemas do que a abordagem comportamental ou se esses problemas pudessem ser resolvidos mais facilmente no contexto da abordagem comportamental, então mencionar tais problemas poderiam nos fornecer motivos para preferir a abordagem comportamental à abordagem neuroimagiológica, porém não vejo nenhuma razão para pensar que seja assim.

39 JONES, O. D. Law, evolution and the brain: applications and open questions. In: ZEKI, S.; GOODENOUGH, O. R. Law \& the brain. New York: Oxford University Press, 2004. p. 57-75. p. 61. 
considerações também impactam em nossas avaliações de responsabilidade dos indivíduos.

Resta, assim, apenas o sexto item da lista - i.e. a afirmação de Maibom de que dados neuroimagiológicos que mostram que alguém carece de uma capacidade relevante à responsabilidade na verdade condenam até mais aquela pessoa, ao invés de escusá-lo da culpa, uma vez que, na sua opinião, tais dados mostram conclusivamente que essa pessoa é má! Contudo, isso não é, a rigor, realmente uma crítica à abordagem neurocientífica per se, mas, sim, um caso de uma preocupação mais ampla com todas as teorias capacitárias de responsabilidade. Qualquer abordagem que afirme ter achado uma forma de revelar as capacidades mentais das pessoas (independentemente de se alegar que faz isso utilizando testes comportamentais ou dados neuroimagiológicos), e que fazendo isso pode nos ajudar a estabelecer o grau de sua responsabilidade, terá de responder à objeção de Maimbom de porque essa abordagem terá dado como certo que a responsabilidade é, em parte, uma questão de quais capacidades uma pessoa tem. Mas já que a objeção de Maibom atinge todas as teorias que sustentam que a responsabilidade de um sujeito depende, em parte, de suas capacidades mentais, e não apenas minha própria afirmação de que a neuroimagem poderia ser usada para auxiliar-nos a avaliar a responsabilidade de um indivíduo ajudando a revelar suas capacidades mentais, eu, então, deixarei de lado a tarefa de defender a mais ampla abordagem capacitária ${ }^{40}$.

A discussão dessa seção destinou-se a afastar rapidamente algumas dúvidas comuns sobre se a neuroimagem pode nos ajudar a avaliar individualmente a responsabilidade dos indivíduos. Conforme eu disse no começo da seção anterior, ninguém está insinuando que essa promissora solução de alta tecnologia para avaliação individualizada da responsabilidade das pessoas seja uma "bala de prata" que responderá a todas as nossas pertinentes questões ou que ela seja completamente livre de problemas. Entretanto, os problemas que a afligem não são (ou pelo menos eles prometem ser de médio a longo prazo) muito maiores do que os problemas que afligem a abordagem comportamental; e a neuroimagiologia ainda consegue superar alguns sérios problemas que afligem a abordagem comportamental e por esse motivo não penso que já devêssemos desistir da ideia de usar a neuroimagiologia para nos auxiliar a avaliar a responsabilidade dos indivíduos.

\section{A falácia modal e a neUroimagiologia funcional}

Até este ponto eu compus uma imagem geral positiva de como a neuroimagem poderia melhorar nossa capacidade para avaliar com precisão a responsabilidade dos indivíduos, mas há ainda uma preocupação adicional que precisa ser resolvida. É uma preocupação que se aplica especificamente à neuroimagiologia funcional (como oposta à estrutural) e que permanecerá relevante até mesmo no futuro, dado que a nossa ciência e tecnologia têm avançado para além de seu ponto atual e, por isso, nesta seção me concentrarei primeiro em descrever essa preocupação e, depois, em mostrar como ela também pode ser resolvida.

\section{UMA QUESTÃo}

Deixe-me começar com a seguinte questão: um escaneamento funcional do cérebro de um indivíduo poderia nos ajudar a avaliar sua responsabilidade? Poderia, por exemplo, um conjunto de imagens que mos-

40 De fato, a abordagem capacitária é defendida por outros. As concepções, por exemplo, de autores como John Martin Fischer e Mark Ravizza, Daniel Dennett, Susan Wolf e Patricia Smith-Churchland (todos citados anteriormente neste ensaio) são todas em certo sentido capacitárias, uma vez que cada um (usando sua própria terminologia) vê a responsabilidade como uma questão de se o agente tem a capacidade de guiar suas ações da maneira correta (e.g. à luz das razões certas) ao invés de, por exemplo, uma questão de liberdade metafísica a ser determinada pela casualidade. VAN INWAGEN, P. The incompatibility of free will and determinism. In: EKSTROM, L. W. Agency and responsibility: essays on the metaphysics of freedom. Boulder: Westview, 2001. p. 17-29. Em suas descrições, o fato de que alguém carece desse tipo de capacidade pode desculpá-lo, ao invés de mostrar que ele é mau. 
tram conclusivamente funções significativamente reduzidas em partes do cérebro, que inegavelmente têm um papel indispensável na subscrição da capacidade de julgamentos morais sólidos, desempenhar a função de exoneração de culpa?

Vários dos autores que citei anteriormente, e também alguns outros, oferecem uma resposta afirmativa a essa questão. Na passagem anteriormente citada, Glannon, por exemplo, expressa a crença de que dados obtidos a partir da neuroimagiologia funcional poderiam eximir uma pessoa da responsabilidade mostrando que ela carecia de uma capacidade relevante à responsabilidade. Os comentários anteriormente citados de Raine e Yang sobre a responsabilidade de populações delinquentes, criminosas, violentas e psicopatas foram em parte informados por dados obtidos a partir de estudos de neuroimagiologia funcional. Igualmente, as reflexões de James Blair acerca da responsabilidade dos psicopatas são também derivadas de dados de neuroimagiologia funcional; por exemplo, dados obtidos a partir de estudos de neuroimagiologia funcional são a base de sua afirmação de que no psicopata a capacidade para intenção é prejudicada por causa de um "aumento do risco de agressão reativa" disfunção da amígdala e do córtex pré-frontal ventromedial (vmPFC)... irão prejudicar seriamente a tomada de decisão nos psicopatas" ${ }^{42}{ }^{43}$. Finalmente, a ideia de que a neuroimagiologia funcional pode ser capaz de revelar a responsabilidade reduzida das pessoas é também evidente no artigo de Claudia Pinto sobre o homem que "era um professor, um marido, um pai [e] então se tornou um pedófilo preocupado com sexo" no qual ela escreve que "assassinos, considerados como grupo, tinham metabolismo de glicose mais baixo no córtex pré-frontal, mostrando atividade diminuída em áreas do cérebro que normalmente funcionam para inibir impulsos agressivos" $"$.

Uma gama de pessoas pensa que a neuroimagiologia funcional poderia, em princípio, ser utilizada para nos ajudar a avaliar a responsabilidade de um indivíduo por meio da revelação de suas capacidades mentais.

\section{A PREOCUPAÇão}

Contudo, poderia se argumentar que uma falácia modal, semelhante àquela que foi descrita anteriormente, pode também estar comprometida se a neuroimagiologia funcional for utilizada para avaliar as capacidades das pessoas ${ }^{45}$. Para ver como isso pode acontecer, considere o seguinte exemplo. Suponha que estejamos tentando estabelecer se Jane e John são capazes de (i.e. se eles têm a capacidade de) fazer cálculos e, para simplificar as coisas, suponha também que essa aptidão matemática, nas pessoas que a tenham, seja implementada em uma única parte do cérebro denominada Área Matemática de Brodmann (AMB) ${ }^{46}$. Nós

41 BLAIR, R. J. R. The cognitive neuroscience of psychopathy and implications for judgments of responsibility. Neuroetbics, v. 1, n. 2, p. 149-157, 2008. p. 153.

42 BLAIR, R. J. R. The cognitive neuroscience of psychopathy and implications for judgments of responsibility. Neuroetbics, v. 1, n. 2, p. 149-157, 2008. p. 154, grifo nosso.

43 A afirmação de Blair de que "duas capacidades importantes são necessárias para a socialização [moral] bem-sucedida. Primeiro, o indivíduo deve ser capaz de achar o sofrimento dos outros aversivo... Segundo, o indivíduo deve ser capaz de desempenhar a aprendizagem estímulo-reforço", comprometendo-o a uma consideração capacitária das condições de responsabilidade (BLAIR, R. J. R. Aggression, psychopathy and free will from a cognitive neuroscience perspective. Behavioral Sciences and the Law, n. 25, p. 321-331, 2007. p. 327).

44 PINTO, C. Putting the brain on trial. 2003. Disponível em: <http://www.rifters.com/real/articles/brainon trial.htm>. Acesso em: 06 jul. 2008.

45 Recapitulando, se comete uma falácia modal quando se sai de uma observação da forma "X não acontece" (i.e. uma observação sobre comportamento) para uma conclusão da forma "X não é capaz de acontecer" (uma afirmação acerca de capacidade) e eu argumentei acima que esse é precisamente o tipo de movimento que é feito na abordagem comportamental porque afirmações sobre as incapacidades dos indivíduos são derivadas de observações sobre quais tipos de comportamento eles não exibem. No entanto, eu argumento então que, pela utilização da abordagem neuroimagiológica, poderíamos evitar cometer uma falácia modal, uma vez que afirmações acerca das capacidades dos indivíduos são derivadas de observações de seus mecanismos cerebrais.

46 Na realidade, nenhuma única área do cérebro é associada à racionalidade matemática, mas, sim, um número de diferentes áreas são implicadas, incluindo o "giro angular, parietal esquerdo e córtex pré-frontal”. KRENDL, A. C.et. al. The negative consequences 
colocamos Jane e John em um aparelho de fMRI, entregamos um certo número de equações a cada um e pedimos para eles responderem se aquelas equações estão corretas ou não. Agora, conforme isso acontece, Jane, que nunca frequentou um curso de matemática, embora esteja empolgada, ao final, desempenha mal suas tarefas - Jane nunca desenvolveu os mecanismos cerebrais necessários para entender e muito menos praticar a matemática (seu AMB não tem a capacidade para realizar cálculos) e, assim, o escaneamento por fMRI mostra uma ativação abaixo da média em seu AMB. Por outro lado, John ministra cursos de pós-graduação em matemática na Big State University, mas, hoje, está se sentindo desmotivado e, assim, ele apenas finge avaliar as equações enquanto na verdade está pensando em outra coisa - John não utiliza sua $\mathrm{AMB}$ e, assim, não surpreendentemente, as imagens de fMRI do cérebro de John se assemelham àquelas do cérebro de Jane. Entretanto, embora os escaneamento por fMRI revelem níveis de ativação abaixo da média nas AMBs de Jane e John, isso certamente não deveria ser tomado como evidência de que ambos carecem da capacidade de realização de cálculos, uma vez que ex hypothesi sabemos que John tem a capacidade de fazer contas, mas apenas não estava exercendo tal capacidade quando escaneamos seu cérebro $!^{47}$

Voltando ao caso em questão, mesmo se notássemos que os cérebros das pessoas que constantemente se saem mal em várias tarefas de julgamentos morais também mostram, de maneira constante, padrões reduzidos de ativação em alguma área do cérebro que normalmente seria utilizada por sujeitos que desempenham bem tais tarefas - por exemplo, na "amígdala e no córtex cingulado anterior rostral / córtex pré-frontal ventromedial (vmPFC)" de seus cérebros não são capazes de funcionar em altos níveis de ativação) em vez de uma simples amostra de que aquelas pessoas não utilizam a capacidade que, ao que sabemos, elas podem realmente possuir? Como poderíamos distinguir se tais pessoas são mais como Jane que, não culposamente ${ }^{49}$, carece da capacidade para matemática (i.e. talvez elas, também não culposamente, careçam da capacidade de avaliar corretamente tarefas de juízos morais), ou se elas são mais como John (talvez elas sejam preguiçosas,... talvez elas apenas não se esforcem o bastante, como o resto de nós, para descobrir qual é a coisa certa a fazer em várias situações) $?^{50} \mathrm{O}$ ponto é que se a neuroimagiologia funcional fosse nossa exclusiva ferramenta de escolha não poderíamos, então, distinguir alguém que possuía uma capacidade, mas falhou em usá-la, de alguém que simplesmente carece totalmente daquela capacidade. Como aponta Walter Glannon, assim como "critérios comportamentais ... não ... nos ajudam a distinguir entre ter alguma ... capacidade e falhar ao exercitá-la ... e

of threat: a functional magnetic resonance imaging investigation of the neural mechanisms underlying women's underperformance in math. Psychological Science, v. 19, n. 2, p. 168-175, 2008. p. 168. Isso se deve ao fato de que parece haver pelo menos dois tipos diferentes de racionalidade matemática: "Aritmética exata põe ênfase em representações específicas da linguagem e depende de um circuito inferior frontal esquerdo também utilizado para gerar associações entre as palavras... Aritmética aproximada, ao contrário, não mostra dependência da linguagem e depende, principalmente, de uma representação da quantidade implementada em redes viso-espaciais dos lobos parietais esquerdo e direito" DEHAENE, S. E. et al. Sources of mathematical thinking: behavioral and brain-imaging evidence. Science, n. 284, p. 970-974, 1999. p. 973, grifo nosso. No entanto, para simplificar esse exemplo, eu falo como se houvesse apenas uma área do cérebro - nomeadamente, a fictícia Área Matemática de Brodmann (AMB) - que é o lugar da aptidão matemática.

47 Nesse exemplo, estou trabalhando sob a simplificada pressuposição de que com maior esforço da habilidade matemática surgem níveis mais altos de ativação da AMB e que com menores esforços surgem níveis mais baixos de ativação da AMB. Mas, conforme um indivíduo estude mais matemática, as conexões entre os neurônios na sua AMB podem se tornar otimizadas através da poda dentrítica e isso pode resultar em níveis cada vez mais baixos de ativação na sua AMB, se tornando mais competente em realizar cálculos. Contudo, eu poderia ter elaborado o idêntico ponto de vista ao mesmo tempo assumindo que há uma relação inversa (ou alguma outra mais complexa) entre o exercício hábil da aptidão matemática e os níveis de ativação da AMB e, assim, peço ao leitor que tenha paciência com essa pressuposição. Sou grata a Jonathan Opie, da Universidade de Adelaide por me apontar isso. 48 BLAIR, R. J. R. The cognitive neuroscience of psychopathy and implications for judgments of responsibility. Neuroethics, v. 1, n. 2, p. 149-157, 2008. p. 151.

49 O ponto da expressão "não culposamente" é interromper a potencial objeção de que porventura essas pessoas sejam responsáveis pela sua incapacidade.

50 Exatamente a mesma questão pode ser formulada com respeito às afirmações sobre capacidades volitivas que são derivadas de dados da neuroimagiologia funcional, exceto que aqui nós perguntaríamos algo como "De que modo poderíamos distinguir se tais pessoas são mais parecidas com Jane (i.e. talvez elas também careçam da capacidade de controlar seus impulsos de raiva), ou se elas são, de fato, mais parecidas com John (talvez elas sejam apenas preguiçosas e não coloquem o mesmo esforço, como o resto de nós colocamos, para nos contermos)?” 
carecer [completamente] da capacidade, observações semelhantes se aplicam a estudos de imagem cerebral" ([46]:161 $\left.11^{51}\right)$.

A fonte desse problema é que, por definição, um escaneamento neuroimagiológico funcional é projetado apenas para revelar partes do cérebro que são utilizadas no desempenho de uma particular tarefa cognitiva e desta forma não deveríamos esperar encontrar quaisquer diferenças em escaneamentos daquelas pessoas que carecem de uma dada capacidade e por isso não a utilizam e aquelas que possuem tal capacidade e mesmo assim não a usam, porque em ambos os casos a área do cérebro associada àquela capacidade não será utilizada. Embora escaneamentos estruturais de seus respectivos cérebros possam de fato parecer diferentes - eles podem, por exemplo, revelar que um indivíduo possui os mecanismos cerebrais necessários, enquanto o outro não - nós não deveríamos esperar que escaneamentos funcionais pareçam diferentes. Ao contrário da neuroimagiologia estrutural, que revela os mecanismos ou o "hardware" nos quais as capacidades das pessoas são implementadas, a neuroimagiologia funcional revela apenas quais partes do cérebro um indivíduo estava utilizando quando alegadamente tentou desempenhar uma particular tarefa cognitiva. Isso significa, entretanto, que quando conclusões sobre as capacidades de um indivíduo são derivadas de um escaneamento funcional de seu cérebro, tais conclusões serão ainda derivadas de observações sobre o comportamento - comportamento do cérebro - e, assim, iria parecer que quando dados de neuroimagiologia funcional são utilizados para sustentar afirmações sobre capacidades, uma falácia modal será, afinal de contas, cometida!

Finalmente, é importante notar que essa preocupação não se prende apenas às atuais técnicas de neuroimagem funcional, mas se prenderá inclusive à futura tecnologia de neuroimagem funcional; se a tecnologia futura revelar apenas dados funcionais, então, de acordo com os argumentos acima, alguém terá cometido uma falácia modal a fim de obter afirmações sobre capacidades a partir daqueles dados. Dessa forma, o que é que justifica a transição da observação (obtida por meio de um escaneamento neuroimagiológico funcional) de que alguma parte do cérebro de um indivíduo mostra constantemente níveis abaixo da média de ativação (i.e. função reduzida) para a afirmação de que essa parte de seu cérebro não é capaz de (i.e. que carece da capacidade para) operar em níveis mais altos de ativação?

\section{As SOLuçõES}

A transição que é feita quando dados de neuroimagem funcional são citados para apoiar afirmações acerca das capacidades dos indivíduos é uma inferência a partir de uma observação sobre comportamento (nesse caso, comportamento cerebral) para uma conclusão sobre capacidades (como o cérebro não é capaz de comportar-se), e a preocupação acima descrita é que essa inferência não se justifica. No entanto, penso que há pelo menos duas maneiras de justificar essa transição e, desse modo, mostrar que essa inferência é, afinal, garantida - uma tem a ver com respostas automáticas e a outra com teorias para a melhor explicação - que desviam a preocupação de que uma falácia modal é cometida quando essa inferência é feita. Irei agora falar algo sobre cada uma dessas justificações.

\section{Respostas aUtomáticas ${ }^{52}$}

A primeira justificação se parece com algo assim.

Se ativadas de forma normal áreas do cérebro nas quais alguma parte da capacidade de um sólido jul-

51 GLANNON, W. Moral responsibility and the psychopath. Neuroethics, v. 1, n. 3, p. 158-166, 2008. p. 161.

52 Sou grata a Philip Gerrans da Universidade de Adelaide por apontar essa justificação para a obtenção de conclusões sobre capacidade a partir de observações sobre funções constantemente reduzidas. 
gamento moral é normalmente executada - e.g. a amígdala - as que se destinam a ativar-se automaticamente sempre que sujeitos são expostos a certos tipos de estímulos (e.g. quando a eles são mostradas imagens de rostos raivosos e tristes ou quando escutam palavras emocionalmente carregadas), então poderíamos, legitimamente, presumir que uma pessoa, de fato, tem reduzida capacidade de sólidos julgamentos morais se aquelas partes de seu cérebro mostram consistentemente níveis reduzidos de ativação quando são apresentados ao tipo correto de estímulo. Um movimento semelhante é feito no diagnóstico de "deficiência visual cortical" na qual a forte falta de atividade no lobo occipital de uma pessoa, quando exposta a apropriados estímulos visuais, pode ser tomada como evidência de que essa parte de seu cérebro carece da capacidade de processar informações visuais ${ }^{53}$. Assim, de forma similar, se a capacidade de um sólido julgamento moral também requer algumas respostas automáticas em certas áreas do cérebro quando os indivíduos são expostos aos tipos corretos de estímulo, então, quando observamos sistematicamente um nível significativamente reduzido de ativação naquelas áreas do cérebro sob exposição àqueles estímulos, deveríamos também ter o direito de concluir que esse indivíduo tem capacidade reduzida para um sólido julgamento moral ${ }^{54}$.

E, de fato, tem sido argumentado que há certas respostas automáticas que podem ser observadas quando indivíduos normais são expostos a estímulos que induzem cognição moral e que são necessários para um sólido julgamento moral. Por exemplo, quando a indivíduos normais são apresentadas imagens de rostos amedrontados ou tristes, eles automaticamente mostram uma elevada resposta de condutibilidade da pele ${ }^{55}$ e aumento da atividade de sua amígdala ${ }^{56}$ e se supõe que ambas as respostas automáticas (e várias outras) são exigidas para um sólido julgamento moral ${ }^{57}$; sem essas respostas automáticas, as pessoas ou falham em perceber importantes sinais morais ou simplesmente não conseguem exercer o tipo correto de processamento cognitivo e, consequentemente, os julgamentos morais de tais pessoas podem, de fato, fracassar em ser sólidos ${ }^{58}$.

Dessa maneira, o primeiro tipo de caso no qual estaremos justificados a tirar uma conclusão sobre a capacidade a partir de uma observação sobre níveis constantemente reduzidos de ativação neural é quando a atividade que faltou era destinada a ser uma resposta automática a um dado estímulo. Dito de outra forma, se a exposição a dado estímulo deveria sempre aumentar o nível de ativação em uma área específica do cérebro de todos os sujeitos, mas, contudo, aquela área do cérebro desse sujeito não mostrou aquela resposta, apesar do fato de que a ele foi apresentado o estímulo certo, então poderíamos justificadamente concluir (i.e. sem cometer uma falácia modal) que um mecanismo que normalmente gera uma resposta automática está quebrado e, portanto, que o sujeito, de fato, tem uma capacidade reduzida para responder de dada maneira.

\section{Teoria para a melhor explicação ${ }^{59}$}

A derivação de afirmações sobre capacidade reduzida a partir de dados neuroimagiológicos funcionais também podem ser justificadas de outro modo.

Se meu automóvel falha constantemente a dar partida nas manhãs frias, mas em manhãs quentes ele

53 Para discussão do uso de técnicas de neuroimagiologia funcional no diagnóstico de deficiência visual cortical, veja SILVERMAN, I. E. et al. Spect in patients with cortical visual loss. The Journal of Nuclear Medicine, v. 34, n. 9, p. 1447-1451, 1993. Que utilizou hexametil-propileno-amina-oxima em seus estudos de tomografia computadorizada por emissão de fóton único (SPECT) para obter dados funcionais ou GOOD, W. V. et. al. Recent advances in cortical visual impairment. Developmental Medicine \& Child Neurology, v. 43, n. 1, p. 56-60, 2001, que sugere que a fMRI pode também ser usada para obter tais dados funcionais.

54 Não obstante, por favor, observe meus comentários na nota 49 acima.

55 DAMASIO, A. R. Descartes' error: emotion, reason, and the human brain. New York, NY: Harper Perennia, 1995.

56 BLAIR, R. J. R. The cognitive neuroscience of psychopathy and implications for judgments of responsibility. Neuroetbics, v. 1, n. 2, p. 149-157, 2008. p. 149-157.

57 GREENE, J.; HAIDT, J. How (and where) does moral judgment work. Trends in Cognitive Sciences, v. 6, n. 12, p. 517-523, 2002.

58 Veja também o útil resumo de GLANNON, W. Moral responsibility and the psychopath. Neuroetbics, v. 1, n. 3, p. 158-166, 2008. p. 159-160.

59 Sou grata a Gert-Jan Lokhorst, da Universidade Tecnológica de Delft por sugerir essa segunda justificação para derivar conclusões sobre a capacidade a partir de observações sobre ativação constantemente reduzida. 
funciona sem qualquer problema visível, então eu começarei a suspeitar que há algo mecanicamente errado com ele - por exemplo, que as velas de ignição estão desgastadas e que em manhãs frias quando o metal deforma o espaço entre os eletrodos das velas de ignição que se tornam muito grande para a eletricidade se arquear com sucesso através deles e inflamar a gasolina nos cilindros do motor. Da mesma forma, se os ônibus constantemente atrasam nas manhãs de segunda-feira, então começarei a suspeitar que haja algo sobre como as pessoas se comportam no primeiro dia de trabalho da semana que causa esse fenômeno - por exemplo, que o congestionamento é causado quando todo mundo aparece ao mesmo tempo nas estradas, nas paradas de ônibus e bondes e estações de trem e que esse congestionamento torna tudo mais lento. Em ambos os casos, minha observação de alguma constante anomalia leva-me a postular a existência de algum mecanismo ainda não analisado que explique o fenômeno observado e, uma vez que eu tiver esse mecanismo, serei, então, capaz de deduzir validamente algumas outras afirmações sobre capacidades - por exemplo, sobre a capacidade reduzida de meu carro para funcionar em manhãs frias e sobre a capacidade reduzida do sistema de transporte público funcionar sem atraso nas manhãs de segunda-feira.

Penso que algo análogo também acontece no caso em questão, em que a afirmação de que alguém carece da capacidade para um sólido julgamento moral (ou algum componente necessário dessa capacidade) também se apresenta como uma conclusão para a melhor explicação - i.e. a observação de um nível constantemente reduzido de atividade em uma determinada parte do cérebro de uma certa pessoa, quando ela é exposta a estímulos que deveriam ter levado a um aumento do nível de ativação, nos leva a supor que deve haver alguma anomalia estrutural ainda não analisada em seu cérebro que explica o baixo nível de atividade constantemente observado e já que nenhuma falácia modal é cometida quando afirmações sobre a capacidade reduzida são derivadas de afirmações sobre estrutura - não é preciso muito para imaginar como uma carência do mecanismo cerebral apropriado pode resultar numa carência das capacidades relacionadas - da mesma forma, nenhuma falácia modal será cometida quando afirmações acerca de capacidades são derivadas de tais hipóteses sobre anormalidades estruturais. Dito de outro modo, uma transição parece ser feita, no caso em questão, a partir de uma observação sobre o perfil funcional do cérebro do indivíduo (derivado de um escaneamento de neuroimagem funcional) para uma hipótese sobre as características funcionais de seu cérebro e a afirmação concernente à capacidade relativa é então derivada da afirmação sobre essa anomalia estrutural hipotética e não diretamente de dados funcionais. Naturalmente, outra objeção pode agora ser levantada - nomeadamente, que a afirmação sobre a capacidade reduzida do indivíduo é derivada agora de algo que é apenas postulado para existir, mas que ainda não foi comprovada a existência - contudo, isso não é o mesmo que o problema da falácia modal.

Assim, no segundo exemplo, a transição da observação de um nível constantemente reduzido de ativação em alguma parte do cérebro de uma pessoa para a afirmação de que essa pessoa tem uma capacidade reduzida para um sólido julgamento moral pode também ser justificado como uma tentativa de oferecer a melhor explicação disponível para o fenômeno observado. A “melhor explicação para a baixa atividade cerebral, funcionalmente mensurada, é que há uma anomalia estrutural que é responsável pelo problema funcional [observado] ${ }^{\prime 60}$, e nenhuma falácia modal é cometida quando conclusões acerca de incapacidade são deduzidas de afirmações sobre características estruturais do cérebro.

\section{Resumo da SEÇÃo}

Assim, existem duas maneiras para derivar afirmações sobre capacidade reduzida a partir de dados de neuroimagem funcional sem cometer uma falácia modal. Em primeiro lugar, nenhuma falácia modal será cometida se a atividade que está ausente era destinada a ser uma resposta automática a alguns estímulos es-

60 Agradeço a Eddy Nahmias, da Universidade do Estado da Geórgia, por essa forma útil de inserir minha colocação. 
pecíficos. Em segundo lugar, se a afirmação sobre capacidade reduzida é derivada não diretamente de dados neuroimagiológicos funcionais propriamente ditos, mas indiretamente de uma hipótese sobre anomalias estruturais ainda não analisadas - uma hipótese que explica aqueles dados funcionais - então, novamente nenhuma falácia modal será cometida, uma vez que afirmações acerca de capacidade reduzida podem ser derivadas de dados estruturais sem se cometer uma falácia modal.

Como um aparte, respostas semelhantes para o problema da falácia modal podem também estar disponíveis para os defensores da abordagem comportamental para a avaliação individualizada de responsabilida$\mathrm{de}^{61}$. Se, por exemplo, tivermos um bom motivo para acreditar que todas as pessoas que possuem capacidade para um sólido julgamento moral irão sempre estremecer toda vez que virem uma foto de alguém em uma situação angustiante e que isso é uma resposta involuntária que não possa ser conscientemente reprimida pelo sujeito que está sendo testado, então quando observamos alguém que falha em exibir essa resposta automática, estaremos também justificados a concluir que esse sujeito tem capacidade reduzida para fazer sólidos juízos morais. De igual modo, se os defensores da abordagem comportamental podem postular um mecanismo psicológico plausível que explique a observada falta de algum comportamento e então derivar suas afirmações sobre a reduzida capacidade cognitiva ou volitiva de uma pessoa específica a partir de afirmações acerca desse mecanismo psicológico ainda não analisado, então, isso também pode habilitá-los a evitar o cometimento de uma falácia modal. Contudo, embora isso sugira que o problema da falácia modal possa não ser tão prejudicial à abordagem comportamental quanto eu inicialmente sugeri (com apoio em McSherry e Sapolsky), isso ainda significa que para a abordagem comportamental nos fornecer evidências úteis devemos utilizar testes mais complexos - i.e. que não permitam que o sujeito, cuja responsabilidade está sendo testada, interfira intencionalmente nos resultados - e que não deveríamos confiar demasiadamente em dados biográficos obtidos a partir de relatos de terceiros sobre a pessoa cuja responsabilidade está sendo avaliada, visto que meus comentários originais a esse respeito ainda se mantêm.

\section{Considerações finais}

Em Roper versus Simmons ${ }^{62}$, a Suprema Corte dos Estados Unidos poupou a vida de Simmons quando decidiu que a sua execução seria inconstitucional porque “[a] Oitava e Décima-Quarta Emendas proíbem a imposição da pena de morte para os menores de 18 anos à época em que os crimes foram cometidos". Presumivelmente, a idade importa para a responsabilidade por causa de sua relação com a maturidade e a maturidade importa para a responsabilidade porque, geralmente, com maior maturidade vêm maiores capacidades mentais - e o mais interessante para nós, aqui, maiores capacidades cognitiva e volitiva. Contudo, as pessoas amadurecem em ritmos diferentes e, assim, não deveríamos confiar na idade como um indicador preciso das verdadeiras capacidades de um indivíduo e de quão responsável ele verdadeiramente é. Dado o que paira sobre as avaliações de responsabilidade - i.e. o tipo e o grau de punição a que uma pessoa acusada será submetida - tais avaliações deveriam ser tão precisas e exatas quanto possível e a maneira de obter maior precisão e exatidão é procurar uma forma mais individualizada de avaliar a responsabilidade dos indivíduos, ao invés de usar a idade de um sujeito como um indicador para o grau de sua responsabilidade.

Um modo de avaliar individualmente a responsabilidade das pessoas é através do que me referi como a abordagem comportamental. No entanto, essa abordagem pode ainda ser terrivelmente imprecisa se depender da veracidade daqueles que estão sendo testados e da veracidade daqueles que são chamados a descrever aquela pessoa e, ademais, a menos que tais abordagens comportamentais sejam devidamente concebidas, elas irão conflitar-se com o problema da falácia modal que foi acima descrito. Por esses motivos deveríamos,

61 Agradeço o editor da Neuroethics por me colocar direto nesse ponto.

62 ROPER, Donald P. Roper v. Simmons. Superintendent, Potosi Correctional Center, Petitioner v. Christopher Simmons. 2005. Disponível em: <http://laws.findlaw.com/us/543/551.html>. Acesso em: 09 out. 2009. 
pelo menos, suprir com algo a mais essas abordagens comportamentais para a avaliação individualizada de responsabilidade.

Argumentei que a neuroimagiologia nos oferece tal suplemento - uma promissora forma para avaliar individualmente a responsabilidade das pessoas. Embora a neuroimagiologia não seja nenhuma "bala de prata" - i.e. na melhor das hipóteses apenas responde algumas das questões que necessitam ser respondidas a fim de avaliar a responsabilidade de uma pessoa - e embora ela também venha com seu próprio conjunto de problemas, ainda assim, com o tempo alguns desses problemas muito provavelmente serão superados e o remanescente desses problemas é também enfrentado pela abordagem comportamental. Assim, dados os argumentos expostos, agora é minha afirmação de que no futuro - i.e. uma vez que a ciência e a tecnologia progrediram suficientemente - a neuroimagiologia realmente pode ser útil a esse respeito. A neuroimagiologia pode nos libertar de nossa dependência atual sobre essas duras-e-prontas regras de ouro como a afirmação de que a responsabilidade de um indivíduo é em parte determinada pela sua idade - regras de ouro que foram bem sucedidas em Roper versus Simmons ${ }^{63}$ - e dado o que está em jogo para aqueles cuja responsabilidade é atualmente avaliada dessa maneira e o fato de que essa regra de ouro é, em última análise, imprecisa, isso só pode ser algo bom.

\section{REFERÊNCIAS}

ABA-1. Christopher Simmons-Jwenile Death Penalty. Disponível em: <http://www.abanet.org/crimjust/juvjus/ simmons.html>. Acesso em: 21 out. 2008.

BLAIR, R. J. R. Aggression, psychopathy and free will from a cognitive neuroscience perspective. Behavioral Sciences and the Law, n. 25, p. 321-331, 2007.

BLAIR, R. J. R. The cognitive neuroscience of psychopathy and implications for judgments of responsibility. Neuroethics, v. 1, n. 2, p. 149-157, 2008.

CHURCHLAND, P. S. The big questions: do we have free will. New Scientist, n. 2.578, p. 42-45, nov. 2006.

DAMASIO, A. R. Descartes' error: emotion, reason, and the human brain. New York, NY: Harper Perennia, 1995.

DEHAENE, S. E. et al. Sources of mathematical thinking: behavioral and brain-imaging evidence. Science, n. 284 , p. 970-974, 1999.

DENNETT, D. C. On giving libertarians what they say they want. In: ARNOLD, N. S.; BENDITT, T. M.; GRAHAM, G. Philosophy then and now. Malden: Blackwell, 1998. p. 119-130.

EASTMAN, N.; CAMPBELL, C. Neuroscience and legal determination of criminal responsibility. Nature Reviews Neuroscience, n. 7, p. 311-318, abr. 2006.

FISCHER, J.M. Reply: the free will revolution. Philosophical Explorations, v. 8, n. 2, p. 145-156, 2005.

FISCHER, J. M.; RAVIZZA, M. Responsibility and control: a theory of moral responsibility. Cambridge: CUP, 1998. p. 240-259.

GERRANS, P.; KENNETT, J. Introduction: is cognitive penetrability the mark of the moral. Pbilosophical Explorations, v. 9, n. 1, p. 3-12, 2006.

GLANNON, W. Moral responsibility and the psychopath. Neuroetbics, v. 1, n. 3, p. 158-166, 2008.

63 ROPER, Donald P. Roper v. Simmons. Superintendent, Potosi Correctional Center, Petitioner v. Christopher Simmons. 2005. Disponível em: <http://laws.findlaw.com/us/543/551.html>. Acesso em: 09 out. 2009. 
GLANNON, W. Neurobiology, neuroimaging, and free will. Midwest Studies in Philosophy, n. 29, p. 68-82, 2005.

GOOD, W. V. et. al. Recent advances in cortical visual impairment. Developmental Medicine \& Child Neurology, v. 43 , n. 1, p. 56-60, 2001.

GOODENOUGH, O. R.; PREHN, K. A neuroscientific approach to normative judgment in law and justice. In: ZEKI, S.; GOODENOUGH, O. R. Law \& the brain. New York: Oxford University Press, 2004.

GREENE, J.; HAIDT, J. How (and where) does moral judgment work. Trends in Cognitive Sciences, v. 6, n. 12, p. $517-523,2002$.

GREENE, J.et. al. The neural bases of cognitive conflict and control in moral judgment. Neuron, n. 44, p. 389-400, 2004.

HART, Herbert L. A. Postscript: responsibility and retribution. In: . Punishment and responsibility. 2. ed. Oxford: Oxford Scholarship Online, 1968.

HERNDON, J.; WAXMAN, S. P. Brief for respondent. In: ROPER; SIMMONS. St. Louis, MO: i-xiv, 1-50, 1a-21a, 2004.

JONES, O. D. Law, evolution and the brain: applications and open questions. In: ZEKI, S.; GOODENOUGH, O. R. Law \& the brain. New York: Oxford University Press, 2004. p. 57-75.

KRENDL, A. C.et. al. The negative consequences of threat: a functional magnetic resonance imaging investigation of the neural mechanisms underlying women's underperformance in math. Psychological Science, v. 19, n. 2, p. 168-175, 2008.

KUTZ, C. Chapter 14: Responsibility. In: COLEMAN, J.; SHAPIRO, S. Jurisprudence and philosophy of law. Oxford: Oxford University Press, 2004. p. 548-587.

LEVY, N. The responsibility of the psychopath revisited. Philosophy, Psychiatry \& Psychology, v. 14, n. 2, p. 129-138, 2007.

LOGOTHETIS, N. K. What we can do and what we cannot do with fMRI. Nature, n. 453, p. 869-878, jun. 2008.

MAIBOM, H. L. The mad, the bad, and the psychopath. Neuroethics, v. 1, n. 3, p. 167-184, 2008.

MATTHEWS, S. Failed agency and the insanity defence. International Journal of Law and Psychiatry, n. 27, p. 413-424, 2004.

MCKENNA, M. Assessing reasons-responsive compatibilism. International Journal of Philosophical Studies, v. 8, n. 1, p. 89-124, 2000.

MCKENNA, M. Book review: Fischer and Ravizza's "Responsibility and control". The Journal of Philosophy, v. 98, n. 2, p. 93-100, 2001.

MCKENNA, M. Reasons reactivity and incompatibilist intuitions. Philosophical Explorations, v. 8, n. 2, p. 131-143, 2005.

MCSHERRY, B. Criminal responsibility, 'Fleeting' states of mental impairment, and the power of selfcontrol. International Journal of Law and Psychiatry, n. 27, p. 224-257, 2004.

MOBBS, D. et. al. Law, responsibility, and the brain. PLoS Biology, v. 5, n. 4, p. 693-700, 2007.

MORSE, S. J. Session 1: neuroscience, brain, and Behavior VI: Neuroscience and the Law, 2004. Disponível em: <http://www.bioethics.gov/transcripts/ sep04/session1.html>. Acesso em: 28 nov. 2007.

MORSE, S. J. Moral and legal responsibility and the new neuroscience. In: ILLES, J. (Ed.) Neuroethics: defining the issues in theory, practice, and policy. Oxford: Oxford University Press, 2006b, p. 33-50. 
MORSE, S. J. Brain overclaim syndrome and criminal responsibility: A diagnostic note. Obio State Journal of Criminal Law, n. 3, p. 397-412, 2006 .

PERRY, Stephen R. Loss, agency, and responsibility for outcomes: three conceptions of corrective justice. Philosophy of law, v. 6, p. 546-559, 2000.

PINTO, C. Putting the brain on trial. 2003. Disponível em: <http://www.rifters.com/real/articles/brainon trial.htm>. Acesso em: 06 jul. 2008.

RAINE, A.; YANG, Y. Neural foundations to moral reasoning and antisocial behavior. Social Cognitive and Affective Neuroscience, v. 1, n. 3, p. 203-213, 2006.

REIMER, M. Psychopathy without (the language of) disorder. Neuroethics, v. 1, n. 3, p. 185-198, 2008.

ROPER, Donald P. Roper v. Simmons. Superintendent, Potosi Correctional Center, Petitioner v. Christopher Simmons. 2005. Disponível em: <http:/ laws.findlaw.com/us/543/551.html>. Acesso em: 09 out. 2009.

ROSKIES, A. Neuroscientific challenges to free will and responsibility. Trends in Cognitive Sciences, v. 10, n. 9 , p. 419-423, 2006.

SAPOLSKY, R. M. The frontal cortex and the criminal justice system. Philosophical Transactions of the Royal Society of. London, n. 359, p. 1787-1796, 2004.

SILVERMAN, I. E. et al. Spect in patients with cortical visual loss. The Journal of Nuclear Medicine, v. 34, n. 9, p. 1447-1451, 1993.

TALLIS, R. Why blame me? It was all my brain's fault: the dubious rise of 'neurolaw'. The Times, 24 de outubro de 2007.

VAN INWAGEN, P. The incompatibility of free will and determinism. In: EKSTROM, L. W. Agency and responsibility: essays on the metaphysics of freedom. Boulder: Westview, 2001. p. 17-29.

VINCENT, N. Responsibility, compensation and accident law reform. Tese (Doutorado) - University of Adelaide, Adelaide, 2006. <http://digital.library.adelaide.edu.au/dspace/handle/2440/39507>. Acesso em: 11 set. 2008.

VINCENT, N. Responsibility, dysfunction and capacity. Neuroethics, v. 1, n. 3, p. 199-204, 2008.

WIKIPEDIA. "Roper v. Simmons". Disponível em: <http://en.wikipedia.org/ wiki/Roper_v._Simmons>. Acesso em: 21 out. 2008.

WOLF, S. Sanity and the metaphysics of responsibility. In: SHOEMAN, F. Responsibility, character and the emotions: New Essays in moral psychology. New York: Cambridge University Press, 1987. p. 46-62.

WOLF, S. The reason view. In: EKSTROM, L. W. Agency and responsibility: essays on the metaphysics of freedom. Boulder: Westview, 2001. p. 205-226. 


\section{NUDGES: INDUÇÃO DE COMPORTAMENTOS E POLÍTICAS PÚBLICAS}




\section{Análise crítica da orientação de cidadãos como método para otimizar decisões públicas por meio da técnica nudge*}

\section{Critical analysis of citizens 'orientation as a method of optimize public decisions through nudge technique}

\author{
Luciana Cristina Souza** \\ Karen Tobias França Ramos*** \\ Sônia Carolina Romão Viana Perdigão****
}

* Recebido em 31/05/2018

Aprovado em 19/08/2018

** Doutorado em Direito pela PUC Minas. Professora de Direito Constitucional do Mestrado em Relações Sociais e Econômicas da Faculdade de Direito Milton Campos; Professora da disciplina Estado Democrático e Políticas Públicas da FaPP/UEMG; Coordenadora do Núcleo de Estudos sobre Gestão de Políticas Públicas (NEGESP), registrado no DGP-CNPq; Pesquisadora FAPEMIG. E-mail: dralucianacsouza@gmail.com

*** Mestranda em Direito nas Relações Econômicas e Sociais pela Faculdade Milton Campos. Membro do grupo de pesquisa Núcleo de Estudos sobre Gestão de Políticas Públicas - NEGESP da Faculdade de Direito Milton Campos. Advogada. E-mail: karentfr@ gmail.com

**** Mestranda em Direito nas Relações Econômicas e Sociais pela Faculdade Milton Campos. Membro do grupo de pesquisa Núcleo de Estudos sobre Gestão de Políticas Públicas - NEGESP da Faculdade de Direito Milton Campos. Advogada. E-mail: soninha. carolina@hotmail.com

\section{Resumo}

Este artigo objetiva refletir criticamente sobre a viabilidade de aplicação da técnica de nudge em processos decisórios públicos envolvendo Estado e cidadãos com base na perspectiva do soft paternalism como proposto por Thaler e Sunstein. A formulação de agenda e outras etapas das políticas públicas, conforme o modelo democrático assumido pelo Estado brasileiro, após a Constituição da República de 1988, deve ser acessível aos cidadãos e transparente, vista a atual importância do modelo de governança colaborativa. Considerando que os instrumentos de participação política podem permitir a organização e otimização do processo de tomada de decisões públicas envolvendo cidadãos, optou-se por efetuar uma análise crítica dos aspectos diversos da aplicação da técnica de nudge na área política de políticas públicas. Também se poderou sobre a necessidade de sua adequação às especificidades democráticas e constitucionais de nossa sociedade, visando proteger a liberdade de escolha e de atuação dos agentes sociais que participam comumente das deliberações com o Poder Público. Por meio da metodologia de análise sob a perspectiva sociopolítica e constitucional sobre o contexto brasileiro, concluiu-se que o nudge poderia ser, potencialmente, aplicado no Brasil.

Palavras-chave: Democracia. Direitos fundamentais. Nudge. Paternalismo. Políticas Públicas.

\section{Abstract}

This article purposes to critically reflect on the feasibility of applying the nudge technique in public decision-making processes involving state and citizens from the perspective of soft paternalism as proposed by Thaler and Sunstein. The agenda setting and other stages of public policies, according to the democratic model assumed by the Brazilian State after the Republican Constitution of 1988 must be accessible to citizens and transparent deeming the current significance of the collaborative governance model. Whereas 
that the instruments of political participation can allow the organization and optimization of the public decision-making process involving citizens, one decided to carry out a critical analysis of the multiple aspects of applying the nudge technique in the political area of public policies. The need to adapt them to the democratic and constitutional particular features of our society was also strengthened in order to protect the freedom of choice and action of the social agents who regularly participate in the deliberations with the Public Power. Through the analysis methodology from socio-political and constitutional perspective on the Brazilian context, one concluded that nudge could potentially be applied in Brazil.

Keywords: Democracy. Fundamental rights. Nudge. Paternalism. Public policies.

\section{INTRODUÇÃO}

O presente artigo procura investigar se as conquistas obtidas pelos cidadãos com a Constituição Cidadã de 1988, em relação aos direitos fundamentais, podem ser prejudicadas pelo uso do nudge no processo de tomada de decisões públicas das quais participem os cidadãos. Ou se, por outro lado, podem servir para otimizar a formulação da agenda de políticas sociais. Essa reflexão é crucial nos tempos atuais porque a promulgação da vigente Constituição da República completa trinta anos de sua vigência após a redemocratização do Estado brasileiro posteriormente ao regime de ditadura militar, o qual perdurou por, também, três décadas. A Carta Constitucional de 1988 fez surgir, então, uma nova forma de gestão pública pautada na governança colaborativa, ou governança em rede.

Governar em rede, de acordo com Goldsmith e Eggers, significa sintetizar quatro tendências atuais das relações entre o setor público e o setor privado: inserir os cidadãos nas decisões públicas, coordenar a gestão governamental, garantir o acesso digital e incrementar o fornecimento de bens e serviços públicos ${ }^{1}$. É uma nova metodologia de governança, mais apropriada para o cenário nacional que se formou após a CR/1988. Nesse cenário voltado ao desenvolvimento do amadurecimento democrático,

estratégias governamentais para uma governança eficiente passam por tornar o Estado mais permeável à influência da sociedade, participando diretamente, quando viável. ${ }^{2}$

Essa governança permeável, que é mais propícia ao processo compartilhado de tomada de decisões sobre políticas públicas, demanda uma estrutura governamental por denominada de Estado Resiliente 3 .

O Estado Resiliente foi, de certa forma, fundado pelos brasileiros em 1988 e consiste em uma infraestrutura política que reconhece direitos, dialoga com a sociedade civil, acolhe os argumentos dos cidadãos antes de tomar decisões públicas e garante o equilíbrio da pluralidade social ${ }^{4}$. Seu principal papel político-jurídico é reafirmar os valores constitucionais consignados no documento máximo do país para assegurar que não se retorne ao totalitarismo e opressão em que se viveu em décadas passadas. Por isso, considerando os problemas brasileiros de proteção das liberdades cívicas, a proposta de aplicação da técnica de nudge deve, sim, ser analisada com cautela. Todavia, isso não impede que esta possa contribuir para otimizar processos públicos de decisão envolvendo muitos sujeitos como se pretende com a CR/1988. Os Conselhos estaduais e

1 GOLDSMITH, Stephen; EGGERS, William D. Governar em rede: o novo formato do setor público. Brasília: Escola Nacional de Administração Pública. ENAP: UNESP, 2011. p. 24-35

2 BENTO, Leonardo Valles. Governança e governabilidade na reforma do Estado: entre eficiência e democratização. São Paulo: Manole, 2003.

3 SOUZA, Luciana Cristina de. Aplicação do princípio da resiliência às relações entre Estado, sociedade e direito. In: ASENSI, Felipe Dutra; PAULA, Daniel Giotti de (Org.). Tratado de direito constitucional. Rio de Janeiro: Campus Jurídico, 2014. p. 197-209. (Cap. 2.5). p. 197.

4 SOUZA, Luciana Cristina de. Refundação do estado democrático de direito pela sociedade civil. In: CONGRESSO BRASILEIRO DE SOCIOLOGIA: GT10: Estado, Cidadania e Identidade, Grupo 4: Estado, Democracia e Sociedade Civil, 13., 2007, Recife (PE), Anais... Recife, 29 de maio a 1 de junho de 2007. Disponível em: <file:///C:/Users/prof/Downloads/sbs2007_gt04_ luciana_de_souza.PDF>. Acesso em: 2 maio 2018. p. 5. 
municipais, por exemplo, possuem um número mais viável de deliberantes; no entanto, conferências, fóruns, audiências públicas e outros meios de participação popular estão abertos a um número maior de atores sociais, logo, precisam de algum tipo de metodologia que melhor os organize para que se possa, efetivamente, extrair uma decisão executável pelo Poder Público.

Exemplo do que este artigo pretende debater é o Orçamento Participativo (OP). Essa metodologia de participação assegura a liberdade de escolha dos cidadãos quanto às obras de seu interesse por meio do processo de formação da lista e de votação nas regionais — o que também aproxima a decisão da realidade de intervenção das políticas públicas. O OP, porém, precisa ser executável do ponto de vista técnico e orçamentário, além de garantir que articulações majoritárias obscureçam os direitos de grupos menos empoderados. Para que isso não aconteça, a aplicação da técnica nudge propicia um guia de participação e de escolha das obras que resulte em um pleito não somente vencedor sob a ótica democrática, como igualmente prático e realizável para não frustrar os vencedores e o restante da população que também se beneficiaria do bem ou serviço demandado. Os laudos técnicos, os critérios de escolha e de votação, a circunscrição às subdivisões dos municípios e das demais normas de orientação sobre como proceder durante as decisões públicas a serem tomadas em um OP são necessárias para fomentar a participação direta efetiva.

Acredita-se que outras modalidades de deliberação abertas a públicos mais numéricos precisam incorporar um conjunto maior de normas que orientem a participação popular com o intuito de preservar a liberdade de atuação dos atores e, ainda, assegurar que uma decisão viável possa ser efetivamente extraída do debate para ser executada pelo Poder Público.

O aspecto da liberdade (libertário, privado) deve, portanto, harmonizar-se com o aspecto social (paternalista, inclusivo) segundo o modo de aplicação da técnica de nudge às políticas públicas proposto por Thaler e Sunstein. A perspectiva do uso da técnica de nudge em políticas públicas como uma forma de soft paternalism apresentada por esses autores se inspirou em pesquisa por eles observada quanto à possibilidade de influenciar as escolhas dos estudantes nas escolas públicas estadunidenses quanto à merenda escolar (bandejões), visando orientar a decisão das crianças e adolescentes de se alimentarem com produtos mais saudáveis ${ }^{5}$.

Thaler e Sunstein estudaram o trabalho dos pesquisadores e agentes relacionados ao setor de alimentação daquelas escolas e escolheram este como o seu leading case para, com base nesse ponto, conduzirem seus próprios estudos sobre aplicação do nudge em políticas públicas considerando não somente o aspecto comportamental, mas também a correlação dessa técnica com os mecanismos usados em processos de tomada de decisão envolvendo Estado e cidadãos. Um dos objetivos, como explica Cass Sunstein, é buscar simplicidade e acesso ao governo para os cidadãos e isto se somaria ao fato de "os nudges oferecerem grandes benefícios à tomada de decisão, sem impor custos elevados" 6 .

É claro que eles admitem que "mais saudável”, "mais benéfico", “dignidade”, "reconhecimento" são categorias, dentre outras, que detêm um certo aspecto subjetivo. Assim, para evitar que uma decisão pública seja manipulada por técnicas de nudging, é muito importante garantir o respeito à base democrática que o novo modelo de governança instaurado com a Constituição da República de 1988, para desse modo respeitar a pluralidade de atores. A proposta de nudge desenvolvida por Thaler e Sunstein considera a essencialidade da garantia das liberdades individuais, mesmo em um sistema mais protecionista, por eles denominado de paternalista no sentido de ordenamento que assegura direitos, e não no sentido pejorativo da herança histórica brasileira. Para a melhor compreender a maneira de se aplicar a técnica de nugde à democracia brasileira, é fulcral entender a perspectiva de análise desses autores.

5 THALER, Richard H.; SUNSTEIN, Cass R. Nudge. New Haven, Conn.: Yale University Press, 2008. p. 1-3.

6 Demostra SUNSTEIN apud MUNIZ, Veyzon Campos. Simpler: the future of government, de Cass Sustein. Revista Brasileira de Politicas Públicas, v. 5, n. 2, p. 315-319, 2015. p. 317-318. 


\section{Nudge: a proposta de Cass R. Sunstein e Richard H. Thaler}

O termo nudge advém da Língua Inglesa e pode ser traduzido como pequeno empurrão ou cotovelada. Para Cass R. Sunstein e Richard h. Thales, o nudge pode ser considerado como um mecanismo de controle comportamental. Os dois autores possuem em conjunto a obra "Nudge: improving decisions about health, wealth, and happiness" que versa sobre o assunto.

Segundo Cass R. Sunstein, o nudge pode ser conceituado como "liberty-preserving approaches that steer people in a particular directions, but that also allow them to go their own way" ". Isso seria o equivalente a dizer que esse mecanismo é uma iniciativa que direcionaria as pessoas para determinados caminhos, porém, ao mesmo tempo em que aponta a direção para o indivíduo, permite que eles possuam liberdade para segui-lo da forma como desejarem. Esse incentivo ou iniciativa não pode se dar de forma impositiva, uma vez que o nudge pauta pela liberdade do sujeito. Este deve estar livre para escolher o caminho da forma como desejar. Se houver imposição, o nudge está descaracterizado ${ }^{8}$. Dessa forma, o uso do poder estatal para orientar as escolhas mantém-se aberto à contribuição dos cidadãos, preservando sua resiliência organizacional, o que é imprescindível no modelo de governança colaborativa ou "em rede".

Logo, resta evidente o motivo de caracterizar o nudge como um mecanismo de economia comportamental, tendo em vista que está voltado para lidar com o comportamento humano. Esta é uma das razões que atrai as instituições públicas e privadas para atingir seus objetivos específicos. Além disso, os custos para a sua implementação podem ser baixos e a taxa de efetividade é considerada alta. Esses elementos fazem do nudge um grande atrativo. ${ }^{9}$ Dentre as formas de nudges $^{10}$, possuímos o GPS, aplicativos que calculam a quantidade de calorias que foram ingeridas pela pessoa no dia anterior, mensagens de texto que informam o vencimento de uma conta ou que informam o agendamento de uma consulta, o cadastro em planos de pensão, dentre outros ${ }^{11}$.

Esse mecanismo comportamental pode ser utilizado por entidades públicas e privadas. Os entes governamentais podem utilizá-lo com diversos fins, como forma de implantar políticas públicas, de efetivar direitos fundamentais e outros. Dentre os exemplos que Cass R. Sunstein ${ }^{12}$ apresentam, estão os alertas gráficos para cigarros, etiquetas para eficiência energética e economia de combustível, painéis de fatos nutricionais em comidas, o prato de comida que seria um guia simples para comer de forma saudável, regras padrões para programas públicos de assistência, sites que produzem grandes pesquisas públicas e lista determinados itens ${ }^{13}$. Ressalta-se que, para sua boa execução, é mister que os gestores públicos estejam capacitados para assumirem uma nova postura dentro do modelo de governança em rede ${ }^{14}$.

7 SUNSTEIN, Cass R. Nudging: a very short guide. 37 J. Consumer Pol'y 583, Harvard Law School; Harvard University; Harvard Kennedy School (hks), p. 1-7, 23 set. 2014. Disponível em: <https://ssrn.com/abstract=2499658>. Acesso em: 27 abr. 2018 . p. 1

8 SUNSTEIN, Cass R. Misconceptions about nudges. Ssrn Electronic Journal, [s.l.], p. 1-13, 2017. (Elsevier BV. http://dx.doi. org/10.2139/ssm.3033101). Disponível em: <https://papers.ssrn.com/sol3/papers.cfm?abstract_id=3033101>. Acesso em: 3 maio 2018. p. 1.

9 SUNSTEIN, Cass R. Misconceptions about nudges. Ssrn Electronic Journal, [s.l.], p. 1-13, 2017. (Elsevier BV. http://dx.doi. org/10.2139/ssrn.3033101). Disponível em: <https://papers.ssrn.com/sol3/papers.cfm?abstract_id=3033101>. Acesso em: 3 maio 2018.

10 In daily life, a GPS is an example of na nudge; so is an "app" that tells people how many calories they ate during the previous day; so is a text message, informing customers that a bill is due or that a doctor's appointment is scheduled for the next day; so is an alarm clock; so is automatic enrollment in a pension plan; so are the default settings on computers and cell phones; so is a system for automatic payment of credit card bills and mortgages.

11 SUNSTEIN, Cass R. Misconceptions about nudges. Ssrn Electronic Journal, [s.l.], p. 1-13, 2017. (Elsevier BV. http://dx.doi.org/10.2139/ ssrn.3033101). Disponível em: < https://papers.ssrn.com/sol3/papers.cfm?abstract_id=3033101>. Acesso em: 3 maio 2018.

12 In government, nudges include graphic warnings for cigarettes; labels for energy efficiency or fuel economy; "nutrition facts" panels on food; the "Food Plate," which provides a simple guide for healthy eating (see choosemyplate.gov); default rules for public assistance programs (as in "direct certification" of the eligibility of poor children for free school meals); a website like data.gov or data.gov.uk, which makes a large number of data sets available to the public; and even the design of government websites, which list certain items first and in large fonts.

13 SUNSTEIN, Cass R. Nudging: a very short guide. 37 J. Consumer Pol'y 583, Harvard Law School; Harvard University; Harvard Kennedy School (hks), p. 1-7, 23 set. 2014. Disponível em: <https://ssrn.com/abstract=2499658>. Acesso em: 27 abr. 2018. p. 1-2 14 GOLDSMITH, Stephen; EGGERS, William D. Governar em rede: o novo formato do setor público. Brasília: Escola Nacional 
Os nudges são produzidos ou elaborados para que possam simplificar a vida das pessoas ou agregar maior segurança. Eles são utilizados na área da saúde, da educação, em avisos públicos e outros que fazem com que seja reduzida a burocracia e os pesos que as pessoas devem suportar. Em razão disso e por ser um guia, algumas pessoas apontam que é uma forma de paternalismo mais brando. Apesar disso, Cass R. Sunstein aponta que o nudge é desenhado para preservar a escolha feita de forma liberal e, além disso, "new nudges typically replace preexisting ones; they do not introduce nudging where it did no exist before" ${ }^{15}$. Essa ideia de paternalismo é uma das críticas enfrentadas pelos adeptos dos nudges.

Para Cass R. Sunstein, há diversos tipos de paternalismo, considerando o termo de modo mais geral ${ }^{16}$ :

a) soft paternalism, considerado mais libertário porque o direito de participação das pessoas e a proteção jurídica de sua liberdade de escolha é mais relevante do que a burocracia de funcionamento do Estado;

b) hard paternalism, no qual o aspecto burocrático ainda possui um forte peso para a organização dos processos deliberativos envolvendo os cidadãos nas tomadas de decisões sobre políticas públicas;

c) means paternalists modalidade cujo foco central são os meios disponíveis e autorizados para se atingir o objetivo;

d) ends paternalists, modalidade cujo foco são as escolhas finais dos indivíduos.

Para o autor, os nudges se encontram na categoria do means paternalism e soft paternalism ${ }^{17}$, pois as decisões sobre políticas públicas tanto precisam respeitar a liberdade de escolhas dos cidadãos quanto oferecer-lhes meios adequados para participarem do processo de escolha. Isto é importante, conforme se acredita, não somente na perspectiva dos indivíduos, mas deve-se levar em conta as organizações da sociedade civil e outros modos desta se articular em grupos de interesse para participar de processos decisórios. É crucial, em um governo democrático, que exista igual acesso de direitos para os indivíduos, ainda que se protejam os segmentos minoritários contra grupos mais fortes política ou economicamente. Por isso o Estado deve garantir os meios para o cidadão assegurar seu papel de sujeito na vida social, como Defensoria Pública, inclusão digital, writs constitucionais, ação civil pública, participação em conselhos, audiências públicas com pleno acesso à informação sobre as decisões etc.

Esse contexto mais democrático quanto à escolha e manutenção da liberdade pelo indivíduo pode ser descrito como uma modalidade de soft paternalism. Também se classifica como means paternalism, já que a atuação cidadã ocorrerá através dos meios disponibilizados para sua participação, os quais permitem a construção de um caminho para se alcançar determinado objetivo. Sunstein ${ }^{18}$ defende que o uso dos nudges pelo governo deve ser realizado de forma transparente e aberta. Além disso, a possibilidade de adoção do nudge deve ser revista e levada para análise pela população. O autor aponta que o crescimento desse mecanismo se eleva, cada vez mais, devido a alguns fatores como o seu baixo custo para se implementá-lo, a entrega de bons resultados e a manutenção da liberdade daquele que o nudge atinge.

de Administração Pública. ENAP: UNESP, 2011. p. 207-208.

15 SUNSTEIN, Cass R. Nudging: a very short guide. 37 J. Consumer Pol'y 583, Harvard Law School; Harvard University; Harvard Kennedy School (hks), p. 1-7, 23 set. 2014. Disponível em: <https://ssrn.com/abstract=2499658>. Acesso em: 27 abr. 2018 . p. 2. 16 Ressalta-se, aqui, que o termo nudge neste artigo tem sido usado na acepção desse marco teórico, visando sua aplicação jurídicopolítica. Sob a perspectiva do behavioral decision-making na Psicologia, outras abordagens são empregadas e a nomenclatura de Thaler e Sunstein não é adotada. Como a presente pesquisa segue metodologia jurídico-constitucional visando sua aplicação em políticas públicas sob o viés do Direito, mantém-se a classificação mencionada neste tópico. Autores mais específicos da linha de estudo comportamental da Psicologia chamam a atenção para a existência de outras modalidades de nudges. Para maiores informações, ler: HANSEN, Pelle Guldborg. The definition of nudge and libertarian paternalism: does the hand fit the glove? European Journal of Risk Regulation, v. 7, n. 1, p. 155-174, 2016. p. 3-6.

17 SUNSTEIN, Cass R. The storrs lectures: behavioral economics and paternalism. Ssrn Electronic Journal, [s.l.], p. 1-60, 29 nov. 2012. (Elsevier BV. http://dx.doi.org/10.2139/ssrn.2182619). Disponível em: <https://papers.ssrn.com/sol3/papers. cfm?abstract_id=2182619>. Acesso em: 3 maio 2018. p. 7.

18 SUNSTEIN, Cass R. Nudging: a very short guide. 37 J. Consumer Pol'y 583, Harvard Law School; Harvard University; Harvard Kennedy School (hks), p. 1-7, 23 set. 2014. Disponível em: <https://ssrn.com/abstract=2499658>. Acesso em: 27 abr. 2018 . p. 2. 
Para Cass R. Sunstein ${ }^{19}$, existem dez tipos de nudges que são os mais usados e serão explicados a seguir. Dentre eles estão as "default rules" que seriam a inclusão automaticamente das pessoas em programas, por exemplo, de saúde ou educação. Por meio dessa inclusão automática, as pessoas melhorariam suas economias e a sua saúde, uma vez que, por exemplo, um programa de aposentadoria faria com que as pessoas obtivessem uma quantia de dinheiro reservada. Além disso, essa inclusão pouparia as pessoas de escolherem se deveriam ou não aderir ao programa e a qual tipo de programa.

A simplificação, também, é vista como um nudge, uma vez que a complexidade pode causar confusão, o que pode provocar descumprimento de preceitos legais, pode aumentar os gastos e impedir a participação em programas importantes. O uso de normas sociais a serem divulgadas para as pessoas é visto como um nudge potencial, tendo em vista que mostra com que tipo de comportamento as demais pessoas estão engajadas. Isso funciona mais em comunidades pequenas.

Outro nudge é conhecido como "increases in ease and convence", exemplificado como opções com valor baixo ou comidas saudáveis mais visíveis. Isso porque as pessoas tendem a escolher a opção que é mais fácil. "Disclosure" pode ser traduzido como divulgação. Esse é um nudge que pode alcançar, de forma satisfativa, seu objetivo caso seja feito de forma compreensível e acessível. Os exemplos disso são os dados dos custos econômicos do uso de energia ou dos custos totais de um cartão de crédito que são disponibilizados para as pessoas.

Os avisos e gráficos, também, podem ser utilizados como nudges. Quando alguns riscos estão previstos em determinadas atitudes, um aviso público pode ser eficaz para avisar as pessoas. Para isso é necessário chamar a atenção do público com um aviso que seja feito com letras grande e cores brilhantes. Sunstein afirma que há mais probabilidade de as pessoas seguirem esse aviso quando ele contém os passos para que as pessoas consigam cumpri-lo. Um exemplo nesse caso são as advertências realizadas em caixas de cigarros.

As estratégias de pré-comprometimento como nudges são aquelas nas quais as pessoas se comprometem com um determinado tipo de ação. Quando as pessoas colocam objetivos para elas mesmas, se torna mais fácil alcançá-los quando estabelecem determinadas ações que serão realizadas para isso. Assim, se comprometer com ações específicas durante determinado tempo no futuro é uma forma de motivar as ações e diminuir a procrastinação.

Os lembretes funcionam como nudges, por exemplo, quando são enviados lembretes por e-mail ou mensagem de texto para lembrar do pagamento de contas ou de compromissos agendados. Isso porque as pessoas não realizam determinadas condutas em razão da sua inércia, procrastinação ou pelo esquecimento. Com o lembrete, as pessoas são lembradas de agir rapidamente.

Outro nudge importante pode ser nomeado de "eliciting implementation intentions". Isso quer dizer que as pessoas são mais propensas a realizar determinada atividade se alguém provocar a sua intenção de implementação. A pergunta se a pessoa planeja vota ou se planeja vacinar o filho são exemplos de provocações que podem levar à implementação da atitude que se espera.

Por fim, o último nudge é informar as pessoas da natureza e das consequências das próprias escolhas que fizeram no passado, como informar os valores gastos em seguros de saúde ou em contas de energia elétrica. Se isso fosse realizado, o comportamento das pessoas mudaria para melhorar, a começar por economizar dinheiro.

Após a análise dos exemplos mais relevantes de nudges, é necessário investigar a forma como podem ser implantados. De acordo com Sunstein ${ }^{20}$, há duas maneiras de implantar os nudges em uma sociedade. Dentre

19 SUNSTEIN, Cass R. Nudging: a very short guide. 37 J. Consumer Pol'y 583, Harvard Law School; Harvard University; Harvard Kennedy School (hks), p. 1-7, 23 set. 2014. Disponível em: <https://ssrn.com/abstract=2499658>. Acesso em: 27 abr. 2018 . p. 3-4. 20 SUNSTEIN, Cass R. Nudging: a very short guide. 37 J. Consumer Pol'y 583, Harvard Law School; Harvard University; Harvard Kennedy School (hks), p. 1-7, 23 set. 2014. Disponível em: <https://ssrn.com/abstract=2499658>. Acesso em: 27 abr. 2018 . p. 1. 
as formas, uma delas seria confiar nos nudges já existentes, o que seria muito melhor do que confiar em dados ou teorias abstratas. Por isso, as autoridades públicas ou privadas devem utilizar as pesquisas e os dados reais que possuem, sem necessidade de ser realizar novas investigações. Para o autor, "this approach is the simplest because it does not require new offices and significant additional funding, but only attention to the relevant issues and a focus on the right appointments'"21.

Outra forma de implantar o nudge seria criar uma instituição, a qual tanto poderia ter uma forma minimalista, com cinco pessoas reunindo dados importantes, quanto reunir um time para realizar uma grande pesquisa. As vantagens de ambos os modos seria criar um time dedicado e especializado com muitas informações e voltados para um trabalho relevante. Entretanto, segundo Sunstein ${ }^{22}$, um número crescente de países tem concluído que é mais eficaz reunir um grupo específico de pessoas dedicadas para o nudge.

Portanto, é possível concluir que os nudges são técnicas de controle comportamental que podem ser utilizados por instituições púbicas ou privadas com o fito de alcançar determinados objetivos sem colocar em prejuízo a liberdade do indivíduo que é o alvo. Para conservar o livre arbítrio, é necessário conscientizar e informar os indivíduos de que eles sofrem a influência de um nudge e permitir que possam seguir o caminho que desejarem.

\section{PossibILIDAde de APLICAÇÃo da tÉCNICA DE NUDGE À DEMOCRACIA BRASILEIRA}

Sendo o nudge, um mecanismo de controle comportamental que pode ser utilizado tanto por instituições privadas quanto públicas para se atingir determinados objetivos, coloca-se em discussão a sua implantação na sociedade brasileira frente ao conceito de cidadania e de democracia. A necessidade dessa discussão se encontra no papel desempenhado pelo cidadão em relação ao Estado, as conquistas alcançadas com a Constituição Cidadã de 1988 e às consequências de implantação dos nudges que podem conflitar com os direitos implícitos e explícitos na Carta Magna.

Com as alterações e modificações sofridas pela Constituição da República de 1988, principalmente na década de 1990, o cidadão passou a interagir com a Administração Pública ${ }^{23}$. A proteção e a importância dos direitos fundamentais dada pela Carta Magna, pela legislação infraconstitucional e pelo ordenamento jurídico como um todo, resultou na cobrança pelos cidadãos de que estes fossem efetivados e respeitados pelo Estado, devendo cumprir o que estava disposto em lei. O Estado precisou remodelar o seu papel e buscar formas de cumprir o que havia prometido. Como exemplo, adotou as políticas públicas que são formuladas com o fito de dar cumprimento e efetividade aos direitos fundamentais.

O papel do cidadão também se modificou, por exemplo, a legislação infraconstitucional que passou a regulamentar a participação dos cidadãos nos Conselhos que versam sobre idosos, adolescentes, saúde e educação. E na Constituição, com dispositivos como o artigo 1º, parágrafo único da Constituição da República de 1998 que dispõe que "todo o poder emana do povo, que o exerce por meio de representantes eleitos ou diretamente, nos termos desta Constituição". E o artigo 14, caput que prevê que "a soberania popular será exercida pelo sufrágio universal e pelo voto direto e secreto, com valor igual para todos, e, nos termos da lei, mediante" o disposto nos incisos I a 3, qual seja o plebiscito, referendo e a iniciativa popular, mecanismos de participação popular que expressam a opinião dos cidadãos.

21 SUNSTEIN, Cass R. Nudging: a very short guide. 37 J. Consumer Pol'y 583, Harvard Law School; Harvard University; Harvard Kennedy School (hks), p. 1-7, 23 set. 2014. Disponível em: <https://ssrn.com/abstract=2499658>. Acesso em: 27 abr. 2018 . p. 7. 22 SUNSTEIN, Cass R. Nudging: a very short guide. 37 J. Consumer Pol'y 583, Harvard Law School; Harvard University; Harvard Kennedy School (hks), p. 1-7, 23 set. 2014. Disponível em: <https://ssrn.com/abstract=2499658>. Acesso em: 27 abr. 2018 . p. 7. 23 SOUZA, Luciana Cristina de. Contribuição das práticas de e-cidadania para a formulação, implantação e monitoramento das políticas públicas. Revista Direito Público, Porto Alegre, v. 13, n. 74, p. 187-202, mar./abr. 2017. p. 193. 
A modificação do papel do cidadão é resultante da transformação que o Estado sofreu para se adaptar às novas necessidades e demandas da sociedade, em razão da “[...] adoção de valores democráticos que obrigam o Poder Público a admitir a inclusão dos indivíduos enquanto sujeitos ativos e agentes de mudanças de leis e políticas administrativas" ${ }^{24}$. A origem dessas mudanças reside no princípio da resiliência estatal que advém do poder do cidadão de se movimentar para modificar e reformular o Estado e

[...] deste em absorver as mudanças respeitando a contribuição que os primeiros oferecem, equilibrando o ideal democrático com a necessidade de existência de uma estrutura organizada para atender às demandas coletivas. ${ }^{25}$

Diante dessa capacidade que o Estado e o cidadão possuem para se reorganizar e reestruturar conjuntamente e da necessidade da sua atuação conjunta frente às demandas existentes na sociedade, principalmente na implantação de políticas públicas, o nudge pode ser visto como um mecanismo que contribua, embora não de modo exclusivo e central, para a organização de tais deliberações. Isso porque este é passível de permitir que os entes estatais promovam políticas de efetivação e respeito aos direitos fundamentais, por exemplo, a promoção da saúde física e psicológica, a proteção do meio ambiente, o incentivo a educação, dentre outros.

Uma ação estatal desenvolvida nos moldes dos mecanismos de controle comportamental pode ser identificada como controladora, por isso se devem aliá-la ao Princípio da Transparência e da Liberdade para que não prejudique a cidadania e a democracia ${ }^{26}$. Esse controle pode ser prejudicial aos princípios constitucionais e aos direitos fundamentais dos cidadãos, por isso, cabe salientar que tanto na sociedade brasileira quanto em outra sociedade, "quando não se causa prejuízo aos indivíduos, deve o Estado se valer dos 'nudges’ — formas de indução de comportamento, ou, literalmente, de 'dar empurrões’ — para incentivar certas condutas $^{27}$ ", ou seja, se o nudge for passível de causar qualquer forma de prejuízo, não deve ser utilizado. Isso porque, sendo o Estado responsável por promover e zelar pelo bem-estar social da sociedade e dos indivíduos, cada um na sua individualidade, não poderia agir de forma negativa perante seus cidadãos.

Especificamente, a Constituição da República de 1998 estabelece, em seu artigo 3º , determinados objetivos que o Estado brasileiro deve perquirir e se identificam com a proposta de melhorias para a sociedade, como o inciso I que procura a construção de uma sociedade livre, justa e solidária ou o inciso IV que dispõe sobre a promoção do bem de todos, sem preconceitos de origem, raça, sexo, cor, idade e quaisquer outras formas de discriminação. Portanto, sendo compatível com os objetivos constitucionais e com os direitos fundamentais, não há objeção à aplicação do nudge.

E, por mencionar a aplicação da Carta Magna, é necessário ressaltar que a aplicação do mecanismo de controle social pelo Estado é visto como uma intervenção estatal, e por isso, deve “[...] seguir os mesmos princípios democráticos e constitucionais que se aplicam às formas tradicionais de regulação ${ }^{28}$ ”. Faz-se imprescindível que o Princípio da Transparência seja respeitado, as pessoas precisam ter ciência de qual nudge será utilizado, onde será aplicado e quais os objetivos que se pretendem, para que dessa forma seja evitado

24 SOUZA, Luciana Cristina de. Contribuição das práticas de e-cidadania para a formulação, implantação e monitoramento das políticas públicas. Revista Direito Público, Porto Alegre, v. 13, n. 74, p. 187-202, mar./abr. 2017. Disponível em: <https://www.academia. edu/33139172/Pra_ticas_de_E-Cidadania_para_Implantac_a_o_de_Poli_ticas_Pu_blicas $>$. Acesso em: 3 maio 2018. p. 193.

25 SOUZA, Luciana Cristina de. Contribuição das práticas de e-cidadania para a formulação, implantação e monitoramento das políticas públicas. Revista Direito Público, Porto Alegre, v. 13, n. 74, p. 187-202, mar./abr. 2017. Disponível em: <https://www.academia.edu/33139172/Pra_ticas_de_E-Cidadania_para_Implantac_a_o_de_Poli_ticas_Pu_blicas >. Acesso em: 3 maio 2018. p. 194 26 HORTA, Ricardo Lins. Arquitetura de escolhas, direito e liberdade: notas sobre o "paternalismo libertário". Pensar: Revista de Ciências Jurídicas, Fortaleza, v. 22, n. 2, p. 651-664, maio/ago. 2017. Disponível em: <http://periodicos.unifor.br/rpen/article/ view/5602/pdf>. Acesso em: 2 maio 2018. p. 661

27 HORTA, Ricardo Lins. Arquitetura de escolhas, direito e liberdade: notas sobre o "paternalismo libertário". Pensar: Revista de Ciências Jurídicas, Fortaleza, v. 22, n. 2, p. 651-664, maio/ago. 2017. Disponível em: <http://periodicos.unifor.br/rpen/article/ view/5602/pdf>. Acesso em: 2 maio 2018. p. 655

28 HORTA, Ricardo Lins. Arquitetura de escolhas, direito e liberdade: notas sobre o "paternalismo libertário". Pensar: Revista de Ciências Jurídicas, Fortaleza, v. 22, n. 2, p. 651-664, maio/ago. 2017. Disponível em: <http://periodicos.unifor.br/rpen/article/ view/5602/pdf>. Acesso em: 2 maio 2018. p. 661 
um Estado ditatorial e opressor. Aliado a esse princípio, deve-se somar um debate aberto com a população, para que seja ouvida a opinião dos indivíduos e seja propiciada uma maior transparência do mecanismo.

A liberdade do cidadão, também, se encontra em jogo, por isso, é necessário que o nudge seja realizado nos moldes propostos por Sunstein, de forma transparente e livre. O indivíduo precisa optar se quer seguir ou não o incentivo que o mecanismo de controle comportamental oferece, ele deve ser livre para seguir o seu caminho da forma como desejar. Diante disso, como nem sempre os indivíduos estão aptos a produzir escolhas racionais e eficientes, surge o que os autores chamam de paternalismo libertário.

Richard Thaler e Cass Sunstein sugerem um modelo de interferência estatal na liberdade individual, como um arquiteto de escolhas, com o objetivo de promover ou evitar determinados comportamentos, auxiliando a escolha dos indivíduos para seguirem o melhor caminho na sua árvore decisória, mas sem adotar nenhum tipo de coerção. O propósito da técnica funda-se sobre o ato de tornar os processos decisórios mais fáceis para os indivíduos, com base no exercício de alguma forma de influência nas suas escolhas e comportamentos. Nesse contexto, as atitudes paternalistas que apenas induzam uma certa escolha não implicam violações de direitos individuais. Libertários paternalistas "pretendem tornar mais fácil para as pessoas seguirem seu próprio caminho, $[\ldots]$ não pretendendo oprimir aquelas que querem exercer sua liberdade ${ }^{29 "}$.

De maneira geral, as decisões tomadas são oriundas de influências de padrões de regras e de contextos em que estão inseridos os indivíduos, e, por isso, seria legítima a influência de um arquiteto de escolhas para auxiliar nos processos decisórios dos indivíduos, de modo a tornar suas vidas melhores. Isto é, as decisões tomadas pelos seres humanos são extremamente influenciáveis aos contextos em que se encontram inseridos, o que chancela a legitimidade da assistência Estatal no processo da melhor escolha.

A política de nudges pode conferir alternativa viável para a implementação de políticas públicas em uma sociedade $^{30}$, todavia estudos comportamentais indicam a possibilidade de os indivíduos realizarem escolhas aparentemente contrárias àquilo que seja capaz de proporcionar o seu próprio bem-estar. Além disso, há a possibilidade de que elas não possam ser adequadamente tomadas caso os indivíduos tenham dificuldade em alcançar conhecimento mais aprofundado sobre as alternativas. Por isso, se fala que o nudge precisa ser um paternalismo libertário, uma vez que deve guiar o indivíduo ao mesmo tempo em que deve deixá-lo livre para fazer as escolhas que desejar. Portanto, se o mecanismo de controle comportamental não for opressor e ditador, não há motivo para vetá-lo.

Nesse ponto, é necessário ressalvar que o paternalismo libertário discutido por Sunstein e Thaler é diferente da acepção que o termo recebe nos estudos de Sérgio Buarque de Holanda, os quais discutem e esboçam as características da sociedade brasileira sobre a distribuição de poder por critérios personalistas. Para Holanda, o paternalismo possui suas raízes no quadro familiar e nas origens coloniais brasileiras, o que extrapola, para a área pública, a vida particular e resulta no mau uso dos recursos públicos e das formas de controle do poder político ${ }^{31}$. Uma das razões desse paternalismo foi a formação dos detentores de posições políticas que estavam inseridos no contexto da família patriarcal, o que como consequência gerou a dificuldades destes em separar o domínio público do privado.

Para o funcionário 'patrimonial', a própria gestão política apresenta-se como assunto de seu interesse particular; as funções, os empregos e os benefícios que deles aufere relacionam-se a direitos pessoas do funcionário e não a interesses objetivos, como sucede no verdadeiro Estado burocrático, em que prevalecem a especialização das funções e o esforço para se assegurarem garantias jurídicas aos cidadãos. ${ }^{32}$

29 THALER, Richard H.; SUNSTEIN, Cass R. Nudge. New Haven, Conn.: Yale University Press, 2008. p. 5.

30 THALER, Richard H.; SUNSTEIN, Cass R. Nudge. New Haven, Conn.: Yale University Press, 2008. Ver também: GALUPPO, Marcelo Campos; ROCHA, Bruno Anunciação. Paternalismo libertário no Estado democrático de direito. Revista de Informação Legislativa, Brasília, v. 53, n. 210, p. 135-148, abr./jun. 2016. Disponível em: < http://www2.senado.leg.br/bdsf/bitstream/handle/ id/522902/001073195.pdf>. Acesso em: 3 maio 2018. p. 140.

31 HOLANDA, Sérgio Buarque de. Raízes do Brasil. São Paulo: Companhia das Letras, 2006. p. 80.

32 HOLANDA, Sérgio Buarque de. Raízes do Brasil. São Paulo: Companhia das Letras, 2006. p. 159. 
Segundo o autor, a experiência brasileira de um corpo administrativo dedicados a interesses objetivos é excepcional. Por isso, ele afirma que

ao contrário, é possível acompanhar ao longo de nossa história, o predomínio constante das vontades particulares que encontram seu ambiente próprio em círculos fechados e pouco acessíveis a uma ordenação impessoal ${ }^{33}$.

Logo, predominou na trajetória brasileira houve durante muitas décadas a atuação de um corpo de agentes do Estado que decidia pelos cidadãos e, não visando o interesse público, mas, sim, de acordo com seus próprios anseios. Isto se contrapõe ao paternalismo libertário da forma como foi descrito na obra de Thaler e Sunstein e pode ser classificado como uma forma de hard paternalismo, agravado por características patrimonialistas. ${ }^{34}$

$\mathrm{Na}$ proposta de soft paternalismo, o indivíduo deve ser livre para decidir qual caminho deve seguir e a noção de um Estado paternal se vincula à ideia de um Poder Público que adote medidas concretas, especialmente quanto às políticas públicas, no sentido de proteger os seus cidadãos, sem, contudo, substituir-lhes a vontade. A atuação conjunta do Estado e dos cidadãos seria passível, no sentido de paternalismo de Thaler e Sunstein, de evitar a manipulação do Estado por elites políticas que representassem grupos particulares, uma vez que os cidadãos estariam cientes dos objetivos da ação proposta e teriam acesso aos mecanismos utilizados para atingi-los. Isso porque tal postura seria uma afronta aos direitos conquistados pelos cidadãos.

Assim, a acepção usual do termo paternalismo no Brasil não é adequada para que se compreenda a perspectiva apresentada neste artigo por estar atrelada ao modo de decidir de vários governos em que os cidadãos não eram sujeitos, mas apenas usuários dos serviços públicos oferecidos. Thaler e Sunstein afirmam que, para evitarmos a manipulação do Estado, é mister que se defina qual será o critério de escolha, observar e vetar nudges que sejam capazes de reduzir o nível de cidadania, impedir que os agentes do Estado realizem a escolha pelo indivíduo.

O nudge é compatível com a democracia brasileira e pode ser aplicado desde que sejam respeitados os princípios constitucionais e democráticos. Dessa forma, é necessário afastar qualquer ação que possa manipular o pensamento e as atitudes do cidadão, ele deve ser livre para optar por qual caminho seguir, ou seja, a sua liberdade deve estar em primeiro lugar. Para isso, é necessário que o caminho a ser percorrido até se implantar o nudge seja guiado pelo Princípio da Transparência, informando a sociedade dos objetivos esperados, requerendo a opinião dos cidadãos e demonstrando os resultados alcançados "permitindo ao cidadão o acesso às informações não apenas individuais, mas de interesse coletivo e difuso". ${ }^{35}$

\section{EFEITO “NUDGING" em POLÍtICAS PÚBLICAS}

O Diário Oficial do Município publicou, em 10 de outubro de 2016, a Lei no 10.982 que pró́be a exposição de sal em mesas e balcões de bares, restaurantes, lanchonetes e similares em Belo Horizonte. Caso deseje consumir o sal, o cliente deverá solicitar ao estabelecimento, que disponibilizará, sem exposição, embalagens individuais (sachês) contendo o produto. Atenta aos males proporcionados pelo seu consumo excessivo e os riscos provocados pela hipertensão, temos uma simples demonstração de uma política pública local de saúde que decidiu por "restringir" o consumo de determinado produto, sem, contudo, proibi-lo absolutamente.

33 HOLANDA, Sérgio Buarque de. Raízes do Brasil. São Paulo: Companhia das Letras, 2006. p. 159-160.

34 MOURA, Emerson Affonso da Costa. Transparência administrativa, Lei Federal no 12.527/2011 e sigilo dos documentos públicos: a inconstitucionalidade das restrições ao acesso à informação. Revista Brasileira de Politicas Públicas, v. 6, n. 2, p. 45-64, 2016. p.41.

35 MOURA, Emerson Affonso da Costa. Transparência administrativa, Lei Federal no 12.527/2011 e sigilo dos documentos públicos: a inconstitucionalidade das restrições ao acesso à informação. Revista Brasileira de Políticas Públicas, v. 6, n. 2, p. 45-64, 2016. p. 39 . 
Diante de tal situação, o sujeito A pode escolher consumir o produto em razão de preferência de paladar. O sujeito B, atento aos males do consumo excessivo, pode escolher se abster do consumo. O sujeito C, ciente dos males, pode, ainda, decidir pelo consumo. Diversas são as possibilidades. Os indivíduos podem não conhecer os efeitos do consumo do sal em longo prazo, podem ignorá-los ou podem subestimá-los. Fato é que as escolhas dos indivíduos, muitas vezes, podem direcioná-los a resultados não desejáveis.

Geralmente, com baixo custo e com boa capacidade para favorecer objetivos econômicos e sociais, como no exemplo citado, além de prezar pela liberdade do indivíduo, a utilização de nudges em políticas públicas no Brasil tem encontrado grande potencial. Objetiva-se com tal política, baseada na existência de falhas cognitivas que podem prejudicar os objetivos de bem-estar definidos individualmente, aumentar a probabilidade do indivíduo de seguir o melhor caminho, sem, contudo, obrigá-lo ou enganá-lo.

Para melhor compreender tal fenômeno, a conceituação do que seja política pública se faz imprescindível, apesar de não ser simples, na visão de Howlett e Ramesh. Os autores argumentam que, apesar da concorrência de definições, todas elas postulam que as políticas públicas são ações intencionais de governos que possuem objetivos articulados e meios para alcançá-los, ainda que precariamente identificados, independentemente de como estejam os objetivos interligados aos meios ${ }^{36}$. Para tanto, considerando que a política pública é resultante de um processo complexo consistente na tomada de inúmeras decisões, Howlett e Ramesh condensaram tal processo em cinco etapas: (1) montagem da agenda; (2) formulação da política; (3) tomada de decisão; (4) implementação e (5) avaliação.

O primeiro momento do ciclo, a formação da agenda, é talvez considerada pelos autores o estágio mais crítico dentre todos os cinco, pois o que é decidido nele tem impacto em todo o processo político. A agenda pode ser entendida como o conjunto de problemas elencados suscetíveis de apreciação pelo governo.

O segundo momento recai sobre a formulação da política, ou seja, trata-se do processo de criação de alternativas para solucionar o problema. Há nesse estágio, um refinamento e uma avaliação sobre a viabilidade das opções.

$\mathrm{Na}$ terceira fase do ciclo, tem se a tomada de decisão acerca das opções selecionadas anteriormente. O governo, com base na tomada de decisão, toma um curso de ação a respeito do processo de resolução de um problema.

A quarta etapa é a da implementação da política pública. Nesse estágio há o planejamento e estruturação da máquina pública de forma a viabilizar a execução da política pública.

No quinto e último estágio, tem-se a avaliação do funcionamento e dos efeitos da política pública. Surge nesse momento a possibilidade de manter o que foi estruturado ou de se repensar a política pública, podendo haver o retorno a alguma fase do ciclo para correção de algum ponto.

Nesse modelo de ciclo, prepondera a ideia de que o processo de implementação de uma política pública inicia-se com base na identificação e no reconhecimento de problemas que requeiram atenção por parte do governo, com consequente processo de formulação e refinamento de propostas sobre o que fazer a respeito, e, finalmente, a tomada de uma decisão.

Cada vez mais o Estado é exigido e questionado sobre o desempenho das suas funções, o processo de criação de uma política pública deve levar em consideração, em especial no Brasil, onde há tantas carências, a identificação daquelas que mais necessitam de atenção. Em razão da razoável "facilidade" de implementação, nos últimos anos, a utilização dos Nudges, traduzidos em atos provenientes de instituições privadas ou públicas direcionados ao aprimoramento das decisões dos indivíduos, vem sendo cada vez mais perquirida, de forma a cumprir com o compromisso ideológico e doutrinário dos direitos fundamentais, pilares básicos

36 HOWLETT, M., RAMESH, M., PERL. A. Politicas públicas: seus ciclos e subsistemas: uma abordagem integradora. Rio de Janeiro: Elsevier, 2013. p. 6. 
do Estado Democrático de Direito.

Tal questão torna-se ainda mais relevante no contexto dos 30 anos da promulgação da Constituição de 1988, a chamada "Constituição Cidadã", cuja matriz, o Estado Democrático de Direito, endossa os direitos e garantias fundamentais do indivíduo. Advinda de um período ditatorial, existia um anseio pelo resgate da democracia e da retomada dos direitos fundamentais. Diante disso, indaga-se: se os indivíduos possuem falhas cognitivas, se são facilmente influenciáveis pelo contexto em que se encontram inseridos, porque não exercer a influência no sentido de tornar sua vida melhor?

A criação de políticas públicas pode ser pensada de forma a contribuir aos resultados das escolhas realizadas pelos indivíduos por meio de estímulos e modificações contextuais que dificultam o processo cognitivo de tomada de decisão de acordo com os verdadeiros interesses de cada pessoa. A política de Nudges formulada por Richard Thaler e Cass Sunstein se traduz em "empurrões" direcionados à otimização do processo cognitivo de escolha, com o intuito de usurpar falhas cognitivas que poderiam levar ao indivíduo deixar de fazer escolhas ótimas.

Indaga-se se a utilização dos nudges poderia configurar espécie de indução de comportamento por parte do governo de forma a criar padrões desejados de conduta. O fato de se desejar tornar os processos decisórios mais fáceis para os indivíduos, por meio do exercício de alguma forma de influência nas suas escolhas e comportamentos, poderia configurar instrumento de subversão da sua intrínseca vontade no intuito de conferir êxito na manipulação de comportamento. Dessa forma, o governo poderia direcionar e operar a atuação dos indivíduos de acordo com seus interesses por meio da utilização de políticas previamente estudadas e planejadas para determinado proveito.

Tomemos por exemplo, as audiências públicas utilizadas na formulação de políticas sociais. A Audiência Pública é um instrumento reconhecido e garantido pela Constituição Federal de 1988 e regulado nos níveis municipal, estadual ou federais, que possibilita a participação democrática popular ${ }^{37}$, podendo ocorrer durante os processos de elaboração e aprovação de leis, projetos e políticas públicas, ou para prestação de contas pelo poder Executivo, Legislativo ou do Ministério Público.

E, nesse sentido, o instituto da audiência pública, além de já positivado em inúmeras leis, vem ganhando projeção no cenário jurídico e político nacional como mecanismo de participação no processo decisório, precipuamente nas decisões da Administração Pública, embora também seja previsto no curso do processo legislativo $\left(\mathrm{CR} / 1988\right.$, art. $58, \mathbb{\S} 2^{\circ}$, II).

De fato, é no campo das decisões administrativas que a audiência pública tem mais importância. $O$ Poder Executivo, destinado a atuar a lei de ofício atendendo a interesses públicos, está diante de uma enorme quantidade de casos concretos em que deve agir visando à satisfação das necessidades coletivas. Por seus agentes públicos, toma decisões relevantes cotidianamente, sendo de fundamental importância o debate público sobre muitos desses temas e desafios, permitindo transparência ao processo decisório e conferindo legitimidade à ação administrativa. ${ }^{38}$

Esse instrumento utilizado pela Administração Pública se trata de uma reunião aberta, na qual a autoridade capta as opiniões e demandas da comunidade acerca de determinado tema ${ }^{39}$. Dessa forma, Eduardo Fortunato Bim esclarece que

[...] a audiência pública visa informar e expor o conteúdo da decisão ou futura decisão à sociedade,

37 SOUZA, Luciana Cristina de. Aplicação do princípio da resiliência às relações entre Estado, sociedade e direito. In: ASENSI, Felipe Dutra; PAULA, Daniel Giotti de (Org.). Tratado de direito constitucional. Rio de Janeiro: Campus Jurídico, 2014. p. 197-209. (Cap. 2.5). 38 CABRAL, Antonio. Os efeitos processuais da audiência pública. Boletim Científico: Escola Superior Do Ministério Público da Uniao, Brasilia, v. 24/25, n. 6, p. 41-65, jul./dez. 2007. Disponível em: <http://boletimcientifico.escola.mpu.mp.br/boletins/boletim-cientifico-n.-24-e-n.-25-julho-dezembro-de-2007-1/os-efeitos-processuais-da-audiencia-publica>. Acesso em: 22 maio 2018. p. 42-43.

39 CABRAL, Antonio. Os efeitos processuais da audiência pública. Boletim Científico: Escola Superior Do Ministério Público da Uniao, Brasilia, v. 24/25, n. 6, p. 41-65, jul./dez. 2007. Disponível em: <http://boletimcientifico.escola.mpu.mp.br/boletins/boletimcientifico-n.-24-e-n.-25-julho-dezembro-de-2007-1/os-efeitos-processuais-da-audiencia-publica>. Acesso em: 22 maio 2018. p. 44-45. 
promovendo a discussão sobre o tema ao dirimir as dúvidas e recolher dos presentes as críticas e sugestões a respeito ${ }^{40}$.

Em razão disso, esse mecanismo administrativo pode (deve) ser utilizado para a elaboração das políticas públicas que dialoguem com os mecanismos de nudge. De grande valia para a definição e implantação de políticas públicas, as audiências públicas têm como um dos seus principais objetivos, o incentivo à busca de soluções de problemas públicos por meio da participação de particulares nos temas de interesse comum.

Para tanto, geralmente realizadas por meio de reuniões que visam à discussão das questões envolvidas com a coleta de dados e informações que possam auxiliar a elaboração e satisfação de interesses, as audiências públicas, são abertas para todo o público, não podendo haver restrição de participação a grupos determinados, sendo, fundamental que o órgão que a convoca priorize a presença das pessoas diretamente afetadas pela política pública ou projeto de lei a ser discutido. Além de constituírem instrumento essencial para a implementação de políticas públicas, elas podem ser feitas, também, após sua implantação para discussão e avaliação de seus resultados e impactos na sociedade.

A audiência pública constitui um espaço de democracia participativa inserida no contexto do Estado Democrático de Direito, endossante dos direitos e garantias fundamentais do indivíduo. Nesse sentido, o cidadão não pode ser, apenas, um mero espectador dos feitos do poder público. Além de ser detentor de direito e garantias, os indivíduos possuem, também, deveres perante a sociedade, na medida em que a vida em sociedade demanda uma postura colaborativa em busca de um bem comum. Dessa forma, os cidadãos teriam um dever cívico de participar das decisões do poder público em tudo aquilo que concerne aos interesses comuns de forma a produzir as melhores escolhas possíveis.

Nesse sentido, Maria Goretti Dal Bosco ${ }^{41}$ pontua que o cidadão

além de ser alguém que exerce direitos, cumpre deveres ou goza de liberdades em relação ao Estado, ele é também o titular, mesmo que de forma parcial, de uma função ou de um poder público.

Assim, nos dizeres do $\$ 1^{\circ}$, do art. $1^{\circ}$ da Constituição Federal de 1988 , todo o poder emana do povo que o deve exercer de forma direta ou com base nos seus representantes legais.

A audiência pública "[...] é um mecanismo eficiente na busca do aperfeiçoamento dos mecanismos de definição das prioridades de investimentos estatais nas chamadas políticas públicas [... ${ }^{42}$ ", uma vez que, por meio delas, é possível ouvir os cidadãos, compreender a opinião e permitir a participação deles. Em razão disto, as audiências públicas estão intrinsicamente ligadas aos mecanismos de nudges, uma vez que, por meio desse instrumento administrativo, é possível definir o nudge que será aplicado à política pública. Ademais, a audiência pública é uma forma de mostrar para a sociedade que determinado nudge será utilizado, respeitando o Princípio da Publicidade, e evitando a manipulação do governo.

Como dito, além da preocupação ética e democrática, também é importante que existam critérios claros e compreensíveis por todos os atores sociais que participarão dos instrumentos deliberativos, como o OP, os conselhos, as conferências, as audiências públicas etc. No caso dessas últimas, um exemplo são as normas do Manual da Agência Nacional de Energia Elétrica - ANEEL ${ }^{43}$. Esse normativo especifica que "Audiência

40 BIM, Eduardo Fortunato. Audiências públicas no direito administrativo e ambiental. In: DE MORAES, Alexandre; KIM, Richard Pae (Coord.). Cidadania: o novo conceito jurídico e a sua relação com os direitos fundamentais, individuais e coletivos. São Paulo: Atlas, 2013. p. 216.

41 BOSCO, Maria Goretti Dal. Audiência pública como direito de participação. Revista Jurídica Unigran, Dourados, v. 4, n. 8, p. 137-157, jul./dez. 2002. Disponível em: <http://www.unigran.br/revista_juridica/ed_anteriores/08/artigos/10.pdf>. Acesso em: 22 maio 2018. p. 137.

42 BOSCO, Maria Goretti Dal. Audiência pública como direito de participação. Revista Jurídica Unigran, Dourados, v. 4, n. 8, p. 137-157, jul./dez. 2002. Disponível em: <http://www.unigran.br/revista_juridica/ed_anteriores/08/artigos/10.pdf>. Acesso em: 22 maio 2018. p. 156.

43 AGÊNCIA NACIONAL DE ENERGIA ELÉTRICA - ANEEL. Manual de normas de procedimentos: audiências públicas. Brasília, 2005. v.3. Disponível em: <http://www2.aneel.gov.br/aplicacoes/audiencia/arquivo/2005/033/documento/procedimentosap. 
Pública é um instrumento de apoio ao processo decisório da ANEEL, de ampla consulta à sociedade, que precede a expedição dos atos administrativos" 44 e serve para recolher informações para o processo decisório da ANEEL, possibilitar o encaminhamento de solicitações de consumidores e clientes, dar publicidade à ação regulatória da ANEEL, entre outros objetivos de transparência. Em 2018 já foram realizadas diversas audiências públicas, destacando-se:

a) ANEEL - AP n. 22/2018: obter subsídios para a definição dos indicadores e das metas da Performance Organizacional - PO do Operador Nacional do Sistema Elétrico - ONS para o ciclo de janeiro a dezembro de 2019 (Modalidade: intercâmbio documental; Período: 18/05 a 17/06 de 2018);

b) ANEEL - AP n. Obter subsídios para regulamentar a aplicação de penalidades por falha no suprimento de combustível, conforme o disposto na Resolução no 18/2017, emitida pelo Conselho Nacional de Política Energética - CNPE (Modalidade: intercâmbio documental; Período: 18/05 a 17/06 de 2018).

In casu, foi escolhida uma modalidade específica, mais rápida e fácil de se organizar, mas há outras previstas em seu Manual de Procedimentos. A ANEEL atua com as seguintes modalidades de AP:

i) Audiência Pública ao vivo - Presencial, de "viva voz";

ii) Audiência Pública Descentralizada - Presencial nas regionais e conveniadas;

iii) Audiência Pública Simultânea - Presencial e teleconferência com as regionais e conveniadas;

iv) Audiência para o Público Interno - Unidades Organizacionais da ANEEL;

v) Audiência Pública por Intercâmbio Documental - Envio de sugestões por escrito, aberto a toda a sociedade civil.

Para consolidar os debates feitos, a ANEEL adota a metodologia de redigir uma Ata das Audiências, bem como um Relatório contendo os elementos a seguir: área responsável, os fatos ocorridos até a data da instauração da AP, descrição de sua evolução, votação, arcabouço legal e a decisão da Diretoria. Além disso, toda a documentação necessária para leitura prévia deve ser disponibilizada. Todas as manifestações devem ser reduzidas a termo ou gravadas para consulta posterior pelos deliberantes, mas compete à Diretoria da área responsável definir os critérios de participação, os tópicos mais relevantes para o momento e definir o tipo de organização das informações disponibilizadas. Como visto, "mais relevante" é tecnicamente decidido, mas possui, ainda, um aspecto subjetivo. Por isso é crucial preservarem-se os valores constitucionais democráticos de 1988 para que essa metodologia de otimização de decisões públicas seja, efetivamente, um contributo para o aperfeiçoamento dos instrumentos deliberativos.

\section{Considerações finais}

Logo, considerando a proposta inicial de analisar se as conquistas obtidas pelos cidadãos com a Constituição Cidadã de 1988 sofreriam prejuízos pelo uso da técnica de nudge no processo de tomada de decisões públicas, como no exemplo citado das audiências públicas, conclui-se que tal solução pode permitir que algumas deliberações fluam melhor e que se possa extrair um resultado — no caso o Relatório — mais aplicável, otimizando o resultado, como na organização da disposição dos alimentos no bandejão escolar nos EUA na pesquisa inicial de Thaler e Sunstein. Da mesma forma, podem propiciar em outras situações, como o OP e outros meios deliberativos diretos da democracia contemporânea, o desenvolvimento da governança colaborativa, ou flexível, no âmbito do Estado Resiliente.

pdf>. Acesso em: 28 maio 2018.

44 AGÊNCIA NACIONAL DE ENERGIA ELÉTRICA - ANEEL. Procedimento para audiência e consulta pública. Disponível em: <http://www2.aneel.gov.br/aplicacoes/consulta_publica/documentos/Procedimentos\%20AP-CP.pdf>. Acesso em: 28 maio 2018. 
Mas gráficos, tabelas e outros meios de informação precisam ser transparentes e representar a pluralidade social brasileira, para evitar sua manipulação no momento da tomada de decisão por parte dos atores sociais ou equívocos quanto ao modo de implementar a técnica de nudge. Orientar comportamentos pode permitir melhor aplicação do orçamento público, por exemplo, em razão da aproximação entre a decisão dos cidadãos e os laudos técnicos. Pode permitir que opiniões distintas de grupos envolvidos e conhecedores da realidade de intervenção sejam ouvidos e tenham, igualmente, influência sobre as ações dos gestores públicos.

Dessa forma, a proposta de Thaler e Sunstein de aplicação da técnica nudge é viável na democracia brasileira para a modalidade de soft paternalismo e means paternalism, desde que sejam respeitados os valores constitucionais de publicidade, diversidade e igualdade entre os cidadãos para que nenhuma grupo sub-empoderado fique à mercê de outro mais forte política, jurídica, econômica ou digitalmente. O cenário mais viável é aquele em que as informações estejam plenamente acessíveis e sejam confiáveis; também aquele no qual não haja superposição constante da maioria contra interesses minoritários, o que reduziria a democracia pátria a um critério meramente numérico e não qualitativo. A redação de regras claras de participação pelos órgãos públicos aponta para uma solução porque esses manuais tanto esclarecem aos atores sobre o modo de sua participação como, ainda, servem de documento que, por estarem disponíveis, podem ser criticamente avaliados de modo contínuo pelos cidadãos, o que garantirá o funcionamento do nudge no âmbito democrático que dele se espera para fortalecer os preceitos fundamentais da trintenária Constituição da República de 1988, a Carta Cidadã.

\section{REFERÊNCIAS}

AGÊNCIA NACIONAL DE ENERGIA ELÉTRICA - ANEEL. Manual de normas de procedimentos: audiências públicas. Brasília, 2005. v.3. Disponível em: <http://www2.aneel.gov.br/aplicacoes/audiencia/arquivo/2005/033/documento/procedimentosap.pdf>. Acesso em: 28 maio 2018.

AGÊNCIA NACIONAL DE ENERGIA ELÉTRICA - ANEEL. Procedimento para audiência e consulta pública. Disponível em: <http://www2.aneel.gov.br/aplicacoes/consulta_publica/documentos/Procedimentos\%20AP-CP.pdf>. Acesso em: 28 maio 2018.

BENTO, Leonardo Valles. Governança e governabilidade na reforma do Estado: entre eficiência e democratização. São Paulo: Manole, 2003.

BIM, Eduardo Fortunato. Audiências públicas no direito administrativo e ambiental. In: DE MORAES, Alexandre; KIM, Richard Pae (Coord.). Cidadania: o novo conceito jurídico e a sua relação com os direitos fundamentais, individuais e coletivos. São Paulo: Atlas, 2013.

BITTAR, Eduardo C. B. Metodologia da pesquisa jurídica. 14. ed. São Paulo: Saraiva, 2016.

BOSCO, Maria Goretti Dal. Audiência pública como direito de participação. Revista Jurídica Unigran, Dourados, v. 4, n. 8, p. 137-157, jul./dez. 2002. Disponível em: <http://www.unigran.br/revista_juridica/ ed_anteriores/08/artigos/10.pdf>. Acesso em: 22 maio 2018.

BRASIL. Constituição (1988). Constituição da República Federativa do Brasil, promulgada em 5 de outubro de 1988. Disponível em: < http://www.planalto.gov.br/ccivil_03/constituicao/constituicao.htm>. Acesso em: 22 jul. 2015.

CABRAL, Antonio. Os efeitos processuais da audiência pública. Boletim Científico: Escola Superior Do Ministério Público da Uniao, Brasilia, v. 24/25, n. 6, p. 41-65, jul./dez. 2007. Disponível em: <http:// boletimcientifico.escola.mpu.mp.br/boletins/boletim-cientifico-n.-24-e-n.-25-julho-dezembro-de-2007-1/ os-efeitos-processuais-da-audiencia-publica>. Acesso em: 22 maio 2018. 
EPSTEIN, Lee; KING, Gary. Pesquisa empírica em direito: as regras de inferência. São Paulo: Direito GV, 2013.

GALUPPO, Marcelo Campos; ROCHA, Bruno Anunciação. Paternalismo libertário no Estado democrático de direito. Revista de Informação Legislativa, Brasília, v. 53, n. 210, p. 135-148, abr./jun. 2016. Disponível em: <http://www2.senado.leg.br/bdsf/bitstream/handle/id/522902/001073195.pdf>. Acesso em: 3 maio 2018.

GOLDSMITH, Stephen; EGGERS, William D. Governar em rede: o novo formato do setor público. Brasília: Escola Nacional de Administração Pública. ENAP: UNESP, 2011.

HANSEN, Pelle Guldborg. The definition of nudge and libertarian paternalism: does the hand fit the glove? European Journal of Risk Regulation, v. 7, n. 1, p. 155-174, 2016.

HOLANDA, Sérgio Buarque de. Raízes do Brasil. São Paulo: Companhia das Letras, 2006.

HORTA, Ricardo Lins. Arquitetura de escolhas, direito e liberdade: notas sobre o "paternalismo libertário". Pensar: Revista de Ciências Jurídicas, Fortaleza, v. 22, n. 2, p. 651-664, maio/ago. 2017. Disponível em: $<$ http://periodicos.unifor.br/rpen/article/view/5602/pdf>. Acesso em: 2 maio 2018.

HOWLET'T, M., RAMESH, M., PERL. A. Políticas públicas: seus ciclos e subsistemas: uma abordagem integradora. Rio de Janeiro: Elsevier, 2013.

MOURA, Emerson Affonso da Costa. Transparência administrativa, Lei Federal no 12.527/2011 e sigilo dos documentos públicos: a inconstitucionalidade das restrições ao acesso à informação. Revista Brasileira de Políticas Públicas, v. 6, n. 2, p. 45-64, 2016.

MUNIZ, Veyzon Campos. Simpler: the future of government, de Cass Sustein. Revista Brasileira de Politicas Públicas, v. 5, n. 2, p. 315-319, 2015.

SOUZA, Luciana Cristina de. Aplicação do princípio da resiliência às relações entre Estado, sociedade e direito. In: ASENSI, Felipe Dutra; PAULA, Daniel Giotti de (Org.). Tratado de direito constitucional. Rio de Janeiro: Campus Jurídico, 2014. p. 197-209. (Cap. 2.5)

SOUZA, Luciana Cristina de. Contribuição das práticas de e-cidadania para a formulação, implantação e monitoramento das políticas públicas. Revista Direito Público, Porto Alegre, v. 13, n. 74, p. 187-202, mar./abr. 2017. Disponível em: <https://www.academia.edu/33139172/Pra_ticas_de_E-Cidadania_para_ Implantac_a_o_de_Poli_ticas_Pu_blicas>. Acesso em: 3 maio 2018.

SOUZA, Luciana Cristina de. Refundação do estado democrático de direito pela sociedade civil. In: CONGRESSO BRASILEIRO DE SOCIOLOGIA: GT10: Estado, Cidadania e Identidade, Grupo 4: Estado, Democracia e Sociedade Civil, 13., 2007, Recife (PE), Anais... Recife, 29 de maio a 1 de junho de 2007. Disponível em: <file:///C:/Users/prof/Downloads/sbs2007_gt04_luciana_de_souza.PDF>. Acesso em: 2 maio 2018.

SUNSTEIN, Cass R. Misconceptions about nudges. Ssrn Electronic Journal, [s.l.], p. 1-13, 2017. (Elsevier BV. http://dx.doi.org/10.2139/ssrn.3033101). Disponível em: <https://papers.ssrn.com/sol3/papers. cfm?abstract_id=3033101>. Acesso em: 3 maio 2018.

SUNSTEIN, Cass R. Nudging: a very short guide. 37 J. Consumer Pol'y 583, Harvard Law School; Harvard University; Harvard Kennedy School (hks), p. 1-7, 23 set. 2014. Disponível em: < https://ssrn.com/ abstract $=2499658>$. Acesso em: 27 abr. 2018.

SUNSTEIN, Cass R. The storrs lectures: behavioral economics and paternalism. Ssrn Electronic Journal, [s.1.], p. 1-60, 29 nov. 2012. (Elsevier BV. http://dx.doi.org/10.2139/ssrn.2182619). Disponível em: < https://papers.ssrn.com/sol3/papers.cfm?abstract_id=2182619>. Acesso em: 3 maio 2018.

THALER, Richard H.; SUNSTEIN, Cass R. Nudge. New Haven, Conn.: Yale University Press, 2008. 


\section{REVISTA BRASILEIRA DE POLÍTICAS PÚBLICAS BRAZILIAN JOURNAL OF PUBLIC POLICY}

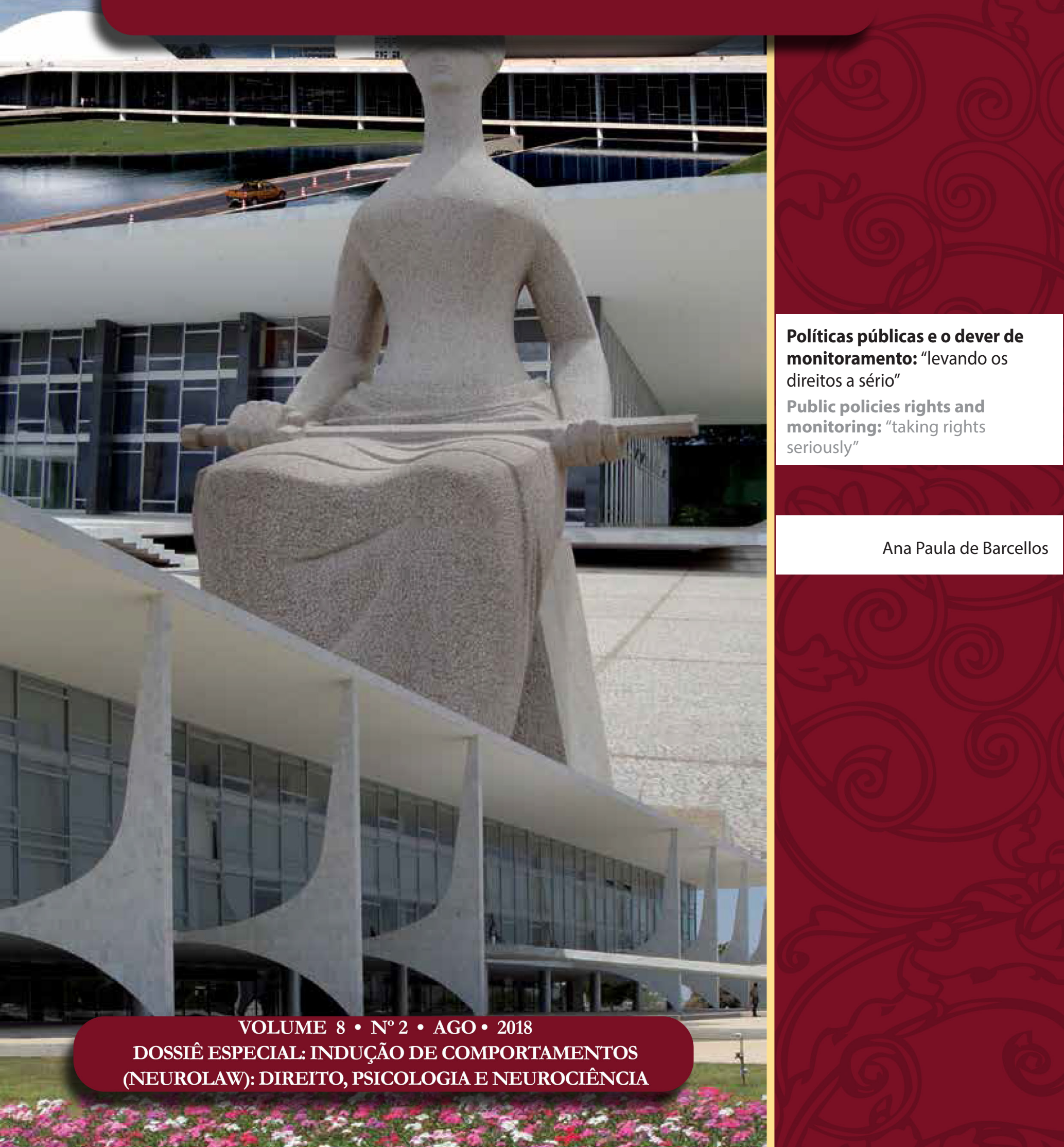




\section{Políticas públicas e o dever de monitoramento: "levando os direitos a sério"*}

\section{Public policies rights and monitoring: "taking rights seriously"}

Ana Paula de Barcellos**

\section{Resumo}

o objetivo deste trabalho consiste em demonstrar que o efetivo respeito, proteção e promoção dos direitos fundamentais depende sobretudo dos resultados concretos de políticas públicas existentes acerca desses direitos, e não apenas da existência de normas ou mesmo de decisões judiciais sobre o tema, de tal modo que o monitoramento e avaliação dos resultados dessas políticas, de forma desagregada, a fim de se captar a desigualdade tanto da realidade quanto da execução da própria política pública, torna-se um tema profundamente relevante para o direito constitucional. Nesse contexto, com base em pesquisa empírica e doutrinária, e com fundamento no método dedutivo, o trabalho passa a propor, em sua segunda parte, uma estrutura básica para o monitoramento das políticas públicas sob a perspectiva da realização dos direitos fundamentais. A terceira parte do trabalho procura sustentar que a existência de sistemas de monitoramento no contexto de políticas públicas de direitos fundamentais deve ser considerado um dever jurídico-constitucional.

Palavras-chave: Políticas públicas. Direitos fundamentais. Monitoramento. Avaliação.

\section{Abstract}

the paper seeks to show that real respect, protection and promotion of fundamental rights depend primarily on the concrete results of existing public policies focused on these rights, not only on the existence of norms or even judicial decisions on the subject. Therefore, the permanent monitoring and evaluation of public policies' results, in a disaggregated way, in order to capture the inequality of both reality and the implementation of public policy itself, is a deeply constitucional matter. In this context, based on empirical and doctrinal research, and the method of deductive approach, the second part of the paper proposes a basic structure for the monitoring of public policies from a fundamental rights perspective. In the third part, the paper argues that the existence of monitoring systems in the context of public policies focused on the promotion of fundamental rights should be considered a constitutional duty.

Key words: Public policies. Fundamental rights. Monitoring. Evaluation.

\footnotetext{
** Professora Titular de Direito Constitucional da Faculdade de Direito da UERJ. PósDoutora - Harvard. Doutora e Mestre - UERJ. Advogada e parecerista. Email: abarcellos@ bfbm.com.br

ber.com.br
}

Recebido em 30/05/2018

Aprovado em 09/07/2018 


\section{INTRODUÇÃO: NORMAS E DECISÕES JUDICIAIS E SEUS LIMITES: DIREITOS FUNDAMENTAIS E POLÍTICAS PÚBLICAS}

O tema dos direitos humanos, no plano internacional, e dos direitos fundamentais, no plano interno, tem sido central e, com razão, nos debates do Direito Constitucional brasileiro nas últimas décadas. A Constituição de 1988 veiculou o compromisso do novo Estado brasileiro, reorganizado naquele momento, com a promoção dos direitos fundamentais, direitos que ela prevê de forma mais ou menos analítica. Também, no plano internacional, desde a Declaração Universal dos Direitos Humanos, em 1948, diversos outros documentos foram celebrados tratando do respeito, proteção e promoção de direitos específicos ou relacionados a grupos humanos em particular.

No Brasil, a respeito das críticas em geral dirigidas ao Poder Legislativo, é certo que houve, nas últimas décadas, uma prolífica produção acerca dos mais variados direitos. O exemplo da saúde é emblemático, mas não é único. Um visitante estrangeiro sem qualquer conhecimento adicional sobre o país que tentasse avaliar a situação dos direitos humanos a partir, exclusivamente, das normas em vigor chegaria a conclusões distantes da realidade.

Considerando-se o exemplo da saúde, cerca de dois anos após a promulgação da Constituição de 1988, foi editada a Lei n 8.080/90, que organizou a estrutura básica do Sistema Único de Saúde, previsto constitucionalmente. Várias alterações foram introduzidas nessa lei ao longo do tempo para adaptar o sistema a novas necessidades e realidades, em geral sempre no sentido de ampliar os serviços que em tese deveriam ser fornecidos à população. A Lei no 12.401/11, por exemplo, alterou a Lei Geral do SUS, dentre outras previsões, para incluir, nas atividades a serem desenvolvidas pelo sistema, os serviços de atendimentos ou atenção domiciliar.

No plano infralegal, normas são constantemente expedidas dispondo sobre os serviços prestados pelo SUS, o relacionamento entre os entes federativos e com os parceiros privados, dentre muitos outros temas. A lista de medicamentos a serem fornecidos pelo SUS divulgada em 2017 (Relação Nacional de Medicamentos Essenciais - RENAME ${ }^{1}$ ), por exemplo, conta com 869 itens, contra 842 da edição de $2014^{2}$. Nada obstante, não é incomum que medicamentos tradicionalmente incluídos nessa listagem, como os usados para atendimentos de emergência, para controle de diabetes, pressão alta, doenças coronarianas dentre outros, estejam em falta em vários pontos do país ${ }^{3}$.

Em alguma medida, é natural que haja um descompasso entre realidade e normas: o direito existe afinal para transformar a realidade; para que tudo permaneça como é, não haveria necessidade de editar norma alguma. De outra parte, porém, é também certo que o direito não é portador de palavras mágicas capazes de, por sua mera enunciação, transformar o mundo real. A transformação efetiva da realidade na linha do que consta das normas é em geral o objetivo da norma, mas, como regra, não se segue a ela de forma automática ou imediata.

Paralelamente à edição de normas pelo Legislativo e Executivo, a doutrina jurídica brasileira dedicou-se, nas últimas décadas, a desenvolver uma dogmática voltada para a expansão da eficácia jurídica e da efetivi-

1 BRASIL. Ministério da Saúde. Relação nacional de medicamentos essenciais: 2017. Disponível em: < http://bvsms.saude.gov.br/bvs/ publicacoes/relacao_nacional_medicamentos_rename_2017.pdf>.

2 BRASIL. Ministério da Saúde. Relação nacional de medicamentos essenciais: 2017. Disponível em: <http://bvsms.saude.gov.br/bvs/ publicacoes/relacao_nacional_medicamentos_rename_2017.pdf>.

3 <http://www.gazetadopovo.com.br/vida-e-cidadania/dois-em-cada-dez-medicamentos-estao-em-falta-nos-postos-de-saudede-curitiba-6rird1cpwq4oni5dmn2upvewr>.; $\quad<$ https://www.viagora.com.br/noticias/parnaiba-vive-problemas-com-falta-demedicamentos-em-postos-de-saude-68091.html ; https://g1.globo.com/ac/acre/noticia/fiscalizacao-detecta-falta-de-medicamento-e-baixo-efetivo-de-profissionais-em-hospital-de-rio-branco.ghtml>; https://www.msemfoco.com.br/cidades/dourados/ idenor-cobra-a-prefeitura-por-falta-de-medicamentos-em-postos-de-saude/177625/>; <https://g1.globo.com/rj/rio-de-janeiro/ noticia/doentes-cronicos-e-transplantados-estao-sem-medicamentos-na-farmacia-do-estado-do-rj.ghtml> (acesso de todos em: 28 abr. 2018). 
dade da Constituição como um todo e dos direitos fundamentais de forma específica. A jurisprudência tem seguido na mesma linha, em todos os ramos do Poder Judiciário e graus de jurisdição, e sequer há necessidade de enumerar exemplos de decisões nesse sentido. O Supremo Tribunal Federal, em múltiplas ocasiões, tem destacado a centralidade dos direitos fundamentais e da dignidade humana no sistema jurídico-constitucional brasileiro.

Todos esses esforços — normativos, doutrinários e jurisprudenciais — pretendem, em última análise, garantir, proteger e promover os direitos fundamentais. E parece certo que eles são efetivamente importantes para a realização dos direitos nos Estados contemporâneos, embora não sejam suficientes. Nada obstante, é preciso reconhecer que a edição de normas, a produção doutrinária e mesmo a prolação de decisões judiciais não garantem, por si, a realização de direitos. $O$ fato de existirem múltiplas normas disciplinando o direito à saúde, doutrina tratando de sua fundamentalidade e eficácia, e mesmo decisões judiciais impondo obrigações nesse sentido, nada disso significa, a rigor, que as normas e as decisões estejam sendo efetivamente executadas e que as pessoas — todas as pessoas — estejam recebendo aquilo que as normas prometem.

O ponto é particularmente importante, pois, durante algum tempo, se alimentou a esperança de que, embora as normas por si não fossem capazes de alterar a realidade, o Judiciário seria capaz de garantir, de forma geral, a efetividade dos direitos fundamentais: mas essa esperança não era realista desde sua origem. Nas últimas décadas, multiplicaram-se decisões judiciais, ao redor do mundo e no Brasil, com o objetivo de promover a realização de direitos fundamentais. Os exemplos envolvendo direitos sociais são provavelmente os mais emblemáticos, mas não são únicos: demandas envolvendo direito à água, à alimentação, a prestações de saúde, à habitação, a saneamento básico etc.

Em primeiro lugar, por mais numerosas que sejam as ações judiciais, elas representam uma parcela pequena da realidade: a maioria absoluta da população brasileira passará toda a sua vida e jamais será beneficiária de uma decisão judicial em matéria de saúde ou educação. Por exemplo, por mais que a judicialização da saúde venha crescendo ${ }^{4}$, essas demandas continuam sendo pontuais no universo de usuários exclusivos do SUS, composto por cerca de $78 \%$ da população brasileira: quase 162 milhões de pessoas ${ }^{5}$. O que a maior parte dessas pessoas fruirá ou não, no que diz respeito a esses direitos, será aquilo que as políticas públicas delineadas e levadas a cabo pelos Poderes Executivo e Legislativo realizarem. E, em geral, essa maioria é a menos privilegiada no contexto da sociedade ${ }^{6}$.

Em segundo lugar, os problemas envolvendo a efetiva execução, no mundo dos fatos, do que tenha sido determinado pelo Judiciário, é um tema que tem suscitado amplo debate entre acadêmicos e ativistas ao redor do mundo. Afinal, em si mesmas, as decisões judiciais também não têm o condão de modificar a realidade: elas são apenas palavras em folhas de papel ou meios digitais. A conclusão preliminar a que já se chegou sobre o ponto, não apenas no Brasil, mas também em outros países, é a de que as decisões judiciais são executadas de forma razoável quando se trate de bens privados postulados em demandas individuais, como, e.g., a entrega de medicamentos para determinado indivíduo.

Entretanto, quando se cuida de ações coletivas e/ou de demandas que envolvem bens públicos, como a alteração, correção ou implantação de uma política pública, a execução das decisões judiciais pode demorar décadas ou eventualmente nunca acontecer ${ }^{7}$. Isso sem ingressar na discussão acerca de quem afinal acessa

4 <http://portalarquivos.saude.gov.br/images/pdf/2014/maio/29/Panorama-da-judicializa----o---2012---modificado-em-junho-de-2013.pdf $>$.

5 <http://www.ans.gov.br/perfil-do-setor/dados-gerais $>$.

6 BILCHITZ. Poverty and fundamental rights. New York: Oxford University Press, 2007.;GARGARELLA, R.; DOMINGO, P.; ROUX, T. (Ed.). Courts and social transformation in new democracies: an institutional voice for the poor?. Aldershot/Burlington: Ashgate, 2006.

7 V. discutindo a questão os textos reunidos na coletânea de GAURI; BRINKS (Ed.). Courting social justice: judicial enforcement of social and economic rights in the developing world. Cambridge: Cambridge University Press, 2008. Veja-se para ações tratando de saneamento no Brasil, BARCELLOS, Ana Paula de. Sanitation rights, public law litigation and inequality: a case study from Brazil. Health and Human Rights, v. 16, n. 2, p. 35-46, 2014. 
o Poder Judiciário para postular demandas em matéria de saúde, embora já se saiba que, raramente, são os mais excluídos da sociedade.

Não se trata de minimizar os vários papéis que as decisões judiciais têm e podem ter no tema dos direitos, mas apenas de constatar que é ilusório imaginar que possa caber ao Judiciário a função de garantir o respeito, proteção ou promoção dos direitos fundamentais em caráter geral. A edição de uma lei criando uma política pública de promoção de determinado direito será um ponto de partida: indispensável, sem dúvida, mas apenas um ponto de partida. Em boa medida o mesmo acontece com decisões judiciais mais complexas, que pretendem interferir com políticas públicas de forma coletiva. A transformação da realidade não se seguirá magicamente à expedição da norma e sequer a execução da própria lei e da política por ela delineada são automáticas.

Haverá, no mínimo, dois grandes processos no percurso que pode levar uma norma a produzir efetivamente a proteção, a promoção ou o respeito de direitos fundamentais no mundo real. Em primeiro lugar, a política pública prevista na norma — isto é: seu conteúdo, as medidas por ela delineadas — precisará de fato ser implementada. Esse primeiro momento dependerá de uma série de providências como, e.g., a criação de estruturas administrativas, a contínua alocação orçamentária, a contratação de pessoal e infraestrutura suficientes para atender a todos os públicos alvo da política, a compra de produtos e a contratação de serviços, a produção de relatórios, pesquisas, o monitoramento etc.

Não é incomum, porém, que uma lei seja aprovada prevendo determinada política e não seja regulamentada. Ou que anos se passem sem que haja previsão orçamentária para a execução da lei, ou que haja previsão orçamentária, mas ela não seja realmente executada. É possível ainda que a política seja implementada apenas em determinadas regiões (do país, do Estado, da cidade) ou apenas em benefício de determinados públicos, ou que os recursos (financeiros, humanos, técnicos) não sejam suficientes para sua execução, dentre outras possibilidades. Enfim, um sem número de questões podem surgir, e efetivamente surgem entre a norma e sua execução.

Dois exemplos ilustram o ponto. A lei que prevê a obrigatoriedade de que vias e espaços públicos sejam adaptados para garantir a acessibilidade de pessoas com mobilidade reduzida é de 2000 (Lei n 10.098), mas até hoje não foi integralmente executada. Além disso, é muito provável que, na maior parte das cidades, os percentuais de sua execução não sejam os mesmos em todos os bairros e que os bairros considerados mais nobres, onde mora a população de maior renda, tenham melhores percentuais de execução da política pública do que as regiões mais carentes da cidade: trata-se de uma tendência observada em várias pesquisas que examinam políticas públicas de caráter geral e sua execução ao longo do tempo ${ }^{8}$.

Em 2015, o IPEA divulgou uma avaliação nacional feita sobre os resultados e a efetividade da Lei Maria da Penha, promulgada em 2006. O estudo revela o impacto positivo da lei de uma forma geral, na média nacional, no que diz respeito à redução proporcional de homicídios contra mulheres. Todavia, o estudo destaca, também, que a execução das políticas previstas pela lei varia bastante regionalmente, e, talvez por isso mesmo, também o impacto esperado da lei não é uniforme, oscilando em função da região examinada.

Uma vez que a norma esteja sendo implementada — e, portanto, esse primeiro aspecto do percurso norma-realidade esteja em andamento - , será preciso verificar se os resultados que dela se esperava estão se produzindo realmente, tanto em caráter geral, quanto, desagregando essa informação, tendo em conta as diferentes regiões e os diferentes grupos humanos no país. Esse processo é um pouco mais complexo, em primeiro lugar, porque, nem sempre, a política pública tinha/tem resultados ou metas claramente definidas.

8 VICTORA, Cesar G. et al. Explaining trends in inequities: evidence from Brazilian child health studies. Lancet, v. 356, p. 1093-1098, 2000; Human Rights Watch. World report. 2012. Disponível em: < https://www.hrw.org/sites/default/files/world_report_download/wr2012.pdf>. Os dois trabalhos ilustram a chamada "inverse equity hypothesis" segundo a qual as populações mais favorecidas tendem a se beneficiar primeiro das políticas públicas gerais, aumentando ainda mais a desigualdade em um primeiro momento.

9 <http://www.ipea.gov.br/atlasviolencia/artigo/22/avaliando-a-efetividade-da-lei-maria-da-penha->. 
E, em segundo lugar, porque muitas vezes não há monitoramento acerca dos resultados que a política pública está ou não efetivamente produzindo e, portanto, não há informação sobre o assunto. Ainda um exemplo ilustra a questão.

Em 2007, o Ministério da Educação criou o programa "Mais Educação" que consistia, basicamente, em ampliar em cerca de 3 h diárias a jornada escolar de estudantes do ensino fundamental nas redes públicas estaduais e municipais a fim de ampliar as oportunidades de aprendizagem. O programa procurou focar em escolas de baixo IDEB e marcadas por situações de vulnerabilidade social. Naturalmente que o resultado pretendido seria a melhoria da aprendizagem desses estudantes. Em 2015 foi divulgado pelo Ministério da Educação estudo realizado pela Fundação Itaú Social e pelo Banco Mundial acerca dos resultados do programa.

Talvez, de forma surpreendente, o que se apurou foi que, até 2011,

não são encontrados resultados de melhoria no desempenho médio dos alunos na Prova Brasil, nem na taxa de abandono, quando comparamos escolas que tiveram o programa com outras sem ele, mas com características similares. ${ }^{10}$

Ou seja: a despeito de a política "Mais Educação" estar sendo executada, e apesar de suas melhores intenções, os resultados pretendidos não estavam se produzindo. Fenômeno similar se observa de forma mais geral, a rigor, no sistema educacional brasileiro. Embora se tenha praticamente obtido a universalização das matrículas para crianças e adolescentes — o que deve ser comemorado - , para um percentual alarmante de estudantes a escolarização não é garantia de alfabetização funcional ou de qualificação para o trabalho ${ }^{11}$, apesar do que dispõe o art. 205 da Constituição ${ }^{12}$.

Esses comentários iniciais revelam as limitações das normas e da jurisdição no que diz respeito à promoção dos direitos fundamentais, e conduzem ao tema do monitoramento de políticas públicas, sobre o que se vai tratar na segunda e na terceira partes deste texto. Na verdade, o que se pretende sustentar é que o monitoramento de políticas públicas em matéria de direitos fundamentais, e dos seus resultados em particular, é essencial para a promoção real desses direitos. Assim, na medida em que se trata de mecanismo essencial para a realização dos comandos constitucionais sobre os direitos fundamentais, a existência de sistemas de monitoramento constitui um dever geral extraído da Constituição.

\section{Monitoramento das políticas públicas em Matéria de diReItos fUndamentais}

O monitoramento e a avaliação de políticas públicas, de forma ampla, pode ser levado a cabo sob diversas outras perspectivas - financeira, orçamentária, organizacional etc. —, aproximando-se de certo modo da avaliação do impacto legislativo (uma vez que a política tenha sido definida em lei) ${ }^{13}$. Naturalmente, nem toda política pública estará diretamente relacionada com a promoção imediata de direitos fundamentais: ainda assim, ela deverá ser objeto de monitoramento e avaliação ${ }^{14}$. No caso das políticas públicas em ma-

10 <https://www.redeitausocialdeavaliacao.org.br/wp-content/uploads/2015/11/relat_Mais_Educa\%C3\%A7\%C3\%A3o_ COMPLETO_20151118.pdf>. A pesquisa sobre a política pública em questão foi desenvolvida no âmbito de grupo de pesquisa do programa de pós-graduação da Faculdade de Direito da UERJ e conduzida de forma específica pelo doutorando Alessandro Molon. 11 <https://www.todospelaeducacao.org.br/biblioteca/1546/inaf---alfabetismo-no-mundo-do-trabalho/>.

12 CF/88: "Art. 205. A educação, direito de todos e dever do Estado e da família, será promovida e incentivada com a colaboração da sociedade, visando ao pleno desenvolvimento da pessoa, seu preparo para o exercício da cidadania e sua qualificação para o trabalho."

13 Sobre o tema, v. ANDRADE, Aparecida de Moura; SANTANA, Héctor Valverde. Avaliação de políticas públicas versus avaliação de impacto legislativo: uma visão dicotômica de um fenômeno singular. Revista Brasileira de Políticas Públicas, Brasília, v. 7, n. 3, p. 781-798, 2017.

14 Para um exemplo de monitoramento e avaliação dos resultados de política pública - no caso, de estímulo à pesquisa e desenvolvimento no âmbito do setor elétrico -, v. MUNHOZ, Igor Polezi; AKKARI, Alessandra Cristina Santos; SANTOS, Neusa Maria 
téria de direitos fundamentais, em particular, seu monitoramento também poderá se ocupar de diferentes dimensões ${ }^{15}$, mas, em qualquer caso, uma perspectiva indispensável a ser considerada será a que enfatiza a realização concreta dos direitos fundamentais que a política pretende promover, e é esse o enfoque que se pretende assumir neste trabalho.

Nesse contexto, o monitoramento envolve verificar se as metas que haviam sido estabelecidas quando da concepção da política estão sendo atingidas (caso, claro, elas tenham sido estabelecidas), acompanhar o que de fato está sendo executado no contexto da política em exame, e apurar os resultados concretos produzidos em face dos direitos fundamentais que se pretende promover, tendo em conta o problema que se pretendia solucionar por meio da política pública afinal ${ }^{16}$. De tal modo que, diante desse conjunto de dados, seja possível rever a política ou aspectos dela de modo a aprimorar sua capacidade de promover os resultados desejados. Esquematicamente, é possível falar, então, de sete etapas na dinâmica do monitoramento.

As duas primeiras etapas na dinâmica do monitoramento são prévias à execução das políticas públicas. Isso, porque, ao conceber uma política pública, os agentes públicos — sejam do Legislativo, do Executivo ou de qualquer outro órgão ou entidade estatal — devem, logicamente, valer-se de informação acerca de qual é o problema que a política pretende enfrentar e qual sua dimensão, bem como estabelecer quais as metas que se pretende atingir com a política proposta. Essas são duas questões bastante básicas, mas que podem ser bastante problemáticas e exigem enfrentamento ${ }^{17}$.

Conceber a política pública com base em informações acerca dos problemas e suas dimensões, para além de uma exigência lógica, é fundamental por ao menos duas razões jurídicas: a garantia da igualdade (art. $5^{\circ}$, caput) e a redução das desigualdades (art. $3^{\circ}$, III). Isso sem mencionar o debate da eficiência (art. 37, caput e art. 74, II), que não se enfrentará neste artigo em virtude da necessidade de limitar o escopo do estudo, e não por sua desimportância.

Em primeiro lugar, a informação é necessária para que seja possível dimensionar os recursos necessários para enfrentar o problema o que, possivelmente, repercutirá na própria concepção da política e nas decisões a serem tomadas. Imagine-se, em um exemplo esquemático, que o problema a ser enfrentado é o tratamento de câncer de mama no âmbito do SUS, e que existam 5 opções terapêuticas possíveis, de custo variado. Avaliar a quantidade estimada de pacientes que fará uso do tratamento nos anos subsequentes, por exemplo, será essencial para que se possa quantificar o custo global da política e assim fazer uma escolha que permita, ao menos tem tese, que todas as mulheres com a doença tenham acesso ao tratamento, e não apenas algumas delas.

Caso as decisões acerca de uma política pública não considerem informações sobre a dimensão do problema que ela pretende enfrentar, há um risco alto de violação da igualdade na fase da execução, já que a política não será capaz de atingir todos aqueles que deveriam ser por ela alcançados. Aparentemente, é o que acontece com parte importante das políticas de fornecimento gratuito de muitos medicamentos do SUS: as listas são generosas, como se viu acima, mas os medicamentos não estão disponíveis no sistema para boa parte da população que deveria recebê-lo, considerada a realidade epidemiológica do país.

Bastos Fernandes dos. Análise dos impactos diretos e indiretos do programa de P\&D da ANEEL no setor elétrico: diferenças com os EUA. Revista Brasileira de Politicas Públicas, v. 5, n. 2, p. 123-144, 2015.

15 A Portaria Interministerial no 102/2016, por exemplo, instituiu no âmbito do Poder Executivo Federal o Comitê de Monitoramento e Avaliação de Políticas Públicas Federais - CMAP cujos objetivos, nos termos de seu art. 1, são "I - aperfeiçoar políticas públicas, programas e ações do Poder Executivo federal para que alcancem melhores resultados; e II - aprimorar a alocação de recursos e melhorar a qualidade do gasto público". Ainda que o primeiro objetivo possa eventualmente abarcar múltiplas perspectivas, o segundo se concentra na gestão financeira das políticas públicas.

16 ORGANIZAÇÃO DAS NAÇÕES UNIDAS. Manual on human rights monitoring. Disponível em: <http://www.ohchr.org/EN/ PublicationsResources/Pages/MethodologicalMaterials.aspx>. Ver também, para uma discussão mais geral sobre o tema, sob a perspectiva da elaboração das normas e do controle de seus resultados, BARCELLOS, Ana Paula de. Direitos fundamentais e direito à justificativa: devido procedimento na elaboração normativa. Minas Gerais: Fórum, 2017.

17 ATIENZA, Manuel. Reasoning and legislation. In: WINTGENS, Luc J. (Org.). The theory and practice of legislation. Aldershot: Ashgate, 2005. p. 297-317. 
Adicionalmente, é provável que a política pública acabe por beneficiar sobretudo as camadas mais favorecidas da sociedade, que terão mais capacidade de influenciar os órgãos do Poder Executivo responsáveis pela execução da política — e, portanto, de obter prioridade no atendimento —, ou que tem maior facilidade de acesso ao Poder Judiciário, a fim de pleitear a adjudicação do que a política prometia, mas não foi entregue. Na realidade, como já se mencionou acima, como regra geral, sabe-se que as políticas públicas já beneficiam, primeiramente, os grupos mais privilegiados da sociedade, atingindo as camadas menos favorecidas apenas depois de algum tempo. É razoável supor que esse quadro se agrave, ainda, mais no caso de uma política que sequer considerou toda a demanda existente em sua concepção: o "depois" pode simplesmente não chegar, violando de forma ainda mais grave a isonomia.

A informação é relevante, também, para estabelecer prioridades caso não seja possível atender a todas as demandas existentes no âmbito de determinada política, tendo em conta que, nos termos constitucionais, a definição de prioridades deve ser orientada pela redução das desigualdades sociais (art. $3^{\circ}$, III). Ou seja: é preciso assegurar o atendimento das necessidades mais básicas para todos antes de avançar para níveis mais amplos de proteção, sob pena de ampliar ainda mais a desigualdade, ao invés de reduzi-la. Assim, por exemplo, localidades que têm educandos, mas não têm sequer escolas oferecendo educação infantil e fundamental, devem ser atendidas prioritariamente no âmbito das políticas públicas em matéria de educação. Já se pode perceber, como apontado acima, que também as informações acerca do problema devem ser regionalizadas e desagregadas em função de elementos que tradicionalmente indicam desigualdade no país, já que determinados grupos ou áreas podem ter realidades bastante diversas em comparação com outras.

Por fim, a informação acerca da realidade do problema que se pretende enfrentar será indispensável, também, para que se possa avaliar, ao longo da execução da política pública, se ela está produzindo algum impacto transformador sobre essa mesma realidade. Imagine-se uma política para estimular a leitura entre jovens e adolescentes. Se não há informação sobre a realidade antes da adoção da política, será difícil avaliar qual terá sido seu impacto (se algum) ao longo da execução da política.

Naturalmente, as informações existentes sobre os problemas - e mais ainda aquelas que procuram prever a evolução deles no futuro - são sempre limitadas e podem se mostrar imprecisas. Trata-se de uma limitação da própria capacidade humana e dos mecanismos de investigação existentes. Sob outra perspectiva, às vezes sequer há informação acerca da dimensão dos problemas a serem enfrentados — e, eventualmente, uma primeira fase da política pública pode envolver justamente a coleta de dados acerca da realidade. Seja como for, a limitação acerca do conhecimento sobre a realidade não justifica a defesa da ignorância, ou a acomodação com ela, pois as consequências dessa ignorância para a promoção efetiva dos direitos fundamentais podem ser dramáticas, e em geral em prejuízo daqueles que já são mais excluídos do acesso aos bens públicos.

Uma segunda etapa do monitoramento, para além da coleta/exame das informações sobre o problema, e também prévia à execução da política pública, envolve a fixação de metas a serem atingidas ao longo do tempo por essa política, metas que, naturalmente, possam ser observadas e avaliadas. Esse ponto pode apresentar algumas complexidades que não caberá ao Direito resolver, mas que ele precisa ao menos compreen$\operatorname{der}^{18}$. Em relação a alguns temas, a fixação de metas observáveis e mensuráveis é razoavelmente objetiva. Políticas envolvendo a ampliação da eletrificação ou das conexões de residências a uma rede de saneamento, por exemplo, podem ser medidas de forma numérica facilmente.

A questão já será mais complexa, por exemplo, em temas de saúde: embora o resultado final (outcome) seja a promoção, proteção e recuperação da saúde (art. 196), em geral é mais fácil estabelecer metas acerca das prestações efetivamente realizadas em relação a cada política específica, isto é: quantos procedimentos foram realizados, ou quantos exames, ou quantas consultas etc. (outputs). Há uma certa presunção relativa

18 GREEN, Maria. What we talk about when we talk about indicators: current approaches to human rights measurement. Human Rights Quarterly, v. 23, p. 1062-1097, 2001. 
de que mais exames, consultas, procedimentos e medicamentos contribuirão para a promoção, proteção e recuperação da saúde das pessoas, mas não é possível ter certeza de que há uma conexão necessária entre esses dois fenômenos sempre e para toda a população.

A complexidade aumenta ainda mais quando se trata do tema educação, por exemplo. Como medir se, após ser usuária dos serviços prestados pelo sistema educacional, a pessoa está preparada para exercer a cidadania, qualificada para o trabalho e plenamente desenvolvida, como pretende a Constituição (art. 205)? Será preciso conceber algum tipo de indicador, ou um proxy, que permita uma aproximação desse fenômeno. Em muitas partes do mundo, a performance dos estudantes em determinados testes padronizados, apesar de suas limitações, é o indicador mais comumente usado para esse fim. Há, porém, muitos debates acerca de qual seria a melhor forma de fazer essa avaliação e do que, afinal, significam pleno desenvolvimento da pessoa, qualificação para o trabalho e preparo para o exercício da cidadania

Um exemplo interessante de outra dimensão dessa complexidade pode ser observado na pesquisa realizada pelo IPEA sobre a Lei Maria da Penha, referida acima, e em sua discussão metodológica que, basicamente, pretendeu responder à seguinte pergunta: como medir e avaliar se a lei produziu resultados na redução da violência doméstica contra a mulher? É impossível saber quais seriam os níveis de violência caso a lei não existisse. O critério usado foi a comparação com os níveis de violência gerais observados da edição da lei, em 2006, até a realização do estudo, imaginando-se que o crescimento da violência doméstica entre as mulheres seria aproximadamente o mesmo: assim, eventual diferença relevante entre esses índices poderia ser razoavelmente imputada ao impacto da lei.

Em resumo: a fixação de metas para uma política pública pode, em si, ensejar uma série de discussões de natureza político-ideológica, além de debates mais técnicos de natureza metodológica, particularmente sob a perspectiva estatística. Esse ponto é importante, pois, embora a fixação de metas seja fundamental para a política pública em matéria de direitos fundamentais - para que seja possível avaliar ao longo do tempo se a política está ou não produzindo os resultados desejados —, ela nem sempre será singela. Essa circunstância, naturalmente, não significa que o tema deva ser deixado de lado, muito ao contrário. Se uma política pública não tem metas claras, observáveis e de alguma forma mensuráveis, simplesmente não será possível saber se o direito fundamental em questão está ou não sendo promovido, protegido ou respeitado. A realidade é complexa, mas é a realidade que o direito pretende transformar, de modo que não é possível fugir dessa complexidade.

Passando para as três próximas etapas lógicas do monitoramento, a doutrina que já existe sobre o tema identifica três grandes grupos de fenômenos que devem ser acompanhados, e sobre os quais se deverá ter informação desagregada ${ }^{19}$. O primeiro fenômeno a ser observado é denominado em geral pela expressão "inputs" e descreve os recursos financeiros, humanos ou de qualquer outra natureza investidos na política pública.

Nesse passo, uma primeira informação relevante a se apurar acerca de uma política públicas será o quanto se está investindo nela, bem como quantas pessoas e meios estão envolvidos na execução da tal política, e essa informação precisa ser desagregada ao menos territorialmente. A informação sobre os inputs não diz muito sobre o impacto efetivo da política na realidade dos direitos fundamentais que ela pretende promover. Nada obstante, tais dados serão importantes para vários tipos de controle relacionados com as despesas públicas. Por meio desses dados, já se pode saber, por exemplo, se as previsões orçamentárias estão sendo efetivamente executadas, se os investimentos mínimos previstos na Constituição, por exemplo, estão sendo dirigidos aos fins gerais previstos e, também, é possível identificar indícios de desvios e superfaturamento.

Além disso, sobretudo por conta da desagregação dos dados, as informações acerca dos inputs permitem avaliar que áreas estão recebendo mais ou menos recursos, e verificar se tais opções se justificam do

19 NORTON, Andy; ELSON, Diane. What's bebind the budget?: politics, rights and accountability in the budget process. London: ODI, 2002. 
ponto de vista constitucional e dos objetivos da própria política. Sobretudo após a edição da Lei de Acesso à Informação (Lei no 12.527/11), esse é o tipo de informação que se pode obter com mais facilidade na realidade brasileira hoje ${ }^{20}$. Mas dinheiro e recursos humanos, físicos ou tecnológicos também não significam automaticamente promoção de direitos fundamentais. É preciso prosseguir.

Um segundo conjunto de dados a ser monitorado é o que se identifica como outputs. Trata-se daquilo que efetivamente foi feito por conta da política: os serviços prestados, as atividades desenvolvidas, os bens fornecidos. A aplicação concreta dos inputs dará origem aos outputs. A informação acerca dos outputs também não revela ainda, realmente, o resultado da política sobre os direitos fundamentais, mas ao menos informa em que os inputs se materializaram concretamente. Uma coisa é saber que foram investidos x milhões de reais em determinada política; outra diversa é ter informação que descreva em que os tais x milhões de reais se transformaram em termos de serviços, produtos etc., e onde esses serviços e produtos foram ou estão sendo prestados ou fornecidos.

Na realidade, e como já referido, existe, apenas, uma presunção de que a realização dessas atividades e o fornecimento desses bens produzirá como resultado a promoção dos direitos fundamentais. Os outputs são atividades-meio: não há uma garantia de que eles conduzirão ao resultado desejado, a rigor, e daí a necessidade de se monitorar, também, os resultados efetivos (outcomes) sobre os direitos fundamentais. De todo modo, é realmente importante monitorar os outputs produzidos pelas políticas públicas de forma desagregada até porque, em geral, essa informação poderá ser mais facilmente coletada do que aquela relacionada com os outcomes.

Por fim, uma terceira informação a ser monitorada diz respeito ao impacto real da política pública sobre os direitos fundamentais: os outcomes. Como já se viu, dependendo do direito fundamental em exame e da política pública em discussão, o tema de como identificar e medir esse impacto será relevante. É importante, porém, perceber que a simples existência de informações sobre os inputs e outputs não é suficiente para avaliar se a política pública está, afinal, produzindo o resultado desejado em termos de direitos ${ }^{21}$. Como no exemplo do "Mais Educação" referido acima, ideias que pareciam ótimas podem não produzir o resultado que se antecipava, e é preciso aprofundar a investigação sobre elas e reavaliá-las (não necessariamente abandoná-las). Fingir que o resultado não é importante e que a simples existência de atividades-meio seria suficiente não produzirá, magicamente, por isso, a promoção, proteção e respeito aos direitos fundamentais.

As duas últimas etapas do monitoramento envolvem a avaliação dos dados produzidos sobre essas várias dimensões da realidade da política pública e sua eventual revisão. O objetivo do monitoramento não é punitivo. Não se trata de punir os responsáveis pela política que não atingiu as metas ou não promoveu os resultados pretendidos. Punições podem, eventualmente, ocorrer, se os dados revelarem práticas ilícitas, por evidente, mas não é esse o foco. O conhecimento e a previsibilidade humanas são falíveis e, mesmo quando

20 MANNARINO, Rosanne. Prestação de contas do governo da República para quem? a sociedade brasileira. In: SOUZA JUNIOR, José Geraldo de (Org.) Sociedade democrática, direito público e controle externo. Brasília: Universidade de Brasília, 2006. p. 229-240.; PEDERIVA, João Henrique. Accountability, constituição e contabilidade. Revista de Informação Legislativa, v. 35, n. 140, p. 17-39, 1998.; PONTES, João Batista; PEDERIVA, João Henrique. Contas prestadas pelo presidente da república: apreciação do Congresso Nacional. Brasília: Senado Federal, Consultoria Legislativa, 2004.

21 FRANCESCO, Fabrizio de.; RADAELLI, Claudio M.; TROEGER, Vera E. Implementing regulatory innovations in Europe: the case of impact assessment. Journal of European Public Policy, p. 1-21, 2011.; FLUECKIGER, Alexandre. Can better regulation be achieved by guiding parliaments and governments?: how the definition of the quality of legislation affects law improvement methods (concluding remarks). Legisprudence, v. 4, n. 2, p. 213-218, 2010.; ISSALYS, Pierre. Analyse d'impact et production normative: de l'efficacité à la légitimité. Revista da Faculdade de Direito da UFMG. n. Especial, p. 245-274, 2013.; MENEGUIM, Fernando B. Avaliação de impacto legislativo no Brasil. Berkeley Program in Law and Economics. Latin American and Caribbean Law and Economics Association (ALACDE) Annual Papers, 2010. Disponível em: <http://escholarship.org/uc/item/8ts831r2>.; RADAELLI, Cláudio M. The diffusion of regulatory impact analysis: best practice or lesson-drawing?. European Journal of Political Research, UK, v. 43 , n. 5, p. 723-747, 2004.; Radaelli, Claudio M. Quality of regulatory governance: impact assessment in comparative perspective. Full research report ESRC end of award report. RES-000-23-1284. Swindon: ESRC, 2009.; e SALINAS, Natasha Schmitt Caccia. Avaliação legislativa no Brasil: apontamentos para uma nova agenda de pesquisa sobre o modo de produção das leis. Revista Brasileira de Políticas Públicas, v. 10, n. 1, p. 228-249, 2013. 
implementadas como previsto, às vezes as normas não atingem os objetivos que pretendiam, ou não os atingem em todos os lugares ou relativamente a todos os grupos sociais ${ }^{22}$. Diante desses eventuais fracassos iniciais, é necessário repensar os meios pelos quais se pode tentar promover o fim inicialmente pretendido.

Isto é: mesmo que a política pública seja efetivamente executada, tal como concebida, não existe qualquer garantia de que a intervenção estatal na realidade produzirá os efeitos desejados sempre. Apenas o monitoramento dos resultados permitirá saber o que de fato está acontecendo, tendo em conta, repita-se, os vários grupos sociais e as várias regiões, já que a mesma política pode produzir efeitos diversos dependendo dos elementos com os quais venha a interagir na realidade ${ }^{23}$. A necessidade de avaliações e de revisões das políticas públicas é natural, mas ela somente poderá ocorrer diante do monitoramento efetivo dessas políticas em face do resultado concreto esperado em termos de direitos fundamentais.

\section{DeVER DE Monitoramento: LeVANDo OS DiReitos À SÉRIO E OUTRAS RAZÕES}

A última questão que cabe examinar pode ser formulada nos seguintes termos: o que o Direito Constitucional teria a ver com o tema do monitoramento das políticas públicas, apresentado sumariamente acima? Por que falar de um dever de monitoramento, no sentido jurídico-constitucional? Por quais razões o Direito Constitucional deveria se ocupar do assunto? O que se pretende demonstrar é que o tema é profundamente constitucional e deve ser objeto de reflexão e aprofundamento pelos estudiosos do Direito, justificando falar-se de um dever constitucional de monitoramento. As razões para isso seguem resumidas na sequência.

Em primeiro lugar, e como já enunciado, o compromisso constitucional com os direitos fundamentais tem uma dimensão de realidade, a saber: que as pessoas efetivamente tenham seus direitos garantidos, protegidos e promovidos no dia a dia. Ora, como se viu, as normas e as decisões judiciais sozinhas não têm o condão de transformar magicamente a realidade. Assim, é possível afirmar que o compromisso constitucional com os direitos fundamentais não é um compromisso propriamente com a existência de normas sobre o assunto, de políticas públicas de direitos fundamentais ou mesmo de decisões judiciais que determinem sua execução. Todos esses mecanismos serão meios para atingir um fim: a garantia efetiva, no dia a dia das pessoas, dos direitos fundamentais.

O percurso entre a norma e seu eventual impacto sobre a realidade não é indiferente para o Direito em geral, e para o Direito Constitucional em particular. Muito ao revés. E se, como se viu, o monitoramento das políticas públicas responsáveis pela promoção desses direitos é essencial para que esse impacto aconteça de fato, e da forma o mais equitativa possível, é natural que o tema deva ingressar na reflexão do Direito Constitucional. Para levar os direitos a sério, é preciso acompanhar, minimamente, o percurso da norma constitucional até a realização de seus propósitos na vida real.

Mas há uma segunda razão que justifica a importância de o Direito Constitucional se ocupar do tema do monitoramento das políticas públicas em matéria de direitos fundamentais. Se de um lado as políticas públicas destinam-se a promover direitos, de outro elas envolvem vultosos recursos públicos, recursos esses retirados da sociedade por meio, sobretudo, da tributação. Não há custo zero nessa dinâmica: nunca há, a rigor. A ação estatal é custeada pela sociedade que, portanto, tem menos recursos para si própria, de modo que as políticas públicas não produzem, apenas, benefícios: elas também restringem liberdades e direitos, na medida em que consomem recursos que poderiam ser alocados para outras finalidades, no âmbito da própria sociedade ou pelo próprio Estado.

22 SCOTT, James C. Seeing like a State: how certian schemes to improve the human condition have failed. New Haven: Yale University Press, 1998.

23 HOFFMANN, Rodolfo. Mensuração da desigualdade e da pobreza no Brasil. In: HENRIQUES, R. (Ed.). Desigualdade e pobreza no Brasil. Rio de Janeiro: IPEA, 2000. p. 81-107.; UNICEF. Social protection: accelerating the MDGs with equity. UNICEF, 2010. 
Retirar recursos da sociedade para a promoção de direitos fundamentais — sobretudo dos menos favorecidos - parece amplamente justificado, se, além do respeito aos limites constitucionais aplicáveis à intervenção do Estado sobre a propriedade, as políticas adotadas efetivamente estejam, tanto quanto possível, promovendo os direitos fundamentais que afirmam pretendem promover. Caso contrário, o Estado estará, apenas, desperdiçando os recursos da sociedade de forma irrazoável. Repita-se o que já se registrou acima: às vezes, a despeito de todo esse esforço de seriedade na elaboração de uma política pública, as coisas não se passarão como se antecipava. O conhecimento sobre o problema era mais limitado do que se supunha, os efeitos pretendidos não se produziram como imaginado e impactos não antecipados se mostraram extremamente graves, exigindo reformulações da política. Nada obstante, parece evidente que, sem monitoramento, a chance de sucesso será sempre mais remota. Ou seja: os fracassos até poderão acontecer como resultado das limitações cognitivas humanas, mas não como resultado de uma displicência institucional. O mínimo que se espera diante da centralidade dos direitos fundamentais e dos efeitos que as normas produzem sobre esses direitos é que toda a seriedade possível seja atribuída às políticas públicas que visam justamente a promover tais direitos.

Em terceiro lugar, o tema do monitoramento demanda atenção por parte do Direito Constitucional pois ele envolve de forma direta o exercício do Poder Político e limites a esse exercício sob uma dimensão contramajoritária: tema clássico do Direito Constitucional. Coletar informações sobre as políticas públicas informações desagregadas —, processá-las e colocá-las à disposição do público é uma atividade complexa, por vezes demorada e custosa, e provavelmente com pouco retorno eleitoral, já que ela pode demonstrar, por exemplo, que os resultados anunciados não foram alcançados. Por isso mesmo não seria contrafático assumir como premissa que o Poder Público preferiria, do ponto de vista político, gerar e divulgar apenas informações que revelem seus avanços e sucessos, ou ainda dados genéricos que não revelem quase nada.

Nada obstante, se o monitoramento e as informações por ele demandadas são fundamentais para a própria promoção dos direitos fundamentais - e sobretudo para a promoção dos direitos dos grupos menos favorecidos socialmente - , monitorar ou não os resultados das políticas públicas não pode ser uma opção livre a cargo dos agentes públicos encarregados dessas políticas. O monitoramento de uma política pública envolve muitas escolhas que exigem não apenas juízos técnicos, mas muitas vezes também políticos. Não se trata de o Direito pretender elaborar um sistema de monitoramento: trata-se, apenas, de impor o dever de que ele exista.

Por fim, em quarto lugar, o monitoramento dos resultados das políticas públicas é uma atividade indispensável para que exista informação acerca dessas políticas, de modo a permitir o debate público sobre elas: informações sobre quais as metas que se pretende alcançar com cada política, informações sobre os recursos investidos (inputs), as atividades desenvolvidas e bens fornecidos (outputs), e informações sobre os resultados efetivamente produzidos (outcomes) pelas políticas públicas ao longo do tempo, e considerando as diferentes regiões e grupos sociais. A garantia de respeito, proteção e a promoção de direitos é uma construção democrática que se desenvolve ao longo do tempo, e informação será sempre essencial nesse processo ${ }^{24}$.

Em uma democracia, além de um direito fundamental em si, o acesso à informação é indispensável para a promoção dos demais direitos, para além do papel. Se, em um república democrática, todos são iguais e responsáveis como cidadãos por deliberar e formular as escolhas coletivas — escolhas essas que vão afinal promover ou não os direitos de que as normas tratam —, o acesso à informação acerca de um tema tão fundamental quanto o da realidade de respeito ou desrespeito aos direitos fundamentais será indispensável para que essas escolhas possam ser feitas de forma minimamente consciente.

24 FREITAS, Juarez. O controle social do orçamento público. Revista Interesse Público, v. 11, p. 13-26, 2001.; MAINWARING, Scott.; WELNA, Christopher. Democratic accountability in Latin America. New York: Oxford University Press, 2003. 


\section{Considerações finais}

Passados 30 anos da Constituição de 1988, é possível afirmar que o discurso acerca da normatividade do texto constitucional e das normas de direitos fundamentais em particular tornou-se amplamente dominante, não apenas na doutrina como na jurisprudência. Também as últimas décadas assistiram a ampla produção normativa acerca da promoção dos mais diferentes direitos. A percepção, porém, é a de que, embora todos esses elementos sejam da maior importância, estão longe de serem suficientes para promover, no mundo real, os direitos das pessoas. É preciso aprofundar a reflexão sobre a estruturação das políticas públicas mecanismos que vão afinal conduzir o percurso das normas até sua efetiva realização —, sobre o monitoramento de seus resultados e sobre a geração e divulgação de informações acerca de todo esse processo.

Nesse sentido, cogitou-se neste artigo um dever jurídico-constitucional de monitoramento de políticas públicas e, também, se deixou claro que a elaboração e implantação de um sistema de monitoramento no âmbito de uma política pública é, em si, também, uma política pública que pode ser bastante complexa. Inicialmente, porém, se registrou, justamente, a dificuldade de execução de decisões judiciais que pretendem interferir em políticas públicas de forma ampla. A pergunta que se coloca é evidente: intervenções como as sugeridas acima não teriam o mesmo destino? A resposta é provavelmente afirmativa.

$\mathrm{Na}$ realidade, e como referido, também as decisões judiciais são apenas um ponto de partida, não de chegada, quando se trata de políticas públicas, no que se inclui a estruturação de sistemas de monitoramento. Inevitavelmente, as políticas públicas serão levadas a cabo por decisões do Legislativo e do Executivo, e os mecanismos de sanção de que o Direito dispõe dificilmente são capazes de compelir as instâncias majoritárias a agirem em determinado sentido caso elas não tenham interesse político de fazê-lo. Mas, então, qual o sentido de sustentar a existência de um dever jurídico-constitucional de monitoramento das políticas públicas? Nem tanto ao mar, nem tanto a terra, como diriam os antigos.

A despeito de suas prováveis limitações, as decisões judiciais podem ter um importante papel de desencadear o debate público e pautar a agenda política ${ }^{25}$, colocando em discussão temas que, sem as decisões judiciais, talvez não atrairiam a atenção da mídia, dos grupos sociais e do público em geral. Ainda que a decisão judicial não seja capaz de, sozinha, produzir o resultado pretendido, ela pode ajudar a desencadear o processo e, em conjunto com outros elementos, gerar estímulos para a construção dos meios necessários à proteção e promoção dos direitos. O Direito não pode tudo, e situar, adequadamente, nosso trabalho e suas potencialidades no contexto mais amplo no qual ele se insere, decorre da percepção de que a promoção dos direitos fundamentais é complexa e exige mais do que, apenas, normas ou decisões judiciais, e de que a sociedade é mais do que o Direito e o Direito é mais do que o Judiciário. O Direito não pode tudo, longe disso, mas ele continua a ter um papel importante a desempenhar e devemos fazê-lo da melhor forma possível.

\section{REFERENCIAS}

ANDRADE, Aparecida de Moura; SANTANA, Héctor Valverde. Avaliação de políticas públicas versus avaliação de impacto legislativo: uma visão dicotômica de um fenômeno singular. Revista Brasileira de Políticas Públicas, Brasília, v. 7, n. 3, p. 781-798, 2017.

ATIENZA, Manuel. Reasoning and legislation. In: WINTGENS, Luc J. (Org.). The theory and practice of legislation. Aldershot: Ashgate, 2005. p. 297-317.

BARCELLOS, Ana Paula de. Sanitation rights, public law litigation and inequality: a case study from Brazil.

25 BIRKLAND, T. Agenda setting in public policy. In: FISCHER, F.; MILLER, G.; SIDNEY, M. (Ed.). Handbook of public policy analysis: theory, politics and methods. New York: CRC Press, 2007. 
Health and Human Rights, v. 16, n. 2, p. 35-46, 2014.

BARCELLOS, Ana Paula de. Direitos fundamentais e direito à justificativa: devido procedimento na elaboração normativa. Minas Gerais: Fórum, 2017.

BILCHITZ. Poverty and fundamental rights. New York: Oxford University Press, 2007.

BIRKLAND, T. Agenda setting in public policy. In: FISCHER, F; MILLER, G.; SIDNEY, M. (Ed.). Handbook of public policy analysis: theory, politics and methods. New York: CRC Press, 2007.

BRASIL. Ministério da Saúde. Relação nacional de medicamentos essenciais: 2017. Disponível em: <http://bvsms. saude.gov.br/bvs/publicacoes/relacao_nacional_medicamentos_rename_2017.pdf>.

BRINKS, Daniel M.; GAURI, Varun. The law's majestic equality?: the distributive impact of judicializing social and economic rights. Perspectives on Politics, v. 12/2, p. 375-393, 2014.

BUGARIN, Maurício Soares; VIEIRA, Laércio Mendes; GARCIA, Leice Maria. Controle dos gastos públicos no Brasil: instituições oficiais, controle social e um mecanismo para ampliar o envolvimento da sociedade. Rio de Janeiro: Konrad-Adenauer-Stiftung, 2003. v. 32.

FLUECKIGER, Alexandre. Can better regulation be achieved by guiding parliaments and governments?: how the definition of the quality of legislation affects law improvement methods (concluding remarks). Legisprudence, v. 4, n. 2, p. 213-218, 2010.

FRANCESCO, Fabrizio de.; RADAELLI, Claudio M.; TROEGER, Vera E. Implementing regulatory innovations in Europe: the case of impact assessment. Journal of European Public Policy, p. 1-21, 2011.

FREITAS, Juarez. O controle social do orçamento público. Revista Interesse Público, v. 11, p. 13-26, 2001.

GARGARELLA, R.; DOMINGO, P.; ROUX, T. (Ed.). Courts and social transformation in new democracies: an institutional voice for the poor?. Aldershot/Burlington: Ashgate, 2006.

GAURI; BRINKS (Ed.). Courting social justice: judicial enforcement of social and economic rights in the developing world. Cambridge: Cambridge University Press, 2008.

GREEN, Maria. What we talk about when we talk about indicators: current approaches to human rights measurement. Human Rights Quarterly, v. 23, p. 1062-1097, 2001.

Hafner-Burton, Emilie M.; Tsutsui, Kiyoteru. Human rights in a globalizing world: the paradox of empty promises. American Journal of Sociology, v. 110/5, p. 1373-1411, 2005.

HOFFMANN, Rodolfo. Mensuração da desigualdade e da pobreza no Brasil. In: HENRIQUES, R. (Ed.). Desigualdade e pobreza no Brasil. Rio de Janeiro: IPEA, 2000. p. 81-107.

Human Rights Watch. World report. 2012. Disponível em: < https://www.hrw.org/sites/default/files/world_ report_download/wr2012.pdf>.

ISSALYS, Pierre. Analyse d'impact et production normative: de l'efficacité à la légitimité. Revista da Faculdade de Direito da UFMG. n. Especial, p. 245-274, 2013.

MAINWARING, Scott.; WELNA, Christopher. Democratic accountability in Latin America. New York: Oxford University Press, 2003.

MANNARINO, Rosanne. Prestação de contas do governo da República para quem? a sociedade brasileira. In: SOUZA JUNIOR, José Geraldo de (Org.) Sociedade democrática, direito público e controle externo. Brasília: Universidade de Brasília, 2006, p. 229-240.

MENEGUIM, Fernando B. Avaliação de impacto legislativo no Brasil. Berkeley Program in Law and Economics. Latin American and Caribbean Law and Economics Association (ALACDE) Annual Papers, 2010. Disponível em: <http://escholarship.org/uc/item/8ts831r2>. 
MUNDAY, Roderick. In the wake of 'good governance': impact assessments and the politicisation of statutory interpretation. Modern Law Review, v. 71/3, p. 385-412, 2008.

MUNHOZ, Igor Polezi; AKKARI, Alessandra Cristina Santos; SANTOS, Neusa Maria Bastos Fernandes dos. Análise dos impactos diretos e indiretos do programa de P\&D da ANEEL no setor elétrico: diferenças com os EUA. Revista Brasileira de Politicas Públicas, v. 5, n. 2, p. 123-144, 2015.

NORTON, Andy; ELSON, Diane. What's bebind the budget?: politics, rights and accountability in the budget process. London: ODI, 2002.

ORGANIZAÇÃO DAS NAÇÕES UNIDAS. Manual on human rights monitoring. Disponível em: < http:// www.ohchr.org/EN/PublicationsResources/Pages/MethodologicalMaterials.aspx>.

PEDERIVA, João Henrique. Accountability, constituição e contabilidade. Revista de Informação Legislativa, v. 35, n. 140, p. 17-39, 1998.

PONTES, João Batista; PEDERIVA, João Henrique. Contas prestadas pelo presidente da república: apreciação do Congresso Nacional. Brasília: Senado Federal, Consultoria Legislativa, 2004.

RADAELLI, Cláudio M. The diffusion of regulatory impact analysis: best practice or lesson-drawing?. European Journal of Political Research, UK, v. 43, n. 5, p. 723-747, 2004.

Radaelli, Claudio M. Quality of regulatory governance: impact assessment in comparative perspective. Full research report ESRC end of award report. RES-000-23-1284. Swindon: ESRC, 2009.

SALINAS, Natasha Schmitt Caccia. Avaliação legislativa no Brasil: apontamentos para uma nova agenda de pesquisa sobre o modo de produção das leis. Revista Brasileira de Políticas Públicas, v. 10, n. 1, p. 228-249, 2013.

SCOTT, James C. Seeing like a State: how certian schemes to improve the human condition have failed. New Haven: Yale University Press, 1998.

UNICEF. Social protection: accelerating the MDGs with equity. UNICEF, 2010.

VICTORA, Cesar G et al. Explaining trends in inequities: evidence from Brazilian child health studies. Lancet, v. 356, p. 1093-1098, 2000. 


\section{Nudges e políticas públicas: um mecanismo de combate ao trabalho em condição análoga à de escravo*}

\author{
Nudges and public policies: a mechanism to \\ fight labor in conditions analogous to slavery
}

\author{
Amanda Carolina Souza Silva** \\ Débhora Renata Nunes Rodrigues*** \\ Saul Duarte Tibaldi****
}

* Recebido em 31/05/2018

Aprovado em 29/06/2018

** Mestranda do Programa de Pós-graduação em Direito da Universidade Federal de Mato Grosso (UFMT). Graduada em Direito pela Universidade do Estado de Mato Grosso (UNEMAT). Graduada em Psicologia pela Faculdade do Pantanal (FAPAN). Especialista em Direito Penal pela Faculdade Damásio de Jesus. Membra do Grupo de Pesquisa Direito do Trabalho Contemporâneo da Faculdade de Direito da UFMT. Bolsista da Capes. E-mail: amandacarolinaadv@gmail.com

*** Mestranda do Programa de Pós-graduação em Direito da Universidade Federal de Mato Grosso (UFMT). Advogada. Membra do Grupo de Pesquisa O meio ambiente do trabalho equilibrado como componente do trabalho decente - GPMAT/UFMT. Graduada em direito pela Universidade Federal de Mato Grosso. E-mail: debhorarenato@hotmail.com

**** Doutor e Mestre em Direito pela Pontifícia Universidade Católica de São Paulo (PUC-SP). Professor nos cursos de Graduação e Mestrado e Diretor da Faculdade de Direito da Universidade Federal de Mato Grosso (UFMT).E-mail: sauldt@ig.com.br

\section{Resumo}

O objetivo deste artigo é analisar como e em que medida os nudges, ou os estímulos de comportamento, adotados pelo Estado por meio de políticas públicas, podem conduzir a uma forma mais eficaz de prevenção e combate ao trabalho em condição análoga à de escravo no Brasil. Para tanto, busca-se, mediante pesquisa bibliográfica e documental e utilização do método dedutivo, tratar da Teoria dos Sistemas, com base em Niklas Luhmann, e examinar o uso de nudges com base em políticas públicas. Posteriormente, aborda-se a relação da dignidade da pessoa humana com o trabalho, apresenta-se o conceito de trabalho decente e uma breve contextualização do trabalho escravo contemporâneo. Por fim, tenta-se verificar os reflexos dos nudges estatais, que, para fins deste estudo, se limitam à Lei no 14.946/2013 (Lei Bezerra) e à "lista suja", no comportamento e atuação das empresas no que concerne ao cumprimento das leis trabalhistas. A pesquisa possibilitou constatar que, além dos nudges de combate ao trabalho escravo contemporâneo terem potencial de serem maximizados, a formulação e a implementação de políticas baseadas no nudge como um incentivo, por meio de benefícios advindos da observância das normas trabalhistas e, portanto, da promoção do trabalho decente, propiciaria, mais eficácia do que apenas a prática condenatória. A hipótese desenvolvida no presente estudo implica considerar, de modo consequente, a análise das questões sociais, baseada numa ótica de transversalidade entre as áreas de conhecimentos, na busca da compreensão do problema, a partir da sua complexidade.

Palavras-chave: Nudges. Políticas públicas. Trabalho em condição análoga à de escravo.

\section{Abstract}

The purpose of this article is to analyze how and to what extent nudges, or behavioral stimuli, adopted by the State through public policies, can lead to a more effective prevention and fight against labor in a condition analogous to slavery in Brazil. In order to do this, we search through bibliographic 
and documentary research and use of the deductive method, to deal with systems theory based on Niklas Luhmann and to examine the use of nudges from public policies. Subsequently, the relation between the dignity of the human person and the work is presented, the concept of decent work is presented and a brief contextualization of contemporary slave labor. Finally, we try to verify the reflexes of the state nudges, which for the purposes of this study are limited, Law 14.946 / 2013 (Lei Bezerra) and the "dirty list", in the behavior and performance of companies regarding compliance of labor laws. The research made it possible to verify that besides nudges to combat contemporary slave labor have the potential to be maximized, the formulation and implementation of policies based on nudge as an incentive, through benefits derived from observance of labor standards and, therefore, promotion of decent work, would be more effective than condemnatory practice. The hypothesis developed in the present study implies considering, in a consequent way, the analysis of social issues, based on a perspective of transversality between the areas of knowledge, in the search for understanding, the problem from its complexity.

Keywords: Nudges. Public policy. Working in a condition analogous to slavery.

\section{INTRODUÇÃo}

Um olhar transdisciplinar baseado na abordagem econômica tradicional e na psicologia comportamental revelou que, por trás do processo de tomada de decisões, dos indivíduos podem existir fatores e aspectos latentes ou não detectáveis a nível consciente que efetivamente influenciam nas mais diversas escolhas, individuais e/ou sociais constantes nas vidas das pessoas. Hábitos, experiências pessoais, interesses, necessidades, desejos e emoções, engendram o complexo mosaico do processo decisório.

A arquitetura das escolhas ou nudge implica uma intervenção no desenho de organização de possibilidades de escolha de uma pessoa, que estimula um determinado comportamento, sem, contudo, restringir a liberdade de decisão desta. A proposta de um nudge pode ser concebida de forma privada a fim de se ter alcance individual e/ ou coletivo ou, ainda, por meio de ações governamentais ou políticas públicas para se estimular condutas positivas ou negativas, da sociedade ou de um determinado segmento social específico ou mais genérico.

As políticas públicas podem ser compreendidas como um conjunto de projetos, programas e atividades realizadas pelo governo em nível nacional, regional ou municipal, a fim de se alcançarem determinados objetivos a longo prazo, que concernem sobretudo à efetivação de direitos fundamentais, dos quais se destacam os direitos sociais.

O Estado Brasileiro, por meio de diversos documentos internacionais, se comprometeu a combater a degradação humana, mediante a proibição da escravidão e da servidão, e também a alcançar o emprego pleno e produtivo e o trabalho decente, por meio da adoção de todas as medidas, legislativas e de outras naturezas que sejam viáveis e necessárias a tal intento.

Submeter alguém a trabalho em condição análoga à de escravo é conduta vedada pelo ordenamento jurídico doméstico, com consequência nas esferas penal, civil, administrativa e trabalhista. Verifica-se que um dos fatores mais preponderantes e que evidenciam a insistente recorribilidade dessa prática nefasta é o arcaísmo das relações produtivas, ainda predominante em determinadas regiões do país. Fator que demonstra uma situação em que o Estado, mesmo munido de distintos instrumentos, de repressão e combate ao trabalho análogo à escravidão, não consegue sanar.

Levando-se em consideração a análise das questões sociais e jurídicas sob uma ótica transdisciplinar e o uso de nudges na abordagem das políticas públicas de prevenção e combate a uma prática social complexa e perversa que afronta a dignidade da pessoa humana, como o trabalho análogo à condição de escravo, busca-se discutir os reflexos desse tipo de intervenção no combate ao trabalho escravo contemporâneo por meio da Lei n’ 14.946/2013 (Lei Bezerra) e da "lista suja". 
A escolha de abordar a Lei Bezerra e o Cadastro de Empregadores que tenham mantido trabalhadores em condições análogas à de escravo se deu em razão da verificação de que essas referidas políticas públicas, uma de âmbito nacional (lista suja) e outra de âmbito estadual (Lei Bezerra), podem ser consideradas como autênticos nudges, na medida em que possuem um aspecto preponderante que denota uma abordagem de incentivo, e não apenas de caráter sancionatório, para que sejam observadas as normas trabalhistas.

Sendo assim, objetivou-se neste trabalho investigar como, e em que medida, os nudges, ou os estímulos de comportamento, adotados pelo Estado por meio de políticas públicas podem conduzir a uma forma mais eficaz de prevenção e combate ao trabalho escravo contemporâneo no Brasil.

Com o objetivo aludido, este trabalho se valerá, essencialmente, da pesquisa bibliográfica e documental com base na utilização do método dedutivo. O artigo está divido em três seções. Inicialmente, serão tecidas algumas considerações sobre a teoria dos sistemas baseada em Niklas Luhmann, de modo a verificar a possibilidade - e necessidade — de transversalidade entre as áreas de conhecimento, mormente levando em consideração o uso de nudges, na elaboração e implementação de políticas públicas. Em seguida busca-se apontar a relação da dignidade da pessoa humana com o direito ao trabalho decente, de modo a conceituá-lo e apresentá-lo como o oposto ao trabalho em condição análoga à de escravo, que representa uma afronta àquele.

Por fim, na terceira seção, verificam-se os reflexos dos nudges, criados por mecanismos públicos — que para fins deste estudo se limitam a Lei n 14.946/2013 (Lei Bezerra) e a "lista suja" (ou cadastro público de empregadores que submeteram trabalhadores a condições análogas à de escravo), — no comportamento e atuação das empresas no que concerne ao cumprimento das leis trabalhistas, bem como discorre-se, brevemente, se as políticas públicas pautadas em incentivos decorrentes da observância das normas trabalhistas poderiam ser maximizadas, de modo a principiar a proteção ao trabalhador.

Busca-se como resultado do presente estudo possibilitar uma melhor reflexão sobre o tema, com base na necessidade da transversalidade entre as áreas de conhecimento, e a superação do pensamento mecanicista cartesiano de que o direito basta para resolver os problemas sociais.

\section{TEORIA DOS SISTEMAS E NUDGES}

Para que se consiga analisar, numa visão ampla, a possibilidade do uso de nudges por meio de políticas públicas, é imprescindível o conhecimento prévio de alguns aspectos da teoria que sustenta a transversalidade entre as áreas de conhecimento, como será demonstrado adiante.

\subsection{Breve introdução à teoria dos sistemas de Niklas Luhmann}

Preliminarmente faz-se mister elucidar que o pensamento sistêmico, enquanto procedimento científico, surge contrapondo-se aos métodos científicos clássicos embasados na filosofia mecanicista cartesiana. $\mathrm{O}$ pensamento cartesiano (que influenciou diversos ramos do conhecimento), em síntese, propugnava, a partir de uma supervalorização da razão, a busca por uma verdade incontestável, identificada por meio de uma dúvida, e verificada por meio do método analítico, que pesquisava seu objeto por meio de uma dimensão individualizada, dissociada de seu contexto. ${ }^{1}$

Sob o influxo de vigorosas críticas em relação ao pensamento mecanicista, dentre as quais se destacava a fragilidade de estudos satisfatórios do objeto de pesquisa isolado de seu contorno, e da necessidade de

1 MENEGAZZI, Piero Rosa. A efetivação do direito à informação no meio ambiente de trabalho: contribuições do pensamento sistêmico, da teoria da complexidade e do estudo dos riscos. São Paulo: LTr, 2011. p. 63-64. 
superação desta, entre outras deficiências, surge o pensamento sistêmico, que trabalha com a concepção de que o todo apresenta características não encontradas nas partes que o integram. ${ }^{2}$ Para Menegazzi “o sistema é avesso às divisões analíticas provindas do método cartesiano, sendo que o comportamento do todo não pode ser entendido totalmente com a observância do comportamento de suas partes isoladas"3.

A partir da valorização da ótica sistêmica, até houve a tentativa de formulação de uma teoria geral dos sistemas, com a elaboração de conceitos e noções que seriam válidos para qualquer sistema, independentemente da natureza de seus integrantes e das relações entre estes, ${ }^{4}$ mas, atualmente, pode-se afirmar que não existe propriamente uma teoria geral dos sistemas.

$\mathrm{Na}$ área da sociologia, o sociólogo alemão Niklas Luhmann propõe uma teoria dos sistemas. Esse autor interpreta a sociedade como formada por vários sistemas (série de eventos relacionados um ao outro, ou de operações), sociais comunicativos que geram condições próprias para si e, também, para os outros sistemas ao redor. O sistema é composto por elementos (unidade indecomponível) e pela relação (estrutura). ${ }^{5}$

Seu objeto de estudo é analisado com base no pensamento sistêmico e de uma abordagem transdisciplinar. Ele desenvolve uma teoria que tem como principais influências a teoria de sistemas sociais de Parsons, a fenomenologia de Husserl, a segunda ordem da cibernética de Heinz e Foerters e o conceito de autopoiesis da biologia desenvolvida por Maturana e Varela; bem como o cálculo de distinção de Spencer Brown ${ }^{6}$.

O sistema teórico da teoria dos sistemas aloca para o interior das ciências sociais conceitos da biologia, como já citado, da psicologia, da economia, da Teoria da Comunicação, da cibernética, utilizando-os no estudo dos fenômenos sociais.

Luhmann classifica, a partir da abordagem sistêmica, três tipos de sistemas: biológicos, psíquicos e sociais. Os modos de operação e reprodução de cada um deles implicam, respectivamente, para a vida, a consciência e a comunicação ${ }^{7}$. O que revela qualquer um desses sistemas não possui, de forma isolada, condão de compreender o mundo e suas interfaces. Cada sistema compreende a si próprio. A Teoria dos Sistemas Sociais tem como principal fator em comum o fato de sua operação básica ser a comunicação.

A Teoria dos Sistemas toma como ponto inicial um princípio de diferenciação. Luhmann elucida que "o sistema não é meramente uma unidade, mas uma diferença". ${ }^{8}$ A diferenciação do sistema não significa a decomposição de um todo em partes, mas da diferenciação de diferenças sistema/entorno. ${ }^{9}$

Faz-se mister a ilustração da concepção de autopoiesis, que para Luhmann "significa que o sistema se produz a si mesmo, além de suas estruturas". ${ }^{10}$ Isto significa que um sistema, qualquer que seja, autoproduz-se e se autocompleta, retirando de seus próprios elementos os meios necessários para evoluir. $\mathrm{O}$ autor ainda destaca que um sistema autopoiético produz as operações necessárias para realizar mais operações, servindo-se da rede de suas próprias operações, sem jamais suprimir a si próprio.

2 MENEGAZZI, Piero Rosa. A efetivação do direito à informação no meio ambiente de trabalbo: contribuições do pensamento sistêmico, da teoria da complexidade e do estudo dos riscos. São Paulo: LTr, 2011. p. 66.

3 MENEGAZZI, Piero Rosa. A efetivação do direito à informação no meio ambiente de trabalbo: contribuições do pensamento sistêmico, da teoria da complexidade e do estudo dos riscos. São Paulo: LTr, 2011. p. 67.

4 MENEGAZZI, Piero Rosa. A efetivação do direito à informação no meio ambiente de trabalho: contribuições do pensamento sistêmico, da teoria da complexidade e do estudo dos riscos. São Paulo: LTr, 2011. p. 68-69.

5 LUHMANN, Niklas. Introdução à teoria dos sistemas. 3. ed. Petrópolis: Vozes, 2011.

6 SEIDL, D.; BECKER, K. H. Organizations as Distinction Generating and Processing Systems: Niklas Luhmann's Contribution to Organization Studies. Organizations. Sage Journal, v. 13, n. 1, p. 9-35, 2006. Disponível em: <http://journals.sagepub.com/doi/ pdf/10.1177/1350508406059635>. Acesso em: 9 maio 2018.

7 BARONE, Fernando. Sociedade e escola: Niklas Luhmann e a abordagem sistêmica. Ponto e vírgula - Revista das Ciências Sociais, São Paulo, n. 12, p. 5-32, 2013. Disponível em: <https://revistas.pucsp.br/index.php/pontoevirgula/article/viewFile/12678/12310>. Acesso em: 20 maio 2018.

8 LUHMANN, Niklas. Introdução à teoria dos sistemas. 3. ed. Petrópolis: Vozes, 2011. p. 101.

9 KUNZLER, Caroline de Morais. A teoria dos sistemas de Nicklan Luhmann. Estudos de Sociologia, Araraquara, v. 16, p. 123-136, 2004. Disponível em: <https://periodicos.fclar.unesp.br/estudos/article/viewFile/146/144>. Acesso em: 20 maio 2018 . p.123.

10 LUHMANN, Niklas. Introdução à teoria dos sistemas. 3. ed. Petrópolis: Vozes, 2011. p. 113. 
O sistema não tem uma estrutura imutável que enfrenta um ambiente complexo. É condição para esse enfrentamento que o próprio sistema transforme-se internamente, criando subsistemas, deixando de ser simples e tornando-se mais complexo, ou seja, evoluindo. Cada um desses subsistemas criados dentro do sistema tem o seu próprio entorno ${ }^{11}$.

Pela Teoria Sistêmica de Luhmann, o direito é um sistema funcionalmente diferenciado da sociedade, cuja função é manter estável as expectativas, ainda que estas sejam frustradas na prática. Essas expectativas são as normas jurídicas, que, assim, permanecem estáveis independentemente de uma eventual violação ${ }^{12}$.

Para o referido autor, o direito, por meio do seu sistema jurídico, faz emergir subsistemas internamente distintos, subsistemas estes que se conectam com outros sistemas (relacionados muitas vezes a outras áreas do saber). O direito, na medida em que reconhece, produz e soluciona conflitos pode ser considerado, levando em consideração a complexidade de sua estrutura, como normativamente fechado e cognitivamente aberto (na medida em que é estimulado pelo próprio ambiente).

Outra concepção que merece destaque quanto à Teoria dos Sistemas é a comunicação. Considerada como o limite da sociedade, a ela é atribuído o papel de reprodução do sistema social. Para o presente trabalho, faz-se imprescindível mencionar a comunicação jurídica, a qual, segundo Andaku, existe toda vez que, havendo controvérsia, alguém reivindique seus direitos e, com isso, a normatividade vigente deve decidir quem possui a razão pelo código da licitude. Nesse sentido, denota-se que o direito é um sistema que resolve os conflitos, mas, ao mesmo tempo, cria outros mediante sua estrutura interna no processo de autopoieses. ${ }^{13}$

Partindo dessas considerações sobre concepções bases da Teoria dos Sistemas, que não se propôs a tecer toda a complexidade do desenho da Teoria de Luhmann, verificar-se-á a transdisciplinaridade entre as áreas das ciências.

\subsubsection{A economia comportamental e o direito}

Com base na Teoria dos Sistemas, vem se verificando, nos estudos científicos, uma tendência de atuação transdisciplinar entre as áreas do conhecimento. Uma nova ótica que vem permite uma melhor compreensão da realidade social e a elaboração de instrumentos políticos que possibilitam resultados mais efetivos para a sociedade.

Para aclarar melhor essa transdisciplinaridade, pode-se verificar a interface entre direito e economia, que possibilitou a gênese da Análise Econômica do Direito (AED), considerada uma área emergente do direito que pressupõe a aplicação da Teoria Econômica para analisar institutos jurídicos e políticas públicas.

A análise econômica do direito parte da premissa de que as pessoas são racionais e reagem aos incentivos a que estão sujeitas. Analisam custos de transação para realizar seus próximos passos; de modo que tomam decisões de acordo com os custos e benefícios. Essa escolha racional pode ser compreendida como a ponderação, uma análise cuidadosa das vantagens e dos respectivos custos, quando o indivíduo exercita a tomada de decisão.

Para Tabak "a existência de custos de transação relevantes podem levar a economia a ficar aquém do seu potencial - revelando ineficiências importantes que, na ausência desses custos, poderiam ser eliminadas”. Essa lógica econômica acaba sendo aplicada quando se trata de direitos trabalhistas. Levando em consideração e relacionando o problema jurídico em questão, percebe-se que muitas empresas, ainda, consideram

11 KUNZLER, Caroline de Morais. A teoria dos sistemas de Nicklan Luhmann. Estudos de Sociologia, Araraquara, v. 16, p. 123-136, 2004. Disponível em: <https://periodicos.fclar.unesp.br/estudos/article/viewFile/146/144>. Acesso em: 20 maio 2018 . p. 125.

12 ANDAKU, Juliana Almenara. O direito na teoria de Niklas Lubmann. Disponível em: <www.agu.gov.br/page/download/index/ id/692917>. Acesso em: 21 maio 2018.

13 ANDAKU, Juliana Almenara. O direito na teoria de Niklas Lubmann. Disponível em: <www.agu.gov.br/page/download/index/ id/692917>. Acesso em: 21 maio 2018. 
o custo-benefício do trabalho análogo ao escravo mais viável e/ou rentável que o cumprimento das leis trabalhistas. Acreditam que o cumprimento dessas leis as deixariam aquém do seu melhor potencial de lucro. As reiteradas escolhas de menores custos e maiores benefícios possíveis trouxe muitas mudanças na organização produtiva do mundo do trabalho e uma consequência nefasta para os direitos trabalhistas: o dumping social.

Contrariamente a análise econômica do direito, a Análise Econômica Comportamental do Direito considera que os indivíduos não tomam decisões baseados, exclusivamente, na racionalidade, mas em aspectos que às vezes podem fazer com que tomem escolhas contrárias aos seus interesses e até mesmo ao seu próprio bem-estar. Essa abordagem demonstra que há mecanismos emocionais e cognitivos, muitas vezes inconscientemente, que estão por trás das escolhas e decisões das pessoas.

A análise econômica comportamental pode ser compreendida como a disciplina "que busca seus fundamentos principalmente na área da Psicologia tentando explicar a motivação dos fenômenos que causam um desvio da atitude humana esperada, considerando-se o ser humano como um ser racional”"14.

Diferentemente da perspectiva de racionalidade exacerbada da análise econômica do direito, a Economia Comportamental enxerga uma realidade formada por pessoas que decidem com base em hábitos, experiências pessoais e regras práticas simplificadas. Aceitam soluções, apenas, satisfatórias, tomam decisões rapidamente e têm dificuldade de conciliar interesses de curto e longo prazo; além disso, são fortemente influenciadas por fatores emocionais e pelas decisões daqueles com os quais interagem ${ }^{15}$.

Com base em tais pressupostos, destaca-se que a análise econômica comportamental do direito tem evoluído na Teoria da Arquitetura das Escolhas (que é um instituto próprio da análise econômica comportamental do direito), conforme será verificado no item 3.1. Entes privados e o próprio Estado, ambos cientes que vieses, comportamentos e ambiente impactam as escolhas dos indivíduos, melhoram a disposição das escolhas para possibilitarem mais chances da tomada de decisões favoráveis aos interesses das pessoas ou aos seus próprios interesses.

A análise econômica comportamental do direito tem exercido na atualidade um papel basilar quanto à formulação e implementação de políticas públicas — que, por razão dos fins desta pesquisa, se limitam à Lei n 14.946/2013 (Lei Bezerra) e à "lista suja" - se configurando como uma das principais áreas da ciência, responsável pela criação e adoção de novas leis que leva em conta a racionalidade limitada ou "enviesada" das pessoas ${ }^{16}$, possibilitando a elas a realização de escolhas melhores, que maximizem sua utilidade, de forma menos invasiva. ${ }^{17}$

Antes o exposto, denota-se que a criação e a implementação de políticas públicas com mais possibilidade de eficácia não podem ser guiadas por uma análise que desconsidere os fundamentos e as ferramentas fornecidas pela transversalidade entre a Econômica Comportamental e o Direito.

14 SCALEA, José Augusto; TABAK, Benjamin Miranda. Direito de propriedade intelectual: formas de proteção, seu impacto no desenvolvimento econômico e propostas para sua melhoria. Revista de Direito Econômico e Socioambiental, Curitiba, v. 7, n. 2, p. 154174, jul./dez. 2016. Disponível em: <https://periodicos.pucpr.br/index.php/direitoeconomico/article/view/5837>. Acesso em: 30 abr. 2018. p. 157.

15 SANSON apud ÁVILA, Flávia; BIANCHI, Ana Maria. Guia de economia comportamental e experimental. São Paulo: economia comportamental.org., 2015. p. 14.

16 SCALEA, José Augusto; TABAK, Benjamin Miranda. Direito de propriedade intelectual: formas de proteção, seu impacto no desenvolvimento econômico e propostas para sua melhoria. Revista de Direito Econômico e Socioambiental, Curitiba, v. 7, n. 2, p. 154174, jul./dez. 2016. Disponível em: <https://periodicos.pucpr.br/index.php/direitoeconomico/article/view/5837>. Acesso em: 30 abr. 2018.

17 O paternalismo libertário é o ponto médio entre o liberalismo (que propõe a intervenção mínima do Estado) e o paternalismo coercitivo. Mantém a possibilidade de escolhas, mas incentiva a escolha adequada. O Estado dá um empurrão (nudge) para a escolha certa. THALER, Richard H; SUNSTEIN, Cass R. Nudge: o empurrão para a escolha certa: aprimore suas decisões sobre saúde, riqueza e felicidade. Rio de Janeiro: Elsevier, 2009. 


\subsection{Nudges, arquitetura de escolhas e políticas públicas}

Pôde-se verificar que é possível utilizar a Teoria Econômica e a Comportamental não apenas para analisar institutos jurídicos e políticas públicas, mas também para aumentar a eficiência de comportamentos que deveriam ser adotados por indivíduos, pela sociedade ou um determinado segmento social. Esse item do presente estudo busca verificar como os mecanismos públicos podem dirigir comportamentos a fim de se influenciar as escolhas e obter resultados desejáveis (sob o prisma dos governos).

\subsubsection{Nudges e a arquitetura das escolhas}

Nos últimos anos, o termo "arquitetura das escolhas", cunhado por Richard h. Thaler e Cass R. Sunstein, na obra Nudge: Improving Decisions about Health, Wealth and Happiness (2008), tornou-se comum em várias áreas das ciências. Um olhar transdisciplinar baseado na abordagem econômica tradicional e na psicologia comportamental revelou que, por trás do processo de tomada de decisões das pessoas, existem fatores e aspectos latentes ou não detectáveis a nível consciente que, efetivamente, decidem as escolhas destas, ainda que essas escolhas caminhem ao desencontro dos seus próprios interesses.

A arquitetura das escolhas ou nudge é uma teoria que pode ser conceituada como uma intervenção no desenho de organização de possibilidades de escolha de uma pessoa, que estimula um determinado comportamento, sem, contudo, restringir a liberdade de decisão desta.

Os proponentes dessa teoria pregam sua aplicabilidade nas mais diversas situações da vida. Um nudge pode ser produzido, de forma privada, a fim de se ter alcance individual e/ou coletivo ou, ainda, por meio de mecanismos públicos ou políticas públicas para se estimular condutas positivas ou negativas da sociedade ou de um determinado segmento social.

Nudge é uma palavra da Língua Inglesa que, segundo o Cambridge dictionary ${ }^{18}$, significa empurrar ou cutucar. Sustein ${ }^{19}$ define nudge como uma intervenção que preserva a liberdade de escolha, ainda que possa influenciar a tomada de decisão ${ }^{20}$. Ambrosino, et al. entendem que o nudge "refere-se à ideia que o comportamento das pessoas pode ser suave ou gentilmente empurrado para um certo curso de ação" 21 . O nudge não visa coagir, mas induzir, influenciar a tomada de decisão.

As escolhas que os seres humanos tomam não são totalmente livres: alguém ou algo está, de alguma forma, influenciando as decisões que são tomadas por cada pessoa ${ }^{22}$. Ademais, todos em maior ou menor proporção realizam escolhas diariamente, sobre uma infinidade de fatos que variam em grau de complexidade. Escolhe-se desde a roupa que se vestirá ao alimento que será ingerido e, independentemente de nossas decisões, sempre sofreremos as consequências de nossas escolhas.

Ocorre, todavia, que podemos escolher de forma equivocada. Levando em consideração que não escolhemos somente com base na racionalidade. A economia comportamental adota como premissa a tese de que o ser humano é conduzido por dois sistemas: o primeiro deles é automático, responsável pelas avalia-

18 CAMBRIDGE INTERNATIONAL. Dictionary of English. New York: CUP, 2000.

19 THALER, Richard H.; SUNSTEIN, Cass R. Nudge: o empurrão para a escolha certa: aprimore suas decisões sobre saúde, riqueza e felicidade. Rio de Janeiro: Elsevier, 2009. Disseminou o conceito de que o comportamento das pessoas pode ser influenciado por incentivos.

20 SUNSTEIN, Cass R. Nudging: a very short guide. p. 1. Disponível em: < https://papers.ssrn.com/sol3/papers.cfm?abstract_ id $=2499658>$. Acesso em: 29 abr. 2018.

21 AMBrosinO, A. Faralla V.; NOVARESE, M. Nudge: a critical perspective. In: MARCIANO, A.; RAMELLO, G. (Eds.). Enciclopédia de Direito e Economia. New York: Springer, 2018. Disponível em: <https://doi.org/10.1007/978-1-4614-7883-6_631-1>. Acesso em: 30 abr. 2018.

22 FRANCO, Claudia Regina Lovato; TABAK, Benjamim Miranda; BIJOS, Leila. A lei no 14.946/2013 (lei bezerra): um nudge para incentivar empresários do setor de confecção da indústria paulista a cumprirem as leis trabalhistas. Revista de Direito Brasileira, São Paulo, v. 16, n. 7, p. 346-362, jan./abr. 2017. p.354 
ções básicas e intuitivas; e o segundo é reflexivo e intencional responsável pelas construções mentais mais elaboradas e demoradas. Thaler e Sunstein elucidam:

Uma maneira de pensar sobre tudo isso é a de que o Sistema automático é a sua reação instintiva, enquanto o Sistema reflexivo é seu pensamento consciente. Os impulsos instintivos podem ser bastante precisos, mas muita vezes cometemos erros porque confiamos demais em nosso sistema automático. O sistema automático diz: "O avião está balançando, vou morrer", enquanto o sistema reflexivo reage: "Aviões são muito seguros!"’33

O ser humano acaba utilizando muito mais o sistema automático e isso interfere, indubitavelmente, na qualidade de suas escolhas. Partindo-se dessas considerações, Thaler e Sunsteim desenvolvem a Teoria da Arquitetura das Escolhas ou nudging, que defende que é possível a organização do contexto no qual as pessoas tomam decisões, com objetivo de influenciá-las de forma previsível pela ciência.

A partir do exame das escolhas, levando-se em consideração um estudo holístico de perspectivas e da análise de escolhas passadas como uma via produtiva na tomada de decisões com a elaboração da arquitetura das escolhas, é possível ajudar as pessoas a fazerem melhores escolhas, pois não há escolhas totalmente livres: alguém ou algo está, de alguma forma, influenciando as decisões que tomamos ${ }^{24}$.

Mister se faz destacar que os nudges preservam uma margem considerável de liberdade de escolha, seja elaborado de forma privada ou por entes governamentais. Todavia quando se trata de mecanismos públicos, qualquer cutucada oficial (nudge) deve ser transparente e aberta em vez de oculta e encoberta. A transparência deve ser sempre incorporada à prática básica ${ }^{25}$.

Partindo-se dessas considerações e das contribuições da análise econômica comportamental do direito, mormente no que concerne ao estudo dos fatores que influenciam as escolhas e as decisões das pessoas, verificar-se-á como os nudges podem ser elaborados sob o prisma governamental.

\subsubsection{Nudges e políticas públicas}

O Estado pode formular nudges, ou estímulos de comportamento por meio da elaboração de leis, políticas públicas ou outras medidas governamentais. As políticas públicas podem ser compreendidas com base em duas vertentes: uma que encara a política pública como um processo de decisão em que há conflito de interesses e outra que decorre do ponto de vista administrativo, ou seja, que entende as políticas públicas como conjunto de projetos, programas e atividades realizadas pelo governo em nível nacional, regional ou municipal a fim de se alcançar determinados objetivos em longo prazo ${ }^{26}$.Essa pesquisa aborda as políticas públicas a partir da segunda vertente. ${ }^{27}$

Brancaleon, et al. explicam que a política pública possui dois elementos fundamentais: a) Intencionalidade pública, ou seja, a motivação para o estabelecimento de ações para tratamento ou para resolução de

23 THALER, Richard H; SUNSTEIN, Cass R. Nudge: o empurrão para a escolha certa: aprimore suas decisões sobre saúde, riqueza e felicidade. Rio de Janeiro: Elsevier, 2009. p. 23.

24 FRANCO, Claudia Regina Lovato; TABAK, Benjamim Miranda; BIJOS, Leila. A lei no 14.946/2013 (lei bezerra): um nudge para incentivar empresários do setor de confecção da indústria paulista a cumprirem as leis trabalhistas. Revista de Direito Brasileira, São Paulo, v. 16, n. 7, p. 346-362, jan./abr. 2017. p.354.

25 SUNSTEIN, Cass R. Nudging: a very short guide. p. 2. Disponível em: < https://papers.ssrn.com/sol3/papers.cfm?abstract_ id $=2499658>$. Acesso em: 29 abr. 2018.

26 BRANCALEON, Brigida Batista et. al. Políticas públicas: conceitos básicos. São Paulo: Universidade de São Paulo, 2015.

27 Neste mesmo sentido discorre Bruno Santos Cunha, para quem o termo políticas públicas deve ser utilizado como programa de ação governamental consistente em um conjunto estruturado de normas e atos com finalidade predeterminada. Disso decorre a necessidade de se pensar, cada vez mais, o horizonte jurídico atrelado à esfera política, traçando laços entre tais patamares que ensejem a criação e formatação de um subsistema que verdadeiramente possa administrar a implementação das referidas políticas de acordo com os ditames teórico-constitucionais. CUNHA, Bruno Santos. Direitos fundamentais: da constituição às políticas públicas. Rev. Bras. Políticas Públicas, Brasília, v. 1, n. 1, p. 65-82, jan./jun. 2011. p. 72. 
um problema; b) Problema público ${ }^{28}$. Isso denota que a motivação da elaboração da política pública não precisa ter gênese somente no Estado, mas também com base em entidades privadas, desde que tenham interesse em dirimir um problema público. Souza sintetiza, entre diversos modelos sobre políticas públicas, seus principais elementos:

A política pública permite distinguir entre o que o governo pretende fazer e o que, de fato, faz. A política pública envolve vários atores e níveis de decisão, embora seja materializada através dos governos, e não necessariamente se restringe a participantes formais, já que os informais são também importantes. A política pública é abrangente e não se limita a leis e regras. A política pública é uma ação intencional, com objetivos a serem alcançados. A política pública envolve processos subsequentes após sua decisão e proposição, ou seja, implica também implementação, execução e avaliação. ${ }^{29}$

Com isso se percebe que a política pública pode ser compreendida como uma ação multifacetada, com objetivos a longo prazo, que compreendem as fases de formação da agenda, formulação, implementação, execução e avaliação da política. Partindo-se dessas considerações, verificaremos a possibilidade da elaboração de nudges por meio de políticas públicas.

Para Thaler e Sunsteim, a vantagem do nudge em relação a ações mais impositivas ou processos regulatórios é a preservação do máximo da autonomia e da liberdade de escolha das pessoas. Esses autores propuseram, em sua obra conjunta, "Nudge: o empurrão para a escolha certa" um dos principais esforços para incorporar as noções da economia comportamental no processo regulatório - a Teoria do Paternalismo Libertário, que pode ser compreendida como um tipo de intervenção estatal mais leve, menos intrusiva, mas que incentiva comportamentos em determinada direção. Para eles o aspecto libertário se refere à liberdade do sujeito de fazer o que quiser e ter opção de sair de arranjos não desejados se assim o quiser, e o aspecto paternalista consiste na possibilidade que o arquiteto de escolhas tem, de tentar influenciar o comportamento de pessoas, a fim de tornar sua vida mais longa, saudável e melhor ${ }^{30}$. Nesse sentido lecionam:

É verdade que algumas cutucadas são propriamente descritas como uma forma de paternalismo "porque orientam as pessoas em uma determinada direção. Mas mesmo quando é assim, esses toques são especificamente projetados para preservar a total liberdade de escolha. Um, gps, guia uma pessoa em uma determinada direção, mas a pessoa têm a liberdade de selecionar sua própria rota ${ }^{31}$.

Isso significa que é possível que um Estado menos intervencionista possa auxiliar seus cidadãos a realizarem melhores escolhas. Mas ele por si não o faz ${ }^{32}$. Ademais os nudges elaborados pelo Estado, conforme elucida Sunstein,

Devem ser transparentes e abertos ao invés de ocultos e encobertos. De fato, a transparência deve ser incorporada à prática básica. Suponha que um governo (ou um empregador privado) adota um programa que automaticamente registra pessoas em um programa de pensão, ou suponha que uma grande instituição (digamos, uma cadeia de lojas privadas, ou aqueles que dirigem cafeterias em prédios do governo) decide tornar os alimentos saudáveis mais visíveis e acessíveis. Em ambos os casos, a ação relevante não deve ser escondida de qualquer forma. As decisões do governo, em particular, devem ser sujeito ao escrutínio público e revisão. Uma vantagem principal dos toques ou cutucadas, em oposição

28 BRANCALEON, Brigida Batista et. al. Políticas públicas: conceitos básicos. São Paulo: Universidade de São Paulo, 2015. p.2.

29 SOUZA, C. Política Públicas: uma revisão da literatura. Sociologias, Porto Alegre, ano 8, n. 16, p. 20-45, jun./dez. 2006. Disponível em: <http://www.scielo.br/pdf/soc/n16/a03n16>. Acesso em: 15 abr. 2018.

30 THALER, Richard H; SUNSTEIN, Cass R. Nudge: o empurrão para a escolha certa: aprimore suas decisões sobre saúde, riqueza e felicidade. Rio de Janeiro: Elsevier, 2009. p. 5.

31 SUNSTEIN, Cass R. Nudging: a very short guide. p. 2. Disponível em: < https://papers.ssrn.com/sol3/papers.cfm?abstract_ id $=2499658>$. Acesso em: 29 abr. 2018.

32 "O paternalismo libertário é um tipo de paternalismo relativamente fraco, brando e não intrusivo porque as escolhas não são bloqueadas, obstruídas ou significativamente sobrecarregadas. Se as pessoas quiserem fumar, comer um monte de doces ou não poupar, os paternalistas libertários não as forçarão para que mudem de comportamento. No entanto, a abordagem recomendada pelos autores conta como paternalista porque arquitetos de escolhas públicos e privados não estão simplesmente tentando rastrear ou implementar as previsões de escolhas das pessoas. Ao revés, estão conscientemente tentando guiar as pessoas em direções que irão melhorar a vida delas. FERREIRA, Felipe Furtado; POTTUMATI, Eduardo Carlos. A licitação pública como instrumento de desenvolvimento na perspectiva do paternalismo libertário. Rev. Bras. Políticas Públicas, Brasília, v. 4, n. 1, p. 201-215, jan./jun. 2014. p. 213. 
aos mandatos e proibições, é que eles evitam a coerção. ${ }^{33}$

Verifica-se, portanto, que, quando se tratar de um nudge formulado pelo Estado, ele deve ser aplicado com total transparência. Outrossim, quando for esse caso, Sunstein aclara que é extremamente importante confiar nas evidências em vez de intuições, anedotas, pensamentos desejosos ou dogmas. O mais eficaz é que se submeta os nudges a testes empíricos, que reflitam uma compreensão realista de como as pessoas responderão às iniciativas do governo. ${ }^{34}$

Sunstein destaca as cutucadas ou nuddges mais importantes para fins de política: a) regras padrão (por exemplo, inscrição automática em programas, incluindo educação, saúde, poupança); b) simplificação das formas e procedimentos (em parte para promover a aceitação de programas existentes); c) usos de normas sociais (enfatizando o que a maioria das pessoas faz, para reforçar um comportamento desejado); d) aumento da facilidade e conveniência (por exemplo, fazendo opções de baixo custo ou alimentos saudáveis visíveis); e) divulgação (por exemplo, os custos econômicos ou ambientais associados ao uso de energia); f) avisos, gráficos ou outros (como para cigarros); g) estratégias de pré-comprometimento (pelas quais as pessoas se comprometem a certa ação); h) lembretes (por exemplo, por e-mail ou mensagem de texto, como por contas em atraso e próximas obrigações ou nomeações); i) indução de intenções de implementação (por exemplo uma pesquisa que busca investigar: "você planeja votar?" - É mais provável que as pessoas se envolvam em atividades se alguém provocar intenções de implementação) j) informando as pessoas sobre a natureza e consequências de seu próprio passado de escolhas. ${ }^{35}$

Utilizando-se de uma dessas formas de empurrão na arquitetura das escolhas sociais, o Estado pode elaborar vários nudges, que conduzam previnam ou desestimulem determinados comportamentos.

\section{A relaÇão entre O trabalHo E A PROMOÇÃo da dignidade hUMANA}

Nessa seção abordaremos institutos de direito, para que a seguir possamos analisar como e em que medida os nudges, ou os estímulos de comportamento, adotados pelo Estado por meio de políticas públicas podem conduzir a uma forma mais eficaz de prevenção e combate ao trabalho análogo ao escravo no Brasil.

A escravidão, em todas as suas formas, representa o desrespeito a direitos fundamentais e difusos da sociedade, consagrados na Carta Magna, tais como: a proteção à dignidade da pessoa humana (art. $1^{\circ}$, III); os valores sociais do trabalho e da livre iniciativa (artigo $1^{\circ}$, IV); a construção de uma sociedade livre, justa e solidária (art. $3^{\circ}$. I); a inviolabilidade do direito à vida, à liberdade, à igualdade, à segurança (art. $5^{\circ}$, caput); o princípio da legalidade (art. $\left.5^{\circ}, \mathrm{II}\right)$; não submissão à tortura ou a tratamento desumano ou degradante (art. $\left.5^{\circ}, \mathrm{III}\right)$; a inviolabilidade da intimidade, da vida privada, da honra e da imagem (art. 5० $\mathrm{X}$ ); a liberdade de exercício de trabalho, ofício ou profissão (art. $5^{\circ}$, XIII); a liberdade de locomoção (art. $5^{\circ}$, XV); a função social da propriedade (art. $5^{\circ}$, XXIII); a proibição de imposição de pena de trabalhos forçados e cruéis (art. $\left.5^{\circ}, \mathrm{XLVI}\right)$; e a proibição de prisão civil por dívida (art. $5^{\circ}$, LXVII). ${ }^{36}$

Com isso, faz-se necessário explanar a relação da dignidade humana com o trabalho decente, para em seguida demonstrar que a antítese deste é o trabalho em condição análoga à de escravo, crime positivado no Código Penal brasileiro.

33 SUNSTEIN, Cass R. Nudging: a very short guide. p. 4. Disponível em: < https://papers.ssrn.com/sol3/papers.cfm?abstract_ id $=2499658>$. Acesso em: 29 abr. 2018.

34 SUNSTEIN, Cass R. Nudging: a very short guide. p. 5. Disponível em: < https://papers.ssrn.com/sol3/papers.cfm?abstract_ $\mathrm{id}=2499658>$. Acesso em: 29 abr. 2018.

35 SUNSTEIN, Cass R. Nudging: a very short guide. p. 3-6. Disponível em: < https://papers.ssrn.com/sol3/papers.cfm?abstract_ id $=2499658>$. Acesso em: 29 abr. 2018.

36 BRASIL. Constituição (1988). Constituição da República Federativa do Brasil. Disponívelem:<http://www.planalto.gov.br/ccivil_03/constituicao/constituicao.htm>. Acesso em: 8 maio 2018. 


\subsection{O direito ao trabalho digno}

Kant afirmou a necessidade de distinção entre coisas que não possuem dignidade, correspondentes àquelas que possuem um preço de modo que podem ser facilmente substituídas por outras, e aquelas que possuem dignidade, ou seja, coisas que estão acima de qualquer preço. Com base nisso, o autor preconizava que a humanidade deveria ser usada sempre "como fim e nunca simplesmente como meio". ${ }^{37}$

Diante das inúmeras transformações ocorridas no decorrer da história, Sarlet propõe uma atualização do clássico conceito de dignidade da pessoa humana, resultando na assertiva de que essa é qualidade inerente de cada pessoa que a faz merecedora de respeito tanto por parte da comunidade quanto do Estado, de maneira a resultar num "complexo de direitos e deveres fundamentais" que garanta o indivíduo contra qualquer ato "degradante e desumano", ou lhe assegure as condições mínimas para uma vida sadia, e ainda na viabilização e promoção da "participação ativa e corresponsável deste nos destinos da própria existência e da vida em comunhão com os demais seres humanos, mediante o devido respeito aos demais seres que integram a rede da vida". ${ }^{38}$

Haja vista a ideia transcrita, já é possível defender que a promoção e proteção da dignidade da pessoa humana requer a observância do direito ao trabalho (e do direito do trabalho). Tal assertiva é corroborada em relação à leitura do artigo 23 da Declaração Universal dos Direitos Humanos de 1948, que deixa positivada a relação versada.

Isso pois, como bem argumenta Miraglia, o trabalho deve ser "instrumento" de promoção da dignidade humana, proporcionando meios para que seja possível a inserção efetiva do trabalhador na "sociedade capitalista" $" 39$.

No âmbito nacional, o explanado possui amparo na Constituição Federal de 1988, que reconhece o direito ao trabalho como jusfundamental em seu artigo $6^{\circ}$, caput, o qual está situado no título II, referente aos direitos fundamentais, que possuem por escopo a promoção e proteção dos fundamentos basilares da República, do Estado Democrático de Direito, qual seja, da dignidade humana, dos valores sociais do trabalho, entre outros, conforme se depreende do artigo $1^{\circ}$ do documento em voga.

Nessa esteira, cumpre ressaltar que, em junho de 1998, a Organização Internacional do Trabalho (OIT) adotou a Declaração de Princípios e Direitos Fundamentais do Trabalho, a qual estabelece, em seu artigo $2^{\circ}$, que todos os membros da OIT, mesmo os que não tenham ratificado convenções específicas, possuem o compromisso de respeitar os princípios relativos aos direitos fundamentais do trabalho, quais sejam: (a) a liberdade sindical e o reconhecimento efetivo do direito de negociação coletiva; (b) a eliminação de todas as formas de trabalho forçado ou obrigatório; (c) a efetiva abolição do trabalho infantil; e (d) a eliminação da discriminação em matéria de emprego e ocupação. ${ }^{40}$

Os princípios mencionados acima surgem como a base do que virá a ser reconhecido pela OIT como trabalho decente. ${ }^{41}$

Em 1999 surge, então, o conceito do trabalho decente formulado pela OIT, que funciona como a síntese dos objetivos da Organização, a qual possui como missão a promoção do trabalho produtivo e de quali-

37 KANT, Immanuel. Fundamentação da metafísica dos costumes. Lisboa: Edições 70, 2007. p. 69-77.

38 SARLET, Ingo Wolfgang. Dignidade da pessoa bumana e direitos fundamentais na Constituição Federal de 1988. 9. ed. Porto Alegre: Livraria do Advogado, 2012. p. 73.

39 MIRAGLIA, Lívia Mendes Moreira. Trabalho escravo contemporâneo: conceituação à luz do princípio da dignidade da pessoa humana. São Paulo: LTR, 2011. p. 88.

40 ORGANIZAÇÃO INTERNACIONAL DO TRABALHO. Declaração da OIT sobre os princípios e direitos fundamentais no trabalho e seu segmento. Disponível em:<http://www.oit.org.br/sites/default/files/topic/international_labour_standards/pub/declaracao_ oit_293.pdf>. Acesso em: 01 maio 2018.

41 ORGANIZAÇÃO INTERNACIONAL DO TRABALHO. Trabalho decente no Brasil. Disponível em: < http://www.ilo.org/ brasilia/temas/trabalho-decente/lang--pt/index.htm>. Acesso em: 01 mai. 2018. 
dade, em condições de liberdade, equidade, segurança e dignidade humanas, considerado como condição fundamental para a superação da pobreza, a redução das desigualdades sociais, a garantia da governabilidade democrática e o desenvolvimento sustentável. ${ }^{42}$

Portanto, para a OIT, o trabalho decente "é um trabalho produtivo e adequadamente remunerado, exercido em condições de liberdade, equidade e segurança, e que garanta uma vida digna a todas as pessoas que vivem do trabalho e a suas famílias", ou seja, "permite satisfazer às necessidades pessoais e familiares de alimentação, educação, moradia, saúde e segurança". Pode ser entendido também como "emprego de qualidade, seguro e saudável, que respeite os direitos fundamentais do trabalho, garanta proteção social quando não pode ser exercido [...] e assegure uma renda para a aposentadoria". A OIT destaca que o trabalho decente está relacionado à dignidade humana. ${ }^{43}$

Sendo assim, o que se verifica é que o trabalho decente "é aquele em que são respeitados os direitos mínimos do trabalhador, necessários à preservação de sua dignidade"44, vislumbrando desenvolvimento equitativo e integrador, o progresso social e a redução da pobreza. Insta frisar que, para Wandelli, o trabalho decente "representa um padrão mínimo de proteção e não um conceito ótimo ou ideal de trabalho". ${ }^{45}$

Com isso, o acesso ao direito fundamental ao trabalho só pode ser tido concretizado, nos casos em que há a observância às condições mínimas de dignidade do trabalhador, ou seja, na promoção do trabalho decente. Face do discorrido, pode-se asseverar que o trabalho decente é a antítese do trabalho escravo contemporâneo, tema que será abordado a seguir.

\subsection{Trabalho escravo contemporâneo}

O termo "escravidão" é tradicionalmente compreendido como submissão de um indivíduo a outro. O primeiro tratado internacional proibindo a escravidão, firmado pela Liga das Nações Unidas, de 1926, define a escravidão como "o estado e a condição de um indivíduo sobre o qual se exercem, total ou parcialmente, alguns ou todos os atributos do direito de propriedade". ${ }^{46}$

No entanto, o referido conceito sofreu alterações passando a ter mais abrangência, cujas violações aos direitos humanos são expressamente combatidas pelo direito internacional, para o qual não há exceções, como assevera Piovesan:

A proibição do trabalho escravo é absoluta no Direito Internacional dos Direitos Humanos, não contemplando qualquer exceção. Vale dizer, em nenhum caso poderão invocar-se circunstâncias excepcionais, como ameaça ou estado de guerra, instabilidade política interna ou qualquer outra emergência pública, como justificativa par ao tratamento escravo. Tal proibição integra o jus cogens, que é o direito cogente e inderrogável no âmbito internacional. Tal como o direito de não ser submetido à tortura, o direito a não ser submetido à escravidão é um direito absoluto, insuscetível de qualquer relativização ou flexibilização, a não permitir qualquer juízo de ponderação. ${ }^{47}$

42 ORGANIZAÇÃO INTERNACIONAL DO TRABALHO. A OIT no Brasil: trabalho decente para uma vida digna. Disponív-

el em: <http://www.justica.sp.gov.br/StaticFiles/SJDC/ArquivosComuns/ProgramasProjetos/NETP/Relat $\%$ C3\%B3rio. $\% 20$ OIT $\% 20$ no $\% 20$ Brasil.pdf $>$. Acesso em: 01 maio 2018.

43 COMISSÃO ECONÔMICA PARA A AMÉRICA LATINA E O CARIBE; PROGRAMA DAS NAÇÕES UNIDAS PARA O DESENVOLVIMENTO; ORGANIZAÇÃO INTERNACIONAL DO TRABALHO. Emprego, desenvolvimento bumano e trabalho decente: a experiência brasileira recente. Brasília: CEPAL/PNUD/OIT, 2008. p. 12.

44 BRITO FILHO, José Claudio Monteiro de. Trabalho escravo: caracterização jurídica. São Paulo: LTr, 2014. p. 31.

45 WANDELLI, Leonardo Vieira. O direito bumano e fundamental ao trabalho: fundamentação e exigibilidade. São Paulo: LTR, 2012. p. 235.

46 ORGANIZAÇÃO DAS NAÇÕES UNIDAS. Convenção sobre a escravatura assinada em Genebra, em 25 de setembro 1926, e emendada pelo protocolo aberto à assinatura ou à aceitação na sede da Organização das Noções Unidas, Nova York, em 7 de dezembro de 1953. Disponível em:<http://pfdc.pgr.mpf.mp.br/atuacao-e-conteudos-de-apoio/legislacao/trabalho-escravo/convencao_escravatura_genebra_1926.pdf $>$. Acesso em: 01 maio 2018.

47 PIOVESAN, Flávia. Trabalho escravo e degradante como forma de violação dos direitos humanos. In: VELLOSO, Gabriel; FAVA, Marcos Neves. Trabalho escravo contemporâneo: o desafio de superar a negação. São Paulo: LTr, 2006. p. 161-162. 
Ainda no âmbito internacional, a Declaração Universal dos Direitos Humanos, em seu art. $4^{\circ}$, prescreve que "ninguém será mantido em escravatura ou em servidão; a escravatura e o trato dos escravos, sob todas as formas, são proibidos". ${ }^{48}$

A partir do Pacto de São José da Costa Rica, de 1969, estabeleceram-se orientações a serem implementadas pelos Estados signatários no combate à degradação humana, mediante a proibição da escravidão e da servidão:

1.Ninguém pode ser submetido a escravidão ou a servidão, e tanto estas como o tráfico de escravos e o tráfico de mulheres são proibidos em todas as suas formas.

2.Ninguém deve ser constrangido a executar trabalho forçado ou obrigatório. Nos países em que se prescreve, para certos delitos, pena privativa da liberdade acompanhada de trabalhos forçados, esta disposição não pode ser interpretada no sentido de que proíbe o cumprimento da dita pena, imposta por juiz ou tribunal competente. $O$ trabalho forçado não deve afetar a dignidade nem a capacidade física e intelectual do recluso.

3.Não constituem trabalhos forçados ou obrigatórios para os efeitos deste artigo:

a.Os trabalhos ou serviços normalmente exigidos de pessoa reclusa em cumprimento de sentença ou resolução formal expedida pela autoridade judiciária competente. Tais trabalhos ou serviços devem ser executados sob a vigilância e controle das autoridades públicas, e os indivíduos que os executarem não devem ser postos à disposição de particulares, companhias ou pessoas jurídicas de caráter privado;

b.O serviço militar e, nos países onde se admite a isenção por motivos de consciência, o serviço nacional que a lei estabelecer em lugar daquele;

c.O serviço imposto em casos de perigo ou calamidade que ameace a existência ou o bem-estar da comunidade; e

d.O trabalho ou serviço que faça parte das obrigações cívicas normais. ${ }^{49}$

Além disso, o Brasil se comprometeu internacionalmente com as metas do milênio ao ratificar a Declaração do Milênio ${ }^{50}$ aprovada por meio da Resolução n ${ }^{\circ}$. A/55/L.2 da Assembleia Geral das Nações Unidas, que tem, dentre as metas, alcançar o emprego pleno e produtivo e o trabalho decente para todos.

Em âmbito nacional, o Código Penal brasileiro traz, em seu artigo 149, os modos de execução do crime de submeter alguém a trabalho em condições análogas à de escravo. Estes podem ser: típicos (trabalho forçado; jornada exaustiva; trabalho em condições degradantes; trabalho com restrição de locomoção, em razão de dívida contraída) ou por equiparação (retenção no local de trabalho quer por cerceamento do uso de qualquer meio de transporte, pela manutenção de vigilância ostensiva ou pela retenção de documentos e/ ou objetos de uso pessoal do trabalhador). ${ }^{51}$ Portanto, o ilícito do referido dispositivo legal apresenta sete modos de execução, dos quais quatro são típicos e três por equiparação.

Outro detalhe que merece destaque é o de que, em todas as formas de execução do crime, faz-se necessário que exista uma relação de trabalho, marcada por uma sujeição entre o trabalhador e o tomador de serviços, que não se confunde com a subordinação presente nas relações de emprego. Isto porque a sujeição, versada neste artigo, terá a capacidade de anular a vontade do trabalhador por parte do empregador, comprometendo, às vezes, a integridade física e psíquica daquele. ${ }^{52}$

48 ORGANIZAÇÃO DAS NAÇÕES UNIDAS. Declaração universal dos direitos humanos.Disponívelem:<http://www.onu.org.br/ img/2014/09/DUDH.pdf>. Acesso em: 01 maio 2018.

49 BRASIL. Decreto $n^{\circ}$. 678, de 6 de novembro de 1992. Disponívelem:<http://www.planalto.gov.br/ccivil_03/Decreto/D0678. $\mathrm{htm}>$. Acesso em: 8 maio 2018.

50 PROGRAMA DAS NAÇÕES UNIDAS PARA O DESENVOLVIMENTO. Declaração do Milénio. Disponível em: < http:// www.br.undp.org/content/brazil/pt/home/>. Acesso em: 26 jun. 2018.

51 BRITO FILHO, José Claudio Monteiro de. Trabalbo escravo: caracterização jurídica. São Paulo: LTr, 2014. p. 67.

52 BRITO FILHO, José Claudio Monteiro de. Trabalho decente: análise jurídica da exploração do trabalho: trabalho escravo e outras formas de trabalho indigno. 3. ed. São Paulo: LTR, 2013. p. 73-74. 
A imprescindibilidade da investigação em voga se faz visível quando da leitura da pesquisa da Organização Internacional do Trabalho (OIT) e da fundação Walk Free, em parceria com a Organização Internacional para Migração (OIM), a qual apontou que, em 2016, 25 milhões de pessoas foram submetidas a trabalho forçado. ${ }^{53}$ No que concerne ao Brasil, segundo dados do governo brasileiro, no ano de 2015, foram resgatados mais de mil trabalhadores em condições análogas à de escravo. ${ }^{54}$

Por isso, com base no exposto e nos dados supra aludidos, pode-se afirmar que é inegável que toda a prática que culmine no trabalho escravo contemporâneo representa uma afronta a dignidade humana, aos direitos mínimos para a promoção desta, e, portanto, ao trabalho decente, requerendo, assim, a intervenção estatal com mecanismos preventivos, que desestimulem tal prática, uma vez que as vítimas em potencial, geralmente, se encontram em situação de vulnerabilidade social.

\section{Aplicação de nUdges no combate ao trabalhado em Condição anÁlogo à de escravo}

Considerando-se todo o transcurso teórico construído até o momento,na presente pesquisa, pretende-se analisar como e em que medida a Lei n 14.946/2013 (lei Bezerra) e a "lista suja" podem ser identificadas como autênticos nudges no combate ao trabalho escravo contemporâneo.

\subsection{Análise da eficácia da lista suja como desestimulo à utilização do trabalho escravo contemporâneo}

Conforme versado anteriormente, as políticas públicas, na forma de nudges, possuem várias formas de atuação. Dentre as políticas públicas implementadas no Brasil com o escopo de combater a escravidão contemporânea, ganha destaque, em âmbito nacional, um cadastro também denominado de lista suja do trabalho escravo, em que constam os nomes das empresas que utilizam do trabalho em condição análoga à de escravo. ${ }^{55}$

A lista suja foi prevista no Plano Nacional para a Erradicação do Trabalho Escravo, elaborado pela Comissão Nacional para a Erradicação do Trabalho Escravo (Conatrae), e instituído com a Portaria no 540 , de 15 de outubro de 2004.

A publicidade da lista em voga decorre da observância do direito fundamental de acesso à informação (inciso XXXIII do art. $5^{\circ}$, no inciso II do $\int 3^{\circ}$ do art. 37 e no $₫ 2^{\circ}$ do art. 216 da Constituição Federal). Com isso, a política pública (ora tratada ou em testilha), qual seja, a publicidade de lista com o nome das empresas que tenham feito uso de trabalho escravo contemporâneo, tem por escopo impedir que estas recebam financiamentos públicos, e, ainda, pode ser concebida como um desestimulador de tal prática, haja vista que reflete na credibilidade da empresa.

Pelo versado, é possível asseverar que tal cadastro constitui uma política pública que se utiliza de uma das formas de nudge, qual seja, a de informar as pessoas (físicas e/ou jurídicas) sobre a natureza e consequências do passado do empregador, de modo a possibilitar que aquelas façam escolhas racionais, conscientes. Trata-se de medida considerada positiva por especialistas no combate ao trabalho escravo e que encontra respaldo em diversos dispositivos do ordenamento jurídico brasileiro.

53 ORGANIZAÇÃO INTERNACIONAL DO TRABALHO. Mundo tem 40 milhões de pessoas na escravidão moderna e 152 milhões de crianças no trabalho infantil. Disponível em: < http://www.ilo.org/brasilia/noticias/WCMS_575482/lang--pt/index.htm>. Acesso em: 20 maio 2018.

54 BRASIL. Governo Federal. Brasil resgatou mais de mil trabalhadores do trabalho escravo em 2015. 2016. Disponível em: <http:/ / www.brasil. gov.br/cidadania-e-justica/2016/01/brasil-resgatou-mais-de-mil-trabalhadores-do-trabalho-escravo-em-2015.> . Acesso em: 20 maio 2018. 55 A referida política pública foi criada pela Portaria MTE $n^{\circ} 1.234 / 2003$, a qual foi substituída pela Portaria $n^{\circ} 540$, de 15 de outubro de 2004, que, posteriormente, foi revogada pela Portaria Interministerial n ${ }^{\circ}$, de 12 de maio de 2011. Atualmente, a lista suja observa as regras previstas na Portaria Interministerial no 4, de 13 de maio de 2016, que revogou a anterior. 
Entretanto, mesmo diante da importância versada anteriormente, é possível afirmar que a eficácia relativa da lista suja decorre, em parte, do alcance de tal publicidade e seus efeitos, uma vez que a eficácia desta está condicionada a uma escolha voltada para o reconhecimento pelo consumidor e contratante (ou celebrante de acordos congêneres) da dignidade daquele que, por meio de seu trabalho, produz o produto a ser adquirido. Ou seja, exigiria uma pesquisa, bem como que o consumidor ignorasse os valores dispendidos para a compra de determinado bem, uma vez que levaria em consideração, no processo de ponderação, as condições a que a pessoa humana foi submetida para a produção da mercadoria, e não apenas a comparação de valores, pois, na maioria das vezes, produtos produzidos com a mão de obra em condição análoga à de escravo são inferiores aos de empresas que promovem o trabalho decente.

Nessa esteira, se faz possível defender que políticas governamentais pautadas no que se denomina de análise econômico comportamental do direito possuem maior aplicabilidade, uma vez que, quando direcionada aos empresários, surtem mais efeitos. Isso pois aquele que detém os meios de produção poderia ser induzido à promoção e proteção do trabalho decente pela benesse de receber as mais diversas formas de incentivos fiscais.

No cenário nacional, não se denotam muitas políticas governamentais pautadas no incentivo versado, mas sim em medidas sancionatórias. O discorrido propicia que, financeiramente, seja embora arriscado, mais vantajoso descumprir gravemente as normas que versam sobre proteção e promoção do trabalho digno, tendo em vista que o empregador atuará na margem de riscos, calculando os ganhos e perdas. Essa última é uma probabilidade que pode nunca ocorrer, principalmente em razão da falta de estrutura para a realização de fiscalização pelo órgão público competente para tanto.

\section{2. $O$ impacto da Lei $n^{\circ}$ 14.946/2013 (Lei Bezerra) para a proteção do trabalhador}

O item anterior abordou uma dentre as inúmeras normas aplicáveis ao combate do trabalho em condições análogas à de escravo no Brasil, nesse momento, nos deteremos à análise de uma medida regional. Para tal intento, optamos por colocar em debate a Lei Estadual nº 14. 946 de 28 de janeiro de 2013, regulamentada pelo Estado de São Paulo, por meio do Decreto Estadual no. 59.171, de 13 de maio de 2013. A lei supracitada dispõe acerca da cassação da inscrição no cadastro de contribuintes do Imposto sobre Operações Relativas à Circulação de Mercadorias e sobre Prestações de Serviços de Transporte Interestadual e Intermunicipal e de Comunicação - ICMS, "de qualquer empresa que faça uso direto ou indireto de trabalho escravo ou em condições análogas". ${ }^{56}$

O Estado de São Paulo, talvez, em razão de concentrar elevado número de empresas que utilizam de mão de obra em condições de escravidão contemporânea, tem se mostrado pioneiro no que tange a ações (relacionadas às regulamentações) de prevenção e repressão do trabalho em condição análoga à de escravo, pois, além da lei versada anteriormente, promulgou, também, a Lei Municipal nº 16.606, de 29 de dezembro de 2016. Por meio da mencionada lei, foram acrescidos os " $\iint 5^{\circ}, 6^{\circ}, 7^{\circ}, 8^{\circ}$ e $9^{\circ}$ ao art. $6^{\circ}$ da Lei $n^{\circ} 10.205$, de 4 de dezembro de 1986, que disciplina a expedição de licença de funcionamento", de modo a prever a possibilidade de que os estabelecimentos que forem responsabilizados pela utilização do trabalho escravo contemporâneo poderão “sofrer" multa de R \$100.000,00 (cem mil reais) a R \$ 100.000.000,00 (cem milhões de reais) e ter cassada a licença de funcionamento- Nesse último caso, devem estar presentes os requisitos de reincidência, "ou da comprovação da extrema gravidade da conduta, na forma de regulamento, respeitado o procedimento previsto no $₫ 7^{\circ}$ ". ${ }^{57}$

A Lei Bezerra prevê que as empresas condenadas por trabalho escravo, em segunda instância, nas esferas

56 SÃO PAULO (Estado). Lei no. 14.946, de 28 de janeiro de 2013. Disponível em: <https://www.al.sp.gov.br/repositorio/legislacao/lei/2013/lei-14946-28.01.2013.html>. Acesso em: 1 maio 2018.

57 SÃO PAULO. Câmara Municipal. Lei no . 16.606, de 29 de dezembro de 2016. Disponívelem:<http:/ /documentacao.camara.sp.gov. br/iah/fulltext/leis/L16606.pdf>. Acesso em: 1 maio 2018. p. 1. 
trabalhista ou criminal, tenham o registro do ICMS (Imposto sobre Circulação de Mercadorias e Serviços) suspenso por dez anos. Sem o qual não é possível comercializar no Estado. Além disso, seus proprietários ficam impedidos, por igual período, de exercer o mesmo ramo de atividade econômica ou entrarem com pedido de inscrição de nova empresa, no mesmo ramo de atividade.

Por essas razões, pode-se identificar a Lei nº 14. 946/2013 como um nudge, empurrão ou estímulo de comportamento a qualquer empresa do Estado de São Paulo que faça uso direto ou indireto de trabalho escravo ou em condições análogas. Essa forma de nudge se enquadraria no que Sunsteins ${ }^{58}$ denominou de uso de normas sociais e isso pode ser compreendido, principalmente, em razão do caráter punitivo e do medo da perda ${ }^{59}$ que a referida lei, se aplicada, pode ocasionar.

Significa dizer que, se os empresários paulistas não quiserem perder suas inscrições no cadastro dos contribuintes, bem como outras formas de punição, devem promover o trabalho decente, zelar pela qualidade do ambiente de trabalho, respeitar e garantir a dignidade da pessoa humana do trabalhador, zelar pelo cumprimento das normas trabalhistas e constitucionais.

Mister se faz mencionar, em razão da aplicabilidade do nudge ora tratado, a decisão proferida pela $54^{a}$ Vara do Trabalho de São Paulo que condenou a M5 Indústria e Comércio, dona da marca M.Officer, em ação civil pública proposta em 2014 pelo Ministério Público do Trabalho de São Paulo (MPT-SP), ao pagamento de $\mathrm{R} \$ 4$ milhões pelos danos morais coletivos e $\mathrm{R} \$ 2$ milhões pela prática de dumping social e a possível cassação da inscrição no cadastro de contribuintes de ICMS, depois da decisão de segunda instância — já que, a partir disso, a Secretaria de Fazenda do Estado de São Paulo será oficiada para dar início ao procedimento administrativo de cassação com base na lei bezerra — por submeter trabalhadores a condições análogas à escravidão $^{60}$.

$\mathrm{Na}$ decisão de $2^{\circ}$ grau, o TRT da $2^{a}$ Região manteve por unanimidade a decisão de $1^{\circ}$ grau, condenando a empresa M5 Indústria e Comércio. Nesse ínterim tudo indica que em breve a Secretaria de Fazenda do Estado de São Paulo será oficiada para dar início ao procedimento administrativo de cassação da inscrição no cadastro de contribuintes de ICMS com base na lei bezerra.

Isso denota, indubitavelmente, um avanço significativo no combate ao trabalho escravo contemporâneo. Além das condenações monetárias e de obrigações de fazer da empresa (que incluem cumprimento das leis trabalhistas), esta por meio de um nudge do Estado de São Paulo terá suas atividades suspensas por um considerado lapso temporal. E com isso um estímulo a um comportamento que promova o trabalho decente, reconheça a dignidade do trabalhador e o valor social do trabalho foi promovido e certamente isso refletirá nas próximas ações da empresa no que concerne ao cumprimento e respeito das leis do trabalho.

O nudge em comento é uma forma de se incentivar o cumprimento da legislação e zelar pela vida digna dos trabalhadores, pois, dessa forma, os outros empresários também poderão avaliar, com a arquitetura do futuro, se pretendem correr o risco de serem penalizados ${ }^{61}$.

Por derradeiro podemos verificar a eficácia da aplicação da análise econômica comportamental do direito, mormente dos nudges, em vários contextos e com diferentes finalidades. O presente trabalho permitiu corroborar a premissa de que se os nudges formulados através de políticas públicas forem formulados, a par-

58 SUNSTEIN, Cass R. Nudging: a very short guide. p. 3-6. Disponível em: < https://papers.ssrn.com/sol3/papers.cfm?abstract_ id $=2499658>$. Acesso em: 29 abr. 2018.

59 As pessoas possuem maior aversão ao risco de perder do que afeição por ganhar. Isso porque o ser humano costuma dar maior peso à derrota do que para a vitória.

60 SÃO PAULO. Tribunal Regional do Trabalho da $2^{\circ}$ região. Recurso Ordinário. RO $n^{\circ}$. 0001779550145020054. Relator: Ricardo Artur Costa e Trigueiros. Disponível em: < https://trt-2.jusbrasil.com.br/jurisprudencia/520126000/17795520145020054sao-paulo-sp/inteiro-teor-520126003>. Acesso em: 02 maio 2018.

61 FRANCO, Claudia Regina Lovato; TABAK, Benjamim Miranda; BIJOS, Leila. A lei no 14.946/2013 (lei bezerra): um nudge para incentivar empresários do setor de confecção da indústria paulista a cumprirem as leis trabalhistas. Revista de Direito Brasileira, São Paulo, v. 16, n. 7, p. 346-362, jan./abr. 2017. 
tir de uma perspectiva transdisciplinar, sistêmica e preservando-se a liberdade de escolha, podem conduzir a comportamentos considerados melhores ou mais adequados, e também possibilitou concluir que essa forma de empurrão comportamental, mormente em forma de incentivo e não apenas de sanção, pode ser uma forma mais eficaz de prevenção e combate ao trabalho análogo ao escravo no Brasil.

\section{Considerações finais}

O presente estudo possibilitou comprovar a necessidade da transversalidade como forma de se entender o problema a partir da sua complexidade, além disso, permitiu verificar que a Análise Econômica do Direito e a Análise Econômica do Direito Comportamental possibilitaram um novo olhar da Teoria Econômica Tradicional e uma nova percepção sobre o processo de escolhas do ser humano.

Ante pese contradições na forma com que cada teoria enxerga o processo de tomada de decisão, uma focada na racionalidade exacerbada e na literalidade da análise custo-benefício, outra em vieses e influencias endógenas e exógenas ao indivíduo, que pressupõe que na verdade nunca estamos totalmente livres quando realizamos escolhas, uma vez que, de alguma forma, somos influenciados por algo ou alguém, ambas proporcionaram uma nova ótica: a arquitetura das escolhas — e como uma estruturação adequada dessa podem conduzir a comportamentos mais desejáveis.

Quando verificamos essa nova ótica ser materializada por meio da elaboração e implementação de políticas públicas que atuam como nudges, podemos ter a confirmação da imprescindibilidade de estudos transdiciplinares abordando economia, direito e psicologia comportamental.

Outrossim, quando, por meio dos estudos supra aludidos, aferimos a possibilidade de utilizar da análise comportamental para anteceder comportamentos a fim de se garantir a promoção do trabalho decente, a valorização da dignidade humana do trabalhador e do valor social do trabalho, caminhamos mais comprometidos com a salvaguarda e o cumprimento desses direitos e, dessa forma, também com o combate ao trabalho escravo contemporâneo.

Por essas razões, as elaborações de medidas governamentais, inclusive leis, que tenham finalidade de nudge, por meio de uma abordagem de estímulo e não apenas sancionatória, voltadas ao cumprimento das normas trabalhistas, nos colocará, cada dia, mais próximos da erradicação do trabalho que mais explora a vulnerabilidade humana.

O trabalho escravo contemporâneo é ainda significativamente incidente no Brasil. É um trabalho que viola muito mais do que os direitos trabalhistas, fere brutalmente os direitos humanos no aspecto individual e coletivo, por isso, deve ser causa comum à sociedade a compreensão de sua configuração e o engajamento no combate as práticas que o configuram, seja na forma de execução típica ou por equiparação.

Por fim, cumpre registrar que se denota, no âmbito brasileiro, a adoção majoritária por parte dos poderes públicos, de políticas públicas pautadas em medidas sancionatórias, o que, frisa-se, não retira os seus méritos. No entanto, se faz imperioso mencionar que a implementação de políticas baseadas no nudge como um incentivo, por meio de benefícios advindos da observância das normas trabalhistas e, portanto, da promoção do trabalho decente, propiciaria, talvez, mais eficácia do que, apenas, a prática condenatória.

\section{REFERÊNCIAS}

ALVAREZ, Alejandro Buagllo. Análise econômica do direito: contribuições e desmistificações. Revista Direito, Estado e Sociedade, v.9, n.29, p. 49-68, jul./dez. 2006. 
AMBROSINO, A. Faralla V.; NOVARESE, M. Nudge: a critical perspective. In: MARCIANO, A.; RAMELLO, G. (Eds.). Enciclopédia de Direito e Economia. New York: Springer, 2018. Disponível em: < https://doi. org/10.1007/978-1-4614-7883-6_631-1>. Acesso em: 30 abr. 2018.

ANDAKU, Juliana Almenara. O direito na teoria de Niklas Lubmann. Disponível em: <www.agu.gov.br/page/ download/index/id/692917>. Acesso em: 21 maio 2018.

ANDRADE, Mariana Dionísio de; REMÍGIO, Rodrigo Ferraz de Castro. Políticas Públicas e escolha racional: o caso do Centro Urbano de Cultura, Arte, Ciência e Esporte de Fortaleza, estado do Ceará. Rev. Bras. de Políticas Públicas, Brasília, v. 7, n. 2, p. 259-265, ago. 2017.

ÁVILA, Flávia; BIANCHI, Ana Maria. Guia de economia comportamental e experimental. São Paulo: economia comportamental.org., 2015.

BARONE, Fernando. Sociedade e escola: Niklas Luhmann e a abordagem sistêmica. Ponto e vírgula - Revista das Ciências Sociais, São Paulo, n. 12, p. 5-32, 2013. Disponível em: < https://revistas.pucsp.br/index.php/ pontoevirgula/article/viewFile/12678/12310>. Acesso em: 20 maio 2018.

BOBBIO, Norberto. Teoria da norma jurídica. 2. ed. São Paulo: Edipro, 2008.

BRANCALEON, Brigida Batista et. al. Políticas públicas: conceitos básicos. São Paulo: Universidade de São Paulo, 2015.

BRASIL. Constituição (1988). Constituição da República Federativa do Brasil. Disponívelem:<http://www.planalto.gov.br/ccivil_03/constituicao/constituicao.htm>. Acesso em: 8 maio 2018.

BRASIL. Decreto $n^{\circ}$ 58.563, de $1^{\circ}$ de junho de 1966. Disponívelem:<http://www2.camara.leg.br/legin/fed/ decret/1960-1969/decreto-58563-1-junho-1966-399220-publicacaooriginal-1-pe.html>. Acesso em: 8 maio 2018.

BRASIL. Decreto n. 678, de 6 de novembro de 1992. Disponívelem:<http://www.planalto.gov.br/ccivil_03/ Decreto/D0678.htm>. Acesso em: 8 maio 2018.

BRASIL. Governo Federal. Brasil resgatou mais de mil trabalhadores do trabalho escravo em 2015. 2016. Disponível em: <http://www.brasil.gov.br/cidadania-e-justica/2016/01/brasil-resgatou-mais-de-mil-trabalhadoresdo-trabalho-escravo-em-2015.>. Acesso em: 20 maio 2018.

BRITO FILHO, José Claudio Monteiro de. Trabalho decente: análise jurídica da exploração do trabalho: trabalho escravo e outras formas de trabalho indigno. 3. ed. São Paulo: LTR, 2013.

BRITO FILHO, José Claudio Monteiro de. Trabalho escravo: caracterização jurídica. São Paulo: LTr, 2014.

CAMBRIDGE INTERNATIONAL. Dictionary of English. New York: CUP, 2000.

COMISSÃO ECONÔMICA PARA A AMÉRICA LATINA E O CARIBE; PROGRAMA DAS NAÇÕES UNIDAS PARA O DESENVOLVIMENTO; ORGANIZAÇÃO INTERNACIONAL DO TRABALHO.

Emprego, desenvolvimento bumano e trabalho decente: a experiência brasileira recente. Brasília: CEPAL/PNUD/ OIT, 2008.

CUNHA, Bruno Santos. Direitos fundamentais: da constituição às políticas públicas. Rev. Bras. Políticas Públicas, Brasília, v. 1, n. 1, p. 65-82, jan./jun. 2011.

FERREIRA, Felipe Furtado; POTTUMATI, Eduardo Carlos. A licitação pública como instrumento de desenvolvimento na perspectiva do paternalismo libertário. Rev. Bras. Políticas Públicas, Brasília, v. 4, n. 1, p. 201-215, jan./jun. 2014.

FRANCO, Claudia Regina Lovato; TABAK, Benjamim Miranda; BIJOS, Leila. A lei no 14.946/2013 (lei bezerra): um nudge para incentivar empresários do setor de confecção da indústria paulista a cumprirem as leis trabalhistas. Revista de Direito Brasileira, São Paulo, v. 16, n. 7, p. 346-362, jan./abr. 2017. 
KANT, Immanuel. Fundamentação da metafísica dos costumes. Lisboa: Edições 70, 2007.

KRUGMAN, Paul R. Introdução à economia. Rio de Janeiro: Elsevier, 2007.

KUNZLER, Caroline de Morais. A teoria dos sistemas de Nicklan Luhmann. Estudos de Sociologia, Araraquara, v. 16, p. 123-136, 2004. Disponível em: < https://periodicos.fclar.unesp.br/estudos/article/viewFile/146/144>. Acesso em: 20 maio 2018.

LUHMANN, Niklas. Introdução à teoria dos sistemas. 3. ed. Petrópolis: Vozes, 2011.

MELLO, Vera Rita de. Psicologia econômica: estudo do comportamento econômico e da tomada de decisão. Rio de Janeiro: Campus-Elsevier, 2008.

MENEGAZZI, Piero Rosa. A efetivação do direito à informação no meio ambiente de trabalho: contribuições do pensamento sistêmico, da teoria da complexidade e do estudo dos riscos. São Paulo: LTr, 2011.

MIRAGLIA, Lívia Mendes Moreira. Trabalho escravo contemporâneo: conceituação à luz do princípio da dignidade da pessoa humana. São Paulo: LTR, 2011.

ORGANIZAÇÃO DAS NAÇÕES UNIDAS. Declaração universal dos direitos humanos.Disponívelem:<http:// www.onu.org.br/img/2014/09/DUDH.pdf>. Acesso em: 01 maio 2018.

ORGANIZAÇÃO INTERNACIONAL DO TRABALHO. A OIT no Brasil: trabalho decente para uma vida digna. Disponível em: <http://www.justica.sp.gov.br/StaticFiles/SJDC/ArquivosComuns/ProgramasProjetos/NETP/Relat\%C3\%B3rio.\%20OIT\%20no\%20Brasil.pdf>. Acesso em: 01 maio 2018.

ORGANIZAÇÃO INTERNACIONAL DO TRABALHO. Declaração da OIT sobre os princípios e direitos fundamentais no trabalbo e seu segmento. Disponível em: <http://www.oit.org.br/sites/default/files/topic/international_labour_standards/pub/declaracao_oit_293.pdf>. Acesso em: 01 maio 2018.

ORGANIZAÇÃO INTERNACIONAL DO TRABALHO. Mundo tem 40 milhões de pessoas na escravidão moderna e 152 milhöes de crianças no trabalho infantil. Disponível em: < http://www.ilo.org/brasilia/noticias/ WCMS_575482/lang--pt/index.htm>. Acesso em: 20 maio 2018.

ORGANIZAÇÃO INTERNACIONAL DO TRABALHO. Trabalho decente no Brasil. Disponível em: $<$ http://www.ilo.org/brasilia/temas/trabalho-decente/lang--pt/index.htm>. Acesso em: 01 mai. 2018.

PAPP, Leonardo. Análise econômica do direito e a (re) inserção da eficácia na teoria do direito. Revista da Associação Mineira de Direito e Economia, Belo Horizonte, v. 9, p. 60-87, jul. 2012. Disponível em: <www.revista. amde.org.br/index.php/ramde/article/download/89/pdf>. Acesso em: 25 abr. 2018.

PIOVESAN, Flávia. Trabalho escravo e degradante como forma de violação dos direitos humanos. In: VELLOSO, Gabriel; FAVA, Marcos Neves. Trabalho escravo contemporâneo: o desafio de superar a negação. São Paulo: LTr, 2006.

PORTO, Antônio José Maristrello. Análise econômica do direito. 2013. Disponívelem:<http://direitorio.fgv. br/sites/direitorio.fgv.br/files/u100/analise_economica_do_direito_20132.pdf>. Acesso em: 15 abr. 2018.

PROGRAMA DAS NAÇÕES UNIDAS PARA O DESENVOLVIMENTO. Declaração do Milênio. Disponível em: <http://www.br.undp.org/content/brazil/pt/home/>. Acesso em: 26 jun. 2018.

RODRIGUES, Vasco. Análise econômica do direito: uma introdução. Coimbra: Gráfica Coimbra, 2007.

SÃO PAULO (Estado). Lei no. 14.946, de 28 de janeiro de 2013. Disponível em: < https://www.al.sp.gov.br/ repositorio/legislacao/lei/2013/lei-14946-28.01.2013.html>. Acesso em: 1 maio 2018.

SÃO PAULO. Câmara Municipal. Lei ñ. 16.606, de 29 de dezembro de 2016. Disponívelem:<http://documentacao.camara.sp.gov.br/iah/fulltext/leis/L16606.pdf>. Acesso em: 1 maio 2018.

SARLET, Ingo Wolfgang. Dignidade da pessoa humana e direitos fundamentais na Constituição Federal de 1988. 9. ed. 
Porto Alegre: Livraria do Advogado, 2012.

SCALEA, José Augusto; TABAK, Benjamin Miranda. Direito de propriedade intelectual: formas de proteção, seu impacto no desenvolvimento econômico e propostas para sua melhoria. Revista de Direito Econômico e Socioambiental, Curitiba, v. 7, n. 2, p. 154-174, jul./dez. 2016. Disponível em: < https://periodicos.pucpr.br/ index.php/direitoeconomico/article/view/5837>. Acesso em: 30 abr. 2018.

SEIDL, D.; BECKER, K. H. Organizations as Distinction Generating and Processing Systems: Niklas Luhmann's Contribution to Organization Studies. Organizations. Sage Journal, v. 13, n. 1, p. 9-35, 2006. Disponível em: <http://journals.sagepub.com/doi/pdf/10.1177/1350508406059635>. Acesso em: 9 maio 2018.

SHILLER, R. J. Behavioral Economics and Institutional Innovation. Southern Economic Journal, v. 72, n. 2, 2005. Disponível em: <http://www.econ.yale.edu/ shiller/pubs/p1150.pdf>. Acesso em: 9 maio 2018.

SIMON, Herbert A. A behavioral model of rational choice. The Quarterly Journal of Economics, v.69, n.1, p.99118, fev. 1955. Disponível em: <http://www.math.mcgill.ca/vetta/CS764.dir/bounded.pdf>. Acesso em: 9 maio 2018.

SOUTO MAIOR, Jorge Luiz; MOREIRA, Ranúlio Mendes Moreira; SEVERO, Valdete Souto. Dumping social nas relaçoes de trabalho. São Paulo: LTr, 2012

SOUZA, C. Política Públicas: uma revisão da literatura. Sociologias, Porto Alegre, ano 8, n. 16, p. 20-45, jun./ dez. 2006. Disponível em: <http://www.scielo.br/pdf/soc/n16/a03n16>. Acesso em: 15 abr. 2018.

STIGLER, George. "Law or Economics?”. The Journal of Law and Economics, v. 35, n. 2, p. 455-468, out. 1992. Disponível em: <https://www.jstor.org/stable/725548?seq=1\#page_scan_tab_contents>. Acesso em: 15 abr. 2018.

SUNSTEIN, Cass R. It's for your own good! Disponível em: <http://www.nybooks.com/articles/archives/2013/mar/07/its-your-own-good/?pagination=false>. Acesso em: 20 maio 2018.

SUNSTEIN, Cass R. Nudging: a very short guide. Disponível em: < https://papers.ssrn.com/sol3/papers. cfm?abstract_id=2499658>. Acesso em: 29 abr. 2018.

TABAK, Benjamim Miranda. A análise econômica do direito: proposições legislativas e políticas públicas. Revista de informação legislativa, Brasília, ano 52, n. 205, p. 321-345 jan./mar. 2015.

THALER, Richard H.; SUNSTEIN, Cass R. Nudge: o empurrão para a escolha certa: aprimore suas decisões sobre saúde, riqueza e felicidade. Rio de Janeiro: Elsevier, 2009.

WANDELLI, Leonardo Vieira. O direito bumano e fundamental ao trabalho: fundamentação e exigibilidade. São Paulo: LTR, 2012. 


\section{Reduzindo a tributação cognitiva: lições comportamentais para a diminuição dos efeitos psicológicos adversos da pobreza*}

\author{
Reducing the cognitive taxes: behavioral \\ lessons to decrease the adverse psychological \\ effects from poverty
}

\author{
Leandro Novais e Silva** \\ Luiz Felipe Drummond Teixeira*** \\ Gabriel Salgueiro Soares**** \\ Otávio Augusto Andrade Santos*****
}

* Recebido em 31/05/2018 Aprovado em 10/08/2018

** Professor de Direito Econômico da FD/ UFMG. Doutor em Direito Econômico pela UFMG. Procurador do Banco Central do Brasil. Coordenador do Grupo de Estudos em Políticas Públicas da FD/UFMG. Email: leandro-novais@uol.com.br

*** Bacharelando em Direito pela UFMG. Membro dos Grupos de Estudo em Políticas Públicas e em Neuroética e Neurodireito da FD/UFMG. Email: luizfelipedrummond@ gmail.com

**** Bacharelando em Direito pela UFMG. Membro dos Grupos de Estudo em Políticas Públicas da FD/UFMG. Email: gsalgueiros@ gmail.com

***** Bacharelando em Direito pela UFMG. Membro dos Grupos de Estudo em Políticas Públicas e em Neuroética e Neurodireito da FD/UFMG. Email: al2012.121.andrade@ gmail.com

\section{Resumo}

A finalidade deste artigo é demonstrar que a pobreza impõe maiores custos cognitivos para a tomada de decisões. Utilizou-se o método de revisão bibliográfica, mediante a extensa análise de pesquisas empíricas das ciências comportamentais. Inicialmente, apresentam-se os pressupostos teóricos da Economia Comportamental, bem como a Teoria dos Prospectos, os Descontos Intertemporais Hiperbólicos e o Esgotamento do Ego. Posteriormente, discute-se como a pobreza potencializa vieses cognitivos, utilizando-se, como exemplo, uma maior aversão ao risco e maiores descontos intertemporais. Cria-se, então, uma verdadeira tributação cognitiva, visto que as decisões econômicas na pobreza são mais custosas cognitivamente. Contribuem para esse cenário, principalmente, um esgotamento do ego mais intenso, cumulado com a diminuição das funções cognitivas, maiores índices de stress e o foco atencional voltado para a escassez. Por fim, discute-se como as agendas de políticas públicas poderiam se pautar na utilização, sobretudo, de nudges como mecanismo de combate aos efeitos da tributação cognitiva. Para isso, serão analisados três exemplos de políticas públicas: duas que funcionam considerando aspectos comportamentais e o PRONATEC, que, por desconsiderá-los, tem conseguido menos êxito do que poderia. Conclui-se, em suma, que a pobreza - por si só - impõe severos custos cognitivos para o processo decisório. A agenda de políticas públicas poderia, nesse contexto, ser aprimorada por meio das teorias econômico-comportamentais, para facilitar a decisão em condição de pobreza. Finalmente, o trabalho destaca a importância dessa agenda de pesquisa, ressaltando a necessidade de dados para contribuições mais efetivas.

Palavras-chave: Esgotamento do Ego; Tributação Cognitiva; Pobreza; Empurrões; Políticas Públicas. 


\section{Abstract}

This paper aims to show that poverty imposes higher cognitive costs to decision-making. To prove this statement, we rely on an extensive review of behavioral science research, especially the experimental one. First of all, we present the theoretical grounds of Behavioral Economics, as well as the Prospects Theory, the Hyperbolic Intertemporal Discounts and the Ego Depletion. After that, we discuss how poverty increases cognitive biases, using, as an example, a greater risk aversion and bigger intertemporal discounts. It creates, therefore, a truly cognitive tax, as long as the decision-making in poverty is more cognitively expensive. Contribute to this situation factors that go mainly through an intensified ego depletion, cumulated with the impairment of cognitive functions, greater stress levels and the attentional focus facing the scarcity. Finally, we discuss how policy making agenda could mainly use nudges as a mechanism to reduce the cognitive taxes. To show that, it will be analyzed three examples of public policies: two that work well relying on behavioral insights and the PRONATEC, which are not having as much success as it could, because it ignore these insights. We conclude, to sum up, that poverty - by itself - imposes severe cognitive costs in decision-making process. In this context, the policy making agenda could be improved by using the behavioral economical theories, as a way to simplify the decision in a poverty condition. Finally, the paper highlights the importance of this research agenda, underlining that data is necessary to contribute in a more effective way to public policy.

Keywords: Ego Depletion; Cognitive Taxes; Poverty; Nudges; Public Policy.

\section{INTRODUÇÃo}

Sob o paradigma da Economia Comportamental, principalmente com base nos estudos de Daniel Kahneman e Amos Tversky, críticos do modelo neoclássico de tomada de decisões, duas formas distintas de pensar podem ser identificadas. A primeira, conhecida como Sistema 1, é intuitiva e impulsiva. Toma decisões rápidas e que exigem pouco esforço cognitivo. O outro modo de pensar é conhecido como Sistema 2 e é deliberativo, baseado na reflexão e com um maior custo cognitivo. Em muitas ocasiões, o processo decisório é guiado pelo Sistema 1, que exige menor esforço, mas que, também, apresenta erros frequentes e previsíveis.

O funcionamento do Sistema 2, por sua vez, demanda um suprimento de recursos psicologicamente escassos, que, quando esgotado, prejudica o rumo das decisões deliberadas. O comportamento passa a ser moldado, então, pelo Sistema 1, rápido, intuitivo e com baixo esforço. Esse processo foi demonstrado experimentalmente por vários autores, sobretudo Roy Baumeister, e ficou conhecido como Esgotamento do Ego (ego depletion). Dessa forma, quando submetidos a decisões complexas, cognitivamente custosas, os humanos esgotam mais rapidamente sua capacidade deliberativa, o que causa prejuízos relacionados ao autocontrole, às decisões reflexivas e, em geral, às escolhas econômicas, como aquelas relacionadas ao desconto intertemporal e à aversão ao risco.

Pessoas em situações de pobreza, submetidas a situações de maior escassez, precisam tomar decisões complexas de maneira mais cotidiana e com implicações mais significativas. Isso porque, a essas pessoas, trade-offs mais importantes se impõem e os custos de oportunidade de qualquer decisão são elevados. O esgotamento do ego, então, parece ser provocado de maneira mais intensa, o que faz com que as decisões econômicas tomadas por tais indivíduos, principalmente a longo prazo, apresentem uma tendência a ser prejudicadas pelo processo psicológico citado anteriormente. Outros fatores se adicionam a essa conjuntura e estão ligados a diminuições das funções cognitivas, stress, afeto negativo e um foco atencional direcionado para a própria situação de escassez. 
Por conta disso, Mani et al. ${ }^{1}$ sugerem que tais indivíduos são submetidos a uma maior tributação cognitiva, em face das pessoas que ocupam os estratos socioeconômicos superiores. Tal expressão - que não pretende significar a cobrança efetiva de tributos - visa a demonstrar, metaforicamente, que há custos cognitivos mais elevados inerentes às decisões feitas em situação de pobreza. Tal fato pode levar a decisões econômicas equivocadas, o que pode ser capaz de criar resultados extremamente regressivos a longo prazo. Estaria estabelecido, pois, um ciclo vicioso, na medida em que os pobres decidem sob maior pressão e com maiores custos de oportunidade e cognitivos, o que faz com que decidam economicamente de maneira insatisfatória com maior frequência. Conseguem, então, por exemplo, terem maiores descontos intertemporais ou se apresentarem mais avessos ao risco em situações em que a aceitação deste poderia levar a um resultado econômico mais satisfatório a longo prazo. A regressividade é, portanto, clara: decisões econômicas insatisfatórias levam a piores resultados econômicos, que, por sua vez, têm o condão de reforçar a situação de pobreza e, dessa forma, as escolhas econômicas futuras se tornam ainda mais difíceis.

Embora seja difícil a superação do ciclo vicioso narrado, pontua-se que essa situação pode ser atenuada com mudanças sutis na arquitetura de escolhas. Para isso, o artigo se baseia na larga revisão da literatura científico-comportamental, especialmente no que diz respeito aos experimentos relacionados ao esgotamento do ego, às más-decisões econômicas relacionadas a este fenômeno e à relação de todas essas condições com a pobreza.

Muitas vezes, inúmeras decisões complexas e ininteligíveis são exigidas dos cidadãos, ainda que eles não sejam capazes de decidir de maneira adequada nessas ocasiões, como, por exemplo, em relação aos planos de previdência ou ao mercado de créditos. O cenário desfavorável parece acelerar o processo de esgotamento do ego, especialmente pernicioso aos indivíduos em situação de pobreza, o que prejudica ainda mais as suas decisões econômicas. O resultado é uma menor taxa de poupança, gastos muitas vezes impulsivos e descontrolados e dívidas de tamanhos assustadores. Obviamente, políticas que atuem diretamente na redistribuição de renda serão impactantes, mas ultrapassam os objetivos deste trabalho. A solução que aqui é proposta passa pelo conceito de nudges, tal como proposto por Thaler e Sunstein. O arquiteto de escolhas, diante de tais circunstâncias, pode alterar a estrutura em que as pessoas tomam decisões, facilitando-as e direcionando-as para resultados que seriam melhores para os indivíduos, segundo as suas próprias concepções. Na formulação de qualquer política, dessa forma, deve-se ter em mente os vieses comportamentais exacerbados em condição de pobreza e esperar o erro, de forma a não o tornar excessivamente penoso.

Nesse contexto, o trabalho apresenta os prejuízos decisórios que a situação de pobreza pode trazer consigo e demonstra que eles podem ser atenuados com a formulação de políticas públicas adequadas. Seria possível, então, diminuir os efeitos psicologicamente adversos da pobreza e fazer com que as pessoas mais pobres pudessem decidir melhor, deliberando de forma mais precisa acerca de questões que lhes sejam mais urgentes. Na seção 2, serão apresentadas algumas lições preliminares baseadas nas ciências comportamentais. Brevemente, serão expostos os conceitos básicos ligados às decisões sob risco, consubstanciados na Teoria dos Prospectos, e aos descontos intertemporais e será feita uma revisão bibliográfica acerca do esgotamento do ego (ego depletion). Na seção 3, expostos tais conceitos comportamentais que se ligam de maneira mais direta ao objeto do trabalho, será demonstrado como a situação de pobreza impacta as decisões econômicas, sobretudo no que diz respeito à aversão ao risco e aos descontos intertemporais excessivos. As razões para tanto parecem girar em torno de um processo de esgotamento do ego intensificado, cumulado com fatores como a diminuição das funções cognitivas, um foco atencional voltado para a escassez e um aumento dos níveis de stress e de afeto negativo. Por fim, a seção 4 apresenta como isso impacta a formulação de políticas públicas, adotando a perspectiva dos nudges para reduzir os efeitos da tributação cognitiva. Serão expostas três políticas públicas diferentes: duas que obtiveram êxito ao considerar aspectos comportamentais e uma que falha ao não considerar tais aspectos. Esta última é o Programa Nacional de Acesso ao Ensino Técni-

1 MANI, A. et al. Poverty impedes cognitive function. Science, [s.1.], v. 341, n. 6149, p. 976-980, 29 ago. 2013. American Association for the Advancement of Science (AAAS). Disponível em: <http://dx.doi.org/10.1126/science.1238041>. p. 980. 
Co - PRONATEC, que, por não esperar o erro dos seus destinatários, apresenta notórios índices de evasão - que colocam em risco o próprio futuro desta política pública. Também serão demonstradas maneiras de se aprimorar tal programa, com o uso de estratégias comportamentais, principalmente na forma de nudges.

\section{A CRÍTICA DA ECONOMIA COMPORTAMENTAL: LIÇÕES PRELIMINARES}

Como ponto de partida, é necessário entender qual a razão de ser da Economia Comportamental. Com base nas diversas influências cognitivas, emocionais e sociais que moldam a tomada de decisão humana, tal corrente econômica elabora uma forte crítica ao modelo de comportamento econômico neoclássico, consubstanciado na figura do Homo Economicus.

Para Ariely², a Economia Neoclássica:

[...] presume que somos racionais - que conhecemos todas as informações pertinentes a nossas decisões, que podemos recalcular o valor das diversas opções com que nos deparamos e que estamos cognitivamente desobstruídos ao pesar as ramificações de cada escolha possível.

O resultado é que se pressupõe que tomamos decisões lógicas e sensatas e, mesmo que tomemos uma decisão errada de vez em quando, a perspectiva da economia tradicional indica que aprenderemos rapidamente com nossos erros, tanto por conta própria quanto com a ajuda das "forças do mercado". Com base nessas hipóteses, os economistas tiram conclusões de longo alcance acerca de qualquer coisa, de tendências em compras, passando pelo direito, a políticas públicas.

Os agentes econômicos, então, para o modelo tradicional da Economia, ponderam os custos e os benefícios de cada alternativa, adotando a conduta capaz de lhes proporcionar o maior bem-estar ${ }^{3}$. É o que se chama de conduta racional maximizadora. Na medida em que os agentes econômicos ponderam custos e benefícios ao decidir, uma mudança na matriz de incentivos altera, consequentemente, as suas condutas e os leva a realizarem outras escolhas ${ }^{4}$.

A Economia Comportamental nasce com um caráter suplementar ao modelo tradicional neoclássico, propondo uma nova abordagem no que diz respeito ao comportamento dos agentes econômicos. Thaler e Sunstein ${ }^{5}$, por exemplo, enfatizam que, apesar de destacarem inúmeros fatores negligenciados pela teoria econômica tradicional, não pretendem sugerir que as forças econômicas tradicionais não são importantes. Por isso, o caráter suplementar.

Tal vertente da Economia propõe, com base em robustas evidências empíricas, que, em vez de essencialmente racionais maximizadores, isto é, seres egoístas, que calculam o custo-benefício de suas ações e donos de preferências estáveis, os humanos, na maior parte das vezes, decidem de forma rápida e intuitiva ${ }^{6}$. Para isso, baseiam suas decisões em heurísticas, isto é, atalhos mentais utilizados para responder perguntas difíceis intuitivamente. Por exemplo, determinar a idade de uma celebridade ou a distância entre duas cidades? Esta forma de pensar, no entanto, leva configuração de vieses, quais sejam, erros sistemáticos e previsíveis.

2 ARIELY, Dan.Previsivelmente Irracional.Rio de Janeiro: Elsevier, 2008. p. 195.

3 GICO JÚNIOR, Ivo Teixeira. Metodologia e epistemologia da análise econômica do direito.Economic Analysis of Law Review, Brasília, v. 1, n. 1, p. 7-33, 11 jun. 2010. Semestral. p. 22.

4 GICO JÚNIOR, Ivo Teixeira. Metodologia e epistemologia da análise econômica do direito.Economic Analysis of Law Review, Brasília, v. 1, n. 1, p. 7-33, 11 jun. 2010. Semestral. p. 22.

5 THALER, Richard H.; SUNSTEIN, Cass R.Nudge:improving decisions about health, wealth and happiness. Londres: Penguin Books, 2009. p. 99.

6 SAMSON, Alain. Introdução à economia comportamental e experimental. In: ÁVILA, Flávia; BIANCHI, Ana Maria.Guia de Economia Comportamental e Experimental.São Paulo: Economiacomportamental.org, 2015. p. 25-59. p. 25.

7 THALER, Richard H.; SUNSTEIN, Cass R.Nudge:improving decisions about health, wealth and happiness. Londres: Penguin Books, 2009. p. 22-23. 
Diversos são as heurísticas e os vieses já mapeados pela Economia Comportamental ${ }^{8}$. Para o escopo deste trabalho, entretanto, foram selecionados apenas os desvios comportamentais que guardam relação mais direta com a temática tratada. Isso não retira a importância dos demais para a adequada compreensão do comportamento humano.

Preliminarmente, é necessário compreender como se operam as distintas formas de pensar que atuam na tomada de decisão do Homo Sapiens. Uma delas funciona de forma intuitiva, rápida e pouco onerosa cognitivamente; a outra, de forma lenta, deliberada e com um alto grau de esforço cognitivo?.

\subsection{Dois sistemas: rápido e devagar}

Em primeiro lugar, considere uma decisão tomada de maneira instantânea. Pense, por exemplo, em um caminhoneiro experiente que dirige pelas rodovias. Ou, mesmo, em um exímio jogador de tênis. Ambos decidem automaticamente. Em razão de suas habilidades, o motorista não delibera os custos e benefícios de cada ultrapassagem, da mesma forma que o jogador não calcula a trajetória da bola a cada saque.

Por outro lado, imagine um engenheiro realizando os cálculos aerodinâmicos de um avião. Ou, ainda, a realização de um exame para ingresso no Ensino Superior. Os dois casos envolvem deliberações e não parecem ser intuitivos. Há ponderações frequentes e o raciocínio é lento e analítico.

Os primeiros exemplos evocam uma forma de pensar instantânea. Por outro lado, os seguintes parecem exigir maior atenção, por se tratarem de problemas nitidamente mais complexos e que, portanto, demandam um pensamento mais deliberado e reflexivo. Para Kahneman ${ }^{10}$, a cognição humana opera conforme dois sistemas distintos, ora de forma rápida (Sistema 1), ora devagar (Sistema 2$)^{11}$.

O Sistema 1, como já foi ressaltado, é automático. Trabalha com pouco esforço e é involuntário. É associativo e habilidoso e não está envolvido com o que, normalmente, é associado ao pensar ${ }^{12}$. Já o Sistema 2 é mais lento. Atua nas atividades mentais trabalhosas, que envolvem maior esforço e concentração ${ }^{13}$. Suas operações são controladas voluntariamente, dedutivas, conscientes e seguem regras lógicas ${ }^{14}$.

É o Sistema 1, portanto, que atua na maior parte do tempo, colocando o Sistema $2 \mathrm{em}$ um confortável modo de pouco esforço, com apenas uma fração de sua capacidade envolvida ${ }^{15}$. Em outros termos, a maior parte do que o sistema reflexivo faz e pensa é originada do sistema automático; para tarefas mais complexas, no entanto, o Sistema 2 assume o controle e, normalmente, tem a última palavra.

O pensamento guiado pelo Sistema 1 é, via de regra, eficiente. Todavia, conforme explica Kahneman ${ }^{16}$,

8 Para a melhor compreensão das heurísticas e vieses, as seguintes obras são sugeridas:

KAHNEMAN, Daniel.Rápido e devagar:duas formas de pensar. Rio de Janeiro: Objetiva, 2012.;

THALER, Richard.Misbehaving:the making of behavioral economics. Nova Iorque: W. W. Norton, 2016.

ARIELY, Dan.Previsivelmente Irracional.Rio de Janeiro: Elsevier, 2008.

ARIELY, Dan.Positivamente irracional:os benefícios inesperados de desafiar a lógica em todos os aspectos de nossas vidas. Rio de Janeiro: Elsevier, 2010.

ÁVILA, Flávia; BIANCHI, Ana Maria.Guia de economia comportamental e experimental.São Paulo: Economiacomportamental.org, 2015.

9 KAHNEMAN, Daniel.Rápido e devagar:duas formas de pensar. Rio de Janeiro: Objetiva, 2012. p. 30-33.

10 KAHNEMAN, Daniel.Rápido e devagar:duas formas de pensar. Rio de Janeiro: Objetiva, 2012. p. 29.

11 Vale ressaltar que o cérebro deve ser visto como uma uniformidade. Os dois sistemas, ainda que representem diversas formas de pensar, não são uma real divisão cerebral, isto é, não são morfologicamente identificáveis, ainda que a atividade cerebral possa ser mais intensa em uma ou outra área, conforme se decide de forma intuitiva ou deliberada.

12 THALER, Richard H.; SUNSTEIN, Cass R.Nudge:improving decisions about health, wealth and happiness. Londres: Penguin Books, 2009. p. 19-20.

13 KAHNEMAN, Daniel.Rápido e devagar:duas formas de pensar. Rio de Janeiro: Objetiva, 2012. p. 29.

14 THALER, Richard H.; SUNSTEIN, Cass R.Nudge.improving decisions about health, wealth and happiness. Londres: Penguin Books, 2009. p. 22-23.

15 KAHNEMAN, Daniel.Rápido e devagar:duas formas de pensar. Rio de Janeiro: Objetiva, 2012. p. 33.

16 KAHNEMAN, Daniel.Rápido e devagar:duas formas de pensar. Rio de Janeiro: Objetiva, 2012. p. 38. 
em situações específicas tal Sistema comete erros sistemáticos:

Como o Sistema 1 opera automaticamente e não pode ser desligado a seu bel-prazer, erros do pensamento intuitivo muitas vezes são difíceis de prevenir. Os vieses nem sempre podem ser evitados, pois o Sistema 2 talvez não ofereça pista alguma sobre o erro. Mesmo quando dicas para prováveis erros estão disponíveis, estes só podem ser prevenidos por meio do monitoramento acentuado e da atividade diligente do Sistema 2. [...] Questionar constantemente nosso próprio pensamento seria impossivelmente tedioso, e o Sistema 2 é vagaroso e ineficiente demais para servir como um substituto para o Sistema 1 na tomada de decisões rotineiras.

Como ressaltado, os vieses são o produto de decisões frequentemente tomadas de maneira intuitiva e o raciocínio lento, que demanda esforço e atenção, é aquele capaz de evitar tais erros sistemáticos. Todavia, conforme será demonstrado, a utilização do Sistema 2 quando da realização de uma escolha ou da resistência à tentação não apenas requer um grande esforço mental, como também consome recursos cognitivos limitados - o que prejudicará decisões subsequentes. É o que se entende na literatura por esgotamento do ego (ego depletion).

Dentre os desvios comportamentais que escapam dos padrões da teoria econômica tradicional e que podem prejudicar a tomada de decisões, relacionam-se de maneira mais direta com os objetivos deste trabalho as anomalias descritas pela Teoria dos Prospectos e os descontos intertemporais hiperbólicos.

Como será oportunamente demonstrado, os efeitos de tais vieses são, provavelmente, ampliados quando se passa pelo esgotamento do ego ${ }^{17}$ e podem criar situações extremamente perniciosas, na medida em que há fortes indícios empíricos de que o processo de esgotamento do ego é exacerbado em ambientes de pobreza extrema.

\subsection{A teoria dos prospectos e os descontos intertemporais hiperbólicos}

Antes de abordar diretamente os efeitos psicologicamente adversos da pobreza, é necessário discutir alguns aspectos comportamentais que destoam do modelo econômico tradicional. Primeiro, será abordada a Teoria dos Prospectos e a forma como ela revolucionou a compreensão do comportamento humano sob risco. Depois, será feita a análise das anomalias que são encontradas nas escolhas intertemporais.

Importante salientar que a exposição minuciosa de todos os detalhes que envolvem tais desvios comportamentais ultrapassa os fins deste trabalho. Busca-se, aqui, meramente expor os conceitos básicos que envolvem a Teoria dos Prospectos e os descontos intertemporais hiperbólicos.

\subsubsection{Decisões sob risco: a ascensão da Teoria dos Prospectos}

Em primeiro lugar, faz-se imperioso o estudo acerca da análise da tomada de decisões em condições de incerteza, no qual Bernoulli ${ }^{18}$ afirma:

Mas qualquer um que considerar o problema com perspicácia e interesse irá verificar que o conceito de valor que nós utilizamos nessa regra pode ser definido de forma a tornar todo o processo universalmente aceitável sem reservas. Para fazer isso, a determinação do valor de um item não deve ser baseada no seu preço, mas na utilidade que ele produz. O preço de um item é dependente apenas da coisa em si mesmo e é igual para todos; a utilidade, entretanto, é dependente de circunstâncias particulares da pessoa que faz a estimativa.

17 Importante ressaltar que o trabalho não pretende demonstrar empiricamente essa correlação. Indica, na verdade, as relações entre a pobreza e os vieses comportamentais, especialmente em ambientes de pobreza, como uma importante e promissora agenda de pesquisa. Com uma maior quantidade de dados, é possível chegar a resultados mais conclusivos desses efeitos.

18 BERNOULLI, Daniel. Exposition of a new theory on the measurement of risk.Econometrica, [s.l.], v. 22, n. 1, p. 22-36, jan. 1954. Disponível em: <https://engineering.purdue.edu/ ipollak/ece302/FALL09/notes/Bernoulli_1738.pdf>. p. 24. Tradução nossa. 
Enquanto isso, vamos usar essa como uma regra fundamental: Se a utilidade de cada possibilidade esperada de lucro for multiplicada pelo número de vezes em que ela pode ocorrer, e então dividirmos a soma desses produtos pelo número total de casos possíveis, uma utilidade média (expectativa moral) será obtida e o lucro que corresponde a essa utilidade será igual ao valor do risco em questão.

Bernoulli, ao expor que a utilidade do primeiro milhar de dólares que um indivíduo ganha é maior que a dos subsequentes, inaugura a noção de aversão ao risco.

Este viés é ilustrado por Thaler ${ }^{19}$, ao narrar que, caso um agente, detentor de riqueza equivalente a cem mil dólares, esteja em uma situação de escolha entre mil dólares adicionais e 50\% de chance de ganhar dois mil dólares, haverá ele de aceitar a coisa certa, porquanto o segundo milhar é menos valorizado que o primeiro, não estando o agente disposto a aceitar o risco de perder o primeiro prêmio de mil dólares em uma tentativa de ganhar o segundo.

O tratamento teórico do processo decisório em situações de risco foi publicado em 1944 por Von Neumann e Morgenstern ${ }^{20}$, que inauguraram a chamada Teoria da Utilidade Esperada - a qual viria a ser, posteriormente, objeto de uma das críticas mais contundentes da Economia Comportamental.

Segundo essa teoria, uma decisão sob risco envolve a escolha entre prospectos, que nada mais são que contratos nos quais, com uma probabilidade $P \mathrm{i}$, atinge-se o resultado $\mathrm{Xi}^{21}$. Prospectos são, portanto, distribuições probabilísticas em torno de um conjunto de consequências ${ }^{22}$. A Teoria da Utilidade Esperada apresenta três axiomas básicos, conforme descreve estudo clássico de Kahneman e Tversky ${ }^{23}$. Primeiro, a utilidade geral de um prospecto seria a utilidade esperada de seus resultados. Além disso, um prospecto seria aceitável se e somente se a utilidade resultante de integrá-lo a um ativo fosse maior que a utilidade do ativo por si só. Por fim, os agentes apresentariam uma prevalência pela aversão ao risco, na medida em que preferem o prospecto certo $\mathrm{X}$ a qualquer prospecto arriscado de valor esperado $\mathrm{X}$.

Sendo assim, para a Teoria da Utilidade Esperada, o comportamento humano buscaria maximizar uma função de valor definida em torno dos prospectos. Os agentes atribuiriam utilidades subjetivas às consequências possíveis dos riscos e a avaliação da utilidade esperada de cada prospecto seria formada pela média das utilidades de seus resultados, ponderados conforme as suas probabilidades ${ }^{24}$. Dessa forma, segundo Kahneman ${ }^{25}$ :

A coisa fica mais interessante, porém, porque há um poderoso argumento de que um tomador de decisão que deseja ser racional deve se conformar ao princípio da expectativa. Esse foi o ponto principal da versão axiomática da teoria da utilidade que Von Neumann e Morgenstern apresentaram em 1944. Eles provaram que qualquer ponderação de resultados que não seja estritamente proporcional à probabilidade leva a inconsistências e outros desastres. A derivação feita por eles do princípio de expectativa a partir de axiomas de escolha racional foi imediatamente reconhecida como uma realização monumental, o que situou a teoria da utilidade esperada no âmago do modelo de agente racional em economia e outras ciências sociais.

Kahneman e Tversky, ao longo de todo o seu trabalho em conjunto, demonstraram diversas situações

19 THALER, Richard.Misbehaving:the making of behavioral economics. Nova Iorque: W. W. Norton, 2016. p. 28-29.

20 VON NEUMANN, John; MORGENSTERN, Orkas.Theory of games and economic behavior.Princeton: Princeton University Press, 1953.

21 KAHNEMAN, Daniel; TVERSKY, Amos. Prospect theory: an analysis of decision under risk.Econometrica, [s.l.], v. 47, n. 2, p. 263-292, mar. 1979. Disponível em: <http://people.hss.caltech.edu/ camerer/Ec101/ProspectTheory.pdf>. p. 263-264.

22 STARMER, Chris. Entendendo preferências: o que podemos aprender com a economia comportamental?. In: ÁVILA, Flávia; BIANCHI, Ana Maria.Guia de Economia Comportamental e Experimental.São Paulo: Economiacomportamental.org, 2015. p. 60-75. p. 63. 23 KAHNEMAN, Daniel; TVERSKY, Amos. Prospect theory: an analysis of decision under risk.Econometrica, [s.l.], v. 47, n. 2 , p. 263-292, mar. 1979. Disponível em: <http://people.hss.caltech.edu/ camerer/Ec101/ProspectTheory.pdf>. p. 263-264.

24 STARMER, Chris. Entendendo preferências: o que podemos aprender com a economia comportamental?. In: ÁVILA, Flávia; BIANCHI, Ana Maria.Guia de Economia Comportamental e Experimental.São Paulo: Economiacomportamental.org, 2015. p. 60-75. p. 63.

25 KAHNEMAN, Daniel.Rápido e devagar:duas formas de pensar. Rio de Janeiro: Objetiva, 2012. p. 390. 
em que os axiomas da Teoria da Utilidade Esperada eram frequentemente violados. Contudo, embora seu êxito como teoria normativa em relação ao comportamento humano ${ }^{26}$, não era frutífera em seu âmbito descritivo, sendo incapaz de prever como seriam as escolhas reais dos seres humanos ${ }^{27}$. Kahneman e Tversky propuseram, em seguida, a Teoria dos Prospectos, que não pretendia ser um guia para a escolha racional, mas sim descrever adequadamente como seria o comportamento humano.

A Teoria dos Prospectos gravita torno de três características cognitivas, conforme é exposto por Kahne$\operatorname{man}^{28}$. Primeiro, as avaliações são realizadas conforme um ponto de referência neutro: o nível de adaptação. Assim, em relação a resultados financeiros, por exemplo, o ponto de referencia é, em geral, o status quo, mas também pode ser o resultado que é esperado ou ao qual o sujeito pensa ter direito. Além disso, há um princípio de sensibilidade decrescente aplicável tanto às dimensões sensoriais quanto à avaliação de mudanças de riqueza. Por exemplo, a diferença subjetiva entre novecentos e mil reais será muito menor que a existente entre cem e duzentos. Por fim, há uma assimetria entre as perdas e os ganhos, isto é, os humanos possuem aversão à perda, de forma que sentem mais intensamente as perdas que os ganhos.

Sugere o autor, então, duas situações de escolha que ilustram a Teoria dos Prospectos, colocando um dado agente, a primeiro, a decidir se optaria por possuir, indubitavelmente, novecentos dólares, ou 90\% de chance de conseguir mil dólares; a segundo, a optar por uma perda inevitável de novecentos dólares, ou 90\% de chance de perder mil dólares ${ }^{29}$.

Conforme exposto por Kahneman ${ }^{30}$, as respostas a esses problemas expõem a essência da Teoria dos Prospectos. No problema 1, a utilidade esperada do ganho de novecentos dólares é, certamente, maior que $90 \%$ da utilidade do ganho de mil dólares. Isso leva a um comportamento avesso ao risco. No problema 2, por sua vez, a utilidade esperada (negativa) de perder novecentos dólares é, consideravelmente, maior do que a utilidade (negativa) de perder mil dólares. Isso porque há a aversão à perda e, logo, tem-se, nessa situação, um comportamento que busca o risco.

Logo, segundo a Teoria dos Prospectos, escolhas extremamente avessas ao risco aparecerão em casos de apostas mistas, em que tanto ganhos quanto perdas são possíveis; já nos casos de escolhas ruins - perda segura comparada com a possibilidade de uma perda maior -, vê-se a atração ao risco, provocada pela sensibilidade decrescente ${ }^{31}$.

Kahneman ${ }^{32}$ aponta que não há qualquer contradição nessas duas situações. Isso porque, no caso misto, as perdas assomam um valor aproximadamente duas vezes maior que os ganhos. Já no caso de escolhas ruins, a sensibilidade decrescente causa atração ao risco, na medida em que a dor de perder novecentos dólares é maior do que $90 \%$ da dor de perder mil dólares.

Para complementar um panorama geral da Teoria dos Prospectos, deve-se discorrer, brevemente, sobre os efeitos da possibilidade e da certeza e sobre o Padrão Quádruplo (fourfold pattern). Todos esses elementos fazem parte da avaliação global de uma perspectiva incerta e de como são atribuídos pesos aos seus resultados. A fim de compreendê-los, Daniel Kahneman ${ }^{33}$ sugere a situação abaixo:

Nos quatro exemplos abaixo, suas chances de receber um milhão melhoram em $5 \%$. As notícias são igualmente boas em cada caso?

A. De 0 a $5 \%$

26 No sentido de estabelecer como seria a maneira correta de se pensar cerca de um problema, isto é, a maneira logicamente consistente.

27 THALER, Richard.Misbehaving:the making of behavioral economics. Nova Iorque: W. W. Norton, 2016. p. 25-29.

28 KAHNEMAN, Daniel.Rápido e devagar:duas formas de pensar. Rio de Janeiro: Objetiva, 2012. p. 350-351.

29 KAHNEMAN, Daniel.Rápido e devagar:duas formas de pensar. Rio de Janeiro: Objetiva, 2012. p. 348.

30 KAHNEMAN, Daniel.Rápido e devagar:duas formas de pensar. Rio de Janeiro: Objetiva, 2012. p. 348.

31 KAHNEMAN, Daniel.Rápido e devagar:duas formas de pensar. Rio de Janeiro: Objetiva, 2012. p. 354.

32 KAHNEMAN, Daniel.Rápido e devagar:duas formas de pensar. Rio de Janeiro: Objetiva, 2012. p. 354-355.

33 KAHNEMAN, Daniel.Rápido e devagar:duas formas de pensar. Rio de Janeiro: Objetiva, 2012. p. 388. 
B. De $5 \%$ a $10 \%$

C. De $60 \%$ a $65 \%$

D. De $95 \%$ a $100 \%$

Pelo princípio da expectativa, exposto por Bernoulli e axiomatizado por Von Neumann e Morgenstern, em todos os casos há um aumento de utilidade exatamente igual a 5\% da utilidade de receber um milhão. Evidentemente, essa previsão não é parecida à lógica de decisões de um Homo Sapiens.

Nitidamente, as opções A e D impressionam mais que as demais. Conforme é descrito ${ }^{34}$, o efeito impactante de $0 \%$ a $5 \%$ é ilustrativo do efeito de possibilidade (possibility effect), que faz com que as pessoas atribuam um peso desproporcional a resultados altamente improváveis, como em casos de jogos em loteria. $\mathrm{Na}$ de $95 \%$ para 100\%, no entanto, é possível perceber o efeito de certeza (certainty effect). Por meio dele, resultados praticamente certos recebem um peso menor do que é justificável pelas suas probabilidades.

Kahneman ${ }^{35}$, então, conclui:

A conclusão é inequívoca: os pesos de decisão que as pessoas atribuem a resultados não são idênticos às probabilidades desses resultados, contrariamente ao princípio de expectativa. Resultados improváveis recebem peso excessivo - isso é o efeito da possibilidade. Resultados que são quase certos recebem peso insuficiente em relação à certeza existente.

Diante desse quadro, dois elementos se destacam na Teoria da Perspectiva: as pessoas atribuem valores a ganhos e perdas e não à riqueza; e os pesos de decisão não são exatamente iguais às probabilidades. A combinação desses dois fatores explica um padrão distintivo de preferências que ficou conhecido como padrão quádruplo e que pode ser resumido, oportunamente, no seguinte esquema ${ }^{36}$ :

1) Alta probabilidade (efeito certeza) de ganhos ( $95 \%$ de chance de ganhar dez mil dólares) e efeito certeza implicam em aversão ao risco, e podem levar, por exemplo, à aceitação de acordos desfavoráveis.

2) Alta probabilidade (efeito certeza) de perdas ( $95 \%$ de chance de perder dez mil dólares) e a esperança de evitar a perda levam o sujeito à busca do risco e, eventualmente, à rejeição de acordos favoráveis.

3) Baixa probabilidade (efeito possibilidade) de ganhos (5\% de chance de ganhar dez mil dólares) e a esperança de grande ganho levam à busca de risco e, eventualmente, à rejeição de acordos favoráveis.

4) Baixa probabilidade de perdas (efeito possibilidade) e o medo de se ter que se desfazer daquilo que já possui leva o gente a ser avesso ao risco e, eventualmente, a aceitar acordos desfavoráveis.

Nesse contexto, algumas conclusões podem ser extraídas ${ }^{37}$. A situação (1) expõe o que era discutido por Bernoulli. Diante de uma perspectiva substancial de ganho, as pessoas são avessas ao risco e estão dispostas a aceitar menos do que o valor esperado de uma aposta para assegurar a certeza do ganho. Já a situação (3) demonstra o efeito da possibilidade e explica a popularidade das loterias. Na situação (4), há a compra da segurança. Os humanos tendem a pagar mais para ter segurança do que o valor esperado - e isso tende a explicar o motivo pelo qual as companhias de seguro conseguem o seu lucro. A situação (2) ilustra o caso das escolhas ruins. Justifica-se por conta da sensibilidade decrescente, que torna a perda certa extremamente aversiva, e por conta do efeito de certeza, que reduz a aversividade da aposta.

Expostas as características gerais da Teoria dos Prospectos e de sua crítica à Teoria da Utilidade Esperada, será feita a análise dos descontos intertemporais hiperbólicos.

34 KAHNEMAN, Daniel.Rápido e devagar:duas formas de pensar. Rio de Janeiro: Objetiva, 2012. p. 388-389.

35 KAHNEMAN, Daniel.Rápido e devagar:duas formas de pensar. Rio de Janeiro: Objetiva, 2012. p. 389.

36 KAHNEMAN, Daniel.Rápido e devagar:duas formas de pensar. Rio de Janeiro: Objetiva, 2012. p. 395.

37 KAHNEMAN, Daniel.Rápido e devagar:duas formas de pensar. Rio de Janeiro: Objetiva, 2012. p. 396-397. 


\subsubsection{Anomalias em escolhas intertemporais: descontos hiperbólicos}

The pleasure which we are to enjoy ten years hence interests us so little in comparison with that which we may enjoy to-day [...]- Adam Smith ${ }^{38}$

Em muitas situações, os custos e benefícios de uma escolha diluem-se no tempo. São as chamadas escolhas intertemporais, que têm como exemplos clássicos a realização, em prol de um futuro tranquilo, de exercícios físicas, de dietas, ou mesmo de poupança. Em todos esses casos - e em muitos outros -, aos esforços despendidos para uma dada atividade não se seguem recompensas imediatas.

O modelo econômico tradicional moderno acerca das escolhas intertemporais foi esboçado por Samuel$\operatorname{son}^{39}$ e denominou-se como "Modelo da Utilidade Descontada Constante"

A principal premissa do modelo da utilidade descontada é que o consumo atual seria mais valorizado pelo indivíduo, se comparado ao futuro ${ }^{41}$. Haveria, então, um desconto do consumo futuro em algum percentual.

Conforme exposto por Faveri ${ }^{42}$ :

O modelo de utilidade descontada constante (MUDC) foi elaborado com o intuito de representar simplificadamente os eventos das escolhas intertemporais, supondo que em cada momento do tempo a satisfação do agente depende exclusivamente do seu consumo naquele momento e que os agentes maximizam o somatório das utilidades descontadas (SAMUELSON, 1937). A utilidade descontada consiste em maximizar o somatório das utilidades de cada período e calcular o seu valor presente (MURAMATSU; FONSECA, 2009).

O exemplo dado por Thaler ${ }^{43}$ ilustra a teoria:

Para entender como funciona o desconto, suponha que exista algum bem, talvez a chance de assistir a uma partida de tênis em Wimbledon. Se a partida for assistida hoje à noite, valeria 100 utils, as unidades arbitrárias utilizadas pelos economistas para descrever níveis de utilidade ou de felicidade. Considere Ted, que desconta a uma taxa constante de $10 \%$ ao ano. Para ele, essa partida valeria 100 utils este ano, 90 no próximo ano, depois 81,72 e assim por diante. Diz-se que, quando alguém desconta a utilidade dessa maneira, está descontando com uma função exponencial.

Nesse caso, é possível dizer que há descontos numa função exponencial, que caracteriza o Modelo de Utilidade Descontada Constante, e haveria, então, "trade-offs explícitos entre os custos e os benefícios que ocorrem em momentos distintos" ${ }^{34}$.

Entretanto, tal como demonstrado experimentalmente pela Economia Comportamental, os humanos não se parecem com o Homo Economicus e cometem erros previsíveis e sistemáticos. São exemplos de anomalias frente ao Modelo de Utilidade Descontada Constante, por exemplo ${ }^{45}$, a miopia, quando se tem preferências enviesadas ao consumo presente; o efeito sinal, no qual as preferências temporais dependem da

38 SMITH, Adam.The theory of moral sentiments.São Paulo: Metalibri, 2006. Disponível em: <https://www.ibiblio.org/ml/libri/s/ SmithA_MoralSentiments_p.pdf>.p. 170.

39 SAMUELSON, Paul A. A note on measurement of utility.The Review of Economic Studies, [s.l], v. 4, n. 2, p. 155-161, fev. 1937. Publicado pela Oxford University Press. Disponível em: <http://www.jstor.org/stable/2967612>.

40 Expor as minúcias da teoria de Samuelson ultrapassa os objetivos deste trabalho. Sendo assim, serão delineadas as suas ideias básicas e, posteriormente, as críticas da Economia Comportamental.

41 THALER, Richard.Misbehaving:the making of behavioral economics. Nova Iorque: W. W. Norton, 2016. p. 89.

42 DE FAVERI, Dinorá Baldo.Impaciência nas escolhas intertemporais:uma abordagem comportamental. 2017. 227 f. Tese (Doutorado) - Curso de Programa de Pós-graduação em Economia, Universidade Federal de Santa Catarina, Florianópolis, 2017. Disponível em: <https://repositorio.ufsc.br/bitstream/handle/123456789/183406/349814.pdf?sequence=1 $>$.

43 THALER, Richard.Misbehaving:the making of behavioral economics. Nova Iorque: W. W. Norton, 2016. Tradução nossa.

44 RICK, Scott; LOEWENSTEIN, George. Intangibilidade na escolha intertemporal. In: ÁVILA, Flávia; BIANCHI, Ana Maria. Guia de economia comportamental e experimental.São Paulo: Economiacomportamental.org, 2015. p. 76-97. p. 76.

45 MURAMATSU, Roberta; FONSECA, Patrícia. Economia e psicologia na explicação da escolha intertemporal.Revista de Economia Mackenzie, São Paulo, v. 6, n. 6, p. 87-112. 2008. Disponível em: <http://editorarevistas.mackenzie.br/index.php/rem/article/ view/810>. p. 93. 
percepção de ganho ou perda ou, ainda, o viés de projeção, em que as preferencias futuras são estimadas de acordo com estados sensoriais e fisiológicos do agente - como o clima a que ele está exposto.

A partir dessas anomalias, um novo modelo foi proposto para explicar os descontos intertemporais com base em como eles são na realidade. No novo sistema, denominado modelo dos descontos hiperbólicos, os indivíduos possuem uma taxa decrescente de preferência no tempo. Conforme explicam Frederick, Loewenstein e O’Donoghue ${ }^{46}$ :

Alguns resultados são usualmente interpretados como evidência para o desconto hiperbólico. Primeiro, quando se solicita a participantes que comparem entre uma recompensa menor e mais atual e uma recompensa maior e futura [...], a taxa implícita de desconto em horizontes maiores de tempo é menor que a taxa implícita em horizontes menores de tempo. [...] Segundo, quando funções matemáticas são explicitamente adequadas a esses dados, uma forma funcional hiperbólica, que impõe descontos decrescentes, adequa-se melhor aos dados que a forma funcional exponencial, que impõe taxas constantes de desconto. [...] Terceiro, pesquisadores têm mostrado que preferências entre duas recompensas atrasadas podem reverter-se em favor de uma recompensa mais próxima, como o tempo para ambas as recompensas diminui - e.g., alguém pode preferir $\$ 110 \mathrm{em} 31$ dias a $\$ 100 \mathrm{em} 30$ dias, mas também preferir $100 \$$ agora a $\$ 110$ amanhã.

Nesse quadro, ao serem analisados os exemplos mais importantes de escolhas intertemporais, pode-se delinear um padrão que parece ser capaz de explicar as razões pelas quais as pessoas tendem a descontar o futuro em taxas decrescentes. $\mathrm{Na}$ maior parte dos casos, enquanto os resultados preliminares tendem a ser concretos, como no caso de comprar um produto ou de consumir uma droga que causa dependência química, os resultados posteriores tendem a ser intangíveis ou indefinidos, por exemplo, a obesidade ou a dependência química ${ }^{47}$.

Conforme ressaltam Rick e Loeweinstein ${ }^{48}$, tal intangibilidade pode ter diferentes causas. Por vezes, é devida à imperceptibilidade do impacto do comportamento, como ocorre com o consumo de uma refeição em relação ao futuro ganho de peso. Em algumas situações, há dificuldade ou impossibilidade de se imaginar as consequências futuras, como quando há o dispêndio de dinheiro em vez da poupança. Por fim, outros casos possuem tal natureza pela incerteza inerente às suas consequências, por exemplo, o consumo de substâncias químicas e a dependência.

Por fim, para compreender como ocorrem os descontos hiperbólicos, considere outro exemplo dado por Thaler" ${ }^{49}$ :

Suponha que Ted e Matthew morem em Londres e sejam ávidos fãs de tênis. Cada um ganhou um sorteio oferecendo um ingresso para uma partida em Wimbledon, com um fator intertemporal. Eles podem escolher entre três opções. A opção A é um bilhete para uma partida da primeira rodada neste ano; na verdade, a partida é amanhã. A opção B é uma partida de quartas de final no torneio do próximo ano. A opção C é a final, no torneio que será realizado daqui a dois anos. Todos os ingressos são garantidos, então podemos deixar as considerações de risco fora de nossa análise, e Ted e Matthew têm gostos idênticos no tênis. Se os jogos forem todos para o torneio deste ano, as utilidades que eles atribuem a eles são os seguintes: A: 100, B: 150, C: 180. Mas, para ir para a sua opção favorita C, a final do torneio, eles têm que esperar dois anos. O que eles farão?

Se Ted tivesse escolha, ele escolheria esperar dois anos e ter o ingresso para a final. Ele o faria porque o valor atribuído no momento para a final em dois anos (o seu "valor presente") é 146 (81\% de 180), o

46 FREDERICK, Shane; LOEWENSTEIN, George; O'DONOGHUE, Ted. Time discounting and time preference: a critical review.Journal of Economic Literature, [s.l.], v. 40, n. 2, p. 351-401, jun. 2002. American Economic Association. Disponível em: < http:// dx.doi.org/10.1257/002205102320161311>. p. 360-361. Tradução nossa.

47 RICK, Scott; LOEWENSTEIN, George. Intangibilidade na escolha intertemporal. In: ÁVILA, Flávia; BIANCHI, Ana Maria. Guia de economia comportamental e experimental.São Paulo: Economiacomportamental.org, 2015. p. 76-97. p. 77.

48 RICK, Scott; LOEWENSTEIN, George. Intangibilidade na escolha intertemporal. In: ÁVILA, Flávia; BIANCHI, Ana Maria. Guia de economia comportamental e experimental.São Paulo: Economiacomportamental.org, 2015. p. 76-97. p. 77.

49 THALER, Richard.Misbehaving:the making of behavioral economics. Nova Iorque: W. W. Norton, 2016. p. 92. Grifo nosso. Tradução nossa. 
que é mais significativo que o valor atual de A (100) e de B (135, ou 90\% de 150). Além disso, após um ano, se questionado acerca da possibilidade de mudar a sua escolha e aceitar a opção B, as quartas de final, ele negaria, na medida em que $90 \%$ do valor de C (162) é ainda maior que o valor de B. Isso é o que significa ter preferencias consistentes no tempo. [...]

E quanto a Matthew? Quando primeiro apresentado à escolha, ele também escolheria a opção C, a final. No momento, ele avalia A em 100, B em 105 (70\% de 150) e C em 113 (63\% de 180). Mas ao contrário de Ted, quando um ano se passa, Matthew mudará de opinião e trocará para B, as quartas de final, porque esperar um ano desconta o valor de $\mathrm{C}$ em $70 \%$ de 126 , o que é menor que 150, o atual valor de B. Ele é inconsistente no tempo.

Expostos os conceitos básicos que envolvem as escolhas intertemporais, bem como o modelo econômico-comportamental que descreve o comportamento humano nessas situações, resta tratar acerca das limitações do autocontrole e do esgotamento do ego.

\subsection{O esgotamento do ego}

O experimento de Danzinger, Levav e Avnaim-Pesso ${ }^{50}$ é um exemplo significativo para se introduzir a temática do esgotamento do ego. Os autores questionam se os resultados de casos judiciais seriam determinados apenas pelos fatos e pelo Direito ou se fatores alheios também teriam o seu impacto. Para tanto, analisaram os padrões decisórios de juízes, que passavam o dia todo revisando pedidos de condicional. O resultado da pesquisa foi esclarecedor:

Apresentamos evidências sugerindo que quando juízes realizam decisões repetidas, eles possuem uma considerável tendência para julgar a favor do status quo. Essa tendência pode ser superada por uma pausa para refeições, o que é consistente com pesquisas anteriores demonstrando os efeitos de um rápido descanso, do bom humor e da glicose para a reposição das reservas mentais. ${ }^{51}$

Os resultados mostram que mesmo juízes, no exercício da função para qual foram preparados, demonstram reduzida capacidade decisória após exercerem significativo esforço cognitivo. Além disso, também é possível perceber que o repouso e a alimentação parecem estar relacionados ao retorno da capacidade cognitiva decisória inicial ${ }^{52}$.

Esse fenômeno foi extensamente demonstrado experimentalmente ${ }^{53}$. Baumeister et al. ${ }^{54}$ utilizam o termo Ego Depletion, aqui traduzido como Esgotamento do Ego, para se referir à redução temporária na capacidade do self $\tilde{f}^{5}$ ou na vontade de iniciar uma ação volitiva, provocada por prévio exercício volitivo.

Os autores citados adotaram como premissa que o self consome uma reserva limitada, semelhante a uma energia ou força, quando realiza atos de volição. Para isso, testaram a hipótese de que atos de escolha e de autocontrole causariam o esgotamento do ego. Mais especificamente, de que após um ato inicial de volição,

50 DANZINGER, Shai; LEVAV, Jonathan; AVNAIM-PESSO, Liora. Extraneous factors in judicial decisions. Proceedings of The National Academy of Sciences of the United States of America, Princeton, v. 108, n. 17, p. 6889-6892, 26 abr. 2011.

51 DANZINGER, Shai; LEVAV, Jonathan; AVNAIM-PESSO, Liora. Extraneous factors in judicial decisions.Proceedings of The National Academy of Sciences of the United States of America, Princeton, v. 108, n. 17, p. 6889-6892, 26 abr. 2011. p. 6892. Tradução nossa.

52 Os autores ressaltam que não é possível determinar de maneira inequívoca se o simples descanso ou a alimentação restauram as reservas mentais dos juízes porque cada uma das pausas foi realizada para o propósito de fazer uma refeição.

53 Para uma extensa revisão bibliográfica acerca do esgotamento do ego, ver:

BAUMEISTER, Roy F; TIERNEY, John.Willpower:rediscovering the greatest human strength. [s.l.]: Penguin Books, 2012.

54 BAUMEISTER, Roy F. et al. Ego depletion: is the active self a limited resource?Journal of Personality and Social Psychology, [s.l.], v. 74 , n. 5 , p. $1252-1265$, maio 1998. p. 1253.

55 Vale ressaltar que self, na terminologia utilizada pelos autores, de nítida influência freudiana, estaria relacionado às escolhas, decisões e comportamentos inibitórios; à realização de planos e à execução destes. Ainda que nem todo o comportamento humano envolva controles deliberados pelo self, uma parte importante do comportamento assim o faz. Não se adota, neste trabalho, uma perspectiva psicanalítica de análise. O que é considerado pelos autores como atuação do self, aqui, é equiparado à atuação do Sistema 2. 
haveria menor reserva mental para os atos subsequentes ${ }^{56}$. Dos experimentos realizados pelos autores, três deles merecem ser destacados.

O primeiro teve por objeto o autocontrole. No grupo de tratamento, os participantes resistiram ao impulso de comer chocolates colocados à sua frente e, em vez disso, esforçaram-se para comer rabanetes. Após essa etapa, as pessoas tiveram que realizar um quebra-cabeça de alto grau de dificuldade. As pessoas que haviam resistido à tentação desistiram muito mais rápido, em comparação com aquelas que puderam comer os chocolates ou que não se submeteram a essa tentação ${ }^{57}$. O experimento demonstrou com êxito, segundo os autores, que o autocontrole, nas duas situações, usa a mesma fonte limitada, de tal forma que a realização de um dos atos impacta no ato subsequente.

No segundo experimento, pretendeu-se testar se um ato de escolha pessoal produziria o mesmo efeito visto no primeiro experimento. Foram solicitados a dois grupos que consentissem livre e deliberadamente a realizar um discurso, favorável ou contrário aos seus pontos de vista pessoais. Um terceiro grupo continha indivíduos que deveriam elaborar discursos, conforme o tema indicado pelos pesquisadores, sem a opção de realizarem uma escolha para tanto. No grupo de participantes que realizaram uma escolha livre e deliberada, foram encontradas maiores taxas de desistência no mesmo desafio do primeiro experimento ${ }^{58}$. Assim, concluíram que fazer uma escolha também parece ser um ato que utiliza a mesma reserva mental que é gasta ao se exercer o autocontrole.

O terceiro experimento pretendeu demonstrar que o prévio exercício de autocontrole impactaria a posterior tomada de decisões. Para isso, o grau de predominância da opção passiva foi mensurado. Pessoas foram expostas a situações de escolha em que deveriam responder ativa ou passivamente. Aquelas que estavam com o ego esgotado, por tarefas semelhantes às realizadas nos dois experimentos narrados anteriormente, apresentavam uma tendência a utilizar as respostas passivas ${ }^{59}$. Para os pesquisadores, as escolhas ativas também consomem a mesma reserva mental consumida pelas demais atividades volitivas, de forma que as pessoas tendem a permanecer mais passivas quanto mais escassos esses recursos forem.

Com estes exemplos, Baumeister et al. ${ }^{60}$ ilustram um padrão amplo do esgotamento do ego:

Tomados em conjunto, esses quatro estudos apontam para um padrão amplo de esgotamento do ego. Em cada um deles, um ato inicial de volição foi seguido por um prejuízo em alguma outra esfera da volição. Nós verificamos que um ato inicial de autocontrole prejudicou o autocontrole subsequente (Estudo 1), que realizar uma decisão responsável prejudicou o autocontrole subsequente (Estudo 2), que o autocontrole diminuiu o desempenho em uma tarefa que requereu autocontrole (Estudo 3), e que um ato inicial de autocontrole leva a uma passividade aumentada (Estudo 4).

Conforme exposto por Kahneman, atividades que impõem altas exigências ao Sistema 2, como escolhas deliberadas e resistir a tentações, requerem autocontrole, o que é exaustivo e desagradável ${ }^{61}$. Constata-se, por exemplo, que pessoas com o ego esgotado têm maior probabilidade de fazer escolhas egoístas, de utilizar linguajar sexista e de fazer julgamentos superficiais socialmente ${ }^{62}$. Kahneman alerta, ainda, que o relaxamento do controle do Sistema 2 - isto é, o esgotamento do ego - não é o único responsável por enfraquecer o

56 BAUMEISTER, Roy F. et al. Ego depletion: is the active self a limited resource?Journal of Personality and Social Psychology, [s.1.], v. 74, n. 5, p. 1252-1265, maio 1998. p. 1253.

57 BAUMEISTER, Roy F. et al. Ego depletion: is the active self a limited resource?Journal of Personality and Social Psychology, [s.l.], v. 74, n. 5, p. 1252-1265, maio 1998. p. 1261.

58 BAUMEISTER, Roy F. et al. Ego depletion: is the active self a limited resource?Journal of Personality and Social Psychology, [s.l.], v. 74, n. 5, p. 1252-1265, maio 1998. p. 1261-1262.

59 BAUMEISTER, Roy F. et al. Ego depletion: is the active self a limited resource?Journal of Personality and Social Psychology, [s.l.], v. 74 , n. 5 , p. 1252-1265, maio 1998. p. 1262.

60 BAUMEISTER, Roy F. et al. Ego depletion: is the active self a limited resource?Journal of Personality and Social Psychology, [s.l.], v. 74 , n. 5, p. 1252-1265, maio 1998. p. 1262. Tradução nossa.

61 KAHNEMAN, Daniel.Rápido e devagar:duas formas de pensar. Rio de Janeiro: Objetiva, 2012. p. 56.

62 KAHNEMAN, Daniel.Rápido e devagar:duas formas de pensar. Rio de Janeiro: Objetiva, 2012. p. 55. 
autocontrole. Por exemplo, algumas doses de álcool ou uma noite insone podem produzir o mesmo efeito ${ }^{63}$.

Contribui com a presente análise o experimento conduzido por Hamilton, Hong e Chernev $^{64}$, com o objetivo de testar se as opções de escolha variariam conforme se escolhe de modo intuitivo ou de modo deliberado. Colhidos os dados, demonstrou-se que estar com o ego esgotado é semelhante a utilizar o Sistema 1: participantes que escolherem com o ego esgotado apresentaram padrões decisórios indistinguíveis daqueles apresentados pelos participantes do grupo que escolhia intuitivamente e ambos eram diversos daqueles apresentados pelos participantes que escolhiam de forma deliberada ${ }^{65}$.

Importante ressaltar que experimentos descartaram algumas explicações alternativas para o padrão de comportamento apresentado com o esgotamento do ego. Por exemplo, efeitos de humor e o sentimento de superdedicação para o experimento ${ }^{66}$ ou o sentimento de ter falhado na primeira tarefa e, logo, de estar com o autocontrole diminuído ${ }^{67}$.

Os recursos mentais consumidos no esgotamento do ego são, normalmente, repostos. As pesquisas originais que identificavam tal fenômeno não determinavam qual seriam os fatores envolvidos nessa reposição $^{68}$. Estudos posteriores ${ }^{69}$, no entanto, apontaram uma correlação entre os níveis de glicose e o esgotamento do ego. Nesse sentido, Kahneman ${ }^{70}$ afirma:

O sistema nervoso consome mais glicose do que outras partes do corpo, e a atividade mental trabalhosa parece ser particularmente dispendiosa na moeda da glicose. Quando você está ativamente envolvido em um raciocínio cognitivo difícil ou ocupado numa tarefa que exige autocontrole, seu nível de glicose no sangue cai. O efeito é análogo a um corredor que suga a glicose armazenada em seus músculos num tiro. A implicação óbvia dessa ideia é que os efeitos do esgotamento do ego podem ser anulados com a ingestão de glicose, e Baumeister e seus colegas confirmaram essa hipótese em diversos experimentos.

Em um desses estudos, Gailliot $e t$ al. ${ }^{71}$ encontraram evidências de que o controle de atenção requer uma quantidade relativamente grande de glicose. Nesse experimento, participantes assistiram a um vídeo de 6 minutos e lhes foi proposto ou que ignorassem um certo estímulo aparecendo na tela ou que assistissem ao vídeo normalmente. Entre os participantes que realizaram o controle de atenção, o nível de glicose diminuiu após realizarem a tarefa, enquanto o outro grupo não apresentou qualquer alteração.

A conclusão desta pesquisa, assim como a de várias outras, é que baixos níveis de glicose no cérebro parecem estar associados a prejuízos no autocontrole. Assim, restaurada a quantidade disponível de glicose para níveis mais altos, o autocontrole deve melhorar. Frise-se, contudo, que o consumo de glicose para além do necessário não implica em incrementos de autocontrole, de tal forma que o efeito é observado apenas quando se disponibiliza glicose suficiente para se recuperar de um estado de ego esgotado ${ }^{72}$.

Pelo impacto que produz no processo decisório, prejudicando as decisões deliberadas, os efeitos do

63 KAHNEMAN, Daniel.Rápido e devagar:duas formas de pensar. Rio de Janeiro: Objetiva, 2012. p. 55.

64 HAMILTON, Ryan; HONG, Jiewen; CHERNEV, Alexander. Perceptual focus effects in choice.Journal of Consumer Research, [s.l.], v. 34, n. 2, p. 187-199, ago. 2007. Oxford University Press (OUP).

65 BAUMEISTER, Roy F. et al. Free will in consumer behavior: Self-control, ego depletion, and choice. Journal of Consumer Psychology, [s.l.], v. 18, n. 1, p. 4-13, jan. 2008. p. 9.

66 BAUMEISTER, Roy F. et al. Self-regulation and personality: how interventions increase regulatory success, and how depletion moderates the effects of traits on behavior.Journal of Personality, [s.1.], v. 74, n. 6, p. 1773-1802, dez. 2006.

67 WALLACE, Harry M.; BAUMEISTER, Roy F. The effects of success versus failure feedback on further self-control.Self and Identity, [s.l.], v. 1, n. 1, p. 35-41, jan. 2002.

68 BAUMEISTER, Roy F. et al. Ego depletion: is the active self a limited resource?Journal of Personality and Social Psychology, [s.l.], v. 74, n. 5, p. 1252-1265, maio 1998. p. 1264.

69 Vide: GAILLIOT, Matthew T.; BAUMEISTER, Roy F. The physiology of willpower: linking blood glucose to self-control. Personality and Social Psychology Review, [s.l.], v. 11, n. 4, p. 303-327, nov. 2007. SAGE Publications.

70 KAHNEMAN, Daniel.Rápido e devagar:duas formas de pensar. Rio de Janeiro: Objetiva, 2012. p. 57.

71 GAILLIOT, Matthew T. et al. Self-control relies on glucose as a limited energy source: willpower is more than a metaphor. Journal of Personality and Social Psychology, [s.1.], v. 92, n. 2, p. 325-336, 2007. American Psychological Association (APA).

72 GAILLIOT, Matthew T.; BAUMEISTER, Roy F. The physiology of willpower: linking blood glucose to self-control.Personality and Social Psychology Review, [s.1.], v. 11, n. 4, p. 303-327, nov. 2007. SAGE Publications. p. 306-307. 
esgotamento do ego podem ser identificados em diversas áreas. Diversos são os exemplos identificados no âmbito do consumo. Vohs e Faber ${ }^{73}$ demonstraram que o esgotamento do ego provoca um aumento nos gastos impulsivos. Vohs e Heatherton ${ }^{74}$, por sua vez, constataram que pessoas em dieta tendem a sair dela quando estão esgotadas. Baumeister $e$ al. constataram ${ }^{75}$ que consumidores esgotados tendem a utilizar menos a sua capacidade de raciocinar e de se informar em suas decisões de consumo, podendo simplificar suas escolhas, baseando-se apenas nos preços e ignorando outros fatores que poderiam levar a uma solução ótima, como as qualidades do produto.

O esgotamento do ego, como já ressaltado, manifesta-se por conta do uso das ferramentas cognitivas em processos decisórios complexos, e prejudica as decisões subsequentes. Como será demonstrado a seguir, esse efeito pode se tornar perverso na medida em que se analisam as escolhas econômicas feitas por pessoas em situação de pobreza.

\section{EFEITOS PSICOLOGICAMENTE ADVERSOS DA POBREZA}

A condição de maior escassez, encontrada na pobreza, traz como implicação direta uma maior complexidade em grande parte das escolhas econômicas. Conforme será demonstrado adiante, enquanto decisões simples, como comprar ou não um sabão, não trazem maiores consequências para os cidadãos mais ricos, podem ser angustiantes para um sujeito na zona rural da Índia ${ }^{76}$.

A chave para se entender a questão é o conceito de custo de oportunidade. O custo de oportunidade de um determinado bem ou serviço é aquilo que o agente abre mão ao fazer uma escolha ${ }^{77}$. Pela análise econômica tradicional, os custos de oportunidade são os grandes motivadores de todas as decisões. A Economia Comportamental, entretanto, vem demonstrando que os humanos, na verdade, não são capazes de avaliar tais custos em diversas situações cotidianas ${ }^{78}$.

Mullainathan e Shafir ${ }^{79}$ ressaltam, entretanto, que, como a Economia como um todo é entendida à luz da mentalidade da escassez, os seus pressupostos tradicionais são vistos de maneira mais real nos indivíduos submetidos a maior escassez. Por isso, pessoas pobres se comportariam de maneira mais semelhante ao Homo Economicus, no sentido de tentar atingir melhores resultados no dia-a-dia e fazer o dinheiro, escasso, render mais. Ao mesmo tempo, agir desta forma faz com que pessoas em situação de pobreza estejam submetidas a trade-offs mais graves cotidianamente, impactando, conforme será demonstrado adiante, a sua forma de decidir.

Spears ${ }^{80}$ conduziu experimento de campo a fim de analisar a sensibilidade a preços de indivíduos nos distrito indiano de Kutch. Para isso, ofereceu sabões aos moradores desse local, ora por três rúpias, ora por 15 rúpias. Parte dos participantes era convidada a deliberar sobre a compra e os demais decidiam automaticamente. Como premissa da pesquisa, estava o conceito de um preço limítrofe subjetivo dos agentes: preços

73 VOHS, Kathleend.; FABER, RonaldJ. Spent resources: self-regulatory resource availability affects impulse buying.Journal of Consumer Research, [s.l.], v. 33, n. 4, p. 537-547, mar. 2007.

74 VOHS, Kathleen D.; HEATHERTON, Todd F. Self-regulatory failure: a resource-depletion approach.Psychological Science, [s.l.], v. 11 , n. 3, p. 249-254, maio 2000.

75 BAUMEISTER, Roy F. et al. Free will in consumer behavior: Self-control, ego depletion, and choice.Journal of Consumer Psychology, [s.l.], v. 18, n. 1, p. 4-13, jan. 2008. p. 10.

76 TIERNEY, John.Do you suffer from decision fatigue?. Disponível em: < https://www.nytimes.com/2011/08/21/magazine/do-yousuffer-from-decision-fatigue.html>.

77 MANKIW, N. Gregory. Introdução à economia. 3. ed. São Paulo: Cengage Learning, 2009. p. 6.

78 THALER, Richard.Misbehaving:the making of behavioral economics. Nova Iorque: W. W. Norton, 2016. p. 58.

79 MULLAINATHAN, Sendhil; SHAFIR, Eldar. Scarcity: why having too little means so much. Nova Iorque: Time Books, Henry Holt \& Company Llc, 2014.

80 SPEARS, Dean. Decision costs and price sensitivity: field experimental evidence from India.Journal Of Economic Behavior \& Organization, [s.1.], v. 97, p. 169-184, jan. 2014. Elsevier BV. Disponível em: <http://dx.doi.org/10.1016/j.jebo.2013.06.012>. 
superiores ao limite seriam rejeitados intuitivamente, mas poderiam ser aceitos se o agente fosse forçado a deliberar sobre a escolha. Para pessoas pobres, a condição de escassez faria com que esse limite fosse muito baixo e exigiria deliberação para ambos os valores colocados.

As premissas foram confirmadas. Segundo o autor ${ }^{81}$ :

[...] No grupo controle $84 \%$ compraram sabão quando ofertado por três rúpias e $29,8 \%$ compraram o sabão vendido por quinze rúpias. Entre os que deliberaram, $82,4 \%$ compraram o sabão por três rúpias e 39\% compraram o sabão por quinze.

[...] A situação de deliberação quase não teve efeito direto entre aqueles aos quais foi oferecido o sabão a três rúpias; [...]. Enquanto a situação de deliberação teve pouco efeito na venda a três rúpias, ela aumentou a aceitação em 10.7 pontos percentuais - ou mais de um terço - na venda a quinze rúpias, na qual o modelo sugere que as ofertas teriam sido ignoradas devido aos custos de deliberação.

Em que pese o benefício do sabão para aqueles indivíduos ${ }^{82}$ e, consequentemente, a expectativa de aquisição intuitiva, constatou-se que em situações próximas ao valor de mercado (15 rúpias ${ }^{83}$ ), a compra de sabão era rechaçada intuitivamente pelos indivíduos; contudo, a existência de deliberações aumentava a probabilidade de aquisição.

Deliberar, tal como narrado outrora, não é um processo gratuito. Considerando que transações relativamente simples já trazem custos cognitivos significativos em ambientes de pobreza extrema, é razoável esperar que outras decisões mais complexas, como as que envolvem o planejamento familiar, seriam ainda mais custosas e poderiam sequer atingir algum resultado. Os resultados do experimento acima não são isolados. Diversos outros experimentos comportamentais que serão abordados a seguir mostram a ampliação de vieses cognitivos em pessoas pobres, fato que pode levar ao autoreforço da própria situação de pobreza. Por isso, é possível dizer que há uma maior tributação cognitiva, nos termos de Mani et a ${ }^{\beta 4}$, sobre as pessoas mais pobres, como será melhor explanado na próxima seção.

Apresenta-se necessário, como antecedente da análise que se segue, o estabelecimento de três restrições metodológicas. A primeiro, de que a pobreza não é apenas a renda insuficiente: falhas das instituições, níveis de criminalidade, dificuldade de acesso a serviços básicos, como à saúde, e inúmeros outros obstáculos compõem esse conceito ${ }^{85}$; a segundo, não se sugere, com os questionamentos colocados neste trabalho, que os pobres seriam os culpados pela sua própria situação: inexistindo certas coincidências ambientais ${ }^{86}$, qualquer pessoa poderia estar nessas mesmas condições; a terceiro, apesar de não serem objeto de análise no presente artigo, abordagens de outros ramos do conhecimento, como a Sociologia e a Antropologia, não devem ser desconsideradas.

\subsection{A pobreza, os descontos intertemporais e a opção pelo caminho mais seguro}

As escolhas intertemporais e as escolhas em situações de risco são de extrema importância para os estudos econômicos. Conforme demonstrado anteriormente, parte da Economia Comportamental se dedicou

81 SPEARS, Dean. Decision costs and price sensitivity: field experimental evidence from India.Journal Of Economic Behavior \& Organization, [s.l.], v. 97, p. 169-184, jan. 2014. Elsevier BV. Disponível em: <http://dx.doi.org/10.1016/j.jebo.2013.06.012>. p. 180. Tradução nossa.

82 Conforme ressaltado por Spears (2014), o distrito de Kutch sofria com diarreia endêmica, que era ampliada pela falta de atos básicos de higiene, como lavar as mãos com sabão.

83 O valor de 15 rúpias, segundo cotações atuais, gira em torno de 83 centavos de real (https://pt.coinmill.com/BRL_INR. html\#INR=15). Conversão em 12 de maio de 2018.

84 MANI, A. et al. MANI, A. et al. Poverty impedes cognitive function. Science, [s.1.], v. 341, n. 6149, p. 976-980, 29 ago. 2013. American Association for the Advancement of Science (AAAS). Disponível em: <http://dx.doi.org/10.1126/science.1238041>. p. 980. 85 HAUSHOFER, J.; FEHR, E. On the psychology of poverty. Science, [s.l.], v. 344, n. 6186, p.862-867, 22 maio 2014. American Association for the Advancement of Science (AAAS). Disponível em: <http://dx.doi.org/10.1126/science.1232491>. p. 862.

86 HAUSHOFER, J.; FEHR, E. On the psychology of poverty. Science, [s.l.], v. 344, n. 6186, p.862-867, 22 maio 2014. American Association for the Advancement of Science (AAAS). Disponível em: < http://dx.doi.org/10.1126/science.1232491>. p. 862. 
a expor empiricamente desvios comportamentais nessas escolhas, em relação ao que previam os teoremas da economia tradicional.

Quanto às preferências intertemporais e escolhas sob risco de pessoas em situação de pobreza, o experimento realizado por Tanaka, Camerer e Nguyen ${ }^{87}$ apresenta-se pertinente. Nessa oportunidade, experimentos foram realizados com famílias vietnamitas de nove vilarejos, com diferenças substanciais nos níveis de renda média e de acesso ao mercado. Foram dadas instruções aos participantes que deveriam manter folhas de registro para cada jogo, com o fim de se avaliar posteriormente os níveis de desconto intertemporal e de aversão ao risco de cada participante ${ }^{88}$.

Os resultados dos autores são conclusivos:

Nossos resultados sugerem que a renda média do vilarejo é relacionada ao risco e às preferências temporais. Pessoas vivendo em vilarejos pobres não têm necessariamente medo da incerteza, no sentido de variação de renda; em vez disso, são avessas à perda. Quando introduzimos as variáveis instrumentais para a variáveis de renda, a renda média de um vilarejo é, também, significativamente correlacionada com aversão ao risco (concavidade da função de utilidade). Do experimento dos descontos no tempo, encontramos que a renda média de um vilarejo é correlacionada com menores taxas de desconto, isto é, pessoas vivendo em vilarejos mais ricos não só são menos avessas ao risco como também mais pacientes $^{89}$.

Além disso, conforme exposto por Haushofer e Fehr ${ }^{90}$, há resultados significativos de que: a) as taxas de desconto em famílias pobres nos Estados Unidos são maiores do que as de famílias ricas ${ }^{91}$; b) famílias agrícolas etíopes ${ }^{92}$ e amostras do sul da Índia ${ }^{93}$ apontam para descontos mais elevados em famílias de rendas mais baixas; c) famílias mais ricas apresentam níveis mais baixos de aversão ao risco ${ }^{94}$.

Esses resultados expõem situações que podem ser perniciosas, na medida em que parecem ser capazes de reforçar a própria condição de pobreza. Isso porque, enquanto indivíduos mais ricos conseguiriam poupar mais para o futuro e assumir pequenos riscos a fim de obter resultados econômicos satisfatórios, a situação de pobreza poderia fazer com que os riscos fossem superestimados e com que o presente fosse privilegiado, em detrimento do futuro.

Ilustra esse potencial ciclo vicioso o trabalho de Shah, Mullainathan e Shafir ${ }^{96}$, no qual se constata a pre-

87 TANAKA, Tomomi; CAMERER, Colin F; NGUYEN, Quang. Risk and time preferences: linking experimental and household survey data from Vietnam. American Economic Review, [s.1.], v. 100, n. 1, p. 557-571, mar. 2010. American Economic Association. Disponível em: <http://dx.doi.org/10.1257/aer.100.1.557>.

88 TANAKA, Tomomi; CAMERER, Colin F; NGUYEN, Quang. Risk and time preferences: linking experimental and household survey data from Vietnam. American Economic Review, [s.l.], v. 100, n. 1, p. 557-571, mar. 2010. American Economic Association. Disponível em: <http://dx.doi.org/10.1257/aer.100.1.557>. p. 559.

89 TANAKA, Tomomi; CAMERER, Colin F; NGUYEN, Quang. Risk and time preferences: linking experimental and household survey data from Vietnam. American Economic Review, [s.1.], v. 100, n. 1, p. 557-571, mar. 2010. American Economic Association. Disponível em: <http://dx.doi.org/10.1257/aer.100.1.557>. p. 569. Tradução nossa.

90 HAUSHOFER, J.; FEHR, E. On the psychology of poverty. Science, [s.l.], v. 344, n. 6186, p.862-867, 22 maio 2014. American Association for the Advancement of Science (AAAS). Disponível em: < http://dx.doi.org/10.1126/science.1232491>. p. 862.

91 LAWRANCE, Emily C. Poverty and the rate of time preference: evidence from panel data.Journal of Political Economy, [s.l.], v. 99, n. 1, p. 54-77, fev. 1991. University of Chicago Press. Disponível em: <http://dx.doi.org/10.1086/261740>.

92 YESUF, Mahmud; BLUFFSTONE, Randall. Wealth and time preference in rural ethiopia.Environment For Development, [s.1.], v. 16, n. 08, p. 1-18, jun. 2008. Disponível em: <http://www.rff.org/files/sharepoint/WorkImages/Download/EfD-DP-08-16.pdf>. 93 PENDER, John L. Discount rates and credit markets: theory and evidence from rural india.Journal Of Development Economics, [s.l.], v. 50, n. 2, p. 257-296, ago. 1996. Elsevier BV. Disponível em: <http://dx.doi.org/10.1016/s0304-3878(96)00400-2>.

94 DOHMEN, Thomas et al. Individual risk attitudes: measurement, determinants, and behavioral consequences.Journal of The European Economic Association, [s.l.], v. 9, n. 3, p. 522-550, 31 mar. 2011. Oxford University Press (OUP). Disponível em: < http:// dx.doi.org/10.1111/j.1542-4774.2011.01015.x>.

95 GUISO, Luigi; PAIELLA, Monica. Risk aversion, wealth, and background risk. Journal of The European Economic Association, [s.l.], v. 6, n. 6, p. 1109-1150, dez. 2008. Oxford University Press (OUP). Disponível em: < http://dx.doi.org/10.1162/jeea.2008.6.6.1109>. 96 SHAH, A. K.; MULLAINATHAN, S.; SHAFIR, E. Some consequences of having too little. Science, [s.l.], v. 338, n. 6107, p. 682-685, nov. 2012. American Association for the Advancement of Science (AAAS). Disponível em: <http://dx.doi.org/10.1126/ science.1222426>. 
valência de comportamentos econômicos danosos a longo prazo, como por exemplo, a baixa poupança, o excesso de empréstimos, muitas vezes com taxas de juros elevadas, o alto percentual de indivíduos pobres que jogam em loterias ${ }^{97}$ e as falhas para se inscrever em programas assistenciais.

O gráfico a seguir, por exemplo, demonstra a evolução da taxa de poupança nos EUA entre diferentes classes sociais e expõe como as pessoas mais pobres tendem a poupar menos, se comparadas às mais ricas:

Figura 1 - Taxa de poupança de acordo com faixas de renda (médias decenais)

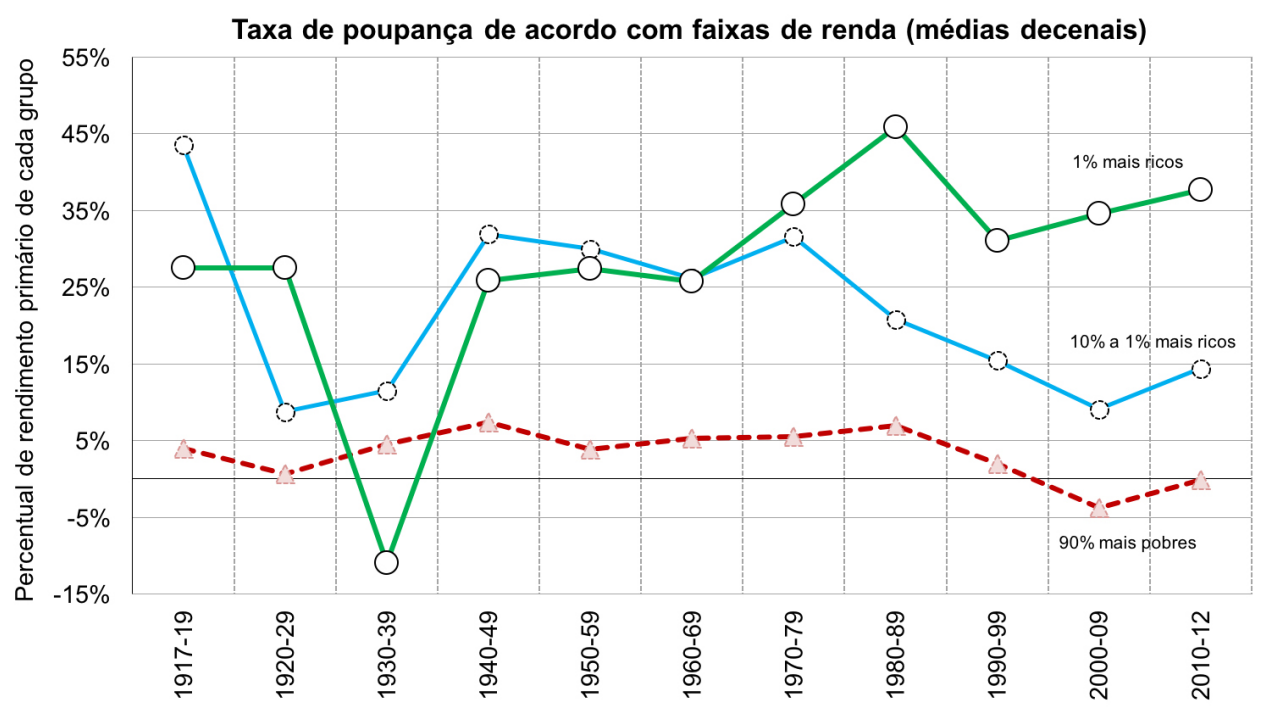

Fonte: Elaboração própria. Fonte: SAEZ, Emmanuel; ZUCMAN, Gabriel. Wealth inequality in the united states since 1913: evidence from capitalized income tax data.National Bureau Of Economic Research, Cambridge, Ma, p. 1-46, out. 2014. Disponível em: <http://dx.doi.org/10.3386/w20625>. Dados adicionais em: <http://gabriel-zucman.eu/files/SaezZucman2015MainData.xlsx>.

Como já ressaltado, todas as escolhas envolvem custos cognitivos. Tendo em vista que mesmo escolhas simples, por exemplo, a compra do sabão do já citado experimento de Spears ${ }^{98}$, são consideravelmente custosas cognitivamente para sujeitos em escassez extrema, é possível dizer que, sobre tais indivíduos, incide uma maior tributação cognitiva, se comparada aos indivíduos mais ricos ${ }^{99}$.

Tal metáfora é extremamente oportuna para ilustrar todo o quadro exposto das decisões econômicas em situação de pobreza. A imposição de alguns tributos - por exemplo, impostos sobre o consumo - pode, como efeito secundário indesejado, ter o condão de reduzir a mobilidade social de uma determinada sociedade. Mantém-se, assim, os níveis de desigualdade social existentes. Diz-se ser regressivos os tributos que possuem esse caráter, em oposição aos tributos progressivos que, em respeito ao princípio da capacidade contributiva, almejam reduzir as desigualdades existentes.

Como ressaltado, as decisões econômicas de pessoas mais pobres são muito mais custosas do que as decisões de pessoas mais ricas. Isso faz com que alguns vieses sejam vistos com maior frequência em situação de pobreza. Por exemplo, descontos intertemporais mais excessivos e maior aversão ao risco. Por conta disso, os resultados econômicos de pessoas mais pobres podem acabar sendo piores, especialmente a longo prazo, que o de pessoas mais ricas. Isso fica bastante evidente quando são analisados os níveis de poupança,

97 Frise-se que tal fato não contradiz a afirmação de que a pobreza implica em uma maior aversão ao risco. Tal assertiva deve ser lida em consonância com o padrão quádruplo. Assim, a interpretação mais adequada parecer ser a de que, em que pese na maior das situações tais indivíduos serem avessos ao risco, há casos, como nas loterias, em que buscam sobremaneira o risco. 98 SPEARS, Dean. Decision costs and price sensitivity: field experimental evidence from India.Journal Of Economic Behavior \& Organization, [s.l.], v. 97, p. 169-184, jan. 2014. Elsevier BV. Disponível em: <http://dx.doi.org/10.1016/j.jebo.2013.06.012>.

99 MANI, A. et al. Poverty impedes cognitive function. Science, [s.1.], v. 341, n. 6149, p. 976-980, 29 ago. 2013. American Association for the Advancement of Science (AAAS). Disponível em: <http://dx.doi.org/10.1126/science.1238041>. p. 980. 
o excesso de empréstimos, o endividamento excessivo e, mesmo, padrões de investimentos com menores riscos, mas também menos rentáveis.

A potencial regressividade de tal tributação ${ }^{100}$ resta evidente quando se percebe que, ao atingir piores resultados econômicos, a própria condição de pobreza é reforçada. Sendo assim, os trade-offs passam a ser ainda mais intensos e, com menos recursos, as decisões ainda mais custosas. Daí a ideia de "tributação cognitiva". Como a tributação propriamente dita, a cognitiva impõe um fardo maior aos indivíduos mais pobres, por conta de os custos cognitivos de decisões idênticas serem muito significativos para eles em comparação com os que ocupam os estratos sociais superiores.

Dada a potencial regressividade de tal tributação, os formuladores de políticas públicas devem estar atentos aos custos cognitivos que são excessivamente impostos aos mais pobres e, com isso, tentar simplificar as suas escolhas. Conforme será demonstrado na seção 4, muitas decisões são excessivamente complexas e trazem custos cognitivos ainda mais intensos para as pessoas em situação de pobreza. Isso porque, nesses casos, há chances enormes de que escolhas inadequadas sejam feitas ou, até mesmo, que o resultado seja o de ausência de escolhas. Simplificar e tornar mais fáceis escolhas como as relativas a poupanças, contratos bancários, planos de previdência etc. pode ser uma forma de combater esses efeitos cognitivamente adversos da pobreza.

Diversas causas são atribuídas para esses problemas. O esgotamento do ego atingido mais rápida e intensamente ${ }^{101}$, prejuízos às funções $\operatorname{cognitivas~}^{102}$, maiores níveis de stress ${ }^{103}$ e a atenção voltada para a escassez são indicados como causas potenciais ${ }^{104}$. A abordagem detalhada de todas essas questões será feita na próxima subseção.

\subsection{Pobreza, esgotamento e funções cognitivas: uma abordagem holística necessária}

Como ressaltado, existem custos cognitivos acentuados relacionados à escassez ${ }^{105}$, o que faz com que as pessoas mais pobres tenham, normalmente, o aprofundamento de alguns vieses comportamentais. Especificamente, trabalhou-se, até aqui, com descontos intertemporais mais acentuados e o excesso de aversão ao risco.

Diversas teorias se propõem a expor as minúcias da relação entre pobreza e comportamento. A primeira delas tem seu fulcro no conceito de escassez ${ }^{106}$. Como a atenção é limitada, os humanos direcionam o seu foco atencional para o que lhes é mais urgente. A pobreza financeira tende a ocupar excessivamente a atenção de uma pessoa, o que reduz o seu desempenho em decisões importantes e em comportamentos $\operatorname{cotidianos}^{107}$.

100 Ressalta-se, novamente, não se estar diante da tributação propriamente dita, isto é, da cobrança de tributos. Trata-se, na verdade, de uma oportuna metáfora para os padrões decisórios - e os seus resultados - encontrados em situação de pobreza.

101 SPEARS, Dean. Economic decision-making in poverty depletes behavioral control.The B.e. Journal of Economic Analysis \& Policy, [s.l], v. 11, n. 1, p. 1-42, 2011. Disponível em: <http://lisagennetian.org/files/92920599.pdf>.

102 MANI, A. et al. Poverty impedes cognitive function. Science, [s.l.], v. 341, n. 6149, p. 976-980, 29 ago. 2013. American Association for the Advancement of Science (AAAS). Disponível em: <http://dx.doi.org/10.1126/science.1238041>.

103 HAUSHOFER, J.; FEHR, E. On the psychology of poverty. Science, [s.l.], v. 344, n. 6186, p.862-867, 22 maio 2014. American Association for the Advancement of Science (AAAS). Disponível em: <http://dx.doi.org/10.1126/science.1232491>.

104 SHAH, A. K.; MULLAINATHAN, S.; SHAFIR, E. Some consequences of having too little. Science, [s.l.], v. 338, n. 6107, p. 682-685, nov. 2012. American Association for the Advancement of Science (AAAS). Disponível em: <http://dx.doi.org/10.1126/ science.1222426>.

105 O termo escassez adquire a conotação similar àquela presente do termo "pouco" - não se confundindo, portanto, com o conceito econômico associado à ideia de "limitado".

106 SHAH, A. K.; MULLAINATHAN, S.; SHAFIR, E. Some consequences of having too little. Science, [s.l.], v. 338, n. 6107, p. 682-685, nov. 2012. American Association for the Advancement of Science (AAAS). Disponível em: <http://dx.doi.org/10.1126/ science.1222426>.

107 SPEARS, Dean. Economic decision-making in poverty depletes behavioral control.The B.e. Journal of Economic Analysis \& Policy, [s.l], v. 11, n. 1, p. 1-42, 2011. Disponível em: <http://lisagennetian.org/files/92920599.pdf>. p. 5. 
A segunda teoria baseia-se na noção de controle cognitivo, que pode ser entendido como um processo que direciona a atenção ou inibe comportamentos em prol de alguma meta ${ }^{108}$. Mani et al. ${ }^{109}$ demonstraram experimentalmente a diminuição das funções cognitivas em períodos de grande pressão econômica. Para isso, aferiram os indicadores relacionados às funções cognitivas de plantadores de cana de açúcar nos períodos pré e pós-colheita. Digna de nota a pressão financeira dos participantes: antes das colheitas, há maior escassez de recursos e maior incerteza quanto aos resultados da próxima safra, em comparação com o período após a colheita. A diminuição das funções cognitivas dos agricultores nesse período de maior pressão financeira é equivalente à que ocorreria com a privação de aproximadamente uma noite de sono.

Além disso, há autores que afirmam que os padrões comportamentais já expostos encontrados na situação de pobreza seriam provocados pelo aumento do stress e do afeto negativo ${ }^{110}$. Haushofer e Fehr constataram experimentalmente que o aumento dos níveis de cortisol e a tristeza podem ser capazes de ampliar a aversão ao risco e de acentuar os descontos intertemporais.

Por fim, a última teoria que se propõe a expor as minúcias da relação entre pobreza e comportamento se baseia na teoria do esgotamento do ego - já exposta na subseção 2.3. Como já ressaltado, a força de vontade é limitada e o controle do comportamento consome tais reservas mentais. Decisões em situação de pobreza implicam em trade-offs mais intensos ligados à escassez, sendo capazes de causar mais rapidamente o esgotamento do ego. Vale lembrar que, no experimento de Spears ${ }^{111}$, a deliberação era exigida para realizar uma transação simples, como comprar um sabão.

A fim de testar essa hipótese, em novo experimento conduzido por Spears, pessoas eram levadas a escolher entre três produtos, quais sejam, uma lata de óleo de cozinha, uma marmita de metal e um pacote de cordas ${ }^{112}$. Dois grupos diferentes foram aleatoriamente separados: um com recursos suficientes para escolher todos os itens mais desejados (óleo e marmita) e o outro que deveria enfrentar um trade-off entre os produtos a serem escolhidos. Os participantes, habitantes de Banswara, na zona rural da Índia, de fato receberiam os produtos escolhidos ao fim do experimento.

Feita a escolha econômica, Spears mediu o autocontrole desses indivíduos ao realizarem uma tarefa simples: apertar um exercitador do tipo handgrip. O pesquisador verificou que as pessoas que se encontravam na condição de maior escassez apertavam o aparelho por menos tempo, apresentando sinais de ocorrência de esgotamento do ego.

O pesquisador, então, conclui ${ }^{113}$ :

Finalmente, descobrir que o efeito da pobreza no controle comportamental depende de reservas pessoais de algum dos recursos hipoteticamente abordados - atenção, força de vontade ou controle cognitivo sugeriria que o esgotamento desses recursos é um mecanismo importante. Os estudos abaixo podem ser sugestivos entre essas distinções, mas sua implicação mais importante é que alguma combinação desses três mecanismos similares importa para o controle comportamental do pobre.

É imprescindível trazer a constatação de que o esgotamento do ego ocorre em diversas situações com qualquer pessoa. Pessoas ricas também lidam com dificuldades de autocontrole, ligadas a recursos mentais

108 SPEARS, Dean. Economic decision-making in poverty depletes behavioral control.The B.e. Journal of Economic Analysis \& Policy, [s.l], v. 11, n. 1, p. 1-42, 2011. Disponível em: <http://lisagennetian.org/files/92920599.pdf>. p. 5.

109 MANI, A. et al. Poverty impedes cognitive function. Science, [s.l.], v. 341, n. 6149, p. 976-980, 29 ago. 2013. American Association for the Advancement of Science (AAAS). Disponível em: <http://dx.doi.org/10.1126/science.1238041>.

110 HAUSHOFER, J.; FEHR, E. On the psychology of poverty. Science, [s.1.], v. 344, n. 6186, p.862-867, 22 maio 2014. American Association for the Advancement of Science (AAAS). Disponível em: <http://dx.doi.org/10.1126/science.1232491>.

111 SPEARS, Dean. Decision costs and price sensitivity: field experimental evidence from India.Journal Of Economic Bebavior \& Organization, [s.1.], v. 97, p. 169-184, jan. 2014. Elsevier BV. Disponível em: <http://dx.doi.org/10.1016/j.jebo.2013.06.012>.

112 SPEARS, Dean. Economic decision-making in poverty depletes behavioral control.The B.e. Journal of Economic Analysis \& Policy, [s.l], v. 11, n. 1, p. 1-42, 2011. Disponível em: <http://lisagennetian.org/files/92920599.pdf>.

113 SPEARS, Dean. Economic decision-making in poverty depletes behavioral control.The B.e. Journal of Economic Analysis \& Policy, [s.l], v. 11, n. 1, p. 1-42, 2011. Disponível em: <http://lisagennetian.org/files/92920599.pdf>. Tradução nossa. 
finitos. Porém, o foco do presente trabalho é evidenciar que a pobreza pode ampliar esses efeitos de esgotamento e, assim, provocar vieses comportamentais mais acentuados.

Não há exclusão de abordagens diversas. Todas as teorias aqui expostas são complementares. Como as pessoas focam a sua atenção -limitada - naquilo que é escasso, o esgotamento do ego acontece de maneira mais rápida, na medida em que as escolhas são mais difíceis. Isso também explica a diminuição das funções cognitivas, que retrata esse efeito em um nível explicativo diferente. Ao cabo, todo o processo pode levar a maiores níveis de stress e ao afeto negativo, que também prejudicam as decisões ${ }^{114}$.

\section{REDUZINDO A TRIBUTAÇÃO COGNITIVA: A OPÇÃO PELOS NUDGES}

Ao longo de todo este trabalho, apontou-se que as consequências psicológicas de possuir poucos recursos financeiros prejudicam a tomada de decisões. Dessa maneira, há maiores custos decisórios para as pessoas mais pobres, o que torna piores os seus resultados econômicos. Cria-se, então, uma situação análoga a uma tributação cognitiva, que pode ter graves efeitos regressivos, no sentido de reforçar a própria situação de pobreza.

Nesse quadro, podem ser formuladas políticas públicas para atuar de três maneiras distintas, como expõe Haushofer e Fehr ${ }^{115}$ :

Finalmente, quais tipos de programas de bem-estar ou intervenções iriam quebrar os relacionamentos discutidos acima? Se o feedback loop proposto for verdadeiro, três possibilidades parecem promissoras para quebrar o ciclo e melhorar o bem-estar: A primeira é enfrentar a pobreza diretamente, a segunda é enfrentar as suas consequências psicológicas, e a terceira é enfrentar os comportamentos econômicos que resultam delas. Essas possibilidades não são mutualmente exclusivas, é claro, mas devem ser estudadas isoladamente assim como combinadas para o entendimento dos seus efeitos.

Neste trabalho, serão analisadas, especificamente, as possibilidades de intervenções que atuam para atenuar os prejuízos gerados por decisões econômicas inadequadas feitas em situação de escassez. Não se descarta, por óbvio, a enorme importância de se enfrentar diretamente a pobreza, bem como de se enfrentar as suas consequências psicológicas, por exemplo, por meio, respectivamente, de políticas redistributivas e de políticas relacionadas à psicoterapias.

A fim de elaborar políticas públicas que enfrentem os prejuízos decisórios provocados pelas consequências psicológicas da pobreza, opta-se, aqui, pelo método dos nudges, tal como proposto por Thaler e Sunstein ${ }^{116}$.

Um nudge, nessa perspectiva, seria:

[...] qualquer aspecto da arquitetura de escolhas que altere o comportamento das pessoas de uma maneira previsível sem proibir quaisquer opções ou modificar significativamente os seus incentivos econômicos. Para contar como um mero nudge, a intervenção deve ser simples e fácil de se evitar. Nudges não são mandados. Colocar a fruta no nível do olho é considerado um nudge. Banir comidas não-saudáveis, não. ${ }^{117}$

114 Importante ressaltar que não é o objetivo deste trabalho expor empiricamente todas essas correlações. Aponta-se, apenas, a relação entre o comportamento e a pobreza como uma importante agenda de estudos a serem desenvolvidos para a comprovação dessas hipóteses.

115 HAUSHOFER, J.; FEHR, E. On the psychology of poverty. Science, [s.l.], v. 344, n. 6186, p.862-867, 22 maio 2014. American Association for the Advancement of Science (AAAS). Disponível em: <http://dx.doi.org/10.1126/science.1232491>. p. 866. 116 THALER, Richard H.; SUNSTEIN, Cass R.Nudge:improving decisions about health, wealth and happiness. Londres: Penguin Books, 2009.

117 THALER, Richard H.; SUNSTEIN, Cass R.Nudge:improving decisions about health, wealth and happiness. Londres: Penguin Books, 2009. p. 6. Tradução nossa. 
A opção pelos nudges se mostra pertinente na medida em que não tolhe as opções de escolha dos agentes econômicos, mas ao mesmo tempo, considera as suas limitações e direciona o rumo de suas decisões. Assim, nudges esperam o erro, simplificam escolhas muito complexas, fornecem feedbacks rápidos e criam padrões (defaults) para as situações em que o sujeito pode permanecer inerte e não realizar escolha alguma. Em suma, nudges são políticas públicas voltadas para humanos, que não estruturam os seus incentivos como esperado pela teoria econômica tradicional, que se pauta no modelo do Homo Economicus ${ }^{118}$.

Brevemente, apresenta-se válido tratar acerca de algumas modalidades de incentivos que podem ser consideradas nudges. A inscrição automática em programas governamentais, por exemplo, voltados para a poupança, é um nudge, que se pauta pela criação ou alteração de regras default $t^{19}$. O programa Save More Tomorrow, idealizado por Thaler e Benartzi ${ }^{120}$, é um exemplo clássico de nudge que obteve êxito ao aumentar consideravelmente os níveis de poupança para a aposentadoria.

Outra modalidade importante é o uso de normas sociais. A esse respeito, Sunstein ${ }^{121}$ aponta:

Um dos nudges mais eficazes consiste em informar às pessoas que a maioria das outras apresenta determinado comportamento. Essa informação frequentemente é tanto mais eficaz quanto mais ela for específica e ligada a uma determinada localidade ("a esmagadora maioria das pessoas da sua comunidade paga seus impostos em dia"). O uso de normas sociais pode reduzir o comportamento criminoso e também comportamentos que sejam prejudiciais, criminosos ou não (como abuso de álcool, tabagismo e discriminação).

Especificamente em relação às regras default, pode-se dizer que elas são inevitáveis. Qualquer política pública traz consigo um padrão para os resultados trazidos pela omissão do agente. Por exemplo, no caso das doações de órgãos, o sujeito se manter inerte pode significar tanto que ele é um doador (consentimento presumido - opt out) ou que ele não é um doador (consentimento explícito - opt in). Comum a qualquer default é a possibilidade de o sujeito modificar a sua situação ao se portar ativamente.

Como já restou demonstrado ao longo de todo trabalho, escolher é custoso cognitivamente e isso se acentua para as pessoas mais pobres. Por conta disso, é possível dizer, metaforicamente, que incide uma maior tributação cognitiva sobre as pessoas mais pobres, que leva-as a piores resultados econômicos e que tende a reforçar a própria situação de pobreza. Regras default, nesse sentido, podem ter o condão de tornar algumas escolhas desnecessárias, trazendo mais liberdade e mais qualidade para a vida dos agentes ${ }^{122}$. Isso se mostra especialmente válido nas situações em que: (i) o contexto é confuso, técnico e desconhecido; (ii) as pessoas iriam preferir não escolher; (iii) aprender não é importante para o agente, e (iv) a população não é heterogênea em qualquer dimensão relevante ${ }^{123}$.

Qualquer política pública envolve a formulação de sua arquitetura de escolhas, ou seja, do contexto no qual as pessoas vão tomar decisões ${ }^{124}$. Os arquitetos de escolha, responsáveis por organizar esse contexto,

118 Ultrapassa os objetivos desse artigo discorrer longamente sobre os nudges, tendo em vista a sua vasta utilização ao redor do planeta. Diversos países criaram centros de análise de políticas públicas para aplicar a Economia Comportamental, tendo por base, principalmente, os nudges. São as chamadas Nudge Units. Para um panorama geral acerca das principais políticas já adotadas nessas unidades, ver: OECD (2017),Behavioural Insights and Public Policy:Lessons from Around the World, OECD Publishing, Paris. http://dx.doi.org/10.1787/9789264270480-en.

119 SUNSTEIN, Cass R. Nudging: um guia bem breve. In: ÁVILA, Flávia; BIANCHI, Ana Maria. Guia de Economia Comportmental e Experimental. São Paulo: Economiacomportamental.org, 2015. p. 109-114. p. 111.

120 THALER, Richard H.; BENARTZI, Shlomo. Save more tomorrow ${ }^{\text {TM}}$ : using behavioral economics to increase employee saving. Journal Of Political Economy, [s.l.], v. 112, n. 1, p. 164-187, fev. 2004. University of Chicago Press. Disponível em: <http://dx.doi. org/10.1086/380085>.

121 SUNSTEIN, Cass R. Nudging: um guia bem breve. In: ÁVILA, Flávia; BIANCHI, Ana Maria. Guia de Economia Comportmental e Experimental. São Paulo: Economiacomportamental.org, 2015. p. 109-114. p. 112.

122 SUNSTEIN, Cass R. Choosing not to choose: understanding the value of choice. New York: Oxford University Press, 2015. p. $14-15$.

123 SUNSTEIN, Cass R. Choosing not to choose: understanding the value of choice. New York: Oxford University Press, 2015. p. 18. 124 THALER, Richard H.; SUNSTEIN, Cass R.Nudge:improving decisions about health, wealth and happiness. Londres: Penguin Books, 2009. p. 3. 
sempre trabalham com incentivos ao elaborar suas políticas. Como ressalta Thaler e Sunstein, um ponto de partida oportuno ao pensar sobre arquitetura de escolhas em particular é delimitar, de imediato, qual é o público-alvo, quem fará as escolhas, quem são os financiadores e quem lucrará com o sistema desenvolvido. ${ }^{125}$

Todo o exposto no presente trabalho mostra que as decisões econômicas de pessoas em condição de pobreza são prejudicadas. Há maior aversão ao risco e maiores descontos intertemporais. Pode-se dizer, ainda, que há uma menor capacidade de autocontrole, relacionada a esgotamento do ego intensificado. Por conta disso, o arquiteto de escolhas, ao formular políticas que tenham como destinatários pessoas em situação de escassez extrema, deve ter ciência desses padrões comportamentais e de como eles impactarão o resultado de sua política.

Ainda que diversos programas sociais sejam criados com o fim de lutar contra a pobreza, muitas vezes a análise dos seus resultados não é voltada para a arquitetura de escolhas existente na própria política - e eventuais fracassos são vistos como a ausência de entendimento ou de motivação dos destinatários da política pública. Note-se que, por vezes, o debate político raso é permeado por ideias calcadas no mérito, que afirmam, por exemplo, que a situação de pobreza é um reflexo da falta de vontade de ascensão social do próprio indivíduo.

Geralmente, as políticas públicas não são desenhadas de forma a esperar o erro dos seus destinatários, que, em se tratando de situação de pobreza, tende a ser mais frequente ${ }^{126}$ : como já ressaltado, a pobreza favorece comportamentos avessos ao risco, enviesados para o presente e diminui as capacidades mentais relacionadas ao autocontrole. Não pode, assim, o formulador de políticas públicas abster-se de esperar falhas em seu projeto, porquanto a situação de seu público-alvo por vezes favorece comportamentos transviados. Em outras palavras, deve o gestor esforçar-se para atenuar a tributação cognitiva, isto é, as políticas públicas devem almejar retirar parte do fardo existente sobre as pessoas mais pobres, de modo a tentar aprimorar o resultado de suas decisões.

Além disso, muitas vezes os programas sociais trazem consigo incentivos ineficazes. Note-se, por exemplo, o Programa de Assistência Temporária para Famílias Necessitadas (Temporary Assistance for Needy Families), do governo estadunidense, no qual se impunha um limite temporal de cinco anos, distribuídos ao longo de toda a vida do beneficiário, para a concessão de benefícios ${ }^{127}$. Isso ignora as dificuldades humanas de lidar com eventos futuros e as falhas de autocontrole ligadas à procrastinação, vieses tais que são agravados com a situação pobreza. Uma alternativa mais adequada, conforme explicam Mullainathan e Shafir ${ }^{128}$, seria a criação de prazos menores e mais frequentes, distribuídos conforme a necessidade do agente, e acompanhados de lembretes acerca dos limites existentes.

A preocupação em desenhar políticas públicas que esperem erros e que criem incentivos eficazes é justificada por conta de os humanos possuírem uma capacidade mental (mental bandwidth) limitada - motivo pelo qual nem todas as informações são processadas conscientemente e a maior parte das decisões é feita de maneira intuitiva.

$\mathrm{Na}$ condição de maior escassez, os trade-offs mais intensos aos quais essas pessoas estão submetidas ocupam boa parte dessa capacidade. Por isso, qualquer situação que exige do sujeito escolhas ativas deve ter ciência de que está consumindo parte dessa capacidade. Deve, ainda, ter noção que as pessoas mais ricas possuem maior capacidade mental (mental bandwidth) disponível - por não estarem tão pressionadas -, fato

125 THALER, Richard H.; SUNSTEIN, Cass R.Nudge:improving decisions about health, wealth and happiness. Londres: Penguin Books, 2009. p. 99.

126 MULLAINATHAN, Sendhil; SHAFIR, Eldar. Scarcity: why having too little means so much. Nova Iorque: Time Books, Henry Holt \& Company Llc, 2014. p. 250.

127 MULLAINATHAN, Sendhil; SHAFIR, Eldar. Scarcity: why having too little means so much. Nova Iorque: Time Books, Henry Holt \& Company Llc, 2014. p. 252.

128 MULLAINATHAN, Sendhil; SHAFIR, Eldar. Scarcity: why having too little means so much. Nova Iorque: Time Books, Henry Holt \& Company Llc, 2014. p. 253. 
que pode trazer elementos regressivos para a política elaborada. De outra maneira: qualquer política - em qualquer de suas fases - deve esperar identificar os elementos que traduzem a tributação cognitiva. Nessas circunstâncias, políticas que, muitas vezes, aparentam ter resultados modestos, podem, na verdade, produzir grandes mudanças na vida de um indivíduo, ao otimizar a utilização de seus recursos mentais ${ }^{129}$. Mullainathan e Shafir ${ }^{130}$ dizem que políticas públicas podem construir essa capacidade mental e exemplificam tal situação da seguinte maneira:

Você é uma mãe solteira que possui dois empregos. Você tem que se desdobrar. Para além dos malabarismos financeiros sobre os quais já discutimos, você tem que se desdobrar para o cuidado diário de suas crianças, que é caro. Você conhece um programa que é altamente subsidiado, mas que somente aceitará uma de suas crianças e fecha muito cedo para ajudar com o seu segundo emprego. Então você utiliza uma colcha de retalhos de soluções. Você deixa o seu filho mais novo com a sua avó. Você consegue transporte da escola para a casa de sua avó para uma das crianças e para a creche para a outra. E como você trabalha no setor de serviços, as necessidades de suas crianças dependem das horas que a sua supervisora lhe fornece. Ela é legal e tenta ajudar, mas há uma volatilidade inevitável.

Agora imagine que oferecemos a você um programa extremamente subsidiado de creches. O que exatamente você está ganhando com isso? Certamente, está poupando o seu tempo levando as crianças para lá e para cá. Nós talvez estaremos também poupando o seu dinheiro, tanto explicitamente (esse programa é mais barato que o anterior) quanto implicitamente (se contarmos com o tempo de sua avó). Mas o que estaríamos dando para você é algo diferente, ainda mais precioso. Algo que você poderia gastar em várias coisas. Nós devolveríamos toda a capacidade mental que você usa atualmente para se afligir, se preocupar e desdobrar todos esses arranjos. Nós retiraríamos uma carga cognitiva. Como vimos, isso ajudaria o seu controle executivo, o seu autocontrole de maneira mais ampla, até mesmo a criação de seus filhos. Isso melhoraria a sua capacidade cognitiva, a sua habilidade de focar, a qualidade do seu trabalho ou qualquer outra coisa para a qual você direcionar a sua mente.

O uso de nudges já possui sólida aplicação internacional. Como exemplo disso, serão expostas duas políticas públicas que obtiveram êxito ao se basear em aspectos comportamentais. Como será demonstrado, a consideração de tais aspectos, à época de se formular uma política pública, promove um ciclo virtuoso de resultados, hábeis a reduzir os danos potenciais da tributação cognitiva e, assim, contribuir para a redução das desigualdades.

A primeira intervenção profícua originou-se no Reino Unido, e foi realizada pelo Behavioral Insights Team junto com o Department for Business, Innovation and Skills ${ }^{131}$. Tinha como objetivo a ampliar as taxas de frequência e diminuir os índices de evasão após as férias escolares, em turmas de educação para adultos. Para isso, enviavam lembretes por SMS para os participantes que tinham baixo desempenho em matemática e língua inglesa, encorajando-os a persistir e introjetando ideias como a importância do estudo e da prática para o sucesso. O resultado foi um aumento de 7\% nas frequências e uma diminuição de 36\% na evasão após as férias. Esse é um claro exemplo de política pública que sabe ter como destinatários humanos que erram previsivelmente, sobretudo se submetidos a condições de pobreza.

A segunda intervenção foi realizada pela instituição financeira dominicana ADOPEM, cuja carteira de clientes se resume a pequenos empresários, como donos de mercearias, de salões de beleza e de lanchonetes ${ }^{132}$. O banco constatou que seus clientes cometiam erros frequentes em seus livros de registro, e decidiu intervir através da educação financeira.

129 MULLAINATHAN, Sendhil; SHAFIR, Eldar. Scarcity: why having too little means so much. Nova Iorque: Time Books, Henry Holt \& Company Llc, 2014. p. 260.

130 MULLAINATHAN, Sendhil; SHAFIR, Eldar. Scarcity: why having too little means so much. Nova Iorque: Time Books, Henry Holt \& Company Llc, 2014. p. 259.

131 OECD.Behavioural insights and public policy:lessons from around the world, OECD Publishing, Paris,Disponível em: <http:// dx.doi.org/10.1787/9789264270480-en>. p. 102-104.

132 DREXLER, Alejandro; FISCHER, Greg; SCHOAR, Antoinette. Keeping it simple: financial literacy and rules of thumb. American Economic Journal: Applied Economics, [s.l.], v. 6, n. 2, p. 1-31, abr. 2014. American Economic Association. Disponível em: $<$ http://dx.doi.org/10.1257/app.6.2.1>. 
Os próprios autores, economistas, encontraram dificuldades para compreender os manuais de contabilidade que eram disponibilizados para seu público-alvo. Assim, em vez de se basearem nesses materiais, analisaram como os pequenos empresários mais bem sucedidos se comportavam e verificaram que eles utilizavam inúmeras "regras de bolso" (rules of thumb) para facilitar o seu cotidiano financeiro. Essas regras se relacionavam com métodos de contabilidade mental, por exemplo, separar em diferentes potes o dinheiro que o negócio estava rendendo do "dinheiro da casa". Diante disso, criaram aulas de educação financeira baseadas nessas "regras de bolso".

Verificou-se que, além da maiores frequência e absorção de conhecimento por parte dos discentes, a receita média dos pequenos empresários cresceu cerca de $25 \%$ especialmente nas semanas ruins, em que a organização financeira apresenta-se mais decisiva.

Os dois exemplos acima citados mostram os efeitos positivos que uma política bem informada acerca dos vieses comportamentais, especialmente aqueles que são identificados excessivamente em pessoas mais pobres, podem atingir. Ademais, são ilustrativos de como uma boa política pode ter o condão de reduzir a tributação cognitiva. Aumentar as habilidades de inglês e de matemática de pessoas adultas, sem maiores custos cognitivos para elas, pode ajudar a romper com uma situação que contribuiria para autoreforçar a pobreza. O mesmo pode ser dito para as classes de educação financeira simplificadas, que utilizavam simples atalhos mentais.

Numa outra vertente, será feita uma análise de uma política que falha ao desconsiderar aspectos comportamentais. O Programa Nacional de Acesso ao Ensino Técnico - PRONATEC, que será o objeto da análise do próximo subitem, não obtém o êxito pretendido. Como será demonstrado, tal política não espera o erro de seus destinatários e, por conta disso, altos índices de evasão têm sido identificados - fato que pode, até mesmo, por em risco o futuro do programa. Também serão expostas maneiras de nítido cunho comportamental para se aprimorar tal política, a fim de contribuir para a redução da tributação cognitiva.

\subsection{O PRONATEC: uma abordagem comportamental}

O Programa Nacional de Acesso ao Ensino Técnico e Emprego - PRONATEC é um exemplo brasileiro de como a desconsideração dos fatores acima elencados pode reduzir drasticamente o impacto esperado de uma política.

O primeiro passo para a análise do Programa é a compreensão da sua razão de ser. Para isso, é extremamente oportuna a leitura da exposição de motivos da Lei 12.513 de 2011. Em diversos pontos desse documento é possível perceber a intenção de promover a inclusão social. É o que se percebe dos excertos a seguir:

O próprio crescimento econômico dos últimos anos aumenta a demanda por qualificação entre os trabalhadores brasileiros - cujo sucesso no mundo do trabalho depende cada vez mais de novas habilidades. É primordial atender esse público por meio de uma nova expansão da oferta de ensino profissional de qualidade. Em 2010, o número total de matrículas em cursos de Formação Inicial e Continuada foi de 2,4 milhões. Tal oferta, que inclui cursos pagos, é ainda tímida para atender a uma força de trabalho que passa dos 100 milhões.

Essa demanda é ainda mais acentuada entre os brasileiros de menor renda. Segundo dados do Cadastro Geral de Empregados e Desempregados - CAGED, mais de 40\% dos beneficiários reincidentes do seguro desemprego não chegaram a cursar o ensino médio. Já dados do Cadastro Único do Ministério do Desenvolvimento Social e Combate à Fome indicam que mais de $52 \%$ dos membros das quase 13 milhões de famílias beneficiadas pelo Programa Bolsa Família têm quatro anos ou menos de estudo formal. Diante dessa realidade, capacitar é incluir.

Este Governo, ciente de seu papel, reconheceu a necessidade de enfrentamento do problema, anunciando como uma das primeiras medidas a serem adotadas a criação de um amplo programa de acesso à formação profissional. O PRONATEC nasce como estratégia não só para resolver a questão 
dos gargalos de mão-de-obra, mas também como instrumento de melhoria da qualidade da educação, especialmente para os estudantes do ensino médio, bem como de inclusão social. ${ }^{133}$

Também pela letra da lei é possível constatar a intenção de se criar um mecanismo de inclusão social que, em última análise, busca reduzir as desigualdades. É o que se infere, por exemplo, dos seus dois primeiros artigos, in verbis:

Art. $1^{\circ}$ É instituído o Programa Nacional de Acesso ao Ensino Técnico e Emprego (Pronatec), a ser executado pela União, com a finalidade de ampliar a oferta de educação profissional e tecnológica, por meio de programas, projetos e ações de assistência técnica e financeira.

Parágrafo único. São objetivos do Pronatec:

I - expandir, interiorizar e democratizar a oferta de cursos de educação profissional técnica de nível médio presencial e a distância e de cursos e programas de formação inicial e continuada ou qualificação profissional;

II - fomentar e apoiar a expansão da rede física de atendimento da educação profissional e tecnológica;

III - contribuir para a melhoria da qualidade do ensino médio público, por meio da articulação com a educação profissional;

IV - ampliar as oportunidades educacionais dos trabalhadores, por meio do incremento da formação e qualificação profissional;

V - estimular a difusão de recursos pedagógicos para apoiar a oferta de cursos de educação profissional e tecnológica.

VI - estimular a articulação entre a política de educação profissional e tecnológica e as políticas de geração de trabalho, emprego e renda. (Incluído pela Lei no 12.816 , de 2013).

Art. $2^{\circ} \mathrm{O}$ Pronatec atenderá prioritariamente:

I - estudantes do ensino médio da rede pública, inclusive da educação de jovens e adultos;

II - trabalhadores;

III - beneficiários dos programas federais de transferência de renda; e

IV - estudante que tenha cursado o ensino médio completo em escola da rede pública ou em instituições privadas na condição de bolsista integral, nos termos do regulamento.

$\int 1^{\circ}$ Entre os trabalhadores a que se refere o inciso II, incluem-se os agricultores familiares, silvicultores, aquicultores, extrativistas e pescadores.

$\int 2^{\circ}$ Será estimulada a participação das pessoas com deficiência nas ações de educação profissional e tecnológica desenvolvidas no âmbito do Pronatec, observadas as condições de acessibilidade e participação plena no ambiente educacional, tais como adequação de equipamentos, de materiais pedagógicos, de currículos e de estrutura física.

$\int 3^{\circ}$ As ações desenvolvidas no âmbito do Pronatec contemplarão a participação de povos indígenas, comunidades quilombolas e adolescentes e jovens em cumprimento de medidas socioeducativas.

$\int 4^{\circ}$ Será estimulada a participação de mulheres responsáveis pela unidade familiar beneficiárias de programas federais de transferência de renda, nos cursos oferecidos por intermédio da Bolsa-Formação. (Incluído pela Lei no 12.816 , de 2013) $)^{134}$

Ainda que o PRONATEC não seja política exclusiva para pessoas de baixa renda, trata-se de política cujos principais destinatários são indivíduos mais pobres. $\mathrm{O}$ art. $2^{\circ}$, acima citado, elucida que o público-alvo do programa é, prioritariamente dentre outras pessoas, aquelas ligadas a situações de pobreza, como no caso

133 BRASIL. Exposição de motivos interministerial no 19, de 28 de abril de 2011. Disponível em: <http://www.planalto.gov.br/ccivil_03/projetos/expmotiv/emi/2011/ 19-mec $\% 20 \mathrm{mte} \% 20 \mathrm{mf} \% 20 \mathrm{mp} \% 20 \mathrm{mds.htm}>$.

134 BRASIL. Lei $n^{\circ}$ 12.513, de 26 de outubro de 2011. Brasília, Disponível em: <http://www.planalto.gov.br/ccivil_03/_ato20112014/2011/lei/112513.htm>. 
de beneficiários de programas federais de transferência de renda. Evidente, pois, tratar-se de política que, ao menos em parte, tem como destinatários as pessoas mais pobres. Logo, os efeitos perniciosos da tributação cognitiva, já expostos durante todo o trabalho, deveriam ser considerados desde a formulação da política, à época da elaboração da arquitetura de escolhas.

Um traço marcante da política, relacionado com a sua aplicação propriamente dita, diz respeito aos níveis de evasão notoriamente altos ${ }^{135}$. A Controladoria-Geral da União procedeu à auditoria do PRONATEC em 2013, tendo o relatório fruto da análise ${ }^{136}$ detectado falhas de controle interno que inviabilizavam a aferição precisa dos níveis de evasão do programa; contudo, índices não-oficiais apontam uma taxa média de abandono em torno de $50 \%{ }^{137} 138$.

Além das questões institucionais que perpassam qualquer análise de política pública, é possível verificar que a arquitetura de escolhas criada pelo PRONATEC desconsiderava que erros humanos são frequentes e que o autocontrole é limitado. Os altos índices de evasão do programa podem, muito bem, ser explicados por conta da desconsideração de problemas de cunho comportamental. Como a política tem como destinatários, principalmente, indivíduos de baixa renda, é evidente que, desde a elaboração de suas regras, deveria existir uma preocupação com os efeitos da tributação cognitiva.

O formulador de sua arquitetura de escolhas, nessas circunstâncias, deveria, desde o início, ter criado mecanismos que buscassem reduzir a evasão dos alunos e, além disso, incentivar a frequência. E, nesses pontos, as lições comportamentais aqui expostas são de extrema valia. Uma política que busca incentivar a formação e a especialização de trabalhadores, muitas vezes de baixa renda, deve esperar o erro e, no mínimo, considerar os possíveis riscos de evasão.

Isso porque, em se tratando de indivíduos em situação de pobreza, o presente trabalho demonstrou dados relacionados a maiores dificuldades de autocontrole, descontos intertemporais mais intensos e uma menor aversão ao risco. Há custos de oportunidade muito mais salientes para pessoas mais pobres, em comparação com as pessoas que ocupam os estratos superiores da sociedade. Com recursos escassos, a sua alocação envolve trade-offs mais intensos, entre bens de importância vital. Daí os maiores custos cognitivos e a maior recorrência de comportamentos enviesados em pessoas mais pobres. Em outras palavras, por essas razões, incide uma maior tributação cognitiva sobre as pessoas mais pobres.

Especificamente no que diz respeito à presença e à frequência em um curso profissionalizante, deve-se levar em conta os inúmeros trade-offs envolvidos para a realização dessa conduta. Não é uma decisão simples e as falhas de comportamento - no caso, os altos índices de evasão - não devem servir para condenar os destinatários do programa, como se a sua conduta fosse moralmente reprovável.

Permanecer em um programa de profissionalização é penoso, em última análise, porquanto significa renunciar tempo presente em benefício de condições futuras intangíveis. Em outros termos, enquanto o sujeito se profissionaliza, os resultados atuais de frequentar o curso podem não ser percebidos. Trata-se de um típico caso de decisão intertemporal. Como visto, as pessoas mais pobres tendem a descontar o futuro em maiores proporções, se comparadas com indivíduos mais ricos. Dificulta mais a questão que, enquanto os resultados intangíveis do curso profissionalizante não chegam, inúmeras necessidades mais prementes do

135 Vide:

http://www.valor.com.br/brasil/5129392/pronatec-teve-efeitos-limitados-e-evasao-alta-aponta-avaliacao;

http://g1.globo.com/educacao/noticia/2015/08/mec-fixa-novas-regras-para-repasse-integral-do-pronatec.html;

https://www.bbc.com/portuguese/noticias/2014/09/140901_evasao_pronatec_eleicoes_salasocial_ru;

136 CONTROLADORIA-GERAL DA UNIÃO.Relatório de auditoria anual de contas:relatório nº: 201406282. Brasília: CGU, 2014. Disponível em: <https://auditoria.cgu.gov.br/download/8990.pdf>.

137 VALOR ECONÔMICO.Programa de ensino técnico tem evasão de 19\%. Disponível em: <http://www.valor.com.br/brasil/3270550/programa-de-ensino-tecnico-tem-evasao-de-19>.

138 INSTITUTO DE PESQUISA ECONÔMICA APLICACDA (Ed.).PRONATEC: múltiplos arranjos e ações para ampliar o acesso à educação profissional.Brasília: IPEA, 2014. 63 p. Disponível em: <http://www.en.ipea.gov.br/agencia/images/stories/ PDFs/TDs/td_1919.pdf>. 
presente clamam pela atenção do sujeito, o que o leva, muitas vezes, a desistir do curso.

Imagine ter que conciliar o estudo profissionalizante com várias horas de trabalho, muitas vezes extremamente desgastantes; com o cuidado com a família, por exemplo, para encontrar um local para os filhos ficarem enquanto o pai se profissionaliza e trabalha; com o transporte para todos esses locais, que pode durar muitas horas, especialmente se o sujeito residir em regiões mais periféricas. Todo esse cenário pode levar o sujeito a desistir do seu curso profissionalizante, que poderia, em um futuro, melhorar a sua inserção no mercado de trabalho.

A situação acima descrita exemplifica de maneira clara os inúmeros e complexos trade-offs aos quais as pessoas mais pobres estão submetidas. A tomada de decisão, então, é consideravelmente mais custosa, o que parece levar mais rapidamente ao esgotamento do ego. Como exposto neste trabalho, tal processo mental prejudica o resultado das decisões - o que ajuda a explicar a incidência de uma maior tributação cognitiva sobre esses indivíduos. É possível supor, desta forma, que também o esgotamento do ego contribui para tornar mais difícil a decisão de permanecer vinculado ao PRONATEC ${ }^{139}$.

Corroboram essas afirmações estudos que apontam como causas para a evasão fatores ligados ao cuidado com a família e à dificuldade de conciliar os estudos com o trabalho ${ }^{140}$. Em um desses estudos, Medina ${ }^{141}$ aponta:

No caso do PRONATEC/OSM identificaram-se cinco problemas relacionados com o público-alvo.

O primeiro deles é a falta de disponibilidade do público para participar. As entrevistas feitas revelaram que a carga horária, as restrições familiares, as questões de saúde e busca de por fonte de renda dificultaram a assiduidade dos alunos. Um segundo problema identificado foi a questão das restrições familiares e de saúde. Encontraram-se casos nos quais as mulheres com filhos pequenos não tinham onde deixá-los ou mulheres que não podem frequentar os cursos porque o marido não permite. Os problemas de saúde do aluno ou de pessoa da família também figuraram como impeditivos importantes.

Outra restrição importante que tem o público-alvo é que a maioria está mais preocupada em conseguir dinheiro que em realizar um curso de qualificação profissional. As difíceis condições econômicas dos beneficiários os obrigam a realizarem atividades informais para subsistência, o que a sua vez impede que os alunos frequentem as aulas. Relacionado a este problema, as entrevistas evidenciaram que uma grande parcela do público-alvo não consegue dimensionar o potencial transformador do curso de qualificação antes de vivenciá-lo. Este problema obedece à falta de interesse intrínseca (sic) que impacta negativamente na adesão aos cursos de qualificação profissional.

Finalmente, a situação de vulnerabilidade destas pessoas é muito complexa. São pessoas carentes de serviços públicos básicos como saúde, saneamento básico e moradia adequada. Muitas delas têm problemas intrafamiliares e são vitimas de violência e marginalização social. Isso tudo em seu conjunto incrementa potencialmente os índices de evasão aos cursos de qualificação profissional.

O trecho citado demonstra, de maneira contundente, como os problemas de evasão do PRONATEC se

139 Necessário frisar que a possível correlação exposta deve ser entendida como uma hipótese a ser testada, subsidiando, eventualmente, conclusões mais significativas.

140 Vide: SANTOS, Talitha Araújo; ZAMBONI, Viviane de Paula Gouveia; OLIVEIRA, Maria Rita Neto Sales.Evasão e permanencia na educação profissional de jovens e adultos nos programas educacionais PROEJA e PRONATEC.In: SIMPOSIO INTERNACIONAL SITRE - TRABALHO, RELAÇÕES DE TRABALHO, EDUCAÇÃO E IDENTIDADE, 6. Disponível em: < http://www.sitre. cefetmg.br/arquivos/Anais/GT-01/sitreGT01p424_-_EVASxO_E_PERMANxNCIA_NA_EDUCAxO_PROFISSIONAL_ DE_JOVENS_E_ADULTOS_NOS_PROGRAMAS_EDUCACIONAIS_PROEJA_E_PRONATEC.pdf>.; e MEDINA, Maria Angélica Lozano. Causas de evasão em programas de qualificação profissional: análise dos casos de osasco e bogotá. 2012. Artigo (Mestrado) - Mestrado profissional em gestão e políticas públicas, Fundação Getúlio Vargas, São Paulo, 2012. Disponível em: <https:// bibliotecadigital.fgv.br/dspace/bitstream/handle/10438/10040/21.08.12\%20MPGPP\%20ARTIGO\%20INDIVIDUAL \%20-\%20 LOZANO $\% 20 \% 281 \% 29$.pdf? sequence $=3$ \&isAllowed $=\mathrm{y}>$.

141 MEDINA, Maria Angélica Lozano. Causas de evasão em programas de qualificação profissional: análise dos casos de osasco e bogotá. 2012. Artigo (Mestrado) - Mestrado profissional em gestão e políticas públicas, Fundação Getúlio Vargas, São Paulo, 2012. Disponível em: <https://bibliotecadigital.fgv.br/dspace/bitstream/handle/10438/10040/21.08.12\%20MPGPP\%20ARTIGO\%20 INDIVIDUAL $\% 20-\% 20$ LOZANO $\% 20 \% 281 \% 29$.pdf? sequence=3\&isAllowed $=\mathrm{y}>$. 
relacionam com as questões aqui levantadas da tributação cognitiva. A decisão de continuar no curso - i. e., não evadir - encontra-se umbilicalmente ligada à situação de pobreza, que prejudica e torna mais difícil o ato de decidir. Nesse caso, em termos claros, não privilegiar o presente não realizando um desconto intertemporal tão intenso é uma decisão extremamente custosa.

Isso se agrava se considerarmos as limitações de capacidade mental (mental bandwidth) provocadas pelos trade-offs mais intensos aos quais as pessoas em situação de pobreza estão submetidas: face à situação de ter que escolher entre estar presente em uma aula ou praticar a atividade que lhe assegure subsistência no presente, é esperado que o aluno se torne infrequente. Cria-se, em sequência, um ciclo vicioso, na medida em que a falta de hoje, prejudica o aprendizado de amanhã - e, pelo caráter cíclico e incremental da situação, ao fim e ao cabo provoca-se a evasão.

Shafir e Mullainathan ${ }^{142}$, ao analisar o contexto de programas de treinamento, como o PRONATEC, descrevem o problema com precisão:

Considere os programas de treinamento, nos quais o absenteísmo é comum e os índices de evasão são altos. O que acontece quando, sobrecarregado e esgotado, um cliente perde uma aula? O que acontece quando a sua mente vaguear durante a aula? A próxima aula se torna muito mais difícil. Perder uma ou duas aulas a mais e desistir se torna o resultado natural, talvez até mesmo a melhor opção, tendo em vista que ele realmente não mais entende muito do que está sendo discutido na aula. Um currículo rígido - cada classe construída sobre a anterior - não é um ajuste que perdoa estudantes cuja capacidade mental está sobrecarregada. [...] O design desses programas presume que se as pessoas estiverem suficientemente motivadas, elas não cometerão erros. Aqueles que não conseguem se dar o trabalho de chegar à aula pontualmente, continua o argumento implícito, não devem importar: eles não "merecem" o treinamento.

Mas a psicologia da escassez prevê que erros como esse serão todos muito comuns, talvez até mesmo inevitáveis, independentemente do quão motivada esteja a pessoa. Imagine que você chega em casa após um dia no trabalho, preocupado sobre como você conseguirá dinheiro para pagar o aluguel desse mês, todas as contas e a festa de aniversário de sua filha. Você não tem dormido bem. Há algumas semanas, você se inscreveu para um programa de treinamento em habilidades informáticas que um dia poderia ajudá-lo a conseguir um emprego melhor. Mas essa noite os benefícios desse treinamento são abstratos e distantes. Você está exausto e sobrecarregado por coisas mais próximas, e você sabe que, mesmo se você for à aula, você não absorverá nada. Agora avance algumas semanas. Nesse momento, você perde outra aula. E quando você vai, você entende menos do que antes. Eventualmente, você decide que não aguenta toda essa carga agora; você desistirá e fará a inscrição em um outro momento, quando a sua vida financeira estiver em melhor condições. O programa que você tentou não foi projetado para tolerar faltas. Ele potencializou os seus erros, que eram previsíveis e essencialmente empurrou-o para fora.

Por isso, o arquiteto de escolhas deve pensar em todos esses fatores e tentar, ao elaborar a arquitetura de escolhas, incentivar a permanência nos cursos, por exemplo, por meio de Nudges. Frise-se que políticas mais paternalistas, com maior grau de intervenção estatal, produziriam algum efeito diante do problema - haja vista as inúmeras intervenções estruturais já catalogadas que versam sobre o tema.

Extrapola os objetivos deste trabalho esgotar todas as abordagens políticas possíveis para aperfeiçoar o PRONATEC. Pretende-se, aqui, apontar possíveis intervenções - principalmente de cunho comportamental - para diminuir os índices de evasão do programa. Por óbvio, para aplicá-las, é necessário, antes de mais nada, avaliar empiricamente a sua efetividade. Por isso, os exemplos trazidos são, principalmente, propostas de agendas de pesquisa que unem elementos comportamentais relacionados com a diminuição dos efeitos psicologicamente adversos da pobreza - isto é, da tributação cognitiva.

De início, um exemplo de nudge que poderia ser implementado sem maiores custos se baseia na ideia de lembretes, que poderiam ser enviados tanto eletronicamente, quanto por meio de correspondências físicas.

142 MULLAINATHAN, Sendhil; SHAFIR, Eldar. Scarcity: why having too little means so much. Nova Iorque: Time Books, Henry Holt \& Company Llc, 2014. p. 249-250. Tradução nossa. 
Em tais mensagens, os benefícios de cursos profissionalizantes poderiam ser enfatizados, em conjunto com a valorização de fatores como a frequência do estudante para o seu bom desempenho. Vale ressaltar que, conforme será demonstrado a seguir, a política de lembretes teve êxito no Reino Unido para diminuir os índices de evasão e de ausências em cursos de educação para adultos.

Os detalhes de tais mensagens variam conforme a própria criatividade do gestor, mas alguns elementos basilares podem ser indicados com base nas ciências comportamentais.

Como os resultados futuros dos cursos são intangíveis, um primeiro aspecto a ser identificado pelo arquiteto de escolhas diz respeito à tentativa de dar maior grau de concretude a esses resultados. Isso poderia acontecer por meio de dados, expostos de maneira simples e chamativa, que enfatizem o resultado positivo que os cursos proporcionam para aqueles que finalizam os seus estudos. Tais indicativos podem girar em torno de elementos como o percentual de inserção no mercado de trabalho, os ganhos de renda e, até mesmo, elementos que apontem para benefícios em termos de poder de compra ou de felicidade. Evidentemente que, para a elaboração da mensagem, o acompanhamento dos resultados do próprio programa deve ser realizado. Não é esta questão técnica, contudo, limitadora de sugestões.

Um outro fator que pode ser considerado, na elaboração dessa mensagem, relaciona-se com as normas sociais. Como já ressaltado, muitos nudges funcionam com base em dar ênfase ao comportamento de uma coletividade. Nessa perspectiva, é possível, por exemplo, destacar, na mensagem, que um percentual x de indivíduos permanece vinculado ao curso. Ainda que se possa afirmar que, caso esse percentual seja baixo, o nudge poderia ter efeitos adversos, as normas sociais podem ser utilizadas ainda de outra maneira. Enfatizar os custos sociais que a conduta evasiva provoca e os benefícios que a conclusão do curso pode gerar para a sociedade também pode ter efeitos positivos.

Por fim, complementando a mensagem proposta, é possível dar feedbacks visuais aos estudantes, por exemplo, acrescentando à mensagem um "emoticon" triste associado à evasão - ou à falta de frequência adotada. Essa estratégia foi utilizada com sucesso em San Marco, na Califórnia, para a redução do consumo de energia ${ }^{143}$. Analogamente, é possível atribuir "emoticons" felizes em mensagens para os indivíduos que têm tido um bom comportamento, de forma a dar um feedback visual positivo à sua conduta. Podem contribuir, para esse contexto, estratégias ligadas à gamificação (gamification), com a atribuição de metas ligadas ao bom desempenho no curso. Cumpridas as metas, feedbacks automáticos seriam enviados para os estudantes, de forma a incentivar que continuem mantendo o bom comportamento. Por exemplo, é possível estabelecer que, após 15 dias seguidos de comparecimento à aula, o sujeito ganhe uma "conquista" que ficaria vinculada à sua conta virtual na plataforma do curso.

A boa aplicação deste nudge envolve o monitoramento dos índices de frequência de cada aluno, cuja diminuição, em geral, pode indicar uma possível desistência próxima. Com esse controle, é possível que, além das mensagens, sejam feitas reuniões com os alunos mais ausentes, nas quais esses valores poderiam ser melhor enfatizados e, ademais, nas quais estratégias individuais possam ser pensadas, conforme as particularidades de cada estudante.

A composição do nudge aqui proposto pode ser melhor identificada nas figuras a seguir:

143 THALER, Richard H.; SUNSTEIN, Cass R.Nudge:improving decisions about health, wealth and happiness. Londres: Penguin Books, 2009. p. 69-70. 
Figura 2

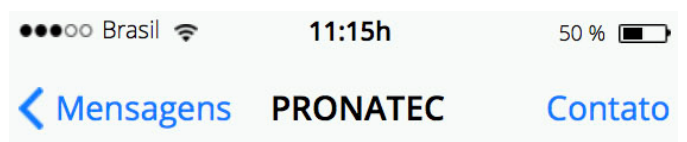

Terça-feira, 22 de maio 20:30h

Fulano, lembre-se de seus

objetivos! Compareça ao seu

curso do PRONATEC!

Segunda-feira, 28 de maio 13:00h

A conclusão do seu curso

técnico oferecido pelo

PRONATEC aumenta as em

$25 \%$ as suas chances de

conseguir um emprego e

aproxima você do sonho da

casa própria em três anos

(estimativa média para sua

localidade e curso).

Compareça ao seu curso,

Fulano!

Sexta-feira, 01 de junho 14:00h

Nas últimas duas semanas

você teve frequência de $20 \%$.

Cuidado :: : :

O. Digite aqui a mensagem.

Fonte: Do autor.144

144 Os dados indicados na figura são meramente ilustrativos. 
Figura 3

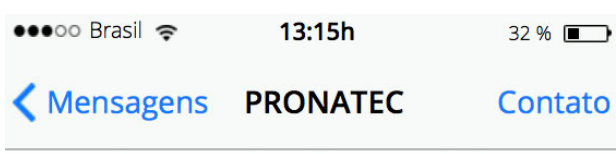

Terça-feira, 05 de junho 15:45h

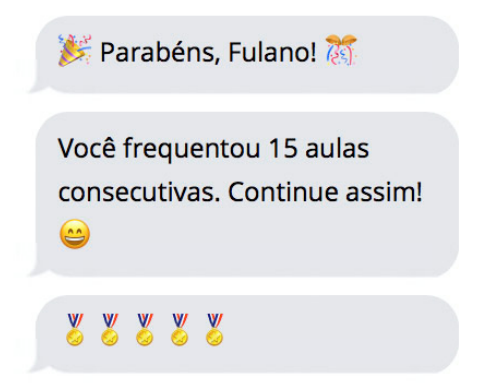

(O) Digite aqui a mensagem. Enviar

Fonte: Do autor.

Nesse ponto, o seguinte alerta é fundamental: deve-se atentar para que o nudge proposto não contribua para reforçar a tributação cognitiva, potencialmente regressiva. Isso porque, sozinho, tal nudge pode ser incapaz de melhorar a situação e pode, ao revés, contribuir apenas para que as decisões dos destinatários da política se tornem mais difíceis. Cumulado com modificações estruturais, tais como a disponibilização de horários mais flexíveis e compatíveis com o trabalho, o nudge poderia potencializar os efeitos dessa política pública. Vale lembrar, aqui, a lição de Loewenstein e Chater ${ }^{145}$ :

[...] compreender muito dos problemas da sociedade e formular soluções de políticas envolverá híbridos entre a economia tradicional e a comportamental, em vez da aplicação pura de qualquer uma das duas. O crescimento da Economia Comportamental deve, portanto, ser visto como suplementar, em vez de substitutivo das análises econômicas e métodos políticos tradicionais. Políticas comportamentais efetivas, e especialmente políticas visando os problemas que colocam os desafios mais significativos para a geração atual, exigirão uma combinação fluída e flexível de insights de ambas as tradições.

Nessa linha de raciocínio, é possível pensar em uma alteração que, apesar de ter fundo nitidamente comportamental ${ }^{146}$, é de cunho mais estrutural, alterando de maneira mais intensa a própria maneira como os cursos do PRONATEC são imaginados.

Como já ressaltado, permanecer vinculado ao PRONATEC é uma decisão intertemporal complexa. Por conta disso, os destinatários da política - na maior parte das vezes, pessoas de baixa renda - têm dificuldades

145 LOEWENSTEIN, George; CHATER, Nick. Putting nudges in perspective. Behavioural Public Policy, [s.1.], v. 1, n. 01, p. 26-53, maio 2017. Cambridge University Press (CUP). Disponível em: <http://dx.doi.org/10.1017/bpp.2016.7>. p. 48. Tradução nossa.

146 Deve-se ter em mente que, em última análise, toda e qualquer política tem aspectos comportamentais. A compreensão do comportamento dos destinatários - ou, ao menos, uma ideia de como ele funciona - é aspecto fundamental tanto para o desenho da política, quanto para a sua posterior aplicação. 
de concluir os cursos e os índices de evasão são consideravelmente elevados. Especificamente quanto a esse problema, Shafir e Mullainathan ${ }^{147}$ oferecem uma intervenção positiva:

Mas não precisa ser dessa maneira. Em vez de insistir na ausência de erros ou para modificar o comportamento, pode-se redefinir o cockpit ${ }^{48}$. Currículos podem ser alterados, por exemplo, para existirem módulos, determinados a começar em diferentes épocas e a prosseguir em paralelo. Você perdeu uma aula e ficou para trás? Vá para a sessão paralela, que está uma ou duas semanas "atrás" dessa. Perca um módulo e você pode voltar aos trilhos na próxima rodada. Certamente, levará mais tempo para você finalizar, mas, ao menos, você chegará lá. Da maneira como é hoje, os programas de treinamento são criados sem que os erros sejam considerados, como se não fossem esperados ou tolerados erros por parte dos participantes. Mas os pobres - mesmo, ou talvez especialmente, quando desempregados - possuem muitas coisas a fazer. E muitas delas não são facilmente conciliáveis com ser um estudante. Faltar aulas em um programa de treinamento enquanto você convive com a escassez não é o mesmo que "matar" aula no colégio. Classes lineares que não podem ser perdidas podem funcionar bem para estudantes de tempo integral; elas não fazem sentido para os pobres malabaristas ${ }^{149}$.

A intervenção proposta por Mullainathan e Shafir é perfeitamente aplicável ao PRONATEC. Em vez de apostar em maneiras de ensino lineares e tradicionais, pode-se utilizar o ensino em módulos, como forma de minimizar os erros dos destinatários da política pública. Assim, se faltas são recorrentes e acabam por levar à desistência, o ensino em módulos pode ser uma forma de atenuar esses problemas. Uma atenção é necessária, contudo, para que tal prática não seja desvirtuada. O objetivo não é, de maneira alguma, perpetuar o período dos estudantes no curso. Por isso, um acompanhamento individual de cada estudante é primordial, cumulado com o nudge proposto acima. Dessa forma, ainda que os sujeitos gastem mais tempo para concluir a sua formação, terão resultados melhores que a mera desistência.

Em suma, o uso cumulado de ambas as estratégias, de forma a se utilizar o nudge elaborado acima, para enviar mensagens personalizadas para cada estudante, e a se adotar o ensino em módulos, é capaz de reduzir os efeitos perversos da tributação cognitiva e melhorar consideravelmente o PRONATEC. Com isso, seus resultados seriam potencializados. O exemplo do PRONATEC mostra como a falta de informação à época da elaboração de uma política pública pode trazer resultados adversos. Os altos índices de evasão contribuem para que os trabalhadores não se profissionalizem, o que dificulta o seu acesso ao mercado de trabalho. Evidentemente, há o reforço de sua própria situação de pobreza e de dependência do Estado. As propostas apresentadas, entretanto, mostram como a consideração de aspectos comportamentais, à época da criação da arquitetura de escolhas, pode aprimorar e sofisticar uma política pública e potencializar os seus resultados - além, é claro, de reduzir a tributação cognitiva.

Portanto, é impositivo que o arquiteto de escolhas, ao desenhar a sua política pública, esteja informado dos vieses comportamentais que estão presentes em todos os humanos, com as peculiaridades expostas da situação pobreza, e atento aos possíveis incentivos perniciosos que sua política pode gerar. Trata-se, pois, de uma abordagem essencial para que resultados positivos possam ser atingidos e contribuam efetivamente para a redução da tributação cognitiva.

147 MULLAINATHAN, Sendhil; SHAFIR, Eldar. Scarcity: why having too little means so much. Nova Iorque: Time Books, Henry Holt \& Company Llc, 2014. p. 250-251. Tradução nossa.

148 Trata-se de metáfora utilizada pelos autores para a arquitetura de escolhas. Num avião, a disposição de controles é feita de modo a minimizar o efeito de erros dos pilotos. Busca-se evitar que, por engano, duas alavancas sejam confundidas, o que poderia provocar um acidente. Analogamente, em uma política pública, não se deve esperar um comportamento perfeito dos destinatários. Deve-se, na verdade, estudar o comportamento humano de forma a, na formulação da arquitetura de escolhas, criar mecanismos que, esperando o erro, minimizem os seus efeitos.

149 A expressão é usada como uma metáfora para as muitas coisas com as quais os pobres têm que lidar. 


\section{Considerações finais}

Conforme demonstrado, a situação de pobreza, por si só, tem o condão de prejudicar as decisões econômicas. As pessoas que se encontram nessa condição, por conta dos trade-offs mais intensos impostos pelo fato dos excessivos custos de oportunidade inerentes à situação de escassez, passam por um processo exacerbado de esgotamento do ego, paralelamente à diminuição das funções cognitivas, ao direcionamento do foco atencional para a própria condição de escassez, ao aumento dos índices de stress e de afeto negativo. Demonstrou-se que, por conta de todos esses fatores, maiores descontos intertemporais e um comportamento mais avesso ao risco são constatados em populações mais pobres.

Utilizou-se, neste trabalho, a expressão figurada tributação cognitiva para representar esse fenômeno, na linha proposta por Mani $e t$ al ${ }^{150}$, tendo em vista que os maiores custos cognitivos que estão presentes nas decisões econômicas de pessoas mais pobres podem ser capazes de reforçar a própria condição de pobreza. Diante desse quadro, o gestor, à época de se formular a arquitetura de escolhas de uma política pública, portanto, deve estar ciente de todos esses resultados. Como ressaltado, os resultados de políticas públicas podem ser desastrosos se não se considera o modo como os seus destinatários se comportam. Isso, para além de saber se tratarem de Homo Sapiens e não de Homo Economicus, implica, também, em ter ciência dos vieses comportamentais mais recorrentes na situação de pobreza. Escolher é sempre custoso e sempre envolve custos de oportunidade. Na situação de maior escassez, isso se agrava e, como demonstrado, os custos cognitivos também são consideravelmente mais intensos.

O PRONATEC é um exemplo claro de política que desconsidera esses fatores e que não espera o erro das pessoas às quais ela se destina. Para melhorá-lo, pode-se criar um nudge, que consistiria em lembretes enviados por mensagem para os alunos, de forma a reforçar valores que são positivos para a diminuição dos índices de evasão. Tais fatores passam pelo uso de normas sociais, pela materialização dos resultados positivos do programa, pelo reforço do comprometimento prévio e por métodos de feedback instantâneos, que incluem estratégias de gamificação (gamification). Outra estratégia que pode ser adotada, na linha proposta por Shafir e Mullainathan ${ }^{151}$, é o ensino em módulo. Assim, é possível amenizar os efeitos de erros dos indivíduos, no caso, das faltas, e criar mais incentivos para que eles permaneçam frequentando as aulas.

Ao mesmo tempo, os casos dos lembretes voltados a diminuir a taxa de evasão e aumentar a frequência no ensino de matemática e inglês para adultos, no Reino Unido, e do ADOPEM, relacionado à educação financeira por meio de simples atalhos mentais, na República Dominicana, mostram a força que podem ter políticas bem informadas em relação ao comportamento humano.

As pessoas não possuem capacidade cognitiva para decidir tudo de maneira adequada. A formulação de políticas públicas deve ter ciência disso - e de como tal situação se intensifica na pobreza - para trabalharem em prol da "construção" dessa capacidade mental. Em outras palavras: deixar que as pessoas deliberem e escolham com maior atenção nas ocasiões que lhes são mais urgentes. A lição que pode ser concluída, por todas as informações trazidas nesse trabalho, é que há uma verdadeira tributação cognitiva imposta a pessoas mais pobres, por conta dos efeitos psicológicos adversos provocados pela própria escassez. Cabe ao gestor, portanto, ter ciência disso para diminuir o impacto de tais efeitos e evitar que os seus efeitos regressivos possam criar uma espécie de ciclo vicioso, com o autorreforço da pobreza.

150 MANI, A. et al. Poverty impedes cognitive function. Science, [s.l.], v. 341, n. 6149, p. 976-980, 29 ago. 2013. American Association for the Advancement of Science (AAAS). Disponível em: <http://dx.doi.org/10.1126/science.1238041>. p. 980.

151 MULLAINATHAN, Sendhil; SHAFIR, Eldar. Scarcity: why having too little means so much. Nova Iorque: Time Books, Henry Holt \& Company Llc, 2014. p. 250-251. 


\section{REFERÊNCIAS}

ARIELY, Dan.Positivamente irracional:os benefícios inesperados de desafiar a lógica em todos os aspectos de nossas vidas. Rio de Janeiro: Elsevier, 2010.

ARIELY, Dan.Previsivelmente Irracional.Rio de Janeiro: Elsevier, 2008.

ÁVILA, Flávia; BIANCHI, Ana Maria.Guia de economia comportamental e experimental.São Paulo: Economiacomportamental.org, 2015.

BAUMEISTER, Roy F. et al. Ego depletion: is the active self a limited resource?Journal of Personality and Social Psychology, [s.1.], v. 74, n. 5, p. 1252-1265, maio 1998.

BAUMEISTER, Roy F. et al. Free will in consumer behavior: Self-control, ego depletion, and choice.Journal of Consumer Psychology, [s.1.], v. 18, n. 1, p. 4-13, jan. 2008.

BAUMEISTER, Roy F. et al. Self-regulation and personality: how interventions increase regulatory success, and how depletion moderates the effects of traits on behavior.Journal of Personality, [s.l.], v. 74, n. 6, p. 17731802, dez. 2006.

BAUMEISTER, Roy F.; TIERNEY, John.Willpower:rediscovering the greatest human strength. [s.1.]: Penguin Books, 2012.

BERNOULLI, Daniel. Exposition of a new theory on the measurement of risk.Econometrica, [s.l.], v. 22, n. 1, p. 22-36, jan. 1954. Disponível em: < https://engineering.purdue.edu/ ipollak/ece302/FALL09/notes/ Bernoulli_1738.pdf>.

BRASIL. Exposição de motivos interministerial nº 19, de 28 de abril de 2011. Disponível em: < http:/ /www.planalto. gov.br/ccivil_03/projetos/expmotiv/emi/2011/ 19-mec\%20mte\%20mf\%20mp\%20mds.htm>.

BRASIL. Lei $n^{0}$ 12.513, de 26 de outubro de 2011. Brasilia, Disponível em: <http://www.planalto.gov.br/ccivil_03/_ato2011-2014/2011/lei/112513.htm>.

CONTROLADORIA-GERAL DA UNIÃO.Relatório de auditoria anual de contas:relatório nº: 201406282. Brasília: CGU, 2014. Disponível em: <https://auditoria.cgu.gov.br/download/8990.pdf>.

DANZINGER, Shai; LEVAV, Jonathan; AVNAIM-PESSO, Liora. Extraneous factors in judicial decisions. Proceedings of The National Academy of Sciences of the United States of America, Princeton, v. 108, n. 17, p. 68896892, 26 abr. 2011.

DE FAVERI, Dinorá Baldo.Impaciência nas escolhas intertemporais:uma abordagem comportamental. 2017. 227 f. Tese (Doutorado) - Curso de Programa de Pós-graduação em Economia, Universidade Federal de Santa Catarina, Florianópolis, 2017. Disponível em: <https://repositorio.ufsc.br/bitstream/ handle/123456789/183406/349814.pdf?sequence $=1>$.

DOHMEN, Thomas et al. Individual risk attitudes: measurement, determinants, and behavioral consequences.Journal of The European Economic Association, [s.1.], v. 9, n. 3, p. 522-550, 31 mar. 2011. Oxford University Press (OUP). Disponível em: <http://dx.doi.org/10.1111/j.1542-4774.2011.01015.x>.

DREXLER, Alejandro; FISCHER, Greg; SCHOAR, Antoinette. Keeping it simple: financial literacy and rules of thumb. American Economic Journal: Applied Economics, [s.1.], v. 6, n. 2, p. 1-31, abr. 2014. American Economic Association. Disponível em: <http://dx.doi.org/10.1257/app.6.2.1>.

FREDERICK, Shane; LOEWENSTEIN, George; O'DONOGHUE, Ted. Time discounting and time preference: a critical review.Journal of Economic Literature, [s.l.], v. 40, n. 2, p. 351-401, jun. 2002. American Economic Association. Disponível em: <http://dx.doi.org/10.1257/002205102320161311>.

GAILLIOT, Matthew T. et al. Self-control relies on glucose as a limited energy source: willpower is more 
than a metaphor.Journal of Personality and Social Psychology, [s.1.], v. 92, n. 2, p. 325-336, 2007. American Psychological Association (APA).

GAILLIOT, Matthew T.; BAUMEISTER, Roy F. The physiology of willpower: linking blood glucose to self-control.Personality and Social Psychology Review, [s.1.], v. 11, n. 4, p. 303-327, nov. 2007. SAGE Publications.

GICO JÚNIOR, Ivo Teixeira. Metodologia e epistemologia da análise econômica do direito.Economic Analysis of Law Review, Brasilia, v. 1, n. 1, p. 7-33, 11 jun. 2010. Semestral.

GUISO, Luigi; PAIELLA, Monica. Risk aversion, wealth, and background risk. Journal of The European Economic Association, [s.1.], v. 6, n. 6, p. 1109-1150, dez. 2008. Oxford University Press (OUP). Disponível em: <http://dx.doi.org/10.1162/jeea.2008.6.6.1109>.

HAMILTON, Ryan; HONG, Jiewen; CHERNEV, Alexander. Perceptual focus effects in choice.Journal of Consumer Research, [s.1.], v. 34, n. 2, p. 187-199, ago. 2007. Oxford University Press (OUP).

HAUSHOFER, J.; FEHR, E. On the psychology of poverty. Science, [s.1.], v. 344, n. 6186, p.862-867, 22 maio 2014. American Association for the Advancement of Science (AAAS). Disponível em: < http:// dx.doi.org/10.1126/science.1232491>.

INSTITUTO DE PESQUISA ECONÔMICA APLICACDA (Ed.).PRONATEC: múltiplos arranjos e ações para ampliar o acesso à educação profissional.Brasília: IPEA, 2014. 63 p. Disponível em: < http:// www.en.ipea.gov.br/agencia/images/stories/PDFs/TDs/td_1919.pdf>.

KAHNEMAN, Daniel.Rápido e devagar:duas formas de pensar. Rio de Janeiro: Objetiva, 2012.

KAHNEMAN, Daniel; TVERSKY, Amos. Prospect theory: an analysis of decision under risk.Econometrica, [s.1.], v. 47, n. 2, p. 263-292, mar. 1979. Disponível em: < http://people.hss.caltech.edu/ camerer/Ec101/ ProspectTheory.pdf $>$.

LAWRANCE, Emily C. Poverty and the rate of time preference: evidence from panel data.Journal of Political Economy, [s.1.], v. 99, n. 1, p. 54-77, fev. 1991. University of Chicago Press. Disponível em: <http://dx.doi. org/10.1086/261740>.

LOEWENSTEIN, George; CHATER, Nick. Putting nudges in perspective. Behavioural Public Policy, [s.l.], v. 1, n. 01, p. 26-53, maio 2017. Cambridge University Press (CUP). Disponível em: <http://dx.doi. org/10.1017/bpp.2016.7>.

MANI, A. et al. Poverty impedes cognitive function. Science, [s.l.], v. 341, n. 6149, p. 976-980, 29 ago. 2013. American Association for the Advancement of Science (AAAS). Disponível em: <http://dx.doi. org/10.1126/science.1238041>.

MANKIW, N. Gregory. Introducão à economia. 3. ed. São Paulo: Cengage Learning, 2009.

MEDINA, Maria Angélica Lozano. Causas de evasão em programas de qualificação profissional: análise dos casos de osasco e bogotá. 2012. Artigo (Mestrado) - Mestrado profissional em gestão e políticas públicas, Fundação Getúlio Vargas, São Paulo, 2012. Disponível em: <https://bibliotecadigital.fgv.br/dspace/bitstream/ handle/10438/10040/21.08.12\%20MPGPP\%20ARTIGO\%20INDIVIDUAL\%20-\%20LOZANO \%20 $\% 281 \% 29$.pdf? sequence $=3 \&$ is Allowed $=\mathrm{y}>$.

MULLAINATHAN, Sendhil; SHAFIR, Eldar. Scarcity: why having too little means so much. Nova Iorque: Time Books, Henry Holt \& Company Llc, 2014.

MURAMATSU, Roberta; FONSECA, Patrícia. Economia e psicologia na explicação da escolha intertemporal.Revista de Economia Mackenz̨ie, São Paulo, v. 6, n. 6, p. 87-112. 2008. Disponível em: < http://editorarevistas.mackenzie.br/index.php/rem/article/view/810>.

OECD.Behavioural insights andpublic policy:lessons from around the world, OECD Publishing, Paris,Disponível 
em: <http://dx.doi.org/10.1787/9789264270480-en>.

PENDER, John L. Discount rates and credit markets: theory and evidence from rural india.Journal Of Development Economics, [s.1.], v. 50, n. 2, p. 257-296, ago. 1996. Elsevier BV. Disponível em: < http://dx.doi. org/10.1016/s0304-3878(96)00400-2>.

RICK, Scott; LOEWENSTEIN, George. Intangibilidade na escolha intertemporal. In: ÁVILA, Flávia; BIANCHI, Ana Maria.Guia de economia comportamental e experimental.São Paulo: Economiacomportamental. org, 2015. p. 76-97.

SAEZ, Emmanuel; ZUCMAN, Gabriel. Wealth inequality in the united states since 1913: evidence from capitalized income tax data.National Bureau Of Economic Research, Cambridge, Ma, p.1-46, out. 2014. National Bureau of Economic Research . Disponível em: <http://dx.doi.org/10.3386/w20625>.

SAMSON, Alain. Introdução à economia comportamental e experimental. In: ÁVILA, Flávia; BIANCHI, Ana Maria.Guia de Economia Comportamental e Experimental.São Paulo: Economiacomportamental.org, 2015. p. 25-59.

SAMUELSON, Paul A. A note on measurement of utility.The Review of Economic Studies, [s.l], v. 4, n. 2, p. 155-161, fev. 1937. Publicado pela Oxford University Press. Disponível em: <http://www.jstor.org/stable/2967612>.

SANTOS, Talitha Araújo; ZAMBONI, Viviane de Paula Gouveia; OLIVEIRA, Maria Rita Neto Sales. Evasão e permanencia na educação profissional de jovens e adultos nos programas educacionais PROEJA e PRONATEC.In: SIMPOSIO INTERNACIONAL SITRE - TRABALHO, RELAÇÕES DE TRABALHO, EDUCAÇÃO E IDENTIDADE, 6. Disponível em: <http://www.sitre.cefetmg.br/arquivos/Anais/ GT-01/sitreGT01p424_-_EVASxO_E_PERMANxNCIA_NA_EDUCAxO_PROFISSIONAL_DE_ JOVENS_E_ADULTOS_NOS_PROGRAMAS_EDUCACIONAIS_PROEJA_E_PRONATEC.pdf $>$.

SHAH, A. K.; MULLAINATHAN, S.; SHAFIR, E. Some consequences of having too little. Science, [s.l.], v. 338, n. 6107, p. 682-685, nov. 2012. American Association for the Advancement of Science (AAAS). Disponível em: < http://dx.doi.org/10.1126/science.1222426>.

SMITH, Adam.The theory of moral sentiments.São Paulo: Metalibri, 2006. Disponível em: < https://www.ibiblio.org/ml/libri/s/SmithA_MoralSentiments_p.pdf>.

SPEARS, Dean. Decision costs and price sensitivity: field experimental evidence from India.Journal Of Economic Behavior \& Organization, [s.1.], v. 97, p. 169-184, jan. 2014. Elsevier BV. Disponível em: < http://dx.doi. org/10.1016/j.jebo.2013.06.012>.

SPEARS, Dean. Economic decision-making in poverty depletes behavioral control.The B.e. Journal of Economic Analysis \& Policy, [s.l], v. 11, n. 1, p. 1-42, 2011. Disponível em: < http://lisagennetian.org/files/92920599. $\mathrm{pdf}>$.

STARMER, Chris. Entendendo preferências: o que podemos aprender com a economia comportamental?. In: ÁVILA, Flávia; BIANCHI, Ana Maria.Guia de Economia Comportamental e Experimental.São Paulo: Economiacomportamental.org, 2015. p. 60-75.

SUNSTEIN, Cass R. Choosing not to choose: understanding the value of choice. New York: Oxford University Press, 2015.

SUNSTEIN, Cass R. Nudging: um guia bem breve. In: ÁVILA, Flávia; BIANCHI, Ana Maria. Guia de Economia Comportmental e Experimental. São Paulo: Economiacomportamental.org, 2015. p. 109-114.

TANAKA, Tomomi; CAMERER, Colin F; NGUYEN, Quang. Risk and time preferences: linking experimental and household survey data from Vietnam. American Economic Review, [s.l.], v. 100, n. 1, p. 557-571, mar. 2010. American Economic Association. Disponível em: <http://dx.doi.org/10.1257/aer.100.1.557>. 
TIERNEY, John.Do you suffer from decision fatigue?. Disponível em: <https://www.nytimes.com/2011/08/21/ magazine/do-you-suffer-from-decision-fatigue.html>.

THALER, Richard H.; BENARTZI, Shlomo. Save more tomorrow ${ }^{\text {TM}}$ : using behavioral economics to increase employee saving. Journal Of Political Economy, [s.l.], v. 112, n. 1, p. 164-187, fev. 2004. University of Chicago Press. Disponível em: <http://dx.doi.org/10.1086/380085>.

THALER, Richard H.; SUNSTEIN, Cass R.Nudge.improving decisions about health, wealth and happiness. Londres: Penguin Books, 2009.

THALER, Richard.Mishehaving:the making of behavioral economics. Nova Iorque: W. W. Norton, 2016.

WALLACE, Harry M.; BAUMEISTER, Roy F. The effects of success versus failure feedback on further self-control.Self and Identity, [s.l.], v. 1, n. 1, p. 35-41, jan. 2002.

VALOR ECONÔMICO.Programa de ensino técnico tem evasão de 19\%. Disponível em: < http:/ /www.valor.com. $\mathrm{br} /$ brasil/3270550/programa-de-ensino-tecnico-tem-evasao-de-19>.

VOHS, Kathleend.; FABER, RonaldJ. Spent resources: self-regulatory resource availability affects impulse buying.Journal of Consumer Research, [s.l.], v. 33, n. 4, p. 537-547, mar. 2007.

VOHS, Kathleen D.; HEATHERTON, Todd F. Self-regulatory failure: a resource-depletion approach.Psychological Science, [s.l.], v. 11, n. 3, p. 249-254, maio 2000.

VON NEUMANN, John; MORGENSTERN, Orkas. Theory of games and economic behavior:Princeton: Princeton University Press, 1953.

YESUF, Mahmud; BLUFFSTONE, Randall. Wealth and time preference in rural ethiopia.Environment For Development, [s.1.], v. 16, n. 08, p. 1-18, jun. 2008. Disponível em: <http://www.rff.org/files/sharepoint/ WorkImages/Download/EfD-DP-08-16.pdf>. 


\section{REVISTA BRASILEIRA DE POLÍTICAS PÚBLICAS BRAZILIAN JOURNAL OF PUBLIC POLICY}

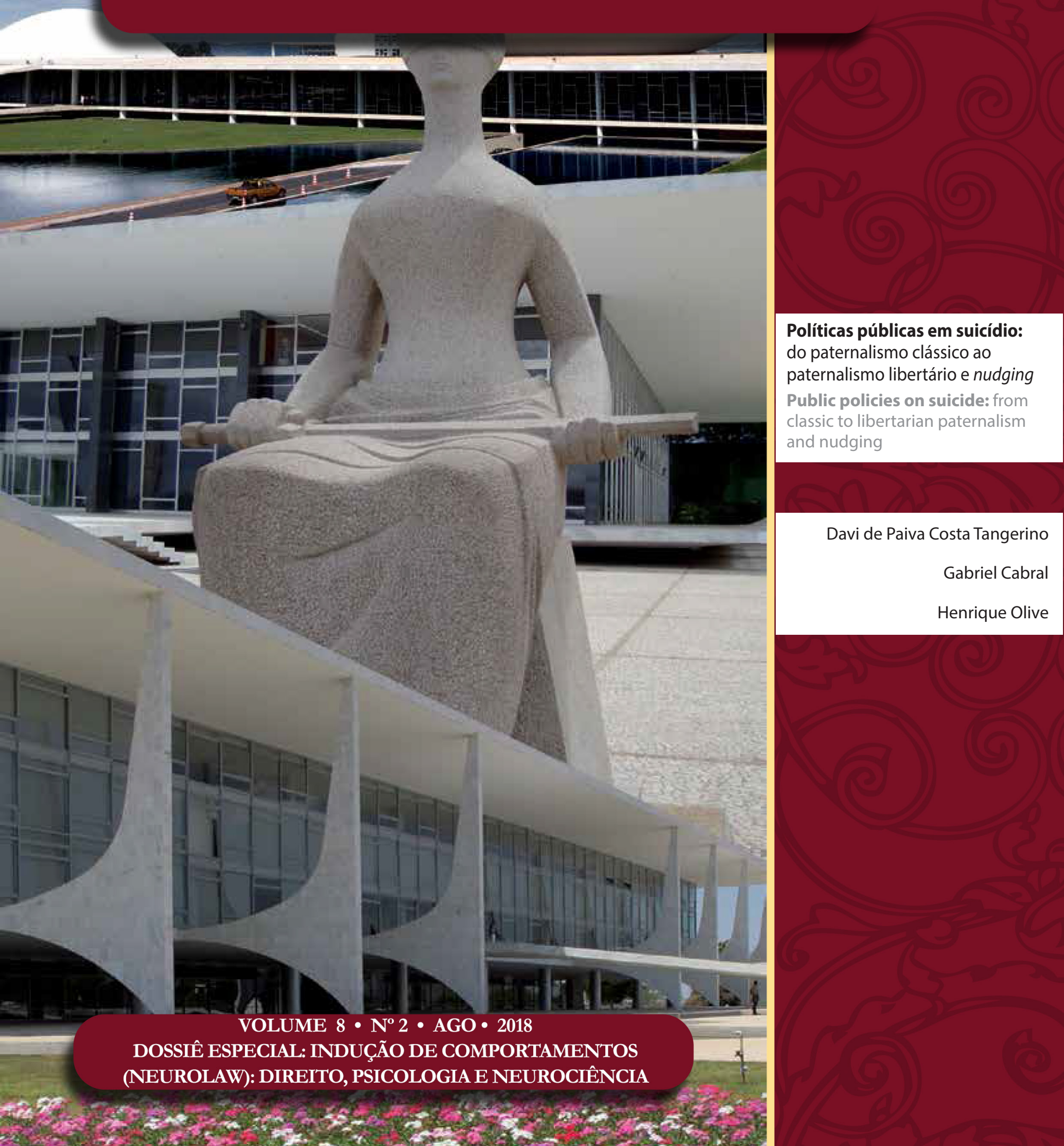




\title{
Políticas públicas em suicídio: do paternalismo clássico ao paternalismo libertário e nudging*
}

\author{
Public policies on suicide: from classic to \\ libertarian paternalism and nudging
}

\author{
Davi de Paiva Costa Tangerino** \\ Gabriel Cabral*** \\ Henrique Olive $e^{* * *}$
}

\section{Resumo}

Os índices dos eventos de suicídio vêm, progressivamente, aumentando em todo o mundo, demandando de entes públicos a implementação de medidas quanto à implementação de medidas efetivas para coibi-los. As políticas públicas tradicionalmente utilizadas, como a inserção de barreiras físicas em hotspots ou a promoção de campanhas de conscientização, não costumam apresentar resultados satisfatórios, apesar do alto custo de implementação. Tendo em vista esse contexto, pretende-se neste artigo promover uma via alternativa de intervenção. Para isto, em primeiro lugar, debate-se a via do nudging, sua forma de operação e o paternalismo de Estado; em segundo, debruça-se sobre os elementos concretos do fenômeno, realizando análises e cruzamentos de dados do Ministério da Saúde do Brasil e do Instituto Brasileiro de Geografia e Estatística, bem como utilizando estudos específicos nacionais e estrangeiros para a identificação de características e padrões dos eventos suicidas; em seguida, debatem-se as experiências estrangeiras em relação ao desenvolvimento e à aplicação de políticas públicas em seu enfrentamento. Com essas informações, discutimos medidas em forma de nudges para a gestão do fenômeno do suicídio, com a pretensão de promover o método e incentivar novas propostas de políticas públicas para esses e outros problemas na esfera da gestão pública.

Palavras-chave: Paternalismo de Estado. Nudge. Paternalismo Libertário. Políticas Públicas. Epidemiologia. Suicídio.

\section{Abstract}

The rates of suicide events have been steadily increasing all over the world, requiring public authorities to make decisions regarding the implementation of effective preventive strategies. Traditionally, interventions undertaken by policymakers such as the installation of physical barriers in hotspots or the promotion of awareness campaigns do not usually present satisfactory results despite the ensuing high cost. With that in mind, this article intends to promote nudging as an alternative course of intervention. 
Firstly, debating its process and state paternalism in general. Following that, we focus on the concrete elements of the phenomenon, analyzing and cross-checking data from the Brazilian Ministry of Health and the Brazilian Institute of Geography and Statistics, as well as using specific Brazilian and foreign studies to identify characteristics and patterns of suicidal events. Thus, we also discuss public policies' assessment about the issue of suicide in other countries. Based on this information, we explore nudging measures as suicide prevention efforts, looking to promote this alternative and its use in future public policies proposals on suicide and other matters in the sphere of public management.

Keywords: State Paternalism. Nudge. Libertarian Paternalism. Public Policies. Epidemiology. Suicide.

\section{INTRODUÇÃO}

Às vezes agimos contra nosso próprio bem-estar: compramos o que não podemos pagar, deixamos de guardar dinheiro para o futuro, comemos mais do que devemos e até mesmo atentamos contra nossas próprias vidas. Isto leva à pergunta: devemos ser protegidos de nós mesmos? Caso a resposta seja positiva, a quem deve incumbir essa proteção?

Essas perguntas se mostram ainda mais inquietantes quando o tema é suicídio, gerando enormes questionamentos acerca da ingerência estatal, de origem moral e/ou religiosa, na esfera mais íntima do indivíduo e seu desejo de viver ou morrer.

Em meio a esse dilema, os casos de suicídio vêm aumentando de forma muito significativa tanto em países com altos índice, como naqueles em que o fenômeno tradicionalmente não se apresentava como um problema mais agudo. Frente a isto, como os Estados devem reagir e em que medida podem/devem promover ações de contenção do fenômeno?

Inúmeras políticas públicas têm sido desenvolvidas no sentido de dificultar ou impedir o ato de suicídio, em especial com base em uma concepção médica, quase unânime, que enxerga no suicida um comportamento necessariamente patológico; posicionamento acompanhado, a título de exemplo, pela jurisprudência brasileira ${ }^{1}$. Com base nisto, pergunta-se: por que não se utilizar (e como fazê-lo), de nudges para promover essa opção política de proteger os indivíduos com ideações suicidas, ainda que de forma complementar a eventuais outras medidas?

Essa é a pergunta que norteia o presente trabalho, de modo que respondê-la perpassa necessariamente por alguns passos, quais sejam: i) debater o paternalismo de Estado e a terceira via dos nudges; ii) conhecer adequadamente fenômeno do suicídio; iii) verificar, com base em sua adequada compreensão, a necessidade, adequação e eficiência da utilização de nudges nesse caso concreto; e, por fim, iv) sugerir algumas medidas dessa natureza para o problema específico.

Por fim, é imprescindível alertar que este trabalho não visa a exaurir o tema de políticas públicas voltadas

\footnotetext{
1 A título de exemplo, veja-se: “isto, porque, longe de demonstrar que não pretende fugir, a atitude do paciente de atentar contra sua própria vida revela desespero e certo desequilíbrio que poderão comprometer o bom andamento da instrução criminal” (TJRJ: HC 0059130-96.2012.8.19.0000, $2^{a}$ Câmara Criminal, 18/12/2012); “a depressão embota os sentidos, tolhe a percepção, dificulta a compreensão, desorienta e abate moralmente os que são por ela acometidos, a ponto de muitos cometerem o suicídio" (TJRJ: ACR 0043099-79.2004.8.19.0000, $3^{\text {a } C a ̂ m a r a ~ C r i m i n a l, ~ 15 / 03 / 2005) ; ~ " r e i t e r a d a s ~ t e n t a t i v a s ~ d e ~ s u i c i ́ d i o, ~ o ~ q u e ~ r e f o r c ̧ a ~ a ~ n e c e s s i d a d e ~}$ de o mesmo ser mantido segregado como forma de garantir a sua própria integridade física e psicológica” (TJES: HC 000154070.2012.8.08.0000, 1a Câmara Criminal, 11/07/2012). Evidencia também este posicionamento o sistemático reconhecimento de responsabilidade civil do Estado por suicídio de pessoas sob custódia do sistema de justiça criminal (STJ: AgRg no AG 1307100/ PR, Primeira Turma, rel. Min. Sérgio Kukina, 24/10/2014; STJ: Resp 847.687/GO, Primeira Turma, rel. Min. Teori Zavascki, 17/10/2006; STJ: EDcl no AgRg no REsp 1305259, Segunda Turma, rel. Min. Mauro Campbell Marques, 15/08/2013; STF: ARE em RE 700927/GO, Segunda Turma, rel. Min. Gilmar Mendes, 28/08/2012; STF, este caso em hospital psiquiátrico: ARE em RE 691744, Segunda Turma, rel. Min. Celso de Mello, 28/08/2012).
} 
para o enfrentamento do quadro de suicídios no Brasil. Em verdade, tem por objetivo demonstrar e promover o modo de operação de políticas públicas baseadas em nudges; e, naturalmente, a publicizar e debater mais detalhadamente os elementos do fenômeno do suicídio para além dos centros de pesquisas médicas e de outras áreas afins. Dito isto, é possível adentrar ao primeiro passo, o paternalismo de Estado.

\section{SOBRE O PATERNALISMO}

\subsection{Definição de paternalismo}

Em 2013, o então prefeito de Nova Iorque, Michael Bloomberg, ao propor um limite para o tamanho de copos de refrigerantes, polarizou opiniões: de um lado, foi criticado por estar restringindo a liberdade de escolha; de outro, foi aplaudido por estar tomando medidas de redução de sobrepeso dos nova-iorquinos. A discussão acerca dos limites do Estado na conciliação de valores, que em determinados contextos tornam-se inconciliáveis — liberdade de escolha e bem-estar —, faz referência ao eixo temático do Paternalismo de Estado.

Contudo, diferentemente do caso de Nova Iorque, opções políticas com teor paternalista não são facilmente perceptíveis; entretanto, ainda que percebidas, sua complexidade dificulta sua compreensão dentro de um contexto polarizado. Em alguns casos, a dicotomia liberdade/paternalismo é notória, como em reformas trabalhistas quanto à autonomia para negociação ou, no caso de vedação, a disposição de saleiros em mesas de restaurantes; em outros, o teor paternalista pode apresentar-se de modo mais sutil, como o estabelecimento de preço mínimo para cigarros nos termos da Lei 12.546/2011, com a finalidade de dificultar o acesso ao produto danoso.

Portanto, questiona-se: quais elementos em regulamentações podem caracterizar uma política paternalista? E, por conseguinte, qual a definição de paternalismo de Estado? Comecemos pela segunda.

Sua definição é especialmente complicada, afinal, sob um aspecto prático, uma regulamentação tida como paternalista pode ter comprometida sua aceitação perante a opinião pública. O termo é percebido por alguns autores como uma ofensa ao substrato ideológico liberal típico do Estado Moderno ${ }^{2}$. Entretanto, por vezes busca-se atenuar esse posicionamento ${ }^{3}$. A título de exemplo, pode ser menos desgastante defender a obrigatoriedade do uso de cinto de segurança em razão da redução de gastos com saúde pública do que sob a alegação de que as pessoas precisam ser protegidas de sua negligência.

John Stuart Mill, considerado o fundador do eixo temático do (combate ao) paternalismo, asseverou:

seu próprio bem [do indivíduo], seja físico ou moral, não é justificação suficiente [para intervenção estatal]. Ele não pode ser legitimamente compelido a fazer ou tolerar porque isso será melhor para ele fazer deste modo, porque o fará mais feliz, porque, na opinião de outros, fazer deste modo seria sábio, ou até correto ${ }^{4}$.

Desde seu nascedouro, a discussão acerca do paternalismo tem latente o engajamento de autores libe-

2 FEINBERG, J. Harm to self: the moral limits to the criminal law. Oxford: Oxford University Press, 1986. v. 3. p. 23; VANDEVEER, D. Paternalistic intervention: the moral bounds of benevolence. Princeton: Princeton University Press, 1986. p. 4-5; ANDERSON, E. What is the point of equality? Ethics, v. 109, n. 2, p. 287-337, 1999. p. 301-302.

3 Esta afirmação pode ser constatada pelo esforço de alguns autores para recorrer a justificativas não paternalistas, como fez Seana Siffrin em relação à unconscionability doctrine do direito contratual americano, segundo a qual juízes podem a recusar a ordem de cumprimento de contratos abusivos. Outro exemplo é o de Elizabeth Anderson em relação à defesa das contribuições compulsórias para seguro de saúde e de aposentadoria (SHIFFRIN, S. V. Paternalism, unconscionability doctrine, and accommodation. Philosophy and Public Affairs, v. 29, n. 3, p. 205-250, 2000; ANDERSON, E. What is the point of equality? Ethics, v. 109, n. 2, p. 287-337, 1999.). 4 MILL, J. S. On liberty. London: Floating Express, 2009. p. 18, tradução livre, [original de 1859]. 
rais contra ingerência do Estado sobre esfera individual. Nesse sentido, a discussão costuma ter caráter propositivo, às vezes panfletário, de estabelecimento de limites para a atuação estatal. Como aponta Gerald Dworkin, as definições de paternalismo são desenvolvidas contextualmente, de acordo com o propósito do autor quanto à limitação ou liberdade de atuação estatal ${ }^{5}$.

Ainda assim, o núcleo semântico do conceito de paternalismo é limitado e costuma transitar em torno de outros conceitos específicos. Vejamos alguns exemplos de conceituação, adaptados e padronizados para observarem a seguinte formulação: $X$ age paternalisticamente em relação a $Y$ se fizer ou deixar de faz̧er Z:

1) $X$ age em relação a $Y$ paternalisticamente se interferir na liberdade ou autonomia de $Y$, sem o consentimento de $\mathrm{Y}$, apenas em razão do aumento do bem-estar, ou de alguma forma de promoção de interesses, valores ou o bem de $\mathrm{Y}^{6}$;

2) X age em relação a $Y$ paternalisticamente se pretende fechar alguma opção que estaria de outra forma aberta a Y ou escolhe para Y uma situação em que $\mathrm{Y}$ é incapaz de escolher por si mesmo. X o faz, em alguma medida, para promover o bem de $\mathrm{Y}^{7}$;

3) $\mathrm{X}$ age em relação a $\mathrm{Y}$ paternalisticamente na medida em que $\mathrm{X}$, para assegurar o bem de $\mathrm{Y}$ como um fim, impõe-se sobre $Y^{8}$;

4) $\mathrm{X}$ age em relação a $\mathrm{Y}$ paternalisticamente ao restringir a liberdade de $\mathrm{Y}$ ou ao desconsiderar as preferências atuais de $\mathrm{Y}$, desde que o faça primariamente considerando o bem de $\mathrm{Y}$ e que as ações de $\mathrm{X}$ sejam uma violação de uma regra moral ou que $\mathrm{X}$ reconheça que suas ações sobre $\mathrm{Y}$ precisam de justificação moral';

5) X age em relação a $Y$ paternalisticamente ao restringir a liberdade de $Y$ ou ao desconsiderar as preferências atuais de $\mathrm{Y}$, desde que o faça primariamente considerando o bem de $\mathrm{Y}^{10}$;

6) X age em relação a Y paternalisticamente ao substituir o julgamento de $\mathrm{Y}$ em questão dentro da esfera de ação legítima de Y, desde que esta substituição seja direcionada aos interesses de Y em áreas que estão legitimamente dentro do controle de $\mathrm{Y}$ e que $\mathrm{X}$ considere seu julgamento sobre os interesses de $\mathrm{Y}$, em algum grau, superior ao de $\mathrm{Y}^{11}$.

É possível notar a recorrência de conceitos como liberdade, autonomia e bem-estar. Contudo, apesar de contribuírem para delimitar o sentido do conceito de paternalismo, para a circunscrição de um núcleo de sentido, não o esclarecem inteiramente, como explicam Le Grand e New:

outra razão para a falta de consenso [sobre o conceito de paternalismo] é que as pessoas inevitavelmente perceberão e interpretarão palavras em modos sutilmente diferentes, particularmente quando [se tratar de] termos abstratos como liberdade, autonomia, bem (good) e consentimento ${ }^{12}$.

Ainda que um conceito abstrato próximo aos exemplos apresentados seja capaz de acomodar intuições linguísticas pessoais, tal conceito não se mostra operacional, ou seja, não serve como instrumento para se identificar paternalismo em uma situação concreta. Uma vez que é possível o conflito de interpretações

5 DWORKIN, G. Defining paternalism. In: COONS, C.; WEBER, M. Paternalism: theory and practice. Cambridge: Cambridge University Press, 2013. p. 26.

6 DWORKIN, G. Paternalism: some second thoughts. In: SARTORIUS, R. Paternalism. Minneapolis: University of Minnesota Press, 1983.

7 CLARKE, S. A definition of paternalism. Critical Review of International Social and Political Philosophy, v. 5, n. 1, p. 81-91. 2002.

8 KLEINIG, J. Paternalism. Manchester: Manchester University Press, 1983.

9 GERT, B.; CULVER, C. The justification of paternalism. Ethics, v. 89, n. 2, p. 199-210, jan. 1979.

10 POPE, T. M. Counting the Dragon's Teeth and Claws: the definition of hard paternalism. Georgia State University Law Review, v. 20, n. 3, p. 659-722, 2004.

11 SHIFFrIN, S. V. Paternalism, unconscionability doctrine, and accommodation. Philosophy and Public Affairs, v. 29, n. 3, p. 205, 2000.

12 LE GRAND, J.; NEW, B. Government paternalism: nanny State or helpful friend? Princeton: Princeton University Press, 2015. p. 8, tradução livre. 
entre o indivíduo destinatário da política paternalista e seu promotor, mostra-se complicada a identificação com segurança de que se está diante de uma manifestação de paternalismo.

Para superar essa dificuldade, suscitada por Le Grand e New, e tornar o conceito operacional, propõe-se fazer um refinamento em relação aos conceitos previamente apresentados: deslocar o foco do conceito para as motivações de quem pratica o paternalismo. Desse modo, consideramos que bastam somente duas condições concomitantes para que se interprete algo como paternalista: que o promotor (i) identifique uma falba na cognição do indivíduo e, baseado nesta identificação, (ii) aja para aumentar o bem-estar deste indivíduo ${ }^{13}$. Portanto, não são relevantes a percepção do destinatário e a efetivação do bem desejado pelo promotor.

\subsection{Paternalismo de Estado}

Essas condições, enquanto caracterizadoras de paternalismo, encontram respaldo até mesmo na obra do antipaternalista Stuart Mill, por atuarem como critérios para o estabelecimento de limites a seu princípio do dano. Por este princípio, a intervenção do Estado apenas se justifica se o destinatário causar danos a terceiro. Porém, Mill prevê uma exceção, situação em que é possível a intervenção destinada a impedir que o indivíduo cause dano a si próprio. Entretanto, apenas se justifica caso seja atendida a condição de atribuição de capacidade cognitiva ao destinatário. Isto é, que exista a crença do interventor de que o indivíduo não tenha conhecimento suficiente quanto aos riscos; porém, havendo conhecimento desse risco, nada pode fazer o interventor além de alertar. A título de exemplo, o caso da ponte:

se um agente público ou qualquer outra pessoa vir uma pessoa tentando atravessar uma ponte que seja considerada perigosa, e não tenha tempo para avisá-la do perigo, podem impedi-la sem nenhuma real violação a sua liberdade; [...] não obstante, quando não se tem certeza [do perigo da ponte], mas apenas há o perigo de descuido da pessoa, ninguém além dela pode fazer este julgamento [...]. Neste caso, ela deve ser apenas alertada ${ }^{14}$.

Nesse caso, empurrar o indivíduo que não sabe do perigo é legítimo, pois o indivíduo não tem informações suficientes para a tomada de decisão. O limite para a intervenção se baseia na existência de percepção do interventor quanto à assimetria de capacidade cognitiva entre as partes. Afinal, se não há atribuição de inferioridade cognitiva seguida de uma ação de substituição de julgamento, não há paternalismo.

Essa concepção explica o porquê de, por exemplo, a persuasão racional, a disponibilização de informações ou a promoção de campanhas educativas não serem intuitivamente assimiladas como paternalistas. Nesses casos, não parece haver uma identificação de falha cognitiva de uma parte em relação à outra. Se há a tentativa de persuasão, há a expectativa de que o outro seja capaz de assimilar os argumentos e realizar por si só o que é melhor para si.

Apesar de o critério defendido neste artigo para identificação de paternalismo ser sólido diante de um caso concreto, esse critério evidencia um problema particular da própria conceituação de paternalismo, especialmente o de Estado: nem sempre é possível distinguir motivações reais de motivações manifestas. Por exemplo, mensagens em embalagens de cigarros são paternalistas?

De acordo com a conceituação simplificada que aqui se defende, a resposta é: depende. É possível que se tenha uma resposta diferente caso se considere a justificação oficial em comparação com uma análise da justificação mais razoável. Vejamos as possibilidades de justificação oficial: (i) as figuras como representação imagética da informação, a substituir ou complementar a textual, de danos do cigarro à saúde individual; (ii)

13 Essa concepção está em consonância com a de diversos outros autores, como Le Grand e New (LE GRAND, J.; NEW, B. Government paternalism: nanny State or helpful friend? Princeton: Princeton University Press, 2015. p. 23), em que pese apontarem também a existência de um incremento no bem-estar como uma condição necessária; e Sarah Conly, que afirma "[...] no paternalismo há uma substituição de julgamento; uma parte assume que o que você precisa é maior do que seu próprio julgamento" (CONLY, S. Against autonomy: justifying coercive paternalism. Cambridge: Cambridge University Press, 2013. p. 36, tradução livre). 14 MILL, J. S. On liberty. London: Floating Express, 2009. p. 163-164, tradução livre, [original de 1859]. 
as figuras como indicação de que há danos coletivos decorrentes do uso de cigarro, como aumento de gastos com Saúde Pública; (iii) as figuras como meio para chocar, para que pessoas associem o fumo de cigarro àquelas realidades ilustradas. Nesse contexto, apenas a justificação (iii) teria cunho paternalista, haja vista que não visa a convencer os fumantes, mas, a assustá-los, a considerar seu bem-estar.

A despeito de qual seja a justificação oficial exposta por órgãos públicos, parece razoável acreditar que o objetivo das figuras seja, de fato, chocar. Por essas razões, ela é paternalista, pois seu planejador diagnosticou um problema cognitivo nas pessoas: elas não seriam capazes de racionalmente assimilar informações e precisariam de uma intervenção extrema para agir em benefício de seu bem-estar.

Identificar uma política como paternalista, como se percebe, é uma tarefa que exige alguma reflexão, que pode se estender ao fato de que o paternalismo não necessariamente busca afetar diretamente eventuais resultados, podendo em realidade almejar interferir na crença das pessoas. Nesse sentido, Cass Sunstein compilou algumas formas de atuação de políticas paternalistas:

(1) afetar os resultados sem afetar as ações e crenças das pessoas; (2) afetar as ações sem influenciar as crenças; (3) afetar as crenças para poder influenciar as ações; ou (4) afetar as preferências, independentemente de afetar as crenças, para influenciar as ações ${ }^{15}$.

Talvez o ponto mais controverso seja o (3): afetar crenças por meio de campanhas educacionais, como cita Sunstein. Ensinar pessoas, a princípio, como argumentamos, não é paternalista. Pode ser paternalista, contudo, se houver referência a um tipo de paternalismo, o paternalismo moral.

Além disto, outra distinção importante se dá entre paternalismo de meios e de fins ${ }^{16}$. De acordo com essa distinção, o paternalismo pode ser direcionado (i) às decisões intermediárias, ou seja, aquelas que as pessoas fazem para atingir certos fins, ou (ii) para os próprios fins. Uma forma de entender esse mecanismo, ainda que não se trate de um exemplo de paternalismo, é o funcionamento de um aplicativo de navegação de trânsito: o aplicativo restringe-se a informar qual a forma mais eficiente (meio) para que seu operador possa chegar ao destino escolhido (fim).

Uma linha divisória entre meios e fins, contudo, pode ser tênue. Nesse sentido, o exemplo dado por Le Grand e New:

[...] desenvolvendo uma justificação para uma política que pretende dissuadir pessoas de fazerem sexo com múltiplos parceiros, é importante estar claro se pretendemos ajudar pessoas a evitar risco excessivo para sua saúde (relacionado a meios) ou considerar errado em si mesmo possuir diversos parceiros sexuais (paternalismo relacionado a fins) ${ }^{17}$.

Nesse exemplo, o paternalismo de fins trata de uma questão relacionada, especificamente, a valores morais, não a bem-estar em um sentido amplo. Isto nos remete a mais uma distinção relevante da discussão sobre paternalismo: entre paternalismo moral, como o caso acima, e moralismo legal. De acordo com Dworkin, moralismo legal trata de previsão legal de proibição de condutas que sejam consideras imorais, mesmo que não sejam danosas, ao passo que paternalismo moral trata de prevenir o dano moral que a pessoa possa causar a si mesma ${ }^{18}$. Nesse caso, a atribuição de falha cognitiva diz respeito à incapacidade de uma pessoa perceber que está se degradando moralmente.

O paternalismo moral está em uma zona limítrofe do conceito de paternalismo, pois trata não de bem-estar, mas de correção moral. Assim, a menos que se considere que estar moralmente melhor também signifique estar com mais bem-estar, paternalismo moral não pode ser considerado uma forma incontroversa de paternalismo ${ }^{19}$.

15 SUNSTEIN, C. Why nudge?: the politics of libertarian paternalism. New Haven: Yale University Press, 2014. p. 53, tradução livre.

16 SUNSTEIN, C. Why nudge?: the politics of libertarian paternalism. New Haven: Yale University Press, 2014. p. 21.

17 LE GRAND, J.; NEW, B. Government paternalism: nanny State or helpful friend? Princeton: Princeton University Press, 2015.

p. 30, tradução livre.

18 DWORKIN, G. Moral paternalism. Law and Philosophy, v. 24, n. 3, p. 305-319, 2005.

19 LE GRAND, J.; NEW, B. Government paternalism: nanny State or helpful friend? Princeton: Princeton University Press, 2015. 


\subsection{Paternalismo libertário}

Além dessa controvérsia relacionada à identificação de bem-estar com moralidade, situações em que não exista um conflito necessário entre restrição de liberdade e aumento de bem-estar também causam dissonância de opiniões. Será possível conceber uma forma de paternalismo que concilie liberdade e aumento de bem-estar? De acordo com Thaler e Sunstein, proponentes do paternalismo libertário, essa aproximação não é apenas possível, mas uma sofisticação da atuação estatal. Para os autores, essa conciliação ocorre com base em "[...] uma abordagem que preserva a liberdade de escolha, mas autoriza instituições públicas e privadas a dirigir pessoas em direções que promoverão seu bem-estar" ${ }^{20}$.

A ideia de "dirigir pessoas em direções que promoverão seu bem-estar" parece fazer referência a tecnologias de atuação estatal e pressupostos teóricos estranhos à tradicional discussão sobre paternalismo. De fato, o debate tradicional tem como objeto as ferramentas à disposição de planejadores de políticas públicas que podiam ser, de um lado, claramente paternalistas: proibições ou incentivos fiscais; de outro, claramente liberais: campanhas de conscientização e disponibilização de informações.

Em comum, adotam como pressuposto a Teoria Econômica Neoclássica, que aposta na capacidade das pessoas de tomar decisões de forma racional, lógica, consistente e autointeressada. O modelo de comportamento humano adotado por essa corrente econômica para análise e predição de decisões é o do homo economicus. Conforme este modelo, as análises econômicas partem de pressupostos de que seres humanos são seres essencialmente racionais: analisam fatos, probabilidades, custos e benefícios para fazer escolhas e agem, consistentemente, com o resultado de sua análise. Conforme Stuart Mill: "[...] é preocupado consigo somente como um ser que deseja possuir riquezas, e que é capaz de julgar a eficácia comparativa de meios para obter este fim" 21 .

A partir desse pressuposto, justificam-se as opções disponíveis ao debate tradicional sobre paternalismo. A opção liberal, de conscientização e disponibilização de informação, justifica-se pela presunção de que más decisões decorrem de falta de informação. Em mesmo sentido, a opção paternalista, de proibições e incentivos fiscais, justifica-se pela presunção de que as pessoas tomarão decisões consistentes com um exame prévio em relação aos custos da decisão.

Essas presunções vêm sendo alvo de críticas, em especial por economistas comportamentais, que tentam demonstrar a falta de realismo psicológico da corrente econômica neoclássica ${ }^{22}$. A economia comportamental tem o mérito de aproximar teorias econômicas, tradicionalmente abstratas e teoréticas, de evidências em psicologia do comportamento. A mudança mais relevante talvez seja a percepção de que não somos tão racionais quanto imaginávamos ou como retratavam — e ainda retratam — modelos econômicos, haja vista que temos nossa racionalidade limitada (bounded rationality).

O conceito de racionalidade limitada foi introduzido de forma crítica por Herbert A. Simon no artigo A Behavioral Model of Rational Choice (1955). Para Simon, a própria ideia de determinar qual a opção mais racional é um tipo de custo que a torna irracional: conseguir as informações e calcular os prós e contras etc. geram custos à ação. Tendo em vista esse claro prejuízo, afirma que as pessoas em realidade se contentam com as opções "boas o suficiente" (“good enough”), que são as mais racionais diante de nossas limitações ${ }^{23}$. Como destaca Simon, (i) falta-nos tempo para refletir; (ii) nem sempre temos acesso a todas as informações

p. 35.

20 THALER, R.; SUNSTEIN, C. Libertarian paternalism. American Economic Review, v. 93, n. 2, p. 175-179, may 2003. p. 179, tradução livre.

21 MILL, J. S. Essays on some unsettled questions of political economy. Kitchener: Batoche Books, 2000. p. 97, tradução livre [Original de 1844].

22 JOLLS, C.; SUNSTEIN, C.; THALER, R. A behavioral approach to law and economics. Stanford Law Review, v. 50, p. 1471 1550, 1998.

23 SIMON, H. A behavioral model of rational choice. Quarterly Journal of Economics, v. 69, n. 1, p. 99-118, feb. 1955. 
necessárias; e (iii) nosso cérebro tem limitações computacionais. Além dessas limitações percebidas por Simon, sofremos de um problema cognitivo mais recentemente constatado: (iv) os vieses da cognição ${ }^{24}$.

Esses vieses da cognição são padrões de comportamento que se desviam de um padrão lógico e racional. Nesse sentido, afirma-se que o "erro de julgamento [um viés] é demonstrado pela comparação entre a resposta das pessoas ou com um fato estabelecido [...] ou com regras aceitas de aritmética, lógica ou estatística" 25 . Assim, pode-se inferir que, para identificar um viés da cognição, deve-se, em primeiro lugar, identificar um parâmetro baseado naquelas regras; posteriormente, testar as pessoas para descobrir se elas respondem sistemática, previsível e diferentemente da resposta prevista pelo parâmetro. Em Thinking fast and slow, Kahneman traz estudos discutindo vieses da cognição; conforme expõe, uma boa explicação para o fato de sermos potencialmente tão racionais, mas agirmos tão irracionalmente, é a existência de dois sistemas de cognição, os sistemas 1 e 2: sistemas intuitivo e reflexivo, respectivamente. Esses sistemas são ativados e solicitados em situações diferentes: quando uma pessoa está aprendendo a dirigir, ela o faz usando o sistema 2. Depois de muita prática, ela começa a dirigir "no automático", usando o sistema 1. As diferenças entre os sistemas vão muito além do tipo de gatilho que os ativa, conforme a Quadro $1^{26}$.

Quadro 1 - Sistema 1 versus Sistema 2

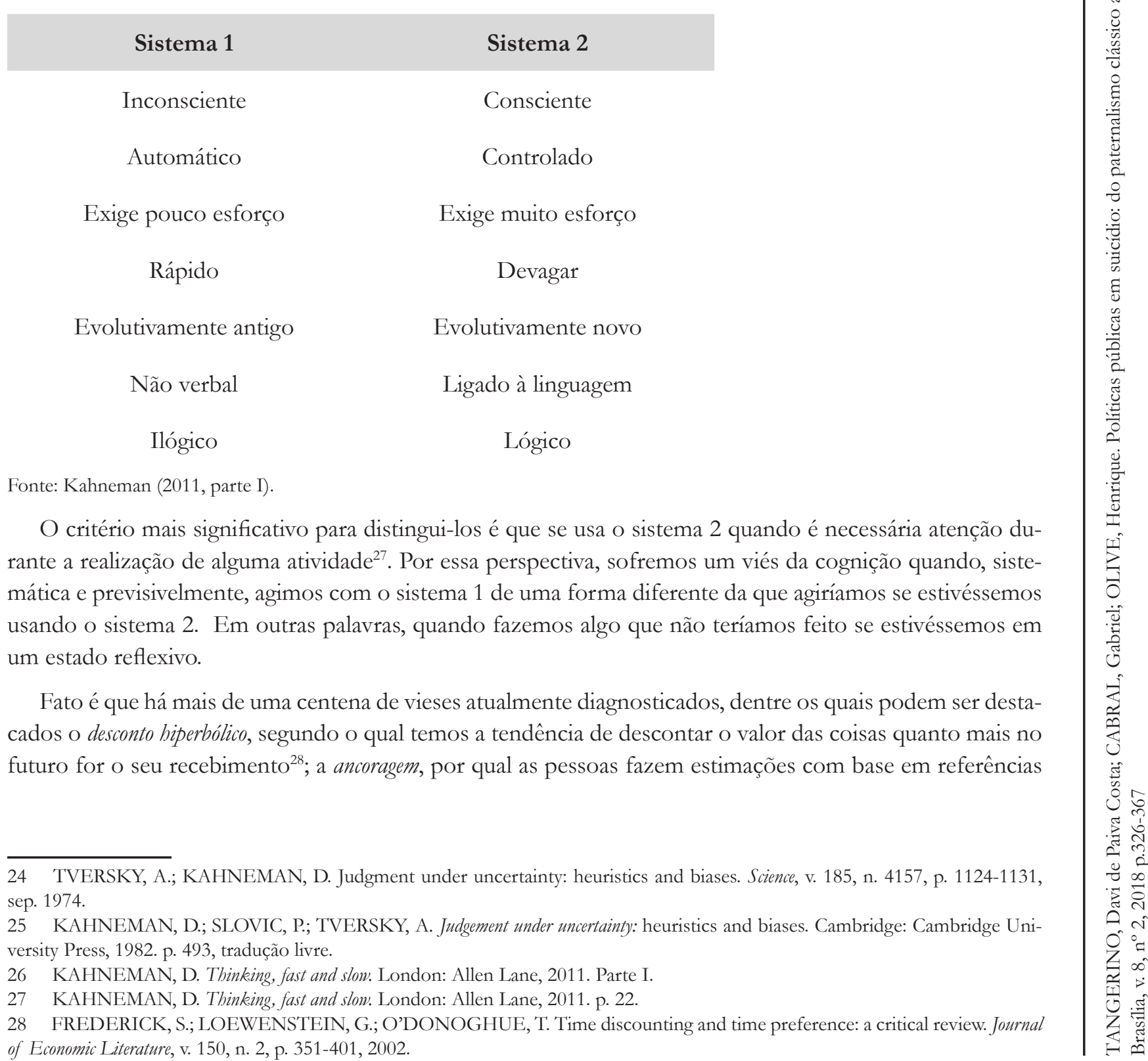
of Economic Literature, v. 150, n. 2, p. 351-401, 2002. 
iniciais que podem ser arbitrárias ${ }^{29}$; e a aversão à perda, isto é, a tendência para valorizar, desproporcionalmente, as perdas em relação aos ganhos ${ }^{30}$.

Com os diversos estudos sobre vieses da cognição, percebe-se que (i) pessoas agem irracionalmente de forma sistemática e previsível e (ii) pequenas intervenções, mesmo as mais sutis, podem fazer a diferença para neutralizar os efeitos negativos dos vieses. Assim, se os erros são previsíveis e pequenas intervenções podem anulá-los, há uma possibilidade de ser paternalista, ajudando pessoas a cometerem menos erros que diminuam seu bem-estar, por meio de pequenas e sutis intervenções. Essas intervenções preservam a liberdade de escolha do indivíduo ${ }^{31}$, afinal são direcionadas à arquitetura da decisão. Nesse sentido, Thaler e Sunstein:

paternalismo libertário é um tipo relativamente fraco, suave e não intrusivo de paternalismo porque escolhas não são bloqueadas, retiradas ou significativamente dificultadas. Se as pessoas querem fumar cigarros, comer muitos doces, escolher um plano de saúde ruim, ou deixar de guardar dinheiro para a aposentadoria, paternalistas libertários não as forçarão a fazer diferente — ou fazer as coisas muito mais difíceis para elas ${ }^{32}$.

Como complementam, "a regra de ouro é assumir que "tudo tem importância"”33. Cada pequeno detalhe da arquitetura da decisão interfere, em algum grau, na tomada de decisão: a cor da caneta usada, a altura das cadeiras, a temperatura do ambiente, o teor dos quadros nas paredes, a ordem das frases, a limpeza do local etc. Cada elemento tem diferentes tipos e intensidades de efeitos de acordo com a forma como são apresentados, mesmo que a arrumação não tenha sido intencional. Por exemplo, um estudo aponta que pessoas estão mais dispostas a comer maçãs em ambientes com iluminação amarela do que azul ${ }^{34}$.

A possibilidade de alteração de comportamentos por meio de pequenas e sutis alterações na arquitetura da decisão, chamados de nudges (empurrõezinhos), é um pressuposto central ao paternalismo libertário.

\subsubsection{Nudges}

Richard Thaler e Cass Sunstein trazem dois conceitos independentes entre si. Primeiro, afirmam que:

é qualquer aspecto da arquitetura da decisão que altera o comportamento das pessoas de forma previsível sem proibir nenhuma opção ou alterar significativamente seus incentivos econômicos. [Esta] intervenção precisa ser simples e fácil de evitar. Nudges não são ordens. Botar a fruta na altura dos olhos conta como um nudge. Banir comida não saudável (junk food), não ${ }^{35}$.

29 TVERSKY, A.; KAHNEMAN, D. Judgment under uncertainty: heuristics and biases. Science, v. 185, n. 4157, p. 1124-1131, sep. 1974. p. 1128-1130.

30 TVERSKY, A.; KAHNEMAN, D. Advances in prospect theory: cumulative representation of uncertainty. Journal of Risk. and Uncertainty, v. 5, p. 297-323, 1992.

31 Segundo Mitchell, Thaler e Sunstein estariam apenas parcialmente corretos ao afirmar que o paternalismo libertário preserva a liberdade (MITCHELL, G. Libertarian paternalism is an oxymoron. Northwestern University Law Review, v. 9, n. 3, p. 1245-1277, 2005.). Há dois tipos de liberdade: a "negativa", que indica indica a ausência de algum obstáculo para a decisão livre, isto é, ser uma "liberdade de" (from); e a "positiva", que indica a presença de autonomia, isto é, uma "liberdade para" (to) (BERLIN, I. Two concepts of liberty. In: BERLIN, I. Four essays on liberty. Oxford: Oxford University Press, 1969. p. 6-8, traduções livres [original de 1958]). Nudges, por alterarem a arquitetura de decisão, de fato, não criam obstáculos significativos para a tomada livre de decisão (liberdade negativa), mas acabam por influenciá-la de tal forma que relativizam o grau de autonomia (liberdade positiva) do tomador de decisão. Em consonância com esta ideia, um estudo recente indicou que pessoas que creem menos em sua autonomia e autodeterminação avaliam nudges mais favoravelmente (HANNIKAINEN, I et. al. A deterministic worldview promotes approval of state paternalism. Journal of Experimental Social Psychology, v. 70, p. 251-259, may 2017.).

32 THALER, R.; SUNSTEIN, C. Nudge: improving decisions about health, wealth and happiness. New Haven: Yale University Press, 2008. p. 5, tradução livre.

33 THALER, R.; SUNSTEIN, C. Nudge: improving decisions about health, wealth and happiness. New Haven: Yale University Press, 2008. p. 3, tradução livre.

34 YANG, L.; CHO, S.; SEO, H. Effects of light color on consumers: acceptability and willingness to eat apples and bell peppers. Journal of Sensory Studies. v. 31, n. 1, p. 3-11, nov. 2016.

35 THALER, R.; SUNSTEIN, C. Nudge: improving decisions about health, wealth and happiness. New Haven: Yale University Press, 2008. p. 6, tradução livre. 
Porém, em seguida, afirmam que "nudge é qualquer fator que, significativamente, altere o comportamento de Humanos, mas que seria ignorado por Econs [homens econômicos]"36.

É possível conciliar essas duas definições? Para alguns autores, nudges, além de serem pequenas intervenções na arquitetura da decisão, precisam ser direcionados às intuições do sistema 1, ignorando apelos à reflexão do sistema $2^{37}$. Nesse sentido, nudges envolvem a manipulação de falhas de cognição, de maneira que sejam manejadas em favor do tomador de decisão. Portanto, os vieses da cognição são aliados dos planejadores de políticas públicas ${ }^{38}$.

De fato, o que torna os nudges genuínos é a ideia de explorar deficiências cognitivas e motivacionais das pessoas de forma paternalista ${ }^{39}$, afinal sempre existiram pequenas intervenções na arquitetura da decisão — como a disposição de placas informativas ou incentivos econômicos —, porém sem a abordagem cientificista na referida exploração.

Essa interpretação mais restrita não parece ser a adotada pelos próprios criadores do termo, como esclarece o próprio Sunstein, segundo o qual definições mais restritas estão equivocadas em, pelo menos, dois aspectos:

primeiro, o universo dos nudges é bem mais amplo [...]. Paternalismo libertário inclui intervenções (como avisos e regras default) que [...] não precisam especificamente neutralizar (counteract) vieses e inadequações decisionais. Segundo, a palavra "neutralizar" é melhor do que "explorar". Nudges podem neutralizar vieses (como otimismo irrealista) sem explorar nada ${ }^{40}$.

Portanto, nudge seria um termo amplo, que engloba diversas intervenções, inclusive aquelas que não se baseiam em ou pretendem neutralizar vieses da cognição; não são intrusivos ${ }^{41}$. Sequer precisam fazer menção a descobertas da psicologia ou economia comportamental, como nos exemplos de disponibilização de informações, lembretes ou avisos.

Para tentar organizar e dar consistência à miríade de exemplos, Robert Baldwin, considerou dividir os nudges em três graus, de acordo com o impacto na autonomia dos indivíduos. As ideias dos autores podem ser resumidas no Quadro 02.

36 THALER, R.; SUNSTEIN, C. Nudge: improving decisions about health, wealth and happiness. New Haven: Yale University Press, 2008. p. 8, tradução livre.

37 BOVENS, L. The ethics of nudge. In: GRÜNE-YANOFF, T.; HANSON, S. Preference change: approaches from philosophy, economics and psychology. Berlin: Springer, 2009. Cap. 10, p. 209; JOHN, P.; SMITH, G.; STOKER, G. Nudge nudge, think think: two strategies for changing civic behaviour. Political Quarterly, v. 80, n. 3, p. 361-370, july 2009; REBONATO, R. Taking liberties: a critical examination of libertarian paternalism. Houndmills: Palgrave Macmillan, 2012. p. 84; CALO, R. Code, nudge, or notice? Iowa Law Review, v. 99, n. 2, p. 773-802. 2014. p. 784; HANSEN, P. The definition of nudge and libertarian paternalism: does the hand fit the glove? The European Journal of Risk Regulation, v. 7, n. 1, p. 155-174, mar. 2016. p. 162.

38 GRÜNE-YANOFF, T.; HERTWIG, R. Nudge versus boost: how coherent are policy and theory? Minds and Machines, v. 26, n. 1, p 149-183, 2016. p. 170.

39 GRÜNE-YANOFF, T.; HERTWIG, R. Nudge versus boost: how coherent are policy and theory? Minds and Machines, v. 26, n. 1, p 149-183, 2016. p. 154.

40 SUNSTEIN, C. Why nudge?: the politics of libertarian paternalism. New Haven: Yale University Press, 2014. p. 59, tradução livre.

41 FERREIRA, F.; POTTUMATI, E. A licitação pública como instrumento de desenvolvimento na perspectiva do paternalismo. Revista Brasileira de Politicas Públicas, v. 4, n. 1, p. 201-213, jan./jun. 2014. p. 210-211. 
Quadro 2 - Tradução da Tabela “Three Degrees of Nudge” (Três graus de Nudges).

\begin{tabular}{|l|l|l|l|}
\hline Grau de Nudge: & Características típicas: & Exemplos: & Impacto na autonomia: \\
\hline Primeiro & $\begin{array}{l}\text { Simples informações ou } \\
\text { lembretes, com o objeti- } \\
\text { vo de aumentar a capaci- } \\
\text { dade das pessoas de fazer } \\
\text { uma escolha informada, } \\
\text { racional e consciente. }\end{array}$ & $\begin{array}{l}\text { 1. Alerta em maços de } \\
\text { cigarro. } \\
\text { 2. Lembrete para pre- } \\
\text { encher a declaração de } \\
\text { imposto. }\end{array}$ & $\begin{array}{l}\text { Respeita a autonomia e } \\
\text { aumenta a racionalidade } \\
\text { do tomador de decisão. }\end{array}$ \\
\hline $\begin{array}{l}\text { Limitações comporta- } \\
\text { mentais ou volitivas são } \\
\text { exploradas de forma a } \\
\text { influenciar decisões em } \\
\text { uma direção escolhida. }\end{array}$ & $\begin{array}{l}\text { 1. A instituição de um } \\
\text { regime opt-out de doação } \\
\text { de órgãos. } \\
\text { 2. Alteração da área } \\
\text { destinada a atividade } \\
\text { fumante para longe da } \\
\text { área de trabalho. }\end{array}$ & $\begin{array}{l}\text { O tomador de decisão po- } \\
\text { deria, ao refletir, descobrir } \\
\text { a natureza e o efeito do } \\
\text { nudge - mas é improvável } \\
\text { que o faça em razão das } \\
\text { limitações comportamen- } \\
\text { tais e tendência a exibir } \\
\text { respostas "automáticas". }\end{array}$ \\
\hline Terceiro & $\begin{array}{l}\text { Estratégias de framing, } \\
\text { respostas emocionais ou } \\
\text { técnicas dissimuladas são } \\
\text { usadas para influenciar } \\
\text { decisões ou preferências. }\end{array}$ & $\begin{array}{l}\text { 1. Uma campanha que } \\
\text { promova hábitos ali- } \\
\text { mentares saudáveis com } \\
\text { slogan: “Don't lose your } \\
\text { looks, junk the junk food!”. } \\
\text { 2. [...] utilização de fo- } \\
\text { tografias de vítimas de } \\
\text { câncer de pulmão para } \\
\text { controlar o fumo. }\end{array}$ & $\begin{array}{l}\text { O tomador de decisão } \\
\text { é influenciado, mas a } \\
\text { reflexão é obstruída ou } \\
\text { materialmente falha para } \\
\text { extensão da influência do } \\
\text { comportamento ou da } \\
\text { preferência. }\end{array}$ \\
\hline
\end{tabular}

Fonte: Baldwin (2014, p. 838, tradução livre).

Essa tabela tem uma função didática, pois esquematiza diversos exemplos em categorias bem definidas. Como pode ser notado, há nudges que incentivam decisões mais racionais (primeiro grau); outros, que não as incentivam, mas podem ser desvendados (segundo grau); e, por fim, aqueles que não as incentivam e também não podem ser descobertos por reflexão (terceiro grau) ${ }^{42}$. Com base nesta classificação, nudges de segundo e terceiro grau têm algo em comum: não incentivam decisões mais racionais, mas contornam essa tentativa, substituindo a decisão racional da pessoa objeto da política por artifícios baseados em estudos comportamentais. Por sua vez, nudges de primeiro grau se diferenciam, substancialmente, dos demais quanto ao grau de atribuição à capacidade de cognição das pessoas. Nudges de primeiro grau, portanto, não são paternalistas.

Antes de debater, especificamente, o tratamento do Estado quanto ao suicídio, é importante conhecer esse fenômeno, analisando índices e locais de ocorrência, quem o realiza e quais são os métodos utilizados, de modo que se possa em seguida discutir, de forma segura, a necessidade e adequação na tomada de decisões e direcionamento de políticas públicas quanto ao fenômeno do suicídio.

42 BALDWIN, R. From regulation to behaviour change: giving nudge the third degree. Modern Law Review, v. 77, n. 6, p. 831-857, 2014. p. 837. 


\section{Características do suicídio no Brasil em perspectiva com a Realidade mundial}

\subsection{Introdução metodológica}

Para conhecer o fenômeno do suicídio no país, é importante utilizar as estatísticas produzidas em âmbito federal pelo Ministério da Saúde do Brasil (MS) e inseridas no Sistema de Informações de Mortalidade (SIM), que é composto pelo "conjunto de ações relativas à coleta, codificação, processamento de dados, fluxo, consolidação, avaliação e divulgação de informações sobre os óbitos no país” "43. Em síntese, os óbitos são avaliados por profissionais de saúde de forma padronizada (por meio da Declaração de Óbito [DO]) de acordo com os parâmetros estabelecidos internacionalmente na Classificação Internacional de Doenças (CID), sendo possível alcançar especificações quanto às causas da morte, como também seu local e características do indivíduo falecido. A título de exemplo, nos termos da CID-10, um caso de suicídio pode ser classificado como "lesão autoprovocada voluntariamente > autointoxicação por e exposição, intencional, a analgésicos, antipiréticos e antirreumáticos".

Ainda assim, por mais que exista no Brasil essa sistematização integrada desde 1976 , não se evita a subnotificação dos eventos suicidas e, consequentemente, a incapacidade dos dados de representar absolutamente a realidade.

Os problemas perpassam desde casos de desconhecimento de óbito pelo sistema de saúde em função de sepultamentos clandestinos ${ }^{45}$ a desconhecimento e desatenção de agentes de saúde, que por vezes preenchem, incorretamente ${ }^{46}$ ou de forma ilegível ou incompleta, as DOs ${ }^{47}$.

Em específico quanto às DOs produzidas em Instituto Médico Legal, responsável pelo exame em casos de suspeita de suicídio, também foram relatados problemas quanto às informações, ainda que em regra sejam mais confiáveis ${ }^{48}$.

Mas o fenômeno da subnotificação não se limita ao Brasil, é mundial, ainda que com maior incidência em países menos desenvolvidos ${ }^{49}$.

43 BRASIL. Ministério da Saúde. Secretaria de Vigilância em Saúde. Portaria n. 116, de 11 de fevereiro de 2009. art. $1^{\circ}$.

44 HECKMANN, I. C. et al. Análise do preenchimento de declarações de óbitos em localidade do Estado do Rio Grande do Sul (Brasil). Revista de Saúde Pública, São Paulo, v. 23, n. 4, p. 292-297, 1989. p. 292.

45 LOVISI, G. et al. Prevalência de transtornos mentais nas tentativas de suicídio em um hospital de emergência no Rio de Janeiro. Cadernos de Saúde Pública, Rio de Janeiro, v. 25, n. 9, p. 2064-2074, set. 2009; FAÇANHA, M. et al. Busca ativa de óbitos em cemitérios da Região Metropolitana de Fortaleza, 1999 a 2000. Epidemiologia e Serviços de Saúde, v. 12, n. 3, p. 131-136. p. 133.

46 HECKMANN, I. C. et al. Análise do preenchimento de declarações de óbitos em localidade do Estado do Rio Grande do Sul (Brasil). Revista de Saúde Pública, São Paulo, v. 23, n. 4, p. 292-297, 1989. p. 293; SCHNITMAN, A. Análise da fidedignidade da declaração de causa básica de morte por câncer em Salvador, Brasil. Revista de Saúde Pública, v. 24, n. 6, p. 490-496, 1990. p. 492; VANDERLEI, L. et al. Avaliação da confiabilidade da causa básica de óbito em unidade terciária de atenção à saúde materno-infantil. Informe Epidemiológico do SUS, v. 11, n. 1, p. 15-23, 2002. p. 19-20; TURRINI, R.; SANTO, A. Infecção hospitalar e causas múltiplas de morte. Jornal de Pediatria, v. 78, n. 6, p. 485-490, 2002. p. 487; LAURENTI, R. et al. Informação em mortalidade: o uso das regras internacionais para a seleção da causa básica. Revista Brasileira de Epidemiologia, v. 12, n. 2, p. 195-203, 2009. p. 198; BARBUSCIA, D.; RODRIGUES-JÚNIOR, A. Completude da informação nas Declarações de Nascido Vivo e nas Declarações de Óbito, neonatal precoce e fetal, da região de Ribeirão Preto, São Paulo, Brasil, 2000-2007. Cadernos de Saúde Pública, Rio de Janeiro, v. 27, n. 6, p. 1192-1200, jun. 2011. p. 1195.

47 SILVA, J. A. et al. Declaração de óbito, compromisso no preenchimento: avaliação em Belém - Pará, em 2010. Revista da Associação Médica Brasileira, v. 59, n. 4, p. 335-340, 2013. p. 337-338.

48 JORGE, M. H. P. M. Situação atual das estatísticas oficiais relativas à mortalidade por causas externas. Revista de Saúde Pública, São Paulo, v. 24, n. 3, p. 217-223, 1990. p. 221; SIMÕES, E.; REICHNHEIM, M. Confiabilidade das informações da causa básica nas declarações de óbito por causas externas em menores de 18 anos no Município de Duque de Caxias - RJ. Cadernos de Saúde Pública, Rio de Janeiro, v. 17, n. 3, p. 521-531, 2001. p. 528; SOUZA, E.; MINAYO, M. C.; CAVALCANTE, F. G. O impacto do suicídio sobre a morbimortalidade da população de Itabira. Ciência \& Saúde Coletiva, v. 11, n. Sup., p. 1333-1342, 2007. p. $1337-1338$. 49 AVANCI, R. et al. Perfil do adolescente que tenta suicídio em uma unidade de emergência. Revista Brasileira de Enfermagem, v. 58, n. 5, p. 535-539, set./out. 2005. p. 536; PRITCHARD, C.; HEAN, S. Suicide undetermined deaths among youths and young adults in Latin America comparison with the 10 major developed countries: a source of hidden suicides? Crisis, v. 29, n 2, p. 145- 
Enquanto há locais com seríssimas limitações no próprio sistema de produção de registros, como Paquistão ${ }^{50}$, China ${ }^{51}$ e Índia ${ }^{52}$, também há outros, como o Brasil, em que se verificam problemas na constatação da causa de morte, em especial com confusões entre suicídio e causas "indeterminada" ou "acidente", como o exemplo relatado por pesquisadores na Finlândia acerca da confusão entre acidentes de carros e suicídios em automóveis ${ }^{53}$.

Ou seja, diversos são os problemas inseridos nas estatísticas de mortalidade por meio das DOs, mas, apesar disto, ainda são o melhor instrumento para compreender esse fenômeno no país. Entretanto, não bastam esses dados, sendo necessário inseri-los em conjuntos populacionais, fornecidos no país pelo Instituto Brasileiro de Geografia e Estatística (IBGE). Neste estudo, utilizam-se os dados de anos censitários conforme os censos e, nos demais, conforme as projeções populacionais mais recentes decorrentes da aplicação do Método das Componentes Demográficas ${ }^{54}$.

Com o cruzamento de dados do SIM e do IBGE, é possível alcançar dados essenciais para o estabelecimento de estratégias, como: i) dados populacionais de regiões, estados ou municípios, incluindo detalhes quanto ao sexo e faixa etária; também ii) dados detalhados quanto aos óbitos, incluindo causa da morte, sexo e idade do falecido, local e data de ocorrência.

\subsection{A dimensão e características dos eventos suicidas}

O suicídio é um evento que merece cada vez mais atenção das autoridades, sendo constatados 804.000 eventos em 2012, o que significou um suicídio a cada quarenta segundos ${ }^{55}$, representando mais de $1 \%$ de todas as mortes registradas ${ }^{56}$; em inúmeros anos seguidos tais índices se mostram superiores às mortes em guerras e homicídios somados ao redor do mundo ${ }^{57}$. A título de exemplo, nos Estados Unidos, foi a décima causa de morte segundo o relatório nacional de estatísticas vitais, lançado pelo Centers for Disease Control and Prevention (CDC), representando 1,6\% de todas as mortes no país ${ }^{58}$.

No Brasil, os índices de suicídio são ainda inferiores em comparação com a maioria de outros países, entretanto isto não significa a inexistência de um problema. Como se vê no Gráfico 01, o crescimento do número de casos de suicídios em todo o país é uma constante. Foram registrados, em todo o país, 10.533 mortes por suicídio em 2013, o que representa, considerado o número de eventos, aumentos de 33,99\%, em relação ao ano de 2003 , e de $89,6 \%$, quanto a 1993. A mesma comparação quando realizada nas regiões oferece os seguintes resultados: região norte: 73,68\% e 196,48\%; região nordeste: 53,95\% e 194,45\%; região sudeste: $31,61 \%$ e $61,19 \%$; região sul: $16,33 \%$ e 56,62\%; região centro-oeste: $25,29 \%$ e $96,70 \%$.

153, 2008. p. 151.

50 KHAN, M. et al. Epidemiology of suicide in Pakistan: determining rates in six cities. Archives of Suicide Research, v. 12, n. 2, p. 155-160, 2008. p. 155.

51 WU, K.; CHEN, Y.; YIP, P. Suicide methods in Asia: implications in suicide prevention. International Journal of Environmental Research and Public Health, v. 9, p. 1135-1158, 2012. p. 1137.

52 RAJENDRA, R. et al. A feasibility study to establish a deliberate self-harm register in a state hospital in Southern India. British Journal of Medical Practioners [online], v. 8, n, 1, mar. 2015. Disponível em: < http://www.bjmp.org/content/feasibility-study-establishdeliberate-self-harm-register-state-hospital-southern-india >. Acesso em: 10 mar. 2018.

53 HERNETKOSKI, M.; KESKINEN, E.; PAKKARI, I. Driver suicides in Finland: are they different in northern and Southern Finland? International Journal of Circumpolar Health, v. 68, n 3, p. 249-260, 2009. p. 257.

54 BRASIL. Ministério do Planeamento, Orçamento e Gestão. Instituto Brasileiro de Geografia e Estatística. Projeção da população: Brasil e Unidades da Federação. Rio de Janeiro: IBGE, 2013.

55 ORGANIZAÇÃO MUNDIAL DE SAÚDE. World Health Statistics 2015. Luxemburgo: WHO Graphics, 2015. p. 22.

56 ORGANIZAÇÃO MUNDIAL DE SAÚDE. World Health Statistics 2014. Itália: WHO Graphics, 2014. p. 22.

57 MINAYO, M. C.; CAVALCANTE, F. G. Suicídio entre pessoas idosas: revisão da literatura. Revista de Saúde Pública, v. 44, n. 4, p. $750-757,2010$. p. 751.

58 UNITED STATES OF AMERICA. Department of Health and Human Services. Centers for Disease Control and Prevention. National Center for Health Statistics. National Vital Statistics Reports. Deaths: Leading Causes for 2013, v. 64, n. 2 , feb. 2016. 
Gráfico 1 - Ocorrência de suicídios em regiões do Brasil - 1993/2013, com intervalos (números absolutos).

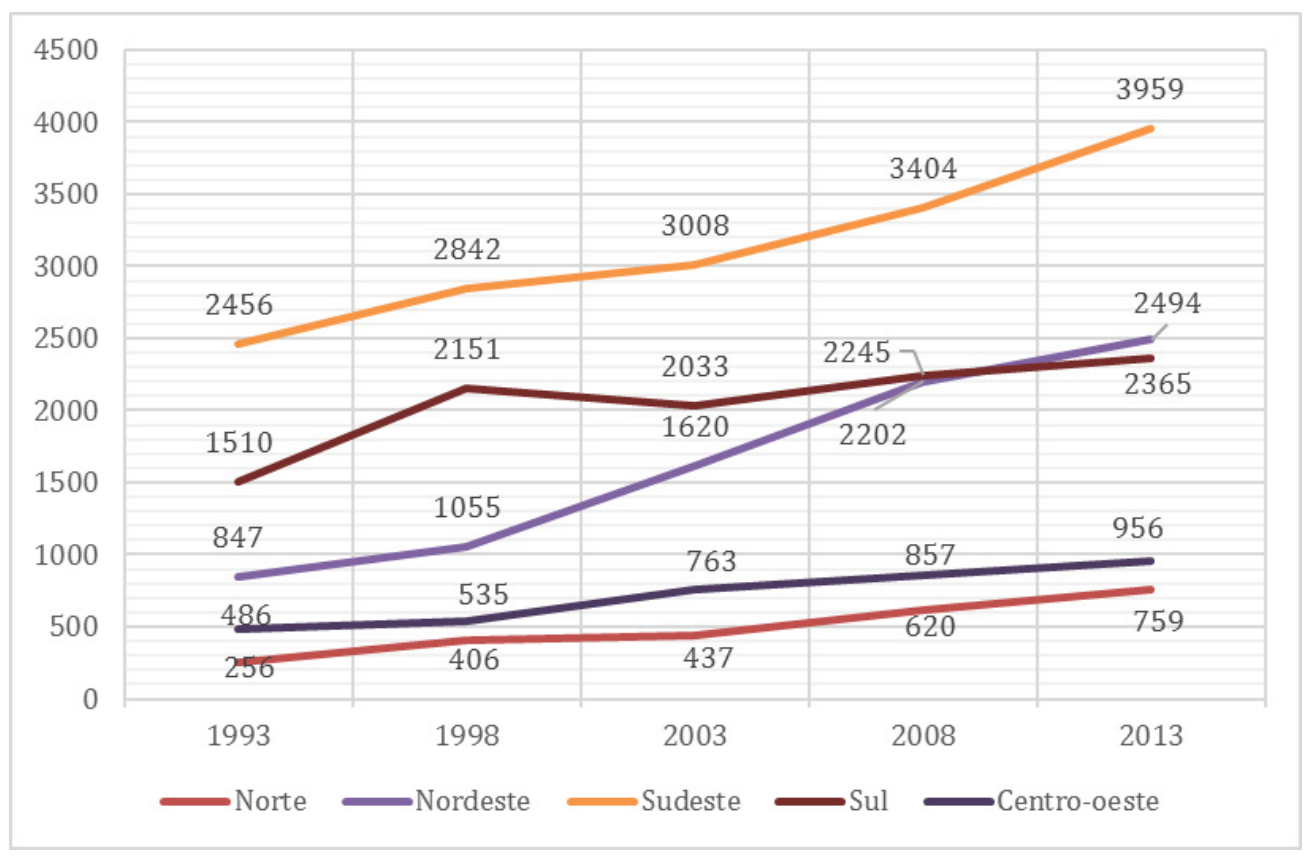

Fonte: SIMSVS/MS; IBGE.

Esses dados em desenvolvimento percentual demonstram o crescimento do convívio de um grupo populacional com eventos suicidas, de modo que se percebe no Brasil uma quantidade aproximada àquela em países como França (9.919 em 2012) e Alemanha (9.964 em 2012), que possuem as maiores quantidades de eventos na União Europeia (UE). Porém, é imprescindível lembrar que esses países possuem população significativamente menor que a brasileira e maior que a de seus vizinhos; por conta disto, deve-se trabalhar com o já referido índice TMG conforme traz o Gráfico 02, em que se percebe não ser significativamente alta a taxa de eventos no Brasil.

Gráfico 2 - Ocorrência de suicídios no Brasil e em países da União Europeia - 2011/2012 (tx/100.000 habitantes).

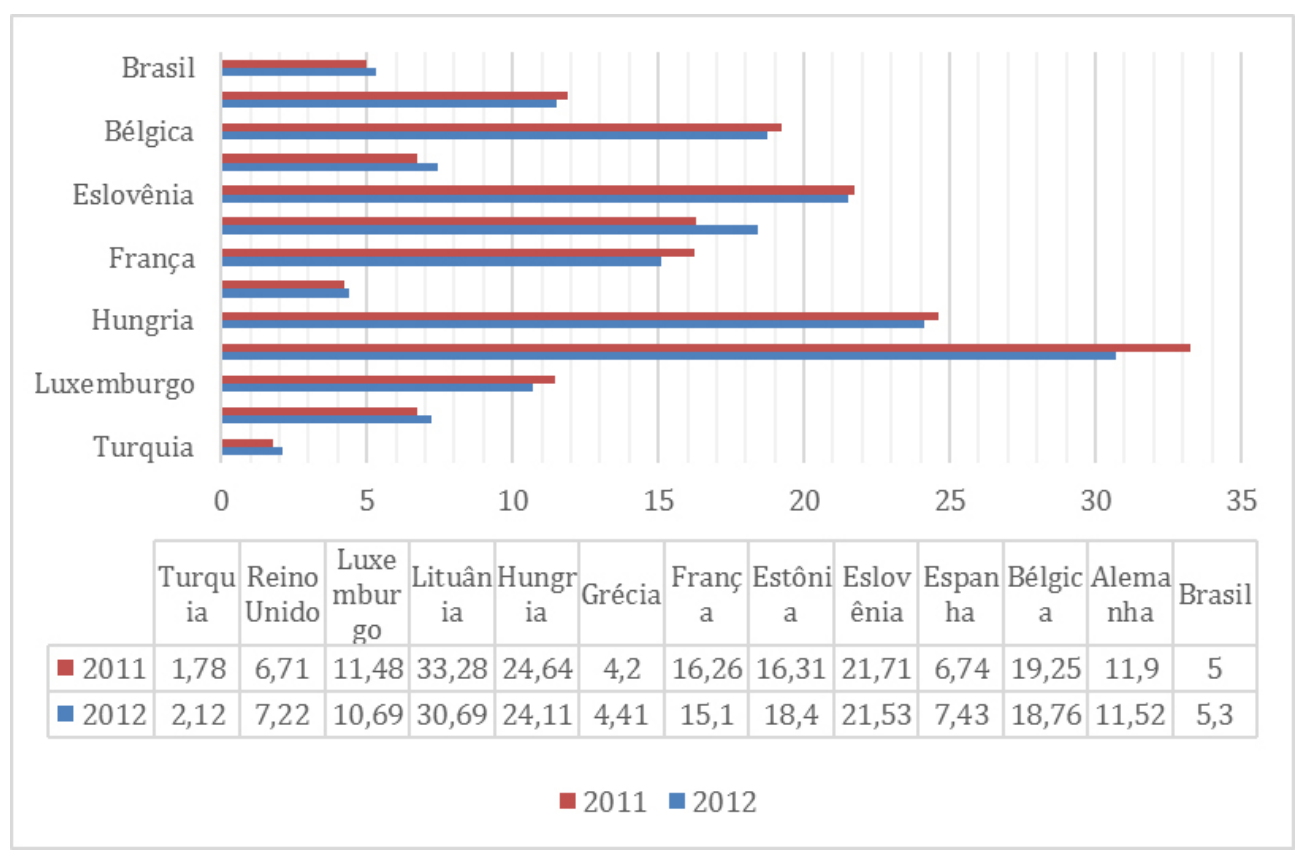

Fonte: SIM/SVS/MS; IBGE; Eurostat ${ }^{59}$.

59 Eurostat disponibiliza registros estatísticos em: <http://www.ec.europa.eu/eurostat/data/database. $>$. 
Quanto a esta, tem-se que não é uniforme se as regiões políticas são comparadas, com destaque para índices mais altos na região sul e o contínuo crescimento de registros nas regiões norte e nordeste, conforme a Tabela 03. Deve-se atentar para o fato de que os índices crescem pouco de ano em ano, mas ganham significativa representatividade em um lapso maior; um fenômeno observado em todo o mundo ${ }^{60}$.

Tabela 1 - Ocorrência de suicídios no Brasil e em suas regiões - 1993/2013, com intervalos (tx/100.000 habitantes).

\begin{tabular}{ccccccc}
\hline & Brasil & Norte & Nordeste & Sudeste & Sul & $\begin{array}{c}\text { Centro- } \\
\text { oeste }\end{array}$ \\
\hline $\mathbf{2 0 1 3}$ & 5,2 & 4,5 & 4,5 & 4,7 & 8,2 & 6,4 \\
$\mathbf{2 0 1 2}$ & 5,3 & 4,2 & 4,3 & 4,9 & 8,5 & 6,5 \\
$\mathbf{2 0 1 1}$ & 5 & 4,3 & 4,3 & 4,8 & 7,8 & 5,7 \\
$\mathbf{2 0 1 0}$ & 4,8 & 3,9 & 4 & 4,6 & 7,9 & 5,8 \\
$\mathbf{2 0 0 9}$ & 4,9 & 3,9 & 3,9 & 4,4 & 8,2 & 6 \\
$\mathbf{2 0 0 8}$ & 4,9 & 4,1 & 4,1 & 4,2 & 8,2 & 6,3 \\
$\mathbf{2 0 0 3}$ & 4,4 & 3,2 & 3,3 & 4 & 7,8 & 6,2 \\
$\mathbf{1 9 9 8}$ & 4,3 & 3,4 & 2,3 & 4,1 & 8,9 & 4,9 \\
$\mathbf{1 9 9 3}$ & 3,7 & 2,4 & 1,9 & 3,8 & 6,7 & 4,9 \\
\hline
\end{tabular}

Fonte: SIM/SVS/MS; IBGE.

\subsubsection{Gênero e método}

Quando observados especificamente por gênero, vê-se que há uma quantidade muito maior de suicídios dentre pessoas do sexo masculino no Brasil. Conforme o Gráfico 03, no ano de 2013, 78,88\% dos suicídios no Brasil foram realizados por homens; em 2012, 78,12\%; em 2011, 78,78\%; em 2010, 78,05\%; em 2005, 78,87\%; em 2004, 78,12\%; em 2003, 79,58\%. Ou seja, tem-se a constante de que, a cada dez suicídios no país, aproximadamente oito são realizados por pessoas do sexo masculino, acompanhando uma realidade mundial dentre os países que publicam as estatísticas, com exceção apenas da China ${ }^{61}$; ainda, pode-se afirmar que, proporcionalmente, o grupo mais atingido são homens idosos, haja vista, proporcionalmente, sua maior incidência frente às demais faixas etárias (Gráfico 04).

60 VÄRNIK, P. Suicide in the world. Int. J. Res. Public Health, v. 9, p. 760-771, 2012. p. 761.

61 VÄRNIK, P. Suicide in the world. Int. J. Res. Public Health, v. 9, p. 760-771, 2012. p. 763. 
Gráfico 3 - Ocorrência de suicídios por sexo no Brasil - 2003/2013 (números absolutos).

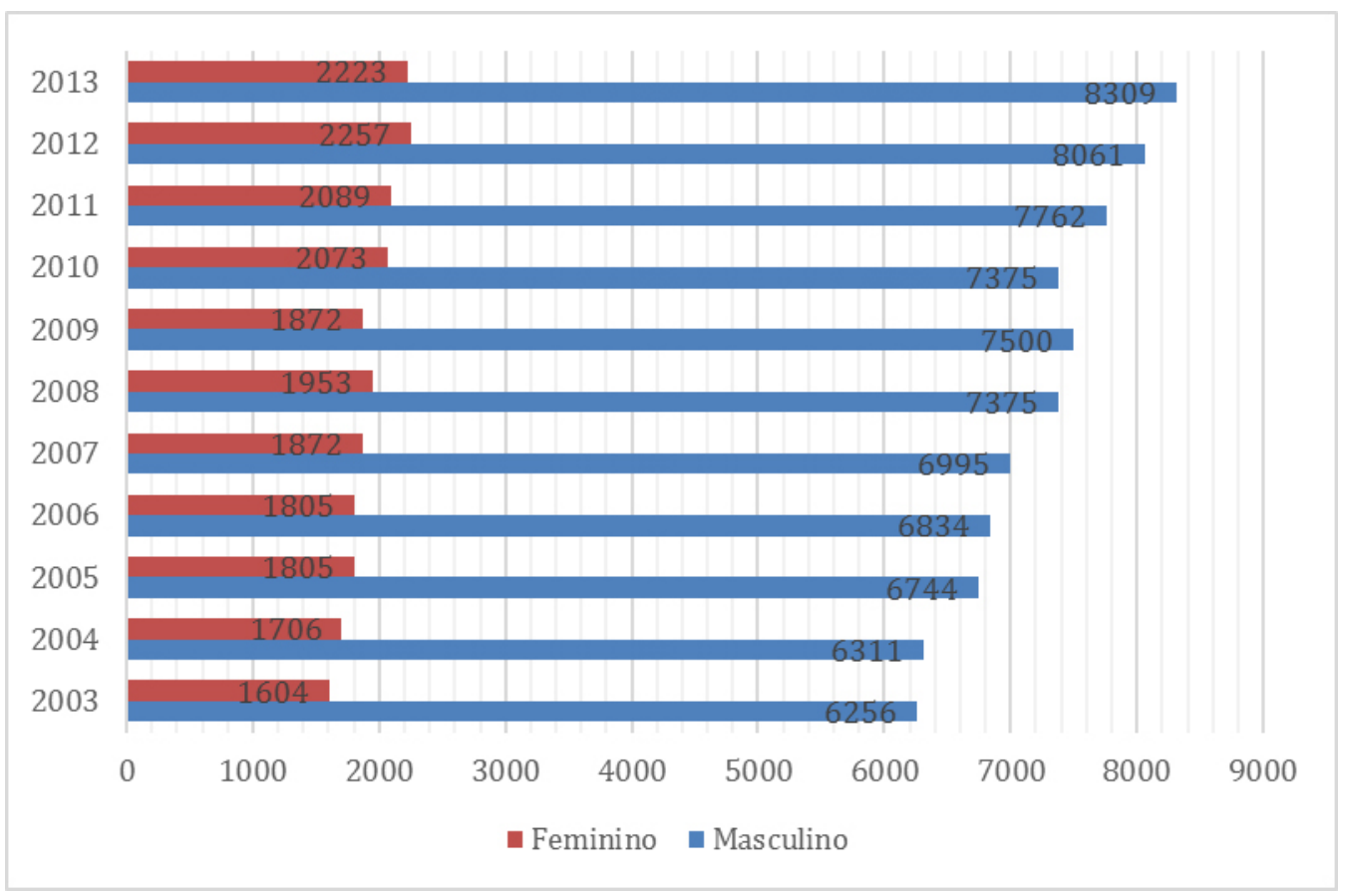

Fonte: SIM/SVS/MS; IBGE.

Gráfico 4 - Ocorrência de suicídios por idade no Brasil— 2010/2013 (tx/100.000 habitantes).

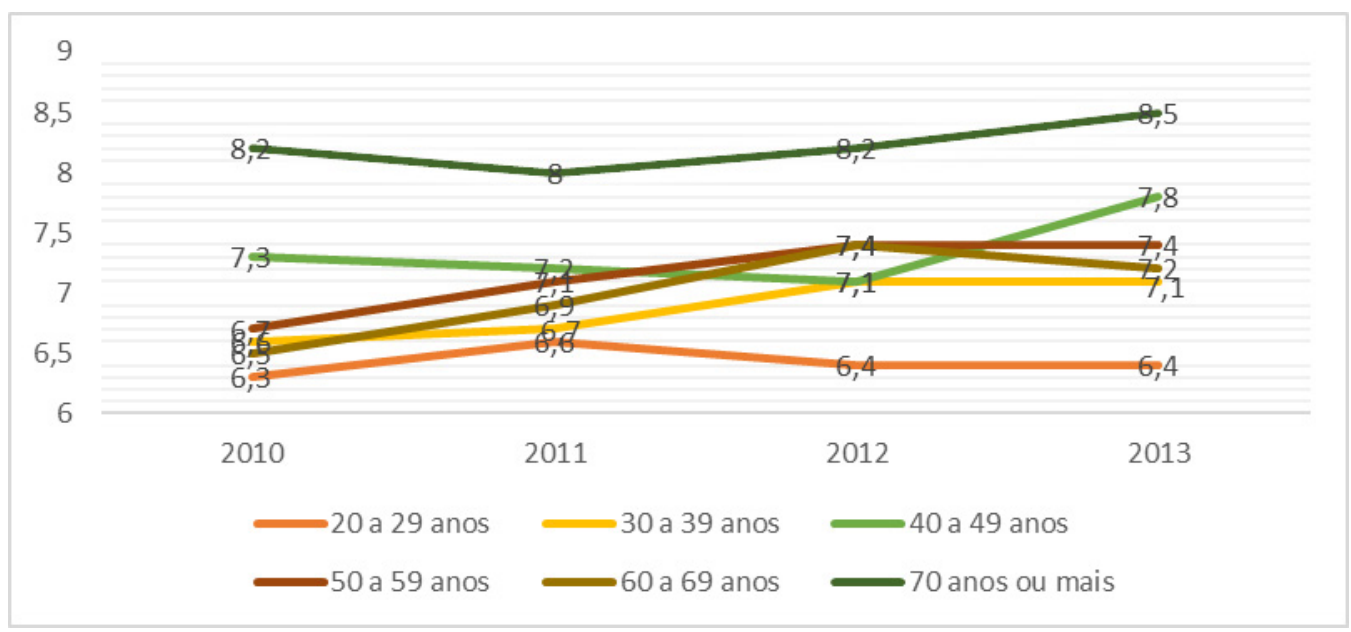

Fonte: SIM/SVS/MS; IBGE.

Ainda, a considerar que o número de mulheres no Brasil é recorrentemente um pouco maior do que o de homens, tem-se que, dentre estes, há um crescimento de eventos superior ao crescimento dentre as mulheres. Em síntese, conforme se vê no Gráfico 05, a cada dia há proporcionalmente mais homens suicidas, ainda que se permaneça a relação 4:1 em relação às mulheres, pois o crescimento populacional feminino está acima do crescimento de suicídios dentre esse sexo, proporcionalmente; o que não ocorre com o sexo masculino. Porém, tanto na China como em outros países asiáticos se percebe e prevê cada vez maior redução dessa diferençç ${ }^{62}$.

62 PHILLIPS, M.; LIU, H.; ZHANG, Y. Suicide and social change in China. Culture, Medicine and Psychiatry, v. 23, p. 25-50, 1999. p. 30; PHILLIPS, M.; LIU, H.; ZHANG, Y. Suicide and social change in China. Culture, Medicine and Psycbiatry, v. 23, p. 25-50, 1999. p. 465-466; 
Gráfico 5 - Ocorrência de suicídios por sexo no Brasil — 2000/2013 (tx/100.000 habitantes).

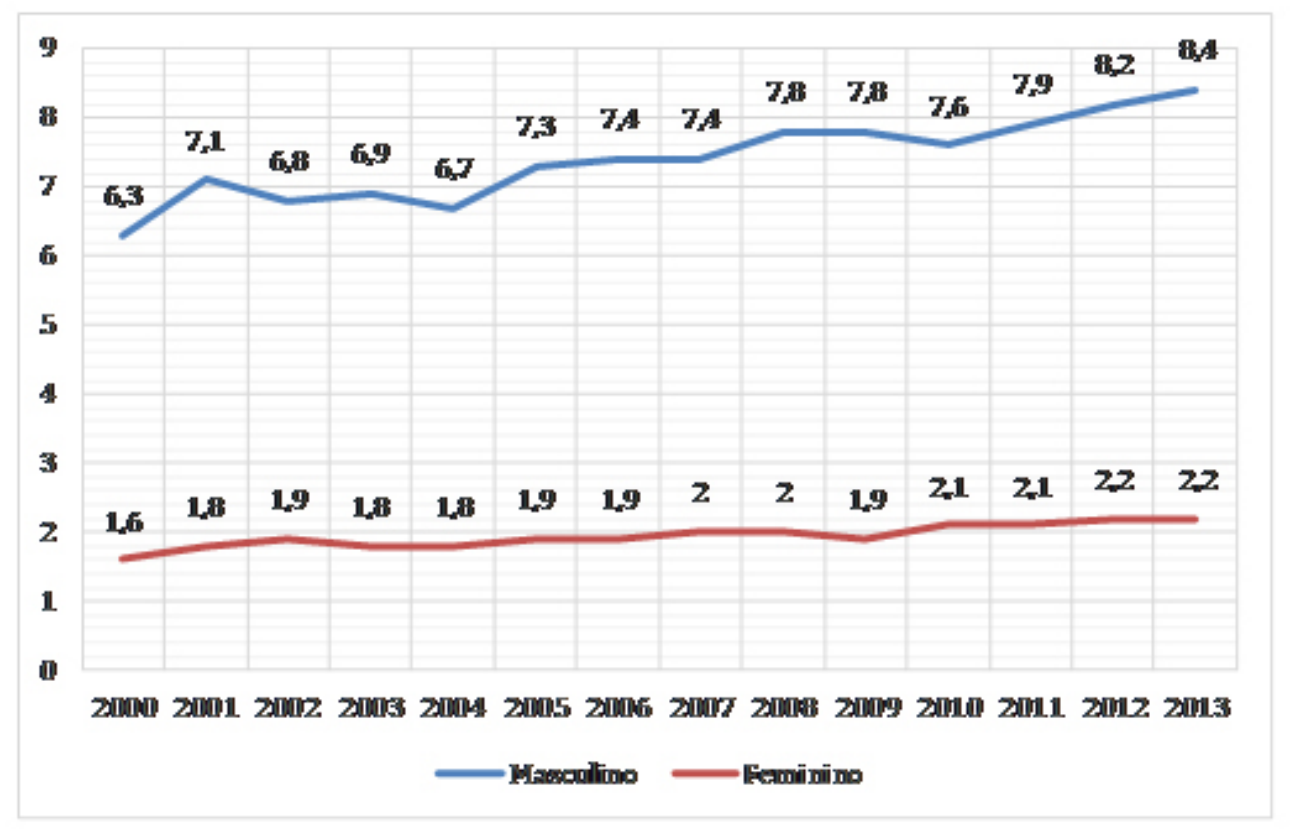

Fonte: SIM/SVS/MS; IBGE.

De qualquer modo, não é possível afirmar que o ato suicida é um evento de predominância dentre homens, afinal, em âmbito global, sabe-se que a considerar apenas as tentativas de suicídio, as estimativas são de que os índices dentre mulheres representam números muito elevados em relação a homens ${ }^{63}$, com estudos realizados em locais de atendimentos emergenciais demonstrando a maior incidência de mulheres, como, por exemplo, no Brasil ${ }^{64}$, na Alemanha ${ }^{65} \mathrm{e}^{\text {Turquia }}{ }^{66}$. Estima-se que, a cada suicídio consumado, vinte indivíduos não conseguiram fazê-lo ${ }^{67}$, o que conduz à estimativa de 16.884 .000 tentativas de suicídios no mundo no ano de 2012, que representaria uma Taxa de Tentativa Geral de 234,5 por 100.000 habitantes ${ }^{68}$.

Essa significativa diferença entre homens e mulheres parece estar atrelada ao método utilizado para a realização do suicídio, haja vista que métodos mais agressivos e letais são tipicamente masculinos ${ }^{69}$.

O uso de arma de fogo é o método mais letal dentre todos os possíveis, atingindo cerca de $90 \%$ de consumação $^{70}$. Um exemplo concreto é a realidade dos Estados Unidos, em que este foi o método prevalente, com $51,42 \%$ dos eventos em 2013, ainda que apenas 5\% dos atos suicidas e auto lesivos se utilizem desse

63 SOUZA, E.; MINAYO, M. C.; CAVALCANTE, F. G. O impacto do suicídio sobre a morbimortalidade da população de Itabira. Ciência \& Saúde Coletiva, v. 11, n. Sup., p. 1333-1342, 2007. p. 1340.

64 HESKETH, J.; CASTRO, A. Fatores correlacionados com a tentativa de suicídio. Revista de Saúde Pública, v. 12, p. 138-146, 1978. p. 145; SÁ, N. B. et al. Atendimentos de emergência por tentativas de suicídio. Revista Médica de Minas, v. 20, n. 2, p. 145-152, 2010. p. 147.

65 BREUER, H.; BREUER, J.; FISCHBACH-BREUER, B. Social, toxicological and meteorological data on suicide attempts. European archives of Psychiatry and Clinical Neuroscience, v. 235, p. 367-370, 1986. p. 368.

66 DOGANAY, Z. et al. Climatic and diurnal variation in suicide attempts in de ED. American Journal of Emergency Medicine, v. 21, n. 4, p. 271-275, july 2003. p. 272.

67 ORGANIZAÇÃO MUNDIAL DE SAÚDE. World Health Statistics 2014. Itália: WHO Graphics, 2014. p. 26.

68 É importante ressaltar que o cálculo foi feito com base na projeção da ONU para a população de 2013 (7,2 bilhões de pessoas), em sua revisão de 2012: ONU. World population prospects. The 2012 revision: comprehensive tables. New York: United Nations, 2013. v. 1.p. 1.

69 JOO, S. et al. Factors associated with suicide completion: a comparison between suicide attempters and completers. Asia-Pacific Psychiatry, v. 8, n. 1, p. 80-86, mar. 2016. p. 82.

70 SHENASSA, E.; CATLIN, S.; BUKA, S. Lethality of firearms relative to other suicide methods: a population based study. Journal of Epidemiology and Community Health, v. 57, n. 2, p. 120-124, feb. 2003. p. 123; ELNOUR, A.; HARRISON, J. Lethality of suicide methods. Injury Prevention, v. 14, p. 39-45, 2008. p. 39; BARBER, C.; MILLER, M. Reducing a suicidal person's access to lethal means of suicide: a research agenda. American Journal of Preventive Medicine, v. 47, n. 352, p. 264-272, 2014. p. 264. 
método ${ }^{71}$. No Brasil, os índices são significativamente mais baixos, tendo sido o método utilizado apenas em 9\% dos suicídios dentre os anos de 2009 e 2013; porém, conforme se vê nos gráficos 06 e 07, muito mais homens dele se utilizam em comparação a mulheres.

Gráfico 6 - Distribuição dos métodos dentre homens no Brasil - 2009/2013.

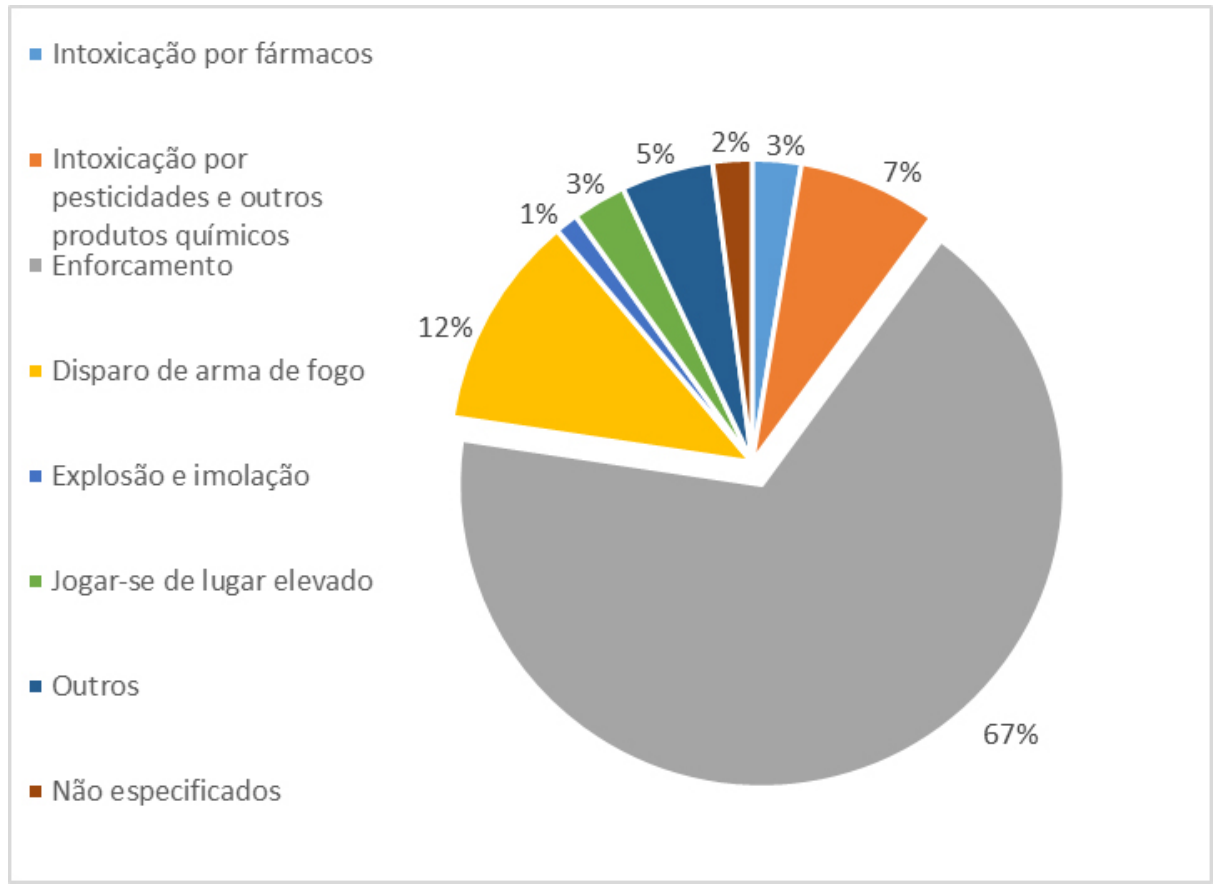

Fonte: SIM/SVS/MS.

Gráfico 7 - Distribuição dos métodos dentre mulheres no Brasil — 2009/2013.
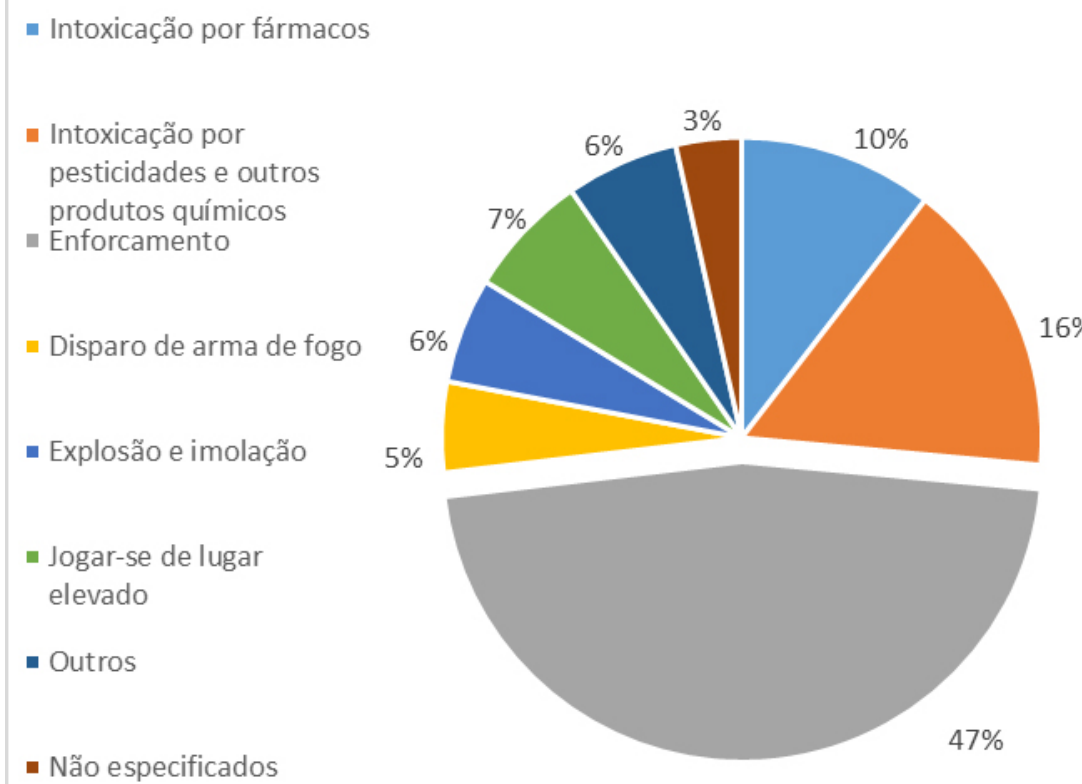

Fonte: SIM/SVS/MS.

71 UNITED STATES OF AMERICA. Department of Health and Human Services. Centers for Disease Control and Prevention. National Center for Health Statistics. National Vital Statistics Reports. Deaths: Leading Causes for 2013, v. 64, n. 2, feb. 2016. p. 84-85.

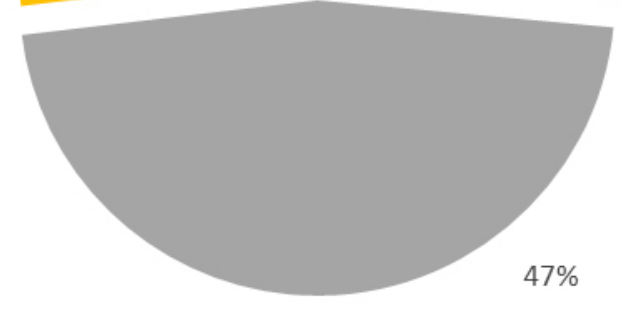


Em seguida, encontra-se o enforcamento, método preferencial para a realização de suicídio no Brasil, que possui alto grau de letalidade $-70 \%{ }^{72}$. É o método mais utilizado em diversos países asiáticos, como Arábia Saudita, Barein, Coreia do Sul, Filipinas, Irã, Tailândia, Taiwan ${ }^{73}$ e Japão ${ }^{74}$, como em países europeus, com exceção da Suíça, em que prevalece o suicídio por arma de fogo ${ }^{75}$.

Em especial quanto a mulheres, como traz o Gráfico 08, ainda que o enforcamento continue sendo o método mais utilizado, sua redução é bastante significativa, contribuindo para a explicação que atribui a utilização de métodos menos letais aos menores índices de suicídio consumados dentre mulheres. Ganha destaque nesse grupo a utilização da autointoxicação, chegando a $26 \%$ do total no período analisado.

A autointoxicação, apesar de genericamente ser método único, varia demasiadamente de acordo com o objeto utilizado para causar a morte, portanto com índice de letalidade variável, e sua utilização decorrerá fundamentalmente da acessibilidade àquele objeto.

É indiscutível que a disponibilidade é elemento central na escolha do método pelo indivíduo ${ }^{76}$. Bons exemplos podem ser obtidos a partir com base na análise do controle e restrição de armas de fogo, como na Coreia do Sul, Japão, Suécia e Taiwan, países com severas legislações de armas e irrisórios índices de suicídio por este método ${ }^{77}$. Isto pode ser ainda melhor evidenciado nos Estados Unidos ao se comparar índices entre estados com severo ou brando controle de $\operatorname{armas}^{78}$.

Em específico quanto à autointoxicação, destacam-se os países orientais, com altíssimos índices de suicídio por esse método dentre mulheres, como Paquistão ${ }^{79}$, Índia ${ }^{80}$, e o notório exemplo do Sri Lanka, que registrava em 1950 taxa de suicídio de 6,6; em 1984, 37,081; chegando a 47,0/100 mil hab. em 1995 ${ }^{82}$, com o uso de pesticidas como principal método ${ }^{83}$. O país, em 1995, adotou medidas muito restritivas ao acesso

72 GUNNEL, D. et al. The epidemiology and prevention of suicide by hanging: a systematic review. International Journal of Epidemiology, v. 34, p. 433-442, 2005. p. 433.

73 WU, K.; CHEN, Y.; YIP, P. Suicide methods in Asia: implications in suicide prevention. International Journal of Environmental Research and Public Health, v. 9, p. 1135-1158, 2012. p. 1145.

74 YOSHIOKA, E. et al. Time trends in method-specific suicide rates in Japan, 1990-2011. Epidemiology and Psychiatric Sciences, v. 25 , n. 1, p. 58-68, feb. 2016. p. 61.

75 VÄRNIK, A. et al. Suicide methods in Europe: a gender-specific analysis of countries participating in the "European Alliance Against Depression”. Journal of Epidemiology and Community Health, v. 62, p. 545-551, 2008. p. 546.

76 YIP, P. et al. Means restriction for suicide prevention. Lancet, v. 23, n. 379, p. 2393-2399, june 2012. p. 2393; BETZ, M. et al. Lethal means access and assessment among suicidal emergency department patients. Depression and Anxiety, v. 33, n. 6, p. 502-511, june 2016. p. 405-408.

77 LIN, J.; LU, T. Suicide mortality trends by sex, age and method in Taiwan, 1971-2005. BMC Public Health [online], v. 8, n. 6, jan. 2008. Disponível em: <https://bmcpublichealth.biomedcentral.com/articles/10.1186/1471-2458-8-6>. Acesso em: 13 mar. 2018 ; CHEN, Y.; PARK, N.; LU, T. Suicide methods used by women in Korea, Sweden, Taiwan and the United States. Journal of the Formosan Medical Association, v. 108, n. 6, p. 452-459, june 2009. p. 456; RUNESON, B. et al. Method of attempted suicide as predictor of subsequente successful suicide: national long term cohort study. BMJ [online], v. 341, 2010. Disponível em: <https://www.ncbi. nlm.nih.gov/pmc/articles/PMC2903664>. Acesso em: 13 mar. 2018; AHN, M. et al. Gender ratio comparisons of the suicide rates and methods in Korea, Japan, Australia, and the United States. Journal of Affective Disorders, v. 142, n. 1-3, p. 161-165, dec. 2012. p. 164. 78 ANESTIS, M.; ANESTIS, J. Suicide rates and state laws regulating access and expositure to handguns. American Journal of Public Health, v. 105, n. 10, p. 2049-2058, oct. 2015. p. 2052-2053.

79 AHMAD, R. et al. Acute poisoning due to commercial pesticides in Multan. Pakistan Journal of Medical Sciences, v. 18, n. 3, p. $227-$ 231, july/sep. 2002. p. 230; KHAN, M. et al. Suicides in the developing world: case study from Pakistan. Suicide and Life-Threatening Behavior, v. 36, n. 1, feb. 2006. p. 78.

80 BANERJEE, G. et al. The vulnerability of indian women to suicide a field-study. Indian J. Psychiatry, v. 32, n. 4, p. 305-308, oct. 1990. p. 307-308; RADHAKRISHNAN, R.; ANDRADE, C. Suicide: an indian perspective. Indian J Psycbiatry [online], v. 54, p. 304-319, 2012. Disponível em: <http://www.indianjpsychiatry.org/text.asp?2012/54/4/304/104793>. Acesso em: 13 mar. 2018. p. 306; PATEL, V. et al. Suicide mortality in India: a nationally representative survey. The Lancet, v. 379, p. 2343-2351, 2012. p. 23462347.

81 LESTER, D. Suicide in emigrants from the Indian subcontinent. Transcultural psychiatry, v. 37, n. 2, p. 243-254, 2000 . p. 248.

82 RATNAYEKE, L. Suicide and crisis intervention in rural communities in Sri Lanka: a column from befrienders international. Crisis, v. 17, n. 4, p. 149-151, 1996. p. 149.

83 WU, K.; CHEN, Y.; YIP, P. Suicide methods in Asia: implications in suicide prevention. International Journal of Environmental Research and Public Health, v. 9, p. 1135-1158, 2012. p. 1145. 
a pesticidas, contribuindo significativamente para a progressiva redução que se verificou a partir de $1998^{84}$.

Com a existência de um combate generalizado a produtos de alta toxicidade e redução a seu acesso, as autointoxicações são redirecionadas (displacement) a produtos de menor letalidade, promovendo mais tentativas do que consumações de suicídio, especialmente dentre mulheres. Entretanto, a dificuldade em promover essa limitação fica evidenciada, por exemplo, com os recorrentes relatos de autointoxicação no Brasil com o uso de proibidos "raticidas", de fácil acesso e baixo custo ${ }^{85}$.

A importância da disponibilidade de um determinado método mostra-se de forma ainda mais evidente no caso de hotsposts, ou seja, lugares que atraem suicidas tanto por seu fácil acesso como por uma mística decorrente de eventos anteriores, como por exemplo a ponte Golden Gate, que registrou quase 20 suicídios por ano entre 1937 e $1991^{86}$.

Em locais como Hong Kong e Singapura, locais em que mais de $80 \%$ da população vive em lugares elevados, jogar-se de lugar elevado (JLE) é o principal método utilizado ${ }^{87}$. No Brasil, conforme os gráficos 07 e 08, JLE seria um método pouco utilizado. Entretanto, esses dados consideram suicídios ocorrentes em inúmeros locais onde sequer há condições físicas para JLE. Portanto, para melhor demonstrar a relevância desse método, apresentam-se, na Tabela 04, índices de suicídios em algumas das grandes metrópoles brasileiras.

Tabela 2 - Suicídios por jogar-se de lugar elevado em grandes capitais brasileiras selecionadas (porcentagem específica dentre homens $[\mathrm{H}]$, dentre mulheres $[\mathrm{M}]$ e o total $[\mathrm{T}]$; tx = suicídios a cada 100 edificações na cidade).

\begin{tabular}{|c|c|c|c|c|c|c|c|c|c|c|c|c|c|}
\hline \multirow[b]{2}{*}{1} & \multicolumn{3}{|c|}{2013} & \multicolumn{3}{|c|}{2012} & \multicolumn{3}{|c|}{2011} & \multicolumn{3}{|c|}{2010} & \multirow[t]{2}{*}{$\mathbf{T x}$} \\
\hline & $\mathbf{H}$ & $\mathbf{M}$ & $\mathbf{T}$ & $\mathbf{H}$ & $\mathbf{M}$ & $\mathbf{T}$ & $\mathbf{H}$ & $\mathbf{M}$ & $\mathbf{T}$ & $\mathbf{H}$ & $\mathbf{M}$ & $\mathbf{T}$ & \\
\hline $\mathrm{BH}$ & 14,2 & 25,6 & 17,5 & 9,3 & 11,3 & 9,9 & 9,0 & 9,4 & 9,1 & 16,7 & 13,6 & 15,7 & 3,5 \\
\hline BSB & 14,4 & 17,6 & 15,2 & 3,0 & 7,1 & 4,2 & 4,4 & 13,0 & 6,2 & 8,6 & 28,6 & 13,9 & 3,0 \\
\hline POA & 4,8 & 24,1 & 9,8 & 10,3 & 23,5 & 12,9 & 7,7 & 24,1 & 12,8 & 12,5 & 21,7 & 14,6 & 1,5 \\
\hline RJ & 6,1 & 14,8 & 9,1 & 0,7 & 6,1 & 2,4 & 3,9 & 13,5 & 6,9 & 18,2 & 38,4 & 20,1 & 0,8 \\
\hline RJ2 $^{89}$ & 30,3 & 34,5 & 31,8 & 25,0 & 35,4 & 28,6 & 19,5 & 29,7 & 20,7 & 22,3 & 40,4 & 28,4 & 1,4 \\
\hline SP & 14,7 & 21,8 & 16,7 & 10,6 & 22,9 & 14,1 & 12,5 & 26,8 & 16,1 & 13,0 & 22,1 & 15,3 & 1,3 \\
\hline
\end{tabular}

Fonte: SIM/SVS/MS; Emporis ${ }^{88}{ }_{-}^{89}{ }_{-}{ }^{90}$.

84 ROBERTS, D. et al. Influence of pesticide regulation on acute poisoning deaths in Sri Lanka. Bulletin of the World Health Organization, v. 81, n. 11, p. 789-798, 2003. p. 795; GUNNEL, D. et al. The impact of pesticide regulations on suicide in Sri Lanka. International Journal of Epidemiology, v. 36, p. 1235-1242, 2007. p. 1240.

85 DAMAS, F. et al. Tentativas de suicídio com agentes tóxicos: análise estatística dos dados do CIT/SC (1994 a 2006). Revista Brasileira de Toxicologia, v. 22, n. 1-2, p. 21-26, 2009. p. 24; FERREIRA, M.; FIGUEIREDO, M. Epidemiologia das intoxicações humanas por raticidas no Brasil. Revista Eletrônica Gestão \& Saúde, v. 4, n. 3, p. 861-870, 2013. p. 863; PIRES, M. C. Indicadores de risco para tentativa de suicídio por envenenamento: um estudo de caso-controle. 2014. 145 f. Tese (Doutorado) - Programa de Pós-Graduação em Neuropsiquiatria e Ciências do Comportamento, Universidade Federal de Pernambuco, Recife, 2014. p. 96; MARTINS, B. et al. Intoxicação por raticida em um Centro de Assistência Toxicológica. Revista da Rede de Enfermagem do Nordeste, v. 17, n. 1, p. 3-9, jan./ fev. 2016. p. 3.

86 GUNNEL, D.; NOWERS, M. Suicide by jumping. Acta Psychiatrica Scandinavica, v. 96, p. 1-6, 1997. p. 1-2.

87 WU, K.; CHEN, Y.; YIP, P. Suicide methods in Asia: implications in suicide prevention. International Journal of Environmental Research and Public Health, v. 9, p. 1135-1158, 2012. p. 1145.

88 Disponível em: <http://www.emporis.com>. Acesso em: 14 mar. 2018.

89 BH: Belo Horizonte/MG; BSB: Brasília/DF; POA: Porto Alegre/RS; RJ: Rio de Janeiro/RJ; SP: São Paulo/SP.

90 Dados do Rio de Janeiro nos anos, da esquerda para a direita, 2009, 2008, 2007 e 2006. 
As cinco cidades, juntas, representaram $63,7 \%$ de todos os suicídios por JLE no país, com uma média de 155,67 suicídios por ano; e, ainda mais, esse método representa grandes índices na totalidade de suicídios nesses locais.

Com essa estratificação, fica ainda mais claro que este é um evento muito mais incidente dentre mulheres, representando grande parcela de eventos suicidas nos grandes centros brasileiros. Incluem em todos os anos analisados não apenas suicídios de seus residentes, mas também, com exceção de POA, significativamente mais "óbitos por ocorrência" do que "óbitos por residência", ou seja: pessoas residentes em outras cidades deslocam-se às capitais para a realização de suicídio.

A inserção de dados referentes à cidade do Rio de Janeiro demonstra uma possível sazonalidade a se estabelecer. Isto porque, no período anterior a 2006, as taxas eram similares àquelas de 2013 a 2010; entretanto, entre 2009 e 2006, percebem-se taxas altíssimas decorrentes não da diminuição de outros métodos, mas do aumento de casos de suicídio por JLE; nenhum evento específico no período foi identificado como vetor desse incremento, mas a observação no futuro pode fornecer novas propostas; em Brasília e em Belo Horizonte, é também possível perceber, mais sutis, indicativos de sazonalidade.

\subsubsection{Sazonalidade}

A sazonalidade dos eventos suicidas é um importante dado a se considerar, caracterizando-se pela ocorrência distribuída no tempo de forma desigual. Como demonstra o Gráfico 09, dezembro-janeiro é um período que se destaca pela quantidade de suicídios no Brasil; setembro-outubro e março também são meses com altas incidências. Entretanto, de mais concreto, o que se pode perceber é que o inverno é o período de menor incidência de suicídios.

Gráfico 8 - Ocorrência de suicídios por meses do ano no Brasil — 2011/2013.

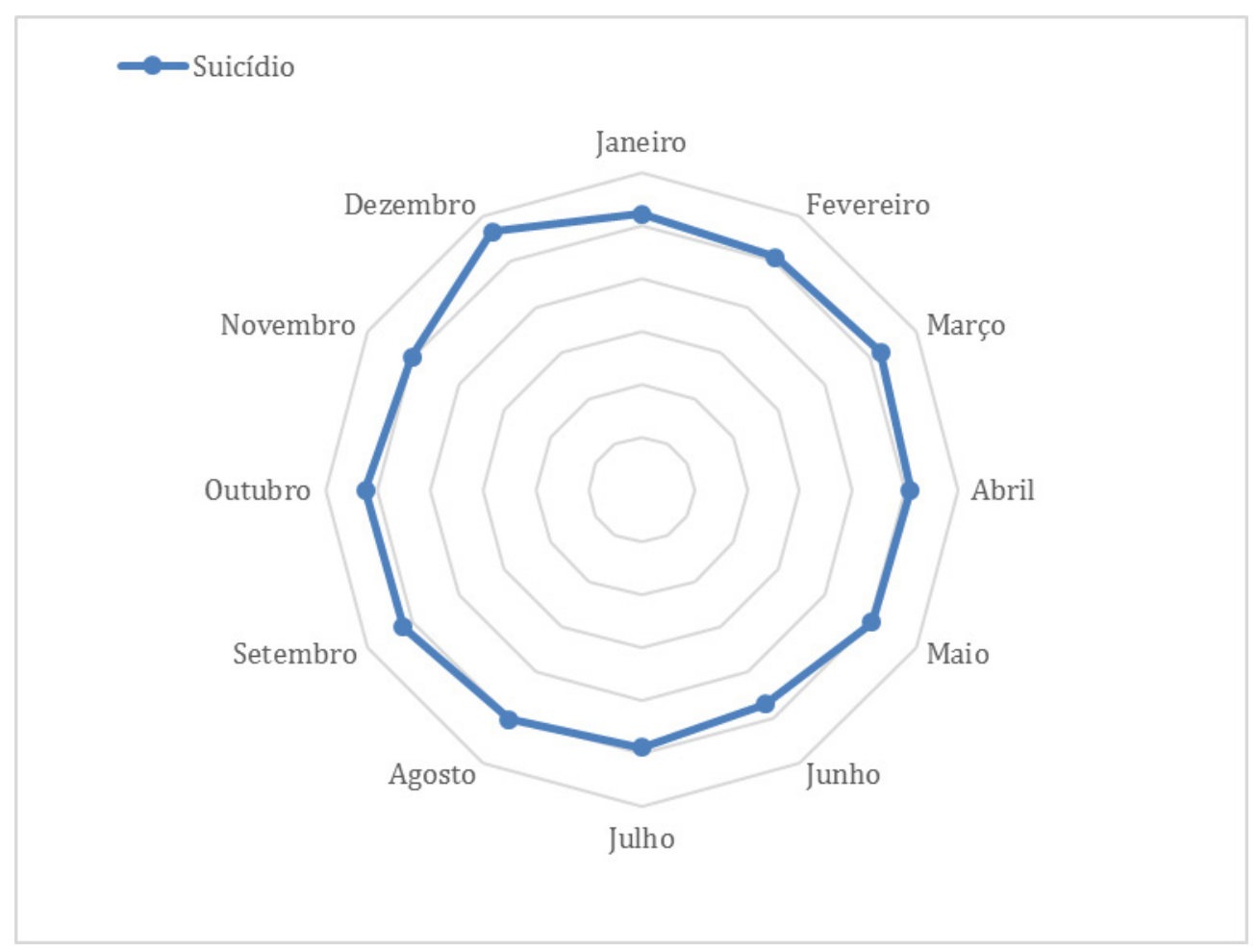

Fonte: SIM/SVS/MS. 
Diversos são os estudos que encontraram maiores índices de suicídios ou tentativas no verão ou na primavera, como estudos realizados em Portugal ${ }^{91}$; Finlândia ${ }^{92}$; Canadá $^{93}$; Bélgica ${ }^{94}$; Turquia ${ }^{95}$; e Lituânia, locais em em que se encontraram picos altíssimos no verão e grandes vazios no inverno ${ }^{96}$. Entretanto, também há estudo que não encontrou picos de suicídio na primavera ou verão ${ }^{97}$, ainda que tenha identificado correlação positiva entre ondas de calor e suicídios, como também encontraram Kovats e Ebi ${ }^{98}$ e Maes ${ }^{99}$.

Ademais, a sazonalidade pode ser ainda melhor demonstrada na análise das ocorrências ao longo da semana. Muitos são os estudos que concluíram haver picos às segundas-feiras e quedas bruscas em finais de semana, em especial no sábado, nos mais variados países, como Hungria ${ }^{100}$; Reino Unido ${ }^{101}$; Lituânia ${ }^{102}$; Suécia ${ }^{103}$ : Japão, em Hokkaido ${ }^{104}$; Eslovênia ${ }^{105}$; Estados Unidos, em Havaí ${ }^{106}$; Austrália ${ }^{107}$ : Estados Unidos, em Califórnia ${ }^{108}$; e Alemanha ${ }^{109}$. Fenômeno similar tem sido registrado em feriados. E alguns concluíram, em síntese, que, em dias anteriores a feriados, as taxas de suicídio caem, consideravelmente, e continuam baixas no dia do feriado, com incrementos sucessivos nos dias seguintes ${ }^{110}$.

91 FREITAS, E. O suicídio em Portugal no Século XX: elementos empíricos para uma pesquisa. Finisterra, Lisboa, v. 18, n. 34, p. 267-300, 1982. p. 282-283.

92 HERNETKOSKI, M.; KESKINEN, E.; PAKKARI, I. Driver suicides in Finland: are they different in northern and Southern Finland? International Journal of Circumpolar Health, v. 68, n. 3, p. 249-260, 2009. p. 257.

93 KIM, C. et al. Seasonal differences in psychopathology of male suicide completers. Comprehensive Psychiatry, v. 45, n. 5, p. 333339, sep./oct. 2004.

94 MAES, M. et al. Seasonal variation in Plasma L-Tryptophan availability in healthy volunteers' relationship to violent suicide occurrence. Arcbives of General Psychiatry, v. 52, p. 937-946, nov. 1995.

95 DOGANAY, Z. et al. Climatic and diurnal variation in suicide attempts in the ED. American Journal of Emergency Medicine, v. 21, n. 4, p. 271-275, july 2003.

96 KELEDIENE, R.; STARKUVIENE, S.; PETRAUSKIENE, J. Seasonal patterns of suicide over the period of socio-economic transition in Lithuania. BMC Public Health, v. 6, n. 40, feb. 2006. Disponível em: < http://www.ncbi.nlm.nih.gov/pmc/articles/PMC1397811>. Acesso em: 14 mar. 2018.

97 PAGE, L.; HAJAT, S.; KOVATS, S. Relationship between daily suicide counts and temperature in England and Wales. British Journal of Psychiatry, v. 191, p. 106-112, aug. 2007.

98 KOVATS, R.; EBI, K. Heatwaves and public health in Europe. European Journal of Public Health, v. 16, n. 6, p. 592-599, 2006.

99 MAES, M. et al. Synchronized annual rhythms in violent suicide rate, ambient temperature and the light-dark span. Acta Psychiatrica Scandinavica, v. 90, p. 391-396, 1994.

100 ZONDA, T. et al. The impact of holidays on suicide in Hungary. Omega, v. 58, n. 2, p. 153-162, 2008/2009.

101 PAGE, L.; HAJAT, S.; KOVATS, S. Relationship between daily suicide counts and temperature in England and Wales. British Journal of Psychiatry, v. 191, p. 106-112, aug. 2007.

102 KALEDIENE, R.; PETRAUSKIENE, J. Inequalities in daily variations of deaths from suicide in Lithuania: identification of possible risk factors. Suicide and Life-Threatening Behavior, v. 34, n. 2, p. 138-146, summer 2004.

103 BRÅDVIK, L.; BERGLUND, M. A suicide peak after weekends and holidays in patients with alcohol dependence. Suicide and Life-Threatening, v. 33, n. 2, p. 186-191, summer 2003.

104 NISHI, M. et al. Relationship between suicide and holidays. Journal of Epidemiology, v. 10, n. 5, p. 317-320, sep. 2000.

105 MARUŠIČ, A. Suicide in Slovenia: lessons for cross-cultural psychiatry. International Review of Psychiatry, v. 11, p. 212-218, 1999.

106 NAKAMURA, J. et al. Temporal variation in adolescent suicide attempts. Suicide and Life-Threatening Behavior, v. 24, n. 4, p. 343-349, 1994.

107 HASSAN, R. Temporal variation in suicide occurrence in Australia: a research note. The Australian \& New Zealand Journal of Statistics, v. 30, n. 2, p. 194-202, aug. 1994.

108 PHILLIPS, D.; SANZONE, A. A comparison of injury date and death date in 42,698 suicides. American Journal of Public Health, v. 78, n. 5, p. 541-543, may 1988.

109 MASSING, W.; ANGERMEYER, M. The monthly and weekly distribution of suicide. Social Science \& Medicine, v. 21, n. 4, p. 433-441, 1985.

110 PHILLIPS, D.; SANZONE, A. A comparison of injury date and death date in 42,698 suicides. American Journal of Public Health, v. 78, n. 5, p. 541-543, may 1988. p. 542; JESSEN, G.; JENSEN, B. Postponed suicide death? Suicides around birthdays and major public holidays. Suicide and Life-Threatening Behavior, v. 29, n. 3, p. 272-283, fall 1999. p. 277; BRÅDVIK, L.; BERGLUND, M. A suicide peak after weekends and holidays in patients with alcohol dependence. Suicide and Life-Threatening, v. 33, n. 2, p. 186-191, summer 2003. p. 189; KALEDIENE, R.; PETRAUSKIENE, J. Inequalities in daily variations of deaths from suicide in Lithuania: identification of possible risk factors. Suicide and Life-Threatening Behavior, v. 34, n. 2, p. 138-146, summer 2004. p. 140; PAGE, L.; HAJAT, S.; KOVATS, S. Relationship between daily suicide counts and temperature in England and Wales. British Journal of Psychiatry, v. 191, p. 106-112, aug. 2007. p. 107; ZONDA, T. et al. The impact of holidays on suicide in Hungary. Omega, v. 58, n. 2, p. 153-162, 2008/2009. p. 159. 
Ainda que com os dados fornecidos pelo SIM não seja possível verificar se essas sazonalidades ocorrem no Brasil, é razoável presumir, para a elaboração de políticas públicas, sua ocorrência, considerando a notória incidência ao redor de todo o mundo.

Com isto, tendo conhecido o fenômeno do suicídio e como ele se apresenta, é possível discutir o atual tratamento dado por governos à questão, bem como apresentar um caminho alternativo.

\section{Medidas de Combate ao SUICídIo}

\subsection{Suicídio como objeto de criminalização}

A partir da compreensão das diversas facetas desse fenômeno, é possível constatar sem embaraço que se trata de um sério e antigo problema pelo mundo.

Em reação, diversas têm sido as políticas públicas direcionadas ao controle desse fenômeno, em especial nas últimas décadas, com a progressiva mudança de entendimento acerca de sua natureza, sendo hoje visto essencialmente como uma questão de saúde pública; por isto, modelos criminalizantes têm sido progressivamente substituídos por modelos de promoção da saúde física e psicológica. Não é à toa que a produção científica acerca do suicídio está quase restrita à área de saúde, com finalidade absoluta de prevenção e cura de um comportamento tipicamente patológico.

Nos dias atuais, são poucos os países a manterem estatutos criminalizantes ${ }^{111}$ quanto a (tentativa de) suicídio, porém enquanto em alguns deles essa legislação raramente tem produzido efeitos, como Nigéria ${ }^{112}$, Líbano e Singapura ${ }^{113}$; há países em que ainda se visa a manter um rígido controle policial dos atos suicidas, como em Gana ${ }^{114}$ e Paquistão ${ }^{115}$.

Porém, com as ressalvas acerca das intenções manifestas e reais acerca de políticas de Estado, não é estranho entender medidas criminalizantes da tentativa de suicídio como não paternalistas. Afinal, inúmeras outras questões e argumentos estão em jogo, como a evitação de custos desnecessários com saúde pública ${ }^{116}$ ou mesmo a concepção de que a vida é sagrada, não pertencente ao indivíduo, mas a uma divindade, como na concepção islâmica ${ }^{117}$. Isto não afasta a possibilidade de que também seja encontrada a percepção — paternalista — de que a criminalização é capaz de proteger o indivíduo, evitando a tentativa e a reincidência ${ }^{118}$.

Pode surpreender, mas a criminalização recente do suicídio não se limita apenas a países asiáticos e africanos. Até 1955, ainda se aplicava na Inglaterra pena para criminosos cujo delito era a tentativa de suicídio ${ }^{119}$,

111 Ressalta-se que texto específico sobre modelos de criminalização do suicídio será publicado pelos autores no futuro próximo.

112 ADINKRAH, M. Anti-suicide laws in nine african countries: criminalization, prosecution and penalization. African Journal of Criminology and Justice Studies, v. 9, n. 1, p. 279-292, may 2016.

113 MISHARA, B.; WESSTUB, D. The legal status of suicide: a global review. International Journal of Law and Psychiatry, v. 44, p. 54-74, jan./feb. 2016.

114 ADINKRAH, M. Criminal prosecution of suicide attempt survivors in Ghana. International Journal of Offender Therapy and Comparative Criminology, v. 57, n. 12, p. 1477-1497, 2012.

115 SAREEN, H.; TRIVEDI, J. Legal implications of suicide problems specific to South Asia. Delhi Psychiatry Journal, v. 12, n. 1, p. 121-125, apr. 2009.

116 SAREEN, H.; TRIVEDI, J. Legal implications of suicide problems specific to South Asia. Delhi Psychiatry Journal, v. 12, n. 1, p. 121-125, apr. 2009.

117 ARAMESH, K.; SHADI, H. Euthanasia: an Islamic ethical perspective. Iranian Journal of Allergy, Asthma and Immunology, v. 6, n. 5 , p. 35-38, feb. 2007. p. 37.

118 OSAFO, J. et al. "We now have a patient and not a criminal": an exploratory study of judges and lawyers' views on suicide attempters and the law in Ghana. International Journal of Offender Therapy and Comparative Criminology [online], p. 1-21, jan. 2017. Disponível em: <http://journals.sagepub.com/doi/abs/10.1177/0306624X17692059>. Acesso em: 13 mar. 2018.

119 MENDELSON, D.; FRECKELTON, I. The interface of the civil and criminal law of suicide at common law (1194-1845). 
cuja descriminalização formal veio a ocorrer apenas com o The Suicide Act 1961; na Nova Zelândia, em 1961 ${ }^{120}$; no Canadá, em 1972 ${ }^{121}$; na Irlanda, em 1993 ${ }^{122}$; e, mesmo que realizada anteriormente, — mas surpreendente por conta da tradição liberal norte-americana - estados como Nova Iorque, Dakota do Sul e Dakota do Norte, no início do século $\mathrm{XX}^{123}$.

Ainda, não há como obliterar o delito de breach of the peace da tradição de common law (frisa-se que em Inglaterra e Canadá não possui status de delito, mas enseja detenção $\left.{ }^{124}\right)$. Destaca-se a jurisprudência escocesa, que se orienta no sentido de que esse delito ocorre quando uma ação é capaz de promover, ainda que não gere concretamente, distúrbio no homem-médio e ameaça a paz social ${ }^{125}$. Segundo esses postulados, considerou-se delito uma tentativa de suicídio em Torbet v. H. M. Advocate, (1998), S.C.C.R. 546, verificando-se uma carta branca para a incriminação também de atos suicidas.

É importante constatar ainda que a criminalização pode, não o sendo necessariamente, também ser instrumento essencialmente paternalista, seja aquela voltada diretamente ao suicida, casos raros atualmente; seja por meio da criminalização de ações auxiliares ou preparatórias de terceiros, extensamente encontrado por todos os continentes.

Em específico no Brasil, encontra-se no artigo 122 do Código Penal o delito de participação em suicídio, cujos elementos centrais compõem o auxílio, moral (sugestão, promoção psicológica) ou material (promoção de métodos), de modo que aquele que de alguma forma ajuda na realização do suicídio de um terceiro pode ser criminalizado, com pena entre dois e doze anos de reclusão. Ao se interpretar o dispositivo conforme a Constituição Federal de 1988, não há solução diversa de entendê-lo com natureza paternalista; porém na origem não era esse o objetivo, ao menos declarado. Constituído à época do Estado Novo, o Código Penal brasileiro não tinha como foco o indivíduo, a promoção de seu bem-estar, mas sim a consecução de uma política coletivista, organicista ${ }^{126}$, de modo que se entende como um bom exemplo da possibilidade de transformação da natureza (paternalista ou não) de determinadas medidas ao longo do tempo.

Enfim, é possível afirmar que esse estatuto brasileiro possui um grau de intermediário rigor quanto à participação em suicídio, pois há países em que a pena para esse delito é prisão perpétua, em especial afri$\operatorname{canos}^{127}$, bem como países que têm progressivamente promovido o suicídio assistido, como por exemplo Suíça ${ }^{128}$ e Bélgica ${ }^{129}$. Notório é o caso suíço, em que a prática é permitida e significativamente regulamentada, sendo exigido que o suicida seja considerado plenamente capaz por um médico, que receitará a droga letal, que será manipulada pelo suicida em parceria com um voluntário de uma ONG credenciada. Essa possibilidade decorre da lacuna existente no Código Penal suíço, que prevê em seu artigo 115 a tipificação da participação em suicídio apenas em casos com motivação egoísta, bem como pela vitória da concepção do

International Journal of Law and Psychiatry, v. 36, n. 5-6, p. 343-349, 2013.

120 LESTER, D. Decriminalization of suicide in New Zealand and suicide rates. Psychological Reports, v. 72, n. 3, p. 1050 , june 1993.

121 LEENAARS, A.; LESTER, D. Comparison of rates and patterns of suicide in Canada and the United States, 1960-1988.

Death Studies, v. 16, n. 5, p. 417-430, 1992. p. 427.

122 NEELEMAN, J. Suicide as a crime in the UK: legal history, international comparisons and present implications. Acta Psychiatrica Scandinavica, v. 94, n. 4, p. 252-257.

123 WITHERS, R. Status of suicide as a crime. The Virginia Law Register, v. 19, n. 9, p. 641-647, jan. 1914. p. 642.

124 FERGUSON, P. Moving from preparation to perpetration? Attempted crimes and breach of the peace in scots law. Obio State Journal of Criminal Law, v. 11, n. 2, p. 687-700, 2014.

125 Smith v. Donnelly, 2002, JC 65; reafirmado na Corte Europeia de Direitos Humanos: Maguire v. Reino Unido, 28 , p. 7.

126 CAMPOS, F. Síntese da reorganização Nacional (entrevista concedida à imprensa, em abril de 1939). In: CAMPOS, F. $O$

Estado Nacional: sua estrutura, seu conteúdo ideológico. Brasília: Senado Federal, 2001. p. 107-136. p. 124-125.

127 ADINKRAH, M. Anti-suicide laws in nine african countries: criminalization, prosecution and penalization. African Journal of Criminology and Justice Studies: v. 9, n. 1, p. 279-292, may 2016.

128 ADORNO, R. Nonphysician-assisted suicide in Switzerland. Cambridge Quarterly of Healthcare Ethics, v. 22, n. 3, p. 246-253, july 2013; STECK, N. et al. Euthanasia and assisted suicide in selected European countries and US States: systematic literature review. Med Care, v. 51, n. 10, p. 938-944, oct. 2013.

129 ZIEGLER, S.; BOSSHARD, G. Role of non-governmental organisations in physician assisted suicide. BMJ, v. 334, p. 295298, feb. 2007. 
direito de morrer, evidenciado na não adesão do entendimento de que essa lacuna poderia ser preenchida com a tipificação da ação do voluntário ou do médico como homicídio ou omissão de socorro ${ }^{130}{ }^{131}$.

Essa regulamentação suíça da participação em suicídio é o mais forte vetor que se tem hoje no sentido da referida descriminalização do suicídio, acompanhando e promovendo essa tendência, entretanto, não exclui a visão patológica, que orienta o tratamento e cura de indivíduos não plenamente capazes, ou seja, não elegíveis para o suicídio assistido.

De qualquer forma, essa polarização (medidas criminalizantes versus atenção médica) evidencia duas formas muito diversas de lidar com o suicídio. Isto porque a criminalização do ato suicida tem por base um agente livre, capaz, consciente; enquanto a criminalização de atos acessórios de terceiros e a medicalização denotam um indivíduo incapaz, doente, desorientado por uma deficiência ou desordem psíquica, ou seja, como se apresentou, o típico destinatário de medidas paternalistas, afinal não é capaz de dirigir-se conforme seu próprio bem-estar.

Por fim, nota-se que opção por modelos criminalizantes parece estar atrelada diretamente a concepções antigas da relação entre Poder Central, vinculadas ou não a sentimentos religiosos, e indivíduos, não guardando qualquer relação concreta com estudos de viabilidade ou efetividade. Nessa seara, apenas se encontram, em específico quanto à tentativa de suicídio, estudos indicando a absoluta incapacidade de políticas repressivas prevenirem sua realização e a ausência de incremento de eventos suicidas a partir de descriminalizações, como detectado, por exemplo, em Sri Lanka ${ }^{132}$, Inglaterra ${ }^{133}$ e Irlanda ${ }^{134}$.

Com isto, modelos criminalizantes se mostram, além de naturalmente custosos, improdutivos se aplicados a um tema de saúde pública como o suicídio, possivelmente gerando inúmeros outros problemas de saúde pública e até mesmo institucionais. Por exemplo, a difusão da corrupção de autoridades policiais paquistaneses responsáveis por hospitais médico-legais a que são obrigatoriamente levados os sobreviventes, com o fim de se evitar as acusações por tentativa de suicídio ${ }^{135}$.

Não é à toa que têm ganhado cada vez mais espaço medidas interventivas de caráter não criminalizantes, políticas públicas de contenção e restrição a disponibilidade de métodos suicidas, como se expõe a seguir.

\subsection{Suicídio como objeto de políticas públicas não criminalizantes}

Como já exposto, é notório que a disponibilidade do método é elemento central na escolha do suicida para realização de seu intento ${ }^{136}$. Com base nisso, têm-se promovido inúmeras medidas interventivas com a finalidade de dificultar ou até mesmo impossibilitar o acesso de indivíduos a meios de suicídio. Também medidas educativas vêm sendo implementadas, sejam em âmbito de atendimento médico, sejam voltadas diretamente a público geral ou de alto risco. Em síntese, é possível afirmar de antemão que se tem promovido a concepção de complementariedade dessas medidas de controle, restrição, informações e educação.

Quanto a medidas restritivas, podem ser citadas como expoentes aquelas relacionadas ao acesso a armas de fogo, o controle e restrição ao tráfego de pessoas em estações e trilhos de sistemas ferro e metroviários, bem como em pontes.

130 HURST, S.; MAURON, A. Assisted suicide in Switzerland: clarifying liberties and claims. Bioethics, v. 31, n. 3, p. $199-208$, mar. 2017.

131 Ressalta-se novamente, que em texto a ser publicado os autores abordarão mais detalhadamente o tema.

132 HOEK, W. et al. Pesticide poisoning: a major health problem in Sri Lanka. Social Science \& Medicine, v. 46, n. 4-5, p. 495-504, feb. 1998.

133 BULlUSU, L.; ALDERSON, M. Suicides 1950-82. Population Trends, v. 35, p 11-17, spring 1984.

134 OSMAN, M.; PARNELL, A.; HALEY, C. "Suicide shall cease to be a crime": suicide and undetermined death trends 19702000 before and after the decriminalization of suicide in Ireland 1993. Irish Journal of Medical Science, v. 186, n. 1, p. 201-205, feb. 2017.

135 KHAN, M. et al. Epidemiology of suicide in Pakistan: determining rates in six cities. Archives of Suicide Research, v. 12, n 2, p. 155-160, 2008.

136 BETZ, M. et al. Lethal means access and assessment among suicidal emergency department patients. Depression and Anxiety, v. 33, n. 6, p. 502-511, june 2016. 


\subsubsection{Controle de armas de fogo}

Em específico quanto a armas de fogo, cujo altíssimo grau de letalidade já foi relatado, visa-se a restringir ao máximo a disponibilidade de armas, seja a todos os indivíduos, seja a grupos de riscos. O debate acerca da disponibilidade de armas de fogo é notoriamente tortuoso, evidenciando o mencionado problema da liberdade individual frente ao paternalismo.

Essa dicotomia se mostra mais evidente nos Estados Unidos, onde há um fortíssimo embate. Portanto, naturalmente, em que pesem inúmeros estudos demonstrarem a direta relação entre posse de arma de fogo e maior risco de evento suicida por arma de fogo ${ }^{137}$, também se encontram aqueles que, em oposição, defendem a utilização de arma de fogo como instrumento essencial e eficaz de defesa contra a criminalidade ${ }^{138}$, a ponto de a National Rifle Association (NRA) ter iniciado um estudo de viabilidade de instalar seguranças armados em escolas após o massacre em Sandy Hook Elementary School, em 2012, sob seu famigerado mantra de que "apenas um bom homem com uma arma é capaz de impedir um homem mau com uma arma"139.

Diversas podem ser as medidas restritivas, mas não impeditivas, do uso de armas de fogo, a saber: a) quanto ao comércio: i) limitação de produção; ii) limitação de importação; iii) banimento de carregadores com grande capacidade; iv) banimento de armas conhecidas como saturday night special, ou seja, pistolas de baixa qualidade e segurança, às vezes de reduzidíssimo tamanho e difícil fiscalização; v) sobretaxação; b) quanto à aquisição: i) idade mínima para aquisição: ii) teste psicológico; iii) conferência de antecedentes criminais; iv) exigência de motivação justificada para aquisição; v) realização de curso de manuseio; vi) cooling off period, ou seja, tempo de espera para efetivação da compra após solicitação; vii) licenciamento ou registro dos comerciantes; viii) registro dos compradores; c) quanto ao uso: i) licença restrita: utilização somente em situações justificadas perante autoridades; ii) especificações quanto à forma de armazenamento, inclusive de munições; iii) utilização de travas de segurança.

Bons resultados foram obtidos em Columbia, que adotou em 1976 um dos mais restritivos programas de controle de armas dos Estados Unidos por meio do Distric of Columbia's Firearms Control Regulations Act, exigindo o registro de armas, seu armazenamento sem munição, desmontadas e com trava de segurança, tendo sido registrada uma grande redução nos índices de suicídio e homicídio, sem a verificação de displacement ${ }^{40}$; em específico quanto aos efeitos de travas de segurança, também obtiveram sucesso os estados de Tennessee e Washington ${ }^{141}$.

Outros dados relevantes são encontrados em um estudo que não identificou redução dos índices de suicídios, bem como de homicídios, dentre jovens, nos estados que limitaram o acesso a armas de fogo a maiores de 21 anos; porém detectou redução de 8\% das taxas de suicídio por arma de fogo nos estados que vedaram as saturday night specials ${ }^{142}$.

137 WINTEMUTE, G. et al. Mortality among recente purchasers of handguns. The New England Journal of Medicine, v. 341, n. 21, p. 1583-1589, 1999; CONNER, K.; ZHONG, Y. State firearm laws and rates of suicide in men and women. American Journal of Preventive Medicine, v. 25, n. 4, p. 320-324, 2003; DAHLBERG, L.; IKEDA, R.; KRESNOW, M. Guns in the home and risk of a violent death in the home: findings from a national study. American Journal of Epidemiology, v. 160, n. 10, p. 929-936, nov. 2004; MILLER, M. et al. The association between changes in household firearm ownership and rates of suicide in the United States, 1981-2002. Injury Prevention, v. 12, n. 3, p. 178-182, june 2006.

138 BRUCE-BRIGGS, B. The great American gun war. The Public Interest, n. 45, p. 37-62, 1976; KLECK, G.; GERTZ, M. Armed resistance to crime: the prevalence and nature of self-defense with a gun. Journal of Criminal Law and Criminology, v. 86, n. 1, p. 150187, fall 1995 .

139 STEIDLEY, T.; COLEN, C. Framing the gun control debate: press releases and framing strategies on the National Rifle Association and the Brady Campaign. Social Science Quarterly, v. 98, n. 2, p. 608-627, june 2017. p. 608.

140 LOFTIN, C. et al. Effects of restrictive licensing of handguns on homicide and suicide in the District of Columbia. The New England Journal of Medicine, v. 325, n. 23, p. 1615-1620, dec. 1991.

141 KELLERMAN, A. L. et al. Suicide in the home in relation to gun ownership. The New England Journal of Medicine, v. $327, \mathrm{p}$. 467-472, aug. 1992.

142 ROSENGART, M. et al. An evaluation of state firearm regulations and homicide and suicide death rates. Injury Prevention, v. 11, n. 2, p. 77-83, apr. 2005. 
Outro bom exemplo a respeito dos efeitos da disponibilidade das armas de fogo é o caso da Suíça, que, tradicionalmente, tem como principal método de suicídio o uso de arma de fogo ${ }^{143}$; e cujos índices de homicídios por arma de fogo estão diretamente relacionados ao número de possuidores ${ }^{144}$. No país, sempre houve uma grande disponibilidade de armas em função do programa militar, que até 2010 mantinha as armas de fogo sob a posse de todos os indivíduos egressos do programa obrigatório ${ }^{145}$; e, desde a referida data, apenas aqueles que obtêm uma licença especial podem detê-las. A própria redução do efetivo do exército, ocorrida em 2003, foi uma medida, ainda que sem esse propósito, eficiente na redução dos índices de suicídio com base na redução geral de disponibilidade de $\operatorname{armas}^{146}$.

Em síntese, é possível afirmar, categoricamente, que, quanto mais armas de fogo disponíveis e/ou maior liberdade em sua forma de uso, maiores os índices de suicídios por arma de fogo e, por consequência, de suicídios em geral, considerando a altíssima letalidade desse método. Também é indiscutível a existência de elevados custos econômicos e políticos na promoção de medidas restritivas nesse campo.

\subsubsection{Limitações à livre-circulação de pessoas em hotspots}

Ainda que boa parte dos atos suicidas ocorram no silêncio e intimidade de residência privadas, é bastante significativo o número de eventos em locais públicos, havendo pesquisas que indicam mais de $30 \%$ dos casos ocorrendo nesses locais ${ }^{147}$. Falando quanto a espaço público, é notória a existência de hotspots, ou seja, aqueles em que uma mística e o histórico promovem a repetição contínua de eventos suicidas, atraindo pessoas e elevando as estatísticas locais; estes podem ser shoppings, pontes, prédios comerciais, universidades, estações de trens etc.

Considerando isto, as características desses lugares, bem como a dinâmica dos eventos suicidas têm sido estudados meios de impedir, fisicamente, o acesso de potenciais suicidas aos pontos críticos desses hotspots. Consequentemente, estudos têm vindo à tona discutindo a efetividade e custo-benefício dessas medidas, seja de forma geral ou específica, com destaque para o estudo de Pirkis e Spittal, que, em uma meta análise, concluíram pela grande eficiência de barreiras de segurança em hotspots ${ }^{148}$. Um bom exemplo desse tipo de local é a ponte Golden Gate, em São Francisco (EUA), que, entre 1937 e 1991, registrou 918 casos, uma média de 19,5 casos por ano ${ }^{149}$, sendo previsto um plano de contenção de suicídios por meio da instalação de redes de segurança de aço inoxidável ao longo de toda sua extensão, que se prevê conclusa em janeiro de 2021, porém ao custo de $\$ 204.000 .000$,00. Entretanto, já se aponta a inexistência de prejuízo econômico — se é que se pode abordar a questão dessa forma — pela economia com despesas decorrentes de eventos (tentados ou consumados) suicidas evitados ${ }^{150}$.

Em específico quanto a evitação de suicídios em pontes, são inúmeros os casos de sucesso por meio

143 VÄRNIK, A. et al. Suicide methods in Europe: a gender-specific analysis of countries participating in the "European Alliance Against Depression". Journal of Epidemiology and Community Health, v. 62, p. 545-551, 2008.

144 AJDACIC-GROSS, V. et al. Firearm suicides and availability of firearms: the swiss experience. European Psychiatry, v. 25, p. 432-434, 2010.

145 HABENSTEIN, A. et al. Chances and limits of method restriction: a detailed analysis of suicide methods in Switzerland. Archives of Suicide Research, v. 17, n. 1, p. 75-87, 2013.

146 REISCH, T. et al. Change in suicides rates in Switzerland before and after firearm restriction resulting from the 2003 "Army XXI" reform. The American Journal of Psychiatry, v. 170, n. 9, p. 977-984, sep. 2013.

147 OWENS, C. et al. Suicide in public places: findings from one English county. European Journal of Public Health, v. 19, n. 6, p. 580-582, apr. 2009; CHEN, Y.; YIP, P. Prevention of suicide by jumping: experiences from Taipei City (Taiwan), Hong Kong and Singapure. In: WASSERMAN, D.; WASSERMAN, C. Oxford Textbook of Suicidology and Suicide Prevention. Oxford: Oxford University Press, 2009. p. 569-572.

148 PIRKIS, J.; SPITTAL, M. The effectiveness of structural interventions at suicide hotspots: a meta-analysis. International Journal of Epidemiology, v. 42, p. 531-548, 2013.

149 GUNNEL, D.; NOWERS, M. Suicide by jumping. Acta Psychiatrica Scandinavica, v. 96, p. 1-6, 1997.

150 WHITMER, D.; WOODS, D. Analysis of the cost effectiveness of a suicide barrier on the Golden Gate Bridge. Crisis, v. 24, n. 2, p. 98-106, 2013. 
da instalação de cercas, redes e outras barreiras. Um amplo estudo suíço quanto a efetividade identificou redução de $82 \%$ de suicídios em hotspots em função de barreiras (barreiras verticais e redes de segurança) completas, ou seja, em torno de todo o perímetro de risco; enquanto identificou redução de 44,8\% em hotspots com barreiras incompletas; ou seja, ainda que se mantenha alguma disponibilidade, possivelmente há um forte impacto psicológico nos potenciais suicidas ${ }^{151}$. Situação similar foi identificada no Münsterplattform, em Berna, cujo impacto se estendeu a toda a cidade, reduzindo os índices desse método drasticamente não apenas nesse botspot ${ }^{152}$.

Ainda, há os casos da Clifton Suspension Bridge, em Bristol, em que o número de suicídios foi reduzido pela metade nos anos seguintes à instalação de barreiras ${ }^{153}$; bem como do Prince Edward Viaduct, em Toronto, onde foi instalado gradeado elevado de cerca de $5 \mathrm{~m}$, o que não impossibilitou a ocorrência de um suicídio, mas, além de reduzir drasticamente os índices no local, aparentemente também ensejou redução de suicídios por esse método em toda a cidade ${ }^{154}$, como se a construção das barreiras tivesse funcionado como uma mensagem com efeitos psicológicos da indesejabilidade daquela espécie de conduta. Entretanto, há também meios mais simples e menos onerosos, como impedir a circulação e travessia de pedestres, em que pese isto não impedir que as pessoas se dirijam até ponto elevado por meio de automóvel para, então, se precipitarem, como muito já ocorreu na Ponte do Bósforo, em Istambul ${ }^{155}$.

Menos custosa do que essas barreiras, a instalação de linhas telefônicas diretas, Helplines, em hotspots, como a MID-Hudson Bridge, no estado de Nova Iorque. Funcionando 24h por dia, o telefone de emergência foi utilizado, em apenas dois anos, por 24 indivíduos com ideação suicida. Apenas um deles, efetivamente, se precipitou da ponte; enquanto os demais foram recolhidos e colocados sob supervisão psiquiátrica ${ }^{156}$. Outro meio menos custoso seria a criação de protocolos de segurança específicos para a construção de novas edificações ${ }^{157}$.

Por fim, pode-se falar da instalação de portas especiais em estações de metrô e trem, que impedem o acesso aos trilhos e se abrem quando os veículos estacionam: as Portas de Plataformas, sejam elas integrais (Platform Screen Doors - PSDs) ou parciais, a meia altura (Platform Edge Doors - PED), encontradas, inclusive, em algumas estações de transporte metroferroviário de São Paulo. Exemplos de sucesso podem ser observados em Tóquio ${ }^{158}$, Hong Kong ${ }^{159}$ e Seul ${ }^{160}$. Entretanto, essas barreiras são significativamente caras, em especial as PSDs, exigindo altos custos não apenas de sua instalação e manutenção, mas também quanto à estrutura da estação.

Em virtude desse alto custo, encontrou-se no Japão uma alternativa de natureza diversa, sem qualquer restrição aos usuários do sistema de transporte: a instalação de luz azul nas estações, com fundamento de

151 HEMMER, A.; MEIER, P.; REISCH, T. Comparing different suicide prevention measures at bridges and buildings: lessons we have learned from a national survey in Switzerland. Plos One, v. 12, n. 1, jan. 2017.

152 REISCH, T.; MICHEL, K. Securing a suicide hot spot: effects of a safety net at the Bern Muenster Terrace. Suicide and LifeThreatening Behavior, v. 35, n. 4, p. 460-467, aug. 2005.

153 BENNEWITH, O.; NOWERS, M.; GUNNEL D. Effect of barriers on the Clifton suspension bridge. The British Journal of Psychiatry, v. 190, p. 266-267, mar. 2007.

154 SINYOR, M.; LEVITT, A. Effect of a barrier at Bloor Street Viaduct on suicide rates in Toronto: natural experiment. BMJ, v. 341, july 2010; SINYOR, M.; SCHAFFER, A.; REDELMEIER, D. et al. Did the suicide barrier work after all? Revisiting the Bloor Viaduct natural experiment and its impact on suicide rates in Toronto. BMJ Open, v. 7, n. 5, june 2017.

155 ÇETIN, G.; GÜNAY, Y.; FINCANCI, S. et al. Suicides by jumping from Bosphorus Bridge in Istanbul. Forensic Science International, v. 116, n. 2-3, p. 157-162, feb. 2001.

156 GLATT, K. Helpline: suicide prevention at a suicide site. Suicide Life-Threatening Behavior, v. 17, n. 4, p. 299-309, winter 1987.

157 PIRKIS, J.; SPITTAL, M. The effectiveness of structural interventions at suicide hotspots: a meta-analysis. International Journal of Epidemiology, v. 42, p. 531-548, 2013.

158 UEDA, M.; SAWADA, Y.; MATSUBAYASHI, T. The effectiveness of installing physical barriers for preventing railway suicides and accidents: evidence from Japan. Journal of Affective Disorders, v. 178, p. 1-4, 2015.

159 LAW, C. et al. Evaluating the effectiveness of barrier installation for preventing railway suicides in Hong Kong. Journal of Affective Disorders, v. 114, n. 1-3, p. 254-262, apr. 2009.

160 CHUNG, Y. et al. The effectiveness of platform screen doors for the prevention of subway suicides in South Korea. Journal of Affective Disorders, v. 194, p. 80-83, apr. 2016. 
que teria efeito, grosso modo, calmante nas pessoas e, portanto, poderia limitar em algum grau comportamentos impulsivo-agressivos, sejam suicídios ou mesmo lesões a terceiros. Similar expediente tem sido implementado lentamente no Reino Unido, entretanto, até o momento apenas um estudo se propôs a analisar os efeitos dessa medida, concluindo pela existência de um grande declínio de suicídios nas estações em que foi implementada, ainda que não haja como fazer correlações absolutas ${ }^{161}$. Portanto, as cidades e suas estruturas podem e devem ser utilizadas tanto como instrumentos de promoção de direitos, como de sua garantia $^{162}$.

\subsection{Protonudging}

Como se observou, as políticas quanto ao suicídio atualmente são consoantes à dicotomia pertinente ao debate tradicional sobre paternalismo de Estado: de um lado, criminalização, proibições, chegando a restrições a consumo e construção de barreiras; de outro, campanhas educacionais, sensibilização de instituições públicas, abertura de linhas telefônicas de suporte etc. A despeito dessa divisão, pelo menos duas iniciativas atuais agregam características de ambos os lados, conformando-se como uma manifestação, ainda que não planejada por seus idealizadores, de paternalismo libertário.

Tendo em vista que a discussão acerca de nudging ainda está em um grau prematuro de penetrabilidade no campo das políticas públicas ${ }^{163}$, essas iniciativas, apesar da viabilidade, não foram enquadradas como nudges à época de sua formulação. Não obstante, esses exemplos podem servir de parâmetro para a elaboração de nudges direcionados ao combate ao suicídio.

O primeiro exemplo é a cartilha criada pela Associação Brasileira de Psiquiatria (ABP) com orientações sobre a abordagem de suicídio na imprensa, criada com base nas diretrizes do respectivo manual da Organização Mundial de Saúde. Manuais e cartilhas, a princípio, têm caráter exclusivamente informativo, afirmando diretrizes gerais, e, por essa razão, são enquadrados como manifestações do extremo liberal no debate tradicional sobre paternalismo de Estado. A cartilha em questão, contudo, vai além da mera exposição de diretrizes, transmitindo sugestões de pequenas e sutis alterações na forma como a informação é apresentada, de modo a direcionar comportamentos sem que opções sejam limitadas.

Nesse sentido, dentre o rol das dicas aos profissionais de imprensa ${ }^{164}$, alguns trechos podem ser destacados, como "evitar a palavra suicídio em chamadas e manchetes. Melhor incluí-la no corpo do texto; evitar termos valorativos, como por exemplo: 'cometeu' suicídio; tentou o suicídio 'sem sucesso'; ou generalizantes, como, por exemplo 'os suicidas', ao referir-se a pessoas falecidas por suicídio”; é “aconselhável não dar destaque à notícia: no caso de jornais, em páginas pares e na parte inferior. Em TV, do terceiro bloco em diante; o mesmo se aplica a programas de rádio. Esclarecer as consequências do ato em si, seja na forma de danos físicos e mentais permanentes (no caso de tentativa), seja no impacto que provoca na família e amigos"; "em alguns casos, é prudente omitir o local onde o ato foi realizado".

Não apenas medidas tidas como liberais podem se aproximar de um caminho intermediário, mas também uma medida comumente enquadrada como uma manifestação de paternalismo forte pode ser relativizada. Por exemplo a restrição a meios letais por meio do cooling off period em aquisição de armas e da intervenção na acessibilidade a carvão em Hong Kong.

161 MATSUBAYASHI, T.; SAWADA, Y.; UEDA, M. Does the installation of the blue lights on train platforms prevent suicide? A before-and-after observational study from Japan. Journal of Affective Disorders, v. 147, p. 385-388, 2013.

162 DIAS, D.; NONATO, D.; RAIOL, R. Interação entre a acessibilidade urbanística e o direito à cidade: possibilidade de inclusão social das pessoas com deficiência. Revista Brasileira de Políticas Públicas, v. 7, n. 2, p. 149-168, ago. 2017.

163 Políticas públicas baseadas em evidências comportamentais vêm ganhando espaço em governos pelo mundo, com destaque para a primeira iniciativa neste sentido, o BIT (Behavioral Insights Team), criado pelo então primeiro ministro David Cameron do Reino Unido em 2010; e o SBST (Social and Behavioral Sciences Team), criado em 2015 pelo ex-presidente dos Estados Unidos Barack Obama. 164 ASSOCIAÇÃO BRASILEIRA DE PSIQUIATRIA. Manual para a imprensa: boas práticas de comunicação e guia com recomendações para um texto claro e esclarecedor sobre doenças mentais e psiquiatria. 2. ed. Rio de Janeiro: ABO, 2009 . p. 85 e ss. 
Em específico quanto a esse último caso, trata-se de experimento levado a cabo entre julho de 2006 e junho de 2007 em dois distritos adjacentes em Hong Kong — Tuen Mun e Yuen Long — com características demográficas e socioeconômicas parecidas, além de altos índices de suicídios com o uso da técnica de queima de carvão ${ }^{165}$. Nos mercados de Tuen Mun (distrito que sofreu a manipulação), o carvão de churrasco deixou de ser ofertado em prateleiras para serem entregues aos consumidores exclusivamente após pedido a funcionários, que teriam que buscar o produto em área interna, processo que levaria, em média, 10 minutos. Os mercados de Yuen Long (distrito usado como controle para o experimento) continuaram vendendo carvão normalmente, ou seja, dispondo livremente em prateleiras.

Ao analisar o resultado da intervenção após um ano, os pesquisadores notaram que, no distrito de Tuen Mun, onde o acesso a carvão foi dificultado, o número de suicídios por esse método diminuiu consideravelmente, de 21 para 10 casos e o número total de suicídios também diminuiu de 88 para 60, o que indica ausência de displacement. A despeito das limitações deste estudo, há evidências de que pequenas alterações no ambiente podem gerar efeitos significativos de dissuasão do comportamento suicida.

Em comum, ambas iniciativas apresentam características típicas de nudges: trata-se de alterações sutis na arquitetura da decisão que não retiram opções das pessoas ${ }^{166}$; direcionam-se à mudança comportamental, não à mudança de opinião ou ao convencimento de seus destinatários ${ }^{167}$; baseiam-se em evidências, não em intuições de seus planejadores, tanto na fase de elaboração quanto na fase de avaliação de resultados ${ }^{168}$; são formuladas a partir de um mapeamento do contexto da decisão, isto é, tendo-se em conta o grau de atenção, as pressões sociais e as heurísticas utilizadas pelas pessoas para a tomada de decisão $0^{169}{ }_{-170}$.

\section{Considerações finais: Pelo desenVolvimento do mÉtodo de NUdGes para políticas PÚBLICAS DE COMBATE A SUICÍDIOS}

Com base nos elementos apresentados, os elementos apresentados: o critério para enquadramento de paternalismo (parte I); as evidências sobre as características e evolução do suicídio (parte II); a metodologia e exemplos de nudges (parte III); pergunta-se: afinal, por que incorporar nudges às políticas públicas no combate ao suicídio?

De acordo com Sunstein: “[a] virtude [dos nudges é] [...] desenvolver políticas sensíveis, e de baixo custo, com referência a como seres humanos realmente pensam e se comportam"171. Políticas públicas comportamentais (behavioral policies) em regra têm a virtude de serem uma alternativa de implementação imediata e simples, além de possuírem melhor custo-benefício em relação às opções tradicionais ${ }^{172}$. Esse menor custo

165 YIP, P. et al. Restricting the means of suicide by charcoal burning. The British Journal of Psychiatry, v. 196, p. 241-242, 2010.

166 THALER, R.; SUNSTEIN, C. Nudge: improving decisions about health, wealth and happiness. New Haven: Yale University Press, 2008. p. 5.

167 SAMSON, A. The behavioral economics guide 2016: with introduction by Gerd Gigerenzer. Londres: Behavioral Science Solutions, 2016. p. 31.

168 SUNSTEIN, C. Nudging: a very short guide. Journal of Consumer Policy, v. 37, n. 4, p. 583-588, dec. 2014.

169 LY, K. et al. A practitioner's guide to nudging. Research Report Series Behavioural Economics in Action, Rotman School of Management, University of Toronto, Toronto, p. 1-28, mar. 2013. p. 15.

170 A título de exemplo, apresentam-se categorias de intervenções mais recorrentes: (i) inscrições automáticas (default) (e.g. inscrição automática no plano de previdência privada mais benéfica, com opção de saída a qualquer momento) (THALER, R.; SUNSTEIN, C. Nudge: improving decisions about health, wealth and happiness. New Haven: Yale University Press, 2008. p. 103-117); (ii) utilização de normas sociais (e.g. dar ênfase ao fato de a maioria dos adultos de uma região estão registrados para doação de órgãos) (p. 182); e (iii) enquadramento (framing) de informações (e.g., reenquadrar a informação de forma a elicitar o viés da aversão à perda no destinatário, como alterar "mantenha-se hidratado" para "pare de perder água") (p. 244). Para uma discussão sobre situações em que se deve optar por nudges, em especial regras default, ou opções tradicionais que exijam escolha ativa por parte do destinatário, ver SUNSTEIN, C. Choosing not to choose: understanding the value of choice. New York: Oxford University Press, 2015.

171 SUNSTEIN, C. Why nudge?: the politics of libertarian paternalism. New Haven: Yale University Press, 2014. p. 25, tradução livre.

172 BENARTZI, S. et al. Should governments invest more in nudging?. Psychological Science, Thousand Oaks, june 2017. Dis- 
não seria apenas econômico (pequenas alterações na arquitetura da decisão em comparação a ampliação de campanhas educacionais ou gastos com mais controle, fiscalização e repressão), mas também político se comparado a medidas de paternalismo forte. Afinal, a defesa de nudges, em razão de seu traço não restritivo ou coercitivo, sofreria menos resistência das pessoas em razão da percepção de preservação de liberdade de escolha.

Portanto, é possível sugerir alguns nudges para o combate ao suicídio, primordialmente com a finalidade de promover o debate quanto à incorporação dessa metodologia às políticas públicas.

1. Considerando que histórico de tentativas é um grande fator de risco ${ }^{173}$, após o atendimento em emergência decorrente de uma tentativa de suicídio, o indivíduo será automaticamente inserido em um programa de atendimento psicológico (regra default) por telefone (helpline). Isto porque é notória, há muito tempo, a indisposição de pacientes a acompanhamento após alta médica $(\text { follow-up })^{174}$. O cancelamento da inscrição nesse programa apenas pode ser feito mediante manifestação que deverá ser entregue, presencialmente, pelo indivíduo no respectivo órgão público (possibilidade de opt-out). Dessa forma, baseado nas evidências de tendência das pessoas a se conformarem ao status quo ou inércia, acreditamos que grande parte das pessoas que podem se beneficiar de apoio psicológico acabariam por continuar recebendo atenção continuada, haja vista existir demonstração de menores índices de suicídios em grupos com intenso contato em follow-up ${ }^{175}$.

2. Em se considerando que há datas de picos de incidência em suicídios, como segundas-feiras ou dias posteriores a feriados e ao longo do verão, uma medida com potencial de eficácia é a sugestão/indicação a profissionais de imprensa para que optem, na medida do possível, por apresentar/retardar notícias com teor positivo, como melhoras em índices econômicos, em/para finais de semana e dias anteriores aos feriados.

3. É razoável considerar que grande parte das pessoas que estão na iminência de realizar suicídio estão passando por uma situação de "tunelamento atencional", isto é, alocando todos recursos cognitivos em linhas de pensamento circulares e repetitivos, deixando de considerar alternativas. Por essa razão, acreditamos que em hotspots, locais comumente de altitude elevada e com grande incidência de suicídios, como pontes, em vez, ou mesmo complementarmente, de se limitar a circulação ou criar barreiras físicas, pode ser razoável usar de meios para causar a interrupção do "túnel atencional" suicida por meios direcionados a engatilhar temporariamente o uso do sistema 2 de raciocínio (vide Quadro 1).

Conforme literatura específica, o sistema 2 é ativado em situações em que as pessoas estão diante de estímulos que causam surpresa, choque ou perplexidade; que criam necessidade de reflexão sobre algo; ou que demandam que o indivíduo recobre a memória sobre algum evento ${ }^{176}$. Nesse sentido, em prol da dissuasão a comportamentos suicidas, acreditamos que possa ser efetiva a fixação de placas em hotspots com conteúdo capaz de ativar o sistema 2, seja por exemplo uma obra de arte surrealista ou um desafio matemático. Um estudo suíço, analisando a efetividade da instalação de sinais em hotspots, ainda que promovida com base em fundamento diverso, concluiu por sua capacidade de interferir, positivamente, na redução de índices de suicídios ${ }^{177}$.

ponível em: <http://journals.sagepub.com/doi/full/10.1177/0956797617702501>. Acesso em: 13 mar. 2018.

173 LOPES, P.; BARREIRA, D.; PIRES, A. Tentativa de suicídio na adolescência: avaliação do efeito de gênero na depressão e personalidade. Psicologia, Saúde \& Doenças, v. 2, n. 1, p. 47-57, 2001. p. 49; WERNECK, G. et al. Tentativas de suicídio em um hospital geral no Rio de Janeiro, Brasil. Cadernos de Saúde Pública, Rio de Janeiro, v. 22, n. 10, p. 2201-2206, out. 2006. p. 2202; CHACHAMOVICH, E. et al. Quais são os recentes achados clínicos sobre a associação entre depressão e suicídio?. Revista Brasileira de Psiquiatria, v. 31, Supl. 1, p. 518-525. p. 519; SANTOS, S. et al. Prevalência de transtornos mentais nas tentativas de suicídio em um hospital de emergência no Rio de Janeiro, Brasil. Cadernos de Saúde Pública, Rio de Janeiro, v. 25, n. 9, p. 2064-2074, set. 2009. p. $2067-2068$. 174 KREITMAN, N. Parasuicide. Londres: Wiley, 1977.; KURZ, A. et al. The psychiatric management of parasuicide patients. Psychiatrische Praxis, v. 11, p. 6-13, 1984; MÖLLER, H. Efficacy of different strategies of after-care for patients who have attempted suicide. Journal of the Royal Society of Medicine, v. 82, p. 643-647, 1989; BRONISCH, T.; HECHT, H. Prospective long-term follow-up of depressed patients with and without suicide attempts. European Archives of Psychiatry and Clinical Neuroscience, v. 242, n. 1, p. 13-19, sep. 1992. 175 MOTTO, J.; BOSTROM, A.; Randomized controlled trial of postcrisis suicide prevention. Psychiatric Services, v. 52, n. 6, p. 828-833, june 2001.

176 KAHNEMAN, D. Thinking, fast and slow. London: Allen Lane, 2011. p. 19-97.

177 HEMMER, A.; MEIER, P.; REISCH, T. Comparing different suicide prevention measures at bridges and buildings: lessons 
4. Sabe-se que o suicida, ao usar meios com alta letalidade, como a ingestão de medicamentos ou pesticidas ou a queima de carvão, quer melhorar sua condição; não quer piorá-la ou passar por grande sofrimento. Esses meios costumam ter em suas embalagens alertas destacados de perigo de morte. Em razão do exposto, acreditamos que destaque para o perigo de morte deveria ser substituído por alertas voltados aos efeitos indesejados. Por exemplo, em vez de anunciar que um produto pode causar morte, é preferível que sejam anunciados males como dores muito fortes, incapacidade motora ou danos cognitivos permanentes.

\section{REFERÊNCIAS}

ADINKRAH, M. Anti-suicide laws in nine african countries: criminalization, prosecution and penalization. African Journal of Criminology and Justice Studies, v. 9, n. 1, p. 279-292, may 2016.

ADINKRAH, M. Criminal prosecution of suicide attempt survivors in Ghana. International Journal of Offender Therapy and Comparative Criminology, v. 57, n. 12, p. 1477-1497, 2012.

ADORNO, R. Nonphysician-assisted suicide in Switzerland. Cambridge Quarterly of Healthcare Ethics, v. 22, n. 3, p. 246-253, july 2013.

AHMAD, R. et al. Acute poisoning due to commercial pesticides in Multan. Pakistan Journal of Medical Sciences, v. 18, n. 3, p. 227-231, july/sep. 2002.

AHN, M. et al. Gender ratio comparisons of the suicide rates and methods in Korea, Japan, Australia, and the United States. Journal of Affective Disorders, v. 142, n. 1-3, p. 161-165, dec. 2012.

AJDACIC-GROSS, V. et al. Firearm suicides and availability of firearms: the swiss experience. European Psychiatry, v. 25, p. 432-434, 2010.

ANDERSON, E. What is the point of equality? Ethics, v. 109, n. 2, p. 287-337, 1999.

ANESTIS, M.; ANESTIS, J. Suicide rates and state laws regulating access and exposure to handguns. American Journal of Public Health, v. 105, n. 10, p. 2049-2058, oct. 2015.

ARAMESH, K.; SHADI, H. Euthanasia: an islamic ethical perspective. Iranian Journal of Allergy, Asthma and Immunology, v. 6, n. 5, p. 35-38, feb. 2007.

ASSOCIAÇÃO BRASILEIRA DE PSIQUIATRIA. Manual para a imprensa: boas práticas de comunicação e guia com recomendações para um texto claro e esclarecedor sobre doenças mentais e psiquiatria. 2. ed. Rio de Janeiro: ABO, 2009.

AVANCI, R. et al. Perfil do adolescente que tenta suicídio em uma unidade de emergência. Revista Brasileira de Enfermagem, v. 58, n. 5, p. 535-539, set./out. 2005.

BALDWIN, R. From regulation to behaviour change: giving nudge the third degree. Modern Law Review, v. 77, n. 6, p. 831-857, 2014.

BANERJEE, G. et al. The vulnerability of indian women to suicide a field-study. Indian J. Psychiatry, v. 32, n. 4, p. 305-308, oct. 1990.

BARBER, C.; MILLER, M. Reducing a suicidal person's access to lethal means of suicide: a research agenda. American Journal of Preventive Medicine, v. 47, n. 352, p. 264-272, 2014.

BARBUSCIA, D.; RODRIGUES-JÚNIOR, A. Completude da informação nas Declarações de Nascido Vivo e nas Declarações de Óbito, neonatal precoce e fetal, da região de Ribeirão Preto, São Paulo, Brasil, 2000-2007. Cadernos de Saúde Pública, Rio de Janeiro, v. 27, n. 6, p. 1192-1200, jun. 2011.

we have learned from a national survey in Switzerland. Plos One, v. 12, n. 1 jan. 2017. 
BENARTZI, S. et al. Should governments invest more in nudging? Psychological Science, Thousand Oaks, june 2017. Disponível em: <http://journals.sagepub.com/doi/full/10.1177/0956797617702501>. Acesso em: 13 mar. 2018.

BENNEWITH, O.; NOWERS, M.; GUNNEL D. Effect of barriers on the Clifton suspension bridge. The British Journal of Psychiatry, v. 190, p. 266-267, mar. 2007.

BERLIN, I. Two concepts of liberty. In: BERLIN, I. Four essays on liberty. Oxford: Oxford University Press, 1969.

BETZ, M. et al. Lethal means access and assessment among suicidal emergency department patients. Depression and Anxiety, v. 33, n. 6, p. 502-511, june 2016.

BOVENS, L. The ethics of nudge. In: GRÜNE-YANOFF, T.; HANSON, S. Preference change: approaches from philosophy, economics and psychology. Berlin: Springer, 2009. Cap. 10.

BRÅDVIK, L.; BERGLUND, M. A suicide peak after weekends and holidays in patients with alcohol dependence. Suicide and Life-Threatening, v. 33, n. 2, p. 186-191, summer 2003.

BRASIL. Ministério do Planeamento, Orçamento e Gestão. Instituto Brasileiro de Geografia e Estatística. Censo demográfico 2010: características gerais da população, religião e pessoas com deficiência. Rio de Janeiro: IBGE, 2012.

BRASIL. Ministério do Planeamento, Orçamento e Gestão. Instituto Brasileiro de Geografia e Estatística. Censo demográfico 2010: características gerais da população e dos domicílios: resultado do universo. Rio de Janeiro: IBGE, 2011.

BRASIL. Ministério do Planeamento, Orçamento e Gestão. Instituto Brasileiro de Geografia e Estatística. Censo demográfico 2000: características gerais da população e dos domićlios: resultado da amostra. Rio de Janeiro: IBGE, 2003.

BRASIL. Ministério do Planeamento, Orçamento e Gestão. Instituto Brasileiro de Geografia e Estatística. Nota metodológica: projeção da população do Brasil por sexo e idade para o período 2000/2060; projeção da população das Unidades da Federação por sexo e idade para o período 2000/2030. Rio de Janeiro: IBGE, 2015.

BRASIL. Ministério do Planeamento, Orçamento e Gestão. Instituto Brasileiro de Geografia e Estatística. Projeção da população: Brasil e Unidades da Federação. Rio de Janeiro: IBGE, 2013.

BRASIL. Ministério do Planeamento, Orçamento e Gestão. Instituto Brasileiro de Geografia e Estatística. Diretoria de Pesquisas. Coordenação de População e Indicadores Sociais. Nota técnica: estimativas da população dos municípios brasileiros com data de referência em 1º de julho de 2014. Rio de Janeiro: IBGE: 2015.

BREUER, H.; BREUER, J.; FISCHBACH-BREUER, B. Social, toxicological and meteorological data on suicide attempts. European archives of Psychiatry and Clinical Neuroscience, v. 235, p. 367-370, 1986.

BRONISCH, T.; HECHT, H. Prospective long-term follow-up of depressed patients with and without suicide attempts. European Archives of Psychiatry and Clinical Neuroscience, v. 242, n. 1, p. 13-19, sep. 1992.

BRUCE-BRIGGS, B. The great american gun war. The Public Interest, n. 45, p. 37-62, 1976.

BULLUSU, L.; ALDERSON, M. Suicides 1950-82. Population Trends, v. 35, p 11-17, spring 1984.

CALO, R. Code, nudge, or notice? Iowa Law Review, v. 99, n. 2, p. 773-802. 2014.

CAMPOS, F. Síntese da reorganização Nacional (entrevista concedida à imprensa, em abril de 1939). In: CAMPOS, F. O Estado Nacional: sua estrutura, seu conteúdo ideológico. Brasília: Senado Federal, 2001. p. 107-136. 
ÇETIN, G.; GÜNAY, Y.; FINCANCI, S. et al. Suicides by jumping from Bosphorus Bridge in Istanbul. Forensic Science International, v. 116, n. 2-3, p. 157-162, feb. 2001.

CHACHAMOVICH, E. et al. Quais são os recentes achados clínicos sobre a associação entre depressão e suicídio?. Revista Brasileira de Psiquiatria, v. 31, Supl. 1, p. 518-525.

CHEN, Y.; PARK, N.; LU, T. Suicide methods used by women in Korea, Sweden, Taiwan and the United States. Journal of the Formosan Medical Association, v. 108, n. 6, p. 452-459, june 2009.

CHEN, Y.; YIP, P. Prevention of suicide by jumping: experiences from Taipei City (Taiwan), Hong Kong and Singapore. In: WASSERMAN, D.; WASSERMAN, C. Oxford textbook of suicidology and suicide prevention. Oxford: Oxford University Press, 2009. p. 569-572.

CHUNG, Y. et al. The effectiveness of platform screen doors for the prevention of subway suicides in South Korea. Journal of Affective Disorders, v. 194, p. 80-83, apr. 2016.

CLARKE, S. A definition of paternalism. Critical Review of International Social and Political Philosophy, v. 5, n. 1, p. 81-91, 2002.

CONLY, S. Against autonomy: justifying coercive paternalism. Cambridge: Cambridge University Press, 2013.

CONNER, K.; ZHONG, Y. State firearm laws and rates of suicide in men and women. American Journal of Preventive Medicine, v. 25, n. 4, p. 320-324, 2003.

DAHLBERG, L.; IKEDA, R.; KRESNOW, M. Guns in the home and risk of a violent death in the home: findings from a national study. American Journal of Epidemiology, v. 160, n. 10, p. 929-936, nov. 2004.

DAMAS, F. et al. Tentativas de suicídio com agentes tóxicos: análise estatística dos dados do CIT/SC (1994 a 2006). Revista Brasileira de Toxicologia, v. 22, n. 1-2, p. 21-26, 2009.

DIAS, D.; NONATO, D.; RAIOL, R. Interação entre a acessibilidade urbanística e o direito à cidade: possibilidade de inclusão social das pessoas com deficiência. Revista Brasileira de Políticas Públicas, v. 7, n. 2, p. 149-168, ago. 2017.

DOGANAY, Z. et al. Climatic and diurnal variation in suicide attempts in the ED. American Journal of Emergency Medicine, v. 21, n. 4, p. 271-275, july 2003.

DWORKIN, G. Defining paternalism. In: COONS, C.; WEBER, M. Paternalism: theory and practice. Cambridge: Cambridge University Press, 2013.

DWORKIN, G. Moral paternalism. Law and Philosophy, v. 24, n. 3, p. 305-319, 2005.

DWORKIN, G. Paternalism: some second thoughts. In: SARTORIUS, R. Paternalism. Minneapolis: University of Minnesota Press, 1983.

ELNOUR, A.; HARRISON, J. Lethality of suicide methods. Injury Prevention, v. 14, p. 39-45, 2008.

FAÇANHA, M. et al. Busca ativa de óbitos em cemitérios da Região Metropolitana de Fortaleza, 1999 a 2000. Epidemiologia e Serviços de Saúde, v. 12, n. 3, p. 131-136.

FEINBERG, J. Harm to self: the moral limits to the criminal law. Oxford: Oxford University Press, 1986. v. 3.

FERGUSON, P. Moving from preparation to perpetration? Attempted crimes and breach of the peace in scots law. Ohio State Journal of Criminal Law, v. 11, n. 2, p. 687-700, 2014.

FERREIRA, F.; POTTUMATI, E. A licitação pública como instrumento de desenvolvimento na perspectiva do paternalismo. Revista Brasileira de Políticas Públicas, v. 4, n. 1, p. 201-213, jan./jun. 2014.

FERREIRA, M.; FIGUEIREDO, M. Epidemiologia das intoxicações humanas por raticidas no Brasil. Revista Eletrônica Gestão \& Saúde, v. 4, n. 3, p. 861-870, 2013. 
FREDERICK, S.; LOEWENSTEIN, G.; O'DONOGHUE, T. Time discounting and time preference: a critical review. Journal of Economic Literature, v. 150, n. 2, p. 351-401, 2002.

FREITAS, E. O suicídio em Portugal no Século XX: elementos empíricos para uma pesquisa. Finisterra, Lisboa, v. 18, n. 34, p. 267-300, 1982.

GERT, B.; CULVER, C. The justification of paternalism. Ethics, v. 89, n. 2, p. 199-210, jan. 1979.

GLAT'T, K. Helpline: suicide prevention at a suicide site. Suicide Life-Threatening Behavior, v. 17, n. 4, p. 299309, winter 1987.

GRÜNE-YANOFF, T.; HERTWIG, R. Nudge versus boost: how coherent are policy and theory? Minds and Machines, v. 26, n. 1, p. 149-183, 2016.

GUNNEL, D. et al. The epidemiology and prevention of suicide by hanging: a systematic review. International Journal of Epidemiology, v. 34, p. 433-442, 2005.

GUNNEL, D. et al. The impact of pesticide regulations on suicide in Sri Lanka. International Journal of Epidemiology, v. 36, p. 1235-1242, 2007.

GUNNEL, D.; NOWERS, M. Suicide by jumping. Acta Psychiatrica Scandinavica, v. 96, p. 1-6, 1997.

HABENSTEIN, A. et al. Chances and limits of method restriction: a detailed analysis of suicide methods in Switzerland. Archives of Suicide Research, v. 17, n. 1, p. 75-87, 2013.

HANNIKAINEN, I. et al. A deterministic worldview promotes approval of state paternalism. Journal of Experimental Social Psychology, v. 70, p. 251-259, may 2017.

HANSEN, P. The definition of nudge and libertarian paternalism: does the hand fit the glove? The European Journal of Risk Regulation, v. 7, n. 1, p. 155-174, mar. 2016.

HASSAN, R. Temporal variation in suicide occurrence in Australia: a research note. The Australian \& New Zealand Journal of Statistics, v. 30, n. 2, p. 194-202, aug. 1994.

HECKMANN, I. C. et al. Análise do preenchimento de declarações de óbitos em localidade do Estado do Rio Grande do Sul (Brasil). Revista de Saúde Pública, S. Paulo, v. 23, n. 4, p. 292-297, 1989.

HEMMER, A.; MEIER, P.; REISCH, T. Comparing different suicide prevention measures at bridges and buildings: lessons we have learned from a national survey in Switzerland. Plos One, v. 12, n. 1, jan. 2017.

HERNETKOSKI, M.; KESKINEN, E.; PAKKARI, I. Driver suicides in Finland: are they different in northern and Southern Finland? International Journal of Circumpolar Health, v. 68, n. 3, p. 249-260, 2009.

HESKETH, J.; CASTRO, A. Fatores correlacionados com a tentativa de suicídio. Revista de Saúde Pública, v. 12, p. 138-146, 1978.

HOEK, W. et al. Pesticide poisoning: a major health problem in Sri Lanka. Social Science \& Medicine, v. 46, n. 4-5, p. 495-504, feb. 1998.

HURST, S.; MAURON, A. Assisted suicide in Switzerland: clarifying liberties and claims. Bioetbics, v. 31, n. 3, p. 199-208, mar. 2017.

JESSEN, G.; JENSEN, B. Postponed suicide death? Suicides around birthdays and major public holidays. Suicide and Life-Threatening Behavior, v. 29, n. 3, p. 272-283, fall 1999.

JOHN, P.; SMITH, G.; STOKER, G. Nudge nudge, think think: two strategies for changing civic behaviour. Political Quarterly, v. 80, n. 3, p. 361-370, july 2009.

JOLLS, C.; SUNSTEIN, C.; THALER, R. A behavioral approach to law and economics. Stanford Law Review, v. 50, p. 1471-1550, 1998. 
JOO, S. et al. Factors associated with suicide completion: a comparison between suicide attempters and completers. Asia-Pacific Psychiatry, v. 8, n. 1, p. 80-86, mar. 2016.

KAHNEMAN, D. Thinking, fast and slow. London: Allen Lane, 2011.

KAHNEMAN, D.; SLOVIC, P.; TVERSKY, A. Judgement under uncertainty: heuristics and biases. Cambridge: Cambridge University Press, 1982.

KALEDIENE, R.; PETRAUSKIENE, J. Inequalities in daily variations of deaths from suicide in Lithuania: identification of possible risk factors. Suicide and Life-Threatening Behavior, v. 34, n. 2, p. 138-146, summer 2004.

KELEDIENE, R.; STARKUVIENE, S.; PETRAUSKIENE, J. Seasonal patterns of suicide over the period of socio-economic transition in Lithuania. BMC Public Health, v. 6, 40, feb. 2006. Disponível em: < http:// www.ncbi.nlm.nih.gov/pmc/articles/PMC1397811>. Acesso em: 14 mar. 2018.

KELLERMAN, A. et al. Suicide in the home in relation to gun ownership. The New England Journal of Medicine, v. 327, n. 7, p. 467-472, aug. 1992.

KHAN, M. et al. Epidemiology of suicide in Pakistan: determining rates in six cities. Archives of Suicide Research, v. 12, n. 2, p. 155-160, 2008.

KHAN, M. et al. Suicides in the developing world: case study from Pakistan. Suicide and Life-Threatening Behavior, v. 36, n. 1, feb. 2006.

KIM, C. et al. Seasonal differences in psychopathology of male suicide completers. Comprehensive Psychiatry, v. 45, n. 5, p. 333-339, sep./oct. 2004.

KLECK, G.; GERTZ, M. Armed resistance to crime: the prevalence and nature of self-defense with a gun. Journal of Criminal Law and Criminology, v. 86, n. 1, p. 150-187, fall 1995.

KLEINIG, J. Paternalism. Manchester: Manchester University Press, 1983.

KOVATS, R.; EBI, K. Heatwaves and public health in Europe. European Journal of Public Health, v. 16, n. 6, p. 592-599, 2006.

KREITMAN, N. Parasuicide. Londres: Wiley, 1977.

KURZ, A.; MÖLLER, H.; BUERK, F. et al. The psychiatric management of parasuicide patients. Psychiatrische Praxis, v. 11, p. 6-13, 1984.

LAURENTI, R.; JORGE, M. H. P. M.; GOTLIEB, S. Informação em mortalidade: o uso das regras internacionais para a seleção da causa básica. Revista Brasileira de Epidemiologia, v. 12, n. 2, p. 195-203, 2009.

LAW, C. et al. Evaluating the effectiveness of barrier installation for preventing railway suicides in Hong Kong. Journal of Affective Disorders, v. 114, n. 1-3, p. 254-262, apr. 2009.

LE GRAND, J.; NEW, B. Government paternalism: nanny State or helpful friend? Princeton: Princeton University Press, 2015.

LEENAARS, A.; LESTER, D. Comparison of rates and patterns of suicide in Canada and the United States, 1960-1988. Death Studies, v. 16, n. 5, p. 417-430, 1992.

LESTER, D. Decriminalization of suicide in New Zealand and suicide rates. Psychological Reports, v. 72, n. 3, p. 1050, june 1993.

LESTER, D. Suicide in emigrants from the Indian subcontinent. Transcultural psycbiatry, v. 37, n. 2, p. 243$254,2000$.

LIN, J.; LU, T. Suicide mortality trends by sex, age and method in Taiwan, 1971-2005. BMC Public He- 
alth [online], v. 8, n. 6, jan. 2008. Disponível em: <https://bmcpublichealth.biomedcentral.com/articles/10.1186/1471-2458-8-6>. Acesso em: 13 mar. 2018.

LOFTIN, C. et al. Effects of restrictive licensing of handguns on homicide and suicide in the District of Columbia. The New England Journal of Medicine, v. 325, n. 23, p. 1615-1620, dec. 1991.

LOPES, P.; BARREIRA, D.; PIRES, A. Tentativa de suicídio na adolescência: avaliação do efeito de gênero na depressão e personalidade. Psicologia, Saúde \& Doenças, v. 2, n. 1, p. 47-57, 2001.

LOVISI, G. et al. Prevalência de transtornos mentais nas tentativas de suicídio em um hospital de emergência no Rio de Janeiro. Cadernos de Saúde Pública, Rio de Janeiro, v. 25, n. 9, p. 2064-2074, set. 2009.

LY, K. et al. A practitioner's guide to nudging. Research Report Series Behavioural Economics in Action, Rotman School of Management, University of Toronto, Toronto, p. 1-28, mar. 2013.

MAES, M. et al. Seasonal variation in Plasma L-Tryptophan availability in healthy volunteers' relationship to violent suicide occurrence. Archives of General Psychiatry, v. 52, p. 937-946, nov. 1995.

MAES, M. et al. Synchronized annual rhythms in violent suicide rate, ambient temperature and the lightdark span. Acta Psychiatrica Scandinavica, v. 90, p. 391-396, 1994.

MARTINS, B. et al. Intoxicação por raticida em um Centro de Assistência Toxicológica. Revista da Rede de Enfermagem do Nordeste, v. 17, n. 1, p. 3-9, jan./fev. 2016.

MARUŠIČ, A. Suicide in Slovenia: lessons for cross-cultural psychiatry. International Review of Psychiatry, v. 11, p. 212-218, 1999.

MASSING, W.; ANGERMEYER, M. The monthly and weekly distribution of suicide. Social Science \& Medicine, v. 21, n. 4, p. 433-441, 1985.

MATSUBAYASHI, T.; SAWADA, Y.; UEDA, M. Does the installation of the blue lights on train platforms prevent suicide? A before-and-after observational study from Japan. Journal of Affective Disorders, v. 147, p. 385-388, 2013.

JORGE, M. H. P. M. Situação atual das estatísticas oficiais relativas à mortalidade por causas externas. Revista de Saúde Pública, São Paulo, v. 24, n. 3, p. 217-223, 1990.

MENDELSON, D.; FRECKELTON, I. The interface of the civil and criminal law of suicide at common law (1194-1845). International Journal of Law and Psychiatry, v. 36, n. 5-6, p. 343-349, 2013.

MILL, J. S. Essays on some unsettled questions of political economy. Kitchner: Batoche Books, 2000.

MILL, J. S. On liberty. London: Floating Express, 2009.

MILLER, M. et al. The association between changes in household firearm ownership and rates of suicide in the United States, 1981-2002. Injury Prevention, v. 12, n. 3, p. 178-182, june 2006.

MINAYO, M. C.; CAVALCANTE, F. G. Suicídio entre pessoas idosas: revisão da literatura. Revista de Saúde Pública, v. 44, n. 4, p. 750-757, 2010.

MISHARA, B.; WESSTUB, D. The legal status of suicide: a global review. International Journal of Law and Psycbiatry, v. 44, p. 54-74, jan./ feb., 2016.

MITCHELL, G. Libertarian paternalism is an Oxymoron. Northwestern University Law Review, v. 9, n. 3, p. 1245-1277, 2005.

MÖLLER, H. Efficacy of different strategies of after-care for patients who have attempted suicide. Journal of the Royal Society of Medicine, v. 82, p. 643-647, 1989.

MOTTO, J.; BOSTROM, A. Randomized controlled trial of postcrisis suicide prevention. Psycbiatric Services, 
v. 52, n. 6, p. 828-833, june 2001.

NAKAMURA, J. et al. Temporal variation in adolescent suicide attempts. Suicide and Life-Threatening Behavior, v. 24, n. 4, p. 343-349, 1994.

NEELEMAN, J. Suicide as a crime in the UK: legal history, international comparisons and present implications. Acta Psychiatrica Scandinavica, v. 94, n. 4, p. 252-257.

NISHI, M. et al. Relationship between suicide and holidays. Journal of Epidemiology, v. 10, n. 5, p. 317-320, sep. 2000.

ORGANIZAÇÃO MUNDIAL DE SAÚDE. World Health Statistics 2014. Itália: WHO Graphics, 2014.

ORGANIZAÇÃO MUNDIAL DE SAÚDE. World Health Statistics 2015. Luxemburgo: WHO Graphics, 2015.

OSAFO, J. et al. "We now have a patient and not a criminal": an exploratory study of judges and lawyers' views on suicide attempters and the law in Ghana. International Journal of Offender Therapy and Comparative Criminology [online], p. 1-21, jan. 2017. Disponível em: <http://journals.sagepub.com/doi/ abs/10.1177/0306624X17692059>. Acesso em: 13 mar. 2018.

OSMAN, M.; PARNELL, A.; HALEY, C. "Suicide shall cease to be a crime": suicide and undetermined death trends 1970-2000 before and after the decriminalization of suicide in Ireland 1993. Irish Journal of Medical Science, v. 186, n. 1, p. 201-205, feb. 2017.

OWENS, C. et al. Suicide in public places: findings from one English county. European Journal of Public Health, v. 19, n. 6, p. 580-582, apr. 2009.

PAGE, L.; HAJAT, S.; KOVATS, S. Relationship between daily suicide counts and temperature in England and Wales. British Journal of Psychiatry, v. 191, p. 106-112, aug. 2007.

PATEL, V. et al. Suicide mortality in India: a nationally representative survey. The Lancet, v. 379, p. 23432351, 2012.

PHILLIPS, D.; SANZONE, A. A comparison of injury date and death date in 42,698 suicides. American Journal of Public Health, v. 78, n. 5, p. 541-543, may 1988.

PHILLIPS, M.; LIU, H.; ZHANG, Y. Suicide and social change in China. Culture, Medicine and Psychiatry, v. 23, p. 25-50, 1999.

PIRES, M. C. Indicadores de risco para tentativa de suicídio por envenenamento: um estudo de caso-controle. 2014. 145 f. Tese (Doutorado) - Programa de Pós-Graduação em Neuropsiquiatria e Ciências do Comportamento, Universidade Federal de Pernambuco, Recife, 2014.

PIRKIS, J.; SPITTAL, M. The effectiveness of structural interventions at suicide hotspots: a meta-analysis. International Journal of Epidemiology, v. 42, p. 531-548, 2013.

POPE, T. M. Counting the Dragon's Teeth and Claws: the definition of hard paternalism. Georgia State University Law Review, v. 20, n. 3, p. 659-722, 2004.

PRITCHARD, C.; HEAN, S. Suicide undetermined deaths among youths and young adults in Latin America: comparison with the 10 major developed countries: a source of hidden suicides? Crisis, v. 29, n. 2, p. 145-153, 2008.

RADHAKRISHNAN, R.; ANDRADE, C. Suicide: an indian perspective. Indian Journal of Psychiatry, [online], v. 54,p.304-319,2012.Disponível em:<http://www.indianjpsychiatry.org/text.asp?2012/54/4/304/104793>. Acesso em: 13 mar. 2018.

RAJENDRA, R. et al. A feasibility study to establish a deliberate self-harm register in a state hospital in Sou- 
thern India. British Journal of Medical Practioners [online], v. 8, n. 1, mar. 2015. Disponível em: <http://www. bjmp.org/content/ feasibility-study-establish-deliberate-self-harm-register-state-hospital-southern-india $>$. Acesso em: 10 mar. 2018.

RATNAYEKE, L. Suicide and crisis intervention in rural communities in Sri Lanka: a column from befrienders international. Crisis, v. 17, n. 4, p. 149-151, 1996.

REBONATO, R. Taking liberties: a critical examination of libertarian paternalism. Houndmills: Palgrave Macmillan, 2012.

REISCH, T. et al. Change in suicides rates in Switzerland before and after firearm restriction resulting from the 2003 "Army XXI" reform. The American Journal of Psychiatry, v. 170, n. 9, p. 977-984, sep. 2013.

REISCH, T.; MICHEL, K. Securing a suicide hot spot: effects of a safety net at the Bern Muenster Terrace. Suicide and Life-Threatening Behavior, v. 35, n. 4, p. 460-467, aug. 2005.

ROBERTS, D. et al. Influence of pesticide regulation on acute poisoning deaths in Sri Lanka. Bulletin of the World Health Organization, v. 81, n. 11, p. 789-798, 2003.

ROSENGART, M. et al. An evaluation of state firearm regulations and homicide and suicide death rates. Injury Prevention, v. 11, n. 2, p. 77-83, apr. 2005.

RUNESON, B. et al. Method of attempted suicide as predictor of subsequent successful suicide: national long term cohort study. BMJ [online], v. 341, 2010. Disponível em: <https://www.ncbi.nlm.nih.gov/pmc/ articles/PMC2903664>. Acesso em: 14 mar. 2018.

SÁ, N. B. et al. Atendimentos de emergência por tentativas de suicídio. Revista Médica de Minas, v. 20, n. 2, p. 145-152, 2010.

SAMSON, A. The behavioral economics guide 2016. (with introduction by Gerd Gigerenzer). Londres: Behavioral Science Solutions, 2016.

SANTOS, S. et al. Prevalência de transtornos mentais nas tentativas de suicídio em um hospital de emergência no Rio de Janeiro, Brasil. Cadernos de Saúde Pública, Rio de Janeiro, v. 25, n. 9, p. 2064-2074, set. 2009.

SAREEN, H.; TRIVEDI, J. Legal implications of suicide problems specific to South Asia. Delbi Psychiatry Journal, v. 12, n. 1, p. 121-125, apr. 2009.

SCHNITMAN, A. Análise da fidedignidade da declaração da causa básica de morte por câncer em Salvador, Brasil. Revista de Saúde Pública, São Paulo, v. 24, n. 6, p. 490-496, 1990.

SHENASSA, E.; CATLIN, S.; BUKA, S. Lethality of firearms relative to other suicide methods: a population based study. Journal of Epidemiology and Community Health, v. 57, n. 2, p. 120-124, feb. 2003.

SHIFFRIN, S. V. Paternalism, unconscionability doctrine, and accommodation. Philosophy and Public Affairs, v. 29, n. 3, p. 205-250, 2000.

SILVA, J. A. et al. Declaração de óbito, compromisso no preenchimento: avaliação em Belém - Pará, em 2010. Revista da Associação Médica Brasileira, v. 59, n. 4, p. 335-340, 2013.

SIMÕES, E.; REICHNHEIM, M. Confiabilidade das informações da causa básica nas declarações de óbito por causas externas em menores de 18 anos no Município de Duque de Caxias - RJ. Cadernos de Saúde Pública, Rio de Janeiro, v. 17, n. 3, p. 521-531, 2001.

SIMON, H. A behavioral model of rational choice. Quarterly Journal of Economics, v. 69, n. 1, p. 99-118, feb. 1955.

SINYOR, M.; LEVITT, A. Effect of a barrier at Bloor Street Viaduct on suicide rates in Toronto: natural experiment. BMJ, v. 341, july 2010. 
SINYOR, M. et al. Did the suicide barrier work after all? Revisiting the Bloor Viaduct natural experiment and its impact on suicide rates in Toronto. BMJ Open, v. 7, n. 5, june 2017.

SOUZA, E.; MINAYO, M. C.; CAVALCANTE, F. G. O impacto do suicídio sobre a morbimortalidade da população de Itabira. Ciência \& Saúde Coletiva, v. 11, n. Sup., p. 1333-1342, 2007.

STECK, N. et al. Euthanasia and assisted suicide in selected European countries and US States. Systematic literature review. Med Care, v. 51, n. 10, p. 938-944, oct. 2013.

STEIDLEY, T.; COLEN, C. Framing the gun control debate: press releases and framing strategies on the National Rifle Association and the Brady Campaign. Social Science Quarterly, v. 98, n. 2, p. 608-627, june 2017.

SUNSTEIN, C. Choosing not to choose: understanding the value of choice. New York: Oxford University Press, 2015.

SUNSTEIN, C. Nudging: a very short guide. Journal of Consumer Policy, v. 37, n. 4, p. 583-588, dec. 2014.

SUNSTEIN, C. Why nudge?: the politics of libertarian paternalism. New Haven: Yale University Press, 2014.

THALER, R.; SUNSTEIN, C. Libertarian paternalism. American Economic Review, v. 93, n. 2, p. 175-179, may 2003.

THALER, R.; SUNSTEIN, C. Nudge: Improving Decisions about Health, Wealth and Happiness. New Haven: Yale University Press, 2008.

TURRINI, R.; SANTO, A. Infecção hospitalar e causas múltiplas de morte. Jornal de Pediatria, v. 78, n. 6, p. 485-490, 2002.

TVERSKY, A.; KAHNEMAN, D. Advances in prospect theory: cumulative representation of uncertainty. Journal of Risk and Uncertainty, v 5, p. 297-323, 1992.

TVERSKY, A.; KAHNEMAN, D. Judgment under uncertainty: heuristics and biases. Science, v. 185, n. 4157, p. 1124-1131, sep. 1974.

UEDA, M.; SAWADA, Y.; MATSUBAYASHI, T. The effectiveness of installing physical barriers for preventing railway suicides and accidents: evidence from Japan. Journal of Affective Disorders, v. 178, p. 1-4, 2015.

UNITED STATES OF AMERICA. Department of Health and Human Services. Centers for Disease Control and Prevention. National Center for Health Statistics. National Vital Statistics Reports. Deaths: Leading Causes for 2013, v. 64, n. 2, feb. 2016.

VANDERLEI, L. et al. Avaliação da confiabilidade da causa básica de óbito em unidade terciária de atenção à Saúde materno-infantil. Informe Epidemiológico do SUS, v. 11, n. 1, p. 15-23, 2002.

VANDEVEER, D. Paternalistic intervention: the moral bounds of benevolence. Princeton: Princeton University Press, 1986.

VÄRNIK, A. et al. Suicide methods in Europe: a gender-specific analysis of countries participating in the "European Alliance Against Depression". Journal of Epidemiology and Community Health, v. 62, p. 545-551, 2008.

VÄRNIK, P. Suicide in the world. International Journal of Environmental Research and Public Health, v. 9, p. 760$771,2012$.

WERNECK, G. et al. Tentativas de suicídio em um hospital geral no Rio de Janeiro, Brasil. Cadernos de Saúde Pública, Rio de Janeiro, v. 22, n. 10, p. 2201-2206, out. 2006.

WHITMER, D.; WOODS, D. Analysis of the cost effectiveness of a suicide barrier on the Golden Gate Bridge. Crisis, v. 24, n. 2, p. 98-106, 2013. 
WINTEMUTE, G. et al. Mortality among recent purchasers of handguns. The New England Journal of Medicine, v. 341, n. 21, p. 1583-1589, 1999.

WITHERS, R. Status of suicide as a crime. The Virginia Law Register, v. 19, n. 9, p. 641-647, jan. 1914.

WU, K; CHEN, Y.; YIP, P. Suicide methods in Asia: implications in suicide prevention. International Journal of Environmental Research and Public Health, v. 9, p. 1135-1158, 2012.

YANG, L.; CHO, S.; SEO, H. Effects of light color on consumers: acceptability and willingness to eat apples and bell peppers. Journal of Sensory Studies, v. 31, n. 1, p. 3-11, nov. 2016.

YIP, P. et al. Means restriction for suicide prevention. Lancet, v. 23, n. 379, p. 2393-2399, june 2012.

YIP, P. et al. Restricting the means of suicide by charcoal burning. The British Journal of Psychiatry, v. 196, p. 241-242, 2010.

YIP, P.; LIU, K. The ecological fallacy and the gender ratio of suicide in China. British Journal of Psychiatry, v. 189, p. 465-466, 2006.

YOSHIOKA, E. et al. Time trends in method-specific suicide rates in Japan, 1990-2011. Epidemiology and Psychiatric Sciences, v. 25, n. 1, p. 58-68, feb. 2016.

ZIEGLER, S.; BOSSHARD, G. Role of non-governmental organisations in physician assisted suicide. BMJ, v. 334, p. 295-298, feb. 2007.

ZONDA, T. et al. The impact of holidays on suicide in Hungary. Omega, v. 58, n. 2, p. 153-162, 2008/2009. 


\title{
Nudges como política pública para aumentar o escasso número de doadores de órgãos para transplante*
}

\author{
Nudges as a public policy to increase \\ the scarce number of organ donors for \\ transplantation
}

\author{
Roberta Marina Cioatto** \\ Adriana de Alencar Gomes Pinheiro ${ }^{* * * * * *}$
}

* Recebido em 26/05/2018 Aprovado em 13/07/2018

** Mestre em Direito com ênfase em Direitos Sociais e Políticas Públicas de Inclusão Social pela Universidade de Santa Cruz do Sul (Unisc/ Brasil) e Mestre em Direito das Autarquias Locais pela Universidade do Minho (Uminho/ Portugal) - regime de dupla titulação. Bacharel em Direito e em Ciências Econômicas pela Universidade de Caxias do Sul (UCS/Brasil). Bolsista do XIII Curso de Introducción a la Ética de la Investigación en Seres Humanos Programa de Educación Permanente en Bioética de la Redbioética Unesco. Professora da Faculdade Paraíso do Ceará. E-mail: roberta. cioatto@fapce.edu.br.

*** Doutora e Mestre em Psicologia pela Universidade de Fortaleza (Unifor/Brasil). Membro da Associação Bras. de Ens. de Psicologia - ABEP e Associação Nacional de Pesquisa e Pós-Graduação em Psicologia - ANPEPP. Professora e Coordenadora do Curso de Psicologia da Faculdade Paraíso do Ceará. E-mail: adriana. alencae@fapce.edu.br

**** Este artigo é o terceiro de uma série de estudos que vêm sendo realizados no Núcleo de Estudos e Pesquisas em Subjetividades, Bioética e Políticas Públicas. Projeto: Bioética, Direito e Políticas Públicas. O primeiro, sobre a atualidade da retomada das discussões a respeito dos transplantes e, o segundo, contrastando números e políticas públicas adotadas pelos doze países com maior quantidade de transplantações, sugerindo a necessidade de estudos para elaboração de políticas públicas específicas de incremento nas doações para transplantes.

\section{Resumo}

Existe uma escassez de órgãos humanos para transplantes. O objetivo deste artigo é analisar a utilização de nudges como política pública para aumentar o escasso número de doadores. Primeiro, expõe-se a problemática em um contexto mundial e, mais especificamente, no Brasil. Em seguida, explana-se a noção de nudges relacionando-se sua definição com os sistemas de consentimento para doação. Por fim, conceituam-se políticas públicas. Trata-se de uma pesquisa bibliográfica, descritiva, e, de certo modo, aplicada. Quanto aos dados quantitativos, mesmo que a título de ilustração, a pesquisa foi limitada no acesso a informações disponíveis online sobre transplantes e, no que pertine à fundamentação teórica, à dificuldade de aquisição de literatura a respeito. Como resultado, sugere-se — dentre outras "cutucadas" - a implantação da doação presumida de órgãos como forma de incrementar o número de doadores. Como consequência, conclui-se que nudges podem ser utilizados como política pública para aumentar o número de doadores de órgãos para transplantes. Com o presente artigo pretende-se contribuir para a discussão sobre a implementação de políticas públicas para o aumento do número de doadores de órgãos para transplantação. Portanto, seu resultado tem implicações práticas, sociais e econômicas, uma vez que os transplantes salvam vidas além de reduzir o custo com saúde. Certamente, não se esgotou a matéria. Estudos semelhantes são exigidos à medida que a população envelhece e a pressão por ampliar a oferta intensifica-se. $\mathrm{O}$ artigo é original, e é o terceiro de uma série de estudos que vêm sendo realizados no grupo de pesquisa.

Palavras-chave: Nudges. Políticas públicas. Doadores de órgãos.

\section{Abstract}

There is a shortage of human organs for transplants. The purpose of this article is to analyze the use of nudges as a public policy to increase the scarce number of donors. First, the problem is exposed in a world context and, more specifically, in Brazil. Next, the notion of nudges is explained, re- 
lating its definition with the consent systems for donation. Finally, public policies are conceptualized. It is a bibliographical research, descriptive, and, in a way, applied. As for the quantitative data, even for illustration purposes, the research was limited in the access to information available on transplants online and, as far as the theoretical basis is concerned, the difficulty of acquiring literature about. As a result, it is suggested - among other nudges - the implantation of organs presumed donation in order to increase the number of donors. As a consequence, it can be concluded that nudges can be used as public policy to increase the number of organ donors for transplants. The present article intends to contribute to the discussion about the implementation of public policies for the increase in the number of donors of organs for transplantation. Therefore, its outcome has practical, social and economic implications, since transplants save lives and reduce health costs. Certainly, the matter has not been exhausted. Similar studies are required as the population ages and the pressure to expand supply intensifies. The article is original and is the third in a series of studies that have been conducted in the research group.

Keywords: Nudges. Public policies. Organ donors.

\section{INTRODUÇÃo}

Existe uma escassez de órgãos humanos para transplantes, porque os órgãos somente podem ser extraídos, de pessoa falecida, após o diagnóstico de morte encefálica, inobstante alguns países permitam a extração também diante do critério de morte cardiocirculatória.

Ocorre que as causas mais comuns de morte encefálica, a conhecida morte cerebral, são traumatismo cranioencefálico e acidente vascular encefálico - fatos que representam uma restrição para o processo de transplantação, uma vez que acontecem em uma pequena parcela das mortes. Em 2015, segundo dados do Registro Brasileiro de Transplantes coletados no IBGE, em relação a 1.264.175 mortes declaradas no país, 34.721 foram de causas neurológicas.

Outrossim, muitos familiares, diante dessa situação, não permitiram e não permitem a extração de órgãos do potencial doador. Como consequência, muitas são as vidas interrompidas pela escassez de órgãos para transplantação.

Tais ocorrências, somadas ao estilo de vida e ao aumento da expectativa de vida da população, fazem com que a demanda por doadores de órgãos seja cada vez maior. ${ }^{1}$ Essa insuficiência exige incessantes esforços para aumentar a oferta, sendo preciso o impulsionamento de políticas públicas a fim de atender ao maior número possível de enfermos, pois o transplante é a melhor — senão a única — solução para o paciente na quase totalidade dos casos.

E o transplante, também, é a melhor resposta para a sociedade em relação a gastos com saúde em comparação com as alternativas, representando uma economia com diálises e medicamentos, além do retorno do indivíduo ao mercado de trabalho.

Na primeira seção deste trabalho, expõe-se a problemática da escassez de órgãos humanos para transplantes em um contexto mundial e, mais especificamente, no Brasil. Em seguida, a noção de nudges é apresentada e relaciona-se sua definição com os sistemas de consentimento para doação de órgãos para transplantação. Por fim, conceituam-se políticas públicas.

Os dados quantitativos, mesmo que a título de ilustração, foram obtidos principalmente consultando-se as fontes conhecidas disponíveis online, dentre as quais o Registro Brasileiro de Transplantes da Associação Brasileira de Transplante de Órgãos.

1 A maioria dos novos casos de insuficiência renal é resultado de pressão alta ou diabetes; ter mais de 60 anos e ter histórico familiar de insuficiência também aumentam o risco de doença renal. 
No que pertine à fundamentação teórica, tomaram-se como referência Cass Sunstein e Richard Thaler, Nobel de Economia de 2017. Expoentes no assunto, esses autores exploram as consequências da racionalidade nos processos de tomada de decisão — a chamada economia comportamental.

Trata-se de uma pesquisa bibliográfica, descritiva, e, de certo modo, aplicada, pois pretende-se contribuir para a discussão sobre a implementação de políticas públicas para o aumento do número de doadores de órgãos para transplantação.

\section{UMA BREVE CONTEXTUALIZAÇÃO SOBRE DOAÇÕES DE ÓRGÃOS E TRANSPLANTES}

Os Estados Unidos da América são o principal país na realização de transplantes de órgãos humanos e, inobstante ostentem o primeiro lugar na lista de números absolutos de transplantes realizados, aproximadamente 120.000 pessoas permanecem em listas de espera no país. Destas, quase 8.000 não viverão para receber o órgão, uma média de 20 pessoas falecidas por dia no aguardo por um transplante. ${ }^{2}$ Sua taxa de doadores efetivos de órgãos por milhão de população é 31, $0,{ }^{3}$ superior ao dobro do índice do Brasil, mas mais de 10 pontos a menos que a Espanha, primeira colocada em doadores por milhão de população.

$\mathrm{Na}$ China, menos de 1\% da população que necessita de um transplante o recebe, em comparação com cerca de $20 \%$ nos Estados Unidos. ${ }^{4}$

Na França, em 2015, 571 pessoas escolheram doar enquanto vivos, 21.000 esperaram por um transplante e 553 morreram enquanto na lista de espera por um órgão. ${ }^{5}$

A Espanha, oitava colocada em números absolutos de transplantes, ostenta, há 26 anos, o recorde mundial de doadores de órgãos falecidos por milhão de habitantes: 43,4 em $2016^{6}$ e 46,9 em 20177. Seu sistema é referência mundial; mesmo assim, não existem órgãos para todos os que deles precisam.

Na Alemanha, menos de 800 pessoas foram doadoras em 2017, e cerca de 10 mil pessoas estão no aguardo de um órgão no país. Em média, 3 pacientes da lista de espera morrem todos os dias. ${ }^{8}$ Nesse mesmo ano, o número de doadores de órgãos atingiu a maior baixa de todos os tempos: 9,3 por milhão de população. ${ }^{9}$

2 OSSOLA, Alexandra. Crisis in America: medical experts use new tech tools to combat the organ transplant shortage. CNBC, 21 jun. 2017. Disponível em: < https://www.cnbc.com/2017/06/20/medical-experts-use-new-tech-tools-to-combat-organ-transplant-shortage.html>. Acesso em: 24 mar. 2018.

3 ASSOCIAÇÃO BRASILEIRA DE TRANSPLANTE DE ÓRGÃOS. Dimensionamento dos Transplantes no Brasil e em cada estado (2010-2017). Registro Brasileiro de Transplantes, São Paulo, ano 23, n. 4, jan./dez. 2017. Disponível em: <http://www.abto.org. $\mathrm{br} /$ abtov03 $/$ default.aspx?mn $=515 \& \mathrm{c}=900 \& \mathrm{~s}=0 \&$ friendly $=$ registro-brasileiro-de-transplantes-estatistica-de-transplantes $>$. Acesso em: 7 nov. 2017.

4 CHINA to cease prisoner organ transplants. DW, 04 dez. 2014. Disponível em: <http://www.dw.com/en/china-to-cease-prisoner-organ-transplants/a-18109346>. Acesso em: 10 fev. 2018; FAN, Jiayang. Can China stop organ trafficking? The New Yorker, 10 jan. 2014. Disponível em: <http://www.newyorker.com/news/news-desk/can-china-stop-organ-trafficking>. Acesso em: 1 maio 2017.

5 A PARTIR DU 1er janvier, tous les Français seront donneurs d'organes par défaut. Lexpress, 29 dec. 2016. Disponível em: < https:// www.lexpress.fr/actualite/societe/sante/a-partir-du-1er-janvier-tous-les-francais-seront-donneurs-d-organes-par-defaut_1864325. html?utm_campaign=Echobox\&utm_medium =Social\&utm_source $=$ Facebook\&link_time $=1483015812 \# x$ tor $=$ CS3-5076>. Acesso em: 7 maio 2018.

6 ESPANHA é campeã do mundo em doações de órgãos. Exame, 17 abr. 2017. Disponível em: <https://exame.abril.com.br/ ciencia/espanha-e-campea-do-mundo-em-doacoes-de-orgaos/>. Acesso em: 13 nov. 2017.

7 EL ÉXITO de los transplantes. El País, 12 ene. 2018. Disponível em: <https://elpais.com/elpais/2018/01/12/opinion/1515782432_390027.html?id_externo_rsoc=TW_CC\&utm_content $=$ buffer2c070\&utm_medium =social\&utm_ source $=$ facebook.com\&utm_campaign=buffer $>$. Acesso em: 10 fev. 2018.

8 WER NICHT widerspricht, wird Organspender. Süddeutsche Zeitung, Munique, 13 feb. 2018. Disponível em: < http://www.sueddeutsche.de/politik/niederlande-wer-nicht-widerspricht-wird-organspender-1.3866596>. Acesso em: 27 mar. 2018.

9 GERMAN patients turn to Croatia for organ donations. DW, 29 jan. 2018. Disponível em: < http://www.dw.com/en/germanpatients-turn-to-croatia-for-organ-donations/a-42357468>. Acesso em: 24 mar. 2018. 
No Brasil, o terceiro país que mais faz transplantes no mundo, a média de doadores efetivos por milhão de população, em 2016, foi 14,6 - a vigésima oitava posição. Em 2017, 32.402 pacientes permaneciam em listas de espera, 1.689 faleceram aguardando e 2.740 doações deixaram de ser concretizadas diante da recusa expressada pelos familiares do potencial doador. O país não superou os 16,6 doadores efetivos por milhão de população, mas ultrapassou, consideravelmente, os 9,9 em 2010. Santa Catarina e Paraná são os estados brasileiros que ultrapassaram os 30 doadores por milhão de população, com índices de 40,8 e 38,0, superando os Estados Unidos e aproximando-se das melhores taxas mundiais. Em 2017, segundo dados do Registro Brasileiro de Transplantes coletados no IBGE, em relação a 10.629 potenciais doadores brasileiros, somente 3.415 tornaram-se doadores efetivos. ${ }^{10}$

Isso quer dizer que a taxa de doadores efetivos por milhão de população saltaria de 16,6 para 51,6 se não houvesse recusas.

\section{NUDGES}

Em 2008, Cass Sunstein e Richard Thaler, vencedor do Nobel de Economia de 2017, publicaram um trabalho nominado Nudges. Para eles, aspectos "aparentemente insignificantes do ambiente em que as decisões são tomadas podem ter um impacto substancial no comportamento das pessoas" (tradução nossa). ${ }^{11}$

Em contextos que variam, nudges referem-se a maneiras de aplicar "toques" para resolver problemas sociais. ${ }^{12}$ Uma espécie de pequeno "empurrão" ou leve "cutucada" que incentiva ou altera determinada escolha individual. $\mathrm{O}$ uso de insights comportamentais como política pública.

Nudges são sutis mudanças de política que incentivam pessoas a tomarem decisões de interesse próprio e no melhor interesse de todos; orientam o comportamento dos indivíduos de uma maneira previsível, sem proibir quaisquer opções. Nudges significam "intervenções e políticas que dependem da ciência comportamental para orientar as pessoas em uma direção específica" (tradução nossa), ${ }^{13}$ sem desconsiderar sua liberdade de escolha.

Baseiam-se em insights da ciência comportamental e, quando usados eticamente, podem ser muito úteis. Assim, um nudge não pode ser empregado para convencer pessoas a tomar decisões das quais se arrependerão mais tarde — nesse caso, tratar-se-ia de phishing ou de um bad nudge. ${ }^{14}$

Os nudges compartilham características: não afetam os incentivos econômicos das pessoas; são centrados no ser humano; são voluntários, preservam a liberdade de escolha; são transparentes e não enganosos.

Três princípios devem orientar o uso de nudges, segundo Richard Thaler:

Todas as cutucadas devem ser transparentes e nunca enganosas. [...] Deve haver boas razões para

10 ASSOCIAÇÃO BRASILEIRA DE TRANSPLANTE DE ÓRGÃOS. Dimensionamento dos Transplantes no Brasil e em cada estado (2010-2017). Registro Brasileiro de Transplantes, São Paulo, ano 23, n. 4, jan./dez. 2017. Disponível em: <http://www.abto. org.br $/$ abtov03 $/$ default.aspx?mn $=515 \& \mathrm{c}=900 \& \mathrm{~s}=0 \&$ friendly $=$ registro-brasileiro-de-transplantes-estatistica-de-transplantes $>$. Acesso em: 7 nov. 2017.

11 TAMS, Carten. Small is beautiful: using gentle nudges to change organizations. Forbes, 22 feb. 2018. Disponível em: < https://www. forbes.com/sites/carstentams/2018/02/22/small-is-beautiful-using-gentle-nudges-to-change-organizations/\#6fc50c8e5a8d $>$. Acesso em: 5 maio 2018.

12 CHU, Ben. What is 'nudge theory' and why should we care? Explaining Richard Thaler's Nobel economics prize-winning concept. Independent, 9 oct. 2017. Disponível em: < https://www.independent.co.uk/news/business/analysis-and-features/nudge-theory-richard-thaler-meaning-explanation-what-is-it-nobel-economics-prize-winner-2017-a7990461.html>. Acesso em: 5 maio 2018. 13 THALER, Richard H. et al. Governments are trying to nudge us into better behaviour: is it working? The Washington Post, 11 aug. 2017. Disponível em: <https://www.washingtonpost.com/news/wonk/wp/2017/08/11/governments-are-trying-to-nudgeus-into-better-behavior-is-it-working/?noredirect=on\&utm_term $=.104 \mathrm{c} 8 \mathrm{ff} 2655 \mathrm{a}>$. Acesso em: 5 maio 2018.

14 Robert Shiller e George Akerlof, ambos economistas ganhadores do Nobel, que escreveram um livro sobre o assunto, Phishing for Phools. 
acreditar que o comportamento que está sendo encorajado melhorará o bem-estar daqueles que estão sendo cutucados. (Tradução nossa) $)^{15}$

Esse recurso não infringe as liberdades civis nem pode ser criticado como paternalista, uma vez que "a opção de não participação permanece sempre disponível para as pessoas". (tradução nossa). ${ }^{16}$

Barack Obama, quando presidente do país, "recrutou Cass Sunstein como consultor e exortou os departamentos do governo dos EUA a adotarem conceitos econômicos comportamentais. Em 2010, o governo do Reino Unido criou uma Equipe de Insights Comportamentais" para desenvolver políticas públicas. (Tradução nossa $)^{17}$.

Em diferentes áreas, os nudges têm um impacto financeiro muito mais representativo do que políticas tradicionais, como subsídios, impostos e educação. Observe-se o caso de vacinas — o tratamento médico preventivo, talvez, mais eficaz. Dados mostraram que, quando solicitados a planificar sobre quando receberiam a vacina contra a gripe, americanos aumentaram as taxas de vacinação em 4,2\%. O resultado apresentou-se cerca de 1,5 vez mais rentável que outras abordagens, como pagar a estudantes para vacinarem-se, ou campanhas educacionais sobre os benefícios da vacinação. ${ }^{18}$

No Reino Unido, para que quitassem seus impostos com pontualidade, "as pessoas recebiam uma carta dizendo que a maioria dos contribuintes pagava seus impostos a tempo, o que teve resultados muito positivos." (Tradução nossa) ${ }^{19}$.

Em 2012, com o intuito de aumentar as baixas taxas de poupança previdenciária entre os trabalhadores do setor privado, o mesmo Reino Unido determinou que os empregadores estabelecessem uma espécie de inscrição automática: os funcionários estariam automaticamente inscritos e as contribuições seriam deduzidas de sua remuneração, a menos que, formalmente, solicitassem a isenção. "A teoria era que muitas pessoas realmente queriam reservar mais dinheiro para a aposentadoria, mas teriam sido impedidas de fazê-lo pela necessidade de tomar o que elas temiam ser decisões complicadas." Assim, tal forma de inscrição facilitaria "o que eles realmente queriam fazer", aumentando as taxas de poupança. Como resultado, a participação ativa em esquemas de pensão do setor privado saltou de 2,7 milhões em 2012 para 7,7 milhões em 2016. (Tradução nossa) $)^{20}$.

No Brasil, o art. $4^{\circ}$ da Lei Federal no $13.183 / 2015$, que acresce parágrafos ao artigo $1^{\circ}$ da Lei $n^{\circ}$ 12.618/2012, também criou a adesão automática do servidor público federal titular de cargo efetivo a fundos de previdência complementar:

$\S 2^{\circ}$ Os servidores e os membros referidos no caput deste artigo com remuneração superior ao limite máximo estabelecido para os benefícios do Regime Geral de Previdência Social, que venham a ingressar no serviço público a partir do início da vigência do regime de previdência complementar de que trata esta Lei, serão automaticamente inscritos no respectivo plano de previdência complementar desde a data

15 THALER, Richard H. The power of nudges, for good and bad. The New York Times, 31 oct. 2015. Disponível em: < https:// www.nytimes.com/2015/11/01/upshot/the-power-of-nudges-for-good-and-bad.html>. Acesso em: 5 maio 2018.

$16 \mathrm{CHU}, \mathrm{Ben}$. What is 'nudge theory' and why should we care? Explaining Richard Thaler's Nobel economics prize-winning concept. Independent, 9 oct. 2017. Disponível em: <https://www.independent.co.uk/news/business/analysis-and-features/nudge-theory-richard-thaler-meaning-explanation-what-is-it-nobel-economics-prize-winner-2017-a7990461.html>. Acesso em: 5 maio 2018. $17 \mathrm{CHU}$, Ben. What is 'nudge theory' and why should we care? Explaining Richard Thaler's Nobel economics prize-winning concept. Independent, 9 oct. 2017. Disponível em: <https://www.independent.co.uk/news/business/analysis-and-features/nudge-theory-richard-thaler-meaning-explanation-what-is-it-nobel-economics-prize-winner-2017-a7990461.html>. Acesso em: 5 maio 2018. 18 THALER, Richard H. et al. Governments are trying to nudge us into better behaviour: is it working? The Washington Post, 11 aug. 2017. Disponível em: <https://www.washingtonpost.com/news/wonk/wp/2017/08/11/governments-are-trying-to-nudgeus-into-better-behavior-is-it-working/?noredirect=on\&utm_term $=.104 \mathrm{c} 8 \mathrm{ff} 2655 \mathrm{a}>$. Acesso em: 5 maio 2018.

19 KEATING, Sarah. The nation that thrived by nudging its population. BBC, 20 feb. 2018. Disponível em: <http://www.bbc. com/future/story/20180220-the-nation-that-thrived-by-nudging-its-population>. Acesso em: 5 maio 2018.

$20 \mathrm{CHU}, \mathrm{Ben}$. What is 'nudge theory' and why should we care? Explaining Richard Thaler's Nobel economics prize-winning concept. Independent, 9 oct. 2017. Disponível em: <https://www.independent.co.uk/news/business/analysis-and-features/nudge-theory-richard-thaler-meaning-explanation-what-is-it-nobel-economics-prize-winner-2017-a7990461.html>. Acesso em: 5 maio 2018. 
de entrada em exercício.

$\int 3^{\circ}$ Fica assegurado ao participante o direito de requerer, a qualquer tempo, o cancelamento de sua inscrição, nos termos do regulamento do plano de benefícios.

$\int 4^{\circ} \mathrm{Na}$ hipótese do cancelamento ser requerido no prazo de até noventa dias da data da inscrição, fica assegurado o direito à restituição integral das contribuições vertidas, a ser paga em até sessenta dias do pedido de cancelamento, corrigidas monetariamente.

$\int 5^{\circ} \mathrm{O}$ cancelamento da inscrição previsto no $\int 4^{\circ}$ não constitui resgate.

$\int 6^{\circ} \mathrm{A}$ contribuição aportada pelo patrocinador será devolvida à respectiva fonte pagadora no mesmo prazo da devolução da contribuição aportada pelo participante.

Inobstante, tramita, no Supremo Tribunal Federal, a Ação Direta de Inconstitucionalidade - ADI n 5.502/DF, que questiona a constitucionalidade dessa adesão automática.

Outros exemplos podem ser elencados, tais como a inscrição automática em energia verde, com a capacidade de recusar; um aviso de que uma fatura está vencendo; o envio de correspondência a famílias comparando seu consumo de energia com o de seus vizinhos. "Quando equiparado com oferecer um desconto aos clientes de serviços públicos se eles reduzissem o consumo de energia, o nudge mostrou-se oito vezes mais econômico."21

Em São Paulo, escolas públicas estaduais usaram a teoria para reduzir a evasão: lembretes via SMS foram remetidos aos pais sobre a importância da frequência escolar. ${ }^{22}$

Em Cingapura, campanhas públicas foram estabelecidas a fim de criar um senso de identidade social em uma população multicultural. Keep Singapore Clean e Plant Trees eram slogans sobre melhorar a limpeza e o meio ambiente. Outras campanhas incentivaram as pessoas a falar mandarim para criar uma sociedade mais coesa, cortês e atenciosa. Mas o país se move em direção a uma abordagem mais sutil de influenciar os comportamentos de seus habitantes. ${ }^{23}$

Um centro médico no Qatar “conseguiu aumentar a aceitação do rastreio de diabetes, oferecendo-se para testar as pessoas durante o Ramadã. As pessoas estavam em jejum de qualquer maneira, então, o incômodo de não comer antes do teste estava removido. Era conveniente e oportuno". ${ }^{24}$ (Tradução nossa).

Outros nudges são ainda mais simples: academias ao ar livre foram construídas próximas das entradas dos prédios, de modo que são fáceis de usar e de serem lembradas constantemente. "Estações de trem têm setas verdes e vermelhas na plataforma indicando onde você deve ficar de modo a acelerar o processo de desembarque." (Tradução nossa). Islândia, Índia e China testaram ilusões de ótica 3D que fazem as passagens em cruzamentos parecer estarem flutuando acima do solo, projetadas para estimular os motoristas a desacelerarem. ${ }^{25}$

Essas técnicas de nudges apresentam-se de muitas formas, mas é o estabelecimento de regras padrão o que interessa para o presente trabalho.

21 THALER, Richard H. et al. Governments are trying to nudge us into better behaviour: is it working? The Washington Post, 11 aug. 2017. Disponível em: <https://www.washingtonpost.com/news/wonk/wp/2017/08/11/governments-are-trying-to-nudgeus-into-better-behavior-is-it-working/?noredirect=on\&utm_term=.104c8ff2655a >. Acesso em: 5 maio 2018.

22 FRAGA, Érica; PINTO, Ana Estela de Sousa. Escolas públicas de São Paulo usam teorias de Nobel para reduzir evasão. Folha de São Paulo, 15 out. 2017. Disponível em: <http://www1.folha.uol.com.br/mercado/2017/10/1927050-escolas-publicas-de-saopaulo-usam-teorias-de-nobel-para-reduzir-evasao.shtml>. Acesso em: 5 maio 2018.

23 KEATING, Sarah. The nation that thrived by nudging its population. BBC, 20 feb. 2018. Disponível em: < http://www.bbc. com/future/story/20180220-the-nation-that-thrived-by-nudging-its-population>. Acesso em: 5 maio 2018.

24 KEATING, Sarah. The nation that thrived by nudging its population. BBC, 20 feb. 2018. Disponível em: <http://www.bbc. com/future/story/20180220-the-nation-that-thrived-by-nudging-its-population>. Acesso em: 5 maio 2018.

25 KEATING, Sarah. The nation that thrived by nudging its population. BBC, 20 feb. 2018. Disponível em: <http://www.bbc. com/future/story/20180220-the-nation-that-thrived-by-nudging-its-population>. Acesso em: 5 maio 2018. 


\section{NudgeS E DOAÇões de ÓRGÃOS PARA tRANSPLANTES}

"A teoria é a mesma que a das pensões: no fundo, a maioria das pessoas quer ser doadora se morrer em um acidente e seus órgãos poderiam ser usados para salvar a vida de outra pessoa, mas por várias razões nunca chegam a se registrar." ${ }^{26}$ Isso porque muitos dos sistemas para obtenção de órgãos é o do consentimento expresso.

Dois são os sistemas para obtenção de órgãos de doadores falecidos para transplantes, segundo a Organização Mundial de Saúde - OMS. O primeiro é o sistema de consentimento expresso (opting in / contracting in). Dependendo da legislação nacional, esse consentimento pode efetuar-se verbalmente ou ser registrado em um cartão de doador, na carteira nacional de habilitação, em documento de identidade, no histórico médico ou em um registro de doadores. Por meio desse sistema, o falecido deve ter manifestado expressamente antes de morrer a autorização para a extração de seus órgãos. Em caso de não ter deixado nenhuma declaração, a autorização é prestada por um familiar, que pode se negar a doar. O segundo sistema é o do consentimento presumido (opting out / contracting out). Diante deste, podem-se extrair órgãos do corpo da pessoa falecida, para fins de transplante, a menos que esta tenha manifestado em vida sua oposição ou que alguém declare que o falecido se opunha.

No Brasil, adota-se o consentimento expresso, mas a decisão sobre a doação pertence aos familiares do potencial doador. Assim, mesmo diante da manifestação em vida do falecido, a família pode recusar-se a permitir a extração. Houve, com a Lei n 9.434 de 1997, uma tentativa de alteração para o consentimento presumido, ${ }^{27}$ de forma a gravar-se a expressão "não doador de órgãos e tecidos" em documento de identificação caso se optasse por não ser doador. Entretanto, o consentimento expresso voltou a ser exigido a partir de uma medida provisória logo convertida na Lei nº 10.211 de 2001.

Portanto, a retirada de órgãos de pessoas falecidas para transplantes ou outra finalidade terapêutica depende, no país, da autorização do cônjuge ou parente firmada em documento subscrito por duas testemunhas presentes à verificação da morte. Em relação às doações intervivos, quando envolverem qualquer pessoa a não ser cônjuge ou parente consanguíneo até o quarto grau, estas devem ser objeto de autorização judicial.

A Alemanha, também, tentou, sem sucesso, em 1978 e em 1997,28 adotar o sistema presumido. No país, a pessoa somente se torna um doador se optar, explicitamente, pelo sistema assinando um cartão de doador de órgãos. ${ }^{29}$ Mas, desde 2012, os alemães, com mais de 16 anos de idade, serão solicitados ao menos uma vez durante sua vida a decidir se querem doar. ${ }^{30}$ A lei determina, ainda, que empresas de seguro médico informem regularmente a seus clientes sobre a doação de órgãos. ${ }^{31}$

Ao menos quatro estados americanos, Connecticut, Texas, Colorado e Pensilvânia, também consideraram alterar sua legislação, sem êxito. Isso porque, nos Estados Unidos, os americanos são contrários ao

26 CHU, Ben. What is 'nudge theory' and why should we care? Explaining Richard Thaler's Nobel economics prize-winning concept. Independent, 9 oct. 2017. Disponível em: <https://www.independent.co.uk/news/business/analysis-and-features/nudge-theory-richard-thaler-meaning-explanation-what-is-it-nobel-economics-prize-winner-2017-a7990461.html>. Acesso em: 5 maio 2018.

27 Em sentido diverso ao que era estabelecido pela Lei no 5.479 de 1968.

28 DEN BÜRGERN reinen Wein einschenken. Süddeutsche Zeitung, Munique, 6 märz. 2018. Disponível em: < http://www.sueddeutsche.de/kolumne/organspende-den-buergern-reinen-wein-einschenken-1.3894155>. Acesso em: 27 mar. 2018.

29 ORGAN SCANDAL forces rethink of donor system. DW, 6 ago. 2012. Disponível em: < http://www.dw.com/en/organscandal-forces-rethink-of-donor-system/a-16146350>. Acesso em: 24 mar. 2018.

30 GERMAN patients turn to Croatia for organ donations. DW, 29 jan. 2018. Disponível em: <http://www.dw.com/en/germanpatients-turn-to-croatia-for-organ-donations/a-42357468>. Acesso em: 24 mar. 2018; ORGAN TRANSPLANT scandal shocks Germany. DW, 21 jul. 2012. Disponível em: <http://www.dw.com/en/organ-transplant-scandal-shocks-germany/a-16116631>. Acesso em: 25 mar. 2018.

31 GERMANY lags behind in organ donations. DW, 4 jan. 2013. Disponível em: <http://www.dw.com/en/germany-lagsbehind-in-organ-donations/a-16498057>. Acesso em: 24 mar. 2018. 
controle do Estado sobre seus corpos. Os direitos individuais, no país, são muito importantes. ${ }^{32}$

Israel, Áustria, ${ }^{33}$ Espanha, Bélgica, Colômbia, França e Holanda adotam o sistema de presunção ou de exclusão. O Reino Unido pretende alterar seu sistema opt in para opt out. ${ }^{34}$

$\mathrm{Na}$ Colômbia, em agosto de 2016, foi sancionada uma lei que torna obrigatória a doação de órgãos no país, exceto nos casos em que as pessoas manifestem em vida o contrário. Eliminou-se a exigência da autorização dos familiares, que eram aqueles que decidiam sobre a doação de órgãos do falecido. ${ }^{35}$

A França adaptou sua legislação a partir de $1^{\circ}$ de janeiro de $2017^{36}$ para regular o princípio do consentimento presumido, ${ }^{37} \mathrm{em}$ vigor no país desde 1976. Presume-se que todos os adultos franceses consentem na remoção de seus órgãos após a morte, a menos que, durante sua vida, tenham expressado uma recusa. ${ }^{38}$ Acredita-se que a taxa de recusas diminua considerando-se uma "melhor informação e conscientização pública e, especialmente, na qualidade do treinamento de profissionais de saúde que entrevistam famílias após a morte de um ente querido." 39

A lei holandesa de fevereiro de 2018 estabeleceu o registro de todos os cidadãos com mais de 18 anos como um doador de órgãos em potencial, a menos que, explicitamente, se oponham. Todos os adultos que ainda não se registraram como doadores de órgãos receberão duas cartas pedindo-lhes que indiquem sua opção. Se eles não responderem após o segundo e-mail, serão automaticamente adicionados à lista, embora possam corrigir seu status a qualquer momento. Diante das dificuldades quando da aprovação do projeto de lei, uma alteração foi inserida, e a família será consultada e dará a decisão final. ${ }^{40}$

Pode-se preferir um sistema de doações de órgãos a serem recusadas. Isso levaria as pessoas a registrarem-se. ${ }^{41}$

32 SAMUEL, Leah. To solve organ shortage, states consider 'opt-out' organ donation laws. Stat News, 6 jul. 2017. Disponível em: <https://www.statnews.com/2017/07/06/opt-solution-organ-shortage/>. Acesso em: 24 mar. 2018.

33 A Áustria tem um sistema no qual as pessoas devem se opor explicitamente a uma doação. GERMANY lags behind in organ donations. DW, 4 jan. 2013. Disponível em: <http://www.dw.com/en/germany-lags-behind-in-organ-donations/a-16498057>. Acesso em: 24 mar. 2018.

34 THERESA May's shift towards presumed-consent organ donation praised by charities and patients. Independent, 5 oct. 2017. Disponível em: <https://www.independent.co.uk/news/uk/politics/theresa-may-organ-donation-policy-praised-transplants-presumed-consent-opt-out-system-conservative-a7984021.html>. Acesso em: 6 maio 2018.

35 COLÔMBIA torna obrigatória a doação de órgãos. Terra, 8 ago. 2016. Disponível em: < https://www.terra.com.br/vida-eestilo/saude/colombia-torna-obrigatoria-a-doacao-de-orgaos,b71ddf2d3c7e71918d945694d75c00cel5rg5lo2.html>. Acesso em: 29 mar. 2018.

36 A PARTIRDU1erjanvier, tous les Français seront donneurs d'organes par défaut. Lexpress, 29 dec. 2016. Disponível em: < https:// www.lexpress.fr/actualite/societe/sante/a-partir-du-1er-janvier-tous-les-francais-seront-donneurs-d-organes-par-defaut_1864325. html?utm_campaign=Echobox\&utm_medium=Social\&utm_source $=$ Facebook\&link_time $=1483015812 \# x$ tor $=$ CS3-5076>. Acesso em: 7 maio 2018.

37 BENJAMIN, Anna. Don d'organe: “Les prélèvements ne seront pas automatiques". Lexpress, 30 dec. 2016. Disponível em: <https://www.lexpress.fr/actualite/societe/sante/don-d-organe-les-prelevements-ne-seront-pas-automatiques_1864548.html>. Acesso em: 7 maio 2018; NEW DUTCH law makes every adult an organ donor. DW, 14 feb. 2018. Disponível em: <http://www. dw.com/en/new-dutch-law-makes-every-adult-an-organ-donor/a-42576784>. Acesso em: 24 mar. 2018.

38 Uma pessoa poderá expressar sua recusa por meio de três possibilidades: cadastro eletrônico no Registro Nacional de Recusa; documento datado e assinado atestando a oposição; e informação oral prestada a um ente querido sobre a oposição. Com a morte, este terá que transcrever a recusa por escrito, mencionando precisamente o contexto e as circunstâncias de sua expressão. A remoção de órgãos não é automática após a morte; acontece quando não tenha havido recusa claramente expressada.

39 BENJAMIN, Anna. Don d'organe: "Les prélèvements ne seront pas automatiques". Lexpress, 30 dec. 2016. Disponível em: <https://www.lexpress.fr/actualite/societe/sante/don-d-organe-les-prelevements-ne-seront-pas-automatiques_1864548.html>. Acesso em: 7 maio 2018.

40 DEN BÜRGERN reinen Wein einschenken. Süddeutsche Zeitung, Munique, 6 märz. 2018. Disponível em: <http://www. sueddeutsche.de/kolumne/organspende-den-buergern-reinen-wein-einschenken-1.3894155>. Acesso em: 27 mar. 2018; NEW DUTCH law makes every adult an organ donor. DW, 14 feb. 2018. Disponível em: < http://www.dw.com/en/new-dutch-lawmakes-every-adult-an-organ-donor/a-42576784>. Acesso em: 24 mar. 2018.

$41 \mathrm{CHU}, \mathrm{Ben}$. What is 'nudge theory' and why should we care? Explaining Richard Thaler's Nobel economics prize-winning concept. Independent, 9 oct. 2017. Disponível em: <https://www.independent.co.uk/news/business/analysis-and-features/nudge-theory-richard-thaler-meaning-explanation-what-is-it-nobel-economics-prize-winner-2017-a7990461.html>. Acesso em: 5 maio 2018. 
Em Illinois, nos Estados Unidos, existe a chamada "escolha obrigatória". Desde 2006, quando o cidadão vai renovar sua carteira de motorista e atualizar sua fotografia, deve responder se deseja ser um doador de órgãos. Este sistema vincula juridicamente os desejos da pessoa de ser doadora, independentemente da vontade ou da oposição de familiares. ${ }^{42}$

Mas, embora bem-intencionada, a adoção do sistema presumido poderia reduzir, e não aumentar, o número de doações. ${ }^{43}$

Para Benjamin, a lei não deve surgir como expressão de uma política agressiva, correndo o risco de ter o efeito oposto. A colheita de órgãos deve, sempre, aparecer como expressão altruísta um ato de generosidade após a morte. ${ }^{44}$ Métodos pesados de influência poderiam reduzir a motivação intrínseca de uma pessoa para se comportar da maneira desejada ou mesmo levar a um desafio de oposição. Os nudges evitariam esses efeitos adversos.

Israel tem um programa para engajar voluntários, ${ }^{45}$ combinando a alocação de órgãos com incentivos. ${ }^{46}$ Em 2008, aprovou-se no país uma legislação que prevê pagamentos do governo para assistência médica de um doador e perdas monetárias relacionadas, bem como autorizou-se o Ministério da Saúde a "dar status preferencial nas listas de espera de transplante para doadores registrados e aqueles que consentiram na doação de um parente." (tradução nossa) ${ }^{47}$

Isso porque "todo transplante economiza um quarto de milhão de dólares nos primeiros cinco anos. Custa US $\$ 90.000$ por ano para fazer diálise, US $\$ 100.000$ para o transplante e US $\$ 20.000$ por ano para medicamentos antirrejeição." 48 (Tradução nossa).

Em que pese a medula óssea não ser um órgão, em 30 de abril de 2018, por meio da Lei Federal n ${ }^{\circ}$ 13.656, o Brasil passou a isentar do pagamento de taxa de inscrição em concursos federais (para provimento de cargo efetivo ou emprego permanente em órgãos ou entidades da administração pública direta e indireta da União) candidatos doadores de medula óssea em entidades reconhecidas pelo Ministério da Saúde.

No estado do Acre, desde 2015, uma lei concede isenção do pagamento da inscrição em concursos públicos para provimento de cargos ou empregos públicos estaduais a candidatos que forem doadores de sangue ou de medula óssea. ${ }^{49}$

\section{Política e políticas públicas}

Diferencia-se a política das políticas públicas. Política é um conceito geral; políticas públicas são assuntos políticos específicos.

42 THALER, Richard H. Opting in vs. Opting out. The New York Times, 26 sep. 2009. Disponível em: <https://www.nytimes. com/2009/09/27/business/economy/27view.html>. Acesso em: 24 mar. 2018. Ver ainda em: <http://www.donatelifeillinois. $\operatorname{org} />$.

43 SAMUEL, Leah. To solve organ shortage, states consider 'opt-out' organ donation laws. Stat News, 6 jul. 2017. Disponível em: <https://www.statnews.com/2017/07/06/opt-solution-organ-shortage/>. Acesso em: 24 mar. 2018.

44 BENJAMIN, Anna. Don d'organe: “Les prélèvements ne seront pas automatiques". Lexpress, 30 dec. 2016. Disponível em: <https://www.lexpress.fr/actualite/societe/sante/don-d-organe-les-prelevements-ne-seront-pas-automatiques_1864548.html>. Acesso em: 7 maio 2018.

45 INSIDE the world of kidney trafficking. The New York Times, 20 aug. 2014. Disponível em: < https://www.nytimes. com/2014/08/21/opinion/inside-the-world-of-kidney-trafficking.html>. Acesso em: 29 mar. 2018.

46 TRUOG, Robert; SEGAL, Brad. Options for increasing the supply of transplantable organs. Harvard Health Policy Review, 2 dec. 2017. Disponível em: <http://bioethics.hms.harvard.edu/news/ethical-constraints-organ-rationing>. Acesso em: 24 mar. 2018.

47 SACK, Kevin. A clash of religion and bioethics complicates organ donation in Israel. The New York. Times, 17 aug. 2014. Disponível em: <https://www.nytimes.com/2014/08/17/world/middleeast/a-clash-of-religion-and-bioethics-complicates-organdonation-in-israel.html>. Acesso em: 4 abr. 2018.

48 SHUTE, Nancy. How an economist helped patients find the right kidney donors. NPR, 11 june 2015. Disponível em: <https://www.npr.org/sections/health-shots/2015/06/11/412224854/how-an-economist-helped-patients-find-the-right-kidney-donor>. Acesso em: 29 mar. 2018.

49 A Lei inicialmente promulgada foi a de $n^{\circ} 2.973$ de 22 de julho de 2015, revogada e substituída pela Lei Complementar nº 345 de 15 de março de 2018. 
A política pode ser entendida como a busca por estabelecer políticas públicas, mas pode existir política sem propostas de políticas públicas.

Diante dos muitos aspectos do conceito de política, três grandes divisões foram estabelecidas: o sistema jurídico e a estrutura institucional político-administrativa (polity), os processos políticos de tomada de decisão (politics) e a congregação de ambos — as políticas públicas (policy). ${ }^{50}$

A primeira dificuldade com a qual se defronta a análise das políticas públicas é o caráter polissêmico do termo "política". As coisas são mais simples para os autores de língua inglesa, pois eles dispõem de termos diferentes para designar o que o francês reúne sob a noção de política. Com efeito, este termo cobre, ao mesmo tempo, a esfera da política (polity), a atividade política (politics) e a ação pública (policies). A primeira faz a distinção entre o mundo da política e a sociedade civil, podendo a fronteira entre os dois, sempre fluida, variar segundo os lugares e as épocas; a segunda designa a atividade política em geral (a competição pela obtenção dos cargos políticos, o debate partidário, as diversas formas de mobilização...); a terceira acepção, enfim, designa o processo pelo qual são elaborados e implementados programas de ação pública, isto é, dispositivos político-administrativos coordenados em princípio em torno de objetivos explícitos. ${ }^{51}$

Nesse contexto, trata-se a política pública de um "fluxo de decisões públicas, orientado a manter o equilíbrio social ou a introduzir desequilíbrios destinados a modificar essa realidade", um sistema de decisões públicas "destinadas a manter ou modificar a realidade de um ou vários setores da vida social, por meio da definição de objetivos e estratégias de atuação e da alocação dos recursos necessários para atingir os objetivos estabelecidos". ${ }^{52}$ É "a coordenação dos meios à disposição do Estado, harmonizando as atividades estatais e privadas para a realização de objetivos socialmente relevantes e politicamente determinados". ${ }^{53}$

Lowi, partindo da força coercitiva de cada uma das políticas públicas, classifica-as em distributivas, regulatórias, redistributivas e constitutivas. Políticas Públicas Distributivas geram maior impacto individual que universal, compreendendo decisões que privilegiam grupos específicos. Políticas Públicas Redistributivas deslocam recursos de uma camada social para outra impondo perdas concretas para certos grupos sociais. Políticas Públicas Regulatórias estabelecem regras, criando normas para a implementação das políticas distributivas e redistributivas. Por fim, as Políticas Públicas Constitutivas, que estruturam processos e procedimentos: ampliando ou diminuindo a autoridade governamental, alterando o exercício dos direitos dos indivíduos, ampliando ou restringindo as opções de ação. ${ }^{54}$

A política pública constitui um processo formado de etapas que, embora nem sempre se separem ou se sucedam, influenciam-se.

A primeira etapa trata-se da "percepção e definição de problemas", sendo que nem todas as necessidades alcançam sua inclusão como assunto público prioritário do governo.

Somente na próxima etapa, relativa à "inclusão da agenda", decide-se se o tema será efetivamente inserido na pauta política. "Para poder tomar essa decisão, é preciso pelo menos uma avaliação preliminar sobre custos e benefícios das várias opções disponíveis de ação, assim como uma avaliação das chances do tema

50 SCHMIDT, João Pedro. Para entender as políticas públicas: aspectos conceituais e metodológicos. In: REIS, Jorge Renato dos; LEAL, Rogério Gesta. (Org.). Direitos sociais e politicas públicas: desafios contemporâneos. Santa Cruz do Sul: EDUNISC, 2008. t. 8. p. 2307-2333. Disponível em: <http://www.mp.go.gov.br/portalweb/hp/10/docs/para_entender_as_politicas_publicas_-_aspectos_conceituais_e_metodologicos.pdf $>$. Acesso em: 4 maio 2013.

51 MULLER, Pierre; SUREL, Yves. A análise das políticas públicas. Pelotas: Educat, 2002. p. 10.

52 SARAVIA, Enrique. Introdução à teoria da política pública. In: SARAVIA, Enrique; FERRAREZI, Elisabete (Org.). Politicas públicas: coletânea. Brasília: ENAP, 2006. v. 1. p. 28-29. Disponível em: <http://www.enap.gov.br/index.php?option=com_ docman\&task $=$ cat_view\&gid $=858>$. Acesso em: 21 jun. 2013.

53 BUCCI, Maria Paula Dallari. Políticas públicas e direito administrativo. Revista de Informação Legislativa, Brasília, v. 34, n. 133, jan./mar. 1997. p. 91.

54 LOWI, Theodore J. Four systems of policy, politics, and choice. Public Administration Review, v. 32, n. 4, p. 298-310, jul./ago. 1972. Disponível em: <http://www.platonicmedia.co.uk/wp-content/uploads/2011/02/Lowi_1972PAR.pdf>. Acesso em: 1 jun. 2013. 
ou projeto de se impor na arena política." ${ }^{55}$

Trata-se da inserção de determinada necessidade ou pleito na lista de prioridades do poder público, transformando-o em objeto de debates e de controvérsias políticas. ${ }^{56}$

Mas nem todas as necessidades transformam-se em demandas, requer-se um processo de politização ou articulação de vontades.

Posteriormente, a terceira etapa, a da elaboração ou "preparação da decisão política": a identificação e delimitação de um problema e possíveis alternativas de solução.

Já a "formulação" inclui a seleção da alternativa entendida como mais conveniente. Constitui a decisão política tomada e a sua formalização por meio de uma norma jurídica.

Uma boa formulação da ação governamental resulta na "implantação", que é a colocação em prática da decisão. É a realização da política, o conjunto de ações destinado a concretizar os objetivos estabelecidos.

O "acompanhamento" consiste no processo de supervisão da execução com objetivo de fornecer informações para eventuais correções necessárias, ${ }^{57}$ enquanto a "avaliação" constitui a mensuração e análise dos resultados produzidos — julga os impactos da política pública na sociedade.

Nessa fase de avaliação e de correção de ação, apreciam-se os impactos efetivos dos programas implementados. "Trata-se de indagar os déficits de impacto e os efeitos colaterais indesejados para poder deduzir consequências para ações e programas futuros.” Alcançados os objetivos, pode-se suspender ou encerrar o ciclo, ou, caso contrário, modificar ou iniciar um novo programa. ${ }^{58} \mathrm{~A}$ adequada valoração da política nessa fase é muito importante porque justifica a preferência por um ou outro programa, servindo de base para posteriores. ${ }^{59}$

No que pertine à otimização de todo o ciclo de políticas públicas,

Nos últimos anos, o governo brasileiro vem investindo na discussão e aprovação de diversas normas para intensificar o uso dos benefícios trazidos pelas tecnologias com o objetivo de otimizar todo o ciclo de políticas públicas. As recentes alterações normativas incluem a nova identificação civil nacional (ICN), a obrigatoriedade da coleta de dados biométricos dos cidadãos, a interoperabilidade entre as bases de dados, a integração dos dados civis (SIRC), a integração dos dados de registro de imóveis (SINTER), a nota fiscal eletrônica de serviços, entre outros. $\mathrm{O}$ aproveitamento da tecnologia nas funções de governo associa-se à discussão sobre a proteção de direitos. Em relação aos projetos de lei em andamento, destacam-se os projetos para estabelecer marco regulatório do uso e proteção dos dados pessoais e sobre valor probante de documentos digitais. ${ }^{60}$

De qualquer modo, "para assegurar a igualdade, importa não apenas garantir a inclusão digital, mas também a educação, a fim de que os debates sejam travados com consciência política, transparência e honesti-

55 FREY, Klaus. Políticas públicas: um debate conceitual e reflexões referentes à prática da análise de políticas públicas no Brasil. Planejamento e Politicas Públicas, n. 21, jun. 2000. p. 227.

56 SARAVIA, Enrique. Introdução à teoria da política pública. In: SARAVIA, Enrique; FERRAREZI, Elisabete (Org.). Políticas públicas: coletânea. Brasília: ENAP, 2006. v. 1. p. 28-29. Disponível em: < http://www.enap.gov.br/index.php?option=com_ docman\&task $=$ cat_view\&gid $=858>$. Acesso em: 21 jun. 2013.

57 SARAVIA, Enrique. Introdução à teoria da política pública. In: SARAIVA, Enrique; FERRAREZI, Elisabete (Org.). Políticas públicas: coletânea. Brasília: ENAP, 2006. v. 1. p. 28-29. Disponível em: <http://www.enap.gov.br/index.php?option=com_ docman\&task $=$ cat_view\&gid $=858>$. Acesso em: 21 jun. 2013.

58 FREY, Klaus. Políticas públicas: um debate conceitual e reflexões referentes à prática da análise de políticas públicas no Brasil. Planejamento e Politicas Públicas, n. 21, jun. 2000.

59 FIGUEIREDO, Marcus Faria; FIGUEIREDO, Argelina M. Cheibub. Avaliação política e avaliação de políticas: um quadro de referência teórica. Análise e Conjuntura, Belo Horizonte, v. 1, n. 3, p. 107-127, set./dez. 1986. Disponível em: <http://www.ssc.wisc. edu/ jmuniz/AC-2007-38.pdf>. Acesso em: 23 jun. 2013.

60 VARELLA, Marcelo D.; OLIVEIRA, Clarice G.; MOESCH, Frederico. Salto digital nas políticas públicas: oportunidades e desafios. Revista Brasileira de Políticas Públicas, v. 7, n. 3, p. 561-584, 2017. Disponível em: < https://publicacoes.uniceub.br/RBPP/ article/view/4808>. Acesso em: 4 jul. 2018. 
dade, devendo-se observar normas quanto ao diálogo". ${ }^{61}$

Por fim, a existência dos direitos sociais decorre do surgimento das políticas públicas, que "repercutem na economia e nas sociedades, daí por que qualquer teoria da política pública precisa também explicar as inter-relações entre Estado, política, economia e sociedade." ${ }^{\prime 2}$

\section{Considerações finais}

Em que pese a importância da utilização econômica dos nudges, estes coexistem em outros campos a não ser o exclusivamente econômico, e a doação de órgãos é um exemplo de uma área em que os nudges merecem ser mais estudados e trabalhados.

Nesse sentido, solicitar aos cidadãos, em mais de uma oportunidade, se gostariam de ser doadores; informá-los regularmente sobre a doação de órgãos para transplante; lembrá-los da importância dos cuidados preventivos no combate a causas de insuficiência de órgãos; enviar-lhes correspondências indicando o incremento nas doações.

Essas são algumas das possibilidades indicadas.

Uma outra alternativa de política pública - e que não exclui as anteriores, é o sistema opt-out, por meio do qual todos os brasileiros seriam automaticamente registrados como doadores de órgãos, a menos que decidissem indicar o contrário. Esse sistema é diferente do opt-in, em que os doadores têm de optar.

Estudos a respeito fazem-se necessários à medida que a população envelhece e a pressão por ampliar a oferta de órgãos intensifica-se.

Impõe-se a inclusão na agenda e a formulação e implantação de políticas públicas eficazes para a redução da escassez de órgãos humanos para transplantes.

Como resultado do trabalho, sugere-se, dentre outras ferramentas, a doação presumida de órgãos como um nudge a incrementar o número de doadores.

Como consequência dos resultados, conclui-se que nudges podem ser utilizados como política pública para aumentar o número de doadores de órgãos humanos para transplantação no Brasil.

Com o presente artigo, pretende-se contribuir para a retomada da discussão sobre o tema e a consequente implementação de políticas públicas com o objetivo de aumentar o número de doadores para transplantes.

Portanto, seu resultado tem implicações práticas, sociais e econômicas, uma vez que os transplantes salvam vidas além de reduzir o custo com saúde.

\section{REFERÊNCIAS}

A PARTIR DU 1er janvier, tous les Français seront donneurs d'organes par défaut. Lexpress, 29 dec. 2016. Disponível em: <https://www.lexpress.fr/actualite/societe/sante/a-partir-du-1er-janvier-tousles-francais-seront-donneurs-d-organes-par-defaut_1864325.html?utm_campaign=Echobox\&utm_

61 MACHADO, Raquel Cavalcanti Ramos; RIVERA, Laura Nathalie Hernandez. Democratização na era digital: desafios para um diálogo consciente e igualitário. Revista Brasileira de Políticas Públicas, v. 7, n. 3, p. 602-617, 2017. Disponível em: <https://publicacoes.uniceub.br/RBPP/article/view/4801>. Acesso em: 4 jul. 2018.

62 SOUZA, Celina. Políticas públicas: uma revisão da literatura. Sociologias, Porto Alegre, ano 8, n. 16, p. 20-45, jul./dez. 2006. Disponível em: <http:// www.scielo.br/pdf/soc/n16/a03n16.pdf>. Acesso em: 4 jun. 2013. 
medium $=$ Social\&utm_source $=$ Facebook\&link_time $=1483015812 \#$ xtor $=C S 3-5076>$. Acesso em: 7 maio 2018.

ACRE. Lei Complementar no 345 de 15 de março de 2018. Disponível em: <http://www.al.ac.leg.br/leis/wpcontent/uploads/2018/03/LeiComp345-1.pdf>. Acesso em: 7 maio 2018.

BENJAMIN, Anna. Don d'organe: "Les prélèvements ne seront pas automatiques". Lexpress, 30 dec. 2016. Disponível em: <https://www.lexpress.fr/actualite/societe/sante/don-d-organe-les-prelevements-ne-seront-pas-automatiques_1864548.html>. Acesso em: 7 maio 2018.

BRASIL. Decreto no 9.175, de 18 de outubro 2017. Disponível em: <http://www.planalto.gov.br/ccivil_03/_ Ato2015-2018/2017/Decreto/D9175.htm\#art56>. Acesso em: 11 nov. 2017.

BRASIL. Lei $n^{\circ} 5.479$ de 10 de agosto de 1968. Disponível em: <http://www.planalto.gov.br/ccivil_03/ leis/1950-1969/L5479.htm>. Acesso em: 11 nov. 2017.

BRASIL. Lei $n^{\circ} 9.434$ de 4 de fevereiro de 1997. Disponível em: <http://www.planalto.gov.br/ccivil_03/leis/ L9434compilado.htm>. Acesso em: 11 nov. 2017.

BRASIL. Lei no 13.183, de 4 de novembro de 2015. Disponível em: < http://www.planalto.gov.br/ccivil_03/_ ato2015-2018/2015/lei/113183.htm>. Acesso em: 26 maio 2018.

BRASIL. Lei no 13.656, de 30 de abril de 2018. Disponível em: <http://www.planalto.gov.br/ccivil_03/_ Ato2015-2018/2018/Lei/L13656.htm>. Acesso em: 7 maio 2018.

BRASIL. Ministério da Saúde. Portaria $n^{0}$ 2.600, de 21 de outubro de 2009. Disponível em: <http://bvsms. saude.gov.br/bvs/saudelegis/gm/2009/prt2600_21_10_2009.html>. Acesso em: 13 abr. 2018.

BRASIL. Supremo Tribunal Federal. Ação Direta de Inconstitucionalidade (ADI) 5502, com pedido de liminar, impugnando dispositivos da Lei 12.618/2012, que instituiu o regime de previdência complementar para os servidores públicos federais titulares de cargo efetivo. Disponível em: <http://www.stf.jus.br/portal/processo/verProcessoAndamento.asp?incidente $=4967555>$. Acesso em: 26 maio 2018.

BUCCI, Maria Paula Dallari. Políticas públicas e direito administrativo. Revista de Informação Legislativa, Brasília, v. 34, n. 133, jan./mar. 1997.

CHINA to cease prisoner organ transplants. DW, 04 dez. 2014. Disponível em: <http://www.dw.com/en/ china-to-cease-prisoner-organ-transplants/a-18109346>. Acesso em: 10 fev. 2018.

CHU, Ben. What is 'nudge theory' and why should we care? Explaining Richard Thaler's Nobel economics prize-winning concept. Independent, 9 oct. 2017. Disponível em: <https://www.independent.co.uk/news/ business/analysis-and-features/nudge-theory-richard-thaler-meaning-explanation-what-is-it-nobel-economics-prize-winner-2017-a7990461.html>. Acesso em: 5 maio 2018.

CIOATTO, Roberta Marina; BOFF, Salete Oro. Concretização de direitos sociais por meio de políticas públicas: uma aproximação necessária. Rev. Fac. Direito UFMG, Belo Horizonte, n. 63, p. 575-613, jul./ dez. 2013. Disponível em: <https://www.direito.ufmg.br/revista/index.php/revista/article/view/P.03042340.2013v63p575/1447>. Acesso em: 3 jul. 2018.

CIOATTO, Roberta Marina; PINHEIRO, Adriana de Alencar Gomes. Transplantes de órgãos humanos no Brasil: a temática não pode ser declarada morta. Revista Direitos e Garantias Fundamentais, Vitória, v. 18, n. 3 , 2017. Disponível em: <http://sisbib.emnuvens.com.br/direitosegarantias/article/view/1130/0>. Acesso em: 25 mar. 2018.

COLÔMBIA torna obrigatória a doaçãodeórgãos. Terra, 8 ago. 2016. Disponível em: $<$ https://www.terra.com. br/vida-e-estilo/saude/colombia-torna-obrigatoria-a-doacao-de-orgaos,b71ddf2d3c7e71918d945694d75c00cel5rg5lo2.html>. Acesso em: 29 mar. 2018. 
DEN BÜRGERN reinen Wein einschenken. Süddeutsche Zeitung, Munique, 6 märz. 2018. Disponível em: $\quad<$ http://www.sueddeutsche.de/kolumne/organspende-den-buergern-reinen-wein-einschenken-1.3894155>. Acesso em: 27 mar. 2018.

ELÉXITO de los trasplantes. ElPaís, 12 ene. 2018. Disponível em: < https:/ / elpais.com/elpais/2018/01/12/ opinion/1515782432_390027.html?id_externo_rsoc=TW_CC\&utm_content=buffer2c070\&utm_ medium=social\&utm_source=facebook.com\&utm_campaign=buffer $>$. Acesso em: 10 fev. 2018.

ESPANHA é campeã do mundo em doações de órgãos. Exame, 17 abr. 2017. Disponível em: <https:// exame.abril.com.br/ciencia/espanha-e-campea-do-mundo-em-doacoes-de-orgaos/>. Acesso em: 13 nov. 2017.

FAN, Jiayang. Can China stop organ trafficking? The New Yorker, 10 jan. 2014. Disponível em: <http://www. newyorker.com/news/news-desk/can-china-stop-organ-trafficking>. Acesso em: 1 maio 2017.

FIGUEIREDO, Marcus Faria; FIGUEIREDO, Argelina M. Cheibub. Avaliação política e avaliação de políticas: um quadro de referência teórica. Análise e Conjuntura, Belo Horizonte, v. 1, n. 3, p. 107-127, set./ dez. 1986. Disponível em: <http://www.ssc.wisc.edu/ jmuniz/AC-2007-38.pdf>. Acesso em: 23 jun. 2013.

FRAGA, Érica; PINTO, Ana Estela de Sousa. Escolas públicas de São Paulo usam teorias de Nobel para reduzir evasão. Folha de São Paulo, 15 out. 2017. Disponível em: <http://www1.folha.uol.com.br/ mercado/2017/10/1927050-escolas-publicas-de-sao-paulo-usam-teorias-de-nobel-para-reduzir-evasao. shtml>. Acesso em: 5 maio 2018.

FREY, Klaus. Políticas públicas: um debate conceitual e reflexões referentes à prática da análise de políticas públicas no Brasil. Planejamento e Políticas Públicas, n. 21, jun. 2000.

GERMAN patients turn to Croatia for organ donations. DW, 29 jan. 2018. Disponível em: < http://www. dw.com/en/german-patients-turn-to-croatia-for-organ-donations/a-42357468 > . Acesso em: 24 mar. 2018.

GERMANY lags behind in organ donations. DW, 4 jan. 2013. Disponível em: <http://www.dw.com/en/ germany-lags-behind-in-organ-donations/a-16498057>. Acesso em: 24 mar. 2018.

INSIDE the world of kidney trafficking. The New York Times, 20 aug. 2014. Disponível em: <https://www. nytimes.com/2014/08/21/opinion/inside-the-world-of-kidney-trafficking.html>. Acesso em: 29 mar. 2018.

KEATING, Sarah. The nation that thrived by nudging its population. BBC, 20 feb. 2018. Disponível em: $<$ http://www.bbc.com/future/story/20180220-the-nation-that-thrived-by-nudging-its-population $>$. Acesso em: 5 maio 2018.

LOWI, Theodore J. Four systems of policy, politics, and choice. Public Administration Review, v. 32, n. 4, p. 298 310, jul./ago. 1972. Disponível em: <http://www.platonicmedia.co.uk/wp-content/uploads/2011/02/ Lowi_1972PAR.pdf>. Acesso em: 1 jun. 2013.

MACHADO, Raquel Cavalcanti Ramos; RIVERA, Laura Nathalie Hernandez. Democratização na era digital: desafios para um diálogo consciente e igualitário. Revista Brasileira de Políticas Públicas, v. 7, n. 3, p. 602-617, 2017. Disponível em: <https://publicacoes.uniceub.br/RBPP/article/view/4801>. Acesso em: 4 jul. 2018.

MULLER, Pierre; SUREL, Yves. A análise das políticas públicas. Pelotas: Educat, 2002.

NEW DUTCH law makes every adult an organ donor. DW, 14 feb. 2018. Disponível em: < http://www. dw.com/en/new-dutch-law-makes-every-adult-an-organ-donor/a-42576784>. Acesso em: 24 mar. 2018.

ORGAN SCANDAL forces rethink of donor system. DW, 6 ago. 2012. Disponível em: <http://www. dw.com/en/organ-scandal-forces-rethink-of-donor-system/a-16146350>. Acesso em: 24 mar. 2018.

ORGAN TRANSPLANT transplant scandal shocks Germany. DW, 21 jul. 2012. Disponível em: < http:// 
www.dw.com/en/organ-transplant-scandal-shocks-germany/a-16116631>. Acesso em: 25 mar. 2018.

OSSOLA, Alexandra. Crisis in America: medical experts use new tech tools to combat the organ transplant shortage. CNBC, 21 jun. 2017. Disponível em: <https://www.cnbc.com/2017/06/20/medical-expertsuse-new-tech-tools-to-combat-organ-transplant-shortage.html>. Acesso em: 24 mar. 2018.

ASSOCIAÇÃO BRASILEIRA DE TRANSPLANTE DE ÓRGÃOS. Dimensionamento dos Transplantes no Brasil e em cada estado (2010-2017). Registro Brasileiro de Transplantes, São Paulo, ano 23, n. 4, jan./dez. 2017. Disponível em: <http:/ www.abto.org.br/abtov03/default.aspx?mn $=515 \& \mathrm{c}=900 \& s=0 \&$ friendly $=\mathrm{re}$ gistro-brasileiro-de-transplantes-estatistica-de-transplantes>. Acesso em: 7 nov. 2017.

SACK, Kevin. A clash of religion and bioethics complicates organ donation in Israel. The New York Times, 17 aug. 2014. Disponível em: <https://www.nytimes.com/2014/08/17/world/middleeast/a-clash-of-religion-and-bioethics-complicates-organ-donation-in-israel.html>. Acesso em: 04 abr. 2018.

SAMUEL, Leah. To solve organ shortage, states consider 'opt-out' organ donation laws. Stat News, 6 jul. 2017. Disponível em: <https://www.statnews.com/2017/07/06/opt-solution-organ-shortage/>. Acesso em: 24 mar. 2018.

SARAVIA, Enrique. Introdução à teoria da política pública. In: SARAIVA, Enrique; FERRAREZI, Elisabete (Org.). Políticas públicas: coletânea. Brasília: ENAP, 2006. v. 1. p. 28-29. Disponível em: <http://www.enap. gov.br/index.php?option=com_docman\&task=cat_view\&gid=858>. Acesso em: 21 jun. 2013.

SCHMIDT, João Pedro. Para entender as políticas públicas: aspectos conceituais e metodológicos. In: REIS, Jorge Renato dos; LEAL, Rogério Gesta. (Org.). Direitos sociais e políticas públicas: desafios contemporâneos. Santa Cruz do Sul: EDUNISC, 2008. t. 8. p. 2307-2333. Disponível em: <http://www.mp.go.gov.br/portalweb/hp/10/docs/para_entender__as_politicas_publicas_-_aspectos_conceituais_e_metodologicos. pdf $>$. Acesso em: 4 maio 2013.

SHUTE, Nancy. How an economist helped patients find the right kidney donors. NPR, 11 june 2015. Disponível em: <https://www.npr.org/sections/health-shots/2015/06/11/412224854/how-an-economisthelped-patients-find-the-right-kidney-donor>. Acesso em: 29 mar. 2018.

SOUZA, Celina. Políticas públicas: uma revisão da literatura. Sociologias, Porto Alegre, ano 8, n. 16, p. 20-45, jul./dez. 2006. Disponível em: <http:// www.scielo.br/pdf/soc/n16/a03n16.pdf>. Acesso em: 4 jun. 2013.

SUNSTEIN, Cass R. Nudging: a very short guide. J. Consumer Pol'y, v. 37, n. 583, 2014. Disponível em: $<$ https://dash.harvard.edu/bitstream/handle/1/16205305/shortguide9_22.pdf? sequence=4>. Acesso em: 6 maio 2018.

TAMS, Carten. Small is beautiful: using gentle nudges to change organizations. Forbes, 22 feb. 2018. Disponível em: <https://www.forbes.com/sites/carstentams/2018/02/22/small-is-beautiful-using-gentlenudges-to-change-organizations/\#6fc50c8e 5a8d>. Acesso em: 5 maio 2018.

THALER, Richard H. Opting in vs. Opting out. The New York Times, 26 sep. 2009. Disponível em: < https:// www.nytimes.com/2009/09/27/business/economy/27view.html>. Acesso em: 24 mar. 2018.

THALER, Richard H. The power of nudges, for good and bad. The New York Times, 31 oct. 2015. Disponível em: <https://www.nytimes.com/2015/11/01/upshot/the-power-of-nudges-for-good-and-bad. html>. Acesso em: 5 maio 2018.

THALER, Richard H. etal. Governments are trying to nudge us into better behaviour: is it working? The Washington Post, 11 aug. 2017. Disponível em: <https://www.washingtonpost.com/news/wonk/wp/2017/08/11/ governments-are-trying-to-nudge-us-into-better-behavior-is-it-working/?noredirect=on\&utm_ term $=.104 \mathrm{c} 8 \mathrm{ff} 2655 \mathrm{a}>$. Acesso em: 5 maio 2018.

THERESA May's shift towards presumed-consent organ donation praised by charities and patients. Inde- 
pendent, 5 oct. 2017. Disponível em: < https://www.independent.co.uk/news/uk/politics/theresa-may-organ-donation-policy-praised-transplants-presumed-consent-opt-out-system-conservative-a 7984021 .html>. Acesso em: 6 maio 2018.

TRUOG, Robert; SEGAL, Brad. Options for increasing the supply of transplantable organs. Harvard Health Policy Review, 2 dec. 2017. Disponível em: < http://bioethics.hms.harvard.edu/news/ ethical-constraintsorgan-rationing $>$. Acesso em: 24 mar. 2018.

VARELLA, Marcelo D.; OLIVEIRA, Clarice G.; MOESCH, Frederico. Salto digital nas políticas públicas: oportunidades e desafios. Revista Brasileira de Políticas Públicas, v. 7, n. 3, p. 561-584, 2017. Disponível em: $<$ https://publicacoes.uniceub.br/RBPP/article/view/4808>. Acesso em: 4 jul. 2018.

WER NICHT widerspricht, wird Organspender. Süddeutsche Zeitung, Munique, 13 feb. 2018. Disponível em: $\quad<$ http://www.sueddeutsche.de/politik/niederlande-wer-nicht-widerspricht-wird-organspender-1.3866596>. Acesso em: 27 mar. 2018.

WORLD HEALTH ORGANIZATION. Global Observatory on Donation and Transplantation. Disponível em: $<$ http://www.transplant-observatory.org/summary/>. Acesso em: 10 nov. 2017.

WORLD HEALTH ORGANIZATION. WHA 63/22. Princípios Orientadores da OMS sobre transplante de células, tecidos y órgãos humanos aprovados pela 63ª Assembleia Mundial de Saúde, de maio de 2010. Disponível em: < http://www.who.int/transplantation/Guiding_PrinciplesTransplantation_WHA63.22sp. pdf?ua=1>. Acesso em: 12 nov. 2017. 


\title{
Os programas de integridade para contratação com a administração pública estadual: nudge ou obrigação legal? Um olhar sobre as duas perspectivas*
}

\section{Integrity programs for hiring with the state public administration: nudge or legal?}

\author{
Cíntia Muniz Rebouças de Alencar Araripe** \\ Raquel Cavalcanti Ramos Machado***
}

\section{Resumo}

O relacionamento do setor privado com a Administração Pública tem passado por profundas transformações, sendo uma delas o incentivo dos Poderes à implementação de programas de integridade nas empresas. Por serem custosos e envolverem, no mais das vezes, transformação de cultura, tais programas vinham sendo implantados tão-somente por imperativos de mercado, figurando-se de extrema valia uma política pública baseada em nudges. Sucede que alguns Estados têm exigido os programas de integridade para contratação com a sua Administração. Tem-se por objetivo geral averiguar como seria uma política pública baseada em nudges e outra em exigências legais, confrontando as duas técnicas, inclusive, sob a ótica de sua constitucionalidade e oportunidade. Como objetivos específicos, destacam-se: a) compreender a política pública baseada em nudges; b) examinar a constitucionalidade e a oportunidade da exigência, por lei estadual, de programas de integridade para contratar com a Administração; c) debater ambas as técnicas, contrapondo os argumentos. Utilizar-se-á de metodologia de cunho dedutivo teórico, prescritivo e dialético. Remonta a outubro/2017 a lei estadual que, primeiramente, veio obrigar as empresas a implementarem tais programas, sendo a discussão ainda incipiente e, portanto, oportuna e atual. Apesar de o STF não ter sido instado a se manifestar sobre a exigência, por lei estadual, de programas de integridade na contratação com a Administração Pública, a dicção que se extrai dos seus julgados é pela sua inconstitucionalidade. Na doutrina, não há consenso sequer sobre a sua oportunidade. O ordenamento jurídico brasileiro, entretanto, dispõe de ferramentas outras, menos controversas, das quais se pode fazer uso.

Palavras-chave: Política pública. Contratação. Administração Pública. Nudge. Obrigatoriedade. Programas de integridade.

\section{Abstract}

The relationship between the private sector and the public administration has undergone profound changes, one of them being the incentive of 
the three branches of Government to implement integrity programs in companies. Because they are costly and they involve, more often than not, the transformation of culture, such programs are only being implemented by market imperatives. A nudge-based public policy is extremely valuable. It so happens that some states have required integrity programs for hiring with their Administration. The general objective of this article is to find out how a public policy based on nudges would be and also another on legal requirements, confronting both techniques, including the point of view of its constitutionality and opportunity. Specific objectives include: a) understanding the public policy based on nudges; b) to examine the constitutionality and the opportunity of the state's requirement of integrity programs to contract with the Administration; c) discuss both techniques. It will use theoretical, prescriptive and dialectical deductive methodology. It goes back to October/2017 the state law that first came to compel companies to implement such programs, so the discussion is still incipient and therefore timely and current. Although the Supreme Court has not been asked to express its view on the requirement by state law for integrity programs in contracting with the Public Administration, it has decided about similar obligations and the understanding is that it's unconstitutional. In doctrine, there is no consensus at all about its opportunity. The Brazilian legal system, however, has other, less controversial, tools that can be used.

Keywords: Public policy. Contracts. Public administration. Nudge. Integrity programs.

\section{INTRODUÇÃo}

Thaller e Sustein introduzem o nudge com a imagem de Carolyn, uma criativa diretora de alimentação das escolas de uma grande cidade, e de seu amigo Adam, um consultor de gestão com larga experiência em cadeias de supermercados e conhecimento em estatísticas. Intrigados com a perspectiva de que a ordem ou o modo como dispostos os produtos poderia vir a influir na escolha dos alunos, Carolyn e Adam decidiram realizar nas cafeterias das escolas por ela geridas um experimento. Foram dadas aos diretores instruções específicas de como organizar os produtos à venda nas suas cafeterias. Nalgumas delas, as batatas fritas foram colocadas ao alcance dos olhos; em outras, os palitos de cenoura. As sobremesas foram postas no começo da fila nalguns locais, enquanto, em outros, foram colocadas em local separado. E assim foi feito com variados produtos alimentícios. Fato é que Carolyn e Adam conseguiram acrescer ou reduzir em até $25 \%$ o consumo de alguns alimentos, sem alterar os preços e os produtos oferecidos no cardápio das cafeterias nem sequer proibir o consumo de um ou de outro, mas apenas e tão-somente com a organização dos alimentos de forma diferenciada, conferindo destaque a determinados produtos. Concluiu-se, assim, que os alunos poderiam ser influenciados com uma simples mudança de contexto. ${ }^{1}$ Isto é nudge. É interferir sutilmente no comportamento de outrem, sem fazer uso de proibições, restrições ou vultosos incentivos financeiros, respeitando, assim, a sua liberdade de escolha.

Nessa senda, pressupondo serem as pessoas, em sua maioria, homo sapiens e não homo economicus e que, ipso facto, não tomariam as melhores decisões em todo o tempo (ou, pelo menos, as melhores decisões que tomariam se quiçá fossem as circunstâncias diferentes), os autores passaram a defender o uso de nudges em numerosas ocasiões. Ter uma alimentação saudável, parar de fumar ou de apostar, fazer investimentos mais rentáveis, salvar para a aposentadoria etc. passaram a ser objeto dos mais variados nudges, prenunciados como respostas intuitivas e descomplicadas e, ao mesmo tempo, novadoras para velhos problemas.

Há longos anos, o Brasil passa por problemas relacionados à corrupção e isto tem repercutido nos contratos, concessões e parcerias firmados pelo setor público. A implantação de programas de integridade nas empresas - e na própria Administração Pública direta e indireta, diga-se de passagem — em muito colaboraria para o enfrentamento desse problema.

1 THALER, Richard H.; SUSTEIN, Cass R. Nudge: improving decisions about health, wealth, and happiness. New York: Penguin Books, 2009. p. 1-2. 
Os programas de integridade abrangem uma série de mecanismos de conformidade e de integridade, a serem continuamente disseminados na empresa/entidade pública e auditados, objetivando prevenir irregularidades, fraudes e atos de corrupção praticados contra a Administração Pública, sem que se olvide a detecção e a punição daqueles que, ainda assim, insistem na prática de tais atos.

Não obstante isso, a implantação de programas de integridade é custosa e, na maioria das vezes, envolve alteração de toda uma cultura, não somente da empresa, mas do próprio ramo em que atua. Daí a extrema valia de uma política pública baseada em nudges para encorajar as empresas que projetam contratos com a Administração Pública a instituírem tais programas. Sucede que alguns Estados têm transposto o nudge com a publicação de legislações que obrigam, a depender do tipo e do valor do objeto/ serviço, a implementação de programas de integridade por empresas que com ele pretendem contratar. Afinal, uma política pública que oriente o relacionamento entre os setores público e privado, incitando a instituição de programas de integridade pelas empresas, deve se basear em nudges ou fazer uso de exigências legais? Eis o dilema.

A doutrina, até o presente momento, não tem se debruçado sobre a questão. Aliás, a discussão sobre a integridade como mecanismo é, ainda, incipiente, tendo sido intensificada a partir de 2013, quando veio a lume a Lei no 12.846, intitulada Lei Anticorrupção. Ademais, data de outubro de 2017 a lei estadual que primeiro veio obrigar o setor privado a implementar programas de integridade. Deveras oportuna e atual, portanto, a discussão.

O artigo perpassará noções de nudge para, empós, ponderar se, ao encorajar as empresas privadas a implementar programas de compliance, o Poder Público estaria a praticar nudge. Em seguida, procura idear como seria uma política pública com esse escopo. É o que se pretende, a princípio, discutir.

$\mathrm{Na}$ sequência, pretende-se ir além do nudge com o exame da constitucionalidade e da oportunidade de algumas leis estaduais que têm obrigado a implementação de programas de integridade nas empresas que firmarem contratos com o Poder Público.

Por derradeiro e à luz do que foi constatado, discutir-se-á a questão da política pública que deve orientar o relacionamento entre a Administração Pública e aqueles que com ela pretendem contratar sob a ótica dos programas de integridade. Nada obstante a adoção desses programas em muito beneficiar o poder público e toda a sociedade — o que neste artigo não se discute, o ordenamento jurídico brasileiro dispõe de ferramentas outras (diferençadas do ato de pura e simplesmente exigir), menos controversas, das quais se pode fazer uso.

No que atine à metodologia, a definição de nudge e o devido enquadramento e desenho de uma política pública que incentive as empresas privadas a implementarem programas de integridade, utilizará o método dedutivo, inicialmente teórico e, posteriormente, prescritivo.

Quanto à análise da constitucionalidade e da oportunidade das leis estaduais que vieram obrigar a implementação desses programas com as empresas que vierem a contratar com as administrações públicas estaduais, far-se-á uso do método dedutivo teórico.

Por fim, o método dialético orientará o exame da política pública em questão com base nos argumentos dissonantes.

\section{TEORIA DO NUDGE NA ADOÇÃO DE PROGRAMAS DE INTEGRIDADE POR EMPRESAS QUE projetam contratos com a Administração Pública}

No ano de 1986, o Congresso norte-americano aprovou o Emergency Planning and Community Right-to-Know Act (EPCRA). Em resposta aos desastres ambientais que se sucederam em Bhopal, na Índia, e em Chernobil, na Ucrânia, e com o fito de atenuar a probabilidade de que símiles desastres ocorressem em território 
americano, o Congresso impôs variados requisitos à indústria e aos governos federal, estaduais e locais. Dentre as providências que foram tomadas, é de ressaltar o Toxics Release Inventory (TRI), que impõe a divulgação obrigatória da quantidade de produtos químicos potencialmente perigosos armazenados ou liberados no meio ambiente, sendo tal informação imediatamente disponibilizada no sítio da Environmental Protection Agency (EPA) para quem quiser acessá-la. O que, a princípio, tinha o condão de informar a EPA, acabou por figurar, ressaltam Thaller e Sustein, um dos casos de maior sucesso no direito ambiental - e, é mister que se diga, um nudge social, afinal, a liberação de produtos tóxicos nos Estados Unidos foi reduzida em grande escala, sem que tenha havido sequer a obrigação de uma mudança de comportamento. Assinalam os autores que a má publicidade acarretada pela inserção das empresas na intitulada enviromental blacklist — a saber, uma lista elaborada por grupos ambientalistas e pela mídia em geral que nominava os piores transgressores — foi o principal motivo para tamanho êxito. Ninguém queria ser listado e o resultado que se obteve foi uma espécie de competição travada entre as companhias, que faziam o possível para não aparecerem na lista negra. ${ }^{2}$

Isto posto, indaga-se: o que é nudge, na perspectiva de Thaller e Sustein?

A nudge, as we will use them, is any aspect of the choice architecture that alters people's behavior in a predictable way without forbidding any options or significantly changing their economic incentives. To count as a mere nudge, the intervention must be easy and cheap to avoid. Nudges are not mandates. Putting the fruit at eye level counts as a nudge. Banning junk food does not. ${ }^{3}$

A ideia central de nudge — a determinar, aliás, que não se faça uso de proibições nem de obrigações — é o paternalismo libertário. Nele, a escolha, apesar de guiada, deve ter a sua liberdade preservada. Paternalismo, como utilizado por Thaller e Sustein, diz respeito à legitimidade que o Poder Público e as instituições privadas têm para influenciar as pessoas nas suas escolhas e, a partir daí, guiá-las para uma vida mais longa, saudável e melhor. Os autores vão além e argumentam que as pessoas necessitam desse direcionamento porquanto, em sua maioria, são homo sapiens e não homo economicus e que, ipso facto, não tomam as melhores decisões em todo o tempo - ou, pelo menos, as melhores decisões que tomariam se quiçá fossem as circunstâncias diferentes. Elucidam Thaller e Sustein:

The paternalistic aspect lies in the claim that it is legitimate for choice architects to try to influence people's behavior in order to make their lives longer, healthier, and better. In other words, we argue for self-conscious efforts, by institutions in the private sector and also by government, to steer people choice's in directions that will improve their lives. In our understanding, a policy is "paternalistic" if it tries to influence choices in a way that will make choosers better off, as judged by themselves. Drawing on some well-estabilished findings in social sciences, we show that in many cases, individuals make pretty bad decisions — decisions they would not have made if they had paid full attention and possessed complete information, unlimited cognitive abilities, and complete self-control. ${ }^{4}$

Assim, se veicular na internet um ranking classificatório das empresas que liberam no meio ambiente produtos químicos potencialmente perigosos pode acarretar o investimento delas em segurança no manuseio desses produtos, por que não o fazer? Não é demais notar, aos que resistem aos nudges por se fiarem em uma liberdade de escolha irrestrita, que não se está a proibir o armazenamento ou a liberação de produtos tóxicos. As empresas não estão sendo obrigadas a qualquer tipo de comportamento. O paternalismo é libertário, preservando, por assim dizer, a liberdade. O paternalismo libertário constitui, por conseguinte, "a relatively weak, soft, and nonintrusive type of paternalism because choices are not blocked, fenced off, or significantly burdened." 5

2 THALER, Richard H.; SUSTEIN, Cass R. Nudge: improving decisions about health, wealth, and happiness. New York: Penguin Books, 2009. p. 192-193.

3 THALER, Richard H.; SUSTEIN, Cass R. Nudge: improving decisions about health, wealth, and happiness. New York: Penguin Books, 2009. p. 6.

4 THALER, Richard H.; SUSTEIN, Cass R. Nudge: improving decisions about health, wealth, and happiness. New York: Penguin Books, 2009. p. 5.

5 THALER, Richard H.; SUSTEIN, Cass R. Nudge: improving decisions about health, wealth, and happiness. New York: Penguin Books, 2009. p. 5. 
Um último aspecto que se considera oportuno para a identificação de nudges diz respeito aos incentivos financeiros. Ao delinear nudges - até para diferenciá-los de situações em que a mudança de comportamento foi ocasionada exclusivamente pelos incentivos pecuniários —-, desconsideraram os autores os cenários em que foram oferecidos substanciais incentivos financeiros.

Uma política pública baseada em nudges, consequentemente, deve visar à alteração de um comportamento sem, no entretanto, se servir nem de proibições nem sequer de obrigações nem mesmo do oferecimento de avultosos incentivos econômicos. É o que se deve ter em mente para a compreensão do que será exposto a seguir.

Dito isto, pergunta-se: o Poder Público pode, via nudges, encorajar as empresas que projetem contratos com a Administração Pública a implementarem programas de integridade? Certamente, sim. Um programa de integridade compreende métodos de análise e gestão de riscos e auditoria, em contínuo monitoramento, voltados não somente para uma gestão de eficiência, como para o cumprimento das normas postas pelos Poderes, órgãos regulamentadores e a própria empresa. Tudo isso integrado no mapa de comunicação da empresa, sendo objeto de cursos e treinamentos, aliado à implementação de um canal de denúncias e a ações de responsabilização daqueles que se desviarem do rumo proposto pela companhia, acaba por constituir verdadeiro mecanismo de integridade, gestão eficiente e proteção à reputação da empresa e ao seu próprio corpo de funcionários. Não obstante isso, a implantação de programas de integridade é custosa e, no mais das vezes, envolve alteração de toda uma cultura não somente da empresa, mas do próprio ramo em que atua. Algumas instituições privadas têm optado — nalguns setores, inclusive, por certa imposição de mercado - a adotar programas de compliance $e^{6}$. Mas o Poder Público seguramente pode acelerar esse processo por meio de uma política pública baseada em nudges.

Como seria uma política pública com esse escopo?

Já se lançou a primeira ideia. Um nudge social. A disponibilização na internet — se possível, no portal da transparência — de uma listagem com as instituições públicas e privadas possuidoras de programas de integridade. Poder-se-ia, inclusive, ir além e relacionar aquelas que já tiveram os seus programas avaliados como efetivos pela Administração Pública. É basicamente o que tem sido feito no programa empresa Pró-Ética? Nele, o Ministério da Transparência e Controladoria-Geral da União (CGU), com o objetivo de incitar a adoção de mecanismos e ações de integridade e combate à corrupção no setor privado, avalia os programas de integridade das empresas que, voluntariamente e em tempo, se inscreveram no programa anual. Em 2017, 23 empresas foram aprovadas e reconhecidas como Empresa Pró-Ética. Urge ressaltar a ênfase dada pela própria CGU ao fato de que o programa não serve de certificação nem sequer de salvo conduto para a prática de irregularidades, tendo a participação das empresas nessa iniciativa os benefícios da publicidade positiva, resultado do reconhecimento público de terem sido identificadas como empresas comprometidas com a prevenção e o combate à corrupção, e de avaliação dos seus programas de integridade por equipe especializada.

Além disso, a mera divulgação da implementação de programas de integridade por empresas que possuem contratos com a Administração Pública já atuaria, consoante Thaller e Sustein, como nudge, servindo como influência social: "Social influences come in two basic categories. The first involves information. If many people do something or think something, their actions and their thoughts convey information about

6 Faz-se mister registrar que programas de compliance e programas de integridade não são sinônimos. A grosso modo, compliance significa estar em conformidade com as leis e regulamentos, internos e externos, ao passo que integridade "significa mais do que simplesmente observar as normas, os códigos e as leis decorrentes dos valores e princípios. As normas e leis proporcionam um limite mínimo, um ponto de partida para a moralidade." BRASIL. Tribunal de Contas da União. Referencial de combate à fraude e corrup̣cão: aplicável a órgãos e entidades da Administração Pública. 2017. Disponível em: <http://portal.tcu.gov.br/biblioteca-digital/ referencial-de-combate-a-fraude-e-corrupcao.htm>. Acesso em: 28 maio 2018). Nessa senda, é que Fonseca sugere que "programa de integridade implica um grau de efetividade mais profundo do que programa de compliance."

7 Para maiores informações, acesse o sítio http://www.cgu.gov.br/assuntos/etica-e integridade/empresa-pro-etica/saiba-mais 
what might be best for you to do or think."”

Nessa perspectiva, acresce notar o experimento realizado por agentes de tributação em Minnesota, descrito pelos autores. Nele, os contribuintes foram divididos em grupos, sendo dadas informações distintas a cada um. Ao primeiro deles, foi dito que o valor despendido pelos seus contribuintes a título de tributos seria gasto em educação, saúde, proteção contra incêndios e várias outras ações. Os contribuintes de outro grupo foram alertados dos riscos e consequências do não pagamento de tributos. Já o terceiro grupo foi orientado a quem se dirigir caso houvesse confusão no preenchimento dos formulários. E o último grupo foi informado que mais de $90 \%$ dos contribuintes de Minnesota já tinham cumprido a totalidade das suas obrigações tributárias. Apenas a última intervenção, salientam Thaller e Sustein, apresentou resultados significativos. Dizem, com extrema propriedade:

Apparently some taxpayers are more likely to violate the law because of a misperception $[\ldots]$ that the level of compliance is pretty low. When informed that the actual compliance level is high, the become less likely to cheat. It follows that either desirable or undesirable behavior can be increased, at least to some extent, by drawing public attention to what others are doing. ${ }^{9}$

Entrementes e como se está a tratar de uma política pública que venha a incitar as empresas que projetem contratos com a Administração Pública a implementar programas de integridade, cabe repisar que, também, a publicidade negativa, resultado da condenação de uma empresa em atos de improbidade administrativa, tem a sua relevância. Nesse contexto, vale registrar o Cadastro Nacional de Empresas Punidas (CNEP), um banco de informações geridas pela CGU que relaciona as empresas que sofreram punições previstas na Lei n ${ }^{\circ}$ 12.846/2013 no âmbito dos Poderes Executivo, Legislativo e Judiciário de todos os entes da federação.

Outra ideia seria tornar acessível e de fácil compreensão não somente os custos associados à corrupção ${ }^{10}$ como a sua repercussão em nível de políticas públicas. Afinal, quanto custa a corrupção para um País? Rose-Ackerman aborda o assunto sob um viés econômico, destacando três tripés: investimento estrangeiro, mercado e respeito à legislação. Com propriedade e rigor, acentua que a corrupção elevada desencoraja o investimento estrangeiro, introduz custos e distorções no mercado e incita o desrespeito ao ordenamento jurídico, especialmente às legislações tributária e a reguladora. ${ }^{11}$ São indubitáveis os efeitos deletérios da corrupção no crescimento do País. Sem embargo, sugere-se que uma política pública baseada em nudges verse sobre os custos da corrupção de modo mais prático, preciso. A percepção da corrupção no setor público no Brasil é extrema. Nessa perspectiva, vale registrar o Corruption Perceptions Index (CPI), criado pela Transparency International ${ }^{2}$ a partir da expertise de analistas e empresários. No ano de 2018, o Brasil foi pontuado, numa escala de 0 a 100, em que 0 significa altamente corrupto e 100 significa um País muito íntegro, com 37 pontos e foi classificado na $96^{a}$ posição, dentre os 180 Países analisados. Tal percepção, em níveis elevados, é conveniente desde que resulte em esforços para o seu enfrentamento. Para evitar que a alta percepção da corrupção no setor público conduza a um sentimento de conformismo, de desesperança, mister se faz salientar os custos da corrupção de forma mais concreta, evidenciando a sua repercussão nas políticas públicas a que se poderia ter levado a cabo se acaso o dinheiro não tivesse sido desviado. Em 2010, a Federação das

8 THALER, Richard H.; SUSTEIN, Cass R. Nudge: improving decisions about health, wealth, and happiness. New York: Penguin Books, 2009. p. 54.

9 THALER, Richard H.; SUSTEIN, Cass R. Nudge: improving decisions about health, wealth, and happiness. New York: Penguin Books, 2009. p. 67.

10 Este artigo não se presta a examinar minuciosamente a corrupção. No entretanto, é relevante ter em mente que, nada obstante o termo corrupção vir sendo largamente utilizado, adotou-se, até por se estar a tratar de custos, a concepção de Rose-Ackerman que praticamente igualou a corrupção ao suborno, identificando-a no momento em que uma terceira pessoa, susceptível de ser favorecida por ato de um funcionário público e buscando influenciar a sua decisão, a ele ilegalmente paga quantia em dinheiro. ROSE-ACKERMAN, Susan. Corruption: a study in political economy. New York: Academic Press, Inc., 1978. p. 6.

11 ROSE-ACKERMAN, Susan. Corruption and government: causes, consequences, and reform. Cambridge: Cambridge University Press, 1999. p. 3.

12 A Transparência Internacional é uma ONG que, desde 1996, anualmente pontua e classifica países e territórios com base na percepção da corrupção no setor público. O seu Índice de Percepção da Corrupção (IPC) é o indicador de corrupção mais utilizado no mundo. 
Indústrias do Estado de São Paulo (FIESP) estimou, com base em dados colhidos entre 1990 a 2008, que o Brasil perde por ano com atos de corrupção em média $\mathrm{R} \$ 41,5$ bilhões a $\mathrm{R} \$ 69,1$ bilhões, o que representava à época $1,38 \%$ a $2,3 \%$ do produto interno bruto brasileiro. ${ }^{13}$ Isto equivalia, no seu percentual mínimo, a $27 \%$ dos gastos efetuados com educação ou, ainda, a 40\% do que se gastou no ano com saúde em todo o Brasil — arrematou a federação no relatório "Corrupção: custos econômicos e propostas de combate". ${ }^{14} \mathrm{O}$ relatório da FIESP poderia ter ido além e aclarado, ainda mais, a repercussão da corrupção nas políticas públicas daquele ano. Bastava ter precisado quantas escolas públicas poderiam ter sido construídas ou reformadas com $\mathrm{R} \$ 41,5$ bilhões ou quantos hospitais poderiam ter sido construídos, reformados e/ou aparelhados ou, ainda, quantos profissionais de educação e de saúde poderiam ter sido contratados com o respectivo valor. O relatório em comento foi publicado na internet em 35 páginas e noticiado em jornais em todo o Brasil, podendo, ainda hoje, ser acessado na íntegra. Assim como ele, inúmeros estudos sobre a corrupção, com definições, causas e custos, foram disponibilizados na internet para o acesso de quem sobre eles tiver interesse. O ritmo acelerado cotidiano, no entretanto, nem sempre permite que as pessoas se inteirem de tudo o que as interessam e, sem informação, acabam não tendo reação. Daí o préstimo de se compilar e se transformar valores e percentuais em perdas concretas em políticas públicas.

O que se propõe guarda similitude com o raciocínio adotado por Thaller e Sustein quando descrevem o caso da EPA e dos adesivos de economia de combustível. Explica-se. Nos Estados Unidos, como medida para se atingir os padrões de economia de combustível esperados dos novos veículos, estimulando uma competição entre as empresas em relação à fabricação de automóveis que consomam menos, os carros novos devem conter adesivo a indicar a economia de combustível que se pode esperar de cada modelo. Neles, Thaller e Sustein identificam poderoso nudge, desde que, além da indicação de milhas por galão, contenham estimativas anual e quinquenal do valor a ser gasto com combustível:

But what, exactly, do mileage numbers mean? For most of us, the answer isn't at all obvious. The goal of promoting competition could be accomplished far more effectively by translating the mileage into dollars, solving the mapping problem. [...] We applaud the new stickers, though we think they might be even more powerful if they computed a five-year figure for money spent on fuel. Imagine the sticker on a Hummer! Even better would be to post these numbers on the back of the car for other drivers to see. ${ }^{15}$

Não é demais observar que informar as milhas por galão mostra-se, na teoria, suficiente para incitar a compra por um carro que consoma menos. Ainda assim e com o objetivo de melhor atingir o objetivo proposto - a saber: proteger o meio ambiente ao reduzir o consumo de combustível —, os autores sugerem uma abordagem mais franca e com maior impacto, enfatizando o custo financeiro. A ideia central, repise-se, é símile à da repercussão dos custos da corrupção nas políticas públicas. Acredita-se que uma melhor conscientização da população tornará propício um ambiente em que empresas que tenham programas de integridade, especialmente aquelas que projetem contratos com a Administração Pública, sejam valorizadas.

No que concerne especificamente ao regime de licitações e contratações pelo poder público, pode-se sugerir, ainda, que a existência de programa de integridade figure como critério de pontuação nas licitações e contratações realizadas pela Administração Pública sob os tipos de melhor técnica e técnica e preço, tudo em consonância com o art. 46, $\$^{\circ}$, I da Lei no 8.666/93. É o que sugerem, com extrema propriedade, Guimarães e Requi:

13 FEDERAÇÃO DAS INDÚSTRIAS DO ESTADO DE SÃO PAULO (FIESP). Corrupção: custos econômicos e propostas de combate. 2010. p. 26. Disponível em: <https: $/$ www.google.com.br $/$ url? $\mathrm{sa}=\mathrm{t} \& \mathrm{rct}=\mathrm{j} \& \mathrm{q}=\&$ esrc $=\mathrm{s} \& \mathrm{source}=\mathrm{web} \& \mathrm{~cd}=1 \& \mathrm{ved}=0 \mathrm{ah}$ UKEwiTiPXCxaTbAhWMfZAKHZJNCj0QFggnMAA\&url=http $\% 3 \mathrm{~A} \% 2 \mathrm{~F} \% 2 \mathrm{Fwww}$.fiesp.com.br $\% 2 \mathrm{Farquivo}$-download $\% 2 \mathrm{~F} \%$ 3Fid\%3D2021\&usg=AOvVaw3nuNdZSkRM1WlFoJrzc3Up>. Acesso em: 26 maio 2018.

14 FEDERAÇÃO DAS INDÚSTRIAS DO ESTADO DE SÃO PAULO (FIESP). Corrup̧cão: custos econômicos e propostas de combate. 2010. p. 28. Disponível em: $<$ https: $/ /$ www.google.com.br $/$ url? $\mathrm{sa}=\mathrm{t} \& \mathrm{rct}=\mathrm{j} \& \mathrm{q}=\& \mathrm{esrc}=\mathrm{s} \& \mathrm{source}=\mathrm{web} \& \mathrm{~cd}=1 \& \mathrm{ved}=0 \mathrm{ah}$ UKEwiTiPXCxaTbAhWMfZAKHZJNCj0QFggnMAA\&url=http $\% 3 \mathrm{~A} \% 2 \mathrm{~F} \% 2 \mathrm{Fwww}$.fiesp.com.br $\% 2 \mathrm{Farquivo}$-download $\% 2 \mathrm{~F} \%$ 3Fid\%3D2021\&usg=AOvVaw3nuNdZSkRM1WlFoJrzc3Up>. Acesso em: 26 maio 2018.

15 THALER, Richard H.; SUSTEIN, Cass R. Nudge: improving decisions about health, wealth, and happiness. New York: Penguin Books, 2009. p. 193-194. 
Nada impede, contudo, que a comprovação da existência de um programa de integridade possa figurar como critério de pontuação de propostas técnicas, em licitações que funcionam sob critérios de técnica e preço ou melhor técnica. Será perfeitamente admissível que exigências assim possam constar dos editais de licitação, com fundamentos no inc. I do $₫ 1^{\circ}$ do art. 46 da Lei no 8.666/93. ${ }^{16}$

Assim, em querendo uma melhor pontuação no procedimento licitatório, a empresa poderia declarar a existência do programa, que, então, seria avaliado pela comissão de licitação. Se, por sua vez, quiser participar da licitação empresa que não tiver programa de integridade, a ela será permitida não somente a participação como a contratação na hipótese de ter sido consagrada vencedora do certame.

Por derradeiro, é importante que a própria Administração Pública desvele o seu comprometimento com o enfrentamento da corrupção, indicando os programas de integridade como uma vereda a ser seguida. Para tanto, a primeira recomendação seria a regulamentação pelos demais entes federados da Lei n $12.846 / 2013$. Até meados de 2018, apenas 16 Estados brasileiros haviam regulamentado a referida lei. ${ }^{17}$ Não é este o local adequado para analisar os motivos e a repercussão dessa não regulamentação. É suficiente, nesse momento, que se esclareça que, apesar de a ausência de regulamentação não impedir a responsabilização civil e administrativa das empresas por atos praticados contra o poder público estadual, dificulta-a, uma vez que não foram atribuídas, no âmbito do ente federado, as competências para fiscalizar e investigar os atos contra a administração pública, aplicar sanções, firmar acordos de leniência, dentre outras.

Ademais, os próprios Estados, a exceção do Estado de Mato Grosso, não têm programas de integridade implementados. O teor da mensagem que o Estado passaria ao empresário no momento em que dele requeresse um programa de integridade seria diferente se ele, ente federado, também o tivesse.

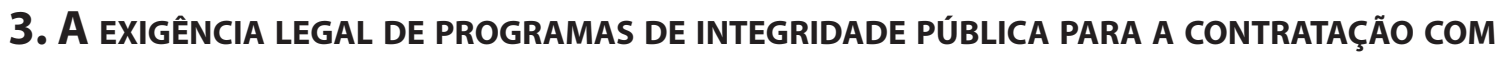 a Administração Pública estadual: Um olhar sobre a sua constitucionalidade e OPORTUNIDADE}

Em outubro de 2017, no Estado do Rio de Janeiro, veio a lume a Lei n ${ }^{\circ} 7.753$, marco legislativo estadual para a exigência de implantação de programas de integridade nas empresas que celebrarem contratos com a Administração Pública carioca nos valores e períodos estipulados.

Com efeito, somente poderão firmar contratos, consórcios, convênios, concessões ou parcerias público-privadas cujos valores sejam superiores aos de licitação na modalidade concorrência e com prazo superior a 680 dias com a administração pública direta, indireta e fundacional do Estado do Rio de Janeiro, empresas com programas de integridade implantados ou em fase de implantação — sujeita esta ao prazo de 180 dias corridos $\left(\operatorname{art} .5^{\circ}\right)$.

O aprofundamento da Lei Estadual n $n^{\circ} 7.753 / 2017$ não seria pertinente neste artigo. É relevante ter em mente, apenas, que a legislação desce a minúcias, trazendo conceitos (art. $3^{\circ}$ ), parâmetros de avaliação (art. $4^{\circ}$ ) e sanções no caso de descumprimento $\left(\operatorname{art.} 6^{\circ}\right)$.

O Distrito Federal, também, aprovou legislação que passou a obrigar a implementação dos programas

16 GUIMARÃES, Fernando Vernalha; REQUI, Érica Miranda dos. Exigência de programa de integridade nas licitações. In: PAULA, Marco Aurélio Borges de; CASTRO, Rodrigo Pironti Aguirre de (Org.). Compliance, gestão de riscos e combate à corrupção: integridade para o desenvolvimento. Belo Horizonte: Fórum, 2018. p. 214.

17 São eles: Tocantins (Decreto no 4.954/13), São Paulo (Decreto no 60.106/14), Paraná (Decreto no 10.271/14), Goiás (Lei no 18.672/14), Rio Grande do Norte (Decreto no 25.177/15), Minas Gerais (Decreto no 46.782/15), Maranhão (Decreto no 31.251/15), Mato Grosso (Decreto no 522/16), Distrito Federal (Decreto no 37.296/16), Espírito Santo (Decreto no 3.956-R/16, com redação alterada pelo Decreto $n^{\circ}$ 3.971-R/16), Santa Catarina (Decreto no 1.106/17), Mato Grosso do Sul (Decreto $n^{\circ}$ 14.890/17), Alagoas (Decreto $n^{\circ}$ 52.555/17), Rio de Janeiro (Decreto $n^{\circ}$ 46.366/2018), Pernambuco (Lei $n^{\circ} 16.309 / 2018$ ) e Paraíba (Decreto $n^{\circ}$ $38.308 / 2018)$. 
em comento por empresas que projetem contratos com a Administração Pública estadual. Apesar de a Lei distrital no 6.112/2018 ter sido estruturada de modo símile à lei carioca, veio obrigar já os contratos cujos valores sejam superiores aos de licitação na modalidade tomada de preços e com prazo superior a 180 dias.

Levando em consideração o art. 22, XXVII da Constituição, que atribui privativamente à União legislar sobre normas gerais de licitação e contratação para as administrações públicas diretas, autárquicas e fundacionais de todos os entes federados, o que dizer da constitucionalidade de dispositivo de lei estadual que impõe obrigações à contratação pública? A doutrina, até o presente momento, não tem se debruçado sobre a questão. Convém proceder à análise de um e outro argumento.

Para os que consideram inconstitucional o dever, por imposição de lei estadual, de as empresas que contratarem com a Administração Pública implementarem programas de integridade, estaria o legislador estadual, ao fazê-lo, malferindo o art. 22, XXVII da Constituição. Isso porque sujeitar a contratação com o poder público, de maneira tão ampla, configuraria norma geral e uma que iria de encontro aos princípios da competitividade e da igualdade de condições entre os participantes de uma licitação pública. Ao analisar as leis do Rio de Janeiro e do Distrito Federal, Pinho alerta para a questão do caráter geral de norma que condiciona a contratação com o poder público e, portanto, da necessidade de que seja veiculada por lei nacional, conforme cita-se: "Inegavelmente, lei estadual criou uma condição especial para a assinatura de contrato administrativo, o que, em nosso modo de ver, acaba por criar restrição que somente poderia se veicular por meio de norma geral, de competência privativa da União."18

O Supremo Tribunal Federal (STF) ainda não teve a oportunidade de se pronunciar sobre o assunto. Contudo, a Corte Constitucional, na ADI n ${ }^{\circ} 3.735 / \mathrm{MS}$, já se manifestou pela inconstitucionalidade da Lei $n^{\circ}$ 3.041/2005, do Estado de Mato Grosso do Sul, que instituía a intitulada Certidão de Violação aos Direitos do Consumidor (CVDC), documento este a ser exigido na contratação com a administração pública estadual e suas autarquias, empresas públicas e sociedades de economia mista que integrasse.

Não é demais observar a similitude entre as exigências da Lei no 3.041/2005, do Mato Grosso do Sul, e das Leis $n^{\circ} 7.753 / 2017$, do Rio de Janeiro, e 6.112/2018, do Distrito Federal. Em todas elas, leis de âmbito estadual exigem documentação fora do art. 27 da Lei no ${ }^{\circ} 8.666 / 1993^{19}$ para a contratação com o poder público estadual.

À vista disso, convém minuciar os fundamentos adotados no julgamento da ADI no 3.735/MS, referida alhures. A decisão da Corte Excelsa se baseou no tripé: autonomia dos entes federados para legislar sobre licitações e contratos, atendimento da legislação estadual à sua competência suplementar e definição das normas gerais do art. 22, XXVII da CF/88. É o que sucintamente se passa a explicar.

A primeira questão que se coloca é a da autonomia dos entes federados para legislar sobre licitações e contratos. Isso porque se questionou se os Estados poderiam legislar sobre o assunto, uma vez que a Constituição, ex vi do art. 22, parágrafo único, reclama lei complementar a autorizá-los a legislar sobre questões específicas sobre as matérias relacionadas no artigo. A interpretação dada pelo STF foi a de que a própria Constituição, ao prever no art. 22, XXVII que "compete privativamente à União legislar sobre normas gerais de licitação e contratação", tornou prescindível a autorização formal para as normas ditas "não gerais". Sendo assim, Estados e Municípios, no exercício das competências que lhes são próprias (arts. 24 e 25 , $\ 1^{\circ}$

18 PINHO, Clóvis Alberto Bertolini de. É preciso cautela ao exigir compliance em contrato público. Revista Consultor Jurídico, 2018. Disponível em: <https://www.conjur.com.br/2018-fev-18/clovis-pinho-preciso-cautela-compliance-contrato-publico>. Acesso em: 28 maio 2018.

19 "Para a habilitação nas licitações exigir-se-á dos interessados, exclusivamente, documentação relativa a: I - habilitação jurídica; II - qualificação técnica; III - qualificação econômico-financeira; IV - regularidade fiscal e trabalhista; V - cumprimento do disposto no inciso XXXIII do art. $7^{\circ}$ da Constituição Federal. " BRASIL. Lei no 8.666, de 21 de junho de 1993. Regulamenta o art. 37, inciso XXI, da Constituição Federal, institui normas para licitações e contratos da Administração Pública e dá outras providências. Diário Oficial da União, Brasília, 22 jun. 1993. Disponível em: < http://www.planalto.gov.br/ccivil_03/Leis/18666cons.htm>. Acesso em: 20 maio 2018. 
e art. 30, II, respectivamente), podem, independentemente de lei complementar autorizativa, legislar sobre licitação e contratação. Saliente-se, porém, não ser essa autonomia de todo incondicionada. Devem os Estados e os Municípios fazer dela uso como se de natureza suplementar fosse. Eis a segunda questão. No particular, merece registro o teor do voto do Ministro Ayres Britto proferido na ADI nº 3.059/RS, que declarou a constitucionalidade de dispositivo de lei estadual que instituía a preferência pela aquisição de softwares livres nas licitações da Administração Pública regional:

É de se questionar, então: as normas gerais de licitação e contratação, editadas pela União, têm por contraponto, no âmbito dos Estados e do Distrito Federal, normas específicas ou normas suplementares? Resposta: a competência que assiste aos Estados e ao Distrito Federal, em matéria de licitação, é de natureza suplementar. Embora topograficamente inserida no art. 22 da Constituição Federal, a competência da União para legislar sobre licitação e contratação, em todas as modalidades, para as Administrações Públicas Diretas, autárquicas e fundacionais da União, Estados, Distrito Federal e Municípios se limita à edição de normas gerais (inciso XXVII do art. 22 da CF), assim como a competência legislativa de todas as matérias referidas no art. 24 da Constituição ( $\$ 1^{\circ}$ do art. 24 da CF). Ademais, inexistindo lei federal sobre normas gerais de licitação, ficam os Estados autorizados a exercer a competência legislativa plena para atender a suas peculiaridades $\left(\$ 3^{\circ}\right.$ do art. 24 da $\left.\mathrm{CF}\right)$. A não ser assim, o que se tem é recusa aos Estados membros quanto a sua própria autonomia administrativa, quebrantando o princípio federativo. ${ }^{20}$

Nessa perspectiva, cabia indagar se a lei sul-mato-grossense, ao exigir aos que contratassem com o poder público estadual uma CVDV, ateve-se aos limites de sua competência suplementar, legislando com base nas normas gerais de contratação veiculadas na Lei no 8.666/1993, ou se, a pretexto de assim proceder, substituiu-se ao legislador nacional, editando normas gerais sobre o assunto que se contrapõem ao regime geral de licitações e contratações. Pela última opção se pronunciou o STF. Desponta a terceira questão: a da definição das normas gerais. Necessário se faz identificar as normas gerais sobre licitação e contratação administrativa para, empós, avaliar o caso concreto e aferir se há contraste entre as disposições de ordem nacional e estadual.

Isto posto, indaga-se: o que são normas gerais em matéria de licitação e contratação com o setor público? Sobre o assunto, não há consenso. Justen Filho preleciona lição de incontestável peso:

Assim, pode-se afirmar que norma geral sobre licitação e contratação administrativa é um conceito jurídico indeterminado cujo núcleo de certeza positiva compreende a disciplina imposta pela União e de observância obrigatória por todos os entes federados (inclusive da Administração indireta), atinente à disciplina de: (a) requisitos mínimos necessários e indispensáveis à validade da contratação administrativa; (b) hipóteses de obrigatoriedade e de não obrigatoriedade de licitação; (c) requisitos de participação em licitação; (d) modalidades de licitação; (e) tipos de licitação; (f) regime jurídico de contratação administrativa. ${ }^{21}$

20 Brasil. Supremo Tribunal Federal. Ação Direta de Inconstitucionalidade. Constitucional e administrativo. Lei 3.041/05, do Estado do Mato Grosso do Sul. Licitações e contratações com o poder público. Documentos exigidos para habilitação. Certidão negativa de violação a direitos do consumidor. Disposição com sentido amplo, não vinculada a qualquer especificidade. Inconstitucionalidade formal, por invasão de competência privativa da União para legislar sobre a matéria (Art. 22, inciso XXVII, da CF). 1. A igualdade de condições dos concorrentes em licitações, embora seja enaltecida pela Constituição (art. 37, XXI), pode ser relativizada por duas vias: (a) pela lei, mediante o estabelecimento de condições de diferenciação exigíveis em abstrato; e (b) pela autoridade responsável pela condução do processo licitatório, que poderá estabelecer elementos de distinção circunstanciais, de qualificação técnica e econômica, sempre vinculados à garantia de cumprimento de obrigações específicas. 2. Somente a lei federal poderá, em âmbito geral, estabelecer desequiparações entre os concorrentes e assim restringir o direito de participar de licitações em condições de igualdade. Ao direito estadual (ou municipal) somente será legítimo inovar nesse particular se tiver como objetivo estabelecer condições específicas, nomeadamente quando relacionadas a uma classe de objetos a serem contratados ou a peculiares circunstâncias de interesse local. 3. Ao inserir a Certidão de Violação aos Direitos do Consumidor no rol de documentos exigidos para a habilitação, o legislador estadual se arvorou na condição de intérprete primeiro do direito constitucional de acesso a licitações e criou uma presunção legal, de sentido e alcance amplíssimos, segundo a qual a existência de registros desabonadores nos cadastros públicos de proteção do consumidor é motivo suficiente para justificar o impedimento de contratar com a Administração local. 4. Ao dispor nesse sentido, a Lei Estadual 3.041/05 se dissociou dos termos gerais do ordenamento nacional de licitações e contratos, e, com isso, usurpou a competência privativa da União de dispor sobre normas gerais na matéria (art. 22, XXVII, da CF). 5. Ação direta de inconstitucionalidade julgada procedente. Procurador Geral da República. Governador do Estado do Mato Grosso do Sul e outro. Relator: Ministro Teori Zavascki. Brasília, DF, 08 de set. de 2016. Diário Oficial da União, Brasília, 2016.

21 JUSTEN FILHO, Marçal. Comentários à lei de licitações e contratos administrativos. 15. ed. São Paulo: Dialética, 2012. p. 16. 
Perceba-se, portanto, que as normas que disponham sobre os requisitos mínimos de contratação e de participação em licitação foram elencadas pelo autor como normas gerais. Esta foi igualmente a opinião exarada pelo relator da ADI n $3.735 / \mathrm{MS}$, o ministro Teori Zavascki, e ratificada pela maioria dos ministros presentes. Daí resulta que o legislador estadual (ou municipal), ao tratar do assunto, deve ter a cautela de, reprise-se, legislar a partir da Lei no 8.666/1993, e não ir de encontro aos seus preceitos. As condicionantes porventura estabelecidas devem, portanto, ater-se a uma classe de objetos contratados (como, e.g., obras de infraestrutura de alta complexidade) ou a peculiaridades do local. Exigir aos que contratassem com o poder público estadual uma CVDV, como intentava a Lei no 3.041/2005, do Estado de Mato Grosso do Sul, era regra por demais ampla para se enquadrar em quaisquer das exceções supracitadas. Nas precisas palavras do relator da $\mathrm{ADI} \mathrm{n}^{\circ} 3.735 / \mathrm{MS}$ :

Ao criar este requisito de habilitação, obrigatório para a grande maioria dos contratos estaduais, o Estado de Mato Grosso do Sul se arvorou na condição de intérprete primeiro do direito constitucional de participar de licitações e criou uma presunção legal, de sentido e alcance amplíssimos, segundo a qual a existência de registros desabonadores nos cadastros públicos de proteção do consumidor é motivo suficiente para justificar o impedimento à contratação de pessoas físicas e jurídicas pela Administração local. Embora a CVDC se aplique apenas aos contratos de valores superiores a cinquenta UFERMS (unidade fiscal estadual de referência de Mato Grosso do Sul), a sua exigência está longe de configurar uma condição especificamente ligada a determinado tipo de objeto. Muito pelo contrário, trata-se de uma limitação não episódica, aplicável linearmente à grande maioria dos contratos estaduais. ${ }^{22}$

Com o apoio da melhor doutrina ${ }^{23}$, Dallari corrobora: "Não é norma geral aquela que corresponde a uma especificação, a um detalhamento. Portanto, norma geral é aquela que cuida de determinada matéria de maneira ampla. Norma geral é aquela que comporta uma aplicação uniforme pela União, Estado e Município."24

Dessarte, ao exigir requisito genérico e inteiramente novo, a lei sul-mato-grossense não teria desdobrado os requisitos constantes no rol do art. 27 da Lei n ${ }^{\circ}$ 8.666/93 para a contratação de uma classe de objetos ou a adequação deles a peculiaridades do local. Ao fazê-lo, o legislador estadual acabou por afrontar, conforme entendimento da maioria dos ministros do STF, a competitividade e a igualdade de condições a todos os concorrentes (art. 37, XXI da CF/88), que, além de normas gerais, podem ser consideradas princípios basilares do procedimento licitatório.

22 BRASIL. Supremo Tribunal Federal. Ação Direta de Inconstitucionalidade. Constitucional e administrativo. Lei 3.041/05, do Estado do Mato Grosso do Sul. Licitações e contratações com o poder público. Documentos exigidos para habilitação. Certidão negativa de violação a direitos do consumidor. Disposição com sentido amplo, não vinculada a qualquer especificidade. Inconstitucionalidade formal, por invasão de competência privativa da União para legislar sobre a matéria (Art. 22, inciso XXVII, da $\mathrm{CF}$ ). 1. A igualdade de condições dos concorrentes em licitações, embora seja enaltecida pela Constituição (art. 37, XXI), pode ser relativizada por duas vias: (a) pela lei, mediante o estabelecimento de condições de diferenciação exigíveis em abstrato; e (b) pela autoridade responsável pela condução do processo licitatório, que poderá estabelecer elementos de distinção circunstanciais, de qualificação técnica e econômica, sempre vinculados à garantia de cumprimento de obrigações específicas. 2. Somente a lei federal poderá, em âmbito geral, estabelecer desequiparações entre os concorrentes e assim restringir o direito de participar de licitações em condições de igualdade. Ao direito estadual (ou municipal) somente será legítimo inovar neste particular se tiver como objetivo estabelecer condições específicas, nomeadamente quando relacionadas a uma classe de objetos a serem contratados ou a peculiares circunstâncias de interesse local. 3. Ao inserir a Certidão de Violação aos Direitos do Consumidor no rol de documentos exigidos para a habilitação, o legislador estadual se arvorou na condição de intérprete primeiro do direito constitucional de acesso a licitações e criou uma presunção legal, de sentido e alcance amplíssimos, segundo a qual a existência de registros desabonadores nos cadastros públicos de proteção do consumidor é motivo suficiente para justificar o impedimento de contratar com a Administração local. 4. Ao dispor nesse sentido, a Lei Estadual 3.041/05 se dissociou dos termos gerais do ordenamento nacional de licitações e contratos, e, com isso, usurpou a competência privativa da União de dispor sobre normas gerais na matéria (art. 22, XXVII, da CF). 5. Ação direta de inconstitucionalidade julgada procedente. Procurador Geral da República. Governador do Estado do Mato Grosso do Sul e outro. Relator: Ministro Teori Zavascki. Brasília, DF, 08 de set. de 2016. Diário Oficial da União, Brasília, 2016.

23 É de ressaltar as lições de Mello, para quem normas gerais são "preceitos que podem ser aplicados uniformemente em todo o País, por se adscreverem a aspectos nacionalmente indiferençados, de tal sorte que repercutem com neutralidade, indiferentemente, em quaisquer de suas regiões ou localidades. " MELLO, Celso Antônio Bandeira de. Curso de Direito Administrativo. 11. ed. São Paulo: Malheiros, 1999.p. 376-377

24 DALLARI, Adilson Abreu. Aspectos jurídicos da licitação. 6. ed. Rio de Janeiro: Saraiva, 1999. p. 20-21. 
Não obstante o acórdão examinado não tratar da exigência, por imposição de lei estadual, de as empresas que contratarem com a Administração Pública implementarem programas de integridade, ocupa-se igualmente de requisito obrigatório para a maioria dos contratos estaduais imposto por legislação regional, prenunciando, assim, um factível posicionamento da Corte Constitucional se acaso for instada a se manifestar sobre a temática.

A predição toma corpo quando se atenta para a jurisprudência do STF, aparentemente consolidada neste sentido, a exemplo da ADI no 3.670/DF, que declarou inconstitucional a Lei Distrital $n^{\circ} 3.705 / 2005$, que proibia a contratação com o poder público de empresas que discriminassem na contratação de mão-de-obra pessoas com os nomes incluídos nos serviços de proteção ao crédito.

Apesar da jurisprudência do STF, não há muitas vozes na doutrina a patrocinarem a inconstitucionalidade da Lei no 7.753/2017, do Rio de Janeiro, ou da Lei no 6.112/2018, do Distrito Federal.

Os que consideram constitucional o dever, por imposição de lei estadual, de as empresas que contratarem com a Administração Pública implementarem programas de integridade o fazem refutando definições muito amplas de normas gerais e argumentando a efetivação pelos referidos programas de um vasto cabedal de princípios valorizados pela Constituição da República, como os da impessoalidade, da moralidade administrativa, da publicidade, da eficiência, da economicidade, dentre outros. É o que se passa a explicar.

A discordância à amplidão do conceito de normas gerais de licitação e contratação encontra suporte no voto dissonante do ministro Marco Aurélio - que, ressalte-se, foi acompanhado pelo ministro Celso de Mello - contido no próprio acórdão da ADI no 3.735/MS, que julgou procedente o pedido formulado para declarar a inconstitucionalidade da Lei no 3.041/2005, do Estado de Mato Grosso do Sul. Diante disso, convém regressar ao acórdão em comento.

Segundo os ministros, correta a definição de normas gerais de Justen Filho trazida aos autos pelo relator. Para o autor - repise-se, normas gerais de licitação e contratação seriam aquelas atinentes a:

(a) requisitos mínimos necessários e indispensáveis à validade da contratação administrativa; (b) hipóteses de obrigatoriedade e de não obrigatoriedade de licitação; (c) requisitos de participação em licitação; (d) modalidades de licitação; (e) tipos de licitação; (f) regime jurídico de contratação administrativa. ${ }^{25}$

O ministro Marco Aurélio, então, enfatiza a expressão “mínimos”, não se esgotando na legislação de competência privativa da União, na sua linha de raciocínio, todos os requisitos de contratação. Fundamentando-se, ademais, na extensa proteção ao consumidor que foi dada pelo ordenamento jurídico brasileiro, encerra: "a meu ver, o Estado atuou, atuou em campo alusivo à defesa do consumidor e atuou sem inobservar as normas gerais, editadas pela União, visando a protegê-lo; atuou a partir de razoabilidade, na espécie, proporcionalidade."26

25 JUSTEN FILHO, Marçal. Comentários à lei de licitaçoes e contratos administrativos. 15. ed. São Paulo: Dialética, 2012. p. 16.

26 BRASIL. Supremo Tribunal Federal. Ação Direta de Inconstitucionalidade. Constitucional e administrativo. Lei 3.041/05, do Estado do Mato Grosso do Sul. Licitações e contratações com o poder público. Documentos exigidos para habilitação. Certidão negativa de violação a direitos do consumidor. Disposição com sentido amplo, não vinculada a qualquer especificidade. Inconstitucionalidade formal, por invasão de competência privativa da União para legislar sobre a matéria (Art. 22, inciso XXVII, da CF). 1. A igualdade de condições dos concorrentes em licitações, embora seja enaltecida pela Constituição (art. 37, XXI), pode ser relativizada por duas vias: (a) pela lei, mediante o estabelecimento de condições de diferenciação exigíveis em abstrato; e (b) pela autoridade responsável pela condução do processo licitatório, que poderá estabelecer elementos de distinção circunstanciais, de qualificação técnica e econômica, sempre vinculados à garantia de cumprimento de obrigações específicas. 2. Somente a lei federal poderá, em âmbito geral, estabelecer desequiparações entre os concorrentes e assim restringir o direito de participar de licitações em condições de igualdade. Ao direito estadual (ou municipal) somente será legítimo inovar nesse particular se tiver como objetivo estabelecer condições específicas, nomeadamente quando relacionadas a uma classe de objetos a serem contratados ou a peculiares circunstâncias de interesse local. 3. Ao inserir a Certidão de Violação aos Direitos do Consumidor no rol de documentos exigidos para a habilitação, o legislador estadual se arvorou na condição de intérprete primeiro do direito constitucional de acesso a licitações e criou uma presunção legal, de sentido e alcance amplíssimos, segundo a qual a existência de registros desabonadores nos cadastros públicos de proteção do consumidor é motivo suficiente para justificar o impedimento de contratar com a Administração local. 4. Ao dispor nesse sentido, a Lei Estadual 3.041/05 se dissociou dos termos gerais do ordenamento nacional de licitações e contratos, 
Não é demais observar ter o voto dissonante silenciado acerca da previsão do art. 27 da Lei nº 8.666/1993 (que arrola a documentação a ser exigida dos licitantes para a habilitação, já analisado) e da questão das normas que, por terem sentido e alcance amplo, podem, em tese, ser aplicadas indistintamente a todos os entes da federação.

O cabedal principiológico da Constituição é decididamente outro dos fundamentos da constitucionalidade de lei estadual exigir programas de integridade para a contratação com o poder público. Isso porque tais programas abrangem uma série de mecanismos de conformidade e de integridade, a serem continuamente disseminados na empresa/entidade pública e auditados, bem como a aplicação de códigos de ética e de conduta, políticas e diretrizes sobre os mais diversos assuntos, objetivando prevenir irregularidades, fraudes e atos de corrupção praticados contra a Administração Pública. Nesse contexto, não apenas princípios diretamente relacionados à ética e à integridade no relacionamento com o poder público são concretizados, como os da moralidade administrativa, da impessoalidade e da publicidade, como outros mais, a exemplo dos que possibilizam uma melhor gestão administrativa e econômica na Administração Pública — princípios da eficácia e da eficiência, respectivamente.

Uma relação com os princípios da moralidade administrativa e da impessoalidade, ambos insculpidos no caput do art. 37 da Constituição, não é difícil de se vislumbrar, derivando basicamente da aplicação dos códigos de conduta e ética e de políticas de relacionamento entre os setores privado e público, um e outro contidos nos programas de integridade.

Também a publicidade, que se densifica nos programas de integridade pública pela recognição que se dá à transparência, é facilmente percebida. Nessa linha de entendimento, Zaganelli e Miranda dilucidam:

[...] embora não seja a única alternativa e seja preciso ainda maiores empenhos, o compliance público contribui, positivamente, para a efetividade das medidas de acesso às informações para o exercício do controle social no combate à malversação dos recursos públicos, tendo em vista os pilares da transparência, integridade e accountability, sendo esse último salutar na esfera pública. ${ }^{27}$

Já o princípio da eficácia se corporifica ante as ferramentas de controle interno e auditorias a serem obrigatoriamente realizadas no âmbito de empresa possuidora de programa de integridade.

Atinente à eficiência, vale registrar a lição de Souza, ao asseverar que "o programa de integridade efetivo, por certo, viabilizará licitações e parcerias administrativas mais eficientes para o Estado, posto que desrevestidas da mácula da corrupção, incrementando os resultados administrativos decorrentes dos negócios jurídicos firmados." 28

Por fim, e sem que haja a pretensão de se esgotar a relação de princípios da administração pública a embasarem os programas de integridade pública, cabe ressaltar os dizeres de Nascimento:

[...] o compliance público aponta para a concretização de uma estratégia inovadora para a esfera pública brasileira, tendo como fundamento os princípios da Administração Pública, previstos no art. 37 da Constituição da. República (legalidade, impessoalidade, moralidade, publicidade e eficiência), entre outros, como a ética, a transparência, a integridade, a justiça, a equidade e a responsabilidade. ${ }^{29}$

Perpassado o ponto da constitucionalidade, resta, ainda, a questão de saber se convém a obrigatoriedade,

e, com isso, usurpou a competência privativa da União de dispor sobre normas gerais na matéria (art. 22, XXVII, da CF). 5. Ação direta de inconstitucionalidade julgada procedente. Procurador Geral da República. Governador do Estado do Mato Grosso do Sul e outro. Relator: Ministro Teori Zavascki. Brasília, DF, 08 de set. de 2016. Diário Oficial da União, Brasília, 2016.

27 ZAGANELLI, Juliana Costa; MIRANDA, Wallace Vieira de. Marco civil da internet e política pública de transparência: uma análise da e-democracia e do compliance público. Revista Brasileira de Políticas Públicas, Brasília, v. 7, n. 3, p. 633-646, 2017.

28 SOUZA, Horácio Mendes Augusto de. A juridicidade da exigência de programa de integridade para participar de licitações e firmar contratos e outras parcerias com o Estado. Revista da Procuradoria-Geral do Estado do Espirito Santo, Vitória, v. 15, n. 15, p. 143169, 2017.

29 NASCIMENTO, Juliana Oliveira. Panorama internacional e brasileiro da governança, riscos, controles internos e compliance no setor público. In: PAULA, Marco Aurélio Borges de; CASTRO, Rodrigo Pironti Aguirre de (Org.). Compliance, gestão de riscos e combate à corrupção: integridade para o desenvolvimento. Belo Horizonte: Fórum, 2018. p. 364. 
por lei estadual, da implementação de programas de integridade para as empresas que contratarem com a Administração Pública regional.

Para Guimarães e Requi, "exigências desta natureza são bem-vindas e concorrem para melhorar o ambiente concorrencial e aperfeiçoar o sistema de contratação pública." ${ }^{30}$

Souza vai além e perfilha o entendimento de que sequer seria necessária legislação federal, estadual ou municipal a exigir programa de integridade nas licitações com a Administração Pública, pois, na sua opinião, a Constituição e a Lei n ${ }^{\circ} 12.846 / 2013$ já ofereceriam substrato para tanto.31_32

Que a evolução na implementação de programas de integridade nas empresas se daria muito mais rapidamente não parece haver dúvida. Seria ela, porém, oportuna? Os especialistas que discordam do dever, por imposição legal, de se ter programa de integridade para firmar contratos com o poder público se baseiam, basicamente, no tripé: efetividade, sistema de avaliação e transferência de custos.

Como cediço, os programas de integridade são deveras custosos. Por isso, uma obrigação de tão significativo impacto e reflexo nas operações cotidianas de inúmeras empresas pode vir a impulsionar o surgimento de programas de integridade "de fachada", isto é, que existem tão-só no papel para que a empresa possa contratar com a Administração Pública.

Daí a importância de um sistema de avaliação dos programas de integridade. Hodiernamente, esses programas são avaliados pontualmente, quer seja no momento em que a empresa voluntariamente o submete ao programa empresa pró-ética, referido alhures, quer seja quando a empresa invoca a sua existência para fins de cálculo na aplicação das sanções da Lei no 12.846/2013 (art. $7^{\circ}$, VIII c/c parágrafo único). A obrigatoriedade da existência de um programa de integridade para a celebração de contratos com a administração pública obviamente provocará um expressivo acréscimo na necessidade de avaliação desses programas, devendo o poder público estar pronto. Isso significa dizer que deve haver uma estrutura permanente e profissionais autônomos e capacitados para tanto. Nessa perspectiva, Costa aponta duas alternativas, que seriam a criação de uma agência anticorrupção, com estrutura e independência funcional e remuneração atraente para os seus membros, voltada à fiscalização das práticas anticorrupção e a concentração da avaliação dos programas de integridade em uma estrutura já existente, preferencialmente com profissionais independentes, técnicos no assunto e afeitos ao lido com a classe empresarial. Elegendo a última alternativa, a autora sugere o Conselho Administrativo de Defesa Econômica (CADE) para o ofício. ${ }^{33}$

Uma outra preocupação, ainda atinente aos custos de implantação desses programas nas empresas, é a de sua transferência para a administração pública. É o que certamente ocorrerá. Sobre o assunto, Souza acentua que, conquanto os custos sejam repassados ao poder público, ainda assim valerá a pena, pois os valores serão menos expressivos do que o que se perde com a corrupção nos dias atuais:

Ainda que as pessoas jurídicas incorram em custos com a implementação do programa de integridade e esses sejam repassados para as propostas e consequentes parcerias firmadas pela administração pública, esses gastos não se comparam aos elevados custos que a corrupção enseja para o Estado e para a

30 GUIMARÃES, Fernando Vernalha; REQUI, Érica Miranda dos. Exigência de programa de integridade nas licitações. In: PAULA, Marco Aurélio Borges de; CASTRO, Rodrigo Pironti Aguirre de (Org.). Compliance, gestão de riscos e combate à corrupcãa: integridade para o desenvolvimento. Belo Horizonte: Fórum, 201. p. 214.

31 Souza perscruta o cabedal principiológico da Constituição (partindo a sua análise de uma abrangência mais lato senso, de princípios como os do Estado Democrático de Direito e da dignidade da pessoa humana, até os princípios da Administração Pública), relacionando-o com os programas de integridade e a disciplina da Lei $n^{\circ} 12.846 / 2013$, para, ao final, sustentar a juridicidade da exigência de programa de integridade para participar de licitações e firmar contratos e outras parcerias com o Estado.

32 SOUZA, Horácio Mendes Augusto de. A juridicidade da exigência de programa de integridade para participar de licitações e firmar contratos e outras parcerias com o Estado. Revista da Procuradoria-Geral do Estado do Espírito Santo, Vitória, v. 15, n. 15, p. 166, 2017.

33 COSTA, Gabriela Revoredo Pereira da. Compliance, Lei da Empresa Limpa e Lei Sapin II: uma análise da aplicação do regime de obrigatoriedade de adoção de programas de integridade corporativa no Brasil. 2017. 111 f. Monografia (Graduação em Direito) Universidade Federal do Rio Grande do Norte, Natal, 2017. p. 88. 
sociedade, em desvios de vultosos recursos públicos, de modo que, se o programa de integridade efetivo contribuir para a redução da corrupção nas parcerias administrativas estatais, o eventual custo citado já estará mais do que justificado, sob a ótica dos princípios da razoabilidade, da proporcionalidade, eficiência e economicidade nas parcerias administrativas. ${ }^{34}$

Perpassadas as questões da constitucionalidade e da oportunidade de se exigir, por lei estadual, a implementação de programas de integridade nas empresas que firmarem contratos com a administração pública, a conclusão a que se chega é a de que, nada obstante a adoção desses programas pelas empresas que se relacionem com a Administração Pública em muito beneficiaria ela e a toda a sociedade (o que aqui não se discute), o ordenamento jurídico brasileiro dispõe de ferramentas outras, menos controversas (diferençadas do ato de pura e simplesmente exigir), das quais se pode fazer uso.

Uma política pública baseada em nudges, como a apresentada neste artigo, seguramente pode acelerar a implementação de programas de integridade nas empresas que com eles queiram se relacionar. Tudo isso de forma menos controversa, antipática e imposta — apesar de indiscutivelmente mais lenta. Há quem sustente, em matéria de licitação, inclusive, que a indução de condutas, ao revés de sua mera imposição, acaba por se mostrar ainda mais eficaz. A esse respeito, esclarecedora é a lição de Ferreira e Pottumati ao asseverar que:

em determinadas atividades e setores, o modelo de regulação que procura, ao invés de impor determinados padrões, induzir o comportamento do mercado em direção a práticas socialmente desejáveis, lançando mão de mecanismos de coordenação estratégica de interesses, pode revelar-se mais eficaz. De fato, a mera imposição de diretivas pode dificultar sua aceitação ou ser tão rigorosa a ponto de se tornar impraticável ou de difícil observância, enquanto que modelos menos invasivos são capazes de preservar, na maior medida possível, a liberdade de escolha, estabelecendo sistemas de incentivo que chamem o particular a colaborar. ${ }^{35}$

Dá-se a predileção em virtude de uma mudança de cultura, pospondo-se a pura e simples obrigatoriedade. É definitivamente o caminho mais longo a se percorrer.

\section{Considerações finais}

Há longos anos, o Brasil passa por problemas relacionados à corrupção e isto tem repercutido nos contratos, concessões e parcerias firmados pelo setor público. A implantação de programas de integridade nas empresas que contratassem com a Administração Pública em muito colaboraria com o enfrentamento desse problema.

Os programas de integridade abrangem uma série de mecanismos de conformidade e de integridade, a serem continuamente disseminados na empresa/entidade pública e auditados, bem como a aplicação de códigos de ética e de conduta, políticas e diretrizes sobre os mais diversos assuntos, objetivando prevenir irregularidades, fraudes e atos de corrupção praticados contra a Administração Pública, sem olvidar a detecção e a punição daqueles que, ainda assim, insistem na prática de tais atos.

Nesse contexto, não somente princípios diretamente relacionados à ética e à integridade no relacionamento com o poder público são concretizados como outros mais, a exemplo dos que possibilizam uma melhor gestão administrativa e econômica na Administração Pública.

Não obstante isso, a implantação de programas de integridade é custosa e, no mais das vezes, envolve alteração de toda uma cultura não apenas da empresa, mas do próprio ramo em que atua. Daí a extrema

34 SOUZA, Horácio Mendes Augusto de. A juridicidade da exigência de programa de integridade para participar de licitações e firmar contratos e outras parcerias com o Estado. Revista da Procuradoria-Geral do Estado do Espirito Santo, Vitória, v. 15, n. 15, p. 161, 2017.

35 FERREIRA, Felipe Furtado; POTTUMATI, Eduardo Carlos. A licitação pública como instrumento de desenvolvimento na perspectiva do paternalismo libertário. Revista Brasileira de Políticas Públicas, Brasília, v. 4, n. 1, p. 201-213, 2014. 
valia de uma política pública baseada em nudges para encorajar as empresas que projetam contratos com a Administração Pública a instituírem tais programas.

Sob essa ótica, nudge é a sutil interferência no comportamento de outrem, sem fazer uso de proibições, restrições ou vultosos incentivos financeiros, respeitando, assim, a sua liberdade de escolha. Centra-se no paternalismo libertário, segundo o qual ao poder público e instituições privadas é legítimo influenciar as escolhas das pessoas, guiando-as para uma vida mais longa, saudável e melhor, contanto que a liberdade delas seja preservada.

E como seria uma política pública de incentivo à implementação de programas de integridade para empresas que pretendam contratar com a Administração Pública baseada em nudges? Seis ideias foram lançadas. A primeira delas, a disponibilização na internet — se possível, no portal da transparência — de uma listagem com as instituições públicas e privadas que possuem contratos com a Administração Pública possuidoras de programas de integridade. Poder-se-ia, inclusive, ir além e relacionar aquelas que já tiveram os seus programas avaliados como efetivos pela Administração Pública. É, ressalte-se, basicamente o que tem sido feito no programa empresa Pró-Ética. Em segundo lugar, destacou-se a publicidade negativa resultado da condenação de uma empresa em atos de improbidade administrativa. Nesse contexto, vale registrar o Cadastro Nacional de Empresas Punidas (CNEP). A terceira ideia foi tornar acessível e de fácil compreensão não somente os custos associados à corrupção como a sua repercussão a nível de políticas públicas. Apesar de inúmeros estudos sobre a corrupção terem sido disponibilizados na internet para o acesso de quem sobre eles tiver interesse, o ritmo acelerado cotidiano nem sempre permite que as pessoas se inteirem de tudo o que as interessam e, sem informação, acabam não tendo reação. Daí o préstimo de se compilar e se transformar valores e percentuais em perdas concretas em políticas públicas. Alvitrou-se, em quarto lugar, a insertação da existência e aplicação de um programa de integridade como critério de pontuação em licitações que funcionam sob critérios de técnica e preço ou melhor técnica. Empós, sugeriu-se que a Administração Pública aclarasse o seu comprometimento com os planos de integridade e o enfrentamento da corrupção a partir não apenas da adoção, pelos próprios entes federados, de programas de integridade como da regulamentação da Lei no 12.846/2013 no âmbito dos Estados e Municípios.

Sucede que alguns Estados têm transposto o nudge com a publicação de legislações que obrigam, a depender do tipo e do valor do objeto/ serviço, a implementação de programas de integridade por empresas que com ele pretendem contratar. É o caso dos Estados do Rio de Janeiro (Lei estadual no 7.753/2017) e do Distrito Federal (Lei distrital no 6.112/2018).

Levando em consideração o art. 22, XXVII da Constituição, que atribui privativamente à União legislar sobre normas gerais de licitação e contratação para as administrações públicas diretas, autárquicas e fundacionais de todos os entes federados, o que dizer da constitucionalidade de dispositivo de lei estadual que impõe obrigações à contratação pública? Sobre o assunto, não há consenso.

Para os que consideram inconstitucional o dever, por imposição de lei estadual, de as empresas que contratarem com a Administração Pública implementarem programas de integridade, estaria o legislador estadual, ao fazê-lo, malferindo o art. 22, XXVII da Constituição. Isso porque sujeitar a contratação com o poder público, de maneira tão ampla, configuraria norma geral e uma que iria de encontro aos princípios da competitividade e da igualdade de condições entre os participantes de uma licitação pública.

Já os que o julgam constitucional, o fazem refutando definições muito amplas de normas gerais e argumentando a efetivação pelos referidos programas de um vasto cabedal de princípios valorizados pela Constituição da República, como os da impessoalidade, da moralidade administrativa, da publicidade, da eficiência, da economicidade, dentre outros.

O Supremo Tribunal Federal, ainda, não teve a oportunidade de se pronunciar sobre o assunto. Contudo, a Corte Constitucional, na ADI no $3.735 / \mathrm{MS}$, já se manifestou pela inconstitucionalidade da Lei $\mathrm{n}^{\circ}$ 3.041/2005, do Estado de Mato Grosso do Sul, que, apesar de não tratar especificamente do assunto das 
Leis $n^{\circ} 7.753 / 2017$, do Rio de Janeiro, e 6.112/2018, do Distrito Federal, exige documentação fora do art. 27 da Lei no 8.666/1993 para a contratação com o poder público estadual. Essa, aliás, é a dicção que se extrai de outros julgados do STF.

Ultrapassada a questão da constitucionalidade e considerando que a evolução na implementação de programas de integridade nas empresas se daria muito mais rapidamente com a exigência, seria ela oportuna? A doutrina contende.

Os especialistas que discordam do dever, por imposição legal, de se ter programa de integridade para firmar contratos com o poder público se baseiam, basicamente, no tripé: efetividade, arriscando o surgimento de programas "de fachada"; necessidade de se ter uma estrutura permanente e profissionais autônomos e capacitados para a avaliação dos programas de integridade; e transferência dos custos de implementação dos programas para as propostas e parcerias firmadas com a Administração Pública.

A conclusão a que se chega é a de que, nada obstante a adoção desses programas pelas empresas que se relacionem com a Administração Pública em muito beneficiaria ela e a toda a sociedade — o que aqui não se discute, o ordenamento jurídico brasileiro dispõe de ferramentas outras (diferençadas do ato de pura e simplesmente exigir), menos controversas, das quais se pode fazer uso.

Uma política pública baseada em nudges, como a apresentada neste artigo, seguramente pode acelerar a implementação de programas de integridade nas empresas que com eles queiram se relacionar. Tudo isso de forma menos controversa, antipática, imposta e, para alguns, até mais eficaz — apesar de indiscutivelmente mais lenta.

Dá-se a predileção é por uma mudança de cultura, pospondo-se a pura e simples obrigatoriedade. É definitivamente o caminho mais longo a se percorrer.

\section{REFERÊNCIAS}

BRASIL. Lei no 8.666, de 21 de junho de 1993. Regulamenta o art. 37, inciso XXI, da Constituição Federal, institui normas para licitações e contratos da Administração Pública e dá outras providências. Diário Oficial da União, Brasília, 22 jun. 1993. Disponível em: <http://www.planalto.gov.br/ccivil_03/Leis/18666cons. htm>. Acesso em: 20 maio 2018.

BRASIL. Lei n ${ }^{\circ}$ 12.846, de $1^{\circ}$ de agosto de 2013. Dispõe sobre a responsabilização administrativa e civil de pessoas jurídicas pela prática de atos contra a administração pública, nacional ou estrangeira, e dá outras providências. Diário Oficial da União, Brasília, 2 ago. 2013. Disponível em: <http://www.planalto.gov.br/ ccivil_03/_ato2011-2014/2013/lei/112846.htm>. Acesso em: 20 maio 2018.

BRASIL. Supremo Tribunal Federal. Ação Direta de Inconstitucionalidade. Constitucional e administrativo. Lei 3.041/05, do Estado do Mato Grosso do Sul. Licitações e contratações com o poder público. Documentos exigidos para habilitação. Certidão negativa de violação a direitos do consumidor. Disposição com sentido amplo, não vinculada a qualquer especificidade. Inconstitucionalidade formal, por invasão de competência privativa da União para legislar sobre a matéria (Art. 22, inciso XXVII, da CF). 1. A igualdade de condições dos concorrentes em licitações, embora seja enaltecida pela Constituição (art. 37, XXI), pode ser relativizada por duas vias: (a) pela lei, mediante o estabelecimento de condições de diferenciação exigíveis em abstrato; e (b) pela autoridade responsável pela condução do processo licitatório, que poderá estabelecer elementos de distinção circunstanciais, de qualificação técnica e econômica, sempre vinculados à garantia de cumprimento de obrigações específicas. 2. Somente a lei federal poderá, em âmbito geral, estabelecer desequiparações entre os concorrentes e assim restringir o direito de participar de licitações em condições de igualdade. Ao direito estadual (ou municipal) somente será legítimo inovar nesse particular se tiver como 
objetivo estabelecer condições específicas, nomeadamente quando relacionadas a uma classe de objetos a serem contratados ou a peculiares circunstâncias de interesse local. 3. Ao inserir a Certidão de Violação aos Direitos do Consumidor no rol de documentos exigidos para a habilitação, o legislador estadual se arvorou na condição de intérprete primeiro do direito constitucional de acesso a licitações e criou uma presunção legal, de sentido e alcance amplíssimos, segundo a qual a existência de registros desabonadores nos cadastros públicos de proteção do consumidor é motivo suficiente para justificar o impedimento de contratar com a Administração local. 4. Ao dispor nesse sentido, a Lei Estadual 3.041/05 se dissociou dos termos gerais do ordenamento nacional de licitações e contratos, e, com isso, usurpou a competência privativa da União de dispor sobre normas gerais na matéria (art. 22, XXVII, da CF). 5. Ação direta de inconstitucionalidade julgada procedente. Procurador Geral da República. Governador do Estado do Mato Grosso do Sul e outro. Relator: Ministro Teori Zavascki. Brasília, 08 de set. de 2016. Diário Oficial da União, Brasília, 2016.

BRASIL. Supremo Tribunal Federal. Ação Direta de Inconstitucionalidade. Direito Administrativo e Constitucional. Lei no 11.871/02, do Estado do Rio Grande do Sul, que institui, no âmbito da Administração Pública Regional, preferência abstrata pela aquisição de softwares livres ou sem restrições proprietárias. Exercício regular de competência legislativa pelo Estado-membro. Inexistência de usurpação de competência legiferante reservada à União para produzir normas gerais em tema de licitação. Legislação compatível com os princípios constitucionais da separação dos Poderes, da impessoalidade, da eficiência e da economicidade. Pedido julgado improcedente. 1. A competência legislativa do Estado-membro para dispor sobre licitações e contratos administrativos respalda a fixação por lei de preferência para a aquisição de softwares livres pela Administração Pública regional, sem que se configure usurpação da competência legislativa da União para fixar normas gerais sobre o tema (CRFB, art. 22, XXVII). 2. A matéria atinente às licitações e aos contratos administrativos não foi expressamente incluída no rol submetido à iniciativa legislativa exclusiva do Chefe do Poder Executivo (CRFB, art. $61, \$ 1^{\circ}$, II), sendo, portanto, plenamente suscetível de regramento por lei oriunda de projeto iniciado por qualquer dos membros do Poder Legislativo. 3. A Lei n $11.871 / 2002$ do Estado do Rio Grande do Sul não engessou a Administração Pública regional, revelando-se compatível com o princípio da Separação dos Poderes (CRFB, art. $2^{\circ}$ ), uma vez que a regra de precedência abstrata em favor dos softwares livres pode ser afastada sempre que presentes razões tecnicamente justificadas. 4. A Lei $n^{\circ} 11.871 / 2002$ do Estado do Rio Grande do Sul não exclui do universo de possíveis contratantes pelo Poder Público nenhum sujeito, sendo certo que todo fabricante de programas de computador poderá participar do certame, independentemente do seu produto, bastando que esteja disposto a celebrar licenciamento amplo desejado pela Administração. 5. Os postulados constitucionais da eficiência e da economicidade (CRFB, arts. 37, caput e 70, caput) justificam a iniciativa do legislador estadual em estabelecer a preferência em favor de softwares livres a serem adquiridos pela Administração Pública. 6. Pedido de declaração de inconstitucionalidade julgado improcedente. DEMOCRATAS. Governador do Estado do Rio Grande do Sul e outro. Relator: Ministro Ayres Britto. Brasília, 09 de abril de 2015. Diário Oficial da União, Brasília, 2015.

BRASIL. Tribunal de Contas da União. Referencial de combate à fraude e corrupção: aplicável a órgãos e entidades da Administração Pública. 2017. Disponível em: < http://portal.tcu.gov.br/biblioteca-digital/referencialde-combate-a-fraude-e-corrupcao.htm>. Acesso em: 28 maio 2018.

COSTA, Gabriela Revoredo Pereira da. Compliance, Lei da Empresa Limpa e Lei Sapin II: uma análise da aplicação do regime de obrigatoriedade de adoção de programas de integridade corporativa no Brasil. 2017. 111 f. Monografia (Graduação em Direito) - Universidade Federal do Rio Grande do Norte, Natal, 2017.

DALLARI, Adilson Abreu. Aspectos jurídicos da licitação. 6. ed. Rio de Janeiro: Saraiva, 1999.

FEDERAÇÃO DAS INDÚSTRIAS DO ESTADO DE SÃO PAULO (FIESP). Corrupcão: custos econômicos e propostas de combate. 2010. Disponível em: <https://www.google.com.br/url?sa=t\&rct=j\&q=\&esr $\mathrm{c}=\mathrm{s} \&$ source $=$ web\&cd $=1 \&$ ved $=0$ ahUKEwiTiPXCxaTbAhWMfZAKHZJNCj0QFggnMAA\&url=http $\% 3$ A $\% 2 \mathrm{~F} \% 2 \mathrm{Fwww}$.fiesp.com.br\%2Farquivo-download $\% 2 \mathrm{~F} \% 3 \mathrm{Fid} \% 3 \mathrm{D} 2021 \&$ usg=AOvVaw3nuNdZSkRM1 WIFoJrzc3Up>. Acesso em: 26 maio 2018. 
FERREIRA, Felipe Furtado; POTTUMATI, Eduardo Carlos. A licitação pública como instrumento de desenvolvimento na perspectiva do paternalismo libertário. Revista Brasileira de Políticas Públicas, Brasília, v. 4, n. 1, p. 201-213, 2014.

FONSECA, Antonio. Programa de Compliance ou Programa de Integridade: o que isso importa para o direito brasileiro?. In: LAMBOY, Christian K. de (Org.). Manual de Compliance. São Paulo: Instituto Arc, 2017.

GUIMARÃES, Fernando Vernalha; REQUI, Érica Miranda dos. Exigência de programa de integridade nas licitações. In: PAULA, Marco Aurélio Borges de; CASTRO, Rodrigo Pironti Aguirre de (Org.). Compliance, gestão de riscos e combate à corrupção: integridade para o desenvolvimento. Belo Horizonte: Fórum, 2018.

JUSTEN FILHO, Marçal. Comentários à lei de licitaçoes e contratos administrativos. 15. ed. São Paulo: Dialética, 2012.

MELLO, Celso Antônio Bandeira de. Curso de Direito Administrativo. 11. ed. São Paulo: Malheiros, 1999.

NASCIMENTO, Juliana Oliveira. Panorama internacional e brasileiro da governança, riscos, controles internos e compliance no setor público. In: PAULA, Marco Aurélio Borges de; CASTRO, Rodrigo Pironti Aguirre de (Org.). Compliance, gestão de riscos e combate à corrupcão: integridade para o desenvolvimento. Belo Horizonte: Fórum, 2018.

PINHO, Clóvis Alberto Bertolini de. É preciso cautela ao exigir compliance em contrato público. Revista Consultor Jurídico, 2018. Disponível em: < https://www.conjur.com.br/2018-fev-18/clovis-pinho-precisocautela-compliance-contrato-publico>. Acesso em: 28 maio 2018.

ROSE-ACKERMAN, Susan. Corruption: a study in political economy. New York: Academic Press, Inc., 1978.

ROSE-ACKERMAN, Susan. Corruption and government: causes, consequences, and reform. Cambridge: Cambridge University Press, 1999.

RIO DE JANEIRO. Lei no 7.753, de 17 de outubro de 2017. Dispõe sobre a instituição do programa de integridade nas empresas que contratarem com a administração pública do Estado do Rio de Janeiro e dá outras providências. Diário Oficial do Estado do Rio de Janeiro, 18 out. 2017.

SOUZA, Horácio Mendes Augusto de. A juridicidade da exigência de programa de integridade para participar de licitações e firmar contratos e outras parcerias com o Estado. Revista da Procuradoria-Geral do Estado do Espirito Santo, Vitória, v. 15, n. 15, p. 143-169, 2017.

THALER, Richard H.; SUSTEIN, Cass R. Nudge: improving decisions about health, wealth, and happiness. New York: Penguin Books, 2009.

ZAGANELLI, Juliana Costa; MIRANDA, Wallace Vieira de. Marco civil da internet e política pública de transparência: uma análise da e-democracia e do compliance público. Revista Brasileira de Políticas Públicas, Brasília, v. 7, n. 3, p. 633-646, 2017. 


\title{
Paternalismo libertário e proteção jurídica do ambiente: por que proteger o ambiente também deve ser proteger as liberdades?*
}

\author{
Libertarian paternalism and legal protection \\ of the environment: because protecting the \\ environment must first of all not eliminate \\ freedoms
}

Mariana Carvalho Victor Coelho**

Patryck de Araujo Ayala***

* Recebido em 01/06/2018

Aprovado em 14/07/2018

** Mestranda em Direito pela Universidade Federal de Mato Grosso. Especialista em Direito Processual Civil pela Fundação Escola Superior do Ministério Público de Mato Grosso. Graduada em Direito pela Universidade Federal de Mato Grosso. Bolsista da FAPEMAT. Pesquisadora do grupo de de pesquisas "JusClima”. E-mail: maricvcoelho@hotmail.com.

*** Doutor e mestre em Direito pela Universidade Federal de Santa Catarina, tendo realizado estágio de doutoramento junto à Faculdade de Direito da Universidade Clássica de Lisboa no ano de 2006 (PDEE/CAPES). Professor adjunto II nos cursos de graduação e de mestrado em Direito da UFMT. Pesquisador do grupo de pesquisas "Direito Ambiental e Ecologia Política na Sociedade de Risco" (certificado pela Instituição e cadastrado no CNPQ), líder do grupo de pesquisas "Jus-Clima", membro da Comission on Environmental Law (Steering Comitee) da IUCN. Membro e sócio-fundador da Associação dos Professores de Direito Ambiental (APRODAB). Membro do Instituto Brasileiro de Advocacia Pública (IBAP). É diretor do Instituto $\mathrm{O}$ Direito por um Planeta Verde. Procurador do Estado de Mato Grosso. E-mail: pkayala@terra.com.br.

\section{Resumo}

O cenário de riscos globais e ameaças sociais e ecológicas, identificado pela Era Geológica do Antropoceno, alerta para a necessidade de transformações nas estruturas política e jurídica, se se espera do Direito uma resposta adequada para o enfrentamento dos problemas ambientais. Para além dos tradicionais imperativos ecológicos de comando e controle aplicados por meio de políticas públicas estatais, a consideração de um princípio estruturante de sustentabilidade pelo Estado de Direito contemporâneo suscita novas formas de juridicidade ambiental em vista de um compromisso com a proteção do ambiente. O objetivo do presente artigo, portanto, consiste na compreensão de como um modelo da Teoria Econômica Comportamental de nudge se relaciona com as orientações de um Direito de sustentabilidade e, mesmo assim, mantém uma de suas principais características: o paternalismo libertário. Nesse contexto, o texto propõe, fazendo-se o uso do método indutivo e de pesquisa essencialmente bibliográfica, que, em uma abordagem de nudge, proteger o ambiente deve considerar como premissa básica a proteção das liberdades individuais, assegurando que estas não sejam eliminadas. Diante dessa análise, suscita-se como problema de pesquisa o de até que ponto a influência estatal exercida para um objetivo de sustentabilidade pode ser considerada ética e, portanto, preservaria o exercício da liberdade pelos indivíduos.

Palavras-chave: Nudge. Paternalismo libertário. Estado de Direito. Princípio de Sustentabilidade. Proteção da natureza.

\section{Abstract}

The scenario of global risks and social and ecological threats identified by the geological age of the Anthropocene warns of the need for transformations in political and legal structures, if an adequate response to environmental problems is expected from the law. In addition to the traditional ecological imperatives of command and control applied through state public 
policies, consideration of a structuring principle of sustainability by the contemporary Rule of Law raises new forms of environmental legality in view of a commitment to protect the environment. The purpose of this article, therefore, is to understand how a model of nudge of the behavioral economic theory relates to the guidelines of a Sustainability Law and yet maintains one of its main characteristics: libertarian paternalism. In this context, the text proposes, using of the inductive method and essentially bibliographic research, that in a nudge approach, protecting the environment should, first of all, do not eliminate individual freedoms. In view of this analysis, it arises as a research problem the question of to what extent the state influence exerted on a sustainability objective is considered ethical, and therefore, preserves or not the exercise of freedom of individuals.

Keywords: Nudge. Libertarian paternalism. Rule of Law. Principle of sustainability. Protection of nature.

\section{INTRODUÇÃo}

O trabalho sustenta que, em um contexto de incremento dos cenários de ameaças institucionais, econômicas e ecológicas aos níveis de proteção da qualidade dos recursos naturais pelo Direito, concretizar um princípio de sustentabilidade deve sercompreendido como um processo que depende de transformações estimuladas na estrutura das funções do Estado e das instituições. Nesse sentido, o texto propõe, fazendo-se o uso do método indutivo e de pesquisa essencialmente bibliográfica, que a primeira e mais relevante transformação que deveria ser estimulada é aquela que define o modo como o Direito se relaciona com a natureza.

Nesse plano de transformações, destaca-se a necessidade de se estimular a proposição de normas diferenciadas que aproximem e compreendam, juntamente a instituições, relações entre os homens e o acesso a recursos naturais, com o interesse de se atingir um objetivo de sustentabilidade. Se nudge é um modelo comportamental de estimulo de escolhas no interesse de se favorecer as liberdades, essas liberdades em um contexto de imperativos ecológicos implicam escolhas que envolvem níveis de compromissos e de responsabilidades decorrentes dessas opções.

Estimular normas que favoreçam sustentabilidade significa favorecer um objetivo que reflete um compromisso moral com as presentes, com as futuras gerações, e com todas as formas de vida. Se em um Estado de Direito, o Estado, as pessoas e o mercado possuem compromissos de colaboração com escolhas que permitam que as liberdades desenvolvam plenamente os projetos de vida, considerar um objetivo de sustentabilidade suscita compromissos diferenciados temporal e moralmente. São compromissos com pessoas, com o futuro e com outras formas de vida.

Ao assumir um imperativo de se estimular um ambiente de liberdades que favoreçam objetivos para além de expectativas individuais e do próprio mercado, alcançando os interesses das futuras gerações, das outras formas de vida, e da coletividade, suscita-se como problema o de até que ponto a influência exercida para um objetivo de sustentabilidade é considerada ética, e, portanto, preserva o exercício de liberdade dos indivíduos.

A primeira seção caracteriza a definição geológica do antropoceno relacionando-a com a capacidade de o homem não apenas interferir sobre processos climáticos, senão exaurir sistemas ecológicos. Pretende-se sustentar nessa ocasião que a definição de políticas públicas regulatórias no domínio da proteção do meio ambiente exige transformações dos métodos de regulação adotados pelo Estado e por meio do Direito.

Para tanto, propõe-se que políticas públicas ambientais reguladas pelo Direito, precisam sê-lo por meio de um Direito que assegure a capacidade de escolher no âmbito de opções moralmente orientadas por um Estado de direito para a natureza.

Pautado num objetivo de compreender o arranjo jurídico-político capaz de adequadamente acessar riscos 
e os problemas ecológicos que identificam a sociedade contemporânea, a segunda seção busca compreender as justificativas das transformações ocorridas na estrutura política estatal para um fim de consideração de valores e compromissos morais diferenciados e expandidos para além da vida humana. Sob essa perspectiva, o texto propõe que um Estado orientado por um Direito de sustentabilidade e compromissado com um Princípio Estruturante de Sustentabilidade requer novas formas de juridicidade ambiental para além dos tradicionais imperativos ecológicos de comando e controle, a fim de melhor alcançar objetivos de proteção do ambiente, como o emprego de recursos de estímulo e influência destinados a promover políticas públicas de sustentabilidade.

A terceira e última seção procura identificar de que modo o modelo de nudge, baseado na Teoria Econômica Comportamental, se relaciona com um Direito de sustentabilidade — posto que pautado em um objetivo estatal de proteção da natureza e de seus ecossistemas - e ainda assim mantém uma de suas principais características: o paternalismo libertário. Para tanto, primeiramente, a terceira seção visa expor e compreender os conceitos-chave que integram o modelo de nudge, como os conceitos de paternalismo libertário, arquiteto de escolhas e liberdade. Aprofunda-se, ainda, na análise de alguns nudges específicos para a proteção do ambiente, salientando, por fim, a compreensão da problemática quanto à questão ética da utilização do nudge de proteção ambiental pelo Estado, visto que, em uma abordagem de nudge, proteger o ambiente, deve ser, antes de tudo, não eliminar as liberdades individuais.

\section{Os DESAFIOS DA PROTEÇão DA NATUREZA NO ANTROPOCENO}

No contexto de uma nova era geológica definida por Paul Krutzen como a era do antropoceno, o homem desafia não apenas os processos climáticos, submetendo-os a níveis extremos, senão todos os processos ecológicos, submetendo-os ao exaurimento a tal ponto de não permitir que estes possam se adaptar às transformações por si impostas. ${ }^{1}$

Em semelhante realidade, é relevante posicionar como primeiro problema a ser enfrentado neste trabalho o de se indagar em que medida uma arquitetura legal de regulação dos problemas ecológicos oriundos desse contexto de agravamento da qualidade dos recursos naturais, poderia oferecer respostas úteis no plano de um imperativo de justiça ecológica².

A questão suscita, em última análise, indagar se a proteção da natureza conseguiria ser adequadamente proposta, em um contexto do antropoceno, por meio de políticas públicas baseadas em que modelo de relação entre o Direito e natureza.

Se a proposta de regulação depender de um modelo regulatório dependente de um Direito ambiental como é normalmente concebido (baseado em técnicas de comando e controle), a solução a ser obtida proporá, basicamente, dois caminhos alcançáveis: a) compensação financeira pela violação de padrões jurídico-ambientais ou; b) prisão pela violação de padrões jurídico-ambientais.

O próprio reconhecimento da existência em curso de uma nova Era Geológica que lida com o problema do exaurimento dos processos ecológicos demonstra com clareza que o modelo regulatório acima descrito não conseguiu proporcionar proteção para a natureza. Em outras palavras, é possível reconhecer que, por meio de um modelo regulatório que privilegie normas jurídicas orientadas para ordens de proibições ou de restrições, não se conseguiu atingir, tampouco impedir a aceleração das iniciativas de fragilização dos ecossistemas e do exaurimento dos processos ecológicos. ${ }^{3}$

1 KOTZE, Louis. Reimaging global environmental law and governance in the anthropocene. 2012. Disponível em: <http://dspace.nwu. ac.za/bitstream/handle/10394/8575/Kotz\%C3\%A9_LJ.pdf;sequence=1>. Acesso em: 26 maio 2018.

2 O conceito e o seu desenvolvimento serão realizados na próxima seção deste trabalho.

3 No mesmo sentido, ROBINSON, Nicholas. Keynote: sustaining society in the anthropocene epoch. Denver Journal of Interna- 
Em semelhante cenário, verifica-se que os padrões regulatórios em vigor não foram capazes de frustrar o antropoceno, não conseguindo, portanto, assegurar, por meio de tais normas, proteção para a natureza.

Se essas normas assim não a puderam alcançar, de que forma, ou por meio de que padrões regulatórios seria possível alcançar a proteção da natureza?

\subsection{Proteger a natureza ou proteger os negócios de sempre?}

O principal desafio proposto pelo antropoceno para a formulação de políticas públicas que possam contemplar o meio ambiente como tarefa pode ser caracterizado, em síntese, pelo de proteger a natureza em uma realidade regulatória definida por Robinson como a realidade dos negócios de sempre (business as usual), compreendida neste artigo como o modo como os processos socio-econômicos tem sido desenvolvidos há séculos pelas nações. ${ }^{4}$

Conforme explica Robinson, muito embora as Nações Unidas acolham a tarefa de proteção do meio ambiente e um imperativo de relacionamento entre homem e natureza sob uma perspectiva de comunidade indivisível, a proliferação de legislação ambiental e de acordos internacionais não foram suficientes para impedir transformações irreversíveis sobre a Terra. ${ }^{5}$

Associado a esse obstáculo também se pode identificar, segundo desafio para a formulação de um modelo regulatório para o antropoceno e que seja capaz de proteger a natureza, a saber, a distância mantida entre o Direito e os processos ecológicos.

A definição de meio ambiente é uma realidade legal e conta, conforme já foi relatado, com o acolhimento nas ordens jurídicas nacional e internacional. Entretanto, a definição de natureza não o é.

Se tratados internacionais e normas jurídicas podem definir que o meio ambiente é um valor que deverá ser protegido, este nem sempre o será por duas razões.

A primeira delas está vinculada à própria realidade dos negócios de sempre acolhida pelas escolhas políticas das nações sobre o meio ambiente.

Como é muito bem explicitado por Robinson, esse quadro pode ser compreendido a partir de uma máxima "se não está quebrado, não é preciso consertar", a qual qualifica o crescimento como o modelo econômico de escolhas desse modelo de sociedade (a sociedade dos negócios de sempre). ${ }^{6}$

A segunda razão diz respeito ao lugar duvidoso e indefinido que a tarefa de proteção da natureza ocupa no ambiente regulatório da sociedade dos negócios de sempre, que tende a materializar instrumentos regulatórios que propõem o que é o meio ambiente, mas que não conseguem alcançar em tal definição, o que é a natureza.

Desse modo não é incomum que se caracterize em semelhante cenário de super-regulação normativa em torno do meio ambiente, resultados frágeis no plano de se obter a conservação da integridade dos processos ecológicos.

A segunda razão pode ser ilustrada por meio do discurso global associado ao conceito de desenvolvimento sustentável, admitido por Koetze como falacioso. ${ }^{7}$ Esse conceito é normalmente assimilado por

tional Law \& Policy, v. 41, n. 4, p. 467-506, 2013.

4 ROBINSON, Nicholas. Keynote: sustaining society in the anthropocene epoch. Denver Journal of International Law \& Policy, v. 41, n. 4, p. 481, 2013.

5 ROBINSON, Nicholas. Keynote: sustaining society in the anthropocene epoch. Denver Journal of International Law \& Policy, v. 41, n. 4, p. 480, 2013.

6 ROBINSON, Nicholas. Keynote: sustaining society in the anthropocene epoch. Denver Journal of International Law \& Policy, v. 41, n. 4, p. 481, 2013.

7 KOTZE, Louis. Reimaging global environmental law and governance in the anthropocene. 2012. Disponível em: <http://dspace.nwu. 
meio da representação de uma tentativa de se conciliar necessidades econômicas, sociais e ambientais, ou aproximar pilares em princípio autônomos.

Esse mesmo conceito pode sugerir que, se a humanidade impuser limites às suas liberdades, a natureza poderá se adaptar às transformações, supondo que a natureza é resiliente. Entretanto, não é possível admitir que sistemas ecológicos suportem intervenções humanas indefinidamente, não havendo, portanto, no plano das leis naturais, o estado de resiliência infinita. Proceder de semelhante maneira significaria admitir que as leis da natureza poderiam ser redefinidas pelas normas regulatórias.

Se, de um lado, o crescimento continua a ser um valor privilegiado pelas escolhas regulatórias, por outro lado, o meio ambiente, embora regulado como valor relevante para as escolhas, não reflete, adequadamente, as leis da natureza.

O Direito não pode modificar, alterar ou ignorar a natureza porque as leis da natureza simplesmente existem.

Se se deseja que políticas públicas devam proteger a natureza, o primeiro passo seria assegurar que as normas regulatórias não ignorassem as leis da natureza.

Não será possível, portanto, proteger a natureza, se, em primeiro lugar, as normas regulatórias não puderem compreender as leis da natureza.

\subsection{Proteger a natureza deve fazer parte dos negócios de sempre}

Se a regulação baseada no modelo de escolhas dos negócios de sempre não conseguiu assegurar um caminho que oferecesse proteção para a natureza, inicia-se neste momento a construção dos argumentos que poderão permitir um caminho que a permita.

Koetze sustenta que, para lidar com os problemas do antropoceno, é necessário que o a regulação se transforme de algumas maneiras: a) nós devemos transformar nossa relação com a natureza; c) O Direito precisa de uma nova referência ética. ${ }^{8}$

Definir liberdades para um ambiente regulatório em transformação exige que nós consideremos que ser livre não é uma concessão. É ser responsável perante uma comunidade, por alguns valores que são importantes nessa comunidade.

Então, as liberdades não podem estar desconectadas dos valores que são importantes para uma comunidade. A dignidade e o respeito a alguns valores definem as liberdades.

Reconhecer que a natureza possui valor e que as leis da natureza devem ser respeitadas não propõem uma resposta correta, ou um caminho correto para as políticas públicas. Propõe direções que, apesar de diferentes, precisam ser reconhecidas como corretas.

Se os padrões de comando e controle falharam na tarefa de apontar o caminho de proteção da natureza, arquiteturas diferenciadas de regulação ganham relevo no enfrentamento dos desafios já descritos.

Em detrimento do conflito entre natureza e crescimento impostos na escala valorativa dos processos de escolha baseados nos negócios de sempre, deve-se supor que a natureza precisa fazer parte dos novos negócios da era do antropoceno, exigindo-se uma ruptura com a prática de séculos que permeia os ideais de bem-estar das sociedades ocidentais, descritas por Robinson?.

ac.za/bitstream/handle/10394/8575/Kotz\%C3\%A9_LJ.pdf;sequence=1>. Acesso em: 26 maio 2018.

8 KOTZE, Louis. Reimaging global environmental law and governance in the anthropocene. 2012. Disponível em: <http://dspace.nwu. ac.za/bitstream/handle/10394/8575/Kotz\%C3\%A9_LJ.pdf;sequence=1>. Acesso em: 26 maio 2018.

9 ROBINSON, Nicholas. Keynote: sustaining society in the anthropocene epoch. Denver Journal of International Law \& Policy, v. 41, n. 4, p. 481, 2013. 
Em detrimento de restrições, proibições ou ordens, é necessário estimular processos de transformação por meio de normas diferenciadas ${ }^{10}$ que aproximem e compreendam, juntamente com instituições, relações entre os homens e o acesso a recursos naturais, relações estas que refletem antes de tudo, um compromisso moral com as presentes e as futuras gerações, e com outras formas de vida.

Para tanto, a próxima seção propõe que o primeiro grande estímulo que pode ser proporcionado, parte da premissa de que é necessário haver um ambiente regulatório e instituições que aproximem mercado de natureza. Há aqui a necessidade de se relacionar Estado, mercado e natureza.

A próxima seção tratará do lugar do Estado nessa relação, reservando-se à ultima seção a tarefa de conectar o Estado e a proteção da natureza por meio de padrões regulatórios diferenciados, baseados em estímulos, com o propósito de se sustentar a necessidade de diminuir a distância entre a lei, a governança, e os processos ecológicos.

\section{A proteção jurídica da natureza no Estado de Direito: objetivos, tarefas e um POUCO MAIS}

Pautado num propósito científico de compreender e oferecer soluções para problemáticas ecológicas como as exploradas no item anterior, o presente trabalho voltará seu foco para o entendimento da relevância de uma proteção estatal da natureza, de como um Estado de Direito pode auxiliar nessa proteção e quais os meios e instrumentos utilizados para a consecução desse objetivo político-jurídico.

Nesse contexto, surgem alguns questionamentos, anteriores a própria constatação da pertinente proteção da natureza pelo Estado, que devem ser devidamente enfrentados: que Estado é este, que se importa com a proteção do ambiente e com a valoração da natureza? Um Estado de Direito, mas que Direito é este, que tem a força de regular o poder estatal em prol desse objetivo de tutela ambiental? Ou seja, de que Estado e de que Direito (Estado de Direito) se esta a falar? Ainda que sob um cenário de emergências sociais, econômicas e ecológicas, a importância de justificação estatal da proteção da natureza é condição que não pode prescindir o bom estudo da temática jurídica ambiental, e se faz justamente para que se evitem abordagens pautadas em radicalismos ideológicos ou reducionismos simplistas.

Para tanto, será analisada, num primeiro momento, a forma pela qual as inculcações com a necessidade de proteção do ambiente foram inseridas no projeto político constitucional — uma justificativa teórico-constitucional da proteção da natureza —-, ou seja, será compreendido o porquê e de que maneira o Estado passou a considerar valores e compromissos morais expandidos e diferenciados, o que auxiliará no esclarecimento de que Estado é este que atribui certo valor à natureza e intenta a sua proteção por meio de tarefas, objetivos e compromissos para com todas as formas de vida e com as futuras gerações.

Num segundo momento, faz-se necessária a investigação em torno da consideração de um princípio de sustentabilidade como um dos princípios estruturantes do Estado de Direito. Pretende-se caracterizar que estrutura de modelo jurídico seria capaz de conformar a atividade estatal em prol da proteção do ambiente. Nessa perspectiva, para além dos tradicionais imperativos mandamentais de proibição e permissão, a consideração de um princípio de sustentabilidade como Princípio Estruturante do Estado sugere uma abordagem de atuação estatal que vai além: aliadas aos imperativos constitucionais ecológicos devem estar as novas formas de juridicidade ambiental, como as ações estatais de estímulo e influência para o fim de se proteger a natureza ${ }^{11}$.

10 ALEMANNO, Alberto; SPINA, Alessandro. Nudging legally: on the checks and balances of behavioral regulation. International Journal of Constitutional Law, v. 12, p. 443, 2014.

11 A referência a um Estado de Direito compromissado com um princípio de sustentabilidade e a exigência de novas formas de juridicidade em busca da realização de um objetivo de se atingir metas ambientais é de Canotilho, em: CANOTILHO, José Joaquim 


\subsection{Uma justificativa teórico-constitucional da proteção da natureza}

O Estado de Direito, construção histórica, social e política, consubstancia-se em um modelo político organizativo pautado no controle e limitação da atuação estatal pela lei, que surgiu como resposta a certas demandas, interesses e necessidades socioeconômicas, e de caráter ético e cultural ${ }^{12}$. O Estado de Direito, simplificadamente, é uma estrutura de organização política que tem sua atuação limitada, orientada e direcionada pela lei, pelo direito ${ }^{13}$. Trata-se de um Estado que deve, necessariamente, estar sujeito e subordinado ao direito, isto é, trata-se de um projeto político que se dá em torno de uma construção de controle normativo e legal da atuação estatal, em vez de se assegurar a máxima de um princípio de legalidade. A visão tradicional e clássica de Estado de Direito é aquela que se fundamentou pelo justificado receio de um abuso estatal em detrimento de liberdades e direitos dos cidadãos, uma forma de se evitar o arbítrio do Estado enquanto exercício do poder público ${ }^{14}$. O Direito tem, nesse momento, a função de conformar os esquemas de poder e de atuação de toda máquina estatal.

Nesse contexto, inicialmente a preocupação precípua de um Estado de Direito era a de garantir os direitos e liberdades individuais perante a atuação dos poderes públicos, em conjunto com a garantia de uma divisão de poderes e com a estrita observância da lei ${ }^{15}$. Para que seja possível alcançar os fins pretendidos pelo presente estudo, a essa breve introdução sobre o conceito do Estado de Direito suscita-se, neste momento, uma reaproximação com a pergunta que se fez anteriormente. De que forma e por que o Estado de Direito evoluiu para um Estado que leva em consideração valores e princípios dotados de uma moralidade diferenciada da tradicionalmente adotada, e em específico, a proteção da natureza?

A preocupação e necessidade de uma proteção do ambiente por meio do direito — nacional e internacional — só foram inseridas nas questões de uma sociedade global muito recentemente. No início de 1970, as primeiras preocupações legais com o ambiente baseavam-se, em sua maioria, em questões de poluição transfronteiriça e proteção específica e fragmentada da fauna e flora ${ }^{16}$. Vale a pena notar que o direito ambiental floresceu e ganhou reconhecimento primeiramente na arena internacional. Muito desse reconhecimento se deve à primeira conferência internacional sobre meio ambiente realizada pela ONU: a conhecida Conferência de Estocolmo sobre o Meio Ambiente Humano, ocorrida em $1972^{17}$.

A expansão da degradação ambiental, o esgotamento dos recursos naturais, a poluição da terra, do ar e da água e a pobreza social que assolou os quatro cantos do mundo levaram os Estados a perceber o enorme impacto da ação humana sobre o meio ambiente ${ }^{18}$. Devido a essa preocupação mundial concernente aos problemas ambientais, que foi percebida ao final da década de sessenta do século XX, se manifestou, tam-

Gomes. O princípio da sustentabilidade como princípio estruturante do direito constitucional. Revista de Estudos Políticos, v. 3, n. 13, p. 10, 2010.

12 DÍAZ, Elías. Estado de derecho y democracia. 2001. p. 203-204. Disponível em: < https://dialnet.unirioja.es/descarga/articulo/831255.pdf>. Acesso em: 26 maio 2018.

13 SILVA, José Afonso. O Estado democrático de direito. 1988. p. 16. Disponível em: <http://bibliotecadigital.fgv.br/ojs/index.php/ rda/article/viewFile/45920/44126>. Acesso em: 26 maio 2018.

14 CANOTILHO, José Joaquim Gomes. O Estado de direito. 1999. p. 3. Disponível em: <https://s3.amazonaws.com/academia. edu.documents $/ 33341061 /$ ijgcoedd.pdf?AWSAccessKeyId=AKIAIWOWYYGZ2Y53UL3A\&Expires=1527800386\&Signature=

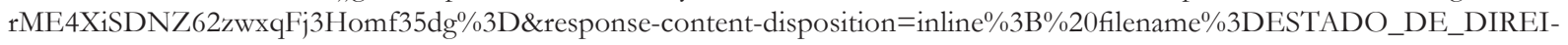
TO.pdf>. Acesso em: 26 maio 2018.

15 SILVA, José Afonso. O Estado democrático de direito. 1988. Disponível em: <http://bibliotecadigital.fgv.br/ojs/index.php/rda/ article/viewFile/45920/44126>. Acesso em: 26 maio 2018.

16 WEISS, Edith Brown. Rule of law for nature in a kaleidoscopic world. In: VOIGT, Christina (Ed.). Rule of law for nature: new dimensions and ideas in environmental law. Cambridge: Cambridge University Press, 2013. p. 28.

17 Note-se que a Conferência de Estocolmo denunciou a conexão entre degradação ambiental e ações antrópicas, principalmente as decorrentes da expansão do processo econômico, afirmando a urgente necessidade de abordar o processo de desenvolvimento humano do ponto de vista da proteção ambiental, tornando-se um marco jurídico de relevância para a consolidação daquilo que viria a ser reconhecido como o direito internacional ambiental.

18 VOIGT, Christina. Sustainable development as a principle of international law: resolving conflicts between climate measures and WTO law. Boston: Martinus Nijhoff Publishers, 2009. p. 13. 
bém, no plano nacional, uma necessidade de inserir as questões ambientais nas normativas fundamentais do Estado.

A partir dessa percepção de riscos ecológicos globais, o Estado de Direito não mais poderia se justificar apenas pela proteção de liberdades e direitos individuais: como resposta a uma crescente crise ecológica, o discurso de proteção ambiental, que se deu com mais força primeiramente no plano normativo internacional, foi absorvido, posteriormente, pelas metas e objetivos estatais, fato que resultou na inclusão gradativa, pelos Estados, do meio ambiente como um bem jurídico em suas constituições.

Trata-se do movimento de constitucionalização do ambiente: devido a essas razões, justificadas por um crescente cenário moral global em favor da proteção da natureza, os sistemas constitucionais iniciaram um processo de reconhecimento do ambiente como um valor suficientemente importante e merecedor de tutela constitucional $^{19}$. Esse reconhecimento constitucional do ambiente - que no Brasil se deu pela promulgação da Constituição da República de 1988 e principalmente por seu artigo 225 — suscita que o Estado de Direito brasileiro considera alguma forma de valor ao meio ambiente, digno de tutela e proteção, inovando o ordenamento jurídico ao considerá-lo como um direito (de todos) e dever (da coletividade e do Poder Público), incluindo, ainda, a preocupação com as futuras gerações e com a preservação e restauração dos processos ecológicos essenciais.

A constitucionalização do ambiente é manifestação normativa de uma evolução da teoria constitucional quanto as preocupações e objetivos de um Estado de Direito. Para muito além das tradicionais responsabilidades para com direitos, garantias e liberdades individuais, a Constituição da República de 1988 se expressa em uma ordem jurídica mais sensível às questões ambientais, firmada sob um compromisso político mais solidário e uma arquitetura moralmente expandida, de forma a favorecer um modelo normativo de valoração diferenciado, como é o caso da inclusão no seio da normativa ambiental constitucional da preocupação com as futuras gerações e com formas de vida para além da humana.

Esse modelo normativo de Estado de Direito, que se baseia em um compromisso moral singularizado, destaca tarefas, responsabilidades e funções estatais que convirjam para a persecução de um objetivo de sustentabilidade. Um Estado de Direito que leve a sério a tutela da comunidade política e social deve se traduzir em um Estado constitucional que leve em consideração responsabilidades eticamente e temporalmente diferenciadas.

Tem-se, portanto, no cenário descrito, uma evolução quanto às preocupações do Estado. Trata-se de uma evolução - e não transformação, visto que não deixou de ser alguma coisa para se transformar em outra; os valores primários desse modelo estatal continuam integrando o seu conceito - na estrutura de um Estado que pretende aproximar a natureza e todas as formas de vida da comunidade moral do direito. Um Estado que se pretende democrático, concretizador de direitos e garantidor de liberdades individuais, não pode prescindir da proteção do ambiente e do objetivo de sustentabilidade; não pode prescindir da proteção de vidas humanas e não humanas e dos processos ecológicos essenciais que as sustentam.

O conceito de Estado de Direito descrito neste texto parte da caracterização de um modelo estruturado sob a consideração de uma pluralidade de valores e de objetivos morais, os quais definem a complexidade dos processos sociais e ecológicos na pós-modernidade com base em um imperativo de proteção ecológica.

19 BENJAMIN, Antonio Herman. Constitucionalização do ambiente e ecologização da Constituição brasileira. In: CANOTILHO, José Joaquim Gomes; LEITE, José Rubens Morato (Org.). Direito constitucional ambiental brasileiro. 5. ed. São Paulo: Saraiva, 2012. p. 86-87. 


\subsection{A consideração de um princípio estruturante de sustentabilidade e o Estado como agente colaborador}

Esclarecida a definição de um Estado que encontra uma justificativa de atuação no reconhecimento de valores plurais e que passa a assumir compromissos ética e moralmente inclusivos a fim de alcançar objetivos de proteção do ambiente, inicia-se um exercício de análise, numa perspectiva de organização político-jurídica, em torno do modelo de Direito capaz de conformar, limitar e dizer a atividade do Estado em prol de ações estatais comprometidas com a proteção da natureza.

Partindo da descrição do conceito de sustentabilidade sustentado por Klaus Bosselmann, o texto propõe a compreensão de um Direito de sustentabilidade ${ }^{20}$ e, portanto, de um Princípio de Sustentabilidade como princípio estruturante do Estado de Direito. Por outro lado, sustenta-se que, juntamente com os tradicionais imperativos mandamentais estatais — como proibição, permissão e ordem — um Estado de Direito realmente comprometido com um Direito de sustentabilidade precisa lançar mão de novos recursos para o fim de se alcançar a proteção do ambiente, como o uso de estímulos ou incentivos destinados a influenciar condutas mais sustentáveis.

A discussão que se pretende fazer em torno de um Direito de sustentabilidade não pode prescindir do reconhecimento da controvertida situação da conceituação do termo "sustentabilidade",21, justamente para firmar um posicionamento claro e suficientemente adequado de um Direito de sustentabilidade que aqui será definido. Muito se fala em sustentabilidade, e sob os mais variados prismas e aspectos: a sustentabilidade como um valor, como um dever, como um direito, como um princípio, como uma política, e assim por diante. Assim como muitos também são os documentos jurídicos, nacionais e internacionais, que tratam dessa seara.

Não obstante a profusão de diferentes conceitos, definições, noções e ideias do que seja sustentabilidade, importa ressaltar que a falta de um absoluto consenso quanto à conceituação do termo não inviabiliza sua utilidade e importância para o adequado tratamento das questões ambientais aqui discutidas. Faz-se necessária, apenas, a correta operacionalização do conceito em torno de um núcleo de consideração essencialmente ecológico.

Há vasta literatura sobre diferentes conceituações do termo, no entanto, se adotará a leitura do conceito com base em Bosselmann, porque sua compreensão sistemática integra valores que apresentam proximidade com a tese que aqui procura-se defender.

A sustentabilidade, para Bosselmann, pode, assim, ser entendida como um princípio ${ }^{22}$ de caráter ou núcleo essencialmente ecológico e de um imperativo de proteção e restauração dos sistemas ecológicos do Planeta $^{23}$. Para que seja possível identificar o conceito, salienta a existência de características biofísicas naturais

20 A título de esclarecimento, o sentido principal que aqui se adota para a expressão "Direito de sustentabilidade" não se dá pela tradicional visão dualista "diretos-titulares", ou seja, não se trata de um direito que implica, necessariamente, um titular, um direito individual à sustentabilidade, mas sim de uma construção jurídico-normativa de estruturação e conformação da organização política estatal, o que será melhor explanado em momento oportuno do trabalho.

21 Ainda que se reconheça a existência de uma discussão crítica em torno do conceito de sustentabilidade, esta não é objeto de investigação do presente trabalho, pronto que aqui não será aprofundada. Para o público leitor que assim se interessar, a discussão pode ser encontrada em: BECKERMAN, Wilfred. Sustainable development: is it a useful concept?. 1994. Disponível em: < http://www. environmentandsociety.org/sites/default/files/key_docs/beckerman_3_3.pdf>. Acesso em: 27 maio 2018.; e BONEVAC, Daniel. Is sustainability sustainable?. 2010. Disponível em: <http://bonevac.info/papers/Sustainability.pdf>. Acesso em: 27 maio 2018.

22 Utiliza-se aqui uma referência de princípios cunhada por ALEXY, Robert. Teoria dos direitos fundamentais. 2. ed. São Paulo: Malheiros, 2017. p. 90-91. Para o autor, princípios são mandamentos de otimização porque, diferentemente das regras, podem ser satisfeitos em variados graus. Nesse contexto, ao contrário do que ocorre com as regras (em que, diante de uma situação de conflito, tem-se a declaração de invalidade de uma das normas), a colisão entre princípios não declara a invalidade do princípio que deva ceder, mas apenas estabelece uma relação de precedência. Isto posto, os princípios ordenam que algo seja realizado na maior medida possível dentro das possibilidades fáticas e jurídicas existentes.

23 BOSSELMANN, Klaus. O princípio da sustentabilidade: transformando direito e governança. São Paulo: RT, 2015. p. 78. 
como indicadoras de sustentabilidade, elementos estes que demandam melhor compreensão: a integridade ecológica e a resiliência dos ecossistemas.

Por integridade ecológica, entendem-se as condições e características físicas, biológicas e químicas que compõem e determinam a integridade, a existência e a manutenção de um ecossistema ${ }^{24}$. Isto é, trata-se de um conjunto de atributos ecológicos que permitem a identificação e caracterização de um ecossistema. Por outro lado, resiliência é definida como a capacidade de um determinado sistema natural de manter as relações entre seus elementos mesmo diante de intervenções que perturbem o fluxo normal das atividades ecológicas que ali se estabelecem ${ }^{25}$. A resiliência, nesse sentido, é entendida como a capacidade de carga que um ecossistema possui para a manutenção de sua estrutura e funcionamento após a ocorrência de distúrbios, a capacidade de se adequar a uma nova realidade biofísica. Todavia, é importante a ressalva de que os sistemas naturais não possuem resiliência infinita, sendo claro afirmar a existência de um limite quanto a sua capacidade de carga e adaptação.

Vale a pena notar que ainda que o princípio de sustentabilidade de Bosselmann integre um conceito-núcleo essencialmente ecológico — diferenciando-se dos conceitos básicos de sustentabilidade que buscam pela integração dos aspectos sociais, econômicos e ambientais - isto não quer dizer que o Direito ou o Estado devam preterir os demais princípios em favor do princípio de sustentabilidade, ou seja, que não devam observar os demais valores assegurados pela ordem normativa e política. Para tanto, já estão devidamente positivados na ordem jurídica constitucional os princípios garantidores de direitos e liberdades individuais que - em uma estrutura de princípios como mandamentos de otimização ${ }^{26}$ — diante de situações jurídicas de colisão com o princípio de sustentabilidade, poderão ser satisfeitos em variados graus, a depender das condições fáticas e jurídicas no caso concreto.

O Princípio de Sustentabilidade defendido por Bosselmann, ao integrar os conceitos de integridade ecológica e resiliência, portanto, apresenta-se melhor como um princípio detentor de um núcleo essencialmente ecológico, que requer o respeito aos limites físicos dos ecossistemas naturais e de proteção e restauração desses sistemas. Portanto, pretende-se construir a ideia de que, com base nas proposições de um princípio jurídico de sustentabilidade defendidas neste artigo, denota-se a existência de um emergente Direito de sustentabilidade.

E, para que seja possível identificar, nos termos anteriormente explicitados, um Direito de sustentabilidade na ordem brasileira, seria necessário que esse modelo normativo suscitasse uma tutela da natureza e dos recursos naturais de forma a incorporar a preocupação com a integridade ecológica e resiliência dos sistemas naturais, assegurando, assim, sua durabilidade e existência.

Isso em vista, as proposições de uma estrutura normativa para um Direito de sustentabilidade no Brasil podem ser constatadas a partir da Política Nacional do Meio Ambiente, por meio de seu artigo $2^{\circ}$, inciso I e II, e art. $5^{\circ}$ - que encontra um forte imperativo de preservação, melhoria e recuperação da qualidade ambiental capaz de orientar e conformar a ação estatal — e, posteriormente, na Constituição Federativa de 1988, a partir de seu artigo 225 — que compreende o núcleo ecológico da constituição, considerando o meio ambiente como um bem essencial a qualidade de vida e das futuras gerações, além de incumbir ao Poder Público o dever de preservar e restaurar os processos ecológicos essenciais.

Retomando a segunda pergunta inicialmente proposta no início do segundo tópico, o Direito capaz de orientar, regular e limitar a ação Estatal em busca de um compromisso eticamente expandido para o futuro e moralmente diferenciado é o Direito de sustentabilidade aqui defendido. Apenas um real Direito de susten-

24 BOSSELMANN, Klaus. Loosing the forest for the trees: environmental reductionism in the law. 2010. p. 2439. Disponível em: <http://www.mdpi.com/2071-1050/2/8/2424>. Acesso em: 26 maio 2018.

25 BOSSELMANN, Klaus. Loosing the forest for the trees: environmental reductionism in the law. 2010. p. 2439. Disponível em: <http://www.mdpi.com/2071-1050/2/8/2424>. Acesso em: 26 maio 2018.

26 A referência a uma teoria de princípios como mandamentos de otimização é de Alexy, e pode ser encontrada em: ALEXY, Robert. Teoria dos direitos fundamentais. 2. ed. São Paulo: Malheiros, 2017. p. 90-91. 
tabilidade - estruturado sob a consideração de um princípio de sustentabilidade ecológico comprometido com a proteção da integridade ecológica e da resiliência dos ecossistemas - é capaz de, adequadamente, orientar o Estado para a consecução desse objetivo.

Sob uma condição de adequação e conformação da ordem política por meio da consideração de um Direito de sustentabilidade e, portanto, de um Estado de Direito firmado sob um compromisso político mais solidário e uma arquitetura moralmente expandida, de forma a favorecer um modelo normativo de valoração diferenciado, tem-se por certo afirmar a necessidade de se estabelecer o Princípio de Sustentabilidade como um dos princípios estruturantes do Estado:

Um conhecido juspublicista alemão (Peter Häberle) escreveu recentemente "que é tempo de considerar a sustentabilidade como elemento estrutural típico do Estado que hoje designamos Estado Constitucional". Mais do que isso: a sustentabilidade configura-se como uma dimensão autocompreensiva de uma constituição que leve a sério a salvaguarda da comunidade política em que se insere.

É necessário reforçar a compreensão de que um Estado de Direito comprometido com um princípio estruturante de sustentabilidade ecológica não se realiza acima ou às custas de todos os outros - e igualmente importantes - valores e princípios adotados por esse modelo de Estado. Mas tão somente se consubstancia pela necessidade em configurar padrões de sustentabilidade a níveis de uma ação estatal em busca da salvaguarda da própria comunidade político-social, caso seja objetivo desse Estado a busca da efetivação de uma ordem política juridicamente organizada de justiça social e ecológica.

Um Princípio de Sustentabilidade como um princípio estruturante do Estado propõe uma visão orientadora e conformadora da ação estatal sob a definição de um imperativo de integridade ecológica, abarcando um objetivo holístico de proteção e preservação dos ecossistemas. Para tanto, impõe ao Estado uma ação de sustentabilidade, que dele requer a concretização de tarefas e deveres através de instrumentos de comando e controle. Mas não somente. Diante das complexas e dicotômicas relações existenciais da pós-modernidade, um princípio de sustentabilidade suscita a necessidade de instrumentos de ação estatal que vão para além dos tradicionais imperativos ecológicos acima especificados: suscita novas formas de juridicidade ambien$\mathrm{tal}^{27}$. É assim que se poderia compreender um Estado implementador de um Direito de sustentabilidade e, além disso, colaborador.

Colaborador porque, em uma instância de incentivos, estímulos e influência de comportamentos sustentáveis por meio do Estado, o conceito-chave que deve guiar essas ações estatais é apenas um: o estimulo de escolhas sustentáveis no interesse de se favorecer as liberdades. Em uma estrutura de influências para um objetivo de comportamentos mais sustentáveis é primordial que se mantenha a liberdade de escolha dos sujeitos cujas ações se pretende estimular. A liberdade de escolha, portanto, é o conceito determinante para avaliar se determinada ação estatal é um mandamento — ordem, permissão ou proibição — ou um estímulo, uma influência.

A ideia que se pretende defender neste trabalho é que o Estado, para além dos imperativos ecológicos já descritos, deve, também, atuar como agente colaborador para o alcance de um objetivo de sustentabilidade. Isto porque, para o enfrentamento dos desafios impostos por uma realidade do Antropoceno, a sustentabilidade suscita uma atuação nas mais variadas instâncias — social, econômica, política, ambiental —, por meio das mais variadas formas de atuação — ordem, permissão, proibição, estímulos e influências. Uma atuação restrita e fragmentada é demasiadamente incapaz de alcançar todas as instâncias em que se precisa exercer a sustentabilidade.

Nessa perspectiva, é possível propor-se que um Estado de Direito que realmente intente uma genuína proteção do ambiente deve agir, além dos imperativos ecológicos mandamentais de comando e controle, de forma a influenciar os cidadãos à adoção de comportamentos sustentáveis. Para tanto, o trabalho utilizará

27 CANOTILHO, José Joaquim Gomes. O princípio da sustentabilidade como princípio estruturante do direito constitucional. Revista de Estudos Políticos, v. 3, n. 13, p. 10, 2010. 
do estudo da economia comportamental de Nudge aplicada ao Governo através de políticas públicas de influência para a proteção do ambiente.

A partir deste momento, procura-se compreender, de forma mais específica, de que maneira o Estado — justificado sob a égide de um Direito de sustentabilidade — pode estimular e influenciar os cidadãos à adoção de comportamentos mais sustentáveis. Para tanto, elege-se como modelo de análise a estrutura econômico-comportamental de nudge, termo originalmente criado por Thaler e Sustein ${ }^{28}$.

Retomando a ideia anteriormente defendida de que um Estado condicionado por um princípio estruturante de sustentabilidade suscita novas formas de juridicidade ambiental para além dos tradicionais instrumentos de ordem, proibição e permissão, em vista da consecução de um objetivo de tutela do ambiente, nesta seção, procura-se desenvolver a noção de que a estrutura econômico-comportamental de nudge pode ser utilizada pelo governo para o fim da proteção ambiental, a partir da influência dos cidadãos rumo à comportamentos mais sustentáveis.

A ideia é desenvolvida, num primeiro momento, por meio da exposição e compreensão de conceitos-chave que integram a compreensão dessa teoria, como os conceitos de nudge, paternalismo libertário, arquiteto de escolhas e liberdade, para que posteriormente seja possível defender a sua relação com um objetivo estatal de proteção da natureza e de seus ecossistemas.

Num segundo momento, o trabalho se aprofunda na ideia que aqui se pretende defender: de uma proteção estatal do ambiente a partir do modelo econômico comportamental de nudge, momento em que serão analisadas algumas formas de nudge, e que serão melhores exploradas as conexões entre um Direito de sustentabilidade e nudge. Salienta-se ainda a necessária ressalva quanto a problemática de uma falta de moralidade ou ética para a aplicação e utilização do nudge. Esse vácuo ético no modelo econômico-comportamental, num sentido de que se pode utilizar o nudge tanto para a influência de comportamentos bons ou ruins, o que será melhor explorado, é especialmente preocupante quando seus objetivos de uso são transpostos e intentados pelo Estado.

Nesse contexto, procura-se responder ao problema inicialmente proposto: até que ponto a influência sobre as escolhas de decisões que colaborem para um objetivo de sustentabilidade pelo Estado pode ser considerada ética? Para tanto, faz-se necessária análise quanto aos fundamentos éticos e morais de nudge, principalmente quando adotado e utilizado por governos.

\subsection{Nudge, paternalismo libertário e arquiteto de escolhas: porque nudge não pode eliminar liberdades}

Antes de adentrar no esclarecimento dos conceitos-chave que identificam o modelo de nudge, é imprescindível compreender as bases científicas da teoria econômica que o fundamenta. O nudge, basicamente, consubstancia-se em um modelo econômico da Teoria chamada Behavioral Economics.

Behavioral Economics consiste em uma recente teoria econômica que considera a inclusão de fatores externos ao próprio ramo da economia (como a psicologia comportamental), pautada num objetivo de fazer com que os modelos econômicos apresentem respostas mais adequadas e consistentes às realidades comportamentais dos indivíduos ${ }^{29}$. A teoria econômica tradicional, diferentemente da comportamental, compreende, em sua maioria, modelos abstratos que se baseiam em comportamentos racionais e idealizados e que, nem sempre, se concretizam com exatidão em uma realidade prática ${ }^{30}$.

28 THALER, Richard H.; SUNSTEIN, Cass R. Nudge: improving decisions about health, wealth and happiness. New York: Penguin Books, 2009.

29 THALER, Richard H. Misbehaving: the making of behavioral economics. New York: W. W. Norton \& Company, 2016. p. 27.

30 THALER, Richard H. Misbehaving: the making of behavioral economics. New York: W. W. Norton \& Company, 2016. p. $19-28$. 
Thaler relata que a premissa básica da teoria econômica tradicional parte da assunção de que os indivíduos exercem suas escolhas de uma forma otimizada e racional. Essa suposição de um comportamento econômico consciente e adequado determinou aquilo chamado de homo economicus: diferentemente do homo sapiens, que exerce suas escolhas de forma nem sempre racional e correta, o homo economicus consubstancia-se em uma figura fictícia do ser humano, que realiza escolhas baseadas em uma racionalidade de otimização $\mathrm{O}^{31}$, e fundamenta os modelos de analise econômica abstrata ${ }^{32}$. O homo economicus, portanto, traduz-se em uma visão idealizada de que todo ser humano é economicamente educado e sofisticado e, portanto, capaz de realizar escolhas racionais e otimizadas ${ }^{33}$.

Todavia, Thaler compreende que esse modelo econômico - que substitui o homo economicus pelo homo sapiens - nem sempre corresponde a realidade fática, e salienta que é preciso que os economistas parem de “(...) supor que esses modelos são descrições precisas do comportamento e par[em] de basear decisões políticas em tais análises, visto que falhas" ${ }^{34}$. Isso demonstra que nem sempre as pessoas irão se comportar da maneira que os tradicionais modelos econômicos preveem, pois há fatores externos que podem influenciar a conduta humana em direções para além das previstas por um modelo pautado na visão de um homo economicus.

Nessa perspectiva, diante de uma necessidade de melhor compreender o comportamento humano a partir de uma abordagem econômica realista - isto é, pautada em um modelo que considere o ser humano como o homo sapiens que é, e não homo economicus - e procurando superar as falhas da teoria econômica tradicional em busca de um melhor entendimento quanto a como os seres humanos podem reagir a determinadas situações, a economia comportamental se dá pela incorporação de elementos e estudos científicos de ramos como a psicologia e de outras ciências sociais, em busca da compreensão dos motivos que impulsionam o ser humano a tomar decisões ${ }^{35}$.

Isso em vista, o nudge, modelo da Teoria Econômica Comportamental que é, preocupa-se com a análise do comportamento individual em busca de melhorar a precisão da previsão de como os seres humanos irão agir diante de determinados contextos e, com base nessa constatação, promover um arranjo contextual que seja favorável a direcionar os indivíduos à adoção de uma conduta desejável. A lógica dessa teoria pode ser melhor compreendida quando esclarecidos os conceitos-chaves que a identificam: paternalismo libertário, arquiteto de escolhas e liberdade. E, para o fim de permitir uma correta compreensão do leitor, opta-se por descrever um exemplo prático e corriqueiro de nudge, com o qual a maioria — senão todos — poderá se identificar.

Imagine um cenário em que, na correria do dia a dia e das multitarefas que são impostas a todos os indivíduos que se encontram inseridos na sociedade do século XXI, e entre variados compromissos profissionais, sociais e pessoais, as pessoas se esqueçam de pagar a conta de seus telefones celulares na data estabelecida para o vencimento. Sem problemas, afinal, o avanço da tecnologia permite efetuar o pagamento por meio de um aplicativo bancário em smartphones, a qualquer hora e em qualquer lugar. Todavia, ainda que diante das facilidades que a tecnologia ofereça, as pessoas continuam se esquecendo de efetuar o pagamento, logo. Logo, elas serão surpreendidas com uma mensagem SMS em seus celulares, enviada por suas operadoras de telefone, lembrando-lhes de efetuar o pagamento da referida conta e incluindo, gentilmente, o correspondente código de barras e informações como o valor a ser pago. Muito conveniente, não?

31 Thaler exemplifica a questão da otimização da seguinte maneira: analisando-se opções disponíveis de bens e serviços que uma determinada família poderia comprar, a escolha desta família sempre será no sentido de comprar o melhor bem ou serviço dentro dos limites de seu orçamento. Esta escolha é o que os economistas chamam de "expectativas racionais". Em: THALER, Richard H. Misbehaving: the making of behavioral economics. New York: W. W. Norton \& Company, 2016. p. 21.

32 THALER, Richard H. Misbehaving: the making of behavioral economics. New York: W. W. Norton \& Company, 2016. p. 20.

33 THALER, Richard H. Misbehaving: the making of behavioral economics. New York: W. W. Norton \& Company, 2016. p. 26.

34 THALER, Richard H. Misbehaving: the making of behavioral economics. New York: W. W. Norton \& Company, 2016. p. 20.

35 THALER, Richard H. Misbehaving: the making of behavioral economics. New York: W. W. Norton \& Company, 2016. p. 27. 
Diante desse simples exemplo, podem-se extrair os conceitos estruturantes de nudge. Assumindo-se o fato de que o interesse da operadora telefônica é exclusiva e genuinamente, apenas, o bem-estar de seus consumidores, ou seja, que tenha como objetivo tão somente evitar que seus consumidores entrem em situações de inadimplência, que, em todo caso, são consideradas indesejáveis e até mesmo prejudiciais, visto que podem causar a interrupção do serviço telefônico desse consumidor, estar-se-á diante de um nudge.

A operadora telefônica, aqui, assume o papel do que é chamado, em um modelo de nudge, de "arquiteto de escolhas". Isto porque, o arquiteto de escolhas é o responsável por organizar o contexto no qual os indivíduos deverão exercer uma decisão, de forma a estruturar uma arquitetura que os influencie a adotar uma conduta pré-determinada e desejada pelo arquiteto ${ }^{36}$. No exemplo analisado, o arquiteto de escolhas - a operadora telefônica - elabora o contexto - envio de mensagem SMS que orienta o pagamento de conta em atraso — em que os consumidores — as pessoas — devem tomar uma decisão: a de efetuar ou não o referido pagamento.

Já a justificativa do envio da mensagem SMS para os consumidores que ainda não tenham efetuado o pagamento em atraso, como já salientado, dá-se por uma preocupação com o próprio bem-estar do consumidor, o que demonstra o paternalismo libertário.

O paternalismo libertário é conceito aparentemente contraditório, que pode causar certa estranheza àqueles que não possuem proximidade com um modelo de nudge, visto que conjuga palavras que, à primeira vista, são antagônicas. Fala-se em paternalismo porque há uma preocupação genuína e justificada do arquiteto de escolhas em tentar influenciar o comportamento dos indivíduos a fim de tornar suas vidas melhores, de forma a facilitar que atinjam seus próprios objetivos em termos de bem-estar ${ }^{37}$. Já o aspecto libertário, que integra o conceito, reside no fato de que as pessoas, em geral, são livres para realizarem suas próprias escolhas e, portanto, possuem a liberdade de fazer o que bem lhes convém ${ }^{38}$. Portando, é paternalismo porque se preocupa em melhorar a qualidade de vida e bem-estar dos indivíduos, mas libertário porque não o faz por meio de mandamentos como ordem, proibição ou permissão, mas tão somente por meio de orientação no sentido da adoção de uma melhor conduta para o seu próprio bem-estar.

Diante dessa percepção, é possível compreender que um dos conceitos mais importantes e que caracterizam o nudge é, além dos já citados paternalismo libertário e arquiteto de escolhas, a liberdade dos próprios indivíduos. O nudge somente é nudge se montado sob uma arquitetura que mantenha e preserve a liberdade de escolha das pessoas. Ações que contenham expressões de ordem, permissão ou proibição não se caracterizam como nudge, porque nesses casos estar-se-á diante de uma ação mandamental, e não de influência. Nudge é, portanto, um modelo comportamental de estimulo de escolhas no interesse de se favorecer as liberdades individuais. Se a "influência" exercida sobre os indivíduos acaba por impor um grande fardo ${ }^{39}$, não se está diante de uma arquitetura de escolhas que favoreça o exercício das liberdades, mas sim de uma imposição, de uma exigência, não restando para o indivíduo a real possibilidade de uma livre decisão.

Segundo Halpern, nudge pode ser entendido como "essencialmente um meio de encorajar ou orientar o comportamento, mas sem exigir ou instruir, e idealmente, sem a necessidade de vultuosos incentivos financeiros ou sanções" ${ }^{40}$.

Isso em vista, o nudge se identifica por intervenções cujo objetivo é o de orientar pessoas em determi-

36 THALER, Richard H.; SUNSTEIN, Cass R. Nudge: improving decisions about health, wealth and happiness. New York: Penguin Books, 2009. p. 5.

37 THALER, Richard H.; SUNSTEIN, Cass R. Nudge: improving decisions about health, wealth and happiness. New York: Penguin Books, 2009. p. 5.

38 THALER, Richard H.; SUNSTEIN, Cass R. Nudge: improving decisions about health, wealth and happiness. New York: Penguin Books, 2009. p. 5.

39 SUNSTEIN, Cass R. Foreword: the ethics of nudging. In: ALEMMANO, Alberto; SIBONY, Anne-lise (Org.). Nudge and the law: a european perspective. Oregon: Hart Publishing, 2015.

40 HALPERN, David. Inside the nudge unit: how small changes can make a big difference. London: WH Allen, 2015. p. 46. 
nadas direções ou, mais especificamente, influenciar indivíduos à adoção de um comportamento primariamente desejado pelo arquiteto de escolhas e em prol daqueles que se pretende influenciar. Todavia, o nudge, não obstante a existência de uma orientação ou influência dos indivíduos em uma certa direção, não tem a capacidade de ordenar e exigir a adoção do comportamento desejado, sendo imprescindível que a liberdade de escolha dos indivíduos seja integralmente respeitada.

Voltando ao exemplo da operadora telefônica, a simples mensagem SMS enviada ao consumidor inadimplente lembrando-o do pagamento atrasado e com a inclusão do correspondente código de barras não demanda ou ordena nenhuma ação do indivíduo, tendo esse total liberdade para decidir se efetua o pagamento ou não, embora seja necessário reconhecer que esse simples lembrete possa criar um ambiente mais propício para o pagamento em atraso do que se nenhuma mensagem fosse a ele enviada. Esta é a ideia básica que sustenta todo esse modelo comportamental: o nudge é uma pequena característica que tem o poder de atrair a atenção e influenciar o comportamento dos indivíduos ${ }^{41}$, sem que lhes retire a liberdade de realizar suas próprias suas escolhas.

Esclarecidos os conceitos-chave do modelo econômico de nudge, o trabalho dedicará atenção especial para a relação entre nudge e o direito, e entre nudge e sustentabilidade. Faz-se necessário esclarecer, primeiramente, que o modelo de nudge a ser utilizado neste trabalho para o argumento de uma proteção do ambiente considerará como arquiteto de escolha, necessariamente, apenas a figura do Estado. Nessa concepção, é possível propor-se a vinculação da necessidade estatal por uma busca de novas formas de juridicidade em prol de um objetivo de sustentabilidade a partir de um modelo econômico comportamental de nudge, visto que propício para uma ação estatal de influência sobre os indivíduos.

\subsection{O Estado como arquiteto de escolhas: até que ponto a influência exercida para um objetivo de sustentabilidade é considerada ética?}

Sunstein afirma que o uso do modelo econômico comportamental de nudge pelos governos é um movimento em expansão, e já ocorre em diversos países como, Estados Unidos, Reino Unido, Alemanha, e muitas outras nações, tendo esses governos recrutado pessoas com experiência na área de ciência comportamental, pautados em um objetivo de identificar abordagens que poderiam auxiliar no alcance dos mais variados fins sociais, como o crescimento econômico, a melhora na saúde pública, a redução da pobreza, e a proteção do ambiente ${ }^{42}$.

Um modelo comportamental de nudge a ser utilizado pelo Estado com o objetivo de proteção do ambiente pode causar certa estranheza num primeiro momento. Isto porque, quando se fala em proteção ambiental pelo Estado, as pessoas, geralmente, tendem a associar essa tutela a uma ideia de deveres e responsabilidades que demandam do agente estatal uma conduta rígida de proteção com base em ações de comando e controle ${ }^{43}$, de restrição e limitação de direitos e liberdades, ou seja, de uma relação antagônica entre a proteção ambiental e o exercício de liberdades dos cidadãos. Importa elucidar que o modelo econômico comportamental de nudge não consegue, por si só, solucionar todo e qualquer problema socioambiental. Isso em vista, faz-se necessário compreender que normas e legislações, permissões e proibições, são inevitáveis e, ainda, mantêm o seu devido lugar, visto que nenhuma sociedade pode existir sem regras ${ }^{44}$.

No entanto, ressalta-se que normas legislativas, por si só, também não são capazes de solucionar todo e qualquer problema socioambiental. Com isso, importa esclarecer que, ainda que a proteção do meio am-

41 THALER, Richard H. Misbehaving: the making of behavioral economics. New York: W. W. Norton \& Company, 2016. p. 502. 42 SUNSTEIN, Cass R. The ethics of influence: government in the age of behavioral science. New York: Cambridge University Press, 2016. p. 5 .

43 THALER, Richard H.; SUNSTEIN, Cass R. Nudge: improving decisions about health, wealth and happiness. New York: Penguin Books, 2009. p. 186.

44 THALER, Richard H. Misbehaving: the making of behavioral economics. New York: W. W. Norton \& Company, 2016. p. 500. 
biente, de fato, suscite algum nível de regulação legislativa, o Estado precisa ir além. Além disso, o pode fazer garantindo ainda o exercício de liberdades dos cidadãos em uma instância de incentivos e influências.

O entendimento que aqui quer se firmar, portanto, é no sentido de que normas legislativas são diferentes de nudge — pois, a primeira é um imperativo que precisa ser atendido, enquanto o segundo, uma influência que garante o exercício da liberdade de escolha. Entretanto, ainda que diferentes, não significa dizer que ambos não possam ser conciliados e utilizados para um objetivo único de sustentabilidade, cada um atuando em seu âmbito de aplicação e de forma singular, o que acaba por permitir um alcance maior e mais efetivo da proteção do ambiente.

Conforme já salientado no segundo item, um Estado de Direito orientado por um princípio estruturante de sustentabilidade requer ações para além dos tradicionais imperativos ecológicos positivados na Constituição da República de 1988 e na Política Nacional do Meio Ambiente, chamadas de novas formas de juridicidade. Para tanto, utiliza-se o modelo econômico comportamental de nudge. E a discussão em torno de uma ação do Estado baseada em um modelo de nudge para um objetivo específico de sustentabilidade não pode prescindir da análise de algumas questões relevantes, que implicam uma abordagem diferenciada da construção da arquitetura de escolha e da justificativa estatal do paternalismo libertário, se se quiser falar em nudge e proteção ambiental.

A primeira delas consiste no alargamento de alguns conceitos-chave da própria estrutura de nudge, para que este seja aplicado sob um objetivo de proteção do ambiente, ideia que aqui se sustenta. Isso porque a justificativa de um paternalismo libertário do nudge tradicional parte do pressuposto que o arquiteto de escolhas pretende influenciar indivíduos à adoção de certos comportamentos para que estes atinjam seus objetivos em termos de bem-estar, como já defendido anteriormente. Assim, visualizando-se a questão ambiental — que implica uma visão holística dos danos ecológicos a partir de externalidades causadas pelos mais variados agentes - , tem-se por certo afirmar que a preocupação do arquiteto de escolhas é outra, fundamentalmente diferenciada da justificação de bem-estar individual: trata-se do bem-estar coletivo e do objetivo de se evitar que indivíduos adotem ações ou comportamentos que interfiram e prejudiquem a vida de terceiros e que imponham danos ao meio ambiente ${ }^{45}$.

A segunda característica diferenciada de nudge para o fim da proteção do ambiente reside na preocupação quanto a qual modelo de arquitetura de escolhas é o mais adequado para influenciar indivíduos à adoção de comportamentos mais sustentáveis. Existem diversas formas de nudge para a proteção ambiental: é possível se falar, por exemplo, em incentivos econômicos e disposição de informações relevantes para orientar os indivíduos a uma tomada de decisão mais sustentável.

Em relação aos incentivos econômicos, cita-se como exemplo o "cap and trade" relacionado às emissões de carbono: aqueles que reduzirem seu grau de poluição à determinados níveis pré-estabelecidos pelo Estado, são autorizados a vender seus créditos de carbono. Thaler e Sunstein defendem que esse tipo de nudge serve, ao mesmo tempo, como desincentivo à poluição e como incentivo para o controle da poluição ${ }^{46}$. Já em relação à disposição de informações relevantes, cita-se como exemplo a exigência do governo às indústrias automobilísticas que disponham, em seus carros, um rótulo que contenha informações relativas ao custo anual estimado de combustível que o veículo consumirá ${ }^{47}$. Essas informações constituem um tipo de nudge, visto que podem influenciar consumidores a optarem por carros que consumam menos combustível fóssil, ainda que a justificativa primária para a escolha tenha fundamentos econômicos.

Todavia, importa salientar que, ao contrário do que se poderia supor, influenciar o comportamento hu-

45 SUNSTEIN, Cass R. The ethics of influence: government in the age of behavioral science. New York: Cambridge University Press, 2016. p. 31 .

46 THALER, Richard H.; SUNSTEIN, Cass R. Nudge: improving decisions about health, wealth and happiness. New York: Penguin Books, 2009. p. 188.

47 THALER, Richard H.; SUNSTEIN, Cass R. Nudge: improving decisions about health, wealth and happiness. New York: Penguin Books, 2009. p. 193-194. 
mano rumo à adoção de ações mais sustentáveis não é uma questão predominantemente econômica, e sim complexa e heterogênea, em que há a inserção de diversas outras características significativas. Explica-se: há diversos outros fatores igualmente relevantes que são levados em consideração no momento em que os indivíduos se encontram diante da necessidade de uma tomada de decisão que promova uma conduta sustentável ou insustentável, o que será demonstrado com base em outra opção de nudge para proteção ambiental.

Para além de incentivos econômicos e informações relevantes, o arquiteto de escolhas pode se valer ainda das chamadas "default rules" (regras-padrão) ${ }^{48}$. Utilizar-se-á de um exemplo concreto de nudge para proteção ambiental explorado por Sunstein para o fim de exemplificar essa forma de arquitetura de escolha. A Universidade do Estado de Nova Jersey-EUA, Rutgers University, adotou um modelo de regras-padrão quanto ao consumo de papel, modificando a configuração das impressoras da instituição de "imprimir em um lado" por um padrão de "imprimir nos dois lados". Esse novo padrão de impressão permitiu uma redução no consumo de papel em mais de 55 milhões de folhas apenas nos três primeiros anos, o que representou uma redução de $44 \%$ do consumo, o equivalente a 4.650 árvores ${ }^{49}$.

Uma arquitetura de escolha baseada em regras-padrão, portanto, se identifica por um padrão pré-estabelecido pelo arquiteto de escolha dentre algumas outras opções, e que acaba permanecendo caso os indivíduos não tomem medidas para alterar e sair desse padrão, ou seja, as regras-padrão se estabelecem quando as pessoas optarem por não fazer nada ${ }^{50}$. Salienta-se que, ainda que essa nudge se baseie no estabelecimento de uma regra-padrão, o exercício das liberdades ainda é respeitado, porque a todo momento os indivíduos possuem a opção de não o adotar, isto é, possuem a liberdade de opt-out. não se trata de restringir ou limitar liberdades, pois todas as demais opções de escolha são mantidas ao alcance do indivíduo.

Sunstein e Reisch afirmam que a melhor forma de realizar nudges para o fim de uma proteção ambiental se dá a partir da adoção pelo arquiteto de escolha de modelos de regras-padrão, sendo este o meio mais efetivo de se conseguir influenciar condutas de proteção ambiental ${ }^{51}$. Isto porque há alguns fatores que contribuem para a sua eficiência, como por exemplo o fator da inércia: compreende-se que para mudar a regra-padrão, as pessoas precisam fazer uma escolha ativa de rejeitar aquela regra previamente estabelecida e, portanto, focar em questões relevantes como se irá decidir por adotar uma ação mais sustentável ou não ${ }^{52}$. Ademais, entende-se que, talvez, seja mais tentador adiar a decisão ou simplesmente não tomar decisão alguma e apenas seguir o padrão estabelecido: isto denota que o poder da inércia pode fazer com que as pessoas acabem mantendo o status quo, que, nesse caso, parte de uma regra-padrão sustentável ${ }^{53}$.

Em uma visão do Estado como arquiteto de escolhas, ideia que aqui se sustenta, uma proposta interessante de nudge para o fim de proteção ambiental poderia se dar pelo estabelecimento de regras-padrão para a impressão "nos dois lados" da folha em todos os órgãos públicos, por exemplo. Pode parecer, à primeira vista, que influências como essas são ligeiramente insignificantes quando colocadas em contraste com as diversas problemáticas ecológicas que desafiam a sociedade contemporânea. Entretanto, como visto no exemplo da Universidade Rutgers — que é apenas uma instituição —, no curto período de três anos, houve a redução do consumo de papel em quase 50\%. Transpor essa ideia de nudge para todos os órgãos do Estado, a um nível nacional, poderia ter um grande impacto na redução do consumo de papel, pelo menos dentro dos órgãos governamentais. E este é, apenas, um exemplo, dentre tantos, do que poderia ser feito em

48 SUNSTEIN, Cass R. Choosing not to choose: understanding the value of choice. New York: Oxford University Press, 2015. p. 5.

49 SUNSTEIN, Cass R. Choosing not to choose: understanding the value of choice. New York: Oxford University Press, 2015. p. 26.

50 SUNSTEIN, Cass R.; REISCH, Lucia A. Automatically green: behavioral economics and environmental protection. 2013. p. 4. Disponível em: <https://papers.ssrn.com/sol3/papers.cfm?abstract_id=2245657>. Acesso em: 29 maio 2018.

51 SUNSTEIN, Cass R.; REISCH, Lucia A. Automatically green: behavioral economics and environmental protection. 2013. p. 11-

15. Disponível em: <https://papers.ssrn.com/sol3/papers.cfm?abstract_id=2245657>. Acesso em: 29 maio 2018.

52 SUNSTEIN, Cass R. The ethics of influence: government in the age of behavioral science. New York: Cambridge University Press, 2016. p. 170.

53 SUNSTEIN, Cass R. The ethics of influence: government in the age of behavioral science. New York: Cambridge University Press, 2016. p. 170. 
prol de uma influência estatal para a adoção de comportamentos sustentáveis.

Por fim, pretende-se analisar a questão ética concernente ao nudge: se a Teoria Econômico-comportamental de nudge é amoral e, portanto, pode ser utilizada para estimular tanto comportamentos bons quanto ruins, ou, até mesmo, manipular, em vez de influenciar, como garantir que o Estado realmente a utilize para estimular condutas que intentem o bem-estar da população e do ambiente? Isto é, até que ponto a influência exercida para um objetivo de sustentabilidade pelo Estado é considerada ética e, portanto, preserva o exercício das liberdades dos cidadãos?

Sunstein afirma que as críticas fundadas em justificativas éticas ao nudge estatal não possuem força, porque, em primeiro lugar, a arquitetura de escolha e nudges são inevitáveis e, portanto, inútil desejar que não ocorram e; em segundo lugar, porque a maioria dos nudges e das arquiteturas de escolhas são defensíveis e mesmo baseados em fundamentos éticos ${ }^{54}$. Todavia, salienta que algumas formas de nudge e arquitetura de escolha são inaceitáveis, principalmente quando baseada em fins ilícitos, como quando intentam a "entrincheirar" o governo atual, ajudar poderosos grupos privados, ou mesmo auxiliar a defesa de certas maiorias raciais ou religiosas ${ }^{55}$.

Para que seja possível identificar, portanto, os limites éticos impostos ao Estado diante da adoção de nudges para a proteção do ambiente, é necessário que o agente estatal observe e respeite quatro valores fundamentais: bem-estar, autonomia, dignidade e autogoverno. Sunstein afirma que se o Estado se preocupa com o bem-estar de seus cidadãos, irá procurar aumentar as chances das pessoas de alcançarem seus objetivos de possuir uma vida melhor, e permitirá, na maioria das vezes, que os indivíduos encontrem seus próprios caminhos, o que identifica o respeito pela autonomia dos cidadãos. Se o Estado se preocupa com a dignidade, ele sempre tratará as pessoas com respeito, e garantirá, igualmente, o autogoverno, o que significa que assegurará a existência e preservação da organização social que permita o exercício da autoridade dos cidadãos quanto ao controle de seus líderes políticos ${ }^{56}$.

A observância desses quatro valores identifica fortes limites éticos sob a ação estatal, seja ela uma ordem ou uma influência. Nesse contexto, governos autoritários não permitem a autonomia, não respeitam o autogoverno e a dignidade, muito menos promovem o bem-estar de seus cidadãos ${ }^{57}$. Todavia, importa ressaltar que, ainda que os fins de uma política de influência para a proteção do ambiente observem esses quatro valores e seja, portanto, legítima, o Estado precisa observar o dever de transparência para com seus cidadãos, e evitar a manipulação.

Isso porque o fato de uma arquitetura baseada em nudge manter o exercício de liberdade de escolha dos indivíduos não quer dizer que o Estado pode fazer aquilo que bem desejar. Deve o Estado justificar suas ações, mesmo as baseadas apenas em influências, pois, uma abordagem de preservação de liberdades, ainda que apresente diversas vantagens, pode abrigar fins ilícitos e surgir, ainda, como forma de manipulação dos indivíduos ${ }^{58}$. Para que o nudge seja considerado ético e lícito, portanto, o Estado deve apresentar uma justificativa, com base na transparência e da observação dos valores de bem-estar, autonomia, dignidade e autogoverno.

Salienta-se que a justificação de um paternalismo libertário para os fins de uma proteção do ambiente se dá

54 SUNSTEIN, Cass R. The ethics of influence: government in the age of behavioral science. New York: Cambridge University Press, 2016. p. 12.

55 SUNSTEIN, Cass R. The ethics of influence: government in the age of behavioral science. New York: Cambridge University Press, 2016. p. 12.

56 SUNSTEIN, Cass R. The ethics of influence: government in the age of behavioral science. New York: Cambridge University Press, 2016. p. 3.

57 SUNSTEIN, Cass R. The ethics of influence: government in the age of behavioral science. New York: Cambridge University Press, 2016. p. 3.

58 SUNSTEIN, Cass R. The ethics of influence: government in the age of behavioral science. New York: Cambridge University Press, 2016. p. 13. 
de forma a estender as estruturas do modelo econômico-comportamental de nudge, visto que, diferentemente da preocupação tradicional de possibilitar que os indivíduos possam alcançar bem-estar e melhorias em suas próprias vidas, a preocupação que reside na abordagem de um paternalismo libertário, quanto à justificativa da proteção ambiental por meio de nudge, encontra-se radicada em valores para além dos indivíduos e da vida humana: tem-se, aqui, a consideração do bem-estar coletivo, das futuras gerações e de todas as formas de vida.

Um Estado que emprega políticas públicas baseadas em nudge para o fim de um objetivo de sustentabilidade respeita todos os valores anteriormente descritos. Isto porque se preocupa com o bem-estar individual e com o respeito à dignidade dos cidadãos, visto que a proteção e preservação da natureza e dos ecossistemas naturais estão intrinsicamente relacionadas com a qualidade de vida, figurando ainda como condição primária para o gozo de direitos humanos ${ }^{59}$. Nesse contexto, a proteção do ambiente figura como condição sine qua non para a realização dos mais variados direitos humanos, como a vida, o bem-estar e a dignidade ${ }^{60}$. Não é outro o raciocínio que se poderia extrair da intrínseca relação entre a proteção do ambiente e o bem-estar e dignidade humanos, não sendo possível se argumentar que a proteção da natureza por meio de nudge não respeita ou promove ambos valores.

Não pode se dizer, de igual forma, que um Estado orientado por um princípio estruturante de sustentabilidade não respeita a autonomia e o autogoverno de seus cidadãos. A consideração pelo Estado de uma proteção do ambiente nos termos aqui defendidos, portanto, com base em um compromisso eticamente expandido para o futuro e moralmente diferenciado, não possui o condão de minar direitos e valores políticos constitucionalmente consagrados, consubstanciando-se, acima de tudo, em um Estado Democrático de Direito e, portanto, configurando-se muito mais sob uma estrutura de incentivo e participação popular do que uma que impeça a soberania popular ${ }^{61}$. Ademais, devido a sua abordagem libertária, não há que se falar em desrespeito à autonomia dos indivíduos sendo importante, principalmente, que não se confunda o nudge ambiental com os tradicionais instrumentos de comando e controle estatais. Estes sim têm o poder de limitar — desde que também devidamente justificada — a conduta humana, ao contrário do modelo econômico-comportamental de nudge.

Sob a afirmação de fins lícitos, justificados e transparentes, portanto, o Estado pode, e deve — visto que um princípio estruturante de sustentabilidade exige novas formas de juridicidade ambiental — utilizar-se de nudges para o fim de atingir um objetivo de sustentabilidade. A abordagem do paternalismo libertário para a proteção jurídica do ambiente é método relevante e que suscita grandes transformações no campo comportamental da sociedade, e deve ser melhor compreendido pelo Direito, para o fim de garantir que a influência exercida pelo governo seja fundamentada em motivos verdadeiramente éticos e respeite os valores fundamentais de bem-estar, dignidade, autonomia e autogoverno, sendo possível se garantir, dessa forma, uma efetiva proteção do ambiente por meio de nudges.

\section{Considerações finais}

Com base na abordagem desenvolvida no presente trabalho, o modelo da Teoria Econômica Comportamental de nudge foi explorado como uma das novas formas de juridicidade ambiental suscitada por um

59 BOSSELMANN, Klaus. Direitos humanos, ambiente e sustentabilidade. RevCEDOUA, n. 21, p. 12, 2008. Disponível em: <https://digitalis-dsp.uc.pt/bitstream/10316.2/8821/3/1.pdf>. Acesso em: 31 maio 2018.

60 BOSSELMANN, Klaus. Direitos humanos, ambiente e sustentabilidade. RevCEDOUA, n. 21, p. 12-13, 2008. Disponível em: <https://digitalis-dsp.uc.pt/bitstream/10316.2/8821/3/1.pdf>. Acesso em: 31 maio 2018.

61 Para Canotilho, o Estado de Direito só é Estado de Direito se subordinado à uma constituição e que respeite a democracia e promova objetivos sociais e de sustentabilidade: CANOTILHO, José Joaquim Gomes. O Estado de Direito. 1999. p. 7. Disponível em:<https://s3.amazonaws.com/academia.edu.documents/33341061/jigcoedd.pdf?AWSAccessKeyId=AKIAIWOWYYGZ2Y 53UL3A\&Expires $=1527800386 \&$ Signature $=r M E 4 X i S D N Z 62 z w x q F j 3 H o m f 35 \mathrm{dg} \% 3$ D\&response-content-disposition $=$ inline $\%$ 3B\%20filename\%3DESTADO_DE_DIREITO.pdf>. Acesso em: 26 maio 2018. 
princípio estruturante de sustentabilidade do Estado de Direito contemporâneo, e que faz parte, em conjunto com os tradicionais imperativos ecológicos estatais de comando e controle, dos instrumentos de uma política pública de sustentabilidade.

Em um contexto de riscos globais e ameaças sociais e ecológicas identificado pela era geológica do Antropoceno, foi possível verificar a existência de uma estrutura dogmática de um Direito que, ao contrário do que se poderia esperar - regulação e orientação dos sistemas econômicos —, acaba por oportunizar a criação de um ambiente propício para que um desenvolvimento pautado em um arquétipo de "business as usual" continue a ser propagado, o que evidência a necessidade de transformações a serem estimuladas na estrutura das funções do Estado e das instituições.

Para o fim de que fosse possível compreender as transformações pelas quais devem passar o Direito e o Estado, portanto, demonstrou-se que a realidade de um Direito dogmático deve ser substituída pela de um Direito de sustentabilidade. Sob esse contexto, foi possível identificar que, mediante o movimento de constitucionalização do ambiente, o Estado passou a considerar valores e compromissos morais inclusivos e diferenciados, visando sua atuação no sentido da proteção do ambiente por meio de tarefas, objetivos e compromissos para com todas as formas de vida e com as futuras gerações.

As proposições de uma estrutura normativa para um Direito de sustentabilidade no Brasil puderam ser constatadas a partir dos imperativos ecológicos da Política Nacional do Meio Ambiente, por meio de seu artigo $2^{\circ}$, inciso I e II, e art. $5^{\circ}$ - que encontra um imperativo reforçado de preservação, melhoria e recuperação da qualidade ambiental capaz de orientar e conformar a ação estatal — e, posteriormente, na Constituição Federativa de 1988, a partir de seu artigo 225 — que compreende o núcleo ecológico da constituição.

Ademais, sob uma condição de adequação e conformação da ordem política por meio da consideração de um Direito de sustentabilidade e, portanto, de um Estado de Direito firmado sob um compromisso político mais solidário e uma arquitetura moralmente expandida, de forma a favorecer um modelo normativo de valoração diferenciado, foi possível identificar a necessidade de se estabelecer o princípio de sustentabilidade como um dos princípios estruturantes do Estado contemporâneo.

A partir dessa análise, restou claro que o Princípio Estruturante de Sustentabilidade suscita novas formas de juridicidade ambiental, prevendo a necessidade do Estado de se valer de recursos de estímulos e influências para o exercício das políticas públicas de sustentabilidade.

Isso posto, para compreender de que maneira o Estado - justificado sob a égide de um Direito de sustentabilidade - poderia estimular e influenciar os cidadãos à adoção de comportamentos mais sustentáveis, o trabalho adotou a teoria econômica comportamental de nudge, momento em que foram esclarecidos os principais conceitos que caracterizam esse modelo, como paternalismo libertário, arquiteto de escolhas e liberdade.

Posteriormente, pode-se demonstrar que o Estado, para além da tradicional atuação mediante imperativos ecológicos de comando e controle, pode agir, também, como colaborador, momento em que se explorou a teoria de nudge fundamentada no Estado como arquiteto de escolhas e pautado no objetivo de influenciar seus cidadãos à adoção de comportamentos mais sustentáveis. Nesse contexto, a análise da relação entre nudge e sustentabilidade se deu com base no estudo de casos práticos de uma arquitetura de escolhas estatal que intentaram a proteção do ambiente.

Por fim, analisou-se a problemática ética que permeia o nudge e a sustentabilidade, sendo possível se concluir que a justificação de um paternalismo libertário para os fins de uma proteção do ambiente se dá de forma a respeitar e promover os valores de bem-estar, autonomia, dignidade e autogoverno, não sendo possível se defender uma crítica ética de nudge no sentido de que proteção do ambiente, necessariamente, implica redução de liberdades e direitos individuais. 
Sob o ângulo de definição do paternalismo libertário, e sob a perspectiva do Estado, foi possível compreender que nudge representa movimento e relacionamento das instâncias onde as liberdades são exercidas. Se não se pode destruir as liberdades sob o pretexto de se proteger a natureza, a ideia de nudge surge como uma tentativa e uma proposta de equilíbrio para que as liberdades continuem a ser respeitadas e exercidas, mas no interesse para além de seus titulares.

\section{REFERÊNCIAS}

ALEMANNO, Alberto; SPINA, Alessandro. Nudging legally: on the checks and balances of behavioral regulation. International Journal of Constitutional Law, v. 12, p. 429-456, 2014.

ALEXY, Robert. Teoria dos direitos fundamentais. 2. ed. São Paulo: Malheiros, 2017.

BECKERMAN, Wilfred. Sustainable development: is it a useful concept?. 1994. Disponível em: <http://www. environmentandsociety.org/sites/default/files/key_docs/beckerman_3_3.pdf>. Acesso em: 27 maio 2018.

BENJAMIN, Antonio Herman. Constitucionalização do ambiente e ecologização da Constituição brasileira. In: CANOTILHO, José Joaquim Gomes; LEITE, José Rubens Morato (Org.). Direito constitucional ambiental brasileiro. 5. ed. São Paulo: Saraiva, 2012.

BONEVAC, Daniel. Is sustainability sustainable?. 2010. Disponível em: < http://bonevac.info/papers/Sustainability.pdf>. Acesso em: 27 maio 2018.

BOSSELMANN, Klaus. O princípio da sustentabilidade: transformando direito e governança. São Paulo: RT, 2015.

BOSSELMANN, Klaus. Loosing the forest for the trees: environmental reductionism in the law. 2010. Disponível em: <http://www.mdpi.com/2071-1050/2/8/2424>. Acesso em: 26 maio 2018.

BOSSELMANN, Klaus. Direitos humanos, ambiente e sustentabilidade. RevCEDOUA, n. 21, 2008. Disponível em: <https:// digitalis-dsp.uc.pt/bitstream/10316.2/8821/3/1.pdf>. Acesso em: 31 maio 2018.

CANOTILHO, José Joaquim Gomes. O princípio da sustentabilidade como princípio estruturante do direito constitucional. Revista de Estudos Políticos, v. 3, n. 13, p. 7-18, 2010.

CANOTILHO, José Joaquim Gomes. O Estado de direito. 1999. Disponível em:<https://s3.amazonaws. com/academia.edu.documents/33341061/ijgcoedd.pdf?AWSAccessKeyId=AKIAIWOWYYGZ2Y53UL 3A\&Expires $=1527800386 \&$ Signature $=$ rME4XiSDNZ62zwxqFj3Homf35dg\%3D\&response-content-disp osition=inline\%3B\%20filename\%3DESTADO_DE_DIREITO.pdf > . Acesso em: 26 maio 2018.

DÍAZ, Elías. Estado de derecho y democracia. 2001. Disponível em:<https://dialnet.unirioja.es/descarga/articulo/831255.pdf>. Acesso em: 26 maio 2018.

HALPERN, David. Inside the nudge unit. how small changes can make a big difference. London: WH Allen, 2015.

KOTZE, Louis J. Global environmental constitutionalism in the antrophocene. London: Hart Publishing, 2016.

KOTZE, Louis. Reimaging global environmental law and governance in the anthropocene. 2012. Disponível em: <http://dspace.nwu.ac.za/bitstream/handle/10394/8575/Kotz\%C3\%A9_LJ.pdf;sequence=1>. Acesso em: 26 maio 2018.

KOTZE, Louis J.; HALPERN, David. Inside the nudge unit: how small changes can make a big difference. Londres: Ebury Press, 2015. 
ROBINSON, Nicholas. Keynote: sustaining society in the anthropocene epoch. Denver Journal of International Law \& Policy, v. 41, n. 4, p. 467-506, 2013.

SILVA, José Afonso. O Estado democrático de direito. 1988. Disponível em: <http://bibliotecadigital.fgv.br/ ojs/index.php/rda/article/viewFile/45920/44126>. Acesso em: 26 maio 2018.

SUNSTEIN, Cass R. The ethics of influence: government in the age of behavioral science. New York: Cambridge University Press, 2016.

SUNSTEIN, Cass R. Choosing not to choose: understanding the value of choice. New York: Oxford University Press, 2015.

SUNSTEIN, Cass R. Foreword: the ethics of nudging. In. ALEMMANO, Alberto; SIBONY, Anne-lise (Org.). Nudge and the law: a european perspective. Oregon: Hart Publishing, 2015.

SUNSTEIN, Cass R.; REISCH, Lucia A. Automatically green: behavioral economics and environmental protection. 2013. Disponível em: <https://papers.ssrn.com/sol3/papers.cfm?abstract_id=2245657>. Acesso em: 29 maio 2018.

THALER, Richard H. Misbehaving: the making of behavioral economics. New York: W. W. Norton \& Company, 2016.

THALER, Richard H.; SUNSTEIN, Cass R. Nudge: improving decisions about health, wealth and happiness. New York: Penguin Books, 2009.

VOIGT, Christina. Sustainable development as a principle of international Law: resolving conflicts between climate measures and WTO Law. Boston: Martinus Nijhoff Publishers, 2009.

WEISS, Edith Brown. Rule of law for nature in a kaleidoscopic world. In: VOIGT, Christina (Ed.). Rule of law for nature: new dimensions and ideas in environmental law. Cambridge: Cambridge University Press, 2013. 


\title{
Políticas públicas baseadas em evidências comportamentais: reflexões a partir do Projeto de Lei 488/2017 do Senado*
}

\section{Behavioral evidence-based policy: reflections on Senate Bill 488/2017}

\author{
Pâmela de Rezende Côrtes** \\ André Matos de Almeida Oliveira*** \\ Fabiano Teodoro de Rezende Lara****
}

* Recebido em 31/05/2018

Aprovado em 01/08/2018

** Doutoranda em Direito pela Universidade Federal de Minas Gerais, Bolsista CAPES. Mestre em Direito e Bacharel em Ciências do Estado pela UFMG. Coordenadora do Projeto de Extensão em Políticas Públicas Baseadas em Evidências. Membro do Grupo de Estudos em Neuroética e Neurodireito. E-mail: pamela.recortes@gmail.com

*** Mestrando em Direito pela Universidade Federal de Minas Gerais, Bolsista CAPES. Bacharel em Direito pela UFMG. Monitor do Grupo de Estudos em Neuroética e Neurodireito. E-mail: andrematosalmeida@hotmail.com

**** Doutor em Direito pela UFMG. Professor Adjunto do Departamento de Direito Público junto à Graduação, Mestrado e Doutorado em Direito da Faculdade de Direito da UFMG e do IBMEC. Advogado. E-mail: fabiano@fabianolara.com.br

\section{Resumo}

O objetivo deste artigo é avaliar se o Projeto de Lei Complementar 488/2017 do Senado (PLS 488/2017) pode aumentar a permeabilidade dos criadores de políticas públicas ao uso de evidências, sobretudo comportamentais. A hipótese é a de que a regulação proposta pode aumentar o uso de evidências na proposição de políticas públicas, ao recomendar mecanismos de controle, de avaliação e atenção ao texto legislativo que se proponha a instituir uma política pública. A metodologia adotada será a revisão bibliográfica dos conceitos relevantes e das evidências comportamentais, assim como uma descrição e análise crítica do texto legislativo estudado. Começamos por apresentar o PLS 488/2017, sua proposta de alteração legislativa e as razões para a sua proposição. Em seguida, discutimos o que pode ser considerado uma política pública, tanto da perspectiva acadêmica quanto da perspectiva do projeto de lei, comparando as definições apresentadas. Posteriormente, abordamos o movimento de políticas públicas baseadas em evidências, expondo seu surgimento, as formas de se compreender o uso de evidências nas políticas, algumas críticas e estratégias importantes para respondê-las. Passamos para o uso de evidências comportamentais nas políticas públicas, primeiro abordando os nudges, que são um tipo de política comportamental relevante no debate acadêmico, e, depois, defendendo um uso mais amplo das evidências comportamentais nos diversos estágios das políticas públicas. Por meio da revisão de literatura, percebemos que o uso de evidências nas políticas pode aumentar a efetividade das políticas e melhorar a atuação do Estado. Por meio da análise crítica do PLS 488/2017, concluímos que ele abre espaço para o uso de evidências comportamentais em alguns de seus dispositivos, sobretudo na tomada de decisão e na implementação da política, e que o projeto pode ser visto como um estímulo ao diálogo entre os criadores de políticas e os coletores de dados e evidências comportamentais relevantes.

Palavras-chave: Políticas públicas baseadas em evidências. Ciências comportamentais. Projeto de Lei 488/2017 do Senado. Regulação de políticas públicas. 


\section{Abstract}

This paper aims to investigate whether Senate Bill 488/2017 can make policy-makers more receptive to the use evidences, especially behavioral ones. Our hypothesis is that the directive in the bill can increase the use of evidences in public policy propositions, in recommending control mechanisms and methods of evaluation of laws that creates new public policies. We will do the analysis by means of a literature review of the relevant concepts we are using and by a critical evaluation of the legislative text we are approaching. The structure of the text is as follows: we start by introducing the bill, its proposed legislative amendment and the reasons for its proposal. Next, we discuss what is a public policy, both from the academic point of view and from what the text of the bill tells us. Then, we approach the evidence-based movement, talking about its emergence, the multiple ways to use evidence in policies, some criticisms of it, and ways to answer them. The next move is the use of behavioral evidence on policies; we first present the nudges, an important type of behavioral policy in academia, and then expand the use of evidences to other stages of policies. We conclude that the use of behavioral evidence can increase the policy's effectiveness and improve the performance of the government, and that the bill, in some of its directives, paves the way for the use of behavioral evidence. The bill can be seen as an incentive for the dialogue and interchange between public policy-makers and researchers collecting relevant behavioral data.

Keywords: Behavioral-evidence-based policy. Behavioral sciences. Senate bill 488/2017. Policies regulation.

\section{INTRODUÇÃO}

Esse artigo pretende avaliar como o Projeto de Lei 488/2017, de iniciativa do Senado (PLS 488/2017), pode aumentar o uso de evidências comportamentais por parte dos criadores de políticas públicas no Brasil.

Para fazer isso, o primeiro passo será fazer uma análise mais ampla do projeto de lei, explicitando seus objetivos e seu âmbito normativo. O projeto de lei busca regular novas proposições de políticas públicas, determinando critérios tanto para a produção de projetos (como vir acompanhado de uma Análise de Impacto Legislativo, AIL) quanto sobre o conteúdo das políticas, exigindo a observância de critérios como economicidade, efetividade, eficácia e eficiência.

Como o foco do projeto são as políticas públicas, a seguir faremos uma breve análise teórica delas e de suas abordagens. A análise, avaliação e controle das políticas públicas são temas cada vez mais relevantes nacional e internacionalmente. As razões para esse interesse, especialmente em países da América Latina, são o aumento do controle dos gastos públicos, a visão do papel dos governos de forma mais restritiva e fiscalmente equilibrada e a dificuldade desses países em formar coalizões políticas coesas e capazes de desenhar boas políticas públicas ${ }^{1}$.

Esse debate pode assumir diversos matizes teóricos, e esse trabalho partirá de uma perspectiva de políticas públicas que sejam baseadas em evidências. O próximo passo, portanto, será o de apresentar essa perspectiva, que tem ganhado espaço nos debates acadêmicos internacionais ${ }^{2}$, mas que é, ainda, bem tímida no Brasil, com exceção da área de saúde pública.

Especificaremos, então, como as evidências provenientes de ciências comportamentais podem ser úteis nas políticas públicas. Discutiremos os nudges, que são a forma mais consolidada de unir as duas áreas. Concluiremos, por fim, que as evidências das ciências comportamentais podem ser úteis em praticamente qual-

1 SOUZA, Celina. Políticas públicas: uma revisão da literatura. Sociologias, Porto Alegre, ano 8, n. 16, p. 20-45, jul./dez. 2006. p. 20.

2 ARGYROUS, George. Evidence based policy: principles of transparency and accountability. Australian Journal of Public Administration, v. 71, n. 4, p. 457-468, 2012. p. 457. 
quer área em que o poder público possa interferir, ampliando o debate e mostrando como o PLS 488/2017 pode ser usado para inserir essas ciências na produção de políticas públicas no país.

\section{O Projeto de Lel $488 / 2017$ do Senado}

O Projeto de Lei de iniciativa do Senado 488/2017 (PLS 488/2017), que tramita, no tempo da redação deste artigo, na Câmara como Projeto de Lei Complementar do Senado (PLS) 494/2018, estabelece limites e critérios para a proposição de políticas públicas. Em linhas gerais, o projeto de lei visa alterar a Lei Complementar no 95 (LC 95), de 26 de fevereiro de 1998, que "dispõe sobre a elaboração, a alteração e a consolidação das leis" e "estabelece normas para a consolidação dos atos normativos que menciona" 3.

Essa lei complementar foi editada como resposta legislativa ao que é ordenado pelo artigo $\mathrm{n}^{\circ} 59$ da Constituição da República (CR/88), que descreve o processo legislativo brasileiro, e, em seu parágrafo único, afirma que "Lei complementar disporá sobre a elaboração, redação, alteração e consolidação das leis" ${ }^{4}$. Antes da edição dessa lei, muito pouco tinha sido produzido no Brasil em termos de doutrina com relação à produção de leis e de qualidade de técnica legislativa ${ }^{5}$.

A LC 95 tem como objetivo principal estabelecer as normas para produção de leis e demais instrumentos normativos ${ }^{6}$; em sua extensão, determina como deve ser feita a redação de uma lei, qual informação deve ser apresentada em que parte da lei (a epígrafe, a ementa, o preâmbulo, o enunciado, o texto das normas, as disposições transitórias etc.) e como deve ser feita a modificação de uma lei já editada.

A LC 95, juntamente ao Decreto $\mathrm{n}^{\circ}$ 4.176, de 28 de março de 2002, regulamentava a técnica legislativa ou a legística formal no Brasil7. Porém, o Decreto foi revogado no ano de 2018, sendo substituído pelo Decreto $\mathrm{n}^{\circ} 9.191$, de $1^{\circ}$ de novembro de $2017^{8}$, que ainda faz par com a LC 95 na regulamentação da legística formal.

A legística

pode ser definida como saber jurídico que evoluiu a partir de algumas das questões recorrentes na história do direito, vale dizer, a necessidade de uma legislação mais eficaz (no sentido de estar disponível e atuante para a produção de efeitos), o questionamento da lei como o instrumento exclusivo para a consecução de mudanças sociais, a necessidade de democratizar o acesso aos textos legais em todos os níveis?.

3 BRASIL. Lei Complementar n ${ }^{\circ}$ 95, de 26 de fevereiro de 1998. Dispõe sobre a elaboração, a redação, a alteração e a consolidação das leis, conforme determina o parágrafo único do art. 59 da Constituição Federal, e estabelece normas para a consolidação dos atos normativos que menciona. Disponível em: <http://www.planalto.gov.br/ccivil_03/leis/lcp/lcp95.htm>. Acesso em: 25 mar. 2018. 4 BRASIL. Constituição (1988). Constituição da República Federativa do Brasil. Disponível em <http://www.planalto.gov.br/ccivil_03/constituicao/constituicao.htm>. Acesso em: 25 mar. 2018.

5 SALINAS, Natasha Schmitt Caccia. Avaliação Legislativa no Brasil: apontamentos para uma nova agenda de pesquisa sobre o modo de produção das leis. Revista Brasileira de Políticas Públicas, Brasília, v. 3, n. 2, p. 243, 2013.

6 Artigo $1^{\circ}$, parágrafo único da LC 95 afirma: "As disposições desta Lei Complementar aplicam-se, ainda, às medidas provisórias e demais atos normativos referidos no art. 59 da Constituição Federal, bem como, no que couber, aos decretos e aos demais atos de regulamentação expedidos por órgãos do Poder Executivo." BRASIL. Lei Complementar n 95, de 26 de fevereiro de 1998. Dispõe sobre a elaboração, a redação, a alteração e a consolidação das leis, conforme determina o parágrafo único do art. 59 da Constituição Federal, e estabelece normas para a consolidação dos atos normativos que menciona. Disponível em: <http://www.planalto.gov.br/ ccivil_03/leis/lcp/lcp95.htm>. Acesso em: 25 mar. 2018.

7 SALINAS, Natasha Schmitt Caccia. Avaliação Legislativa no Brasil: apontamentos para uma nova agenda de pesquisa sobre o modo de produção das leis. Revista Brasileira de Politicas Públicas, Brasília, v. 3, n. 2, p. 244, 2013.

8 BRASIL. Decreto $n^{\circ}$ 9.191, de $1^{\circ}$ de novembro de 2017. Estabelece as normas e as diretrizes para elaboração, redação, alteração, consolidação e encaminhamento de propostas de atos normativos ao Presidente da República pelos Ministros de Estado. Disponível em: < http://www.planalto.gov.br/CCIVil_03/_Ato2015-2018/2017/Decreto/D9191.htm\#art60>. Acesso em: 26 jul. 2018.

9 SOARES, Fabiana de Menezes. Legística e desenvolvimento: a qualidade da lei no quadro da otimização de uma melhor legislação. Revista da Faculdade de Direito da UFMG, Belo Horizonte, n. 50, p. 124-142, jan./jul. 2007, p. 125. Disponível em: <https:// www.direito.ufmg.br/revista/articles/31.pdf>. Acesso em: 27 jul. 2018. 
A legística formal, por sua vez, "atua sobre a otimização do círculo de comunicação legislativa e fornece princípios destinados à melhoria da compreensão e do acesso aos textos legislativos" ${ }^{10}$.

Embora a inobservância da técnica prevista na lei não seja suficiente para declarar uma lei inconstitucional, ainda assim parece importante que os legisladores e demais criadores de atos normativos tentem "empreender esforços para incorporar seus preceitos em prol de uma produção normativa que venha a cumprir com maior eficiência suas finalidades, sob pena de se criar mais conflitos do que aqueles que se pretendeu apaziguar" "11. Infelizmente, pode-se dizer que a própria LC 95 ignorou suas recomendações, já que "seu próprio texto contradiz os seus fins e artigos que fixaram prazo para a consolidação foram revogados". O mesmo pode-se dizer do extinto Decreto nº 4.176 de 2002, que "prevê um instrumento para avaliação de impacto dos atos normativos", mas vinha "sendo ignorado pelo executivo, contraditoriamente pródigo na sua atividade legislativa" ${ }^{12}$. O Decreto no 9.191 de 2017 é, ainda, muito recente para ser avaliado em termos de efetividade, mas não há razões para crer que ele será muito mais efetivo que seu antecessor.

O projeto de lei a ser avaliado, PLS 488/2017, por sua vez, tem como objetivo inserir um novo capítulo na LC 95, que se intitulará: “Capítulo III-A Dos Projetos De Lei que instituam Políticas Públicas”. Seu objetivo geral é o de "estabelecer normas e diretrizes para encaminhamento de proposições legislativas que instituam políticas públicas, propiciando melhor responsabilidade gerencial na Administração Pública" ${ }^{13}$. Se o PLS 488/17 for aprovado nos termos atuais, serão inseridos três novos artigos na LC 95: 17-A, 17-B e $17-C^{14}$.

10 SOARES, Fabiana de Menezes. Legística e desenvolvimento: a qualidade da lei no quadro da otimização de uma melhor legislação. Revista da Faculdade de Direito da UFMG, Belo Horizonte, n. 50, p. 124-142, jan./jul. 2007. p. 126. Disponível em: <https:// www.direito.ufmg.br/revista/articles/31.pdf>. Acesso em: 27 jul . 2018.

11 ALVAREZ, Adela Duarte. Elaboração Legislativa: aspectos gerais. Revista do Parlamento Paulista - RPP, São Paulo, v.2, n.3, p.112123, jul./dez. 2012. p. 122.

12 SOARES, Fabiana de Menezes. Legística e desenvolvimento: a qualidade da lei no quadro da otimização de uma melhor legislação. Revista da Faculdade de Direito da UFMG, Belo Horizonte, n. 50, p. 124-142, jan./jul. 2007. p. 139-140. Disponível em: <https:// www.direito.ufmg.br/revista/articles/31.pdf>. Acesso em: 27 jul. 2018.

13 BRASIL. Projeto de Lei Complementar do Senado no 488 de 2017 - Texto final. Acrescenta dispositivos à Lei Complementar $\mathrm{n}^{\circ}$ 95, de 26 de fevereiro de 1998, com o intuito de estabelecer normas e diretrizes para encaminhamento de proposições legislativas que instituam políticas públicas, propiciando melhor responsabilidade gerencial na Administração Pública. Disponível em: <https://legis.senado.leg.br/sdleg-getter/documento?dm=7326614\&disposition=inline> Acesso em: 15 maio 2018.

14 Essa é a redação atual dos artigos a serem inseridos: "Art. 17-A: Os projetos de lei que instituam políticas públicas serão acompanhados de avaliação prévia de impacto legislativo, com o intuito de garantir a economicidade, a efetividade, a eficácia e a eficiência das ações públicas. $\$ 1^{\circ}$ : Para fins deste artigo, entende-se por: I - política pública, a mobilização político-administrativa para articular e alocar recursos e esforços para tentar solucionar dado problema coletivo; II - economicidade, a minimização dos custos dos recursos utilizados na consecução de uma atividade, sem comprometimento dos padrões de qualidade; III - efetividade, o alcance dos resultados pretendidos, a médio e longo prazo; IV - eficácia, o alcance das metas programadas e cumprimento dos objetivos imediatos; e V - eficiência, a menor relação entre os custos impostos pela lei e os benefícios oriundos dela. Art. 17-B: Na concepção das políticas públicas, de forma a incrementar a capacidade de governança e gestão da Administração Pública, devem ser definidos: I - os responsáveis pela coordenação e articulação das ações concernentes à política; II - a atuação dos diversos órgãos, instituições e esferas de governo envolvidos, garantindo a coerência e a sinergia da ação estatal nas dimensões econômica, social e ambiental e incentivando a participação social no processo decisório das políticas públicas; III - as competências das principais partes envolvidas na política pública, incluindo os respectivos objetivos, papéis, responsabilidades, recursos e obrigações; IV - o grau de focalização ou universalização da política pública, considerando as necessidades do público-alvo, bem como os recursos disponíveis; V - a abordagem para tratar a solução de conflitos, bem como estabelecer formas de revisão, fixando a periodicidade da avaliação de desempenho da política com o intuito de se promover ajustes que se façam necessários; VI - plano de gestão de riscos com a identificação dos principais problemas que podem surgir juntamente com as respectivas medidas mitigadoras para tratar esses riscos; VII - os marcos de verificação, indicadores-chave e metas para os principais objetivos que permitam a medição do progresso e facilitem a identificação de interdependências e obstáculos; VIII - a formalização dos processos decisórios correlatos, incluindo o registro da motivação e do conjunto de evidências que embasam a escolha política; IX - mecanismos e procedimentos internos de integridade e auditoria na aplicação efetiva de códigos de ética e de conduta, bem como de formalização de instrumentos de transparência; e X - plano de gestão documental, com o intuito de preservar a memória unificada de todas as fases da política pública desde a sua concepção. Parágrafo único: O órgão responsável pela condução da política deverá publicar, para conhecimento de todas as partes interessadas, a estrutura de governança vigente na política pública. Art. 17-C: A avaliação prévia do impacto legislativo, consoante o que dispõe o art. 17-A, conterá: I - parecer conclusivo sobre a constitucionalidade, a juridicidade e a regularidade formal do ato normativo proposto; e II - notas explicativas que demonstrem, no que for pertinente, a economicidade, a efetividade, a eficácia e a eficiência das medidas constantes do projeto, contendo: a) síntese qualitativa e quantitativa do problema ou da situação 
O PLS 488/2017 é de autoria do Senador Federal Roberto Muniz, do Partido Progressista, PP, do estado da Bahia. Na justificação do projeto, porém, são apontados outros atores que participaram da elaboração do documento. Assim, faz alusão a discussões com o Tribunal de Contas da União, reconhece a participação da Consultoria Legislativa do Senado e as manifestações de técnicos da Câmara dos Deputados e do IPEA ${ }^{15}$.

O Projeto de Lei parece estar em sintonia, de alguma forma, com o documento produzido pela Casa Civil da Presidência, chamado: "Avaliação de políticas públicas: guia prático de análise ex ante" (feita antes), publicado nesse ano de 2018. Esse guia é uma "medida prática de adoção de mecanismo de liderança e estratégia", que busca "direcionar ações para a busca de resultados para a sociedade, encontrando soluções tempestivas e inovadoras para lidar com a limitação de recursos e com as mudanças de prioridades" e, de forma mais direta, direcionar a atenção para custos e benefícios quando algum ator político for propor, expandir ou aperfeiçoar uma política pública ${ }^{16}$.

O projeto aponta algumas razões para a sua proposição. Dentre elas, fala explicitamente do "amadurecimento democrático da sociedade brasileira", que demanda cada vez mais controle sobre a atuação estatal, sobretudo quanto à "efetividade das ações que empreende visando à melhora da realidade socioeconômica" 17.

Considerando-se que o IPEA foi diretamente citado como parte ativa no processo de construção do projeto de lei, é razoável concluir que as produções do guia e do projeto tenham se beneficiado dos mesmos debates e inquietações dos pesquisadores do instituto. Uma das razões fundamentais para a produção do guia é a edição da Emenda Constitucional no 95/2016 (EC 95), que estabelece um Novo Regime Fiscal e ficou conhecida como a "PEC dos gastos públicos" ou ainda "PEC do fim do mundo". A EC 95 limita os gastos públicos por "vinte exercícios financeiros", ou seja, 20 anos $^{18}$. Essa limitação orçamentária de 20 anos aumentaria a "necessidade de um debate mais qualificado sobre a priorização de políticas públicas e as decisões alocativas do orçamento" ${ }^{19}$. Esse debate qualificado parece ter necessidade ainda maior quando se nota que, em vários casos, as políticas públicas do país não atingem os resultados esperados. Relatório recente do IPEA estima que, desde o mandato de Lula, o governo brasileiro deu subsídios de R $\$ 173$ bilhões a programas sem efeitos significativos; dos 20 programas analisados, 4 não trouxeram nenhum retorno ${ }^{20}$

Parece-nos, portanto, que a contingência orçamentária despertou no legislativo o interesse em aumentar

que reclama providências; b) objetivos da proposição e sua vinculação com o problema definido; c) alternativas existentes para a solução do problema identificado, com respectiva previsão dos impactos econômicos e sociais, justificando a escolha da solução ou providência contida no projeto proposto, com comparação das análises de custo-benefício global de cada alternativa; d) custos administrativos da solução ou providência contida no projeto proposto, caso a alternativa estabelecida na proposição entre em vigor; e e) indicação da existência de prévia dotação orçamentária ou a fonte de recursos, quando a proposta demandar despesas, e como a ação está enquadrada no Plano Plurianual vigente".

15 BRASIL. Projeto de Lei Complementar do Senado no 488 de 2017 - Texto preliminar. Acrescenta dispositivos à Lei Complementar $\mathrm{n}^{\circ}$ 95, de 26 de fevereiro de 1998, com o intuito de estabelecer normas e diretrizes para encaminhamento de proposições legislativas que instituam políticas públicas, propiciando melhor responsabilidade gerencial na Administração Pública. Disponível em: <https://legis.senado.leg.br/sdleg-getter/documento?dm=7326614\&disposition=inline> Acesso em: 15 maio 2018.

16 BRASIL. Casa Civil da Presidência da República. Avaliação de políticas públicas: guia prático de análise ex ante. Casa Civil da Presidência da República, Instituto de Pesquisa Econômica Aplicada. Brasília: Ipea, 2018. v. 1, p. 7.

17 BRASIL. Projeto de Lei Complementar do Senado no 488 de 2017 - Texto preliminar. Acrescenta dispositivos à Lei Complementar no 95 , de 26 de fevereiro de 1998, com o intuito de estabelecer normas e diretrizes para encaminhamento de proposições legislativas que instituam políticas públicas, propiciando melhor responsabilidade gerencial na Administração Pública. Disponível em: <https:// legis.senado.leg.br/sdleg-getter/documento?dm=7326614\&disposition=inline > Acesso em: 15 maio 2018.

18 BRASIL. Emenda Constitucional n ${ }^{\circ}$ 95, de 15 de dezembro de 2016. Altera o Ato das Disposições Constitucionais Transitórias, para instituir o Novo Regime Fiscal, e dá outras providências. Disponível em: < http://www.planalto.gov.br/ccivil_03/constituicao/ emendas/emc/emc95.htm>. Acesso em: 22 mar. 2018. artigo 106.

19 BRASIL. Casa Civil da Presidência da República. Avaliação de políticas públicas: guia prático de análise ex ante. Casa Civil da Presidência da República, Instituto de Pesquisa Econômica Aplicada. Brasília : Ipea, 2018. v.1. p. 11.

20 WIZIACK, Júlio; PRADO, Maeli. Governo deu R 173 bi em subsídios a programas sem efeitos, diz estudo. São Paulo. Folha de São Paulo. 22 jul. 2018. Disponível em: <https://www1.folha.uol.com.br/mercado/2018/07/governo-deu-r-173-bi-em-subsidiosa-programas-sem-efeitos-diz-estudo.shtml>. Acesso em: 26 jul. 2018. 
o controle dos gastos ou investimentos públicos, e que o estabelecimento de regras para proposição de políticas públicas tenha como objetivo implícito o de aumentar a consciência da finitude do orçamento por parte do agente público. Um objetivo louvável, mas que não precisa da edição de atos normativos que chamem a atenção para o orçamento, já que o controle orçamentário é "o instrumento pelo qual se positiva toda a atividade financeira do Estado, tendo sua sede na Constituição" ${ }^{21}$.

Outra questão interessante suscitada pelo projeto diz respeito à legitimidade do Poder Legislativo como órgão fiscalizador do Poder Executivo. O projeto afirma que o amadurecimento democrático aumenta a necessidade de controle, e afirma que "setores representativos da sociedade" devem se "aparelhar" para acompanhar o "ciclo de políticas públicas", conferindo a si mesmo, ou seja, ao "Congresso Nacional", um papel de destaque. É fato que esse poder é conferido pela própria Constituição, que afirma, em seu artigo 49, que é "da competência exclusiva do Congresso Nacional", e prossegue no inciso X elencando: "fiscalizar e controlar, diretamente, ou por qualquer de suas Casas, os atos do Poder Executivo, incluídos os da administração indireta" 22 .

No entanto, considerando as críticas recentes quanto à estrutura e legitimidade dos poderes, sobretudo no Brasil, resta questionar se esse controle deva ser feito, exclusivamente, pelo Poder Legislativo, ou se já seria possível prever instâncias de controle social ou popular na proposição de políticas públicas. Ao reconhecer-se como "representativo", o Congresso não parece acompanhar as importantes críticas contemporâneas ao seu funcionamento e à sua (in)capacidade de apresentar aos eleitores opções viáveis e ideologicamente consistentes ${ }^{23}$.

Essa crítica se revela, sobretudo, tendo em vista a ineficiência de sua produção legislativa para a solução de problemas do país. Um estudo do Instituto Brasileiro de Planejamento e Tributação revela que, do período que vai da promulgação da Constituição de 88 até setembro de 2016, foram editados 5,4 milhões de textos normativos no Brasil, o que equivale a 769 normas por dia útil24. Essa "hipertrofia legislativa", no entanto, não torna o poder legislativo eficiente aos olhos do cidadão, mas combina-se com a falta de representatividade e leva a crer que a atuação legislativa acontece para privilegiar grupos de interesse capazes de exercer pressão sobre deputados e senadores. Esse excesso também leva a edição de normas cada vez mais vagas com conceitos jurídicos indeterminados, o que abre espaço para discricionariedade judicial e administrativa ${ }^{25}$, ao invés de aumentar a accountability.

Essas críticas preliminares são importantes ao analisar o PLS 488/2017. Embora seja importante que existam regulações para a produção de projetos de lei que constituam políticas públicas, isso não quer dizer que a simples edição de leis levará a uma maior eficiência na produção legislativa brasileira. Essa eficiência deve ser garantida por outras formas, que utilizem a lei, mas não apostem todas as suas fichas nela.

Isso vale, sobretudo, para as políticas públicas. Considerando-se as determinações sugeridas pelo projeto, vale uma reflexão antes de prosseguir para a avaliação de seu conteúdo, uma espécie de meta-avaliação: o próprio PLS 488/2017 poderia ser pensado à luz dos quesitos de avaliação que propõe, sendo ele mesmo um projeto de lei que constitui políticas públicas? Não se pode esperar que os proponentes do projeto se

21 BOGOSSIAN, Andre. Levando o orçamento a sério como instrumento de controle de políticas públicas. Revista Brasileira de Politicas Públicas, Brasília, v. 5, n. 3, p. 178-198, 2015. p. 185.

22 BRASIL. Constituição da República Federativa do Brasil de 1988. Disponível em < http://www.planalto.gov.br/ccivil_03/constituicao/constituicao.htm>. Acesso em: 25 mar. 2018.

23 BAHIA, Alexandre; NUNES, Dierle. Crise da Democracia Representativa - infidelidade partidária e seu reconhecimento judicial. Revista Brasileira de Estudos Politicos, v. 100, p. 57-84, p. 59-60, 2010.

24 AMARAL, Gilberto Luiz do; OLENIKE, João Elói; STEINBRUCH, Fernando et al. Quantidade de normas editadas no Brasil: 28 anos da Constituição Federal de 1988. São Paulo: Instituto Brasileiro de Planejamento Tributário, 2016. Disponível em: <https:// ibpt.com.br/img/uploads/novelty/estudo/2603/QuantidadeDeNormas201628AnosCF.pdf>. Acesso em: 27 jul. 2018.

25 SODRÉ, Habacuque Wellington. As deficiências da atuação como fator de ativismo: hipertrofia e omissão legislativa. Uma análise da sociologia jurídica sobre o caso brasileiro de ativismo judicial. Direito Público, Porto Alegre, v. 8, n. 43, p. 178-181, jan./ fev. 2012. 
sintam obrigados por uma lei que, ainda, não foi editada (curiosamente, o próprio projeto), mas, ainda assim, a aplicação pode nos ajudar a entender a extensão do próprio PLS 488/2017. A definição de política pública é disputada ${ }^{26}$, e o PLS 488/2017 dá sua própria definição do termo. Faremos, portanto, uma análise da definição do projeto, vendo se ele mesmo cumpriria os requisitos teóricos, e depois expandiremos essa análise. Seguiremos um pequeno roteiro proposto por Secchi para refletir sobre o conceito de política pública, já que, como não há consenso científico, qualquer definição de política pública será arbitrária ${ }^{27}$. As perguntas que parecem nortear as diversas definições são: 1) "Políticas públicas são elaboradas exclusivamente por atores estatais?”; 2) "Políticas públicas também se referem à omissão, ou à negligência?”; 3) "Apenas diretrizes estruturantes (de nível estratégico) são políticas públicas?”28.

O artigo 17-A do PLS 488/2017, em seu $\ 1^{\circ}$, faz uma espécie de glossário, esclarecendo os termos apontados no caput. Assim, política pública está definida no inciso I como "mobilização político-administrativa para articular e alocar recursos e esforços com vistas a solucionar problema coletivo" ${ }^{29}$. É uma definição sucinta, mas é suficiente para avaliar qual a tendência adotada no projeto, e se o projeto pode ser previamente enquadrado. Com relação à $1^{a}$ pergunta, parece-nos que o conceito aqui está restrito ao Estado como ator das políticas reguladas (chamado no projeto de mobilização político-administrativa), já que o objetivo é regular políticas públicas que demandem proposições legislativas, o que vale para o próprio PLS 488/2017. Quanto à $2^{a}$ pergunta, ao dizer que políticas públicas devem fazer alocação de "recursos" e "esforços", parece-nos que a omissão ou negligência não pode ser considerada uma política pública no conceito abordado pelo PLS 488/2017, respondendo, de forma negativa, ao segundo questionamento levantado pelo autor. Além disso, essa questão é de menor importância no debate, já que o projeto regula políticas públicas que demandem projeto de lei, portanto, ação e não omissão ou negligência. Por fim, com relação à $3^{a}$ pergunta, analisando-se, apenas, o conceito de política pública do PLS 488/2017, não parece ser possível aduzir se os propositores pensaram em políticas num nível estratégico ou operacional. Porém, a leitura completa do projeto faz-nos crer que, ao entrar em minúcias e apontar responsabilidades, o projeto não esteja restringindo políticas públicas a apenas um nível de atuação do Estado (micro ou macro). Isso pode apontar que, em relação à normativa proposta pelo PLS 488/2017, qualquer nível estratégico que demande recursos ou esforços dos atores políticos envolvidos pode estar submetido à sua normatização, o que, ainda, não o exclui, em termos conceituais, de ser ele mesmo um projeto de lei que constitua política pública.

Expandindo a reflexão, e acompanhando a sistematização das tipologias feita por Secchi, uma das possíveis classificações de políticas públicas (proposta por Theodore Lowi) é a de políticas constitutivas. Assim, as políticas constitutivas são aquelas que "definem as competências, jurisdições, regras da disputa política e da elaboração de políticas públicas". Além disso, elas podem provocar "conflito entre os entes e os atores diretamente interessados", porque possuem a "capacidade de alterar o equilíbrio de poder existente". Ainda, essas políticas são pouco discutidas, já que "os usuários das políticas públicas e o cidadão comum raramente se interessam por esse tipo de política, já que não tratam de prestação de serviço ou de ações concretas de governo" ${ }^{30}$.

Parece-nos claro que o PLS 488/2017 é, por si mesmo, uma política pública, que tem como objetivo regular a proposição das políticas públicas que tenham como instrumento a proposição legislativa, ou seja, trata-se de uma meta-política. Acompanhando a reflexão de Secchi, parece-nos fundamental que essas meta-políticas sejam, também, avaliadas e acompanhadas, sobretudo porque têm influência direta em todas as

26 SOUZA, Celina. Políticas públicas: uma revisão da literatura. Sociologias, Porto Alegre, ano 8, n. 16, p. 20-45, jul./dez. 2006.

27 SECCHI, Leonardo. Políticas públicas: conceitos, esquemas de análise, casos práticos. São Paulo: Cengage Learning, 2010 , p. 2.

28 SECCHI, Leonardo. Políticas públicas: conceitos, esquemas de análise, casos práticos. São Paulo: Cengage Learning, 2010 , p. 2.

29 BRASIL. Projeto de Lei Complementar do Senado nº 488 de 2017 - Texto final. Acrescenta dispositivos à Lei Complementar $n^{\circ} 95$, de 26 de fevereiro de 1998, com o intuito de estabelecer normas e diretrizes para encaminhamento de proposições legislativas que instituam políticas públicas, propiciando melhor responsabilidade gerencial na Administração Pública. Disponível em: <https:// legis.senado.leg.br/sdleg-getter/documento?dm=7326614\&disposition=inline> Acesso em: 15 maio 2018.

30 SECCHI, Leonardo. Políticas públicas: conceitos, esquemas de análise, casos práticos. São Paulo: Cengage Learning, 2010. p. 18. 
demais políticas e, se mal formuladas, podem dificultar ou a atuação do Poder Executivo ou o controle sobre ela.

Essa reflexão permite que façamos, ao mesmo tempo, uma análise do PLS 488/2017 tanto em termos de conteúdo e aplicação a outros projetos quanto em termos formais, nos próprios termos a que pretende submeter as demais propostas, que é o que faremos em seguida. Porém, como nos submeteremos a uma linha teórica específica das políticas públicas baseadas em evidências comportamentais, faremos antes uma apresentação dessa corrente.

\section{Políticas públicas baseadas em EVIdênCias}

Dentre as possíveis abordagens às políticas públicas, é possível assumir uma perspectiva prescritiva (como deve ser feita a política pública) ou descritiva (como é feita a política pública). A abordagem que enfatiza o uso das evidências (evidence-based policy) é uma abordagem prescritiva, e que pode ser compatibilizada com a compreensão descritiva das políticas em termos de ciclos, que é uma das mais tradicionais do campo de políticas públicas. O modelo dos ciclos de políticas públicas possui cinco passos ou cinco etapas: montagem de agenda, formulação da política, tomada de decisão, implementação da política e avaliação da política.

Na primeira etapa, a montagem de agenda, o problema está sendo reconhecido pelos atores políticos e há diversidade de escolhas e soluções. Na segunda etapa, formulação da política, excluem-se as opções não executáveis e cada um dos atores políticos envolvidos age tentando fazer com que a sua solução favorita do problema seja a escolhida. Na terceira etapa, relativa à tomada de decisão, o governo ou o responsável, efetivamente, escolhe uma das soluções, que será concretizada na quarta etapa, relativa à implementação da política. Nesse momento, a decisão é colocada em ação, usando ferramentas disponíveis à administração pública, que visem alterar distribuição de recursos e serviços na sociedade. A quinta etapa, por fim, é a de avaliação da política, quando tanto atores estatais quanto sociais monitoram os resultados alcançados pela política $^{31}$.

Esse modelo baseado em etapas ajuda a vislumbrar a política em seu aspecto prático, possibilitando, inclusive, que haja critérios específicos para cada uma das fases: aquilo que é necessário saber e fazer na fase de implementação certamente diverge daquilo que se precisa na fase de avaliação, até mesmo em termos de capacidades e agentes. No entanto, como qualquer modelo, essa categorização das políticas em ciclos é uma idealização do processo real no campo de atuação. Na prática, essas fases se "apresentam misturadas" e as "sequências se alternam" 32 .

As evidências científicas em geral podem ser utilizadas em diversas etapas do ciclo de políticas públicas, e de diversas formas. Uma das formas possíveis de conexão entre evidência e política pública consiste em usar as próprias políticas como fonte de evidências. Assim, os atores políticos aprenderiam com o passado e utilizariam políticas anteriores como base para novos desenhos de políticas. As evidências devem vir, portanto, antes da proposição das políticas, por meio de análises sistemáticas dos efeitos de políticas similares. Não se pode recusar a utilidade desse tipo de evidência, e

claro é que a pesquisa em política tem muito a ganhar seguindo uma sequência em que as intervenções sociais são instadas a tentar, tentar e tentar de novo resolver os problemas com os quais a sociedade moderna se confronta. Essa é a raison d'être por trás da atual explosão do interesse nas políticas baseadas em evidências ${ }^{33}$.

31 HOWLET'T, Michael; GIEST, Sarah. The policy-making process. In: ARARAL, Eduardo Araral Jínior et al (Org.). Routledge Handbook of Public Policy. Canada: Routledge, 2013. p. 17-28. p. 17.

32 SECCHI, Leonardo. Políticas públicas: conceitos, esquemas de análise, casos práticos. São Paulo: Cengage Learning, 2010. p. 33.

33 Tradução livre de: "What is clear is that policy research has much to gain by following the sequence whereby social interventions are mounted in trying, trying, and then trying again to tackle the stubborn problems that confront modern society. This is the raison d'etre bebind the current explosion 
Um bom exemplo de evidência proveniente das próprias políticas é o estudo de judicialização das políticas de saúde. Nesse caso, vê-se que o poder judiciário pode interferir na produção de políticas, e busca-se verificar a extensão dessa interferência. Percebe-se que a judicialização "da saúde apresenta uma característica incomum, quando identificado o caráter individualista dos processos litigiosos que englobam pretensões por tratamentos específicos, atingindo o interesse coletivo, ao destinar um recurso não previsto da saúde para contemplar uma demanda específica". Essa percepção localizada deve permitir que os formuladores compreendam onde estão os problemas das políticas de saúde e discutam quem são os atores legítimos no processo decisional de alocação de recursos da área ${ }^{34}$.

Essa abordagem, no entanto, limita-se ao uso de evidências de dentro, provenientes das políticas e dos estudiosos da área. Outra forma de vislumbrar o uso de evidências nas políticas públicas passa pela compreensão de que as evidências devem ser capazes de informar o tomador de decisão, sem limitar a fonte de onde provém essas evidências.

O uso de evidências de fora nas políticas públicas é defendido num movimento acadêmico, que vem se consolidando, de análise de políticas públicas, que busca a "geração e mobilização de conhecimento" com base científica que possa "dar suporte ou influenciar o processo das políticas públicas, especialmente a tomada de decisão e a formulação das políticas", mas também o momento de "implementação" e de "avaliação" 35. A concepção de um movimento é útil para juntar aqueles que estão se esforçando para "reconceber o papel dos governos na sociedade e renegociar aspectos da relação entre indivíduos, coletividades e governos" 36 .

Nota-se, nessa definição, um foco no uso de evidências ou de conhecimento com base científica. É um movimento que busca fazer análises para políticas públicas, fazendo pesquisas que ajudem a formulação, implementação e avaliação das políticas, inserindo as pesquisas nos ciclos das políticas públicas ${ }^{37}$. O movimento de políticas públicas baseadas em evidências é, de alguma forma, uma continuação recente desse esforço $^{38}$.

O próprio movimento em geral de práticas baseadas em evidências surgiu na medicina nos anos 1990, e então se espalhou por diversos campos do saber ${ }^{39}$. No caso das políticas públicas baseadas em evidências, costuma-se dar foco na importância do uso de evidências nos processos de tomada de decisão, buscando diminuir a distância que existe entre a expectativa do criador de política pública e as condições concretas em que as ações serão executadas ${ }^{40}$. Os primeiros estudos que se preocupavam com a tomada de decisão, não apenas na esfera pública, mas também na esfera privada, afirmavam que os tomadores de decisão deveriam "seguir um método sistemático para chegar a decisões lógicas e eficientes" ${ }^{41}$. Assim, o movimento de

of interest in evidence-based policy". PAWSON, Ray. Evidence-based policy: in search of a method. Evaluation, v. 8, n. 2, p. 157-181, 2002. 34 DIAS, Maria Socorro de Araújo et al. Judicialização da saúde pública brasileira. Revista Brasileira de Políticas Públicas, Brasília, v. 6, n. 2, p. 132-145, 2016.

35 Tradução livre de: "Policy analysis — defined as the generation and mobilization of knowledge (with a scientific base) to support or influence public policy process, especially decision-making and policy formulation, but also its implementation and evaluation." FARAH, Marta Ferreira Santos. An analysis of public policies in Brazil: from an unnamed practice to the institutionalization of the" public field". Revista de Administração Pública, v. 50, n. 6, p. 964, 2016.

36 Tradução livre de trechos de: "The rise of policy analysis is usefully construed as a movement. Use of this term implies a deliberate effort on the part of many people to reconceive the role of government in society and renegotiate aspects of the relationships that exist between individuals, collectivities and governments.". MINTROM, Michael, WILLIAMS, Claire. Public policy debate and the rise of policy. In: ARARAL, Eduardo Araral Júnior et al (Org.). Routledge Handbook of Public Policy. Canada: Routledge, 2013. p. 3. 37 FARAH, Marta Ferreira Santos. An analysis of public policies in Brazil: from an unnamed practice to the institutionalization of the" public field". Revista de Administração Pública, v. 50, n. 6, p. 964-973, 2016.

38 HOWLETT, Michael. Policy analytical capacity and evidence-based policy-making: lessons from Canada. Canadian public administration, v. 52, n. 2, p. 154, 2009.

39 TRINDER, Liz. Introduction: the context of evidence-based practice. In: TRINDER, Liz; REYNOLDS, Shirley (Org.). Evidence-based practice: a critical appraisal. Oxford: Blackwell, 2003. p. 2.

40 HOWLETT, Michael. Policy analytical capacity and evidence-based policy-making: Lessons from Canada. Canadian public administration, v. 52, n. 2, p. 154, 2009.

41 Tradução livre de trecho de: "Many early studies of policy-making in companies, governments, and organizations conducted largely by students 
política pública baseada em evidências (PPBE) reconhece a responsabilidade do tomador de decisões de usar evidências de forma conscienciosa para desenhar, gerir e reformar sistemas de suporte a comunidades de uma forma previsivelmente capaz de trazer benefícios. Em teoria, PPBE significa que cientistas produzem evidências que decisores públicos podem usar em suas decisões ${ }^{42}$.

Antes de prosseguirmos para a apresentação do movimento de análise de políticas públicas ou de políticas públicas baseadas em evidências no Brasil, é importante, primeiramente, destacar as críticas que podem ser feitas ao uso de evidências nas políticas públicas. Uma delas diz respeito à capacidade de o tomador de decisão público acessar, criticar e avaliar as evidências provenientes de diversas áreas do saber. Não se pode presumir essa capacidade e uma dificuldade importante do movimento é a de como fornecer "aos trabalhadores do setor público" as "ferramentas necessárias para avaliar a qualidade da evidência" 43 . Isso demanda que o ator político seja capaz de acessar, de alguma forma, essas evidências, seja sabendo qual a área pode lhe ser conveniente, seja sendo capaz de acessar os pesquisadores de uma determinada área ou, ainda, ter acesso a periódicos científicos de qualidade, se souber como e o que procurar. Essa crítica ainda ressalva a importância de se considerar o contexto político e, inclusive, educacional no qual o criador de política pública está inserido. Um estudo no Canadá demonstrou a disparidade de capacidade analítica e política de atores em diversas esferas político-administrativas, assim como dificuldade em utilizar evidências nos processos de decisão ${ }^{44}$. E se isso vale para países desenvolvidos, a questão é provavelmente ainda mais complexa em países em desenvolvimento, como é o caso do Brasil.

Há algumas formas de mitigar essa dificuldade de acesso às evidências disponíveis na literatura. Uma delas é cobrando dos tomadores de decisão transparência e accountability no processo de produção de políticas públicas baseadas em evidências. A transparência permite ao público em geral que acompanhe o processo de utilização das evidências, diminuindo o risco de haver "erros simples, desenhos de pesquisa insuficientes e enviesamento completo de resultados e conclusões" 45 . Para tornar a PPBE mais transparente, sugere-se tornar "os dados não tratados disponíveis", o "instrumento de coleta de dados disponível", permitir acesso aos "metadados"; tornar as "assunções analíticas explícitas"; fazer "escolhas analíticas e testá-las explicitamente"; tornar a "perspectiva teórica explícita"; deixar clara a relação com "pesquisas passadas" e declarar "interesses financeiros" e de outros tipos ${ }^{46}$.

No processo de accountability, a questão é abrir espaço não apenas para que vejam os dados usados, mas para que possam argui-lo, questioná-lo. O termo accountability incorpora "conceitos correlatos como 'discussão', 'revisão', 'avaliação' ou 'consulta”'. Mas, além de abrir a conversa, demanda do criador de políticas que ele engaje "outras pessoas significativas" nesse debate. Aqueles para os quais a PPBE deve ser accountable são "aqueles afetados pelas políticas"; "aqueles que possuem diferentes estruturas conceituais"; aqueles que

of public and business administration, for example, argued that decision-makers attempt to follow a systematic method for arriving at logical, efficient decisions." HOWLETT, Michael; GIEST, Sarah. The policy-making process. In: ARARAL, Eduardo Araral Jr. et al (Orgs.). Routledge Handbook of Public Policy. Simultaneously published in the USA and Canada: Routledge, 2013, p. 20.

42 Tradução livre de: "Evidence-based policy (EBP) acknowledges the responsibility of decision makers for the conscientious use of evidence to design, manage and reform systems of support for communities in a manner that predictably yield outcomes of benefit. In theory, EBP means-scientists produce evidence, which policy decision makers can use for decisions." REDDY, K. Srikanth; SAHAY, Seema. Voices of decision makers on evidencebased policy: a case of evolving TB/HIV co-infection policy in India. AIDS care, v. 28, n. 3, p. 397, 2016, p.

43 Tradução livre de trechos de: "Another area of research around EBP aims to provide public sector workers with the tools needed to assess the quality of evidence." ARGYROUS, George. Evidence based policy: principles of transparency and accountability. Australian Journal of Public Administration, v. 71, n. 4, p. 457, 2012.

44 HOWLETT, Michael. Policy analytical capacity and evidence-based policy-making: Lessons from Canada. Canadian public administration, v. 52, n. 2, p. 153-175, 2009.

45 Tradução livre de: "In other words, transparency is a safeguard against simple errors, poor research design, and outright biasing of results and conclusions."

46 Tradução livre de: "1. Make raw data available; 2. Make the data collection instrument available; 3. Make metadata available; 4. Make analytical assumptions explicit; 5. Make analytical choices and their testing explicit; 6. Make theoretical perspectives explicit; 7. Make the relationship with past research explicit; 8. Declare financial and other interests.". ARGYROUS, George. Evidence based policy: principles of transparency and accountability. Australian Journal of Public Administration, v. 71, n. 4, p. 457-468, 2012, p. 459. 
possuem "expertise" e "leitores inteligentes ou potenciais usuários das evidências" ${ }^{47}$.

Essa estratégia de transparência e accountability parece mais adequada, inicialmente, para a perspectiva do uso de evidências geradas pelas próprias políticas públicas. No entanto, transparência e accountability também devem ser requeridas na escolha e na aplicação de evidências provenientes de outras áreas e pesquisadores, diminuindo vieses de seleção nas evidências escolhidas, além de evitar pesquisas pouco relevantes ou com falhas metodológicas. Além disso, essa estratégia pode conferir ao criador de política a responsabilidade de abrir diálogo com aqueles que podem auxiliá-lo, por deter conhecimentos específicos, atribuindo também aos pesquisadores capazes a responsabilidade de se engajar com as questões políticas concretas dos contextos em que estão inseridos.

Outra crítica que merece menção questiona o próprio papel das políticas públicas e do ator político, e pode ser colocada de forma geral como uma crítica à tecnocracia. O que é argumentado é que usar evidências já constitui um processo natural na produção de políticas públicas e o que está em discussão, na verdade, são quais evidências serão válidas, não o seu uso. Assim, os agentes estariam depositando na ciência uma fé que não é corroborada nem pela ciência nem pelo público em geral. Essa fé capacita os atores a mascarar suas decisões políticas em evidências racionais, colocando-se acima das críticas sob o manto da racionalidade prática (escolhendo aquilo que funciona). Essa perspectiva ignoraria a importância da interpretação dessas evidências e o caráter inter-relacional de uma decisão pública. Em última instância, as evidências seriam usadas, apenas, para reforçar uma decisão já tomada, sobretudo se contra-majoritária, dando poder aos técnicos ou aos que utilizam desse discurso tecnocrata ${ }^{48}$.

De fato, o movimento de políticas públicas baseadas em evidências considera dados advindos de diversas áreas do conhecimento e outros órgãos que se proponham a sistematizar e compreender a realidade por meio de métodos confiáveis e verificáveis, e está clamando por um uso de evidências especificamente controladas. Isso, no entanto, não deveria ser tomado como uma crítica ao movimento, mas como um alerta aos cidadãos para que façam um controle democrático e acessem os métodos decisórios e as justificativas dos tomadores de decisão. $\mathrm{O}$ uso das evidências não é a fonte do discurso tecnocrata, mas apenas uma ferramenta que pode ser assumida por políticos, e que pode ser usada para sustentar decisões diversas e alcançar objetivos igualmente diversos. O combate à tecnocracia se faz com conhecimento do público em geral, não com o desencorajamento do uso de evidências.

\subsection{O movimento de análise de políticas públicas e de políticas públicas baseadas em evidências no Brasil e o PLS 488/2017}

No Brasil, o interesse pela análise de políticas públicas pode ser considerado um movimento ocorrido pós-1930, com a tomada do poder pelo Presidente Getúlio Vargas ${ }^{49}$. No entanto, da perspectiva acadêmica, a literatura específica sobre políticas públicas em geral criada no Brasil começa a se consolidar, apenas, nos anos 2000. Quanto ao método adequado para a análise das políticas públicas, não havia, ao menos até 2016, nenhum livro publicado originalmente no país ${ }^{50}$.

47 Tradução livre de: 'In this way, accountability incorporates related concepts such as 'discussion', 'review', 'evaluation', or 'consultation' [...]But is also demands more of the policy-maker in terms of the extent to which they need to engage the views of 'significant others', [...] 1. Those affected by policy; 2 . Those with different conceptual frameworks; 3 . People with technical expertise; 4. Intelligent readers or potential users of the evidence". ARGYROUS, George. Evidence based policy: principles of transparency and accountability. Australian Journal of Public Administration, v. 71, n. 4, p. 463-464, 2012.

48 BLACK, Nick. Evidence based policy: proceed with care. British Medical Journal (BMJ), v. 323, n. 7307, p. 275, 2001; CLARENCE, Emma. Technocracy reinvented: the new evidence based policy movement. Public Policy and Administration, v. 17, n. 3 , p. $1-11$, July 2002.

49 FARAH, Marta Ferreira Santos. An analysis of public policies in Brazil: from an unnamed practice to the institutionalization of the" public field". Revista de Administração Pública, v. 50, n. 6, p. 965, 2016; SECCHI, Leonardo. Policy analysis in Brazil: a comparison of rationalist and argumentative approaches. Journal of Comparative Policy Analysis: research and practice, v. 18, n. 1, p. 89, 2016.

50 SECCHI, Leonardo. Policy Analysis in Brazil: a Comparison of Rationalist and Argumentative Approaches. Journal of Compara- 
Esse cenário se mantém e é ainda mais difícil encontrar material escrito em Língua Portuguesa sobre políticas públicas baseadas em evidências. Uma busca rápida no Portal Capes ${ }^{51} \mathrm{com}$ a expressão "políticas públicas baseadas em evidências" e afins ${ }^{52}$ retornou apenas quatro resultados. O que não quer dizer, é claro, que não se usam evidências nas abordagens acadêmicas às políticas públicas no Brasil, ou que pesquisadores brasileiros não têm produzido trabalhos nessa área até mesmo em outros idiomas, mas dá uma ideia do quão recente é essa abordagem por aqui.

Uma das áreas das políticas públicas que está mais avançada em termos de uso de evidências no Brasil e no mundo é a área da saúde pública. Talvez porque o movimento baseado em evidências em geral tenha surgido na medicina, ou porque, no contexto da própria área da saúde, a

ciência básica na qual as decisões tomadas baseadas em evidências estão sediadas é a epidemiologia, e a saúde pública está numa posição ideal para liderar o trabalho da tomada de decisão baseada em evidências porque é uma das poucas disciplinas nas quais a epidemiologia é a ciência basilar ${ }^{53}$.

Um trabalho interessante, por exemplo, busca compreender o uso de evidências científicas para o controle do cigarro no Brasil, defendendo uma diminuição da distância (gap) entre a ciência e a saúde pública. Demonstra que, dentre as lições extraídas do controle de cigarro, há a necessidade de ações coordenadas de diferentes atores e grupos influenciando os objetivos da saúde pública brasileira e de que a pesquisa científica deve auxiliar os criadores de políticas com evidências de suas respectivas áreas ${ }^{54}$.

As pesquisas na área já começam, inclusive, a fazer críticas à qualidade dos dados usados pelo governo. Um dos problemas diz respeito às conquistas e às dificuldades do SUS, o Sistema Único de Saúde. Assim, se

o objetivo é o de gerar informação relevante para iluminar a tomada de decisão referente às políticas públicas em saúde, devemos nos dedicar de forma sistemática a avaliar, pelo método científico, os resultados assistenciais do SUS. Entretanto, passados 25 anos da implantação do SUS, temos poucas evidências científicas, especialmente que representem o país continental que somos, quais são os resultados assistenciais finalísticos do SUS ${ }^{55}$.

Percebe-se com isso que o debate sobre as políticas públicas baseadas em evidências, ainda que incipiente no Brasil com relação aos aspectos teóricos e metodológicos, já foi iniciado por alguns estudiosos e criadores de políticas públicas, especialmente da área da saúde.

Tanto o guia de análise ex ante das políticas públicas e o PLS 488/2017 são, também, outras possíveis aberturas, no cenário brasileiro, para a importância do uso de evidências nas políticas públicas. O guia expressa a importância das evidências em dois momentos. O primeiro se refere à identificação dos problemas, sendo essencial "a apresentação de dados quantitativos e estudos qualitativos para evidenciar a natureza e a dimensão do problema identificado e, quando possível, a sua evolução ao longo do tempo" ${ }^{56}$. O segundo,

tive Policy Analysis: Research and Practice, v. 18, n. 1, p. 91, 2016.

51 "O Portal de Periódicos, da Coordenação de Aperfeiçoamento de Pessoal de Nível Superior (Capes), é uma biblioteca virtual que reúne e disponibiliza a instituições de ensino e pesquisa no Brasil o melhor da produção científica internacional. Ele conta com um acervo de mais de 38 mil títulos com texto completo, 134 bases referenciais, 11 bases dedicadas exclusivamente a patentes, além de livros, enciclopédias e obras de referência, normas técnicas, estatísticas e conteúdo audiovisual.” Disponível em: < http:// www-periodicos-capes-gov-br.ez27.periodicos.capes.gov.br/index.php?option $=$ com_pcontent\&view $=$ pcontent\&alias $=$ missaoobjetivos\&Itemid=102>. Acesso em: 10 abril 2018.

52 Foram utilizadas também: "política pública baseada em evidência"; "políticas públicas baseadas em evidência"; "política pública fundamentada em evidência"; "políticas públicas fundamentadas em evidências"; "política pública fundamentada em evidências". 53 Tradução livre de: "The basic science on which evidence-based decision-making is based is epidemiology, and public health is ideally positioned to lead work in evidence-based decision-making because it is one of the few disciplines in which epidemiology is one of the basic sciences." GRAY, J. A. Muir. Evidence-Based Public Health. In: TRINDER, Liz; REYNOLDS, Shirley (Orgs.). Evidence-based practice: A critical appraisal. Oxford: Blackwell, p. 1-16, 2003, p. 105.

54 COSTA E SILVA, Vera Luiza et al. Bridging the gap between science and public health: taking advantage of tobacco control experience in Brazil to inform policies to counter risk factors for non-communicable diseases. Addiction, v. 108, n. 8, p. 1360-1366, 2013. 55 OLIVEIRA, Jussiely Cunha; BARRETO-FILHO, José Augusto. Políticas Públicas em Saúde Embasadas em Ciência "Made In Brazil": um desafio para os Arquivos Brasileiros de Cardiologia. Arq. Bras. Cardiol., v. 105, n. 3, p. 211, 2015. p.

56 BRASIL. Casa Civil da Presidência da República. Avaliação de políticas públicas: guia prático de análise ex ante. Brasília: Ipea, 2018. 
à fundamentação da escolha ou tomada de decisão, quando se devem expor

todas as informações que auxiliaram o processo de construção da política e justificam a escolha da intervenção conforme apresentada. Para compor esta etapa, sempre que possível, deve-se apresentar uma revisão de literatura indicando que o modelo lógico proposto tem o potencial de alcançar os impactos esperados. Outras fontes de informação utilizadas na construção da política - como grupos focais, entrevistas com especialistas, exemplos de outras experiências similares nacionais ou internacionais devem ser especificadas quando pertinentes. ${ }^{57}$.

O PLS 488/2017, por sua vez, trata de outro espaço interessante para o uso de evidências. No art. 17-A, o projeto estabelece que os projetos de lei que instituam política pública deverão ser "acompanhados de avaliação prévia de impacto legislativo, com o intuito de garantir a economicidade, a eficácia, a eficiência e a efetividade das ações públicas." ${ }^{58}$. Numa Análise de Impacto Legislativo (AIL) devem constar: qual o problema que se quer resolver; quais os objetivos da proposição legislativa; quais as opções disponíveis para alcançar esses objetivos; qual o arcabouço jurídico que importa ao tema; quais os possíveis impactos econômicos e sociais que podem ser gerados caso a proposição seja aprovada ${ }^{59}$.

Mas AILs não devem ser feitas em qualquer espécie de proposição legislativa. Merecem avaliações de impacto legislativo as proposições legislativas que "imponham ou reduzam custos à iniciativa privada, ao terceiro setor ou ao próprio setor público", dependendo do valor, além das "situações em que ocorrerá uma grande redistribuição de custos e benefícios entre grupos da sociedade" ${ }^{60}$.

Assim, fica claro que as proposições que instituam políticas públicas atingem os critérios auferidos por MENEGUIN. Em termos de ciclo das políticas públicas, parece-nos adequado dizer que essa AIL deve acontecer como resultado da tomada de decisão (terceira etapa do ciclo de políticas públicas), quando as opções já foram cogitadas e decidiu-se por um curso de ação, e que é também a etapa do ciclo de política pública em que o movimento de política pública baseada em evidências costuma focar. A proposição de um projeto de lei é uma resposta a uma decisão, e pode ser considerada parte da implementação da política, já que começa a demandar esforços, articulações, enfim, alguma espécie de ação por parte do agente político.

A diferença entre uma AIL e uma avaliação de política pública num sentido mais amplo não é óbvia.

Após detida análise dos conceitos e exemplos encontrados na literatura sobre os dois temas, pode-se depreender que o entendimento vigente diferencia o que seja avaliação de políticas públicas, avaliação de programas de governo e avaliação de impacto legislativo. A percepção que se tem é que: a) os programas públicos, dada sua complexidade, não necessitam de previsão normativa para sua legitimação; b) a análise de políticas públicas ocorre somente sobre políticas sociais; e c) a análise de impacto legislativo incide sobre o processo de elaboração normativa stricto senso $\mathrm{s}^{61}$.

Como a proposição de políticas públicas pressupõe algum arcabouço legal que a permita e regule,

ao se considerar os objetivos, a metodologia e os princípios aplicados, pode-se afirmar que avaliação de políticas públicas e avaliação de impacto legislativo partem dos mesmos pressupostos de ação e

v. 1. p. 58 .

57 BRASIL. Casa Civil da Presidência da República. Avaliação de políticas públicas: guia prático de análise ex ante. Brasília: Ipea, 2018 v. 1. p. 58 .

58 BRASIL. Projeto de Lei Complementar do Senado n 488 de 2017 - Texto final. Acrescenta dispositivos à Lei Complementar $n^{\circ} 95$, de 26 de fevereiro de 1998, com o intuito de estabelecer normas e diretrizes para encaminhamento de proposições legislativas que instituam políticas públicas, propiciando melhor responsabilidade gerencial na Administração Pública. Disponível em: <https:// legis.senado.leg.br/sdleg-getter/documento?dm=7326614\&disposition=inline >. Acesso em: 15 maio 2018.

59 MENEGUIN, Fernando B. Avaliação de impacto legislativo no Brasil. Brasília: Senado Federal, Consultoria Legislativa, Textos para Discussão 70. 2010. p. 10-11. Disponível em: < https://www12.senado.leg.br/publicacoes/estudos-legislativos/tipos-de-estudos/ textos-para-discussao/td-70-avaliacao-de-impacto-legislativo-no-brasil>. Acesso em: 25 abr. 2018.

60 MENEGUIN, Fernando B. Avaliação de impacto legislativo no Brasil. Brasília: Senado Federal, Consultoria Legislativa, Textos para Discussão 70, 2010. P.10 Disponível em: <https://www12.senado.leg.br/publicacoes/estudos-legislativos/tipos-de-estudos/ textos-para-discussao/td-70-avaliacao-de-impacto-legislativo-no-brasil>. Acesso em: 25 abril 2018.

61 ANDRADE, Aparecida de Moura; SANTANA, Héctor Valverde. Avaliação de políticas públicas versus avaliação de impacto legislativo: uma visão dicotômica de um fenômeno singular. Revista Brasileira de Políticas Públicas, Brasília, v. 7, n. 3, p. $796,2017$. 
compartilham dos mesmos resultados da avaliação de impacto legislativo: avaliar a eficiência, eficácia e efetividade da norma que institui uma política pública, seja ela distributiva, redistributiva ou regulatória ${ }^{62}$.

Embora o texto do PLS 488/2017 recomende a todos os projetos de lei que deem origem a políticas públicas que façam uma Análise do Impacto Legislativo (AIL), ainda assim não tivemos acesso a nenhuma AIL feita para o projeto em si, já que não há nada nesse sentido anexado ao projeto ou disponibilizado em documentos durante a tramitação no Senado ou na Câmara. Dentre as razões para o não cumprimento das exigências, como já foi especulado na seção 1 do presente artigo, pode-se levantar a de que os propositores do projeto não consideraram-no uma proposição de política pública, ou, ainda, se dever à ausência de um texto anterior que os "obrigue".

Tendo mapeado a possibilidade do uso de políticas públicas baseados em evidências em geral, e sua ainda incipiente aparição em território nacional, cabe agora passar ao tema mais específico das evidências comportamentais nas políticas públicas.

\section{As POLÍTICAS PÚBLICAS E AS EVIDÊNCIAS COMPORTAMENTAIS}

O movimento de políticas públicas baseadas em evidências costuma abarcar estudos que buscam entregar evidências que ajudem os criadores de políticas públicas no processo de tomada de decisão. Uma das áreas mais fortes dessa corrente, atualmente, é a que busca utilizar evidências comportamentais para propor alterações em políticas públicas e em processos de decisão privados, os chamados nudges (pequenos empurrões). Um nudge é um aspecto da "arquitetura de escolha" que visa alterar o comportamento das pessoas de "forma previsível, sem proibir ou alterar significativamente os incentivos econômicos". Assim, um nudge deve ser uma intervenção não explícita, não mandatária e que possa ser recusada pelo público-alvo ${ }^{63}$.

Um nudge é um “empurrãozinho" planejado para influir, positivamente, nas escolhas das pessoas, não as alterando, mas facilitando a escolha considerada melhor. Esses nudges foram propostos no contexto de um "paternalismo libertário", expressão, de alguma forma irônica, cunhada por THALER e SUNSTEIN. Esse paternalismo seria uma versão leve do paternalismo, já que, ao invés de bloquear, cercear, limitar ou alterar significativamente as escolhas das pessoas, o objetivo dos nudges é levar as pessoas a fazerem escolhas melhores, sem com isso decidir por elas ${ }^{64}$.

Essa influência no comportamento por meio dos nudges pode acontecer com base em mecanismos inconscientes; corrigindo incompreensões sobre as normas sociais; alterando o perfil de escolhas ou a forma como as escolhas são apresentadas; mudando a regra padrão (aquela que não demanda esforço do indivíduo), obrigando-o a escolher ativamente uma opção mais custosa ou menos saudável, por exemplo; ou criando incentivos financeiros para que as pessoas façam escolhas melhores, sem criar prejuízos caso elas não as façam ${ }^{65}$.

Os nudges parecem ter ampla aceitação por parte dos cidadãos de diversas nações, tais como Austrália, Canadá, China, Rússia e Brasil ${ }^{66}$. Eles são um tipo de política comportamental (behavioral policy), conceituada

62 ANDRADE, Aparecida de Moura; SANTANA, Héctor Valverde. Avaliação de políticas públicas versus avaliação de impacto legislativo: uma visão dicotômica de um fenômeno singular. Revista Brasileira de Políticas Públicas, Brasília, v. 7, n. 3, p. $796,2017$.

63 Tradução livre de trechos de: "A nudge, as we will use the term, is any aspect of the choice architecture that alters people's behavior in a predictable way without forbidding any options or significantly changing their economic incentives. To count as a mere nudge, the intervention must be easy and cheap to avoid. Nudges are not mandates." THALER, Richard H.; SUNSTEIN, Cass R. Nudge: improving decisions about health, wealth, and happiness. New Haven: Yale University Press, 2008. p. 6.

64 THALER, Richard H.; SUNSTEIN, Cass R. Nudge: improving decisions about health, wealth, and happiness. New Haven: Yale University Press, 2008. p. 5.

65 BONELL, Chris et al. One nudge forward, two steps back. British Medical Journal (BMJ), v. 342, n. jan. 25, p. d401, 2011.

66 SUNSTEIN, Cass R.; REISCH, Lucia A.; RAUBER, Julius. A worldwide consensus on nudging? not quite, but almost. Regulation \& Governance, v. 12, n. 1, p. 3-22, 2018. 
como "intervenções no ambiente de escolha que tem por objetivo afetar o comportamento sem incentivo ou coerção" ${ }^{67}$. Os nudges são uma das formas possíveis de intervenção, mas há outras.

Outra forma importante de política comportamental é a abordagem de boost (impulso). Se nos nudges há uma decisão externa em modificar o comportamento, ainda que de forma suave, nos boosts a ideia é ajudar as pessoas a tomarem decisões mais acertadas levando em conta suas limitações. A abordagem de boosts "admite um tomador de decisão cujas competências podem ser melhoradas", no sentido de melhorar o "repertório de habilidades e ferramentas decisionais e/ou reestruturando o ambiente para que essas habilidades existentes e ferramentas possam ser utilizadas de forma mais efetiva" ${ }^{68}$. Assim, os boosts diferem dos nudges por levarem em conta, também, o melhor da capacidade decisional do público-alvo, e não apenas a alteração do comportamento.

Uma das críticas que podem ser feitas aos nudges ou às políticas comportamentais como um todo diz respeito ao uso de evidências laboratoriais ou de estudos controlados em políticas públicas. Ao transferir as conclusões advindas de uma experiência controlada para outra no mundo real, outras variáveis podem alterar o resultado. Os dados que demonstram os efeitos comportamentais derivados de uma mudança no ambiente de escolha costumam ser extraídos de ambientes diversos daqueles em que serão efetivamente aplicados pelos criadores de políticas públicas, mesmo sendo experimentos de campo ${ }^{69}$. O uso de evidências deve ser sempre acompanhado de prudência nas generalizações e de compreensão dos limites metodológicos dos estudos.

No caso das evidências comportamentais em nudges, há três mecanismos diversos que podem estar atuando. As alterações comportamentais podem estar acontecendo porque os sujeitos preferem não fazer esforço cognitivo, limitando sua decisão à opção menos cognitivamente dispendiosa quando se modifica a escolha padrão disponível ${ }^{70}$. Essa tentativa de evitar a fadiga cognitiva está relacionada ao viés de status quo, que implica dizer que tendemos à inércia, sobretudo pela falta de atenção ou de interesse ao que está sendo apresentado (algo como uma "heurística do 'tanto faz"). Assim, essa tendência é facilmente explorável, já que as pessoas podem, sobretudo, pagar por algo como resultado dessa inércia, preferindo a escolha-padrão a ativamente escolher algo com menos custos $^{71}$.

Outro mecanismo que pode estar operando é da aversão à perda. Quando comparados os ganhos de uma escolha com as perdas de outras, as pessoas tendem a dar maior peso para as perdas, ainda que elas sejam relativamente equivalentes aos ganhos da escolha alternativa ${ }^{72}$. Como os indivíduos tendem a evitar as perdas, quando se muda a escolha-padrão pode ser que se mude também a perspectiva do sujeito com relação à perda e ao ganho de determinada escolha ${ }^{73}$.

O terceiro mecanismo que pode explicar o que ocorre quando uma política comportamental funciona é o efeito da recomendação. Nesse caso, a escolha-padrão pode servir como um sinal de que aquele que formulou o ambiente de escolha está recomendando que se faça a escolha dada como default. Se aquele que

67 Tradução livre de: "Behavioural policies are interventions in the choice environment that aim at affecting behaviour without incentive change or coercion.” GRÜNE-YANOFF, Till. Why behavioural policy needs mechanistic evidence. Economics \& Philosophy, v. 32, n. 3, p. 463-483, 2016, p. 463.

68 Tradução livre de trechos de: "The boost approach, in contrast, assumes a decision maker whose competences can be improved by enriching his or her repertoire of skills and decision tools and/or by restructuring the environment such that existing skills and tools can be more effectively applied”. GRÜNE-YANOFF, Till; HERTWIG, Ralph. Nudge versus boost: How coherent are policy and theory? Minds and Machines, v. 26, n. 1-2, p. 149-183, 2016.

69 GRÜNE-YANOFF, Till. Why behavioural policy needs mechanistic evidence. Economics \& Pbilosophy, v. 32, n. 3, p. 466, 2016.

70 GRÜNE-YANOFF, Till. Why behavioural policy needs mechanistic evidence. Economics \& Philosophy, v. 32, n. 3, p. 467, 2016.

71 THALER, Richard H.; SUNSTEIN, Cass R. Nudge: improving decisions about health, wealth, and happiness. New Haven: Yale University Press, 2008. p. 35.

72 KAHNEMAN, Daniel. Rápido e devagar: duas formas de pensar. Tradução Cássio de Arantes Leite. Rio de Janeiro: Objetiva, 2012. p. 351.

73 GRÜNE-YANOFF, Till. Why behavioural policy needs mechanistic evidence. Economics \& Philosophy, v. 32, n. 3, p. 468, 2016. 
escolhe confia nos formuladores da política, tende a confiar na escolha-padrão ${ }^{74}$.

Não é suficiente que a política comportamental apenas funcione. É preciso entender o mecanismo que faz com que a mudança de comportamento funcione no ambiente experimental, para que, assim, essa evidência possa ser carregada para outras políticas públicas. Sem essa informação, não se pode alegar a efetividade da política, sua robustez ou persistência, ou ainda se ela possui mecanismos positivos de aumento do bem-estar ${ }^{75}$. Todo esse debate demonstra como o uso de evidências comportamentais deve ser mais amplo e como é importante avaliar os dados que estão sendo utilizados.

A proposição de políticas públicas baseadas em evidências não precisa, porém, estar restrita ao uso de nudges. Num sentido mais amplo, as ciências comportamentais devem ser inseridas em diversas outras etapas dos ciclos de políticas públicas, levando em conta não apenas o objetivo esperado, mas também o público-alvo e mesmo o próprio tomador de decisão, melhorando a qualidade das políticas públicas propostas.

Faremos a seguir uma análise mais detalhada das possibilidades de uso de evidências comportamentais no Brasil, à luz do PLS 488/2017.

\subsection{O uso de evidências comportamentais nas políticas públicas no Brasil à luz do PLS 488/2017}

Embora as políticas públicas devam ser baseadas em evidências diferentes, que interfiram no problema público a ser resolvido, as evidências comportamentais, por sua vez, são virtualmente de interesse de qualquer formulador de política pública. A razão para tal é que, em última instância, um dos riscos de praticamente qualquer política é o de interferir de forma não prevista na situação social, afetiva e cognitiva do público-alvo. Além disso, todo tomador de decisão deve estar ciente das razões pelas quais escolheu uma evidência como relevante e deve estar preparado para negociar, explicar e convencer outros atores da força, qualidade e abrangência das evidências usadas.

As ciências comportamentais podem ajudar a alcançar determinado objetivo, e, nesse caso, os nudges podem ser considerados, assim como os boosts ou outras estratégias que usem evidências comportamentais, quando é preciso tomar uma decisão quanto a qual caminho seguir. Eles podem aumentar a efetividade da política pública, compreendida no PLS 488/2017 como o "alcance dos resultados pretendidos, a médio e longo prazo" 76 .

Assim, o PLS 488/2017 abre um espaço importante para que as ciências comportamentais sejam utilizadas para a produção de políticas públicas no Brasil. Essa abertura é detectável em alguns momentos do projeto. No artigo 17-B, inciso IV, afirma-se que os projetos de lei deverão explicitar o "o grau de focalização ou universalização das políticas públicas, considerando as necessidades do público-alvo e os recursos disponíveis" ${ }^{77}$. Essas necessidades devem ser matizadas pelas evidências nas ciências comportamentais, sobretudo tendo em vista a incompletude de nossa consciência de nossas próprias necessidades.

Os nudges são mecanismos que visam "auxiliar" o público-alvo em escolhas determinadas, "facilitando"

74 GRÜNE-YANOFF, Till. Why behavioural policy needs mechanistic evidence. Economics \& Pbilosophy, v. 32, n. 3, p. 469, 2016.

75 GRÜNE-YANOFF, Till. Why behavioural policy needs mechanistic evidence. Economics \& Philosophy, v. 32, n. 3, p. 463-483. 2016.

76 BRASIL. Projeto de Lei Complementar do Senado $n^{\circ} 488$ de 2017 - Texto final. Acrescenta dispositivos à Lei Complementar $\mathrm{n}^{\circ} 95$, de 26 de fevereiro de 1998, com o intuito de estabelecer normas e diretrizes para encaminhamento de proposições legislativas que instituam políticas públicas, propiciando melhor responsabilidade gerencial na Administração Pública. Disponível em: <https:// legis.senado.leg.br/sdleg-getter/documento?dm=7326614\&disposition=inline $>$. Acesso em: 15 maio 2018.

77 BRASIL. Projeto de Lei Complementar do Senado n 488 de 2017 - Texto final. Acrescenta dispositivos à Lei Complementar no 95 , de 26 de fevereiro de 1998, com o intuito de estabelecer normas e diretrizes para encaminhamento de proposições legislativas que instituam políticas públicas, propiciando melhor responsabilidade gerencial na Administração Pública. Disponível em: <https:// legis.senado.leg.br/sdleg-getter/documento?dm=7326614\&disposition=inline > Acesso em: 15 maio 2018. 
a escolha melhor para o longo prazo, mas nem sempre prazerosa no curto prazo. Um exemplo clássico é a mudança na disposição de comidas mais saudáveis em supermercados. Num estudo nos Estados Unidos, mudar a posição de um lanche mais saudável fez com que ele fosse escolhido mais vezes ${ }^{78}$. Em resposta, uma série de estudos tentou averiguar se a mudança da disposição dos produtos poderia levar a mudanças nas escolhas, sem limitar as possibilidades do consumidor. Outras áreas em que há estudos promissores, embora modestos, de nudges, são: transporte, com nudges que encorajam o uso de meios sustentáveis de transporte no Reino Unido; e energia, ao levar a uma diminuição do consumo por meio de pequenas mudanças nas informações disponíveis nas contas de luz $z^{79}$.

Outra sugestão, nesse caso dentro do contexto brasileiro, é a de aproveitar os nudges como forma de combate à corrupção pública, por meio da "utilização de lembretes morais e pela manipulação das normas sociais descritivas". Isso já foi feito em experimentos sociais, nos quais o experimentador lembrava antes aos participantes de regras morais aceitas por eles; e na Índia, ao desenvolver uma cédula correspondente a "zero rúpia”, que indicaria a não aceitação de suborno ${ }^{80}$.

De fato, um exemplo tem sido dado pela Prefeitura do Rio de Janeiro, por meio da recente criação da "Nudge.Rio", uma "célula dentro da estrutura do Instituto Fundação João Goulart" que tem por objetivo "disseminar o conceito de Ciência Comportamental Aplicada nos órgãos da Prefeitura da Cidade do Rio de Janeiro", tendo como foco os nudges ${ }^{81}$.

No caso das necessidades do público-alvo, é importante refletir, portanto, se essas necessidades serão sempre as que puderem ser declaradas pelos cidadãos, sendo escolhas conscientes, ou se é possível considerar que há necessidades que não estão no foco do cidadão no curto prazo, mas que podem beneficiá-lo no longo prazo. Esse é o grande dilema do paternalismo libertário, e deve ser encarado quando se fala em políticas públicas que busquem satisfazer necessidades dos cidadãos.

Assim, o PLS 488/2017 pode ser um bom estímulo a mais núcleos de inovação pública no Brasil, além do estudo das experiências com evidências comportamentais feitas em outros países, ao enfocar a importância do uso de evidências e a explicitação das necessidades a que as políticas públicas pretendem atender.

As ciências comportamentais são ainda mais relevantes para aquele que está decidindo sobre como as políticas públicas deverão ser formuladas, que é o caso do PLS 488/2017. Como já afirmamos, não tivemos acesso a nenhuma AIL do PLS 488/2017. Assim, não podemos, portanto, ter certeza de quais problemas o projeto está tentando resolver, se é uma resposta a alguma demanda específica de algum grupo organizado ou estrutura governamental, se foi feito um estudo de impacto e quais os objetivos mensuráveis que essa política pretende alcançar. Resta-nos, portanto, especular sobre os problemas a serem enfrentados por essa proposição, tendo em vista a estrutura e o conteúdo dos artigos.

Além disso, ao fazer uma avaliação do PLS 488/2017 como um projeto que institui uma política pública, aproveitaremos para demonstrar como o uso de evidências comportamentais pode funcionar na proposição de políticas públicas no Brasil. O próprio projeto pode servir como um estudo de caso interessante de medida que se beneficiaria do uso de evidências no processo de decisão, justamente por tentar desenhar estratégias para a tomada de decisão de futuros criadores de políticas públicas.

78 KELLER, Carmen; MARKERT, Franziska; BUCHER, Tamara. Nudging product choices: the effect of position change on snack bar choice. Food Quality and Preference, v. 41, p. 41-43, 2015.

79 LEHNER, Matthias; MONT, Oksana; HEISKANEN, Eva. Nudging-A promising tool for sustainable consumption behaviour? Journal of Cleaner Production, v. 134, p. 166-177. 2016.

80 COSTA, Natalia Lacerda Macedo. "Nudge" como abordagem regulatória de prevenção à corrupção pública no Brasil. Revista de informação legislativa: RIL, v. 54, n. 214, p. 91-111, abr./jun. 2017. Disponível em: < http://www12.senado.leg.br/ril/edicoes/54/214/ ril_v54_n214_p91>. Acesso em: 27 julho 2018.

81 Informações disponíveis em <http://www.rio.rj.gov.br/web/fjg/exibeconteudo?id=8059802\#>. Acesso em: 28 julho 2018. 


\subsection{Aplicando evidências comportamentais a propostas de políticas públicas: análise de duas recomendações do PLS 488/2017}

Para finalizar nossa discussão, portanto, destacaremos duas recomendações feitas pelo projeto e como elas podem ser compreendidas à luz de evidências comportamentais. A primeira diz respeito às próprias estratégias sugeridas para a tomada de decisão. O PLS 488/2017 pode ser vinculado a um movimento maior de racionalização das decisões. Ao sugerir em seu artigo 17-B, inciso VIII, que os projetos apresentem "a formalização dos processos decisórios correlatos, incluindo o registro da motivação e do conjunto de evidências que embasam a escolha política" 82 está conectado, de alguma forma, a esse movimento mais amplo que busca racionalizar os processos decisórios dos poderes e atores públicos, seja por meio da AIL, seja por uma avaliação de política pública, esse último mais claramente especificado no guia de análise ex ante das políticas públicas.

A análise racionalista é uma "metodologia para recomendar alternativas de políticas para questões públicas usando técnicas tais quais análise de custo-benefício, de custo-efetividade, análise de risco e outros métodos quantitativos" ${ }^{83}$. No país, alguns dos bastiões desse movimento podem ser encontrados no IPEA e no Ministério do Planejamento e outros espaços governamentais ${ }^{84}$.

No PLS 488/2017, os elementos apontados como importantes a serem respeitados na proposição da política pública pelo projeto de lei (economicidade, a efetividade, a eficácia e a eficiência) são frutos da influência desse movimento de racionalização e "da política fiscal restritiva de gasto, adotada por vários governos", fazendo com que a eficiência fosse "vista como o principal objetivo de qualquer política pública, aliada à importância do fator credibilidade e à delegação das políticas públicas para instituições com 'independência’ política" ${ }^{85}$.

Também no guia de análise ex ante das políticas públicas, conseguimos vislumbrar a influência desse movimento de racionalização. O guia afirma que a

avaliação das políticas públicas deve começar no nascedouro, por meio da análise ex ante, a fim de verificar, fundamentalmente, se respondem a um problema bem delimitado e pertinente. Em função disso, observa-se se há um objetivo claro de atuação do Estado e se propõe um desenho que efetivamente possa ser alcançado.[...] Como a demanda da sociedade é crescente, o desafio do governo para esta e as próximas gerações não é apenas conter a expansão do gasto público mas também avaliar em que pontos ele é pouco produtivo, com o propósito de procurar fazer mais com menos recursos e priorizando a efetividade e a eficiência das políticas públicas. Nesse sentido, a análise ex ante pode contribuir para que as decisões alocativas sejam orientadas por critérios mais claros e transparentes, baseados em análises técnicas mais robustas. O fundamento da análise ex ante é orientar a decisão para que ela recaia sobre a alternativa mais efetiva, eficaz e eficiente. ${ }^{86}$

O movimento racionalista também costuma ser vinculado às políticas públicas baseadas em evidências. Seria racional o processo decisório que seguisse um "método sistemático" para chegar a uma decisão "eficiente e lógica". Assim, os tomadores de decisão públicos atingem resultados melhores quando "primeiro

82 BRASIL. Projeto de Lei Complementar do Senado n 488 de 2017 - Texto final. Acrescenta dispositivos à Lei Complementar $\mathrm{n}^{\circ} 95$, de 26 de fevereiro de 1998, com o intuito de estabelecer normas e diretrizes para encaminhamento de proposições legislativas que instituam políticas públicas, propiciando melhor responsabilidade gerencial na Administração Pública. Disponível em: <https:// legis.senado.leg.br/sdleg-getter/documento?dm=7326614\&disposition=inline>. Acesso em: 15 maio 2018.

83 Tradução livre de: "Rationalist policy analysis is a methodology for recommending policy alternatives to public issues using techniques such as cost-benefit analysis, cost-effectiveness, risk analysis and other quantitative methods.". SECCHI, Leonardo. Policy Analysis in Brazil: a comparison of rationalist and argumentative approaches. Journal of Comparative Policy Analysis: research and practice, v. 18, n. 1, p. 93, 2016.

84 SECCHI, Leonardo. Policy analysis in Brazil: a comparison of rationalist and argumentative approaches. Journal of Comparative Policy Analysis: Research and Practice, v. 18, n. 1, p. 95, 2016.

85 SOUZA, Celina. Políticas públicas: uma revisão da literatura. Sociologias, Porto Alegre, ano 8, n. 16, p. 34, jul/dez 2006.

86 BRASIL. Casa Civil da Presidência da República. Avaliação de políticas públicas: guia prático de análise ex ante. Casa Civil da Presidência da República, Instituto de Pesquisa Econômica Aplicada. Brasília: Ipea, 2018. v. 1. p. 11. 
estabelecem um objetivo", em seguida "exploram alternativas para alcançá-lo"; depois tentam prever as "consequências e a probabilidade de ocorrência" de cada uma das alternativas; e, então, escolhem "a opção que maximiza os potenciais benefícios ao menor custo ou risco". Assim, isso é racional porque estabelece um "conjunto padrão de procedimentos para a feitura de políticas" que levem sempre aos "meios mais eficientes de atingir o objetivo da política" ${ }^{87}$.

No entanto, o uso de evidências em geral nas políticas públicas, em vários de seus estágios, não deve estar restrito à modelagem de decisão imposta aos agentes públicos. Isso porque o uso de evidências deve ser requerido, inclusive, na escolha do processo de tomada de decisão. E o que se pode demonstrar é que "pesquisas empíricas sobre o processo de tomada de decisão" descobriram que nem sempre a negociação da política se dá através de "deliberações racionais e cálculos de custos e benefícios", e os tomadores de decisão e criadores de políticas públicas não são "necessariamente neutros ou competentes" 88.

Embora seja questionável que a teoria exija tanto assim dos tomadores de decisão, é fato que não se pode escolher a priori uma teoria sem antes validá-la por evidências, se se quer levar a sério a evidência científica nas políticas públicas.

O uso da Teoria da Escolha Racional no próprio movimento de políticas públicas baseadas em evidências levantou críticas. Sobretudo em seu espraiamento inicial entre os atores e práticos das políticas públicas, o uso de evidências em políticas públicas ensejou uma "versão ingênua", em que a tarefa de inserir evidências em políticas públicas seria a de fornecer um guia "racional" ou "objetivo" para a tomada de decisão, "sem se deixar levar pelas influências distorcidas da tradição, interesse privado, ideologia ou vieses pessoais daqueles que estão no poder" ${ }^{89}$. Assim, a teoria parece apontar para uma racionalidade que reduz a própria tomada de decisão e posterior produção da política pública para uma questão de "aplicar evidências robustas do 'que funciona' para promover de forma mais efetiva o alcance dos objetivos políticos estabelecidos" ${ }^{90}$.

Para responder a essa crítica, primeiramente, é importante compreender a diferença entre teorias prescritivas e descritivas da tomada de decisão. Tomada num sentido puramente instrumental, essa concepção de racionalidade nos parece adequada, já que ela não pressupõe que os indivíduos tomadores de decisão são movidos por objetivos racionais ou lógicos, mas apenas que devem tentar se concentrar nas evidências e tentar diminuir a influência dos elementos pessoais e ideológicos quando eles não forem aumentar a eficiência da política. Considerada dentro de uma perspectiva prescritiva, portanto, a adoção de racionalidade instrumental no processo de tomada de decisão parece bastante plausível.

87 Tradução livre de: “[...] argued that decision-makers attempt to follow a systematic method for arriving at logical, efficient decisions. [...] They argued that policy-makers achieved superior results when they first established a goal; explored alternative strategies for achieving it; attempted to predict its consequences and the likelihood of each occurring; and then chose the option which maximized potential benefits at least cost or risk [...].This model was "rational" in the sense that it prescribed a standard set of procedures for policymaking which were expected to lead in all circumstances to the choice of the most efficient means of achieving policy goals [...]”. HOWLETT, Michael; GIEST, Sarah. The policy-making process. In: ARARAL, Eduardo Araral Junior et al (Org.). Routledge handbook of public policy. Simultaneously published in the USA and Canada: Routledge, p. $20,2013$.

88 Tradução livre de trechos de: "Empirical research into decision-making processes, however, has discovered that political processes of bargaining and negotiation often outweigh "rational" deliberations and calculations of costs and benefits are subject to substantive and procedural limitations. Policy-makers were often found to be neither necessarily neutral nor competent and other models of the public policy decision-making processes have argued that this is not an accidental situation but rather an inherent and unavoidable characteristic of the policy-making exercise.”. HOWLETT, Michael; GIEST, Sarah. The policy-making process. In: ARARAL, Eduardo Araral Junior et al (Org.). Routledge Handbook of Public Policy. Canada: Routledge, p. $20,2013$.

89 Tradução livre de trechos de: “The term 'evidence-based policy' (EBP) has gained wide currency, but in the process has been subjected to substantial critique. In its naive version, best expressed by former Australian Prime MinisterKevin Rudd, the task of EBP is to provide a 'rational' or 'objective' guide to decision-making, unswayed by the distorting influences of tradition, private interest, ideology, or the personal biases of those in power (2008).” ARGYROUS, George. Evidence based policy: principles of transparency and accountability. Australian Journal of Public Administration, v. 71, n. 4, p. 457, 2012.

90 Tradução livre de trechos de: "The key proposition of this article, then, is that much of the contemporary debate about EBP is conducted within the confines of an 'instrumental rationality' that reduces the matter to a technical task of applying robust evidence of 'what works' to promote more effective achievement of given policy goals." SANDERSON, Ian. Complexity,'practical rationality'and evidence-based policy making. Policy \& politics, v. 34, n. 1, p. 127, 2006. 
Mesmo como instrumento, essa teoria deve ser matizada. As pessoas em geral nem sempre são capazes de acessar as melhores escolhas para elas, ou de chegar sem nenhuma preconcepção às evidências e soluções ao problema público analisado. Essa incapacidade decorre de vários mecanismos cognitivos que turvam a nossa avaliação da realidade, dos argumentos e das opções, chamados, convencionalmente, de "vieses" e "heurísticas". Os vieses são os erros sistemáticos e previsíveis que nosso sistema cognitivo comete ao avaliar alguma situação ${ }^{91}$. Já a heurística é um procedimento cognitivo por meio do qual buscamos dar uma resposta adequada a uma pergunta difícil, embora a resposta possa se mostrar imperfeita ou incompleta ${ }^{92}$.

O PLS 488/2017, quando afirma, no artigo 17-B, que o projeto de lei que institua política pública deve vir acompanhado de uma "formalização dos processos decisórios correlatos, incluindo o registro da motivação e do conjunto de evidências que embasam a escolha política", parece anuir a essa tentativa de uniformizar processos decisórios, ao mesmo tempo em que pode-se considerar que ele apele pela diminuição de ruídos cognitivos (como: tradição, interesse privado, ideologia e vieses). O mesmo é indicado no artigo 17-C, que afirma que o projeto deve apresentar uma AIL que indique "alternativas existentes para a solução da situação ou do problema identificado", "justificando-se a escolha da solução ou da providência contida no projeto proposto" 93 .

Os tomadores de decisão não podem ser considerados isentos desses mesmos vieses e heurísticas. Assim, quando se fala em racionalidade ou uso de evidências, devem-se considerar as fortes evidências que apontam num sentido contrário ao de uma racionalidade absoluta e neutra.

A segunda recomendação do projeto de lei que pode ser avaliada à luz das evidências comportamentais diz respeito à periodicidade da avaliação da política e a previsão de quais problemas podem ser gerados no futuro. O artigo 17-B afirma que a proposição legislativa deverá conter "a periodicidade da avaliação de desempenho das políticas públicas e a abordagem para solucionar conflitos e estabelecer formas de revisão, de modo a promover ajustes necessários", e o "o plano de gestão de riscos, identificando-se os principais problemas que podem surgir e as medidas mitigadoras para tratá-los" 94.

Esse foco na imaginação de cenários futuros pode auxiliar a diminuição de uma heurística e de um viés relacionados que podem acontecer quando um agente público está planejando uma intervenção qualquer na sociedade. A heurística de disponibilidade, que Kahneman chama de WYSIATI (what you see is all there is: o que você vê é tudo o que há), faz com que julguemos determinado evento como relevante ou determinada escolha como adequada simplesmente porque pensamos constantemente neles ou estamos submetidos a informações constantes sobre eles, e somos, por isso, capazes de criar uma narrativa coerente e crível. Por exemplo, as pessoas tendem a superestimar o risco de um acidente aéreo, porque as imagens são vívidas e a cobertura midiática é ampla. Essas informações nos levam a tirar conclusões sobre o risco de um acidente, embora na prática tenhamos informações insuficientes e não poderíamos, de forma sustentável, julgar esse risco ${ }^{95}$.

91 KAHNEMAN, Daniel. Rápido e devagar: duas formas de pensar. Tradução de Cássio de Arantes Leite. Rio de Janeiro: Objetiva, 2012. p. 10.

92 KAHNEMAN, Daniel. Rápido e devagar: duas formas de pensar. Tradução de Cássio de Arantes Leite. Rio de Janeiro: Objetiva, 2012. p. 127.

93 BRASIL. Projeto de Lei Complementar do Senado n 488 de 2017 - Texto final. Acrescenta dispositivos à Lei Complementar $n^{\circ} 95$, de 26 de fevereiro de 1998, com o intuito de estabelecer normas e diretrizes para encaminhamento de proposições legislativas que instituam políticas públicas, propiciando melhor responsabilidade gerencial na Administração Pública. Disponível em: <https:// legis.senado.leg.br/sdleg-getter/documento?dm=7326614\&disposition=inline >. Acesso em:15 maio 2018.

94 BRASIL. Projeto de Lei Complementar do Senado no 488 de 2017 - Texto final. Acrescenta dispositivos à Lei Complementar $n^{\circ} 95$, de 26 de fevereiro de 1998, com o intuito de estabelecer normas e diretrizes para encaminhamento de proposições legislativas que instituam políticas públicas, propiciando melhor responsabilidade gerencial na Administração Pública. Disponível em: <https:// legis.senado.leg.br/sdleg-getter/documento?dm=7326614\&disposition=inline > Acesso em: 15 maio 2018.

95 KAHNEMAN, Daniel. Rápido e devagar: duas formas de pensar. Tradução de Cássio de Arantes Leite. Rio de Janeiro: Objetiva, 2012, p. 111; THALER, Richard H.; SUNSTEIN, Cass R. Nudge: Improving decisions about health, wealth, and happiness. New Haven: Yale University Press, 2008. p. 24-25. 
Isso é especialmente aplicável quando o tomador de decisão está enfrentando um evento que acontecerá apenas uma vez. Nesse caso, não há dados confiáveis da probabilidade de que aquele evento ocorra, já que não se pode testar ou estudar a repetição desse evento no passado, então o tomador de decisão está num cenário completo de incertezas. Assim, quando estimamos a probabilidade de que algo ocorra, e esse algo é único, como é o caso de uma proposição de uma política pública inédita, há grandes chances de nos guiarmos pelas informações que nos parecem relevantes, sem ter claros mecanismos de correção e, geralmente, sem considerar as outras possíveis decorrências, aquelas que simplesmente não foram previstas porque nunca vivenciamos aquele evento ${ }^{96}$.

Relacionado a ela esta o viés de otimismo ou superconfiança. Por meio dele, temos uma confiança muito grande nas próprias decisões, sobretudo quando somos capazes de construir uma narrativa agradável que amarre as esparsas informações que temos sobre determinada situação ou escolha. Essa superconfiança atrapalha a avaliação sobre o futuro, uma vez que tendemos a superestimar o efeito positivo das nossas escolhas (ou até mesmo o efeito das nossas escolhas sobre o futuro, já que o acaso cumpre um papel maior do que costumamos atribuí-lo). Confundimos a facilidade de explicar o passado com a previsibilidade do futuro ${ }^{97}$.

Uma revisão de literatura sobre estudos do viés de otimismo demonstram, porém, que ao enfocar os riscos a que estariam submetidas, as pessoas tenderam a apresentar menos viés de otimismo, o que pode nos ajudar a pensar se o tomador de decisão pública não está também submetido a esse viés ${ }^{98}$. Não é difícil pensar que, ao propor uma estratégia, o tomador de decisão coloque grandes expectativas no sucesso desta, tanto por razões próprias de sua função quanto por razões pessoais como prestígio entre os pares e chance de ascensão profissional.

Ao obrigar o agente público a imaginar cenários futuros diversos, tanto de conflitos quanto de riscos possíveis decorrentes da implementação de dada política pública, o PLS 488/2017 pode estar estimulando o agente a considerar informações diversas das que se colocam salientes no momento, e que provavelmente levaram à escolha daquele problema como politicamente relevante. Assim, ele o leva a considerar que a ação imediata pode levar a decorrências não desejadas, além de ajustar as possibilidades efetivas de interferência no mundo e de solução absoluta dos problemas públicos. Imaginar cenários pessimistas diminui a superconfiança possível de determinado propositor de política pública.

Além disso, o próprio uso de evidências pode ajudar a evitar o que pode ser chamado de falácia do planejamento, quando planos "estão irrealisticamente próximos de hipóteses superotimistas" e "podem ser melhorados com uma consulta às estatísticas de casos semelhantes" ${ }^{99}$. Nesse caso, o otimismo exacerbado pode ser mitigado com o uso de probabilidades e com a consideração de experiências testadas anteriormente que sejam de mesma classe e devem ajudar a informar o agente público das chances de essa interferência na realidade ser mais adequada ${ }^{100}$.

Um estudo, por exemplo, cogitou que uma possível explicação para a demora na entrega na conclusão de megaprojetos de transportes nos EUA é justamente o viés de otimismo, com falsas expectativas sobre os benefícios do projeto, disponibilidade de orçamento e a capacidade de o projeto resolver o problema.

96 TVERSKY, Amos; KAHNEMAN, Daniel. Availability: A heuristic for judging frequency and probability. Cognitive psychology, v. 5, n. 2, p. 207-232, 1973.

97 KAHNEMAN, Daniel. Rápido e devagar. duas formas de pensar. Tradução de Cássio de Arantes Leite. Rio de Janeiro: Objetiva, 2012. p. 272-273.

98 HELWEG-LARSEN, Marie; SHEPPERD, James A. Do moderators of the optimistic bias affect personal or target risk estimates? a review of the literature. Personality and Social Psychology Review, v. 5, n. 1, p. 74-95, 2001.

99 KAHNEMAN, Daniel. Rápido e devagar: duas formas de pensar. Tradução de Cássio de Arantes Leite. Rio de Janeiro: Objetiva, 2012. p. 311.

100 KAHNEMAN, Daniel. Rápido e devagar: duas formas de pensar. Tradução de Cássio de Arantes Leite. Rio de Janeiro: Objetiva, 2012. p. 309. 
Assim, os tomadores de decisão são levados à falácia do planejamento ${ }^{101}$. Embora seja importante, é claro, considerar que há outras informações importantes na tomada de decisão, como possíveis interesses em superestimar um orçamento ou ter uma visão otimista das consequências como estratégia política e como uma decisão economicamente acertada ${ }^{102}$.

A mesma falácia do planejamento pode ser mitigada pela obrigação de constar um orçamento, que é o que está sendo expressamente requisitado pelo artigo 17-C do PLS 488/2017, e pela atribuição de responsabilidade, como disposto no artigo 17-B. Ao saber qual era o plano original, e quem era o responsável por cumpri-lo, abre-se a possibilidade de responsabilização quando as contas não estiverem batendo, uma forma interessante de melhorar a capacidade de planejamento dentro de uma organização em geral ${ }^{103}$.

Como o PLS 488/2017 se propõe a regular a proposição de políticas públicas que se utilizem de projetos de lei, é importante que ele esteja atento em buscar minimizar o efeito dos turvamentos de escolha (vieses e heurísticas) ou dos ruídos cognitivos (tradição, interesse privado, ideologia e vieses) da parte dos próprios agentes públicos.

\section{Considerações Finais}

As políticas públicas são a materialização do Estado e a forma por meio da qual ele responde a anseios sociais e interfere na realidade. Nesse sentido, as políticas públicas são aquilo que o governo deve entregar à sociedade, é o objetivo último de um governo legítimo.

A importância de controlar os gastos públicos não deve ser menosprezada. Os recursos são finitos, e o poder público tem a obrigação de ser responsável com o uso dos recursos, dentre eles o próprio orçamento disponível. Nesse sentido, os esforços do poder público de tornar a produção de políticas públicas fiscalmente responsável devem ser reconhecidos.

O PLS 488/2017 e o "guia prático de análise ex ante" de políticas públicas parecem indicar que o Estado brasileiro está se tornando cada vez mais atento às condições orçamentárias e aos limites que a realidade impõe àqueles que pretendem usar o Estado para alterar determinada realidade. A efetividade desse objetivo, porém, deve ser acompanhada de perto pelos cidadãos através de mecanismos de accountability e controle social, para que a edição dos textos normativos seja acompanhada de um impacto real na sociedade e nos poderes do Estado.

Apenas o controle de gastos, porém, não é capaz de levar a ação governamental a cumprir os objetivos de um Estado Democrático de Direito. Quando se aproveita do conhecimento produzido pela sociedade como um todo e aprende-se com as experiências anteriores, o resultado é um melhoramento gradual e cumulativo nas modificações concretas que o Estado faz.

O uso de evidências na formulação de políticas públicas pode aumentar a capacidade de ação do Estado, melhorando sua atuação e aprimorando o trabalho dos criadores de políticas públicas. O movimento de políticas públicas baseadas em evidências tem bastante força em outros países e cenários acadêmicos, e começa a surgir no contexto brasileiro. Na área da saúde pública, já há estudos interessantes que demonstram como

101 PLOTCH, Philip Mark. What's taking so long? identifying the underlying causes of delays in planning transportation megaprojects in the United States. Journal of Planning Literature, v. 30, n. 3, p. 282-295, 2015.

102 FLYVBJERG, Bent. Policy and planning for large-infrastructure projects: problems, causes, cures. Environment and Planning B: Planning and Design, v. 34, n. 4, p. 578-597, 2007.

103 BRASIL. Projeto de Lei Complementar do Senado n 488 de 2017 - Texto final. Acrescenta dispositivos à Lei Complementar $n^{\circ} 95$, de 26 de fevereiro de 1998, com o intuito de estabelecer normas e diretrizes para encaminhamento de proposições legislativas que instituam políticas públicas, propiciando melhor responsabilidade gerencial na Administração Pública. Disponível em: <https:// legis.senado.leg.br/sdleg-getter/documento?dm=7326614\&disposition=inline > Acesso em: 15 maio 2018; KAHNEMAN, Daniel. Rápido e devagar: duas formas de pensar. Tradução de Cássio de Arantes Leite. Rio de Janeiro: Objetiva, 2012. p. $312-314$. 
as evidências podem aprimorar a atuação do Estado nesse setor. Outra forma de aproximar as evidências das políticas que está crescendo no Brasil e no mundo é por meio das políticas reconhecidas como nudges. Assim, o PLS 488/2017 deve ser compreendido como uma forma de inserir o uso de evidências rigorosas e a reflexão cuidadosa do tomador de decisão que se proponha a instaurar ou modificar uma política pública, e como um estímulo para ampliar os debates acadêmicos sobre o movimento de práticas baseadas em evidências.

Mais especificamente, as evidências comportamentais podem auxiliar os criadores de políticas públicas. Elas podem ajudar na análise de impacto que a política pública terá em seu público-alvo e no entorno, trazendo à atenção dos agentes as consequências das suas ações e estratégias alternativas de alteração da realidade, como os nudges e os boosts.

$\mathrm{E}$ as ciências comportamentais podem ajudar, também, a compreender como as decisões são tomadas e como as políticas serão interpretadas pelos outros atores políticos e sociais relevantes, aumentando a efetividade do ator político e a capacidade de implementação. Nesse sentido, vincular a produção de projetos de lei a metas e mecanismos de decisão pode ajudar a diminuir os vieses e heurísticas que atrapalham a própria proposição das políticas.

O PLS 488/2017 abre espaço para que insiramos as evidências comportamentais no planejamento da ação governamental, como demonstrado. Caso aprovado, ele deve ser assumido pelos atores estatais e pelos atores acadêmicos e outros que estejam em condições de compreender e classificar de forma sistemática a realidade como um convite ao diálogo e à corresponsabilidade pela melhoria da atuação do Estado brasileiro.

\section{REFERÊNCIAS}

ALVAREZ, Adela Duarte. Elaboração Legislativa: aspectos gerais. Revista do Parlamento Paulista - RPP, São Paulo, v.2, n.3, p.112-123, jul./dez. 2012.

AMARAL, Gilberto Luiz do et al. Quantidade de normas editadas no Brasil: 28 anos da Constituição Federal de 1988. São Paulo: Instituto Brasileiro de Planejamento Tributário, 2016. Disponível em <https://ibpt. com.br/img/uploads/novelty/estudo/2603/QuantidadeDeNormas201628AnosCF.pdf>. Acesso em: 27 jul. 2018.

ANDRADE, Aparecida de Moura; SANTANA, Héctor Valverde. Avaliação de políticas públicas versus avaliação de impacto legislativo: uma visão dicotômica de um fenômeno singular. Revista Brasileira de Políticas Públicas, Brasília, v. 7, n. 3, p. 781-798, 2017.

ARGYROUS, George. Evidence based policy: principles of transparency and accountability. Australian Journal of Public Administration, v. 71, n. 4, p. 457-468, 2012.

BAHIA, Alexandre; NUNES, Dierle. Crise da Democracia Representativa: infidelidade partidária e seu reconhecimento judicial. Revista Brasileira de Estudos Políticos, v. 100, p. 57-84, 2010.

BLACK, Nick. Evidence based policy: proceed with care. British Medical Journal (BMJ), v. 323, n. 7307, p. 275, 2001.

BOGOSSIAN, André. Levando o orçamento a sério como instrumento de controle de políticas públicas. Revista Brasileira de Políticas Públicas, Brasilia, v. 5, n. 3, p. 178-198, 2015.

BONELL, Chris et al. One nudge forward, two steps back. British Medical Journal (BMJ), v. 342, n. 25, p. d401, jan. 2011.

BRASIL. Decreto $n^{0}$ 9.191, de $1^{\circ}$ de novembro de 2017. Estabelece as normas e as diretrizes para elaboração, redação, alteração, consolidação e encaminhamento de propostas de atos normativos ao Presidente da 
República pelos Ministros de Estado. Disponível em: <http://www.planalto.gov.br/CCIVil_03/_Ato20152018/2017/Decreto/D9191.htm\#art60>. Acesso em: 26 jul. 2018.

BRASIL. Emenda Constitucional n 95, de 15 de dezembro de 2016. Altera o Ato das Disposições Constitucionais Transitórias, para instituir o Novo Regime Fiscal, e dá outras providências. Disponível em: <http://www. planalto.gov.br/ccivil_03/constituicao/emendas/emc/emc95.htm>. Acesso em: 22 mar. 2018.

BRASIL. Constituição (1988). Constituição da República Federativa do Brasil de 1988. Disponível em <http:// www.planalto.gov.br/ccivil_03/constituicao/constituicao.htm>. Acesso em: 25 mar. 2018.

BRASIL. Lei Complementar n 95, de 26 de fevereiro de 1998. Dispõe sobre a elaboração, a redação, a alteração e a consolidação das leis, conforme determina o parágrafo único do art. 59 da Constituição Federal, e estabelece normas para a consolidação dos atos normativos que menciona. Disponível em: < http://www.planalto.gov. br/ccivil_03/leis/lcp/lcp95.htm>. Acesso em: 25 mar. 2018.

BRASIL. Projeto de Lei Complementar do Senado n 488 de 2017 - Texto preliminar. Acrescenta dispositivos à Lei Complementar $n^{\circ}$ 95, de 26 de fevereiro de 1998, com o intuito de estabelecer normas e diretrizes para encaminhamento de proposições legislativas que instituam políticas públicas, propiciando melhor responsabilidade gerencial na Administração Pública. Disponível em: < https://legis.senado.leg.br/sdleg-getter/doc umento?dm=7326614\&disposition=inline $>$ Acesso em: 15 maio 2018.

BRASIL. Projeto de Lei Complementar do Senado no 488 de 2017 - Texto final. Acrescenta dispositivos à Lei Complementar $\mathrm{n}^{\circ} 95$, de 26 de fevereiro de 1998, com o intuito de estabelecer normas e diretrizes para encaminhamento de proposições legislativas que instituam políticas públicas, propiciando melhor responsabilidade gerencial na Administração Pública. Disponível em: <https://legis.senado.leg.br/sdleg-getter/documento? $\mathrm{dm}=7326614 \&$ disposition=inline $>$ Acesso em: 15 maio 2018.

BRASIL. Casa Civil da Presidência da República. Avaliação de políticas públicas: guia prático de análise ex ante. Brasília: Ipea, 2018. v. 1

CLARENCE, Emma. Technocracy reinvented: the new evidence based policy movement. Public Policy and Administration, v. 17, n. 3, p. 1-11, July 1, 2002.

COSTA E SILVA, Vera Luiza et al. Bridging the gap between science and public health: taking advantage of tobacco control experience in Brazil to inform policies to counter risk factors for non-communicable diseases. Addiction, v. 108, n. 8, p. 1360-1366, 2013.

COSTA, Natalia Lacerda Macedo. "Nudge" como abordagem regulatória de prevenção à corrupção pública no Brasil. Revista de informação legislativa: RIL, v. 54, n. 214, p. 91-111, abr./jun. 2017. Disponível em: < http:// www12.senado.leg.br/ril/edicoes/54/214/ril_v54_n214_p91>. Acesso em: 27 jul. 2018.

DIAS, Maria Socorro de Araújo et al. Judicialização da saúde pública brasileira. Revista Brasileira de Políticas Públicas, Brasília, v. 6, n. 2, p. 132-145, 2016.

FARAH, Marta Ferreira Santos. An analysis of public policies in Brazil: from an unnamed practice to the institutionalization of the" public field". Revista de Administração Pública, v. 50, n. 6, p. 959-979, 2016.

FLYVBJERG, Bent. Policy and planning for large-infrastructure projects: problems, causes, cures. Environment and Planning B: Planning and Design, v. 34, n. 4, p. 578-597, 2007.

GRAY, J. A. Muir. Evidence-Based Public Health. In: TRINDER, Liz; REYNOLDS, Shirley (Org.). Evidence-based practice: a critical appraisal. Oxford: Blackwell, 2003.

GRÜNE-YANOFF, Till. Why behavioural policy needs mechanistic evidence. Economics \& Philosophy, v. 32, n. 3, p. 463-483, 2016.

GRÜNE-YANOFF, Till; HERTWIG, Ralph. Nudge versus boost: how coherent are policy and theory?. Minds and Machines, v. 26, n. 1-2, p. 149-183, 2016. 
HELWEG-LARSEN, Marie; SHEPPERD, James A. Do moderators of the optimistic bias affect personal or target risk estimates? A review of the literature. Personality and Social Psychology Review, v. 5, n. 1, p. 74-95, 2001.

HOWLETT, Michael. Policy analytical capacity and evidence-based policy-making: lessons from Canada. Canadian public administration, v. 52, n. 2, p. 153-175, 2009.

HOWLETT, Michael; GIEST, Sarah. The policy-making process. In: ARARAL, Eduardo Araral Junior et al (Org.). Routledge Handbook of Public Policy. Canada: Routledge, 2013. p. 17-28.

KAHNEMAN, Daniel. Rápido e devagar. duas formas de pensar. Rio de Janeiro: Objetiva, 2012.

KELLER, Carmen; MARKERT, Franziska; BUCHER, Tamara. Nudging product choices: the effect of position change on snack bar choice. Food Quality and Preference, v. 41, p. 41-43, 2015.

LEHNER, Matthias; MONT, Oksana; HEISKANEN, Eva. Nudging-A promising tool for sustainable consumption behavioura. Journal of Cleaner Production, v. 134, p. 166-177, 2016.

MENEGUIN, Fernando B. Avaliação de impacto legislativo no Brasil. Brasília: Senado Federal, Consultoria Legislativa, Textos para Discussão 70, de Março de 2010. Disponível em: <https://www12.senado.leg.br/ publicacoes/estudos-legislativos/tipos-de-estudos/textos-para-discussao/td-70-avaliacao-de-impacto-legislativo-no-brasil>. Acesso em: 25 abr. 2018.

MINTROM, Michael; WILLIAMS, Claire. Public policy debate and the rise of policy. In: ARARAL, Eduardo Araral Júnior et al (Org.). Routledge Handbook of Public Policy. Canada: Routledge, 2013. p. 3-16,

OLIVEIRA, Jussiely Cunha; BARRETO-FILHO, José Augusto. Políticas públicas em saúde embasadas em ciência "made in Brazill": um desafio para os arquivos brasileiros de cardiologia. Arq Bras Cardiol, v. 105, n. 3, p. 211-213, 2015.

PAWSON, Ray. Evidence-based policy: a realist perspective. London; Thousand Oaks; New Delhi: Sage, 2006.

PAWSON, Ray. Evidence-based policy: in search of a method. Evaluation, v. 8, n. 2, p. 157-181, 2002.

PLOTCH, Philip Mark. What's taking so long? Identifying the underlying causes of delays in planning transportation megaprojects in the United States. Journal of Planning Literature, v. 30, n. 3, p. 282-295, 2015.

REDDY, K. Srikanth; SAHAY, Seema. Voices of decision makers on evidence-based policy: a case of evolving TB/HIV co-infection policy in India. AIDS care, v. 28, n. 3, p. 397-400, 2016.

SALINAS, Natasha Schmitt Caccia. Avaliação Legislativa no Brasil: apontamentos para uma nova agenda de pesquisa sobre o modo de produção das leis. Revista Brasileira de Políticas Públicas, Brasília, v. 3, n. 2, 2013.

SANDERSON, Ian. Complexity, 'practical rationality' and evidence-based policy making. Policy \& politics, v. 34, n. 1, p. 115-132, 2006.

SECCHI, Leonardo. Policy Analysis in Brazil: a comparison of rationalist and argumentative approaches. Journal of Comparative Policy Analysis: Research and Practice, v. 18, n. 1, p. 88-101, 2016.

SECCHI, Leonardo. Políticas públicas: conceitos, esquemas de análise, casos práticos. São Paulo: Cengage Learning, 2010.

SOARES, Fabiana de Menezes. Legística e desenvolvimento: a qualidade da lei no quadro da otimização de uma melhor legislação. Revista da Faculdade de Direito da UFMG, Belo Horizonte, n. 50, p. 124-142, jan./ jul. 2007. Disponível em: <https://www.direito.ufmg.br/revista/articles/31.pdf>. Acesso em: 27 jul. 2018.

SODRÉ, Habacuque Wellington. As deficiências da atuação como fator de ativismo: hipertrofia e omissão legislativa. Uma análise da sociologia jurídica sobre o caso brasileiro de ativismo judicial. Direito Público, Porto Alegre, v. 8, n. 43, p. 160-194, jan./fev. 2012. 
SOUZA, Celina. Políticas públicas: uma revisão da literatura. Sociologias, Porto Alegre, ano 8, n. 16, p. 20-45, jul./dez. 2006.

SUNSTEIN, Cass R.; REISCH, Lucia A.; RAUBER, Julius. A worldwide consensus on nudging? not quite, but almost. Regulation \& Governance, v. 12, n. 1, p. 3-22, 2018.

THALER, Richard H.; SUNSTEIN, Cass R. Nudge: Improving decisions about health, wealth, and happiness. New Haven: Yale University Press, 2008.

TRINDER, Liz. Introduction: the context of evidence-based practice. In: TRINDER, Liz; REYNOLDS, Shirley (Org.). Evidence-based practice: a critical appraisal. Oxford: Blackwell, 2003.

TVERSKY, Amos; KAHNEMAN, Daniel. Availability: a heuristic for judging frequency and probability. Cognitive psychology, v. 5, n. 2, p. 207-232, 1973.

WIZIACK, Júlio; PRADO, Maeli. Governo deu R \$ 173 bi em subsídios a programas sem efeitos, diz estudo. São Paulo. Folha de São Paulo. Publicado em 22 de julho de 2018. Disponível em: <https://www1.folha. uol.com.br/mercado/2018/07/governo-deu-r-173-bi-em-subsidios-a-programas-sem-efeitos-diz-estudo. shtml>. Acesso em: 26 jul. 2018. 


\section{ECONOMIA COMPORTAMENTAL: VIESES COGNITIVOS E POLÍTICAS PÚBLICAS}




\section{REVISTA BRASILEIRA DE POLÍTICAS PÚBLICAS BRAZILIAN JOURNAL OF PUBLIC POLICY}

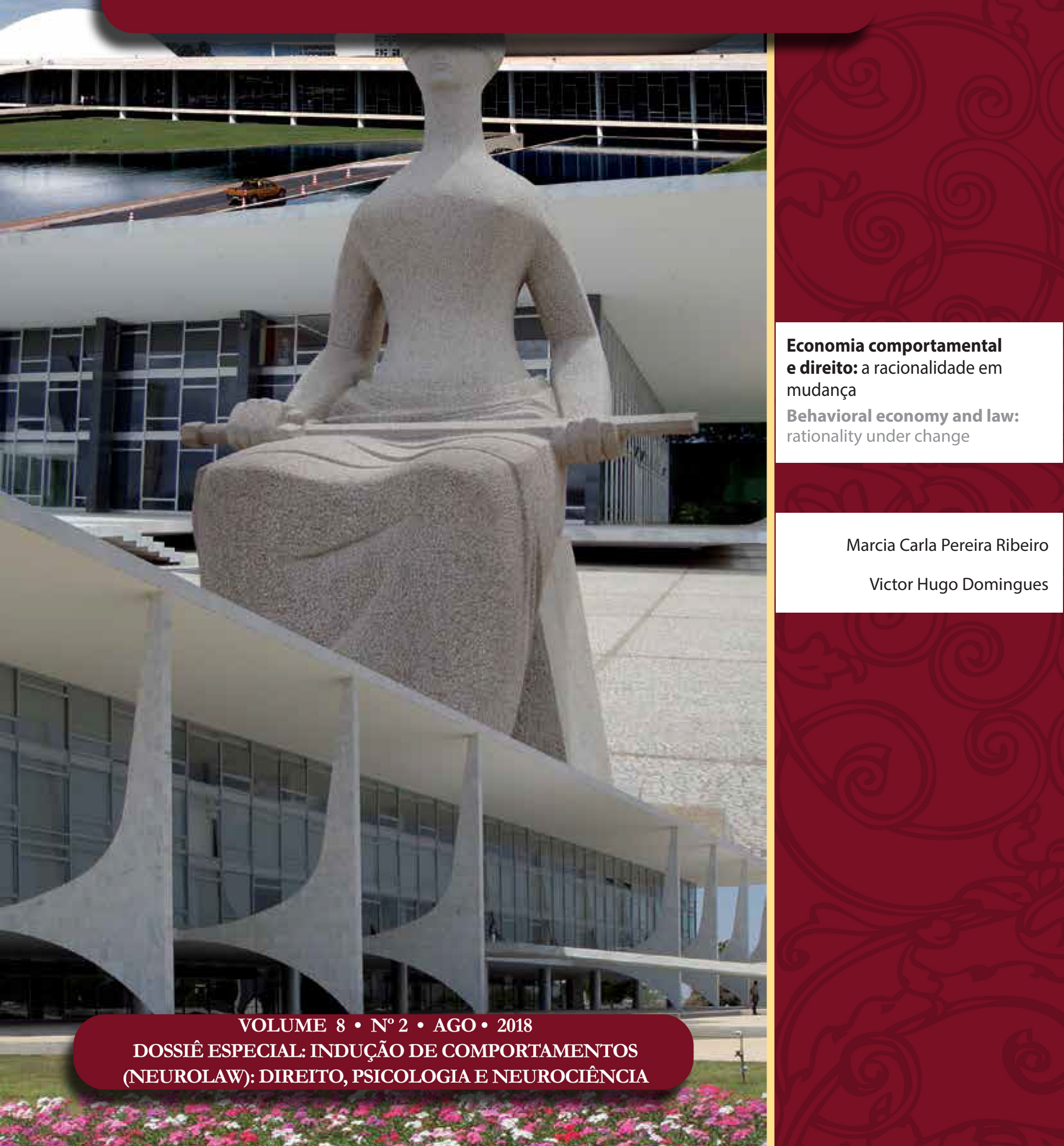




\title{
Economia comportamental e direito: a racionalidade em mudança*
}

\section{Behavioral economy and law: rationality under change}

\author{
Marcia Carla Pereira Ribeiro** \\ Victor Hugo Domingues***
}

\section{Resumo}

$\mathrm{O}$ artigo busca demonstrar a mudança de paradigma do conceito de racionalidade econômica a partir da Economia Comportamental e como a ocorrência desse fenômeno alterou a formulação de políticas públicas e o seu conjunto de proposições normativas. Para isso apresenta-se a trajetória histórica do pensamento econômico, que transitou de um conceito de racionalidade forte, para o qual o indivíduo tem preferências completas e estáveis, para um conceito de racionalidade fraca, no qual o indivíduo não apresenta condições de realizar as melhores escolhas, uma vez que está condicionado por vieses psicológicos que afetam suas preferências e, por via reflexa, sua condição de bem-estar social. Em seguida, com base nas descobertas da Teoria da Prospecção de Amos Tversky e Daniel Kahneman, demonstrou-se como as políticas públicas foram influenciadas pelos mecanismos de Economia Comportamental, mediante aplicação de um novo desenho de incentivos, especialmente de natureza normativa. Concluiu-se que que a mudança da concepção do conceito de racionalidade foi determinante para a adoção de novos formatos de políticas públicas. Da mesma forma, foi possível concluir que a Economia Comportamental, quando aplicada às políticas públicas, amplia a interferência do Estado regulador em ambientes antes reservados à autonomia privada. Finalmente, propõe-se a ampliação de um debate que ainda não foi realizado no Brasil, sobre os limites e perspectivas de aplicação de ferramentas da Economia Comportamental às políticas públicas.

Palavras-chave: Racionalidade. Economia Comportamental. Políticas Públicas.

* Recebido em 18/04/2018 Aprovado em 21/05/2018

** Mestre e Doutora em Direito. Professora titular do Programa de Pós Graduação em Direito da PUCPR. Professora Associada da graduação e do Programa de Pós Graduação em Direito da UFPR. Advogada. Parecerista e Árbitra. E-mail: marcia.ribeiro@pucpr.br

*** Mestre em Direito pela PUCPR. Doutorando na PUCPR. Secretário Municipal de Balneário Camboriú, SC. E-mail: victorhugodom@gmail.com

\section{Abstract}

The purpose of this article is to present the paradigm shift that took place in economic rationality through Behavioral Economics; how this has provided a new mindset in public policies development and its legal system. At first, the paper sets forth the evolvement of economic thinking from the concept of strong to weak rationality. The first concept took the individual for capable of full and stable preferences, whereas the second one (weak rationality) stated that individuals weren't able to make the best choices, be- 
cause they were conditioned by psychological biases that affected their preferences and social well-being. Following, the article will depict the Prospecting Theory of Amos Tversky and Daniel Kahneman, through which it came through that public policies were influenced by Behavioral Economics mechanisms. The authors' work was relevant in stablishing new incentive design, especially normative ones. The concluding part implies that this transition in rationality concept resulted from the adoption of new formats of Public Policies. The conclusion went further, suggesting that Behavioral Economics, when applied to Public Policies, causes regulatory State meddling to increase, particularly in private environments. The outcome is to engender a debate quite not held in Brazil yet, regarding limits and perspectives of the Behavioral Economy as the main element in public policies development.

Keywords: Rationality. Behavioral Economics. Public Policies.

\section{INTRODUÇÃo}

O artigo buscou percorrer o trajeto teórico científico da Teoria da Racionalidade Econômica e compreender como a Economia Comportamental alterou, significativamente, as bases analíticas sobre a natureza dos processos de decisão dos indivíduos em sociedade. Por sua vez, essa modificação de paradigmas foi determinante para incluir nas ferramentas de políticas públicas mecanismos de influência, delimitação e orientaçãoão das escolhas. A partir dos questionamentos acerca da racionalidade do agente econômico, a Economia Comportamental invalidou uma série de pressupostos que vinham sendo reiterados pela economia ortodoxa. O principal deles é a suposição de que as pessoas sempre escolhem o melhor para si mesmas e que sempre maximizarão suas preferências de acordo com um critério próprio de utilidade escalonada. Conforme ficará demonstrado adiante, tais pressupostos deixaram de ser cientificamente válidos, já que os indivíduos podem falhar durante o processo decisional, seja por razões externas ou por razões de natureza psicológica.

Muitas vezes, as escolhas realizadas sob a influência de processos mentais obscuros conduzem os indivíduos a tomar decisões deletérias. Os exemplos adiante mencionados poderão evidenciar os comportamentos vulneráveis, tomados por impulso de problemas de cognição, os quais formam um padrão de repetição contrária ao interesse dos próprios agentes. Quando somadas, essas armadilhas mentais provocadas por vieses e heurísticas da condição humana, reduzem, significativamente, a condição de bem-estar social.

O artigo traz à reflexão a constatação de que se, por um lado, as pessoas fazem suas escolhas de forma equivocada, causando a diminuição da sua própria qualidade de vida, compete ao Estado de Bem-Estar social providenciar meios para que as pessoas façam melhores escolhas. Justifica-se, dessa forma, a intervenção do planejador central como agente influenciador do processo de formação das preferências. Logo, todo um arcabouço de técnicas normativas é criado para influenciar o comportamento das pessoas. É o que se busca demonstrar na terceira parte deste artigo. Ao final, destacou-se possíveis problemas acerca da violação da autonomia pessoa, da livre e consentida escolha dentro da lei e o autogoverno das ações individuais.

Por todos esses desafios à razão, as dúvidas quanto ao alcance da Economia Comportamental estão hoje na pauta das discussões acadêmicas e políticas dos países de elevado grau de desenvolvimento social e econômico. Por outro lado, os valores jurídicos da autonomia, do livre consentimento e da liberdade de ação levantam novos questionamentos sobre os limites da atuação dos programas governamentais que, em nome do bem-estar social, fazem uso do behaviorismo como instrumento de efetivação de políticas públicas. 


\section{A ECONOMIA COMPORTAMENTAL COMO PONTO DE PARTIDA}

A história da regulação estatal não é recente. Toda organização política estipula, com maior ou menor interferência, as regras de comportamentos tolerados pela coletividade. Apenas recentemente, instituições governamentais foram persuadidas a utilizar o ferramental da Economia Comportamental como um instrumento para atingir os objetivos sociais do bem-estar social ${ }^{1}$. Porém, há uma diferença significativa entre coagir e influenciar, exigir e manipular. Esses exercícios de conformação dos comportamentos são mais controversos quando, revestidos da força normativa do ente estatal, influem no domínio privado das escolhas econômicas e sociais. Os seus mecanismos de persuasão, como mencionado no título do último livro de Cass Sustein ${ }^{2}$, levantam questionamentos de ordem ética e política, a respeito de onde e como a aplicação dessa influência estatal está de acordo com outros princípios informadores da legislação. Identificar os caminhos pelos quais esse debate tomou forma, especialmente por meio da análise histórica do pensamento econômico e social, facilita o entendimento sobre o plano geral em que se situa a teoria econômica behaviorista e sua aplicação nas políticas públicas dos mais variados setores.

\subsection{O Behaviorismo: Passado, Presente e Futuro}

A Economia Comportamental, também conhecida como Behaviorismo, surgiu em meados da década de 70 do Século passado, como uma resposta sólida e sistematizada ao pressuposto dogmático da racionalidade econômica ${ }^{3}$, pilar teórico da Escola Neoclássica da Economia.

A ciência econômica se apresentou, nas últimas décadas do Século XX, como instrumento político hábil para desvendar o enigma da alocação da riqueza, sinalizando o destino dos recursos finitos com vista à eficiência econômica. No caso, a Teoria da Racionalidade ${ }^{4}$ das Escolhas, pilar fundamental da política econômica do século passado, pressupõe que as opções humanas seriam sempre estáveis, constantes e transitivas, de forma a permitir que as previsões econômicas pudessem gozar de alto grau de confiança e previsibilidade.

A História do Pensamento Econômico está repleta de vertentes e teorias que seguiram por diferentes caminhos para solucionar o problema da alocação da riqueza em uma sociedade de bens escassos ${ }^{5}$. Partindo-se do interesse de Alfred Marshall em desvendar as causas da pobreza, até os recentes escritos de Amartya Sen ${ }^{6}$, a defender a plena liberdade individual de escolha como sinônimo de desenvolvimento econômico, nota-se que a excessiva matematização de modelos racionais não foi uma construção teórica unânime e imune às críticas. Uma análise pormenorizada da evolução científica da Economia, e a latente controvérsia sobre seu estatuto epistemológico sugere a existência de forte relação entre as formas de atuação do Estado no cenário político econômico, e o programa jurídico-político que lhe dá fundamento ${ }^{7}$. A construção das teorias

1 O Governo Britânico faz parte da comissão especialmente dedicada para elaborar políticas públicas comportamentais, denominado The Behavioral Insights Team (BIT). É a primeira iniciativa governamental de criação de um bureau para propor políticas públicos de baixo custo e de fácil adaptação ao público em geral. Um dos seus objetivos é propiciar que "as pessoas façam melhor escolhas para elas mesmas". Para conferir a recente discussão sobre Políticas Públicas e Economia Comportamental na Colômbia cfr. MONROY, Daniel. Nudges y Decisiones inconscientes: sesgo de statu quo y políticas públicas em Colombia. Revista desafios, Bogotá, v. 29, n. 1, p. 211-247, dic. 2016. Sobre o impacto do Direito e da Economia Comportamental ao redor do globo cfr. WHITEHEAD, Mark et al. Nudging all over the World: assessing the global impact of the behavioural sciences on public policy. Economic \& Social Research Council, Aberystwyth, p. 1-38, sep. 2014.

2 SUSTEIN, Cass. The ethics of influence. New York: Cambridge University Press, 2017.

3 RIBEIRO, Márcia Carla Pereira. Racionalidade limitada. In: RIBEIRO, Márcia Carla Pereira; KLEIN, Vinicius (Coord.) O que é análise econômica do direito: uma introdução. 2. ed. Belo Horizonte: Fórum, 2016. p. 64-65.

4 PRADO, Eleutério F. S. A ortodoxia neoclássica. Estudo Avançados, São Paulo, v. 15, n. 41, p. 9-20, jan./abr. 2001.

5 MURAMATSU, R. The death and resurrection of economics with psychology: remarks from a methodological standpoint. Revista de Economia Política, São Paulo, v. 29, p. 62-81, 2009.

6 SEN, A. Desenvolvimento como liberdade. São Paulo: Cia. das Letras, 2000.

7 Não existem programas políticos completamente neutros do ponto de vista ideológico. Mesmo as cartas constitucionais elaboradas após o advento do Estado moderno carregam valores políticos ideológicos capaz de classificar os Estados em maior ou menor 
e modelos econômicos parece ter sido fortemente influenciada pelas escolas científicas contemporâneas e pelas concepções vigentes acerca do que era ciência econômica, do que deveria ser a ciência econômica e de como deveria ser a apresentação formal de um conhecimento propriamente científico a dar sustentação aos programas políticos com fundamento em pressupostos econômicos.

Durante o Século XX, as interferências recíprocas entre a Economia e a Matemática — ora tida como ferramenta, ora declarada como objetivo - materializaram esse conflito. Da mesma forma, se deu a relação entre Psicologia e a Economia ${ }^{8}$. Em muitos momentos, as teorias econômicas deixaram de apresentar unanimidade acerca do que seria o próprio objeto de estudo da Economia. Alguns defensores do mainstream ${ }^{9}$ econômico afirmaram que a falta de concordância entre economistas provém, apenas, da dificuldade em reduzir realidades complexas em modelos teóricos com pouca fidedignidade. Os críticos sugerem que esse movimento em direção à matematização da Economia não contribuiu para a confirmação dos pressupostos da racionalidade (preferências estáveis e contínuas), visto que as previsões econômicas demonstraram pouca capacidade normativa, gerando uma espécie de vácuo epistemológico. Os trabalhos de economistas como Herbert Simon ${ }^{10}$, Shira Lewin ${ }^{11}$ e Robert Sugden ${ }^{12}$ assinalam que houve uma bifurcação na teorização econômica a partir da década de 50 do Século passado, uma guinada da Economia para a excessiva matematização dos modelos e predições econômicas ${ }^{13},{ }^{14}$.

As construções dos primeiros teóricos refletiam essa busca pelo entendimento acerca das causas do comportamento econômico. Suas análises se debruçavam sobre os fatores que propulsionavam a ação, e por isso eram extremamente subjetivas (ênfase para o desenvolvimento da Teoria da Utilidade ${ }^{15}$ ). Para teorizar sobre a causa geradora da ação econômica, era necessário considerar, também, as motivações subjetivas, campo de estudos afeto à psicologia humana. Num segundo momento, os teóricos neoclássicos deixaram ao largo todas as variáveis que pudessem denotar razões de natureza subjetiva ${ }^{16}$, dando ênfase à teoria hipotética em prejuízo da experiência empírica. A Teoria da Utilidade — principal construção dos Primeiros

grau de adesão à liberdade e à autonomia individual, por exemplo. Cf. SOWELL, Thomas. Conflito de visões: origens ideológicas das lutas políticas. São Paulo: É Realizações, 2011.

8 Sobre a discussão acerca da inconstante relação da Economia com a Psicologia cfr. LEWIN, Shira B. Economics and psychology: lessons for our own day from the early twentieth century. Journal of Economic Literature, v. 34, n. 3, p. 1293-1323, set. 1996, e MURAMATSU, Roberta; FONSECA, Patrícia. Um enigma do comportamento do consumidor no Brasil: análise comportamental do consumo procrastinado em um cenário inflacionário. In: ENCONTRO DA ANPAD, 32., Rio de Janeiro, 2008.

Para uma leitura sobre o desencontro de percepções acerca do papel da Matemática na Economia, consultar as distintas compreensões de MARSHAL, Alfred. Principles of economics. 8. ed. Londres: McMillian, 1920; e SAMUELSON, Paul. Fundamentos da análise econômica. São Paulo: Nova Cultural, 1998; o primeiro defende o papel acessório e secundário da Matemática na Economia, enquanto o último a apresenta como central para a construção e evolução da teorização econômica.

9 A corrente teórica predominante na Ciência Econômica é regularmente citada como mainstream, e alguns autores e economistas usam a palavra como um sinônimo para Economia Neoclássica, que seria uma das correntes existentes em teorização econômica e sem dúvida a mais disseminada. No entanto faz-se necessária aqui uma ressalva, visto que o termo é utilizado de forma equivocada e incompleta. Economia Neoclássica como vulgarmente se apresenta é mais precisamente a Economia Neoclássica do pós-guerra. Cf. MANDLER, Michael. Dilemmas in economic theory: persisting foundational problems in microeconomics. New York: Oxford, 1999, profundamente enraizada na matematização, e em modelos abstratos e gerais, incrustados na noção de racionalidade. As obras de grande parte do que seriam os "primeiros neoclássicos" (ou Neoclássicos da primeira geração), diferem pontualmente desse segundo grupo em termos de inspiração, metodologia, objeto de estudo e objetivos, merecendo portanto tal distinção.

10 SIMON, H. Alternative visions of rationality. In: ARKES, H.; HAMMONDS, K. (Coord.) Judgement and decision making. Cambridge: Cambridge University Press, 1986.

11 LEWIN, Shira B. Economics and psychology: lessons for our own day from the early twentieth century. Journal of Economic Literature, v. 34, n. 3, p. 1293-1323, sep. 1996.

12 BRUNI, Luigino; SUNGDEN, Robert. The road not taken: how psychology was removed from economics, and how it might be brought back. The Economic Journal, Rio de Janeiro, v. 117, n. 516, p.146-173, 2007.

13 MURAMATSU, R. The Death and resurrection of economics with psychology: remarks from a methodological standpoint. Revista de Economia Política, São Paulo, v. 29, p. 62-81, jan./mar. 2009.

14 MURAMATSU, R. The death and resurrection of economics with psychology: remarks from a methodological standpoint. Revista de Economia Política, São Paulo, v. 29, p. 62-81, jan./mar. 2009.

15 Sobre a Teoria da Utilidade cf. JEVONS, Willian S. The theory of political economy. Londres: McMillian, 1888.

16 LEWIN, Shira B. Economics and psychology: lessons for our own day from the early twentieth century. Journal of Economic Literature, v. 34, n. 3, p. 1293-1323, set. 1996. 
Neoclássicos - postulava que as pessoas escolhem buscando maximizar o prazer e minimizar a dor. Numa segunda fase da Teoria Econômica Neoclássica, a inovação teórica consistia no conceito de "marginalidade", em que o consumo de bens ou produtos cessa quando a utilidade marginal (ou utilidade advinda com a compra de mais uma unidade) se iguala ao custo de obtê-la.

A "Revolução Marginalista", tendo como centro o desenvolvimento da supracitada Teoria da Utilidade, compreendeu que o valor de um bem é definido não somente pelo trabalho (custo), mas também pela utilidade marginal que o indivíduo espera obter das escolhas realizadas. A "Revolução Marginalista" traz as primeiras representações de curvas de oferta (lado dos custos) e curvas de demanda (lado da utilidade) para a determinação de preços de mercado. No começo do Século XX, a Teoria da Utilidade enfrentava considerável crise epistemológica ${ }^{17}$. Não era possível matematizar as motivações de cunho psicológico dos agentes. Os modelos racionais baseados na estabilidade e previsibilidade das escolhas humanas não explicavam os desvios no padrão das escolhas esperadas. Enquanto a Economia se mantinha com suas suposições de racionalidade e escolha consciente, a Psicologia, Sociologia e outras Ciências Sociais caminhavam para as conclusões de seus experimentos que muitas vezes mostravam que as escolhas dos agentes econômicos podem se dar num ambiente desprovido de lógica raciona ${ }^{18}$. A Economia se viu assim frente a um dilema. Matematizar era contribuir para o avanço científico da área, no entanto não era possível traduzir a inconstância psicológica humana para o rigor e estabilidade de funções matemáticas. Os conceitos psicológicos contidos nas teorias econômicas (p. ex. utilidade e prazer) não eram passíveis de matematização ${ }^{19}$.

Esse foi o estopim de um movimento que levou a Teoria Econômica a se afastar dos preceitos psicológicos em relação à formulação das análises normativas e positivas. Abandonava, assim, não somente a discussão acerca dos valores morais de que fazia uso, mas toda e qualquer fundamentação psicológica. A Matemática tornou-se, a partir de então, um objetivo da ciência Econômica, e não mais uma ferramenta. Desse modo, toda a inspiração psicológica que existia nas teorias até o começo do Século XX foi ignorada pela ciência econômica. Durante o Século XX, as considerações de Adam Smith sobre como a simpatia, enquanto guia das atitudes econômicas, foi relegada a pesquisas de natureza unicamente filosóficas. Ficaram para trás, também, as considerações de Nassau Senior e William Stanley Jevons sobre aspectos emocionais da postergação do consumo presente, assim como as considerações morais, altruístas e culturais no hábito de poupança feitas pelo economista Irwing Fisher ${ }^{20}$.

Não era possível, dentro do novo paradigma científico pretendido pela Economia, discorrer sobre emoção, simpatia, altruísmo, moralidade ou cultura. Nenhuma dessas variáveis compunha as fórmulas quantitativas da Economia do Século XX. Nesse passo, a Teoria da Racionalidade Econômica contribuiu para o argumento tautológico da abordagem das preferências reveladas. De acordo com a Teoria das Preferências Reveladas, um agente revelava suas preferências no momento da escolha, e essa conclusão de que os agentes "escolhem o que preferem" era derivada do argumento circular de que os agentes racionais "preferem o que escolhem". Essa simplificação retórica fundamentou o afastamento dos contributos da Psicologia na ciência econômica, uma vez que não era mais necessário investigar as motivações humanas subjacentes às escolhas, como faziam os primeiros economistas clássicos. A partir de então, as motivações do agente econômico não seriam mais consideradas para calcular os desdobramentos da formação da vontade e do exercício da escolha ${ }^{21}$.

17 A crise epistemológica da Teoria da Utilidade se refere a modificação de um dos seus pressupostos elementares, o de que os comportamentos dos agentes econômicos são determinados unicamente pelas suas preferências individuais. Cfr. SANTOS, Cordeiro dos. The social epistemology of experimental economics. New York: Routledge, 2009. p. 162.

18 MURAMATSU, R. The death and resurrection of economics with psychology: remarks from a methodological standpoint. Revista de Economia Política, São Paulo, v. 29, p. 62-81, jan./mar. 2009.

19 MURAMATSU, Roberta; FONSECA, Patrícia. Economia e psicologia na explicação da escolha intertemporal. Revista de Economia Macken₹ie, São Paulo, v. 6, n. 6, p. 87-112, 2008.

20 FISHER, Irwing. The theory of interest. New York: Macmillan, 1930.

21 MURAMATSU, R. The death and resurrection of economics with psychology: remarks from a methodological standpoint. Revista de Economia Política, São Paulo, v. 29, p. 62-81, jan./mar. 2009. 
Desse modo, o princípio da racionalidade não somente permitiu, de um lado, o afastamento da Psicologia por meio da Teoria das Preferências Reveladas, como impulsionou a matematização da Economia. Assim, a Economia postulava como suposição auxiliar que "agentes racionais são consistentes". Ser consistente significa que uma pessoa escolhe, entre duas alternativas, a mesma opção tanto hoje quanto em qualquer outro momento do tempo ${ }^{22}$. Dizer isso é negar a existência de instâncias de arrependimento, e a possibilidade de ocorrência de aprendizado e socialização, instâncias do comportamento que são fundamentais para o estudo da norma jurídica, por exemplo.

A superação do paradigma da racionalidade absoluta do agente econômico ocorreu somente no início da década de 70, com o conjunto de estudos atribuídos a Amos Tversky e Daniel Kahneman, pesquisadores que ganharam notoriedade no meio acadêmico por suas pesquisas no âmbito da economia e psicologia comportamental. A Teoria da Perspecção fundou um novo ramo da economia, então nomeado behavioral economics. A Economia Comportamental ganhou notoriedade por contestar um dos mais preciosos fundamentos do mainstream acadêmico: a racionalidade do homus economicus. Segundo Taversky e Kahneman ${ }^{23}$, as motivações racionais e as motivações emocionais têm papel preponderante no processo de escolhas econômicas, e atuariam de forma a moldar a percepção dos incentivos econômicos, tanto positivamente quanto negativamente. A quantidade e a procura de determinados bens são influenciadas por uma série de variáveis que refogem à simples análise dos preços, ou mesmo à disponibilidade da renda, muito embora se reconheça o impacto fundamental que esses dados objetivos apresentam para a formação da curva da oferta e demanda. É nesse ponto que a Economia Comportamental exerce um papel central ao criticar o pressuposto da racionalidade dos agentes econômicos ${ }^{24}$.

Para os comportamentalistas, há muito mais que dados objetivos a influir entre as preferências declaradas e as escolhas efetivamente realizadas; e, em relação a isso, a identificação dos desvios cognitivos e dos equívocos decorrentes de processos mentais obscuros pode explicar, com mais precisão, as razões pelas quais os agentes econômicos não se comportam como previsto pelos modelos economáticos. Amos Tversky e Daniel Kahneman foram os cientistas mais notáveis nesse campo do conhecimento, sendo, inclusive, agraciados com o Nobel de Economia em 2002. A Prospect Theory - elaborada pelos dos dois cientistas após inúmeros experimentos — descobriu que as decisões nem sempre são ótimas, e que estão sujeitas a uma série de distorções do julgamento (vieses) e atalhos mentais muitas vezes simplórios, que, diante de problemas complexos, apresentam respostas singelas e automatizadas, entretanto, nem sempre corretas (heurísticas) ${ }^{25}$.

Tversky e Kahneman descobriram que, diante de um quadro de incertezas, ou de informações incompletas, as pessoas apresentam uma série de reações que não podem ser consideradas racionais, conforme intuiam os economistas neoclássicos. Ao contrário, as pessoas são limitadamente racionais, uma vez que suas efetivas escolhas dependem, dentre outras coisas, da forma como as questões são apresentadas (framing) e de sua disposição para assumir riscos (risk aversion), especialmente num ambiente de incertezas.

Por tais motivos, as escolhas não são racionais, mas sim limitadas a uma série de fatores que bloqueiam a opção ótima. A disposição de manter o status quo (inertia), o sentimento de apego e posse (endowment effect), o equívoco no julgamento sobre os efeitos ao longo do tempo (byperbolic discount), a insistência em escolhas ruins (sunk cost) etc. são manifestações neurocognitivas que podem ser estimuladas ou evitadas de acordo com os incentivos aos quais os agentes econômicos são expostos (arquitetura dos incentivos).

Por essa razão, a Economia Comportamental pode exercer um papel relevante na elaboração de políticas

22 MURAMATSU, R. The death and resurrection of economics with psychology: remarks from a methodological standpoint. Revista de Economia Política, São Paulo, v. 29, p. 62-81, jan./mar. 2009.

23 TVERSKY, Amos; KAHNEMAN, Daniel. Judgement under uncertainty: heuristics and biases. Science, v. 185, n. 4157, p. $1124-$ 1131, sep. 1974.

24 SHAFIR, Eldar. The behavioral foundations of public policy. Princeton: Princeton, 2012. p. 32.

25 MURAMATSU, R. The death and resurrection of economics with psychology: remarks from a methodological standpoint. Revista de Economia Política, São Paulo, v. 29, p. 62-81, jan./mar. 2009. 
públicas ${ }^{26}$ que buscam evitar a tomada de decisões trágicas no cenário econômico. $\mathrm{O}$ behaviorismo não pressupõe que as pessoas sejam sensatas e plenamente consciente de suas escolhas (racionalidade forte) ${ }^{27}$, ao contrário. Seus pressupostos consistem em sugerir que os agentes econômicos são irracionais, e a consequência de suas escolhas podem ser desatrosas ${ }^{28}$. Um conjunto de decisões equivocadas pode conduzir o destino de uma sociedade a um elevado risco de vulnerabilidade social. Uma perspectiva mais realista do comportamento dos agentes econômicos informa, de maneira mais fidedigna, os agentes políticos, de maneira a evitar, informar e corrigir comportamentos indesejados, ou mesmo viciados pela falsa presunção de racionalidade.

$\mathrm{Na}$ verdade, o pano de fundo do debate sobre a Teoria da Racionalidade Econômica e suas diferentes correntes traz, mesmo que de forma implícita, os programas políticos e econômicos que orbitam em torno da questão da intervenção do Estado no domínio econômico ${ }^{29}$. A racionalidade forte, como sustentavam os economistas neoclássicos, foi um importante fundamento de defesa em favor do lessaiz faire e do livre mercado. Como as escolhas dos agentes econômicos eram estáveis, o ajuste econômico da curva da oferta e demanda se ajustaria, automaticamente, mediante a natureza prórpria do equilíbrio entre as forças da produção e do consumo. A teoria se ajustava, perfeitamente, à ideia da mão invisível de Adam Smith, em que a autoregulação e os interesses recíprocos e voluntários eram suficientes para perfeito funcionamento das trocas que caracterizam o livre mercado, por exemplo.

De outro lado, supor que as escolhas econômicas não são estáveis, ou melhor, supor que as necessidades econômicas estão e são recortadas por elementos de natureza psicológica e comportamental ${ }^{30}$ modifica, completamente, o paradigma da ciência econômica, num primeiro momento. Num segundo momento, justificaria a intervenção estatal no domínio econômico para conduzir os comportamentos individuais a um nível socialmente desejado. Isso porque, invariavelmente, todo programa jurídico-político concede ao Estado importante papel em relação à promoção da Economia e do Bem-estar geral da sociedade ${ }^{31}$.

\section{O BEHAVIORISMO E A QUESTÃO SOCIAL}

A complexidade do comportamento humano e, principalmente, seus reflexos nos diversos segmentos sociais exigem novas abordagens políticas para tratar dos riscos e efeitos sociais de escolhas trágicas. As políticas públicas levadas adiante pelo Estado de bem-estar social devem buscar a mais verossímil aproximação do que efetivamente busca modificar ou estimular incentivos de natureza neuro-comportamental. Muitas vezes, pequenos ajustes de natureza legislativa podem transformar a forma como as pessoas reagem aos incentivos.

Um dos exemplos mais conhecidos sobre incentivos em políticas públicas foi testado com base no viés da "opção padrão" (option default) e no "enquadramento noticioso" (framing) em relação ao problema da es-

26 BARON, Jonathan. Biases in the quantitative measurement of values for public decisions. Psychological Bulletin, Filadélfia, n. 122, p. 72-88, 1997.

27 Williamson defende a existência de três tipos de racionalidade: forte, semiforte ou limitada e fraca. Assim, a racionalidade atribuída à teoria econômica neoclássica é classificada como racionalidade forte, que supõe o pleno conhecimento de todos os custos de transação pelo agente econômico. Cf. WILLIAMSON, O. E. The economic institutions of capitalism. New York: Free Press, 1985. 28 ARIELY, Dan. Positivamente irracional. Rio de Janeiro: Elsevier, 2010. p. 5.

29 Existem vários instrumentos constitucionais de intervenção no domínio econômico, todavia, sem qualquer menção aos mecanismos da Economia Comportamental. Para verificar uma análise de todas essas formas de intervenção permitidas no sistema constitucional cfr. NEVES, Antônio Francisco Frota; SANTANA, Hector Valverde. A intervenção direta e indireta na atividade econômica em face da ordem jurídica brasileira. Revista Brasileira de Políticas Públicas, Brasília, v. 7, n. 2, p. 332-348, ago. 2017.

30 LOHRENZ, Terry; MONTAGUE, P. Read. Neuroeconomics: what neuroscience can learn from economics. In: LEWIS, Alan. (Org.). The Cambridge handbook of psychology and economic behaviour. Cambridge: Cambridge University Press, 2008. p. 457.

31 BARON, Jonathan. Biases in the quantitative measurement of values for public decisions. Psychological Bulletin, Filadélfia, n. 122, p. 72-88, 1997. 
cassez de doação de órgãos ${ }^{32}$. Países com consentimento presumido sobre a doação tendem a colher resultados mais satisfatórios para a política pública de doação. Por excessiva manutenção do estado inercial, eventuais doadores de órgãos nunca efetivariam a doação por não terem uma postura ativa acerca da afirmação expressa da intenção de doar. Logo, optam pela opção padrão, ou seja, não se manifestam e não efetivam a doação. Com simples ajustes na política de doação de órgãos, alterando o enquadramento noticioso (framing) do programa de doação, de forma a tornar todas as pessoas doadoras presumidas (opt-out), o número das doações aumentou significativamente. Logo, a opção ativa (opt-in), que gera algum tipo de ação positiva do agente, passou a ser obrigação das pessoas que, efetivamente, não querem doar seus órgãos, devendo fazer manifestação expressa nesse sentido ${ }^{33}$.

Portanto, a integração entre o Direito, Economia Comportamental e Políticas Públicas pode ser justificada pela busca de métodos mais eficazes para evitar tragédias sociais provocadas pelo "espírito animal" dos agentes econômicos ${ }^{34}$. Sabe-se que um dos objetivos do Estado de Bem-estar Social contempla o papel do planejador central como ente regulador, por isso, a função do Estado tem relação direta com o comportamento dos agentes econômicos no ambiente social. Agir de acordo com os incentivos gerados pelo Poder Público revela um processo pelo qual uma organização ou indivíduo busca maximizar a função utilidade pelo ajustamento deliberado e consciente dos meios e fins ${ }^{35}$. Conforme já mencionado, para os behavioristas, empresas e pessoas não agem sempre conscientemente. Aliás, as escolhas sociais são conduzidas por vieses que levam a uma decisão não ótima ${ }^{36}$.

Condutas anticompetitivas provocadas por vieses de seleção, comportamento de manada em mercados de ativos, utilização irracional de bens comuns ${ }^{37}$ — levando à escassez de recursos ambientais —, são apenas alguns exemplos em que o Estado Regulador pode ser chamado a evitar conflitos decorrentes de comportamentos predatórios. A finalidade do Estado Regulador buscará os melhores incentivos comportamentais para evitar que os agentes econômicos sejam vítimas de suas próprias escolhas. Isso não seria possível sem antes superar o paradigma da racionalidade do agente econômico.

Nesse sentido, e mediante experimentos empíricos, a Teoria Econômica do Comportamento vem se destacando ao traduzir, cientificamente, os impulsos inconscientes das pessoas. A forma como as pessoas se prostram diante dos incentivos, e seus influxos recíprocos no seio do sistema legal, tornaram a Bebavioural Law and Economics uma área de estudos de alta relevância ${ }^{38}$. Por tal razão, o aspecto paternalista da ação governamental, segundo os behavioristas, levará o agente econômico a tomar decisões mais eficientes, com maior disponibilidade de informações, e menos suscetíveis às armadilhas mentais influenciadas por vieses e heurísticas.

A arquitetura de incentivos, utilizada como componente do sistema de regras jurídicas, se revelou uma alternativa indispensável para adequar as propostas políticas no campo social ${ }^{39}$. Por via dessa nova proposta

32 DAVIDAI, Shai; GILOVICH, Thomas; ROSS, Lee D. The meaning of default options for potential organ donors. Proceedings of the National Academy of Sciences, v. 109, n. 38, p. 15201-15205, sep. 2012.

33 DAVIDAI, Shai; GILOVICH, Thomas; ROSS, Lee D. The meaning of default options for potential organ donors. Proceedings of the National Academy of Sciences, v. 109, n. 38, p. 15201-15205, sep. 2012.

34 A expressão "espírito animal” é comumente atribuída à John Maynard Keynes, que para descrever as emoções que influenciam o comportamento humano. Cf. AKERLOFF, George; SHILLER, Robert. O espírito animal. Rio de Janeiro: Elsevier, 2009.

35 RIBEIRO, Márcia Carla Pereira. Racionalidade limitada. In: RIBEIRO, Márcia Carla Pereira; KLEIN, Vinicius (Coord.). O que é análise econômica do direito: uma introdução. 2. ed. Belo Horizonte: Fórum, 2016. p. 68.

36 Uma decisão não ótima aqui mencionada tem seu conceito extraído da Análise Econômica do Direito, no caso uma decisão de impacto jurídico que não obtém os máximos benefícios que poderiam advir se os recursos fossem empregados de maneira mais eficiente para a mesma situação.

37 CÁRDENAS, Juan Camilo. Groups, commons and regulations: experiments with villagers and students in Colombia. In: AGARWAL, Bina; VERCELLI, Alessandro (Eds.). Psychology, rationality and economic behavior. New York: Palgrave MacMillan, 2005. p. 241.

38 ARAÚJO, Fernando. Análise econômica do direito: programa e guia de estudo. Lisboa: Almedina, 2008. p. 37.

39 Dentre os behavioristas um argumento que é comumente utilizado para defender a formatação de programas jurídico-políticos mediante uso de incentivos comportamentais remonta à justificativa de John Stuart Mill, em defesa da liberdade e do princípio do 
metodológica de engenharia social, concede-se ao indivíduo maior capacidade de escolha. O indivíduo poderá decidir mais claramente entre as possibilidades que se lhe apresentam, sobretudo quando identificadas as limitações cognitivas às quais está submetido. Tal "clareamento" das escolhas serve, sobretudo, para descobrir as causas que enviesam as escolhas dos agentes ${ }^{40}$. São vastos os exemplos utilizados para sustentar a aplicação do behaviorismo em programas políticos ligados à promoção do Estado de Bem-estar social. Veja-se, por exemplo, as opções que envolvem questões como poupança e aposentadoria. Nesses casos específicos, os indivíduos apresentam severas dificuldades com o planejamento — e suas projeções — ao longo do tempo. A Teoria da Escolha Racional, baseada fundamentalmente no predicado estrito do autointeresse dos agentes econômicos, prevê que, em todas as ocasiões, as escolhas recairão sobre a hipótese da maximização dos benefícios próprios. No entanto, a Teoria Comportamentalista vem desmentindo tal característica atribuída ao indivíduo ${ }^{41}$. Por influência de uma perspectiva míope em relação ao futuro (viés de miopia), os indivíduos são dissuadidos de poupar para a senescência. Entretanto, quando atingem o momento da aposentadoria, o rendimento previdenciário é insuficiente para manter o mesmo nível de vida que gozavam quando em plena atividade econômica, o que leva muitos idosos a prorrogar o retiramento programado pelo governo.

Por muito tempo, os economistas ortodoxos permaneceram reticentes em acolher razões de natureza psicológica em políticas públicas. Todavia, a Economia Comportamental demonstra que existe um campo de atuação para influenciar (nudging) o comportamento dos agentes limitadamente racionais ${ }^{42}{ }^{43}$.

Ao permitir que os agentes econômicos tomem a melhor decisão num contexto de incertezas, o behaviorismo parte do pressuposto de que as pessoas, quando bem informadas, são incialmente dispostas a contribuir para o bem público e individual ${ }^{44}$, ou seja, os agentes são naturalmente altruístas, e esperam contribuições recíprocas de outras pessoas. A análise econômica comportamental, como menciona Cristhine Jolls $s^{45}$, quando atende um programa político desejado pelo Estado (ex: redução do uso de drogas, utilização de equipamentos de proteção individual no ambiente de trabalho, redução da obesidade mórbida etc.), deve fazer uso dos instrumentos de incentivos para atingir o comportamento que imagina ser adequado ${ }^{46}$. A análise econômica comportamental, unida ao Direito Público, visa diminuir a assimetria de informações para que o indivíduo tome a decisão de forma menos enviesada, cujo resultado amplia a rede de benefícios que, de outra forma, não estariam disponíveis ao indivíduo em condições normais, sem apresentar qualquer externalidade negativa. ${ }^{47}$

utilitarismo. Segundo Mill, as mais usuais formas de coerção vêm do aparato estatal, decorrentes do poder de polícia atribuído ao Estado para manter a ordem social. Tais formas de regulação não ofendem o princípio da liberdade individual, desde que tomadas com vista a evitar danos à terceiros (maior felicidade geral) in MILL, John Stuart. Utilitarismo. São Paulo: Hunter Books, 2014. p. 69. Argumento igualmente defendido em THALLER, Richard; SUSTEIN, Cass R. Libertarian paternalism is not an oxymoron. University of Chicago Public Law \& Legal Theory: Working paper, Chicago, n. 43, p. 09, 2003.

40 SUSTEIN, Cass. Why nudge? the politics of libertarian paternalism. Londres: Yale University Press, 2012. p. 163.

41 Inúmeras críticas direcionadas à teoria da racionalidade são feitas a partir de pressupostos behavioristas, por exemplo: STAATS, Arthur W. Behaviorismo social: uma ciência do homem com liberdade e dignidade. Arquivos Brasileiros de Psicologia, São Paulo, v. 32, n. 4, p. 97-116, 1980.

42 MURAMATSU, Roberta; FONSECA, Patrícia. Freedom of choice in a world of boundedly rational agents: remarks about the light paternalistic policy implications of behavioral economics. Disponível em: <http://www.econ.uba.ar/www/institutos/epistemologia/marco_archivos/trabajos_XV_archivos/Muramatsu $\% 20 \mathrm{y} \% 20$ Fonseca $\% 20-\% 20$ Freedom $\% 20$ of $\% 20$ Choice $\% 20$ in $\% 20 \mathrm{a} \%$ 20World \%20of\%20Bounde.pdf>. Acesso em: 17 jan. 2018.

43 KOROBKIN, Russell B.; ULEN, Thomas S. Law and behavioral science: removing rationality assumption from law and economics. California Law Review, v. 88, p. 1138-1144, 2000.

44 KOROBKIN, Russell B.; ULEN, Thomas S. Law and behavioral science: removing rationality assumption from law and economics. California Law Review, v. 88, p. 1138-1144, 2000.

45 JOLLS, Christine et al. A behavioral approach to law and economics. In: SUSTEIN, Cass R. (Coord.). Behavioral law \& economics. New York: Cambridge University Press, 2000. p. 46.

46 THALER, Richard H.; SUNSTEIN, Cass R. Nudge: improving decisions about health, wealth and happiness. London: Penguin, 2008. p. 94.

47 THALER, Richard H. Misbehaving: the making of behavioral economics. New York: Norton \& Company, 2015. p. 323. 


\subsection{A Arquitetura das Escolhas e as Políticas Públicas}

No âmbito das políticas públicas que consideram o comportamento psicológico como elemento fundamental do ato político, ganhou notoriedade o termo anglófono "nudge". O termo "nudge" alcançou destacada relevância dentro do contexto político norte-americano, quando alguns gestores públicos ligados à Behavioural Law and Economics tomaram assento nos setores estratégicos da gestão do então presidente americano Barack Hussein Obama ${ }^{48}$. A tradução não oficial do vocábulo demonstra seu significado: "nudge" pode ser entendido como um "empurrão", um "cutucão", uma espécie de "indicação" não explícita e não vinculativa de opções previamente programadas pelo agente público. Em 2008, o livro "Nudge: o empurrão para escolha certa" $"$, de Cass Sustein e Richard Thaler, consagrou o termo nudge. De forma geral, ele atua como um mecanismo influenciador de escolhas individuais com vista ao incremento do bem-estar em diversos setores sociais, como saúde, educação, finanças e segurança. Um dos exemplos citados no livro refere-se à regulação da disposição de alimentos não saudáveis em escolas primárias nos Estados Unidos. A fim de combater a hábitos alimentares inadequados entre crianças em idade escolar, escolas foram incentivadas a posicionar alimentos saudáveis no campo de visão mediano da altura das crianças, de modo que alimentos não saudáveis ficavam ou muito acima ou muito abaixo do campo de visão, levando as crianças a optar, inconscientemente, pelo consumo de alimentos com melhor condição nutricional ${ }^{50}$.

A partir de então, inúmeros países buscam implementar tais ferramentas no contexto de seus programas políticos procurando mensurar e promover a sensação de bem-estar mediante aplicação de programas políticos nesse sentido ${ }^{51}$. O nudging é um mecanismo sugestivo. Como não é obrigatório, o incentivo funciona como um plano de prévio de persuasão colocado à avaliação do agente no momento da escolha.

Para os teóricos da Behavioural Law and Economics, os agentes econômicos estão envoltos em uma série de armadilhas não declaradas, por isso, compete ao Estado, imbuído de sua missão social de buscar o bem-estar coletivo, ordenar as opções considerando os programas políticos previamente definidos no âmbito das políticas públicas. $\mathrm{O}$ agente econômico, além de estar submetido a um conjunto de informações limitadas, está, totalmente, influenciado por uma série de fatores que conduzem suas escolhas ao nível não ótimo. Para equilibrar o contexto das opções, a Behavioural Law and Economics sugestiona que o gestor das políticas públicas incorpore o papel de um "arquiteto das escolhas".

Ao promover um esclarecimento orientado, a política pública baseada em nudge ambiciona conduzir as opções a um estágio avançado de bem-estar social ${ }^{52}$. Para os comportamentalistas, o desenho de incentivos já é praticado no ambiente social, seja para o bem ou para mal. São inúmeros os exemplos de ofertas de serviços e bens materiais que fazem uso de mecanismos psicológicos para induzir o comportamento dos consumidores, ao menos no ambiente de trocas privadas na economia de mercado.

A arquitetura das escolhas conduzidas pelo Estado regulador preservaria a liberdade de escolha das pes-

48 Notoriamente, o professor americano Cass Sustein, um dos mais proeminentes juristas americanos e cientista no âmbito da Economia e Direito Comportamental, ocupou entre 2009 e 2012 o Office of Information and Regulatory Affairs, da Casa Branca. Outros têm contribuído para esse desenvolvimento, tais como Richard Thaler, Christine Jolls, Alexander Korobkin, Thomas Ulen, Owen Jones ou Jonathan Baron, sendo esse último, inclusive, responsável pela inovadora disciplina de Behavioral Law and Economics na Universidade da Pensilvânia em 2010.

49 Versão brasileira do original lançado em inglês "Nudge: Improving Decisions About Health, Wealth and Happiness".

50 Ver MELLO, Vera Rita Ferreira de; SAPUNAR, Barbara. Nudging for good: o caso do Programa Unidos Por Crianças Mais Saudáveis. Centro de Estudos em Finanças GVcef, 2016-08 Disponível em: <https://bibliotecadigital.fgv.br/dspace/bitstream/ handle/10438/18898/GVcef_Ferreira\%3b\%20Sapunar.pdf?sequence=1\&isAllowed=y >. Acesso em: 10 fev. 2018.

51 Em seu último livro, Daniel Kahneman pontuou que as medições da sensação de bem-estar têm sido, usualmente, praticada em todo o mundo desenvolvido. Estados Unidos, Canadá e Europa contam avançadas técnicas de pesquisa em larga escala. Khaneman citou a pesquisa Gallup World Poll (Gallup-Healthways Well-Being Index), com levantamentos simultâneos em mais de 150 países sobre como as pessoas julgam as condições da própria vida e os fatores circunstanciais que as levam a pensar como pensam, como saúde física, afetividade familiar, condições financeiras etc. Consultar KAHNEMAN, Daniel. Rápido e devagar. Rio de Janeiro: Objetiva, 2012. p. 494.

52 THALER, Richard H. Misbehaving: the making of behavioral economics. New York: Norton \& Company, 2015. p. 255. 
soas enquanto são conduzidas para incrementar sua condição de bem-estar. Evitar os riscos do tabagismo, fazer opções alimentares saudáveis, poupar para a terceira idade, fazer exercícios diários etc. O objetivo central é promover escolhas melhores e, por consequência, obter melhores resultados coletivamente. Para Roberta Muramatsu e Patrícia Fonseca ${ }^{53}$, as políticas que consideram a arquitetura das escolhas uma alternativa viável são vitais para o incremento do bem-estar social. Ajustes de programas que contemplem mecanismos indutivos de comportamento, como disposição de informações em ordem de interesse, incentivos comportamentais para a tomada de decisões, contrapartidas financeiras para a tomada de comportamentos considerados ótimos são alguns modelos que podem ser usados pelo gestor público para conduzir o comportamento dos agentes econômicos.

Ocorre, porém, que nenhuma política pública é levada a efeito sem antes deflagrar certo grau de conflito entre posições antagônicas, embates ideológicos ou choque de interesses. No caso do behaviorismo não é diferente. Ao fazer uso em larga escala dos instrumentos normativos com base em mecanismos comportamentais, as políticas públicas formuladas com base na ciência econômica comportamental são completamente diferentes dos tradicionais instrumentos de coeração pura e explícita, caracteristicas das normas jurídicas clássica elaboradas com base no Poder de Polícia.

No caso da Economia Comportamental, busca-se, por meio da influêcia das escolhas, preservar certo grau de liberdade dentro de um quadro predefinido de opções, de baixo custo e impacto reduzido ${ }^{54}$, sempre com vistas a melhorar a condição de vida das pessoas, que, por essa mesma liberdade, poderiam num ambiente sem influência tomar uma decisão ruim.

Residem nesse específico ponto as críticas daqueles que se opõem à utilização da Economia Comportamental como ferramenta programática do bem-estar social. Ao predefinir uma quadro de opções já articuladas, o Estado induz, ilegalmente, os comportamentos de forma obscura, uma vez que prescinde da autonomia da vontade individual, da declaração consentida e da manifestação inequívoca de intenções. Uma vez que as opções já estão previamente definidas pelo gestor público, reduzindo o campo da liberdade das escolhas, as pessoas já não gozam mais da livre escolha, do "direito de errar" e aprender com o próprio erro $^{55}$. Assim, o conflito ético está localizado, justamente, nessa parodaxal missão do Direito e da Economia Comportamental: ampliar a liberdade de escolha, limitando as livres escolhas do agente econômico.

Em inúmeras situaçãos, a arquitetura dos incentivos pode ser acusada de não respeitar as escolhas dos agentes econômicos, levantando questionamenos de natureza moral e ética ${ }^{56}$. Em alguns casos de nudging, o planejador central prescinde da escolha plena e consciente ${ }^{57}$.

No plano jurídico político institucional, a vinculação de opções políticas à instituição de metas, diretrizes ou princípios, por meio das espécies jurídico-normativas ${ }^{58}$, com o intuito de promover a redução das

53 MURAMATSU, Roberta; FONSECA, Patrícia. Um enigma do comportamento do consumidor no Brasil: análise comportamental do consumo procrastinado em um cenário inflacionário. In: ENCONTRO DA ANPAD, 32., Rio de Janeiro, 2008. p. 8.

54 SUSTEIN, Cass R. The ethics of influence. New York: Cambridge University Press, 2017. p. 98.

55 FERGUSIN, Andrew. Nudge, nudge, wink wink: behavioral rconomics - The Governing Theory of Obama's Nanny State. Time Magazine, n. 19, abr. 2010, em que o Autor aponta fortes críticas à administração de Barack Obama como o "dream team" do comportamentalismo, que realizaria os desejos de transformação silenciosa e paternalista da sociedade americana. Disponível em: <http://www.weeklystandard.com/nudge-nudge-wink-wink/article/433737>. Acesso em: 09 dez. 2017.

56 EPSTEIN, Richard. Behavioral economics: human errors and market corrections. University of Chicago Law Review, Chicago, n. 73.1, p. 111-132, 2006.

57 BOWLES, Samuel. The moral economy, why good incentives are no substitue for good citizens. New York: Yale University Press, 2016.

58 Dworkin esclarece que as normas constitucionais são o gênero das espécies normativas regras, princípios e políticas (policies). Sustenta o autor que, com certa frequência, o termo princípio é utilizado de modo genérico, isto é, projetado de maneira negativa, representando todo o conjunto de padrões normativos que não são regras. Inicialmente, há que se apontar uma distinção mais apurada entre princípios e políticas. Dworkin assevera que política é aquele tipo de padrão que estabelece um objetivo a ser alcançado, em geral uma melhoria em algum aspecto econômico, político ou social da comunidade (ainda que certos objetivos sejam negativos pelo fato de estipularem que algum Estado atual deve ser protegido contra mudanças adversas). Já princípio pode ser tido como um padrão que deve ser observado, não porque vá promover ou assegurar uma situação econômica, política ou social considerada desejável, mas porque é uma exigência da justiça ou equidade ou alguma outra dimensão da moralidade. Assim, o padrão 
desigualdades sociais, por exemplo, é estabelecido por um consenso mínimo a ser seguido pela maioria, especialmente para a formulação de políticas específicas ${ }^{59}$. Assim, falar em consenso no âmbito das políticas públicas implica reconhecer a presciência dos instrumentos políticos e econômicos que deverão ser aplicados para a consecução das finalidades constitucionais, o que poderia, ao menos em tese, conflitar com qualquer política pública que opere no campo da inconsciência dos indivíduos. No caso, o principal risco à liberdade e à autonomia individual é o indiscriminado uso política do behaviorismo como elemento normativo, uma vez que não exigem o consenso mínimo ou acordo democrático, como nos casos das tradicionais normas coercitivas ${ }^{60}$. Além dessa inexorável vinculação das políticas públicas aos fins constitucionais, fundadas nos valores republicano da autonomia e liberdade individual, há duras críticas sobre o papel do Estado para construir políticas que, ao fim e ao cabo, retiram do indivíduo a liberdade de escolha, uma vez que as finalidades a serem alcançadas por esse mecanismo (nudge) de intervenção no domínio econômico são previamente "desenhadas" pelo agente regulador.

O papel do Estado como ente regulador tem relação direta com o comportamento dos agentes no ambiente socioeconômico. Agir de acordo com os incentivos gerados pelo Poder Público revela nada mais que um processo pelo qual uma organização ou indivíduo busca maximizar a função utilidade pelo ajustamento das suas preferências ${ }^{61}{ }^{62}$. A Economia Comportamental diverge desse último ponto. Para os comportamentalistas, firmas e pessoas não agem sempre conscientemente, razão pela qual Estado Regulador pode ser chamado a "empatar" o jogo dos incentivos com a políticas de intervenção comportamental.

Colocam-se inúmeros questionamentos acerca dos limites do Estado na interferência do domínio privado. A relevância do debate que envolve a Economia Comportamental e seus mecanismos na busca pelo incremento do bem-estar social constitui, possivelmente, uma das mais polêmicas formas de intervenção do Estado no domínio econômico, especialmente a partir da virada do Século XX. A relevância do desgin comportamental em Políticas Públicas foi, inclusive, distinguida com o Prêmio de Ciências Econômicas em Memória de Alfred Nobel de 2017. O cientista comportamental Richard Thaler ${ }^{63}$, responsável por incorporar os pressupostos da psicologia aos mecanismos de regulação do comportamento econômico, foi escolhido como o prêmio do ano. Eis a importância de considerar elemento cognitivo-comportamental como variável indispensável para condução dos comportamentos. Essa nova forma de avaliar a ingerência do Estado no domínio econômico introduz, no debate científico, respostas oriundas de outros campos da ciência, sobremaneira quando um dos objetivos do programa jurídico-político é alcançar o bem-estar social. Por trás dos posicionamentos a favor ou contra a adoção de tais medidas, uma ampla discussão se faz necessária: sobre os limites éticos e morais que circundam a aplicação do nudging como forma de efetivar as mudanças comportamentais.

que estabelece que o IDH deve ser majorado é uma política e o padrão segundo o qual nenhum homem deve beneficiar-se de seus próprios delitos é um princípio. A distinção se torna problemática, entretanto, se tomarmos um princípio como expressão de um objetivo social (é objetivo de uma sociedade que nenhum homem se beneficie de seu próprio delito), ou interpretarmos uma política como resultado de um princípio, ou seja, o princípio de que o objetivo que a contém é meritório. Os princípios são proposições que descrevem direitos; as políticas são proposições que descrevem objetivos. DWORKIN, Ronald. Levando os direitos a sério. São Paulo: M. Fontes, 2007. p. 36.

59 BARCELLOS, Ana Paula de. Neoconstitucionalismo, direitos fundamentais e controle das políticas públicas. Revista de Direito Administrativo, Rio de Janeiro, n. 240, p. 83-103, abr./jun. 2005.

60 SARLET, Ingo Wolfgang. A eficácia dos direitos fundamentais. Porto Alegre: Livraria do Advogado, 2009. p. 364.

61 RIBEIRO, Márcia Carla Pereira. Racionalidade limitada. In: RIBEIRO, Márcia Carla Pereira; KLEIN, Vinicius (Coord.). O que é análise econômica do direito: uma introdução. 2. ed. Belo Horizonte: Fórum, 2016. p. 64.

62 Williamson defende a existência de três tipos de racionalidade: forte, semiforte ou limitada e fraca. Assim, a racionalidade atribuída à teoria econômica neoclássica é classificada como racionalidade forte, que supõe o pleno conhecimento de todos os custos de transação pelo agente econômico. WILLIAMSON, O. E. The economic institutions of capitalism. New York: Free Press, 1985. 63 "Richard H. Thaler foi o ganhador do Prêmio Nobel de Ciências Econômicas em 2017 por suas contribuições para a Economia Comportamental. Thaler estuda economia e finanças comportamentais, bem como a psicologia da tomada de decisões. Seu foco de investigação são as implicações quanto ao pressuposto econômico padrão da racionalidade econômica, onde supostamente todos agentes são racionais e egoístas. Richard Thaler é o diretor do Center for Decision Research e co-diretor (com Robert Shiller) do Behavioral Economics Project no National Bureau of Economic Research." Tradução livre da biografia publicada no website da Universidade de Chicago. Disponível em: <https://www.chicagobooth.edu/faculty/directory/t/richard-h-thaler>. Acesso em: 10 dez. 2017. 
Por fim, os pressupostos teóricos desse debate devem compreender essa modificação de paradigmas sobre o conceito de racionalidade. Quando as políticas públicas não cogitavam fazer uso da tecnologia comportamental, o modelo sobe os quais estavam fixadas suas bases tinham em conta um indivíduo de preferências estáveis, completamente consciente de suas ações. Com a contestação do paradigma da racionalidade, e as recentes descobertas da Teoria da Prospecção e suas derivações, esse paradigma foi completamente alterado. Essa modificação foi determinante para o acolhimento de mecanismos comportamentais na formulação de políticas públicas. Pode-se afirmar que existe, hoje, um campo jurídico autônomo de proteção dos indivíduos. Uma ampliação da tutela das más-escolhas. Esse novo campo jurídico de atuação do Estado pressupõe que os agentes sociais não são racionais, e às vezes tomam decisões prejudiciais e em desacordo com o que realmente escolheriam se não estivessem sob a influência dos processos mentais enviesados.

\section{Considerações finais}

A modificação dos paradigmas da racionalidade econômica provocou uma nova forma de ver o indivíduo como destinatário final de políticas públicas. Isso decorreu da experiência de adoção das análises comportamentalistas em relação à formulação dos programas políticos, a partir da virada do Século XX. Da mesma forma, houve a ampliação da atuação do Estado em setores da vida privada que antes não eram afetados pelas políticas públicas. O nudge foi adotado em ambientes de escolhas estritamente particulares, com vistas a alterar o comportamento dos indivíduos e incrementar o seu bem-estar social.

Não obstante, a regulação dos comportamentos com base na Economia Comportamental carece de limites claros e específicos. Historicamente, escolhas individuais que conduzem as pessoas ao fracasso ou à ruína nem sempre demandaram a intervenção estatal. Mesmo assim, em inúmeros outros casos, a correção dos comportamentos indesejados é um convite à intervenção reguladora do ente público. Por isso, a abrangência do behaviorismo e o desenho dos incentivos espalharam-se por campos diversos do Direito, como no Direito do Consumidor, nas leis antitruste, na segurança alimentar e na preservação de recursos ambientais. Enfim, muito há que se discutir sobre as hipóteses em que é desejável, ou juridicamente legítima, a intervenção do Estado no domínio socioeconômico. Se, por um lado, as escolhas dos agentes econômicos não detêm plena racionalidade como se pressupunha, por outro, há o risco da entrega de parcela significativa da autonomia individual ao Estado regulador. No caso brasileiro, nada foi suscitado sobre políticas públicas desenhadas com mecanismos de Economia Comportamental. $\mathrm{O}$ debate pode ser incipiente num primeiro momento, sobretudo quando se acrescenta a dimensão normativa aos mecanismos comportamentais. Entretanto, como determina nossa ordem econômica constitucional, o Estado tem o dever de assegurar a todos existência digna.

Por essa razão, acredita-se, abre-se a oportunidade de se provocar a reflexão sobre o potencial desse método de abordagem, também, na esfera jurídica, aproveitando-se alguns elementos de Economia Comportamental com vistas a aferir maior efetividade às determinações constitucionais.

\section{REFERÊNCIAS}

AKERLOFF, George; SHILLER, Robert. O espirito animal. Rio de Janeiro: Elsevier, 2009.

ARAÚJO, Fernando. Análise económica do direito: programa e guia de estudo. Lisboa: Almedina, 2008.

ARIELY, Dan. Positivamente irracional. Rio de Janeiro: Elsevier, 2010.

BARCELLOS, Ana Paula de. Neoconstitucionalismo, direitos fundamentais e controle das políticas públi- 
cas. Revista de Direito Administrativo, Rio de Janeiro, n. 240, p. 83-103, abr./jun. 2005.

BARON, Jonathan. Biases in the quantitative measurement of values for public decisions. Psychological Bulletin, Filadélfia, n. 122, p. 72-88, 1997.

BOWLES, Samuel. The moral economy: why good incentives are no substitue for good citizens. New York: Yale University Press, 2016.

BRUNI, Luigino; SUNGDEN, Robert. The road not taken: how psychology was removed from economics, and how it might be brought back. The Economic Journal, Rio de Janeiro, v. 117, n. 516, p. 146-173, 2007.

CÁRDENAS, Juan Camilo. Groups, commons and regulations: experiments with villagers and students in Colombia. In: AGARWAL, Bina; VERCELLI, Alessandro. (Ed.). Psychology, rationality and economic behavior. New York: Palgrave MacMillan, 2005.

DAVIDAI, Shai; GILOVICH, Thomas; ROSS, Lee D. The meaning of default options for potential organ donors. Proceedings of the National Academy of Sciences, v. 109, n. 38, p. 15201-15205, sep. 2012.

DWORKIN, Ronald. Levando os direitos a sério. São Paulo: M. Fontes, 2007.

EPSTEIN, Richard. Behavioral economics: human errors and market corrections. University of Chicago Law Review, Chicago, n. 73.1, p. 111-132, 2006.

FERGUSIN, Andrew. Nudge, nudge, wink wink: behavioral economics - The Governing Theory of Obama’s Nanny State. Time Magazine, n. 19, abr. 29, 2010. Disponível em: < http://www.weeklystandard.com/ nudge-nudge-wink-wink/article/433737>. Acesso em: 28 maio 2018.

FISHER, Irwing. The theory of interest. New York: Macmillan, 1930.

JEVONS, Willian S. The theory of political economy. Londres: McMillian, 1888.

JOLLS, Christine et al. A behavioral approach to law and economics. In: SUSTEIN, Cass R. (Coord.). Behavioral law \& economics. New York: Cambridge University Press, 2000.

KAHNEMAN, Daniel. Rápido e devagar. Rio de Janeiro: Objetiva, 2012.

KOROBKIN, Russell B.; ULEN, Thomas S. Law and behavioral science: removing rationality assumption from law and economics. California Law Review, v. 88, p. 1138-1144, 2000.

LEWIN, Shira B. Economics and psychology: lessons for our own day from the early twentieth century. Journal of Economic Literature, v. 34, n. 3, p. 1293-1323, set. 1996.

LOHRENZ, Terry; MONTAGUE, P. Read. Neuroeconomics: what neuroscience can learn from economics. In: LEWIS, Alan. (Org.). The Cambridge handbook of psychology and economic behaviour. Cambridge: Cambridge University Press, 2008.

MANDLER, Michael. Dilemmas in economic theory: persisting foundational problems in microeconomics. New York: Oxford, 1999.

MARSHAL, Alfred. Principles of economics. 8. ed. Londres: McMillian, 1920.

MELLO, Vera Rita Ferreira de; SAPUNAR, Barbara. Nudging for good: o caso do programa unidos por crianças mais saudáveis. Centro de Estudos em Finanças GVcef, 2016. Disponível em: <https://bibliotecadigital.fgv.br/dspace/bitstream/handle/10438/18898/GVcef_Ferreira\%3b\%20Sapunar. pdf ?sequence $=1 \&$ isAllowed $=\mathrm{y}>$. Disponível em: 28 maio 2018 .

MILL, John Stuart. Utilitarismo. São Paulo: Hunter Books, 2014.

MONROY, Daniel. Nudges y decisiones inconscientes: sesgo de status quo y políticas públicas em Colombia. Revista Desafios, Bogotá, v. 29, n. 1, p. 211-247, dic. 2016. 
MURAMATSU, R. The death and resurrection of economics with psychology: remarks from a methodological standpoint. Revista de Economia Política, São Paulo, v. 29, p. 62-81, jan./mar. 2009.

MURAMATSU, Roberta; FONSECA, Patrícia. Freedom of choice in a world of boundedly rational agents: remarks about the light paternalistic policy implications of behavioral economics. Disponível em: <http://www. econ.uba.ar/www/institutos/epistemologia/marco_archivos/trabajos _XV_archivos/Muramatsu\%20 y $\% 20$ Fonseca $\% 20-\% 20$ Freedom $\% 20$ of $\% 20$ Choice $\% 20$ in $\% 20 \mathrm{a} \%$ 20World $\% 20$ of $\% 20$ Bounde.pdf $>$. Acesso em: 28 maio 2018.

MURAMATSU, Roberta; FONSECA, Patrícia. Um enigma do comportamento do consumidor no Brasil: análise comportamental do consumo procrastinado em um cenário inflacionário. In: ENCONTRO DA ANPAD, 32., 2008, Rio de Janeiro.

NEVES, Antônio Francisco Frota; SANTANA, Hector Valverde. A intervenção direta e indireta na atividade econômica em face da ordem jurídica brasileira. Revista Brasileira de Políticas Públicas, Brasília, v. 7, n. 2, p. 332-348, ago. 2017.

PRADO, Eleutério F. S. A ortodoxia neoclássica. Estudo Avançados, São Paulo, v. 15, n. 41, jan./abr. 2001.

RIBEIRO, Márcia Carla Pereira. Racionalidade limitada. In: RIBEIRO, Márcia Carla Pereira; KLEIN, Vinicius (Coord.). O que é análise econômica do direito: uma introdução. 2. ed. Belo Horizonte: Fórum, 2016.

SAMUELSON, Paul. Fundamentos da análise econômica. São Paulo: Nova Cultural, 1998.

SANTOS, Ana Cordeiro dos. The social epistemology of experimental economics. New York: Routledge, 2009.

SARLET, Ingo Wolfgang. A eficácia dos direitos fundamentais. Porto Alegre: Livraria do Advogado, 2009.

SEN, A. Desenvolvimento como liberdade. São Paulo: Cia. das Letras, 2000.

SHAFIR, Eldar. The behavioral foundations of public policy. Princeton: Princeton, 2012.

SIMON, H. Alternative visions of rationality. In: ARKES, H.; HAMMONDS, K. (Coord.). Judgement and decision making. Cambridge: Cambridge University Press, 1986.

SOWELL, Thomas. Conflito de visões: origens ideológicas das lutas políticas. São Paulo: É Realizações, 2011.

SUSTEIN, Cass. The ethics of influence. New York: Cambridge University Press, 2017.

SUSTEIN, Cass. Why nudge? the politics of libertarian paternalism. Londres: Yale University Press, 2012.

THALER, Richard H. Misbehaving: the making of behavioral economics. New York: Norton \& Company, 2015.

THALLER, Richard; SUSTEIN, Cass R. Libertarian paternalism is not an oxymoron. University of Chicago Public Law \& Legal Theory: Working paper, Chicago, n. 43, p. 09, 2003.

THALER, Richard H.; SUNSTEIN, Cass R. Nudge: improving decisions about health, wealth and happiness. London: Penguin, 2008.

TVERSKY, Amos; KAHNEMAN, Daniel. Judgement under uncertainty: heuristics and biases. Science, v. 185, n. 4157, sep. 1974.

WILLIAMSON, O. E. The economic institutions of capitalism. New York: Free Press, 1985. 


\title{
Vieses cognitivos e desenho de políticas públicas*
}

\section{Cognitive biases and public policy design}

\author{
Benjamin Miranda Tabak** \\ Pedro Henrique Rincon Amaral***
}

\section{Resumo}

A identificação e consideração de vieses cognitivos nos indivíduos cujos comportamentos são regulados pelo Estado pode aumentar a efetividade do processo de formulação das políticas públicas. O combate aos vieses cognitivos decisórios observados nos formuladores de políticas públicas é fundamental para garantir que a intervenção estatal não incorra em regulamentações ineficientes e tendenciosas em decorrência da racionalidade humana limitada. Por meio de uma abordagem qualitativa e descritiva, apoiada em revisão da literatura da área, o presente artigo busca identificar os vieses mais comuns a que reguladores e regulados estão sujeitos, proporcionar aos formuladores de políticas públicas uma melhor percepção de falhas que ameaçam o alcance dos objetivos propostos pela política pública e incentivar a melhoria do processo regulatório. Por fim, foi possível identificar como os vieses cognitivos podem afetar a decisão racional dos agentes e impactar a regulamentação de forma a torná-la ineficiente, desnecessária. Além disso, observou-se que é necessário repensar a arquitetura decisória desses agentes no sentido de incorporar ferramentas estruturadas de correção desses vieses.

Palavras-chave: Políticas públicas. Vieses cognitivos. Formuladores de política. Paternalismo libertário. Nudge.

* Recebido em 28/05/2018 Aprovado em 23/07/2018

** Professor Doutor da Escola de Políticas Públicas e Governo da Fundação Getúlio Vargas (FGV/EPPG). Tem experiência na área de Economia e Direito, com ênfase em Regulação Financeira, Análise Econômica do Direito e Análise Econômica do Direito Comportamental. Pesquisa na área de Economia Bancária, Finanças e Direito, com artigos científicos e livros publicados nessa área assim como em áreas correlatas. Editor associado de revistas especializadas nacionais e estrangeiras. E-mail: benjaminm.tabak@gmail.com

*** Servidor público federal, no cargo de Analista de Comércio Exterior do Ministério da Indústria, Comércio Exterior e Serviços (MDIC), com atuação desde julho de 2014 no Departamento de Negociações Internacionais. Atua primordialmente no ramo de barreiras não-tarifárias ao comércio.

E-mail: pedrophra@hotmail.com

\section{Abstract}

Identifying and taking into consideration the biases of individuals whose behavior is regulated by the State may increase the effectiveness of policymaking processes, while addressing policymakers biases is fundamental to guarantee that state intervention will not produce inefficient or biased regulation as a result of human bounded rationality. Through a qualitative and descriptive approach, supported by an extensive review of existing literature on the subject, this paper aims at identifying the most common biases to which public regulators and regulated individuals are subject and both to provide policymakers with a better perception of the biases which may potentially hinder the achievement of policy objectives, and to stimulate the improvement of policymaking processes. Finally, it was possible to identify how cognitive bias may affect a rational agent's decision and impact regulation in a way to make it inefficient, unnecessary and even unfair, and that it is necessary to rethink the decision-making architecture of such actors in 
order to incorporate structures bias correction tools.

Keywords: Behavioral economics. Decision-making. Cognitive bias. Policymakers. Libertarian paternalism. Nudge.

\section{INTRODUÇÃo}

O axioma econômico de que todo indivíduo é racional ao tomar uma decisão tem sido recorrentemente flexibilizado com o intuito de se compreender melhor a dinâmica observada na prática decisória. A economia comportamental tem se destacado como ferramenta para avaliar tal flexibilização, uma vez que busca utilizar elementos da psicologia para compreender os desvios da racionalidade nas tomadas de decisão. Assim, tem se ocupado de identificar os principais vieses e deficiências cognitivas dos consumidores, da população regulada de uma forma geral, além dos agentes responsáveis pela elaboração da regulação. Se os agentes dispõem de racionalidade limitada, esta deve ser considerada na análise.

Cooper e Kovacic ${ }^{1}$ examinam as implicações de falhas cognitivas sofridas pelos tomadores de decisão que enviesam os resultados efetivos em relação à maximização do resultado esperado. O termo "viés" pode ser entendido como qualquer dinâmica cognitiva que leva os indivíduos a processarem as informações de uma maneira que sistematicamente tenha o potencial de frustrar o alcance de seus objetivos ${ }^{2}$. Tendo essa distorção em mente, tornam-se cada vez mais demandadas intervenções estatais que eliminem ou reduzam o efeito irracional dos vieses sobre as decisões que realmente impactam o funcionamento social.

A literatura apresenta estudos sobre motivos para desvios de racionalidade de investidores, proporcionando menor previsibilidade às variações do mercado financeiro, o que traria benefícios apenas a atores específicos e não à coletividade. No entanto, pouco se concentram nos vieses dos agentes formuladores de política pública, cujas decisões carregam um potencial maior de impacto no bem-estar de toda a sociedade, assim como nos vieses dos atores regulados, que notadamente também deixam de fazer as melhores escolhas.

Quem toma as decisões são os indivíduos, e não grupos genéricos como "comunidade" ou "sociedade" $\left(\right.$ Shughart $\left.\mathrm{II}^{3}\right)$. Nesse sentido, o formulador de política pública não é a figura romanticamente desenhada de um servidor público altruísta e benevolente que somente se preocupa com o bem-estar social em suas decisões, as quais refletem necessária e precisamente o desejo do povo. Embora considere o bem-estar social, o formulador de políticas públicas também é um ser humano, que toma decisões que maximizem sua utilidade e, para isso, leva em consideração seus próprios interesses, motivações e vieses, o que pode envolver a busca da maior receita possível destinada pela administração, visibilidade, possibilidades de promoção e prestígio profissional. Assim, é relevante entender os aspectos que se apresentam e influenciam o formulador de política pública na compreensão de possíveis falhas observadas na política a ser implementada. Para evitar que tais vantagens levem os agentes a deturparem a finalidade das políticas, é fundamental a criação de mecanismos de controle da discricionariedade dos reguladores.

Como as instituições e os governos raramente estudam ou levantam informações a respeito dos vieses de seus tomadores de decisão, não é incomum o desconhecimento sobre quanto dos resultados da atuação institucional e da política pública são de alguma forma enviesados. Tal fato impossibilita desenhar ações para

1 COOPER, James C.; KOVACIC, William E. Behavioral Economics: Implications for Regulatory Behavior. Journal of Regulatory Economics, v. 41, n. 41-58, 2012.

2 KAHAN, Dan M. et al. Motivated numeracy and enlightened self-government. [New Haven]: Yale Law School, 2013. (Working Paper, n. 307).

3 SHUGHART II, William F. Public choice: the concise encyclopedia of economics. 2008. Disponível em < http://www.econlib. org/library/Enc/PublicChoice.html>. Acesso em: 19 jan. 2018. 
mitigar seus efeitos e levar os agentes públicos a efetivamente empregarem os princípios da administração pública de impessoalidade, moralidade e eficiência no processo de formulação das políticas.

Releva observar que, na ausência de mecanismos competitivos, caso da formulação de políticas, a avaliação do processo regulador é feita em nível político, que é bem menos eficiente que mercados econômicos e comprova que grande parte das políticas públicas não alcançam o objetivo pretendido. Para o "mercado político" funcionar, seria necessário que os eleitores entendessem sobre o assunto, atribuíssem relevância ao tema, compreendessem suas causas e consequências, julgassem os resultados da política em comparação a contrafatos que possuem algum grau de incerteza, e se expressassem concordando com a política a ser implementada. ${ }^{4}$ Choi e Pitchard ${ }^{5}$ explicam que, quanto mais monopolistas são as agências regulatórias, mais propícias estão a vieses comportamentais, de modo que elas não deveriam ser responsáveis pela criação de regulamentos que visem à correção dos mercados. Além disso, defendem que os mecanismos de mercado são mais efetivos contra os diversos vieses apresentados e que o governo deve se esforçar para balancear o viés dos regulados com os vieses dos reguladores, que são mais fortes e estruturais.

Para aplicar a economia comportamental ao campo das políticas públicas, é necessário perceber que as políticas escolhidas pelos métodos de elaboração tradicionalmente empregados nem sempre promovem a melhor opção disponível. Uma política mal formulada pode: a) apresentar benefícios notoriamente satisfatórios, mas a custos desnecessariamente altos; b) atingir objetivos diferentes daqueles pretendidos; c) perseguir problemas triviais sem alcançar a raiz do problema enfrentado; d) favorecer grupos específicos, utilizando recursos públicos, sem um critério razoável de justiça distributiva. O resultado dessas más políticas usualmente são críticas de que o governo, na prática, cria mais obstáculos do que efetivamente contribui para a vida do cidadão e do mercado ${ }^{6}$.

No processo de elaboração de um regulamento, quando se considera a interação entre regulador e regulado em um contexto de incentivos pré-existentes, o conteúdo da política pública desenhada deixa de se restringir apenas à normatização e passa a incluir ações que promovam maior participação da sociedade regulada, o que pode ocorrer por meio de novos incentivos. Dessa forma, a efetividade da política pública tende a ser aumentada, bem como o nível de accountability e, consequentemente, da responsabilidade e da transparência dos agentes políticos, uma vez que a prestação de contas à população se torna mais intensa. Além disso, a introdução de regras bem desenhadas, combinando-se corretamente obrigações e incentivos, pode reforçar, consideravelmente, a cooperação e trazer um equilíbrio ao comportamento esperado dos agentes regulados ${ }^{7}$.

A discussão sobre os vieses dos tomadores de decisão, no entanto, não se restringe apenas, ao comportamento dos cidadãos sujeitos ao instrumento normativo e à formulação e implementação de políticas públicas (Poder Executivo), mas também pode ser estendida à criação de novas leis ou normas jurídicas (Poder Legislativo), pela própria dinâmica de interesses defendidos pelos representantes populares no Congresso Nacional. Além disso, a aplicação das normas e leis (Poder Judiciário) pode sofrer vieses relevantes, uma vez que são executadas por um juiz, um ser humano, exercendo um ato de vontade do Estado. Para ilustrar, pode-se pensar no impacto das convicções ideológicas de magistrados na dosimetria de uma pena, ou da empatia de um juiz com a situação do inquilino ou de um consumidor em sua decisão.

4 TASIC, Slavisa. Are regulators rational? Journal des Economistes et des Etudes Humaines, v. 17, n. 1, 2011. Disponível em: < http:// www.bepress.com/jeeh/vol17/iss1/art3>. Acesso em: 19 jan. 2018.

5 CHOI, Stephen J.; PRITCHARD, Adam C. Behavioral economics and the SEC. Michigan Law School. Law and Economic Working Paper, n. 03-002, 2003.

6 RACHLINSKI, Jeffrey J.; FARINA, Cynthia R. Cognitive psychology and optimal government design. 2002. Disponível em: <http:// scholarship.law.cornell.edu/facpub/755>. Acesso em: 19 jan. 2018.

7 SIQUEIRA, L. S.; RIBEIRO, D. C.; TABAK, B. M. A participação social nas políticas de segurança pública como instrumento de redução de vieses à luz da análise econômico comportamental do direito. Revista Culturas Jurídicas, v. 4, p. 389-420, 2017; GALBIATI, Roberto; VERTOVA, Pietro. How laws affect behavior: obligations, incentives and cooperative behavior. International Review of Law and Economics, v. 38, p. 48-57, 2014. 
O entendimento dos efeitos dos vieses nesses três poderes pode levar a uma atuação mais assertiva para sua mitigação por parte do Ministério Público. Neto e Tabak ${ }^{8}$ apontam que o Ministério Público, órgão destinado à defesa da "ordem jurídica, do regime democrático, dos interesses sociais e individuais indisponíveis", deve se envolver no controle das decisões que impactam a formulação de políticas públicas, com o intuito de garantir sua qualidade, que é constitucionalmente prevista. A aplicação do citado controle asseguraria a conformação da discricionariedade a princípios constitucionais fundamentais, como a eficiência da ação pública, no sentido de evitar políticas públicas ineficientes, desperdícios de recursos públicos, corrupção, entre outras práticas que desviam a política pública de seu alvo, que é garantir o bem-estar social. No entanto, para desempenhar essa função com qualidade, o Ministério Público careceria de ferramentas jurídicas que gerem contingências comportamentais capazes de modificar o ambiente político, e que lhe permitam gerenciar relações de reforço/punição aptas a impulsionar o comportamento dos agentes públicos no sentido desejado pela coletividade.

O presente artigo busca contribuir para o debate sobre a qualidade da formulação de políticas públicas e a efetividade de seus resultados. Os formuladores de políticas públicas e os agentes que tomam decisões sobre a implementação dessas políticas estão sujeitos a vieses cognitivos, os quais podem prejudicar a eficácia e efetividade das respectivas políticas. Além disso, para o desenvolvimento de políticas mais assertivas, torna-se cada vez mais valiosa a consideração dos vieses dos atores regulados. Em um mundo em que os recursos são cada vez mais escassos, é imperativo reconhecer essas limitações e discutir de que modo poderiam ser evitadas.

Nesse sentido, o presente artigo busca promover uma ampla discussão sobre a temática, apresentando-se como resultado de uma pesquisa qualitativa e de ampla revisão da bibliografia existente. Está organizado de forma que a seção 2 apresentará alguns vieses cognitivos que são extremamente relevantes no campo da formulação de políticas públicas, devido a sua reiterada ocorrência, exemplificando casos de intervenção estatal que podem estar eivados de vieses, no intuito de evidenciar a forma em que as políticas podem ser afetadas. A seção 3, por sua vez, apresentará uma discussão dos nudges que podem ser aplicados ao público objeto da política para um resultado mais efetivo da atuação governamental, bem como aos seus elaboradores de modo a corrigir esses vieses. A seção 4 discute a arquitetura de decisões e sua relevância no desenho das políticas públicas assim como para o seu aprimoramento, e a seção 5 conclui o artigo explorando conclusões indutivas a partir do conteúdo discutido.

\section{Vieses COGNITIVOS}

Segundo Kahneman e Tversky ${ }^{10}$, dentre os fatores que mais influenciam a tomada de decisões estão a estrutura de apresentação do problema, bem como normas, hábitos e características pessoais do agente tomador de decisão. Esses elementos podem originar vieses que levam ao abandono da racionalidade no julgamento intuitivo e, consequentemente, a decisões equivocadas do ponto de vista racional.

Para tomar uma decisão racional, maximizando os retornos possíveis, o indivíduo deve considerar uma grande quantidade de informações e relacioná-las sistematicamente, utilizando a racionalidade humana, que possui limitações. Por isso, é bastante comum o uso de atalhos mentais, chamados heurística, para se chegar a decisões de qualidade, de forma mais prática e com melhor custo-benefício. Assim, processam-se as

8 SILVAS NETO, Nathan da; TABAK, Benjamin Miranda. Políticas Públicas e Racionalidade Limitada: O controle das decisões políticas pelo Ministério Público. Revista de Direito Internacional Econômico e Tributário, Brasília, v. 12, n. 1, p. 482-539, jan./jun. 2017.

9 Artigo 127 da Constituição Federal Brasileira de 1988. BRASIL. Constituição (1988). Constituição da República Federativa do Brasil. Disponível em: <http://www.planalto.gov.br/ccivil_03/Constituicao/Constituicao.htm>.

10 Tversky, A.; Kahneman, D. Judgment under uncertainty: heuristics and biases. Science, v. 185, n. 4157, p. 1124-1131, 1974. Disponível em <http://dx.doi.org/10.1126/science.185.4157.1124>. Acesso em: 7 fev. 2018.; KAHNEMAN, D.; Tversky, A. The framing of decisions and psychology of choice. Science, v. 21, n. 4481, p. 453-458, 1981. 
informações empregando tempo, conhecimento e estruturas mentais mínimas para se fazer escolhas adaptativas em ambientes reais, de forma que, na maioria das vezes, a decisão esteja correta. Em determinadas circunstâncias, no entanto, o emprego da heurística pode produzir armadilhas, como levar um indivíduo a aceitar como verdadeira uma proposição simplesmente por ser de mais fácil compreensão. Dessa forma, o indivíduo tomaria uma decisão equivocada acreditando convictamente que seu discernimento está correto.

A seguir são apresentados e melhor explorados os vieses que se acreditam influenciarem mais decisivamente os desenhos e resultados das políticas públicas.

\subsection{Viés da confirmação}

O viés da confirmação ocorre quando o indivíduo dá um peso maior a suas crenças, ideias, interpretações ou experiências prévias do que a novas evidências apresentadas. Esse viés ocorre quando o indivíduo busca informações e leituras que confirmem sua percepção sobre o problema proposto, ou quando ele lembra, seletivamente, de acontecimentos ou argumentos, ao mesmo tempo em que flexibiliza e invalida argumentos contrários, ainda que lógicos e convincentes.

Como exemplo empírico, pode-se pensar no indivíduo que toma a decisão desinformada de adquirir uma lancha para atravessar a Baía de Guanabara até seu trabalho. Mesmo após descobrir que os custos de seu empreendimento em muito superam os benefícios pretendidos, a pessoa passa a justificar a aquisição alegando a percepção de novos benefícios, como a emoção de viver diariamente a beleza e o clima dessa travessia. Além disso, ela pode deixar de reconhecer alguns dos custos atribuíveis à lancha, como, por exemplo, o aumento da distância que terá de caminhar da ancoragem da lancha até seu local de trabalho. Nota-se que uma vez que a pessoa tenha se comprometido com a ideia ou curso de ação, qualquer evidência que demonstre seu equívoco se defrontará com forte resistência.

Segundo o Teorema de Bayes, uma nova evidência apresentada sempre deve ser pesada pelo indivíduo para se calcular a probabilidade de que a decisão seja alterada ou mantida. O que ocorre no viés da confirmação é que os pesos atribuídos pelo indivíduo a cada probabilidade e tendência no cálculo da melhor decisão no novo contexto apresentado são endógenos. Assim, sua reação será diferente a depender da predisposição ou crenças anteriores. Sem uma revisão real desses pesos, a decisão tomada pode desviar-se consideravelmente da mais racional na nova realidade apresentada.

No contexto regulatório, a observância do viés da confirmação leva seu formulador a ignorar ou a interpretar erroneamente novas evidências científicas, e a resistir fortemente a mudanças do curso regulatório em vigor, ainda que haja substancial evidência contrária. Assim, pode ocorrer de ser menos imprecisa e equivocada a decisão de um agente mal informado com corretos pressupostos do que a de um agente melhor informado, mas sujeito ao viés da confirmação. Para exemplificar, pode-se citar um decisor público que acredita que a autorregulação do mercado funciona. Tal agente, quando confrontado com evidência em favor da intervenção do Estado, tenderá a desacreditar tal evidência ou exigir provas mais robustas para modificar sua ideia original ${ }^{11}$.

Tendo-se como pressuposto que a regulação visa atacar, da maneira mais efetiva e menos onerosa possível, um problema à coletividade identificado, o embasamento científico acerca do melhor método a ser utilizado e evidências empíricas que indiquem o maior sucesso de sua implementação frente a alternativas possíveis, bem como indícios do impacto que a regulação trará ao público, espera-se que a ação estatal seja norteada pela maior racionalidade possível e que o decisor pondere adequadamente as opções que se lhe apresentam. Quando crenças, ideologias ou experiências vividas sopesam fortes argumentos racionais, o resultado da atuação governamental pode ser desastroso ou pouco efetivo.

11 COOPER, James C.; KOVACIC, William E. Behavioral Economics: Implications for Regulatory Behavior. Journal of Regulatory Economics, v. 41, n. 41-58, 2012. 
Um tipo de confirmação observado por Barnuri et al ${ }^{12}$ e que afeta potencialmente os formuladores de políticas públicas é a predisposição ou adesão ideológica do indivíduo. A militância ou mesmo simpatia por uma ideologia específica: liberal, conservadora, protecionista, intervencionista, de esquerda, de direita; tendem a sobrepesar no mecanismo decisório do regulador, de forma a sustentar alternativas que vão ao encontro de suas ideias, a despeito de evidências contrárias observadas. Nesse sentido, buscou identificar se a utilização de uma evidência científica pelos indivíduos é uniforme e depende exclusivamente de sua capacidade numérica e cognitiva, de interpretação e aplicação de dados, ou se oscila quando se envolvem temas em que há polarização ideológica. Para isso, foram apresentados dados de uma suposta pesquisa científica fictícia a respeito da efetividade de um creme facial no combate a espinhas e outra pesquisa sobre a efetividade do controle de armas em uma cidade. Embora aplicado utilizando os mesmos valores como resultado das pesquisas realizadas, o que deveria proporcionar decisões equivalentes, ficou latente que o viés ideológico que envolve a discussão do desarmamento influenciou as decisões tomadas consideravelmente.

\subsection{Viés da ancoragem}

O viés da ancoragem ocorre quando o indivíduo é exposto a uma informação ou experiência previamente à decisão que servirá de base (ou âncora) a seu raciocínio ao considerar estimativas e realizar julgamentos. Ele existe devido à forte tendência que a mente humana tem de fazer associações. Pode-se visualizar o efeito de uma âncora em um simples aviso de promoção em uma vitrine. Observa-se, também, a ancoragem amplamente utilizada nas barraquinhas de pipoca dos cinemas. Enquanto o pacote pequeno de pipoca apresenta um valor exorbitante ou artificialmente elevado em relação ao valor usualmente atribuído pelo consumidor, o pacote grande recebe um preço proporcionalmente menor. Dessa forma, o pequeno oferece uma âncora negativa, que viabiliza, na mente do consumidor, a aquisição do grande, por estar "mais barato".

Tal fenômeno ocorre porque os indivíduos usualmente tomam decisões partindo de um valor de referência inicial e realizando ajustes mentais para se chegar a um resultado final que considerem satisfatório. No entanto, o ajuste pode não ser suficiente, de forma que o ponto de partida ou o elemento de comparação sugerido pelo problema influencia a escolha. Da mesma forma, a decisão pode ser profundamente influenciada pela computação incompleta da estimação.

Para ilustrar o efeito da ancoragem, Tversky e Kahneman ${ }^{13}$ aplicaram um simples experimento com alunos colegiais que consistia em que estimassem, em cinco segundos, o resultado de 8! (oito fatorial). A forma de apresentação do problema, no entanto, foi diferente para cada grupo. Ao primeiro grupo, a problemática foi apresentada de forma descendente, pedindo que se calculasse o valor de $8 \times 7 \times 6 \times 5 \times 4 \times 3 \times 2 \times 1$. Ao segundo grupo, utilizou-se uma arquitetura ascendente, solicitando aos alunos que estimassem o valor de 1x2x3x4x5x6x7x8. Sabendo que o resultado correto é 40.320, releva notar que a média das decisões sobre o primeiro problema foi de 2.250, enquanto a do segundo, 512. Observa-se, assim, que o ponto de partida foi determinante na resposta dada, já que, mesmo com ajuste incompleto, a resposta obtida a partir de um ponto mais próximo do correto reduziu o equívoco da resposta.

$\mathrm{O}$ viés da ancoragem existente no agente regulado pode trazer importantes considerações ao regulador. Releva observar, por exemplo, os vieses decisórios de indivíduos que cometem crimes, no sentido de compreender seus comportamentos, motivações e influências e moldar políticas de contraterrorismo. Além disso, torna-se possível identificar âncoras usadas na atuação governamental no combate ao criminoso, e,

12 BANURI, Sheheryar; DERCON, Stefan; GAURI, Varun. Biased policy professionals. Washington, D.C.: World Bank Group, 2017 Disponível em: <http://documents.worldbank.org/curated/en/685691498482210671/Biased-policy-professionals>. Acesso em: 2 mar. 2018; Para identificar a existência do viés da confirmação, os autores se basearam no trabalho de KAHAN, Dan M. et al. Motivated numeracy and enlightened self-government. [New Haven]: Yale Law School, 2013.

13 Tversky, A.; Kahneman, D. Judgment under uncertainty: heuristics and biases. Science, v. 185, n. 4157, p. 1124-1131, 1974. Disponível em: <http://dx.doi.org/10.1126/science.185.4157.1124>. Acesso em: 7 fev. 2018. 
consequentemente, as decisões tomadas por agentes policiais quando há suspeita substancial de que um cidadão seja um criminoso em potencial, ou quando se identifica ser elevado o risco de que ocorra um ataque terrorista. Como no caso do assassinato do brasileiro Jean Charles de Menezes pela polícia britânica, quando se suspeita fortemente que um indivíduo apresenta potencial de causar um grande desastre, tem-se uma âncora forte, um viés de que ele seja culpado, levando os agentes públicos a abandonarem, em suas considerações para a tomada de decisão, o Princípio da Presunção de Inocência. Os ajustes necessários para uma efetiva comprovação antes da ação policial podem ser insuficientes e o resultado apresentado não ser o correto ou o ideal de uma avaliação racionalmente perfeita. ${ }^{14}$

As políticas públicas que tratam do racismo no Brasil também devem se preocupar fortemente com o viés da ancoragem. Baseia-se, claramente, em uma âncora racial o raciocínio do empregador que pretere um indivíduo afrodescendente mais bem qualificado para contratar um indivíduo de pele clara menos capaz de realizar as funções previstas para o cargo. O critério irrelevante aplicado acaba sobrepujando as qualidades exigidas pelo emprego ofertado. A política de combate ao racismo deve investigar mecanismos para eliminar tal âncora na escolha dos empregadores, o que pode ser feito por meio de adaptações na arquitetura da decisão desses indivíduos.

\subsection{Viés do enquadramento}

O ser humano utiliza uma caixa de ferramentas adaptativas para tomar decisões, que consiste em regras ou heurísticas para avaliar as informações que se tem disponível e escolher de acordo com suas expectativas de melhores resultados, nem sempre munido de todos os dados necessários, sob pressão ou tempestivamente, em ambientes distintos. A heurística não tem base matemática ou algorítmica, mas se baseia em um processo simplificado, não raro sem muita consistência ou coerência.

O indivíduo submetido a uma decisão que lhe demanda algum raciocínio tem como ponto de partida alguma lembrança, experiência ou situação possível e, por meio da caixa de ferramentas adaptativas, realiza ajustes mentais em seu ponto de partida até chegar à alternativa que lhe apresente maior valor. Uma vez que os ajustes são imprecisos, se a maneira com que o problema é apresentado for alterada, o indivíduo pode ser levado a um ponto de partida diferente, e consequentemente a um resultado também distinto. A literatura denomina de viés do enquadramento a esses resultados diversos, em consequência da forma com que o problema é apresentado. ${ }^{15}$

Os indivíduos são influenciados pela maneira em que a informação é apresentada ou enquadrada, o que pode ser evidenciado pelo fato de um maior número de pacientes tender a aceitar uma cirurgia se lhes for dito que, após 5 anos, $90 \%$ das pessoas que passam por aquele procedimento estão vivas, do que se lhes for dito que $10 \%$ estão mortas ao final desse tempo.

Banuri et $\mathrm{a}^{16}$ avaliam o efeito do enquadramento para a tomada de decisão dos agentes públicos. $\mathrm{O}$ experimento aborda a decisão entre dois tratamentos diferentes para o combate a uma séria epidemia que atinge 12 mil pessoas. Usando o enquadramento de ganhos, expôs-se que o primeiro tratamento salvaria 4 mil certamente e o segundo tratamento poderia salvar todos os 12 mil com uma probabilidade de 1/3, mas que ninguém seria salvo com probabilidade de $2 / 3$. No enquadramento usando perdas, argumentou-se no

14 KEBBELL, Mark R.; MULLER Damon; MARTIN, Kirsty. Understanding and managing bias. In: BAMMER, Gabriele (Ed.). Dealing with uncertainties in policing serious crimes. Canberra: ANU Press, 2010.

15 Tversky, A.; Kahneman, D. Judgment under uncertainty: heuristics and biases. Science, v. 185, n. 4157, p. 1124-1131, 1974. Disponível em <http://dx.doi.org/10.1126/science.185.4157.1124>. Acesso em: 7 fev. 2018; Polič, Marko. Decision making: between rationality and reality. Department of Psychology, Faculty of Arts, University of Ljubljana, Ljubljana, Slovenia. Interdisciplinary Description of Complex Systems, v. 7, n. 2, p. 78-89, 2009.

16 BANURI, Sheheryar; DERCON, Stefan; GAURI, Varun. Biased policy professionals. Washington, D.C.: World Bank Group, 2017. Disponível em: <http://documents.worldbank.org/curated/en/685691498482210671/Biased-policy-professionals>. Acesso em:

2 mar. 2018. Replicou a uma amostra de formuladores de política pública um experimento de Tversky e Kahneman 
Tratamento 1 que 8 mil pessoas morreriam com certeza e no Tratamento 2 que existe $1 / 3$ de probabilidade de que ninguém morra, mas $2 / 3$ de probabilidade de que todos os 12.000 pereçam.

O Tratamento 1 apresentado seria a opção mais segura, enquanto o Tratamento 2 o mais arriscado. Os resultados obtidos demonstraram que pouco mais de $20 \%$ dos entrevistados escolhem a opção arriscada sob o enquadramento de ganhos, enquanto mais de $60 \%$ a escolheram sob o de perdas. Sabendo-se que se não houvesse interferência cognitiva o resultado em ambas as formas deveria ser igual, evidenciou-se forte viés decisório.

\subsection{Desconto hiperbólico}

A sociedade utiliza recompensas para adiamento do usufruto de um benefício no presente para um melhor aproveitamento do recurso no futuro, o que permite dizer que o desconto hiperbólico representa a taxa de desconto aplicada pela sociedade para comparar os benefícios de maneira intertemporal (Tabak $\left.{ }^{17}\right)$.

Assim, quanto mais alta a taxa de desconto, mais pressa, impaciência ou valor atribuído ao usufruto presente possui o indivíduo ou a sociedade. Uma alta taxa de desconto, também, leva o indivíduo a abrir mão de benefícios futuros demasiadamente altos se comparados aos custos correntes que se teria de abrir mão para alcançá-los. Em geral, os indivíduos apresentam um considerável grau de impaciência, que os leva a tomarem decisões com resultados de curto prazo menores comparativamente a alternativas que lhes renderiam um ganho maior a ser recebido no longo prazo.

Elevadas taxas de desconto intertemporal podem gerar severos problemas de autocontrole. Tal dificuldade pode ser observada no indivíduo que decide por uma dieta mais rigorosa, que perpassa por não consumir uma determinada sobremesa após sua refeição, segundo foco nos resultados de longo prazo, mas não consegue resistir quando, após terminada a refeição, a sobremesa lhe é apresentada, e o ganho de curto prazo, embora menor que o estrategicamente pretendido em longo prazo, acaba dominando sua decisão. ${ }^{18}$

Quando os agentes com esse viés formulam política pública, há forte tendência de se produzirem políticas que maximizam retornos de curto prazo em detrimento de metas de longo prazo, mais estratégicas e estruturantes. Pode-se exemplificar com a decisão de correção de falhas no asfalto de rodovias brasileiras. $\mathrm{Na}$ recorrente decisão de se empregar um material de mais qualidade e substituir o asfalto existente por outro com maior tecnologia, por um lado, ou executar políticas "tapa buraco", por outro lado, muitas vezes se opta pela última, dado o menor tempo e custo de execução, proporcionando maior visibilidade à administração, a despeito do potencial da primeira opção de agregar maior valor e vida útil à rodovia. A decisão irracional com benefícios menores em curto prazo, na prática, acaba aumentando o custo total gasto na reconstrução desse bem público.

Uma forma de evitar essa falta de controle que pode ser observada é a autoimposição de penalidades em caso de descumprimento do objetivo estratégico de longo prazo, o que, aparenta trazer resultados expressivos. Tomando essa solução como eficiente, uma forma de reduzir o viés do desconto hiperbólico nas políticas públicas poderia ser a utilização de estímulos de autocontrole que se apliquem, especificamente, a cada situação que se deseja controlar ou atitude que se deseja modificar do servidor público.

\subsection{Viés da retrospectiva}

O viés da retrospectiva apresenta a tendência de um indivíduo em conceder um peso relativamente alto

17 TABAK, B. M. A. Análise econômica do direito: proposições legislativas e políticas públicas. Revista de Informação Legislativa, Brasília, ano 52, n. 205, p. 321-349, jan./mar. 2015.

18 LYNCH Jr, John G.; ZAUBERMAN, Gal. When do you want it?: time, decisions, and public policy. Journal of Public Policy \& Marketing, Spring, v. 25, n. 1, p. 67-78, 2006. 
a avaliações e eventos passados para tomar sua decisão no presente. Assim, ele tende a superestimar a probabilidade ex ante de um evento acontecer dado que ele já ocorreu em algum momento anterior. $\mathrm{O}$ viés da retrospectiva apresenta uma superestimação da facilidade de ocorrência de um sucesso e uma simplificação exagerada, a partir de eventos e resultados anteriores, sobre o que deveria ser feito na situação em análise. ${ }^{19}$

Para compreender como esse viés é observado, podem-se analisar os estudos sobre eficiência de um mercado, os quais se baseiam no tempo de reação do mercado para responder a um novo conjunto de informações disponíveis. No entanto, nem sempre se considera se tal resposta é correta ao ser aplicada à nova realidade apresentada. Embora o mercado responda, rapidamente, a informações públicas, a maior parte dos agentes não tem conhecimento imediato dessas novas informações.

Nesse sentido, Gilson e Kraakman ${ }^{20}$ avaliam as teorias de valoração de ativos e suas falhas e apresentam os esforços da economia comportamental em elucidar os motivos pelos quais os agentes tomam decisões irracionais em mercados que muitas vezes apresentam informações assimétricas a seus agentes. Concluem que há vieses direcionais dependendo do ponto de partida da tomada de decisão, e que nem mesmo profissionais que ponderam bem suas decisões recorrentemente são usualmente capazes de corrigir adequadamente em suas previsões os equívocos de investidores menos racionais. Por isso, as previsões de valores de ativos raramente são precisas.

Embora os autores reconheçam as limitações da economia comportamental em gerar coeficientes precisos que reflitam cada viés cognitivo, o simples reconhecimento de sua existência já traz considerável evolução às discussões de precificação de ativos, e o viés da retrospectiva parece ser a distorção mais razoável e comum na racionalidade dos tomadores de decisão financeira.

Ao se aplicar esse viés às políticas públicas, fica evidente que a percepção de eventos anteriores nem sempre é a mais confiável para a formulação de novas políticas públicas. A concepção prévia de que uma determinada indústria trará malefícios ambientais pela própria natureza de suas atividades, por exemplo, tende a levar os reguladores a impor severos custos à sua operacionalização, ainda que, eventualmente, novas tecnologias limpas estejam revolucionando, positivamente, o setor.

\subsection{Viés da ação}

Trata-se de um viés de reação exagerada do indivíduo confrontado por uma situação de risco ou incerteza. Pode ocorrer uma reação além do que seria o racional, ou a falta total de ação, o que oscila de acordo com a familiaridade que o indivíduo tem com a situação enfrentada. A reação exagerada parece ter relação, também, com o crédito que se pode conseguir ao reagir ao risco apresentado.

Tasic $^{21}$ exemplifica com a reação de goleiros em cobranças de pênaltis. Ainda que evidências científicas demonstrem que a melhor estratégia seja esperar a cobrança sem pular, a maioria dos goleiros de elite escolhe um canto e salta para tentar evitar o gol, mesmo sabendo que sua probabilidade de acerto é reduzida. Em decorrência da audiência e da expectativa do público sobre o goleiro, sua reação exagerada pode ter forte relação com o crédito de sua reação em caso de sucesso.

$\mathrm{Na}$ formulação de políticas públicas, esse viés pode ser expressivo se considerarmos que há situações em que uma regulamentação não traria substanciais melhorias à realidade social, ou até um aumento do caos

19 KEBBELL, Mark R.; MULLER Damon; MARTIN, Kirsty. Understanding and managing bias. In: BAMMER, Gabriele (Ed.). Dealing with uncertainties in policing serious crimes. Canberra: ANU Press, 2010.

20 Gilson, Ronald J.; Kraakman, Reinier. The mechanisms of market efficiency twenty years later: the hindsight bias. Columbia Law and Economics. Working Paper n. 240, Stanford Law and Economics Olin Working Paper n. 270; Harvard Law and Economics Discussion Paper, n. 446, out. 2003. Disponível em: <https://ssrn.com/abstract=462786 ou http://dx.doi.org/10.2139/ ssrn.462786>. Acesso em: 19 jan. 2018.

21 TASIC, Slavisa. Are regulators rational? Journal des Economistes et des Etudes Humaines, v. 17, n. 1, 2011. Disponível em: <http:// www.bepress.com/jeeh/vol17/iss1/art3 >. Acesso em: 19 jan. 2018. 
existente, mas o crédito obtido por demonstrar alguma reação motiva os formuladores de políticas públicas a agir. Esse tipo de viés na política pública é evidenciado por ações governamentais irracionais ou atrapalhadas quando se está na iminência de uma crise econômica, como a regulação de conduta coorporativa introduzida nos EUA logo após o caso Enron, que acabou por levar diversos investidores a outros mercados.

\subsection{Ilusão de foco ou heurística de disponibilidade}

O presente viés ocorre quando um evento recente ou visível se sobrepõe ao impacto de todos os demais fatores na tomada de decisão. A heurística da disponibilidade, que relaciona um evento à lembrança mais vívida, notória ou significativa que o indivíduo encontra disponível em sua mente, apregoa que os indivíduos tendem a superestimar a semelhança e os efeitos a um evento mais facilmente lembrado, concedendo peso indevido a tal evento.

Kahneman et $\mathrm{al}^{22}$ demonstram que muitas pessoas relacionam maior riqueza a maior felicidade, o que se deve principalmente à ilusão de foco, já que diversos outros fatores para o bem-estar, como vida social ou questões circunstanciais, apresentam considerável peso na real mensuração da felicidade do indivíduo. Ainda assim, as lembranças que relacionam o bem-estar a situações proporcionadas pela disponibilidade de recursos financeiros são destacadas na mente do indivíduo.

Tal heurística pode levar os regulamentadores a atuarem na defesa dos interesses de grupos específicos, não por serem corruptos, mas por internalizarem, cognitivamente, os objetivos desses grupos, que os pressionam e expõem suas dificuldades, reforçando os efeitos que são notórios ao público. Esse fenômeno é conhecido como "Captura Regulatória Cognitiva". O mesmo fenômeno ocorre, por exemplo, na regulamentação do mercado financeiro, em que os interesses da regulação global acabam sendo preteridos pelas metas de grupos menores que exercem pressão nos regulamentadores. ${ }^{23}$

Nota-se que a natureza desse viés permite a geração de uma reação regulatória demasiadamente forte, em casos em que haja comoção nacional ou um acontecimento que tenha marcado os regulamentadores, o que é comumente visto na elaboração de políticas industriais em período de crises, quando há forte movimento de comoção nacional devido a demissões em larga escala, em que a política vise proteger e prover maiores subsídios aos setores mais intensivos em mão de obra, como os setores têxtil ou de construção civil, ainda que outros setores sejam mais afetados pela crise ou viriam a reagir mais positivamente aos incentivos governamentais.

\subsection{Excesso de confiança}

Quando o formulador de política pública julga ter todo o conhecimento e entendimento do mercado para regulá-lo devidamente e melhorar sua eficiência, há boa possibilidade de que ele esteja diante de um viés de excesso de confiança. Tal viés ocorre quando o indivíduo superestima suas habilidades e capacidades; quando a intuição errônea da completude de seu conhecimento o leva a achar que entende fenômenos complexos em uma profundidade muito maior do que realmente entende. É o caso da pessoa que olha a ponta do iceberg e acredita conseguir descrever com a total precisão seu tamanho e formato, fenômeno chamado pela literatura de ilusão da "profundidade explicatória"24.

O autor chama a atenção de que o problema é agravado nos regulamentadores não apenas por não

22 KAHNEMAN, Daniel et al. Would you be happier if you were richer?: a focusing illusion. Science, v. 312, n. 5782, p. 1908-1910, 2006.

23 TASIC, Slavisa. Are regulators rational? Journal des Economistes et des Etudes Humaines, v. 17, n. 1, 2011. Disponível em: < http:// www.bepress.com/jeeh/vol17/iss1/art3>. Acesso em: 19 jan. 2018.

24 TASIC, Slavisa. Are regulators rational? Journal des Economistes et des Etudes Humaines, v. 17, n. 1, 2011. Disponível em: <http:// www.bepress.com/jeeh/vol17/iss1/art3>. Acesso em: 19 jan. 2018. 
terem o domínio total dos mecanismos do mercado, mas também por não terem a consciência de que não possuem tal domínio.

O excesso de confiança tem estreita relação com o viés do otimismo, em que o indivíduo superestima a probabilidade de conseguir um bom resultado. Para os formuladores de políticas públicas, tal viés pode resultar em uma superestimação do sucesso de uma iniciativa regulatória e levar o Estado à ilusão de que melhorará o ambiente regulatório com uma medida que não trará quaisquer benefícios à sociedade ou que possivelmente dificultará os negócios de seus agentes.

\subsection{Viés do status quo}

Ao tomar uma decisão, os indivíduos se mostram, ainda que de forma imperceptível, tendenciosos a manterem o estado atual da situação, a menos que os benefícios de uma eventual mudança sejam expressivos. O viés decisório pelo status quo pode gerar escolhas irracionais, que não logrem maximizar a utilidade esperada do indivíduo.

O viés do status quo pode ser observado nas situações em que o indivíduo não tem familiaridade com o assunto ou está demasiadamente confuso para escolher dentre as opções apresentadas. Assim, com o intuito de fugir dos riscos ou pelo medo de se mover para uma opção que traga piores resultados, é grande a probabilidade de se escolher a resposta padrão (default). ${ }^{25}$

Thaler e Sutter ${ }^{26}$ avaliam a escolha de poupança previdenciária de um grupo de funcionários e afirmam que a opção desenhada como default parece carregar um sentido de legitimidade, como se elaborada por pensadores conscientes e preocupados com a maioria dos agentes que farão escolhas. A mudança do status quo demandaria tempo e esforço de análise, o que tende a promover procrastinação e inércia. O status quo está na tendência de se manter no poder o político correntemente no mandato, bem como na dificuldade em se abandonar uma marca ou um plano de saúde.

Samuelson e Zeckhauser ${ }^{27}$ identificaram atuação não desprezível desse viés no subconsciente humano. Explicam, também, que tal viés ocorre em presença de três fatores: a) decisão racional considerando os custos de transação ou as incertezas existentes; b) percepção cognitiva equivocada, o que relaciona esse viés com o efeito dotação ${ }^{28}$ e com o viés da ancoragem; e c) comprometimento psicológico.

O efeito dotação é um dos vieses que tende a manter as pessoas no status quo, uma vez que as leva a demandar uma compensação maior para se desfazerem daquilo que já possuem do que o montante que aceitariam abrir mão para adquirir aquele bem. Em termos de políticas públicas, o efeito dotação depende da política inicial, que deverá nortear as decisões políticas que serão adotadas a partir de então. Assim, o status quo gera políticas ligadas ao estado atual, por meio da inércia regulatória.

Já o comprometimento psicológico relaciona o viés do status quo com os custos afundados, que é a relutância do indivíduo em realizar suas perdas. Trata-se da percepção de que já se investiu muito em um empreendimento para abandoná-lo, ainda que o levar adiante traga um benefício marginal inferior à alternativa de descontinuá-lo.

Um sonoro exemplo é a consideração que, segundo alguns historiadores, teria feito Truman ao final da Segunda Guerra Mundial após gastar bilhões de dólares no projeto Manhattan para desenvolvimento das bombas atômicas. Optar por não as usar significaria assumir o prejuízo de todo esse recurso financeiro. Des-

25 FRANCO, Claudia Regina Lovato; TABAK, B. M.; BIJOS, Leila. A Lei no 14.946/2013 (Lei Bezerra): um nudge para incentivar empresários do setor de confecção da indústria paulista a cumprirem as leis trabalhistas. Revista Brasileira de Direito, São Paulo, v. 16, n. 7 , p. $346-362$, jan./abr. 2017.

26 THALER, Richard H.; SUNSTEIN, Cass R. Libertarian paternalism. The American Economic Review, v. 93, n. 2, 175-179, 2003.

27 SAMUELSON, W.; ZECHJAUSER, R. J. Status quo bias in decision making. Journal of Risk \& Uncertainty, n. 1, p. 7-59, 1988. Disponível em: <http://dx.doi.org/10.1007/BF00055564>. Acesso em: 19 jan. 2018.

28 KAHNEMAN, D.; Tversky, A. Prospect theory: an analysis of decision under risk. Econometrica, v. 47, n. 2, p. 263-292, 1979. 
considerando questões de estratégias de guerra, Truman teria tomado a decisão de utilizar as bombas devido à sensação de custo afundado (preocupação com montante já investido no empreendimento).

\section{NUDGE}

A economia comportamental pode contribuir com o poder preditivo e analítico do direito ao se considerarem as preferências reveladas dos indivíduos na tentativa maximizar o bem-estar social. Nesse sentido, o governo poderia, sem adotar qualquer ação coercitiva, auxiliar as pessoas a tomarem a melhor decisão social, com base em um desenho de políticas que efetivamente ajudem os indivíduos a seguirem o melhor caminho dentre as potenciais opções. ${ }^{29}$

Thaler e Sunstein ${ }^{30}$ defendem que, se uma política é selecionada no sentido de influenciar pessoas a tomarem as decisões que sejam melhores para todos, o "paternalismo" utilizado deveria ser aceito até pelos mais ardentes liberais. Em resposta às críticas de que o Estado estaria manipulando as ações das pessoas, os autores sugerem que, uma vez que a política a ser implementada necessitará de algum desenho ou de uma opção padrão, essa opção seja modelada no sentido de induzir a escolha em direção ao melhor bem-estar individual e social. Esse paternalismo libertário, portanto, auxilia a tomada de decisão individual, sem aplicação de qualquer preceito coercitivo.

A Teoria da Escolha Racional avalia como os indivíduos escolhem, visando maximizar seu bem-estar. Uma das metodologias mais estudadas a partir das premissas dessa teoria é o nudge, que envolve

qualquer aspecto da arquitetura da escolha que altere o comportamento das pessoas de uma forma previsível, sem proibir qualquer das opções disponíveis ou alterar significativamente seus incentivos econômicos $^{31}$

Trata-se, portanto, de mecanismos que visem induzir, influenciar ou empurrar o cidadão, sem obrigá-lo legalmente, a escolher o caminho desejado pelo regulamento, dados os incentivos econômicos existentes no contexto da escolha.

Enquanto a economia comportamental é uma subdisciplina científica, o nudge se diferencia por ser uma forma particular de aplicar suas descobertas às políticas. O nudge incorpora métodos, tais como experimentos empíricos comportamentais, ao contexto específico em análise, considerando que as escolhas são baseadas na simplicidade da informação e na lista de opções disponíveis, que as pessoas são levadas às opções mais convenientes, especialmente as default, e que a proeminência, a projeção ou o ressalto das opções ou atributos podem afetar seu peso na decisão a ser tomada. São exemplos de nudge: o uso do GPS, que orienta, mas não obriga o condutor; os avisos dos malefícios à saúde presentes nas embalagens de cigarros; ou as informações nutricionais de alimentos. Por outro lado, não são nudges: subsídios, taxas, sentenças ou multas, por exemplo, já que retiram do indivíduo a liberdade de escolha. Para melhor elucidação: deixar frutas à vista do consumidor é um nudge, diferentemente da proibição do consumo de alimentos industrializados. ${ }^{32}$

Essa ferramenta vem sendo amplamente aplicada pelos membros da OCDE, em especial pelos EUA ${ }^{33}$ e

29 JOLLS, Christine; SUNSTEIN, Cass R.; THALER, Richard. A behavioral approach to law and economics. Disponível em <http:// digitalcommons.law.yale.edu/fss_papers/1765>. Acesso em: 6 fev. 2018.

30 THALER, Richard H.; SUNSTEIN, Cass R. Libertarian paternalism. The American Economic Review, v. 93, n. 2, 175-179, 2003.

31 THALER, Richard H.; SUNSTEIN, Cass R. Nudge: improving decisions about health, wealth, and happiness. Yale: Yale University Press, 2008.

32 SUNSTEIN, Cass R. Nudges that fail. Behavioural Public Policy, v. 1, n. 1, p. 4-25, 2017. LUNN, Pete. Regulatory policy and behavioural economics. OECD Publishing, 2014. Disponível em: <http://dx.doi.org/10.1787/9789264207851-en>. Acesso em: 2 mar. 2018.

33 Em 2009, os EUA estabeleceram o Credit Card Accountability Responsibility and Disclosure Act (CARD Act), baseado nas evidências comportamentais de que os consumidores têm dificuldades em perceber o custo real do crédito. 
pelo Reino Unido ${ }^{34}$, e tem apresentado benefícios relevantes ao complementar análises de custo-benefício e estudos de impacto regulatório. Com efeito, já é visível a aplicação da economia comportamental às políticas públicas, de forma que alguns formuladores de políticas econômicas e jurídicas já têm apresentado propostas de regulamentação desenhadas com base no comportamento observado dos indivíduos, segundo experimentos comportamentais cujo êxito para correção das distorções de comportamento já seja comprovado. Ainda assim, a economia comportamental é pouco visível nas políticas públicas brasileiras. ${ }^{35}$

Para citar um dos poucos casos de nudges empregados em decisões públicas no Brasil, pode-se mencionar a Lei 12.618, de 30 de abril de 2012, que instituiu o regime de previdência complementar para servidores públicos federais titulares de cargo efetivo, criando-se a Funpresp (Executivo, Legislativo e Judiciário). Um dos problemas identificados na referida lei consistiu na baixa adesão aos planos de previdência complementar por parte dos novos ingressantes no serviço público. Em 2016, o Presidente da República enviou o Projeto de Lei 6.086 para o Congresso Nacional, alterando a Lei 12.618/12 e fazendo uma modificação importante do ponto de vista da economia comportamental: a inscrição na Funpresp passou a ser automática e o participante precisa fazer a opção por se retirar do plano.

O projeto altera a arquitetura de escolhas dos participantes. As escolhas são as mesmas que os participantes tinham antes. Podem optar por ficar dentro do plano (opt in) ou por sair do plano (opt out). No entanto, a opção default é alterada para a inscrição no plano, sendo necessário ao servidor solicitar sua retirada caso não o queira.

Tal mudança legislativa segue as premissas do nudge, uma vez que os participantes têm suas escolhas asseguradas e garantidas. Apenas a opção default foi alterada, de modo a exigir que o participante precise escolher sair do plano. Se muitos participantes não entravam no plano simplesmente pela dificuldade em fazer cálculos relativos à sua aposentadoria, a mesma dificuldade vale para a opção de se retirar do plano, o que gera uma maior adesão. Assim, o formulador da referida política incentiva os usuários dos planos de aposentadoria a decidirem pela opção que entende ser a mais acertada, o que deve lhes permitir acumular riqueza para uma aposentadoria com mais recursos e suavizando seu consumo ao longo do ciclo de vida.

\section{Arquitetura da decisão}

Com base no entendimento de que as pessoas não são completamente racionais o tempo todo, de que tanto o regulador quanto o regulado possuem racionalidade limitada, e de que há ferramentas capazes de induzir os indivíduos a atitudes cujos resultados sejam mais benéficos à sociedade, sem constrangê-los coercitivamente, resta entender como os formuladores de políticas públicas podem intervir na arquitetura da

34 Em 2010, o governo britânico criou o "Behavioural Insights Team” (UKBIT), primeira instituição governamental dedicada ao estudo e aplicação de ciências comportamentais à atuação governamental, fornecendo consultoria aos formuladores de política pública. Atuando em intensa parceria com acadêmicos renomados, o UKBIT trabalha no redesenho dos serviços públicos a partir de experimentos empíricos na população local, favorecendo melhores escolhas na população e apoiando o movimento de desregulamentação e reregulamentação inteligente. O trabalho do UKBIT já apresenta resultados positivos em áreas como saúde pública, política do consumidor, evasão fiscal e consume de energia.

Em 2011, introduziu o "Red Tape Challenge" como uma ampla estratégia governamental para reduzir o estoque de regulação, com o sistema de gestão regulatória “One-in, Two-out", desde 2013, e exigência de que todos os reguladores deem a devida consideração do impacto de suas ações para o crescimento econômico. Além disso, sob iniciativas de Better Regulation, diversos órgãos foram criados e destinados à supervisão regulatória.

35 Franco et. al. avaliam como o nudge empregado em uma regulação pode levar os empresários a respeitarem as normas laborais e constitucionais; FRANCO, Claudia Regina Lovato; TABAK, B. M.; BIJOS, Leila. A Lei no 14.946/2013 (Lei Bezerra): um nudge para incentivar empresários do setor de confecção da indústria paulista a cumprirem as leis trabalhistas. Revista Brasileira de Direito, São Paulo, v. 16, n. 7, p. 346-362, jan./abr. 2017; Ver também Rios e Tabak sobre aplicação de nudges em políticas de reciclagem de resíduos sólidos; RIOS, Rafael S.; RIOS, Rafael S.; TABAK, B. M. Pequenos incentivos importam: promovendo coleta seletiva entre geradores de resíduos sólidos domiciliares. Economic Analysis of Law Review, v. 5, n.1, p. 118-137, 2014. 
decisão a ser tomada pelo cidadão para aprimorar a efetividade das políticas implementadas.

Arquitetos da decisão são aqueles agentes que têm a responsabilidade de organizar o contexto no qual as pessoas tomarão decisões. São arquitetos da decisão o médico ao indicar um tratamento a seu paciente; os pais, ao explicarem ao filho adolescente as opções de cursos de nível superior disponíveis; o dono de uma lanchonete, ao decidir a ordem de disposição dos alimentos; bem como o formulador de política previdenciária, ao apresentar as opções de planos de aposentadoria aos servidores públicos, para citar alguns exemplos. ${ }^{36}$

Uma das mais poderosas formas de influenciar a arquitetura da decisão é o desenho da opção default, que é modelada para todos os tipos de escolhas. O resultado da inércia pode ser espantoso ao se moldar a escolha com a opção de rejeitar/sair (opt-out) ou com a opção de aderir (opt-in). Além disso, como demonstrado por Kahneman e Tversky ${ }^{37}$, as pessoas têm maior aversão ao risco em caso de perdas do que em casos de ganhos, o que faz da opção default a referência à avaliação de perdas e ganhos. Assim, a necessidade de mudar a escolha padrão em busca de ganhos encontrará maior rejeição do que a decisão de permanecer na opção padrão com algum risco de perdas.

A opção default, quando inteligentemente desenhada, pode reduzir desperdícios desnecessários ou mesmo levar o ator a tomar a decisão tendo suas preferências conscientemente manifestadas. Essas vantagens podem ser facilmente visualizadas em simples arquiteturas de decisão no campo da informática, como na definição de que todas as impressoras de uma repartição pública estejam configuradas com a opção "impressão em frente e verso" por default, e na exigência de seleção das opções desejadas na instalação de um software, simplesmente deixando sem nenhuma marcação padrão campos obrigatórios.

Ao desenhar uma arquitetura de decisão, devem ser considerados alguns pontos decisivos, tais como mecanismos que diminuam o possível erro humano ${ }^{38}$, que deem feedback das ações aos agentes para que possam prevenir ou corrigir seus erros ${ }^{39}$, ou que o auxiliem a mapear as possibilidades ou categorizá-las numericamente, de forma que possam comparar características e valores. Os incentivos percebidos pelos agentes também são cruciais na modelagem decisória, inclusive nos casos em que os incentivos não estão constantemente reforçados na mente que deverá tomar a decisão ${ }^{4041}$.

O uso de nudges nas regras default pode afetar a arquitetura decisória de diversas maneiras, inclusive de forma ineficiente ou equivocada. Evidentemente, mesmo que as pessoas tenham a liberdade de escolha, outros fatores como opções default, avisos, lembretes, advertência sobre normas sociais e outras modelagens da arquitetura da decisão podem afetar, significativamente, o comportamento apresentado. Com efeito, se o contexto decisório for mal arquitetado, o nudge pode apresentar efeitos insignificantes, reação inversa ao esperado ou até ameaçar o alcance de outras metas pretendidas.

Com efeito, um nudge pode falhar por diversos motivos, dentre os quais a informação estar confusa ou difícil de processar; o nudge ter efeito somente no curto prazo; o arquiteto da decisão desconhecer as reais

36 THALER, Richard H.; SUNSTEIN, Cass R.; BALZ, John P. Choice Architecture. The bebavioral foundations of public policy. 2014. Disponível em SSRN: <https://ssrn.com/abstract=2536504>. Acesso em: 7 fev. 2018.

37 Kahneman e Tversky desenvolvem a teoria do prospecto e demonstram que os indivíduos são mais propensos ao risco em situações de perdas e mais avessos ao risco em situação que envolva ganhos. KAHNEMAN, D.; Tversky, A. Prospect theory: an analysis of decision under risk. Econometrica, v. 47, n. 2, p. 263-292, 1979.

38 São exemplos de ações para reduzir a ocorrência de erros humanos em ambientes de decisão desde um checklist dos procedimentos a serem cumpridos em um hospital para evitar erros que causem danos graves aos pacientes à redução de acidentes de trânsito em Londres pela inclusão de avisos de "olhe para a direita" ao pedestre em várias esquinas,

39 A luz que indica que o combustível do carro está na reserva é um exemplo de sinal de feedback para que o agente previna uma situação difícil.

40 THALER, Richard H.; SUNSTEIN, Cass R.; BALZ, John P. Choice Architecture. The behavioral foundations of public policy. 2014. Disponível em SSRN: <https://ssrn.com/abstract=2536504>. Acesso em: 7 fev. 2018.

41 No caso de consumo de energia, por exemplo, o consumidor estaria mais consciente dos custos de uso de seus aparelhos elétricos caso cada um apontasse o valor gasto conforme houvesse a utilização. Tal método seria mais efetivo do que o destaque a aumentos do valor da tarifa, embora a última alternativa também apresente impacto no uso da eletricidade. 
motivações dos agentes; ou devido a incentivos que produzem efeitos adversos ou comportamento compensatório. Além disso, podem falhar, também, quando existe forte preferência por uma opção diferente daquela que é padrão (default), o que pode ocorrer com base em normas, constrangimentos sociais ou em uma avaliação de maior impacto financeiro em seu bem-estar. Assim, a preferência distinta da opção proposta pelo nudge se torna a referência base de medição do potencial de perdas. ${ }^{42}$

Uma política pública pode atuar regulamentando um contranudge no sentido de proteger os consumidores de nudges aplicáveis por entidades privadas para maximizar seus próprios interesses a despeito do desejo da coletividade. Pode-se pensar no caso em que alguns bancos cobrem, automaticamente, taxas de seus clientes a menos que o cliente explicitamente faça a adesão a um programa específico do banco. Uma forma de combater esse contranudge pela política pública seria a proibição desse tipo de cobrança automática. Outro caso não raro de se ver no mercado e que poderia ser resolvido com a regulação da opção padrão seria a não permissão às companhias de celulares de cobrança de taxa de deslocamento automaticamente, e, assim, exigindo a expressa autorização prévia do consumidor.

A constatação de que um nudge falhou pode trazer importantes elementos de observação ao arquiteto da decisão. Quando um nudge se torna inefetivo, o arquiteto da decisão pode optar por: não fazer nada; alterá-lo para um nudge melhor; ou fortalecer os efeitos do nudge, por meio de um contranudge positivo, de incentivos diferentes, ou mesmo de uma ação mais coercitiva como uma proibição legal. Um novo desenho que o simplifique ou a criação de nudges específicos para perfis diferentes de indivíduos podem resolver o impasse encontrado, mas a falha pode demonstrar a necessidade de se projetar outros métodos para alteração do comportamento, tais como um contranudge, uma regulamentação coercitiva ou a proibição de se praticar a ação combatida. Aumentar o custo de mudança da escolha padrão, também, pode intensificar o empurrão dado ao indivíduo para tomar a decisão pretendida.

\section{Considerações finais}

A existência de inúmeros vieses cognitivos nos formuladores de política pública parece incontestável e suas consequências são evidenciadas em instrumentos normativos ineficientes e injustos. Com efeito, o primeiro passo para derrotar um inimigo é conhecê-lo, mas é indispensável o desenvolvimento de mecanismos sistemáticos e estruturais que visem ao aprimoramento da atividade regulatória.

Quadro 1 - Visão Geral de Vieses Regulatórios

\begin{tabular}{|l|l|l|}
\hline \multicolumn{1}{|c|}{ Viés } & \multicolumn{1}{|c|}{ Descrição } & \multicolumn{1}{|c|}{ Implicação para os reguladores } \\
\hline Viés da confirmação & $\begin{array}{l}\text { Abrir mão da informação verda- } \\
\text { deira que seja contrária a crenças } \\
\text { anteriores. }\end{array}$ & $\begin{array}{l}\text { Resistência a mudar o curso regu- } \\
\text { latório mesmo frente a evidências } \\
\text { contrárias }\end{array}$ \\
\hline Viés da ancoragem & $\begin{array}{l}\text { Decidir com base em uma im- } \\
\text { pressão externa que possa ser asso- } \\
\text { ciada ao caso em análise. }\end{array}$ & $\begin{array}{l}\text { Desenvolver políticas não adapta- } \\
\text { das à realidade local ou recheadas } \\
\text { de percepções preconcebidas. }\end{array}$ \\
\hline $\begin{array}{l}\text { Viés do enquadra- } \\
\text { mento }\end{array}$ & $\begin{array}{l}\text { Decidir de forma distinta com base } \\
\text { na maneira em que o problema é } \\
\text { apresentado. }\end{array}$ & $\begin{array}{l}\text { Partir de pressupostos equivocados } \\
\text { ou regulamentar apenas elementos } \\
\text { secundários ao problema. }\end{array}$ \\
\hline
\end{tabular}

42 SUNSTEIN, Cass R. Nudges that fail. Behavioural Public Policy, v. 1, n. 1, p. 4-25, 2017. 


\begin{tabular}{|l|l|l|}
\hline \multicolumn{1}{|c|}{ Viés } & \multicolumn{1}{|c|}{ Descrição } & \multicolumn{1}{|c|}{ Implicação para os reguladores } \\
\hline Desconto hiperbólico & $\begin{array}{l}\text { Abrir mão de benefícios futuros } \\
\text { muito altos comparados aos custos } \\
\text { correntes. }\end{array}$ & $\begin{array}{l}\text { Persegue políticas que maximizam } \\
\text { recompensas de curto prazo a de- } \\
\text { speito de metas de longo prazo. }\end{array}$ \\
\hline Viés da retrospectiva & $\begin{array}{l}\text { Superestimar a probabilidade ex } \\
\text { ante de um evento ocorrer dado } \\
\text { que ele já ocorreu. }\end{array}$ & $\begin{array}{l}\text { Tende a achar que práticas que tra- } \\
\text { zem algum dano violam uma norma } \\
\text { legal. }\end{array}$ \\
\hline Viés da ação & $\begin{array}{l}\text { Reagir de forma exagerada a um } \\
\text { estímulo. }\end{array}$ & $\begin{array}{l}\text { Regula em momentos cuja melhor } \\
\text { decisão seria nada fazer. }\end{array}$ \\
\hline $\begin{array}{l}\text { Ilusão de Foco / } \\
\text { Heurística da disponi- } \\
\text { bilidade }\end{array}$ & $\begin{array}{l}\text { Conceder peso indevido a eventos } \\
\text { recentes ou notórios. }\end{array}$ & $\begin{array}{l}\text { Comprometimento com uma } \\
\text { reação regulatória exagerada. }\end{array}$ \\
\hline Excesso de confiança & $\begin{array}{l}\text { Superestimar as habilidades pes- } \\
\text { soais para lidar com um determina- } \\
\text { do fenômeno. }\end{array}$ & $\begin{array}{l}\text { Acredita que os efeitos de sua ação } \\
\text { serão maiores e mais efetivos do } \\
\text { que realmente serão. }\end{array}$ \\
\hline Otimismo & $\begin{array}{l}\text { Superestimar a probabilidade de } \\
\text { um resultado positivo. }\end{array}$ & $\begin{array}{l}\text { Superestima o êxito de uma iniciati- } \\
\text { va regulatória }\end{array}$ \\
\hline Viés do status quo & $\begin{array}{l}\text { Permanecer, irracionalmente, no } \\
\text { estado atual. }\end{array}$ & $\begin{array}{l}\text { Causa inércia regulatória e trajetória } \\
\text { regulatória dependente. }\end{array}$ \\
\hline
\end{tabular}

Fonte: Adaptado de Cooper e Kovacic ${ }^{43}$.

A literatura aborda alguns métodos que podem ser empregados para combater vieses nas decisões de políticas públicas, dentre os quais: visualização (manter toda a informação visível e explicitar a incerteza), análise de hipóteses concorrentes, conferência de assunções-chave, tomada de decisão estruturada, red-teaming, "advogado do diabo", Time A / Time B, desenvolvimento de cenários, deliberação colegiada e conhecimento do funcionamento dos vieses, também, podem reduzir sua ocorrência ${ }^{44}$.

Choi e Pitchard ${ }^{45}$ explicam que os vieses de enquadramento podem ser reduzidos com a simples explicação do funcionamento desses efeitos ao tomador de decisão. Assim, entendem que mecanismos estruturais podem reduzir vieses comportamentais. A partir desse entendimento, propõem os seguintes antídotos aos vieses da Comissão de Seguros e Câmbio dos EUA (SEC): organização interna, revisão judicial e supervisão política. Além disso, incapazes de propor uma estrutura completamente diferente, os autores acreditam que a avaliação regulatória é a melhor forma disponível de correção de vieses dentro da estrutura existente atualmente nos órgãos regulamentadores ${ }^{46}$.

A Organização para Cooperação e Desenvolvimento Econômico (OCDE) defende o compartilhamento de informações e a coordenação governamental na concepção, análise, elaboração e execução das regulações. $\mathrm{Na}$ busca de uma melhor gestão regulatória, além do nudge, a instituição é entusiasta da Análise de Impacto Regulatório - ferramenta que auxilia os regulamentadores na identificação do problema a ser

43 COOPER, James C.; KOVACIC, William E. Behavioral Economics: Implications for Regulatory Behavior. Journal of Regulatory Economics, v. 41, n. 41-58, 2012.

44 KEBBELL, Mark R.; MULLER Damon; MARTIN, Kirsty. Understanding and managing bias. In: BAMMER, Gabriele (Ed.). Dealing with uncertainties in policing serious crimes. Canberra: ANU Press, 2010; BANURI, Sheheryar; DERCON, Stefan; GAURI, Varun. Biased policy professionals. Washington, D.C.: World Bank Group, 2017 Disponível em: <http://documents.worldbank.org/ curated/en/685691498482210671/Biased-policy-professionals>. Acesso em: 2 mar. 2018.

45 CHOI, Stephen J.; PRITCHARD, Adam C. Behavioral economics and the SEC. Michigan Law School. Law and Economic Working Paper, n. 03-002, 2003.

46 Sunstein defende que a análise de custo-benefício seja feita para toda regulamentação. SUNSTEIN, Cass R. Cognition and costbenefit analysis: cost-benefit analysis: legal, economic, and philosophical perspectives. Chicago: University of Chicago Press, 2001. 
enfrentado, dos objetivos, dos stakeholders, bem como dos prováveis benefícios, custos e efeitos das possíveis alternativas. Auxilia, também, o formulador na criação de políticas públicas mais efetivas ${ }^{47}$.

Em suma, o presente artigo analisou uma série de vieses que podem afetar a decisão racional de um agente econômico e como sua existência nos formuladores de políticas públicas pode impactar a regulamentação de forma a torná-la ineficiente, desnecessária ou até mesmo injusta, frente aos objetivos pretendidos. Ao se compreenderem a existência desses vieses e como eles ocorrem no processo cognitivo do ser humano, podem-se cogitar mecanismos de correção para sua eliminação ou para a mitigação de seus efeitos no processo decisório.

No entanto, a dificuldade de geração de processos decisórios que incorporem, naturalmente ou de forma estruturada, as ferramentas de correção de vieses, ainda, é um desafio a ser enfrentado. Para os formuladores de políticas públicas, a aplicação de estudos comportamentais sobre o público regulado para um desenho mais apropriado da arquitetura da decisão, utilizando nudges, bem como o aprimoramento da AIR e sua efetiva implementação, com participação cada vez maior do público-alvo da medida, mostram ser as formas mais efetivas de se lidar com os vieses cognitivos decisórios na elaboração das políticas públicas.

Com efeito, a compreensão pelo Estado dos fenômenos cognitivos que impactam a racionalidade dos seus agentes faz-se cada vez mais urgente e os benefícios estruturais de ações concretas para mitigação desses efeitos são indispensáveis à melhor atuação governamental. Não se pretende esgotar a vasta possibilidade de ações para aplicação dos fundamentos da economia comportamental sintetizados neste artigo, mas certamente passa pelo melhor desenho de processos chave da prática regulatória, como na definição dos critérios que uma lei ou regulamento precisam atender para serem aprovados, no estabelecimento das condições de discussão das ações públicas, definindo número e perfil das pessoas envolvidas, estabelecendo uma equipe revisora, com métodos objetivos de comprovação do uso das evidências científicas existentes e das alternativas possíveis, ou metodologia para evidenciar a eliminação de distorções nas políticas.

\section{REFERÊNCIAS}

AIMONE, Jason A.; BALL, Sheryl; KING-CASAS, Brooks. 'Nudging' risky decision-making: the causal influence of information order. Economics Letters, v. 149, p. 161-163, dez. 2016.

BANURI, Sheheryar; DERCON, Stefan; GAURI, Varun. Biased policy professionals. Washington, D.C.: World Bank Group, 2017. Disponível em: < http://documents.worldbank.org/curated/en/685691498482210671/ Biased-policy-professionals>. Acesso em: 2 mar. 2018.

BRASIL. Constituição (1988). Constituição da República Federativa do Brasil. Disponível em: < http://www.planalto.gov.br/ccivil_03/Constituicao/Constituicao.htm>. Acesso em: 2 mar. 2018

CHOI, Stephen J.; PRITCHARD, Adam C. Behavioral economics and the SEC. Michigan Law School. Law and Economic Working Paper, n. 03-002, 2003.

COOPER, James C.; KOVACIC, William E. Behavioral Economics: Implications for Regulatory Behavior. Journal of Regulatory Economics, v. 41, n. 41-58, 2012.

Deighton-Smith, R.; Erbacci, A.; Kauffmann, C. Promoting inclusive growth through better regulation: the role of regulatory impact assessment. Paris: OECD Publishing, 2016.

FRANCO, Claudia Regina Lovato; TABAK, B. M.; BIJOS, Leila. A Lei no 14.946/2013 (Lei Bezerra): um nudge para incentivar empresários do setor de confecção da indústria paulista a cumprirem as leis trabalhistas.

47 Deighton-Smith, R.; Erbacci, A.; Kauffmann, C. Promoting inclusive growth through better regulation: the role of regulatory impact assessment. Paris: OECD Publishing, 2016. 
Revista Brasileira de Direito, São Paulo, v. 16, n. 7, p. 346-362, jan./abr. 2017.

Frederick, S.; Loewenstein, G.; O’Donoghue, T. Time discounting and time preference: a critical review. Journal of Economic Literature, v. 40, p. 351-401, 2002

GALBIATI, Roberto; VERTOVA, Pietro. How laws affect behavior: obligations, incentives and cooperative behavior. International Review of Law and Economics, v. 38, p. 48-57, 2014.

Gilson, Ronald J.; Kraakman, Reinier. The mechanisms of market efficiency twenty years later: the hindsight bias. Columbia Law and Economics. Working Paper n. 240, Stanford Law and Economics Olin Working Paper n. 270; Harvard Law and Economics Discussion Paper, n. 446, out. 2003. Disponível em: <https://ssrn. com/abstract=462786 ou http://dx.doi.org/10.2139/ssrn.462786>. Acesso em: 19 jan. 2018.

HASTIE, Reid; SUNSTEIN, Cass. Wiser: getting beyond groupthink to make groups smarter. Boston, MA: Harvard Business Review Press, 2015.

JOLLS, Christine; SUNSTEIN, Cass R.; THALER, Richard. A behavioral approach to law and economics. Disponível em: <http://digitalcommons.law.yale.edu/fss_papers/1765>. Acesso em: 6 fev. 2018.

KAHAN, Dan M. Cognitive bias and the Constitution. [New Haven]: Yale Law School Faculty Scholarship, 2013. Disponível em: <http://digitalcommons.law.yale.edu/fss_papers/4693>. Acesso em: 3 dez. 2017.

KAHAN, Dan M. et al. Motivated numeracy and enlightened self-government. [New Haven]: Yale Law School, 2013.

KAHNEMAN, D.; Tversky, A. Prospect theory: an analysis of decision under risk. Econometrica, v. 47, n. 2 , p. 263-292, 1979.

KAHNEMAN, D.; Tversky, A. The framing of decisions and psychology of choice. Science, v. 21, n. 4481, p. 453-458, 1981.

KAHNEMAN, Daniel et al. Would you be happier if you were richer?: a focusing illusion. Science, v. 312, n. 5782, p. 1908-1910, 2006.

Kahneman, Daniel. Thinking, fast and Slow. New York: Farrar, Straus and Giroux, 2011.

KEBBELL, Mark R.; MULLER Damon; MARTIN, Kirsty. Understanding and managing bias. In: BAMMER, Gabriele (Ed.). Dealing with uncertainties in policing serious crimes. Canberra: ANU Press, 2010.

LUNN, Pete. Regulatory policy and behavioural economics. OECD Publishing, 2014. Disponível em: http:// dx.doi.org/10.1787/9789264207851-en. Acesso em: 2 mar. 2018.

LYNCH Jr, John G.; ZAUBERMAN, Gal. When do you want it?: time, decisions, and public policy. Journal of Public Policy \& Marketing, v. 25, n. 1, p. 67-78, 2006.

Manne, Geoffrey A.; Zywicki, Todd J. Uncertainty, evolution, and behavioral economic theory. Journal of Law, Economics and Policy, n. 14-04, mar. 2014. Disponível em: <https://ssrn.com/abstract=2406175>. Acesso em: 19 jan. 2018.

Polič, Marko. Decision making: between rationality and reality. Interdisciplinary Description of Complex Systems, v. 7, n. 2, p. 78-89, 2009.

RACHLINSKI, Jeffrey J.; FARINA, Cynthia R. Cognitive psychology and optimal government design. 2002. Disponível em: <http://scholarship.law.cornell.edu/facpub/755>. Acesso em: 19 jan. 2018.

RIOS, Rafael S.; TABAK, B. M. Pequenos incentivos importam: promovendo coleta seletiva entre geradores de resíduos sólidos domiciliares. Economic Analysis of Law Review, v. 5, n.1, p. 118-137, 2014.

SAMUELSON, W.; ZECHJAUSER, R. J. Status quo bias in decision making. Journal of Risk \& Uncertainty, n. 1, p. 7-59, 1988. Disponível em: <http://dx.doi.org/10.1007/BF00055564>. Acesso em: 19 jan. 2018. 
SHUGHART II, William F. Public choice: the concise encyclopedia of economics. Library of Economics and Liberty, out. 2017. Disponível em <http://www.econlib.org/library/Enc/PublicChoice.html>. Acesso em: 19 jan. 2018.

SILVAS NETO, Nathan da; TABAK, Benjamin Miranda. Políticas Públicas e Racionalidade Limitada: O controle das decisões políticas pelo Ministério Público. Revista de Direito Internacional Econômico e Tributário, Brasília, v. 12, n.1, p. 482-539, jan./jun. 2017.

SIQUEIRA, L.S.; RIBEIRO, D.C.; TABAK, B. M. A participação social nas políticas de segurança pública como instrumento de redução de vieses à luz da análise econômico comportamental do direito. Revista Culturas Jurídicas, v. 4, p. 389-420, 2017.

SUNSTEIN, Cass R. Cognition and cost-benefit analysis: cost-benefit analysis: legal, economic, and philosophical perspectives. Chicago: University of Chicago Press, 2001.

SUNSTEIN, Cass R. Empirically informed regulation. University of Chicago Law Review, n. 78, p. 1348-1429, 2011.

SUNSTEIN, Cass R. Nudges that fail. Behavioural Public Policy, v. 1, n. 1, p. 4-25, 2017.

TABAK, B. M. A. Análise econômica do direito: proposições legislativas e políticas públicas. Revista de Informação Legislativa, Brasília, ano 52, n. 205, p. 321-349, jan./mar. 2015.

TASIC, Slavisa. Are regulators rational? Journal des Economistes et des Etudes Humaines, v. 17, n. 1, 2011. Disponível em: <http://www.bepress.com/jeeh/vol17/iss1/art3>. Acesso em: 19 jan. 2018.

THALER, Richard H.; SUNSTEIN, Cass R. Libertarian paternalism. The American Economic Review, v. 93, n. 2, 175-179, 2003.

THALER, Richard H.; SUNSTEIN, Cass R. Nudge: improving decisions about health, wealth, and happiness. Yale: Yale University Press, 2008.

THALER, Richard H.; SUNSTEIN, Cass R.; BALZ, John P. Choice Architecture. The behavioral foundations of public policy, 2014. Disponível em: <https://ssrn.com/abstract=2536504>. Acesso em: 7 fev. 2018.

Tversky, A.; Kahneman, D. Judgment under uncertainty: heuristics and biases. Science, v. 185, n. 4157, p. 1124-1131, 1974. Disponível em: <http://dx.doi.org/10.1126/science.185.4157.1124>. Acesso em: 7 fev. 2018. 


\title{
A neurociência da moralidade na tomada de decisões jurídicas complexas e no desenho de políticas públicas*
}

\author{
The neuroscience of morality, hard cases \\ decision-making process and the public \\ policies design
}

Erik Navarro Wolkart**

\section{Resumo}

O presente artigo aborda o problema da utilização de princípios gerais de justiça como premissa para a tomada de decisões jurídicas complexas e para o desenho de políticas públicas, o que, frequentemente, provoca resultados que diminuem o bem-estar social geral. Propõe-se adoção da neurociência da moralidade (e o pragmatismo profundo, daí decalcado) como guia filosófico para esse desenho, sempre focado nas consequências das políticas públicas para o bem-estar social. As matrizes teóricas aqui utilizadas são a economia do bem-estar, a análise econômica do e o utilitarismo. A metodologia é a revisão de literatura a respeito do tema. Relatando diversos experimentos neurocientíficos, demonstraremos como nosso cérebro incide, sistematicamente, em erros de julgamento que fazem crer na utilização preponderante de princípios de justiça no desenho de políticas públicas, em detrimento do aumento do bem-estar social. Inicialmente, apresentaremos o novo campo filosófico conhecido como neurociência da moralidade. Posteriormente, descreveremos a forma dual de funcionamento do cérebro, demonstrando a origem de nossos instintos e sentimentos de justiça. Finalmente, revelaremos como o pragmatismo pode auxiliar o debate de questões difíceis para o desenho correto de políticas públicas, considerando a forma dual de funcionamento da mente, bem como os erros cognitivos a que estamos sujeitos, o que é inédito no direito brasileiro. Concluiremos que teorias que conferem caráter preponderante a princípios de justiça nada mais são do que racionalizações de julgamentos intuitivos e imprecisos de nosso cérebro, de modo que devem ceder espaço para premissas utilitaristas na tomada de decisões jurídicas complexas e no desenho de políticas públicas, essas sim, capazes de elevar o nível de bem-estar social.

Palavras-chave: Direito. Neurociência. Economia. Bem-estar Social.

* Recebido em 11/06/2018 Aprovado em 16/07/2018

** Juiz Federal, Doutor em Direito pela UERJ em colaboração com a Harvard Law School. Email: eriknavarrowolkart@gmail.com

\section{Abstract}

This paper deals with the use of the neuroscience of morality (and deep pragmatism, derived from it) as a philosophical guide for hard cases decision-making process and the public policies design. The theoretical matri- 
ces which will be used are the welfare economics, the economic analysis of law and the utilitarianism. By reporting on various neuroscientific experiments, we will demonstrate how our brain systematically makes mistakes that lead us to believe that the design of public policies needs to be based on principles of justice to the detriment of increasing social welfare. Initially, we will present the new philosophical field known as neuroscience of morality. Afterwards, we will describe the dual-process brain, demonstrating the origin of our instincts and feelings of justice. Finally, we will demonstrate how pragmatism can help to debate hard questions for the correctness of public policies designing, considering the dual process brain, and the bounded rationality. This framework is unprecedented in the Brazilian law. We conclude that theories based mainly on principles of justice derive from rationalizations of our intuitions and our cognitive biases so that they must give room to utilitarian premises in the design of public policies, which in turn must be focused exclusively in increasing social welfare.

Keywords: Law. Neuroscience. Economics. Social Welfare

\section{INTRODUÇÃo}

O presente artigo trata da utilização da neurociência da moralidade (e do pragmatismo profundo, daí decalcado) como guia filosófico na tomada de decisões jurídicas complexas e no desenho de políticas públicas que delas decorram. Acreditamos que, no Brasil, a confecção de políticas públicas, aí incluídas a elaboração e a interpretação da lei, baseia-se precipuamente em princípios absolutos de justiça, normalmente de matriz kantiana, conferindo-se pouca atenção para seu impacto no aumento do bem-estar social, o que é problemático.

A utilização da neurociência da moralidade como guia é uma tentativa de conferir maior cientificidade a essa atividade. É, ainda, uma busca pelo fortalecimento da matriz utilitarista na condução da coisa pública, na medida em que a neurociência revela as fraquezas do kantianismo enquanto fruto de nossas próprias limitações cognitivas.

Apresentaremos a Neurociência da Moralidade como campo científico e filosófico, focando principalmente na forma dual de funcionamento do cérebro. Posteriormente, utilizando diversos experimentos derivados do Dilema do bonde desgovernado, demonstraremos como nosso julgamento intuitivo é, às vezes, inconsistente e como ele se relaciona com nossos sentimentos de justiça. $\mathrm{Na}$ sequência, veremos que os imperativos categóricos kantianos são racionalizações de nossos instintos, que funcionam bem na maioria das vezes, mas que, em alguns casos, podem levar a julgamentos inconsistentes e dissociados da realidade. Por fim, com base no conhecimento das estruturas envolvidas nos dois modos de pensar do cérebro, estudaremos como é possível afastar os erros de julgamento na tomada de decisões importantes sobre questões difíceis. Concluiremos que, na tomada de decisões jurídicas complexas e no desenho de políticas públicas, a rapidez imprecisa do modo instintivo de pensar deve ceder a ponderações racionais de base científica, sempre calcadas no aumento do bem-estar social.

No nosso estudo, utilizamos, preponderantemente, as pesquisas de Joshua Greene. Greene é neurocientista e fundador do pragmatismo profundo, também conhecido como neurociência da moralidade. Sua obra é bastante técnica, mas de fácil compreensão. Suas pesquisas, todas muito recentes, mas bem-estabelecidas e utilizadas por um sem-número de cientistas, modernizaram o utilitarismo, atualizando-o e justificando-o pelas descobertas da neurociência. A vantagem da utilização desse tipo de pragmatismo é a sua capacidade de indicar caminhos para discussões de temas difíceis e polêmicos, como sói acontecer no desenho de políticas públicas. Essa abordagem, todavia, não traz formulas definitivas, mas tem a grande vantagem de evitar equívocos básicos do administrador e do jurista que, no afã de racionalizar seus instintos de justiça, acabam descuidando do verdadeiro objetivo do Estado Democrático de Direito, que é a promoção do bem-comum. 


\section{A Neurociência da Moralidade}

A neurociência da moralidade (ou pragmatismo profundo) pode ser considerada como uma atualização da filosofia utilitarista ${ }^{1}$, renovada e fortificada pelos fantásticos avanços científicos da neurociência e da psicologia. Trata-se da revisão de paradigmas filosóficos das teorias morais com base em insights neurocientíficos. Fundada por vários pesquisadores, ${ }^{2}$ essa nova fronteira tem por pressuposto uma das mais importantes descobertas da psicologia moderna, a Teoria do Sistema Dual de Pensamento (dualprocess brain) fundada por Seymor Epstein, Johnathan Evans ${ }^{3}$, Steven Sloman, Keith Stanovich e Richard West ${ }^{4}$, mas popularizada no best-seller de Daniel Kahneman "Thinking, fast and slow"

A hoje bem estabelecida Teoria das Duas Formas de Pensar (Dual Process Brain) pode ser assim resumida: por razões evolutivas, nosso cérebro desenvolveu-se com dois sistemas de funcionamento do pensamento que atuam de forma paralela e complementar: o sistema intuitivo, chamado de sistema 1, e o sistema reflexivo, denominado sistema 2. O sistema 1 é rápido, eficiente, automático, inconsciente e pouco preciso. Foi moldado para oferecer uma avaliação contínua dos problemas que um organismo deve resolver para sobreviver. Já o sistema 2 é reflexivo, meticuloso, detalhista e lento. Ele procura sempre a precisão, buscando o maior número de dados para fazer uma pergunta ou dar uma resposta. ${ }^{6}$ Cada um desses sistemas funciona com base em específicas estruturas cerebrais ${ }^{7}$, mas eles atuam de modo conjugado, de forma que mesmo o sistema reflexivo funciona influenciado por informações rapidamente oferecidas pelo sistema intuitivo.

Exemplos ajudam a demonstrar como esses sistemas funcionam. Todorov e colaboradores demonstraram como o sistema 1 avalia, rapidamente, a segurança da nossa interação com estranhos (por exemplo, alguém de uma tribo diferente da nossa) por meio dos olhos e da expressão facial ${ }^{8}$. De acordo com a pesquisa, ao divisarmos o rosto de alguém, nosso cérebro julga até que ponto aquela pessoa é ameaçadora (ou seja, dominante, o que se dá pelo formato quadrado do rosto) e confíavel (pelas expressões faciais, principalmente o sorriso $)^{9}$.

Todorov demonstra por ultrassonografia que esse tipo de julgamento intuitivo envolve a participação de regiões cerebrais específicas, o que sugere sua importância na nossa história evolutiva ${ }^{10}$. Todavia, como esses julgamentos são, algumas vezes, dissociados da realidade, acabam causando influências perniciosas eventuais

1 Que, aliás, está sempre em evolução. CALABRESI, Guido. The Future of Law and Economics. New Haven, CT: Yale University, 2016. p. 6

2 Como Joshua Greene, Jonathan Cohen, R. Brian Sommerville, John Darley e outros. (GREENE, Joshua D. et al. An fMRI Investigation of Emotional Engagement in Moral Judgment. Science, v. 293, n. 5.537, p. 2.105-2.108, set. 2001; NEERGAARD, L. Brain Scan Shows Emotion in Decisions. Washington Post, set. 2001; NEARY, Walter. Personal Decisions Exercise the Emotional Part of the Brain, 2001. Disponível em: <http://www.washington.edu/news/2001/11/26/personal-decisions-exercise-the-emotional-partof-the-brain>. Acesso em: 16 fev. 2018).

3 Apesar de Locke, Descartes, Freud e outros intuírem e até mesmo trabalharem com a contraposição raz̧ão e intuição, a primeira Teoria do Dual Process tem por figura central Johnatan Evans e seus trabalhos nas décadas de 1970 e 1980. Kahneman e Tversky aportaram importantes contribuições à forma intuitiva de pensar com seus estudos sobre heurísticas e vieses. Já as teorias mais influentes do sistema dual (que define que as duas formas de pensar são devidas a dois sistemas diferentes) são devidas a Sloman, Evans e Over, Stanovich, e Epstein nos anos 1990. Para um histórico completo do desenvolvimento do tema, ver: FRANKISH, Keith. Dual-Process and Dual-System Theories of Reasoning. Philosophy Compass, v. 5, n. 10, p. 914-926, 2010.

4 STANOVICH, Keith E.; WEST, Richard F. Individual Differences in Reasoning: Implications for the Rationality Debate? Behavioral and Brain Sciences, v. 23, n. 5, p. 645-726, out. 2000.

5 KAHNEMAN, Daniel. Thinking: fast and slow. New York: Farrar, Straus and Giroux, 2011. [Kindle]. location 249.

6 KAHNEMAN, Daniel. Thinking: fast and slow. New York: Farrar, Straus and Giroux, 2011. [Kindle], location 266.

7 FRANKISH, Keith. Dual-Process and Dual-System Theories of Reasoning. Philosophy Compass, v. 5, n. 10, p. 914-926, 2010.

8 TODOROV, Alexander; BARON, Sean G.; OOSTERHOF Nikolaas N. Evaluating Face Trustworthiness: A Model Based Approach. Social Cognitive and Affective Neuroscience, v. 3, n. 2, p. 119-127, jun. 2008.

9 Veja-se que esse é um julgamento extremamente impreciso. Quantas pessoas pouco confiáveis têm um sorriso estampado no rosto?

10 TODOROV, Alexander; PAKRASHI, Manish; OOSTERHOF Nikolaas N. Evaluating Faces on Trustworthiness after Minimal Time Exposure. Social Cognition, v. 27, n. 6, p. 813-833, 2009. 
em processos sociais importantes como nas eleições democráticas ${ }^{11}$.

Essa pesquisa aponta, ainda, para uma ancoragem entre o raciocínio reflexivo e o raciocinio intuitivo. $\mathrm{O}$ sistema reflexivo, quanto menos informado, mais ancora suas reflexões e deliberações no sistema intuitivo. Demonstrou-se, por exemplo, que, quanto menos educado e informado o eleitorado, maior a importância do sistema 1 no processo. Pesquisas posteriores apontaram que a influência da chamada competência facial do candidato — uma combinação entre as características faciais de dominância (por exemplo: queixo quadrado) e de confiança (por exemplo: sorriso) — é três vezes maior entre o eleitorado pobre que assiste televisão por muitas horas, quando comparada com a influência no eleitorado mais bem informado e abastado ${ }^{12}$.

Por ser veloz, o sistema 1 trabalha com preconcepções e memórias armazenadas por nossa história evolutiva, além de recordações de experiências da vida. Diante da necessidade de prover respostas, esse sistema apresenta respostas simples (heurísticas) e pré-concebidas (vieses), que podem ou não corresponder à realidade.

Já o sistema 2 trabalha sempre buscando dados e racionalizando. O problema é que, como vimos nas pesquisas de Todorov, o sistema 2 acaba racionalizando sobre os dados ofertados pelo sistema 1 (ancoragem). Ele supervisiona essas respostas prontas que o sistema 1 traz automaticamente (respostas default), ora endossando-as, ora alterando-as ou mesmo substituindo-as por outras mais rentes aos dados reais ${ }^{13}$. Isso pode ser extremamente eficiente em alguns casos, mas pode causar erros grotescos de avaliação em outros ${ }^{14}$.

Por exemplo, em uma pesquisa ${ }^{15}$ que se seguiu a um acidental derramamento de óleo com impactos em

11 TODOROV, Alexander et al. Inferences of Competence from Faces Predict Election Outcomes. Science, v. 308 , n. 5.728 , p. 1.623-1.626, 10 jun. 2005.

12 LENZ, Gabriel S.; LAWSON, Chappell. Looking the Part: Television Leads Less Informed Citizens to Vote Based on Candidates' Appearance. American Journal of Political Science, v. 55, n. 3, p. 574-589, jul. 2011. Os autores assim resumem sua descoberta: "Specifically, we test whether the effect of appearance is more pronounced among those who know little about politics but are exposed to visual images of candidates. To do so, we combine appearance-based assessments of U.S. Senate and gubernatorial candidates with individual-level survey data measuring vote intent, political knowledge, and television exposure. Confirming long-standing concerns about image and television, we find that appealing-looking politicians benefit disproportionately from television exposure, primarily among less knowledgeable individuals."

13 KAHNEMAN, Daniel; SHANE Frederick. Representativeness Revisited: Attribute Substitution in Intuitive Judgment. In: GILOVICH, Thomas; GRIFFIN, Dale; KAHNEMAN, Daniel (Eds.). Heuristics and Biases: The Psychology of Intuitive Judgment. Cambridge: Cambridge University, 2002. p. 49-81.

14 Frankish apresenta uma tabela bastante atual das diferenças entre a forma de pensar intuitiva (protagonizada pelo sistema 1) e a forma de pensar reflexiva (devida ao sistema 2). (FRANKISH, Keith. Dual-Process and Dual-System Theories of Reasoning. Philosophy Compass, v. 5, n. 10, p. 914-926, 2010. p. 924).

\begin{tabular}{lll}
\hline & System 1 & System 2 \\
\hline Processes & Fast & Slow \\
& Automatic & Controlled \\
& Nonconscious or preconscious & Conscious \\
& Low effort, high capacity & High effort, low capacity \\
& Heuristic & Analytic \\
& Associative & Rule-based \\
Attitudes & Implicit & Explicit \\
& Cultural stereotypes & Personal beliefs \\
& Slow acquisition and change & Fast acquisition and change \\
& Fast access & Slow access \\
Content & Actual & Hypothetical \\
& Concrete & Abstract \\
& Contextualised & Decontextualised \\
& Domain-specific & Domain-general \\
Architecture & A set of systems, modular & A single system \\
& Parallel & Serial \\
& Does not use working memory & Uses working memory \\
Evolution & Evolutionarily old & Evolutionarily recent \\
& Shared with animals & Unique to humans \\
& Nonverbal & Language involving \\
& Serves genetic goals ('short leash' control) & Serves individual goals ('long-leash' control) \\
Variation & Independent of general intelligence & Linked to general intelligence \\
& Little variation across cultures and individuals & Variable across cultures and individuals \\
& Relatively unresponsive to verbal instruction & Responsive to verbal instruction \\
\hline
\end{tabular}


aves nativas, perguntou-se quanto as pessoas estariam dispostas a doar para salvar, respectivamente, 2 mil, 20 mil, ou 200 mil pássaros. Os valores ficaram em 80, 78 e 88 dólares, respectivamente, e nem de longe correspondem ao número de pássaros a serem salvos. Verificou-se que o que realmente compeliu as pessoas a doarem valores maiores não foram os números (dados que seriam os mais relevantes para a definição do montante), mas a apresentação da imagem de uma ave desamparada, afogando-se com as penas encharcadas de óleo. Isso ocorre porque as memórias evolutivas impregnadas no sistema 1 ancoram e enviesam os julgamentos do sistema $2^{16}$. Mais à frente, ao estudarmos as possibilidades cooperativas na fase cognitiva do processo, abordaremos técnicas de ancoragem como o priming, capazes de elevar o comportamento cooperativo, evitando, por exemplo, a litigância de má-fé.

Joshua Greene é autor de uma analogia para explicar o sistema dual de pensamento. Ele utiliza a imagem de uma câmera fotográfica, que pode operar de modo manual ou automático. A forma automática é rápida e tira boas fotos na maior parte das vezes, mas é pouco flexível a variações de luz e profundidade, por exemplo. Nessas circunstâncias, ela pode falhar. Já o modo manual é lento, exige conhecimento e esforço na operação. Todavia, quando utilizado, produz fotografias incríveis, mesmo em condições adversas ${ }^{17}$. $\mathrm{O}$ grande segredo de um bom fotógrafo é saber escolher o modo de operação correto para cada situação.

Morfologicamente, sabe-se que o sistema 1 funciona, preponderantemente, na região do córtex pré-frontal ventromedial (VMPFC), enquanto o sistema 2 é orquestrado pelo córtex pré-frontal dorso lateral (DLPFC). Como explica Greene, o córtex pré-frontal dorso lateral não é o responsável solitário pelo raciocínio reflexivo. Em verdade ele opera como um maestro, recebendo imputs de diversas regiões do cérebro, inclusive do córtex pré-frontal ventromedial ${ }^{18}$.

Pacientes com lesões no VMPFC apresentam problemas importantes para o processo tomada de decisão. Sobre o tema, são famosos os experimentos de Antônio Damasio, elaborados com base no trágico caso de seu paciente Phineas Gage. Recuperadas suas habilidades cognitivas após uma explosão que destruiu a região acima do nariz (atacando o VMPFC, mas preservando o sistema 2, o DLPFC), Gage tornou-se um péssimo tomador de decisões, em razão de déficit emocional, ainda que fosse capaz de realizar operações matemáticas. Diversos experimentos apontam que a preservação de habilidades cognitivas com déficit emocional (to know but not to feel) ${ }^{19}$ implica, por exemplo, que apenas os efeitos imediatos das decisões passem a ser considerados ${ }^{20}$ pelo indivíduo, advindo daí trágicas consequências ${ }^{21}$, inclusive para possibilidades cooperativas estáveis ${ }^{22}$. Essa dependência do sistema 2 ao sistema 1 relembra o adágio de David Hume, que afirmava

DESVOUSGES, William H. et al. Measuring Nonuse Damages Using Contingent Valuation: An Experimental Evaluation of Accuracy. 2. ed. Research Triangle Park, NC: RTI, 2010. Disponível em: < https://www.rti.org/sites/default/files/resources/bk-0001-1009_ web.pdf>. Acesso em: 16 fev. 2018.

16 KAHNEMAN, Daniel. Thinking: fast and slow. New York: Farrar, Straus and Giroux, 2011. [Kindle], location 2.080.

17 GREENE, Joshua D. Moral Tribes: Emotion, Reason and the Gap Between Us and Them. New York: Penguin Books, 2013. p. 137.

18 GREENE, Joshua D. Moral Tribes: Emotion, Reason and the Gap Between Us and Them. New York: Penguin Books, 2013. p. 122-123.

19 DAMASIO, Antônio. Descartes' Error: Emotion, Rationality and the Human Brain. New York: Penguim; Grosset, 1994. [Kindle]. p. 45.

20 BECHARA, Antonie et al. Insensitivity to Future Consequences Following Damage to Human Prefrontal Cortex. Cognition, v. 50 , p. $7-15,1994$.

21 Por exemplo, impossibilidade de manter um emprego, ou uma família. Há, em verdade, completa perda do senso de responsabilidade, e uma quase total impossibilidade de fazer escolhas óbvias na vida real, ainda que, em teoria, o paciente compreenda tudo e faça escolhas corretas. O que se dá é uma incapacidade de aprender com os erros. O VMPFC retém experiências ruins em forma de emoções e transfere essa informação ao DLPFC, que aprende e corrige a postura. (DAMASIO, Antônio. Descartes' Error: Emotion, Rationality and the Human Brain. New York: Penguim; Grosset, 1994. [Kindle]. p. 34-35 e 49; GREENE, Joshua D. Moral Tribes: Emotion, Reason and the Gap Between Us and Them. New York: Penguin Books, 2013. p. 142).

22 Há evidências de um egoísmo exacerbado, que não leva em conta possibilidades cooperativas futuras. (THOMAS, Bradley C. et al. Arrested Development: Early Prefrontal Lesions Impair the Maturation of Moral Judgement. Brain: A Journal of Neurology, v. 137 , n. 4, p. 1.254-1.261, abr. 2014). 
que a razão é a escrava das paixões ${ }^{23}$.

Por outro lado, pacientes com lesões severas no DLPFC (o oposto do ocorrido com Gage) perdem, completamente, a capacidade cognitiva, o grande diferencial humano ${ }^{24}$.

O que o funcionamento do cérebro de duas formas diferentes tem a ver com a filosofia da moralidade? Segundo Greene e colegas, tudo ${ }^{25}$. Se a engrenagem mental formada por dois sistemas foi a forma escolhida pela natureza para nos tornar a espécie dominante do planeta, cabe-nos utilizá-la da melhor forma, desenvolvendo uma espécie de habilidade capaz de dizer qual o melhor sistema a preponderar para cada tipo de situação ${ }^{26}$.

Nossa preocupação não são os casos em que decisões muito rápidas ou ligadas à sobrevivência são tomadas, mas sim aqueles que envolvem temas complexos da modernidade, aí incluída a escolla de politicas públicas. É principalmente nesses casos que escolhas feitas com base preponderante nos instintos podem ser extremamente traiçoeiras.

\section{Explicando as traições do sistema 1: a troleologia de Joshua Greene}

Ao longo dos últimos vinte anos, Joshua Greene e outros cientistas ${ }^{27}$ vêm utilizando variações do famoso dilema do bonde desgovernado (trolley problem) para, com o auxílio da ressonância magnética e de outras tecnologias, demonstrar as falhas de julgamento do sistema 1, colocando em xeque determinados princípios absolutos de justiça, e abrindo espaço para o avanço de parâmetros utilitaristas na confecção de políticas públicas ${ }^{28}$.

Tal como o dilema do prisioneiro, o problema do bonde tem sido usado por décadas para discutir importantíssimas questões éticas envolvendo o comportamento humano ${ }^{29}$.

Em uma das versões concebidas por Thompson, o dilema propõe o seguinte:

Um bonde desgovernado está prestes a atropelar e matar cinco pessoas (digamos, operários que trabalham nos seus trilhos ${ }^{30}$ ).

23 HUME, David. A Treatise of Human Nature. Oxford: Clarendon, 1896. [Kindle]. p. 274: "Reason is, outht only to be the slave of the passions, and can never pretend to any other office than to serve and obey them." A relação entre Hume e o dual process mode é de Greene (GREENE, Joshua D. Moral Tribes: Emotion, Reason and the Gap Between Us and Them. New York: Penguin Books, 2013. p. 122).

24 O sistema 2 só existe em serem humanos. (FRANKISH, Keith. Dual-Process and Dual-System Theories of Reasoning. Philosophy Compass, v. 5, n. 10, p. 914-926, 2010. p. 922).

25 GREENE, Joshua D. Moral Tribes: Emotion, Reason and the Gap Between Us and Them. New York: Penguin Books, 2013. p. $141-143$.

26 Para ser um bom motorista, por exemplo, primeiro é preciso apreender a dirigir, usando preponderantemente o sistema 2. Após, boa parte das tarefas da direção torna-se automática, operando-se a partir do sistema 1 (não todas, até porque decisões complexas são tomadas a todo instante quando dirigimos. Muitas delas, todavia, podem ser tomadas com rapidez, porque estão ancoradas em experiências já vividas e armazenadas no sistema 1. (GREENE, Joshua D. Moral Tribes: Emotion, Reason and the Gap Between Us and Them. New York: Penguin Books, 2013. p. 143).

27 BARON, J.; GREENE, J. D. Determinants of Insensitivity to Quantity in Valuation of Public Goods: Contribution, Warm Glow, Budget Constraints, Availability, and Prominence. Journal of Experimental Psychology, v. 2, n. 2, p. 107-125, 1996; GREENE, Joshua D. et al. An fMRI Investigation of Emotional Engagement in Moral Judgment. Science, v. 293, n. 5.537, p. 2.105-2.108, set. 2001.

28 Trata-se, no nosso entender, de uma revisitação do embate farness versus welfare, muito bem desenvolvido por Shavell e Kaplow, em KAPLOW, Louis; SHAVELL, Steven. Fairness Versus Welfare. Harvard Law Review, v. 114, n. 4, p. 961-1.390, fev. 2001.

29 O responsável pela montagem do modelo original foi Philippa Foot, em 1967 (FOOT, Philippa. The Problem of Abortion and the Doctrine of the Double Effect. Oxford Review, n. 5, p. 5-15, 1967). Nove anos depois, Thompson rediscutiu as ideias de Foot e criou importantes variações para o modelo. Recentemente, o tema foi revisitado por SANDEL, Michael. Justice: What's the Right Thing to Do? New York: Farrar, Straus and Giroux, 2008, p. 18. O tema atualmente vem ganhando enorme importância, principalmente em razão dos chamados "carros autônomos", cuja programação certamente enfrentará dilemas parecidos com o do bonde desgovernado. Nesse sentido: HUANG, Bert I. Book Review: Law and Moral Dilemmas. Harvard Law Review, v. 130, p. 659-699, dez. 2016, p. 661.

30 Comentário nosso 
Um homem muito gordo (suponhamos, um funcionário da ferrovia ${ }^{31}$ ) está em pé, sobre uma ponte, entre o bonde e os operários. Uma outra pessoa na mesma ponte percebe que, se empurrar o homem gordo, seu volume será capaz, de parar o bonde, matando-o, mas salvando as cinco pessoas. O dilema consiste em empurrar ou não o funcionário ${ }^{32}$.

Figura $1 \square$ Versão de Thompson do dilema do bonde desgovernado (footbridge case) ) $^{33}$

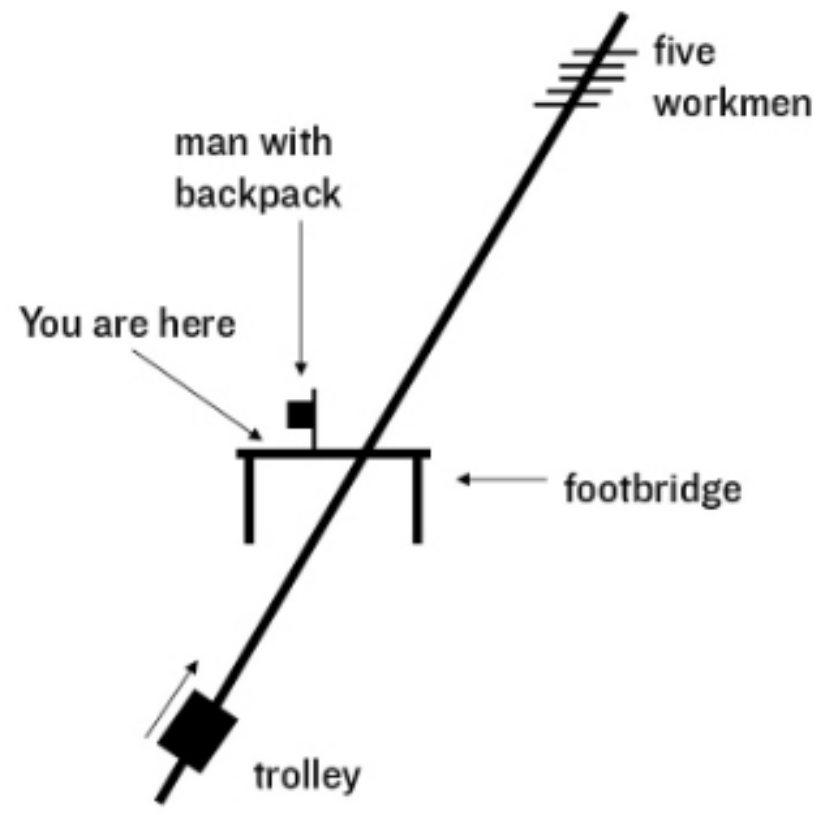

O dilema do bonde é, em verdade, um modelo simples, ${ }^{34}$ que contrapõe a busca de um bem maior com os direitos individuais fundamentais de alguém. Trata-se de uma espécie de contraposição artificial entre Kant e Mill ${ }^{35}$.

Grande parte dos textos que abordam o dilema concluem, kantianamente, que empurrar o funcionário da companhia seria errado ${ }^{36}$. Independentemente das consequências, empurrar o funcionário seria fundamentalmente errado, pois violaria o princípio categórico kantiano segundo o qual o ser humano jamais pode ser tratado como um meio, devendo, sempre, ser considerado como o fim de todas as coisas ${ }^{37}$.

31 Comentário nosso.

32 Adaptação do original: "George is on a footbridge over the trolley tracks. He knows trolleys, and can see that the one approaching the bridge is out of control. On the track back of the bridge there are five people; the banks are so steep that they will not be able to get off the track in time. George knows that the only way to stop an out-of-control trolley is to drop a very beavy weight into its path. But the only available, sufficiently beavy weight, is a fat man, also watching the trolley from the footbridge. George can shove the fat man onto the track in the path of the trolley, killing the fat man; or he can refrain from doing this, letting the five die." (THOMSON, Judith. Killing, Letting Die, and the Trolley Problem. Monist: Journal of General Philosophical Inquiry, v. 59, n. 2, p. 204-217, 1976).

33 GREENE, Joshua D. Moral Tribes: Emotion, Reason and the Gap Between Us and Them. New York: Penguin Books, 2013. p. 114.

34 A utilidade de modelos desse tipo está não em propor qual escolha deveria ser feita na vida real — onde certamente as incertezas e as variáveis dariam pesos muito diferentes para as possibilidades em jogo —, mas sim em isolar os problemas morais envolvidos e permitir um estudo mais preciso a respeito. (SANDEL, Michael. Justice: What's the Right Thing to Do? New York: Farrar, Straus and Giroux, 2008. p. 22).

35 GREENE, Joshua D. Moral Tribes: Emotion, Reason and the Gap Between Us and Them. New York: Penguin Books, 2013, p. 116.

36 No dilema original de Foot, discutia-se, apenas, se o motorista do bonde deveria mudá-lo de direção, para matar uma pessoa ao invés de cinco. A autora conclui que não. Já Thompson, ao rever o dilema e propor suas variantes, traz resposta positiva para a questão (no dilema original), trazendo em seguida a complexidade do footbridge case. Curiosamente, em participação na obra recentíssima de F. M. Kamm, Judith Thomsom traz novos comentários sobre o tema, revendo sua posição e aderindo à posição inicial de Foot. Assim, para ela, hoje, não haveria dilema algum, e tanto a mudança de rota do bonde quanto o empurrão do funcionário da ponte seriam sempre errados. (THOMSON, Judith. Kamm on the Trolley Problems. In: KAMM, F. M. The Trolley Problem Mysteries. Oxford: Oxford University, 2016, p. 113-133. [Kindle]. p. 113).

37 GREENE, Joshua D. Moral Tribes: Emotion, Reason and the Gap Between Us and Them. New York: Penguin Books, 2013. p. 115; KANT, Immanuel. Fundamental Principles of the Metaphysics of Morals. Tradução Thomas Kingsmill Abbott. [Kindle: The ultimate 
Grande parte das críticas ao utilitarismo funda-se na suposta desvalorização dos direitos fundamentais, ao permitir sua violação eventual com fundamento nas consequências finais do ato. O que Greene e outros procuram provar é, de um lado, a inconsistência da máxima kantiana quando aplicada a variações do mesmo dilema e, a partir daí, que o utilitarismo não merece a crítica kantiana ${ }^{38}$.

Uma das primeiras variações do dilema (chamada de switch dilema), utilizada por Thomson ${ }^{39}$ e outros, é a seguinte:

Um bonde desgovernado está prestes a atropelar e matar cinco operários que trabalham nos seus trilhos. Uma pessoa encontra-se em pé, ao lado do trilho. Ao alcance de suas mãos está uma alavanca capaz de mudar a direção do bonde para um outro trilho onde trabalha apenas um funcionário da companbia. Deve a pessoa acionar a alavanca para mudar a direção do bonde, evitando a morte dos cinco trabalhadores e permitindo a morte do funcionário?

$\mathrm{Na}$ figura 6, temos a representação gráfica dessa versão.

Figura 2 - Switch dilemma ${ }^{40}$

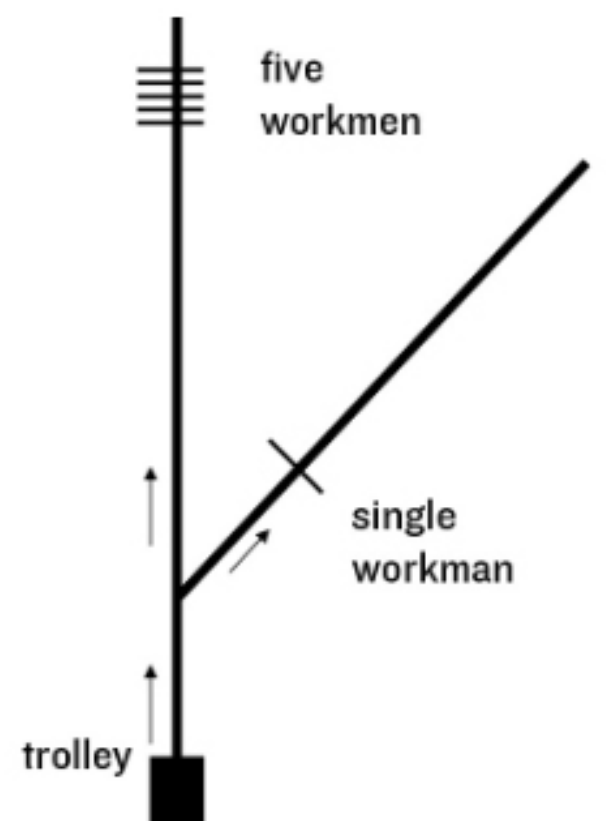

Nessa segunda versão, seria moralmente aceitável que se acionasse a alavanca? Thomson, que originalmente criou esse novo enredo, respondia afirmativamente ${ }^{41}$, bem como a maioria das pessoas, como veremos.

collected works of 14 books]. location 12.728 .

38 É interessante referir recentíssima pesquisa a respeito das questões morais envolvendo o dilema em países orientais. É surpreendente que, quando aplicado a budistas no Tibete (cidade de Lhasa), a aprovação moral do footbridge case chega a impressionantes 83\%, contra apenas 19\% em Guangzhou, na China. (XIANG, Xin. Would the Buddha Push the Man Off the Footbridge? Systematic Variations in the Moral Judgment and Punishment Tendencies of Han Chinese, Tibetans and Americans. 2014. Monografia (Trabalho de Conclusão de Curso). Harvard University, Cambridge, MA, 201 XIANG, Xin. Would the Buddha Push the Man Off the Footbridge?: Systematic Variations in the Moral Judgment and Punishment Tendencies of Han Chinese, Tibetans and Americans. 2014. f. Monografia--(Trabalho de Conclusão de Curso). Harvard University, Cambridge, MA, 2014).

39 Adaptação do original: "Frank is a passenger on a trolley whose driver has just shouted that the trolley's brakes have failed, and who then died from the shock. On the track abead are five people; the banks are so steep that they will not be able to get off the track in time. The track has a spur leading off to the right, and Frank can turn the train onto it. Unfortunately there is one person on the right-hand track. Frank can turn the train, killing the one; or he can refrain from turning the train, letting the five die." (THOMSON, Judith. Killing, Letting Die, and the Trolley Problem. Monist. Journal of General Philosophical Inquiry, v. 59, n. 2, p. 204-217, 1976, p. 207).

40 GREENE, Joshua D. Moral Tribes: Emotion, Reason and the Gap Between Us and Them. New York: Penguin Books, 2013. p. 115.

41 Como dissemos acima, em obra recentíssima, Thomson mudou de ideia. (THOMSON, Judith. Kamm on the Trolley Problems. In: KAMM, F. M. The Trolley Problem Mysteries. Oxford: Oxford University, 2016, p. 113-133. [Kindle]. p. 113). 
O que se pode ver, claramente, a partir dessas duas versões, quando nós mesmos respondemos à questão, é o fato de que nosso cérebro gera intuições diferentes para casos similares. A ação na versão original parece claramente errada, o que não acontece no segundo caso ${ }^{42}$.

A resposta a esse aparente conflito intuitivo sobre o que venha a ser moralmente correto pode ser extraída do acima referido dual-process system, aliado ao que Cohen denominou controle cognitivo, que é a babilidade de coordenar pensamento e ação de acordo com nossos objetivos ${ }^{43}$.

Um experimento clássico exemplifica bem as dificuldades do controle cognitivo: a tarefa de identificar a cor com que uma determinada palavra aparece projetada em uma tela (color-naming Stroop task). Indivíduos não têm qualquer dificuldade de acertar a tonalidade, salvo quando a palavra projetada refere o nome de outra cor. Por exemplo: se projetarmos a palavra vermelho em vermelho, pessoas sem limitações visuais cumprirão com facilidade a tarefa. Todavia, quando projetamos a palavra vermelho escrita em verde, boa parte das pessoas pronuncia vermelho, quando o correto seria pronunciar verde $e^{44}$.

Isso ocorre porque a leitura é uma atividade mais automatizada do que a identificação de $\operatorname{cores}^{45}$. Com um pouco de tempo, todavia, as pessoas saem-se bem na tarefa, nomeando a cor corretamente. Neurologicamente, o que se dá aqui é um conflito interno, com parte dos neurônios empenhada na leitura e parte empenhada na identificação da cor. O papel do controle cognitivo é exatamente orquestrar essas duas atividades e conferir respostas corretas. Essa função cabe a circuitos neurais localizados no sistema 2 (dorso lateral, ou DLPFC), nosso sistema reflexivo, lento e preciso ${ }^{46}$.

Após Cohen, Greene comprova que o dilema do bonde atua de forma semelhante ao experimento acima, provocando respostas conflitantes em nossa mente ${ }^{47}$. Estudos que monitoram o cérebro de indivíduos respondendo à pergunta do dilema do bonde nas duas versões demonstram que a primeira provoca uma atividade maior no sistema 1 (ventro medial, ou VMPFC) e na amígdala (estrutura responsável pela atenção e vigilância a perigos).

Ou seja, por algum motivo, no switch case, a atividade no sistema 1 é menos intensa do que no footbridge case, de modo que, agora, o sistema 2, responsável pelo controle cognitivo, é capaz de conter o impulso instintivo do sistema 1, fazendo prevalecer uma regra utilitária de julgamento capaz de salvar um número maior de vidas ${ }^{48}$. Essa seria a razão pela qual um grande número de pessoas aprova a conduta do agente no switch case $(87 \%)^{49}$, o que não ocorre no footbridge case (apenas $31 \%$ dos participantes, em média, aprovam o empurrão) ${ }^{50}$.

42 GREENE, Joshua D. Moral Tribes: Emotion, Reason and the Gap Between Us and Them. New York: Penguin Books, 2013, p. 117. Mesmo para quem julga a segunda conduta como moralmente errada, muito provavelmente ela parecerá menos errada do que a primeira.

43 COHEN, Jonathan D.; MILLER, Earl K. An Integrative Theory of Prefrontal Cortex Function. Annual Review of Neuroscience, v. 24, p. 167-202, 2001. "The prefrontal cortex has long been suspected to play an important role in cognitive control, in the ability to orchestrate thought and action in accordance with internal goals. Its neural basis, however, has remained a mystery. Here, we propose that cognitive control stems from the active maintenance of patterns of activity in the prefrontal cortex that represent goals and the means to achieve them. They provide bias signals to other brain structures whose net effect is to guide the flow of activity along neural pathways that establish the proper mappings between inputs, internal states, and outputs needed to perform a given task." (p. 167).

44 COHEN, Jonathan D.; MILLER, Earl K. An Integrative Theory of Prefrontal Cortex Function. Annual Review of Neuroscience, v. 24, p. 167-202, 2001. p. 170.

45 COHEN, Jonathan D.; MILLER, Earl K. An Integrative Theory of Prefrontal Cortex Function. Annual Review of Neuroscience, v. 24, p. 167-202, 2001. p. 170.

46 GREENE, Joshua D. Moral Tribes: Emotion, Reason and the Gap Between Us and Them. New York: Penguin Books, 2013. p. 120.

47 GREENE, Joshua D. Moral Tribes: Emotion, Reason and the Gap Between Us and Them. New York: Penguin Books, 2013. p. 121.

48 GREENE, Joshua D. Moral Tribes: Emotion, Reason and the Gap Between Us and Them. New York: Penguin Books, 2013. p. 121.

49 GREENE, Joshua D. Moral Tribes: Emotion, Reason and the Gap Between Us and Them. New York: Penguin Books, 2013. p. 220.

50 GREENE, Joshua D. Moral Tribes: Emotion, Reason and the Gap Between Us and Them. New York: Penguin Books, 2013. p. 215. 
Múltiplos experimentos com diversas versões desses e de outros dilemas demonstram que dilemas "pessoais" como o footbridge case provocam maior atividade na amigdala e no VMPFC, enquanto que dilemas "menos pessoais", como o switch case, ativam essas estruturas com intensidade inferior.

A figura abaixo corresponde à identificação das três estruturas cerebrais envolvidas nos julgamentos morais, compondo o sistema 1 (amigdala e VMPFC) e o sistema 2 (DLPFC):

Figura 3 - Estruturas cerebrais envolvidas nos julgamentos morais ${ }^{51}$

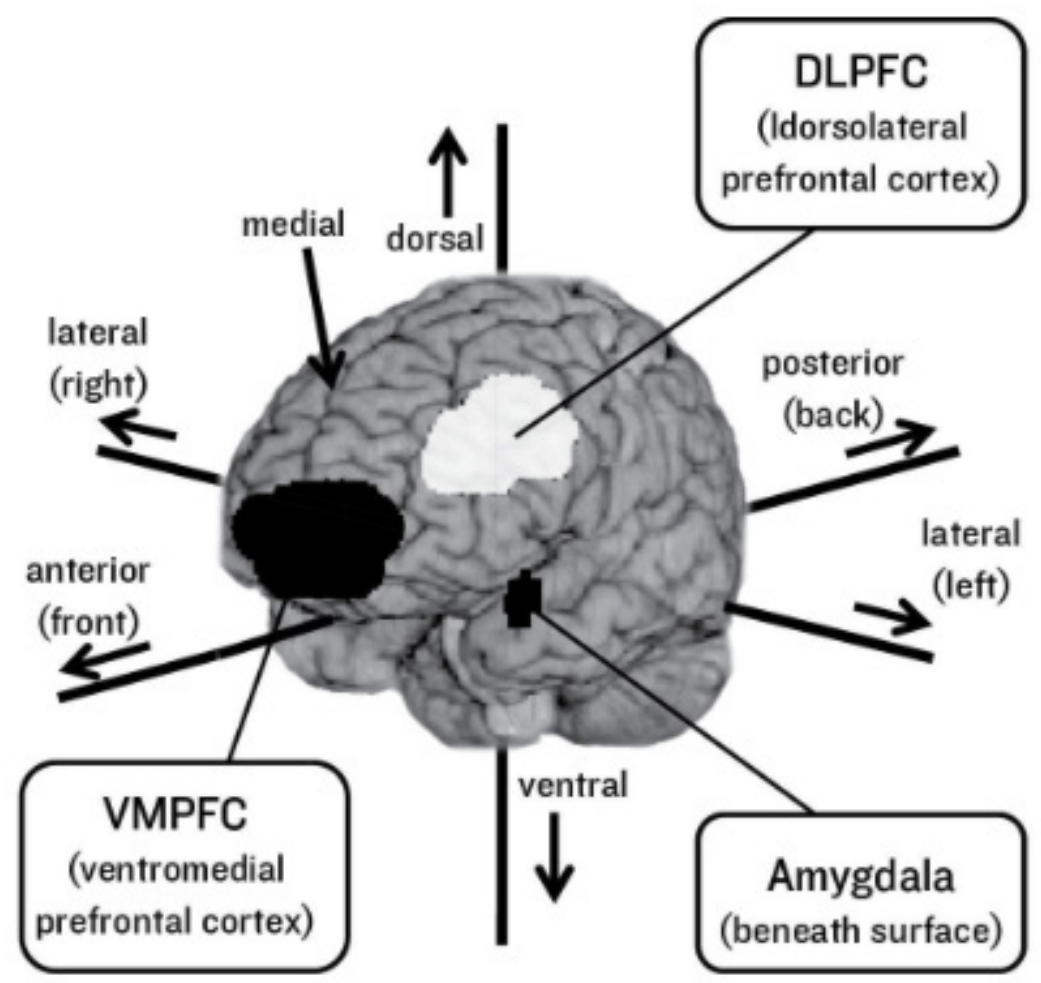

Interessante estudo aplicou o dilema em sua versão original (footbridge case) a pacientes com demência frontotemporal, ou seja, com deficiência específica no sistema 1, semelhante àquela que acometia Phineas Gage ${ }^{52}$, por nós já estudada. Enquanto no grupo de controle apenas 20\% das pessoas aprovaram a ação de empurrar o funcionário da ponte, a aprovação entre os pacientes com deficiência frontotemporal foi de $80 \%{ }^{53}$.

De outro lado, pesquisas foram desenhadas para medir o resultado das respostas aos dilemas quando o sistema 2 é desativado ou amortecido. Para tanto, utilizaram-se duas técnicas: a primeira consistiu em realizar o teste dos dilemas enquanto o sistema 2 é ocupado com atividades cognitivas demandantes ${ }^{54}$ (como realizar

51 GREENE, Joshua D. Moral Tribes: Emotion, Reason and the Gap Between Us and Them. New York: Penguin Books, 2013. p. 123.

52 MENDEZ, Mário F.; ANDERSON, E.; SHAPIRA, J. S. An Investigation of Moral Judgement in Frontotemporal Dementia. Cognitive Behavioral Neurology, v. 18, n. 4, p. 193-197, dez. 2005.

53 A importância desse estudo foi a de dar um passo adiante do inicialmente oferecido pelas imagens de ultrassonografia. Enquanto o ultrassom mostrava evidente correlação entre julgamentos morais e o dual-process mode, o experimento de Mendez e colegas, ao expor paciente com sistema 1 defeituoso, evidenciou causalidade entre a resposta repulsiva aos dilemas pessoais e as estruturas do sistema 1. Pesquisas mais recentes confirmaram o mesmo padrão de resultado, mesmo quando os pacientes são levados a escolher entre salvar membros da própria família em número menor em prol de estranhos em número maior. (THOMAS, Bradley C.; CROFT, Katie E.; TRANEL, Daniel. Harming Kin to Save Strangers: Further Evidence for Abnormally Utilitarian Moral Judgments after Ventromedial Prefrontal Damage. Journal of Cognitive Neuroscience, v. 23, n. 9, p. 2.186-2.196, set. 2011). Ainda sobre o tema, com resultados semelhantes: MORETTO, Giovanna; LÀDAVAS, Elisabetta, MATTIOLI, Flavia; DI PELLEGRINO, Giuseppe. A psychophysiological investigation of moral judgment after ventromedial prefrontal damage. Journal of Cognitive Neuroscience, v. 22, n. 8, p. 1.888-1.899, 2009. Como veremos mais à frente, uma das leis da cooperação é que ela exista entre membros da família, fato que ocorre inclusive entre animais.

54 GREENE, Joshua D.; MORELLI, Sylvia A.; LOWENBERG, Kelly; NYSTROM, Leigh E., COHEN, Jonathan D. Cognitive 
uma operação matemática ou memorizar um número); a segunda implicou aplicar os testes com curto lapso para deliberação, comparando os resultados obtidos com as respostas dadas com maior tempo para reflexão do participante ${ }^{55}$. Em ambos os casos, o coeficiente de respostas utilitaristas caiu bastante.

Demonstrada a relação entre as repostas aos dilemas e o funcionamento das estruturas que correspondem aos dois sistemas que operam no cérebro (dual processo brain), é necessário entender o porquê de esses sistemas operarem com intensidades diferentes nas duas versões do dilema. Trocando em miúdos, é preciso entender a razão de nós aceitarmos o trade-off de uma vida pela salvação de cinco no 'switch case', mas não no 'footbridge case'.

Duas outras versões do dilema comprovam a influência da pessoalidade do enredo no nível de participação do sistema 1 (instintos) quando das respostas. Trata-se do remote footbridge case e do footbridge switch case, hipóteses muito semelhantes à original, com a única diferença de que, em vez de empurrar o funcionário, a pessoa aciona uma alavanca que abre a ponte fazendo-o cair, provocando sua morte e salvando as cinco outras vidas. No remote footbridge case, o agente e a alavanca estão distantes dos trilhos, enquanto no footbridge switch case eles encontram-se sobre a ponte, próximos ao funcionário. As representações gráficas de ambas as versões estão representadas nas figuras 4 e 5 .

Figura 4 - Remote footbridge $\operatorname{case}^{56}$

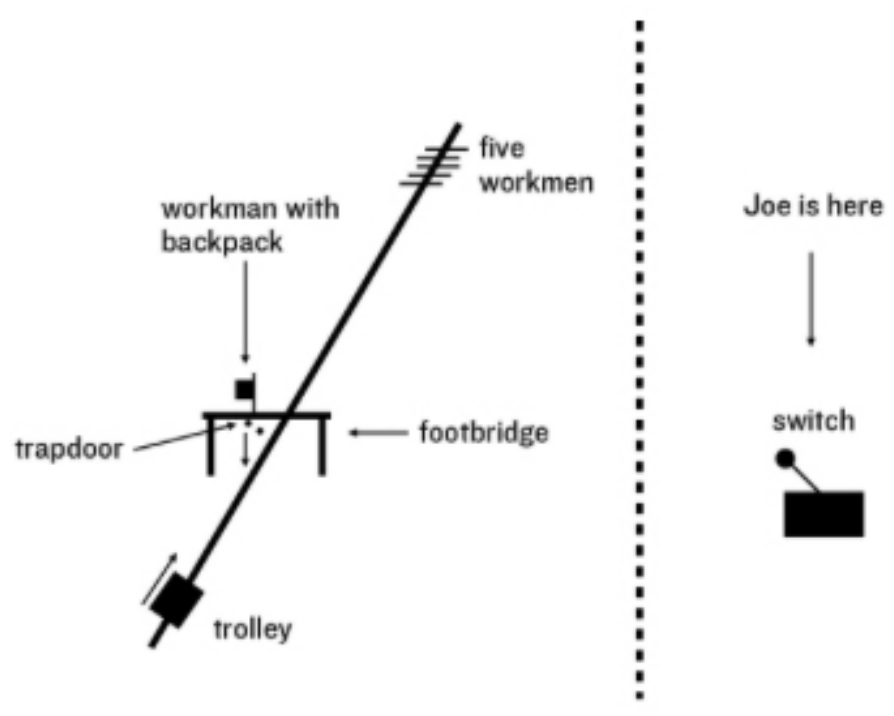

Load Selectively Interferes with Utilitarian Moral Judgment. Journal of Cognitive Neuroscience, v. 22, n. 8, p. 1.888-1.899, jun. 2008.

55 Obviamente, em grupos diferentes, com todos os controles envolvidos. (SUTER, Renata S.; HERTWIG, Ralph. Time and Moral Judgment. Cognition, v. 119, n. 3, p. 454-458, jun. 2011).

56 GREENE, Joshua D. Moral Tribes: Emotion, Reason and the Gap Between Us and Them. New York: Penguin Books, 2013. p. 214. 
Figura 5 - Footbridge switch case $e^{57}$

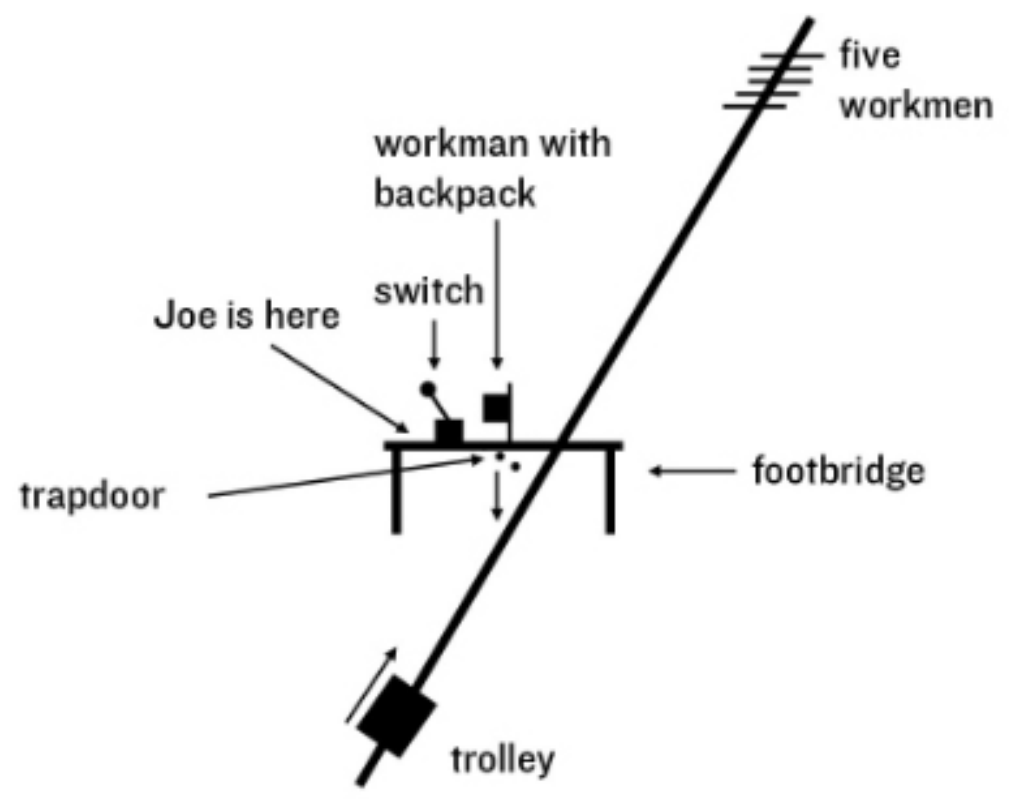

O estudo submeteu o mesmo grupo de pessoas às três versões do footbridge case. Enquanto na versão original (a do empurrão) a aprovação do resultado utilitarista foi de apenas 31\%, nessas novas versões, a aprovação foi de $63 \%$ e $59 \%$, respectivamente.

Note-se que a segunda versão se caracteriza por duas diferenças em relação à original: (i) o agente está mais distante da vítima; (ii) o agente não toca o corpo da vítima. Já a terceira versão diferencia-se da primeira apenas pela falta de toque no corpo da vítima (já que a alavanca está sobre a ponte, próxima do funcionário). Importa, então, saber qual das duas diferenças realmente impactou o resultado.

A resposta está no contato pessoa ${ }^{58}$. Sem o contato pessoal, os exemplos se parecem muito com o switch case (que tinha $87 \%$ de aprovação). A única diferença é o fato de que, no footbridge switch case (59\% de aprovação), a alavanca (e, logo, o agente) está muito mais próxima do funcionário do que no switch case e no remote footbridge case (63\% de aprovação), hipóteses em que o agente e a alavanca estão fora da ponte e, logo, mais distantes do funcionário que servirá de obstáculo.

Não há diferenças estatisticamente significantes de aprovação entre o switch case e o remote footbridge case, mas a diferença percentual entre esses enredos e aquele que inclui o contato pessoal (footbridge case, com apenas $31 \%$ de aprovação) é enorme, indicando que não é a alteração de distância que impacta o sistema 1, mas sim o contato pessoal ${ }^{59}$.

Ocorre que, na versão original do footbridge case, mais do que o contato pessoal, o que ocorre é realmente um empurrão, ou seja, a aplicaşão de força muscular contra a vítima. Assim, é preciso saber em que medida importa tocar ou aplicar força muscular sem tocar o funcionário.

Conduziu-se, então, outro estudo com uma nova alteração da versão original. Aqui, o agente não toca no funcionário, mas empurra-o com um bastão. A figura 6 representa graficamente a situação:

57 GREENE, Joshua D. Moral Tribes: Emotion, Reason and the Gap Between Us and Them. New York: Penguin Books, 2013. p. 215.

58 CUSHMAN, F.; YOUNG, L.; HAUSER, M. The Role of Conscious Reasoning and Intuition in Moral Judgment: Testing Three Principles of Harm. Psychology Science, v. 17, n. 12, p. 1.082-1.089. 2006.

59 GREENE, Joshua D. Moral Tribes: Emotion, Reason and the Gap Between Us and Them. New York: Penguin Books, 2013. p. 216. 
Figura 6 - Footbridge pole dilemma ${ }^{60}$

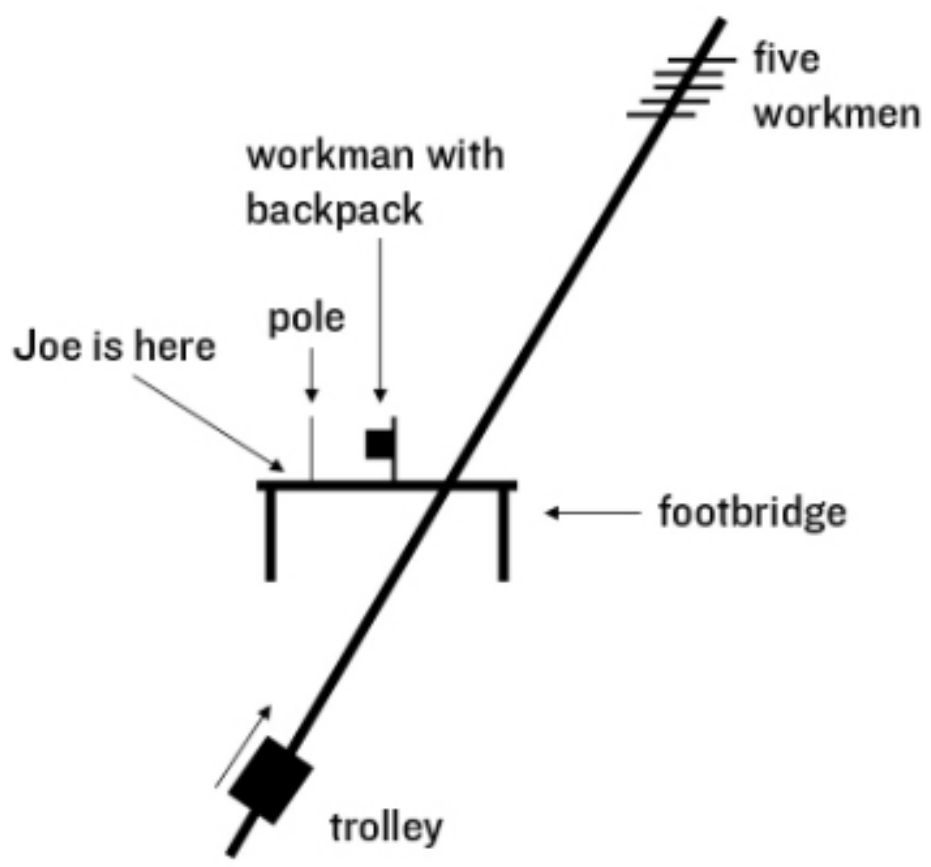

Nesse caso, o percentual de aprovação foi semelhante ao da versão tradicional, ou seja, o relevante para o sistema 1, mais do que o toque, é a aplicação de força pessoal sobre uma outra pessoa, ainda que por intermédio de um objeto.

Há uma abordagem do dilema que procura relacioná-lo à máxima kantiana já referida de que as pessoas não devem ser tratadas como meio, mas sim como o fim de qualquer atividade ${ }^{61}$.

$\mathrm{Na}$ versão original do footbridge case, a pessoa é realmente utilizada como um meio para parar o bonde, mas, no switch case, a morte do funcionário é um efeito colateral da tentativa de salvar cinco vidas. Explicando melhor: ao empurrar o funcionário da ponte, o agente usa o corpo do funcionário como um obstáculo que impede o bonde de matar os cinco operários. Já no switch case, as cinco vidas são salvas pelo desvio do curso do bonde, acionado pela alavanca. A morte do funcionário é um efeito colateral desse desvio, porque ele está acidentalmente sobre os trilhos laterais. Não é, portanto, utilizado como meio para parar o bonde ${ }^{62}$.

Para medir a sensibilidade do sistema 1 em relação a essa distinção (meio versus efeito colateral), estudou-se uma nova versão do dilema, chamada de obstacle collide case. Nesse novo enredo, o curso do bonde pode ser alterado movendo-se uma alavanca (como no switch case). A alavanca, o agente e o funcionário estão sobre a ponte (como no footbridge switch case). A diferença agora é que a ponte está sobre o trilho lateral, o funcionário encontra-se entre o agente e a alavanca, e a única forma de o agente alcançar a alavanca é empurrando o funcionário e derrubando-o sobre os trilhos. A figura 7 representa a nova situação:

60 GREENE, Joshua D. Moral Tribes: Emotion, Reason and the Gap Between Us and Them. New York: Penguin Books, 201. p. 216.

61 Antes de Kant, Tomás de Aquino trata do mesmo tema, com a mesma opinião, sob outra perspectiva. Aquino cria a doutrina do duplo efeito, segundo a qual é moralmente permitido que uma conduta cause um mal, inclusive a morte de alguém, como efeito colateral da promoção de um bem maior. (MCINTYRE, Alison. Doctrine of Double Effect. In: ZALTA, Edward N. (Ed.). The Stanford Encyclopedia of Philosophy, inverno 2014. Disponível em: < https://plato.stanford.edu/archives/win2014/entries/double-effect>. Acesso em: 16 fev. 2018).

62 Para visualizarmos essa ideia, basta retirar mentalmente o funcionário do trilho nas duas hipóteses. No footbridge case, o bonde seguiria em frente e atropelaria os cinco trabalhadores. No switch case, os cinco trabalhadores seria salvos. 
Figura 7 - Obstacle collide dilemma ${ }^{63}$

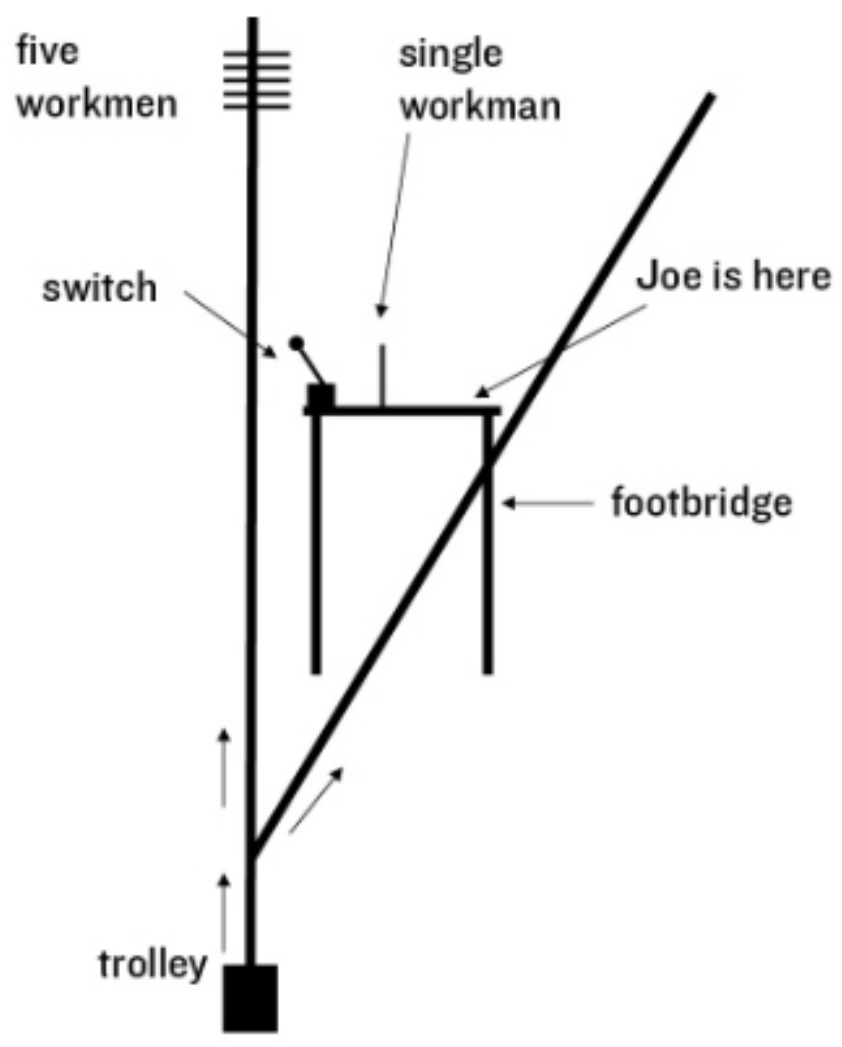

Nessa versão, assim como na original, há pessoalidade na ação, mas o funcionário não é utilizado como meio. Trata-se de um misto entre o footbridge case (pessoalidade) e o switch case (colateralidade). O percentual de aprovação aqui foi de $81 \%$, algo muito próximo da aprovação do switch case (87\%), demonstrando que o sistema 1 de fato é altamente sensível à diferença entre meio/ efeito colateral apresentada ${ }^{64}$.

O resultado parece demonstrar que nossa intuição aponta como imoral o ato de ferir alguém como meio, mas aprova a moralidade de fazê-lo como efeito colateral de um ato de salvamento de um número maior de pessoas.

Todavia, em duas das versões aqui apresentadas (remote footbridge case e footbridge switch case), as pessoas aprovaram o ato de utilizar o funcionário como meio para parar o bonde, ainda que com índices de aprovação inferiores (63\% e 59\%, respectivamente). Esse é um dado intrigante e que coloca em dúvida nosso apreço intuitivo em relação ao imperativo categórico kantiano.

Uma outra versão do dilema traz ainda mais controvérsia à discussão. Trata-se do loop case $e^{65}$. Essa hipótese é quase idêntica ao switch case original, com a diferença de que o acionamento da alavanca desvia o bonde para um trilho que segue paralelo ao primeiro, mas faz uma curva antes de voltar à trilha original, onde estão os operários. Nessa curva encontra-se o funcionário, que acaba morrendo e impedindo que o bonde volte ao trilho original onde estão os cinco operários, que acabam sendo salvos. A hipótese está representada na figura 8:

63 GREENE, Joshua D. Moral Tribes: Emotion, Reason and the Gap Between Us and Them. New York: Penguin Books, 2013. p. 219.

64 GREENE, Joshua D. Moral Tribes: Emotion, Reason and the Gap Between Us and Them. New York: Penguin Books, 2013. p. 219-220.

65 A intrigante versão foi novamente criada por Thomson, anos depois do paper original. (THOMSON, Judith. The Trolley Problem. The Yale Law Journal, v. 94, n. 6, p. 1.395-1.415, maio, 1985. Especificamente p. 1.402-1.403). 
Figura 8 - Loop case $e^{66}$

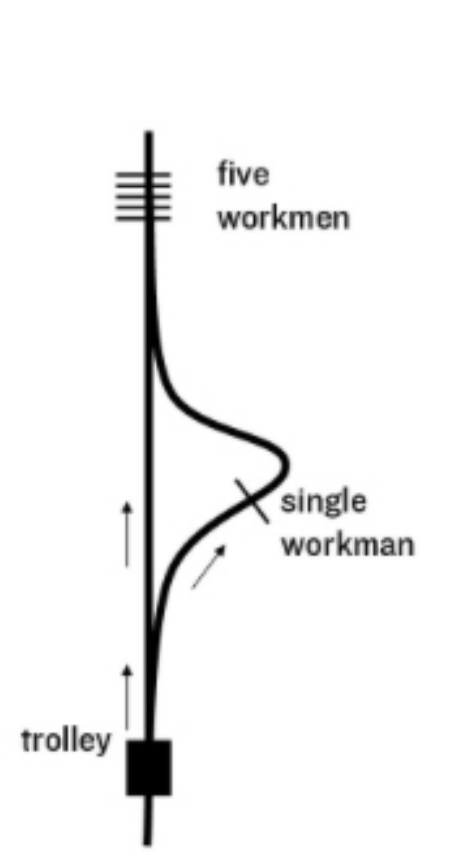

Joe is here

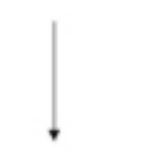

switch

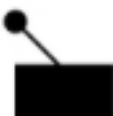

Pela figura, pode-se notar que a diferença para o switch case original é o fato de o funcionário ser utilizado como meio para parar o bonde. Isso porque a alavanca desvia o curso do bonde apenas momentaneamente e, não fosse o funcionário, ele voltaria ao curso original, matando os cinco operários. Mesmo assim, 81\% dos participantes aprovam a conduta do agente nesse caso, o que parece lançar ainda mais dúvidas sobre a relação intuitiva da nossa mente com o imperativo categórico kantiano em questão ${ }^{67}$.

Após a análise de todas essas versões em conjunto, podemos identificar dois fatores que realmente alteram o julgamento das pessoas: (i) a utiliz̧ação de força pessoal (empurrar versus mover uma alavanca); (ii) a utilização de uma pessoa como meio para parar o bonde (morte como decorrência direta versus morte como decorrência colateral).

Todavia, a mesma análise mostra que a influência desses dois fatores é inconsistente. A força pessoal pode ou não causar reprovação (footbridge pole versus obstacle collide, respectivamente). Da mesma forma, a utilização da pessoa como meio pode importar ou não (footbridge case versus loop case $)^{68}$.

Green conclui que o que realmente modifica o julgamento pela ativação do sistema 1 é a interação entre os dois fatores, ou seja, a aplicação de força pessoal e a utilização da pessoa como meio. ${ }^{69}$ A utilização de força pessoal que mata o funcionário como efeito colateral não é reprovável (81\% de aprovação para o obstacle collide), bem como a utilização do funcionário como meio sem utilização de força pessoal (81\% de aprovação para o loop case). Todavia, quando combinados os dois fatores, a reprovação é substancial (apenas 31\% de aprovação

66 GREENE, Joshua D. Moral Tribes: Emotion, Reason and the Gap Between Us and Them. New York: Penguin Books, 2013. p. 220.

67 Há outras variações do dilema cujos resultados levantam a mesma questão. (GREENE, Joshua D. GREENE, Joshua D. Moral Tribes: Emotion, Reason and the Gap Between Us and Them. New York: Penguin Books, 2013. p. 221).

68 Em um experimento, o footbridge case e o switch case foram aplicados para filósofos com $\mathrm{PhD}$, divididos em dois grupos. No grupo 1, o footbridge case era apresentado antes do switch case. No grupo 2, a apresentação era invertida. Descobriu-se que, quando o footbridge case era apresentado após o switch case, o percentual de aprovação moral subia à razão de $50 \%$. Em outras palavras, o percentual de aprovação do footbridge case no grupo 2 foi $50 \%$ superior ao percentual de aprovação do grupo 1. (SCHWITZGEBEL, Eric; CUSHMAN, Fiery. Expertise in Moral Reasoning? Order Effects on Moral Judgment in Professional Philosophers and NonPhilosophers. Mind \& Language, v. 27, p. 135-153, 2012).

69 GREENE, Joshua D. Moral Tribes: Emotion, Reason and the Gap Between Us and Them. New York: Penguin Books, 2013. p. 222. 
para o footbridge case e 33\% para o footbridge pole).

O que se conclui desses estudos é que a diferença de julgamentos para situações com resultados idênticos (trade-off entre a morte de um funcionário e a salvação de cinco operários) é causada pelo nível de atividade do sistema 1, ou seja, pela nossa intuição/instinto moral. Ao que tudo indica, todavia, o sistema é falho, porque, conquanto não haja qualquer diferença moralmente relevante entre empurrar (footbridge) ou mover uma manivela (remote footbridge) e derrubar alguém de uma ponte com o intuito de parar um bonde, o sistema 1 responde de modo diferente à duas situações, reprovando um caso e aprovando o outro.

Se é assim, qual seria a explicação para o enorme corpo filosófico que rejeita a ideia de utilizar pessoas como meio para qualquer objetivo? Como explicar as diferenças valorativas entre matar alguém como meio ou como efeito colateral nos casos em que o agente sabe de antemão que a morte vai acontecer? Porque somente se reprova o primeiro caso, se o resultado e as intenções são exatamente as mesmas (salvar mais pessoas, sabendo que dessa conduta decorrerá a morte de alguém)?

A hipótese sustentada é no sentido de que as teorias são apenas racionalizações dos julgamentos intuitivo ${ }^{70} A$ intuição viria primeiro (sistema 1), e seria racionalizada pelo sistema 2. Em outras palavras, o sistema reflexivo atuaria ancorado nos instintos, organizando-os de forma imperfeita e inconsistente ${ }^{71}$. Não é o imperativo categórico kantiano que justifica os instintos, mas os instintos que justificam o imperativo categórico ${ }^{72}$.

Aceita essa hipótese, resta ainda uma pergunta: de onde vêm esses instintos?

\section{A raiz biológica dos instintos transformada em imperativo categórico Kantiano (a TEORIA DA MIOPIA MODULAR)}

A Teoria da Miopia Modular de Greene é fruto de uma reflexão sobre os julgamentos morais produzidos pelo dual-process system, fundada na forma como nossa mente representa ações. Em resumo, a hipótese defendida é a de que nós temos um subsistema cognitivo que monitora nossos planos comportamentais e aciona um alarme emocional sempre que divisamos a possibilidade de ferir fisicamente alguém. A hipótese segue para sugerir que esse sistema de alarme é mípe, porque simplesmente não detecta efeitos nocivos visualizados pelo agente, atentando, apenas, para aqueles planejados como meio para atingimento do objetivo final ${ }^{73}$.

Esse sistema, ou módulo, é responsável por alertar-nos contra a prática de atos básicos de violência. Suas limitações não atingem a cognição dos efeitos colaterais, mas sim as emoções que dela decorreriam. Em outras palavras, para os efeitos nocivos colaterais, o sistema 2 funciona perfeitamente, mas o sistema 1 não ${ }^{74}$.

\footnotetext{
70 As pessoas ao redor do mundo, independentemente do nível intelectual ou cultural, intuem a máxima kantiana, sem saber de que se trata de uma doutrina. Nesse sentido: HAUSER, Marc; CUSHMAN, Fiery; YOUNG, Liane; JIN, R. Kang-Xing; MIKHAIL, John. A Dissociation Between Moral Judgments and Justifications. Mind \& Language, v. 22, n. 1, p. 1-21, fev. 2007: “[...] a majority of subjects failed to provide justifications that could account for their judgments. These results indicate that the principle of the double effect may be operative in our moral judgments but not open to conscious introspection." (p. 1).

71 KAHNEMAN, Daniel. Thinking: fast and slow. New York: Farrar, Straus and Giroux, 2011. [Kindle], location 2.080.

72 CUSHMAN, F.; GREENE, J. D. The Philosopher in the Theater. In: MIKULINCER, M.; SHAVER, P. R. (Eds.). Social Psychology of Morality: The Origins of Good and Evil. APA, 2011. Disponível em: <http://cushmanlab.fas.harvard.edu/docs/ cushman\&greene_2011b.pdf > . Acesso em: 16 fev. 2018. Os autores afirmam que, da mesma forma que teorias científicas tendem a refletir as estruturas do mundo concreto, as teorias filosóficas tendem a refletir as estruturas da mente (cérebro). (p. 6). Lembramos ainda a pesquisa em que o dilema do bonde foi aplicado a doutores em filosofia. A mera ordem de apresentação dos problemas alterou o resultado. (SCHWITZGEBEL, Eric; CUSHMAN, Fiery. Expertise in Moral Reasoning? Order Effects on Moral Judgment in Professional Philosophers and Non-Philosophers. Mind \& Language, v. 27, p. 135-153, 2012).

73 GREENE, Joshua D. Moral Tribes: Emotion, Reason and the Gap Between Us and Them. New York: Penguin Books, 2013. p. 224.

74 GREENE, Joshua D. Moral Tribes: Emotion, Reason and the Gap Between Us and Them. New York: Penguin Books, 2013. p. 224. Também sobre o tema: BLAIR, R. J. R. A Cognitive Developmental Approach to Morality: Investigating the Psychopath. Cognition, v. 57, p. 1-29, 1995.
} 
Esse sistema cognitivo dual existe por razões evolutivas já reveladas pela biologia e pela neurociência. Em algum momento de sua história natural/evolutiva, o homo sapiens desenvolveu um importante diferencial competitivo em relação às outras espécies: a capacidade de raciocinar e planejar suas ações (sistema 2$)^{75}$. Com isso, foi possível, por exemplo, criar estratégias mais elaboradas de sobrevivência, estabelecer objetivos de longo prazo e construir ferramentas que tornaram o homem/mulher mais forte que as demais espécies.

O custo desse sistema, porém, é a capacidade de premeditação de violência contra membros da própria espécie. Sem o sistema 2, a violência é, apenas, um impulso. Com esse novo sistema, ela pode ser escalada para níveis capazes de ameaçar toda a coletividade (grupo ou tribo). Capacidade cooperativa é um diferencial evolutivo para qualquer espécie, dentro de tribos ou famílias, os atos de violência são normalmente punidos com violência (vingança), colocando em risco a estabilidade do grupo e abrindo a possibilidade de invasão e domínio por outras tribos ou espécies ${ }^{76}$.

Exatamente para evitar essa violência desenfreada, desenvolvemos esse sistema de alerta. Esse inspetor de planejamento e ação não objeta todo e qualquer ato de violência, mas apenas aqueles que colocam em xeque a cooperação como diferencial evolutivo. Assim, o sistema desliga, por exemplo, quando praticamos atos violentos para nos defender, ou para atacar um inimigo ${ }^{77}$.

É preciso entender, todavia, por que esse sistema é míope para os efeitos nocivos colaterais às nossas ações. Em verdade, ambos os sistemas são, de certa forma, incompletos. O sistema 2, por exemplo, é egoísta ao extremo no planejamento de suas ações, racional quanto às perdas e ganhos de determinada situação e cego para potenciais perigos daí advindos, principalmente no longo prazo, uma vez que a reciprocidade não é facilmente verificável (cognoscível) no curto prazo (como vimos, os pacientes de Antonio Damasio apresentavam sérios problemas de tomada de decisão).

Já o sistema 1 é automático e rápido. Para isso, ele trabalha com atalhos, heurísticas e pressuposições. Confia em pistas imperfeitamente relacionadas àquilo que deve detectar. Funciona, por exemplo, como um alarme com sensores infravermelhos, instalado para a segurança dos moradores de uma casa, do qual espera-se um disparo capaz apontar a presença de um criminoso invasor da propriedade. Todavia, se um gato de rua atravessar seu raio de ação, o alarme disparará, alertando (e assustando) os moradores sem motivo relevante. Assim, o sistema 1 oferece de maneira rápida, eficiente e imprecisa, alarmes e avisos para os potenciais perigos das ações antevistas pelo sistema 2. Mas também dispara em razão de eventos apenas aparentemente perigosos.

A prova do funcionamento desse sistema decorre de experimentos desenhados para simular sinais de violência para o sistema $1 \mathrm{e}$, ao mesmo tempo, informar o sistema 2 da inexistência de qualquer violência real. Se o sistema modular realmente existe e funciona de forma automática, então, ele deve ser acionado mesmo quando estamos conscientes de que o ato violento por nós praticado é, apenas, uma simulação.

Para entender melhor o funcionamento do sistema de alerta, um interessante experimento foi conduzido por Cushman, Mendes e colegas ${ }^{78}$. Nele, os participantes praticavam atos de violência simulada, conscientes dessa circunstância. Eles foram convidados a, por exemplo, esmagar bonecos, martelar a perna falsa de uma pessoa e apontar uma arma de brinquedo para alguém.

Sempre que o ato de violência simulada era praticado, o agente experimentava uma forte constrição no

75 Como vimos, o sistema 2 é uma exclusividade do bomo sapiens. (FRANKISH, Keith. Dual-Process and Dual-System Theories of Reasoning. Philosophy Compass, v. 5, n. 10, p. 914-926, 2010. p. 914).

76 Sobre o tema: NOWAK, Martin A. Five Rules for the Evolution of Cooperation. Science, v. 314, n. 5.805, p. 1.560-1.563, 8 dez. 2006. Disponível em: <https://www.ncbi.nlm.nih.gov/pmc/articles/PMC3279745>. Acesso em: 16 fev. 2018.

77 GREENE, Joshua D. Moral Tribes: Emotion, Reason and the Gap Between Us and Them. New York: Penguin Books, 2013. p. 226.

78 CUSHMAN, F.; GAFFEY, A.; GRAY, K.; MENDES, W. B. Simulating Murder: The Aversion to Harmful Action. Emotion, v. 12, n 1, p. 2-7, 2012. Disponível em: <https://cushmanlab.fas.harvard.edu/docs/cushman_gray_gaffey\&mendes_2012.pdf>. Acesso em: 30 jul. 2017. 
sistema vascular periférico (uma espécie de calafrio). Essa sensação não se desencadeava com a mesma intensidade quando o participante, apenas, assistia ao ato simulado ou quando o praticava contra objetos não assemelhados a humanos (por exemplo, quando martelavam um prego, em vez da cabeça de uma boneca) ${ }^{79}$.

Esses resultados indicam que o sistema 1 é acionado automaticamente mesmo com base em um sinal cuja falsidade seja conhecida do agente, desde que para frear atos pessoais de violência ${ }^{80}$.

Se, por um lado, o sistema dispara na presença de falsos sinais de violência, por que ele não é acionado para atos que possuem consequências danosas reais colaterais? Em outras palavras, por que o sistema é cego em relação aos efeitos colaterais?

A resposta está no modo como nosso cérebro representa ações - em forma de diversas cadeias causais - e na incapacidade de processamento simultâneo de todas elas para a produção de respostas rápidas.

Segundo John Mikhail, o cérebro humano representa ações em termos de cadeias causais planificadas, voltadas ao alcance de determinado objetivo ${ }^{81}$. A cadeia inicial consiste em uma sequência de eventos causais necessários ao atingimento de uma específica finalidade. Por exemplo, no switch case, a cadeia é composta pelo movimento muscular que move as mãos do agente, causando o acionamento da alavanca, a subsequente alteração dos trilhos e o desvio do bonde, que termina por resultar na salvação dos cinco operários. Já a morte do funcionário no trilho secundário não compõe essa cadeia causal principal, mas sim uma cadeia adjacente (colateral).

Já no footbridge case, a cadeia causal principal é a seguinte: o movimento muscular do agente move suas mãos para empurrar o funcionário, causando sua queda e a parada do bonde, implicando a morte do funcionário e a preservação das cinco vidas. Não há qualquer cadeia causal colateral (salvo o sofrimento da família e dos amigos do funcionário morto).

Qual a diferença fundamental entre as cadeias causais principais nos dois casos? É o fato de que a morte do agente somente a compõe no segundo caso (footbridge case), não no primeiro. No switch case, a morte não é detectada pelo sistema modular porque ele é desenhado apenas para antecipar automaticamente os efeitos diretos, não os colaterais. Em outras palavras, o sistema automático de alarme percebe apenas causalidades lineares ${ }^{82}$. A figura 9 representa as cadeias causais principais e colaterais dos dois casos:

79 A figura abaixo representa os atos que os participantes foram levados a protagonizar. Os atos da primeira linha geraram contrição vascular periférica bem mais intensa que os da segunda (p. 4).

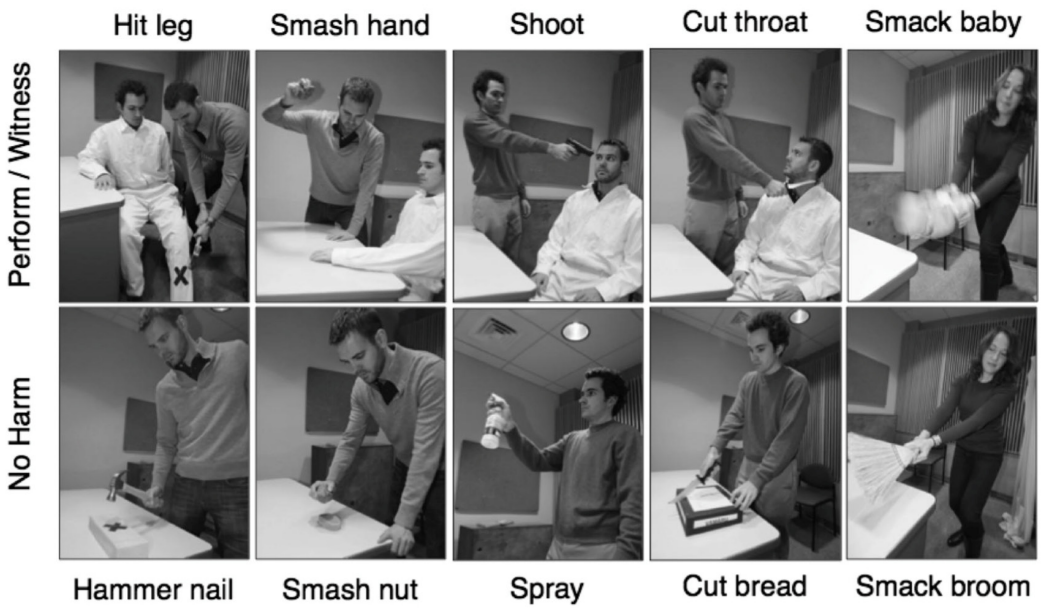

80 CUSHMAN, F.; GAFFEY, A.; GRAY, K.; MENDES, W. B. Simulating Murder: The Aversion to Harmful Action. Emotion, v. 12, n 1, p. 2-7, 2012, p. 5. Disponível em: <https://cushmanlab.fas.harvard.edu/docs/cushman_gray_gaffey\&mendes_2012.pdf>. Acesso em: 30 jul. 2017.

81 MIKHAIL, John. Elements of Moral Cognition: Rawl's Linguistic Analogy and the Cognitive Science of Moral and Legal Judgment. Cambridge, UK: Cambridge University, 2011. [Kindle]. location 3.260.

82 MIKHAIL, John. Elements of Moral Cognition: Rawl's Linguistic Analogy and the Cognitive Science of Moral and Legal Judgment. Cambridge, UK: Cambridge University, 2011. [Kindle]. location 4.233. 
Figura 9 - Cadeias causais, Switch e Footbridge cases $^{83}$

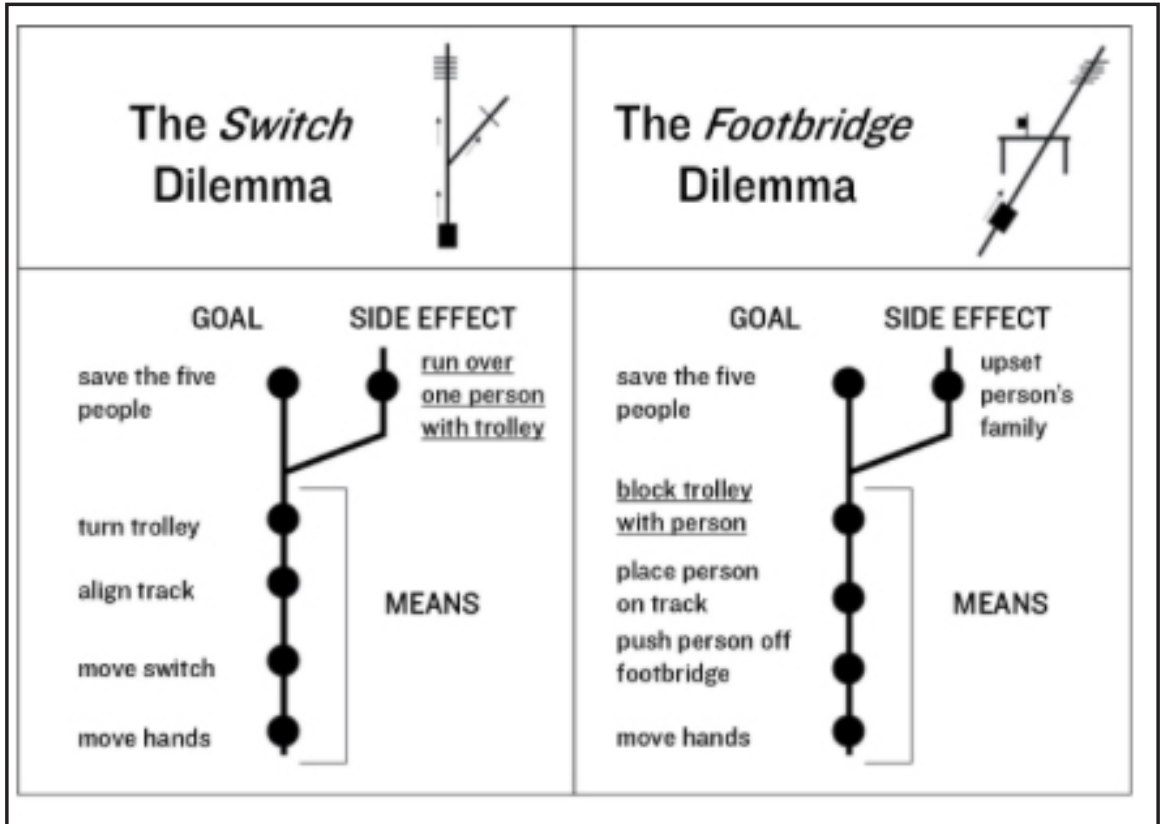

Os efeitos colaterais são conhecidos e previstos pelo agente (o sistema 2 sabe que eles existem). Ele, todavia, não os interpreta como errados, porque o sistema de alarme soa apenas para os eventos componentes da cadeia causal de eventos necessários para atingir o objetivo (trata-se dos eventos que compõem a cadeia causal principal, em linha reta nos dois exemplos da figura acima) ${ }^{84}$.

Todavia, como explicar, por essa teoria, o loop case? Lembramos que, nesse caso, a morte do funcionário encontra-se, sem dúvida, na cadeia causal principal, assim composta: o agente movimenta os músculos para mover a mão; a mão move a alavanca; a alavanca altera a trajetória do bonde para o trilho curvo e o bonde atropela o funcionário, matando-o e salvando a vida dos cinco operários ao impedir a volta do veículo ao trilho original.

O problema do loop case é que ele foi desenhado para enganar o sistema $1^{85}$. Conquanto tenhamos consciência de que a morte do funcionário compõe a cadeia causal principal (ele é um meio necessário para salvar as cinco vidas), o sistema 1 enxerga a hipótese de modo semelhante ao switch case, ou seja, ele percebe, apenas, que há um movimento muscular, um acionamento de alavanca e um desvio de trajetória que salva cinco vidas. O sistema, todavia, não soa o alarme para um efeito principal que parece colateral: a morte do agente. O exemplo, assim, engana o sistema 1.

As figuras 10 e 11 representam, respectivamente, a verdadeira cadeia causal principal do loop case e a cadeia causal tal como percebida pelo sistema 1.

83 GREENE, Joshua D. Moral Tribes: Emotion, Reason and the Gap Between Us and Them. New York: Penguin Books, 2013. p. 229.

84 Para que a diferença causal fique clara, basta, mais uma vez, suprimir o funcionário do exemplo. Se ele não existisse, os cinco operários estariam salvos na figura da esquerda, mas morreriam na figura da direita. Logo, na cadeia causal da figura direita, o funcionário é causa direta da preservação de cinco vidas. Em outras palavras, sua morte é o meio utilizado para salvar os operários.

85 GREENE, Joshua D. Moral Tribes: Emotion, Reason and the Gap Between Us and Them. New York: Penguin Books, 2013. p. 234. 
Figura 10 - Cadeia causal real do loop case $^{86}$

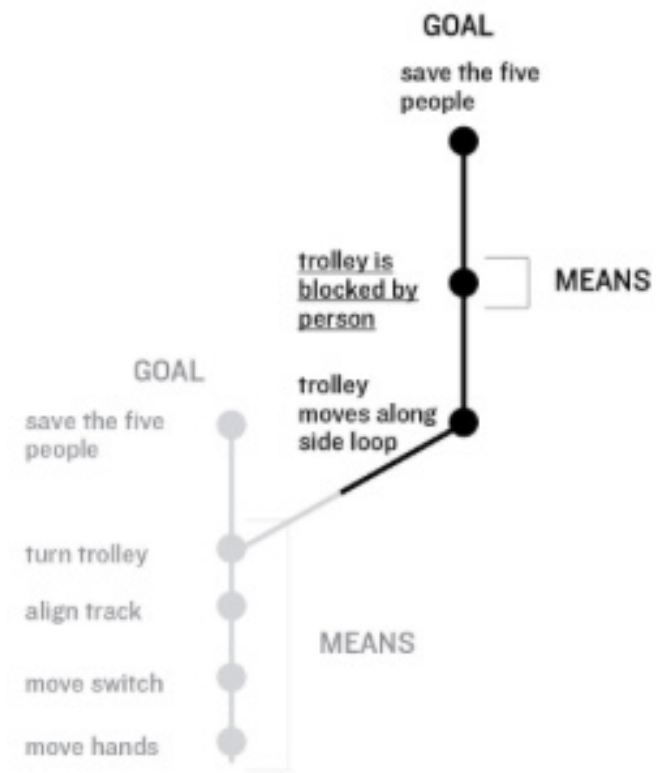

Figura 11 - Cadeia causal do loop case tal como percebida pelo sistema 1 (ignorando o que parece ser um efeito colateral) ${ }^{87}$

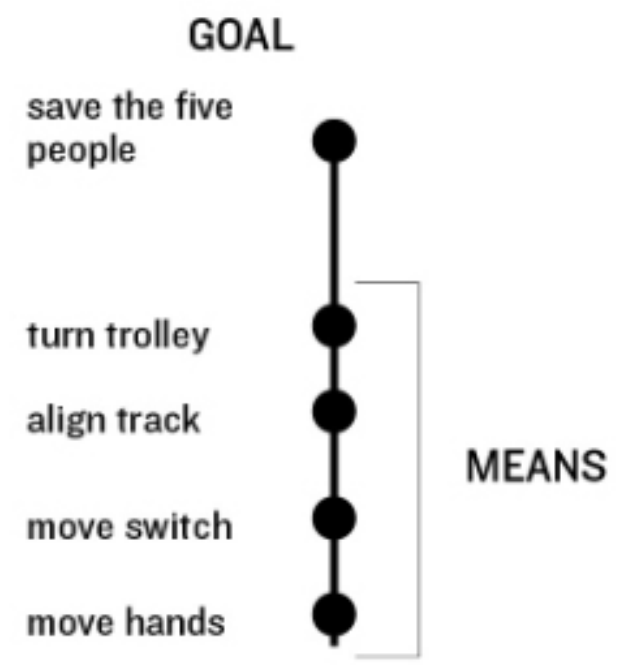

Uma diferença essencial entre o footbridge case e o loop case é, como vimos, o ato de empurrar alguém (força pessoal). É exatamente esse ato que conecta o alerta do sistema 1, trazendo o funcionário para seu radar, de modo que a cadeia causal principal possa ser detectada, ativando o alarme. Isso não ocorre no loop case, hipótese em que a cadeia causal fica dissimulada. Outras linhas de pesquisa demonstram que a mente tende a representar causas em termos de forças, robustecendo relações causais na proporção da concretude de um determinado cenário ${ }^{88}$.

Alguém poderia perguntar o que ocorreria, então, no loop case se, no trilho principal, houvesse, apenas, 1 funcionário, e, no trilho curvo adjacente, estivessem os cinco trabalhadores. Será que a imperfeição do sistema 1 nos faria mover a manivela por não enxergarmos a cadeia causal aparentemente adjacente, induzindo-nos a

86 GREENE, Joshua D. Moral Tribes: Emotion, Reason and the Gap Between Us and Them. New York: Penguin Books, 2013 , p. 233.

87 GREENE, Joshua D. Moral Tribes: Emotion, Reason and the Gap Between Us and Them. New York: Penguin Books, 2013 , p. 232.

88 PINKER, Steven. The Stuff of Thought. Language as a Window Into Human Nature. New York: Penguin, 2007. [Kindle]. p. 1. 
trocar, tragicamente, cinco vidas por apenas uma? A resposta parece-nos negativa. É preciso lembrar que o sistema 2, quando funciona, sempre faz julgamentos utilitários. Ele, sempre, responde positivamente à proposta de trocar uma vida por cinco, mas jamais o contrário. O contrário ocorre, apenas, nos casos em que o sistema 1 é acionado com intensidade, fazendo-nos agir por impulso para refrear um ato de violência que esteja na cadeia causal detectável pelo seu radar, inibindo os cálculos do sistema $2^{89}$.

Em todos os nossos exemplos, o agente sabe, conscientemente, que o trade-off proposto é o de cinco vidas por uma. Não fosse o sistema 1, essa troca sempre seria aceita. De outro lado, com ou sem sistema 1, a troca oposta (uma vida por cinco) jamais ocorreria.

Nesse ponto da nossa explicação, é importante relembrar: o sistema 1, dispositivo fundamental de sobrevivência da espécie humana, funciona de forma rápida e imperfeita. O sistema 2 funciona de forma reflexiva. Mas eles não funcionam isolados. Ao contrário, trabalham integrados ${ }^{90}$. Como ensina Kahneman, julgamentos

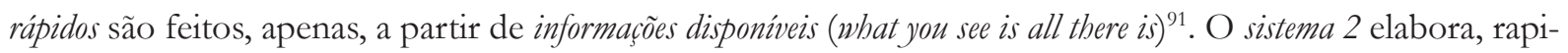
damente, as intuições do sistema 1, sem necessariamente considerar todas as circunstâncias relevantes.

Uma pergunta importante: se o sistema 2 funciona tão bem, porque não somos todos psicopatas (em outras palavras, por que não eliminamos o sistema 1)? Há duas razões para isso. A primeira diz para com as múltiplas funções do sistema 1, capaz de responder rápido e garantir nossa sobrevivência em uma série de situações dinâmicas da vida (seja na selva ao fugir de uma cobra ou na cidade ao pular para evitar um atropelamento surpresa). A segunda decorre da nossa incapacidade de calcular custos e benefícios com a rapidez ou a precisão necessária. Como o percentual de acerto do sistema 1 é bastante razoável ${ }^{92}$, ele leva grande vantagem em relação ao sistema 2 no dia a dia, auxiliando, inclusive, a manutenção da cooperação dentro do grupo, como um diferencial evolutivo.

Mas, ainda que saibamos que o sistema 1 é muito útil, não podemos esquecer que ele é limitado e impreciso.

Segundo a neurociência, as limitações do alarme do sistema 1 são de três espécies ${ }^{93}$ : (i) ele responde mais a ofensas causadas como meio do que como efeito colateral (ou seja, ofensas dolosas, intencionalmente causadas); (ii) responde mais a ofensas causadas ativamente do que passivamente; (iii) responde mais a ofensas causadas diretamente pela força física, do que indiretamen$t e^{94}$. Ou seja, o alarme é sensível a atos de violência básica, prototipada, como estapear, bater, esmagar, empurrar.

Nesse momento, já é possível entender por que o sistema modular de alarme é míope. Não seria melhor que ele enxergasse todas as cadeias causais? Não, porque, caso isso ocorresse, o sistema simplesmente travaria. $\mathrm{Na}$ vida real, em vez das duas cadeias causais aqui estudadas de forma simplificada, existem múltiplas. Nosso cérebro não possui, ao que sabemos, capacidade cognitiva para rastrear e reagir rapidamente a tantas

89 GREENE, Joshua D. Moral Tribes: Emotion, Reason and the Gap Between Us and Them. New York: Penguin Books, 2013, p 126.

90 Essa integração, com a emoção como componente da razão, é o que diferencia a Teoria de Greene (GREENE, Joshua D. Moral Tribes: Emotion, Reason and the Gap Between Us and Them. New York: Penguin Books, 2013, p. 230) e de Mikhail (MIKHAIL, John. Elements of Moral Cognition: Rawl's Linguistic Analogy and the Cognitive Science of Moral and Legal Judgment. Cambridge, UK: Cambridge University, 2011. [Kindle]. location 1.355).

91 KAHNEMAN, Daniel. Thinking: fast and slow. New York: Farrar, Straus and Giroux, 2011. [Kindle]. location 2.080.

92 KAHNEMAN, Daniel. Thinking: fast and slow. New York: Farrar, Straus and Giroux, 2011. [Kindle]. location 323.

93 GREENE, Joshua D. Moral Tribes: Emotion, Reason and the Gap Between Us and Them. New York: Penguin Books, 2013. p. 247.

94 GREENE, Joshua D. Moral Tribes: Emotion, Reason and the Gap Between Us and Them. New York: Penguin Books, 2013. p. 246. Isso significa, também, que ele responde mais ativamente a possibilidades lesivas causadas por ações do que por omissões. Pior, essa descoberta aponta que nossos alarmes funcionam muito mal quando as lesões são causadas indiretamente. Por exemplo, é certamente instintivamente mais desconfortável disparar uma arma de fogo no rosto de alguém do que apertar um botão que pode disparar um míssil à distância, matando milhares de pessoas. Nossa intuição, para falar de um problema brasileiro, é no sentido de que os crimes de colarinho branco e de corrupção não geram a mesma revolta (nem as mesmas penas) dos crimes clássicos contra a vida - como o homicídio — por razões semelhantes. O tema é tratado no interessantíssimo trabalho de PAHAIA, Neeru; Karim S.; GREENE, Joshua D; BAZERMAN, Max H. Dirty Work, Clean Hands: The Moral Psychology of Indirect Agency. Organizational Behavior and Human Decision Processes. Disponível em: <https://dash.harvard.edu/handle/1/4264764>. Acesso em: 16 fev. 2018. 
cadeias assim. Como um computador sobrecarregado, ele travaria, o que acabaria por comprometer nossa sobrevivência em situações de risco ${ }^{95}$.

Um outro aspecto que escapa do sistema 1 são os benefícios eventualmente causados pela violência. Em uma versão do footbridge case, os participantes defrontam-se com a possibilidade de empurrar o funcionário da ponte e salvar milhares de pessoas (imagine-se que o bonde desgovernado baterá em um paiol de pólvora, próximo a uma represa, causando uma explosão e rompendo a barragem) ${ }^{96}$. Nesse caso, o percentual de aprovação foi a $70 \%$. Conquanto bem mais alto que os $31 \%$ originais, ele, anda, é inferior à aprovação moral do switch case $(87 \%)^{97}$.

Como pode o movimento de uma manivela que mata uma pessoa para salvar cinco vidas valer mais do que um empurrão que mata a mesma quantidade para salvar milhões? Claramente, nesse caso, o alarme do sistema 1 foi ativado por conta do empurrão, mas foi só parcialmente compensado pelo clamor dos números altos. A magnitude dos números certamente afetou o julgamento ${ }^{98}$, mas de forma totalmente desproporcional ao número de vidas em risco, tudo por conta do alarme do sistema 1. Sabemos o quanto isso soa desconfortável, mas a verdade é que os benefícios da violência no caso do paiol de pólvora não foram corretamente valorados pelas pessoas.

Um paralelo interessante entre neurociência e direito diz respeito à interpretação do art. 139, IV, do CPC/2015, especificamente no que concerne à execução/cumprimento de sentença de obrigação de pagar quantia certa. Existe grande resistência da doutrina de direito processual quando se trata de permitir a aplicação de meios executivos atípicos logo após o inadimplemento do devedor (após o prazo do art. 523 do CPC/2015). As resistências aumentam ainda mais quando se discutem quais seriam esses meios coercitivos/ indutivos corretos, com ponderações claramente pendentes às garantias processuais do devedor.

Como veremos, e provaremos, a utilização de meios executivos rigorosos pode produzir alto nível de cooperação no processo, elevando sobremaneira o nível de bem-estar social. Esse efeito, todavia, é sistêmico, sendo difícil visualizá-lo de imediato.

Por outro lado, esses atos estão realmente embutidos de certa violência voltada para uma pessoa determinada (o devedor). Quando surgem os debates, a evidente violência individualizada, contraposta ao benefício sistêmico e difuso, implica um debate no qual dificilmente a frieza da estatística superará as cores fortes da violência individualizada (normalmente traduzidas em expressões como processo justo ou devido processo legal).

Por exemplo, o alarme acionado pela concretude $e^{99}$ do drama de um devedor que tem sua $\mathrm{CNH}$ ou o seu passaporte retido (sistema 1), possivelmente superará, no debate, os benefícios sistêmicos quase invisíveis que podem ser gerados quando se estabelece uma jurisprudência rigorosa para o cumprimento de decisões judiciais (credible threat) ${ }^{100}$.

Sistema 1 e sistema 2 desenvolveram-se e funcionam juntos. A quase totalidade da história natural do homo

95 GREENE, Joshua D. Moral Tribes: Emotion, Reason and the Gap Between Us and Them. New York: Penguin Books, 2013. p. 238-239. A metáfora do computador é nossa.

96 PAXTON, Joseph M.; UNGAR, Leo; GREENE, Joshua D. Reflection and Reasoning in Moral Judgment. Cognitive Science, v. 36, n. 1, p. 163-177, jan./ fev. 2012. O exemplo foi um pouco modificado por nós.

97 GREENE, Joshua D. Moral Tribes: Emotion, Reason and the Gap Between Us and Them. New York: Penguin Books, 2013. p. 248.

98 PAXTON, Joseph M.; UNGAR, Leo; GREENE, Joshua D. Reflection and Reasoning in Moral Judgment. Cognitive Science, v. 36, n. 1, p. 163-177, jan./ fev. 2012. p. 252.

99 Para usar o termo de Pinker, já referido. Ocorre que, assim como números altíssimos de vidas a serem protegidas tiveram algum impacto na aprovação do footbridge case (quando ele está prestes a romper a barragem), também o cenário de tragédia da Justiça, e principalmente da execução no Brasil, começa a abrir espaço para uma postura mais pragmática da doutrina e da jurisprudência. 100 A ameaça crível (ou credible threat) é necessária para que as partes alterem suas estratégias em um determinado jogo, passando, muitas vezes, a adotar uma postura cooperativa. No caso específico do cumprimento de sentença que condena no pagamento de quantia certa, a ideia cooperativa por excelência é o cumprimento da sentença no prazo do art. 523 do CPC/2105. A ameaça real de um "mal maior", entra na conta de utilidade do devedor, que pondera de forma mais rigorosa as consequências do inadimplemento, ajustando seu comportamento. 
sapiens é selvagem e pode ser vista como uma luta pela sobrevivência cotidiana, com enfrentamento de perigos fisicamente próximos e prática de atos violentos cujas consequências não iam muito além dos limites físicos de quem os perpetrava ${ }^{101}$.

A partir do momento em que não somos mais selvagens e em que criamos sociedades desenvolvidas e globalizadas, nós aprimoramos nossas ferramentas e temos, cada vez mais, tecnologia para medir os custos e benefícios de nossas escolhas. Os atos potencialmente mais violentos (nocivos e perigosos) de hoje decorrem do aperto de um botão de disparo atômico ou do desvio silencioso ilícito de recursos públicos, e não de uma agressão a uma pessoa próxima ${ }^{102}$.

A busca adequada do bem comum, por sua vez, depende do desenho de políticas públicas pensadas ex ante para beneficiar o maior número de pessoas, sendo mesmo inevitável que, ex post, algumas delas sejam prejudicadas.

É na ponderação consciente entre custos e benefícios, jamais perdendo de vista os vieses e heurísticas causados pelo dual process mode, que o Estado pode maximizar seu papel de gerador de bem-estar social.

É exatamente na seara da confecção de políticas públicas, iluminada pela descoberta dessa forma dual de pensar e de como realizamos nossos juízos morais, que surge a atualização da filosofia utilitarista, chamada por alguns de pragmatismo profundo ${ }^{103}$.

\section{Pragmatismo profundo e políticas públicas: Como debater QUestões difíceis, PASSÍVEIS DE REGULAÇÃO PELO DIREITO}

Como procuramos demonstrar, a neurociência da moralidade alerta que, conquanto importantíssimas, as intuições do sistema 1 não devem ser elevadas à condição de princípios categóricos, inviabilizando a ponderação entre custos e benefícios de atos a priori violentos ${ }^{104}$.

101 O gráfico abaixo mostra que o desenvolvimento das potencialidades do homo sapiens foi estável por milhares de anos, sofrendo uma guinada apenas recentemente, mais especificamente após a revolução industrial. (MORRIS, Ian. Why the West Rules: For Now: The Patterns of History and What They Reveal About the Future. New York: Farrar, Straus and Giroux, 2010. [Kindle]. location 2.638).

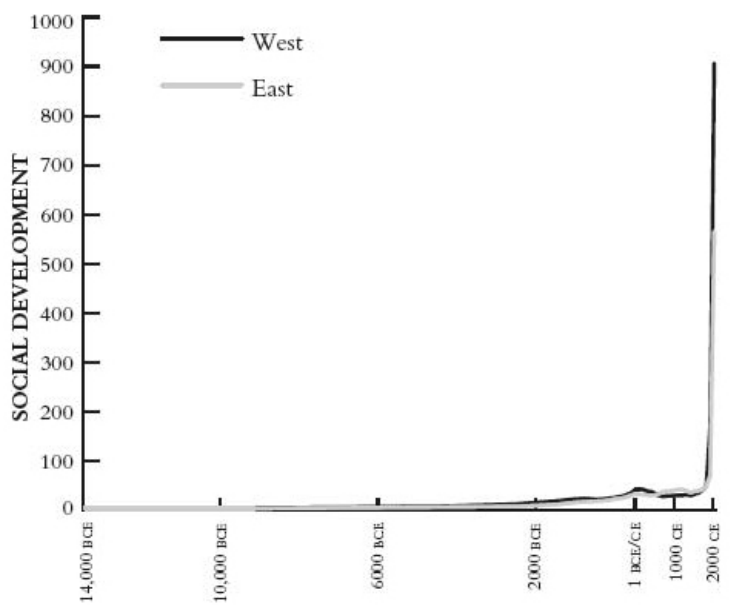

102 Obviamente, não estamos defendendo as agressões pessoais, que continuam sendo abomináveis. O que pretendemos é apontar para a insuficiência do alarme mental automático quando se trata de lidar com atos nocivos impessoais, cada vez mais comuns na era da tecnologia avançada.

103 GREENE, Joshua D. Moral Tribes: Emotion, Reason and the Gap Between Us and Them. New York: Penguin Books, 2013, p. 289.

104 GREENE, Joshua D. The Rat-a-gorical Imperative: Moral Intuition and the Limits of Affective Learning. Cognition. no prelo [aceito 6 mar. 2017]. Disponível em: <https://static1.squarespace.com/static/54763f79e4b0c4e55ffb000c/t/594d6a53a5790aaf12 
Nossa indisposição ao uso de força pessoal, à colocação do ser humano como meio causal primário ou às condutas ativas violentas não implica que esses atos sejam intrinsecamente ruins, independentemente de suas consequências, mas sim que nosso sistema 1, dentro de suas limitações cognitivas, elegeu as formas mais básicas, perceptíveis e evidentes de violência para emitir um alerta, auxiliando na tomada de decisões rápidas. Trata-se um importante diferencial evolutivo.

Esse desvendamento da forma de funcionamento do cérebro (dualprocess model) tem impactos diretos em questões absolutamente sensíveis, como tortura, pena de morte, prisão perpétua, guerras, aborto e outras. Isso não significa, todavia, que sejamos favoráveis a todas elas. Existem boas razões utilitaristas para oposição ou defesa de algumas delas e a resposta, ao final do dia, depende, sempre, de uma ponderação entre custos e benefícios.

O problema é que a mesma cegueira que não permite enxergar determinados benefícios derivados de atos aparentemente violentos também esconde os malefícios de posturas e políticas aparentemente inofensivas, como aquelas que atacam o meio ambiente, por exemplo, ou que tratam as pessoas de forma desigual sem qualquer motivo, como os casos de corrupção e favorecimento pessoal, claramente subvalorizados pelo sistema penal quando comparados com crimes violentos clássicos, como o homicídio ou o latrocínio.

O mesmo ocorre no sistema processual. Quase todas as abordagens do Princípio do Devido Processo Legal (ao menos em países de civil law) partem de princípios absolutos de justiça, atrelados a garantias fundamentais a serem preservadas a qualquer custo, ainda que esse custo seja uma ineficiência sistêmica e uma tragédia não cooperativa que prejudique toda a sociedade. Em nosso sentir, contraditório, ampla defesa e outras derivações do devido processo legal são importantes não porque têm valor absoluto, mas sim pela sua contribuição para que o sistema de justiça funcione de modo mais efetivo, trazendo o maior conforto e bem-estar possível para o maior número de pessoas.

A neurociênica da moralidade vai longe, discutindo, de forma pragmática, diversos temas difíceis, muitas vezes sem conclusão definitiva. A ponderação entre custos e benefícios, de forma sistêmica, como exige-se no esboço de políticas públicas, é certamente uma tarefa árdua. Há, dentro dessa filosofia, discussões interessantíssimas sobre o que é bom, o que é felicidade, como ela pode ser medida, qual o valor da liberdade e da democracia, além de muitas outras questões.

Para os limites deste artigo, todavia, basta lembrarmos de como funciona nosso cérebro e de onde vêm nossas intuições morais. Posto isso, é necessário que não se lhes dê, a priori, valor absoluto, buscando-se sempre uma ponderação possível entre custos e benefícios, principalmente quando se trata de buscar os melhores desenhos para políticas públicas, de lege ferenda ou de lege lata.

Para problemas difíceis, não há solução mágica. Uma abordagem pragmática, todavia, jamais rejeitará qualquer hipótese por princípio. Dentro da premissa do Estado Democrático de Direito, a jurisprudência e a administração pública somente podem atuar nos limites da lei, mas a hermenêutica deve ser, dentro do possível, preservada de nossos impulsos ideológicos dissociados da efetiva busca do bem-estar social.

Uma das premissas do pragmatismo profundo é a de que a dificuldade de resolver questões difíceis decorre do fato de que cada tribo (aqui incluídos grupos sociais, países, etnias e culturas) possui seus próprios instintos de certo e errado, ou seja, suas configuraçôes específicas do sistema 1, forjadas por cultura, meio ambiente, religião e experiências de vida ${ }^{105}$. Discussões sobre o valor intrínseco dessas questões, portanto, tendem, apenas,

07eb76/1498245716080/greene-rat-a-gorical-cogn-17.pdf>. Acesso em: 16 fev. 2018.

105 GREENE, Joshua D. Moral Tribes: Emotion, Reason and the Gap Between Us and Them. New York: Penguin Books, 2013, p. 291. Experimento recente demonstrou divergências na moralidade ao longo de culturas bastante diferentes, que conferem graus diferentes à importância da intenção por detrás das ações (moral intent hypotesis). Em sociedade menores, os padrões são bem mais variáveis do que em sociedades industrializadas. (BARRETT, H. Clark; BOLYANATZ, Alexander; CRITTENDEN, Alyssa N.; FESSLER, Daniel M. T.; FITZPATRICK, Simon; GURYEN, Michael; HENRICH, Joseph; KANOVSKY, Martin; KUSHNICK, Geoff; PISOR, Anne, SCLEZA, Brooke A.; STICH, Stephen; VON RUEDEN, Chris; ZHAO, Wanying; LAURENCE, Stephen. Small-scale societies exhibit fundamental variation in the role of intentions in moral judgment. PNAS, v. 113, n. 17, abr. 2016). 
a aprofundar as diferenças. ${ }^{106} \mathrm{~A}$ única solução, portanto, seria estabelecer uma moeda comum, uma espécie de medidor metamoral para buscar soluções de consenso. Para Greene, e para qualquer utilitarista, essa moeda é a felicidade, pelo simples fato de que, independentemente de nossas convicções morais, todos queremos ser felizes $^{107}$.

O que diferencia o pragmatismo do pragmatismo profundo é a intenção explícita de deixar de lado as diferenças intrínsecas de julgamento para questões difíceis e trabalhar a felicidade como bússola moral a guiar essas discussões ${ }^{108}$.

Segundo Greene, o segredo do pragmatismo é utilizar a forma correta de pensarpara o tipo correto de problema. Para problemas básicos do dia a dia, o sistema 1 funciona muito bem. Para problemas mais complexos, aí incluído o desenho de politicas públicas, é o sistema 2 que tem de ser preponderantemente utilizado ${ }^{109}$.

A ideia básica é: quando os interesses dos envolvidos conflitarem, utilizar o modo manual de pensar ${ }^{110}$. A dificuldade básica é: como alterar a forma de pensar do modo automático para o modo manual?

Segundo Botvinick e March ${ }^{111}$, o cérebro resolve esse problema utilizando um monitoramento de conflito, que funciona em uma estrutura chamada córtex cingulado anterior (anterior cingulate cortex - ACC). A estrutura é ativada, sempre, que respostas incompatíveis aparecem simultaneamente ${ }^{112}$ emitindo um sinal para o DLPFC (dorso lateral, sistema 2), que ativa o modo manual. Comprovadamente, dilemas morais difíceis, quando discutidos, ativam tanto o ACC quanto o DLPFC ${ }^{113}$.

Quando se debatem temas controvertidos, nosso primeiro impulso é argumentar a partir do que julgamos correto. O pragmatismo profundo propõe que se deixem de lado as preconcepções e que haja um engajamento colaborativo na busca da solução capaz de maximizar o bem-estar social. Note-se que o pragmatismo não ensina qual o exato caminho a ser percorrido, mas pressupõe que problemas difíceis são encaminhados a partir de argumentos concretos, dados e pesquisas ${ }^{114}$.

É preciso fugir daquilo que Rozemblid e Keil identificaram como the illusion of explanatory depth ${ }^{115}$. Por uma questão de conforto cognitivo ${ }^{116}$, as pessoas imaginam entender, profundamente, aquilo que elas sequer compreendem. Trata-se de uma derivação do viés de otimismo, que atinge, inclusive, especialistas na matéria da discussão provocadora da ilusão de entendimento ${ }^{117}$.

106 POSNER, Richard A. Law, Pragmatism and Democracy. Cambridge, MA; London: Harvard University, 2003. p. $143-154$.

107 GREENE, Joshua D. Moral Tribes: Emotion, Reason and the Gap Between Us and Them. New York: Penguin Books, 2013. p. 291; MILL, John Stuart. Utilitarianism and the 1896 Speech on Capital Punishment. 2. ed. Indianápolis: George Sher, 2001. [Kindle]. p. 6-26.

108 GREENE, Joshua D. Moral Tribes: Emotion, Reason and the Gap Between Us and Them. New York: Penguin Books, 2013. p. 292.

109 GREENE, Joshua D. Moral Tribes: Emotion, Reason and the Gap Between Us and Them. New York: Penguin Books, 2013. p. 292.

110 GREENE, Joshua D. Moral Tribes: Emotion, Reason and the Gap Between Us and Them. New York: Penguin Books, 2013. p. 293.

111 BOTVINICK, Matthew M.; BRAVER, Todd S.; BARCH, Deanna M.; CARTER, Cameron S.; COHEN, Jonathan D. Conflict Monitoring and Cognitive Control. Psychological Review, v. 108, n. 3, p. 624-652, 2001.

112 Por exemplo, quando a palavra "vermelho" aparece escrita em verde, como vimos no color-naming Stroop task.

113 GREENE, Joshua D. et al. The Neural Bases of Cognitive Conflict and Control in Moral Judgment. Neuron, v. 44, p. 389-400, 14 out. 2004; CUSHMAN, F. et al. Judgment Before Principle: Engagement of the Frontoparietal Control Network in Condemning Harms of Omission. Social Cognitive and Affective Neuroscience, v. 7, n. 8, p. 888-895, nov. 2012.

114 Nada muito diferente do que sempre alertava Barbosa Moreira, quando comentava da dificuldade de discutirem-se alterações processuais sem pesquisa empírica. (BARBOSA MOREIRA, José Carlos. As reformas do Código de Processo Civil: condições de uma avaliação objetiva. In: Temas de Direito Processual Civil. São Paulo: Saraiva, 1997, p. 81-94.).

115 Nas palavras dos autores: "People feel they understand complex phenomena with far greater precision, coherence, and depth than they really do; they are subject to an illusion — an illusion of explanatory depth. The illusion is far stronger for explanatory knowledge than many other kinds of knowledge, such as that for facts, procedures or narratives." (ROZENBLIT, Leonid; KEIL, Frank. The Misunderstood Limits of Folk Science: An Illusion of Explanatory Depth. Cognitive Science, v. 26, n. 5, p. 521-562, set. 2002).

116 KAHNEMAN, Daniel. Thinking: fast and slow. New York: Farrar, Straus and Giroux, 2011. [Kindle]. location 940.

117 KAHNEMAN, Daniel. Thinking: fast and slow. New York: Farrar, Straus and Giroux, 2011. [Kindle]. location 3.923. 
Por exemplo, quando se discutem os recortes dos princípios do devido processo legal, são comuns as referências à legitimação pela participação, à dignidade da pessoa humana e à busca da verdade no processo. Mas até que ponto cada uma das caraterísticas do devido processo legal realmente colabora no alcance desses objetivos? Quais são as consequências positivas e negativas de um determinado modelo de processo? Como calcular os custos envolvidos e em que medida isso impacta no bem-estar social? Esses temas são pouco discutidos, não somente no Brasil, mas na maioria dos países de tradição europeia continental.

Greene sustenta que, nas discussões sobre temas difíceis, há uma confusão entre razão e racionalização ${ }^{118}$. Razão seria algo que se busca com pesquisas e argumentos concretos. Já a racionalização estaria mais para um adorno teórico que moldura nossos instintos. Algo muito próximo do que os neurocientistas chamam de confabulação (confabulation) ${ }^{119}$.

O ponto do pragmatismo profundo permanece: se os desacordos sobre questões difíceis decorrem de diferenças no sistema 1 herdadas de experiências nossas ou de nossos antepassados, qualquer discussão ancorada nessas intuições tende ao fracasso ${ }^{120}$. O sistema 1 é, nesse sentido, cognitivamente impenetrável ${ }^{121}$. Qualquer avanço interlocutório tem de ser guiado por reflexões típicas do sistema 2, ou seja, aquelas capazes de promover o maior bem-estar possível entre os envolvidos ${ }^{122}$.

No trato específico do direito, suspeitamos que posições peremptórias sobre temas difíceis, fundadas em dogmas impenetráveis que não encontram um amparo explícito na Constituição Federal, trajam as vestes do sistema $1^{123}$.

Veja-se, por exemplo, o tema da vinculação das cortes inferiores aos precedentes estabelecidos pelas Cortes Superiores, na forma do art. 926 do CPC/2015. Afora nuances, não há norma explícita na Constituição Federal que torne inconstitucionais os precedentes apontados pelo CPC/2015 como obrigatórios. Não estamos afirmando que não seja possível tecer argumentos pela inconstitucionalidade da obrigatoriedade do respeito aos precedentes, ou mesmo discutir qual é o grupo de precedentes obrigatórios e ou vinculantes. Essa é, no fim do dia, uma questão de interpretação da norma constitucional. E o diabo reside exatamente nesse ponto.

Nesse tipo de discussão, o sistema 2 ancora sua racionalização em determinados valores fornecidos pelo sistema 1, criando-se um debate que deixa de lado o que verdadeiramente importa: o bom funcionamento do sistema judicial, de acordo com as circunstâncias brasileiras. Quais os problemas e virtudes do sistema

118 GREENE, Joshua D. Moral Tribes: Emotion, Reason and the Gap Between Us and Them. New York: Penguin Books, 2013. p. 302-309.

119 Pacientes com danos cerebrais como amnésia ou desconexão dos hemisférios (split-brain) tendem a criar enredos fidedignos para preencher os evidentes brancos mentais. Note-se que o dano mental não cria a capacidade de confabulação. Todos nós somos confabuladores (GREENE, Joshua D. Moral Tribes: Emotion, Reason and the Gap Between Us and Them. New York: Penguin Books, 2013. p. 299) e em uma discussão de política pública isso deve ser levado bastante sério. O equivalente moral da confabulação é a racionalização (GREENE, Joshua D. Moral Tribes: Emotion, Reason and the Gap Between Us and Them. New York: Penguin Books, 2013. p. 300), uma roupagem teórica para os nossos instintos. (STUSS, D. T. et al. An Extraordinary Form of Confabulation. Neurology, v. 28, n. 11, p. 1.166-1.172, nov. 1978). Sobre pacientes com split-brain: GAZZANIGA, Michael. One Brain or Two? The Split Brain in Man. Scientific American, v. 217, n. 2, p. 24-29, 1967.

120 Esse é um forte argumento para a visão pragmática schumpeteriana, defendida por Posner (POSNER, Richard A. Law, Pragmatism and Democracy. Cambridge, MA; London: Harvard University, 2003).

121 GREENE, Joshua D. Moral Tribes: Emotion, Reason and the Gap Between Us and Them. New York: Penguin Books, 2013. p. 303.

122 Para um exemplo sobre as dificuldades desse caminho, e sobre como ele pode ser percorrido, ver discussão a respeito da possibilidade de aborto em GREENE, Joshua D. Moral Tribes: Emotion, Reason and the Gap Between Us and Them. New York: Penguin Books, 2013. p. 309.

123 Não obstante, é crescente o número de artigos brasileiros que partem de uma premissa utilitarista, essencialmente preocupada com o aumento do bem estar-social quando da interpretação da norma jurídica. Nesse sentido: SILVA, Juvêncio Borges; JUCATELLI, João Paulo. Judicialização da saúde, ativismo judicial e o consequente desequilíbrio do orçamento público. Revista Brasileira de Políticas Públicas, v.7, n. 1, p. 99-116, 2017. SANTANA, Héctor Valverde. Análise econômica do direito: a eficiência da norma jurídica na prevenção e reparação de danos sofridos pelo consumidor. Revista Brasileira de Políticas Públicas, v.4, n. 1, p. 224-337, 2014. , Matthew M.; BRAVER, Todd premissa pragmatista por nlitarista, essencialmente preocupada com o aumento do bem estar-socail 
de justiça brasileiro? Quais os benefícios concretos da adoção de um sistema de precedentes vinculantes? Quais os possíveis malefícios? Entre prós e contras, no geral, a adoção implicaria um sistema mais eficiente para a sociedade como um todo? ${ }^{124}$

Essas perguntas, para serem respondidas, precisam, necessariamente, do aporte de outras ciências, como a economia, a psicologia e a sociologia, além de pesquisas empíricas. Mais do que isso, essa resposta pode mudar ao longo do tempo, de acordo com as circunstâncias. Não há uma resposta de fé para esse tipo de questão. Qualquer princípio absoluto de direito processual do qual não se arrede pé parece mais um escudo para as racionalizações dos instintos do sistema 1 do que um argumento consistente ${ }^{125}$.

\section{Considerações finais}

De forma geral, identificamos que, nas discussões difíceis que normalmente antecedem a tomada de decisões jurídicas complexas e o desenho de políticas públicas, argumentos exclusivamente valorativos ou principiológicos são um passe livre intelectual, um atalho preguiçoso, instintivo, às vezes, autoritário, e, simplesmente, deixa de lado o que realmente importa: a realidade. Pessoas não vivem argumentos. Vivem a vida. O que define a correção de um posicionamento sobre um tema difícil é, em última instância, uma questão empírica.

O pragmatismo profundo reserva aos direitos um papel fundamental na sociedade: conferir segurança para temas que estejam mais ou menos assentados, não porque sejam verdades universais, mas porque, por razões práticas, os membros daquela determinada sociedade concordam com a solução e não estão dispostos a discuti-la a todo instante ${ }^{126}$. Nesses casos, o risco de a escolha protegida com um direito ser incorreta é menor do que o risco de não haver uma firme resolução a respeito.

Todavia, nos temas difíceis, para os quais não haja norma escrita ou jurisprudencial clara, a revisão de literatura demonstrou a existência de um corpo consistente de experimentos que demonstram que o debate deve centrar-se na pesquisa dos benefícios e dos malefícios daquele posicionamento para a coletividade, apesar de a nossa intuição forçar-nos a decidir com base em convicções principiológicas, muitas vezes dissociadas da realidade. Ficou claro que o entendimento de como o cérebro funciona é fundamental para superar esse problema e mudar as premissas utilizadas nas escolhas públicas.

Quando se trata da busca do que é melhor para a sociedade, ao menos no que se refere ao desenho de políticas públicas, não há fórmulas mágicas. O aumento do bem-estar social e a utilização de métodos científicos teóricos e empíricos, todavia, são premissas inafastáveis.

\section{REFERÊNCIAS}

BARON, J.; GREENE, J. D. Determinants of Insensitivity to Quantity in Valuation of Public Goods: Contribution, Warm Glow, Budget Constraints, Availability, and Prominence. Journal of Experimental Psychology, v. 2, n. 2, p. 107-125, 1996.

BARRETT, H. Clark et al. Small-scale societies exhibit fundamental variation in the role of intentions in moral judgment. PNAS, v. 113, n. 17, abr. 2016.

124 Todavia, abordando o tema com a premissa pragmatista por nós proposta, GICO Jr., Ivo. Anarquismo Judicial e Segurança Jurídica. Revista Brasileira de Políticas Públicas, v. 5, n. especial, p. 480-500, 2015.

125 Sobre direitos como escudos e armas, para o bem e para o mal: GREENE, Joshua D. Moral Tribes: Emotion, Reason and the Gap Between Us and Them. New York: Penguin Books, 2013, p. 306-309.

126 GREENE, Joshua D. Moral Tribes: Emotion, Reason and the Gap Between Us and Them. New York: Penguin Books, 2013, p. 306. 
BECHARA, Antonie et al. Insensitivity to Future Consequences Following Damage to Human Prefrontal Cortex. Cognition, v. 50, p. 7-15, 1994.

BLAIR, R. J. R. A Cognitive Developmental Approach to Morality: Investigating the Psychopath. Cognition, v. 57, p. $1-29,1995$.

BOTVINICK, Matthew M. et al. Conflict Monitoring and Cognitive Control. Psychological Review, v. 108, n. 3, p. 624-652, 2001.

CALABRESI, Guido. The Future of Law and Economics. New Haven, CT: Yale University, 2016.

COHEN, Jonathan D.; MILLER, Earl K. An Integrative Theory of Prefrontal Cortex Function. Annual Review of Neuroscience, v. 24, p. 167-202, 2001.

CUSHMAN, F.; GAFFEY, A.; GRAY, K.; MENDES, W. B. Simulating Murder: The Aversion to Harmful Action. Emotion, v. 12, n 1, p. 2-7, 2012. Disponível em: <https://cushmanlab.fas.harvard.edu/docs/ cushman_gray_gaffey\&mendes_2012.pdf>. Acesso em: 30 jul. 2017.

CUSHMAN, F.; GREENE, J. D. The Philosopher in the Theater. In: MIKULINCER, M.; SHAVER, P. R. (Eds.). Social Psychology of Morality: The Origins of Good and Evil. APA, 2011. Disponível em: < http:// cushmanlab.fas.harvard.edu/docs/cushman\&greene_2011b.pdf>. Acesso em: 16 fev. 2018.

CUSHMAN, F. et al. Judgment Before Principle: Engagement of the Frontoparietal Control Network in Condemning Harms of Omission. Social Cognitive and Affective Neuroscience, v. 7, n. 8, p. 888-895, nov. 2012.

CUSHMAN, F.; YOUNG, L.; HAUSER, M. The Role of Conscious Reasoning and Intuition in Moral Judgment: Testing Three Principles of Harm. Psychology Science, v. 17, n. 12, p. 1.082-1.089, 2006.

DAMASIO, Antônio. Descartes' Error: Emotion, Rationality and the Human Brain. New York: Penguim; Grosset, 1994. [Kindle].

DESVOUSGES, William H. et al. Measuring Nonuse Damages Using Contingent Valuation: An Experimental Evaluation of Accuracy. 2. ed. Research Triangle Park, NC: RTI, 2010. Disponível em: < https://www.rti. org/sites/default/files/resources/bk-0001-1009_web.pdf>. Acesso em: 16 fev. 2018.

FOOT, Philippa. The Problem of Abortion and the Doctrine of the Double Effect. Oxford Review, n. 5, p. 5-15, 1967.

FRANKISH, Keith. Dual-Process and Dual-System Theories of Reasoning. Philosophy Compass, v. 5, n. 10, p. 914-926, 2010.

GAZZANIGA, Michael. One Brain or Two? The Split Brain in Man. Scientific American, v. 217, n. 2, p. 2429, 1967.

GICO Jr., Ivo. Anarquismo Judicial e Segurança Jurídica. Revista Brasileira de Políticas Públicas, v.5, número especial, p. 480-500, 2015.

GREENE, Joshua D. Moral Tribes: Emotion, Reason and the Gap Between Us and Them. New York: Penguin Books, 2013.

GREENE, Joshua D. The Rat-a-gorical Imperative: Moral Intuition and the Limits of Affective Learning. Cognition, no prelo [aceito 6 mar. 2017]. Disponível em: <https://static1.squarespace.com/ static/54763f79e4b0c4e55ffb000c/t/594d6a53a5790aaf1207eb76/1498245716080/greene-rat-a-goricalcogn-17.pdf>. Acesso em: 16 fev. 2018.

GREENE, Joshua D. et al. Cognitive Load Selectively Interferes with Utilitarian Moral Judgment. Journal of Cognitive Neuroscience, v. 22, n. 8, p. 1.888-1.899, jun. 2008.

GREENE, Joshua D. et al. The Neural Bases of Cognitive Conflict and Control in Moral Judgment. Neuron, 
v. 44, p. 389-400, 14 out. 2004.

GREENE, Joshua D. et al. An fMRI Investigation of Emotional Engagement in Moral Judgment. Science, v. 293 , n. 5.537, p. 2.105-2.108, set. 2001.

HAUSER, Marc et al. A Dissociation Between Moral Judgments and Justifications. Mind \& Language, v. 22, n. 1, p. 1-21, fev. 2007.

HUANG, Bert I. Book Review: Law and Moral Dilemmas. Harvard Law Review, v. 130, p. 659-699, dez. 2016.

KAHNEMAN, Daniel. Thinking: fast and slow. New York: Farrar, Straus and Giroux, 2011. [Kindle].

KAHNEMAN, Daniel; SHANE Frederick. Representativeness Revisited: Attribute Substitution in Intuitive Judgment. In: GILOVICH, Thomas; GRIFFIN, Dale; KAHNEMAN, Daniel (Eds.). Heuristics and Biases: The Psychology of Intuitive Judgment. Cambridge: Cambridge University, 2002. p. 49-81.

KANT, Immanuel. Fundamental Principles of the Metaphysics of Morals. Tradução: Thomas Kingsmill Abbott. [Kindle: The ultimate collected works of 14 books].

KAPLOW, Louis; SHAVELL, Steven. Fairness Versus Welfare. Harvard Law Review, v. 114, n. 4, p. 961-1.390, fev. 2001

LENZ, Gabriel S.; LAWSON, Chappell. Looking the Part: Television Leads Less Informed Citizens to Vote Based on Candidates' Appearance. American Journal of Political Science, v. 55, n. 3, p. 574-589, jul. 2011.

MCINTYRE, Alison. Doctrine of Double Effect. In: ZALTA, Edward N. (Ed.). The Stanford Encyclopedia of Philosophy, inverno 2014. Disponível em: < https://plato.stanford.edu/archives/win2014/entries/doubleeffect>. Acesso em: 16 fev. 2018.

MENDEZ, Mário F.; ANDERSON, E.; SHAPIRA, J. S. An Investigation of Moral Judgement in Frontotemporal Dementia. Cognitive Behavioral Neurology, v. 18, n. 4, p. 193-197, dez. 2005.

MIKHAIL, John. Elements of Moral Cognition: Rawl's Linguistic Analogy and the Cognitive Science of Moral and Legal Judgment. Cambridge, UK: Cambridge University, 2011. [Kindle].

MILL, John Stuart. Utilitarianism and the 1896 Speech on Capital Punishment. 2. ed., Indianápolis: George Sher, 2001. [Kindle].

MOREIRA, José Carlos Barbosa. As reformas do Código de Processo Civil: condições de uma avaliação objetiva. In: Temas de Direito Processual Civil. São Paulo: Saraiva, 1997, p. 81-94. [6. série].

MORETTO, Giovanna et al. A psychophysiological investigation of moral judgment after ventromedial prefrontal damage. Journal of Cognitive Neuroscience, v. 22, n. 8, p. 1.888-1.899, 2009.

MORRIS, Ian. Why the West Rules: For Now: The Patterns of History and What They Reveal About the Future. New York: Farrar, Straus and Giroux, 2010. [Kindle].

NEARY, Walter. Personal Decisions Exercise the Emotional Part of the Brain, 2001. Disponível em: <http://www. washington.edu/news/2001/11/26/personal-decisions-exercise-the-emotional-part-of-the-brain > . Acesso em: 16 fev. 2018

NEERGAARD, L. Brain Scan Shows Emotion in Decisions. Washington Post, set. 2001.

NOWAK, Martin A. Five Rules for the Evolution of Cooperation. Science, v. 314, n. 5.805, p. 1.560-1.563, 8 dez. 2006. Disponível em: <https://www.ncbi.nlm.nih.gov/pmc/articles/PMC3279745>. Acesso em: 16 fev. 2018.

PAHAIA, Neeru et al. Dirty Work, Clean Hands: The Moral Psychology of Indirect Agency. Organizational Behavior and Human Decision Processes. Disponível em: <https://dash.harvard.edu/handle/1/4264764 >. Acesso em: 16 fev. 2018. 
PAXTON, Joseph M.; UNGAR, Leo; GREENE, Joshua D. Reflection and Reasoning in Moral Judgment. Cognitive Science, v. 36, n. 1, p. 163-177, jan./ fev. 2012.

PINKER, Steven. The Stuff of Thought: Language as a Window Into Human Nature. New York: Penguin, 2007. [Kindle].

POSNER, Richard A. Law, Pragmatism and Democracy. Cambridge, MA; London: Harvard University, 2003.

ROZENBLIT, Leonid; KEIL, Frank. The Misunderstood Limits of Folk Science: An Illusion of Explanatory Depth. Cognitive Science, v. 26, n. 5, p. 521-562, set. 2002.

SANDEL, Michael. Justice: What's the Right Thing to Do? New York: Farrar, Straus and Giroux, 2008.

SANTANA, Héctor Valverde. Análise econômica do direito: a eficiência da norma jurídica na prevenção e reparação de danos sofridos pelo consumidor. Revista Brasileira de Políticas Públicas, v.4, n. 1, p. 224-337, 2014.

SCHWITZGEBEL, Eric; CUSHMAN, Fiery. Expertise in Moral Reasoning? Order Effects on Moral Judgment in Professional Philosophers and Non-Philosophers. Mind \& Language, v. 27, p. 135-153, 2012

SILVA, Juvêncio Borges; JUCATELLI, João Paulo. Judicialização da saúde, ativismo judicial e o consequente desequilíbrio do orçamento público. Revista Brasileira de Políticas Públicas, v.7, n. 1, p. 99-116, 2017.

STANOVICH, Keith E.; WEST, Richard F. Individual Differences in Reasoning: Implications for the Rationality Debate? Behavioral and Brain Sciences, v. 23, n. 5, p. 645-726, out. 2000.

STUSS, D. T.; ALEXANDER, M. P.; LIEBERMAN, A.; LEVINE, H. An Extraordinary Form of Confabulation. Neurology, v. 28, n. 11, p. 1.166-1.172, nov. 1978.

SUTER, Renata S.; HERTWIG, Ralph. Time and Moral Judgment. Cognition, v. 119, n. 3, p. 454-458, jun. 2011.

THOMAS, Bradley C. et al. Arrested Development: Early Prefrontal Lesions Impair the Maturation of Moral Judgement. Brain: A Journal of Neurology, v. 137, n. 4, p. 1.254-1.261, abr. 2014.

THOMAS, Bradley C.; CROFT, Katie E.; TRANEL, Daniel. Harming Kin to Save Strangers: Further Evidence for Abnormally Utilitarian Moral Judgments after Ventromedial Prefrontal Damage. Journal of Cognitive Neuroscience, v. 23, n. 9, p. 2.186-2.196, set. 2011.

THOMSON, Judith. Kamm on the Trolley Problems. In: KAMM, F. M. The Trolley Problem Mysteries. Oxford: Oxford University, 2016, p. 113-133. [Kindle].

THOMSON, Judith. Killing, Letting Die, and the Trolley Problem. Monist: Journal of General Philosophical Inquiry, v. 59, n. 2, p. 204-217, 1976.

THOMSON, Judith. The Trolley Problem. The Yale Law Journal, v. 94, n. 6, p. 1.395-1.415, maio 1985.

TODOROV, Alexander; BARON, Sean G.; OOSTERHOF Nikolaas N. Evaluating Face Trustworthiness: a Model Based Approach. Social Cognitive and Affective Neuroscience, v. 3, n. 2, p. 119-127, jun. 2008.

TODOROV, Alexander et al. Inferences of Competence from Faces Predict Election Outcomes. Science, v. 308, n. 5.728, p. 1.623-1.626, 10 jun. 2005.

TODOROV, Alexander; PAKRASHI, Manish; OOSTERHOF Nikolaas N. Evaluating Faces on Trustworthiness after Minimal Time Exposure. Social Cognition, v. 27, n. 6, p. 813-833, 2009.

XIANG, Xin. Would the Buddha Push the Man Off the Footbridge?: Systematic Variations in the Moral Judgment and Punishment Tendencies of Han Chinese, Tibetans and Americans. 2014. Monografia--(Trabalho de Conclusão de Curso). Harvard University, Cambridge, MA, 2014. 


\section{REVISTA BRASILEIRA DE POLÍTICAS PÚBLICAS BRAZILIAN JOURNAL OF PUBLIC POLICY}
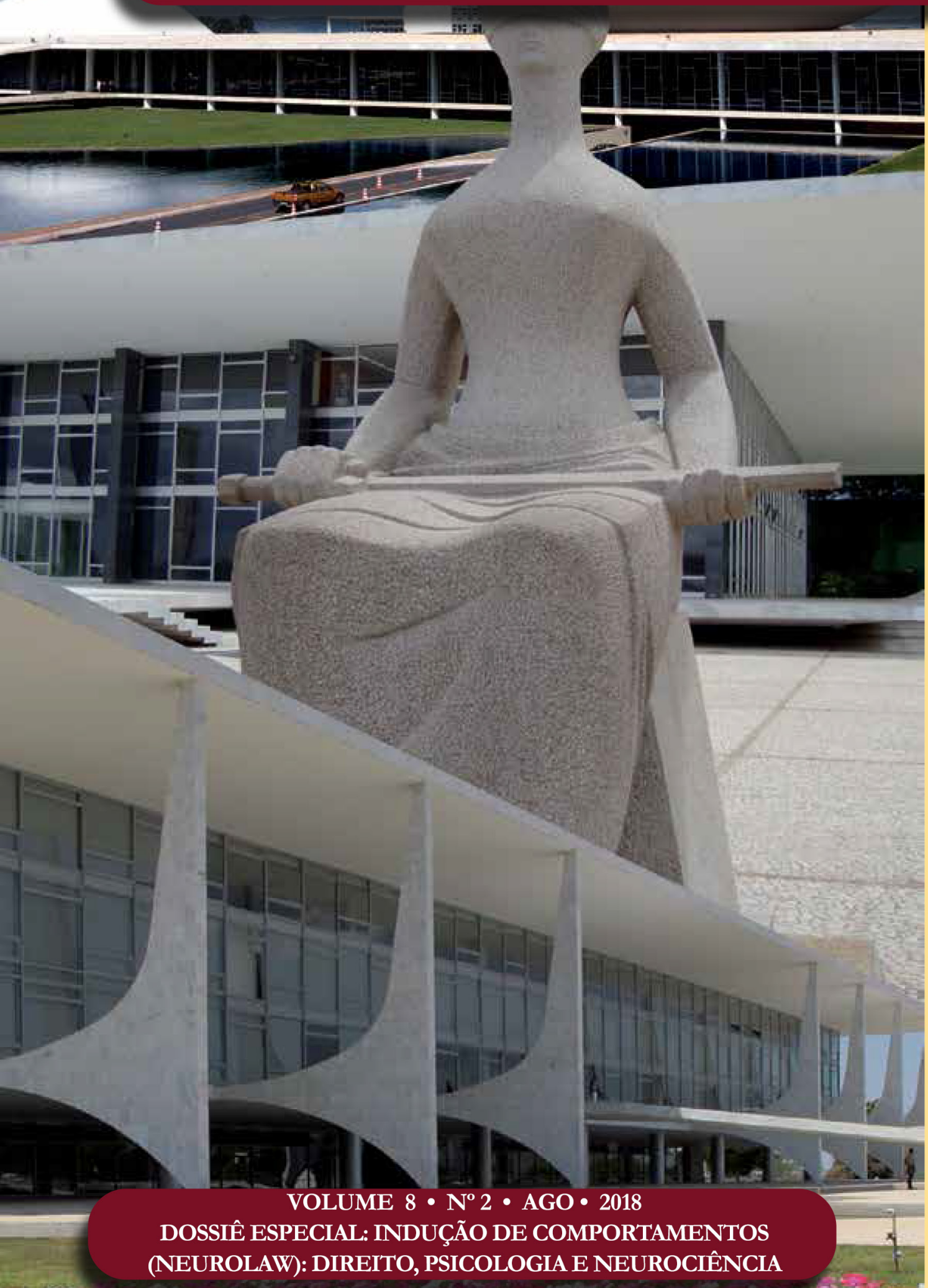

Desvio de caráter ou simplesmente humano? Economia comportamental aplicada ao comportamento desonesto

Bad character or simply human? Behavioral economics applied to dishonest behavior
Diana Orghian

Gabriel Cabral

André Pinto

Alessandra Fontana 


\title{
Desvio de caráter ou simplesmente humano? Economia comportamental aplicada ao comportamento desonesto*
}

\author{
Bad character or simply human? Behavioral \\ economics applied to dishonest behavior
}

\author{
Diana Orghian** \\ Gabriel Cabral*** \\ André Pinto**** \\ Alessandra Fontana*****
}

* Artigo convidado

** Doutorada em Cognição Social na Faculdade de Psicologia da Universidade de Lisboa. Investigadora no Media Lab, Massachussetts Institute of Technology (MIT). Conselheira Cientifica (Scientific Advisor) em CLOO Behavioral Insight Unit. E-mail: dorghian@mit. edu.

*** Professor substituto de Direito da Universidade Federal do Rio de Janeiro (UFRJ), Mestre em direito pela Pontifícia Universidade Católica do Rio de Janeiro (PUC-RJ). Consultor em CLOO Behavioral Insight Unit. E-mail: gcabral@cloo.pt.

**** Psicólogo Social e Mestre integrado em Cognição Social Aplicada pela Faculdade de Psicologia da Universidade de Lisboa. Consultor em CLOO Behavioral Insight Unit. E-mail: apinto@cloo.pt.

***** Jornalista pela Pontifícia Universidade Católica de Paraná e Mestre em Relações Internacionais e Desenvolvimento pela University of East Anglia (UK). Pesquisadora e colaboradora em CLOO Behavioral Insight Unit. Email: alessandrafontana@hotmail.com.

\section{Resumo}

Neste artigo, apresentamos uma abordagem de combate à corrupção e ao comportamento desonesto baseada na economia comportamental, psicologia cognitiva e psicologia social. A economia comportamental tem sido extensivamente aplicada à criação de políticas de alteração de comportamentos na área da saúde e educação, sendo a aplicação ao combate à corrupção uma área ainda incipiente. Neste artigo, tendo por base uma revisão da literatura científica sobre o comportamento desonesto, demonstramos que as pessoas nem sempre agem de forma racional, coerente e previsível, e nem sempre incorporam análises de custo-benefício nas suas decisões, tal como é previsto pelos modelos econômicos tradicionais. Também, demonstramos que existem fatores inconscientes e mais sutis que podem estar contribuindo para o comportamento desonesto. Esses fatores são: i) a cognição humana e os vieses que afetam a tomada de decisão (e.g. racionalização motivada, licença moral, dissonância cognitiva etc.); ii) as características do contexto que influenciam determinado comportamento desonesto (e.g. ambiguidade nos procedimentos, falta de clareza, distância psicológica em relação ao dinheiro etc.); iii) os fatores sociais que podem ser relevantes ao comportamento desonesto (reciprocidade, difusão da responsabilidade, normas sociais etc.). Uma vez conhecidos estes fatores, um rol de intervenções pode ser sugerido para conduzir as pessoas a agirem de forma mais honesta. Este artigo é direcionado a atores do setor público e privado interessados na temática do combate à corrupção e tem dois objetivos: i) descrever os fatores psicológicos que influenciam o comportamento desonesto e ii) apresentar soluções de fácil implementação e baixo custo (nudges), que podem ser integradas nas políticas de integridade e combate à corrupção.

Palavras-chave: Economia comportamental. Heurísticas. Desonestidade. Nudge. 


\section{Abstract}

In this paper we present a human-centered approach to fighting corruption inspired by behavioral economics, cognitive and social psychology. Behavioral Science has been used extensively to design policies in areas such health and education. However, their application to dishonest behavior has been incipient. The current policy approaches to corruption follow mostly a traditional 'rational' model of behavior. Here, we argue that people do not always incorporate cost-benefit analysis in their decisions and they have unconscious biases and heuristics driving their dishonest behaviors. Knowing how these biases operate is a crucial step to understand why corrupt behavior happens and how we can discourage it more effectively. Our approach to corruption analyses three components influencing human behavior: i) human cognition and biases that affect decision making (motivated reasoning, moral licensing, cognitive dissonance, etc.); ii) the attributes of the context that push us toward dishonest behavior (ambiguity in the procedures, lack of clarity of consequences, psychological distance to money, etc.); iii) the social factors that lead us to behave unethically (reciprocity, diffusion of responsibility, social norms, etc.). These factors can be intervened in order to nudge people towards ethical actions, improving the effectiveness of anti-corruption policies and increasing trust. This paper targets public and private sector stakeholders interested in fighting corruption, and its goal is two-folded: i) to describe the major psychological factors that affect lead to dishonest behaviors, and ii) present a set of effective solutions that can be easily implemented at low cost within public and private policy.

Keywords: Behavioral science. Heuristics. Dishonesty. Nudge.

\section{INTRODUÇÃo}

Os comportamentos desonestos afetam a sociedade em diversos níveis, desde a violação de regras internas no local de trabalho (e.g. declarar despesas excessivas de viagens) ou violação de deveres fiscais (e.g. a evasão fiscal e o não pagamento de multas), até ações fraudulentas com consequências mais sistêmicas (e.g. lavagem de dinheiro, superfaturamento de obras públicas ou desvio de dinheiro público).

No Brasil, o tema do combate à corrupção se tornou objeto de atenção generalizada em decorrência de investigações policiais altamente midiatizadas, como a Lava Jato. No Fórum Econômico Mundial para a América Latina de 20181, o Ministro Torquato Jardim afirmou que "O que se conbece da Lava Jato é 10\%, é a ponta do iceberg”. Diante de afirmações dramáticas como esta, indaga-se: que estratégias utilizar para combater a corrupção e como tornar essas estratégias mais eficazes? A corrupção é um problema complexo e, como tal, demanda respostas holísticas.

Estratégias de combate à corrupção devem incorporar elementos de natureza variada, desde programas de prevenção à esforços de criminalização, de atos da administração pública a iniciativas dos cidadãos e do setor privado. As intervenções empreendidas no setor público e privado para resolver o problema podem ser diversas: aumentar a fiscalização, aumentar as penas para crimes de corrupção, privatizar os serviços públicos, promover campanhas de conscientização da população, realizar cursos de treinamento, reciclagem ética de agentes públicos etc.

Em um cenário de muito ressentimento, é compreensível que as políticas públicas mais tradicionais de combate à corrupção ganhem espaço na opinião pública: de um lado, mais denúncia, investigação e punição; de outro, mais conscientização, informação e educação. Como uma ilustração desse fenômeno, mais de duas milhões de pessoas assinaram o projeto de Iniciativa Popular criada pelo Ministério Público Federal (MPF),

1 FÓRUM Econômico Mundial para América Latina 2018. Disponível em: <https://www.weforum.org/es/focus/forum-economico-mundial-para-a-america-latina-2018>. Acesso em: 21 maio 2018. 
intitulado 10 medidas contra a corrupção ${ }^{2}$. Ilustrativo do investimento na punição, no banner referente às medidas, apresentam-se frases como as seguintes: "[é preciso] quebrar o círculo de impunidade" e "corrupção será um crime de alto risco!".

A segunda tendência diz respeito à criação de departamentos de compliance em empresas e a implementação de programas de integridade em órgãos públicos. As estratégias de compliance e integridade, diferentemente das 10 medidas do MPF, não possuem, apenas, um aspecto persecutório e punitivo, mas também um aspecto pedagógico, informativo, e de esclarecimento de condutas ilícitas e indesejadas. Essa difusão deve-se, majoritariamente, à vigência, a partir de 2014, da "Lei Anticorrupção" (Lei 12.846/13), que, grosso modo, prevê a responsabilização objetiva de empresas em casos de práticas de atos lesivos contra a Administração Pública, como a corrupção ativa. Seguindo essa linha, dois anos depois, por meio da Portaria n ${ }^{\circ} 748 / 16$, foi instituído o Programa de Fomento da Integridade Pública da Controladoria-Geral da União (PROFIP), cuja principal função é orientar e capacitar órgãos do Poder Executivo Federal e empresas aderentes ao Programa a criar medidas de compliance $e^{3}$.

Assim, atualmente no Brasil, tem-se, de um lado, o MPF e outras instâncias públicas, como os Tribunais de Contas, apostando na vigilância e punição; e, de outro lado, a CGU, que por meio do PROFIP, aposta na educação e informação como meios para combater a corrupção ${ }^{4}$. Diante desse quadro, a questão que fazemos é: será que essas apostas são baseadas em pressupostos realistas sobre o comportamento humano? Será que há algum mecanismo que possa potencializar o efeito dessas medidas ou, ainda, que apresente um caminho alternativo, ou complementar, entre punir e informar?

O ser humano como ser racional serve de guia a muitos dos modelos de análise de comportamento empregados na Economia tradicional ou Neoclássica. Nesses modelos, os seres humanos são descritos como seres que agem de acordo com a Teoria da Ação Racional ${ }^{5}$. No contexto do crime, um modelo frequentemente utilizado para explicar as razões pelas quais as pessoas cometem crimes é o Simple Model of Rational Crime on Rational crime theory ${ }^{6}$. De acordo com esse modelo, a decisão de cometer um crime resulta de uma análise de custo-benefício realizada com base nas informações a que se têm acesso. Assim, o indivíduo comete o crime se a recompensa for maior do que os potenciais malefícios, nomeadamente: a chance de a pessoa ser descoberta, a chance de ser condenada criminalmente e, em caso de condenação, o montante da pena.

Em consonância com esse paradigma racional, para que um agente público venha a se corromper, basta que os benefícios de sua corrupção sejam maiores do que as possíveis penalizações decorrentes da persecução sancionatória. Isto significa que, se medidas severas contra a corrupção forem aplicadas, cometer atos corruptos será mais custoso, e, como consequência, as pessoas deixarão de cometer esse crime.

Mas será mesmo assim? Não negamos que existam momentos em que o ser humano se comporte segundo esse modelo racional, há décadas utilizado na política criminal. Entretanto, apesar de intuitivo e sedutor, esse modelo vem sendo alvo de constantes críticas por não subsistir a um contraste com a realidade. As críticas decorrem das assunções que o modelo racional faz relativamente à natureza humana ${ }^{7}$. Além da natureza

2 Consultar: <http://www.dezmedidas.mpf.mp.br/campanha/produtos/pdf/Banner_LONA.pdf>. Acesso em: 21 maio 2018.

3 O manual do PROFIP de apoio elaborado pela CGU pode ser encontrado em: <http://www.cgu.gov.br/Publicacoes/etica-eintegridade/arquivos/manual_profip.pdf/view>; Acesso em: 25 jul. 2018.

4 Existe, ainda, a atuação da sociedade civil e da mídia que, também, executam investigação, informação e conscientização e são parte do arcabouço anticorrupção da maioria dos países democráticos. Entretanto, como esse texto se dedica a analisar políticas públicas desenhadas e implementadas por órgãos públicos, não analisamos os impactos da economia comportamental sobre as atividades desses atores.

5 Há como alternativa, por exemplo, o homo sociologicus, que enfatiza o homem como resultado das pressões sociais ou o homo reciprocans, em que o caráter de reciprocidade e cooperação humana são salientados.

6 HARFORD, Tim. The logic of life: the rational economics of an irrational world. New York: Random House, 2008 e CLARKE, Ronald; FELSON, Marcus. Routine activity and rational choice: advances in criminological theory, v. 5, 1993.

7 Cf. PERSSON, Anna; ROTHSTEIN, Bo; TEORELL, J. Why anticorruption reforms fail: systemic corruption as a collective action problem. Governance, New Jersey, v. 26, n. 3, p. 449-471, jul. 2013. 
complexa inerente à problemática da corrupção, muitos dos comportamentos desonestos que conduzem a atos corruptos devem-se a vieses ${ }^{8}$ que operam de forma inconsciente ${ }^{9}$. Perante vieses inconscientes, criar mais regras, leis, ou sanções, bem como dar mais informações às pessoas, pode ter pouco ou nenhum impacto no comportamento. A boa notícia é que é possível conhecer esses vieses, entender como operam e criar intervenções eficazes para combatê-los. Nesta análise, apresentaremos alguns dos vários fatores cognitivos, contextuais e sociais que podem promover comportamentos desonestos.

\section{ECONOMIA COMPORTAMENTAL: UMA BASE TEÓRICA DIFERENTE PARA FUNDAMENTAR AÇÕES PRÁTICAS CONTRA A CORRUPÇÃO}

A Economia Comportamental é o domínio científico que resulta do cruzamento entre a Psicologia, em particular a Psicologia Social e a Psicologia Cognitiva, e a Economia, tendo como principal objetivo estudar a tomada de decisão do ponto de vista comportamental. A economia comportamental tem o mérito de aproximar teorias econômicas, tradicionalmente abstratas e teóricas, de evidências das ciências comportamentais. Um bom sinal dessa aproximação entre psicologia e economia é o fato de o psicólogo Daniel Kahneman ter ganhado o Prêmio Nobel da Economia em $2002^{10}$ pelas suas descobertas relativamente ao julgamento humano e tomada de decisão em situações de incerteza. Mais recentemente, o mesmo prêmio foi atribuído em 2017 a Richard Thaler, economista que utiliza a Economia Comportamental não apenas para compreender o comportamento humano, mas também como um meio para desenvolver políticas públicas mais eficazes e baseadas em evidências científicas (nudges).

Para cientistas comportamentais, os seres humanos não são tão racionais quanto retratam os modelos tradicionais, dispondo de uma racionalidade limitada (bounded rationality), conceito introduzido por Herbert Simon $^{11}$. Para Simon, a própria ideia de determinar qual é a opção mais racional constitui um custo que a torna irracional. Conseguir as informações necessárias a uma decisão racional, processá-la atentamente, computar todas as opções e calcular os prós e contras de cada uma são tarefas exigentes em termos cognitivos e requerem tempo. Tendo em vista esse claro custo cognitivo, Simon afirma que as pessoas acabam tomando uma decisão que não é perfeita, mas é satisfatória ${ }^{12}$ (“good enough"). Essa decisão é a mais racional diante de nossas limitações, pois: (i) falta-nos tempo para refletir sobre todas as opções disponíveis, (ii) nem sempre temos acesso a todas as informações necessárias e (iii) nosso cérebro tem limitações em termos da quantidade que consegue computar. Além dessas limitações, a investigação mostra que somos afetados por vieses cognitivos: mecanismos psicológicos simplificados, muitas vezes automáticos, que guiam o nosso comportamento e a nossa tomada de decisão, e que em certas situações se afastam, consideravelmente, do que seria considerado adequado de um ponto de vista racional.

Além de não considerar a nossa racionalidade limitada e os vieses cognitivos, o modelo do agente racional não considera uma das motivações mais características do ser humano, e que tem grande relevância para o comportamento desonesto: a nossa necessidade de manter uma imagem positiva de nós mesmos e perante

\footnotetext{
8 Vieses cognitivos são mecanismos cognitivas de simplificação da informação que conduzem a tendências comportamentais previsíveis e sistemáticos. No livro Thinking fast and slow (2011), Daniel Kahneman traz uma compilação de décadas de evidências sobre vieses da cognição.

9 BAZERMAN, Max; LOEWENSTEIN, George; MOORE, Don. Why good accountants do bad audits. Harvard Business Review, Cambridge, v. 80, p. 96-103, nov. 2002.

10 Seu prêmio foi dividido com Vernon L. Smith.

11 SIMON, H. A behavioral model of rational choice. The Quarterly Journal of Economics, Cambridge, v. 69, n. 1, p. 99-118, fev. 1955.

12 De uma forma mais técnica, o autor refere-se a um neologismo: "satisficing", que corresponde à justaposição entre satisfy e suffice, de forma a indicar que se trata de um conceito diferente e mais exigente do que a forma como o termo satisfação é usado no senso comum.
} 
os outros ${ }^{13}$. Assim, temos duas motivações básicas que entram em conflito, uma que nos diz para maximizar os nossos lucros pessoais, o que às vezes implica agir de forma desonesta, e a outra, que pretende manter uma boa autoimagem, uma imagem de alguém que é honesto e que merece respeito dos outros. Por essa perspectiva, a magnitude da desonestidade observada na sociedade deve-se a pessoas que se consideram honestas e que se convencem de que estão cometendo desvios pequenos e triviais (como explicado adiante). É importante notar que as pessoas, de forma geral, têm uma motivação intrínseca para a honestidade ${ }^{14}$. Apenas uma percentagem muito reduzida da população tem a motivação explícita de agir de forma desonesta ${ }^{15}$.

Conhecendo quais os fatores relevantes que contribuem para o comportamento desonesto e sabendo como estes operam, podemos realizar sutis alterações (nudges) no contexto da decisão de forma a facilitar os comportamentos desejados (honestos) e dificultar os comportamentos indesejados (desonestos).

Neste artigo iremos analisar os principais fatores psicológicos e contextuais que motivam o comportamento desonesto. Esses fatores estão divididos em três grupos (Figura 1): os fatores cognitivos (a forma como a nossa arquitetura mental funciona), contextuais (atributos do contexto que facilitam a ocorrência de atos desonestos) e sociais (a forma como os comportamentos dos outros e as interações sociais nos influenciam). Os nudges, principal elemento prático da ciência comportamental, são, então, intervenções aplicadas ao indivíduo, no momento de sua tomada de decisão, que alteram a maneira como ele responde aos fatores discutidos abaixo. O nudge influi no processo de decisão tendo em conta os elementos do contexto e tem o poder de reduzir, significativamente, certos vieses cognitivos, como discutido em seguida.

Figura 1: sumário dos principais fatores que contribuem para comportamentos desonestos divididos em três categorias: cognitivos, contextuais e sociais

\begin{tabular}{|l|l|l|l|}
\hline - dissonância cognitiva \\
- racionalização/justificação \\
- distância psicológica \\
- necessidade de manter uma \\
autoimagem positiva \\
- o risco das pequenas infrações \\
- licença moral (moral licensing) \\
- depleção/esgotamento do ego \\
(ego-depletion) \\
- controle/autoregulação
\end{tabular}

13 MAZAR, Nina; AMIR, On; ARIELY, Dan. The dishonesty of honest people: a theory of self-concept maintenance. Journal of Marketing Research, Chicago, v. 45, n. 6, p. 633-644, dez. 2008.

14 AQUINO, Karl; REED II, Americus. The self-importance of moral identity. Journal of Personality and Social Psychology, Washington, v. 83, n. 6, p. 1423-1440, dez. 2002.

15 HARE, Robert. Psychopathy: a clinical and forensic overview. Psychiatric Clinics of North America, Amsterdam, v. 29, n. 3, p. 709-724, set. 2006. 


\section{UMA BÚSSOLA MORAL QUEBRADA: FATORES COGNITIVOS}

Nesta seção vamos explorar os mecanismos psicológicos que impactam o julgamento e a tomada de decisão.

Dan Ariely e colegas descrevem, num conjunto de estudos clássicos (e no seu livro intitulado $A$ mais pura verdade sobre desonestidade ${ }^{16}$ ), que serviram de fundamento para investigar muitos dos fenômenos psicológicos da desonestidade, um dos fatores cognitivos com maior impacto em situações de dilemas éticos: a necessidade de manter uma autoimagem positiva. Nesses estudos, os pesquisadores pediam a alunos universitários para resolver puzzles matemáticos. Os participantes eram instruídos a marcar o par de números que somados dão 10 (e.g. $4.81+5.19$ ) em cada puzzle (Figura 2). Para realizar essa tarefa, tinham 5 minutos, e, por cada puzそle correto, receberiam 50 cents. Terminado o tempo, cada participante entregava os seus purzles aos pesquisadores que, por sua vez, contavam o número de acertos e pagavam aos participantes de acordo com o número acertos. Nessa condição (que vamos chamar condição de controle), os participantes acertaram, em média, 4 puzzles. Esse valor foi importante, pois serviu como parâmetro para que diversas hipóteses sobre comportamento desonesto foram testadas e seus resultados comparados com o do grupo de controle.

Figura 2: matrizes matemáticas (ARIELY, 2012, p. 18)

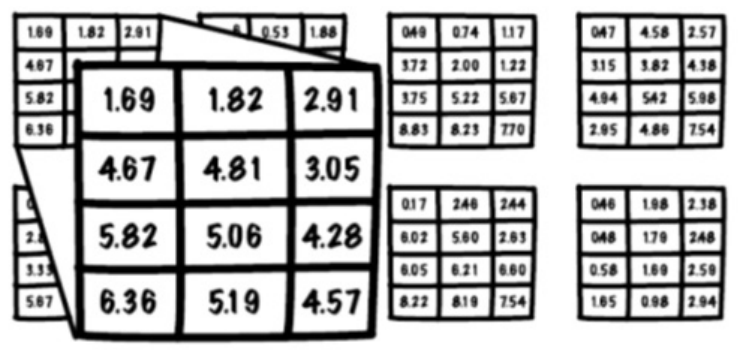

Para testar o nível de desonestidade dos participantes, Ariely e colegas criaram uma condição em que era dada a oportunidade aos participantes de agirem de forma desonesta. Nessa condição (a que vamos chamar a condição-trituradora), em vez de entregarem a matriz com os puzそles aos pesquisadores (para verificarem o número de puzzles resolvidos), os participantes eram solicitados a somar o número de acertos individualmente (sem a presença dos pesquisadores) e, em seguida, triturar as matrizes numa máquina localizada ao fundo da sala. Com a oportunidade de trapacear e sem o perigo de serem descobertos, os participantes relataram ter acertado, em média, 6 questões, duas a mais do que no grupo de controle. Isto sugere que os participantes agiram de uma forma desonesta, mas numa magnitude muito mais baixa do que o possível, de forma a poderem sustentar uma autoimagem positiva, apesar do seu comportamento desonesto. Esse aumento de desonestidade não se deveu ao fato de algumas pessoas terem relatado muito mais, mas sim ao fato de muitas pessoas terem relatado, apenas, um pouco mais do que na realidade acertaram ${ }^{17}$.

Diante dos resultados da condição-trituradora, diversos estudos de follow-up, cada qual com pequenas alterações em relação ao original, foram realizados para testar premissas da teoria econômica tradicional. Por exemplo, em um deles, testou-se se o pagamento recebido por cada puz:le resolvido $(0.50 \$, 1 \$, 2 \$$ ou 5 \$), que afetava a incidência e a magnitude do comportamento desonesto. Os resultados revelaram que as pessoas não foram sensíveis aos aumentos no retorno do ato desonesto, continuando a relatar que resolveram, em média, mais dois puzzles, contrariamente ao que preveem os modelos racionais (mais desonestidade para mais benefícios). Tendo em vista os diversos experimentos realizados, os resultados convergem para uma conclusão sobre a psicologia da desonestidade: quando lidamos com situações que envolvam a possi-

16 ARIELY, Dan. A mais pura verdade sobre a desonestidade. Rio de Janeiro: Elsevier, 2012.

17 De acordo com Ariely, em relação ao número de quase 40 mil pessoas que participaram do experimento da matriz em suas diversas variações, aproximadamente 28 mil (ou 70\%) foram um pouco desonestas, ao passo que 20 (ou 0,05\%) pessoas foram extremamente desonestas. 
bilidade de agir desonestamente, mesmo as pessoas mais honestas podem agir de forma desonesta. Nesse tipo de situações, ativa-se um conjunto de mecanismos psicológicos que permite às pessoas conciliar o que a princípio é inconciliável: agir desonestamente e, simultaneamente, manter uma autoimagem positiva de elas próprias.

As pessoas, internamente, traçam um referencial que distingue e separa o que é moralmente aceitável do que não é aceitável para elas. Quando o indivíduo percebe que ultrapassou o seu referencial moral interno, entra num estado de conflito interno. Esse estado de desconforto e de conflito interno, causado pela discrepância entre o comportamento desonesto das pessoas e a sua motivação de se verem como moralmente íntegras, chama-se dissonância ética ${ }^{18}$. Esse referencial é flexível e extremamente sensível à situação, podendo ser ajustado à medida que pequenos atos desonestos são cometidos. Há dois tipos de dissonâncias éticas: 1) dissonância antecipada (no momento em que o indivíduo está considerando realizar o ato) e 2) dissonância experienciada (após o ato) ${ }^{19}$. Mas seja qual for o momento da dissonância, há mecanismos cognitivos que nos permitem lidar com esse desconforto interno e com a culpa.

Em resposta a situações de dissonância ética, adotamos um conjunto de mecanismos cognitivos de racionalização e justificação, com o objetivo de restaurar a nossa autoimagem moralmente íntegra ${ }^{20}$. Um desses mecanismos é a racionalização motivada. ${ }^{21} \mathrm{~A}$ racionalização motivada consiste na reinterpretação das nossas ações ou do contexto, de forma a ficarem mais em sintonia com os nossos valores morais e autoimagem. A racionalização motivada de um ato desonesto pode ocorrer de diferentes formas: pode-se justificar uma transação corrupta reinterpretando-a como sendo uma reparação de uma injustiça anterior, uma ação altruísta indireta ou porque não se está a prejudicar ninguém diretamente.

Algumas situações típicas envolvendo atos de corrupção ilustram esse mecanismo de racionalização. Por exemplo, policiais justificam propinas recebidas de motoristas que querem evitar uma infração com base em baixos salários. Entretanto, estudos revelam que alterar apenas um elemento de contexto, nesse caso, aumentar os salários, não diminui necessariamente a atividade corrupta ${ }^{22}$. $\mathrm{O}$ uso de nudges $-\mathrm{em}$ momentos-chave na rotina dos policiais, como lembretes do código de honra da corporação em momentos de abordagem de trânsito, poderia levar alguns a mudar de decisão quanto a solicitar propinas.

No mesmo sentido, ser usufrutuário de um trust que tem cinco milhões de dólares suspeitos soa menos repugnante do que ser dono de uma conta pessoal com cinco milhões de dólares. Abstrações, como trusts, facilitam a racionalização motivada de quem está sendo desonesto. Nesse sentido, intervenções que chamem a atenção de forma explícita para a equivalência dessas abstrações e o montante correspondente em dinheiro ou que classifiquem, de forma inequívoca, o ato desonesto como tal, podem dificultar ou prevenir racionalizações. O nosso poder criativo nesse campo é imenso, e, quanto mais ambíguas forem as regras, mais espaço há para este tipo de justificações ${ }^{23}$.

18 MAZAR, Nina; ARIELY, Dan. Dishonesty in everyday life and its policy implications. Journal of Public Policy \& Marketing, Chicago, v. 25, n. 1, p. 117-126, mar. 2006.

19 BARKAN, Rachel; AYAL, Shahar; ARIELY, Dan. Ethical dissonance. justifications, and moral behavior. Current Opinion in Psychology, New York, v. 6, p. 157-161, dec. 2015.

20 BARKAN, Rachel et al. The pot calling the kettle black: distancing response to ethical dissonance. Journal of Experimental Psychology: General, Washington, v. 141, n. 4, p. 757-773, nov. 2012.

21 KUNDA, Ziva. The case for motivated reasoning. Psychological Bulletin, Washington, v. 108, n. 3, p. 480-498, nov. 1990.

22 O exemplo dos policiais e um caso real no Afeganistão apresentado no artigo do jornal inglês The Guardian que mostra como a percepção de injustiça causada pelos baixos salários cria uma justificativa para o ato corrupto. Entretanto, estudo feito com policiais em Gana que receberam um aumento salarial indica que eles continuam solicitando propina mesmo após o aumento. SIEFF, Kevin. Low pay and one minor promotion for the most honest man in Afghanistan. The Washington Post, 31 Jan 2014. Disponível em: <https://www.theguardian.com/world/2014/jan/31/afghanistan-corruption-honest-police-officer> e FOLTZ, Jeremy D.; OPOKU-AGYEMANG, Kweku A. Do higher salaries lower petty corruption? A policy experiment on West Africa's highways. 2015. Disponível em: <http://cega.berkeley.edu/assets/miscellaneous_files/Opoku-Agyemang_WGAPE_2015.pdf>.

23 GINO, Francesca; ARIELY, Dan. The dark side of creativity: original thinkers can be more dishonest. Journal of Personality and Social Psychology, v. 102, n. 3, p. 445-459, nov. 2012. 
Além da necessidade de manter uma autoimagem positiva, existem outros fatores cognitivos igualmente relevantes para o comportamento desonesto.

O primeiro diz respeito ao fenômeno cognitivo da distância psicológica. A distância psicológica aumenta a flexibilidade com que se consegue reinterpretar atos desonestos como honestos. Assim, quando existe uma distância psicológica relativamente ao dinheiro ${ }^{24}$ (como no exemplo do usufrutuário de um trust, ou da latinha de refrigerante), os comportamentos desonestos tendem a ocorrer mais. Imagine a diferença entre pegar uma caneta esferográfica (de dois reais) da mala de um amigo e pegar dois reais da mala do seu amigo para comprar uma esferográfica para si. Apesar do valor monetário ser igual nos dois casos, psicologicamente, a primeira opção é sentida como muito mais próxima, o que, por sua vez, causa uma dissonância menor e é mais facilmente justificada.

No mesmo sentido, voltando aos puzそles acima mencionado de Ariely e colegas, demonstrou-se, em uma das condições, que introduzir um meio intermediário no processo de pagamento (ser pago em tokens que são posteriormente convertidos em dinheiro) aumenta a incidência de comportamentos desonestos. Os tokens, nesse caso, servem como uma forma de o participante se distanciar do ato desonesto.

Para além da questão da distância psicológica, quando cometemos um ato desonesto, podemos sentir a necessidade de compensá-lo com um ato honesto ou pró-social, fenômeno chamado ajuste ou balanceamento moral (moral balancing $g^{25}$ ). Por exemplo, as pessoas tendem a desinfetar mais as suas mãos depois de transcreverem uma história que narre comportamentos desonestos ${ }^{26}$, numa tentativa inconsciente de "se limparem" do ato desonesto (fenômeno chamado moral cleansing).

Noutro estudo ${ }^{27}$, pediu-se aos participantes para copiarem uma lista de traços positivos (e.g. generoso, justo), negativos (e.g. desleal, egoísta) ou objetos inanimados (ex.: livro, chaves). Depois de copiarem a lista de palavras, os participantes escreveram uma história curta sobre eles próprios, que incluía todas as palavras que tinham copiado. Ao final do experimento, perguntaram-se aos participantes se queriam fazer uma pequena doação (até \$10) e se pediu para escreverem o nome da instituição para a qual desejariam doar e o montante da doação. Verificou-se que os participantes que copiaram a lista de traços positivos doaram, em média, $\$ 1,07$, enquanto os participantes na condição de traços negativos doaram, em média, \$5,30. Esses resultados sugerem que salientar uma identidade moral positiva "dá licença" às pessoas para serem, nesse caso, não propriamente desonestas, mas menos pró-sociais do que as pessoas cujos aspetos negativos da sua identidade moral estivessem bem presentes.

Esse fenômeno do balanceamento moral, infelizmente, também funciona ao contrário: um ato moralmente positivo (e.g. fazer uma doação a uma instituição de caridade) pode criar um sentimento de licença moral para fazer algo negativo seguidamente, como agir de forma desonesta (moral self-licencing) ${ }^{28}$.

24 MAZAR, Nina; ARIELY, Dan. Dishonesty in everyday life and its policy implications. Journal of Public Policy \& Marketing, Chicago, v. 25, n. 1, p. 117-126, mar. 2006.

25 SACHDEVA, Sonya; ILIEV, Rumen; MEDIN, Douglas. Sinning saints and saintly sinners: the paradox of moral self-regulation. Psychological Science, Washington, v. 20, n. 4, p. 523-528, abr. 2009.

26 ZHONG, Chen-Bo; LILJENQUIST, Katie. Washing away your sins: threatened morality and physical cleansing. Science, Washington, v. 313, n. 5792, p. 1451-1452, set. 2006.

27 SACHDEVA, Sonya; ILIEV, Rumen; MEDIN, Douglas. Sinning saints and saintly sinners: the paradox of moral self-regulation. Psychological Science, Washington, v. 20, n. 4, p. 523-528, abr. 2009.

28 HOUSER, Daniel; VETTER, Stefan; WINTER, Joachim. Fairness and cheating. European Economic Review, Amsterdam, v. 56, n. 8 , p. $1645-1655$, nov. 2012.

PLONER, Matteo; REGNER, Tobias. Self-image and moral balancing: an experimental analysis. Journal of Economic Behaviors and Organization, Amsterdam, v. 93, p. 374-383, set. 2013.

CARLSMITH, J. Merrill; GROSS, Alan. Some effects of guilt on compliance. Journal of Personality and Social Psychology, Washington, v. 11, n. 3, p. 232-239, mar. 1969

GNEEZY, Uri; IMAS, Alex; MADARÁSZ, Kristóf. Conscience accounting: emotion dynamics and social behavior. Management Science, Maryland, v. 60, n. 11, p. 2645-2658, ago. 2014.

KALANTHROFF, Eyal; ASLAN, Chen; DAR, Reuven. Washing away your sins will set your mind free: physical cleansing modulates the effect of threatened morality on executive control. Cognition and Emotion, London, v. 31, n. 1, p. 185-192, 2017. 
Adicionalmente, a forma como as pessoas lidam com situações de tentação, e as suas capacidades de autocontrole perante as mesmas, pode ter um impacto significativo no comportamento. Funcionários do setor público e privado lidam, sistematicamente, com tentações, tais como ofertas de propinas por terceiros, possibilidade de abuso de poder etc. Nesse contexto, o fenômeno de ego-depletion tem um papel crítico. Esse fenômeno refere-se a um estado mental debilitado em termos de recursos cognitivos devido a fatores como o cansaço físico ou mental, a falta de tempo ou a ansiedade. Os recursos cognitivos são importantes para exercer o autocontrole necessário para lidar com essas situações de tentação, e, na falta destes, sucumbimos a motivações egoístas, favorecendo uma gratificação imediata ${ }^{29}$.

Num estudo ${ }^{30}$, os participantes foram convidados a escrever um pequeno ensaio não podendo usar palavras que tivessem as letras "a" ou " $\mathrm{n}$ " (condição depletion) ou as letras " $\mathrm{x}$ " ou " $\mathrm{z}$ " (condição no-depletion). A ideia é que escrever sem as letras "a" ou " $n$ " é uma tarefa que demanda muito mais recursos cognitivos do que sem as letras " $x$ " ou " $z$ ". Depois dessa tarefa, os participantes tiveram de resolver os mesmos puzzles matemáticos dos estudos referidos anteriormente. Cada puzそle resolvido valia $\$ 0,25$. Numa das condições (experimenter-scored), os participantes entregavam a folha de respostas ao experimentador, que lhes pagava de acordo com o número de puzzles resolvidos. $\mathrm{Na}$ outra condição experimental (self-scored), os participantes contavam quantos puzzles tinham resolvido, e eram colocados dois envelopes sobre uma mesa, antes da chegada dos participantes: um tinha 20 moedas de $\$ 0,25$ e o outro estava vazio. Os participantes tinham de deixar $\$ 0,25$ por cada puzそle que tivessem resolvido, e transferir os restantes $\$ 0,25$ para o envelope vazio, deixando-o sobre a mesa. Os resultados mostraram que os participantes na condição no-depletion "afirmaram" ter resolvido mais $25 \%$ de puzzles quando eram eles próprios a verificar o seu desempenho do que quando era o experimentador. Em contraste, na condição depletion, essa diferença subiu para 104\%, o que sugere um aumento da desonestidade quando os recursos cognitivos dos participantes eram baixos.

Assim, é importante evitar que funcionários tomem decisões que envolvam a possibilidade de agir desonestamente e que demandem autocontrole em estado de forte ego-depletion, como após horas sem intervalo ou na parte final do expediente.

A literatura, também, indica que antecipar situações de tentação é uma forma eficaz de treinamento e permite às pessoas deliberar sobre as ações honestas específicas a tomar, tornando-as mais preparadas para agir de forma honesta quando uma situação semelhante acontecer na realidade ${ }^{31}$. Algumas categorias de funcionários públicos recebem, por exemplo, treinamento sobre como identificar uma situação de corrupção quando operam em setores onde há incidência significativa de atividade corrupta. ${ }^{32}$ Ainda que o treinamento possa ser esquecido com o tempo, a exposição a situações baseadas em fatos ajuda os funcionários a racionar, num espaço protegido, e decidir que passos deveriam tomar frente ao problema. Quando e se eles vierem a ter contato com tal situação no futuro, a chance de tomarem a melhor decisão e maior.

Finalmente, as pessoas, também, podem interpretar positivamente os seus atos desonestos, focando-se nos benefícios que esses comportamentos têm para outros, e não nos seus ganhos pessoais ${ }^{33}$. Por exemplo,

ZHONG, Chen-Bo; LILJENQUIST, Katie. Washing away your sins: threatened morality and physical cleansing. Science, Washington, v. 313, n. 5792, p. 1451-1452, set. 2006.

29 Para mais acerca da importância da gratificação imediata ver: BAZERMAN, Max; TENBRUNSEL, Ann. Blind spots: why we fail to do what's right and what to do about it. Princeton: Princeton University Press, 2011.

30 MEAD, Nicole et al. Too tired to tell the truth: self-control resource depletion and dishonesty. Journal of Experimental Social Psychology, Amsterdam, v. 45, n. 3, p. 594-597, maio 2009.

31 SHELDON, Oliver; FISHBACH, Ayelet. Anticipating and resisting the temptation to behave unethically. Personality and Social Psychology Bulletin, California, v. 41, n. 7, p. 962-975, jul. 2015.

32 Por exemplo, diplomatas e pessoal de cooperação internacional em muitos países passam por treinamento presencial ou virtual obrigatório antes de assumir um posto de trabalho. Esses treinamentos muitas vezes incluem vivenciar situações fictícias elaboradas a partir de casos de corrupção reais envolvendo o órgão público no passado (OECD, 2017).

33 AYAL, Shahar; GINO, Francesca. Honest rationales for dishonest behavior. In: MIKULINCER, Mario; SHAVER, Philip (Org.). The social psychology of morality: exploring the causes of good and evil. Washington: American Psychological Association, 2012. p. 149-166. 
em um dos follow-ups dos estudos com puzzles matemáticos já citado, Gino, Ayal e Ariely $y^{34}$ pediram aos participantes para solucionar os puzzles individualmente, em pares ou em grupos de três pessoas. Os resultados indicaram que os participantes reportaram mais puzzles resolvidos quando em grupos de três pessoas, uma vez que a situação podia ser reinterpretada como "ajudando os outros" 35 . No caso da corrupção, um gestor pode resguardar-se, mentalmente, da reprovabilidade de um ato corrupto em razão dos benefícios que este traz para a sua organização ou para um grupo de colaboradores. Estudos etnográficos da corrupção mostram como pressões de grupo ou família podem ser fatores poderosos para que o indivíduo cometa atos de corrupção que não o beneficiam individualmente, mas sim a alguém do grupo, e encontrem justificativas morais para seus atos. ${ }^{36}$

\section{AJUDANDO O INDIVÍDUO HONESTO A CONTINUAR HONESTO: FATORES CONTEXTUAIS}

O contexto em que o indivíduo está inserido pode ter um papel significativo no seu comportamento. Conforme ressaltam Thaler e Sunstein no seminal livro Nudge $e^{37}$, uma contribuição dos estudos comportamentais para as políticas públicas é a ênfase nos fatores contextuais. Nas palavras dos autores: “[...] detalhes pequenos e aparentemente insignificantes podem ter grande impacto no comportamento das pessoas. Uma boa regra de ouro (rule of thumb) é assumir que tudo importa." ${ }^{38}$. Nesta seção, vamos explorar alguns dos fatores contextuais com impactos no comportamento desonesto, desde mensagens explícitas (como códigos de ética e regulamentos) e implícitas (o que as outras pessoas fazem de fato) que o contexto transmite, às suas inconsistências e ambiguidades.

Como já mencionado acima, uma solução tradicionalmente proposta no contexto do combate à corrupção, é alterar o contexto aumentando o nível de controle e fiscalização. No entanto, os mecanismos de controle têm o risco de diminuir a motivação intrínseca das pessoas para agir de forma íntegra ${ }^{39}$. As intervenções baseadas em fiscalização e penalização sinalizam desconfiança e dão a indicação de que a norma social (o que os outros fazem) é agir, de forma desonesta, o que, por sua vez, pode levar a ainda mais comportamentos desonestos. Uma possível forma de diminuir a desconfiança, quando se implementa um sistema de controle, é de ter uma entidade externa fazendo a fiscalização e não alguém interno (da organização ou da equipe).

Há outros fatores contextuais e não relacionados a um controle direto que afetam a forma como interpretamos a informação ou a situação e a forma como nos comportamos seguidamente. Em primeiro lugar, em contextos de ambiguidade (em que os riscos e consequências do ato desonesto são ambíguos ou quando o alvo afetado ou a vítima não são facilmente identificáveis), é mais provável que ocorra a racionalização motivada ${ }^{40}$ e que os chamados self-serving biases entrem em ação, distorcendo a interpretação das situações e

34 GINO, Francesca; AYAL, Shahar; ARIELY, Dan. Self-serving altruism? The lure of unethical actions that benefit others. Journal of Economic Behavior \& Organization, Amsterdam, v. 93, p. 285-292, set. 2013.

35 AYAL, Shahar; GINO, Francesca. Honest rationales for dishonest behavior. In: MIKULINCER, Mario; SHAVER, Philip (Org.). The social psychology of morality: exploring the causes of good and evil. Washington: American Psychological Association, 2012. p. $149-166$.

36 Anders (2005) estudou o caso das obrigações familiares no Malauí (por exemplo, empregar familiares quando um indivíduo alcança um cargo público). Estes atos são considerados obrigações morais e não atos corruptos.

37 THALER, Richard; SUNSTEIN, Cass. Nudge: como melhorar as decisões sobre saúde, dinheiro e felicidade. Lisboa: Academia do Livro, 2009.

38 THALER, Richard; SUNSTEIN, Cass. Nudge: como melhorar as decisões sobre saúde, dinheiro e felicidade. Lisboa: Academia do Livro, 2009. p. 16.

39 LAMBSDORFF, Johann. Preventing corruption by promoting trust: insights from behavioral science. Passauer Diskussionspapiere: Volkswirtschaftliche Reihe, Passau, v. 69, n. 15, p. 1-16, 2015.

SCHULZE, Günther; FRANK, Björn. Deterrence versus intrinsic motivation: experimental evidence on the determinants of corruptibility. Economics of Governance, Cham, v. 4, n. 2, p. 143-160, ago. 2003.

40 HSEE, Christopher. Elastic justification: how tempting but task-irrelevant factors influence decisions. Organizational Behavior 
contextos de acordo com os objetivos egoístas do indivíduo.

Em segundo, quando as consequências de uma ação são tardias e não imediatas, o comportamento desonesto é mais provável. Isto ocorre porque temos a tendência a dar mais peso a benefícios e custos imedia-

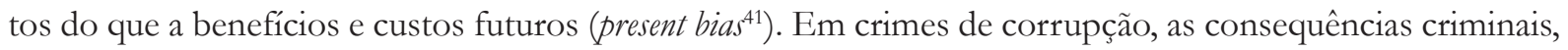
quando acontecem, são concretizadas muito tempo depois do ato corrupto, enquanto os benefícios desse ato são muitas vezes imediatos (em forma de benefícios financeiros, como propina, ou favor).

Em terceiro, nos casos em que a vítima do ato desonesto não é fácil de identificar, a probabilidade de ocorrerem comportamentos desonestos aumenta ${ }^{42}$. A corrupção consiste, muitas vezes, em cadeias complexas de intermediários que tornam os danos menos visíveis e imediatos. Nas situações em que é o "Estado" ou a "população como um todo" os prejudicados, trata-se de um caso de vítima indireta ou social, pois ambas as entidades (Estado e população) são muito abstratas e o prejuízo da corrupção, por sua vez, é difícil de mensurar. Um exemplo dessa complexidade são os efeitos que a corrupção da classe política tem nos serviços públicos. Ainda que os danos existam, estabelecer uma relação causal direta entre um ato de corrupção específico e a degradação de um serviço público é bastante difícil. ${ }^{43}$

Mas como podemos alterar o contexto de forma a influenciar positivamente o comportamento das pessoas? Uma forma é implementar lembretes morais em momentos-chave da tomada de decisão, de forma a conduzi-las momentaneamente a um mindset ético. A ideia é que, lembradas de sua honestidade, as pessoas vão reforçar, momentaneamente, sua autoimagem íntegra, o que, por sua vez, tornará mais severa a dissonância cognitiva entre suas ações desonestas e autoimagem. Em particular, estes lembretes podem ser implementados em lugares onde o comportamento ocorre, de modo a que possam ser vistos oportunamente, isto é, antes do ato ocorrer. Uma mensagem como "obrigada pela sua honestidade" pode servir de lembrete moral ${ }^{44}$. É importante ressaltar que os lembretes morais devem ser usados com cautela, porque, quando utilizados com frequência e apresentados sempre da mesma forma, podem deixar de ter efeito devido à habituação. Assim, é importante personalizar e incluir, constantemente, detalhes novos nos lembretes.

Imaginemos um código de conduta que os funcionários públicos têm que assinar. Primeiramente, esses códigos são consultados (quando o são) e assinados uma única vez, no momento em que a pessoa toma posse da função. Essa atividade tem muito pouco impacto no comportamento porque é facilmente esquecida e a atividade do dia a dia não requer a sua consulta regular. Uma possível alteração implicaria pedir aos funcionários que consultassem o código de conduta ética e assinassem uma declaração de honra a cada novo contrato público em que o funcionário fosse participar (antes do mesmo ser realizado). Nesse exemplo, para evitar habituação ao conteúdo da declaração e ao ato de assinar (que quando repetido muitas vezes, pode

and Human Decision Processes, Amsterdam, v. 62, n. 3, p. 330-337, jun. 1995.

HSEE, Christopher. Elastic justification: how unjustifiable factors influence judgments. Organizational Behavior and Human Decision Processes, Amsterdam, v. 66, n. 1, p. 122-129, abr. 1996.

41 O'DONOGHUE, Ted; RABIN, Matthew. Doing it now or later. American Economic Review, Pittsburgh, v. 89, n. 1, p. 103-124, mar. 1999.

42 FALK, Armin; SZECH, Nora. Organizations, diffused pivotality and immoral outcomes. 2013. Disponível em: < https://polit.econ.kit. edu/downloads/papers/Falk_Szech_WP_2_Pivotality_Fal_Szech_DP-2.pdf>. Acesso em: 2 maio 2018.

HAMMAN, John; LOEWENSTEIN, George; WEBER, Roberto. Self-interest through delegation: an additional rationale for the principal-agent relationship. American Economic Review, Tennessee, v. 100, n. 4, p. 1826-1846, set. 2010.

43 Um exemplo de investigação que estabeleceu relação causal entre corrupção e degradação de serviços públicos envolve o colapso da fábrica de roupas Rana em Bangladesh em 2013, em que faleceram centenas de empregados. Uma investigação comprovou que houve corrupção na aprovação de uso do edifício onde operava a fábrica, que não respeitava normas de segurança e, ainda assim, continuava funcionando. RANA Plaza owner jailed for three years over corruption. 29 August 2017. Disponível em: < https:// www.aljazeera.com/news/2017/08/rana-plaza-owner-jailed-years-corruption-170829161742916.html>.

44 BURSZTYN, Leonardo et al. Moral incentives in credit card debt repayment: evidence from a field experiment. The National Bureau of Economic Research Working Paper, n. 21611, Nov. 2017.

MAZAR, Nina; ARIELY, Dan. Dishonesty in everyday life and its policy implications. Journal of Public Policy \& Marketing, Chicago, v. 25, n. 1, p. 117-126, mar. 2006.

PRUCKNER, Gerald; SAUSGRUBER, Rupert. Honesty on the streets: a field study on newspaper purchasing. Journal of the European Economic Association, New Jersey, v. 11, n. 3, p. 661-679, jun. 2013. 
ficar automático), o texto dessa declaração deveria variar ligeiramente em cada contrato. Essa declaração ativaria standards morais internos na altura crítica em que a pessoa fosse confrontada com um eventual momento de tentação de agir desonestamente.

Mazar, Amir, e Ariely ${ }^{45}$, utilizaram um lembrete diferente num estudo experimental para conduzir os participantes a um mindset moral. Esse lembrete consistiu em pedir aos participantes para se recordarem e escreverem os 10 Mandamentos da Bíblia (versus os últimos 10 livros que leram, na condição de controle do estudo). Ao terem que pensar nos 10 Mandamentos (independentemente da sua religião, de acreditarem em Deus, ou de se recordarem de fato dos Mandamentos), os padrões morais dos participantes ficaram mais salientes e, por isso, os participantes tenderam a agir mais honestamente. Em seguida, os participantes resolveram pu₹そles matemáticos semelhantes aos descritos anteriormente. Na condição trituradora (em que a prova do número de pu₹そles corretos era destruída pelo próprio participante), verificou-se que, depois de se lembrarem dos 10 livros, os participantes relataram, em média, 4.2 pu₹zles, enquanto os participantes que tiveram de escrever os 10 Mandamentos relataram, em média, 2.8 puzzles. Tendo por base esse resultado, os pesquisadores concluíram que, ativando valores morais, diminui-se a incidência de comportamentos desonestos.

\section{SOCIALMENTE DESONESTO: FATORES SOCIAIS}

O comportamento desonesto, também, pode ser influenciado pela interação com outras pessoas. O que a maioria das outras pessoas está fazendo (prova social) influencia, fortemente, o nosso comportamento e contribuem para a definição de nossos padrões morais comportamentais ${ }^{46}$, especialmente em situações de incerteza. Essa influência, por sua vez, é maior quanto mais nos identificamos com essas pessoas ${ }^{47}$. Assim, se outras pessoas à volta agirem de forma desonesta, e se esses outros forem do in-group (pessoas com quem compartilhamos características, tais como a mesma profissão ou cidade de residência), o risco de contágio do comportamento desonesto aumenta. Assim, um médico tem maior probabilidade em praticar superfaturamento se outros médicos do mesmo departamento o fizerem.

Além de modelar diretamente o comportamento de acordo com o comportamento dos outros, há outros fatores sociais que podem contribuir para que as pessoas ajam de forma desonesta. Um desses fatores é a tendência de agir de forma desonesta em prol dos outros. Isso acontece quando o comportamento desonesto beneficia alguém, sendo esse efeito, uma vez mais, mais forte quanto mais próxima for a pessoa beneficiada. Como exemplo, imaginemos uma situação comum: de uma enfermeira que trabalha num hospital público onde a lista de espera para consultas é extremamente longa. Uma amiga da enfermeira precisa de uma consulta e a enfermeira vê-se numa situação em que pode ajudar facilmente esta amiga a furar a longa fila de espera. Nesse caso, o fato de ser uma amiga a pedir esse favor, e não um desconhecido, aumenta, de forma significativa, a probabilidade de ocorrência do ato desonesto, o que configura um caso típico de altruistic cheating ${ }^{48}$.

Adicionalmente, há investigação que mostra que as pessoas são mais desonestas em situações de desigualdade de tratamento ${ }^{49}$, isto é, se a pessoa acha que está sendo injustiçada ou que a outra parte está

45 MAZAR, Nina; AMIR, On; ARIELY, Dan. The dishonesty of honest people: a theory of self-concept maintenance. Journal of Marketing Research, Chicago, v. 45, n. 6, p. 633-644, dez. 2008.

46 MOORE, Celia; GINO, Francesca. Ethically adrift: how others pull our moral compass from true north, and how we can fix it. Research in Organizational Behavior, Amsterdam, v. 33, p. 53-77, 2013.

47 GINO, Francesca; AYAL, Shahar; ARIELY, Dan. Contagion and differentiation in unethical behavior: the effect of one bad apple on the barrel. Psychological Science, California, v. 20, n. 3, p. 393-398, mar. 2009.

48 De notar, no entanto, que há questões culturais que guiam os nossos comportamentos na interação com os outros e que nos podem levar a agir de forma desonesta devido a práticas altamente difusas na população e aceites por toda gente.

49 GINO, Francesca; PIERCE, Lamar. Dishonesty in the name of equity. Psychological Science, Washington, v. 20, n. 3, p. 1153- 
tendo maiores benefícios do que o devido em determinado contexto. Além da desigualdade, as situações de reciprocidade ${ }^{50,51}$ também podem ter efeitos potencialmente negativos para a integridade. O ser humano, em todas as culturas, é altamente sensível à reciprocidade, de forma que, quando recebemos um benefício, seja um pequeno presente ou um favor, sentimos uma forte pressão para retribuir. Essa força psicológica é um fator-chave na criação e manutenção da corrupção, uma vez que a corrupção baseia-se num acordo entre pelo menos dois parceiros - o corruptor ativo, que fornece o bem em questão, e o corrupto passivo, que aceita a transação corrupta. Esse acordo, por sua vez, tende a caracterizar-se por uma elevada incerteza, o que reforça a exigência normas de reciprocidade que criem confiança entre os agentes envolvidos ${ }^{52}$.

Aumentar a transparência é considerado um meio eficaz para reduzir a corrupção. A ideia é que, quanto mais mecanismos de transparência maior o risco de se descubram desvios e, consequentemente, menos pessoas estarão dispostas a cometer desvios. No entanto, a literatura comportamental demonstra que, em diversas situações, a transparência pode ter efeitos inversos do esperado.

Um mecanismo de transparência é a declaração dos conflitos de interesse (por exemplo, de um médico pode declarar para o paciente que está diagnosticando, que tem benefícios diretos na execução de determinada cirurgia) pode ter o efeito oposto, isto é, pode legitimar ações desonestas ${ }^{53}$. O investigador americano George Loewenstein e os seus colaboradores mostraram que, a seguir a uma declaração de conflitos de interesses, as pessoas sentem-se mais à vontade para agir, abertamente, de forma enviesada porque sentem que não estão a esconder nada ${ }^{54}$. A transparência, nesse caso, pode funcionar como absolvição do comportamento desonesto. Simultaneamente, a pessoa a quem o conflito de interesses pode afetar (paciente) interpreta essa divulgação de informação relativamente aos conflitos de interesse como um sinal de confiança da outra parte, levando a uma clara assimetria de circunstâncias.

Nesse sentido, é necessário ficar ciente de que uma governança transparente, com políticas de livre e pleno acesso aos dados, pode ter um efeito oposto ao desejado, se outros mecanismos de accountability precisam ser postos em prática. Portanto, a sociedade civil e a mídia têm um papel importante na salientação de que os atos são indesejados podem ter um papel crucial para que os mecanismos de transparência sejam eficazes.

Por fim, um último fator social relevante é a difusão da responsabilidade ${ }^{55}$. Em situações em que um grupo de pessoas age de forma corrupta em conjunto, há uma desresponsabilização generalizada no grupo, que resulta numa atribuição de menor responsabilidade individual a cada uma das pessoas do grupo. Tendo em vista esse fator social, o conhecido princípio dos "quatro olhos", que consiste em ter mais pessoas envolvidas e criar diversas camadas sucessivas de fiscalização, pode não funcionar tão bem devido à difusão da responsabilidade entre os vários agentes envolvidos.

1160, set. 2009.

50 BOWLES, Samuel; GINTIS, Herbert. Schooling in capitalist America: educational reform and the contradictions of economic life. Chicago: Haymarket Books, 2011.

51 HENRICH, Joseph, et al. "Economic man" in cross-cultural perspective: behavioral experiments in 15 small-scale societies. Behavioral and Brain Sciences, New York, v. 28, n. 6 p. 795-855, dez. 2005.

52 SOUSA, Luís de. Corrupção. Lisboa: Fundação Francisco Manuel dos Santos, 2011.

53 SAH, Sunita; LOEWENSTEIN G.; CAIN, Daylian. The burden of disclosure: increased compliance with distrusted advice. Journal of Personality and Social Psychology, Washington, v. 104, n. 2, p. 289-304, fev. 2013.

54 CAIN, Daylian; LOEWENSTEIN, George; MOORE, Don. The dirt on coming clean: perverse effects of disclosing conflicts of interest. Journal of Legal Studies, Chicago, v. 34, n. 1, p. 1-25, jan. 2005.

CAIN, Daylian; LOEWENSTEIN, George; MOORE, Don. When sunlight fails to disinfect: understanding the perverse effects of disclosing conflicts of interest. Journal of Consumer Research, Chicago, v. 37, n. 5, p. 836-857, fev. 2011.

LOEWENSTEIN, G.; SAH, Sunita; CAIN, Daylian. The unintended consequences of conflict of interest disclosure. The Journal of the American Medical Association, Chicago, v. 307, n. 7, p. 669-670, fev. 2012.

55 SCHIKORA, Jan. Bringing the four-eyes-principle to the lab. 2011. Disponível em:

<https://epub.ub.uni-muenchen.de/12160/1/The4EP_Schikora.pdf>. Acesso em: 10 maio 2018.

WILTERMUTH, Scott. Cheating more when the spoils are split. Organizational Behavior and Human Decision Processes, Amsterdam, v. 115, n. 2, p. 157-168, jul. 2011.

MOORE, Celia; GINO, Francesca. Ethically adrift: how others pull our moral compass from true north, and how we can fix it. Research in Organizational Behavior, Amsterdam, v. 33, p. 53-77, 2013. 
Os exemplos da transparência e da fiscalização mostram que, por diversas vezes, as soluções tradicionalmente empreendidas, por mais intuitivas que pareçam, nem sempre funcionam de forma linear e podem ter efeitos contrários aos previstos devido a mecanismos sociais sutis.

\section{Considerações finais}

Neste artigo, apresentamos diversos fatores cognitivos, contextuais e sociais que, apesar de relevantes para o comportamento desonesto, não costumam ser considerados em abordagens tradicionais. Em específico, afirmamos que as pessoas não são necessariamente racionais, coerentes e previsíveis nas suas decisões, e relativamente insensíveis a análises de custo-benefício em relação às consequências de comportamentos desonestos. Além disto, identificamos como central o conceito de autoimagem e o fato de essa não ser tão condicionada pelo cometimento de atos desonestos como seria de esperar.

Por fim, indicaremos um rol de soluções baseadas em intervenções comportamentais e alterações na arquitetura da decisão, que podem ser implementadas com o objetivo de guiar o comportamento no sentido de mais integridade.

Uma dessas intervenções comportamentais refere-se aos protocolos de conduta e aos códigos de ética. Como vimos, para serem mais eficazes, estes devem ser desenvolvidos tendo por base dois objetivos principais: 1) evitar ambiguidades e 2) e levar à ativação de standards morais internos, especialmente em momentos críticos de decisão. Esses objetivos visam mitigar a nossa tendência natural de racionalizar, reinterpretar e justificar as nossas ações desonestas. Portanto, para mitigar essa tendência, protocolos e guias devem tornar questões cinzentas ou ambíguas em categorias dicotômicas em que os comportamentos são claramente honestos ou desonestos, sem meio termo. Nesse sentido, é importante classificar um rol de comportamentos como desonestas, informar acerca da sua ilegalidade e indicar, com o máximo de detalhamento possível, qual a forma correta de agir. Esses códigos de conduta e protocolos podem, por exemplo, fazer menção aos subornos em formato de presentes, deixando clara a ilegalidade destes e indicando como agir se detectar tal situação (encorajando e guiando o whistleblowing). Os protocolos de conduta, por sua vez, podem prever o engatilhamento (trigger) de alarmes e valores morais, especialmente em momentos críticos, isto é, logo antes da oportunidade do comportamento desonesto. Uma forma de o fazer é pedindo ao agente para se lembrar dos seus deveres éticos (e.g assinar uma declaração de honra) em situações em que exista vulnerabilidade de ser corrompido, e não em momentos inócuos, como é habitualmente feito ${ }^{56}$.

O treinamento ético é outra medida que pode preparar as pessoas para a detecção de irregularidades em si mesmas e nos outros ${ }^{57}$. É importante que as pessoas aprendam a identificar quais são os principais momentos de tentação na sua função dentro da organização, para que se possam simular, em treino, medidas a tomar se e quando essas irregularidades ocorrerem na prática ${ }^{58}$.

Uma outra forma de tornar a pessoa mais consciente do seu próprio processo de decisão consiste em pedir para explicar as decisões tomadas (ex.: pedir ao médico para justificar porque aconselha determinada cirurgia ou equipamento, ou pedir a um funcionário público para justificar determinada compra pública ou

56 SHU, L. et al. Signing at the beginning makes ethics salient and decreases dishonest self-reports in comparison to signing at the end. Proceedings of the National Academy of Sciences of the United States of America, Washington, v. 109, n. 38, p. 15197- 15200 , set. 2012. 57 ASHFORTH, Blake; ANAND, Vikas. The normalization of corruption in organizations. Research in Organizational Behavior, Amsterdam, v. 25, p. 1-52, 2003.

58 Prever e antecipar todas as situações de corrupção, em todas as suas formas e especificidades, é muito difícil, senão impossível devido ao fator criatividade. Mas uma organização pode fazer um levantamento das irregularidades mais comuns e preparar os seus funcionários a reagir às mesmas. Uma possível solução, que já tem vindo a ser adoptada, é criar linhas de apoio e conselho para que funcionários possam pedir esclarecimento e conselhos em como agir sem medo de represália. Mas neste caso o alarme moral tem que ser interno ao indivíduo, e esses alarme pode nunca soar devido aos vieses a respeito dos quais falamos neste artigo. 
determinada atribuição de fundos). Isto coloca uma responsabilidade acrescentada no decisor e o torna mais consciente de possíveis vieses cognitivos automáticos que poderão ter conduzido a decisões desonestas.

Finalmente, é importante estar atento para as dinâmicas sociais das organizações. Essas dinâmicas podem estar contribuindo para comportamentos desonestos, tornando-os mais aceitáveis e favorecendo o seu "contágio" entre os colaboradores. Isto é especialmente verdade em situações em que não estão claras as consequências negativas dos comportamentos desonestos e quando o desrespeito às normas éticas ocorre de forma gradual e não-abrupta. Uma forma de frear este "contágio", especialmente em situações em que o comportamento desonesto (ainda) não está completamente difundido na organização, é comunicar às pessoas normas sociais positivas, deixando claro que grande parte das pessoas age de forma honesta, que isso é o normal nos contextos em questão.

Para finalizar, é importante perceber as limitações das intervenções baseadas na ciência comportamental no campo do combate à corrupção e ao comportamento desonesto. Apesar de a aplicação das ciências comportamentais fornecer formas promissoras de alterar comportamentos (porque são fundamentadas em investigação, têm baixo custo e consistirem em alterações sutis, e de fácil implementação, na arquitetura da decisão), essas formas não são suficientes para reduzir drasticamente os níveis de corrupção numa sociedade ou numa dada organização. Por isso, a melhor forma de aplicar a Economia Comportamental é complementando-a com as práticas tradicionais, nomeadamente, integrando intervenções comportamentais nas políticas de conscientização e educação, por um lado, e nas políticas de fiscalização e punição, por outro. Essa complementaridade é útil por três razões: a primeira refere-se às vantagens que existem em combinar várias ferramentas para solucionar o mesmo problema; a segunda refere-se às intervenções baseadas nas ciências comportamentais são direcionadas aos indivíduos que são desonestos de forma casual e que têm motivação intrínseca para a integridade, que, apenas, precisam de um "empurrãozinho" para agir de forma honesta. Para as pessoas sem essa motivação intrínseca e que são deliberadamente desonestas, a lei, fiscalização e punição devem ser as ferramentas prioritárias. Finalmente, a terceira razão refere-se ao facto de muitos casos de intervenções tradicionais anticorrupção, apesar de muito eficazes, foram desenhados sem consciência dos aspectos cognitivos, contextuais e sociais que podem influenciar o processo de tomada de decisão. Tomar consciência desses fatores, ajudaria a potencializar o resultado de políticas tradicionais através de pequenos ajustes, como o exemplo do código de conduta a ser assinado em um momento-chave, como sugerido acima. Portanto, a economia comportamental aplicada não é incompatível com as políticas tradicionais, mas oferece ferramentas para aprimorá-las e complementá-las. Dessa forma, incorporar as ciências comportamentais pode ser um fator fundamental aumentar o sucesso das estratégias de luta contra a corrupção no Brasil e ao redor do mundo.

\section{REFERÊnCIAS}

ANDERS, G. Civil servants in Malawi: cultural dualism, moonlighting and corruption in the shadow of good governance. 2005. Thesis (PhD) - University of Rotterdam, Rotterdam, 2005.

AQUINO, Karl; REED II, Americus. The self-importance of moral identity. Journal of Personality and Social Psychology, Washington, v. 83, n. 6, p. 1423-1440, dez. 2002.

ARIELY, Dan. A mais pura verdade sobre a desonestidade. Rio de Janeiro: Elsevier, 2012.

ASHFORTH, Blake; ANAND, Vikas. The normalization of corruption in organizations. Research in Organizational Behavior, Amsterdam, v. 25, p. 1-52, 2003.

AYAL, Shahar; GINO, Francesca. Honest rationales for dishonest behavior. In: MIKULINCER, Mario; SHAVER, Philip (Org.). The social psychology of morality: exploring the causes of good and evil. Washington: American Psychological Association, 2012. p. 149-166. 
BARKAN, Rachel et al. The pot calling the kettle black: distancing response to ethical dissonance. Journal of Experimental Psychology: General, Washington, v. 141, n. 4, p. 757-773, nov. 2012.

BARKAN, Rachel; AYAL, Shahar; ARIELY, Dan. Ethical dissonance: justifications, and moral behavior. Current Opinion in Psychology, New York, v. 6, p. 157-161, dec. 2015.

BAZERMAN, Max; LOEWENSTEIN, George; MOORE, Don. Why good accountants do bad audits. Harvard Business Review, Cambridge, v. 80, p. 96-103, nov. 2002.

BAZERMAN, Max; TENBRUNSEL, Ann. Blind spots: why we fail to do what's right and what to do about it. Princeton: Princeton University Press, 2011.

BOWLES, Samuel; GINTIS, Herbert. Schooling in capitalist America: educational reform and the contradictions of economic life. Chicago: Haymarket Books, 2011.

BURSZTYN, Leonardo et al. Moral incentives in credit card debt repayment: evidence from a field experiment. The National Bureau of Economic Research Working Paper, n. 21611, nov. 2017.

CAIN, Daylian; LOEWENSTEIN, George; MOORE, Don. The dirt on coming clean: perverse effects of disclosing conflicts of interest. Journal of Legal Studies, Chicago, v. 34, n. 1, p. 1-25, jan. 2005.

CAIN, Daylian; LOEWENSTEIN, George; MOORE, Don. When sunlight fails to disinfect: understanding the perverse effects of disclosing conflicts of interest. Journal of Consumer Research, Chicago, v. 37, n. 5, p. 836-857, feb. 2011.

CARLSMITH, J. Merrill; GROSS, Alan. Some effects of guilt on compliance. Journal of Personality and Social Psychology, Washington, v. 11, n. 3, p. 232-239, mar. 1969.

CLARKE, Ronald; FELSON, Marcus. Routine activity and rational choice: advances in criminological theory, v. 5, 1993.

FALK, Armin; SZECH, Nora. Organizations, diffused pivotality and immoral outcomes. 2013. Disponível em: <https://polit.econ.kit.edu/downloads/papers/Falk_Szech_WP_2_Pivotality_Fal_Szech_DP-2.pdf>. Acesso em: 2 maio 2018.

FOLTZ, Jeremy D.; OPOKU-AGYEMANG, Kweku A. Do higher salaries lowerpetty corruption? A policy experiment on West Africa's highways. 2015. Disponível em: <http://cega.berkeley.edu/assets/miscellaneous_ files/Opoku-Agyemang_WGAPE_2015.pdf>.

GINO, Francesca; AYAL, Shahar; ARIELY, Dan. Contagion and differentiation in unethical behavior: the effect of one bad apple on the barrel. Psychological Science, California, v. 20, n. 3, p. 393-398, mar. 2009.

GINO, Francesca; AYAL, Shahar; ARIELY, Dan. Self-serving altruism? The lure of unethical actions that benefit others. Journal of Economic Behavior \& Organization, Amsterdam, v. 93, p. 285-292, set. 2013.

GINO, Francesca; PIERCE, Lamar. Dishonesty in the name of equity. Psychological Science, Washington, v. 20, n. 3, p. 1153-1160, set. 2009.

GNEEZY, Uri; IMAS, Alex; MADARÁSZ, Kristóf. Conscience accounting: emotion dynamics and social behavior. Management Science, Maryland, v. 60, n. 11, p. 2645-2658, ago. 2014.

HAMMAN, John; LOEWENSTEIN, George; WEBER, Roberto. Self-interest through delegation: an additional rationale for the principal-agent relationship. American Economic Review, Tennessee, v. 100, n. 4, p. 1826-1846, set. 2010.

HARE, Robert. Psychopathy: a clinical and forensic overview. Psychiatric Clinics of North America, Amsterdam, v. 29, n. 3, p. 709-724, set. 2006.

HARFORD, Tim. The logic of life: the rational economics of an irrational world. New York: Random House, 
2008.

HENRICH, Joseph, et al. "Economic man" in cross-cultural perspective: behavioral experiments in 15 small-scale societies. Behavioral and Brain Sciences, New York, v. 28, n. 6, p. 795-855, dez. 2005.

HOUSER, Daniel; VETTTER, Stefan; WINTER, Joachim. Fairness and cheating. European Economic Review, Amsterdam, v. 56, n. 8, p. 1645-1655, nov. 2012.

HSEE, Christopher. Elastic justification: how tempting but task-irrelevant factors influence decisions. Organizational Behavior and Human Decision Processes, Amsterdam, v. 62, n. 3, p. 330-337, jun. 1995.

HSEE, Christopher. Elastic justification: how unjustifiable factors influence judgments. Organizational Behavior and Human Decision Processes, Amsterdam, v. 66, n. 1, p. 122-129, abr. 1996.

KALANTHROFF, Eyal; ASLAN, Chen; DAR, Reuven. Washing away your sins will set your mind free: physical cleansing modulates the effect of threatened morality on executive control. Cognition and Emotion, London, v. 31, n. 1, p. 185-192, 2017.

KUNDA, Ziva. The case for motivated reasoning. Psychological Bulletin, Washington, v. 108, n. 3, p. 480-498, nov. 1990.

LAMBSDORFF, Johann. Behavioural and experimental economics as a guidance to anticorruption. In: SERRA, Danila; WANTCHEKON, Leonard (Org.). New advances in experimental research on corruption. Bingley: Emerald Group Publishing Limited, 2012. p. 279-300.

LAMBSDORFF, Johann. Preventing corruption by promoting trust: insights from behavioral science. Passauer Diskussionspapiere: Volkswirtschaftliche Reihe, Passau, v. 69, n. 15, p. 1-16, 2015.

LOEWENSTEIN, G.; SUNITA, Sah; CAIN, Daylian. The unintended consequences of conflict of interest disclosure. The Journal of the American Medical Association, Chicago, v. 307, n. 7, p. 669-670, fev. 2012.

MARQUETTE, Heather; PEIFFER, Caryn. Corruption and collective action. Research Paper 32. Developmental leadership programme and U4 Anti-Corruption Resource Centre. Disponível em: $<$ http://publications.dlprog.org/CorruptionandCollectiveAction.pdf>.

MAZAR, Nina; AMIR, On; ARIELY, Dan. The dishonesty of honest people: a theory of self-concept maintenance. Journal of Marketing Research, Chicago, v. 45, n. 6, p. 633-644, dez. 2008.

MAZAR, Nina; ARIELY, Dan. Dishonesty in everyday life and its policy implications. Journal of Public Policy \& Marketing, Chicago, v. 25, n. 1, p. 117-126, mar. 2006.

MEAD, Nicole et al. Too tired to tell the truth: self-control resource depletion and dishonesty. Journal of Experimental Social Psychology, Amsterdam, v. 45, n. 3, p. 594-597, maio 2009.

MOORE, Celia; GINO, Francesca. Ethically adrift: how others pull our moral compass from true north, and how we can fix it. Research in Organizational Behavior, Amsterdam, v. 33, p. 53-77, 2013.

O’DONOGHUE, Ted; RABIN, Matthew. Doing it now or later. American Economic Review, Pittsburgh, v. 89, n. 1, p. 103-124, mar. 1999.

OECD. Recommendation of the Council for Development Co-operation Actors on Managing the Risk of Corruption: compendium of existing practices. DCD/DAC(2017)39. 2017. Disponível em: <http://www.oecd.org/ officialdocuments/publicdisplaydocumentpdf/?cote=DCD/DAC(2017)39\&docLanguage $=$ En $>$.

PERSSON, Anna; ROTHSTEIN, Bo; TEORELL, J. Why anticorruption reforms fail: systemic corruption as a collective action problem. Governance, New Jersey, v. 26, n. 3, p. 449-471, jul. 2013.

PLONER, Matteo; REGNER, Tobias. Self-image and moral balancing: An experimental analysis. Journal of Economic Behaviors and Organization, Amsterdam, v. 93, p. 374-383, set. 2013. 
PRUCKNER, Gerald; SAUSGRUBER, Rupert. Honesty on the streets: a field study on newspaper purchasing. Journal of the European Economic Association, New Jersey, v. 11, n. 3, p. 661-679, jun. 2013.

RANA Plaza owner jailed for three years over corruption. 29 August 2017. Disponível em: <https://www. aljazeera.com/news/2017/08/rana-plaza-owner-jailed-years-corruption-170829161742916.html>.

SACHDEVA, Sonya; ILIEV, Rumen; MEDIN, Douglas. Sinning saints and saintly sinners: the paradox of moral self-regulation. Psychological Science, Washington, v. 20, n. 4, p. 523-528, abr. 2009.

SAH, Sunita; LOEWENSTEIN G.; CAIN, Daylian. The burden of disclosure: increased compliance with distrusted advice. Journal of Personality and Social Psychology, Washington, v. 104, n. 2, p. 289-304, fev. 2013.

SCHIKORA, Jan. Bringing the four-eyes-principle to the lab. 2011. Disponível em: <https://epub.ub.uni-muenchen.de/12160/1/The4EP_Schikora.pdf>. Acesso em: 10 maio 2018.

SCHULZE, Günther; FRANK, Björn. Deterrence versus intrinsic motivation: experimental evidence on the determinants of corruptibility. Economics of Governance, Cham, v. 4, n. 2, p. 143-160, ago. 2003.

SHELDON, Oliver; FISHBACH, Ayelet. Anticipating and resisting the temptation to behave unethically. Personality and Social Psychology Bulletin, California, v. 41, n. 7, p. 962-975, jul. 2015.

SHU, L. et al. Signing at the beginning makes ethics salient and decreases dishonest self-reports in comparison to signing at the end. Proceedings of the National Academy of Sciences of the United States of America, Washington, v. 109, n. 38, p. 15197-15200, set. 2012.

SIEFF, Kevin. Low pay and one minor promotion for the most honest man in Afghanistan. The Washington Post, 31 jan. 2014. Disponível em: < https://www.theguardian.com/world/2014/jan/31/afghanistan-corruption-honest-police-officer>.

SIMON, H. A behavioral model of rational choice. The Quarterly Journal of Economics, Cambridge, v. 69, n. 1, p. 99-118, fev. 1955.

SOUSA, Luís de. Corrupção. Lisboa: Fundação Francisco Manuel dos Santos, 2011.

THALER, Richard; SUNSTEIN, Cass. Nudge: como melhorar as decisões sobre saúde, dinheiro e felicidade. Lisboa: Academia do Livro, 2009.

WILTERMUTH, Scott. Cheating more when the spoils are split. Organizational Behavior and Human Decision Processes, Amsterdam, v. 115, n. 2, p. 157-168, jul. 2011.

ZHONG, Chen-Bo; LILJENQUIST, Katie. Washing away your sins: threatened morality and physical cleansing. Science, Washington, v. 313, n. 5792, p. 1451-1452, set. 2006. 


\title{
Políticas públicas e a concretização de direitos sociais: tomada de decisão, arquitetura de escolhas e efetividade*
}

\author{
Public policies and the concretization of \\ social rights: decision-making, architecture of \\ choices and effectiveness
}

Ana Elizabeth Neirão Reymão**

Ricardo dos Santos Caçapietra***

\section{Resumo}

O objetivo do presente trabalho é discutir a utilização da ciência comportamental para o desenho e implementação de políticas públicas, contribuindo, assim, para a concretização de direitos sociais como educação e saúde. Para tal, apresenta uma metodologia de avaliação de impacto de políticas públicas. A pesquisa é exploratória, de abordagem qualitativa, tendo como procedimento a revisão bibliográfica. Discute, inicialmente, os principais modelos analíticos, expondo, em seguida, os recentes avanços comportamentais e cognitivos, os conceitos introdutórios sobre o julgamento e a tomada de decisão. Aborda, também, a arquitetura de escolhas como uma técnica de desenho de políticas públicas capaz de incentivar melhores resultados, bem como o método do experimento aleatório controlado (EAC) como uma ferramenta de mensuração dos impactos das ações governamentais. Ao final, expõe exemplos internacionais de insights comportamentais utilizados em políticas públicas de saúde e educação. Com a escassez crescente de recursos públicos, é fundamental que os gestores se sensibilizem para a necessidade de desenvolver ações eficientes e capazes de produzir resultados significativos para a vida das pessoas, para a materialização dos direitos sociais definidos na Constituição de 1988. O texto revela que arquiteturas de escolhas melhor formatadas, levando em consideração percepções cognitivos-comportamentais, poderão produzir políticas públicas mais eficientes e efetivas e, em consequência, maior efetivação dos direitos sociais.

Palavras-chave: Direitos sociais. Políticas públicas. Tomada de decisão. Arquitetura de escolhas. Efetividade.

\section{Abstract}

The objective of this study is to discuss the use of behavioral science in the design and implementation of public policies, thus contributing to the realization of social rights such as education and health. To do so, it presents a methodology for assessing the impact of public policies. The research is exploratory, with a qualitative approach, having as a procedure 
the bibliographic review. It discusses, initially, the main analytical models, then exposing the recent behavioral and cognitive advances, the introductory concepts about the judgment and the decision making. It also approaches the architecture of choices as a public policy design technique capable of encouraging better results, as well as the randomized controlled experiment (EAC) method as a tool to measure the impacts of governmental actions. At the end, it exposes international examples of behavioral insights used in public policies of health and education. With the growing scarcity of public resources, it is essential that managers become aware of the need to develop efficient actions that can produce significant results in people's lives, in the materialization of the social rights defined in the 1988 Constitution. better-formatted choices, considering cognitive-behavioral perceptions, may produce more efficient and effective public policies and, consequently, a greater realization of social rights.

Keywords: Social rights. Public policy. Decision making. Architecture of choices. Effectiveness.

\section{INTRODUÇÃO}

O objetivo deste artigo é discutir a utilização da ciência comportamental para o desenho e implementação de políticas públicas e sua relação com a concretização de direitos sociais, tais como educação e saúde. Nesse sentido, busca-se apresentar uma metodologia apta a mensurar o impacto das ações governamentais levando em consideração a análise de evidências.

Sob a perspectiva de ser um caminho para o desenvolvimento nacional, a Constituição Federal de 1988 elenca diversos objetivos fundamentais, que dependem do planejamento e execução de políticas eficientes e efetivas, para as quais experimentos conduzidos com base na ciência comportamental podem contribuir.

Assim, para que se compreenda com a necessária profundidade a temática das políticas públicas e sua estreita relação com a materialização de direitos sociais, em especial saúde e educação, deve-se construir abordagens fundamentadas na interdisciplinaridade e aperfeiçoar ferramentas de pesquisa empírica capazes de indicar caminhos seguros para esse objetivo.

A ciência comportamental, ao contrário do pensamento econômico clássico fundado na racionalidade plena, pressupõe que as pessoas apresentam racionalidade limitada. Nessa seara, intervenções comportamentais baseadas em evidências, num contexto de recursos escassos e demandas sociais ilimitadas, são desejáveis, pois podem contribuir para um melhor processo de formulação e implementação de políticas públicas, gerando melhores resultados.

Diante desse cenário, a análise de política pública encontra, no âmbito da ciência comportamental, uma metodologia capaz de interpretar e compreender o impacto de determinada política, vista como estruturas de incentivos capazes de orientar os seres humanos a determinados comportamentos. A arquitetura de escolhas e os nudges, como será visto mais à frente, podem ajudar nessa tarefa.

Nas últimas décadas, o desenvolvimento de ferramentas comportamentais incentivou pesquisas científicas em diversos países, favorecendo a construção de uma metodologia baseada no "testar, aprender e adaptar" no âmbito dos governos. Uma das abordagens possíveis é o sistema dual apresentado por Daniel Kahneman, que afirma que, em regra, a tomada de decisão individual não obedece a parâmetros racionais.

Para o ganhador do prêmio Nobel de Economia em 2002, a maior parte das escolhas acontece no âmbito daquilo que denominou de sistema " 1 ". Nesse caso, os processos de pensamento são intuitivos e automáticos, geralmente baseados em experiências anteriores ou até mesmo decorrentes da inconsciência. Por outro lado, o sistema "2", embora pouco utilizado, se bem estimulado, pode produzir melhores decisões, posto que é caracterizado por uma maior reflexão.

Já as dimensões temporais e sociais, no design de políticas públicas, assumem extrema relevância. Enquan- 
to a primeira afirma que eventos presentes recebem mais atenção do que situações futuras; a segunda alerta que, além dos aspectos comportamentais, as pessoas levam em consideração a percepção do ambiente social no momento das escolhas, variando de acordo com a cultura e o contexto em que estão inseridas.

A título exemplificativo, sobre a influência do ambiente no comportamento individual, os norte-americanos estão mais condicionados a julgamentos baseados em custos e benefícios, enquanto os franceses escolhem alternativas levando em consideração aspectos estéticos e sociais.

Por outro lado, uma análise experimental prática pode assegurar uma tomada de decisão mais equilibrada, com a estruturação de casos com base em pesquisas quantitativas e qualitativas, consistência metodológica e consolidação de dados, distinguindo argumentos normativos de análises descritivas.

Com essa leitura, pode-se compreender e descrever as políticas públicas, demonstrando gargalos e obstáculos a serem superados para a busca de alternativas eficazes, ou seja, que produzam resultados impactantes na vida das pessoas.

Não obstante essa questão já esteja em estágio mais avançado em outros países, somente muito embrionariamente o Brasil passou a fazer uso dos estudos empíricos e métodos de pesquisa aplicada em políticas públicas, inclusive preditivas, com experimentos laboratoriais, naturais e de campo.

Diante disso, o presente trabalho será desenvolvido partindo da assertiva de que o desenho de políticas públicas pode ser melhor estruturado, contribuindo para a concretização de direitos sociais, com base na observância de critérios comportamentais e cognitivos. Do ponto de vista da avaliação de impacto, a metodologia do experimento aleatório controlado (EAC) pode contribuir para uma melhor avaliação da intervenção estatal (causa-efeito) e para a manutenção de um ciclo positivo de aprendizado baseado no trinômio "testar, aprender e adaptar".

A pesquisa apresentada é exploratória, de abordagem qualitativa e tem como procedimento a revisão bibliográfica. Além da introdução e da conclusão, o texto traz, na seção dois, uma breve introdução sobre a relação entre as políticas públicas e os direitos sociais. A terceira seção apresenta quatro modelos teóricos de análise de políticas públicas, a saber: ciclo das políticas públicas, modelo dos fluxos múltiplos, modelo do equilíbrio interrompido e o modelo das coalizões de defesa. Na seção quatro, serão introduzidos conceitos comportamentais básicos sobre o julgamento, a tomada de decisão individual e abordados a arquitetura de escolhas e os nudges, como formas de intervenção estatal relacionadas com o comportamento dos indivíduos. Na parte cinco, será verificado o experimento aleatório controlado (EAC) e seu papel na mensuração dos impactos. Exemplos de insights comportamentais em políticas públicas e sua relação com a concretização de direitos sociais como saúde e educação serão objeto da sexta seção e finalizam este artigo.

\section{Políticas PÚBlicas E diREITOS SOCIAIS: UMA BREVE INTRODUÇão}

A carta magna de 1988 constitui-se, grosso modo, num plano político-normativo para o desenvolvimento dos brasileiros e, por conseguinte, do país, tanto que no art. $3^{\circ}$ são elencados os objetivos fundamentais, tais como: construir uma sociedade livre, justa e solidária; garantir o desenvolvimento nacional; erradicar a pobreza e a marginalização, reduzir as desigualdades sociais e regionais; e promover o bem de todos, sem preconceitos de origem, raça, sexo, cor, idade e quaisquer outras formas de discriminação.

O art. $6^{\circ}$ da Constituição de 1988 destaca que são direitos sociais a educação, a saúde, a alimentação, o trabalho, a moradia, o transporte, o lazer, a segurança, a previdência social, a proteção à maternidade e à infância, e a assistência aos desamparados.

José Afonso da Silva compreende os direitos sociais como prestações positivas de responsabilidade do Estado, descritas em normas constitucionais, que têm como finalidade propiciar melhores condições de 
vida aos indivíduos mais vulneráveis da sociedade. Dessa forma, os direitos sociais exercem um papel muito importante na redução das desigualdades sociais ${ }^{1}$.

Como se percebe, o atendimento das condições materiais necessita da correspondente intervenção do Estado, desenvolvida com base em um processo de tomada de decisão, que envolve de um lado a existência de variadas necessidades humanas e do outro as possíveis alternativas. No meio dessa relação, entre demanda e possibilidade, está a escassez de recursos e a certeza de que a concretização de direitos custa dinheiro.

Assim, a política pública é uma atividade estatal que engloba normas e atos específicos, instrumento de concretização de direitos fundamentais e de viabilização da justiça social. Conforme escólio de Bruno Santos Cunha, "pouco vale o mero reconhecimento de direitos se não existem os instrumentos que os efetivem"2.

Ignacy Sachs ${ }^{3}$ afirma que a população deve acessar políticas públicas, dentre outras, como educação e saúde, para dispor de um processo includente, sustentável e participativo de desenvolvimento. Destaca que a educação tem valor intrínseco, pois colabora para a autonomia humana, a autoconfiança e a autoestima, além de apresentar uma função direta com a participação no mercado de trabalho e o aumento da produtividade do trabalhador. A saúde é outro direito social essencial ao desenvolvimento humano. Com uma alimentação adequada, acesso a serviços básicos de saúde, acesso à água potável e a saneamento básico, as pessoas podem desenvolver melhor suas potencialidades.

Nesse sentido, quando se fala em direito à educação, existe uma contrapartida estatal relacionada com a oferta e a qualidade dos serviços oferecidos, dotando, assim, o indivíduo de competências mínimas capazes de aperfeiçoar o raciocínio e o pensamento, além de qualificar o crescimento pessoal e, por conseguinte, o desenvolvimento da sociedade como um todo.

Como consequência, tem-se que o poder público, titular do dever jurídico correlato ao direito à educação, conforme expressamente previsto no artigo 205 da CF/88, deverá organizar-se para fornecer os serviços educacionais a todos, de acordo com os princípios estatuídos na Constituição, sempre no sentido de ampliar cada vez mais as possibilidades de que todos venham a exercer igualmente este direito 4 .

Nessa seara, ao se refletir sobre o direito à liberdade, em sentido contemporâneo, com a possibilidade de ir e vir, de realizar esta ou aquela profissão, pensa-se na atividade governamental relacionada com o provimento de saúde básica, apta a dar condições às pessoas de exercerem de fato a liberdade, de participarem de uma atividade laborativa, de ter uma vida com expectativas individuais e profissionais. O direito à saúde, conforme destaca Urá Lobato Martins, deve ser priorizado pelo Estado, afinal:

Quantificar ou relativizar o direito à saúde significa ofender à inviolabilidade de dignidade humana. Se as políticas públicas não asseguram os direitos dos cidadãos em sua totalidade, caberá ao Estado rever suas prioridades e direcionar seus gastos em prol da sociedade, mas tal argumento jamais poderá ser utilizado como óbice para a fruição individual do direito fundamental à saúde 5 .

Dessa forma, direitos sociais como educação e saúde são temas recorrentes dentro da agenda nacional e necessitam das respectivas políticas públicas para serem implementados. Mas não só isso, ficam condicionados ao planejamento e à execução de políticas eficientes e efetivas, que tenham por fundamento não apenas argumentos decorrentes do senso comum ou de respeito a esta ou aquela moral, mas sim evidências obtidas em experimentos conduzidos com método científico.

1 SILVA, José Afonso da. Curso de direito constitucional positivo. São Paulo: Malheiros, 1992. p. 258.

2 CUNHA, Bruno Santos. Direitos fundamentais da constituição às políticas públicas. Revista Brasileira de Políticas Públicas, Brasília, v. 1, n. 1, p. 65-82, 2011. p. 71.

3 SACHS, Ignacy. Desenvolvimento: includente, sustentável e sustentado. Rio de Janeiro: Garamond, 2008. p. 39-40.

4 DUARTE, Clarice Seixas. A educação como um direito fundamental de natureza social. Educ. Soc. Campinas, v. 28, n. 100, p. 691-713, 2007. p. 698.

5 MARTINS, Urá Lobato. A judicialização das políticas públicas e o direito subjetivo individual à saúde, à luz da teoria da justiça distributiva de John Rawls. Revista Brasileira de Políticas Públicas, v. 5, Número Especial, p. 309-328, 2015. p. 326. 
Políticas públicas são o resultado da transferência de recursos financeiros por parte da sociedade, por meio de impostos, para que o Estado gerencie a distribuição desses mesmos recursos mediante a provisão das necessidades coletivas e da mediação dos conflitos sociais. Consistem na atividade estatal de elaboração, planejamento, execução e financiamento de ações para a consolidação do Estado Democrático de Direito, com vistas à proteção e à promoção dos direitos humanos ${ }^{6}$.

Políticas públicas, dentro desse contexto, podem ser consideradas como estratégias capazes de consolidar direitos assegurados primeiramente na Constituição do país e em outros dispositivos normativos que tratam do assunto, como defende Maria Paula Dallari Bucci ${ }^{7}$

Trata-se de um conceito jurídico, complementar ao de autores como Thomas Dye ${ }^{8}$, para quem a política pública é "o que o governo escolhe fazer ou não fazer"; como Harold Dwight Laswell, para quem uma política pública é um programa planejado de objetivos, valores e práticas dos governos; ou Guy Peters, que a define como a soma das atividades dos governos, que agem diretamente ou por meio de delegação, e que influenciam a vida dos cidadãos ${ }^{10}$.

Importante destacar que a crescente desconfiança para com a carta de 1988 decorre justamente da ineficiência e ineficácia na implementação de políticas públicas, que em quase 30 anos não foram capazes de concretizar a maior parte dos direitos sociais dispostos no texto constitucional.

A importância de se compreender o papel das políticas públicas na melhoria da vida das pessoas vem crescendo exponencialmente, em particular, por ser compreendida como a ação governamental que tem por objetivo a concretização dos direitos sociais, vistos como instrumentos capazes de potencializar o pleno desenvolvimento humano, à luz do que defende Amartya Sen ${ }^{11}$.

Pode-se elencar, pelo menos, três fatores que corroboram para a crescente importância da análise de políticas públicas e sua relação com a concretização de direitos. Primeiramente, com a restrição de recursos advinda de questões macroeconômicas, o planejamento, a estruturação e os critérios de escolha de políticas públicas, tanto econômicas como sociais, passaram a ser mais valorizados e pesquisados. Segundo, com o avanço da filosofia neoliberal, o ajuste fiscal levou a implementação de orçamentos equilibrados entre receita e despesa, além da não intervenção estatal nas políticas sociais, ampliando ainda mais o fosso das desigualdades não somente na sociedade brasileira, mas em grande parte do mundo. Por fim, e talvez o mais importante diante do cenário nacional, o fato de que os países em desenvolvimento não conseguiram até o presente momento apresentar capacidade política, técnica e gerencial de implementar políticas públicas que impulsionem a universalização e a concretização dos direitos sociais ${ }^{12}$.

Para Camila Japiassu Dores, não é mais no âmbito do direito, garantido formalmente, que se encontra a exclusão do acesso a serviços básicos como saúde, por exemplo, mas sim na falta de efetividade do processo de formulação e implementação de políticas públicas ${ }^{13}$.

A respeito desse aspecto, políticas públicas não podem ser vistas, apenas, como uma concatenação cronológica de atos administrativos, mas sim como uma intensa negociação de interesses, com base no comportamento, do julgamento e da tomada de decisão dos participantes, envolvendo desafios complexos que

6 ANDRADE, Aparecida de Moura; SANTANA, Héctor Valverde. Avaliação de políticas públicas versus avaliação de impacto legislativo: uma visão dicotômica de um fenômeno singular. Revista Brasileira de Políticas Públicas, Brasília, v. 7, n. 3, p. 781-798, 2017. p. 785-786.

7 BUCCI, Maria Paula Dallari. Buscando um conceito de políticas públicas para a concretização de direitos humanos. In: BUCCI, Maria Paula Dallari et. al. Direitos humanos e políticas públicas. São Paulo: Pólis, 2001. p. 5-16. p. 13.

8 DYE, Thomas R. Understanding Public Policy. Englewood Cliffs, N.J.: Prentice-Hall, 1984. p. 2.

9 LASSWELL, Harold. Politics: who gets what, when, how. Cleveland: Meridian Books, 1936/1958.

10 PETERS, B. Guy. American Public Policy. Chatham, N.J.: Chatham House, 1986.

11 SEN, Amartya. Desenvolvimento como liberdade. São Paulo: Companhia das Letras, 2010. p. 16.

12 SOUZA, Celina. Políticas públicas: uma revisão da literatura. Sociologias, Porto Alegre, ano 8, n. 16, p. 20-45, 2006.

13 DORES, Camila Japiassu. As bases da saúde lançadas pela Constituição Federal de 1988: um sistema de saúde para todos? Revista Brasileira de Politicas Públicas, Brasília, v. 3, n. 1, p. 77-89, 2013. p. 80. 
devem ser enfrentados por planos intersetoriais e com enfoque interdisciplinar. Diante disso, torna-se importante analisar algumas teorias que buscam compreender os processos de políticas públicas, objetivo da seção a seguir.

\section{Modelos de ANÁlise de políticas públicas}

Tradicionalmente, numa perspectiva estrutural, algumas teorias analisam os processos de políticas públicas, visando explicar a lógica da ação pública, as regras de funcionamento, suas continuidades e rupturas, interações de atores e instituições nos processos políticos, além da distribuição de recursos. Alguns modelos teóricos se destacam: ciclo das políticas públicas, modelo dos fluxos múltiplos, modelo do equilíbrio interrompido e o modelo das coalizões de defesa, serão discutidos nessa seção.

\subsection{Ciclo das políticas públicas}

Segundo esse modelo, as políticas públicas resultam de um processo que se desenvolve em ciclos e etapas, ou seja, em fases sucessivas que se relacionam entre si de uma forma lógica. Um dos principais representantes dessa abordagem sequencial é Harold Dwight Lasswell, para quem uma política pública é um programa planejado de objetivos, valores e práticas dos governos ${ }^{14}$.

Lasswell entende políticas públicas como tomada de decisões com base em etapas subsequentes, as quais podem ser investigadas isoladamente ou relacionadas entre si. Essa compreensão exerceu forte influência nos estudos de políticas públicas subsequentes, pois auxilia na compreensão do processo, reduzindo seu grau de complexidade.

Seu modelo de análise sequencial inicia-se com a contextualização das políticas públicas e percorre um caminho até a avaliação. As fases são: informação, promoção, prescrição, invocação, aplicação, conclusão e avaliação $^{15}$.

Quer dizer, elas vão desde a coleta dos dados, aprovação de medidas, passando pela formulação de medidas e regras, especificação de benefícios e sanções, até a concretização das medidas, finalizando com a identificação do sucesso ou insucesso destas.

Destaca-se nesse modelo a importância de cada etapa e a racionalidade associada à ação tomada pelo Estado em otimizar o uso dos recursos disponíveis. O foco é na tomada de decisão e implementação das ações.

Tal proposta foi desenvolvida pelo autor no esforço de consolidar a Ciência Política enquanto campo teórico e habilitar a ação dos decisores políticos. Lasswell defendia a racionalidade do processo de tomada de decisão e o desenvolvimento de uma ciência baseada no conhecimento "no e do processo político", destacam Luísa Araújo e Maria de Lurdes Rodrigues ${ }^{16}$.

Para ele, o cientista político deveria atuar como um integrador de conhecimento e ação, mediando os especialistas de áreas específicas de conhecimento, os decisores políticos e os cidadãos.

Essa proposta de políticas públicas em fases inspirou vários outros estudiosos, como o americano Charles O. Jones, em An Introduction to the Study of Public Policy (1970), que adotou a análise da política como uma sequência racional e linear de decisões. Jones desenvolveu uma classificação mais detalhada, com dez etapas:

14 LASSWELL, Harold. Politics: who gets what, when, how. Cleveland: Meridian Books, 1936/1958.

15 LASSWELL, 1962 apud VIANA, Ana Clara. Abordagens metodológicas em políticas públicas. Revista de Administração Pública, Rio de Janeiro, v. 30, n. 2, 1996, p. 6.

16 ARAÚJO, Luísa; RODRIGUES, Maria de Lurdes. Modelos de análise das políticas públicas. Sociologia, Problemas e Práticas, n. 83, p. 11-35, 2017. Disponível em: <http://www.scielo.mec.pt/pdf/spp/n83/n83a01.pdf>. Acesso em: 17 maio 2018. p. 14. 
"percepção do problema; agregação; organização; representação do público-alvo; agendamento; formulação; orçamentação; concretização; avaliação; ajustamento ou conclusão"17.

Michael Howlett e M. Ramesh, no que chamaram de modelo de resolução aplicada de problemas, dividem o ciclo em cinco estágios: agenda-setting (formação de agenda), policy formulation (formulação de política), decision making (tomada de decisão), policy implementation (implementação da política) e policy evaluation (análise da política $)^{18}$. Os autores compreendem as políticas públicas como subsistemas político-administrativos, sendo cada área ou setor formado por um conjunto articulado de atores, instituições e ideias próprio, constituindo-se, dessa forma, parte de um sistema político e econômico mais amplo.

Embora os próprios expoentes desse modelo de ciclos reconheçam as fragilidades da abordagem, ela é muito difundida. Lasswell definia o modelo de ciclos como mais ideal que real. Howlett e Ramesh reconhecem que ele pouco leva em consideração as influências externas sobre o Estado, presume um número reduzido de atores envolvidos, com destaque para os burocratas, além de avaliar a política, apenas, ao final.

Ainda assim, esse método de análise exerceu forte influência nos estudos de políticas públicas subsequentes, por ter muita validade analítica, ao permitir relacionar de forma coerente todos os aspectos das políticas públicas.

Nesse contexto, diversos outros autores apresentaram propostas alternativas de classificação ou ciclos, “contribuindo para a consolidação de um modelo heurístico de decomposição do processo político em sequências ou etapas, para fins analíticos" $"$.

Dentre os brasileiros que adotam essa visão, destaca-se Leonardo Secchi. Em sua obra, o autor faz uma ampla revisão da literatura sobre políticas públicas, atualizando um dos pioneiros trabalhos brasileiros nesse sentido, o de Celina Souza ${ }^{20}$. Para ele, as políticas públicas tratam do conteúdo concreto e do conteúdo simbólico de decisões políticas, e do processo de construção e atuação dessas decisões.

Três questões fundamentais norteiam a discussão sobre a definição de política pública em Secchi: (1) quem as elabora: somente atores estatais ou atores não estatais também? (2) políticas públicas também se referem à omissão ou à negligência? (3) As diretrizes mais operacionais também podem ser consideradas políticas públicas, ou somente as diretrizes estruturantes, de nível estratégico? ${ }^{21}$

Na mesma linha dos demais, aponta a utilidade heurística do ciclo de política pública, mas reconhece que ele, raramente, reflete a real dinâmica ou vida de uma política pública, pois "as fases geralmente se apresentam misturadas e as sequências se alternam"22.

Assim, apesar da falta de consenso quanto às etapas, essa visão de ciclo é muito difundida. Considerando a proposta de Secchi, uma política pública, o ciclo possui sete fases principais: identificação do problema, formação de agenda, formulação de alternativas, tomada de decisão, implementação, avaliação e extinção.

A identificação do problema consiste em constatar a discrepância entre o status quo e uma situação ideal possível, ou seja, aquilo que diverge daquilo que se gostaria que fosse a realidade pública, explica Secchi. Percebe-se a situação, delimita-se seus elementos e avalia-se a possibilidade de resolução.

17 ARAÚJO, Luísa; RODRIGUES, Maria de Lurdes. Modelos de análise das políticas públicas. Sociologia, Problemas e Práticas, n. 83, p. 11-35, 2017. Disponível em: < http://www.scielo.mec.pt/pdf/spp/n83/n83a01.pdf>. Acesso em: 17 maio 2018 . p. 19.

18 HOWLETT, M.; RAMESH, M. Studying public policy: policy cycles and policy subsystems. New York: Oxford University Press, 1995.

19 ARAÚJO, Luísa; RODRIGUES, Maria de Lurdes. Modelos de análise das políticas públicas. Sociologia, Problemas e Práticas, n. 83 , p. 11-35, 2017. Disponível em: <http://www.scielo.mec.pt/pdf/spp/n83/n83a01.pdf>. Acesso em: 17 maio 2018 . p. 19.

20 SOUZA, Celina. Políticas públicas: uma revisão da literatura. Sociologias, Porto Alegre, ano 8, n. 16, p. 20-45, 2006.

21 SECCHI, Leonardo. Políticas públicas: conceitos, esquemas de análise, casos práticos. 2. ed. São Paulo: Cengage Learning, 2010. p. 2.

22 SECCHI, Leonardo. Políticas públicas: conceitos, esquemas de análise, casos práticos. 2. ed. São Paulo: Cengage Learning, 2010. p. 33 . 
Destacando o aspecto racional dessa fase, o autor explica que atores como os partidos políticos, agentes políticos e organizações não governamentais "encaram o problema público como matéria prima de trabalho" 23 , oportunidades, que podem ser a de um partido ou político demonstrarem seu trabalho ou até de uma ONG criar uma entidade de defesa de uma espécie em extinção, por exemplo.

Problemas que figuram a prioridade de atuação formam a agenda, definida como o conjunto de temas relevantes. Após ser introduzido na agenda, seja ela política (temas merecedores da intervenção pública) ou formal (temas que o poder público já decidiu enfrentar), surge a formulação de alternativas.

Essa etapa é constituída dos esforços de construção e combinação de construção de alternativas de solução, estabelecendo objetivos e estratégias das mesmas, bem como o estudo das respectivas potenciais consequências. Assim, a formulação de alternativas consiste na elaboração de métodos, programas, estratégias ou ações para alcançar os objetivos traçados.

Em tal formulação, segundo Secchi, o policymaker dispõe de quatro mecanismos para a indução do comportamento: premiação (influenciar comportamentos com prêmios positivos), coerção (influenciar comportamentos com prêmios negativos), conscientização (influenciar comportamentos por meio da construção e apelo ao senso de dever moral) e soluções técnicas (influência indireta por meio de soluções práticas). Cada um desses tem um custo de elaboração quanto ao tempo adequado para produzir efeitos práticos sobre os comportamentos, devendo este ser investigado pelo formulador ${ }^{24}$.

A tomada de decisão, quarta fase do ciclo de políticas públicas de Secchi, é o momento em que os interesses dos atores são equacionados e são explicitados os objetivos e métodos para o enfrentamento do problema público.

$\mathrm{Na}$ implementação, fase seguinte, as regras, rotinas e processos sociais deixam de ser intenções e passam a ser ações. Secchi lembra que nela podem ocorrer não apenas problemas técnicos ou administrativos, mas também elementos políticos que frustram planejamentos. Podem surgir obstáculos e falhas, bem como serem visualizados erros anteriores à tomada de decisão, detectados problemas e objetivos mal formulados. Também, pode ocorrer com maior ou menor interação entre tomadores de decisão e implementadores: modelo bottom-up (de baixo para cima) ou top-down (de cima para baixo), respectivamente.

A avaliação, etapa seguinte, é aquela em que se identificam o sucesso ou as falhas dos projetos que foram colocados em prática, destaca Secchi. Permite conhecer o desempenho das fases anteriores. Ela pode ser anterior ou posterior à implementação (ex-ante ou ex-post) ou, ainda, formativa (in itinere, também chamada de monitoramento), a qual permite ajustes imediatos.

A última etapa consiste em o término ou extinção da política pública, que o autor lembra só de ter sido enfatizada mais recentemente, a partir dos anos 1970. A questão aqui é compreender o que leva à substituição de uma política por outra, dado que fatores como a relutância dos beneficiados, a inércia institucional, o conservadorismo, bem como obstáculos legais e altos custos de iniciação tornam difícil essa fase.

\subsection{Modelo dos fluxos múltiplos}

Um segundo modelo de análise de políticas públicas é o de fluxos múltiplos, que questiona a ideia de racionalidade em que a tomada de decisão obedece a passos sequenciais em um determinado padrão, trazida pelo modelo de ciclos.

Segundo a ideia de ciclos, os policymakers têm um problema e partem em busca de soluções. O modelo

23 SECCHI, Leonardo. Políticas públicas: conceitos, esquemas de análise, casos práticos. 2. ed. São Paulo: Cengage Learning, 2010. p. 35.

24 SECCHI, Leonardo. Políticas públicas: conceitos, esquemas de análise, casos práticos. 2. ed. São Paulo: Cengage Learning, 2010. p. 38. 
analítico proposto por John Kingdon argumenta que o requisito para o nascimento de uma política pública é a confluência de problemas, soluções e condições políticas favoráveis ${ }^{25}$.

Kingdon procura "explicar como é que os problemas se transformam em problemas políticos, isto é, como captam a atenção do público e dos políticos e entram na agenda da ação pública"26.

Preocupado em como algumas questões passaram a constituir itens da agenda dos governos, em como as escolhas foram feitas pelos tomadores de decisão, ele indaga por que uma lista de temas são objeto de séria atenção por parte das autoridades governamentais, e outros não:

Mas o que faz chegar o momento de se considerar uma ideia? Essa pergunta é na verdade parte de um quebra-cabeças maior: o que faz com que as pessoas, dentro e ao redor do governo, se dediquem, em um dado momento, a alguns temas, e não a outros. Cientistas políticos têm aprendido bastante sobre a promulgação de leis e, de forma mais ampla, sobre como as decisões são tomadas, em diferentes instâncias do governo. No entanto, processos pré-decisórios permanecem território pouco explorado ${ }^{27}$.

Três tipos de agenda são identificados: sistêmica ou não governamental; governamental; e de decisão:

Na primeira estariam os assuntos que há anos preocupam a sociedade, mas que não merecem atenção do governo. Na segunda, os assuntos são alvo de preocupação governamental; e, na terceira, estaria a listados problemas a serem decididos. A passagem de um assunto da agenda sistêmica para a governamental poderia ocorrer quando há eventos dramáticos ou crises, influência de indicadores ou acumulação de experiências ${ }^{28}$.

Kingdon chama atenção que a agenda de governo e a agenda de decisões são definidas por processos bastante diferentes. Muitas alternativas são concebíveis, mas algumas são consideradas mais seriamente que outras. O processo de especificação de alternativas reduz o número das que serão concebíveis do conjunto daquelas que são realmente consideradas.

Conceitos como o de comunidades políticas, os empreendedores políticos e janela de oportunidade política são fundamentais para o autor. As comunidades políticas são formadas por investigadores, deputados, funcionários públicos, analistas, grupos de interesse etc., que partilham a preocupação acerca de um tema ou problemas e que difundem ideias em diferentes fóruns. Os empreendedores políticos são atores que mediam e negociam processos de agendamento. Por fim, a janela de oportunidade política é uma situação em que os defensores de determinada causa podem oferecer soluções ou chamar atenção para problemas que consideram especiais.

Luísa Araújo e Maria de Lurdes Rodrigues lembram que tal janela se abre quando convergem três fluxos de variáveis: "a percepção pública dos problemas (fluxo dos problemas), o conhecimento de soluções políticas e técnicas adequadas aos valores dominantes (fluxo das políticas) e as condições de governação (fluxo da política) ${ }^{\prime 29}$.

Esses fluxos de problemas, políticas e política fluem autonomamente no sistema político, com regras e dinâmicas próprias, segundo Kingdon: os primeiros são decorrentes de construções sociais de atores nos processos das políticas públicas; os segundos são as alternativas geradas no interior das comunidades políticas, decorrentes de processos de persuasão e difusão de ideias; enquanto o terceiro depende de um sentimento nacional e partilhamento de ideias comuns, da organização de partidos e grupos de interesse,

25 SECCHI, Leonardo. Políticas públicas: conceitos, esquemas de análise, casos práticos. 2. ed. São Paulo: Cengage Learning, 2010. p. 42.

26 ARAÚJO, Luísa; RODRIGUES, Maria de Lurdes. Modelos de análise das políticas públicas. Sociologia, Problemas e Práticas, n. 83 , p. 11-35, 2017. Disponível em: <http://www.scielo.mec.pt/pdf/spp/n83/n83a01.pdf>. Acesso em: 17 maio 2018. p. 20.

27 KINGDON, John. Como chega a hora de uma ideia? e juntando as coisas. In: SARAVIA, Enrique; FERRAREZI, Elisabete. (Org.). Políticas públicas. São Paulo: ENAP, 2006. p. 219-244. p. 219.

28 RAEDER, Savio. Ciclo de políticas: uma abordagem integradora dos modelos para análise de políticas públicas. Perspectivas em Políticas Públicas, Belo Horizonte, v. 7, n. 13, p. 121-146, 2014. p. 131.

29 ARAÚJO, Luísa; RODRIGUES, Maria de Lurdes. Modelos de análise das políticas públicas. Sociologia, Problemas e Práticas, n. 83, p. 11-35, 2017. Disponível em: <http://www.scielo.mec.pt/pdf/spp/n83/n83a01.pdf>. Acesso em: 17 maio 2018. p. 21. 
bem como de mudanças nos ciclos políticos, nos governos e hierarquias de administração, por exemplo.

As comunidades mantêm vivas as alternativas e soluções, que são apresentadas quando é aberta a janela de oportunidade por influência dos outros dois fluxos, o dos problemas e da política, sendo então possível ocorrer mudanças na agenda.

Como se observa, nesse modelo os eventos não ocorrem organizadamente em estágios. Kingdon entende que existem dinâmicas independentes que fluem pelo sistema ao mesmo tempo, cada uma com vida própria, unidas no momento em que surge a janela de oportunidade. Portanto, a defesa de soluções é anterior à atenção aos problemas aos quais se associam. Quer dizer: soluções procuram problemas, e não o contrário. As agendas não são estabelecidas em primeiro lugar: as alternativas são defendidas por algum tempo e depois entram na agenda. "Muitas coisas acontecem separadamente em cada caso, para depois se unirem em momentos críticos", afirma o autor ${ }^{30}$.

Secchi lembra que esse modelo é adaptado do modelo da lata de lixo de Cohen, March e Olsen, segundo o qual as decisões são meros encontros casuais dos problemas, das soluções e das oportunidades de tomada de decisão ${ }^{31}$. Celina Souza lembra que, para esses autores, as escolhas de políticas públicas são feitas como se as alternativas estivessem em uma "lata de lixo", havendo vários problemas e poucas soluções, as organizações trabalham em favor da construção de preferências para a solução dos problemas. Não são as preferências que constroem a ação. "A compreensão do problema e das soluções é limitada, e as organizações operam em um sistema de tentativa e erro", destaca a autora ${ }^{32}$.

Dentre as críticas que são feitas a esse modelo dos fluxos múltiplos, destacam-se as relativas à autonomia e imprevisibilidade dos fluxos, bem quanto à necessidade de considerar o contexto institucional no qual decorre a ação política:

Alguns autores têm defendido que a análise seria mais proveitosa e fosse considerada a interdependência dos fluxos, em que as mudanças ocorridas num deles tivessem impacto na trajetória dos outros, o que tornaria o processo de coupling mais estratégico, ultrapassando a ideia de imprevisibilidade do processo. Vários autores consideram que a principal fragilidade do modelo reside na pouca atenção que dá ao contexto institucional no qual decorre a ação política, sendo necessário salvaguardar essa análise complementar ${ }^{33}$.

O próprio Kingdon reconhece que suas ideias são baseadas em probabilidades, nas quais alguns eventos têm mais ou menos chances, enquanto outras estão em "áreas cinzentas" de imprevisibilidade. Assim, sugere pesquisas adicionais para tentarem compreender melhor a precisão dos fenômenos.

\subsection{Modelo do equilíbrio interrompido}

Esse modelo foi desenvolvido por Frank Baumgartner e Bryan Jones e tem como base a ideia de que os processos políticos são caracterizados por estabilidade e incrementalismo, pontuado ou interrompido, ocasionalmente, por mudanças de grande envergadura. Para os autores, a política pública é caracterizada pela estabilidade, embora as crises aconteçam. Nesse contexto, a compreensão do processo político requer analisar as condições de estabilidade e as da mudança $a^{34}$.

30 KINGDON, John. Como chega a hora de uma ideia? e juntando as coisas. In: SARAVIA, Enrique; FERRAREZI, Elisabete. (Org.). Políticas públicas. São Paulo: ENAP, 2006. p. 219-244. p. 240.

31 SECCHI, Leonardo. Políticas públicas: conceitos, esquemas de análise, casos práticos. 2. ed. São Paulo: Cengage Learning, 2010. p. 43.

32 SOUZA, Celina. Políticas públicas: uma revisão da literatura. Sociologias, Porto Alegre, ano 8, n. 16, p. 20-45, 2006. p. 31.

33 ARAÚJO, Luísa; RODRIGUES, Maria de Lurdes. Modelos de análise das políticas públicas. Sociologia, Problemas e Práticas, n. 83 , p. 11-35, 2017. Disponível em: <http://www.scielo.mec.pt/pdf/spp/n83/n83a01.pdf>. Acesso em: 17 maio 2018. p. 23.

34 ARAÚJO, Luísa; RODRIGUES, Maria de Lurdes. Modelos de análise das políticas públicas. Sociologia, Problemas e Práticas, n. 83, p. 11-35, 2017. Disponível em: <http://www.scielo.mec.pt/pdf/spp/n83/n83a01.pdf>. Acesso em: 17 maio 2018 . p. 24. 
Tal noção é influenciada pela biologia, mas o modelo também se baseia na computação e pressupõe limites na capacidade das pessoas processarem informação, como explica Celina Souza:

O modelo do "equilíbrio interrompido" (punctuated equilibium) foi elaborado por Baumgartner e Jones (1993), baseado em noções de biologia e computação. Da biologia veio a noção de "equilíbrio interrompido", isto é, a política pública se caracteriza por longos períodos de estabilidade, interrompidos por períodos de instabilidade que geram mudanças nas políticas anteriores. Da computação e dos trabalhos de Simon, vem a noção de que os seres humanos têm capacidade limitada de processar informação, daí por que as questões se processam paralelamente e não, de forma serial, ou seja, uma de cada vez $z^{35}$.

Preocupados em explicar as interrupções e as continuidades das políticas, os autores defendem a ideia de que o mesmo sistema institucional gera as mudanças pequenas e graduais, e as grandes rupturas. Seus estudos sobre políticas públicas têm abordagem qualitativa e quantitativa, investigando as mudanças de longo prazo nas mesmas.

Os conceitos de imagem política e de subsistema político são fundamentais para compreender as mudanças na agenda política, isto é, as interrupções ou descontinuidades dos equilíbrios.

A ideia de imagem política relaciona-se à sua percepção pública, sendo a maneira como uma política pública é discutida dependente dessa imagem. Quer dizer, a forma como a comunidade partilha seus problemas e soluções é importante, havendo um monopólio político quando uma imagem é largamente partilhada e aceita.

Tais monopólios mantêm o equilíbrio e a estabilidade dos sistemas. Os defensores de ideias diferentes podem criar divergências e acabar por desestabilizá-lo. Essas imagens políticas alternativas emergem com base em dois tipos de componentes: as informações e dados empíricos, e questões emotivas, ambas geradoras de disputas para a alteração das políticas.

O micro fundamento do modelo de Frank Baumgartner e Bryan Jones é que os tomadores de decisão têm racionalidade limitada. Segundo essa premissa, rejeita-se a ideia de racionalidade abrangente, na qual os humanos calculam os custos e benefícios, e escolhem o melhor curso de ação. Ao contrário, as decisões são canalizadas por suas arquiteturas cognitivas e emocionais. "Em particular, os tomadores de decisão são prisioneiros de sua atenção limitada, e o governo da alocação de atenção: emoção", destacam os autores ${ }^{36}$.

Outro conceito importante nesse modelo é o de subsistema político, constituído por comunidades de especialistas numa determinada área, para os quais os governos incumbem o processamento de questões políticas. Frank Baumgartner e Bryan Jones argumentam que os governos não conseguem lidar em simultâneo com uma grande diversidade de assuntos, e é justamente a partir desses subsistemas políticos que são processados os problemas e toda a informação disponível. Neles haveria um processamento paralelo de grandes volumes de informação diversificada.

Uma questão entra na agenda das políticas públicas, transformando-se em um problema político, se ela deixa de circular somente entre os especialistas e passa a ser discutida no governo, isso é, o agendamento é quando um problema sai do subsistema e vai para o macrossistema.

Luísa Araújo e Maria de Lurdes Rodrigues destacam que: “tal como Kingdon, Baumgartner e Jones defendem que as questões políticas não se transformam automática e naturalmente em problemas políticos. Para esses autores, é a imagem política que estabelece a ligação entre o problema, a solução e a possibilidade do seu agendamento" ${ }^{37}$.

35 SOUZA, Celina. Políticas públicas: uma revisão da literatura. Sociologias, Porto Alegre, ano 8, n. 16, p. 20-45, 2006. p. 33.

36 JONES, Bryan D.; BAUMGARTNER, Frank R. From there to here: punctuated equilibrium to the general punctuation thesis to a theory of government information processing. Policy Studies Journal, v. 40, n. 1, p. 1-19, 2012. p. 3.

37 ARAÚJO, Luísa; RODRIGUES, Maria de Lurdes. Modelos de análise das políticas públicas. Sociologia, Problemas e Práticas, n. 83, p. 11-35, 2017. Disponível em: <http://www.scielo.mec.pt/pdf/spp/n83/n83a01.pdf>. Acesso em: 17 maio 2018 . p. 25. 
Nesse contexto, a percepção pública é fundamental, pois o monopólio político depende do controle sobre o discurso e a visão dos problemas: da imagem política. Quando os problemas são controlados, impede-se a mudança, mas se existe competição entre grupos com poder e isso muda a imagem de um determinado problema, novos atores, com novas ideias, poderão agendar novos problemas e novos debates, transformando o monopólio político.

Sobre essa questão, destaca Celina Souza:

Os subsistemas de uma política pública permitem ao sistema político-decisório processar as questões de forma paralela, ou seja, fazendo mudanças a partir da experiência de implementação e de avaliação, e somente em períodos de instabilidade ocorre uma mudança serial mais profunda. Este modelo, segundo os autores, permite entender por que um sistema político pode agir tanto de forma incremental, isto é, mantendo o status quo, como passar por fases de mudanças mais radicais nas políticas públicas. Fundamental ao modelo é a construção de uma imagem sobre determinada decisão ou política pública (policy image), e a mídia teria papel preponderante nessa construção ${ }^{38}$.

Os autores trazem, portanto, uma nova forma de olhar as políticas públicas, pois tentam explicar os longos períodos de estabilidade da ação pública, ao lado de suas rápidas e explosivas mudanças. O equilíbrio dominante é dado por subsistemas políticos como arranjos institucionais que garantem a estabilidade e as ideias são fundamentais.

Dentre as críticas ao modelo, Luísa Araújo e Maria de Lurdes Rodrigues informam que a sua metodologia não permite identificar relações causais entres as agendas da mídia, da opinião pública e das arenas políticas, bem como o fato de que ele negligencia a capacidade que os decisores políticos têm de agir segundo as suas preferências ${ }^{39}$

\subsection{Coalizões de defesa (ou coligações de interesse)}

O modelo ACF (do inglês Advocacy Coalition Framework), desenvolvido por Paul Sabatier e Jenkins-Smith, propõe uma nova forma de pensar o processo político, tendo como objetivos construir uma abordagem alternativa ao modelo heurístico das etapas ou ciclo de políticas; melhor compreender a ideia de bottom-up (de baixo para cima) e de top-down (de cima para baixo), relativas à implementação de políticas; além de como incorporar informação técnica nas teorias do processo político.

Entre as características do ACF, modelo proposto na década de 1980, destacam-se a inserção de crenças, valores e o papel da aprendizagem política como importantes conceitos no processo de construção e mudanças nas políticas públicas. A coalizão de defesa (ou de interesse) é entendida como:

pessoas de uma variedade de posições (representantes eleitos e funcionários públicos, líderes de grupos de interesse, pesquisadores, intelectuais e etc), que (i) compartilham determinado sistema de crenças: valores, ideias, objetivos políticos, formas de perceber os problemas políticos, pressupostos causais e (ii) demonstram um grau não trivial das ações coordenadas ao longo do tempo ${ }^{40}$.

O que mantém uma coalizão de defesa unida é o compartilhamento de crenças dos seus membros sobre assuntos políticos fundamentais, ou seja, os sistemas de crenças determinam a direção que uma coalizão dará à determinada política pública.

Assim, para compreender o desenvolvimento do processo político, alguns conceitos são fundamentais: sistema de crenças, subsistema político, coalizão de defesa (coligação de causas) e mediadores políticos.

38 SOUZA, Celina. Políticas públicas: uma revisão da literatura. Sociologias, Porto Alegre, ano 8, n. 16, p. 20-45, 2006. p. 33.

39 ARAÚJO, Luísa; RODRIGUES, Maria de Lurdes. Modelos de análise das políticas públicas. Sociologia, Problemas e Práticas, n. 83 , p. 11-35, 2017. Disponível em: <http://www.scielo.mec.pt/pdf/spp/n83/n83a01.pdf>. Acesso em: 17 maio 2018. p. 25.

40 SABATIER, Paul. An advocacy coalition framework of policy change and the role of policy oriented learning therein. Policy Sciences, v. 21, p. 129-168, 1988. p. 139. 
O sistema de crenças envolve ideias, valores ontológicos e normas, bem como percepções sobre as causas dos problemas, os efeitos e a eficácia das soluções políticas, das instituições e dos recursos envolvidos, sendo partilhados por atores envolvidos em determinada política.

O subsistema político é a unidade de análise mais adequada para interpretar o processo político e é entendido como um conjunto de atores, integrados em organizações públicas e privadas, que se interessam, ativamente, por uma dada área de política e tentam influenciar o desenvolvimento político na mesma. Constitui-se de todos os que participam e desempenham um papel importante para a geração, disseminação e avaliação das ideias políticas em relação a um tema ou área específica, como analistas, grupos de interesse, burocratas, políticos eleitos, acadêmicos, jornalistas e pessoas governo, por exemplo ${ }^{41}$.

Em um processo político, alianças são formadas e é a partilha de um mesmo sistema de crenças que mantém os atores unidos no subsistema. Ao agirem em favor de determinados objetivos políticos, forma-se a coalizão de defesa, coligação de interesse. Quando elas se associam ou competem, emergem dinâmicas de mudança nas políticas públicas e novas questões. Os subsistemas integram uma diversidade de coligações, as quais se distinguem umas das outras pelos recursos de que dispõem, bem como pelas ideias que defendem, e competem entre si para influenciar a tomada de decisão política.

Os mediadores políticos (policy brokers), por sua vez, são os atores que tentam gerar compromissos entre as posições das diferentes coligações, visando apresentar propostas de mudança política viáveis e influenciar a posição dos decisores políticos e das instituições governamentais.

Tais mediadores são atores com algum poder para fazer com que compromissos entre coalizões competidoras sejam assumidos e ocorram de fato. Podem ser burocratas, parlamentares, juízes, promotores de justiça ou até cidadãos, que podem atuar em favor de acordos razoáveis que reduzam a intensidade de conflito entre as coalizões no interior do subsistema. A mudança na política pública é interpretada como uma função ou da competição no interior do subsistema ou da influência dos eventos exógenos.

No âmbito interno, são gerados os programas ou políticas públicas (policy outputs) os quais, frequentemente, incorporam elementos ou princípios defendidos por diferentes coalizões. Ou seja, as políticas públicas decorrem dos processos de interação das coalizões no âmbito do subsistema, e são resultados de mudanças nas regras institucionais e de alocação de recursos impostas pela coalizão vencedora. Assim, cada coalizão possui um dado conjunto de recursos e opta por estratégias específicas, influenciadas pelo sistema de crenças, para atingir seus objetivos políticos ${ }^{42}$.

Externo ao subsistema, há os parâmetros relativamente estáveis e do sistema e os dinâmicos. Dentre os estáveis, há os atributos básicos da área do problema ou bem, objeto de uma determinada área de política pública; a distribuição básica de recursos naturais; valores socioculturais fundamentais e estrutura social; bem como a estrutura constitucional das regras básicas do sistema político. Quanto aos eventos externos ou choques, há as mudanças nas condições socioeconômicas e na opinião pública, as mudanças nas coalizões governamentais, as decisões políticas e impactos de outros subsistemas.

Vicente e Calmon explicam como os fatores externos influenciam o subsistema:

A influência desses fatores exógenos no subsistema é mediada pelo grau de consenso necessário para a mudança na política, pelo grau de abertura do regime político, bem como pelas limitações e recursos dos atores do subsistema ${ }^{43}$.

Uma síntese dos cinco pressupostos básicos do modelo ACF é apresentada por Sabatier e Jenkins-Smith:

41 ARAÚJO, Luísa; RODRIGUES, Maria de Lurdes. Modelos de análise das políticas públicas. Sociologia, Problemas e Práticas, n. 83, p. 11-35, 2017. Disponível em: <http://www.scielo.mec.pt/pdf/spp/n83/n83a01.pdf>. Acesso em: 17 maio 2018 . p. 26.

42 VICENTE, Victor Manuel Barbosa; CALMON Paulo Carlos Du Pin. A Análise de Políticas Públicas na Perspectiva do Modelo de Coalizões de Defesa. Anais do XXXV Encontro da ANPAD. Rio de Janeiro, 4 a 7 de setembro de 2011, p. 5-6.

43 VICENTE, Victor Manuel Barbosa; CALMON Paulo Carlos Du Pin. A Análise de Políticas Públicas na Perspectiva do Modelo de Coalizões de Defesa. Anais do XXXV Encontro da ANPAD. Rio de Janeiro, 4 a 7 de setembro de 2011, p. 5. 
(i) que a compreensão dos processos de mudança política e o papel da aprendizagem política a ela associada requer uma perspectiva ampliada de tempo (uma década ou mais);

(ii) que a unidade de análise mais útil para o estudo dessa mudança é por meio de subsistemas políticos;

(iii) que esses subsistemas têm que incluir a dimensão intergovernamental;

(iv) que políticas públicas — ou programas — podem ser conceituadas da mesma maneira por sistemas de crenças (conjuntos de prioridades e assunções causais sobre como realizá-las); e

(v) o papel central das informações técnicas e científicas no processo de mudança política, pois facilita o aprendizado político ${ }^{44}$.

Assim, considerando que as políticas públicas são cada vez mais intersetoriais e transversais, o modelo ACF busca compreender seus padrões de mudança de modo alternativo ao de ciclo, apresentando uma abordagem mais integrada dos processos de emergência e de formulação das políticas públicas.

Outra questão importante que se coloca para as políticas públicas é uma estruturação capaz de contribuir para a concretização de direitos sociais. Tal medida requer uma discussão sobre a tomada de decisão com fundamento em conceitos teóricos desenvolvidos pela ciência comportamental, ou seja, da perspectiva de como as pessoas agem e tomam decisões, naquilo que denominamos de micropolítica, como se verá na próxima seção.

\section{TOMADA DE DECISÃo INDIVIDUAL E ARQUITETURA DE ESCOLHAS}

Evidências científicas, baseadas na ciência comportamental, têm ajudado a desenvolver novas abordagens, caracterizadas por serem mais impactantes na realidade das pessoas e apresentarem mais benefícios do que custos, quando comparados com as formas tradicionais de formulação de políticas públicas.

Alguns países constituíram escritórios com a função de aplicar as ciências comportamentais na melhoria da atividade governamental e, por conseguinte, na vida dos cidadãos. O Behavioural Insights Team no Reino Unido dedica-se à aplicação desses conceitos, com três objetivos: tornar os serviços públicos mais eficientes e mais acessíveis aos cidadãos; introduzir na formulação de políticas públicas métodos relacionados com o comportamento humano; e permitir que as pessoas façam melhores escolhas para $\mathrm{si}^{45}$.

A ciência comportamental tem por objeto de estudo as influências cognitivas, sociais e emocionais que recaem sobre o comportamento dos indivíduos. A partir de pesquisas experimentais, desenvolve um arcabouço teórico sobre o julgamento e a tomada de decisão. Ao contrário da visão econômica clássica, que afirma ser o indivíduo plenamente racional, movido pelo desejo de aumentar seu bem-estar, defende que as pessoas nem sempre agem com racionalidade plena, tampouco têm condições de mensurar o custo-benefício em todas as suas ações.

Gary S. Becker, em 1976, publicou a obra The Economic Approach to Human Behavior, apresentado uma série de fundamentos conhecidos como a "Teoria da Escolha Racional". O autor replicou essa teoria para problemas tão díspares como crime e casamento. Esse arcabouço teórico é baseado na hipótese de que os indivíduos têm preferências estáveis e procuram maximizar o comportamento ${ }^{46}$.

Na mesma época, outra corrente teórica confrontava o pensamento econômico clássico. Baseada em dados empíricos coletados com base em estudos de casos reais, a Teoria da Perspectiva de Amos Tversky e

44 SABATIER, Paul; JENKINS-SMITH, H. The advocacy coalition framework: an assessment. In: SABATIER, P. A. (Ed.). Theories of the policy process. Boulder: Westview Press, 1999. p. 118.

45 BEHAVIOURAL INSIGHTS TEAM. [Sitio oficial na Internet]. Disponível em: < http://www.behaviouralinsights.co.uk/aboutus/>. Acesso em: 16 dez. 2017.

46 SAMSON, Alain. Guia de economia comportamental e experimental. São Paulo: EconomiaComportamental.org., 2015. p. 27. 
Daniel Kahneman demonstra que, na maioria das vezes, as opções escolhidas não são ótimas. Existem uma série de fatores que influenciam na tomada de decisão, tais como, heurísticas e vieses ${ }^{47}$.

Como já citado na introdução, o sistema dual desenvolvido Kahneman abarca, no sistema "1", processos de pensamentos intuitivos, automáticos e inconscientes, conhecido como a casa das heurísticas e dos vieses; e outra parte mais reflexiva, controlada e analítica que compõe o sistema " 2 " 48 .

A maior parte das situações do dia a dia são caracterizadas pela dúvida e pela incerteza. Diante desse cenário, a tomada de decisão busca uma normatização com base na identificação de ações que minimizam as probabilidades de que ocorram resultados não desejados.

Cabe destacar que, no âmbito de uma sociedade caracterizada por rápidas mudanças, as pessoas têm utilizado métodos simplificados de julgamento, que naturalmente não conseguem propor soluções adequadas para os complexos problemas da modernidade.

A tomada de decisão envolve escolher uma opção entre várias possíveis. Você provavelmente terá de decidir em que universidade irá estudar, quais disciplinas irá cursar e assim por diante. Os fatos envolvidos na tomada de decisão dependem da importância da decisão a ser tomada. Por exemplo, os processos envolvidos na decisão sobre que carreira seguir são muito mais complexos e demandam mais tempo do que aqueles envolvidos na decisão sobre tomar Coca-Cola ou Pepsi-Cola ${ }^{49}$ !

Diante disso, o processo de julgamento e a tomada de decisão, o primeiro definido como a avaliação entre duas opções ou mais, o segundo como a escolha feita entre as alternativas apresentadas, independentes e complexos, mas inter-relacionados, apresentam alguns desvios de racionalidade, conhecidos como heurísticas, que prejudicam uma escolha ótima ${ }^{50}$.

Conceitualmente, heurísticas são atalhos mentais que facilitam a tomada de decisão, "um procedimento simples que ajuda a encontrar respostas adequadas, ainda que geralmente imperfeitas, para perguntas difíceis. A palavra vem da mesma raiz que heureca" ${ }^{51}$.

Por exemplo, sob incerteza, os indivíduos tendem a decidir sobre quantias ajustando a sua resposta com base em algum valor referencial inicial, que servirá de âncora. Estamos diante da heurística de ancoragem e julgamento.

A ancoragem ocorre, também quando o indivíduo baseia sua estimativa de resultado de um cálculo incompleto. Em outro estudo de Tversky e Kahnemam (1974), foi solicitado que um grupo de alunos fizessem uma estimativa, dentro de cinco segundos, do produto $8 \times 7 \times 6 \times 5 \times 4 \times 3 \times 2 \times 1$, enquanto que outro grupo deveria estimar, no mesmo intervalo de tempo, o produto de $1 \times 2 \times 3 \times 4 \times 5 \times 6 \times 7 \times 8$. A média estimada na primeira sequência foi 2.250 , enquanto a média estimada para a segunda foi de 512 . O resultado dos primeiros passos de multiplicação serviu como âncora para a estimativa final dos dois grupos ${ }^{52}$.

Uma heurística que acaba propiciando uma tomada de decisão simplificada, levando muitas vezes a equívocos, erros ou vieses e, por isso, é constantemente utilizada no julgamento, é a disponibilidade. Essa heurística é fundamentada nas nossas experiências passadas ou informações anteriores sobre um respectivo assunto.

Assim, se pedirmos para um grupo de pessoas estimar o grau de violência de sua cidade, por exemplo, muito provavelmente, as pessoas que já tiveram sido assaltadas, que já passaram por algum evento relacionado à violência urbana ou mesmo que tenham assistido uma reportagem televisiva sobre o

47 SAMSON, Alain. Guia de economia comportamental e experimental. São Paulo: EconomiaComportamental.org., 2015. p. 28-29.

48 SAMSON, Alain. Guia de economia comportamental e experimental. São Paulo: EconomiaComportamental.org., 2015. p. 30.

49 EYSENCK, Michael W.; KEANE, Mark T. Manual de psicologia cognitiva. 7. ed. Porto Alegre: Artmed, 2017. p. 547.

50 TONETTO, Leandro M. et. al. O papel da heurística no julgamento e na tomada de decisão sob incertera. Campinas: Estudos de Psicologia, 2006. p. 182.

51 KAHNEMAN, Daniel. Rápido e devagar: duas formas de pensar. Rio de Janeiro: Objetiva, 2011.

52 TONETTO, Leandro M. et al. O papel da heurística no julgamento e na tomada de decisão sob incerteza. Campinas: Estudos de Psicologia. 2006, p. 184. 
assunto irão avaliar o risco de agressão como sendo mais intenso do que aquelas que não tiveram nenhum tipo de experiência negativa nesse sentido ${ }^{53}$.

Como se percebe, em determinadas situações "a facilidade com que um determinado fato é lembrado ou imaginado pelo indivíduo pode determinar uma hiper ou subestimação da probabilidade ou frequência desse evento ocorrer" ${ }^{34}$.

Por outro lado, de acordo com a heurística da representatividade, as pessoas, ao construírem seus julgamentos, apoiam-se no fato de que é "conferida alta probabilidade de ocorrência a um evento quanto esse é típico ou representativo de um tipo de situação" 55 .

O afeto é outra heurística que produz julgamentos precipitados. Esse atalho cognitivo pode levar a exclusão de certas hipóteses, pelo aparecimento automático de sentimentos bons ou maus, quando pensamos em determinada situação. A título exemplificativo, consumidores podem considerar muito baixos os benefícios dos preservativos e muito altos os custos desses produtos, levando a uma avaliação de risco-benefício negativa, que pode ocasionar um aumento significativo de doenças sexuais ${ }^{56}$.

Apesar das heurísticas serem úteis para produzir julgamentos rápidos, inclusive poupando energia no raciocínio, conduzem, rotineiramente, a alternativas equivocadas. Conforme o Teorema de Bayes "os indivíduos ao julgar deveriam levar em conta a informação da frequência de base (a frequência relativa com que um evento ocorre em determinada população)" ${ }^{\prime 57}$.

A partir da redução do esforço cognitivo, as heurísticas acabam gerando vieses de pensamento, um círculo vicioso que decorre de uma tomada de decisão que não leva em consideração a lógica ou a probabilista sobre fatos passados, violando, rotineiramente, alguma forma de racionalidade e, consequentemente, produzindo decisões ruins.

Embora muitos erros no processo de julgamento estejam relacionados com as heurísticas, como as que se viu acima, outras formas podem distorcer ou limitar a racionalidade na tomada de decisão e influenciar nos rumos de uma política pública.

Os vieses cognitivos são vistos como uma sistemática limitação à racionalidade. Dentre outros, a inércia consiste numa tendência das pessoas a não mudar o comportamento a menos que exista um incentivo forte para fazê-lo. A supervalorização do presente em detrimento de ações futuras, como acontece com relação aos cuidados com a saúde e a poupança para a aposentadoria, também se constitui num viés cognitivo.

Outro julgamento que pode limitar a ação racional decorre do otimismo exagerado com o futuro, que acaba levando os indivíduos a subestimar a relação entre o tempo e as dificuldades para concluir uma tarefa, criando um pensamento vicioso, que, no âmbito das políticas públicas, pode gerar um planejamento falacioso $^{58}$.

Por serem "satisfatórios" aos decisores, os atalhos de raciocínio provenientes das heurísticas ou os erros decorrentes de uma resposta incompleta, como no caso dos vieses, quando relacionados com as políticas públicas e a concretização de direitos sociais, podem significar a diferença entre viver ou morrer, entre o desenvolvimento pessoal ou uma vida com restrições e dependências.

No âmbito das ações governamentais, compreender a tomada de decisão na ótica comportamental é

53 TONETTO, Leandro M. et al. O papel da heurística no julgamento e na tomada de decisão sob incerteza. Campinas: Estudos de Psicologia. 2006, p. 185.

54 TONETTO, Leandro M. et al. O papel da heurística no julgamento e na tomada de decisão sob incerteza. Campinas: Estudos de Psicologia. 2006, p. 184.

55 TONETTO, Leandro M. et al. O papel da heurística no julgamento e na tomada de decisão sob incerteza. Campinas: Estudos de Psicologia. 2006, p. 186.

56 SAMSON, Alain. Guia de economia comportamental e experimental. São Paulo: EconomiaComportamental.org., 2015 . p. 31.

57 EYSENCK, Michael W.; KEANE, Mark T. Manual de psicologia cognitiva. 7. ed. Porto Alegre: Artmed, 2017. p. 548.

58 SAMSON, Alain. Guia de economia comportamental e experimental. São Paulo: EconomiaComportamental.org., 2015. p. 32-33. 
muito importante, pois não são poucas as medidas implementadas que não produzem qualquer impacto positivo para a sociedade, ou que apresentam um custo muito maior do que os benefícios, não obstante, de tempos em tempos insistam em voltar à pauta da agenda política, sem qualquer análise sobre os resultados alcançados ou de como se comportaram os atores políticos e a sociedade diante dos incentivos propostos.

Além de heurísticas e vieses, o julgamento individual está cercado por fatores emocionais que acabam influenciando na decisão sobre as alternativas. Particularmente, a neurociência tem contribuído para as pesquisas sobre o assunto, associando a amígdala e o córtex pré-frontal ventromedial com o processamento das emoções durante a tomada de decisão.

Fatores emocionais têm participação importante na tomada de decisão. Mais especificamente, perdas antecipadas ou ocorridas podem produzir reações emocionais negativas no indivíduo (p.ex. ansiedade) causando aversão à perda. Boa parte das pesquisas relevantes estão dentro da neuroeconomia, na qual é utilizada a neurociência para ampliar a compreensão sobre as decisões econômicas ${ }^{59}$.

Fatores sociais também influenciam o julgamento. Muito frequentemente as pessoas agem como políticos intuitivos, tentando antecipar objeções que serão feitas no curso das escolhas realizadas. Diante disso, a necessidade de prestar contas é um fator que influencia a tomada de decisão. Outro ponto relevante é a responsabilização:

As pressões de responsabilização também influenciam as decisões de especialistas. Schwartz e colaboradores (2004) pediram a médicos especialistas que escolhessem o tratamento para um paciente com osteoartrose. A tomada de decisão foi mais enviesada quando eles se viram mais comprometidos com sua decisão por terem que se justificar por escrito sabendo que poderiam ser contatados mais tarde para discuti-la ${ }^{60}$.

Essas questões se agravam quando se considera que a realidade impõe às pessoas, e especialmente aos decisores políticos, problemas compostos de vários elementos relacionados, que merecem uma análise acurada na escolha das alternativas. Em muitos casos, não se trata de apenas uma decisão, mas de uma série de decisões dentro de um lapso temporal exíguo em muitas situações. Tomada de decisão complexa exige estratégia clara e definida, capaz de reduzir a incerteza e o risco.

A teoria da utilidade, desenvolvida por Wright, estabelece uma sequência de fases para a tomada de decisão, a saber: identificar os atributos relevantes para a decisão; decidir como ponderar esses atributos; listar as opções consideradas; pontuar cada opção para todos os atributos; e obter uma utilidade total escolhendo aquele com maior peso total ${ }^{61}$.

Simon, por sua vez, desenvolve o conceito de racionalidade limitada, afirmando que um processo de tomada de decisão está cercado por questões ambientais (custo da informação) e cognitivas (limite de atenção). Em contraposição aos maximizadores e perfeccionistas, esse arcabouço teórico produz uma decisão definida como "satisfaciente", ou seja, uma opção satisfatória e suficiente ${ }^{62}$.

De outro modo, os especialistas em determinado assunto apresentam uma tomada de decisão particularizada, afinal, decidem com base em informações conhecidas e armazenadas na memória de longo prazo, fazendo uso de padrões de reconhecimento com base em uma simulação mental.

Kahneman e Klein (2009) ressaltaram que o modelo da decisão com base em reconhecimento enfatiza a acurácia do julgamento e da tomada de decisão humanos. Todavia, a abordagem com base em heurísticas e vieses de Kahneman concentra-se mais no erro humano. Essa diferença ocorre porque o modelo de decisão com base em reconhecimento se aplica aos especialistas, enquanto aquele com base em heurísticas e vieses, não. Em média, os especialistas tomam decisões melhores do que os não especialistas $^{63}$.

59 EYSENCK, Michael W.; KEANE, Mark T. Manual de psicologia cognitiva. 7. ed. Porto Alegre: Artmed, 2017. p. 573.

60 EYSENCK, Michael W.; KEANE, Mark T. Manual de psicologia cognitiva. 7. ed. Porto Alegre: Artmed, 2017. p. 576-577.

61 EYSENCK, Michael W.; KEANE, Mark T. Manual de psicologia cognitiva. 7. ed. Porto Alegre: Artmed, 2017. p. 577.

62 EYSENCK, Michael W.; KEANE, Mark T. Manual de psicologia cognitiva. 7. ed. Porto Alegre: Artmed, 2017. p. 578.

63 EYSENCK, Michael W.; KEANE, Mark T. Manual de psicologia cognitiva. 7. ed. Porto Alegre: Artmed, 2017. p. 583. 
Todos os elementos destacados, desde o julgamento e a tomada de decisão, heurísticas, vieses, além das teorias sobre a tomada de decisão complexa, particularmente dos especialistas, são capazes de fornecer uma base sólida para a melhoria dos processos de construção de políticas públicas destinadas à concretização dos direitos sociais, em especial da saúde e educação.

Nesse cenário, os arquitetos de escolhas podem ajudar as pessoas a tomarem melhores decisões, potencializando o bem-estar individual, reduzindo custos e aumentando benefícios para todos, afinal o "choice architect has the responsibility for organizing the context in which people make decisions ${ }^{204}$.

Do ponto de vista da ação governamental, a arquitetura de escolhas deve levar em consideração a relação entre o sistema "1" e o sistema "2", afinal muitos dos erros e desvios são produzidos, basicamente, pelo sistema "1", que como já falamos, constitui-se num modelo imediatista e focado no curto prazo, pouco ou quase nada reflexivo.

Por essa razão, os agentes públicos deveriam empreender esforços para a estruturação de programas, com base em uma metodologia capaz de fortalecer o sistema "2", sempre avaliando custos e benefícios, a partir de uma reflexão cuidadosa das opções disponíveis e suas respectivas consequências.

Nudge ou "empurrões" podem ser definidos como pequenos impulsos, desenhados por arquitetos de escolha, que fazem uso de estudos comportamentais capazes de preservar a autonomia dos indivíduos, mas que têm a possibilidade de orientá-los para um maior bem-estar, sem proibir qualquer opção ou alterar, significativamente, seus incentivos econômicos ${ }^{65}$.

O desenho de programas deve ser orientado por evidências trazidas pelas ciências comportamentais sobre como as pessoas agem e tomam decisões. Pequenas mudanças na forma como uma mensagem ou escolha é enquadrada, ou como um processo é estruturado, podem ter um impacto relevante sobre possíveis decisões e ações. Um dos exemplos mais potentes de instrumentos da arquitetura de escolha são as escolhas-padrão (defaults), opções pré-selecionadas que deixam aberta aos indivíduos a possibilidade de migrar para outra opção $(o p t-o u t)^{66}$.

Por intermédio dos "empurrões" a sociedade pode mudar comportamentos individuais indesejáveis fortalecendo o bem-comum. Além disso, esses insights respeitam a liberdade de escolha dos cidadãos, reduzindo a possibilidade de que o governo atue abusivamente.

Assim, a arquitetura de escolhas pode ajudar as pessoas a decidirem por melhores alternativas. Essa construção decorre de um complexo ciclo de aprendizagem, baseado em evidências, capazes de criar incentivos significativos para os comportamentos desejáveis.

Em face disso, os experimentos aleatórios controlados servem para avaliar e aperfeiçoar o desenho de políticas públicas, levando em consideração a reação dos indivíduos diante dos incentivos, como mostra a próxima seção.

\section{EXPERIMENTO aLEATÓRIO CONTROLADO (EAC)}

Afinal, se os recursos são escassos, o objetivo primordial dessa seção é demonstrar uma metodologia aplicada à pesquisa em políticas públicas, destacando o método experimental como ferramenta útil à uni-

64 THALER, Richard H.; SUNSTEIN, Cass R.; BALZ, John P. Choice Architecture. Disponível em: < https://papers.ssrn.com/ sol3/papers.cfm?abstract_id=1583509>. Acesso em: 25 mar. 2018.

65 THALER, Richard H.; SUNSTEIN, Cass R. Nudge: improving decisions about health, wealth, and happiness. New York: Penguin Publishing Group, 2009. p. 6.

66 CAMPOS FILHO, Antonio Claret; PAIVA, Luis Henrique. Insights comportamentais e politicas de superação da pobreza. Disponível em: <http://www.ipc-undp.org/pub/port/PRB60PT_Insights_comportamentais_politicas_de_superacao_da_pobreza.pdf>. Acesso em: 15 jan. 2018. 
versalização e à concretização de direitos sociais, a partir da seleção aleatória dos grupos de tratamento e controle e da comparação entre o desempenho daqueles que sofreram a intervenção com aqueles que não foram beneficiados.

Isso permite ao governo melhorar a construção de um programa, tornar a despesa pública mais eficiente e estabelecer um ciclo de aprendizado sobre políticas públicas e, por conseguinte, do seu papel na materialização dos direitos sociais, baseando a análise em evidências factuais e pesquisa de campo e não em premissas decorrentes de ideologias, do senso comum ou argumentos de autoridade, como destacam Faya Silveira Bedé e Robson Sabino Sousa ${ }^{67}$.

Estudos experimentais, em regra, são realizados em laboratório diante de um número limitado de variáveis. Dentro de um ambiente controlado os pesquisadores expõem os participantes a estímulos ou pedem que sejam cumpridas determinadas tarefas.

Partindo de estudos de causa e efeito são adquiridas noções sobre a regularidade de determinado comportamento. Esse tipo de experimento apresenta algumas limitações relacionadas com a artificialidade do ambiente e com a restrição da amostragem, o que pode levar a resultados inadequados. Por outro lado, apresenta uma série de vantagens que vão desde uma melhor replicabilidade, alto controle de variáveis até a alta validação interna da relação entre causa e efeito.

Experimento natural ou quase-experimento é um tipo experimental mais restrito que não apresenta capacidade de replicação, sendo caracterizados por serem apenas observacionais. Nessa pesquisa os participantes não são agrupados em condições de tratamento e controle. São experimentos baratos quando comparados aos outros dois métodos.

A metodologia apta a investigar relações de causa e efeito conduzidas num ambiente natural é o experimento de campo. Esse modelo apresenta uma maior validade externa e ecológica, no entanto, apresenta menor controle sobre variáveis que não fazem parte da experiência.

O experimento aleatório controlado (EACs) é um método de análise aplicável para políticas públicas, que envolve pesquisas realizadas em campo. Embora tenha sido desenvolvido para testar a eficiência de medicamentos, os EACs são cada vez mais utilizados na análise da eficiência de custos em diferentes programas de desenvolvimento e redução da pobreza ${ }^{68}$.

Ao contrário das metodologias tradicionais de avaliação de políticas públicas, que não conseguem identificar a ação dos fatores externos relacionados com determinada intervenção governamental, o EACs designa, aleatoriamente, as pessoas aos grupos de controle ou de experimento, eliminando a possibilidade de que fatores externos possam interferir na avaliação, fazendo com que os resultados sejam decorrentes apenas da diferença de tratamento que receberam.

Existe um crescente interesse sobre o uso de EACs como ferramenta para a tomada de decisão em políticas públicas. Diante da escassez de recursos dos orçamentos públicos, é essencial que os gestores governamentais tenham consciência da necessidade de desenvolver ações eficientes, capazes de produzir resultados significativos na vida das pessoas, na materialização dos direitos sociais.

Os EACs, geralmente, são mais baratos do que as formas tradicionais de intervenção, pois são capazes de "demonstrar quanto mais ou menos eficaz o tratamento foi em relação ao status quo, os formuladores de políticas públicas podem determinar se o custo da intervenção justifica os benefícios” ${ }^{\text {‘9 }}$.

67 BEDÉ, Fayga Silveira; SOUSA, Robson Sabino. Por que a área do direito não tem cultura de pesquisa de campo no Brasil? Revista Brasileira de Políticas Públicas, Brasília, v. 8, n. 1, p. 781-796, 2018. p. 784.

68 HAYNES, Laura et. al. Testar, aprender, adaptar: desenvolver as políticas públicas mediante experimentos aleatórios controlados. Planejamento e Políticas Públicas, Brasília, n. 41, p. 11-43, jul./dez. 2013. p. 11.

69 HAYNES, Laura et. al. Testar, aprender, adaptar: desenvolver as políticas públicas mediante experimentos aleatórios controlados. Planejamento e Políticas Públicas, Brasília, n. 41, p. 11-43, jul./dez. 2013. p. 24. 
São necessários nove estágios para a estruturação de um EAC, envolvendo três subfases: teste, aprendizado e adaptação ${ }^{70}$.

1) a primeira medida é identificar duas ou mais ações governamentais para estabelecer a comparação. Pode ser uma versão moderna versus uma antiga, ou até mesmo variantes diferenciadas de uma mesma política.

2) O próximo passo é determinar o impacto que a política pretende alcançar e como será feita a mensuração dos resultados durante o experimento.

3) Logo em seguida, deve ser feito o recorte da pesquisa que será randomizado, definindo os grupos de controle e de experimento no nível individual, de grupo, institucional ou até mesmo levando em consideração espaços geográficos como bairros e cidades.

4) Após, definir uma amostra representativa para alcançar resultados verossímeis.

5) Aplicar a cada unidade de amostra um tipo de intervenção, fazendo uso de um forte método de randomização.

6) Aplicar as ações governamentais sobre os grupos respectivos.

7) Avaliar os resultados e verificar os impactos decorrentes das intervenções.

8) Ajustar a política pública de acordo com os resultados obtidos; e

9) Retornar à primeira fase, aperfeiçoando o ciclo de aprendizado.

Um ponto muito importante na realização dos EACs está relacionado com a transparência sobre a metodologia utilizada. Além disso, é necessário que os resultados alcançados sejam divulgados. Essas medidas servem tanto para verificar se o experimento foi apropriado, quanto para servir de modelo em reproduções futura do programa, inclusive em outras áreas de pesquisa. Recomenda-se a publicação do protocolo de experiência antes do início do teste, com a informação de qual resultado o experimento pretende alcançar ${ }^{71}$.

Nessa lógica, o EAC não pode ser visto como um instrumento isolado de avaliação de um único programa, é interessante pensar nele como parte de um grande ciclo de aprendizado na implementação de políticas públicas, que possibilita que as intervenções futuras sejam mais impactantes, principalmente quando se trata da materialização de direitos como educação e saúde. Na próxima seção, serão apresentados insights comportamentais que tratam desse assunto.

\section{INSIGHTS COMPORTAMENTAIS EM POLÍTICAS PÚBLICAS QUE TRATAM DE DIREITOS SOCIAIS}

Como se viu, mesmo guiados por seus próprios interesses, os indivíduos não tomam decisões de maneira plenamente racional. Diante disso, esta seção exporá exemplos práticos que envolvem a formulação de políticas públicas de saúde e educação, tendo como ponto de partida uma arquitetura de escolhas que leve em consideração incentivos comportamentais no seu design, além de experimentos aleatórios controlados como forma de mensuração de impacto.

Um exemplo interessante, relacionado com o direito à saúde trata da estruturação de acampamentos destinados à vacinação infantil na Índia. O objetivo do experimento aleatório controlado foi verificar a eficácia de incentivos não financeiros na melhoria das taxas de imunização de crianças entre 1 e 3 anos na área rural

70 HAYNES, Laura et. al. Testar, aprender, adaptar: desenvolver as políticas públicas mediante experimentos aleatórios controlados. Planejamento e Políticas Públicas, Brasília, n. 41, p. 11-43, jul./dez. 2013. p. 27.

71 HAYNES, Laura et. al. Testar, aprender, adaptar: desenvolver as políticas públicas mediante experimentos aleatórios controlados. Planejamento e Políticas Públicas, Brasília, n. 41, p. 11-43, jul./dez. 2013. p. 39. 
de Rajasthan ${ }^{72}$.

Participaram do experimento 1640 crianças, 134 aldeias foram randomizadas para um dos três grupos: um grupo composto, apenas, pela disponibilidade do serviço de vacinação nos acampamentos; um grupo com a disponibilidade do serviço de vacinação nos acampamentos e mais um incentivo (lentilhas cruas e pratos de metal); e um grupo de controle sem nenhuma intervenção.

Os pesquisadores constataram que o aumento representativo das taxas de vacinação não estava relacionado com a simples disponibilidade do serviço, mas sim com a utilização de nudges de baixo custo, como a distribuição de um pacote de lentilha cada vez que os pais traziam seus filhos para serem vacinados ou a doação de um prato de metal diante da imunização completa da criança.

Sabe-se que crianças com menos de cinco anos, com boa nutrição e estimulação psicossocial, apresentam melhores níveis de desenvolvimento físico e neurológico. No entanto, a falta desses incentivos é recorrente em muitos países em desenvolvimento, tornando-se um problema de saúde pública.

Para verificar essa questão, um experimento avaliatório foi conduzido na Colômbia. Fazendo uso da capacidade administrativa e das redes comunitárias existentes, pesquisadores mensuraram o impacto de um programa que estimulou as mães de baixa renda a fornecer às crianças nutrientes, estimulação psicossocial ou ambos. As intervenções duraram 18 (dezoito) meses.

Os resultados práticos desse experimento demonstraram que incentivar as mães a interagir e brincar mais com seus filhos pode levar a melhorias no desenvolvimento cognitivo das crianças, enquanto, por sua vez, a melhoria da nutrição não teve efeitos detectáveis. A combinação dos dois programas também não levou a uma maior cognição. Com uma despesa de U\$ 500,00 por indivíduo, essa política custou menos da metade de alguns programas de desenvolvimento infantil na Colômbia, que chegam até U\$1.500,00 por criança ${ }^{73}$.

Quando se fala em educação, não faltam estudos que demonstram a importância da qualidade e do engajamento do corpo docente na melhoria do aprendizado e do desempenho dos alunos. Professores motivados são essenciais nesse processo.

Uma pesquisa realizada na cidade de Chicago Heights, localizada a quarenta e oito quilômetros ao sul de Chicago, utilizando insights comportamentais no desenho de incentivos, sugere que a motivação relacionada com aportes financeiros para professores tem mais relação com a aversão à perda do que com a possibilidade de ganhos futuros.

O distrito contém nove escolas K-8, com um total de aproximadamente 3.200 alunos, sendo composto, principalmente, por estudantes de minorias de baixa renda que apresentam taxas de desempenho abaixo da média. No ano anterior ao experimento, apenas $64 \%$ dos alunos atingiram o padrão mínimo do Illinois State Achievement Test (ISAT) em comparação a 81\% dos estudantes em todo o estado. Em síntese, foram separados aleatoriamente professores em grupos relacionados com a possibilidade de perdas e em grupos com a possibilidade de ganhos.

Ao final do experimento, verificou-se que os docentes que foram recompensados no início, assinando um contrato que os obrigava a devolver o valor da premiação caso os alunos não atingissem as metas estipu-

72 BANERJEE, Abhijit Vinayak et. al. Improving immunisation coverage in rural India: clustered randomised controlled evaluation of immunisation campaigns with and without incentives. British Medical Journal, v. 340, n. c2220, p. 1-9, 2010. Disponível em: <https://www.bmj.com/content/bmj/340/bmj.c2220.full.pdf>. Acesso em: 25 jul. 2018.

73 ATTANASIO, Orazio et. al. Estimating the production function for buman capital: results from a randomized control trial in Colombia. Disponível em: <http://www.nber.org/papers/w20965>. Acesso em: 20 maio 2018. 
ladas, tiveram um desempenho muito melhor, em comparação àqueles que seriam recompensados, apenas, ao final do programa caso os resultados fossem alcançados ${ }^{74}$.

Percebe-se, com base nos exemplos destacados acima, que experimentos aleatórios controlados em combinação com estudos comportamentais podem contribuir para que as políticas públicas alcancem melhores resultados, fazendo uso, inclusive, de menos recursos públicos, concretizando direitos sociais com base em evidências comprovadas cientificamente.

\section{Considerações finais}

O texto buscou discutir a relação entre a implementação de políticas públicas e a concretização de direitos sociais, a partir de conceitos da ciência comportamental sobre o julgamento e a tomada de decisão individual.

Há um estreito relacionamento entre políticas públicas e esses direitos, como mostrou a seção dois, posto que elas podem ser vistas como estratégias que têm por finalidade consolidar direitos assegurados na carta magna e em outros dispositivos normativos.

Compreender os processos de políticas públicas, sua lógica e regras de funcionamento é o que tentam fazer diversos modelos, como os do ciclo das políticas públicas, dos fluxos múltiplos, do equilíbrio interrompido e o das coalizões de defesa, discutidos na seção três do presente texto.

Diante disso, o julgamento e a tomada de decisão devem levar em consideração não apenas só as perspectivas externas, do ponto de vista macro político, mas principalmente o fato de que os indivíduos reagem aos incentivos da política pública com determinado comportamento. Não se pode olvidar que heurísticas e vieses permeiam o pensamento, produzindo erros na tomada de decisão.

Assim, arquiteturas de escolhas melhor formatadas, com a observância das percepções cognitivos-comportamentais, poderão produzir políticas públicas mais eficientes e efetivas, ou seja, com melhor relação custo-benefício e impactantes na vida das pessoas e, por conseguinte, garantindo maior efetivação dos direitos sociais.

Além disso, os programas devem ser constantemente avaliados de acordo com a metodologia dos EACs, compondo, assim, um ciclo positivo de aprendizado, caracterizado pelo trinômio "testar, aprender, adaptar".

Alguns exemplos foram apresentados e, diante da escassez de recursos e das necessidades prementes de mudança na realidade social, a pesquisa, o planejamento e a execução de políticas públicas baseadas em evidências científicas vem se difundindo.

Essa abordagem ganha relevância especificamente no Brasil, onde não deve haver mais espaço para amadorismo ou irresponsabilidade com o recurso público, sob pena de gerações de brasileiros serem condenados à miséria, a não terem a oportunidade do pleno desenvolvimento das suas liberdades individuais. Mudar a maneira como essa triste realidade é enfrentada é essencial.

\section{REFERÊNCIAS}

ANDRADE, Aparecida de Moura; SANTANA, Héctor Valverde. Avaliação de políticas públicas versus avaliação de impacto legislativo: uma visão dicotômica de um fenômeno singular. Revista Brasileira de Políticas

74 FRYER, Roland G. et. al. Enhancing the efficacy of teacher incentives through loss aversion: a field experimente. Disponível em: < http:// www.nber.org/ papers/w18237>. Acesso em: 15 abr. 2018. 
Públicas, Brasília, v. 7, n. 3, p. 781-798, 2017.

ARAÚJO, Luísa; RODRIGUES, Maria de Lurdes. Modelos de análise das políticas públicas. Sociologia, Problemas e Práticas, n. 83, p. 11-35, 2017. Disponível em: <http://www.scielo.mec.pt/pdf/spp/n83/n83a01. pdf>. Acesso em: 17 maio 2018.

ATTANASIO, Orazio et. al. Estimating the production function for human capital: results from a randomized control trial in Colombia. Disponível em: <http://www.nber.org/papers/w20965>. Acesso em: 20 maio 2018.

BANERJEE, Abhijit Vinayak et. al. Improving immunisation coverage in rural India: clustered randomised controlled evaluation of immunisation campaigns with and without incentives. British Medical Journal, v. 340, n. c2220, p. 1-9, 2010. Disponível em: < https://www.bmj.com/content/bmj/340/bmj.c2220.full.pdf>. Acesso em: 25 jul. 2018.

BAUMGARTNER, Frank R.; JONES, Bryan D. Agendas and instability in american politics. Chicago: University of Chicago Press, 1993.

BECKER, Gary S. The economic approach to human behavior. Chicago: University of Chicago Press, 2013.

BEDÉ, Fayga Silveira; SOUSA, Robson Sabino. Por que a área do direito não tem cultura de pesquisa de campo no Brasil? Revista Brasileira de Políticas Públicas, Brasília, v. 8, n. 1, p. 781-796, 2018.

BEHAVIOURAL INSIGHTS TEAM. [Sitio oficial na Internet]. Disponível em: < http://www.behaviouralinsights.co.uk/about-us/>. Acesso em: 16 dez. 2017.

BUCCI, Maria Paula Dallari. Buscando um conceito de políticas públicas para a concretização de direitos humanos. In: BUCCI, Maria Paula Dallari et. al. Direitos humanos e políticas públicas. São Paulo: Pólis, 2001. p. 5-16.

CAMPOS FILHO, Antonio Claret; PAIVA, Luis Henrique. Insights comportamentais e politicas de superação da pobreza. Disponível em: <http://www.ipc-undp.org/pub/port/PRB60PT_Insights_comportamentais_politicas_de_superacao_da_pobreza.pdf $>$. Acesso em: 15 jan. 2018.

CUNHA, Bruno Santos. Direitos fundamentais da constituição às políticas públicas. Revista Brasileira de Politicas Públicas, Brasília, v. 1, n. 1, p. 65-82, 2011.

DORES, Camila Japiassu. As bases da saúde lançadas pela Constituição Federal de 1988: um sistema de saúde para todos? Revista Brasileira de Políticas Públicas, Brasília, v. 3, n. 1, p. 77-89, 2013.

DUARTE, Clarice Seixas. A educação como um direito fundamental de natureza social. Educ. Soc., Campinas, v. 28, n. 100, p. 691-713, 2007.

DYE, Thomas R. Understanding Public Policy. Englewood Cliffs, N.J.: Prentice-Hall, 1984.

EYSENCK, Michael W.; KEANE, Mark T. Manual de psicologia cognitiva. 7. ed. Porto Alegre: Artmed, 2017.

FRYER, Roland G. et. al. Enhancing the efficacy of teacher incentives through loss aversion: a field experimente. Disponível em: <http://www.nber.org/ papers/w18237>. Acesso em: 15 abr. 2018.

HAYNES, Laura et. al. Testar, aprender, adaptar: desenvolver as políticas públicas mediante experimentos aleatórios controlados. Planejamento e Políticas Públicas, Brasília, n. 41, p. 11-43, jul./dez. 2013.

HOWLETT, M.; RAMESH, M. Studying public policy: policy cycles and policy subsystems. New York: Oxford University Press, 1995.

JONES, Bryan D.; BAUMGARTNER, Frank R. From there to here: punctuated equilibrium to the general punctuation thesis to a theory of government information processing. Policy Studies Journal, v. 40, n. 1, p. 1-19, 2012.

JONES, Bryan D.; CHARLES, O. An introdution to the study of public policy. 3. ed. Monterey, CA: Brooks Cole 
Publishing, 1984.

KAHNEMAN, Daniel. Rápido e devagar: duas formas de pensar. Rio de Janeiro: Objetiva, 2011.

KINGDON, John. Como chega a hora de uma ideia? e juntando as coisas. In: SARAVIA, Enrique; FERRAREZI, Elisabete. (Org.). Políticas públicas. São Paulo: ENAP, 2006. p. 219-244.

LASSWELL, Harold. Politics: who gets what, when, how. Cleveland: Meridian Books, 1936/1958.

LASSWELL, Harold. The public interest. In: FRIEDRICH, C. F. (Ed.). The public interest. New York: Atherton Press, 1962.

MARTINS, Urá Lobato. A judicialização das políticas públicas e o direito subjetivo individual à saúde, à luz da teoria da justiça distributiva de John Rawls. Revista Brasileira de Políticas Públicas, v. 5, Número Especial, p. 309-328, 2015.

PETERS, B. Guy. American Public Policy. Chatham, N.J.: Chatham House, 1986.

RAEDER, Savio. Ciclo de políticas: uma abordagem integradora dos modelos para análise de políticas públicas. Perspectivas em Políticas Públicas, Belo Horizonte, v. 7, n. 13, p. 121-146, 2014.

SABATIER, Paul. An advocacy coalition framework of policy change and the role of policy oriented learning therein. Policy Sciences, v. 21, p. 129-168, 1988.

SACHS, Ignacy. Desenvolvimento: includente, sustentável e sustentado. Rio de Janeiro: Garamond, 2008.

SAMSON, Alain. Guia de economia comportamental e experimental. São Paulo: EconomiaComportamental.org., 2015 .

SECCHI, Leonardo. Políticas públicas: conceitos, esquemas de análise, casos práticos. 2. ed. São Paulo: Cengage Learning, 2010.

SEN, Amartya. Desenvolvimento como liberdade. São Paulo: Companhia das Letras, 2010.

SILVA, José Afonso da. Curso de direito constitucional positivo. São Paulo: Malheiros, 1992.

SOUZA, Celina. Políticas públicas: uma revisão da literatura. Sociologias, Porto Alegre, ano 8, n. 16, p. 20-45, 2006.

THALER, Richard H.; SUNSTEIN, Cass R. Nudge: improving decisions about health, wealth, and happiness. New York: Penguin Publishing Group, 2009.

THALER, Richard H.; SUNSTEIN, Cass R.; BALZ, John P. Choice Architecture. Disponível em: < https:// papers.ssrn.com/sol3/papers.cfm?abstract_id=1583509>. Acesso em: 25 mar. 2018.

TONETTO, Leandro M. et. al. O papel da heurística no julgamento e na tomada de decisão sob incerteza. Campinas: Estudos de Psicologia, 2006.

VIANA, Ana Clara. Abordagens metodológicas em políticas públicas. Revista de Administração Pública, Rio de Janeiro, v. 30, n. 2, p. 5-43, 1996.

VICENTE, Victor Manuel Barbosa; CALMON Paulo Carlos Du Pin. A análise de políticas públicas na perspectiva do modelo de coalizões de defesa. Disponível em: <http://www.anpad.org.br/admin/pdf/APB2163.pdf>. Acesso em: 17 maio 2018. 


\title{
Behavioral economics e direito do consumidor: novas perspectivas para o enfrentamento do superendividamento*
}

\author{
Behavioral economics and consumer \\ law: new perspectives to confront the \\ overindebtedness
}

Samir Alves Daura**

\section{Resumo}

O objetivo deste artigo é analisar a compatibilidade entre a Behavioral Economics e o Direito do Consumidor, especialmente em relação ao enfrentamento do superendividamento. Em primeiro lugar, o estudo procurou explicar a origem e o desenvolvimento da Economia Comportamental, notadamente a forma como a descoberta das heurísticas e dos vieses passaram a influenciar o pensamento econômico, com especial ênfase para as pesquisas de Daniel Kahneman e Amos Tversky. Posteriormente, o estudo tratou do diálogo entre a Economia Comportamental e o Direito, denominado de Análise Econômico-Comportamental do Direito, assim como das novas perspectivas que essa abordagem interdisciplinar poderá propiciar ao campo jurídico. Foi conferida especial ênfase à valorização que a Economia Comportamental fornece ao princípio da vulnerabilidade, expressamente previsto pelo Código de Defesa do Consumidor no Brasil. Ainda, foram abordadas diversas heurísticas e vieses comumente relacionados ao problema do endividamento excessivo. Em conclusão, demonstrou-se que a Economia Comportamental poderá ser útil tanto para a identificação das causas do superendividamento quanto para a elaboração de leis mais condizentes com a realidade e de políticas públicas mais eficientes. Adotou-se o método indutivo e a abordagem interdisciplinar. Finalmente, o presente artigo visou contribuir com os demais estudiosos que acreditam nos avanços que a Economia Comportamental poderá propiciar ao Direito do Consumidor no Brasil.

Palavras-chave: Economia comportamental. Direito do consumidor. Superendividamento. Heurísticas. Vieses. Políticas públicas.

** Mestre em Direito pela Faculdade de Direito "Prof. Jacy de Assis" da Universidade Federal de Uberlândia (UFU). Especialista em Direito Tributário pelo Instituto Brasileiro de Estudos Tributários (IBET). Bacharel em Direito pela Faculdade de Direito Milton Campos (FDMC). Foi pesquisador bolsista da Coordenação de Aperfeiçoamento de Pessoal de Nível Superior (CAPES), nível mestrado. Professor de Direito do Centro de Ensino Superior de Catalão/GO (CESUC). Advogado. E-mail: samirdaura@gmail.com

\section{Abstract}

The purpose of this paper is to analyze the relationship between Behavioral Economics and Consumer Law, especially regarding the manner of overindebtedness. First, the study seeks to explain the origin and development of Behavioral Economics, notably how the discovery of heuristics and bias began to influence economic thinking, with special emphasis on the 
research of Daniel Kahneman and Amos Tversky. Subsequently, the study dealt with the dialogue between Behavioral Economics and Law, called Behavioral Law and Economics, as well as the new perspectives that this interdisciplinary approach could provide to the legal field. Special emphasis was given to the valorization that the Behavioral Economics provides to the principle of vulnerability, expressly foreseen by the Code of Consumer Protection in Brazil. Also, several heuristics and biases commonly related to the problem of excessive indebtedness were addressed. In conclusion, it was demonstrated that behavioral economics could be useful both for the identification of the causes of over indebtedness and for the elaboration of laws more in keeping with reality and more efficient public policies. The inductive method and the interdisciplinary approach were adopted. Finally, the present article aimed to contribute with the other scholars who believe in the advances that the Behavioral Economics can give to Consumer Law in Brazil.

Keywords: Behavioral Economics. Consumer law. Heuristics. Bias. Overindebtedness. Public policies.

\section{INTRODUÇÃO}

Ao questionar o princípio de que o ser humano age de acordo com um modelo de racionalidade ilimitada, visam aos estudiosos em Behavioral Economics (Economia Comportamental) realizar uma análise realista - e certamente consciente - das capacidades cognitivas das pessoas quando da tomada de decisão, o que de forma alguma deve ser visto sob um prisma melancólico ou deprimente. Se o mundo fosse composto por bilhões de indivíduos plenamente racionais, as decisões equivocadas praticamente inexistiriam, o que simplificaria demasiadamente a experiência humana no planeta Terra. $\mathrm{Na}$ realidade, a vida tem se mostrado uma experiência complexa — sobretudo na sociedade de consumo hodierna —, de modo que o reconhecimento das próprias limitações é o primeiro passo para o enfrentamento dos desafios contemporâneos. ${ }^{1}$

Se a Economia Comportamental é uma disciplina recente, parte dos seus fundamentos já podiam ser verificados em obras clássicas, como em relação ao primeiro livro escrito por Adam Smith, "The Theory of Moral Sentiments", de 1759. Essa obra, concebida por importantes economistas comportamentais como um manancial para futuras descobertas a respeito do comportamento dos seres humanos, visou analisar as preferências sob a dupla perspectiva da paixão e do espectador imparcial, possibilitando insights importantes para o que hoje compreende-se como aversão à perda, escolha intertemporal e confiança excessiva. ${ }^{2}$

George Loewenstein, um dos principais estudiosos da Economia Comportamental e um confesso admirador da obra de Adam Smith, juntamente a Nava Ashraf e Colin Camerer, informam que a perspectiva psicológica observada no pensamento do clássico economista britânico, muitas vezes mal compreendido e interpretado, pode ser decididamente observada em estudos avançados de psicólogos, neurocientistas e economistas comportamentais com base na década de 1990 até hodiernamente, o que representa um feito notável. ${ }^{3}$

Os estudos que abarcam a temática da racionalidade também são importantes fontes, tanto para a Teoria Econômica Neoclássica (mainstream) quanto para a Economia Comportamental. Para os neoclássicos, o ser

1 ARIELY, Dan. Behavioral economics: an exercise in design and humility. In: SAMSON, Alain (Ed.). The behavioral economics guide 2015. Disponível em: <http://www.behavioraleconomics.com/BEGuide2015.pdf>. Acesso em: 3 out. 2017.

2 Por exemplo, Smith visualizava uma evidente contradição entre o homem guiado pela paixão e a figura do expectador imparcial, haja vista que o primeiro, com a sua visão distorcida da realidade, optaria por usufruir dos prazeres momentâneos ao invés de vislumbrar uma situação satisfatória a longo prazo. Smith também dizia que para o ser humano, a dor é um sentimento muito mais marcante do que o prazer. As ideias do que entendemos hoje como decisão intertemporal ou desconto hiperbólico e aversão a perda, respectivamente, estão contidas nessas reflexões, tendo sido posteriormente aprofundadas por importantes economistas comportamentais e neurocientistas. ASHRAF, Nava; CAMERER, Colin F.; LOEWENSTEIN, George. Adam Smith, behavioral economist. In: LOEWENSTEIN, George (Ed.). Exotic preferences: behavioral economics and human motivation, New York: Oxford University Press, 2007. p. 90-92.

3 ASHRAF, Nava; CAMERER, Colin F.; LOEWENSTEIN, George. Adam Smith, behavioral economist. In: LOEWENSTEIN, George (Ed.). Exotic preferences: behavioral economics and human motivation, New York: Oxford University Press, 2007. p. 90. 
humano visa maximizar o seu próprio bem-estar, sendo necessário para corroborar essa afirmação a defesa de um modelo de racionalidade compatível com a figura do chamado economic man (homem econômico), ou seja, um sujeito que, perante o mercado, sempre tomará as decisões que são mais satisfatórias aos seus próprios interesses, com capacidade ainda para lidar com um número extraordinário de informações. Veja-se, por exemplo, a seguinte sistematização da Teoria da Utilidade Esperada Subjetiva, uma das principais vertentes do pensamento econômico neoclássico, que, em relação às escolhas realizadas pelos agentes econômicos atuantes no mercado, determina que elas ocorrerão da seguinte forma:

[...] (a) dentro de um conjunto fixo dado de alternativas, (b) com uma distribuição de probabilidade conhecida subjetivamente, (c) de maneira a maximizar o valor esperado de uma dada função utilidade. ${ }^{4}$

A ideia de que o ser humano sempre alcança a maximização do seu próprio bem-estar tem sido alvo de reflexões desde décadas anteriores ao surgimento da Economia Comportamental, apresentando especial importância os estudos relativos à tomada de decisão. Herbert Simon, um cientista social com relevante atuação em diversas áreas, dentre elas a Economia e a Psicologia, desde 1947, com a publicação do livro "Administrative behavior: a study of decision-making", passou a questionar a noção de racionalidade global empregada pelos neoclássicos, já que para ele haveria uma clara contradição entre esse modelo e o real comportamento do ser humano quando da tomada de decisão, comportamento esse limitado por limitações cognitivas inerentes à condição humana. ${ }^{5}$

No artigo "A Behavioral Model of Rational Choice", de 1955, Simon descreveu o homem econômico na perspectiva dos neoclássicos como sendo um sujeito racional, com um controle praticamente completo de seu vasto conhecimento. ${ }^{6}$ A obtenção da maximização da utilidade decorreria de sua habilidade para se organizar e estabelecer escolhas apropriadas ao seu próprio interesse, de acordo com uma capacidade computacional garantidora da melhor tomada de decisão, dentre todas as alternativas existentes.

Simon foi um dos principais defensores da substituição da racionalidade global substantiva que abarca a figura do "homem econômico neoclássico", estabelecendo a necessidade de implantação de um modelo de racionalidade que explicasse o comportamento humano de forma realista e que reconhecesse as suas limitações cognitivas. ${ }^{7}$ Adotando esse norte, Simon passou a dedicar os seus estudos à conceptualização da racionalidade limitada (bounded rationality), temática que marcou a sua obra e lhe conferiu o recebimento do prêmio Nobel em Economia no ano de 1978.

Vale o registro de que Herbert A. Simon efetivamente não foi um dos criadores da Economia Comportamental, enquanto disciplina autônoma. Por outro lado, os seus estudos questionadores da figura do homem econômico que abarcaram a temática da "racionalidade limitada" e renovaram o pensamento econômico tradicional com insights oriundos da psicologia cognitiva e da sociologia, embora considerados radicais, foram importantes para a construção da mencionada teoria, servindo como a inspiração inicial para o aprofundamento da análise do comportamento humano em relação à tomada de decisão. ${ }^{8}$ Com efeito, é interessante notar que o próprio Simon reconhecia a necessidade de construção de um conhecimento empírico mais sólido para a formulação de uma teoria definitiva, ${ }^{9}$ conhecimento esse que foi posteriormente conduzido

4 LAGES, André Maia Gomes. A contribuição singular de Simon e sua repercussão teórica relevante. Análise, v. 17, n. 1, p. 47-66, jan./jul. 2006.

5 BARROS, Gustavo. Herbert A. Simon and the concept of rationality: boundaries and procedures. Brazilian Journal of Political Economy, v. 30, n. 3, p. 455-472, jul./set. 2010.

6 'Traditional economic theory postulates an 'economic man', who, in the course of being 'economic' is also 'rational'. This man is assumed to have knowledge of the relevant aspects of his environment which, if not absolutely complete, is at least impressively clear and voluminous. He is assumed also to have a well-organized and stable system of preferences, and a skill in computation that enables him to calculate, for the alternative courses of action that are available to him, which of these will permit him to reach the highest attainable point on his preference scale". SIMON, Herbert A. A behavioral model of rational choice. The Quarterly Journal of Rational Choice, v. 69, n. 1, p. 99-118, fev. 1955.

7 SIMON, Herbert A. A behavioral model of rational choice. The Quarterly Journal of Rational Choice, v. 69, n. 1, p. 99-118, fev. 1955. 8 SCHWARTZ, Hugh. Herbert Simon and behavioral economics. Journal of socio-Economics, v. 31, p. 181-189, 2002.

9 "Lacking the kinds of empirical knowledge of the decisional processes that will be required for a definitive theory, the hard facts of the actual world can, at the present stage, enter the theory only in a relatively unsystematic and unrigorous way". SIMON, 
pelos estudos de Amos Tversky, Daniel Kahneman e outros pesquisadores, possibilitando uma análise mais aprofundada das heurísticas, dos vieses e, especialmente para o estudo ora realizado, da vulnerabilidade cognitiva do consumidor, ${ }^{10}$ especialmente do consumidor (superendividado) inserto na atual e complexa sociedade de consumo.

O objetivo deste estudo, nesse sentido, é demonstrar a compatibilidade entre a Economia Comportamental e o Direito, especialmente o Direito do Consumidor, no tocante à temática do superendividamento. ${ }^{11}$ No Brasil, o Código de Defesa do Consumidor (CDC) prevê expressamente o princípio da vulnerabilidade, norma essa que amolda-se perfeitamente às descobertas em Behavioral Economics, notadamente a constatação das limitações cognitivas que podem prejudicar a tomada de decisão do consumidor, podendo, inclusive, levá-lo a uma condição de superendividado.

A respeito das maneiras pelas quais o Direito poderia se beneficiar com os insights provenientes dos estudos em Economia Comportamental, os trabalhos empíricos que podem ser elaborados com as ferramentas dessa última área do saber, sobretudo para traçar explicações para determinadas causas que podem ocasionar o superendividamento, constituem importantes referenciais científicos para a compreensão de uma visão do Direito condizente com a realidade da sociedade de consumo. Ainda, a Economia Comportamental poderá trazer soluções para o problema, especialmente para a elaboração de uma legislação mais eficiente, para a regulamentação do mercado e, principalmente, para a elaboração de políticas públicas.

Em relação ao aspecto metodológico, adotou-se o método indutivo, baseado nas descobertas empíricas da Economia Comportamental (heurísticas e vieses), a fim de se estabelecer a compatibilidade entre a mencionada disciplina e o Direito do Consumidor. Quanto à abordagem, foi realizada uma análise interdisciplinar que conjugou elementos próprios da Economia, da Psicologia e do Direito. O presente estudo tem o intuito de dar continuidade às investigações relativas à Análise Econômico-Comportamental do Direito, já realizadas por importantes juristas brasileiros, ${ }^{12}$ cumprindo o papel de demonstrar que a construção de um conhecimento interdisciplinar, calcado no diálogo e no compartilhamento de métodos científicos, poderá ser de grande valia para o enfrentamento do superendividamento no Brasil.

\section{As heurísticas, os vieses e a Teoria dos Prospectos: a afirmação da Behavioral ECONOMICS}

Amos Tversky, ainda na década de 1960, durante o seu período de doutoramento nos Estados Unidos sob a orientação do psicólogo Ward Edwards, dedicou-se ao estudo da Teoria da Tomada de Decisão, adotando como objetivo principal demonstrar a maneira correta de se empregar os axiomas da Teoria da Mensuração (Measurement Theory), de acordo com o contexto descritivo dos experimentos realizados. Nesse primeiro momento, Tversky era um apoiador da Teoria Subjetiva da Utilidade esperada nos termos propostos por Savage, ou seja, de que as escolhas realizadas pelos indivíduos podem ser descritas pelo ideal da

Herbert A. A behavioral model of rational choice. The Quarterly Journal of Rational Choice, v. 69, n. 1, p. 99-118, fev. 1955.

10 OLIVEIRA, Amanda Flávio de; FERREIRA, Felipe Moreira dos Santos. Análise econômica do direito do consumidor em períodos de recessão: uma abordagem a partir da economia comportamental. Revista de Direito do Consumidor, v. 81, p. 13-38, jan./ mar. 2012

11 O superendividamento pode ser conceituado como sendo “[...] a impossibilidade global de o devedor pessoa física, consumidor, leigo e de boa-fé, pagar todas as suas dívidas atuais e futuras de consumo (excluídas as dívidas com o fisco, oriunda de delitos e alimentos)". MARQUES, Cláudia Lima. Sugestões para uma Lei sobre o tratamento do superendividamento de pessoas físicas em contratos de crédito ao consumo: proposições com base em pesquisa empírica de 100 casos no Rio Grande do Sul. In: MARQUES, Cláudia Lima; CAVALLAZZI, Rosângela Lunardelli (Org.). Direitos do consumidor endividado: superendividamento e crédito. São Paulo: Revista dos Tribunais, 2006. p. 256.

12 OLIVEIRA, Amanda Flávio de; CARVALHO, Diógenes Faria de. Vulnerabilidade comportamental do consumidor: por que é preciso proteger a pessoa superendividada. Revista de Direito do Consumidor, v. 104, p. 181-201, mar./abr. 2016. 
maximização da utilidade esperada. ${ }^{13}$

No entanto, ao aprofundar os seus estudos e realizar os trabalhos empíricos para comprová-los cientificamente, Tversky passou a observar que os axiomas da Teoria Econômica dominante, algumas vezes, eram sistematicamente violados pelos resultados encontrados nos experimentos, o que ao final levou-o a admitir que o aspecto normativo da Teoria Econômica Dominante, até então considerada o melhor modelo descritivo do comportamento racional, não seria suficiente para responder às questões de ordem comportamental, que comprovadamente influenciavam a tomada de decisão do ser humano. Portanto, uma nova teoria econômica deveria ser elaborada, a fim de descrever a forma como as escolhas são feitas no mundo real, o que, necessariamente, implicava o reconhecimento de que as questões de ordem cognitiva deveriam ser levadas em consideração. ${ }^{14}$

De outro lado, Daniel Kahneman, durante a década de 1960, dedicou-se, em um primeiro momento, ao estudo dos diferenciais semânticos, visando traçar previsões que poderiam ser consideradas confiáveis em relação ao futuro desempenho profissional dos trabalhadores de certas carreiras, adotando como norte determinadas características relacionadas ao caráter e à personalidade dos indivíduos. Diante do fracasso obtido nesses primeiros estudos, Kahneman migrou o seu foco para a Psicologia Experimental, especialmente sobre a análise da visão (optometria), tendo produzido durante mais de 10 anos diversos artigos científicos, o que o fez ser reconhecido como uma das principais referências intelectuais na área sob questão. ${ }^{15}$

A partir dos estudos em optometria, Kahneman teve a oportunidade de analisar a forma como o ser humano comporta-se quando executa tarefas simultâneas. Em outras palavras, ele constatou que a combinação de diferentes atividades pode levar os indivíduos ao cometimento de erros de julgamento, ou seja, equívocos de ordem cognitiva. ${ }^{16}$ São essas primeiras observações que acabaram direcionando os estudos do autor para o campo da Psicologia Cognitiva, tornando-se fundamentais para o descortinar da Economia Comportamental.

Amos Tversky e Daniel Kahneman são psicólogos de formação, apesar de seus estudos terem marcado, decisivamente, o pensamento econômico, inclusive tendo o segundo recebido o Prêmio Nobel em Economia no ano de 2002 (Tversky não recebeu a premiação em decorrência de seu falecimento no ano de 1996). O trabalho em parceria realizado por ambos, que resultou em dezenas de artigos e alguns livros publicados ao longo de mais de duas décadas, forneceu as bases para a elaboração da Behavioral Economics, que, hodiernamente, repercute em diversos campos do saber.

A parceria entre os dois pesquisadores foi oportunizada pelo retorno de ambos à Universidade Hebraica de Jerusalém, depois de completarem os seus estudos nos EUA. Kahneman, visando elaborar novos experimentos para comprovar a sua, então, recente descoberta de que os indivíduos cometem erros sistemáticos de julgamento em razão de fatores cognitivos, vislumbrou nos estudos de Tversky, notadamente no campo da Teoria da Tomada de Decisão com a diferenciação dos aspectos normativo e descritivo, uma oportunidade única de unir esforços para a criação de uma nova teoria capaz de afetar decisivamente o pensamento econômico mainstream.

Já no ano de 1971, Kahneman e Tversky elaboraram o primeiro artigo em coautoria, relatando uma pesquisa realizada em 1969 no encontro entre a Associação Americana de Psicologia e a Sociedade de Psicologia Matemática, oportunidade em que foi apresentado um questionário para 84 participantes do evento contendo perguntas a respeito da confiabilidade de estimativas estatísticas reais. ${ }^{17}$ Diante das respostas obtidas, os pesquisadores observaram que os respondentes confiavam bastante em amostras estatísticas

13 HEUKELOM, Floris. Behavioral economics: a history. New York: Cambridge University Press, 2014. p. 98-100.

14 HEUKELOM, Floris. Behavioral economics: a history. New York: Cambridge University Press, 2014. p. 102-104.

15 HEUKELOM, Floris. Behavioral economics: a history. New York: Cambridge University Press, 2014. p. 106-108.

16 KAHNEMAN, Daniel. Rápido e devagar: duas formas de pensar. Rio de Janeiro: Objetiva, 2012. p. 46.

17 HEUKELOM, Floris. Behavioral economics: a history. New York: Cambridge University Press, 2014. p. 112-114. 
consideradas pequenas, respondendo rápida e intuitivamente às questões, em vez de realizar reflexões mais longas e calculadas, que inclusive poderiam ser facilmente realizadas, dado o grau de conhecimento dos participantes nos assuntos dispostos no questionário. A conclusão foi a de que o ser humano, seja qual for o seu nível de instrução, ${ }^{18}$ nem sempre baseia as suas decisões de acordo com o aspecto normativo das teorias da probabilidade ou da estatística, mas sim faz uso das chamadas heurísticas — no caso sob tela, a heurística da representatividade —, situação que pode levá-lo ao cometimento de erros. ${ }^{19}$

A partir desse primeiro estudo, que deu início ao programa de heurísticas e vieses, os autores puderam chegar a uma importante constatação: a tomada de decisão idealizada sob o prisma do modelo de racionalidade defendido pela Teoria Econômica Dominante é parte do seu aspecto normativo. Já a efetiva tomada de decisão, aquela realizada no mundo real e que abarca a utilização das heurísticas, situa-se em outro aspecto, qual seja, o descritivo. Portanto, adotar o domínio normativo como parâmetro para as escolhas que os indivíduos fazem no decorrer de suas vidas representa um equívoco, posto que os experimentos até então realizados já constatavam que as pessoas, sistematicamente, adotavam comportamentos que se desviavam do ideal de maximização do bem-estar. Em outras palavras, Kahneman e Tversky distanciaram-se da Teoria da Utilidade Subjetiva esperada de Savage, pois, para que ela fosse aplicada, os autores deveriam concluir que os seus experimentos empíricos não eram confiáveis ou que a teoria normativa estava incorreta. Considerando justamente contrário, ou seja, apoiados e confiantes nos resultados dos seus experimentos, os pesquisadores concluíram que, ao tomarem decisões de forma intuitiva, as pessoas às vezes não se comportam nos termos idealizados pelo modelo normativo racional, o que, de certa forma, é válido, mas insuficiente para promover a devida descrição da realidade..$^{20}$

Aprofundando os estudos, Kahneman e Tversky publicaram em 1974, na Revista Science, um dos seus trabalhos mais importantes em coautoria: "Judgment under uncertainty: heuristics and biases". Nesse artigo, os autores expressamente destacaram que no momento de efetuar escolhas, os seres humanos não se comportam de acordo com a lógica fria dos cálculos matemáticos. Na realidade, muitas vezes, eles se apoiam em heurísticas como forma de simplificar o processo de tomada de decisão, o que consequentemente pode acarretar em vieses, ou seja, erros sistemáticos e previsíveis motivados por falhas cognitivas.

This article shows that people rely on a limited number of heuristic principies which reduce the complex tasks of assessing probabilities and predicting values to simpler judgmental operations. In general, these heuristics are quite useful, but sometimes they lead to severe and systematic errors. ${ }^{21}$

Floris Heukelom informa que a palavra "heurística" não foi propriamente introduzida por Kahneman e Tversky. Entre os anos de 1950 e 1970, Herbert Simon já utilizava o termo em seus trabalhos críticos à teoria econômica neoclássica, o que de certa forma pode ter influenciado os pesquisadores israelenses. No entanto, é preciso esclarecer que existem diferenças claras e importantes entre as mencionadas concepções. Para Simon, as heurísticas seriam utilizadas como forma de otimizar a tomada de decisão por parte do indivíduo, visando dessa forma superar os problemas cognitivos e informacionais que caracterizam a sua racionalidade limitada, tornando a sua escolha satisfatória. Poderiam elas, portanto, serem ajustadas pelo próprio tomador da decisão, a fim de melhor satisfazê-lo. Por exemplo, ao estabelecer que será aceita a primeira oferta realizada acima do valor mínimo para a compra de uma casa, estará o sujeito fazendo uso de uma heurística. Caso nenhuma oferta seja realizada, poderá o proprietário diminuir o valor mínimo estabelecido, gerenciando a

18 Veja-se que os respondentes desse primeiro experimento eram especialistas em suas áreas.

19 KAHNEMAN, Daniel; FREDERICK, Shane. Representativeness revisited: attribute substitution in intuitive judgment. In: GILOVICH, T.; GRIFFIN, D.; KAHNEMAN, D. (Ed.). Heuristics and biases: the psychology of intuitive judgment. New York: Cambridge University Press, 2002. p. 49-81. p. 49.

20 HEUKELOM, Floris. Behavioral economics: a history. New York: Cambridge University Press, 2014. p. 115-116.

21 Tradução livre: este artigo mostra que as pessoas confiam em um número limitado de princípios heurísticos que reduzem o nível de complexidade das tarefas que envolvem a avaliação de probabilidades e previsão de valores, o que simplifica as operações de julgamento. Em geral, essas heurísticas são bastante úteis, mas às vezes elas acabam propiciando o cometimento de erros graves e sistemáticos. KAHNEMAN, Daniel; TVERSKY, Amos. Judgment under uncertainty: heuristics and biases. Science, v. 185, n. 4157, p. 1124-1131, set. 1974. 
heurística de acordo com o seu interesse. Em contraste, para Kahneman e Tversky, as heurísticas não são responsáveis por conduzir a decisão, mas sim por reorganizar as informações existentes, de forma a simplificar, facilitar a compreensão e tornar possível por parte do ser humano a realização da escolha em situações de incerteza. Seriam elas, portanto, relacionadas às questões intuitivas do pensamento, sendo mesmo um recurso inevitável e não manipulável. ${ }^{22}$

As heurísticas são comumente retratadas como "atalhos mentais", ou seja, tratam-se de estratégias cognitivas utilizadas pelo ser humano para facilitar e agilizar a tomada de decisão. Nesse sentido, elas podem ser consideradas um recurso importante e útil, sobretudo porque em diversas ocasiões as pessoas de fato são instadas a tomarem decisões rápidas e intuitivas. O problema surge quando essas decisões são influenciadas por uma visão equivocada ou enviesada da realidade, dando forma às escolhas que contradizem o ideal da maximização da utilidade.

No supracitado artigo de 1974, Kahneman e Tversky apresentaram três importantes heurísticas comumente utilizadas pelo ser humano: representatividade (representativeness), disponibilidade (availability) e ancoragem e ajustamento (anchoring and adjustment). Em relação à primeira, trata-se dos julgamentos que podem ser afetados pela utilização de estereótipos. Os autores exemplificam com o caso do indivíduo considerado tímido, retraído, prestativo, de fácil trato, organizado e detalhista, mas que demonstra pouco interesse em se relacionar com as pessoas e com o mundo à sua volta. De acordo com essas características apresentadas, questionam os pesquisadores como as pessoas tendem a analisar a probabilidade de o indivíduo descrito pertencer a determinada categoria profissional, como a de um vendedor, físico, piloto de avião ou bibliotecário. No caso, por fazerem uso da heurística da representatividade, as pessoas tendem a imaginar a profissão de acordo com os estereótipos de cada uma delas. Por exemplo, se reputarem o indivíduo como um bibliotecário, esse julgamento se dará, simplesmente, pela semelhança observada entre as suas características e o estereótipo de um bibliotecário. Com efeito, a utilização dessa heurística pode levar a pessoa ao cometimento de erros graves, posto que a análise de representatividade ou similitude não leva em consideração fatores cruciais que devem ser observados nos casos de julgamentos que envolvem probabilidades. ${ }^{23}$

Sobre a heurística da disponibilidade, informam os autores que as pessoas tendem a julgar a frequência ou a probabilidade de ocorrência de um dado evento, de acordo com a facilidade com que eventos semelhantes ou que aconteceram recentemente recorrem em suas mentes. Como exemplo, os indivíduos costumam aferir a probabilidade de ocorrência de problemas cardíacos em pessoas de meia-idade a partir da lembrança de casos semelhantes em suas famílias. Veja-se que essa heurística pode até ser útil, mas indiscutivelmente poderá levar aquele que a utiliza ao cometimento de erros previsíveis, posto que a disponibilidade também é influenciada por outros fatores além da probabilidade e da frequência. ${ }^{24} \mathrm{~A}$ heurística da disponibilidade também é comumente relacionada com os riscos sob os quais as pessoas apresentam enorme aversão e incapacidade de controle. Como exemplo, há os acidentes de avião e os ataques terroristas.

Finalmente, a terceira heurística analisada por Kahneman e Tversky foi a chamada ancoragem e ajustamento. De acordo com os autores, as pessoas tendem a se apoiar em informações recentemente incorporadas a fim de tomar as suas decisões. A partir de um determinado valor ou dado que funcionará como uma âncora ou um ponto de apoio, o tomador da decisão tende a ajustar a sua resposta para efetivamente realizar a escolha. Como exemplo, os pesquisadores realizaram um experimento que consistia em perguntas sobre quantidades em termos percentuais, como por exemplo, "qual o percentual de países africanos que fazem parte da ONU?". Para responder a cada questionamento, os participantes deveriam girar uma roleta para selecionar um número aleatório de 0 a 100. Com os resultados coletados, os autores perceberam que

22 HEUKELOM, Floris. Behavioral economics: a history. New York: Cambridge University Press, 2014. p. 117.

23 KAHNEMAN, Daniel; TVERSKY, Amos. Judgment under uncertainty: heuristics and biases. Science, v. 185, n. 4157, p. 11241131, set. 1974.

24 KAHNEMAN, Daniel; TVERSKY, Amos. Judgment under uncertainty: heuristics and biases. Science, v. 185, n. 4157, p. 11241131, set. 1974. 
o número sorteado na roleta funcionou como uma âncora, exercendo grande influência sobre as respostas dadas. Ilustrando, diante do sorteio do número 10, os participantes, em média, estimaram que $25 \%$ dos países africanos faziam parte da ONU, enquanto que, diante do número 65, os participantes, em média, estimaram que o percentual seria de 45. Dentre os vieses que podem ser gerados por essa heurística, um dos principais problemas está no ajuste insuficiente da âncora, ou seja, na total possibilidade de o ponto de apoio não representar um dado seguro e eficaz para a tomada de decisão, o que poderá levar o indivíduo ao erro. ${ }^{25}$

Dando continuidade às pesquisas, Kahneman e Tversky publicaram em 1979 um dos artigos mais importantes para o posicionamento da Economia Comportamental no cenário do pensamento econômico e para a repercussão da disciplina sobre outras áreas do conhecimento (como o próprio Direito). Trata-se do trabalho "Prospect theory: an analysis of decision under risk", publicado pela Revista Econometrica. Com a teoria dos prospectos, visaram os pesquisadores elaborar uma nova teoria descritiva do comportamento humano, capaz de abarcar a efetiva tomada de decisão em situações de incerteza.

A Teoria dos Prospectos é notadamente conhecida por ser a primeira teoria que, efetivamente, propôs um modelo descritivo do comportamento humano em relação à tomada de decisão em situações de incerteza. Trata-se de uma importante sistematização dos estudos de Kahneman e Tversky em direção à formação de um robusto arcabouço teórico (empiricamente comprovado), que definitivamente trouxe a Economia Comportamental para as discussões relativas ao pensamento econômico mainstream Nesse sentido, o trabalho ora analisado não representa uma mera continuação do programa de heurísticas e vieses analisado acima, apesar de suas bases estruturais continuarem apoiando-se na constatação de que os seres humanos, ao tomarem as decisões, baseiam as suas escolhas em diversas heurísticas que podem levá-los ao cometimento de erros sistemáticos. ${ }^{26}$

Logo na introdução do artigo, os autores reconheceram o domínio exercido pela Teoria da Utilidade Esperada no cenário do pensamento econômico, tanto sob o aspecto normativo quanto descritivo.

EXPECTED UTILITY THEORY has dominated the analysis of decision making under risk. It has been generally accepted as a normative model of rational choice, and widely applied as a descriptive model of economic behavior, e.g. Thus, it is assumed that all reasonable people would wish to obey the axioms of the theory, and that most people actually do, most of the time. ${ }^{27}$

Em relação à citação acima, Floris Heukelom destaca que se tratou de uma forma bastante inteligente de iniciar o texto, sobretudo porque ela agradou tanto os psicólogos cognitivos - com a separação entre os domínios normativo e descritivo - quanto os economistas positivistas, com a afirmação de que presume-se que as pessoas razoáveis obedecem aos axiomas da teoria da utilidade esperada. ${ }^{28}$ Ainda, restou evidente a preocupação dos autores em, além de situar as suas descobertas no campo da Economia, deixar claro que os estudos realizados não correspondiam à mera continuação de linhas de pesquisas anteriores, especialmente em relação ao trabalho de Herbert Simon na temática da racionalidade limitada. ${ }^{29}$

25 KAHNEMAN, Daniel; TVERSKY, Amos. Judgment under uncertainty: heuristics and biases. Science, v. 185, n. 4157, p. 11241131, set. 1974.

26 HEUKELOM, Floris. Behavioral economics: a history. New York: Cambridge University Press, 2014. p. 119.

27 Tradução livre: A teoria da utilidade esperada tem sido dominante em relação à análise da tomada de decisão sob situações de risco. Em termos gerais, ela foi aceita como sendo o modelo normativo da escolha racional, tendo sido amplamente aplicada como modelo descritivo do comportamento econômico. Ademais, presume-se que todas as pessoas razoáveis desejariam obedecer aos axiomas desta teoria e que a maioria das pessoas realmente comportam-se dessa forma, na maioria das vezes. KAHNEMAN, Daniel; TVERSKY, Amos. Prospect theory: an analysis of decision under risk. Econometrica, v. 47, n. 2, p. 263-292, mar. 1979.

28 HEUKELOM, Floris. Behavioral economics: a history. New York: Cambridge University Press, 2014. p. 120.

29 Não é por outro motivo que informamos na introdução deste artigo que o trabalho de Simon serviu como inspiração para os estudos posteriores em Economia Comportamental, mas efetivamente não pode ser considerado como sendo fundador da disciplina. "Note, furthermore, that Kahneman and Tversky carefully avoided the term rational and used reason-able instead. Evoking the term rational might have suggested that this was an article in the line of critique of economics. The use of rational would certainly have induced some economists to think that these two psychologists had the same research program as Simon, who had won the Nobel memorial prize in economics the year before. From the start, prospect theory was carefully constructed to be able to broaden the scope to economists especially". HEUKELOM, Floris. Behavioral economics: a history. New York: Cambridge University 
Portanto, é possível afirmar que a Economia Comportamental não refuta o modelo da "maximização da utilidade", empregado pelos economistas neoclássicos. Em outras palavras, pode-se comparar os seres humanos à figura do "homem econômico", pois, em última análise, as pessoas de fato tomam decisões econômicas a todo momento, visando maximizar o seu bem-estar. Contudo, a grande contribuição da Behavioral Economics está no reconhecimento empírico de que, muitas vezes, determinadas "anomalias comportamentais" impedem a maximização da utilidade subjetiva esperada, afastando o modelo idealizado do bomo economicus em relação ao ser humano que vive no "mundo real", como do consumidor inserto na sociedade de consumo. ${ }^{30}$

Dessa forma, a proposta parte da investigação da capacidade humana de se comportar de acordo com o aspecto normativo da teoria da utilidade esperada. Por meio de diversos experimentos que foram realizados, Kahneman e Tversky constataram que a tomada de decisão por parte dos seres humanos, em diversas ocasiões, violava os axiomas da mencionada teoria, levando-os à conclusão de que ela não poderia ser utilizada como um modelo descritivo do real comportamento econômico dos indivíduos. Portando, uma nova teoria, sobretudo para fins descritivos, deveria ser elaborada: trata-se, como já informado, da Teoria dos Prospectos.

Uma das principais críticas da Teoria dos Prospectos em relação à Teoria da Utilidade esperada está na ausência de diferenciação, por parte da segunda, das funções entre a utilidade do ganho e a utilidade da perda. Isso se explica em virtude de a Teoria da Utilidade Esperada adotar como parâmetro a comparação entre níveis de riqueza, o que implica uma simetria entre perdas e ganhos. Para Kahneman e Tversky, a função valor é assimétrica, sendo os ganhos e as perdas observados com base em um ponto de referência. De acordo com os experimentos realizados, constataram os autores que, em relação aos ganhos, a função valor mostrou-se côncava, indicando uma aversão ao risco. De outro lado, quanto às perdas, a função valor mostrou-se convexa e mais suscetível ao risco. Sobre o ponto de referência (origem), a função valor é mais íngreme para as perdas do que para os ganhos. ${ }^{31}$ Em conclusão, tem-se que a perda é mais valorizada pelas pessoas do que os ganhos (aversão à perda), sendo esse estudo extremamente importante para futuras descobertas em Economia Comportamental, destacando-se a análise das decisões intertemporais, que tem sido retratadas como problemas cognitivos que afetam a tomada de decisão do consumidor, com especial relação com o superendividamento.

De fato, ao levar em consideração o processo cognitivo envolvido na realização das escolhas, a Teoria dos Prospectos transcendeu a abordagem tradicional das demais teorias que até então preocupavam-se com o estudo da tomada de decisão por parte do "homem econômico", 32 passando a preocupar-se com o real comportamento das pessoas, especialmente em decorrência das constatações empíricas de que os desvios comportamentais geram consequências relevantes, o que leva à necessidade de não serem ignorados.

Após anos de estudos, em que destacam-se a construção do programa de heurísticas e vieses, e a teoria dos prospectos, Kahneman e Tversky, definitivamente, passaram a influenciar o pensamento econômico, seja reunindo apoiadores ou tornando-se alvo de críticas. ${ }^{33}$ Considerados os pioneiros do novo ramo da Economia Comportamental, uma disciplina autônoma e com métodos próprios, ${ }^{34}$ esses autores uniram

Press, 2014. p. 120.

30 OLIVEIRA, Amanda Flávio de; FERREIRA, Felipe Moreira dos Santos. Análise econômica do direito do consumidor em períodos de recessão: uma abordagem a partir da economia comportamental. Revista de Direito do Consumidor, v. 81, p. 13-38, jan./ mar. 2012.

31 KAHNEMAN, Daniel; TVERSKY, Amos. Prospect theory: an analysis of decision under risk. Econometrica, v. 47, n. 2, p. 263-292, mar. 1979.

32 HASTIE, Reid; DAWES, Robyn M. Rational choice in an uncertain world: the psychology of judgment and decision making. 2 ed. Los Angeles: SAGE, 2010. p. 476.

33 Em relação às principais críticas à Economia Comportamental, GIGERENZER, Gerd. How to make cognitive illusions disappear: beyond "heuristics and biases. European Review of Social Psychology, v. 2, n. 1, p. 83-115, 1991. Veja também a resposta de Daniel Kahneman e Amos Tversky: KAHNEMAN, Daniel; TVERSKY, Amos. On the reality of cognitive ilusions. Psycological Review, v. 103, n. 3, p. 582-591, jul. 1996.

34 Originalmente, os economistas comportamentais baseavam-se, fortemente, em evidências encontradas em experimentos. 
determinados saberes da Psicologia juntamente à Economia, ideia extremamente controversa durante o período da chamada revolução econômica neoclássica, ${ }^{35}$ o que possibilitou uma compreensão mais realista e consciente do comportamento humano. Ainda, é preciso registrar o grande esforço dos autores, especialmente expresso nos artigos de 1974 e 1979, em adotar uma linguagem técnica, capaz de chamar a atenção dos economistas. ${ }^{36}$

De fato, pode-se considerar que a Economia Comportamental somente passou a influenciar, de alguma forma, o cenário econômico mainstream quando os economistas passaram a notá-la. ${ }^{37}$ Nesse sentido, Richard Thaler, um economista norte-americano, certamente foi um dos principais responsáveis pelo fortalecimento e divulgação dessa nova área do saber, sobretudo porque os seus estudos adotaram e posteriormente desenvolveram as descobertas realizadas por Kahneman e Tversky, especificamente a respeito da insuficiência do modelo normativo da teoria econômica tradicional para descrever o processo de escolha do consumidor no mundo real, oportunidade em que o autor constatou que as ilusões mentais podem levar esse sujeito ao cometimento de erros sistemáticos.

This paper presents a group of economic mental illusions. These are classes of problems where consumers are particularly likely to deviate from the predictions of the normative model. By highlighting the specific instances in which the normative model fails to predict behavior, I hope to show the kinds of changes in the theory that will be necessary to make it more descriptive. Many of these changes are incorporated in a new descriptive model of choice under uncertainty called prospect theory [Kahneman and Tversky (1979)]. Therefore I begin this paper with a brief summary of prospect theory. Then several types of predicted errors in the normative theory are discussed. Each is first illustrated by an anecdotal example. These examples are intended to illustrate the behavior under discussion in a manner that appeals to the reader's intuition and experiences. ${ }^{38}$

Com trabalhos importantes que abordam, principalmente, os temas finanças comportamentais, efeito

Todavia, com a evolução da teoria, a EC passou a utilizar todos os métodos tradicionalmente utilizados pelos economistas. Cite-se as pesquisas de campo, experimentos de campo, simulação em computadores e até mesmo escaneamento cerebral. A EC utiliza bastante a pesquisa empírica, tanto aquela feita dentro do laboratório, quanto a realizada fora dele, sempre observando a realidade em termos psicológicos por meio da aplicação econômica. CAMERER, Colin F.; LOEWENSTEIN, George. Behavioral economics: past, present, future. In: CAMERER, Colin F., LOEWENSTEIN, George; RABIN, Matthew. Advances in behavioral economics, New York: Princeton University Press, 2002. p. 7.

35 A rejeição da Psicologia pelos economistas é observada com maior rigor com base no estabelecimento das correntes neoclássicas, que visaram conferir ao pensamento econômico uma roupagem de ciência natural, destacando-se a construção do homo economicus. No entanto, essa separação rígida ocorreu de forma gradativa, posto que no início do século XX, economistas como Irving Fisher e posteriormente John Maynard Keynes, ainda utilizavam determinados saberes da Psicologia em seus estudos, o que veio a ser praticamente abolido apenas na metade do século. A partir de 1955, estudos críticos ao modelo de racionalidade empregado pelos neoclássicos começaram a surgir, destacando-se a obra de Herbert Simon e anos mais tarde os trabalhos de Kahneman e Tversky. CAMERER, Colin F.; LOEWENSTEIN, George. Behavioral economics: past, present, future. In: CAMERER, Colin F., LOEWENSTEIN, George; RABIN, Matthew. Advances in behavioral economics, New York: Princeton University Press, 2002. p. 5-6.

36 A título de registro histórico, Kahneman e Tversky desenvolveram o artigo da teoria dos prospectos durante 5 anos, até a sua publicação na Revista Econometrica, em 1979. Dentro desses 5 anos, nos últimos 4 anos, os autores praticamente direcionaram os seus esforços para adotar uma linguagem técnica, adequada ao pensamento econômico e ao seu público. HEUKELOM, Floris. Behavioral economics: a history. New York: Cambridge University Press, 2014. p. 119.

37 Em relação à necessidade de as teorias econômicas serem julgadas pelos critérios da congruência com a realidade, generalidade e tratabilidade, Lowenstein informa que, em que pese haverem questionamentos entorno da ocorrência dos três critérios mencionados junto à Economia Comportamental, pode-se ilustrar a presença de todos eles com o experimento que constatou a aversão à perda. CAMERER, Colin F.; LOEWENSTEIN, George. Behavioral economics: past, present, future. In: CAMERER, Colin F., LOEWENSTEIN, George; RABIN, Matthew. Advances in behavioral economics, New York: Princeton University Press, 2002 . p. 4.

38 Tradução livre: citam-se um grupo de ilusões mentais discutidas no âmbito do pensamento econômico. Tratam-se de classes de problemas em que os consumidores estão particularmente propensos a desviarem-se das predições do modelo normativo. Ao destacar as instâncias específicas em que o modelo normativo não consegue prever o comportamento, espero demonstrar o que precisa ser alterado na teoria para torná-la mais descritiva. Muitas dessas mudanças são incorporadas em um novo modelo descritivo de escolha sob incerteza, denominado teoria dos prospectos [Kahneman e Tversky (1979)]. Por isso, eu começo esse artigo com um breve resumo dessa teoria dos prospectos. Em seguida, serão discutidos vários tipos de erros previsíveis na teoria normativa. Cada um será primeiramente exemplificado com uma anedota. Esses exemplos destinam-se a ilustrar o comportamento em discussão de uma maneira atrativa à intuição e às experiências do leitor. THALER, Richard. Toward a positive theory of consumer choice. Journal of Economic Behavior and Organization, v. 1, p. 39-60, mar. 1980. 
dotação (endowment effect), contabilidade mental (mental accounting), valoração da vida e mais recentemente, na área do Direito e das Políticas Públicas, com a formulação da "arquitetura da escolha" (nudges), ${ }^{39}$ Thaler decididamente pode ser considerado um dos principais economistas comportamentais de nosso tempo, tendo em 9 de outubro de 2017 recebido o Prêmio Nobel em Economia por suas relevantes contribuições.

Enfim, apresentada a Economia Comportamental, cumpre registrar que o presente estudo considera ser extremamente importante a incorporação das contribuições dessa disciplina para o enfrentamento do superendividamento, haja vista que esse fenômeno é causado por fatores estruturais (como por exemplo, a facilitação e massificação do acesso ao crédito) e comportamentais (como por exemplo, as ilusões cognitivas que afetam a tomada de decisão), ${ }^{40}$ de modo que conhecer e estudar o comportamento do consumidor no mercado de consumo, inclusive das ilusões cognitivas a que está submetido, torna-se crucial para que seja possível traçar maneiras de prevenir o mencionado problema.

\subsection{O funcionamento do pensamento humano diante da tomada de decisões complexas}

Após anos de trabalho em conjunto, em que se destacam o programa de heurísticas e vieses e a formulação da teoria dos prospectos, Kahneman e Tversky, pioneiros da Economia Comportamental, acabaram forçadamente terminando a parceria em virtude do falecimento do segundo.

No entanto, Daniel Kahneman continuou aprofundando os seus estudos, o que resultou nas descobertas relativas ao "sistema de processamento duplo" ou "Teoria do Processamento Dual do Pensamento". Em trabalho conjunto com Shane Frederick - um reconhecido estudioso dos aspectos cognitivos envolvidos na tomada de decisão-, denominado "Representativeness Revisited: Attribute Substitution in Intuitive Judgment", propuseram os autores uma espécie de revisitação ao programa de heurísticas e vieses, a fim de abordar determinados questionamentos que somente nesse momento estavam devidamente maduros para serem enfrentados. Em síntese, diante das constatações realizadas ainda nos primeiros estudos sobre as heurísticas e os vieses, sobretudo de que as pessoas tendem a utilizar atalhos mentais expressos por meio de escolhas intuitivas para tomarem suas decisões em situações de incerteza, passaram os autores a questionar como essas respostas intuitivas que podem causar erros sistemáticos são corrigidas e controladas pelo próprio pensamento. $^{41}$

De acordo com os autores, o processo cognitivo do ser humano pode ser explicado pela existência de dois sistemas representativos da mente, tema esse recorrente no cenário acadêmico da Psicologia. Adotando a denominação criada por Keith Stanovich e Richard West, sobretudo por ser ela simples e didática, Kahneman e Frederick trataram esses dois modos do pensamento como Sistema 1 e Sistema 2, que se diferenciam pela velocidade com que atuam, pela capacidade de controle, bem como pelas atribuições exercidas por cada um. $^{42}$

O Sistema 1 é aquele que opera de maneira automática, instintiva, sem que o ser humano proceda com esforço (ou esforço relevante) para utilizá-lo. O raciocínio rápido, intuitivo, associativo, assim como determinadas habilidades, são características que o acompanham. Por exemplo, ao responder que $4+4=8$ e que a capital da França é Paris, o respondente estará fazendo uso do Sistema 1, proferindo respostas intuitivas.

39 THALER, Richard H.; SUNSTEIN, Cass R. Nudges: improving decisions about health, wealth, and happiness. New Haven: Yale University Press, 2008.

40 BRAUCHER, Jean. Theories of overindebtedness: interaction of structure and culture. Arizona Legal Studies, Theoretical Inquires in Law, p. 323-346, 2006. p. 324.

41 KAHNEMAN, Daniel; FREDERICK, Shane. Representativeness revisited: attribute substitution in intuitive judgment. In: GILOVICH, T.; GRIFFIN, D.; KAHNEMAN, D. (Ed.). Heuristics and biases: the psychology of intuitive judgment. New York: Cambridge University Press, 2002. p. 49-81. p. 50.

42 KAHNEMAN, Daniel; FREDERICK, Shane. Representativeness revisited: attribute substitution in intuitive judgment. In: GILOVICH, T.; GRIFFIN, D.; KAHNEMAN, D. (Ed.). Heuristics and biases: the psychology of intuitive judgment. New York: Cambridge University Press, 2002. p. 49-81. p. 51. 
De outro lado, o Sistema 2 é aquele que opera de forma controlada, atenciosa, seriada, analítica, exigindo esforços cognitivos relevantes e uma maior concentração por parte do ser humano. O raciocínio trabalhoso, lento, consciente e reflexivo o caracteriza em comparação com o Sistema 1. Por exemplo, ao realizar um cálculo matemático complexo, ao preencher um formulário para uma vaga de trabalho ou ao manobrar um veículo, estará o indivíduo fazendo uso do Sistema 2.

O Sistema 1 é considerado mais antigo do que o Sistema 2, não sendo uma conquista exclusiva dos seres humanos. No entanto, isso não quer dizer que o Sistema 2 seja mais desenvolvido ou complexo. Como bem destacam Kahneman e Frederick, é possível verificar atividades cognitivas complexas, que a princípio pertenceriam ao Sistema 2, mas que, devido a exigências relacionadas ao desenvolvimento de certas habilidades e competências, acabam por migrar para o Sistema 1. Como exemplo, os autores citam a habilidade dos enxadristas em movimentar as peças de maneira instantânea, traçando jogadas importantes e complexas. ${ }^{43}$

Considera-se que ambos os sistemas atuam de maneira interativa e inteligente. Enquanto o Sistema 1 está sempre em modo ativo e automático, o Sistema 2 permanece à disposição para atuar apenas quando necessário. Nesse sentido, o Sistema 1 é responsável por enviar sugestões ao Sistema 2, que poderão ser aprovadas, modificadas ou canceladas. ${ }^{44}$ Esse último sistema atua de forma a controlar as atividades do outro, mas apenas quando encontra motivos para fazê-lo, já que, na maior parte do tempo, as pessoas são instadas a agirem de forma intuitiva, rápida e eficiente, sendo o Sistema 1 normalmente capaz de proporcionar essas exigências de maneira satisfatória, sem a necessidade de haver um controle constante. ${ }^{45}$

No entanto, como já amplamente analisado no tópico anterior, os seres humanos não são tão infalíveis como alguns podem pensar. Em outras palavras, o funcionamento dos sistemas estudados não ocorre de maneira perfeita e totalmente eficiente; muito pelo contrário, o Sistema 1, em diversas ocasiões, sobretudo diante de situações complexas, atua com base em heurísticas, situação que pode levar a pessoa ao cometimento de vieses. No entanto, o problema não se dá, apenas, por esse motivo, mas sim pela falha do Sistema 2, quando esse não realiza o controle do Sistema 1, endossando os erros e as ilusões cognitivas provocados.

Um exemplo amplamente conhecido e que confirma o exposto no parágrafo acima é o problema da bola e do bastão. Somados os valores de uma bola e de um bastão, temos o total de $\mathrm{R} \$ 1,10$. Sabendo que o bastão custa $\mathrm{R} \$ 1,00$ a mais que a bola, qual seria o preço dessa última? Com efeito, os pesquisadores constataram que as pessoas tendem a informar que a resposta seria $R \$ 0,10$, separando intuitivamente a soma de $R \$$ 1,10 em $R$ \$ 1,00 e $R$ \$ 0,10. No entanto, ao fazer uma simples conta matemática — que demanda a utilização do Sistema 2 - o respondente facilmente encontraria a resposta correta, que é $\mathrm{R} \$ 0,05$. Esse simples problema já foi formulado para alunos de Harvard, do MIT e de Princeton, sendo as respostas surpreendentes. Mais de 50\% dos alunos dessas prestigiadas instituições responderam de forma equivocada, aumentando em $80 \%$ o percentual de erro em outras Universidades. De acordo com Kahneman, esse problema retrata duas conclusões importantes: as pessoas tendem a confiar excessivamente em suas intuições (viés da confiança excessiva), além de não se esforçarem o suficiente em termos cognitivos. ${ }^{46}$

Característica geral do julgamento realizado com base em heurísticas, a substituição corresponde ao pro-

43 KAHNEMAN, Daniel; FREDERICK, Shane. Representativeness revisited: attribute substitution in intuitive judgment. In: GILOVICH, T.; GRIFFIN, D.; KAHNEMAN, D. (Ed.). Heuristics and biases: the psychology of intuitive judgment. New York: Cambridge University Press, 2002. p. 49-81. p. 51.

44 Um exemplo ilustrativo a respeito do funcionamento dos dois sistemas é o teste Stroop. No caso, os respondentes são instados a dizer qual a cor utilizada em determinadas palavras. Quando são utilizadas palavras que retratam cores, mas que estão pintadas com outra cor (ex: utiliza-se a palavra "amarelo" pintada de verde), as pessoas tendem a hesitar, mas ao final, na maior parte das vezes, acabam respondendo corretamente. Intuitivamente, o respondente tende a responder que a cor é amarela, pois é forte a atração que a leitura da palavra evoca. No entanto, fazendo uso do Sistema 2, a sugestão imediatamente fornecida pelo Sistema 1 é corrigida. KAHNEMAN, Daniel; FREDERICK, Shane. Representativeness revisited: attribute substitution in intuitive judgment. In: GILOVICH, T.; GRIFFIN, D.; KAHNEMAN, D. (Ed.). Heuristics and biases: the psychology of intuitive judgment. New York: Cambridge University Press, 2002. p. 49-81. p. 57.

45 KAHNEMAN, Daniel. Rápido e devagar: duas formas de pensar. Rio de Janeiro: Objetiva, 2012. p. 34.

46 KAHNEMAN, Daniel. Rápido e devagar: duas formas de pensar. Rio de Janeiro: Objetiva, 2012. p. 59-60. 
cesso cognitivo pelo qual a pessoa, ao ser instada a responder a uma pergunta difícil, acaba por substituir esse questionamento por outro mais fácil, a fim de proferir a resposta. A pergunta complexa recebe a denominação de "pergunta-alvo", enquanto a pergunta mais simples, que a substitui, é chamada de "pergunta heurística". Como exemplo, Kahneman e Frederick imaginam o caso de um professor que ouviu uma entrevista de emprego de um candidato a professor e ao considerar a pergunta "qual é a probabilidade desse candidato ser contratado para atuar em nosso departamento?", a fim de facilitar a sua resposta, formula em sua mente como pergunta heurística o seguinte questionamento, muito mais simples para ser respondido: "quão impressionante foi a entrevista de emprego?". Com efeito, esse arranjo cognitivo é produzido pelo Sistema 1, podendo causar erros graves e sistemáticos, especialmente quando a pergunta heurística não corresponder à pergunta-alvo. No caso, como já visto, o erro será chancelado se o Sistema 2 não atuar para evitar as escolhas enviesadas. ${ }^{47}$

Foram estudados, até o momento, três temas que estão interconectados: a tomada de decisão, a Economia Comportamental e o sistema dual de pensamento. Com efeito, é justamente nesse contexto que inserimos a análise da tomada de crédito, bem como os perigos que a acompanham. O endividamento excessivo corresponde a um fenômeno complexo, causado por fatores estruturais e comportamentais. Em relação aos últimos, nos próximos tópicos, destacaremos a relação existente entre a Economia Comportamental e o Direito, oportunidade em que serão trabalhadas com maior profundidade as principais heurísticas e os vieses que podem estar relacionados com o superendividamento dos consumidores, estudos esses que poderão proporcionar novas perspectivas de enfrentamento do fenômeno.

\section{DiÁlogos ENTRE O DiREITO E A ECONOMIA COMPORTAMENTAL: POR QUE É IMPORTANTE COMPREENDER A FORMA COMO O CONSUMIDOR SE COMPORTA NO MERCADO DE CRÉDITO?}

Especialmente nas últimas duas décadas, a afirmação da Economia Comportamental tornou-se um fato incontestável. No entanto, o sucesso da disciplina, expresso por suas construções teóricas e empíricas, não se restringe aos campos da Economia e da Psicologia. Diante do seu propósito descritivo da realidade de detectar heurísticas e vieses, otimizando o processo de tomada de decisão, verifica-se, cada vez mais, a abrangência da Behavioral Economics para outras áreas do conhecimento, tais como os campos das Finanças, Publicidade, Políticas Públicas e o Direito.

Para o presente artigo, a análise da relação entre a Economia Comportamental e o Direito do Consumidor apresenta grande relevância, haja vista o reconhecimento de que o superendividamento corresponde a um problema de ordem estrutural e cultural, sendo as questões comportamentais, principalmente os erros de julgamento, importantes para uma compreensão mais abrangente das causas que levam a pessoa física a se endividar excessivamente, especialmente diante da tomada do crédito.

No entanto, antes de abordar os problemas cognitivos relacionados ao superendividamento, cumpre informar a maneira pela qual as teorias econômicas vêm sendo incorporadas ao ramo jurídico. A denominada Análise Econômica do Direito (AED) ou Law and Economics (LEE) corresponde a um método interpretativo aplicado ao Direito, em que prepondera a observação do custo-benefício e as consequências geradas pelas normas jurídicas e pelas políticas públicas perante a sociedade, oportunidade em que os juristas e economistas poderão avaliar o grau de eficiência das mesmas. ${ }^{48}$

Trata-se de uma aproximação entre os pensamentos jurídico e econômico, especialmente da utilização

47 KAHNEMAN, Daniel; FREDERICK, Shane. A model of heuristic judgment. In: HOLYOAK, Keith James; MORRISON, Robert G. The Cambridge handbook of thinking and reasoning. New York: Cambridge University Press, 2005. p. 267-294. p. 269-270.

48 OLIVEIRA, Amanda Flávio de; CASTRO, Bruno Braz de. Proteção do consumidor de crédito: uma abordagem a partir da economia comportamental. Revista de Direito do Consumidor, v. 93, p. 231-249, maio/jun. 2014. 
dos suportes teórico e empírico da Economia como forma de expansão dos horizontes do Direito. Enquanto o escopo desse último está na regulamentação do comportamento, visa à Economia analisar a tomada de decisão do ser humano em um mundo cujos os recursos são escassos e as escolhas geram consequências. De acordo com aqueles que empregam a metodologia da AED, a tradicional teoria jurídica, que perpassa os períodos do jusnaturalismo, do juspositivismo e hodiernamente do pós-positivismo, não consegue realizar explicações satisfatórias e suficientes em relação a determinados problemas que afetam os seres humanos e a sociedade de maneira geral, sobretudo porque o apego às formulações eminentemente teóricas não permite a análise das consequências e do grau de eficiência que as normas jurídicas, as decisões judiciais e as políticas públicas exercem sobre a vida das pessoas. ${ }^{49}$

Nesse sentido, Louis Kaplow e Steven Shavell, professores da Harvard Law School, informam que a AED visa, basicamente, responder a dois questionamentos: a) quais são os efeitos que as normas jurídicas geram sobre o comportamento dos seus destinatários; e b) se os mencionados efeitos gerados pelas normas jurídicas são de fato desejados pela sociedade..$^{50}$

Já sedimentada nos EUA, a AED tradicionalmente emprega a sua metodologia baseada nas seguintes postulações: a) os recursos existentes no mundo são escassos; b) as pessoas, ao realizarem as escolhas, acabam lidando com o custo de oportunidade, que corresponde a um trade-off ou um conflito entre os benefícios e os prejuízos que estão, necessariamente, implicados em cada tomada de decisão; c) ao sopesar os custos e os benefícios, os seres humanos optarão pelas decisões que irão maximizar o seu bem-estar, de modo que poderão alterar o comportamento caso recebam incentivos melhores (as pessoas respondem a incentivos). A partir desse comportamento maximizador por parte dos agentes econômicos ocorrido perante o mercado, as trocas por eles efetuadas chegarão a uma situação de equilíbrio. ${ }^{51}$

A descrição dos três postulados acima guarda total correspondência com a Teoria da Escolha Racional, de orientação microeconômica, que pretende observar a forma como os agentes econômicos comportam-se no mercado. Um dos principais defensores hodiernos da AED sob a perspectiva da Teoria da Decisão Racional é o jurista Richard Posner, grande expoente da tradicional Escola de Chicago, para o qual [...] "economics is the science of rational choice in a world — our world — in which resources are limited in relation to human wants". ${ }^{52}$ Portanto, para Posner e os defensores do método ora analisado, o objetivo principal da AED é justamente explorar a pressuposição de que o ser humano é um maximizador do seu próprio bem-estar, ou seja, de que age com base nos seus próprios interesses (selfinterest) e que sempre reagirá aos incentivos ofertados no mercado, alterando o seu comportamento para obter a maior satisfação ou felicidade individual, como expressões de sua força de vontade (willpower). ${ }^{53}$

Ainda a respeito do comportamento racional maximizador da utilidade, ou seja, da capacidade de o indivíduo escolher a melhor alternativa para o seu próprio interesse, Robert Cooter e Thomas Ulen, professores de Direito das Universidades de Berkeley e Illinois, respectivamente, afirmam:

Economists usually assume that each economic actor maximizes something: Consumers maximize utility (that is, happiness or satisfaction), firms maximize profits, politicians maximize votes, bureaucracies maximize revenues, charities maximize social welfare, and so forth. Economists often say that models assuming maximizing behavior work because most people are rational, and rationality requires maximization. One

49 GICO JR, Ivo T. Metodologia e epistemologia da análise econômica do direito. Economic Analysis of Law Review, v. 1, n. 1, p. 7-33 jan./jun. 2010.

50 KAPLOW, Louis; SHAVELL, Steven. Economic analysis of law. In: AUERBACH, Alan J.; FELDSTEIN, Martin (Ed.). Handbook of public economics. Rio de Janeiro: Elsevier, 2002. v. 3. p. 1666.

51 GICO JR, Ivo T. Metodologia e epistemologia da análise econômica do direito. Economic Analysis of Law Review, v. 1, n. 1, p. 7-33 jan./jun. 2010.

52 Tradução livre: [...] a economia é a ciência que estuda a escolha racional em um mundo - o nosso mundo - em que os recursos são limitados em relação às aspirações dos seres humanos. POSNER, Richard. Economic Analysis of law. 3 ed. Boston: Little, Brown and Company, 1986. p. 3.

53 POSNER, Richard. Economic analysis of law. 3 ed. Boston: Little, Brown and Company, 1986. p. 3-4. 
conception of rationality holds that a rational actor can rank alternatives according to the extent that they give her what she wants. In practice, the alternatives available to the actor are constrained. For example, a rational consumer can rank alternative bundles of consumer goods, and the consumer's budget constrains her choice among them. A rational consumer should choose the best alternative that the constraints allow. Another common way of understanding this conception of rational behavior is to recognize that consumers choose alternatives that are well suited to achieving their ends. ${ }^{54}$

No mesmo sentido, Alessio Pacces e Louis Visscher informam que a L\&E pode ser definida pela aplicação da teoria da decisão racional, o que implica três constatações: a) os seres humanos tomam decisões com base nas opções que lhes garantam a melhor satisfação ao atender às suas expectativas; b) as expectativas são avaliadas de acordo com todas as informações disponíveis; e c) as pessoas possuem a capacidade de reunir e utilizar uma quantidade ótima de informações. De acordo com os autores, a junção desses elementos explicaria a habilidade dos indivíduos em maximizar a utilidade por eles esperada. ${ }^{55}$

Dando seguimento à metodologia utilizada pela AED, Amanda Flávio de Oliveira e Bruno Braz de Castro informam que os seus seguidores utilizam a Teoria dos Preços e dos Mercados, a fim de analisar as consequências de uma norma jurídica ou de uma política pública. ${ }^{56}$ Sobre a aplicação dessas teorias, Richard Posner, observando a Lei da Demanda, destaca que há uma relação inversa entre o preço cobrado e a quantidade demandada, o que se explicaria pela pressuposição de que o consumidor é um sujeito racional e autointeressado. Por exemplo, se o preço do filé aumentar e o preço de outros cortes de carne permanecerem inalterados, o consumidor reagirá a esse incentivo averiguando a possibilidade de realizar a substituição do filé, posto que o preço dos demais cortes ficarão mais atrativos. Em relação aos preços, esses não necessitam ser monetariamente explícitos. Posner exemplifica com o caso dos professores impopulares, que pretendem aumentar o número de alunos interessados em suas classes elevando a média das notas dos estudantes. ${ }^{57}$

Dessa forma, adotando o consumidor como parâmetro a ser estudado, visto ser esse o objeto da presente pesquisa, tem-se que para a teoria da decisão racional incorporada pela AED tradicional, esse agente econômico seria plenamente capaz de separar as suas preferências daquilo que não lhe interessa, bem como processar e lidar de maneira satisfatória com todas as informações disponibilizadas, o que resultaria em escolhas ótimas em relação aos diversos produtos e serviços oferecidos pelos fornecedores no mercado de consumo. Em outras palavras, seria o consumidor capaz de exercer a autonomia da vontade em sua plenitude, de modo a obter o resultado prático dos seus interesses.

\subsection{A análise econômico-comportamental do direito}

A metodologia empregada pela Análise Econômica do Direito está diretamente relacionada ao debate travado entre os economistas neoclássicos e os economistas ou cientistas comportamentais. Ao adotar a

54 Tradução livre: Geralmente, os economistas presumem que cada ator econômico maximiza algo: os consumidores maximizam a utilidade (isto é, a felicidade ou a satisfação), as empresas maximizam os lucros, os políticos maximizam os votos, os burocratas maximizam a arrecadação, as instituições de caridade maximizam o bem-estar social e assim por diante. Os economistas costumam dizer que os modelos econômicos presumem a maximização do comportamento, porque a maioria das pessoas é racional e a racionalidade requer a maximização. Uma concepção da racionalidade sustenta que um ator racional pode classificar as alternativas de acordo com a amplitude em que elas lhe propiciarão o que ele quer. Na prática, as alternativas disponíveis para esse ator são limitadas. Por exemplo, um consumidor racional pode classificar pacotes alternativos de bens de consumo, sendo o seu orçamento um limitador para as suas escolhas. Um consumidor racional deve escolher a melhor alternativa que as restrições permitirem. Outra maneira comum de entender essa concepção do comportamento racional é reconhecer que os consumidores escolhem alternativas adequadas para alcançar os seus objetivos. COOTER, Robert; ULEN, Thomas. Law and economics, 6th ed. Berkeley Law Books, 2016. Disponível em: <http://scholarship.law.berkeley.edu/books/2/>. Acesso em: 07 nov. 2017.

55 PACCES, Alessio; VISSCHER. Louis. Methodology of law and economics. 2011. Disponível em: <https://repub.eur.nl/ pub/31466/>. Acesso em: 07 nov. 2017.

56 OLIVEIRA, Amanda Flávio de; CASTRO, Bruno Braz de. Proteção do consumidor de crédito: uma abordagem a partir da economia comportamental. Revista de Direito do Consumidor, v. 93, p. 231-249, maio/jun. 2014.

57 POSNER, Richard. Economic analysis of law. 3 ed. Boston: Little, Brown and Company, 1986. p. 4-5. 
Teoria da Decisão Racional, os defensores da Law and Economics acabam por assumir um discurso consubstanciado no pensamento econômico tradicional (mainstream), considerando os consumidores como sujeitos plenamente racionais, com capacidade para sempre tomar decisões maximizadoras do seu bem-estar.

De certa forma, a discussão retorna ao ponto inicial deste estudo, oportunidade em que foi demonstrada as diferenças entre o pensamento econômico neoclássico e o posicionamento crítico da Economia Comportamental. Nesse momento, cumpre deixar claro que o presente estudo concorda e adota as contribuições oferecidas por essa última disciplina, sobretudo porque considera o consumidor um sujeito vulnerável, completamente passível de ser afetado por erros de ordem comportamental, principalmente diante dos diversos desafios que encontra perante o mercado de consumo. Portanto, para que seja possível compreender corretamente e de forma realista a maneira como o consumidor é levado a fazer escolhas, importante é construir um modelo jurídico que leve em consideração as limitações cognitivas que atuam sobre os seres humanos de maneira geral.

Justamente com esse objetivo, tem ganhado força a denominada Análise Econômico-Comportamental do Direito ou Análise Econômica do Direito Comportamental, que se apresenta como uma vertente crítica da tradicional L\&E, já que os seus adeptos, apoiados pelas descobertas da Economia Comportamental, oportunizadas por pesquisadores como Daniel Kahneman, Amos Tversky, Richard Thaler, George Loewenstein, entre outros, discordam do modelo de racionalidade característico do "homem econômico neoclássico", haja vista que, em diversas circunstâncias, vários estudos comprovaram que o comportamento humano pode divergir sistematicamente daquele previsto pelo pensamento econômico tradicional.

De acordo com Christine Jolls, Cass Sunstein e Richard Thaler, a incorporação da Economia Comportamental tem o mérito de revigorar o Direito, respeitando as funções positiva, prescritiva e normativa que se espera de qualquer abordagem jurídica. Em relação ao aspecto positivo, visará à Análise Econômico-Comportamental de o Direito explicar os efeitos e o conteúdo das normas, perquirindo, dentre outras questões, o modo como elas podem afetar as escolhas dos indivíduos, a fim de se construir um entendimento mais completo e preciso sobre o comportamento humano. Quanto à análise prescritiva, trata-se de observar como as normas jurídicas e as políticas públicas podem ser utilizadas para que determinados objetivos sejam alcançados. Com a abordagem normativa, que ganha uma nova roupagem com os saberes da Behavioral Economics, visa-se obter uma visão mais satisfatória e ampla dos propósitos almejados pelo próprio sistema jurídico. ${ }^{58}$

Os supracitados autores, expoentes da Análise Econômico-Comportamental do Direito, partem da constatação de que as "pessoas reais" se diferenciam do "homem econômico neoclássico" em razão de três limitações que as caracterizam, sendo esses limites conflitantes com os seguintes postulados representativos do pensamento econômico tradicional: a) maximização da utilidade; b) preferências estáveis; c) expectativas racionais; e d) capacidade de processamento ótimo das informações. ${ }^{59}$

O primeiro limite é o da racionalidade limitada (bounded rationality), temática inicialmente abordada por Herbert Simon e depois aprofundada por Kahneman e Tversky. Como a própria semântica indica, trata-se da constatação de que os seres humanos apresentam limitações cognitivas naturais, o que os afasta do comportamento idealizado da maximização do bem-estar como regra. Para lidar com essas limitações, conforme já retratado na presente pesquisa, diversos experimentos e estudos constataram que as pessoas utilizam heurísticas — de maneira previsível — durante o processo decisório, situação essa que pode ser até útil em várias ocasiões, mas também desencadear erros sistemáticos — e não aleatórios — motivados por escolhas enviesadas. $^{60}$

58 JOLLS, Christine; SUNSTEIN, Cass R.; THALER, Richard. A behavioral approach to law and economics. Stanford Law Review, v. 50, p. 1471-1550, jul. 1998.

59 JOLLS, Christine; SUNSTEIN, Cass R.; THALER, Richard. A behavioral approach to law and economics. Stanford Law Review, v. 50, p. 1471-1550, jul. 1998.

60 JOLLS, Christine; SUNSTEIN, Cass R.; THALER, Richard. A behavioral approach to law and economics. Stanford Law Review, v. 50, p. 1471-1550, jul. 1998. 
O segundo limite é a força de vontade limitada (bounded willpower). No caso, trata-se da constatação de que as pessoas tendem a adotar comportamentos sabidamente contrários aos seus interesses a longo prazo. O exemplo dado pelos autores é o do fumante que tem plena ciência de que o cigarro é extremamente prejudicial à saúde, mas, mesmo assim, continua adotando o hábito de fumar. Existem formas de mitigar os efeitos negativos dessa limitação, como simplesmente evitando guardar doces e alimentos gordurosos em casa em períodos de dieta. ${ }^{61}$ Com o contínuo desenvolvimento da Economia Comportamental, atualmente, os pesquisadores têm identificado novas maneiras de evitar a procrastinação e a inércia, elementos que estão presentes na força de vontade limitada. Nesse sentido, a conceptualização da arquitetura da escolha com os chamados defaults, temática desenvolvida por Cass Sunstein e Richard Thaler, tem ganhado destaque enquanto referencial para a elaboração de políticas públicas mais eficientes.

Quanto ao terceiro limite retratado, trata-se do autointeresse limitado (bounded self-interest). Os autores destacam que essa limitação age, diretamente, sobre a função utilidade verificada no comportamento dos indivíduos, proporcionando uma visão mais ampla do que aquela disposta na teoria econômica neoclássica. De acordo com o modelo da Economia Comportamental, as pessoas preocupam-se em agir e serem tratadas de forma justa, mas desde que esse comportamento seja recíproco. Assim, Jolls, Sunstein e Thaler concluem que as pessoas podem ser tanto agradáveis quanto vingativas, o que resulta no auto interesse limitado, contraditando com a teoria econômica tradicional. Ilustrativamente, essa limitação pode manifestar-se quando uma pessoa adota um comportamento completamente contrário ao esperado, fazendo com que a outra parte disponha inclusive de recursos financeiros para punir a ação injusta. ${ }^{62}$

A presente pesquisa considera importante a incorporação dos três limites acima à abordagem jurídica. Reconhecer e identificar as limitações cognitivas do ser humano pode transformar positivamente o sistema jurídico, pois ao analisar os erros comportamentais — causados por heurísticas e vieses — sofridos e produzidos por agentes dos setores público e privado, torna-se possível otimizar a produção de políticas públicas e a edição de normas jurídicas, reduzindo os custos envolvidos nesse processo e aumentando a eficiência das medidas. Por exemplo, a constatação de que os consumidores são influenciados por campanhas de marketing que visam desencadear um aumento excessivo do otimismo deve ser um fato a ser considerado em uma legislação que visa à proibição da publicidade agressiva como forma de prevenir o superendividamento ou para a elaboração de uma política pública educativa.

No entanto, merece atenção a análise feita por Jon D. Hanson e Douglas A. Kysar, professores de Direito nas Universidades de Harvard e Yale, respectivamente. De acordo com os autores, indubitavelmente a incorporação dos aspectos comportamentais ao Direito por parte dos defensores da AED comportamental representou um grande avanço, possibilitando um olhar mais realista das escolhas que as pessoas realizam em suas vidas. Porém, é importante registrar que esses mesmos defensores ainda estão muito ligados ao modelo tradicional da $L \& E$, o que os leva a isolar os problemas comportamentais como se fossem relacionados, apenas, à tomada de decisão propriamente dita, impossibilitando o reconhecimento de que juntamente às heurísticas e os vieses, estão, os seres humanos suscetíveis a outro acontecimento: serem manipulados pelo mercado.

This Article contributes to that reassessment by focusing on the problem of manipulability. Our central contention is that the presence of unyielding cognitive biases makes individual decisionmakers susceptible to manipulation by those able to influence the context in which decisions are made. More particularly, we believe that market outcomes frequently will be heavily influenced, if not determined, by the ability of one actor to control the format of information, the presentation of choices, and, in general, the setting within which market transactions occur. Once one accepts that individuals systematically behave in nonrational

61 JOLLS, Christine; SUNSTEIN, Cass R.; THALER, Richard. A behavioral approach to law and economics. Stanford Law Review, v. 50, p. 1471-1550, jul. 1998.

62 JOLLS, Christine; SUNSTEIN, Cass R.; THALER, Richard. A behavioral approach to law and economics. Stanford Law Review, v. 50, p. 1471-1550, jul. 1998. 
ways, it follows from an economic perspective that others will exploit those tendencies for gain. ${ }^{63}$

É importante a constatação de que não são apenas e tão somente as questões comportamentais que causam o endividamento excessivo, mas também, e principalmente, a maneira como esses problemas cognitivos são explorados por agentes que detêm o poderio econômico e o domínio sobre a informação útil em face da pessoa física consumidora, pois, acima de tudo, ilustra a forma como a vulnerabilidade desse último sujeito é agravada no mercado de consumo. ${ }^{64}$

De acordo com Hanson e Kysar, o pouco interesse dos defensores da AED comportamental em analisar o tema da manipulação pode ser explicado pelos seguintes fatores: a) em primeiro lugar, muitos estudiosos entendem que o problema da manipulação não corresponde de fato à uma preocupação da Economia Comportamental, posto que os autores pioneiros, como Kahneman e Tversky, não realizaram estudos nesse sentido; b) em segundo lugar, em que pese os pontos positivos da contribuição crítica da AED comportamental com a incorporação do aspecto cognitivo que contradiz o modelo idealizado do "homem econômico", são os seus adeptos ainda bastante influenciados pelas ferramentas tradicionais utilizadas pela AED clássica. ${ }^{6566}$

Sobre o primeiro fator, o estudo ora realizado compreende como sendo um equívoco não atentar para o problema da manipulação do mercado e como ela se relaciona com as ilusões cognitivas, tendo como justificativa não ser esse um assunto abordado pelos principais autores que foram responsáveis pela afirmação da Economia Comportamental. Quando Kahneman, Tversky e outros estudiosos abriram os caminhos para o surgimento da disciplina, a preocupação era eminentemente no sentido de desenvolver uma teoria científica descritiva, capaz de agregar ao pensamento econômico tradicional a constatação de que os seres humanos baseiam as suas decisões em diversas heurísticas, que são estratégias cognitivas úteis, mas que também podem gerar erros sistemáticos e previsíveis graves (vieses). Portanto, não estavam esses autores preocupados em repercutir os seus estudos em relação a outras áreas do saber. ${ }^{67} \mathrm{Na}$ realidade, essa preocupação surgiu logo em seguida, quando os representantes de outras disciplinas atentaram para a importância das novas descobertas para as suas respectivas áreas de atuação.

Quanto ao segundo fator, de acordo com Hanson e Kysar, o apego às ferramentas tradicionais da AED clássica leva os defensores da AED comportamental a cometerem o seu principal equívoco. Para eles, as

63 Tradução livre: Este artigo contribui com essa reapreciação do tema, focando no problema da manipulação. A nossa discórdia central está no fato de que a presença das ilusões cognitivas inflexíveis torna os tomadores de decisões individuais suscetíveis à manipulação por aqueles que são capazes de influenciar o contexto em que as decisões são tomadas. Mais particularmente, acreditamos que os resultados do mercado serão fortemente influenciados, se não determinados, pela capacidade de um ator controlar o formato da informação, a apresentação das opções e, em geral, a configuração em que as transações de mercado ocorrem. Dado que as pessoas se comportam, sistematicamente, de maneira não racional, é possível inferir a partir de uma perspectiva econômica que outros sujeitos explorarão as tendências informadas acima em proveito próprio. HANSON, Jon D.; KYSAR, Douglas A. Taking behavioralism seriously: the problem of market manipulation. New York University Law Review, v. 74, n. 3, p. 630-749, jun. 1999. 64 Nos EUA, uma das principais tarefas da Agência de Proteção Financeira ao Consumidor é utilizar as ferramentas da Economia Comportamental como forma de coibir a exploração do consumidor pelos demais agentes econômicos atuantes no mercado. "Bad consumer deals, often structured using complicated and nasty terms buried in long forms, are an old problem, and the law has long struggled to find adequate tools to deal with them.1 Thus, it comes as good news that the fledgling Consumer Financial Protection Bureau (CFPB) is honing a brand new tool handed to it by Congress: the concept of abusive practices. 2 Using insights from behavioral economics, the CFPB is paying close attention to the substance of consumer financial products - that is, to whether consumers are being exploited. The new anti-abuse authority shows promise, particularly because the CFPB has incorporated this authority into its examination standards, which can be used to pressure financial institutions to stop employing exploitative practices and to identify practices to target in its enforcement actions". BRAUCHER, Jean. Form and substance in consumer financial protection. Brook. J. Corp. Fin. \& Com. L., v. 7, p. 107-129, 2012.

65 HANSON, Jon D.; KYSAR, Douglas A. Taking behavioralism seriously: the problem of market manipulation. New York. University Law Review, v. 74, n. 3, p. 630-749, jun. 1999.

66 A respeito do segundo fator, veja-se: "The unifying idea in our analysis is that behavioral economics allows us to model and predict behavior relevant to law with the tools of traditional economic analysis, but with more accurate assumptions about human behavior, and more accurate predictions and prescriptions about law. JOLLS, Christine; SUNSTEIN, Cass R.; THALER, Richard. A behavioral approach to law and economics. Stanford Law Review, v. 50, p. 1471-1550, jul. 1998.

67 HANSON, Jon D.; KYSAR, Douglas A. Taking behavioralism seriously: the problem of market manipulation. New York University Law Review, v. 74, n. 3, p. 630-749, jun. 1999. 
ilusões cognitivas seriam elementos exógenos em relação ao comportamento individual das pessoas, ou seja, a influência das heurísticas e dos vieses sobre o comportamento humano seria vista de maneira estanque e fixa, não sendo elas afetadas por outros fatores, como a estratégia de manipulação publicitária adotada por determinados agentes econômicos atuantes no mercado. ${ }^{68}$

Nesse sentido, os autores informam que uma devida incorporação da Economia Comportamental ao Direito deveria resultar em uma reestruturação mais abrangente desse último. Dessa forma, os elementos comportamentais que influenciam a tomada de decisão individual devem ser vistos de maneira endógena, ou seja, os problemas de ordem cognitiva influenciam não apenas o comportamento dos seres humanos, mas também podem servir como incentivo para a atuação estratégica de outros agentes econômicos. Ilustrativamente, determinados agentes com capacidade para gerir a disponibilização da informação poderiam influenciar o comportamento dos consumidores, explorando determinado viés em benefício próprio, manifestando-se, assim, o seu poder de manipulação, normalmente exercido por meio de expedientes como a publicidade, a precificação dos produtos e serviços, bem como a utilização de promoções chamativas visando ao incentivo ao consumo. ${ }^{69}$

Por fim, cumpre reconhecer que aproximação entre o Direito e a Economia Comportamental, certamente, corresponde a uma das principais novidades que contribuem com a necessária renovação do pensamento jurídico, principalmente diante do constante surgimento de novos desafios, que tornam a atividade dos juristas cada vez mais complexa. O olhar realista para a tomada de decisão e para as suas consequências, somado à defesa dos valores e princípios fundamentais que regem a ordem jurídica do Estado, contribuem com o aprimoramento da produção normativa e a formulação de políticas públicas, permitindo uma melhor aferição da eficiência dessas medidas para a sociedade. Nesse sentido, a Análise Econômico-Comportamental do Direito tem muito a oferecer para o estudo e prática do Direito no Brasil, mas desde que a sua incorporação ocorra de maneira ampla, com o reconhecimento de que as ilusões cognitivas agravam a vulnerabilidade do consumidor pessoa física, seja porque afeta a sua capacidade de julgamento, seja porque podem ser exploradas em benefício de determinados agentes econômicos que se posicionam de maneira dominante no mercado de consumo.

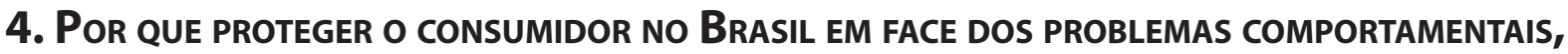 SE VIVEMOS EM UMA ECONOMIA DE MERCADO?}

A partir de uma simples leitura do art. 170 da Constituição da República de 1988, que trata da ordem econômica e financeira do Estado, fica evidente que o Brasil adotou o capitalismo como sistema econômico, instrumentalizado por meio de um modelo de economia de mercado, sob o qual participam diversos agentes econômicos, norteados pelas garantias da livre iniciativa e da valorização do trabalho humano.

De acordo com Amanda Flávio de Oliveira, é interessante notar que a Constituição Federal de 1988, fruto do constitucionalismo contemporâneo do segundo pós-guerra, conjuga tanto normas características do Estado Liberal quanto do Estado Social, o que, de maneira alguma, descaracteriza o sistema capitalista adotado. Dessa forma, conjuntamente ao direitos civis e políticos, convivem, harmonicamente, os direitos sociais e econômicos, todos eles incorporados ao ordenamento jurídico, que adota a dignidade da pessoa humana como fundamento a ser observado no âmbito das diversas relações jurídicas. ${ }^{70}$

68 HANSON, Jon D.; KYSAR, Douglas A. Taking behavioralism seriously: the problem of market manipulation. New York University Law Review, v. 74, n. 3, p. 630-749, jun. 1999.

69 HANSON, Jon D.; KYSAR, Douglas A. Taking behavioralism seriously: the problem of market manipulation. New York University Law Review, v. 74, n. 3, p. 630-749, jun. 1999.

70 OLIVEIRA, Amanda Flávio de. Desenvolvimento econômico, capitalismo e direito do consumidor no Brasil: afastando o argumento de "paternalismo jurídico". Revista de Direito do Consumidor, v. 108, p. 243-263, nov./dez. 2016. 
Em relação aos direitos sociais ${ }^{71}$ e econômicos, o Direito do Consumidor recebeu atenção especial e expressa por parte do constituinte, sendo elencado como um princípio da ordem econômica limitador da livre iniciativa, nos termos do inciso V, do artigo 170 da CRFB, tendo em vista a disparidade de forças existente entre os consumidores e os fornecedores de produtos e serviços atuantes no mercado. Para garantia desse desiderato, foi estabelecido o dever do Estado em promover a defesa do consumidor (art. $5^{\circ}$, XXXII), especialmente com a edição de um código específico, conforme determinação do art. 48 do Ato das Disposições Constitucionais Transitórias - ADCT.

Atendendo ao mandamento constitucional, no dia 11 de setembro de 1990, foi publicada a lei $\mathrm{n}^{\circ} 8.078$, mais conhecida como Código de Defesa do Consumidor, estatuindo normas de ordem pública voltadas à defesa e proteção do consumidor no Brasil. No artigo $4^{a}$ do CDC, foi incorporada a política nacional de relações de consumo, ${ }^{72}$ estabelecendo "O atendimento das necessidades dos consumidores, o respeito à sua dignidade, saúde e segurança, a proteção de seus interesses econômicos, a melhoria da sua qualidade de vida, bem como a transparência e harmonia das relações de consumo". No inciso I, o legislador tratou de um dos princípios mais importantes da disciplina, qual seja o Princípio da Vulnerabilidade, reconhecendo, expressamente, que o consumidor é um sujeito vulnerável no mercado de consumo.

Em relação à vulnerabilidade, destaca-se que o CDC adota uma presunção de que o consumidor pessoa física e não profissional é um sujeito vulnerável, o que não ocorre com as pessoas jurídicas e os profissionais, já que ambos, via de regra, possuem melhores condições para obter os conhecimentos necessários a respeito das questões jurídicas e econômicas. A vulnerabilidade, que consiste na necessidade de o Direito passar a tutelar positivamente "o diferente", que é aquele que se encontra em uma situação de fraqueza frente à relação jurídica, visando assim equilibrar a disparidade de forças nela verificada, deve ser entendida como corolário do Princípio da Igualdade Material, evidenciando a sua matriz constitucional. ${ }^{73}$

Tradicionalmente, a vulnerabilidade tem sido subdividida de acordo com os seguintes aspectos: técnica, jurídica, fática e informacional. ${ }^{74} \mathrm{~A}$ vulnerabilidade técnica expressa-se pelo menor conhecimento do consumidor em relação ao fornecedor sobre as características e aproveitamento dos produtos ou serviços adquiridos ${ }^{75}$ sendo ela presumida, apenas, para o consumidor não profissional. Trata-se de fato incontestável, que, inclusive, pode gerar prejuízos ao consumidor, já que por ter um menor conhecimento técnico sobre o produto adquirido ou o serviço prestado, a possibilidade de ser ludibriado pelo parceiro contratual amplia-se consideravelmente.

71 A respeito da importância de se adotar a técnica hermenêutica adequada para a utilização dos direitos sociais perante a globalização econômica, em que se destaca a proteção do consumidor. FARIA, José Eduardo. O direito na economia globalizada. São Paulo: Malheiros, 2004. p. 277.

72 A respeito da política nacional de defesa do consumidor, Amanda Flávio de Oliveira informa que a sua construção começou antes mesmo do mandamento constitucional que ordenou a criação do CDC ter sido editado, tratando-se de um movimento que nasceu em razão de manifestação espontânea da sociedade civil. Veja-se: "Por sua vez, a política nacional de defesa do consumidor surgiu e se desenvolveu, no País, antes mesmo do reconhecimento constitucional do direito correlato. Mesmo em um cenário normativo hostil (os contratos eram regidos pelo Código Civil de 1916, claramente inspirado em ideais liberais), a sociedade civil organizou-se em associações de proteção do consumidor (a primeira associação, de Porto Alegre, data de 1975), o Ministério Público criou promotorias especializadas (década de 1980) e foram criados órgãos públicos vocacionados à tutela do consumidor (o primeiro Procon, de São Paulo, é de 1976). Na origem espontânea do movimento consumerista, no seio da sociedade civil, talvez repouse a razão do decantado êxito da política que se institucionalizaria em nível constitucional anos depois: a proteção do consumidor no Brasil surgiu, efetivamente, de um anseio social claro $^{41}$ e contém elementos que tornam essa política pública única se comparada com políticas de defesa do consumidor adotadas e implementadas em outros países capitalistas". OLIVEIRA, Amanda Flávio de. Desenvolvimento econômico, capitalismo e direito do consumidor no Brasil: afastando o argumento de "paternalismo jurídico". Revista de Direito do Consumidor, v. 108, p. 243-263, nov./dez. 2016.

73 MARQUES, Cláudia Lima; MIRAGEM, Bruno. O novo direito privado e a proteção dos vulneráveis. 2. ed. São Paulo: Revista dos Tribunais, 2014. p. 164.

74 MARQUES, Cláudia Lima; MIRAGEM, Bruno. O novo direito privado e a proteção dos vulneráveis. 2. ed. São Paulo: Revista dos Tribunais, 2014. p. 156.

75 PRUX, Oscar Ivan. O direito do consumidor em tempos de crise econômica persistente: problemática das relações entre fornecedores e consumidores. Revista de Direito do Consumidor, v. 89, p. 59-106, set./out. 2013. 
A vulnerabilidade jurídica ou científica retrata a presunção de que o consumidor pessoa física e não profissional apresenta um conhecimento limitado ou mesmo inexistente sobre questões jurídicas, contábeis e econômicas, o que o coloca, via de regra, em posição de desvantagem em relação ao fornecedor, sobretudo diante das relações contratuais massificadas, normalmente travadas por meio de contratos de adesão. ${ }^{76}$ Como bem destacam Cláudia Lima Marques e Bruno Miragem, essa forma de vulnerabilidade é característica dos contratos de empréstimo bancário e financiamento, em que a complexidade das cláusulas contratuais, que englobam questões atinentes a juros, formas de dedução das parcelas, multas, entre outros assuntos, dificulta o entendimento do consumidor, podendo levá-lo a se vincular a um contrato efetivamente não satisfatório para o seu melhor interesse, muitas vezes até mesmo lesivo. ${ }^{77}$

Tendo em vista que é o superendividamento dos consumidores pessoas físicas é o objeto do presente estudo, vale registrar que o reconhecimento da vulnerabilidade jurídica torna-se condição primordial básica para a tutela desse sujeito de direito, principalmente porque o endividamento excessivo está diretamente relacionado com o crédito, o que nos leva a concluir que o parceiro contratual do indivíduo superendividado em grande parte dos casos, pode ser representado pelas instituições financeiras ou empresas de médio a grande porte, que possuem obviamente melhores condições para a contratação de assessorias jurídicas ou contábeis.

A vulnerabilidade fática ou socioeconômica manifesta-se pela disparidade existente entre o consumidor - especialmente a pessoa física não profissional - e o fornecedor de produtos e serviços, marcada normalmente pela fragilidade do primeiro em contraste com o maior poderio econômico do segundo, capaz, por esse motivo, de se impor perante as relações de consumo a partir de "sua posição de monopólio, fático ou jurídico", ou mesmo em razão da "essencialidade do serviço" prestado. ${ }^{78}$ Os contratos de adesão ilustram essa forma de vulnerabilidade, pois impedem qualquer tentativa de negociação das cláusulas, sendo dirigidos de maneira massificada ao conjunto da sociedade.

Quanto à vulnerabilidade informacional, a princípio, poder-se-ia pensar que seria ela a constatação de que os consumidores detêm menos informações importantes do que os fornecedores, o que indubitavelmente corresponde a uma realidade, ao menos via de regra, conforme já analisado acima. No entanto, a própria vulnerabilidade técnica já pressupõe o problema da informação como algo que caracteriza e marca o consumidor frente ao seu parceiro contratual, tornando-se injustificável a separação entre as duas espécies de vulnerabilidade sob essa fundamentação.

Por outro lado, se o consumidor sofre, naturalmente, com um déficit de informação em relação ao fornecedor de produtos e serviços, paradoxalmente, com o desenvolvimento contínuo dos meios de comunicação, com destaque para a internet e as redes sociais, é preciso reconhecer que as pessoas nunca tiveram tanto acesso à informação como ocorre hodiernamente. Porém, como bem apontam Cláudia Lima Marques e Bruno Miragem, além de abundante, a informação também é "manipulada, controlada e, quando fornecida, no mais das vezes, desnecessária". ${ }^{79}$ São justamente essas características que evocam a necessidade de consideração da existência da vulnerabilidade informacional, cujo reconhecimento encontra respaldo no princípio da dignidade da pessoa humana.

A questão da informação tornou-se tão complexa em nossa sociedade de consumo, que fala-se na existência de uma hipervulnerabilidade do consumidor, ${ }^{80}$ que, apesar de ser constantemente "informado" pelos

76 PAIVA, Rafael Augusto de Moura. Repensando o "ser" consumidor. Revista de Direito do Consumidor, v. 88, p. 103-142, jul./ ago. 2013.

77 MARQUES, Cláudia Lima; MIRAGEM, Bruno. O novo direito privado e a proteção dos vulneráveis. 2. ed. São Paulo: Revista dos Tribunais, 2014. p. 157-159.

78 MARQUES, Cláudia Lima; MIRAGEM, Bruno. O novo direito privado e a proteção dos vulneráveis. 2. ed. São Paulo: Revista dos Tribunais, 2014. p. 160.

79 MARQUES, Cláudia Lima; MIRAGEM, Bruno. O novo direito privado e a proteção dos vulneráveis. 2. ed. São Paulo: Revista dos Tribunais, 2014. p. 160.

80 Veja-se a seguinte decisão do STJ: Recurso especial. Direito do consumidor. Ação indenizatória. Propaganda enganosa. 
fornecedores, principalmente por meio de campanhas publicitárias, muitas vezes, na realidade, acaba sendo manipulado pelo parceiro contratual, que, ao fim e ao cabo, é aquele que realmente possui acesso à informação, e o mais relevante, à informação que de fato é importante para a relação de consumo, sobretudo para o seu desfecho positivo: a aquisição do produto ou do serviço. Esse poder à disposição do fornecedor pode se tornar uma completa fraude aos direitos consumeristas, principalmente se os deveres de fidúcia que acompanham a boa-fé objetiva não forem devidamente observados pelos fornecedores no plano contratual prático, expondo uma violação inconteste do princípio da igualdade substancial, fundamental para equilibrar as relações entre os agentes econômicos sob análise.

Reforçando as características multifacetada e aberta da vulnerabilidade, Fernando Rodrigues Martins e Keila Pacheco Ferreira defendem a necessidade de consideração de uma nova subespécie do princípio, qual seja, a vulnerabilidade financeira, que por oportuno, guarda direta relação com todas as espécies acima trabalhadas. Para os autores, essa forma de vulnerabilidade pode ser observada em duas ocasiões: a) em relação aos negócios jurídicos cujo o objeto é caracterizado pela promoção ilícita do lucro fácil; ou b) em face dos negócios jurídicos ainda não regulados no âmbito legislativo, sendo um dos principais exemplos as empresas de marketing multinivel, muitas vezes relacionadas com esquemas de pirâmides financeiras no Brasil e em outros países, sendo ambos os casos prejudiciais à economia popular, vista como um bem fundamental, imprescindível para a estabilidade da sociedade. ${ }^{81}$

Paulo Valério Dal Pai Moraes também destaca a existência de uma vulnerabilidade política ou legislativa, ${ }^{82}$ caracterizada pela maior influência política exercida por determinados agentes econômicos, visando à prevalência dos seus interesses, inclusive sobre o grupo social. No caso, em decorrência do lobby praticado nas Casas Legislativas por certos grupos representativos de determinados agentes econômicos atuantes no mercado, a aprovação ou rejeição das proposições legislativas se torna uma forma de perpetuação do status quo, dificultando sobremaneira a participação política de grupos como os dos consumidores, que muitas vezes são incapazes de se organizar para lutar por suas reivindicações.

Veja-se, portanto, que a temática da vulnerabilidade é extremamente rica e aberta, no sentido de possibilitar e exigir do jurista contemporâneo a identificação de determinados grupos presentes na sociedade, que, em decorrência de suas fraquezas, demandam a tutela jurídica calcada na proteção da pessoa humana, resultando no reconhecimento de novos sujeitos de direito, protegidos pelo princípio constitucional da igualdade material.

Cogumelo do sol. Cura do câncer. Abuso de direito. Art. 39, inciso iv, do CDC. Hipervulnerabilidade. Responsabilidade objetiva. Danos morais. Indenização de vida. Dissídio jurisprudencial comprovado.

1. Cuida-se de ação por danos morais proposta por consumidor ludibriado por propaganda enganosa, em ofensa a direito subjetivo do consumidor de obter informações claras e precisas acerca de produto medicinal vendido pela recorrida e destinado à cura de doenças malignas, dentre outras funções. 2. O Código de Defesa do Consumidor assegura que a oferta e apresentação de produtos ou serviços propiciem informações corretas, claras, precisas e ostensivas a respeito de características, qualidades, garantia, composição, preço, garantia, prazos de validade e origem, além de vedar a publicidade enganosa e abusiva, que dispensa a demonstração do elemento subjetivo (dolo ou culpa) para sua configuração. 3. A propaganda enganosa, como atestado pelas instâncias ordinárias, tinha aptidão a induzir em erro o consumidor fragilizado, cuja conduta subsume-se à hipótese de estado de perigo (art. 156 do Código Civil). 4. A vulnerabilidade informacional agravada ou potencializada, denominada hipervulnerabilidade do consumidor, prevista no art. 39, IV, do CDC, deriva do manifesto desequilíbrio entre as partes. 5. O dano moral prescinde de prova e a responsabilidade de seu causador opera-se in re ipsa em virtude do desconforto, da aflição e dos transtornos suportados pelo consumidor. 6. Em virtude das especificidades fáticas da demanda, afigura-se razoável a fixação da verba indenizatória por danos morais no valor de $\mathrm{R} \$ 30.000,00$ (trinta mil reais). 7. Recurso especial provido. BRASIL. Superior Tribunal de Justiça. Recurso Especial. REsp 1329556/SP. Terceira Turma. Rel.: Ministro Ricardo Villas Bôas Cueva. Brasília, 25 de novembro de 2014. Disponível em: <https://stj.jusbrasil.com.br/jurisprudencia/157527150/recurso-especial-resp-1329556-sp-2012-0124047-6/relatorio-e-voto157527162 ? ref=juris-tabs>. Acesso em: 21 jun. 2018.

81 MARTINS, Fernando Rodrigues; FERREIRA, Keila Pacheco. Vulnerabilidade financeira e economia popular: promoção de bem fundamental social em face da prática de institutos lucrativos ilusórios: das pirâmides ao marketing multinível. Revista de Direito do Consumidor, v. 98, p. 105-134, mar./abr. 2015.

82 MORAES, Paulo Valério Dal Pai. Código de Defesa do Consumidor: o princípio da vulnerabilidade no contrato, na publicidade e nas demais práticas comerciais: interpretação sistemática do direito. Porto Alegre: Livraria do Advogado, 2009. 
Nesse sentido, o presente estudo está de acordo com todas as vertentes do princípio da vulnerabilidade trabalhadas acima. No entanto, partindo das relevantes contribuições ofertadas pelas pesquisas em Economia Comportamental, já amplamente analisadas, cumpre concordar com os estudos que defendem a existência de uma outra manifestação da vulnerabilidade, ínsita à condição humana. Trata-se da vulnerabilidade cognitiva ou comportamental, ${ }^{83}$ ilustrativa da racionalidade limitada que caracteriza o comportamento do consumidor, exposto às diversas heurísticas e vieses durante o processo de tomada de decisão, situação essa capaz de gerar problemas graves e previsíveis, em especial, o superendividamento.

Com efeito, retoma-se nesse ponto a discussão já enfrentada sobre a Análise Econômico-Comportamental do Direito, que, em relação à proteção do consumidor no mercado de consumo, mais do que útil, tem se mostrado imprescindível para a obtenção de uma tutela mais eficaz e abrangente em relação a esse sujeito de direito, já que a sua vulnerabilidade não pode ser destacada do aspecto cognitivo, posto que o consumidor está a todo momento diante da necessidade de tomar decisões complexas — que impactarão a sua vida —, escolhas que poderão se desviar completamente do modelo de racionalidade defendido pelas correntes neoclássicas. ${ }^{84}$

Veja-se, novamente, que o reconhecimento da vulnerabilidade comportamental também guarda direta relação com o problema da manipulação do mercado, tema estudado no tópico anterior a partir da análise feita por Jon Hanson e Douglas Kysar. A prevenção do superendividamento por meio de modelos legislativos ou pela promoção de políticas públicas não pode prescindir do reconhecimento de que o consumidor está constantemente exposto às estratégias publicitárias por parte dos fornecedores, que ao identificar os principais problemas cognitivos que o afeta, muitas vezes acabarão por explorá-los visando, imediatamente, ao consumo dos produtos e serviços.

A temática ora analisada vem ganhando cada vez mais destaque no Brasil, principalmente no campo do Direito do Consumidor. Ronaldo Porto Macedo Júnior, já no início da década passada, reconhecia que a "racionalidade limitada" é própria do ser humano, sendo ela um impeditivo para o processamento ótimo de todas as informações disponíveis e para a previsão de problemas futuros, sendo essa situação agravada diante da tomada de decisões complexas. Para o autor, "[...] esse conceito é de fundamental importância para a regulação dos contratos de consumo", já que muitas vezes o consumidor realiza negócios jurídicos a longo prazo - como os contratos relacionais —, envolvendo assuntos complexos, tais como os contratos de crédito e de prestação de serviços. ${ }^{85}$

No mesmo sentido, Amanda Flávio de Oliveira e Diógenes Faria de Carvalho ressaltam os benefícios que a Economia Comportamental pode oportunizar para os estudos consumeristas.

Particularmente para o direito do consumidor brasileiro, a perspectiva de uma racionalidade limitada do agente econômico é capaz de produzir um impacto significativo na compreensão do princípio da vulnerabilidade, ponto fulcral da lei. Evidencia-se, assim, mais um relevante fundamento para a ainda debatida condição de fragilidade necessária em que se encontra o consumidor na relação jurídica que estabelece com o fornecedor. ${ }^{86}$

Portanto, o presente estudo compreende como crucial o reconhecimento da vulnerabilidade cognitiva

83 OLIVEIRA, Amanda Flávio de; FERREIRA, Felipe Moreira dos Santos. Análise econômica do direito do consumidor em períodos de recessão: uma abordagem a partir da economia comportamental. Revista de Direito do Consumidor, v. 81, p. 13-38, jan./mar. 2012.; OLIVEIRA, Amanda Flávio de; CARVALHO, Diógenes Faria de. Vulnerabilidade comportamental do consumidor: por que é preciso proteger a pessoa superendividada. Revista de Direito do Consumidor, v. 104, p. 181-201, mar./abr. 2016.

84 RAMSAY, Iain. Acess to credit in the alternative consumer credit market. Paper prepared for: Office of consumer affairs, industry Canada and ministry of the attorney general. British Columbia, 2000. Disponível em: <https://www.ic.gc.ca/eic/site/cmccmc.nsf/rwapj/ramsay_e.pdf/\$FILE/ramsay_e.pdf>. Acesso em: 26 nov. 2017.

85 MACEDO JÚNIOR, Ronaldo Porto. Direito à informação nos contratos relacionais de consumo. Revista de Direito do Consumidor, v. 35, p. 113-122, jul./set. 2000.

86 OLIVEIRA, Amanda Flávio de; CARVALHO, Diógenes Faria de. Vulnerabilidade comportamental do consumidor: por que é preciso proteger a pessoa superendividada. Revista de Direito do Consumidor, v. 104, p. 181-201, mar./abr. 2016. 
do consumidor, principalmente para que seja possível alcançar uma tutela mais efetiva e ampla desse sujeito de direito, conforme espera-se desse novo Direito Privado que emerge no Brasil com a Constituição da República de 1988, guiado pelo fundamento da dignidade da pessoa humana. Ademais, trata-se de uma temática cuja cientificidade é incontestável, ${ }^{87}$ comprovada por meio de diversos estudos empíricos e teóricos no campo da Economia Comportamental, estudos esses que podem auxiliar o Estado e a sociedade civil de diversas maneiras.

\section{Principais heurísticas e Vieses que podem Ser relacionados ao superendividamento}

O superendividamento dos consumidores está diretamente relacionado ao crédito ao consumo. Muito mais do que um problema apenas jurídico, trata-se de um fenômeno que gera consequências econômicas, financeiras e sociais, sendo causado por fatores estruturais e culturais (comportamentais), demandando uma análise interdisciplinar para uma perspectiva mais ampla e eficiente.

Dessa forma, para que o endividamento excessivo seja enfrentado de maneira satisfatória, deve o jurista compreender que uma proposta eminentemente legalista, consubstanciada apenas na necessidade de regulamentação legal do mercado de crédito e de adoção de um modelo processual para tratamento dos casos já constatados, não seria capaz de abarcar o problema em toda a sua complexidade, já que os erros cognitivos, também, causam o superendividamento, sobretudo na sociedade de consumo hodierna.

Nos Estados Unidos, na Europa e no Brasil, já existem importantes estudos que adotam as contribuições da Economia Comportamental para uma abordagem mais realista e eficiente do problema do endividamento excessivo, especialmente para a identificação das principais causas do fenômeno que estão relacionadas com as heurísticas, os vieses e as ilusões cognitivas, o que propicia conhecimentos extremamente importantes para a edição de modelos preventivos, de tratamento e promoção de políticas públicas mais assertivas. Com esse intuito, logo abaixo, serão abordados os principais erros comportamentais relacionados ao superendividamento, quais sejam: o otimismo excessivo, a ilusão do controle, a superconfiança, a heurística da disponibilidade e as decisões intertemporais.

O viés do otimismo excessivo tem sido elencado como um dos problemas cognitivos que mais afetam o julgamento dos seres humanos. Desde os estudos iniciais de Neil D. Weinstein ${ }^{88}$ até hodiernamente, diversos experimentos têm confirmado a existência desse viés, que pode ser explicado como uma espécie de supervalorização da ocorrência de resultados positivos decorrentes de eventos externos por parte das pessoas, resultados esses que na realidade podem não ocorrer na prática, não havendo garantias mínimas ou seguras para tanto.

De acordo com os juristas Ron Harris e Einat Albin, as primeiras ações governamentais visando reduzir os prejuízos causados pelo otimismo excessivo ocorreram na área da saúde pública, especialmente por meio de políticas públicas visando a redução de hábitos prejudiciais, como o fumo e o consumo de bebidas alcoólicas, posto que as pessoas tendem a acreditar que os problemas de saúde decorrentes desses hábitos não ocorrerão com elas, em que pese estarem cientes dos malefícios envolvidos no uso. Posteriormente, o mencionado viés passou a ser relacionado com a concessão do crédito, destacando-se os estudos que analisaram a forma como esse problema cognitivo afetava a decisão de estudantes universitários, cujo acúmulo

87 OLIVEIRA, Amanda Flávio de; FERREIRA, Felipe Moreira dos Santos. Análise econômica do direito do consumidor em períodos de recessão: uma abordagem a partir da economia comportamental. Revista de Direito do Consumidor, v. 81, p. 13-38, jan./ mar. 2012.

88 "According to popular belief, people tend to think they are invulnerable. They expect others to be victims of misfortune, not themselves. Such ideas imply not merely a hopeful outlook on life, but an error in judgment that can be labeled unrealistic optimism". WEINSTEIN, Neil D. Unrealistic optimism about future life events. Journal of Personality and Social Psychology, v. 39, n. 5, p. 806-820, 1980. 
excessivo de débitos decorrentes do uso do crédito estava diretamente ligado ao superotimismo, sobretudo pela percepção dos jovens de que não passarão por problemas no futuro. ${ }^{89}$

Outro viés que afeta a tomada de decisão dos seres humanos é a "ilusão do controle", tema introduzido pela professora de psicologia em Harvard, Ellen Langer. ${ }^{90}$ Trata-se de uma falsa percepção de controle de uma dada situação, que na realidade não pode ser controlada. Um exemplo ilustrativo é a percepção da maioria dos motoristas que pensam estar mais seguros ao volante do automóvel do que se estivessem como carona. De uma maneira geral, os estudiosos desse viés reputam que a sua utilização decorre da tentativa do indivíduo em suportar de forma mais satisfatória situações da vida que são efetivamente incertas.

Tanto o superotimismo quanto a ilusão do controle podem ser relacionados com o crédito e, especialmente, com o superendividamento. Ron Harris e Einat Albin consideram ambos os problemas cognitivos como os mais relevantes vieses quando se trata da análise do endividamento excessivo, principalmente porque estão eles diretamente conectados com a principal causa desse fenômeno: os acidentes da vida. Ao contratar de alguma forma o crédito, agindo de forma excessivamente otimista e seguro de que está no controle da situação, o consumidor acaba por subestimar a possibilidade de ocorrência de eventos negativos em sua vida e sobrestimar futuros acontecimentos positivos, eventos esses que na realidade não podem ser acuradamente previstos, já que são fatores exógenos na vida da pessoa. Essa situação pode levá-lo a uma condição de superendividado, posto que a junção entre os problemas financeiros e as contingências da vida têm se mostrado extremamente danosa em diversos países, não sendo diferente no Brasil. ${ }^{91}$

$\mathrm{Na}$ mesma linha de raciocínio, Jason J. Kilborn trabalha com o viés da superconfiança, tratando-o de maneira semelhante ao otimismo excessivo, ao contrário de alguns estudiosos, que fazem uma diferenciação entre ambos (o primeiro seria a superestimação das próprias habilidades pessoais, enquanto o segundo a superestimação da ocorrência de eventos externos positivos). De acordo com o autor, a história do crédito ao consumo nos Estados Unidos está ligada à exploração dos vieses do superotimismo e da ilusão do controle, havendo, desde a segunda guerra mundial, o uso de políticas econômicas estimulando a contratação do crédito, utilizando para tanto campanhas publicitárias com frases de impacto, como "Vamos fazer dar certo", "A vida sempre será melhor do que antes, talvez muito melhor", "Estes problemas nunca acontecerão comigo" etc. Tal situação foi responsável por potencializar o endividamento excessivo no país, principalmente por subestimar o acontecimento de problemas de ordem financeira. ${ }^{92}$

De uma certa forma, essa situação parece ter sido reproduzida no Brasil com as recentes políticas governamentais incentivadoras do consumo, com grande ênfase para a expansão do volume de crédito no país, que no período de 2001 a 2011, saltou de aproximadamente $27 \%$ para mais de $50 \%$ do PIB. ${ }^{93}$ Acompanhando essa tendência de aposta no crédito, Diógenes Faria de Carvalho e Cristiano Coelho destacam que o Brasil tornou-se a "pátria das parcelas", ${ }^{4}$ situação representada pelo uso maciço dos consumidores pelos instrumentos de parcelamento, com especial ênfase para os cartões de crédito. Para garantir o sucesso da estratégia de alavancagem do uso do crédito como forma de estímulo ao consumo, a publicidade ganhou

89 HARRIS, Ron; ALBIN, Einat. Bankruptcy policy in light of manipulation in credit advertising. Theoretical Inquiries in Law, v. 7, p. 431-466, 2006.

90 De acordo com a autora, a ilusão do controle pode ser definida como sendo "[...] an expectancy of a personal success probability inappropriately higher than the objective probability would warrant". LANGER, Ellen J. The illusion of control. Journal of Personality and Social Psychology, v. 32, n. 2, p. 311-328, 1975. p. 313.

91 HARRIS, Ron; ALBIN, Einat. Bankruptcy policy in light of manipulation in credit advertising. Theoretical Inquiries in Law, v. 7, p. 431-466, 2006.

92 KILBORN, Jason J. Behavioral economics, overindebtedness and comparative consumer bankruptcy: searching for causes and evaluating solutions. Emory Bankruptcy Developments Journal, v. 22, p. 13-46, abr. 2005.

93 INSTITUTO DE PESQUISA ECONÔMICA APLICADA. Impactos macroeconômicos da expansão do crédito no Brasil: o período 2001-2011. p. 7. Disponível em: <http://www.ipea.gov.br/portal/images/stories/PDFs/TDs/td_2333.pdf>. Acesso em: 3 dez. 2017.

94 CARVALHO, Diógenes Faria de; COELHO, Cristiano. Consumo e (super)endividamento: vulnerabilidade e escolhas intertemporais. Goiânia: Espaço Acadêmico, 2017. p. 79. 
papel de destaque, sobretudo com campanhas exaltando o lado positivo da aquisição creditícia, visando, assim, aumentar a percepção otimista dos consumidores a respeito do futuro, o que contribui certamente para o aumento das relações negociais perante o mercado.

É interessante observar que o disposto acima confirma algo essencial para o presente estudo: que o superenvidamento pode ser causado por fatores estruturais e culturais (o que inclui os problemas cognitivos), sendo incorreto rotular as duas correntes como antagônicas. No caso, causas estruturais do endividamento excessivo, como por exemplo o desemprego, ${ }^{95}$ acabam por ser de certa forma potencializadas pelas causas comportamentais (superotimismo e ilusão do controle) — visto que o consumidor tende a não considerar a possibilidade de ocorrência das contingências da vida quando da contratação do crédito —, demonstrando haver uma relação muitas vezes intensa entre ambas.

A heurística da disponibilidade também tem sido relacionada com o superendividamento. De acordo com Jason J. Kilborn, muitos consumidores tendem a subestimar a possibilidade de se superendividarem, simplesmente por esse fenômeno ser visto como de difícil ocorrência, não sendo facilmente recorrente na mente das pessoas — tanto a recorrência quanto a não recorrência de um dado evento podem alterar o comportamento do sujeito. Se o consumidor, pessoalmente, nunca passou por uma situação de endividamento excessivo, a presença dessa heurística torna-se ainda mais forte, de modo que até mesmo a prestação de informações atinentes a dados estatísticos constatando que o problema existe e que tem afetado outros indivíduos em número elevado tem se mostrado não tão eficiente, contribuindo para uma avaliação errônea da realidade. O problema cognitivo gerado pelo atalho da disponibilidade pode ser potencializado, caso conjuntamente esteja presente o viés da confiança excessiva. ${ }^{96}$

Com efeito, a presença dessa heurística está relacionada, diretamente, ao cartão de crédito, um instrumento que permite a realização de várias e pequenas compras a prazo, o que pode gerar no sujeito que o utiliza a percepção de que os riscos envolvidos na operação são diminutos e facilmente controláveis. No entanto, essa situação pode levar o indivíduo a passar por uma severa crise financeira, ${ }^{97}$ especialmente em razão do cartão de crédito normalmente envolver altas taxas de juros, muitas vezes somada à inadimplência, ao pagamento mínimo das faturas, bem como à superestimação da capacidade de redução dos gastos de consumo futuros.

Finalmente, as decisões intertemporais ou o chamado desconto hiperbólico constituem em estudos elaborados por economistas comportamentais, que adotaram a variável tempo como objeto de análise. Trata-se da constatação de que os seres humanos tendem a supervalorizar os benefícios momentâneos, imediatos e, consequentemente, subestimar as gratificações mais vantajosas, porém futuras, o que pode ocasionar em decisões enviesadas. Dessa forma, os custos futuros envolvidos em uma escolha caracterizada pelo desconto hiperbólico tendem a ser minimizados, havendo "[...] preferência por recompensas menores, que venham mais rápido, àquelas maiores, porém posteriores". ${ }^{98}$

Ilustrativamente, a decisão intertemporal pode ser representada pela preferência das pessoas - estatisticamente comprovada — em receber $\mathrm{R} \$ 1.000,00$ hoje a $\mathrm{R} \$ 1.100,00 \mathrm{em}$ um ano. A recompensa maior de $\mathrm{R}$ \$ 100,00 em longo prazo é descontada, conferindo a percepção de que a primeira opção é mais vantajosa.

95 "Jobs are so important to the well-being and identity of the American middle class that a job loss may trigger other unhappy events. The accounts of several of the debtors show how a job problem can stimulate other problems, especially family disruption. The loss of a job often precipitates a series of events, one of which may be bankruptcy but many of which are unpleasant". SULLIVAN, Teresa A.; WARREN, Elizabeth; WESTBROOK, Jay Lawrence. The fragile middle class: americans in debt. New Haven: Yale University Press, 2000. p. 96.

96 KILBORN, Jason J. Behavioral economics, overindebtedness and comparative consumer bankruptcy: searching for causes and evaluating solutions. Emory Bankruptcy Developments Journal, v. 22, p. 13-46, abr. 2005.

97 KILBORN, Jason J. Behavioral economics, overindebtedness and comparative consumer bankruptcy: searching for causes and evaluating solutions. Emory Bankruptcy Developments Journal, v. 22, p. 13-46, abr. 2005.

98 CARVALHO, Diógenes Faria de; COELHO, Cristiano. Consumo e (super)endividamento: vulnerabilidade e escolhas intertemporais. Goiânia: Espaço Acadêmico, 2017. p. 111. 
Por outro lado, a situação inverte-se quando a percepção da vantagem se desloca para o futuro. No caso, entre receber $\mathrm{R} \$ 1.000,00 \mathrm{em}$ um ano e $\mathrm{R} \$ 1.100,00$ em um ano e uma semana, as pessoas tendem a optar pela segunda opção, aplicando o desconto em ambos os casos.

Jason J. Kilborn faz uma interessante análise da união entre a decisão intertemporal e o problema da "força de vontade limitada", especialmente da propensão que as pessoas têm em assumir os benefícios imediatos de uma dada atividade de risco — como fumar um cigarro —, ignorando, por meio do desconto hiperbólico, os custos futuros dessa ação. Em relação à tomada de crédito, o autor informa que essa união pode ser ilustrada pelo uso, cada vez maior, do cartão de crédito, um instrumento que incentiva o consumo imediato por meio da percepção de que a sua utilização permite o "comprar agora" e o "pagar depois", refletindo uma supervalorização dos benefícios momentâneos e uma subestimação dos custos futuros que, necessariamente, estão implicados nessa operação, mas que acabam sendo descontados em razão dos aspectos cognitivos informados. ${ }^{99}$

Portanto, indubitavelmente, os estudos das decisões intertemporais são extremamente relevantes para uma abordagem realista do ato consumo, principalmente por serem importantes fontes explicativas do consumo excessivo do crédito - principalmente daquele contratado em pequena escala, sendo o cartão de crédito um dos principais exemplos —, que, definitivamente, é uma marca da sociedade de consumo hodierna. ${ }^{100}$

Segundo Diógenes Faria de Carvalho e Cristiano Coelho, há uma estreita relação entre o problema do desconto hiperbólico e o viés do autocontrole, visto que os consumidores tendem a esperar por um futuro mais seguro, próspero e consciente, porém, no momento de colocá-lo em prática, sucumbem aos benefícios imediatos da compra a crédito, ignorando vantagens maiores que poderiam ser auferidas se pensassem a longo prazo. Assim, essa superconfiança no futuro acaba por permanecer, apenas, no plano da imaginação, fazendo com que o consumidor, na prática, passe a ignorar, sistematicamente, os custos futuros dos seus atos, como o pagamento de altas taxas de juros, o endividamento excessivo, o consumismo insustentável, entre outros. ${ }^{101}$

Dessa forma, no presente tópico, foram elencados os principais problemas comportamentais causadores do superendividamento. Na concepção adotada no presente estudo, as heurísticas e os vieses atuantes sobre o ato de consumo justificam a construção da vulnerabilidade cognitiva, principalmente quando o próprio mercado age de forma a explorá-las, gerando benefícios para aqueles agentes econômicos mais poderosos, que detém o poder sobre a informação, conduzindo as relações negociais de acordo com os seus interesses.

\section{Considerações finais}

O desenvolvimento e amadurecimento da Behavioral Economics no âmbito do pensamento econômico é inquestionável. As descobertas reveladoras das diversas heurísticas e vieses, que decididamente influenciam a tomada de decisão, têm contribuído para uma análise mais "humanizada" do comportamento humano, possibilitando o desenvolvimento de novas estratégias e frentes de combate para os problemas contemporâneos.

Come efeito, a abordagem interdisciplinar entre a Economia Comportamental e o Direito, denominada

99 KILBORN, Jason J. Behavioral economics, overindebtedness and comparative consumer bankruptcy: searching for causes and evaluating solutions. Emory Bankruptcy Developments Journal, v. 22, p. 13-46, abr. 2005.

100 LOEWENSTEIN, George; O’DONOGHUE, Ted; RABIN, Matthew. Projection bias in predicting future utility. In: LOEWENSTEIN, George (Ed.). Exotic preferences: behavioral economics and buman motivation. New York: Oxford University Press, 2007. p. 365.

101 CARVALHO, Diógenes Faria de; COELHO, Cristiano. Consumo e (super)endividamento: vulnerabilidade e escolhas intertemporais. Goiânia: Espaço Acadêmico, 2017. p. 111-121. 
Análise Econômico-Comportamental do Direito, tem sido desenvolvida em vários países, sobretudo para agregar novas perspectivas no processo legislativo e, especialmente, para a elaboração de políticas públicas. No Brasil, apesar de ainda haver um grande espaço para crescimento desse estudo interdisciplinar, importantes quadros da doutrina já vêm demonstrando o quão positiva pode ser essa análise conjunta, especialmente para o enfrentamento de problemas multifacetados, como é o caso do superendividamento.

O fenômeno complexo do superendividamento, um problema estrutural e cultural (comportamental), que comporta abordagens de ordem jurídica, econômica, social e financeira, corresponde a uma das temáticas que reclamam um olhar interdisciplinar, a fim de ser enfrentado de forma mais eficiente e efetiva. Nesse sentido, relacionar a Economia Comportamental com o endividamento excessivo, implica analisar determinadas causas comportamentais que podem explicar o surgimento do fenômeno, além de traçar medidas de combate, como a elaboração de políticas públicas mais eficientes e de legislações mais conectadas com a realidade.

Ainda, a respeito da relação entre o superendividamento e a Economia Comportamental, o presente artigo procurou demonstrar a forma como determinadas heurísticas e vieses prejudicam a tomada de decisão do consumidor, notadamente as ilusões cognitivas do otimismo excessivo, da ilusão do controle, da superconfiança, da disponibilidade e das decisões intertemporais.

Com as contribuições da Economia Comportamental, registre-se que o Direito do Consumidor no Brasil será ainda mais fortalecido, posto que o Princípio da Vulnerabilidade, expressamente previsto no CDC, passa a ser ainda mais valorizado com as constatações empíricas que demonstram a forma como as ilusões cognitivas podem afetar a tomada de decisão desse sujeito de direito, especialmente quando essas ilusões são exploradas em benefício de agentes econômicos, que de fato detém o poder sobre a informação. Dessa forma, novas frentes de proteção do consumidor serão abertas, em prol da higidez do mercado de consumo.

\section{REFERÊNCIAS}

ARIELY, Dan. Behavioral economics: an exercise in design and humility. In: SAMSON, Alain (Ed.). The behavioral economics guide 2015. Disponível em: <http:/ /www.behavioraleconomics.com/BEGuide2015.pdf>. Acesso em: 3 out. 2017.

ASHRAF, Nava; CAMERER, Colin F.; LOEWENSTEIN, George. Adam Smith, behavioral economist. In: LOEWENSTEIN, George (Ed.). Exotic preferences: behavioral economics and human motivation, New York: Oxford University Press, 2007.

BARROS, Gustavo. Herbert A. Simon and the concept of rationality: boundaries and procedures. Brazilian Journal of Political Economy, v. 30, n. 3, p. 455-472, jul./set. 2010.

BRAUCHER, Jean. Form and substance in consumer financial protection. Brook. J. Corp. Fin. \& Com. L., v. 7, p. 107-129, 2012.

BRAUCHER, Jean. Theories of overindebtedness: interaction of structure and culture. Arizona Legal Studies, Theoretical Inquires in Law, p. 323-346, 2006.

CAMERER, Colin F.; LOEWENSTEIN, George. Behavioral economics: past, present, future. In: CAMERER, Colin F., LOEWENSTEIN, George; RABIN, Matthew. Advances in behavioral economics, New York: Princeton University Press, 2002.

CARVALHO, Diógenes Faria de; COELHO, Cristiano. Consumo e (super)endividamento: vulnerabilidade e escolhas intertemporais. Goiânia: Espaço Acadêmico, 2017.

COOTER, Robert; ULEN, Thomas. Law and economics, 6th ed. Berkeley Law Books, 2016. Disponível em: 
<http://scholarship.law.berkeley.edu/books/2/>. Acesso em: 7 nov. 2017.

FARIA, José Eduardo. O direito na economia globalizada. São Paulo: Malheiros, 2004.

GICO JR, Ivo T. Metodologia e epistemologia da análise econômica do direito. Economic Analysis of Law Review, v. 1, n. 1, p. 7-33 jan./jun. 2010.

GIGERENZER, Gerd. How to make cognitive illusions disappear: beyond "heuristics and biases. European Review of Social Psychology, v. 2, n. 1, p. 83-115, 1991.

HANSON, Jon D.; KYSAR, Douglas A. Taking behavioralism seriously: some evidence of the problem of market manipulation. Harvard Law Review, v. 112, p. 1420-1572, maio 1999.

HANSON, Jon D.; KYSAR, Douglas A. Taking behavioralism seriously: the problem of market manipulation. New York University Law Review, v. 74, n. 3, p. 630-749, jun. 1999.

HARRIS, Ron; ALBIN, Einat. Bankruptcy policy in light of manipulation in credit advertising. Theoretical Inquiries in Law, v. 7, p. 431-466, 2006.

HASTIE, Reid; DAWES, Robyn M. Rational choice in an uncertain world: the psychology of judgment and decision making. 2. ed. Los Angeles: SAGE, 2010.

HEUKELOM, Floris. Behavioral economics: a history. New York: Cambridge University Press, 2014.

INSTITUTO DE PESQUISA ECONÔMICA APLICADA. Impactos macroeconômicos da expansão do crédito no Brasil: o período 2001-2011. p. 7. Disponível em: <http://www.ipea.gov.br/portal/images/stories/PDFs/ TDs/td_2333.pdf>. Acesso em: 03 dez. 2017.

JOLLS, Christine; SUNSTEIN, Cass R.; THALER, Richard. A behavioral approach to law and economics. Stanford Law Review, v. 50, p. 1471-1550, jul. 1998.

KAHNEMAN, Daniel. Rápido e devagar: duas formas de pensar. Rio de Janeiro: Objetiva, 2012.

KAHNEMAN, Daniel; FREDERICK, Shane. A model of heuristic judgment. In: HOLYOAK, Keith James; MORRISON, Robert G. The Cambridge handbook of thinking and reasoning. New York: Cambridge University Press, 2005. p. 267-294.

KAHNEMAN, Daniel; FREDERICK, Shane. Representativeness revisited: attribute substitution in intuitive judgment. In: GILOVICH, T.; GRIFFIN, D.; KAHNEMAN, D. (Ed.). Heuristics and biases: the psychology of intuitive judgment. New York: Cambridge University Press, 2002. p. 49-81.

KAHNEMAN, Daniel; TVERSKY, Amos. Judgment under uncertainty: heuristics and biases. Science, v. 185, n. 4157, p. 1124-1131, set. 1974.

KAHNEMAN, Daniel; TVERSKY, Amos. On the reality of cognitive ilusions. Psycological Review, v. 103, n. 3, p. 582-591, jul. 1996.

KAHNEMAN, Daniel; TVERSKY, Amos. Prospect theory: an analysis of decision under risk. Econometrica, v. 47, n. 2, p. 263-292, mar. 1979.

KAPLOW, Louis; SHAVELL, Steven. Economic analysis of law. In: AUERBACH, Alan J.; FELDSTEIN, Martin (Ed.). Handbook of public economics. Rio de Janeiro: Elsevier, 2002. v. 3.

KILBORN, Jason J. Behavioral economics, overindebtedness and comparative consumer bankruptcy: searching for causes and evaluating solutions. Emory Bankruptcy Developments Journal, v. 22, p. 13-46, abr. 2005.

LAGES, André Maia Gomes. A contribuição singular de Simon e sua repercussão teórica relevante. Análise, v. 17, n. 1, p. 47-66, jan./jul. 2006.

LANGER, Ellen J. The illusion of control. Journal of Personality and Social Psychology, v. 32, n. 2, p. 311-328, 
1975.

LOEWENSTEIN, George; O'DONOGHUE, Ted; RABIN, Matthew. Projection bias in predicting future utility. In: LOEWENSTEIN, George (Ed.). Exotic preferences: behavioral economics and human motivation. New York: Oxford University Press, 2007.

MACEDO JÚNIOR, Ronaldo Porto. Direito à informação nos contratos relacionais de consumo. Revista de Direito do Consumidor, v. 35, p. 113-122, jul./set. 2000.

MARQUES, Cláudia Lima. Sugestões para uma Lei sobre o tratamento do superendividamento de pessoas físicas em contratos de crédito ao consumo: proposições com base em pesquisa empírica de 100 casos no Rio Grande do Sul. In: MARQUES, Cláudia Lima; CAVALLAZZI, Rosângela Lunardelli (Org.). Direitos do consumidor endividado: superendividamento e crédito. São Paulo: Revista dos Tribunais, 2006.

MARQUES, Cláudia Lima; MIRAGEM, Bruno. O novo direito privado e a proteção dos vulneráveis. 2. ed. São Paulo: Revista dos Tribunais, 2014.

MARTINS, Fernando Rodrigues; FERREIRA, Keila Pacheco. Vulnerabilidade financeira e economia popular: promoção de bem fundamental social em face da prática de institutos lucrativos ilusórios: das pirâmides ao marketing multinível. Revista de Direito do Consumidor, v. 98, p. 105-134, mar./abr. 2015.

MORAES, Paulo Valério Dal Pai. Código de Defesa do Consumidor. o princípio da vulnerabilidade no contrato, na publicidade e nas demais práticas comerciais: interpretação sistemática do direito. Porto Alegre: Livraria do Advogado, 2009.

OLIVEIRA, Amanda Flávio de. Desenvolvimento econômico, capitalismo e direito do consumidor no Brasil: afastando o argumento de "paternalismo jurídico". Revista de Direito do Consumidor, v. 108, p. 243-263, nov./dez. 2016.

OLIVEIRA, Amanda Flávio de; CARVALHO, Diógenes Faria de. Vulnerabilidade comportamental do consumidor: por que é preciso proteger a pessoa superendividada. Revista de Direito do Consumidor, v. 104, p. 181-201, mar./abr. 2016.

OLIVEIRA, Amanda Flávio de; CASTRO, Bruno Braz de. Proteção do consumidor de crédito: uma abordagem a partir da economia comportamental. Revista de Direito do Consumidor, v. 93, p. 231-249, maio/jun. 2014.

OLIVEIRA, Amanda Flávio de; FERREIRA, Felipe Moreira dos Santos. Análise econômica do direito do consumidor em períodos de recessão: uma abordagem a partir da economia comportamental. Revista de Direito do Consumidor, v. 81, p. 13-38, jan./mar. 2012.

PACCES, Alessio; VISSCHER. Louis. Methodology of law and economics. 2011. Disponível em: < https:// repub. eur.nl/pub/31466/>. Acesso em: 07 nov. 2017.

PAIVA, Rafael Augusto de Moura. Repensando o "ser" consumidor. Revista de Direito do Consumidor, v. 88, p. 103-142, jul./ago. 2013.

POSNER, Richard. Economic Analysis of law. 3. ed. Boston: Little, Brown and Company, 1986.

PRUX, Oscar Ivan. O direito do consumidor em tempos de crise econômica persistente: problemática das relações entre fornecedores e consumidores. Revista de Direito do Consumidor, v. 89, p. 59-106, set./out. 2013.

RAMSAY, Iain. Acess to credit in the alternative consumer credit market. Paper prepared for: Office of consumer affairs, industry Canada and ministry of the attorney general. British Columbia, 2000. Disponível em: <https://www.ic.gc.ca/eic/site/cmc-cmc.nsf/vwapj/ramsay_e.pdf/\$FILE/ramsay_e.pdf>. Acesso em: 26 nov. 2017. 
SCHWARTZ, Hugh. Herbert Simon and behavioral economics. Journal of Socio-Economics, v. 31, p. 181-189, 2002.

SIMON, Herbert A. A behavioral model of rational choice. The Quarterly Journal of Rational Choice, v. 69, n. 1, p. 99-118, fev. 1955.

SIMON, Herbert A. Rationality as process and as product of thought. American Economic Association, v. 68, n. 2, p. 1-16, maio 1978.

SULLIVAN, Teresa A.; WARREN, Elizabeth; WESTBROOK, Jay Lawrence. The fragile middle class: americans in debt. New Haven: Yale University Press, 2000.

THALER, Richard H.; SUNSTEIN, Cass R. Nudges: improving decisions about health, wealth, and happiness. New Haven: Yale University Press, 2008.

THALER, Richard. Toward a positive theory of consumer choice. Journal of Economic Behavior and Organization, v. 1, p. 39-60, mar. 1980.

WEINSTEIN, Neil D. Unrealistic optimism about future life events. Journal of Personality and Social Psychology, v. 39, n. 5, p. 806-820, 1980. 


\section{A educação formal para o consumo é garantia para uma presença refletida do consumidor no mercado? Uma análise com base na behavioral law and economics (economia comportamental)*}

\author{
Is the formal education for consumption a \\ guarantee for a reflected presence of the \\ consumer in the market? An analysis from \\ behavioral law and economics
}

\author{
Marcia Carla Pereira Ribeiro** \\ Edson Mitsuo Tiujo***
}

\section{Resumo}

O Código do Consumidor, para além do direito à informação (art. $6^{\circ}$, III), previu o direito básico à educação (art. $6^{\circ}$, II), como forma de assegurar a liberdade de escolha e a igualdade nas contratações. O artigo analisa esse direito básico pela metodologia da Análise Econômica do Direito, notadamente, pela vertente da economia comportamental. Verifica se a educação formal tem o condão de influir na alteração de comportamento do consumidor, proporcionando-lhe um maior poder de reflexão. Partindo-se do pressuposto de que a melhor forma de aprendizagem do consumidor é pelos erros cometidos no passado (experiência) e que as distorções cognitivas (heurísticas e vieses) são invencíveis, mesmo diante de ostensiva informação e educação, os behavioristas parecem não crer na educação formal, como o meio primordial para amenizar a limitação da racionalidade.

Palavras-chave: Direito à educação. Direito do consumidor. Economia comportamental. Heurísticas e vieses.

\begin{abstract}
The Consumer Code, in addition to the right to information (art. $6^{\circ}$, III), established the basic right to education (art. $6^{\circ}$, II), as a way of ensuring the liberty of choice and equality in contracting. The article analyzes this basic right by the methodology of the economic analysis of the law, especially by the behavioral economy. It verifies whether formal education has any influence on the consumer behavior change, providing a greater power of reflection. Based on the assumption that the best way of learning, for the consumer, is by the mistakes he made on the past (experience) and that the cognitive distortions (heuristics and biases) are invincible, even when facing
\end{abstract}


the ostensive information and education, the behaviorists seems not to believe in formal education as a crucial means to soften the limitation of rationality.

Keywords: Right to education. Consumer law. Behavioral economics. Heuristics and biases.

\section{INTRODUÇÃo}

O artigo busca correlacionar normas do Direito do Consumidor à luz de uma inovadora abordagem do Direito, a Análise Econômica do Direito ou law and economics. Com base na economia comportamental ou behavioral law and economics, foram consideradas a coerência e a plausibilidade de algumas das regras básicas do Direito do Consumidor.

O estudo traz uma aproximação do direito básico à educação formal do consumidor com os insights da economia comportamental, notadamente, com o intuito de apresentar, de uma maneira bastante inicial, a coerência (ou não) dessa moderna metodologia de estudo.

A proposta de estudo partiu de alguns questionamentos prévios em relação ao consumidor relacionadas à sua vulnerabilidade; às práticas comerciais dos fornecedores como fator de influência no comportamento consumista dos consumidores; e, especialmente, sobre a potencialidade de a educação formal possibilitar maior poder de reflexão aos consumidores, especialmente quando delegado aos fornecedores o dever de prestá-la.

O primeiro desses questionamentos está superado e pacificado, qual seja, os consumidores realmente se encontram em posição de inferioridade frente aos fornecedores. Sobre ele, estão de acordo, tanto juristas como economistas e psicólogos. É preciso, agora, verificar se a educação formal para o consumo (direito básico do consumidor) é primordial e essencial para eliminação ou exclusão dessa situação do consumidor, permitindo-lhe uma atuação mais refletida no mercado.

Para tanto, o presente artigo é dividido em quatro partes, sendo a primeira destinada à exposição do conteúdo do direito à educação para o consumo. Nesse tópico, são expostos os fundamentos legais e doutrinários acerca do direito à educação, distinguindo-o do direito à informação e, ao fim, expondo-se as práticas comerciais e as políticas econômicas, notadamente aquelas indutoras do consumismo, às quais os consumidores estão constantemente submetidos.

A segunda e a terceira partes incursionam o leitor pela metodologia da Análise Econômica do Direito, especificamente na linha da economia comportamental. O terceiro tópico é destinado à exposição e à exemplificação de algumas heurísticas e vieses (manifestações neurocognitivas) que podem alterar os comportamentos dos consumidores, conduzindo-os a erros sistemáticos.

Por último, o quarto tópico destina-se à correlação das duas variáveis objeto de estudo, quais sejam, a educação formal e inicial para o consumo à luz da economia comportamental. Procura-se verificar se a educação de crianças e jovens, como política pública, tende a alterar o comportamento do consumidor no mercado de consumo, permitindo-lhes um maior poder de reflexão.

\section{O diREITO BÁsico À EdUCAÇão PARA O CONSUMO COMO GARANTIA DE PROTEÇÃo aO CONSUMIDOR, DIANTE DAS PRÁTICAS COMERCIAIS E DAS POLÍTICAS ECONÔMICAS INDUTORAS DO CONSUMO}

A Constituição da República de 1988 assegurou ampla proteção ao consumidor, alçando a sua tutela a direito fundamental (art. 5', XXXII), bem como Princípio da Ordem Econômica (art. 170, V). Nesse 
enfoque, estabeleceu, ainda, que a defesa do consumidor deve ser realizada ao lado de outros importantes princípios como os da propriedade, da livre iniciativa e da livre concorrência, aparentemente contraditórios, mas em verdades correspondentes.

Para a concretização dessa proteção, o Poder Constituinte ordenou ao legislador ordinário, por meio do art. 48 do Ato das Disposições Constitucionais Transitórias, a elaboração de uma lei de defesa do consumidor, a qual foi aprovada e entrou em vigência em 1990, sendo conhecida como Código de Defesa do Consumidor (Lei n. 8.078).

O Código de Defesa do Consumidor, por sua vez, garantiu como direito básico do consumidor o direito à informação (art. $6^{\circ}, \mathrm{III}$ ), mas não apenas isso, previu, ainda, o direito à educação do consumidor como forma de assegurar a liberdade de escolha e a igualdade nas contratações (art. $6^{\circ}$, II).

O direito básico à informação é exaustivamente difundido pela doutrina, aplicado pela jurisprudência e seguido pelos fornecedores, na medida dos seus custos e estratégias comerciais. O direito à informação consiste em transmitir ao consumidor informações sobre o produto e/ou serviço comercializado, notadamente, no que se refere a suas características, quantidade, qualidades, composição, preço, garantia, prazos de validade, origem e os riscos que apresentam à saúde e à segurança dos consumidores (art. 30 do Código do Consumidor).

O direito à informação decorre dos princípios da transparência e da vulnerabilidade do consumidor (art. $4^{\circ}$, I do Código do Consumidor). Esse postulado pode ser relacionado a um elemento da Análise Econômica do Direito, a assimetria informacional.

Nos estudos de Maria Paula Costa Bertran Muñoz ${ }^{1}$, a vulnerabilidade do consumidor é o reflexo jurídico da assimetria de informações. Isso significa que os agentes possuem uma racionalidade que é limitada pela incompletude do conhecimento, bem como das competências cognitivas de receber, armazenar, recuperar e processar as informações ${ }^{2}$. Em simples palavras, reconhecer a assimetria de informações em determinados mercados específicos é reconhecer o fato de que uma das partes sabe muito mais sobre as reais qualidades do que está negociando do que a outra ${ }^{3}$, acarretando situações indesejadas (falhas de mercado) e obstaculizando relações econômicas mais eficientes ${ }^{4}$.

O exemplo típico de uma situação informacional assimétrica, citado por Arkelof, é o mercado de veículos usados. É inegável que os vendedores têm maior conhecimento sobre a qualidade do carro do que os compradores. No entanto, no mercado, bons veículos e maus veículos têm o mesmo preço, de modo que é impossível para o comprador observar essa diferença no momento da negociação ${ }^{5}$.

Ademais, embora pareça bastante, a proteção ao consumidor não se limita à sua adequada (art. $6^{\circ}$, III do Código do Consumidor), necessária (art. $8^{\circ}$ ) e ostensiva (art. $9^{\circ}$ ) informação. Vai além. O Código do Consumidor assegurou, ainda, como direito básico do consumidor, o direito à sua educação.

O direito à educação, portanto, é um direito distinto do direito à informação. O direito à educação consiste no direito do consumidor em ser dotado de poder de reflexão e de conscientização acerca do consumo de bens e serviços (art. $6^{\circ}$, II do Código do Consumidor), minimizando, assim, a sua irracionalidade, a sua

1 MUÑOZ, Maria Paula Costa Bertran. Paralelismo entre assimetria de informações e vulnerabilidade dos consumidores: uma análise acerca de juros em contratos de concessão de crédito. Revista de Direito do Consumidor, São Paulo, v. 86, p. 47-63, mar./abr. 2013. p. 52.

2 WILLIAMSON, Oliver. The mecanisms of governance. New York: Oxford University Press, 1996. p. 377.

3 MUÑOZ, Maria Paula Costa Bertran. Paralelismo entre assimetria de informações e vulnerabilidade dos consumidores: uma análise acerca de juros em contratos de concessão de crédito. Revista de Direito do Consumidor, São Paulo, v. 86, p. 47-63, mar./abr. 2013. p. 52.

4 RIBEIRO, Marcia Carla Pereira; GALESKI JUNIOR, Irineu. Teoria geral dos contratos: contratos empresariais e análise econômica. 2. ed. São Paulo: Revista dos Tribunais, 2015. p. 110-111.

5 RIBEIRO, Marcia Carla Pereira; GALESKI JUNIOR, Irineu. Teoria geral dos contratos: contratos empresariais e análise econômica. 2. ed. São Paulo: Revista dos Tribunais, 2015. p. 110-111. 
limitação decorrente da assimetria de informações, notadamente frente ao fornecedor, e o desequilíbrio da relação de consumo em virtude do poder econômico do fornecedor.

A racionalidade limitada, a assimetria de informações e o poder econômico são postulados da Análise Econômica do Direito e tidos como falhas de mercado. A presença dessas falhas de mercado, notadamente nas relações de consumo, impedem que as relações econômicas possam alcançar a plena eficiência apenas pela transação entre os agentes, cabendo às regras jurídicas, quando possível, dirimir tais falhas ${ }^{6}$.

Nesse aspecto, tanto consumeristas quanto economistas, notadamente os comportamentalistas, estão de acordo a respeito de a propensão da relação jurídica consumerista sofrer os efeitos das falhas de mercado, podendo-se imaginar que a alteração dessa realidade se processe por meio da educação para o consumo.

A Associação de Educação Financeira do Brasil (AEFB) propõe que os consumidores aprendam a controlar seus recursos e respeitar seu orçamento, administrar seus bens e alocar seus recursos e, primordialmente, quer estimular a promoção de uma mudança de comportamento e de velhos hábitos com relação ao uso do dinheiro. Em outras palavras, seu escopo consiste em desenvolver nos jovens as competências e habilidades necessárias para lidar com as decisões financeiras que tomarão ao longo de suas vidas?

Afora iniciativas dessa ordem, ao que se nota, os objetivos propostos pelos idealizadores ${ }^{8}{ }^{9}$ da educação para o consumo são: (a) incutir no consumidor o poder de reflexão e o juízo crítico, especialmente diante das políticas econômicas de incentivo ao consumo e as práticas comerciais (oferta e publicidade) dos fornecedores; (b) proteger o consumidor, especialmente as crianças, pré-adolescentes e adolescentes diante das práticas comerciais (oferta e publicidade) dos fornecedores; (c) promover a sustentabilidade e o consumo consciente, com vistas à proteção do meio ambiente para as gerações futuras; e, sobretudo, (d) incutir no espírito de cada consumidor uma nova mentalidade, mais exigente e aguerrida, especialmente, quanto à postulação dos seus direitos, tornando-o um cidadão mais forte, ciente de seus direitos e com a verdadeira vontade de brigar por eles.

O direito à educação, por outro lado, não se refere à transmissão de conhecimentos financeiros ou econômicos, como noções sobre juros ou capitalização de juros, encargos embutidos e aquisições em longo prazo. Tampouco consiste em um conjunto de ferramentas de cálculos matemáticos. Notadamente, tais conhecimentos, ainda que relevantes, não têm o condão de alterar, substancialmente, o comportamento do consumidor, já que não age em seu consciente refletido, como será mais bem exposto nos tópicos abaixo.

$\mathrm{Na}$ lição de Sergio Cavalieri Filho ${ }^{10}$, a educação para o consumo envolve dois aspectos: o formal e o informal. O primeiro, desenvolve-se por meio de políticas de inserção de temas relacionados ao direito do consumo e consumidor nos currículos escolares, desde o ensino fundamental, em escolas públicas e privadas, até o ensino universitário, em disciplina com autonomia científica e pedagógica, constituindo importante ferramenta para a construção da cidadania e para a formação de indivíduos conscientes. O segundo desenvolve-se por meio das mídias de comunicação social e/ou institucional, direcionadas a um público geral ou específico, com o intuito de prestar informações, orientações e/ou esclarecimentos aos consumidores.

Ezequiel Morais et alii ${ }^{11}$, em acréscimo, ensina que a educação se volta para dois planos: o inicial e a con-

6 RIBEIRO, Marcia Carla Pereira; GALESKI JUNIOR, Irineu. Teoria geral dos contratos: contratos empresariais e análise econômica. 2. ed. São Paulo: Revista dos Tribunais, 2015. p. 107-108.

7 ASSOCIAÇÃO DE EDUCAÇÃO FINANCEIRA DO BRASIL. Educação financeira nas Escolas. Disponível em: < http://www. aefbrasil.org.br/index.php/programas-e-projetos/educacao-financeira-nas-escolas/>. Acesso em: 6 fev. 2018.

8 CAVAliERI FILHO, Sergio. Programa de direito do consumidor. 4. ed. São Paulo: Atlas, 2014. p. 101-102.

9 EFING, Antônio Carlos; POLEWKA, Gabriele; OYAGUE, Olenka Woolcott. A crise econômica brasileira e o superendividamento da população: emergência do aprimoramento legislativo para a tutela social. Revista de Direito do Consumidor, São Paulo, v. 24, n. 101, set./out. 2015. p. 327.

10 CAVALIERI FILHO, Sergio. Programa de direito do consumidor. 4. ed. São Paulo: Atlas, 2014. p. 101-102.

11 MORAIS, Ezequiel; PODESTÁ, Fábio Henrique; CARAZAI, Marcos Marins. Código de Defesa do Consumidor comentado. São Paulo: Revista dos Tribunais, 2010. p. 93. 
tínua (ou permanente). O primeiro é aquele inserido no currículo escolar, nos anos iniciais da vida escolar, preparando o cidadão para a construção de um projeto de vida. O segundo é aquele ofertado, continuamente, no mercado de consumo, com o objetivo de proporcionar o conhecimento mínimo de dados referentes à qualidade dos produtos e serviços, nos seus aspectos de saúde, segurança, informação, associativismo e para o próprio consumo.

Diante dessas proposições, denota-se que o direito à educação para o consumo deve fazer parte de toda a vida do cidadão, estando presente na sua vida escolar e orientando-o no mercado de consumo, sendo tal encargo de responsabilidade, principalmente, da própria família, ainda que modo informal, do Estado e, pontual e excepcionalmente, do fornecedor. Nesse particular, não se corrobora o entendimento de que o fornecedor deva promover a educação do consumidor, não por causa do conflito de interesses, mas sim porque, na mentalidade dos economistas, isso geraria maiores custos de transação ${ }^{12}$, acarretando a transferência desses custos para o próprio mercado de consumo.

O assunto ora discutido e estudado torna-se ainda mais relevante quando se percebe a apelação das práticas comerciais do mercado de consumo e também a política econômica adotada pelo país. É evidente que o empresário que atua no mercado com o objetivo exclusivo de lucro deverá envidar todos os seus esforços para a comercialização de seus produtos e serviços, disponibilizando, para tanto, ofertas e publicidades direcionadas a angariar clientes consumidores. Da mesma forma, o Estado brasileiro que é, por opção, capitalista, tende à adoção de políticas econômicas voltadas ao crescimento e desenvolvimento econômicos. É certo, contudo, que esse mesmo Estado não pode se dissociar do bem-estar social, o que não é contraditório, mas perfeitamente conciliável ${ }^{13}$. Inclusive, a Constituição da República, em seu art. 170 e incisos, dispôs como Princípios da Ordem Econômica, a livre iniciativa, a propriedade privada e a livre concorrência ao lado da defesa do consumidor.

O fornecedor (empresário) afeta a racionalidade do consumidor, buscando distorcer a sua liberdade de atuação e escolha, por uma série de fatores, como (a) as práticas comerciais de oferta e publicidade, constantemente renovadas por técnicas cada vez mais bem elaboradas e, muitas delas, agressivas ${ }^{14}$ e super-estimuladoras do consumo. Por essa razão, chamadas de "armas de sedução do fornecedor" ${ }^{15}$ com o intuito de influenciar o público em geral; (b) o desenvolvimento tecnológico dos computadores e telefones móveis, aliado à melhoria da qualidade dos sinais de internet e a facilitação do acesso do público em geral a esses produtos (computadores e celulares) e serviços (internet); (c) a facilitação na concessão / aquisição de créditos pelos consumidores, "sobretudo a concessão do "dinheiro de plástico" (cartões de crédito) e cheques especiais" "16 além do crédito consignado em benefício previdenciário e salário e os créditos on line; e (d) o não cumprimento a contento pelos fornecedores (empresários) das regras básicas de proteção ao consumidor, especialmente, no que se refere à oferta de preços, regulada pelo Decreto n. 5.903/2006, a qual impõe uma série de regras que não são aplicadas no dia a dia do mercado de consumo ${ }^{17}$.

Como consequência de tais práticas comerciais, os consumidores mais açodados e consumistas têm sido levados a uma situação de desespero diante do consumo exagerado ${ }^{18}$, os consumidores menos reflexivos têm sido vítimas frequentes de armadilhas promocionais do tipo "pague 2 e leve 3" e "prestações sem ju-

12 Custos de transação são os custos das partes para realizar negociações e para fazer cumprir as obrigações.

13 COURI, Sergio. Liberalismo e societalismo. Brasília: UnB, 2001. p. 5 e seguintes.

14 MARQUES, Cláudia Lima. Manual de direito do consumidor. 6. ed. São Paulo: Revista dos Tribunais, 2014. p. 75.

15 TARTUCE, Flavio; NEVES, Daniel Amorim Assumpção. Manual de direito do consumidor: direito material e processual. 2 . ed.

São Paulo: Método, 2013. p. 326.

16 FILOMENO, José Geraldo Brito. Manual de direitos do consumidor. 13. ed. São Paulo: Atlas, 2015. p. 127.

17 Por exemplo, o art. $3^{\circ}$ do referido Decreto estabelece que, na concessão de crédito, o fornecedor deverá informar de maneira discriminada, o valor total a ser pago com financiamento; o número, periodicidade e valor das prestações; os juros; e, os eventuais acréscimos e encargos que incidirem sobre o valor do financiamento ou parcelamento. Tais regras, no entanto, dificilmente são vistas cumpridas no dia-a-dia do mercado de consumo.

18 FILOMENO, José Geraldo Brito. Manual de direitos do consumidor. 13. ed. São Paulo: Atlas, 2015. p. 127. 
ros", e os consumidores hipervulneráveis, notadamente crianças e adolescentes, têm sido bombardeados por incentivos publicitários ao consumo ilimitado.

Não bastassem os fornecedores (empresários), o Poder Público, também, tem o condão de afetar, em determinadas situações, a liberdade de atuação e escolha do consumidor, notadamente, quando promove políticas econômicas de incentivo ao consumo. Em cenário assim, o cidadão fica, absolutamente, impotente e indefeso, como bem esclarece Antônio Carlos Efing ${ }^{19}$, "o homem não é nada para além da economia, submetendo-se a ela e às suas leis, não sendo sujeito na economia, não sendo titular de direitos, mas objeto visto que é destinatário sem estatuto dos produtos, moldados à conveniência do mercado" e acrescente-se, também, do Estado.

Apenas a título de exemplificação, nos últimos anos, diante da crise econômica que assolou o país, o Governo Brasileiro editou uma série de leis com o claro intuito de incentivar o consumo e aquecer a economia e, em determinadas situações, até mesmo provocar inegáveis distorções na liberdade de escolha dos consumidores. Assim, citam-se as leis de redução / exclusão do IPI (imposto sobre produtos industrializados), redução da taxa de juros e liberação do FGTS inativo (Fundo de Garantia sobre Tempo de Serviço) (Lei n. 13.446/2017), com o manifesto intuito de alavancar a economia. E, ainda, foi editada lei com o intuito de favorecimento do fornecedor em detrimento do consumidor, como ocorreu com a edição da recente lei que autorizou a variabilidade dos preços em virtude do instrumento de pagamento utilizado (Lei n. 13.455/2017).

A consequência dessa política econômica é, apenas, paliativa e pode trazer resultados diversos e, às vezes, indesejáveis. De fato, a injeção de dinheiro no mercado pode restabelecer a economia que se encontra estagnada, mas, por outro lado, é princípio básico da economia que o aumento na quantidade de moeda no mercado pode acarretar a inflação ${ }^{20}$, em desfavor do próprio consumidor, aumentando a discussão em torno da forma e modo de intervenção do Estado no mercado.

Tecidas tais considerações sobre o direito à educação para o consumo e a educação financeira, passa-se, agora, a analisar a sua relevância do ponto de vista da economia comportamental. Para tanto, alguns questionamentos são importantes: (a) a educação financeira influencia, eficientemente, o comportamento do consumidor no mercado de consumo? (b) de quem é a "culpa" pelo (super)endividamento do consumidor? e, (c) a educação financeira terá o condão de amenizar ou eliminar as falhas de mercado?

\section{Os POSTULADOS DA ECONOMIA COMPORTAMENTAL EM UMA COMPARAÇÃo COM A TEORIA ECONÔMICA CLÁSSICA}

A economia comportamental ou behavioral law consiste em um seguimento da Análise Econômica do Direito ou law and economics. A economia comportamental, pode-se dizer, é uma etapa mais recente de estudos da Análise Econômica do Direito, que já havia promovido intrigantes investigações jurídico-econômicas com base nos postulados da economia clássica e neoclássica. Por isso, para sua compreensão, é necessário entender, inicialmente, os postulados da teoria econômica clássica e neoclássica.

Para a Teoria Econômica Clássica, todo agente econômico (bomo economicus), incluindo, o consumidor, é racional maximizador de suas utilidades ${ }^{21}$ e retentor de uma quantidade ótima de informações em uma variedade de mercados. Em consequência disso, para a economia clássica, o indivíduo tem capacidade plena

19 EFING, Antônio Carlos. Direito do consumo e direito do consumidor: reflexões oportunas. Revista Luso-Brasileira de Direito do Consumo, Brasília, v. 1, n. 1, p. 103-120, 2011. p. 106.

20 MANKIW, Nicholas Gregory. Introdução à economia. São Paulo: Cengage Learning, 2013. p. 15.

21 Os administradores de empresas, por outro lado, são maximizadores de lucros. MANKIW, Nicholas Gregory. Introdução à economia. São Paulo: Cengage Learning, 2013. p. 453. 
para reagir a determinados incentivos (ou desincentivos) ${ }^{22}$, sempre optando pelo melhor curso de ação possível. Tudo e todos, portanto, seriam plenamente previsíveis. Em termos práticos, para a Teoria Econômica Clássica, o consumidor não é vulnerável e tem condições de decidir e escolher, livre e espontaneamente, no mercado de consumo.

Contudo, os economistas clássicos não levam em consideração, em suas percepções, que as pessoas são dotadas de imperfeições, como o fato de serem esquecidas, impulsivas, confusas, emotivas e de horizontes curtos. Tais imperfeições, de outro lado, são levadas em consideração pela psicologia e são relevantes nas tomadas de decisões dos agentes ${ }^{23}$. Isso significa que, o comportamento humano e suas decisões não são tão previsíveis assim. E é exatamente isso que a economia comportamental se debruça em estudar.

A economia comportamental, assim, decorre de estudo interdisciplinar promovido pela economia, a partir de descobertas da psicologia. Os seus primeiros precursores foram Herbert Simon, Richard Cyert, James March, Amos Tiverski e Daniel Kahneman. A partir de então, estudiosos do Direito passaram a empregá-la, tanto em análise normativa (elaboração de novas normas) quanto em análise descritiva (verificação do comportamento humano).

A economia comportamental não exsurgiu para anular a Teoria Clássica ${ }^{24}$, ao contrário, sua finalidade é modificar os elementos sem plausibilidade dessa teoria e suplementar os elementos inadequados, de modo a criar uma ferramenta com maior poder preditivo em situações específicas ${ }^{25}$.

Para a Teoria Econômica Clássica, os agentes sabem o que fazem e sempre fazem buscando o melhor para si (maximização de utilidades). Para a economia comportamental, por outro lado, o comportamento dos sujeitos não conduzirá, necessariamente, às melhores opções ${ }^{26}$. Os agentes não são absolutamente precisos na busca de suas utilidades, uma vez que maximizam sua satisfação (são satisficers) ${ }^{27}$, podendo, nesse intento, cometer erros sistemáticos por decisões imediatas e irrefletidas, notadamente, aqueles que se encontram na posição de consumidores.

Em outros termos, para os comportamentalistas, há muito mais que dados objetivos a influir entre as preferências declaradas e as escolhas efetivamente realizadas ${ }^{28}$. Manifestações neurocognitivas podem alterar, substancialmente, as escolhas dos agentes, ainda que suas preferências sejam mantidas. Enfim, estudos da economia comportamental partem do pressuposto de que, não raras são as vezes em que os agentes possuem uma racionalidade limitada, diante de uma série de vieses e heurísticas, ou seja, de erros sistemáticos provocados por atalhos cognitivos.

Amos Tiverski e Daniel Kahneman foram os economistas que deram os contornos mais atuais da economia comportamental, com base na obra intitulada Prospect Theory. Segundo seus estudos, os economistas chegaram aos seguintes postulados (erros sistemáticos): (a) as decisões estão sujeitas a uma série de distorções do julgamento (vieses) e atalhos mentais muitas vezes simplórios, que, diante de problemas complexos, apresentam respostas singelas e irrefletidas, nem sempre corretas (heurísticas); (b) diante de um quadro de

22 SANTOLIM, Cesar. Behavoral law and economics e a teoria dos contratos. In: MARQUES, Cláudia Lima; GSELL, Beate. Novas tendências do direito do consumidor. São Paulo: Revista dos Tribunais, 2015. p. 167.

23 MANKIW, Nicholas Gregory. Introdução à economia. São Paulo: Cengage Learning, 2013. p. 453.

24 Para Ivo Teixira Gico Júnior, a economia comportamental, de fato, diverge do modelo econômico tradicional em várias circunstâncias, mas essa divergência seria sistemática e não aleatória, o que significa que as características dos agentes são semelhantes, apenas é preciso adaptar os modelos para incorporar limitações cognitivas. GICO JÚNIOR, Ivo Teixeira. Introdução ao direito e economia. In: TIMM, Luciano Benetti. Direito e economia no Brasil. São Paulo: Atlas, 2012. p. 26-27.

25 SANTOLIM, Cesar. Behavoral law and economics e a teoria dos contratos. In: MARQUES, Cláudia Lima; GSELL, Beate. Novas tendências do direito do consumidor. São Paulo: Revista dos Tribunais, 2015. p. 168-169.

26 ALVES, Giovani Ribeiro Rodrigues. Economia comportamental. In: RIBEIRO, Marcia Carla Pereira; KLEIN, Vinicius. O que é análise econômica do direito: uma introdução. 2. ed. Belo Horizonte: Fórum, 2016. p. 75.

27 MANKIW, Nicholas Gregory. Introdução à economia. São Paulo: Cengage Learning, 2013. p. 454.

28 DOMINGUES, Victor Hugo. Vieses e heurísticas. In: RIBEIRO, Marcia Carla Pereira; DOMINGUES, Victor Hugo; KLEIN, Vinicius. Análise econômica do direito. Curitiba: CRV, 2016. p. 51. 
incertezas, ou de informações incompletas, as pessoas apresentam uma série de reações que não podem ser consideradas racionais; (c) as decisões dependem da forma como as questões são apresentadas (framing) e de sua disposição para assumir riscos (risk aversion), especialmente, num ambiente de incertezas; e, (d) as decisões são moldadas por uma série de fatores que bloqueiam a opção ótima²9.

Esses erros sistemáticos ocorrem, pelos estudos realizados por Daniel Kahneman ${ }^{30}$, em virtude de dois tipos de processos cognitivos (chamados de Sistemas 1 e 2, respectivamente), que fazem parte da mente humana, sendo o primeiro responsável pelas operações mentais rápidas e automáticas, sempre baseadas em associações e relacionadas à intuição e, o segundo, é mais controlado, vagaroso, flexível, autogovernado, associado ao raciocínio, representações e tempo.

Uma das principais funções do Sistema 2 é a de monitorar e controlar os pensamentos, bem como as ações automáticas "sugeridos” do Sistema $1^{31}$. Quando o consumidor é exposto a ilusões, alucinações, pressões de grupo e paixões, é o Sistema 2 o encarregado de corrigir essas soluções falaciosas, o que nem sempre acontece, acarretando os erros e desvios nas tomadas de decisões. É preciso, portanto, levar em consideração toda a questão emocional envolvida no funcionamento mental nas tomadas de decisões, pois todo estímulo tem uma avaliação afetiva que não é consciente ${ }^{32}$.

A partir dessas constatações e postulados, no próximo tópico, serão apresentadas algumas heurísticas de julgamento que podem exemplificar e comprovar a teoria em estudo. Posteriormente, após a análise dessas distorções neurocognitivas, avaliar-se-á de que modo a educação formal para o consumo pode eliminar ou amenizar os erros sistemáticos.

\section{HeURísticas e Vieses: as distorções neUROCognitivas nas tomadas de deCisões dos CONSUMIDORES}

Heurísticas e vieses são pensamentos que vêm à mente rapidamente e sem muita reflexão ${ }^{33}$. São decisões popularmente conhecidas como "bate-pronto". Trata-se, enfim, de uma simplificação no processo decisório do agente que pode levá-lo a decisões adequadas e imperfeitas. Apesar disso, não se pode condená-los totalmente no dia a dia das relações de mercado, especialmente as relações de consumo, haja vista que o mercado é dinâmico e necessita de decisões rápidas, mesmo diante de situações com grande quantidade de dados e variáveis.

Muitas das heurísticas e vieses (manifestações neurocognitivas) podem ser estimuladas ou evitadas de acordo com os incentivos aos quais as pessoas são expostas ${ }^{34}$. Isto quer dizer que práticas comerciais e políticas econômicas podem influir nas decisões dos consumidores, nos diversos mercados de consumo. Aliás, isso é inerente ao mercado de consumo, já que consumidor e fornecedor possuem comportamentos distintos, mas complementares. Se, de um lado, o consumidor tem necessidades de bens e serviços para a sua subsistência, bem-estar e comodidade, de outro lado, o fornecedor precisa vender tais bens e serviços. Assim, enquanto o fornecedor visa ao lucro, o consumidor visa ao bem-estar (satisfação e comodidade); enquanto os fornecedores aspiram custos momentâneos e benefícios futuros, os consumidores aspiram

29 DOMINGUES, Victor Hugo. Vieses e heurísticas. In: RIBEIRO, Marcia Carla Pereira; DOMINGUES, Victor Hugo; KLEIN, Vinicius. Análise econômica do direito. Curitiba: CRV, 2016. p. 51-52.

30 KAHNEMAN, Daniel. Rápido e devagar: duas formas de pensar. Rio de Janeiro: Objetiva, 2012. p. 58.

31 KAHNEMAN, Daniel. Rápido e devagar: duas formas de pensar. Rio de Janeiro: Objetiva, 2012. p. 58.

32 OLIVEIRA, Amanda Flávio de; CARVALHO, Diógenes Faria de. Vulnerabilidade comportamental do consumidor: por que é preciso proteger o consumidor superendividado. Revista de Direito do Consumidor, São Paulo, v. 104, mar./abr. 2016. p. 185.

33 KAHNEMAN, Daniel. Rápido e devagar: duas formas de pensar. Rio de Janeiro: Objetiva, 2012. p. 156.

34 DOMINGUES, Victor Hugo. Vieses e heurísticas. In: RIBEIRO, Marcia Carla Pereira; DOMINGUES, Victor Hugo; KLEIN, Vinicius. Análise econômica do direito. Curitiba: CRV, 2016. p. 52. 
benefícios momentâneos e custos futuros (desconto hiperbólico).

O chamado desconto hiperbólico, provavelmente, representa uma das descobertas mais plausíveis da economia comportamental e revela um problema de autocontrole. Segundo essa descoberta, as pessoas sofrem conflitos entre as alternativas de longo e curto prazo e que podem resultar em escolhas totalmente inconsistentes. É o dilema que o consumidor se depara, quando se pretende adquirir um produto de valor considerável em uma determinada loja: (a) comprar em curto prazo e sair imediatamente com a mercadoria ou, (b) poupar em longo prazo e adquirir a mercadoria no futuro ${ }^{35}$.

Gregory Mankiw ${ }^{36}$ exemplifica a situação da seguinte forma: imagine as seguintes opções, em que uma determinada pessoa é submetida a decidir: (a) passar 50 minutos cumprindo uma tarefa irritante imediatamente ou passar 60 minutos cumprindo a tarefa irritante amanhã? A maioria das pessoas preferem a segunda opção; (b) passar 50 minutos cumprindo a tarefa irritante daqui a 90 dias ou passar 60 minutos cumprindo a tarefa irritante daqui a 91 dias? A maioria das pessoas preferem a primeira opção.

Quando olham para o futuro, as pessoas minimizam a quantidade de tempo dedicada à tarefa. Mas, diante da perspectiva de cumprir imediatamente, as pessoas preferem adiar. Os economistas acreditam que a decisão consumo-poupança é um exemplo importante dessa inconsistência ao longo do tempo. Para muitas pessoas, os gastos (consumo) representam uma forma de satisfação imediata. Por outro lado, poupar (poupança) exige um sacrifício do presente em troca de uma recompensa futura ${ }^{37}$.

Dessa distorção cognitiva decorrem os chamados consumidores míopes, ou seja, que enxergam apenas de perto e possuem uma visão embaçada no longo alcance. Essa constatação da economia comportamental explica, de maneira bastante convincente e plausível, as decisões dos consumidores por compras a prazo ou por aquisição de créditos bancários, acarretando o comprometimento das suas rendas e resultando nos endividamentos frequentes.

O viés do desconto hiperbólico é, ainda, exacerbado por outro viés reconhecido pela economia comportamental, qual seja, o do otimismo. A ocorrência desse viés torna o agente (consumidor) acomodado, impedindo-o de agir preventivamente, pois ele acredita que "o pior" não vai acontecer, ou que são muito maiores as probabilidades de uma situação desagradável acontecer aos outros e não a ele mesmo ${ }^{38}$.

O viés do otimismo é nitidamente verificado na realidade do dia a dia, em que os consumidores, de forma precipitada, aumentam mais e mais seus gastos, com a convicção otimista de que "as coisas irão melhorar"39, "vamos conseguir pagar", "não vamos passar por dificuldades".

Outra modalidade de heurística que pode influir no julgamento dos agentes é a chamada heurística de disponibilidade. Essa manifestação neurocognitiva explica que os agentes tendem a adotar as informações que lhe vêm mais instantaneamente à mente, seja por que são mais recentes, seja porque são marcantes. Assim, os agentes avaliam e tomam suas decisões de acordo com eventos anteriores, que são hiperestimados ou subestimados, de acordo com o momento ou a importância em que ocorreram.

A heurística da disponibilidade mostra que, se um consumidor se informou sobre um dado evento negativo ou positivo, recentemente, essa pessoa tende a superestimar a probabilidade da ocorrência desse evento, tal como um acidente violento, cuja mensagem forma uma base disponível e pronta para superestimar o risco de similar incidente no futuro ${ }^{40}$.

35 OLIVEIRA, Amanda Flávio de; CARVALHO, Diógenes Faria de. Vulnerabilidade comportamental do consumidor: por que é preciso proteger o consumidor superendividado. Revista de Direito do Consumidor, São Paulo, v. 104, p. 181-201, mar./abr. 2016. p. 185.

36 MANKIW, Nicholas Gregory. Introdução à economia. São Paulo: Cengage Learning, 2013. p. 456-457.

37 MANKIW, Nicholas Gregory. Introdução à economia. São Paulo: Cengage Learning, 2013. p. 458.

38 FORGIONI, Paula A. Contratos empresariais: teoria geral e aplicação. 2. ed. São Paulo: Revista dos Tribunais, 2016. p. 102.

39 OLIVEIRA, Amanda Flávio de; CARVALHO, Diógenes Faria de. Vulnerabilidade comportamental do consumidor: por que é preciso proteger o consumidor superendividado. Revista de Direito do Consumidor, São Paulo, v. 104, p. 181-201, mar./abr. 2016 . p. 187.

40 OLIVEIRA, Amanda Flávio de; CARVALHO, Diógenes Faria de. Vulnerabilidade comportamental do consumidor: por que é 
Da mesma forma, pode ocorrer o inverso, quando a ocorrência do evento não é frequente ou é distante, provocando a subestimação de sua nova ocorrência na vida do consumidor.

$\mathrm{Na}$ relação consumerista, isso pode ocorrer com as chamadas publicidades dissimuladas em forma de reportagem jornalística ${ }^{41}$. Por exemplo, uma fornecedora de produtos lácteos pode divulgar uma publicidade com a seguinte informação: "o iogurte é fundamental para a prevenção ao câncer". Diante dessa publicidade, os consumidores podem superestimar o consumo do iogurte, como forma de prevenir a doença ${ }^{42}$.

A heurística de ancoragem, para citar outra modalidade de manifestação neurocognitiva, revela que, em julgamentos sob incerteza, quando as pessoas devem realizar estimativas ou decidir sobre alguma quantia, elas tendem a ajustar a sua resposta com base em algum valor inicial disponível que servirá como âncora ${ }^{43}$. Trata-se, assim, de uma espécie de sugestão que o consumidor acaba tomando por base para tomar suas decisões ${ }^{44}$.

Kahneman expõe uma situação bastante elucidativa acerca da heurística de ancoragem. Afirma que, certa vez, o supermercado Sioux City, localizado em Iowa, ofertou uma promoção 10\% (dez por cento) abaixo do preço normal para a sopa da marca Campbell's. A promoção foi anunciada de duas formas. Na primeira, o produto foi anunciado com limite quantitativo de aquisição de 12 (doze) unidades, por pessoa. Na segunda, o produto foi anunciado sem limites quantitativos de aquisição. Por meio desse exemplo, verifica-se, perfeitamente, o efeito da ancoragem na mente dos consumidores. Enquanto na primeira oferta os consumidores adquiriram, em média, 7 (sete) unidades do produto, na segunda, os consumidores adquiriram, apenas, 3 (três) ${ }^{45}$.

A heurística em questão pode explicar mecanismos de indução ao consumo ou indução ao consumo em maior escala a partir de ofertas e publicidades agressivas ou direcionadas e que pode contribuir para o superendividamento do consumidor ${ }^{46}$.

Por último, a heurística de representatividade, nos ensinamentos de Russel Korobkin e Thomas Ulen ${ }^{47}$, refere-se à tendência dos sujeitos de superestimar a correlação entre o que algum objeto aparenta ser e o que esse objeto realmente é. Essa heurística leva o consumidor a considerar as semelhanças entre dois objetos (ou eventos) para inferir que um deles possui as características de outro ao qual ele se assemelha. Em simples palavras, trata-se de generalizar, em uma categoria mais ampla, os objetos de comparação, tomando-se por base as experiências anteriores.

No campo das relações de consumo, a heurística de representatividade pode ser verificada no desempenho de determinado produto no passado ou presente ser representativo de um desempenho geral que o produto continuará a ter no futuro. É o que ocorre com determinados produtos de marcas famosas que representam, na mente do consumidor, sempre um bom desempenho, como é o caso, do sabão em pó da cor azul escuro.

preciso proteger o consumidor superendividado. Revista de Direito do Consumidor, São Paulo, v. 104, p. 181-201, mar./abr. 2016. p. 187. 41 A publicidade dissimulada é proibida pelo Conar, no art. 30, que estabelece: "A peça jornalística sob a forma de reportagem, artigo, nota, texto-legenda ou qualquer outra que se veicule mediante pagamento, deve ser apropriadamente identificada para que se distinga das matérias editoriais e não confunda o consumidor".

42 O art. 36 do Código do Consumidor adota a regra da obrigatória identificação da publicidade, por meio do qual o consumidor deve ter consciência inequívoca de que é o destinatário de uma publicidade. E, com base nesse fundamento legal, é que se proíbe as publicidades que sejam dissimuladas, clandestinas e subliminares e que têm o condão de distorcer a racionalidade do consumidor.

43 SANTOLIM, Cesar. Behavoral law and economics e a teoria dos contratos. In: MARQUES, Cláudia Lima; GSELL, Beate. Novas tendências do direito do consumidor. São Paulo: Revista dos Tribunais, 2015. p. 170.

44 KAHNEMAN, Daniel. Rápido e devagar: duas formas de pensar. Rio de Janeiro: Objetiva, 2012. p. 156.

45 KAHNEMAN, Daniel. Rápido e devagar: duas formas de pensar. Rio de Janeiro: Objetiva, 2012. p. 161.

46 OLIVEIRA, Amanda Flávio de; CARVALHO, Diógenes Faria de. Vulnerabilidade comportamental do consumidor: por que é preciso proteger o consumidor superendividado. Revista de Direito do Consumidor, São Paulo, v. 104, p. 181-201, mar./abr. 2016. p. 188. 47 KOROBKIN; ULEN apud OLIVEIRA, Amanda Flávio de; FERREIRA, Felipe Moreira dos Santos. Análise econômica do direito do consumidor em períodos de recessão: uma abordagem a partir da economia comportamental. Revista de Direito do Consumidor, São Paulo, v. 81, p. 13-38, jan./mar. 2012. p. 23. 
Enfim, essas heurísticas e vieses estão presentes na vida das pessoas quando se faz escolhas e, o Direito, por missão institucional e vocação temática, é o campo da ciência que pode moldar com eficiência o design dos incentivos ${ }^{48}$. A alternativa que o presente artigo se propõe a averiguar diz respeito à educação formal e inicial do consumidor, como forma de potencializar a reflexão e a crítica do consumidor. É o que se passa a analisar com base no próximo tópico.

\section{A EDUCAÇão Formal E INICIAL PARA O CONSUMO PELA Ótica da ECONOMIA COMPORTAMENTAL GARANTE A PRESENÇA REFLETIDA DO CONSUMIDOR NO MERCADO?}

Muito se discute acerca da educação formal destinada ao consumidor, como forma de preveni-lo e de orientá-lo a uma presença mais refletida no mercado de consumo, evitando, assim, as armadilhas decorrentes das práticas comerciais e, mesmo, da política econômica, os quais, frequentemente, acarretam o consumismo e, consequentemente, o endividamento do consumidor.

Mas de quem é, efetivamente, a "culpa" pelo endividamento ou superendividamento do consumidor? Seria do próprio consumidor que anseia pelo seu bem-estar e comodismo, fazendo gastos desnecessários e supérfluos ou seria dos fornecedores, notadamente, os de crédito, que adotam práticas comerciais agressivas e exploradoras da irracionalidade do consumidor e não avaliam corretamente o perfil do seu beneficiário?

A discussão é profunda e parece entrar em um círculo vicioso: ora, é o consumidor que não reflete sobre seus atos de consumo, ora, é o fornecedor o responsável por distorcer o comportamento do consumidor.

Um fato, no entanto, é certo. Economistas, psicólogos e juristas concordam que o consumidor se encontra em situação de inferioridade frente ao fornecedor, no mercado de consumo. No entanto, enquanto os juristas nominam esse fato como vulnerabilidade, os economistas o nominam de racionalidade limitada. Essa limitação da racionalidade, na esfera econômica, decorre da assimetria de informações, ao passo que a vulnerabilidade, na esfera jurídica, decorre do reconhecimento da presunção de inferioridade técnica, econômica, fática e jurídica do consumidor. São, portanto, dois conceitos muito aproximados. Em verdade, a perspectiva da racionalidade limitada (elemento econômico) é mais um fundamento para a compreensão da vulnerabilidade (elemento jurídico).

O reconhecimento dessa inferioridade do consumidor é importante para a percepção, também, da necessidade de intervenção do Estado na relação e no mercado de consumo. E é, nesse tema, que se diferenciam as abordagens clássica e behaviorista. Consoante Cesar Santolin"4, "a behavioral, ao prestigiar as limitações da racionalidade acaba por enfatizar não somente a conveniência mas até a necessidade de um maior dirigismo contratual, abrindo portas para soluções que a abordagem neoclássica qualifica como paternalista".

$\mathrm{Na}$ concepção dos comportamentalistas, portanto, a intervenção do Estado na relação e no mercado de consumo é necessária, mesmo porque o mercado de consumo deve ser harmônico e equilibrado ${ }^{50}$, para proteger não apenas a pessoa do consumidor, mas também a saúde do próprio mercado de consumo. Mas, como deve ser feita essa intervenção? Qual a política pública a ser adotada para assegurar a harmonia das relações e do mercado de consumo? Uma das alternativas propostas por este artigo é a educação formal e

48 DOMINGUES, Victor Hugo. Vieses e heurísticas. In: RIBEIRO, Marcia Carla Pereira; DOMINGUES, Victor Hugo; KLEIN, Vinicius. Análise econômica do direito. Curitiba: CRV, 2016. p. 52.

49 SANTOLIM, Cesar. Behavoral law and economics e a teoria dos contratos. In: MARQUES, Cláudia Lima; GSELL, Beate. Novas tendências do direito do consumidor. São Paulo: Revista dos Tribunais, 2015. p. 176.

50 O inciso II do art. $4^{\circ}$ do Código do Consumidor assegura o princípio da harmonização, como princípio da Política Nacional das Relações de Consumo, ao prescrever: "harmonização dos interesses dos participantes das relações de consumo e compatibilização da proteção do consumidor com a necessidade de desenvolvimento econômico e tecnológico, de modo a viabilizar os princípios nos quais se funda a ordem econômica (art. 170, da Constituição Federal), sempre com base na boa-fé e equilíbrio nas relações entre consumidores e fornecedores". 
inicial dos consumidores, ainda jovens, como forma de preparar os seus comportamentos para o mercado de consumo.

Diante dessas primeiras impressões, há uma aparente condução a que conclua, a partir da economia comportamental, pela necessidade da educação formal e inicial do consumidor. Mas será essa política pública, de fato, efetiva e eficiente para proteger o consumidor frente às estratégias do fornecedor?

Apesar de reconhecer a necessidade da intervenção estatal, parece que a economia comportamental não vê, na educação formal e inicial, a chave para solucionar desequilíbrios e oportunismos do mercado de consumo. Evidentemente, não se pode negar que informação e educação nunca são de menor relevância, sendo indiscutivelmente importante para amenizar as discrepâncias do mercado.

A educação formal para o consumo é importante na medida em que está diretamente relacionada ao exercício típico da cidadania, sendo ato inerente à vida de todos os cidadãos. Tanto isso o é verdade que, o Presidente norte-americano, John Fitzgerald Kennedy, já em 1962, encaminhou Mensagem Especial ao Congresso dos Estados Unidos, com os seguintes dizeres:

Consumidores, por definição, somos todos nós. Os consumidores são o maior grupo econômico na economia, afetando e sendo afetado por quase todas as decisões econômicas, públicas e privadas [...]. Mas são o único grupo importante da economia não eficazmente organizado e cujos posicionamentos quase nunca são ouvidos ${ }^{51}$.

Entretanto, o mercado, sempre, é dinâmico. Os fornecedores, sempre, maximizarão seus lucros, buscando mecanismos (e armadilhas) diversos para chamar a atenção do consumidor. E os consumidores sempre maximizarão seu bem-estar, no sentido de satisfazer as suas diversas necessidades e comodismos, destinando seus rendimentos para o consumismo, o que, aliás, faz parte da economia capitalista, como explicam Amanda Flavio de Oliveira e Rute Saraiva ${ }^{52}$ : "se o capitalismo está escolhido e consagrado como modelo econômico, a ação dos agentes econômicos privados é, portanto, legítima".

Outrossim, segundo Oren Bar-Grill, em certos mercados, os erros dos consumidores e as estratégias dos fornecedores como resposta a esses erros são responsáveis por perdas substanciais de bem-estar, ou seja, os fornecedores são e sempre serão oportunistas e se aproveitarão da condição de inferioridade do consumidor para atingir o seu intento (o lucro). O consumidor, por outro lado, não é uma máquina com capacidade computacional ilimitada e em um ambiente ceteris paribus ${ }^{53}$, estando, pois, submetidos às estratégias do fornecedor.

Por conseguinte, é de se destacar, ainda, que as heurísticas e vieses são regras gerais de influência ${ }^{54}$ do comportamento que afetam o psicológico e o inconsciente do ser humano. Ao agirem dessa forma, as heurísticas e vieses tornam-se invencíveis, mesmo diante de ostensiva informação e educação, ou, como diz Daniel Kahneman ${ }^{55}$, "os insights cognitivos e as heurísticas são mais poderosos que a informação".

Aliás, a adoção da educação formal e inicial para o consumo, no ensino básico ${ }^{56}$, contraria postulados

51 KENNEDY, 1962 apud CAVALIERI FILHO, Sergio. Programa de direito do consumidor. 4. ed. São Paulo: Atlas, 2014. p. 101-102. 52 OLIVEIRA, Amanda Flávio de; SARAIVA, Rute. O Tribunal de Justiça de São Paulo e a anulação de multa aplicada à McDonald's em razão de publicidade abusiva: ou, a quem cabe educar as nossas crianças? Revista de Direito do Consumidor, São Paulo, v. 106, p. 325-355, jul./ago. 2016. p. 327.

53 OLIVEIRA, Amanda Flávio de; SARAIVA, Rute. O Tribunal de Justiça de São Paulo e a anulação de multa aplicada à McDonald's em razão de publicidade abusiva: ou, a quem cabe educar as nossas crianças? Revista de Direito do Consumidor, São Paulo, v. 106, p. 325-355, jul./ago. 2016. p. 338.

54 SANTOLIM, Cesar. Behavoral law and economics e a teoria dos contratos. In: MARQUES, Cláudia Lima; GSELL, Beate. Novas tendências do direito do consumidor. São Paulo: Revista dos Tribunais, 2015. p. 170.

55 KAHNEMAN, Daniel. Rápido e devagar: duas formas de pensar. Rio de Janeiro: Objetiva, 2012. p. 156.

56 O Sistema Educacional Brasileiro é constituído por dois níveis [art. 21 da Lei n. 9.394/1996 (Lei de Diretrizes e Bases da Educação)]: (a) Educação básica; e, (b) Educação superior. O primeiro nível, por sua vez, é composto por três etapas: (a) educação infantil (crianças de até 6 (seis) anos de idade); (b) ensino fundamental (crianças e adolescentes dos 7 (sete) até os 15 (quinze) anos); e, (c) ensino médio (adolescentes de 16 (dezesseis) a 18 (dezoito) anos). 
da própria economia comportamental, notadamente, a heurística de disponibilidade, já que a criança e o adolescente, por ocasião do momento em que recebem a educação, ainda não são efetivos consumidores, no sentido de ser participantes da relação de consumo como compradores e adquirentes, o que somente vem a ocorrer na fase adulta, quando o aprendizado já se tornou informação distante, provocando no agente uma subestimação dos ensinamentos transmitidos.

No mesmo sentido, Bruna Giacomini Lima e Vitor Hugo do Amaral Ferreira ${ }^{57}$ dissertam que a simples educação passiva, teórica e abstrata não encontra equivalência nas poderosas forças psicológicas. A educação e a informação são certamente valiosas, entretanto, é precioso reconhecer-se a limitação dessas iniciativas e valer-se de instrumentos adicionais de tutela.

A pesquisa, portanto, não desconsidera a elaboração de eventual política pública, no âmbito da educação formal para o consumo. Mas, uma ação governamental para a educação do consumidor seria, apenas, um reforço, um complemento, destinado a atuar, significativamente, na mudança de mentalidade e comportamento do cidadão. Este, que está, no mercado de consumo, sujeito a práticas comerciais que distorcem a sua racionalidade e por políticas econômicas que, apesar de lhe proporcionar o bem-estar, também o incentiva ao consumo, causando-lhe drásticas consequências sociais e financeiras, como o endividamento e a escassez de recursos naturais.

Pensa-se como Esptein ${ }^{58}$, que as manifestações neurocognitivas (heurísticas e vieses) conduzem à conclusão de que a melhor forma de aprendizagem para o consumidor é a partir dos erros cometidos no passado. Trata-se do conhecimento obtido pela experiência. E, nesse particular, a educação para o consumo deve partir e contar com a participação da família, a qual tem o primordial dever de educar as suas crianças e jovens, em corresponsabilidade com a sociedade e o Estado, como preconiza o art. $227^{59}$ da Constituição da República.

Ainda que nem todas as famílias tenham familiaridade com as heurísticas e vieses do mercado de consumo, é pela educação transmitida pela família que o futuro consumidor toma conhecimento dos erros sistemáticos cometidos em compras desnecessárias, dos problemas patrimoniais decorrentes do endividamento e do superenvididamento, do tamanho do poder aquisitivo da família, das prioridades familiares na aquisição de produtos e na contratação de serviços, da conscientização acerca do desperdício de alimentos e, especialmente, do equilíbrio entre receitas e despesas.

\section{Considerações finais}

Economistas, psicólogos e juristas concordam que o consumidor se encontra em situação de inferioridade frente ao fornecedor no mercado de consumo. No entanto, enquanto os juristas nominam esse fato como vulnerabilidade, os economistas o nominam de racionalidade limitada. O reconhecimento dessa inferioridade do consumidor é importante para que se analise o papel de intervenção do Estado na relação e no mercado de consumo, fato este não reconhecido pelos economistas clássicos em razão de seu caráter paternalista.

57 LIMA, Bruna Giacomini; FERREIRA, Vitor Hugo do Amaral. Homo economicus: os (des)encontros da sociedade de consumo superendividada. In: FERREIRA, Vitor Hugo do Amaral; CARVALHO, Diógenes Faria de; SANTOS, Nivaldo dos. Sociedade de consumo: pesquisas em direito do consumidor. Goiânia: Espaço Acadêmico, 2015. p. 64.

58 ESPTEIN apud SANTOLIM, Cesar. Behavoral law and economics e a teoria dos contratos. In: MARQUES, Cláudia Lima; GSELL, Beate. Novas tendências do direito do consumidor. São Paulo: Revista dos Tribunais, 2015. p. 178.

59 Art. 227. É dever da família, da sociedade e do Estado assegurar à criança, ao adolescente e ao jovem, com absoluta prioridade, o direito à vida, à saúde, à alimentação, à educação, ao lazer, à profissionalização, à cultura, à dignidade, ao respeito, à liberdade e à convivência familiar e comunitária, além de colocá-los a salvo de toda forma de negligência, discriminação, exploração, violência, crueldade e opressão. BRASIL. Constituição (1988). Constituição da República Federativa do Brasil. Disponível em: <http://www.planalto.gov.br/ccivil_03/constituicao/constituicao.htm>. Acesso em: 5 maio 2018. 
Práticas comerciais do mercado de consumo e algumas políticas econômicas adotadas pelo governo conduzem o agente ao ato de consumo. Tais fatos, no entanto, são totalmente legítimos. É evidente que o empresário que atua no mercado com o objetivo exclusivo de lucro deverá envidar todos os seus esforços para a comercialização de seus produtos e serviços, disponibilizando, para tanto, ofertas e publicidades direcionadas a angariar clientes consumidores. Da mesma forma, o Estado brasileiro que é, por opção, capitalista, tende à adoção de políticas econômicas voltadas ao crescimento e desenvolvimento econômicos.

A educação formal para o consumo, do ponto de vista da economia comportamental, pode não ser suficiente para corrigir ou amenizar as distorções neurocognitivas (heurísticas e vieses) que afetam o consumidor. Isso porque o mercado não é perfeito e estático e o consumidor não é um biônico e nem um maximizador racional, de modo que tais distorções neurocognitivas tornam-se invencíveis, mesmo diante de ostensiva informação e educação.

A melhor forma de aprendizagem para o consumidor, portanto, começa com os erros cometidos no passado (experiência). E, nesse particular, a educação para o consumo deve partir e contar com a participação da família, em corresponsabilidade com a sociedade e o Estado, pois é nesse ambiente que a criança e o jovem consumidor tende a receber o aprendizado mais efetivo e eficiente, baseado em experiências normalmente já vivenciadas e capazes de lhe proporcionar a captação de uma racionalidade mais adequada.

Por último, não se corrobora o entendimento de que o fornecedor não deva ser tomado como o principal responsável pela promoção da educação do consumidor, não por causa do conflito de interesses, mas sim porque, economicamente, esse dever de educação geraria maiores custos de transação ao fornecedor, acarretando a transferência desses custos para o próprio mercado de consumo.

\section{REFERÊNCIAS}

ALVES, Giovani Ribeiro Rodrigues. Economia comportamental. In: RIBEIRO, Marcia Carla Pereira; KLEIN, Vinicius. O que é análise econômica do direito: uma introdução. 2. ed. Belo Horizonte: Fórum, 2016. p. 75-82.

ASSOCIAÇÃO DE EDUCAÇÃO FINANCEIRA DO BRASIL. Educação financeira nas Escolas. Disponível em: <http://www.aefbrasil.org.br/index.php/programas-e-projetos/educacao-financeira-nas-escolas/>. Acesso em: 6 fev. 2018.

CAVALIERI FILHO, Sergio. Programa de direito do consumidor. 4. ed. São Paulo: Atlas, 2014.

COURI, Sergio. Liberalismo e societalismo. Brasília: UnB, 2001.

DOMINGUES, Victor Hugo. Vieses e heurísticas. In: RIBEIRO, Marcia Carla Pereira; DOMINGUES, Victor Hugo; KLEIN, Vinicius. Análise econômica do direito: justiça e desenvolvimento. Curitiba: CRV, 2016. p. 49-53.

EFING, Antônio Carlos. Direito do consumo e direito do consumidor: reflexões oportunas. Revista LusoBrasileira de Direito do Consumo, Brasília, v. 1, n. 1, p. 103-120, 2011.

EFING, Antônio Carlos; POLEWKA, Gabriele; OYAGUE, Olenka Woolcott. A crise econômica brasileira e o superendividamento da população: emergência do aprimoramento legislativo para a tutela social. Revista de Direito do Consumidor, São Paulo, v. 24, n. 101, set./out. 2015.

FILOMENO, José Geraldo Brito. Manual de direitos do consumidor. 13. ed. São Paulo: Atlas, 2015.

FORGIONI, Paula A. Contratos empresariais: teoria geral e aplicação. 2. ed. São Paulo: Revista dos Tribunais, 2016. 
GICO JUNIOR, Ivo Teixeira. Introdução ao direito e economia. In: TIMM, Luciano Benetti. Direito e economia no Brasil. São Paulo: Atlas, 2012. p. 1-33.

GRUNDMANN, Stefan. A proteção funcional do consumidor: novos modelos de consumidor à luz de teorias recentes. In: MARQUES, Cláudia Lima; GSELL, Beate. Novas tendências do direito do consumidor. São Paulo: Revista dos Tribunais, 2015. p. 23-45.

KAHNEMAN, Daniel. Rápido e devagar: duas formas de pensar. Rio de Janeiro: Objetiva, 2012.

LIMA, Bruna Giacomini; FERREIRA, Vitor Hugo do Amaral. Homo economicus: os (des)encontros da sociedade de consumo superendividada. In: FERREIRA, Vitor Hugo do Amaral; CARVALHO, Diógenes Faria de; SANTOS, Nivaldo dos. Sociedade de consumo: pesquisas em direito do consumidor. Goiânia: Espaço Acadêmico, 2015. p. 52-72.

MANKIW, Nicholas Gregory. Introdução à economia. São Paulo: Cengage Learning, 2013.

MARQUES, Cláudia Lima. Manual de direito do consumidor. 6. ed. São Paulo: Revista dos Tribunais, 2014.

MORAIS, Ezequiel; PODESTÁ, Fábio Henrique; CARAZAI, Marcos Marins. Código de Defesa do Consumidor comentado. São Paulo: Revista dos Tribunais, 2010.

MUÑOZ, Maria Paula Costa Bertran. Paralelismo entre assimetria de informações e vulnerabilidade dos consumidores: uma análise acerca de juros em contratos de concessão de crédito. Revista de Direito do Consumidor, São Paulo, v. 86, p. 47-63, mar./abr. 2013.

OLIVEIRA, Amanda Flávio de; CARVALHO, Diógenes Faria de. Vulnerabilidade comportamental do consumidor: por que é preciso proteger o consumidor superendividado. Revista de Direito do Consumidor, São Paulo, v. 104, p. 181-201, mar./abr. 2016.

OLIVEIRA, Amanda Flávio de; FERREIRA, Felipe Moreira dos Santos. Análise econômica do direito do consumidor em períodos de recessão: uma abordagem a partir da economia comportamental. Revista de Direito do Consumidor, São Paulo, v. 81, p. 13-38, jan./mar. 2012.

OLIVEIRA, Amanda Flávio de; SARAIVA, Rute. O Tribunal de Justiça de São Paulo e a anulação de multa aplicada à McDonald's em razão de publicidade abusiva: ou, a quem cabe educar as nossas crianças? Revista de Direito do Consumidor, São Paulo, v. 106, p. 325-355, jul./ago. 2016.

RIBEIRO, Marcia Carla Pereira. Racionalidade limitada. In: RIBEIRO, Marcia Carla Pereira; KLEIN, Vinicius. O que é análise econômica do direito: uma introdução. 2. ed. Belo Horizonte: Fórum, 2016. p. 59-65.

RIBEIRO, Marcia Carla Pereira; GALESKI JUNIOR, Irineu. Teoria geral dos contratos: contratos empresariais e análise econômica. 2. ed. São Paulo: Revista dos Tribunais, 2015.

RIBEIRO, Marcia Carla Pereira; MARTINEZ, Sergio Rodrigo. A ética econômica no ensino do direito ambiental segundo a perspectiva de Amartya Sen. In: RIBEIRO, Marcia Carla Pereira; MARTINEZ, Sergio Rodrigo. Desenvolvimento e meio ambiente: o pensamento econômico de Amartya Sen. Belo Horizonte: Fórum, 2011. p. 129-147.

SANTOLIM, Cesar. Behavoral law and economics e a teoria dos contratos. In: MARQUES, Cláudia Lima; GSELL, Beate. Novas tendências do direito do consumidor. São Paulo: Revista dos Tribunais, 2015. p. 166-181.

TARTUCE, Flavio; NEVES, Daniel Amorim Assumpção. Manual de direito do consumidor: direito material e processual. 2. ed. São Paulo: Método, 2013.

VERÇOSA, Haroldo Malheiros Duclerc. Direito comercial: teoria geral do contrato. 2. ed. São Paulo: Revista dos Tribunais, 2014.

WILLIAMSON, Oliver. The mecanisms of governance. New York: Oxford University Press, 1996. 


\title{
Libet, determinismo e consumo: as influências do marketing e a relevância da deliberação consciente na superação condicional de hábitos de consumo perigosos*
}

\author{
Libet, determinism and consumption: \\ influences of marketing and the relevance \\ of conscious deliberation in overcoming \\ dangerous consumer habits
}

Émilien Vilas Boas Reis**

Leonardo Cordeiro de Gusmão***

\section{Resumo}

Este artigo investiga se os indivíduos são capazes, mediante ato volitivo, de superar hábitos de consumo que colocam em risco o direito fundamental à segurança, inclusive aqueles formados por influências ao seu inconsciente, exercidas por estímulos aos sentidos e/ou emoções, promovidos pelo marketing na intenção de induzir o indivíduo a um comportamento orientado pelos interesses de mercado de seu patrocinador. Sob tal propósito, utiliza-se do método de raciocínio dedutivo com pesquisa qualitativa, descritiva e explicativa, mediante uma análise bibliográfica e documental. Após as verificações dos estudos de Benjamin Libet e das respectivas interpretações, faz-se uma breve abordagem com base nas reflexões filosóficas de Martin Heidegger, levando à compreensão de que o ser humano não é completamente determinado, sendo suas escolhas resultado tanto de processos mentais inconscientes quanto de atos volitivos. Posteriormente, destaca-se a vulnerabilidade do consumidor diante de estímulos ao seu inconsciente, promovidos pelo marketing na intenção de induzi-lo a um comportamento que, se repetido no tempo, em condições estáveis, transformar-se-á em hábito de consumo. Ao final, conclui-se que os indivíduos estão aptos a superar, mediante deliberação consciente, hábitos de consumo perigosos, até mesmo aqueles formados em razão de estímulos promovidos pelo marketing, desde que tenham acesso às informações sobre os riscos relacionados aos produtos comercializados e, intencionalmente, em razão de motivações pessoais, modifiquem as circunstâncias ambientais que sustentam o hábito que desejam evitar. A originalidade do estudo está na constatação da possibilidade de o indivíduo exercer certa autonomia perante ações de marketing, por meio de deliberação consciente.

Palavras-chave: Benjamin Libet. Martin Heidegger. Marketing. Direitos fundamentais do consumidor. Hábitos de consumo perigosos. Deliberação consciente. 


\section{Abstract}

This paper investigates whether individuals are capable, from a volitional act, of overcoming consumer habits that endanger the fundamental right to security, including those formed from influences to the unconscious, exercised by incentives to the senses and/or emotions promoted by marketing in order to induce the individual to behave oriented by the market interests of its sponsor. For that purpose, it's used the method of deductive reasoning with qualitative, descriptive and explanatory research, through a bibliographical and documentary research technique. After exposing Benjamin Libet studies and respective interpretations, a brief approach is made about philosophical reflections of Martin Heidegger, which lead to the understanding that the human being is not completely determined, so his choices are result of both, unconscious mental processes and volitional acts. Then, it's highlighted the vulnerability of the consumer before the incentives promoted by marketing in order to induce him to a behavior that if repeated in time and in stable conditions, will turn into habits of consumption. In the end, it's concluded that individuals are able to overcome dangerous consumption habits through conscious deliberation, even those formed by incentives made by marketing, since they have access to information about the risks related to the products marketed and, intentionally, by reason of personal motivations, modify the environmental circumstances that sustain the habit that they wish to avoid. The originality of the paper lies in the realization of the possibility of the individual exercise his autonomy before marketing actions through conscious deliberation.

Keywords: Benjamin Libet. Martin Heidegger. Marketing. Fundamental consumer rights. Dangerous consumer habits. Conscious deliberation.

\section{INTRODUÇÃo}

O presente trabalho tem a pretensão de verificar se os indivíduos são capazes, mediante ato volitivo, de superar hábitos de consumo que colocam em risco o direito fundamental à segurança do consumidor hábitos perigosos —, inclusive aqueles formados com base em influências ao seu inconsciente, exercidas por estímulos aos seus sentidos e/ou emoções, os quais são promovidos pelo marketing com a intenção de induzir o consumidor a um comportamento orientado por interesses de mercado de seu patrocinador. Para tanto, utilizar-se-á do método de raciocínio dedutivo com pesquisa qualitativa, descritiva e explicativa, mediante uma análise bibliográfica e documental.

Relevante salientar que a noção de superação de hábitos a ser investigada nesse artigo não se refere à sua supressão definitiva da mente do consumidor, mas sim à possibilidade de evitá-los, desde que sejam mantidas as condições intencionalmente estabelecidas com tal propósito. Far-se-á uma ressalva, também, em relação a determinismos fisiológicos e psíquicos, que variam de acordo com os indivíduos, e que dificultam a superação, mesmo que condicional, de hábitos perigosos consolidados.

Sob tal perspectiva, inicialmente, serão relatados os experimentos científicos de Benjamin Libet, por meio dos quais se analisará o momento da manifestação de impulsos elétricos cerebrais em situações específicas, com a intenção de constatar se as escolhas realizadas pelos seres humanos têm origem em processos mentais exclusivamente inconscientes ou se a deliberação consciente, também, tem relevância.

Em seguida, serão mencionadas as interpretações que surgiram em consequência da pesquisa de Libet, dando-se destaque, por um lado, à própria interpretação de Libet e uma crítica sobre seu entendimento, e, por outro, às críticas a certas interpretações do experimento que veem nele uma "prova" do determinismo absoluto nas decisões volitivas. Posteriormente, tal compreensão será debatida à luz das reflexões filosóficas de Martin Heidegger, que também permitem questionar um pretenso determinismo incondicional nas ações humanas. 
No segundo tópico, serão analisadas as estratégias utilizadas pelo marketing, estabelecidas com base em pesquisas da neurociência, visando estimular os sentidos e/ou emoções do consumidor, com a intenção de influenciar suas escolhas de compra. Nesse contexto, ponderar-se-á sobre a legalidade da manipulação do inconsciente do consumidor para fins mercadológicos por meio da publicidade subliminar, considerando os limites impostos pelos direitos fundamentais à privacidade, intimidade, liberdade de manifestação do pensamento, liberdade de consciência, segurança e informação.

Por fim, delimitar-se-ão os elementos que contribuem para a formação dos hábitos de consumo, investigando a capacidade de autodeterminação consciente do consumidor. Será analisada, nesse viés, a possibilidade de o indivíduo superar um hábito de consumo que represente risco à segurança individual ou coletiva, mediante a criação de um novo hábito fundado em comportamento praticado com base em deliberação consciente.

Este estudo pode ser de interesse para as áreas do Direito, da Filosofia, da Neurociência, da Psicologia e do Marketing.

\section{O experimento de Benjamin Libet e algumas reflexões}

Em 1983, o psicólogo Benjamin Libet (1916-2007), juntamente a outros pesquisadores, produziu um paper denominado Time of conscious intention to act in relation to onset of cerebral activity (readiness-potential). The unconscious initiation of a freely voluntary act na revista Brain. Esse texto foi responsável por aquecer a antiga querela a respeito da existência do livre arbítrio, tão importante para a filosofia, a religião e o direito.

No texto, Libet et al. ${ }^{1}$ chamam a atenção para uma atividade cerebral denominada potencial de prontidão (Readiness-Potential - RP), descoberta na década de 60 por Hans Helmut Kornhuber (1928-2009) e Lüder Deecke $(1938)^{2}$, por meio de um experimento no cérebro, e que consistiu em verificar impulsos elétricos (RP) anteriores à "decisão" de um indivíduo movimentar um dedo, o que sugeriria uma atividade cerebral não consciente antes que alguém, conscientemente, decidisse escolher qual dedo mover. Libet et al. retomam o experimento com o intuito de verificar uma longa diferença temporal entre o potencial de prontidão e o ato voluntário, por meio da atividade cerebral anterior ao movimento deliberado.

A pesquisa contou com a participação de seis alunos universitários divididos em grupos de três, um dos participantes foi descartado posteriormente. Os universitários foram versados a iniciarem seus movimentos rapidamente, a fim de realizarem o movimento entre 10 e 20 milissegundos, sendo medidos por um eletromiograma (eletromyogram - EMG), que estava associado ao corpo por meio de eletrodos na cabeça, e registrado por um computador. ${ }^{3}$

Para verificação da tomada de consciência dos participantes ao moverem os dedos, pediu-se aos colaboradores que observassem a posição de um ponto de luz que girava tal como um ponteiro em círculo, o que lembrava um relógio. Assim, eles tinham de recordar em qual posição estava o ponteiro no momento que decidissem mover um dedo. ${ }^{4}$ Os participantes ficaram responsáveis por averiguarem o ponteiro que estava ligado a um osciloscópio de raios catódicos (cathode ray oscilloscope - CRO), observando a posição do

1 LIBET, Benjamin et. al. Time of conscious intention to act in relation to onset of cerebral activity (Readiness-Potential). The unconscious initiation of a freely voluntary act. Brain, Oxford, n. 106, p. 623-642, 1983.

2 KORNHUBER Helmut H.; DEECKE Lüder. Hirnpotentialanderungen bei Willkiirbewegungen und passiven Bewegungen des Menschen: Bereitschaftspotential und reafferente Potentiale. Pfiigers Archivfur Gesamte Physiologie, n. 284, p. 1-17, 1965.

3 LIBET, Benjamin et. al. Time of conscious intention to act in relation to onset of cerebral activity (Readiness-Potential). The unconscious initiation of a freely voluntary act. Brain, Oxford, n. 106, p. 623-642, 1983. p. 624-625.

4 LIBET, Benjamin et. al. Time of conscious intention to act in relation to onset of cerebral activity (Readiness-Potential). The unconscious initiation of a freely voluntary act. Brain, Oxford, n. 106, p. 623-642, 1983. p. 624. 
ponto no momento de sua percepção. Foram empregadas duas maneiras de registrar a memória do evento, a saber, (A), absoluto (absolute), onde o sujeito verificava a escala de tempo circular no aparelho, informando a posição do tempo em segundos (cada posição correspondia a 42,7 ms), e (O), ordenado (order), em que foi pedido ao sujeito que relatasse a posição final do ponteiro no osciloscópio no instante de sua consciência. ${ }^{5}$

Então, Libet et al. ${ }^{6}$ cronometraram três tipos distintos de experiências subjetivas conscientes:

a) Série W (wanting): foi pedido ao sujeito que anotasse e, posteriormente, relatasse o horário de sua consciência de "querer" realizar um determinado movimento auto iniciado.

b) Série M (actually moved): foi verificado o tempo de conscientização do sujeito que "realmente fez um movimento" num ato auto iniciado, sendo relatada cada tentativa.

c) Série S (awarennes of the sensation): foi anotado e relatado cada tentativa do tempo de "consciência da sensação" provocada por um estímulo externo aleatório em tempos irregulares nas costas da mão.

Após algumas séries de treinamento, foram registrados 40 tempos em cada série (W, M ou S). Os valores médios de W foram de $-200 \mathrm{~ms}$, já os valores médios de $\mathrm{S}$ foram de $-50 \mathrm{~ms}$. Ao subtrair a média de W da média de $\mathrm{S}$, os valores de $\mathrm{W}$ foram alterados para -150 ms. Já os valores médios de $\mathrm{M}$ foram de $-85 \mathrm{~ms}$. Ao subtrair S de M resta um tempo entre $-40 \mathrm{~ms}$ e $-35 \mathrm{~ms}$. A constatação foi de que a consciência de querer mover precedeu a percepção de realmente mover. $^{7}$

Libet et al., também, confrontaram o potencial de prontidão (RP) anterior ao tempo do ato voluntário do querer agir (W). Os RPs foram categorizados com base no tempo do desvio principal negativo (main negati$v e-\mathrm{MN}$ ). Os RPs do tipo II e III foram obtidos por meio dos movimentos auto iniciados na série média, relatados pelos indivíduos como se tivessem surgidos espontânea e caprichosamente, sem lembranças de experiências pré-planejadas. Os RPs do tipo I estão associados aos planejamentos prévios ao movimento. ${ }^{8}$

Ao compararem nos gráficos das atividades cerebrais dos participantes o tempo (W) de aparecimento da intenção consciente de agir e o tempo de início dos processos cerebrais antes do ato, o potencial de prontidão (RP), Libet et al. notaram que, com raras exceções, o início do RP aconteceu antes do tempo da intenção consciente de agir. ${ }^{?}$

Está claro que os processos neuronais que precedem uma ação voluntária auto iniciada, como refletida no potencial de prontidão, geralmente começam substancialmente antes do surgimento da intenção consciente de realizar esse ato específico. Esta diferença temporal de várias centenas de milissegundos apareceu de forma bastante consistente, independentemente de quais dos critérios disponíveis para o início da RP ou para o tempo de consciência são adotados. ${ }^{10}$

Nos RPs (II), o RP foi anterior ao tempo (W) em média $350 \mathrm{~ms}$, com um mínimo de $150 \mathrm{~ms}$. Nos RPs (I), o RP antecedeu W em média 800 ms. Mesmo com outras variáveis, em que RP (I) chegou a 500 ms, o

5 LIBET, Benjamin et. al. Time of conscious intention to act in relation to onset of cerebral activity (Readiness-Potential). The unconscious initiation of a freely voluntary act. Brain, Oxford, n. 106, p. 623-642, 1983. p. 626.

6 LIBET, Benjamin et. al. Time of conscious intention to act in relation to onset of cerebral activity (Readiness-Potential). The unconscious initiation of a freely voluntary act. Brain, Oxford, n. 106, p. 623-642, 1983. p. 627.

7 LIBET, Benjamin et. al. Time of conscious intention to act in relation to onset of cerebral activity (Readiness-Potential). The unconscious initiation of a freely voluntary act. Brain, Oxford, n. 106, p. 623-642, 1983. p. 629-632.

8 LIBET, Benjamin et. al. Time of conscious intention to act in relation to onset of cerebral activity (Readiness-Potential). The unconscious initiation of a freely voluntary act. Brain, Oxford, n. 106, p. 623-642, 1983. p. 632.

9 LIBET, Benjamin et. al. Time of conscious intention to act in relation to onset of cerebral activity (Readiness-Potential). The unconscious initiation of a freely voluntary act. Brain, Oxford, n. 106, p. 623-642, 1983. p. 634.

10 "It is clear that neuronal processes that precede a self-initiated voluntary action, as reflected in the readiness-potential, generally begin substantially before the reported appearance of conscious intention to perform that specific act. This temporal difference of several hundreds of milliseconds appeared fairly consistently regardlessof which of the available criteria for onset of RP or for the time of awareness are adopted." LIBET, Benjamin et. al. Time of conscious intention to act in relation to onset of cerebral activity (Readiness-Potential). The unconscious initiation of a freely voluntary act. Brain, Oxford, n. 106, p. 623-642, 1983. p. 635636. (tradução nossa). 
início cerebral de um ato voluntário foi precedido por um processo não consciente. ${ }^{11}$

No restante do artigo, Libet et al. procuram defender a credibilidade dos relatos dos participantes como adequadas, já que o valor médio de $\mathrm{W}$ e os valores individuais dos relatos de W são próximos. Para os pesquisadores, os eventos subjetivos são acessíveis, apenas, por meio dos dizeres dos participantes. Assim, se valeram de três métodos para avaliar os relatos:

1. Simultaneidade dos juízos (Simultaneity of judgements) - foi exigido dos participantes que verificassem, simultaneamente, o início de um evento mental, por meio de um desejo consciente, e a posição percebida do ponto de luz giratório no relógio. A série S, induzida pelo estímulo externo, serviu de modelo. Foi notado que o RP de S era similar às séries W e M.

2. Tempo de um evento mental endógeno (Timing of an endogenous mental event), ou seja, a intenção consciente de agir espontaneamente - o tempo relatado para a intenção de mover na série $S$, não pode ser validado diretamente, dependendo do relatório da experiência introspectiva do indivíduo participante. Pode-se levantar a questão de que haja discrepâncias entre os tempos iniciais reais e os da percepção. Mas Libet et al. afirmam que, caso isso se confirmasse, haveria uma maior diferença entre o início de RP e o tempo W real.

Prova adicional relacionada com a validade dos tempos comunicados (Additional evidence bearing on the validity of the reported timings) - para avaliar e aprimorar a confiança dos tempos relatados, foram utilizados a leitura absoluta (A) e a leitura ordenada $(\mathrm{O})$ em relação às posições finais. Ambas leituras apresentaram valores próximos para os tempos $\mathrm{W}, \mathrm{M}$ e $\mathrm{S} .^{12}$

Assim, destacam os autores sobre a pesquisa que: 1) os indivíduos que participaram da pesquisa distinguiram a experiência e o tempo de consciência de querer mover-se (W) em S e M; 2) os tempos de início de RP (I) e RP (II) foram normalmente semelhantes na série W e na série S, ilustrando que não houve diferença significativa entre o início de RP e W, independentemente dos conjuntos mentais associados; 3) os participantes se concentraram em notar a percepção inicial de qualquer impulso/intenção de se mover; 4) o conjunto mental para notar o tempo de $\mathrm{W}$ era diferente para o tempo de M; 5) a evidência indica que os participantes se preocuparam mais em descrever a consciência de se moverem (M), induzindo-os a relatarem o querer realizar (W) em média 50 ms mais negativos em relação ao tempo zero do EMG. ${ }^{13}$

Os autores terminam o artigo enfatizando a iniciação inconsciente de determinados processos neurológicos, tecendo algumas considerações a respeito de suas constatações.

Uma vez que o início do RP começa regularmente pelo menos várias centenas de milissegundos antes do aparecimento de um tempo relatável para conscientização de qualquer intenção subjetiva ou desejo de agir, parece que alguma atividade neuronal associada com o eventual desempenho do ato começou bem antes de qualquer (recordável) iniciação consciente ou intervenção poder ser possível. Dito de outra forma, o cérebro, evidentemente, "decide" iniciar ou, no mínimo, preparar-se para iniciar o ato de cada vez, antes que haja qualquer percepção subjetiva relatável de que tal decisão tenha ocorrido. Concluise que a iniciação cerebral, mesmo de um ato voluntário espontâneo, do tipo estudado aqui, pode e geralmente começa inconscientemente. O termo "inconsciente" refere-se aqui simplesmente a todos os processos que não são expressos como uma experiência consciente; isso pode incluir e não distingue entre pré-conscientes, subconscientes ou outros possíveis não reportáveis processos inconscientes. ${ }^{14}$

11 LIBET, Benjamin et. al. Time of conscious intention to act in relation to onset of cerebral activity (Readiness-Potential). The unconscious initiation of a freely voluntary act. Brain, Oxford, n. 106, p. 623-642, 1983. p. 636.

12 LIBET, Benjamin et. al. Time of conscious intention to act in relation to onset of cerebral activity (Readiness-Potential). The unconscious initiation of a freely voluntary act. Brain, Oxford, n. 106, p. 623-642, 1983. p. 637-639.

13 LIBET, Benjamin et. al. Time of conscious intention to act in relation to onset of cerebral activity (Readiness-Potential). The unconscious initiation of a freely voluntary act. Brain, Oxford, n. 106, p. 623-642, 1983. p. 639-640.

14 "Since onset of RP regularly begins at least several hundreds of milliseconds before the appearance of a reportable time for awareness of any subjective intention or wish to act, it would appear that some neuronal activity associated with the eventual performance of the act has started well before any (recallable) conscious initiation or intervention could be possible. Put another way, 
Haveria, portanto, uma atividade cerebral não consciente ou não intencional anterior ao desejo de realizar um ato voluntário. Os atos voluntários se iniciariam de maneira inconsciente, o que colocaria em questão a capacidade de os indivíduos exercerem o início e o controle consciente dos atos voluntários. Apesar de tais constatações, os pesquisadores, ainda, levantam a hipótese de que poderia haver um veto consciente, percebido e relatado por alguns dos participantes ao longo do experimento; além de sugerirem que a deliberação consciente esteja presente em atividades que não sejam automáticas. ${ }^{15}$

Libet retoma a noção de veto consciente em outro importante texto seu de 1985, Unconscious cerebral initiative and the role of conscious will in voluntary action, em que procura aprofundar a proposta, implícita no final do artigo anterior, entre a compatibilidade de suas descobertas com a noção de livre arbítrio, e, com isso, também salvaguardar a noção de responsabilidade:

Eu proponho a tese de que o controle volitivo consciente pode operar não para iniciar o processo volitivo, mas para selecioná-lo e controlá-lo, seja permitindo ou desencadeando o resultado motor final do processo inconscientemente iniciado, seja vetando a progressão para a ativação motora real. ${ }^{16}$

Em suma, Libet compreende livre arbítrio como a capacidade volitiva que tem a competência de parar um processo que se inicia inconscientemente.

Apesar dos esforços em defender certo entendimento de que há uma "liberdade" humana, as descobertas do pesquisador foram interpretadas de diferentes maneiras. Recentemente, por meio de tecnologias mais avançadas do que na época de Libet, alguns retomaram suas pesquisas para enfatizar o início inconsciente de ações deliberadas ${ }^{17}$, em até quase uma dezena de segundos ${ }^{18}$, muito além do que constatava a pesquisa de Libet. Por outro lado, outros criticaram o método empregado, o vocabulário não rigoroso filosófico e as deduções da pesquisa. ${ }^{19}$ Outros, ainda, contrários ao próprio Libet, tomaram a pesquisa como uma comprovação do determinismo neurológico ou biológico. ${ }^{20}$

O experimento de Libet implicou na noção de que o livre arbítrio constitui uma ilusão, o que colocaria em questão a responsabilidade, e afetaria áreas como o Direito, a religião e a moral. Em sentido prático, um determinismo radical solaparia as bases do que se entende hoje por Direito. O determinismo pode ser caracterizado de uma forma geral na descrição a seguir:

Parece que já não é possível atribuir a origem das ações a agentes individuais; em vez disso, elas se convertem em componentes do fluxo de eventos no mundo do qual o agente é parte. A forma mais fácil de produzir esse efeito é pensar na possibilidade de que todas as ações sejam causalmente determinadas, mas essa não é a única maneira. A fonte essencial do problema é a visão de que pessoas e suas ações fazem parte da ordem natural, seja ela causalmente determinada ou não. Essa concepção, se incorporada,

the brain evidently 'decides' to initiate or, at the least, prepare to initiate the act at a time before there is any reportable subjective awareness that such a decision has taken place. It is concluded that cerebral initiation even of a spontaneous voluntary act, of the kind studied here, can and usually does begin unconsciously. The term 'unconscious' refers here simply to all processes that are not expressed as a conscious experience; this may include and does not distinguish among preconscious, subconscious or other possible nonreportable unconscious processes." LIBET, Benjamin et. al. Time of conscious intention to act in relation to onset of cerebral activity (Readiness-Potential). The unconscious initiation of a freely voluntary act. Brain, Oxford, n. 106, p. 623-642, 1983. p. 640. (tradução nossa).

15 LIBET, Benjamin et. al. Time of conscious intention to act in relation to onset of cerebral activity (Readiness-Potential). The unconscious initiation of a freely voluntary act. Brain, Oxford, n. 106, p. 623-642, 1983. p. 641.

16 "I propose the thesis that conscious volitional control may operate not to initiate the volitional process but to select and control it, either by permitting or triggering the final motor outcome of the unconsciously initiated process or by vetoing the progression to actual motor activation." LIBET, Benjamin. Unconscious cerebral initiative and the role of conscious will in voluntary action. The behavioral and brain sciences, n. 8, p. 529-66, 1985. p. 529. (tradução nossa).

17 BODE, Stefan et. al. Tracking the Unconscious Generation of Free Decisions Using UItra-High Field fMRI. Plos One, v. 6, n. 6, p. 1-13, jun. 2011.

18 SOON, Chun Siong et al. Unconscious determinants of free decisions in the human brain. Nature Neuroscience, v. 11, n. 5, p. 543-545, maio 2008.

19 BENNETT, M. R.; HACKER, P.M.S. Fundamentos filosóficos da neurociência. Lisboa: Piaget, 2003. p. 247-255.

20 RUBIA, Francisco J. El fantasma de la libertad: datos de la revolución neurocientífica. Barcelona: Crítica, 2009. (E vale destacar os alemães Gerhard Roth e Wolf Singer.). 
produz a sensação de que não somos agentes em absoluto, de que somos impotentes e não somos responsáveis pelo que fazemos. ${ }^{21}$

O determinismo pautado no materialismo não é recente, podendo ser encontrado vestígios em autores tão díspares e distantes como Lucrécio (99 a.C - 55 a.C), Thomas Hobbes (1588-1679), Julien Offray de La Mettrie (1709-1751) e Barão d'Holbach (1723-1789).

O experimento de Libet seria mais um fato para aqueles que defendem o determinismo (neurológico/ biológico). Entretanto, existem algumas críticas que colocam em dúvida vários aspectos e resultados do experimento. Em sua obra: "Fundamentos Filosóficos da Neurociência", Bennett e Hacker elencam uma série de censuras ao experimento de Libet:

1- Confusos pressupostos da experiência - para um ato ser voluntário, ele não precisa ser precedido por uma intenção ou querer realizá-lo.

2- Os sentimentos de volição não são necessários para o movimento voluntário - quando se mexe voluntariamente, como segurar uma caneta ou abrir uma porta, não se sente quaisquer impulsos, desejos ou intenções.

3- Os sentimentos de volição não são suficientes para o movimento voluntário - não é considerado um movimento voluntário o que é antecedido por um impulso, por exemplo, o impulso de espirrar antes do espirro não o torna voluntário. Para Libet, após o impulso cerebral, há, apenas, o controle de inibir ou permitir o movimento.

4- O movimento causado por um impulso sentido não é voluntário - por exemplo, pode-se ter um desejo de beber, comer ou mexer a mão, mas a causa da realização de tais ações não é o impulso inicial, mas acabar com a sede, com a fome ou tocar algo agradável, respectivamente.

5- A questão de Libet pressupôs uma concepção incorreta da ação voluntária -a constatação de que os neurônios no córtex motor suplementar se excitarem milissegundos antes do sentimento vir à tona, não é uma prova de uma decisão inconsciente, mas apenas ilustra que os processos neuronais que ativam os músculos são anteriores ao sentimento de desejo. ${ }^{22}$

As reflexões em torno do experimento de Libet, paradigmático às neurociências, é importante para que não se faça um reducionismo em outras áreas do saber, como o direito. É temerária a afirmação de que as neurociências reduziriam o direito às relações cerebrais, entretanto, é importante destacar que as neurociências têm importantes contribuições à área, como será ilustrado a posteriori.

Há uma relação intrínseca entre os elementos físico-químicos cerebrais e o pensamento. Não poderia haver pensamento humano sem o cérebro. O reducionista toma esse fato para afirmar que o pensamento pode ser reduzido ao cérebro, o que excluiria a noção de livre arbítrio. Por outro lado, não se exclui a noção de que existam aspectos não conscientes nas ações humanas, que, ainda, serão explicitados.

Há em toda essa problemática o enigma natureza versus liberdade, que é uma questão filosófica.

Sem dúvida alguma, em meio aos modismos epistemológicos, um problema ou ao menos um microproblema, é o que se situa nas fronteiras entre natureza e liberdade, ou ainda, entre causalidade e teleologia. Fazendo concessões ao espírito do tempo, poderíamos denomina-lo uma questão metaepistemológica. Já que não se trata, propriamente, de uma discussão sobre uma área específica do campo das ciências empírico-matemáticas ou das ciências humanas. É, realmente, uma questão de fronteira entre as duas epistemologias. Somente a filosofia poderá levantar conjeturas a respeito.(grifo do autor) ${ }^{23}$

Apesar do processo biológico/evolucionário ter sido determinante para se chegar na constituição do

21 NAGEL, Thomas. Visão a partir de lugar nenbum. São Paulo: Martins Fontes, 2004. p. 183.

22 BENNETT, M. R.; HACKER, P.M.S. Fundamentos filosóficos da neurociência. Lisboa: Piaget, 2003. p. 252-254.

23 STEIN, Ernildo. Anamnese: a filosofia e o retorno do reprimido. Porto Alegre: EDIPUCRS, 1997. p. 17. 
que hoje é o ser humano, este não pode ser reduzido a tais processos. A afirmação de que o ser humano é determinado por algum aspecto biológico/neurológico, já leva em consideração uma pré-compreensão de mundo. Vejamos como o filósofo Martin Heidegger (1889-1976) levanta tal discernimento.

Em sua obra Ser e Tempo, Heidegger tem como grande preocupação a questão do Ser. Para lidar com ela, se dirige ao ente capaz de levantar esse questionamento, ou seja, o Dasein (ser-a1), o homem enquanto questiona pelo Ser. A obra é um exame fenomenológico a respeito do Dasein.

Para Heidegger, a existência é o que caracteriza o Dasein, isto é, o "próprio ser com a qual a presençą ${ }^{24}$ pode se comportar dessa ou daquela maneira e com a qual ela sempre se comporta de alguma maneira. [...] A questão da existência sempre só poderá ser esclarecida pelo próprio existir." 25 O Dasein não é determinado por uma essência, no sentido de ser um ente determinado. "A 'essência' da pre-sença está em sua existência." 26 É arbitrário, portanto, definir o homem como "animal racional", "imagem de Deus", "res cogitans" ou "consciência", por exemplo, pois são acepções tomadas como evidentes", assim como a afirmação de que o homem seria determinado biologicamente, pois tais assertivas carregam uma compreensão metafísica sobre ele.

Tomando a etnologia como exemplo, mas um modelo que serve para a reflexão sobre as demais áreas das ciências, Heidegger assevera que ela está inserida em "determinadas concepções prévias e interpretações da pre-sença humana em geral" ${ }^{28}$. Quando a ciência tem a pretensão de compreender o mundo universalmente, e faz afirmações taxativas sobre ele, ela também já carrega em si uma pré-compreensão sobre a realidade, que depende do Dasein. É questionável a noção de uma ciência livre de preconceitos, pois:

[...] quando o material empírico está sendo simplesmente coletado, os fundamentos já estão sempre "presentes". O fato de as pesquisas positivas não verem os fundamentos e considera-los evidentes não constitui uma prova de que eles não se achem à base e que não sejam problemáticos, num sentido mais radical do que poderá ser uma tese das ciências positivas. ${ }^{29}$

O ser humano, para se autocompreender, deve, sim, levar em consideração os aspectos biológicos/ evolucionários (naturais), mas não pode ser reduzido a eles, pois essa compreensão passa, prontamente, por uma experiência reflexiva, por isso, cultural.

Quando se fala sobre experimentos mentais, não se pode abdicar de que a mente depende de um mundo. E o sentido de mundo, o qual a mente está inserida, é uma construção humana, ou, como diz Heidegger: “ 'Mundo' é um caráter da própria pre-sença”’30, por isso ele denomina o Dasein ser-no-mundo. Isso significa que o homem é um ente que se relaciona com os demais entes compreendendo-os dentro de um contexto de significados, por meio da linguagem. ${ }^{31}$

Portanto, quando se afirma que o homem é completamente determinado biologicamente/neurologicamente, tal declaração já se insere numa pré-compreensão, que, por sua vez, não pode ser reduzida a esses mesmos aspectos naturais. Quando um indivíduo defende o determinismo ou tenta "salvar" a liberdade por meio do experimento de Libet, ele já está imerso numa autocompreensão, e, por isso, da ordem da deliberação.

Uma tal dificuldade nos obriga a perceber que a vida humana não se reduz à materialidade da coisa bioquímica, exigindo-se que a vida humana se constitua pelo próprio fato de o ser humano se compreender previamente [...] Assim, o fato da vida humana que delibera, rompe a barreira da coisa bioquímica, acrescentando, assim, a si mesmo, a autocompreensão que é mais do que os componentes

24 Pre-sença é o termo utilizado pela tradutora da versão em Português utilizada da obra Ser e Tempo para designar Dasein.

25 HEIDEGGER, Martin. Ser e Tempo. 15. ed. Petrópolis: Vozes, 2005. p. 39.

26 HEIDEGGER, Martin. Ser e Tempo. 15. ed. Petrópolis: Vozes, 2005. p. 77.

27 HEIDEGGER, Martin. Ser e Tempo. 15. ed. Petrópolis: Vozes, 2005. p. 85-87.

28 HEIDEGGER, Martin. Ser e Tempo. 15. ed. Petrópolis: Vozes, 2005. p. 88.

29 HEIDEGGER, Martin. Ser e Tempo. 15. ed. Petrópolis: Vozes, 2005. p. 87.

30 HEIDEGGER, Martin. Ser e Tempo. 15. ed. Petrópolis: Vozes, 2005. p. 105.

31 HEIDEGGER, Martin. Sobre o “Humanismo”: carta a Jean Beaufret. São Paulo: Abril Cultural, 1979. p. 156. 
genéticos. A vida humana é mais que a soma dos elementos genéticos que lhe servem de vetor. ${ }^{32}$

As considerações anteriores ilustram que o puro determinismo é uma posição problemática, entretanto, não se defende neste artigo, ingenuamente, uma suposta liberdade infinita, mesmo porque, o homem é fruto de um processo físico, e, por isso, sujeito às leis da natureza, assim como está sujeito às influências sociais e aos aspectos inconscientes de sua psiché.

\section{O COMPORTAMENTO DO CONSUMIDOR PERANTE OS ESTÍMULOS AO SEU INCONSCIENTE E A SUA CAPACIDADE DE AUTODETERMINAÇÃO CONSCIENTE}

$\mathrm{Na}$ parte inicial do tópico anterior, foram apresentadas conclusões dos experimentos científicos realizados por Benjamin Libet, indicando que os comportamentos individuais seriam resultado de processos inconscientes, afirmação esta que implicaria a incapacidade de controle consciente dos próprios atos. Contudo, em texto redigido posteriormente, Libet deu maior profundidade ao tema, dispondo que, embora os comportamentos individuais tenham início em processos inconscientes, seria possível interrompê-los mediante deliberação consciente.

Apesar das ressalvas de Libet — informando a relevância dos atos volitivos —, seus estudos foram interpretados de diversas formas. Alguns, valendo-se de uma concepção reducionista, alegaram a existência de um determinismo neurológico ou biológico do ser humano, de modo que as condutas das pessoas seguiriam um fluxo de eventos do mundo do qual é parte.

Ressaltou-se que o último posicionamento mencionado - do determinismo puro — traria sérias repercussões para o direito, haja vista que, diante da incapacidade volitiva, ninguém seria responsável pelos próprios atos.

Nesse viés, fez-se necessário ampliar a discussão, razão pela qual na segunda parte do tópico, combateu-se a interpretação da existência do determinismo puro nas ações humanas. Foram utilizadas as reflexões de Martin Heidegger, as quais revelam que toda compreensão, inclusive aquela resultante de experimentos científicos, não se reduz a aspectos naturais causais, pois a própria afirmação de que o homem é determinado já está além do próprio reducionismo determinista.

Desse modo, argumentou-se que o comportamento humano teria origem tanto em processos inconscientes, resultantes de influências diversas, quanto de atos volitivos praticados mediante o exercício da capacidade deliberativa individual. A partir das considerações expostas, no presente tópico, serão examinados quais os fatores determinantes para as escolhas de compra do consumidor - a relevância dos processos inconscientes e dos atos volitivos - , averiguando suas repercussões jurídicas.

A primeira parte enfocará a forma pela qual o marketing explora os processos inconscientes dos indivíduos visando formar hábitos de consumo que sejam capazes de proporcionar uma relação mais duradoura com determinado produto ou serviço, verificando-se a efetividade de tal estratégia. Além disso, averiguar-se-á a legalidade da manipulação do consumidor mediante estímulos ao seu inconsciente — publicidade subliminar —, ponderando os limites impostos pelos direitos fundamentais à privacidade, intimidade, liberdade de manifestação do pensamento, liberdade de consciência, informação e segurança.

Por sua vez, no segundo tópico, serão evidenciados os elementos que contribuem para a formação de hábitos de consumo, averiguando a relevância da deliberação consciente tanto na criação quanto na modificação dos mesmos, em especial quando oferecerem riscos à segurança do consumidor.

Relevante salientar que os termos, "consciente" e "inconsciente" serão utilizados para se referir as con-

32 STEIN, Ernildo. Exercícios de fenomenologia: limites de um paradigma. Ijuí: Unijuí, 2004. p. 183. 
dutas que, respectivamente, tenham origem em intenções e motivações deliberadas pelo indivíduo ou que decorram de estímulos aos seus sentidos e/ou emoções.

\subsection{Marketing, neurociência e os estímulos ao inconsciente do consumidor à luz dos direitos fundamentais}

Devido à compreensão de que o inconsciente do consumidor teria papel relevante em sua tomada de decisão, foram aprimorados preceitos no ramo da economia e do marketing, visando desenvolver as relações mercadológicas - por meio da economia comportamental e do neuromarketing. Nos dois casos, o foco é o comportamento do consumidor, em especial aqueles decorrentes de processos mentais inconscientes, considerando-se a influência exercida por estímulos às suas emoções e/ou sentidos.

Gustavo Binenbojm, ao se manifestar sobre a economia comportamental, sustenta que essa limitação quanto à capacidade de escolha consciente pelo consumidor, em especial quando houver riscos e incertezas associados ao produto ou serviço comercializado, deve ensejar, no exercício do poder de polícia regulador pelo Estado, na pretensão de proteger o consumidor, parte vulnerável nas relações de mercado.

[...] a chamada economia comportamental (behavioral economics) sustenta que deva haver regulação em determinadas situações — sobretudo naquelas que envolvam risco e incerteza - nas quais os agentes não se comportam de maneira racional. Trata-se de uma área de fronteira do conhecimento, que envolve economia, psicologia e neurologia, que tem se dedicado a investigar as circunstâncias em que o indivíduo diverge do comportamento racional [...] o modelo de ação humana típico da economia comportamental é o da heurística, caracterizado por raciocínios rápidos, semi-intuitivos e influenciados por impulsos e emoções. As escolhas realizadas em heurística seriam especialmente propensas a erros de diagnóstico e de prognóstico, justificando alguma espécie de regulação estatal como forma de proteger os indivíduos contra sua própria irracionalidade (correção de falhas de escolha).(grifo do autor) ${ }^{33}$

Tais considerações estão em plena consonância com o objetivo traçado no inciso I do artigo $3^{\circ}$ da Constituição da República Federativa do Brasil de $1.988^{34}$ (CRFB/88), consistente na construção de uma sociedade livre, no qual se insere a garantia da liberdade de escolha do consumidor — no sentido de não ser manipulado a adotar determinado comportamento por estímulos ao seu inconsciente. Sob tal perspectiva, no presente tópico, serão delimitados aspectos relacionados ao marketing, especificando como ocorre a exploração mercadológica do inconsciente do consumidor na sociedade atual. Simultaneamente, será analisada a situação da publicidade subliminar perante o ordenamento jurídico brasileiro, em especial no que tange aos direitos fundamentais assegurados ao consumidor.

Convém realçar, inicialmente, quais são os objetivos do marketing, nas palavras de Philip Kotler e Kevin Lane Keller:

O objetivo do marketing é atender e satisfazer as necessidades e os desejos dos clientes-alvo melhor do que os concorrentes. Os profissionais de marketing devem ter plena compreensão de como os consumidores pensam, sentem e agem para oferecer um valor adequado a cada consumidor-alvo. ${ }^{35}$ (grifo do autor)

Seguindo a perspectiva exposta, Rafael Tocantins Maltez afirma que "A função do marketing é mercadológica; visa provocar um aumento na demanda, além de investigar as necessidades e desejos do consumidor". ${ }^{6}$ Relevante notar, pois, que a prioridade de uma ação de marketing consiste na fidelização do consumidor a

33 BINENBOJM, Gustavo. Poder de polícia, ordenação, regulação: transformações político-jurídicas, econômicas e institucionais do direito administrativo ordenador. Belo Horizonte: Fórum, 2016.

34 BRASIL. Constituição (1988). Constituição da República Federativa do Brasil. Disponível em: <http://www.planalto.gov.br/ccivil_03/constituicao/constituicao.htm>. Acesso em: 23 maio 2018.

35 KOTLER, Philip; KELLER, Kevin Lane. Administração de marketing. 14. ed. São Paulo: Pearson Education do Brasil, 2012.

36 MALTEZ, Rafael Tocantins. Direito do consumidor e publicidade: análise jurídica e extrajurídica da publicidade subliminar. Curitiba: Juruá, 2011. p. 74. 
determinado produto/marca, sendo ela definida após uma vasta pesquisa acerca de suas necessidades e desejos.

Kotler e Keller afirmam que a efetividade do marketing depende da prévia compreensão acerca dos diversos fatores que influenciam na tomada de decisão do consumidor:

1. O comportamento do consumidor é influenciado por três fatores: culturais (cultura, subculturas e classes sociais), sociais (grupos de referência, família, papéis e status) e pessoais (idade, estágio no ciclo de vida, ocupação, circunstâncias econômicas, estilo de vida, personalidade e autoimagem). A pesquisa de todos esses fatores pode fornecer sugestões sobre como atingir e atender os clientes de maneira mais efetiva.

2. Quatro processos psicológicos principais influenciam o comportamento de compra: motivação, percepção, aprendizagem e memória.

3. Para compreender como os consumidores tomam decisões de compra, os profissionais de marketing devem identificar quem é o decisor e quem interfere na decisão; as pessoas podem ser iniciadoras, influenciadoras, decisoras, compradoras ou usuárias. Diferentes campanhas de marketing podem ser dirigidas a cada tipo de perfil.

4. O processo de compra comum consiste na seguinte sequência de etapas: reconhecimento do problema, busca de informações, avaliação de alternativas, decisão de compra e comportamento póscompra. É função do profissional de marketing entender o comportamento do comprador em cada etapa. As atitudes de outros, os fatores situacionais imprevistos e o risco percebido podem afetar a decisão de compra, bem como os níveis de satisfação pós-compra, o uso e o descarte por parte dos consumidores e as ações por parte da empresa.

5. Os consumidores são tomadores de decisão construtivos e estão sujeitos a muitas influências contextuais. Eles geralmente exibem baixo envolvimento em suas decisões, usando muita heurística em decorrência disso. ${ }^{37}$

Compete, agora, destacar que as ações de marketing podem ser qualificadas como propaganda ou publicidade. Embora muitas vezes ocorra uma divergência quanto à definição dos termos, para o presente trabalho adotar-se-á a perspectiva esboçada por Antônio Herman V. Benjamin:

A publicidade tem um objetivo comercial, enquanto a propaganda visa a um fim ideológico, religioso, filosófico, político, econômico ou social. Fora isso, a publicidade, além de paga, identifica seu patrocinador, o que nem sempre ocorre com a propaganda. ${ }^{38}$

As ponderações adiante aduzidas serão todas relacionadas à publicidade - que tem objetivo comercial - , haja vista que o presente trabalho visa averiguar a capacidade de autodeterminação consciente do consumidor, tendo em vista a influência comportamental desempenhada pelos estímulos ao seu inconsciente, promovido pelo marketing.

Pode-se afirmar, assim, que a efetividade de uma campanha publicitária depende do conhecimento de situações da vida pessoal do consumidor, uma vez que este é influenciado não apenas por seus desejos e necessidades próprias, mas também por outras pessoas e pelo ambiente em que está inserido. Nesse contexto foi desenvolvido o neuromarketing, que estuda o comportamento do consumidor com o objetivo intenção de elaborar estratégias capazes de influenciar em suas escolhas de compra.

No que tange ao neuromarketing, faz-se pertinente mencionar as considerações de Theodore Voorhees Jr., Daniel L. Spiegel e Daniel Cooper:

Neuromarketing envolve o uso de pesquisas da neurociência para o desenvolvimento de publicidade e estratégias de marketing para que as marcas se conectem com os consumidores de uma forma mais profunda e duradoura.

37 KOTLER, Philip; KELLER, Kevin Lane. Administração de marketing. 14. ed. São Paulo: Pearson Education do Brasil, 2012. p. 190. 38 BENJAMIN, Antônio Herman V. Oferta e publicidade. In: BENJAMIN, Antônio Herman V.; MARQUES, Claudia Lima; BESSA, Leonardo Roscoe. Manual de direito do consumidor. 7. ed. São Paulo: Revista dos Tribunais, 2016. p. 515-557. p. 281. 
Neurocientistas afirmam que a inabilidade dos consumidores em articular sua verdadeira opinião resulta do fato de que algumas das mais poderosas influências que afetam sua fidelidade à marca e seu comportamento de compra são processos inconscientes, além de sua razão ${ }^{39}$.

Entretanto, os objetivos do neuromarketing encontram limites no ordenamento jurídico brasileiro, tendo em vista a vedação à publicidade subliminar, constante no artigo 36 da Lei 8.078/90 — Código de Defesa do Consumidor (CDC): "A publicidade deve ser veiculada de tal forma que o consumidor, fácil e imediatamente, a identifique como tal". ${ }^{40}$ Como o marketing tem uma função mercadológica, ele deve se submeter às normas de proteção do consumidor, em consonância com a disposição contida no inciso V do artigo 170 da $\mathrm{CRFB} / 88^{41}$.

Nesse sentido, Rizzato Nunes assevera que a técnica usualmente denominada como merchandising — existem controvérsias sobre sua definição — somente será permitida no ordenamento jurídico brasileiro quando a identificação da publicidade for evidente:

O merchandising é a técnica utilizada para veicular produtos e serviços de forma indireta por meio de inserções em programas e filmes.

\section{$[\ldots]$}

Existem várias maneiras de produzir o chamado merchandising.

Haverá aquele que, apesar de se caracterizar por inserção indireta, não se reveste de clandestinidade. É que, em alguns casos, fica claro para o consumidor — ou telespectador — que se trata de publicidade. Cite-se como exemplo o caso do apresentador que, durante o transcurso do programa de auditório, oferece produtos e até os elogia. ${ }^{42}$

É expressamente proibido o merchandising fundamentado na clandestinidade, isto é, aquele em que a intenção publicitária é disfarçada, que aproveita da diminuta atenção do consumidor em períodos de lazer — constituindo-se como publicidade subliminar. De acordo com Antônio Herman V. Benjamin, "A publicidade só é lícita quando o consumidor puder identificá-la. Mas tal não basta: a identificação há de ser imediata (no momento da exposição) e fácil (sem esforço ou capacitação técnica)". ${ }^{43}$

Tal vedação se justifica pela pretensão de preservar os direitos fundamentais à liberdade de manifestação do pensamento e à liberdade de consciência — artigo $5^{\circ}$, caput e incisos IV e VI da CRFB $/ 88^{44}$; artigo $6^{\circ}$, incisos II e IV do $\mathrm{CDC}^{45}$ — que asseguram ao indivíduo, inclusive nas relações de consumo, o exercício da autonomia privada e sua autodeterminação consciente.

39 "Neuromarketing involves the use of neuroscience research to shape advertising and marketing strategies so that brands will connect with consumers in deeper and more lasting ways.

$[\ldots]$

Neuroscientists assert that consumers' inability to articulate their true feelings arises from the fact that some of the most powerful influencers affecting their brand loyalty and purchase behavior are unconscious brain processes beyond their reckoning." VOORHEES JR., Theodore; SPIEGEL, Daniel L.; COOPER, Daniel. Neuromarketing: legal and policy issues: a covington white paper, 2011. Disponível em: <https://www.prnewswire.com/news-releases/covington-releases-paper-on-neuromarketings-legaland-policy-issues-203681701.html>. Acesso em: 23 maio 2018. (Tradução nossa)

40 BRASIL. Lei $n^{\circ} 8.078$ de 11 de setembro de 1990. Disponível em: <http://www.planalto.gov.br/ccivil_03/leis/L8078.htm>. Acesso em: 23 de maio de 2018.

41 BRASIL. Constituição (1988). Constituição da República Federativa do Brasil. Disponível em: <http://www.planalto.gov.br/ccivil_03/constituicao/constituicao.htm>. Acesso em: 23 maio 2018.

42 NUNES, Rizzato. Comentários ao Código de Defesa do Consumidor. 8. ed. São Paulo: Saraiva, 2015. p. 556.

43 BENJAMIN, Antônio Herman V. Oferta e publicidade. In: BENJAMIN, Antônio Herman V.; MARQUES, Claudia Lima; BESSA, Leonardo Roscoe. Manual de direito do consumidor. 7. ed. São Paulo: Revista dos Tribunais, 2016. p. 515-557. p. 287.

44 BRASIL. Constituição (1988). Constituição da República Federativa do Brasil. Disponível em: <http://www.planalto.gov.br/ccivil_03/constituicao/constituicao.htm>. Acesso em: 23 maio 2018.

45 BRASIL. Lei no 8.078, de 11 setembro de 1990. Disponível em: <http://www.planalto.gov.br/ccivil_03/leis/L8078.htm>. Acesso em: 23 maio 2018. 
Segundo Christiane Gade, "por percepção subliminar se entende a influência exercida sobre a atitude ou o comportamento por uma mensagem ou informação que não é percebida conscientemente". ${ }^{46}$ Rafael Tocantins Maltez, ao comentar sobre esses eventos subliminares, assinala que "a mensagem subliminar pode ficar armazenada materialmente no cérebro, penetrar diretamente no inconsciente e lá fixar-se, sem o filtro do consciente". ${ }^{47}$

Nesse sentido, por publicidade subliminar deve-se compreender qualquer tipo de mensagem que visa induzir o consumidor a determinado comportamento, por meio de estímulos ao inconsciente — explorando sentidos e emoções - , retirando-lhe a capacidade de autodeterminação consciente em suas escolhas de compra. Rafael Tocantins Maltez exemplifica algumas formas de estímulo subliminar:

[...] são formas de estímulo subliminar: a) um estímulo visual a um índice muito rápido; b) utilização de um discurso acelerado em mensagens de auditório; c) inserção de símbolos, imagens ou palavras escondidas, mascaradas ou camufladas; d) estímulos olfativos em revistas ou lojas; e) utilização de efeitos sonoros em volume baixo e em diversas faixas de som, velocidade e frequência, inaudíveis pelo ouvido humano consciente; f) utilização da visão periférica; g) quando captado por uma atitude de excitação emotiva por parte do receptor; h) produção de uma saturação de informações; i) comunicações indiretas e aceitas de uma maneira inadvertida. ${ }^{48}$

Até o momento não há comprovação científica de que a publicidade subliminar possa induzir o consumidor à escolha de um produto específico. Rafael Tocantins Maltez, ao fazer menção à pesquisa realizada por Ahmed Channouf, afirmou que:

[...] não existem efeitos específicos das imagens subliminares, mas efeitos não específicos. A exposição subliminar a imagens de bebidas aumenta a possibilidade de consumir uma bebida sem orientar o comportamento de consumação em direção a determinado produto. ${ }^{49}$

O trecho supramencionado confirma a possibilidade de manipulação do comportamento do consumidor via publicidade subliminar, mas deixa em dúvida a capacidade de direcionamento a um produto específico - como exemplo, a publicidade subliminar poderia induzir o consumidor a comprar algo para beber durante uma sessão de cinema, mas talvez não consiga manipulá-lo a adquirir especificamente uma Coca-Cola.

Ademais, pode-se assinalar que a existência de um hábito consolidado que seja incompatível com o produto ou serviço objeto do marketing, consiste num obstáculo à efetividade da publicidade subliminar, no que tange à pretensão de induzi-lo à aquisição de um produto ou serviço específico — por exemplo, se o indivíduo tem o hábito de consumir apenas alimentos e bebidas naturais, dificilmente será manipulado a consumir refrigerante em razão de publicidade subliminar, embora possa ser induzido a comprar algo para beber.

Faz-se pertinente, portanto, averiguar a existência de alguma estratégia de marketing desenvolvida com o intuito de contornar os problemas de efetividade da publicidade subliminar, isto é, se foram desenvolvidos métodos capazes de induzir o consumidor à aquisição de um produto específico e/ou de modificar seus hábitos de consumo consolidados com base em interesses mercadológicos específicos.

Em princípio, ressalte-se que o avanço da internet e a popularização das redes sociais, além de auxiliar na disseminação da informação e conectar pessoas — ao romper com limites geográficos —, municiou empresas com diversas informações pessoais de seus usuários, antes restritas ao seu íntimo. Isso tornou viável a elaboração de uma publicidade personalizada, ou seja, direcionada a um consumidor específico, considerando, muitas vezes, necessidades e desejos não anunciados, mas que foram identificados com base

46 GADE, Christiane. Psicologia do consumidor e da propaganda. São Paulo: EPU, 1998. p. 42.

47 MALTEZ, Rafael Tocantins. Direito do consumidor e publicidade: análise jurídica e extrajurídica da publicidade subliminar. Curitiba: Juruá, 2011. p. 206.

48 MALTEZ, Rafael Tocantins. Direito do consumidor e publicidade: análise jurídica e extrajurídica da publicidade subliminar. Curitiba: Juruá, 2011. p. 228-229.

49 CHANNOUF, 2000 apud MALTEZ, Rafael Tocantins. Direito do consumidor e publicidade: análise jurídica e extrajurídica da publicidade subliminar. Curitiba: Juruá, 2011. 
em uma análise de suas atividades online.

O ativista social e escritor Eli Pariser, em sua obra "O Filtro Invisível", chama atenção para o alto índice de personalização da informação e da publicidade veiculada na internet, e, também, para sua eficiência no aumento das vendas dos produtos ofertados:

A fórmula dos gigantes da internet para essa estratégia de negócios é simples: quanto mais personalizadas forem suas ofertas de informação, mais anúncios eles conseguirão vender e maior será a chance de que você compre os produtos oferecidos. E a fórmula funciona. A Amazon vende bilhões de dólares em produtos prevendo o que cada cliente procura e colocando esses produtos na página principal de sua loja virtual. Até $60 \%$ dos filmes alugados pela Netflix vêm de palpites personalizados feitos pelo site sobre as preferências dos clientes - a esta altura, a Netflix consegue prever o quanto iremos gostar de certo filme com margem de erro de aproximadamente meia estrela. A personalização é uma estratégia fundamental para os cinco maiores sites da internet - Yahoo, Google, Facebook, YouTube e Microsoft Live - e também para muitos outros. ${ }^{50}$

Embora a situação não envolva relação de consumo — que é o enfoque do presente trabalho —, pertinente abordar o recente escândalo ocorrido nos Estados Unidos e amplamente noticiado pela mídia, envolvendo a utilização de informações relativas a milhares de americanos usuários do Facebook, em propagandas políticas — tipo de marketing — veiculadas na campanha eleitoral do Presidente Donald Trump ${ }^{51}$.

Cumpre salientar que o compartilhamento e a exploração comercial de informações pessoais não declaradas como públicas pelos usuários do Facebook caracterizam violação aos direitos fundamentais à intimidade e privacidade. Da mesma forma que os dados pessoais dos indivíduos foram utilizados em propagandas eleitorais, também, são intensamente aplicados à criação de publicidade de produtos e serviços, veiculada principalmente na internet.

A utilização desses dados pessoais viabiliza a personalização da publicidade —inclusive a subliminar —, tornando-a mais efetiva por aumentar a possibilidade de indução do consumidor e de sua fidelização a um produto específico. No âmbito das redes sociais, observa-se com facilidade a existência de publicidade subliminar direcionada a um usuário específico, em especial pelo método de saturação de informação. O histórico de navegação de um determinado indivíduo revelará produtos e serviços com os quais ele provavelmente se identifica — por necessidade e/ou desejo. Posteriormente, ele sofrerá com uma saturação de publicidade quanto àqueles produtos e/ou serviços, mediante e-mail, rede social etc.

Relevante atentar que a utilização desautorizada de dados pessoais — não declarados como públicos — dos usuários de internet para fins mercadológicos representa violação aos direitos fundamentais à intimidade e à privacidade, assegurados pelo artigo $5^{\circ}$, inciso X e XII, da CRFB $/ 88^{52}$. Ademais, tais direitos também são tutelados pelos incisos I, II e VII do artigo $7^{\circ}$ da Lei 12.965/14 $4^{53}$ - Marco Civil da Internet.

Fato é que não tem sido efetiva a proteção desses dados pessoais dos consumidores, razão pela qual há uma constante violação da privacidade e intimidade que lhes são constitucionalmente assegurados, conforme salienta Héctor Valverde Santana e Rafael Souza Viana:

A constante evolução tecnológica e, consequentemente, a insegurança gerada em relação à proteção de dados e informações pessoais, fomenta a busca por uma série de direitos que outrora não se dava o merecido destaque, caso da privacidade e da intimidade, integrantes dos direitos da personalidade. ${ }^{54}$

50 PARISER, Eli. O filtro invisivel: o que a internet está escondendo de você. Rio de Janeiro: Zahar, 2012.

51 MARTÍ, Silas. Entenda o escândalo de uso de dados do Facebook: informações foram utilizadas para influenciar na eleição de Trump. 2018. Disponível em: <https://www1.folha.uol.com.br/mercado/2018/03/entenda-o-escandalo-do-uso-de-dados-do-facebook. shtml>. Acesso em: 23 maio 2018.

52 BRASIL. Constituição (1988). Constituição da República Federativa do Brasil. Disponível em: < http://www.planalto.gov.br/ccivil_03/constituicao/constituicao.htm>. Acesso em: 23 maio 2018.

53 BRASIL. Lei n $n^{\circ}$ 12.965, de 23 abril de 2014. Disponível em: <http://www.planalto.gov.br/ccivil_03/_ato2011-2014/2014/lei/ 112965.htm>. Acesso em: 23 maio 2018.

54 SANTANA, Héctor Valverde; VIANA, Rafael Souza. O compartilhamento de dados e informações pessoais dos consumidores: 
A situação que se expõe, de violação à intimidade, à privacidade, à autonomia e à autodeterminação consciente do consumidor — liberdade da manifestação do pensamento e liberdade de consciência —, por intermédio de campanhas publicitárias, foi destacada por Voorhees Jr., Spiegel e Cooper:

O rápido desenvolvimento do neuromarketing também provocou o crescimento de uma inquietação global entre os defensores da privacidade, que há muito tempo se preocupam com a acelerada expansão das tecnologias de coleta de informações na era da Internet [...] Porém, questões mais amplas e potencialmente mais relevantes em relação à privacidade surgem à medida que a publicidade aprimorada pela neurociência causa impactos aos consumidores. Os críticos afirmam que essas técnicas resultam em intrusões sem precedentes nos padrões de pensamento do consumidor e, consequentemente, desprezam a inviolabilidade "do eu interior" do indivíduo ${ }^{55}$.

A veiculação de publicidade subliminar — personalizada ou não —, apesar de ilegal, continua sendo realizada por meio de diversos estímulos ao inconsciente do consumidor. Como já dito, sua utilização tem a capacidade de proporcionar uma maior efetividade às campanhas de marketing por criar obstáculos à autodeterminação consciente do consumidor.

Outro alegado empecilho à efetividade do marketing e da publicidade subliminar são os hábitos preexistentes de determinado consumidor, caso sejam incompatíveis com determinado produto e/ou serviço que se pretende promover. Compete, pois, explicitar a forma pela qual surgem os hábitos e suas repercussões individuais e coletivas. Sob tal propósito, cita-se um trecho de artigo escrito por Bas Verplanken:

Enquanto um único ato pode ter relevantes consequências pessoais, quando comportamentos se repetem, eles exercem um impacto significativo e cumulativo nos resultados médicos, sociais e econômicos experimentados tanto por consumidores individuais quanto pela sociedade como um todo. Um importante aspecto da repetição é que os comportamentos repetitivos podem se tornar hábitos. Um hábito pode ser conceituado como um padrão de comportamento recorrente, geralmente inconsciente, que é adquirido a partir de repetições frequentes em um contexto estável. ${ }^{56}$

Pode-se afirmar, então, que os hábitos têm relevantes consequências individuais e coletivas e se formam com base na repetição de determinado comportamento que se estabiliza no tempo, por meio de uma rotina estabelecida no ambiente em que o indivíduo está inserido. Sob tal perspectiva, a exploração do inconsciente do consumidor, ao conduzi-lo a determinado comportamento, caso se transforme em hábito, afetará sua liberdade nas escolhas de compra.

De acordo com Kotler e Keller, a criação de hábitos de consumo — denominado, na ocasião, como “aprendizagem" — são possíveis, desde que seja utilizado o estímulo adequado:

Quando as pessoas agem, elas aprendem. A aprendizagem consiste em mudanças no comportamento de uma pessoa decorrentes da experiência. Os teóricos da aprendizagem acreditam que ela nasce da interação entre impulsos, estímulos, sinais, respostas e reforços.

o abuso dos fornecedores e as propostas apresentadas no PLS 181/2014. Revista Brasileira de Políticas Públicas, Brasília, v. 7, n. 1, 2017. Disponível em: <https://www.publicacoesacademicas.uniceub.br/RBPP/article/view/4579/pdf>. Acesso em: 23 maio 2018.

55 "The rapid emergence of neuromarketing has also raised global alarm among privacy advocates, who have long been concerned by the rapid expansion of information-gathering technologies during the Internet era that have become increasingly invasive in response to the threat of international terrorism. Privacy concerns arise most immediately in the clinical setting where basic neuroscience research for advertising purposes is carried out on human subjects. But broader and potentially more consequential privacy issues arise as neuroscience-enhanced advertising impacts individual consumers. Critics claim that these techniques result in unprecedented intrusions into the consumer's thought patterns and thus trample on the sanctity of the individual's "inner self." VOORHEES JR., Theodore; SPIEGEL, Daniel L.; COOPER, Daniel. Neuromarketing: legal and policy issues: a covington white paper, 2011. Disponível em: <https://www.prnewswire.com/news-releases/covington-releases-paper-on-neuromarketings-legaland-policy-issues-203681701.html>. Acesso em: 23 maio 2018. (tradução nossa).

56 "While a single act may have important personal consequences, when behaviors are repeated, they exert significant, cumulative impact on medical, social, and economic outcomes experienced by both individual consumers and society as a whole. An important aspect of repetition is that repeating behaviors may turn these into habits. A habit can be conceptualized as a recurrent, often unconscious pattern of behaviour that is acquired through frequent repetition in a stable context." VERPLANKEN, Bas. Habit and consumer behavior: implications for interventions and behavior change. Advances in Consumer Research, v. 35, p. 125-128, 2008. Disponível em: < http://www.acrwebsite.org/volumes/13268/volumes/v35/NA-35>. Acesso em: 23 maio 2018. (tradução nossa). 
Um impulso é um forte estímulo interno que impele à ação. Os sinais são estímulos menos intensos que determinam quando, onde e como a pessoa reage [...]

A teoria da aprendizagem ensina aos profissionais de marketing que eles podem criar demanda para um produto associando-o a fortes impulsos, usando sinais motivadores e fornecendo reforço positivo. ${ }^{57}$ (grifo do autor).

Consoante já destacado no presente tópico, a utilização de publicidade subliminar para manipular a tomada de decisão do consumidor, reforçada pela coleta de seus dados pessoais identificados com base em suas atividades online, caracteriza violação dos direitos fundamentais à intimidade, privacidade, liberdade de manifestação do pensamento e liberdade de consciência. Ofende, da mesma forma, o direito fundamental ao acesso à informação.

Tal situação pode se agravar quando a publicidade subliminar induzir o consumidor a um comportamento que seja capaz de se transformar em um hábito de consumo que represente risco à sua segurança — física, psíquica, ambiental, social ou econômico-financeira. Vale ressaltar que o direito fundamental à segurança do consumidor impõe ao Poder Público a obrigação de protegê-lo contra produtos e serviços perigosos, e está garantido pelo artigo $5^{\circ}$, caput e inciso XXXII da CRFB/88, pelos artigos 196 e 225 da CRFB/88 ${ }^{58}$ e pelo artigo $6^{\circ}$, inciso I, do $\mathrm{CDC}^{59}$.

Desse modo, no próximo tópico se investigará a possibilidade do consumidor, a partir de uma deliberação consciente, superar um hábito de consumo perigoso - que representa risco à sua segurança ou da coletividade na qual está inserido — e se proteger contra a publicidade subliminar.

\subsection{A relevância da deliberação consciente na superação condicional de hábitos de consumo perigosos}

A partir da exposição contida no tópico anterior, pode-se afirmar que a veiculação de publicidade subliminar, em especial quando personalizada, tem a capacidade de retirar do consumidor a capacidade de escolha consciente, moldando seu comportamento de consumo. Caso esse comportamento seja constantemente repetido, eventualmente se tornará um hábito de consumo - que é um comportamento padrão inconsciente, ou seja, automático e impulsivo, que se deflagra a partir de deixa existente no ambiente em que o consumidor está introduzido.

Tal situação se torna um problema quando o comportamento inconsciente do consumidor o conduz a um hábito de consumo contrário a valores voluntariamente adotados e/ou traz riscos à sua segurança. Como exemplo, pode-se conjecturar a hipótese em que o indivíduo é conduzido ao consumo de produtos que causam dependência ou outras patologias, tais como: cigarro, bebida alcoólica, refrigerante, fast food etc.

Além de riscos individuais, os hábitos de consumo podem ser perigosos por se configurar como uma ameaça à segurança de uma determinada coletividade. Pode-se citar como exemplos de riscos coletivos, o endividamento familiar e a poluição gerada pelo excesso de lixo eletrônico gerado pelo sistema industrial de produção em massa, visando atender à demanda de consumo incentivada pelo marketing - incentivo que pode acarretar no consumo compulsivo (oneomania).

Em um contexto no qual os hábitos dos consumidores, formados a partir de estímulos proporcionados pelo marketing - especialmente via publicidade subliminar -, representam risco à segurança individual ou coletiva, faz-se necessário adotar medidas de precaução visando proteger sua autodeterminação consciente

57 KOTLER, Philip; KELLER, Kevin Lane. Administração de marketing. 14. ed. São Paulo: Pearson Education do Brasil, 2012.

58 BRASIL. Constituição (1988). Constituição da República Federativa do Brasil. Disponível em: <http://www.planalto.gov.br/ccivil_03/constituicao/constituicao.htm>. Acesso em: 23 maio 2018.

59 BRASIL. Lei no 8.078, de 11 setembro de 1990. Disponível em: < http://www.planalto.gov.br/ccivil_03/leis/L8078.htm>. Acesso em: 23 maio 2018. 
perante tais riscos. Trata-se de incumbência atribuída tanto ao Poder Público quanto aos próprios indivíduos, em consonância com os preceitos contidos nos artigos 196 e 225 da CRFB/88 — visando proteger a saúde individual e coletiva, e o meio ambiente equilibrado, essencial à sadia qualidade de vida de todos.

Urge a necessidade, nesse viés, de investigar a possibilidade de superação desses hábitos nocivos praticados — inconscientemente — pelo consumidor. Cumpre salientar que seu êxito não será verificado na hipótese de um indivíduo mudar seu comportamento por um curto período, mas sim, quando ele desenvolver um hábito substituto.

Sob tal propósito, inicialmente, convém mencionar que, para Gustavo Binenbojm, a deficiência de informações é um fator que contribui para inviabilizar a escolha racional do consumidor, caracterizando-se como uma falha de mercado. Desse modo, deve o Poder Público atuar com a intenção de efetivar o direito fundamental à informação, assegurando ao consumidor a possibilidade de uma escolha consciente:

A falta de informações adequadas pode decorrer de diversas razões, eventualmente relacionadas à (i) ignorância sobre aspectos técnicos envolvidos, (ii) falta de experiência, (iii) capacidade individual de processamento de alguns tipos de informação ou, até mesmo, (iv) sonegação de informações por alguma das partes envolvidas com finalidade estratégica.

$[\ldots]$

A situação de assimetria informacional torna-se uma falha de mercado quando dificulta ou inviabiliza a escolha racional do consumidor, criando empecilhos à livre concorrência e perda de eficiência econômica. Daí a função da regulação de criar formas de facilitação e compreensão da informação, a fim de contribuir para relações econômicas mais eficientes e equitativas $[. ..]{ }^{60}$

Tal posicionamento também é realçado por Antônio Herman V. Benjamin, ao salientar que

o Estado intervém para assegurar, em face da falha de funcionamento do mercado, que os consumidores recebam informações adequadas que os habilitem a exercer, de maneira consciente e livre, suas opções de consumo. ${ }^{61}$

O acesso à informação torna-se, ainda, mais relevante em relação a produtos e/ou serviços que oferecem riscos à segurança.

Vale ressaltar que o acesso facilitado a informações acerca de riscos relacionados aos produtos comercializados no mercado é um direito fundamental do consumidor, assegurado pelo artigo $5^{\circ}$, incisos XIV, XXXII e XXXIII da CRFB $/ 88^{62}$, e pelo artigo $6^{\circ}$, inciso III do $\mathrm{CDC}^{63}$. O indivíduo bem informado sobre os riscos atrelados ao seu comportamento pode evitá-lo conscientemente, impedindo, assim, a formação de hábitos de consumo perigosos — caso não tenha a intenção de assumir o risco.

A relevância da informação para a gestão dos riscos da modernidade, por parte dos consumidores, tal como aqueles relacionados à saúde e ao equilíbrio ambiental, é destacada por Patrícia Santos Précoma Pellanda:

[...] a informação serve como meio de conscientização da população para o consumo consciente de produtos industriais e provenientes de novas tecnologias. Portanto, conclui-se que a aplicação do princípio da informação nesta seara contribui à alimentação adequada e à garantia da segurança alimentar, tendo em vista que o consumidor estará apto a consumir somente o alimento que acredita ser o mais adequado às suas necessidades alimentares. Além disso, a conscientização por meio da informação influencia a forma de consumir e os tipos produtos efetivamente consumidos, podendo o consumidor, desta forma,

60 BINENBOJM, Gustavo. Poder de polícia, ordenação, regulação: transformações político-jurídicas, econômicas e institucionais do direito administrativo ordenador. Belo Horizonte: Fórum, 2016. p. 183-184.

61 BENJAMIN, Antônio Herman V. Oferta e publicidade. In: BENJAMIN, Antônio Herman V.; MARQUES, Claudia Lima; BESSA, Leonardo Roscoe. Manual de direito do consumidor. 7. ed. São Paulo: Revista dos Tribunais, 2016. p. 515-557. p. 272.

62 BRASIL. Constituição (1988). Constituição da República Federativa do Brasil. Disponível em: <http://www.planalto.gov.br/ccivil_03/constituicao/constituicao.htm>. Acesso em: 23 maio 2018.

63 BRASIL. Lei no 8.078, de 11 setembro de 1990. Disponível em: <http://www.planalto.gov.br/ccivil_03/leis/L8078.htm>. Acesso em: 23 maio 2018. 
contribuir com a preservação do meio ambiente, por meio do consumo de produtos menos impactantes aos recursos naturais. A aplicação do princípio da informação, portanto, reflete na observância, ainda que indireta, do princípio da precaução e, por fim, da tão almejada sustentabilidade. ${ }^{64}$

No entanto, o fornecimento de informações ostensivas alertando ao indivíduo quanto aos riscos associados ao seu comportamento de consumo não é suficiente para modificação de um hábito perigoso já consolidado. Em um contexto no qual o consumidor já possui um hábito de consumo nocivo, embora a informação de advertência sirva como um gatilho de acesso à consciência, essa normalmente não prevalecerá, sucumbido à deixa que deflagra o comportamento padrão inconsciente — por "deixa", deve-se compreender algum sinal que toca os sentidos e/ou emoções do indivíduo, conduzindo-o a uma determinada conduta estabelecida em uma rotina.

Além do acesso facilitado à informação acerca dos riscos relacionados a determinado produto, o ambiente no qual o sujeito está inserido, também, contribui para a criação do hábito de consumo - e para sua mudança. Assim, quem deseja modificar seus hábitos deve também alterar seu ambiente, de modo a possibilitar uma nova rotina — uma nova repetição de comportamentos — que poderá ensejar na formação de um novo hábito.

Pertinente, assim, trazer à tona as conclusões realizadas por Bas Verplaken e Wendy Wood: Em resumo, as expectativas estabelecidas por meio do comportamento repetitivo e a realização automática dos hábitos são forças conservadoras que reduzem a abertura a novas informações e perpetuam condutas rotineiras, apesar das pessoas intentarem fazer o contrário. Esses aspectos do desempenho dos hábitos são obstáculos à efetividade de intervenções no foco individual, tal como campanhas informativas e estratégias de autoajuda. Intervenções que municiam as pessoas com informações acerca da coisa certa a se fazer ou que aumentam sua compreensão sobre como adotar um comportamento, provavelmente serão efetivas em relação a condutas que não são praticadas por hábito. Quando o comportamento visado é habitual, as intenções, desejos e julgamento das pessoas não superam facilmente a reação automática à deixa emitida pelo ambiente. Embora esse vínculo entre os hábitos e os aspectos ambientais represente uma barreira ao uso da informação, essa característica dos hábitos também representa uma fonte única de vulnerabilidade; ou seja, os hábitos podem ser alterados mediante mudanças dessas circunstâncias. ${ }^{65}$

Pode-se inferir que um hábito de consumo perigoso - ao indivíduo e/ou à coletividade — pode ser superado mediante a modificação das circunstâncias do ambiente no qual o indivíduo está inserido, mais precisamente da deixa — que é o sinal que deflagra o comportamento repetitivo.

Mais adiante, no mesmo trabalho, Bas Verplaken e Wendy Wood indicam que o êxito na modificação dessas circunstâncias que sustentam o hábito perigoso dependerá de uma deliberação consciente do indivíduo, estabelecendo uma intenção de promover mudanças em seu comportamento.

A efetividade das intervenções depende não apenas da mudança de hábitos existentes e do início de um novo comportamento, mas também da manutenção desse comportamento. A criação de novos hábitos é um mecanismo por meio do qual se garante a continuidade das novas reações.

64 PELLANDA, Patrícia Santos Précoma. A sociedade de risco e o princípio da informação: uma abordagem sobre a segurança alimentar na produção de transgênicos no Brasil. Revista Veredas do Direito, Belo Horizonte, v. 10, n. 19, 2013. Disponível em: <http://www.domhelder.edu.br/revista/index.php/veredas/article/view/258/341>. Acesso em: 23 maio 2018.

65 "In summary, the expectations established through behavior repetition and the automaticity of habit performance are conservative forces that reduce openness to new information and that perpetuate well-practiced behaviors despite people's intentions to do otherwise. These aspects of habit performance significantly hinder the effectiveness of downstream, individually focused interventions, such as informational campaigns and self-help strategies. Interventions that provide people with information about the right thing to do or that increase their understanding about how to perform a behavior are likely to be effective primarily with actions that are not practiced habitually. When the target behavior is habitual, people's intentions, desires, and judgments do not easily overcome the practiced response that is cued automatically by the environment. Although the dependence of habits on stable aspects of the environment presents a barrier to information use, this feature of habits also represents a unique source of vulnerability; namely, habits can be changed through changes in those circumstances.” VERPLANKEN, Bas; WOOD, Wendy. Interventions to break and create consmer habits. Journal of Public Policy \& Marketing, n. 1, p. 90-103, 2006. Disponível em: < https:/ / dornsife. usc.edu/assets/sites/208/docs/Verplanken.Wood.2006.pdf>. Acesso em: 23 maio 2018. (tradução nossa) 
$[\ldots]$

Adotar e repetir uma nova ação depende, em grande parte, do discernimento das pessoas no sentido de que o resultado que ela oferece é mais desejável do que as oferecidas por ações alternativas.

$[\ldots]$

Existem vários reforços que podem promover o desempenho de um novo comportamento. Algumas pessoas podem achar que viver com valores importantes de saúde ou ambientais é suficientemente reforçador para motivar repetidos desempenhos. Para outros, esses valores abstratos não são especialmente motivadores, e reforços mais potentes são os resultados comportamentais de eficiência, lucratividade e conveniência. ${ }^{66}$

Verifica-se, portanto, que eventuais hábitos de consumo perigosos, formados com base em técnicas publicitárias, em especial a subliminar — que é ilegal, mas continua sendo realizada —, podem ser superados a partir de deliberação consciente. Nas palavras de Wendy Wood e David T. Neil: “as intenções, por si só, não produzem associações de hábito na memória, mas facilitam sua formação por fomentar a repetição inicial do comportamento em contextos estáveis". ${ }^{67}$ À medida que esse novo comportamento for repetido no tempo em um ambiente estável, tornar-se-á um padrão, sendo formado um novo hábito que substituirá o antigo.

Necessário frisar que a referida superação não ocorrerá em caráter definitivo, mas apenas enquanto se mantiverem estáveis as condições ambientais que viabilizaram a inserção do hábito substituto. Nesse caso, o hábito perigoso permanecerá adormecido no inconsciente do consumidor, podendo voltar à tona acaso sejam retomadas as circunstâncias — as deixas — que deflagram sua prática.

Além do mais, faz-se oportuno realçar que devido à existência de certos determinismos fisiológicos e psíquicos inerentes diferentemente em cada indivíduo, mesmo com a modificação das condições ambientais que irrompem o hábito perigoso, este pode não ser superado, de modo que o processo mental inconsciente prevalecerá sobre a deliberação consciente do consumidor, impedindo a modificação de comportamento com base nas informações adquiridas.

Ante todo o exposto, é possível afirmar que o inconsciente do consumidor tem papel relevante em suas escolhas, sendo capaz de proporcionar um comportamento repetitivo que, posteriormente, se transformará em hábito de consumo. Entretanto, hábitos também podem ser criados ou modificados a partir da deliberação consciente do consumidor, considerando suas intenções e motivações.

A preservação da liberdade de escolha do consumidor ganha relevância diante das inúmeras campanhas de marketing veiculadas em diversos meios de comunicação — inclusive por publicidade subliminar personalizada —, as quais podem induzi-lo à escolha por produtos e/ou serviços que muitas vezes são contrários aos seus valores pessoais e/ou que oferecem risco à sua segurança individual ou da coletividade.

66 "The effectiveness of interventions depends not only on the change of existing habits and the initiation of a new behavior but also on the maintenance of that behavior. One mechanism to ensure that new responses continue is through the creation of new habits.

$[\ldots]$

Adopting and repeating a new action depends largely on people's judgments that the outcome it affords is more desirable than those offered by alternative actions.

$[\cdots]$

There are various reinforcements that can promote performance of a new behavior. Some people may find that living up to important health or environmental values is sufficiently reinforcing to motivate repeated performance. For others, these abstract values are not especially motivating, and more potent reinforcements are the behavioral outcomes of efficiency, profitability, and convenience." VERPLANKEN, Bas; WOOD, Wendy. Interventions to break and create consmer habits. Journal of Public Policy \& Marketing, n. 1, p. 90-103, 2006. Disponível em: <https://dornsife.usc.edu/assets/sites/208/docs/Verplanken.Wood.2006.pdf>. Acesso em: 23 maio 2018. (Tradução nossa).

67 "Intentions do not directly produce habit associations in memory but rather facilitate their formation by fueling the initial repetition of behavior in stable contexts". WOOD, Wendy; NEIL, David T. The habitual consumer. Journal of Consumer Psychology, v. 19, p. 579-592, 2009. Disponível em: < https://dornsife.usc.edu/assets/sites/545/docs/Wendy_Wood_Research_Articles/Habits/ wood.neal.2009._the_habitual_consumer.pdf>. Acesso em: 23 maio 2018. (tradução nossa). 
Contudo, consonante já destacado anteriormente, as deliberações conscientes do indivíduo, somente, terão possibilidade de predominar num cenário em que as informações pertinentes aos riscos associados a determinado produto ou serviço sejam prestadas de forma ostensiva. Isso porque, tais informações servirão como gatilho de acesso à sua consciência, viabilizando que ele exerça sua escolha de compra em efetiva liberdade.

O Poder Público tem papel relevante na preservação da autodeterminação consciente do consumidor. Primeiramente, tem a obrigação de garantir o acesso à informação acerca dos riscos à segurança proporcionados por produtos ou serviços. Em segundo plano, deve intensificar a combatividade à publicidade subliminar, que apesar de ilegal é constantemente utilizada, tendo sido, inclusive, fortalecida pela também ilegal exploração mercadológica de dados pessoais de usuários de internet e redes sociais, que viabilizou a publicidade subliminar personalizada.

\section{Considerações finais}

Os experimentos científicos realizados por Benjamin Libet indicaram a manifestação de impulsos elétricos no cérebro humano pouco antes do indivíduo teoricamente realizar uma escolha. A partir daí, surgiram interpretações no sentido de que um indivíduo não seria capaz de controlar conscientemente seus próprios atos, havendo um determinismo neurológico ou biológico do ser humano, de modo que suas decisões seriam consequência de aspectos naturais causais — determinismo puro.

Essa concepção a favor do determinismo puro, caso prevalente, traria várias consequências para o direito, uma vez que ao reconhecer a incapacidade dos indivíduos em controlar conscientemente seus próprios atos, admitir-se-ia que eles não poderiam ser responsabilizados pelos mesmos. Contudo, o próprio Libet reconheceu a relevância da deliberação consciente nas escolhas empreendidas pelos indivíduos, apesar de seu pouco rigor filosófico em tal constatação, o que pode ser constatado nas críticas a respeito de sua interpretação.

Ademais, essa compreensão pelo determinismo puro fica fragilizada ao se considerar as construções filosóficas de Martin Heidegger, a partir das quais se pode afirmar que até mesmo as conclusões no sentido de que o homem é determinado, já dependeriam de uma deliberação prévia fundamentada na linguagem.

Desse modo, pode-se dizer que, apesar da crítica apresentada ao determinismo puro, as tomadas de decisão dos indivíduos têm origem tanto em processos mentais inconscientes quanto na sua capacidade deliberativa consciente.

Diante da constatação da relevância do inconsciente nas escolhas individuais, os agentes de marketing, inspirados pelas descobertas da neurociência - neuromarketing —, desenvolveram estratégias a fim de estimular os sentidos e/ou emoções do consumidor e, assim, influenciar seu inconsciente, induzindo-o a um comportamento favorável às pretensões de seu patrocinador, ou seja, manipulando-o à aquisição de determinado produto ou serviço. Esse comportamento, se repetido no tempo em condições ambientais estáveis, transformar-se-á num hábito do consumo.

Entretanto, embora pesquisadores tenham constatado o papel que estímulos ao inconsciente do indivíduo desempenham na criação de uma demanda, manipulando os desejos do consumidor, não conseguiram confirmar se seriam capazes de induzi-lo à aquisição de um produto específico, em especial quando existir um hábito consolidado que se revele incompatível.

Tais obstáculos, porém, estão sendo estrategicamente contornados mediante a coleta de informações pessoais dos consumidores, constantes em suas atividades online, em especial aquelas inseridas em redes sociais - apesar de se tratar de prática ilegal, por violar os direitos fundamentais à intimidade e privacidade. 
O acesso a essas informações viabilizou a veiculação de publicidade subliminar personalizada - direcionada a um determinado indivíduo —, aumentando a possibilidade de indução à aquisição de um produto ou serviço específico.

A publicidade subliminar é vedada no ordenamento jurídico brasileiro, uma vez que todo marketing deve ser identificável imediatamente pelo consumidor, sem a necessidade de qualquer esforço ou capacitação técnica. Além disso, ao inviabilizar a autonomia e autodeterminação do consumidor, induzindo-o inconscientemente a um determinado comportamento, verifica-se ofensa aos direitos fundamentais à liberdade de manifestação do pensamento, liberdade de consciência e acesso à informação. Apesar disso, tal técnica publicitária continua sendo utilizada e, além do mais, foi aprimorada pela personalização, conforme já mencionado.

A manipulação do consumidor se torna um problema maior quando o produto ou serviço adquirido por indução for contrário aos seus valores pessoais e, especialmente, quando oferecerem riscos à segurança individual ou da coletividade. Vale ressaltar que a segurança contra produtos ou serviços que representem riscos à segurança também é direito fundamental do consumidor.

Cabe ao Poder Público, nesse sentido, atuar de forma mais efetiva em relação à proteção dos dados pessoais dos usuários de internet e no combate às publicidades subliminares. Também é relevante elaborar políticas públicas orientando o consumidor a determinados comportamentos - por exemplo, evitando o consumo compulsivo que causa endividamento familiar e sustenta os níveis alarmantes de degradação ambiental - e assegurar o acesso às informações pertinentes aos produtos e serviços comercializados, com especial atenção àqueles que oferecem risco à segurança individual ou coletiva — álcool, cigarros, fast food, refrigerantes etc.

O acesso à informação representa um gatilho de acesso à consciência do consumidor, sendo de suma relevância à autodeterminação consciente em suas escolhas de compra. No entanto, dificilmente esse acesso à informação será suficiente, por si só, para promover a superação de um hábito de consumo perigoso já consolidado. Nessa situação, a deliberação consciente do consumidor, a partir de motivações pessoais que ensejam na intenção de mudar seu comportamento padrão, torna-se indispensável.

Diante das orientações sedimentadas em políticas públicas e do acesso facilitado às informações de advertência quanto aos riscos associados a determinado produto ou serviço, o consumidor pode motivar-se a mudar seu comportamento e, intencionalmente, modificar as circunstâncias ambientais que deflagram o hábito de consumo perigoso. Poderá, pois, inserir uma nova rotina que, com o passar do tempo, transformar-se-á num novo hábito — este sim, escolhido conscientemente —, em substituição àquele.

Desse modo, pode-se concluir que os consumidores são capazes, a partir de ato volitivo, de superar hábitos de consumo consolidados que colocam em risco o direito fundamental à segurança, inclusive aqueles formados por influências ao seu inconsciente, constantes em ações de marketing. Para tanto, far-se-á imprescindível o acesso ostensivo às informações relacionadas aos produtos e serviços comercializados, além da modificação das circunstâncias do ambiente no qual o indivíduo está inserido, evitando as deixas que deflagram o hábito de consumo perigoso.

Contudo, esse hábito perigoso não será definitivamente extirpado da mente do consumidor, podendo voltar a se manifestar em caso de retorno das circunstâncias — deixas — que o sustenta. Além disso, aspectos fisiológicos e psíquicos podem se configurar como obstáculo à superação do hábito perigoso, fazendo com que este prevaleça a despeito de orientações, do acesso à informação e da modificação das condições ambientais. 


\section{REFERÊNCIAS}

BENJAMIN, Antônio Herman V. Oferta e publicidade. In: BENJAMIN, Antônio Herman V.; MARQUES, Claudia Lima; BESSA, Leonardo Roscoe. Manual de direito do consumidor. 7. ed. São Paulo: Revista dos Tribunais, 2016. p. 515-557.

BENNETT, M. R.; HACKER, P.M.S. Fundamentos filosóficos da neurociência. Lisboa: Piaget, 2003.

BINENBOJM, Gustavo. Poder de polícia, ordenação, regulação: transformações político-jurídicas, econômicas e institucionais do direito administrativo ordenador. Belo Horizonte: Fórum, 2016.

BODE, Stefan et. al. Tracking the unconscious generation of ffree decisions using uItra-high field fMRI. Plos One, v. 6, n. 6, p. 1-13, jun. 2011.

BRASIL. Constituição (1988). Constituição da República Federativa do Brasil. Disponível em: <http://www.planalto.gov.br/ccivil_03/constituicao/constituicao.htm>. Acesso em: 23 maio 2018.

BRASIL. Lei no 8.078, de 11 setembro de 1990. Disponível em: <http://www.planalto.gov.br/ccivil_03/leis/ L8078.htm>. Acesso em: 23 maio 2018.

BRASIL. Lein 12.965, de 23 abril de 2014. Disponível em: < http://www.planalto.gov.br/ccivil_03/_ato20112014/2014/lei/112965.htm>. Acesso em: 23 maio 2018.

GADE, Christiane. Psicologia do consumidor e da propaganda. São Paulo: EPU, 1998.

KORNHUBER, Helmut H.; DEECKE, Lüder. Hirnpotentialanderungen bei Willkiirbewegungen und passiven Bewegungen des Menschen: Bereitschaftspotential und reafferente Potentiale. Pfiigers Archivfur Gesamte Physiologie, n. 284, p. 1-17, 1965.

KOTLER, Philip; KELLER, Kevin Lane. Administração de marketing. 14. ed. São Paulo: Pearson Education do Brasil, 2012.

LIBET, Benjamin et. al. Time of conscious intention to act in relation to onset of cerebral activity (Readiness-Potential). The unconscious initiation of a freely voluntary act. Brain, Oxford, n. 106, p. 623-642, 1983.

LIBET, Benjamin. Unconscious cerebral initiative and the role of conscious will in voluntary action. The behavioral and brain sciences, n. 8, p. 529-66, 1985.

MALTEZ, Rafael Tocantins. Direito do consumidor e publicidade: análise jurídica e extrajurídica da publicidade subliminar. Curitiba: Juruá, 2011.

MARTÍ, Silas. Entenda o escândalo de uso de dados do Facebook: Informações foram utilizadas para influenciar na eleição de Trump. 2018. Disponível em: <https://www1.folha.uol.com.br/mercado/2018/03/entenda-oescandalo-do-uso-de-dados-do-facebook.shtml>. Acesso em: 23 maio 2018.

NAGEL, Thomas. Visão a partir de lugar nenhum. São Paulo: Martins Fontes, 2004.

NUNES, Rizzato. Comentários ao Código de Defesa do Consumidor. 8. ed. São Paulo: Saraiva, 2015.

PARISER, Eli. O filtro invisivel: o que a internet está escondendo de você. Rio de Janeiro: Zahar, 2012.

PELLANDA, Patrícia Santos Précoma. A sociedade de risco e o princípio da informação: uma abordagem sobre a segurança alimentar na produção de transgênicos no Brasil. Revista Veredas do Direito, Belo Horizonte, v. 10, n. 19, 2013. Disponível em: <http://www.domhelder.edu.br/revista/index.php/veredas/article/ view/258/341>. Acesso em: 23 maio 2018.

RUBIA, Francisco J. El fantasma de la libertad: datos de la revolución neurocientífica. Barcelona: Crítica, 2009.

SANTANA, Héctor Valverde; VIANA, Rafael Souza. O compartilhamento de dados e informações pessoais dos consumidores: o abuso dos fornecedores e as propostas apresentadas no PLS 181/2014. Revista 
Brasileira de Políticas Públicas, Brasilia, v. 7, n. 1, 2017. Disponível em: < https://www.publicacoesacademicas. uniceub.br/RBPP/article/view/4579/pdf>. Acesso em: 23 maio 2018.

SOON, Chun Siong et al. Unconscious determinants of free decisions in the human brain. Nature Neuroscience, v. 11, n. 5, p. 543-545, maio 2008.

STEIN, Ernildo. Anamnese: a filosofia e o retorno do reprimido. Porto Alegre: EDIPUCRS, 1997.

STEIN, Ernildo. Exercícios de fenomenologia: limites de um paradigma. Ijuí: Unijuí, 2004.

VERPLANKEN, Bas. Habit and consumer behavior: implications for interventions and behavior change. Advances in Consumer Research, v. 35, p. 125-128, 2008. Disponível em: < http://www.acrwebsite.org/volumes/13268/volumes/v35/NA-35>. Acesso em: 23 maio 2018.

VERPLANKEN, Bas; WOOD, Wendy. Interventions to break and create consmer habits. Journal of Public Policy \& Marketing, n. 1, p. 90-103, 2006. Disponível em: < https://dornsife.usc.edu/assets/sites/208/docs/ Verplanken.Wood.2006.pdf>. Acesso em: 23 maio 2018.

VOORHEES JR., Theodore; SPIEGEL, Daniel L.; COOPER, Daniel. Neuromarketing: legal and policy issues: a covington white paper. 2011. Disponível em: <https://www.prnewswire.com/news-releases/covington-releases-paper-on-neuromarketings-legal-and-policy-issues-203681701.html>. Acesso em: 23 maio 2018.

WOOD, Wendy; NEIL, David T. The habitual consumer. Journal of Consumer Psychology, v. 19, p. 579-592, 2009. Disponível em: <https://dornsife.usc.edu/assets/sites/545/docs/Wendy_Wood_Research_Articles/Habits/wood.neal.2009._the_habitual_consumer.pdf>. Acesso em: 23 maio 2018. 


\title{
Ciência do direito tributário, economia comportamental e extrafiscalidade*
}

\section{Tax law research, behavioral economy and regulatory taxes}

\author{
Hugo de Brito Machado Segundo**
}

\section{Resumo}

Desde meados do Século XX, o estudo do Direito Tributário no Brasil desenvolveu-se com base na premissa segundo a qual, para ser científico, seria necessário limitar-se à descrição de seu objeto, as normas vigentes sobre tributação. Objetiva-se neste trabalho examinar se tal visão, certamente não homogênea e já a enfrentar críticas importantes, é compatível com a atual compreensão, no âmbito da Epistemologia, do que caracteriza o conhecimento como científico. Com a finalidade de aferir se o aludido reducionismo causa, efetivamente, prejuízos ao conhecimento, almeja-se verificar se, no campo da tributação extrafiscal, há incapacidade de os juristas que a adotam lidarem com seus aspectos substanciais. Verifica-se, então, com o uso do método falibilista, hipotético dedutivo, e partindo de pesquisa bibliográfica na literatura especializada, se, quanto ao uso de estímulos ou desestímulos econômicos, gênero do qual a tributação extrafiscal é espécie, constatações da neurociência e da economia comportamental revelam que, dependendo da forma como são concedidos, alguns incentivos podem conduzir a resultado contrário ao pretendido, sendo importante descobrir as razões disso, algo somente possível dada a interdisciplinariedade que caracteriza essas novas formas de conhecimento. Conclui-se, a partir de incursão na bibliografia relativa à economia comportamental e à neurociência, que a compreensão de tais fenômenos é necessária ao jurista, pois não se pode estudar a correção no uso de um remédio sem se conhecerem os seus efeitos. O entendimento dos efeitos dos incentivos sobre o comportamento humano pode alterar, significativamente, a forma como se utiliza o tributo com função extrafiscal, tornando-a mais eficiente e isonômica.

Palavras-chave: Epistemologia do Direito Tributário. Neurociência. Economia Comportamental. Extrafiscalidade.

* Recebido em 10/05/2018 Aprovado em 19/06/2018

** Mestre e Doutor em Direito. Advogado. Membro do ICET - Instituto Cearense de Estudos Tributários e do IBDT - Instituto Brasileiro de Direito Tributário. Professor da Faculdade de Direito da Universidade Federal do Ceará (Graduação, Mestrado e Doutorado) e do Centro Universitário Christus (Graduação e Mestrado). Visiting Research Scholar da Wirtschaftsuniversität, Viena, Áustria (2012/2013 - 2015/2016). Email de contato: hugo.segundo@ufc.br

\section{Abstract}

Since the mid-twentieth century, the study of tax law in Brazil has developed from the premise that, to be considered "scientific", it should only describe its object, namely tax law rules. This paper aims to review if this approach, certainly not homogenic and already criticized by recent literature, is compatible with actual comprehension, in the field of Epistemology, regarding to what characterizes an approach as scientific. In order to verify 
whether the aforementioned reductionism effectively causes prejudice to knowledge, this work also verifies whether, in the field of regulatory taxation, there is an inability of the jurists who adopt it to deal with substantial aspects of the topic. Considering the fallibilistic method, and regarding the specialized literature, it is verified that, regarding the use of economic stimulus or discouragement, genre of which regulatory taxation is a species, findings of neuroscience and behavioral economics show that, depending on how they are granted, some incentives may lead to a result that is contrary to the intended, and it is important to discover why, something only possible given the interdisciplinarity that characterizes these new forms of knowledge. It is concluded, then, from an incursion into the literature on behavioral economics and neuroscience, that the understanding of such phenomena is necessary also for legal scholars because one cannot study the correction in the use of a medicine without knowing their effects. The comprehension of the effects of incentives on human behavior can significantly improve the way regulatory taxes are used, making them more efficient and fair.

Keywords: Epistemology of Tax Law. Neuroscience. Behavioral Economics. Regulatory taxes.

\section{INTRODUÇÃo}

Durante muito tempo, o Direito Tributário, sobretudo no Brasil, foi marcado por uma intensa busca por "rigor científico", característica que seria supostamente obtida por um estudo que deveria - além de atender a outros requisitos - proceder a uma cuidadosa delimitação de seu objeto, atendo-se somente a ele. Seria preciso centrar-se nas normas, e, mais especificamente, nas normas de tributação, e, apenas, nelas. Disposições normativas referentes a outras matérias seriam objeto de ramos diversos da Ciência do Direito, ao passo que o estudo dos motivos que levaram à edição das normas ou das finalidades a serem com elas buscadas não seria sequer jurídico, cabendo à Economia, à Política ou à Sociologia.

Essa segmentação, se, por um lado, permitiu maior aprofundamento formal no estudo de temas como a estrutura da norma jurídica, a relação das normas umas com as outras, a dinâmica da incidência e o funcionamento em geral da ordem jurídica, por outro, no que diz respeito a aspectos substanciais, divorciou o Direito das finalidades que com ele se pretendem buscar.

Neste artigo, pretende-se examinar, de maneira específica, como esse reducionismo na delimitação do objeto da Ciência do Direito levou a uma diminuição de sua utilidade, de forma específica no campo da extrafiscalidade ${ }^{1}$, porquanto premissas dadas como certas por tributaristas nesse campo - por partirem de uma ideia de homo economicus ${ }^{2}$ que a Psicologia e a Economia contemporâneas estão desconstruindo — nem

1 Entende-se por extrafiscalidade, como se sabe, "o fenômeno jurídico por meio do qual o Estado, por meio da imposição de uma obrigação tributária, procura realizar finalidade constitucional diversa da mera arrecadação para o custeio de suas atividades." PIMENTA, Daniel de Magalhães. Limitações à extrafiscalidade aplicáveis ao fator acidentário de prevenção: FAP. Revista Brasileira de Políticas Públicas, v. 6, n. 1., p. 77, jan./jul. 2016. Como explica Casalta Nabais, a "extrafiscalidade traduz-se no conjunto de normas que, embora formalmente integrem o direito fiscal, tem por finalidade principal ou dominante a consecução de determinados resultados econômicos ou sociais através da utilização do instrumento fiscal e não a obtenção de receitas para fazer face às despesas públicas. Trata-se assim de normas (fiscais) que, ao preverem uma tributação, isto é, uma ablação ou amputação pecuniária (impostos), ou uma não tributação ou uma tributação menor à requerida pelo critério da capacidade contributiva, isto é, uma renúncia total ou parcial a essa ablação ou amputação (benefícios fiscais), estão dominadas pelo intuito de actuar directamente sobre os comportamentos econômicos e sociais dos seus destinatários, desincentivando-os, neutralizando-os nos seus efeitos económicos e sociais ou fomentando-os, ou seja, de normas que contém medidas de política económica e social." NABAIS, José Casalta. O dever fundamental de pagar impostos: contributo para a compreensão do estado fiscal contemporâneo. Coimbra: Livraria Almedina, 2009. p. 52.

2 Entende-se por homo economicus aquele arquétipo de ser humano em torno do qual se desenvolveu a economia clássica. Na dicção de Hanno Beck, aqui livremente traduzida, ele é racional, maximiza seu interesse próprio, é livre de emoções e não comete erros na aquisição e processamento de informações. Assemelha-se ao "Sr. Spock", da série "Jornadas nas Estrelas". No original: "Der Homo Oeconomicus ist die zentrale Annahme der klassischen Ökonomie: Er ist rational, maximiert seinen Eigennuts, ist frei von Emotionen und macht keine Febler in der Informationsaufnahme und-Verarbeitung. Mit anderen Worten er ist ungefähr so realistisch wie der legendäre Mr. Spocke aus der Fernsehserie „Raumschiff Enterprise“” BECK, Hanno. Behavioral economics: eine einführung. Heidelberg: Springer, 2014. p. 1. 
sempre são procedentes. Objetiva-se aferir, ainda, se a consideração de aspectos ligados aos efeitos de um incentivo fiscal, por estar voltada, também, a fatos, faz com que deixe de ser jurídica uma pesquisa, tornando-se impertinente a quem se ocupa do Direito. Essa última análise será levada a cabo a partir de constatações feitas no âmbito da neurociência e da economia comportamental, as quais revelam o quanto ainda se sabe pouco sobre a maneira como as pessoas reagem a incentivos, os quais, mal idealizados, podem terminar por induzir a comportamentos contrários aos pretendidos.

\section{Algumas nOtas Sobre epistemologia Jurídica}

Como dito, partindo-se de uma concepção de conhecimento científico como sendo aquele meramente descritivo de uma realidade objetivamente posta diante do estudioso, a quem, de forma desinteressada, caberia fazer afirmações sobre como essa realidade é, e jamais sobre como ela poderia ou deveria ser, desenvolveu-se, no estudo do Direito Tributário no Brasil, em meados do Século XX, a ideia de que caberia ao pesquisador ou estudioso, apenas, descrever as normas em vigor. E apenas as normas referentes à tributação, deixando-se de lado aquelas dedicadas ao Direito Financeiro, e aos demais "ramos" da ordem jurídica. Embora uno e indivisível, o ordenamento, enquanto objeto, e a autonomia do Direito Tributário, enquanto ciência, exigiriam essa delimitação ${ }^{3}$.

Não se quer, neste artigo, sugerir que todos os tributaristas brasileiros adotam essa visão, de forma homogênea, desde os anos 1960 até hoje. Há notáveis exceções, em várias épocas. Pode-se citar Aliomar Baleeiro ${ }^{4}$ e Ruy Barbosa Nogueira ${ }^{5}$, entre 1960 e 1980, Alcides Jorge Costa ${ }^{6}$, nos anos 1980 e 1990, Marco Aurelio Greco $^{7}$ e Ricardo Lobo Torres ${ }^{8}$, notadamente a partir do ano 2000, e, nas últimas duas décadas, Luis Eduardo Schoueri ${ }^{9}$, Marciano Seabra de Godoi ${ }^{10}$ e Humberto Ávila, apenas para citar alguns nomes. São, contudo, exceções a uma visão dominante em sentido contrário, como aponta, também, de forma crítica, James Marins ${ }^{11}$. Aliás, tem-se assistido a um crescimento no número de autores que sustentam a necessidade de uma revisão na epistemologia tributária, rol no qual podem, ainda, ser inseridos escritos mais recentes de Humberto Ávila ${ }^{12}$ e de André Folloni ${ }^{13}$. Este artigo, embora por fundamentos diversos, pretende contribuir com essa crítica.

3 Cf., v.g., ATALIBA, Geraldo. Hipótese de incidência tributária. 6. ed. São Paulo: Malheiros, 2001. p. 41; BECKER, Alfredo Augusto. Teoria geral do direito tributário. São Paulo: Saraiva, 1963. p. 20; CARVALHO, Paulo de Barros. Curso de direito tributário. 12. ed. São Paulo: Saraiva, 1999. p. 3.

4 BALEEIRO, Aliomar. Uma introdução à ciência das finanças. 17. ed. Rio de Janeiro: Forense, 2010. Destaque-se que a primeira edição da obra, de interdisciplinariedade que sempre marcou os estudos de Baleeiro, é de 1955.

5 NOGUEIRA, Ruy Barbosa. Direito financeiro: curso de direito tributário. São Paulo: José Bushatsky, 1964; Direito tributário comparado. São Paulo: Saraiva, 1971. Túllio Ascarelli e o direito tributário do Brasil. São Paulo: IBDT, 1979.

6 Cf., v.g., COSTA, Alcides Jorge. História do direito tributário: I e II. In: FERRAZ, Roberto (Coord.). Princípios e limites da tributação. São Paulo: Quartier Latin, 2005.

7 GRECO, Marco Aurélio. Dinâmica da tributação: uma visão funcional. São Paulo: RT, 1979. Marco Aurelio é um dos pioneiros na revisão desse paradigma epistemológico na academia em São Paulo, o que se tornou mais evidente em suas obras posteriores sobre contribuições e sobre planejamento tributário. Cf. ___. Contribuições - uma figura "sui generis". São Paulo: Dialética, 2000; . Planejamento tributário. São Paulo: Dialética, 2004.

8 TORRES, Ricardo Lobo. Liberdade, consentimento e princípios de legitimação do direito tributário. Revista Internacional de Direito Tributário, Belo Horizonte, v. 5, p. 223-244, jan./jun. 2006.

9 SCHOUERI, Luis Eduardo. Direito tributário. São Paulo: Saraiva, 2012.

10 GODOI, Marciano Seabra de. O quê e o porquê da tipicidade tributária. In: RIBEIRO, Ricardo Lodi; ROCHA, Sérgio André (Coord.). Legalidade e tipicidade no direito tributário. São Paulo: Quartier Latin, 2008.

11 MARINS, James. A teoria do campo científico de Pierre Bourdieu e a ciência do direito tributário brasileiro. Direito Tributário Atual, n. 34, p. 120-156, 2015.

12 ÁVILA, Humberto Bergmann. Função da ciência do direito tributário: do formalismo epistemológico ao estruturalismo argumentativo. Revista Direito Tributário Atual, São Paulo, n. 29, 2013.

13 FOLLONI, André. Ciência do direito tributário no Brasil. São Paulo: Saraiva, 2013. 
Com efeito, conquanto tenha conduzido a um aprofundamento no estudo da estrutura da norma jurídica tributária, e à melhor compreensão de institutos formais como a incidência, a aplicação, a responsabilidade tributária, as divisões de competência, à identificação dos elementos distintivos entre algumas espécies tributárias etc., essa abordagem reducionista do objeto da ciência do Direito Tributário levou a um empobrecimento de seu estudo, no que se refere a aspectos substanciais ligados aos seus objetivos e fins ${ }^{14}$.

No que tange à extrafiscalidade, por exemplo, as discussões, levadas a efeito pela literatura especializada que parte dessa premissa epistemológica, centravam-se em questões meramente formais, ligadas ao veículo normativo a ser usado na concessão de isenções ( $v . g$., se um tratado internacional poderia concedê-las, no que tange a tributos municipais ou estaduais), ou à sua sujeição a limitações constitucionais ao poder de tributar como a anterioridade ${ }^{15}$. Pouca ou nenhuma atenção se dava a problemas relacionados aos efeitos ou aos fins de um incentivo, sobretudo por se tratar, nesse caso, de uma discussão talvez ligada à Economia ou à Política, mas não ao Direito Tributário.

Mesmo em estudos menos formais, quando se consideram fins, no âmbito da extrafiscalidade, isso no máximo acontece para se contrastarem ou ponderarem os objetivos atendidos com a tributação extrafiscal - que se pressupõem como sempre integralmente atendidos - e outros que com eles entrariam, eventualmente, em choque, como igualdade, capacidade contributiva e não confisco, por exemplo ${ }^{16}$. É o que tem ocorrido com estudos mais recentes desenvolvidos em torno do assunto, os quais, conquanto aparentemente se desvencilhem do aludido reducionismo epistemológico, em nenhum momento aventam sequer a possibilidade de, mesmo supostamente prestando-se à consecução de uma finalidade, o incentivo em nada contribuir para ela, ou mesmo conduzir ao efeito contrário ${ }^{17}$. E não é de se estranhar que isso não seja feito por juristas, mesmo pelos que não levam tão a sério as referidas premissas epistemológicas reducionistas, ou até as criticam, porquanto até mesmo os Economistas eram cegos a essas questões, antes de iniciarem um diálogo com psicólogos e neurocientistas ${ }^{18}$. Daí por que mesmo para pesquisadores da área do Direito que consideram insights de outras ciências, como a Economia, no âmbito, v.g., da análise econômica do Direito, as constatações da chamada Economia Comportamental representam novidade que deve ser levada a sério. Como será explicado mais adiante, inclusive, a riqueza da Economia Comportamental decorre de, também, ela ser fruto da superação de um reducionismo dentro da Economia, verificado a partir de quando esta passou a dialogar com a Psicologia e com a neurociência.

Nessa ordem de ideias, se um incentivo tem a finalidade de reduzir desigualdades regionais, o simples fato de ele ser concedido a quem se estabelece em região menos desenvolvida costuma ser tido como suficiente para a pressuposição de que sua finalidade é essa e está, em tese, sendo atendida, o que justificaria a atribuição de tratamento menos oneroso (sem se discutir tampouco quão menos oneroso) que aquele ao qual os demais contribuintes se submetem. Seria o caso de o jurista aferir, apenas, aspectos formais como o de saber se há autorização do CONFAZ (se se tratar de incentivo relacionado ao ICMS), se há previsão legal em lei específica, se esta foi editada pela entidade competente para tanto e assim por diante.

Quando muito, no que tange, especificamente, aos incentivos, além de estudar aspectos ligados ao Direito Tributário como os resenhados no parágrafo anterior, seria possível ao jurista mais ousado, no campo

14 Criando o que James Marins batizou de "Direito Tributário arrecadador". MARINS, James. Defesa e vulnerabilidade do contribuinte. São Paulo: Dialética, 2009. p. 20.

15 Cf., v.g., COELHO, Sacha Calmon Navarro. Curso de direito tributário brasileiro. 9. ed. Rio de Janeiro: Forense, 2006. p. 630. ROCHA, Valdir de Oliveira. Tratados internacionais e vigência das isenções por eles concedidas, em face da constituição de 1988. Repertório IOB de Jurisprudência, n. 5, 1991.

16 É o caso, por exemplo, de PIMENTA, Daniel de Magalhães. Limitações à extrafiscalidade aplicáveis ao fator acidentário de prevenção: FAP. Revista Brasileira de Políticas Públicas, v. 6, n. 1, p. 74-94, jan./jul. 2016.

17 GODOI, Marciano Seabra de. Extrafiscalidad y sus límites constitucionales. Revista Internacional de Direito Tributário da Associação Brasileira de Direito Tributário, Belo Horizonte, v. 1, p. 219-262, 2004.

18 O que houve, aliás, foi uma modificação, pela psicologia, pela biologia e pela neurociência, da própria noção que se tem de ser humano, enquanto ser racional. E isso se reflete, como é natural, em todas as áreas do conhecimento que o ser humano e suas decisões são o objeto central, seja o Direito, a Economia, as ciências ditas “humanas” em geral, e a própria Filosofia. 
do Direito Financeiro - de forma também “jurídica", mas situada "fora dos limites" da Ciência do Direito Tributário - ocupar-se da legislação que exige estudos do impacto dos incentivos (que levam à desoneração tributária) sobre receitas, bem como a precisão de mecanismos de compensação ${ }^{19}$. Mesmo assim, aferir se o incentivo realmente está cumprindo a finalidade que o justifica continuaria sendo tema "não jurídico", dentro da visão antes resumida do que seria o papel do cientista do direito.

É preciso perceber, porém, que a referida visão da Ciência do Direito em geral, e do Direito Tributário em particular, está equivocada. O erro, no caso, consiste na própria concepção de Ciência da qual ela parte, já não mais defendida no âmbito da Epistemologia há quase um século. E a melhor demonstração de que se trata de um equívoco reside nas limitações por ela trazidas ao próprio conhecimento de seu objeto, propósito último de qualquer ciência.

De início, deve ser afastada a visão de que o conhecimento científico é meramente descritivo. Caso a pura e simples descrição, sem nenhum juízo de valor, presidisse o comportamento dos pesquisadores, ver-se-iam cientistas pesquisando sobre a quantidade de folhas existentes na copa de uma mangueira situada no campus da Universidade em determinado dia e horário. Ou descrevendo a quantidade de grãos de areia presentes em uma praia, ou o número de vezes em que um aluno coçou a cabeça enquanto respondia as questões de uma prova. Esses exemplos revelam, de forma eloquente, que somente descrever não basta. Procura-se conhecer a realidade a partir de problemas ${ }^{20}$, para, conhecendo-a, conseguir solucioná-los ${ }^{21}$.

Por outro lado, as divisões que as pessoas traçam na realidade, para melhor compreendê-la, não existem por si. No tempo e no espaço, os objetos em que a mente humana decompõe a realidade estão em constante interação, interseção e interpenetração uns com os outros. Não há separação clara e estanque entre eles, com exceção de algumas figuras abstratas, como os números primos ${ }^{22}$. Isso vale para seres vivos, sistemas em constante troca de substâncias e de informações com outros seres e com o meio em que se acham inseridos, e, também, para a ordem jurídica. No caso do Direito, aliás, pode-se mesmo dizer que tanto as normas que integram o ordenamento relacionam-se umas com as outras, sendo, apenas, didática e, ainda assim, muito relativa a sua divisão em "ramos", como essas normas são elaboradas a partir de elementos hauridos de outras parcelas da realidade, visando interferir, também, em fatores ou elementos situados fora da ordem jurídica.

Quando uma norma proíbe pessoas de conduzirem veículos automotores sob a influência de álcool, por exemplo, tem-se a sua edição feita nos termos do processo legislativo previsto na Constituição. A forma como essa norma será aplicada, o processo a ser seguido, a competência das autoridades correspondentes, tudo está disciplinado em outras normas do sistema, que por isso mesmo se diz uno e indivisível. Mas não só. Essa proibição decorre da crença de que o álcool interfere nas capacidades cognitivas, no tempo de reação e no autocontrole dos indivíduos, levando-os a uma condução sensivelmente mais perigosa, para si e especialmente para terceiros. Com a finalidade imediata de fazer com que as pessoas não dirijam sob a influência do álcool, e o propósito mediato de com isso reduzir acidentes, define-se a conduta como ilícita, com a imposição de pena que se acredita apta, necessária e não excessiva para coibir a sua prática.

Resta bastante incompleto, nessa ordem de ideias, o estudo do Direito que dá as costas para os fatores que levam à edição da norma, e especialmente para os propósitos e efeitos a serem com ela alcançados ${ }^{23}$. O

19 Cite-se como exemplo o art. 113 do ADCT, nele inserido pela Emenda Constitucional 96/2017, que estabeleceu o "novo regime fiscal", conhecido como "teto dos gastos públicos", e do art. 14 da Lei Complementar 101/2000 (Lei de Responsabilidade Fiscal).

20 Cf. POPPER, Karl. O mito do contexto: em defesa da ciência e da racionalidade. Tradução de Paula Taipas. Lisboa: Edições 70 , 2009. p. 108; RESCHER, Nicholas. Epistemology: an introduction to the theory of knowledge. Albany: State University of New York Press, 2003. p. 69.

21 Ainda que o leitor encontre uma utilidade para estudos exóticos como os dos exemplos, justificando uma pesquisa a seu respeito, isso não invalidará a tese que com eles se pretendeu fundamentar. Pelo contrário, os exemplos terão sido tornados impertinentes precisamente por se ter mostrado a utilidade de uma pesquisa a seu respeito, que não seria, portanto, meramente descritiva.

22 Cf. DEEMTER, Kees Van. Not exactly. In: Praise of vagueness. Oxford: Oxford University Press, 2010. p. 117.

23 VASCONCELOS, Arnaldo. Teoria da norma jurídica. 5. ed. São Paulo: Malheiros, 2000. p. 17. 
mais importante, porém, é notar que tais considerações não são “metajurídicas". São, ou podem ser, passíveis de exame jurídico, assim entendido aquele que busca conhecer as relações de tais fatos com as normas em vigor. Exemplificando, caso o álcool não alterasse as capacidades cognitivas do guiador (v.g., como a água mineral não altera), seria inválida a norma que veiculasse a proibição de dirigir tendo-o consumido. $\mathrm{Na}$ mesma ordem de ideias, se a sanção aplicada pela lei estivesse, por alguma razão, estimulando as pessoas a beber e dirigir com ainda maior intensidade, seria preciso rever a validade de tal disposição. Veja-se, nessa mesma linha de raciocínio, o que se dá com o tabaco, cuja industrialização e comercialização sofrem severas restrições, as quais seriam inválidas, por contrariedade a princípios como o da livre iniciativa, se a nocividade do produto à saúde não estivesse a elas subjacentes, justificando-as. Não se pode dizer, assim, que os danos causados pelo cigarro à saúde são assunto não jurídico.

Por essa razão, não se pode concluir que o estudioso do Direito deve montar um laboratório e iniciar pesquisas em torno da nocividade do cigarro, ou dos efeitos do álcool no cérebro. Não seria possível aos pesquisadores dar conta em profundidade da totalidade dos assuntos, sendo necessário escolher ponto ou aspecto a ser verticalizado. Quando se defende a necessidade de considerar a realidade em sua inteireza, dado o caráter relativo das divisões nela efetuadas para fins de estudo, pretende-se afirmar a necessidade de diálogo ${ }^{24}$ entre pessoas que se ocupam de aspectos ou nuances diversos de um mesmo objeto, ou de objetos relacionados, de modo a que não ignorem - por alegada "impertinência" ao seu objeto - as constatações umas das outras.

Aliás, o que caracteriza um conhecimento como científico não é o seu objeto ${ }^{25}$, mas a postura, a abordagem, ou a forma como o sujeito se aproxima desse objeto, que pode ser qualquer um. Não há objetos científicos e objetos não científicos, mas formas científicas e não científicas de se examinar qualquer parcela da realidade. Tampouco uma abordagem será científica por incorrer, pretensamente, na mera descrição de um objeto, a qual, a rigor, é impossível. Não existe observação não interpretada, pois o próprio surgimento dos órgãos dos sentidos, em alguma medida, é fruto de uma "teoria", assim entendida uma maneira encontrada pelo processo de seleção natural para superar um problema colocado à sobrevivência ${ }^{26}$. Além disso, há mecanismos inatos, também selecionados naturalmente, que fazem aos seres cognoscentes atribuir significações pré-concebidas a determinadas sensações, como o medo que se sente de uma sombra que se aproxima rapidamente, ou de um barulho grave e estranho ${ }^{27}$. É biologicamente impossível, assim, a mera descrição, mesmo no que tange às ciências ditas naturais. E isso para não referir aspectos de toda ordem, culturais e mesmo ligados à história de vida de cada sujeito, os quais têm influência ainda mais relevantes diante de realidades como o Direito, que são essencialmente interpretativas ${ }^{28}$, dada sua condição de fatos institucionais ${ }^{29}$.

É a abertura à possibilidade de estar errado, avessa a todo dogmatismo, que, em última análise, caracteriza o

24 FOLLONI, André. Ciência do direito tributário no Brasil. São Paulo: Saraiva, 2013. p. 400.

25 MARQUES NETO, Agostinho Ramalho. A ciência do direito. 2. ed. Rio de Janeiro: Renovar, 2001. p. 184 e ss.

26 POPPER, Karl. O mito do contexto: em defesa da ciência e da racionalidade. Tradução de Paula Taipas. Lisboa: Edições 70, 2009. p. 108.

27 JOYCE, Richard. The evolution of morality. Cambridge: MIT Press, 2006. p. 7; GAZZANIGA, Michael S. Who's in charge?: free will and the science of the brain. New York: Harper Collins, 2011. p. 43-44;51. Veja-se que isso tolda até mesmo a distinção entre o que é inato ao indivíduo e o que provém de suas experiências, visto que as experiências de antepassados podem de algum modo moldar ideias inatas de seus descendentes. Para uma associação entre tais constatações biológicas e a teoria das ideias inatas de Platão, veja-se VASCONCELOS, Arnaldo. Teoria pura do direto: repasse crítico de seus principais fundamentos. Rio de Janeiro: Forense, 2003. p. 94.

28 Para a interferência de experiências pretéritas na atribuição de sentido às palavras, veja-se: CHRISTIAN, Brian. O bumano mais bumano: o que a inteligência artificial nos ensina sobre a vida. São Paulo: Companhia das Letras, 2013. p. 93; BERGEN, Benjamin K. Louder than words: the new science of how the mind makes meaning. New York: Basic Books, 2012. p. 150. Isso se dá porque "when we hear or read about objects, we mentally simulate them from the perspective of someone actually experiencing the scene." (BERGEN, Benjamin K. Louder than words: the new science of how the mind makes meaning. New York: Basic Books, 2012. p. 71), a revelar a influência das experiências anteriores do intérprete na própria construção do sentido a ser atribuído às palavras.

29 Para a distinção entre fatos brutos - assim entendidos aqueles que existem por si, independentemente de quem os observe, como uma pedra - e fatos institucionais - que existem como fruto de um pacto intersubjetivo, como as regras de um jogo, veja-se: SEARLE, John R. Libertad y neurobiologia. Tradução de Miguel Candel. Barcelona: Paidós, 2005. p. 99. 
empreendimento científico, sendo capaz, assim, de depurar eventuais interferências de aspectos subjetivos nas observações feitas pelos sujeitos cognoscentes a respeito de uma realidade que lhes é exterior, objetiva (no caso de fatos brutos) ou intersubjetiva (em se tratando de fatos institucionais). Em suma: o conhecimento deve ser aberto à crítica, sendo passível de falsificação, a fim de que, enquanto não se demonstrar sua falsidade, seja considerado (provisoriamente) verdadeiro. Não importa, para que um conhecimento seja considerado "ciência", saber se aquele que o leva a efeito colocou em si antolhos, como os usados em cavalos de corrida, que os impedem de olhar em outras direções. O relevante é saber se o conhecimento produzido é passível de crítica e se é possível falseá-lo.

Tais aspectos já vêm sendo destacados por estudiosos do Direito Tributário, os quais começam a verificar as limitações das premissas epistemológicas nas quais esse ramo do conhecimento se embaraçou na segunda metade do Século XX, no Brasil. Não é o caso de renovar neste artigo todo o seu estudo, já levado a efeito pela literatura especializada em trabalhos específicos ${ }^{30}$. O relevante é explorar um dos pontos nos quais a visão positivista e reducionista do fenômeno jurídico tornou aqueles que elaboram, aplicam e estudam normas jurídicas desprovidos de elementos para exercer, adequadamente, o seu ofício. Daí o exame, a seguir, de questões relacionadas à extrafiscalidade.

\section{NeUROCIÊNCIA E ECONOMIA COMPORTAMENTAL}

A chamada "neurociência" talvez seja a demonstração mais eloquente do que se tentou explicar no item anterior, no que tange à maior riqueza de um estudo que não procede à mutilação reducionista de seu objeto. Surgida do diálogo entre neurologistas, psicólogos, psiquiatras, cientistas da cognição, filósofos e até estudiosos de inteligência artificial, ela se ocupa das mesmas realidades - mente e cognição - de forma interdisciplinar, servindo o diálogo entre especialidades para que umas supram as lacunas das outras, ajudando a complementar os "pontos cegos" inerentes a cada forma de estudar ou se aproximar da mesma realidade ${ }^{31}$.

Outra demonstração eloquente pode ser encontrada na literatura que se tem produzido, no âmbito da chamada economia comportamental, na qual os contributos daqueles que se ocupam da mente humana e de como se tomam decisões estão modificando, de maneira significativa, a compreensão de estudiosos de outros ramos do conhecimento, como a Economia. A concessão do prêmio Nobel de Economia a um psicólogo, como se deu com Daniel Kahneman ${ }^{32}$, é indicativa da relevância e da fertilidade de tais diálogos.

Quanto à sua relevância para o Direito, deve-se lembrar que este disciplina a conduta humana, sendo a decisão um elemento central à sua atuação. Seja a decisão do agente, em realizar ou não uma conduta considerada desejável ou indesejável, no plano da observância das normas, seja a do agente administrativo e a do julgador de conflitos, no plano da aplicação; para examiná-las e teorizá-las, a compreensão sobre a forma como se dá a tomada de decisões é fundamental. Não por outra razão, Arnaldo Vasconcelos observava a necessidade de o Teórico e o Filósofo do Direito terem clara de qual concepção antropológica estão par-

30 Veja-se, a propósito, FOLLONI, André. Ciência do direito tributário no Brasil. São Paulo: Saraiva, 2013. MARINS, James. Defesa e vulnerabilidade do contribuinte. São Paulo: Dialética, 2009; MARINS, James. A teoria do campo científico de Pierre Bourdieu e a ciência do direito tributário brasileiro. Direito Tributário Atual, n. 34, p. 120-156, 2015. MACHADO, Raquel Cavalcanti Ramos Machado. Competência tributária: entre a rigidez do sistema e a atualização interpretativa. São Paulo: Malheiros, 2014. p. 225 e ss; MACHADO SEGUNDO, Hugo de Brito. Science, complexity, and the study of tax law. In: FABÓ, Edit; FERONE, Emilia; CHEN, James Ming. (Org.). Systemic Actions in Complex Scenarios. Cambrigde: Cambridge Scholars Publishing, 2017. v. 1, p. 170-190.

31 Esse aspecto epistemológico do surgimento interdisciplinar da neurociência é ressaltado por outro estudioso do assunto, também ganhador do Prêmio Nobel (nesse caso, de Medicina, em 2000). Confira-se: KANDEL, Eric. Em busca da memória: o nascimento de uma nova ciência da mente. Tradução de Rejane Rubino. São Paulo: Companhia das Letras, 2009.

32 Para uma amostra da relevância dessas ideias para a Economia, veja-se KAHNEMAN, Daniel. Thinking, fast and slow. New York: Farrar, Straus and Giroux, 2011., passim. E ainda ALTMAN, Morris. The nobel prize in behavioral and experimental economics: a contextual and critical appraisal of the contributions of Daniel Kahneman and Vernon Smith. Review of Political Economy, v. 16, n. 1, p. 3-41, jan. 2004 
tindo ${ }^{33}$. Não há como entender o Direito sem compreender o ser humano, sendo essencial, nessa ordem de ideias, conhecer a sua mente.

São múltiplas, portanto, as zonas nas quais a neurociência tem grande relevância para a compreensão de fenômenos jurídicos. Discutem-se, por exemplo, as relações do livre arbítrio com a imputabilidade jurídica, bem como os aspectos neurológicos e comportamentais do aprendizado e seus reflexos sobre o ensino jurídico, e ainda implicações éticas de tecnologias destinadas a conhecer o íntimo dos pensamentos e das inclinações inatas de candidatos em entrevistas de emprego. Além disso, há desdobramentos no campo probatório e na questão de como testemunhas constroem suas memórias ${ }^{34}$, na regulamentação de substâncias capazes de otimizar o uso do cérebro etc. Isso para não mencionar os efeitos jurídicos de estudos eventualmente aptos a indicar tendências violentas ou criminosas em determinados sujeitos. Este artigo busca enfrentar apenas uma dessas várias zonas de interseção, a saber, a relevância de constatações feitas no âmbito da neurociência e da economia comportamental no que tange ao uso de incentivos e punições, palavras usadas em sentido bastante amplo, para direcionar o comportamento humano. Não parece haver ponto mais pertinente ao Direito do que este, o de saber como prêmios e castigos podem, efetivamente, levar pessoas a fazer ou a deixar de fazer o que com eles se espera, mas, dadas as limitações de espaço próprias de um artigo, isso será realizado tomando-se como referência a chamada extrafiscalidade, no âmbito do Direito Tributário.

\subsection{Economia comportamental e extrafiscalidade}

Como se sabe, o tributo pode ser usado para obtenção de recursos para os cofres públicos da entidade competente para a sua instituição, dizendo-se, nesse caso, que sua função é fiscal. Caso sua função seja a de obter recursos para entidade diversa daquela dotada da competência para a sua criação, diz-se que sua função é parafiscal. Mas, ao lado dessas duas funções, diz-se que o tributo pode ter uma terceira, que é a extrafiscal. Nessa hipótese, não se tem função exercida de maneira exclusiva e excludente de outra, mas, apenas, em maior ou menor grau relativamente a outra, dizendo-se extrafiscal aquele em que essa função prepondera em relação à fiscal (ou à parafiscal). Dito de outro modo, um tributo até pode ser, apenas, fiscal, ou, apenas, parafiscal, se contrastadas essas duas funções. Mas, se entra em cena a função extrafiscal, ela, sempre, estará presente, em maior ou menor grau, em qualquer tributo. Quando houver preponderância dela, dir-se-á que o tributo é extrafiscal.

Por extrafiscalidade, convém definir, entende-se a utilização do tributo como forma de estimular ou desestimular condutas, tornando-as menos ou mais onerosas. Explora-se, com ela, a função indutora do tributo ${ }^{35}$, ou regulatória ${ }^{36}$. Embora a literatura especializada, geralmente, aponte como extrafiscais tributos os impostos aduaneiros (no Brasil, imposto de importação e imposto de exportação), e, ainda, embora em menor medida, o imposto sobre produtos industrializados (IPI) e o imposto sobre operações financeiras (IOF) ${ }^{37}$, a rigor todo tributo pode ser usado com essa função. Os tributos aduaneiros, o IPI e o IOF, anteriormente apontados, são assim identificados, apenas, porque, neles, a extrafiscalidade é proeminente.

A título ilustrativo, quando a União majora as alíquotas do imposto sobre a importação de determinado produto, seu objetivo não é obter uma maior arrecadação, mas sim desestimular a importação de referido bem. Dá-se o mesmo, de maneira inversa, quando da redução do imposto: a ideia é estimular a sua importação. Com isso, tem-se um mecanismo destinado a influenciar as decisões dos que atuam no âmbito do comércio exterior.

33 VASCONCELOS, Arnaldo. Teoria pura do direto: repasse crítico de seus principais fundamentos. Rio de Janeiro: Forense, 2003. p. 210.

34 SHEN, Francis X. Law and neuroscience 2.0. Arizona State Law Journal, v. 48, n. 1043, 2016.

35 SCHOUERI, Luis Eduardo. Direito tributário. São Paulo: Saraiva, 2012. p. 32.

36 AVI-YONAH, Reuven S. Os três objetivos da tributação, em direito tributário atual. Revista do IBDT/Dialética, São Paulo, n. 22, p. 7-29, 2008.

37 A rigor, trata-se de imposto sobre “operações de crédito, câmbio e seguro, e relativas a títulos e valores mobiliários”. Por economia de palavras, contudo, tornou-se usual denominá-lo simplesmente "imposto sobre operações financeiras - IOF". 
Operando com a imposição de um maior ou menos ônus tributário, a extrafiscalidade parte da premissa, ainda relativamente difundida na Economia, de que o ser humano pauta as suas decisões por um cálculo de custo $\mathrm{x}$ benefício movido, apenas, pelo interesse econômico do agente. Em termos mais diretos, a extrafiscalidade trata o contribuinte como um bomo economicus.

Entende-se por homo economicus, como dito, a idealização de um ser humano que toma decisões com base, apenas, em seu próprio interesse, ou, em outras palavras, ponderando aquilo que tem a ganhar e perder, diante das diversas opções ou alternativas possíveis, sem cometer erros de julgamento e sem se deixar levar por fatores outros que não o dos ônus e bônus econômicos inerentes a cada opção. A escolha "racional", feita nesses termos, seria a daquele caminho que trouxesse as menores perdas e os maiores ganhos para 0 sujeito que decide, presumidamente sempre preocupado apenas consigo mesmo. Durante longas décadas, por influência de uma leitura fragmentada (e equivocada) de economistas clássicos como Adam Smith, a Economia adotou esse modelo de agente decisório premissa para seus estudos.

Deve-se observar, contudo, em primeiro lugar, que autores clássicos, dos quais essa ideia teria surgido, não a subscreveram da forma como a Economia contemporânea a encampou. Autores como Machiavel ${ }^{38} \mathrm{e}$ Adam Smith ${ }^{39}$ não afirmaram que o ser humano é assim; ao contrário, chegaram mesmo a reconhecer que ele quase sempre não é assim, agindo com base em sentimentos morais que o impelem ao altruísmo. Entretanto, o que tais autores indicam é que, como tais sentimentos morais são às vezes insuficientes, há situações em que eles - os seres humanos - têm de ser submetidos a instituições que os devem tratar como se fossem o "bomo economicus". O que a Economia contemporânea fez foi, aos poucos, distorcer essa compreensão, de modo a tratar os seres humanos como se eles, sempre, decidissem nessa condição egoísta, perseguir, apenas, os próprios interesses materiais.

Nessa ordem de ideias, o que estudos recentes de neurociência e economia comportamental resgatam é a ideia de que não, o ser humano não age sempre como bomo economicus, não somente em virtude de sentimentos morais que, eventualmente, os levam a comportamentos altruístas, mas em virtude de outros fatores ${ }^{40}$ que interferem em suas decisões, as quais são menos "racionais" do que se imaginava ${ }^{41}$, incluindo limitações cognitivas e vieses ${ }^{42}$. Estudos nesse âmbito, basicamente, foram os que ensejaram a atribuição do Prêmio

38 MACHIAVELLI, Niccolò. Discorsi sopra la prima deca di Tito Livio. Firenze: Ami books, Associazione Mazziniana Italiana, 2003. p. 10. Embora Maquiavel diga que a necessidade leva os homens a fazerem coisas boas (antecipando, nessa ordem de ideias, Adam Smith), ele ressalta, logo adiante, que "e dove una cosa per sé medesima sanza la legge opera bene, non è necessária la legge; ma quando quella buona consuetudine manca, è subito la legge necessaria.” Ou seja, as pessoas realizam condutas corretas por motivações outras, sendo a sanção jurídica necessária apenas quando essas motivações se mostram insuficientes.

39 Embora sempre lembrado pela ideia de mão invisível e pelo trecho em que afirma não ser o nosso jantar decorrente da benevolência do açougueiro, do cervejeiro e do padeiro ("It is not from the benevolence of the butcher, the brewer, or the baker that we expect our dinner, but from their regard to their own interest. We address ourselves, not to their bumanity but to their self-love..."SMITH, Adam. An inquiry into the nature and causes of the wealth of nations. Chicago: University of Chicago Press, 1977. p. 30), Adam Smith escreveu livro intitulado "Teoria dos Sentimentos Morais" (SMITH, Adam. The theory of moral sentiments. London: A Millar, 1790), no qual ressalva o comportamento naturalmente altruísta do ser humano em diversas situações, antecipando muitas das constatações hoje feitas por biólogos e neurocientistas. Sobre essa deturpação do pensamento de Smith e seus efeitos sobre o estudo da Economia no período subsequente, veja-se: SEN, Amartya. Sobre ética e economia. Tradução de Laura Teixeira Mota. São Paulo: Cia das Letras, 1999. No mesmo sentido: PEDRAJAS. La transformación ética de la racionalidad económica en Amartya Sen: una recuperación de Adam Smith. Quaderns de filosofia y ciència, v. 36, p. 105-117, 2006.

40 Dentre os quais podem ser citadas inclinações inatas do cérebro a preferir informações que confirmam suas crenças prévias àquelas que as contrariam, ou a dar crédito a informações apenas porque repetidas à exaustão por terceiros, passando assim a resistir a evidências de sua falsidade; a sofrer mais quando perde do que quando deixa de ganhar; a ser demasiadamente otimista diante das dificuldades de projetos futuros etc. Cf., v.g., SUNSTEIN, Cass. Why nugde?: the politics of libertarian paternalism. New Haven: Yale University Press, 2014.

41 "Economists, who have placed the act of choosing at the center of all human activity, have now discovered, in short, that people are no very good choosers." BOWLES, Samuel. The moral economy: why good incentives are no substitute for good citizens. New Haven: Yale University Press. 2016.

42 Cf. KOOREMAN, Peter; PRAST, Henri ette. What does behavioral economics mean for policy?: challenges to savings and health policies in the netherlands. De Economist, v. 158, p. 101-122, 2010. 
Nobel de Economia de 2002 a Daniel Kahneman ${ }^{43}$.

Tais constatações comportamentais têm impacto direto sobre a concessão de prêmios e castigos como forma de interferir nas decisões tomadas por seres humanos. Como o ser humano não decide, apenas, levando em conta perdas e ganhos para $\mathrm{si}^{44}$, é preciso conhecer quais outros fatores motivam suas escolhas, pois muitas vezes um prêmio, ou um castigo, por ser concedido à revelia de tais outros fatores, conduz ao efeito contrário do pretendido.

Há, na literatura especializada, a referência a várias situações nas quais esse "tiro pela culatra" (backfire) acontece. Muitos deles foram objeto de estudo por Samuel Bowles ${ }^{45}$, que toma como ponto de partida o caso paradigmático da creche em Haifa, em Israel, que experimentava problemas com pais de crianças que se atrasavam para apanhá-las ao final do dia. Isso fazia com que a creche precisasse manter funcionários com as crianças até que os pais chegassem para buscá-las, por um tempo adicional ao do funcionamento normal do estabelecimento, o que representava um custo. Estabeleceu-se, então, uma multa para aqueles pais que chegassem atrasados. A ideia, naturalmente, não era a de arrecadar recursos com a tal multa, mas a de desestimular os pais a chegarem atrasados. Contrariando as expectativas de quem idealizou a multa, contudo, depois de sua implementação os atrasos se tornaram mais frequentes e mais longos. Houve, ainda, um aspecto ainda mais danoso: quando a creche resolveu abolir a multa, pelo efeito indesejado que trouxe, era tarde demais: os atrasos não diminuíram de modo a voltar ao patamar anterior.

Pode ser citada, também, a situação dos bombeiros da cidade de Nova Iorque ${ }^{46}$, que, eventualmente, faltavam ao trabalho alegando doença, sendo-lhes permitido fazê-lo sem a apresentação de atestado médico. Como, porém, na visão de seus superiores, essas faltas estariam ocorrendo com muita frequência, principalmente às sextas e às segundas feiras, estabeleceu-se que cada funcionário somente poderia faltar por motivos de saúde, sem apresentar atestado médico, por até 15 dias no ano. Mais que isso, a apresentação do atestado seria necessária. O efeito, uma vez mais, foi o de que os bombeiros passaram a faltar muito mais, pois todos eles passaram a faltar os 15 dias "a que tinham direito", e as faltas se concentraram justamente em feriados e datas festivas, como Natal e Ano Novo.

Situação semelhante foi a da fábrica da G.E. que, diante da suspeita de que seus funcionários poderiam estar levando algumas ferramentas para casa, passou a determinar que todas elas fossem guardadas em um armário, a ser fechado a chave pelo supervisor ao final do expediente. A medida fez com que o "desaparecimento" de tais objetos aumentasse exponencialmente ${ }^{47}$.

Embora fatores culturais possam ter alguma influência, a questão tem bases biológicas ${ }^{48}$, ligadas à Teoria

43 Veja-se, a propósito, o já referido KAHNEMAN, Daniel. Thinking, fast and slow. New York: Farrar, Straus and Giroux, 2011.

44 Demonstração bastante simples disso é dada por Samuel Bowles quando lembra que "except on the whiteboards of economics classrooms, people try to avoid dealing with Homo economicus". BOWLES, Samuel. The moral economy: why good incentives are no substitute for good citizens. New Haven: Yale University Press. 2016. Na mesma ordem de ideias, Debra Satz observa que o homo economicus "may be out only for himself, but he must not generally steal, lie, cheat, or murder in order to maximize his gains if markets are to work." SATZ, Debra. Why some things should not be for sale: the moral limits of markets. New York: Oxford University Press, 2010. p. 29.

45 BOWLES, Samuel. The moral economy: why good incentives are no substitute for good citizens. New Haven: Yale University Press. 2016.

46 BOWLES, Samuel. The moral economy: why good incentives are no substitute for good citizens. New Haven: Yale University Press. 2016.

47 BOWLES, Samuel. The moral economy: why good incentives are no substitute for good citizens. New Haven: Yale University Press. 2016

48 Sobre a origem biológica dos sentimentos morais que igualmente interferem - ao lado de fatores econômicos de custo benefício - no comportamento humano (e de outros animais também), a revelar que a questão transcende aspectos culturais, veja-se, por exemplo: WAAL, Frans de. Good natured: the origins of right and wrong in humans and other animals. Cambridge: Harvard University Press, 1996; WAAL, Frans de et al. (Ed.). Evolved morality: the biology and philosophy of human conscience. Boston: Brill, 2014. RUSE, M. Evolutionary ethics: a phoenix arisen. Zygon, v. 21, n. 1, p. 95-112, 1986. CHAGEUX, J. P.; DAMASIO, Antonio R.; SINGER, W.; CHRISTEN, Y. (Ed.). Neurobiology of human values. Heidelberg: Springer, 2005. Curiosamente, como já apontado, o próprio Adam Smith havia antecipado isso (SMITH, Adam. The theory of moral sentiments. London: A Millar, 1790), pelo que é equivocada a atribuição a ele da ideia de homo economicus. 
dos Jogos ${ }^{49}$, transcendendo aspectos religiosos ou relacionados a qualquer outro background histórico ${ }^{50}$ dos sujeitos envolvidos ${ }^{51}$. Com efeito, mesmo em estudos com crianças muito pequenas, percebeu-se que a premiação com brinquedos reduz a sua disposição para ajudar terceiros, ajuda que prestavam com maior intensidade e frequência na ausência do incentivo. Premiar crianças que gostavam de desenhar, na mesma ordem de ideias, levou-as a produzir menos desenhos, com qualidade inferior àqueles feitos em um ambiente em que os incentivos estavam inteiramente ausentes ${ }^{52}$.

O próprio leitor pode fazer, consigo, uma experiência. Se estiver passando a pé por uma calçada de sua cidade, e uma pessoa pedir ajuda para empurrar seu automóvel, que está com problemas na bateria, é possível que o empurrão seja dado, caso o leitor não esteja apressado para algum compromisso. A probabilidade aumenta se outra pessoa já estiver ajudando a empurrar o veículo também, mas seu esforço se estiver mostrando insuficiente. Agora se imagine passando pela mesma situação, e recebendo da pessoa em dificuldade a oferta para empurrar o carro por $\mathrm{R} \$ 10,00$ (dez reais) ${ }^{53}$. Caso se estivesse diante de um homo economicus, a oferta de dinheiro, ainda que de pequena monta, poderia ser um motivo para realizar esse esforço em favor de um terceiro. Entretanto, invariavelmente é o inverso que ocorre, como experimentos empíricos têm demonstrado: em tais casos, a oferta de dinheiro diminui, espetacularmente, a propensão das pessoas a ajudar.

São muitas, enfim, as demonstrações empíricas, seja em experimentos construídos para esse fim, como o das crianças desenhistas, seja ao acaso, diante de situações em que, simplesmente, um resultado inesperado acontece, como na creche israelense, onde os incentivos e as punições podem conduzir a um resultado inverso daquele esperado. É importante ao legislador que os pretende estabelecer, portanto, saber por que isso ocorre.

Samuel Bowles sugere ${ }^{54}$, nesse sentido, três razões pelas quais um prêmio ou uma punição podem conduzir a um resultado inverso do previsto. Tais razões não se excluem, podendo um incentivo ser desastrado por incorrer em mais de uma delas ao mesmo tempo, estando todas relacionadas ao fato de que, ao lado de fatores econômicos, motivações de ordem moral, ou mesmo instintiva, também interferem nas decisões humanas. Fatores econômicos e motivações outras se ligam muitas vezes de forma inseparável, interferindo uns nos outros. Por isso, pode ocorrer de o incentivo, em tese, reforçar o trabalho dessas outras motivações, neutralizá-las, ou mesmo invertê-las, dependendo de como seja concedido.

A primeira razão está ligada ao fato de que os incentivos podem levar ao temporário "desligamento" dos sentimentos morais. A instituição de uma multa pode fazer com que aquele, a quem ela é direcionada, passe a enxergar a questão como sendo meramente econômica, sendo a multa um preço a pagar para poder praticar a conduta correspondente. Parece ter sido o que ocorreu na creche em Haifa: os pais das crianças, que se sentiam constrangidos em atrasar e o faziam o mínimo possível, viram na multa um conforto para chegarem um pouco mais atrasados; como se o atraso não fosse mais considerado errado desde que estivessem pagando por isso.

49 Cf. AXELROD, Robert. A evolução da cooperação. Tradução de Jusella Santos. São Paulo: Leopardo, 2010., passim; VENKATACHALAM, L. Ecological economics, v. 67, p. 643, 2008 ; HOFFMAN, Elizabeth; MCCABE, Kevin A.; SMITH, Venon L. Behavioral foundations of reciprocity: experimental economics and evolutionary psychology. Economic inquiry, v. 36, p. 335-352, jul. 1998.

50 Marc Hauser, a propósito, realizou pesquisa precisamente em torno da (i)rrelevância de fatores culturais, históricos ou religiosos quanto às respostas que as pessoas dão a certos dilemas morais, como o famoso caso do "trolley car" que ilustra debates em torno do utilitarismo e da ética kantiana. Cf. HAUSER, Marc. Moral minds. New York: Harper Collins, 2006.

51 A esse respeito, Debra Satz afirma que não há infans economicus. Cf. SATZ, Debra. Why some things should not be for sale: the moral limits of markets. New York: Oxford University Press, 2010. p. 158.

52 BOWLES, Samuel. The moral economy: why good incentives are no substitute for good citizens. New Haven: Yale University Press. 2016.

53 Emir Kamenica observa, nesse sentido, que "contrary to what you would expect based on a standard introductory text in microeconomics, if you pay a person more for doing a task, she might be less willing to work on it, she might be less productive given her efforts, and she may enjoy the task less. If you start charging a fee for something, more people might start doing it" KAMENICA, Emir. Behavioral economics and psychology of incentives. Annual Review of Economics, v. 4, n. 1, p. 428, 2012.

54 BOWLES, Samuel. The moral economy: why good incentives are no substitute for good citizens. New Haven: Yale University Press, 2016. 
Outro exemplo desse "desligamento", em um contexto diverso, reside na maior adesão de doadores a causas humanitárias quando se usa a fotografia do rosto triste de uma criança faminta, indicando-se seu nome, de modo a aproximá-la do potencial doador: a taxa de adesão a doações é muito maior do que quando se utilizam estatísticas sobre a mortalidade infantil, as quais podem parecer ao cérebro do doador como frias e distantes ${ }^{55}$. Aliás, o uso da foto, sozinha, faz com que as doações sejam mais frequentes do que quando as estatísticas lhes são acrescentadas. Uma resposta possível para essa mudança é dada pela neurociência, que aponta a ativação do "sistema 2", ou da forma "devagar" de pensar, racional, como responsável pela inibição do "sistema 1", ou "rápido", ou "emocional”, o qual estaria ligado a uma maior empatia por certos grupos, a exemplo de crianças necessitadas ${ }^{56}$. Não que o sistema rápido, ou intuitivo, seja necessariamente altruísta. Não é. Como registra Bowles, a forma rápida ou intuitiva/instintiva de pensar pode ser altamente egoísta, ou extremamente altruísta, dependendo dos fatores que a levam a ser posta em funcionamento ${ }^{57}$.

É o caso de lembrar do pensamento de Joshua Greene, que parte das ideias de Kahneman sobre "as duas formas de pensar" para comparar o cérebro humano a uma máquina fotográfica, equipada de um "modo automático", rápido, eficiente para situações pensadas pelo fabricante, e um "modo manual”, mais lento, mas necessária em situações novas e imprevistas, para as quais o modo automático não oferece a melhor solução ${ }^{58}$. Nas relações vistas pelo cérebro como havidas entre pessoas consideradas "do mesmo grupo", intituladas relações "eu versus nós", o comportamento automático, a que uso da forma rápida ou do "sistema 1" conduz, tende a soluções altruístas, com a prevalência do nós, por razões ligadas à seleção natural. Apenas nas relações vistas como "nós versus eles" sentimentos de competição e egoísmo são despertados, para que o interesse do grupo "nós" prevaleça sobre o "eles", por razões, também, ligadas à seleção natural. É para esses casos que Greene aponta que a filosofia deve procurar soluções racionais que visem inibir essas tendências inatas, justificando uma postura diversa, cooperativa.

A segunda razão reside em os incentivos e as punições transmitirem aos seus destinatários uma "mensagem", a qual pode interferir nas outras inclinações (morais, sentimentais etc.) para as condutas humanas, reforçando-as ou revertendo-as. Essa, talvez, seja a explicação para o aumento no desaparecimento de ferramentas na fábrica da G.E, depois que se estabeleceu a política de trancá-las a sete chaves ao final do expediente: a mensagem era a de que o patrão não confiava neles, achando que estavam a furtar. Essa mensagem fez com que, mesmo aqueles que não surrupiavam ferramentas, passassem a fazê-lo. Algo bem diferente, em outro exemplo citado por Bowles ${ }^{59}$, deu-se em uma fábrica da HP, em que os funcionários foram incentivados a levar ferramentas para casa, pois se entendeu que com isso uma boa ideia que tivessem ao final de semana ou em tempo livre poderia ser desde logo colocada em prática. Além de transmitir-lhes uma mensagem de confiança, fez com que tivessem a intenção de trabalhar mesmo em seu tempo livre.

É provável que essa também tenha sido a razão pela qual os bombeiros de Nova Iorque passaram a faltar mais, depois de se estabelecer que eles somente poderiam fazê-lo por até quinze dias. A mensagem passada por seus superiores foi a de que desconfiavam deles, acreditando que as faltas eram motivadas por motivos diversos da doença; e mais: que não haveria problema em fazê-lo desde que no limite dos tais quinze dias. Isso não apenas os estimulou a faltar todas as vezes toleradas, como comprometeu o sentimento daqueles que trabalhavam em feriados e dias festivos por razões idealistas. Daí o aumento nas faltas ${ }^{60}$. O mesmo ocor-

55 SINGER, Peter. The most good you can do: how effective altruism is changing ideas about living ethically. London: Yale University Press. 2015. p. 80.

56 Confira-se, a propósito, GREENE, Joshua. Moral tribes. New York: Penguin Press, 2013.

57 BOWLES, Samuel. The moral economy: why good incentives are no substitute for good citizens. New Haven: Yale University Press, 2016.

58 GREENE, Joshua. Moral tribes. New York: Penguin Press, 2013.

59 BOWLES, Samuel. The moral economy: why good incentives are no substitute for good citizens. New Haven: Yale University Press, 2016.

60 Bowles destaca que "goodwill maybe eroded by policies that seem well conceived for a world in which feelings of trust and mutual concern do not exist or do not matter." BOWLES, Samuel. The moral economy: why good incentives are no substitute for good citizens. New Haven: Yale University Press, 2016. Sobre a influência da ideia de reciprocidade - para além da questão salarial - no ambiente de trabalho, 
re quando se paga muito pouco para alguém desempenhar uma tarefa que, sem a retribuição financeira, seria feita de qualquer modo: o sujeito pode considerar humilhante trabalhar por tão pouco, sendo mais honroso fazê-lo gratuitamente ${ }^{61}$.

Finalmente, a terceira razão de insucesso dos incentivos consiste em uma "necessidade de autonomia" que eles, eventualmente, despertam naquele cuja conduta deveria ser por ele estimulada. O sujeito, que até então seria capaz de adotar a postura que se quer incentivar espontaneamente, pode sentir-se controlado por quem concede o incentivo, passando por isso a fazer justamente o contrário, para se livrar da sensação de controle. Esta é uma explicação possível para o fato de crianças, que espontaneamente ajudam adultos em outras tarefas, ou mesmo são capazes de passar horas desenhando com muito prazer, passarem a fazê-lo em quantidade e qualidade muito menores quando "estimuladas" por uma premiação especificamente voltada para esse fim. Emir Kamenica identifica uma razão adicional para isso: se a pessoa tem dúvida sobre se desenhar poderia ser algo prazeroso em si, o pagamento envia uma mensagem de que na verdade não o é, tornando necessário que lhe paguem para que a atividade seja levada a efeito. A "mensagem" do pagamento, nesse caso, é a de que o prazer gerado pela conduta não seria, na visão de quem concede o incentivo, bastante em si mesmo para que ela fosse levada a efeito. ${ }^{62}$

É curioso notar, ainda, que tais experimentos revelam o caráter mesmo corrosivo de alguns incentivos. Tratar as pessoas como homo economicus, ou como se elas fossem egoístas e pensassem, apenas, no que teriam a ganhar com suas condutas, pode fazer com que elas efetivamente passem a se comportar assim em uma intensidade maior do que a verificável na ausência dos incentivos ${ }^{63}$. Como alerta Bowles, os experimentos mostram que "policies premised on the belief that citizens or employees are entirely self-interested often induce people to act exactly that way" ${ }^{\prime \prime}$.

Há, ainda, o efeito narrado por Emir Kamenica, referente àquelas situações em que o incentivo é alto demais, causando nervosismo e excesso de responsabilidade naquele a quem é dirigido, o que pode levar, por igual, a uma diminuição em seu desempenho na tarefa incentivada. Basta pensar na maior dificuldade em se bater um pênalti em uma final de copa do mundo, bem maior do que a de realizar a mesma tarefa em treino, sendo que, "objetivamente", a dificuldade pode ser a mesma, ou, ainda que diversa, não o é na mesma proporção em que sentida pelo jogador. ${ }^{65}$

Isso não quer dizer, naturalmente, que incentivos e punições não devam ser utilizados pelo legislador para estimular ou desestimular condutas consideradas respectivamente desejáveis ou indesejáveis. Apenas tais fatores devem ser estudados e conhecidos para que se concedam incentivos que se somem às outras motivações que o agente já teria para adotar a conduta pretendida, em vez de invertê-las. Bowles ${ }^{66}$ sugere, nessa ordem de ideias, partindo de lições hauridas dos incentivos usados pelos Gregos na Antiguidade para obter a adesão da população em empreitadas coletivas como uma guerra, que os incentivos trabalhem com

veja-se GNEEZY, Uri; LIST, John A. Putting behavioral economics to work: testing for gift exchange in labor markets using field experiments. Econometrica, v. 74, n. 5, p. 1381, set. 2006.

61 KAMENICA, Emir. Behavioral economics and psychology of incentives. Annual Review of Economics, v. 4, n. 1, p. $436,2012$.

62 KAMENICA, Emir. Behavioral economics and psychology of incentives. Annual Review of Economics, v. 4, n. 1, p. $429,2012$.

63 Em 1954, K William Kapp já observada que "the concept of human nature and human behavior must be a 'holistic' one in the sense of being capable of taking adequate account of the totality of factors which influence human behavior. No theory of human behavior which operates with single determinants (whether the pursuit of wealth, or any other partial "drive") is likely to prove adequate for the explanation of human behavior at any level and under any of the various conditions under which man acts as a consumer, worker, enterpreneur, or member ofa social or political group." KAPP, K. William. Economics and the behavioral sciences: economics and the interdisciplinary Problem. Kyklos, v. 7, n. 3, 1954.

64 BOWLES, Samuel. The moral economy: why good incentives are no substitute for good citizens. New Haven: Yale University Press, 2016.

65 KAMENICA, Emir. Behavioral economics and psychology of incentives. Annual Review of Economics, v. 4, n. 1, p. $434,2012$. 66 BOWLES, Samuel. The moral economy: why good incentives are no substitute for good citizens. New Haven: Yale University Press. 2016, ерub. Na mesma ordem de ideias, Kamenica registra ser "belpful to distinguish those tasks that people certainly do not want to do unless they are paid for them from those that people may or may not engage in, depending on the details of their choice-making environment." KAMENICA, Emir. Behavioral economics and psychology of incentives. Annual Review of Economics, v. 4, n. 1, p. 447, 2012. 
a necessidade de aprovação pelos pares que as pessoas têm, e com a importância que para as pessoas tem a reputaçã $0^{67}$. Isso fez, por exemplo, com que a cobrança de um valor adicional pelo uso de sacos plásticos em supermercados, a ser paga por aqueles que não levam suas sacolas de pano reutilizáveis, tivesse sim o efeito esperado, ao contrário do que ocorreu na creche israelense, embora a forma de atuação do incentivo fosse aparentemente semelhante. As pessoas não passaram a ver o custo adicional do saco plástico como um preço a pagar pela falta, que deixaria, então, de ser reprovável. Isso porque a mensagem transmitida pelo incentivo não era a de que a reprovabilidade do ato estaria sendo corrigida pelo mero pagamento do ônus. Ao contrário, a mensagem subjacente ao maior ônus imposto às sacolas de plástico passou a sinalizar a todos daquela sociedade, quando informados da razão de ser do ônus, que há um problema em se usar o referido material para conduzir as compras feitas no supermercado, independentemente de quanto se pague por ele. Assim, depois que todos na Irlanda sabiam o motivo do custo adicional do saco plástico, ao andar pela rua com um deles, o consumidor estaria mostrando aos demais que ele não estaria colaborando com o esforço de todos por um ambiente melhor. Isso causa constrangimento, inclusive, porque, como lembra Sunstein, "people are often affected by the social meaning of their action"*8. Desse modo, o ônus econômico e os sentimentos morais, mesmo intuitivos, somam-se em prol do mesmo objetivo, em vez de mutuamente se excluírem.

Para minimizar o efeito de gerar uma "necessidade de autonomia", por sua vez, os incentivos e as punições podem ser estabelecidas por processos de deliberação destinados a lhes conferir maior legitimidade, de modo que, em alguma medida, o próprio sujeito cujo comportamento se quer incentivar contribua para com a definição da política de incentivo e sobretudo concorde com ela, pelo menos quando aplicada aos outros. Quando houver a concessão de incentivo, ou a ameaça de punição, ele não se sentirá controlado por um terceiro, em cerceamento de sua autonomia, o que minimizará sua resistência quanto à adoção do comportamento pretendido ${ }^{69}$.

Tais estudos, conquanto em estágios iniciais, e aqui apenas rapidamente referidos, revelam o quanto às cegas a extrafiscalidade vem sendo utilizada no Brasil, deficiência cuja superação jamais será superada se mantida a postura reducionista e isolacionista que a doutrina brasileira, por muito tempo, adotou e, em alguma medida, ainda adota.

\section{RefLeXos No ÂMBITO dA EXTRAFISCALIDADE TRIBUTÁRIA}

As reflexões feitas no item anterior, como se pode perceber, têm reflexos inevitáveis no âmbito da extrafiscalidade, porquanto por meio dela se usa o tributo exatamente como forma de tornar menos ou mais onerosa uma atividade ou um comportamento, agindo, apenas, sobre fatores levados em conta por um homo economicus. Ao fazê-lo, portanto, é preciso cuidado para não desligar ou mesmo inverter as motivações que os contribuintes já teriam, mesmo sem o diferencial no ônus tributário, para se comportar da maneira pretendida.

Aliás, mesmo que não haja neutralização ou inversão dos referidos motivos, um incentivo não deve ser concedido quando se está diante de situação na qual a conduta a ser incentivada seria adotada de uma forma

67 Para uma análise da relevância da reputação, calcada na Teoria dos Jogos, veja-se: Veja-se, a propósito, BALEEIRO, Aliomar. Uma introdução à ciência das finanças. 17. ed. Rio de Janeiro: Forense, 2010. p. 14-18.

68 SUNSTEIN, Cass. Why nugde?: the politics of libertarian paternalism. New Haven: Yale University Press, 2014. Por isso mesmo, além da intensidade da punição, ou do desincentivo, é necessário que sua aplicação seja efetiva, sob pena de tanto reduzir a sensação de risco de sofrer prejuízos (no cálculo econômico de custos e benefícios), como conduzir a uma ideia de conivência social com a conduta, que deixa de ser vista como moralmente reprovável. Como destacam Armando Freitas da Rocha e Fábio Theoto Rocha, "se os outros fazem, por que eu não posso?” ROCHA, Armando Freitas da; ROCHA, Fábio Theoto. Neuroeconomia e processo decisório. Rio de Janeiro: LTC, 2011. p. 95-96.

69 BOWLES, Samuel. The moral economy: why good incentives are no substitute for good citizens. New Haven: Yale University Press, 2016. 
ou de outra ${ }^{70}$. O incentivo somente será eficiente se a "renúncia de receita" por ele causada corresponder à exata quantia necessária à alteração do comportamento do agente econômico na direção desejada. Não parecem fazer muito sentido, nessa ordem de ideias, incentivos destinados a atrair empreendimentos para áreas isoladas do litoral do Nordeste Brasileiro, quando destinados a resorts, pois, obviamente, esses resorts não estão escolhendo o aludido local por conta da redução tributária, tampouco optariam por se estabelecer no centro da cidade de São Paulo se houvesse neutralidade na tributação incidente sobre a atividade.

Já o exemplo dos pais das crianças da creche israelense deve ser lembrado quando se cogita, no âmbito da extrafiscalidade ambiental, de aplicar o princípio do poluidorpagador. Para que surta o efeito pretendido, ele não deve ser visto como o preço a ser pago pelo direito de poluir, devendo o ônus adicional representado por um tributo com feição ambiental ser associado a fatores ligados à reputação e ao reconhecimento social. Pode-se estabelecer, por exemplo, um prêmio, não pecuniário, àquele que adota as práticas ecologicamente adequadas, associado a formas de tornar públicos os nomes daqueles que pagam o ônus adicional porque poluem mais. Não se está, por certo, sugerindo aqui que os contribuintes sujeitos a tributo extrafiscal ambiental, mais oneroso sobre produtos mais poluentes, comportar-se-ão exata e necessariamente como os pais das crianças da creche de Haifa. A questão é que isso pode ocorrer, assim como efeitos colaterais outros, igualmente indesejáveis, podem advir, algo que a consideração bitolada das normas, à luz de uma ideia ultrapassada de homo economicus, não será capaz de enfrentar ou mesmo de compreender. Ou, em termos mais diretos: é preciso entender o comportamento humano diante de incentivos para que se possa desenvolver uma cognição mais adequada sobre como estes devem ser usados. Isso, aliás, é bastante óbvio: se a neurociência, a psicologia e a economia comportamental estão modificando (por permitirem um melhor conhecimento) a concepção que se tem de ser humano e de como ele se comporta e toma decisões, seus reflexos sobre o estudo e a operação do Direito são evidentes e não podem ser desprezados.

Jason F. Shogren, Gregory M. Parkhust e Prasenjit Banerjee destacam, a propósito da relação entre economia comportamental e proteção ao meio ambiente, que

Environmental economists will view behavioral economics as constructive if it helps them make better policy recommendations. Categorizing and cataloging deviations from rational choice theory while necessary is not sufficient. An inspired behavioral environmental economics will emerge when we better explain why inefficiencies arise, create tools to lower health risks today and into the future, reduce resource conflicts and promote better coordination/cooperation, design more effective incentive systems, measure values with more precision and less bias, and generate more protection at less costs. ${ }^{71}$

Em suma, compreender que as decisões humanas nem sempre são "racionais" é necessário, mas não é suficiente. Devem ser apontados mecanismos para corrigir desvios, para cuja construção a compreensão das causas de tais distorções é essencial. É precisamente para isso que Bowles procura contribuir com a obra aqui várias vezes referida, além de outros estudiosos da economia comportamental, realidade para a qual os que se ocupam do Direito não devem dar as costas, seja porque podem, também, colaborar com o enfrentamento das mesmas questões, seja porque podem se beneficiar das constatações de estudiosos de áreas correlatas. Por outros termos, juristas podem e devem participar do debate, juntamente a psicólogos, economistas e outros cientistas sociais. Isso permitirá, inclusive, a correção de políticas tributárias desastradas, e a eventual responsabilização de quem as tiver levado a efeito. Aliás, essa possibilidade de aferição da efetividade, ou não, da consecução das finalidades, fará mesmo com que os que integram o Poder Público sejam mais responsáveis no emprego da tributação com função indutiva ${ }^{72}$.

70 O incentivo fiscal concedido a quem já adotaria a conduta incentivada de uma forma ou de outra, quando implica renúncia de receita, além de ineficiente, é contrário, também, à igualdade. Cf. MALHERBE, Jacques. Ascensão e queda dos incentivos fiscais no cenário internacional. Revista Direito Tributário Atual, São Paulo, n. 23, 2009.

71 SHOGREN, Jason F.; PARKUST, Gregory M.; BANERJEE, Prasenjit. Two cheers and a qualm for behavioral environmental economics. Environ Resource Econ, v. 46, p. 235-247, 2010.

72 COOPER, James C.; KOVACIC, William E. Behavioral economics: implications for regulatory behavior. J Regul Econ, v. 41, p. $41-58,2012$. 
Ainda na seara ambiental, a extrafiscalidade pode ser usada para, simplesmente, equalizar o ônus tributário entre comportamentos ecologicamente corretos, e aqueles em que o custo ambiental é simplesmente socializado, em uma externalidade negativa; não necessariamente onerando mais o poluidor, mas desonerando aquele que não polui. Tributos como o ICMS e o IPI, por exemplo, da forma como cobrados no Brasil, muitas vezes tornam mais oneroso reciclar do que extrair da natureza, no que tange a plástico, papel ou alumínio, ou mais cara a energia oriunda de fontes limpas, como a solar, do que aquela advinda de combustíveis fósseis. Tais distorções, que, na maioria das vezes não são intencionais, podem ser corrigidas sem que isso interfira - pelo contrário - nas razões não econômicas que igualmente levam as pessoas a comportamentos ecologicamente adequados.

No caso dos cigarros, em outro exemplo, veja-se que muito mais eficiente que uma elevada tributação pelo Imposto sobre Produtos Industrializados, cuja alíquota supera os 300\% do valor do produto, foi uma forte campanha contra o seu consumo, inclusive com a aposição de fotografias repugnantes nos produtos. Tais fotografias, a trabalhar com o "sistema automático" do cérebro humano, e o sentimento de reprovação social gerado, fizeram com que o fumante quase que tenha vergonha dessa sua condição, levando a uma redução no tabagismo significativa, a qual o IPI, conquanto cobrado há muito tempo por percentuais tão altos, não havia conseguido. Nesse caso, porém, diversamente do que pode ocorrer em relação a um tributo ambiental mais elevado amparado na ideia de "poluidor pagador", o ônus adicional representado pelo IPI não neutraliza e muito menos inverte a tendência gerada por tais imagens ou mesmo pela crença, já generalizada na população, de que o tabagismo é prejudicial à saúde, algo semelhante ao que ocorreu com a cobrança de valores adicionais pelo uso de sacolas plásticas na Irlanda. Ao contrário, o ônus tributário muito elevado se justifica, inclusive, sob a perspectiva da economia comportamental. Em primeiro lugar, porque ele não neutraliza ou inverte o efeito de outras formas utilizadas para desestimular o consumo do tabaco, como as tais imagens coladas aos maços de cigarro. E, em segundo, porque se trata de finalidade ou propósito - o abandono do hábito de fumar - que muitos fumantes desejam, mas não conseguem fazer com que uma maior saúde, em longo prazo (da qual o "Sistema 2" é consciente), iniba a vontade de satisfazer o prazer no consumo do produto em curto prazo (desejado pelo "Sistema 1"). O custo elevado ajuda nesse balanço, em favor de uma escolha mais racional pela redução no consumo ${ }^{73}$.

Mais importante do que examinar, aqui, os diversos casos ou exemplos de uso do tributo com função extrafiscal, é notar que, sempre que se confere tratamento diferenciado, menos ou mais oneroso, a um grupo de contribuintes, ou àqueles que adotam certos comportamentos, é preciso, até para que se afira a compatibilidade da discriminação com o princípio da igualdade, aferir se o diferencial no ônus realmente conduzirá à finalidade anunciada. Se não, seja por inocuidade, seja, a fortiori, por conta de uma inversão nas motivações dos agentes (backfire), sua invalidade será evidente, e a questão será, diversamente do que pode parecer à doutrina tradicional, eminentemente jurídica.

\section{Considerações finais}

A extrafiscalidade trabalha basicamente com a redução ou com o aumento do ônus tributário, de forma específica sobre pessoas que adotam condutas que se deseja estimular ou desestimular. Sua finalidade é interferir nos comportamentos, e não, de forma precípua, arrecadar recursos aos cofres públicos. A forma como a redução ou o aumento do ônus tributário efetivamente interfere no comportamento das pessoas, porém, e os resultados daí decorrentes, constituem aspectos que os estudiosos do Direito Tributário costumam afastar de suas preocupações, por serem considerados "não jurídicos". Partindo de uma crença de que ao tributarista cabe descrever as normas tributárias como elas são, sendo os fatores que levam à sua criação, e

73 Cherukupalli, Rajeev. A behavioral economics perspective on tobacco taxation. American Journal of Public Health, v. 100, n. 4, p. $609-615,2015$. 
os efeitos decorrentes de sua aplicação, objeto de "outras ciências", a doutrina do Direito Tributário tornou-se inteiramente incapaz de versar sobre questões ligadas ao conteúdo e aos efeitos dessas normas, quando utilizado o tributo em sua função indutora.

Estudos empíricos de economia comportamental e de neurociência revelam, todavia, que estímulos e desestímulos econômicos nem sempre funcionam, e às vezes têm efeito inverso ao pretendido. Adicionalmente, são capazes de corroer motivações outras, de ordem não econômica, para a adoção de condutas desejáveis. Isso não conduz à conclusão de que não devam ser concedidos, mas de que isso não pode ocorrer às cegas, sendo preferível a não intervenção àquela capaz de causar efeito colateral pior que a doença. Essa é mais uma razão a demonstrar a insuficiência e mesmo a insustentabilidade de uma abordagem do Direito Tributário que não leve em conta esses fatores, a qual, certamente, não deixará de ser jurídica por conta disso.

\section{REFERÊNCIAS}

ALTMAN, Morris. The nobel prize in behavioral and experimental economics: a contextual and critical appraisal of the contributions of Daniel Kahneman and Vernon Smith. Review of Political Economy, v. 16, n. 1, p. 3-41, jan. 2004.

ATALIBA, Geraldo. Hipótese de incidência tributária. 6. ed. São Paulo: Malheiros, 2001

AVI-YONAH, Reuven S. Os três objetivos da tributação, em direito tributário atual. Revista do IBDT/ Dialética, São Paulo, n. 22, p. 7-29, 2008.

ÁVILA, Humberto Bergmann. Função da ciência do direito tributário: do formalismo epistemológico ao estruturalismo argumentativo. Revista Direito Tributário Atual, São Paulo, n. 29, 2013.

AXELROD, Robert. A evolução da cooperação. Tradução de Jusella Santos. São Paulo: Leopardo, 2010.

BALEEIRO, Aliomar. Uma introdução à ciência das finanças. 17. ed. Rio de Janeiro: Forense, 2010.

BECK, Hanno. Behavioral economics: eine einführung. Heidelberg: Springer, 2014.

BECKER, Alfredo Augusto. Teoria geral do direito tributário. São Paulo: Saraiva, 1963.

BERGEN, Benjamin K. Louder than words: the new science of how the mind makes meaning. New York: Basic Books, 2012.

BOWLES, Samuel. The moral economy: why good incentives are no substitute for good citizens. New Haven: Yale University Press, 2016.

CARVALHO, Paulo de Barros. Curso de direito tributário. 12. ed. São Paulo: Saraiva, 1999.

CHAGEUX, J. P.; DAMASIO, Antonio R.; SINGER, W.; CHRISTEN, Y. (Ed.). Neurobiology of human values. Heidelberg: Springer, 2005.

Cherukupalli, Rajeev. A behavioral economics perspective on tobacco taxation. American Journal of Public Health, v. 100, n. 4, p. 609-615, 2015.

CHRISTIAN, Brian. O bumano mais bumano: o que a inteligência artificial nos ensina sobre a vida. São Paulo: Companhia das Letras, 2013.

COELHO, Sacha Calmon Navarro. Curso de direito tributário brasileiro. 9. ed. Rio de Janeiro: Forense, 2006.

COOPER, James C.; KOVACIC, William E. Behavioral economics: implications for regulatory behavior. J Regul Econ, v. 41, p. 41-58, 2012. 
COSTA, Alcides Jorge. História do direito tributário: I e II. In: FERRAZ, Roberto (Coord.). Princípios e limites da tributação. São Paulo: Quartier Latin, 2005.

DEEMTER, Kees Van. Not exactly. In: Praise of vagueness. Oxford: Oxford University Press, 2010.

FOLLONI, André. Ciência do direito tributário no Brasil. São Paulo: Saraiva, 2013.

GAZZANIGA, Michael S. Who's in charge?: free will and the science of the brain. New York: Harper Collins, 2011.

GNEEZY, Uri; LIST, John A. Putting behavioral economics to work: testing for gift exchange in labor markets using field experiments. Econometrica, v. 74, n. 5, p. 1365-1384, set. 2006.

GODOI, Marciano Seabra de. Extrafiscalidad y sus límites constitucionales. Revista Internacional de Direito Tributário da Associação Brasileira de Direito Tributário, Belo Horizonte, v. 1, p. 219-262, 2004.

GODOI, Marciano Seabra de. O quê e o porquê da tipicidade tributária. In: RIBEIRO, Ricardo Lodi; ROCHA, Sérgio André (Coord.). Legalidade e tipicidade no direito tributário. São Paulo: Quartier Latin, 2008.

GRECO, Marco Aurélio. Dinâmica da tributação: uma visão funcional. São Paulo: RT, 1979.

GRECO, Marco Aurélio. Contribuições: uma figura “sui generis”. São Paulo: Dialética, 2000.

GRECO, Marco Aurélio. Planejamento tributário. São Paulo: Dialética, 2004.

GREENE, Joshua. Moral tribes. New York: Penguin Press, 2013.

HAUSER, Marc. Moral minds. New York: Harper Collins, 2006.

HOFFMAN, Elizabeth; MCCABE, Kevin A.; SMITH, Venon L. Behavioral foundations of reciprocity: experimental economics and evolutionary psychology. Economic inquiry, v. 36, p. 335-352, jul. 1998.

JOYCE, Richard. The evolution of morality. Cambridge: MIT Press, 2006.

KAHNEMAN, Daniel. Thinking, fast and slow. New York: Farrar, Straus and Giroux, 2011.

KAMENICA, Emir. Behavioral economics and psychology of incentives. Annual Review of Economics, v. 4, n. 1, 2012.

KANDEL, Eric. Em busca da memória: o nascimento de uma nova ciência da mente. Tradução de Rejane Rubino. São Paulo: Companhia das Letras, 2009.

KAPP, K. William. Economics and the behavioral sciences: economics and the interdisciplinary Problem. Kyklos, v. 7, n. 3, 1954.

KOOREMAN, Peter; PRAST, Henri ette. What does behavioral economics mean for policy?: challenges to savings and health policies in the netherlands. De Economist, v. 158, p. 101-122, 2010.

MACHADO SEGUNDO, Hugo de Brito. Science, complexity, and the study of tax law. In: FABÓ, Edit; FERONE, Emilia; CHEN, James Ming. (Org.). Systemic Actions in Complex Scenarios. Cambrigde: Cambridge Scholars Publishing, 2017. v. 1, p. 170-190.

MACHADO, Raquel Cavalcanti Ramos Machado. Competência tributária: entre a rigidez do sistema e a atualização interpretativa. São Paulo: Malheiros, 2014.

MACHIAVELLI, Niccolò. Discorsi sopra la prima deca di Tito Livio. Firenze: Ami books, Associazione Mazziniana Italiana, 2003.

MALHERBE, Jacques. Ascensão e queda dos incentivos fiscais no cenário internacional. Revista Direito Tributário Atual, São Paulo, n. 23, 2009.

MARINS, James. Defesa e vulnerabilidade do contribuinte. São Paulo: Dialética, 2009. 
MARINS, James. A teoria do campo científico de Pierre Bourdieu e a ciência do direito tributário brasileiro. Direito Tributário Atual, n. 34, p. 120-156, 2015.

MARQUES NETO, Agostinho Ramalho. A ciência do direito. 2. ed. Rio de Janeiro: Renovar, 2001.

NABAIS, José Casalta. O dever fundamental de pagar impostos: contributo para a compreensão do estado fiscal contemporâneo. Coimbra: Livraria Almedina, 2009.

NOGUEIRA, Ruy Barbosa. Direito financeiro: curso de direito tributário. São Paulo: José Bushatsky, 1964.

NOGUEIRA, Ruy Barbosa. Direito tributário comparado. São Paulo: Saraiva, 1971.

NOGUEIRA, Ruy Barbosa. Túllio Ascarelli e o direito tributário do Brasil. São Paulo: IBDT, 1979.

PEDRAJAS. La transformación ética de la racionalidad económica en Amartya Sen: una recuperación de Adam Smith. Quaderns de filosofia y ciència, v. 36, p. 105-117, 2006.

PIMENTA, Daniel de Magalhães. Limitações à extrafiscalidade aplicáveis ao fator acidentário de prevenção: FAP. Revista Brasileira de Politicas Públicas, v. 6, n. 1., jan./jul. 2016.

POPPER, Karl. O mito do contexto: em defesa da ciência e da racionalidade. Tradução de Paula Taipas. Lisboa: Edições 70, 2009.

RESCHER, Nicholas. Epistemology: an introduction to the theory of knowledge. Albany: State University of New York Press, 2003.

ROCHA, Armando Freitas da; ROCHA, Fábio Theoto. Neuroeconomia e processo decisório. Rio de Janeiro: LTC, 2011.

ROCHA, Valdir de Oliveira. Tratados internacionais e vigência das isenções por eles concedidas, em face da constituição de 1988. Repertório IOB de Jurisprudência, n. 5, 1991.

RUSE, M. Evolutionary ethics: a phoenix arisen. Zygon, v. 21, n. 1, p. 95-112, 1986.

SATZ, Debra. Why some things should not be for sale: the moral limits of markets. New York: Oxford University Press, 2010.

SCHOUERI, Luis Eduardo. Direito tributário. São Paulo: Saraiva, 2012.

SEARLE, John R. Libertad y neurobiologia. Tradução de Miguel Candel. Barcelona: Paidós, 2005.

SEN, Amartya. Sobre ética e economia. Tradução de Laura Teixeira Mota. São Paulo: Cia das Letras, 1999.

SHEN, Francis X. Law and neuroscience 2.0. Arizona State Law Journal, v. 48, n. 1043, 2016.

SHOGREN, Jason F.; PARKUST, Gregory M.; BANERJEE, Prasenjit. Two cheers and a qualm for behavioral environmental economics. Environ Resource Econ, v. 46, p. 235-247, 2010.

SINGER, Peter. The most good you can do: how effective altruism is changing ideas about living ethically. London: Yale University Press. 2015.

SMITH, Adam. An inquiry into the nature and causes of the wealth of nations. Chicago: University of Chicago Press, 1977.

SMITH, Adam. The theory of moral sentiments. London: A Millar, 1790.

SUNSTEIN, Cass. Why nugde?: the politics of libertarian paternalism. New Haven: Yale University Press, 2014.

TORRES, Ricardo Lobo. Liberdade, consentimento e princípios de legitimação do direito tributário. Revista Internacional de Direito Tributário, Belo Horizonte, v. 5, p. 223-244, jan./jun. 2006. 
VASCONCELOS, Arnaldo. Teoria pura do direto: repasse crítico de seus principais fundamentos. Rio de Janeiro: Forense, 2003.

VASCONCELOS, Arnaldo. Teoria da norma jurídica. 5. ed. São Paulo: Malheiros, 2000.

WAAL, Frans de et al. (Ed.). Evolved morality: the biology and philosophy of human conscience. Boston: Brill, 2014.

WAAL, Frans de. Good natured: the origins of right and wrong in humans and other animals. Cambridge: Harvard University Press, 1996.

VENKATACHALAM, L. Ecological economics, v. 67, p. 640-64, 2008. 


\section{COMPORTAMENTO JUDICIAL: INFLUÊNCIA DE FATORES EXTRAJURÍDICOS}




\section{Fatores metaprocessuais e suas influências para a formação da decisão judicial*}

* Recebido em 02/05/2018

Aprovado em 24/05/2018

** Doutorando em Direito, Processo e Cidadania pela Universidade Católica de Pernambuco (UNICAP/PE). Mestre em Direito Econômico pela Universidade Federal da Paraíba (UFPB). Professor do Centro Universitário de João Pessoa (UNIPÊ/PB). Juiz federal em João Pessoa/PB. Email: rogerioroberto@hotmail.com.

*** Professor Adjunto III da Universidade Católica de Pernambuco, onde é pesquisador e leciona nos cursos de graduação, especialização, Mestrado e Doutorado em Direito. Possui graduação em Ciências Jurídicas pela Universidade Federal de Pernambuco (1989), Mestrado em Direito pela Universidade Federal de Pernambuco (1994) e Doutorado em Ciências Jurídicas pela Universidade de Lisboa (2002). Atua nas áreas de Direito Processual Civil e Hermenêutica Jurídica, Membro do grupo de pesquisa LOGOS - Processo, Linguagem e Tecnologia. Parecerista em diversos periódicos jurídicos, dentre outros: RBDPRO, Revista Eletrônica de Direito Processual, Revista do Centro de Estudos Judiciários da Justiça Federal e Revista da Esmape. Coordenador de Publicações da ENFAM/STJ. Conselheiro Fiscal da ABDPRO (Associação Brasileira de Direito Processual). Secretário Adjunto do IBDP (Instituto Brasileiro de Direito Processual). Membro da ANNEP (Associação Norte-Nordeste de Professores de Processo). Já exerceu o magistério na condição de professor visitante em diversas pós-graduações brasileiras. Autor de diversas publicações jurídicas. Juiz de Direito em Recife-PE. Email: luciograssi13@gmail.com.

**** Mestrado (1992) e Doutorado (1999) em Linguística pela Universidade Federal de Pernambuco (UFPE). Realizou estágio pósdoutoral em Direito, na Universidade de Brasília, em 2011. Atualmente, é professora, adjunta IV, da Universidade Católica de Pernambuco (UNICAP), atuando na graduação, mestrado e doutorado em Direito. Tem experiência na área de Linguística Aplicada ao Direito, atua na linha de pesquisa da Análise Crítica do Discurso Jurídico, construída no âmbito do PPGD-UNICAP. Ministra disciplinas relativas à linguagem jurídica em diversas escolas de magistratura no país. Fundadora da Associação de Linguagem e Direito (ALIDI - www.alidi.com.br) criada no âmbito do Grupo de Pesquisa Linguagem e Direito (Plataforma Lattes $\mathrm{CNPq}$ ), do qual é líder. Integra o Grupo de pesquisa Logos: processo, linguagens e tecnologias (Plataforma Lattes CNPq).Email: virginia.colares@gmail.com.

\section{Metaprocessual factors and its influence on the judicial decision-making process}

\author{
Rogério Roberto Gonçalves de Abreu** \\ Lúcio Grassi de Gouveia*** \\ Virgínia Colares****
}

\section{Resumo}

Nosso objetivo, no presente trabalho, está em examinar, brevemente, a influência que influxos alheios aos fatos, às provas e ao direito - aqui chamados de fatores metaprocessuais da decisão — podem produzir no processo de tomada de decisão judicial. Para tanto, partimos do exame das ideias freudiana e junguiana sobre o inconsciente, especialmente acerca de sua existência no dispositivo psíquico humano e do papel que desempenha para a formação dos estímulos produtores de ações e decisões. Na sequência, examinamos a noção de neutralidade do juiz em cotejo com a abordagem sobre o inconsciente freudiano, concluindo por sua inexistência como fato no mundo e pelo reconhecimento de sua natureza mítica. Posteriormente, analisamos, como fatores metaprocessuais de significativa relevância, as tendências implícitas, a idade e os valores religiosos do julgador com base nos trabalhos de pesquisadores que investigaram, empiricamente, o papel de tais influxos para o processo de tomada de decisão judicial em determinadas espécies de demandas. Ao final do trabalho, sustentamos que os achados empíricos examinados nos permitem concluir pela verificação de uma forte associação entre os fatores metaprocessuais analisados e os resultados de decisões judiciais. Acreditamos que o trabalho possa colaborar para melhor compreensão do processo de formação da decisão judicial, dada a escassez de textos especificamente sobre o tema.

Palavras-chave: Processo de tomada de decisão judicial. Fatores metaprocessuais. Influência.

\section{Abstract}

In the Brazilian justice system, the judicial decision-making process must comprehend the facts, the evidences and the law related to the case under judgment. Accordingly, judges are forbidden to take into account elements not related to these inputs, lest their decisions are completely void and unable to produce any effect. Nonetheless, in real life, we can find external inputs playing an important role in judicial decision-making process, what has made us to conduct a brief study on the matter. We start from the examen of some freudian and junguian writings on the unconscious, specially 
about its existence in the human psychic device and the possible role it plays at the genesis of the stimulus as to which actions and decisions are grounded. Afterwards, we examine the notion of judicial neutrality according to the freudian unconscious approach, so as to conclude for its non-existence as a fact in the world and for the acknowledgement of its mythical nature. In the next step, we analyze, as such remarkable types of external inputs, the implicit biases, the age and the religious values of the judges, taking into account a few works whereby researchers have published their findings on the influence of such inputs to the judicial decision-making process in certain instances of claims. In the end, we support the idea according to which the empirical findings allow us to verify a strong association between the before mentioned external factors and the outcomes of the judicial decision-making process. Whereas the scant literature about the issue in Brazil, we believe we can collaborate to a better comprehension on the judicial decision-making process.

Keywords: Judicial decision-making process. Metaprocess factors. Influence.

\section{INTRODUÇÃO}

A função jurisdicional se define como aquela, entre as funções do poder do Estado, responsável pela resolução dos conflitos por meio da elucidação dos fatos e da aplicação do ordenamento jurídico na justa composição da lide. Escrevendo sobre Teoria Geral do Processo, ensinam os clássicos que o exercício da jurisdição, entre outras finalidades, compreenderia a pacificação social e a garantia da autoridade do Direito ${ }^{1}$, sem prescindir da legitimação das decisões pela participação em contraditório.

No que diz respeito ao Princípio do Contraditório, já não podemos defini-lo como a mera garantia de audição das partes, especialmente daquela contra quem se haja apresentado alguma demanda. A decisão judicial é algo a ser construído pelo trabalho conjunto de todos os sujeitos do processo, que são alçados à condição de iguais para efeito dessa empresa colaborativa, a sentença. O contraditório funcionaria como um combustível devidamente catalisado pelo Princípio da Cooperação ${ }^{2}$, para que a resposta do poder judiciário, mais do que simplesmente correta e justa, seja dotada da necessária legitimidade democrática, requisito de qualquer ato estatal em tempo de paz

A verdadeira participação em contraditório depende da efetiva influência das partes para a construção do conteúdo da decisão, que já não pode ser produto exclusivo do trabalho do juiz. O novo Código de Processo Civil, em sintonia com esse pensamento, proíbe ao julgador decidir com base em fundamento sobre

1 Sobre os escopos do processo civil: DINAMARCO, Cândido Rangel. Instituições de direito processual civil. 4. ed. São Paulo: Malheiros, 2004. v.1. p. 125. DINAMARCO, Cândido Rangel. A instrumentalidade do processo. 5. ed. São Paulo: Malheiros, 1996. p. 149.

2 Considerando que o contraditório funciona a partir do empoderamento das partes para a construção da decisão judicial com o juiz, o princípio da cooperação tem o condão de lhe conferir substância e materialidade. Sob esse viés, a decisão se legitima a partir da efetiva participação de sujeitos processuais (partes e juiz) no processo de sua formação, sujeitos que dialogam e cooperam ativamente na composição do núcleo da prestação judicial. Podemos dizer, pois, que não pode haver contraditório legitimador sem cooperação.

Nessa linha, afirma Lúcio Grassi de Gouveia:

"A presença ativa e participante das partes servirá como forma de controle dos amplos poderes do juiz na tradução jurídica do fato social, limitando o arbítrio, favorecendo o processo dialógico, que é a garantia maior de objetividade e da maior abertura na decisão. A parte passa a ter efetiva possibilidade de atuar sobre o desenvolvimento e sobre o êxito da controvérsias tendo importância não só o resultado a ser obtido mas a forma como o mesmo o será, no que podemos vislumbrar até mesmo uma função A função legitimadora do princípio da cooperação intersubjetiva no processo civil brasileiro legitimadora do princípio da cooperação intersubjetiva no processo civil moderno, inclusive no brasileiro”. GOUVEIA, Lúcio Grassi de. A função legitimadora do princípio da cooperação intersubjetiva no processo civil brasileiro. Revista de Processo, São Paulo, v. 172, p. 32-53, jun. 2009.

3 Sobre a legitimação da jurisdição pelo contraditório e pelo devido processo legal, conferir: DINAMARCO, Cândido Rangel. Instituições de direito processual civil. 4. ed. São Paulo: Malheiros, 2004. v.1. p. 215. Conferir também, do mesmo autor: DINAMARCO, Cândido Rangel. Fundamentos do processo civil moderno. 5. ed. São Paulo: 2002. v. 1. p. 124. Ainda sobre o tema, mas com os olhos no processo penal: LOPES JÚNIOR., Aury. Introdução crítica ao processo penal: fundamentos da instrumentalidade constitucional. 4. ed. Rio de Janeiro: Lumen Juris, 2006. p. 267. 
o qual não tenham tido as partes a oportunidade de se manifestar. Embora seja possível argumentar que, nesse momento, o legislador tinha em mente apenas os fundamentos jurídicos, parece lógico que a norma compreenda, predominantemente, os aspectos fáticos: seria absurdo que o juiz pudesse decidir a demanda com base em juízo sobre fatos ao arrepio de qualquer alegação ou discussão dos sujeitos parciais.

Em vista disso, a decisão judicial deve espelhar com exatidão o que haja ocorrido no curso do processo, levando em conta as afirmações de fato, a produção de provas e as alegações de direito. É a aplicação do antigo brocardo segundo o qual “o que não está nos autos, não está no mundo". Ainda que o resultado da decisão, pela procedência ou improcedência da pretensão, seja uma surpresa para as partes, os elementos de fato e de direito vertidos linguisticamente na sentença como razões de decidir não podem ser estranhos ou desconhecidos a qualquer delas.

Toda essa linha de pensamento fundamenta um princípio básico em matéria de processo e exercício da jurisdição: no que diz respeito às afirmações de fato e aos meios de prova, o juiz somente poderá julgar com base no que for produzido ou discutido pelos sujeitos processuais e regularmente internalizado nos autos. Quanto aos fundamentos jurídicos, poderão as partes apresentar seus argumentos, permitindo-se ao juiz julgar com base em fundamento jurídico diverso, desde que o submeta à discussão das partes (CPC, art. 10). Enfim, tudo que possa ou deva influir no desfecho do processo e no resultado do julgamento deve ser conhecido pelos litigantes, acessível à discussão e passível de reforço, esclarecimento ou oposição.

Para controle de tal imposição, exige-se que o julgador demonstre às partes conhecer os fatos e as provas, o que deverá fazer nos tópicos da identificação e, mais particularmente, do relatório da sentença. Em seguida, terá de revelar linguisticamente o processo mental que o conduziu à decisão por fim adotada, lidando, exclusivamente, com os elementos fáticos já contidos no relatório e com os fundamentos normativos que lhe darão suporte à conclusão. A resolução da lide, apresentada às partes como a resposta do Estado a seu pedido de justiça, deverá surgir ao final do raciocínio do julgador - linguisticamente descrito na sentença - e guardar absoluta coerência com os elementos examinados e confrontados.

Na teoria, pelo menos, é o que deveria ocorrer. A confiança popular na justiça da jurisdição estatal depende da crença nesse hermetismo processual que, supostamente, expurgaria do processo de tomada de decisão tudo que não se considerem fatos, provas e normas ${ }^{5}$, o que seria controlável com base em um exame sobre o relatório e a fundamentação do ato decisório. Parece-nos, contudo, que esse bermetismo não possa eliminar da equação um elemento ainda essencial ao ato de julgar: a natureza invariavelmente humana do julgador.

O juiz é, naturalmente, um ser humano. Expõe-se, desde a infância, a toda sorte de abalos psicológicos e emocionais que lhe caracterizam a história de vida, compondo-o como um sujeito único no mundo, dotado de qualidades e defeitos que lhe influenciarão toda a existência. Ao decidir, o juiz não se despe da condição de ser humano. $\mathrm{O}$ ato de julgar, portanto, é praticado nessa condição: a de quem carrega uma infinidade de caracteres que fazem dele, juiz e ser humano, tudo que ele é ${ }^{6}$. A necessidade desse processo mental — que consiste no raciocínio para chegar à conclusão a partir dos elementos de fato e de direito pertinentes à causa - abre o flanco da função jurisdicional a uma gama de interferências de impossível previsão e controle. Tais interferências podem não aparecer na fundamentação textual do julgado, mas seus reflexos se inserem no processo mental de decidir, ainda que o julgador não saiba. Algumas dessas interferências são estudadas no presente trabalho.

Partindo da premissa de que o ato de julgar é um processo mental e, assim, um produto da mente do

4 Cf. arts. $9^{\circ}$ e 10 do CPC, 2015.

5 Cf:: PAMPLONA FILHO, Rodolfo. O mito da neutralidade do juiz como elemento de seu papel social. Ciência Jurídica, ano. 12, v. 81, p. 32-45, maio/jun. 1998.

6 "O processo decisório poderá consistir em opções valorativas conflitantes em que, diante de algumas decisões possíveis, o aplicador, utilizando-se de sua carga de conhecimentos, ideologia, emoções, personalidade e formação, escolherá a que entender adequada". GOUVEIA, Lúcio Grassi de. A função legitimadora do princípio da cooperação intersubjetiva no processo civil brasileiro. Revista de Processo, São Paulo, v. 172, p. 32-53, jun. 2009. 
julgador ${ }^{7}$, procuramos discutir por que o juiz não conseguiria expurgar de seu trabalho todo e qualquer insumo alheio aos fundamentos fáticos e jurídicos da lide. Daí a proposta de analisar elementos teóricos que fundamentem, tanto quanto possível, a influência do inconsciente sobre os atos humanos conscientes, o que nos levou a um breve exame sobre as ideias freudiana e junguiana acerca dessa intrigante parte do dispositivo psíquico.

Na sequência, procuramos tratar da ideia de neutralidade judicial, buscando demonstrar que os mesmos fatores que moldam o inconsciente humano - compondo-o como uma parte poderosa e influente na formação e produção dos estímulos que se transformam em nossos atos conscientes - estão presentes na visão daqueles que enxergam a natureza mítica da neutralidade do julgador e que, portanto, negam-lhe existência como um fato da vida real.

Por fim, analisamos como estudos empíricos verificaram a conexão entre determinados fatores externos — os quais chamamos aqui de fatores metaprocessuais, em oposição aos fatores (ordinariamente) processuais, quais sejam, os fatos, as provas e as normas (o direito) — e o resultado de decisões judiciais. Nessa parte do trabalho, examinamos publicações sobre pesquisas empíricas que investigaram a influência de determinados influxos sobre o processo de tomada de decisão judicial: as inclinações implícitas, a idade e, finalmente, os valores religiosos do julgador.

\section{O INCONSCIENTE COMO INSUMO NA DECISÃO DITA RACIONAL}

A decisão judicial é um produto do intelecto humano ${ }^{8}$. De fato, não podemos concordar que o juiz, ao decidir, exerça um trabalho puramente mecânico, por mais repetitivas que sejam as sentenças sobre determinados temas, mais facilidades que a adoção do processo judicial eletrônico traga ao serviço forense e, finalmente, por mais reiteradas que sejam as pretensões nos julgamentos das demandas de massa. Julgar é um trabalho intelectual e, portanto, um ato puramente mental'.

Tomando de empréstimo a visão kelseniana que classifica a interpretação jurídica como ato de cognição ou de vontade ${ }^{10}$, poderíamos dizer que, sob determinado ponto de vista, a decisão judicial se apresenta como

7 Sem prejuízo da colaboração das partes no fornecimento dos dados de fato e de direito considerados pelo juízo em seu raciocínio como processo mental. A afirmação de que a decisão é um "produto da mente do julgador" não invalida a afirmação anterior de que a decisão deva ser um produto do trabalho colaborativo dos sujeitos do processo, em sintonia com os princípios do contraditório e da cooperação.

8 No presente trabalho, tratamos da decisão judicial sob um viés individual, não institucional, como o faz José Rodrigo Rodriguez em sua interessante crítica à racionalidade jurídica e judicial no Brasil, na obra Como decidem as cortes?: para uma crítica do direito (brasileiro), publicada pela Editora FGV. Nesse trabalho, Rodriguez examina a fundamentação das decisões judiciais sob o prisma da argumentação e racionalidade, criticando a forma opinativa de decidir individualmente e assistemática de decidir coletivamente. Seu alvo, portanto, não se confunde com o nosso, mas não podemos negar que o autor compartilha conosco da preocupação sobre a gênese do processo de tomada de decisão.

9 É óbvio que o ato de julgar não se confunde com o de redigir a decisão, de assiná-la ou de validá-la no sistema. Esses não seriam atos puramente mentais, a começar da lógica razão de serem condutas, ou seja, ações materialmente externas em relação à mente humana. Atentando sempre para a precisão possível do significado das palavras, encontramos no ato de julgar aquele processo mental por meio do qual um problema é resolvido, uma escolha é feita, uma valoração é formulada. A externalização desse julgamento pelos diversos meios possíveis é outro ato, que não se confunde com o primeiro e que, em verdade, sequer precisa existir. Ao estudarmos o "processo de tomada de decisão", precisamos especificar que a "decisão" a que nos referimos ainda não é o ato processual decisório, mas o processo mental que forma na mente do juiz aquilo que, no futuro, constituirá a essência do primeiro.

10 De acordo com Kelsen, a interpretação jurídica realizada pelo aplicador do direito diferiria daquela realizada pelo cientista. Uma vez que não seria possível chegar, a partir de determinado texto, a uma "única decisão correta", o trabalho interpretativo do cientista se limitaria a conhecer e apontar todas as possibilidades de resultado, não lhe cabendo escolher qualquer delas. Já o aplicador do direito, tendo que resolver o caso concreto e deparando-se com uma pluralidade de soluções, terá que escolher aquela que melhor atenda às peculiares necessidades do caso, motivo por que sua atuação ultrapassaria a simples "cognição" para se tornar um ato de "vontade". Por essa razão, o autor afirma que, "através deste ato de vontade se distingue a interpretação jurídica feita pelo órgão aplicador do Direito de toda e qualquer outra interpretação, especialmente da interpretação levada a cabo pela ciência 
ato de cognição e de vontade. Como ato de cognição, traduz-se no trabalho do juiz em conhecer os fatos, as provas e o direito aplicável para, em seguida, formular o raciocínio que lhe permitirá estabelecer as soluções possíveis para o problema jurídico apresentado pelas partes. Como ato de vontade, consistirá na opção definitivamente realizada entre aquelas possíveis e, simultaneamente, em sua aplicação ao caso, fixando a norma in concreto que o disciplinará, ativando os poderes do Estado para efetivá-la no mundo real. Esse aspecto nos mostra a insuficiência da atividade cognitiva para o propósito da decisão como instrumento da função jurisdicional. Dado que não caberia ao Estado apenas prover soluções em tese, o juiz deve, decidindo a demanda, impor a vontade condicionadora do Estado, capaz de eliminar a dúvida, transformar relações jurídicas e mesmo reconstruir o mundo dos fatos ${ }^{11}$ : tudo quanto seja necessário para a restauração da ordem jurídica.

Tratando a decisão como um produto da mente, poderíamos ceder à tentação de identificá-la como ato puramente racional. É natural acreditar que decisões judiciais, como produtos da razão, sejam atos racionais. Afinal, é mandamento constitucional que os atos decisórios sejam fundamentados, sob pena de invalidade e ilegitimidade democrática ${ }^{12}$. No entanto, pensamos que tal associação compreenda, implicitamente, uma outra, ligada à ideia de que os aspectos cognitivo e volitivo da decisão exigem que o ato de julgar e o produto do julgamento sejam dotados não apenas de coerência interna (estrutural), mas igual e principalmente de coerência externa (conexão com os fatos, as provas e o direito), o que demandaria do julgador pleno contato com a realidade. Em outras palavras, além de racional, a decisão judicial também teria que ser um produto do intelecto consciente do julgador, perfeitamente apto a conhecer e a compreender os dados do mundo exterior que lhe permitirão o cumprimento de seu dever. Por esse prisma, a decisão judicial seria um ato puramente racional e consciente.

Essa compreensão negaria, contudo, a existência de um inconsciente humano atuante e efetivo em relação à prática dos atos racionais. Com base em escritos de Sigmund Freud e Carl Gustav Jung, pensamos que a decisão judicial, como qualquer conduta humana, seja tomada sob o influxo de ideias e percepções conscientes e inconscientes, o que impediria ao juiz purificar o ato de decidir, eliminando totalmente quaisquer fatores externos ou mesmo sua influência no resultado do julgamento. Em sintonia, acreditamos que fatores externos ao processo, alheios aos fatos, provas e fundamentos jurídicos apresentados e discutidos pelos sujeitos processuais, influenciem o ato de julgar e, consequentemente, o resultado dos julgamentos. Tais influências, obviamente, não podem figurar na fundamentação da decisão e, a priori, ainda que discutidas pelas partes, não podem justificar lógica e coerentemente a conclusão do julgador. Sem embargo, cremos que elas tenham um papel significativo como insumos subliminares, infiltrando-se no raciocínio do juiz a partir de seu inconsciente. Daí a necessidade, muito bem sentida por Nereu Giacomolli e Liza Duarte ${ }^{13}$, de examinar, com a necessária atenção, os referidos escritos de Freud e Jung.

jurídica”. KELSEN, Hans. Teoria pura do direito. Trad. João Baptista Machado. 7. ed. São Paulo: M. Fontes, 2006. p. 394.

11 Utilizamos a expressão "vontade condicionadora do Estado" como forma de sintetizar as possíveis decisões judiciais segundo seu efeito em face da realidade. Sob esse viés, a atuação do Estado é condicionadora da realidade porque se presta a influir efetivamente no mundo, imprimindo-lhe a situação fática que esteja em conformidade com o direito. Se há dúvida acerca da existência ou da validade de uma relação jurídica, caberá ao Estado expurgá-la (sentença declaratória); em se verificando a ocorrência de fatos que, segundo o ordenamento jurídico, imponham o surgimento, a modificação ou a extinção de uma relação jurídica, caberá ao Estado transformar os vínculos jurídicos individuais para adaptá-los ao que prescreve o direito (sentença constitutiva); finalmente, em se constatando a ocorrência de fatos que, segundo o ordenamento jurídico, imponham a existência de determinada situação de fato, caberá ao Estado operar essa transformação (sentenças condenatória, mandamental, executiva).

12 Cândido Rangel Dinamarco destaca que a exigência de motivação das decisões judiciais está ligada ao pressuposto político da necessidade de controle das atividades do juiz, sem a qual ficariam abertas as portas ao arbítrio. Ao fundamentar, o juiz presta contas de sua atuação às partes do processo, aos órgãos superiores da magistratura e à própria sociedade. Por fim, o autor destaca que essa fundamentação deve ser coerente e completa, conferindo ao leitor a sensação de que a conclusão ali exposta tenha sido o resultado da apreciação do julgador sobre os elementos de fato e de direito constantes dos autos, sem omitir quaisquer pontos que possam influir e, até mesmo, modificar o resultado do julgamento. DINAMARCO, Cândido Rangel. Instituiçôes de direito processual civil. 4. ed. São Paulo: Malheiros, 2004. v.1. p. 242-243.

13 GIACOMOLLI, Nereu José; DUARTE, Liza Bastos. O mito da neutralidade na motivação das decisões judiciais: aspectos epistemológicos. Revista da AJURIS, v. 33, n. 102, jun./2006. 


\subsection{O inconsciente freudiano: um marco teórico}

De acordo com Freud $^{14}$, a diferenciação do psíquico em consciente e inconsciente é a premissa básica da psicanálise. Ele destaca que o consciente não é a essência, mas uma qualidade do psíquico, que poderá estar ao lado de outras qualidades ou sequer estar presente. Desde o início de sua exposição, mais do que simplesmente afirmar a existência do inconsciente, o autor se atribui a tarefa de desconstruir uma suposta proeminência da consciência nas expressões da vida humana. Para ele, o estado de consciência seria efêmero e passageiro. Um elemento psíquico (uma ideia, um pensamento) se tornaria consciente num instante e inconsciente em outro, sempre podendo voltar à consciência. Nesse intervalo, as ideias são inconscientes, mas apresentam-se em um tal estado de latência que sua iminente passagem à consciência sugeriria um estado de pré-consciência, alcançando tais ideias facilmente o estado de consciência.

No pensamento freudiano, a consciência não resume o alcance da mente humana. O universo do psiquismo não se limitaria ao que é consciente, pois as ideias e pensamentos que deixam o âmbito da consciência não simplesmente desaparecem, mas, ao contrário, mantêm-se no dispositivo psíquico em forma inconsciente. A afirmação de que o estado de consciência sobre determinado pensamento seria passageiro e efêmero sugere que a mente humana seja um imenso repositório inconsciente, cujo conteúdo pode atingir a consciência, mas, apenas, de forma muito limitada, resumida e, assim mesmo, provisória.

Essa linha é desenvolvida pelo autor sob um viés descritivo, em contraste com a abordagem dinâmica que apresenta na sequência, basicamente uma resposta às objeções de cientistas e filósofos de que não haveria elementos inconscientes no dispositivo psíquico. Não obstante seu raciocínio já aponte a existência do inconsciente, Freud avança por outra frente. Segundo o autor, os estudos e pesquisas psicanalíticas sugerem a existência de

poderosos processos ou ideias psíquicas [...] que podem ter, na vida psíquica, todos os efeitos que têm as demais ideias, incluindo efeitos tais que, por sua vez, podem tornar-se conscientes como ideias, embora eles mesmos não se tornem conscientes ${ }^{15}$.

Em termos mais simples, podemos dizer que essas ideias e pensamentos (os "poderosos processos ou ideias psíquicas”) são capazes de produzir efeitos totalmente acessíveis à percepção e sobre os quais o indivíduo pode se tornar perfeitamente consciente - ainda que não tenha, em absoluto, a menor consciência ou percepção sobre a existência das ideias e pensamentos que lhe causariam tais efeitos.

Não deixa de ser fácil ilustrar essa afirmação. Não raramente, pessoas são acometidas de verdadeiras fobias que se lhes apresentam como inexplicáveis à primeira vista. Se o receio de cair e se lesionar pode explicar, em certa medida, o medo de altura, o que explicaria o medo de palhaços, de lugares abertos ou fechados, de multidões, entre outros? Em tais situações e na exata linha do pensamento freudiano, apontaríamos para a existência de ideias contidas no dispositivo psíquico sobre as quais o sujeito não tem consciência, mas cujos efeitos ele sente e percebe, a exemplo dos medos e fobias que o assolam aparentemente sem causa, motivo ou explicação.

Ocorre que tais ideias inconscientes permaneceriam nesse estado de inconsciência porque uma força lhes impediria a passagem à consciência. Caso contrário, explica Freud que tais ideias passariam à consciência e seria fácil perceber que, em muito pouco, difeririam das ideias conscientes. Ele sustenta a irrefutabilidade da teoria, afirmando que teriam sido encontrados, a partir da técnica psicanalítica, meios com os quais seria

14 O exame das ideias de Freud acerca da existência e do papel do inconsciente no dispositivo psíquico humano, para os fins do presente trabalho, concentrou-se no texto intitulado "O Eu e o Id", de 1923, a partir da edição para kindle, da Amazon, das obras completas do autor, de modo que as remissões, salvo anotação diversa, se referem a esse texto. Como se trata de uma tradução do idioma alemão para o português, adotamos as mesmas escolhas vocabulares do tradutor para facilitar as remissões. FREUD, Sigmund. Frend 1923-1925 o en e o id, autobiografia e outros textos: obras completas. São Paulo: Companhia das Letras, 2011. v. 16.

15 FREUD, Sigmund. Freud 1923-1925 o en e o id, autobiografia e outros textos: obras completas. São Paulo: Companhia das Letras, 2011. v. 16. p. 123-133. 
possível cancelar a força opositora e tornar conscientes as ideias em questão. Ao estado em que, por efeito daquela força contrária, as ideias se mantêm enclausuradas no inconsciente, deu o nome de repressão; à força que manteve a repressão, deu o nome de resistência. A psicanálise, portanto, teria o objetivo de anular essa força e afastar a resistência oposta ao afloramento consciente das ideias e pensamentos inconscientes que produzem efeitos sobre a vida consciente do indivíduo. Com a análise, o sujeito adquiriria consciência dessas ideias, o que lhe permitiria lidar com as causas dos efeitos até aquele momento percebidos, mas para os quais simplesmente não tinha explicação.

Freud confirma, assim, que seu conceito de inconsciente parte da Teoria da Repressão. Explica que haveria dois tipos de inconsciente: o primeiro, descrito como um estágio de latente e iminente consciência, seria chamado de pré-consciente; o segundo, denominado simplesmente de inconsciente, seria composto pelas ideias que não podem se tornar conscientes por efeito da força de resistência (i.e., as ideias reprimidas ou, simplesmente, o reprimido). Até esse ponto, conclui pela existência de três conceitos com os quais se deve trabalhar: o de consciente, o de pré-consciente (mais próximo do consciente) e o de inconsciente (dinamicamente reprimido e que não pode facilmente tornar-se consciente), destacando, ainda, que, sob o aspecto descritivo, os dois últimos seriam inconscientes; sob o aspecto dinâmico, apenas o último.

Em relação a esse ponto, o próprio Freud afirma que a diferenciação acima formulada não seria suficiente para explicar a configuração do dispositivo psíquico e resolver os problemas decorrentes de seus estudos psicanalíticos. Ele afirma a existência de diversas outras distinções, com destaque para uma em particular, cuja formulação inclui a função da percepção e apresenta os conceitos de Eu, Ide Super Eu (ou Ideal do Eu) ${ }^{16}$.

No pensamento freudiano, o Eu seria a "organização coerente dos processos psíquicos" de um indivíduo, a que se ligaria a própria consciência. Também no Eu se originaria a repressão, responsável por eliminar do consciente (ou melhor, manter no inconsciente reprimido) determinadas tendências psíquicas. Como não existe consciência sobre essa resistência, Freud conclui pela constatação de um elemento inconsciente no próprio $\mathrm{Eu}$, que se comporta como o inconsciente reprimido, produzindo efeitos sobre o indivíduo sem se tornar consciente. A um só tempo, o Eu concentraria as funções de perceber os influxos externos e internos, organizar os pensamentos conscientes e barrar o acesso do reprimido à consciência.

Dessa forma, caberia à psicanálise a tarefa de abolir as resistências opostas pelo Eu em lidar com as ideias reprimidas. Freud relata que, durante a análise, pacientes teriam experimentado dificuldades ao serem submetidos a determinadas tarefas, falhando em suas associações ${ }^{17}$ quando instados a se aproximarem do reprimido. Acrescenta que, nesses casos, ainda que não o soubessem e mesmo se o percebessem apenas a partir da sensação de desprazer por eles sentida, tais pacientes estariam sob o domínio de uma resistência originária no $\mathrm{Eu}^{18}$.

Em suma, a partir de uma compreensão estrutural, seriam três, não duas, as modalidades de inconscien-

16 Conquanto Giacomolli e Duarte tenham se estendido ao exame do Id e do Super Eu, pensamos que nenhuma contribuição trouxeram com isso para o estudo que realizaram sobre a natureza mítica da neutralidade judicial. Por tal motivo, preferimos aprofundar o exame do inconsciente freudiano no âmbito do Eu para, em seguida, harmonizá-lo com as ideias junguianas. GIACOMOLLI, Nereu José; DUARTE, Liza Bastos. O mito da neutralidade na motivação das decisões judiciais: aspectos epistemológicos. Revista da AJURIS, v. 33, n. 102, jun. 2006.

17 Não apenas Freud, mas também JUNG tratou do teste de associações. Nesse particular, disseram Giacomolli e Duarte: “Convém aqui lembrar Jung, que, através do chamado teste de associações, procurou demonstrar a existência de um inconsciente pulsante e interativo. Com o teste das associações, Jung consegue comprovar a existência de uma atividade inconsciente. As palavras-estímulo que apresentavam um tempo maior de reação em seus experimentos eram por ele consideradas como a expressão da atividade de complexos inconscientes. O complexo inconsciente é definido pelo autor como a imagem de uma determinada situação psíquica de forte carga emocional e, além disso, incompatível com as disposições ou atitudes habituais da consciência". GIACOMOLLI, Nereu José; DUARTE, Liza Bastos. O mito da neutralidade na motivação das decisões judiciais: aspectos epistemológicos. Revista da AJURIS, v. 33, n. 102, jun. 2006.

18 É particularmente interessante o relato das falhas nas associações dos pacientes, das dificuldades no cumprimento de determinadas tarefas e, principalmente, da sensação de desprazer como indício de aproximação ao reprimido no contexto da análise. A constatação empírica sugere a exatidão da tese segundo a qual as ideias reprimidas, apesar de inconscientes, produzem efeitos que interferem no mundo consciente do indivíduo, efeitos absolutamente perceptíveis em intensidade variada, com potencial para influenciar pensamentos, ideias, condutas, decisões. Esse ponto será retomado adiante. 
te: o inconsciente latente, chamado de pré-consciente; o inconsciente reprimido pelo Eu; e um terceiro, existente no Eu e responsável pela repressão que mantém o reprimido fora da consciência. Todos os três atuariam simultaneamente no dispositivo psíquico do ser humano, participando ativamente da composição de cada estímulo que se converteria naquelas atitudes humanas que chamamos de racionais - ainda que, no dia a dia, não tenhamos a menor ideia disso.

\subsection{A colaboração de Jung}

Discípulo de Freud, Carl Gustav Jung trabalhou a temática do inconsciente. Na obra intitulada "Man and his simbols"19, apesar de concentrar seu foco no papel dos sonhos para a psicanálise e no poder da mente humana para criar os símbolos que exsurgem de seu inconsciente, sua abordagem se aproxima, em diversos pontos, daquela de seu mentor. Na verdade, parece combater na mesma frente contra aqueles que se contrapõem à tese da existência do inconsciente no dispositivo psíquico humano, postura que explica nossa escolha em relação à obra e ao autor como objeto de análise para a formação do marco teórico no presente trabalho.

Jung inicia a construção de seu argumento afirmando a absoluta impossibilidade de o homem apreender e compreender completamente os estímulos que lhe chegam aos sentidos. A capacidade de percepção dos influxos provenientes do mundo exterior seria limitada, como limitados são os órgãos dos sentidos. Por mais que determinados instrumentos possam ajudar na recepção de sons e imagens, nossa aptidão para a captação dos estímulos externos, em determinado momento, chega a um limite além do qual o conhecimento e a percepção consciente não conseguem ir.

Segundo o pensamento junguiano, chegando aos sentidos, os estímulos do mundo exterior são internalizados, conduzidos ao aparelho mental e, nesse ambiente, transformam-se em eventos psíquicos internos, tornando-se por isso incompreensíveis e incognoscíveis ${ }^{20}$. Dessa forma, cada experiência do homem compreenderia uma imensa quantidade de aspectos desconhecidos, de maneira que, paradoxalmente, a capacidade humana de percepção e internalização dos influxos externos teria limites que vão além do que é considerado consciente. Em outras palavras, se, por um lado, a percepção humana seria limitada pelas deficiências e fragilidades dos órgãos dos sentidos, por outro, não se limitaria aos processos de captação exclusivamente conscientes.

Em razão disso, Jung afirma que o ser humano percebe inconscientemente uma pluralidade indefinida de estímulos externos e, internalizando-os, transforma-os, também inconscientemente, em eventos e processos psíquicos. Tais eventos psíquicos internalizados, ainda que ignorados pelo sujeito, ressurgem, posteriormente, para produzir-lhe toda sorte de efeitos. Embora o destaque do autor seja para os sonhos ${ }^{21}$, vê-se em Freud que tais efeitos podem assumir diversas formas, o que autoriza a suposição de que possam figurar emoções, pensamentos, ideias, tendências e sentimentos que formam o complexo universo psicoemocional humano.

Temos, portanto, que as percepções humanas nem sempre são conscientes. Os aparelhos sensoriais captam, permanentemente, os estímulos do exterior, que passam pelo processo de internalização, transfor-

19 Precisamente no primeiro capítulo, de sua autoria, que leva o título de "Approaching the Uncounscious".

20 Não sustentamos, com a presente afirmação, um ceticismo científico em qualquer de suas formas. Não é propriamente ao objeto do conhecimento que nos referimos como impossível de compreender, mas a natureza e a forma do próprio evento psíquico em que se transforma o estímulo interno a partir do processo de internalização. Não temos, em suma, como "fotografar" um pensamento, embora possamos ter alguma ideia sobre o que estamos pensando.

21 O autor registra, no entanto, como uma questão de história, a afirmação de ter sido exatamente o estudo dos sonhos que permitiu aos psicólogos estudar os aspectos inconscientes dos eventos psíquicos conscientes, assumindo, assim, a existência do inconsciente, o que seria negado por cientistas e filósofos sob o fundamento de que uma tal assunção implicaria a admissão da existência de duas personalidades no mesmo indivíduo. Se era sua intenção ser irônico, não sabemos, mas o autor, confirmando a suspeita, afirma que essa duplicidade da personalidade era exatamente o que se podia implicar. 
mando-se em eventos psíquicos. Ao contrário do que se pensa, nem sempre o sujeito tem consciência dessa assimilação. Se tais percepções ocorrem de forma inconsciente, isso pode decorrer de várias causas, como falta de atenção, sutileza do estímulo etc. ${ }^{22}$ Malgrado tudo isso, uma vez que tais influxos são internalizados, tornam-se aptos a produzir efeitos como qualquer outro evento psíquico, compondo o acervo inconsciente que poderá ou não ser levado ao consciente, integrando o conjunto de fatores responsáveis pelo comportamento humano.

O inconsciente é, assim, o repositório de pensamentos, ideias e sentimentos que atuam subliminarmente, influindo nas ações e omissões do sujeito sem que ele, necessariamente, o perceba. Esse repositório é formado por tudo quanto haja sido internalizado ou produzido pela mente humana, durante toda a vida do indivíduo. Trata-se de sua história de vida, seus traumas, paixões, medos, frustrações etc. Por mais que sejamos tentados a acreditar na racionalidade das decisões humanas, esse complexo de fatores que permeia o inconsciente compõe o dispositivo psíquico do ser humano, de forma que o produto racional do indivíduo acaba necessariamente tributário, em sua maior parte, do que está abaixo da linha da consciência, a que não se pode negar, ordinariamente, o adjetivo racional. Em vista disso, parece inevitável concluir que os atos ditos racionais jamais são puramente conscientes, sofrendo a intensa influência do que está no vasto e desconhecido acervo inconsciente, que participa decisivamente da construção mental de cada uma das ações e reações humanas. ${ }^{23}$

Não é difícil, no cotidiano, observar sinais do inconsciente humano. Jung chama a atenção para aquelas situações, mais do que frequentes, em que o indivíduo, em determinado momento, não se lembra do que estava para dizer, ou que, apresentando um amigo, esquece seu nome no exato instante em que o diria. É comum imaginar-se que o pensamento haja simplesmente sumido. Explica o mesmo autor que, nessas situações, esses pensamentos não desaparecem da mente do sujeito, tornando-se apenas inconscientes. Conquanto temporariamente em estado de inconsciência, estão prontos para retornar à consciência quando devidamente ativados.

Daí a visão de que pelo menos parte do inconsciente compreenda uma variedade de pensamentos, impressões e imagens temporariamente obscuros, mas que, longe de estarem perdidos, continuam no inconsciente a influenciar a mente do indivíduo. Jung ilustra essa ideia, descrevendo o comportamento do sujeito que se desloca a um cômodo da casa para pegar alguma coisa e esquece o que queria ao chegar. Perplexo, ele hesita, mexe em objetos como se estivesse sonâmbulo, totalmente alheio em relação à busca. Repentinamente, ele se lembra. Embora lhe pareça ter recuperado a memória perdida, a verdade é que jamais a perdera: estava o tempo todo em seu inconsciente, obscurecida, mas, ainda assim, pronta para ser restaurada e focalizada pelo dispositivo consciente.

Essa proposição de que os pensamentos e ideias esquecidos não desaparecem da mente, mas ali permanecem no inconsciente, converge com a ideia freudiana sobre o estado de latência consciente que refere como característico do âmbito pré-consciente, permeado de eventos psíquicos prontos a retornar à consciência tão logo demandados. Jung destaca que isso aconteceria porque o consciente dirigiria a luz de sua atenção a outras ideias, deixando no escuro inconsciente aquelas anteriormente iluminadas. Mais uma vez,

22 Como ilustração, o autor relata a história de um professor que, imerso em uma interessante conversa com um aluno enquanto caminhavam por um lugarejo na zona rural, sente-se repentinamente interrompido por um abrupto fluxo de memórias de sua longínqua infância, sem que pudesse perceber de onde proviria, dado que nenhum dos pontos da conversa se referiria a isso. Sugeriu ao aluno que fizessem a caminhada de volta e, enquanto caminhavam, percebeu o odor de gansos, tendo assim descoberto o influxo de que haviam decorrido as recordações de sua mocidade: ele havia sido criado em uma fazenda onde se criavam gansos. Explica, finalmente, que o odor não gerou, na ocasião, uma percepção suficientemente forte para desviar-lhe a atenção, mas isso não o impediu de agir subliminarmente, fazer exsurgir suas remotas lembranças.

23 "Falo aqui sobre coisas que, conscientemente, vimos ou ouvimos e, subsequentemente, esquecemos. Mas todos nós vemos, ouvimos, cheiramos e provamos muitas coisas sem percebê-las no momento, seja porque nossa atenção está desviada ou mesmo porque o estímulo aos nossos sentidos é muito sutil para deixar uma impressão consciente. O inconsciente, contudo, terá tomado nota deles, e tais percepções sensoriais subliminares representam uma parte significante de nossa vida cotidiana. Sem que o percebamos, elas influenciam no modo como reagimos aos eventos e pessoas" JUNG, Carl Gustav. Man and his symbols. Random House Publishing Group, 2012. p. 414-418. (Tradução Nossa). 
está em sintonia com o pensamento freudiano segundo o qual o que é consciente apenas permanece nesse estado por pouco tempo, isto é, pelo tempo que durar a atenção consciente, antes de o foco se concentrar no objeto seguinte.

Para concluir, retomamos, brevemente, a afirmação segundo a qual as ideias em estado consciente não seriam tão precisas quanto se acredita, que seu significado racional e emocional se revelaria tanto mais impreciso quanto mais atentamente fossem examinadas. Jung explica que, na verdade, toda percepção, todas as experiências, inclusive as que são mantidas no aparelho consciente, passariam ao estado inconsciente, adquirindo nessa ambiência uma tonalidade (igualmente inconsciente) que, dali em diante, tingirá a ideia sempre que restaurada. Assim, aparece como natural que todas as impressões conscientes sejam permeadas por elementos subliminares do inconsciente, ainda que o sujeito não esteja ciente dessa interferência ou dos efeitos que dela decorram para suas decisões, ideias e sentimentos. Apesar da ignorância, todos seriam em parte moldados pelo que se encontra em seu inconsciente, que aflora e lhes tinge cada uma das expressões da vida consciente e, por que não dizer, racional ${ }^{24}$.

\subsection{A decisão judicial como produto (in)consciente do trabalho do julgador}

Em relação ao que propomos nos tópicos anteriores, a existência do inconsciente como integrante do aparelho psíquico perde a condição de mito para assumir um papel de significativa relevância na explicação do que se refira à própria condição humana. A partir dele — ou, melhor, do que se possa encontrar nele — podemos investigar tendências, inclinações e preconceitos, como também sugerir explicações para determinadas condutas e reações em face de certas condições.

A caracterização do ato de julgar como produto da mente do juiz não poderia prescindir de uma abordagem sobre o aparelho psíquico responsável pelo processo mental em que consiste o raciocínio do julgador. Se, de acordo com o ordenamento jurídico, esse raciocínio deve se ater aos fatores ordinariamente integrantes da atividade de julgar (os fatos, as provas, o direito), o que observamos com base nos ensinamentos de Sigmund Freud e Carl Gustav Jung afasta completamente a viabilidade de um hermetismo processual que seja minimamente capaz de expurgar do processo de tomada de decisão os elementos já existentes no dispositivo psíquico do juiz ${ }^{25}$.

O juiz julga com a mente. No processo interno de julgamento, utiliza um aparelho de configuração única, formatado por influxos absolutamente singulares recebidos durante uma vida inteira, permeado por eventos psíquicos que, no dispositivo mental, adquirem uma tonalidade própria e passam a influir em cada pensamento que aflora ao consciente e em cada conduta a partir dali estimulada. Com a sentença, não poderia ser diferente. Ainda que o juiz não mencione quaisquer fatores estranhos ao processo, que faça o possível para omiti-los ou que sequer tenha noção de sua existência, seu acervo inconsciente participa da formação de seus pensamentos conscientes, de forma que, apesar de sua fundamentação lhe parecer puramente racional, a decisão frequentemente reflete suas ideias inconscientes ${ }^{26}$.

24 "Talvez seja mais fácil entender esse ponto se percebermos o fato de que as ideias com as quais lidamos em nossa aparentemente disciplinada vida consciente não são, de forma alguma, tão precisas quanto gostamos de acreditar. Ao contrário, seu sentido (e sua significação emocional para nós) se torna tanto mais impreciso quanto mais de perto as examinamos. A razão para isso está em que tudo que ouvimos e experimentamos pode se tornar subliminar — ou seja, pode passar ao inconsciente. E mesmo o que nós retemos em nossa mente consciente e podemos reproduzir à vontade adquire uma tonalidade inconsciente que dará cor à ideia sempre que ela for recuperada. Nossas impressões inconscientes, de fato, rapidamente assumem um elemento de sentido inconsciente que é fisicamente significante para nós, ainda que não estejamos conscientemente alertas sobre a existência desse sentido subliminar ou do modo como estende e confunde o sentido convencional. JUNG, Carl Gustav. Man and his symbols. Random House Publishing Group, 2012. p. 508-515. (Tradução nossa).

25 Sem prejuízo de que tais elementos possam ser ativados por fatores externos em qualquer tempo, esteja o sujeito consciente disso ou não. Como dissemos linhas acima, não raramente o indivíduo desconhece determinados eventos psíquicos de seu inconsciente, mas percebe claramente os efeitos deles decorrentes.

26 Considerando-se que a decisão é, quase sempre, antes o produto da percepção e do livre convencimento do julgador que de 
Todos esses fundamentos poderiam sugerir que juízes decidam sempre com base em seus preconceitos, ou mesmo que as decisões judiciais sejam contaminadas por fatores não estritamente processuais e que, dessa forma, reflitam antes as idiossincrasias do julgador do que a justa solução para o litígío. Em nossa opinião, juízes procuram julgar com base nos fatos e provas, interpretando e aplicando o ordenamento jurídico com justiça e equidade. Por mais que suas inclinações pessoais traduzam simpatia ou antipatia por determinado estereótipo, não se propõem, como regra, a abandonar a busca pelo ideal do justo para satisfação de suas preferências. Em outras palavras, não se trata de uma postura consciente do julgador. Não se trata de má-fé ou prevaricação.

Por outro lado, não podemos negar as dificuldades em explicar certos dados relacionados à atividade judicante. Consideremos aleatoriamente uma determinada comarca com cinco varas criminais não especializadas, que recebam feitos por distribuição. Como explicar um número sensivelmente maior de condenações proferidas por um juiz em relação aos demais, ou mesmo a significativa diferença entre o que mais condenou e o que mais absolveu? Nas sentenças condenatórias, como explicar que alguns juízes, analisando casos com idênticas circunstâncias judiciais ${ }^{27}$, fixem penas-bases tão discrepantes das fixadas por outros julgadores? Em matéria de responsabilidade civil, como explicar que alguns juízes definam indenizações significativamente inferiores ou superiores às de seus colegas com mesma competência, ainda que julgando casos semelhantes? Por que alguns juízes condenam mais, ou em maiores valores, sociedades empresárias do que os entes da administração indireta? Por que conferem indenizações maiores ou menores para certos estereótipos de pessoas (pobre/rico, branco/negro, empresário/empregado, mulher/homem, jovem/idoso)?

Em nossa opinião, considerando substratos fáticos e jurídicos similares e apreciações judiciais tão discrepantes, todos esses questionamentos convergem ao mesmo ponto: o inconsciente, com tudo aquilo que carrega, atua fortemente na formação dos critérios de decisão do julgador e em sua particular forma de enxergar o mundo, o que repercute, inevitavelmente, no processo de tomada de decisão e no resultado de seus julgamentos. Embora racional, a decisão não deixa de ser um ato apenas parcialmente consciente.

\subsection{A neutralidade judicial como mito e o inconsciente do julgador}

A imanente polarização exercida pelo inconsciente sobre o conjunto do dispositivo psíquico humano, fazendo de suas decisões eventos psíquicos nunca inteiramente conscientes, torna, para dizer o mínimo, extremamente duvidosa a possibilidade de se agir com neutralidade em qualquer situação da vida real, seja nos atos mais comuns do cotidiano, seja no desempenho das funções mais relevantes do Estado. Malgrado a multiplicidade semântica do vocábulo, a própria ideia de neutralidade contrasta, à evidência, com a atividade de julgar.

Sobre o tema da neutralidade judicial, trabalhos como os de Rodolfo Pamplona Filho e, posteriormente, de Nereu Giacomolli e Liza Duarte podem ser considerados como significativas contribuições de autores nacionais. Suas linhas de abordagem são diversas, mas ambos convergem para o ponto central do debate que nos interessa: a neutralidade, como fato da vida real, não existe.

Nesses dois trabalhos, seus autores se preocupam em distinguir neutralidade e imparcialidade. Destacam

um processo racional de argumentação, a forma eminentemente opinativa de decidir do juiz brasileiro, denunciada por José Rodrigo Rodriguez em Como decidem as Cortes?. Acentua a importância em se examinar de perto quaisquer influxos que possam conduzir o juiz a julgar em determinado sentido. RODRIGUEZ, José Rodrigo. Como decidem as cortes?: para uma crítica do direito (brasileiro). Rio de Janeiro: FGV, 2013.

27 As circunstâncias judiciais estão previstas no art. 59 do Código Penal e compõem a primeira parte do critério trifásico de fixação da pena, previsto no art. 68. Nos passos seguintes, o juiz analisa as circunstâncias atenuantes e agravantes para, ao final, analisar as causas de redução ou aumento de pena. Como nem sempre esses últimos passos são dados em razão da inexistência de elementos de fato que os imponham, preferimos nos ater às circunstâncias judiciais, que são sempre e em todo caso examinadas para fixação da pena-base. Na ausência de fatos que se enquadrem em alguma das circunstâncias ou condições dos passos seguintes, a pena-base se torna definitiva. 
que a imparcialidade é uma postura a ser adotada pelo julgador, que se caracteriza por uma virtual ou simbólica autocolocação em posição equidistante das partes. Além disso, consiste em garantia de legitimidade do processo como função estatal, instrumento do contraditório e do devido processo legal. O juiz imparcial, em resumo, seria aquele que não assume a condição de parte, não toma partido entre a pretensão e a defesa, garante aos sujeitos processuais idênticas oportunidades de influir no desenvolvimento e na conclusão do processo e, por fim, resolve o conflito com justiça, procurando dar a cada um o que lhe seja de direito.

$\mathrm{Na}$ visão de Pamplona Filho ${ }^{28}$, a verdadeira neutralidade exigiria do sujeito um radical distanciamento em face do objeto, uma completa ausência de escolha, algo que considera impossível por entrar em contradição com a própria atitude de escolher um objeto (como no caso do cientista, que precisa selecionar seu objeto de estudo) ou mesmo de se pretender neutro em face dele. Como não seria materialmente possível ao indivíduo abstrair-se completamente de adotar alguma posição, não haveria uma tal neutralidade como fato no mundo real.

Tratando da figura do "juiz neutro", o mesmo autor insiste na tese de sua inexistência, sustentando que nenhum ser humano conseguiria abstrair totalmente "seus traumas, complexos, paixões e crenças (sejam ideológicas, filosóficas ou espirituais) no desempenho de suas atividades", especialmente porque "a manifestação de sentimentos é um dos aspectos fundamentais que diferencia a própria condição de ente humano em relação ao frio 'raciocínio' das máquinas computadorizadas" 29 . O atributo da neutralidade seria, pois, inconciliável com a lenta e arrastada construção de uma história de vida, com a forja da identidade e da personalidade do indivíduo no fogo das emoções positivas e negativas que o viver carrega em si.

A visão de Giacomolli e Duarte ${ }^{30}$ é convergente com esse pensamento. Para eles, nada impede que o juiz julgue de forma imparcial, mantendo-se equidistante das partes, mas isso não significa que seja neutro. A neutralidade implicaria abstrair-se o juiz de suas vivências pessoais, "seus gostos e desgostos, suas paixões, seu eu, seu modo de ser no mundo", o que seria impossível. Sobre o tema, Almeida, Albrecht e Bagatini afirmam que a neutralidade seria uma característica inexigível de qualquer magistrado, uma vez que, ao decidir, ele "inevitavelmente exporá as convicções formadas ao longo de sua vida, mediante a sedimentação de preconceitos, a observação e o desenvolvimento de seu conhecimento" ${ }^{31}$.

Pensamos que imparcialidade e neutralidade, de fato, sejam conceitos bem diversos ${ }^{32}$. Se a imparcialidade, na linha dos autores acima, pode ser traduzida como uma postura a ser adotada pelo juiz como condição de validade do processo e legitimidade da jurisdição concretamente exercida, a neutralidade, por seu turno, não seria uma postura, mas um atributo ou característica do próprio sujeito, que o qualificaria e distinguiria, e de que não se poderia destacar ou despir. Embora essa distinção — entre imparcialidade como postura e neutralidade como atributo — não tenha sido claramente adotada pelos autores referidos, parece ser exatamente o que desponta de seus argumentos contra a existência da neutralidade: o juiz neutro seria aquele ser que conseguiu se desconectar das condições históricas que lhe moldaram a personalidade e o caráter durante toda a vida, deixando de ser a pessoa que era para se tornar uma não-pessoa. Em suma, a neutralidade não implicaria simplesmente adotar-se uma postura, mas, antes, tornar-se um ser diferente ou, melhor ainda, um não-ser, sem história, sem personalidade, sem identidade.

A tese da neutralidade como mito, contudo, não se sustenta apenas na distinção com a imparcialidade.

28 PAMPLONA FILHO, Rodolfo. O mito da neutralidade do juiz como elemento de seu papel social. Ciência Jurídica, ano. 12, v. 81, p. 32-45, maio/jun. 1998.

29 PAMPLONA FILHO, Rodolfo. O mito da neutralidade do juiz como elemento de seu papel social. Ciência Jurídica, ano. 12, v. 81, p. 32-45, maio/jun. 1998.

30 GIACOMOLLI, Nereu José; DUARTE, Liza Bastos. O mito da neutralidade na motivação das decisões judiciais: aspectos epistemológicos. Revista da AJURIS, v. 33, n. 102, jun. 2006.

31 ALMEIDA, Bruno Rotta; ALBRECHT, Diego Alan Schöfer; BAGATINI, Júlia. O juiz e as motivações no ato de julgar: para além das legais. Revista do Departamento de Ciências Jurídicas e Sociais da UNIJUÍ, Ijuí, ano. 20, n. 35, p. 75-99, jan./jun. 2011.

32 Dinamarco afirma que "imparcialidade não se confunde com neutralidade nem importa um suposto dever de ser ética ou axiologicamente neutro”. DINAMARCO, Cândido Rangel. Instituições de direito processual civil. 4. ed. São Paulo: Malheiros, 2004. v.1. p. 201. 
No caso particular da neutralidade do juiz em sua atividade de julgar, convém retomarmos a base teórica dos itens anteriores para examinarmos o papel do inconsciente na descaracterização do juiz como entidade neutra e, bem assim, da decisão judicial como produto hermético de uma atividade ao mesmo tempo cognitiva, volitiva, racional e consciente do julgador.

A decisão judicial, como produto do ato de julgar, seria trabalhada a partir de influxos formados em dois campos distintos: um de "manipulação consciente" e outro de "determinação inconsciente" 33. O campo de manipulação consciente compreenderia o juízo do julgador sobre as afirmações de fato, as provas e os fundamentos jurídicos, elementos sobre os quais racionalmente constrói a versão linguística de sua decisão, ou seja, o texto com base em que procura justificar sua conclusão, convencer os destinatários e viabilizar aos tribunais o exercício de eventual atividade de controle e revisão.

O campo de determinação inconsciente é explicado pela influência que o acervo inconsciente exerce no dispositivo psíquico, que é, por sua vez, responsável pelo processo mental por meio de que se constrói a decisão. Considerando que a decisão judicial não deixa de ser produto do raciocínio consciente do julgador, as expressões "manipulação" (consciente) e "determinação" (inconsciente) nos parecem mal colocadas. Melhor, no segundo caso, a denominação de campo de influência inconsciente, afastando-se a ideia de que o inconsciente decida e o consciente apenas formule uma expressão linguística racional para justificar a decisão. Ainda assim, a decisão judicial — não apenas a versão linguística ou textual mas o ato materialmente decisório e seu produto — seria sempre influenciada pelo inconsciente do julgador.

A inexistência do atributo da neutralidade se daria, finalmente, em razão da natureza humana do juiz ${ }^{34}$. Como ser humano, o juiz é exposto, desde o nascimento, aos diversos influxos que lhe construirão o acervo inconsciente, projetando-se em todas as expressões de sua vida consciente. Sua história de vida é marcada por experiências particularmente relevantes para a formação de seu caráter e personalidade, seus conceitos e preconceitos, afinidades e antipatias. O ser humano que se torna é o resultado dessa vivência, não lhe sendo possível desvestir-se da condição humana para investir-se em uma outra, intitulada juiz, sem referência, sem passado, sem história.

As decisões desse juiz bumano, a cuja composição psíquica não se nega a existência de um inconsciente poderoso e atuante, não se limitam àquela motivação baseada em fatos, provas e normas. Como já dito, toda sua estrutura psíquica, integrada por elementos conscientes e inconscientes, atua na percepção dos insumos externos e na formação do raciocínio que orienta a fundamentação e conduz ao resultado do julgamento ${ }^{35}$. É nessa arena que se torna possível buscar respostas para as perguntas anteriormente apresentadas, explicando por que os juízes, no desempenho natural de seu trabalho, revelam determinadas tendências de julgamento, seja condenando mais que absolvendo, seja acolhendo mais que indeferindo certas pretensões, seja, ainda, fixando maiores ou menores indenizações para determinadas tipos de danos.

Nessa linha, Giacomolli e Duarte afirmam que:

Esta influência, quase que imperceptível pelo próprio julgador, é inafastável e difícil de ser constatada por quem apreciará a decisão em grau recursal ou nas instâncias superiores. Os juízos, as frases, as

33 GIACOMOLLI, Nereu José; DUARTE, Liza Bastos. O mito da neutralidade na motivação das decisões judiciais: aspectos epistemológicos. Revista da AJURIS, v. 33, n. 102, jun. 2006.

34 “[...] no ato de julgar está um ser humano que também implode em suas questões existenciais, em seus porquês, em suas emoções, nos sentidos que busca da vida e nas próprias expectativas e intenção do que pretende comunicar na sentença". GIACOMOLLI, Nereu José; DUARTE, Liza Bastos. O mito da neutralidade na motivação das decisões judiciais: aspectos epistemológicos. Revista da AJURIS, v. 33, n. 102, jun. 2006.

35 "Não deveríamos dispensar todo conhecimento que diz de nós mesmos. Não deveríamos deixar de reconhecer que somos cegos às escuras de nosso inconsciente que trabalha paralelamente à consciência racional de nós mesmos e do mundo. Não deveríamos deixar de reconhecer que, mesmo quando dizemos estar atuando de maneira racional, é nosso inconsciente que pauta nossas escolhas, justificadas ponto a ponto sob premissas racionais, mas que no fundo maquiam opções impetuosamente inconscientes". GIACOMOLLI, Nereu José; DUARTE, Liza Bastos. O mito da neutralidade na motivação das decisões judiciais: aspectos epistemológicos. Revista da AJURIS, v. 33, n. 102, jun. 2006. 
palavras, estão assentadas nessas estruturas psíquicas, próprias de cada julgador, de cada ser humano. É a totalidade do ser do juiz que produz e determina a decisão, refletindo-se na própria decisão, nas linhas ou nas entrelinhas. A decisão também é o que é o seu prolator ${ }^{36}$.

Não é fácil encontrar na fundamentação linguística as respostas para nossas perguntas, pela mesma razão que não é tão simples detectar, nessas situações, os motivos que orientaram realmente o julgador. Caso contrário, várias seriam as decisões anulatórias proferidas por tribunais em recursos de apelação, mas não é o que acontece. Daí a advertência acima, de que os vestígios dessas influências são praticamente imperceptíveis àqueles que revisam o mérito em grau recursal e apreciam o texto da sentença em busca de mera conformidade entre os fundamentos e o objeto da decisão.

A despeito disso, as influências estão ali, cristalizadas na decisão judicial, essa última sempre um produto não completamente consciente de seu prolator, mas, ainda assim, totalmente identificado com ele. $\mathrm{Na}$ construção da sentença, aos fatores ordinariamente processuais, juntam-se outros, estranhos aos autos do processo, mas nunca ao dispositivo psíquico do juiz. Esses últimos, os fatores metaprocessuais ou extraprocessuais, podem ser definidos como tudo aquilo que, afora os fatos, as provas e o direito, influem no raciocínio do julgador, no processo de tomada de decisão e, ao final, no resultado do julgamento.

\section{FatORES METAPROCESSUAIS ESPECífICOS E A CONSTATAÇÃo EMPírICA DE SUA INFLUÊNCIA NA TOMADA DE DECISÃO}

Como dissemos acima, se existe o que ainda não possa ser excluído do processo de tomada de decisão judicial, em prol de um hermetismo processual que purifique o julgamento de quaisquer fatores alheios aos fatos, às provas e ao direito, é a natureza humana do juiz e tudo que ela carrega, incluindo seu acervo inconsciente, fator de singular relevância para a formação de sua identidade e composição das mais diversas expressões de sua vida. Se é verdade que, quando julga determinada demanda, o juiz procura compor sua fundamentação com base nos fatores ordinariamente processuais, não menos verdade é que, em "se derramando" no ato de julgar, confere ao julgado seu próprio DNA, imprimindo-lhe os reflexos e marcas de sua história de vida.

Ao tratarmos, no tópico anterior, de fatores metaprocessuais, pretendíamos destacar a existência desses insumos que, não compreendidos nos argumentos de fato e de direito das partes e sequer externados pelo juiz, tomam parte no processo de tomada de decisão e influem no julgamento concretamente realizado. Integram, portanto, o "DNA" da decisão. Apesar da multiplicidade de espécies que tais fatores possam assumir, analisamos, nos limites do presente trabalho, apenas três: as inclinações ou tendências implícitas (implict bias), a idade e os valores religiosos do julgador.

\subsection{Inclinações implícitas do julgador}

No contexto de uma pesquisa sobre fatores metaprocessuais da decisão judicial, as inclinações implícitas se revelam um fator de relevante influência no processo de tomada de decisão. Estudos relatam a condução de experimentos para detecção e identificação dessas tendências, analisando como poderiam atuar no resultado de decisões judiciais em casos particulares. A ideia de implicit bias, fundada na ciência da cognição implícita ${ }^{37}$,

36 GIACOMOLLI, Nereu José; DUARTE, Liza Bastos. O mito da neutralidade na motivação das decisões judiciais: aspectos epistemológicos. Revista da AJURIS, v. 33, n. 102, jun. 2006.

37 Irwin e Real evitam, desde o início, atribuir ao termo "bias" uma conotação pejorativa. Buscam, antes, um significado que traduza um desvio de curso, motivo pelo qual nos pareceu mais apropriado traduzi-lo como inclinação ou tendência, em vez de preconceito. Cf. IRWIN, John F.; REAL Daniel L. Unconscious influences on judicial decision-making: the ilusion of objectivity. McGeorge L. Rev. v. 42, n. 1, 2010-2011. 
sugere que o agente nem sempre tem consciência ou controle sobre os processos de percepção, impressão e valoração que motivam suas decisões. Figura a existência de diversos processos mentais implícitos que atuam para além de seu foco consciente, incluindo memórias, percepções, atitudes e estereótipos alojados do campo inconsciente do dispositivo psíquico. ${ }^{38}$

A título de definição, Irwin e Real afirmam que inclinações implícitas constituem processos mentais inconscientes, baseados em atitudes ou estereótipos implícitos, que tomam parte, quase sempre de maneira imperceptível, nas decisões do cotidiano. Salientam ainda que tais inclinações estão radicadas na mecânica fundamental dos processos de pensamento, em que se aprende, desde a infância, a associar itens que, normalmente, aparecem juntos e a logicamente esperar que coexistam em outras circunstâncias, como trovão e chuva, cabelos brancos e idade avançada etc. Os autores ainda afirmam que inclinações implícitas são atitudes e correlações inconscientes, formadas com base nas experiências de vida do indivíduo e mantidas à espreita sob a superfície do plano consciente. A conturbada relação entre o consciente e o inconsciente é novamente destacada e, embora os autores não o digam, parece clara sua conexão a tudo quanto dissemos, com base em Freud e Jung, sobre o papel do acervo inconsciente no processo racional de tomada de decisão.

Quanto à pesquisa empírica em si, os autores relatam que, em meados da década de 1990, o Professor Tony Greenwald (Universidade de Washington) desenvolveu uma ferramenta experimental — conhecida pelo nome de Implicit Association Test (LAT) ou Teste de Associação Implícita - para estudar inclinações implícitas. O teste consistia em apresentar ao examinando, em uma tela de computador, uma sucessão de palavras ou imagens que deveriam ser associadas aos conceitos de "bom" ou "mau" em curtíssimo espaço de tempo. Os indivíduos precisavam avaliar como "bom" ou "mau” palavras como "amor", "alegria", "dor", "tristeza", e, ao mesmo tempo, deviam valorar, como positivos ou negativos, rostos de pessoas (dependendo da inclinação pesquisada) brancas ou negras, jovens ou idosas, magras ou obesas etc. O teste se propunha a detectar e expor inclinações implícitas pela verificação de mudanças no tempo de reação necessário à associação de determinados conjuntos de palavras e imagens.

De acordo com os resultados, mesmo pessoas que acreditavam não possuir inclinações implícitas contrárias a determinados grupos (raciais, etários ou de gênero), descobriram-se portadoras dessas tendências, uma vez que levaram mais tempo para associar esses grupos a palavras positivas, diversamente do tempo necessário em relação a outros grupos. Em outras palavras, a valoração positiva, nesses casos, levava mais tempo para determinados grupos do que para outros, o que sugeria, pela sutil diferença de tempo e espontaneidade, uma propensão implícita que lhes seria negativa.

Em 1998, juntamente à Professora Mahzarin R. Banaji (Universidade de Harvard) e o Professor Brian Nosek (Universidade de Virginia), o Professor Greenwald disponibilizou o IAT na internet e, com a consequente ampliação de seu alcance, obteve resultados interessantes. A partir dos milhões de testes realizados, eles afirmam ter constatado, em síntese, que:

a) $75 \%$ (setenta e cinco por cento) dos indivíduos demonstraram algum tipo de inclinação implícita em favor dos estereótipos “jovem", "rico" e "branco";

b) a negação pessoal consciente de quaisquer inclinações não lhes afastava a presença (e, acrescentaríamos, a detecção);

c) os membros de grupos minoritários se mostravam menos propensos a demonstrar inclinações por seus grupos do que os membros de grupos majoritários;

d) pessoas que tenham demonstrado inclinações implícitas nos testes IAT seriam mais susceptíveis de se comportar de acordo com essas inclinações nas situações da vida real (face-to-face interactions) em que se aplicariam.

38 Conquanto os autores afirmem, na primeira nota de rodapé de seu texto, a divergência do conceito junguiano de inconsciente com os adotados por autores mais modernos, parece-nos que as ideias de Freud e Jung, retratadas no presente trabalho, estejam em perfeita sintonia com a ideia dos pesquisadores sobre o papel do inconsciente para a noção por eles apresentada sobre implicit bias. 
No tocante a esse último ponto, os autores afirmam que a análise dos dados colhidos com os testes lhes permitiu concluir que o IAT possuiria "validade preditiva", expondo uma significante correlação entre as influências implícitas sugeridas pelos resultados e o comportamento dos sujeitos na vida real. Em outras palavras, a partir da identificação das inclinações e tendências implícitas fundadas no dispositivo psíquico inconsciente do indivíduo, seria possível predizer-lhe um padrão de comportamento em determinadas situações reais. Afirmam, inclusive, que essas inclinações tenderiam a levar o indivíduo a atitudes discriminatórias em face de determinados grupos.

Naquilo que nos interessa mais de perto, colocamos a seguinte questão: de que forma e com que intensidade essas inclinações implícitas apareceriam no contexto do processo de tomada de decisão judicial?

É comum discutir-se, no meio jurídico, se juízes pensam suas decisões da mesma forma que as fundamentam textualmente na sentença. Em outras palavras, questiona-se se o raciocínio real do magistrado seguiria, rigorosamente, o itinerário descrito em seu raciocínio formalmente apresentado na peça decisória. No âmbito forense $^{39}$, muitos afirmam acreditar que os julgadores decidam a causa antes de a conhecer totalmente, tornando pública sua fundamentação apenas para justificar a conclusão já aprioristicamente formulada e cumprir o mandamento constitucional da necessidade de motivação. A academia, de sua parte, não fechou os olhos à questão.

Como reportam os textos de Guthrie, Rachlinski e Wistrich ${ }^{40}$ e de Irwin e Real ${ }^{41}$, estudos anteriores sobre como os juízes chegariam a suas decisões categorizaram duas formas de decidir: uma primeira (modelo formalista), denominada "deliberativa", sugere que a decisão seja o resultado lógico de um raciocínio silogístico, aplicando o juiz a lei aos fatos para obter, de forma racional e ponderada, o resultado; uma segunda (modelo realista), denominada "intuitiva", sugere que o juiz simplesmente decida, ou seja, que chegue ao resultado por meio de processos intuitivos e, posteriormente, se encarregue de construir o raciocínio que explicará deliberativamente a decisão.

A constatação da insuficiência dessas correntes levou Guthrie, Rachlinski e Wistrich a uma nova proposta que, captando traços específicos de ambas, melhor retrataria a realidade do processo de tomada de decisão. Seria o modelo de julgamento intuitive-override. Com fundamento em pesquisas contemporâneas na área de psicologia e em suas próprias observações empíricas, afirmam os autores que, de acordo com o modelo, juízes geralmente decidem segundo processos intuitivos, mas conseguem às vezes anular ou sobrepujar (override) voluntariamente a intuição (processo intuitivo de decisão) por meio da deliberação (processo deliberativo de decisão) ${ }^{42}$.

Nesse ponto, devemos chamar a atenção para um aspecto essencial à compreensão do tema: juízes tomam decisões em situações fundamentalmente diversas. Nos casos em que a decisão deva ser tomada imediatamente, no "calor" da audiência ou sessão em tribunal, o juiz tenderia a um processo de decisão "intuitivo" (blinking). Já nos casos em que a decisão possa ser tomada com ponderação e, por isso mesmo, construída a partir de um raciocínio mais elaborado, o juiz tenderia a um processo decisório "deliberativo" (staring). Daí a hipótese, apresentada por Irwin e Real, de que as inclinações implícitas dos juízes, dada a falta de tempo e oportunidade para uma maior reflexão, possam ser mais influentes nos primeiros (blinking decision-making process) que nos últimos (deliberative decision-making process).

39 Ou seja, fora do âmbito acadêmico e sem qualquer base empírica metodologicamente pesquisada.

40 GUTHRIE, Chris; RACHLINSKI, Jeffrey J.; WISTRICH, Andrew J. Blinking on the bench: how judges decide cases. Cornell Law Faculty Publications, paper 917, 2007.

41 IRWIN, John F.; REAL Daniel L. Unconscious influences on judicial decision-making: the ilusion of objectivity. McGeorge L. Rev. v. 42, n. 1, 2010-2011.

42 "Nosso modelo, em suma, nem enxerga os juízes como os agentes de tomada de decisão puramente dedutivos dos formalistas, nem como como os racionalizadores intuitivos dos primeiros realistas. Antes, enxerga os juízes como pessoas normais que tendem a tomar decisões intuitivas, mas que podem substituir suas reações intuitivas por complexos raciocínios deliberativos. (Tradução nossa). GUTHRIE, Chris; RACHLINSKI, Jeffrey J.; WISTRICH, Andrew J. Blinking on the bench: how judges decide cases. Cornell Law Faculty Publications, paper 917, 2007. 
Ainda sobre esse ponto, afirmam os autores que as inclinações implícitas operariam efeitos de intensidade variável de acordo com o estágio do andamento processual. Nas situações surgidas no curso de um julgamento, o juiz seria chamado a apresentar soluções mais imediatas, prevalecendo a intuição. Nos tribunais de apelação, os juízes seriam mais propensos a decisões deliberadas ao examinarem as postulações, mas atuariam de forma preponderantemente intuitiva em face de requerimentos ou argumentações dirigidas por advogados na sustentação oral, situação que demanda, ordinariamente, uma resposta imediata sob pressão.

As inclinações implícitas se revelam, dessa forma, como uma presença permanente nos juízos e tribunais, participando dos julgamentos e influindo no resultado das decisões. Convencidos disso, os autores afirmam a conveniência de que magistrados se submetam a testes para a identificação de suas eventuais inclinações para melhor conhecê-las, contendo possíveis influências discriminatórias na atividade de julgar. Sugerem, ainda, que os programas de formação de magistrados incluam essa investigação em seus currículos. À guisa de conclusão, parece-nos digno de nota que, a despeito de tudo isso - especialmente do reconhecimento da influência que as inclinações implícitas operam sobre o ato de decidir e o resultado da decisão, como também da conveniência em se adotarem meios para a contenção de interferências indevidas —, os autores reafirmam a crença de que juízes buscam, a todo momento e como regra geral, julgar da maneira mais justa, correta e ética possível ${ }^{43}$.

\subsection{A idade do julgador}

Para tratarmos da idade do julgador como elemento de influência no processo de tomada de decisão judicial, examinamos o estudo conduzido pelos professores Kenneth L. Manning, Bruce A. Caroll e Robert A. Carp, publicado sob o título "Does age matter? Judicial decision making in age discrimination cases" na revista "Social Science Quarterly" (mar./2004). No trabalho em questão, partindo da premissa de que raça e gênero moldariam a visão de juízes no julgamento de casos de discriminação em que esses aspectos estariam em jogo, seus autores procuraram investigar a possível influência que a idade dos julgadores exerceria na composição dos critérios de julgamento do juiz em casos de discriminação ou preconceito etário.

Considerando os resultados de estudos prévios — que constataram a influência de determinados fatores socioeconômicos (como a etnia e o gênero dos juízes) para a orientação de decisões em casos de discriminação especificamente relacionada a tais fatores - os autores hipotetizaram que a idade dos juízes desempenharia um papel importante no processo de tomada de decisão em demandas sobre discriminação etária. Eles esperavam constatar que juízes mais idosos, em comparação com os mais jovens, revelariam maior tendência ao acolhimento de pleitos em demandas por discriminação com base na idade quando apresentados por pessoas igualmente mais idosas ${ }^{44}$.

43 "Juízes naturalmente lutam para chegar a decisões corretas tanto no mérito quanto sob uma perspectiva ética. Inclinações implícitas podem comprometer a capacidade de juízes de chegar a decisões corretas em qualquer dessas perspectivas. O simples reconhecimento da possível influência que inclinações implícitas possam ter na tomada da decisão judicial garante aos juízes mais uma oportunidade de considerar cuidadosamente todos os aspectos da decisão a fim de que possam chegar ao resultado mais correto em ambas as perspectivas. O reconhecimento de inclinações implícitas e da maneira pela qual elas possam impactar a tomada de decisão é o primeiro passo na busca por eliminar quaisquer influências impróprias que elas possam trazer ao processo de tomada de decisão" (Tradução nossa). IRWIN, John F.; REAL Daniel L. Unconscious influences on judicial decision-making: the ilusion of objectivity. McGeorge L. Rev. v. 42, n. 1, 2010-2011. p. 7.

44 "Nossa hipótese é de que juízes mais velhos exibirão um padrão de tomada de decisão mais "pró-demandante" em casos de discriminação etária quando comparados a juízes mais jovens. Essa hipótese é construída a partir de um largo material acadêmico que identificou casos em que atributos sociais como raça ou gênero têm moldado a maneira de ver determinadas questões jurídicas relativas a tais atributos. Por exemplo, Davis, Haire e Songer (1993), Gryski, Main e Dixon (1986) e Allen e Wall (1993) mostraram que juízas são as mais fortemente acolhedoras de demandas promovidas por mulheres em casos de discriminação de gênero. Walker e Barrow (1985) identificaram efeitos de gênero similares na tomada de decisão em cortes distritais, e Songer, Davis e Haire (1994) identificaram um padrão de tomada de decisão diferente para mulheres em casos de discriminação nas relações de trabalho. Outros estudos identificaram influências similares na área racial. Welch, Combs e Gruhl (1988) e Mustard (1998) concluíram que, enquanto juízes brancos tendem a impor penas mais severas a réus afroamericanas do que a réus brancos, juízes afroamericanos tendem a ser mais lenientes em face de réus afroamericanos. Apesar de a literatura nessa área ser pouco conclusiva, estudos sugerem que gênero 
No desenvolvimento do trabalho, eles afirmam ter analisado 544 decisões monocráticas (bench trials) de 287 juízes das cortes distritais federais em casos de discriminação com base na idade, julgados entre 1984 e 1995 em 42 estados americanos, além do Distrito de Columbia e de Puerto Rico. A opção pelas cortes federais distritais teria sido motivada por seu papel como primeira arena em que tais demandas são discutidas, como também por cumprirem uma importante função na elucidação e interpretação dos fatos e na produção das provas. Paralelamente, esses autores teriam examinado 1592 decisões em casos de discriminação racial e de gênero, proferidas no mesmo período e nas mesmas cidades que as decisões mencionadas no parágrafo anterior, examinadas segundo a mesma metodologia.

No tratamento dos dados, a par da minuciosa descrição de sua metodologia de trabalho, dos instrumentos utilizados, do emprego da estatística etc., destacou-se a estratégia em classificar as decisões, segundo a idade de seu respectivo prolator, em três faixas etárias: a primeira, composta pelos magistrados com idade não inferior a 65 anos (idade em que normalmente se aposentam); a segunda, composta por aqueles com idade inferior a 65 e superior a 45 anos; por fim, a terceira faixa, composta pelos juízes com idade não superior a 45 anos (escolhida com base na média de idade no momento do ingresso nas cortes analisadas: 48 anos).

Embora o objetivo declarado dos pesquisadores fosse investigar a conexão entre a idade dos juízes e o resultado de suas decisões em casos de preconceito etário, eles sentiram a necessidade de adotar estratégias para evitar que seus achados fossem questionados como inconclusivos, o que ocorreria se não fossem aptos a refutar explicações alternativas. A constatação, por exemplo, de que juízes idosos acolheriam pleitos fundados em discriminação etária mais frequentemente do que juízes jovens não necessariamente comprovaria a relação entre a idade do julgador e a orientação dos julgados nesse especifico tipo de discriminação, a menos que os dados permitissem excluir uma suposta ligação entre a idade dos juízes e outros tipos de discriminação ${ }^{45}$. Foi exatamente por isso que os pesquisadores empreenderam a coleta e a analise de dados levando em conta também a vinculação político-partidária dos juízes e suas posições no julgamento de casos de discriminação racial e de gênero.

Os resultados obtidos lhes confirmaram a hipótese. Em primeiro lugar, constataram que juízes democratas julgariam mais frequentemente em prol dos demandantes que juízes republicanos nos três casos de discriminação examinados. Constataram, contudo, que a menor diferença percentual (entre julgados pró-requerentes proferidos por juízes democratas e republicanos) foi encontrada, exatamente, nas demandas sobre discriminação etária, significando que a vinculação política exerceria, nos casos de preconceito com base na idade, menos influência do que nas demais formas de discriminação.

Em segundo lugar, constataram que, independentemente da vinculação político-partidária, juízes enquadrados na faixa etária mais idosa (de 65 anos acima) julgariam mais frequentemente em favor dos reclamantes do que os juízes da faixa intermediária (entre 45 e 65 anos). Esses últimos, de sua parte, também julgariam com maior frequência em favor dos reclamantes do que os da faixa mais jovem (até 45 anos). As diferenças seriam muito significativas entre a primeira e a terceira faixas etárias ${ }^{46}$ e se verificariam, inclusive,

e/ou raça podem influenciar perspectivas judiciais em questões jurídicas pertinentes a tais características.” (Tradução nossa). MANNING Kenneth L.; CAROLL Bruce A; CARP, Robert A. Does age matter?: judicial decision making in age discriminations cases. Social Science Quarterly, v. 85, n. 1, mar. 2004. p. 4.

45 Se os pesquisadores analisassem apenas casos de discriminação etária, a constatação de que juízes idosos são estatisticamente mais favoráveis que juízes jovens às demandas por discriminação etária não comprovaria a pretendida vinculação entre idade do juiz e julgamentos favoráveis em discriminação etária. Basta imaginarmos um segundo pesquisador que, analisando eventual vinculação entre a idade do juiz e os resultados de julgamentos em casos de discriminação racial e de gênero, viesse a encontrar percentuais similares ao primeiro, que examinara apenas casos de discriminação etária. A vinculação, portanto, seria caracterizada entre a idade do julgador e qualquer caso de discriminação.

46 "Comparando as faixas dos juízes mais jovens e dos juízes mais velhos, nós identificamos uma razão de probabilidades de 2.66. Isso indica que juízes mais velhos são duas vezes mais propensos que seus colegas mais jovens a proferir um julgamento pródemandante em casos de discriminação etária, sugerindo que a idade seria um influente elemento na formação de decisões em casos fundados na idade." MANNING Kenneth L.; CAROLL Bruce A; CARP, Robert A. Does age matter?: judicial decision making in 
entre juízes com a mesma vinculação política ${ }^{47}$. Esses resultados confirmariam, a priori, que, quanto mais avançada a idade do juiz, maior sua tendência em julgar favoravelmente pretensões sobre discriminação etária, independentemente de sua origem democrata ou republicana.

Esse achado, contudo, ainda comportaria a explicação de que juízes mais idosos poderiam, simplesmente, se tornar mais liberais (mais flexíveis, mais sensíveis, mais "bonzinhos") e, assim, tenderiam a acolher com mais frequência a pretensão em quaisquer casos de discriminação. Com o objetivo de eliminar uma explicação alternativa como essa, os pesquisadores submeteram os dados coletados sobre preconceito racial e de gênero a idêntico tratamento metodológico, enquadrando as decisões nas mesmas faixas etárias que aquelas sobre preconceito etário. Assim, testaram igualmente a influência da idade dos juízes sobre o resultado de seus julgamentos em questões de discriminação com base na raça e no gênero.

A partir do confronto entre os resultados de suas análises, os pesquisadores concluíram que a idade dos juízes não exerceria um papel significativo na definição dos julgados em questões de preconceito racial e de gênero, diferentemente do que ocorreria nos casos de preconceito etário, quando o enquadramento em uma ou outra faixa etária revelou sensíveis diferenças estatísticas na definição dos juízes em prol dos reclamantes ou reclamados. Concluíram, assim, que o avanço da idade dos juízes não os tornava, simplesmente, mais receptivos a quaisquer pleitos sobre discriminação, mas, diversamente, que a idade do julgador tinha um papel proeminente, inclusive com aptidão preditiva, especificamente nos casos de discriminação fundada na idade.

A partir dessas conclusões, os pesquisadores sugerem uma intrigante implicação de suas descobertas: a possibilidade de que juízes venham a, com o passar tempo e à medida que avancem de uma para outra faixa etária, alterar sua postura decisória em questões de preconceito etário. Considerando que aspectos como gênero e raça são invariáveis no tempo, a influência que tais fatores exerceriam sobre o processo de tomada de decisão seria relativamente estável durante a vida do juiz. Já no caso da idade, não se poderia dizer o mesmo. Afinal, juízes envelhecem.

\subsection{Os valores religiosos do julgador}

Entre todos os fatores metaprocessuais de influência na tomada de decisão, um dos mais delicados e, de certa forma, que mais preocupam a sociedade em geral e a comunidade jurídica em particular é aquele ligado aos valores religiosos do julgador, à religião por ele professada, seu sentimento de pertença a determinado grupo ou comunidade religiosa. De maneira semelhante a outros fatores como os vínculos político-partidários e as bases culturais, morais e filosóficas, os valores religiosos podem influir decisivamente nos critérios de julgamento em questões de interesse geral da população. Sua importância, assim, é inquestionável.

Para evitar os percalços naturalmente envolvidos com a ausência de consenso sobre determinadas ideias, devemos fixar alguns conceitos para melhor compreensão. Esse cuidado em estabelecer um sentido mínimo para termos como religião e religiosidade foi adotado por Idleman, que, desde o início de seu trabalho, mostrou-se preocupado com as repercussões que seu alcance poderia trazer. Ele afirma que, quanto mais amplo for o conceito de religião e mais liberal o de religiosidade, maior será o campo de exclusão para aqueles que veem como espúria a influência de valores religiosos nas decisões de agentes do Estado ${ }^{48}$. Podemos dizer que, em contrapartida, quanto menor o âmbito conceitual, maiores poderão ser as restrições nessa área ao exercício de direitos por iniciativa estatal, sob o argumento da inexistência de conflito com a garantia da liberdade religiosa.

age discriminations cases. Social Science Quarterly, v. 85, n. 1, mar. 2004. p. 10. (Tradução nossa).

47 "Os dados revelam que, em cada faixa etária, os Republicanos evidenciam menor probabilidade de proferir uma decisão 'liberal" do que os Democratas dentro da mesma faixa. Contudo, mesmo no âmbito de cada partido, a probabilidade de uma decisão 'liberal' aumenta na faixa etária dos mais idosos". MANNING Kenneth L.; CAROLL Bruce A; CARP, Robert A. Does age matter?: judicial decision making in age discriminations cases. Social Science Quarterly, v. 85, n. 1, mar. 2004. p. 14.

48 IDLEMAN, Scott C. The role of religious values in judicial decision making. Indiana Law Journal, v. 68, n. 2, article 3, 1993. p. 435. 
Parece-nos intuitivo incluir na categoria de religiosos todos aqueles valores professados por instituições que se autodenominam e que são popularmente reconhecidas como religiosas, fundadas ou inspiradas em uma crença teísta. A Igreja Católica, por exemplo, pregaria valores religiosos na medida em que seus dogmas seriam fundados na crença e na doutrina de um ser superior (Deus). Da mesma forma, também nos parece intuitivo classificar como religiosos aqueles valores que digam respeito às grandes questões do homem e da humanidade, a exemplo da origem e do sentido da vida, do amor ao próximo, da proteção do mais fraco, da perpetuação da espécie, da vida após a morte, do destino do mundo, da moral, entre outros.

A primeira opção conduz a um raciocínio que fundamenta a natureza religiosa dos valores, princípios e dogmas exclusivamente em sua origem, sem qualquer pertinência com o mérito ou conteúdo. Grandes e pequenas questões se equivaleriam, desde que confirmada a fonte por uma instituição organizada que se considere e seja reconhecida como religiosa, e cuja doutrina seja fundada na existência de um ser superior e absoluto. A segunda opção, reconhecendo um significado religioso às grandes questões, a despeito de como e de onde tenham surgido, traz em si o problema de como distinguir o elemento religioso do que seja essencialmente moral ou filosófico. Questões puramente filosóficas, mas de grande importância para a humanidade, se classificariam como religiosas segundo esse ponto de vista.

No afã de discutir tais problemas, Idleman traça um paralelo entre atividades religiosas e não religiosas a partir de aspectos que, a priori, serviriam para distingui-las. Evidencia, contudo, que as atividades compartilhariam os aspectos analisados independentemente de sua categorização ou não como religiosas. Em termos mais simples, afirma que a busca por definir o que seria religioso a partir de um rol de características - como a crença teísta, o uso de um ritual, o uso de textos sagrados, o conceito de prece ou meditação e a expectativa da revelação — resultaria infrutífera por dois motivos: em primeiro lugar, porque cada uma dessas características seria compartilhada por atividades religiosas e não religiosas, de forma que sua presença em determinada instituição não a tornaria, apenas por isso, religiosa; em segundo lugar, porque determinadas instituições reconhecidamente religiosas nem sempre reuniriam todas as características, de forma que sua ausência, por si só, não lhe excluiria a natureza religiosa ${ }^{49}$. Em qualquer caso, esse check list somente levaria a resultados equivocados.

Em uma abordagem mais inclusiva (procurando evitar o que chama de cristianismo-centrismo ou ocidente-centrismo), o mesmo autor refere-se à posição que categoriza como religioso aquilo que o sujeito clama como tal, a depender do quão intenso e valioso seja para si o significado da atividade, princípio, valor ou dogma em questão. Religiosas, portanto, seriam as preocupações máximas (ultimate concerns) do indivíduo, aquilo que, de tão importante e significativo, relegaria a um plano secundário todo o restante ${ }^{50}$.

O problema com tal raciocínio é que sua enorme abrangência conduziria à aceitação, como religiosos, de valores e atividades culturalmente havidos como não religiosos. Além disso, preocupações de absoluta relevância para determinadas religiões poderiam ser consideradas trivialidades pelas demais. Em uma nação multicultural e tolerante como o Brasil, seria inadmissível classificar como não relevantes determinados valores apenas pelo fato de não suscitarem, sob o ponto de vista das correntes religiosas principais, grandes preocupações da bumanidade. A necessária abertura motivada pela tolerância nos reconduziria à advertência de Idleman, pois ampliaria, significativamente, o universo de valores a serem excluídos do processo de tomada de decisão nos atos do poder público.

A preferência do autor ora examinado é pela adoção do conceito mais restrito de religião, fundado na natureza teísta da doutrina segundo a qual o valor seja afirmado, na autodeclaração e no reconhecimento social como religiosa da instituição que o professa. Com exceção de Idelman, os autores que trataram da temática dos valores religiosos e cujos textos foram analisados no presente trabalho não se dispuseram a tratar do conceito de religião. Ainda assim, parece-nos que a abordagem por eles conduzida não se diferencia da noção aqui apresentada, mas com ela se harmoniza nos limites da proposta que cada um assumiu, o que nos

49 IDLEMAN, Scott C. The role of religious values in judicial decision making. Indiana Law Journal, v. 68, n. 2, article 3, 1993 . p. 437.

50 IDLEMAN, Scott C. The role of religious values in judicial decision making. Indiana Law Journal, v. 68, n. 2, article 3, 1993. p. 438. 
conduz, quase necessariamente, a adotá-la como conceito de trabalho para os fins do estudo ora proposto ${ }^{51}$.

No que diz respeito às pesquisas empíricas sobre a influência dos valores religiosos do juiz no processo de tomada de decisão judicial, examinamos três significativos trabalhos sobre o tema, os quais relatam e criticam outras pesquisas empíricas, com a vantagem de que, referindo-se às vezes a um mesmo trabalho, esses autores nos permitiram comparar suas avaliações acerca dos dados e resultados, concedendo-nos a oportunidade de uma compreensão mais clara de suas ideias.

Em seu trabalho, Feldman trata da existência de dois tipos de estudos que investigaram as influências que a religião exerceria sobre a tomada de decisão ${ }^{52}$. O primeiro, mais geral, parte da psicologia social e assenta que o sentimento de pertencimento a determinado grupo social seria capaz de afetar o indivíduo em seus valores e percepções. Desse modo, o sujeito passaria a compartilhar os objetivos e visões de mundo do grupo a que se sente pertencer, ao mesmo tempo em que começaria a enxergar como inconciliáveis e, às vezes, antagônicos aqueles compartilhados por integrantes de grupos diversos.

A conclusão do autor aponta para o reconhecimento de uma tendência de decisão, no caso dos juízes e do processo de tomada de decisão, mais atrelada às visões de mundo, preferências, percepções e valores acolhidos em seu próprio meio social, o que pode implicar o repúdio aos interesses dos integrantes de grupos sociais diversos cujos valores não se identifiquem com os seus. A abordagem é visivelmente mais generalista, pois esse fundamento poderia explicar não apenas que juízes cristãos, por exemplo, sejam menos afeitos às pretensões de litigantes muçulmanos, mas também que juízes idosos sejam mais favoráveis aos pleitos de pessoas idosas, que juízes negros, de sua parte, sejam mais afeitos aos pleitos de minorias raciais etc.

Tratando dos tipos mais específicos de estudos sobre a influência da religião nas decisões judiciais, Feldman classifica-os, conquanto em pequeno número, conforme cuidem ou não de demandas relativas ao exercício da liberdade religiosa. Em ambos os tipos, afirma que os achados empíricos permitiram aos pesquisadores confirmar a hipótese de que a religião dos julgadores exerceria forte influência no resultado das decisões. Dos trabalhos examinados por Feldman, destacam-se os de Daniel R. Pinello ${ }^{53}$, analisando decisões relativas ao que denominou de "gay rights"; de Donald R. Songer e Susan J. Tabrizi ${ }^{54}$, que analisaram decisões singulares de juízes estaduais sobre pena de morte, discriminação de gênero e obscenidade ${ }^{55}$; e o trabalho de Gregory C. Sisk, Michael Heise e Andrew P. Morriss ${ }^{56}$, sobre a resolução de questões de liberdade religiosa em cortes inferiores federais.

51 O Supremo Tribunal Federal brasileiro, examinando pleito em que se demandava a aplicação da imunidade tributária dos templos de qualquer culto a uma loja maçônica do Rio Grande do Sul (Recurso Extraordinário n. 562.351/RS), optou por um conceito restritivo de religião e religiosidade, excluindo dessa forma o enquadramento das atividades ritualísticas da maçonaria do conceito de culto desenvolvido em um templo. O próprio relator, Ministro Ricardo Lewandowski, assentou que, em matéria de imunidade tributária, a exegese teria que ser necessariamente restritiva. Em interpretação sistemática da Constituição Federal, a maioria dos ministros entendeu pela aplicação da imunidade aos templos em que se desempenhassem cultos necessariamente religiosos, o que pressupunha o preenchimento de requisitos alheios aos rituais desenvolvidos pelos associados do demandante. Em divergência, o ministro Marco Aurélio entendeu que a maçonaria, considerados seus objetivos e a realização de seus rituais, se enquadraria no conceito de religião em um sentido amplo, pelo que se lhe aplicaria a imunidade. A definição do significado de religião e religiosidade, como se observa, também no Brasil está longe de ser pacífica.

52 FELDMAN, Stephen M. Empiricism, religion, and judicial decision-making. William \& Mary Bill of Rights Journal, v. 15, n. 1, 2006. Disponível em: <http://scholarship.law.wm.edu/cgi/viewcontent.cgi?article=1132\&context=wmborj>. Acesso em: 12 jun. 2018.

53 Gay Rights and American Law, de 2003.

54 Referenciado no texto como: SONGER, Donald R.; TABRIZI, Susan J. The religious right in court: the decision making of christian evangelicals in State supreme courts, v. 61 n. 507, 1999.

55 Esses dois trabalhos foram também analisados por Bornstein e Miller e, por isso, cuidaremos deles adiante. BORNSTEIN, Brian H.; MILLER, Monica K. Does a judge's religion influence decision making? Court Review: the Journal of the American Judges Association, paper 300, 2009.

56 Referenciado no texto como: Gregory C. Sisk et al., Searching for the Soul of Judicial Decision making: An Empirical Study of Religious Freedom Decisions, 65 OHIO ST. L.J. 491 (2004). No decorrer da pesquisa que levou à elaboração do presente trabalho, tivemos acesso ao texto dos autores, de modo que pudemos examiná-lo como fonte direta. Cf. SISK, Gregory C.; HEISE, Michael; MORRISS, Andrew P., Searching for the soul of fudicial decisionmaking: an empirical study of religious freedom decisions. Cornell Law Faculty Publications, paper 729, 2004. 
Nesse último trabalho, Sisk, Heise e Morriss, referindo-se, especificamente, às demandas pelo exercício da liberdade religiosa, apontam a religião — seja em termos de afiliação do reclamante, de formação do juiz ou de composição demográfica da comunidade — como o mais proeminente, destacado e consistente fator de influência sobre o processo de tomada de decisão encontrado em sua investigação ${ }^{57}$. O estudo sugere, entre outras proposições, que juízes judeus e cristãos ditos minoritários (ou seja, não vinculados às correntes principais do cristianismo) são significativamente mais susceptíveis ao acolhimento de pleitos relativos ao exercício da liberdade religiosa, ao passo que reclamantes provenientes de comunidades religiosas católicas e batistas seriam os menos suscetíveis de vitória ${ }^{58}$.

Alguns achados interessantes foram registrados por Sisk, Heise e Morriss, descritos também por Feld$\operatorname{man}^{59}$. De acordo com os primeiros, os integrantes de correntes religiosas principais demandariam significativamente menos pela garantia do exercício da liberdade religiosa do que aqueles pertencentes a grupos minoritários, o que se daria porque aqueles grupos majoritários dominariam as instâncias produtoras de normas, de modo que raramente enfrentariam limitações dessa natureza ao exercício de sua religião. Por outro lado, em termos estatísticos, os adeptos de grupos religiosos minoritários sairiam mais vencedores em suas demandas, o que estaria em harmonia com dois estudos anteriores, de Frank Way e Barbara J. Burt, como também de Joseph A. Ignagni, igualmente examinados por Feldman ${ }^{60}$.

Nesses casos particulares, os demandantes pleiteavam providências contra o Estado para a garantia da liberdade religiosa em suas possíveis formas de expressão. Considerando esse aspecto, os resultados acima relatados nos parecem lógicos, na medida em que a natureza e o alcance da liberdade religiosa sejam explícita ou implicitamente definidos pelo direito objetivo, produto natural dos valores inerentes à sociedade, sobretudo daquela parcela que, compondo o grupo majoritário, imprime ao direito positivo seus próprios valores. A influência dos valores religiosos, nesse caso, se faria sentir já no processo de produção de normas gerais e abstratas, o que não implicaria sua ausência dos tribunais. Ao contrário, essa influência repercutiria vivamente em decisões de juízes adeptos de correntes religiosas minoritárias, os quais se revelariam mais receptivos a demandas pela garantia da liberdade.

Mais interessante, em nosso sentir, é a temática da influência dos valores religiosos em demandas sobre temas eminentemente seculares, ou seja, compreendendo questões nitidamente não religiosas. Bornstein e Miller ${ }^{61}$ afirmam a existência de estudos empíricos que teriam comparado posturas de juízes católicos e protestantes em casos não unânimes sobre determinada variedade de casos-tipos pré-definidos. Alguns desses estudos foram igualmente examinados por Feldman.

Analisando quinze espécies de demandas, Stuart S. Nagel ${ }^{62}$ teria detectado um padrão de decisão nitida-

57 "Em nosso estudo sobre decisões em matéria de liberdade religiosa, o mais proeminente, saliente e consistente fator de influência no processo de tomada de decisão judicial foi a religião — religião em termos de afiliação do demandante, a formação do juiz e o perfil demográfico da comunidade" SISK, Gregory C.; HEISE, Michael; MORRISS, Andrew P., Searching for the soul of fudicial decisionmaking: an empirical study of religious freedom decisions. Cornell Law Faculty Publications, paper 729, 2004. p. 614. (Tradução nossa).

58 “Talvez os mais notáveis achados, os quais são discutidos adiante, foram que juízes de formação judaica e cristã da corrente minoritária se revelaram mais propensos ao acolhimento de demandas por acomodação, enquanto que demandantes de comunidades religiosas católicas e batistas foram significativamente menos propensos ao sucesso em suas pretensões” SISK, Gregory C.; HEISE, Michael; MORRISS, Andrew P., Searching for the soul of fudicial decisionmaking: an empirical study of religious freedom decisions. Cornell Law Faculty Publications, paper 729, 2004. p. 557. (Tradução nossa).

59 FELDMAN, Stephen M. Empiricism, religion, and judicial decision-making. William \& Mary Bill of Rights Journal, v. 15, n. 1, 2006. Disponível em: <http://scholarship.law.wm.edu/cgi/viewcontent.cgi?article=1132\&context=wmborj $>$. Acesso em : 12 jun. 2018.

60 Referenciados no texto de Feldman como: Frank Way \& Barbara J. Burt, Religious Marginality and the Free Exercise Clause, 77 AM. POL. SCI. REV. 652 (1983) e Joseph A. Ignagni, U.S. Supreme Court Decision-Making and the Free Exercise Clause, 55 REv. POL 511 (1993).

61 BORNSTEIN, Brian H.; MILLER, Monica K. Does a judge's religion influence decision making? Court Review: the Journal of the American Judges Association, paper 300, 2009.

62 Referenciado no texto como: Stuart S. Nagel, "The Relationship Between the Political and Ethnic Affiliation of Judges, and Their Decision-making," in: Judicial behavior: a reader in theory and research (G. Schubert ed., 1964). O objetivo da pesquisa estava em 
mente liberal nos julgamentos proferidos por juízes católicos em quatro espécies de demandas (demandas criminais, regulações negociais, divórcio e danos ao empregado), em contraste com o que afirmou ser a ausência de qualquer tendência decisória por parte dos julgadores protestantes em todas as espécies investigadas. $\mathrm{O}$ autor ainda registrou a ressalva de que a pequena quantidade de juízes judeus não lhe permitira a inclusão dos resultados para efeitos estatísticos.

Em sua pesquisa, Sheldon Goldman ${ }^{63}$ teria constatado que, em geral, julgadores católicos apresentaram uma tendência claramente favorável à causa de pessoas lesadas e dos economicamente vulneráveis. Malgrado a pequena quantidade de juízes judeus, sua média revelara uma tendência ainda mais liberal que a dos magistrados católicos e protestantes em todos os tipos de demandas. Os julgadores protestantes, de sua parte, em momento algum se revelaram mais liberais em qualquer tipo de causa, sugerindo o pesquisador que a religião não influiria em sua orientação decisória.

Os dois trabalhos a seguir foram examinados por Feldman e por Bornstein e Miller. No primeiro, que tivera por base julgados proferidos por tribunais de apelação entre os anos de 1981 e 2000 sobre questões compreendidas no conceito de "gay rights" ${ }^{\circ 4}$, Daniel R. Pinello afirma que, em geral, constatou-se uma tendência relativamente liberal de juízes judeus em comparação com juízes protestantes, como também uma tendência mais conservadora de juízes católicos nessas questões ${ }^{65}$.

No segundo, Donald R. Songer e Susan J. Tabrizi examinaram votos de juízes em cortes supremas estaduais entre 1970 e 1993, especificamente em três questões: pena de morte, discriminação de gênero e obscenidade. Mesmo após o controle de outras variáveis, os autores afirmaram que a religião dos julgadores estaria fortemente associada a suas decisões. De acordo com os resultados, juízes evangélicos se mostraram significativamente mais conservadores ${ }^{66}$ que os adeptos das demais religiões nas três espécies de causas. $\mathrm{Na}$ outra ponta, os juízes judeus se apresentaram como os mais liberais. Juízes das correntes protestantes principais se revelaram liberais em casos de pena de morte e obscenidade, mas conservadores (embora não tanto quanto os evangélicos) nos de discriminação de gênero. Juízes católicos se apresentaram como liberais em questões de discriminação de gênero, moderados nos casos de pena de morte e quase tão conservadores quanto os juízes evangélicos nos casos de obscenidade.

Nesse ponto, é impossível não perceber a mudança de comportamento decisório de juízes católicos conforme o tema objeto de decisão. Tanto Stuart Nagel quanto Sheldon Goldman compararam as decisões de juízes católicos, protestantes e judeus em uma pluralidade de casos, concluindo que católicos e judeus seriam mais liberais e, portanto, mais pró-autores que juízes protestantes, sempre mais conservadores. A partir do trabalho de Daniel Pinello, percebemos que não existe uma correspondência rígida que vincule católicos e judeus ao conceito de liberal e protestantes ao de conservador. A investigação de Pinello, envolvendo questões de liberdade sexual, revelou que juízes católicos podem ser mais conservadores que juízes protestantes, tudo a depender do objeto da discussão e decisão. Essa conclusão, por fim, é corroborada pelos estudos de Do-

investigar a relação entre decisões judiciais e a religião dos juízes. Para isso, foram analisados julgados de 313 juízes de cortes supremas estaduais e federais no ano de 1955.

63 Referenciado no texto como: Sheldon Goldman, Voting Behavior on the United States Courts of Appeals Revisited, 69 AMER. POL. SCI. REV. 491 (1975). Afirma que foram comparadas decisões proferidas por juízes de apelação católicos e protestantes, usando o pesquisador como base de dados decisões das Cortes de Apelação de 1965 a 1971.

64 "Os casos compreendiam questões de famílias lésbicas/gays (inclusive casamento de pessoas de mesmo sexo), discriminação por orientação sexual, gays nas forças armadas, sodomia consensual e legislação de solicitação e liberdade de expressão e associação" (Tradução nossa). BORNSTEIN, Brian H.; MILLER, Monica K. Does a judge's religion influence decision making? Court Review: the Journal of the American Judges Association, paper 300, 2009. p. 113.

65 Podemos citar, como exemplos de julgados brasileiros em tribunais superiores sobre a mesma temática: ADPF 132/RJ, ADI 4277/DF, RESP 1183378 (união homoafetiva), RESP 1333086, RESP 1281093 , RESP 889852 (adoção em família homoafetiva), RESP 1302467 (alimentos), RE-AgR 607562, RESP 932653 (pensão por morte).

66 Ou seja, "eles mais frequentemente votaram pela aplicação da pena de morte, manutenção da distinção de gênero e restrição à liberdade de expressão em casos de obscenidade” BORNSTEIN, Brian H.; MILLER, Monica K. Does a judge’s religion influence decision making? Court Review: the Journal of the American Judges Association, paper 300, 2009. p. 114. (Tradução nossa). 
nald Songer e Susan Tabrizi, figurando juízes católicos, conforme o caso a decidir, como liberais, moderados ou até conservadores.

Considerando o quanto ainda dependemos de novos estudos empíricos sobre o tema, é no mínimo honesto dizer que quaisquer conclusões formadas no presente trabalho só podem ser provisórias. A despeito disso, e tomando por base todos os trabalhos aqui examinados, ousamos concluir afirmativamente pela existência de fortes indícios de que os valores religiosos do julgador - na medida em que componham o conjunto de valores e princípios integradores de sua identidade, formadores de seu caráter e definidores de seu modo de ver o mundo - exerçam significativa influência em seu processo de tomada de decisão, interferindo e, até mesmo, condicionando o resultado de seus julgamentos.

\section{SíNTESE CONCLUSIVA}

Como processo mental, a atividade de tomar decisões desenvolve-se no dispositivo psíquico humano e, por conta disso, expõe-se ao magnífico conjunto de influências historicamente cristalizadas na identidade e no caráter do indivíduo. Nesse ambiente, apenas parte do raciocínio que conduz ao resultado transita e trabalha com elementos que estão sobre a linha consciente: a maior parte do trajeto e dos influxos com os quais tem de lidar permanece oculta no misterioso universo do inconsciente humano. Toda decisão, portanto, é apenas em parte racional e consciente.

Isso nos permite explicar por que a neutralidade judicial - algo como uma blindagem ética e valorativa, uma despersonalização, uma fuga da história de vida e dos influxos emocionais que ela carrega — não existe como fato no mundo. Todo ser humano tem uma identidade, construída ao longo da vida, a partir de tudo quanto se insira em sua história: seus sucessos e fracassos, medos e realizações, em toda sua intensidade. Ao decidir, o juiz se transfigura para a decisão, que passa a existir com seu "DNA", com ele se identificando ao ponto de compartilharem os mesmo defeitos, qualidades, inclinações e preconceitos. Se é certo que cabe ao juiz buscar o valor do justo no ato de decidir e colocá-lo acima de suas manias e preferências, não menos certo que jamais conseguirá se neutralizar como ser humano.

A influência dessa gama de fatores que compõem a identidade e o caráter do juiz, formando-lhe a personalidade e atuando na construção de seus critérios de decisão e dos filtros por meio dos quais enxerga o mundo, tem despertado a atenção de pesquisadores interessados em saber até que ponto o processo de tomada de decisão pode sofrer seus efeitos. Conquanto iniciativas desse tipo ainda sejam uma grave lacuna na cultura brasileira, há, sobre o tema, estudos publicados fora do Brasil de indiscutível relevância.

No presente trabalho, procuramos examinar estudos empíricos que investigaram a possível influência de inclinações implícitas, da idade e dos valores religiosos de juízes para os resultados de suas decisões. Como vimos, os resultados apontaram, fortemente, para a constatação de que tais influxos desempenham um importante papel no processo de tomada de decisão, chegando a fornecer, em alguns casos típicos, validade preditiva. A despeito dos quanto tais estudos nos tenham permitido avançar, nossa única certeza é que a necessidade de pesquisas empíricas nessa área permanece tão atual quanto a insignificância de nosso conhecimento sobre a vastidão do universo psicológico, emocional e intelectivo do ser humano.

\section{REFERÊNCIAS}

ALMEIDA, Bruno Rotta; ALBRECHT, Diego Alan Schöfer; BAGATINI, Júlia. O juiz e as motivações no ato de julgar: para além das legais. Revista do Departamento de Ciências Jurídicas e Sociais da UNIJUÍ, Ijuí, ano. 20, n. 35, p. 75-99, jan./jun. 2011. 
BORNSTEIN, Brian H.; MILLER, Monica K. Does a judge's religion influence decision making? Court Review: The Journal of the American Judges Association, paper 300, 2009.

BRASIL. Supremo Tribunal Federal. Agravo regimental. Agravo regimental no recurso extraordinário com agravo 866.422/RJ. Segunda turma. Relator: min. Celso de Mello, Agte.(s): Loja Rosacruz Rio de Raneiro AMORC, Adv.(a/s): Artur Miranda de Sá e Silva e outro (a/s), Agdo.(a/s): município do Rio de Janeiro, Proc.(a/s)(es): procurador -geral do município do Rio de Janeiro. Brasília, 24 de março de 2015. Disponível em: <http://redir.stf.jus.br/paginadorpub/paginador.jsp?docTP $=$ TP\&docID=8255429>. Acesso em: 12 jun. 2018.

DINAMARCO, Cândido Rangel. A instrumentalidade do processo. 5. ed. São Paulo: Malheiros, 1996.

DINAMARCO, Cândido Rangel. Fundamentos do processo civil moderno. 5. ed. São Paulo: 2002. v.1.

DINAMARCO, Cândido Rangel. Instituições de direito processual civil. 4. ed. São Paulo: Malheiros, 2004. v.1.

FELDMAN, Stephen M. Empiricism, religion, and judicial decision-making. William \& Mary Bill of Rights Journal, v. 15, n. 1, 2006. Disponível em: <http://scholarship.law.wm.edu/cgi/viewcontent.cgi?article=1132 \&context=wmborj>. Acesso em: 12 jun. 2018.

FERNANDES, Ricardo Vieira de Carvalho. As influências extrajurídicas sobre as decisões do Supremo Tribunal Federal. Revista jurídica da Procuradoria-Geral do Distrito Federal, Brasília, v. 38, p. 95-112, 2012.

FREUD, Sigmund. Freud 1923-1925 o en e o id, autobiografia e outros textos: obras completas. São Paulo: Companhia das Letras, 2011. v. 16.

GIACOMOLLI, Nereu José; DUARTE, Liza Bastos. O mito da neutralidade na motivação das decisões judiciais: aspectos epistemológicos. Revista da AJURIS, v. 33, n. 102, jun. 2006.

GOUVEIA, Lúcio Grassi de. A função legitimadora do princípio da cooperação intersubjetiva no processo civil brasileiro. Revista de Processo, São Paulo, v. 172, p. 32-53, jun. 2009.

GRIFFEN, Wendell L. The case for religious values in judicial decision-making, Marq. L. Rev, v. 81, n. 513, 1998.

GUTHRIE, Chris; RACHLINSKI, Jeffrey J.; WISTRICH, Andrew J. Blinking on the bench: how judges decide cases. Cornell Law Faculty Publications, paper 917, 2007.

IDLEMAN, Scott C. The role of religious values in judicial decision making. Indiana Law Journal, v. 68, n. 2, article 3, 1993.

IRWIN, John F.; REAL Daniel L. Unconscious influences on judicial decision-making: the ilusion of objectivity. McGeorge L. Rev. v. 42, n. 1, 2010-2011.

JUNG, Carl Gustav. Man and his symbols. Random House Publishing Group, 2012.

KELSEN, Hans. Teoria pura do direito. Trad. João Baptista Machado. 7. ed. São Paulo: M. Fontes, 2006.

LOPES JÚNIOR, Aury. Introdução crítica ao processo penal: fundamentos da instrumentalidade constitucional. 4. ed. Rio de Janeiro: Lumen Juris, 2006.

MANNING Kenneth L.; CAROLL Bruce A; CARP, Robert A. Does age matter?: judicial decision making in age discriminations cases. Social Science Quarterly, v. 85, n. 1, mar. 2004.

PAMPLONA FILHO, Rodolfo. O mito da neutralidade do juiz como elemento de seu papel social. Ciência Jurídica, ano. 12, v. 81, p. 32-45, maio/jun. 1998.

RODRIGUEZ, José Rodrigo. Como decidem as cortes?: para uma crítica do direito (brasileiro). Rio de Janeiro: FGV, 2013. 
SISK, Gregory C.; HEISE, Michael; MORRISS, Andrew P., Searching for the soul of fudicial decisionmaking: an empirical study of religious freedom decisions. Cornell Law Faculty Publications, paper 729, 2004.

SONGER, Donald R.; TABRIZI, Susan J. The religious right in court: the decision making of christian evangelicals in State supreme courts, v. 61 n. 507, 1999. 


\section{REVISTA BRASILEIRA DE POLÍTICAS PÚBLICAS BRAZILIAN JOURNAL OF PUBLIC POLICY}
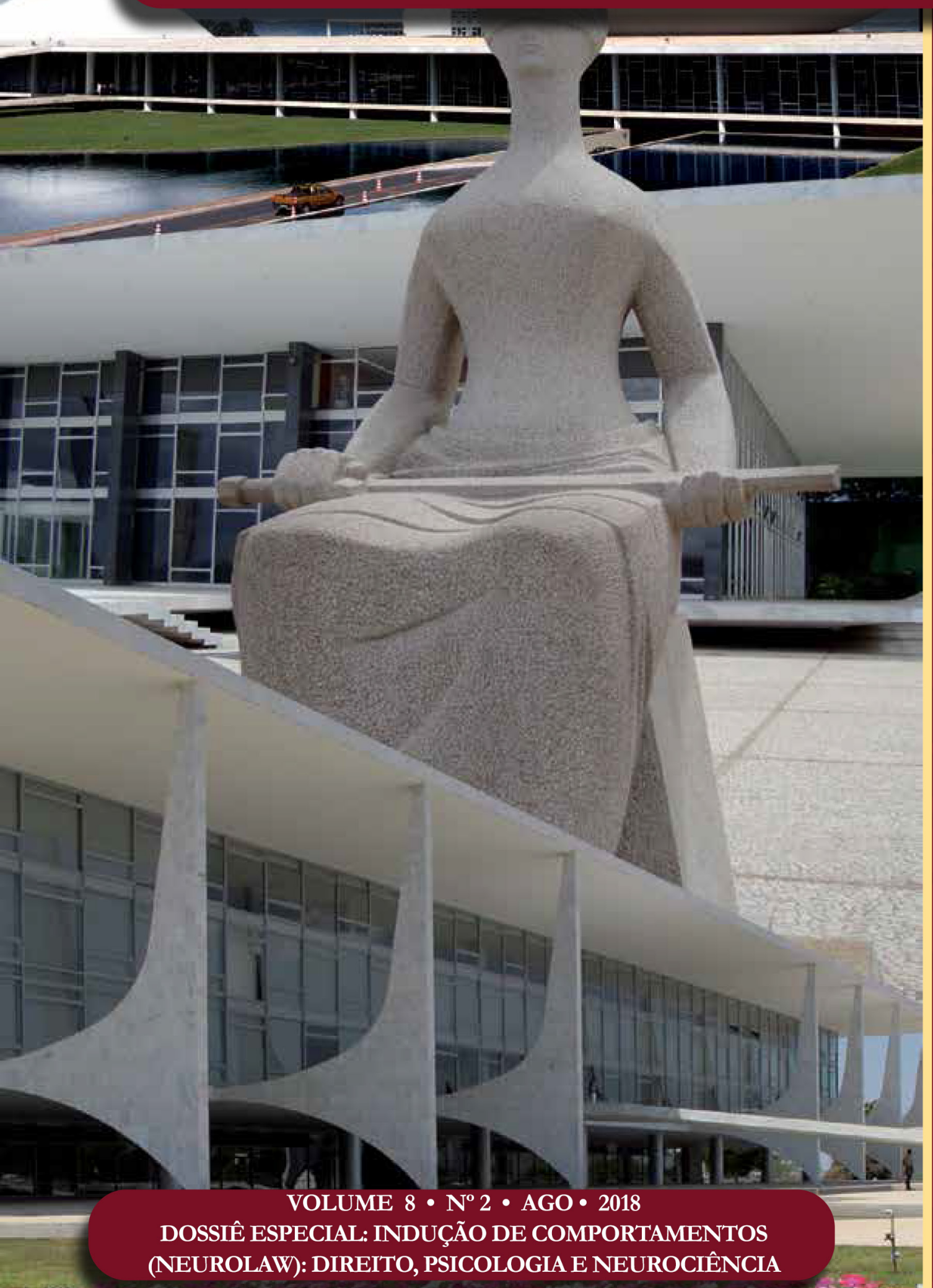

"A vida como ela é":

comportamento estratégico nas cortes

"Life how it is": strategic behavior

in the courts

Patrícia Perrone Campos Mello 


\title{
"A vida como ela é": comportamento estratégico nas cortes*
}

\section{"Life how it is": strategic behavior in the courts}

\author{
Patrícia Perrone Campos Mello** \\ Se os fatos são contra mim, pior para os fatos. \\ Nelson Rodrigues
}

\section{Resumo}

O presente artigo tem o objetivo de examinar como as cortes decidem na vida real. Quais são os fatores jurídicos e extrajurídicos que interferem no processo decisório. $\mathrm{O}$ trabalho identifica três modelos principais para a compreensão do comportamento judicial: (i) o modelo legalista, (ii) o modelo ideológico e (iii) o modelo estratégico. Opta, contudo, por explorar com maior profundidade o modelo estratégico, quer por ser ele objeto de poucos trabalhos no Brasil, quer por apresentar importante potencial explicativo do processo decisório do Supremo Tribunal Federal. O trabalho se divide em três partes. Na primeira parte, os modelos de comportamento são descritos e ilustrados com exemplos. A segunda parte dedica-se a um exame aprofundado do modelo estratégico, abrangendo sua perspectiva interna (referente à autuação dos juízes dentro do colegiado) e a sua perspectiva externa (relacionada à interação entre as cortes, os demais Poderes e a opinião pública). A terceira parte desenvolve um estudo de caso com base em decisões proferidas pelo Supremo Tribunal Federal à luz do modelo estratégico.

Palavras-chave: Supremo Tribunal Federal. Comportamento judicial. Modelo legalista. Modelo ideológico. Modelo estratégico. Interação entre Poderes.

\section{Abstract}

This paper aims to examine how courts decide in real life. What are the legal and extralegal factors that interfere in the decision-making process. It is based on the premise that there are three main models for understanding the judicial behavior: (i) the legalist model, (ii) the attitudinal model and (iii) the strategic model. It opts, however, for a more in-depth exploration of the strategic model, since there are not many Brazilian works about it, although it has an important explanatory potential for the Brazilian Supreme Court decision-making process. The work is divided in three parts. In the first part, the mentioned behavioral judicial models are described and illustrated with examples. The second part is devoted to an in-depth examination of the strategic model, covering its internal perspective (regarding the relation among the judges within the court) and its external perspective (regarding

** Doutora e Mestre pela Universidade do Estado do Rio de Janeiro. Professora do Programa de Mestrado e Doutorado do Centro Universitário de Brasília - UniCEUB. Procuradora do Estado do Rio de Janeiro. E-mail: pcamposmello@uol.com.br 
the interaction between the courts, other branches of government and public opinion). The last part develops a case study based on decisions handed down by the Brazilian Supreme Court in light of the strategic model.

Keywords: Brazilian Supreme Court. Judicial behavior. Legalist model. Attitudinal model. Strategic model. Interaction with other branches of government.

\section{INTRODUÇÃo}

Como decidem as cortes? Quais são os argumentos efetivamente capazes de convencer os juízes? Que tipo de constrangimento pode influenciar o processo decisório dos tribunais na vida real? Grande parte da literatura jurídica dedica-se a tratar dos textos das normas, dos precedentes judiciais e das múltiplas teorias normativas que discutem como tais textos e precedentes devem ser interpretados e aplicados. Poucas obras cuidam de descrever como os juízes realmente decidem, como as cortes funcionam na prática, o que verdadeiramente fazem. Há uma dimensão fundamental da vida jurídica brasileira que consta em poucos livros e que raramente é tratada nas universidades: a dimensão real da "vida como ela é"1.

Debatemos muito como as decisões devem ser tomadas, mas cuidamos pouco de descrever como elas realmente ocorrem. O resultado são teorias normativas desconectadas da realidade. Idealizações sobre o papel a ser desempenhado pelos magistrados que desconsideram as condições em que trabalham e os limites a que estão sujeitos. Uma incompreensão generalizada sobre como argumentar, sustentar um ponto de vista ou defender um caso com chances de êxito em juízo. Se compete ao Judiciário interpretar as normas e decidir os conflitos de interesse, uma parte fundamental da compreensão do que o Direito é depende do adequado entendimento de como os juízes e as cortes decidem, dos fatores e argumentos que importam em uma perspectiva empírica.

A noção de que as cortes julgam os casos que lhes são submetidos apenas com base nos textos normativos, nos precedentes ou na dogmática jurídica — conjunto que se denominará, neste artigo, "material jurídico ortodoxo" - precisa ser superada. Há uma compreensão crescente no sentido de que outros fatores são capazes de interferir substancialmente sobre as decisões judiciais². Há, ainda, importantes estudos empíricos estrangeiros que procuraram identificar tais fatores, inclusive com o propósito de predizer como novos casos seriam decididos ${ }^{3}$. Esse será o objeto deste artigo.

1 “A vida como ela é..." é o título de uma série de contos e, ainda, o nome da coluna diária que Nelson Rodrigues escreveu, por dez anos, no jornal Última Hora. Nelson Rodrigues foi um grande dramaturgo, que se notabilizou por retratar a realidade brasileira com histórias picantes que giravam em torno de traições, adultérios e intenções inconfessáveis. A inclusão da expressão no título e ao longo deste artigo tem por base o sentimento de que o trabalho descreve, em alguma medida, uma realidade sobre as cortes que é menos "nobre" do que aquela que gostaríamos de enxergar. Talvez por isso seja pouco verbalizada e, em alguma medida, rejeitada. O propósito, contudo, não é escandalizar, mas sim conhecer. Sem compreendê-la, não é possível superá-la ou avançar. V. RODRIGUES, Nelson. A vida como ela é: o homem fiel e outros contos. São Paulo: Companhia das Letras, 1992.

2 FRANK, Jerome. Justice and emotions. In: FRANK, Jerome. Courts on trial: myth and reality in american justice. Nova Jersey: Princeton University, 1949. p. 405-415; POSNER, Richard. How judges think. Cambridge: Harvard University, 2008; SEGAL, Jeffrey A.; SPAETH, Harold J. The Supreme Court and the attitudinal model revisited. Nova York: Cambridge University, 2002; EPSTEIN, Lee; KNIGHT, Jack. The choices justices make. Washington: CQ Press, 1998; BAUM, Lawrence. Judges and their audiences: a perspective on judicial behavior. Nova Jersey: Princeton University, 2008; SUNSTEIN, Cass R. et al. Are judges political? An empirical analysis of the federal Judiciary. Washington: Brookings Institution, 2006. Na literatura nacional, v. MELLO, Patrícia Perrone Campos. Nos bastidores do Supremo Tribunal Federal. Rio de Janeiro: Forense, 2017.

3 Além das obras já indicadas acima (nota 2), v., a título ilustrativo: ASHENFELTER, Orley; EISENBERG, Theodore; SCHWAB, Stewart. Politics and the Judiciary: the influence of judicial background on case outcomes. Journal of Legal Studies, Filadelfia, v. 24, n. 2, p. 257, jun. 1995. Disponível em: <http://scholarship.law.cornell.edu/cgi/viewcontent.cgi?article =1411\&context=facpub $>$. Acesso em: 15 mar. 2018; BRENNER, Saul; WHITMEYER, Joseph M. Strategy on the United States Supreme Court. Nova York: Cambridge University, 2009; CROSS, Frank B.; NELSON, Blake J. Strategic institutional effects on Supreme Court decisionmaking. New York University Law Review, Nova York, v. 95, p. 1437, 2001; MILES, Thomas J.; SUSTEIN, Cass R. The new legal realism. Chicago: University of Chicago, 2007. Disponível em: <http://papers.ssrn.com/sol3/papers.cfm?abstract_id=1070283\#\#>. Acesso em: 15 
De modo geral, os mencionados estudos aludem a três modelos capazes de explicar o comportamento judicial: os modelos legalista, ideológico e estratégico ${ }^{4}$. Cada qual deles procura examinar a atuação dos magistrados com base em um fator principal. O modelo legalista aposta na primazia do Direito, em sua concepção ortodoxa, como principal fator explicativo das decisões. O modelo ideológico centra-se na demonstração de que a ideologia do magistrado é o principal elemento determinante dos julgados. O modelo estratégico concebe o processo decisório de uma forma mais sofisticada, como o resultado da interação dos magistrados com múltiplas influências, tais como: as suas próprias preferências, as preferências dos seus colegas de colegiado, os demais Poderes e a opinião pública.

O presente artigo defende que esses três modelos são relevantes para a compreensão do funcionamento das cortes de modo geral e do Supremo Tribunal Federal em particular. Opta, contudo, por explorar com maior profundidade o modelo estratégico, quer em razão da limitação de espaço, quer por se tratar de um modelo ainda pouco estudado e com importante potencial explicativo do processo decisório do STF. Com esse propósito, o artigo se divide em três seções. A primeira seção apresenta os referidos modelos, suas principais características e as críticas que lhes são dirigidas. A segunda seção do artigo dedica-se a uma análise aprofundada do modelo estratégico de comportamento judicial, tanto em relação ao seu aspecto interno (atuação estratégica dentro de um colegiado) quanto no que se refere ao seu aspecto externo (interação estratégica entre cortes e agentes e instituições externos). A última seção do artigo analisa alguns casos julgados pelo Supremo Tribunal Federal à luz do modelo estratégico de comportamento.

A compreensão dos elementos que efetivamente interferem no processo decisório do Supremo constitui questão de inequívoca relevância, tanto se considerada a posição ocupada pelo Tribunal no ordenamento jurídico brasileiro quanto se considerado o atual contexto em que o país se insere. Trata-se, primeiramente, do tribunal de mais alta hierarquia para se manifestar sobre matéria constitucional, no contexto de uma Constituição analítica ${ }^{5}$, que dispôs sobre um rol amplíssimo de matérias ${ }^{6}$ e que se valeu de cláusulas abertas ${ }^{7}$ para isso. Decidir sobre o significado de tal Constituição significa percorrer campos muito amplos e diversos do saber e examinar questões de grande importância, com base em referenciais jurídicos incompletos ${ }^{8}$.

mar. 2018; PINELLO, Daniel R. Linking party to judicial ideology in American courts: a meta-analysis. Justice System Journal, Denver, v. 20, p. 219, 1999.

4 Sobre os três modelos, com ênfase variada em cada qual: CROSS, Frank P.; TILLER, Emerson H. Judicial partisanship and obedience to legal doctrine: whistleblowing on the Federal Courts of Appeals. Yale Law Journal, New Haven, v. 107, p. 2155, 1998; FRIEDMAN, Barry. The politics of judicial review. Texas Law Review, Austin, v. 84, p. 257, 2005; FRIEDMAN, Barry. The importance of being positive: the nature and function of judicial review. University of Cincinnati Law Review, Cincinnati, v. 72, p. 1257, 2004; EPSTEIN, Lee; KNIGHT, Jack. Documenting strategic interaction on the U.S. Supreme Court, 1995. Disponível em: <http:/ / epstein.wustl. edu/research/conferencepapers.1995APSA.pdf>. Acesso em: 30 jun. 2018; MARTIN, Andrew D. et al. Competing approaches to predicting Supreme Court decision-making. Perspectives on Politics, New York, v. 2, p. 761, 2004.

5 Constituições analíticas, em oposição às constituições sintéticas, são constituições longas, que descem a minúcias (SOUZA NETO, Cláudio Pereira; SARMENTO, Daniel. Direito constitucional: teoria, história e métodos de trabalho. Rio de Janeiro: Forum, 2013. p. 56).

6 BARROSO, Luís Roberto. Curso de direito constitucional contemporâneo: os conceitos fundamentais e a construção de um novo modelo. São Paulo: Saraiva, 2009. p. 351-380; FACHIN, Luiz Edson (Org.). Repensando fundamentos do direito civil contemporâneo. Rio de Janeiro: Renovar, 1998; SOUZA NETO, Cláudio Pereira; SARMENTO, Daniel. A constitucionalização do direito: fundamentos teóricos e aplicações específicas. Rio de Janeiro: Lumen Juris, 2007. p. 309 e ss; MORAES, Maria Celina Bodin. A caminho de um direito civil constitucional. Revista de Direito Civil, n. 65, 1993.

7 Cláusulas abertas ou cláusulas gerais são termos de conteúdo fluido, geralmente reconhecido como gênero e passível de subdivisão nas espécies: (i) conceitos jurídicos indeterminados e (ii) princípios. Os conceitos jurídicos indeterminados são noções de conteúdo relativamente indefinido, cujos termos não exaurem seu significado, passíveis de determinação à luz do caso concreto. Os conceitos jurídicos indeterminados comportam uma zona de certeza positiva, em que o conceito certamente se verifica; uma zona de certeza negativa, em que o conceito não se verifica; e uma zona interpretação, em que a verificação é discutível. São exemplos de tais conceitos: ambiente insalubre, ordem pública e interesse social. Quanto aos princípios, trata-se de noções que remetem a um valor, a um conteúdo axiológico, como dignidade humana, igualdade, liberdade de expressão. BARROSO, Luís Roberto. Curso de direito constitucional contemporâneo: os conceitos fundamentais e a construção de um novo modelo. São Paulo: Saraiva, 2009. p. $309-318$. 8 Afirma-se que os referenciais jurídicos são incompletos porque muitas vezes o texto, os precedentes e a dogmática oferecem apenas o ponto de partida para a solução do caso concreto, que dependerá da atuação criativa do intérprete. V. BARROSO, Luís Roberto. Curso de direito constitucional contemporâneo: os conceitos fundamentais e a construção de um novo modelo. São Paulo: Saraiva, 
O STF detém, ainda, competência originária para processar e julgar um rol vasto de autoridades em matéria penal ${ }^{9}$. Trata-se, contudo, de competência para a qual alegadamente o Tribunal apresenta reduzidas aptidões institucionais. De modo geral afirma-se que o STF não está estruturado para atuar como instância originária em matéria penal, colhendo provas, como um juízo de primeiro grau. Alega-se, ainda, que esse fator, associado à sobrecarga enfrentada pela Corte, constitui um considerável óbice à adequada apreciação de tais ações, ensejando a impunidade de altas autoridades e o descrédito do Tribunal ${ }^{10}$. Por outro lado, o país enfrenta um contexto de corrupção sistêmica que parece ter alcançado parte substancial das suas instituições e autoridades mais relevantes, de modo que a Corte é cada vez mais provocada a apreciar esse tipo de assunto.

Em razão desses múltiplos fatores, a apreciação das pertinentes ações penais lançou o Tribunal na posição de "escrutinador" das condutas de autoridades presentes em todos os Poderes da República, sob o olhar atento da imprensa e da opinião pública — um estado de coisas que não favorece em absoluto a estabilidade institucional da própria Corte e que a sujeita a avanços e recuos nos temas que aprecia, em decorrência de tal interação. É com essa perspectiva que se passa ao exame dos modelos de comportamento judicial, tal como proposto acima.

\section{Os MODELOS TRADICIONAIS DE COMPORTAMENTO JUDICIAL}

Como já observado, a literatura tradicional sobre modelos de comportamento judicial alude a três modelos principais: (i) o legalista, (ii) o ideológico e (iii) o estratégico. Cada qual desses modelos elege um fator como elemento preponderantemente apto a explicar (e até mesmo a prever) como uma determinada questão será decida. Esses modelos não exaurem todos os fatores que podem explicar uma decisão. Apenas identificam o elemento que julgam dominante ${ }^{11}$. A literatura reconhece outros modelos de comportamento que não serão abordados no presente trabalho ${ }^{12}$. Para os fins deste artigo, os três modelos de comportamento judicial antes mencionados são suficientes.

\subsection{Modelo legalista}

O modelo legalista de comportamento judicial aposta no "material jurídico ortodoxo" como o fator preponderante apto a explicar e a prever como um juiz ou uma corte decidirá um caso. Como já esclarecido, o material jurídico ortodoxo corresponde aos textos normativos, aos precedentes judiciais, à hermenêutica, à dogmática jurídica tradicionalmente utilizada na aplicação do direito. Na perspectiva do modelo legalista de decisão, se um texto é expresso acerca de determinado comando, se há um precedente vinculante em um dado sentido, se regras hermenêuticas favorecerem um entendimento, este será o tratamento adotado pelo

2009. p. 306-351; SOUZA NETO, Cláudio Pereira; SARMENTO, Daniel. A constitucionalização do direito: fundamentos teóricos e aplicações específicas. Rio de Janeiro: Lumen Juris, 2007. p. 357-465.

9 BRASIL. Constituição (1988). Constituição da República Federativa do Brasil. Brasília: Senado Federal, 2010. Art. 102, I, alíneas b, c, d e i.

10 O debate sobre o tema não é novo. Neste sentido, STF, Pleno, DJ, 9 nov. 2001, Inq. 687, Rel. Min. Sydney Sanches. A questão voltou a ser objeto de apreciação recentemente: STF, Pleno, AP 937 QO, Rel. Min. Luís Roberto Barroso, julgamento em curso.

11 Para outros fatores, v., ilustrativamente: POSNER, Richard. What do judges maximize? (the same thing everybody else does). Supreme Court Economic Review, Nova York, v. 3, p. 1, 1993.

12 O modelo estratégico é uma espécie do modelo institucional de comportamento judicial. O modelo institucional pode ser subdividido em: (i) comportamento institucional sincero, que se explica pela adequação voluntária e involuntária às instituições e regras que as regem; e (ii) comportamento institucional estratégico, que se explica pela interação entre os juízes, as regras que regem o funcionamento das instituições e sua aspiração de influenciar o desenvolvimento do direito em um determinado sentido. Optouse, contudo, por abordar apenas o modelo estratégico, tendo em vista a limitação de espaço. Para essa classificação, cf.: MELLO, Patrícia Perrone Campos. Nos bastidores do Supremo Tribunal Federal. Rio de Janeiro: Forense, 2015. p. 147 e ss. 
juízo. Tais fatores constituiriam o elemento determinante de como o juízo decidirá um caso.

A expressão "legalista" não é a mais adequada para se pensar o comportamento de uma corte constitucional ou de uma suprema corte que julgue matéria constitucional, já que a alusão à lei remete à norma infraconstitucional. Entretanto, a Constituição, também, é norma e, em virtude disso, as reflexões do modelo legalista podem ser transplantadas para o exame que se pretende desenvolver. Uma suprema corte que adote um comportamento legalista, na acepção desse modelo, se caracterizaria por proferir decisões que podem ser predominantemente explicadas e antevistas com base no texto da Constituição, nos precedentes da própria corte e na dogmática acerca da interpretação constitucional, ou seja, no mencionado material jurídico ortodoxo.

Como é intuitivo, o modelo legalista é insuficiente para explicar o comportamento dos juízes em uma multiplicidade de casos comumente enfrentados em matéria constitucional. O texto constitucional é repleto de cláusulas abertas e pode ser insuficiente para o preenchimento de conceitos jurídicos indeterminados ou para a solução de conflitos entre princípios constitucionais, em circunstâncias em que tampouco os precedentes e a dogmática oferecerão respostas incontestáveis ${ }^{13}$. Nesse caso, o material jurídico ortodoxo é insuficiente para indicar a solução a ser dada a um determinado debate. Além disso, o modelo legalista não se presta a enfrentar a solução de casos em que a aplicação mecânica de uma solução pré-existente conduz a situações de injustiça flagrante. Tampouco explica a superação de precedentes ou a oscilação jurisprudencial. Tanto o julgamento de casos em que a aplicação do modelo ortodoxo conduziria a decisões evidentemente teratológicas quanto as decisões que implicam a alteração de precedentes ou o seu tratamento inconsistente evidenciam que fatores diversos daqueles identificados pelo modelo legalista têm um papel relevante para a compreensão do comportamento judicial ${ }^{14}$.

O modelo legalista de comportamento judicial tem, contudo, o seu valor. A solução de uma grande gama de casos que chega às cortes constitucionais e supremas cortes pode ser explicada por meio desse modelo. Trata-se, geralmente, de casos em que o texto constitucional é explícito acerca da solução, ou cuja questão de fundo geralmente já foi apreciada. Nessas situações, as cortes se engajam em uma atividade de correção de erro e de retificação das decisões proferidas pelas demais instâncias. Na Suprema Corte norte-americana, esse é o caso das causas admitidas para exame sumário (summary consideration), consideradas mais simples, em que, geralmente, as decisões são unânimes ${ }^{15}$. No Supremo Tribunal Federal, do mesmo modo, um grande quantitativo de recursos — na verdade a grande maioria deles — é decidido com base na mera reiteração de jurisprudência ou, ainda, com base em critérios formais de (in)admissibilidade ${ }^{16}$. Nessas hipóteses, o comportamento legalista pode apresentar um grande potencial explicativo do comportamento judicial ${ }^{17}$.

13 Para o debate sobre a operação com conceitos jurídicos indeterminados e sobre a superação de conflitos entre princípios constitucionais na doutrina brasileira, v. BARROSO, Luís Roberto. Curso de direito constitucional contemporâneo: os conceitos fundamentais e a construção de um novo modelo. São Paulo: Saraiva, 2009. p. 311-338; SOUZA NETO, Cláudio Pereira; SARMENTO, Daniel. $A$ constitucionalização do direito: fundamentos teóricos e aplicações específicas. Rio de Janeiro: Lumen Juris, 2007, p. 385-391 e 493-531.

14 Sobre o tratamento inconsistente de precedentes e a participação de fatores não legalistas no processo decisório, v. MELLO, Patrícia Perrone Campos; BAQUEIRO, Paula Andrade. Distinção inconsistente e superação de precedentes no Supremo Tribunal Federal. Revista Brasileira de Políticas Públicas, v. 8, n. 1, p. 668-690, abr. 2018.

15 SONGER, Donald R.; LINDQUIST, Stefanie. Not the whole story: the impact of justices' values on Supreme Court decisionmaking. American Journal of Political Science, Detroit, v. 40, n. 4, p. 1049-1063, nov. 1996. Em sentido semelhante, reconhecendo que o modelo legalista tem algum poder explicativo sobre o comportamento da Suprema Corte, tendo em vista que os precedentes ideologicamente divergentes do pensamento da atual composição são mantidos por ela, v. POSNER, Richard. How judges think. Cambridge: Harvard University, 2008. p. 52-56.

16 Para o quantitativo de recursos decididos com base em mera reiteração de jurisprudência, v. FALCÃO, Joaquim; CERDEIRA, Pablo de Camargo; ARGUELHES, Diego Werneck. I Relatório Supremo em números: o múltiplo Supremo. Rio de Janeiro: Escola de Direito do Rio de Janeiro da Fundação Getúlio Vargas, abr. 2011.

17 Não se deve desconsiderar, contudo, que a argumentação legalista também pode ser utilizada de forma estratégica, para ocultar as verdadeiras razões que motivam uma determinada decisão. A invocação do dogma do legislador negativo, por exemplo, eventualmente se presta a essa função no Supremo Tribunal Federal. Ministros que aceitam abertamente a utilização de decisões aditivas (técnica por meio da qual o STF acrescenta conteúdo à norma, ao interpretá-la) eventualmente invocam o superado dogma do Legislador negativo para afirmar que o Tribunal não pode criar direito, mas tão-somente afastar a aplicação de normas tidas por inconstitucionais. Uma justificativa possível para a inconsistência metodológica é de que argumento legalista está sendo usado de 
A título ilustrativo, é o que se passa quando: os tribunais, por seus órgãos fracionários, deixam de aplicar uma norma, por julgá-la inconstitucional, sem levar a matéria à apreciação do pleno, e o STF cassa a decisão, por violação à Súmula Vinculante 10, firmada com base em reiteradas decisões da Corte no mesmo sentido $^{18}$; quando uma lei de iniciativa parlamentar dispõe sobre regime de pessoal do Executivo, e é declarada inconstitucional por vício de iniciativa, com base na jurisprudência consolidada no Tribunal sobre a questão ${ }^{19}$; ou quando a lei vincula a receita de um imposto a uma despesa específica, e se declara a sua inconstitucionalidade, por violação ao art. 167, IV, da Constituição, já reiteradamente interpretado pelo STF. Trata-se de casos cujo julgamento pode ser explicado pelo modelo legalista.

Entretanto, não são essas as causas que chamam a atenção do público em geral e que rendem as manchetes de jornal. Os julgamentos que atraem os olhares para os trabalhos das cortes constitucionais e supremas cortes são justamente aqueles em que uma questão paradigmática está sendo apreciada pela primeira vez, em que as cortes se desviaram de seus precedentes anteriores, em que ofereceram uma interpretação menos evidente do texto da Constituição ou, ainda, os julgamentos em que questões polêmicas, que dividem a comunidade, são enfrentadas. A própria natureza desses casos produz uma maior indeterminação do direito e, nessas circunstâncias, os modelos ideológico e estratégico podem apresentar um grande potencial explicativo de como as decisões são tomadas.

\subsection{Modelo ideológico}

O modelo ideológico identifica a ideologia dos magistrados como o fator determinante do seu comportamento judicial. A ideologia, no caso, é concebida de forma ampla, como o conjunto de valores e de ideias que integram a visão de mundo do magistrado. A partir desse conjunto, procura-se explicar ou até mesmo predizer como determinado juiz votará em um caso inédito e controvertido. Os fundamentos utilizados pelo magistrado para decidir, as normas jurídicas e os argumentos invocados para justificar a sua decisão constituiriam, em verdade, uma mera racionalização produzida a posteriori, depois de tomada a decisão, com o fim de legitimá-la ${ }^{20}$.

O desenvolvimento de estudos empíricos voltados a mensurar a participação da ideologia dos magistrados em seus processos decisórios foi muito favorecido pelo ambiente ideológico norte-americano. O ambiente norte-americano é bipartido e polarizado entre democratas e republicanos, e suas divergências ideológicas têm uma projeção muito clara em matéria constitucional. Os democratas são geralmente mais progressistas do ponto de vista da tutela de direitos fundamentais e mais favoráveis à intervenção do Estado na economia. Os republicanos são mais conservadores e, portanto, menos protetivos em matéria de direitos fundamentais e menos abertos à intervenção estatal. Nessa linha, a título ilustrativo, os democratas são as-

forma estratégica. V., sobre o tema: v. MELLO, Patrícia Perrone Campos. Nos bastidores do Supremo Tribunal Federal. Rio de Janeiro: Forense, 2015. p. 159-167.

18 STF, Súmula Vinculante 10: "Viola a cláusula de reserva de plenário (CF, artigo 97) a decisão de órgão fracionário de Tribunal que embora não declare expressamente a inconstitucionalidade de lei ou ato normativo do poder público, afasta sua incidência, no todo ou em parte".

19 BRASIL. Constituição (1988). Constituição da República Federativa do Brasil. Brasília: Senado Federal, 2010. Art. 61, §1º, II, a e c; STF, Pleno, DJe, 11.10.2016, ARE 8.911 RG, Rel. Min. Gilmar Mendes, reafirmação de jurisprudência.

20 O modelo ideológico foi inspirado por ideias oriundas do realismo jurídico. O realismo jurídico foi uma corrente do pensamento norte-americano articulada como reação ao formalismo e à fundamentação jurídica artificial das decisões judiciais. Seus estudiosos defendiam uma mudança de foco no estudo do direito, propondo o abandono das discussões teóricas sobre como as normas devem ser interpretadas e aplicadas, voltando-se para a compreensão do que efetivamente se passa nos tribunais (à semelhança do que se propõe neste artigo). O realismo jurídico teve por precursores, entre outros, Oliver Wendell Holmes Jr., Benjamin Cardozo, Karl Llewelyn e Jerome Frank. Holmes é o autor da citadíssima frase: "o direito é apenas a previsão acerca do que as cortes efetivamente farão e nada mais do que isso" (HOLMES, Oliver Wendell Jr. The path of the law. Harvard Law Review, v. 110, p. 991, 1897, p. 994). Para acessar o pensamento dos demais autores, v. CARDOZO, Benjamin N. The nature of the judicial process. Nova York: Dover Publications, 2005; LLEWELYN, Karl N. The common law tradition: deciding appeals. Boston: Little, Brown and Company, 1960; FRANK, Jerome. Are judges human?. In: FRANK, Jerome. Courts on trial: myth and reality in american justice. Nova Jersey: Princeton University Press, 1949. p. 146-156. 
sociados a posições mais protetivas de grupos minoritários, como negros, mulheres, hispânicos e minorias sexuais, quando em questão o respeito ao direito à igualdade ${ }^{21}$. Em matéria econômica, geralmente se manifestam a favor da manutenção de normas regulatórias, da tutela ao meio ambiente e de sindicatos, quando seus direitos entram em conflito com interesses de empresas privadas ${ }^{22}$. Os republicanos são associados ao posicionamento oposto.

Nesse contexto, os estudos empíricos sobre o comportamento judicial ideológico valeram-se do seguinte método: (i) buscaram identificar ideologicamente o magistrado como predominantemente progressista/democrata ou conservador/republicano; (ii) reuniram um conjunto de casos e procuraram antecipar como tais casos seriam decididos por cada juiz, de acordo com o seu perfil ideológico; (iii) ao final, verificaram como foram efetivamente decididos na prática e, com base nesse confronto, avaliaram a acuidade do modelo na previsão do comportamento do magistrado.

Tais estudos desenvolveram dois métodos principais para a identificação ideológica dos juízes. O primeiro método se voltou à explicação do comportamento dos juízes da Suprema Corte norte-americana. Em sua origem, foi desenvolvido por Segal e Cover, que produziram uma indexação ideológica de tais juízes, com base em editoriais de jornal. Esses autores extraíram as informações publicadas sobre os magistrados dos editoriais produzidos entre a sua indicação para a Suprema Corte e a sua confirmação. Consideraram, originalmente, quatro jornais de grande circulação, sendo dois de inclinação democrata e dois de inclinação republicana ${ }^{23}$. A partir de como tais juízes foram descritos e avaliados pelos jornais, os estudiosos os escalonaram entre os números -1 , equivalente a extremamente conservador, e +1 , extremamente progressista. Quanto mais próximo de zero fosse o índice de um juiz, mais moderadas eram consideradas as suas posições.

Os índices obtidos revelavam, portanto, a percepção da imprensa a respeito da ideologia de tais juízes, e os escalonavam em graus de inclinação progressista ou conservadora. Com esse critério, os estudiosos obtiveram uma medida independente da ideologia dos magistrados (que não tinha por base os seus próprios votos $)^{24}$. Na sequência, examinaram como esses magistrados votaram em determinados casos com projeções ideológicas claras e verificaram o nível de acerto do modelo, ou seja, em que medida o índice ideológico atribuído ao juiz era capaz de indicar como votaria em determinada questão. Esse primeiro modelo revelou um alto potencial preditivo da forma de decidir dos magistrados. Em um conjunto de casos sobre direitos fundamentais decididos entre os anos de 1953 e 1999, constatou-se uma convergência da ordem de 76\% (setenta e seis por cento) entre as decisões dos magistrados e suas inclinações ideológicas. Em outro estudo, que reuniu casos de busca policial, entre 1962 e 1998, o percentual de acerto foi de 71\% (setenta e um por cento) dos votos.

O segundo método empírico de estudo do comportamento ideológico foi utilizado para o estudo da atua-

21 SEGAL, Jeffrey A.; COVER, Albert D. Ideological values and votes of U.S. Supreme Court Justices. American Political Science Review, Washington, v. 83, p. 557, 1989; SEGAL, Jeffrey A. et al. Ideological values and the votes of U.S. Supreme Court justices revisited. Journal of Politics, West Nyack, v. 57, p. 815, 1995; SOLBERG, Rorie Spill. Judicial behavior in constitutional challenges before the Rehnquist Court. Journal of Empirical Legal Studies, Oxford, v. 3, p. 245, jul. 2006.

22 SEGAL, Jeffrey A. et al. Ideological values and the votes of U.S. Supreme Court justices revisited. Journal of Politics, West Nyack, v. 57, p. 815, 1995; REVESZ, Richard L. Environmental regulation, ideology, and the D.C. circuit. Virginia Law Review, Charlottesville, v. 83, p. 1717, 1997; SUNSTEIN, Cass R. et al. Are judges political? An empirical analysis of the federal judiciary. Washington: Brookings Institution, 2006. p. 24 e ss.

23 A indexação original, produzida por Segal e Cover, foi posteriormente atualizada por Segal e Spaeth, ampliando-se inclusive o universo de periódicos examinados com esse objetivo. v. SEGAL, Jeffrey A.; COVER, Albert D. Ideological values and the votes of U. S. Supreme Court Justices. American Political Science Review, Washington, v. 83, p. 557, 1989; SEGAL, Jeffrey A.; SPAETH, Harold J. The Supreme Court and the attitudinal model revisited. Nova York: Cambridge University, 2002. p. 322.

24 A obtenção de uma medida da ideologia dos magistrados que independesse de seus próprios votos era fundamental para a viabilidade do modelo. Era preciso apurar a ideologia com base em um critério objetivo e, na sequência, testar a capacidade preditiva da ideologia sobre os casos já decididos pelos magistrados. Se a ideologia fosse inferida a partir do próprio conjunto de casos decididos pelos magistrados, esse conjunto não se prestaria a confirmar a hipótese da influência da ideologia porque teria servido de base para a identificação ideológica. Haveria, nessa hipótese, um problema de circularidade no método aplicado, que poderia distorcer o resultado final. 
ção de juízes federais norte-americanos. Esse método associava a orientação ideológica do juiz ao presidente que o indicou. Nos Estados Unidos, os juízes federais são indicados pelo Chefe do Executivo e aprovados pelo Senado Federal. Assumiu-se que o presidente, ao indicar um magistrado, buscava candidatos que fossem minimamente convergentes com as suas próprias convicções, em uma tentativa de influenciar os rumos do Direito. Por isso, utilizou-se como critério objetivo para determinar as inclinações ideológicas de um dado juiz o partido a que pertencia o presidente que o selecionou. Com base nisso, procurava-se identificar como o juiz votaria nos diferentes casos que lhe seriam submetidos, tendo em conta a mesma lógica já descrita acima: decisões mais progressistas seriam produto de juízes indicados por democratas, ao passo que decisões mais conservadoras seriam tomadas por juízes indicados por republicanos ${ }^{25}$.

Tais estudos empíricos demonstraram que algumas matérias eram mais propensas a votações ideológicas do que outras, mas, de modo geral, confirmaram a hipótese de votação ideológica. Nessa linha, constatou-se que juízes democratas julgavam mais favoravelmente a grupos minoritários, em casos de ações afirmativas, de discriminação sexual e de assédio sexual; que produziam mais decisões reconhecendo a ocorrência de segregação racial; que julgavam favoravelmente a deficientes físicos, em casos de arguição de violação a seu direito à igualdade; que se manifestavam mais em favor do direito de veicular pornografia, sob a invocação da liberdade de expressão; e que validavam mais normas restritivas sobre financiamento de campanhas eleitorais ${ }^{26}$.

A principal crítica dirigida aos referidos estudos diz respeito ao fato de que o universo de casos utilizados para o exame da interferência da ideologia sobre o processo decisório era pequeno, razão pela qual suas conclusões não deveriam ser generalizadas. Afirma-se, ainda, que tal exame recai sobre um conjunto de casos em que o Direito está menos definido, e que desconsidera, por isso, um rol mais amplo de casos mais simples, superdimensionando a participação da ideologia no processo decisório ${ }^{27}$. Alguns estudos procuram demonstrar, ainda, que um juiz pode passar por alterações ideológicas ao longo do tempo, o que comprometeria a capacidade preditiva de um modelo baseado em uma inclinação ideológica medida em um momento temporal específico ${ }^{28}$.

Veja-se, contudo, que as conclusões dos estudos empíricos em questão são importantes mesmo que aplicáveis a um conjunto menor de casos, em que o direito ainda se apresenta indeterminado. É que é de extrema relevância para a compreensão do comportamento judicial identificar quais são os fatores que interferem no convencimento dos juízes nas situações em que justamente há um alto grau de indeterminação

25 SISK, Gregory C.; HEISE, Michael. Judges and ideology: public and academic debates about statistical measures. Northwestern University Law Review, Chicago, v. 99, p. 743, 2005. p. 748 e ss; SUNSTEIN, Cass R. et al. Are judges political? An empirical analysis of the federal Judiciary. Washington: Brookings Institution Press, 2006.

26 SEGAL, Jeffrey A.; SPAETH, Harold J. The Supreme Court and the attitudinal model revisited. Nova York: Cambridge University, 2002. p. 320 e ss; FRIEDMAN, Barry. The politics of judicial review. Texas Law Review, Austin, v. 84, p. 257, 2005. p. 273. Ver, ainda, sobre o tema, MILES, Thomas J.; SUNSTEIN, Cass R. Do judges make regulatory policy? An empirical investigation of Chevron. University of Chicago Law Review, Chicago, v. 73, p. 823, 2006. p. 823; BENESH, Sara C.; SPAETH, Harold J. The Supreme Court justice-centered judicial databases: the Warren, Burger, and Rehnquist Courts 1953-2000. East Lansing: Michigan State University, 2003. p. 20-22 Disponível em: <http://artsandsciences.sc.edu/poli/juri/flpdcodebk.pdf>. Acesso em: 15 mar. 2018; SUNSTEIN, Cass R. et al. Are judges political? An empirical analysis of the federal Judiciary. Washington: Brookings Institution, 2006 . p. 24 e ss. 27 MILES, Thomas J.; SUNSTEIN, Cass R. The new legal realism. Chicago: University of Chicago, 2007. Disponível em: <http://papers.ssrn.com/sol3/papers.cfm?abstract_id=1070283\#\#>. Acesso em: 15 mar. 2018, p. 7 e ss.; SONGER, Donald R.; LINDQUIST, Stefanie A. Not the whole story: the impact of justices' values on Supreme Court decision-making. American Journal of Political Science, v. 40, n. 4, p. 1049, 1996. p. 1053-1054 e 1058; WALD, Patricia. A response to Tiller and Cross. Columbia Law Review, Nova York, v. 99, 1999, p. 244 e ss.; TAHA, Ahmed E. Judge shopping: testing whether judges' political orientation affect case filings. University of Cincinnati Law Review, v. 20, p. 101-130, 2010, p. 104 e ss.; SISK, Gregory C.; HEISE, Michael. Judges and ideology: public and academic debates about statistical measures. Nortbwestern University Law Review, Chicago, v. 99, 2005. p. 773.

28 MARTIN, Andrew D.; QUINN, Kevin M. Assessing preference change on the U.S. Supreme Court. Journal of Law, Economics, and Organization, p. 1, 11 maio 2007. p. 16-18. Disponível em: <http://www.law.berkeley.edu/files/prefchange.pdf>. Acesso em: 30 jun. 2018; EPSTEIN, Lee et al. Do political preferences change? A longitudinal study of U.S. Supreme Court justices. Journal of Politics, West Nyack, v. 60, n. 3, p. 801-818, ago. 1988; SHAUER, Frederick. Incentives, reputation and the inglorious determinants of judicial behavior. Cincinnati Law Review, v. 68, p. 615-636, 2000. 
acerca do direito e, portanto, nas quais o material jurídico ortodoxo é insuficiente. Estes tendem a ser os casos difíceis apreciados pelas cortes.

O transplante da metodologia utilizada pelo modelo de comportamento ideológico norte-americano (attitudinal mode) para o sistema brasileiro é bastante difícil. Não há no Brasil o mesmo universo ideológico plenamente definido e com projeção em matéria constitucional. Tampouco parece possível antecipar o posicionamento de um ministro sobre determinado tema apenas com base nas inclinações ideológicas do presidente que o nomeou ou do partido do presidente ${ }^{29}$. Apesar disso, acredita-se que os achados e os insights do modelo ideológico são importantes para a compreensão do comportamento judicial também no Brasil. A influência da ideologia no processo decisório manifesta, em verdade, o quanto tal processo é permeável à subjetividade do magistrado. A subjetividade abrange um conjunto amplo de experiências, valores, pré-compreensões, que compõem o background de um juiz e que é fortemente responsável por suas inclinações ideológicas ${ }^{30}$.

Por isso, ainda que não seja possível desenvolver uma análise do comportamento de um ministro do Supremo Tribunal Federal a partir do presidente que o indicou para o cargo, existem outros elementos que podem funcionar como indicadores das suas inclinações. A identidade das pessoas em geral é construída na interação com o outro e, por conseguinte, os grupos de identificação de um magistrado influenciam suas concepções de mundo e revelam tendências decisórias. A família, a criação, os amigos, a religião e a vinculação com movimentos sociais são alguns elementos que podem funcionar como indicadores de tais tendências ${ }^{31}$.

A origem profissional de um juiz — se ele vem da advocacia ou da magistratura — pode ser determinante de certos comportamentos. A literatura já demonstrou, por exemplo, que juízes que atuaram como advogados criminalistas tendem a ser mais protetivos dos direitos de defesa dos réus, e que juízes pertencentes a grupos minoritários tendem a julgar mais favoravelmente a tais grupos em casos de discriminação ou assédio ${ }^{32}$.

Há, assim, estudos que indicam que a ideologia e a subjetividade têm uma participação importante no processo decisório dos magistrados, notadamente em casos difíceis, nos quais o direito se encontra mais indeterminado. Nessa medida, identificar o background dos juízes e tentar associá-lo a um padrão decisório em determinadas matérias pode ajudar a compreender suas inclinações, pode orientar a argumentação das partes e eventualmente permitirá prever a forma como se manifestará sobre determinada matéria ou, ainda, o tipo de argumento ao qual ele se mostrará mais sensível.

No que respeita ao Supremo Tribunal Federal, diversos ministros já reconheceram a influência das suas visões de mundo sobre os votos que proferem. A título ilustrativo, quando de sua confirmação pelo Senado,

29 No plano do modelo ideológico, há uma hipótese que procura relacionar a forma de votar dos ministros com as consequências que seu voto produzirá no cenário político do momento e/ou sobre determinados personagens da política. Sobre o tema, v. ARGUELHES, Diego Werneck; RIBEIRO, Leandro Molhano. Quando a unanimidade não esclarece. Valor, 22 jun. 2012. Disponível em: <http://www.osconstitucionalistas.com.br/quando-a-unanimidade-nao-esclarece>. Acesso em: 15 mar. 2018. Essa hipótese não será examinada aqui.

30 GROSSMAN, Joel B. Social backgrounds and judicial decision-making. Harvard Law Review, Cambridge, v. 79, p. 1551, 1966; BAUM, Lawrence. Judges and their audiences: a perspective on judicial behavior. Nova Jersey: Princeton University, 2008. p. 26-28; ASHENFELTER, Orley; EISENBERG, Theodore; SCHWAB, Stewart. Politics and the judiciary: the influence of judicial background on case outcomes. Journal of Legal Studies, v. 24, p. 257, 1995. Disponível em: <http://scholarship.law.cornell.edu/cgi/ viewcontent.cgi?article $=1411 \&$ context $=$ facpub $>$. Acesso em: 15 mar. 2018.

31 MELLO, Patrícia Perrone Campos. Nos bastidores do Supremo Tribunal Federal. Rio de Janeiro: Forense, 2015. p. 127-144.

32 SISK, Gregory C.; HEISE, Michael; MORRISS, Andrew P. Charting the influences on the judicial mind: an empirical study of judicial reasoning. New York University Law Review, New York, v. 73, p. 1377, 1998. p. 1457; PERESIE, Jennifer. Female judges matter: gender and collegial decision-making in the Federal Appellate Courts. Yale Law Journal, New Haven, v. 114, n. 7, may 2005. p. 1786-1787. Disponível em: <https://www.yalelawjournal.org/note/female-judges-matter-gender-and-collegial-decisionmaking-inthe-federal-appellate-courts>. Acesso em: 26 mar. 2018; COX, Adam; MILES, Thomas. Judging the Voting Rights Act. Disponível em: $<$ https://chicagounbound.uchicago.edu/cgi/viewcontent.cgi?article=8033\&context=journal_articles >. Acesso em: 30 jun. 2018. 
o Ministro Gilmar Mendes afirmou que, em sua atuação no STF, defenderia suas posições com a mesma veemência com que as defendera em sua vida pública pregressa ${ }^{33}$. O Ministro Joaquim Barbosa declarou que desejava levar ao Supremo uma visão do direito influenciada por sua própria trajetória ${ }^{34}$. O Ministro Marco Aurélio reconheceu expressamente: "Primeiro idealizo a solução mais justa. Só depois vou buscar apoio na lę"35.

O julgamento de casos como pesquisas com células tronco embrionárias ${ }^{36}$, interrupção da gestação de fetos anencefálicos ${ }^{37}$ e uniões homoafetivas ${ }^{38}$ deixa entrever a inevitabilidade da influência das visões de mundo dos magistrados (sobre a proteção à vida, à liberdade e à autonomia) sobre suas decisões ${ }^{39}$. Um exemplo típico desse comportamento consiste no voto proferido pelo saudoso Ministro Menezes Direito no primeiro desses casos. As pesquisas com células tronco envolviam o emprego de embriões não utilizados na fertilização in vitro, ensejando a sua destruição. A questão suscitava sentimentos conflitantes acerca da proteção do direito à vida, tendo contado com a atuação da Conferência Nacional dos Bispos do Brasil (CNBB), na condição de amicus curiae, contra a validade das pesquisas nessas condições.

O Ministro Direito era um ministro sabidamente muito católico. Entretanto, tinha plena compreensão da importância de proferir, na hipótese, uma decisão que não impusesse a visão de mundo de um determinado grupo religioso e reconheceu isso em seu voto ${ }^{40}$. A despeito disso, a fundamentação da sua decisão aludia a sumas papais, a reflexões teológicas e filosóficas e ponderava que o direito à vida tinha relação com valores que "não se esgotam em um só segmento do conhecimento humano", o que imporia, a seu ver, uma abordagem interdisciplinar sobre o tema ${ }^{41}$. Ao final, o Ministro Direito concluiu que as pesquisas com células

33 MENDES, Gilmar. Vou defender minhas posições. Jornal do Brasil, Rio de Janeiro, 26 maio 2002. p. 10. Entrevista concedida a Gustavo Krieger. Disponível em: <http://www.stf.jus.br/arquivo/biblioteca/PastasMinistros/GilmarMendes/Entrevistas/2002_ maio_26.pdf>. Acesso em: 02 abr. 2018.

34 GOMES, Joaquim Benedito Barbosa. Vivi muita pobreza até os 17 anos. O Estado de São Paulo, São Paulo, 8 maio 2003. Nacional, p. A9. Entrevista concedida a Mariângela Gallucci. Disponível em: < http://www.stf.jus.br/arquivo/biblioteca/PastasMinistros/JoaquimBarbosa/Entrevistas/2003_maio_08_002.pdf>. Acesso em: 30 jun. 2018.

35 MELLO, Marco Aurélio. Competência: palavra que melhor resume o nosso Ministro do Supremo Tribunal Federal. Jornal da Cidade, Sergipe, 7 out. 2003. Suplemento especial. Disponível em: < http://www.stf.jus.br/arquivo/biblioteca/PastasMinistros/ MarcoAurelio/Entrevistas/2003_out_07.pdf>. Acesso em: 29 mar. 2018.

36 STF, Pleno, DJe, 28.05.2010, ADI 3510, Rel. Min. Ayres Britto.

37 STF, Pleno, DJe, 30.04.2013, ADPF 54, Rel. Min. Marco Aurélio.

38 STF, Pleno, DJe, 14.10.2011, ADI 4277 e ADPF 132, Rel. Min. Ayres Britto.

39 Para um estudo dos três casos e da influência da ideologia ou do backeground dos magistrados sobre os seus votos, v. MELLO, Patrícia Perrone Campos. Nos Bastidores do Supremo Tribunal Federal. Rio de Janeiro: Forense, 2015. p. 127-144.

40 Trecho do voto do Ministro Menezes Direito: "Neste julgamento, penso que deve ficar claro que não se trata aqui de buscar uma definição científica de determinado evento fazendo uma declaração de princípios de natureza religiosa, canônica. Não se pode pôr a questão sob esse ângulo. Trata-se, ao contrário, de decidir uma questão sob o ângulo jurídico, o que não afasta a necessidade de buscar perspectiva interdisciplinar considerando valores apropriados que não se esgotam em um só segmento do conhecimento humano. [...]. O que a Suprema Corte do Brasil está desafiando não é, portanto, uma questão religiosa. É uma questão jurídica, posta no plano da interpretação constitucional. A religião pertence à intimidade do ser do homem e todos nós devemos abrir nossos corações com humildade e grandeza para proclamar nossa fé no mais íntegro respeito moral pela pluralidade que é marca indissociável das sociedades livres. Tentar estabelecer a ideologização da ciência ou enxergar o obscurantismo nos que creem e defendem sua fé é indigno desse trânsito da história da humanidade. É por essa razão que devemos pôr com toda claridade que estamos julgando o alcance constitucional da proteção à vida e à dignidade da pessoa humana” (ADIn 3510, p. 237-239, grifos originais suprimidos).

41 A título ilustrativo, confira-se outra passagem do voto do Ministro Menezes: "A beleza do tema está bem-posta no diálogo epistolar entre o Cardeal Carlo Maria Martini e Umberto Eco (Em que creem os que não creem. Record, 2002). Na correspondência trocada em junho de 1995, Umberto Eco pergunta: 'Quando tem início a vida humana?' (pág. 31). E responde afirmando que todos ‘já consideram como ser humano o recém-nascido ainda ligado ao cordão umbilical. De quanto é possível retroceder? Se a vida e a humanidade já estão no sêmen (ou até mesmo no programa genético), podemos considerar que o desperdício do sêmen é um delito comparável ao homicídio?' (págs. 31/32). Prossegue lembrando as posições de Tertuliano, Santo Agostinho e Santo Tomás em torno do momento em que a alma é transmitida. E depois de anotar que o não crente também se coloca o problema, assevera que 'talvez estejamos condenados a saber apenas que existe um processo, que seu resultado final é o milagre do recém-nascido e que o momento em que se teria o direito de intervir nesse processo e em que não seria mais lícito fazê-lo não pode ser esclarecido nem discutido. Logo, tanto não tomar jamais tal decisão, quanto tomá-la é um risco pelo qual a mãe responde apenas ou diante de Deus ou diante do tribunal da própria consciência e da humanidade' (pág. 33). E faz a terrível advertência: 'O senhor sabe que tais questões não implicam somente uma reflexão sobre o aborto, mas uma série dramática de questões novíssimas, como, por exemplo, a engenharia genética e a bioética, discutidas hoje por todos, crentes ou não. Como se posiciona o teólogo diante do criacionismo 
tronco seriam constitucionais apenas se fossem realizadas sem a destruição do embrião. Caso contrário, violariam o direito à vida ${ }^{42}$. A argumentação, tal como desenvolvida no voto, demonstrava a dificuldade de um juiz decidir casos difíceis sem qualquer influência da sua compreensão de mundo, ainda que procurasse ser neutro.

\subsection{Modelo estratégico}

O modelo estratégico de comportamento judicial corresponde ao terceiro modelo comportamental tradicionalmente referenciado pela literatura. É compatível, ao menos em parte, com as ideias do modelo ideológico. Tanto no modelo ideológico quanto no modelo estratégico, acredita-se que os juízes tendem a decidir de forma a influenciar o desenvolvimento do direito no sentido que consideram mais adequado. No modelo ideológico, contudo, os magistrados simplesmente votam de acordo com as suas preferências. No modelo estratégico, apresentam um comportamento mais sofisticado. $\mathrm{Na}$ atuação estratégica, o fato de a decisão de um juiz depender do comportamento de outros agentes para lograr prevalecer ou influenciar o desenvolvimento do direito em um determinado sentido interfere sobre suas escolhas. Em um órgão colegiado, o juiz que deseja influenciar o desfecho de um caso precisa levar em consideração que seu entendimento necessitará da adesão da maioria para prevalecer. Ele até poderia votar conforme as suas preferências pura e simplesmente, mas se o seu propósito é produzir um determinado desfecho, que considera o mais adequado, precisa considerar o pensamento dos demais membros do colegiado e avaliar se suas preferências pessoais contarão com o apoio dos demais.

Nessas circunstâncias é possível que ele procure identificar como os outros membros de um colegiado se comportarão em determinado julgamento e opte por votar não propriamente conforme as suas convicções, mas de acordo com um entendimento mais moderado e capaz de conquistar a adesão da maioria — o que o modelo estratégico convencionou chamar de second best decision. Entre votar como deseja e restar vencido, ou proferir um voto que não considera o ideal, mas que tem chance de ser aprovado pelo colegiado, é possível que o juiz opte pela segunda alternativa. Nesse caso, o magistrado agirá estrategicamente.

Os estudiosos do modelo estratégico recorrem a duas teorias: à Teoria das Escolhas Racionais e à Teoria dos Jogos. De acordo com a Teoria das Escolhas Racionais, os agentes e, portanto, também, os juízes têm determinados objetivos e optam pelas atitudes que acreditam que são mais aptas à sua consecução. Para que a atuação estratégica logre alcançar um bom resultado, algumas condições devem ser preenchidas, a saber: (i) em primeiro lugar, o comportamento adotado deve possibilitar a maximização do benefício pretendido; (ii) em segundo lugar, a percepção quanto ao comportamento que cumpre essa função precisa ter uma base sólida; e, portanto, (iii) o agente precisa fazer um investimento ótimo para a obtenção de informação acerca do comportamento que pode esperar dos demais agentes de quem a sua conduta e a consecução do resultado perseguido dependem ${ }^{43}$. No caso dos juízes, o benefício a ser maximizado seria adoção de uma decisão

clássico hoje?' (pág. 33), para terminar: 'Definir o que seja, e onde tem início, a vida é questão em que está em jogo a nossa vida. Colocar-me estas questões é um duro peso moral, intelectual e emotivo - creia - para mim também (p. 34). A resposta do Cardeal Martini mostra a complexidade do tema: "O senhor se refere justamente às sutis reflexões de Tomás sobre as diversas fases do desenvolvimento do vivente. Não sou filósofo nem biólogo e não quero adentrar-me em tais questões. Mas todos sabemos que hoje se conhece melhor o dinamismo do desenvolvimento humano e a clareza de suas determinações genéticas a partir de um ponto que, pelo menos teoricamente, pode ser precisado. A partir da concepção, nasce, de fato, um ser novo. Novo significa diverso dos dois elementos que, unindo-se, o formaram. Tal ser inicia um processo de desenvolvimento que o levará a tornar-se aquela 'criança maravilhosa, milagre natural ao qual se deve aderir’. É este o ser de que se trata, desde o início. Há uma continuidade na identidade” (págs. 38/39). E aduz: "O senhor conclui dizendo: 'definir o que é e onde tem início a vida é questão em que está em jogo a nossa vida'. Estou de acordo, pelo menos sobre 'o que é’ e já dei minha resposta. O 'onde’ pode continuar misterioso, mas está submetido ao valor do 'o que é"'.

42 Trata-se de entendimento extremamente restritivo da realização das pesquisas, que possivelmente teria ensejado sua supressão, se houvesse prevalecido, já que o método voltado à extração das células tronco sem a destruição dos embriões ainda não tinha tido sua viabilidade científica, eficácia e segurança comprovadas (ADIn 3510, p. 289-290).

43 ELSTER, Jon. Introduction. In: ELSTER, Jon. Rational choice. Nova York: New York University Press, 1986. p. 1-33; EPSTEIN, Lee; KNIGHT, Jack. Documenting strategic interaction on the U.S. Supreme Court. p. 2 Disponível em: <http://epstein.wustl.edu/ 
convergente com as suas expectativas. Para alcançar essa finalidade, precisam obter informação sobre como seus demais colegas pretendem votar, a fim de avaliar se conseguirão construir uma maioria que apoie as suas preferências. A Teoria dos Jogos, a seu turno, explica a ação humana justamente quando a consecução de um objetivo depende do comportamento de terceiros, demonstrando que, nessas condições, o agente definirá a sua conduta com base nas atitudes que espera dos demais. Por isso, se um juiz acreditar que suas preferências sinceras não obterão o apoio da maioria, ele tenderá a moderar seu entendimento, a fim de produzir um voto que possa ser apoiado pelos demais, optando por uma second best decision ${ }^{44}$.

Diversas críticas são tecidas ao modelo estratégico de comportamento judicial e, portanto, à utilização da teoria das escolhas racionais e da Teoria dos Jogos para prever ou para explicar o comportamento dos magistrados. Afirma-se, em primeiro lugar, que os agentes não agem de forma puramente racional. Suas pré-compreensões podem interferir sobre a sua percepção dos problemas, sobre as suas escolhas e até mesmo sobre o acerto ou desacerto na avaliação da atitude que esperam dos demais membros do colegiado. Há vieses ${ }^{45}$ que poderiam levar os juízes a "cálculos" equivocados sobre como agir, a exemplo do viés de confirmação, por meio do qual há uma tendência a interpretar informações de modo a que confirmem preconceitos detidos pelo intérprete, inclinação que conduz à dissonância cognitiva ${ }^{46}$. Assim, o comportamento estratégico seria difícil de prever e poderia inclusive se revelar irracional ${ }^{47}$.

De fato, achados da economia comportamental têm demonstrado que as pessoas apresentam reações não otimizadoras dos benefícios que perseguem. Comportamentos motivados pela aversão à perda ou pela aversão ao risco (dentre outros) ilustram bem essa afirmação. Um exemplo de cada qual desses fenômenos ajuda a compreender melhor o argumento. A respeito da aversão à perda, a mera forma de descrever um problema pode interferir sobre o comportamento do agente. Tome-se o exemplo da introdução do uso de cartões de crédito no mercado. A tarifa cobrada pelas empresas de cartão gerava um aumento do custo do produto. Tais empresas compreendiam bem os mecanismos mentais dos consumidores. Por essa razão, orientaram os lojistas a oferecerem descontos em compras à vista, em lugar de cobrarem um sobrepreço nas compras com cartão. Com isso, as alteravam a referência de preço do consumidor, conscientes do fato de que, do ponto de vista dele, as perdas repercutiriam mais do que os ganhos. Era mais fácil para o consumidor lidar com a ideia de não receber um desconto do que aceitar pagar uma sobretaxa pelo uso do cartão (muito embora, do ponto de vista econômico, as duas situações fossem equivalentes) ${ }^{48}$.

Situação semelhante ocorre com o fenômeno da aversão ao risco, bem ilustrada pelo dilema do prisioneiro. Nesse caso clássico, dois agentes envolvidos em um mesmo crime são encarcerados e recebem a seguinte informação: (i) se nenhum dos dois prisioneiros delatar o outro, ambos serão liberados em um ano; (ii) se apenas um prisioneiro delatar o outro, o delator será liberado ao passo que o delatado passará dez anos na prisão; (iii) se ambos os prisioneiros delatarem um ao outro, os dois ficarão na prisão por cinco anos. Como o objetivo dos dois agentes é ficar o menor tempo possível na prisão, o comportamento otimizador do benefício para ambos seria que nenhum dos dois delatasse. Nessa hipótese, ambos permaneceriam, apenas, um ano na prisão. Entretanto, esta não mostrou ser a opção adotada pelos prisioneiros. Ao contrário, o temor

research/conferencepapers.1995APSA.pdf>. Acesso em: 30 jun. 2018; PETTIT, Philip. Institutional design and rational choice. In: GOODIN, Robert E. The theory of institutional design. Nova York: Cambridge University Press, 1996. p. 62 e ss.

44 CORAM, Bruce Talbot. Second best theories and the implications for institutional design. In: GOODIN, Robert E. The theory of institutional design. Cambridge: Cambridge University Press, 1995, p. 92; ELSTER, Jon. Explaining social behavior: more nuts and bolts for the social sciences. Nova York: Cambridge University, 2007. p. 299 e ss.; ELSTER, Jon. Introduction. In: ELSTER, Jon. Rational choice. Nova York: New York University, 1986. p. 7 e ss.

45 Vieses cognitivos constituem inclinações à produção de julgamentos equivocados decorrentes de limitações neurológicas ao processamento de informações, estudados pela economia comportamental.

46 TVERSKY, Amos; KAHNEMAN, Daniel. The framing of decisions and the psychology of choice. In: ELSTER, Jon. Rational choice. Nova York: New York University, 1986. p. 123-141.

47 TVERSKY, Amos; KAHNEMAN, Daniel. The framing of decisions and the psychology of choice. In: ELSTER, Jon. Rational choice. Nova York: New York University Press, 1986. p. 123-141.

48 TVERSKY, Amos; KAHNEMAN, Daniel. The framing of decisions and the psychology of choice. In: ELSTER, Jon. Rational choice. Nova York: New York University Press, 1986. p. 123-141. 
de passar dez anos na cadeia (no caso de ser delatado pelo colega e de não o delatar) levava ambos os prisioneiros a delatar e a, com isso, permanecerem presos por cinco anos, em lugar de permanecerem por apenas um ano. O dilema do prisioneiro demonstra, portanto, que a racionalidade do comportamento humano é prejudicada pelo fenômeno da aversão ao risco ${ }^{49}$.

Os estudiosos do comportamento estratégico reconhecem que os aludidos fenômenos podem, efetivamente, interferir sobre a capacidade do modelo de explicar e prever as condutas dos magistrados. Em algumas circunstâncias, somente o estado de espírito que precede a tomada de decisão será capaz de explicá-la. Entretanto, ponderam que os juízes, como as pessoas em geral, ainda que não sejam plenamente racionais, desejam sê-lo e que, por isso, mesmo que tal racionalidade seja parcialmente comprometida por aspectos subjetivos, o modelo ainda tem um bom potencial explicativo ${ }^{50}$.

Uma última crítica dirigida ao modelo estratégico argumenta que a sua comprovação empírica é inviável, uma vez que um mesmo comportamento pode ser explicado com base em justificativas concorrentes. Alega-se que, na verdade, o enquadramento de certas atitudes como estratégicas ocorre a posteriori, em decorrência de interpretações desenvolvidas para explicar eventos que já se passaram e que essa particularidade faz com que o próprio observador perca a imparcialidade na compreensão dos fenômenos e gere, involuntariamente, percepções confirmadoras da sua hipótese. Como a atuação estratégica é de difícil comprovação, o modelo estratégico seria questionável do ponto de vista científico.

Trata-se de uma crítica importante e procedente. De fato, a comprovação do modelo estratégico por meio de estudos empíricos quantitativos, como aqueles que evidenciaram o comportamento ideológico, é de difícil viabilidade. Isso não significa, contudo, que o modelo estratégico não ofereça importantes insights acerca do comportamento judicial. Tampouco impede que estudos qualitativos sejam desenvolvidos, ou que tais estudos ofereçam evidências importantes da sua ocorrência. A próxima seção dedica-se a lançar um olhar mais aprofundado sobre o modelo estratégico de comportamento judicial. Acredita-se que esse modelo tem um bom potencial explicativo tanto da interação entre magistrados dentro de um mesmo colegiado, quanto da interação entre as cortes e outros agentes que lhes são externos. É o que se passa a demonstrar.

\section{O MODELO ESTRATÉGICO: DIMENSÕES INTERNA E EXTERNA}

O comportamento judicial estratégico pode ser pensado em dois âmbitos: interno e externo às cortes. O estudo do comportamento estratégico interno diz respeito à compreensão da interação entre juízes de um mesmo órgão colegiado. Como esclarecido acima, cada juiz depende da adesão da maioria para fazer o seu entendimento prevalecer. $\mathrm{O}$ juiz agirá estrategicamente quando: (i) puder antecipar como votarão os demais e (ii) formular seu voto de modo a capitanear tal maioria, sacrificando o encaminhamento que considera ideal, para defender a decisão mais próxima das suas preferências que seja capaz de obter o apoio dos demais (second best decision $)^{51}$.

O estudo do comportamento estratégico externo tem por objeto a interação entre as cortes e/ou entre os

49 ELSTER, Jon. Explaining social behavior: more nuts and bolts for the social sciences. Nova York: Cambridge University, 2007. p. 319 e ss.; PETTIT, Philip. Institutional design and rational choice. In: GOODIN, Robert E. The theory of institutional design. Nova York: Cambridge University, 1996. p. 71 e ss.

50 ELSTER, Jon. Explaining social behavior: more nuts and bolts for the social sciences. Nova York: Cambridge University, 2007. p. 19 e ss.

51 EPSTEIN, Lee; KNIGHT, Jack. The choices justices make. Washington: CQ Press, 1998, p. 79-98; CALDEIRA, Gregory A.; WRIGHT, John R. Organized interest and agenda setting in the U.S. Supreme Court. American Political Science Review, Washington, v. 82, p. 1109-1127, 1988, p. 1120-1121; EPSTEIN, Lee; KNIGHT, Jack. Documenting strategic interaction on the U.S. Supreme Court, 1995. Disponível em: <http://epstein.wustl.edu/research/conferencepapers.1995APSA.pdf>. Acesso em: 30 jun. 2018 , p. 17 e ss.; SEGAL, Jeffrey A.; SPAETH, Harold J. The Supreme Court and the attitudinal model revisited. Nova York: Cambridge University, 2002. p. 358 e ss. 
seus membros e instituições e agentes que lhes são externos, dentre os quais: o Poder Executivo, o Poder Legislativo e a opinião pública. É certo que o Poder Judiciário e seus membros são cercados de garantias cujo propósito é assegurar a independência das suas decisões. Acredita-se, contudo, que, em algumas circunstâncias, as cortes podem ser sensíveis a como certos agentes responderão a seus julgados e, se forem capazes de prever uma grande reação negativa a eles, possivelmente moderarão seus entendimentos de forma a minimizá-las.

Como se pretende demonstrar a seguir, a atuação estratégica, em ambos os casos, tem relação com as regras que regem o funcionamento das instituições, quer internamente quer externamente. São justamente tais regras que estabelecem uma interdependência entre os agentes, que determinam a possibilidade de interferência de uma instituição na outra e que definem as condições em que tal interação ocorrerá. Por consequência, a extensão em que o comportamento estratégico ocorre, tanto dentro do Judiciário quanto externamente a ele, é produto do design institucional produzido pela Constituição e pelas demais normas que regulam tal interação. Apresentam-se, a seguir, alguns casos que ilustram o funcionamento do modelo estratégico em suas dimensões interna e externa.

\subsection{Modelo estratégico interno: 0 caso Craig v. Boren}

O caso Craig v. Boren ${ }^{52}$ constitui um bom exemplo de atuação estratégica interna. O Estado de Oklahoma havia aprovado uma lei que estabelecia que as mulheres poderiam adquirir bebida de baixo teor alcoólico a partir de 18 (dezoito) anos, mas que proibia a venda de bebida alcoólica para homens com menos de 21 (vinte e um) anos. A justificativa para a adoção de critérios etários diversos para homens e mulheres estava nas estatísticas de acidentes de veículos por embriaguez. De acordo com tais estatísticas, os homens abaixo de 21 (vinte e um) anos tinham mais propensão a se envolver nesse tipo de acidente do que as mulheres, que tinham baixo índice de participação nesse tipo de evento.

A constitucionalidade da norma estadual foi questionada em uma ação proposta por um rapaz de 20 (vinte) anos, Craig, e por uma vendedora de bebidas. Na ação, alegava-se que a lei em questão produzia uma discriminação em razão do gênero, e que leis com esse teor deveriam ser objeto de controle de constitucionalidade com base no standard denominado strict scrutiny test. Esse standard corresponde ao critério mais rigoroso utilizado pela Suprema Corte norte-americana para apreciar a constitucionalidade de uma lei. Com base nele, a Corte impõe ao Estado o ônus de demonstrar que a norma impugnada é a medida menos restritiva possível apta a preservar um interesse estatal relevante, de modo a justificar a sua validade. As normas examinadas com base no strict scrutiny dificilmente são validadas pela Corte.

O Estado de Oklahoma, a seu turno, defendeu que a norma deveria ser examinada com base no rationality basis test, um standard mais brando, pelo qual o Poder Público precisa demonstrar, apenas, que uma dada norma constitui uma medida razoável para promover um objetivo estatal legítimo e, portanto, por meio do qual havia mais chance de sair vitorioso.

A definição do standard de controle da norma era extremamente relevante. Ele tendia a ser determinante para o julgamento do mérito, mas não era, apenas, esse o ponto. O standard de revisão adotado nesse caso pela Suprema Corte possivelmente serviria como precedente e, portanto, como critério para o controle da constitucionalidade futuro de outras normas discriminatórias em razão do gênero. No caso em exame, a discriminação de gênero se dava em prejuízo de um homem, mas em regra esse tipo de discriminação ocorre em prejuízo de membros de um grupo minoritário. Portanto, a definição de um standard como o strict scrutiny, nesse caso, favorecia a proteção de tais grupos e, nesse sentido, atendia a preocupações progressistas.

A causa foi julgada em favor do Poder Público na instância inferior e chegou à Suprema Corte. O pro-

52 Craig v. Boren, 429 U.S. 190 (1976). 
cesso decisório na Suprema Corte envolve uma primeira reunião, a portas fechadas, entre os 09 (nove) juízes que a compõem. Nessa oportunidade, os juízes fazem uma avaliação prévia de como votarão. Caso o presidente da Corte esteja alinhado ao pensamento da maioria, cabe a ele a definição do juiz que redigirá o voto em nome dela. Caso o presidente se alinhe com a minoria, cabe ao juiz mais senior que integre a maioria a definição do redator do voto. O certo é que, a partir da primeira reunião, o redator é capaz de identificar as inclinações de cada um dos seus colegas. Na sequência, ele produz uma minuta de decisão que circula entre os membros da Corte. Nesse processo, os termos da minuta podem ser negociados e novas adesões ao voto podem ser conquistadas ou perdidas ${ }^{53}$.

No caso em exame, a redação da opinião da maioria foi distribuída a Brennan, um juiz progressista, partidário da declaração da inconstitucionalidade da norma e da adoção do strict scrutiny test. Ocorre que, embora houvesse maioria quanto ao desfecho do caso, no sentido de julgar a norma inconstitucional, não havia maioria para a adoção de tal standard de revisão. Apenas três outros juízes apoiavam a adoção do strict scrutiny. Brennan propôs, então, um standard intermediário, denominado heightened ou midlevel scrutiny, segundo o qual classificações com base no gênero deveriam atender a objetivos estatais relevantes e ser essenciais à sua consecução, sob pena de inconstitucionalidade.

Esse entendimento não correspondia à preferência pessoal de Brennan, tampouco à preferência de alguns dos justices que votaram em favor do standard intermediário ${ }^{54}$. A opção por esse standard decorreu de um cálculo estratégico. Era melhor abrir mão do escrutínio estrito, que não seria aceito pela maioria, e tentar aprovar um escrutínio intermediário (second best decision), do que correr o risco de a maioria votar pelo standard mais brando (rationality test) ou, ainda, de não se definir um standard, em virtude de uma dispersão de votos. Ao votar nesses termos, Brennan atuou estrategicamente: sacrificou suas preferências pessoais (em parte) pela decisão que mais se aproximava daquela que considerava a ideal e que tinha melhores chances de ser adotada pelo colegiado. Adotou, portanto, uma second best decision.

A atuação nesses termos foi produto da interação dos juízes e das regras institucionais que regiam tal interação e que mediam o processo colegiado de decisão. Havia necessidade de uma maioria votando em um mesmo standard para que um precedente sobre essa questão fosse formado. O procedimento, tal como previsto, permitiu que o justice Brennan antecipasse o comportamento de cada qual dos seus colegas de Corte, por meio da reunião interna que precede a produção do voto, quando tais membros indicam suas preferências e inclinações. Ao verificar que não havia espaço para a aprovação do strict scrutiny, Brennan fez um "cálculo" da melhor estratégia, à luz do comportamento dos demais, como na Teoria dos Jogos. Optou pela adoção do standard intermediário de controle da constitucionalidade, conclusão que maximizava o seu interesse, tal como previsto pela teoria das escolhas racionais ${ }^{55}$.

53 EPSTEIN, Lee; KNIGHT, Jack. The choices justices make. Washington: CQ Press, 1998. p. 31 e ss; SEGAL, Jeffrey A.; SPAETH, Harold J. The Supreme Court and the attitudinal model revisited. Nova York: Cambridge University, 2002. p. 367 e ss; EPSTEIN, Lee; KNIGHT, Jack. Documenting strategic interaction on the U.S. Supreme Court, 1995. p. 23 e ss. Disponível em: < http:// epstein.wustl.edu/research/conferencepapers.1995APSA.pdf>. Acesso em: 30 jun. 2018.

54 EPSTEIN, Lee; KNIGHT, Jack. The choices justices make. Washington: CQ Press, 1998, p. 31 e ss.

55 O caso é ilustra o que se convencionou denominar "efeito colegiado" (panel effect). Julgar em um órgão colegiado é diferente de julgar monocraticamente. A necessidade de formação de maiorias faz com que o entendimento de cada qual dos membros influencie e modere o entendimento dos demais. O efeito-colegiado é justificável, ainda, com base nos mecanismos de: (i) aversão ao dissenso e (ii) "efeito-alerta" (whistleblower effect). No que respeita à aversão ao dissenso, estudos empíricos já demonstraram que o relator de um caso, observados certos limites, tende a preferir moderar seu voto a provocar a apresentação de um voto vencido por algum membro do colegiado. $\mathrm{O}$ voto vencido geralmente incomoda o relator e, a depender de sua força argumentativa, prejudica a estabilização do entendimento majoritário. Por outro lado, a não apresentação de um voto vencido cria um sentimento de reciprocidade e de colaboração entre vencedores e vencidos, evitando a não apresentação de votos vencidos e a moderação em novas situações, quando o vencido de hoje for o relator da maioria de amanhã. Por essas razões, a aversão ao dissenso produz a moderação de entendimentos em um colegiado. Já no caso do efeito-alerta, o que se verifica é que a diversidade ideológica na composição de um colegiado também pode alterar as preferências dos magistrados por razões sinceras. A exposição dos magistrados a pontos de vista, experiências e concepções com as quais não tinham tido um contato relevante até então pode provocar uma moderação sincera da decisão final, que é produto da deliberação. V. SUNSTEIN, Cass R. et al. Are judges political? An empirical analysis of the federal Judiciary. Washington: Brookings Institution, 2006. p. 8-9; POSNER, Richard A. How judges think. Washington: Brookings Institution, 2006. 


\subsection{Modelo estratégico externo: Marbury v. Madison}

Marbury v. Madison ${ }^{56}$ é possivelmente o caso mais famoso da história do constitucionalismo, ao qual é atribuída a definição das bases do controle da constitucionalidade, tal como se estabeleceria, posteriormente, em todo o mundo ocidenta ${ }^{57}$. É, ainda, um excelente exemplo de interação estratégica externa. A história de Marbury v. Madison começou nas eleições de 1800, quando o então presidente John Adams e seus partidários federalistas se viram derrotados pela eleição de Jefferson para chefia do Executivo, e de uma maioria republicana para o Congresso, e procuraram permanecer no poder por meio de nomeações para o Judiciário.

No prazo remanescente de seu mandato, Adams e o Congresso, no qual ainda detinha maioria (os novos eleitos ainda não haviam tomado posse), aprovam duas novas leis. A primeira delas (the Circuit Court Act) reduziu o número de cargos da Suprema Corte, com o propósito de impedir a nomeação de novos justices por Jefferson ${ }^{58}$, e criou 16 (dezesseis) novos cargos de juiz, de modo a possibilitar novas nomeações de magistrados por Adams, antes da conclusão do seu mandato. A segunda lei criou 42 (quarenta e dois) cargos de juiz de paz no Distrito de Columbia (the Organic Act of the District of Columbia). Os novos juízes foram nomeados por Adams e aprovados pelo Senado, às vésperas da posse de Jefferson, de modo que não foi possível ao então Secretário de Estado de Adams, John Marshall, entregar todos os diplomas de nomeação (comissions) antes da assunção da presidência por Jefferson ${ }^{59}$.

Obviamente, a manobra foi compreendida por Jefferson, o novo Presidente eleito. Ocorre que, para que os juízes nomeados ocupassem seus cargos, eles precisavam receber seus diplomas de nomeação, e Jefferson sustou a entrega dos diplomas pendentes, impedindo a posse daqueles juízes que ainda não haviam recebido o documento. Na sequência, o novo Congresso, de maioria republicana, revogou o Circuit Court Act ${ }^{60} \mathrm{e}$ postergou o início do ano judiciário por 14 (catorze) meses, até que as medidas se consolidassem como um fato consumado. Por essa razão, a Suprema Corte não funcionou no ano de $1802^{61}$.

William Marbury foi um daqueles juízes que, apesar de nomeado, não recebeu seu diploma e, portanto, não conseguiu tomar posse. Irresignado, Marbury ajuizou uma ação diretamente na Suprema Corte, com base em uma lei que havia estendido a competência da Corte para julgar causas dessa ordem. O presidente da Suprema Corte, também foi nomeado por Adams: tratava-se de John Marshall, o anterior secretário de Estado que não lograra entregar todos os diplomas de nomeação em tempo e que, portanto, devia ser favorável ao pleito de Marbury. O contexto era consideravelmente complexo. Como já mencionado, havia grande animosidade política. O novo Congresso apoiava Jefferson. A Suprema Corte ficara 14 (catorze) meses sem funcionar. A posse de juízes em situação semelhante à de Marbury era vista como uma manobra daqueles que, vencidos nas urnas, buscavam artifícios para se manterem no poder. As circunstâncias indicavam, ainda, que uma decisão favorável a Marbury poderia ser descumprida e, eventualmente, ensejar o impeachment de Marshall.

Nessas condições, abriram-se para Marshall três possibilidades de decisão. Em primeiro lugar, Marshall poderia apreciar a causa, julgar desfavoravelmente a Marbury, preservar a estabilidade institucional da Suprema Corte, e seu próprio cargo, contrariando os interesses federalistas e suas próprias convicções, no sentido

p. 24-45; PERESIE, Jennifer. Female judges matter: gender and collegial decision-making in the Federal Appellate Courts. Yale Law Journal, New Haven, v. 114, n. 7, p. 1786-1787, maio 2005.

56 Marbury v. Madison, 5 U.S. (1 Cranch) 137 (1803).

57 BARROSO, Luís Roberto. O controle de constitucionalidade no direito brasileiro. 7. ed. São Paulo: Saraiva, 2016. p. 25-33.

58 Um dos juízes da Corte, William Cushing, estava bastante idoso e acreditava-se que seria substituído em breve, muito embora sua substituição só tenha vindo a ocorrer efetivamente em 1810, quando do seu falecimento.

59 STONE, Seidman; SUNSTEIN, Tushnet. Constitutional law. 3. ed. Boston: Little, Brown and Company, 1992. p. 31-32.

60 A lei que criou os cargos de juiz de paz no Distrito de Columbia não chegou a ser revogada, tal como ocorreu no caso do Circuit Court Act, o que tampouco ensejaria a posse daqueles que haviam sido nomeados por Adams, mas não haviam recebido seu diploma de posse.

61 Stone, Seidman; Sunstein, Tushnet. Constitutional law. 3. ed. Boston: Little, Brown and Company, 1992. p. 32. 
de que Marbury tinha direito ao cargo. Uma segunda opção consistia em julgar favoravelmente a Marbury e às suas convicções e correr o risco de a decisão ser manifestamente descumprida. Nessa segunda hipótese, se a decisão fosse descumprida, os interesses do partido e os direitos de Marbury não se veriam atendidos, a Corte sairia desgastada e eventualmente a posição institucional de Marshall como Chief Justice seria ameaçada. A terceira alternativa envolvia não apreciar a causa, a pretexto de que uma norma infraconstitucional não poderia alterar a competência originária da Suprema Corte, sendo, por isso, nula. Como a lei era nula, faleceria à Suprema Corte competência para conhecer do caso.

Marshall optou pela terceira solução. Ao fazê-lo, principiou afirmando que Marbury tinha razão e que tinha direito ao cargo - entendimento que correspondia às suas preferências sinceras. Concluiu, contudo, que a Corte não poderia declarar tal direito porque a norma que lhe dava competência para isso violava a Constituição e, por isso, era inválida. Ao usar essa estratégia, por via transversa, afirmou o poder do Judiciário para julgar a validade de todo e qualquer ato do Executivo ou do Legislativo que fossem contestados em face da Constituição, algo inédito à época. A decisão, a pretexto de declarar a Corte incompetente, expandia o poder do Judiciário e lhe dava a última palavra sobre os atos do Executivo e do Legislativo. E como não determinava medida de qualquer ordem, já que deixava de conhecer do caso, não podia ser descumprida ou contestada.

Mais uma vez, tratava-se de comportamento estratégico possibilitado pelo desenho das normas que regulavam a interação entre as instituições envolvidas. O Judiciário é um poder independente, mas, nas famosas palavras de Bickel, não detém o uso da força ou a chave do cofre ${ }^{62}$. Depende, portanto, da adesão dos demais Poderes para ter as suas decisões cumpridas e pode ter seus juízes impedidos. Nessas circunstâncias, de nada valia a Marshall ou aos demais juízes da Corte decidir em favor de Marbury. Provavelmente, a decisão seria inócua e a Corte sofreria grande desgaste. Por outro lado, como tribunal incumbido de decidir sobre o significado da Constituição, podia manifestar-se sobre o alcance de seu próprio poder. Assim, a Corte abriu mão de decidir conforme a sua preferência imediata, mas produziu um entendimento que lhe asseguraria maior poder no futuro. Ao agir assim, atuou estrategicamente, calculando como agiriam seus opositores e maximizando seus benefícios.

\section{O modelo estratégico no Supremo Tribunal Federal}

Os casos acima demonstram que, ainda que não seja possível comprovar o comportamento estratégico, por meio de estudos empíricos quantitativos, há evidências importantes de que o modelo pode oferecer elementos para a compreensão do modo de funcionar do Supremo Tribunal Federal. A atuação conforme a Teoria das Escolhas Racionais e a Teoria dos Jogos é inerente ao comportamento humano e encontra-se presente, também, no Supremo. As regras que dispõem sobre a admissibilidade de recursos, sobre o modo de funcionar interno do Tribunal e sobre a sua interação com os demais Poderes abrem margem a comportamentos estratégicos. Esses comportamentos têm por base decisões sobre procedimento ou sobre o mérito das causas propriamente.

A atuação estratégica, no que respeita ao procedimento, pode ter o propósito de evitar o julgamento de casos de baixa relevância, de forma a gerir o volume de feitos recebidos pela Corte. O controle do volume ou da relevância dos casos é um benefício que se pode buscar maximizar. A atuação estratégica procedimental pode, ainda, se traduzir na tentativa de postergar ou de obstar o julgamento de um recurso, com base em argumentos processuais, quando o magistrado acreditar que o caso terá um desfecho divergente das suas preferências.

Já o comportamento estratégico em decisões substantivas, como explicitado acima, leva o juiz a moderar seus entendimentos ou a optar por uma decisão que acomode suas preferências à necessidade de obter a adesão

62 BICKEL, Alexander M. The least dangerous branch: the Supreme Court at the bar of politics. New Haven: Yale University, 1986. 
da maioria do colegiado, ou, ainda, que evite embates com o Executivo, com o Legislativo ou com a opinião pública. Esse comportamento pode, inclusive, levar o Tribunal a recuar de entendimentos já firmados, a fim de contornar crises ou de evitar o descumprimento das suas decisões. Passa-se, a seguir, a tratar de alguns casos de possível atuação estratégica no STF.

\subsection{Atuação estratégica com base em decisões procedimentais}

No que respeita à atuação estratégica com base em decisões procedimentais, normas que regulam a admissibilidade dos recursos extraordinários preveem a exigência de diversos requisitos de admissibilidade. Para que seja admissível, o recurso não pode implicar o revolvimento de matéria de fato ${ }^{63}$, não pode envolver o exame de direito local ${ }^{64}$ e deve ensejar a discussão de inconstitucionalidade direta e não reflexa ${ }^{65}$. Além disso, a questão objeto do recurso deve ter sido enfrentada pela decisão recorrida (prequestionamento) ${ }^{66}$. Trata-se de requisitos que foram construídos pelo que se convencionou chamar jurisprudência defensiva do STF, cumprindo a função de conter o volume de casos que chega à Corte e de produzir um filtro sobre seu acervo de processos. A aferição desses requisitos nem sempre é puramente objetiva e é, inclusive, relativizada em casos que a Corte, pelas mais diversas razões, se disponha a apreciar. ${ }^{67}$

$\mathrm{O}$ requisito da repercussão geral pode igualmente dar margem a comportamentos estratégicos ${ }^{68}$. De acordo com o novo Código de Processo Civil, considera-se presente a repercussão geral quando a questão constitucional veiculada por meio de recurso extraordinário for relevante do ponto de vista econômico, político, social ou jurídico, e seu julgamento, por essa razão, ultrapassar os interesses subjetivos do processo ${ }^{69}$. A sua demonstração é condição de procedibilidade do recurso. Entretanto, a noção de repercussão geral constitui um conceito jurídico indeterminado, que comporta uma zona de certeza positiva, uma zona de certeza negativa e uma zona de interpretação, em que o alcance do conceito se sujeita à discussão. A sua aferição comporta alguma discrição e abre margem para a atuação defensiva da Corte, de forma a limitar o volume de recursos que chegam a ela ${ }^{70}$.

63 STF, Súmula 279.

64 STF, Súmula 280.

65 STF, Súmula 636.

66 STF, Súmulas 282 e 356.

67 Essa poderia ser a explicação, a título exemplificativo, para que o Supremo ter apreciado discussão sobre o número de dias de férias dos procuradores federais, questão em que parecia predominar matéria infraconstitucional e na qual, por consequência, eventual invocação de inconstitucionalidade poderia ser considerada reflexa. V. STF, Pleno, DJe, 04.02.2015, RE 602.381, Rel. Min. Cármen Lúcia. Poderia, ainda, justificar a mudança de entendimento que levou o Tribunal a apreciar recurso extraordinário em que se debatia a validade de acordo ou convenção coletiva de trabalho, matéria que, por muito tempo, teve sua revisão rejeitada pela Corte, por ser considerada infraconstitucional, e que recentemente passou a ser apreciada pelo Tribunal, à luz do art. $7^{\circ}$, XXVI, da Constituição. V. STF, Pleno, DJe, 29.05.2015, RE 590.415, Rel. Min. Luís Roberto Barroso. No caso das férias, o STF possivelmente revelava uma sensibilidade corporativista. No caso das convenções e acordos coletivos, havia uma demanda da sociedade por um avanço em termos de respeito e consolidação do direito coletivo do trabalho.

68 A exigência de repercussão geral foi inserida no sistema como requisito de admissibilidade dos recursos extraordinários por meio da Emenda Constitucional (EC) no 45/2004 e regulamentado pela Lei 11.418/2006.

69 CPC/2015, art. 1.035: “O Supremo Tribunal Federal, em decisão irrecorrível, não conhecerá do recurso extraordinário quando a questão constitucional nele versada não tiver repercussão geral, nos termos deste artigo. $\int 1^{\circ}$ Para efeito de repercussão geral, será considerada a existência ou não de questões relevantes do ponto de vista econômico, político, social ou jurídico que ultrapassem os interesses subjetivos do processo. [...]. \ $3^{\circ}$ Haverá repercussão geral sempre que o recurso impugnar acórdão que: I - contrarie súmula ou jurisprudência dominante do Supremo Tribunal Federal; [...]; III - tenha reconhecido a inconstitucionalidade de tratado ou de lei federal, nos termos do art. 97 da Constituição Federal”.

70 Nesse sentido, há, inclusive, proposta de releitura do requisito, de modo a que a Corte reconheça um número limitado de repercussões gerais por ano, correspondente ao que estimadamente é capaz de apreciar em um mesmo ano. No caso, a análise da existência de repercussão geral envolveria não apenas um juízo de relevância em termos absolutos, mas igualmente em termos relativos, devendo-se escolher, anualmente, por comparação, os processos mais importantes da temporada. Nessa linha: BARROSO, Luís Roberto; MONTEDÔNIO, Frederico. Como salvar a repercussão geral: transparência, eficiência e realismo na escolha do que o Supremo Tribunal Federal vai julgar. In: BARROSO, Luís Roberto. Um outro país: transformações no direito, na ética e na agenda do Brasil. Belo Horizonte: Forum, 2018. p. 121-146; BARROSO, Luís Roberto. Reflexões sobre as competências e o funcionamento 
O requisito da repercussão geral permite, ainda, que eventualmente se rejeite a apreciação de alguns casos que, por razões estratégicas ou ideológicas, não se deseja enfrentar. Veja-se, a título exemplificativo, o julgamento acerca da existência de repercussão geral no recurso extraordinário que debatia a constitucionalidade das candidaturas avulsas ${ }^{71}$. $\mathrm{O}$ assunto tinha indiscutível relevância do ponto de vista político, jurídico e social. Possibilitar as candidaturas avulsas significaria, na prática, ampliar o universo de candidatos que poderiam concorrer em uma eleição. Houve, contudo, considerável resistência da Corte em admitir o recurso extraordinário que veiculava a discussão, ao fundamento de que teria perdido seu objeto, uma vez que as eleições que o haviam motivado já tinham ocorrido ${ }^{72}$.

Entretanto, no dia anterior ao julgamento em que se debateu se as candidaturas avulsas atendiam à exigência de repercussão geral, a Corte tinha apreciado um outro caso na mesma situação (de perda de objeto do caso concreto). Nessa oportunidade, sequer se questionou a existência da repercussão geral. Simplesmente julgou-se o caso. De fato, o art. 998, parágrafo único, do novo Código de Processo Civil ${ }^{73}$, prevê que a desistência do recurso não impede a análise da repercussão geral, de modo que se passou a entender que esse instituto operara uma espécie de "objetivação" do controle difuso da constitucionalidade, em virtude da relevância transindividual da questão, ensejando a apreciação da matéria constitucional, ainda que o interesse subjetivo das partes já estivesse superado, a fim de assentar o entendimento da Corte.

A inconsistência entre o tratamento do precedente do dia anterior e o do dia subsequente pelo plenário do Supremo sugeria que um fator extrajurídico poderia estar influenciando o reconhecimento da existência de repercussão geral no recurso que debatia as candidaturas avulsas. Talvez o assunto "candidatura avulsa" fosse desconfortável. É possível que parte da Corte acreditasse que o mero conhecimento do recurso geraria instabilidade que poderia perturbar as eleições vindouras ou que poderia, ainda, produzir desdobramentos que não era capaz de controlar. É possível, igualmente, que alguns ministros partilhassem do entendimento sincero de que o texto da Constituição veda as candidaturas avulsas de forma expressa, por exigir a filiação partidária como condição de elegibilidade e que, nesse caso, julgassem que não fazia sentido reconhecer a repercussão geral para tão somente confirmar o quadro normativo atual ${ }^{74}$. Quaisquer que fossem as justificativas para o comportamento incongruente, o fato é que, depois de alguma resistência, a repercussão geral acabou reconhecida no caso das candidaturas avulsas. Afinal, se tratava, em termos imediatos, apenas, de admitir o processamento do recurso e não de julgar seu mérito.

A liberação de uma ação, pelo relator, e o pedido da sua inclusão em pauta para julgamento pelo colegiado podem igualmente envolver um cálculo, pelo próprio relator, sobre as perspectivas de um desfecho convergente com as suas convicções acerca da melhor decisão a ser tomada no caso concreto. O momento e a mudança de composição podem ser aliados de causas "cujo tempo ainda não havia chegado" quando foram propostas. Basta lembrar, por exemplo, a ação em que se apreciou a possibilidade de interrupção da gestação de fetos anencefálicos. No início de sua tramitação, a cautelar foi indeferida pelo plenário, que não demonstrou receptividade à tese. Entretanto, sete anos mais tarde, quando o mérito foi julgado, sob uma nova composição, a situação já era diversa ${ }^{75}$. Por isso, a compreensão sobre a inclinação do pleno em determinado tema (ou sobre a alteração de tal inclinação, por conta de mudança da composição dos membros do colegiado) interfere no momento de submissão dos feitos ao plenário ${ }^{76}$.

do Supremo Tribunal Federal. In: BARROSO, Luís Roberto. Um outro país: transformações no direito, na ética e na agenda do Brasil. Belo Horizonte: Forum, 2018. p. 331-345.

71 STF, Pleno, DJe, 09.03.2018, ARE 1054490 QO, Rel. Min. Luís Roberto Barroso.

72 Nesse sentido, manifestação do Ministro Lewandowski, nos debates do ARE 1054490 QO.

73 CPC/2015, art. 988, par. único: "A desistência do recurso não impede a análise de questão cuja repercussão geral já tenha sido reconhecida e daquela objeto de julgamento de recursos extraordinários ou especiais repetitivos".

74 BRASIL. Constituição (1988). Constituição da República Federativa do Brasil. Brasília: Senado Federal, 2010. Art. 14, \$3º, V. 75 STF, Pleno, DJe, 30.04.2013, ADPF 54, Rel. Min. Marco Aurélio.

76 No caso, a liminar deferida pelo relator para autorizar a realização de interrupções de gestações foi rejeitada pelo plenário em abril de 2005. Diante disso, a continuidade da instrução do feito, com a convocação de audiência pública, só ocorreu em 2008 , três anos depois. E o mérito da ação foi levado a julgamento em 2012, sete anos mais tarde. Nessa oportunidade, o entendimento 
A afetação de um caso que se encontra sob a apreciação da turma ao pleno, para julgamento, também pode constituir um comportamento estratégico. O Regimento Interno do STF admite que o relator requeira tal afetação quando julgar a matéria relevante de modo a justificar uma apreciação por todos os componentes da Corte $^{77}$. Na prática, pode ocorrer de o relator optar por lançar mão dessa providência quando julgar que a composição do plenário é mais favorável do que a da turma para a produção de um julgamento convergente com as suas convicções ${ }^{78}$.

Do mesmo modo, a inclusão de um feito em pauta, pela presidência do Supremo Tribunal Federal, dá margem a comportamentos estratégicos. A decisão sobre quais casos incluir na pauta envolve uma escolha discricionária do ministro que exerce a presidência, e pode levá-lo a não pautar temas que considera importante, mas que acredita que terão um desfecho divergente das suas convicções. Dado o grande volume de casos apreciados pela Corte, há um considerável "congestionamento" da fila de ações e de recursos que aguardam inclusão na pauta. Os casos não são incluídos com base em um critério cronológico ou com base em qualquer outro critério objetivo facilmente aferível. Diante da impossibilidade de se apreciar tudo o que há a ser apreciado, a presidência acaba fazendo sua própria seleção das matérias que serão levadas a julgamento - uma realidade que demonstra que a sobrecarga da Corte é grave não apenas à luz dos princípios do acesso à jurisdição e da razoável duração do processo. É grave, igualmente, por conta da discricionariedade que abre a um único ministro (aquele que ocupa a presidência) para decidir sobre o que a Corte efetivamente julgará.

Outro instrumento de atuação estratégica, cujo uso tem sido bastante criticado, são os pedidos de vista interruptivos das sessões de julgamento. O regimento interno do Tribunal prevê a possibilidade e estabelece a devolução do processo, para prosseguimento da votação, até a segunda sessão ordinária subsequente ${ }^{79}$. $\mathrm{Na}$ prática, contudo, os pedidos de vista podem se alongar por muitos meses, até anos, e eventualmente obstar a conclusão de julgamentos com os quais o ministro que requereu a vista não concorda ${ }^{80}$. Há, inclusive, casos de pedidos de vista em momentos em que já há maioria formada em determinado sentido no plenário do $\mathrm{STF}^{81}$.

Por essa razão, os pedidos de vista acabaram apelidados jocosamente de "perdidos de vista" ${ }^{82}$. Instalou-se, a seu respeito, uma percepção segundo a qual certos integrantes da Corte, ao verem prevalecer um entendimento de que divergem, em matéria que lhes é muito cara, eventualmente consideram a opção estratégica de parar "o jogo", por meio da vista, de modo a evitar a decisão ou de, ao menos, postergá-la. Justamente por isso, alguns membros da Corte têm antecipado o voto em tais casos, quer de forma a reforçar a maioria já formada, quer para evidenciar a manobra.

Obviamente, as condutas indicadas acima também poderiam ser sinceras, e não estratégicas. O voto contra a inconstitucionalidade reflexa ou em (des)favor de uma repercussão geral, a afetação de um julgamento ao pleno, a decisão de incluir ou não um processo na pauta e o pedido de vista podem ser explicados por outras razões. Essa é a dificuldade de comprovação do modelo estratégico: a multiplicidade de interpretações

afirmado na cautelar (com o qual o relator não concordava) foi revertido, reconhecendo-se a possibilidade das interrupções de gestação na hipótese.

77 RISTF, art. 22: “O Relator submeterá o feito ao julgamento do Plenário, quando houver relevante arguição de inconstitucionalidade ainda não decidida. Parágrafo único. Poderá o Relator proceder na forma deste artigo: a) quando houver matérias em que divirjam as Turmas entre si ou alguma delas em relação ao Plenário; b) quando, em razão da relevância da questão jurídica ou da necessidade de prevenir divergência entre as Turmas, convier pronunciamento do Plenário”.

78 BULLA, Beatriz et al. Fachin manda habeas de Palocci para plenário do Supremo. Estadão. Política. Brasília, 03 maio 2017.

79 RISTF, art. 134.

80 Para um levantamento sobre a longa duração dos pedidos de vista, v. FALCÃO, Joaquim; HARTMANN, Ivar A.; CHAVES, Vitor P. III Relatório Supremo em números: o Supremo e o tempo. Rio de Janeiro: Escola de Direito do Rio de Janeiro da Fundação Getúlio Vargas, 2014. p. 89-100.

81 V., ilustrativamente, AP 937 QO, Rel. Min. Luís Roberto Barroso, j. 23 nov. 2017, acórdão pendente de publicação.

82 BARROSO, Luís Roberto. A judicialização da vida e o papel do Supremo Tribunal Federal. Belo Horizonte: Fórum, 2018. Expressão usada pelo autor na apresentação da obra. 
concorrentes para um mesmo evento, e o fato de as explicações serem produzidas a posteriori e, portanto, de serem tendenciosamente confirmadoras da hipótese com que trabalha o intérprete. A certeza acerca do comportamento estratégico é, nessa medida, de difícil obtenção. Trata-se de limitação do próprio modelo, reconhecida por seus estudiosos. Essa circunstância não afasta, contudo, a sua relevância. A despeito da dificuldade de comprovação empírica, o modelo joga luz e favorece a compreensão do comportamento das cortes em geral e do Supremo em particular.

\subsection{Atuação estratégica com base em decisões substantivas}

No que respeita à atuação estratégica com base em decisões substantivas, o caso da descriminalização do porte de drogas para uso pessoal permite que se especule a respeito ${ }^{83}$. $\mathrm{Na}$ hipótese, o Ministro Luís Roberto Barroso explicitou três ordens diferentes de razões para limitar a descriminalização do porte de droga à maconha. A primeira razão, ligada à Teoria do Precedente e, portanto, alinhada com o comportamento legalista, era de que o caso concreto, ao qual foi conferida repercussão geral, tratava, exclusivamente, do porte de maconha, de modo que essa era a moldura fática que delimitava a questão jurídica submetida à Corte. Não se debateu, na ação, o uso ou as consequências dos outros tipos de droga, mas apenas da maconha, de modo que somente era possível decidir e produzir uma tese sobre o que fora debatido ${ }^{84}$.

A segunda razão invocada pelo Ministro, ligada à primeira, de prudência, e que reconhecia o limite das capacidades institucionais da Corte na matéria, relacionava-se ao fato de não se ter acessado ou produzido no caso uma massa satisfatória de dados acerca da descriminalização de outras drogas, de modo que havia um problema de assimetria de informações e, portanto, risco de se extraírem conclusões a partir da maconha e de aplicá-las a drogas como a cocaína ou o crack, a respeito das quais o conhecimento era limitado.

Por fim, a terceira razão oferecida pelo Ministro poderia ser interpretada como a adoção de uma second best decision. Segundo o Ministro, o Supremo tem um modo de deliberar em que (diferentemente do que se narrou no caso da Suprema Corte norte-americana) não há uma reunião interna prévia, na qual é possível identificar com segurança as inclinações dos demais juízes que integram o colegiado. Embora desconhecesse como exatamente votariam os seus colegas, ele acreditava que uma posição mais restritiva quanto à descriminalização — que tratasse apenas da maconha — tinha mais chances de sensibilizar a maioria. Essa convicção — e, portanto, a dinâmica interna do colegiado — teriam influenciado a forma como se posicionou.

O Ministro Barroso declarou, ainda, que também se preocupara, no caso, com a opinião geral da população sobre a questão e como esta reagiria à decisão da Corte. Na sua visão, a maioria era resistente à descriminalização das drogas, e ir muito longe neste tema poderia ensejar "uma reação da sociedade contra a decisão, o que os americanos chamam de backlash" 85 . De fato, essa última consideração do Ministro confirma que os membros do STF podem ser sensíveis, em seu processo decisório, não apenas à interação com os demais membros do

83 STF, Pleno, j. 10.09.2015, RE 635.659, Rel. Min. Gilmar Mendes, julgamento iniciado em agosto de 2015. Votaram pelo provimento do recurso, os Ministros Gilmar Mendes e Luís Roberto Barroso; pelo provimento parcial, o Min. Edson Fachin. Na sequência, pediu vista dos autos o Min. Teori Zavascki, estando o julgamento ainda pendente de conclusão.

84 Fundamento semelhante foi utilizado pelo Ministro Luís Barroso Barroso, no RE 669.069, Rel. Teori Zavascki, para limitar a tese do julgado à prescritibilidade das ações para ressarcimento ao erário público em caso de ilícito civil, de modo a evitar que o STF decidisse e produzisse tese igualmente sobre a hipótese de (im)prescritibilidade em caso de ação de ressarcimento de dano decorrente de improbidade administrativa, hipótese não abrangida pelo caso concreto ao qual se conferiu repercussão geral. Nesse sentido, ambas as decisões parecem guardar coerência do ponto de vista do comportamento legalista. STF, Pleno, DJe, 28.04.2016, RE 669.069, Rel. Teori Zavascki.

85 O backlash se caracteriza pela rejeição social de uma decisão judicial, a ponto de se recusar seu cumprimento e/ou de se provocar a atuação das instâncias representativas — Congresso e Executivo — a fim de superá-la. V., sobre o tema: EGAN, Patrick J.; CITRIN, Jack. Opinion leadership, backlash, and delegitimation: Supreme Court rulings and public opinion. Social Science Research Network, Rochester, ago. 2009. Disponível em: <http://ssrn.com/abstract=1443631>. Acesso em: 15 mar. 2018; POST, Robert C.; SIEGEL, Reva B. Roe Rage. Democratic constitutionalism and backlash. Yale Law School Legal Scholarship Repository. Faculty Scholarship Series. Paper 169. Disponível em: <http://digitalcommons.law.yale.edu/fss_papers/169>. Acesso em: 15 maio 2018. 
colegiado, mas igualmente ao comportamento de agentes e instituições externas, tais quais a opinião pública e os demais Poderes. Veja-se ${ }^{86}$ :

A terceira razão, possivelmente uma das mais importantes, é que eu não sei bem qual é a posição do Tribunal. Nós temos um estilo de deliberação em que as pessoas não conversam internamente. Eu achei que uma posição um pouco menos avançada teria mais chance de conquistar a maioria.

Também tive a preocupação de nós não perdermos a interlocução com a sociedade, que não apoia majoritariamente a descriminalização das drogas. Mas eu acho que em relação à maconha é possível conquistar, nesse momento, com explicações racionais, essa adesão da sociedade. Ao passo que, em relação às drogas mais pesadas, isso seria mais difícil. (Grifou-se)

Embora a Constituição de 1988 assegure a independência do Poder Judiciário, ela prevê uma série de regras que funcionam como um sistema de freios e contrapesos, por meio das quais um Poder pode interferir no outro. Assim, se, por um lado, compete ao Poder Judiciário apreciar a validade de atos e normas produzidos pelo Executivo e pelo Legislativo, por outro lado, o Executivo detém o uso da força, que pode ser necessária inclusive para assegurar o cumprimento das decisões judiciais. E cabe a seu chefe indicar os ministros do Supremo. O Legislativo, por sua vez, aprova o orçamento ${ }^{87}$, o reajuste de juízes e de serventuários da Justiça e pode produzir emendas constitucionais superadoras das decisões do STF ${ }^{88}$. Cabe ao Senado, ainda, a confirmação dos ministros do Supremo indicados pelo Executivo, bem como o julgamento desses ministros por crime de responsabilidade ${ }^{89}$.

Resulta desse desenho institucional que o Supremo Tribunal Federal depende da adesão dos demais Poderes para o cumprimento dos seus julgados, e que parte da sua legitimidade deriva da credibilidade e da consistência dos argumentos que os justificam e do apoio de que gozam juntamente à população, a quem as instâncias majoritárias são (em alguma medida) responsivas ${ }^{90}$. Em razão disso, a experiência demonstra que as cortes constitucionais, a fim de preservar a própria estabilidade institucional e a sua capacidade de dizer o direito em longo prazo, produzem uma espécie de "cálculo" sobre até onde podem ir com suas decisões. Se puderem antever um grande embate com os demais Poderes, avaliarão se têm o apoio da opinião pública. Se puderem antecipar que enfrentarão a oposição da opinião pública, buscarão apoio nos demais Poderes. Se estiverem isoladas, possivelmente avaliarão se possuem capital político para seguir em frente, se o desgaste compensa, e se não é o caso de moderar seus entendimentos e de aguardar oportunidade mais favorável para determinados avanços.

Sendo capaz de antecipar a reação de outros players, como o Executivo, o Legislativo e a opinião pública, as cortes agem como explicado pela teoria dos jogos: avaliam o movimento esperado dos demais e, em caso de ameaça institucional importante, produzem julgados que não consideram ideais, mas que são as decisões possíveis no contexto, maximizando benefícios e preservando sua estabilidade, nos termos da teoria das escolhas racionais. As cortes produzem, portanto, comportamentos estratégicos também quando em interação com agentes externos ${ }^{91}$.

86 SCHREIBER, Mariana. Ministro do STF diz que Brasil deve "legalizar a maconha e ver como isso funciona na vida real". $B B C$ Brasil. 14 set. 2015. Disponível em: <http://www.bbc.com/portuguese/noticias/2015/09/150914_drogas_barroso_ms>. Acesso em: 15 mar. 2018.

87 BRASIL. Constituição (1988). Constituição da República Federativa do Brasil. Brasília: Senado Federal, 2010.Art. 165, III.

88 BRASIL. Constituição (1988). Constituição da República Federativa do Brasil. Brasília: Senado Federal, 2010. Art. 60, observados os limites do par. $4^{\circ}$.

89 BRASIL. Constituição (1988). Constituição da República Federativa do Brasil. Brasília: Senado Federal, 2010. Art. 52, II.

90 Nessa linha: EASTON, David. A re-assessment of the concept of popular support. British Journal of The Politics Science, West Nyack, n. 5, p. 435, 1975; FRIEDMAN, Barry. The will of the people: how public opinion has influenced the Supreme Court and shaped the meaning of the Constitution. Nova York: Farrar, Strauss e Giroux, 2009; LAIN, Corinna Barrett. Upside-down judicial review. Social Science Research Network, Rochester, 12 Jan. 2012. p. 2-4. Disponível em: <http://ssrn.com/abstract=1984060>. Acesso em: 15 mar. 2018; EGAN, Patrick J.; CITRIN, Jack. Opinion leadership, backlash, and delegitimation: supreme court rulings and public opinion. Social Science Research Network, Rochester, ago. 2009. Disponível em: <http://ssrn.com/abstract=1443631>. Acesso em: 15 mar. 2018; GILES, Michael W.; BLACKSTONE, Bethany; VINING, Richard L. The Supreme Court in american democracy: unraveling the linkages between public opinion and judicial decision-making. Journal of Politics, West Nyack, v. 70, p. 293-306, 2008. 91 Sobre a atuação estratégica relacionada à opinião pública no Supremo Tribunal Federal, v. BARROSO, Luís Roberto. Con- 
De fato, alguns casos recentes julgados pelo Supremo Tribunal Federal podem ser explicados com base nessa perspectiva. Em 2014, teve início a fase ostensiva das investigações da operação Lava Jato ${ }^{22}$, que tinham por objeto um grande esquema de corrupção e de desvio de recursos públicos envolvendo a Petrobrás, empresas de infraestrutura contratadas pelo Poder Público, partidos políticos e altas autoridades da República ${ }^{93}$. Em 2015, as investigações da Lava Jato alcançaram autoridades detentoras de foro especial no STF, como deputados, senadores e ministros de Estado, e revelaram um esquema de corrupção sistêmica que alcançava parcela substancial do meio político. Por isso, parte de tais investigações passou a correr no Supremo. No mesmo ano, teve início o processo de impeachment da presidente Dilma Rousseff, concluído com sua cassação em $2016^{94}$.

O ambiente de desconfiança, denuncismo e conflagração que se instalou no país colocou o Supremo Tribunal Federal em uma posição institucional bastante delicada. Mandados de segurança, recursos e ações de habeas corpus pertinentes ao processo de impeachment, à Lava Jato e a outros casos que envolviam políticos relevantes chegaram à Corte e despertaram a atenção da imprensa. Passou-se a exigir do Tribunal o reiterado escrutínio dos atos dos demais Poderes. Até mesmo a escolha de ministros de Estado foi judicializada ${ }^{95}$. Ações penais de autoridades de grande peso começaram a tramitar e a ser apreciadas diante do olhar da imprensa e da opinião pública. Diversos membros de Poderes tornaram-se alvos de investigações e passaram a ser alcançados por decisões do Supremo. Sucessivos escândalos e uma instabilidade política, econômica e institucional sem precedentes se instalou.

Nesse contexto, o presidente do Senado, autoridade que se colocava na linha sucessória da presidência da República, teve uma denúncia recebida contra si por peculato. Ocorre que a maioria da Corte já havia manifestado entendimento, no âmbito da ADPF 402, no sentido de que as autoridades que figurassem como réus em processos criminais não poderiam ocupar cargos que integrassem tal linha sucessória. Por essa razão, o relator da ADPF determinou, monocraticamente, o afastamento cautelar do parlamentar da presidência do Senado. A decisão, todavia, gerou enorme resistência e foi interpretada como uma intromissão em outro Poder. A despeito da eficácia imediata da decisão, a mesa diretora do Senado declarou que só a cumpriria após a confirmação pelo plenário do STF. Rumores indicavam que, em caso de confirmação da liminar, a autoridade buscaria o apoio de seus pares, a fim de desobedecer a decisão e desautorizar o Tribunal.

Na semana seguinte, o pleno do Supremo Tribunal Federal rejeitou a cautelar na parte em que afastava o parlamentar da Presidência do Senado e assentou apenas que, estando em curso processo criminal, o senador não poderia substituir o(a) presidente da República, devendo a substituição, se necessária, ser efetuada pela autoridade subsequente na linha sucessória ${ }^{96}$. Em síntese, diante do risco de descumprimento da decisão, a Corte recuou.

Episódio semelhante envolveu o afastamento cautelar do exercício do mandato de outro senador, deter-

stituição, democracia e supremacia judicial: direito e política no Brasil contemporâneo. Revista da Faculdade de Direito - UERJ, v. 2, n. 21, jan./jun. 2012; MELLO, Patrícia Perrone Campos. Nos bastidores do Supremo Tribunal Federal. Rio de Janeiro: Forense, 2015. p. 293-370. Sobre atuação semelhante na Suprema Corte norte-americana, v. FRIEDMAN, Barry. The will of the people: how public opinion has influenced the Supreme Court and shaped the meaning of the Constitution. Nova York: Farrar, Strauss e Giroux, 2009. p. 244-246.

92 As investigações relacionadas à operação tiveram início no ano de 2009. As primeiras interceptações telefônicas ocorreram em julho de 2013. A fase ostensiva ocorre com o cumprimento de mandados de busca e apreensão, de prisão temporária, de prisão preventiva e de busca e apreensão. V. MINISTÉRIO PÚBLICO FEDERAL. Caso Lava Jato. Disponível em: <http://www.mpf. mp.br/para-o-cidadao/caso-lava-jato/atuacao-na-1a-instancia/investigacao/historico>. Acesso em: 07 maio 2018.

93 V. MINISTÉRIO PÚBLICO FEDERAL. Caso Lava Jato. Disponível em: < http://www.mpf.mp.br/para-o-cidadao/caso-lavajato/entenda-o-caso>. Acesso em: 07 maio 2018.

94 GARCIA, Gustavo et al. Senado aprova impeachment, Dilma perde mandato e Temer assume. G1. Política. 31 ago 2016. Disponível em: <http://g1.globo.com/politica/processo-de-impeachment-de-dilma/noticia/2016/08/senado-aprova-impeachmentdilma-perde-mandato-e-temer-assume.html>. Acesso em: 15 maio 2018.

95 V. STF, Pleno, DJe, 01.08.2016, ADPF 388, Rel. Min. Gilmar Mendes; STF, Pleno, DJe, 08.08.2017, ADPF 390 AgR, Rel. Min. Alexandre de Moraes.

96 STF, Pleno, DJe, 01.02.2017, ADPF 402 MC, redator p/ o referendo de liminar Min. Celso de Mello, pendente. 
minada pela Primeira Turma do STF ${ }^{97}$. No ano anterior, o Tribunal determinara o afastamento cautelar do presidente da Câmara, da presidência e do mandato, por decisão unânime de seus membros, com base em indícios de que o parlamentar vinha praticando atos voltados à obstrução de investigações criminais ${ }^{98}$. $\mathrm{O}$ deputado tivera uma atuação extremamente ostensiva e sua imagem encontrava-se bastante desgastada. $\mathrm{O}$ afastamento foi cumprido pela Câmara sem grandes sobressaltos.

A Lava Jato continuou a avançar. O número de autoridades e de políticos envolvidos em investigações era cada vez maior. Um ano mais tarde, a Primeira Turma determinou o afastamento de um senador, figura que até então gozara de alta proeminência, por graves indícios de solicitação de vantagem indevida a particulares. Nessa oportunidade, contudo, a decisão gerou fortes reações. As relações entre Supremo e Senado voltaram a se esgarçar e falava-se, novamente, na possibilidade de descumprimento da decisão.

Nesse contexto, levou-se ao plenário do STF uma ação direta em que se postulava que o Tribunal reconhecesse que qualquer decisão cautelar que interferisse no exercício do mandato parlamentar deveria ser ratificada pela respectiva casa legislativa ${ }^{99}$. O Supremo mudou de entendimento e concluiu, por uma maioria de 6 a 5, que tais afastamentos deveriam passar a ser ratificados pelo Legislativo ${ }^{100}$. Na sequência, o Senado rejeitou a cautelar que ensejava o afastamento do senador, por uma decisão de 44 a $26 \operatorname{votos}^{101}$. Mais uma vez, o Supremo recuava diante do Senado.

Houve quem entendesse que a decisão do STF apenas dava adequado julgamento à matéria, corrigindo o erro cometido nos precedentes anteriores. Houve quem apostasse que a decisão do STF não teria sido descumprida e que, ao decidir de tal modo, a própria Corte se desautorizara e fragilizara sua posição institucional. Muitos, contudo, interpretavam o episódio como uma "saída honrosa" articulada pelo Supremo, para evitar o aberto descumprimento da sua decisão.

A atuação estratégica encontra dificuldades em situação de assimetria de informações, como já antecipado. Saber se a decisão do Supremo será realmente descumprida de antemão pode ser difícil. Nessas circunstâncias, a credibilidade da ameaça (de descumprimento) e a gravidade das suas consequências para a autoridade do Tribunal podem ser suficientes para levar parte de seus membros a optar por uma second best decision. A decisão (de afastamento do senador) já estava tomada, mas se abriu caminho à sua superação pelo Senado, ao decidir que a palavra final sobre o assunto ficava com a casa legislativa.

O fato é que, na sequência, a imunidade reconhecida aos parlamentares federais foi aplicada pelas casas legislativas estaduais. As Assembleias Legislativas passaram a entender, por simetria, que também lhes cabia dar a última palavra acerca de cautelares que embaraçassem o exercício de mandato por seus membros. Novas ações diretas foram ajuizadas, então, para discutir a questão ${ }^{102}$. Por meio delas, alegava-se que somente as imunidades materiais detidas pelos deputados federais se estendiam aos deputados estaduais, mas não as imunidades formais, muito embora o art. $27, \S 1^{\circ}$, da Constituição, que tratava do assunto, não fizesse

97 STF, Primeira Turma, AgR no Terceiro AgR na AC 4327, DJe, 27.10.2017, Rel. Min. Marco Aurélio, Red. p/ acórdão Min. Luís Roberto Barroso.

98 AC 4070, Pleno, j. 05.05.2016, Rel. Min. Teoria Zavascki.

99 O argumento constitucional envolvia a interpretação conforme dos arts. 312 e 319 do Código de Processo Penal, que previam a possibilidade do deferimento de cautelares (inclusive a suspensão do exercício de função pública), à luz do art. 53 , par. $2^{\circ}$, da Constituição. Esse dispositivo determinava: "Desde a expedição do diploma, os membros do Congresso Nacional não poderão ser presos, salvo em flagrante de crime inafiançável. Nesse caso, os autos serão remetidos dentro de vinte e quatro horas à Casa respectiva, para que, pelo voto da maioria de seus membros, resolva sobre a prisão". Alegava-se que o propósito desse dispositivo era preservar o princípio da separação dos Poderes e o exercício do mandato parlamentar, razão pela qual a decisão final sobre qualquer cautelar de afastamento do mandato, e não apenas acerca da prisão, deveria caber à respectiva Casa Legislativa.

100 STF, Pleno, j. 11.10.2017, ADI 5526, Rel. Min. Edson Fachin, Red. p/ acórdão Min. Alexandre de Moraes.

101 AGÊNCIA SENADO. Plenário rejeita medidas cautelares contra Aécio Neves e senador retoma mandato. 17 out. 2017. Disponível em: <https://www12.senado.leg.br/noticias/materias/2017/10/17/senado-derruba-decisao-do-stf-contra-aecio>. Acesso em: 15 abr. 2018.

102 STF, Pleno, ADI 5823 MC, Rel. Min. Marco Aurélio, ADIs 5824 e 5825 MC, Rel. Min. Edson Fachin, j. 07.12.2017, julgamento não concluído. 
qualquer diferença expressa no ponto ${ }^{103}$. Ao apreciar as ações, uma maioria de 5 a 4 do STF se manifestou pela não aplicação aos deputados estaduais da imunidade formal na extensão proclamada em favor dos parlamentares federais.

O julgamento foi interrompido para aguardar a manifestação dos Ministros Barroso e Lewandowski, que estavam ausentes da sessão. De todo modo, estabeleceu-se uma diferença entre o tratamento dado aos deputados federais e aos deputados estaduais, em uma matéria em que o texto constitucional não fazia qualquer distinção expressa. Uma explicação possível para a aparente inconsistência é que, no caso das Assembleias Legislativas, eventual descumprimento era menos crível ou menos grave para a Corte. As Assembleias Legislativas representavam uma ameaça menor à posição institucional do Supremo Tribunal Federal e à sua autoridade do que o Congresso Nacional. Sem um risco institucional relevante para o Supremo, não havia incentivo suficiente para provocar uma atuação estratégica em favor dos deputados estaduais.

\section{Considerações finais}

Pensar em uma Corte Constitucional simplesmente como um órgão que atua na preservação dos direitos fundamentais e no adequado funcionamento do processo democrático, com base em princípios e no melhor argumento, significa idealizar o papel desempenhado pelas cortes, fechar os olhos para o contexto em que elas operam e, por consequência, deixar de compreender os limites e constrangimentos reais que enfrentam no desempenho das suas funções. Embora o comportamento judicial legalista tenha o seu valor para explicar o processo decisório do Supremo Tribunal Federal em um grande conjunto de casos, em que a Corte opera na correção de erros e na reiteração da jurisprudência, ele, possivelmente, terá baixo potencial explicativo nas decisões de casos difíceis, em que o material jurídico ortodoxo oferece balizas incompletas para a decisão, ou em face de uma situação de conflagração entre Poderes.

Nesses casos, o modelo de comportamento ideológico e o modelo de comportamento estratégico têm uma função explicativa que precisa ser considerada. Segundo o modelo ideológico, em casos difíceis, em que os referenciais normativos são fluidos e as questões são moralmente controvertidas, os magistrados tendem a decidir, de forma consciente ou até mesmo inconsciente, com base em suas convicções ideológicas, em suas pré-compreensões e em suas experiências pretéritas. Nesse contexto, conhecer esses elementos é importante para produzir uma argumentação capaz de sensibilizá-los, para compreender e controlar vieses cognitivos e para produzir um juízo crítico sobre a atuação da Corte. Por um lado, o comportamento ideológico encontra limites no modelo legalista: o texto, os precedentes e a dogmática restringem as suas possibilidades ou, ao menos, tornam a atuação ideológica mais evidente. Por outro lado, encontra limites na necessidade de atuação estratégica.

Segundo o comportamento estratégico, os juízes agem como agentes racionais e pautam sua conduta pela teoria dos jogos. Ao proferirem seus votos procuram maximizar benefícios, influenciar o Direito e fazê-lo avançar de forma convergente com as suas preferências. Ocorre que um juiz constitucional não decide sozinho. Depende dos demais colegas para fazer prevalecer o seu entendimento. Depende dos demais Poderes para ter as suas decisões cumpridas. Depende do apoio popular para manter a sua autoridade. Portanto, se pretende verdadeiramente influenciar o conteúdo do Direito, precisa buscar proferir decisões que obtenham a adesão da maioria da Corte, que sejam cumpridas pelos outros Poderes e que tenham o suporte da opinião pública. Os confrontos são possíveis e as decisões impopulares são sustentáveis pontualmente, mas não de forma contínua e sistemática, sem um grande desgaste político ou sem importantes ameaças

103 BRASIL. Constituição (1988). Constituição da República Federativa do Brasil. Brasília: Senado Federal, 2010. Art. 27, \1: "Será de quatro anos o mandato dos Deputados Estaduais, aplicando-se-lhes as regras desta Constituição sobre sistema eleitoral, inviolabilidade, imunidades, remuneração, perda de mandato, licença, impedimentos e incorporação às Forças Armadas”. 
institucionais. Uma corte sob forte pressão dos demais Poderes só atuará a contento se movida por muito apoio popular. Esse cálculo político é parte do processo de autopreservação das instituições.

De fato, a credibilidade do Judiciário deriva, ao menos em parte, da percepção de que decide com base em princípios e orientado por normas preexistentes, infensas à política. A atuação judicial politizada é negativa para a imagem dos tribunais e para sua autoridade. Contudo, para que as cortes se aproximem desse modelo alegadamente ideal, é preciso entender como a vida funciona na prática. É preciso atentar para o contexto e as resistências poderosas que enfrentam. É preciso compreender os limites e incentivos que favorecem uma maior independência ou uma maior politização. E é fundamental atuar sobre eles. Teorias normativas sobre a função judicial devem partir de descrições realistas de como o Judiciário e os Poderes Políticos atuam. Em síntese, portanto, para buscarmos o Supremo Tribunal Federal que desejamos, precisamos enxergar o Supremo de que dispomos - "o Supremo como ele é".

\section{REFERÊNCIAS}

ARGUELHES, Diego Werneck; RIBEIRO, Leandro Molhano. Quando a unanimidade não esclarece. Valor, 22 jun. 2012. Disponível em: <http://www.osconstitucionalistas.com.br/quando-a-unanimidade-naoesclarece>. Acesso em: 15 mar. 2018.

ASHENFELTER, Orley; EISENBERG, Theodore; SCHWAB, Stewart. Politics and the judiciary: the influence of judicial background on case outcomes. Journal of Legal Studies, Filadélfia, v. 24, n. 2, p. 257, jun. 1995. Disponível em: <http://scholarship.law.cornell.edu/cgi/viewcontent.cgi?article $=1411 \&$ context $=$ fac pub>. Acesso em: 15 mar. 2018.

BARROSO, Luís Roberto. A judicialização da vida e o papel do Supremo Tribunal Federal. Belo Horizonte: Fórum, 2018.

BARROSO, Luís Roberto. Constituição, democracia e supremacia judicial: direito e política no Brasil contemporâneo. Revista da Faculdade de Direito - UERJ, v. 2, n. 21, jan./jun. 2012.

BARROSO, Luís Roberto. Curso de direito constitucional contemporâneo: os conceitos fundamentais e a construção de um novo modelo. São Paulo: Saraiva, 2009.

BARROSO, Luís Roberto. O controle de constitucionalidade no direito brasileiro. 7. ed. São Paulo: Saraiva, 2016.

BARROSO, Luís Roberto. Reflexões sobre as competências e o funcionamento do Supremo Tribunal Federal. In: BARROSO, Luís Roberto. Um outro país: transformações no direito, na ética e na agenda do Brasil. Belo Horizonte: Fórum, 2018.

BARROSO, Luís Roberto; MONTEDÔNIO, Frederico. Como salvar a repercussão geral: transparência, eficiência e realismo na escolha do que o Supremo Tribunal Federal vai julgar. In: BARROSO, Luís Roberto. Um outro país: transformações no direito, na ética e na agenda do Brasil. Belo Horizonte: Fórum, 2018.

BAUM, Lawrence. Judges and their audiences: a perspective on judicial behavior. Nova Jersey: Princeton University, 2008.

BENESH, Sara C.; SPAETH, Harold J. The Supreme Court justice-centered judicial databases: the Warren, Burger, and Rehnquist Courts 1953-2000. East Lansing: Michigan State University, 2003. Disponível em: < http:// artsandsciences.sc.edu/poli/juri/flpdcodebk.pdf>. Acesso em: 15 mar. 2018.

BICKEL, Alexander M. The least dangerous branch: the Supreme Court at the bar of politics. New Haven: Yale University, 1986.

BRASIL. Constituição (1988). Constituição da República Federativa do Brasil. Brasília: Senado Federal, 2010. 
BRASIL. Lei nº 13.105, de 16 de marco de 2015. Código de Processo Civil. 2015.

BRASIL. Supremo Tribunal Federal. AC 4070, Pleno, j. 05.05.2016, Rel. Min. Teori Zavascki.

BRASIL. Supremo Tribunal Federal. Pleno, ADI 3510, DJe, 28.05.2010, Rel. Min. Ayres Britto.

BRASIL. Supremo Tribunal Federal. Pleno, ADI 4277 e ADPF 132, DJe, 14.10.2011, Rel. Min. Ayres Britto.

BRASIL. Supremo Tribunal Federal. Pleno, ADI 5526, j. 11.10.2017, Rel. Min. Edson Fachin, Red. p/ acórdão Min. Alexandre de Moraes.

BRASIL. Supremo Tribunal Federal. Pleno, ADI 5823 MC, Rel. Min. Marco Aurélio, julgamento não concluído.

BRASIL. Supremo Tribunal Federal. Pleno, ADIs 5824 e 5825 MC, Rel. Min. Edson Fachin, julgamento não concluído.

BRASIL. Supremo Tribunal Federal. Pleno, ADPF 402 MC, DJe, 01.02.2017, Red. p/ o referendo de liminar Min. Celso de Mello, acórdão pendente.

BRASIL. Supremo Tribunal Federal. Pleno, ADPF 54, DJe, 30.04.2013, Rel. Min. Marco Aurélio.

BRASIL. Supremo Tribunal Federal. Pleno, AP 937 QO, j. 03.05.2018, Rel. Min. Luís Roberto Barroso, acórdão pendente de publicação.

BRASIL. Supremo Tribunal Federal. Pleno, ARE 1054490 QO, DJe, 09.03.2018, Rel. Min. Luís Roberto Barroso.

BRASIL. Supremo Tribunal Federal. Pleno, Inq. 687, DJ, 9 nov. 2001, Rel. Min. Sydney Sanches.

BRASIL. Supremo Tribunal Federal. Pleno, RE 590.415, DJe, 29.05.2015, Rel. Min. Luís Roberto Barroso.

BRASIL. Supremo Tribunal Federal. Pleno, RE 602.381, DJe, 04.02.2015, Rel. Min. Cármen Lúcia.

BRASIL. Supremo Tribunal Federal. Pleno, RE 669.069, DJe, 28.04.2016, Rel. Min. Teori Zavascki.

BRASIL. Supremo Tribunal Federal. Primeira Turma, AgR no Terceiro AgR na AC 4327, DJe, 27.10.2017, Red. p/ acórdão Min. Luís Roberto Barroso.

BRASIL. Supremo Tribunal Federal. Regimento Interno: [atualizado até julho de 2016]: consolidado e atualizado até maio de 2002 por Eugênia Vitória Ribas. Brasília: STF, 2016.

BRENNER, Saul; WHITMEYER, Joseph M. Strategy on the United States Supreme Court. Nova York: Cambridge University, 2009.

BULLA, Beatriz et al. Fachin manda habeas de Palocci para plenário do Supremo. Estadão. Política. Brasília, 3 maio 2017.

CALDEIRA, Gregory A.; WRIGHT, John R. Organized interest and agenda setting in the U.S. Supreme Court. American Political Science Review, Washington, v. 82, p. 1109-1127, 1988.

CARDOZO, Benjamin N. The nature of the judicial process. Nova York: Dover Publications, 2005.

CORAM, Bruce Talbot. Second best theories and the implications for institutional design. In: GOODIN, Robert E. The theory of institutional design. Cambrige: Cambridge University Press, 1995.

COX, Adam; MILES, Thomas. Judging the voting rights act. Disponível em: < https://chicagounbound.uchicago.edu/cgi/viewcontent.cgi?article=8033\&context=journal_articles $>$. Acesso em: 30 jun. 2018.

CROSS, Frank B.; NELSON, Blake J. Strategic institutional effects on Supreme Court decisionmaking. New York University Law Review, Nova York, v. 95, p. 1437, 2001.

CROSS, Frank P.; TILLER, Emerson H. Judicial partisanship and obedience to legal doctrine: whistle- 
blowing on the Federal Courts of Appeals. Yale Law Journal, New Haven, v. 107, p. 2155, 1998.

EASTON, David. A re-assessment of the concept of popular support. British Journal of The Politics Science, West Nyack, n. 5, p. 435, 1975.

EGAN, Patrick J.; CITRIN, Jack. Opinion leadership, backlash, and delegitimation: supreme court rulings and public opinion. Social Science Research Network, Rochester, ago. 2009. Disponível em: <http://ssrn.com/ abstract $=1443631>$. Acesso em: 15 mar. 2018.

ELSTER, Jon. Explaining social behavior: more nuts and bolts for the social sciences. Nova York: Cambridge University, 2007.

ELSTER, Jon. Introduction. In: ELSTER, Jon. Rational choice. Nova York: New York University, 1986.

EPSTEIN, Lee et al. Do political preferences change?: a longitudinal study of U.S. Supreme Court justices. Journal of Politics, West Nyack, v. 60, n. 3, p. 801-818, ago. 1988.

EPSTEIN, Lee; KNIGHT, Jack. Documenting strategic interaction on the U.S. Supreme Court, 1995. Disponível em: <http:/ / epstein.wustl.edu/research/conferencepapers.1995APSA.pdf>. Acesso em: 30 jun. 2018.

EPSTEIN, Lee; KNIGHT, Jack. The choices justices make. Washington: CQ Press, 1998.

FACHIN, Luiz Edson (Org.). Repensando fundamentos do direito civil contemporâneo. Rio de Janeiro: Renovar, 1998.

FALCÃO, Joaquim; CERDEIRA, Pablo de Camargo; ARGUELHES, Diego Werneck. I Relatório Supremo em Números: o múltiplo Supremo. Rio de Janeiro: Escola de Direito do Rio de Janeiro da Fundação Getúlio Vargas, abr. 2011. Disponível em: <http://bibliotecadigital.fgv.br/ojs/index.php/rda/article/view/8913>. Acesso em: 30 jun. 2018.

FALCÃO, Joaquim; HARTMANN, Ivar A.; CHAVES, Vitor P. III Relatório Supremo em números: o Supremo e o tempo. Rio de Janeiro: Escola de Direito do Rio de Janeiro da Fundação Getúlio Vargas, 2014. Disponível em: $<$ https://bibliotecadigital.fgv.br/dspace/bitstream/handle/10438/12055/III\%20Relat\%C3\%B3rio\%20 Supremo $\% 20 \mathrm{em} \% 20 \mathrm{~N} \% \mathrm{C} 3 \%$ BAmeros $\% 20-\% 20 \mathrm{O} \% 20$ Supremo $\% 20 \mathrm{e} \% 20 \mathrm{o} \% 20$ Tempo.pdf $>$. Acesso em: 30 jun. 2018.

FRANK, Jerome. Are judges human?. In: FRANK, Jerome. Courts on trial: myth and reality in american justice. Nova Jersey: Princeton University Press, 1949.

FRIEDMAN, Barry. The importance of being positive: the nature and function of judicial review. University of Cincinnati Law Review, Cincinnati, v. 72, p. 1257, 2004.

FRIEDMAN, Barry. The politics of judicial review. Texas Law Review, Austin, v. 84, p. 257, 2005.

FRIEDMAN, Barry. The will of the people: how public opinion has influenced the Supreme Court and shaped the meaning of the Constitution. Nova York: Farrar, Strauss e Giroux, 2009.

GILES, Michael W.; BLACKSTONE, Bethany; VINING, Richard L. The Supreme Court in american democracy: unraveling the linkages between public opinion and judicial decision-making. Journal of Politics, West Nyack, v. 70, p. 293-306, 2008.

GOMES, Joaquim Benedito Barbosa. Vivi muita pobreza até os 17 anos. O Estado de São Paulo. São Paulo, 8 maio 2003. Nacional, p. A9. Entrevista concedida a Mariângela Gallucci. Disponível em: <http://www.stf. jus.br/portal/cms/ver'Texto.asp?servico=bibliotecaConsultaProdutoBibliotecaPastaMinistro\&pagina=Joa quimBarbosaEntrevistas.pdf>. Acesso em: 30 jun. 2018.

GROSSMAN, Joel B. Social backgrounds and judicial decision-making. Harvard Law Review, Cambridge, v. 79, p. 1551, 1966.

HOLMES, Oliver Wendell Jr. The path of the law. Harvard Law Review, v. 110, p. 991, 1897, p. 994. 
LAIN, Corinna Barrett. Upside-down judicial review. Social Science Research Network, Rochester, 12 jan. 2012. Disponível em: <http://ssrn.com/abstract=1984060>. Acesso em: 15 mar. 2018.

LLEWELYN, Karl N. The common law tradition: deciding appeals. Boston: Little, Brown and Company, 1960.

MARTIN, Andrew D. et al. Competing approaches to predicting Supreme Court decision-making. Perspectives on Politics, New York, v. 2, p. 761, 2004.

MARTIN, Andrew D.; QUINN, Kevin M. Assessing preference change on the U.S. Supreme Court. Journal of Law, Economics, and Organization, p. 16-18, 11 maio 2007. Disponível em: <http://www.law.berkeley.edu/ files/prefchange.pdf $>$. Acesso em: 26 set. 2013.

MELLO, Marco Aurélio. Competência: palavra que melhor resume o nosso Ministro do Supremo Tribunal Federal. Jornal da Cidade. Sergipe, 7 out. 2003. Suplemento especial. Disponível em: < http://www.stf.jus.br/ arquivo/biblioteca/PastasMinistros/ MarcoAurelio/Entrevistas/2003_out_07.pdf>. Acesso em: 29 mar. 2018.

MELLO, Patrícia Perrone Campos. Nos bastidores do Supremo Tribunal Federal. Rio de Janeiro: Forense, 2015.

MELLO, Patrícia Perrone Campos; BAQUEIRO, Paula Andrade. Distinção inconsistente e superação de precedentes no Supremo Tribunal Federal. Revista Brasileira de Políticas Públicas, v. 8, n. 1, p. 668-690, abr. 2018.

MENDES, Gilmar. Vou defender minhas posições. Jornal do Brasil. Rio de Janeiro, 26 maio 2002. p. 10. Entrevista concedida a Gustavo Krieger. Disponível em: < http://www.stf.jus.br/arquivo/biblioteca/PastasMinistros/GilmarMendes/Entrevistas/2002_maio_26.pdf>. Acesso em: 2 abr. 2018.

MILES, Thomas J.; SUNSTEIN, Cass R. Do judges make regulatory policy? An empirical investigation of Chevron. University of Chicago Law Review, Chicago, v. 73, p. 823, 2006.

MILES, Thomas J.; SUNSTEIN, Cass R. The new legal realism. Chicago: University of Chicago, 2007. Disponível em: <http://papers.ssrn.com/sol3/papers.cfm?abstract_id=1070283\#\#>. Acesso em: 15 mar. 2018.

MORAES, Maria Celina Bodin. A caminho de um direito civil constitucional. Revista de Direito Civil, n. 65, 1993.

PERESIE, Jennifer. Female judges matter: gender and collegial decision-making in the Federal Appellate Courts. Yale Law Journal, New Haven, v. 114, n. 7, may 2005. Disponível em: <https://www.yalelawjournal. $\mathrm{org} /$ note/female-judges-matter-gender-and-collegial-decisionmaking-in-the-federal-appellate-courts $>$. Acesso em: 26 mar. 2018.

PETTIT, Philip. Institutional design and rational choice. In: GOODIN, Robert E. The theory of institutional design. Nova York: Cambridge University, 1996.

PINELLO, Daniel R. Linking party to judicial ideology in american courts: a meta-analysis. Justice System Journal, Denver, v. 20, p. 219, 1999.

POSNER, Richard. How judges think. Cambridge: Harvard University, 2008.

POSNER, Richard. What do judges maximize? (the same thing everybody else does). Supreme Court Economic Review, Nova York, v. 3, p. 1, 1993.

POST, Robert C.; SIEGEL, Reva B. Roe Rage. Democratic constitutionalism and backlash. Yale Law School Legal Scholarship Repository. Faculty Scholarship Series. Paper 169. Disponível em: < http://digitalcommons. law.yale.edu/fss_papers/169>. Acesso em: 15 maio 2018.

REVESZ, Richard L. Environmental regulation, ideology, and the D.C. circuit. Virginia Law Review, Charlottesville, v. 83, p. 1717, 1997. 
RODRIGUES, Nelson. A vida como ela é: o homem fiel e outros contos. São Paulo: Companhia das Letras, 1992.

SCHREIBER, Mariana. Ministro do STF diz que Brasil deve "legalizar a maconha e ver como isso funciona na vida real”. BBC Brasil. 14 set. 2015. Disponível em: <http://www.bbc.com/portuguese/noticias/2015/09/150914_drogas_barroso_ms>. Acesso em: 15 mar. 2018.

SEGAL, Jeffrey A. et al. Ideological values and the votes of U.S. Supreme Court justices revisited. Journal of Politics, West Nyack, v. 57, p. 815, 1995.

SEGAL, Jeffrey A.; COVER, Albert D. Ideological values and the votes of U. S. Supreme Court Justices. American Political Science Review, Washington, v. 83, p. 557, 1989.

SEGAL, Jeffrey A.; SPAETH, Harold J. The Supreme Court and the attitudinal model revisited. Nova York: Cambridge University, 2002.

SHAUER, Frederick. Incentives, reputation and the inglorious determinants of judicial behavior. Cincinnati Law Review, v. 68, p. 615-636, 2000.

SISK, Gregory C.; HEISE, Michael. Judges and ideology: public and academic debates about statistical measures. Northwestern University Law Review, Chicago, v. 99, 2005.

SISK, Gregory C.; HEISE, Michael; MORRISS, Andrew P. Charting the influences on the judicial mind: an empirical study of judicial reasoning. New York University Law Review, New York, v. 73, p. 1377, 1998.

SOLBERG, Rorie Spill. Judicial behavior in constitutional challenges before the Rehnquist Court. Journal of Empirical Legal Studies, Oxford, v. 3, p. 245, jul. 2006.

SONGER, Donald R.; LINDQUIST, Stefanie. Not the whole story: the impact of justices' values on Supreme Court decision-making. American Journal of Political Science, Detroit, v. 40, n. 4, p. 1049-1063, nov. 1996.

SOUZA NETO, Cláudio Pereira; SARMENTO, Daniel. A constitucionalização do direito: fundamentos teóricos e aplicações específicas. Rio de Janeiro: Lumen Juris, 2007.

SOUZA NETO, Cláudio Pereira; SARMENTO, Daniel. Direito constitucional: teoria, história e métodos de trabalho. Rio de Janeiro: Forense, 2013.

Stone, Seidman; Sunstein, Tushnet. Constitutional law. 3. ed. Boston: Little, Brown and Company, 1992.

SUNSTEIN, Cass R. et al. Are judges political? An empirical analysis of the federal judiciary. Washington: Brookings Institution, 2006.

TAHA, Ahmed E. Judge shopping: testing whether judges' political orientation affect case filings. University of Cincinnati Law Review, v. 20, p. 101-130, 2010.

TVERSKY, Amos; KAHNEMAN, Daniel. The framing of decisions and the psychology of choice. In: ELSTER, Jon. Rational choice. Nova York: New York University Press, 1986.

U.S. SUPREME COURT. Craig v. Boren, 429 U.S. 190 (1976).

U.S. SUPREME COURT. Marbury v. Madison, 5 U.S. (1 Cranch) 137 (1803).

WALD, Patricia. A response to Tiller and Cross. Columbia Law Review, Nova York, v. 99, 1999. 


\section{REVISTA BRASILEIRA DE POLÍTICAS PÚBLICAS BRAZILIAN JOURNAL OF PUBLIC POLICY}

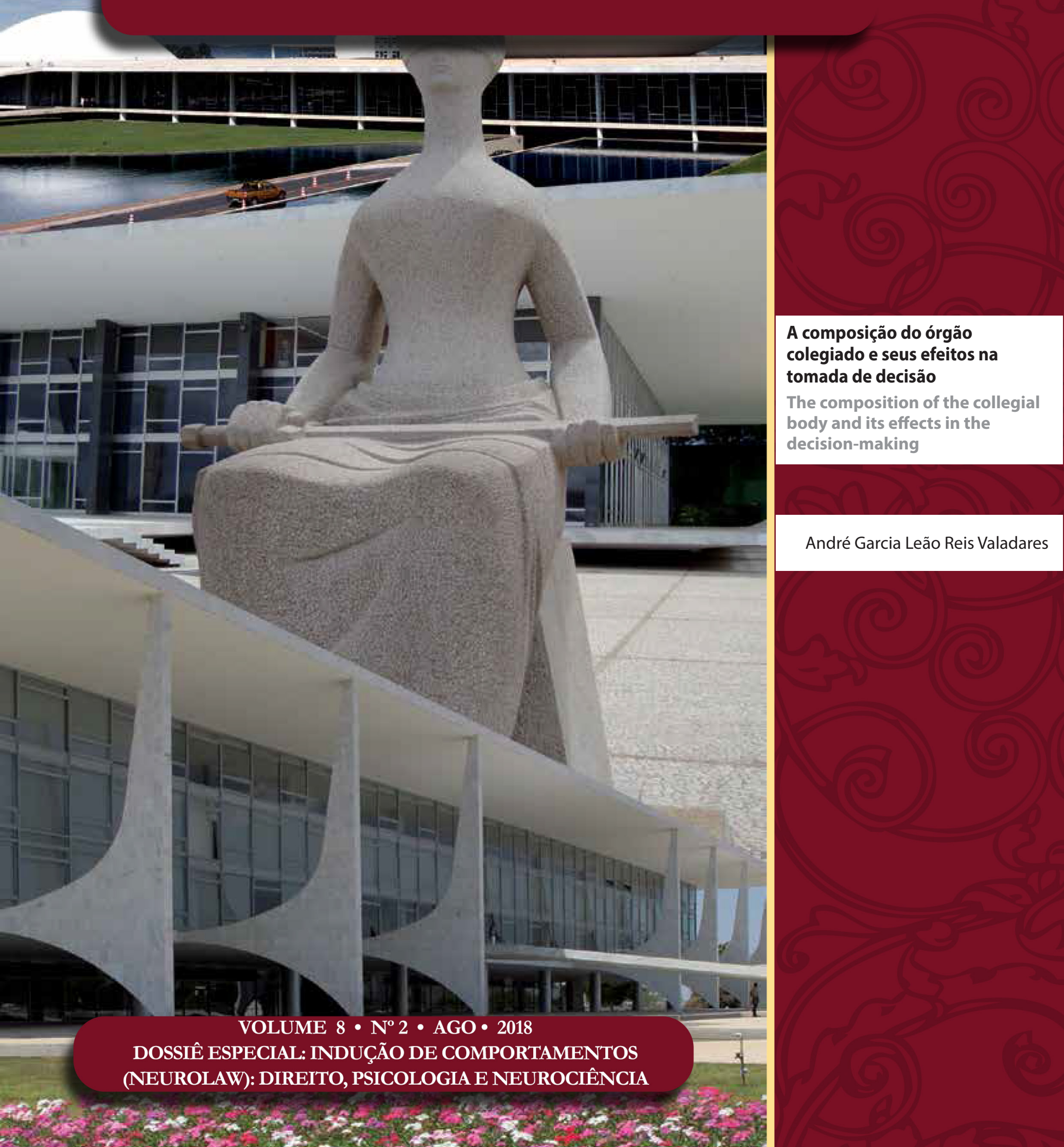




\section{A composição do órgão colegiado e seus efeitos na tomada de decisão*}

\section{The composition of the collegial body and its effects in the decision-making}

André Garcia Leão Reis Valadares**

\section{Resumo}

O presente artigo pretende analisar, com base no conceito de colegialidade e de deliberação, os efeitos gerados pela composição do órgão colegiado no processo de tomada de decisão em um Tribunal. Inicialmente, o trabalho debate a estrutura colegiada dos Tribunais, especialmente as características e os propósitos de se organizar os órgãos julgadores em formato coletivo. Posteriormente, busca-se compreender o fenômeno deliberativo, sua base filosófica no campo da política e sua relação com a colegialidade. Em seguida, tomando-se como base pesquisas empíricas realizadas no país e no exterior, o trabalho examina como a diversidade (ou a sua ausência) afeta a forma como os casos são julgados e o comportamento dos julgadores em órgãos colegiados, especialmente em relação ao seu desempenho deliberativo. Ao final, conclui-se que a diversidade pode afetar o grau de deliberatividade entre os seus membros, seja mitigando diferenças em prol da unanimidade, seja polarizando o grupo em direção a posições extremas.

Palavras-chave: Colegialidade. Deliberação. Composição. Comportamento.

\section{Abstract}

This article aims to analyze, from the concept of collegiality and deliberation, the effects generated by the composition of the collegial body in the decision-making process in a Court. Initially, the paper discusses the structure in which trials are ruled by a panel of judges, especially the characteristics and purposes of organizing the courts in a collective body. Afterwards, it is sought to comprehend the deliberative phenomenon, its philosophical base in the politics area and its relationship with collegiality. Then, based on empirical research conducted in Brazil and abroad, the paper examines how diversity (or its absence) affects the way cases are judged and the behavior of judges in collegial bodies, especially their deliberative performance. At the end, it is concluded that diversity can affect the degree of deliberativeness among its members, either by mitigating differences in favor of unanimity, or by polarizing the group towards extreme positions.

Keywords: Collegiality. Deliberation. Composition. Behavior.

** Mestre em Direito pela Universidade Federal de Minas Gerais. Pós-Graduado em Direito Tributário pela Faculdade Milton Campos. Advogado. E-mail: agarciavaladares@yahoo.com.br.
Recebido em 21/05/2018 Aprovado em 05/07/2018 


\section{INTRODUÇÃo}

Desde a década de 1990, vê-se o esforço legislativo (constitucional e infraconstitucional) em reforçar a orientação firmada pelos tribunais. São vários os exemplos nas reformas constitucionais, como a Emenda Constitucional no 45/2004, que introduziu o instituto da Súmula Vinculante, e infraconstitucionais, como a Lei no 9.756/98, que alterou a redação do art. 557 do Código de Processo Civil de 1973 (CPC/73), para que o relator pudesse negar seguimento a recurso manifestamente inadmissível, improcedente, prejudicado ou em confronto com súmula ou com jurisprudência dominante do respectivo tribunal, do STF ou de tribunal superior. Foi a primeira vez que se inseriu no CPC/73 a influência da jurisprudência dominante dos tribunais.

Em adequação ao comando constitucional da Emenda no 45/04, a Lei no 11.418/06 acresceu os arts. 543-A e 543-B ao CPC/73. O primeiro regulamentou o instituto da repercussão geral, que passou a ser, conforme o texto constitucional, requisito de admissibilidade do recurso extraordinário. O segundo criou a nova sistemática de julgamento de recurso extraordinário representativo de controvérsia, para a análise da repercussão geral quando houvesse multiplicidade de recursos com fundamento em idêntica controvérsia. A Lei $\mathrm{n}^{\circ} 11.672 / 08$, por sua vez, ao acrescentar o art. 543-C ao CPC/73, criou, também para o recurso especial, a sistemática de julgamento de recurso representativo de controvérsia, quando houvesse multiplicidade de recursos com fundamento em idêntica questão de direito.

Essa orientação foi reafirmada e reforçada com o Código de Processo Civil de 2015 (CPC/15 - Lei n. 13.105/15). O novo código estabeleceu, pela primeira vez no ordenamento processual brasileiro, um sistema de precedentes. $\mathrm{O}$ art. 926 trouxe como orientação a necessidade de os tribunais uniformizarem sua jurisprudência e de mantê-la estável, íntegra e coerente. Por sua vez, o art. 927 lista os "tipos" de julgamento de observância obrigatória pelos juízes e pelos tribunais. São eles: (i) as decisões do STF em controle concentrado de constitucionalidade, conforme também previsto no art. 102, $\$ 2^{\circ}$, da Constituição; (ii) os enunciados de súmula vinculante, como estipulado no art. 103-A da Constituição; (iii) os acórdãos em incidente de assunção de competência ou de resolução de demandas repetitivas e em julgamento de recursos extraordinário e especial repetitivos; (iv) os enunciados das súmulas do STF em matéria constitucional e do STJ em matéria infraconstitucional, observado que, nos termos do art. 926, $\iint 1^{\circ}$ e $2^{\circ}$, esses tribunais devem editar enunciados de súmula correspondentes a sua jurisprudência dominante, atendo-se às circunstâncias fáticas dos precedentes que motivaram sua criação; (v) a orientação do plenário ou do órgão especial aos quais estiverem vinculados. As hipóteses listadas incluem situações que são alcançadas necessariamente por meio do julgamento colegiado.

Com efeito, o CPC/15 impõe uma lógica relacionada ao art. 927. Ao longo do código, treze dispositivos preveem situações específicas envolvendo súmulas, jurisprudência dominante ou julgamento de casos repetitivos. ${ }^{1}$ Nota-se, portanto, que, por opção do legislador, o CPC/15 deu uma grande importância ao entendimento firmado pelos tribunais.

É por esse motivo que, com o CPC/15, revela-se ainda mais importante conferir a devida atenção aos julgamentos colegiados. São desses julgamentos que se extraem os entendimentos que servirão de norte para o julgamento em primeiro (eficácia vertical) e em segundo (eficácia horizontal) graus de jurisdição.

Diante desse contexto, é preciso enfrentar o modo como as decisões colegiadas são formadas. O que se desenvolverá adiante é, primordialmente, consequência de uma revisitação do princípio da colegialidade e dos motivos de se organizar os tribunais em órgãos colegiados. Posteriormente, a esse conceito será inserida a ideia de deliberação e sua base filosófica no campo da política, como critério a nortear o julgamento colegiado nos Tribunais. Com isso, passa-se, em seguida, a se debater, levando-se como base pesquisas empíricas

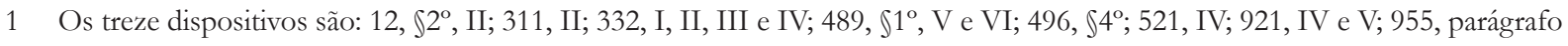
único, I e II; 988, IV; 1.022, parágrafo único, I; 1.030, I, ‘b’; 1.035, $\$ 3^{\circ}, \mathrm{I} ; 1.035, \S 7^{\circ}$. 
realizadas no país e no exterior, especificamente como a composição do órgão colegiado afeta a forma que os julgadores se portam e são influenciados pelos outros julgadores.

\section{A colegialidade}

Os Tribunais, no Brasil e no mundo, tendem a se organizar por meio de órgãos colegiados. No nosso país, são compostos por câmaras, turmas e/ou órgãos especiais, cada qual contendo um certo número de juízes e suas respectivas funções regimentais. ${ }^{2}$ Em contraposição ao método de julgamento de primeira instância - como padrão, realizado monocraticamente, isto é, por juízes singulares ${ }^{3}$ 一, o julgamento nos Tribunais envolve, em regra, mais de um juiz. ${ }^{4}$

De forma geral (ou seja, não restrita para a colegialidade no âmbito do Poder Judiciário), a entidade coletiva se caracteriza pela união de pessoas num esforço coordenado na busca por um fim em comum. Para Kornhauser e Sager ${ }^{5}$, o formato coletivo pode se qualificar de quatro diferentes modos: (i) distributivo, (ii) de equipe, (iii) redundante e (iv) colegial.

As formas distributiva e de equipe se distinguem uma da outra pela maneira que cada uma estabelece a coordenação entre os membros. No modelo distributivo, apesar de os indivíduos agirem isoladamente, há a prévia separação (e a necessária coordenação) dos trabalhos. Nos modelos distributivos mais básicos, os participantes possuem tarefas idênticas, multiplicando a performance, que será, em verdade, a reprodução em conjunto da mesma atividade. Kornhauser e Sager citam como exemplo a situação de várias pessoas pintando uma casa ou trabalhadores cuidando de um campo. Nos modelos mais complexos, cada um dos participantes possui sua respectiva tarefa. É o caso das linhas de produção industriais, em que cada envolvido atua de forma independente, mas sempre vinculado à finalidade comum. O objetivo, nesse caso, consiste em otimizar ou acelerar o desempenho buscado.

A coletividade de equipe, por sua vez, exige dos membros uma atitude coordenada durante a atuação. Cada participante deve considerar (e responder a) o trabalho feito pelos outros durante o seu desempenho;

2 Lei Complementar n. 35/79 (Lei Orgânica da Magistratura): “Art. 101 - Os Tribunais compor-se-ão de Câmaras ou Turmas, especializadas ou agrupadas em Seções especializadas. A composição e competência das Câmaras ou Turmas serão fixadas na lei e no Regimento Interno.

$\int 1^{\circ}$ - Salvo nos casos de embargos infringentes ou de divergência, do julgamento das Câmaras ou Turmas, participarão apenas três dos seus membros, se maior o número de composição de umas ou outras.

$\int 2^{\circ}$ - As Seções especializadas serão integradas, conforme disposto no Regimento Interno, pelas Turmas ou Câmaras da respectiva área de especialização.

$\int 3^{\circ}$ - A cada uma das Seções caberá processar e julgar:

a) os embargos infringentes ou de divergência das decisões das Turmas da respectiva área de especialização;

b) os conflitos de jurisdição relativamente às matérias das respectivas áreas de especialização;

c) a uniformização da jurisprudência, quando ocorrer divergência na interpretação do direito entre as Turmas que a integram;

d) os mandados de segurança contra ato de Juiz de Direito;

c) as revisões criminais e as ações rescisórias dos julgamentos de primeiro grau, da própria Seção ou das respectivas Turmas.

$\int 4^{\circ}$ - Cada Câmara, Turma ou Seção especializada funcionará como Tribunal distinto das demais, cabendo ao Tribunal Pleno, ou ao seu órgão especial, onde houver, o julgamento dos feitos que, por lei, excedam a competência de Seção."

3 No Brasil, o julgamento monocrático em primeira instância é considerado neste texto como regra por comportar exceção. Mencione-se, por exemplo, a ressalva contida na Lei n. 12.694/12, que dispõe sobre o processo e o julgamento colegiado em primeiro grau de jurisdição de crimes praticados por organizações criminosas. Na Europa, também existem julgamentos colegiados em primeiro grau. É o caso da França, em que se admite a colegialidade, em primeira instância, não apenas em matéria penal (como na Cour d'Assises, que julga crimes cujas penas superam 10 anos), mas também em matéria cível (como no Tribunal de Grande Instance, que julga litígios que superam 10 mil euros).

4 A regra do julgamento colegiado nos Tribunais se excepciona pela possibilidade de julgamento monocrático nas hipóteses especificadas no art. 932, III, IV e V, do Código de Processo Civil de 2015.

5 KORNHAUSER, Lewis. A.; SAGER, Lawrence G. The one and the many: adjudication in collegial courts. California Law Review, v. 81 , n. 1 , p. 3-5, 1993. 
o resultado somente é alcançado por meio da atuação coordenada dos envolvidos. Nessa situação, o desempenho que se busca realizar é redefinido, intrinsecamente, pela relação entre os membros da equipe; isto é, a interação dos membros da coletividade é essencial para o objetivo final. Kornhauser e Sager ilustram esse modelo com as orquestras e com os times de esportes coletivos — basquete, futebol etc.

Por outro lado, os modelos redundante e colegial não buscam amplificar ou remodelar o desempenho da tarefa desejada. Em vez disso, têm como finalidade realizar tarefas que, a princípio, poderiam representar o esforço de uma só pessoa; executá-las por entidades coletivas visa trazer o desempenho para mais perto do ideal.

De acordo com Kornhauser e Sager, a coletividade redundante se baseia numa estrutura externa de múltiplos esforços independentes. São caracterizados por independência dos envolvidos, que não atuam de forma colaborativa. Processos e regras regulam e vinculam a atuação dos membros da coletividade. Muitas vezes, a interação entre os membros é, inclusive, vedada, justamente para preservar uma revisão influenciada pela conclusão alheia. Exemplos mencionados pelos autores são o controle de qualidade num processo de automação industrial, composto por três inspetores, ou o julgamento em eventos esportivos, integrado por três jurados. No primeiro caso, um inspetor pode concluir pela rejeição do processo, enquanto os outros dois podem aprová-lo; o resultado pode ser a aprovação por unanimidade ou pela maioria. Na segunda hipótese, cada jurado avalia a performance do atleta sem consultar seus colegas e os resultados são agregados (seja pela soma, seja pela média, seja por qualquer outro método de apuração).

A coletividade colegial, a seu turno, assemelha-se à atuação por equipe (mencionada anteriormente), já que deve levar em consideração os colegas que também realizam a tarefa. Caracteriza-se pela colaboração e pela deliberação dos seus membros. Enquanto a interação e a troca de informações não são buscadas na coletividade redundante, elas são vitais para o resultado do modelo colegial. O resultado alcançado pela coletividade colegial é, na verdade, produto único da interação daquela entidade coletiva. É por isso que se diz que a coletividade colegial pressupõe a alteração na forma de atuação individual para uma atuação em grupo. Kornhauser e Sager citam o trabalho de cientistas em uma pesquisa e de alunos em um trabalho escolar.

Também no Poder Judiciário, não há regra na atuação colegiada. No Tribunal do Júri, por exemplo, a atuação dos sete jurados ocorre segundo o modelo redundante. Uma vez sorteados, os jurados não podem comunicar-se entre si e com outrem, nem manifestar sua opinião sobre o processo (art. 466, \$1 ${ }^{\circ}$, do Código de Processo Penal - CPP). A votação ocorre de maneira sigilosa e por meio de respostas simples (sim ou não) inseridas em um papel (arts. 486 e 487 do CPP). Não há — e não deve haver — colaboração ou deliberação entre os jurados.

A questão deve ser vista de outra forma, porém, caso se trate dos julgamentos colegiados nos Tribunais. No julgamento monocrático, o juiz deve, à luz da lide posta e das provas produzidas nos autos, julgar o caso com base nas suas reflexões e convicções sobre o direito. ${ }^{6}$ Por sua vez, o julgamento colegiado nos Tribunais, em tese, pode se dar de duas formas.

Se os julgadores do órgão colegiado refletem isoladamente, consultam apenas as suas próprias fontes e expõem suas conclusões sem levar em consideração os seus pares, o colegiado estará a atuar de forma redundante. A adoção da regra da maioria, pura e simplesmente, portanto, aproxima o julgamento desse modelo (redundante) de coletividade. Nesses casos, os votos serão individualmente considerados na perspectiva agregativa. $\mathrm{O}$ resultado do julgamento pode ser à unanimidade, mas a construção da decisão — por meio da agregação dos votos — se dá pela reflexão individual — e não colaborativa — dos membros do órgão julgador. Essa é uma possibilidade, pois a corte colegiada não seria, na essência, um corpo deliberativo. ${ }^{7}$

6 SHAPIRO, ao tratar de deliberação, conclui: "Deliberation is not an isolated activity. Rather it is an interactive one involving two or more people. We can be individually reflective but not individually deliberative". SHAPIRO, Ian. Optimal deliberation?. The Journal of Political Philosophy, v. 10, n. 2, p. 197, 2002.

7 MENDES, Conrado Hübner. Constitutional courts and deliberative democracy. Oxford: Oxford University Press, 2013. p. 62. 
Em outras palavras, na atuação redundante, o julgador do órgão colegiado atua de forma idêntica ao juiz monocrático. A presença dos demais membros julgadores não gera efeitos na reflexão a respeito da controvérsia nem na tomada de decisão. A existência de outros julgadores nessa hipótese serve, apenas, para a contabilização dos votos.

Por outro lado, a atuação do órgão julgador colegiado também pode se realizar pelo formato colegial. Nesse caso, os membros julgadores atuam de forma colaborativa e deliberativa, a partir da troca de informações, na busca da melhor solução jurídica para o caso. Isto é, os julgadores trabalham como um grupo, não como participantes individuais com função meramente agregativa dos seus entendimentos. ${ }^{8}$

Com base nessa realidade, devem-se revisitar as razões subjacentes à opção pela estruturação dos tribunais em órgãos colegiados. Em resumo, são identificadas quatro razões: (i) a despersonificação; (ii) a contenção do arbítrio individual; (iii) a abertura a várias vozes e ao desacordo; e (iv) o reforço das chances de acerto.

A despersonificação, em que a decisão tomada pelo colegiado é resultado de um juízo construído pela instituição, dissociada de seus membros, pode ser apontada como um reforço do caráter da impessoalidade, da independência e da imparcialidade dos membros julgadores do órgão colegiado. Com a contenção do arbítrio individual, evita-se a concentração de muito poder nas mãos de uma só pessoa, tutelando o jurisdicionado e o conteúdo da prestação jurisdicional. ${ }^{9}$ A abertura a várias vozes e ao desacordo, além de traduzir o reconhecimento de que o conceito de Direito (ou a interpretação do Direito), por sua complexidade, deve estar aberto à argumentação e à divergência, proporciona a concretização do princípio constitucional do contraditório, enquanto garantia de participação influente das partes na elaboração do provimento judicial. Como consequência das três razões anteriores, a colegialidade, ao aumentar o número de juízes na tomada de decisões, amplifica a possibilidade de que o resultado seja uma melhor decisão, por instigar o diálogo, a difusão de novas ideias, a consideração atenta das críticas e a percepção de que o resultado do julgamento é coletivo e não individual.

A exposição dos quatro elementos da colegialidade — despersonificação, contenção do arbítrio individual, abertura a várias vozes e ao desacordo e reforço das chances de acerto — reforça o caráter colegial (ou deliberativo) que deve guiar os trabalhos nos Tribunais.

Assim, o sentido da estrutura colegiada dos Tribunais, pautados pelas mencionadas características, deve promover a interação dos seus variados membros para, a partir da construção conjunta da decisão, potencializar o melhor resultado. Nessa linha de raciocínio, o ambiente deliberativo deve afastar a ideia de mera contagem agregativa — redundante — de votos individuais dos julgadores.

Enfim, dentro da ideia de um ambiente deliberativo, que será melhor exposto no tópico II, é possível perceber que a composição do órgão colegiado possui forte influência na tomada de decisão individual dos julgadores, tema que será mais bem trabalhado, a partir de pesquisas empíricas, no tópico III.

8 Saul Tourinho Leal, ao discorrer sobre Cortes Supremas (em especial o STF e a Suprema Corte americana), comenta a diferença entre uma corte redundante e uma corte colegial: "Muito se diz sobre as Supremas Cortes. O ritual, a solenidade, os protocolos, os mantos negros sobre as costas dos julgadores e o poder de suas decisões contribuem para todo tipo de comentário, alguns reais, outros mera ficção. Fala-se que elas seriam espécies de confrarias, ou, então, um tipo bem peculiar de clube. Também se comenta que ali teríamos uma arena. Pode ser uma constelação, com inúmeras estrelas ou quem sabe um arquipélago, repleto de ilhas, às vezes, bem distantes umas das outras." LEAL, Saul Tourinho. Por dentro das supremas cortes: bastidores, televisionamento e a magia da tribuna. Revista Brasileira de Políticas Públicas, v. 5, número especial, p. 539, 2015.

9 Interessante notar que a despersonificação, de um lado, e a contenção do arbítrio individual, de outro, são elementos da tensão entre a garantia da independência judicial e o dever de prestar contas, discutida por Marcelo Roseno de Oliveira em seu artigo "A responsabilidade social da magistratura brasileira: accountability e responsividade em meio à tensão entre o dever de prestar contas e a garantia da independência judicial”. Para o autor, "[e]m algumas situações, parece evidente que uma maior permeabilidade à opinião pública é salutar e reforçará o valor da legitimidade democrática do Poder Judiciário. Em outras, porém, pode aparentar um risco à independência judicial conferir espaço significativo à opinião pública ou a outros instrumentos populares de pressão e influência, sob pena de que ponha em risco a própria missão institucional da magistratura" OLIVEIRA, Marcelo Roseno de. A responsabilidade social da magistratura brasileira: accountability e responsividade em meio à tensão entre o dever de prestar contas e a garantia da independência judicial. Revista Brasileira de Políticas Públicas, v. 6, n. 3, p. 30, 2016. 


\section{A DeLIBERAÇÃo}

A deliberação tem sido considerada, para a teoria política democrática, um valioso componente da tomada de decisões coletivas. ${ }^{10} \mathrm{~A}$ introdução desse elemento na teoria política difere da teoria da democracia agregativa. ${ }^{11}$ Nesta, as preferências dos cidadãos e dos seus representantes são aceitas como são dadas, independentemente de qualquer justificativa. A decisão, nessa linha de raciocínio, é alcançada pela mera tomada da maioria ou pelo filtro do custo-benefício (utilitarista). ${ }^{12}$

A maior crítica à teoria agregativa é considerá-la inadequada para a tarefa de produzir normas aplicáveis a toda a sociedade a partir, apenas, do mecanismo eleitoral. ${ }^{13}$ Além disso, a agregação de preferências individuais dissociada de justificativas, além de reforçar as distribuições de poder existentes na sociedade, não permite que os cidadãos questionem os próprios métodos da agregação. ${ }^{14}$

Nesse sentido, a deliberação, como elemento da democracia, consiste (i) na atividade interativa e cooperativa dos participantes, (ii) que expõem e discutem as razões que justificam suas preferências, (iii) dispostos a mudá-las, (iv) com o propósito (não necessário) de se alcançar o consenso sobre a melhor decisão. Nas palavras de Mendes: ${ }^{15}$

10 MENDES, Conrado Hübner. Constitutional courts and deliberative democracy. Oxford: Oxford University Press, 2013. p. 14.

11 A propósito, KNIGHT, Jack; JOHNSON, James. Aggregation and deliberation: on the possibility of democratic legitimacy. Political Theory, v. 22, p. 277-296, 1994; GUTMANN, Amy; THOMPSON, Dennis. O que significa democracia deliberativa. Revista Brasileira de Estudos Constitucionais, Belo Horizonte, ano 1, n. 1, p. 17-78, jan./mar. 2007.

12 GUTMANN, Amy; THOMPSON, Dennis. O que significa democracia deliberativa. Revista Brasileira de Estudos Constitucionais, Belo Horizonte, ano 1, n. 1, p. 30-31, jan./mar. 2007.

13 KNIGHT, Jack; JOHNSON, James. Aggregation and deliberation: on the possibility of democratic legitimacy. Political Theory, v. 22, p. 277, 1994. O seguinte trecho demonstra as críticas ao mecanismo exclusivo do voto:

"According to William Riker, social choice theory highlights two sorts of difficulty with voting: instability and ambiguity. Voting is unstable because, under certain conditions to which we return below, all known aggregation mechanisms can generate cyclical or intransitive social orderings. Because of this indeterminacy, electoral outcomes are subject to manipulation via strategic voting or agenda control. And in any particular case it is typically impossible to know whether or not a decision is the product of such manipulation.

Voting is ambiguous because electoral outcomes are, at least in part, artifacts of the process by which votes are counted. Starting from the same initial profile of individual preferences, different methods of aggregation — different methods of counting votes — yield different, sometimes dramatically different, social outcomes. Moreover, Riker argues that because each sort of aggregation mechanism violates one or another common criterion of fairness or consistency, no independent, external standard exists for discriminating between methods of vote counting. In particular, there is no way to determine which voting method most accurately represents the popular or collective will". Jeremy Waldron. WALDRON, Jeremy. A dignidade da legislação. São Paulo: M. Fontes, 2003. p. 1-2), por sua vez, faz duras críticas à ideia de que o majoritarismo, por si só, é inadequado enquanto teoria política:

"Acredito que a legislação e as legislaturas têm má fama na filosofia jurídica e política, uma fama suficientemente má para lançar dúvidas quanto a suas credenciais como fontes do direito respeitáveis. Se essa má fama é ou não merecida por causa das extravagâncias, passadas e presentes, digamos, dos membros da Câmara dos Comuns britânica ou das duas casas do Congresso dos EUA, é uma questão sobre a qual não me pronunciarei. Isso porque o problema que percebo é que nem sequer desenvolvemos uma teoria normativa da legislação que pudesse servir como base para criticar ou corrigir tais extravagâncias. Mais importante, não possuímos um modelo jurisprudência capaz de compreender normativamente a legislação como forma genuína de direito, a autoridade que ela reivindica e as exigências que faz aos outros atores em um sistema jurídico.

$[\ldots]$

Não apenas não temos os modelos de legislação normativos ou aspiratórios de que precisamos, mas a nossa jurisprudência está repleta de imagens que apresentam a atividade legislativa comum como negociata, troca de favores, manobras de assistência mútua, intriga por interesses e procedimentos eleitoreiros — na verdade, como qualquer coisa, menos decisão política com princípios. E há razão para isso. pintamos a legislação com essas cores soturnas para dar credibilidade à ideia de revisão judicial (isto é, revisão judicial da legislação, sob a autoridade de uma carta de direitos) e ao silêncio que, de outra maneira, seria o nosso embaraço quanto às dificuldades democráticas ou 'contramajoritárias' que, às vezes, pensamos que a revisão judicial implica."

14 GUTMANN, Amy; THOMPSON, Dennis. O que significa democracia deliberativa. Revista Brasileira de Estudos Constitucionais, Belo Horizonte, ano 1, n. 1, p. 33, jan./mar. 2007.

15 MENDES, Conrado Hübner. Constitutional courts and deliberative democracy. Oxford: Oxford University Press, 2013. p. 14. No original: "Deliberation features no less than a respectful and inclusive practice of reasoning together while continuously seeking solutions for decisional demands, of forming your position through the give-and-take of reasons in the search of, but not necessarily reaching, consensus about the common good. Thus, participants of deliberation, before counting votes, are open to transform their preferences in the light of well-articulated and persuasive arguments". 
Deliberação significa não menos que uma prática respeitosa e inclusiva de raciocínio conjunto enquanto se busca, constantemente, soluções para uma demanda, se forma uma posição a partir da troca de razões na busca, mas não necessariamente no alcance, do consenso sobre o bem comum. Assim, participantes da deliberação, antes da contagem dos votos, estão abertos à alterar suas preferências à luz de argumentos bem articulados e persuasivos. (tradução livre)

Cada peça desse conceito merece ser mais bem detalhada. A atividade deliberativa pressupõe interação e cooperação. Não se trata de uma atividade isolada. ${ }^{16} \mathrm{E}$ não se trata, tampouco, de simplesmente tomar uma decisão em grupo na forma da classificação redundante de Kornhause e Sager. ${ }^{17}$ Isto é, não basta agregar entendimentos; a deliberação impõe, para se chegar ao resultado, a interação e a troca de informações, na forma do modelo colegial de Kornhauser e sager. ${ }^{18}$

É justamente a presença de interação e de cooperação que leva à segunda e à terceira características da deliberação. Por transcender a mera agregação de opiniões, exige-se que os participantes exponham as razões que fundamentam suas preferências, de modo que, a partir do exercício mútuo de justificações, são viabilizados a discussão e o diálogo antes da decisão coletiva ser tomada. ${ }^{19}$

Gutmann e Thompson apontam a exigência de justificação (reason-giving) como a primeira e mais importante característica da democracia deliberativa. ${ }^{20}$ Para eles, "as pessoas não deveriam ser meramente tratadas como objetos da legislação, como sujeitos passivos a serem governados". Ao contrário, no seu entender, os administrados devem ser compreendidos "como agentes autônomos que fazem parte do governo de sua própria sociedade, diretamente ou através de seus representantes". ${ }^{21}$ Os motivos, portanto, devem ser aceitos pelas pessoas que buscam termos justos de cooperação.

A exposição das razões, porém, não basta. Ela deve ser a faísca para a interação entre os deliberadores. E, nesse sentido, os participantes devem buscar ou ao menos estarem dispostos a ouvir e a revisar o ponto de vista inicial. ${ }^{22}$ A própria natureza do processo deliberativo significa que os participantes desejam participar de um diálogo em que as razões dadas e as razões contra-argumentadas podem se alterar. ${ }^{23}$

A exposição das razões e a disposição para ouvi-las funcionam, também, como compartilhamento de informações. ${ }^{24}$ É plausível assumir que, quanto mais bem informados, maiores as chances de que os partici-

16 SHAPIRO, Ian. Optimal deliberation?. The Journal of Political Pbilosophy, v. 10, n. 2, p. 197, 2002. "Deliberation is not an isolated activity. Rather, it is an interactive one involving two or more people. We can be individually reflective but not individually deliberative. [...] As well as being interactive, deliberation is a cooperative activity in the sense of being a common enterprise".

17 KORNHAUSER, Lewis. A.; SAGER, Lawrence G. The one and the many: adjudication in collegial courts. California Law Review, v. 81, n. 1, p. 3-5, 1993. Como explicado no capítulo anterior, o modelo redundante de coletividade se caracteriza pela independência dos membros, que não atuam de forma colaborativa.

18 KORNHAUSER, Lewis. A.; SAGER, Lawrence G. The one and the many: adjudication in collegial courts. California Law Review, v. 81, n. 1, p. 3-5, 1993. O modelo colegial, a seu turno, é aquele em que os membros da colegialidade levam em consideração a opinião dos demais participantes, caracterizando-se, portanto, pela colaboração e pela deliberação da entidade coletiva.

19 MENDES, Conrado Hübner. Constitutional courts and deliberative democracy. Oxford: Oxford University Press, 2013. p. 15.

20 O conceito de democracia deliberativa de Gutmann E Thompson é o seguinte: "uma forma de governo na qual os cidadãos livres e iguais (e seus representantes) justificam suas decisões, em um processo no qual apresentam um aos outros motivos que são mutuamente aceitos e geralmente acessíveis, com o objetivo de atingir conclusões que vinculem no presente todos os cidadãos, mas que possibilitam uma discussão futura". GUTMANN, Amy; THOMPSON, Dennis. O que significa democracia deliberativa. Revista Brasileira de Estudos Constitucionais, Belo Horizonte, ano 1, n. 1, p. 23, jan./mar. 2007.

21 GUTMANN, Amy; THOMPSON, Dennis. O que significa democracia deliberativa. Revista Brasileira de Estudos Constitucionais, Belo Horizonte, ano 1, n. 1, p. 19-20, jan./mar. 2007. A exigência de justificação será, oportunamente, relacionada com o dever de fundamentação das decisões judiciais; igualmente, a ideia de que o administrado não deve ser tratado como objeto da legislação, mas como agente atuante, também será confrontado com o contraditório no processo judicial.

22 MENDES, Conrado Hübner. Constitutional courts and deliberative democracy. Oxford: Oxford University Press, 2013. p. 16. FEREJOHN, Jonh; PASQUINO, Pasquale. Constitutional courts as deliberative institutions: towards an institutional theory of constitutional justice. In: SADURSKI, wojciech. Constitutional justice, east and west. The Hague, London, New York: Kluwer Law International, 2003. p. 23. 23 GUTMANN, Amy; THOMPSON, Dennis. O que significa democracia deliberativa. Revista Brasileira de Estudos Constitucionais, Belo Horizonte, ano 1, n. 1, p. 37, jan./mar. 2007.

24 FEARON, James D. Deliberation as discussion. In: ELSTER, Jon. Deliberative democracy. Cambridge: Cambridge University Press, 1998, p. 45. 
pantes da deliberação tomem decisões mais acertadas. ${ }^{25} \mathrm{O}$ compartilhamento de informações, aliás, é parte importante da interação e cooperação entre os membros da deliberação. A tomada de decisão, ainda que individual, deve garantir a oportunidade para que todos os partícipes tenham conhecimento das informações a que outros membros tiveram acesso, além da opinião de cada um.

É por isso que Gutmann e Thompson também elencam, entre as principais características da democracia deliberativa, que os motivos dados no processo deliberativo sejam "acessíveis a todos os cidadãos aos quais eles são endereçados". ${ }^{26}$ Eles sustentam que "a deliberação possui maior chance de êxito à medida que os deliberadores sejam mais bem informados, possuam relativamente as mesmas fontes, e levam a sério as opiniões de seus adversários". ${ }^{27}$

Dispondo de todas as informações, e abertos a revisitar o respectivo entendimento, os deliberadores podem, inclusive, chegar a conclusões não alcançadas com base em reflexões isoladas. A troca de informações e compreensões provoca um recíproco "enlightenment", nas palavras de Silva: ${ }^{28}$

Quando problemas são complexos, ideias individuais, ainda que compartilhadas, podem não levar a uma decisão ótima. O que é preciso é um intenso intercâmbio de argumentos, um 'esclarecimento recíproco', para que novas ideias possam surgir. Qualquer pessoa que, em qualquer ponto de sua vida, teve que resolver um problema complexo com outras pessoas, certamente sabe os benefícios e o poder criativo da tempestade de ideias (brainstorming). No procedimento de mera agregação de votos, não há espaço para a tempestade de ideias. Somente o processo deliberativo pode nutrir a criatividade para o novo, soluções construídas coletivamente. (tradução livre)

Ao fim, diante de todas as características anteriores, a atividade deliberativa, por possuir a mesma finalidade (no caso da política, o bem comum), deve buscar o consenso. ${ }^{29}$ Mendes enumera cinco tipos de consenso: espontâneo, produto de parcerias, pragmático, advindo do compromisso sem princípios e coercivo. ${ }^{30}$

O consenso espontâneo é aquele que resulta, automaticamente, da prática deliberativa. A partir da deliberação, os participantes expõem suas ideias, debatem e naturalmente convencem uns aos outros. ${ }^{31}$ É o tipo de consenso que se espera de um processo deliberativo puro, fundado na única e exclusiva busca pelo melhor resultado.

Caso o consenso não nasça espontaneamente, há outros métodos intermediários (mas não exatamente puros) que podem construí-lo. Essas estratégias envolvem como elemento necessário o compromisso, que

25 SILVA, Virgílio Afonso da. Deciding without deliberation. International Journal of Constitutional Law, v. 11, p. 561, 2013. Veja-se: "It is plausible to assume that in almost every decisional situation, the better the person is informed, the greater is the likelihood that she will make a wise decision. Even if it is true that the greater the amount of information, the more complex the decision-making process may turn out to be, it is also true that ignoring crucial information may lead, to say the least, to suboptimal decisions".

26 GUTMANN, Amy; THOMPSON, Dennis. O que significa democracia deliberativa. Revista Brasileira de Estudos Constitucionais, Belo Horizonte, ano 1, n. 1, p. 20, jan./mar. 2007.

27 GUTMANN, Amy; THOMPSON, Dennis. O que significa democracia deliberativa. Revista Brasileira de Estudos Constitucionais, Belo Horizonte, ano 1, n. 1, p. 27, jan./mar. 2007.

28 SILVA, Virgílio Afonso da. Deciding without deliberation. International Journal of Constitutional Law, v. 11, p. 561, 2013. No original: "When problems are complex, individual ideias, even if shared, may not lead to an optimal decision. What is needed is an intense exchange of arguments, a 'reciprocal enlightenment', so that new ideias may emerge. Any person who, at any point in her life, had to solve complex problems together with other persons, surely knows the benefits and the creative power of 'brainstorming'. In purely aggregative voting procedures, there is no room for brainstorming. Only deliberative procedures can foster the creativity for new, collectively constructed solutions". As considerações de MENDES são no mesmo sentido: "Deliberation would still fuel the ability of the group to come up with solutions not envisioned by any individual alone. It would be, therefore, a (iii) creative-sparkling exercise." MENDES, Conrado Hübner. Constitutional courts and deliberative democracy. Oxford: Oxford University Press, 2013. p. 24. Igualmente, SHAPIRO: "[...] there may sometimes be solutions to conflicts which no party is likely to figure out on her own, but might emanate from collective brainstorming in a context where reason-seeking sets a backdrop of cooperative expectations. [...] Regardless of possible transformative or cathartic effects on preferences, deliberation may throw up ways of dealing with conflicts that otherwise might not come to the fore". SHAPIRO, Ian. Optimal deliberation?. The Journal of Political Philosophy, v. 10, n. 2, p. $199,2002$.

29 SHAPIRO, Ian. Optimal deliberation?. The Journal of Political Philosophy, v. 10, n. 2, p. 198, 2002.

30 MENDES, Conrado Hübner. Constitutional courts and deliberative democracy. Oxford: Oxford University Press, 2013. p. 26.

31 MENDES, Conrado Hübner. Constitutional courts and deliberative democracy. Oxford: Oxford University Press, 2013. p. 26. 
pode ser de três tipos. Um deles é o compromisso como produto de parcerias. Acontece na hipótese em que um participante cede à opinião do colega por não estar seguro do melhor resultado. Diante dessa situação de incerteza, acompanha a ideia de outro participante, a partir de critérios de parceria e confiança. ${ }^{32}$ Outra possibilidade é o consenso pragmático. Nessa situação, o participante também cede a sua ideia principal, para que haja consenso sobre a sua segunda melhor opção. ${ }^{33}$ Em vez de manter o dissenso, o participante opta por consentir sobre sua segunda opção, a fim de evitar a indecisão ou mesmo um cenário pior. Em ambos os casos, porém, o compromisso advém de comportamentos baseados na busca pelo bem comum. O terceiro tipo de consenso que depende de certo compromisso, por outro lado, é aquele em que o bem comum não é o objetivo do participante. É o consenso advindo do compromisso sem princípios, fundado na busca do bem privado, por meio da barganha. Ou seja, é o acordo alcançado pela concessão de ideias, baseado em trocas mútuas de interesse. ${ }^{34}$

Por fim, o quinto tipo de consenso é aquele imposto pela força. Isto é, ocorre no caso em que o consenso não advém de ideias ou compromissos, mas, unicamente, pela coerção de um participante sobre outro. ${ }^{35}$

Entretanto, nem todos os tipos de consenso são compatíveis com a deliberação. O consenso coercivo, por exemplo, afasta qualquer tipo de troca de ideias; e, por isso, nem se pode dizer, propriamente, em consenso. Nos casos de compromisso, o consenso produto de parcerias pressupõe a deliberação. É que, apesar de o participante não ter certeza sobre a melhor opção, ele ouviu as razões dos outros membros. O consenso pragmático, também, comporta a deliberação, uma vez que pressupõe que o participante que cede sua primeira opção saiba as alternativas. Por fim, o consenso advindo do compromisso sem princípios não comporta qualquer tipo de deliberação. Como, nesse caso, o participante busca o benefício próprio, não há intercâmbio de ideias que o faça interessar pelo debate a respeito do melhor resultado para o bem comum.

A deliberação, porém, não necessariamente deve alcançar o consenso. Se ela pode ensejar a interação entre os participantes e a disposição de expor e ouvir, essa prática pode revelar diferenças até então não visíveis. Ao fim, pode ampliar o desentendimento em vez de eliminá-lo. ${ }^{36}$

Por isso, o consenso é um ideal a ser buscado, mas não um fim a qualquer custo. As pessoas podem, apesar da deliberação, não concordarem umas com as outras e não há mal nisso. O propósito da deliberação deve ser possibilitar o conhecimento de todos os argumentos para se chegar ao melhor resultado. Nem sempre, porém, todos concordarão com o mesmo melhor resultado. A divergência, nos casos em que o consenso não é alcançado, deve ser resguardada, até para que o argumento de quem não consinta não seja perdido. ${ }^{37}$

Tendo-se em vista a possibilidade de divergência, e considerando-se que toda deliberação deve terminar com uma decisão, a democracia deve se apoiar em outros métodos conclusivos, como o voto. ${ }^{38}$ Ou seja, ainda que o processo de decisão final não seja deliberativo, como não o é propriamente o voto, ele deve ter um fim, ainda que essa decisão valha, apenas, por certo período de tempo.

No âmbito da aplicação da lei ao caso concreto (e não na teoria política), há duas formas de relacioná-la à deliberação. A primeira forma seria estabelecer uma relação com o conceito de argumentação jurídica. Para Mendes, ${ }^{39}$ o direito é deliberativo por permitir a ponderação de várias razões para a ação. Ou seja, o

32 MENDES, Conrado Hübner. Constitutional courts and deliberative democracy. Oxford: Oxford University Press, 2013. p. 27. 33 MENDES, Conrado Hübner. Constitutional courts and deliberative democracy. Oxford: Oxford University Press, 2013 . p. 27. 34 MENDES, Conrado Hübner. Constitutional courts and deliberative democracy. Oxford: Oxford University Press, 2013 . p. 27. 35 MENDES, Conrado Hübner. Constitutional courts and deliberative democracy. Oxford: Oxford University Press, 2013 . p. 27. 36 SHAPIRO, Ian. Optimal deliberation?. The Journal of Political Philosophy, v. 10, n. 2, p. 198, 2002.

37 Gutmann e Thompson observam que o processo de tomada de decisão na democracia deliberativa é dinâmico. Significa dizer que a decisão final não é vinculante de forma definitiva (isto é, é provisória) e que se mantém aberta a possibilidade de um diálogo continuado. GUTMANN, Amy; THOMPSON, Dennis. O que significa democracia deliberativa. Revista Brasileira de Estudos Constitucionais, Belo Horizonte, ano 1, n. 1, jan./mar. 2007 GUTMANN, Amy; THOMPSON, Dennis. O que significa democracia deliberativa. Revista Brasileira de Estudos Constitucionais, Belo Horizonte, ano 1, n. 1, p. 22, jan./mar. 2007.

38 MENDES, Conrado Hübner. Constitutional courts and deliberative democracy. Oxford: Oxford University Press, 2013. p. 35.

39 MENDES, Conrado Hübner. Constitutional courts and deliberative democracy. Oxford: Oxford University Press, 2013. p. 53. 
direito demanda um engajamento discursivo. A segunda forma, por sua vez, ocorreria por uma relação institucional, tendo em vista que juízes deliberam, uns com os outros, nos julgamentos colegiados. A relação, nesse sentido, corresponde ao conceito de deliberação tratado anteriormente, ou seja, a atividade interativa e cooperativa dos juízes na aplicação da lei ao caso concreto.

Isto é, a deliberação seria elemento característico da própria forma de estruturação dos Tribunais. Ou melhor, componente ínsito, inseparável da estrutura colegiada dos órgãos julgadores de segunda instância e de instâncias superiores.

Com efeito, é sabido que, na prática, colegialidade não significa necessariamente deliberação. Os julgadores possuem, à sua disposição, outros modos de agir que não a forma deliberativa. Uma dessas opções consiste em agir por barganha. Porém, a barganha, por meio da negociação de interesses pessoais, é absolutamente incompatível com a noção básica de imparcialidade do julgador e, portanto, com a aplicação do direito ao caso concreto. ${ }^{40}$

Outra opção é a agregação de votos, que abrange três diferentes tipos. O primeiro, baseado no puro interesse privado, não é admitido pelos mesmos motivos da barganha. Ou seja, pela incompatibilidade com a aplicação do direito, ante a exigência de imparcialidade do juízo. O segundo, fundado na preferência advinda da reflexão individual. $\mathrm{O}$ terceiro, correspondente à preferência resultante da deliberação. Nasce, então, o questionamento de Mendes:

deve um grupo de juízes preferir agregar suas opiniões legais de plano ou, antes, esse grupo deve se empenhar em deliberar e submeter suas posições iniciais ao filtro deliberativo? Por que agregar após deliberar em vez de agregar sem qualquer tom de deliberação?. ${ }^{41}$

A resposta a essas perguntas deve ser buscada levando-se em consideração o confronto das características da deliberação e da colegialidade, já expostas anteriormente. A deliberatividade se sustenta nos seguintes elementos: (i) na atividade interativa e cooperativa dos participantes, (ii) que expõem e discutem as razões que justificam suas preferências, (iii) dispostos a mudá-las, (iv) com o propósito (não necessário) de se alcançar o consenso sobre a melhor decisão.

O primeiro aspecto - a interação interpessoal - é mais capaz do que a atividade solitária da mera agregação de votos em esclarecer as premissas em jogo, maximizar as informações úteis para a decisão e permitir soluções criativas não pensadas isoladamente pelos membros julgadores. Essas atividades, ao fim, têm o propósito de se alcançar a melhor decisão. ${ }^{42}$

Além do aspecto da interação interpessoal, a busca pelo consenso também deve ser considerada como um elemento importante para a melhor decisão. Especialmente porque os Tribunais são importantes atores na fixação de entendimentos jurídicos que guiam a compreensão da sociedade sobre o direito ou a interpretação da lei, de modo que a atribuição de racionalidade à norma jurídica é uma de suas principais responsa-

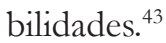

A par desses dois elementos - interação interpessoal e busca pelo consenso —, a deliberação, ainda, assegura a sensação de respeito aos demais membros do órgão julgador e aos próprios litigantes, ao garantir que os diversos pontos de vista foram devidamente considerados. A atenção aos diferentes argumentos, além de reforçar as informações necessárias ao melhor julgamento, propicia um ambiente de colaboração entre os pares e contribui para a aceitação da decisão, ainda que desfavorável, pelas partes.

40 MENDES, Conrado Hübner. Constitutional courts and deliberative democracy. Oxford: Oxford University Press, 2013. p. 65.

41 MENDES, Conrado Hübner. Constitutional courts and deliberative democracy. Oxford: Oxford University Press, 2013. p. 65. No original: "[...] should a group of judges prefer to aggregate their legal opinions right away, or should they, first, engage in deliberation and subject their initial positions to the deliberative filter? Why aggregation after deliberation rather than aggregation without any tint of deliberation?".

42 MENDES, Conrado Hübner. Constitutional courts and deliberative democracy. Oxford: Oxford University Press, 2013. p. 66.

43 MENDES, Conrado Hübner. Constitutional courts and deliberative democracy. Oxford: Oxford University Press, 2013. p. 67. 
O que se percebe da exposição das promessas da deliberação é a reafirmação das razões subjacentes à colegialidade: o órgão colegiado deliberativo enseja a despersonificação, pois seu resultado é diferente da mera soma das opiniões iniciais dos julgadores; torna a decisão aberta a várias vozes, não apenas como resultado da interação dos julgadores, mas também por meio da participação das partes; e transforma o ponto fulcral da decisão final do aspecto quantitativo para o aspecto qualitativo da argumentação jurídica.

Mendes sempre salientou o propósito de uma corte colegiada: "uma empreitada coletiva cujo resultado pretende ser melhor que a soma das opiniões individuais". Essa tarefa "exige, de cada um, disposição para duvidar de suas convicções iniciais, vontade de minimizar o desacordo e o reconhecimento da importância de uma opinião institucional coesa, fundada em razões claras". Num órgão colegiado, os membros devem falar, mas, sobretudo, escutar; devem formar um time, "sem estrelismos individuais"; são colegas, que cooperam, e não adversários, que competem. ${ }^{44}$

É possível, assim, estabelecer uma relação entre colegialidade e deliberação. Para Silva, a colegialidade implica: (i) a disposição dos membros do colegiado para trabalharem em grupo; (ii) a ausência de hierarquia entre os juízes, ao menos no sentido de que os seus argumentos possuem o mesmo valor; (iii) a disposição dos julgadores em ouvir os seus pares (e isso significa estar aberto a ser convencido por eles); (iv) um processo de tomada de decisão cooperativo; (v) respeito mútuo entre os juízes; (vi) o propósito de se comunicar, sempre que possível, não como a soma de vozes individuais, mas como uma instituição, resultante da deliberação em busca de consenso. ${ }^{45}$ Significa dizer que, quanto maior são os elementos da colegialidade, maior o potencial deliberativo da corte.

A deliberação, portanto, deve ser, também, elemento institucional dos Tribunais, enquanto incentivador da atividade interativa e cooperativa dos juízes em julgamentos colegiados.

\section{A COMPOSIÇÃo do ÓRGÃo COLEGIADO E A TOMADA DE DECISÃo}

Williams e O'Reilly elaboraram trabalho destinado a revisar a bibliografia sobre o efeito da diversidade nos trabalhos em grupo. A intenção dos autores consistia em responder se a diversidade facilita ou dificulta a tarefa colegiada. ${ }^{46}$

A diversidade compreende a situação em que alguma característica de algo ou de alguém é diferente de outra coisa ou outra pessoa. Pode corresponder a atributos demográficos — e, portanto, imutáveis, como sexo, raça ou idade — ou pessoais — e mutáveis, como especialidade ou experiência. ${ }^{47}$

Os autores apresentam três teorias que explicam os efeitos da diversidade no desempenho de colegiados. A primeira teoria, conhecida como Categorização Social, indica que as características demográficas tendem a fazer com que um sujeito se sinta parte de um grupo de iguais. Nesse contexto, os membros desse grupo têm a tendência de achar que aqueles que são diferentes são menos confiáveis ou colaborativos que os seus semelhantes. ${ }^{48}$ Nesse caso, há um processo de estereotipagem e polarização, diminuindo o nível de coesão e de cooperação interna.

A segunda teoria, chamada do Paradigma de Similaridade/Atração, encontra amparo na ideia de que a

44 MENDES, Conrado Hübner. Onze ilhas. Folha de São Paulo, São Paulo, Caderno Opinião, 1 fev. 2010.

45 SILVA, Virgílio Afonso da. Deciding without deliberating. International Journal of Constitutional Law, v. 11, p. 562-563, 2013.

46 WILLIAMS, Katherine Y.; O'REILLY, Charles A. Demography and diversity in organizations: a review of 40 years of research. Research in Organizational Behavior, v. 20, p. 77, 1998.

47 JACKSON, Susan E.; STONE, Veronica K.; ALVAREZ, Eden B. Socialization amidst diversity: the impact of demographics on work team oldtimers and newcomers. Research in Organizational Behavior, v. 15, p. 56, 1993.

48 WILLIAMS, Katherine Y.; O'REILLY, Charles A. Demography and diversity in organizations: a review of 40 years of research. Research in Organizational Behavior, v. 20, p. 84, 1998. 
similaridade nas características demográficas aumenta a atração interpessoal. Isso significa que indivíduos que possuem experiências similares tendem a compartilhar dos mesmos valores. ${ }^{49} \mathrm{~A}$ interação entre esses membros, assim, se torna mais fácil e natural. Também nesse caso, a atração entre os contatos considerados como similares diminui o potencial interativo e a comunicação entre membros que se veem como diferentes.

A seu turno, a terceira teoria, da Informação e da Tomada de Decisão, diverge das conclusões alcançada pelas anteriores. Considerando-se a diversidade num determinado grupo, os indivíduos estão propensos a um maior acesso à informação, tendo em vista o compartilhamento de diferentes pontos de vista na interação do colegiado. Nesse sentido, a diversidade gera um impacto positivo no aumento de habilidades, informação e conhecimento num processo de trabalho em grupo. ${ }^{50} \mathrm{O}$ compartilhamento de informações, portanto, tem íntima relação com a atividade interativa, cooperativa e criativa dos membros do órgão colegiado.

Com efeito, é certo que há, de fato, o risco mencionado nas duas primeiras teorias de que os similares se aproximem e estabeleçam estereótipos e preconceitos em relação aos membros considerados desiguais. Se, de um lado, reconhece-se o risco de aproximação entre julgadores que se consideram similares por alguma atribuição que lhes é comum, de outro, não há como rechaçar o possível benefício reconhecido pela terceira teoria mencionada por Williams e O’Reilly. Com efeito, quanto mais diversificado um órgão colegiado, maior é possibilidade de que se tenha à mesa diferentes experiências, especialidades, conhecimentos e habilidades. Cuida-se, assim, da efetivação de um dos elementos inerentes à colegialidade: a abertura a várias vozes e ao desacordo.

No Brasil, Oliveira, em pesquisa feita no STF, buscou encontrar a "formação de redes" em julgamentos não unânimes de Ações Diretas de Inconstitucionalidades (ADIs). A autora sustenta a hipótese de que "os agrupamentos dão-se de acordo com a nomeação presidencial, ou seja, ministros nomeados por um mesmo Presidente da República são mais propensos a votar em conjunto do que a dividir seus votos". ${ }^{51}$

A pesquisa de Oliveira sobre a formação de redes — ou, nas suas palavras, coalizões ou panelinhas — se deu com base em blocos formados de acordo com a nomeação presidencial. Ou seja, a autora dividiu os ministros do STF de 1999 a 2006 em cinco blocos: aqueles nomeados pelos presidentes militares, por Sarney, por Collor/Itamar, por Fernando Henrique e por Lula. Concluiu-se que, com exceção do bloco Collor/Itamar (em razão do comportamento do ministro Marco Aurélio, que é campeão isolado em votos vencidos), os demais blocos presidenciais possuem coesão maior entre si do que a média da Corte. ${ }^{52}$

A autora conclui que há "fortes indícios de que os ministros nomeados por um mesmo Presidente tendem a comportar-se como um grupo coeso" e que "os ministros nomeados por um mesmo Presidente são mais propensos a votar em conjunto do que a dividir os seus votos". ${ }^{33}$

49 WILLIAMS, Katherine Y.; O'REILLY, Charles A. Demography and diversity in organizations: a review of 40 years of research. Research in Organizational Behavior, v. 20, p. 85, 1998.

50 WILLIAMS, Katherine Y.; O'REILLY, Charles A. Demography and diversity in organizations: a review of 40 years of research. Research in Organizational Behavior, v. 20, p. 87, 1998.

51 OLIVEIRA, Fabiana Luci. Processo decisório no Supremo Tribunal Federal: coalizões e "panelinhas". Revista de Sociologia e Política, v. 20, n. 44, p. 151, 2012. Nesse caso, a diversidade não se refere a atributos demográficos, mas a atributos pessoais: o critério de diferença considerado entre os ministros do STF era o Presidente da República que fez a sua nomeação.

52 Oliveira, porém, afirma que "os valores de coesão dos grupos, se analisados isoladamente ou em comparação com valores de combinação aleatória, não são suficientes para afirmar a influência da nomeação presidencial. Para isso é preciso ter uma base para comparação com o Tribunal como um todo, no sentido de garantir que a coesão do bloco não reflita somente o alto nível de coesão que já existia no STF no período" OLIVEIRA, Fabiana Luci. Processo decisório no Supremo Tribunal Federal: coalizões e "panelinhas". Revista de Sociologia e Política, v. 20, n. 44, p. 151, 2012.

53 OLIVEIRA, Fabiana Luci. Processo decisório no Supremo Tribunal Federal: coalizões e "panelinhas". Revista de Sociologia e Política, v. 20, n. 44, p. 152, 2012. Sobre a questão, Ana Paula de Almeida Lopes observa que, embora a lógica por trás da previsão de indicação dos ministros do STF pelo Presidente da República, ouvido o Senado Federal, privilegie "a participação integrada dos Poderes Executivos e Legislativos, o que garantiria o caráter democrático ao processo", o sistema não estaria livre de abusos. Em suas considerações, "o cumprimento dos requisitos constitucionais de notável saber jurídico e reputação ilibada é uma das principais dificuldades enfrentadas na história constitucional brasileira"; além disso, sustenta que "a inércia do Senado quanto à aprovação dos nomes torna protocolar o exame da indicação, uma vez que aprova de modo automático a designação que lhe é submetida pelo 
Outro exemplo em que a diferença de ideologias (não apenas política) pode gerar aproximações de determinados indivíduos num determinado grupo, se refere aos órgãos colegiados que possuem representantes de determinadas entidades com o fim de criar um cenário de paridade, como em diversos órgãos administrativos de julgamento em matéria tributária. Mencione-se o exemplo do Conselho Administrativo de Recursos Fiscais (CARF): organizado em órgãos colegiados paritários,${ }^{54}$ suas turmas de julgamento são compostas por oito conselheiros, sendo quatro representantes da Fazenda Nacional e quatro representantes dos contribuintes..$^{55}$ Por determinação do Decreto n ${ }^{0} 70.235 / 72$, os cargos de presidente das turmas da Câmara Superior de Recursos Fiscais (CSRF), das câmaras e das turmas do CARF serão ocupados por conselheiros representantes da Fazenda Nacional, que, em caso de empate, possuem o voto de qualidade. Isto é, o seu voto, nesse caso, vale por dois, desempatando o julgamento. ${ }^{56}$

A especificidade do CARF, portanto, consiste em que parte de sua composição é representante da Fazenda Nacional — e, naturalmente, tendem a compreender a controvérsia mais facilmente pelo olhar do fisco - e outra parte é representante dos contribuintes — e, igualmente, possuem a propensão de enxergar esse lado da moeda.

Embora, de um lado, o relatório disponibilizado pelo CARF sobre as decisões proferidas entre janeiro e agosto de 2016 demonstra que quase 70\% das decisões foram tomadas à unanimidade, não se desconhece, respeitada a imparcialidade dos seus julgadores, a maior disposição dos conselheiros em concordarem com os aqueles julgadores de mesma representação. Isto é, é inegável que os conselheiros representantes da Fazenda Nacional possuem maior disposição em acompanhar o entendimento dos representantes da Fazenda Nacional e que os conselheiros representantes dos contribuintes estão mais predispostos a concordarem com as razões dos representantes dos contribuintes. Isso não lhes retira a imparcialidade, mas demonstra que a heterogeneidade de histórico e de experiências influencia as perspectivas e os posicionamentos dos julgadores.

Essa afirmativa se comprova a partir de levantamento das decisões da Câmara Superior de Recursos Fiscais dos anos de 2015 e $2016 .{ }^{57}$ De acordo com o referido estudo, foram analisados 959 acórdãos, que enfrentaram 1.022 assuntos levados à apreciação das três turmas da Câmara Superior do CARF. Desse total, em 347 oportunidades, o julgamento se resolveu pelo voto de qualidade do presidente da turma, tendo em vista ter ocorrido empate. Em todos esses casos (ou seja, em 100\% dos casos em que o julgamento se resolveu pelo voto de qualidade), o resultado do julgamento foi favorável ao Fisco.

Sobre a questão, é válida a referência à pesquisa empírica empreendida por Sunstein a respeito da influência da ideologia dos juízes das cortes de apelação norte-americanas — tendo por base o partido (democrata

Presidente" LOPES, Ana Paula de Almeida Lopes. A judicialização do processo político e a politização do poder judiciário: uma análise da intervenção do Supremo Tribunal Federal no processo político partidário. Revista Brasileira de Políticas Públicas, v. 1, n. 2, p. 158, 2011.

54 Decreto $n^{\circ}$ 70.235/72: “Art. 25. O julgamento do processo de exigência de tributos ou contribuições administrados pela Secretaria da Receita Federal compete: (Vide Decreto n ${ }^{\circ} 2.562$, de 1998)(Redação dada pela Medida Provisória no 2.158-35, de 2001): [...] II - em segunda instância, ao Conselho Administrativo de Recursos Fiscais, órgão colegiado, paritário, integrante da estrutura do Ministério da Fazenda, com atribuição de julgar recursos de ofício e voluntários de decisão de primeira instância, bem como recursos de natureza especial. (Redação dada pela Lei no 11.941, de 2009) ".

55 RICARF: "Art. 23. As Turmas de Julgamento são integradas por 8 (oito) conselheiros, sendo 4 (quatro) representantes da Fazenda Nacional e 4 (quatro) representantes dos Contribuintes.".

Nesse caso, o critério de diferenciação entre os conselheiros do CARF também não se relaciona com atributos demográficos, mas sim com atributos pessoais: a representatividade do conselheiro — se representante da Fazenda Nacional, indicados pelo Ministro de Estado da Fazenda a partir de lista tríplice encaminhada pela Receita Federal do Brasil, ou se representante dos contribuintes, também indicados pelo Ministro de Estado da Fazenda a partir de lista tríplice elaborada pelas confederações representativas de categorias econômicas e pelas centrais sindicais.

56 Decreto n ${ }^{\circ}$ 70.235/72: “Art. 25. [...]ฐ $9^{\circ}$ Os cargos de Presidente das Turmas da Câmara Superior de Recursos Fiscais, das câmaras, das suas turmas e das turmas especiais serão ocupados por conselheiros representantes da Fazenda Nacional, que, em caso de empate, terão o voto de qualidade, e os cargos de Vice-Presidente, por representantes dos contribuintes. (Incluído pela Lei $\mathrm{n}^{\circ}$ 11.941, de 2009)."

57 O VOTO de qualidades em números. Disponível em: < https://jota.info/colunas/observatorio-do-carf/observatorio-carf-ovoto-de-qualidade-em-numeros-12082016> . Acesso em: 25 mar. 2017. 
ou republicano) do Presidente que os indicou — na tomada de decisão colegiada. A pergunta que busca ser respondida por Sunstein é: um juiz vota de forma diferente a depender se ele julga com nenhum, um ou dois outros juízes indicados por um presidente do mesmo partido político ${ }^{58}$

Para respondê-la, Sunstein examina três hipóteses: (i) em casos que envolvem as maiores controvérsias da atualidade — como aborto, ações afirmativas, pena de morte, discriminação racial ou sexual etc. —, a tendência ideológica de um juiz pode ser prevista pelo partido do presidente que o indicou; (ii) a tendência ideológica de um juiz pode ser mitigada se ele julga num colegiado com dois juízes de um partido político diferente; ou seja, na análise de Sunstein, um juiz democrata estaria menos tendente a votar "estereotipicamente" 59 de forma liberal quando compusesse uma turma com outros dois juízes republicanos e um juiz republicano estaria menos tendente a votar "estereotipicamente" de forma conservadora quando compusesse uma turma com outros dois juízes democratas; e (iii) a tendência ideológica de um juiz pode ser acentuada se ele julga num colegiado com dois juízes de um mesmo partido político; isto é, um juiz democrata estaria mais tendente a votar "estereotipicamente" de forma liberal quando compusesse uma turma com outros dois juízes democratas e um juiz republicano estaria mais tendente a votar "estereotipicamente" de forma conservadora quando compusesse uma turma com outros dois juízes republicanos. ${ }^{60} \mathrm{~A}$ primeira hipótese, chamaremos de efeitos partidários; a segunda e terceira hipóteses, de efeitos da composição colegiada.

Após a análise de 6.408 decisões colegiadas e 19.224 votos individuais, o trabalho de Sunstein chegou a três diferentes conclusões. A primeira se refere ao fato de que, em algumas áreas do direito e algumas discussões, a ideologia decorrente do partido político de indicação não funciona como um elemento previsor do voto, afastando as três hipóteses mencionadas acima. No estudo de Sunstein, essa situação ocorre no julgamentos de apelações criminais e de cláusulas comerciais. Nesse caso, a indicação partidária do juiz não afeta o resultado do julgamento, de modo que não há diferença entre juízes indicados por presidentes democratas ou republicanos.

A segunda afirma que, na maior parte das áreas do direito e das discussões da atualidade, as três hipóteses indicadas acima são confirmadas. É o que ocorre, por exemplo, em matérias como ações afirmativas, discriminação sexual, abuso sexual e discriminação racial. Nesse sentido, o partido político do presidente que indicou o juiz é um bom previsor de como o indicado votará. Todavia, o partido político do presidente que indicou os outros dois juízes da turma é igualmente um importante elemento de previsão de como aquele primeiro juiz votará. ${ }^{61}$

A terceira conclusão se relaciona com o fato de que, em outras duas situações, a indicação partidária tem relevância, mas as hipóteses (ii) e (iii) — mitigação ou acentuação da tendência ideológica decorrente da composição da turma — não são confirmadas, o que se aplica aos casos de aborto e de pena de morte, ocasiões em que a conviç̧ões pessoais não são afetadas pela composição do colegiado.

Quais foram as razões apontadas por Sunstein para justificar os dados coletados e as três conclusões alcançadas? Embora seu estudo se baseie na polarização democratas/republicanos, as explicações por ele apresentadas valem para qualquer tipo de diferentes ideologias (não apenas partidárias).

No primeiro caso — em que não há efeitos partidários ou da composição colegiada —, Sunstein aponta duas possíveis explicações. A primeira se relaciona à clareza e à vinculação da lei ou do entendimento firmado pelo Poder Judiciário; ou seja, às hipóteses em que a lei não comporta controvérsia pela sua clareza

58 SUNSTEIN, Cass. R. et al. Are judges political?: an empirical analysis of the federal judiciary. Washington: The Brookings Institution, 2006. p. 7.

59 Diz-se "estereotipicamente" porque o senso comum de que um juiz indicado por um presidente democrata seria mais liberal e de que um juiz indicado por um presidente republicado seria mais conservador não passa, naturalmente, de um estereótipo.

60 SUNSTEIN, Cass. R. et al. Are judges political?: an empirical analysis of the federal judiciary. Washington: The Brookings Institution, 2006. p. 8-9.

61 SUNSTEIN, Cass. R. et al. Are judges political?: an empirical analysis of the federal judiciary. Washington: The Brookings Institution, 2006. p. 10. 
ou em que, apesar da controvérsia, o judiciário já consolidou a forma de interpretá-la. A segunda se refere à inexistência de controvérsia ideológica para a solução da lide; isto é, aos casos em que a carga ideológica não afeta a solução jurídica do caso. ${ }^{62}$

$\mathrm{Na}$ terceira situação - em que existem efeitos partidários, mas em que os efeitos da composição colegiada são nulos - , Sunstein defende sua ocorrência em ocasiões em que as convicções pessoais dos juízes são tão fortes e enraizadas que a composição colegiada não produz qualquer efeito. Nos dados de Sunstein, percebeu-se sua ocorrência em julgados que envolviam aborto e pena de morte. Trata-se, portanto, de discussões que carregam grande carga moral e religiosa.

No caso mais comum - a segunda conclusão alcançada por Sunstein, no sentido de que, na maioria dos casos difíceis, a ideologia partidária e a composição colegiada causam efeitos no voto individual dos juízes —, são vários os aspectos que influenciam os julgadores. Sunstein divide esses elementos em três grandes grupos de fatores: a conformidade, o efeito denúncia e a polarização do grupo. ${ }^{63}$

O fator da conformidade é explicado, de forma mais simples e direta, pela cooperação colegiada, que se fundamenta, basicamente, na deferência e no respeito ao colega. A cooperação colegiada advém, segundo Sunstein, de dois principais motivos.

O primeiro é que o voto de um membro da turma (geralmente o do relator, a quem cabe preparar o julgamento colegiado) carrega informações que estão supostamente corretas. Se o relator, ao se debruçar sobre o processo e obter certas informações, chegou a tal conclusão, é possível que ele esteja certo. Se um dos juízes concorda com o relator, a situação fica ainda mais "confortável” para o terceiro juiz. Isto é, o terceiro juiz — ainda que possa possuir ideologia diversa — pode se convencer do entendimento emanado pelos colegas, por confiar no juízo feito por eles.

A segunda razão apontada por Sunstein para justificar a cooperação colegiada se refere à inutilidade prática para o resultado do julgamento, de, num órgão colegiado de três juízes, apenas um apresentar um voto vencido. A impressão, no estudo empírico realizado por Sunstein, é que, na maioria das vezes, o voto vencido não convencerá a maioria formada e significará, apenas, desperdício de tempo. ${ }^{64}$

Esses elementos da cooperação colegiada ajudam a entender o porquê de, nos casos extremos, como aborto e pena de morte, não haver efeitos da composição colegiada. Em tais situações, o entendimento individual do juiz é tão forte que as informações trazidas por um dos colegas não são suficientes para afetar a convicção já firmada. Além disso, a concepção legal individual tão consistentemente firmada torna apropriada e necessária a elaboração de voto dissidente. Ou seja, a pretensão de conformidade não se aplica a essas ocasiões.

O segundo fator tido por Sunstein como razão para explicar os efeitos partidários e a composição colegiada é chamado de efeito denúncia. Trata-se de elemento que mitiga a tendência ideológica como resultado do efeito da composição colegiada. O efeito denúncia consiste no fato de que a presença de um juiz com ideologia diversa dos demais — seja mais conservador, seja mais liberal — afeta, ainda que implicitamente e sem a necessidade da elaboração de um voto divergente, o resultado do julgamento.

Imagine que, na turma com três juízes, dois possuem ideologia mais conservadora e outro mais liberal. Os dois juízes conservadores já sabem que o juiz mais liberal não seguirá um entendimento conservador extremo eventualmente proposto. Nesse cenário, há duas possibilidades: a primeira, que os juízes conservadores mantenham o entendimento extremo, sabedores de que o juiz liberal elaborará voto dissidente; o

62 SUNSTEIN, Cass. R. et al. Are judges political?: an empirical analysis of the federal judiciary. Washington: The Brookings Institution, 2006. p. 60.

63 SUNSTEIN, Cass. R. et al. Are judges political?: an empirical analysis of the federal judiciary. Washington: The Brookings Institution, 2006. p. 63.

64 SUNSTEIN, Cass. R. et al. Are judges political?: an empirical analysis of the federal judiciary. Washington: The Brookings Institution, 2006. p. 65 
segundo, que os juízes conservadores moderem o entendimento extremo, a fim de alcançar, num viés pró-colegialidade, a unanimidade.

Ou seja, a presença do potencial dissidente pode levar à mitigação de entendimentos extremos, como nítido efeito da composição colegiada e do fator de conformidade. Haverá, nesse caso, concessão de ambos os entendimentos, alcançando-se, assim, a unanimidade. Ou seja, nessa hipótese, a conformidade tende à moderação.

Nesse caso, porém, não é o juiz isolado que concorda com a opinião majoritária. São os juízes que compõem a maioria que concedem e se afastam de entendimentos extremos em prol da unanimidade a ser formada com o voto do minoritário.

Por fim, o terceiro fator considerado por Sunstein para justificar os efeitos partidários e da composição colegiada é da polarização do grupo, ou seja, o fato de que, em grupos formados por pessoas com mesma ideologia, existe a tendência de que se alcancem entendimentos extremos. Nesse sentido, num grupo em que há pessoas conservadoras, a deliberação tende a que esse grupo chegue a decisões mais conservadoras; num grupo em que há pessoas liberais, a deliberação tende a que este grupo chegue a decisões mais liberais.

A polarização do grupo, portanto, atua como elemento que acentua a tendência ideológica como decorrência dos efeitos da composição colegiada. Nesse contexto, Sunstein assevera ser plausível admitir que uma turma homogênea (ideologicamente falando) é menos propensa a ser moderada do que uma turma heterogênea. ${ }^{65}$

Três razões explicam a polarização do grupo, de acordo com Sunstein. A primeira delas é a presença de diversos argumentos numa só direção. Isto é, a polarização decorre do fato de que, num grupo homogêneo, todos os participantes apresentam diferentes argumentos para uma mesma conclusão. O entendimento inicial de cada julgador somente tende a se reafirmar a cada novo argumento, permitindo que posições moderadas cheguem a extremos. ${ }^{66}$

O segundo motivo seria a pressão social advinda da comparação. Segundo esse argumento, o posicionamento inicial (e moderado) de um membro do colegiado pode ser alterado para se adaptar ao posicionamento mais extremo de outros julgadores, como decorrência da vontade de agradar os demais julgadores. ${ }^{67}$ Trata-se de um dos vieses do fator da conformidade (explicado acima), em que um sujeito com ideologia diferente acaba por se submeter à ideologia dos demais membros por respeito e deferência ao entendimento já exposto por dois colegas. No entanto, no caso da pressão da comparação, o fator da conformidade tende ao extremo.

Por fim, a terceira causa da polarização de grupo advém da percepção de que pessoas com convicções extremas tendem a ter maior confiança e de que, ao adquirirem mais confiança, pessoas pendem a posições extremas. ${ }^{68}$ Em sentido contrário, pessoas com menos confiança e mais inseguras sobre suas convicções têm a tendência à moderação. Nessa linha de raciocínio, não é difícil imaginar que, ao ter seus argumentos corroborados pelos demais membros, um juiz se torne mais confiante de suas razões.

Por esses três motivos, portanto, a homogeneidade da composição do órgão colegiado tende à polarização do grupo.

Sobre a diversidade na composição do Poder Judiciário brasileiro, é digno de nota que o Conselho Na-

65 SUNSTEIN, Cass. R. et al. Are judges political?: an empirical analysis of the federal judiciary. Washington: The Brookings Institution, 2006. p. 72.

66 SUNSTEIN, Cass. R. et al. Are judges political?: an empirical analysis of the federal judiciary. Washington: The Brookings Institution, 2006. p. 73.

67 SUNSTEIN, Cass. R. et al. Are judges political?: an empirical analysis of the federal judiciary. Washington: The Brookings Institution, 2006. p. 74.

68 SUNSTEIN, Cass. R. et al. Are judges political?: an empirical analysis of the federal judiciary. Washington: The Brookings Institution, 2006. p. 75. 
cional de Justiça (CNJ) mapeou, pela primeira vez em 2013, o perfil dos seus magistrados ${ }^{69}$ e servidores e disponibilizou, em 2014, o relatório chamado de Censo do Poder Judiciário. ${ }^{70}$

Esse estudo concluiu, por exemplo, que 64,1\% dos magistrados brasileiros são do sexo masculino e $35,9 \%$ do sexo feminino. Além disso, $84,2 \%$ dos magistrados se declaram brancos, enquanto 15,6\% se declaram negros e $0,1 \%$, indígenas. Outro dado interessante é que apenas $0,9 \%$ dos magistrados possuem algum tipo de deficiência. Em relação ao total dos magistrados, $78,4 \%$ são casados ou estão em união estável com pessoa de outro sexo, 11,4\% são solteiros, 7,2\% são divorciados, 1,2\% são separados judicialmente, 1,1\% são casados ou em união estável com pessoa de mesmo sexo e $0,6 \%$ são viúvos.

No âmbito dos Tribunais, os números são ainda mais discrepantes. 78,5\% dos desembargadores são homens e $21,5 \%$ mulheres; $81,6 \%$ dos ministros de tribunal superior ou do STF são do sexo masculino e apenas 18,4\% são mulheres. Nos tribunais superiores e no STF, $91,1 \%$ se declaram brancos e $8,9 \%$ se declaram negros. Ainda em relação aos tribunais superiores/STF, 2,5\% dos ministros possuem algum tipo de deficiência.

A diversidade na composição do órgão julgador é elemento intrinsecamente relacionado com o potencial deliberativo de uma instituição. ${ }^{71}$ Quanto, especificamente, à diversidade racial, Edwards conclui ser esta necessária para assegurar não apenas a qualidade, mas também a legitimidade da tomada de decisão judicial. Embora registre que a questão racial não pode determinar o resultado do julgamento, já que juízes julgam com base no estado de direito e não com base em ideologias, a presença da diversidade racial nas cortes pode refinar o processo deliberativo justamente por ampliar a variedade de perspectivas inseridas no debate. ${ }^{72}$

O contrário, no entanto, também é verdade: a depender da deliberatividade da corte, a diversidade pode acentuar divergências e preconceitos entre os seus membros. ${ }^{73}$

A respeito da acentuação de preconceitos, é digno de registro que o desempenho deliberativo ótimo vai além da mera presença da diversidade no órgão colegiado. Em recente estudo sobre a Suprema Corte americana, Jacobi e Schweers observaram, a partir de estatísticas obtidas nas sessões de sustentação oral

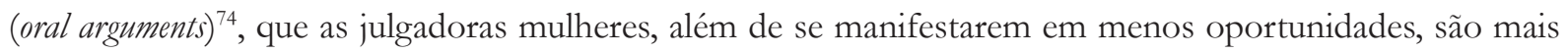
interrompidas quando o fazem do que os juízes homens. Ademais, as juízas são interrompidas inclusive por advogados, o que é proibido pelas diretrizes da corte. ${ }^{75}$

69 Para o perfil dos magistrados, levaram-se em consideração os seguintes tipos de carreira: juiz substituto, conselheiro do CNJ, juiz titular, juiz substituto de $2^{\circ}$ grau, desembargador, ministro de tribunal superior/STF, juiz eleitoral da classe dos advogados.

70 BRASIL. Conselho Nacional de Justiça. Censo do Poder Judiciário: vetores iniciais e dados estatísticos. Brasília: CNJ, 2014. No Reino Unido, há uma preocupação crescente com a diversidade do Poder Judiciário. De acordo com "The Report of the Advisory Panel on Judicial Diversity 2010", "in a democratic society the judiciary should reflect the diversity of society and the legal profession as a whole. Judges drawn from a wide range of backgrounds and life experiences will bring varying perspectives to bear on critical legal issues. A judiciary which is visibly more reflective of society will enhance public confidence”. Disponível em: <https:// www.ucl.ac.uk/laws/judicial-institute/files/Report_of_the_Advisory_Panel_on_Judicial_Diversity.pdf>. Acesso em: 10 abr. 2017. As estatísticas da diversidade do judiciário britânico referentes ao ano de 2016 demonstram que cerca de $28 \%$ dos juízes das cortes britânicas são mulheres. Atualmente, mais da metade (cerca de 51\%) dos juízes com menos de 40 anos são mulheres. Apenas $6 \%$ se declaram negros, asiáticos ou de etnias minoritárias. Entre os juízes com menos de 40 anos, esse número sobe para 9\% Disponível em: <https://www.judiciary.gov.uk/wp-content/uploads/2016/07/judicial-diversity-statistics-2december.pdf>. Acesso em: 10 abr. 2017.

71 MENDES, Conrado Hübner. Constitutional courts and deliberative democracy. Oxford: Oxford University Press, 2013. p. 153. EDWARDS também destaca a importância da diversidade da composição colegiada: "I believe that a collegial court becomes greater than the sum of its diverse parts and that demographic diversity can promote, not impede, collegiality. Why? Judges are whole people who have multiple identities and experiences. But judges also serve as equals who are obliged to enforce the law no matter their distinctive perspectives." EDWARDS, Harry T. The effects of collegiality on judicial decision making. University of Pennsylvania Law Review. v. 151, n. 5, p. 1670, 2003.

72 EDWARDS, Harry T. Race and the judiciary. Yale Law \& Policy Review, v. 20, Issue 2, p. 329, 2002.

73 EDWARDS, Harry T. The effects of collegiality on judicial decision making. University of Pennsylvania Law Review, v. 151, n. 5, p. 1667, 2003. EDWARDS fala em aumento de conflitos emocionais, que impediriam o funcionamento do grupo.

74 Vale lembrar, apenas as sessões de oral arguments são abertas ao público; a deliberação dos juízes ocorre em sessão secreta.

75 JACOBI, Tonja; SCHWEERS, Dylan. Justice, interrupted: the effect of gender, ideology and seniority at Supreme Court 
Os autores chamaram a atenção, ainda, para o fato de que, com o tempo, as juízas alteram o estilo discursivo, de um estilo de questionamento menos assertivo para uma maneira mais direta, típica dos juízes homens, com o objetivo de serem menos interrompidas. ${ }^{76}$

Enfim, a composição do órgão julgador pode afetar o grau de deliberatividade entre os seus membros. A partir dessa característica, a cooperação colegiada ou o efeito denúncia podem mitigar diferenças em prol da unanimidade. Por outro lado, a polarização do grupo pode acentuar posições extremas.

Contudo, há, também, situações em que a composição do órgão colegiado não afeta a posição dos seus membros, seja porque a matéria não gera controvérsias ideológicas ou já foi consolidada nos tribunais, seja porque a controvérsia ideológica é tão profunda que cada julgador já possui seu entendimento firmado.

\section{Considerações Finais}

Com base na realidade dos Tribunais, o artigo retomou o conceito de colegialidade, revisitando as razões subjacentes à opção pela estruturação dos tribunais em órgãos colegiados. Em resumo, foram identificadas quatro razões: (i) a despersonificação; (ii) a contenção do arbítrio individual; (iii) a abertura a várias vozes e ao desacordo; e (iv) o reforço das chances de acerto.

A despersonificação, em que a decisão tomada pelo colegiado é construída pela instituição, dissociada de seus membros, pode ser apontada como um reforço do caráter da impessoalidade, da independência e da

oral arguments. Virginia Law Review, n. 103, p. 4, 2017. Em números absolutos, isto é, sem levar em consideração a proporção entre homens e mulheres na Suprema Corte Americana, os autores observam que, do total de interrupções, 49,05\% são homens interrompendo mulheres, 35,78\% são homens interrompendo homens, 10,19\% são mulheres interrompendo homens e 4,98\% são mulheres interrompendo mulheres (p. 57).

76 Jacobi e Schweers transcrevem trechos de oral arguments em que evidencia que as juízas mais antigas - como Sandra Day O'Connor e Ruth Bader Ginsburg, em julgamentos mais recentes, adotam um estilo mais direto de discurso e acabaram sendo menos interrompidas, enquanto as juízas mais recentes — como Sonia Sotomayor e Elena Kagan — se manifestam por meio de um estilo mais educado — iniciando suas frases com "desculpa" ou frases como "posso lhe perguntar" — e, por tal razão, são mais interrompidas pelos colegas. Os exemplos indicados pelos autores são interessantes:

"Notably the more Junior female Justices — Sotomayor and Kagan — appear to also utilize this less assertive questioning style and they get interrupted far more than any other Justice on bench. This is a seen in Fisher v. University of Texas with = Sotomayor: Bert W. Rein: ... What you're trying to measure is to what extend did the use of race boost over the use of the PAI on a nonracial basis.

Sonia Sotomayor: I'm sorry. I thought you said -

John G. Roberts, Jr.: But in Parents — in Parents Involved, you indicated that at some point the actual benefit of the program turns out to be not really worth the very difficult decision to allow race to be considered if at the end of the day it generates a certain number. I'm trying to figure out what that number is.

Bert W. Rein: And — and I am saying that, as we said in our briefs, and we tried to — there's no perfect measurement because you don't have them running simultaneously.

Kagan suffers the same fate, as seen in Kansas v. Carr:

Rachel P. Kovner: ... And that's equally true at sentencing.

Elena Kagan: Sorry, but I'm not -

Antonio Scalia: You - you would need two — two separate juries, wouldn't you?

Rachel P. Kovner: That's — that's what the Kansas Supreme Court said here.

Both Sotomayor and Kagan start with 'sorry', which are examples of Ainsworth's 'women's speech'. O'Connor and Ginsburg appear to have transitioned, or changed, their ways of asking questions so as to not be interrupted as much. There are numerous examples of Kagan and Sotomayor framing their questions by asking if they may interrupt the advocate, only to get interrupted themselves as seen in Fisher v. University of Texas,

Sonia Sotomayor: May I ask -

John G. Roberts, Jr.: Could you associate a number with 'the very small'? I guess it would be the number of students who were admitted with the consideration of the race who were not also -

Bert W. Rein: Correct.

Kagan and Sotomayor often frame their questions with a question, such as 'may I ask', or 'could I ask', rather than just asking the question. This indirectness is exactly what Ainsworth was referring to when she described 'women's speech' as more polite. These framing words provide the opportunity for an interruption to occur before the Justice even gets to the heart of the question." 
imparcialidade dos membros julgadores do órgão colegiado. Com a contenção do arbítrio individual, evita-se a concentração de muito poder nas mãos de uma só pessoa, tutelando o jurisdicionado e o conteúdo da prestação jurisdicional. A abertura a várias vozes e ao desacordo, além de traduzir o reconhecimento de que o conceito de Direito (ou a interpretação do Direito), por sua complexidade, deve estar aberto à argumentação e à divergência, proporciona a concretização do princípio constitucional do contraditório, enquanto garantia de participação influente das partes na elaboração do provimento judicial. Como consequência das três razões anteriores, a colegialidade, ao aumentar o número de juízes na tomada de decisões, amplifica a possibilidade de que o resultado seja uma melhor decisão, por instigar o diálogo, a difusão de novas ideias, a consideração atenta das críticas e a percepção de que o resultado do julgamento é coletivo e não individual.

Diante das quatro características da colegialidade, buscou-se compreender o fenômeno deliberativo, sua base filosófica no campo da política e sua compatibilidade no âmbito do Poder Judiciário. Viu-se que, no campo da teoria política, a democracia deliberativa introduz o aspecto da justificação na tomada de decisão. A deliberação, como elemento da democracia, consiste (i) na atividade interativa e cooperativa dos participantes (ii) que expõem e discutem as razões que justificam suas preferências, (iii) dispostos a mudá-las, (iv) com o propósito (não necessário) de se alcançar o consenso sobre a melhor decisão.

No âmbito da aplicação da lei nos tribunais, a deliberação se relaciona de duas maneiras. Uma, como elemento da argumentação jurídica; a lei, por seu caráter argumentativo, admite a deliberação. Outra, como atividade interativa e cooperativa dos juízes, componente ínsito à estrutura colegiada dos órgãos de julgamento.

Dessa forma, com base nos conceitos de colegialidade e deliberação, debateu-se acerca da composição do órgão colegiado, especialmente a respeito dos riscos e da importância da diversidade (sexo, raça, idade etc.) dos membros julgadores. Se a diversidade, de um lado, pode categorizar e atrair os membros que compartilham os mesmos valores, de outro, permite o compartilhamento de diferentes pontos de vista na interação do colegiado, com o incremento de conhecimentos e informações.

\section{REFERÊNCIAS}

BRASIL. Conselho Nacional de Justiça. Censo do poder judiciário: vetores iniciais e dados estatísticos. Brasília: CNJ, 2014.

EDWARDS, Harry T. Race and the judiciary. Yale Law \& Policy Review, v. 20, Issue 2, 2002.

EDWARDS, Harry T. The effects of collegiality on judicial decision making. University of Pennsylvania Law Review, v. 151, n. 5, 2003.

FEARON, James D. Deliberation as discussion. In: ELSTER, Jon. Deliberative democracy. Cambridge: Cambridge University Press, 1998.

FEREJOHN, Jonh; PASQUINO, Pasquale. Constitutional courts as deliberative institutions: towards an institutional theory of constitutional justice. In: SADURSKI, wojciech. Constitutional justice, east and west. The Hague, London, New York: Kluwer Law International, 2003.

GUTMANN, Amy; THOMPSON, Dennis. O que significa democracia deliberativa. Revista Brasileira de Estudos Constitucionais, Belo Horizonte, ano 1, n. 1, jan./mar. 2007.

JACKSON, Susan E.; STONE, Veronica K.; ALVAREZ, Eden B. Socialization amidst diversity: the impact of demographics on work team oldtimers and newcomers. Research in Organizational Behavior, v. 15, 1993.

JACOBI, Tonja; SCHWEERS, Dylan. Justice, interrupted: the effect of gender, ideology and seniority at Supreme Court oral arguments. Virginia Law Review, n. 103, 2017. 
KNIGHT, Jack; JOHNSON, James. Aggregation and deliberation: on the possibility of democratic legitimacy. Political Theory, v. 22, 1994.

KORNHAUSER, Lewis. A.; SAGER, Lawrence G. The one and the many: adjudication in collegial courts. California Law Review, v. 81, n. 1, 1993.

LEAL, Saul Tourinho. Por dentro das supremas cortes: bastidores, televisionamento e a magia da tribuna. Revista Brasileira de Políticas Públicas, v. 5, número especial, 2015.

LOPES, Ana Paula de Almeida Lopes. A judicialização do processo político e a politização do poder judiciário: uma análise da intervenção do Supremo Tribunal Federal no processo político partidário. Revista Brasileira de Políticas Públicas, v. 1, n. 2, 2011.

MENDES, Conrado Hübner. Onze ilhas. Folha de São Paulo, São Paulo, Caderno Opinião, 1 fev. 2010.

MENDES, Conrado Hübner. Constitutional courts and deliberative democracy. Oxford: Oxford University Press, 2013.

OLIVEIRA, Fabiana Luci. Processo decisório no Supremo Tribunal Federal: coalizões e "panelinhas". Revista de Sociologia e Política, v. 20, n. 44, 2012.

OLIVEIRA, Marcelo Roseno de. A responsabilidade social da magistratura brasileira: accountability e responsividade em meio à tensão entre o dever de prestar contas e a garantia da independência judicial. Revista Brasileira de Políticas Públicas, v. 6, n. 3, 2016.

SHAPIRO, Ian. Optimal deliberation?. The Journal of Political Philosophy, v. 10, n. 2, 2002.

SILVA, Virgílio Afonso da. Deciding without deliberation. International Journal of Constitutional Law, v. 11, 2013.

SUNSTEIN, Cass. R. et al. Are judges political?: an empirical analysis of the federal judiciary. Washington: The Brookings Institution, 2006.

WALDRON, Jeremy. A dignidade da legislação. São Paulo: M. Fontes, 2003.

WILLIAMS, Katherine Y.; O'REILLY, Charles A. Demography and diversity in organizations: a review of 40 years of research. Research in Organizational Behavior, v. 20, 1998. 


\section{REVISTA BRASILEIRA DE POLÍTICAS PÚBLICAS BRAZILIAN JOURNAL OF PUBLIC POLICY}
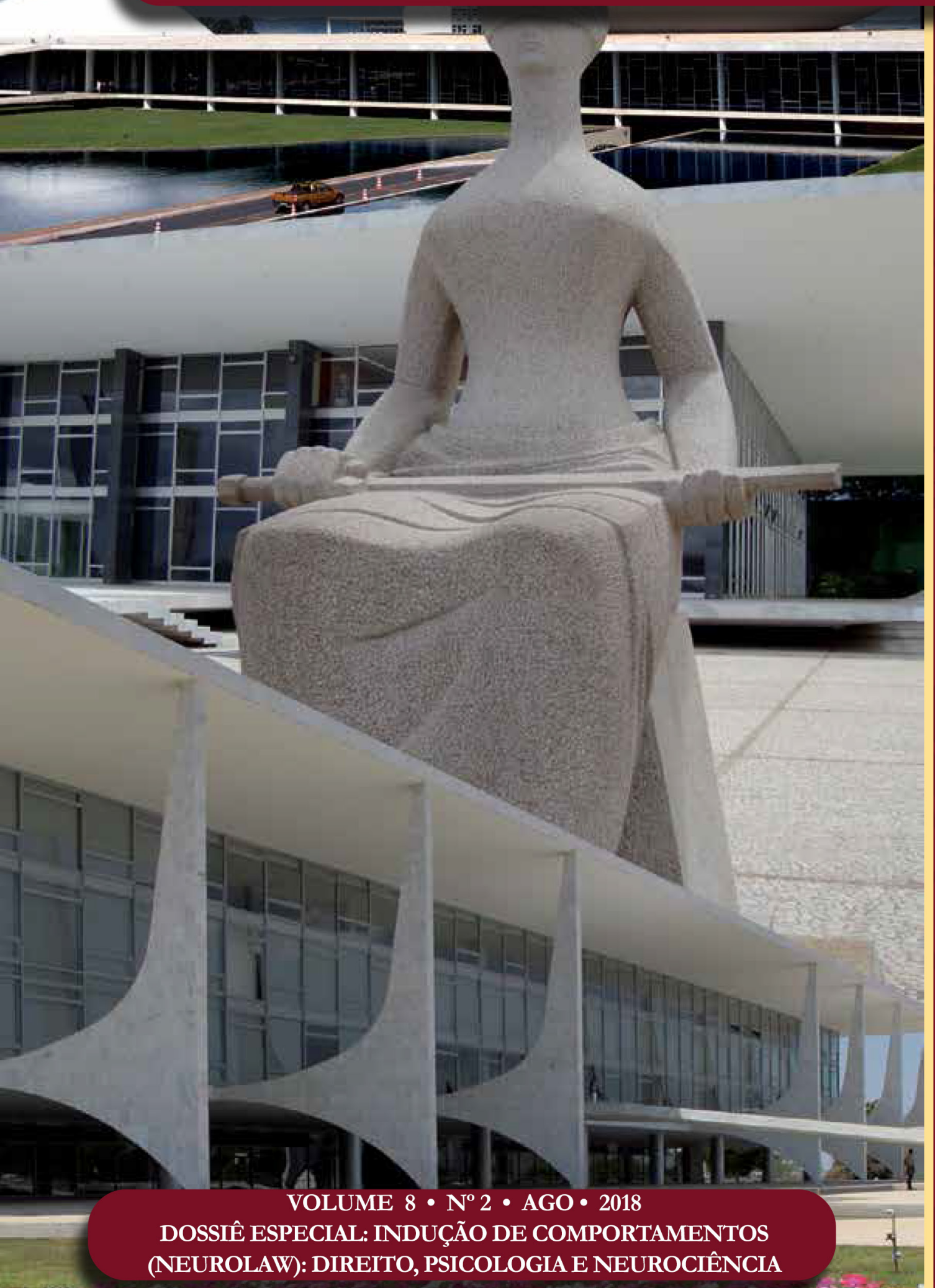

Das 11 ilhas ao centro do arquipélago: os superpoderes do Presidente do STF durante o recesso judicial e férias

From the 11 islands to the center of the archipelago: the superpowers of the Brazilian Supreme Court's Chief Justice during judicial recession and vacation

José Mário Wanderley Gomes Neto

Flávia Danielle Santiago Lima 


\section{Das 11 ilhas ao centro do arquipélago: os superpoderes do Presidente do STF durante o recesso judicial e férias*}

\author{
From the 11 islands to the center of the \\ archipelago: the superpowers of the Brazilian \\ Supreme Court's Chief Justice during judicial \\ recession and vacation
}

José Mário Wanderley Gomes Neto**

Flávia Danielle Santiago Lima***

\section{Resumo}

Compete ao Ministro Presidente do Supremo Tribunal Federal a apreciação de "questões urgentes" (art. 13, VIII, RISTF), nos períodos de recesso e nas férias coletivas dos ministros (janeiro e julho). Durante esse breve momento, as normas acima referidas ampliam a competência decisória da Presidência do Tribunal, permitindo-lhe conhecer e decidir as mais diversas questões, bem como concentram todas as resoluções na pessoa de quem esteja no exercício da função nesse período excepcional (Presidente ou Vice-Presidente). Mas como descrever o comportamento desse relevante ator jurídico-político durante esse período, diante dos diversos modelos explicativos da denominada Política Judicial (Judicial Politics)? Para responder a essa pergunta, emprega-se uma metodologia exploratória e descritiva, com exposição das normas que regulam o papel do Presidente do Tribunal e suas atividades durante o recesso (modelo legal-institucional), com discussão - a partir de decisões tomadas (casos) — das suas possibilidades de interação com os demais atores políticos (modelo estratégico). Trata-se de análise de caso qualitativa, que aborda decisões tomadas durante os recessos de 2011, 2013, 2015, 2017 e 2018, abrangendo a Presidência de quatro Ministros do STF. Referida análise justifica-se pelo objetivo de compreender como é construída a concepção de urgência, para efeitos de atuação do Ministro Presidente durante o período excepcional. Conclui-se que, no puzzle da formação da agenda decisória judicial, o desenho normativo do Tribunal assegura ao Presidente instrumentos processuais que viabilizam uma ampla gama de possibilidades decisórias, explicativas da inserção desse ator específico no concerto entre os poderes da República e suas relações com a sociedade.

Palavras-Chave: Supremo Tribunal Federal. Comportamento judicial. Judicialização da política. Ministro Presidente. Recesso forense e férias coletivas.

*** Doutora em Direito pela UFPE. Professora no PPGD da UFPE, na Universidade de Pernambuco - UPE e na Universidade Católica de Pernambuco - UNICAP.

Email: flavia-santiago@uol.com.br.
* Recebido em 31/05/2018

** Mestre em Direito Público e Doutor em Ciência Política pela UFPE. Professor na Universidade Católica de Pernambuco e no Centro Universitário CESMAC, AL.

Email: josemwgomes@gmail.com. 


\section{Abstract}

It is incumbent upon the Chief Justice of Brazilian Supreme Court to consider "urgent matters" (article 13, VIII, RISTF), during the recess periods and on the collective vacations of justices (January and July). During this brief moment, the above rules extend the decision-making powers of the Chief Justice, enabling her to hear and decide on a wide range of issues, as well as concentrating all resolutions. But how can we describe the behavior of this relevant legal-political actor during this period, given the different explanatory models of the so-called Judicial Politics? To answer this question, an exploratory and descriptive methodology was used, with an exposition of the norms (legal-institutional model) that regulate the role of the Chief Justice and its activities during the recess and vacations, with discussion - based on decisions taken (cases ) - of its possibilities of interaction with other political actors (strategic model). This is a qualitative case analysis, which addresses decisions taken during the recess and vacations periods of 2011, 2013, 2015, 2017 and 2018, covering the tenure of four chief justices. This analysis is justified by the objective of understanding how the concept of urgency is constructed, for the purposes of the performance of the Chief Justice during the exceptional period. It is concluded that, in the puzzle of the formation of the judicial decision-making agenda, the Court's normative design assures the Chief Justice procedural instruments that enable a wide range of decision-making possibilities, explaining the insertion of this specific actor in the concert between the political branches and its relations with the society.

Keywords: Brazilian Supreme Court. Judicial Behaviour. Judicialization of politics. Chief Justice. Judicial recess and vacations.

\section{INTRODUÇÃO: QUEM PRESIDE O BRASIL?}

Em 28 de dezembro de 2017, a Presidente do Supremo Tribunal Federal (STF), em decisão monocrática proferida durante o recesso judicial, após provocação da Procuradora-Geral da República, suspendeu artigos do tradicional decreto de indulto natalino concedido pelo Presidente da República. A decisão chama a atenção por suas repercussões no arranjo entre os poderes. O "poder de graça" se insere nas competências privativas do Chefe do Executivo Federal, nos termos do art. 84, XII, da Constituição da República Federativa do Brasil (CRFB).

Aliás, de acordo com a jurisprudência do STF, caberia ao Presidente decidir sobre a "conveniência, oportunidade e requisitos de sua concessão"1, que não poderia ser objeto de limitação pelo legislador ordinário ${ }^{2}$.

Contudo, ao entender pelo desvio de finalidade na concessão do indulto, foi concedida a liminar na medida cautelar ${ }^{3}$ e seus termos seriam apreciados pelo relator da ADI 5874 MC / DF, Ministro Luís Roberto Barroso, após o mencionado recesso, em fevereiro.

Tem-se, portanto, uma decisão monocrática produzida em dissonância com as manifestações anteriores do próprio Tribunal, cujos efeitos se estendem por considerável período, sem a possibilidade de manejo de recurso pelo titular privativo da competência constitucional sobre o tema.

Referida possibilidade, em termos constitucionais, parece distante da previsão do princípio da separação

1 BRASIL. Supremo Tribunal Federal. RHC 71.400. Relator: Ministro Ilmar Galvão, j. 7-6-1994, 1a T, DJ de 30-9-1994. Disponível em: $<$ http://redir.stf.jus.br/paginadorpub/paginador.jsp?docTP=AC\&docID=102538>.

2 BRASIL. Supremo Tribunal Federal. Habeas-Corpus n 81.565, Relator: Ministro Sepúlveda Pertence, j. 19-2-2002, 1 T, DJ de 22-3-2002. Disponível em: $<$ http://stf.jus.br/portal/jurisprudencia/listarJurisprudencia.asp?s1=\%28HC $\% 24 \% 2 \mathrm{ESCLA} \% 2 \mathrm{E}+\mathrm{E}$ $+81565 \% 2 \mathrm{ENUME} \% 2 \mathrm{E} \% 29+\mathrm{OU}+\% 28 \mathrm{HC} \% 2 \mathrm{EACMS} \% 2 \mathrm{E}+\mathrm{ADJ} 2+81565 \% 2 \mathrm{EACMS} \% 2 \mathrm{E} \% 22 \&$ base $=$ baseAcordaos\&url=ht tp://tinyurl.com/nbxsmu7>.

3 BRASIL. Supremo Tribunal Federal. Medida Cautelar na Ação Direta de Inconstitucionalidade 5.874 Distrito Federal. Disponível em: <http://portal.stf.jus.br/processos/downloadPeca.asp?id=313543293\&ext=.pdf $>$. 
entre os poderes que, desde sua formulação liberal, impede a concentração de atribuições, além do estabelecimento de mecanismos específicos de controles recíprocos entre os titulares das funções estatais. Para tal fim, Montesquieu previu as faculdades de impedir e estatuir ${ }^{4}$; denominadas, após a elaboração de Bolingbroke, checks and balances, e posteriormente incorporadas ao arranjo político norte-americano ${ }^{5}$. Mesmos as formulações mais recentes, como a de Bruce Ackerman, reconhecem o papel garantidor desses controles, sobretudo para ao projeto popular de autogoverno ${ }^{6}$.

Não é a primeira vez, contudo, que importante decisão é tomada nesse período do ano, o que permite questionar acerca do desenho e práticas institucionais que viabilizam esse tipo de comportamento judicial e, além disso, sua conformidade com o arranjo constitucional.

Com efeito, o enquadramento do STF como uma instituição política despertou a curiosidade de muitos pesquisadores brasileiros que se debruçaram sobre o tema e buscaram explicar ou contextualizar o Tribunal como uma instituição capaz de causar alterações significativas nas relações estabelecidas entre os poderes. Há vasta literatura que traz à tona a discussão teórica sobre o cabimento e os limites do judicial review no Brasil, geralmente sob a caracterização de uma judicialização da política e considerações acerca do mérito das decisões (e omissões), a partir dos conceitos operativos de ativismo e autocontenção judicial7.

Dos estudos empíricos sobre o STF, exsurge a necessidade de exploração do modelo institucional do órgão e suas consequências para o exercício de suas amplas atribuições. Nesse sentido, destacam-se leituras que privilegiam o papel das onze ilhas, na ampla margem para manifestações individuais dos ministros (relatores, especialmente) em detrimento de sua atuação colegiada ${ }^{8}$, arranjo, também, conhecido como "ministocracia"”.

Nesse sentido, Falcão e Arguelhes ressaltam o fenômeno da fragmentação decisória e do esvaziamento do Colegiado do STF, ao apontar que, no ano de 2016, as decisões judiciais mais importantes (do ponto de vista de seu impacto político-institucional) vieram de atos judiciais monocráticos (constituídos do exercício do poder de revisão judicial por um único membro da corte sem submissão imediata a seus pares), revelando comportamentos estratégicos dos ministros frente a seus colegas ${ }^{10}$.

Além do poder de decidir, revela-se. também. a discricionariedade sobre a gestão dos processos judiciais. Em regra geral, a formação da pauta está a cargo do Presidente do STF. E os Ministros, na qualidade de relatores dos processos em tramitação, decidirem. estrategicamente. o que e quando levar a julgamento, individual ou coletivamente. Assim, um único Ministro também pode influenciar a formação da pauta (agenda), isto é, a ordem segundo a qual as questões seriam decididas.

Reconhece-se que manifestações individuais e formação de agenda são variáveis explicativas do comportamento do STF ${ }^{11}$. Contudo, tem-se todos os anos períodos em que, apenas, uma pessoa responde por

4 MONTESQUIEU, Charles Louis de Secondat. O espírito das leis. São Paulo: Martins Fontes, 1999. p. 150-162.

5 CAPPELLETTI, Mauro. ¿Renegar de Montesquieu?: la expansión y la legitimidad de la "justicia constitucional”. Revista Española de Derecho Constitucional, ano 6, n. 17, p. 9-47, mayo/ago. 1996

6 ACKERMAN, Bruce. The new separation of powers. Harvard Law Review, v. 113, n. 3, p. 663-727, jan. 2000. Disponível em: $<$ http://www.edesp.edu.br/files/eventos/papers/Ackerman.pdf>. Acesso em: 28 ago. 2005. p. 634.

7 LIMA, Flávia Danielle Santiago; GOMES NETO, José Mário Wanderley. Autocontenção à brasileira? uma taxonomia dos argumentos jurídicos (e estratégias políticas?) explicativo (a) s do comportamento do STF nas relações com os poderes majoritários. Revista de Investigações Constitucionais, v. 5, n. 1, p. 221-247, 2018.

8 SILVA, Virgílio Afonso da. Deciding without deliberating. I•CON, v. 11, n. 3, p. 557-584, 2011.

9 ARGUELHES, Diego Werneck; RIBEIRO, Leandro Molhano. Ministrocracia?: o Supremo Tribunal individual e o processo democrático brasileiro. Novos estudos CEBRAP, v. 37, n. 1, 2018.

10 FALCÃO, Joaquim; ARGUELHES, Diego. Onze Supremos: todos contra o plenário. In: FALCÃO, Joaquim; ARGUELHES, Diego W.; RECONDO, Felipe (Org.). Onze Supremos: o Supremo em 2016. Rio de Janeiro: Fundação Getúlio Vargas, 2017. p. $20-21$. 11 ARGUELHES, Diego Werneck; RIBEIRO, Leandro Molhano. 'The Court, it is I'?: individual judicial powers in the Brazilian Supreme Court and their implications for constitutional theory. Global Constitutionalism, v. 7, n. 2, p. 236-262, 2018. RIBEIRO, Leandro Molhano; ARGUELHES, Diego Werneck. Preferências, estratégias e motivações: pressupostos institucionais de teorias sobre comportamento judicial e sua transposição para o caso brasileiro. Revista Direito e Práxis, v. 4, n. 7, p. 85-121, 2013. 
toda a atividade do Tribunal: seu Ministro Presidente. Durante o recesso e férias judiciais, cabe a ele(a) decidir se uma questão é urgente ou não; caso sim, poderá estabelecer um juízo provisório sobre a matéria, suspendendo — como na situação acima descrita — ou mantendo decisões de outros titulares de poder.

Durante o recesso, "Sua Excelência ou Vossa Majestade"12 torna-se o único guardião do "maravilhoso mistério do tempo"13, mas não há estudos que destrinchem essa possibilidade institucional e suas consequências para o sistema constitucional brasileiro. Como é regulamentada essa atividade? E que instrumentos processuais, a partir do desenho normativo do Tribunal, o Presidente do STF dispõe na sua interação com os demais atores políticos? Para responder a essas perguntas, emprega-se uma metodologia exploratória e descritiva, com exposição das normas que regulam o papel do Presidente do Tribunal e suas atividades durante o recesso, com discussão - - a partir de decisões tomadas (casos) — da inserção desse ator específico no concerto entre os poderes da República e suas relações com a sociedade.

\section{DeSENHOS INSTITUCIONAIS E MOdELOS ESTRATÉGICOS: RELEVÂNCIA PARA A COMPREENSÃo dAS CORTES NO CONTEXTO DA JUDICIAL POLITICS}

Nas mais diversas situações, as instituições atraem a atenção dos pesquisadores em Economia, Ciência Política e Ciências Sociais. Dentre os últimos, recentemente, os pesquisadores em Direito dedicam-se à explicação do comportamento dos atores governamentais e dos órgãos judiciais, sob uma interessante perspectiva, resultante de sua natureza peculiar: sua eventual capacidade de moldar o comportamento humano, através de sofisticadas redes de incentivos.

As instituições são as regras do jogo em uma sociedade ou, mais formalmente, são constrangimentos artificiais (de origem humana) que moldam a interação humana, isto é, formam incentivos estruturais relativos às interações entre os atores, sejam políticas, sociais ou econômicas ${ }^{14}$. Todo comportamento, traduzido numa ação ou numa omissão, resulta de uma decisão, tomada por determinado agente, num determinado contexto. Se as instituições respectivas são capazes, ou não, de influir nesse comportamento, incentivando ou constrangendo, são importantes para a compreensão dos mecanismos causais inerentes a ele.

É possível verificar, sem muito esforço, ao longo da legislação brasileira, vários exemplos nesse sentido: a) ao prever a conclusão de cursos de mestrado e de doutorado como fatores favoráveis à progressão funcional de servidores públicos, a legislação incentiva, positivamente, a qualificação progressiva do funcionalismo público; b) ao estabelecer um regime de tolerância zero a níveis de alcoolemia em condutores de veículos automotivos, as normas de trânsito auxiliaram a redução dos acidentes com vítimas, graves ou fatais, bem como influenciaram na mudança dos hábitos dos consumidores de bebidas alcoólicas; c) ao prescrever que instituições de ensino superior devam atender a parâmetros de qualidade na prestação do serviço público concedido, ao risco de serem mal avaliadas ou perderem direitos e prerrogativas inerentes à concessão, as normas editadas pelo Ministério da Educação (MEC) visam contribuir, favoravelmente, à qualidade da educação.

Nessas três hipóteses exemplificativas, as instituições efetivamente influem no comportamento dos atores envolvidos, mediante mecanismos que incentivam e/ou constrangem as tomadas de decisão: seja pela perspectiva de benefícios; seja pela iminência de sanções, constrangimentos ou punições; seja pelo risco da suspensão ou da perda de prerrogativas, direitos ou liberdades. As consequências dos atos passam a se

12 LIMA, Flávia Danielle Santiago; ANDRADE, Louise Dantas de; OLIVEIRA, Tassiana Moura de. Emperor or president?: understanding the (almost) unlimited power of the Brazilian Supreme Court's President. Revista Brasileira de Direito, v. 13, p. 161 176, 2017.

13 BICKEL, Alexander M. The least dangerous branch: the Supreme Court at the bar of politics. Indianapolis: Bobbs-Merrill, 1962. p. 26.

14 NORTH, Douglass C. Institutions, institutional change, and economic performance. New York: Cambridge University Press, 1990. 
inserir no cálculo decisório dos atores, com base em estrutura institucional que circunscreve o processo de tomada de decisões, podendo, ou não, exercer a esperada influência sobre o comportamento, a depender do contexto específico de cada situação.

Se determinado desenho institucional está associado a um comportamento, as instituições não apenas importam, mas a compreensão de seus mecanismos de interação é determinante para se entender (ou até prever) o fenômeno da ação ou da omissão do ator destinatário (consumidor, servidor público, empresa concessionária, membro do ministério público etc.) frente a circunstâncias político e socialmente relevantes.

Não seria diferente em relação aos órgãos judiciais: o entendimento acerca da existência de instituições (normas constitucionais, infraconstitucionais ou regimentais) que favoreçam e/ou incentivem condutas importa para compreender os papéis desempenhados pelos juízes, nas mais diversas esferas do Poder Judiciário. Notadamente, em resposta à judicialização das questões politicamente relevantes ${ }^{15}$.

Como visto, no Estado Democrático de Direito, espera-se que as normas (constitucionais, infraconstitucionais e regimentais), que estruturam o arcabouço do referido desenho, estabeleçam freios e contrapesos (checks and balances) recíprocos, internos e externos, capazes de constranger o exercício desmedido e arbitrário de poder institucional e de promover o necessário equilíbrio entre os atores ${ }^{16}$. Mecanismos formais como o non liquet, a colegialidade decisional (como regra esperada), os deveres de publicidade e de fundamentação, a distribuição aleatória dos processos entre os membros da corte, dentre outros, circunscrevem a atividade jurisdicional, coletiva e principalmente individual, incentivando comportamentos politicamente virtuosos e dificultando determinadas condutas, v.g., politicamente reprováveis ou pouco republicanas.

Entretanto, Arguelhes e Ribeiro denunciam relevante fenômeno em sentido contrário, o qual denominam "ministocracia": o desenho institucional de nosso Tribunal Supremo fornece mecanismos (v.g., liminares, pedidos de vista) para que os Ministros possam descentralizada e individualmente decidir, sinalizar e definir agenda, a política constitucional se torna errática, criando problemas para a justificação do poder do tribunal em um regime democrático ${ }^{17}$. A compreensão de tal fenômeno (a crescente atuação judicial individual), relacionado aos mecanismos internos de funcionamento do tribunal e à maneira como o arcabouço institucional incentiva ou constrange as ações e as tomadas de decisão, é crucial para se compreender os papéis que o Supremo Tribunal Federal tem desempenhado na arena democrática, em suas relações com as demais instituições e com outros atores relevantes.

Nesse sentido, a influência do desenho institucional sobre o comportamento dos agentes — no caso, sobre o comportamento judicial — é estudada com base na aplicação de modelos formais, os quais consistem na apresentação de elementos que se propõem a explicar os motivos (fatores) pelos quais as decisões são tomadas, a serem confirmados por meio de testes empíricos aplicados sobre dados codificados com base em informações relacionadas às referidas decisões.

[A] causalidade é uma propriedade de um modelo hipotético. Um modelo totalmente articulado dos fenômenos estudados precisamente define estados hipotéticos ou contrafactuais. [...] Um modelo é um conjunto de mundos possíveis contrafactuais construídos sob algumas regras. As regras podem ser as leis da física, as consequências da maximização da utilidade, ou as normas que regem as interações sociais, para tomar apenas três dos muitos exemplos possíveis ${ }^{18}$.

Em um modelo formal de pesquisa, ocorre o teste de variáveis, premissas e/ou equações, tomadas como representações de um fato ou de um fenômeno, materializada numa ferramenta útil a captar o conteúdo de

15 CASEY, Gerard; WHITTINGTON, Keith E. Constitutional interpretation: textual meaning, original intent, and judicial review. The Review of Metaphysics, v. 54, n. 1, p. 179-180, 2000.

16 EPSTEIN, Lee; WALKER, Thomas G. Constitutional Law for a Changing America: institutional powers and constraints. Washington: Cq Press, 2010.

17 ARGUELHES, Diego Werneck; RIBEIRO, Leandro Molhano. Ministrocracia?: o Supremo Tribunal individual e o processo democrático brasileiro. Novos estudos CEBRAP, v. 37, n. 1, 2018.

18 HECKMAN, James J. The scientific model of causality. Sociological Methodology, v. 35, p. 2, 2005. 
um comportamento e explicar os processos intrínsecos à sua ocorrência ${ }^{19}$.

Um modelo consiste numa representação simplificada da realidade; não se trata da realidade em si. Modelos propositadamente ignoram certos aspectos da realidade e, em contrapartida, focam em selecionados, às vezes até relacionados, conjuntos de fatores cruciais ${ }^{20}$.

A compreensão das decisões judiciais sob o prisma comportamental é realizada pelo emprego de modelos formais de pesquisa das mais diversas matizes - atitudinais, estratégicas, organizacionais, culturais, históricas, dentre outras ${ }^{21}$ — sendo os modelos legalista, atitudinal e estratégico os mais presentes na literatura sobre comportamento judicial e sobre judicial politics.

Primeiramente, o modelo legalista estuda o ato de julgar como uma atividade puramente neutra e técnica, isto é, testa hipóteses para as quais os juízes decidem casos baseados estritamente naquilo que está escrito na lei, bem como nos princípios, nos precedentes e nas demais fontes jurídicas. Para tanto, verifica se e como tais fatores jurídicos estritos estão associados aos julgamentos ${ }^{22}$.

Já os modelos atitudinais, por sua vez, testam hipóteses nas quais os juízes realizam escolhas em seus julgamentos baseadas em suas preferências individuais (atitudes) construídas no decorrer de sua trajetória pessoal e profissional, ou seja, os julgamentos de hoje seriam fruto de sucessivas vivências pretéritas do julgador, a influenciar na formação de sua personalidade ${ }^{23}$. Esse teste de relação entre o passado do juiz e o presente decisional é operado por variáveis representativas de fatores como ideologia, religião, correntes de pensamento, história familiar etc.

Finalmente, os modelos estratégicos enfrentam hipóteses para as quais, ao decidir, os órgãos jurisdicionais ponderam "os custos e benefícios relativos que irão resultar de suas decisões formais e de seus esforços informais de influência" ${ }^{24}$, sofrendo constrangimentos nas suas preferências, por meio da influência de fatores externos, v.g., a expectativa de outros atores políticos, a opinião pública sobre o papel da instituição ou as consequências econômicas da escolha realizada entre as pretensões submetidas ${ }^{25}$.

Tais modelos não são excludentes e/ou competitivos entre si, mas, em sentido oposto, são complementares: representam dimensões diferentes de um mesmo fenômeno complexo, com muitas facetas, cujas explicações, em alguns momentos, dependerá da utilização conjunta de mais de um modelo numa mesma pesquisa.

In casu, a compreensão de como é construída a concepção de urgência, para efeitos de atuação do Ministro Presidente durante o período excepcional, bem como da influência do desenho institucional da Corte em relação à opção de exercer, ou não, a revisão judicial monocrática sobre a questão submetida, enquadra-se no puz:le da formação da agenda decisória judicial, tema inerente às hipóteses do modelo estratégico.

Conforme o arcabouço institucional referido, compete ao Ministro Presidente do Supremo Tribunal Federal a apreciação de "questões urgentes" (art. 13, VIII, RISTF), nos períodos de recesso (20 de dezembro a 6 de janeiro) e nas férias coletivas dos ministros (janeiro e julho), conforme disposto no art. $66, \sqrt{\$} 1^{\circ}$, da LC

19 NAGEL, S.; NEEF, M. Models of judicial Decision-Making. In: JOHNSON, G. W. (Ed.). American political science research guide. New York: IFI/Plenum Data Company, 1977. v. 1.

20 SEGAL, Jeffrey A.; SPAETH, Harold J. The Supreme Court and the attitudinal model revisited. New York: Cambridge University Press, 2002. p 45 .

21 GIBSON, James L. Challenges to the impartiality of state supreme courts: legitimacy theory and "new-style" judicial campaigns. American Political Science Review, v. 102, n. 01, p. 59-75, 2008.

22 GILLMAN, Howard. What's Law got to do with it?: judicial Behavioralists test the "Legal Model" of judicial decision making. Law \& social inquiry, v. 26, p. 465-504, 2001.

23 Sobre o tema: GILLMAN, Howard; CLAYTON, Cornell W. Beyond judicial attitudes: institutional approaches to Supreme Court Decision-Making. In: CLAYTON, Cornell W.; GILLMAN, Howard (Ed.). Supreme Court decision-making: new institutionalist approaches. Chicago: University of Chicago Press, 1999. SEGAL, Jeffrey A. Judicial Behavior. In: WHITTINGTON, Keith E.; KEL-

EMEN, R. Daniel; CALDEIRA, Gregory A. (Ed.). The Oxford Handbook of Law and politics. Oxford: Oxford University Press, 2008.

24 MURPHY, Walter F. Elements of judicial strategy. Chicago: University of Chicago Press, 1964.

25 EPSTEIN, Lee; KNIGHT, Jack. The Choices Justices Make. Washington: Congressional Quarterly, 1998. 
35/1979, art. 78, caput, RISTF e Portaria 187/2013/GDG.

Durante esse breve momento, as normas acima referidas ampliam a competência decisória da Presidência do Tribunal, permitindo-lhe conhecer e decidir as mais diversas questões, bem como concentram todas as resoluções na pessoa de quem esteja no exercício da função nesse período excepcional (Presidente ou Vice-Presidente).

Tal ambiente incentiva os múltiplos atores com acesso à jurisdição do Supremo Tribunal, seja pela via concentrada ou pela via difusa, a submeter demandas durante esse período — principalmente aquelas que refletem preferências anteriormente externalizadas pelo Ministro Presidente - beneficiados pela temporária concentração decisória, em oposição à posterior distribuição aleatória entre os demais órgãos componentes da Corte.

Da mesma forma, a ausência de constrangimentos institucionais e a ampla margem de definição subjetiva do que seria "urgente" permitem que o Presidente exerça total seletividade quanto ao que deve, ou não, ser decidido naquele momento sui generis ou relegado ao momento posterior (quando será apreciada por outro membro do Tribunal), sendo o timing decisional um fator importante para compreensão da racionalidade das decisões tomadas, bem como daquela envolvendo os casos não decididos (em autorrestrição silenciosa).

Nesse diapasão, leciona Joaquim Falcão que o STF "seria um tribunal político não apenas porque concorda ou discorda do Executivo ou do Congresso. Mas antes porque controla o tempo de concordar ou discordar" ${ }^{\prime 26}$. Assim, o tempo mostra-se um relevante fator para a compreensão da interação do Tribunal com o sistema político, notadamente as estratégias envolvidas, sobretudo em relação às decisões monocráticas e suas dinâmicas decisórias.

\section{O centro do arquipélago no recesso: o Super Presidente do STF}

Compreende-se o modelo institucional atribuído ao STF como um dos elementos-chave para a compreensão da sua relevância no jogo político após a Constituição de 1988: ao destinar ao Tribunal a função de guardião do texto constitucional, na conjugação de instrumentos dos modelos clássicos de revisão judicial de legislação (difuso e concentrado), competência para julgamento das mais altas autoridades da República e outros, tem-se uma instituição diferenciada em comparação com a "história de cortes existentes em outras democracias, mesmo as mais proeminentes" ${ }^{\prime 27}$.

Não há disciplinamento específico, na CRFB, do exercício das diversas competências processuais (art. 102) pelos Ministros, tampouco são estabelecidas diretrizes para sua estrutura organizacional. Referida tarefa caberia, portanto, ao legislador ordinário, ao tratar dos diversos institutos jurídicos à disposição dos atores legitimados à provocação do Tribunal, ou na legislação processual. Sua estrutura, organização e trâmites, como corolário do princípio da autonomia organizacional (art.93, CRFB) são regulados por um Regimento Interno (RI/STF) elaborado e aprovado pelo órgão plenário do próprio Tribunal, que determina a distribuição de competências e responsabilidades de cada um dos ministros e, principalmente, do Presidente.

Como sabido, a estrutura do STF é organizada em torno do Plenário, da distribuição dos 11 ministros em duas Turmas e na figura do seu Presidente. A CRFB atribui, em diversas oportunidades, relevantes atribuições para esse agente, perante o Tribunal, mas na gestão do próprio Poder Judiciário, uma vez que ocupa a posição de cúpula de todo o complexo sistema judiciário brasileiro e, eventualmente, em substituição aos titulares de outros poderes.

26 FALCÃO, Joaquim. O Supremo: compreenda o poder, as razões e as consequências das decisões da mais alta Corte do Judiciário no Brasil. Rio de Janeiro: Edições de Janeiro, 2015. p. 93.

27 VIEIRA, Oscar Vilhena. Supremocracia. Revista Direito GV, v. 4, p. 441-459, 2008. 
O Presidente do STF concentra um relevante poder sobre a magistratura, ao acumular a Chefia do Conselho Nacional de Justiça (art. 103-B, I, \$1 ${ }^{\circ}$ ), centralizando o controle administrativo, financeiro e disciplinar da instituição. As relações com os demais poderes são por ele intermediadas, ao deter iniciativa privativa de propositura de projeto de lei (complementar) para regras gerais da magistratura e divisão judiciárias (art. 93, II, CF) ou iniciativa de projeto de lei para fixação de seus próprios subsídios, que e constituem no limite remuneratório do serviço público.

Em caso de afastamento temporário do Chefe do Executivo, cabe-lhe aguardar a possibilidade de ocupar o último posto na cadeia de suplência do Presidente da República (art. 80, CRFB). Já a Presidência do Senado Federal é exercida para acompanhar o processamento do julgamento de altas autoridades por crime de responsabilidade pela casa parlamentar, assegurando a observância do devido processo legal (parágrafo único do art. 52, CRFB)

A despeito dessas relevantes funções, a CRFB não estabeleceu critérios específicos para a escolha do Presidente do STF. Desse modo, coube ao Regimento Interno (RISTF) a regulação do procedimento de sua eleição. E o RISTF dispõe que o Presidente será escolhido pelo Plenário (art. $7^{\circ}$ ), por meio de votação secreta, na segunda sessão ordinária do mês anterior ao da expiração do mandato, ou na segunda sessão ordinária imediatamente posterior à ocorrência de vaga por outro motivo. O mandato será de dois anos, e o quórum mínimo para que seja eleição é de oito ministros (art. 12 do RISTF).

Tradicionalmente, trata-se um procedimento meramente simbólico ${ }^{28}$, em que a escolha recai sobre o Ministro que exerce suas funções há mais tempo e que não tenha exercido o cargo ${ }^{29}$.

Considerando-se a vitaliciedade dos ministros, cuja aposentadoria compulsória deve ocorrer aos setenta e cinco anos de idade, é possível — mas não provável ${ }^{30}$ — que algum Ministro presida o STF em mais de uma oportunidade. E, em caso de ausências ou impedimentos, será substituído pelo Vice-Presidente e este pelos demais Ministros, na ordem decrescente de antiguidade (art. 37, RISTF).

Ao longo de seu mandato, o Presidente dispõe de grande autonomia para imprimir sua marca à gestão do Tribunal e, na condição de Chefe do Poder Judiciário e Presidente do Conselho Nacional de Justiça, estabelecer prioridades para toda a instituição. Contudo, as relevantes funções que lhe são acometidas não são acompanhadas de instrumentos mais fortes de accountability ${ }^{31}$ de sua atividade, após notável resistência ao estabelecimento de sistemas mais específicos de controle ${ }^{32}$.

Embora sujeitos a impeachment em decorrência de condenação por crime de responsabilidade (Lei Federal 1.079/1950) e às limitações previstas na Lei Orgânica da Magistratura Nacional, Lei Complementar 35/1979, a estrutura judicial e as garantias da instituição insulariam os Ministros do STF — especialmente

28 Durante o Estado Novo, o então Presidente Getúlio Vargas editou o Decreto-lei n. 2.770/40, que atribuiu ao Chefe do Executivo a competência de nomear, por tempo indeterminado, dentre os Ministros, Presidente e o Vice-Presidente do Supremo Tribunal Federal. VIEIRA, Oscar Vilhena. Supremo Tribunal Federal: jurisprudência política. São Paulo: Malheiros, 2002. p. 121.

29 VALE, André Rufino do. Novo presidente do Supremo deverá enfrentar grandes desafios em sua gestão. Observatório Constitucional, Brasília, 2 ago. 2014. Disponível em: <http://www.conjur.com.br/2014-ago-02/observatorio-constitucional-presidentesupremo-devera-enfrentar-grandes-desafios-gestao>. Acesso em: 25 maio 2018.

30 A partir de dados do STF, Frederico de Almeida pondera que a média de permanência no Tribunal é relativamente baixa. No período de 1984-2014, de apenas 9,82 anos. ALMEIDA, Frederico de. Judicialização da política e composição dos tribunais superiores. Revista Parlamento e Sociedade, São Paulo, v. 3, n. 4, p. 75-98, jan./jun. 2015.

31 Sobre o papel do Conselho Nacional de Justiça na accountability do Judiciário Brasileiro TOMIO, Fabrício Ricardo de Limas; ROBL FILHO, Ilton Noberto. Accountability e independência judiciais: uma análise da competência do Conselho Nacional de Justiça (CNJ). Revista de Sociologia e Politica, v. 21, n. 45, p. 29-46, mar. 2013.

32 "Diante de um contexto de forte resistência contrária à instituição de um órgão de controle do Poder Judiciário, principalmente por parte da magistratura brasileira, os atores que visavam à sua criação apelaram: 1) ora para argumentos moralizantes sobre a necessidade de um órgão capaz de corrigir problemas do Judiciário, 2) ora para argumentos técnicos sobre a importância de se imprimir maior celeridade na justiça brasileira.” RIBEIRO, Leandro Molhano; PAULA, Christiane Jalles. Inovação institucional e resistência corporativa: o processo de institucionalização e legitimação do Conselho Nacional de Justiça. Revista Brasileira de Políticas Públicas, Brasília, v. 6, n. 3, p. 13-28, 2016. 
seu Presidente - quanto a eventuais controles sobre sua atuação, ainda mais porque submetidos ao Conselho Nacional de Justiça ${ }^{33}$.

As funções do Presidente na condução do STF estão dispostas no art. 13 do Regimento Interno, a englobar a representação do Tribunal, direção dos trabalhos e cumprimento das disposições regimentais nas sessões plenárias, relatoria de processos até sua distribuição, convocação de audiências públicas, decisões de questões de ordem e outros.

Num universo tão amplo, uma atividade de relevantes consequências político-jurídico-sociais se destaca: estabelecer a pauta (agenda decisória) do Plenário do STF.

Considerando-se que são recebidas milhares de ações todos os anos (buscar dados) e que os critérios normativos são relativamente abertos $^{34}$, tem-se um alto grau de discricionariedade.

Certamente, os trâmites internos (finalização do relatório do processo, pedidos de vista, providências das partes, finalização de diligências e outros) revelam que os ministros, também, dispõem de instrumentos para influir na agenda decisória, podendo conformar suas ações (e omissões) estrategicamente.

Mas cabe ao Presidente estabelecer, dentre as ações que possuem condições de julgamento, qual será levada a Plenário, quando será iniciado ou retomado o julgamento. Não por acaso, os discursos de posse, sempre, expõem as preocupações e prioridades da gestão. O Min. Ricardo Lewandowski, por exemplo, anunciou "prioridade ao julgamento de recursos extraordinários" e às súmulas vinculantes, como instrumento para reduzir o número de demandas no Tribunal, no exercício 2014-201635.

Por sua vez, a Presidente Cármen Lúcia não estabeleceu metas específicas para sua gestão iniciada em 2016, mas afirmou um papel proativo da instituição na garantia do direito e da ética ${ }^{36}$.

Destarte, características dos procedimentos pelos quais é realizada a formação de agenda, bem como dos processos decisórios, ambos frutos do ambiente institucional da corte, incentivam o agir estratégico dos julgadores ${ }^{37}$, in casu, do Ministro em exercício da Presidência do Tribunal.

Não bastasse a gestão da atividade julgadora cotidiana do STF, durante 74 dias por ano, o Presidente possui total controle sobre a agenda e sobre as decisões a serem tomadas: com efeito, cabe-lhe a apreciação de "questões urgentes" (art. 13, VIII, RISTF), nos períodos de recesso de 20 de dezembro a 6 de janeiro e nas férias coletivas dos ministros (janeiro e julho), conforme disposto no art. 66, \ $1^{\circ}$, da LC 35/1979, art. 78, caput, RISTF e Portaria 187/2013/GDG.

Tal mecanismo excepcional confere ao Ministro Presidente total permissão institucional (embora temporária) para decidir, sinalizar e definir a agenda (pauta) decisória judicial, sendo relevante produto da concentração individual e descentralizada de poder, denunciada por Arguelhes e Ribeiro ${ }^{38}$.

33 LIMA, Flávia Danielle Santiago; ANDRADE, Louise Dantas de; OLIVEIRA, Tassiana Moura de. Emperor or president?: understanding the (almost) unlimited power of the Brazilian Supreme Court's President. Revista Brasileira de Direito, v. 13, p. $161-176,2017$. 34 De acordo com o Código de Processo Civil (Lei n. 13.105/2015), tem prioridade de tramitação as causas em que figurem pessoas com mais de 60 anos ou doença grave (art. 1.048). Já o art. 145 do RI/STF estabelece os procedimentos prioritários para julgamento (habeas corpus, pedidos de extradição, causas criminais - e, dentre estas, as de réu preso -, conflitos de jurisdição, recursos oriundos do Tribunal Superior Eleitoral, mandados de segurança, reclamações, representações, pedidos de avocação e as causas avocadas), cabendo nas demais situações todos os esforços institucionais para o cumprimento da ordem cronológica dos atos e das decisões processuais, instituída pelo regime jurídico recém codificado (art.12).

35 BRASIL. Supremo Tribunal Federal. Discurso de posse do Ministro Ricardo Lewandowski na Presidência do Supremo Tribunal Federal. p. 5-6. Disponível em: <http://www.stf.jus.br/arquivo/cms/noticiaNoticiaStf/anexo/discursoMinistroRL.pdf>. Acesso em: 18 jan. 2018.

36 Após dirigir-se ao "cidadão brasileiro", a Ministra terminou seu discurso com a seguinte exortação: "o Judiciário brasileiro não desertará desse seu encargo. A tarefa é dificultosa, sei-o bem. Mas não deixaremos em desalento direito e ética que a Constituição impõe que resguardemos." BRASIL. Supremo Tribunal Federal. Discurso de posse da Ministra Carmen Lúcia Antunes Rocha na Presidência do Supremo Tribunal Federal. p. 14 Disponível em: <http://static.congressoemfoco.uol.com.br/2016/09/carmen-lucia.pdf>. Acesso em: 18 jan. 2018. 37 CALDEIRA, Gregory A.; WRIGHT, John R.; ZORN, Christopher J. W. Sophisticated voting and gate-keeping in the Supreme Court. Journal of Law, Economics, and Organization, v. 15, n. 3, p. 549-572, 1999.

38 ARGUELHES, Diego Werneck; RIBEIRO, Leandro Molhano. Ministrocracia?: o Supremo Tribunal individual e o processo 
Importante notar, por exemplo, que, além da mulitiplicidade de competências previstas no art. 102 da CRFB, diversas delas viabilizam pedidos cautelares, a demandar um juízo acerca da urgência do pedido e do cabimento da concessão de eventual liminar. Dos remédios constitucionais às ações do controle concentrado de constitucionalidade, quaisquer desses procedimentos contemplam um pedido de apreciação liminar.

Se as dinâmicas sociais, políticas e econômicas são constantes, como o STF se insere nesse concerto, no período em que suas atividades institucionais estariam — a rigor — suspensas?

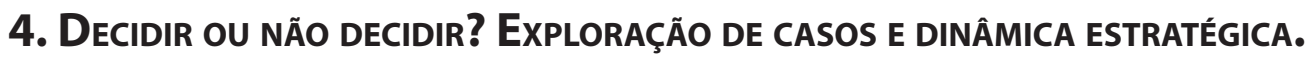

A vasta amplitude dos casos em que a Presidência do STF foi provocada a decidir durante o referido período extraordinário mostra a complexidade da questão ora examinada, bem como indícios de uma atividade estratégica dos sucessivos Ministros que ocuparam essa cadeira, na hora de definir o que era "urgente" e o que não era, bem como o que poderia ser deferido, ou não, a partir do contexto de cada demanda submetida à jurisdição do Tribunal.

Em 4 de janeiro de 2011, nos autos da Arguição de Descumprimento a Preceito Fundamental 223, o partido político Democratas (DEM), questionando a constitucionalidade da interpretação dada pelo Tribunal Superior Eleitoral (TSE) a dispositivos da Lei Eleitoral e do Código Eleitoral, pela qual não poderiam ser computados para o respectivo partido ou coligação os votos dados a um candidato com registro indeferido no dia da eleição. Nesse sentido, requereu liminar para suspender os efeitos da decisão do TSE, de modo a aproveitar os referidos votos do candidato impugnado, em favor da legenda ou da coligação.

O então Presidente do STF, Ministro César Peluso, recebeu a demanda durante o recesso forense e dela não conheceu, determinando sua distribuição à relatoria, após o período extraordinário, e tacitamente negando a urgência necessária à atuação concentrada da Presidência.

Noutro precedente (Reclamação 11987, férias, 15 de julho de 2011) o mesmo Ministro não conheceu um pedido liminar em favor do coronel da Polícia Militar do Pará Mário Pantoja, condenado a 228 anos de prisão (no episódio conhecido como Massacre de Eldorado dos Carajás), cujo objeto era suspensão de processo (em que se pedia novo julgamento pelo tribunal do júri) em tramitação no Superior Tribunal de Justiça, no qual foi negado o julgamento pela $3^{\text {a }}$ Seção daquela Corte, de divergência de entendimento entre a $5^{a}$ e a $6^{a}$ Turmas. Já nesse caso, afirmou, expressamente, não haver "situação de urgência que [justificasse], nos termos do art. 13, VIII, do Regimento Interno, atuação [da] Presidência", pelo que determinou a distribuição do processo, para posterior análise pelo respectivo relator.

Agiu da mesma maneira na Reclamação 12003 (férias, 25 de julho de 2011), na qual o Sindicato dos Policiais Civis de Carreira no Estado do Ceará (Sinpoci/CE) requereu a suspensão da decisão judicial que decretou, em caráter liminar, a ilegalidade da greve deflagrada pela categoria. O Ministro Presidente, em sua decisão, consignou não haver "no caso, situação de urgência que [justificasse], nos termos da norma regimental, atuação [da] Presidência, pois não [haveria] dano irreversível ou perecimento de direito", pelo que não conheceu do pedido e determinou a distribuição por sorteio a um relator, beneficiando, tacitamente, os interesses do Governo do Ceará, ao deixar intocada a decisão judicial cearense, que declarou a ilegalidade do movimento grevista.

Também, durante período de recesso forense (31 de dezembro de 2013), o Ministro Joaquim Barbosa, então Presidente do STF, recebeu pedido de liminar na ADI 4905, proposta pela Confederação Nacional da Indústria - CNI, contra dispositivos da Lei n. ${ }^{\circ}$ 9.430, de 27 de dezembro de 1996, com a redação introduzida pela Lei n. ${ }^{\circ} 12.249$, de 11 de junho de 2010, e, por arrastamento, os artigos 36 , caput e $45, \int 1{ }^{\circ}$, inciso I

democrático brasileiro. Novos estudos CEBRAP, v. 37, n. 1, 2018. 
da Instrução Normativa RFB n. ${ }^{\circ}$ 1.300, de 20 de novembro de 2012 - DOU 21.11.2012, retificada no DOU 05.12.2012, os quais estabeleciam a aplicação de multa calculada à razão de $50 \%$ do crédito tributário, em caso de compensação indeferida pelas autoridades fiscais. Na decisão monocrática que apreciou o pedido, o Ministro não conheceu da questão, entendendo "ausente a urgência inadiável que autorizaria a concessão da medida liminar no período extraordinário do recesso (art. 13, VIII do RISTF)".

Por sua vez, em 21 de dezembro de 2015 (recesso), o Ministro Ricardo Lewandowski, no exercício da Presidência, indeferiu pedido de liminar na Ação Cautelar Originária (ADI) 4067, que pretendia o afastamento de deputado federal investigado por comissão parlamentar de inquérito de função administrativa exercida na Confederação Brasileira de Futebol - CBF, alegando que "o plantão de recesso forense não oferece oportunidade para a reapreciação de pedidos já examinados e deferidos, ou não, por Ministros da Suprema Corte, sob pena de ofensa ao princípio do juízo natural (inciso XXXVII do art. $5^{\circ}$ da CF)". Da mesma forma, argumentou não se tratar de questão urgente a ensejar a apreciação excepcional da questão.

Em seguida, o mesmo Ministro, em 29 de dezembro de 2015 (recesso), deferiu medida liminar no Mandado de Segurança 33952 no sentido de permitir a posse de suplente no cargo de deputado federal (em virtude do afastamento do titular do cargo), negada pelo então Presidente da Câmara dos deputados, deputado Eduardo Cunha, sob a alegação de que um vereador licenciado não poderia assumir mandato parlamentar federal. Entendeu, nesse caso, presente "indispensável demonstração do atendimento do requisito do perigo na demora [urgência], se amoldando à hipótese prevista no art. 13, VIII, do RISTF, a autorizar, por ora, o exercício desta excepcional competência".

Em caso específico, a Presidente do STF, Ministra Cármen Lúcia, negou tutela provisória de urgência na Ação Cível Originária 3091 (recesso, 27/12/2017), na qual o Estado do Amapá buscava afastar exigências formais para celebração de termo aditivo de contrato de refinanciamento da dívida pública com a União. Em sua decisão, assentou a Ministra que a "ausência de identidade entre a controvérsia jurídica posta [naquela] ação e naquelas invocadas como paradigmas pelo Amapá desautoriza sejam [...]aqui adotados os fundamentos jurídicos que justificaram o deferimento das medidas antecipatórias naquelas ações”. A Presidente conheceu a questão submetida, pelo que entendeu presente a urgência da apreciação da matéria, mas indeferiu o pedido, para evitar "comprometer o equilíbrio esperado nas relações entre as atribuições da União e os demais entes federados”.

Noutro contexto, recebeu a Ministra Carmem Lúcia Agravo Regimental na ADI 3406 (férias, 31 de janeiro de 2018), interposto pelo Governador do Rio de Janeiro, contra decisão da relatoria, que deferiu tutela de urgência para modular os efeitos da declaração de inconstitucionalidade do art. $2^{\circ}$ da Lei n 9.055/1995, até a publicação do acórdão respectivo, requerendo a eficácia imediata do acórdão que julgou a ação de controle abstrato. Manifestando-se sobre o recurso, a Ministra Presidente limitou-se a afirmar que o caso não se enquadrava na previsão do art. 13, inc. VIII, do Regimento Interno do Supremo Tribunal Federal, simplesmente encaminhando o processo à Ministra Relatora e tacitamente negando a urgência do pedido.

De modo geral, as respostas dos Ministros Presidentes do Supremo Tribunal Federal às demandas por decisões monocráticas, apresentadas durante o referido período excepcional, são sumarizadas no quadro a seguir, o qual aponta os caminhos que podem ser escolhidos, estrategicamente, pelo julgador Presidente.

A função da Presidência do STF empodera-se, temporariamente, da jurisdição constitucional plena (abstrata e difusa), uma vez que controla a definição subjetiva, durante o período excepcional, do que seria urgente, ou não, definindo, via de consequência, uma agenda decisória para aquela série temporal, bem como os temas a serem por ele decididos, direta e monocraticamente, em prejuízo do exercício jurisdicional pelos relatores aleatoriamente definidos para os casos ou pelos órgãos judiciais colegiados. 
Tabela 1 - Estratégias dos Ministros Presidentes do Supremo Tribunal Federal quando provocados a decidir durante o período excepcional

\begin{tabular}{|l|l|l|l|}
\hline Admissibilidade & Resultado & Favorecido & Estratégia \\
\hline $\begin{array}{l}\text { Conhece o pedido } \\
\text { (urgente) }\end{array}$ & Defere a pretensão & Requerente & $\begin{array}{l}\text { Ativa e/ou } \\
\text { Contramajoritária }\end{array}$ \\
\hline $\begin{array}{l}\text { Conhece o pedido } \\
\text { (urgente) }\end{array}$ & Indefere a pretensão & Requerido & $\begin{array}{l}\text { Passiva e/ou } \\
\text { Majoritária }\end{array}$ \\
\hline $\begin{array}{l}\text { Não conhece o pedido } \\
\text { (não urgente) }\end{array}$ & Deixa de decidir & Requerido & Autorrestrição Expressa \\
\hline $\begin{array}{l}\text { Não se manifesta sobre } \\
\text { u urgência, deixando ex- } \\
\text { pressamente para o Mini- } \\
\text { stro Relator decidir } \\
\text { (não urgente) }\end{array}$ & Deixa de decidir & Requerido & Autorrestrição Tácita \\
\hline $\begin{array}{l}\text { Silencia até o fim do } \\
\text { período excepcional } \\
\text { (não urgente) }\end{array}$ & Deixa de decidir & Requerido & Autorrestrição Tácita \\
\hline
\end{tabular}

Fonte: elaboração dos autores com base nas decisões colhidas diretamente no sítio eletrônico do Supremo Tribunal Federal.

Conforme se verifica a partir do exposto, o desenho institucional do Supremo Tribunal Federal favorece situações em que as demandas excepcionais (em períodos de não funcionamento regular do tribunal) não seriam decididas, reduzindo os custos decisórios nesse sentido, concentrando esses custos nas situações de conhecimento e deferimento ou indeferimento do pedido, cabendo ao Ministro Presidente, seja a partir das expectativas dos outros atores envolvidos, seja ponderando as consequências potenciais envolvidas (v. g., sociais, políticas ou econômicas), escolher, estrategicamente, quando assumir o custo de reconhecer urgente a questão submetida.

Tais escolhas decorrem, direta ou indiretamente, do seu sentir quanto ao timing decisório e quanto ao contexto em que a demanda foi deduzida em juízo, notadamente em relação àsexpectativas dos envolvidos e da opinião pública, às consequências (jurídicas, políticas e econômicas) da decisão a ser tomada ou aos diálogos institucionais ou dinâmicas entre atores políticos.

\section{Considerações finais: As RePerCusSões da CONCENTRAÇÃo de PODER DECISÓRIO do Ministro Presidente nos períodos de Recesso e de fÉrias Judicials.}

Diante do exposto, como descrever o comportamento desse relevante ator jurídico-político durante o excepcional período (recesso e férias), com base nos diversos modelos explicativos?

Momentos distintos, estratégias diferentes: 0 mesmo poder. $\mathrm{O}$ arranjo institucional atribui poderes e cabe ao ministro no exercício da Presidência do STF exercê-los, com base em um ambiente institucional muito específico. Nesse sentido, verifica-se que os requisitos normativos são abertos (modelo legal-institucional), viabilizando uma ampla margem decisória, desacompanhada de mecanismos de accountability mais fortes, consideradas as amplas garantias asseguradas aos membros do Poder Judiciário e, especialmente, aos ministros do STF, sujeitos, apenas, à responsabilidade jurídico-política do crime de responsabilidade. Saliente-se 
que seu regime jurídico distinto não lhes desobriga do compromisso com a transparência no exercício das suas atividades ${ }^{39}$.

Após reconhecer a relevância dos condicionamentos legais, David Robertson ${ }^{40}$, na análise das múltiplas explicações quanto ao comportamento judicial, chega a uma conclusão inconteste: trata-se de um complexo exercício de política aplicada. Compreender a atuação dos tribunais demanda resgatar os motivos que levam a determinadas decisões, a partir dos chamados "constrangimentos" ou fatores que repercutem na decisão judicial: os valores pessoais e interação entre os juízes, o ambiente político e social no qual a corte está inserida ${ }^{41}$.

Assegura-se, assim, alto grau de independência no exercício da jurisdição, com possibilidade do controle do fator decisivo para a compreensão da atuação do Tribunal em suas interações com os demais agentes políticos, econômicos, sociais e até jurídicos: a oportunidade para prolatar (ou não) uma decisão. Em outras palavras: a manipulação estratégica do fator tempo.

Por mais que o arranjo assegure aos ministros diversas possibilidades de atuações (ou omissões) individuais, em prejuízo da Instituição enquanto tribunal colegiado (em sua atuação Plenária ou na estrutura de suas Turmas), fato é que - eventualmente — as expectativas dos pares podem se constituir num elemento de pressão (aliada a outros mecanismos como, v. g., opinião pública, crise econômica ou expectativas sociais) que coíba essas posturas.

Por exemplo, a concessão ou negativa de uma liminar pode ser questionada por meio de recurso; um pedido de vistas - por prazo "indeterminado" - pode ter seu tema objeto de questão de ordem ou sujeitar-se à inclusão em pauta de outra ação com objeto semelhante. Desse modo, os demais ministros, por meio do julgamento de recursos ou de instrumentos de manifestações monocráticas — com apoio de seus colegas - dispõem de mecanismos regimentais para eventual reversão dessas posturas individuais.

No excepcional período do recesso e das férias judiciais, contudo, essas variáveis são relativizadas, de sorte que pode o Presidente do STF atuar como protagonista e ator solo do Tribunal, temporariamente sem qualquer ameaça de instrumentos institucionais de reversão de suas decisões. No pu₹žle da formação da agenda decisória judicial, o desenho normativo do Tribunal assegura ao Presidente instrumentos processuais que viabilizam uma ampla gama de possibilidades decisórias, podendo convertê-las em estratégias distintas, explicativas da inserção desse ator específico no concerto entre os poderes da República e suas relações com a sociedade.

Num sistema de separação de poderes, deve-se ressaltar que a Constituição Federal é específica quanto aos eventuais afastamentos (viagens ao exterior, por exemplo) do Presidente da República e do Vice-Presidente, assim como em relação à regulamentação dos recessos parlamentares de dezembro a fevereiro e julho. Alteração quanto ao Congresso nacional, inclusive, foi objeto de emenda constitucional. As questões referentes ao exercício das atividades dos atores políticos per excellence, portanto, têm status constitucional. Já a atuação isolada do Presidente do STF, sobretudo no recesso judicial, é viabilizada pela legislação processual e pelo regimento interno do próprio tribunal. Resta saber, contudo, como - e por quanto tempo — essa prerrogativa permanecerá sem regulamentação específica dos seus limites, sujeita à discricionariedade do próprio ator interessado e desprovida de controles formais.

39 Ainda CHEVITARESE, Aléssia de Barros. A (des)harmonia entre os poderes e o diálogo (in)tenso entre democracia e república. Revista Brasileira de Políticas Públicas, Brasília, v. 5, p. 500-517, 2015.

40 ROBERTSON, David. The judge as a political theorist. contemporary judicial review. Princeton: Princeton University Press, 2010. p. 34. Isto porque os cientistas políticos tendem a ver as cortes como mais um corpo político, mas as encaixam no esquema do Poder Judiciário, e qualquer de suas atuações é vista como exercício da mera política.

41 BAUM, Lawrence. The Supreme Court. Ohio: CQ Press, 2010. p. 114-202. 


\section{REFERÊNCIAS}

ACKERMAN, Bruce. The new separation of powers. Harvard Law Review, v. 113, n. 3, p. 663-727, jan. 2000. Disponível em: <http://www.edesp.edu.br/files/eventos/papers/Ackerman.pdf>. Acesso em: 28 ago. 2005.

ALMEIDA, Frederico de. Judicialização da política e composição dos Tribunais Superiores. Revista Parlamento e Sociedade, São Paulo, v. 3, n. 4, p. 75-98, jan./jun. 2015.

ARGUELHES, Diego Werneck; RIBEIRO, Leandro Molhano. 'The Court, it is I'?: individual judicial powers in the Brazilian Supreme Court and their implications for constitutional theory. Global Constitutionalism, v. 7, n. 2, p. 236-262, 2018.

ARGUELHES, Diego Werneck; RIBEIRO, Leandro Molhano. Ministrocracia?: o Supremo Tribunal individual e o processo democrático brasileiro. Novos estudos CEBRAP, v. 37, n. 1, 2018.

BAUM, Lawrence. The Supreme Court. Ohio: CQ Press, 2010.

BICKEL, Alexander M. The least dangerous branch: the Supreme Court at the bar of politics. Indianapolis: Bobbs-Merrill, 1962.

BRASIL. Constituição (1988). Constituição da República Federativa do Brasil, de 5 de outubro de 1988. Diário Oficial da União, Rio de Janeiro, 1988. Disponível em: <http://www.planalto.gov.br/ccivil_03/constituicao/constituicao.htm>. Acesso em: 6 jun. 2015.

BRASIL. Constituição (1988). Emenda constitucional no 88, de 7 de maio de 2015. Altera o art. 40 da Constituição Federal, relativamente ao limite de idade para a aposentadoria compulsória do servidor público em geral, e acrescenta dispositivo ao Ato das Disposições Constitucionais Transitórias. Diário Oficial da União, Brasil, 2015. Disponível em: <http://www.planalto.gov.br/ccivil_03/constituicao/emendas/emc/emc88. htm>. Acesso em: 11 nov. 2016.

BRASIL. Lei Complementar no 35, de 14 de março de 1979. Dispõe sobre a Lei Orgânica da Magistratura Nacional. Diário Oficial da União, Brasilia, 1979. Disponível em: <http://www.planalto.gov.br/ccivil_03/ leis/LCP/Lcp35.htm>. Acesso em: 16 jun. 2016.

BRASIL. Lei $\mathrm{n}^{\circ}$ 1.079, de 10 de abril de 1950. Define os crimes de responsabilidade e regula o respectivo processo de julgamento. Diário Oficial da União, Rio de Janeiro, 1950. Disponível em: < http://www.planalto. gov.br/ccivil_03/leis/L1079.htm>. Acesso em: 16 jun. 2016.

BRASIL. Lei no 13.105, de 16 de março de 2015. Código de Processo Civil. Diário Oficial da União, Brasília, 2015. Disponível em: <http://www.planalto.gov.br/ccivil_03/_ato2015-2018/2015/lei/113105.htm>. Acesso em: 17 jun. 2016.

BRASIL. Supremo Tribunal Federal. Discurso de posse da Ministra Carmen Lúcia Antunes Rocha na Presidência do Supremo Tribunal Federal. Disponível em: < http://static.congressoemfoco.uol.com.br/2016/09/carmenlucia.pdf>. Acesso em: 18 jan. 2018.

BRASIL. Supremo Tribunal Federal. Discurso de posse do Ministro Ricardo Lewandowski na Presidência do Supremo Tribunal Federal. Disponível em: < http://www.stf.jus.br/arquivo/cms/noticiaNoticiaStf/anexo/discursoMinistroRL.pdf>. Acesso em: 18 jan. 2018.

BRASIL. Supremo Tribunal Federal. Habeas-Corpus n 81.565, Relator: Ministro Sepúlveda Pertence, j. 19-22002, $1^{\text {a }}$ T, DJ de 22-3-2002. Disponível em:<http://stf.jus.br/portal/jurisprudencia/listarjurisprudencia. asp?s1 $=\% 28 \mathrm{HC} \% 24 \% 2 \mathrm{ESCLA} \% 2 \mathrm{E}+\mathrm{E}+81565 \% 2 \mathrm{ENUME} \% 2 \mathrm{E} \% 29+\mathrm{OU}+\% 28 \mathrm{HC} \% 2 \mathrm{EACMS} \% 2 \mathrm{E}+\mathrm{A}$ DJ2+81565\%2EACMS\%2E\%29\&base=baseAcordaos\&url=http:/ tinyurl.com/nbxsmu7>.

BRASIL. Supremo Tribunal Federal. Regimento interno do Supremo Tribunal Federal, atualizado até julho de 2016. 
Brasília, 2016. Disponível em: <http://www.stf.jus.br/arquivo/cms/legislacaoRegimentoInterno/anexo/ RISTF.pdf>. Acesso em: 15 nov. 2016.

BRASIL. Supremo TribunalFederal. RHC 71.400. Relator: Ministro Ilmar Galvão, j. 7-6-1994, 1ª T, DJ de 30-91994. Disponível em:<http://redir.stf.jus.br/paginadorpub/paginador.jsp?docTP=AC\&docID=102538>.

CASEY, Gerard; WHIT'TINGTON, Keith E. Constitutional interpretation: textual meaning, original intent, and judicial review. The Review of Metaphysics, v. 54, n. 1, p. 179-180, 2000.

CALDEIRA, Gregory A.; WRIGHT, John R.; ZORN, Christopher J. W. Sophisticated voting and gatekeeping in the Supreme Court. Journal of Law, Economics, and Organization, v. 15, n. 3, p. 549-572, 1999.

CAPPELLETTI, Mauro. ¿Renegar de Montesquieu?: la expansión y la legitimidad de la “justicia constitucional". Revista Española de Derecho Constitucional, ano 6, n. 17, p. 9-47, mayo/ago. 1996

CHEVITARESE, Aléssia de Barros. A (des)harmonia entre os poderes e o diálogo (in)tenso entre democracia e república. Revista Brasileira de Políticas Públicas, Brasília, v. 5, p. 500-517, 2015.

EPSTEIN, Lee; KNIGHT, Jack. The Choices Justices Make. Washington: Congressional Quarterly, 1998.

EPSTEIN, Lee; WALKER, Thomas G. Constitutional Law for a Changing America: institutional powers and constraints. Washington: Cq Press, 2010.

FALCÃO, Joaquim. O Supremo: compreenda o poder, as razões e as consequências das decisões da mais alta Corte do Judiciário no Brasil. Rio de Janeiro: Edições de Janeiro, 2015.

FALCÃO, Joaquim; ARGUELHES, Diego. Onze Supremos: todos contra o plenário. In: FALCÃO, Joaquim; ARGUELHES, Diego W.; RECONDO, Felipe (Org.). Onze Supremos: o Supremo em 2016. Rio de Janeiro: Fundação Getúlio Vargas, 2017.

FALCÃO, Joaquim; HARTMANN, Ivar A.; CHAVES, Vitor P. Relatório Supremo em números: o Supremo e o tempo. Rio de Janeiro: Escola de Direito do Rio de Janeiro da Fundação Getúlio Vargas, 2014.

GIBSON, James L. Challenges to the impartiality of state supreme courts: legitimacy theory and "newstyle" judicial campaigns. American Political Science Review, v. 102, n. 01, p. 59-75, 2008.

GILLMAN, Howard; CLAYTON, Cornell W. Beyond judicial attitudes: institutional approaches to Supreme Court Decision-Making. In: CLAYTON, Cornell W.; GILLMAN, Howard (Ed.). Supreme Court DecisionMaking: new institutionalist approaches. Chicago: University of Chicago Press, 1999.

GILLMAN, Howard. What's Law got to do with it?: judicial Behavioralists test the "Legal Model" of judicial decision making. Law \& Social Inquiry, v. 26, p. 465-504, 2001.

GOMES NETO, José Mário Wanderley; LIMA, Flávia Danielle Santiago. Poder de agenda e estratégia no STF: uma análise a partir da decisão liminar nos mandados de segurança no 34.070 e no 34.071. In: MARTINS, Argemiro Cardoso Moreira et al. (Org.). Constituição e democracia II. Florianópolis: CONPEDI, 2016.

HECKMAN, James J. The scientific model of causality. Sociological Methodology, v. 35, 2005.

LIMA, Flávia Danielle Santiago; ANDRADE, Louise Dantas de; OLIVEIRA, Tassiana Moura de. Emperor or president?: understanding the (almost) unlimited power of the Brazilian Supreme Court's President. Revista Brasileira de Direito, v. 13, p. 161 - 176, 2017.

LIMA, Flávia Danielle Santiago; GOMES NETO, José Mário Wanderley. Autocontenção à brasileira? uma taxonomia dos argumentos jurídicos (e estratégias políticas?) explicativo (a) s do comportamento do STF nas relações com os poderes majoritários. Revista de Investigações Constitucionais, v. 5, n. 1, p. 221-247, 2018.

MONTESQUIEU, Charles Louis de Secondat. O espirito das leis. São Paulo: Martins Fontes, 1999.

MURPHY, Walter F. Elements of judicial strategy. Chicago: University of Chicago Press, 1964. 
NAGEL, S.; NEEF, M. Models of judicial Decision-Making. In: JOHNSON, G. W. (Ed.). American political science research guide. New York: IFI/Plenum Data Company, 1977. v.1.

NORTH, Douglass C. Institutions, institutional change, and economic performance. New York: Cambridge University Press, 1990.

RIBEIRO, Leandro Molhano; ARGUELHES, Diego Werneck. Preferências, estratégias e motivações: pressupostos institucionais de teorias sobre comportamento judicial e sua transposição para o caso brasileiro. Revista Direito e Práxis, v. 4, n. 7, p. 85-121, 2013.

RIBEIRO, Leandro Molhano; PAULA, Christiane Jalles. Inovação institucional e resistência corporativa: o processo de institucionalização e legitimação do Conselho Nacional de Justiça. Revista Brasileira de Políticas Públicas, Brasília, v. 6, n. 3, p. 13-28, 2016.

ROBERTSON, David. The judge as a political theorist: contemporary judicial review. Princeton: Princeton University Press, 2010.

SILVA, Virgílio Afonso da. Deciding without deliberating. $I \bullet C O N$, v. 11, n. 3, p. 557-584, 2011.

SEGAL, Jeffrey A.; SPAETH, Harold J. The Supreme Court and the attitudinal model revisited. New York: Cambridge University Press, 2002.

SEGAL, Jeffrey A. Judicial Behavior. In: WHITTINGTON, Keith E.; KELEMEN, R. Daniel; CALDEIRA, Gregory A. (Ed.). The Oxford Handbook of Law and politics. Oxford: Oxford University Press, 2008.

TOMIO, Fabrício Ricardo de Limas; ROBL FILHO, Ilton Noberto. Accountability e independência judiciais: uma análise da competência do Conselho Nacional de Justiça (CNJ). Revista de Sociologia e Política, v. 21, n. 45, p. 29-46, mar. 2013.

VALE, André Rufino do. Novo presidente do Supremo deverá enfrentar grandes desafios em sua gestão. Observatório Constitucional, Brasília, 2 ago. 2014. Disponível em: <http://www.conjur.com.br/2014-ago-02/ observatorio-constitucional-presidente-supremo-devera-enfrentar-grandes-desafios-gestao $>$. Acesso em: 25 maio 2018.

VIEIRA, Oscar Vilhena. Supremo Tribunal Federal: jurisprudência política. São Paulo: Malheiros, 2002.

VIEIRA, Oscar Vilhena. Supremocracia. Revista Direito GV, v. 4, p. 441-459, 2008. 


\title{
Razão, emoção e deliberação: as adequações regimentais do Superior Tribunal de Justiça para a formação de precedentes eficazes*
}

\author{
Reason, emotion and deliberation: The \\ Superior Crazilian Court of Justice regimental \\ adjustments in order to obtain effective \\ precedents
}

\author{
Peter Panutto** \\ Lana Olivi Chaim***
}

\section{Resumo}

Trata-se da implantação de um sistema de precedentes judiciais e da consequente necessidade de alteração dos mecanismos institucionais dos Tribunais para efetiva criação e cumprimento de precedentes pelo Código de Processo Civil (CPC) de 2015. Destaca-se o papel dos mecanismos mentais pertinentes à formação da decisão que levam um indivíduo a produzir uma opinião naturalmente enviesada e os eventuais resultados nocivos desses elementos para a tomada da decisão. Demonstra-se a importância da atuação deliberativa com o confronto de argumentos como alternativa para afastar os efeitos nocivos das decisões individualizadas em um colegiado. Realiza-se um estudo das normas do Regimento Interno (RI) do Superior Tribunal de Justiça (STJ) para averiguar a existência de mecanismos de votação colegiada para se chegar a uma decisão institucional. Por essa razão, deu-se preferência ao método dedutivo de análise. O STJ foi o tribunal escolhido dado seu pioneirismo e interesse para a adaptação de seu RI ao CPC de 2015. Ao final, o objetivo da pesquisa, materializada neste artigo consistiu em demonstrar que a não adequação do procedimento deliberativo dos Tribunais acarretará na ineficácia do sistema de precedentes, pois tais decisões representarão o entendimento individual do julgador, sem o estabelecimento de um entendimento institucional sobre o tema. Como resultado, verificou-se que o RI do STJ formulou regras que facilitam a tomada de voto bem informado, diminuindo-se o viés individual na deliberação colegiada, mas que ainda, precisa ser aprimorado para a criação de mecanismos visando à interação entre os magistrados, para o pleno aproveitamento de toda a potencialidade do colegiado.

Palavras-Chave: Precedentes. Colegialidade. Opinião Enviesada. Ônus Argumentativo. Segurança Jurídica.

\footnotetext{
*** Graduanda do $9^{\circ}$ período da Faculdade de Direito da Pontifícia Universidade Católica de Campinas. Orientanda de Iniciação Científica. Bolsista CNPQ. Email: lanaolc@gmail.com.
}

Recebido em 21/05/2018

** Bacharel em Direito (1997) e Mestre em Direito Processual Civil (2004) pela Pontifícia em Direito - Área de Concentração: Sistema Constitucional de Garantia de Direitos pela Instituição Toledo de Ensino (2012). Doutor em Direito - Área de Concentração: Sistema Constitucional de Garantia de Direitos pela InDireito Processual Civil, Direito Constitucional e de Direito Eleitoral da Faculdade de Direito da Pontifícia Universidade Católica de Campinas. Professor doutor pesquisador, da Pontifícia Universidade Católica de Campinas. Advogado nas áreas Cível, Eleitoral e Administrativo. Email: ppanutto@hotmail.com. 


\section{Abstract}

This article is about the implementation of a biding precedents system by the Civil Procedure Code from 2015, and the consequent need of alteration of the courts institutional mechanisms in order to obtain the effective fulfilment and creation of those precedents. It is emphasized the role of the mental mechanisms concerning the formation of the decision that takes the subject to produce a natural biased opinion and the eventual harmful results of this elements for the decision making. It is demonstrated the importance of the deliberative action using the confront of arguments as an alternative to obviate the prejudicial effects of the individualized decisions taken in the board. It was performed a study of the norms that integrate the Internal Regiment (IR) of the Brazilian Superior Court of Justice (SCJ) to investigate the existence of collegiate voting mechanisms directed to the obtainment of an institutional decision. Therefore, it was given preference to the deductive analyses method. This court was chosen for its pioneering and interest in adapting its IR to the Civil Procedure Law. This research, materialized in this article, aims to demonstrate that the inadequacy of the courts deliberative proceedings might result in the ineffectiveness of the precedents system, for the reason that such decisions represents the individual understanding of the judge, with the absence of an institutional understanding about the subject. As a result, it was found that the IR from the SCJ has norms that make possible a well-informed vote taking, diminishing the individual bias on collegiate voting. However, there is still the need of enhancements in the creation of mechanism concerning the integration between the judges, in order to use the collegiate in its full potential.

Keywords: Precedents. Collegiality. Biased Opinion. Argumentative Onus. Legal Security.

\section{INTRODUÇÃo}

Quando do enriquecimento e detalhamento do controle de constitucionalidade pela Constituição de 1988, surgiram questionamentos quanto à legitimidade do Poder Judiciário para o exercício dessa função, desconhecendo-se, naquele momento, a importância dessa ferramenta para a democracia. Estudos enfocavam a justificativa para a conferência de poderes às Cortes Constitucionais, quando deveriam, de fato, concentrar-se na análise da forma como esse poder é exercido ${ }^{1}$.

Em razão da grande exposição na mídia dos Tribunais Superiores, os quais proferem decisões com efeitos sobre grande número de casos, essa pauta da legitimidade jurisdicional voltou à discussão, observando-se, contudo, o viés equivocado do problema, por discutir a justificativa da conferência de poderes e não o mecanismo deliberação que permita a apresentação de resultados bem fundamentados. Sustenta-se, neste trabalho, que a deliberação e a argumentação constituem aspectos de extrema importância, não apenas para a formação de precedentes, mas para a própria atividade decisória ${ }^{2}$, e que, por meio desse procedimento, seriam sanados os questionamentos quanto à legitimidade e à aceitação das decisões das Cortes Superiores.

Por mais que hoje não se questione em grande quantidade a legitimidade do exercício do controle de constitucionalidade pelos Tribunais, há uma presente insatisfação quanto às justificativas produzidas pelos magistrados em suas decisões. Com a Constituição de 1988 e a implementação de normas abertas para a interpretação com alta carga axiológica, o ônus argumentativo dos juízes para justificarem sua escolha valo-

1 VALE, André Rufino do. Argumentação constitucional. 2015. 415 f. Tese (Doutorado) - Universidade de Brasília com cotutela da Universidade de Alicante, Brasília, 2015. p. 38.

2 FAREJOHN, John; PASQUINO, Pasquale. Constitutional courts as deliberative institutions: towards an institutional theory of constitutional justice. In: SADURSKI, Wojciech. Constitutional Justice, East and West: democratic legitimacy and constitutional courts in post-communist Europe in a comparative perspective. The Hague: Kluwer Law International, 2013. p. 21-36. Disponível em: < https://is.muni.cz/el/1422/jaro2013/MVV2868K/um/FEREJOHN_PASQUINO_-_Constitutional_Courts_as_Deliberative_ Institutions.pdf >. Acesso em: 12 dez. 2016. 
rativa aumentou consideravelmente, mas é frequentemente negligenciado.

Diante desse cenário, em uma tentativa de uniformizar a jurisprudência e de conquistar a isonomia nos julgados, com a consequente diminuição de recursos para os Tribunais superiores, foi implementado um sistema de precedentes judiciais vinculantes pelo Código de Processo Civil de 2015, o que intensifica os questionamentos quanto à legitimidade dos Tribunais Superiores em produzir decisões que geram efeitos para além dos casos em análise. Com tamanha repercussão das decisões, fica clara a necessidade de se fomentar uma discussão mais densa acerca do desenho institucional dos órgãos jurisdicionais colegiados, tendo em vista que, para a formação de precedentes eficazes, a legitimidade em proferir esse tipo de decisão não pode estar em xeque.

São poucos os estudos que tratam da deliberação colegiada para a formação da decisão nos Tribunais brasileiros, pois a discussão, na maior parte das vezes, volta-se para a decisão do juiz singularmente considerado. Além disso, há vieses pessoais, também pouco estudados, que têm seu peso em uma decisão colegiada, já que qualquer discussão em grupo, sobre um determinado tema, envolve atividade mental individual.

Isso revela a importância de se estudar os mecanismos de decisão colegiada no país, pois, se não houver mecanismos de elaboração de decisões, tipificadas como precedentes judiciais vinculantes pelo Código de Processo Civil de 2015, que resultem plenamente em entendimento institucional sobre o tema, a segurança jurídica almejada pelos precedentes não será atingida.

Por ter sido o Superior Tribunal de Justiça o primeiro a implementar mudanças institucionais, a fim de acompanhar as alterações legislativas tocantes à introdução de precedentes no Brasil, seu Regimento Interno será objeto de estudo deste artigo.

Tal pioneirismo servirá de molde e de experiência para a implementação e a maturação do sistema de precedentes no país, o que evidencia a importância da iniciativa desse tribunal e a pertinência de se analisar seu Regimento Interno no tocante ao procedimento decisório para a formação de precedentes vinculantes eficazes.

Para concluir sobre a importância do entendimento institucional materializado em precedentes, usou-se o método dedutivo, cuja premissa se baseia na formação dos precedentes, como forma processual de garantir a segurança jurídica do sistema, mediante pronunciamos institucionais, e não personalizados dos Ministros de um tribunal. O resultado da pesquisa ficou materializado nesse texto, estruturado em três tópicos: no primeiro, abordam-se os mecanismos subjetivos de elaboração da decisão; no segundo, são estudados os procedimentos deliberativos para se alcançar uma decisão institucional sobre o tema e, ao final, são analisadas, criticamente, as recentes alterações no Regimento Interno do STJ, impulsionadas pelo sistema de precedentes ora implementado no Brasil.

\section{RAZÃO E EMOÇÃO NA PRODUÇÃO DECISÓRIA INDIVIDUAL}

$\mathrm{Na}$ mesma medida em que se discute um padrão de racionalidade argumentativa que tenha a aptidão de sustentar a legitimidade de uma decisão, no qual a racionalidade teria um papel de correção e justificação das escolhas feitas pelos membros do colegiado, há teorias que questionam a racionalidade como parâmetro, pois consistiriam, apenas, em "conforto cognitivo" em razão de que as decisões, de fato, são tomadas previamente, e as justificativas são dadas para confirmar as "crenças [sic] pré-existentes", sobretudo nos "casos difíceis", nos quais "são os valores e as crenças dos juízes que proporcionam a verdadeira explicação

3 HORTA, Ricardo Lins e. Argumentação estratégia e cognição: Subsídios para a formulação de uma teoria da decisão judicial. Revista Direito e Liberdade, ESMARN, v. 18, n. 2, p. 153-154, maio/ago. 2016. 
para seus votos"

As decisões formuladas com base em experiências pessoais e emoções são vistas muitas vezes como opiniões discricionárias, por não serem detentoras de fundamentos compartilhados pelos demais, o que prejudica sua aceitação pelos jurisdicionados. Afinal, a vida traz, a cada indivíduo, experiências que geram uma bagagem singular, formando visões de mundo diversas até entre aqueles que tiveram a mesma criação e o mesmo círculo de contatos.

Não se pretende, com a racionalidade judicial, sustentar a visão de que o juiz poderia atuar, em seus argumentos, a partir de uma lógica racional "imaculada" por fatores emocionais injustificados. Isto porque não seria razoável supor que o juiz, ao fazer escolhas, possa se despir de sua qualidade humana para proferir sua decisão de modo totalmente dissociado de suas experiências e de suas preferências pessoais.

De fato, diversos experimentos feitos com base nas teorias do Realismo Jurídico constatam que a opinião dos julgadores pode ser enviesada, não apenas por motivações políticas, mas por agirem de maneira intuitiva e emocional, confiando na heurística para responder, favoravelmente, aos litigantes e às causas com quem eles se simpatizam, muitas vezes, de forma inconsciente ${ }^{5}$. Os próprios mecanismos biológicos de percepção de fatores externos e de decisão do indivíduo estão intimamente ligados à lembrança (memória) e à interpretação de eventos passados ${ }^{6}$.

De acordo com o Tratado de Fisiologia Médica de Guyton e Hall, o processo de armazenamento de informações (memória) ocorre quando aquela informação nova se torna parte do mecanismo de processamento do cérebro, para ser usada sob forma de pensamento no futuro, pois os "processos cognitivos cerebrais comparam as novas experiências sensoriais com as memórias armazenadas"7.

Guyton e Hall explicam que a nova informação é processada por meio dos "arquivos de armazenagem de memórias", comparando-se o novo e o velho a respeito de semelhanças e diferenças. Portanto, durante a consolidação, há associação direta da nova informação com outras memórias do mesmo tipo, de forma que o armazenamento não sucede de forma aleatória. Ademais, no decorrer da formação do pensamento, ocorre um mecanismo que associa aquela informação a determinadas sensações e sentimentos. Segundo os autores:

o pensamento resulta de um padrão de estimulação de diversas partes do sistema nervoso ao mesmo tempo, provavelmente envolvendo de forma mais importante o córtex cerebral, o tálamo, o sistema límbico e a formação reticular do tronco cerebral. Isso é chamado de teoria holística dos pensamentos. As áreas estimuladas do sistema límbico, tálamo e formação reticular, acredita-se que determinam a natureza geral dos pensamentos, dando suas qualidades como prazer, desprazer, dor conforto [... $]^{8}$

Dessa forma, constata-se que qualquer pensamento sobre fato do mundo real poderá vir acompanhado de sentimentos e de impressões que se construíram na mente daquele que decide?. Esse mecanismo poderia funcionar fornecendo conceitos predeterminados sobre fatos, fundamentos, narrações e até mesmo a aparência física daquele que usa sua voz na corte.

Isso tem implicações no conceito de racionalidade, pois, no que se refere à escolha de princípios ou de premissas, todas seriam "de fato resultado inconsciente de preferencias instintivas e convicções não

4 MELLO, Patrícia Perrone Campos. Nos bastidores do STF. Rio de Janeiro: Forense, 2015. p. 57.

5 SUSSMAN, Edna. Arbitrator decision-making:unconscious psychological influences and what you can do about then. The American Review of International Arbitration, New York, v. 24, n. 3, p. 487-514, 2013. Disponível em: < http://arbitragem.pt/conselhos/deontologia/doutrina/internacional/arbitrator-decision-making-unconscious-psychological-influences--edna-sussman.pdf $>$. Acesso em: 1 nov. 2017.

6 DROBAK, John N.; NORTH, Douglas C. Understanding judicial decision-making: The importance of constraints on nonrational deliberations. Law \& The New Institutional Economics. Washington University, v. 26, p. 130-152, 2008. p. 138. Disponível em: <http://openscholarship.wustl.edu/law_journal_law_policy/vol26/iss1/7>. Acesso em: 1 ago. 2017.

7 GUYTON, Arthur C.; HALL, J. E. Tratado de fisiologia médica. 11. ed. Rio de Janeiro: Elsevier, 2006. p. 557.

8 GUYTON, Arthur C.; HALL, J. E. Tratado de fisiologia médica. 11. ed. Rio de Janeiro: Elsevier, 2006. p. 723

9 GUYTON, Arthur C.; HALL, J. E. Tratado de fisiologia médica. 11. ed. Rio de Janeiro: Elsevier, 2006. p. 723. 
articuladas" ${ }^{10}$, visto que a valoração dos fundamentos a serem escolhidos como base em uma decisão, com o afastamento das demais possibilidades, é afetada, como tudo o que passa pelo processamento mental do indivíduo, por suas experiências, por valores, por sentimentos e por preferências ideológicas ${ }^{11}$.

Não obstante, é sempre possível que a experiência prática, quando processada pelo cérebro, sofra alguma "distorção", levando à formação de uma fonte de comparação equivocada ${ }^{12}$, o que, futuramente, poderá gerar decisões erradas.

Por outro lado, vislumbra-se que esse processo mental que envolve a comparação da situação em análise com uma memória já fixada é um processo normalmente mais rápido, pois com ele se permite que sejam preenchidas lacunas da situação nova com informações da memória já fixada, dispensando nova pesquisa sobre as informações que não estão disponíveis. Se a situação padrão e a situação em análise são semelhantes, não há qualquer risco em se fazer essa comparação, sendo, inclusive, desejável o uso de tal mecanismo, seja pela sua rapidez, seja por poupar trabalho, tempo e pesquisa por parte de quem toma a decisão ${ }^{13}$.

Esse processo pode, no entanto, limitar a quantidade de informações novas que o participante da deliberação procuraria para formar sua decisão, já que não se buscam novas informações quando se acredita ter o quadro integral da situação posta. Havendo fatores relevantes para a decisão que diferenciem a situação posta das informações que estão contidas na memória e o indivíduo não estiver ciente deles, ele terá grandes chances de tomar uma decisão com base em uma visão distorcida sobre a causa ${ }^{14}$.

Daí a ideia de que os juízes partem de uma decisão preconcebida para depois buscarem justificativas para suas afirmações ${ }^{15}$. Há estudos que provam uma disposição natural humana por procurar evidências que sustentam as hipóteses pelas quais se tem maior afinidade ${ }^{16}$. Com a experiência prática, o histórico pessoal, a formação e demais fatores que remetem o caso prático à memória do juiz, este, de pronto, identificará o caso em análise com alguma situação fixada em sua memória, e, inevitavelmente, fará uma comparação, formando uma opinião prévia sobre o caso. Ao final, ele deve buscar, apenas, formular uma justificativa para uma decisão que tomou anteriormente.

Ocorre que, por ser um mecanismo muitas vezes imperceptível, o indivíduo, mesmo com boas intenções, poderia não notar o uso de uma comparação, ainda mais quando não fosse adequada a aplicação desse pro-

10 "Every important principle which is developed by litigation is in fact and at the bottom the result of more or less definitely understood views or public policy; most generally, to be sure, under our practice and traditions, the unconscious result of instinctive preferences and inarticulated convictions". HOLMES, Oliver Wendell. The common law. Typographical Society of University of Toronto Law School, 2011. p. 35. Disponível em: <http://www.general-intelligence.com/library/commonlaw.pdf>. Acesso em: 5 abr. 2018.

11 "A liberal or conservative ideological preference is a tendency to choose legal rules associated with liberalism or conservatism. A preference may be obvious or hard to discern; it may be knowledged or denied; and it may be conscious, unconscious or half-conscious. A preference, in common usage, is more than a factual pattern (though sometimes economists use it in this very limited sense). When we impute a preference, we suppose we are giving an explanation or an interpretation of patterned action, by attributing it to a psychological disposition of the actor". KENNEDY, Ducan. Strategizing strategic behavior in legal interpretation. Utah Law Review, 1996. Disponível em <http://duncankennedy.net/documents/Photo\%20articles/Strategizing $\% 20$ Strategic\% $\%$ Behavior\%20in\%20Legal\%20Interpretation.pdf>. Acesso em: 19 abr. 2018.

12 "It follows that the experiences that have shaped the mental classifications in the mind can and frequently will lead to misinterpretations of the problems confronting the individual”. DROBAK, John N.; NORTH, Douglas C. Understanding judicial decision-making: the importance of constraints on non-rational deliberations. Law \& The New Institutional Economics. Washington University, v. 26, p. 130-152, 2008. p. 137-138. Disponível em: <http://openscholarship.wustl.edu/law_journal_law_policy/vol26/ iss1/7>. Acesso em: 1 ago. 2017.

13 "If target and standard are highly similar, then information transfer is unlikely to impede accuracy, because the transferred standard information and the missing target information are likely to have similar implications". MUSSWEILER, Tomas; EPSTUDE, Kai. Relatively fast!: efficiency advantages of comparative thinking. Journal of Experimental Psychology, v. 138, n. 1, p. 1-21, 2009.

14 MUSSWEILER, Tomas; EPSTUDE, Kai. Relatively fast!: efficiency advantages of comparative thinking. Journal of Experimental Psychology, v. 138, n. 1, p.1-21, 2009. p. 4-5.

15 ROSS, Alf. Direito e justiça. 2. ed. Bauru: Edipro, 2007. p. 182.

16 NICKERSON, Reimond S. Confirmation bias: a ubiquitous phenomenon in many guises. Review of General Psychology, v. 2 , n. 2, p. 211, 1998. 
cedimento para o caso. Por esses motivos, deveriam ser observadas formas de controle desse mecanismo, especialmente quando se tratam de Cortes Superiores, em razão da importância e da abrangência de suas decisões e das possíveis consequências indesejáveis do "pensamento rápido" 17 que dispense nova construção racional de justificativa para a tomada de uma decisão.

Ao que se percebe, o problema da racionalidade judicial não reside, apenas, em se tomar uma decisão prévia e buscar, posteriormente, uma justificativa para embasá-la. A ordem de como essas etapas acontecem, em si, não seria relevante, visto que, mesmo quando a decisão é tomada, antes da confecção da justificativa, ela pode ser aceita pela sociedade como a melhor decisão dentre os resultados possíveis. Em verdade, a distorção acontece, apenas, quando a memória e a situação fática não se encaixam perfeitamente quando feita a comparação ${ }^{18}$, ou quando as classificações mentais geradas pela experiência podem levar o sujeito a interpretar o problema de maneira incorreta ${ }^{19}$.

Interessante ressaltar que o cérebro é sempre submetido a uma enxurrada de informações sensoriais provenientes de todos os nossos sentidos, sendo que a consequência de lembrar de todas essas informações seria o esgotamento de nossa capacidade de memória em segundos. Assim, nosso cérebro tem um mecanismo para descartar informações que entender desnecessárias ${ }^{20}$. Trata-se do chamado "esquecimento". Se as informações são interpretadas de maneira distinta por indivíduos que tiveram experiências diversas sobre o mesmo assunto, então, elas podem ter sido descartadas ou armazenadas de acordo com suas prioridades, o que poderá provocar alterações indesejáveis no resultado.

Deve-se considerar, ainda, que a ordem da apresentação das informações pode levar à formação de conclusões precipitadas durante o processo decisório. Existem evidências de que os fatos apresentados para as pessoas, no início do processo, têm mais relevância sobre suas decisões do que os apresentados posteriormente $^{21}$. Dessa forma, o ideal seria que, em um sistema deliberativo, as informações fossem apresentadas em um único momento, ou que, na proximidade da decisão, fossem relembradas de forma sintetizada para que esse problema da valoração, por ordem de apresentação, seja dirimido.

\section{A plena deliberação colegiada como garantia da legitimidade da Corte}

Pela falta de um órgão em uma escala de hierarquia superior, as Cortes Superiores seriam aquelas com a menor possibilidade de controle sobre os efeitos inconscientes das preferências dos julgadores ${ }^{22}$. Entretanto, contam com o controle dos próprios membros do colegiado, em razão da diluição do efeito da opinião individual pela opinião de outros membros.

Não obstante, se, na própria deliberação, houvesse a exigência de se justificar premissas e de confrontar argumentos opostos com os demais ${ }^{23}$, possíveis efeitos das crenças pessoais seriam dirimidos pela razão de

17 O termo "pensamento rápido" foi utilizado para designar o processo cognitivo de comparação. MUSSWEILER, Tomas; EPSTUDE, Kai. Relatively fast!: efficiency advantages of comparative thinking. Journal of Experimental Psychology, v. 138, n. 1, p. 1-21, 2009.

18 MUSSWEILER, Tomas; EPSTUDE, Kai. Relatively fast!: efficiency advantages of comparative thinking. Journal of Experimental Psychology, v. 138, n. 1, p. 1-21, 2009. p. 4-5.

19 DROBAK, John N.; NORTH, Douglas C. Understanding judicial decision-making: the importance of constraints on nonrational deliberations. Law \& The New Institutional Economics. Washington University, v. 26, p. 130-152, 2008. Disponível em: <http:// openscholarship.wustl.edu/law_journal_law_policy/vol26/iss1/7>. Acesso em: 1 ago. 2017.

20 GUYTON, Arthur C.; HALL, J. E. Tratado de fisiologia médica. 11. ed. Rio de Janeiro: Elsevier, 2006. p. 726.

21 ROSS, Lee; LEPPER, Mark R.; HUBBARD, Michael. Perseverance in self-perception and social perception: biased attributional processes in the debriefing paradigm. Journal of personality and social psychology, v. 32, n. 5, p. 889, 1975.

22 DROBAK, John N.; NORTH, Douglas C. Understanding judicial decision-making: the importance of constraints on nonrational deliberations. Law \& The New Institutional Economics. Washington University, v. 26, p., 2008. p. 148. Disponível em: < http:// openscholarship.wustl.edu/law_journal_law_policy/vol26/iss1/7>. Acesso em: 1 ago. 2017.

23 Existe a visão de que a lei não deixa espaço para confronto argumentativo, o que faz alguns juízes adotarem uma postura pas- 
que essas exigências testam as afirmações e as escolhas, principalmente, quando se trata das preferências axiológicas do membro do colegiado, as quais, muitas vezes, podem ser derivadas de um pensamento rápido ou de comparativo com experiências semelhantes à situação fática. Havendo erro na classificação da experiência ou na comparação feita na mente do juiz, o escrutínio de sua opinião o forçaria a repensar a classificação do fato ${ }^{24}$, podendo resultar na mudança de seu posicionamento, dada a impossibilidade de sustentá-lo, fato que acaba, também, por tornar o debate mais rico e transparente, permitindo aos jurisdicionados e, ao próprio colegiado, conhecerem o processo de ponderação feito por aquele que deu o voto, mediante a construção e a defesa dos demais pontos de vista.

Argumentos convincentes, capazes de mudar opiniões contrárias, fazem com que juízes e jurisdicionados aceitem a decisão e a apliquem com maior facilidade, o que, consequentemente, diminui as tentativas de se obter uma resposta jurisdicional diversa por parte dos sucumbentes. Se, ao contrário, forem apresentados argumentos refutáveis para a decisão, a solução para o caso assume um tom arbitrário, visto ter o juiz adotado uma opção, sem justificar, adequadamente, sua escolha, desgastando a imagem do tribunal por diminuir sua legitimidade perante os jurisdicionados.

Dessa forma, o desenho institucional que prima por uma decisão colegiada deve fomentar a discussão entre os julgadores, permitindo-se o equilíbrio no confronto de argumentos, posto ser este um mecanismo que testa as afirmações feitas por um magistrado, ao mesmo tempo que deve favorecer que o julgador seja convencido pelas opiniões dos demais, se bem embasadas ${ }^{25}$.

Cumpre ressaltar que a razão, por sua vez, somente empresta, à decisão, um ar de certeza, cientificidade e lógica, se houver universalidade do raciocínio aplicado. Afinal, se é possível usar uma determinada justificativa para a tomada de uma decisão, essa justificativa deveria ser completamente aplicável aos casos análogos, pois, caso contrário, vislumbrar-se-ia arbitrariedade na escolha feita. Assim, a universalidade consistiria em um critério de correção para a racionalidade das decisões individuais ${ }^{26}$.

Ademais, acredita-se que a própria consciência de que nossos posicionamentos podem ser tendenciosos atuaria como uma advertência pessoal para abrir-se às novas evidências. Dessa maneira, é possível cogitar que, ao prover uma justificativa para sua opinião, aquele que participa da deliberação possa pensar, como um exercício, em hipóteses alternativas de resultado logo no início do processo mental de decisão, visando evitar que o viés opinativo possa interferir, de forma indesejável, na decisão ${ }^{27}$.

Critica-se o Sistema Judiciário Brasileiro pelo desrespeito ao ônus argumentativo, uma vez que são muito comuns, tanto nas manifestações de juízes quanto de membros do Ministério Público e de advogados,

siva, mesmo quando discordem do sentido que eles lhe empregam. Isso ocorre em razão da crença de que a deliberação, quando ocorrer, deve ser feita antes da formação da lei e não na sua aplicação. MENDES, Conrado Hübner. Constitucional courts and deliberative democracy. Oxford: Oxford University Press, 2013. p. 54.

24 Quando tratam do mecanismo de reinterpretação da realidade, Drobak e North tecem as seguintes considerações: "A reinterpretation of reality occurs when the prevailing model, or set of maps, produces unanticipated results, forcing a reclassification. However, such reclassification is constrained by deep-seated tacit rules that determine the flexibility of the mind to adjust". DROBAK, John N.; NORTH, Douglas C. Understanding judicial decision-making: the importance of constraints on non-rational deliberations. Law \& The New Institutional Economics. Washington University, v. 26, p. 130-152, 2008. p. 137-138. Disponível em: $<$ http://openscholarship.wustl.edu/law_journal_law_policy/vol26/iss1/7>. Acesso em: 1 ago. 2017.

25 Aquele que participa de uma deliberação sobre questões públicas deve se abrir à possibilidade de mudar suas preferências pessoais e crenças se razões convincentes forem dadas. Por outro lado, o indivíduo também deve se empenhar para tentar convencer os demais. FAREJOHN, John; PASQUINO, Pasquale. Constitutional courts as deliberative institutions: towards an institutional theory of constitutional justice. In: SADURSKI, Wojciech. Constitutional justice, east and west: democratic legitimacy and constitutional courts in post-communist Europe in a comparative perspective. The Hague: Kluwer Law International, 2013. p. 23. Disponível em: < https://is.muni.cz/el/1422/jaro2013/MVV2868K/um/FEREJOHN_PASQUINO_-_Constitutional_Courts_as_Deliberative_ Institutions.pdf >. Acesso em: 12 dez. 2016.

26 MARINONI, Luiz Guilherme. O STJ enquanto corte de precedentes: recompreensão do sistema processual da corte suprema. 2. ed. São Paulo: Revista dos Tribunais, 2014. p. 107-108.

27 NICKERSON, Reimond S. Confirmation bias: a ubiquitous phenomenon in many guises. Review of General Psychology, v. 2 , n. 2, p. 211, 1998. 
momentos em que são citados argumentos de autoridade ${ }^{28}$ de doutrinadores ou da jurisprudência, fora de qualquer contexto e na ausência de argumentos que embasem a discussão, usados, apenas, em função dos resultados e não dos fundamentos. ${ }^{29}$ Dessa feita, na ausência de fundamentação coerente da decisão, fica difícil diferenciá-la de uma simples opinião pessoal.

Não obstante, nas votações colegiadas, o voto dos julgadores funcionaria como mera agregação de opiniões, visto que os votos são proferidos de forma individual, seja por escrito, seja por transcrição de votos orais. Desse modo, não havendo organização da decisão de maneira unificada, fica prejudicada a efetividade de um sistema de precedentes pela dificuldade de se encontrar a ratio nessas decisões, assim como suas circunstâncias geradoras. ${ }^{30}$

Entre os mecanismos para se tomar decisões por meio de práticas deliberativas, existem três possibilidades procedimentais básicas: (i) a corte soma todos os votos individuais e cria a decisão final com um aglomerado de votos, denominada decisão seriatim; (ii) os indivíduos deliberam, chegam a um consenso e formulam um voto que consistirá na decisão final, denominada decisão per curiam; (iii) a corte soma todos os votos individuais e cria, com base nos aspectos comuns entre eles, uma decisão da corte, resultante da majoritariam practice. ${ }^{31}$

A decisão feita de forma colegiada poderá colher os benefícios da deliberação, tais como: I - a possibilidade de se revelar informações antes privadas, de modo a gerar um esclarecimento recíproco ${ }^{32}$; II - a superação dos efeitos do bounded rationality ${ }^{33}$; III - a recordação de questões pertinentes entre os membros do colegiado; IV - o estímulo para que os integrantes justifiquem suas escolhas ${ }^{34}$; $\mathrm{V}$ - o teste de premissas com o confronto entre as opiniões ${ }^{35}$; VI - além dos benefícios políticos, como o de não concentrar nas mãos de um único indivíduo o poder e a responsabilidade sobre a decisão. Esse último permite um balanço entre a inibição dos excessos ao mesmo tempo que admite que a instituição tome decisões politicamente controversas $^{36}$.

Assim, tem-se que o benefício da decisão colegiada ultrapassa a legitimidade numérica de votação, per-

28 José Rodrigo Rodriguez traça uma crítica sobre como o poder judiciário e os profissionais do direito vêm atuando em relação à prática argumentativa, diagnosticando uma primazia de individualidade dos juízes em detrimento da produção de um posicionamento institucional, o uso de argumentos sem fundamentação robusta com o uso de argumentos de autoridade, a ausência de uma sistemática para argumentação jurídica, entre outras deficiências. RODRIGUEZ, José Rodrigo. Como decidem as cortes: para uma crítica do direito (brasileiro). Rio de Janeiro: FGV, 2013.

29 Sobre a necessidade de incremento da educação jurídica para melhor compreensão da necessidade de criação e respeito aos precedentes judiciais consultar PANUTTO, Peter. Precedentes judiciais vinculantes: o sistema jurídico-processual brasileiro antes e depois do Código de Processo Civil de 2015: Lei no 13.105, de 16 de março de 2015. Florianópolis: Empório do Direito, 2017.

30 RODRIGUEZ, José Rodrigo. Como decidem as cortes: para uma crítica do direito (brasileiro). Rio de Janeiro: FGV, 2013. p. $59-66$.

31 KORNHAUSER, Lewis A. Deciding together. New York University School of Law and Economics Working Papers, v. 1, n. 1, p. 40-61, 2013. Disponível em: < http://1sr.nellco.org/nyu_lewp/358/>. Acesso em: 1 dez. 2016.

32 SILVA, Virgílio Afonso da. Deciding without deliberating. International Journal of Constitutional Law, v. 11, p. 561, set. 2013. Disponível em: <https://academic.oup.com/icon/article-lookup/doi/10.1093/icon/mot019>. Acesso em: 20 out. 2016.

33 Este é o conceito usado para explicar o fenômeno que determina a limitação da racionalidade dos argumentos pela quantidade de informações que estão disponíveis para os indivíduos em uma deliberação. SILVA, Virgílio Afonso da. Deciding without deliberating. International Journal of Constitutional Law, v. 11, p. 561, set. 2013. Disponível em: <https://academic.oup.com/icon/ article-lookup/doi/10.1093/icon/mot019>. Acesso em: 20 out. 2016.

34 Esse estímulo se dá, pois o indivíduo procura tornar seu ponto de vista mais legítimo perante os olhos do grupo. SILVA, Virgílio Afonso da. Deciding without deliberating. International Journal of Constitutional Law, v. 11, p. 561, set. 2013. Disponível em: <https://academic.oup.com/icon/article-lookup/doi/10.1093/icon/mot019>. Acesso em: 20 out. 2016.

35 A presença de membro que discorda e contesta as propostas, força o grupo a testar as premissas e as afirmações feitas, o que reduz a incidência de falhas deliberativas por exigir do grupo esforço a fim de justificar suas escolhas. HESSICK, F. Andrew; JORDAN, Samuel P. Setting the size of the Supreme Court. Arizona State Law Journal, v. 41, p. 645-708, set./dez. 2009. Disponível em: $<$ https://papers.ssrn.com/sol3/papers.cfm?abstract_id=1576809>. Acesso em: 1 mar. 2017.

36 Há arranjos que permitem que a responsabilidade da decisão seja removida do indivíduo e ligada a instituição. Assim, a instituição ganha identidade própria, dissociada de seus membros. Como vantagem, os membros da corte ficam menos susceptíveis a pressões externas em casos mais polêmicos. MENDES, Conrado Hübner. Constitucional Courts and deliberative democracy. Oxford: Oxford University Press, 2013. p. 63. 
cebendo-se maiores benefícios da interação intelectual entre os membros do grupo, ainda mais quando a discussão trata de questões de interesse público.

A deliberação deve permitir que se desenvolva a capacidade de as pessoas estarem abertas para ouvir argumentos alheios, colhendo-se vantagens do esclarecimento recíproco, o que possibilita aos julgadores alterar suas próprias preferências e crenças, caso sejam dadas opiniões convincentes ${ }^{37}$. Entretanto, é necessário envolvimento e esforço para tentar convencer os demais sobre seu próprio ponto de vista ${ }^{38}$, além de disposição para falar em nome da instituição ${ }^{39}$.

No modelo de decisão seriatim ${ }^{40}$, um dos membros da deliberação anunciará o resultado endossado pela maioria dos julgadores no colegiado. Os fundamentos para a decisão são articulados individualmente. Com essa prática, não há a apresentação de uma razão da corte e, consequentemente, a ratio criada por essa decisão permanece incerta ${ }^{41}$. Esse resultado, no Brasil, é agravado pela prática comum, nas Cortes Superiores, de se levar longos votos escritos para a leitura pública durante o procedimento de decisão, fato que leva a uma imensa dificuldade para também identificar claramente as circunstâncias relevantes ${ }^{42}$. A falta do escrutínio das opiniões pela quase impossibilidade da ocorrência de um debate propriamente dito entre os membros da corte, favorece o aparecimento de votos arbitrários, o que diminui a aceitação da população quanto ao resultado das votações. ${ }^{43}$

No modelo per curiam, é a corte que anuncia seu entendimento com os fundamentos institucionais, após a prática deliberativa, mais comumente realizada a portas fechadas. Nela, verifica-se um maior empenho deliberativo, já que os membros da corte devem produzir uma única decisão. Essa unicidade facilita a identificação da ratio decidendi e dos fundamentos que levaram à confecção do precedente. No entanto, esse tipo de deliberação impõe a busca do consenso pelos membros do colegiado, o que implica a exigência de empenho durante a deliberação, pois, ao final, a maioria deve estar convencida dos argumentos apresentados para endossá-los, a fim de torná-los o posicionamento da própria corte ${ }^{44}$, o que resulta em um fardo muito

37 Os autores evidenciam a dificuldade de os indivíduos mudarem de posicionamento mesmo quando são oferecidas evidências contrárias, após justificarem seus posicionamentos ROSS, L. D. et al. Social explanation and social expectation: effects of real and hypothetical explanations on subjective likelihood. Journal of Personality and Social Psychology, v. 35, n. 11, p. 826, 1977.

38 FAREJOHN, John; PASQUINO, Pasquale. Constitutional courts as deliberative institutions: towards an institutional theory of constitutional justice. In: SADURSKI, Wojciech. Constitutional justice, east and west: democratic legitimacy and constitutional courts in post-communist Europe in a comparative perspective. The Hague: Kluwer Law International, 2013. p. 21-36. Disponível em: <https://is.muni.cz/el/1422/jaro2013/MVV2868K/um/FEREJOHN_PASQUINO_-_Constitutional_Courts_as_Deliberative_ Institutions.pdf >. Acesso em: 12 dez. 2016.

39 Virgílio Afonso da Silva ainda sustenta que, no colegiado, não deve existir hierarquia entre as opiniões dos membros do grupo. Em suas palavras: "Collegiality implies, among other things, (i) the disposition to work as a team; (ii) the absence of hierarchy among the judges (at least in the sense that the arguments of any and all judges have the same value); (iii) the willingness to listen to arguments advanced by other judges (i.e. being open to being convinced by good arguments of other judges); (iv) a cooperativeness in the decision-making process; (v) mutual respect among judges; (vi) the disposition to speak, whenever possible, not as a sum of individuals but as an institution (consensus seeking deliberation)." SILVA, Virgílio Afonso da. Deciding without deliberating. International Journal of Constitutional Law, v. 11, p. 566, set. 2013. Disponível em: < https://academic.oup.com/icon/article-lookup/ doi/10.1093/icon/mot019>. Acesso em: 20 out. 2016.

40 O modelo seriatim, há muito tempo, é o adotado pelo Brasil, Argentina e Chile. MERRYMAN, John Henry; PERDOMO, Rogelio Pérez. The civil law tradition: An introduction to the legal systems of Europe and Latin America. Stanford University Press, 2007. 41 KORNHAUSER, Lewis A. Deciding together. New York University School of Law and Economics Working Papers, 2013, v. 1, n. 1, p. 50-51, 2013. Disponível em: <http://lsr.nellco.org/nyu_lewp/358/>. Acesso em: 1 dez. 2016.

42 Segundo Wilson Steimetz e Riva Sobrado Freitas, essa desarticulação entre os magistrados não é suficiente para "refutar a consistência e a adequação da estrutura metodológica do exame de proporcionalidade em suas três etapas (adequação, necessidade e ponderação)". Esse modelo de ponderação seria baseado na teoria de Robert Alexy, sendo que, no Brasil, afirmam que esta ponderação se realiza de forma arbitrária, por não haver critérios racionais. STEINMETZ, Wilson; FREITAS, Riva Sobrado. Modelo Seriatim de deliberação judicial e controlabilidade da ponderação: uma questão institucional e metodológica para o caso brasileiro. Revista da Faculdade de Direito do Sul de Minas, Pouso Alegre. v. 30, n. 1, p. 221-236, jan./jun. 2014.

43 VALE, André Rufino do. Argumentação constitucional. 2015. 415 f. Tese (Doutorado) - Universidade de Brasília com cotutela da Universidade de Alicante, Brasília, 2015. p. 271.

44 KORNHAUSER, Lewis A. Deciding Together. New York University School of Law and Economics Working Papers, 2013, v. 1, n. 1, p. 40-61, 2013. Disponível em: <http://lsr.nellco.org/nyu_lewp/358/> Acesso em: 1 dez. 2016. 
maior ao grupo do que o exigido no modelo seriatim. Destaca-se que, nesse modelo, os votos contrários são omitidos do resultado final. Acredita-se que, dessa forma, obtém-se um fortalecimento da decisão da corte.

Por fim, o majoritarian practice $e^{45}$, modelo de votação colegiada adotado pela Suprema Corte estadunidense, segue inicialmente o rito da decisão seriatim, com a colheita dos votos individuais dos julgadores. Atingida a maioria, com o devido respeito aos votos vencidos, os quais integrarão o julgado, a corte segue na deliberação para definição da ratio decidendi, contendo o entendimento institucional acerca dos fundamentos e do dispositivo da decisão. Entende-se que esse modelo de decisão seria o mais adequado para o judiciário brasileiro, pois preserva a tradição da apresentação dos votos em série, do respeito aos votos vencidos, ao mesmo tempo em que busca um entendimento institucional sobre o tema ${ }^{46}$.

Um modelo de deliberação próximo ao majoritarian practice, aparentemente, tenta ser adotado pelo Superior Tribunal de Justiça para aplicação nos casos em que os fundamentos determinantes não tenham adesão da maioria dos Ministros. Esta foi uma das mais impactantes alterações em relação à deliberação adotada pelo Regimento Interno desse Tribunal, em uma tentativa de se tornar eficaz a nova sistemática de precedentes implantada pelo Código de Processo Civil de 2015. Essa modalidade de deliberação, adotada pelo Superior Tribunal de Justiça, tem algumas particularidades, a qual, como se verá adiante, é restrita a, apenas, alguns tipos de decisão colegiada.

O confronto argumentativo com o esgotamento dos argumentos implica a manifestação dos membros do colegiado sobre os pontos de vista apresentados, o que poderá acarretar tempo maior de deliberação, algo extremamente indesejado em Cortes tão atarefadas. Diante dessa realidade, tornam-se necessários mecanismos para se tornar o debate mais eficiente em relação ao tempo, tais como a delimitação dos fundamentos a serem discutidos e a distribuição antecipada, aos colegas, do voto do Relator, o que permitiria aos membros do colegiado conhecer, previamente à sessão, as informações sobre o que seria debatido, com o raciocínio já delineado, de modo a se concentrar, apenas, nas questões pertinentes ao deslinde do caso, afastando, da deliberação, questões paradoxais ${ }^{47}$.

\section{As adequações regimentais Pelo Superior Tribunal de Justiça para a formação de PRECEDENTES EFICAZES}

O Superior Tribunal de Justiça, tomando a frente, providenciou diversas alterações em seu Regimento Interno ${ }^{48}$, diante do sistema de precedentes instituído pelo novo Código de Processo Civil, de modo que seu pioneirismo servirá de molde e de experiência para a implementação e a maturação da sistemática de precedentes nos demais Tribunais do país ${ }^{49}$. Entretanto, tais alterações serão analisadas de forma crítica, para se constatar se são adequadas e suficientes, especialmente no tocante ao procedimento de deliberação

45 KORNHAUSER, Lewis A. Deciding together. New York University School of Law and Economics Working Papers, 2013, v. 1, n. 1, p. 40-61, 2013. Disponível em: <http://lst.nellco.org/nyu_lewp/358/>. Acesso em: 1 dez. 2016.

46 PANUTTO, Peter. A plena deliberação interna do Supremo Tribunal Federal para a efetiva criação dos precedentes judiciais vinculantes estabelecidos pelo Novo Código de Processo Civil. Revista Direitos e Garantias Fundamentais, Vitória, v. 18, n. 2, p. 205226, maio/ago. 2017.

47 MARINONI, Luiz Guilherme. Julgamento nas cortes supremas: precedente e decisão do recurso diante do novo CPC. São Paulo: Revista dos Tribunais, 2015. p. 101-104.

48 BRASIL. Supremo Tribunal de Justiça (STJ). Regimento Interno. Disponível em: < http://www.stj.jus.br/publicacaoinstitucional/ index.php/Regimento/issue/view/1/showToc>. Acesso em: 6 abr. 2018.

49 Uma das medidas que ilustra esse comprometimento do tribunal se encontra no texto dos motivos para a criação da Emenda Regimental no 26, de 13 de dezembro de 2016, que concebe a Comissão Permanente Gestora de Precedentes: "A Comissão Permanente Gestora de Precedentes terá elevado papel na atuação do Superior Tribunal de Justiça — a fim de garantir maior efetividade às novas regras do Código de Processo Civil sobre a padronização de procedimentos que propiciem melhor formação, criação e divulgação de precedentes qualificados nessa Corte - e norteará, em conjunto com as definições da Presidência do STJ, o trabalho desenvolvido pelo Núcleo de Gerenciamento de Precedentes - Nugep". 
colegiada com vistas à obtenção da ratio institucional.

Foram, ao todo, sete emendas regimentais desde o início da vigência do Código de Processo Civil de 2015, as quais trouxeram alterações com o objetivo de promover maior efetividade da justiça por meio da aplicação dos princípios da celeridade, da isonomia e da instrumentalidade no processo. A alteração mais significativa promovida no Regimento Interno do Superior Tribunal de Justiça, para aproximação com o sistema de precedentes ora implantado, foi a Emenda Regimental n ${ }^{\circ} 24$ :

O Projeto de Emenda Regimental ora submetido ao Plenário, em continuação às alterações voltadas à adaptação do Regimento Interno do STJ ao novo Código de Processo Civil (Lei no 13.105/2015), versa, entre outros, sob os seguintes temas: a competência da Corte Especial, Seções e Turmas, a atribuição e competência do Presidente, do Vice-Presidente, dos Presidentes das Seções, dos Relatores, da substituição de Ministro em caso de vaga ou afastamento, da vista ao Ministério Público, do registro, classificação e distribuição dos feitos, dos prazos, do registro e formação dos precedentes qualificados, da inscrição na Súmula, da homologação de decisão estrangeira, do recurso especial, dos recursos especiais repetitivos, dos agravos regimentais em matéria penal, dos agravos internos, dos embargos de declaração, dos recursos para o STF, dos incidentes de assunção de competência, do cumprimento das decisões do Tribunal e da carta de sentença. ${ }^{50}$

Observa-se que o Superior Tribunal de Justiça procura se adaptar às inovações trazidas pelo Código de Processo Civil de 2015, e, conforme ganha experiência com os novos institutos ${ }^{51}$, busca aperfeiçoar as ferramentas de trabalho por meio de seu Regimento Interno.

\subsection{Da organização da manifestação dos membros dos colegiados no STJ}

Primeiramente, cumpre ressaltar que o STJ adotou uma ordem de exposição dos votos no colegiado, nos termos do art. 163 do $\mathrm{RI}^{52}$, a qual ocorre da seguinte maneira: pelo Presidente se dá a tomada do voto do Relator, posteriormente, do revisor, e dos demais Ministros na ordem decrescente de antiguidade. Encerrada a votação, o Presidente proclama a decisão. Essa ordem de manifestação se faz por meio de requisitos objetivos, garantindo equidade entre os Ministros ${ }^{53}$, demarcando-se a atribuição exercida por aquele membro da corte naquele julgamento.

O art. 161 do RI, por sua vez, estabelece como ocorrerá a exposição dos argumentos pelos participantes do processo:

Art. 161. Cada Ministro poderá falar duas vezes sobre o assunto em discussão e mais uma vez, se for o caso, para explicar a modificação de voto. Nenhum falará sem que o Presidente lhe conceda a palavra, nem interromperá aquele que a estiver usando.

Parágrafo único. Em qualquer fase do julgamento, posterior ao relatório ou à sustentação oral, poderão os julgadores pedir esclarecimentos ao relator, ao revisor e aos advogados dos litigantes, quando presentes, sobre fatos e circunstâncias pertinentes à matéria em debate, ou, ainda, pedir vista dos autos, caso em que o julgamento será suspenso. Surgindo questão nova, o próprio relator poderá pedir a suspensão do julgamento. ${ }^{54}$

50 BRASIL. Supremo Tribunal de Justiça (STJ). Emenda Regimental n² 24, de 28 de setembro de 2016. Disponível em: < https://bdjur. stj.jus.br/jspui/bitstream/2011/105283/Emr_24_2016_PRE.pdf>. Acesso em: 12 jun. 2018.

51 A Emenda Regimental n ${ }^{\circ}$ 25, que trata da sustentação oral em sessão de julgamento, foi editada, segundo a justificativa para sua criação, com base na experiência adquirida com o instituto, demonstrando-se a agilidade do tribunal para criar adaptações às necessidades apresentadas na experiência empírica.

52 "Art. 163. Concluído o debate oral, o Presidente tomará os votos do relator, do revisor, se houver, e dos outros Ministros, que os seguirem na ordem decrescente de antiguidade. Esgotada a lista, o imediato ao Ministro mais moderno será o mais antigo. Encerrada a votação, o Presidente proclamará a decisão."

53 "One of the preconditions of fair deliberation and one of the previously mentioned elements of collegiality is equality among justices within a court." SILVA, Virgílio Afonso da. Deciding without deliberating. International Journal of Constitutional Law, v. 11, p. 557-584, set. 2013. Disponível em: <https://academic.oup.com/icon/article-lookup/doi/10.1093/icon/mot019>. Acesso em: 20 out. 2016.

54 O parágrafo único do artigo contribui para o fortalecimento dos argumentos dos Ministros por permitir que se recorra aos outros participantes do processo para esclarecimentos, o que proporciona maior racionalidade aos votos. O tempo extra para se 
A deliberação, desse modo, entre os Ministros é organizada de forma a facilitar a exposição da posição pessoal de cada um dos participantes, permitindo que o colegiado tenha uma visão clara de todos os pontos de vista, sem interrupção do raciocínio de quem profere seu voto.

O fato de não se permitir interrupções sugere maior participação geral dos membros, pois essa regra inibe o comportamento daqueles membros mais agressivos que tendem ao hábito de "confiscar" as oportunidades de manifestação, em detrimento do tempo e da oportunidade da exposição dos demais ${ }^{55}$.

Por se admitir duas oportunidades para que um membro do colegiado fale sobre o assunto, permite-se que, em tese, haja contestação dos argumentos do outro membro. Isso sugere que há espaço para interação entre os membros na deliberação. Cabe indagar se a quantidade dessas oportunidades para falar é suficiente para o esgotamento de todos os pontos de vista e se são dadas oportunidades em um número aceitável para que os Ministros sejam convencidos por outra opinião, uma vez que, dependendo de como for oferecida a segunda oportunidade para manifestação, o resultado do debate poderá ser diverso. ${ }^{56}$

Não há no art. 161 do RI limite de tempo para a manifestação, mas acredita-se que deve ser aquele período necessário para a exposição completa da opinião e das premissas adotadas pelo locutor. Esse tempo varia conforme a complexidade do assunto, mas pode resultar em votos muito longos ${ }^{57}$. Entretanto, a política do tribunal é a de que os votos não podem ser interrompidos, estimulando a existência de um ambiente em que não há hierarquia entre os membros do colegiado, para que haja respeito aos posicionamentos individuais.

O fato de os Ministros levarem o voto escrito pronto na votação e no momento da exposição fazerem sua leitura, além de causar dispersão dos demais, esvazia por completo o sentido de se fazer um debate, dado que, com esse tipo de apresentação, muitas vezes não ficam claros os pontos de controvérsia entre os Ministros, os quais acabam deixando de discutir questões conflituosas. No que pese o caput do art. 161 permitir a possibilidade de o ministro mudar seu posicionamento mais de uma vez, alerta-se para o fato de que o voto pronto, somado à publicidade das votações, inibe a prática do debate, mesmo porque, após a exposição do voto, raramente o ministro reconsiderará seu posicionamento ${ }^{58}$. Vale ressaltar que a apresentação da fundamentação não pode ser demasiadamente longa, pois esse fator corrobora o esquecimento de questões importantes, o que deve ser evitado.

Muito mais produtivo seria se os votos dos membros do colegiado fossem previamente distribuídos entre os colegas que participariam da votação, para que, assim, todos viessem preparados para a argumentação, munidos das informações necessárias para o confronto das opiniões, o que, certamente, faria com que se testassem os posicionamentos adotados por todos os Ministros ${ }^{59}$.

discutir as questões novas, com a possibilidade de se suspender o processo, também garante maior maturidade dos votos, já que será necessário, para formar uma decisão racional, maior quantidade de informações e confronto de argumentos, o que demanda tempo. 55 HESSICK, F. Andrew; JORDAN, Samuel P. Setting the size of the Supreme Court. Arizona State Law Journal, v. 41, p. 685, set./ dez. 2009. Disponível em: <https://papers.ssrn.com/sol3/papers.cfm?abstract_id=1576809>. Acesso em: 1 mar. 2017.

56 Se a segunda oportunidade for oferecida antes de todos se manifestarem, aqueles que se manifestaram duas vezes não poderão fazer reflexões acerca do que será falado por aqueles que ainda não expuseram seu ponto de vista, fazendo com que os determinados pontos não sejam completamente debatidos. Isso implica a possibilidade de que aqueles que já se manifestaram nas duas oportunidades, sem a apreciação das opiniões dos demais, tomem suas decisões de acordo com uma visão distorcida sobre o assunto, visto que não há margem para o escrutínio de sua opinião. Assim, esse membro terá mais chances de formar sua opinião por meio de uma fonte de comparação equivocada. Se, entretanto, a regra determinar que é a segunda manifestação apenas seja permitida depois que todos os membros já falaram ao menos uma vez, não há que se questionar acerca da eficácia do procedimento.

57 VALE, André Rufino do. Argumentação constitucional. 2015. 415 f. Tese (Doutorado) - Universidade de Brasília com cotutela da Universidade de Alicante, Brasília, 2015. p. 230.

58 SILVA, Virgílio Afonso da. Um voto qualquer: o papel do ministro relator na deliberação do Supremo Tribunal Federal. Revista de Estudos Institucionais, Rio de Janeiro, v. 1, n. 1, p. 191, 2015. Disponível em: < https://estudosinstitucionais.com/REI/article/ view/21>. Acesso em: 11 nov. 2016.

59 Virgílio Afonso da Silva discorre sobre as vantagens da prévia distribuição do voto do Relator. Como um dos empecilhos a esta prática seria o fato dos juízes não estarem confortáveis em ter seus votos expostos ao escrutínio dos demais. Sugerimos a exposição prévia de todos os votos para que haja o enriquecimento do debate com o preparo maior dos juízes para a deliberação. Seria contra produtivo permitir que vaidades e preferências de Ministros, que tem receio da produção de contra-argumentos mais robustos, 


\subsection{Do pedido de vista, dos ministros ausentes e da desvalorização do confronto de argumentos}

De acordo com o art. 162 do RI $^{60}$, com redação determinada pela Emenda Regimental n ${ }^{\circ} 17$, de 17/12/2014, há possibilidade de que os Ministros possam proferir seus votos mesmo sem ouvir aquele membro que pediu vista, rompendo, dessa forma, com o ônus argumentativo. Um argumento de relevo, que jamais ocorreria para aquele Ministro que tenha votado, poderia ser levantado por aquele membro que pediu vista dos autos. Se os membros podem votar sem ao menos ouvir todas as opiniões, resta claro que haverá ocasiões em que determinados pontos de controvérsia não serão debatidos, o que resulta na vulnerabilidade do resultado final e em distorções de racionalidade das decisões.

Cabe ressaltar que, atualmente, com os processos eletrônicos, os autos são facilmente acessados no site do tribunal, fato que leva ao questionamento da necessidade do pedido de vista, ato que prejudica o desenvolvimento da discussão colegiada, favorecendo o esquecimento das questões relevantes pelos demais membros em razão da interrupção ${ }^{61}$.

Ademais, o art. $162, \S 3^{\circ}$, do RI, determina que sejam computados os votos dos Ministros mesmo que não compareçam ou tenham deixado o exercício do cargo nos julgamentos que já tiverem sido iniciados. Por um lado, não há porque anular votos proferidos por Ministros que não atuam mais no julgamento, uma vez que seus argumentos já foram expostos e já passaram a influenciar, em tese, os demais Ministros. No entanto, quando o Ministro usar apenas uma, de duas de suas chances de se manifestar sobre a causa, e eventualmente se afastar do processo, não ocorrerá a chance dos outros Ministros de convencê-lo em adotar outra posição. Aquele voto proferido não sofreria interferência do debate do colegiado, tanto pela impossibilidade de o Ministro ausente ouvir os argumentos levantados por outros em seus votos, como por não atender a possibilidade de alterar seu voto caso mudasse de ideia com os demais argumentos apresentados.

Essa regra demonstra que o desenho institucional não está voltado para as possibilidades de o Ministro ser convencido pelo debate com os demais membros do colegiado. Em uma votação, na qual seja necessária unanimidade para a formação de precedente, como é o caso da súmula, tal regra poderá trazer empecilhos à sua votação. ${ }^{62}$

sobrepusessem-se ao desenho institucional do tribunal. Afinal, a prática deliberativa racional envolve a possibilidade de o membro do colegiado ter seu voto exposto ao escrutínio, confrontar sua opinião com os demais, e, quando apresentados argumentos melhores, ser capaz de mudar seu ponto de vista. Afinal, deve-se ter em mente que o resultado da deliberação será o posicionamento da corte e não daquele ministro que proferiu o argumento mais convincente. SILVA, Virgílio Afonso da. Um voto qualquer: o papel do ministro relator na deliberação do Supremo Tribunal Federal. Revista de Estudos Institucionais, Rio de Janeiro, v. 1, n. 1, p. $194,2015$. Disponível em: < https://estudosinstitucionais.com/REI/article/view/21>. Acesso em: 11 nov. 2016.

60 "Art. 162. Nos julgamentos, o pedido de vista não impede votem os Ministros que se tenham por habilitados a fazê-lo, e o Ministro que o formular restituirá os autos ao Presidente do Órgão Julgador dentro de, no máximo, sessenta dias a contar do momento em que os autos lhe forem disponibilizados, devendo prosseguir o julgamento do feito na sessão subsequente ao fim do prazo, com ou sem o voto-vista. $\int 1^{\circ} \mathrm{O}$ prazo a que se refere o caput poderá ser prorrogado por trinta dias, mediante requerimento fundamentado ao Colegiado. $\ 2^{\circ} \mathrm{O}$ prazo de restituição dos autos ficará suspenso nos períodos de recesso e de férias coletivas. $\int$ $3^{\circ} \mathrm{O}$ julgamento que tiver sido iniciado prosseguirá, computando-se os votos já proferidos pelos Ministros, mesmo que não compareçam ou hajam deixado o exercício do cargo, ainda que o Ministro afastado seja o relator. $\int 4^{\circ}$ Não participará do julgamento o Ministro que não tiver assistido ao relatório, salvo se se declarar habilitado a votar. $\ 5^{\circ}$ Se, para efeito do quórum ou desempate na votação, for necessário o voto de Ministro que não tenha assistido à leitura do relatório, esta será renovada, bem como a sustentação oral, computando-se os votos anteriormente proferidos. $\int 6^{\circ}$ Se estiver ausente o Ministro que houver comparecido ao início do julgamento, mas ainda não tiver votado, o seu voto será dispensado, desde que obtidos sufi cientes votos concordantes sobre todas as questões (arts. 174, 178 e 181). $\int 7^{\circ}$ Ausente o Presidente que iniciou o julgamento, este prosseguirá sob a presidência de seu substituto. Na Corte Especial ou na Seção, a substituição será feita por quem não houver proferido voto."

61 Ao que parece, desenvolveu-se uma cultura que permite que o ato seja usado por membros do colegiado por motivos alheios ao deslinde da questão. De todo modo, qualquer pedido de vista deveria ser justificado, pois todo ato de poder individual, que interfere no desenvolvimento do exercício do poder colegiado ou na esfera jurídica do particular, deveria ser justificado MARINONI, Luiz Guilherme. Julgamento nas cortes supremas: precedente e decisão do recurso diante do novo CPC. São Paulo: Revista dos Tribunais, 2015. p. 106.

62 A propósito, o art.162, \5 , do RI, determina que se for necessário voto para desempate de ministro que não assistiu a leitura 


\subsection{Do recurso especial representativo da controvérsia}

Um dos empecilhos para o trabalho deliberativo de um órgão colegiado é o fato de que nem sempre todos os membros se manifestam sobre as mesmas questões durante a deliberação ou no decorrer da votação. Por isso, o art. 256, $\mathbb{\int} 2^{\circ}$, I, RI ${ }^{63}$, com redação determinada pela Emenda Regimental no 24, de 28/09/2016, é de suma importância para que haja delimitação da questão de direito a ser discutida pelo grupo, em prol da manifestação dos membros do colegiado sobre os mesmos assuntos. Assim, há prévia delimitação do que deverá ser discutido pelo tribunal quando do julgamento do recurso especial repetitivo, que representa a controvérsia. Com essa prática, tem-se o controle racional da decisão, pois se permite a estipulação de um limite das questões a serem analisadas, restringindo o assunto às questões realmente pertinentes à solução daquele caso e dos futuros.

Dessa forma, referido artigo acaba cuidando da delimitação geral do tema a ser discutido, direcionando os trabalhos da corte, reduzindo tempo e esforço deliberativo e colaborando com o fator de correção da racionalidade da deliberação diante da restrição das escolhas possíveis para a tomada de decisões. ${ }^{64}$

\subsection{Dos fundamentos determinantes dos precedentes decorrentes de incidente de assunção de competência e de recursos especiais repetitivos}

Em geral, no Superior Tribunal de Justiça, o acórdão é redigido pelo Relator, o qual deve se reportar às notas taquigráficas ${ }^{65}$, que registram a discussão, os votos fundamentados (o que exclui os votos que meramente acompanham o Relator), as perguntas feitas aos advogados e as suas respostas. ${ }^{66}$

Todavia, o art. 104-A do $\mathrm{RI}^{67}$ traz certas determinações quanto aos acórdãos proferidos em incidente de assunção de competência e de recursos especiais repetitivos, fazendo com que o resultado final siga os moldes dos arts. 984, \$ $2^{\circ}$ e 1038 do Código de Processo Civil de 2015. Assim, segundo referido art. 104-A

do relatório, esta etapa deverá ser refeita. O mesmo deverá ocorrer com a sustentação oral. Fica clara a intenção da corte de providenciar a instrução adequada dos Ministros sobre o feito a ser julgado, para que, obviamente, não se vote às cegas. No entanto, caso seja possível gravar a audiência por meios eletrônicos, não parece ser necessário refazer a leitura, o que economizaria tempo e recursos da corte. $\mathrm{O}$ fato de o ministro que perdeu a leitura do voto poder, simplesmente, ler o voto escrito do colega, também esvazia o sentido dessa regra, afinal, assistindo ou lendo o voto, ele teria condições para participar do debate pois seria portador das informações necessárias.

63 “Art. 256. Havendo multiplicidade de recursos especiais com fundamento em idêntica questão de direito, caberá ao presidente ou ao vice-presidente dos Tribunais de origem (Tribunal de Justiça ou Tribunal Regional Federal), conforme o caso, admitir dois ou mais recursos especiais representativos da controvérsia, que serão encaminhados ao Superior Tribunal de Justiça, ficando os demais processos, individuais ou coletivos, suspensos até o pronunciamento do STJ. $\int 1^{\circ}$ Os recursos especiais representativos da controvérsia serão selecionados pelo Tribunal de origem, que deverá levar em consideração o preenchimento dos requisitos de admissibilidade e, preferencialmente: I - a maior diversidade de fundamentos constantes do acórdão e dos argumentos no recurso especial; II - a questão de mérito que puder tornar prejudicadas outras questões suscitadas no recurso; III - a divergência, se existente, entre órgãos julgadores do Tribunal de origem, caso em que deverá ser observada a representação de todas as teses em confronto. $\ 2^{\circ} \mathrm{O}$ Tribunal de origem, no juízo de admissibilidade: I - delimitará a questão de direito a ser processada e julgada sob o rito do recurso especial repetitivo, com a indicação dos respectivos códigos de assuntos da Tabela Processual Unificada do Conselho Nacional de Justiça; II - informará, objetivamente, a situação fática específica na qual surgiu a controvérsia; III - indicará, precisamente, os dispositivos legais em que se fundou o acórdão recorrido; IV - informará a quantidade de processos que ficarão suspensos na origem com a mesma questão de direito em tramitação no STJ; V - informará se outros recursos especiais representativos da mesma controvérsia estão sendo remetidos conjuntamente, destacando, na decisão de admissibilidade de cada um deles, os números dos demais; VI - explicitará, na parte dispositiva, que o recurso especial foi admitido como representativo da controvérsia."

64 DROBAK, John N.; NORTH, Douglas C. Understanding judicial decision-making: the importance of constraints on nonrational deliberations. Law \& The New Institutional Economics. Washington University, v. 26, p. 130-152, 2008. p. 147. Disponível em: $<$ http://openscholarship.wustl.edu/law_journal_law_policy/vol26/iss1/7>. Acesso em: 1 ago. 2017.

65 "Art. 103. Em cada julgamento, as notas taquigráficas registrarão o relatório, a discussão, os votos fundamentados, bem como as perguntas feitas aos advogados e suas respostas, e serão juntadas aos autos, com o acórdão, depois de revistas e rubricadas."

66 "Art. 100. As conclusões da Corte Especial, da Seção e da Turma, em suas decisões, constarão de acórdão no qual o relator se reportará às notas taquigráficas do julgamento, que dele farão parte integrante."

67 Com redação determinada pela Emenda Regimental n 24, 28/09/2016. 
do RI, o acórdão deverá conter:

I - os fundamentos relevantes da questão jurídica discutida, favoráveis ou contrários, entendidos esses como a conclusão dos argumentos deduzidos no processo capazes de, em tese, respectivamente, confirmar ou infirmar a conclusão adotada pelo órgão julgador; II - a definição dos fundamentos determinantes do julgado ${ }^{68}$; III - a tese jurídica firmada pelo órgão julgador, em destaque; IV - a solução dada ao caso concreto pelo órgão julgador. $\ 1^{\circ}$ Para definição dos fundamentos determinantes do julgado, o processo poderá ter etapas diferentes de deliberação, caso o órgão julgador, mesmo com votos convergentes, tenha adotado fundamentos diversos para a solução da causa. $\$ 2^{\circ}$ O Presidente do órgão julgador, identificando que o(s) fundamento(s) determinante(s) para o julgamento da causa não possui(em) a adesão da maioria dos votos dos Ministros, convocará, na mesma sessão de julgamento, nova etapa de deliberação, que contemplará apenas a definição do(s) fundamento(s) determinante(s).

$\mathrm{O}$ art. 104-A, em seu $\$ 1^{\circ}$, deixa clara, ainda, a possibilidade de se rever, na deliberação, a definição dos fundamentos determinantes do julgado. Essa situação será possível quando os votos forem convergentes, mas resultantes de fundamentos distintos, situação que impediria a formação da ratio, o que demonstra a preocupação institucional com a garantia da eficácia dos precedentes. Esse padrão de procedimento vai de acordo com o majoritarian practice, pois determina uma nova votação para que se tenha uma maior unidade e coerência de fundamentos.

Contudo, não há determinação de como se realizará essa votação dos fundamentos determinantes, tampouco quem fará parte da votação. Note-se que, se a votação for realizada por meio de soma de votos, ou se realizada pela deliberação, haverá implicações diferentes a serem analisadas. Se a votação for realizada por meio de soma de votos, cumpre questionar se aquele que formulou voto divergente faria parte da votação dos fundamentos. Ora, o Ministro, que proferiu voto divergente, poderia votar nos fundamentos que embasaram voto contrário ao seu? Não parece lógico permitir que ele faça parte da votação dos fundamentos, visto que os fundamentos adotados o levaram a conclusão completamente diferente de seus pares.

Por esses motivos, apenas na hipótese de haver uma nova deliberação faria sentido se permitir que o Ministro com voto divergente participasse da nova votação dos fundamentos. Isso porque, com a argumentação, esclarecimento dos pontos de vista e do questionamento das premissas, ele seria plenamente capaz de optar por algum dos posicionamentos. Caso contrário, por não compartilhar das mesmas premissas que seus colegas, ele não teria aptidão para realizar uma votação racional em torno de fundamentos que levaram a um resultado com o qual ele não concordou.

Não obstante, cabe indagar quantos votos convergentes com fundamentos dissidentes seriam necessários para que fosse estabelecida nova votação, e se a votação para a escolha dos fundamentos deveria resultar em unanimidade, maioria absoluta ou maioria simples. Não consta nesse art. 104-A se a nova votação seguirá a regra do art. 161 do RI, que oferece duas oportunidades de manifestação para os membros antes da votação, ou se consistirá, apenas, na aprovação numérica dos fundamentos postos à votação, sem maiores discussões. Ora, como explicado em momento anterior, não parece lógica a votação por soma, sem qualquer discussão prévia, visto que aqueles Ministros que usaram fundamentos dissidentes não poderiam ser convencidos pelos seus pares a tomar novo posicionamento. Seria necessária nova discussão para que houvesse o confronto entre as premissas adotadas.

Também não há qualquer referência ao lapso temporal necessário para os Ministros votarem nos fundamentos. Seria razoável entender que os Ministros precisassem de tempo para preparar seus votos, caso fosse realizada nova prática deliberativa.

Assim, parece haver algumas carências no modelo de deliberação aparentemente baseado no majoritarian

68 Nota-se que foram separados os fundamentos relevantes para a questão jurídica, daqueles que determinaram o julgado. Essa diferença é de suma importância para a posterior aplicação do precedente, dado que a ratio será apenas composta pelo fundamento determinante do julgamento. Os fundamentos relevantes para a questão jurídica servem ao ônus argumentativo e também para o caso de futuras revisões, caso o precedente se torne anacrônico. 
practice, adotado pelo Superior Tribunal de Justiça, para a formação de precedentes. Por outro lado, ao exigir que o próprio Tribunal aponte no acórdão os elementos fundamentais do precedente, permite-se que a corte transmita uma opinião institucional mais concisa e coerente.

\subsection{Da garantia democrática nas audiências}

O art. 185 do RI $^{69}$ enumera as audiências que serão públicas, entre elas, as do Presidente ou do Relator destinadas a ouvir pessoas ou entidades com experiência e conhecimento em matéria de interesse, para a fixação ou para a alteração de tese repetitiva ou de enunciado de súmula. A publicidade, somada à possibilidade de participação de amicus curiae, torna as audiências mais democráticas, resultando no aumento da legitimidade das decisões judiciais ${ }^{70}$.

Fica garantido, também, pelo art. 186, $\ 4^{\circ}, \mathrm{II}$, do $\mathrm{RI}^{71}$, que o debate seja munido de diferentes opiniões, garantindo fontes originais para o preenchimento de lacunas nas possíveis teorias mentais traçadas previamente pelos Ministros, permitindo, também, o uso do pensamento rápido de forma positiva. Além disso, o fato de essa manifestação ser realizada antes de qualquer decisão por parte dos julgadores, após constar nos relatórios e de inibir os efeitos do esquecimento, atua como controle racional da decisão, por dirimir a valoração por ordem de apresentação.

Cabe ao Ministro que presidirá a audiência, o papel de selecionar os participantes e de organizar as manifestações das pessoas e das entidades que serão ouvidas. O Presidente teria, portanto, a possibilidade de afastar a exposição de ideias de determinados grupos que fossem contrários às suas crenças pessoais, devendo, por esse motivo, justificar a decisão de afastar determinado grupo, para que não haja pessoalidade na decisão, visto que isso poderia favorecer uma decisão com fontes de comparação equivocadas.

\section{Considerações Finais}

Não se pode desprezar que o procedimento de argumentação racional e o debate com o esgotamento e com o confronto de argumentos terão como efeito adverso o consumo maior de tempo para tomada de decisão, algo extremamente indesejado em Cortes tão atarefadas.

69 “Art. 185. Serão públicas as audiências: I - do Presidente ou do relator para ouvir pessoas ou entidades com experiência e conhecimento em matéria de interesse para a fixação ou alteração de tese repetitiva ou de enunciado de súmula; II - do relator, para instrução do processo, salvo exceção legal." Com redação determinada pela Emenda Regimental no 24, de 28/09/2016.

70 Audiências públicas também carregam o escopo de controle social das decisões, principalmente no que tange ao cumprimento das garantias fundamentais. SILVA, Virgílio Afonso da. Deciding without deliberating. International Journal of Constitutional Law, v. 11, p. 557-584, set. 2013. Disponível em: <https://academic.oup.com/icon/article-lookup/doi/10.1093/icon/mot019>. Acesso em: 20 out. 2016.

71 “Art. 186. O Ministro que presidir a audiência deliberará sobre o que lhe for requerido, ressalvada a competência da Corte Especial, da Seção, da Turma e dos demais Ministros. $\int 1^{\circ}$ Respeitada a prerrogativa dos advogados e dos membros do Ministério Público, nenhum dos presentes se dirigirá ao Presidente da audiência, a não ser de pé e com a sua licença. $\int 2^{\circ} \mathrm{O}$ Secretário da audiência fará constar em ata o que nela ocorrer. $\int 3^{\circ} \mathrm{A}$ audiência pública prevista no inciso I do art. 185 será presidida pelo Ministro que a convocou, facultada a delegação a outro Ministro. $\int 4^{\circ} \mathrm{O}$ Ministro que convocou a audiência prevista no inciso I do art. 185 divulgará, com antecedência mínima de trinta dias, as orientações gerais sobre o procedimento a ser adotado, observado o seguinte: I - o despacho convocatório da audiência pública será amplamente divulgado e delimitará a(s) questão(ões) objeto de debate, fixará prazo para a indicação das pessoas a serem ouvidas e determinará a notificação dos Ministros do respectivo Órgão Julgador e o encaminhamento de convites a pessoas ou a entidades que possuam estreita relação com a questão a ser apresentada; II - será garantida a participação de pessoas ou de entidades que defendam diferentes opiniões relativas à matéria objeto da audiência pública; III - caberá ao Ministro que presidir a audiência pública selecionar as pessoas que serão ouvidas, divulgar a lista dos habilitados, determinar a ordem dos trabalhos, fixar o tempo de que cada um disporá para se manifestar e zelar, na medida do possível, pela garantia de pluralidade de expositores; IV - os depoentes deverão limitar-se à questão em debate; $\mathrm{V}$ - os trabalhos da audiência pública serão registrados e juntados aos autos do processo e ao projeto de súmula e disponibilizados no sítio eletrônico do Tribunal; VI - os casos omissos serão resolvidos pelo Ministro que convocou a audiência." Com redação determinada pela Emenda Regimental no 24, de 28/09/2016. 
Vislumbra-se, no entanto, que, no futuro, com a consolidação do uso dos precedentes, com a consequente previsibilidade deles advindas, o número de processos tende a cair, diminuindo a carga de trabalho das Cortes, fazendo com que a oferta de tempo para a tomada de decisões possa ser maior. Ademais, se uma decisão se encontra bem fundamentada, será mais difícil encontrar argumentos para modificá-la, o que lhe garante maior legitimidade e aceitabilidade ${ }^{72}$, diminuindo, assim, o número de feitos em trâmite perante as Cortes Superiores. ${ }^{73}$

Não restam dúvidas de que o Superior Tribunal de Justiça se empenhou em sua adaptação institucional para a nova cultura de precedentes, demonstrando estar aberto para se engajar na elaboração de decisões bem informadas, de modo a garantir a criação de precedentes judiciais eficazes.

Entretanto, mesmo adotada a política institucional de deliberação, em algumas situações específicas, com o esgotamento de argumentos, bem como com o confronto de opiniões para diminuir os efeitos das crenças e dos sentimentos pessoais, ficou claro que os mecanismos de deliberação carecem de melhor atenção.

Verifica-se que, de forma geral, há uma ausência de mecanismos para se cobrar o confronto argumentativo, não oferecendo, também, um ambiente que permita o convencimento do Ministro na presença de bons argumentos. Não há equilíbrio entre o tempo de voto e o respeito ao voto individual, o que poderá redundar no esquecimento de fundamentos importantes, com a consequente distorção do resultado final. Essa despreocupação com a deliberação ficou, ainda, mais clara quando se trata da segunda votação para a fundamentação do incidente de assunção de competência e do recurso especial repetitivo, inexistindo qualquer diretriz acerca de como ocorrerá essa deliberação.

Em uma visão geral, portanto, verifica-se que o Regimento Interno do Superior Tribunal de Justiça formulou regras que facilitam a tomada de voto bem informado, mas não se preocupou com mecanismos para a interação entre os Ministros na tomada de decisão. Dessa forma, o desenho institucional não permite que o tribunal usufrua de toda a potencialidade do colegiado.

Mesmo tendo em mente a imensa quantidade de processos com a qual o Superior Tribunal de Justiça lida diariamente, não se pode sustentar que a corte possa tomar decisões que se revelarão como base para a solução de casos futuros sem usar todo o potencial da deliberação colegiada.

É de reconhecer o empenho do Superior Tribunal de Justiça nas adequações regimentais frente ao sistema de precedentes judicias vinculantes implementado pelo Código de Processo Civil de 2015, mas esse tribunal deve manter a preocupação em relação à contínua revisão regimental, com vistas à plena deliberação colegiada, de modo a garantir a criação de precedentes eficazes, com o consequente aumento da legitimidade de suas decisões.

\section{REFERÊNCIAS}

BRASIL. Supremo Tribunal de Justiça (STJ). Emenda Regimental nº 26, de 13 de dezembro de 2016. Disponível em:< https://ww2.stj.jus.br/publicacaoinstitucional//index.php/Regimento/article/view/3306/3338>. Acesso em: 10 jul. 2018.

BRASIL. Supremo Tribunal de Justiça (STJ). Emenda Regimental n 24, de 28 de setembro de 2016. Disponível em: <https://bdjur.stj.jus.br/jspui/bitstream/2011/105283/Emr_24_2016_PRE.pdf>. Acesso em: 12

72 "A aceitabilidade racional seria assim um princípio regulativo da argumentação jurídica [...] o qual deve tentar sempre lograr conclusões que possam contar com o apoio racional da maioria dos membros da comunidade jurídica”. VALE, André Rufino do. Argumentação constitucional. 2015. 415 f. Tese (Doutorado) - Universidade de Brasília com cotutela da Universidade de Alicante, Brasília, 2015. p. 57.

73 PANUTTO, Peter. Precedentes Judiciais Vinculantes: o sistema jurídico-processual brasileiro antes e depois do Código de Processo Civil de 2015: Lei no 13.105, de 16 de março de 2015. Florianópolis: Empório do Direito, 2017. p. 75. 
jun. 2018.

BRASIL. Supremo Tribunal de Justiça (STJ). Emenda Regimental n 25, de 13 de dezembro de 2016. Disponivel em:<http://bdjur.sti.jus.br/jspui/handle/2011/106849>. Acesso em: 10 jul. 2018.

BRASIL. Supremo Tribunal de Justiça (STJ). Regimento Interno. Disponível em:<http://www.stj.jus.br/publicacaoinstitucional/index.php/Regimento/issue/view/1/showToc>. Acesso em: 6 abr. 2018.

DROBAK, John N.; NORTH, Douglas C. Understanding judicial decision-making: the importance of constraints on non-rational deliberations. Law \& The New Institutional Economics. Washington University, v. 26, p. 130-152, 2008. Disponível em: < http://openscholarship.wustl.edu/law_journal_law_policy/vol26/ iss1/7>. Acesso em: 1 ago. 2017.

FAREJOHN, John; PASQUINO, Pasquale. Constitutional courts as deliberative institutions: towards an institutional theory of constitutional justice. In: SADURSKI, Wojciech. Constitutional Justice, East and West: democratic legitimacy and constitutional courts in post-communist Europe in a comparative perspective. The Hague: Kluwer Law International, 2013. Disponível em: < https://is.muni.cz/el/1422/jaro2013/ MVV2868K/um/FEREJOHN_PASQUINO_-_Constitutional_Courts_as_Deliberative_Institutions.pdf >. Acesso em: 12 dez. 2016.

GUYTON, Arthur C.; HALL, J. E. Tratado de fisiologia médica. 11. ed. Rio de Janeiro: Elsevier, 2006.

HESSICK, F. Andrew; JORDAN, Samuel P. Setting the size of the Supreme Court. Arizona State Law Journal, v. 41, p. 645-708, set./dez. 2009. Disponível em: < https://papers.ssrn.com/sol3/papers.cfm?abstract_ id=1576809>. Acesso em: 1 mar. 2017.

HOLMES, Oliver Wendell. The common law. Typographical Society of University of Toronto Law School, 2011. Disponível em: <http://www.general-intelligence.com/library/commonlaw.pdf>. Acesso em: 5 abr. 2018.

HORTA, Ricardo Lins e. Argumentação estratégia e cognição: Subsídios para a formulação de uma teoria da decisão judicial. Revista Direito e Liberdade, ESMARN, v. 18, n. 2, p. 153-154, maio/ago. 2016.

KENNEDY, Ducan. Strategizing strategic behavior in legal interpretation. Utah Law Review, 1996. Disponível em <http://duncankennedy.net/documents/Photo\%20articles/Strategizing\%20Strategic\%20Behavior\%20in\%20Legal\%20Interpretation.pdf>. Acesso em: 19 abr. 2018.

KORNHAUSER, Lewis A. Deciding together. New York University School of Law and Economics Working Papers, v. 1, n. 1, p. 40-61, 2013. Disponível em: < http://1sr.nellco.org/nyu_lewp/358/>. Acesso em: 1 dez. 2016.

MARINONI, Luiz Guilherme. Julgamento nas cortes supremas: precedente e decisão do recurso diante do novo CPC. São Paulo: Revista dos Tribunais, 2015.

MARINONI, Luiz Guilherme. O STJ enquanto corte de precedentes: recompreensão do sistema processual da corte suprema. 2. ed. São Paulo: Revista dos Tribunais, 2014.

MELLO, Patrícia Perrone Campos. Nos bastidores do STF. Rio de Janeiro: Forense, 2015.

MENDES, Conrado Hübner. Constitucional courts and deliberative democracy. Oxford: Oxford University Press, 2013.

MERRYMAN, John Henry; PERDOMO, Rogelio Pérez. The civil law tradition: An introduction to the legal systems of Europe and Latin America. Stanford University Press, 2007.

MUSSWEILER, Tomas; EPSTUDE, Kai. Relatively fast!: efficiency advantages of comparative thinking. Journal of Experimental Psychology, v. 138, n. 1, p. 1-21, 2009.

NICKERSON, Reimond S. Confirmation bias: a ubiquitous phenomenon in many guises. Review of General Psychology, v. 2, n. 2, 1998. 
PANUTTO, Peter. A plena deliberação interna do Supremo Tribunal Federal para a efetiva criação dos precedentes judiciais vinculantes estabelecidos pelo Novo Código de Processo Civil. Revista Direitos e Garantias Fundamentais, Vitória, v. 18, n. 2, p. 205-226, maio/ago. 2017.

PANUTTO, Peter. Precedentes judiciais vinculantes: o sistema jurídico-processual brasileiro antes e depois do Código de Processo Civil de 2015: Lei no 13.105, de 16 de março de 2015. Florianópolis: Empório do Direito, 2017.

RODRIGUEZ, José Rodrigo. Como decidem as cortes: para uma crítica do direito (brasileiro). Rio de Janeiro: FGV, 2013.

ROSS, Alf. Direito e justiça. 2. ed. Bauru: Edipro, 2007.

ROSS, L. D. et al. Social explanation and social expectation: effects of real and hypothetical explanations on subjective likelihood. Journal of Personality and Social Psychology, v. 35, n. 11, p. 826, 1977.

ROSS, Lee; LEPPER, Mark R.; HUBBARD, Michael. Perseverance in self-perception and social perception: biased attributional processes in the debriefing paradigm. Journal of personality and social psychology, v. 32, n. 5 , 1975.

SILVA, Virgílio Afonso da. De quem divergem os divergentes: os votos vencidos no Supremo Tribunal Federal. Direito, Estado e Sociedade, Rio de Janeiro, n. 47, p. 205-225, jul./dez. 2015. Disponível em: < http:// www.jur.puc-rio.br/revistades/index.php/revistades/article/view/605>. Acesso em: 6 nov. 2016.

SILVA, Virgílio Afonso da. Deciding without deliberating. International Journal of Constitutional Law, v. 11, set. 2013. Disponível em: <https://academic.oup.com/icon/article-lookup/doi/10.1093/icon/mot019>. Acesso em: 20 out. 2016.

SILVA, Virgílio Afonso da. Um voto qualquer: o papel do ministro relator na deliberação do Supremo Tribunal Federal. Revista de Estudos Institucionais, Rio de Janeiro, v. 1, n. 1, 2015. Disponível em: < https:// estudosinstitucionais.com/REI/article/view/21>. Acesso em: 11 nov. 2016.

STEINMETZ, Wilson; FREITAS, Riva Sobrado. Modelo Seriatim de deliberação judicial e controlabilidade da ponderação: uma questão institucional e metodológica para o caso brasileiro. Revista da Faculdade de Direito do Sul de Minas, Pouso Alegre. v. 30, n. 1, p. 221-236, jan./jun. 2014.

SUSSMAN, Edna. Arbitrator decision-making:unconscious psychological influences and what you can do about then. The American Review of International Arbitration, New York, v. 24, n. 3, p. 487-514, 2013. Disponível em: < http://arbitragem.pt/conselhos/deontologia/doutrina/internacional/arbitrator-decisionmaking-unconscious-psychological-influences--edna-sussman.pdf>. Acesso em: 1 nov. 2017.

VALE, André Rufino do. Argumentação constitucional. 2015. 415 f. Tese (Doutorado) - Universidade de Brasília com cotutela da Universidade de Alicante, Brasília, 2015. 


\title{
Heurística de ancoragem e fixação de danos morais em juizados especiais cíveis no Rio de Janeiro: uma nova análise*
}

\author{
Anchoring-and-adjustment heuristic and \\ the setting of moral damages in small claims \\ courts in Rio de Janeiro: a new analysis
}

\author{
Fernando Leal** \\ Leandro Molhano Ribeiro***
}

\section{Resumo}

O objetivo deste trabalho é investigar, empiricamente, a influência de fatores intuitivos na tomada de decisão jurídica. Especificamente, pretende-se medir a influência da heurística de ajuste e ancoragem sobre juízes provocados a fixar valores de indenização por danos morais causados em consumidores. Partiu-se da hipótese de que os valores pedidos pelas partes a título de indenização por dano moral atuam como âncoras para a fixação da indenização homologada pelo juiz. Essa hipótese geral foi testada a partir de casos reais em 524 processos dos I e II Juizados Especiais Cíveis da Regional Barra da Tijuca entre 2011 e 2014, a partir de informações exatas sobre os valores de indenização pedidos pelos consumidores e os valores de indenização deferidos na decisão judicial. Assim, a presente investigação avança em relação à análise anteriormente feita com o mesmo objetivo deste estudo, mas desenvolvida buscando correlacionar o valor da causa com os pedidos deferidos judicialmente. Embora os resultados encontrados indiquem que há, em geral, pouco efeito de ancoragem dos pedidos feitos pelas partes a título de indenização por danos morais na decisão do juiz, identificamos variações interessantes que podem indicar a influência de julgamentos intuitivos em determinadas situações: quando as partes pedem valores bem abaixo do teto legalmente permitido (o que significa, sendo mais preciso, quando os valores não excedem o valor mediano pedido nos processos) e quando pedem valores "quebrados". Foi feita, também, uma análise comparativa das relações entre valores pedidos e deferidos em grandes áreas ("telecomunicações", "varejo", "bancos" e "aéreas"). Nesse caso, observou-se que as correlações seguem o mesmo padrão geral de baixa correlação, exceto em "aéreas", cujo índice de correlação de Spearman alcança 0,57, o que sugere efeitos de ancoragem. Este último dado também representa um avanço em relação ao estudo anterior sobre ancoragem e danos morais, no qual setores específicos não foram analisados.

Palavras-chave: Heurísticas e vieses. Ancoragem. Raciocínio jurídico. Danos morais. Incerteza. Regulação.

\footnotetext{
*** Doutor e Mestre em Ciência Política pelo IUPERJ. Graduado em Ciências Sociais pela UFMG. Professor da Graduação e do Mestrado em Direito da Regulação da FGV Direito Rio.

E-mail: leandro.ribeiro@fgv.br

** Doutor em Direito pela Christian-Albrechts-Universität zu Kiel, com bolsa do Serviço Alemão de Intercâmbio Acadêmico (DAAD). Doutor e mestre em Direito Público pela UERJ. Professor da Graduação e do Mestrado em Direito da Regulação da FGV Direito Rio. E-mail: fernando.leal@fgv.br
}

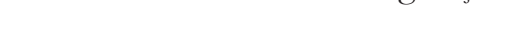




\section{Abstract}

This study aims to assess the influence of intuitive aspects in judicial decision-making. More specifically, it intends the influence of the anchoring and adjustment heuristic over judges in cases involving the setting of moral damages involving consumer issues. The hypothesis we test is that the amount claimed by the parties in moral damages anchors the amount set in the sentence by the judge if the plaintiff wins. This general hypothesis has been tested in a sample composed by 524 real cases at the I and II Small Claims Courts (Juizados Especiais Cíveis) of the Barra da Tijuca region in Rio de Janeiro, between the years 2011 and 2014 on the basis of the exact amounts claimed by the plaintiffs and the final value attributed by judges. In this sense, this investigation goes forward in comparison to previous analysis with the same aim, but developed focusing on possible correlations between the amount attributed to the legal issue ("valor da causa") and the setting of moral damages. After the correlation tests, anchoring effects over the judicial decision could not be identified. However, there are interesting variations in the dataset that suggests that the decision-making context may somehow soften the possible effects of the anchoring and adjustment heuristic. Although we found a low correlation between the amounts attributed to the cases involving moral damages and the amounts the defendants were sentenced to pay, we identify some variations that might indicate the influence of intuitive judgements in certain situations: when the plaintiffs ask for an amount far below the legally permitted limit (i.e. when the value does not exceed the median value claimed in the cases) and when they claim non-zero decimal values. Moreover, we also compare the relationship between the amounts claimed and the amounts fixed by the judges in four big areas: telecommunications, retail, banks and aviation. In these scenarios, the analysis follows the same low correlation pattern, except in the aviation sector, in which the Spearman correlation index reaches 0,57 , what suggests anchoring effects in this area. This last finding represents also a step further in comparison to previous analysis on anchoring effects and moral damages, since it doesn't focus on specific sectors.

Keywords: Heuristics and biases. Anchoring. Legal reasoning. Damages in personal injury cases. Uncertainty. Regulation.

\section{INTRODUÇÃo}

\subsection{Teorias normativas e limites reais para a tomada de decisão}

Teorias jurídicas costumam ser empreendimentos normativos. Elas almejam orientar as práticas nos espaços de criação e aplicação do direito por meio de prescrições sobre como, por exemplo, legisladores devem atuar, como o processo legislativo deve se organizar, como juízes devem se comportar quando são provocados a rever atos de outros poderes, como a Constituição deve ser interpretada e como o administrador público deve justificar as suas escolhas. Com essas pretensões, teorias jurídicas são construídas comumente visando aproximar a realidade de algum estado ideal de coisas, justificado em nome da realização de objetivos social ou politicamente relevantes ${ }^{1}$, ou mesmo com base em exigências supostamente conceituais ${ }^{2}$.

1 Tome-se como exemplo o tipo de teoria sobre a qual se constrói o constitucionalismo brasileiro da efetividade, que prescreve como os aplicadores da Constituição devem lidar com os seus comandos a partir de uma preocupação com a realização da maior efetividade constitucional. V. sobre o assunto SOUZA NETO, Cláudio Pereira de. Fundamentação e normatividade dos direitos fundamentais: uma reconstrução teórica à luz do princípio democrático. In: BARROSO, Luís Roberto (Org). A nova interpretação constitucional: ponderação, direitos fundamentais e relações privadas. Rio de Janeiro: Renovar, 2006. e BARROSO, Luís Roberto. A doutrina brasileira da efetividade. In: BARROSO, Luís Roberto. (Org.). O direito constitucional e a efetividade de suas normas: limites e possibilidades da Constituição brasileira. 8. ed. Rio de Janeiro: Renovar, 2006.

2 V. como exemplo o projeto de institucionalização de Robert Alexy e a sua relação com a sua concepção da dupla natureza do 
No primeiro caso, teorias normativas se justificariam na medida em que recomendariam a adoção de certos comportamentos considerados necessários para a promoção de alguma concepção de objetivos relevantes como a justiça social, a igualdade, a separação de poderes, a democracia ou a liberdade ${ }^{3}$. No segundo caso, agir da forma prescrita pela teoria é considerado uma necessidade para que se possa continuar a chamar certa prática social, norma ou conjunto normativo de, por exemplo, "jurídica" ou "democrática".

A construção de teorias normativas, no entanto, é cercada por riscos permanentes. O principal deles é o de descolamento com a realidade. Esse pode se dar por duas razões: por diagnósticos imperfeitos ou por idealização. Por um lado, teorias normativas podem partir de diagnósticos imprecisos ou simplesmente falsos sobre o mundo. A realidade problemática que se pretende alterar por meio das prescrições da teoria, com outras palavras, pode ser completamente diferente daquela pressuposta pelo modelo teórico que ergue a pretensão de partir de uma descrição confiável do mundo. Recomenda-se, por exemplo, que o Judiciário deve ser sempre deferente a escolhas regulatórias em razão das suas reduzidas capacidades institucionais quando, no mundo real, o que se constata pode ser exatamente um déficit de capacidade institucional de certa Agência Reguladora (por não estar, por exemplo, com o seu quadro técnico completo e por estar politicamente capturada) relativamente às capacidades apreensíveis de um órgão do Poder Judiciário organizado e no qual especialistas confiáveis são chamados a se manifestar sobre a solução de temas complexos ${ }^{4}$. Nesse caso, o problema da prescrição é de tentar lidar com um problema, de fato, inexistente. Com isso, corre-se o risco de orientar a realidade para um ponto não necessariamente melhor. Por outro lado, a segunda maneira pela qual um descolamento com a realidade pode se dar na construção de teorias normativas está relacionada às idealizações que informam as prescrições. A teoria, nesse caso, pode ser simplesmente irrelevante para alterar a realidade na direção por ela visada porque pressupõe agentes ideais ou ambientes ideais nos quais agentes (reais ou ideais) decidem. Em ambos os casos, a importância efetiva da teoria para conduzir a prática decisória se dilui, permanecendo, no máximo, o seu potencial crítico.

As dificuldades apontadas que parecem afetar, tradicionalmente, teorias jurídicas normativas não são novidades, porém, na economia. Herbert Simon, em meados do século passado, denunciou o baixo interesse em microeconomia descritiva. Para Simon, entender o comportamento de agentes econômicos individuais se limitava ao necessário para fornecer as bases para construções macroeconômicas normativas 5 . Havia, nesse sentido, apenas, a pressuposição de uma teoria pouco desenvolvida sobre o comportamento humano, alicerçada sobre como as pessoas devem decidir. A normatividade de teorias econômicas se sustentava, assim, sobre pressupostos também normativos. Com isso, fortes previsões sobre o comportamento humano eram feitas sem que pessoas reais fossem observadas. ${ }^{6}$ Nas palavras de Simon: "a teoria clássica [que assumia a racionalidade de agentes econômicos e competição perfeita $\left.{ }^{7}\right]$ é a teoria de um indivíduo escolhendo entre alternativas postas e conhecidas, para cada qual são vinculadas consequências conhecidas. No entanto, quando percepção e cognição intervêm entre o tomador de decisão e o seu ambiente objetivo, esse modelo não se prova mais adequado. Precisamos de uma descrição do processo de escolha que reconhece que alternativas

direito. Cf. ALEXY, Robert. Principais elementos de uma teoria da dupla natureza do direito. Revista de Direito Administrativo, n. 253, p. 9-29, 2010.

3 Como exemplo, v. a prescrição sugerida para a atuação judicial em uma teoria sobre a legitimidade da jurisdição constitucional conceitualmente compatível com diferentes concepções sobre democracia de BARROSO, Luís Roberto. A razão sem voto. Revista Brasileira de Políticas Públicas, v. 5, n. esp., p. 23-50, 2015.

4 Sobre os problemas relacionados à criação de nirvanas institucionais pela ausência de base empírica v. ARGUELHES, Diego Werneck; LEAL, Fernando. O argumento das “capacidades institucionais” entre a banalidade, a redundância e o absurdo. Direito, Estado e Sociedade, n. 38, p. 6-50, jan./jun. 2011. p. 41.

5 SIMON, Herbert A. Theories of decision-making in economics and behavioral science. The American Economic Review, v. 49, n. 3, p. 253-283, jun. 1959. p. 254.

6 SIMON, Herbert A. Theories of decision-making in economics and behavioral science. The American Economic Review, v. 49, n. 3, p. 253-283, jun. 1959. p. 254.

7 SIMON, Herbert A. Theories of decision-making in economics and behavioral science. The American Economic Review, v. 49, n. 3, p. 253-283, jun. 1959. p. 254. V. também SIMON, Herbert A. A behavioral model of rational choice. The Quarterly Journal of Economics, v. 69, n. 1, p. 99-118, fev. 1955. p. 99. 
não são dadas, mas devem ser procuradas; e uma descrição que considera a ardorosa tarefa de determinar quais consequências se seguirão de cada alternativa". ${ }^{8}$ Dado esse possível descompasso entre o que se assume correto e o que pode ser verdadeiro sobre a tomada de decisão humana, base empírica sobre como as pessoas realmente enfrentam e decidem problemas passa a ser crucial para o sucesso de teorias prescritivas. Por isso, para Simon, o quanto a economia depende de diálogos com a psicologia depende, entre outros fatores, de até que ponto podemos confiar na suposição de que é possível se aproximar desse ideal de decisor?.

É exatamente por ser questionável a descrição do comportamento humano como perfeitamente racional e a suposição de que podemos reunir e processar informações sobre o nosso ambiente em contextos reais de tomada de decisão que Simon cunhou a expressão racionalidade limitada. Por meio desse rótulo, expressa-se a concepção de que tomadores de decisão "de carne e osso" (i) não são seres necessariamente maximizadores de suas preferências e (ii) não possuem a capacidade computacional de processamento nem o acesso às informações necessárias para agir dessa maneira ${ }^{10}$. Seres humanos reais, ao contrário do que o conceito de homo economicus pressupõe, tendem a ajustar as suas aspirações ao atingível ${ }^{11}$. Às vezes, o curso de ação privilegiado por pessoas reais é aquele que produz um resultado considerado "bom o suficiente", o que sugere que o comportamento maximizador é, em diversos momentos, substituído pela satisfação com o que se revela suficiente em dado contexto decisório. Assim, no modelo de racionalidade limitada proposto por Simon, a maximização da utilidade é substituída pela disposição ao comportamento "satissuficiente" (satisficing) ${ }^{12}$.

Esse ataque lançado contra os pressupostos da economia clássica inspirou uma longa agenda de pesquisa empírica preocupada com o mapeamento da racionalidade limitada. Nesse aspecto, os trabalhos desenvolvidos por Daniel Kahneman e Amos Tversky desempenham um papel central, na medida em que buscam explorar os vieses sistemáticos que separam (i) as crenças que as pessoas possuem e as escolhas que eles realizam (ii) das crenças ótimas pressupostas por modelos inspirados em agentes plenamente racionais ${ }^{13}$.

Essa é, sem dúvida, uma longa história. E, ao contrário do que possa parecer, sua utilidade não se limita à necessidade de um repensar de certos pressupostos de modelos econômicos. Porque teorias jurídicas também são tradicionalmente construídas idealizações e negligenciam descrições acuradas sobre a realidade e o comportamento humano, elas podem igualmente estar sujeitas a críticas (i) por menosprezarem as condições de racionalidade limitada sob as quais pessoas reais decidem problemas e (ii) não atentarem para os vieses de julgamento a que essas pessoas estão sujeitas quando são chamadas a decidir ${ }^{14}$. Este é o ponto de partida para justificar por que agendas de pesquisa empírica preocupadas com processos reais de tomada de decisão deveriam também passar a ocupar as preocupações de juristas.

8 SIMON, Herbert A. Theories of decision-making in economics and behavioral science. The American Economic Review, v. 49, n. 3, p. 253-283, jun. 1959. p. 272.

9 SIMON, Herbert A. Theories of decision-making in economics and behavioral science. The American Economic Review, v. 49, n. 3, p. 253-283, jun. 1959. p. 279.

10 SIMON, Herbert A. A behavioral model of rational choice. The Quarterly Journal of Economics, v. 69, n. 1, p. 99-118, fev. 1955. p. 99.

11 SIMON, Herbert A. Theories of decision-making in economics and behavioral science. The American Economic Review, v. 49, n. 3, p. 253-283, jun. 1959. p. 263.

12 V. KAHNEMAN, Daniel. Maps of bounded rationality: psychology for behavioral economics. The American Economic Review, v. 93, n. 5, p. 1449-1475, dez. 2003. p. 1449. V. tb. VERMEULE, Adrian. Three strategies of interpretation. San Diego Law Review, v. 42, p. 607-628, 2005.

13 V. KAHNEMAN, Daniel. Maps of bounded rationality: psychology for behavioral economics. The American Economic Review, v. 93, n. 5, p. 1449-1475, dez. 2003. p. 1449.

14 Para uma articulação entre estudos de economia comportamental para a adequada regulação ambiental v. BASTIANETTO, Lorena Machado Rogedo; GOMES, Magno Federici. Regulação ambiental da atividade minerária: uma análise econômica de compliance. Revista Brasileira de Políticas Públicas, v. 1, n. 1, p. 207-219, 2017. 


\subsection{Propósito do trabalho e colocação do problema de pesquisa}

No contexto apresentado, o presente trabalho propõe uma investigação empírica sobre a influência de fatores intuitivos na tomada de decisão jurídica. O que se pretende é obter um diagnóstico confiável a respeito da interferência de erros de julgamento provocados por sugestões, ainda que inconscientes, de participantes do discurso jurídico na tomada de decisão judicial. Mais especificamente, o texto dialoga com pesquisa anterior destinada a medir a influência da heurística de ajuste e ancoragem sobre juízes provocados a fixar valores de indenização por danos morais causados em consumidores. ${ }^{15}$

Heurísticas podem ser definidas como regras de experiência que permitem a tomada de decisão rapidamente a baixo custo. São atalhos que sugerem respostas quase automáticas (intuitivas, portanto) para problemas com base em padrões fixados com base em vivências anteriores. Graças ao papel desempenhado por essas regras na tomada de decisão, não precisamos mobilizar uma grande quantidade de recursos para enfrentar todos os problemas com os quais nos deparamos diariamente ${ }^{16}$. Fazê-lo envolveria custos proibitivos. Contudo, se, por um lado, a observância de heurísticas implica vantagens para a ação de seres que não detêm capacidade infinita para processar informações e atuam em um ambiente repleto de limitações, por outro, o resultado da aplicação dessas regras de experiência nem sempre nos leva ao julgamento correto, i.e., ao resultado a que chegaríamos se desativássemos esse lado intuitivo com base no qual o cérebro funciona corriqueiramente. Essas falhas de julgamento causadas pela observância de padrões intuitivos são chamadas de vieses cognitivos.

Investigar quais são as heurísticas e como vieses interferem nos processos humanos de tomada de decisão sob condições de incerteza está no centro do programa de pesquisa desenvolvido por Kahneman e Tversky ${ }^{17}$. Uma dessas heurísticas é a de ajuste e ancoragem ou simplesmente heurística de ancoragem. Como já tivemos a oportunidade de esclarecer, a ancoragem está relacionada ao "efeito causado pela confiança intuitivamente atribuída a um número dado" quando somos chamados a dar respostas numéricas em cenários de incerteza ${ }^{18}$. Nessas condições, o cérebro começaria a calibrar uma resposta com base em ajustes efetuados tomando como ponto de partida o número de referência. Suponha, por exemplo, que alguém seja submetido à seguinte pergunta: de acordo com o último registro divulgado, quantos livros estão catalogados no sistema da biblioteca do Congresso dos EUA, considerada a maior do mundo? Essa parece ser uma questão difícil exatamente porque, muito provavelmente, o interrogado não faz muita ideia do número exato. No entanto, talvez fizesse alguma diferença para a resposta se a mesma questão fosse formulada nos seguintes termos: de acordo com o último registro divulgado, quantos livros estão catalogados no sistema da biblioteca do Congresso dos EUA, considerada a maior do mundo: mais ou menos de 8 milhões? Agora com o referencial numérico (a âncora que atrai o julgamento), espera-se que o número indicado seja menor do que aquele que seria obtido caso a referência fosse alterada para, por exemplo, 56 milhões ${ }^{19}$. A razão

15 LEAL, Fernando; RIBEIRO, Leandro Molhano. O direito é sempre relevante? Heurística de ancoragem e fixação de valores indenizatórios em pedidos de dano moral em juizados especiais do Rio de Janeiro. Direitos Fundamentais e Justiça, Belo Horizonte, a. 10, n. 35, p. 253-284, jul./ dez. 2016.

16 V. KAHNEMAN, Daniel. Maps of bounded rationality: psychology for behavioral economics. The American Economic Review, v. 93, n. 5, p. 1449-1475, dez. 2003. p. 1450, para quem “ (i) a maior parte dos juízos e as escolhas são feitos intuitivamente e (ii) as regras que governam a instituição são comumente similares às regras de percepção”.

17 KAHNEMAN, Daniel. Maps of bounded rationality: psychology for behavioral economics. The American Economic Review, v. 93, n. 5, p. 1449-1475, dez. 2003. p. 1449. V. também KAHNEMAN, Daniel. Rápido e devagar: duas formas de pensar. Objetiva: Rio de Janeiro, 2012. KAHNEMAN, Daniel; SLOVIC, Paul; TVERSKY, Amos. Judgment under uncertainty: heuristics and biases. New York: Cambridge University Press, 1982.

18 LEAL, Fernando; RIBEIRO, Leandro Molhano. O direito é sempre relevante? Heurística de ancoragem e fixação de valores indenizatórios em pedidos de dano moral em juizados especiais do Rio de Janeiro. Direitos Fundamentais e Justiça, Belo Horizonte, a. 10 , n. 35 , p. 253-284, jul./ dez. 2016. p. 259.

19 De acordo com o site da biblioteca, o número exato é de 24.356 .449 livros catalogados. V. ESTADOS UNIDOS DA AMÉRICA. Library of Congress. General information. Disponível em: < https://www.loc.gov/about/general-information/\#year-at-aglance>. Acesso em: 22 maio 2018. 
dessa diferença é simplesmente o efeito causado pela âncora.

Verificar a influência dessa heurística nos valores fixados a título de danos morais em questões de consumo constituiu o objetivo central da nossa primeira pesquisa e segue sendo o objetivo central do presente trabalho. No entanto, dessa vez a pesquisa pretende avançar por duas razões centrais. Em primeiro lugar, as investigações serão feitas no presente estudo com base no valor efetivamente pedido pelas partes, e não apenas com base no valor da causa, único dado disponível quando da realização da primeira análise. Em segundo lugar, em função da qualidade da nova base, foi possível diferenciar, em razão da matéria levada a julgamento em Juizados Especiais Cíveis, setores específicos (no caso, os setores de varejo, telecomunicações, bancário e aéreo), no âmbito do qual correlações entre valor pedido e valor deferido puderam ser especificamente buscadas. Sem embargo desses novos passos, o problema que guiará a presente pesquisa segue podendo ser formulado da seguinte maneira: é possível constatar o efeito de ancoragem nos valores deferidos a título de danos morais em processos judiciais reais? À época, a escolha pela investigação no universo dos danos morais se justificou nos seguintes termos:

este nos pareceu um tipo de problema plenamente adequado para a verificação de efeito de ancoragem, uma vez que a fixação de dano moral pressupõe análises particularistas relacionadas a eventuais restrições a direitos fundamentais que não são claramente parametrizadas por regras do direito. Havendo, portanto, altas margens de liberdade para o magistrado, pretendemos investigar, no fundo, se, para a fixação do quantum devido, dada a indeterminação do direito, como a psicologia cognitiva sugere, os juízes são simplesmente enviesados a ajustar os valores deferidos em função do pedido formulado pela parte - o que pode ser, por exemplo, um obstáculo para a efetiva concretização da proteção ao consumidor como garantia constitucional ${ }^{20}$.

Para além da adequação temática, as investigações apresentadas neste texto voltadas a constatar a eventual influência de fatores intuitivos na tomada de decisão judicial também se justificam pela tentativa de levá-las adiante com base em casos reais. Nesse sentido, a pesquisa desenvolvida escapa da proposta tradicional de trabalhos voltados a estudar heurísticas e vieses ${ }^{21}$, que partem da realização de experimentos controlados. Assim, por exemplo, fizeram, em relação à heurística de ancoragem, tanto Guthrie, Rachlinski e Wistrich ${ }^{22}$, como Englich, Mussweiler e Strack ${ }^{23}$.

20 LEAL, Fernando; RIBEIRO, Leandro Molhano. O direito é sempre relevante? Heurística de ancoragem e fixação de valores indenizatórios em pedidos de dano moral em juizados especiais do rio de janeiro. Direitos Fundamentais e Justiça, Belo Horizonte, a. 10, n. 35, p. 253-284, jul./ dez. 2016. p. 261.

21 Uma exceção é o trabalho de FARIÑA, Francisca; ARCE, Ramón; NOVO, Mercedes. Anchoring in judicial decision-making. Psychology in Spain, v. 7, n. 1, p. 56-65, 2003. No texto, os autores analisam 555 decisões criminais, proferidas entre 1980 e 1995 , de cortes superiores e cortes criminais da região autônoma da Galícia. O objetivo do estudo era investigar a influência do tempo pedido de condenação do promotor sobre a decisão judicial e, em casos de recurso, da decisão judicial anterior sobre a decisão do órgão ad quem. Em conclusão, os autores localizaram que 63,6\% dos casos são dirigidos por efeitos de ancoragem produzidos pelos pedidos da promotoria e pela decisão judicial do tribunal a quo (p. 60).

22 GUTHRIE, Chris; RACHLINSKI, Jeffrey; WISTRICH, Andrew. Blinking on the bench: how judges decide cases. Cornell Law Faculty Publications, v. 93, paper 917, p. 1-43, 2007. p. 20. Os autores submeteram dois grupos de juízes a um mesmo caso envolvendo um acidente de trânsito e, ao final, pediam que cada um deles fixasse um valor indenizatório. Como expusemos anteriormente, "[n]a situação, o autor da ação quebrou três costelas e sofreu graves danos no seu braço direto. Em razão dos danos, o autor ficou uma semana no hospital e perdeu, no total, seis semanas de trabalho. Para os juízes do grupo de controle, a única informação passada além dos fatos do caso foi a de que o autor pretende obter "uma reparação monetária significativa". Para outro grupo de magistrados, no entanto, foi dito que o autor reivindicava uma indenização de dez milhões de dólares. Os resultados, não surpreendentemente, confirmam o poder da âncora. Enquanto os magistrados do grupo de controle atribuíram, na média, uma indenização de 808.000 dólares, com mediana de 700.000 dólares, os juízes expostos à âncora defeririam, na média, o valor de 2.210 .000 de dólares, com mediana de um milhão de dólares. Do ponto de vista das informações fornecidas aos dois grupos, apenas o valor pedido era diferente, o que confirma o viés de ancoragem nas manifestações dos juízes". V. LEAL, Fernando; RIBEIRO, Leandro Molhano. O direito é sempre relevante? Heurística de ancoragem e fixação de valores indenizatórios em pedidos de dano moral em juizados especiais do Rio de Janeiro. Direitos Fundamentais e Justiça, Belo Horizonte, a. 10, n. 35, p. 253-284, jul./ dez. 2016. p. 260. 23 ENGLICH, Birte; MUSSWEILER, Thomas; STRACK, Fritz. Playing dice with criminal sentences: the influence of irrelevant anchors on expert's judicial decision-making. Personality and Social Psychology Bulletin, v. 32, n. 2, p. 188-200, fev. 2006. Nesse trabalho, investigou-se a influência de âncoras sobre os valores de penas sugeridas em três contextos diferentes: por um jornalista, por um pedido aleatório (sendo esse dado claramente informado aos participantes do experimento) feito por um promotor e por uma referência a que os próprios participantes do experimento teriam que chegar após jogarem um par de dados viciados a sempre 


\subsection{Hipótese, metodologia e conclusões da primeira análise}

Para enfrentar o problema de pesquisa colocado, partimos da hipótese de que seria constatável o efeito de ancoragem nos valores fixados a títulos de danos morais por juízes em processos reais, ainda que o efeito da âncora pudesse variar quando as correlações fossem exploradas em setores específicos, como questões envolvendo problemas bancários, no setor de varejo ou de telefonia. Com outras palavras, esperava-se encontrar correlações relevantes entre os valores de danos morais pedidos pelas partes e os valores deferidos pelos julgadores.

Para testar a hipótese, analisamos, no primeiro trabalho, 1.102 processos dos I e II Juizados Especiais Cíveis da Barra da Tijuca, localizados no Rio de Janeiro. Os casos foram julgados entre os anos de 2004 e 2015. Naquele momento, porém, como já antecipado, a base de dados sobre a qual a análise foi feita não incluía qualquer referência aos valores pedidos pelas partes, mas tão somente aos valores atribuídos às causas, que não necessariamente correspondem aos primeiros. Ainda assim, assumindo que eventual diferença entre "valor pedido" e "valor da causa" poderia ser reduzida no âmbito de causas levadas a julgamento em Juizados Especiais ${ }^{24}$, diversas análises de correlação foram feitas.

As conclusões, ainda que, repita-se, baseadas no valor da causa, indicaram, em um primeiro momento, a inexistência de influência de heurística de ancoragem no total de casos analisados. No entanto, análises mais específicas revelaram correlações mais fortes entre o valor da causa e o valor pedido quando (i) os valores das causas estavam mais distantes dos tetos de 20 e 40 salários mínimos e, em especial, quando eles eram mais baixos ${ }^{25}$ (o que sugeriu, como hipótese explicativa, que os limites impostos pela lei 9.099/95 para litigar sem e com advogado neutralizam, na prática, os efeitos das âncoras, ao despertarem no magistrado um olhar mais cuidadoso sobre a questão discutida) e (ii) quando as partes autoras pediam valores "quebrados"26 (o que, em mais uma possível explicação, pode sugerir que valores quebrados facilitam o efeito da âncora por erguerem a pretensão de serem produto de uma análise mais precisa e, portanto, confiável do dano efetivamente sofrido). Finalmente, constatou-se que um dos possíveis motivos pelos quais não se identificou a influência da heurística de ancoragem nos casos pode estar relacionado à adoção, pelo magistrado, de um tabelamento linear de danos morais, ou seja, da atribuição de valor único para uma série de casos que não necessariamente são próximos entre si. Este, no entanto, antes de ser um achado positivo das análises empreendidas, uma vez que refutariam a influência de fatores intuitivos nos julgamentos, revelam um tratamento disfuncional do instituto "dano moral", que exige análises particularistas e se mostra, assim, conceitualmente incompatível com a atribuição de um valor único para situações diferentes que envolvem lesões diferentes à personalidade ${ }^{27}$.

fornecerem os mesmos números (para um grupo os números eram sempre 1 e 2, enquanto para o outro grupo, os números eram 3 e 6). No primeiro caso, participaram do experimento 23 juízes e 19 promotores; no segundo, 37 juízes e 2 promotores; no terceiro, 52 bacharéis em direito que participavam de um programa de pós-graduação na German University of Administrative Sciences, em Speyer. Um quarto experimento foi realizado, ainda, em um cenário muito parecido com o terceiro experimento, mas, dessa vez, com 57 bacharéis recém-formados que tinham recentemente adquirido as suas primeiras experiências como juízes. Todos os participantes foram divididos, em cada experimento, em grupos e submetidos a diferentes âncoras em casos criminais cujas sugestões de penas variavam. Como conclusão, constatou-se que âncoras claramente irrelevantes produzem efeitos de ancoragem de similar magnitude aos de âncoras claramente relevantes (p. 198).

24 LEAL, Fernando; RIBEIRO, Leandro Molhano. O direito é sempre relevante? Heurística de ancoragem e fixação de valores indenizatórios em pedidos de dano moral em juizados especiais do Rio de Janeiro. Direitos Fundamentais e Justiça, Belo Horizonte, a. 10 , n. 35, p. 253-284, jul./ dez. 2016. p. 268, nota 22.

25 LEAL, Fernando; RIBEIRO, Leandro Molhano. O direito é sempre relevante? Heurística de ancoragem e fixação de valores indenizatórios em pedidos de dano moral em juizados especiais do Rio de Janeiro. Direitos Fundamentais e Justiça, Belo Horizonte, a. 10, n. 35, p. 253-284, jul./ dez. 2016. p. 271.

26 LEAL, Fernando; RIBEIRO, Leandro Molhano. O direito é sempre relevante? Heurística de ancoragem e fixação de valores indenizatórios em pedidos de dano moral em juizados especiais do Rio de Janeiro. Direitos Fundamentais e Justiça, Belo Horizonte, a. 10, n. 35, p. 253-284, jul./ dez. 2016. p. 276.

27 LEAL, Fernando; RIBEIRO, Leandro Molhano. O direito é sempre relevante? Heurística de ancoragem e fixação de valores indenizatórios em pedidos de dano moral em juizados especiais do Rio de Janeiro. Direitos Fundamentais e Justiça, Belo Horizonte, 


\section{O PRESENTE ESTUDO}

$\mathrm{Na}$ nova análise que se propõe, parte-se do mesmo problema de pesquisa e da mesma hipótese. A diferença desta vez, porém, reside no fato de as análises propostas serem feitas, efetivamente, com base no valor pedido pelas partes, e não mais apenas a partir do valor da causa. Além disso, foi possível diferenciar os casos analisados por setores específicos, o que permitiu investigar se o efeito de ancoragem poderia variar em razão do assunto levado a julgamento.

\subsection{Os dados dos I e II Juizados Especiais Cíveis da Regional Barra da Tijuca e a definição dos processos a serem analisados}

A análise se baseou em informações inicialmente disponibilizadas pelos I e II Juizados Especiais Cíveis da Regional Barra da Tijuca sobre processos de pedidos de danos morais entre os anos de 2004 e 2015. A base de dados disponibilizada pelos juizados é formada por 30.620 processos de pedidos de danos morais, contendo as seguintes informações:

- Código Processo;

- Valor Causa (Valor pedido no processo. Os valores foram atualizados pelo Índice Geral de Preços para valores de 2015);

- Comarca (Todos os processos são da Regional da Barra da Tijuca);

- Nome da Serventia;

- Data da Primeira Distribuição;

- Valor Condenação/Homologação (Valor da condenação ou da homologação. Não há uma informação sobre os processos em que houve um ou outro caso. Os valores foram atualizados pelo Índice Geral de Preços para valores de 2015);

- Nome Classe (Todos os dados referem-se a "Procedimento do Juizado Civil/Fazendário");

- Código Assunto (Códigos que se referem aos assuntos: 30.016=Dano Moral - Outros/Indenização por Dano Moral ou 30.006 Dano Moral Outros - CDC);

- Nome Assunto (Os assuntos disponibilizados são Dano Moral - Outros/Indenização por Dano Moral ou Dano Moral Outros - CDC);

- Nome Competência (Todos os processos são do Juizado Especial Cível);

- Nome da Serventia (Os processos são do Cartório do I Juizado Especial Cível ou do Cartório do II Juizado Especial Cível);

- Código do Andamento (do processo);

- Nome do Andamento (Apensação; Arquivamento; Ato Ordinatório Praticado; Conclusão ao Juiz; Conclusão ao Juiz Tabelar; Conclusão ao Juiz Vinculado; Decisão em Audiência; Decurso de Prazo; Desentranhamento; Desentranhamento de Mandado; Despacho em Audiência; Digitação de Carta Precatória; Digitação de Documentos; Envio Automático de Documento Eletrônico; Envio de Documento Eletrônico; Expedição de Documentos; Início da Execução; Juntada; Juntada de AR; Juntada de Mandado; Pedido de Desarquivamento; Publicação de Edital; Remessa; Remessa ao Juiz

a. 10, n. 35, p. 253-284, jul./ dez. 2016. p. 281. 
Leigo; Sentença em Audiência; Trânsito em Julgado; Vista ao Advogado);

- Código (Código referente a cada um dos andamentos listados acima);

- $\quad$ Nome do Tipo do Ato do Andamento (Assinatura, Decisão, Despacho ou Sentença);

- Código do Tipo do Ato do Andamento (Código referente a cada ato do andamento listados acima)

- Código do Ato do Juiz do Andamento;

- $\quad$ Descrição do Ato do Juiz do Andamento;

- Data do Início do Andamento.

Com base nesses dados, se extraíram os processos analisados no primeiro estudo sobre a eventual influência da heurística de ancoragem nas decisões judiciais. $\mathrm{Na}$ ocasião, foram considerados para análise, apenas, os processos cujos pedidos tinham sido deferidos, o que correspondeu a 1.343 processos do total de 30.620 processos disponibilizados pelos juizados. Desses 1.343 foram ainda retirados todos os processos que apresentaram fortes indícios de problemas de registro, o que resultou em uma base de dados final com 1.102 processos com provimento entre 2004 e 2015.

Uma limitação do estudo anterior, como indicado, era a impossibilidade de saber exatamente os valores de danos morais pedidos e concedidos, uma vez que essas informações estavam agregadas, respectivamente, nas informações "valores da causa" e "valores da condenação" constantes na base de dados disponibilizada. Para este estudo, contudo, foi possível obter diretamente dos processos eletrônicos os valores de indenização por danos morais pedidos pelas partes do processo, assim como os valores exatos de indenização deferidos pelos juízes. Por isso, este estudo se baseia em um conjunto de processos retirado dos 1.343 processos selecionados para o estudo anterior. A justificativa para não considerar apenas os 1.102 processos da base de dados final anterior se deve à possibilidade de conferir, na própria fonte, os dados originais sobre os pedidos de danos morais e, se fosse o caso, corrigi-los.

Em relação aos 1343 processos, cinco foram descartados após a observação de que houve acordo entre as partes homologado judicialmente, o que resultou em uma base de dados inicial com 1.338 casos. A distribuição anual desses processos pode ser visualizada no gráfico abaixo. Nele, observa-se o reduzido número de processos com deferimento até 2007 nos dois juizados analisados. Entre 2008 e 2010, tem-se uma elevação no número de processos, que atinge um pico de mais de 500 processos em 2011. A partir de 2011, contudo, a quantidade de processos cai significativamente. 
Gráfico 1- Distribuição anual dos processos: número de processos entre 2004 e 2104

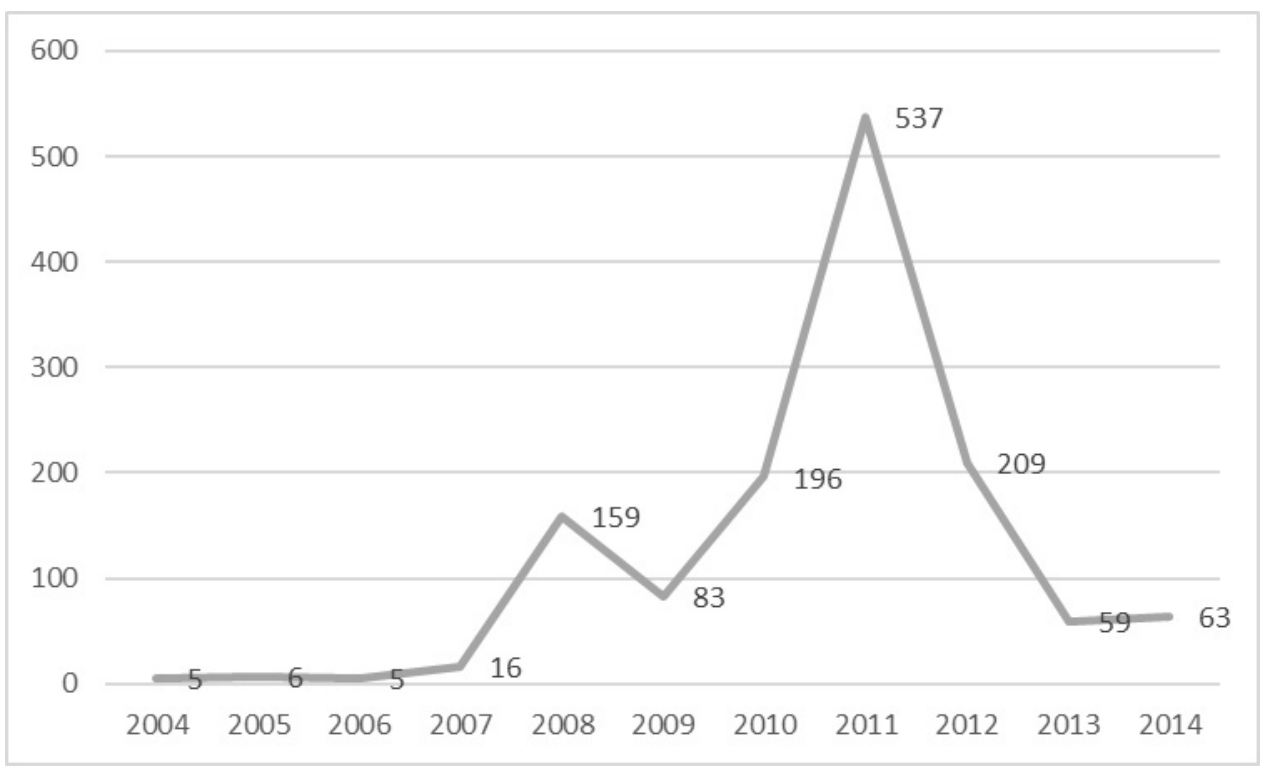

Fonte: TJRJ. Elaboração própria.

Como o objetivo da pesquisa é o teste da hipótese de ancoragem em decisões judiciais envolvendo pedidos de danos morais, foi necessário identificar os valores exatos de indenização pedidos pelas partes, assim como os valores de indenização deferidos pelos juízes. A pesquisa realizada para essa identificação foi feita em 683 processos eletrônicos. Ou seja, foram deixados de fora da análise 655 processos distribuídos nos juizados no formato não eletrônico.

Em relação aos 683 processos eletrônicos, constatou-se que 159 não tinham pedidos de danos morais diretamente formulados pelas partes. Nesses casos, foi pedido que o próprio juiz fixasse o valor de dano moral, o que inviabiliza a análise de influência da heurística de ancoragem, que pressupõe a identificação de um referencial (a "âncora") que afeta o julgamento. Assim, foram coletadas informações de 524 processos com pedidos de indenização de danos morais e que, potencialmente, poderiam ser usados na análise a respeito da influência da heurística de ancoragem. A distribuição anual desses 683 processos (sendo 524 com dados de pedidos de danos morais — "com âncora" - e 159 "sem âncora) pode ser observada no gráfico abaixo. Observa-se que os processos eletrônicos se iniciam em 2011, momento de pico de pedidos de indenização por danos morais nesses juizados, como foi apresentado no gráfico anterior., Dados de 2004 a 2010, portanto, não foram incluídos na análise. Em 2012 há uma forte queda na quantidade de processos, tendência que permanece, embora de forma bem menos acentuada, nos anos seguintes. 
Gráfico 2 - Distribuição anual dos processos eletrônicos: com e sem âncora

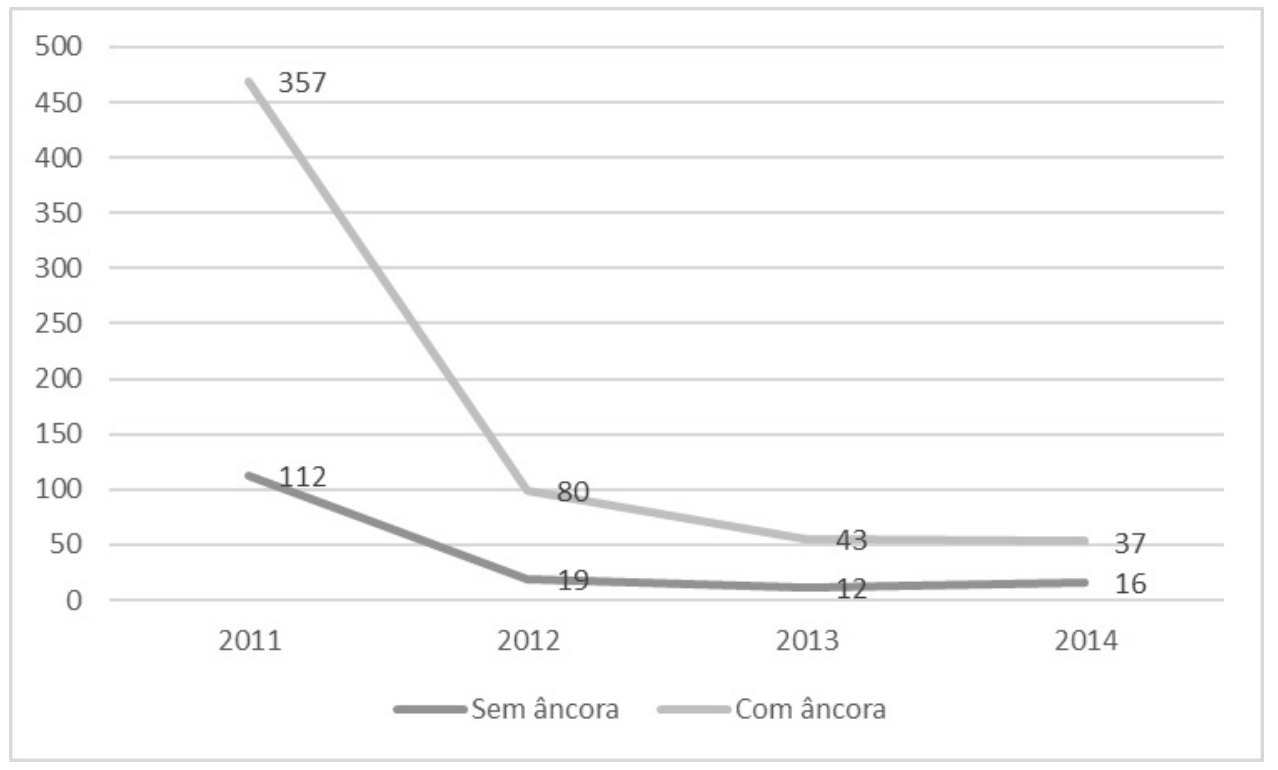

Fonte: TJRJ. Elaboração própria.

Por fim, todos os valores de pedidos de indenização por danos morais foram analisados. Foram excluídos vinte e oito casos que apresentaram inconsistências, com valores de indenização deferidos acima do que foi pedido pelas partes, sessenta e sete casos com valores deferidos computados como zero e outros sete casos, que apresentaram valores muito acima de 40 salários mínimos. Isso resultou em um universo final de 422 processos eletrônicos contendo todos os dados necessários para análise ${ }^{28}$.

\section{ANÁLISE}

Seguindo os procedimentos usados no trabalho anterior, foram realizadas análises de correlação entre os valores de indenização, dessa vez, efetivamente pedidos pelas partes e deferidos na decisão judicial. Vale ressaltar que, ainda, não foi possível identificar claramente processos envolvendo problemas idênticos, mas com variação, apenas, nos valores de pedidos de indenização por danos morais feitos pelas partes ${ }^{29}$. Esta seria uma situação ideal para o teste sobre efeitos de ancoragem em decisões judiciais, comparável ao tipo de teste feito em experimentos. O que se conseguiu fazer foi identificar grandes áreas de pedidos de indenização que podem tornar os processos um pouco mais comparáveis. As áreas definidas foram as seguintes: a) "varejo", o que inclui processos contra empresas de vendas de produtos diversos no varejo, envolvendo empresas como Casas Bahia, Ricardo Eletro, Ponto Frio etc.; b) "telecomunicações”, que se refere a processos

28 Neste estudo foram analisados todos os processos eletrônicos com informações consistentes de pedidos de danos morais dos I e II Juizados Especiais Cíveis. Nesse caso, os processos analisados se enquadram no que Moretin e Bussab chamam de "levantamentos observacionais". Diferente de levantamentos amostrais probabilísticos "que usam mecanismos aleatórios de seleção dos elementos de uma amostra, atribuindo a cada um deles uma probabilidade, conhecida a priori, de pertencer à amostra", nos levantamentos observacionais "os dados são coletados sem que o pesquisador tenha o controle sobre as informações obtidas, exceto eventualmente sobre possíveis erros grosseiros”. Cf. MORETIN, Pedro Alberto; BUSSAB, Wilton de Oliveira. Estatística básica. São Paulo: Saraiva, 2004. p. 261.

29 Isso não significa, porém, que casos semelhantes não tenham sido constatados. Um exemplo envolve os processos 1731 98.2011.8.19.0209 e 15246-06.2011.8.19.0209. Nos dois casos estava em jogo a entrega intempestiva de eletrodomésticos comprados em sites de varejo (respectivamente um ventilador de teto e um refrigerador). Nos dois casos os consumidores começaram a pagar parcelas de financiamento do produto antes de recebê-lo. No primeiro caso, o pedido de indenização por danos morais foi de $\mathrm{R} \$ 10.141,00$, enquanto no segundo o pedido foi de $\mathrm{R} \$ 5.000,00$. Após as decisões, os pedidos de indenização foram deferidos nos montantes de, respectivamente, $\mathrm{R} \$ 4.480,66$ (correspondente a 44,2\% do pedido) e $\mathrm{R} \$ 1.629,37$ (correspondente a 32,58\% do pedido). 
contra empresas de telecomunicações, como empresas de telefonia, provedores de internet etc.; "bancos", que diz respeito a processos contra bancos e financeiras; e "aéreas", formada por processos contra companhias aéreas. Como se nota, os setores foram definidos em função dos réus das ações. Sendo assim, foram feitas análises dos dados com todos os processos, em um primeiro momento e análises em cada uma dessas grandes áreas. Da mesma forma que argumentado no estudo anterior, apesar de não haver condições para um teste ideal sobre os efeitos de ancoragem nas decisões judiciais, o estudo permite observar correlações interessantes entre pedidos de danos morais feitos pelas partes e os valores de indenização por danos morais feitos pelos juízes que podem oferecer algumas pistas a respeito de situações que podem alterar os efeitos desse tipo de heurística. A grande diferença desse estudo, como anunciado, é poder contar com valores exatos de pedidos e deferimentos de danos morais, além de poder observar correlações em áreas específicas (telecomunicações, varejo, bancos, aéreas).

\subsection{Valores pedidos e valores deferidos: análise com todos os processos}

Os valores de indenização por danos morais pedidos apresentam muita variação, como pode ser visualizado no gráfico 3. Em média os pedidos giram em torno de $\mathrm{R} \$ 15.950,00$, mas com elevado desvio padrão (quase $\mathrm{R} \$ 8.786,00)$. O valor mediano é próximo da média, chegando a $\mathrm{R} \$ 13.900,00$. Poucos casos, no entanto, ultrapassam o valor máximo de 40 salários mínimos, já que 75\% dos casos são de até R $24.628,00$ — valor de 40 salários mínimos em 2015 seria de R \$31.520,00. Por outro lado, os valores de indenização deferidos são bem inferiores. A média das indenizações por danos morais concedida no período foi de cerca de $R$ \$ 4.268,00. A distribuição das indenizações deferidas revela que os valores se concentram em níveis relativamente baixos. A grande maioria dos processos (75\%) não obteve indenização acima de $\mathrm{R} \$ 5.733,00$ (gráfico 4).

Gráfico 3 - Distribução dos valores de pedidos de danos morais (dados deflacionados 2015)

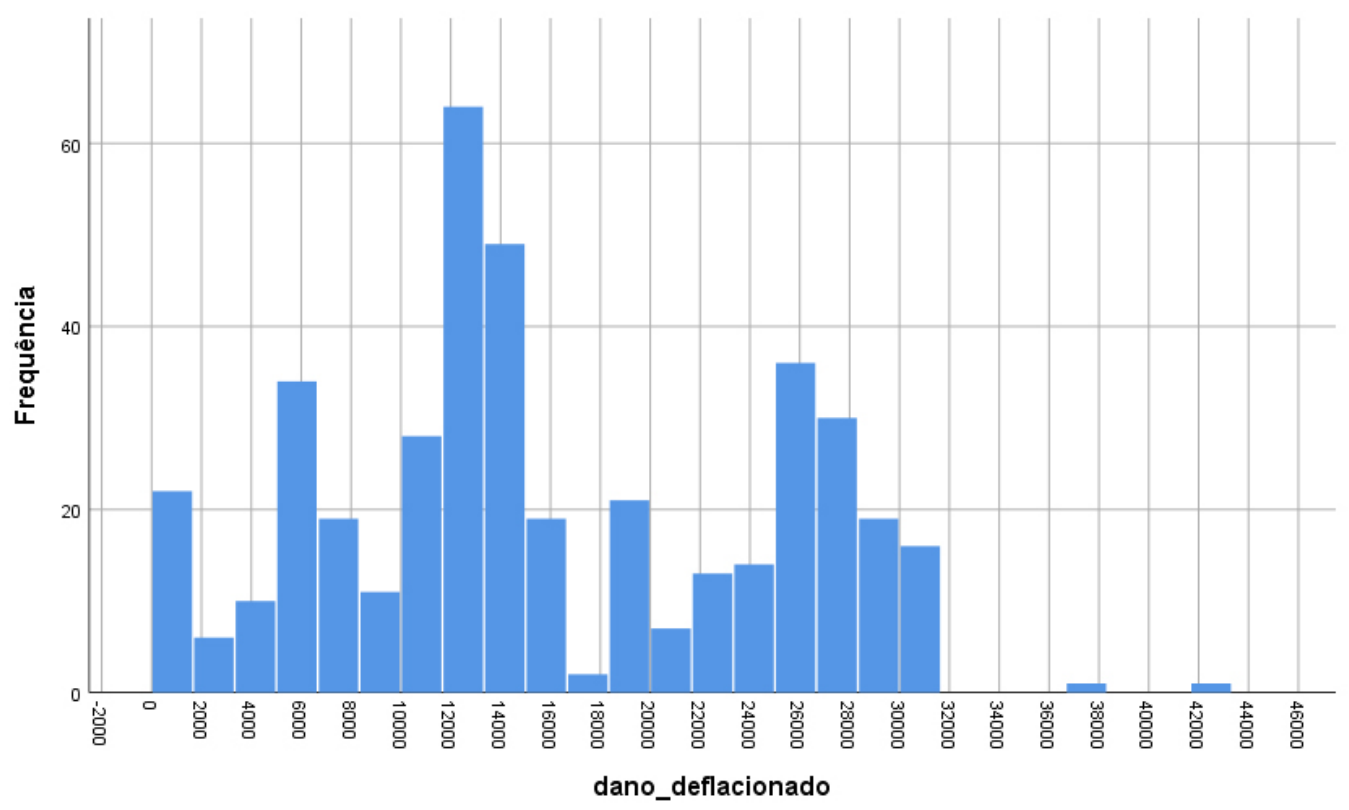

Fonte: TJRJ. Elaboração própria. 
Gráfico 4 - Distribuição dos valores de pedidos de danos morais (dados deflacionados 2015)

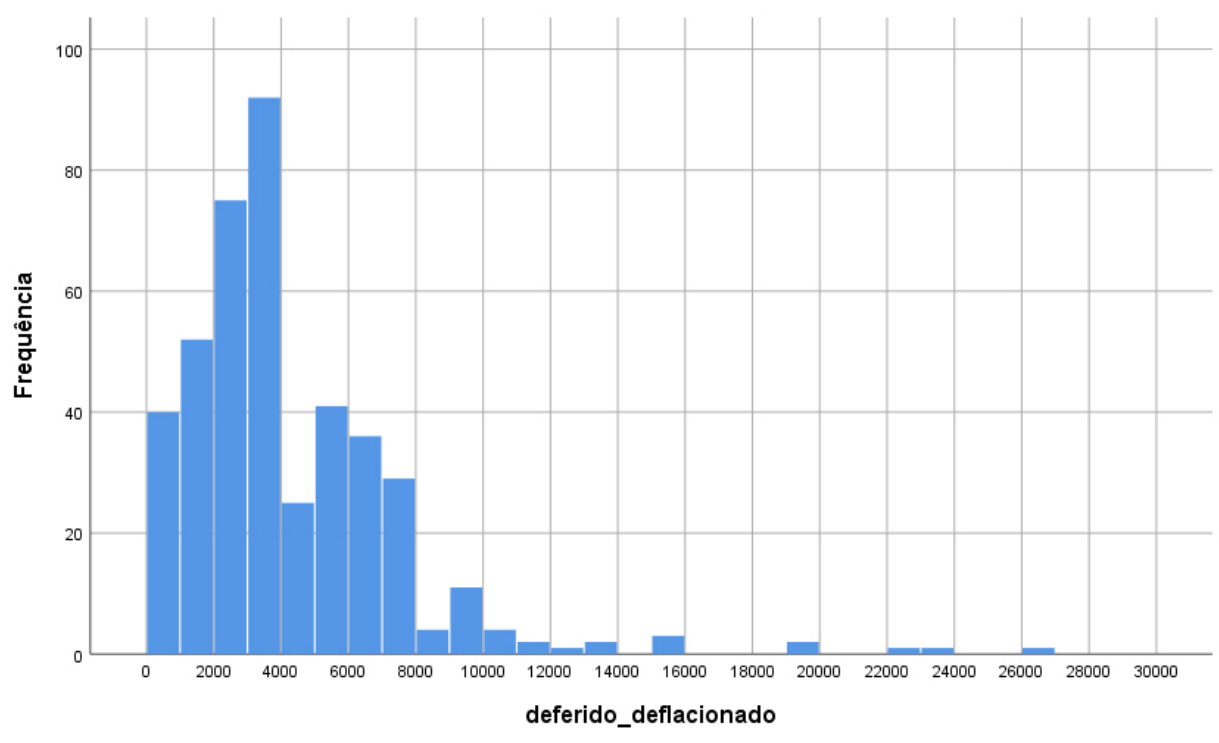

Fonte: TJRJ. Elaboração própria.

Tabela 1 - Valores pedidos e deferidos de indenização por danos morais: média, desvio padrão, mediana e percentil 75

\begin{tabular}{l|l|l}
\hline & $\begin{array}{l}\text { Valores Pedidos } \\
(\mathbf{R} \$ \mathbf{)}\end{array}$ & $\begin{array}{l}\text { Valores deferidos } \\
(\mathbf{R} \$ \mathbf{)}\end{array}$ \\
\hline Média & 15950,7 & 4268,0 \\
\hline Desvio & 8786,8 & 3346,0 \\
\hline Mediana & 13912,5 & 3860,9 \\
\hline Percentil 0,75 & 24628,9 & 5733,3 \\
\hline
\end{tabular}

Fonte: TJRJ. Elaboração própria.

A correlação entre os valores de indenização por danos morais pedidos e os valores deferidos pelos juízes revelam uma associação fraca entre ambos (gráfico 5). O Índice de Correlação de Spearman nesse caso é de $0,38^{30}$. Como pode ser observado no gráfico abaixo, a variação em torno da reta de ajuste é bastante elevada, o que indica que há muita variação nos valores deferidos para um mesmo valor pedido. Ou seja, não há uma clara tendência de aumento de valor deferido à medida que as partes aumentam os valores pedidos. A princípio, portanto, haveria poucos indícios de algum tipo de efeito de ancoragem na decisão judicial. No entanto, é importante lembrar que os dados agregam casos bastante diferentes, que vão desde pedidos de indenização feitos a companhias aéreas a casos envolvendo telecomunicações ou empresas de entregas de produtos de varejo.

30 Para mensurar o grau de associação entre os valores de danos morais pedidos e deferidos, foi utilizado a correlação de Spearman, que é um teste estatístico não paramétrico e que, portanto, não exige nenhum pressuposto de normalidade na distribuição dos dados analisados. A correlação de Spearman foi escolhida uma vez que, tanto os valores de pedidos de danos morais como os valores deferidos pelos juízes não apresentam uma distribuição normal. 
Gráfico 5 - Relação entre valor de indenização por dano moral pedido e valor deferido

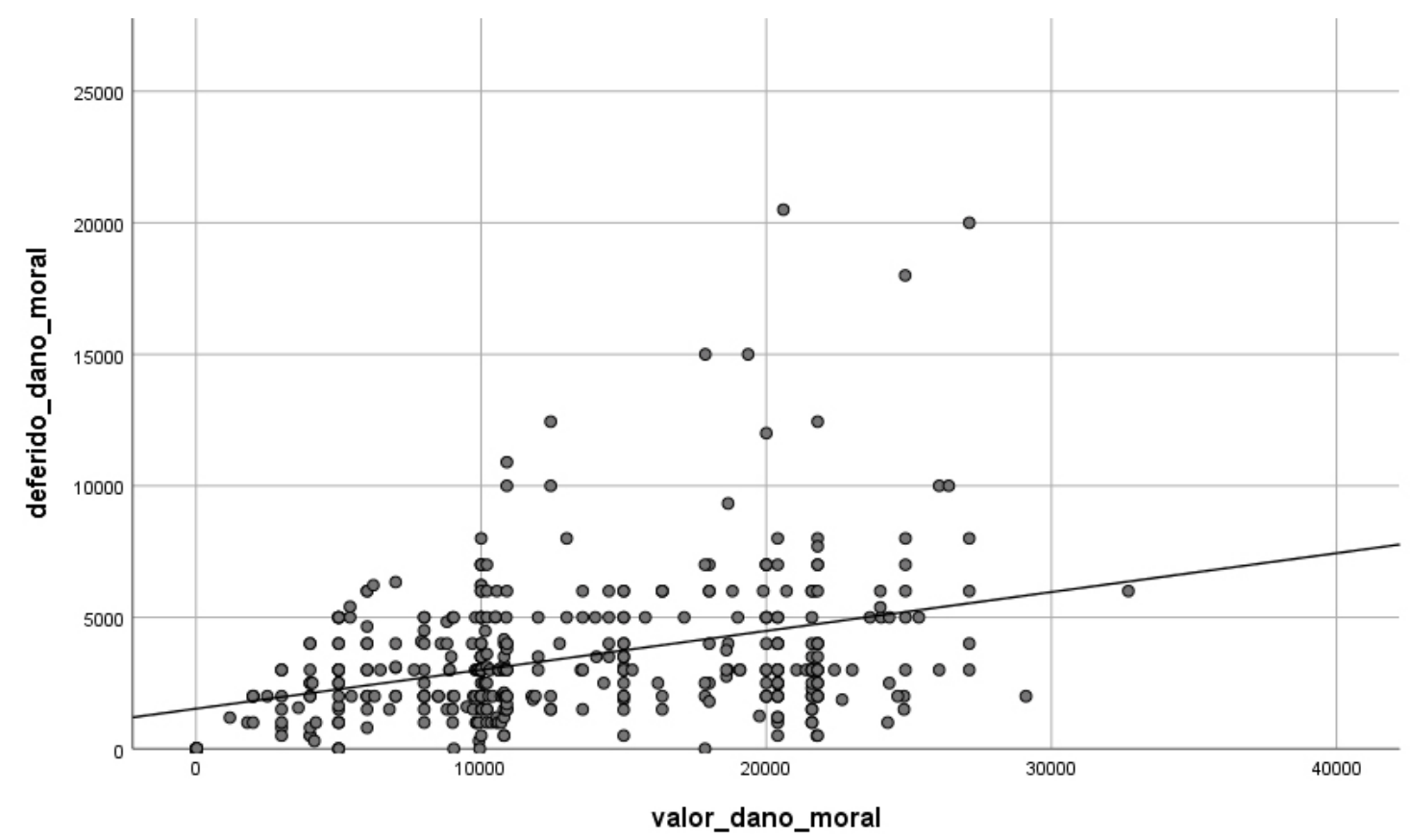

Fonte: TJRJ. Elaboração própria.

Mesmo assim, o estudo explorou hipóteses alternativas capazes de fornecer indicações do efeito de ancoragem nas decisões. Especificamente e seguindo os achados do estudo anterior, foram feitas correlações para testar se as seguintes situações poderiam alterar possíveis efeitos de ancoragem nas decisões judiciais: se pedidos de indenização com valores mais baixos (abaixo do valor mediano) ou pedidos de indenização com valores "redondos" poderiam deixar os juízes mais suscetíveis à influência da heurística de ancoragem do que processos em que os pedidos apresentam valores mais elevados ou em que os pedidos são formulados por meio de valores "quebrados". A grande diferença é que, neste estudo, foi possível realizar esses testes contando com os valores exatos dos pedidos de indenização por danos morais feitos pelas partes concedidos na decisão judicial.

Nesse sentido, foi realizada uma comparação nas correlações entre os pedidos de indenização e a quantia deferida na decisão judicial envolvendo um grupo com processos com valores abaixo de $\mathrm{R} \$ 15.000,00$ (aproximadamente o valor mediano e aproximadamente o correspondente ao valor de 20 salários mínimos) e outro com os demais casos (acima de $\mathrm{R} \$ 15.000,00)$. Os resultados das correlações nesse caso revelam diferença substantiva ente a intensidade da associação entre os valores pedidos e concedidos nas duas situações. A respeito dos pedidos feitos abaixo do valor de $\mathrm{R} \$ 15.000,00$, a correlação é de 0,36. Em relação aos processos com pedidos acima desse valor, a correlação é muito fraca, atingindo 0,06 . Essa diferença é mais acentuada que a encontrada no trabalho anterior $(0,26$, contra 0,18$)$. Ainda assim, poderíamos manter a hipótese explicativa levantada no texto anterior de acordo com a qual a aproximação do pedido de dano moral do teto estabelecido em lei acaba por neutralizar a influência da heurística de ancoragem, o que pode derivar tanto da experiência acumulada dos magistrados como de eventual papel dissuasivo da regra jurídica dos vieses que podem ser produzidos pela influência de fatores intuitivos no julgamento. 
Gráfico 6 - Relação entre valores pedidos e valores deferidos abaixo de $\mathrm{R} \$ 15 \mathrm{mil}(\mathrm{N}=244)$

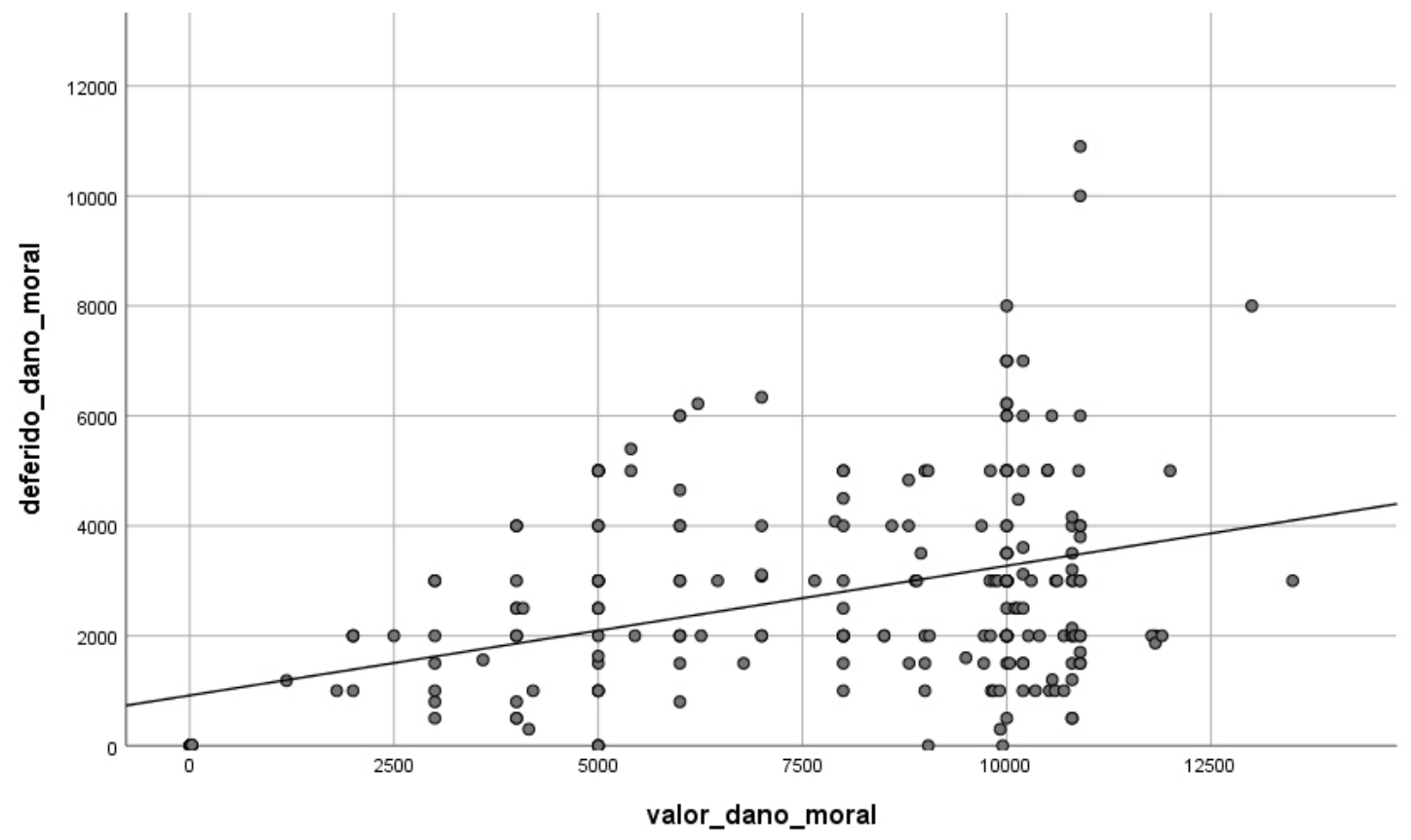

Fonte: TJRJ. Elaboração própria.

Gráfico 7 - Relação entre valores pedidos e valores deferidos acima de R $\$ 15$ mil (N 121)

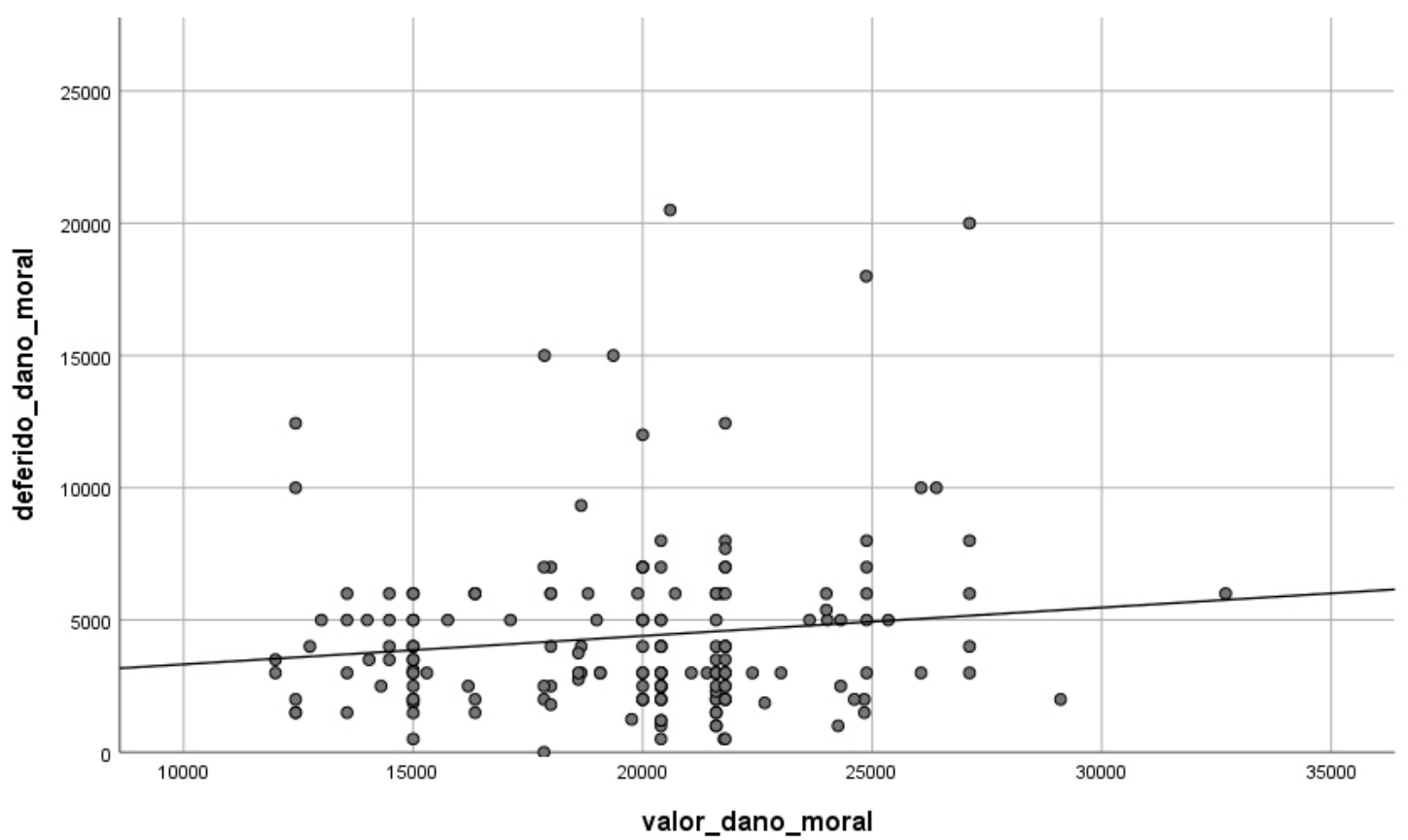

Fonte: TJRJ. Elaboração própria.

A outra hipótese testada refere-se à possibilidade de diferença no efeito de ancoragem nos casos em que os pedidos de indenização por danos morais apresentam valores "redondos" e aqueles em que os pedidos tem valores "quebrados". Da mesma forma que o teste feito acima, esses dois grupos foram separados e a correlação entre os valores pedidos e os valores deferidos foi calculada em cada caso. A correlação observada entre valores pedidos e deferidos para o grupo de pedidos com valores "redondos" é de 0,27, bem menor que o de 0,59 observado no grupo com pedidos com valores "quebrados". Embora a diferença entre essas correlações não seja elevada, esse resultado segue na mesma direção do estudo anterior e sugere que os 
pedidos baseados em valores quebrados levariam a um maior esforço de quantificação dos danos morais por parte dos juízes do que os valores redondos. Ou seja, assim como no estudo anterior, as análises comparativas acima parecem indicar que o contexto da tomada de decisão afeta os efeitos da heurística de ancoragem em decisões judiciais - no caso valores elevados e quebrados levariam a um maior esforço de quantificação da indenização feita pelos juízes.

Gráfico 8 - Relação entre valores pedidos e valores deferidos para valores redondos $\mathrm{N}=300$

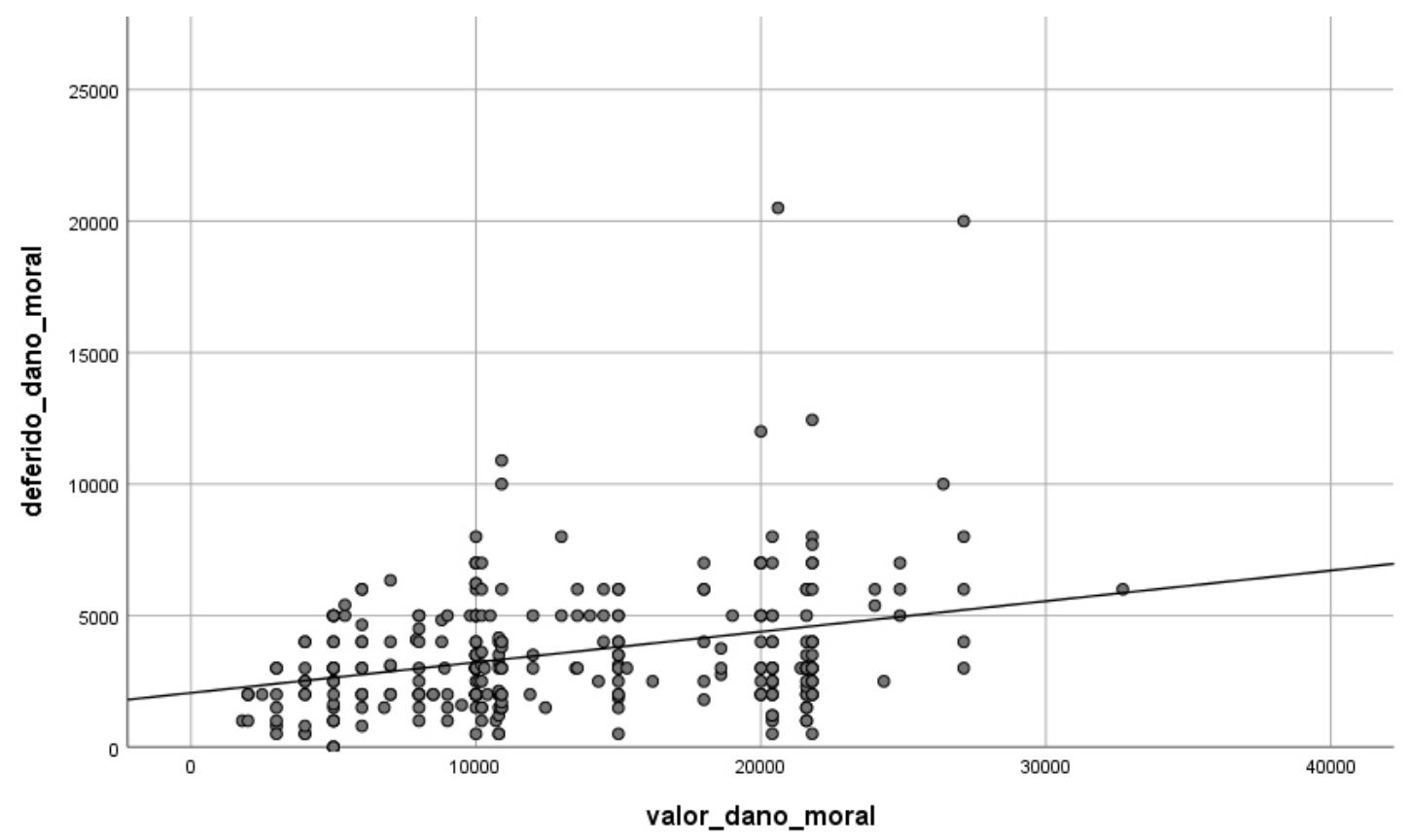

Fonte: TJRJ. Elaboração própria.

Gráfico 9 - Relação entre valores pedidos e valores deferidos para valores quebrados $\mathrm{N}=137$

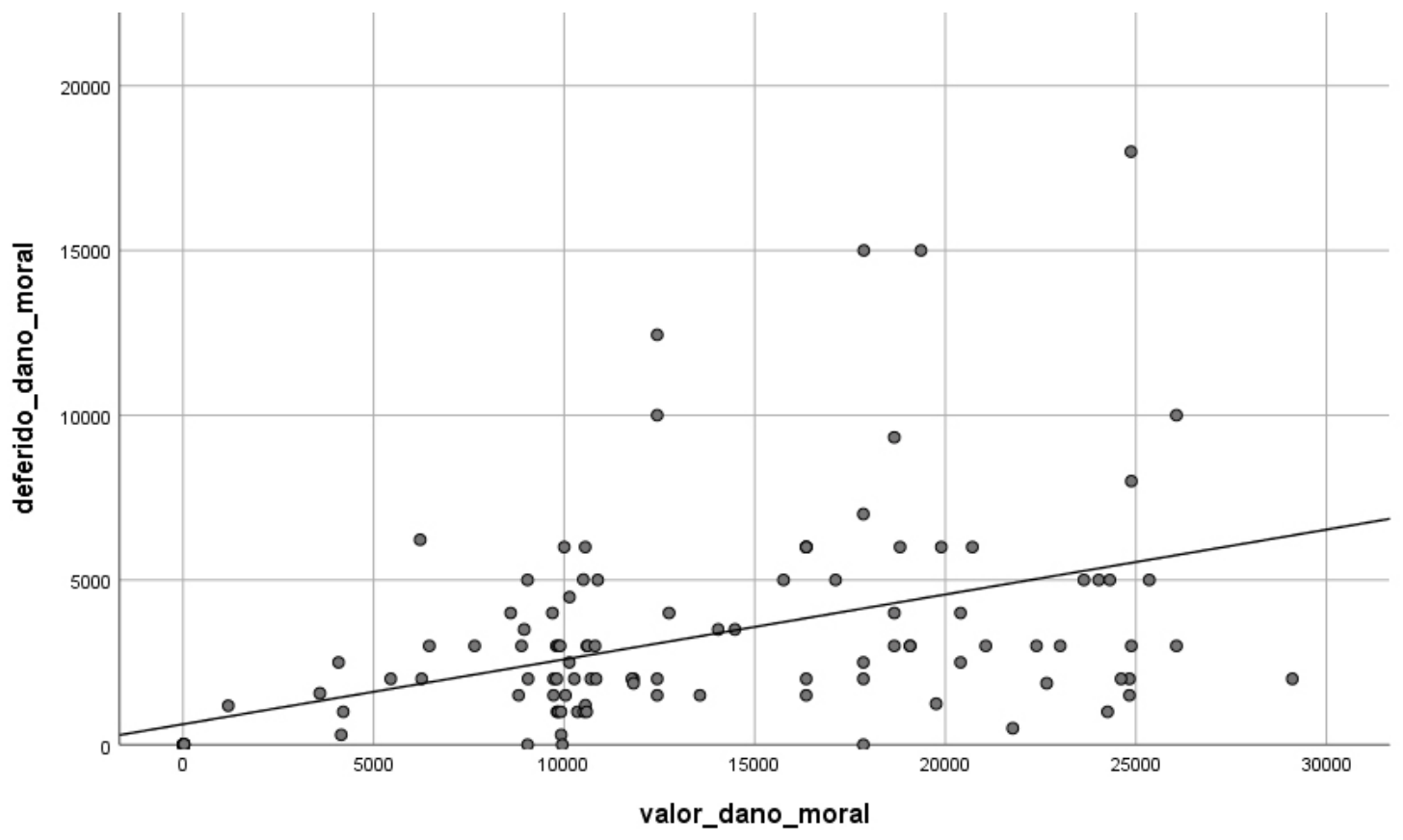

Fonte: TJRJ. Elaboração própria. 
3.2. Valores pedidos e valores deferidos: análise das áreas de telecomunicações, varejo, bancos e setor aéreo

Por fim, foram realizados testes de correlação em cada uma das áreas definidas acima: telecomunicações, varejo, bancos e aéreas. Os casos foram agrupados nesses grupos em razão dos réus. Em relação ao primeiro estudo, a base de dados permitiu estudos mais focados em razão do tema envolvido, o que possibilitou explorar eventuais variações do efeito de ancoragem. A partir dessa categorização, os valores médios de indenização por danos morais feitos nas áreas de telecomunicações e bancos são superiores aos valores pedidos nas demais áreas - e, também superior ao valor médio considerando-se todos os casos analisados (tabela 1). Assim como ocorre em todos os casos, há uma grande diferença entre os valores pedidos e os valores deferidos na decisão judicial. Em síntese, pode-se observar que os valores pedidos em questões que envolvem o setor bancário são os maiores, enquanto os valores deferidos no setor aéreo são os mais elevados. Vale ressaltar que, na média, os valores deferidos no caso das aéreas chega a ser quase o dobro do valor deferido nas áreas varejo e telecomunicações.

Tabela 2 - Valores pedidos e deferidos de indenização por danos morais nas áreas de telecomunicações, varejo, bancos e aéreas: média, desvio padrão, mediana e percentil 75

\begin{tabular}{|c|c|c|c|c|c|c|c|c|}
\hline & \multicolumn{2}{|c|}{ Telecomunicações } & \multicolumn{2}{|c|}{ Varejo } & \multicolumn{2}{|c|}{ Bancos } & \multicolumn{2}{|c|}{ Setor aéreo } \\
\hline & $\begin{array}{c}\text { Valor } \\
\text { pedido } \\
(\mathrm{R} \$)\end{array}$ & $\begin{array}{c}\text { Valor } \\
\text { deferido } \\
(\mathrm{R} \$)\end{array}$ & $\begin{array}{c}\begin{array}{c}\text { Valor } \\
\text { pedido }\end{array} \\
(\mathrm{R} \$)\end{array}$ & $\begin{array}{c}\text { Valor } \\
\text { deferido } \\
(\mathrm{R} \$)\end{array}$ & $\begin{array}{c}\text { Valor } \\
\text { pedido } \\
(\mathrm{R} \$)\end{array}$ & $\begin{array}{c}\text { Valor } \\
\text { deferido } \\
(\mathrm{R} \$)\end{array}$ & $\begin{array}{c}\text { Valor } \\
\text { pedido } \\
(\mathrm{R} \$)\end{array}$ & $\begin{array}{c}\text { Valor } \\
\text { deferido } \\
(\mathrm{R} \$)\end{array}$ \\
\hline Média & 18287,9 & 3725,1 & 14438,3 & 3468,6 & 19135,3 & 4878,5 & 15756,1 & 6717,7 \\
\hline Desvio & 9077,1 & 2166,7 & 8811,2 & 2313,1 & 8184,4 & 4390,2 & 8082,9 & 5358,5 \\
\hline Mediana & 13003,6 & 3901,1 & 13003,6 & 2600,7 & 19505,4 & 3901.0 & 14066,6 & 5650,0 \\
\hline Percentil 75 & 26527,3 & 4057,3 & 21260,9 & 4885,9 & 26783,2 & 5350,1 & 23211,4 & 7802,1 \\
\hline Spearman & \multicolumn{2}{|c|}{0,29} & \multicolumn{2}{|c|}{0,38} & \multicolumn{2}{|c|}{0,25} & \multicolumn{2}{|c|}{0,52} \\
\hline $\mathbf{N}$ & \multicolumn{2}{|c|}{73} & \multicolumn{2}{|c|}{182} & \multicolumn{2}{|c|}{50} & \multicolumn{2}{|c|}{54} \\
\hline
\end{tabular}

Fonte: TJRJ. Elaboração própria.

As correlações entre os valores de indenização pedidos e deferidos segue o mesmo padrão dos valores encontrados na análise com todos os casos, em torno de 0,30 , exceto no setor "aéreas". De fato, a correlação encontrada nesse setor regulado difere muito das demais, atingindo um índice de 0,52 - a correlação mais forte observada em todo o estudo. As correlações entre os valores de danos morais pedidos e concedidos dessas quatro grandes áreas podem ser observadas nos gráficos abaixo. O gráfico 10 apresenta a correlação calculada para os pedidos de danos morais da área telecomunicações. Observa-se dois grandes agrupamentos de pedidos, um em torno de $\mathrm{R} \$ 10.000,00$ e outro em torno de $\mathrm{R} \$ 20.000,00$ a $\mathrm{R} \$ 25.000,00$. Em ambos os caos há uma grande variação de valores de danos morais deferidos. $\mathrm{Na}$ linha de pedidos na casa dos 25 mil reais, por exemplo, os valores deferidos vão de cerca de 2 mil reais a 12 mil reais. Seria preciso saber se há grandes diferenças nos problemas relacionados aos pedidos nesse setor para entender os motivos dessa variação. No entanto, embora a correlação seja baixa e a variação seja razoavelmente alta, os valores mais altos homologados nas decisões judiciais se encontram justamente nos pedidos de danos morais mais elevados. No primeiro agrupamento, por exemplo, os valores deferidos de danos morais não chegam a 8 mil reais. Uma das possíveis explicações para essa aparente homogeneização pode ser o tabelamento dos valores deferidos pelos juízos. Para explorar essa hipótese explicativa, buscamos a ocorrência de valores que se repetem com alguma frequência.

No universo total de casos, os valores exatos de $\mathrm{R} \$ 2.000,00$ e $\mathrm{R} \$ 3.000,00$ são os mais recorrentes, correspondendo, respectivamente, a 14,9\% e 15,2\% do total - sendo que os valores exatos de $\mathrm{R} \$ 1.000,00$ (5\%), $\mathrm{R} \$ 2.000,00(14,9 \%), \mathrm{R} \$ 3.000,00(15,2 \%), \mathrm{R} \$ 4.000,00$ e $\mathrm{R} \$ 5.000,00$ (7,3\%) somam um pouco mais de me- 
tade das indenizações por danos morais (51,9\%). Esse padrão de valores frequentes de indenização se repete nos setores de telecomunicações - no qual o valor de indenização de $\mathrm{R} \$ 2.000,00$ corresponde a 15,1\% e o de $\mathrm{R} \$ 3.000,00$ soma $23,3 \%$ dos processos - e varejo - com o valor de indenização de $\mathrm{R} \$ 2.000,00$ atingindo $17 \%$ dos casos e o de $\mathrm{R} \$ 3.000,0013,2 \%$. No setor aéreas, os valores de indenização mais recorrentes são de $\mathrm{R} \$ 3.000,00$ (20,4\%) e R \$ 6.000,00 (18,4\%). Já no setor bancos as indenizações mais frequentes são, as de $\mathrm{R} \$ 2.000,00, \mathrm{R} \$ 3.000,00$ e $\mathrm{R} \$ 4.000,00$, todas elas igualmente atingindo 16\% do total de processos. Embora não se possa inferir a existência de tabelamento a partir dos dados levantados, é curioso notar a concentração de valores deferidos em uma faixa que varia de $\mathrm{R} \$ 1.000,00$ a $\mathrm{R} \$ 5.000,00$. Além disso, a frequência com que os mesmos valores aparecem nos Juizados analisados podem sugerir que casos diferentes recebem o mesmo tratamento.

Gráfico 10 - Relação entre valor de indenização por dano moral pedido e valor deferido: Telecomunicações

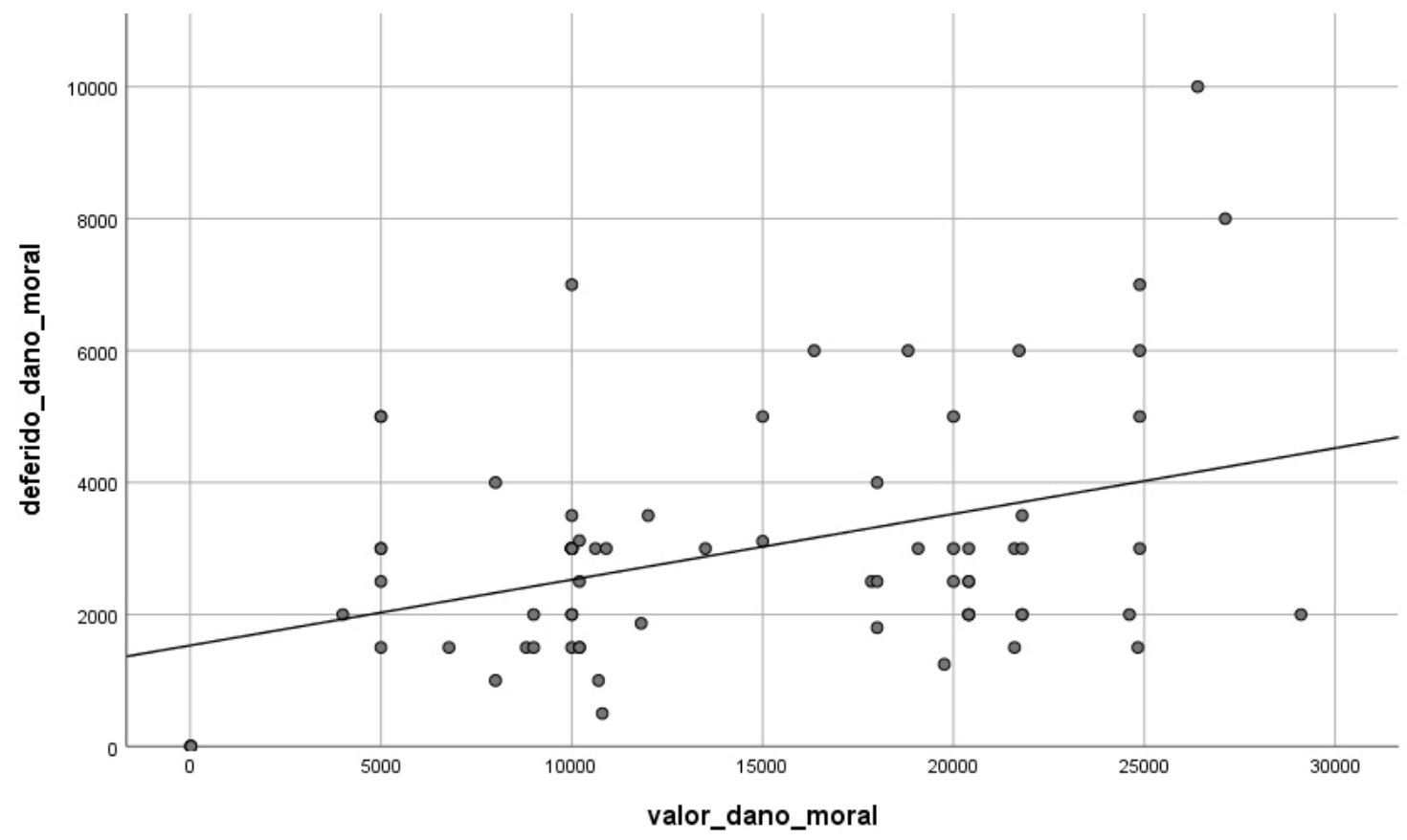

Fonte: TJRJ. Elaboração própria.

As correlações encontradas no setor de varejo e nos bancos apresentam uma distribuição um pouco diferente. Há uma grande dispersão de valores deferidos em todas as faixas de pedidos de indenização por danos morais, atingindo em sua maioria até 8 mil reais no primeiro caso e até 7 mil reais no segundo (gráficos 11 e 12). A diferença é que no setor bancos há um caso discrepante em que um alto valor de indenização foi pedido e concedido (o valor pedido, atualizado para valores de 2015 , foi de $R \$ 26.787,87$ e o valor deferido foi de $\mathrm{R} \$ 26.657,34)$. 
Gráfico 11 - Relação entre valor de indenização por dano moral pedido e valor deferido: Varejo

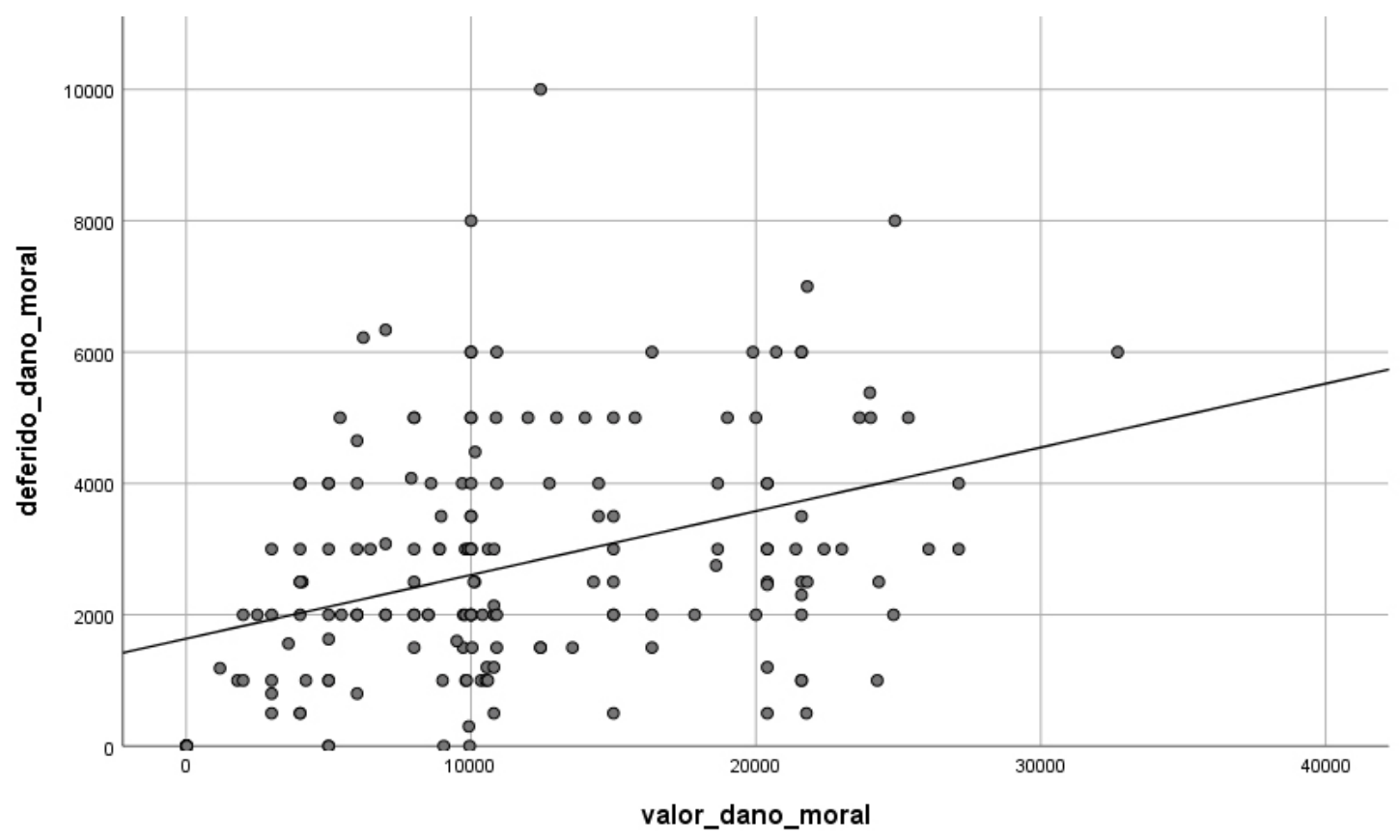

Fonte: TJRJ. Elaboração própria.

Gráfico 12 - Relação entre valor de indenização por dano moral pedido e valor deferido: Bancos

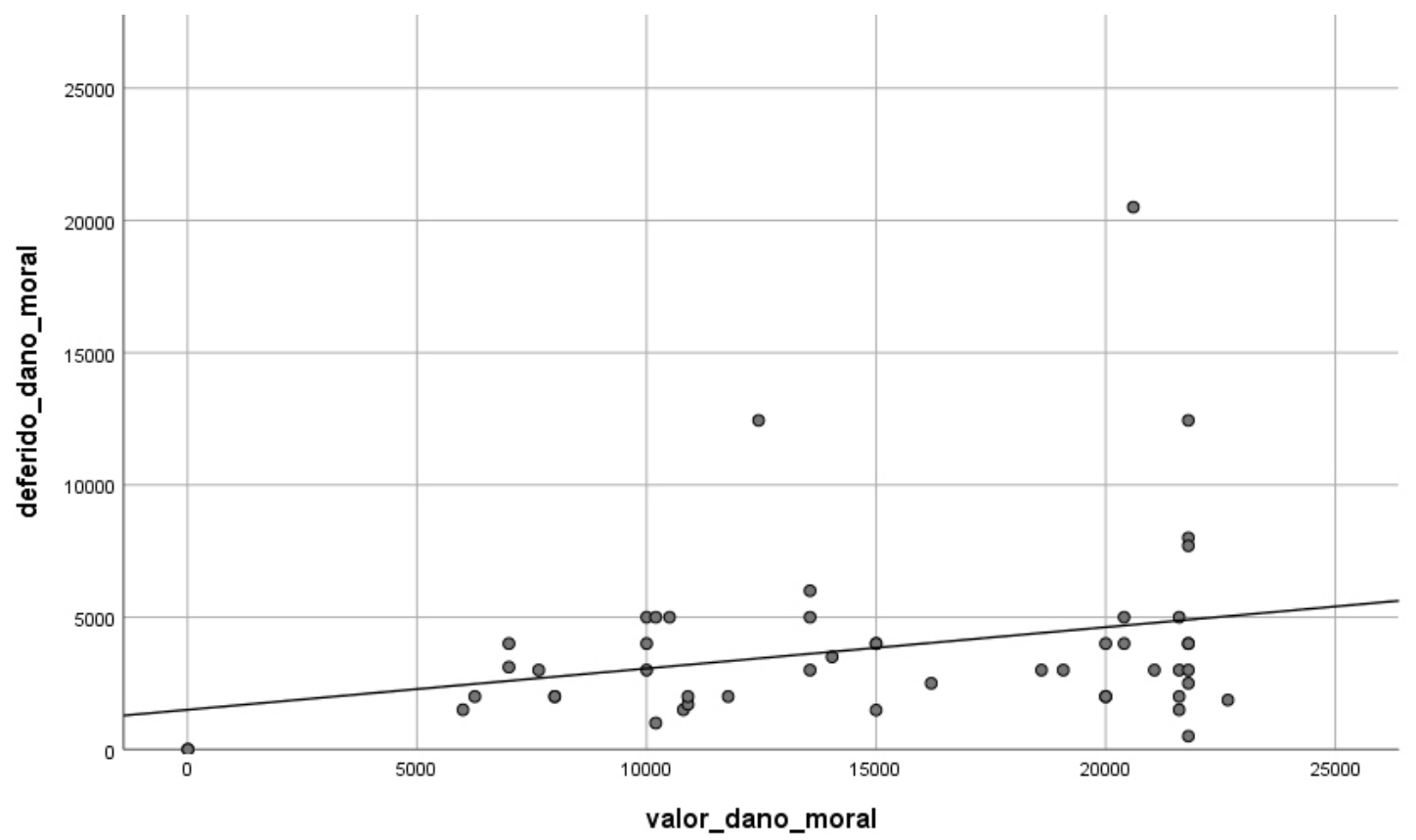

Fonte: TJRJ. Elaboração própria.

Por fim, o gráfico 13 apresenta a correlação calculada para o setor aéreas. Observa-se nitidamente a correlação média entre o valor de dano moral pedido e concedido nesse caso. A questão seria saber o que diferenciaria esse setor dos demais casos em que as correlações encontradas são mais baixas e mais semelhantes a encontrada quando todos os dados são levados em consideração. 
Gráfico 13 - Relação entre valor de indenização por dano moral pedido e valor deferido: Aéreas

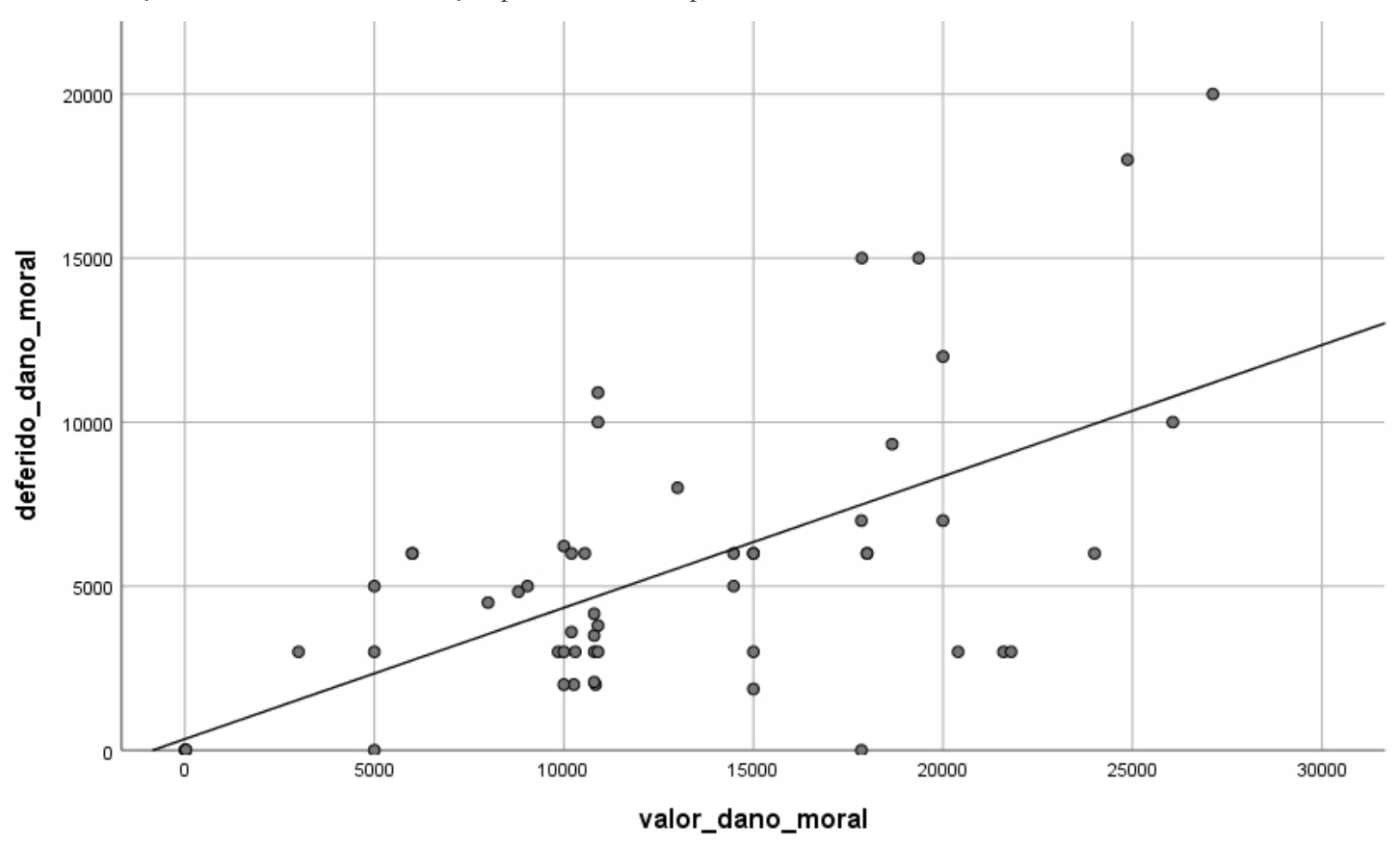

Fonte: TJRJ. Elaboração própria.

\section{Considerações finais}

O presente trabalho buscou investigar a influência de fatores intuitivos na tomada de decisão judicial. Mais especificamente, testes de correlação foram feitos visando à identificação de efeitos de ancoragem na apreciação de pedidos de danos morais em Juizados Especiais da Barra da Tijuca, no Rio de Janeiro. Ao contrário do que foi feito em estudo anterior, desta vez foi possível reunir informações suficientes para apreciar as correlações entre o valor efetivamente pedido pelas partes (e não o valor da causa) e o valor de danos morais deferido ao final. Além disso, foi possível, em razão dos réus, agrupar os casos analisados em quatro setores específicos (varejo, telecomunicações, bancário e aéreo), o que permitiu explorar correlações em diferentes universos. Partiu-se da hipótese de que os valores sugeridos pelas partes funcionariam como âncoras a partir das quais os juízes fixariam os valores, ainda que pudessem variar por setores. Assim, casos semelhantes poderiam ter tratamento diferente apenas em razão dos valores pedidos pelas partes em cada caso.

As análises foram feitas com um conjunto de 524 processos tomando como referência o valor pedido efetivamente pelos autores, e não o valor da causa. As análises de correlação, no geral, confirmaram as conclusões encontradas quando apenas o valor da causa foi usado como possível âncora. Isso significa, em primeiro lugar, que, assim como na análise anterior, valores pedidos mais altos tendem a manter uma associação mais fraca com os valores deferidos. Ao contrário disso, em segundo lugar, quanto mais baixo o valor pedido, maior é a correlação que se pode estabelecer entre a referência indicada pelo autor e o valor deferido judicialmente. Ademais, em terceiro lugar, valores "quebrados" tendem a estar mais fortemente correlacionados aos montantes deferidos, ao contrário do que ocorre com valores "redondos". Em todos os casos, no entanto, as correlações não foram fortes o suficiente para justificarem a constatação de influência da heurística de ajuste e ancoragem nos julgamentos, o que permite afirmar que a hipótese da qual se partiu não foi confirmada. Finalmente, a presente análise confirmou a plausibilidade da análise anterior, que assumiu não ser necessariamente um problema na análise de possível influência de heurística de ancoragem 
em decisões de Juizados Especiais Cíveis explorar as correlações tendo como referência o valor atribuído à causa. Isso porque, em razão de características típicas dos processos (como a possibilidade de a ação ser proposta sem assistência advocatícia, a regra de acesso sem a necessidade de pagamento de custas e não haver, salvo na hipótese de recurso, sucumbência ${ }^{31}$ ), tenderia a haver identidade entre o valor da causa e o valor pedido pelas partes, notadamente nos casos em que o pedido de dano moral não fosse cumulado com pedido de dano material.

As informações contidas na nova base dados explorada neste trabalho permitiram, ainda, testes de correlação entre valores pedidos e deferidos em razão do tema envolvido nos casos. Tomando por base os diferentes réus em face dos quais foram propostas as ações apreciadas, os processos foram agrupados em quatro grandes setores: telecomunicações, varejo, transporte aéreo e bancário. Em cada um dos setores, as correlações gerais se mantiveram, exceto nas questões envolvendo o setor aéreo. Nesse terreno, o índice de correlação de Spearman atinge 0,57 , o que sugere uma influência mais forte da heurística de ancoragem na tomada de decisão judicial. Esse é, sem dúvida, um dado que merece a especial atenção em estudos posteriores.

A não constatação de influência da heurística de ancoragem, ressalvado os casos envolvendo o setor aéreo, não pode, contudo, ser considerado de todo irrelevante. Se, por um lado, parece haver pouco espaço para a afetação de processos decisórios reais por fatores intuitivos, por outro não se pode dizer que a prática judicial relacionada à fixação de danos morais possa ser considerada funcional. Tabelamentos de danos morais e outras inclinações do comportamento judicial que evitam a particularização dos casos podem revelar problemas jurídicos que estão para além da influência de vieses na tomada de decisão. A não confirmação da hipótese de que se partiu e a sugestão de que outras disfuncionalidades podem afetar a decisão judicial seguem como conclusões importantes para inspirar o desenvolvimento de futuras pesquisas destinadas à compreensão empiricamente informada de processos reais de tomada de decisão jurídica e a busca por soluções adequadas para os diagnósticos formulados.

\section{REFERÊNCIAS}

ALEXY, Robert. Principais elementos de uma teoria da dupla natureza do direito. Revista de Direito Administrativo, n. 253, p. 9-29, 2010.

ARGUELHES, Diego Werneck; LEAL, Fernando. O argumento das “capacidades institucionais" entre a banalidade, a redundância e o absurdo. Direito, Estado e Sociedade, n. 38, p. 6-50, jan./jun. 2011.

BARROSO, Luís Roberto. A doutrina brasileira da efetividade. In: BARROSO, Luís Roberto. (Org.). O direito constitucional e a efetividade de suas normas: limites e possibilidades da Constituição brasileira. 8. ed. Rio de Janeiro: Renovar, 2006.

ENGLICH, Birte; MUSSWEILER, Thomas; STRACK, Fritz. Playing dice with criminal sentences: the influence of irrelevant anchors on expert's judicial decision-making. Personality and Social Psychology Bulletin, v. 32, n. 2, p. 188-200, fev. 2006.

ESTADOS UNIDOS DA AMÉRICA. Library of Congress. General information. Disponível em: < https:// www.loc.gov/about/general-information/\#year-at-a-glance>. Acesso em: 22 maio 2018.

FARIÑA, Francisca; ARCE, Ramón; NOVO, Mercedes. Anchoring in judicial decision-making. Psychology in Spain, v. 7, n. 1, p. 56-65, 2003.

31 LEAL, Fernando; RIBEIRO, Leandro Molhano. O direito é sempre relevante? Heurística de ancoragem e fixação de valores indenizatórios em pedidos de dano moral em juizados especiais do Rio de Janeiro. Direitos Fundamentais e Justiça, Belo Horizonte, a. 10 , n. 35, p. 253-284, jul./ dez. 2016. p. 268, nota 22. 
GUTHRIE, Chris; RACHLINSKI, Jeffrey; WISTRICH, Andrew. Blinking on the bench: how judges decide cases. Cornell Law Faculty Publications, v. 93, paper 917, p. 1-43, 2007.

KAHNEMAN, Daniel. Maps of bounded rationality: psychology for behavioral economics. The American Economic Review, v. 93, n. 5, p. 1449-1475, dez. 2003.

KAHNEMAN, Daniel. Rápido e devagar: duas formas de pensar. Objetiva: Rio de Janeiro, 2012.

KAHNEMAN, Daniel; SLOVIC, Paul; TVERSKY, Amos. Judgment under uncertainty: heuristics and biases. New York: Cambridge University Press, 1982.

LEAL, Fernando; RIBEIRO, Leandro Molhano. O direito é sempre relevante? Heurística de ancoragem e fixação de valores indenizatórios em pedidos de dano moral em juizados especiais do Rio de Janeiro. Direitos Fundamentais e Justiça, Belo Horizonte, a. 10, n. 35, p. 253-284, jul./dez. 2016.

MORETIN, Pedro Alberto; BUSSAB, Wilton de Oliveira. Estatística básica. São Paulo: Saraiva, 2004.

SIMON, Herbert A. A behavioral model of rational choice. The Quarterly Journal of Economics, v. 69, n. 1, p. 99-118, fev. 1955.

SIMON, Herbert A. Theories of decision-making in economics and behavioral science. The American Economic Review, v. 49, n. 3, p. 253-283, jun. 1959.

SOUZA NETO, Cláudio Pereira de. Fundamentação e normatividade dos direitos fundamentais: uma reconstrução teórica à luz do princípio democrático. In: BARROSO, Luís Roberto (Org). A nova interpretação constitucional: ponderação, direitos fundamentais e relações privadas. Rio de Janeiro: Renovar, 2006.

VERMEULE, Adrian. Three strategies of interpretation. San Diego Law Review, v. 42, p. 607-628, 2005. 


\section{La protección de los derechos políticos frente a las funciones disciplinarias de las autoridades administrativas: subsidiariedad y deferencia en el sistema interamericano de derechos humanos*}

\author{
The protection of political rights against \\ the disciplinary functions of administrative \\ authorities: subsidiarity and deference in the \\ inter-american human rights system
}

Jorge Ernesto Roa Roa**
* Artigo convidado

** Doctor en Derecho (summa cum laude) por la Universidad Pompeu Fabra de Barcelona. LL.M. en Ciencias Jurídicas Avanzadas por la Universidad Pompeu Fabra de Barcelona y LL.M. en Gobernanza y Derechos Humanos por la Universidad Autónoma de Madrid. Profesor de Derecho Constitucional y Derecho Público Comparado de la Universidad Externado de Colombia. Email: jorgeroaroa@gmail. com

\section{Resumen}

Este artículo analiza una de las tensiones más importantes entre la protección de los derechos políticos -tanto de los funcionarios públicos elegidos popularmente como de sus electores- $y$ las funciones disciplinarias de algunas autoridades administrativas. Esa tensión se profundiza en la medida en que las normas constitucionales nacionales y los tratados internacionales también protegen esas funciones de las autoridades disciplinarias con el fin de que estas persigan y sancionen la corrupción. El objetivo es preservar los recursos públicos que se destinan, entre otros fines, a la satisfacción de los Derechos Económicos, Sociales, Culturales y Ambientales. La investigación propone que, en el ámbito del Sistema Interamericano de Protección de los Derechos Humanos, esa tensión se puede superar mediante una fórmula de mutua deferencia que puede ser aplicada en todos los Estados. La deferencia debe existir de parte de la Corte Interamericana de Derechos Humanos con los Estados y de parte de las autoridades disciplinarias internas con los estándares establecidos por el tribunal interamericano. El artículo también señala las condiciones necesarias para que ocurra la mutua deferencia y advierte sobre los peligros de que la Corte Interamericana mantenga una interpretación textualista y austera del artículo 23 de la Convención Americana sobre Derechos Humanos.

Palabras clave: Derechos políticos. DESCA. Sistema Interamericano de Derechos Humanos. Democracia. Deferencia.

\section{Abstract}

This article analyzes one of the most important tensions between the protection of political rights - of both popularly elected officials and their constituents - and the disciplinary functions of some administrative authorities. This tension is deepened insofar as national constitutional norms and international treaties also protect the functions of disciplinary authorities 
with a view to enabling the prosecution and punishment of corruption. The objective is to preserve public resources which necessary, among other purposes, to the satisfaction of Economic, Social, Cultural and Environmental Rights. The research proposes that, within the framework of the Inter-American System for the Protection of Human Rights, this tension can be overcome through a formula of mutual deference that can be applied in all States. The deference must exist on behalf of the Inter-American Court of Human Rights in what concerns the States and on the part of the internal disciplinary authorities in what concerns the standards established by the Inter-American Court. The article also indicates the necessary conditions for mutual deference to occur and warns about the dangers of the Inter-American Court maintaining a textual and austere interpretation of Article 23 of the American Convention on Human Rights.

Keywords: Political rights. ESCER. Inter-American Human Rights System. Democracy. Deference.

\section{INTRODUCCIÓN}

El objetivo de este artículo es defender la existencia de una interpretación compatible de la Convención Americana sobre Derechos Humanos $(\mathrm{CADH})$ con las normas constitucionales y legales que facultan a algunas autoridades administrativas (e.g. Procuraduría General de la Nación) para sancionar a funcionarios públicos que han sido elegidos popularmente. La interpretación propuesta sugiere que esas autoridades administrativas actúan legítimamente cuando aplican un estándar alto y estricto en relación con las garantías judiciales establecidas en los artículos 8 y 25 de la CADH. En esos casos, las limitaciones introducidas por estas autoridades al artículo 23 de la CADH son legítimas en virtud de que han observado materialmente las condiciones establecidas por la Corte Interamericana de Derechos Humanos (Corte IDH).

En el artículo se defiende que esta interpretación de lege ferenda solo es plausible si tanto la Corte IDH como las autoridades nacionales actúan con deferencia. Eso implica que el tribunal interamericano aplique una versión material del principio de subsidiariedad y sea deferente con las autoridades nacionales que tienen funciones disciplinarias. Al mismo tiempo, las autoridades nacionales deben asumir y aplicar los más altos estándares sobre las garantías judiciales dentro de sus procesos disciplinarios con el fin de atender a la protección especial establecida en la jurisprudencia de la Corte IDH para los derechos políticos. En el artículo se indican claramente las diferencias entre el enfoque de deferencia y el margen de apreciación nacional para advertir que las funciones disciplinarias de las autoridades administrativas son compatibles con la CADH bajo un enfoque de deferencia que no requiere del margen de apreciación nacional utilizado por el Tribunal Europeo de Derechos Humanos.

La estructura del artículo es la siguiente. En la primera parte se describe la antinomia entre el artículo 23 de la CADH, tal y como ha sido interpretado por la Corte IDH, y las normas constitucionales y legales que facultan a la Procuraduría General de la Nación de Colombia para sancionar a los funcionarios públicos elegidos popularmente. También se dará cuenta de algunas de las razones por las cuales ocurre esa antinomia y de la complejidad de la misma. En la segunda parte se hace referencia a los mecanismos concretos del principio de subsidiariedad y a la deferencia dentro del Sistema Interamericano de Derechos Humanos (SIDH). Finalmente, se concretará la tesis sobre la compatibilidad de las funciones disciplinarias de la Procuraduría General de la Nación con una interpretación sistemática y material de los artículos 8, 23 y 25 de la CADH. 


\section{LOS DERECHOS POLÍTICOS PROTEGIDOS POR LA CADH FRENTE A LAS FUNCIONES DISCIPLINARIAS DE LAS AUTORIDADES ADMINISTRATIVAS}

La Corte IDH ha interpretado el artículo 23.2 de la CADH y ha fijado claramente los tres requisitos necesarios y concurrentes para que una restricción a los derechos políticos sea legítima. En efecto, para el tribunal interamericano, la restricción debe ser producto de una decisión judicial, adoptada por un juez competente y en relación con la comisión de un delito. Como lo ha indicado la propia Corte IDH:

"El artículo 23.2 de la Convención determina cuáles son las causales que permiten restringir los derechos reconocidos en el artículo 23.1, así como, en su caso, los requisitos que deben cumplirse para que proceda tal restricción. En el presente caso, que se refiere a una restricción impuesta por vía de sanción, debería tratarse de una "condena, por juez competente, en proceso penal". Ninguno de esos requisitos se ha cumplido, pues el órgano que impuso dichas sanciones no era un "juez competente", no hubo "condena" y las sanciones no se aplicaron como resultado de un "proceso penal", en el que tendrían que haberse respetado las garantías judiciales consagradas en el artículo 8 de la Convención Americana”.

Esa interpretación del artículo 23.2 de la CADH fue establecida en el contexto del caso López Mendoza $V$ s. Venezuela del año 2011. En esa decisión contenciosa, la Corte Interamericana condenó al Estado de Venezuela por la violación de los artículos 8 y 23 de la CADH en virtud de que un funcionario administrativo (Contralor General de la República) había impuesto dos sanciones de inhabilitación al señor Leopoldo López Mendoza. La decisión sancionatoria había sido adoptada en el contexto de un procedimiento administrativo y con base en unas faltas que no eran constitutivas de ningún delito.

La interpretación del artículo 23.2 de la CADH realizada en el contexto del caso López Mendoza Vs. Venezuela es vinculante para todos los Estados que han ratificado la CADH. Eso implica que el Estado colombiano también está obligado a observar ese estándar de protección de los derechos políticos de los funcionarios públicos elegidos popularmente. De esta premisa se infiere que existe una especie de antinomia entre la mencionada interpretación de la Corte IDH sobre el artículo 23.2 de la CADH y las normas constitucionales (artículo 277-6 y 278) y legales (Ley 734 de 2002) que facultan a la Procuraduría General de la Nación de Colombia para destituir e inhabilitar funcionarios públicos que han sido elegidos popularmente.

A la anterior conclusión se arriba después de contrastar el estándar interamericano que fija las tres condiciones para limitar legítimamente los derechos políticos de los funcionarios elegidos popularmente con el contenido de las normas que regulan la naturaleza y los procedimientos de la Procuraduría General de la Nación.

Para comprender integralmente el desarrollo y la complejidad de esa antinomia, es necesario hacer referencia a las decisiones de la Corte Constitucional de Colombia que han definido la constitucionalidad de las competencias de la Procuraduría General de la Nación y a la forma como esas competencias pueden coexistir con la mencionada interpretación del artículo 23.2 de la CADH (sección 1.1.). Además, es importante destacar la complejidad de esa contradicción normativa que pone en cuestión la eficacia de los mecanismos clásicos para superar una antinomia entre las normas jurídicas internas y el derecho internacional de los derechos humanos (sección 1.2.).

1 CORTE IDH. Caso López Mendoza Vs. Venezuela. Fondo Reparaciones y Costas. Sentencia de 1 de septiembre de 2011 Serie C No. 233, párr. 107. 


\subsection{La profundización de la antinomia por la vía de la jurisprudencia constitucional²}

El régimen de control disciplinario colombiano ha sido objeto de múltiples pronunciamientos de la Corte Constitucional. Además, la propia Ley 734 de 2002 ha sido demandada varias veces ante ese tribunal constitucional $^{3}$. Sin embargo, en relación con la jurisprudencia sobre la constitucionalidad de las competencias disciplinarias de la Procuraduría General de la Nación es importante destacar las sentencias C-028 de 2006 y SU-712 de 2013. Como se puede inferir, la primera decisión judicial se profirió antes de que la Corte IDH estableciera la interpretación del artículo 23.2 de la CADH en el año 2011, mientras que la segunda sentencia se dictó con posterioridad al caso López Mendoza Vs. Venezuela.

En la sentencia C-028 de 2006, la Corte Constitucional resolvió una acción pública de constitucionalidad interpuesta en contra de los artículos 44, 45 y 46 de la Ley 734 de 20024. Estas disposiciones legales facultan al Procurador General de la Nación para imponer las sanciones de destitución e inhabilidad a los servidores públicos, incluidos aquellos que han sido elegidos popularmente.

El principal argumento de los demandantes acusaba una contradicción entre el amplio poder sancionatorio que la Constitución y la ley atribuyen al Procurador General de la Nación y el artículo 23 de la Convención Americana sobre Derechos Humanos. En concreto, los demandantes consideraban que el proceso disciplinario adelantado por el Procurador General de la Nación no era compatible con las condiciones convencionales para la restricción de los derechos políticos mediante una condena, proferida por un juez competente dentro de un proceso penat. Asimismo, para los demandantes resultaba evidente que el Procurador no era un juez sino un funcionario administrativo, que podía iniciar procesos disciplinarios por razones diferentes a la comisión de un delito y que tal proceso no tenía las mismas garantías de un proceso penal.

En contra de los argumentos de los demandantes, la Corte Constitucional declaró la validez constitucional de las disposiciones demandadas. En sus fundamentos, el tribunal constitucional de Colombia tuvo en cuenta que existían disposiciones constitucionales (artículo 277-6) que expresamente facultaban al Procurador General de la Nación para ejercer el poder disciplinario contra los servidores públicos, incluidos aquellos que habían sido elegidos popularmente.

Además, la Corte Constitucional de Colombia sostuvo tres argumentos para declarar la constitucionalidad de las normas demandadas y la compatibilidad de las mismas con la CADH. En primer lugar, para el tribunal colombiano era necesario realizar una interpretación sistemática y teleológica de la CADH que tuviera en cuenta los cambios sociales y los nuevos desafíos de la comunidad internacional. Entre estas transformaciones debía considerarse, como un elemento central, el aumento de la corrupción en toda Latinoamérica ${ }^{6}$.

Además de la interpretación evolutiva, la Corte Constitucional sostuvo que era posible encontrar una interpretación que armonizara la $\mathrm{CADH}$ con otros tratados que no establecían derechos humanos ni protegían la dignidad humana, pero creaban obligaciones para los Estados en relación con la persecución y sanción de la corrupción?

\footnotetext{
2 Una versión extensa de esta sección se puede consultar en: ROA ROA, Jorge Ernesto. "Las antinomias entre las Constituciones y la Convención Americana sobre Derechos Humanos: el gran dilema del juez constitucional y convencional interamericano". En: SAIZ ARNAIZ, Alejandro. (Coord.); SOLANES, Joan; ROA, Jorge (Ed.). Diálogos judiciales en el Sistema Interamericano de Derechos Humanos. Valencia: Tirant lo Blanch, 2017. p. 139-148.

3 La ley 734 de 2002 ha sido objeto de múltiples demandas de constitucionalidad que fueron resueltas por la Corte Constitucional de Colombia, entre otras, en las Sentencias: C-181 de 2002, C-948 de 2002, C-1076 de 2002, C-124 de 2003.

4 Esta fue la primera demanda en la que el punto central de los argumentos consistía en la incompatibilidad de la ley 734 de 2002 con el artículo 23 de la Convención Americana sobre Derechos Humanos. Precisamente, por considerar que se trataba de un nuevo cargo de constitucionalidad, la Corte Constitucional consideró que las decisiones de control de la ley 734 de 2002 no constituían cosa juzgada. $5 \mathrm{CADH}$ (artículo 23.2). "2. La ley puede reglamentar el ejercicio de los derechos y oportunidades a que se refiere el inciso anterior, exclusivamente por razones de edad, nacionalidad, residencia, idioma, instrucción, capacidad civil o mental, o condena, por juez. competente, en proceso penal'. (cursiva fuera de texto)

6 CORTE CONSTITUCIONAL DE COLOMBIA. Sentencia C-028 de 2006, Fundamento Jurídico 6.4.

7 CORTE CONSTITUCIONAL DE COLOMBIA. Sentencia C-028 de 2006, Fundamento Jurídico 6.4.
} 
Finalmente, la Corte consideró que las convenciones de la Organización de Estados Americanos (OEA) y de la Organización de las Naciones Unidas (ONU) contra la corrupción permitían que los Estados establecieran e impusieran medidas disciplinarias para sancionar la corrupción de los servidores públicos ${ }^{8}$. En una referencia concreta al artículo 23 de la $\mathrm{CADH}$, la Corte Constitucional de Colombia sostuvo lo siguiente:

“[...] en lo que concierne a la imposición de restricciones legales al ejercicio del derecho de acceder a cargos públicos por la imposición de condenas penales, siendo interpretado sistemáticamente con otros instrumentos internacionales universales y regionales de reciente adopción en materia de lucha contra la corrupción, no se opone a que los Estados Partes en aquél adopten otras medidas, igualmente sancionatorias aunque no privativas de la libertad, encaminadas a proteger el erario público, y en últimas, a combatir un fenómeno que atenta gravemente contra el disfrute de los derechos económicos, sociales y culturales, consagrados en el Protocolo de San Salvador"'.

En síntesis, en la sentencia C-028 de 2006, la Corte Constitucional consideró que la interpretación sistemática de la $\mathrm{CADH}$, en relación con las obligaciones de Colombia respecto de la persecución de la corrupción, restaban fuerza a una supuesta tensión (antinomia) entre las disposiciones constitucionales que facultaban al Procurador para imponer las sanciones de destitución e inhabilitación y el texto de la CADH. Al mismo tiempo, esas obligaciones fueron el fundamento de la declaratoria de constitucionalidad de las disposiciones legales demandadas.

Después de seis años del pronunciamiento comentado anteriormente, la Corte Constitucional de Colombia seleccionó para revisión una decisión de tutela incoada por una ciudadana que había sido destituida del cargo de senadora de la República y a quien se le había impuesto la sanción de inhabilitación para ejercer cargos públicos por un periodo de dieciocho años. En su escrito, la ciudadana consideraba que le habían vulnerado sus derechos políticos porque las sanciones en su contra las había impuesto el Procurador General de la Nación con fundamento en el artículo 277-6 de la Constitución y en la Ley 734 de 2002.

En la Sentencia SU-712 de 2013, la Corte Constitucional enfrentó nuevamente el problema de la convencionalidad de las facultades disciplinarias del Procurador General de la Nación. La estructura argumentativa de la Corte Constitucional se basó en la reiteración de los mismos tres planteamientos esbozados en la Sentencia C-028 de 2006 (interpretación evolutiva, interpretación armónica y existencia de otros tratados que imponen obligaciones a los estados para perseguir la corrupción) ${ }^{10}$.

A diferencia del proceso de constitucionalidad del año 2008, en el proceso de revisión de tutela del año 2013 la Corte Constitucional de Colombia debió analizar la compatibilidad de su ordenamiento interno (Constitución y Ley) con la interpretación del artículo 23.2 de la CADH realizada por la Corte IDH en el contexto del caso López. Mendoza Vs. Venezuela. A pesar de la existencia de ese precedente interamericano, la Corte Constitucional de Colombia mantuvo su interpretación sobre el ordenamiento jurídico interno con base en los siguientes cinco argumentos.

En primer lugar, la Corte Constitucional sostuvo que el caso López Mendoza había ocurrido en un contexto jurídico y fáctico diferente. En especial, la Corte Constitucional se centró en destacar que la Constitución de Venezuela establecía la exigencia de decisión judicial para limitar los derechos políticos, frente a la Constitución de Colombia que faculta directamente al Procurador General de la Nación.

En segundo lugar, la Corte Constitucional afirmó que la CADH autoriza la imposición de sanciones administrativas o disciplinarias, siempre y cuando en el proceso de sanción se respeten las garantías judiciales del artículo 8 de la Convención. Como se indicará más adelante, este es uno de los pilares de la interpretación compatible del ordenamiento jurídico colombiano con la CADH que se defenderá en este capítulo.

8 CORTE CONSTITUCIONAL DE COLOMBIA. Sentencia C-028 de 2006, Fundamento Jurídico 6.4 
Por otra parte, el tribunal colombiano se basó en el voto concurrente formulado por el juez Diego García Sayán en el caso López. Mendoza. En ese voto, el juez interamericano señaló la necesidad de realizar una lectura restrictiva de la sentencia con el fin de evitar obstaculizar las acciones de los Estados para perseguir la corrupción.

En cuarto lugar, la Corte Constitucional afirmó que una interpretación extrema de los requisitos para la imposición de sanciones a los servidores públicos establecidas por la Corte IDH en el caso López Mendoza conduciría a vaciar las competencias para limitar derechos políticos de algunas autoridades internas, como el Procurador General y el Consejo de Estado. Finalmente, la Corte Constitucional sostuvo que la CADH se debía interpretar armónicamente con el diseño constitucional de cada Estado. De acuerdo con ese enfoque, se imponía el respeto a las facultades de la Procuraduría General de la Nación ${ }^{11}$.

A modo de conclusión, en la Sentencia SU-712 de 2013, la Corte Constitucional de Colombia sostuvo que la competencia del Procurador General de la Nación para investigar y sancionar a los servidores públicos elegidos popularmente se infería de un:

“[...] diálogo entre las normas constitucionales que regulan las garantías para el ejercicio de la actividad parlamentaria, con las normas del mismo nivel que atribuyen al Procurador facultades disciplinarias, de donde se advierte que las garantías institucionales de los congresistas no comprenden una suerte de inmunidad disciplinaria ante el Ministerio Público"’12.

Las normas que dialogan, para seguir la expresión que utilizó la Corte Constitucional, son los artículos 118, 123 y 277-6 de la Constitución de 1991. El primero establece que el Procurador General de la Nación tiene el deber de vigilar la conducta de quienes desempeñan funciones públicas; el segundo señala que se consideran servidores públicos a los miembros de las corporaciones públicas y; el tercero, faculta al procurador para vigilar a quienes ejercen funciones públicas e imponer sanciones, incluso a quienes han sido elegidos popularmente.

La estructura del mencionado diálogo es la siguiente: i) el procurador general puede vigilar y sancionar a quienes desempeñan funciones públicas, aun cuando sean elegidos popularmente; ii) desempeñan funciones públicas quienes pertenecen a las corporaciones públicas; iii) el Congreso es una corporación pública; iv) los congresistas desempeñan funciones públicas y pueden ser vigilados por el procurador.

Lo anterior significa que la jurisprudencia constitucional ha hecho una defensa de las facultades disciplinarias de la Procuraduría General de la Nación, incluso frente a la interpretación expresa de la Corte IDH sobre esa misma materia. Desde luego, la propia Corte Constitucional ha reiterado esta misma defensa en otras oportunidades ${ }^{13}$ y otros tribunales internos ${ }^{14}$, como el Consejo de Estado ${ }^{15}$ y el Consejo Superior de la Judicatura ${ }^{16}$, se han referido a esta misma contradicción del ordenamiento jurídico interno con la CADH. Algunos de esos tribunales han realizado una especie de control de convencionalidad para proteger los derechos políticos de los funcionarios destituidos e inhabilitados que fueron sancionados por la Procuraduría General de la Nación ${ }^{17}$. Adicionalmente, en virtud de que la Procuraduría General de la Nación ha ejercido nuevamente esas mismas competencias disciplinarias, se han suscitado pronunciamientos de la CIDH, tanto

11 CORTE CONSTITUCIONAL DE COLOMBIA. Sentencia SU-712 de 2013, Fundamento Jurídico 7.6.3.

12 CORTE CONSTITUCIONAL DE COLOMBIA. Sentencia SU-712 de 2013, Fundamento Jurídico 7.

13 CORTE CONSTITUCIONAL DE COLOMBIA. Sentencia T-514 de 2016.

14 TRIBUNAL ADMINISTRATIVO DE CUNDINAMARCA. Sección Segunda, Subsección A, Sentencia de 13 de enero de 2014, Proceso A.T. No. 2013-07052-00, Magistrado Ponente: José María Armenta Fuentes.

15 CONSEJO DE ESTADO. Sala Plena de lo Contencioso Administrativo. Sentencia del 15 de noviembre de 2017. Radicado No. 11001032500020140036000 . Magistrado Ponente: César Palomino Cortés.

16 CONSEJO SUPERIOR DE LA JUDICATURA. Sala Jurisdiccional Disciplinaria, Sentencia del 6 de marzo de 2014, Radicado No. 11001110200020130812001 , Salvamento de Voto del Magistrado Néstor Osuna Patiño.

17 TRIBUNAL CONTENCIOSO ADMINISTRATIVO DE LA GUAJIRA. Sentencia de 5 de junio de 2018. Radicado No. 44-001-23-40-000-2018-00062-00. Magistrada Ponente: Carmen Dalis Argote Solano. También las decisiones del Consejo de Estado previamente citadas. 
en la vía de las medidas cautelares ${ }^{18}$ como en la vía del procedimiento inicial de las peticiones individuales ${ }^{19}$.

\subsection{La complejidad de la antinomia: el fracaso de la interpretación conforme y del principio pro persona}

Las contradicciones entre las Constituciones nacionales y el derecho internacional de los derechos humanos son mucho más complejas que las antinomias entre las demás normas internas y el derecho internacional. En efecto, una contradicción normativa entre la Constitución y la CADH resulta especialmente difícil porque supone un verdadero dilema para el juez constitucional.

Cuando se trata de una verdadera antinomia, eso significa que el juez nacional no ha podido hallar ni una sola interpretación compatible de sus normas internas con la $\mathrm{CADH}$, tampoco ha podido interpretar armónicamente el contenido normativo de las disposiciones nacionales con el derecho internacional de los derechos humanos. Además, el principio pro persona no ha sido útil porque la mayor protección de un derecho por parte de las normas internacionales implica la menor protección de otros derechos también protegidos por esas normas internacionales y por las normas nacionales.

Ante el fracaso de la interpretación conforme, de la aplicación armónica y del principio pro persona, el juez interno se enfrenta al siguiente dilema: cumplir con la obligación de aplicar el derecho interno con la consecuente vulneración de un estándar interamericano en relación con la protección de un derecho humano o inaplicar su Constitución para aplicar directamente la CADH con el correlativo desconocimiento del contenido de otros derechos y valores fundamentales. Además del problema jurídico que esta situación representa, sobre los tribunales nacionales pesa la carga de su rol como jueces internos, la presión política y de la opinión pública. En definitiva, se trata de una situación compleja desde el plano jurídico, político y social.

Además de estos factores de articulación jurídica, en el caso concreto de los derechos políticos de los funcionarios elegidos popularmente y las funciones disciplinarias de la Procuraduría General de la Nación existe un problema adicional derivado de la austeridad de la jurisprudencia interamericana sobre derechos políticos y de los fundamentos que respaldaron la sentencia del caso López.Mendoza Vs. Venezuela.

En efecto, en la sentencia del caso López. Mendoza Vs. Venezuela, la Corte IDH se abstuvo de enfrentar el problema de la compatibilidad del artículo 23.2 de la CADH con los tratados internacionales que tienen como objetivo la persecución de la corrupción. En la nota a pie de página 208 de esa sentencia, la Corte IDH estableció que el tribunal: “[...] considera que la lucha contra la corrupción es de suma importancia y tendrá presente esa circunstancia cuando se le presente un caso en que deba pronunciarse al respecto"20.

Esta nota a pie de página presenta varios problemas. En primer lugar, se trata de una confesión de la Corte IDH sobre el conocimiento que ese tribunal tenía respecto de la colisión de su interpretación del artículo 23.2 de la CADH con las obligaciones de los Estados en materia de persecución de la corrupción. En segundo lugar, se trata de una aclaración insólita en la medida en que el marco fáctico descrito por la Corte IDH y el problema jurídico planteado en el caso López. Mendoza V s. Venezuela presentaban una relación directa con sanciones impuestas por actos de corrupción.

Si la Corte IDH hubiese asumido su rol como intérprete de la CADH en relación con otros tratados internacionales, habría resuelto el problema de la compatibilidad de las obligaciones internacionales que ordenan perseguir y sancionar la corrupción con los derechos políticos del artículo 23 de la CADH. Como ya ha quedado demostrado por los casos contenciosos que actualmente se tramitan ante la CIDH, la evasión del problema en una nota a pie de página no evitará que la Corte IDH se vea enfrentada muchas veces a

18 CIDH. Resolución 5 de 2014, Medida Cautelar No. 374-13. 18 de marzo de 2014, Fundamento 15.

19 CIDH. Informe de Fondo No. 130/17. Caso 13.044. Gustavo Francisco Petro Urrego. 25 de octubre de 2017.

20 CORTE IDH. Caso López. Mendoza Vs. Venezuela. Fondo Reparaciones y Costas. Sentencia de 1 de septiembre de 2011 Serie C No. 233, nota. 208. 
esta cuestión en la vía contenciosa, cuando sean sometidas a su conocimiento las peticiones individuales de ciudadanos colombianos que ya han presentado sus casos ante la CIDH.

Asimismo, es importante considerar que la interpretación del artículo 23.2 de la CADH puede afectar las competencias de varios órganos públicos de diferentes países de América Latina. Desde luego, este es un dato que no justifica per se un cambio de interpretación de la Corte IDH sino que sugiere la necesidad de abrir un diálogo institucional para encontrar una interpretación que haga compatibles la protección de los derechos políticos y las garantías judiciales con: i) las obligaciones internacionales impuestas a los Estados en materia de persecución y sanción de la corrupción y ii) las estructuras e instituciones nacionales encargadas de cumplir con esas obligaciones internacionales.

A partir de esta descripción de la antonimia, de sus complejidades y del desarrollo jurisprudencial, en la siguiente sección se hará referencia a los mecanismos que permiten garantizar la subsidiariedad material y la deferencia dentro del SIDH. Estas herramientas servirán de contexto para construir una propuesta de interpretación que sea compatible con el contenido normativo del artículo 23.2 de la CADH y con las funciones disciplinarias de la Procuraduría General de la Nación de Colombia.

\section{La deferencia y el PRinCiPIO de SUbSidiariedad en el Sistema InTERAmericano de Protección de los Derechos Humanos}

El sistema de protección de los derechos humanos creado en el marco de la OEA, como todos los sistemas regionales de protección de los derechos humanos, se rige por el principio de subsidiariedad ${ }^{21}$. Este principio es un elemento esencial para conciliar las competencias de los Estados, el pluralismo, la diversidad cultural y el valor intrínseco de los procedimientos nacionales de decisión con la existencia de unos valores universales y de unos objetivos globales que trascienden las fronteras estatales y que se expresan en los tratados sobre derechos humanos ${ }^{22}$. En términos generales, la subsidiariedad califica la relación entre dos instituciones, normas o sistemas normativos de manera que una de esas instituciones, normas o sistemas normativos complementa al otro solo cuando se cumplen determinadas circunstancias ${ }^{23}$.

El principio de subsidiariedad que rige a los sistemas de protección de los derechos humanos es una expresión del reconocimiento de que las instituciones domésticas de cada uno de los Estados son los escenarios en los cuales se deben adoptar las medidas necesarias para cesar, investigar, sancionar, reparar y garantizar la no repetición de las violaciones a los derechos humanos. El principio de subsidiariedad también refleja un concepto especial de implementación de los estándares internacionales sobre derechos humanos que centra sus esfuerzos en que las autoridades nacionales decidan los casos de violaciones a los derechos humanos con base en los criterios que habría utilizado el juez internacional ${ }^{24}$. Esta visión se opone a la idea de que todos los casos de violaciones a los derechos humanos sean conocidos por los tribunales supranacionales e internacionales.

21 Vid. CADH (Preámbulo). Un texto esencial sobre el origen histórico, el concepto y la aplicación del principio de subsidiariedad en los sistemas de protección internacional de los derechos humanos: Carozza, Paolo. "Subsidiarity as a Structural Principle of International Human Rights Law". The American Journal of International Law, vol. 97, no 1, 2003, pp. 38-79.

22 CAROZZA, Paolo. "Subsidiarity as a Structural Principle of International Human Rights Law". The American Journal of International Law, v. 97, n. 1, p. 63, 2003. Sobre la dificultad para construir un concepto preciso de subsidiariedad y justificarlo cuando se trata de la protección internacional de los derechos humanos: Besson, Samantha. "Subsidiarity in International Human Rights Law — What Is Subsidiary about Human Rights?”. The American Journal of Jurisprudence, v. 61, n. 1, p. 69-107, 2016.

23 NEUMAN, Gerald. "Subsidiarity". En: SHELTON, Dinah (Ed.). The Oxford Handbook of International Human Rights Law. Oxford: Oxford University Press, 2013. p. 362.

24 Algunas autoras se refieren a este fenómeno bajo la idea de los efectos reflejo de las sentencias de la Corte Interamericana. Vid. Acosta-López, Juana Inés; LONDOÑO LÁZARO, María Carmelina. "El papel de la justicia nacional en la garantía del derecho a un recurso efectivo internacional”. International Law. Revista Colombiana de Derecho Internacional, n. 16, p. 96, 2010. 
Como señala Gerald Neuman, la subsidiariedad impone una obligación y constituye una oportunidad para los Estados. La obligación proviene de la necesidad de que a nivel interno se establezcan las normas y los procedimientos para garantizar los derechos. La oportunidad deriva del hecho de que, cumplir adecuadamente con la anterior obligación, generará una menor intervención de los sistemas regionales de protección de los derechos humanos ${ }^{25}$.

En el mismo sentido, Paolo Carozza afirma que la subsidiariedad es un principio paradójico que, por una parte, limita la intervención de los tribunales internacionales cuando la protección estatal interna de los derechos es adecuada. Sin embargo, por otra parte, la subsidiariedad también es la fuente de legitimidad de la intervención de los tribunales internacionales cuando esta se requiere y justifica en razón de las fallas estatales en la protección de los derechos ${ }^{26}$.

En el ámbito de los sistemas regionales de protección de los derechos humanos existen diferentes mecanismos para implementar la dimensión procedimental del principio de subsidiariedad, inter alia, el agotamiento de los recursos internos o la fórmula de la cuarta instancia. Desde luego, el principio de subsidiariedad de los sistemas de protección de los derechos humanos se complementa con la deferencia que los tribunales internacionales muestran a favor de los Estados en el análisis de fondo de los casos (e.g. margen de apreciación nacional) y en las medidas de reparación o remedios que puede proferir un tribunal (deferencia remedial $)^{27}$.

Por ejemplo, en materia de reparación a las violaciones a los derechos humanos, el Tribunal Europeo de Derechos Humanos permite que los Estados adopten medidas de reparación adicionales a la justa compensación. Por el contrario, la Corte Interamericana adopta medidas de reparación integral y ordena la adopción de medidas de satisfacción y de garantías de no repetición que dejan poco margen a los Estados. Además, la supervisión del cumplimiento de las decisiones del Tribunal Europeo le corresponde exclusivamente al Consejo de Europa mientras que en América esas funciones las realiza tanto la propia Corte IDH como la Asamblea General de la OEA.

Aún más, en algunos casos, las medidas de reparación ordenadas por la Corte Interamericana son criticadas porque se confunden con las políticas sociales del Estado y van más allá del remedio del daño para dejar a la víctima en una situación cualitativamente mejor a la que tenía antes de sufrir el daño. Estas medidas, que se denominan transformadoras, han dado origen a discusiones interesantes sobre la función compensatoria o redistributiva de la reparación ${ }^{28}$. Esta discusión interamericana refleja que la deferencia en materia de reparaciones tiene un alcance menor en el Sistema Interamericano en comparación con lo que ocurre en el ámbito del Consejo de Europa.

Ahora bien, como se verá a continuación, en el marco del Sistema Interamericano se han aplicado los mecanismos de agotamiento de los recursos internos y la fórmula de la cuarta instancia mientras que se discute sobre el uso excepcional e implícito del margen de apreciación nacional.

25 NEUMAN, Gerald. "Subsidiarity". En: SHELTON, Dinah (Ed.). The Oxford Handbook of International Human Rights Law. Oxford: Oxford University Press, 2013. p. 365.

26 CAROZZA, Paolo. "Subsidiarity as a Structural Principle of International Human Rights Law". The American Journal of International Law, v. 97, n. 1, p. 44, 2003.

27 NEUMAN, Gerald. "Subsidiarity". En: SHELTON, Dinah (Ed.). The Oxford Handbook of International Human Rights Law. Oxford: Oxford University Press, 2013. p. 373-364.

28 HENAO, Juan Carlos. "Las formas de reparación en la responsabilidad del Estado: hacia su unificación sustancial en todas las acciones contra el Estado". Revista de Derecho Privado, n. 28, p. 277-366, 2015 y UPRIMNY, Rodrigo; GUZMÁN, Diana. "En búsqueda de un concepto transformador y participativo para las reparaciones en contextos transicionales". Revista Colombiana de Derecho Internacional, n. 17, p. 231-286, 2010. 


\subsection{El previo agotamiento de los recursos internos: reglas, excepciones y carga de la prueba}

En primer lugar, el agotamiento de los recursos internos es una vía de subsidiariedad negativa, según la cual, los órganos internacionales no pueden intervenir cuando dentro del sistema doméstico se adoptaron todas las medidas necesarias para reparar una violación a los derechos humanos. Dicho de otra manera, como el sistema de protección internacional de los derechos humanos es complementario del sistema interno de cada Estado, el primero solo puede intervenir cuando este último ha fallado. El mecanismo de la subsidiariedad mediante el agotamiento de los recursos internos se encuentra establecido en los artículos 46.1.a de la Convención Americana y 31.1 del Reglamento de la $\mathrm{CIDH}^{29}$.

Estas dos disposiciones establecen que los peticionarios deben manifestarle a la Comisión Interamericana los recursos judiciales internos que agotaron antes de acudir al Sistema Interamericano. En sus opiniones consultivas y en su jurisprudencia contenciosa, la Corte Interamericana ha precisado las características esenciales que deben satisfacer los recursos internos para ser considerados como requisitos de procedibilidad ante el Sistema Interamericano: disponibilidad, adecuación y efectividad.

Por una parte, los recursos deben estar disponibles y eso significa que deben estar previstos formalmente dentro del ordenamiento y ser de fácil acceso para los individuos. Además, la idoneidad o adecuación se refiere a la existencia de una relación directa entre la vulneración del derecho y la función del recurso para lograr el objetivo de superar esa situación de violación a los derechos humanos. Finalmente, la eficacia de los recursos internos significa que estos tengan el potencial para producir el resultado jurídico y fáctico para el cual fueron diseñados ${ }^{30}$.

Además de los anteriores aspectos, la Corte Interamericana ha analizado situaciones especiales en las que ha considerado el tiempo en que son resueltos los recursos judiciales internos, el grado de independencia de las autoridades judiciales ante las cuales se tramitan esos recursos, el contexto de violencia y terror que puede condicionar el resultado de los recursos internos o las competencias de las autoridades domésticas para hacer cumplir sus decisiones frente a los particulares y a las demás autoridades nacionales ${ }^{31}$.

Cuando el Estado considera que los peticionarios no han agotado los recursos internos, asume la carga de probar la existencia de los recursos, su disponibilidad, idoneidad, adecuación y efectividad ${ }^{32}$. El Estado puede introducir ese argumento dentro del procedimiento contencioso mediante la presentación de una excepción preliminar con el fin de que la Comisión Interamericana declare inadmisible la petición ${ }^{33}$. El Estado tiene la carga de presentar esa excepción preliminar durante la fase de admisibilidad del procedimiento

29 Sobre el agotamiento de los recursos internos en el ámbito del Sistema Interamericano: Burgorgue-Larsen, Laurence; ÚBEDA DE TORRES, Amaya. The Inter-American Court of Human Rights. Case Law and Commentary. Oxford: Oxford University Press, 2011. p. 129-145 y PASQUALUCCI, Jo M. The Practice and Procedure of the Inter-American Court of Human Rights. Cambridge: Cambridge University Press, 2013. p. 92-98. Sobre el agotamiento de los recursos internos en el ámbito del Sistema Europeo de Protección de los Derechos Humanos: Convenio Europeo para los Derechos y las Libertades Fundamentales (artículo 35.1) y TEDH. Asunto Vučković y otros $v$. Serbia, no 17153/11, sentencia de 25 de marzo de 2014, párrs. 69-91.

30 En este aspecto, la jurisprudencia de la Corte Interamericana es muy cercana a la del Tribunal Europeo de Derechos Humanos sobre la misma materia. Vid. SPANO, Robert. "Universality or Diversity of Human Rights? Strasbourg in the Age of Subsidiarity". Human Rights Law Review, v. 14, n. 3, p. 500.

31 CORTE IDH. Excepciones al agotamiento de los recursos internos (Arts. 46.1, 46.2. a y 46.2.b, Convención Americana sobre Derechos Humanos). Opinión Consultiva OC-11/90 de 10 de agosto de 1990. Serie A No. 11, párrs. 32 y 35. Algunos casos difíciles sobre el cumplimiento del requisito de agotamiento de los recursos internos en: Pasqualucci, Jo M. The Practice and Procedure of the Inter-American Court of Human Rights. Cambridge University Press, Cambridge, 2013, pp. 97-98.

32 CORTE IDH. Caso Cantoral Benavides Vs. Perú. Excepciones Preliminares. Sentencia de 3 de septiembre de 1998. Serie C No. 40, párr. 31.

33 El Estado no puede alegar la falta de agotamiento de los recursos internos cuando la violación a los derechos humanos constituye un delito que debe ser investigado y sancionado de oficio por las autoridades nacionales (i.e. desaparición forzada). TOJO, Liliana; ELIZALDE, Pilar. "Competencia de la Comisión Interamericana de Derechos Humanos". En: STEINER, Christian; URIBE, Patricia. (Ed.). Convención Americana sobre Derechos Humanos. Comentario. Bogotá: Temis-Konrad Adenauer Stiftung, 2014. p. 779. 
ante la Comisión ${ }^{34}$. Esta carga de diligencia evita que los Estados utilicen este argumento como una defensa tardía cuando el proceso se encuentra en una etapa avanzada, cuando se han formulado las consideraciones de fondo por parte de la Comisión o cuando el caso ya ha sido deferido a la Corte ${ }^{35}$.

Del mismo modo, cuando el Estado presenta la excepción preliminar ante la Comisión y esta es rechazada, el Estado puede insistir en el mismo argumento ante la Corte con el fin de que el tribunal revise si la CIDH decidió la excepción con información completa y veraz ${ }^{36}$. Esta posibilidad ha generado críticas porque implica una dilación y la duplicidad de los procedimientos. Sin embargo, se ha mantenido bajo el criterio de que la Corte Interamericana no reexamina totalmente la excepción preliminar, sino que verifica que la Comisión la haya resuelto con todos los elementos de juicio necesarios ${ }^{37}$. Adicionalmente, la intervención de la Corte en el control de legalidad de una actuación realizada por la Comisión está orientada por la necesidad de garantizar el derecho de defensa de las partes del proceso interamericano ${ }^{38}$.

Desde luego, las víctimas de una violación a los derechos humanos no deben agotar los recursos internos cuando estos no satisfacen los requisitos de idoneidad establecidos por la Corte Interamericana. Además, el artículo 46.2 de la Convención y 31.2 del Reglamento de la Comisión establecen tres excepciones al deber de agotamiento de los recursos internos.

Por una parte, no se puede exigir a la víctima que agote un recurso interno cuando este no ofrece garantías suficientes en el marco del debido proceso. En segundo lugar, tampoco se aplica la regla del agotamiento de los recursos internos cuando la víctima aduce precisamente la violación de su derecho a un recurso efectivo en virtud de que se le impidió materialmente acceder al sistema judicial nacional. En tercer lugar, la regla del agotamiento de los recursos internos no es exigible cuando existe una dilación injustificada de los procedimientos internos que debían ser agotados, de manera tal, que se ha producido un incumplimiento del plazo razonable ${ }^{39}$.

En este ámbito opera una carga dinámica de la prueba que funciona de la siguiente manera. Si el peticionario aduce que no debía agotar los recursos internos porque concurría una de las excepciones, el Estado asume la carga de probar que los recursos existían, se encontraban disponibles, eran adecuados y efectivos ${ }^{40}$. En cualquiera de los dos casos, tanto el requisito de agotamiento de los recursos internos como sus excepciones deben ser interpretados a favor de las víctimas ${ }^{41}$.

La regla del agotamiento de los recursos internos es un mecanismo de subsidiariedad establecido a favor de los Estados, "pues busca dispensarlo de responder ante un órgano internacional por actos que se le

34 CORTE IDH. Caso Brewer Carías Vs. Venezuela. Excepciones Preliminares. Sentencia de 26 de mayo de 2014. Serie C No. 278 , párr. 77. 35 CORTE IDH. Caso Herrera Ulloa V s. Costa Rica. Excepciones Preliminares, Fondo, Reparaciones y Costas. Sentencia de 2 de julio de 2004. Serie C No. 107, párr. 81. Sobre la estrategia de litigio de los Estados mediante la utilización tardía de la excepción preliminar de falta de agotamiento de los recursos internos: Burgorgue-Larsen, Laurence; ÚBEDA DE TORRES, Amaya. The InterAmerican Court of Human Rights. Case Law and Commentary. Oxford: Oxford University Press, 2011. p. 132-136.

36 Hasta el momento, el único proceso en el que la excepción del agotamiento de los recursos internos ha prosperado cuando el caso ya se encontraba bajo el conocimiento de la Corte Interamericana fue: CORTE IDH. Caso Brewer Carías Vs. Venezuela. Excepciones Preliminares. Sentencia de 26 de mayo de 2014. Serie C No. 278, párr. 144.

37 PASQUALUCCI, Jo M. The Practice and Procedure of the Inter-American Court of Human Rights. Cambridge: Cambridge University Press, 2013. p. 94.

38 CORTE IDH. Caso Brewer Carías Vs. Venezuela. Excepciones Preliminares. Sentencia de 26 de mayo de 2014. Serie C No. 278, párr. 102.

39 La Corte Interamericana ha diseñado un test para evaluar la posible existencia de dilaciones injustificadas y la resolución de los recursos internos dentro de un plazo razonable en los términos del artículo 8.1. de la Convención. De acuerdo con el Tribunal Interamericano, el plazo razonable varía en función de cuatro criterios: i) la complejidad del asunto, ii) la actividad probatoria y el interés del afectado, iii) la conducta de las autoridades judiciales y iv) el impacto sobre los derechos de los peticionarios derivado de su situación jurídica. Vid. CORTE IDH. Caso Valle Jaramillo y otros Vs. Colombia. Fondo, Reparaciones y Costas. Sentencia de 27 de noviembre de 2008. Serie C No. 192, párr. 155.

40 CORTE IDH. Caso Brewer Carías Vs. Venezuela. Excepciones Preliminares. Sentencia de 26 de mayo de 2014. Serie C No. 278, párr. 84.

41 Burgorgue-Larsen, Laurence; ÚBEDA DE TORRES, Amaya. The Inter-American Court of Human Rights. Case Law and Commentary. Oxford: Oxford University Press, 2011. p. 138-143. 
imputen, antes de haber tenido la ocasión de remediarlos con sus propios medios" ${ }^{\prime 2}$. De esa consideración se deriva que se trata de un beneficio renunciable expresamente cuando los Estados así lo señalan o tácitamente cuando no se invoca la excepción preliminar de manera oportuna ${ }^{43}$.

\subsection{La mal denominada fórmula de la cuarta instancia}

El segundo mecanismo de subsidiariedad que opera en el ámbito del Sistema Interamericano es la incorrectamente denominada fórmula o regla de la cuarta instancia. Esta tiene el objetivo de evitar que los tribunales internacionales se erijan en una instancia más de revisión de los errores procesales, probatorios o de interpretación en que pueden incurrir los jueces domésticos ${ }^{44}$.

Esta fórmula se aplica cuando una petición individual solicita que los órganos del Sistema Interamericano revisen la manera como los jueces nacionales valoraron el material probatorio o interpretaron y aplicaron el derecho interno ${ }^{45}$. Según la propia Corte Interamericana, esa institución "no es, por tanto, un tribunal de alzada o de apelación para dirimir los desacuerdos que tengan las partes sobre determinados alcances de la prueba o de la aplicación del derecho interno en aspectos que no estén directamente relacionados con el cumplimiento de obligaciones internacionales en derechos humanos" ${ }^{\prime 46}$.

La fórmula de la cuarta instancia establece que la mera inconformidad con las decisiones judiciales de las instancias nacionales no es un fundamento suficiente para buscar la protección de una pretensión ante los órganos del Sistema Interamericano. En consecuencia, se puede haber agotado los recursos internos y obtenido una decisión judicial desfavorable a las pretensiones y, ese hecho por sí solo, no justifica la intervención de los órganos del Sistema Interamericano. La idea central es que la protección internacional no es una instancia más a la que se puede acudir para revisar o corregir las decisiones de los jueces nacionales.

En definitiva -y más allá de su incorrecta denominación- la fórmula de la cuarta instancia evita la intervención de la Corte Interamericana para lograr la perfectibilidad de los sistemas judiciales nacionales o el mejoramiento de sus métodos de investigación, juzgamiento o decisión ${ }^{47}$. En consecuencia, no existe ninguna razón para pensar que el derecho de acceso a la jurisdicción interamericana es una especie de recurso de apelación de las decisiones judiciales nacionales o que representa una ruptura de la idea de unos tribunales de cierre dentro de los ordenamientos jurídicos nacionales.

\subsection{El margen de apreciación nacional}

A diferencia de los dos anteriores mecanismos de subsidiariedad, el margen de apreciación nacional es un instrumento de deferencia. Se trata de una herramienta propia del sistema Europeo de Derechos Humanos ${ }^{48}$

42 CORTE IDH. Caso Duque Vs. Colombia. Excepciones Preliminares, Fondo, Reparaciones y Costas. Sentencia de 26 de febrero de 2016. Serie C No. 310, párr. 35.

43 CORTE IDH. Caso Brewer Carias Vs. Venezuela. Excepciones Preliminares. Sentencia de 26 de mayo de 2014. Serie C No. 278 , párr. 57. 44 NEUMAN, Gerald. "Subsidiarity". En: SHELTON, Dinah (Ed.). The Oxford Handbook of International Human Rights Law. Oxford: Oxford University Press, 2013. p. 372.

45 DUHAIME, Bernard. "Subsidiarity in the Americas. What room is there for deference in the Inter-American System? ”. En: GRUSZCZYNSKI, Lukasz; WERNER, Wouter. Deference in International Courts and Tribunals. Oxford: Oxford University Press, 2014. p. 291 y 292.

46 CORTE IDH. Caso González. Medina y familiares Vs. República Dominicana. Excepciones Preliminares, Fondo, Reparaciones y Costas. Sentencia de 27 de febrero de 2012. Serie C No. 240, párr. 38.

47 "La Corte recuerda que corresponde a los tribunales del Estado el examen de los hechos y las pruebas presentadas en las causas particulares. No compete a este Tribunal sustituir a la jurisdicción interna estableciendo las modalidades específicas de investigación y juzgamiento en un caso concreto para obtener un mejor o más eficaz resultado, sino constatar si en los pasos efectivamente dados a nivel interno se violaron o no obligaciones internacionales del Estado derivadas de los artículos 8 y 25 de la Convención americana". CORTE IDH. Caso Nogueira de Carvalho y otro Vs. Brasil. Excepciones Preliminares y Fondo. Sentencia de 28 de noviembre de 2006. Serie C No. 161, párr. 80.

48 Algunos elementos del margen de apreciación nacional también han sido aplicados en el derecho internacional de las inversiones 
que apareció por primera vez en informes de la extinta Comisión Europea de Derechos Humanos desde el año $1958^{49}$ y que ha sido aplicada por el Tribunal Europeo desde el asunto Handyside v. Reino Unido en el año $1976^{50}$. Se trata de un reconocimiento de que los Estados tienen condiciones y circunstancias especiales que justifican diferentes maneras de cumplir con sus obligaciones internacionales y de garantizar los derechos establecidos en el Convenio ${ }^{51}$.

Yourow lo definió como una libertad de actuar, un margen de autonomía o un espacio discrecional que el Tribunal Europeo confiere a las autoridades domésticas para restringir o limitar un derecho establecido en el Convenio ${ }^{52}$. Por su parte, Samantha Besson señala que el margen de apreciación es una herramienta que "reconoce la existencia de una variedad de interpretaciones diferentes pero justificadas del derecho internacional de los derechos humanos que dependen del contexto doméstico" 53 .

Desde una visión positiva, el margen de apreciación nacional reconoce que los derechos protegidos por el Convenio pueden ser efectivamente garantizados por los Estados de diferentes maneras de acuerdo con sus particulares condiciones y contextos ${ }^{54}$. Como señalan Mowbray y MATTHEw, el margen de apreciación nacional establece un criterio de deferencia con las decisiones de las autoridades políticas y judiciales nacionales ${ }^{55}$ que consulta aspectos como la legitimidad democrática de las instituciones nacionales, su mejor posición funcional para evaluar las necesidades y condiciones locales y la calidad de sus procedimientos ${ }^{56}$. Según algunos estudios, el margen de apreciación nacional se ha aplicado en más de 700 sentencias del Tribunal Europeo de Derechos Humanos ${ }^{57}$.

Desde el año 2013, el Consejo de Europa ha iniciado un proceso para reelaborar y fortalecer el concepto de subsidiariedad y de deferencia de la jurisdicción del Tribunal Europeo de Derechos Humanos. Uno de los aspectos esenciales de ese proceso es el Protocolo xv al Convenio Europeo de Derechos Humanos. En este Protocolo se adiciona un párrafo final al Preámbulo del Convenio en el que se hace referencia expresa a la subsidiariedad y al margen de apreciación nacional en los siguientes términos:

"Afirmando que las Altas Partes Contratantes, de conformidad con el principio de subsidiariedad, tienen la responsabilidad primordial de garantizar los derechos y las libertades establecidas en el presente Convenio y sus Protocolos y que, al hacerlo, gozan de un margen de apreciación sujeto a la supervisión

y por parte de la Corte Internacional de Justicia. Vid. LEONHARDSEN, Erlend. "Treaty Change, Arbitral Practice and the Search for a Balance: Standards of Review and the Margin of Appreciation in International Investment Law”. En: GRUSZCZYNSKI, Lukasz; WERNER, Wouter. Deference in International Courts and Tribunals. Oxford: Oxford University Press, 2014. p. 135-151. RAGNI, Chiara. "Standard of Review and the Margin of Appreciation before the International Court of Justice". En: GRUSZCZYNSKI, Lukasz; WERNER, Wouter. Deference in International Courts and Tribunals. Oxford: Oxford University Press, 2014. p. 319-336.

49 GREER, Steven. "The margin of appreciation: interpretation and discretion under the European Convention of Human Rights”. Human Rights Files, n. 17, p. 5, Consejo de Europa, Estrasburgo, 2010 y GARCÍA ROCA, Javier. El margen de apreciación nacional en la interpretación del Convenio Europeo de Derechos Humanos: soberanía e integración. España: Thomson Reuters-Civitas, 2010. p. 107-112.

50 TEDH. Asunto Handyside v. Reino Unido, n 5493/72, sentencia del 7 diciembre de 1976, párrs. 48, 49 y 54.

51 Arai-Takahashi, Yutaka. The margin of appreciation doctrine and the principle of proportionality in the jurisprudence of the ECHR. Intersentia, Antwerp, 2002. p. 1-2.

52 YOUROW, Howard Charles. The margin of appreciation doctrine in the dynamics of European Human Rights jurisprudence. The Hague: Kluwer Law International, 1996. p. 13

53 Besson, Samantha. "Subsidiarity in International Human Rights Law — What Is Subsidiary about Human Rights?". The American Journal of Jurisprudence, v. 61, n. 1, p. 81, 2016.

54 Ambrus, Mónika. "The European Court of Human Rights and Standars of Proof: An evidential approach toward the margin of appreciation”. En: GRUSZCZYNSKI, Lukasz; WERNER, Wouter. Deference in International Courts and Tribunals. Oxford: Oxford University Press, 2014. p. 236.

55 Sobre la aplicación del principio de subsidiariedad en el ámbito del Tribunal Europeo de Derechos Humanos con información estadística acerca de las referencias al principio de subsidiariedad en las decisiones del tribunal desde el año 1992 hasta el año 2014 : MOWBRAY, Alastair. "Subsidiarity and the European Convention on Human Rights". Human Rights Law Review, v. 15, n. 2, p. 313-341, 2015.

56 SAUL, Matthew. "The European Court of Human Rights' Margin of Appreciation and the Processes of National Parliaments". Human Rights Law Review, v. 15, n. 4, p. 772, 2015.

57 GREER, Steven. "The margin of appreciation: interpretation and discretion under the European Convention of Human Rights”. Human Rights Files, n. 17, p. 5, Consejo de Europa, Estrasburgo, 2010. 
por parte de la jurisdicción del Tribunal Europeo de Derechos Humanos establecido por el presente Convenio" 58 .

Esta reforma al Preámbulo del Convenio ha generado lecturas contradictorias. Para algunos autores, se trata de una modificación menor que no introduce nada que ya no se encontrara incorporado en la jurisprudencia del tribunal. Para otros, esta adenda aumentará la relevancia del margen de apreciación nacional dentro de las deliberaciones del Tribunal Europeo ${ }^{59}$.

La reforma mencionada tiene una causa estructural y una causa política. La primera está relacionada con el aumento del número de casos que llegan al Tribunal Europeo y con la necesidad de que el remedio a las violaciones a los derechos humanos sea ordenado por las autoridades nacionales de los Estados miembros (reclamo de subsidiariedad). La segunda tiene que ver con el aumento de la tensión entre el Tribunal Europeo y algunos Estados que critican el activismo y la invasión de las competencias propias de sus autoridades nacionales por parte de los jueces de Estrasburgo (reclamo de deferencia) ${ }^{60}$.

Además del Protocolo xv, la propia jurisprudencia del Tribunal Europeo sobre el margen de apreciación nacional ha aumentado el enfoque de deferencia con los Estados. En ese ámbito, por ejemplo, el tribunal ha establecido que la calidad del proceso legislativo interno es un criterio relevante para examinar el grado de deferencia que debe tener el tribunal cuando evalúa una medida legislativa que limita el contenido o el ejercicio de un derecho establecido en el Convenio ${ }^{61}$. También es muy relevante la calidad de los procesos judiciales internos que revisan las medidas legislativas o administrativas que limitan los derechos establecidos en el Convenio ${ }^{62}$. Todos estos factores han llevado a que RoBert Spano señale que "la siguiente fase en la vida de la Corte de Estrasburgo puede ser definida como la era de la subsidiariedad, una fase en la cual se manifestará el compromiso del tribunal con el empoderamiento de los Estados Miembros para que estos verdaderamente 'traigan los derechos a casa', no solo en el Reino Unido sino en toda Europa" ${ }^{\text {. }}$.

En el marco del Sistema Interamericano no existe una jurisprudencia consolidada sobre el margen de apreciación nacional ${ }^{64}$. Sin embargo, según algunos autores, la Corte Interamericana aplicó expresamente el margen de apreciación nacional en la Opinión Consultiva 4 de $1984^{65}$ y en el caso Barreto Leiva v. Venezuela de

58 Vid. Protocolo xv reformatorio del Convenio Europeo para la Protección de los Derechos Humanos y las Libertades Fundamentales (artículo 1). La reforma del Protocolo fue abierta a la firma de los Estados el 24 de junio de 2013.

59 SAUL, Matthew. "The European Court of Human Rights' Margin of Appreciation and the Processes of National Parliaments". Human Rights Law Review, v. 15, n. 4, p. 749, 2015, y Besson, Samantha. "Subsidiarity in International Human Rights Law — What Is Subsidiary about Human Rights?”. The American Journal of Jurisprudence, v. 61, n. 1, p. 60--61, 2016.

60 Las críticas por el activismo judicial del Tribunal Europeo de Derechos Humanos aparecen resumidas y contestadas en: SPANO, Robert. "Universality or Diversity of Human Rights? Strasbourg in the Age of Subsidiarity". Human Rights Law Review, v. 14, n. 3, p. 488-502. 61 TEDH. Asunto Animal Defenders International v United Kingdom, n 48876/08, sentencia de 22 de abril de 2013, párr. 108. Los criterios con los cuales el Tribunal Europeo evalúa los procedimientos legislativos nacionales han sido resumidos en: SAUL, Matthew. "The European Court of Human Rights' Margin of Appreciation and the Processes of National Parliaments". Human Rights Law Review, v. 15, n. 4, p. 753-767, 2015.

62 SPANO, Robert. "Universality or Diversity of Human Rights? Strasbourg in the Age of Subsidiarity". Human Rights Law Review, v. 14, n. 3, p. 499-502.

63 SPANO, Robert. "Universality or Diversity of Human Rights? Strasbourg in the Age of Subsidiarity”. Human Rights Law Review, v. 14, n. 3, p. 491.

64 Algunos ejemplos de aplicación del margen de apreciación nacional por parte de la Comisión Interamericana de Derechos Humanos en: DUHAIME, Bernard. "Subsidiarity in the Americas. What room is there for deference in the Inter-American System?”. En: GRUSZCZYNSKI, Lukasz; WERNER, Wouter. Deference in International Courts and Tribunals. Oxford: Oxford University Press, 2014. p. 303-308. Para un análisis de los casos en los cuales se ha solicitado a la Corte Interamericana que aplique el margen de apreciación nacional y la recepción de esos argumentos por parte del Tribunal Interamericano, se sugiere consultar los trabajos compilados en: Acosta Alvarado, Paola Andrea; Nuñez Poblete, Manuel. El margen de apreciación en el sistema interamericano de derechos bumanos: proyecciones regionales y nacionales. México: IIJ-UNAM, 2012. p. 3-381.

65 Se hace referencia al margen de apreciación que la Corte Interamericana reconoció al Estado de Costa Rica en relación con la garantía efectiva del derecho a la nacionalidad (artículo 20 de la Convención) mediante el establecimiento de una serie de requisitos para adquirir la nacionalidad de ese país. Vid. CORTE IDH. Propuesta de modificación a la Constitución Política de Costa Rica relacionada con la naturalización. Opinión Consultiva OC-4/84 de 19 de enero de 1984. Serie A No. 4, párrs. 58, 59, 62 y 63. La tesis según la cual en esta Opinión Consultiva se aplicó el margen de apreciación se puede encontrar en: Arai-Takahashi, Yutaka. The margin of appreciation doctrine and the principle of proportionality in the jurisprudence of the ECHR. Intersentia, Antwerp, 2002. p. 4. 
$2009^{66}$ e implícitamente en el caso Herrera Ulloa v. Costa Rica de $2004^{67}$.

No obstante estos tres ejemplos concretos de potencial aplicación del margen de apreciación nacional, es importante señalar que, en el caso Artavia Murillo v. Costa Rica de 2012, la Corte Interamericana omitió pronunciarse sobre los argumentos del Estado que solicitaba expresamente el reconocimiento de un margen de apreciación nacional sobre la regulación de la técnica de reproducción asistida, denominada fecundación in vitro. El tribunal consideró que, una vez comprobado el carácter desproporcionado de la medida interna, no era necesario pronunciarse respecto al reclamo del Estado sobre el margen de apreciación nacional ${ }^{68}$.

Aun así, los primeros brotes del margen de apreciación nacional en el marco del Sistema Interamericano han sido considerados como un resultado de la consolidación democrática de los Estados de la región que ha llevado al Tribunal Interamericano a ampliar su agenda para intervenir en casos sobre temas más cotidianos. En ese contexto, habría surgido nuevamente una preocupación por el grado de intervención de los órganos internacionales en los asuntos de los Estados ${ }^{69}$, un reclamo por la adopción de enfoques de deferencia y una tendencia a aceptar una versión más fuerte del principio de subsidiariedad ${ }^{70}$.

La anterior explicación es seductora pero bastante optimista. Si bien es cierto que la agenda de la Corte Interamericana se ha ampliado y que existe una aparente consolidación de la democracia y del Estado de Derecho en la mayor parte de los países de la región, también es importante reconocer las deficiencias estructurales que se mantienen incólumes en relación con la garantía efectiva de los derechos humanos más básicos, los déficits de las judicaturas nacionales para responder a las demandas masivas de acceso a la justicia y los nuevos peligros para la democracia y el Estado de Derecho derivados de la extensión de los regímenes de presidencialismo exacerbado. Como lo ha señalado AIDA TORRES, algunas de estas amenazas se extienden hacia la propia independencia de la Corte Interamericana de Derechos Humanos debido a la alta influencia de los Gobiernos nacionales en el nombramiento de los jueces de ese tribunal, a la generalidad de los requisitos para ser juez de la Corte Interamericana, al déficit de transparencia de los procesos de elección y a la práctica de intercambio de votos entre los Gobiernos latinoamericanos para la elección de los diferentes cargos internacionales ${ }^{71}$. En todos estos ámbitos, América Latina todavía se encuentra muy lejos de los parámetros europeos que permiten la deferencia del tribunal de Estrasburgo con los Estados del Consejo de Europa.

En ese contexto, la Corte Interamericana debe restringir el ámbito de aplicación de esta herramienta europea o descartarla completamente, por lo menos, hasta tanto los Estados que se encuentran bajo su jurisdicción no demuestren que satisfacen plenamente el fundamento democrático que justifica la deferencia del

66 CORTE IDH. Caso Barreto Leiva Vs. Venezuela. Fondo, Reparaciones y Costas. Sentencia de 17 de noviembre de 2009. Serie C No. 206, párr. 90. La tesis según la cual en este caso se aplicó el margen de apreciación se puede encontrar en: SAGÜÉS, Néstor Pedro. La Constitución bajo tensión. México: Instituto de Estudios Constitucionales del Estado de Querétaro, 2016. p. 392.

67 CORTE IDH. Caso Herrera Ulloa Vs. Costa Rica. Excepciones Preliminares, Fondo, Reparaciones y Costas. Sentencia de 2 de julio de 2004. Serie C No. 107, párr. 161. La tesis según la cual en este caso se aplicó el margen de apreciación se puede encontrar en: CONTRERAS, Pablo. "Control de convencionalidad, deferencia internacional y discreción nacional en la jurisprudencia de la Corte Interamericana de Derechos Humanos". Revista Ius et Praxis, v. 20, n. 2, p. 242-243, 2014.

68 El Estado de Costa Rica solicitó el reconocimiento de un margen de apreciación nacional en relación con la regulación de la técnica de reproducción asistida, denominada fecundación in vitro, sobre la base de la inexistencia de un consenso científico y regional sobre momento del inicio de la vida humana, el estatuto jurídico del embrión y la regulación de esa técnica de reproducción. La Corte Interamericana señaló que no era pertinente pronunciarse sobre ese tipo de argumentos porque ya se había comprobado el carácter desproporcionado de la medida nacional que limitaba el uso de la fecundación in vitro. Vid. CORTE IDH. Caso Artavia Murillo y otros ("Fecundación in vitro") Vs. Costa Rica. Excepciones Preliminares, Fondo, Reparaciones y Costas. Sentencia de 28 noviembre de 2012. Serie C No. 257, párrs. 170 y 316.

69 CORTE SUPREMA DE JUSTICIA DE LA NACIÓN ARGENTINA. Sentencia de 14 de febrero de 2017. CSJ368/1998 34 M)/CS1. Ministerio de Relaciones Exteriores y Cultos/informe sentencia dictada en el caso "Fontevecchia y D'Amico vs. Argentina" por la Corte Interamericana de Derechos Humanos.

70 FOLLESDAL, Andreas. "Exporting the margin of appreciation: Lessons for the Inter-American Court of Human Rights". International Journal of Constitutional Law, v. 15, n. 2, p. 359-371, 2017.

71 TORRES PÉREZ, Aida. "La independencia de la Corte Interamericana de Derechos Humanos desde una perspectiva institucional”. En: IGLESIAS VILA, Marisa et al. Derechos Humanos: posibilidades teóricas y desafíos prácticos. Buenos Aires: Libraria, 2014. p. 66-88. 
sistema internacional con los procedimientos legislativos y judiciales internos, y hasta tanto no se fortalezcan los mecanismos judiciales internos y las garantías de independencia para las judicaturas nacionales a fin de considerar que estas se encuentran en una mejor posición funcional que el propio tribunal de San José ${ }^{72}$. Hasta el momento, muchas de las decisiones contenciosas de la Corte Interamericana constituyen la verdad judicial sobre casos de violaciones a los derechos humanos y estas contrastan con las dilaciones o con los modestos resultados de los procesos judiciales internos en esos mismos casos ${ }^{73}$.

\subsection{Enfoques de deferencia como alternativa al margen de apreciación nacional}

El rechazo a la aplicación del margen de apreciación nacional en el ámbito del SIDH no quiere decir que la Corte IDH deba ser insensible a consideraciones contextuales y a argumentos relacionados con las condiciones específicas de cada uno de los Estados. No se trata de un margen de apreciación sino del análisis concreto que supone la existencia de un caso contencioso que ha ocurrido en un Estado determinado, dentro de unas condiciones acotadas y en un marco fáctico preciso.

Eso significa que es posible aplicar enfoques de deferencia y contextuales sin necesidad de llegar al extremo de reconocer un margen de apreciación nacional. La deferencia implica analizar la calidad democrática de las decisiones legislativas adoptadas por los parlamentos nacionales, el grado de deliberación social sobre decisiones que han resuelto un desacuerdo dentro de un Estado, los atributos de los procedimientos judiciales internos, el grado de apertura a la ciudadanía de los foros políticos y judiciales, y la actitud de las autoridades nacionales hacia la apertura y el diálogo con los estándares fijados por los tribunales internacionales.

De manera que los esfuerzos probados, reiterados, constantes y productivos de las instancias nacionales para aplicar, implementar y adaptar sus normas y prácticas internas a los estándares interamericanos son parámetros relevantes para aplicar un enfoque de deferencia. Esos criterios le permiten identificar a la Corte IDH cuando se encuentra dentro de un proceso dialéctico y deliberativo genuino con las autoridades nacionales. Ese proceso ocurre cuando ambas instancias se hallan dentro de un foro en el que ocurre una discusión respetuosa, cada una de las partes toma con la mayor seriedad y respeto la mejor versión de los argumentos de la otra y tiene toda la disposición para modificar su posición inicial frente a un argumento cualificado contrario a su punto de partida.

Desde luego, en ese diálogo institucional tiene que existir una definición. Se trata de una especie de última palabra, que será siempre provisional en la medida en que los estándares interamericanos pueden cambiar y las prácticas nacionales pueden variar. Eso significa que la ampliación de las herramientas de deferencia de los tribunales internacionales con las autoridades nacionales debe estar precedida de un análisis sobre la calidad de los recursos internos y los mecanismos procesales domésticos para graduar la intensidad del escrutinio que realizan los tribunales internacionales respecto de las actuaciones de las autoridades nacionales. Dicho de otra manera, la legitimidad de los procedimientos legislativos, judiciales y administrativos internos y la calidad de los mismos permite determinar si debe existir una mayor intervención o deferencia de parte de los tribunales internacionales.

Desde el SIDH se pueden asumir enfoques deferentes o de intervención, según corresponda, a manera de reconocimiento, estímulo y presión para que los Estados mejoren progresivamente sus sistemas judi-

72 Una crítica a los sistemas judiciales nacionales como argumento para evaluar el grado de subsidiariedad del Sistema Interamericano de Derechos Humanos: KLETZEL, Gabriela et al. "Democracia y subsidiariedad". En: BARRETO MAIA, Camila et al. Desafíos del Sistema Interamericano de Derechos Humanos. Nuevos tiempos, viejos retos. Bogotá: DeJusticia, 2015. p. 191-228.

73 CORTE IDH. Caso de la "Masacre de Mapiripán" Vs. Colombia. Sentencia de 15 de septiembre de 2005. Serie C No. 134 y Corte IDH. Caso Rodríguez. Vera y otros (Desaparecidos del Palacio de Justicia) Vs. Colombia. Excepciones Preliminares, Fondo, Reparaciones y Costas. Sentencia de 14 de noviembre de 2014. Serie C No. 287. Un diagnóstico en este sentido: ACOSTA ALVARADO, Paola Andrea. "Los casos colombianos ante el sistema interamericano y el uso del margen de apreciación: ¿ausencia justificada?". En: ACOSTA ALVARADO, Paola Andrea; NUÑEZ POBLETE, Manuel. El margen de apreciación en el Sistema Interamericano de Derechos Humanos: Proyecciones Regionales y Nacionales. Universidad Nacional Autónoma de México, 2012. p. 183-238. 
ciales, administrativos y disciplinarios internos. Según este punto de vista, la cualificación de los sistemas internos de protección de los derechos también es una contribución central al mejor funcionamiento del SIDH porque reduce el número de casos que se pueden incluir dentro de las competencias de los tribunales internacionales, se reduce la carga de trabajo dentro de esas instancias y permite que la jurisdicción internacional se concentre en diversos temas de la agenda de protección de los derechos humanos.

Con base en todo lo anterior, en la siguiente sección se defenderá que es plausible considerar que los procedimientos sancionatorios realizados por la Procuraduría General de la Nación de Colombia aplican materialmente las garantías judiciales establecidas en los artículos 8 y 25 de la CADH. Esa tesis permitirá avanzar en la búsqueda de una interpretación compatible de la CADH con las funciones de esa importante entidad del Estado colombiano mediante la aplicación de un criterio de deferencia mutua. Bajo ese parámetro, se mantendrá que la Corte IDH debe realizar un análisis integral y deferente de todo el procedimiento sancionatorio y del control judicial del mismo. Al mismo tiempo, la Procuraduría General de la Nación y las autoridades judiciales internas deben optimizar el nivel de satisfacción de todas las garantías judiciales para obtener el máximo respeto a los derechos políticos -tanto de los electores como los elegidos- en el marco de los procesos sancionatorios que se adelantan contra funcionarios elegidos popularmente.

\section{UNA INTERPRETACIÓN COMPATIBLE DE LA CADH CON LAS FUNCIONES DISCIPLINARIAS DE LAS AUTORIDADES ADMINISTRATIVAS BAJO EL ENFOQUE DE LA DEFERENCIA Y LA APLICACIÓN DEL DERECHO CONVENCIONAL}

El estándar de protección de los derechos políticos establecido en el caso López. Mendoza Vs. Venezuela tiene todas las fortalezas y todas las debilidades propias de una interpretación originalista textualista del artículo 23.2 de la CADH. Desde luego, parece una interpretación sólida porque la exigencia de que las limitaciones a los derechos políticos sean impuestas por un juez, con las garantías equivalentes a las del proceso penal y como consecuencia de un delito coincide plenamente con la intención original de los redactores de la CADH plasmada en las palabras utilizadas en ese instrumento internacional.

Sin embargo, la propia Corte IDH ha señalado que la CADH es un texto vivo que debe ser interpretado de manera evolutiva. Eso significa que es posible dejar atrás la idea de que solo las autoridades judiciales -y dentro de estas los jueces penales- aplican satisfactoriamente las garantías establecidas en el artículo 8 de la $\mathrm{CADH}$. Ese rezago interpretativo invitaba a penalizar determinadas conductas, no por la gravedad de las mismas, sino porque se consideraba que estas debían ser conocidas por los jueces penales que aplicaban parámetros procedimentales más exigentes. Una muestra de esa visión se encuentra detrás del estándar fijado en el caso López. Mendoza Vs. Venezuela. Por ejemplo, en el informe de fondo que la CIDH presentó a la Corte IDH en ese caso, la CIDH indicó lo siguiente:

[...] la imposición de una sanción de inhabilitación para la postulación a un cargo de elección popular, por un periodo de tiempo, tiene la naturaleza de sanción penal por lo que obliga a exigir, a quien tiene la facultad de imponerla, el respeto de ciertas garantías procesales propias de un procedimiento de índole penal, las cuales son más estrictas que las garantías del debido proceso que se exigen en los procedimientos administrativos ${ }^{74}$. (subrayado fuera de texto)

El presupuesto de la CIDH en ese informe es que el estándar de garantías judiciales aplicado por las autoridades administrativas es inferior al que aplica el juez penal. Por esa razón -bajo esa lógica- la única forma de garantizar que el proceso de inhabilitación de un funcionario público elegido popularmente satisfaga las garantías judiciales del artículo 8 de la CADH es restringir la facultad sancionatoria al juez penal. Este postulado contraría la propia jurisprudencia de la Corte IDH que ha indicado que las autoridades ad-

74 CIDH. Informe 92/09. Caso 12.668. Fondo, Leopoldo López Mendoza, Venezuela, 8 de agosto de 2009, párr. 91. 
ministrativas también deben aplicar las garantías judiciales pertinentes del artículo 8 de la CADH. Además, constituye una especie de falsa penalización tutelar en la que no se acota el universo de hechos que puede dar lugar a la inhabilidad o destitución, sino que se penalizan todas las faltas, incluso aquellas que por su levedad no ameritan un tratamiento punitivo.

Para avanzar en una interpretación material, evolutiva y sistemática de la CADH resulta pertinente formular la siguiente pregunta: ¿es legítimo que una autoridad administrativa sancione a un funcionario público elegido popularmente si esa autoridad aplica un estándar de garantías judiciales equivalente o superior al estándar que aplicaría el juez penal? Desde luego, eso habilitaría a las autoridades administrativas para destituir e inhabilitar funcionarios públicos elegidos popularmente y mantendría una distinción entre faltas disciplinarias y delitos.

La respuesta a esa pregunta es que una lectura material de las garantías exigidas por el artículo 23.2 de la CADH y por la jurisprudencia de la Corte IDH permite inferir que es plausible evaluar si una determinada autoridad administrativa aplica el estándar de garantías judiciales equivalente al del proceso penal cuando el procedimiento tiene por objetivo decidir sobre una sanción a un funcionario público elegido popularmente. Si esa evaluación es favorable a la autoridad que realiza el procedimiento sancionatorio, nada impide que la Corte IDH adopte un enfoque de deferencia y privilegie las garantías judiciales esenciales para la preservación de los derechos políticos sobre la nomenclatura o clasificación accidental de la autoridad que impone la sanción disciplinaria.

La anterior es una interpretación que confiere el mayor efecto útil a la CADH y a los estándares establecidos por la Corte IDH en materia de protección de los derechos políticos. Este efecto útil se obtiene sin vaciar de competencias a las autoridades disciplinarias internas y sin trastocar el complejo esquema nacional de responsabilidad disciplinaria. Asimismo, esta interpretación preserva una distinción entre faltas disciplinarias y delitos y evita la conversión en delitos de todas las faltas disciplinarias. En suma, se trata de una interpretación que encuentra el núcleo de la protección de los derechos políticos, tanto de los electores como de los elegidos, y lo centra en el conjunto de garantías que deben rodear el proceso que conduce a la destitución e inhabilitación de un funcionario público elegido popularmente.

Como se trata de una interpretación evolutiva de lege ferenda, a continuación se indicarán las condiciones de esa interpretación y las ventajas de la misma para los Estados, para el propio SIDH y para la satisfacción efectiva de los derechos políticos y las garantías judiciales, en el marco de los procesos que realizan las autoridades nacionales para perseguir y sancionar la corrupción.

\subsection{Las condiciones de la interpretación compatible: derechos políticos y garantías judiciales}

La interpretación evolutiva implica reconocer que el paso del tiempo produce una distancia inevitable entre el texto normativo y la realidad sobre la cual este debe operar. Desde luego, no se trata de que la realidad determine la eficacia de las normas sino de que estas sean aplicadas racionalmente y con base en elementos contextuales. El objetivo de la interpretación evolutiva es reducir la brecha intergeneracional que se crea entre la generación de quienes escriben y aprueban una norma y las generaciones posteriores. Además, la interpretación evolutiva aumenta la eficacia normativa y permite resolver conflictos o antinomias.

Desde luego, el solo paso del tiempo o el cambio generacional no justifican una interpretación evolutiva. Además, cuando este tipo de interpretación resulta razonable, es importante fijar el conjunto de condiciones que hacen plausible esa nueva interpretación. Por esa razón, en el caso de la antinomia entre la CADH y las funciones disciplinarias de la Procuraduría General de la Nación, la condición compleja esencial es la deferencia mutua. Eso implica que, tanto la CIDH y la Corte IDH como los órganos (judiciales y administrativos) internos, deben tomar con seriedad la posición de la CADH, la interpretación de la misma y las condiciones institucionales y contextuales en que esta opera en el caso de los procedimientos disciplinarios que realiza la Procuraduría General de la Nación contra funcionarios públicos elegidos popularmente. 
Desde el punto de vista del Estado, la condición compleja para que la interpretación sugerida en esta investigación sea plausible consiste en que se implementen las recomendaciones formuladas por la CIDH con el fin de adecuar, al máximo posible, el ordenamiento jurídico interno a los estándares interamericanos sobre los artículos 8, 23 y 25 de la CADH. Como ya ha sido establecido expresamente por la CIDH, eso implica que se expidan las normas necesarias para: i) asegurar la imparcialidad de la autoridad disciplinaria al distinguir las autoridades encargadas de formular los cargos de aquellas que deciden de fondo sobre la responsabilidad disciplinaria, ii) asegurar la accesibilidad y efectividad de los recursos contra las decisiones disciplinarias, iii) asegurar que los recursos contra las decisiones disciplinarias permitan una revisión integral de esas decisiones y iv) asegurar que todas las acciones de nulidad y restablecimiento del derecho serán decididas dentro de un plazo razonable ${ }^{75}$.

Desde la perspectiva de la CIDH y la Corte IDH, la condición de plausibilidad de esta interpretación pasa por el reconocimiento de que la interpretación vigente (lege lata) ofrece una protección aparente, formal y textual de los derechos establecidos en el artículo 23 de la CADH. Asimismo, los órganos del SIDH deben examinar el contexto concreto de cada autoridad nacional que ejerce funciones disciplinarias respecto de funcionarios públicos elegidos popularmente y la calidad convencional de sus procedimientos. Desde luego, es importante que la Corte IDH interprete todas las normas internacionales relevantes que incluyen deberes de los Estados en materia de persecución y sanción de la corrupción y asuma un enfoque más amplio relacionado con el impacto de la corrupción en la garantía efectiva de los derechos económicos, sociales, culturales y ambientales (DESCA). Además, la CIDH y la Corte IDH deben promover el diálogo institucional con las autoridades nacionales que realizan procedimientos disciplinarios contra funcionarios públicos.

En el caso concreto de la Procuraduría General de la Nación, los órganos del SIDH deben reconocer que existe actualmente un diálogo institucional en el que el órgano nacional ha demostrado una apertura absoluta a los parámetros convencionales que orientan los procedimientos judiciales y administrativos. Dentro de ese diálogo, la Procuraduría General de la Nación ha iniciado proyectos de difusión del derecho convencional, una revisión crítica y en clave constructiva del procedimiento disciplinario y ha convertido en una prioridad el respeto de los derechos políticos de conformidad con el estándar interamericano. Poner punto final de manera prematura a ese diálogo con la simple reiteración del precedente López Mendoza Vs. Venezuela constituiría una pérdida de oportunidad institucional para avanzar en la protección convencional de las garantías judiciales, los derechos políticos, la lucha contra la corrupción y la protección de los DESCA en América Latina.

Finalmente, es importante señalar que no existe una obligación de deferencia en el SIDH. La deferencia es el resultado razonable y espontáneo de los esfuerzos institucionales mutuos, compartidos y probados por aumentar la protección de los derechos humanos en un caso concreto. Eso significa que la deferencia no se exige ni se concede. Como mucho, la deferencia puede ser provocada con acciones de apertura unilaterales que abren paso a la deliberación inter-institucional. En cualquier caso, la carga de la prueba opera sobre la institución que reclama la deferencia y existen buenas razones para considerar que la Procuraduría General de la Nación de Colombia ha abierto ese espacio de deliberación con los órganos del SIDH.

\subsection{A modo de conclusión. Las ventajas de la interpretación compatible: diálogo, deferencia, legitimidad y eficacia no contenciosa del sistema interamericano}

La interpretación de lege ferenda propuesta en esta investigación tiene varias ventajas institucionales y para la protección efectiva de los derechos humanos, especialmente, para las garantías judiciales, el acceso a un recurso efectivo y los derechos políticos. La primera de esas ventajas institucionales es que esta interpretación es el resultado de un diálogo o deliberación institucional entre los órganos del SIDH y las autoridades

75 Estas modificaciones corresponden a las ordenadas por la CIDH en: CIDH. Informe de Fondo No. 130/17. Caso 13.044. Gustavo Francisco Petro Urrego. 25 de octubre de 2017, párr. 149. 
internas. Desde luego, no se trata de un culto ciego a la deliberación como procedimiento para resolver desacuerdos sociales o normativos, sino del aprovechamiento de las ventajas intrínsecas de ese intercambio entre autoridades que actúan en diferentes esferas normativas que inevitablemente se superponen parcialmente.

En segundo lugar, el hecho de que la interpretación propuesta en esta investigación sea el producto de una deliberación marcada por la deferencia, implica que tanto las autoridades nacionales como los órganos del SIDH abandonan las viejas trincheras de la jerarquía, de la soberanía o de la mejor posición institucional para abrir paso a relaciones de interacción y coordinación mucho más complejas y constructivas. No solo hay reconocimiento mutuo, sino que existe contacto deliberativo, respetuoso y constructivo frente a un desacuerdo normativo.

En tercer lugar, la deliberación institucional rechaza la eficacia coercitiva exclusiva del SIDH y asume un concepto especial de implementación del derecho internacional de los derechos humanos. Bajo este parámetro, la implementación sugiere que las autoridades nacionales deben decidir los casos como si estos hubiesen sido resueltos por las autoridades del SIDH. Por el contrario, la eficacia coercitiva del SIDH apuesta por introducir dentro de la jurisdicción contenciosa del SIDH el mayor número de casos posible para que desde fuera ser corrija lo que se hace mal dentro de los Estados. La idea de implementación no contenciosa que aquí se defiende traslada la eficacia del SIDH a otros escenarios, como la función consultiva y la deliberación institucional; lo cual resulta más compatible con el principio de subsidiariedad material y genera mejores resultados para la protección efectiva de los derechos humanos.

En cuarto lugar, esta forma de resolver desacuerdos normativos complejos aumenta la legitimidad tanto de los órganos del SIDH como de las autoridades nacionales. Los primeros dejan de reclamar un espacio que las autoridades nacionales perciben como interferencia y pasan a formar parte de un trabajo colaborativo y coordinado para lograr la protección cooperativa de los derechos humanos. A su vez, los segundos entienden su rol dentro de un sistema internacionalizado y dentro de la aplicación de un derecho convencionalizado en el que la ley y la Constitución se leen de acuerdo con parámetros normativos internacionales.

En definitiva, hay mucho de valioso en resolver un desacuerdo normativo mediante la deliberación y la deferencia mutua, en comparación con la simple eficacia coercitiva de un texto normativo o de una autoridad que reclama mayor poder que otra. En el caso de la antinomia entre las funciones disciplinarias de la Procuraduría General de la Nación de Colombia y la actual comprensión del artículo 23.2 de la CADH fijada por la CIDH y la Corte IDH, se abre paso una interpretación de lege ferenda-como la que se ha sugerido- que avanzará en la mejor articulación de las autoridades nacionales e internacionales y de las normas nacionales con el derecho internacional de los derechos humanos. El objetivo último es siempre la mayor protección de todos los derechos humanos de quienes habitan los Estados que forman parte del Sistema Interamericano de Derechos Humanos.

\section{Bibliografía}

ACOSTA ALVARADO, Paola Andrea. "Los casos colombianos ante el sistema interamericano y el uso del margen de apreciación: ¿ausencia justificada?". En: ACOSTA ALVARADO, Paola Andrea; NUÑEZ POBLETE, Manuel. El margen de apreciación en el Sistema Interamericano de Derechos Humanos: Proyecciones Regionales y Nacionales. Universidad Nacional Autónoma de México, 2012.

Acosta-López, Juana Inés; LONDOÑO LÁZARO, María Carmelina. "El papel de la justicia nacional en la garantía del derecho a un recurso efectivo internacional". International Law. Revista Colombiana de Derecho Internacional, n. 16, 2010.

Arai-Takahashi, Yutaka. The margin of appreciation doctrine and the principle of proportionality in the jurisprudence of the ECHR. Intersentia, Antwerp, 2002. 
Besson, Samantha. "Subsidiarity in International Human Rights Law - What Is Subsidiary about Human Rights?”. The American Journal of Jurisprudence, v. 61, n. 1, p. 69-107, 2016.

Burgorgue-Larsen, Laurence; ÚBEDA DE TORRES, Amaya. The Inter-American Court of Human Rights. Case Law and Commentary. Oxford: Oxford University Press, 2011.

CAROZZA, Paolo. "Subsidiarity as a Structural Principle of International Human Rights Law". The American Journal of International Law, v. 97, n. 1, p. 38-79, 2003.

CIDH. Informe 92/09. Caso 12.668. Fondo, Leopoldo López Mendoza, Venezuela, 8 de agosto de 2009.

CIDH. Informe de Fondo No. 130/17. Caso 13.044. Gustavo Francisco Petro Urrego. 25 de octubre de 2017.

CIDH. Resolución 5 de 2014, Medida Cautelar No. 374-13. 18 de marzo de 2014.

CONSEJO DE ESTADO. Sala Plena de lo Contencioso Administrativo. Auto del 13 de febrero de 2018. Radicado No. 11001032500020140036000. Magistrado Ponente: César Palomino Cortés.

Consejo de Estado. Sala Plena de lo Contencioso Administrativo. Sentencia del 15 de noviembre de 2017. Radicado No. 11001032500020140036000 . Magistrado Ponente: César Palomino Cortés.

CONSEJO SUPERIOR DE LA JUDICATURA. Sala Jurisdiccional Disciplinaria, Sentencia del 6 de marzo de 2014, Radicado No. 11001110200020130812001, Salvamento de Voto del Magistrado Néstor Osuna Patiño.

CONTRERAS, Pablo. "Control de convencionalidad, deferencia internacional y discreción nacional en la jurisprudencia de la Corte Interamericana de Derechos Humanos". Revista Ius et Praxis, v. 20, n. 2, p. $242-$ 243, 2014.

CORTE CONSTITUCIONAL DE COLOMBIA. Sentencia C-028 de 2006.

CORTE CONSTITUCIONAL DE COLOMBIA. Sentencia C-1076 de 2002.

CORTE CONSTITUCIONAL DE COLOMBIA. Sentencia C-124 de 2003.

CORTE CONSTITUCIONAL DE COLOMBIA. Sentencia C-181 de 2002.

CORTE CONSTITUCIONAL DE COLOMBIA. Sentencia C-948 de 2002.

CORTE CONSTITUCIONAL DE COLOMBIA. Sentencia SU-712 de 2013.

CORTE CONSTITUCIONAL DE COLOMBIA. Sentencia T-514 de 2016.

CORTE IDH. Caso Artavia Murillo y otros ("Fecundación in vitro") Vs. Costa Rica. Excepciones Preliminares, Fondo, Reparaciones y Costas. Sentencia de 28 noviembre de 2012. Serie C No. 257.

CORTE IDH. Caso Brewer Carías Vs. Venezuela. Excepciones Preliminares. Sentencia de 26 de mayo de 2014. Serie C No. 278.

CORTE IDH. Caso Cantoral Benavides Vs. Perú. Excepciones Preliminares. Sentencia de 3 de septiembre de 1998. Serie C No. 40.

CORTE IDH. Caso de la "Masacre de Mapiripán" Vs. Colombia. Sentencia de 15 de septiembre de 2005. Serie C No. 134.

CORTE IDH. Caso Duque Vs. Colombia. Excepciones Preliminares, Fondo, Reparaciones y Costas. Sentencia de 26 de febrero de 2016. Serie C No. 310.

CORTE IDH. Caso González. Medina y familiares Vs. República Dominicana. Excepciones Preliminares, Fondo, Reparaciones y Costas. Sentencia de 27 de febrero de 2012. Serie C No. 240. 
CORTE IDH. Caso Herrera Ulloa Vs. Costa Rica. Excepciones Preliminares, Fondo, Reparaciones y Costas. Sentencia de 2 de julio de 2004. Serie C No. 107.

CORTE IDH. Caso López. Mendoza Vs. Venezuela. Fondo Reparaciones y Costas. Sentencia de 1 de septiembre de 2011 Serie C No. 233.

CORTE IDH. Caso Nogueira de Carvalho y otro Vs. Brasil. Excepciones Preliminares y Fondo. Sentencia de 28 de noviembre de 2006. Serie C No. 161.

CORTE IDH. Caso Rodríguez. Veray otros (Desaparecidos del Palacio de Justicia) Vs. Colombia. Excepciones Preliminares, Fondo, Reparaciones y Costas. Sentencia de 14 de noviembre de 2014. Serie C No. 287.

CORTE IDH. Caso Valle Jaramillo y otros Vs. Colombia. Fondo, Reparaciones y Costas. Sentencia de 27 de noviembre de 2008. Serie C No. 192.

CORTE IDH. Excepciones al agotamiento de los recursos internos (Arts. 46.1, 46.2. a y 46.2.b, Convención Americana sobre Derechos Humanos). Opinión Consultiva OC-11/90 de 10 de agosto de 1990. Serie A No. 11.

CORTE SUPREMA DE JUSTICIA DE LA NACIÓN ARGENTINA. Sentencia de 14 de febrero de 2017. CSJ368/1998(34-M)/CS1. Ministerio de Relaciones Exteriores y Cultos/informe sentencia dictada en el caso "Fontevecchia y D’Amico vs. Argentina" por la Corte Interamericana de Derechos Humanos.

DUHAIME, Bernard. "Subsidiarity in the Americas. What room is there for deference in the Inter-American System?”. En: GRUSZCZYNSKI, Lukasz; WERNER, Wouter. Deference in International Courts and Tribunals. Oxford: Oxford University Press, 2014. p. 291-292.

FOLLESDAL, Andreas. "Exporting the margin of appreciation: Lessons for the Inter-American Court of Human Rights”. International Journal of Constitutional Law, v. 15, n. 2, p. 359-371, 2017.

GARCÍA ROCA, Javier. El margen de apreciación nacional en la interpretación del Convenio Europeo de Derechos Humanos: soberanía e integración. Thomson Reuters-Civitas, España, 2010.

GREER, Steven. "The margin of appreciation: interpretation and discretion under the European Convention of Human Rights”. Human Rights Files, n 17, Consejo de Europa, Estrasburgo, 2010.

GRUSZCZYNSKI, Lukasz y Werner, Wouter. Deference in International Courts and Tribunals. Oxford University Press, Oxford, 2014.

HENAO, Juan Carlos. "Las formas de reparación en la responsabilidad del Estado: hacia su unificación sustancial en todas las acciones contra el Estado". Revista de Derecho Privado, n. 28, p. 277-366, 2015.

KLETZEL, Gabriela et al. "Democracia y subsidiariedad". En: BARRETO MAIA, Camila et al. Desafios del Sistema Interamericano de Derechos Humanos. Nuevos tiempos, viejos retos. Bogotá: DeJusticia, 2015. p. 191-228.

LEONHARDSEN, Erlend. "Treaty Change, Arbitral Practice and the Search for a Balance: Standards of Review and the Margin of Appreciation in International Investment Law”. En: GRUSZCZYNSKI, Lukasz; WERNER, Wouter. Deference in International Courts and Tribunals. Oxford: Oxford University Press, 2014. p. 135-151.

MOWBRAY, Alastair. "Subsidiarity and the European Convention on Human Rights". Human Rights Law Review, v. 15, n. 2, p. 313-341, 2015.

NEUMAN, Gerald. "Subsidiarity". En: SHELTON, Dinah (Ed.). The Oxford Handbook of International Human Rights Law. Oxford: Oxford University Press, 2013.

PASQUALUCCI, Jo M. The Practice and Procedure of the Inter-American Court of Human Rights. Cambridge: Cambridge University Press, 2013.

RAGNI, Chiara. "Standard of Review and the Margin of Appreciation before the International Court of 
Justice". En: GRUSZCZYNSKI, Lukasz; WERNER, Wouter. Deference in International Courts and Tribunals. Oxford: Oxford University Press, 2014. p. 319-336.

ROA ROA, Jorge Ernesto. "Las antinomias entre las Constituciones y la Convención Americana sobre Derechos Humanos: el gran dilema del juez constitucional y convencional interamericano". En: SAIZ ARNAIZ, Alejandro. (Coord.); SOLANES, Joan; ROA, Jorge (Ed.). Diálogos judiciales en el Sistema Interamericano de Derechos Humanos. Valencia: Tirant lo Blanch, 2017. p. 139-148.

SAGÜÉS, Néstor Pedro. La Constitución bajo tensión. México: Instituto de Estudios Constitucionales del Estado de Querétaro, 2016.

SAUL, Matthew. "The European Court of Human Rights' Margin of Appreciation and the Processes of National Parliaments". Human Rights Law Review, v. 15, n. 4, 2015.

SPANO, Robert. "Universality or Diversity of Human Rights? Strasbourg in the Age of Subsidiarity". Human Rights Law Review, v. 14, n. 3, p. 500.

TEDH. Asunto Handyside v. Reino Unido, n 5493/72, sentencia del 7 diciembre de 1976.

TEDH. Asunto Vuckković y otros v. Serbia, no 17153/11, sentencia de 25 de marzo de 2014.

TOJO, Liliana; ELIZALDE, Pilar. "Competencia de la Comisión Interamericana de Derechos Humanos". En: STEINER, Christian; URIBE, Patricia. (Ed.). Convención Americana sobre Derechos Humanos. Comentario. Bogotá: Temis-Konrad Adenauer Stiftung, 2014.

TORRES PÉREZ, Aida. "La independencia de la Corte Interamericana de Derechos Humanos desde una perspectiva institucional”. En: IGLESIAS VILA, Marisa et al. Derechos Humanos: posibilidades teóricas y desafíos prácticos. Buenos Aires: Libraria, 2014. p. 66-88.

TRIBUNAL ADMINISTRATIVO DE CUNDINAMARCA. Sección Segunda, Subsección A, Sentencia de 13 de enero de 2014, Proceso A.T. No. 2013-07052-00, Magistrado Ponente: José María Armenta Fuentes.

TRIBUNAL CONTENCIOSO ADMINISTRATIVO DE LA GUAJIRA. Sentencia de 5 de junio de 2018. Radicado No. 44-001-23-40-000-2018-00062-00. Magistrada Ponente: Carmen Dalis Argote Solano.

UPRIMNY, Rodrigo; GUZMÁN, Diana. "En búsqueda de un concepto transformador y participativo para las reparaciones en contextos transicionales". Revista Colombiana de Derecho Internacional, n. 17, p. 231-286, 2010.

YOUROW, Howard Charles. The margin of appreciation doctrine in the dynamics of European Human Rights jurisprudence. The Hague: Kluwer Law International, 1996. 
V. A INFLUÊNCIA DO GÊNERO NO PROCESSO DECISÓRIO JUDICIAL 


\section{REVISTA BRASILEIRA DE POLÍTICAS PÚBLICAS BRAZILIAN JOURNAL OF PUBLIC POLICY}

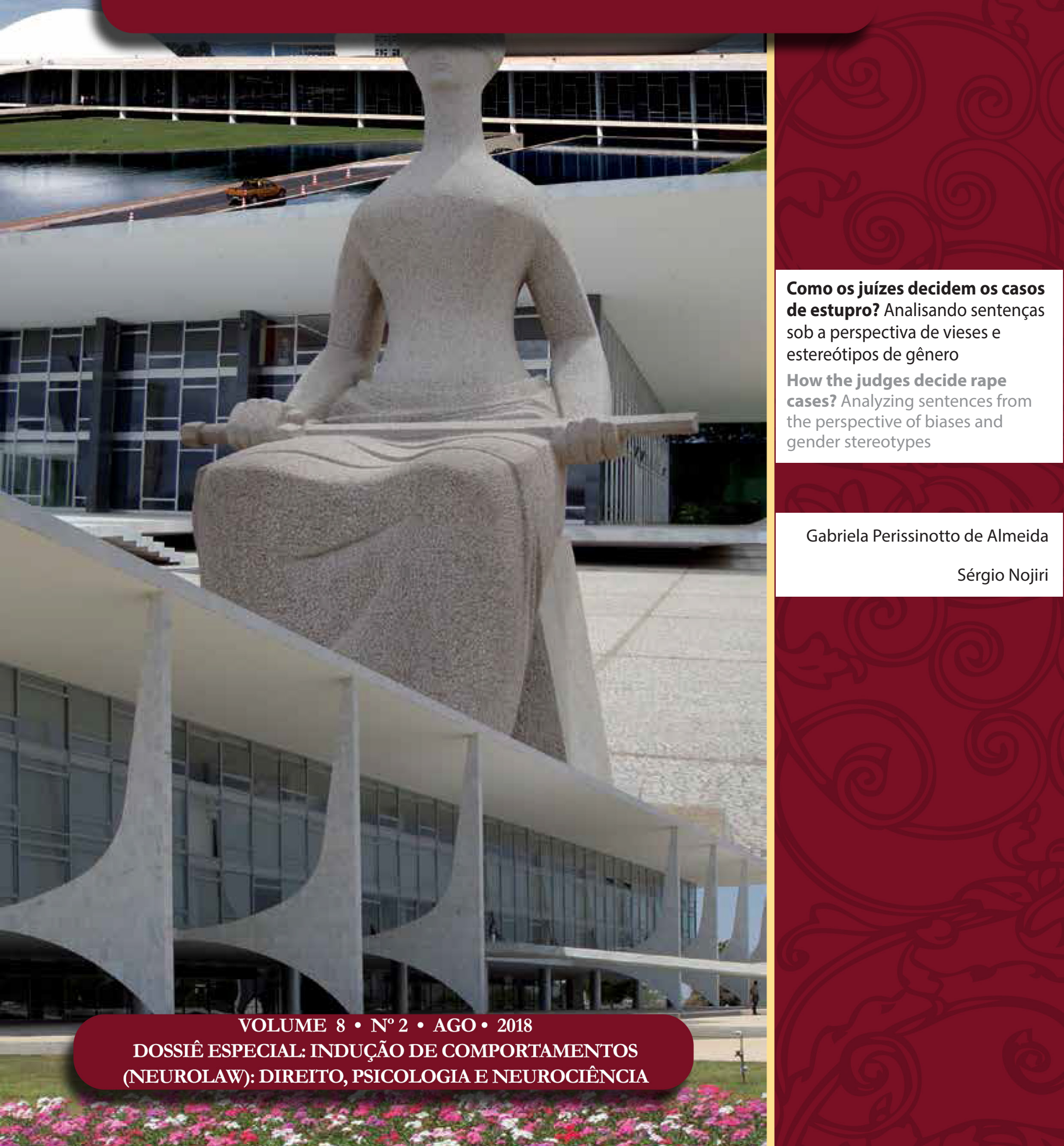




\title{
Como os juízes decidem os casos de estupro? Analisando sentenças sob a perspectiva de vieses e estereótipos de gênero*
}

\author{
How the judges decide rape cases? Analyzing \\ sentences from the perspective of biases and \\ gender stereotypes
}

Gabriela Perissinotto de Almeida**

Sérgio Nojiri****

\section{Resumo}

Estereótipos sobre as mulheres estão presentes em abundância na sociedade e no Judiciário. Partindo desse diagnóstico, o objetivo deste artigo é identificar quais são os principais estereótipos que dificultam o acesso das mulheres à justiça em casos de estupro, além de compreender de que forma esses estereótipos atuam nos três níveis em que eles estão imbricados na sociedade: individual, coletivo e mais geral. Para tanto, são analisadas sentenças de $1^{\circ}$ grau do Tribunal de Justiça do estado de São Paulo, do ano de 2016. Embora a amostra que embasou o estudo seja limitada a 63 sentenças, foi possível aferir que as mulheres têm seus depoimentos valorizados, apenas, se corresponderem ao ideal de mulher honesta e se parecerem ter sido vítimas; caso contrário, são retratadas como alguém de quem se deve desconfiar, passando, rápida e frequentemente, de vítimas a culpadas. Nesse contexto, o estereótipo da mulher honesta, assim como os estereótipos de vítima, no nível individual, atua como atalho cognitivo para a tomada das decisões judiciais, levando a sentenças enviesadas, que desconsideram as peculiaridades dos casos concretos. De modo semelhante, esses estereótipos sustentam e são sustentados, nos níveis coletivo e mais geral, por uma estrutura social que subalterniza mulheres. Esperamos que a identificação desses estereótipos e a busca por explicações acerca da sua atuação nos três níveis em que estão imbricados na sociedade auxilie a formulação de políticas públicas que visem mitigar esses estereótipos e seus efeitos e, assim, garantir a efetividade do acesso das mulheres à justiça.

Palavras-chave: Estereótipos. Viés de gênero. Estupro. Acesso à justiça.

\section{Abstract}

Stereotypes about women are frequent in society and the judiciary. Based on this diagnosis, the objective of this article is to identify which are the main stereotypes that hinder women's access to justice in cases of rape, and to understand how these stereotypes act on the three levels in which they are entrenched in society: individual, collective and more general. In order 
to do so, we analyze first-degree sentences of Tribunal de Justiça do Estado de São Paulo, of the year 2016. Although the sample that supported the study is limited to 63 sentences, it was possible to verify that the women have their statements well valued only if they correspond to the ideal of an honest woman and if they seem to have been victims; otherwise they are portrayed as someone to be distrusted, passing quickly and often from victims to guilty. In this context, the honest woman stereotype, as well as the victim stereotypes, act as cognitive shortcuts in judicial decisions making, leading to biased sentences that ignore the peculiarities of the concrete cases. Similarly, these stereotypes support and are supported, collectively and more generally, by a social structure that subordinates women. We hope that the identification of these stereotypes and the search for explanations about their performance in the three levels in which they are entrenched in society will help formulate public policies that aim to mitigate these stereotypes and their effects and thus guarantee the effectiveness of women's access to justice.

Keywords: Stereotypes. Gender bias. Rape. Access to justice.

\section{INTRODUÇÃo}

O $9^{\circ}$ Anuário Brasileiro de Segurança Pública mostrou que mais de 90\% das mulheres entrevistadas têm medo de ser vítima de agressão sexual — medo que tem fundamento empírico: apenas em 2014 foram registrados 47.646 casos de estupro no Brasil, dados que representam um estupro a cada onze minutos ${ }^{1}$. As vítimas, em cerca de $90 \%$ dos casos, são mulheres, e sofrem consequências tanto físicas quanto psicológicas: lesões nos órgãos genitais, contusões e fraturas, que podem levar ao óbito; gravidez indesejada; Doenças Sexualmente Transmissíveis (DST); e/ou transtornos, como depressão, fobias, ansiedade, uso de drogas ilícitas, tentativas de suicídio e síndrome de estresse pós-traumático. O agressor, por sua vez, em mais de 95\% dos casos, é um homem².

Outra estimativa alarmante é que apenas 7,5\% dos casos de estupro que acontecem no Brasil são notifi$\operatorname{cados}^{3}$. Diante desse dado, poderíamos questionar: por que mais de $90 \%$ dos agressores não são denunciados? O dossiê Violência Contra as Mulheres - Violência Sexual, da Agência Patrícia Galvão, aponta que a maioria das mulheres não denuncia o estupro por medo de que não acreditem nela - medo potencializado pelo fato de a maioria dos estupros ser cometido por amigos ou pessoas conhecidas ${ }^{4}$. Além disso, há diversos relatos de vitimização secundária no processo de denúncia, em que as mulheres sofrem discriminação, preconceito e humilhação ao reportar a violência sofrida. Estereótipos e mitos relacionados ao estupro também reforçam esse medo, já que contribuem para a imagem de um agressor desconhecido e de uma mulher cujo comportamento foi responsável pela violência sofrida.

Todos esses fatores levam à naturalização da violência sexual contra as mulheres, reforçando a sensação de impunidade, insegurança, culpabilização da vítima e, assim, à cultura do estupro - expressão que remete a um ambiente que banaliza, legitima e justifica a violência contra as mulheres.

Nesse contexto, ninguém está imune: todos nós somos suscetíveis a produzir e reproduzir estereótipos de gênero e a contribuir para a perpetuação da cultura do estupro - inclusive o Judiciário, que exerce um

1 FÓRUM BRASILEIRO DE SEGURANÇA PÚBLICA (FBSP), 9., Anuário Brasileiro de Segurança Pública. São Paulo: FBSP, 2015. p. 7 e 116.

2 INSTITUTO DE PESQUISA ECONÔMICA APLICADA (IPEA). Estupro no Brasil: uma radiografia segundo os dados da saúde. Brasília: IPEA, 2014a. p. 9.

3 INSTITUTO DE PESQUISA DATAFOLHA; CENTRO DE ESTUDOS DE CRIMINALIDADE E SEGURANÇA PÚBLICA. Pesquisa Nacional de Vitimização: questionário SENASP. São Paulo: Datafolha/Crisp, 2013. p. 14. Disponível em: <http:// www.crisp.ufmg.br/wp-content/uploads/2013/10/Relat\%C3\%B3rio-PNV-Senasp_final.pdf>. Acesso em: 10 jan. 2017.

4 AGÊNCIA PATRÍCIA GALVÃO. Dossiê violência contra as mulheres: violência sexual. Disponível em: <http://www.agenciapatriciagalvao.org.br/dossie/violencias/violencia-sexual/>. Acesso em: 10 jan. 2017. 
papel central tanto em relação à eliminação quanto à perpetuação dos estereótipos de gênero. Mulheres constantemente retratadas como mentirosas, vingativas ou loucas, têm seus depoimentos valorizados, apenas, se corresponderem à figura de vítima idealizada pela sociedade e pelo Judiciário, caso contrário, podem passar de vítimas a culpadas.

Esses e outros estereótipos comumente associados às mulheres, como veremos, atuam no sentido de tolher o acesso das mulheres à justiça - diagnóstico que mostra a urgência de medidas que eliminem tais obstáculos e promovam os direitos humanos das mulheres. Diante disso, são necessárias políticas públicas que visem aprimorar o sistema de justiça e a sociedade como um todo, e também pesquisas sobre essa temática, que auxiliem a identificação de pontos-chave e contribuam, efetivamente, para o desenvolvimento das práticas sociais.

Com a finalidade de somar a esse processo, o objetivo geral deste artigo será identificar quais são os principais estereótipos que dificultam o acesso das mulheres à justiça em casos de estupro, além de buscar compreender de que forma esses estereótipos atuam no processo de tomada de decisão dos magistrados e das magistradas. Esse objetivo está articulado aos fatores contextuais que explicam como os estereótipos contribuem para a estratificação social e a subordinação das mulheres.

Rebecca Cook e Simone Cusack dividem esses fatores em três níveis sociais em que estão imbricados os estereótipos, sendo eles: (i) individual, que consistem em fatores relativos ao processamento cognitivo dos estereótipos, que os tornam profundamente arraigados em nosso inconsciente; (ii) coletivo, que se referem aos ambientes que nos cercam, como familiar e de trabalho; e (iii) mais geral, que incluem fatores históricos, culturais, religiosos, econômicos e legais ${ }^{5}$.

Articulando essa ideia e o objetivo explicitado, o artigo se estruturará da seguinte forma: inicialmente, trataremos do viés de gênero, buscando compreender de que forma os estereótipos são utilizados como atalhos cognitivos para a tomada das decisões. Na sequência, explicaremos o processo de formação dos estereótipos e como eles passam a ser compartilhados e a sustentar uma estrutura patriarcal. Passaremos, então, ao crime de estupro e à análise das sentenças. Por fim, concluiremos ressaltando a importância da temática e quais os caminhos que políticas públicas poderiam seguir no sentido de incorporar esses estudos, tornando mais efetivo o acesso das mulheres à justiça.

Começaremos, a seguir, explicando o que são atalhos cognitivos e vieses, tratando, em especial, do viés de gênero.

\section{VIÉS DE GÊNERO}

As decisões que tomamos, em geral, são realizadas em um contexto de informação ou de conhecimento limitados sobre a situação. São decisões que devem ser tomadas rapidamente e cujo resultado nem sempre é conhecido. Podemos falar que essas são decisões tomadas em situação de incerteza.

Para auxiliar o processo de tomada de decisão, utilizamos heurísticas, isto é, atalhos cognitivos que atuam no julgamento como mecanismos simplificadores. Nas palavras de Kahneman: "a definição técnica de heurística é um procedimento simples que ajuda a encontrar respostas adequadas, ainda que geralmente imperfeitas, para perguntas difíceis.” Essas heurísticas costumam ser úteis e podem produzir julgamentos corretos, mas, em determinadas circunstâncias, podem levar a erros graves e sistemáticos de avaliação e controle. Esses erros também podem ser chamados de vieses.

5 COOK, Rebecca; CUSACK, Simone. Estereotipos de género: perspectivas legales transnacionales. Bogotá: Profamilia, 2010. p. 37-39.

6 KAHNEMAN, Daniel. Rápido e devagar. Rio de Janeiro: Objetiva, 2012. p. 127. 
Podemos falar em dois tipos de vieses. O primeiro deles se dá quando os erros são cometidos em razão de uma crença explícita ou de uma intenção consciente de agir, de modo que o sujeito esteja ciente da ação e de seus resultados ao tomar uma decisão - nessa hipótese falamos em vieses explícitos.

No entanto, as ciências cognitivas sugerem que os indivíduos nem sempre tem consciência dos processos mentais de percepção social e julgamento que motivam suas ações e decisões, de modo que também existem vieses implícitos - discriminações baseadas em atitudes ou estereótipos implícitos que levam a um tipo de preconceito especialmente problemático. Isso porque se trata de um preconceito que fica à margem das leis antidiscriminatórias, as quais partem da premissa de que os seres humanos, por serem racionais, estão no controle de suas ações?

Nesse contexto se insere o viés de gênero, definido por Deborah Round como uma tendência a levar o sexo em consideração ao pensar sobre pessoas ou comportar-se em relação a elas. Especificamente no contexto das decisões judiciais ${ }^{8}$, o viés de gênero resulta em decisões ou ações baseadas em noções pré-concebidas dos papeis sexuais, em detrimento de julgamentos justos e imparciais dos casos concretos?

Para Nancy Levit ${ }^{10}$, contudo, não basta que a sentença tenha efeitos discriminatórios com relação ao gênero, também é necessário que esses efeitos decorram do uso de uma heurística. Assim, a autora parte das heurísticas propostas por Kahneman e Tversky ${ }^{11}$, e as interpreta de modo mais abrangente.

A heurística da ancoragem, que, na concepção apresentada por Kahneman e Tversky, está relacionada ao uso de valores iniciais disponíveis para fazer estimativas ou decidir sobre alguma quantia, de modo que o valor final, ainda que sofra um ajustamento, seja baseado no valor inicial (âncora), poderá corresponder, seguindo a proposição de Nancy, a um apego a noções obsoletas e equivocadas. A professora mostra como isso ocorre relacionando o uso da heurística da ancoragem à definição de estupro.

Adaptando esse exemplo para o contexto brasileiro, podemos afirmar que, apesar de o artigo 213 do Código Penal brasileiro nada dispor acerca da resistência física por parte da vítima de estupro, no imaginário social, e às vezes até nos tribunais ${ }^{12}$, esse tipo de resistência é considerada condição para que o crime se configure. Crenças dessa natureza sustentam e são sustentadas por outros mitos em que os indivíduos, conscientemente ou não, ancoram suas impressões, o que produz efeitos claramente enviesados.

Um raciocínio semelhante poderia ser empregado com relação às heurísticas da disponibilidade e da representatividade. A primeira, na concepção de Kahneman e Tversky, relaciona a facilidade com que o indivíduo se lembra de um determinado fato à super ou subestimação da probabilidade de que um dado evento ocorra. Nesse sentido, a frequência de um evento será julgada maior ou menor a depender das experiências pessoais que o indivíduo teve e de eventos semelhantes evocados em sua memória, que, por sua vez, dependerão do grau de interesse da pessoa pelo assunto e da carga emocional envolvida.

7 GREENWALD, Anthony G.; KRIEGER, Linda Hamilton. Implicit bias: scientific foundations. California Law Review, v. 94 , n. 4, p. 945 - 967, jul. 2006. p. 946-951.

8 É importante esclarecer que uma série de estudos têm evidenciado que, assim como a população em geral, os juízes e juízas também são suscetíveis ao emprego de heurística e à incidência em vieses. GUTHRIE, Chris; RACHLINSKI, Jeffrey J.; WISTRICH, Andrew J. Inside the judicial mind. Cornell Law Review, v. 86, p. 776-830, 2001.

9 ROUND, Deborah Ruble. Gender bias in the judicial system. Southern California Law Review, v. 61, n. 6, p. 2193-2220, 1998. p. 2193.

10 LEVIT, Nancy. Confronting conventional thinking: the heuristics problem in feminist legal theory. Cardozo Law Review, v. 28, p. $1-82,2006$.

11 Os autores identificaram três heurísticas utilizadas como atalhos cognitivos em decisões tomadas em situação de incerteza: ancoragem, disponibilidade e representatividade. TVERSKY, Amos; KAHNEMAN, Daniel. Judgment under uncertainty: heuristics and biases. Science, v. 185, p. 1124-1131, set. 1974.

12 Em 2016, a mídia internacional noticiou o caso da juíza espanhola que perguntou à vítima de estupro se ela havia fechado as pernas para tentar evitar o crime. O exemplo mostra que a questão não é abordada de maneira problemática apenas no eixo latinoamericano, dos países considerados subdesenvolvidos, mas uma questão de apelo global. Vale esclarecer que a legislação penal espanhola também não impõe como requisito a resistência física da vítima para que o referido crime se configure. 
Essa heurística também ajuda a explicar a razão de comumente prestarmos atenção em alguns aspectos mais disponíveis, ou seja, que chamam mais a nossa atenção, em detrimento de outras características ou da análise do todo. Ou seja, adotando uma interpretação mais extensiva, essa heurística poderia explicar o porquê de algumas provas serem consideradas mais relevantes que outras, ainda que a legislação vigente determine a ponderação entre todos os elementos do complexo probatório.

A heurística da representatividade, por sua vez, é associada por Kahneman e Tversky à tendência dos indivíduos fazerem julgamentos com base no que consideram típico ou representativo de uma determinada categoria. Essa heurística pode ser considerada útil quando avaliamos, por exemplo, frutas ou animais; no entanto, ela nos estimula a cometer graves erros quando usada no julgamento de categorias sociais mais complexas, como os seres humanos. Isso porque essa heurística envolve o julgamento por estereótipo, que, ao ser utilizado enquanto atalho no processamento de informações sobre pessoas, pode levar a julgamentos e decisões discriminatórias.

Nancy Levit destaca que o viés de gênero pode afetar de maneiras muito mais sutis as percepções das pessoas sobre questões de gênero e, por poderem influenciar decisões sem que os indivíduos tenham consciência disso, essas discriminações podem ficar à margem das legislações antidiscriminatórias.

Os estudos que apresentaremos na sequência, que exemplificam algumas das linhas de pesquisa na temática de viés de gênero, podem dar alguns sinais do que a pesquisadora quis dizer com isso. Entre esses estudos, está a questão da feminização das profissões jurídicas e das barreiras - visíveis e invisíveis - que (ainda) dificultam o acesso e a permanência das profissionais do direito em posições de poder. Essas barreiras se manifestam por meio de um tratamento enviesado e discriminatório com relação às advogadas no exercício da profissão $\mathrm{O}^{13}$, pela associação do homem à figura de juiz e das mulheres a características relacionadas ao lar ${ }^{14}$, e até mesmo após o ingresso das mulheres em cargos como a magistratura, com a criação de critérios de avaliação e de promoção que são prejudiciais para as mulheres ${ }^{15}$.

Também são discutidas, sob a perspectiva dos vieses, as possíveis diferenças entre as decisões proferidas por juízes e por juízas, ou seja, a depender do sexo daquele que julga a ação, e/ou do sexo de quem recorre ao Judiciário (demandante). A seguir, destacamos dois desses estudos.

Christina Boyd, Lee Epstein e Andrew Martin analisaram demandas no tema de igualdade ou não discriminação, tanto em decisões monocráticas quanto em decisões colegiadas. O estudo mostrou que juízas, em decisões monocráticas, tendem a dar provimento a demandas cujo mérito é o reconhecimento de discriminação cerca de 10\% mais vezes em relação a juízes. De modo semelhante, concluíram que a presença de pelo menos uma juíza em decisões colegiadas leva ao aumento do percentual de julgamentos que reconhecem a discriminação nos litígios analisados ${ }^{16}$.

No Brasil, Stefânia Grezzana buscou aferir a existência de viés de gênero nos julgamentos realizados pelo Tribunal Superior do Trabalho (TST), com base na análise dos impactos da composição de gênero das Turmas julgadoras e do sexo do Ministro Relator nos resultados dos processos. A pesquisadora verificou, em três das dezesseis categorias temáticas criadas, a incidência do viés de gênero, de modo que Ministras tendiam a julgar mais vezes a favor das demandantes e Ministros, a favor dos demandantes. Essas categorias foram: equiparação (salarial, de direitos, de jornada de trabalho); enquadramento (funcional e sindical, vínculo de emprego, cargo de confiança); e outros (multas por embargos protelatórios e outros trâmites processuais) ${ }^{17}$.

13 ROUND, Deborah Ruble. Gender bias in the judicial system. Southern California Law Review, v. 61, n. 6, p. $2193-2220,1998$.

14 LEVINSON, Justin D.; YOUNG, Danielle. Implicit Gender Bias in the Legal Profession: An Empirical Study. Duke Journal of Gender Law \& Police, v. 18, n. 01, p. 1-44, 2010.

15 ELEK, Jennifer; ROTTMAN, David. Methodologies for measuring judicial performance: the problem of bias. Oñati Socio-legal Series, v. 4, n. 5, p. 863-879, 2014.

16 BOYD, Christina; EPSTEIN, Lee; MARTIN, Andrew. Untangling the causal effects of sex on judging. American Journal of Politic Science, v. 54, n. 2, p. 389-411, 2010.

17 GREZZANA, Stefânia. Viés de gênero no Tribunal Superior do Trabalbo brasileiro. 2011. 61 f. Dissertação (Mestrado em Economia) 
É interessante notar que a denominação "viés", em todos esses trabalhos, pressupõe um desvio com relação a uma suposta posição correta ou neutra. Essa nomenclatura e seu significado parecem bastante apropriados quando pensamos no uso de estereótipos relacionados ao estupro para o reconhecimento do crime, ou quando analisamos estudos sobre feminização da profissão - afinal, se mulheres são contratadas ou promovidas em menor proporção do que homens, evidencia-se um claro desvio com relação ao que entendemos como justo. No entanto, quando falamos em julgamentos enviesados, no sentido de juízas julgarem de modo diferente de juízes, e considerando que o neutro no direito é masculino ${ }^{18}$, talvez o problema seja continuar considerando o julgamento do juiz-homem como o padrão.

Para entender melhor esse viés, é necessário compreender o que são e como se formam os estereótipos. Essa análise também permitirá verificarmos como eles atuam no nível coletivo e mais geral ${ }^{19}$, como veremos na sequência.

\section{Estereótipos de GÊNERO}

Desde a infância, entramos em contato com uma quantidade enorme de informações. Para que possamos lidar com todo esse contingente e para que ele faça sentido, fazemos uso de alguns mecanismos, como a categorização - processo mental básico por meio do qual agrupamos, por semelhança, as informações com as quais nos deparamos ${ }^{20}$. Esse mecanismo é a base para uma série de outros processos cognitivos, como a percepção e a aprendizagem, e nos permite estruturar as informações e incorporá-las à nossa rede de conhecimento sobre um determinado assunto. Conforme entramos em contato com novos elementos, essa rede cresce, criando novas estruturas e associações. Isso permite que esses elementos não sejam percebidos de modo isolado, mas como parte de um conjunto ordenado e coerente.

Podemos categorizar objetos, ideias, ou mesmo pessoas, tendo em vista o ambiente no qual estamos inseridos e o modo como respondemos a ele. A criação de categorias sociais, ou seja, compostas por pessoas, ocorre nesse contexto. Em um primeiro momento, categorizamos com a finalidade de julgar pessoas como confiáveis ou não; na sequência, continuamos a fazer uma série de outras classificações, apoiadas em diferentes critérios e atributos.

A partir desse processo, são formadas as primeiras impressões sobre alguém. Como isso acontece com base em informações limitadas, é possível que nessa intuição inicial recorramos a estereótipos, definidos por Henri Tajfel como generalizações de uma característica para toda uma categoria ou grupo de pessoas ${ }^{21}$.

Estereotipamos as pessoas: (i) para reduzir a incerteza e a complexidade do mundo exterior, ou seja, para economizar esforços ou energia; (ii) para classificar as pessoas como diferentes de nós e do grupo ao qual pertencemos; e (iii) como um guia de identidade, para prescrever atributos, papéis e condutas aos quais homens e mulheres devem se adequar ${ }^{22}$. Nesse sentido, Eugene Borgida, Corrie Hunt e Anita Kim afirmam que o gênero é uma dimensão fundamental da categorização. Isso leva as pessoas, por exemplo, a frequentemente confiarem mais em estereótipos sobre as mulheres, no processo de formação das primeiras impressões, que nas informações individuais sobre uma determinada mulher ${ }^{23}$.

- Escola de Economia de São Paulo, Fundação Getúlio Vargas, São Paulo, 2011.

18 Sobre a suposta neutralidade do direito ser, na verdade, uma construção masculina, veja: SMART, Carol. Las teorías feministas y el discurso jurídico. In: BIRGIN, Haidée et al. El derecho en el género y el género en el derecho. Buenos Aires: Biblos, 2000.

19 Embora as expressões "coletivo" e "mais geral" possam ser consideradas, juntas, redundantes, optamos por mantê-las com o intuito de nos atermos à classificação de Rebecca Cook e Simone Cusack, tal como explicamos na introdução deste artigo.

20 LIMA, Gercina Ângela Borém de Oliveira. Categorização como um processo cognitivo. Ciências \& Cognição, v. 11, p. 156-167, 2007. p. 157.

21 TAJFEL, Henri. Cognite aspects of prejudice. Journal of Social Issues, v. 25, n. 4, p. 79-97, 1969. p. 81-82.

22 COOK, Rebecca; CUSACK, Simone. Estereotipos de género: perspectivas legales transnacionales. Bogotá: Profamilia, 2010. p. 16-23.

23 BORGIDA, Eugene; HUNT, Corrie; KIM, Anita. On the use of gender stereotyping research in sex discrimination litigation. 
Quando falamos em estereótipos de gênero, as generalizações se referem a características, comportamentos e papéis que a sociedade espera que as mulheres ou os homens desempenhem, a depender de seu sexo. Com base nessas presunções, a sociedade cria hierarquias que têm reforçado a situação de subordinação das mulheres na sociedade, violando a igualdade entre homens e mulheres e restringindo direitos, especialmente das mulheres que se comportam de maneira contraestereotípica. Em razão disso, teóricas feministas têm afirmado que "estereotipar é uma ação política de controle sobre os corpos das mulheres"24.

Assim, quando os estereótipos prescrevem atributos, papéis e comportamentos aos quais homens e mulheres devem se conformar, nomeamos esse grupo de estereótipos como prescritivos ou normativos ${ }^{25}$. Enquadram-se nessa classificação afirmações como: "mulheres devem ser submissas aos homens", "todas as mulheres devem sonhar em casar", entre outros.

Esses estereótipos podem, no entanto, passar de prescrições de conduta a agentes que naturalizam a violência contra as mulheres e contribuem para a cultura do estupro. Nesse sentido, em pesquisa recente, $65 \%$ dos participantes concordaram total ou parcialmente com a frase "mulher que é agredida e continua com o parceiro gosta de apanhar" e 59\%, com a frase "se as mulheres soubessem como se comportar, haveria menos estupros"26.

Uma característica agravante dos estereótipos, e das primeiras impressões de modo geral, é que eles tendem a perdurar. Assim, noções perversas, como as apontadas acima, não levam, apenas, a práticas discriminatórias contra as mulheres no momento em que são enunciadas, mas contribuem para a reprodução desses estereótipos em longo prazo e para a manutenção de uma estrutura social que subalterniza as mulheres. Em razão disso, Rebecca Cook e Simone Cusack acrescentam à persistência dos estereótipos a sua dominação social como um fator que colabora para a situação de subordinação das mulheres. Essa dominação está relacionada, para as autoras, ao fato dos estereótipos se articularem por meio dos setores da sociedade e por meio das culturas ${ }^{27}$.

Percebemos, a partir disso, que a estereotipia não decorre, apenas, de um processo cognitivo. O que permite reconhecermos a existência de preconceitos e estereótipos sociais é justamente o fato de eles serem compartilhados. Isso faz com que esse suposto consenso seja utilizado como critério de validade e de adequação. Nesse sentido, os estereótipos também atuam no âmbito sociocultural de construção da realidade. A Teoria das Representações Sociais, proposta por Serge Moscovici, explica como isso acontece.

As representações sociais compõem um conjunto de conhecimentos organizados sobre o mundo físico e social do qual as pessoas fazem parte e que permite a elas compreendê-lo. Seria, assim, uma forma de criação coletiva, produto das relações sociais, ou seja, da interação e comunicação, com função de convencionar acerca de objetos, pessoas e acontecimentos, e de prescrever condutas e pensamentos.

Sendo esse processo construído a partir das relações sociais, é possível afirmar que esse conhecimento apresenta certa permeabilidade, já que ele pode se transformar à medida que a própria sociedade se modifica e vice-versa. Nesse sentido, Moscovici afirma que essas representações poderiam ser vistas como a versão contemporânea do senso comum, que está continuamente sendo criado e recriado na sociedade e que

Journal of Law and Police, v. 13, n. 2, p. 613-628, 2005. p. 616-617.

24 SEVERI, Fabiana Cristina. Justiça em uma perspectiva de gênero: elementos teóricos, normativos e metodológicos. Revista Digital de Direito Administrativo, v. 3, n. 3, p. 574-601, 2016. p. 575.

25 As autoras discorrem também acerca de estereótipos descritivos on estatísticos - aqueles que buscam descrever como as mulheres são; eles podem até, de modo geral, corresponder à realidade, mas são problemáticos por generalizarem as experiências de todas as mulheres. Por exemplo: homens, em geral, podem ser mais fortes que mulheres; mas lutadoras de Mixed Martial Arts (MMA) podem ser mais fortes que muitos homens. COOK, Rebecca; CUSACK, Simone. Estereotipos de género: perspectivas legales transnacionales. Bogotá: Profamilia, 2010. p. 18-21.

26 INSTITUTO DE PESQUISA ECONÔMICA APLICADA (IPEA). Sistema de Indicadores de Percepcão Social: tolerância social à violência contra as mulheres. Brasília: IPEA, 2014b. p. 22-23.

27 COOK, Rebecca; CUSACK, Simone. Estereotipos de género: perspectivas legales transnacionales. Bogotá: Profamilia, 2010. p. 25-26. 
envolve todo o conhecimento que permeia a comunicação e interação, o que inclui noções equivocadas e estereótipos ${ }^{28}$.

Para o autor, os estereótipos estão inseridos nas representações sociais e com elas se comunicam. Isso porque, assim como as representações sociais, os estereótipos são compartilhados por um grupo e simultaneamente produzidos por ele. Nesse processo de produção de estereotipia, interviria de modo automático a representação correspondente à categoria, bem como as características aplicáveis aos seus membros.

Nessa estrutura também haveria representações relacionados ao gênero, como explica Lígia Amâncio.

Nesta perspectiva, os saberes comuns sobre os homens e as mulheres constituem representações sociais que se alimentam dos valores, crenças e ideologias dominantes e que adquirem sentido através da objectivação das diferenças entre os sexos. No entanto, a construção destes saberes comuns não se configura numa mera diferenciação, mas sim na assimetria dos modelos masculino e feminino. ${ }^{29}$

O senso comum, portanto, é baseado em representações sobre o masculino e o feminino não apenas diferentes, mas assimétricas, que são utilizadas como instrumento para manutenção das hierarquias de gênero que subalternizam as mulheres. Essas hierarquias se manifestam de diversas formas, como a partir da associação do ser homem ao ser indivíduo.

Essas afirmações estão em consonância com estudos feministas, que têm em comum identificar a situação de opressão das mulheres na sociedade e a dominação masculina, questionando a atribuição dessa hierarquia a aspectos naturais. Quanto a esse ponto, Joan Scott explica que a categoria gênero sugere uma rejeição ao determinismo biológico e esclarece que as ideias sobre os papéis sociais próprios aos homens e às mulheres são construções sociais. $\mathrm{O}$ termo, ainda, insere uma dimensão relacional na análise, pois sugere que homens e mulheres são definidos um a partir do outro, de modo que o estudo sobre as mulheres implica o estudo sobre os homens e vice-versa.

Subjacente à percepção de subordinação das mulheres como construção social, está a possibilidade de transformação dessa situação, pois o que é construído pode ser modificado. Diante disso, a historiadora propõe que o gênero deve ser redefinido e reestruturado em conjunto com uma visão de igualdade política e social que, também, leve em consideração a classe e a raça - categorias que, ao lado do gênero, organizam as desigualdades de poder e compõem os pilares das relações sociais ${ }^{30}$.

Essa conjuntura excludente com relação às mulheres repercute em todas as esferas sociais e institucionais - o que inclui o contexto do Direito. Nesse sentido, em virtude de estarem presentes nas tramas sociais e arraigados nas consciências dos indivíduos, os estereótipos de gênero também são absorvidos e reproduzidos pelos operadores do direito, muitas vezes de maneira inconsciente, mas que repercute na atividade jurisdicional. Essa reprodução de práticas discriminatórias e o reforço de estereótipos de gênero ocorrem acobertados pelo suposto paradigma de neutralidade do Direito, que naturaliza estereótipos e impõem padrões de conduta, especialmente às mulheres.

Fabiana Severi afirma que, quando não correspondem a esses padrões, as mulheres são retratadas pelo Judiciário como uma categoria suspeita: aquela que emite relatos exagerados ou mentirosos sobre a violência sofrida, que utiliza o Direito como instrumento de vingança ou para obter vantagens e/ou que são corresponsáveis pelos abusos, por se comportarem de maneira contraestereotípica. Para a autora, estes e outros estereótipos, além de serem prejudiciais às mulheres de modo geral, são formas de violência institucional, praticadas pelo Estado e seus agentes, e compõem um obstáculo ao acesso das mulheres à justiça ${ }^{31}$.

28 MOSCOVICI, Serge. Representações sociais: investigações em psicologia social. 5. ed. Petrópolis: Vozes, 2007. p. 95.

29 AMÂNCIO, Lígia. Género: representações e identidades. Sociologia: Problemas e Práticas, n. 14, p. 127-140, 1993. p. 129.

30 SCOTT, Joan. El género: una categoria útil para el análisis histórico. In: LAMAS, Marta (Comp.) El género: la construcción cultural de la diferencia sexual. PUEG: México, 1996. p. 265-302. p. 302.

31 SEVERI, Fabiana Cristina. Justiça em uma perspectiva de gênero: elementos teóricos, normativos e metodológicos. Revista Digital de Direito Administrativo, v. 3, n. 3, p. 574-601, 2016. p. 576. 
Nesse sentido, Guita Grin Debert e Maria Filomena Gregori afirmam que vivemos em um grande paradoxo no Brasil: embora a Constituição de 1988 seja uma das mais avançadas no mundo em termos de direitos e garantias fundamentais, persiste a desigualdade entre homens e mulheres no acesso à justiça ${ }^{32}$. Essa desigualdade, além de comprometer a efetividade dos direitos previstos no ordenamento jurídico brasileiro, consiste em uma forma de violação dos direitos humanos, como apontou o Comitê da CEDAW, na Recomendação Geral no 33 sobre o acesso das mulheres à justiça.

Com base na análise dos Relatórios submetidos pelos Estados Partes, o Comitê identificou uma série de obstáculos e restrições no acesso das mulheres à justiça, tais como leis discriminatórias, estereótipos de gênero e procedimentos e práticas em matéria probatória, além da violência de gênero. Diante disso, e com a finalidade de modificar essa realidade, a Recomendação elencou seis componentes essenciais para garantir esse direito, sendo eles: (i) justiciabilidade; (ii) disponibilidade; (iii) acessibilidade; (iv) boa qualidade dos sistemas de justiça; (v) provisão de remédios; e (vi) prestação de contas do sistema de justiça.

Esses componentes visam superar tanto as barreiras sociais ao acesso das mulheres à justiça, apontando como diretriz a capacitação e o empoderamento das mulheres para reivindicarem seus direitos, quanto as barreiras institucionais, como ao sugerir medidas que tornem os espaços fisicamente acessíveis às mulheres e os julgamentos sensíveis à questão de gênero. Para que isto ocorra, é necessário, como o próprio documento recomenda, que as regras probatórias, investigações e outros procedimentos judiciais sejam imparciais e não influenciados por estereótipos ou preconceitos de gênero.

Essa diretriz se torna particularmente difícil de implementar quando observamos que, na prática, esses estereótipos são cotidianamente empregados por juízes e juízas, como evidenciou a própria Recomendação Geral no 33:

Com frequência, juízes adotam rígidos estândares sobre comportamentos que consideram apropriados para as mulheres, penalizando aquelas que não agem conforme esses estereótipos. Os estereótipos também afetam a credibilidade dada às vozes, aos argumentos e depoimentos das mulheres [...]. Esses estereótipos podem levar juízes a mal interpretarem ou aplicarem as leis. Isso tem profundas consequências, por exemplo, no direito penal, quando resulta que perpetradores de violações a direitos das mulheres não sejam considerados juridicamente responsáveis, mantendo-se assim uma cultura de impunidade. Em todas as áreas do direito, os estereótipos comprometem a imparcialidade e integridade do sistema de justiça, que podem, por sua vez, levar à denegação da justiça, incluindo a revitimização de denunciantes. ${ }^{33}$

Esse diagnóstico, do qual parte a Recomendação e que decorre da análise dos relatórios emitidos pelos Estados Partes da CEDAW, além de identificar o uso de estereótipos como uma forma de violência e violação dos direitos humanos das mulheres, mostrou que a reprodução de estereótipos sobre as mulheres no Judiciário compromete o princípio da imparcialidade e, em última instância, mitiga o acesso das mulheres à justiça.

Quando falamos em estupro, a situação se agrava - por essa razão, passaremos a abordar esse tema, para, então, tratarmos dos estereótipos de gênero comumente associados às vítimas desse crime.

\section{Como os juízes decidem os Casos de estupro}

O caput do artigo 213 do Código Penal brasileiro traz o conceito normativo de estupro: "constranger alguém, mediante violência ou grave ameaça, a ter conjunção carnal ou a praticar ou permitir que com ele

32 DEBERT; Guita Grin; GREGORI, Maria Filomena. Violência e gênero: novas propostas, velhos dilemas. Revista Brasileira de Ciências Sociais, v. 35, n. 66, p. 165-211, fev. 2008. p. 166.

33 COMITÊ DE ELIMINAÇÃO DA DISCRIMINAÇÃO CONTRA AS MULHERES (CEDAW). Recomendação Geral n 33 sobre o acesso das mulheres à justiça. CEDAW, 2015. p. 14. 
se pratique outro ato libidinoso". Compreende, assim, tanto a conjunção carnal quanto os atos libidinosos praticados sem o consentimento da vítima.

Embora os homens também possam ser vítimas desse crime, as mulheres continuam sendo os principais alvos, tratando-se de uma forma de violência praticada, sobretudo, por homens contra mulheres. Essa constatação é sintomática de uma cultura de subordinação social das mulheres, como explica Catharine Mackinnon:

Rape is a sex-specific violation. Not only are the victims of rape overwhelmingly women, perpetrators overwhelmingly men, but also the rape of women by men is integral to the way inequality between the sexes occurs in life. Intimate violation with impunity is an ultimate index of social power. Rape both evidences and practices women's low status relative to men. Rape equates female with violable and female sexuality with forcible intrusion in a way that defines and stigmatizes the female sex as a gender. Threat of sexual assault is threat of punishment for being female. ${ }^{34}$

Assim, ao mesmo tempo em que o estupro é resultado de uma estrutura social que coloca as mulheres em situação de desvantagem, ele contribui para que essa estrutura se mantenha por meio da violência contra as mulheres. O estupro é, portanto, um tipo de violência de gênero, e conjuga violência sexual, física e psicológica, além de poder ser praticado no ambiente doméstico-familiar, ou fora dele.

É necessário observar que a estrutura que contribui para a subordinação social das mulheres e sustenta as agressões sexuais praticadas contra elas é a mesma que coloca em dúvida a validade da palavra da vítima, que, na teoria, é considerada o vértice das provas nos crimes sexuais ${ }^{35}$.

Pela própria natureza do delito, esses crimes não costumam deixar vestígios e são praticados na ausência de terceiros, o que leva à dificuldade de comprovação dos fatos por outras provas materiais ou pela participação de testemunhas no processo, além de aumentar a incidência de estereótipos de gênero sobre a vítima, o agressor e o crime.

Esses estereótipos se confundem com os mitos sobre o estupro, definidos como preconceitos, estereótipos e falsas crenças sobre o estupro, a vítima e o agressor ${ }^{36}$. São exemplos de mitos sobre o estupro: a mulher que realmente foi estuprada teria resistido fisicamente, teria lesões físicas graves e visíveis e informaria o ocorrido, imediatamente, à polícia; o estuprador é um monstro e um desconhecido da vítima; o estupro é causado por um impulso estimulado pela aparência, roupa ou comportamento da mulher ${ }^{37}$.

Nesse sentido, quando a vítima não for considerada recatada e respeitável, quando conhecer o agressor, quando não tiver resistido ou não puder provar que resistiu, ou quando não tiver denunciado o crime imediatamente à polícia, não será avaliada como uma vítima genuína ${ }^{38}$. Ou seja, quando não corresponder ao estereótipo de vítima, ou de mulher honesta, ela poderá passar, rapidamente, de vítima a responsável pela violência. Por essa razão, Silvia Pimentel, Ana Lúcia Schritzmeyer e Valéria Pandjiarjian afirmam que o estupro é "o único crime do mundo em que a vítima é acusada e considerada culpada da violência praticada

34 Tradução livre: O estupro é uma forma específica de violência contra as mulheres. Não só as vítimas de estupro são esmagadoramente mulheres, os agressores são esmagadoramente homens, mas também o estupro de mulheres por homens é parte integrante da forma como a desigualdade entre os sexos ocorre na vida. Violência íntima somada à impunidade é o maior indicativo que pode haver de poder social. O estupro evidencia e reproduz o status de inferioridade das mulheres com relação aos homens. O estupro equipara o feminino ao violável e a sexualidade feminina a uma intrusão forçada, de modo a definir e estigmatizar o sexo feminino como gênero. A ameaça de agressão sexual é uma ameaça de punição por ser mulher. MACKINNON, Catharine A. Toward feminist jurisprudence. In: SMITH, Patricia (Ed.). Feminist jurisprudence. New York: Oxford University Press, , 1993. p. 610-619. p. 615. 35 PIMENTEL, Silvia; SCHRITZMEYER, Ana Lúcia Pastore; PANDJIARJIAN, Valéria. Estupro: crime ou "cortesia"?: abordagem sociojurídica de gênero. Porto Alegre: Fabris, 1998. p. 204.

36 BURT, Martha B. Cultural myths and supports for rape. Journal of Personality and Social Psychology, v. 38, n. 2, p. 217-230, 1980. p. 217.

37 SCHAFRAN, Lynn Hecht. Barriers to credibility: understanding and countering rape myths. National Judicial Education Program Legal Momentum, 2005.

38 SCHULLER, Regina A. et al. Jugments of sexual assault: the impact of complainant emotional demeanor, gender, and victim stereotypes. New Criminal Law Review, v. 13, n. 4, p. 759-780, 2010. p. 762-764. 
contra ela" 39 . As autoras abordam essa inversão dos polos do processo na obra Estupro: crime ou cortesia? A partir da análise qualitativa de processos judiciais de estupro, e concluem que a culpabilização das vítimas decorre muitas vezes de um esforço da defesa em desqualificá-la com base no manejo dos diversos estereótipos associados à mulher no processo.

Como forma de denunciar a articulação desses estereótipos em prejuízo das mulheres, as autoras cunharam a expressão in dubio pro stereotypo, que faz alusão ao princípio da presunção de inocência (in dubio pro reo). Trata-se de uma crítica aos casos em que a presunção de inocência extravasa seus limites e se transforma em um julgamento por estereótipo: "além de contar com o benefício da dúvida, o réu conta também, a seu favor, com o benefício do estereótipo e da discriminação social, em detrimento do respeito à cidadania da vítima mulher." ${ }^{40}$.

Notamos, portanto, que as diversas reformas legais realizadas no ordenamento jurídico brasileiro não foram suficientes para alterar a cultura de gênero vigente no Judiciário. Nesse sentido, destacamos a importância de programas de conscientização e capacitação para os agentes do sistema de justiça como medida indispensável para a mudança deste paradigma ${ }^{41}$. Somado a isso, é preciso tornar essas violências naturalizadas visíveis, o que Rebecca Cook e Simone Cusack sugerem que se faça por meio da nomeação dos estereótipos.

As autoras propõem que a erradicação das múltiplas formas de discriminação contra as mulheres depende da eliminação dos estereótipos de gênero. Nesse contexto, identificar e nomear esses estereótipos seria uma etapa indispensável, parte de uma tarefa semelhante ao diagnóstico de uma enfermidade, sem o qual é impossível iniciar um tratamento. Afirmam, desse modo, que nomear permite revelar um dano individual inicialmente oculto e, com isso, reconhecer e dar visibilidade às experiências coletivas de opressão decorrentes desses estereótipos ${ }^{42}$.

Tendo em vista essa necessidade de nomear os estereótipos de gênero que integram o Judiciário e que obstam o acesso das mulheres à justiça e, assim, a efetivação dos direitos humanos das mulheres, buscamos identificar quais são os estereótipos que obstam o acesso das mulheres vítimas de estupro à justiça. Para tanto, analisamos sentenças de $1^{\circ}$ grau do Tribunal de Justiça de São Paulo (TJSP) proferidas no ano de 2016 em crimes de estupro, como explicaremos a seguir.

\subsection{Observações preliminares}

A referida busca foi realizada por meio da Consulta de julgados de $1^{\circ}$ Grau, no Portal de Serviços E-SAJ, do TJSP ${ }^{43}$, sendo obtidas 63 (sessenta e três) sentenças ${ }^{44}$.

39 PIMENTEL, Silvia; SCHRITZMEYER, Ana Lúcia Pastore; PANDJIARJIAN, Valéria. Estupro: crime ou “cortesia”?: abordagem sociojurídica de gênero. Porto Alegre: Fabris, 1998. p. 57.

40 PIMENTEL, Silvia; SCHRITZMEYER, Ana Lúcia Pastore; PANDJIARJIAN, Valéria. Estupro: crime ou "cortesia”?: abordagem sociojurídica de gênero. Porto Alegre: Fabris, 1998. p. 131.

41 COMITÊ DE ELIMINAÇÃO DA DISCRIMINAÇÃO CONTRA AS MULHERES (CEDAW). Recomendação Geral $n^{\circ} 33$ sobre o acesso das mulheres à justiça. CEDAW, 2015. p. 14-15.

BRAGA, Ana Gabriela Mendes; ANGOTTI, Bruna; MATSUDA, Fernanda Emy. Das violências reais e simbólicas: violência sexual contra as mulheres no Brasil. Boletim IBCCRIM, n. 254, jan. 2014. p. 8.

42 COOK, Rebecca; CUSACK, Simone. Estereotipos de género: perspectivas legales transnacionales. Bogotá: Profamilia, 2010. p. 54-57.

43 PORTAL DE SERVIÇOS E-SAJ. Acesso em: < https://esaj.tjsp.jus.br/cjpg/>. Foram utilizadas as seguintes coordenadas: (i) em Pesquisa Livre: "213" e "NÃO vulnerável”; (ii) em Classe: foi selecionada a opção: "Ação Penal - Procedimento Ordinário"; (iii) em Assunto, a opção: "Estupro"; e (iv) em data inicial 01/01/2016 e data final 31/12/2016. Foram descartadas as sentenças relativas ao estupro de vulnerável, termos de audiência e despachos, além de sentenças de embargos declaratórios e de extinção de punibilidade. Por fim, foram excluídas as sentenças de casos anteriores a 2010, pois em 2009 foi promulgada a Lei no 12.015 , que alterou o artigo 213, do Código Penal, unindo em um único tipo penal o crime de estupro e o crime de atentado violento ao pudor.

44 Uma justificativa para a quantidade reduzida de sentenças obtidas é que os crimes contra a dignidade sexual devem tramitar em segredo de justiça, hipótese em que o acesso ao processo se torna restrito às partes e aos seus advogados (artigo 234-B do Código Penal). 
Inicialmente, foram observados dois aspectos na amostra. O primeiro deles foi o sexo de vítimas e agressores nas sentenças analisadas: enquanto nesta pesquisa ${ }^{45} 97 \%$ das vítimas são do sexo feminino, em relatórios oficiais, esse percentual é próximo de 90\%; de modo semelhante, nesta pesquisa todos os agressores são do sexo masculino, o que corresponde aos dados oficiais, segundo os quais $97 \%$ dos agressores são homens ${ }^{46}$.

Os dados desta pesquisa correspondem ao esperado não apenas por se aproximarem dos dados que constam nos relatórios oficiais, produzidos com base em amplas amostras, mas também por ratificarem o que mostram estudos de gênero: o estupro é um crime cometido majoritariamente por homens contra mulheres. Assim, não se trata de um crime cometido apenas contra mulheres, mas predominantemente contra mulheres, o que reitera que o crime de estupro é um tipo de violência de gênero.

O segundo aspecto analisado remete à relação entre a vítima e o agressor nos casos analisados. De modo geral, classificamos o acusado: (i) como familiar, quando tinha uma relação de parentesco com a vítima (pai, tio, padrasto e companheiro da mãe); (ii) como parceiro intimo, quando os agressores já tinham tido qualquer relação amorosa, afetiva e/ou sexual com a vítima (ex-ficante, ex-namorado ou ex-marido); (iii) como conbecidos os amigos da família, vizinhos, colega de trabalho e locatário da vítima; e, por fim, (iv) como desconbecidos, aqueles que conheciam de vista a vítima, sem nunca terem conversado, e os desconhecidos de fato, que nunca tinham se visto antes.

Ao somarmos as categorias familiar, parceiro intimo e conbecido, chegamos a 55\% do total das sentenças analisadas. Assim, os dados obtidos nesta pesquisa são próximos aos dados levantados pelo IPEA, em que cerca de $60 \%$ dos estupros foram cometidos por um agressor que conhecia a vítima (familiar, ex-parceiro, amigo ou conhecido $)^{47}$.

Os dados sugerem, ainda, que parece haver uma relação inversamente proporcional entre proximidade vítima/réu e condenação. Ou seja, quanto mais íntima a relação entre a vítima e o agressor, mais difícil que o réu seja condenado - ou mais difícil acreditar na vítima. Desse modo, quando a vítima e o réu tiveram um relacionamento anterior, mais de $80 \%$ dos casos resultaram em absolvição; quando o acusado era uma familiar, mais de 60\% das sentenças foram absolutórias; e, quando o agressor era um conhecido, a probabilidade de condenação era de 50\%. Em contrapartida, caso o réu fosse um desconhecido, a chance de condenação era de $80 \%$ - o que reforça um dos principais mitos relacionados ao estupro: o estuprador como um desconhecido da vítima. ${ }^{48}$

Após algumas observações iniciais, que focaram em aspectos quantitativos, passamos a uma abordagem predominantemente qualitativa. Assim, as sentenças foram submetidas à análise de conteúdo, ou seja, elas foram examinadas a partir de um conjunto de técnicas empregadas com o objetivo de descrever as mensagens e manipulá-las, de modo a realçar aquilo que está por trás delas, o que permite inferir sobre uma realidade para além da mensagem ${ }^{49}$.

Para alcançar esse objetivo, deve-se ter em vista três fases no desenvolvimento da análise: (i) a pré-análise, que consiste na fase de organização do material e envolve a escolha dos documentos a serem analisados e

45 Este artigo é resultado de uma pesquisa desenvolvida em âmbito de mestrado, de modo que mais detalhes poderão ser consultados na dissertação: ALMEIDA, Gabriela Perissinotto de. Estereótipos de gênero sobre mulheres vítimas de estupro: uma abordagem a partir do viés de gênero e dos estudos de teóricas feministas do direito. 2017. 149 f. Dissertação (Mestrado em Ciências) - Faculdade de Direito de Ribeirão Preto da Universidade de São Paulo, São Paulo, 2017.

46 INSTITUTO DE PESQUISA ECONÔMICA APLICADA (IPEA). Estupro no Brasil: uma radiografia segundo os dados da saúde. Brasília: IPEA, 2014a. p. 8-9.

47 INSTITUTO DE PESQUISA ECONÔMICA APLICADA (IPEA). Estupro no Brasil: uma radiografia segundo os dados da saúde. Brasília: IPEA, 2014a. p. 10.

48 É importante ter em mente, ao observarmos esses dados, que a amostra que os embasa nesta pesquisa é pequena; portanto, por mais que os dados apresentados possam dar indícios do que comumente acontece no estado de São Paulo, eles devem ser lidos com cautela, a fim de evitar falsas generalizações.

49 BARDIN, Laurence. Análise de conteúdo. São Paulo: M. Fontes, 2001. p. 46. 
a formulação das hipóteses e dos objetivos do estudo; (ii) a exploração do material, que está relacionada à criação das categorias analíticas; e (iii) o tratamento dos resultados, a inferência e a interpretação, que se referem à análise propriamente dita ${ }^{50}$.

Assim, as sentenças desta pesquisa foram lidas e organizadas por eixos temáticos, a fim de identificar como as mulheres (vítimas) eram retratadas, o que subsidiou a construção de categorias de análise. Admitimos como pressuposto a necessidade de identificar e nomear os estereótipos de gênero, como destacaram Rebecca Cook e Simone Cusack. Com isso, chegamos a duas categorias: mulher honesta e mulheres não são confáveis, que serão apresentadas a seguir, em conjunto com a análise propriamente dita.

\subsection{Mulher honesta}

O termo mulher honesta era expressamente previsto em três artigos do Código Penal ${ }^{51}$, sendo revogado apenas em 2005, com a promulgação da Lei no 11.106 . Ao contrário do que se poderia supor, a expressão não remete à ética ou integridade da mulher, mas à sua conduta social, como explicou Daniella Georges Coulouris:

[...] o conceito de mulher honesta compreendia a forma de se comportar socialmente, as roupas utilizadas, o tipo de trabalho que realizavam (ou que de preferência não realizavam), o ambiente social que frequentavam ou em que residiam, sua adequação à moral sexual discursivamente prescrita em textos legais, orientações religiosas, médicas, familiares, educativas, manuais de etiqueta social e revistas femininas populares no Brasil desde o início do século XX..$^{52}$

Assim, é possível notar que a honestidade a que se refere o termo envolve, sobretudo, a adequação do seu comportamento aos padrões sociais vigentes na época, inclusive quanto ao (não) exercício de sua sexualidade. Ou seja, um bom comportamento deveria ser acompanhado pela retidão sexual, isto é, pela castidade da mulher.

Ressaltamos que o termo mulher tem sido empregado no singular justamente porque a expressão mulher bonesta tem um sentido essencialista e universalista, que representa como todas as mulheres deveriam ser, o que obsta o exercício da individualidade e da autonomia plena das mulheres. Trata-se, portanto, de um estereótipo prescritivo, pois designa um ideal de mulher a que todas as mulheres deveriam se conformar. Nesse contexto, as mulheres que se encaixam nesse estereótipo de honestidade têm sua credibilidade chancelada pelo Poder Judiciário, como mostram os dois trechos transcritos a seguir, citados pelos juízes nas suas respectivas sentenças.

É irrecusável que a palavra da vítima, nos crimes de violência sexual, assume excepcional relevância, devendo merecer credibilidade e prevalecer sobre a palavra do acusado, quando apoiada nas demais provas dos autos, e goze de boa reputação (TJSP - AC - Rel. Alves Braga - RT 448/339). (Sentença 24; Sentença 36; Sentença 56) (grifo nosso).

O primeiro deles, citado em três das sentenças analisadas, mostra como a noção de mulher honesta continua viva no imaginário do Judiciário: é a mulher que se adéqua às convenções sociais de comportamento e, por isso, goza de prestígio e confiança. Nesse caso, há um deslocamento da pauta do julgamento do crime para a vida pregressa da mulher, de modo que sua conduta familiar, afetiva e sexual será investigada a fim de deliberarem sobre a lisura da sua reputação e, consequentemente, sobre a credibilidade atribuída à sua palavra. Algo semelhante ocorre no segundo trecho, citado em duas das sentenças analisadas, em que o juiz

50 BARDIN, Laurence. Análise de conteúdo. São Paulo: M. Fontes, 2001. p. 95-141.

51 Artigo 215, então denominado posse sexual mediante fraude; artigo 216, que tipificava o atentado ao pudor mediante fraude; e, por fim, artigo 219, que descrevia o rapto violento ou mediante fraude.

52 COULOURIS, Daniella Georges. Violência, gênero e impunidade: a construção da verdade nos casos de estupro. 2004.237 f. Dissertação (Mestrado em Ciências Sociais) - Faculdade de Filosofia e Ciências da Universidade Estadual Paulista, Universidade Estadual Paulista, 2004. p. 12. 
enaltece a figura da mulher recatada.

Os crimes contra os costumes, via de regra, a prova não é coletânea dos fatos, quase sempre sendo mais circunstancial que direta. Assim, a palavra da vítima é de maior valor probante, especialmente quando se trata de mulher recatada, sem aparente interesse em prejudicar o indigitado autor do delito (TJSP - AC - Rel. Hoeppner Dutra - RT 419/88). (Sentença 24; Sentença 56) (grifo nosso).

Nesse caso, o juiz entende como mulher recatada aquela que não tem interesse em prejudicar o agressor; admite, assim, de maneira implícita, que a mulher que exerce a sua sexualidade poderá acusar o réu, apenas, para prejudicá-lo.

É interessante observarmos que a escolha dos juízes de reproduzir esses acórdãos demonstra uma anuência tácita com relação ao seu conteúdo; ou seja, se o juiz citou o trecho transcrito, é porque concorda com ele. Outra possibilidade é que ele, simplesmente, transcreva esses excertos, sem refletir sobre eles. Em ambas as hipóteses, estereótipos são reproduzidos acriticamente e, com isso, ocorre sua perpetuação.

Tratando agora apenas dos textos escritos pelos juízes e juízas responsáveis pelas sentenças analisadas, sem mais nos referirmos às citações por eles empregadas, observamos como há uma expectativa de que a mulher honesta seja, também, uma super-heroína em defesa da sua honra. Os trechos abaixo ilustram esse ponto.

Ora, em razão da pronta reação da ofendida que bravamente lutou contra seu algoz, não é possível determinar se ele realmente tinha ou não a intenção de estuprá-la, muito embora todos os indícios apontem neste sentido. (Sentença 47)

Já o crime de estupro, entretanto, foi apenas tentado. O réu, para satisfazer sua lasciva, despiu-se, deitouse sobre a vítima e passou a ameaça-la, mas ela não cedeu, ao contrário, resistiu bravamente e conseguiu sair-se ilesa, ao menos fisicamente. (Sentença 50) (grifos nossos).

É curioso notar como é, de certa forma, paradoxal a expectativa com relação à vítima: ao mesmo tempo em que ela deve ser frágil e recatada, espera-se que ela reaja bravamente diante de qualquer ameaça à sua honra. E deve, ainda, tomar cuidado para que essa reação não seja tão eficaz a ponto de impedir que o juiz identifique qual era a real intenção do réu ao abordá-la. Nesse sentido, no primeiro caso, a pronta reação da ofendida impossibilitou que o juiz deduzisse se o réu pretendia, de fato, estuprá-la - mesmo que o réu tenha dito na Delegacia que a tinha estuprado - , razão pela qual o acusado foi absolvido. Já no segundo, a condenação foi por tentativa de estupro, uma vez que a bravura da vítima permitiu que ela saísse ilesa ao menos fisicamente.

Sendo assim, parece que a reação da vítima em sua própria defesa é considerada uma característica associada ao perfil da mulher honesta; no entanto, se sua atuação for tão efetiva a ponto do crime não deixar vestígios físicos, ela poderá deixar de corresponder ao estereótipo de vítima e, com isso, não mais receber a proteção do Estado.

Quanto ao estereótipo de vítima, observamos com base nas sentenças que, de modo geral, não basta que a mulher honesta tenha sido vítima de estupro, é preciso que ela pareça ter sido vítima. Assim, é curioso como juízes e juízas ressaltam trechos dos depoimentos das testemunhas em que é descrito o estado emocional da vítima. Nesse contexto, ganham destaque os depoimentos dos policiais militares, por entrarem em contato com a vítima logo após o crime.

Expressões como: "(a vítima) mostrou-se muito abalada quando o viu (réu)" (Sentença 38), "encontraram a vítima nua e visivelmente com o estado emocional alterado" (Sentença 44) e "a vítima explicou o que havia acontecido, confirmando o estupro, estando bastante abalada e com ferimento no lábio e o rosto vermelho" (Sentença 59) são alguns exemplos de como os juízes ressaltam esses aspectos nas sentenças. Com relação a esses casos, é interessante destacar dois pontos: primeiro, que as três citações apresentadas se referem, justamente, às falas de policiais militares, cujos depoimentos gozam de fé pública, isto é, presunção de veracidade; e, segundo, que as três sentenças resultaram na condenação dos respectivos réus. 
Seria possível argumentar que os juízes e juízas não consideraram esses depoimentos provas centrais. No entanto, como esses trechos foram transcritos nas sentenças, provavelmente, foram levados em consideração, ao menos, ao julgar a credibilidade da vítima. Em alguns casos, essa influência se torna mais explícita, como na Sentença 49:

Nos crimes sexuais, que ocorrem na clandestinidade, a palavra da vítima é de suma importância, ainda quando congruente nas duas fases da persecução em que é ouvida. Mas somado a isto, reforço mais uma vez, que os policiais militares Getúlio e Dário, esclareceram para este julgador, que mantiveram contato com a ofendida logo em seguida aos fatos, e destacaram que a ofendida estava muito nervosa, abalada, em pânico, e que diante disto demonstrava dižer a verdade. (Sentença 49). (grifo nosso).

O trecho nos gera a dúvida se o juiz, de fato, considera central a palavra da vítima, ou se, apenas, acreditou nela porque os policiais reforçaram, por intermédio de suas impressões pessoais, seu estado emocional.

É possível, também, que a vítima se emocione em juízo e o juiz leve esse fato em consideração, como ocorreu na Sentença 56: "a vítima Danielle apresentou importante relato em Juízo, tendo ficado visivelmente emocionada e abalada ao relatar o ocorrido" (grifo nosso). Tanto a Sentença 49, quanto a Sentença 56 foram condenatórias.

Essas sentenças mostram uma tendência geral: as pessoas acreditam que as mulheres foram vítimas de agressão sexual com maior frequência quando elas aparentam estar emotivas e tristes, em detrimento de quando parecem calmas e controladas. Esta é uma realidade preocupante e que vai de encontro ao que acontece na realidade, em que cada vítima reage à sua maneira e segundo as suas forças.

Para que a vítima mereça credibilidade, portanto, não basta que ela seja considerada uma mulher honesta, tampouco que ela demonstre estar emotiva, parecendo ter sido vítima de estupro, é preciso corresponder a ambos os estereótipos. Além da emotividade, outro indício de que a mulher que denuncia o estupro parece ter sido vítima de violência sexual consiste nas marcas resultantes da agressão física, como mostrou a pesquisa de Janice Du Mont, Karen-Lee Miller e Terri Myhr.

O estudo revelou que a agressão física e o uso de força são indicativos de que a vítima em questão é uma vítima de verdade (real victim) e de que o crime alegado corresponde, de fato, a um estupro (real rape) - isto é, trata-se de um ato de violência, praticado por um desconhecido e, de preferência, em um lugar público e deserto. As pesquisadoras verificaram, ainda, que as vítimas têm maior probabilidade de denunciar a agressão sexual sofrida quando foram fisicamente agredidas durante o crime ${ }^{53}$.

Juízes parecem concordar que a agressão física comprova que a mulher é, de fato, vítima, como mostra a Sentença 62.

A vítima Karina ${ }^{54}$ disse que estava amamentando, quando o réu entrou pela porta, que estava aberta, e pegou a faca na cozinha, levando a vítima ao banheiro e trancando a porta. O acusado mandou a vítima tirar as vestes e rasgou-as. A ofendida disse que foi xingada e ameaçada de morte. Karina entrou em luta corporal com o réu e chamou por ajuda. [...]

Saliente-se que a versão da vítima, isto é, de que entrou em luta corporal com o acusado, encontra-se amplamente comprovada pelo laudo pericial de fl. 33, o qual atesta que Karina sofreu inúmeras lesões, conforme dito por ela na fase administrativa e em juízo. (Sentença 62)

No caso, a vítima estava dentro de sua casa amamentando sua filha quando foi surpreendida pelo réu. A amamentação, como exercício da maternidade e do cumprimento do papel que a sociedade espera de uma mulher, permite caracterizá-la como honesta. De modo semelhante, as inúmeras lesões sofridas e comprovadas pelo laudo pericial qualificam-na como vítima. O perfil de mulher honesta, acompanhado das agressões físicas, levou à condenação do réu.

53 DU MONT, Janice; MILLER, Karen-Lee; MYHR, Terri. The Role of "Real rape" and "real victim" stereotypes in the police reporting practices of sexually assaulted women. Violence Against Women, v. 9, n. 4, p. 466-486, abr. 2003. p. 469 e 478.

54 O nome da vítima foi alterado, a fim de preservar sua identidade. 
Podemos concluir, dessa forma, que mulher honesta é aquela que se comporta segundo os padrões de conduta impostos pela sociedade. Ela deve defender sua honra bravamente e, se for sexualmente agredida, deverá aparentar ser vítima, comportando-se de maneira emotiva ou apresentando marcas físicas da violência, perpetradas por um desconhecido. Somente admitidas essas condições, a vítima terá sua credibilidade reconhecida pelo juiz. Nesse sentido, Silvia Pimentel, Ana Lucia Schritzmeyer e Valéria Pandjiarjian:

O Código Penal e a própria doutrina explicitam que, no crime de estupro, é a liberdade sexual da mulher que é protegida, independentemente de sua moralidade. A doutrina é uníssona quanto à palavra da vítima constituir o vértice de todas as provas nos crimes contra os costumes. Entretanto, na avaliação das provas, pouco ou nenhum valor têm suas palavras quando não se caracteriza sua 'honestidade. ${ }^{55}$

Assim, as pesquisadoras afirmam que, embora o Código Penal e a doutrina sejam harmônicos quanto à importância da palavra da vítima em casos de estupro, na prática, sua credibilidade dependerá da caracterização de sua honestidade. Esta qualidade será de difícil comprovação, sobretudo, tendo em vista a tradição histórica de considerá-la (a honestidade) uma virtude antinatural para as mulheres ${ }^{56}$, como se, na verdade, a mulher honesta fosse uma exceção.

Veremos, na sequência, o que acontece quando a mulher não cumpre as condições exigidas para ser considerada honesta.

\subsection{Mulheres não são confiáveis}

O estereótipo mulheres não são confiáveis, diferente de quando falamos da mulher honesta, é um estereótipo descritivo. Isso não significa que ele, de fato, descreva uma característica atribuível às mulheres, revela, apenas, que as pessoas acreditam, consciente ou inconscientemente, que essa generalização é válida para todas elas. Nesse sentido, se, para ser considerada uma mulher honesta, é necessário que a mulher cumpra todos os pré-requisitos relacionados à conduta familiar, social e, até mesmo, sexual; para que ela não seja considerada confiável, basta ser mulher.

Daniella Georges Coulouris inicia sua tese de doutorado apresentando a história da desconfiança das mulheres, por meio da narrativa do caso de Artemísia Gentileschi (1593-1656), primeira mulher a ser aceita na Academia de Belas Artes de Florença, na Itália. Quando Artemísia completou 17 anos, foi estuprada por um pintor famoso, amigo de seu pai. Ao invés de ter seu agressor condenado, Artemísia foi torturada.

Do Século XVII aos dias atuais muitas coisas mudaram; no entanto, a desconfiança com relação à palavra da vítima não parece ser uma delas. Ainda hoje, há uma crença amplamente compartilhada de que as mulheres mentem sobre terem sido sexualmente violentadas, imputando falsamente o crime ao acusado.

Embora essa crença vá de encontro a estudos que mostram que o percentual de falsas acusações de estupro é baixíssimo, próximo a $2 \%$ do total de denúncias ${ }^{57}$, essa ideia parece imperar inclusive no Judiciário, em que, quando as mulheres não corresponderem ao estereótipo de gênero da mulher honesta e/ou não parecerem ter sido vítimas de estupro, terão sua credibilidade questionada, como ocorreu na Sentença 12.

Em Juízo, o réu negou a prática do crime. Disse que a relação íntima foi consentida e que ambos já tinham um relacionamento anterior.

Por outro lado, comparando os depoimentos da vítima e das testemunhas ouvidas, em juízo, não se conclui com a certeza necessária ter o acusado empregado violência física on grave ameaça contra a vítima, para praticar os atos libidinosos.

55 PIMENTEL, Silvia; SCHRITZMEYER, Ana Lúcia Pastore; PANDJIARJIAN, Valéria. Estupro: crime ou "cortesia”?: abordagem sociojurídica de gênero. Porto Alegre: Fabris, 1998. p. 204.

56 HESPANHA, António Manuel. El estatuto jurídico de la mujer en el derecho común clásico. Revista Jurídica, Madrid, n. 4, Universidad Autónoma de Madrid, p. 71-88, 2001. p. 85-86.

57 GRUBB, Amy; TURNER, Emily. Attribution of blame in rape cases: a review of the impact of rape myth acceptance, gender role conformity and substance use on victim blaming. Aggression and Violent Behavior, n. 17, p. 443-452, 2012. p. 445. 
É que a prova oral também indica que o depoimento da vítima não foi convincente, militando a dúvida em favor do acusado.

O próprio policial destacon que a vítima não aparentava ter sido vítima de crime de estupro. (Sentença 12) (grifo nosso).

Nessa sentença, a alegação do réu de que ele teria tido um relacionamento anterior com a vítima sugere que ela mentiu, deixando de corresponder à figura da mulher honesta; somado a isso, o depoimento do policial destacou que a mulher não aparentava ter sido vítima. O juiz demonstrou concordar com essa afirmação ao alegar que não constatou que o acusado tenha empregado violência física ou grave ameaça. É importante destacar, quanto a esse ponto, que o juiz interpreta restritivamente o artigo 213 do Código Penal, que tipifica o estupro, pois o crime não exige que a violência seja física. Decidindo dessa forma, ele reforça, não apenas o estereótipo de vítima, mas também o estereótipo de estupro.

Daniella Coulouris afirma que há uma tendência geral a desconfiar da vítima quando não há ou não parece ter havido uso de violência física no crime: "a mulher adulta que denuncia um homem por estupro será sempre vista com desconfiança, principalmente se não for agredida ou explicitamente ameaçada" 58 . Na Sentença 51, a violência física como requisito para que a mulher realmente tenha sido vítima de estupro se repete.

Deve ser ressaltado que a vítima não apresentava quaisquer sinais de lesões pelo corpo, a denotar possível ação de resistência ao agressor. Além disso, apresentava deflorada na data do exame, de data não recente.

Os relatos da vítima são extremamente confusos, impregnado de incerteza e dúvidas, não autorizando o édito condenatório.

A prova testemunhal não permite concluir que o acusado agiu da forma como descrita na imputação, pois a versão incriminadora apresentada pela vítima carece de verossimilhança. (Sentença 51) (grifo nosso).

Nesse caso, a ausência de marcas físicas que provassem a resistência à agressão impede que a mulher corresponda ao estereótipo de vítima e que seja considerada a heroína que a mulher honesta deve ser. Além disso, o fato de a vítima ter sido deflorada em data não recente, ou seja, não ser virgem, parece ser o atestado final de que não se trata de uma mulher honesta.

É interessante observarmos que nessa sentença o juiz tanto acredita na inocência do réu, que denomina a versão dos fatos apresentada pela vítima de incriminadora, denotando que o réu é inocente, a vítima é que quer toná-lo um criminoso. Nesse contexto, até mesmo a sanidade mental da mulher poderá ser questionada, como ocorreu na Sentença 11, em que o magistrado solicitou laudo psicológico a fim de averiguar o pleno exercício das faculdades mentais da vítima.

Ela (vítima) foi ouvida pela psicóloga do setor técnico deste fórum e o laudo apontou que ela apresenta 'curso e forma do pensamento dentro da normalidade com elaboração de crítica adequada e planificação futura consciente'. Disso se depreende que, ao menos no plano teórico, não parece haver indicativos de que ela mente. (Sentença 11) (grifo nosso).

É interessante observar que, de maneira implícita à requisição de perícia psicológica, estão outros dois estereótipos bastante comuns: as mulheres são "loucas" e, por isso, elas mentem.

Como veremos na sequência, a partir da análise de outros casos, o estereótipo da mulher mentirosa é frequentemente compartilhado por juízes e se manifesta de formas variadas. Mulheres mentem porque são loucas, porque querem incriminar o réu, porque são vingativas, porque demoraram a denunciar o estupro, porque são interesseiras, ou simplesmente porque são mulheres. Nesse sentido, na Sentença 26, o juiz considerou inverossímil e contraditória a versão dos fatos narrada pela vítima por considerá-la diferente do que costumeiramente acontece em casos de estupro.

58 COULOURIS, Daniella Georges. Violência, gênero e impunidade: a construção da verdade nos casos de estupro. 2004.237 f. Dissertação (Mestrado em Ciências Sociais) - Faculdade de Filosofia e Ciências da Universidade Estadual Paulista, Universidade Estadual Paulista, 2004. p. 147. 
A prova produzida, durante a instrução criminal, é fraca e malsegura, uma vez que os relatos da vítima são absolutamente incompatíveis com o que no mais das vezes ocorre, ferindo a razoabilidade. Os depoimentos tomados, conquanto tendentes a confortar a versão incriminadora da vítima, mostram-se dissociados do que costumeiramente acontece e de todo o colhido não se extrai certeza de violência capaz de mitigar reação da vítima. (Sentença 26) (grifo nosso).

Apesar dos depoimentos das testemunhas terem sido considerados harmônicos com relação ao depoimento da vítima, o magistrado não acreditou nos fatos narrados por considerá-los diferentes do que ele acredita que costuma acontecer nesses casos. Em outras palavras, a versão dos fatos, apresentada pela vítima, não coincidia com os estereótipos compartilhados pelo magistrado sobre o crime de estupro. O curioso (e preocupante) é que o juiz não relata na sentença qual a versão da vítima quanto aos fatos, tampouco o que ele acredita ser habitual em casos de agressão sexual.

Também são frequentes os casos em que a mulher é considerada mentirosa com base em uma análise minuciosa de sua conduta pregressa, sobretudo, de sua vida sexual. É o que ocorreu na Sentença 13, em que, a fim de deliberar acerca da credibilidade da palavra da vítima, a juíza desloca o julgamento dos fatos para o comportamento da mulher, passando a investigar se ela era ou não virgem à época do ocorrido.

Ocorre que a vítima afirmou a esta magistrada que a sua primeira relação sexual foi com o réu, quando a testemunha Guilherme, advertido sob o compromisso de dizer a verdade e, mesmo maior e capaz, acompanhado do pai em audiência, asseverou ter namorado Beatriz antes do nascimento da irmã e que tiveram relação sexual, por duas vezes, em dois finais de semana que dormiu na casa da namorada. (Sentença 13) (grifo nosso).

Não se trata de saber se a vítima mentiu ou não quanto a ser virgem, uma vez que sua virgindade não deveria sequer estar em pauta, pois evidentemente não faz parte do mérito da ação. Além disso, não podemos deixar de notar que a palavra da vítima é totalmente desconsiderada diante do depoimento da testemunha: seu ex-namorado. Quanto a este ponto, é importante observar que, embora a vítima seja frequentemente acusada de imputar falsamente a denúncia ao réu, especialmente quando eles já tiveram um relacionamento anterior, o mesmo raciocínio (e desconfiança) não se aplica a testemunhas do sexo masculino que já se relacionaram com a vítima.

A Sentença 13 não é um caso isolado: várias decisões fazem alusão ao comportamento da vítima - para absolver o réu ou para condená-lo. Isso significa que, mesmo quando o Judiciário conclui pela culpa do agressor, a vítima não estará a salvo de ser revitimizada. Nesse sentido, pudemos observar que, em alguns casos, o comportamento da vítima é sopesado na dosimetria da pena, como a seguir: "por fim, não há o que se analisar sobre o comportamento da vítima" (Sentença 30), "o comportamento da vítima não influenciou na prática do crime" (Sentença 52) e "a vítima em nenhum momento contribuiu para a prática do crime" (Sentença 60).

Assim, para que a vítima não seja considerada culpada pelo estupro praticado contra ela, o magistrado terá que "absolvê-la" na sentença. Essa prática é uma grande evidência de que os polos processuais, de fato, podem se inverter nos crimes de estupro, sendo a vítima colocada em julgamento juntamente ao réu ou, até mesmo, em seu lugar.

Nesse contexto de desconfiança, qualquer alteração na versão dos fatos apresentada pela vítima poderá ser um indício do desvio de seu comportamento. Na Sentença 45, por exemplo, o juiz ressalta: “a vítima Verônica quando ouvida na fase investigativa relatou que o réu lhe fez sexo oral, mas não pediu que ela fizesse nele; em juízo mudou a versão afirmando que o denunciado a obrigou a manter sexo oral nele". Aparentemente, essa pequena mudança no depoimento da vítima ao narrar os fatos fez com que a vítima fosse considerada mentirosa. Possivelmente, de maneira paralela, o fato de a vítima ter sido apontada pelo réu como prostituta deve ter contribuído, conscientemente ou não, para que o juiz determinasse a absolvição do réu.

Há casos, ainda, em que o juiz sequer indica a suposta alteração que ele teria identificado no depoimento da vítima. Na Sentença 8, por exemplo, o juiz apenas afirma: “a versão apresentada em Juízo pela vítima 
divergiu daquela apresentada à Autoridade Policial" e, de modo semelhante, na Sentença 20: "a vítima apresentou versões diversas na delegacia e em juízo". Essas sentenças comprometem o acesso das mulheres à justiça, por cercear a possibilidade da vítima recorrer da decisão, já que ela desconhece o fundamento que a embasa.

Quando a vítima tiver, de fato, alterado seu depoimento, o resultado será ainda mais cruel. É o que ocorre na Sentença 3, em que ela afirmou em juízo que não teve relacionamento anterior com o réu, para depois, na acareação, admitir que já havia tido relação sexual com ele em outras três oportunidades. O magistrado acrescentou a essa informação o fato de a vítima ter mentido sobre estar menstruada na data dos fatos e decidiu: "remetam-se cópias dos depoimentos prestados em juízo ao Ministério Público para análise de denunciação caluniosa pelas vítimas." (Sentença 3) (grifo nosso).

É interessante notar que o juiz ignora a possibilidade de a vítima ter mentido quanto ao relacionamento anterior por ter conhecimento acerca da persistente impunidade nos crimes praticados por agressores conhecidos, especialmente parceiros íntimos, como mostram alguns dados apresentados nesta pesquisa. Além disso, a sentença alimenta o estereótipo segundo o qual, em razão de o réu e a vítima já terem se relacionado anteriormente, ela, necessariamente, consentiu.

Nesse sentido, Amy Grubb e Emily Turner relatam estudo em que os promotores foram menos propensos a dar prosseguimento à denúncia em casos de estupro quando a vítima admitiu ter flertado com o acusado, permitiu que ele a levasse para a casa, consentiu com a prática de alguns atos sexuais, ou tinha ingerido álcool antes da ocorrência dos fatos criminosos ${ }^{59}$. Tratam-se, portanto, de formas variadas de culpabilizar a vítima pela agressão sofrida.

A análise das sentenças confirmou que existe uma tendência dos juízes acreditarem que a consequência lógica do consentimento com relação a alguns atos, como os apresentados acima, é a anuência com relação a todos os atos subsequentes. Isso significa que será difícil que o juiz acredite na palavra da vítima quando ela tiver saído com o réu "por vontade própria", o que parece, aos olhos do magistrado, ser suficiente para que a vítima tenha consentido com o que quer que tenha acontecido depois.

Saliente-se que a vítima Laura estava em companhia do acusado por vontade própria. Foi a vítima e sua irmã Ana que solicitaram carona ao réu e pediram para que ele as levasse para passear na cidade de Ariranha, e ainda que chamasse seu amigo Albert, para acompanhar Ana, restando mais que evidente que a intenção de todos era ter uma aventura amorosa naquela noite. (Sentença 55) (grifo nosso).

O consentimento da mulher ganha ainda menos importância quando o juiz aponta o fato da vítima ter ingerido álcool antes dos fatos terem ocorrido, o que a descaracteriza como mulher honesta.

Ademais, deve ser ressaltado que foi noticiado nos autos que em referida lanchonete, a vítima fez ingestão de considerável quantia de bebida alcoólica, conforme admitido por ela própria e por sua irmã Ana, arrolada como testemunha de acusação. [...] Não que isso comprove a inocorrência dos fatos ou o consentimento da vítima para eventual conjunção carnal e ato libidinoso, mas ao menos indica essa possibilidade, ou seja, de que a vítima possa ter consentido para o ato, até mesmo por estar sob o efeito de álcool, e depois tenba se arrependido.

Neste diapasão, também é possivel que o desmaio, vômito e mesmo crise de choro da ofendida, relatado pelas testemunhas Ana e Leandro, possam ser decorrentes de eventual estado de embriaguez, de Laura. (Sentença 55) (grifo nosso).

O magistrado chega a afirmar que a emoção exibida pela vítima após os fatos teria sido, na verdade, efeito do álcool. Com isso, admite, como hipótese, que a vítima poderia ter consentido com o ato sexual e se arrependido posteriormente - motivo que a teria levado a incriminá-lo.

Assim como nesse caso, estudos mostram que a ingestão de álcool pela vítima é um fator que comumente leva à sua culpabilização. Nesse sentido, Amy Grubb e Emily Turner relatam que vítimas que ingeriram

59 GRUBB, Amy; TURNER, Emily. Attribution of blame in rape cases: a review of the impact of rape myth acceptance, gender role conformity and substance use on victim blaming. Aggression and Violent Behavior, n. 17, p. 443-452, 2012. p. 445. 
bebidas alcoólicas antes de serem sexualmente violentadas são mais responsabilizadas pela agressão sofrida que vítimas que não as consumiram. Além disso, os acusados são considerados menos culpados pelo crime praticado quando a vítima estiver bêbada, o que, curiosamente, independe do fato de eles terem ingerido álcool antes dos fatos ${ }^{60}$.

No entanto, não é necessário que a vítima tenha ingerido bebidas alcoólicas para que desconfiem dela, sobretudo se existir uma relação anterior entre ela e o réu. Nessa hipótese, o agressor pode ser um ex-parceiro, um vizinho, ou um familiar; o fato é que, se for um conhecido, será ainda mais difícil que acreditem na vítima $^{61}$. Na Sentença 58, por exemplo, o relacionamento anterior, cumulado com a demora da vítima para denunciá-lo e com o suposto medo de seus pais, levou à absolvição do réu.

Embora a vítima tenha relatado os fatos em audiência, na forma como descritos na denúncia, se mostrando até emocionada, o acusado negou os fatos.

É certo que autor e vítima namoravam, alegando o acusado que a conjunção carnal foi consentida, sendo que a ofendida alegou que o fato ocorreu com violência.

No entanto, embora seja bem possível que o crime tenha sido praticado, não há nos autos provas suficientes para uma condenação.

Isto porque, a vítima demorou quase um mês para apresentar boletim de ocorrência, sendo que eventuais lesões sofridas para a prática do ato, não puderam mais ser constatadas.

Foi constatada gravidez, mas não foi realizado exame de $D N A$, não sendo possível verificar se a gravidez era decorrente de ato sexual praticado com o réu.

E, por fim, ainda que o ato tenha sido praticado com o acusado, não há prova segura da violência. (Sentença 58) (grifo nosso).

O juiz afirma que, no caso, "há apenas a palavra da vítima contra a do acusado", e, ao que parece, a palavra do réu vale mais - especialmente quando há um motivo para a vítima ter mentido.

[...] no presente caso, a palavra da vítima tem que ser verificada com parcimônia, pois ela tinha muito temor dos seus familiares que eram muito rígidos em razão da religião e não permitiam que ela namorasse com ninguém e, quando descobriu a gravidez, isso pode ter motivado a invenção da versão de que o ato sexual não fora consentido, para se eximir da sua responsabilidade perante os familiares. (Sentença 58) (grifo nosso).

Daniella Coulouris afirma que, em casos de estupro praticados por um agressor conhecido, há uma busca, com base no comportamento da vítima, por motivos que poderiam tê-la levado a incriminar falsamente o réu. Há, também, diversos casos em que as vítimas voltam atrás na denúncia no desenvolvimento do processo $^{62}$. Isto ocorre, sobretudo, quando réu e vítima têm relação de parentesco. Nesses casos, há, ainda, uma conspiração do silêncio, caracterizada por um longo período de violação e de silêncio, até que um fato concreto rompa com ele. É o que explicam Silvia Pimentel, Ana Lucia Schritzmeyer e Valéria Pandjiarjian:

Ainda no caso de estupro praticado pelo pai ou padrasto contra meninas, ocorrido na unidade doméstica, há três importantes questões a serem ressaltadas. A primeira delas diz respeito à reiteração e continuidade da violação que caracteriza a maior parte dos processos desta natureza; a segunda refere-se ao longo período de silêncio - dificilmente rompido - em que, em geral, permanecem as vítimas desse tipo de violência doméstica ("conspiração do silêncio"); por fim, a terceira diz respeito ao frequentemente alegado (pseudo?) desconhecimento por parte da mãe da vítima da violação praticada. ${ }^{63}$

60 GRUBB, Amy; TURNER, Emily. Attribution of blame in rape cases: a review of the impact of rape myth acceptance, gender role conformity and substance use on victim blaming. Aggression and Violent Behavior, n. 17, p. 443-452, 2012. p. 449.

61 SCHULLER, Regina A. et al. Jugments of sexual assault: the impact of complainant emotional demeanor, gender, and victim stereotypes. New Criminal Law Review, v. 13, n. 4, p. 759-780, 2010. p. 763.

62 COULOURIS, Daniella Georges. Violência, gênero e impunidade: a construção da verdade nos casos de estupro. 2004.237 f. Dissertação (Mestrado em Ciências Sociais) - Faculdade de Filosofia e Ciências da Universidade Estadual Paulista, Universidade Estadual Paulista, 2004. p. 158.

63 PIMENTEL, Silvia; SCHRITZMEYER, Ana Lúcia Pastore; PANDJIARJIAN, Valéria. Estupro: crime ou "cortesia”?: abordagem sociojurídica de gênero. Porto Alegre: Fabris, 1998. p. 204-205. 
A reiteração da violação e o longo período de silêncio estão presentes no caso apresentado a seguir, que ilustra como esse processo de silenciamento da vítima ocorre.

De plano, verifica-se que a própria narrativa da vítima não demonstra a grave ameaça ou violência que teria sido praticada pelo réu. Aliás, pela narrativa da vítima, os fatos se aproximaram muito mais de uma relação consensual do que propriamente de grave ameaça. Segundo a vítima, pediu para ele parar, tentando empurrar com os pés. Porém, não se verifica até que ponto esse pedido se mostrou verossímil no caso em questão. [...]

No mais, soa estranho a vítima em juízo narrar que vinha sofrendo abuso desde infante. Isso porque, se ela já tem 21 anos, poderia ter denunciado muito antes a questão e não o fer:

Por fim, o comportamento em audiência, requerendo de qualquer forma retirar a representação em face do réu, ou melhor, dizendo que não representou o réu, é elemento que torna ainda mais fraca a tese de que ocorreu grave ameaça. (Sentença 19) (grifo nosso).

Nessa decisão, embora a vítima tenha sofrido abusos sexuais desde os 8 anos de idade, o elemento concreto que rompe seu silêncio é a conjunção carnal, praticada contra ela aos 21 anos. Observamos que, quando a vítima altera seu depoimento para não mais acusar o réu, o juiz, automaticamente, assume que a denúncia inicial era falsa e sequer cogita a possibilidade de a vítima ter retirado a denúncia por outro motivo - seja ameaça ou pressão familiar.

Os casos narrados demonstram como os estereótipos estão arraigados no Judiciário, fato que discutiremos a seguir.

\section{DisCUSSÃo}

A partir das sentenças analisadas, é possível observar como os estereótipos estão imbricados nos três níveis sociais, como propuseram Rebecca Cook e Simone Cusack, ou seja, no nível individual, coletivo e geral.

Quanto ao nível individual, relativo ao processamento cognitivo, percebemos que o viés de gênero costuma estar presente nas sentenças analisadas e pode decorrer das três heurísticas cunhadas por Tversky e Kahneman: ancoragem, representatividade e disponibilidade.

Nesse sentido, a ancoragem pode ser observada no apego a noções obsoletas, identificadas nesta pesquisa com os seguintes estereótipos: a figura da mulher honesta e a representação da mulher como alguém de quem se deve desconfiar - concepções revogadas do ordenamento jurídico e que não deveriam ser empregadas sequer indiretamente, especialmente tendo em vista a promulgação da Constituição Federal, em 1988, que estabeleceu o marco normativo com relação à igualdade de gênero.

A representatividade, por sua vez, diz respeito ao uso de estereótipos para chegar a uma decisão. Se o juiz considera que apenas mulheres honestas dizem a verdade quando são sexualmente agredidas, ele comparará a vítima do caso com o que ele acredita corresponder ao perfil da mulher honesta. Assim, se for uma trabalhadora do sexo, ela não deve ser honesta. O mesmo raciocínio vale se a vítima ingeriu álcool antes dos fatos, e assim sucessivamente.

No caso da disponibilidade, o indivíduo leva em consideração apenas um componente ou evidência ao decidir, em detrimento de todo um complexo de informações. Trata-se justamente do que acontece quando o juiz decide com base no estereótipo de mulher honesta, no comportamento da vítima, na existência de um relacionamento anterior entre a vítima e o réu, em detrimento de uma análise que pondere os elementos do conjunto probatório.

Diante disso, notamos que as três heurísticas se articulam no emprego dos estereótipos como atalhos cognitivos. Por exemplo, ao decidir com base na reação emocional da vítima, o indivíduo fica ancorado na 
ideia de que as vítimas reagem de uma determinada maneira ao estupro, independentemente dos estudos mostrarem que cada indivíduo reage à sua maneira a situações traumáticas ${ }^{64}$; de modo semelhante, a representatividade faz com que esse sujeito acredite que, se algumas vítimas ficam emotivas após sofrerem uma agressão, essa reação será aplicável a todas as vítimas; já a disponibilidade faz com que o juiz foque na emotividade e ignore outras evidências.

O mesmo raciocínio poderia ser aplicado à crença de que as mulheres mentem sobre terem sido vítimas de estupro. O julgador fica ancorado na crença histórica e religiosa de que mulheres não são confiáveis e imputam falsamente o crime ao agressor; como acredita que ser mentirosa é representativo da categoria mulheres, aplica essa falsa crença a todas elas; a disponibilidade completa a tríade, e leva o sujeito a ignorar as estatísticas que mostram o baixíssimo percentual de falsas acusações.

Se as heurísticas e os vieses atuam no nível individual, as representações sociais criadas sobre as mulheres permitem que esses estereótipos atuem no nível coletivo. Assim, por exemplo, os ambientes familiares reforçam a crença de que as mulheres devem ser submissas, de modo que, até mesmo quando são estupradas por alguém da família, são pressionadas para não denunciar o crime ou para retirar a denúncia, alterando sua versão dos fatos. De modo semelhante, os mitos sobre o crime, o agressor e a vítima de estupro são amplamente compartilhados e levam, por exemplo, à impunidade do agressor quando ele é um conhecido da vítima, reforçando a ideia de que o estuprador é um desconhecido. Isso quando, como mostrou o relatório do IPEA, o estupro é o crime que acontece às segundas-feiras ${ }^{65}$, em que o agressor se aproveita de uma relação prévia de confiança para praticar a violência.

Todos esses fatores levam à consolidação dos estereótipos a um nível mais geral, pois sustentam uma cultura de subordinação das mulheres. Nesse contexto, crenças religiosas, fatos históricos e leis revogadas continuam a influenciar o senso comum e a consolidar ideias ultrapassadas (e equivocadas). É importante destacarmos, quanto a esse ponto, que os estereótipos nomeados nesta pesquisa já tinham sido identificados há 20 anos, no estudo que resultou na publicação da obra Estupro: crime ou cortesia?

É possível que os estereótipos se manifestem de maneira menos explícita atualmente, mas é preocupante o fato deles continuarem vigentes na sociedade e sendo reproduzidos nas sentenças. Isso porque a perpetuação dos estereótipos permite que eles ofereçam suporte a práticas discriminatórias contra as mulheres, dificultando o seu acesso à justiça e obstando a efetivação dos direitos humanos das mulheres.

É certo que, dentre as 63 sentenças analisadas, algumas adotaram uma perspectiva de gênero; no entanto, na maioria dos casos, foram reproduzidos estereótipos de gênero ou foi adotada uma postura de omissão com relação às representações estereotipadas sobre a vítima. Em ambos os casos, o juiz ou a juíza mitiga o acesso das mulheres à Justiçç ${ }^{66}$, tornando-a um espaço de investigação sobre a vida pregressa da mulher e, portanto, de revitimização. Enfrentar a produção e reprodução de estereótipos nesse contexto é uma medida urgente.

64 Nesse sentido, embora os estereótipos muitas vezes digam o contrário, a reação das mulheres são variadas; podendo perfeitamente aparentar calma. BUDDIE, Amy M.; MILLER, Arthur G. Beyond rape myths: a more complex view of perceptions of rape victims. Sex Roles, v. 45, n. 3/4, p. 139-160, ago. 2001. p. 143-144.

65 O relatório mostrou a seguinte ocorrência de estupro (em percentual) por dias da semana: segunda-feira - 21,1\%; terça-feira 16,5\%; quarta-feira - 15,9\%; quinta-feira - 14,9\%; sexta-feira - 14,5\%; sábado - 8\%; domingo - 9,2\%. INSTITUTO DE PESQUISA ECONÔMICA APLICADA (IPEA). Estupro no Brasil: uma radiografia segundo os dados da saúde. Brasília: IPEA, 2014a. p. $26-27$. 66 É necessário compreendermos o acesso à justiça em dois momentos: da denúncia da agressão sofrida; e do direito a um julgamento de boa qualidade. O primeiro consiste em promover um ambiente receptivo e acolhedor para que as mulheres se sintam seguras para denunciar o crime - o que não acontece, tendo em vista as já apresentadas taxas de subnotificação em casos de estupro; e o segundo compreende ter acesso a um bom julgamento, livre de estereótipos, em que a vítima não seja culpabilizada pela agressão praticada contra ela. Nesse sentido, apesar de focarmos, neste trabalho, no segundo momento, uma vez que a análise de sentenças remete a casos em que as mulheres já passaram pelo primeiro momento (denúncia), é preciso compreender o acesso à justiça de maneira sistêmica. Garantir um acesso à justiça de boa qualidade às mulheres pode ajudar a tornar este um espaço seguro e acolhedor para que elas denunciem as agressões. Assim, a garantia do "acesso secundário" ao sistema de justiça poderá contribuir para que o "acesso primário" também se torne efetivo. 


\section{Considerações finais}

As alterações legais ${ }^{67}$ relativas ao crime de estupro, acompanhadas da ratificação e promulgação de tratados internacionais sobre gênero ${ }^{68}$, são importantes para o projeto de efetivação e consolidação dos direitos das mulheres, no entanto, essas modificações ainda não têm sido suficientes para transformar as práticas sociais com relação ao gênero, havendo uma enorme distância entre o direito formal e o direito que se pratica. Uma justificativa para isso pode ser encontrada na concepção de Direito apresentada por Alda Facio, que se contrapõe ao positivismo legalista, ou seja, não é entendido como sinônimo de lei promulgada, pois ganha contornos muito mais amplos, incluindo normas de administração da justiça, normas de interpretação e também regras informais, que surgem a partir dos costumes, tradições e práticas políticas. Alda Facio propõe e sistematiza esse conceito a partir de três eixos: (i) componente formal-normativo; (ii) componente estrutural; e (iii) componente político-cultural.

O componente formal-normativo diz respeito às leis escritas e formalmente promulgadas, ou seja, que passaram pelo procedimento legislativo necessário para que se tornassem leis. São as leis constitucionais, infraconstitucionais, tratados internacionais, decretos, regulamentos, entre outros. O componente estrutural, por sua vez, é formado pelas instituições jurídicas e pelo conteúdo que os atores do sistema de justiça atribuem às leis ao aplicá-las e interpretá-las - conteúdo este que se torna tão efetivo e vigente quanto às próprias leis escritas. Por fim, o componente politico-cultural, que corresponde aos sentidos que as pessoas conferem às leis e à sua aplicação com base na doutrina jurídica, nas tradições e nos costumes, assim como o uso que elas fazem tanto das leis existentes, quanto daquelas que seguem vigentes como senso comum, apesar de terem sido formalmente revogadas ${ }^{69}$.

Facio explica que esses componentes são imbricados, ou seja, estão relacionados entre si, de modo que cada um deles é influenciado, limitado e definido pelo outro. Por exemplo, a própria interpretação que um tribunal atribui a uma lei (componente estrutural) depende da existência de uma lei (componente formal-normativo) e dos sentidos que os especialistas e os cidadãos atribuem a ela (componente político-cultural). Isso significa que, para que se apreenda o conteúdo e os efeitos de uma lei, é necessário analisá-la sob essas três perspectivas. Essa compreensão ampliada do fenômeno jurídico é especialmente importante para as mulheres, porque inclui as leis não escritas e as regras informais, que são frequentemente retomadas nas práticas e nos discursos jurídicos e acabam por reforçar a mentalidade institucional que compactua com a subordinação das mulheres na sociedade.

Partindo dessa compreensão de Direito, verificamos que, apesar de as mudanças terem sido promovidas quanto ao componente formal-normativo (leis e convenções, por exemplo), pouco se tem feito quanto aos componentes estrutural e político-cultural, que fazem parte do processo de atribuição de sentido às normas. Assim, as alterações legais têm seu efeito positivo mitigado pela ainda arraigada cultura sexista e discriminatória contra as mulheres que influencia a interpretação e aplicação das leis, tal qual o senso comum vigente.

São necessárias, portanto, políticas públicas no sentido de transformar a cultura de subordinação de gênero. Nesse sentido, Eva Blay propõe que o enfrentamento dessa cultura requer "políticas públicas transversais que atuem modificando a discriminação e a incompreensão de que os Direitos das Mulheres são Direitos Humanos" ${ }^{\text {"70 }}$. Ela afirma que essa iniciativa depende de uma ação conjugada, que articule programas de diferentes Ministérios (da Justiça, Educação, Saúde, Planejamento, entre outros), sendo fundamental, em termos de educação, a inclusão da dimensão de gênero nos programas escolares.

67 Especialmente, pelas Leis no 11.106/2005 e no 12.015/2009.

68 Com destaque para a CEDAW e a Convenção de Belém do Pará.

69 FACIO, Alda. Cuando el género sueña cambios trae: uma metodología para el análisis de género del fenômeno legal. Costa Rica: ILANUD, 1999. p. 64.

70 BLAY, Eva Alterman. Violência contra a mulher e políticas públicas. Estudos Avançados, São Paulo, v. 17, n. 49, p. 87-98, dez. 2003. p. 96. 
Essas políticas públicas, também, devem levar em consideração a variedade de sujeitos a quem elas se destinam, bem como suas múltiplas experiências, ou seja, deve-se adotar uma perspectiva interseccional nessa atuação. A título de exemplo, o Mapa da Violência 2015: homicídio de mulheres no Brasil mostrou que, embora o número de homicídios de mulheres brancas tenha diminuído cerca de 10\% entre 2003 e 2015, o homicídio de mulheres negras aumentou mais de $50 \%$ no mesmo período ${ }^{71}$. Esses dados reforçam o entendimento de que a transformação da cultura patriarcal e a ampliação dos direitos humanos em termos de gênero também deve se atentar às diversas formas pelas quais o gênero se intersecta com outros marcadores sociais, como a raça, mas também a classe, a sexualidade, a nacionalidade, a idade, entre outras.

A ampliação dos direitos humanos das mulheres - em termos de intersecção, inclusive - depende de políticas que atuem nos três níveis em que estão imbricados os estereótipos: individual, coletivo e geral ${ }^{72}$. No nível individual, esse enfrentamento deve passar pela implantação de medidas que visem mitigar os efeitos do viés de gênero no julgamento dos magistrados e magistradas; no coletivo e geral, devem ser aplicadas medidas propostas em estudos feministas do direito que visem diminuir os efeitos sociais gerados pelos estereótipos. Essa dupla ação é necessária porque, se, no nível individual, o objetivo é evitar que o viés de gênero comprometa o processamento cognitivo dos juízes e juízas ao decidir, e influencie, ainda que inconscientemente, a tomada de decisão judicial; no coletivo e mais geral ${ }^{73}$ a finalidade é identificar como os estereótipos se mantêm e sustentam a estrutura social vigente de subordinação das mulheres. Nesse sentido, concordamos com Nancy Levit que é necessária a articulação entre essas frentes de atuação, pois ela permite a conjugação desses eixos no enfrentamento aos estereótipos.

A primeira medida a ser adotada, a fim de combater os estereótipos, seja em termos de viés de gênero ou de práticas sexistas, consiste em conhecê-los, conscientizando-nos de sua existência e identificando/ nomeando esses estereótipos ${ }^{74}$, sendo a educação o caminho mais adequado e capaz de viabilizar essa primeira medida. Nesse sentido, a Recomendação Geral no 35 da CEDAW sobre violência de gênero contra as mulheres ressalta ser esta uma medida preventiva, que visa enfrentar as causas subjacentes à violência (incluindo estereótipos de gênero), e promover o empoderamento, a atuação e a voz das mulheres. Assim, sugere a integração do conteúdo de igualdade de gênero nos currículos de todos os níveis educacionais públicos e privados, que deverá abordar papeis estereotipados de gênero e promover valores de igualdade e não discriminação. Além disso, sugere a criação de programas de conscientização que mostrem que a violência de gênero e a culpabilização da vítima são inaceitáveis ${ }^{75}$.

De modo semelhante, a Recomendação Geral no 33 da CEDAW sobre acesso das mulheres à justiça sugere a adoção de programas de conscientização e capacitação dos agentes do sistema de justiça e estudantes de direito, para eliminar os estereótipos de gênero e incorporar essa perspectiva em todos os aspectos do sistema de justiça. Esses programas de capacitação devem incluir profissionais de outras áreas, como a saúde, e tratar de alguns temas em especial, como da questão da credibilidade e do peso dado às vozes, aos argumentos e depoimentos das mulheres, seja como partes ou como testemunhas ${ }^{76}$. Esse investimento na educação como chave preventiva visa, sobretudo, proporcionar uma nova bagagem aos estudantes e pro-

71 FACULDADE LATINO-AMERICANA DE CIÊNCIAS SOCIAIS (FLACSO). Mapa da violência 2015: homicídio de mulheres no Brasil. Brasília: Flacso Brasil, 2015. p. 30.

72 COOK, Rebecca; CUSACK, Simone. Estereotipos de género: perspectivas legales transnacionales. Bogotá: Profamilia, 2010. p. 231.

73 Veja a nota 19. GREZZANA, Stefânia. Viés de gênero no Tribunal Superior do Trabalho brasileiro. 2011. 61 f. Dissertação (Mestrado em Economia) - Escola de Economia de São Paulo, Fundação Getúlio Vargas, São Paulo, 2011.

74 PIMENTEL, Silvia; SCHRITZMEYER, Ana Lúcia Pastore; PANDJIARJIAN, Valéria. Estupro: crime ou "cortesia"?: abordagem sociojurídica de gênero. Porto Alegre: Fabris, 1998. p. 33.

COOK, Rebecca; CUSACK, Simone. Estereotipos de género: perspectivas legales transnacionales. Bogotá: Profamilia, 2010 . p. 3.

75 COMITÊ DE ELIMINAÇÃO DA DISCRIMINAÇÃO CONTRA AS MULHERES (CEDAW). Recomendação Geral No 35 sobre violência de gênero contra as mulheres. CEDAW, 2017.

76 COMITÊ DE ELIMINAÇÃO DA DISCRIMINAÇÃO CONTRA AS MULHERES (CEDAW). Recomendação Geral nº 33 sobre o acesso das mulheres à justiça. CEDAW, 2015. p. 14. 
fissionais do direito. Levando em consideração o que expusemos neste trabalho, no sentido de que juízes não são imparciais, mas julgam de acordo com uma série de fatores, a educação atuaria no sentido de proporcionar a eles uma nova experiência, pautada nos ideais democráticos de igualdade de gênero e de justiça.

Necessário, também, adotar uma perspectiva de gênero na ação jurisdicional, para impedir que sejam reproduzidos estereótipos sobre as mulheres vítimas de estupro nos tribunais. A perspectiva de gênero toma a realidade e as experiências das mulheres como ponto de referência e permite que seja oferecida uma resposta adequada à demanda, livre de estereótipos e de revitimizações. Nesse sentido, destacamos o Protocolo para Juəgar con perspectiva de género ${ }^{77}$, formulado pela Suprema Corte de Justiça da Nação, do México, que apresenta diretrizes para um julgamento que seja democrático com relação ao gênero. O Protocolo destaca que julgar com perspectiva de gênero é realizar o direito à igualdade. Trata-se de um método que deve ser aplicado sempre, não apenas em demandas relacionadas à temática das mulheres, e que visa detectar os diferentes impactos que uma norma pode gerar, além de buscar soluções, a partir do Direito, que levem em consideração as relações assimétricas de poder presentes na sociedade.

Também deve tornar os julgados mais democráticos a adoção dos marcos jurídicos dos direitos humanos das mulheres, como a CEDAW e a Convenção de Belém do Pará, tanto na análise dos casos concretos, quanto ao serem proferidas as decisões judiciais. Quanto a esse ponto, observamos, na análise das sentenças realizada neste estudo, que nenhuma delas fez menção a esses tratados. Assim, atentar-se a esses documentos poderia ser um importante passo para democratização dos julgamentos.

Outra medida relevante é tornar a composição da magistratura mais heterogênea. Isso porque, cada vez mais, a base de legitimidade do Poder Judiciário tem sido percebida a partir da composição de seus membros. Em uma sociedade que se autointitula democrática, é insustentável que o poder decisório seja exercido por uma parcela tão pouco representativa da população.

Diversificar o corpo da magistratura, além de assegurar a legitimidade democrática da instituição, significa garantir que outros pontos de vista sejam inseridos no processo de deliberação judicial, sendo formuladas decisões mais justas, que garantam o direito das mulheres a um julgamento livre de estereótipos. Nesse sentido, a implantação de medidas afirmativas pode ser um bom caminho para auxiliar nesse processo de diversificação, que poderá, inclusive, ajudar a reduzir os vieses implícitos no Judiciário, uma vez que, com base na diversidade de pensamentos, os indivíduos são levados a debater sobre outros argumentos ${ }^{78}$.

Essas são medidas centrais para o processo de democratização social e a efetivação do acesso das mulheres à justiça, a fim de garantir que as instituições deixem de ser instrumento de reforço de violações de direitos e passem a fornecer respostas adequadas, segundo princípios de igualdade substantiva.

\section{REFERÊNCIA}

AGÊNCIA PATRÍCIA GALVÃO. Dossiê violência contra as mulheres: violência sexual. Disponível em: < http:// www.agenciapatriciagalvao.org.br/dossie/violencias/violencia-sexual/>. Acesso em: 10 jan. 2017.

ALMEIDA, Gabriela Perissinotto de. Estereótipos de gênero sobre mulheres vitimas de estupro: uma abordagem a partir do viés de gênero e dos estudos de teóricas feministas do direito. 2017. 149 f. Dissertação (Mestrado em Ciências) - Faculdade de Direito de Ribeirão Preto da Universidade de São Paulo, São Paulo, 2017.

AMÂNCIO, Lígia. Género: representações e identidades. Sociologia: Problemas e Práticas, n. 14, p. 127-140, 1993.

77 SUPREMA CORTE DE JUSTICIA DE LA NACION (SCJN). Protocolo para juzgar con perspectiva de género: haciendo realidad el derecho a la igualdad. México: Suprema Corte de Justicia de la Nación, 2013.

78 JOLLS, Christine; SUSTEIN, Cass R. The law of implicit bias. California Law Review, p. 1-40, 2006. p. 24. 
BARDIN, Laurence. Análise de conteńdo. São Paulo: M. Fontes, 2001.

BLAY, Eva Alterman. Violência contra a mulher e políticas públicas. Estudos Avançados, São Paulo, v. 17, n. 49, p. 87-98, dez. 2003.

BORGIDA, Eugene; HUNT, Corrie; KIM, Anita. On the use of gender stereotyping research in sex discrimination litigation. Journal of Law and Police, v. 13, n. 2, p. 613-628, 2005.

BOYD, Christina; EPSTEIN, Lee; MARTIN, Andrew. Untangling the causal effects of sex on judging. American Journal of Politic Science, v. 54, n. 2, p. 389-411, 2010.

BRAGA, Ana Gabriela Mendes; ANGOTTI, Bruna; MATSUDA, Fernanda Emy. Das violências reais e simbólicas: violência sexual contra as mulheres no Brasil. Boletim IBCCRIM, n. 254, jan. 2014.

BRASIL. Lei no 11.106, de 28 de março de 2005. Disponível em: < http://www.planalto.gov.br/ccivil_03/_ ato2004-2006/2005/lei/111106.htm>. Acesso em: 28 jun. 2018.

BRASIL. Lei n $n^{0}$ 12.015, de 7 agosto de 2009. Disponível em: < http://www.planalto.gov.br/ccivil_03/_ ato2007-2010/2009/lei/112015.htm>. Acesso em: 28 jun. 2018.

BUDDIE, Amy M.; MILLER, Arthur G. Beyond rape myths: a more complex view of perceptions of rape victims. Sex Roles, v. 45, n. 3/4, p. 139-160, ago. 2001.

BURT, Martha B. Cultural myths and supports for rape. Journal of Personality and Social Psychology, v. 38, n. 2, p. 217-230, 1980.

COMISIÓN INTERAMERICANA DE DERECHOS HUMANOS (CIDH). Relatoría sobre los derechos de la mujer: acceso a la justicia para mujeres víctimas de violencia en las Américas. San José: CIDH, 2007.

COMITÊ DE ELIMINAÇÃO DA DISCRIMINAÇÃO CONTRA AS MULHERES (CEDAW). Recomendação Geral no 33 sobre o acesso das mulheres à justiça. CEDAW, 2015.

COMITÊ DE ELIMINAÇÃO DA DISCRIMINAÇÃO CONTRA AS MULHERES (CEDAW). Recomendação Geral Nº 35 sobre violência de gênero contra as mulheres. CEDAW, 2017.

COOK, Rebecca; CUSACK, Simone. Estereotipos de género: perspectivas legales transnacionales. Bogotá: Profamilia, 2010.

COULOURIS, Daniella Georges. Violência, gênero e impunidade: a construção da verdade nos casos de estupro. 2004. 237 f. Dissertação (Mestrado em Ciências Sociais) - Faculdade de Filosofia e Ciências da Universidade Estadual Paulista, Universidade Estadual Paulista, 2004.

DEBERT; Guita Grin; GREGORI, Maria Filomena. Violência e gênero: novas propostas, velhos dilemas. Revista Brasileira de Ciências Sociais, v. 35, n. 66, p. 165-211, fev. 2008.

DU MONT, Janice; MILLER, Karen-Lee; MYHR, Terri. The Role of "Real rape" and "real victim" stereotypes in the police reporting practices of sexually assaulted women. Violence Against Women, v. 9, n. 4, p. 466-486, abr. 2003.

ELEK, Jennifer; ROTTMAN, David. Methodologies for measuring judicial performance: the problem of bias. Oñati Socio-legal Series, v. 4, n. 5, p. 863-879, 2014.

FACIO, Alda. Cuando el género sueña cambios trae: uma metodología para el análisis de género del fenômeno legal. Costa Rica: ILANUD, 1999.

FACULDADE LATINO-AMERICANA DE CIÊNCIAS SOCIAIS (FLACSO). Mapa da violência 2015: homicídio de mulheres no Brasil. Brasília: Flacso Brasil, 2015.

FÓRUM BRASILEIRO DE SEGURANÇA PÚBLICA (FBSP), 9., Anuário Brasileiro de Segurança Pública. São Paulo: FBSP, 2015. 
GREENWALD, Anthony G.; KRIEGER, Linda Hamilton. Implicit bias: scientific foundations. California Law Review, v. 94, n. 4, p. 945 - 967, jul. 2006.

GREZZANA, Stefânia. Viés de gênero no Tribunal Superior do Trabalbo brasileiro. 2011. 61 f. Dissertação (Mestrado em Economia) - Escola de Economia de São Paulo, Fundação Getúlio Vargas, São Paulo, 2011.

GRUBB, Amy; TURNER, Emily. Attribution of blame in rape cases: a review of the impact of rape myth acceptance, gender role conformity and substance use on victim blaming. Aggression and Violent Behavior, $\mathrm{n}$. 17, p. 443-452, 2012.

GUTHRIE, Chris; RACHLINSKI, Jeffrey J.; WISTRICH, Andrew J. Inside the judicial mind. Cornell Law Review, v. 86, p. 776-830, 2001.

HESPANHA, António Manuel. El estatuto jurídico de la mujer en el derecho común clásico. Revista Jurídica, Madrid, n. 4, Universidad Autónoma de Madrid, p. 71-88, 2001.

INSTITUTO DE PESQUISA DATAFOLHA; CENTRO DE ESTUDOS DE CRIMINALIDADE E SEGURANÇA PÚBLICA. Pesquisa Nacional de Vitimização: questionário SENASP. São Paulo:Datafolha/Crisp, 2013. Disponível em: <http://www.crisp.ufmg.br/wp-content/uploads/2013/10/Relat\%C3\%B3rio-PNVSenasp_final.pdf $>$. Acesso em: 10 jan. 2017.

INSTITUTO DE PESQUISA ECONÔMICA APLICADA (IPEA). Estupro no Brasil: uma radiografia segundo os dados da saúde. Brasília: IPEA, 2014a.

INSTITUTO DE PESQUISA ECONÔMICA APLICADA (IPEA). Sistema de Indicadores de Percep̧ão Social: tolerância social à violência contra as mulheres. Brasilia: IPEA, 2014b.

JOLLS, Christine; SUSTEIN, Cass R. The law of implicit bias. California Law Review, p. 1-40, 2006.

KAHNEMAN, Daniel. Rápido e devagar. Rio de Janeiro: Objetiva, 2012.

LEVINSON, Justin D.; YOUNG, Danielle. Implicit Gender Bias in the Legal Profession: An Empirical Study. Duke Journal of Gender Law \& Police, v. 18, n. 01, p. 1-44, 2010.

LEVIT, Nancy. Confronting conventional thinking: the heuristics problem in feminist legal theory. Cardozo Law Review, v. 28, p. 1-82, 2006.

LIMA, Gercina Ângela Borém de Oliveira. Categorização como um processo cognitivo. Ciências \& Cognição, v. 11, p. 156-167, 2007.

MACKINNON, Catharine A. Toward feminist jurisprudence. In: SMITH, Patricia (Ed.). Feminist jurisprudence. New York: Oxford University Press, 1993. p. 610-619.

MOSCOVICI, Serge. Representações sociais: investigações em psicologia social. 5. ed. Petrópolis: Vozes, 2007.

PIMENTEL, Silvia; SCHRITZMEYER, Ana Lúcia Pastore; PANDJIARJIAN, Valéria. Estupro: crime ou "cortesia”?: abordagem sociojurídica de gênero. Porto Alegre: Fabris, 1998.

ROUND, Deborah Ruble. Gender bias in the judicial system. Southern California Law Review, v. 61, n. 6, p. 2193-2220, 1998.

SCHAFRAN, Lynn Hecht. Barriers to credibility: understanding and countering rape myths. National Judicial Education Program Legal Momentum, 2005.

SCHULLER, Regina A. et al. Jugments of sexual assault: the impact of complainant emotional demeanor, gender, and victim stereotypes. New Criminal Law Review, v. 13, n. 4, p. 759-780, 2010.

SCOTT, Joan. El género: una categoria útil para el análisis histórico. In: LAMAS, Marta (Comp.) El género: la construcción cultural de la diferencia sexual. PUEG: México, 1996. p. 265-302. 
SEVERI, Fabiana Cristina. Justiça em uma perspectiva de gênero: elementos teóricos, normativos e metodológicos. Revista Digital de Direito Administrativo, v. 3, n. 3, p. 574-601, 2016.

SMART, Carol. Las teorías feministas y el discurso jurídico. In: BIRGIN, Haidée et al. El derecho en el género y el género en el derecho. Buenos Aires: Biblos, 2000.

SUPREMA CORTE DE JUSTICIA DE LA NACION (SCJN). Protocolo para juzgar con perspectiva de género: haciendo realidad el derecho a la igualdad. México: Suprema Corte de Justicia de la Nación, 2013.

TAJFEL, Henri. Cognite aspects of prejudice. Journal of Social Issues, v. 25, n. 4, p. 79-97, 1969.

TVERSKY, Amos; KAHNEMAN, Daniel. Judment under uncertainty: heuristics and biases. Science, v. 185, p. 1124-1131, set. 1974. 


\section{Gênero e comportamento judicial no supremo tribunal federal: os ministros confiam menos em relatoras mulheres?*}

\author{
Gender relations and judicial behavior in the \\ brazilian supreme court: do justices distrust \\ female rapporteurs?
}

\author{
Juliana Cesario Alvim Gomes** \\ Rafaela Nogueira*** \\ Diego Werneck Arguelhes****
}

* Recebido em 31/05/2018

Aprovado em 13/07/2018

** Doutoranda e Mestre em Direito pela Universidade do Estado do Rio de Janeiro (UERJ). Master of Laws (LL.M.) pela Universidade Yale (EUA). Email: julianacesarioalvim@gmail.com

*** Professora da FGV Direito Rio. Doutora em Economia pela EPGE/FGV. Email: rafaela. nogueira@fgv.br

**** Professor da FGV Direito Rio. Doutor em Direito pela Universidade Yale (EUA). Email: dwarguelhes@gmail.com

Uma versão preliminar desses dados foi apresentada na conferência "Beyond buman rights? rethinking gender equality in law and politics", realizada em Outubro de 2017, em Bogotá. Gostaríamos de agradecer aos participantes do evento pelas úteis críticas e debates. Gostaríamos também de agradecer a Ivar Hartmann, pelas valiosas discussões na construção do trabalho e por nos ajudar com os dados do Supremo em Números; a Cecilia Machado, pela ajuda no manejo dos dados empíricos; e a Renan Medeiros de Oliveira pelo auxílio na preparação do manuscrito.

\section{Resumo}

Tribunais constitucionais com frequência se apresentam como instituições particularmente bem posicionadas para defender e promover direitos de minorias, incluindo a igualdade de gênero. No entanto, vieses de gênero e até discriminação por gênero podem ocorrer dentro dessas próprias instituições. Embora uma série de estudos empíricos já venha discutindo gênero como variável explicativa de decisões judiciais, estereótipos e hierarquias de gênero, também, podem influenciar o comportamento judicial para além do conteúdo das decisões - por exemplo, em como os juízes interagem entre si no processo decisório. Este artigo enfoca uma faceta desse fenômeno no âmbito do Supremo Tribunal Federal. Examinando um banco de dados com todas as decisões tomadas no plenário e nas turmas do tribunal entre 2001 e 2013, analisamos o impacto da variável gênero em duas dimensões do comportamento judicial em um ambiente colegiado. Mais especificamente, testamos se o gênero do(a) ministro(a) afeta o comportamento de seus(suas) colegas quando se trata de (i) divergir ou não do voto do relator; e (ii) pedir ou não vista dos autos. Nossos resultados apontam para um possível impacto do gênero nas atitudes dos juízes em relação a mulheres relatoras, em ao menos uma dessas duas dimensões. Quando o relator do caso é do sexo feminino, os outros juízes têm maior probabilidade de divergir do seu voto. Esses resultados sugerem que certos estereótipos de gênero - por exemplo, a ideia de que as mulheres são menos competentes ou confiáveis, e/ou menos capazes de retaliar - podem ajudar a explicar o comportamento dos juízes no STF e nos tribunais brasileiros em geral.

Palavras-chave: Supremo Tribunal Federal. Comportamento judicial. Processo decisório judicial. Votos vencidos. Pedidos de vista. Gênero. Discriminação. 


\section{Abstract}

Supreme Courts are generally portrayed as institutions particularly well-positioned to defend and promote rights of minorities, including gender rights. However, gender discrimination often occurs within these institutions. Although existing empirical studies have largely focused on how the gender of the judge affects his or her decisions on the merits of the case, gender hierarchy and gender stereotypes can have an impact in other aspects of Court's operation, such as in how judges relate to one another during deliberations. The paper aims to explore two facets of this phenomenon by looking at gendered relations in the Brazilian Supreme Court decision-making process. By examining a database containing all the court rulings debates between 2001 and 2013, we analyze the impact of gender in two key dimension of judicial behavior in a collegiate setting. More specifically, we test whether the gender of their colleagues affect how Brazilian Supreme Court Justices behaves when it comes to (i) dissenting from the case reporter's opinion; and (ii) asking for deliberations to be suspended, after the case reporter has spoken, in order to further study the arguments and case files. In both dimensions, we expect the justices' confidence in the reporter's or the dissenter's knowledge or authority on the issues being discussed plays an important role, which makes them relevant to understanding the role of gender stereotypes. Our preliminary results point to gender biases in the Justices' attitudes towards female case reporters and female dissenters in at least one of these dimensions: when the case reporter is female, the other Justices are more likely to dissent. We interpret these results as suggesting that gender stereotypes - for example, that women are less competent or reliable, and/ or less likely or less able to retaliate - might help us understand decision-making in the STF and in Brazilian courts more generally.

Keywords: Supreme Court. Constitutional court. Judicial behaviour. Judicial decision-making. Vista requests. Dissenting opinions. Brazil. Gender.

\section{INTRODUÇÃO}

Em maio de 2017, após um breve diálogo entre a ministra Rosa Weber e o ministro Luiz Fux, a presidente do Supremo Tribunal Federal (STF), ministra Cármen Lúcia, passou a palavra Weber para que lesse seu voto. O ministro Fux interveio, dirigindo-se à ministra Weber: "Concedo-lhe a palavra para [que você possa apresentar seu] voto integral”. A Presidente do Supremo Tribunal, Cármen Lúcia, respondeu:

Como concede a palavra? É a vez dela de votar. Ela é que concede, se quiser, a Vossa Excelência, um aparte. Foi feita agora uma análise, só um parêntese [...]. O número de vezes em que as mulheres são aparteadas [em tribunais constitucionais em que há mulheres] é 18 vezes maior do que entre os ministros [do sexo masculino]. [...] A ministra [Sonia] Sotomayor [da Suprema Corte dos EUA] me perguntou: "E lá [no Brasil], como é que é?" "Lá, em geral, eu e a ministra Rosa - não nos deixam falar. Então, nós não somos interrompidas". Mas agora é a vez da ministra Rosa, por direito constitucional, de votar. Tem a palavra, Ministra [Weber] $]^{1}$.

Essa não foi a primeira vez que a ministra Cármen Lúcia confrontou seus colegas do sexo masculino por questões de gênero². Em novembro de 2014, por exemplo, episódio semelhante ocorreu na discussão da constitucionalidade de uma lei que concedia às trabalhadoras o direito a um intervalo de 15 minutos antes de cumprir horas extras 3 . Argumentando pela inconstitucionalidade, o ministro Marco Aurélio afirmou: "se pudesse apontar um sexo forte, apontaria que é o feminino, mesmo porque, no lar, tenho um matriarcado,

1 STF. RE 612043, Pleno, Maio 10, 2017.

2 Para mais exemplos, ver GOMES, Juliana Cesario Alvim. O Supremo Tribunal Federal em uma perspectiva de gênero: mérito, acesso, representatividade e discurso. Direito \& Práxis, Rio de Janeiro, v. 7, n. 3, p. 652-676, jul./set. 2016.

3 STF. RE 658312, Pleno, 27 Novembro 2014. 
a começar pela Sandra, que é juíza, e juíza na área criminal!’. Posteriormente, a ministra Cármen Lúcia respondeu:

[...] na verdade, todo mundo é a favor dos direitos iguais das mulheres em público; à boca pequena, e seguramente na prática, os deboches, as brincadeiras continuam sendo uma demonstração de que estamos muito longe a chegar a uma igualdade substancial. [...] Ministro Marco Aurélio, somos, sim, o sexo frágil. Frágil em direitos, porque somos a maioria da população brasileira e temos muito menos direitos.

O ministro Marco Aurélio a interrompe: "É interessante: estou sob a sua presidência!". A ministra Cármen Lúcia, em seguida, acrescenta: "Mas eu estive, muitas vezes e com muita honra, sob a presidência por questão organizacional interna, apenas, e com absoluta tranquilidade".

Essas cenas soarão familiares para mulheres trabalhando em diferentes áreas e organizações. Tribunais constitucionais e cortes supremas, porém, com frequência, se apresentam como instituições particularmente bem posicionadas para defender e promover direitos de minorias em razão de seu papel contramajoritário, incluindo a igualdade de gênero e os direitos das mulheres. ${ }^{4}$ Assim, a ocorrência de discriminação de gênero dentro dessas instituições é particularmente preocupante - entre os próprios juízes, e mesmo quando o caso não envolve questões de gênero. Embora estudos empíricos venham enfocando o impacto do gênero como variável explicativa das decisões judiciais, estereótipos e hierarquias de gênero podem influenciar do comportamento judicial para além do conteúdo das decisões - como na forma pela qual os juízes se relacionam entre si como se dirigem aos seus colegas durante as deliberações.

Neste artigo, exploramos uma faceta desse fenômeno, examinando as relações de gênero ${ }^{5}$ entre ministros no processo decisório do Supremo Tribunal Federal. Examinando um banco de dados com todas as decisões tomadas no plenário e nas turmas do tribunal entre 2001 e 2013, analisamos o impacto da variável gênero em duas dimensões do comportamento judicial nos ambientes colegiados do STF. Mais especificamente, testamos se o gênero do(a) ministro(a) (masculino ou feminino) afeta o modo como seus(suas) colegas se comportam quando se trata de (i) divergir ou não do voto do relator; e (ii) pedir ou não vista dos autos.

Também investigamos se essas dinâmicas são afetadas por um ambiente no qual o comportamento de ministras do sexo feminino é influenciado pela presença de outras ministras (o que chamamos de "efeito de sororidade"), de duas maneiras diferentes: se elas são afetadas (a) pela presença de uma segunda ministra na composição do STF, e (b) pela presença de uma mulher na presidência do tribunal ou da turma, definindo a pauta e coordenando as deliberações.

Com base no desenho do processo decisório no STF, esperamos que o comportamento dos(as) ministros(as) seja influenciado, em todas essas dimensões, pela confiança que têm no conhecimento ou autoridade do relator sobre os assuntos em discussão. Nesse sentido, estereótipos de gênero podem influenciar comportamentos com relação a relatoras do sexo feminino. Isso pode ocorrer, por exemplo, devido a uma crença implícita de que as ministras são menos competentes ou menos confiáveis, ou à expectativa de que mulheres devem ser menos agressivas e mais colegiais e que, portanto, as juízas se sentiriam mais constrangidas em entrar em conflito com um colega do sexo masculino. Nossos resultados preliminares de fato apontam para vieses de gênero nas atitudes dos ministros em relação às relatoras. Quando o relator do caso é do sexo feminino, o restante do tribunal tem maior probabilidade de discordar do seu voto.

4 Uma recorrente justificativa para legitimar o poder de juízes não eleitos realizarem constitucionalidade de leis e atos normativos é a de que, pelo fato de seus integrantes não serem eleitos e contarem com uma série de garantias, Cortes Constitucionais poderiam e deveriam atuar de forma independente da vontade da maioria da população e, assim, a favor do direito de minorias incapazes de se defender adequadamente na arena política. Ver, por exemplo, BARROSO, Luís Roberto. Constituição, democracia e supremacia judicial: direito e política no Brasil contemporâneo. Revista da Faculdade de Direito-UERJ, v. 2, n. 21, jan./jun. 2012.

5 "As relações de gênero atravessam a sociedade, e seus sentidos e efeitos não estão restritos às mulheres. O gênero é, assim, um dos eixos centrais que organizam nossas experiências no mundo social. Onde há desigualdades que atendem a padrões de gênero, ficam definidas também posições relativas de mulheres e de homens — ainda que o gênero não o faça isoladamente, mas numa vinculação significativa com classe, raça e sexualidade". MIGUEL, Luís Felipe; BIROLI Flávia. Feminismo e política: uma introdução. São Paulo: Boitempo, 2014. p. 8. 
Embora as dimensões de análise sejam pontuais, elas fornecem insumos para um debate mais amplo com vistas a "expor as práticas e rituais, incentivos e hábitos, relacionamentos e normas culturais não verbalizadas tomados como certos" " que possam expressar e reforçar uma hierarquia de gênero dentro do STF e, talvez, para o judiciário e a comunidade jurídica como um todo. $\mathrm{Na}$ verdade, é possível que olhar para dinâmicas de gênero em um espaço judicial possa ajudar a revelar padrões presentes na sociedade brasileira de forma mais geral ${ }^{7}$.

\section{Gênero e tribunais no Brasil}

De um ponto de vista teórico, estudos de variados pontos de vista disciplinares têm destacado diferentes aspectos pelos quais o gênero influencia o funcionamento das instituições jurídicas: (i) a lei frequentemente impõe desvantagens às mulheres; (ii) o conteúdo dessa lei tem um viés "masculino", sendo construído por advogados e juízes do sexo masculino que impõem seus ideais, ainda que com suposta neutralidade e objetividade; (iii) a lei é uma "tecnologia de gênero", capaz de criar gênero em si. Esses insights fornecem úteis pontos de partida e hipóteses para estudos empíricos sobre como concepções, práticas e discursos de gênero podem ajudar a entender como o funcionamento do direito na prática.

Do ponto de vista empírico, apesar da centralidade que o STF desempenha na política brasileira, até muito recentemente o escopo da literatura sobre questões de gênero no tribunal se mostrava limitado. Abordagens mais tradicionais enfocam as discussões de mérito em casos envolvendo direitos das mulheres", enquanto trabalhos mais recentes têm procurado entender como o gênero pode impactar o funcionamento do tribunal, para além da substância de suas decisões. Nesse sentido, por exemplo, Gomes chama a atenção para os danos aos direitos das mulheres causados pelas dinâmicas internas, práticas, silêncios e discursos usados durante o processo de tomada de decisão pelos ministros, mesmo quando decidem casos em favor dessa minoria ${ }^{10}$; Annenberg examina o uso de estereótipos na fundamentação dos ministros em casos envolvendo gênero ${ }^{11}$; Machado e Bracarense investigam o papel desempenhado pelos movimentos de mulheres na promoção de sua agenda de direitos junto ao STF ${ }^{12}$.

Para além do STF, a literatura sobre tribunais e gênero no Brasil também incluiu temas como a aplicação da legislação sobre violência doméstica ${ }^{13}$ e violência de gênero ${ }^{14}$ nos tribunais nacionais. Especificamente so-

6 GUINIER, Lani; MINOW, Martha. Dynamism, not just diversity. Harvard Journal of Law \& Gender, Cambridge, v. 30, n. 2, p. 269-277, jun./nov. 2007.

7 Ver RESNIK, Judith. On the Bias: feminist reconsiderations of the aspirations for our judges. Southern California Law Review, Los Angeles, v. 61, n. 6, p. 1877-1944, Sep. 1988.

8 A frase foi tirada do título do livro de 1987 de Teresa de Lauretis “Technologies of gender: essays on theory, film and fiction”. 9 PIOVESAN, Flávia; GONÇALVES, Tamara Amoroso. Gênero no Supremo Tribunal Federal. In: SARMENTO, Daniel; SARLET, Ingo Wolfgang (Org.). Direitos fundamentais no Supremo Tribunal Federal: balanço e crítica. Rio de Janeiro: Lúmen Júris, 2011. p. 367-390.

10 GOMES, Juliana Cesario Alvim. O Supremo Tribunal Federal em uma perspectiva de gênero: mérito, acesso, representatividade e discurso. Direito es Práxis, Rio de Janeiro, v. 7, n. 3, p. 652-676, jul./set. 2016.

11 ANNENBERG, Flávia Xavier. Gender-based provisions in the united states and in brazil: tensions between the anti-stereotyping doctrine and the positive discrimination approach. Artigo inédito, 2017.

12 MACHADO, Marta Rodriguez de Assis; BRACARENSE, Ana Carolina. O caso do feto anencefálico: direitos sexuais e reprodutivos, confronto e negociação argumentativa no Supremo Tribunal Federal. Direito \& Práxis, Rio de Janeiro, v. 7, n. 3, p. 677-714, jul./set. 2016.

13 E.g., DIAS, Maria Berenice. A Lei Maria da Penha na Justiça: a efetividade da Lei 11.340/2006 de combate à violência doméstica e familiar contra a mulher. São Paulo: Revista dos Tribunais, 2007; FREITAS, Lúcia; LOIS, Cecilia Caballero. Acórdãos do STF sobre Lei Maria da Penha: Um estudo piloto da relação direito, gênero e linguagem. In: OLIVEIRA JUNIOR, José Alcebíades de; MENDES, Regina Lucia Teixeira; SCAMARELLA, Maria Luisa (Org.). Sociologia, Antropologia e Cultura jurídicas. Curitiba: CONPEDI/ UNICURITIBA, 2013. p. 247-265.

14 E.g., CASTILHO, Ela Wiecko Volkmer de. Criminalização do tráfico de mulheres: proteção das mulheres ou reforço da violência de gênero?. Cadernos Pagu, Campinas, n. 31, p. 101-123, jul./dez. 2008; PIMENTEL, Silvia; PANDJIARJIAN, Valeria; BEL- 
bre a estrutura interna e o funcionamento dos tribunais, os estudos existentes, em menor medida, discutem se as juízas femininas decidiriam de maneira diferente de seus colegas do sexo masculino ${ }^{15}$ e, principalmente, investigam os obstáculos à admissão e promoção de magistradas do sexo feminino ${ }^{16}$.

Com relação a esse último aspecto, vale observar que, entre 2002 e 2011, a proporção de mulheres admitidas na carreira judicial no Brasil aumentou. Durante esse período, as mulheres representaram 38,9\% de todos os novos juízes. No entanto, essa proporção caiu para 35,9\% entre 2012 e 2013. Em 2013, 42,8\% dos juízes substitutos eram mulheres, enquanto, nos tribunais de segunda instância e tribunais superiores, as mulheres representavam, respectivamente, $21,5 \%$ e $18 \%$ dos juízes. Vale notar que a maioria absoluta dessas mulheres é branca; apenas 15,2\% de todos os juízes no Brasil se declaram pardos, 1,5\% se declaram pretos e $1,4 \%$ nativos brasileiros ${ }^{17}$.

Em uma perspectiva regional, a participação feminina no judiciário brasileiro é baixa. Em 2016, entre 37 países do Caribe e da América Latina, o Brasil teve a quarta menor taxa de mulheres no tribunal de cúpula $(18,2 \%)^{18}$. Esse fenômeno não pode ser explicado por um número reduzido de mulheres nas profissões jurídicas (isto é, por um reduzido grupo de potenciais nomeadas para os tribunais superiores). Na realidade, 48\% dos mais de um milhão de membros da Ordem dos Advogados do Brasil são mulheres ${ }^{19}$; além disso, na população em geral, as mulheres tendem a ser mais educadas que os homens ${ }^{20}$. As raízes da disparidade de gênero no judiciário brasileiro ${ }^{21}$ parecem ser semelhantes a alguns padrões que Schultz identificou em outros países, especialmente a falta de conexões políticas necessárias para acessar posições importantes que só podem ser preenchidas por nomeação, bem como a imposição do ônus das responsabilidades domésticas às profissionais do sexo feminino. ${ }^{22}$

$\mathrm{Na}$ vasta literatura empírica nos EUA sobre comportamento judicial, problemas de gênero no funcionamento de tribunais vêm sendo explorados há muitos anos. A maioria desses trabalhos enfoca basicamente as mesmas duas questões: (1) o gênero do juiz faz com que seu comportamento ou decisão mude? (2) A presen-

LOQUE, Juliana. "Legítima defesa da honra", ilegítima impunidade de assassinos: um estudo crítico da legislação e jurisprudência da América Latina. In: CORRÊA, Mariza; SOUZA, Érica Renata (Org.). Vida em família: uma perspectiva comparativa sobre crimes de honra. Campinas: UNICAMP, 2006. p. 65-208.

15 SEVERI, Fabiana Cristina. O gênero da justiça e a problemática da efetivação dos direitos humanos das mulheres. Direito $e$ Práxis, Rio de Janeiro, v. 7, n. 1, p. 80-115 jan./mar. 2016; JUNQUEIRA, Eliane Botelho. Women in the Judiciary: a Perspective from Brazil. In: SCHULTZ, Ulrike; SHAW, Gisela (Org.). Women in the world's legal professions. Oxford: Hart, 2003; GREZZANA, Stefânia. Viés de Gênero no Tribunal Superior do Trabalho Brasileiro. 2011. 61f. Dissertação (Mestrado) - Escola de Economia de São Paulo, FGV, São Paulo, 2011.

16 E.g., SEVERI, Fabiana Cristina. O gênero da justiça e a problemática da efetivação dos direitos humanos das mulheres. Direito e Práxis, Rio de Janeiro, v. 7, n. 1, p. 80-115 jan./mar. 2016; BONELLI, Maria da Glória. Brazilian judges in-between professionalism, gender and difference. International Journal of the Legal Profession, v. 22, n. 2, p. 134-150, Apr. 2015; BONELLI, Maria da Glória. Profissionalismo, diferença e diversidade na advocacia e na magistratura paulistas. Revista Brasileira de Ciências Sociais, São Paulo, v. 28, n. 83, p. 125-140, out. 2013; FRAGALE FILHO, Roberto; MOREIRA, Rafaela Selem; SCIAMMARELLA, Ana Paula de O. Magistratura e gênero: um olhar sobre as mulheres nas cúpulas do judiciário brasileiro, 2015. Disponível em: <https://journals.openedition.org/ eces/1968>. Acesso em: 15 jun. 2016. SADEK, Maria Teresa. Magistrados: uma imagem em movimento. Rio de Janeiro: FGV, 2006.

17 CONSELHO NACIONAL DE JUSTIÇA. Censo do poder judiciário. Brasília: CNJ, 2014.

18 CEPAL. Judicial power: percentage of women judges in the highest court or Supreme Court < http://oig.cepal.org/en/indicators/judicial-power-percentage-women-judges-highest-court-or-supreme-court> Acesso em: 16 jul. 2018.

19 MIGALHAS. Dados da OAB mostram que quase metade dos advogados do país são mulheres, 2017. Disponível em: < http://www.migalhas.com.br/Quentes/17,MI265657,11049-Dados+da+OAB+mostram+que+quase+metade+dos + advogados + do + pais + sao $>$. Acesso em: 16 jul. 2018.

20 INSTITUTO BRASILEIRO DE GEOGRAFIA E ESTATÍSTICA. Estatísticas de gênero: uma análise do Censo Demográfico 2010. Rio de Janeiro: IBGE, 2014.

21 SMART, Carol. Las teorías feministas y el discurso jurídico. In: BIRGIN, Haidée et al (Org.). El derecho en el género y el género en el derecho. Buenos Aires: Biblos, 2000.

22 SCHULTZ, Ulrike; SHAW, Gisela (Org.). Women in the world's legal professions. Oxford: Hart, 2003; SEVERI, Fabiana Cristina. O gênero da justiça e a problemática da efetivação dos direitos humanos das mulheres. Direito e Práxis, Rio de Janeiro, v. 7, n. 1, p. 80115 jan./mar. 2016; BONELLI, Maria da Glória. Profissionalismo e diferença de gênero na magistratura paulista. Civitas: Revista de Ciências Sociais, Porto Alegre, v. 10, n. 3. p. 270-292, set./dez. 2010. BONELLI, Maria da Glória. Carreiras jurídicas e vida privada: interseções entre trabalho e família. Cadernos Pagu (UNICAMP), Campinas, n. 46, p. 245-277, jan./abr. 2016. 
ça de uma juíza no tribunal influencia o comportamento de seus colegas do sexo masculino? Nosso objetivo neste projeto é mais próximo dessa segunda vertente de análise. Investigamos o impacto do gênero no processo de decisão judicial além do conteúdo real de decisões e opiniões judiciais, incluindo comportamentos que ocorrem antes e durante as deliberações. Enfocamos o que poderia ser chamado de comportamento processual, colegial e deliberativo dos juízes, isto é, suas escolhas e ações dentro do funcionamento do maquinário da corte, independentemente de sua posição individual sobre o mérito de cada caso. Nosso objetivo é entender como o gênero afeta a maneira como os membros da corte se comportam em relação aos seus componentes do sexo feminino. ${ }^{23}$ Até que ponto os estereótipos e a discriminação de gênero explicam as atitudes judiciais de seus colegas no processo de tomada de decisão do STF? Como discutiremos na próxima seção, acreditamos que o STF é um ambiente institucional particularmente interessante para estudar essas questões.

\section{Gênero, colegialidade e julgamento no Supremo Tribunal Federal}

\subsection{Mulheres no STF ${ }^{24}$}

Desde sua criação em 1890 — ou desde 1824, se enfatizarmos a continuidade institucional com o Supremo Tribunal de Justiça do Império - , apenas três mulheres foram nomeadas para o Supremo Tribunal Federal. A primeira ministra mulher, Ellen Gracie, foi nomeada apenas em dezembro do ano 2000 e a segunda, Cármen Lúcia, em junho de 2006. A ministra Gracie presidiu o STF entre abril de 2006 e abril de 2008, quando a ministra Cármen Lúcia já fazia parte do tribunal. Em dezembro de 2011, a terceira mulher, a ministra Rosa Weber, foi indicada para preencher a vaga aberta pela aposentadoria da ministra Gracie. Em setembro de 2016, a ministra Cármen Lúcia se tornou presidente do Tribunal, cargo que ocupará até 2018.

Os caminhos dessas três ministras foram marcados por questões de gênero de muitas maneiras diferentes. Até a nomeação de Ellen Gracie em 2000, mulheres não podiam usar calças no prédio da Suprema Corte. Mas apenas em 2007 Cármen Lúcia se tornaria a primeira ministra a usá-las na sessão plenária do tribunal ${ }^{25}$. Na verdade, o gênero das ministras já influenciava como eram tratadas e percebidas mesmo antes de seu ingresso formal no tribunal, ainda no seu processo de nomeação ${ }^{26}$. Uma análise de suas sabatinas perante o Senado ilustra os obstáculos que enfrentaram. De fato, a maioria dos senadores, do sexo masculino, não pôde deixar de expressar, mesmo que às vezes implicitamente, seu desconforto com o fato de os nomeados serem mulheres. Apesar das diferenças nos três processos, em todos eles o gênero da ministra nomeada foi um "fantasma" na sala ${ }^{27}$.

23 Nesse sentido, nosso projeto se aproxima do trabalho pioneiro de Jacobi e Schweers sobre interrupções, durante os argumentos orais, na Suprema Corte dos EUA. Nesse artigo, os autores usam uma variedade de estratégias para tentar desvendar, explicando o que torna os juízes mais propensos a interromper um ao outro, os efeitos do gênero a partir dos efeitos da antiguidade e da ideologia. Na próxima fase deste projeto de pesquisa, esperamos poder responder questões semelhantes às de Jacobi e Schweers, incluindo qual é o papel do gênero na explicação de como os juízes interrompem uns aos outros durante as deliberações no STF. JACOBI, Tonja; SCHWEERS, Dylan. Justice. Interrupted: the effect of gender, ideology and seniority at Supreme Court oral arguments. Virginia Law Review, v. 103, p. 1379-1485, 2017.

24 Algumas das ideias desenvolvidas nesta seção foram previamente trabalhadas em GOMES, Juliana Cesario Alvim. O Supremo Tribunal Federal em uma perspectiva de gênero: mérito, acesso, representatividade e discurso. Direito \& Práxis, Rio de Janeiro, v. 7 , n. 3, p. 652-676, jul./set. 2016.

25 MINISTRA quebra tradição e usa calça no STF. 2007. Disponível em: <http://g1.globo.com/Noticias/Politica/0,MUL115655601,00-MINISTRA+QUEBRA+TRADICAO+E+USA+ CALCA+NO+STF.html>. Acesso em: 15 jul. 2018.

26 Analisando a sabatinas judiciais nos EUA, Sally J. Kenney chama atenção para o fato de que "as mulheres julgadoras enfrentaram mais duras sabatinas do que suas contrapartes masculinas; elas tiveram sua competência e objetividade mais frequentemente e descaradamente questionadas; e elas foram removidas do cargo em estados onde os ministros são rotineiramente mantidos. Estes são apenas alguns exemplos das maneiras pelas quais as mulheres experimentam preconceitos de gênero no sistema judicial" (tradução livre). KENNEY, Sally J. Gender \& Justice: Why women in the Judiciary really matter. New York: Routledge, 2013, p. 135-136.

27 Claude M. Steele em seu livro "Whistling Vivaldi: and other clues to how stereotypes affect us" se refere a estereótipos como 
Na sabatina da ministra Ellen Gracie, em 2000, os senadores a louvariam por ser a primeira mulher nomeada para a corte. Falaram sobre o que viam como "momento histórico", ao mesmo tempo em que faziam comentários tendenciosos de gênero. Um senador, por exemplo, incluiu o seguinte comentário em sua celebração da indicação de Gracie:

Adão estava dormindo, assim diz o Gênesis, foi retirada uma parte da costela de Adão, e Deus criou a mulher e disse que ambos formariam uma só carne. Então, eu acho que fomos nós, os homens, que desobedecemos ao Criador, e as mulheres, também, por sua timidez, talvez, ficaram muito tempo dedicadas aos afazeres domésticos e não participavam ativamente ${ }^{28}$.

Mais tarde, durante a sua confirmação como Presidente do Conselho Nacional de Justiça em 2006, a ministra Ellen Gracie foi submetida a comentários sexistas ainda mais sérios e explícitos "29: "O meu voto ainda leva em conta a beleza e o charme. Assim voto com muito prazer.", disse um senador; "Como ginecologista, aprendi a lidar de perto com as mulheres, a entender muito profundamente a sensibilidade feminina", disse outro. Um terceiro declarou que a ampla aceitação da nomeação da ministra se devia "à elegância física e moral, à dignidade e sobretudo à competência [da ministra]", e ainda outro acrescentou que Gracie estaria lá não para "ser sabatinada, mas [para ser] homenageada" 30 .

Como segunda mulher indicada ao STF — privando assim os senadores da oportunidade de celebrar o evento formal de sabatinar "a primeira mulher" —, o tratamento da ministra Cármen Lúcia foi diferente. Alguns senadores tentaram minimizar sua condição de gênero, enfatizando suas qualidades humanas e sua competência independentemente de seu gênero:

Para mim é indiferente e eu digo isso dissentindo da grande maioria que o Supremo Tribunal Federal seja composto por onze negros, ou onze brancos, ou por onze mulheres ou por onze homens. Me importa sim saber que lá estão onze magistrados ${ }^{31}$.

Por fim, durante o processo de nomeação da ministra Rosa Weber, o tópico mal foi levantado de forma explícita, na mesma tendência observada no caso de Carmen Lúcia. Uma das poucas exceções aconteceu quando uma senadora pediu sua opinião sobre a Lei Maria da Penha, acrescentando que Weber era uma fonte de orgulho e inspiração para ela e para as mulheres em geral.

Em geral, a questão de gênero no caso de Weber só ficou visível nas "entrelinhas" ${ }^{2}$. Alguns comentários dos senadores recorriam, implicitamente, a estereótipos. Um senador, por exemplo, comentou:

Sei que V. Ex é até exageradamente humilde, veio até aqui de preto. Quer dizer, poderia ter vindo com uma cor mais bonita; V. Exª é uma senhora bonita, respeitável. Parece que fez tudo para não se apresentar.

Além disso, em vez de fazer as perguntas típicas, para os padrões brasileiros, sobre a vida ou carreira do nomeado, ou mesmo sobre as controvérsias constitucionais da ordem do dia, os senadores se desdobraram

\footnotetext{
"fantasmas na sala" (2010).

28 COMISSÃO DE CONSTITUIÇÃO, JUSTIÇA E CIDADANIA. Ata da da $2^{a}$ Sessão Legislativa Extraordinária, da $51^{a}$ Legislatura, realizada em 21 novembro de 2000.

29 O Presidente do Conselho Nacional de Justiça, criado pela Emenda Constitucional n. 45/2004, é o atual presidente do Supremo Tribunal. Mesmo assim, a emenda constitucional exigia que cada novo presidente passasse por um processo de sabatina e confirmação perante o Senado. Este sistema foi modificado em 2009 (o presidente é, hoje, o único membro do Conselho Nacional de Justiça que não precisa ser sabatinado pelo Senado), e a ministra Gracie foi o último presidente do CNJ a passar pelo Senado antes de tomar posse.

30 MACHISMO marca sabatina de Ellen Gracie. 2006. Disponível em: <https://www1.folha.uol.com.br/fsp/ brasil/ fc2303200617.htm>. Acesso em: 16 jul. 2018.

31 COMISSÃO DE CONSTITUIÇÃO, JUSTIÇA E CIDADANIA. Ata da 11 a Reunião Ordinária, da $52^{a}$ Legislatura realizada em 10 de maio de 2006. Vale ressaltar que, ao contrário de seus pares do sexo masculino, as senadoras femininas enfatizaram o aspecto de gênero da nomeação.

32 A tensão em torno do gênero das mulheres nomeadas é "encoberta" por meio do tempo — talvez não visível, mas ainda assim parte da dinâmica. Em contraste com essa visão, no entanto, Araújo argumenta que podemos identificar um processo de "exclusão de gênero" à medida que mais mulheres são nomeadas (2015).
} 
para desafiar sua competência profissional e testar seu conhecimento legal. Por exemplo, um senador fez mais de vinte perguntas sobre diferentes áreas do Direito, sem interrupção, por mais de 20 minutos — o que nunca aconteceu a um homem indicado ao tribunal ${ }^{33}$.

Essas narrativas e anedotas, embora digam respeito ao comportamento de outras autoridades públicas (os senadores), sugerem ser provável que os estereótipos e a discriminação de gênero também desempenhem algum papel na maneira como os juízes do STF se relacionam com suas colegas do sexo feminino. A questão é onde e como exatamente procurar por essas dinâmicas dentro do processo decisório do tribunal. Discutiremos essas questões na próxima seção.

\subsection{Gênero e o papel do relator no processo decisório do STF}

O Supremo Tribunal cumpre, ao mesmo tempo, as funções de um tribunal constitucional, de uma corte de cassação (como instância máxima de decisão potencial sobre todos os recursos vindos de instâncias inferiores), de um tribunal de primeira instância em alguns dos procedimentos dentro de sua jurisdição ${ }^{34}$. Essa última função fornece ao STF a maior parte de sua vasta carga de trabalho. Nos últimos anos, o Tribunal recebeu uma média de mais de 60.000 novos casos anualmente. A grande maioria desses casos, no entanto, nunca é decidida pelo tribunal plenário ou pelas câmaras. Desde 1988, em média, mais de $95 \%$ das decisões no STF são tomadas por ministros individuais e suas equipes, embora os mecanismos exatos pelos quais os casos são filtrados, ainda, não tenham sido totalmente mapeados ${ }^{35}$.

Em todos esses papéis, nesse grande volume de processos, a figura do relator do processo é decisiva. Um dos ministros (excluindo o atual presidente) é aleatoriamente designado como relator quando um processo ingressa na pauta do tribunal ${ }^{36}$. O relator é responsável por administrar o caso dentro da burocracia interna do STF e tem poderes significativos antes que a turma ou o plenário possam se manifestar: pode dar decisões liminares em algumas circunstâncias; pode sumariamente rejeitar um recurso ou petição que seja "manifestamente infundada", ou que contradiga a jurisprudência estabelecida pelo tribunal; e, finalmente, compete ao relator decidir quando o caso está pronto para ser julgado por uma das instâncias de decisão coletiva do tribunal (turma ou plenário). O relator, portanto, tem poderes aparentemente absolutos de definição de pauta em relação ao caso ${ }^{37}$. Após a liberação do caso pelo relator, o presidente deve, então, colocá-lo

33 COMISSÃO DE CONSTITUIÇÃO, JUSTIÇA E CIDADANIA. Reunião Extraordinária da Comissão de Constituição, Justiça e Cidadania da $1^{a}$ Sessão Legislativa Ordinária da 54ª Legislatura, realizada, 64., 6 de dezembro de 2011.

34 FALCÃO, Joaquim; CERDEIRA, Pablo Camargo; ARGUELHES, Diego Werneck. I Relatório Supremo em números: o múltiplo Supremo. Rio de Janeiro: FGV, 2011; VIEIRA, Oscar Vilhena. "Supremocracia”. Revista Direito GV, São Paulo, v. 4, n. 2, p. 441-463, jul./dez. 2008.

35 Ver, por exemplo, VERÍSSIMO, Marcos Paulo. A Constituição de 1988, vinte anos depois: Suprema Corte e 'ativismo judicial à brasileira'. Revista Direito GV, São Paulo, v. 4, n. 2, p. 407-440, jul./dez. 2008. (discutindo um “writ of certiorari, no estilo brasileiro”). Ver também ROSEVEAR, Evan; HARTMANN, Ivar; ARGUELHES, Diego Werneck. Disagreement on the Brazilian Supreme Court. an exploratory analysis. 2015. Disponível em: <https://papers.ssrn.com/sol3/papers.cfm?abstract_id=2629329>. Acesso em: 16 jul. 2018, para uma discussão destes números e comparações com outros tribunais supremos e constitucionais; e ARGUELHES, Diego Werneck; RIBEIRO, Leandro Molhano. Ministrocracia: o Supremo Tribunal Individual no processo democrático brasileiro. Novos Estudos CEBRAP, v. 37, n. 1, p. 13-32, jan./abr. 2018.

36 Se o algoritmo que atribui os casos aos ministros é ou não verdadeiramente "aleatório", no sentido matemático tem sido um tema de debate na comunidade acadêmica brasileira (ver CHADA, Daniel; HARTMANN, Ivar. A distribuição de processos no Supremo é realmente aleatória?. 2016. Disponível em: <https://jota.info/colunas/supra/distribuicao-dos-processos-no-supremo-e-realmentealeatoria-25072016>. Acesso em: 15 jun. 2018. Em todo caso, porém, dado nosso atual conhecimento do sistema e do discurso oficial da Corte, assumimos que o mecanismo de designação de relatores não permite a alocação deliberada de um caso a um ministro específico.

37 ARGUELHES, Diego Werneck; RIBEIRO, Leandro Molhano. Ministrocracia: o Supremo Tribunal Individual no processo democrático brasileiro. Novos Estudos CEBRAP, v. 37, n. 1, p. 13-32, jan./abr. 2018. ARGUELHES, Diego Werneck; RIBEIRO, Leandro Molhano. 'The Court, it is I'? individual judicial powers in the Brazilian Supreme Court and their implications for constitutional theory. Global Constitutionalism, v. 7, n. 2, p. 236-262, 2018.; e FALCÃO, Joaquim; ARGUELHES, Diego Werneck. Onze supremos, todos contra o Plenário. In: FALCÃO, Joaquim; ARGUELHES, Diego Werneck; RECONDO, Felipe (Org.). Onz̧e supremos: o Supremo em 2016. Rio de Janeiro: FGV, 2017. p. 20-29. 
na pauta do Tribunal, fixando determinada data para que seu julgamento ocorra. Ambas as decisões — as do relator e da presidente — têm sido, na prática, totalmente discricionárias, não estando sujeitas a nenhum prazo relevante ${ }^{38}$.

O STF é um tribunal seriatim: formalmente falando, o processo de deliberação e decisão não resulta em um "voto do tribunal", mas apenas nos votos individuais dos ministros. ${ }^{39}$ Espera-se que o relator apresente um voto por escrito, que inclui um relatório dos principais fatos e histórico processual envolvendo o processo ("relatório"), bem como seus argumentos e decisão provisória para o caso ("voto"). Após o relator, os outros ministros seguem, em ordem de antiguidade reversa. O presidente é sempre o último a votar, além de ter o poder de dar o voto de minerva em algumas circunstâncias.

Por fim, vale notar que todas as deliberações no STF são públicas. Desde 2002, as deliberações no plenário são transmitidas ao vivo pelo canal oficial TV Justiça (e, desde 2006, também no canal oficial do YouTube). Em entrevistas, alguns ministros já mencionaram a ocorrência de reuniões informais, fechadas e pré-deliberações em alguns casos importantes. Contudo, há outros ministros, antigos e atuais, que alegam não ter participado de tais reuniões e/ou se opõem a tais práticas ${ }^{40}$.

\subsubsection{Votos vencidos e confiança no relator}

A vasta carga de trabalho do STF faz com que os ministros só consigam decidir, colegiadamente, uma fração do número total de $\operatorname{casos}^{41}$. Aproximadamente, 2000 casos por ano são decididos por uma das duas turmas de cinco juízes ou pelo plenário com todos os 11 magistrados presentes no caso. Mesmo essa fração do total de casos ainda é alta demais, na prática, para permitir análise e deliberação profundas por parte de todos os ministros em todos esses casos. Nesse cenário, os ministros devem escolher prioridades e selecionar quais casos merecem sua atenção total — não apenas dentre os processos de sua relatoria, mas também dentre os que estão com seus colegas. Com isso, espera-se que eles acabem confiando, de maneira geral, na posição do relator na maioria dos casos. Além disso, os ministros podem sentir que discordar uns dos outros, em uma sessão pública e sem preparação ou discussão interna prévias, pode fazê-los parecer mal aos olhos dos advogados presentes nas sessões e, talvez, mais significativamente, por quem esteja acompanhando o julgamento no YouTube ou na TV Justiça, no caso das sessões plenárias ${ }^{42}$.

Na prática, isso pode ajudar a explicar o alto nível de decisões unânimes no STF ${ }^{43}$. Nessas cerca de duas

38 ARGUELHES, Diego Werneck; HARTMANN; Ivar A. timing control without docket control: how individual justices shape the Brazilian Supreme Court's agenda. Journal of Law and Courts, Chicago, v. 5, n. 1, p. 105-140, mar./maio 2017; DIMOULIS, Dimitri; LUNARDI, Soraya. A tendência passivista do Supremo. In: FALCÃO, Joaquim; ARGUELHES, Diego Werneck; RECONDO, Felipe (Org.). O Supremo em 2015. Rio de Janeiro: FGV, 2016. p. 303-306.

39 MENDES, Conrado Hubner. O projeto de uma corte deliberativa. In: VOJVODIC, Adriana; PINTO, Henrique Motta; PAGANI, Rodrigo (Org.). Jurisdição constitucional no Brasil. São Paulo: Malheiros, 2012; MENDES, Conrado Hubner. The Supreme Federal Court of Brazil. In: JAKAB, András; DYEVRE, Arthur; ITZCOVICH, Giulio (Org.). Comparative constitutional reasoning. Nova York: Cambridge University Press, 2017.

40 Veja, por exemplo, as entrevistas para o projeto História Oral do Supremo Tribunal - especialmente as entrevistas dos ministros Carlos Velloso, Rafael Mayer, Nelson Jobim. FONTAINHA, Fernando et al. História Oral do Supremo Tribunal Federal. Rio de Janeiro: FGV, 2015-2016. Veja, em contraste, lamentando a ausência de tais encontros, as entrevistas com os juízes Cezar Peluso e Roberto Barroso. FONTAINHA, Fernando et al. História Oral do Supremo Tribunal Federal. Rio de Janeiro: FGV, 2015-2016.

41 FALCÃO, Joaquim; CERDEIRA, Pablo Camargo; ARGUELHES, Diego Werneck. O Supremo Tribunal Federal Processual. In: MARTINS, Ives Gandra S.; ROSSET, Patricia; AMARAL, Antonio Carlos R. (Org.). Estudos: Direito Público. Homenagem ao Ministro Carlos Mário da Silva Velloso. São Paulo: Lex Magister, 2013. p. 299-308.; SILVA, Virgílio Afonso da. O relator dá voz ao STF?: uma réplica a Almeida e Bogossian. Revista Estudos Institucionais, Rio de Janeiro, v. 2, n. 2, p. 648-669, 2016; VERÍSSIMO, Marcos Paulo. A Constituição de 1988, vinte anos depois: Suprema Corte e 'ativismo judicial à brasileira'. Revista Direito GV, São Paulo, v. 4, n. 2, p. 407-440, jul./dez. 2008.

42 SILVA, Virgílio Afonso da. Deciding without deliberating. International Journal of Constitutional Law, New York, v. 11, n. 3, p. 557-584, Jul. 2013.

43 Outra explicação adicional possível (e em contraste com o caso dos EUA) é a falta de "viés de seleção" no caso do Supremo Tribunal Federal. RIBEIRO, Leandro Molhano; ARGUELHES, Diego Werneck. Preferências, estratégias e motivações: pressupos- 
mil decisões colegiadas tomadas pelo tribunal a cada ano, em média, cerca de $93 \%$ são unânimes, enquanto 5,3\% tinham um único voto vencido (vale notar, porém, que essa média tem diminuído ao longo do tempo, desde os anos 90) ${ }^{44}$. Além disso, um estudo empírico constatou que, em relação a 692 decisões em Ações Diretas de Inconstitucionalidade (ADIs) decididas entre 1999 e 2006, o voto do relator correspondia à decisão final em 99\% dos casos ${ }^{45}$. Silva (2015), no entanto, relata que, em entrevistas anônimas, ministros atuais e antigos consideram a opinião do relator como "uma opinião como qualquer outra". ${ }^{46}$

A melhor maneira de compatibilizar esses dois tipos de achados contrastantes, como Silva observa, parece ser fazer uma distinção entre casos "fáceis" ou "rotineiros" (nos quais os juízes quase sempre se submetem ao relator e não investem muito tempo escrevendo suas próprias opiniões de antemão) e casos "difíceis" ou "importantes" (nos quais eles quase sempre chegam à sessão com suas opiniões plenamente desenvolvidas, ao invés de simplesmente confiarem no relator). ${ }^{47}$ Embora essa distinção seja insuficientemente teorizada nos estudos jurídicos existentes, parece plausível argumentar que, dadas as limitações de tempo e recursos com que os ministros operam, faria sentido supor que os ministros escolhem quais dos casos sob a responsabilidade de seus colegas são relevantes o suficiente para merecer o tempo e a atenção de seu gabinete.

Neste artigo, procuramos contribuir para explicar essas escolhas e comportamentos utilizando uma variável ainda não explorada pela literatura no caso do STF: gênero. Em estudo preliminar sobre as concordâncias na Suprema Corte dos Estados Unidos, Turner sugere que o tribunal

é um local antigo, de elite, conservador, no qual a presença relativamente recente de mulheres pode parecer perturbadora e os ministros que não estão habituados a serem deferentes às mulheres sentirão a necessidade de "corrigir" ou "esclarecer" uma opinião com a qual eles concordem mais nesses casos. ${ }^{48}$

De modo geral, acreditamos que o mesmo tipo de raciocínio é aplicável aos votos vencidos no STF. Entendemos que a propensão a divergir e o gênero estão conectados por meio do modo como os juízes percebem o papel do relator, e de como podem mudar especificamente seu comportamento quando o relator é do sexo feminino.

Operamos com a suposição de que divergir e/ou votar vencido no STF são ações minimamente custosas para o ministro que as adota ${ }^{49}$. Todo ministro tem a opção de simplesmente seguir a opinião do relator e

tos institucionais de teorias sobre comportamento judicial e sua transposição para o caso brasileiro. Direito e Práxis, Rio de Janeiro, v. 4, n. 7, p. 85-121, out./dez. 2013. O grande volume de casos, que pode em parte ser explicado pelo baixo custo dos recursos, torna improvável que os casos que chegam ao STF sejam necessariamente casos "difíceis". Ou seja, um grande número desses casos provavelmente tem soluções legais claras, simples e tecnicamente consensuais.

44 ROSEVEAR, Evan; HARTMANN, Ivar; ARGUELHES, Diego Werneck. Disagreement on the Brazilian Supreme Court. an exploratory analysis. 2015. Disponível em: <https://papers.ssrn.com/sol3/papers.cfm?abstract_id =2629329>. Acesso em: 16 jul. 2018.

45 OLIVEIRA, Fabiana Luci de. Supremo relator: processo decisório e mudanças na composição do STF nos governos FHC e Lula. Revista Brasileira de Ciências Sociais, São Paulo, v. 27, n. 80, p. 89-115, out. 2012 ("Em apenas 6 das 692 ações julgadas no período considerado, o voto do relator foi diferente do resultado final da decisão, ou seja, em $99 \%$ dos casos o voto do relator é igual à decisão final da corte. E como o relator é o primeiro a votar, isso implica que conhecer a direção desse voto é saber o resultado final em $99 \%$ das vezes.")

46 Para um importante debate em torno do papel do relator no processo de deliberação do STF, a partir do trabalho de SILVA, Virgílio Afonso da. 'Um Voto Qualquer?’: o papel do ministro relator na deliberação no Supremo Tribunal Federal. Revista de Estudos Institucionais, Rio de Janeiro, v. 1, n. 1, p. 180-200, 2015, ver ALMEIDA, Danilo; BOGOSSIAN, André. Nos termos do voto do relator: considerações acerca da fundamentação coletiva nos acórdãos do STF. Revista Estudos Institucionais, Rio de Janeiro, v. 2, n. 1, p. 263-297, 2016; SILVA, Virgílio Afonso da. O relator dá voz ao STF?: uma réplica a Almeida e Bogossian. Revista Estudos Institucionais, Rio de Janeiro, v. 2, n. 2, p. 648-669, 2016.

47 SILVA, Virgílio Afonso da. O relator dá voz ao STF?: uma réplica a Almeida e Bogossian. Revista Estudos Institucionais, Rio de Janeiro, v. 2, n. 2, p. 648-669, 2016.

48 TURNER, Charles C. Gender, judging, and the decision to concur: female justices and the Supreme Court. In: ENCONTRO ANNUAL DA "WESTERN POLITICAL SCIENCE ASSOCIATION", 2015, Las Vegas, Nevada, 2015.

49 EPSTEIN, Lee; LANDES, William; POSNER, Richard A. Why (and when) judges dissent: a theoretical and empirical analysis. Journal of Legal Analysis, Cambridge, v. 3, n. 1, p 101-137, mar. 2011; ROSEVEAR, Evan; HARTMANN, Ivar; ARGUELHES, Diego Werneck. Disagreement on the Brazilian Supreme Court. an exploratory analysis. 2015. Disponível em: <https://papers.ssrn.com/sol3/ 
declarar suas razões verbalmente; em vários casos, no processo decisório do STF, isso equivale, apenas, a dizer "sigo o relator". Se, de fato, os estereótipos de gênero e a discriminação estiverem em jogo na maneira como os juízes percebem os relatores, esperamos que os ministros estejam relativamente mais propensos a acatar a opinião de um relator do sexo masculino e simplesmente segui-la.

Com efeito, os ministros podem discordar com mais frequência quando o relator é do sexo feminino por dois tipos de razões. Primeiro, assumindo que os ministros se importam em chegar à decisão "correta", eles podem estar mais inclinados a discordar porque pensam que as juízas do sexo feminino são, de maneira geral, menos competentes, informadas e/ou confiáveis - isto é, eles sentem que podem ser levados a concordar com a decisão "errada" se confiarem demais em uma relatora mulher. Em segundo lugar, supondo que as deliberações no STF sejam parte de uma interação de longo prazo, baseada em colegialidade e respeito mútuo entre esses atores profissionais, um ministro pode achar que discordar de uma colega será menos custoso do que divergir de ministros do sexo masculino. Isto pode se dar devido à percepção de que, em razão dos arranjos de poder do tribunal, as mulheres terão menor possibilidade do que os homens de fazer prevalecer sua posição ou de exercer retaliações no futuro - tanto dentro do tribunal, como nos círculos sociais e profissionais mais amplos dos quais os ministros fazem parte. Com isso, mulheres seriam encaradas como alvos mais fáceis para desafios públicos ao seu conhecimento ou autoridade ${ }^{50}$.

\subsubsection{Interrompendo deliberações: pedidos de vista e confiança na opinião do relator}

Como em todos os outros tribunais no Brasil, uma vez iniciadas as deliberações no colegiado, qualquer juiz no STF pode pedir vista dos autos, suspendendo o julgamento para que os arquivos do caso sejam enviados ao seu gabinete para uma análise mais aprofundada. Pelo regimento interno do STF e pelas regras de direito processual vigente, o pedido de vista se justifica quando o ministro sente que não está suficientemente familiarizado com fatos ou argumentos do caso, e a duração da vista seria limitada a algumas semanas. Contudo, estudos recentes desconstruíram essa visão oficial sobre o uso do pedido de vista.

Usando o banco de dados do projeto Supremo em Números, um estudo revelou que (i) os pedidos de vista raramente são retornados dentro dos prazos oficiais - na verdade, sua duração média é de quase um ano e meio, ou cerca de 3 anos para vistas ainda não devolvidas quando o estudo foi realizado; (ii) não há casos de pedidos de vista fora do prazo sendo cancelados pelo tribunal plenário, o que indica que cada juiz tem, na prática, uma escolha livre acerca do momento em que permitirá que o caso retorne a julgamento ${ }^{51}$. Nesse cenário, os autores argumentam que os pedidos de vista devem ser interpretados como um poder de agenda negativo — uma espécie de veto - atribuído a cada um dos integrantes do tribunal, que podem, então, utilizá-lo para suspender as deliberações sobre casos ou temas que considere inconvenientes ou em contextos inoportunos ${ }^{52}$.

Como reconhecem os autores, porém, a falta de restrições formais ao uso de pedidos de vistas não exclui, necessariamente, que haja limites e custos informais associados ao uso dessa forma de controle da agenda

papers.cfm?abstract_id=2629329>. Acesso em: 16 jul. 2018.

50 Na literatura norte-americana sobre comportamento judicial e divergências, existem muitas teorias sobre os benefícios esperados que um ministro obtém ao divergir ou, pelo menos, ao ameaçar divergir. Por exemplo, a ameaça de abandonar uma coalizão de voto e adotar uma posição vencida ou concorrente pode permitir que obtenha algumas concessões daquela coalizão, sobretudo se ela representar o voto "majoritário" ou "da Corte". Ou, ainda, a possibilidade de atenção do público para um aspecto específico e controverso da decisão da maioria. Ver ROSEVEAR, Evan; HARTMANN, Ivar; ARGUELHES, Diego Werneck. Disagreement on the Brazilian Supreme Court. an exploratory analysis. 2015. Disponível em: < https://papers.ssrn.com/sol3/papers.cfm?abstract_ id=2629329 . . Acesso em: 16 jul. 2018. para uma discussão sobre a aplicabilidade de tais teorias ao caso brasileiro. Para os propósitos deste artigo, não vemos nenhuma razão clara para acreditar que os juízes esperariam obter benefícios diferentes com seus votos vencidos dependendo do gênero do relator.

51 ARGUELHES, Diego Werneck; HARTMANN; Ivar A. Timing control without docket control: how individual justices shape the Brazilian Supreme Court's agenda. Journal of Law and Courts, Chicago, v. 5, n. 1, p. 105-140, mar./maio 2017.

52 ARGUELHES, Diego Werneck; HARTMANN; Ivar A. Timing control without docket control: how individual justices shape the Brazilian Supreme Court's agenda. Journal of Law and Courts, Chicago, v. 5, n. 1, p. 105-140, mar./maio 2017. 
do Tribunal. De fato, se não houvesse nenhum custo para o uso dos pedidos de vista, qualquer ministro que sentisse estar em minoria poderia evitar, indefinidamente, qualquer derrota, em qualquer caso. $\mathrm{O}$ fato de o tribunal decidir tantos casos, sem que esse veto seja empregado na esmagadora maioria das deliberações, sugere que pode haver restrições informais no uso desse poder, ou custos associados ao seu emprego excessivo dentro do tribunal ${ }^{53}$.

Mais uma vez, como no caso de votos vencidos, podemos supor que há algum custo em usar esse poder, especialmente porque os juízes podem usar pedidos de vistas uns contra os outros, em retaliação a obstruções praticadas por seus colegas. Isso é verdade tanto em relação ao discurso oficial sobre pedidos de vista, quanto em relação à releitura feita pelos estudos mencionados acima. No primeiro caso, no uso "normal", as vistas apresentam um desafio à autoridade do relator do caso: o ministro pede vista quando acha que precisa de mais tempo para considerar os argumentos apresentados até agora, indicando que não deseja, simplesmente, confiar nos fatos e argumentos apresentados pelo relator sem uma análise mais detida. Em seu uso "estratégico", mapeado na literatura mencionada acima, os pedidos de vista bloqueiam uma decisão que o relator escolheu levar a tribunal e para a qual já havia preparado relatório e voto.

Estas são, portanto, as hipóteses que informam nosso estudo: esperamos que uma dinâmica de gênero seja perceptível no comportamento judicial no STF tanto quanto aos pedidos de vista, quanto às divergências com o relator. Relatoras do sexo feminino deveriam aumentar a probabilidade de ocorrência tanto de votos vencidos, quanto de pedidos de vista. Essas hipóteses se ancoram em duas teorias possíveis e não excludentes sobre o comportamento judicial nessas dimensões.

Em primeiro lugar, se mulheres forem consideradas menos competentes ou confiáveis como relatoras por seus pares em razão de seu gênero, relatoras do sexo feminino aumentariam a probabilidade de pedidos de vista por juízes que, nessa narrativa estereotipada, sentiriam menos confiança no trabalho da relatora em explicar as controvérsias envolvidas no caso e em oferecer a melhor solução. Aqui, o gênero interage com deferência à competência ou conhecimento do relator.

Em segundo lugar, o gênero, também, pode interagir com a colegialidade, entendida aqui como o conjunto de relações de reciprocidade, minimamente cordiais e profissionais, que membros de um órgão judicial coletivo devem desenvolver e manter uns com os outros ao longo do tempo. Os custos esperados de bloquear uma decisão por uma relatora do sexo feminino devem ser menores se as mulheres forem de fato consideradas menos poderosas que os homens no tribunal, e, por isso, tiverem menos propensão a impor seu posicionamento ou retaliar do que suas contrapartes masculinas. Esses dois conjuntos de motivos não são excludentes, e ambos nos levam a supor que os juízes terão maior probabilidade de usar vistas para interromper e impedir decisões quando o relator for do sexo feminino.

\section{Metodologia de Pesquisa e Resultados}

\subsection{Dados e Estratégia Empírica}

Com base nas teorias discutidas na seção anterior, testamos se o gênero do relator influencia a probabilidade de (i) algum ministro pedir vista e ii) algum ministro votar vencido (isto é, a probabilidade de a decisão ser ou não unânime). Também investigamos se o gênero aumenta (iii) a chance de haver divergência, expressa no número de votos vencidos, nos casos não unânimes. Além disso, procuramos dar alguns passos preliminares para investigar se tais efeitos são amplificados ou não quando há mais de uma mulher no tribunal

53 ARGUELHES, Diego Werneck; HARTMANN; Ivar A. Timing control without docket control: how individual justices shape the Brazilian Supreme Court's agenda. Journal of Law and Courts, Chicago, v. 5, n. 1, p. 105-140, mar./maio 2017. 
("efeito de sororidade") e, em particular, quando a presidente do Supremo é uma mulher. A essa variedade do "efeito sororidade", chamaremos "Efeito Ellen Gracie". A ministra Ellen Gracie foi a primeira presidente mulher do STF, e foi a única mulher presidente no período abrangido por nossos dados até agora.

Os dados utilizados neste trabalho são provenientes do projeto Supremo em Números, da FGV Direito Rio, banco de dados com mais de 1,8 milhão de ações judiciais do STF, entre 1988 e 2016. A amostra deste trabalho abrange um período de janeiro de 2001 a dezembro de 2013, resultando em uma amostra de 1.034 processos, selecionados por meio de amostragem aleatória estratificada com um único estágio. A amostra utilizada é composta por diversas variáveis, como o número do processo no sistema interno de gestão de processos do STF, o nome do relator, os nomes do autor da ação e do réu, o número de vistas solicitadas pelos magistrados, a data de arquivamento, a data do parecer produzido pelo Ministério Público etc.

Nossa especificação para medir o efeito de gênero do relator é:

$$
\text { Yit }=\beta 0+\beta 1 \text { Gêneroi }+\beta 2 \text { D_Anoi }+\beta 3 \text { D_Sororidadeit }+\beta 4 \text { D_EllenGracieit }+ \text { sit }
$$

Em que Yit é um resultado do processo i (número de vistas, decisão unânime e dissidência) no tempo t. Gênero é uma variável dummy ${ }^{54}$ (gênero do relator do processo). Gênero é igual a 1 se for do sexo feminino e a 0 caso contrário. D_Ano é um conjunto de efeitos fixos de ano que considera possíveis efeitos de tempo comuns entre os processos. D_Sororidade é uma variável dummy que explica a presença de mais de uma ministra no STF (quando há mais de uma ministra a variável assume valor igual 1 - e assume valor $0 \mathrm{em}$ caso contrário). D_EllenGracie é outra variável dummy que responde por Ellen Gracie como presidente do STF. A variável sit é o termo de erro.

\subsection{Resultados Preliminares}

Os resultados da Eq. (1) estão apresentados na Tabela 1.

Tabela 1 - Efeito de gênero no STF: pedido de vista.

Tabela 1

Efeito de Gênero no STF

\begin{tabular}{|c|c|c|c|c|c|c|c|}
\hline \multicolumn{8}{|c|}{ Pedido de Vista } \\
\hline & (1) & (2) & (3) & (4) & (5) & (6) & (7) \\
\hline & \multicolumn{4}{|c|}{ Todos } & Plenário & 12 Turma & $2 \pm$ Turma \\
\hline Relatora mulher & $0,02(0,02)$ & $0,02(0,02)$ & $0,01(0,02)$ & $0,01(0,02)$ & $0,02(0,06)$ & $-0,0(0,02)$ & $0,01(0,04)$ \\
\hline Sororidade & $\mathrm{N}$ & $Y$ & $Y$ & $Y$ & $\mathrm{Y}$ & $Y$ & $Y$ \\
\hline Efeito Ano & $\mathrm{N}$ & $\mathrm{N}$ & $Y$ & $Y$ & $\mathrm{Y}$ & $\mathrm{Y}$ & $\mathrm{Y}$ \\
\hline Efeito Ellen & $\mathrm{N}$ & $\mathrm{N}$ & $\mathrm{N}$ & $Y$ & $Y$ & $\mathrm{Y}$ & $\mathrm{Y}$ \\
\hline Constante & 0,03 & 0,03 & 0,02 & 0,02 & 0,13 & 0 & 0,04 \\
\hline
\end{tabular}

Os resultados das Colunas (1) - (4) são para plenário, primeira e segunda turma juntos. A coluna (1) relata o resultado de uma regressão via Método dos Mínimos Quadrados Ordinários ${ }^{55}$ (MQO) para o número de

54 Uma variável dummy é uma variável binária, cujo caso mais simples ocorre quando fazemos a variável igual a 1 para uma categoria e 0 para a categoria mutuamente exclusiva à primeira. Uma variável de gênero é uma dummy, pois assume valor igual a 1 se for do sexo feminino e 0 caso seja do sexo masculino.

55 O Método dos Mínimos Quadrados Ordinários é uma técnica de otimização matemática que procura encontrar o melhor ajuste para um conjunto de dados tentando minimizar a soma dos quadrados das diferenças entre o valor estimado e os dados observados (tais diferenças são chamadas "resíduos"). Para maiores informações, ver GUJARATI, D. N. Basic econometrics. Tata McGraw-Hill Education, 2009. 
pedidos de vista sem quaisquer controles. Coluna (2) inclui o controle efeito "Sororidade"; Coluna (3) inclui efeitos fixos de ano; e Coluna (4) inclui efeito "Ellen Gracie". Independentemente da especificação, os resultados mostram que o gênero do relator não afeta a probabilidade de pedido de vista. Os resultados não mudam quando consideramos, apenas, as decisões tomadas pelo plenário, primeira turma e segunda turma, expostos na Coluna (5), Coluna (6) e Coluna (7), respectivamente.

Tabela 2 - Efeito de gênero no STF: divergência.

Tabela 2

\section{Efeito de Gênero no STF}

\begin{tabular}{|c|c|c|c|c|c|c|c|}
\hline \multicolumn{8}{|c|}{ Divergência } \\
\hline & (1) & $(2)$ & (3) & (4) & (5) & (6) & (7) \\
\hline & \multicolumn{4}{|c|}{ Todos } & Plenário & 1a Turma & 2a Turma \\
\hline Relatora mulher & $0,19 * *$ & $0,17^{*}$ & $0,19^{*}$ & $0,19^{*}$ & $0,32^{* *}$ & 0,08 & 0,55 \\
\hline Sororidade & $\mathrm{N}$ & Y & Y & $\mathrm{Y}$ & $\mathrm{Y}$ & $\mathrm{Y}$ & $\mathrm{Y}$ \\
\hline Efeito Ano & $\mathrm{N}$ & $\mathrm{N}$ & Y & Y & Y & Y & $\mathrm{Y}$ \\
\hline Efeito Ellen & $\mathrm{N}$ & $\mathrm{N}$ & $\mathrm{N}$ & Y & Y & Y & $\mathrm{Y}$ \\
\hline Constante & $-0,15$ & $-0,18$ & $-0,35$ & $-0,35$ & $-0,11$ & $-0,14$ & $-0,25$ \\
\hline
\end{tabular}

$\mathrm{N}=1034$

A Tabela 2 reporta os resultados da Eq. (1) com a variável dependente "divergência". A fim de estimar o impacto de gênero na probabilidade de voto vencido dos ministros, precisamos usar uma outra distribuição de erros, já que, dado o tamanho da corte (11 juízes), a variável "divergências" somente pode assumir 6 valores possíveis ( 0 votos vencidos, 1 voto vencido, 2 votos vencidos, 5 votos vencidos).

A coluna (1) relata o resultado de uma regressão de $\operatorname{Poisson}^{56}$ para votos vencidos sem controles. Os resultados da Tabela 2 revelam que, independentemente dos controles adotados, o efeito de gênero nos votos vencidos é positivo e significativo, ou seja, se o relator é do sexo feminino, há uma maior probabilidade de votos divergentes.

Para saber em que medida o gênero (feminino) do relator aumenta a probabilidade de os ministros votarem vencidos, precisamos fazer a seguinte conta:

$$
\exp (0,19)=1,20
$$

Ou seja, a taxa de divergência para relatoras do sexo feminino é 1,2 vez maior do que para os relatores do sexo masculino.

A coluna (5) da Tabela 2 apresenta o resultado apenas do plenário. Nesse caso, o efeito de gênero é, ainda, maior e mais significativo. A taxa de divergência para uma relatora mulher é 1,37 vez maior do que para o relator homem. Os resultados para a primeira e a segunda turmas não são significativos, o que pode ser explicado pela baixa representatividade de mulheres. Se há uma mulher na primeira turma, então (com exceção de alguns períodos) não haverá mulher na segunda turma, e vice-versa.

Ao tentarmos abordar a mesma questão — relatoria feminina aumenta a probabilidade de divergências — de um ângulo diferente, chegamos à Tabela 3, que reporta os resultados da Eq. (1) com "unanimidade"

56 Em estatística, regressão de Poisson é uma forma de análise de regressão usada para modelar contagem de dados e tabelas de contingência. Regressão de Poisson assume a variável resposta Y como uma distribuição de Poisson, e assume que o logaritmo de seu valor esperado pode ser modelado por uma combinação linear de parâmetros desconhecidos. Ver, por exemplo, CASELLA, George; BERGER, Roger L. Statistical inference. 5. ed. Belmont: Duxbury, 2002. 
(ou seja, se o resultado da decisão foi uma decisão unânime ou não unânime) como variável dependente. A coluna (1) relata os resultados de uma regressão MQO para unanimidade, sem controles.

Tabela 3 - Efeito de gênero no STF: unanimidade.

Tabela 3

\section{Efeito de Gênero no STF}

\section{Unanimidade}

\begin{tabular}{|c|c|c|c|c|c|c|c|}
\hline & (1) & (2) & (3) & (4) & (5) & (6) & (7) \\
\hline & \multicolumn{4}{|c|}{ Todos } & Plenário & $1^{12}$ Turma & $2^{2}$ Turma \\
\hline Relatora mulher & $-0,06^{*}$ & $-0,07^{*}$ & $-0,04$ & $-0,04$ & $-0,33^{* * *}$ & 0,06 & 0,02 \\
\hline Sororidade & $\mathrm{N}$ & $Y$ & $\mathrm{Y}$ & $Y$ & $\mathrm{Y}$ & $\mathrm{Y}$ & Y \\
\hline Efeito Ano & $\mathrm{N}$ & $\mathrm{N}$ & $Y$ & Y & $\mathrm{Y}$ & $\mathrm{Y}$ & $\mathrm{Y}$ \\
\hline Efeito Ellen & $\mathrm{N}$ & $\mathrm{N}$ & $\mathrm{N}$ & Y & $\mathrm{Y}$ & Y & Y \\
\hline Constante & 0,84 & 0,85 & 0,86 & 0,86 & 0,45 & 0,99 & 0,72 \\
\hline
\end{tabular}

$\mathrm{N}=1034$

Os resultados da Tabela 3 revelam que, quando adicionamos todos os controles, como mostrado na coluna (4), o impacto do gênero na unanimidade de votos não é significativo. No entanto, quando olhamos, apenas, para os casos decididos pelo plenário, os resultados revelam que, quando o relator é do sexo feminino, a chance de unanimidade diminui $0,73 \%$ com significância de $1 \%$. Os resultados para a primeira e segunda turma não são significativos.

Em resumo, a partir dos dados coletados, nossos resultados sugerem que os relatores femininos tendem a atrair 1,2 vez mais votos vencidos do que os relatores masculinos, efeito aumenta para 1,37 quando consideramos apenas o tribunal pleno. Com relação aos pedidos de vista, com nossos dados atuais, no entanto, não fomos capazes de encontrar nenhum resultado estatisticamente significativo.

\section{ESTEREÓtIPO dE GÊNERO E dISCUSSÃo dOS RESULTADOS}

As teorias mais influentes sobre gênero e poder têm enfatizado o papel central dos estereótipos de gênero explicando a sub-representação de mulheres em cargos de liderança. ${ }^{57}$ Por um lado, diversas teorias enfatizam como crenças sobre semelhanças e diferenças entre os sexos fazem com que as pessoas tendam a ver as mulheres como menos qualificadas para esse tipo de cargo do que os homens. Por outro, crenças normativas das pessoas sobre como homens e mulheres deveriam agir fazem com que mulheres que não ajam de maneira compatível com o estereótipo "feminino" sejam classificadas como desagradáveis, indignas de recompensas organizacionais, e até sujeitas a penalidades sociais e econômicas.

Experimentos mostram a existência de bias desfavoráveis às mulheres que impedem que sua competência seja identificada. Experimento realizado em 2012, nos Estados Unidos, contatou que, mesmo apresentando candidaturas idênticas, candidatos homens eram considerados por cientistas homens e mulheres mais competentes e mais adequados para vagas de gerente de laboratório científico do que as contrapartes femininas,

57 Por exemplo: EAGLY, Alice; CARLI, Linda L. Women and the labyrinth of leadership. Harvard Business Review, Cambridge, v. 85, n. 9, p. 62-67, Sep. 2007; MOSS-RACUSIN, Corinne. A.; RUDMAN, Laurie. A. Disruptions in women's self-promotion: the backlash avoidance model. Psychology of Women Quarterly, Piscataway, v. 34, n. 2, p. 186-202, apr./jun. 2010. 
além de receberem ofertas de salário $\$ 4,000$ maiores e outras vantagens ${ }^{58}$ Em outro estudo, pesquisadores concluíram que empregadores, quando tinham conhecimento do sexo do candidato, tendiam a contratar duas vezes mais homens do que mulheres com base em uma tarefa aritmética que homens e mulheres, na média, desempenham de maneira igual. ${ }^{59}$

Como se vê nos casos elencados acima, a condutas dos empregadores, ao avaliar o melhor candidato para uma vaga, frequentemente não se baseia em uma escolha racional. O que mostra a literatura é que, nesse processo, os estereótipos de gênero têm um papel central. Estereótipos de gênero são generalizações acerca das diferenças entre homens e mulheres que pressupõe que (i) essa diferença existe; (ii) é relevante e relativamente fixa; e (iii) envolve uma série de características, como, por exemplo, uma inclinação feminina para questões domésticas. ${ }^{60}$

Estereótipos, com relação às mulheres, podem se manifestar tanto de maneira hostil quanto de maneira benevolente. No primeiro caso, se materializam como "ressentimento em relação a mulheres percebidas como querendo controlar homens". No segundo, quando as mulheres são tratadas como "criaturas frágeis". Em qualquer uma de suas manifestações, estereótipos causam danos aos indivíduos que, ora se vêem pressionados a se conformarem, ora são punidos por não o fazerem. Como ressaltem Peter Glick e Susan T. Fiske, estereótipos não são

meramente descritivos, mas prescritivos, por que um funcionamento social eficiente requer que os indivíduos sejam socializados para possuir os traços requeridos para uma performance bem-sucedida do papel que desemprenha no grupo. ${ }^{61}$

$\mathrm{Na}$ medida em que cargos de gerência e de chefia são vistos como cargos masculinos, a "discriminação ocorre quando os avaliadores parte do pressuposto de que homens mais do que mulheres possuem esses traços estereotipicamente masculinos". ${ }^{62}$ Do mesmo modo, a maneira por meio da qual as características são percebidas é influenciada pelos estereótipos de gênero. Por exemplo, “o mesmo comportamento pode ser descrito como 'muito assertivo' para uma mulher e ‘não muito assertivo' para um homem”. ${ }^{63}$ Além disso, em avaliações subjetivas, o critério considerado mais importante para o desempenho da profissão pode ser alterado, subjetivamente, para justificar discriminação contra mulheres. Avaliando candidatos para o cargo de chefe de polícia, por exemplo, participantes de um estudo mudaram o critério que consideravam o mais importante para o desempenho da profissão — de educação formal para "malandragem da rua" (streetwise) — de forma a beneficiar o candidato do sexo masculino. ${ }^{64}$

Além dos estereótipos, dois outros fatores influenciam as dinâmicas de gênero em ambientes de trabalho e impactam diretamente na divisão de poderes nesses espaços. Um deles é a existência de redes de relaciona-

58 MOSS-RACUSIN, Corinne A. Science faculty's subtle gender biases favor male students. Proceedings of the National Academy of Sciences, v. 109, n. 41, p. 16474-16479, 2012.

59 REUBEN, Ernesto; SAPIENZA, Paola; ZINGALES, Luigi. How stereotypes impair women's careers in science. Proceedings of the National Academy of Sciences, v. 111, n. 12, p. 4403-4408, 2014.

60 SCHULTZ, Vicki. Telling stories about women and work: judicial interpretations of sex segregation in the workplace in Title VII cases raising the lack of interest defense. Harvard Law Review, v. 103, p. 1749-1843, 1990.

61 E continuam os autores: "Assim, mulheres são punidas quando violam a prescrição de serem afetuosas ou agregativas. Atos de autopromoção ou assertividade por parte de mulheres são punidos por irem de encontro a ideias de agradabilidade feminina, são fortemente desgostados e podem gerar discriminação para contratação ou promoção. Em contraste, não é particularmente esperado que homens sejam agradáveis (e definitivamente é esperado que sejam assertivos), eles não são punidos por esse tipo de comportamento. Normas prescritivas de gênero criam um dilema para as mulheres no trabalho na medida em que trilham a fina linha entre exibir traços estereotipicamente masculinos que são geralmente associados com o mundo do trabalho e aparentarem não serem assertivas (e logo, não agradáveis)". GLICK, Peter; FISKE, Susan T. Sex discrimination: the psychological approach. In: CROSBY, Faye et al (Ed.). Sex discrimination in the workplace: multidisciplinary perspectives. Malden, MA: Blackwell, 2007. p. 162.

62 GLICK, Peter; FISKE, Susan T. Sex discrimination: the psychological approach. In: CROSBY, Faye et al (Ed.). Sex discrimination in the workplace: multidisciplinary perspectives. Malden, MA: Blackwell, 2007. p. 16.

63 GLICK, Peter; FISKE, Susan T. Sex discrimination: the psychological approach. In: CROSBY, Faye et al (Ed.). Sex discrimination in the workplace: multidisciplinary perspectives. Malden, MA: Blackwell, 2007. p. 167-168.

64 GLICK, Peter; FISKE, Susan T. Sex discrimination: the psychological approach. In: CROSBY, Faye et al (Ed.). Sex discrimination in the workplace: multidisciplinary perspectives. Malden, MA: Blackwell, 2007. p. 168-169. 
mento (networking) que surgem e se desenvolvem marcadas por características de sociabilidade masculina. Trata-se de redes que se desenvolvem fora do ambiente de trabalho, em atividades que tradicionalmente excluem as mulheres. Estudos sugerem que homens e mulheres tendem a desenvolver redes de relacionamento homofílicas (ou seja, com pessoas do mesmo sexo ${ }^{65}$ ) contudo, homens tenderiam a se beneficiar de tal fato por estarem tradicionalmente presentes em maior número em posições hierarquicamente superiores.

Um terceiro fator, de estrema relevância tanto para as dinâmicas de gênero em ambientes de trabalho, é a questão do assédio. O assédio está relacionado a uma estratégia masculina de ativamente excluir as mulheres de certos ambientes de trabalho como forma de não perder seu status e/ou identidade. $O$ assédio não se limita a "fazer da mulher o objeto de sua atenção sexual", mas abrange um amplo rol de atividades que "minam a confiança [da mulher] e a [sua] imagem como uma trabalhadora capaz". ${ }^{66}$

Na prática, o assédio funciona como "um guardião do gênero" por meio da corrosão da capacidade das mulheres de exercerem um trabalho satisfatório, ao mesmo tempo em que "policia as fronteiras do trabalho e protege a imagem masculina idealizada, assim como a identidade daqueles que o praticam". ${ }^{67}$

Esses achados, embora resultantes de pesquisas realizadas em outros contextos, são um pano de fundo importante para a leitura dos resultados deste trabalho. Na seção anterior, mostramos que há maior divergência no STF quando mulheres são relatoras. Uma primeira explicação seria simplesmente o fato de que mulheres (seja no geral, sejam as que estavam no STF no período analisado) são "piores", como relatoras, do que os homens, o que explicaria seu menor sucesso, nessa posição, do que seus pares masculinos.

No entanto, a literatura já mencionada, bem como as pesquisas indicadas nos parágrafos anteriores, nos leva a crer resultados como os que obtivemos neste trabalho pedem explicações alternativas para essa diferença de gênero no caso das divergências no STF.

Além da adesão a certos estereótipos relativos à incompetência e à falta de conhecimento, a divisão de poderes dentro do tribunal decorrente desses estereótipos (que fariam com o que as mulheres tivessem menor poder para fazer valer suas posições e para retaliar) são úteis para explicar o elevado índice de divergência 1.2 (e 1.37 no plenário) maior quando a relatora é mulher.

\section{Considerações finais}

Estereótipos de gênero e discriminação (bem como as dinâmicas de poder que deles advém) podem impactar o comportamento judicial e a dinâmica dos tribunais de muitas maneiras diferentes. Neste artigo, nos propusemos a usar o gênero para explicar como os ministros se relacionam entre si no mais alto tribunal do Brasil, o Supremo Tribunal Federal. O STF é um cenário particularmente útil para discutir o impacto do gênero no comportamento judicial, além da real posição substantiva dos ministros sobre os méritos de um caso. Devido à grande carga de trabalho do tribunal, os juízes somente podem concentrar sua atenção em um número muito limitado de ações judiciais. Nesse cenário, a literatura existente sugere que o papel do

65 TORRES, Lise; HUFFMAN, Matt L. Social networks and job search outcomes among male and female professional, technical, and managerial workers. Sociological Focus, v. 35, n. 1, 2002.

66 SCHULTZ, Vicki. Reconceptualizing sexual harassment. Yale Law Journal, v. 107, p. 1687, 1998. Entre tais práticas, Vicky Schultz enumera: "caracterizar o trabalho apenas como sendo apropriado para homens; depreciar a performance ou habilidade das mulheres ao executarem o trabalho; prover formas benevolentes de ajuda para a execução do trabalho; reter informação, treinamento ou oportunidades de aprender a fazer bem o trabalho; promover sabotagem deliberada do trabalho; oferecer avaliações sexistas relativas à performance das mulheres ou negar promoções merecidas, isolar mulheres de redes sociais (networking) que conferem um sentido de pertencimento, negar às mulheres os prerequisitos ou privilégios requeridos para o sucesso; designar às mulheres tarefas fora das atribuições do trabalho em razão de estereótipos de gênero (como realizar a limpeza ou servir café); pregar peças, insultar ou realizar outras formas de maus-tratos com intuito de lembrar às mulheres que elas são diferentes e estão fora do lugar, e fisicamente investir ou ameaçar as mulheres que ousarem reagir". Loc. cit.

67 SCHULTZ, Vicki. Reconceptualizing sexual harassment. Yale Law Journal, v. 107, p. 1691, 1998. 
relator se torna crucial na explicação de padrões de tomada de decisão no STF em um grande número de casos, já que os ministros não teriam escolha de se dedicar à informação, expertise e argumentos trazidos na sessão pelo relator nos casos que eles não consideram particularmente relevantes, complexos ou delicados.

Se isso é verdade, então, as expectativas de gênero podem moldar como os outros juízes se comportam em relação aos relatores em um grande número de casos. De fato, nossos resultados neste artigo sugerem que os relatores femininos tendem a atrair 1.2 vezes mais votos vencidos do que os relatores masculinos. Isso pode ser explicado tanto pela percepção enviesada de que as ministras são menos confiáveis e/ou competentes que suas contrapartes masculinas, quanto pela possibilidade de serem percebidas como menos propensas a fazer valer seu posicionamento e/ou retaliar (divergindo mais no futuro, por exemplo) contra seus pares, que se veriam, portanto, mais encorajados a discordar publicamente de relatoras do que de relatores. Esse efeito aumenta para 1.37 quando consideramos, apenas, o tribunal pleno. As deliberações no STF são sempre públicas, mas apenas no plenário são transmitidas ao vivo pela TV Justiça. Isso pode sugerir que pode haver uma conexão entre o comportamento de gênero em relação ao relator e o aumento da exposição, e percepção de relevância pública, pelos ministros, dos casos em discussão.

Estudos existentes mostraram que as atitudes dos juízes em relação às regras internas de procedimentos do Tribunal são notoriamente frouxas quando se trata de certos poderes que eles têm sobre a agenda do tribunal. ${ }^{68}$ Isso cria espaço para um alto nível de informalidade na forma como eles usam essas prerrogativas, como o uso desses poderes na negociação entre os ministros em um grande número de casos. Em tal cenário, mais uma vez, o comportamento com viés de gênero pode estar em jogo. Neste artigo, investigamos se os juízes tenderiam a ser mais agressivos no uso de seus poderes negativos de definição de agenda ("pedidos de vista") quando o relator de caso é do sexo feminino. Com nossos dados atuais, no entanto, não fomos capazes de encontrar nenhum resultado estatisticamente significativo para essa pergunta.

Considerando a presença de apenas três mulheres no STF em todo o período analisado, não podemos realmente excluir, com nossos dados, a possibilidade que os resultados se explicam por características específicas das três ministras individuais que estava no tribunal - e não pelo fato de serem mulheres. Nesse sentido, é importante que futuros estudos retornem a essas mesmas perguntas, conforme o número de mulheres no tribunal for aumentando, para testar essas diferentes explicações para essas variações de comportamento dos ministros quanto às mulheres relatoras.

Na próxima etapa, nesse mesmo projeto de pesquisa, utilizaremos um novo conjunto de dados, incluindo a frequência e a duração das falas e interrupções entre ministros e ministras do STF durante as deliberações e uma série de outras variáveis de controle, como taxas de absenteísmo, duração dos votos, nomeações presidenciais, experiências profissionais anteriores dos ministros e o gênero dos outros ministros (não apenas do relator do caso). Embora este trabalho seja um passo inicial, nossa constatação de que o gênero do relator de caso pode explicar padrões de divergência sugere que a dinâmica de gênero é uma variável útil a ser levada em consideração em pesquisas futuras. Além disso, ao apontar uma potencial discriminação de gênero, consciente ou não, dentro de uma instituição que deveria agir como um guardião imparcial dos direitos das mulheres e das minorias, esperamos que nossos resultados contribuam para tornar esse tipo de pesquisa ainda mais urgente.

\section{REFERÊNCIAS}

ALMEIDA, Danilo; BOGOSSIAN, André. Nos termos do voto do relator: considerações acerca da fundamentação coletiva nos acórdãos do STF. Revista Estudos Institucionais, Rio de Janeiro, v. 2, n. 1, p. 263-297,

68 ARGUELHES, Diego Werneck; RIBEIRO, Leandro Molhano. Ministrocracia: o Supremo Tribunal Individual no processo democrático brasileiro. Novos Estudos CEBRAP, v. 37, n. 1, p. 13-32, jan./abr. 2018. 
2016.

ANNENBERG, Flávia Xavier. Gender-based provisions in the united states and in Brazil: tensions between the anti-stereotyping doctrine and the positive discrimination approach. Artigo inédito, 2017.

ARAÚJO, Heloisa Bianquini. Qual o gênero do Supremo?: diálogo institucional nas sabatinas para o STF, poder e profissionalismo. 2015. 264 f. Monografia (Graduação) - Faculdade de Direito, Universidade de São Paulo, São Paulo, 2015.

ARGUELHES, Diego Werneck; HARTMANN; Ivar A. Timing control without docket control: how individual justices shape the Brazilian Supreme Court's agenda. Journal of Law and Courts, Chicago, v. 5, n. 1, p. 105-140, mar./maio 2017.

ARGUELHES, Diego Werneck; RIBEIRO, Leandro Molhano. 'The Court, it is I'?: individual judicial powers in the Brazilian Supreme Court and their implications for constitutional theory. Global Constitutionalism, v. 7, n. 2, p. 236-262, 2018.

ARGUELHES, Diego Werneck; RIBEIRO, Leandro Molhano. Ministrocracia: o Supremo Tribunal Individual no processo democrático brasileiro. Novos Estudos CEBRAP, v. 37, n. 1, p. 13-32, jan./abr. 2018.

ARGUELHES, Diego Werneck; RIBEIRO, Leandro Molhano. O Supremo Individual: mecanismos de atuação direta dos ministros sobre o processo político. Direito, Estado e Sociedade, Rio de Janeiro, v. 46, p. 121-155, jan./jun. 2015.

BARROSO, Luís Roberto. Constituição, democracia e supremacia judicial: direito e política no Brasil contemporâneo. Revista da Faculdade de Direito-UERJ, v. 2, n. 21, jan./jun. 2012.

BONELLI, Maria da Glória. Brazilian judges in-between professionalism, gender and difference. International Journal of the Legal Profession, v. 22, n. 2, p. 134-150, Apr. 2015.

BONELLI, Maria da Glória. Carreiras jurídicas e vida privada: interseções entre trabalho e família. Cadernos Pagu (UNICAMP), Campinas, n. 46, p. 245-277, jan./abr. 2016.

BONELLI, Maria da Glória. Profissionalismo e diferença de gênero na magistratura paulista. Civitas: Revista de Ciências Sociais, Porto Alegre, v. 10, n. 3. p. 270-292, set./dez. 2010.

BONELLI, Maria da Glória. Profissionalismo, diferença e diversidade na advocacia e na magistratura paulistas. Revista Brasileira de Ciências Sociais, São Paulo, v. 28, n. 83, p. 125-140, out. 2013.

CASELLA, George; BERGER, Roger L. Statistical inference. 5. ed. Belmont: Duxbury, 2002.

CASTILHO, Ela Wiecko Volkmer de. Criminalização do tráfico de mulheres: proteção das mulheres ou reforço da violência de gênero?. Cadernos Pagu, Campinas, n. 31, p. 101-123, jul./dez. 2008.

CHADA, Daniel; HARTMANN, Ivar. A distribuição de processos no Supremo é realmente aleatória?, 2016. Disponível em: < https://jota.info/colunas/supra/distribuicao-dos-processos-no-supremo-e-realmente-aleatoria-25072016>. Acesso em: 15 jun. 2018

COMISSÃO DE CONSTITUIÇÃO, JUSTIÇA E CIDADANIA. Ata da 11 a Reunião Ordinária, da $52^{a}$ Legislatura realizada em 10 de maio de 2006.

COMISSÃO DE CONSTITUIÇÃO, JUSTIÇA E CIDADANIA. Ata da da $2^{a}$ Sessão Legislativa Extraordinária, da 51 Legislatura, realizada em 21 novembro de 2000.

COMISSÃO DE CONSTITUIÇÃO, JUSTIÇA E CIDADANIA. Reunião Extraordinária da Comissão de Constituição, Justiça e Cidadania da $1^{a}$ Sessão Legislativa Ordinária da 54ª Legislatura,64., 6 de dezembro de 2011.

CONSELHO NACIONAL DE JUSTIÇA. Censo do poder judiciário. Brasília: CNJ, 2014. 
DIAS, Maria Berenice. A Lei Maria da Penha na justiça: a efetividade da Lei 11.340/2006 de combate à violência doméstica e familiar contra a mulher. São Paulo: Revista dos Tribunais, 2007.

DIMOULIS, Dimitri; LUNARDI, Soraya. A tendência passivista do Supremo. In: FALCÃO, Joaquim; ARGUELHES, Diego Werneck; RECONDO, Felipe (Org.). O Supremo em 2015. Rio de Janeiro: FGV, 2016. p. 303-306.

DOLAN, Kathleen A. When does gender matter? Women candidates and gender stereotypes in American elections. New York: Oxford University Press, 2014

EAGLY, Alice; CARLI, Linda L. Women and the labyrinth of leadership. Harvard Business Review, Cambridge, v. 85, n. 9, p. 62-67, Sep. 2007.

EPSTEIN, Lee; LANDES, William; POSNER, Richard A. Why (and when) judges dissent: a theoretical and empirical analysis. Journal of Legal Analysis, Cambridge, v. 3, n. 1, p 101-137, mar. 2011.

FALCÃO, Joaquim; ARGUELHES, Diego Werneck. Onze supremos, todos contra o Plenário. In: FALCÃO, Joaquim; ARGUELHES, Diego Werneck; RECONDO, Felipe (Org.). Onæe supremos: o Supremo em 2016. Rio de Janeiro: FGV, 2017. p. 20-29.

FALCÃO, Joaquim; CERDEIRA, Pablo Camargo; ARGUELHES, Diego Werneck. I Relatório Supremo em números: o múltiplo Supremo. Rio de Janeiro: FGV, 2011.

FALCÃO, Joaquim; CERDEIRA, Pablo Camargo; ARGUELHES, Diego Werneck. O Supremo Tribunal Federal Processual. In: MARTINS, Ives Gandra S.; ROSSET, Patricia; AMARAL, Antonio Carlos R. (Org.). Estudos: Direito Público. Homenagem ao Ministro Carlos Mário da Silva Velloso. São Paulo: Lex Magister, 2013. p. 299-308.

FALCÃO, Joaquim; HARTMANN, Ivar A.; CHAVES. Vitor P. III Relatório Supremo em números: O Supremo e o tempo. Rio de Janeiro: FGV, 2014.

FONTAINHA, Fernando et al. História oral do Supremo Tribunal Federal. Rio de Janeiro: FGV, 2015-2016.

FRAGALE FILHO, Roberto; MOREIRA, Rafaela Selem; SCIAMMARELLA, Ana Paula de O. Magistratura e gênero: um olhar sobre as mulheres nas cúpulas do judiciário brasileiro, 2015. Disponível em: < https:// journals.openedition.org/eces/1968>. Acesso em: 15 jun. 2016

FREITAS, Lúcia; LOIS, Cecilia Caballero. Acórdãos do STF sobre Lei Maria da Penha: um estudo piloto da relação direito, gênero e linguagem. In: OLIVEIRA JUNIOR, José Alcebíades de; MENDES, Regina Lucia Teixeira; SCAMARELLA, Maria Luisa (Org.). Sociologia, antropologia e cultura jurídicas. Curitiba: CONPEDI/ UNICURITIBA, 2013. p. 247-265.

GLICK, Peter; FISKE, Susan T. Sex discrimination: the psychological approach. In: CROSBY, Faye et al (Ed.). Sex discrimination in the workplace: multidisciplinary perspectives. Malden, MA: Blackwell, 2007.

GOMES, Juliana Cesario Alvim. O Supremo Tribunal Federal em uma perspectiva de gênero: mérito, acesso, representatividade e discurso. Direito \& Práxis, Rio de Janeiro, v. 7, n. 3, p. 652-676, jul./set. 2016.

GREZZANA, Stefânia. Viés de Gênero no Tribunal Superior do Trabalho Brasileiro. 2011. 61f. Dissertação (Mestrado) - Escola de Economia de São Paulo, FGV, São Paulo, 2011.

GUINIER, Lani; MINOW, Martha. Dynamism, Not Just Diversity. Harvard Journal of Law \& Gender, Cambridge, v. 30, n. 2, p. 269-277, Jun./Nov. 2007.

GUJARATI, D. N. Basic econometrics. Tata McGraw-Hill Education, 2009.

HARTMANN, Ivar A.; FERREIRA, Lívia. Ao relator, tudo: o impacto do aumento do poder do ministro relator no Supremo. Opinião Jurídica, Fortaleza, v. 13, n. 17, p. 268-283, jan./dez. 2015. 
INSTITUTO BRASILEIRO DE GEOGRAFIA E ESTATÍSTICA. Estatísticas de gênero: uma análise do Censo Demográfico 2010. Rio de Janeiro: IBGE, 2014.

JACOBI, Tonja; SCHWEERS, Dylan. Justice. Interrupted: the effect of gender, ideology and seniority at Supreme Court oral arguments. Virginia Law Review, v. 103, p. 1379-1485, 2017.

JUNQUEIRA, Eliane Botelho. Women in the judiciary: a perspective from Brazil. In: SCHULTZ, Ulrike; SHAW, Gisela (Org.). Women in the world's legal professions. Oxford: Hart, 2003.

KENNEY, Sally J. Gender \& Justice: Why women in the Judiciary really matter. New York: Routledge, 2013.

MACHADO, Marta Rodriguez de Assis; BRACARENSE, Ana Carolina. O caso do feto anencefálico: direitos sexuais e reprodutivos, confronto e negociação argumentativa no Supremo Tribunal Federal. Direito \& Práxis, Rio de Janeiro, v. 7, n. 3, p. 677-714, jul./set. 2016.

MENDES, Conrado Hubner. O projeto de uma corte deliberativa. In: VOJVODIC, Adriana; PINTO, Henrique Motta; PAGANI, Rodrigo (Org.). jurisdição constitucional no Brasil. São Paulo: Malheiros, 2012.

MENDES, Conrado Hubner. The Supreme Federal Court of Brazil. In: JAKAB, András; DYEVRE, Arthur; ITZCOVICH, Giulio (Org.). Comparative constitutional reasoning. Nova York: Cambridge University Press, 2017.

MIGUEL, Luís Felipe; BIROLI Flávia. Feminismo e política: uma introdução. São Paulo: Boitempo, 2014.

MOSS-RACUSIN, Corinne A. Science faculty's subtle gender biases favor male students. Proceedings of the National Academy of Sciences, v. 109, n. 41, p. 16474-16479, 2012.

MOSS-RACUSIN, Corinne. A.; RUDMAN, Laurie. A. Disruptions in women's self-promotion: the backlash avoidance model. Psychology of Women Quarterly, Piscataway, v. 34, n. 2, p. 186-202, apr./jun. 2010.

OLIVEIRA, Fabiana Luci de. Supremo relator: processo decisório e mudanças na composição do STF nos governos FHC e Lula. Revista Brasileira de Ciências Sociais, São Paulo, v. 27, n. 80, p.89-115, out. 2012.

PIMENTEL, Silvia; PANDJIARJIAN, Valeria; BELLOQUE, Juliana. "Legítima defesa da honra”, ilegítima impunidade de assassinos: um estudo crítico da legislação e jurisprudência da América Latina. In: CORRÊE, Mariza; SOUZA, Érica Renata (Org.). Vida em família: uma perspectiva comparativa sobre crimes de honra. Campinas: UNICAMP, 2006. p.65-208.

PIOVESAN, Flávia; GONÇALVES, Tamara Amoroso. Gênero no Supremo Tribunal Federal. In: SARMENTO, Daniel; SARLET, Ingo Wolfgang (Org.). Direitos fundamentais no Supremo Tribunal Federal: balanço e crítica. Rio de Janeiro: Lúmen Júris, 2011. p. 367-390.

RESNIK, Judith. On the Bias: Feminist reconsiderations of the aspirations for our judges. Southern California Law Review, Los Angeles, v. 61, n. 6, p. 1877-1944, Sep. 1988.

REUBEN, Ernesto; SAPIENZA, Paola; ZINGALES, Luigi. How stereotypes impair women's careers in science. Proceedings of the National Academy of Sciences, v. 111, n. 12, p. 4403-4408, 2014.

RIBEIRO, Leandro Molhano; ARGUELHES, Diego Werneck. Preferências, estratégias e motivações: pressupostos institucionais de teorias sobre comportamento judicial e sua transposição para o caso brasileiro. Direito e Práxis, Rio de Janeiro, v. 4, n. 7, p. 85-121, out./dez. 2013.

ROSEVEAR, Evan; HARTMANN, Ivar; ARGUELHES, Diego Werneck. Disagreement on the Brazilian Supreme Court. an exploratory analysis. 2015. Disponível em: <https://papers.ssrn.com/sol3/papers. cfm?abstract_id=2629329>. Acesso em: 16 jul. 2018.

RUDMAN, Laurie. A. et al. Status incongruity and backlash effects: defending the gender hierarchy motiva- 
tes prejudice against. Journal of Experimental Social Psychology, v. 48, n. 1, p. 165-179, Jan. 2012.

SADEK, Maria Teresa. Magistrados: uma imagem em movimento. Rio de Janeiro: FGV, 2006.

SCHULTZ, Ulrike; SHAW, Gisela (Org.). Women in the world's legal professions. Oxford: Hart, 2003.

SCHULTZ, Vicki. Reconceptualizing sexual harassment. Yale Law Journal, v. 107, p. 1683-1805, 1998.

SCHULTZ, Vicki. Telling stories about women and work: judicial interpretations of sex segregation in the workplace in Title VII cases raising the lack of interest defense. Harvard Law Review, v. 103, p. 1749-1843, 1990.

SEVERI, Fabiana Cristina. O gênero da justiça e a problemática da efetivação dos direitos humanos das mulheres. Direito e Práxis, Rio de Janeiro, v. 7, n. 1, p. 80-115 jan./mar. 2016.

SHIELDS, Stephanie. A. Speaking from the heart. gender and the social meaning of emotion. Cambridge: Cambridge University Press, 2002.

SILVA, Virgilio Afonso da. Deciding without deliberating. International Journal of Constitutional Law, New York, v. 11, n. 3, p. 557-584, Jul. 2013.

SILVA, Virgílio Afonso da. Do we deliberate?: if so, how?. European Journal of Legal Studies, Florença, v. 9, n. 2, p. 209-240, 2017.

SILVA, Virgílio Afonso da. O relator dá voz ao STF?: uma réplica a Almeida e Bogossian. Revista Estudos Institucionais, Rio de Janeiro, v. 2, n. 2, p. 648-669, 2016.

SILVA, Virgílio Afonso da. 'Um Voto Qualquer?’: o papel do ministro relator na deliberação no Supremo Tribunal Federal. Revista de Estudos Institucionais, Rio de Janeiro, v. 1, n. 1, p. 180-200, 2015.

SMART, Carol. Las teorías feministas y el discurso jurídico. In: BIRGIN, Haidée et al (Org.). El derecho en el género y el género en el derecho. Buenos Aires: Biblos, 2000.

TORRES, Lise; HUFFMAN, Matt L. Social networks and job search outcomes among male and female professional, technical, and managerial workers. Sociological Focus, v. 35, n. 1, 2002.

TURNER, Charles C. Gender, judging, and the decision to concur: female justices and the Supreme Court. In: ENCONTRO ANNUAL DA “WESTERN POLITICAL SCIENCE ASSOCIATION”, 2015, Las Vegas, Nevada, 2015.

VERÍSSIMO, Marcos Paulo. A Constituição de 1988, vinte anos depois: Suprema Corte e 'ativismo judicial à brasileira'. Revista Direito GV, São Paulo, v. 4, n. 2, p. 407-440, jul./dez. 2008.

VIEIRA, Oscar Vilhena. "Supremocracia”. Revista Direito GV, São Paulo, v. 4, n. 2, p. 441-463, jul./dez. 2008. 


\section{Hércules, Hermes e a pequena sereia: Uma reflexão sobre estereótipos de gênero, subpresentação das mulheres nos tribunais e (i) legitimidade democrática do Poder Judiciário*}

\section{Hércules, Hermes and The Little Mermaid: \\ a reflection on gender stereotypes, women subpresentation in the courts and the democratic (i)legitimacy of the judiciary}

Jane Reis Gonçalves Pereira**

Renan Medeiros de Oliveira***

\begin{abstract}
"Once we accept that who the judge is matters, then it matters who our judges are".

Erica Rackley ${ }^{1}$
\end{abstract}

\section{Resumo}

O presente artigo tem por objetivo explorar as correlações entre os estereótipos de gênero, déficits de representatividade feminina nas cúpulas do poder judiciário e o debate sobre a (i)legitimidade democrática desse ramo de poder. Em primeiro lugar, apresentamos a divisão público-privado na teoria feminista e analisamos os arquétipos do juiz ideal na teoria jurídica. Para isso, recorremos à metodologia da revisão bibliográfica. Em sequência, fazemos um levantamento de dados sobre a composição dos órgãos de cúpula do poder judiciário, com foco nos tribunais superiores e na justiça federal, que demonstram baixa representatividade de gênero e indicam uma tendência à estratificação na composição desses setores. Por fim, com base na análise dos dados, desenvolvemos a tese prescritiva de que o incremento da diversidade na composição da magistratura é um requisito para a afirmação da sua legitimidade democrática. Em conclusão, formulamos uma defesa não essencialista do equilíbrio de gênero na composição dos órgãos do judiciário, escorada na premissa de que a diversidade nos órgãos estatais é uma exigência do princípio democrático. A conexão entre representatividade como pressuposto da legitimidade democrática do judiciário é um tópico ainda pouco explorado, que ganha relevância no contexto em que se dissemina a ideia de que as cortes constitucionais têm papel representativo.

Palavras-Chave: Diversidade de gênero. Poder Judiciário. Legitimidade Democrática. no Centro de Justiça e Sociedade da Fundação Getulio Vargas (CJUS/FGV) e na Clínica de Direitos Fundamentais da Faculdade de Direito da UERJ - Clínica UERJ Direitos. Pesquisador Permanente do Laboratório de Regulação Econômica da UERJ - UERJ Reg.

E-mail: renanmedeirosdeoliveira@gmail.com
1 RACKLEY, Erika. Women, judging and the Judiciary: from difference to diversity. New York: Routledge, 2013. p. 164. 
The purpose of this article is to explore the correlations between gender stereotypes, deficits of female representation in the judiciary, and the debate about the democratic (i)legitimacy of this branch of power. First, we present the public-private division in feminist theory and analyze the archetypes of the ideal judge in legal theory. For this, we resorted to the methodology of the bibliographic review. In the sequence, we collect data on the composition of the highest-level organs of the judiciary, focusing on the higher courts and federal courts, which show a low gender representation and indicate a tendency to stratification in the composition of these sectors. Finally, based on the analysis of the data, we develop the prescriptive thesis that increasing the diversity in the composition of the judiciary is a requirement for affirming the democratic legitimacy of the judiciary. In conclusion, we formulate a non-essentialist defense of gender balance in the composition of the organs of the judiciary, based on the premise that diversity in state organs is a requirement of the democratic principle. The connection between representativeness as a presupposition of the democratic legitimacy of the judiciary is a topic still little explored, which gains relevance in the context in which the idea that the constitutional courts would have a representative role is disseminated.

Keywords: Gender diversity. Judicial power. Democratic legitimacy.

\section{INTRODUÇÃo}

Os alicerces básicos das democracias liberais foram desenhados quando as mulheres praticamente não participavam dos processos deliberativos do Estado. Essa conjuntura histórica ainda repercute no cotidiano, mas nem sempre é simples notar como a dinâmica dos espaços de decisão espelha uma assimetria ancestral de poder entre homens e mulheres.

A esfera pública estatal costuma ser idealizada como neutra em relação ao gênero ${ }^{2}$. As discussões sobre a estrutura do estado constitucional - imaginada como imparcial e objetiva - raramente levam em conta o fato de que sua configuração foi traçada em um contexto de distribuição desigual dos papeis dos homens e das mulheres nos espaços públicos e privados. Na prática jurídica, não é comum debater de que forma os estereótipos de gênero condicionam a arquitetura institucional dos órgãos do Estado. A apreciação e crítica dessa dinâmica está insulada nos estudos feministas, permanecendo negligenciada pela teoria política e constitucional hegemônica.

Exemplos caricatos ilustram como o ethos $^{3}$ dos órgãos do estado é impregnado de vieses masculinos. Até o ano 2000, era proibida a entrada de mulheres vestindo calças no plenário do Supremo, sendo que apenas em 2007 esse traje foi usado por uma ministra pela primeira vez ${ }^{4}$. Somente em 2016 o plenário do Senado em Brasília, inaugurado em 1960, passou a ter um banheiro para as senadoras ${ }^{5}$. Nas sabatinas que precedem

2 No presente estudo, adotamos o sentido de gênero empregado por SCOTT, Joan. Gênero: uma categoria útil de análise histórica. Educação \& Realidade, Porto Alegre, v. 20, n. 2, p. 71-99, jul./dez. 1995.

3 Sobre o conceito de ethos, cf. BOURDIEU, Pierre. The logic of practice. Cambridge: Polity Press, 1990. BOURDIEU, Pierre. Esboço de uma teoria da prática: precedido de três estudos de etnologia kabila. Oeiras: Celta, 2002. BOURDIEU, Pierre. Distinction: a social critique of the judgment of taste. Cambridge: Harvard University Press, 1984. AMOSSY, Ruth (Org.). Imagens de si no discurso: a construção do ethos. São Paulo: Contexto, 2005. WACQUANT, Loïc. Esclarecer o habitus. Educação \& Linguagem, ano 10, n. 16, p. 63-71, jul./dez. 2007.

4 D’ELLA, Mirella. Ministra quebra tradição e usa calça no STF. Brasília. 2007. Disponível em: <http://g1.globo.com/Noticias/ Politica/0,MUL11565-5601,00-MINISTRA+QUEBRA+TRADICAO+E+USA+CALCA+NO+STF.html>. Acesso em: 27 maio 2018.

5 ALEGRETTI, Laís. Plenário do Senado terá banheiro feminino 55 anos após inauguração. Brasília. 2016. Disponível em: < http:// g1.globo.com/politica/noticia/2016/01/plenario-do-senado-tera-banheiro-feminino-55-anos-apos-inauguracao.html>. Acesso em: 27 maio 2018. 
as nomeações ao STF, as ministras depararam-se com perguntas constrangedoras que abordam sua beleza e "elegância física”.

A resistência à inserção das mulheres nos espaços de poder, porém, vai muito além da alteração de códigos de vestimenta, das reformas arquitetônicas e da etiqueta no tratamento em contextos profissionais. $\mathrm{O}$ poder judiciário, especialmente nos estratos mais elevados, é um ambiente particularmente refratário à discussão sobre diversidade de gênero. Não raro, a questão é minimizada sob o argumento de que a paridade na composição dos tribunais surgirá como um efeito natural da inserção das mulheres no mercado de trabalho. Nesse cenário, as recentes iniciativas no sentido de apurar e monitorar dados sobre a disparidade entre homens e mulheres abrem um campo importante de reflexão sobre o tema?

O presente artigo tem por objetivo analisar as relações entre a dicotomia público-privado, os estereótipos relacionados à figura do juiz ideal, a baixa representação feminina em tribunais e as implicações dessa configuração para a legitimação democrática do judiciário.

Quanto ao recorte do objeto de estudo, é importante fazer uma advertência inicial. Assumimos que a noção de diversidade na magistratura e suas implicações para as demandas de inclusão e legitimação democrática envolve mais que gênero ${ }^{8}$, abarcando também questões como raça, orientação sexual, origem social e até mesmo background profissional. Todavia, o presente artigo focará apenas a disparidade de gênero no judiciário, sem que isso signifique pressupor que esse aspecto é único ou preponderante nos debates sobre diversidade e democracia.

As questões de gênero e suas relações com a magistratura têm ganhado destaque na produção acadêmica nacional e internacional. Todavia, a conexão entre representatividade de gênero como pressuposto da legitimidade democrática do judiciário é um tópico ainda pouco explorado, que ganha relevância no contexto em que se dissemina a ideia de que as cortes constitucionais desempenham um papel representativo.

O estudo está dividido em três blocos. Na primeira parte, a dinâmica de gênero no poder judiciário é analisada a partir de dois referenciais teóricos. De um lado, abordamos a produção filosófica feminista que indica como a dicotomia público versus privado é generificada. Em sequência, avaliamos como, na filosofia do direito, a discussão sobre o juiz ideal é povoada por arquétipos mitológicos masculinos. O objetivo, nesse ponto, não é explorar quais são os melhores modelos de juiz, mas demonstrar como o repertório simbólico

6 ARAUJO, Heloisa Bianquini. Qual o gênero do Supremo?: diálogo institucional nas sabatinas para o STF, poder e profissionalismo. 2015. Trabalho de Conclusão de Curso (Graduação em Direito) - Escola de Formação da Sociedade Brasileira de Direito Público, São Paulo, 2015. p. 62.

7 COMISSÃO AJUFE MULHERES. Nota Técnica: AJUFE mulheres 01/2017: resultados da pesquisa para se conhecer o perfil das associadas da AJUFE. Brasília: AJUFE Mulheres, 2017. FRAGALE FILHO, Roberto; MOREIRA, Rafaela Selem; SCIAMMARELLA, Ana Paula de O. Magistratura e gênero: um olhar sobre as mulheres nas cúpulas do judiciário brasileiro. E-cadernos CES, n. 24, p. 57-77, 2015. BONELLI, Maria da Glória. Profissionalismo, gênero e significados da diferença entre juízes e juízas estaduais e federais. Contemporânea, n. 1, p. 103-123, jan./jun. 2011.

8 O feminismo interseccional surgiu a partir do feminismo negro e foi tratado, inicialmente, por Kimberlé Williams Crenshaw, que pontuou que as leis tratavam raça e gênero de formas distintas e nunca interconectadas. Cf. CRENSHAW, Kimberlé Williams; CHO, Sumi; MCCALL, Lesli. Mapping the margins: intersectionality, identity politics, and violence against women of color. Stanford Law Review, v. 43, n. 6, p. 1241-1299, 1991; CRENSHAW, Kimberlé Williams; CHO, Sumi; MCCALL, Lesli. Demarginalizing the intersection of race and sex: a black feminist critique of antidiscrimination doctrine, feminist theory and antiracist politics. The University of Chicago Legal Forum, v. 139, p. 139-167, 1989; CRENSHAW, Kimberlé Williams; CHO, Sumi; MCCALL, Lesli. Toward a field of intersectionality studies: theory, applications, and praxis. Signs: Journal of Women in Culture and Society, v. 38, n. 4, p. 785-810, 2013. bell hooks também contribuiu para o avanço dos estudos sobre interseccionalidade, analisando gênero, raça e classe social. Cf. HOOKS, Bell. Ain't i a woman: black women and feminism. Boston: South End Press, 1981. HOOKS, Bell. Teaching to transgress: education as the practice of Freedom. New York: Routledge, 1994. HOOKS, Bell. Feminism is for everybody: passionate politics. London: Pluto Press, 2000. O feminismo interseccional vem ganhando cada vez mais adeptos, que destacam aspectos importantes que devem ser considerados quando da análise de discriminações e de vulnerabilidades, como orientação sexual. Também há grupos com menor visibilidade, como de feministas mães, de minorias religiosas, dentre outros. Veja-se sobre o tema, ainda: DAVIS, Angela. Mulheres, raça e classe. São Paulo: Boitempo, 2016. HIRATA, Helena. Gênero, classe e raça: interseccionalidade e consubstancialidade das relações sociais. Tempo Social, São Paulo, v. 26, n. 1, p. 61-73, 2014. BRAH, Avtar. Diferença, diversidade e diferenciação. Cardenos Pagu, Campinas, v. 26, p. 329-376, jan./jun. 2006. 
que descreve a figura modelar do bom juiz é marcado por formas masculinas. Na segunda parte, examinamos, descritivamente, como as mulheres estão sub-representadas nas cúpulas do Poder Judiciário, bem como analisamos a aparente tendência à estratificação, uma vez que o aumento na composição nos tribunais superiores não acompanha, proporcionalmente, a inclusão das mulheres nas carreiras jurídicas. Na terceira parte, formulamos a tese de que o incremento da diversidade de gênero no Judiciário é um pressuposto da sua legitimidade democrática e uma exigência para que se possa reconhecer que esse ramo de poder tem uma faceta representativa.

Para os fins buscados no presente artigo, nos valemos, na primeira parte, da revisão bibliográfica sobre a dicotomia público e privado na teoria feminista e o tratamento do juiz ideal na filosofia jurídica. No segundo item, expomos levantamentos de dados colhidos dos sites dos tribunais superiores e de pesquisas recentes, com foco na justiça federal, para expor a baixa representatividade feminina na cúpula do judiciário brasileiro. A partir disto, expomos, na terceira parte, a tese prescritiva de que esse ramo de poder, para aumentar sua legitimidade democrática, deve passar por um incremento da pluralidade na composição de seus órgãos.

Antes de prosseguir, é necessário fazer outro registro quanto ao objeto de análise. Neste estudo, perfilhamos a tese de que a baixa representatividade de gênero no poder judiciário representa um déficit de legitimidade democrática. Contudo, não apresentamos propostas para contornar a baixa presença de mulheres no judiciário. Formulações sobre esse tema são necessárias, mas se enquadrariam em outro campo de investigação.

\section{A DICOTOMIA PÚBLICO-PRIVADO E OS ESTEREÓtIPOS DE GÊNERO NA CONSTRUÇÃO DO JUIZ IDEAL}

\subsection{A dicotomia público-privado na teoria feminista}

Quando se pensa sobre a dicotomia público-privado, costuma-se recorrer à tradição do pensamento liberal como ponto de partida. De acordo com a narrativa típica dessa vertente teórica ${ }^{9}$, a referida divisão desempenharia a função de descrever as duas esferas onde as atividades humanas se desenvolvem, que se distinguem por serem governadas por valores distintos. A primeira representaria a dimensão do exercício da cidadania, sendo o locus por excelência de debate sobre questões de justiça. Já a segunda permaneceria inteiramente apolítica, caracterizando-se como um espaço de autonomia individual, em que a personalidade humana encontraria espaço para florescer. A não intervenção do Estado nessa segunda esfera seria uma premissa para realizar os valores centrais do liberalismo. $\mathrm{Na}$ imagem usualmente evocada, as dimensões podem ser representadas por um jardim e por uma praça ${ }^{10}{ }^{11}$.

A teoria feminista tem como um de seus aspectos fundamentais voltar-se contra a construção dessa divisão e as consequências que dela decorrem ${ }^{12}$. Como pontua Seyla Benhabib ${ }^{13}$, desde a origem da família burguesa, apresentava-se uma tensão decorrente da circunstância de que a família era regida pela lógica da

9 É importante destacar que tratar do liberalismo como uma corrente unívoca é uma simplificação, uma vez que há diversas vertentes dessa corrente de pensamento. No presente estudo, tratamos de concepções que colocam a autonomia como valor central. 10 SALDANHA, Nelson. O jardim e a praça: ensaio sobre o lado privado e o lado público da vida social e histórica. Porto Alegre: Sergio Antonio Fabris Editor, 1986.

11 Note que John Stuart Mill, um dos pais do liberalismo, já criticava, no século XVIII, a sujeição da mulher. Cf. MILL, John Stuart. The subjection of women. Indianapolis: Hackett Publishing Company, 1988.

12 Na sempre lembrada afirmação de Carole Pateman, a dicotomia público-privado é, em última análise, o tema central do feminismo. PATEMAN, Carole. The sexual contract. Stanford: Stanford University Press, 1988. p. 11-12.

13 BENHABIB, Seyla. Situating the self: gender, community and postmodernity in contemporary ethics. Cambridge: Polity, 1992. p. 109. 
subordinação à autoridade patriarcal, enquanto, na esfera pública, buscava-se a afirmação de ideias como consentimento, igualdade e liberdades religiosa e econômica. Essa contradição reforçava-se pela retórica de não intrusão na esfera íntima e de que preocupações com justiça seriam estranhas à esfera privada, regida pelo ideal de busca da vida boa.

Conquanto guiada pelo propósito liberal de preservar espaços de escolhas individuais, a divisão público- privado acaba por desconsiderar quais indivíduos têm sua liberdade de escolha protegida, negligenciando a reflexão sobre se algumas pessoas teriam sua autonomia esvaziada no domínio privado. Se um dos postulados máximos do liberalismo é o primado do indivíduo sobre estruturas coletivas (dentre as quais pode-se incluir a família $\left.{ }^{14}\right)$, como explicar a omissão da teoria liberal em questionar se a esfera doméstica - tal como estruturada pelo casamento e demais institutos de um dado ordenamento jurídico - impede o exercício da autonomia pelas mulheres? Conforme aponta Martha Nussbaum, embora construída a partir da noção de centralidade do indivíduo, a teoria liberal é contraditoriamente negligente quanto ao exame da incidência desse valor à mulher ${ }^{15}$.

Um exemplo eloquente dessa incongruência é a descrição fornecida por John Rawls em sua Teoria da Justiça a respeito da família. Ele afirma que a família, em sua concepção ideal e, frequentemente, também na prática, constitui um espaço de altruísmo, em que o agir de seus membros é norteado não pela busca da maximização de vantagens individuais, mas pelo desejo de obter ganhos apenas se estes forem passíveis de beneficiar os demais familiares ${ }^{16}$.

A caracterização da família feita por Rawls é desconcertante por diversos fatores, o primeiro deles a sua dissonância com a realidade. Relatório da ONU de 2015 expôs que 1/3 das mulheres no mundo já sofreu violência física ou sexual de seus parceiros e que, de todos os casos de homicídios perpetrados no contexto familiar, $2 / 3$ tiveram mulheres como vítimas ${ }^{17}$. Longe de um jardim idílico onde suas potencialidades humanas seriam cultivadas, a experiência da mulher no âmbito privado muitas vezes mais se aproxima de uma selva.

Do ponto de vista da divisão e do acesso ao trabalho, o mesmo relatório das Nações Unidas apontou que mulheres habitantes de países em desenvolvimento trabalham, em média, três horas a mais por dia do que homens em atividades não remuneradas e duas horas a mais em países desenvolvidos. No mercado de trabalho, mulheres estatisticamente recebem entre $70 \%$ a $90 \%$ do que homens que trabalham no mesmo setor e durante o mesmo expediente. Outros dados apresentados são os de que o ensino superior traz maior retorno financeiro aos homens do que às mulheres e que estas têm maior probabilidade de buscar trabalhos com jornada de trabalho reduzida ${ }^{18}$.

O modelo de Rawls ilustra como há uma confusão entre os planos descritivo e normativo ao se analisar a dicotomia público-privado. Nesse sentido, uma caracterização factual idealizada e irrealista da esfera privada repercute nas considerações sobre como deve ser tratada. Pode-se cogitar, ainda, que a ambiguidade opere no sentido invertido: buscando legitimar um modelo normativo não intervencionista, ao qual se adere $a$ priori, constrói-se um relato da vida privada que torne essa concepção normativa mais atraente, quando não uma exigência de justiça.

14 Sobre o tema da teoria da justiça e da família, veja-se DUARTE, Cláudia Türner Pereira. O sistema familiar na teoria política: repensando o lugar da criança na teoria da justiça. 2016. Dissertação (Mestrado em Direito) - Universidade do Estado do Rio de Janeiro, Rio de Janeiro, 2016.

15 NUSSBAUM, Martha C. Sex \& social justice. Oxford: Oxford University Press, 1999.

16 RAWLS, John. A theory of justice. Cambridge: Harvard University Press, 2003. p. 90.

17 UNITED NATIONS. The world's women 2015. 2015. Disponível em: < https://unstats.un.org/unsd/gender/chapter4/chapter4.html>. Acesso em: 10 maio 2018.

18 UNITED NATIONS. The world's women 2015. 2015. Disponível em: < https://unstats.un.org/unsd/gender/chapter4/chapter4.html>. Acesso em: 10 maio 2018. 
Tudo isso resulta na frustração de qualquer possibilidade de igualdade de oportunidades. Susan Okin ${ }^{19}$, em sua crítica à forma como a teoria da justiça liberal trata a esfera doméstica, pondera que o casamento é injusto, pois há uma assimetria na capacidade de se deixar a relação, alimentada por uma alocação desigual do trabalho remunerado e não remunerado entre os membros do casal, que ocorre de maneira quase automática, em função do gênero e pela expectativa, que incide muito mais intensamente sobre a mulher, de que terá de conciliar uma eventual carreira com a criação dos filhos. Essa configuração é incompatível com os

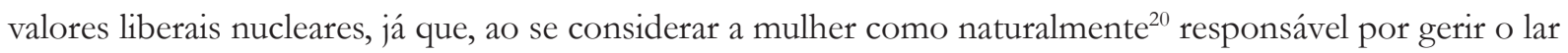
e criar filhos, ela é reduzida à condição de meio para o atingimento de fins alheios, como se a sua dimensão mais elementar fosse a de ser parte da família, e não a de indivíduo autônomo ${ }^{21}$.

O espaço doméstico, como domínio propenso ao exercício de poder e à cristalização de desequilíbrios, com a consequente limitação das opções de quem na sua dinâmica está em situação de desvantagem, não deve ser enxergado como alheio ao espaço público. Nesse sentido é a síntese do célebre slogan feminista: 0 pessoalé político ${ }^{22}$. Esse mote não significa que o público e o privado são (ou devam ser) indistintos, mas que a decisão sobre o que é inserido ou excluído da arena da deliberação público-estatal é inescapavelmente política $^{23}$. Isso altera a forma como se enxergam os contornos do domínio público e do privado, enfraquecendo a visão de que os contornos da vida doméstica seriam naturais, como que um resquício pré-político ${ }^{24}$.

Longe de serem estanques, as duas esferas são permeáveis a influências recíprocas. Público e privado são interdependentes. Por um lado, temas outrora tidos como puramente privados merecem ser tratados como problemas de justiça, pois são pressupostos para garantir um grau de autonomia às pessoas que qualquer versão coerente da teoria liberal entenderia como fundamental ${ }^{25}$. Por outro lado, os espaços públicos estatais também não podem ser encarados como imunes à separação de papéis de gênero que a clássica dicotomia pressupõe. As instituições estatais contemporâneas foram edificadas a partir de uma divisão estereotipada e determinista de tarefas destinadas aos homens e às mulheres, escorada na premissa de que estas se ocupariam das tarefas de cuidado no campo do doméstico, enquanto aos homens competiria ocupar os espaços públicos de poder. Susan Okin formulou com clareza os questionamentos que defluem dessa configuração:

É preciso perguntar: as práticas nos locais de trabalho, no mercado ou no Parlamento seriam as mesmas se elas tivessem se desenvolvido pressupondo que seus participantes teriam de acomodar-se às necessidades de dar à luz, educar um filho, e às responsabilidades da vida doméstica? As políticas e seus resultados seriam os mesmos se aqueles que nelas estão engajados fossem pessoas que também tivessem responsabilidades cotidianas significativas voltadas para os cuidados dos outros, ao invés de

19 OKIN, Susan Moller. Justice, gender and the family. New York: Basic Books, 1989.

20 Parte da teoria feminista dedica-se, com razão, à desconstrução de visões essencialistas, que atribuem como dados naturais e fixos do gênero feminino, atributos socialmente construídos e variáveis. Além de confundir aspectos biológicos com questões sociais, o essencialismo tende a ser excludente, já que dificilmente todas as mulheres se enquadrarão no que é considerado como inerente ao gênero feminino. Para um debate sobre essa e outras vertentes do essencialismo, v.: WITT, Charlotte (Coord.). Feminist metaphysics: explorations in the ontology of sex, gender and the self. Londres: Springer, 2011.

21 NUSSBAUM, Martha C. Sex \& social justice. Oxford: Oxford University Press, 1999. p. 11.

22 O slogan é originado dos escritos de Carol Hanisch. Cf. HANISCH, Carol. The personal is political. Disponível em: < http:// www.carolhanisch.org/CHwritings/PIP.html>. Acesso em: 30 maio 2018. Confira-se o que Susan Okin afirma sobre o tema: "That the personal sphere of sexuality, of housework, of child care and family life is political became the underpinning of most feminist thought. Feminists of different political leanings and in a variety of academic disciplines have revealed and analyzed the multiple interconnections between women's domestic roles and their inequality and segregation in the workplace, and between their socialization in gendered families and the psychological aspects of their oppression. We have strongly and persistently challenged the longstanding underlying assumption of almost all political theories: that the sphere of family and personal life is so separate and distinct from the rest of social life that such theories can justifiably assume but ignore it". OKIN, Susan Moller. Justice, gender and the family. New York: Basic Books, 1989. p. 125-126.

23 OKIN, Susan Moller. Justice, gender and the family. New York: Basic Books, 1989. p. 130.

24 Para uma análise aprofundada de como as teorias contratualistas do período liberal enxergavam na submissão da mulher na esfera privada uma continuação de uma natural assimetria entre os sexos, a qual não constituía um problema político, v. PATEMAN, Carole. The sexual contract. Stanford: Stanford University Press, 1988.

25 BENHABIB, Seyla. Situating the self: gender, community and postmodernity in contemporary ethics. Cambridge: Polity, 1992. p. 109. 
serem aqueles que menos probabilidade têm, em toda a sociedade, de ter essa experiência? ${ }^{26}$

Essas perguntas, formuladas há quarenta anos, ainda são decisivas e atuais para a análise crítica da configuração das instituições judiciárias e das implicações práticas e teóricas da baixa diversidade de gênero nos espaços onde é exercido o poder.

\subsection{A dimensão de gênero na construção da figura do juiz ideal}

Os estereótipos de gênero são perceptíveis na construção da figura do juiz ideal no imaginário jurídico. Nas formulações filosóficas a respeito dos atributos que constituem o bom juiz, são apresentados arquétipos que remetem a figuras heroicas, supra-humanas e masculinas ${ }^{27}$. Esse repertório simbólico desponta com clareza até mesmo na indumentária dos tribunais. As vestes talares estabelecem associações inconscientes com heróis e sacerdotes e buscam demonstrar que o juiz representa a instituição e tem a tarefa de julgar com imparcialidade, deixando de lado suas visões pessoais. Até mesmo a cor da toga é uma escolha política ${ }^{28}$ : o preto - que indica a ausência de cor e que não reflete as luzes que absorve - representa a imparcialidade judicial e o luto ${ }^{29}{ }^{30}$.

A produção no campo da filosofia do direito sobre os modelos de juiz ideal é ilustrativa da associação do ato de julgar com formas masculinas ${ }^{31}$. Um exemplo emblemático e muito conhecido é o modelo de juiz Hércules concebido por Ronald Dworkin. Em sua conhecida formulação sobre a "resposta certa" a ser dada nos casos difíceis, Dworkin expõe o conceito de direito como integridade. De acordo com o autor, a interpretação jurídica é uma atividade que reconstrói racionalmente as escolhas políticas por meio da atribuição de significado aos princípios. Para dar conta desse requisito de unidade e coerência do sistema, é apresentada a figura utópica do juiz Hércules, dotado de capacidades extraordinárias que o tornam apto a realizar a missão de interpretar o ordenamento jurídico levando em consideração todas as informações possíveis, conciliando o dinamismo requerido pelas transformações sociais com a necessidade seguir os precedentes ${ }^{32}$.

26 OKIN, Susan Moller. Gênero, o público e o privado. Estudos Feministas, Florianópolis, v. 16, n. 2, p. 305-332, maio/ago. 2008.

27 Como observa Clara da Mota Alves, a atividade de julgar é, na sua origem, projetada para homens, o que cria diversos tensionamentos entre as ordens pública e privada, sobretudo quando mulheres se tornam juízas. Nas palavras da autora, "[e]stes tensionamentos entre público e privado estão em permanente ação e comunicação. Não há dificuldade doméstica que não corresponda a um problema também no universo público, afinal estamos falando de ambientes e cargos inteiramente projetados para indivíduos que não deveriam ter nenhum tipo de responsabilidade familiar. Tudo isso se reflete na carga horária projetada como oficial para o trabalho, na falta crônica de creches e berçários nas dependências do Poder Judiciário, no desenho institucional das promoções e titularizações que, via de regra, ocasionam permanente mudança de sede de jurisdição. São inúmeros os exemplos e aspectos que densificam esta percepção de que o espaço público da magistratura é condicionado por um determinado modelo de vida privada hegemônica patriarcal e masculina". ALVES, Clara da Mota Santos Pimenta. Gênero, espaço público e poder: uma análise sobre a composição das comissões examinadoras de concurso da magistratura. Revista Publicum, Rio de Janeiro, v. 3, n. 1, p. $352-370,2017$. 28 Sobre os significados da cor preta na vestimenta, cf. HARVEY, John. Homens de preto. São Paulo: Unesp, 1995. p. 62.

29 ISAULA, Rodolfo. Toga de jueces, um luto de siglos. El Heraldo, abr. 2014. Disponível em: <http://www.elheraldo.hn/alfrente/566256-209/toga-de-jueces-un-luto-de-siglos>. Acesso em: 31 maio 2018.

30 Para um debate sobre a (in)adequação do uso das togas, cf. FRANK, Jerome. The cult of the robe. In: FRANK, Jerome. Courts on trial: myth and reality in american justice. Princeton: Princeton University Press, 1973. KENNEDY, Walter B. The cult of the robe: a dissent. Fordham Law Review, v. 14, n. 2, p. 192-196, 1945.

31 Aqui cabe um esclarecimento. Ao afirmarmos que a teoria jurídica costuma operar com modelos masculinos, levamos em consideração os arquétipos que personificam os ideais de comportamentos e atributos judiciais referenciados na filosofia contemporânea. Ou seja, apontamos os heróis que, na visão de filósofos do direito, seriam emulados pelos juízes reais. Essa apreciação não significa ignorar que mitos femininos também povoam a simbologia jurídica. O mais famoso mito relacionado à justiça e ao direito é a figura da deusa Têmis. Na cultura grega, ela corresponde à voz oracular que ensina piedade, equilíbrio e prudência. Ela encarna a lei divina, o direito e o costume. Nesse contexto, Têmis não funciona como um modelo de juiz, mas como um referencial abstrato da ideia de justiça a que os juízes devem estar sujeitos. É interessante notar que os códigos de ética judicial se referem aos juízes como "servos de Têmis". Cf. o art. 29 do Draft Code of Ethics of Judges da Comissão Europeia para a Democracia Através do Direito.

32 DWORKIN, Ronald. O império do direito. São Paulo: Martins Fontes, 1999. p. 294: "Nenhum juiz real poderia impor nada que, de uma só vez, se aproxime de uma interpretação plena de todo o direito que rege sua comunidade. É por isso que imaginamos um juiz hercúleo, dotado de talentos sobre-humanos e com um tempo infinito a seu dispor. Um juiz verdadeiro, porém, só pode imitar Hércules até certo ponto". 
O filósofo belga François Ost, em texto clássico e influente sobre os modelos de juiz relacionados às diversas etapas de evolução do pensamento jurídico ${ }^{33}$, recorre também às figuras mitológicas como alegorias explicativas das maneiras de julgar. $\mathrm{Na}$ sua construção metafórica, são apresentados três arquétipos. O juiz Júpiter é associado ao referencial positivista e à concepção do ordenamento como uma estrutura hierárquica, em cujo ápice está a Constituição. O juiz Hércules, que fora idealizado por Ronald Dworkin e é reconstruído por Ost, é aquele que decide os casos difíceis e pode encontrar a única resposta correta. O juiz Hermes, apresentado como o melhor modelo na visão do autor, é uma síntese dos anteriores. Ele atua em rede, como transmissor e tradutor da linguagem. Hermes é o mensageiro que ocupa o vazio das coisas e assegura a comunicação entre os personagens épicos. Ele é, de acordo com a mitologia grega, filho e mensageiro de Zeus, dotado de singular capacidade intelectual e de entendimento ${ }^{34}$. Age como mediador entre os Deuses do Olimpo e os mortais, trazendo a estes a vontade divina decodificada. Ele não conhece outra lei além dos discursos transmitidos e é com base neles que julga ${ }^{35}$.

Os modelos de juiz mencionados ganharam prestígio na teoria jurídica, ao ponto de pautar uma parte da discussão acadêmica no campo da hermenêutica ${ }^{36}$. As referidas construções, por um lado, são reveladoras de como o aparato alegórico imaginado na busca dos traços desejáveis no magistrado é estabelecido por meio de alegorias masculinas. Mas, por outro lado, as facetas heroica, sobrenatural e supra-humana dos arquétipos mitológicos revelam, também, a expectativa de que os juízes deixem de lado suas personalidades e traços individuais ao decidir. Essa perspectiva está presente em vários aspectos da idealização sobre a atividade de julgar. Ela desponta, por exemplo, na visão do positivismo legalista de que o juiz deve atuar estritamente subordinado à lei e que seu papel como intérprete consiste, apenas, em revelar o conteúdo preexistente da norma, despindo-se de suas perspectivas particulares ${ }^{37}$. Também nas togas que os magistrados vestem está embutida a mensagem subliminar de que suas singularidades pessoais devem ser deixadas do lado de fora das cortes.

Há traços de desumanização tanto nos modelos filosóficos ideais de juiz quanto no conjunto de qualidades que se espera que magistrados apresentem para serem percebidos como confiáveis e imparciais. De um lado, há uma expectativa de que possuam habilidades sobre-humanas - típicas dos heróis mitológicos - para decidir da melhor forma possível. De outro, o sistema é conformado para que as particularidades pessoais e os traços de falibilidade humana dos juízes sejam obliterados, ou, pelo menos, encobertos.

Esses elementos adquirem relevância na discussão sobre o significado e o impacto da presença de mulheres nas carreiras jurídicas, em geral, e na magistratura, em particular ${ }^{38}$. Na produção feminista, há um grupo de trabalhos que expõe a ideia de que mulheres possuem um estilo diferente e peculiar de argumentar e de julgar $^{39}$. Essas leituras derivam de um conhecido estudo de Carol Gilligan ${ }^{40}$, que, partindo de uma investiga-

33 OST, François. Júpiter, Hércules, Hermes: tres modelos de juez. Doxa: Cuadernos de Filosofía del Derecho, n. 14, p. 169-194, 1993.

34 Nesse sentido, veja-se: CAMARGO, Margarida Maria Lacombe. Interpretação constitucional. In: CAMARGO, Margarida Maria Lacombe. (Org.). 1988-1998: uma década de constituição. Rio de Janeiro: Renovar, 1999. p. 431.

35 OST, François. Júpiter, Hércules, Hermes: tres modelos de juez. Doxa: Cuadernos de Filosofía del Derecho, n. 14, p. 169-194, 1993. p. 189.

36 Título de exemplo, veja-se STRECK, Lenio. O pós-positivismo e os propalados modelos de juiz (Hércules, Júpiter e Hermes) dois decálogos necessários. Revista de direitos e garantias fundamentais, v. 7, p. 15-45, 2011. OLIVEIRA, Rafael Tomaz de. Decisão judicial e o conceito de princípio: a hermenêutica e a (in)determinação do direito. Porto Alegre: Livraria do Advogado, 2008. MOTTA, Francisco J. Borges. Levando o direito a sério: uma crítica hermenêutica ao protagonismo judicial. Florianópolis: Conceito, 2010.

37 Sobre o positivismo, cf. BOBBIO, Norberto. O positivismo jurídico: lições de filosofia do direito. São Paulo: Ícone, 1995.

38 Um amplo panorama dos debates envolvendo mulheres e a atividade de julgar pode ser conferido em FEENAN, Dermot. Editorial introduction: women and judging. Feminist Legal Studies, v. 17, p. 1-9, 2009. Uma análise sobre as teses que perfilham distinções entre a forma de julgar de homens e mulheres pode ser encontrada em KENNEY, Sally J. Thinking about gender and judging. International Journal of the Legal Profession, v. 15, n. 1-2, p. 87-110, mar./jul. 2008.

39 WILSON, Bertha. Will women judges really make a difference? Osgoode Hall Law Journal, v. 28, n. 3, p. 507-522, 1990. ABRAHAMSON, Shirley S. The woman has robes: four questions. Golden Gate Law Review, v. 14, n. 3, p. 489-503, 1984.

40 GILLIGAN, Carol. In a different voice: psychological theory and women's development. Cambridge: Harvard University Press, 2003. 
ção sobre o desenvolvimento da argumentação moral em crianças, sugere que meninas formulariam julgamentos éticos de forma distinta dos meninos. Alguns estudos nesse âmbito recorrem à personagem Portia, do Mercador de Veneza, de Shakespeare, para desenvolver a noção de que as mulheres têm uma voz típica e uma forma de raciocinar juridicamente distinta ${ }^{41}$. Dessa proposição advém a tese de que o incremento na participação feminina no judiciário repercutiria na forma como o direito é entendido.

Tal leitura, porém, não é largamente aceita ${ }^{42}$. Muitas formulações críticas afirmam, com razão, que a noção de que as mulheres possuem uma "voz diferente" parte de uma visão estereotipada e essencialista sobre o feminino. Argumenta-se que imaginar uma voz fundamentalmente feminina cria um modelo padronizado e reduzido, que acaba por discriminar as mulheres que não se enquadram nessa fórmula, além de reforçar a oposição entre masculino e feminino ${ }^{43}$. Não obstante, as questões formuladas por Gilligan tiveram o mérito de jogar luz sobre a falsa universalidade dos modelos de argumentação associados ao discurso jurídico, abrindo espaço para o debate sobre formas alternativas de deliberação ${ }^{44}$. Em última análise, foi colocada em cena a discussão sobre em que proporção as formas jurídicas promovem limitações reducionistas, que empobrecem a discussão ao rejeitar procedimentos distintos de argumentação ${ }^{45}$. Coloca-se, nesse tema, a questão sobre se a presença de mulheres nos tribunais traria outros pontos de vista, alargando o campo de visão do direito e promovendo transformações no pensamento jurídico. Pondera-se que o horizonte do direito seria alargado pelo input de novas perspectivas, incluindo a experiência das mulheres inclusive no que se refere à vivência de "uma cultura jurídica que tende a desconfiar, não compreender e excluir" ${ }^{46}$ elas mesmas.

Nesse ponto entra em cena outra metáfora literária. Erica Rackley, ao explorar esses problemas, coloca em pauta o fato de que as pessoas com perspectivas diferentes, quando inseridas em ambientes que tendem a uniformizar comportamentos e esvanecer a singularidade, sucumbem à tentação de se render, de se conformar e de reprimir as especificidades. Para descrever como se opera esse processo, a autora recorre ao conto A Pequena Sereia, de Hans Christian Andersen. A sereia, que habitava as profundezas do mar, apaixona-se por um príncipe após salvá-lo de um naufrágio. Para ter a chance de se aproximar dele, ela precisa assumir a forma humana. Pede, então, ajuda à bruxa, que lhe oferece uma poção que transformará sua cauda de peixe em pernas. Esta, porém, adverte à sereia que caminhar será tão doloroso como pisar em facas afiadas, e exige em troca da poção que lhe entregue sua voz. A sereia aceita a troca e se lança no universo humano emudecida, assumindo com isso o risco de sequer ser notada pelo príncipe. Para Rackley, a sereia é uma alegoria mais adequada para explanar a relação dos juízes (e sobretudo das juízas) com o sistema jurídico do que o mito de Hércules. O juiz ideal no imaginário jurídico é aquele que transcende, apaga ou nega o seu

41 V., por exemplo, MENKEL-MEADOW, Carrie. Portia in a different voice: speculations on a women's lawyering process. Berkley Journal of Gender, Law \& Justice, v. 1, n. 1, p. 39-63, 1985.

42 Críticas ao entendimento de Carol Gilligan podem ser conferidas SENCHUK, D.M. Listening to a different voice: a feminist critique of Gilligan. Studies in Philosophy and Education, v. 10, n. 3, p. 233-249, 1990. COLBY, Anne; COLBY, Anne; DAMON, William. Listening to a different voice: a review of Gilligan's "in a different voice". Merrill-Palmer Quarterly, v. 29, n. 4, p. 473-481, oct. 1983. GREENO, Catherine G.; MACCOBY, Eleanor E. How different is the “different voice”?. Signs, v. 11, n. 2, p. 310-316, 1986. 43 Sobre a crítica ao essencialismo, cf. CONAGHAN, J. Reassessing the Feminist Theoretical Project in law. Journal of Law \& Society, v. 27, n. 3, p. 351-385, 2000. Gilligan rejeita essas críticas, argumentando que, embora seu trabalho tenha abordado empiricamente as mulheres, a associação não seria absoluta ou necessária. Nas palavras da autora, "[m]y questions are about voice and relationship. And, my questions are about psychological processes and theory, particularly theories in which men's experience stands for all of human experience-theories which eclipse the lives of women" and shut out women's voices. I saw that by maintaining these ways of seeing and speaking about human lives, men were leaving out women, but women were leaving out themselves." GILLIGAN, Carol. In a different voice: psychological theory and women's development. Cambridge: Harvard University Press, 2003.

44 RACKLEY, Erika. Representations of the (woman) judge: Hercules, the little mermaid, and the vain and naked Emperor. Legal Studies, v. 22, n. 4, p. 602-624, nov. 2002. BERNS, Sandra. To speak as a judge: difference, voice and power. Dartmouth: Ashgate, 1999. 45 "While all law students - male and female - are subject to this process of alienation, for women it is a peculiarly distorting experience, as the self they strive to become is imbued with gendered cultural signifiers which render unstable their newly acquired sense of legal identity". RACKLEY, Erika. Representations of the (woman) judge: Hercules, the little mermaid, and the vain and naked Emperor. Legal Studies, v. 22, n. 4, p. 602-624, nov. 2002.

46 RACKLEY, Erika. Representations of the (woman) judge: Hercules, the little mermaid, and the vain and naked Emperor. Legal Studies, v. 22, n. 4, p. 612, nov. 2002. 
ego, submetendo-o a algo mais grandioso e elevado ${ }^{47}$. Em suas palavras:

Ela [a juíza mulher] também permanece como uma sereia. Sua aparência física ameaça perturbar as normas estéticas; sua presença é uma irritação inescapável, simultaneamente confirmando e criando uma disjunção à masculinidade estabelecida no poder [judiciário]. Como tal, a mulher juíza é quase uma contradição em termos. Ela é tão desviante que está inevitavelmente sujeita a um desejo irreprimível de se conformar. Como a sereia de Andersen, ela é induzida a negar a si mesma e vender sua voz; sua chamada de sirene perigosa é silenciada e no silêncio a diferença é perdida. ${ }^{48}$

A imagem da sereia como metáfora do apagamento da individualidade escancara uma dificuldade da discussão sobre a carência de diversidade na composição dos tribunais ${ }^{49}$. O funcionamento do direito em geral - e, de forma ainda mais intensa, a lógica dos julgamentos - encerra um ideal de imparcialidade e objetividade que demanda a alienação da personalidade, criando uma exigência de auto-obliteração vinculante tanto para os homens como para as mulheres ${ }^{50}$.

Nesse contexto, é importante enfatizar que debater diversidade no âmbito no judiciário, em larga medida, pressupõe contestar o mito de que os "juízes são oráculos de um direito mais elevado, um corpo de uma 'lei' absoluta e infalível", e que "simplesmente vestindo uma toga preta e fazendo o juramento de juiz, um homem deixa de ser humano e se despoja de todas as predileções, torna-se uma máquina pensante sem paixão" 51 .

É preciso, portanto, desprender-se do mito de que os juízes transcendem suas circunstâncias, reconhecendo que a forma como o direito é operado e aplicado é condicionada pelo seu passado e pelos pontos de vista dos intérpretes.

47 RACKLEY, Erika. Representations of the (woman) judge: Hercules, the little mermaid, and the vain and naked Emperor. Legal Studies, v. 22, n. 4, p. 614, nov. 2002.

48 Tradução livre. Lê-se, no original: "She [the woman judge] too remains cast as a mermaid. Her physical appearance threatens to upset aesthetic norms; her presence is an inescapable irritant, simultaneously confirming and disrupting the established masculinity of the bench. As such, the woman judge is almost a contradiction in terms. She is so deviant that she is inevitably subject to an irrepressible desire to conform. Like Andersen's mermaid, she is induced to deny herself and sell her voice; her dangerous siren call is silenced and in the silence difference is lost". RACKLEY, Erika. Representations of the (woman) judge: Hercules, the little mermaid, and the vain and naked Emperor. Legal Studies, v. 22, n. 4, p. 603, nov. 2002.

49 No Brasil, um estudo sobre profissionalismo na magistratura paulista descreve os processos aqui abordados: "Tal como já observado em outros estudos sobre as juízas, encontram-se narrativas que negam a persistência das diferenças de gênero na carreira. Entendemos esta visão como uma forma de atuar sobre o processo de formação da subjetividade e modelar a identificação profissional. Ativamente, elas afirmam o apagamento das diferenças, a partir da experiência da conquista de posições de poder, elevando o status social que a sociedade nega à mulher. $\mathrm{O}$ enfrentamento discursivo ocorre entre o apagamento e a visibilidade do gênero, seja ao apontar o preconceito ou ao essencializar o gênero, atribuindo às magistradas as marcas do feminino que fragilizam a carreira. Quanto à sexualidade, a invisibilidade é a forma hegemônica de tribunal lidar com essa diferença, não havendo ambivalência nos sinais emitidos sobre ela como registramos para o gênero.” BONELLI, Maria da Glória. Profissionalismo e diferença de gênero na magistratura paulista. Civitas, Porto Alegre, v. 10, n. 2, p. 290, maio/ago. 2010.

50 GILLIGAN, Carol. In a different voice: psychological theory and women's development. Cambridge: Harvard University Press, 2003. p. x: "'If I were to speak for myself,' a graduate student said one day in the middle of her oral exam-and then stopped. Hearing the sound of dissociation-the separation of herself from what she was saying, she began to question her relationship to what she was saying and what she was not saying. For whom was she speaking, and where was she in relation to herself? In the immediate aftermath of the Roe v. Wade decision, many women were openly questioning the morality of the Angel in the House-that nineteenth-century icon of feminine goodness immortalized by the poet Coventry Patmore: the woman who acts and speaks only for others. Discovering through experience the consequences of not speaking in relationships-the trouble that selfless behavior can cause-women were exposing the morality of the Angel as a kind of immorality: an abdication of voice, a disappearance from relationships and responsibility. The voice of the Angel was the voice of a Victorian man speaking through a woman's body. Virginia Woolf's realization that she had to strangle this Angel if she were to begin writing illuminates women's need to silence false feminine voices in order to speak for themselves.".

51 Tradução livre. Lê-se, no original: "Much harm is done by the myth that, merely by putting on a black robe, and taking the oath of office as a judge, a man ceases to be human and strips himself of all predilections, becomes a passionless thinking machine". FRANK, Jerome. The cult of the robe. In: FRANK, Jerome. Courts on trial: myth and reality in american justice. Princeton: Princeton University Press, 1973. p. 414. 


\section{A baixa representatividade de GÊnero nas CúPULAs do Judiciário e na Justiça Federal}

Quando se aborda o déficit de diversidade de gênero no judiciário, é lugar comum a afirmação de que esta surgirá, no futuro, como um desdobramento natural e incoercível da inclusão das mulheres no mercado de trabalho. Em outras palavras, mais diversidade de gênero nos órgãos judiciais de cúpula seria uma mera questão de tempo ${ }^{52}$, algo que brotaria como um efeito natural e automático da chegada das mulheres nas profissões jurídicas. Contudo, os dados atuais sobre a presença feminina nesse ramo de poder vêm demonstrando que o tempo, por si só, não é um fator decisivo para assegurar um crescimento proporcional da representatividade ${ }^{53}$. Quase vinte anos depois da virada do milênio, o equilíbrio de gênero nos espaços de poder parece, ainda, um horizonte incerto e remoto. A paisagem no judiciário brasileiro como um todo não sugere que haja um ritmo de evolução irrefreável em direção à paridade. Vale notar que, nos últimos anos, o Brasil caiu de posição no ranking de Igualdade de Gênero elaborado pelo Fórum Econômico Mundial. Em 2006, na primeira edição da pesquisa, o país ficou em $67^{\circ}$. Em 2015, o país ficou na posição 85. Em 2016, na 79. Já em 2017, caiu para a posição $90^{54}$.

Nesse tópico, apresentamos dados dos tribunais superiores brasileiros e da Justiça Federal, que constituem uma amostra ilustrativa do déficit de diversidade de gênero em segmentos importantes do judiciário nacional. A escolha de examinar os dados de tribunais superiores brasileiros deve-se ao fato de que o acesso a essas cortes se dá por critérios preponderantemente políticos, não havendo a possibilidade de neles ingressar por antiguidade nem por concurso público. O uso de dados da Justiça Federal, por sua vez, se justifica: (i) por serem dados muito recentes, produzidos pela Comissão AJUFE Mulheres; (ii) pelo fato de a Justiça Federal ser um ramo poder judiciário que passou por amplo crescimento e reformulação com a Constituição de 1988 (o Tribunal Federal de Recursos foi extinto e criaram-se cinco Tribunais Regionais Federais), de modo que o marco normativo que a rege é, na origem de seu desenho atual, o princípio da igualdade entre homens e mulheres; e (iii) por serem apenas cinco tribunais, é mais simplificada a análise do impacto dos critérios políticos no acesso ao tribunal (promoção por mérito), quando comparadas à promoção por antiguidade ${ }^{55}$.

A inserção das mulheres no universo jurídico é um fenômeno recente. A primeira advogada no Brasil, Myrthes Gomes de Campos, só foi registrada no Instituto dos Advogados do Brasil em 1906, apesar de ter concluído o bacharelado em Ciências Jurídicas e Sociais em $1898^{56}$. Apenas em 1954 o quadro de juízes passou a contar com uma mulher, Thereza Grisólia Tang, que ouviu do presidente do Tribunal de Justiça de Santa Catarina que ela seria um "teste" ${ }^{\text {". A }}$ A primeira professora de direito no país, Bernadete Pedrosa, só

52 Para Marina Ito e Marília Scriboni, como os homens ocupam os cargos de cúpula há mais tempo e por conta das regras de promoção aos tribunais, que privilegiam os membros mais antigos da corte, a ascensão das mulheres à condição de desembargadoras seria vista em "pouco tempo". ITO, Marina; SCRIBONI, Marília. Em pouco tempo, mulheres estarão na cúpula da Justiça. Consultor Jurídico, mar. 2012. Disponível em: < https://www.conjur.com.br/2012-mar-08/aumenta-numero-mulheres-direito-sao-chegamcupula> . Acesso em: 28 maio 2018. Roberto Fragale Filho, Rafaela Moreira e Ana Paula Sciammarella adotam entendimento similar, apesar de afirmarem que "O significado e o alcance dessa chegada [das mulheres às cúpulas judicias brasileiras] ainda constitui um espaço de contenda”. FRAGALE FILHO, Roberto; MOREIRA, Rafaela Selem; SCIAMMARELLA, Ana Paula de O. Magistratura e gênero: um olhar sobre as mulheres nas cúpulas do judiciário brasileiro. E-cadernos CES, n. 24, p. 57-77, 2015.

53 Um panorama global pode ser encontrado na coletânea HEIDENSOHN, Frances (Ed.). Gender and justice: new concepts and approaches. Portland: Willan Publishing, 2006.

54 Os resultados globais estão disponíveis em: <http://reports.weforum.org/global-gender-gap-report-2017/results-and-analysis/>. Acesso: 26 maio 2018. Os demais dados estão disponíveis no site do Fórum: <http://reports.weforum.org>. Acesso em: 26 maio 2018.

55 Optamos por não analisar a promoção de juiz substituto para juiz titular. Por mais que, em regra, essa ascensão na carreira também se dê por antiguidade e por merecimento, na prática, os tribunais tratam dessa matéria de formas distintas. No TRF-2, por exemplo, as promoções ocorrem, predominantemente, por antiguidade.

56 GUIMARÃES, Lúcia Maria Paschoal; FERREIRA, Tania Maria Tavares. Myrthes Gomes de Campos (1875-?): pioneirismo na luta pelo exercício da advocacia e defesa da emancipação feminina. Revista do Instituto de Estudos de Gênero, Niterói, v. 9, n. 2, p. 135-151, 2009.

57 CONHEÇA a primeira mulher a ocupar o cargo de juíza no país. Donna, out. 2008. Disponível em: < http://revistadonna. 
começou a lecionar em $1965^{58}$. Já as posses da primeira ministra em tribunal superior (Cnéa Cimini Moreira) e da primeira ministra do Supremo Tribunal Federal (Ellen Gracie Northfleet) só ocorreram, respectivamente, em $1990^{59}$ e $2000^{60}$.

Em todos os ramos do judiciário brasileiro, o número de magistrados homens é superior ao de mulheres. O Censo do Poder Judiciário de 2014 indica que a média geral de magistrados é de 64,1\% contra 35,9\% de magistradas $^{61}$. Na Justiça do Trabalho, observa-se um certo equilibrio na composição - o que sugere que os fatores que determinam a baixa presença de mulheres não são associados à qualificação profissional, mas são razões outras que merecem ser estudadas -, mas, ainda assim, o coeficiente de mulheres é menor do que o de homens.

Os números relativos à diversidade de raça no judiciário como um todo revelam disparidades ainda mais profundas: $84,2 \%$ dos magistrados se declararam brancos, ao passo que apenas 15,6\% se declararam negros e $0,1 \%$, indígena ${ }^{62}$. O censo do $\mathrm{CNJ}$ é omisso quanto ao número de mulheres negras no poder judiciário ${ }^{63}$.

O gráfico abaixo detalha o percentual de magistrados em cada ramo do poder judiciário de acordo com o gênero:

Gráfico 1 - Percentual de magistrados segundo ramos do poder judiciário, de acordo com o gênero.

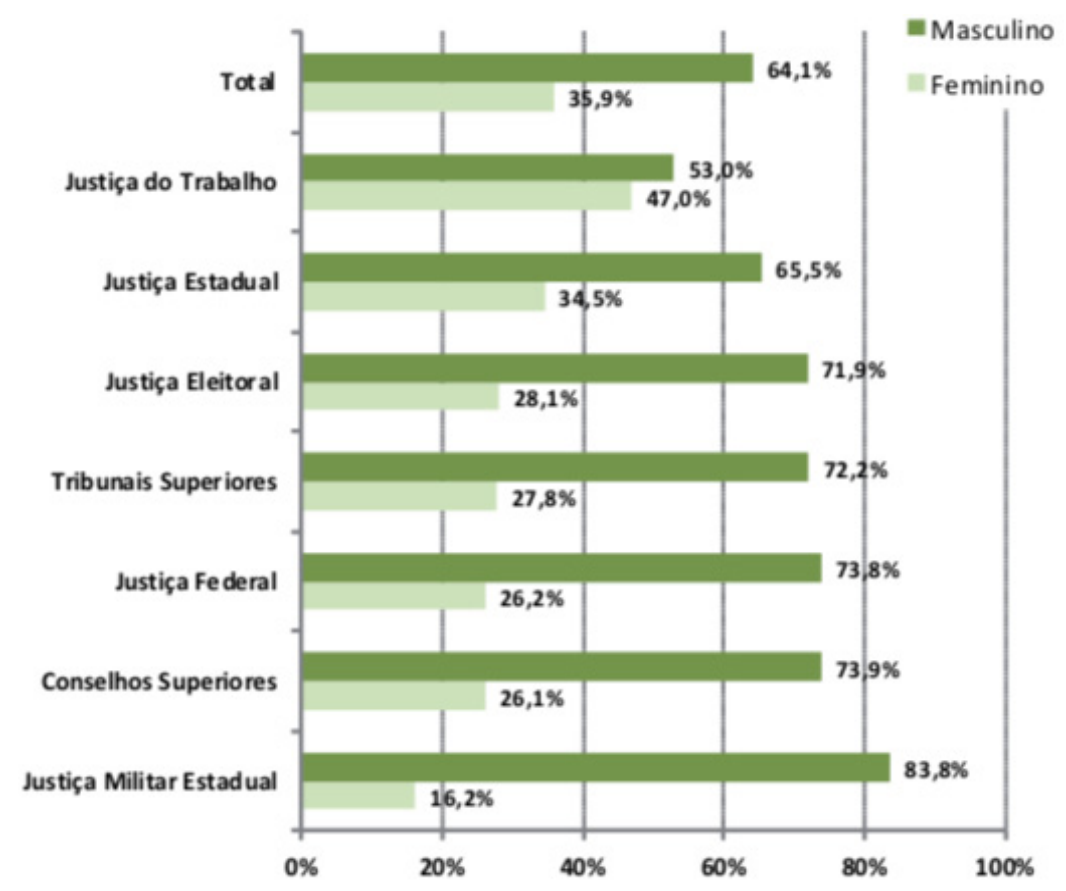

Fonte: BRASIL. Conselho Nacional de Justiça. Censo do Poder Judiciário: VIDE: Vetores iniciais e dados estatísticos. Brasília: CNJ, 2014. p. 37. Título original do gráfico: "Percentual de magistrados segundo tipo de carreira, por sexo. Brasil, 2013".

clicrbs.com.br/noticia/conheca-a-primeira-mulher-a-ocupar-o-cargo-de-juiza-no-pais/>. Acesso em: 29 maio 2018.

58 BERNADETE Pedrosa, a primeira mulher a ser admitida como professora da Faculdade de Direito do Recife em 1965. 2018. Disponível em: <https://www.ufpe.br/arquivoccj/curiosidades/-/asset_publisher/x1R6vFfGRYss/content/1965-primeiraprofessora-de-direito-no-recife/590249>. Acesso em: 29 maio 2018.

59 MORRE primeira mulher a ocupar cargo de ministra no TST. Consultor Jurídico, abr. 2008. Disponível em: < https://www.conjur.com.br/2008-abr-23/morre_primeira_mulher_ocupar_cargo_ministra_tst>. Acesso em: 28 maio 2018.

60 A TRAJETÓRIA da primeira mulher a integrar o Supremo. Consultor Jurídico, São Paulo, ago. 2011. Disponível em: < https:// www.conjur.com.br/2011-ago-11/ellen-gracie-trajetoria-primeira-mulher-integrar-supremo> . Acesso em: 29 maio 2018.

61 BRASIL. Conselho Nacional de Justiça. Censo do Poder Judiciário: VIDE: Vetores iniciais e dados estatísticos. Brasília: CNJ, 2014 . p. 37. 62 BRASIL. Conselho Nacional de Justiça. Censo do Poder Judiciário: VIDE: Vetores iniciais e dados estatísticos. Brasília: CNJ, 2014. p. 41.

63 Quanto às problemáticas raciais no judiciário, cf. CRUZ, Adriana Alves dos Santos; ALVIM, Alcione Escobar da Costa. As questões raciais e poder judiciário: enfrentamentos necessários. In: PIMENTA, Clara Mota et al. (Orgs.). Magistratura e equidade: estudos sobre gênero e raça no poder judiciário. Belo Horizonte: D’Plácido, 2018. p. 27-44. 
Uma análise da configuração dos tribunais superiores e dos tribunais federais sugere que a presença das mulheres em muitos setores no poder judiciário, especialmente nos estratos mais elevados, não acompanha o ritmo das transformações sociais. Observamos, nos números analisados, uma tendência à estratificação. É possível que esses dados sejam reflexo do fenômeno que estudos nesse campo qualificam como um "padrão de mecanismos internos de fechamento generificados nas profissões jurídicas" ${ }^{4}$. Mesmo quando ocorre aumento do coeficiente de mulheres nas instâncias inferiores, em decorrência dos modelos de recrutamento por concurso público ${ }^{65}$, a sub-representação permanece naqueles setores acessados por critérios nos quais preponderam avaliações subjetivas. Podemos observar que, nos órgãos compostos por nomeação política, os percentuais de mulheres são sistematicamente menores. No Brasil, o fenômeno é bastante claro. Nos contextos em que critérios políticos têm peso elevado, como nas promoções por merecimento e nomeações para tribunais superiores, o número de mulheres é menor. Atualmente, dos 93 ministros de tribunais superiores, por exemplo, apenas 16 são mulheres, o que representa um coeficiente de 17,2\%. A quantidade de mulheres nas cúpulas do judiciário reflete a baixa de mulheres em espaços de poder no Brasil (onde 50,67\% da população é composta por mulheres $\left.{ }^{66}\right)$. De forma similar, no poder legislativo brasileiro, em 2017 , havia apenas $10,7 \%$ de mulheres, o que fez com que o país ficasse na posição 154 do Ranking Mundial de Igualdade nos Parlamentos ${ }^{67}$ e em $32^{\circ}$ na América Latina ${ }^{68}$.

Em 2017, a Comissão AJUFE Mulheres, da Associação de Juízes Federais do Brasil (AJUFE), realizou pesquisa entre 185 magistradas federais de todos os cinco Tribunais Regionais Federais e apurou que, dentre as associadas que responderam ao questionário, mais de $86 \%$ consideram que a representatividade feminina é baixa ou razoável (no sentido de que houve avanços, mas há muito o que fazer) ${ }^{69}$. Dentre os fatores principais destacados pelas participantes para a presença reduzida de mulheres nos níveis mais altos da magistratura, estavam a dupla jornada e o rompimento da unidade familiar derivado da necessidade de mudar de residência em função do trabalho ${ }^{70}$. Além disso, o levantamento indicou a percepção, entre as magistradas consultadas, de que o ambiente judicial submete as mulheres a frequentes questionamentos sobre sua capacidade e performance. Muitas relatam que não basta serem aprovadas no concurso de seleção de magistrados e demonstrar um bom rendimento no trabalho: elas precisam, constantemente, mostrar que a condição feminina não interfere em seu desempenho, e que são capazes de exercer a atividade de julgar com

64 BOLTON, Sharon C.; MUZIO, Daniel. Can't live with 'Em; Can't Live without 'Em: gendered segmentation in the legal profession. Sociology, Chicago, v. 41, n. 1, p. 50, 2007.

65 Note que mesmo o concurso público ainda é permeado por problemas que demonstram como o preconceito de gênero opera no poder judiciário. Como observa Maria da Gloria Bonelli, na década de 1990, as provas para ingresso na magistratura eram identificadas com o nome do candidato, o que resultava em elevada eliminação de mulheres. Com a substituição do nome por números, cresceu o número de mulheres aprovadas nesta etapa, mas a prova oral e a entrevista com a banca ainda fazem com que a presença feminina decresça. BONELLI, Maria da Glória. Profissionalismo e diferença de gênero na magistratura paulista. Civitas, Porto Alegre, v. 10, n. 2, p. 106, maio/ago. 2010. Além disso, a presença de mulheres nas bancas de concurso público para ingresso na magistratura federal é praticamente nula (ALVES, Clara da Mota Santos Pimenta. Gênero, espaço público e poder: uma análise sobre a composição das comissões examinadoras de concurso da magistratura. Revista Publicum, Rio de Janeiro, v. 3, n. 1, p. 352-370, 2017.). Por conta disso, a conselheira do Conselho Nacional de Justiça (CNJ) Maria Tereza Uille Gomes emitiu, em 30 de maio de 2018, o Ofício n 79/GAB para o Conselho Nacional do Ministério Público (CNMP) solicitando a realização de estudos "sobre a viabilidade de edição de ato normativo ou Recomendação no âmbito deste Conselho, a fim de assegurar a (sic) percentual mínimo de participação feminina nos seguintes espaços: 1) Órgãos da administração superior; 2) Bancas de concurso para ingresso na carreira; 3) Nos painéis - na qualidade de expositora - de seminários, congressos e outros eventos acadêmicos".

66 Essa é a projeção de população feita pelo IBGE para o ano de 2018. Os dados estão disponíveis em: <https://www.ibge.gov. br/apps/populacao/projecao/>. Acesso em: 26 maio 2018.

67 UNITED NATIONS. Women in politics: 2017. 2017. Disponível em: < https://www.ipu.org/resources/publications/infographics/2017-03/women-in-politics-2017>. Acesso em: 30 maio 2018.

68 PODER Legislativo: porcentagem de mulheres no órgão legislativo nacional: Câmara baixa ou única. 2018. Disponível em: $<$ https://oig.cepal.org/pt/indicadores/poder-legislativo-porcentagem-mulheres-no-orgao-legislativo-nacional-camara-baixa-ou>. Acesso em: 30 maio 2018.

69 COMISSÃO AJUFE MULHERES. Nota Técnica: AJUFE mulheres 01/2017: resultados da pesquisa para se conhecer o perfil das associadas da AJUFE. Brasília: AJUFE Mulheres, 2017. p. 6.

70 COMISSÃO AJUFE MULHERES. Nota Técnica: AJUFE mulheres 01/2017: resultados da pesquisa para se conhecer o perfil das associadas da AJUFE. Brasília: AJUFE Mulheres, 2017. p. 9. 
excelência ${ }^{71}{ }^{72}$.

Outro aspecto, observado no gráfico 2, refere-se ao fato de que o aumento do coeficiente de mulheres nos órgãos de cúpula do poder judiciário brasileiro de 2000 a 2018 foi intermitente e que o percentual estagnou nos últimos dez anos. Ao contrário do pensamento comum mencionado no começo desse tópico, os dados apurados sugerem que a paridade de gênero no judiciário não é mera questão de tempo.

Os dados do CNJ no Censo do Poder Judiciário de 2014 deixam clara a dificuldade que as mulheres encontram para avançar na carreira da magistratura. Quando foi feito o levantamento, havia 42,8\% de juízas substitutas, ao passo que apenas $21,5 \%$ das mulheres eram desembargadoras ${ }^{73}$. Nesse sentido, nota-se a existência de um teto de vido (glass ceiling) no judiciário, como há em outros setores que envolvem poder ${ }^{74}$.

Em algumas cortes, a carência de diversidade é mais expressiva. No Tribunal Regional Federal da $5^{a}$ Região - que exerce jurisdição sobre os estados de Alagoas, Ceará, Paraíba, Pernambuco, Rio Grande do Norte e Sergipe -, desde 2014, não há nenhuma mulher na composição da $2^{\mathrm{a}}$ instância, que abarca 15 desembargadores federais ${ }^{75}$.

Outro exemplo é a Justiça Militar da União. Com mais de 200 anos de existência, o Superior Tribunal Militar teve apenas uma mulher na sua história, que ocupou a presidência durante 8 meses e a vice-presidência durante 1 ano e 3 meses (Maria Elizabeth Guimarães T. Rocha).

Confira-se gráfico que indica a proporção de magistradas nos tribunais superiores brasileiros:

71 Como destacou uma magistrada na pesquisa realizada pela Comissão AJUFE Mulheres, "[p]ara o homem muitas vezes basta apresentar um currículo apresentando seu amplo POTENCIAL. A mulher tem que provar seu DESEMPENHO excelente" (grifos no original). COMISSÃO AJUFE MULHERES. Nota Técnica: AJUFE mulheres 01/2017: resultados da pesquisa para se conhecer o perfil das associadas da AJUFE. Brasília: AJUFE Mulheres, 2017. p. 6.

72 Examinando outra realidade não abordada neste artigo, Maria Bonelli chegou a conclusões semelhantes. Como nota a autora, na magistratura paulista "encontram-se narrativas que negam a persistência das diferenças de gênero na carreira. Entendemos esta visão como uma forma de atuar sobre o processo de formação da subjetividade e modelar a identificação profissional. Ativamente, elas afirmam o apagamento das diferenças, a partir da experiência da conquista de posições de poder, elevando o status social que a sociedade nega à mulher." BONELLI, Maria da Glória. Profissionalismo e diferença de gênero na magistratura paulista. Civitas, Porto Alegre, v. 10, n. 2, p. 270-292, maio/ago. 2010.

73 BRASIL. Conselho Nacional de Justiça. Censo do Poder Judiciário: VIDE: Vetores iniciais e dados estatísticos. Brasília: CNJ, 2014. p. 37.

74 A imagem do teto de vidro é empregada para designar a barreira invisível que há, nas carreiras em geral, para que as mulheres possam obter cargos mais elevados e com rendimentos mais elevados. Tais barreiras são perceptíveis quando se faz uma análise geral de progressão na carreira, mas são invisíveis devido ao fato de os critérios internos de promoção em muitas empresas não serem públicos sequer para os próprios funcionários. Sobre o tema, cf MORRISON, Ann M.; WHITE, Randall P.; VELSOR, Ellen Van. Breaking the glass ceiling: can women reach the top of America's largest corporations?. 2. ed. Beverly: Basic Books, 1994. DAVIDSON, M. J.; COOPER, C. L. Shattering the glass ceiling: the woman manager. London: Paul Chapman Publishing, 1992. MOORE, Dorothy Perrin; BUTTNER, E. Holly. Women entrepreneurs: moving beyond the glass ceiling. Thousand Oaks: SAGE Publications, 1997.

75 A composição do Tribunal está disponível em: <http://www.trf5.jus.br/index.php?option=com_content\&view=article\&id= 661\&Itemid=241 > . Acesso em: 24 maio 2018. 
Gráfico 2 - Representatividade feminina nos tribunais superiores brasileiros.

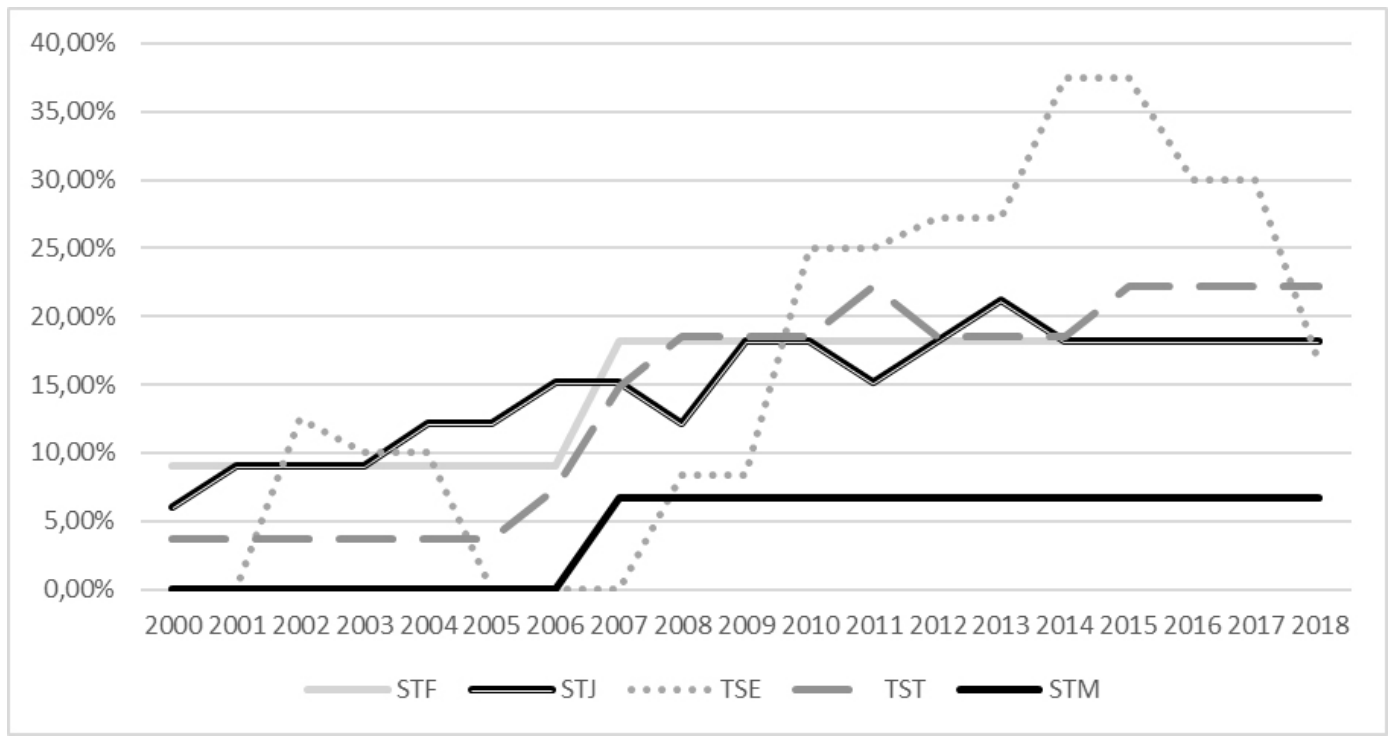

Fonte $^{76}$ : Sites dos tribunais. Elaboração própria.

Como se pode notar, no início do século XXI houve um crescimento significativo dos índices de presença feminina nos tribunais superiores. Todavia, nos últimos dez anos, verifica-se uma tendência à estabilidade em patamares médios que gravitam em torno de 15-16\%, o que sugere a estratificação.

Na magistratura federal, a quantidade de mulheres na carreira é visivelmente inferior à de homens. Nos níveis iniciais da carreira, as diferenças são perceptíveis, mas é na função de desembargador que se verifica maior assimetria:

Gráfico 3 - Presença feminina na magistratura federal, desde 1988.

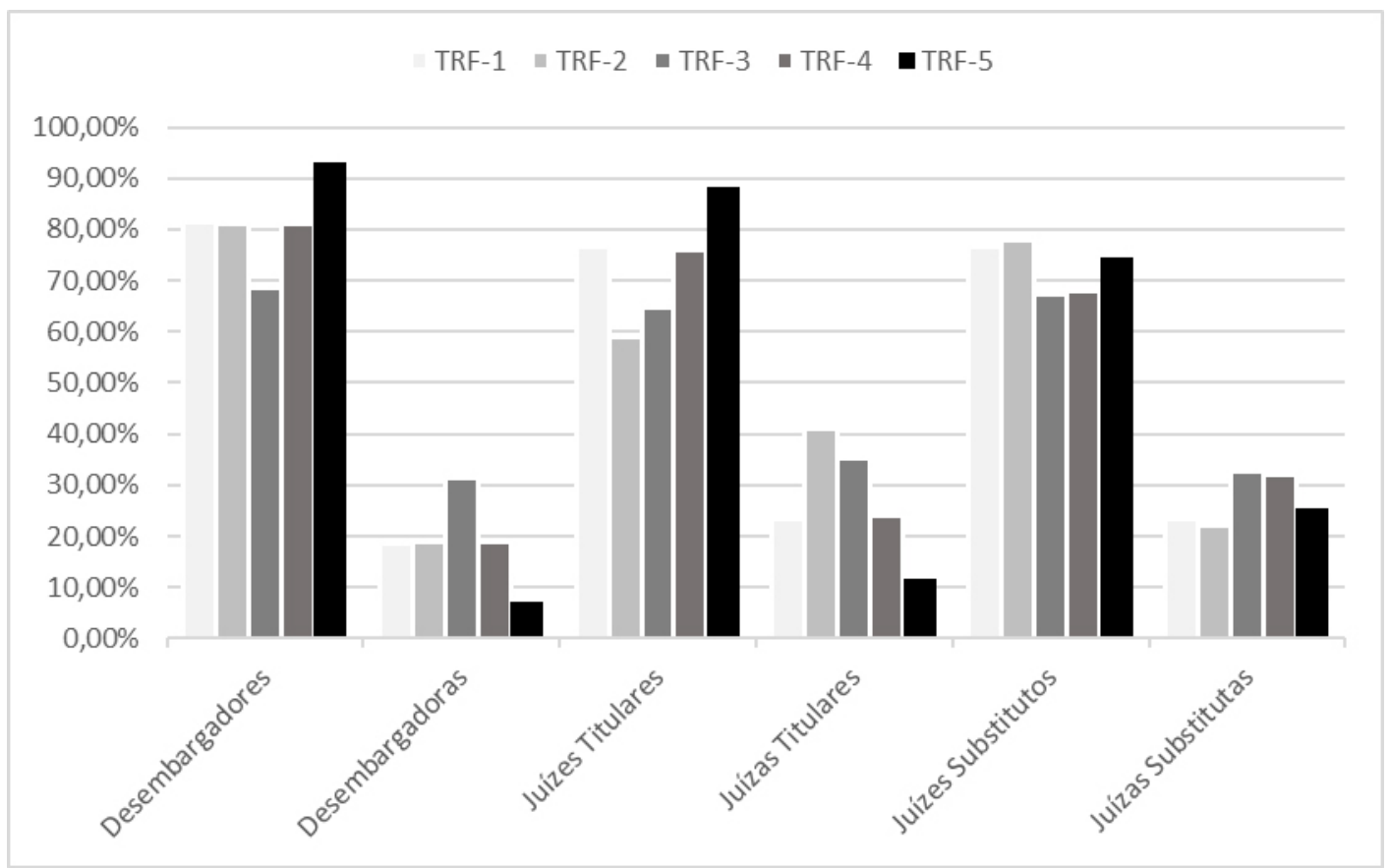

Fonte: Comissão AJUFE Mulheres. Elaboração própria.

76 Os dados referentes à composição anual dos tribunais foram obtidos a partir dos sítios eletrônicos oficiais de cada tribunal. Incluímos, no total de ministros dos tribunais, as vagas ociosas. Note que o número total de ministros no Tribunal Superior Eleitoral é variável. Utilizamos, como $100 \%$, o número total de magistrados para cada ano. 
Desbordaria dos limites e objetivos deste estudo explorar de forma sólida as razões para o desequilíbrio de gênero no judiciário. Todavia, no campo especulativo, é possível tangenciar algumas questões.

Os números gerais relativos à entrada no ensino superior e à sua conclusão sugerem que essas assimetrias não são relacionadas a diferenças na qualificação formal de homens e mulheres. Ainda que, desde o século $\mathrm{XX}$, a educação tenha se tornado fator primordial para a inserção social ${ }^{77}$, mais níveis de instrução formal não correspondem, automaticamente, a melhores posições na sociedade. Cerca de 55\% dos ingressantes em cursos de graduação presenciais são mulheres, ao passo que elas respondem por $60 \%$ dos concluintes ${ }^{78}$. No curso de Direito, em 2015, 55,3\% dos matriculados eram mulheres ${ }^{79}$ e o mesmo percentual indicava a quantidade de concluintes ${ }^{80}$. Em 2004, as mulheres já eram responsáveis por 56,4\% das matrículas na educação superior de forma geral ${ }^{81}{ }^{82}$. A frequência escolar no ensino médio também é superior quando se trata do sexo feminino ${ }^{83}$. Isso contraria a média salarial das mulheres, que é de $\mathrm{R} \$ 1.764,00$ contra $\mathrm{R} \$ 2.306,00$ dos homens ${ }^{84}$. Nos cursos de graduação em Direito, as mulheres também correspondem a mais de $50 \%$ dos alunos $^{85}$. A quantidade de cargos de gerência ocupados por elas também vai de encontro aos dados referentes aos níveis de educação: apenas 39,1\% de tais cargos são ocupados por mulheres ${ }^{86}$. Assim, por mais que as mulheres tenham conquistado inúmeros espaços, ainda há, nas esferas de poder e decisão, o fenômeno identificado como "masculinização do comando e feminização da subalternidade" de mando permanece fiel à lógica da cultura patriarcal".

$\mathrm{Na}$ análise sobre as causas da sub-representação feminina no judiciário de outros países, um amplo leque de fatores costuma ser aventado ${ }^{88}$. Especula-se sobre a existência de gargalos e vieses nos critérios de

77 MELO, Hildete Pereira de; THOMÉ, Débora. Mulheres e poder: histórias, ideias e indicadores. Rio de Janeiro: FGV, 2018. p. 93. 78 MULHERES são maioria no ingresso e na conclusão de cursos superiores. 2017. Disponível em: <http://www.brasil.gov. br/editoria/educacao-e-ciencia/2015/03/mulheres-sao-maioria-no-ingresso-e-na-conclusao-de-cursos-superiores?TSPD_101_R0 $=$ dee602bb551a76a45283dee5ab5e0d4cc1Q00000000000000000c279eb1 ffff00000000000000000000000000005b11770d0076024 db4>. Acesso em: 29 maio 2018.

79 INSTITUTO NACIONAL DE ESTUDOS E PESQUISAS EDUCACIONAIS. Censo da Educação Superior 2015: resumo técnico. Brasília: INEP, 2018. p. 23.

80 INSTITUTO NACIONAL DE ESTUDOS E PESQUISAS EDUCACIONAIS. Censo da Educação Superior 2015: resumo técnico. Brasília: INEP, 2018. p. 34.

81 INSTITUTO NACIONAL DE ESTUDOS E PESQUISAS EDUCACIONAIS. Censo da Educação Superior 2015: resumo técnico. Brasília: INEP, 2018. p. 34.

82 Uma análise da presença de mulheres nos cursos de graduação e de pós-graduação pode ser conferida em GUEDES, Moema de Castro. A presença feminina nos cursos universitários e nas pós-graduações: desconstruindo a idéia da universidade como espaço masculino. História, Ciências, Saúde - Manguinhos, Rio de Janeiro, v. 15, p. 117-132, jun. 2008.

83 INTITUTO BRASILEITO DE GEOGRAFIA E ESTATÍSTICA. Estatísticas de gênero: indicadores sociais das mulheres no Brasil. Estudos e Pesquisas - Informação Demográfica e Socioeconômica, n. 38, 2018.

84 Além disso, de acordo com dados do Ministério do Trabalho e Previdência Social, "[a]s mulheres com cinco a oito anos de estudo receberam por hora, em média, $\mathrm{R} \$ 7,15$, e os homens, com a mesma escolaridade, $\mathrm{R} \$ 9,44$, uma diferença de $\mathrm{R} \$ 24 \%$. Para 12 anos de estudo ou mais, essa diferença na remuneração vai a 33,9\%, com R $\$ 22,31$ para mulheres e R $\$ 33,75$ para homens”. MULHERES são maioria em universidades e cursos de qualificação. 2016. Disponível em: < http://www.brasil.gov.br/economia-e-emprego/2016/03/mulheres-sao-maioria-em-universidades-e-cursos-de-qualificacao?TSPD_101_R0=146a5e670db17b1d43690f8f6 5521871n6o00000000000000000c279eb1ffff00000000000000000000000000005b117bb600ea8281fc>. Acesso em: 29 maio 2018.

85 ALMEIDA, Rodolfo; ZANLORENSSI, Gabriel. Gênero e raça de estudantes do ensino superior no Brasil por curso e área. Nexo Jornal, dez. 2017. Disponível em: <https://www.nexojornal.com.br/grafico/2017/12/13/Gênero-e-raça-de-estudantes-doensino-superior-no-Brasil-por-curso-e-área>. Acesso em: 29 maio 2018.

86 INTITUTO BRASILEITO DE GEOGRAFIA E ESTATÍSTICA. Estatísticas de gênero: indicadores sociais das mulheres no Brasil. Estudos e Pesquisas - Informação Demográfica e Socioeconômica, n. 38, 2018.

87 A expressão é do Comitê de monitoramento da Aplicação da Convenção sobre a Eliminação de Todas as Formas de Discriminação Contra a Mulher. Cf. MELO, Mônica de; NASTARI, Marcelo; MASSULA, Letícia. A participação da mulher na magistratura brasileira. Disponível em: <http://www.spm.gov.br/assuntos/poder-e-participacao-politica/programas-acoes/desigualdades-entremulheres-e-homens/judiciario/dados_parciais_de_1999_a_20.pdf?TSPD_101_R0=58c632ceeac2b962cdb498af875432cdoB2000 00000000000000c279eb1ffff00000000000000000000000000005b11ef5d001b0182d8>. Acesso em: 28 maio 2018.

88 Sobre esse tópico, cf. KENNEY, Sally J. Thinking about gender and judging. International Journal of the Legal Profession, v. 15, n. 1-2, p. 87-110, mar./jul. 2008; RACKLEY, Erika. Women, judging and the Judiciary: from difference to diversity. New York: Routledge, 2013. KENNEY, Sally J. Gender \& justice: why women in the judiciary really matter. New York: Routledge, 2012. SCHULTZ, Ulrike; SHAW, Gisela (Ed.). Gender and judging. Oxford: Hart Publishing, 2013. 
seleção dos magistrados, sobre razões relacionadas à cultura das profissões jurídicas, bem como sobre os efeitos dos arranjos sociais mais abrangentes. Fala-se, também, nas dinâmicas corporativas de socialização, como confrarias ${ }^{89}$. De outro lado, são mencionados motivos culturais e pessoais, uma vez que as mulheres, muitas vezes, não buscariam posições mais elevadas ${ }^{90}$. Contudo, não é possível pensar nessas duas ordens de justificativa de forma apartada.

A configuração dos tribunais superiores sugere uma correlação entre maior peso das dinâmicas políticas na forma de ingresso e baixa representatividade feminina. Os critérios de seleção dos ministros são predominantemente políticos. A cúpula não é formada por um critério de ascensão interno à carreira do judiciário, de modo que não há acesso por antiguidade ou promoção por mérito. $\mathrm{O}$ critério passa por requisitos de idade, tempo de carreira, conhecimento jurídico e reputação ${ }^{91}$. Como visto no gráfico 2 , a presença feminina nesses tribunais é baixa.

De forma semelhante, são baixos os coeficientes de nomeações de mulheres nos tribunais regionais federais. Aqui, critérios políticos também exercem influência. É possível tornar-se desembargador desses tribunais de duas formas: i) por merecimento (critério no qual pesam fatores políticos e avaliações subjetivas); e ii) por antiguidade (critério puramente objetivo). Os dados mostram que a promoção de mulheres para os tribunais é baixa nos dois casos, mas quando as lentes se voltam para a promoção por merecimento, os números são ainda mais díspares:

89 BOHNET, Iris. What works: gender equality by design. London: Harvard University Press, 2016. p. 91.

90 RACKLEY, Erika. Women, judging and the Judiciary: from difference to diversity. New York: Routledge, 2013.

91 Para que um cidadão seja nomeado pelo Presidente da República como ministro do STF, após a aprovação da maioria absoluta do Senado Federal, é necessário ter mais de trinta e cinco anos e menos de sessenta e cinco anos de idade, ter notável saber jurídico e reputação ilibada (art. 101, CF). No STJ, os ministros devem ser "brasileiros com mais de trinta e cinco e menos de sessenta e cinco anos, de notável saber jurídico e reputação ilibada” (art. 104, CF). A nomeação do Presidente da República deve ser dentre os nomes constantes das listas tríplices elaboradas pelo próprio tribunal de juízes dos tribunais regionais federais e de desembargadores dos tribunais de justiça. Os demais membros devem ser, em partes iguais, dentre advogados e membros do Ministério Público Federal, Estadual, do Distrito Federal e Territórios, alternadamente, indicados na forma do art. 94. No STM, os ministros devem ser brasileiros com mais de trinta e cinco anos de idade, sendo "I - três dentre advogados de notório saber jurídico e conduta ilibada, com mais de dez anos de efetiva atividade profissional; II - dois, por escolha paritária, dentre juízes auditores e membros do Ministério Público da Justiça Militar". Os ministros devem ser "três dentre oficiais-generais da Marinha, quatro dentre oficiais-generais do Exército, três dentre oficiais-generais da Aeronáutica, todos da ativa e do posto mais elevado da carreira, e cinco dentre civis". (art. 123, CF). O TSE tem composição variável, devendo ter, no mínimo, sete membros. A escolha se dá: "I - mediante eleição, pelo voto secreto: a) três juízes dentre os Ministros do Supremo Tribunal Federal; b) dois juízes dentre os Ministros do Superior Tribunal de Justiça; II - por nomeação do Presidente da República, dois juízes dentre seis advogados de notável saber jurídico e idoneidade moral, indicados pelo Supremo Tribunal Federal." (art. 119, CF). Por fim, os ministros do TST devem ser brasileiros com mais de trinta e cinco anos e menos de sessenta e cinco anos, de notável saber jurídico e reputação ilibada. São nomeados pelo Presidente da República após aprovação da maioria absoluta do Senado Federal. A composição do tribunal deve ser de: "I um quinto dentre advogados com mais de dez anos de efetiva atividade profissional e membros do Ministério Público do Trabalho com mais de dez anos de efetivo exercício, observado o disposto no art. 94; (Incluído pela Emenda Constitucional n 45, de 2004) II os demais dentre juízes dos Tribunais Regionais do Trabalho, oriundos da magistratura da carreira, indicados pelo próprio Tribunal Superior. (Incluído pela Emenda Constitucional no 45, de 2004)." (art. 111-A, CF). 
Gráfico 4 - Promoção por merecimento, desde a criação dos tribunais.
Gráfico 5 - Promoção por antiguidade, desde a criação dos tribunais.
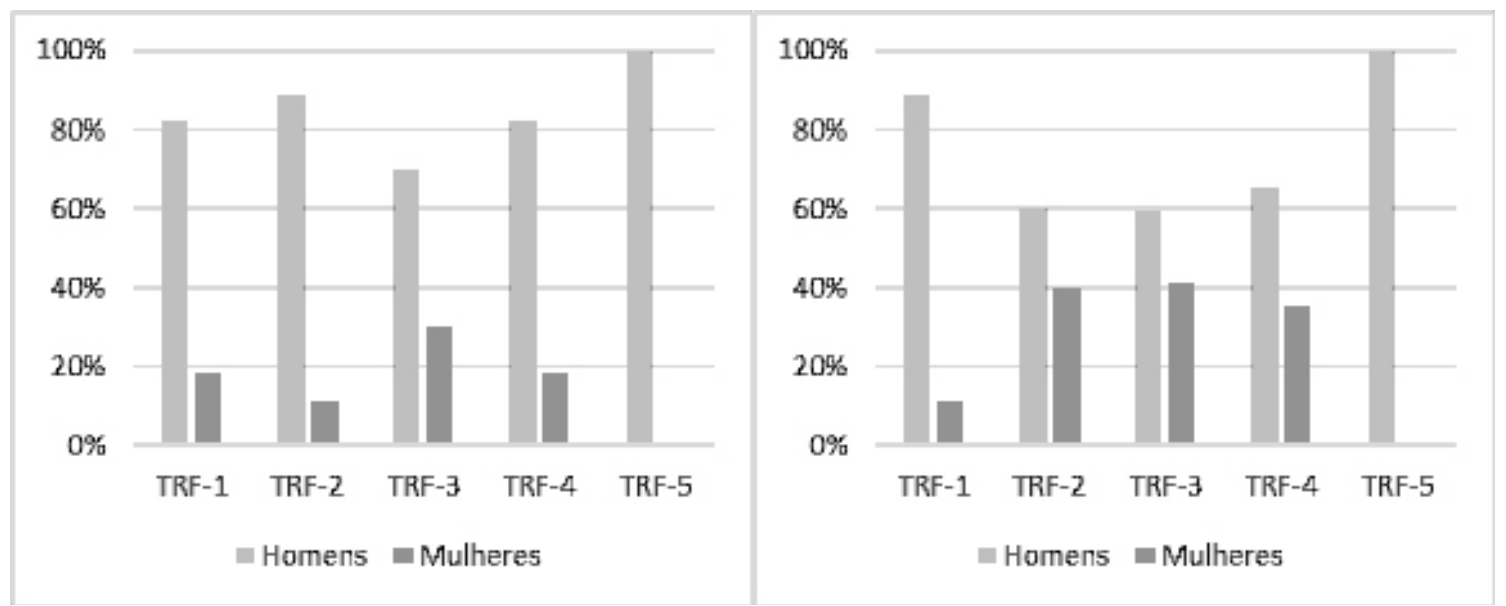

Fonte: Comissão AJUFE Mulheres. Elaboração própria.

Quando o acesso aos tribunais se dá por meio do quinto constitucional ${ }^{92}$, com maior peso de critérios políticos e subjetivos, a quantidade de mulheres é ainda menor. No TRF-1 e no TRF-2, apenas uma desembargadora que compõe cada corte atualmente ingressou pelo quinto constitucional. No TRF-4 e no TRF-5, não há sequer uma desembargadora que acessou o tribunal dessa forma. Já no TRF-3, há três desembargadoras que ingressaram por esse canal. As demais mulheres que fazem parte dos tribunais chegaram até eles por ascensão na própria carreira de magistratura. Confira-se o gráfico abaixo, que indica a quantidade de homens e mulheres nos TRFs e a forma com que acessaram os tribunais:

Gráfico 6 - Acesso aos TRFs, por gênero e por forma de ingresso, da composição de 2017.

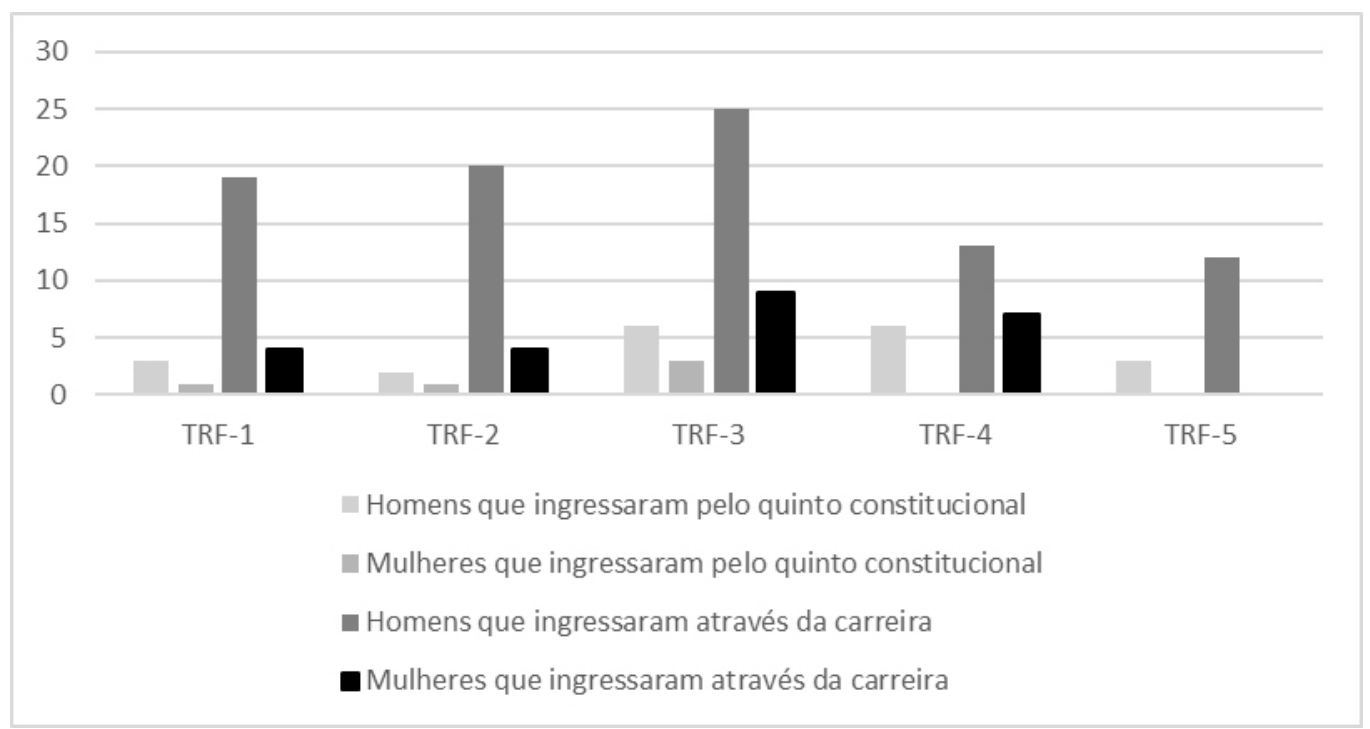

Fonte: Comissão AJUFE Mulheres. Elaboração própria.

92 Constituição Federal de 1988, Art. 94. "Um quinto dos lugares dos Tribunais Regionais Federais, dos Tribunais dos Estados, e do Distrito Federal e Territórios será composto de membros, do Ministério Público, com mais de dez anos de carreira, e de advogados de notório saber jurídico e de reputação ilibada, com mais de dez anos de efetiva atividade profissional, indicados em lista sêxtupla pelos órgãos de representação das respectivas classes.

Parágrafo único. Recebidas as indicações, o tribunal formará lista tríplice, enviando-a ao Poder Executivo, que, nos vinte dias subseqüentes, escolherá um de seus integrantes para nomeação". 
De acordo com os dados, o marcador gênero parece atuar como uma desvantagem competitiva nos processos políticos de promoção e de nomeação ${ }^{93}$. Nesse sentido, outro aspecto que precisa ser considerado é a ideia de que as promoções e seleções - tanto as calcadas em critérios exclusivamente políticos, quanto as que se dão de forma objetiva, mas que envolvem a análise pessoal do candidato em alguma etapa, como entrevista - operam com vieses cognitivos.

Entra em pauta, aqui, a reflexão sobre em que medida as decisões tomadas na esfera pública são pautadas pela razão. Os estudos de Economia Comportamental ${ }^{14}$ já demonstraram que as decisões humanas no geral não são particularizadas e formuladas racionalmente. Na realidade, as pessoas normalmente são irracionais e impulsionadas por tendências cognitivas (motivated reasoning/cognitive bias) na hora de tomar decisões. Daniel Kahneman ${ }^{95}$, vencedor do Prêmio Nobel de Economia, demonstrou, através de estudos realizados por anos, que nossas decisões raramente são tomadas de forma objetiva e com análises aprofundadas sobre as diversas alternativas. Sofremos o influxo de inúmeros fatores que diminuem nossa capacidade de julgar e de agir de forma racional. Segundo Kahneman, possuímos duas formas de pensar: uma rápida e pouco refletida (Sistema 1) e outra mais lenta, responsável por situações que exigem maior atenção (Sistema 2). Contudo, em alguns casos, decisões que demandariam a atuação da segunda forma de raciocinar seriam influenciadas por estereótipos e a reflexão não seria suficiente para superá-los.

Por mais que as pessoas queiram acreditar que suas decisões são, na maior parte do tempo, refletidas, os estudos têm mostrado que o Sistema 1 de pensamento é o que predomina. Não bastasse isso, as informações que temos a nosso dispor, nossas experiências e ideias influenciam no momento em que fazemos escolhas, ainda que de forma inconsciente ${ }^{96}$, sendo que, mesmo quando o Sistema 2 está atuando, depende de influxos do Sistema 1. Nesse sentido, por exemplo, as pessoas podem ser sugestionadas pela presença de advertências sobre os riscos para a saúde nas embalagens de produtos nocivos, bem como podem acreditar mais na probabilidade de repetição de um acontecimento se o tiverem vivido anteriormente do que se só tivessem lido a respeito em uma revista. Nesse panorama, desenvolveu-se a ideia de que seria possível criar determinadas influências positivas para que as pessoas fizessem a melhor escolha no momento de decidir ${ }^{97}$.

Dentre os diversos elementos que sugestionam as decisões e percepções das pessoas, há aquele que se baseia no gênero. Poderíamos enquadrar isso dentro do que em doutrina se conhece por viés da representatividade. Quando as pessoas são indagadas sobre se A deveria pertencer à categoria B, respondem após refletirem em que medida A é semelhante à imagem ou ao estereótipo que têm de B. Muitas vezes, essa heurística

93 Outro aspecto que merece uma análise cuidadosa é a quantidade de homens e mulheres que são convocados para atuar nos tribunais e quantos desses são promovidos a desembargadores por merecimento. Dados do TRF-1, por exemplo, indicam que há uma correlação entre esses números. Entre 2007 e 2017, 28 mulheres (16,96\%) e 137 homens (83,04\%) foram convocados para o tribunal. Desse total, $81,48 \%$ dos desembargadores promovidos no respetivo tribunal foram convocados anteriormente. Os dados a que tivemos acesso não fazem distinção por gênero quanto à promoção. Contudo, a partir desses dados é possível ter um indicativo de que esse é um campo de análise que merece ser explorado.

94 Sobre o tema, cf THALER, Richard H. Misbehaving: the making of behavioral economics. New York: W. W. Norton \& Company, 2016. CAMERER, Colin F.; LOEWENSTEIN, George; RABIN, Matthew (Eds.). Advances in behavioral economics. Princeton: Princeton University Press, 2004.

95 Cf. KAHNEMAN, Daniel; TVERSKY, Amos. Thinking, fast and slow. New York: Farrar Straus Giroux, 2013.; KAHNEMAN, Daniel; TVERSKY, Amos. The simulation heuristic. In: KAHNEMAN, Daniel; TVERSKY, Amos; SLOVIC, P. (Org.). Judgment under uncertainty: heuristics and biases. New York: Cambridge University Press, 1982. p. 201-208; TVERSKY, Amos; KAHNEMAN, Daniel. The framing of decisions and the psychology of choice. Science, v. 211, p. 453-458, 1981.

96 BANAJI, M.; GREENWALD, A. Blindspot: hidden biases of good people. New York: Delacorte Press, 2013.

97 Este é o modelo de ação que ficou conhecido como paternalismo libertário. De forma mais analítica, o governo não proíbe condutas nem compele o indivíduo a fazer algo que é bom para si mesmo, mas normatiza o contexto em que ele se insere, para o induzir a eleger a melhor alternativa. Trata-se de uma interferência do Estado na arquitetura da escolha, amparada na premissa de que nenhum ambiente de escolha é neutro. Assim, por exemplo, se, nas relações comerciais, os fornecedores tendem a sugestionar os consumidores a fazer as escolhas que tornam o negócio mais lucrativo, o governo poderia agir de forma a neutralizar essa influência, criando um panorama favorável à decisão que promova sua segurança ou saúde. THALER, Richard H.; SUNSTEIN, Cass R. Nudge: improving decisions about health, wealth, and happiness. New Haven: Yale University Press, 2008. SUNSTEIN, Cass R. Why nudge: the politics of libertarian paternalism. New Haven: Yale University Press, 2014. 
está certa, mas também pode provocar erros graves, o que se deve, principalmente, ao fato de que a maioria das pessoas não está disposta a admitir a probabilidade de que suas crenças arraigadas estejam erradas ${ }^{98}$. Nesse sentido, se socialmente predomina um padrão de pensamento enviesado de acordo com o qual as mulheres são associadas à família e ao trabalho doméstico e os homens, ao mundo dos negócios e à carrei$\mathrm{ra}^{99}$, esse modelo tenderá a motivar as decisões e julgamentos em variados cenários de forma insidiosa. Tais estereótipos atuam, muitas vezes, de forma implícita, afetando as mulheres em todas as esferas da vida ${ }^{100}$.

Nesse contexto, é preciso questionar se as próprias instituições e as fórmulas de acesso estão desenhadas e estruturadas de forma a favorecer o ingresso e a progressão na carreira de pessoas parecidas com aquelas responsáveis pelos processos de seleção e promoção. Como visto no item 1, o design dos órgãos estatais não é neutro. Para lidar com as desigualdades de gênero institucionalizadas, Iris Bohnet sustenta que é possível adotar mecanismos de design comportamental voltados para ambientes de preconceito (e não para pessoas individualmente consideradas), com foco nos locais de trabalho e em escolas ${ }^{101}$. A autora investiga quais as práticas institucionais vão de encontro à igualdade de gênero e, a partir disso, analisa formas de intervir no preconceito. Em outras palavras, recorre-se a nudges como meio de implementar uma política de paridade. Nessa fórmula, os indivíduos seriam encorajados a questionar suas ideias preconcebidas ao mesmo tempo em que a organização a que pertencem criaria novas formas de agir. Bohnet destaca que os anúncios de emprego e o próprio recrutamento para a composição do quadro de pessoal das organizações são generificados e permeados por discriminações, ainda que implícitas ${ }^{102}$. Nesse sentido, (re)delinear e (re)modelar os comportamentos dessas instituições pode ser uma forma de lidar com a desigualdade de gênero. Concomitantemente, é preciso incentivar nos indivíduos a autopercepção de que eles não devem agir de modo a anular suas perspectivas e individualidades em prol da assimilação da maioria. Caso contrário, o distanciamento entre aqueles que estão nos altos cargos em relação aos que se localizam nos cargos mais baixos seria acentuado e a igualdade estaria cada vez mais distante de ser atingida. Diante disso, a autora propõe práticas que promoveriam um maior engajamento do grupo e valorização das diferenças, como normas que promovam o empenho da equipe.

É possível aplicar essa forma de pensar e de combater a desigualdade também em ambientes mais amplos e em instituições políticas. Seriam adotadas normas sociais encorajadoras da compreensão do compor-

98 THALER, Richard H.; SUNSTEIN, Cass R. Nudge: improving decisions about health, wealth, and happiness. New Haven: Yale University Press, 2008. p. 26-31.

99 No Brasil, Maria Cândida Almeida explorou essa correlação de forma pioneira. Na avaliação da autora, esses preconceitos, que podem exercer influência no pensamento das próprias mulheres, impede que a presença feminina em espaços de poder seja mais elevada. Nas suas palavras: "Em razão dos vieses implícitos, tudo indica que os parâmetros de comparação entre homens e mulheres sejam mesmo distintos. E, como visto, as próprias mulheres não escapam desses preconceitos implícitos contra si. Isso as impede de protagonizar as mudanças estruturais que seriam necessárias para aumentar a sua representatividade nos espaços de poder. Não querem ser vistas como 'agressivas' ou 'confrontadoras' ou como alguém que requer tratamento especial. Cobramse mais e são mais cobradas. Sobre elas, impõem-se também expectativas quanto ao seu papel na família e o seu relacionamento com colegas e, por consequência, a sua exclusão do networking. Tais preconceitos também têm repercussão não só sobre relações profissionais entre magistrados e magistradas e o espaço que as juízas ocupam no Judiciário, como também sobre as interações com servidoras, estagiárias e advogadas”. ALMEIDA, Maria Cândida. Mulheres, vieses implícitos e o judiciário. Jota, mar. 2018. Disponível em: <https://www.jota.info/opiniao-e-analise/artigos/mulheres- vieses-implicitos-e-o-judiciario-12032018>. Acesso em: 29 maio 2018.

100 A título exemplificativo, cf. CECCHI-DIMEGLIO, P. How Gender Bias corrupts performance reviews, and what to do about it. Harvard Business Review, apr. 2017. Disponível em: <https://hbr.org/2017/04/how-gender-bias-corrupts-performancereviews-and-what-to-do- about-it>. Acesso em: 29 maio 2018. GVOZDANOVIC, J. Implicit bias in academia: a challenge to the meritocratic principle and to women's career - and what to do about it. League of European Research Universities, n. 23, 2018. LEE, Connie. Gender Bias in the Courtroom: combating implicit Bias against women trial attorneys and litigators. Cardozo Journal of Law \& Gender, v. 22, n. 229, p. 229-252, 2016. NEGOWET'TI, N. E. Implicit Bias and the legal profession's 'diversity crisis': a call for self-reflection. Nevada Law Journal, Las Vegas, v. 15, p. 431-460, 2015.

101 BOHNET, Iris. What works: gender equality by design. London: Harvard University Press, 2016.

102 Para solucionar o problema no recrutamento e na promoção de pessoal, Bohnet destaca três passos que deveriam ser tomados: i) avaliação comparativa e contratação e promoção em grupo; ii) exclusão de informações demográficas dos currículos (o gênero e a raça dos candidatos também poderiam ser retirados); e iii) entrevistas estruturadas para a avaliação dos candidatos. Cf. BOHNET, Iris. What works: gender equality by design. London: Harvard University Press, 2016. p. 123. 
tamento do outro e da forma de lidar com o grupo. Assim, Bohnet questiona os preconceitos inconscientes e o pensamento corrente a fim de enfrentar a desigualdade de gênero institucionalizada. Um exemplo de mecanismo fornecido pela autora é o encorajamento no sentido de mostrar às mulheres que elas podem atuar em "empregos de homem" sem perder sua feminilidade, como os Estados Unidos já fizeram. Até mesmo aspectos que podem parecer simples, como as paredes de quadros de dirigentes, diretores e afins, geram impactos na candidatura ou não de mulheres a determinados cargos ${ }^{103}$. Cotas de gênero também são vistas de forma positiva, já que garantem maior participação de indivíduos qualificados, mas sub-representados ${ }^{104}$.

Uma possível crítica que poderia ser levantada a essa tese consiste na ideia de que um ponto de vista feminista também pode ser considerado enviesado ${ }^{105}$. Todavia, na linha do que afirmamos até aqui, nenhuma perspectiva pode assumir a pretensão de neutralidade. O ponto de vista de quem formula um entendimento é sempre conformado pelas suas experiências e seu lugar no mundo. Nesse contexto, a contribuição que o raciocínio exposto neste estudo oferece é o de incentivar a reflexão sobre que tipos de vieses os variados pontos de vista incentivam. Para que tais vieses sejam, em alguma medida, superados, o primeiro passo é o seu reconhecimento. Escolhas racionais e informadas só se tornam possíveis quando a reflexão sobre as variáveis e preconceitos infiltrados no processo decisório é estimulada.

Paralelamente, reconhecer que as perspectivas, as pré-compreensões e os vieses determinam a forma pela qual decisões relevantes são tomadas nos permite repensar de que forma os critérios de escolha dos juízes dialogam com a noção de democracia. Se o ponto de vista dos agentes que formulam decisões é determinante, se sua biografia e experiências são elementos decisivos na arquitetura das escolhas e juízos que formularão, a discussão sobre a (falta de) legitimidade democrática de tribunais carentes de diversidade assume importância. Esse ponto é explorado no tópico a seguir.

\section{OS DILEMAS DA REPRESENTAÇÃO E POR QUE DIVERSIDADE IMPORTA}

Como visto nos tópicos anteriores, a identificação de estereótipos masculinos na formação da figura do juiz ideal e o diagnóstico sobre desequilíbrio de gênero nos tribunais abre um extenso campo de reflexão. É possível debater suas causas, desdobramentos e possíveis mecanismos de reversão. Porém, para que essas questões sejam assumidas como relevantes, uma pergunta crucial precisa ser enfrentada: por que diversidade na composição das instituições judiciárias importa?

Respostas a essa questão poderiam enveredar por múltiplas linhas. Seria possível, por exemplo, desde uma perspectiva de justiça constitucional substantiva, indagar se a configuração do judiciário revela violações ao princípio da igualdade e perquirir se há discriminações indiretas ${ }^{106}$ envolvidas nos processos de seleção e ascensão profissional das magistradas. Outra possibilidade seria, usando lentes institucionalistas e avaliações empíricas, pesquisar as potenciais consequências práticas de composições mais plurais na performance institucional das cortes ${ }^{107}$.

103 BOHNET, Iris. What works: gender equality by design. London: Harvard University Press, 2016. p. 201.

104 BOHNET, Iris. What works: gender equality by design. London: Harvard University Press, 2016. p. $204-219$.

105 Nesse sentido, o juiz da Corte da Inglaterra Jonathan Sumption sugeriu que vieses a favor da igualdade de gênero poderiam afastar homens talentosos da Corte. Cf. WALKER, Peter. Don't rush gender equality in UK judiciary, says supreme court judge. The Guardian, sep. 2015. Disponível em: <https://www.theguardian.com/law/2015/sep/22/gender-equality-warning- uk-legalprofession-supreme-court-judge-jonathan-sumption>. Acesso em: 31 maio 2018.

106 A ideia de discriminação indireta surgiu na seara trabalhista e, posteriormente, foi aplicada em diversos outros campos do Direito. Originou-se nos Estados Unidos, onde é conhecida como Teoria do Impacto Desproporcional (disparate impact theory). Sobre o tema, cf. CORBO, Wallace. Discriminação indireta: conceito, fundamentos e uma proposta de enfrentamento à luz da Constituição de 1988. Rio de Janeiro: Lumen Juris, 2017. HUNTER, Rosemary C.; SHOBEN, Elaine W. Disparate impact discrimination: american oddity or internationally accepted concept? Berkley Journal of Employment and Labor Law, v. 19, n. 1, p. 108-152, 1998. WILLBORN, Steven L. The disparate model of discrimination: theory and limits. American University Law Review, v. 34, p. 799-839, 1985.

107 Um amplo panorama das variadas pesquisas nesse campo pode ser encontrado em KENNEY, Sally J. Gender \& justice: why 
Esses campos de investigação, bem como outros não enumerados, são instigantes e merecem atenção. Nesse tópico, exploramos um aspecto teórico basilar relacionado à legitimação do poder dos tribunais. Defendemos a tese de que o atributo da diversidade na composição dos órgãos do poder judiciário deve ser compreendido como uma materialização do princípio democrático.

As democracias constitucionais contemporâneas foram edificadas a partir de promessas de promoção do pluralismo e igualdade. Nesse contexto, é natural o surgimento de demandas no sentido de que os órgãos do estado expressem coerência institucional, manifestando que esses valores estão presentes na sua própria composição. É intuitivo que a defesa normativa da diversidade na composição desses órgãos desponte como um desdobramento do próprio conjunto de valores pressuposto pelas democracias liberais ${ }^{108}$.

Essa linha de pensamento foi empregada recentemente por Lady Hale ${ }^{109}$, presidente da Suprema Corte do Reino Unido que durante oito anos foi a única juíza da corte ${ }^{110}$ :

Em uma democracia governada pelo povo e não por um monarca absoluto, ou mesmo por uma classe governante de aristocratas, o judiciário deve refletir a comunidade como um todo, e não apenas um pequeno segmento desta. Deve ser possível ao público sentir que as cortes são suas cortes; que seus casos estão sendo decididos e que o direito está sendo produzido por pessoas como eles, e não por alienígenas de outro planeta. No mundo moderno, onde a "deferência social" desapareceu em larga escala, isso deve potencializar em vez de minar a confiança do público no direito e no sistema jurídico.

A essa conexão mais ampla e intuitiva, que correlaciona diversidade e democracia, pode ser acrescentada uma outra perspectiva de análise. A discussão política costuma estabelecer uma ligação de sentido entre a ideia de representação e o princípio democrático. Nesse contexto, quando certo órgão do estado é rotulado como representativo, fica implícito que seu funcionamento atende a pressupostos democráticos. A correspondência de significado assumida no vocabulário contemporâneo é nítida: mais representação, geralmente, denota mais democracia.

Um exemplo dessa equivalência é a propagação da tese de que o judiciário angaria legitimidade democrática por também poder ser entendido como um poder representativo ${ }^{111}$. Essa discussão passou a circular de forma mais abrangente e literal na produção nacional a partir da defesa, por Robert Alexy ${ }^{112}$, da ideia de que o Judiciário age como representante argumentativo do povo. Para o autor, essa modalidade de representação opera de forma complementar e dialética à representação volitiva parlamentar ${ }^{113}$. No debate brasileiro, a tese se infiltrou na fundamentação das decisões do STF e na produção acadêmica. O ministro Gilmar Mendes, em decisões e entrevistas no ano de 2008, passou a sustentar que o Supremo atua como representante argumentativo da sociedade, para fundamentar a intromissão do Tribunal em questões difíceis ${ }^{114}$. De forma semelhante,

women in the judiciary really matter. New York: Routledge, 2012. p. 22.

108 Seguindo um itinerário diferente, mas concluindo que a razão fundamental para justificar o incremento da presença de mulheres no judiciário é a democracia, v. MALLESON, Kate. Justifying gender equality on the bench: why difference won’t do. Feminist Legal Studies, v. 11, p. 1-24, 2003.

109 HALE, Brenda. Lady Hale gives the Fiona wolf lecture for the women lanyers' division of the Law Society: women in the Judiciary. 2014. Disponível em: <https://www.supremecourt.uk/docs/speech-140627.pdf>. Acesso em: 27 maio 2018.

110 Em outubro de 2017, Lady Black tornou-se a segunda Juíza da Suprema Corte do Reino Unido.

111 EISGRUBER, Christopher L. Constitutional self-government. Cambridge: Harvard University Press, 2001.

112 ALEXY, Robert. Balancing, constitutional review and representation. International Journal of Constitutional Law, v. 3, n. 4, p. 572-581, out. 2005.

113 Alexy sustenta que, paralelamente à representação volitiva e decisória dos Parlamentos, um modelo de democracia discursiva deve conter elementos de representação argumentativa. Desse modo, enquanto a representação política parlamentar é pautada na intersecção desses dois aspectos representativos - instrumentalizados através do voto, da deliberação e da reeleição -, a representação exercida pelas Cortes Constitucionais é "puramente argumentativa", ou seja, pautada na persuasão e correção dos argumentos utilizados pelos magistrados, considerando que estes não são diretamente eleitos pela população. $\mathrm{O}$ autor pontua, todavia, que "a existência de argumentos bons e plausíveis não basta [...] para a representação. Para isso, é necessário que o tribunal não só promova a pretensão de que seus argumentos são os argumentos do povo ou do cidadão; um número suficiente de cidadãos precisa, pelo menos em perspectiva mais prolongada, aceitar esses argumentos como corretos." (tradução livre). ALEXY, Robert. Balancing, constitutional review and representation. International Journal of Constitutional Law, v. 3, n. 4, p. 580, out. 2005.

114 Confira-se a entrevista publicada em junho de 2008 no jornal Valor Econômico, na qual o Ministro, então presidente do STF, 
Thamy Pogrebinschi ${ }^{115}$ defendeu uma releitura da representação política, expandindo seus fundamentos e as condições de validade e legitimidade. Conectando o conceito de representação com as categorias da delegação, da accountability e da legitimação pelo resultado, a autora afirma que o conceito de representação pode ser aplicado ao judiciário. Em linha análoga, o ministro Luís Roberto Barroso ${ }^{116}$ tem desenvolvido, nos últimos anos, a ideia de que a jurisdição constitucional desempenha uma função representativa, paralelamente à contramajoritária ${ }^{117}$.

A tese de que o judiciário possui legitimidade democrática por funcionar como representante da sociedade, da forma como foi sustentada pelos ministros do STF, é permeada por dilemas. Ela encerra o risco de que juízes, ao invocarem o status de representantes como um fator de legitimação ex ante para agir em nome do povo, internalizem uma autoimagem institucional idealizada e divorciada da realidade. Nesse sentido, um papel representativo evocado pelos próprios juízes pode gerar um efeito contrário ao que a noção de representação democrática costuma perseguir. A experiência recente tem mostrado que "não é pequeno o risco de que esse conceito seja invocado e naturalizado com o propósito puramente persuasivo de invocar uma legitimação a priori da ação do Tribunal"118_119.

Não obstante, a ideia de que o judiciário tem uma faceta representativa pode operar como um ideal regulativo. Nessa perspectiva, a atuação representativa não deve ser entendida como um atributo inerente à função judicial ou como um fator de legitimação formal prévia, mas como um ônus institucional a ser perseguido pelas cortes, traduzido em um dever de abertura, porosidade e conformação do judiciário às demandas democráticas. Entendemos que descritivamente só será possível aferir se o Judiciário atuou de forma representativa por meio de análises retrospectivas sobre sua estruturação e funcionamento, que avaliem os impactos substantivos das decisões e as práticas processuais adotadas. Normativamente, o conceito de representação democrática do judiciário deve funcionar como um fator de avaliação das cortes quanto à transparência institucional, porosidade às demandas da sociedade civil e abertura a diversos de pontos de vista. Entendida sob essa perspectiva, a noção de representação argumentativa pressupõe que as cortes sejam institucionalmente estruturadas como organismos com composição plural.

afirma que este é “'Casa do povo' com a função de suprir as deficiências do Poder Legislativo, o Congresso Nacional”. BASILE, Juliano. Para p-l $\quad$-residente do STF, tribunal supre deficiências do Legislativo. Valor Econômico, São Paulo, jun. 2008. Disponível em: <http://www.valoronline.com.br/valoreconomico/285/primeirocaderno/politica/Para + o + presi dente+do+STF + tribunal + supre + deficiencias + do + Legislativo, ,60,4973950.html?highlight $=\& \quad$ newsid $=4973950$ \&areaid $=60 \&$ editionid $=2023>$. Acesso em: 27 maio 2018. No mesmo sentido, Gilmar Mendes se referiu aos juízes como “representantes argumentativos” da sociedade em seu voto prolatado no julgamento da ADI 3510-0.

115 POGREBINSCHI, Thamy. Judicialização ou representação: política, direito e democracia no Brasil. Rio de Janeiro: Elsevier, 2011. p. 165-183.

116 BARROSO, Luís Roberto; MENDONÇA, Eduardo. A razão sem voto: o Supremo Tribunal Federal e o governo da maioria. Revista Brasileira de Políticas Públicas, v. 5, p. 23-50, 2015. BARROSO, Luís Roberto. Contramajoritário, representativo e iluminista: os papeis dos tribunais constitucionais nas democracias contemporâneas. Direito \& Práxis, Rio de Janeiro, 2017., Ahead of print. Apresentando uma visão crítica a esse entendimento, veja-se PEREIRA, Jane Reis Gonçalves. Representação democrática do Judiciário: reflexões preliminares sobre os riscos e dilemas de uma ideia em ascensão. Juris Poiesis, Rio de Janeiro, v. 17, p. 343-359, 2014.

117 “[O] fato é que um olhar reconstrutivo sobre a jurisprudência e a própria postura da Corte permite concluir que ela tem desenvolvido, de forma crescente, uma nítida percepção de si mesma como representante da soberania popular. Mais precisamente, como representante de decisões soberanas materializadas na Constituição Federal e difundidas por meio de um sentimento constitucional que, venturosamente, se irradiou pela sociedade como um todo". BARROSO, Luís Roberto; MENDONÇA, Eduardo. Retrospectiva 2012: STF entre seus papéis contramajoritário e representativo. 2012. Disponível em: < http://www.conjur.com. br/2013- jan-03/retrospectiva-2012-stf-entre-papeis-contramajoritario-representativo >. Acesso em: 27 maio 2018.

118 PEREIRA, Jane Reis Gonçalves. Representação democrática do Judiciário: reflexões preliminares sobre os riscos e dilemas de uma ideia em ascensão. Juris Poiesis, Rio de Janeiro, v. 17, p. 343-359, 2014. Há variações dessa ideia externadas em NONATO, Israel. O Supremo não é oráculo: conversas acadêmicas com Jane Reis. 2013. Disponível em: <http://www.osconstitucionalistas. com.br/jane-reis-o-supremo-nao-e-oraculo>. Acesso em: 29 maio 2018. e PEREIRA, Jane Reis Gonçalves. Retrospectiva direito constitucional 2008: a expansão do Judiciário e o constitucionalismo cosmopolita. Revista Direito do Estado, v. 13, p. 23-53, 2008. 119 Um exemplo desse uso do conceito ocorreu no julgamento da constitucionalidade da Lei de Biossegurança ADI nº 3510, em que o Ministro Gilmar Mendes afirmou que o STF "pode ser uma casa do povo, tal qual o Parlamento". 
O conceito de representação pode ser abordado sob um enfoque formal ou material ${ }^{120}$. Nesse sentido, podemos distinguir representação técnico-jurídica e representação política. No primeiro sentido, jurídico-formal, todos os órgãos do estado são representativos, pois exercem poderes e funções em decorrência de uma autorização tácita dos cidadãos que deflui da própria estrutura e desenho das instituições. Na segunda abordagem, de ordem política, é pressuposto um nexo de legitimação genética entre a vontade do povo e o agir dos órgãos de representação democrática, que decorre do processo de designação eleitoral. Nesse segundo sentido, a representação pressupõe uma conexão do povo como as decisões tomadas pelos órgãos eleitos.

No clássico estudo de Hannah Pitkin ${ }^{121}$, que parte da segunda compreensão, são enumeradas quatro formas pelas quais a representação política costuma ser explicada ${ }^{122}$, que podem ser assim sintetizadas: i) representação formalista, que diz respeito à autorização que os órgãos estatais recebem dos cidadãos para agir, bem como da responsividade que possuem; ii) representação simbólica, na qual o foco recai sobre o grau de apoio e de correspondência às expectativas dos cidadãos que o representante possui; iii) representação descritiva ou identitária, de acordo com a qual as instituições do estado devem ser um espelho da composição social; e iv) representação substantiva, que destaca que os representantes devem atender às preferências e aos interesses dos representados.

A defesa de que os órgãos de cúpula do poder judiciário devem respeitar a pluralidade social, em geral, e a diversidade de gênero, em particular, coloca em foco o conceito de representação descritiva ou identitária. Além do gênero, que é o objeto central deste artigo, traços identitários como raça, religião, nacionalidade e origem também demandam atenção ${ }^{123}$. Para ter sua legitimidade reforçada, "é desejável, nas democracias plurais, que todos os órgãos do Estado reflitam simbolicamente os variados segmentos sociais" 124 . Nessa dimensão, assume importância que os representantes guardem alguma afinidade de características com os representados, de modo que os órgãos estatais reflitam as diferenças presentes na sociedade.

Partindo desse foco de análise, emerge uma conexão entre a representação descritiva e a legitimidade democrática do poder judiciário para interceder em questões submetidas às instâncias representativas eleitas. A associação entre legitimidade e diversidade na composição pode ficar clara, por exemplo, na preocupação de cortes supranacionais quanto à pluralidade de nacionalidade dos juízes ${ }^{125}$. Em sentido parecido, há, na Suprema Corte do Canadá, esforço para atingir uma representação continental e multiétnica: critérios geográficos são adotados para selecionar os magistrados da Corte ${ }^{126}$. Os novos modelos de constitucionalismo

120 De acordo com Ernst-Wolfgang Böckenförde, no sentido formal, representação significa a autorização que os órgãos de direção política recebem dos cidadãos. Nessa acepção, a representação é o "nexo de legitimação e de imputação que existe ou se estabelece entre a ação dos órgãos de direção e o povo". No sentido material, a representação se refere ao fato de que os cidadãos devem poder reconhecer-se nas ações dos órgãos de Estado, relacionando-se à "capacidade dos atos emanados do Estado de gerar aceitação e inclinação à obediência” (tradução livre). BÖCKENFÖRDE, Ennst-Wolfgang. Democracia y representación: crítica a la discusión actual sobre la democracia. In: BÖCKENFÖRDE, Ernst-Wolfgang. Estudios sobre el Estado de Derecho y la democracia. Madrid: Trotta, 1993. p. 145-146.

121 PITKIN, Hannah Fenichel. The concept of representation. Berkeley: University of California Press, 1967.

122 Destacando os quatro sentidos de representação aqui elencados, cf. PEREIRA, Jane Reis Gonçalves. Representação democrática do Judiciário: reflexões preliminares sobre os riscos e dilemas de uma ideia em ascensão. Juris Poiesis, Rio de Janeiro, v. 17, p. 343-359, 2014.

123 O chief constable inglês Peter Fahy fez interessante observação quanto à etnia dos julgadores, cuja importância variaria de acordo com o tema em debate: "When your house is burning down you are not interested in the ethnicity of the firefighter, but when it is a long term issue of youth alienation, countering extremism or dealing with complex matters such as female genital mutilation the ethnicity of the law enforcer makes a huge difference". O entendimento foi expresso por Peter Fahy em conversa com a juíza inglesa Lady Hale, como ela afirmou em palestra proferida em 2014. Disponível em: <https://www.supremecourt.uk/ docs/speech-140627.pdf>. Acesso em: 29 maio 2018.

124 PEREIRA, Jane Reis Gonçalves. Representação democrática do Judiciário: reflexões preliminares sobre os riscos e dilemas de uma ideia em ascensão. Juris Poiesis, Rio de Janeiro, v. 17, p. 352, 2014.

125 DANNENBAUM, Tom. Nationality and the international judge: the nationalist presumption governing the international judiciary and why it must be reversed. Cornell International Law Journal, v. 45, p. 77-184, 2012.

126 SONGER, Donald R. The transformation of the Supreme Court of Canada: an empirical examination. Toronto: University of Toronto Press, 2008. 
plurinacional também têm colocado a demanda de composição pluriétnica como um de seus desafios ${ }^{127}$.

Vale ressaltar que, na visão perfilhada no clássico estudo de Hannah Pitkin ${ }^{128}$, é o que uma instituição faz e não o que ela é que determina se é representativa. Todavia, compreensões mais inclusivas da representação legislativa, que envolvem a perspectiva das minorias, reconhecem a importância da inserção dos grupos historicamente excluídos do processo político como representantes ${ }^{129}$. De acordo com Anne Phillips, mesmo que os representantes promovam com eficiência os interesses dos marginalizados, isso não seria suficiente, por se tratar de uma proteção paternalista que perpetua a exclusão e mantém diminuído o status político dos excluídos da arena de representação. Nesse contexto, por mais bem-intencionados que sejam os representantes, determinados grupos de cidadãos permaneceriam alienados e infantilizados no processo decisório ${ }^{130}$. Essa noção de representação simbólica dos diversos grupos sociais como uma exigência democrática, construída em relação ao legislativo, também pode ser aplicada ao judiciário ${ }^{131}$.

Estudos acadêmicos têm demonstrado que fatores extrajurídicos influenciam na tomada de decisão por parte dos juízes ${ }^{132}$. Ainda que raramente se possa estabelecer correlações decisivas entre os entendimentos adotados e a identidade do juiz, algumas pesquisas sugerem que, pelo menos em questões sensíveis ao gênero, como discriminação, assédio sexual e violência doméstica, a mera presença de mulheres em órgãos colegiados interfere no resultado dos julgamentos, possivelmente porque a diversidade na composição exerceria impacto também nos entendimentos adotados pelos juízes homens ${ }^{133}$. No entanto, sob o ângulo da legitimação das cortes, não são apenas os resultados dos julgamentos que importam. O argumento mais consistente em favor da pluralidade de composição não decorre da convicção de que cortes heterogêneas vão produzir julgamentos mais acertados, mas da circunstância de que o equilibrio de gênero torna os tribunais mais legítimos sob a ótica democrática.

O caso Hobby Lobby ${ }^{134}$, decidido pela Suprema Corte dos Estados Unidos em 2014, exemplifica como o gênero na composição das Cortes pode repercutir na percepção social sobre o entendimento adotado pelos juízes em questões sensíveis nesse campo. Estavam em discussão as formas pelas quais mulheres poderiam obter acesso a diferentes métodos anticoncepcionais nos planos de saúde oferecidos por empresas. A decisão da Corte foi no sentido de que pequenas empresas poderiam invocar a liberdade religiosa para não serem obrigadas a custear formas de contracepção que conflitem com crenças de seus proprietários. Esse entendimento, porém, deu-se por meio de apertada maioria. Foram cinco votos corroborando essa opinião e quatro votos contrários, dos quais três foram das juízas que integram a corte. A juíza Ruth Ginsburg, que redigiu o voto dissidente, afirmou, posteriormente, que "os juízes homens não compreendem o que Hobby Lobby significou para as mulheres" ${ }^{135}$. Tal episódio, ainda que não possa ser tomado como indicativo da existência de um nexo de causalidade entre o gênero dos julgadores e seus entendimentos, explicita que a baixa diversidade na composição das cortes pode suscitar inquietações que repercutem na percepção exter-

127 TIERNEY, Stephen. We the peoples: constituent power and constitutionalism in plurinational states. In: WALKER, Neil;

LOUGHLIN, Loughlin (Org.). The paradox of Constitutionalism. Oxford: Oxford University Press, 2007, p. 229-246. p. $229-246$.

128 PITKIN, Hannah Fenichel. The concept of representation. Berkeley: University of California Press, 1967.

129 PHILLIPS, Anne. The politics of presence. Oxford: Oxford University Press, 1995.

130 PHILLIPS, Anne. The politics of presence. Oxford: Oxford University Press, 1995. p. 39.

131 Nesse sentido, MALLESON, Kate. Justifying gender equality on the bench: why difference won’t do. Feminist Legal Studies, v. 11, p. 1-24, 2003. KENNEY, Sally J. Gender \& justice: why women in the judiciary really matter. New York: Routledge, 2012.

132 V., por todos, MELLO, Patrícia Perrone Campos. Nos bastidores do Supremo Tribunal Federal: Constituição, emoção, estratégia e espetáculo. São Paulo: GEN, 2015.

133 BOYD, Christina L.; EPSTEIN, Lee; MARTIN, Andrew D. Untangling the causal effects of sex on judging. American Journal of Political Science, v. 54, n. 2, p. 389-411, 2010.; KENNEY, Sally J. Thinking about gender and judging. International Journal of the Legal Profession, v. 15, n. 1-2, p. 87-110, mar./jul. 2008.

134 O inteiro teor da decisão (Burwell v. Hobby Lobby, 573 U.S, 2014) está disponível em: <http://www.supremecourt.gov/ opinions/13pdf/13-354_olp1.pdf>. Acesso em: 29 maio 2018.

135 FLATOW, Nicole. Ruth Bader Ginsburg: male justices don't understand what hobby lobby meant for women. Think Progress, jul. 2014. Disponível em: <thinkprogress.org/justice/2014/07/31/3466213/ruth-bader-ginsburg-male-justices-dont- understandwhat-hobby-lobby-meant-for-women>. Acesso em: 29 maio 2018. 
na sobre os julgamentos. Além disso, apesar de o resultado ter sido desfavorável às mulheres, a apresentação de votos divergentes pelas juízas cumpre um papel democrático ao pluralizar os pontos de vista e enriquecer o debate público com o acréscimo de perspectivas.

Essa tese está sintonizada com a ideia de que a representação serve como um canal de compartilhamento de perspectivas sociais. Iris Marion Young, desenvolvendo as formulações de Hanna Pitkin, sustenta que a representação pode ser calcada em opiniões, interesses e perspectivas. Segundo a autora, a "diferenciação de grupos propicia recursos para um público democrático comunicativo que visa estabelecer a justiça, uma vez que pessoas diferentemente posicionadas têm diferentes experiências, histórias e compreensões sociais, derivadas daquele posicionamento" ${ }^{136}$. Isso significa que, conforme a posição que ocupam na sociedade, as pessoas elaboram significados e se engajam em certas formas de relacionamentos sociais distintos, com os quais pessoas de grupos diferentes não se associam, sendo que, em certos cenários, sequer terão consciência de como operam. Em geral, a inserção em determinado grupo social confere às pessoas entendimentos distintos dos fatos sociais e de seus desdobramentos. Portanto, "cada grupo diferentemente posicionado tem uma experiência ou um ponto de vista particular acerca dos processos sociais precisamente porque cada qual faz parte desses processos e contribui para produzir suas configurações". Para Young, "é especialmente quando estão situadas em diferentes lados das relações de desigualdade estrutural que as pessoas entendem essas relações e suas consequências de modos diferentes"137.

Nesse contexto, para que o judiciário atenda ao ideal regulativo de ser apto a atuar na condição de representante da sociedade no debate jurídico, as cortes devem espelhar a pluralidade da sociedade.

\section{ENCERRAMENTO}

A expansão da esfera de ação do poder judiciário é um fenômeno presente na maior parte das democracias ocidentais contemporâneas.

No cenário brasileiro, os tribunais converteram-se em protagonistas incontornáveis nos debates políticos. Na última década, os ministros do Supremo passaram a falar abertamente na corte como "uma casa de fazer destino"138, a imputar aos juízes a função de "representantes argumentativos" 139 da sociedade e a entender que podem agir como intérpretes do "sentimento social"140.

Os julgamentos televisionados transformaram-se em espetáculos ${ }^{141}$ fascinantes que ora se apresentam como reações aos movimentos sociais, ora operam como ações que deflagram combustões políticas.

Essa centralidade no judiciário na dinâmica estatal e social - ainda que preocupante e criticável por ser qualificada como causa ou talvez como sintoma da disfuncionalidade das instâncias tradicionais de representação - coloca em evidência que as fronteiras que separam direto e política, que jamais foram claras, estão cada vez mais borradas.

Uma vez que os juízes são percebidos como atores relevantes na dinâmica da construção do significado do direito e das políticas públicas, torna-se natural aplicar à sua composição a premissa essencial do ideal democrático, segundo a qual aqueles que são afetados pelas decisões do estado devem estar aptos a acessar

136 YOUNG, Iris Marion. Representação política, identidade e minorias. Lua Nova, São Paulo, n. 67, p. 139-190, 2006.

137 YOUNG, Iris Marion. Representação política, identidade e minorias. Lua Nova, São Paulo, n. 67, p. 162, 2006.

138 Foi o que afirmou o Ministro Carlos Britto em seu voto durante o julgamento da ADI 3510-0.

139 Foi o que afirmou o Ministro Gilmar Mendes em seu voto durante o julgamento da ADI 3510- 0.

140 ROXO, Sérgio. Barroso diz que Constituição deve ser interpretada em 'sintonia com o sentimento social'. O Globo, abr. 2018. Disponível em: <https://oglobo.globo.com/brasil/barroso-diz-que-constituicao-deve-ser-interpretada-em- sintonia-comsentimento-social-22549589>. Acesso em: 31 maio 2018.

141 MELLO, Patrícia Perrone Campos. Quando julgar se torna um espetáculo: a interação entre o Supremo Tribunal Federal e a opinião pública, a partir de reflexões da literatura estrangeira. Revista de Direito Internacional, Brasília, v. 14, n. 1, p. $402-423,2017$. 
os órgãos que as formulam. Conforme aumenta o poder dos juízes de interferir no rumo da vida social, cresce em importância a discussão sobre quem integra os tribunais, que critérios de acesso são empregados e de que forma se deve buscar que os vários grupos sociais estejam neles representados.

Não se trata de adotar uma leitura essencialista, segundo a qual as mulheres teriam atributos particulares que representariam um ganho de resultado na performance ou na qualidade da decisão das cortes. A questão crucial no debate sobre a carência de diversidade nos tribunais repousa no ganho de legitimidade que advém do fato de serem compostos por pessoas de perspectivas diferentes, bem como na ativação da dimensão simbólica da democracia. Essa leitura não é incompatível com o ideal de que os juízes atuem com imparcialidade, precisamente porque não se presume que os julgamentos serão diferentes pelo fato de serem conduzidos por homens ou mulheres. Trata-se de reconhecer que, no plano simbólico, a confiança nas decisões depende não apenas dos resultados que produzem, mas da percepção de que são institucionalmente acessíveis àqueles que são destinatários de suas ordens. Um judiciário que encerra equilíbrio de gênero expressa em sua textura institucional uma mensagem de equivalência de status cívico entre homens e mulheres. Isso porque, afinal, o pessoal é político, e o judiciário também.

\section{REFERÊNCIAS}

A TRAJETÓRIA da primeira mulher a integrar o Supremo. Consultor Jurídico, São Paulo, ago. 2011. Disponível em: <https://www.conjur.com.br/2011-ago-11/ellen-gracie-trajetoria-primeira-mulher-integrarsupremo>. Acesso em: 29 maio 2018.

ABRAHAMSON, Shirley S. The woman has robes: four questions. Golden Gate Law Review, v. 14, n. 3, p. 489-503, 1984.

ALEGRETTI, Laís. Plenário do Senado terá banbeiro feminino 55 anos após inauguração. Brasília. 2016. Disponível em: <http://g1.globo.com/politica/noticia/2016/01/plenario-do-senado-tera-banheiro-feminino-55-anos-apos-inauguracao.html>. Acesso em: 27 maio 2018.

ALEXY, Robert. Balancing, constitutional review and representation. International Journal of Constitutional Law, v. 3, n. 4, p. 572-581, out. 2005.

ALMEIDA, Maria Cândida. Mulheres, vieses implícitos e o judiciário. Jota, mar. 2018. Disponível em: <https://www.jota.info/opiniao-e-analise/artigos/mulheres-vieses-implicitos-e-o-judiciario-12032018>. Acesso em: 29 maio 2018.

ALMEIDA, Rodolfo; ZANLORENSSI, Gabriel. Gênero e raça de estudantes do ensino superior no Brasil por curso e área. Nexo Jornal, dez. 2017. Disponível em: <https://www.nexojornal.com.br/grafico/2017/12/13/Gênero-e-raça-de-estudantes-do-ensino-superior-no-Brasil-por-curso-e-área>. Acesso em: 29 maio 2018.

ALVES, Clara da Mota Santos Pimenta. Gênero, espaço público e poder: uma análise sobre a composição das comissões examinadoras de concurso da magistratura. Revista Publicum, Rio de Janeiro, v. 3, n. 1, p. 352370, 2017.

AMOSSY, Ruth (Org.). Imagens de si no discurso: a construção do ethos. São Paulo: Contexto, 2005.

ARAUJO, Heloisa Bianquini. Qual o gênero do Supremo?: diálogo institucional nas sabatinas para o STF, poder e profissionalismo. 2015. Trabalho de Conclusão de Curso (Graduação em Direito) - Escola de Formação da Sociedade Brasileira de Direito Público, São Paulo, 2015.

BANAJI, M.; GREENWALD, A. Blindspot: hidden biases of good people. New York: Delacorte Press, 2013.

BARROSO, Luís Roberto. Contramajoritário, representativo e iluminista: os papeis dos tribunais constitu- 
cionais nas democracias contemporâneas. Direito \& Práxis, Rio de Janeiro, 2017.

BARROSO, Luís Roberto; MENDONÇA, Eduardo. A razão sem voto: o Supremo Tribunal Federal e o governo da maioria. Revista Brasileira de Políticas Públicas, v. 5, p. 23-50, 2015.

BARROSO, Luís Roberto; MENDONÇA, Eduardo. Retrospectiva 2012: STF entre seus papéis contramajoritário e representativo. 2012. Disponível em: <http://www.conjur.com.br/2013-jan-03/retrospectiva2012-stf-entre-papeis-contramajoritario-representativo>. Acesso em: 27 maio 2018.

BASILE, Juliano. Para presidente do STF, tribunal supre deficiências do Legislativo. Valor Econômico, São Paulo, jun. 2008. Disponível em: < http://www.valoronline.com.br/valoreconomico/285/primeirocaderno/politica/Para + o+ presidente + do + STF + tribunal+supre+deficiencias + do +Legislativo, ,60,4973950.htm l?highlight $=$ \&newsid $=4973950$ \&areaid=60\&editionid=2023 $>$. Acesso em: 27 maio 2018.

BENHABIB, Seyla. Situating the self: gender, community and postmodernity in contemporary ethics. Cambridge: Polity, 1992.

BERNADETE Pedrosa, a primeira mulher a ser admitida como professora da Faculdade de Direito do Recife em 1965. 2018. Disponível em: <https://www.ufpe.br/arquivoccj/curiosidades/-/asset_publisher/ x1R6vFfGRYss/content/1965-primeira-professora-de-direito-no-recife/590249>. Acesso em: 29 maio 2018.

BERNS, Sandra. To speak as a judge: difference, voice and power. Dartmouth: Ashgate, 1999.

BOBBIO, Norberto. O positivismo jurídico: lições de filosofia do direito. São Paulo: Ícone, 1995.

BÖCKENFÖRDE, Ernst-Wolfgang. Democracia y representación: crítica a la discusión actual sobre la democracia. In: BÖCKENFÖRDE, Ernst-Wolfgang. Estudios sobre el Estado de Derecho y la democracia. Madrid: Trotta, 1993.

BOHNET, Iris. What works: gender equality by design. London: Harvard University Press, 2016.

BOLTON, Sharon C.; MUZIO, Daniel. Can't live with 'Em; Can't Live without 'Em: gendered segmentation in the legal profession. Sociology, Chicago, v. 41, n. 1, p. 47-64, 2007.

BONELLI, Maria da Glória. Profissionalismo e diferença de gênero na magistratura paulista. Civitas, Porto Alegre, v. 10, n. 2, p. 270-292, maio/ago. 2010.

BONELLI, Maria da Glória. Profissionalismo, gênero e significados da diferença entre juízes e juízas estaduais e federais. Contemporânea, n. 1, p. 103-123, jan./jun. 2011.

BOURDIEU, Pierre. Distinction: a social critique of the judgment of taste. Cambridge: Harvard University Press, 1984 [1979].

BOURDIEU, Pierre. Esboço de uma teoria da prática: precedido de três estudos de etnologia kabila. Oeiras: Celta, 2002 [1972].

BOURDIEU, Pierre. The logic of practice. Cambridge: Polity Press, 1990 [1980].

BOYD, Christina L.; EPSTEIN, Lee; MARTIN, Andrew D. Untangling the causal effects of sex on judging. American Journal of Political Science, v. 54, n. 2, p. 389-411, 2010.

BRAH, Avtar. Diferença, diversidade e diferenciação. Cardenos Pagu, Campinas, v. 26, p. 329-376, jan./jun. 2006.

BRASIL. Conselho Nacional de Justiça. Censo do Poder Judiciário: VIDE: Vetores iniciais e dados estatísticos. Brasília: CNJ, 2014.

CAMARGO, Margarida Maria Lacombe. Interpretação constitucional. In: CAMARGO, Margarida Maria Lacombe (Org.). 1988-1998: uma década de constituição. Rio de Janeiro: Renovar, 1999. 
CAMERER, Colin F.; LOEWENSTEIN, George; RABIN, Matthew (Eds.). Advances in behavioral economics. Princeton: Princeton University Press, 2004.

CECCHI-DIMEGLIO, P. How gender Bias corrupts performance reviews, and what to do about it. Harvard Business Review, apr. 2017. Disponível em: < https://hbr.org/2017/04/how-gender-bias-corrupts-performance-reviews-and-what-to-do-about-it>. Acesso em: 29 maio 2018.

COLBY, Anne; DAMON, William. Listening to a different voice: a review of Gilligan's "in a different voice". Merrill-Palmer Quarterly, v. 29, n. 4, p. 473-481, oct. 1983.

COMISSÃO AJUFE MULHERES. Nota Técnica: AJUFE mulheres 01/2017: resultados da pesquisa para se conhecer o perfil das associadas da AJUFE. Brasília: AJUFE Mulheres, 2017.

CONAGHAN, J. Reassessing the Feminist Theoretical Project in law. Journal of Law \& Society, v. 27, n. 3, p. 351-385, 2000.

CONHEÇA a primeira mulher a ocupar o cargo de juíza no país. Donna, out. 2008. Disponível em: < http:// revistadonna.clicrbs.com.br/noticia/conheca-a-primeira-mulher-a-ocupar-o-cargo-de-juiza-no-pais/>. Acesso em: 29 maio 2018.

CORBO, Wallace. Discriminação indireta: conceito, fundamentos e uma proposta de enfrentamento à luz da Constituição de 1988. Rio de Janeiro: Lumen Juris, 2017.

CRENSHAW, Kimberlé Williams; CHO, Sumi; MCCALL, Lesli. Demarginalizing the intersection of race and sex: a black feminist critique of antidiscrimination doctrine, feminist theory and antiracist politics. The University of Chicago Legal Forum, v. 139, p. 139-167, 1989.

CRENSHAW, Kimberlé Williams; CHO, Sumi; MCCALL, Lesli. Mapping the margins: intersectionality, identity politics, and violence against women of color. Stanford Law Review, v. 43, n. 6, p. 1241-1299, 1991.

CRENSHAW, Kimberlé Williams; CHO, Sumi; MCCALL, Lesli. Toward a field of intersectionality studies: theory, applications, and praxis. Signs: Journal of Women in Culture and Society, v. 38, n. 4, p. 785-810, 2013.

CRUZ, Adriana Alves dos Santos; ALVIM, Alcione Escobar da Costa. As questões raciais e poder judiciário: enfrentamentos necessários. In: PIMENTA, Clara Mota et al (Orgs.). Magistratura e equidade: estudos sobre gênero e raça no poder judiciário. Belo Horizonte: D’Plácido, 2018.

DANNENBAUM, Tom. Nationality and the international judge: the nationalist presumption governing the international judiciary and why it must be reversed. Cornell International Law Journal, v. 45, p. 77-184, 2012.

DAVIDSON, M. J.; COOPER, C. L. Shattering the glass ceiling: the woman manager. London: Paul Chapman Publishing, 1992.

DAVIS, Angela. Mulheres, raça e classe. São Paulo: Boitempo, 2016.

D’ELLA, Mirella. Ministra quebra tradição e usa calça no STF. Brasília. 2007. Disponível em: <http://g1.globo. com/Noticias/Politica/0,MUL11565-5601,00-MINISTRA+QUEBRA+TRADICAO+E+USA+CALCA +NO+STF.html>. Acesso em: 27 maio 2018.

DUARTE, Cláudia Türner Pereira. O sistema familiar na teoria política: repensando o lugar da criança na teoria da justiça. 2016. Dissertação (Mestrado em Direito) - Universidade do Estado do Rio de Janeiro, Rio de Janeiro, 2016.

DWORKIN, Ronald. O império do direito. São Paulo: Martins Fontes, 1999.

EISGRUBER, Christopher L. Constitutional self-government. Cambridge: Harvard University Press, 2001.

FEENAN, Dermot. Editorial introduction: women and judging. Feminist Legal Studies, v. 17, p. 1-9, 2009.

FLATOW, Nicole. Ruth Bader Ginsburg: male justices don't understand what hobby lobby meant for wo- 
men. Think Progress, jul. 2014. Disponível em: <thinkprogress.org/justice/2014/07/31/3466213/ruth-bader-ginsburg-male-justices-dont-understand-what-hobby-lobby-meant-for-women>. Acesso em: 29 maio 2018 .

FRAGALE FILHO, Roberto; MOREIRA, Rafaela Selem; SCIAMMARELLA, Ana Paula de O. Magistratura e gênero: um olhar sobre as mulheres nas cúpulas do judiciário brasileiro. E-cadernos CES, n. 24, p. 57-77, 2015.

FRANK, Jerome. The cult of the robe. In: FRANK, Jerome. Courts on trial: myth and reality in american justice. Princeton: Princeton University Press, 1973.

GILLIGAN, Carol. In a different voice: psychological theory and women's development. Cambridge: Harvard University Press, 2003.

GREENO, Catherine G.; MACCOBY, Eleanor E. How different is the "different voice"?. Signs, v. 11, n. 2, p. 310-316, 1986.

GUEDES, Moema de Castro. A presença feminina nos cursos universitários e nas pós-graduações: desconstruindo a idéia da universidade como espaço masculino. História, Ciências, Saúde - Manguinhos, Rio de Janeiro, v. 15 , p. $117-132$, jun. 2008.

GUIMARÃES, Lúcia Maria Paschoal; FERREIRA, Tania Maria Tavares. Myrthes Gomes de Campos (1875?): pioneirismo na luta pelo exercício da advocacia e defesa da emancipação feminina. Revista do Instituto de Estudos de Gênero, Niterói, v. 9, n. 2, p. 135-151, 2009.

GVOZDANOVIC, J. Implicit bias in academia: a challenge to the meritocratic principle and to women's career - and what to do about it. League of European Research Universities, n. 23, 2018.

HALE, Brenda. Lady Hale gives the Fiona woolf lecture for the women lawyers' division of the Law Society: women in the Judiciary. 2014. Disponível em: <https://www.supremecourt.uk/docs/speech-140627.pdf>. Acesso em: 27 maio 2018.

HANISCH, Carol. The personal is political. Disponível em: < http://www.carolhanisch.org/CHwritings/PIP. html>. Acesso em: 30 maio 2018.

HARVEY, John. Homens de preto. São Paulo: Unesp, 1995.

HEIDENSOHN, Frances (Ed.). Gender and justice: new concepts and approaches. Portland: Willan Publishing, 2006.

HIRATA, Helena. Gênero, classe e raça: interseccionalidade e consubstancialidade das relações sociais. Tempo Social, São Paulo, v. 26, n. 1, p. 61-73, 2014.

HOOKS, Bell. Ain't i a woman: black women and feminism. Boston: South End Press, 1981.

HOOKS, Bell. Feminism is for everybody: passionate politics. London: Pluto Press, 2000.

HOOKS, Bell. Teaching to transgress: education as the practice of Freedom. New York: Routledge, 1994.

HUNTER, Rosemary C.; SHOBEN, Elaine W. Disparate impact discrimination: american oddity or internationally accepted concept? Berkley Journal of Employment and Labor Law, v. 19, n. 1, p. 108-152, 1998.

INSTITUTO NACIONAL DE ESTUDOS E PESQUISAS EDUCACIONAIS. Censo da Educação Superior 2015: resumo técnico. Brasília: INEP, 2018.

INTITUTO BRASILEITO DE GEOGRAFIA E ESTATÍSTICA. Estatísticas de gênero: indicadores sociais das mulheres no Brasil. Estudos e Pesquisas - Informação Demográfica e Socioeconômica, n. 38, 2018.

ISAULA, Rodolfo. Toga de jueces, um luto de siglos. El Heraldo, abr. 2014. Disponível em: <http://www. elheraldo.hn/alfrente/566256-209/toga-de-jueces-un-luto-de-siglos>. Acesso em: 31 maio 2018. 
ITO, Marina; SCRIBONI, Marília. Em pouco tempo, mulheres estarão na cúpula da Justiça. Consultor Jurídico, mar. 2012. Disponível em: <https://www.conjur.com.br/2012-mar-08/aumenta-numero-mulheres-direitosao-chegam-cupula>. Acesso em: 28 maio 2018.

KAHNEMAN, Daniel; TVERSKY, Amos. The simulation heuristic. In: KAHNEMAN, Daniel; TVERSKY, Amos; SLOVIC, P. (Org.). Judgment under uncertainty: heuristics and biases. New York: Cambridge University Press, 1982.

KAHNEMAN, Daniel; TVERSKY, Amos. Thinking, fast and slow. New York: Farrar Straus Giroux, 2013.

KENNEDY, Walter B. The cult of the robe: a dissent. Fordham Law Review, v. 14, n. 2, p. 192-196, 1945.

KENNEY, Sally J. Gender \& justice: why women in the judiciary really matter. New York: Routledge, 2012.

KENNEY, Sally J. Thinking about gender and judging. International Journal of the Legal Profession, v. 15, n. 1-2, p. 87-110, mar./jul. 2008.

LEE, Connie. Gender Bias in the Courtroom: combating implicit Bias against women trial attorneys and litigators. Cardozo Journal of Law \& Gender, v. 22, n. 229, p. 229-252, 2016.

MALLESON, Kate. Justifying gender equality on the bench: why difference won't do. Feminist Legal Studies, v. 11, p. 1-24, 2003.

MELLO, Patrícia Perrone Campos. Nos bastidores do Supremo Tribunal Federal: Constituição, emoção, estratégia e espetáculo. São Paulo: GEN, 2015.

MELLO, Patrícia Perrone Campos. Quando julgar se torna um espetáculo: a interação entre o Supremo Tribunal Federal e a opinião pública, a partir de reflexões da literatura estrangeira. Revista de Direito Internacional, Brasília, v. 14, n. 1, p. 402-423, 2017.

MELO, Hildete Pereira de; THOMÉ, Débora. Mulheres e poder: histórias, ideias e indicadores. Rio de Janeiro: FGV, 2018.

MELO, Mônica de; NASTARI, Marcelo; MASSULA, Letícia. A participação da mulher na magistratura brasileira. Disponível em: <http://www.spm.gov.br/assuntos/poder-e-participacao-politica/programas-acoes/ desigualdades-entre-mulheres-e-homens/judiciario/dados_parciais_de_1999_a_20.pdf?TSPD_101_R0=5 8c632ceeac2b962cdb498af875432cdoB200000000000000000c279eb1 ffff 000000000000000000000000000 05b11ef5d001b0182d8>. Acesso em: 28 maio 2018.

MENKEL-MEADOW, Carrie. Portia in a different voice: speculations on a women's lawyering process. Berkley Journal of Gender, Law \& Justice, v. 1, n. 1, p. 39-63, 1985.

MILL, John Stuart. The subjection of women. Indianapolis: Hackett Publishing Company, 1988.

MOORE, Dorothy Perrin; BUTTNER, E. Holly. Women entrepreneurs: moving beyond the glass ceiling. Thousand Oaks: SAGE Publications, 1997.

MORRE primeira mulher a ocupar cargo de ministra no TST. Consultor Jurídico, abr. 2008. Disponível em: $<$ https://www.conjur.com.br/2008-abr-23/morre_primeira_mulher_ocupar_cargo_ministra_tst $>$. Acesso em: 28 maio 2018.

MORRISON, Ann M.; WHITE, Randall P.; VELSOR, Ellen Van. Breaking the glass ceiling: can women reach the top of America's largest corporations?. 2. ed. Beverly: Basic Books, 1994.

MOTTA, Francisco J. Borges. Levando o direito a sério: uma crítica hermenêutica ao protagonismo judicial. Florianópolis: Conceito, 2010.

MULHERES são maioria em universidades e cursos de qualificação. 2016. Disponível em: <http://www. brasil.gov.br/economia-e-emprego/2016/03/mulheres-sao-maioria-em-universidades-e-cursos-de-qualifi- 
cacao?TSPD_101_R0=146a5e670db17b1d43690f8f65521871n6o00000000000000000c279eb1ffff0000000 $0000000000000000000005 b 117 b b 600$ ea8281fc>. Acesso em: 29 maio 2018.

MULHERES são maioria no ingresso e na conclusão de cursos superiores. 2017. Disponível em: < http:// www.brasil.gov.br/editoria/educacao-e-ciencia/2015/03/mulheres-sao-maioria-no-ingresso-e-na-conclusao-de-cursos-superiores?TSPD_101_R0=dee602bb551a76a45283dee5ab5e0d4cc1Q00000000000000000 c279eb1ffff00000000000000000000000000005b11770d0076024db4>. Acesso em: 29 maio 2018.

NEGOWETTT, N. E. Implicit Bias and the legal profession's 'diversity crisis': a call for self-reflection. Nevada Law Journal, Las Vegas, v. 15, p. 431-460, 2015.

NONATO, Israel. O Supremo não éoráculo: conversas acadêmicas com Jane Reis. 2013. Disponível em: < http:/ / www.osconstitucionalistas.com.br/jane-reis-o-supremo-nao-e-oraculo>. Acesso em: 29 maio 2018.

NUSSBAUM, Martha C. Sex \& social justice. Oxford: Oxford University Press, 1999.

OKIN, Susan Moller. Gênero, o público e o privado. Estudos feministas, Florianópolis, v. 16, n. 2, p. 305-332, maio/ago. 2008.

OKIN, Susan Moller. Justice, gender and the family. New York: Basic Books, 1989.

OLIVEIRA, Rafael Tomaz de. Decisão judicial e o conceito de princípio: a hermenêutica e a (in)determinação do direito. Porto Alegre: Livraria do Advogado, 2008.

OST, François. Júpiter, Hércules, Hermes: tres modelos de juez. Doxa: Cuadernos de Filosofía del Derecho, n. 14, p. 169-194, 1993.

PATEMAN, Carole. The sexual contract. Stanford: Stanford University Press, 1988.

PEREIRA, Jane Reis Gonçalves. Representação democrática do Judiciário: reflexões preliminares sobre os riscos e dilemas de uma ideia em ascensão. Juris Poiesis, Rio de Janeiro, v. 17, p. 343-359, 2014.

PEREIRA, Jane Reis Gonçalves. Retrospectiva Direito Constitucional 2008: a expansão do Judiciário e o constitucionalismo cosmopolita. Revista Direito do Estado, v. 13, p. 23-53, 2008.

PHILLIPS, Anne. The politics of presence. Oxford: Oxford University Press, 1995.

PITKIN, Hannah Fenichel. The concept of representation. Berkeley: University of California Press, 1967.

PODER Legislativo: porcentagem de mulheres no órgão legislativo nacional: Câmara baixa ou única. 2018. Disponível em: < https://oig.cepal.org/pt/indicadores/poder-legislativo-porcentagem-mulheres-no-orgaolegislativo-nacional-camara-baixa-ou>. Acesso em: 30 maio 2018.

POGREBINSCHI, Thamy. Judicialização ou representação: política, direito e democracia no Brasil. Rio de Janeiro: Elsevier, 2011.

RACKLEY, Erika. Representations of the (woman) judge: Hercules, the little mermaid, and the vain and naked Emperor. Legal Studies, v. 22, n. 4, p. 602-624, nov. 2002.

RACKLEY, Erika. Women, judging and the Judiciary: from difference to diversity. New York: Routledge, 2013. RAWLS, John. A theory of justice. Cambridge: Harvard University Press, 2003.

ROXO, Sérgio. Barroso diz que Constituição deve ser interpretada em 'sintonia com o sentimento social'. O Globo, abr. 2018. Disponível em: <https://oglobo.globo.com/brasil/barroso-diz-que-constituicao-deveser-interpretada-em-sintonia-com-sentimento-social-22549589>. Acesso em: 31 maio 2018.

SALDANHA, Nelson. O jardim e a praça: ensaio sobre o lado privado e o lado público da vida social e histórica. Porto Alegre: Sergio Antonio Fabris Editor, 1986.

SCHULTZ, Ulrike; SHAW, Gisela (Ed.). Gender and judging. Oxford: Hart Publishing, 2013. 
SCOTT, Joan. Gênero: uma categoria útil de análise histórica. Educação \& Realidade, Porto Alegre, v. 20, n. 2, p. 71-99, jul./dez. 1995.

SENCHUK, D. M. Listening to a different voice: a feminist critique of Gilligan. Studies in Philosopby and Education, v. 10, n. 3, p. 233-249, 1990.

SONGER, Donald R. The transformation of the Supreme Court of Canada: an empirical examination. Toronto: University of Toronto Press, 2008.

STRECK, Lenio. O pós-positivismo e os propalados modelos de juiz (Hércules, Júpiter e Hermes) - dois decálogos necessários. Revista de Direitos e Garantias Fundamentais, v. 7, p. 15-45, 2011.

SUNSTEIN, Cass R. Why nudge: the politics of libertarian paternalism. New Haven: Yale University Press, 2014.

THALER, Richard H. Mishehaving: the making of behavioral economics. New York: W. W. Norton \& Company, 2016.

THALER, Richard H.; SUNSTEIN, Cass R. Nudge: improving decisions about health, wealth, and happiness. New Haven: Yale University Press, 2008.

TIERNEY, Stephen. We the peoples: constituent power and constitutionalism in plurinational states. In: WALKER, Neil; LOUGHLIN, Loughlin (Org.). The paradox of Constitutionalism. Oxford: Oxford University Press, 2007. p. 229-246.

TVERSKY, Amos; KAHNEMAN, Daniel. The framing of decisions and the psychology of choice. Science, v. 211, p. 453-458, 1981.

UNITED NATIONS. The world's women 2015. 2015. Disponível em: < https:/ unstats.un.org/unsd/gender/ chapter4/chapter4.html>. Acesso em: 10 maio 2018.

UNITED NATIONS. Women in politics: 2017. 2017. Disponível em: <https://www.ipu.org/resources/publications/infographics/2017-03/women-in-politics-2017>. Acesso em: 30 maio 2018.

WACQUANT, Loïc. Esclarecer o habitus. Educação \& Linguagem, ano 10, n. 16, p. 63-71, jul./dez. 2007.

WALKER, Peter. Don't rush gender equality in UK judiciary, says supreme court judge. The Guardian, sep. 2015. Disponível em: < https://www.theguardian.com/law/2015/sep/22/gender-equality-warning-uklegal-profession-supreme-court-judge-jonathan-sumption>. Acesso em: 31 maio 2018.

WILLBORN, Steven L. The disparate model of discrimination: theory and limits. American University Law Review, v. 34, p. 799-839, 1985.

WILSON, Bertha. Will women judges really make a difference? Osgoode Hall Law Journal, v. 28, n. 3, p. 507$522,1990$.

WITT, Charlotte (Coord.). Feminist metaphysics: explorations in the ontology of sex, gender and the self. Londres: Springer, 2011.

YOUNG, Iris Marion. Representação política, identidade e minorias. Lua Nova, São Paulo, n. 67, p. 139-190, 2006.

Agradecimentos

Agradecemos à Adriana Cruz, ao Gabriel Accioly Gonçalves e ao Leandro Carlos Dias Conde pelos debates e pela revisão deste artigo, bem como à Comissão AJUFE Mulheres, na pessoa de Clara Mota Alves, pelo compartilhamento de dados. 


\section{REVISTA BRASILEIRA DE POLÍTICAS PÚBLICAS BRAZILIAN JOURNAL OF PUBLIC POLICY}

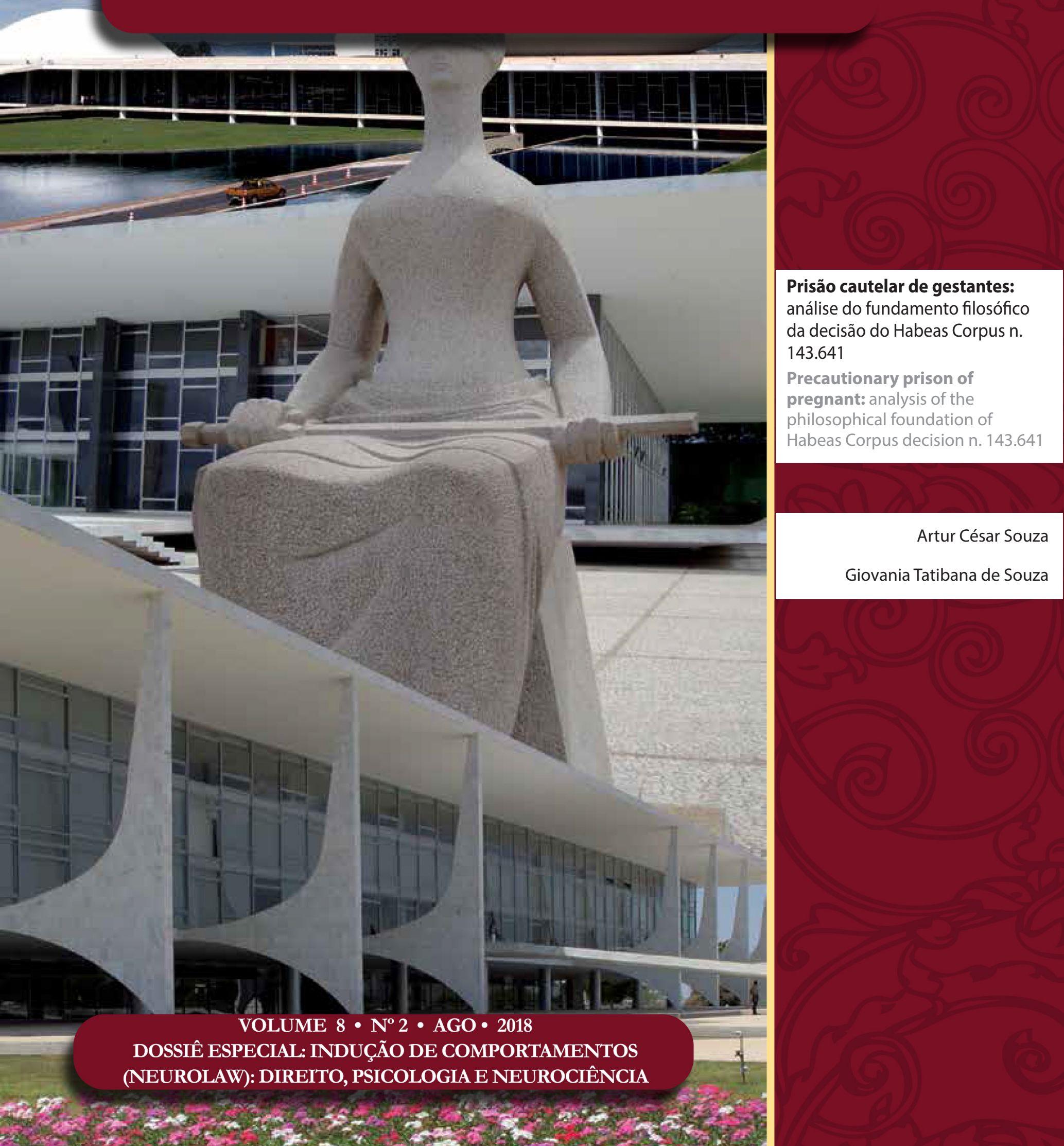




\section{Prisão cautelar de gestantes: análise do fundamento filosófico da decisão do Habeas Corpus n. $143.641^{*}$}

\author{
Precautionary prison of pregnant: analysis of \\ the philosophical foundation of Habeas Corpus \\ decision n. 143.641
}

\author{
Artur César Souza** \\ Giovania Tatibana de Souza***
}

* Recebido em 25/04/2018 Aprovado em 21/05/2018

** Pós-Doutor pelas seguintes Universidades: a) Università Statale di Milano; b) Universidad de Valencia; c) Faculdade de Direito da Universidade de Lisboa; d) Universidade Federal de Santa Catarina - UFSC. Doutor em Direito das Relações Sociais pela Universidade Federal do Paraná. Doutorando em Filosofia pela Universidade de Barcelona. Professor do Curso de Doutorado e Mestrado na UNIMAR-Universidade de Marília. Juiz Federal convocado, no Tribunal Regional Federal da $4^{\mathrm{a}}$ Região. Email: arturcesarsouza@gmail.com

*** Professora da UNOPAR - Universidade Norte do Paraná. Especialista em Direito Processual pela UEL - Universidade Estadual de Londrina. Advogada.

Email: geovaniatatibana@gmail.com

\section{Resumo}

O Supremo Tribunal Federal, em 21 de fevereiro de 2018, ao proferir decisão no Habeas Corpus n. 143.611, em favor das mulheres presas preventivamente e que ostentam a condição de gestantes, de puérperas ou de mães de crianças sob sua responsabilidade, deixou evidenciado, de certa forma, quais seriam os fundamentos da dogmática jurídica penal, constitucional, criminológica, sociológica e do direito das gentes que serviram de base para a proteção coletiva das pacientes. O objetivo do presente trabalho, porém, é encontrar, nas entrelinhas da referida, decisão judicial um fundamento ético filosófico que possa se compatibilizar com o resultado do julgamento. Para tanto, utilizando-se de um método de revisão doutrinária, analítico dedutivo, realiza-se um diálogo interdisciplinar entre a ciência jurídica e a ética filosófica, para, ao final, tentar demonstrar-se que, em todos os discursos linguísticos, ainda que jurídicos, há um fundamento ético filosófico que contribui, ativamente, para o resultado a ser alcançado.

Palavras-chaves: Decisão judicial. Fundamento. Ética filosófica. Racionalidade do outro.

\section{Abstract}

The Supreme Federal Court, on February 21, 2018, when rendering a ruling in Habeas Corpus n. 143,611, in favor of women preemptively detained and bearing the status of pregnant women, mothers of children under their responsibility, has left to a certain extent what would be the basis of criminal, constitutional, criminological, sociological and law which served as the basis for the collective protection of patients. The objective of the present work, however, is to find in the lines of the aforementioned judicial decision an ethical philosophical foundation that can be compatible with the result of the judgment. To do so, using an analytical deductive method, an interdisciplinary dialogue between legal science and philosophical ethics is done, in order to try to demonstrate that in all linguistic discourses, even if 
legal, there is a philosophical ethical foundation which actively contributes to the outcome to be achieved.

Keywords: Judicial decision. Background. Philosophical ethics. Rationality of the other.

\section{INTRODUÇÃo}

Eloísa Machado de Almeida, Bruna Soares Angotti, André Ferreira, Nathalie Fragoso e Hilem Oliveira, membros do Coletivo de Advogados em Direitos Humanos, impetraram Habeas Corpus Coletivo n. 143.641, com pedido de medida liminar, perante o Supremo Tribunal Federal, em favor de todas as mulheres presas, preventivamente, que ostentam a condição de gestantes, de puérperas ou de mães de crianças sob sua responsabilidade, bem como em nome das próprias crianças.

O Supremo Tribunal Federal, no dia 20 de fevereiro de 2018, em decisão 'paradigmática' e inédita, de relatoria do Ministro Ricardo Lewandowski, concedeu a ordem de Habeas Corpus para o fim de determinar a substituição da prisão preventiva pela domiciliar, sem prejuízo da aplicação concomitante das medidas alternativas no art. 319 do Código de Processo Penal — de todas as mulheres presas, gestantes, puérperas, ou mães de crianças e deficientes sob sua guarda, nos termos do art. $2^{\circ}$ do Estatuto da Criança e do Adolescente e da Convenção sobre Direitos das Pessoas com Deficiências (Decreto Legislativo n. 186/2008 e Lei n. 13.146/2015).

É possível extrair-se do discurso linguístico produzido no inteiro teor do acórdão os fundamentos jurídicos da dogmática penal e do direito constitucional, assim como os fundamentos sociológicos, criminológicos, e do direito das gentes que serviram de base para a proteção das mulheres presas preventivamente.

Porém, o objetivo do presente trabalho é ir um pouco mais além. Pretende-se analisar qual o fundamento ético filosófico que mais se compatibiliza com a concessão da ordem de Habeas Corpus coletivo.

A escolha de uma perspectiva ética filosófica, e que se indica no presente trabalho, não significa afirmar que não haja outras concepções éticas também justificáveis. O que se pretende demonstrar justamente é que o discurso linguístico realizado pela ciência jurídica e pela filosofia não está desconectado ou isolado, mas, sim, muito bem entrelaçado e sugestionado.

\section{Os FUNDAMENTOS APARENTES E EXPRESSAMENTE CONSIGNADOS NA DECISÃO PROFERIDA NO Habeas Corpus n. 143.641}

O presente trabalho tem por objetivo analisar os fundamentos que deram sustentação à decisão proferida no Habeas Corpus n. 143.641, em especial o fundamento filosófico. No presente tópico, pretende-se indicar os fundamentos aparentes e expressamente consignados nos votos e no acórdão da decisão objeto do presente estudo, a saber:

\subsection{Fundamento com base na dogmática penal}

A decisão proferida no Habeas Corpus n. 143.641 do Supremo Tribunal deixa muito bem evidenciado quais sãos os fundamentos jurídicos que justificam a proteção das mulheres presas, preventivamente, e que ostentam a condição de gestantes.

O fundamento jurídico penal respalda-se no argumento de que, com a entrada em vigor da Lei n. 13.257/2016, que alterou o Código de Processo Penal, há possibilidade de substituição da prisão preventiva 
por prisão domiciliar para gestantes e mães de crianças.

Além disso, a Lei n. 11.942/2009, que promoveu mudanças na Lei de Execução Penal, estabelece os seguintes direitos subjetivos à mulher: a) acompanhamento médico à mulher, principalmente no pré-natal e no pós-parto, extensivo ao recém-nascido; b) estabelecimentos penais destinados a mulheres serão dotados de berçário, onde as condenadas possam cuidar de seus filhos, inclusive, amamentá-los, no mínimo, até 6 (seis) meses de idade; c) a penitenciária de mulheres será dotada de seção para gestante e parturiente e de creche para abrigar crianças maiores de 6 (seis) meses e menores de 7 (sete) anos, com a finalidade de assistir a criança desamparada cuja responsável estiver presa, inclusive, à presa provisória (art. 42 da Lei de Execução Penal).

\subsection{Fundamento jurídico constitucional}

Além das regras jurídicas penais acima indicadas, a decisão, também, se respalda em princípios jurídicos de direito constitucional, a saber: a aplicação do princípio da intranscendência, segundo o qual a pena não pode passar da pessoa do condenado, e do princípio da primazia dos direitos da criança, da vedação de penas cruéis e da individualização da pena.

A forte violação de direitos fundamentais, alcançando a transgressão à dignidade da pessoa humana e ao próprio mínimo existencial justifica a atuação do Poder Judiciário em prol da mulher preventivamente presa. ${ }^{1}$

A decisão proferida pelo Supremo Tribunal Federal nada mais fez do que dar concreção ao que a Constituição, em sua redação original, já determinava: a) - art. $5^{\circ}$, II - ninguém será submetido à tortura nem a tratamento desumano ou degradante; b) - art. $5^{\circ}$, XLI - a lei punirá qualquer discriminação atentatória dos direitos e liberdades fundamentais; c) art. $5^{\circ}$, XLV - nenhuma pena passará da pessoa do condenado [...]; d) - art. $5^{\circ}, \mathrm{L}$ - às presidiárias serão asseguradas condições para que possam permanecer com seus filhos durante o período de amamentação; e) - art. $5^{\circ}$, XLVIII - a pena será cumprida em estabelecimentos distintos, de acordo com a natureza do delito, a idade e o sexo do apenado; f) - art. $5^{\circ}$, XLIX - é assegurado aos presos o respeito à integridade física e moral.

\subsection{Fundamento criminológico}

O fundamento criminológico teve papel preponderante na decisão proferida pelo Supremo Tribunal Federal, em especial quando se asseverou que a política criminal responsável pelo expressivo encarceramento feminino é discriminatória e seletiva, impactando, de forma desproporcional, as mulheres pobres e suas famílias.

O Levantamento Nacional de Informações Penitenciárias - INFOPEN Mulheres², preconiza que “a população absoluta de mulheres encarceradas no sistema penitenciário cresceu $567 \%$ entre os anos 2000 e 2014", incremento muito superior ao da população masculina, que, ainda assim, aumentou exagerados 220\% no mesmo período, a demonstrar a tendência geral de aumento do encarceramento no Brasil. Especificamente no tocante à prisão provisória, "enquanto 52\% das unidades masculinas são destinadas ao recolhimento de presos provisórios, apenas $27 \%$ das unidades femininas têm esta finalidade", apesar de 30,1\% da população prisional feminina ser provisória.

1 "A dignidade humana é requisito essencial do regime democrático brasileiro tendo em vista seu caráter ideal abstrato que orienta as decisões do Poder Público no sentido de implementar políticas públicas que efetivem direitos fundamentais e garantam a qualidade de vida dos cidadãos". SOUZA, Luciana Cristina. Dignidade humana na webesfera governamental brasileira. Revista Brasileira de Políticas Públicas. v. 7, n. 3, dez. 2017. p. 203.

2 BRASIL. Ministério da Justiça. Infopen Mulheres. Levantamento nacional de informações penitenciárias. 2014. p. 18-19. Disponível em: $<$ https://www.justica.gov.br/news/estudo-traca-perfil-da-populacao-penitenciaria-feminina-no-brasil/relatorio-infopen-mulheres. pdf>. Acesso em: 7 jun. 2018. 
Outro dado de fundamental interesse diz respeito ao fato de que $68 \%$ das mulheres estão presas por crimes relacionados ao tráfico de entorpecentes, delitos que, na grande maioria dos casos, não envolvem violência nem grave ameaça a pessoas, e cuja repressão recai, não raro, sobre a parcela mais vulnerável da população, em especial sobre os pequenos traficantes, quase sempre mulheres, vulgarmente denominadas de "mulas do tráfico". ${ }^{3}$ Nesses casos, quase sempre, como revelam os estudos especializados, a prisão preventiva mostra-se desnecessária, já que a prisão domiciliar prevista no art. 318 do Código de Processo Penal pode, com a devida fiscalização, impedir a reiteração criminosa.

O retrato que ora se vai delineando em tudo coincide com os documentos produzidos no âmbito do sistema universal de direitos humanos sobre o tema (vide, em especial, o texto destinado a orientar os trabalhos da Força-Tarefa do Sistema ONU (Organizações das Nações Unidas) sobre o Crime Organizado e o Tráfico de Drogas, como Ameaças à Segurança e Estabilidade. UN Women. A genderperspective on the impact of drug use, the drug trade, and drug control regimes, 2014): o envolvimento das mulheres no uso e tráfico de drogas reflete seu déficit de oportunidades econômicas e status político. Quando se engajam em atividades ilícitas, são relegadas às mesmas posições vulneráveis que pavimentaram o caminho desse engajamento. Quando alvos da persecução penal, deparam-se com um sistema judiciário que desacredita seus testemunhos e com a atribuição de penas ou medidas cautelares que negligenciam suas condições particulares como mulheres ${ }^{4}$.

\subsection{Fundamento no direito das gentes}

A decisão proferida pelo Supremo Tribunal Federal encontra justificativa em normas e acordos de direito internacional. Enfatiza-se o cabimento de habeas corpus coletivo na defesa da liberdade de locomoção de determinados grupos de pessoas, com fulcro na garantia de acesso à Justiça, e considerando o caráter sistemático de práticas que resultam em violação maciça de direitos. Invoca-se o art. 25, I, da Convenção Americana de Direitos Humanos, que garante o direito a um instrumento processual simples, rápido e efetivo, apto a tutelar direitos fundamentais lesionados ou ameaçados.

O Brasil não tem sido capaz de garantir cuidados relativos à maternidade nem mesmo às mulheres que não estão em situação prisional. Nesse sentido, relembre-se o "caso Alyne Pimentel”, que representou a

primeira denúncia sobre mortalidade materna acolhida pelo Comitê para a Eliminação de todas as Formas de Discriminação contra a Mulher [...] incumbido de monitorar o cumprimento pelos Estadosparte da Convenção relativa aos Direitos das Mulheres, adotada pelas Nações Unidas em 1979", tratando-se da "única 'condenação' do Estado brasileiro proveniente de um órgão do Sistema Universal de Direitos Humanos.

O cuidado com a saúde maternal é considerado como uma das prioridades que deve ser observada pelos distintos países no que concerne ao seu compromisso com a promoção de desenvolvimento, conforme consta do Objetivo de Desenvolvimento do Milênio - ODM no 5 (melhorar a saúde materna) e do Objetivo de Desenvolvimento Sustentável - ODS no 5 (alcançar a igualdade de gênero e empoderar todas as mulheres e meninas), ambos documentos subscritos no âmbito da Organização das Nações Unidas. Aliás, a reiteração da ênfase conferida pela ONU sobre o tema foi reforçada nos ODSs justamente porque, durante o tempo em que vigeram os ODMs (2000-2015), foi possível constatar "a falta de avanço em algumas áreas, particularmente aquelas relacionadas com saúde materna, neonatal e infantil e saúde reprodutiva".

3 SOARES, B. M.; ILGENFRITZ, I. Prisioneiras: vida e violência atrás das grades. Rio de Janeiro: Garamond, 2002. p. 22.

4 UN WOMEN. A gender perspective on the impact of drug use, the drug trade, and drug control regimes. 2014. p. 34-35. Disponível em: <https://www.unodc.org/documents/ungass2016/Contributions/UN/Gender_and_Drugs_-_UN_Women_Policy_Brief.pdf>. Acesso em: 7 jun. 2018.

5 ALBUQUERQUE, Aline S. de Oliveira; BARROS, Julia Schirmer. Caso Alyne Pimentel: uma análise à luz da abordagem baseada em direitos humanos. Revista do Instituto Brasileiro de Direitos Humanos, Fortaleza, n. 12, jul. 2016. p. 11.

6 MACHADO FILHO, Haroldo. Dos objetivos do milênio aos objetivos do desenvolvimento sustentável: lições aprendidas e desafios. In: UNLÃO Europeia, Brasil e os desafios da agenda do desenvolvimento sustentável. Rio de Janeiro: Konrad Adenauer Stiftung, 
Faz-se referência, ainda, às Regras das Nações Unidas para o Tratamento de Mulheres Presas e Medidas Não Privativas de Liberdade para Mulheres Infratoras, também conhecidas como Regras de Bangkok.

Apesar de o Governo Brasileiro ter participado, ativamente, das negociações para a elaboração das Regras de Bangkok e a sua aprovação na Assembleia Geral das Nações Unidas, até o momento, elas não foram plasmadas em políticas públicas consistentes, em nosso país, sinalizando, ainda, o quanto carece de fomento a implementação e a internalização eficaz pelo Brasil das normas de direito internacional dos direitos humanos. E cumprir essa regra é um compromisso internacional, Revisado Habeas Corpuns 143641/SP, assumido pelo Brasil. Embora se reconheça a necessidade de impulsionar a criação de políticas públicas de alternativas à aplicação de penas de prisão às mulheres, é estratégico abordar o problema primeiramente sob o viés da redução do encarceramento feminino provisório. De acordo com as Regras de Bangkok, deve ser priorizada solução judicial que facilite a utilização de alternativas penais ao encarceramento, principalmente para as hipóteses em que ainda não haja decisão condenatória transitada em julgado".

\subsection{Fundamento político ou de gestão política}

Extrai-se da decisão proferida pelo Supremo Tribunal Federal alguns fundamentos políticos ou de gestão política. Os estabelecimentos prisionais não são preparados, de forma adequada, para atender à mulher presa, especialmente a gestante e a que é mãe.

Segundo dados oficiais, faltam berçários e centros materno-infantis e que, em razão disso, as crianças se ressentem da falta de condições propícias para seu desenvolvimento, o que não somente afeta sua capacidade de aprendizagem e de socialização, como também vulnera, gravemente, seus direitos constitucionais, convencionais e legais.

Embora a Lei de Execução Penal (LEP) determine como obrigatória, nos estabelecimentos penais, a presença de instalações para atendimento a gestantes e crianças, essas disposições legais vêm sendo sistematicamente desrespeitadas. A constatação de deficiência estrutural, especificamente em relação à situação da mulher presa, foi reconhecida na Ação de Descumprimento de Preceito Fundamental (ADPF n. 347 MC/ $\mathrm{DF}){ }^{7}$

A ausência de medidas legislativas, administrativas e orçamentárias eficazes representa falha estrutural a gerar tanto a violação sistemática dos direitos quanto a perpetuação e o agravamento da situação. A inércia não é de uma única autoridade pública — do Legislativo ou do Executivo de uma particular unidade federativa -, e sim do funcionamento deficiente do Estado como um todo. Os poderes, órgãos e entidades federais e estaduais, em conjunto, vêm se mantendo incapazes e manifestando verdadeira falta de vontade em buscar superar ou reduzir o quadro objetivo de inconstitucionalidade. Faltam sensibilidade legislativa e motivação política do Executivo. ${ }^{8}$

\footnotetext{
2016. p. 88.

7 Conforme bem afirmou o Ministro Marco Aurélio, em seu voto na ADPF n. 347 MC/DF: "A ausência de medidas legislativas, administrativas e orçamentárias eficazes representa falha estrutural a gerar tanto a violação sistemática dos direitos, quanto a perpetuação e o agravamento da situação. A inércia, como dito, não é de uma única autoridade pública - do Legislativo ou do Executivo de uma particular unidade federativa -, e sim do funcionamento deficiente do Estado como um todo. Os poderes, órgãos e entidades federais e estaduais, em conjunto, vêm se mantendo incapazes e manifestando verdadeira falta de vontade em buscar superar ou reduzir o quadro objetivo de inconstitucionalidade. Faltam sensibilidade legislativa e motivação política do Executivo. É possível apontar a responsabilidade do Judiciário no que $41 \%$ desses presos, aproximadamente, estão sob custódia provisória. Pesquisas demonstram que, julgados, a maioria alcança a absolvição ou a condenação a penas alternativas, surgindo, assim, o equívoco da chamada 'cultura do encarceramento"'.

$8 \mathrm{Na}$ verdade, "qualquer análise que possa ser feita do sistema penitenciário brasileiro indica a existência de uma situação, absolutamente, desastrosa e abusiva. Desastrosa, na perspectiva da existência de um sistema anacrônico, de matizes medievais, sem condições estruturais básicas para atendimento das regras constitucionais ou dos direitos fundamentais dos presos. Abusiva porque o simples ingresso de um apenado em um cárcere desse sistema, ressalvadas algumas situações excepcionais que felizmente ainda podem ser encontradas, já indica que a possibilidade será quase total de que venha a ser submetidos a atos de violência a ameaças, a
} 
Mais graves, porém, são os dados sobre infraestrutura relativa à maternidade no interior dos estabelecimentos prisionais, sobre os quais cabe apontar que: a) nos estabelecimentos femininos, apenas 34\% dispõem de cela ou dormitório adequado para gestantes, apenas 32\% dispõem de berçário ou centro de referência materno infantil e apenas 5\% dispõem de creche (INFOPEN Mulheres); (b) nos estabelecimentos mistos, apenas $6 \%$ das unidades dispõem de espaço específico para a custódia de gestantes, apenas 3\% dispõem de berçário ou centro de referência materno infantil e nenhum dispõe de creche?.

\subsection{Fundamento sócio/econômico}

Verificam-se, na decisão do Supremo Tribunal Federal, alguns fundamentos econômicos. Destaca-se a vulnerabilidade socioeconômica das mulheres presas preventivamente no Brasil.

Nesse diapasão, ressaltam-se dados da pesquisa "Panorama de Acesso a 4 Revisado Habeas Corpus 143641/SP Justiça no Brasil, 2004 a 2009”"10, os quais demonstram que, abaixo de determinado nível de escolaridade e renda, o acesso à Justiça praticamente não se concretiza. Tal pesquisa, dentre outras revelações, ressalta o quanto esse acesso, como direito de segunda geração ou dimensão, tem encontrado dificuldades para se realizar no Brasil, esbarrando, sobretudo, no desalento, ou seja, nas dificuldades relacionadas a custo, distância e desconhecimento que impedem as pessoas mais vulneráveis de alcançar o efetivo acesso à Justiça.

\section{FundAMENTO ÉtICO-FILOSÓFICO}

A partir deste momento, pretende-se aviventar certa concepção ética filosófica que possa ter servido de inspiração para a prolação da decisão no Habeas Corpus n. 143.611, levando-se em conta todas as circunstâncias já observadas nos fundamentos acima indicados.

O fio condutor do presente trabalho, a partir desse momento, é justamente os pressupostos filosóficos fundamentais que justificam a proteção das mulheres presas preventivamente que ostentam a condição de gestantes, de puérperas ou de mães de crianças sob sua responsabilidade, bem como em nome das próprias crianças.

Pretende-se, nessa última etapa do trabalho, percorrer um caminho diametralmente oposto daquele traçado por Elio Fazzalari, quando, ao analisar os princípios reguladores do processo jurisdicional, peremptoriamente, afirmou que o juiz não pode, na relação jurídica processual, reconhecer o "outro", reconhecer a debilidade econômica, cultural, social ou mesmo psicológica do "outro", pois, se assim proceder, poderá produzir possíveis decisões iníquas. ${ }^{11}$

cooptação por organizações criminosas, a contraírem doenças e a não receberem qualquer ação efetiva que pudesse implicar a sua futura reinserção social”. ROCHA, Lilian Rose Lemos; CARDOZO, José Eduardo. Precariedade do sistema penitenciário brasileiro como base temática para a proibição ou legalização das drogas. Revista Brasileira de Políticas Públicas, v. 7, n.3, dez. 2017.

9 BRASIL. Ministério da Justiça. Infopen Mulheres. Levantamento nacional de informações penitenciárias. 2014. p. 18-19. Disponível em: $<$ https://www.justica.gov.br/news/estudo-traca-perfil-da-populacao-penitenciaria-feminina-no-brasil/relatorio-infopen-mulheres. pdf>. Acesso em: 7 jun. 2018.

10 BRASIL. Conselho Nacional de Justiça. PANORAMA de Acesso a 4 Revisado Habeas Corpus 143641/ SP Justiça no Brasil, 2004 a 2009. Brasília: Conselho Nacional de Justiça, 2011.

11 "Potrebbe sembrare al profano o all'osservatore superficiale che al giudice incomba almeno di sopperire alla debolezza del non abbiente. Ma no è così. La Carta fondamentale è chiarissima nel volere che a quel cittadino siano forniti, mediante appositi istituti, mezzi d'assistenza per agire e difendersi in giudizio; ma, proprio per questo, essa non consente che, in difetto di mezzi e permanendo l'inadempienza costituzionale dello Stato, il giudice manifesti una qualsiasi parzialità nei confronti del non abbiente: secondo la Costituzione questi deve comparire davanti a lui già munito dell'usbergo che lo metta al sicuro dalla sua stessa debolezza e che renda omnimamente superflui poteri, per così dire suppletori, del giudice in di lui vantaggio. [...]. Chè, se invece la norma sostanziale non contempli o non supplisca a quella debolezza, il giudice non può, in sede di giudizio di diritto, abbandonarsi al dubbio o cedere alla tentazione di scegliere, come metro di giudizio, un altro valore (o, più semplicemente, la propria personale 
Apesar da admiração e do respeito que se deve ter pelo trabalho intelectual do eminente processualista italiano, não se pode deixar de considerar que sua visão está inserida na totalidade racional da Europa continental, o que favorece a postulação de um juiz totalmente divorciado das necessidades e das precariedades humanas, e a perspectiva de uma leitura da imparcialidade apenas no âmbito abstrato e meramente formal.

Realçando-se as particularidades da periferia do mundo, especialmente as desigualdades materiais da América Latina, não se pode permanecer numa visão meramente formal e abstrata da imparcialidade do juiz. Diante desses aspectos materiais, há necessidade de se reconhecer a "alteridade do outro". ${ }^{12}$

O Estado-Juiz deve atuar de modo tal que todos os sujeitos processuais tenham iguais perspectivas de levar adiante suas pretensões. Nessa alternativa, o Estado-Juiz:

[...] debe tratar desigualmente a sus ciudadanos, de modo que — después de la actuación del estado todos ellos tengan iguales probabilidades de llevar a cabo su plan de vida. Puesto que el estado actúa en este caso me parece adecuado rebautizar a esta alternativa denominándola neutralidad positiva. ${ }^{13}$

São as próprias conjecturas estruturais que impedem que as pessoas sejam iguais entre si. Para Max Weber, as pessoas são desigualmente dotadas do ponto de vista físico, intelectual e moral. Na verdade, há uma verdadeira loteria genética no ponto de partida da existência humana: “[...] os genes que recebemos dependem, no sentido exato do termo, de um cálculo de probabilidades". ${ }^{14}$

Segundo Enrique Dussel:

Ninguém surge do acaso ou aparece por geração espontânea. Todo homem, mesmo o mais simples camponês ou o mais humilde trabalhador urbano, tem história. É fruto de uma herança genética, de um contexto sócio-político-econômico-cultural e de uma opção pessoal assumida e trabalhada há anos. O resultado de tudo isto é o homem na sua concretude. ${ }^{15}$

E, para se visualizar a pessoa em sua concretude, não basta o desenvolvimento de um processo meramente formal, sem que se pense numa ética de conteúdo ou material a ser introduzida na relação jurídica processual, sem que se perceba as diferenças empíricas entre os sujeitos da relação jurídica processual penal ou civil.

Piero Pajardi ressaltou: “[...] quanto di humanità e di socialità ed ancora quanto di valori etici e di fattori esistenziali stia dietro l' apparente freddezza tecnica di una norma processuale". ${ }^{16}$

Para Fábio Konder Comparato, por muito tempo, a justiça foi concebida more geometricu, como ente exclusivo da razão, sem qualquer vínculo com a sensibilidade valorativa. Aliás, sua representação simbólica insere-se numa personagem cega, neutra, implacável e impassível. Contudo, “[...] a verdadeira justiça, muito ao contrário, é sempre parcialíssima. Ela não se coaduna com equidistâncias formais nem se contenta com equilíbrio de circunstâncias". ${ }^{17}$

valutazione); nè può travisare quella norma. [...]." FAZZALARI, Elio. La imparzialità del giudice. Rivista di Dirito Processuale, Padova, Cedam, n. 2, p. 193-203, 1972.

12 "La alteridad para E. Levinas no es un concepto abstracto, sino un momento estructural del sentir humano. El yo y la libertad se alzan en esta específica sensibilidad humana por la que el otro es otro antes que concepto. La noción idealista de sujeto sólo es posible desconociendo que 'el mundo sensible desborda la libertad de la representación'. El rostro, el cara-cara son expresiones plásticas de una alteridad insalvable e irreductible del sentir humano. Esta alteridad es precisamente el fundamento de la ética.” COROMINAS, Jordi. Ética primera: aportación de X. Zubiri al debate ético contemporáneo. Bilbao: Desclée de Brouwer, 2000. p. 92.

13 FARRELL, Martin D. Algunas maneras de entender a la neutralidad. Doxa, p. 15-16, 1994. p. 183. Disponível em: <http:// www.cervantesvirtual.com/servlet/SirveObras/01361620824573839199024/cuaderno15/voll/doxa15_09.pdf>. Acesso em: 3 ago. 2005.

14 PENNA, Antônio Gomes; NALINI, José Renato (Coord.). Uma nova ética para o juiz: São Paulo: RT, 1994. p. $30-31$.

15 ZIMMERMANN, Roque. América Latina o não ser. 2. ed. Rio de Janeiro: Vozes, 1987. p. 27.

16 PAJARDI, Piero. I provvedimenti d'urgenza atipici nel processo civile. Milano: Pirola, 1988. p. 283.

17 COMPARATO, Fábio Konder. Papel do jurista num mundo em crise de valores. Revista dos Tribunais, São Paulo, ano 84, v. 713, mar. 1995. p. 283. 
Humanizar o processo é personalizá-lo; enfim, socializá-lo com os ares generosos da solidariedade. ${ }^{18}$ Numa ética filosófica material, procura-se afirmar que o ser humano e sua produção, reprodução e desenvolvimento são referência para o exercício da atividade jurisdicional e que as questões processuais não estão enclausuradas, apenas, no âmbito jurídico e dogmático da relação jurídica processual, pois extrapolam os limites do processo, como no caso das gestantes, em que o seu entorno, em especial a criança, faz a diferença no momento de se escolher determinada decisão.

Essa postulação humanitária de uma nova leitura do princípio da (im)parcialidade reclama o efetivo reconhecimento das diferenças existentes entre as pessoas, para que se possa vislumbrar uma decisão final équo e justa.

Seguindo-se o critério apresentado por Maria Teresa de Melo Ribeiro, pode-se resumir a aplicação principiológica da imparcialidade nos seguintes termos: (a) a tendência para reservar ao princípio da imparcialidade um entendimento amplo e abrangente, do qual resulta a atribuição ao princípio da imparcialidade de um conteúdo simultaneamente negativo e positivo; (b) a tendência para identificar a vertente positiva com a obrigação de o Poder Judiciário considerar todos os interesses legalmente relevantes no caso concreto, sejam eles públicos ou privados; (c) a tendência para considerar o princípio da imparcialidade um princípio jurídico vinculativo de toda atividade jurisdicional; (d) a tendência para ligar o princípio da imparcialidade à realização de um ideal de justiça. ${ }^{19}$

Focando-se nessa perspectiva positiva do princípio da imparcialidade do juiz, recomenda-se uma conduta ética universal do juiz na relação jurídica processual de maneira que tal conduta reconheça as necessidades das vítimas de um sistema totalizador, e que, a partir dessas vítimas, possa promover um equacionamento racional visando a um processo justo e équo. ${ }^{20}$

E essa ética de caráter universal somente pode decorrer, conforme afirma o filósofo argentino, radicado no México, Enrique Dussel, da constatação antropológica de que o ser humano é o único ser vivente responsável pela sua própria vida e da “[...] obligación universal de producir, reproducir y desarrollar la vida humana concreta de cada sujeto ético em comunidad”. ${ }^{21}$ Esse princípio caracteriza-se por ser um princípio a priori universal e também fundamental, ainda que não suficiente, para a construção de uma ética da libertação, isto é, "[...] de una ética que intenta justificar filosoficamente las luchas de los oprimidos".22

É na produção, reprodução e desenvolvimento da vida humana que Enrique Dussel estabelecerá o fundamento material de sua ética filosófica da vida. A vida humana, portanto, é o conteúdo específico da ética. ${ }^{23}$ Trata-se de um critério que tem por objeto produzir, reproduzir e desenvolver a vida humana concreta de cada sujeito ético em comunidade. Para Enrique Dussel, esse critério serve de fundamentação a um princípio que, por sua vez, terá pretensão de universalidade, realizando-se por meio das culturas e dos valores a serem perseguidos. ${ }^{24}$

18 MORELLO, Augusto. El proceso justo. Buenos Aires: Abeledo-Perrot, 1994. p. 16-17.

19 RIBEIRO, Maria Teresa de Melo. O princípio da imparcialidade da administração pública. Coimbra: Almedina, 1996. p. 108-109.

20 O conteúdo material, também, faz parte do pensamento de Pietro Barcellona, nos seguintes termos: "Bastaría con que el jurista se limitase a salir del círculo mágico de sus fórmulas abstractas, del cerrado horizonte de las normas, y afrontase directamente el problema de los contenidos materiales de la justicia. Pero actuando de esta forma, está claro, debería renunciar a la aparente esterilidad axiológica de sus construcciones, a la indiferencia ante los valores, a la neutralidad frente a los conflictos. Debería sumergirse en la política, en la ética, en la práctica". BARCELLONA, Pietro; HART, Dieter; MÜCKENBERGER, Ulrich. La formación del jurista: capitalismo monopolístico y cultura jurídica. Madrid: Civitas, 1993. p. 44.

21 COROMINAS, Jordi. Ética primera: aportación de X. Zubiri al debate ético contemporáneo. Bilbao: Desclée de Brouwer, 2000 . p. 74. 22 COROMINAS, Jordi. Ética primera: aportación de X. Zubiri al debate ético contemporáneo. Bilbao: Desclée de Brouwer, 2000. p. 74.

23 “[...] O ser humano acede à realidade que enfrenta dia a dia a partir do âmbito de sua própria vida. A vida humana não é um fim nem um mero horizonte mundano-ontológico. A vida humana é o modo de realidade do sujeito ético (que não é o de uma pedra, de um animal irracional ou da 'alma' angélica de Descartes), que dá o conteúdo a todas as suas ações, que determina a ordem racional e também o nível das necessidades, pulsões e desejos, que constitui o marco dentro do qual se fixam fins. Os 'fins' (relativamente à razão instrumental formal weberiana) são ‘colocados' a partir das exigências da vida humana.” DUSSEL, Enrique. Ética da libertação na idade da globalização e da exclusão. Rio de Janeiro: Vozes, 2000. p. 131.

24 DUSSEL, Enrique. Ética da libertação na idade da globalização e da exclusão. Rio de Janeiro: Vozes, 2000. p. 93 
Em razão desse princípio ético material,

[...] toda norma, ação, microestrutura, instituição ou eticidade cultural têm sempre e necessariamente como conteúdo último algum momento da produção, reprodução e desenvolvimento da vida humana em concreto. ${ }^{25}$

A Ética da concreção é a ética moderna, isto é:

A ética do nosso tempo é uma ética existencial, que põe acima de tudo a pessoa humana, não como abstração, à maneira de Boécio, mas como uma concreção vital, como valor fonte dos demais valores. ${ }^{26}$

É com base no critério material (vida humana concreta) que se devem subsumir os outros aspectos materiais (como os valores, a lógica das pulsões etc.). Esse critério material, igualmente, permite fundamentar ou desenvolver um princípio ético universal, supracultural. ${ }^{27}$

Esse critério de produção, reprodução e desenvolvimento da vida humana não é algo a ser imputado à consciência humana, a um certo "consciencialismo" moderno que faz perder o sentido da corporalidade orgânica da existência ética. ${ }^{28}$ Se a espécie humana está formatada, neurocerebralmente, para a preservação e desenvolvimento da vida humana, tal critério não é diferente nas relações sociais, como é o caso do direito e do processo, razão pela qual a atuação do juiz deverá ser guiada por esse "critério de verdade" prática. ${ }^{29}$

Esse critério material sobre o qual se funda a ética, produção reprodução e desenvolvimento da vida humana, é universal, não solipsista, mas comunitário. Diz respeito a uma comunidade de vida.

Se a humanidade perdesse essa consciência do outro, diante de sua miséria, de sua impotência social, econômica e cultural, poderia precipitar-se num suicídio coletivo. ${ }^{30}$

O reconhecimento do outro, como forma de produção, reprodução de desenvolvimento da vida humana, transforma-se de um critério de verdade prática numa exigência ética: no dever-reconbecer. ${ }^{31}$

O Poder Judiciário, como instrumento dessa ética existencial, pois é uma instituição que, também, atua mediante princípios éticos, deve pautar sua ação prática racional, no momento de realizar sua atividade básica e essencial, segundo o princípio material universal de produção, reprodução e desenvolvimento da vida bumana. Para tanto, deve (princípio ético) reconhecer as desigualdades sociais, econômicas e culturais, que possam existir no âmbito da relação jurídica processual. Em outras palavras, deve reconhecer o "outro" vítima potencial de um sistema totalizado.

25 DUSSEL, Enrique. Ética da libertação na idade da globalização e da exclusão. Rio de Janeiro: Vozes, 2000. p. 93

26 REALE, Miguel. A ética do juiz na cultura contemporânea. In: NALINI, José Renato (Coord.). Uma nova ética para o juiz: São Paulo: RT, 1994. p. 146.

27 “De fato, não há ‘um horizonte último comum’ cultural, mas há um princípio material universal interno a cada uma e a todas as culturas, e isto Taylor não vê. Não é um 'horizonte’; é um modo de realidade: a própria vida humana.” DUSSEL, Enrique. Ética da libertação na idade da globalização e da exclusão. Rio de Janeiro: Vozes, 2000. p. 122.

28 DUSSEL, Enrique. Ética da libertação na idade da globalização e da exclusão. Rio de Janeiro: Vozes, 2000. p. 95.

29 "Do ponto de vista cerebral, o sistema avaliativo/afetivo cerebral responde da seguinte forma: em primeiro lugar responde às necessidades objetivas primeiras; em segundo lugar, articula-se com o nível linguístico-cultural e histórico; em terceiro lugar responde às exigências superiores e culturais universais de uma ética crítica.” DUSSEL, Enrique. Ética da libertação na idade da globalização e da exclusão. Rio de Janeiro: Vozes, 2000. p. 104.

30 "O projeto da libertação dos oprimidos e dos excluídos é aberto, partindo da exclusão do outro e indo mais além (jenseits) de qualquer situação apresentada. A estruturação de alternativas - mesmo que fosse necessária (o que não podemos descartar a priori) a de uma utopia ou a de uma nova sociedade — não consiste na 'aplicação' de algum modelo ou situação ideal ou transcendental, nem tampouco na execução autêntica de um determinado 'mundo da vida' (quer seja ele o moderno ou outro diferente), muito menos se for idealizado como efeito indestrutível de uma lógica necessária (a da teologia ou razão histórica de Hegel ou a do marxismo standart ou de Stalin); mas deverá ser uma 'des-coberta' responsável, como resposta à 'interpelação' do outro, dentro de um lento processo de prudência (em que a teoria de uma 'comunidade de comunicação real' — que racional e processualmente chega a um consenso de validade intersubjetiva — nos ajuda a compreender melhor o progredir seletivo da fronésis de libertação), durante o qual o filósofo (tal como 'intelectual orgânico' de Gramsci deve tratar com seriedade as motivações ética (com Taylor) da libertação dos oprimidos e excluídos.” DUSSEL, Enrique. Filosofia da libertação: crítica à ideologia da exclusão. 2. ed. São Paulo: Paulus, 1995. p. 119-120.

31 DUSSEL, Enrique. Ética da libertação na idade da globalização e da exclusão. Rio de Janeiro: Vozes, 2000. p. 141. 
Essa ética filosófica está expressamente consignada e fundamentada no próprio texto constitucional brasileiro, quando afirma, em seu art. 1. ${ }^{\circ}$, que a República Federativa do Brasil, da qual faz parte o Judiciário, constitui-se em um Estado Democrático de Direito, e tem como fundamento a dignidade da pessoa bumana, ou seja, a produção, reprodução e desenvolvimento da vida humana.

Por sua vez, em seu art. 3. ${ }^{\circ}$, a Constituição Federal estabelece que constituem objetivos fundamentais da República Federativa do Brasil a construção de uma sociedade livre, justa e solidária, mediante a erradicação da pobreza e da marginalização, conjugando esforços no sentido de reduz̧ir as desigualdades sociais e regionais. Em outras palavras, a Constituição Federal exige uma ética universal material no sentido de que os órgãos e instituições da República Federativa do Brasil ajam de forma a produzir, reproduzir e desenvolver a vida bumana.

Por tudo isso:

[...] propomos a seguinte descrição inicial do que chamaremos princípio material universal da ética, princípio da corporalidade como 'sensibilidade' que contém a ordem pulsional, cultural-valorativa (hermenêutica-simbólica), de toda norma, ato, microfísica estrutural, instituição ou sistema de eticidade, a partir do critério da vida humana em geral: aquele que atua eticamente deve (como obrigação) produzir, reproduzir e desenvolver autorresponsavelmente a vida concreta de cada sujeito humano, numa comunidade de vida, a partir de uma 'vida boa' cultural e histórica (seu modo de conceber a felicidade, com uma certa referência aos valores e a uma maneira fundamental de compreender o ser como deverser, por isso também, com pretensão de retidão) que se compartilha pulsional e solidariamente, tendo como referência última toda a humanidade, isto é, é um enunciado normativo com pretensão de verdade prática e, em além disso, com pretensão de universalidade. ${ }^{32}$

Mas, diante das desigualdades sociais, econômicas e culturais, somente se pode postular um critério/ princípio da produção, reprodução e desenvolvimento da vida humana no âmbito processual, sob um aspecto material positivo, desde que se perceba o surgimento do "rosto" que se destaca na ordem social vigente, e que representa as vítimas não intencionais ou mesmo intencionais de um determinado sistema totalizado e porque não dizer globalizado. Isto é, "[...] o rosto sensível do outro homem, que tem fome e sangue, encontra-se para além do sistema onde o ser é o pensar [...]. O 'tu', outro homem, é exterior ao âmbito ser-pensar [...].”.33

Enrique Dussel, voltado para a efetiva existência de vítima de um determinado sistema, reporta-se, a partir dessa vítima, à verdade do sistema totalizador que começa a ser descoberta como não verdade, ao válido como não válido, e ao factível como não eficaz. A construção temática passa do âmbito da positividade para a negatividade da existência de vítima.

A ética propriamente dita é a que a partir das vítimas pode julgar, criticamente, a "totalidade" de um sistema de eticidade. A partir das vítimas pode julgar e pôr em dúvida a verdade e a legitimidade da concepção ontológica da imparcialidade do juiz.

É a partir da exterioridade de uma dada totalidade, em que se situam as vítimas, que se estabelece uma consciência crítica do sistema de eticidade dado. As vítimas "[...] são reconhecidas como sujeitos éticos, como seres humanos que não podem reproduzir ou desenvolver sua vida, que foram excluídos da participação na discussão [...]". ${ }^{34}$ No sistema de eticidade, “o bem" inverte-se no "mal" e causa dor, sofrimento, infelicidade ou a própria morte das vítimas.

É na alteridade do outro "como outro" que o sistema ético crítico se impõe. É a alteridade da vítima

32 DUSSEL, Enrique. Ética da libertação na idade da globalização e da exclusão. Rio de Janeiro: Vozes, 2000. p. 143.

33 DUSSEL, Enrique. Ética da libertação na idade da globalização e da exclusão. Rio de Janeiro: Vozes, 2000. p. 148.

34 " [...] o sistema de eticidade vigente, que era para a consciência ingênua (que pode ser científica, ocupar a função de autoridade política ou econômica, ou ainda ser membro da elite moral do sistema, a 'raça sacerdotal' de Nietzsche) a medida do 'bem' e do 'mal', converte-se diante da presença de suas vítimas, enquanto sistema, no perverso (o 'mau'). É toda a questão do 'fetichismo' de Marx, a 'inversão dos valores' de Nietzsche, a descoberta do 'superego' repressor em Freud, a sociedade 'excludente' de Foucault, a 'dialética negativa' em Adorno e 'totalidade’ de Lévinas.” DUSSEL, Enrique. Ética da libertação na idade da globalizaç̧ão e da exclusão. Rio de Janeiro: Vozes, 2000. p. 303. 
como oprimida (classe) ou como excluída (mulher pobre e subjugada no sistema carcerário). É o descobrimento do "outro" que se encontra encoberto pelo mito da modernidade. Trata-se de uma ética que demonstra o terror de uma razão fechada na totalidade, entre outras, a razão da modernidade..$^{35}$

A responsabilidade pelo outro conduz a uma filosofia de vida em que se revela um profundo compromisso com a vida. A vida é realizada e confirmada segundo a concretude de cada dia.

Para Martin Buber, o projeto da filosofia é explicitar a concretude vivida da existência humana a partir do próprio interior da vida. ${ }^{36}$

No interior dessa filosofia de vida, Emmanuel Lévinas procura construir a subjetividade e a intersubjetividade humanas num nível pré-originário, o qual seria anterior a qualquer tematização. "O existente humano singular e concreto já se move num âmbito anterior ao mundo como horizonte de compreensão". ${ }^{37}$ Existe um nível anterior ao ser e à sua obra de ser, e encontrá-lo e nele se refugiar é o que se entende por sair do ser sem apelar para sua negação. Sair do ser é criar um intervalo no ser, sem, contudo, negá-lo. O primeiro, portanto, não é ontológico, não o ser, não é a aventura de compreender e do saber, é algo diferente. É a ética como anterior à ontologia. ${ }^{38}$

Em defesa da ética como filosofia primeira, Emmanuel Lévinas sustenta ou identifica a ontologia com o dogmatismo, e demonstra que a crítica é anterior ao dogmatismo. A ética é crítica, portanto, a ética é anterior a ontologia fundamental que é dogmática. O dogmatismo é uma postura epistemológica existente no interior da ontologia em que se afirma a liberdade cognoscente do sujeito diante da exterioridade do objeto cognoscível. Por isso: "Ser livre significa que o saber é uma relação do próprio com o outro onde o outro se reduz ao próprio [...] onde o pensamento se refere ao outro, mas onde o outro já não é outro enquanto tal, onde ele já é o próprio, já meu". ${ }^{39}$

O sujeito se reconhece ser humano ao mesmo tempo em que reconhece ao outro como ser humano, e, por isso, lhe atribui sua própria "consciência humana", o que explica que:

[...] a cada separación o divergencia con el otro en los combates y enfrentamientos, el individuo tenga, espontáneamente, tendencia a romper la pertenencia común, a priva al otro de su conciencia moral, a rechazarlo, simbólica o legalmente, fuera de la humanidad. ${ }^{40}$

Transportando-se o pensamento de Emmanuel Lévinas para a ética da libertação de Enrique Dussel, pode-se afirmar que o sistema de eticidade corresponde a um nível ontológico de totalidade, que começa a ser questionado, refutado, por um juízo ético material da razão crítica negativa que se encontra na exterioridade do rosto das vítimas.

Portanto, na perspectiva de Emmanuel Lévinas, a ética é metafísica. A sensibilidade (pré-ontológica) anterior a toda inteligibilidade parte de uma concepção do sujeito que deve reconhecer o outro como exterioridade (pós-ontológica).

Eis aí, portanto, a fundamentação ética preconizada no HC n. Habeas Corpus n. 143.641, em que o Supre-

35 A perspectiva filosófica formulada neste trabalho vem ao encontro da nova tendência do processo penal moderno, em que se levam em consideração as vítimas. Segundo Antonio Beristain: "Hasta finales del siglo XX, el centro del proceso lo ocupan, cada día más las víctimas. Por otra parte, ante la policía, los jueces y los peritos, las víctimas sufrían una segunda victimación que ahora se critica severamente, y, con frecuencia, se procura evitar. En algunos casos se llega más adelante: se va logrando que la meta principal del proceso no sea la pena al condenado sino la reparación a las víctimas" BERISTAIN, Antonio. Nuevo proceso penal desde las víctimas. In: PIERANGELI, José Henrique (Coord.). Direito criminal. Belo Horizonte: Del Rey, 2001. p. 26. Evidentemente que neste trabalho não se restringe a análise da vítima apenas na perspectiva do sujeito que sofre um dano em face do delito, mas em face da totalidade dos sujeitos envolvidos na relação jurídica processual.

36 BUBER, Martin. Eu e tu. 8. ed. São Paulo: Cortez \& Moraes, 1974. p. xxviii.

37 ANDRE, Manuel da Costa. Sobre as proibições de prova em processo penal. Coimbra: Coimbra, 1992. p. 24.

38 ANDRE, Manuel da Costa. Sobre as proibições de prova em processo penal. Coimbra: Coimbra, 1992. p. 25.

39 LÉVINAS, Emmanuel. Transcendência e inteligibilidade. Lisboa: Edições 70, 1984. p. 14.

40 MORIN, Edgar; PIATTELLI-PALMARINI, Massimo. La unidad del hombre: interdisciplinariedad y ciencias humanas. Madrid: Tecnos, 1983. p. 211. 
mo Tribuna Federal reconheceu a ética da racionalidade do outro como uma sensibilidade pré-ontológica.

Por meio de uma racionalidade crítica que rompe com a totalidade processual dominante (cárcere a qualquer custo), o juiz deve abandonar sua subjetividade solipsista de apenas realizar um ato de conhecimento no âmbito de atividade jurisdicional, para, por meio de sua sensibilidade, reconhecer a exterioridade das vítimas, das diferenças sociais, econômicas e culturais.

É possível ao juiz libertar-se da dogmática de seu "solipsismo", de sua "subjetividade egoística", no seu conforto da imparcialidade como neutralidade, para alcançar o "outro" que se encontra num âmbito transcendental, e confirmar a sua responsabilidade que é pré-ontológica.

O juiz não deve tematizar o outro (vítima inferiorizada na relação jurídica processual), mas deixar transparecer um desejo metafísico de proferir uma decisão équo e justa, pois o juiz, em relação às vítimas do sistema, tem uma responsabilidade ética pré-originária à totalidade do sistema jurídico dominante.

Tendo em vista essa responsabilidade ética pré-originária não tematizadora do outro, o método que antecede a própria dialética (que para Enrique Dussel seria o método por excelência da totalidade), a ser desenvolvido pré-originariamente no processo, seria o método analítico que permite a abertura efetiva ao outro e, concomitantemente, a derrubada do sistema e da totalidade cerrada, para o fim de liberar o outro negado em sua dignidade.

\section{Considerações finais}

O Supremo Tribunal Federal, ao proferir decisão, no Habeas Corpus n. 143.611, em favor das mulheres presas preventivamente e que ostentam a condição de gestantes, de puérperas ou de mães de crianças sob sua responsabilidade, deixou, de certa forma, evidenciado quais seriam os fundamentos da dogmática jurídica penal, constitucional, criminológica, sociológica e do direito das gentes que serviram de base para a proteção coletiva dos pacientes.

Porém, é possível constar da complexidade dos argumentos introduzidos no referido julgamento um fundamento ético material que justifica, filosoficamente, a conclusão adotada no remédio constitucional.

Trata-se de um fundamento em que a ética material é inserida como filosofia primeira, antes mesmo da ontologia. E essa ética é uma ética de concreção, que coloca, acima de tudo, a dignidade da mulher presa preventivamente como critério de produção, reprodução e desenvolvimento da pessoa humana.

Em razão dessa ética material, como filosofia primeira, justifica-se um novo estereótipo da representação simbólica da Justiça, no sentido de que a venda da deusa da Justiça seja retirada para que se possa reconhecer no processo a racionalidade do outro, a sua diferença sociocultural-político-econômica. A balança, diante da realidade latino-americana deve ser desequilibrada, a fim de representar as desigualdades sociais, econômicas e culturais existentes num continente regrado por injustiças sociais. E a espada, por fim, deve ser substituída por uma "lupa", para que se possam avistar as concepções ideológicas que existem por trás de um determinado ordenamento jurídico de cunho sexista e discriminatório.

\section{REFERÊNCIAS}

ALBUQUERQUE, Aline S. de Oliveira; BARROS, Julia Schirmer. Caso Alyne Pimentel: uma análise à luz da abordagem baseada em direitos humanos. Revista do Instituto Brasileiro de Direitos Humanos, Fortaleza, n. 12, jul. 2016. 
ANDRE, Manuel da Costa. Sobre as proibições de prova em processo penal. Coimbra: Coimbra, 1992.

BARCELLONA, Pietro; HART, Dieter; MÜCKENBERGER, Ulrich. La formación del jurista: capitalismo monopolístico y cultura jurídica. Madrid: Civitas, 1993.

BERISTAIN, Antonio. Nuevo proceso penal desde las víctimas. In: PIERANGELI, José Henrique (Coord.). Direito criminal. Belo Horizonte: Del Rey, 2001.

BRASIL. Conselho Nacional de Justiça. PANORAMA de Acesso a 4 Revisado Habeas Corpus 143641/ SP Justiça no Brasil, 2004 a 2009. Brasília: Conselho Nacional de Justiça, 2011.

BRASIL. Ministério da Justiça. Infopen Mulheres. Levantamento nacional de informacões penitenciárias. 2014. p. 18-19. Disponível em: <https://www.justica.gov.br/news/estudo-traca-perfil-da-populacao-penitenciariafeminina-no-brasil/relatorio-infopen-mulheres.pdf>. Acesso em: 7 jun. 2018.

BUBER, Martin. Eu e tu. 8. ed. São Paulo: Cortez \& Moraes, 1974.

COMPARATO, Fábio Konder. Papel do jurista num mundo em crise de valores. Revista dos Tribunais, São Paulo, ano 84, v. 713, p. 283, mar. 1995.

COROMINAS, Jordi. Ética primera: aportación de X. Zubiri al debate ético contemporáneo. Bilbao: Desclée de Brouwer, 2000.

DUSSEL, Enrique. Ética da libertação na idade da globalização e da exclusão. Rio de Janeiro: Vozes, 2000.

DUSSEL, Enrique. Filosofia da libertação: crítica à ideologia da exclusão. 2. ed. São Paulo: Paulus, 1995.

FARRELL, Martin D. Algunas maneras de entender a la neutralidad. Doxa, p. 15-16, 1994. Disponível em: <http://www.cervantesvirtual.com/servlet/SirveObras/01361620824573839199024/cuaderno15/voll/ doxa15_09.pdf>. Acesso em: 3 ago. 2005.

FAZZALARI, Elio. La imparzialità del giudice. Rivista di Dirito Processuale, Padova, Cedam, n. 2, p. 193-203, 1972.

LÉVINAS, Emmanuel. Transcendência e inteligibilidade. Lisboa: Edições 70, 1984.

MACHADO FILHO, H. União Europeia, Brasil e os desafios da agenda do desenvolvimento sustentável. In: SOBRENOME, Nome. Dos objetivos do milênio aos objetivos do desenvolvimento sustentável: lições aprendidas e desafios. Rio de Janeiro: Konrad Adenauer Stiftung, 2016.

MORELLO, Augusto. El proceso justo. Buenos Aires: Abeledo-Perrot, 1994.

MORIN, Edgar; PIATTELLI-PALMARINI, Massimo. La unidad del hombre: interdisciplinariedad y ciencias humanas. Madrid: Tecnos, 1983.

PAJARDI, Piero. I provvedimenti d'urgenza atipici nel processo civile. Milano: Pirola, 1988.

PENNA, Antonio Gomes; NALINI, José Renato (Coord.). Uma nova ética para o juiz: São Paulo: RT, 1994.

REALE, Miguel. A ética do juiz na cultura contemporânea. In: NALINI, José Renato (Coord.). Uma nova ética para o juiæ: São Paulo: RT, 1994.

REQUJO PAGÉS, J. L. Jurisdicción e independencia judicial. Madrid: Centro de Estudios Constitucionales, 1989.

RHODE, Deborah L. Access to justice. New York: Oxford, 2004.

RIBEIRO, Maria Teresa de Melo. O princípio da imparcialidade da administração pública. Coimbra: Almedina, 1996.

RICOEUR, Paul. Interpretação e ideologias. Rio de Janeiro: Livraria Alves, 1977.

ROCHA, Leonel Severo. A problemática jurídica: uma introdução transdisciplinar. Porto Alegre: Fabris, 1985. 
ROCHA, Lilian Rose Lemos; CARDOZO, José Eduardo. Precariedade do sistema penitenciário brasileiro como base temática para a proibição ou legalização das drogas. Revista Brasileira de Políticas Públicas, v. 7, n.3, dez. 2017.

RORTY, Richard. A filosofia e o espelho da natureza. 3. ed. Rio de Janeiro: Relume Dumará, 1994.

SAMUELS, Andrew. Jung e os pós-junguianos. Rio de Janeiro: Imago, 1989.

SANTIAGO, Silviano. Pósfácio. In: LYOTARD, Jean-François. A condição pós-moderna. 7. ed. Rio de Janeiro: José Olympio, 2002.

SANTOS, Boaventura Souza. O discurso e o poder. Estudos em homenagem ao Prof. Doutor J. J. Teixeira Ribeiro. Coimbra: II Iuridica, 1979.

SATTA, Salvatore. Astensione del giudice. Enciclopedia del diritto. Milano: Giuffrè, 1958. t.3.

SCHMIDT, Eberhard. Los fundamentos teóricos y constitucionales del derecho procesal penal. Buenos Aires: Bibliográfica Argentina, 1957.

SCHOEPFLIN, Marurizio. L'amore ama il Bene, parola di Lévinas. Disponível em: <http://lgxserver.unib.it/ lei/rassegna/010512a.htm>. Acesso em: 26 mar. 2004.

SCILLITANI, Marco. Il giusto processo: associazione tra gli studiosi del proceso penale. Milano: Giuffrè, 1998.

SOARES, B. M.; ILGENFRITZ, I. Prisioneiras: vida e violência atrás das grades. Rio de Janeiro: Garamond, 2002.

SOUZA, Luciana Cristina. Dignidade humana na webesfera governamental brasileira. Revista Brasileira de Políticas Públicas, v. 7, n. 3, dez. 2017.

UN WOMEN. A gender perspective on the impact of drug use, the drug trade, and drug control regimes. 2014. p. 3435. Disponível em: <https://www.unodc.org/documents/ungass2016/Contributions/UN/Gender_and_ Drugs_-_UN_Women_Policy_Brief.pdf>. Acesso em: 7 jun. 2018.

ZIMMERMANN, Roque. América Latina o não ser. 2. ed. Rio de Janeiro: Vozes, 1987. 


\section{NEURODIREITO APLICADO AO DIREITO E AO PROCESSO PENAL}




\section{REVISTA BRASILEIRA DE POLÍTICAS PÚBLICAS BRAZILIAN JOURNAL OF PUBLIC POLICY}

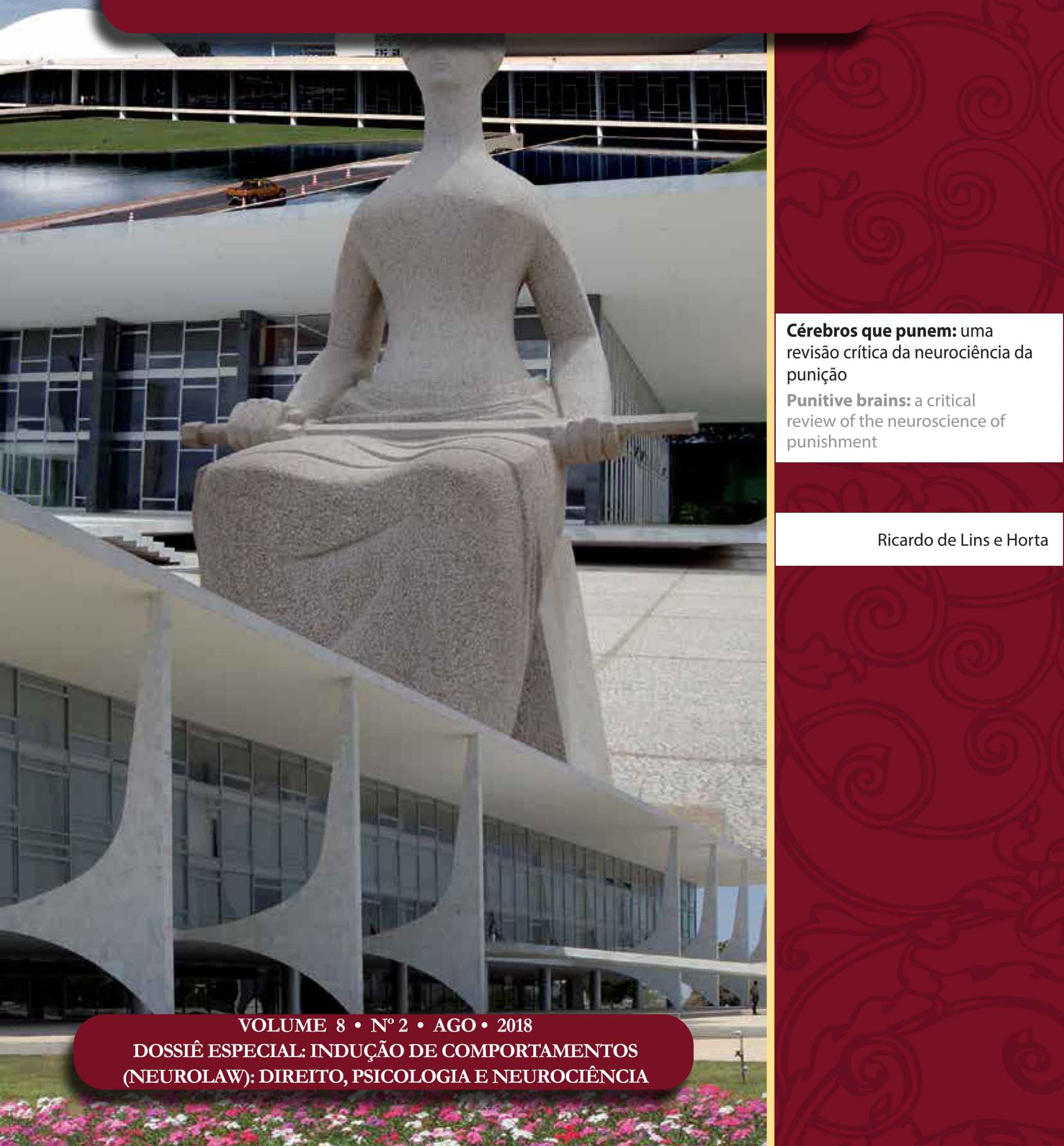




\title{
Cérebros que punem: uma revisão crítica da neurociência da punição*
}

\author{
Punitive brains: a critical review of the \\ neuroscience of punishment
}

Ricardo de Lins e Horta*****

\section{Resumo}

Os profissionais envolvidos com o sistema penal, rotineiramente, tomam decisões sobre a culpabilidade e a punibilidade de transgressores. $\mathrm{O}$ comportamento de punir um ofensor tem sido estudado por psicólogos e neurocientistas, que buscam compreender quais as motivações subjacentes ao ato de punir, bem como quais as estruturas cerebrais envolvidas no processamento de informações sobre a intencionalidade e gravidade de uma ofensa. Estudos recentes apontam que a decisão de punir envolve áreas cerebrais específicas, cuja origem estaria ligada à funcionalidade, no contexto de evolução da espécie, de estabilizar a cooperação em grupos, por intermédio do reforço das normas sociais mediante a aplicação de sanções. Neste artigo, buscamos fazer uma revisão crítica dessa literatura, apontando que, apesar da importância dos estudos da chamada Neurociência da Punição, os pressupostos por eles adotados ainda são discutíveis, do ponto de vista da biologia evolucionista e da neurociência cognitiva.

Palavras-chave: Acesso à justiça. Neurodireito. Psicologia da punição. Teorias da pena. Retributivismo.

* Recebido em 31/05/2018 Aprovado em 02/07/2018

** Doutorando em Direito (UnB), Mestre em Neurociências e Graduado em Direito (UFMG). Foi pesquisador visitante na École Normale Supérieure, em Paris (2016-2017). Integrante da carreira de Especialista em Políticas Públicas e Gestão Governamental (EPPGG) federal, é atualmente Coordenador-Geral de Articulação Institucional da Escola Nacional de Administração Pública (ENAP).

Email: ricardolinshorta@gmail.com

*** Versão anterior deste trabalho foi apresentada como conferência no III Seminário de Direito, Psicologia e Neurociência, organizado pelo grupo de estudos em Direito, Psicologia e Neurociência (DIPSIN) da Faculdade de Direito de Ribeirão Preto da USP, em 17/10/2017. Agradecemos os valiosos comentários do professor Noel Struchiner (PUC/RJ), que contribuíram para o esclarecimento de diversos pontos do manuscrito original.

\section{Abstract}

Professionals involved in the criminal justice system routinely make decisions about the culpability of offenders. The behavior of punishing an offender has been studied by psychologists and neuroscientists, who seek to understand the motivations underlying the act of punishing, as well as which brain structures are involved in processing information about the intentionality and severity of an offense. Recent studies indicate that the decision to punish involves specific brain areas related to the function, in the context of evolution of the species, to stabilize cooperation in groups, through the reinforcement of social norms due to the application of sanctions. In this article, we seek to make a critical review of this literature, pointing out that, despite the importance of the studies of the so-called Neuroscience of $\mathrm{Pu}$ nishment, its assumptions are still debatable from the point of view both of Evolutionary Biology and Cognitive Neuroscience.

Keywords: Neurolaw. Psychology of Punishment. Theories of punishment. Retributivism. 


\section{INTRODUÇÃO}

O que se passa na mente de uma testemunha de um crime, ou de alguém que presencia o sofrimento de uma vítima de um delito? Por que e como alguém decide que um violador de normas sociais deve ser punido? Esses são problemas sobre os quais cientistas vêm se debruçando recentemente, utilizando avançadas técnicas experimentais.

Nas últimas décadas, as Ciências Comportamentais vêm adotando um conjunto de métodos de pesquisa que permitem traçar um cenário cada vez mais preciso desse complexo fenômeno que é o comportamento humano. Explicações biopsicossociais hoje são corriqueiras tanto para os comportamentos comumente identificados com os demais animais não humanos, como a agressão e o desejo sexual; quanto para aqueles que um dia se sustentou, equivocadamente, serem exclusivos da espécie humana, como a linguagem, as relações de poder ou os comportamentos altruístas e cooperativos ${ }^{1}$. Nesse sentido, os resultados mais promissores e frutíferos da ciência mais recente são aqueles que, em vez de insistirem numa estéril contraposição entre fatores sociais, de um lado, e fatores biológicos, de outro, abraçam a noção de que o comportamento humano resulta de uma interação entre ambos. Com efeito, mesmo fenômenos sociais sofisticados e multifacetados são melhor compreendidos somando-se, ao lado dos olhares sociológico, antropológico, etc., as variáveis biológicas, presentes em sua gênese e desenvolvimento².

Do ponto de vista da ciência psicológica, décadas de estudos estabeleceram que o ato de punir não é resultado de um cálculo deliberado e racional, mas é, em grande medida, um processo cognitivo intuitivo e automático ${ }^{3}$. Violações de normas e agressões tendem a despertar uma sensação de ultraje moral nas vítimas e em testemunhas, e é essa reação instintiva que leva ao desejo de punir. O julgamento moral influencia a avaliação da gravidade de uma situação que o Direito Penal tipifica como crime 4 .

A Psicologia tradicionalmente realizou estudos utilizando métodos que perscrutavam a esfera comportamental, simulando situações em que sujeitos de pesquisa tinham que responder a questionários, ou que mediam reações a hipotéticas violações de normas. Nos últimos anos, porém, com a disponibilidade de técnicas e métodos de neuroimagem, tornou-se possível estudar não apenas o comportamento observável, mas também os padrões de funcionamento cerebral in vivo e em tempo real. Em virtude disso, tornou-se viável formular a questão de como são processadas as informações referentes a uma transgressão no cérebro.

Entender isso é a tarefa a que neurocientistas se propuseram nos últimos 15 anos, e assim uma profusão de experimentos se dedicou a delimitar estruturas neurais específicas que seriam recrutadas no cérebro do sujeito que toma a decisão de punir alguém. Segundo essa linha de estudos, tal como existem estruturas cerebrais muito especializadas no processamento de informações referentes à visão, à fala ou ao tato, existiria uma circuitaria cerebral específica para o ato de avaliar a culpabilidade e a necessidade de punir um transgressor.

Essa discussão é importante para a comunidade jurídica porque traz consequências para a forma como se encara a centralidade da punição no sistema normativo. Do ponto de vista das teorias da pena, a sanção penal historicamente foi justificada com argumentos preventivos ou retributivistas. Não se admite, contemporaneamente, que a vingança seja um argumento legítimo para a resposta penal a uma conduta delitiva; não obstante, o neorretributivismo é uma das tendências mais fortes na discussão teórica das últimas dé-

1 SAPOLSKY, Robert M. Behave: the biology of humans at our best and worst. New York: Penguin Press, 2017; Vide também, sobre o questionável (mas disseminado) argumento da exclusividade humana; WAAL, Frans de. Are we smart enough to know how smart animals are? New York: W. W. Norton \& Company, 2016.

2 NETTLE, Daniel. Tyneside neighbourhoods. Cambridge, UK: Open Book Publishers, 2016.

3 CARLSMITH, Kevin M.; DARLEY, John M. Psychological aspects of retributive justice. Advances in Experimental Social Psychology, v. 40, n. 7, p. 193-236, 2008.

4 DARLEY, John M. Morality in the law: the psychological foundations of citizens' desires to punish transgressions. Annual Review of Law and Social Science, v. 5, n. 1, p. 1-23, 2009. 
cadas. Nas propostas mais recentes da dogmática penal, categorias conceituais como "reprovabilidade da conduta", "censura" ou "denunciação" figuram como finalidades da pena. Admite-se teoricamente, assim, que a gravidade da ofensa serve de medida para a proporcionalidade da pena - dito de outra forma, que o restabelecimento da justiça após uma transgressão passa pela sanção proporcional ao dano causado. Não raro, no debate público e acadêmico, sugere-se que há uma demanda psicológica das vítimas e dos cidadãos em geral por punição aos criminosos, oriunda de anseios retributivistas 5 .

As sanções jurídicas podem ser defendidas filosoficamente como maneiras de induzir a aderência a regras, especialmente por parte dos transgressores. Além dos mecanismos sociais de internalização de normas e de conformidade aos valores vigentes no grupo, o receio de sanções pode funcionar como um incentivo para que as normas vigentes no grupo sejam respeitadas ${ }^{6}$.

$\mathrm{Na}$ literatura que analisaremos a seguir, é frequente que se encontrem argumentos evolucionistas como explicações para a existência de uma circuitaria cerebral específica para o comportamento punitivo. Esse argumento evolucionista, que será melhor explicado no item seguinte, poderia ser sintetizado da seguinte maneira: num contexto interativo, em que os indivíduos podem ou não adotar um comportamento cooperativo, se os trapaceiros não são punidos, eles se locupletam, a confiança se perde, os grupos não conseguem mais cooperar, e a ordem social se desestabiliza. Grupos que punem os transgressores, por sua vez, funcionam de forma cooperativa e são bem-sucedidos. Nessa concepção, a punição dos transgressores é o que torna possível a vida em sociedade. Consequentemente, seria razoável supor que a evolução dos grupos humanos estaria intimamente associada à existência de uma determinada reação moral à transgressão, ou um mecanismo cognitivo para este fim.

A literatura em Psicologia Evolucionista frequentemente associa "módulos mentais" específicos a desafios encontrados pelos seres humanos no ambiente ancestral da espécie. As estruturas especializadas do cérebro humano, assim, seriam resultado de um processo de seleção natural ao longo de milhões de anos. Essa discussão, que é muito extensa para ser tratada aqui, está presente nos estudos em Neurociência da Punição, que geralmente associam a circuitaria cerebral engajada nas ações de avaliar uma transgressão, e de punir seu autor, ao desafio, presente no ambiente evolucionário, de manter a coesão dos grupos sociais ${ }^{7}$.

O que vale examinar, assim, é se, à luz do que se sabe atualmente na literatura especializada - e aqui estamos falando de experimentos recentes, publicados em periódicos científicos de prestígio, discutidos nas universidades de ponta —, é possível compreender o que ocorre no cérebro da pessoa que decide punir alguém que agiu contrariamente à norma ou à expectativa legítima de quem pune. E, se esses estudos nos dizem algo relevante, quais seriam as consequências disso para a discussão da área penal ou da política criminal?

Iniciaremos esse percurso estabelecendo os pressupostos teóricos da literatura em Neurociência da Punição. Em seguida, faremos uma revisão dos experimentos que vinculam comportamentos punitivos à atividade cerebral de áreas específicas. Por fim, analisaremos as limitações metodológicas e o problema das possíveis implicações dessa literatura para as políticas públicas da área criminal.

5 HORTA, Ricardo de Lins e. A desalentadora função das prisões: revisitando as teorias da pena à luz da psicologia experimental. Manuscrito.

6 STRUCHINER, Noel; CHRISMANN, Pedro H. V. Aspectos filosóficos e psicológicos das punições: Reunindo algumas peças do quebra-cabeça. Caderno CRH, v. 25, n. 2, p. 133-150, 2012; ALMEIDA, Fabio Portela Lopes. As origens evolutivas da cooperação humana, Revista DireitoGV, v. 9, n. 1, p. 243-268, 2013.

7 Aqui é relevante lembrar a forte influência que as perspectivas evolucionárias adquiriram na ciência psicológica mainstream nos últimos 40 anos. Embora a chamada Psicologia Evolucionista, como campo de investigação, ainda sofra diversas críticas, não há controvérsia científica relevante sobre a premissa de que o comportamento humano resulta de um processo de milhões de anos de pressões seletivas ao longo da evolução da espécie. 


\section{Os PRESSUPOSTOS TEÓRICOS DA NEUROCIÊNCIA DA PUNIÇÃO}

Examinaremos, neste trabalho, os estudos que buscam experimentalmente entender como funciona o comportamento punitivo no cérebro humano. Antes, porém, é necessário analisar seus pressupostos. Os estudos de Neurociência da Punição partilham de duas hipóteses relevantes, uma de ordem evolucionista, outra de ordem neurocientífica: (i) a de que a cooperação humana foi estabilizada, em termos evolucionários, por meio do comportamento de punir trapaceiros, e (ii) o de que a punição, como comportamento antigo da espécie, recruta áreas cerebrais específicas, ligadas, respectivamente, ao estabelecimento da responsabilidade do agente e à determinação da punição que deveria ser aplicada no caso ${ }^{8}$.

É praticamente um truísmo na literatura psicológica mais recente afirmar que, no ambiente ancestral, grupos em que se puniam os aproveitadores cooperavam de forma mais estável, e, portanto, perseveraram. Desse modo, a circuitaria cerebral da punição cumpriria a função evolucionária essencial de dar efetividade às normas sociais, prevenindo que trapaceiros se beneficiem às custas dos outros.

O pano de fundo disso é a discussão do problema da evolução da cooperação na espécie humana, uma das questões que mais tem mobilizado estudiosos e estimulado debates entre biólogos, psicólogos, antropólogos e etólogos nos últimos 20 anos. A explicação a respeito da razão pela qual diversas espécies animais cooperam parece relativamente simples: animais não humanos, geralmente, cooperam apenas com indivíduos geneticamente aparentados, o que traz benefícios evolucionários evidentes, ao perpetuar seus genes. Algumas espécies também estabelecem relações de reciprocidade direta, em que os benefícios da interação são compartilhados com uma expectativa futura de retribuição.

Na espécie humana, porém, o nível de cooperação é ainda mais elevado. Em grupos humanos, a cooperação ocorre de forma relativamente comum entre indivíduos sem parentesco genético, e sem perspectiva de interação futura. Humanos ajudam estranhos, sem terem garantia ou certeza de que algum dia serão recompensados de volta por isso, apenas porque é o certo a se fazer. É a existência das normas morais que viabiliza, na espécie humana, a cooperação em larga escala entre indivíduos não aparentados, permitindo o surgimento e o desenvolvimento de grupos maiores, de cidades, de civilizações. O problema da evolução da cooperação é, assim, essencialmente, o problema de por que somos seres morais?

$\mathrm{Na}$ narrativa mais disseminada, esse diferencial humano estaria ligado às normas sociais: os humanos são cooperadores condicionais, que estão dispostos a colaborar entre si se a regra vigente no grupo for a reciprocidade. Contudo, a presença de trapaceiros no grupo e a consequente falta de uma norma de reciprocidade fariam com que o comportamento não cooperativo, egoísta, fosse a melhor estratégia, e, portanto, a regra seria a não cooperação. Porém, se os trapaceiros são punidos, o comportamento aproveitador tem um custo, e assim se produz um estímulo para a aderência à norma de reciprocidade: se há sanção, a trapaça não compensa, e a norma social da reciprocidade vigora no grupo ${ }^{10}$.

Assim, esses estudos partem do pressuposto de que, para entender o comportamento punitivo, devemos antes sondar as origens evolucionárias da chamada "reciprocidade forte": pessoas punem porque instintivamente é assim que se sentem obrigadas a fazer — não por acaso, punir um ofensor pode ser uma ação prazerosa, como de resto são outras que cumprem uma função evolucionária, como o sexo ou a saciedade alimentar. Nessa perspectiva, nutrir emoções negativas contra um aproveitador, e tomar a iniciativa de puni-lo, é uma ação pró-social: por essa razão, o termo "punição altruística"11. Em termos evolucionários, incor-

8 KRUEGER, Frank; HOFFMAN, Morris. The emerging neuroscience of third-party punishment. Trends in Neurosciences, v. 39 , n. 8, p. 499-501, 2016. Disponível em: <http://dx.doi.org/10.1016/j.tins.2016.06.004>.

9 BAUMARD, Nicolas. The origins of fairness: how evolution explains our moral nature. New York: Oxford University Press, 2016. 10 FEHR, Ernst; FISCHBACHER, Urs. Social norms and human cooperation. Trends in Cognitive Sciences, v. 8, n. 4, p. 185-190, 2004.

11 FEHR, Ernst; GÄCHTER, Simon. Altruistic punishment in humans. Nature, v. 415, n. 6868, p. 137-140, 2002. Disponível em: $<$ http://www.nature.com/doifinder/10.1038/415137a>. 
rer em um custo para si mesmo ao punir um transgressor beneficia o grupo como um todo - correr o risco de se envolver num conflito com o transgressor é um sacrifício compensado pelo fato de que as normas serão cumpridas, e, assim, todos se beneficiarão de estar num grupo em que as normas sociais funcionam. Se não há punição, não há cooperação possível; se há punição, porém, todos são incentivados a cooperar. Assim, estaria resolvido o paradoxo: instintos punitivos estabilizam a cooperação ${ }^{12}$.

É relevante compreender a distinção traçada por essa literatura entre as punições em primeira, segunda e terceira pessoa ${ }^{13}$. Ao causar mal a outrem, ao cometer uma agressão ou violação de norma social, o indivíduo poderia sofrer, como potencial consequência, três dimensões de "punição". Em "primeira pessoa", ela corresponde à culpa, remorso ou consciência interna que o próprio transgressor sentiria. Não sendo ela capaz de inibir o comportamento, poderia haver a "punição em segunda pessoa", que pode ser caracterizada como "retaliação" - em que o próprio agredido retribuiria a ofensa por conta própria, num ato de legítima defesa ou vingança. E, por fim, a "punição em terceira pessoa" (third-party punishment), que consistiria no fato de um terceiro, não diretamente envolvido no conflito ou agressão, arriscar-se para atribuir ao transgressor a devida punição.

Esse papel de terceiro, que atualmente seria desempenhado de forma institucionalizada pelo sistema de justiça e de persecução penal, seria, na concepção dos defensores dessa narrativa da evolução dos comportamentos punitivos, correspondente ao chefe tribal, ou à figura dominante do grupo, em contextos ancestrais de caçadores-coletores. O terceiro, não originalmente envolvido no conflito, seria a figura neutra que faria cumprir a norma social vigente.

Desde já, esse modelo proposto requer explicar o seguinte problema: por que, do ponto de vista evolucionário, faria sentido se arriscar para punir um indivíduo que causou mal a outrem, e não a si mesmo? Punir alguém envolve o risco de reação, ou de se envolver num conflito originalmente surgido de conflitos de interesses não pertinentes a si mesmo. Logo, se é fácil buscar uma explicação evolucionária para a "punição de segunda pessoa” - retaliar um agressor é uma forma óbvia de cessar ou intimidar futuros atos de agressão — não é nada evidente a explicação da "punição em terceira pessoa".

Buscando solucionar esse problema, entraram em cena os defensores das teorias da seleção multinível ou "seleção de grupo". O terceiro que pune beneficia o grupo, ao manter a aplicabilidade da norma social, e, assim, indiretamente beneficia a si próprio. Grupos cooperativos tendem a prosperar, ao contrário de grupos onde não há cooperação - estes tendem a se extinguir, aqueles prosperam e deixam herdeiros. $\mathrm{O}$ comportamento punitivo seria, assim, um traço universal humano, que recrutaria circuitos neurais para uma função de extrema importância evolucionária ${ }^{14}$.

Esse modelo teórico evolucionário revelou-se altamente influente na literatura psicológica contemporânea, e onipresente na discussão sobre o comportamento de adesão a normas, sobre como ocorre a cooperação em sociedades, bem como a origem dos instintos morais humanos ${ }^{15}$. Não por acaso, seus proponentes e teorias são citados na introdução da maioria dos artigos científicos da Neurociência da Punição.

É preciso analisar esse ponto para compreender sua consequência lógica: se comportamentos humanos presentes desde o ambiente evolucionário ancestral acabam por recrutar áreas cerebrais bastante especia-

12 BOYD, R. et al. The evolution of altruistic punishment. Proceedings of the National Academy of Sciences, v. 100, n. 6, p. 3531-3535, 2003. Disponível em: < http://www.pnas.org/cgi/doi/10.1073/pnas.0630443100>.

13 HOFFMAN, Morris B. The punisher's brain: the evolution of judge and jury. New York: Cambridge University Press, 2014; KRUEGER, Frank; HOFFMAN, Morris. The emerging neuroscience of third-party punishment. Trends in Neurosciences, v. 39, n. 8 , p. 499-501, 2016. Disponível em: <http://dx.doi.org/10.1016/j.tins.2016.06.004>.

14 BUCKHOLTZ, Joshua W; MAROIS, René. The roots of modern justice: cognitive and neural foundations of social norms and their enforcement. Nature Neuroscience, v. 15, n. 5, p. 655-661, 2012. Disponível em: <http://www.nature.com/doifinder/10.1038/ nn. 3087>.

15 BOWLES, Samuel; GINTIS, Herbert. A cooperative species: human reciprocity and its evolution. Princeton: Princeton University Press, 2011; HENRICH, Natalie; HENRICH, Joseph. Why bumans cooperate: a cultural and evolutionary explanation. New York: Oxford University Press, 2007. 
lizadas - e assim, o córtex occipital processa estímulos visuais, as áreas temporais do cérebro processam estímulos referentes à linguagem etc. - então, o mesmo ocorreria com o comportamento punitivo. O cérebro teria um "módulo" especializado em punir transgressores.

Em seguida, revisaremos os estudos que giram em torno dessa narrativa, bem como as evidências neurocientíficas deles resultantes.

\section{OS RESULTADOS DA NEUROCIÊNCIA DA PUNIÇÃO}

Há duas vertentes de métodos experimentais adotados em Neurociência da Punição. Muitos deles proliferaram, nos últimos 15 anos, em paralelo com o crescimento de experimentos em Neuroeconomia, que combinam técnicas de neuroimagem com tarefas de interação social que envolvem ganhos e perdas num contexto de jogos econômicos. Assim, uma das vertentes desses estudos é o emprego de jogos como “Trust", Ditador, Ultimato, Dilema dos Prisioneiros etc. Cria-se, num contexto de laboratório, uma situação de trapaça, seguida da possibilidade de punição do transgressor, e experimentalmente se utiliza de alguma técnica de neuroimagem. Assim, mede-se a atividade cerebral enquanto o sujeito reage ao fato de ser trapaceado ou de ver alguém ser vítima de trapaça.

Outra linhagem de pesquisas deriva da tradição dos estudos em Psicologia da Punição, em que textos curtos, vinhetas, são apresentadas aos sujeitos de pesquisa, geralmente descrevendo o cometimento de delitos ou de atos de transgressão, e os indivíduos devem assinalar um determinado nível de punição adequado ao caso ${ }^{16}$. Essa segunda vertente combina essas vinhetas fictícias com a neuroimagem.

Em ambas as linhas de estudos, verifica-se, desde então, o uso de técnicas neurocientíficas cada vez mais sofisticadas e precisas: os primeiros estudos utilizam o PET scan, além de ressonância magnética funcional (fMRI) e técnicas de estimulação transcraniana nos estudos mais recentes.

A literatura em Neurociência da Punição tem como um dos marcos inaugurais o experimento de cientistas da Universidade de Zurich que examina se a punição, ao ser um comportamento prazeroso, recrutaria áreas cerebrais ligadas ao sistema de recompensa ${ }^{17}$. Nesse estudo, foi conjugado um jogo econômico do estilo "trust game" com tomografia por emissão de pósitrons (PET scan) — um método comum à época, que investiga a ativação de áreas cerebrais valendo-se de contrastes radioativos.

No contexto do jogo, o sujeito recebia 10 unidades monetárias e podia escolher por dividi-la com outro jogador ou não. Se confiasse no outro jogador e repassasse a quantia, o montante era quadruplicado. Porém, o outro jogador podia tanto guardar tudo para si, trapaceando; ou dividir o montante multiplicado com o sujeito que havia confiado nele. Assim, o delineamento experimental simulava uma condição de trapaça, e, em seguida, avaliava cenários em que o sujeito podia punir ou não o trapaceiro, seja a custo zero, seja com custo em unidades monetárias. Os resultados revelaram que, ao punir o trapaceiro, de forma gratuita ou custosa, havia uma ativação no núcleo caudado, estrutura cerebral relacionada ao sistema de recompensa. A ativação dessa estrutura, aliás, estava correlacionada ao investimento na punição, no caso em que punir tinha custo. Além disso, o estudo mostrou ativação nas áreas pré-frontais mediais nos casos em que punir envolvia custos, em contraste com o cenário em que a punição era gratuita. $\mathrm{Na}$ interpretação dos pesquisadores, isso ocorreria porque punir com custos envolve um cálculo de custo-benefício: o investimento necessário no ato de punir versus o prazer derivado dele. Assim, o córtex pré-frontal integraria esse cálculo.

16 CARLSMITH, Kevin M.; DARLEY, John M. Psychological aspects of retributive justice. Advances in Experimental Social Psychology, v. 40, n. 7, p. 193-236, 2008.

17 QUERVAIN, D. J. F. de The neural basis of altruistic punishment. Science, v. 305, n. 5688, p. 1254-1258, 2004. Disponível em: <http://www.sciencemag.org/cgi/doi/10.1126/science.1100735>. 
Importante destacar que esse experimento tratava da "punição em segunda pessoa", ou retaliação, e não propriamente da punição por terceiros. A partir desse estudo inicial, outros se seguiram, focando em áreas de interesse próximas ao outrora chamado sistema límbico — tradicionalmente associado ao processamento da carga emocional, como é o caso da amígdala —, e as regiões pré-frontais — implicadas na literatura com comportamentos racionais e planejados. Com base em estudos com animais sobre estímulos aversivos, a amígdala, ligada ao medo e a reações aversivas, assim como a ínsula anterior, foram logo apontadas como áreas que poderiam estar ligadas ao processamento de informação nessas situações de trapaça. Áreas do córtex pré-frontal, por sua vez, estariam ligadas a comportamentos de cálculo de custo-benefício, ou de planejamento de cursos de ação possíveis, o que seria o caso da decisão de punir ${ }^{18}$.

Um dos primeiros experimentos a analisar a Neurociência da "punição em terceira pessoa", e separando a etapa de determinação da culpabilidade da assinalação da punição, foi o de Joshua Buckholtz e colegas ${ }^{19}$. O método utilizado foi o de mostrar 50 vinhetas de crimes mais ou menos graves a 16 sujeitos submetidos à ressonância magnética funcional (fMRI). As condições experimentais eram: situações em que não havia cometimento de delitos; o cometimento de delitos leves, como furto; ou graves, como estupro e homicídio; e os mesmos crimes, mas com circunstâncias atenuantes da conduta do transgressor, que justificariam sua ação ou excluiriam a ilicitude da conduta. Os sujeitos tinham que, então, assinalar uma pena a cada situação, de uma escala de 0 (ausência de punição) a 9 (a punição mais severa possível).

Como resultado, o estudo mostrou associação entre a magnitude da punição assinalada e maior ativação da amígdala, córtex pré-frontal medial e córtex cingulado posterior, áreas ligadas ao processamento de estímulos socioemocionais. Para os autores, isso seria uma evidência do processamento emocional no momento de definição da punição. Por outro lado, verificou-se maior ativação da junção temporoparietal nos casos em que os indivíduos precisavam considerar as circunstâncias atenuantes da responsabilidade do ofensor para os pesquisadores, essa área, ligada à Teoria da Mente, ou avaliação dos estados mentais alheios, seria recrutada para este fim. Finalmente, o córtex pré-frontal dorsolateral direito era mais ativado quando havia punição, tanto na presença de atenuantes, quanto na ausência delas.

Um ponto relevante é que os mesmos circuitos que vinham sendo implicados na "punição em segunda pessoa" seriam aqueles ativados nos casos em que um terceiro observador assinalaria a punição justa, na "punição em terceira pessoa" 20 . A amígdala processaria a carga emocional do observador; em seguida, a integração entre o dano causado e a intenção do agente seria feita no córtex pré-frontal medial; e, posteriormente, o córtex pré-frontal dorsolateral sopesaria essas informações com aquelas oriundas de áreas posteriores (da junção temporoparietal e do sulco intraparietal) sobre o contexto e as intenções por trás do comportamento transgressor.

Em linha com esse modelo, um estudo posterior, com metodologia semelhante, buscou variar os cenários das vinhetas conforme sua carga emocional: o mesmo crime era descrito ou de forma relativamente neutra e objetiva, ou sensacionalista, com crueza nos detalhes. Novamente, verificava-se sempre, nos sinais da fMRI, ativação do córtex pré-frontal dorsolateral. Mas, mais importante, a ativação do input originário das amígdalas era fortemente aumentada nos cenários de descrição das vinhetas com componentes emocionais. Por sua vez, nos casos em que o dano causado era não intencional, o córtex cingulado dorsolateral e a junção temporoparietal entravam em cena, enviando sinais top-down para a amígdala e inibindo sua atividade. Dito de outra forma, se, por um lado, a amígdala enviava sinais para o córtex pré-frontal no caso de condutas graves; por outro, quando essas condutas eram escusáveis, um circuito temporoparietal-medial-pré-frontal suprimia a sua atividade ${ }^{21}$.

18 SEYMOUR, Ben; SINGER, Tania; DOLAN, Ray. The neurobiology of punishment. Nature Reviews Neuroscience, v. 8, n. 4, p. 300-311, 2007. Disponível em: <http://www.nature.com/doifinder/10.1038/nrn2119>.

19 BUCKHOLTZ, Joshua W. et al. The neural correlates of third-party Punishment. Neuron, v. 60, n. 5, p. 930-940, 2008.

20 BUCKHOLTZ; MAROIS, The roots of modern justice: cognitive and neural foundations of social norms and their enforcement. Nature Neuroscience, v. 15, n. 5, p. 655-661, 2012. Disponível em: <http://www.nature.com/doifinder/10.1038/nn.3087>.

21 TREADWAY, Michael T. et al. Corticolimbic gating of emotion-driven punishment. Nature Neuroscience, v. 17, n. 9, p. 12701275, 2014. Disponível em: <http://www.nature.com/neuro/journal/v17/n9/abs/nn.3781.html>. 
Nesse ponto, os pesquisadores consideravam ter alguma clareza sobre o papel da amígdala e dessa circuitaria temporoparietal, mas o papel do córtex dorsolateral persistia como um mistério. Sabia-se há tempos que o córtex pré-frontal está implicado nas funções executivas, na memória de trabalho, no planejamento de longo prazo, na integração superior de informações. Essa área, sempre, mostrava ativação em decisões de punir, mas não se sabia, exatamente, qual tipo de processamento ela estaria fazendo. A equipe de pesquisadores liderada por Joshua Buckholtz, então, partiu para um outro método, a estimulação magnética transcraniana (TMS), capaz de desativar, seletivamente, áreas cerebrais com sinais magnéticos. Ao temporariamente “desligá-las", seria em tese possível desvendar qual função desempenham.

Nesse experimento, 66 voluntários leram vinhetas de transgressões que, como nos estudos anteriores, descreviam ofensas das menos às mais graves, e que continham ou não circunstâncias atenuantes da responsabilidade do agente. Na condição de terceiros, precisavam decidir se alguma punição era devida, e qual seria, em cada um dos casos. Os resultados revelaram que, mesmo "desativando" o córtex pré-frontal dorsolateral, a avaliação da responsabilidade do agente não era afetada. Porém, a decisão de punir era afetada: com a aplicação da TMS, as punições assinaladas eram menos severas. $\mathrm{O}$ achado mais importante dessa pesquisa, assim, consistiu em mostrar que há uma dissociação entre o julgamento a respeito da culpabilidade do agente e a integração de informações relevantes subjacentes à decisão sobre a intensidade da punição "justa"22.

Diante de objeções de que estudos com vinhetas e jogos econômicos seriam pouco realistas, outra equipe de pesquisadores se valeu de uma metodologia diferente. 33 participantes tinham que interagir com outros sujeitos enquanto estavam deitados no tubo de fMRI, onde poderiam levar choques ministrados por meio de agulhas intraepidérmicas, choques efetivamente dolorosos. Após receber os choques, os sujeitos eram informados a respeito do fato de haver ou não intenção, por parte de seu parceiro, de machucá-los. Além disso, os sujeitos eram informados se tinham, ou não, a opção de retaliar seu parceiro ou perdoá-lo um cenário que pode ser descrito como de "punição em segunda pessoa", portanto. Como nem sempre a decisão de aplicar um choque era bem-sucedida, os pesquisadores puderam avaliar a condição de "tentativa" — intenção de agredir, frustrada por motivos alheios ao agente.

O estudo mostrou haver um circuito cerebral que ligaria a junção temporoparietal e o giro frontal inferior anterior (aIFG) à amígdala, inibindo a atividade desta quando o choque era acidental ou não intencional. Porém, se o outro participante tinha a intenção de ministrar o choque, mas falhava, a amígdala era esti-

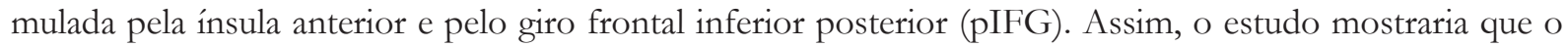
processamento de informações sobre a intencionalidade do agente modularia a resposta emocional a uma agressão ${ }^{23}$. Poderíamos, de forma ilustrativa, evocar o célebre dizer de Oliver Wendell Holmes: "até mesmo um cão sabe a diferença entre ser tropeçado e ser chutado".

Outros achados convergentes vieram de um estudo de tomografia computadorizada feita com veteranos da Guerra do Vietnã que sofreram danos cerebrais ${ }^{24}$. Estudos de lesão são tradicionais em Neuropsicologia, e ajudam a colocar à prova evidências oriundas de técnicas de neuroimagem. Nesse caso, os resultados mostraram que lesões nas áreas pré-frontais e parietais implicadas nos estudos anteriormente revisados afetavam a decisão de assinalar punição "em terceira pessoa" a condutas transgressoras.

Por fim, estudos mais recentes adotam técnicas estatísticas mais sofisticadas. Um estudo de vinhetas com 38 sujeitos e fMRI dissociou os momentos da decisão de punir por área cerebral: o processamento de informações sobre o dano causado (ínsula, regiões pré-frontais), sobre a intencionalidade do agente (circuitaria

22 BUCKHOLTZ, Joshua W. et al. From blame to punishment: disrupting prefrontal cortex activity reveals norm enforcement mechanisms. Neuron, v. 87, n. 6, p. 1369-1380, 2015.

23 YU, H.; LI, J.; ZHOU, X. Neural substrates of intention-consequence integration and its impact on reactive punishment in interpersonal transgression. Journal of Neuroscience, v. 35, n. 12, p. 4917-4925, 2015. Disponível em: <http://www.jneurosci.org/cgi/ doi/10.1523/JNEUROSCI.3536-14.2015>.

24 GLASS, Leila et al. Neural signatures of third-party punishment: evidence from penetrating traumatic brain injury. Social Cognitive and Affective Neuroscience, v. 11, n. 2, p. 253-262, 2015. 
frontoparietal ligada à Teoria da Mente), e o momento em que se integra ambas informações (especialmente o córtex pré-frontal dorsolateral, com input das amígdalas). O modelo sugerido, porém, era ligeiramente mais complexo do que anteriormente proposto pelos estudos anteriores ${ }^{25}$.

Em outro estudo recente com o uso de fMRI e vinhetas, focado na direcionalidade dos inputs dos circuitos, foi sugerido que o polo temporal e o córtex pré-frontal servem como "hubs" da "rede de mentalização", a qual processa a informação sobre responsabilidade do agente, e, por sua vez, alimenta outras áreas como a junção temporoparietal e o córtex cingulado posterior ${ }^{26}$.

Um outro estudo recente combinou um jogo chamado "Jogo da Justiça" com fMRI, visando comparar a ativação cerebral num contexto de "punição em segunda pessoa" com o de "punição em terceira pessoa" 27. Os sujeitos recebiam uma quantidade de recursos, estando ou na posição da vítima ou de terceiros-observadores. Então, um ofensor tomava parte desses recursos, e o sujeito de pesquisa podia gastar parte dos seus próprios recursos para puni-lo. Esse estudo previa, também, a hipótese de compensação — o sujeito de pesquisa que estivesse na posição de terceiro, vendo a vítima ser "furtada", podia compensá-la com parte dos seus próprios recursos, ou punir o transgressor. Os resultados mostraram que, quanto maior o "furto", mais os sujeitos queriam gastar seus próprios recursos para punir o transgressor - e que, na posição de terceiros, eles preferiam gastar para punir o transgressor a gastar para compensar a vítima. Outro achado relevante refere-se ao fato de que a quantidade de recursos gastos com a punição do transgressor era maior quando o sujeito era a própria vítima lesada, e não um terceiro observador.

Ainda como resultados, a decisão de punir recrutava uma área associada ao processamento de recompensas, o estriado ventral, ao passo que a decisão de compensar a vítima em vez de punir o transgressor revelava maior ativação da junção temporoparietal. Além disso, a "punição em segunda pessoa" envolvia maior ativação da ínsula anterior, ao passo que a "punição em terceira pessoa" mostrava maior ativação do córtex pré-frontal dorsolateral.

Em síntese, as mesmas áreas de interesse vêm sendo implicadas por diferentes estudos experimentais da chamada Neurociência da Punição. Numa formulação recente, foi proposto que os circuitos cerebrais envolvidos na decisão de punir seriam três, dissociáveis entre si, os quais processariam graus diferentes de informação para a decisão de punir um transgressor. Uma "rede de saliência" envolveria a ínsula anterior, o córtex cingulado anterior dorsal e a amígdala no processamento de informações aversivas, referentes à intensidade do dano causado pela transgressão. A segunda rede, ligada à “Teoria da Mente”, envolveria o córtex pré-frontal medial, o córtex cingulado posterior e a junção temporoparietal e integraria informações sobre o dano causado à vítima e a intenção do agente ofensor. Por fim, uma rede executiva central, ligada ao córtex pré-frontal dorsolateral, faria avaliações sobre as informações disponíveis e o contexto da ofensa, resultando numa decisão efetiva sobre a punição ${ }^{28}$.

O grau de precisão desses estudos pode parecer surpreendente, e dar a impressão de que a "caixa preta" do comportamento de punir no cérebro está, definitivamente, sendo aberta. Todavia, embora impressionantes, esses resultados, ainda, dizem muito pouco, pois enfrentam limitações significativas. É o que analisaremos na sequência.

25 GINTHER, Matthew R. Parsing the behavioral and brain mechanisms of third-party punishment. The Journal of Neuroscience, v. 7, n. Sep, p. 9420-9434, 2016.

26 BELLUCCI, Gabriele et al. Effective connectivity of brain regions underlying third-party punishment: Functional MRI and Granger causality evidence. Social Neuroscience, v. 12, n. 2, p. 124-134, 2017. Disponível em: < http://dx.doi.org/10.1080/17470919 .2016.1153518>.

27 STALLEN, Mirre et al. Neurobiological mechanisms of responding to injustice. The Journal of Neuroscience, v. 38, n. 12, p. $1242-$ 1247, 2018. Disponível em: <http://www.jneurosci.org/lookup/doi/10.1523/JNEUROSCI.1242-17.2018>.

28 KRUEGER, Frank; HOFFMAN, Morris. The emerging neuroscience of third-party punishment. Trends in Neurosciences, v. 39, n. 8, p. 499-501, 2016. Disponível em: <http://dx.doi.org/10.1016/j.tins.2016.06.004>. 


\section{LIMITAÇÕES E PROBLEMAS DA NEUROCIÊNCIA DA PUNIÇÃO}

As sofisticadas técnicas empregadas pela literatura de Neurociência da Punição mostram padrões de ativação de áreas cerebrais específicas em contextos experimentais em que se simulam injustiças ou transgressões. O que isso nos diz sobre a mente de quem decide punir? Quais inferências se pode extrair desses resultados? É importante, primeiramente, destacar que as interpretações desses dados dependem dos pressupostos teóricos adotados por essas pesquisas. E, ao menos até o presente momento, esses enfrentam objeções significativas.

Do ponto de vista metodológico, a ativação de áreas cerebrais específicas é um achado relevante na medida que confirma que o cérebro é um órgão altamente especializado, em que computações ocorrem de acordo com uma determinada estrutura citoarquitetônica, uma dinâmica de neurotransmissores e uma organização complexa de conexões neuronais. A base da Neurociência Cognitiva Social é o pressuposto de que o processamento de informações sociais ocorre em áreas específicas — as quais, se lesionadas, comprometidas ou afetadas, podem impactar o comportamento social do indivíduo. Porém, embora se saiba a função que várias dessas áreas desempenham, a dinâmica do "cérebro social" como um todo ainda é objeto de muita investigação ${ }^{29}$.

Contudo, descrever um maior nível de oxigenação cerebral durante uma atividade, que é o que a maioria das técnicas de neuroimagem faz, não quer dizer que aquela área é exclusivamente ligada a um determinado comportamento. As estruturas cerebrais descritas não necessariamente são áreas cerebrais "para o fim de punição". É possível arguir, por exemplo, que as áreas de interesse da Neurociência da Punição seriam estruturas de "domínio-geral", isto é, ligadas ao comportamento interpessoal em geral, recrutadas para respostas comportamentais diversas no contexto social, e não apenas para a punição.

Um outro ponto de cautela relevante deriva da recente discussão sobre os limites metodológicos da ciência psicológica em geral. Russell Poldrack induziu a discussão no campo das neurociências a um novo patamar quando lembrou que verificar a ativação de áreas cerebrais não permite inferir estados mentais ${ }^{30}$. Ademais, o método utilizado pelas técnicas de neuroimagem é o de subtração: comparam-se os padrões de funcionamento do cérebro em estado de repouso com aqueles padrões correlacionados ao momento de realização da tarefa experimental — ler uma vinheta, participar de um jogo econômico etc.

O que a neuroimagem "mede", assim, não necessariamente é um processo ou estado mental; pode ser que ele aponte, apenas, estruturas relacionadas à adoção de uma determinada estratégia cognitiva, empregada para a solução da tarefa pelo sujeito de pesquisa. Em resumo: podemos medir padrões de ativação cerebral, mas segue sendo uma impropriedade metodológica sugerir, com base nessas técnicas, afirmações como "o sujeito sente prazer quando pune um ofensor"; ou ainda, "o sujeito sente indignação moral pela transgressão, como se pode inferir da ativação da amígdala".

Além disso, uma objeção óbvia, mas importante de ser ressaltada, é o problema da validade ecológica de achados oriundos de contextos laboratoriais extremamente artificiais. $\mathrm{Na}$ discussão especializada, permanece aberto em debate a questão metodológica de até que ponto ser trapaceado num jogo de "Trust" ou "Justiça", dentro de um tubo de ressonância magnética funcional, equivale à experiência de ser vítima ou testemunha de um delito, do ponto de vista da dinâmica cerebral. O que estudos com jogos econômicos mostram é o comportamento de pessoas... que participam de jogos econômicos. O contexto real de decisão é substancialmente mais complexo. É possível que os sujeitos de pesquisa estejam "pagando" para punir trapaceiros porque, num contexto de estudos num laboratório, em que as regras do jogo são explicitadas antes do experimento, eles

29 WANG, Yin; OLSON, Ingrid R. The original social network: white matter and social cognition. Trends in Cognitive Sciences, v. 22, n. 6, p. 1-13, 2018. Disponível em: <https://doi.org/10.1016/j.tics.2018.03.005>.

30 POLDRACK, Russell A. Inferring mental states from neuroimaging data: from reverse inference to large-scale decoding. Neuron, v. 72, n. 5, p. 692-697, 2011. Disponível em: < http://dx.doi.org/10.1016/j.neuron.2011.11.001>. 
apenas acreditem que o esperado deles é que optem pela opção de punir que lhes é disponibilizada. Pode ser que a existência de poucas alternativas, derivada da necessidade experimental de isolar variáveis, acabe induzindo comportamentos dos sujeitos — se só é possível punir ou não punir um trapaceiro, por que não o punir? É possível, ainda, que eles acreditem que é isso que os experimentadores esperem deles, ou a sinalização correta a se fazer. Não é possível inferir, com base nesse tipo de achado, porém, que exista um fenômeno universal humano chamado "punição altruísta" ou algo do gênero. É possível que o que os experimentos com jogos econômicos estejam demonstrando é que, em determinados contextos, as pessoas apostam recursos para revidar trapaceiros, e que as inferências amplas e profundas sobre o comportamento humano extraídas daí não passem de artefatos derivados da escolha metodológica dos pesquisadores ${ }^{31}$.

Para além das limitações metodológicas das ciências psicológicas em geral, porém, o estudo neurocientífico da punição enfrenta um desafio ainda mais formidável quando se examinam seus pressupostos teóricos. Não é pacífico na discussão em Psicologia Evolucionista que a "punição em terceira pessoa" seja um comportamento selecionado ao longo de milhões de anos.

A antropologia fornece importantes insights para a discussão de Psicologia Evolucionista, uma vez que a etnografia de sociedades tradicionais se debruça sobre grupos de caçadores-coletores relativamente pequenos - semelhantes à realidade que o Homo sapiens provavelmente experimentou na maior parte do seu tempo no planeta Terra. E, ao contrário do que sugerem os estudos da literatura revisada, as evidências antropológicas disponíveis em favor da existência da "punição de terceira pessoa" são escassas. Em sociedades tradicionais, geralmente, não há uma figura de autoridade neutra que pune transgressores — e é muito raro que alguém se arrisque a punir um ofensor, apenas, para defender "as normas vigentes no grupo". Existe a chamada "punição em segunda pessoa": se atacadas ou lesadas, as pessoas revidam. Mas ninguém incorre em custos para defender os interesses do grupo, como sugerido nos estudos de jogos econômicos ${ }^{32}$.

Uma alternativa mais vantajosa para indivíduos que se sentiram trapaceados é deixar de interagir com os ofensores. De fato, as evidências antropológicas apontam nesse sentido ${ }^{33}$. Pessoas que contribuem com o grupo, que dividem recursos de forma equânime, que cooperam, têm boa reputação e são escolhidos com maior frequência para interações sociais. Já os aproveitadores sofrem desaprovação e deixam de ser vistos como sujeitos confiáveis. Assim, em comunidades tradicionais, a indiferença, o ostracismo, a popularmente dita "fofoca", que visam destruir a reputação de um transgressor e isolá-lo no grupo, por exemplo, constituem formas de sanção frequentes ${ }^{34}$. Embora, inequivocamente, elas sejam formas de sanção social, elas não se enquadram na definição que a literatura em Neurociência da Punição tem empregado para a "punição em terceira pessoa": "incorrer em custo para si próprio para defender as regras vigentes".

Não por acaso, a maior parte dos conflitos sociais não chega a ser objeto de intervenção da área penal. Seja em relações econômicas de mercado, seja em relações de amizade, as pessoas simplesmente expressam preferência por interagir com aquelas que lhes proporcionam as relações mais benéficas do seu ponto de vista. A maioria dos comportamentos desaprovados socialmente são objeto de sanções informais, e não necessariamente de punição. Humanos cooperam e agem moralmente de forma rotineira, não porque toda transgressão seja passível de punição, mas porque ser cooperativo é um comportamento que geralmente é reconhecido e recompensado pelos seus pares ${ }^{35}$.

31 O trabalho mais completo ao apontar as diversas fraquezas metodológicas e impropriedades das inferências feitas a partir de experimentos com jogos econômicos é: GUALA, Francesco. Reciprocity: weak or strong? what punishment experiments do (and do not) demonstrate. Behavioral and Brain Sciences, v. 35, n. 1, p. 1-15, 2012.

32 BAUMARD, Nicolas. Has punishment played a role in the evolution of cooperation?: a critical review. Mind and Society, p. 1-22, 2010 .

33 FÜRER-HAIMENDORF, Chris Von. Morals and merit: a study of values and social controls in South Asian Societies. Chicago: The University of Chicago Press, 1967.

34 GURVEN, Michael. To give and to give not: the behavioral ecology of human food transfers. Behavioral and Brain Sciences, v. 27 , n. 04, p. 543-583, 2004. Disponível em: <http://www.journals.cambridge.org/abstract_S0140525X04000123>.

35 GUALA, Francesco. Reciprocity: weak or strong? what punishment experiments do (and do not) demonstrate. Behavioral and 
A própria tese evolucionária da "seleção de grupo" permanece sendo altamente controversa, havendo teóricos do campo que defendem que há outras explicações de origem darwinista para o problema da cooperação humana mais parcimoniosas e menos problemáticas ${ }^{36}$. A evolução da moralidade humana pode ser explicada, também, por modelos mutualistas, como a Teoria da "Partner Choice", que propõe que nossas intuições morais derivam da seleção de indivíduos mais cooperativos ao longo da história da espécie ${ }^{37}$.

De fato, os experimentos mais recentes apontam que a busca pela reputação, ou de uma boa imagem social, é um motivador muito mais poderoso para a conduta moral que o medo de ser punido ${ }^{38}$. Estudos utilizando novos paradigmas experimentais revelam que, diante de uma transgressão ou injustiça, pessoas se indignam e sentem raiva, mas não sacrificam a si próprios para punir quem lesou terceiros ${ }^{39}$. Dito de outra forma, embora a "punição em segunda pessoa", a retaliação, seja onipresente entre humanos - e mesmo em outras espécies ${ }^{40}$ — a chamada "punição em terceira pessoa" pode ter tido sua existência exagerada por algumas pesquisas, e definitivamente não pode ser considerada a base da cooperação em sociedades humanas.

Toda essa literatura teórica e empírica, que contesta a tese da "punição altruísta" e da "seleção de grupo", está ausente das revisões com as quais se iniciam os estudos de Neurociência da Punição.

De fato, a tese da "punição altruísta" sugere que quem pune transgressores, por se sacrificar pelo grupo em nome da vigência das normas, seria apreciado pela moralidade do seu comportamento. Porém, mesmo no paradigma de jogos econômicos, evidências mais recentes apontam que as pessoas atribuem melhor reputação e preferem mais interagir com quem ajuda vítimas, ou busca ampará-las, do que com quem toma a inciativa de punir transgressores ${ }^{41}$.

Em suma, encarar a punição como única forma de restabelecer a balança da justiça acaba se revelando uma premissa teórica altamente contestável. A mente humana pode ter instintos vingativos ou retributivistas, mas não se resume a isso - ao contrário, se fosse esse o caso, não se verificariam em grupos sociais diversos comportamentos como as desculpas, o perdão e a reconciliação ${ }^{42}$.

Além disso, a tese da "punição altruísta" padece de uma tremenda pobreza antropológica — historicamente e ao redor do mundo, existem inúmeras respostas sociais possíveis a transgressões, que vão de mecanismos alternativos de composição de conflitos a formas institucionalizadas e bem-sucedidas de lidar com crimes graves, a exemplo das práticas de justiça restaurativa, um exemplo notável de política pública efetiva, baseada em evidências ${ }^{43}$.

Brain Sciences, v. 35, n. 1, p. 1-15, 2012.

36 BAUMARD, Nicolas. The origins of fairness: how evolution explains our moral nature. New York: Oxford University Press, 2016; PINKER, Steven. The false allure of group selection. In: BUSS, David M. (Org.). The handbook of evolutionary psychology. Hoboken, New Jersey: John Wiley \& Sons, 2016. p. 867-880.

37 BAUMARD, Nicolas; ANDRÉ, Jean-Baptiste; SPERBER, Dan. A mutualistic approach to morality: the evolution of fairness by partner choice. Behavioral and Brain Sciences, v. 36, p. 59-122, 2013.

38 GRIMALDA, Gianluca; PONDORFER, Andreas; TRACER, David P. Social image concerns promote cooperation more than altruistic punishment. Nature Communications, v. 7, p. 1-8, 2016. Disponível em: <http://dx.doi.org/10.1038/ncomms12288>. 39 PEDERSEN, Eric J.; MCAULIFFE, William H B; MCCULLOUGH, Michael E. The unresponsive avenger: more evidence that disinterested third parties do not punish altruistically. Journal of Experimental Psychology: General, v. 147, n. 4, p. 514-544, 2018. Disponível em: <http://www.psy.miami.edu/faculty/mmccullough/Papers/2018-Unresponsive Avenger.pdf > .

PEDERSEN, E. J.; KURZBAN, R.; MCCULLOUGH, M. E. Do humans really punish altruistically? a closer look. Proceedings of the Royal Society B: Biological Sciences, v. 280, n. 1758, 2013. Disponível em: < http://rspb.royalsocietypublishing.org/cgi/doi/10.1098/ rspb.2012.2723>.

40 RAIHANI, Nichola J.; THORNTON, Alex; BSHARY, Redouan. Punishment and cooperation in nature. Trends in Ecology and Evolution, v. 27, n. 5, p. 288-295, 2012. Disponível em: <http://dx.doi.org/10.1016/j.tree.2011.12.004>.

41 PATIL, Indrajeet; DHALIWAL, Nathan A; CUSHMAN, Fiery. Reputational and cooperative benefits of third-party compensation. PsyArXiv PrePrint, p. 1-6, 2018.

42 MCCUllough, Michael E.; KURZBAN, Robert; TABAK, Benjamin A. Cognitive systems for revenge and forgiveness. Behavioral and Brain Sciences, v. 36, n. 01, p. 1-15, 2013. Disponível em: < http://www.journals.cambridge.org/abstract_ S0140525X11002160>.

43 STRANG, Heather et al. Restorative justice conferencing (RJC) using face-to-face meetings of offenders and victims: effects 
Por fim, e não menos importante, a decisão de punir alguém vai além de uma escolha num contexto experimental. No mundo real, a decisão de punir ocorre num contexto social dialógico, em que as pessoas analisam as consequências das ações alheias e produzem justificativas sobre por que punir — ou não. E, se por um lado, o retributivismo parece ser mesmo uma reação intuitiva automática a transgressões e injustiças, o processo de racionalização pode levar à revisão de decisões impulsivas ${ }^{44}$. $\mathrm{O}$ esforço em justificar socialmente as próprias decisões exige que se produzam argumentos, e a entrada em cena do raciocínio deliberado pode reverter decisões intuitivas. Nesse sentido, a Neurociência da Punição se beneficiaria em incorporar, aos seus métodos experimentais, um fator sempre presente no contexto real da tomada de decisão humana: a necessidade de justificar as escolhas perante os pares ${ }^{45}$.

\section{Considerações finais}

As Neurociências têm avançado a passos largos para descrever o que ocorre, no nível neurofisiológico, quando as pessoas tomam decisões ou desempenham comportamentos complexos. Nesse sentido, é oportuno que a punição, fenômeno central no âmbito jurídico, seja objeto desse escrutínio.

Porém, uma revisão crítica da literatura disponível sugere que ainda é cedo para cantar vitória. A descrição de que certas estruturas cerebrais são recrutadas durante tarefas executadas em equipamentos de neuroimagem não permite que se façam inferências amplas sobre o papel do comportamento punitivo na mente humana, ou ainda, sobre sua suposta importância na trajetória evolucionária da espécie. Os pressupostos teóricos adotados ainda são muito mais frágeis do que alguns desses estudos parecem sugerir.

Entre os experimentos revisados e as estruturas sociais vigentes, há diversos níveis explicativos ainda em aberto. Quando um experimento neurocientífico, que conjuga neuroimagem com jogos econômicos, utiliza a palavra "punição", refere-se a um fenômeno muito específico. Não se pode equiparar esse achado experimental com um conceito mais amplo de "sanção", ou, mais ainda, com "pena". Como mostramos neste artigo, há uma série de sanções informais, não penais, que são respostas rotineiras a comportamentos transgressivos e normas sociais. Além disso, para além da "retaliação", da "vingança" e de outras respostas específicas, seres humanos também respondem a ofensas com comportamentos de reconciliação, compensação, reparação e perdão, e só recentemente estes têm sido incorporados por psicólogos nos desenhos experimentais.

Sobretudo, e aqui fica o alerta para os juristas que arriscam dar seus passos nesse campo interdisciplinar que vem sendo denominado "Neurodireito": por mais interessantes que sejam os resultados obtidos até agora, eles são circunscritos aos contextos dos delineamentos experimentais de cada estudo. Não é possível afirmar, até o presente, que os seres humanos tenham uma "tendência inata", um "instinto" ou "módulo mental específico" voltados para a punição de transgressores. O estado da arte não permite que se faça saltos teóricos entre estudos neurocientíficos e supostas justificativas de por que punimos na sociedade contemporânea. Especialmente por se tratar de um campo de pesquisa novo, que se embrenha em um tema ideologicamente carregado: o Direito Penal e as teorias da pena. Seria precipitado, assim, realizar inferências de política penal ou formular propostas de desenho institucional baseadas no que sabemos até agora em Neurociência da Punição.

on offender recidivism and victim satisfaction. Campbell Systematic Reviews, v. 12, 2013. Disponível em: < https://campbellcollaboration.org/library/restorative-justice-conferencing-recidivism-victim-satisfaction.html>.

44 AHARONI, Eyal; FRIDLUND, Alan J. Punishment without reason: isolating retribution in lay punishment of criminal offenders. Psychology, Public Policy, and Law, v. 18, n. 4, p. 599-625, 2012. Disponível em: < http://doi.apa.org/getdoi.cfm?doi=10.1037/ a0025821>; FINCHER, Katrina M.; TETLOCK, Philip E. Brutality under cover of ambiguity. Personality and Social Psychology Bulletin, v. 41, n. 5, p. 629-642, 2015. Disponível em: <http://journals.sagepub.com/doi/10.1177/0146167215571090>.

45 MERCIER, Hugo; SPERBER, Dan. The enigma of reason. Cambridge, Massachussetts: Harvard University Press, 2017. 
Esse alerta é importante porque, em obras recentes sobre o tema da Psicologia da Punição, especialmente no contexto estadunidense, tem sido sustentado, com base nos experimentos revisados, que as "intuições retributivistas" descobertas nos experimentos deveriam ser levadas em conta pelos formuladores da lei penal ${ }^{46}$. Todavia, como pretendemos demonstrar neste trabalho, seria um erro afirmar que os resultados da Neurociência da Punição levam a tal conclusão. Muitos estudos ainda são necessários para que se tenha uma visão mais abrangente dos mecanismos psicológicos que entram em cena quando alguém é vítima ou testemunha de um delito. Somente a partir de uma teoria mais completa, seria possível pensar se as instituições punitivas que existem satisfazem os anseios de justiça das pessoas - e ainda assim, seriam necessários diversos argumentos morais, políticos e de política pública para um debate de uma questão dessa magnitude.

Um último ponto merece destaque ao se tratar dos estudos experimentais sobre a punição e o que eles podem acrescentar ao debate teórico penal. Do ponto de vista psicológico, pode-se afirmar que a punição funciona? A análise comportamental já nos respondeu essa pergunta há muito tempo: sim, mas em circunstâncias muito específicas - desde que haja regras muito claras, que ela ocorra sempre e imediatamente depois que um comportamento indesejável ocorre ${ }^{47}$. O sistema punitivo que temos está muito longe de cumprir esses requisitos. A sanção penal, quando ocorre, é errática, seletiva, morosa - nem todos os que cometem delitos são descobertos, nem todos os delitos são investigados, nem todos os acusados chegam a ser sentenciados; injustiças ocorrem, inocentes são punidos, ofensores podem sair impunes, a depender da capacidade investigativa dos órgãos de persecução penal, da seletividade do sistema, etc. Em suma, a reação jurídica a delitos vigente não poderia ser mais contrária ao que as ciências comportamentais preconizam que "funciona". Não por acaso, a pena de prisão, essa recentíssima invenção humana, não apenas tem efeitos preventivos altamente contestáveis, como há evidências significativas de seu caráter criminogênico ${ }^{48}$.

Aí reside o maior risco enfrentado atualmente pela chamada Neurociência da Punição: ela dá muita centralidade a um fenômeno que não é a única forma que a mente humana tem de reagir a transgressões, podendo até mesmo se prestar a justificar respostas jurídicas empiricamente ineficazes. Caracterizar a punição como forma "natural" de reação pode ser uma forma de legitimar um sistema falido e, pior, impedir que métodos alternativos de lidar com conflitos ganhem espaço. Contra esse risco, insistimos que a boa ciência aplicada não é aquela que limita; é aquela que amplia as possibilidades de imaginação institucional.

\section{REFERÊNCIA}

AHARONI, Eyal; FRIDLUND, Alan J. Punishment without reason: isolating retribution in lay punishment of criminal offenders. Psychology, Public Policy, and Law, v. 18, n. 4, p. 599-625, 2012. Disponível em: < http:// doi.apa.org/getdoi.cfm?doi=10.1037/a0025821>.

ALMEIDA, Fabio Portela Lopes. As origens evolutivas da cooperação humana. Revista DireitoGV, v. 9, n. 1, p. 243-268, 2013.

BAUMARD, Nicolas. Has punishment played a role in the evolution of cooperation?: a critical review. Mind and Society, p. 1-22, 2010.

BAUMARD, Nicolas. The origins of fairness: how evolution explains our moral nature. New York: Oxford University Press, 2016.

46 Um dos expoentes dessa tendência recente é Paul H. Robinson, renomado pesquisador que sugere que as "intuições de justiça" partilhadas pela comunidade deveriam ser incorporadas à lei penal como forma de fortalecer sua legitimidade social. Implícita nessa proposta está uma opção teórica pelo neorretributivismo como justificativa legítima para a lei penal.

47 MILTENBERGER, Raymond G. Behavior modification: principles \& procedures. 5. ed. Belmont, CA: Cengage Learning, 2012. p. 101-119.

48 NAGIN, Daniel S. Deterrence in the twenty- first century. Crime and Justice, v. 42, n. 1, p. 199-263, 2013. 
BAUMARD, Nicolas; ANDRÉ, Jean-Baptiste; SPERBER, Dan. A mutualistic approach to morality: the evolution of fairness by partner choice. Behavioral and Brain Sciences, v. 36, p. 59-122, 2013.

BELLUCCI, Gabriele et al. Effective connectivity of brain regions underlying third-party punishment: Functional MRI and Granger causality evidence. Social Neuroscience, v. 12, n. 2, p. 124-134, 2017. Disponível em: <http://dx.doi.org/10.1080/17470919.2016.1153518>.

BOWLES, Samuel; GINTIS, Herbert. A cooperative species: human reciprocity and its evolution. Princeton: Princeton University Press, 2011.

BOYD, R. et al. The evolution of altruistic punishment. Proceedings of the National Academy of Sciences, v. 100, n. 6, p. 3531-3535, 2003. Disponível em: <http://www.pnas.org/cgi/doi/10.1073/pnas.0630443100>.

BUCKHOLTZ, Joshua W. et al. From blame to punishment: disrupting prefrontal cortex activity reveals norm enforcement mechanisms. Neuron, v. 87, n. 6, p. 1369-1380, 2015.

BUCKHOLTZ, Joshua W. et al. The neural correlates of third-party Punishment. Neuron, v. 60, n. 5, p. 930$940,2008$.

BUCKHOLTZ, Joshua W.; MAROIS, René. The roots of modern justice: cognitive and neural foundations of social norms and their enforcement. Nature Neuroscience, v. 15, n. 5, p. 655-661, 2012. Disponível em: <http://www.nature.com/doifinder/10.1038/nn.3087>.

CARLSMITH, Kevin M.; DARLEY, John M. Psychological aspects of retributive justice. Advances in Experimental Social Psychology, v. 40, n. 7, p. 193-236, 2008.

DARLEY, John M. Morality in the law: the psychological foundations of citizens' desires to punish transgressions. Annual Review of Law and Social Science, v. 5, n. 1, p. 1-23, 2009.

FEHR, Ernst; FISCHBACHER, Urs. Social norms and human cooperation. Trends in Cognitive Sciences, v. 8, n. 4, p. 185-190, 2004.

FEHR, Ernst; GÄCHTER, Simon. Altruistic punishment in humans. Nature, v. 415, n. 6868, p. 137-140, 2002. Disponível em: < http://www.nature.com/doifinder/10.1038/415137a>.

FINCHER, Katrina M.; TETLOCK, Philip E. Brutality under cover of ambiguity. Personality and Social Psychology Bulletin, v. 41, n. 5, p. 629-642, 2015. Disponível em: <http://journals.sagepub.com/ doi/10.1177/0146167215571090>.

FÜRER-HAIMENDORF, Chris Von. Morals and merit: a study of values and social controls in South Asian Societies. Chicago: The University of Chicago Press, 1967.

GINTHER, Matthew R. Parsing the behavioral and brain mechanisms of third-party punishment. The Journal of Neuroscience, v. 7, n. Sep, p. 9420-9434, 2016.

GLASS, Leila et al. Neural signatures of third-party punishment: evidence from penetrating traumatic brain injury. Social Cognitive and Affective Neuroscience, v. 11, n. 2, p. 253-262, 2015.

GRIMALDA, Gianluca; PONDORFER, Andreas; TRACER, David P. Social image concerns promote cooperation more than altruistic punishment. Nature Communications, v. 7, p. 1-8, 2016. Disponível em: < http:// dx.doi.org/10.1038/ncomms12288>.

GUALA, Francesco. Reciprocity: weak or strong? what punishment experiments do (and do not) demonstrate. Behavioral and Brain Sciences, v. 35, n. 1, p. 1-15, 2012.

GURVEN, Michael. To give and to give not: the behavioral ecology of human food transfers. Behavioral and Brain Sciences, v. 27, n. 04, p. 543-583, 2004. Disponível em: <http://www.journals.cambridge.org/abstract_S0140525X04000123>. 
HENRICH, Natalie; HENRICH, Joseph. Why bumans cooperate: a cultural and evolutionary explanation. New York: Oxford University Press, 2007.

HOFFMAN, Morris B. The punisher's brain: the evolution of judge and jury. New York: Cambridge University Press, 2014.

HORTA, Ricardo de Lins e. A desalentadora função das prisões: revisitando as teorias da pena à luz da psicologia experimental. Manuscrito.

KRUEGER, Frank; HOFFMAN, Morris. The emerging neuroscience of third-party punishment. Trends in Neurosciences, v. 39, n. 8, p. 499-501, 2016. Disponível em: <http://dx.doi.org/10.1016/j.tins.2016.06.004>.

MCCULLOUGH, Michael E.; KURZBAN, Robert; TABAK, Benjamin A. Cognitive systems for revenge and forgiveness. Behavioral and Brain Sciences, v. 36, n. 01, p. 1-15, 2013. Disponível em: <http://www. journals.cambridge.org/abstract_S0140525X11002160>.

MERCIER, Hugo; SPERBER, Dan. The enigma of reason. Cambridge, Massachussetts: Harvard University Press, 2017.

MILTENBERGER, Raymond G. Behavior modification: principles \& procedures. 5. ed. Belmont, CA: Cengage Learning, 2012.

NAGIN, Daniel S. Deterrence in the twenty- first century. Crime and Justice, v. 42, n. 1, p. 199-263, 2013.

NETTTLE, Daniel. Tyneside neighbourhoods. Cambridge, UK: Open Book Publishers, 2016.

PATIL, Indrajeet; DHALIWAL, Nathan A.; CUSHMAN, Fiery. Reputational and cooperative benefits of third-party compensation. PsyArXiv PrePrint, p. 1-56, 2018.

PEDERSEN, E. J.; KURZBAN, R.; MCCULLOUGH, M. E. Do humans really punish altruistically? a closer look. Proceedings of the Royal Society B: Biological Sciences, v. 280, n. 1758, 2013. Disponível em: < http:// rspb.royalsocietypublishing.org/cgi/doi/10.1098/rspb.2012.2723>.

PEDERSEN, Eric J.; MCAULIFFE, William H. B.; MCCULLOUGH, Michael E. The unresponsive avenger: more evidence that disinterested third parties do not punish altruistically. Journal of Experimental Psychology: General, v. 147, n. 4, p. 514-544, 2018. Disponível em: <http://www.psy.miami.edu/faculty/mmccullough/Papers/2018-Unresponsive Avenger.pdf>.

PINKER, Steven. The false allure of group selection. In: BUSS, David M. (Org.). The handbook of evolutionary psychology. Hoboken, New Jersey: John Wiley \& Sons, 2016. p. 867-880.

POLDRACK, Russell A. Inferring mental states from neuroimaging data: from reverse inference to largescale decoding. Neuron, v. 72, n. 5, p. 692-697, 2011. Disponível em: <http://dx.doi.org/10.1016/j.neuron.2011.11.001>.

QUERVAIN, D. J. F. The neural basis of altruistic punishment. Science, v. 305, n. 5688, p. 1254-1258, 2004. Disponível em: <http://www.sciencemag.org/cgi/doi/10.1126/science.1100735>.

RAIHANI, Nichola J.; THORNTON, Alex; BSHARY, Redouan. Punishment and cooperation in nature. Trends in Ecology and Evolution, v. 27, n. 5, p. 288-295, 2012. Disponível em: < http://dx.doi.org/10.1016/j. tree.2011.12.004>.

SAPOLSKY, Robert M. Behave: the biology of humans at our best and worst. New York: Penguin Press, 2017.

SEYMOUR, Ben; SINGER, Tania; DOLAN, Ray. The neurobiology of punishment. Nature Reviews Neuroscience, v. 8, n. 4, p. 300-311, 2007. Disponível em: <http://www.nature.com/doifinder/10.1038/nrn2119>. STALLEN, Mirre et al. Neurobiological mechanisms of responding to injustice. The Journal of Neuroscience, 
v. 38, n. 12, p. 1242-1247, 2018. Disponível em: <http://www.jneurosci.org/lookup/doi/10.1523/JNEUROSCI.1242-17.2018>.

STRANG, Heather et al. Restorative justice conferencing (RJC) using face-to-face meetings of offenders and victims: effects on offender recidivism and victim satisfaction. Campbell Systematic Reviews, v. 12, 2013. Disponível em: <https://campbellcollaboration.org/library/restorative-justice-conferencing-recidivismvictim-satisfaction.html>.

STRUCHINER, Noel; CHRISMANN, Pedro H. V. Aspectos filosóficos e psicológicos das punições: Reunindo algumas peças do quebra-cabeça. Caderno CRH, v. 25, n. 2, p. 133-150, 2012.

TREADWAY, Michael T. et al. Corticolimbic gating of emotion-driven punishment. Nature Neuroscience, v. 17, n. 9, p. 1270-1275, 2014. Disponível em: < http://www.nature.com/neuro/journal/v17/n9/abs/ nn.3781.html>.

WAAL, Frans de. Are we smart enough to know how smart animals are? New York: W. W. Norton \& Company, 2016.

WANG, Yin; OLSON, Ingrid R. The original social network: white matter and social cognition. Trends in Cognitive Sciences, v. 22, n. 6, p. 1-13, 2018. Disponível em: <https://doi.org/10.1016/j.tics.2018.03.005>.

YU, H.; LI, J.; ZHOU, X. Neural substrates of intention-consequence integration and its impact on reactive punishment in interpersonal transgression. Journal of Neuroscience, v. 35, n. 12, p. 4917-4925, 2015. Disponível em: <http://www.jneurosci.org/cgi/doi/10.1523/JNEUROSCI.3536-14.2015>. 


\title{
A intuição do dolo em direito penal: correlatos neurais da teoria da mente, raciocínio indutivo e a garantia da convicção justificada*
}

\author{
Intuitive attribution of criminal intent: \\ neural correlates of theory of mind, inductive \\ reasoning and the guarantee of justified \\ cognition
}

Thiago Dias de Matos Diniz**

Renato César Cardoso***

\section{Resumo}

Esse artigo integra resultados significativos das ciências cognitivas contemporâneas - especialmente de estudos com imagens obtidas por ressonância magnética funcional e apoiados em psicologia comportamental para a compreensão da construção argumentativa do dolo em direito penal, bem como de uma seletividade penal política e moralmente focada no nível psicológico-individual. Tanto os elementos psicológicos que se encontram subjacentes à conceituação e classificação dos tipos dolosos quanto os vieses que afetam o juízo de imputação do elemento subjetivo são tematizados sob um enfoque empírico. Uma vantagem dessa abordagem interdisciplinar é tornar evidente, entre outros aspectos, a associação natural e espontânea de institutos jurídicos, especialmente penais, com concepções morais pronta e automaticamente disponíveis, e os limites de eficácia de tradicionais garantias cognitivas do juízo penal. A metodologia utilizada foi preponderantemente a revisão de literatura, tanto na área específica da neurociência, destacadamente, correlatos neurais da Teoria da Mente (ToM), quanto da psicologia comportamental, com foco nos fatores intervenientes na atribuição de conhecimento, vontade e intenção (estados mentais) aos agentes, e sua relação com o sentido social (normativo) da sua ação. Foram verificadas assimetrias na avaliação de ações moralmente relevantes, que considera diversos fatores além dos estados mentais do agente (conhecimento e vontade) — os quais, inclusive, podem ser determinados não como premissa, mas como justificação de uma reprovação intuitiva. Identificou-se uma base psicológica da punição a título de dolo eventual, conforme o processamento cerebral dos efeitos colaterais negativos de uma ação. Constatou-se um efeito do perfil do agente (histórico de condutas etc.) na avaliação da reprovabilidade, da intencionalidade e, inclusive, da contribuição causal da sua ação em relação ao efeito lesivo. Por fim, notou-se que a interpretação de uma ação como intencional pode variar conforme se mostre materialmente danosa, ou apenas violadora de uma norma social. Esses resultados são importantes para o direito penal, especialmente para balizar o reforço permanente das suas garantias. 
Palavras-chave: Neurodireito. Vieses no Raciocínio Judicial. Teoria da Mente. Dolo. Direito e Garantias Penais.

\section{Abstract}

This article takes relevant evidences from contemporary cognitive sciences - especially behavioural and fMRI studies - to understand the argumentative elaboration of criminal intent (dolo) and the selectivity of criminal policy, politically and morally focused on the psychological and individual level. Both the psychological elements, which underlie conceptualization and classification of intentional crimes, and the biases that affect the judgment of subjective elements adscription are issued with an empirical and interdisciplinary approach. So it is possible to explore the natural and spontaneous association of legal institutes, criminal especially, and some readily available moral conceptions; also the limits of efficacy of some traditional cognitive guarantees within the criminal process. The employed methodology was mainly bibliographical review, both on neuroscience, mainly, on neural correlates of Theory of Mind, and behavioural psychology, with emphasis on intervenient factors on attribution of knowledge, will and intention (mental states) to agents, and its relationship with the social (normative) meaning of his action. Some asymmetries on actions evaluations were identified, in a way that signalizes other factors beyond the agent's mental states (knowledge and will) to play an important role on their moral status - actually, those same states may play a role not as premises on moral judgement, but to further justify some initial intuitive reprobation. A psychological base for conditional intent (dolo eventual) was also identified, according to the neural processing of negative side effects of some actions. Furthermore, there is a noticeable effect of the agent's previous record on the evaluation of blame, intentionality and of the causal contribution of his action to the verified result. Finally, the interpretation of an action as intentional may vary depending on its occurrence along with a harmful event, or its being only a violation of social norm. These results are important to criminal law, especially to guide the never-ending efforts to make its guarantees effective.

Keywords: Neurolaw. Judicial Reasoning Biases. Theory of Mind. Criminal Intent. Criminal Law's Guarantees.

\section{INTRODUÇÃo}

Grande parte do mérito da Teoria do Garantismo Penal reside nas garantias processuais oferecidas, especialmente aquelas de caráter epistemológico, que asseguram critérios pragmáticos de decisão ou condições de justificação do raciocínio indutivo judicial.

A aplicação em juízo das normas relativas ao elemento subjetivo do tipo, dando-se normalmente por satisfeita com a determinação doutrinária do conceito de dolo, seja por meio de elementos psicológicos (por exemplo, a intenção do agente), ou normativos (por exemplo, o perigo criado), costuma negligenciar a necessidade processual de justificação lógico-indutiva explícita e consistente com os elementos do conceito adotado, como se sua verificação dependesse, em regra, de uma intuição sobre o caso concreto.

Quando se opta, deontologicamente, pelo modelo de direito penal garantista, suas implicações lógicas devem, na medida do possível, ser seguidas. É inegável, porém, que, se o direito penal pressupõe, substancialmente, uma base moral, os preceitos da razão garantista podem, em alguma medida, entrar em choque com certas intuições naturais, como descritas pelo modelo intuicionista social e conforme a linha de estudos nas ciências cognitivas que avançaram, nesse sentido, nas últimas décadas. Indaga-se, então, pelos contornos desse choque entre, por um lado, a argumentação que segue idealmente os critérios lógicos da verdade 
processual (formal), para se alcançar uma determinação da esfera subjetiva do autor ou do sentido social da sua ação, e, por outro lado, um raciocínio socialmente funcional, mantido, especialmente, por presunções espontaneamente induzidas. Como se verá, os fundamentos teóricos do dolo têm, ainda, que avançar, bem além da divisão entre psicologismo e normativismo.

O modelo cognitivo-garantista de aproximação da verdade processual, firmada como hipótese explicativa, de natureza provável, dado um conjunto de fatos, dos elementos fundamentadores do tipo de ação imputada a um sujeito ${ }^{1}$, pode ser descrito como uma inferência indutiva, cujas premissas contém a descrição do fato e as respectivas provas, "além de generalidades habitualmente subentendidas (entimemáticas) no atendimento de experiências análogas", ao que sucede a conclusão, com "a enunciação do fato que se aceita como provado pelas premissas e que equivale à sua hipótese de explicação”3.

Assim, a verificação, em cada caso, da ocorrência dos elementos constitutivos do tipo penal limita-se a uma comprovação "logicamente provável ou razoavelmente plausível de acordo com um ou vários princípios de indução" "Trataremos neste artigo de um modo pelo qual esse processo logicamente indutivo é influenciado, de partida, por nossas intuições morais. Ou do modo pelo qual, por outro lado, também pode apresentar-se como uma racionalização posterior (post hoc) de um julgamento moral inicialmente intuitivo.

Especialmente complexa, se torna a questão quando se consideram não apenas o fato delituoso e sua autoria, mas o caráter intencional da ação que fundamenta o injusto, o elemento subjetivo, em regra, dos tipos, e a intenção que se tem normalmente atribuída aos agentes de crimes mais graves. Desde a concepção ética platônica-aristotélica, o propósito deliberado ou a intenção do agente é expressamente tratado e justificado como um aspecto fundamental da ação para a sua responsabilização moral ${ }^{5}$. Levá-la em consideração é essencial para a valoração e intepretação do sentido da conduta ${ }^{6}$.

Assim, importa indagar que implicação teria o fato - comprovado em estudos comportamentais e de neuroimagem, com ressonância magnética funcional, a seguir descritos — de que nossas atribuições de intenções se encontram de partida, especialmente no contexto que interessa ao direito penal, enviesadas, dado que nosso cérebro funciona naturalmente como "acusador intuitivo" ", buscando evidência, no agente, de estados mentais que indiquem dolo no caso de eventos danosos ou cujo resultado é incerto.

A relevância dessa investigação é patente quando se trata, na interpretação e argumentação jurídico-penal, de verificar o ônus da prova e a admissibilidade de provas indiretas ou indiciárias do dolo, e, sobretudo, para criticar presunções de fato veladas que pragmaticamente sustentam em juízo a comprovação do elemento subjetivo. Além disso, reflete uma percepção já defendida segundo a qual, muitas vezes, para se modificarem as práticas penais, "o ponto de vista deve mover-se do plano metodológico e epistemológico para o plano ontológico", ou empírico. Este parece especialmente o caso quando se tematiza "a hegemonia da concepção subjetivista/individualista/psicologista nas teorias do crime e da pena desenvolvidas no Brasil e sua repercussão em termos de práticas institucionais penais". As capacidades preventivas do direito penal, que devem orientar a elaboração das suas categorias dogmáticas, suas capacidades de atuação em cada caso,

1 FERRAJOLI, Luigi. Direito e razão: teoria do garantismo penal. 4. ed. São Paulo: Revista dos Tribunais, 2014. p. 125.

2 FERRAJOLI, Luigi. Direito e razão: teoria do garantismo penal. 4. ed. São Paulo: Revista dos Tribunais, 2014. p. 55.

3 FERRAJOLI, Luigi. Direito e razão: teoria do garantismo penal. 4. ed. São Paulo: Revista dos Tribunais, 2014. p. 55.

4 FERRAJOLI, Luigi. Direito e razão: teoria do garantismo penal. 4. ed. São Paulo: Revista dos Tribunais, 2014. p. 56.

5 ARISTÓTELES. Retórica. In: ARISTÓTELES: Obras completas. 2. ed. Lisboa: Centro de Filosofia da Universidade de Lisboa; Imprensa Nacional-Casa da Moeda, 2005. v. 8. t. 1. p. 147, 1374b.

6 WELZEL, Hans. Teoria de la acción finalista. Buenos Aires: Depalma, 1951.

7 SCHOLZ, J.; SAXE, R.; YOUNG, L. Neural evidence for "intuitive prosecution": the use of mental state information for negative moral verdicts. Disponível em: < http://saxelab.mit.edu/resources/papers/in_press/IntuitiveProsecution_SN.pdf>. Acesso em: 20 jan. 2018.

8 SANTOS, André Leonardo Copetti; LUCAS, Doglas Cesar. A relação entre criminogênese e práticas penais e o debate sobre a teoria da ação entre subjetivistas e objetivistas. Rev. Bras. Polít. Públicas, Brasília, v. 8, n.1, 2018. p. 127.

9 SANTOS, André Leonardo Copetti; LUCAS, Doglas Cesar. A relação entre criminogênese e práticas penais e o debate sobre a teoria da ação entre subjetivistas e objetivistas. Rev. Bras. Polít. Públicas, Brasília, v. 8, n. 1, 2018. p. 131. 
assim como a capacidade de operacionalizar um ordenamento processual com garantias dependem invariavelmente, como todo fenômeno normativo, de condições de eficácia que se deparam justamente no plano fático ou empírico ${ }^{10}$, as quais são especialmente sensíveis no campo do direito penal. Um descompasso entre categorias penais efetivamente aplicadas e as demandas ou garantias processuais de justificação repercute, enfim, no obscurecimento dos limites da intervenção penal no âmbito da subjetividade daquele que se encontra sob a força persecutória do aparato estatal.

Na primeira seção do artigo, serão descritas, com base nas ciências cognitivas, as relações entre o raciocínio moral, intuição moral e Teoria da Mente, especialmente no que pode afetar a prova cotidiana do dolo. $\mathrm{Na}$ segunda seção, será abordada a estrutura retórica comum dos juízos de atribuição do dolo e a necessidade de critérios para sua comprovação, o que pode se mostrar mais sensível conforme o tipo de delito em questão. A compreensão de mecanismos naturais por trás dos nossos juízos morais e de critérios necessários à convicção motivada em processo penal pode viabilizar um controle maior sobre as decisões judiciais contra o decisionismo processual ou intuições não justificadas da espistemologia antigarantista.

Metodologicamente, o tópico selecionado em ciência cognitiva, conforme a demanda do nosso objeto de estudo, é, como destacado, a Teoria da Mente (ToM). Para início de pesquisa sobre o tema, utilizou-se, na plataforma Scielo, em busca por todos os índices, o indexador "Theory of Mind", e foram revisadas todas as entradas que não diziam respeito, unicamente, a deficiências específicas e aprendizagem infantil. A maior atenção foi direcionada a artigos que versam sobre as relações entre Teoria da Mente e formação dos juízos morais - os quais impactam a teoria e prática penais e reforçam a seletividade do sistema penal. Antes, porém, alguns artigos ajudaram a compreender o desenvolvimento do conceito no campo das neurociências. Com base nas referências então encontradas, foi possível traçar o estado atual das pesquisas nesse campo, com base nos autores normalmente citados com seus estudos seminais e de maior impacto na comunidade científica, bem como desdobramentos desses estudos, em artigos que se referenciam, entre os autores da área, em concordância ou discordância — havendo, curiosamente, mais pontos de concordância do que discordância nessa área, naquilo que interessa ao nosso estudo. Ainda na revisão de literatura nesse campo, foi feita uma busca no Google Acadêmico com os índices "Theory of Mind" e "moral", simultaneamente, e foram selecionados para a revisão os artigos e livros encontrados que complementavam ou diziam respeito, diretamente, à bibliografia previamente estudada. Os resultados dessas pesquisas são, no decorrer deste trabalho, relacionados ao campo de atuação do sistema penal, especialmente no que afeta à delimitação das condutas típicas dolosas — cuja definição não prescinde, em um Estado Democrático, de um apoio nas razões que justificam a punição em maior grau pelo aparato sancionador estatal, ou seja, nas razões de política criminal balizadas pelos fins do direito penal e inseparáveis das condições empíricas de atuação que lhes subjazem.

\section{O MODELO INTUICIONISTA SOCIAL}

Com a noção de intuição moral, faremos referência ao processo rápido e automático de valoração espontânea de uma pessoa ou ação, sem consciência do caminho lógico ou dos motivos internos que teriam conduzido a esse juízo valorativo. O raciocínio moral, por outro lado, pode ser definido como uma atividade mental conscientemente controlada, que processa a informação disponível sobre as pessoas e suas ações para chegar a um julgamento moral ${ }^{11}$.

Haidt defende o Princípio da Primazia Intuitiva, segundo o qual o raciocínio moral, diante de um fato

10 A esse respeito, CALIL, Mário Lúcio Garcez; SANTOS, José Eduardo Lourenço dos. A formulação da agenda políticocriminal com base no modelo de ciência conjunta do direito penal. Rev. Bras. Polít. Públicas, Brasília, v. 8, n. 1, p. 44-48, 2018.

11 HAIDT, J. The new synthesis in moral psychology. Science, v. 316, maio 2007. p. 998. 
dado, é normalmente "um processo post hoc no qual buscamos evidência para sustentar nossa reação intuitiva inicial" ${ }^{12}$. Ademais, raramente se buscam hipóteses ou evidências desconformes à primeira impressão, e as pessoas, em geral, "são muito boas em encontrar suporte para aquilo em que desejam acreditar"13.

Um exemplo de intuição moral fortemente arraigada é o peso dado às volições e intenções no juízo de reprovabilidade de uma ação, que chegam, inclusive, a preponderar sobre as contrições externas sobre agente, por exemplo, a possibilidade de conduta diversa. Woolfolk, Doris e Darley, em um estudo desse aspecto da culpa moral, apresentaram aos participantes a seguinte estória: um homem está viajando de avião com a esposa e o melhor amigo, e, sabendo que tiveram um caso amoroso, deseja mata-lo. O avião é sequestrado, e os criminoso obrigam o homem a atirar na cabeça do amigo; caso contrário, todos morrem. Em uma variação da estória, quando o avião é tomado, o homem já não desejava matar o amigo, pois o havia perdoado. Os participantes no estudo, em geral, julgaram o homem mais responsável e reprovável pela morte do amigo no primeiro caso, mesmo que seu desejo não tivesse nenhuma influência causal no resultado ${ }^{14}$.

Em outro estudo, Alicke mostrou que um agente que acelerava o carro desmedidamente com o fim de chegar rápido à sua casa para esconder cocaína que havia deixado à vista era julgado, na ocorrência de um acidente, como mais reprovável e mais responsável, causalmente, pelo acidente, em relação a um indivíduo que tivesse acelerado igualmente com o fim de esconder um presente que havia comprado para os pais ${ }^{15}$.

Diferenças individuais na disposição para engajar em processos cognitivos, ou, por outro lado, processos intuitivos ou emocionais, determinam diferentes respostas a dilemas morais clássicos ${ }^{16}$. O padrão de predisposição a uma avaliação cognitiva parece relacionar-se com os preceitos da ética utilitarista, com base na ativação do respectivo subsistema cerebral em padrões neurais no córtex pré-frontal, correlacionados ao raciocínio abstrato e controle cognitivo ${ }^{17}$. Esse padrão explicaria punições mais lenientes, capazes de ponderar fatores situacionais, pessoais, entre outros, especialmente em face de comportamentos imprudentes ou negligentes, enquanto indivíduos mais predispostos ao padrão afetivo-emocional tendem a punir mais severamente esse tipo de conduta, reagindo automaticamente a resultados danosos, que são, assim, levados mais em conta ${ }^{18}$.

\section{Os CORRELATOS NEURAIS DA ATRIBUIÇÃo DE ESTADOS MENTAIS}

Entre nove e doze meses de idade, crianças são capazes de representar, distintamente, as finalidades de um agente e alguns dos meios disponíveis para alcançá-las, e já esperam desse agente, com base nisso, um comportamento racionalmente mais econômico ${ }^{19}$. Aproximadamente aos dois anos de idade, as crianças adquirem o conceito de desejo, reconhecem que outras pessoas podem ter desejos diferentes e são capazes de inferi-los mesmo de ações incompletas ou tentadas ${ }^{20}$. Crianças de aproximadamente cinco anos de idade ${ }^{21}$

12 HAIDT, J. The new synthesis in moral psychology. Science, v. 316, maio 2007. p. 998.

13 HAIDT, J. The new synthesis in moral psychology. Science, v. 316, maio 2007. p. 998.

14 WOOLFOLK, R. L.; DORIS, J. M.; DARLEY, J. M. Identification, situational constraint, and social cognition: Studies in the attribution of moral responsibility. Cognitio, v. 100, n. 2, 2006.

15 ALICKE, M. D. Culpable causation. Journal of Personality and Social Psychology, n. 63, 1992, p. 369.

16 GREENE, J. D. et al. An fMRI Investigation of Emotional Engagement in Moral Judgment. Science, 2001, p. $2105-2108$.

17 GREENE, J. D. et al. The Neural Bases of Cognitive Conflict and Control in Moral Judgment. Neuron, v. 44, p. 389-400, out. 2004.

18 YOUNG, L.; SAXE, R. Innocent intentions: A correlation between forgiveness for accidental harm and neural activity. Neuropsychologia, v. 47, n.10, 2009. p. 2070.

19 CSIBRA, Gergely. Teleological and referential understanding of action in infancy. Philosophical Transactions of The Royal Society B Biological Sciences, v. 358, n. 1431, 2003, p. 447-458.

20 MAlLE, F; GUGLIELMO, S.; MONROE, A. E. Moral, Cognitive and Social: The nature of blame. In: FORGAS, J. et al. Social Thinking and interpersonal behaviour. Philadelphia, PA: Psychology Press, 2011. p. 317.

21 Ressalvando a possibilidade de que essa capacidade já se verifique mais cedo ou conforme variações individuais no desenvolvi- 
são capazes de formular predições de comportamento, explicitamente, a partir da inferência de crenças e intenções de outra pessoa, ou seja, baseadas em modelos internos relativamente abstratos sobre a mente dos outros em geral.

Em síntese, Teoria da Mente (ToM) é uma categoria ou habilidade cognitiva que designa o fato de pensarmos nos estados mentais de outras pessoas (pensamentos, desejos, intenções etc.) ${ }^{22}$. Essa capacidade de inferir estados mentais, especialmente a percepção ou atribuição de falsas crenças, ou sensibilidade à presença e ausência de conhecimento em outro sujeito, pode ser notada, inclusive, por meio de experimentos que não se baseiam na capacidade de articulação e interpretação verbal, em crianças de três anos ${ }^{23}$ e até mesmo de dezoito meses de idade ${ }^{24}$.

Predições de comportamento com base na inferência de estados mentais apresentam correlação com padrão de atividade da junção temporo-parietal direita, conforme estudos com ressonância magnética funcional. Quando o resultado de uma ação é esperado, ou consistente com a intenção atribuída ao agente, identifica-se um padrão de atividade menor, ao passo que desvios da predição, um resultado incompatível com a intenção previamente representada, resultam em uma ativação maior ${ }^{25}$. Nesse caso, o processo de integração entre uma intuição inicial sobre a intenção do agente observado e o resultado verificado demanda um esforço cognitivo maior, e exige uma maturação da região apontada, que ocorre, em média, aos sete anos de idade.

Isso significa que apenas então se verifica a capacidade de desculpar ou atenuar a culpa por danos acidentais causados por uma pessoa. Indivíduos com danos na junção temporo-parietal direita, autismo, ou submetidos à estimulação magnética transcraniana nessa região, apesar de obterem sucesso em adscrever crenças falsas, perdem aquela capacidade e, além disso, julgam as meras tentativas de dano como menos reprováveis. Mesmo entre adultos, há evidência de relevante variação individual na atribuição de culpa a causadores de danos acidentais ${ }^{26}$.

Investigações futuras dessas diferenças individuais podem apontar explicações para as variações nos juízos, em direito, sobre aquilo que se entende pela razoabilidade do erro de fato, no âmbito da tipicidade penal, bem como sobre a linha tênue que separa o dolo eventual da culpa consciente.

Tratando-se da reprovabilidade do comportamento acidentalmente danoso, seu processamento, pelo cérebro, é mais complexo. As pessoas ultrapassam as explicações retrospectivas, a história causal (interna, situacional ou cultural) do comportamento, e iniciam considerações prospectivas sobre a recorrência potencial do comportamento e suas possibilidades de antecipação ou prevenção ${ }^{27}$ - com o que notamos, ainda, que considerações extradogmáticas ou conforme a metodologia teleológica, de política criminal, são necessárias já para a compreensão de aspectos fundamentais da tipicidade, como o elemento subjetivo, conforme

mento. SAXE, R. The new puzzle of Theory of Mind Development. In: BANAJI, M. R.; GELMAN, S. A. (Eds.). Navigating the social world: what infants, children, and other species can teach us. New York, NY, US: Oxford University Press, 2013.

22 BZDOK, Danilo et al. The neurobiology of moral cognition: relation to theory of mind, empathy, and mind-wandering. In: CLAUSEN, Jens; LEVY, Neil (Coord.). Handbook of Neuroetbics. Heildelberg. Nova Iorque, Londres: Springer, 2015. p. 129.

23 RHODES, Marjorie; BRANDONE, Amanda C. Three-year-olds' theories of mind in actions and words. Frontiers in Psychology, v. 5, n. $263,2014$.

24 SODIAN, Beate. Theory of mind: the case for conceptual development. In: SCHNEIDER et al. Young children's cognitive development: interrelationships among executive functioning, working memory, verbal ability, and theory of mind. New York; London: Psychology Press, 2013. p. 100, 107. BJORKLUND; CORNIER; ROSENBERG. The evolution of theory of mind: big brains, social complexity and inhibition. In: SCHNEIDER, et al. Young children's cognitive development: interrelationships among executive functioning, working memory, verbal ability, and theory of mind. New York; London: Psychology Press, 2013. p. 160.

25 Para uma concepção diversa, KLIEMANN, D. et al. The influence of prior record on moral judgment. Neuropsychologia, v. 46, p. 2949-2957, 2008.

26 YOUNG, L.; SAXE, R. Innocent intentions: a correlation between forgiveness for accidental harm and neural activity. Neuropsychologia, v. 47, n. 10, p. 2065-2072, 2009.

27 MALLE, F.; GUGLIELMO, S.; MONROE, A. E. Moral, cognitive and social: the nature of blame. In: FORGAS, J. et al. Social Thinking and interpersonal behaviour. Philadelphia, PA: Psychology Press, 2011. p. 318. 
já aceito por grande parte da doutrina ${ }^{28}$.

Malle et al. entendem que, apesar de os casos de culpa, em sentido amplo, apresentarem elementos retributivos (retrospecção), "a função geral da culpa, e especialmente sua expressão social, é primariamente prospectiva (reformativa), pois é um dos instrumentos da comunidade para regular o comportamento" 29 . Em um sentido análogo, se também pudermos entender, ainda que pela riqueza da imagem, os recursos básicos do sistema jurídico como aquisição evolutiva, a afirmação precedente faz eco ao funcionalismo sistêmico de Jakobs:

Uma falta de conhecimento é, per se, um déficit psíquico e nada mais, e no limite entre a reprovação da culpabilidade mais grave e a mais leve não pode orientar-se segundo o originado na psiquê, senão apenas segundo a função da reprovação de culpabilidade ${ }^{30}$.

A consideração dessas colocações ilustra o modo como há, nas ciências penais, uma polarização que "estabelece, de um lado, fortes conexões entre uma ênfase estrutural/coletiva e o objetivismo, e, por outro, estreitas ligações entre uma perspectiva individualista/psicologista e o subjetivismo ligado à filosofia da consciência"31. Uma consequência do domínio da perspectiva metodológica individualista no campo penal teria sido a adoção, pelos sistemas jurídicos ocidentais, de um modelo de direito penal baseado na vontade e na finalidade do agente, de modo que as "fórmulas normativas que estruturam a positivação desse modelo de direito penal representam a institucionalização de uma concepção subjetivista da criminogênese" 32 . Por outro lado, acusa-se que uma "tendência jurídica de nosso tempo se dirige a uma concepção objetiva da personalidade penal, conforme a qual se atende mais às consequências materiais do ato, a lesão jurídica e a ofensa real ocasionada à sociedade, que à consciência e à intenção do sujeito ativo"33.

Com o presente trabalho, mostramos de que modo ambas as perspectivas, que se fundamentam no plano teórico, encontram-se, empiricamente, no âmbito da formação cognitiva dos nossos juízos morais, inter-relacionadas e indissociáveis.

\section{Cognição moral e Teoria da Mente}

Os juízos sobre a reprovabilidade moral de uma conduta se pautam, entre outros fatores, alguns correlacionados, pelas crenças e desejos do agente, seus antecedentes, a relevância do dano, os meios utilizados e coerções externas identificáveis à sua conduta ${ }^{34}$. Há, para cada um desses elementos, normas positivadas que eximem, atenuam, agravam ou qualificam a pena, segundo o juízo de reprovação pessoal (culpabilidade), e postulados de interpretação e aplicação do tipo penal, como a lesividade.

Nem a atribuição de intenções tampouco a cognição moral depende, apenas, do módulo da Teoria da Mente. O córtex pré-frontal dorsolateral já foi relacionado à "habilidade de gerar pensamentos independentes de estímulos para explicar aspectos dos estados mentais de outras pessoas que podem não ser dire-

28 ROXIN, Claus. Estudos de Direito Penal. Rio de Janeiro: Renovar, 2006. p. 61 ss.

29 MALLE, F.; GUGLIELMO, S.; MONROE, A. E. Moral, cognitive and social: the nature of blame. In: FORGAS, J. et al. Social Thinking and interpersonal behaviour. Philadelphia, PA: Psychology Press, 2011. p. 318.

30 JAKOBS, Günther. La imputación jurídico-penal y las condiciones de la vigência de la norma. In: DÍEZ, Carlos Gómez-Jara (Ed.). Teoría de Sistemas y derecho penal: fundamentos y posibilidades de aplicación. Granada: Editorial Comares, 2005. p. 184.

31 SANTOS, André Leonardo Copetti; LUCAS, Doglas Cesar. A relação entre criminogênese e práticas penais e o debate sobre a teoria da ação entre subjetivistas e objetivistas. Rev. Bras. Polit. Públicas, Brasília, v. 8, n. 1, 2018. p. 129-130.

32 SANTOS, André Leonardo Copetti; LUCAS, Doglas Cesar. A relação entre criminogênese e práticas penais e o debate sobre a teoria da ação entre subjetivistas e objetivistas. Rev. Bras. Polít. Públicas, Brasília, v. 8, n. 1, 2018. p. 145.

33 SANTOS, André Leonardo Copetti; LUCAS, Doglas Cesar. A relação entre criminogênese e práticas penais e o debate sobre a teoria da ação entre subjetivistas e objetivistas. Rev. Bras. Polit. Públicas, Brasília, v. 8, n. 1, 2018. p. 142-143.

34 KOSTER-HALE et al. Decoding moral judgments from neural representations of intentions. Proceedings of the National Academy of Sciences, v. 110, n. 14, p. 5648-5653, 2013. p. 4. 
tamente observáveis em seu comportamento" 35 . Na miríade de fatores relacionados ao juízo de reprovação ou responsabilização, os contornos entre os dados externos e objetivos, de um lado, e os aspectos pessoais do autor, de outro, acabam muitas vezes se dissolvendo sob a névoa de hipóteses e fórmulas mágicas que transformam postulados e conceitos jurídicos em meras ideias regulativas - a exemplo do direito penal do fato e do dolo como conhecimento e vontade efetivos.

As intenções e desejos do agente ainda parecem ter, na nossa tradição cultural ${ }^{36}$, a maior relevância no juízo moral. Resultados de meta-análise com base em vários experimentos com neuroimagem produzida com ressonância magnética funcional, destacando-se os padrões neurais verificados durante tarefas de cognição moral, revelaram uma sobreposição significativa com os padrões neurais identificados durante a ativação espontânea de uma Teoria da Mente ${ }^{37}$.

A maior evidência de que uma região cerebral está envolvida em uma tarefa cognitiva refere-se ao fato de que uma interferência na região específica (por exemplo, por estimulação magnética transcraniana) resulta em vieses ou perturbação no desempenho da tarefa.

A estimulação transcraniana da junção temporo-parietal direita, mas não de regiões próximas selecionadas para controle, resultou em julgamentos morais desviados de considerações acerca dos estados mentais: importava menos o que o agente acreditava que estava fazendo, e mais o que efetivamente acontecia. Nesse caso, as pessoas não perdiam a habilidade de raciocinar moralmente, mas de integrar as considerações acerca dos estados mentais do agente em seus julgamentos morais ${ }^{38}$.

A atribuição de maior intencionalidade, segundo os experimentos conduzidos por Young et al..$^{39}$, parece correlacionar-se com uma maior ativação da junção temporo-parietal. Enquanto ações eram descritas aos participantes, com menção explícita às crenças dos agentes, a ativação neural, destacada graficamente nessa região, apresentava uma resposta inicial que não dependia do valor da crença (negativa ou neutra), e, quando o resultado lhes era relatado, uma maior ativação dependia, sim, do valor do resultado (danoso ou não). Isso permite concluir que a atividade cognitiva associada a esses padrões neurais é explicada tanto por um processamento inicial das informações disponíveis sobre os conhecimentos e intenções dos agentes quanto pelo processo de integração subsequente desses conhecimentos com os resultados, com o fim de embasar o julgamento moral ${ }^{40}$.

Há uma assimetria entre julgamentos morais de autores de crimes incompetentes ou inábeis, cujas crenças falsas preveniram o resultado intencionado de ocorrer, e de inocentes mal-afortunados, cujas crenças falsas os fizeram causar danos não intencionados ${ }^{41}$. Os primeiros julgamentos são severos, recrutando, especialmente, o módulo da Teoria da Mente. Os segundos não desculpam totalmente o agente pela causação do dano, e análises cerebrais revelaram o recrutamento de regiões associadas ao conflito cognitivo. Desse modo, no contexto de dano acidental previamente desconhecido, o observador precisa superar parcialmente, o julgamento espontâneo contra o dano, para desculpar o agente com base em sua falsa crença (erro). O julgamento moral, assim, parece representar "o produto de dois distintos e às vezes competitivos processos; um responsável pela representação de resultados danosos, e outro pela representação de cren-

35 SCHILBACH, L. et al. Introspective minds: using ale meta-analyses to study commonalities in the neural correlates of emotional processing, social and unconstrained cognition. PLoSONE, v. 7, n. 2, e30920, 2012. p. 7.

36 Para um estudo sobre variações etnográficas no emprego dos conceitos de Teoria da Mente e sobre a possibilidade de uma base universal. LILLARD, A. Ethnopsychologies: cultural variations in theories of mind. Psychological Bulletin, v. 123, n. 1, p. 3-32, 1998.

37 BZDOK, Danilo e outros. The Neurobiology of moral cognition: relation to theory of mind, empathy, and mind-wandering. In: CLAUSEN, Jens; LEVY, Neil (Coord.). Handbook of Neuroethics. Heildelberg, Nova Iorque, Londres: Springer, 2015. p. 134-135. 38 KOSTER-HALE, J.; R. SAXE. Functional neuroimaging of theory of mind: understanding other minds. 3. ed. Baron-Cohen, Lombardo \& Tager-Flusberg, 2013. p. 143.

39 YOUNG, L. et al. The neural basis of the interaction between theory of mind and moral judgment. PNAS, v. 104, n. $20,2007$.

40 KLIEMANN, D. et al. The influence of prior record on moral judgment. Neuropsychologia, v. 46, p. 2949-2957, 2008. p. 2950.

41 YOUNG, L. et al. The neural basis of the interaction between theory of mind and moral judgment. PNAS, v. 104, n. 20, 2007. p. 8239. 
ças e intenções" ${ }^{\prime 2}$. Nosso direito reconhece a impunibilidade de ambos os extremos, não punindo o crime impossível (tentativa inidônea), a despeito da intenção do agente, nem a cogitação delitiva, refletida em atos meramente preparatórios.

\section{A base pSicológica-intUITIVA do dolo eVENTUAL}

Alguns institutos ou categorias jurídicas parecem contar com um suporte intuitivo evidenciado na experiência. Por exemplo, pesquisas comportamentais e testes com neuroimagem atestam, curiosamente, que há uma atribuição espontânea de conhecimentos, intenções e vontade — ou dos elementos associados ao dolo - a agentes coletivos, a qual é dissociada da mesma atribuição a seus membros ou dirigentes, sendo uma independente da outra ${ }^{43}$. Assim como a pragmática cognitiva ${ }^{44}$ não veria problema em conceber-se uma intenção do legislador como primeiro balizador interpretativo do sentido, igualmente a suposta estrutura psicológica do dolo (psicologismo) já não é cabível como argumento contrário à responsabilização penal de pessoas jurídicas - a qual pode, entretanto, ser criticada por outras razões.

Quanto ao que nos interessa especialmente no momento, na esteira dos estudos sobre Teoria da Mente e cognição moral, é possível traçar disposições ou tendências neurais para o processamento do dolo eventual. Seu fundamento empírico-psicológico estaria, entre outros fatores, naquilo que Knobe descobriu como o fenômeno do efeito efeito-colateral ${ }^{45}$.

Como visto, as pessoas empregam uma Teoria da Mente para justificar suas convicções morais, e o oposto, também, ocorre: essas convicções servem como input para o processo que subjaz à aplicação dos conceitos da Teoria da Mente ${ }^{46}$ — inferência de estados mentais como crenças e intenções. Assim, o que determina se as pessoas percebem um comportamento como intencional ou não pode ser, antes, o próprio status moral intuído por meio do comportamento - qualificação que pode estar enviesada por fatores como o resultado danoso.

Knobe aponta essa relação de mão dupla entre Teoria da Mente e raciocínio moral por meio do seguinte estudo seminal, em que breves descrições de uma situação eram feitas aos participantes ${ }^{47}$. No primeiro cenário, o CEO de uma companhia sabia que o novo programa lucrativo a ser implantado danificaria o meio ambiente, mas ele não se importava; o programa era iniciado, e o meio ambiente danificado. Nesse caso, $85 \%$ dos participantes consideraram intencional a conduta. No segundo cenário, o programa lucrativo ajudaria o ambiente, o CEO, também, o sabia e não se importava, havendo, de fato, ajudado o meio ambiente. Nessa situação, 23\% dos participantes julgaram intencional a conduta.

Diversa, ainda, é a situação quando há risco quanto à ocorrência de um resultado incerto (efeito colateral da ação adotada). Se aquele CEO sabe que um efeito danoso ou benéfico ao meio ambiente pode ocorrer, mas este não é certo, em face do que se mantém indiferente (ou simplesmente não deixa de agir), e o resultado vem a ser danoso, as pessoas tendem a julgar sua ação como efetivamente intencional, e o resultado como desejado, de fato, por ele. Caso contrário, se o resultado for benéfico, tende a ser visto como não intencionado, e nenhum mérito assiste ao CEO.

A investigação da linguagem e da psicologia popular por trás desse tipo de viés vem sendo tematizada

42 YOUNG, L. et al. The neural basis of the interaction between theory of mind and moral judgment. PNAS, v. 104, n. 20, 2007. p. 8239.

43 JENKINS et al. The neural bases of directed and spontaneous mental state attributions to group agents. PLoSOne, v. 9, n. 8, e105341, 2014.

44 GRICE, Paul. Meaning revisited. In: SMITH, N. V. (Ed.). Mutual knowledge. New York: Academic Press, 1982. p. $223-243$.

45 KNOBE, J. Intentional action and side effects in ordinary language. Analysis, v. 63, p. 190-193, 2003.

46 KNOBE, J. Theory of mind and moral cognition: exploring the connections. Trends in Cognitive Sciences, v. 9, n. 8, 2005. p. 357.

47 KNOBE, J. Theory of mind and moral cognition: exploring the connections. Trends in Cognitive Sciences, v. 9, n. 8, 2005 , p. 358. 
pela chamada filosofia experimental ${ }^{48}$. Segundo Mele, há evidências de que a concepção popular de ação intencional está longe de ser unânime e uma mesma pessoa pode, inclusive, apresentar concepções assimétricas no juízo sobre ações particulares, acerca da respectiva intencionalidade, conforme seus efeitos sejam valorados positiva ou negativamente ${ }^{49}$.

\section{A RELEVÂNCIA do HISTÓRICO do AGENTE NA ATRIBUIÇÃo de INTENÇão E REPROVABILIDADE MORAL DA CONDUTA}

O registro de qualquer antecedente negativo, seja a conduta social (moral), ou alguma juridicamente ilícita, conduz a que os sujeitos atribuam, espontaneamente, mais intencionalidade, ou, no caso do direito, dolo, a agentes que causam resultados negativos. Assim concluem Kliemann, Young, Scholz, e Saxe, na esteira da literatura especializad $a^{50}$. E suscitam uma vez mais a questão: esse efeito é causa ou consequência de uma mudança no julgamento moral, ou seja, de um aumento da reprovabilidade da conduta ${ }^{51}$ ?

No experimento por eles conduzido, participantes, primeiramente, jogaram, aos pares, um jogo econômico de investimento, no qual poderia haver jogadas cooperativas ou, por parte dos jogadores injustos, trapaças. Em um segundo momento, os participantes leram pequenas vinhetas que descreviam uma ação de algum dos jogadores (identificado), a qual mostrava um resultado positivo ou negativo. Nenhuma informação era dada sobre a intenção dos agentes. Ao final, foi pedido aos participantes que avaliassem, em uma escala, quão intencional era a ação descrita e quão reprovável era. Essa atividade foi conduzida dentro de um escâner de ressonância magnética funcional. Os resultados obtidos foram os seguintes: quanto maior a diferenciação feita, pelos participantes, entre jogadores justos e injustos em seus investimentos, mais os participantes julgavam que jogadores injustos intencionavam o resultado negativo em níveis maiores que os jogadores justos o teriam feito; os participantes julgaram jogadores previamente injustos como merecedores de mais culpa em relação aos jogadores justos, quando suas ações tinham resultado negativo; e os participantes foram significativamente mais lentos ao julgar jogadores previamente justos cujas ações tiveram resultados negativos ${ }^{52}$.

Destacou-se, no experimento, que o viés no julgamento moral foi acompanhado por um padrão de ativação neural. A junção temporo-parietal mostrou resposta significativamente maior aos resultados danosos causados pelos agentes injustos. Uma descoberta relevante referiu-se ao fato de que o efeito do caráter do jogador sobre a resposta neural do participante ocorria em um momento posterior na escala de tempo, posteriormente ao julgamento moral. A interpretação oferecida pelos pesquisadores é que, após os sujeitos julgarem uma ação como reprovável, eles continuam a considerar o estado mental possível do agente, o que significaria que os sujeitos de início e intuitivamente condenam o referido agente por causar o resultado negativo verificado, e, em momento subsequente, tentam justificar instintivamente o impulso inicial ao atribuir-lhes intenções negativas ${ }^{53}$.

48 KNOBE, J. Intentional action and side effects in ordinary language. Analysis, v. 63, p. 190-193, 2003. p. 191.

49 MELE, Alfred R. Folk Conceptions of Intentional Action. Philosophical Issues, v. 22, 2012. p. 293. Nesse mesmo texto, trata das diferentes concepções populares envolvendo ações intencionais e sua relação com efeitos colaterais e fortuitos, e propõe reformulações do experimento de Knobe. Sobre o mesmo tópico, Frank Hindriks conclui que a noção de ação intencional deve ser analisada em termos de razões normativas subjacentes. HINDRIKS, Frank. Intentional action and the praise-blame asymmetry. The Philosophical Quarterly, v. 58, n. 233, out. 2008. p. 641.

50 KLIEMANN, D. et al. The influence of prior record on moral judgment. Neuropsychologia, v. 46, 2008. p. 2950.

51 KLIEMANN, D. et al. The influence of prior record on moral judgment. Neuropsychologia, v. 46, 2008. p. 2950.

52 KLIEMANN, D. et al. The influence of prior record on moral judgment. Neuropsychologia, v. 46, p. 2949-2957, 2008 . p. 2955.

53 KLIEMANN, D. et al. The influence of prior record on moral judgment. Neuropsychologia, v. 46, p. 2949-2957, 2008. p. 2958. 


\section{BREVES CONSIDERAÇÕES SOBRE OS DESAFIOS EMPíRICOS DA PROVA DO DOLO}

Dado o fenômeno da racionalização moral, por meio do que os sujeitos buscam "evidências" post hoc para amparar seu julgamento, é preciso atenção para os expedientes de justificação jurídica que visam a racionalizar, sem comprovação empírica, um pré-julgamento sobre determinadas condutas. Nesse sentido, é comum o apelo a danos hipotéticos ou consequências inventadas ${ }^{54}$. Em direito penal, isso pode ser identificado em argumentações sobre o tipo objetivo (presunção de lesões ou perigo de lesões, especialmente de bens jurídicos coletivos), que violam o postulado da lesividade, assim como no entendimento jurisprudencial sobre a verificação do tipo subjetivo, que, a partir da hipótese de lesão a suposto bem jurídico (alguns também criados ad hoc), acaba, de fato, a depender do grau do risco criado sobre o bem, atribuindo o dolo. Isso não seria, por si, um problema, desde que se adotasse uma concepção normativa do dolo, ou seja, desde que se considerasse seu elemento determinante, especialmente a vontade, não em sentido psicológico, com independência, portanto, do que o agente efetivamente quis ou assumiu como risco — o que não é o caso do direito brasileiro ${ }^{55}$. Assim, a consideração dos vieses sobre a adscrição de estados mentais ganha ainda mais relevância no nosso cenário.

Nos crimes de resultado, diante da ocorrência do evento danoso, há, conforme observado, uma presunção de fato do dolo. O elemento subjetivo, assim, no juízo condenatório penal, é dado em uma premissa implícita (entimemática), cuja plausibilidade é sustentada conforme o modelo da psicologia popular ${ }^{56}$ : espera-se que os agentes sejam consistentes e coerentes em suas ações ${ }^{57}$, assumindo-se, portanto, que agem em conformidade com suas crenças. Uma imputação ainda menos onerada argumentativamente é comum nos crimes de mera conduta e parecer requerer, para tanto, uma racionalização adicional sobre danos hipotéticos, como meio de esquivar-se, veladamente, do ônus de prova e justificação do dolo.

Há diferentes modos, com variação na estrutura linguística e conceitual, pelos quais um observador pode explicar uma ação intencional, sujeito à interferência do viés pessoal, da assimetria entre fatores pessoais vs fatores situacionais na base da explicação, ou mesmo da relevância explicativa dos antecedentes causais das razões ou motivos do agente ${ }^{58}$.

A explicação de uma ação intencional, no juízo penal, confunde-se em parte com a justificação — verificação probatória controlada ou convicção motivada — da tipicidade subjetiva da conduta. Há, porém, uma diferença entre explicação e justificação para a qual pouco se atentou no problema de fundamentação do dolo. A justificação pressupõe, nesse caso, um controle das hipóteses explicativas — limitando o subjetivismo inquisitivo judicial. Esse controle implica, com base nas garantias processuais penais, a validade epistemológica de critérios, com base nos quais se possa decidir entre hipóteses concorrentes, o que significa tornar previamente explícito, por exemplo, o peso relativo da personalidade do autor, da sua conduta social e dos seus conhecimentos especiais, como provas indiretas ou indiciárias do dolo, diante de circunstâncias objetivas que permitam, hipotética e racionalmente, uma conclusão diversa. Implica, em termos gerais, que o intérprete judicial deve conscientizar-se e tornar explícitas, de partida, as premissas fáticas que adota e enfrentar qualquer hipótese mais racional ou mesmo contra-intuitiva que se lhe possa apresentar, a qual deve prevalecer, em benefício do réu, na falta de prova direta do elemento subjetivo a ser provado - o que pode não ser tão marcante nos tipos que constituem o núcleo do direito penal, mas pode implicar resultados significativamente diversos em âmbitos penais nos quais os sentidos da ação e do resultado são mais fluídos.

54 SCHOLZ, J.; SAXE, R.; YOUNG, L. Neural evidence for "intuitive prosecution": The use of mental state information for negative moral verdicts. Disponível em: <http://saxelab.mit.edu/resources/papers/in_press/IntuitiveProsecution_SN.pdf $>$. Acesso em: 20 jan. 2018.

55 Vide, por todos, e com considerável análise, TAVARES, Juarez. Teoria do injusto penal. Belo Horizonte: Del Rey, 2003. p. 333.

56 GODFREY-SMITH, Peter. Folk Psychology as a Model. Philopher's Imprint, v. 5, n. 6, p. 1-16, nov. 2005.

57 HAMILTON; SHERMAN apud KOSTER-HALE, J.; R. SAXE. Theory of Mind: a neural prediction problem. Neuron, v. 79, 2013. p. 841.

58 MALLE, Bertram F. How People explain behavior: a new theoretical framework. Personality and Social Psychology Review, v. 3 , n. 1, p. 23-48, 1999 . 


\section{Considerações finais}

A atribuição de crenças ou intenções é um processo que ocorre espontânea e naturalmente no cérebro. Como tal, já é possível testá-lo e, inclusive, manipulá-lo — em laboratório, por meio de estimulação transcraniana, ressonância magnética funcional, ou em pesquisa comportamental, conforme sejam introduzidos e constatados vieses de julgamento. Se crenças e intenções, o que equivale a dizer ações conscientes e intencionais, são relevantes para o direito, e se o processo natural subjacente à sua atribuição, apesar de evolutiva e cotidianamente adaptado, é suscetível a tantos vieses justamente nos casos de condenação por atos ilícitos - contrariamente ao modelo cognitivo racional-reflexivo pressuposto nas regras de prova e conhecimento (garantias) em um processo judicial -, então cabe indagar se, em função disso, o direito penal, em seu aspecto conceitual e prático, é de algum modo abalado.

O relevo em aspectos internos do agente, identificados como estados mentais, franquearam o uso de conceitos como conhecimento, crença, intenção e vontade, os quais estiveram, na tradição ocidental, profundamente vinculados ao juízo moral, quando requisitados no campo da razão prática. Isso não se deve tanto a uma conquista conceitual-abstrata - a qual pode, sim, ter reforçado aquele vínculo —, mas a condicionantes possivelmente universais — ou, pelo menos, salientes nas culturas ocidentais hegemônicas — da cognição humana, especialmente da apreciação de cenários social e moralmente relevantes. Entendendo um pouco mais dessas bases naturais do fenômeno associado à atribuição de culpa e intencionalidade, e de posse de ferramentas que permitem rastrear, na medida do possível, sua ocorrência empírica, vislumbram-se ganhos tanto para a tarefa analítica-pragmática de esclarecimento dos usos cotidianos daqueles conceitos psicológicos, quanto para a revisão crítica e permanente das nossas concepções normativas.

Especialmente para a qualificação de um caso como doloso, que, no direito brasileiro, confunde-se com a atribuição de conhecimento e vontade ao agente direcionados à realização dos elementos do tipo penal, constatou-se que são natural e espontaneamente considerados diversos fatores além daqueles estados mentais, que, empiricamente, são processados pelo cérebro - como visto em análises de correlação com os padrões neurais verificados em tarefas cognitivas que recrutam a atribuição daqueles estados - não como ponto de partida (premissa), mas como justificação de uma reprovação intuitiva. Há uma base psicológica para a reprovação ou punição mais graves de uma ação, conforme a percepção dos efeitos colaterais negativos dessa ação - que determina, retroativamente, seu próprio caráter intencional. A consideração da vida pregressa ou da personalidade do agente, tão comum nas instituições que aplicam o direito penal, é indissociável da avaliação da reprovabilidade, da intencionalidade e, inclusive, da contribuição causal da sua ação em relação ao resultado lesivo - ainda que nosso sistema de garantias preveja que sejamos julgados não por aquilo que somos, mas pelas nossas ações.

\section{REFERÊNCIAS}

ALICKE, M. D. Culpable causation. Journal of Personality and Social Psychology, n. 63, p. 368-378, 1992.

ARISTÓTELES. Retórica. In: ARISTÓTELES: Obras completas. 2. ed. Lisboa: Centro de Filosofia da Universidade de Lisboa; Imprensa Nacional-Casa da Moeda, 2005. v. 8, t. 1.

BJORKLUND; CORNIER; ROSENBERG. The evolution of theory of mind: big brains, social complexity and inhibition. In: SCHNEIDER, et al. Young children's cognitive development: interrelationships among executive functioning, working memory, verbal ability, and theory of mind. New York; London: Psychology Press, 2013. p. 147-174.

BZDOK, Danilo et al. The neurobiology of moral cognition: relation to theory of mind, empathy, and mind-wandering. In: CLAUSEN, Jens; LEVY, Neil (Coord.). Handbook of Neuroethics. Heildelberg. Nova 
Iorque, Londres: Springer, 2015.

CALIL, Mário Lúcio Garcez; SANTOS, José Eduardo Lourenço dos. A formulação da agenda políticocriminal com base no modelo de ciência conjunta do direito penal. Rev. Bras. Polít. Públicas, Brasília, v. 8, n. 1, p. 36-53, 2018.

CSIBRA, Gergely. Teleological and referential understanding of action in infancy. Philosophical Transactions of The Royal Society B Biological Sciences, v. 358, n. 1431, p. 447-458, 2003.

FERRAJOLI, Luigi. Direito e razão: teoria do garantismo penal. 4. ed. São Paulo: Revista dos Tribunais, 2014.

GODFREY-SMITH, Peter. Folk Psychology as a Model. Philopher's Imprint, v. 5, n. 6, p. 1-16, nov. 2005.

GREENE, J. D. et al. An fMRI Investigation of Emotional Engagement in Moral Judgment. Science, p. 2105-2108, 2001.

GREENE, J. D. et al. The neural bases of cognitive conflict and control in moral judgment. Neuron, v. 44, p. 389-400, out. 2004,

GREGO, Luís. Um panorama da teoria da imputação objetiva. São Paulo: Revista dos Tribunais, 2014.

GRICE, Paul. Meaning revisited. In: SMITH, N. V. (Ed.). Mutual Knowledge. New York: Academic Press, 1982. p. 223-243.

HAIDT, J. The new synthesis in moral psychology. Science, v. 316, p. 998-1002, maio 2007.

HINDRIKS, Frank. Intentional Action and the Praise-Blame Asymmetry. The Philosophical Quarterly, v. 58, n. 233 , out. 2008.

JAKOBS, Günther. La imputación jurídico-penal y las condiciones de la vigência de la norma. In: DÍEZ, Carlos Gómez-Jara (Ed.). Teoría de sistemas y derecho penal: fundamentos y posibilidades de aplicación. Granada: Editorial Comares, 2005.

JENKINS, A. C. et al. The neural bases of directed and spontaneous mental state attributions to group agents. PLoSOne, v. 9, n. 8, e105341, 2014.

KLIEMANN, D. et al. The influence of prior record on moral judgment. Neuropsychologia, v. 46, p. 29492957, 2008.

KNOBE, J. Intentional action and side effects in ordinary language. Analysis, v. 63, p. 190-193, 2003.

KNOBE, J. Theory of mind and moral cognition: exploring the connections. Trends in Cognitive Sciences, v. 9 , n. 8, p. 357-359, 2005.

KOSTER-HALE, J. et al. Decoding moral judgments from neural representations of intentions. Proceedings of the National Academy of Sciences, v. 110, n. 14, p. 5648-5653, 2013.

KOSTER-HALE, J.; SAXE, R. Functional neuroimaging of theory of mind: understanding other minds. 3. ed. Baron-Cohen, Lombardo \& Tager-Flusberg, 2013. p. 132-163.

KOSTER-HALE, J.; SAXE, R. Theory of Mind: a neural prediction problem. Neuron, v. 79, p. 836-848, 2013.

LILLARD, A. Ethnopsychologies: cultural variations in theories of mind. Psychological Bulletin, v. 123, n. 1, p. 3-32, 1998.

MALLE, Bertram F. How People explain behavior: a new theoretical framework. Personality and Social Psychology Review, v. 3, n. 1, p. 23-48, 1999.

MALLE, F.; GUGLIELMO, S.; MONROE, A. E. Moral, cognitive and social: the nature of blame. In: FORGAS, J. et al. Social thinking and interpersonal behaviour. Philadelphia, PA: Psychology Press, 2011, p. 313-331. 
MELE, Alfred R. Folk Conceptions of Intentional Action. Philosophical Issues, v. 22, 2012.

PIZARRO, D. A.; UHLMANN, E.; BLOOM, P. Causal deviance and the attribution of moral responsibility. Journal of Experimental Social Psychology, n. 39, p. 653-660, 2003.

RHODES, Marjorie; BRANDONE, Amanda C. Three-year-olds' theories of mind in actions and words. Frontiers in Psychology, v. 5, n. 263, 2014.

ROXIN, Claus. Estudos de direito penal. Rio de Janeiro: Renovar, 2006.

SANTOS, André Leonardo Copetti; LUCAS, Doglas Cesar. A relação entre criminogênese e práticas penais e o debate sobre a teoria da ação entre subjetivistas e objetivistas. Rev. Bras. Polít. Públicas, Brasília, v. 8, n. 1, p. 127-161, 2018.

SAXE, R. The new puzzle of Theory of Mind Development. In: BANAJI, M. R.; GELMAN, S. A. (Eds.). Navigating the social world: what infants, children, and other species can teach us. New York, NY, US: Oxford University Press, 2013.

SCHILBACH, L. et al. Introspective minds: using ALE meta-analyses to study commonalities in the neural correlates of emotional processing, social and unconstrained cognition. PLoSONE, v. 7, n. 2, e30920, 2012.

SCHOLZ, J.; SAXE, R.; YOUNG, L. Neural evidence for "intuitive prosecution": the use of mental state information for negative moral verdicts. Disponível em: < http://saxelab.mit.edu/resources/papers/in_press/ IntuitiveProsecution_SN.pdf>.Acesso em: 20 jan. 2018.

SODIAN, Beate. Theory of mind: the case for conceptual development. In: SCHNEIDER et al. Young children's cognitive development: interrelationships among executive functioning, working memory, verbal ability, and theory of mind. New York; London: Psychology Press, 2013. p. 95-131.

TAVARES, Juarez. Teoria do injusto penal. Belo Horizonte: Del Rey, 2003.

WELZEL, Hans. Teoria de la acción finalista. Buenos Aires: Depalma, 1951.

WOOLFOLK, R. L.; DORIS, J. M.; DARLEY, J. M. Identification, situational constraint, and social cognition: studies in the attribution of moral responsibility. Cognition, v. 100, n. 2, p. 283-301, 2006.

YOUNG, L. at al. The neural basis of the interaction between theory of mind and moral judgment. PNAS, v. 104, n. 20 , p. 8235-8240, 2007.

YOUNG, L.; SAXE, R. Innocent intentions: A correlation between forgiveness for accidental harm and neural activity. Neuropsychologia, v. 47, n. 10, p. 2065-2072, 2009. 


\section{REVISTA BRASILEIRA DE POLÍTICAS PÚBLICAS BRAZILIAN JOURNAL OF PUBLIC POLICY}

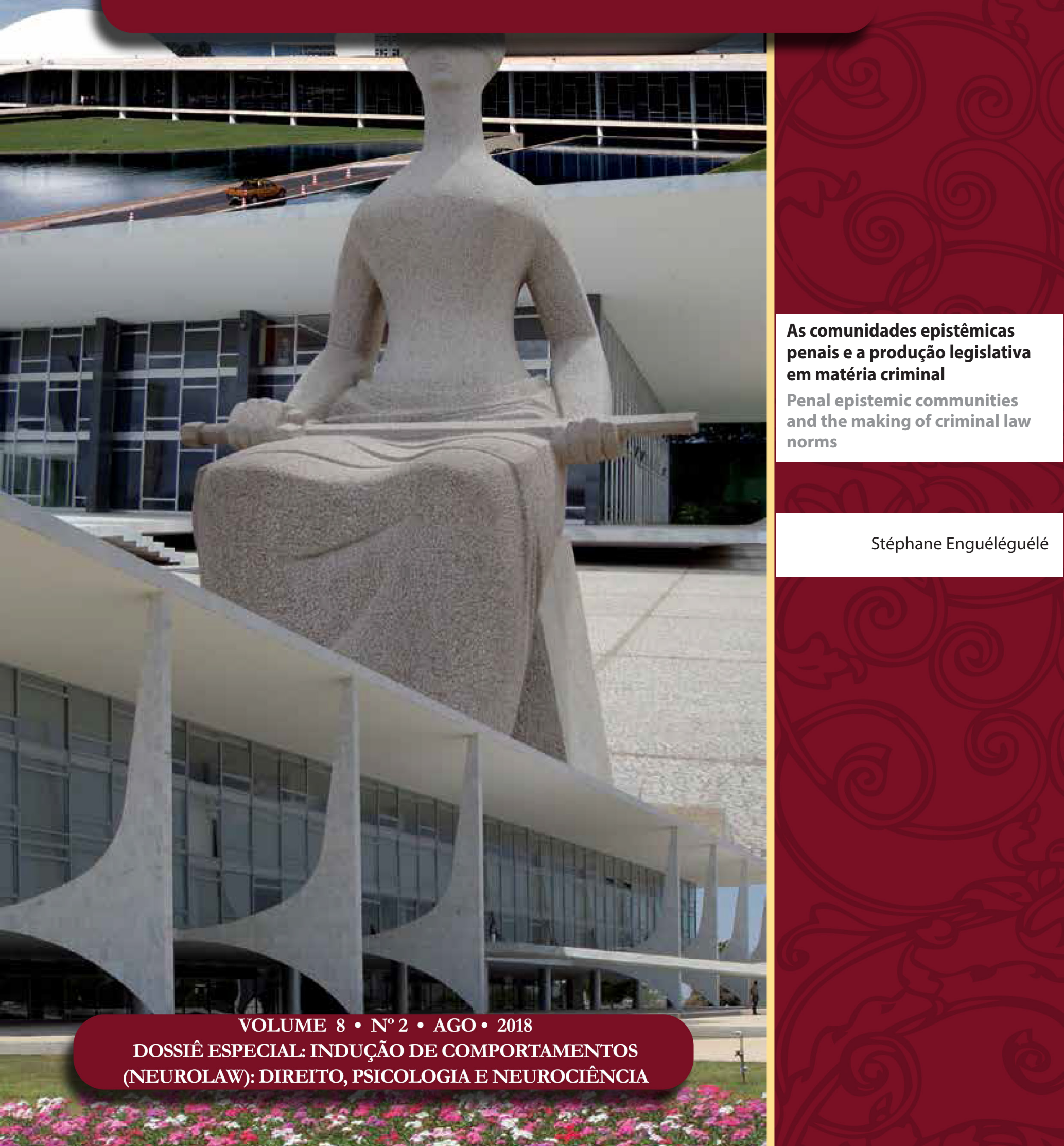




\title{
As comunidades epistêmicas penais e a produção legislativa em matéria criminal*
}

\section{Penal epistemic communities and the making of criminal law norms}

\author{
Stéphane Enguéléguélé ${ }^{* * * *}$
}

\section{Resumo}

Ao redescobrir a riqueza da obra de Max Weber, os sociólogos do direito vão restituir ao direito sua característica de ficção operativa (de procedimento) no processo de regulação social. Essa renovação teórica conduz, em matéria penal, a um conjunto de estudos em que a produção normativa, tanto processual como de direito material, é descrita como uma oportunidade para a implantação de estratégias inéditas por atores, advogados e políticos profissionais, que submetem a norma penal à satisfação de interesses específicos. O conceito de "comunidade epistêmica penal" ajudará a avaliar a influência das ideias e conhecimentos sobre a definição da estratégia criminal e medir o potencial de ação de alguns atores do campo penal que, em várias configurações, imprimem à lei penal um estilo que se ajusta com as suas preferências teóricas.

Palavras-chave: Comunidades epistêmicas. Doutrina penal. Questões penais. Paradigmas penais. Política criminal.

* Artigo convidado.

** Atualmente, Stéphane Bobé Enguéléguélé é advogado, Consultor Internacional Sênior, professor e especialista em análise de políticas públicas, seu trabalho centra-se na justiça e na mudança nas políticas criminais e de segurança. Está trabalhando em mecanismos de avaliação de políticas de combate à corrupção, lavagem de dinheiro, financiamento do terrorismo e proliferação de armas de destruição em massa. Ele é Conselheiro do Comitê de Libertação de Prisioneiros Políticos (CL2P) http://cl2p.org/. É autor de vários livros, incluindo «États Corruption et Blanchiment», pela editora L'Harmattan, 2015, e «Politiques pénales et tolérance zéro », pela mesma editora em 2010.

*** Tradução: Wagner Amorim Madoz. Revisão: Bruno Amaral Machado. Artigo «Les communautés épistémiques pénales et la production législative en matière criminelle», publicado na Revista Droit et Societé, no 40, Ano 1998, pp. 563-581. CURAPP, Université de Picardie Jules Verne, Pôle Universitaire Cathédrale, BP 2716, F-80027 Amiens cedex 1. Acrescentamos notas bibliográficas dos autores citados por Stéphane Enguéléguélé para facilitar a compreensão.

\section{Abstract}

Rediscovering the heuristic potential of Max Weber's patterns, researchers in the field of legal sociology present law as an operative fiction in the social regulation process. In many monographies on the penal field, the making of criminal law is depicted as a game between actors who want to achieve specific goals in the process. The concept of «penal epistemic communities » will help to evaluate the influence of knowledge on the building of penal strategies, and to weigh the action potential of social networks on the penal field, whose members try to orient the formal response to criminal problems.

Keywords: Criminal doctrine. Doctrinal communities. Penal issues. Penal paradigms. Penal policy.

\section{INTRODUÇÃo}

A análise da produção normativa penal se compõe idealmente de dois momentos-chave: a criminalização primária e a secundária. O primeiro refe- 
re-se à instituição da criminalidade, ou seja, como mostrado muito bem por Xavier Rousseaux, ${ }^{1}$ "a inclusão normativa de um comportamento entre os crimes [assim como] os processos que levam as pessoas a aceitarem esta definição incriminadora". O segundo momento refere-se à aplicação concreta da legislação elaborada; em outras palavras, são "todos os mecanismos de repressão, tratamento e punição de crimes efetivamente aplicados em um conjunto social". Os principais trabalhos consagrados à elaboração da estratégia penal oficial, na sua grande maioria, obedecem a esses dois componentes temporais da normatividade penal, mesmo que, em razão notadamente da opacidade da ação administrativa, há o interesse em priorizar a produção legislativa mais do que na atividade normativa da administração. ${ }^{4}$ A sociologia legislativa encontra no objeto penal um terreno privilegiado de experimentação de novos instrumentos de análises da criação do direito. Ela vai explorar, muito cedo, as aberturas e os deslocamentos teóricos sugeridos pela sociologia do direito lato sensu e pela sociologia penal.

Ao redescobrirem a riqueza da sociologia jurídica durkheiniana e weberiana, os sociólogos do direito vão restituir ao sistema jurídico sua característica de "ficção operacional com finalidade reguladora"s e ao direito sua dimensão prática que é de fato uma atividade social suscetível de uma análise compreensiva. ${ }^{6}$ Retomando de Durkheim a relação entre os tipos de organização social e as modalidades de regulação, os sociólogos jurídicos suprem, definitivamente, os equívocos que constituem a leitura positivista do funcionamento dos sistemas jurídicos. Segundo Weber, o direito, no processo de racionalização que caracteriza as sociedades capitalistas, mostra que as atividades jurídicas são indissociáveis dos atos de expressão e de formalização do direito, o qual se apoia acima de tudo a questão da atividade dos juristas. O direito desviante suscetível de uma abordagem renovada: longe da ficção de um sistema de normas fechado e "acabado", produto da vontade de um legislador abstrato, e aparece doravante como uma realidade cultural. ${ }^{7}$ Consequência direta da modernização da organização social e dos avanços da economia capitalista, ele também pode ser analisado em relação às atividades de um grupo social especializado na formalização e na aplicação das regras jurídicas.

Esse deslocamento tem repercussões no campo criminal: em vários estudos do tipo sócio-histórico, a norma penal vai, gradualmente, ser vista como uma questão do poder em geral. Visto por meio do prisma da moral e da religião, a regra de incriminação concretizará, sob o Antigo Regime (Ancien Regime), "uma forma de compromisso moral e jurídico do Estado face à 'sociedade civil'."' Transformado em crime por um artifício de diversas operações de estigmatização, o comportamento incriminado é descrito como um ataque à hierarquia dos valores sociais e instituições públicas: ele «atenta contra a "moral" e a "ordem política" que um pacto social frágil tenta corresponder [...] As consequências morais e concretas desse fato é ser estigmatizado no ritual público da reparação simbólica que mancha a honra e quebra o corpo.» ${ }^{9}$ Colocados ao serviço da proteção de uma ordem social e política determinada, as normas de direito penal e processual penal será, sob a Revolução, os meios para materializar e assegurar a tradução jurídica em atenção a uma nova moral coletiva, e de novos princípios de organização política. ${ }^{10}$

1 Xavier Rousseaux, pesquisador belga, especialista em história do crime e da justiça, tem publicado obras sobre a história da justiça, período medieval, na Revolução francesa e até a Primeira Guerra mundial.

2 ROUSSEAUX, Xavier. La répression de l'homicide en Europe occidentale (Moyen Âge-Temps modernes), Genèses, n. 19, p. 122-147, 1995. p. 122

3 ROUSSEAUX, Xavier. La répression de l'homicide en Europe occidentale (Moyen Âge-Temps modernes), Genèses, n. 19, p. 122-147, 1995. p. 123.

4 FAUGERON, Claude. Du pénal à la discipline: l'ordre et le contrôle pénal en France. Bilan de la recherche en France depuis 1980. In : ROBERT, Philippe ; VAN OUTRIVE, Lode. (Ed.). Crime et justice en Europe. Paris: L'Harmattan, 1993. (Coll. Logiques sociales). p. 115-167.

5 LASCOUMES, Pierre. Pluralité d'acteurs, pluralité d'actions dans la création contemporaine des lois. In: Études en hommage à Christian Debuyst, Liège. Bruxelles : Mardaga, 1990. p. 145-163.

6 LASCOUMES, Pierre; SERVERIN, Évelyne. Le droit comme activité sociale: pour une approche wébérienne des activités juridiques, Droit et Société, n. 9, p. 165-187, 1988.

7 Veja, por exemplo, mais perto das nossas preocupações : ASSIER-ANDRIEU, Louis. La norme pénale comme enjeu culturel, Les cahiers de la sécurité intérieure, n. 18, 1994, p. 39-49, 1994.

8 PORRET, Michel. Les réquisitoires des procureurs généraux de Genève au XVIIIe siècle, Genèses, n. 19, 1995. p. 5.

9 PORRET, Michel «Les réquisitoires des procureurs généraux de Genève au XVIIIe siècle », Genèses, n. 19, 1995 . p. 6.

10 Ver BADINTER, Robert. La prison républicaine. Paris: Fayard, 1992. p. 9-25; veja também, sobre a elaboração do Código Penal: 
Enquanto isso, emergindo da criminologia da reação social, uma "sociologia penal" se constitui em um objeto alvo. Tal como claramente mostrado por Philippe Robert, ${ }^{11}$ esse deslocamento corresponde a três momentos que caracterizam o campo da criminologia. O primeiro é a chamada criminologia clássica que, de fato, está interessada, exclusivamente, em colocar em evidência as determinantes da passagem ao ato, bem como o estabelecimento de características que diferenciam os criminosos dos "não criminosos". ${ }^{12}$ Com a entrada no campo da criminologia de questões relativas à organização da reação social ao crime, essa primeira tradição se desmorona e cede lugar às pesquisas que combinam a análise do ato infracional e estudos das condições para melhorar a reação penal. Este trabalho, no entanto, pecou pela inexistência ou fragilidade do material teórico. As reflexões se resumem à proposição de esquemas interpretativos da estratégia penal, a ele falta um "esforço de reflexão sobre os paradigmas criminológicos." "13 A terceira fase viu a construção da normatividade penal como objeto de pesquisa, com base na decomposição dos componentes temporais da normatividade criminal: criminalização primária e criminalização secundária. O estudo da normatividade criminal se torna um meio entre outros de se interessar o processo penal. Renunciando a análise abstrata e desencarnada desses processos, optando por um conhecimento mais aprofundado, centrada sobre os jogos e as relações de poder que se desenvolvem entre os atores do sistema penal pelo controle do seu funcionamento. Estamos interessados na criação de estratégias de canalização da criminalidade, apreendida como tantas outras questões "em jogo nas lutas pela influência travada por diferentes grupos sociais". ${ }^{14}$

Se a criação legislativa é um dos prismas pelo qual é analisada a produção normativa penal, a reconstituição dos atores e dos sistemas de interesse, das interações e da articulação dos processos legislativos aos contextos constituem, mais além dos esquemas interpretativos sugeridos, a verdadeira chave da pesquisa. ${ }^{15}$ Essas análises, entretanto, apresentam um certo número de inconvenientes. Elas conduzem a abordagem a focalizar o essencial da pesquisa sobre o que pode ser chamado de "momento legislativo", mesmo que o processo legislativo seja sempre considerado em relação ao funcionamento das instituições penais. O risco é, por conseguinte, ignorar uma dimensão essencial do processo legislativo: sua inscrição no fluxo contínuo da ação pública, na dinâmica da competição política e na rede dos jogos políticos. Em seguida, eles subestimam a dimensão cognitiva da ação pública em matéria penal: como bem indicado por Schattscheinder ${ }^{16}$ um dos recursos centrais da política é o poder de que dispõe para determinar as metas das políticas públicas. As ideias, o conhecimento, as elaborações teóricas têm um papel determinante ao mesmo tempo na definição e na renovação das prioridades da ação estatal. Autores como Joachim J. Savelsberg, ${ }^{17}$ Robin Stryker ${ }^{18}$ ou, mais proximamente, Martine Kaluszynski ${ }^{19}$ revelaram a existência de um liame entre o estado de conheci-

LASCOUMES, Pierre. PONCELA, Pierrette; LENOËL, Pierre. Au nom de l'ordre. Une histoire du Code pénal. Paris : Hachette, 1989.

11 ROBERT, Philippe. De la "criminologie de la réaction pénale" à une "sociologie pénale", L'année sociologique, v. 31, 1981. p. 253.

12 NT: O autor denomina de "abstinents".

13 Ibid., p. 269.

14 LÉVY, René; ROUSSEAUX, Xavier. États, justice pénale et histoire: bilan et perspectives, Droit et Société, n. 20-21, 1992, p. 249-279, 1992

15 Ver, por exemplo, os estudos reunidos por Philippe Robert: ROBERT, Philippe. (Éd.). Entre l'ordre et la liberté, la détention provisoire: deux siècles de débats. Paris: L'Harmattan, 1992. (Coll. Logiques juridiques); ver também, do mesmo autor : La création de la loi et ses acteurs. L'exemple du droit pénal. Oñati : IISL, 1991. (Coll. Oñati Proceedings); podemos, também, nos referir a várias monografias: BERNAT DE CELIS, Jacqueline. Fallait-il créer un délit d'usage illicite de stupéfiant? Une étude de sociologie législative. Paris : CESDIP, 1992. (Coll. Déviance et contrôle social); SAVELSBERG, Joachim J. The Making of Criminal Law Norms in Welfare States, Law and Society Review, v. 21, n. 4, 1987. p. 529; HOPKINS, Andrew. Crime, Law and Business: the Sociological Sources of Australian Monopoly Law. Canberra: Australian Institute of Criminology, 1978; LASCOUMES, Pierre ; ROTH, R. ; SANSONNETI, R. L'incrimination en matière économique. Genève: CETEL, Université de Genève, 1989.

16 SCHATTSCHEINDER, Elmer E. The Semi-Sovereign People. New York: Holt, 1960.

17 SAVELSBERG, Joachim J. Rationalities and Experts in the Making of Criminal Law against Economic Crime, Law and Policy, n. 2-3, 1988.

18 STRYKER, Robin. Government Regulation. In: BORGATTA, Edgard F; BORGATTA, Marie L. (Ed). Encyclopedia of Sociology. New York: Mac Millan, 1992; STRYKER, Robin. Rules, Resources, and Legitimacy Process: Some Implications for Social Conflict, Order, and Change, American Journal of Sociology, v. 99, n. 4, 1994. p. 847.

19 KALUSZYNSKI, Martine. Production de la loi et genèse des politiques pénales. La Société générale des prisons 1897-1900, Rapport terminal. Grenoble: CERAT, 1996. 
mento sobre o crime e a edição de legislações específicas. Mas se, para esses autores, os "produtores de reflexão" proporcionam ao legislador os instrumentos essenciais à organização da luta "anti-crime", eles não propõem esquemas que, na reproblematização da questão da institucionalização do saber penal, possibilitam dar conta da construção de paradigmas penais e dos modos de sua recepção pela política.

O que falta é a existência de conceitos específicos o suficiente para analisar as atividades organizacionais e cognitivas, ao termo das quais os paradigmas específicos emergem e são gradualmente apropriados pelos atores políticos que os transcrevem na lei. O que tentamos fazer foi utilizar o conceito de comunidade epistêmica penal para, antes de tudo, mensurar a influência estruturante exercida pelas ideias e conhecimentos sobre a definição da estratégia criminal formal; e, em seguida, avaliar o potencial de ação de que dispõe certos atores do campo penal, que lhe permitem, nas diversas configurações, imprimir à política criminal um estilo que se encaixa nas suas preferências normativas e teóricas; é, em fim, identificar as modalidades de direção dos sistemas de decisão penal: haveria de fato uma forma específica de condução dos sistemas de decisões penais, e ela não se deixa apreender pela simples reconstituição do processo legislativo.

Grupos de atores particularmente densos atuam por meio do campo penal, as comunidades epistêmicas penais são um elemento estruturante das atividades desse campo. Pela sua produção teórica, eles contribuem para a promoção ou a renovação dos processos de reação penal; eles dispõem, ainda, de formas de organização e construção de estratégias de ação que lhes permitem, em função das configurações, institucionalizar sua influência.

\section{COMUNIDADES EPISTÊMICAS: PRODUÇÃO TEÓRICA E DEFINIÇÃO DE PROCESSOS DE REAÇÃO PENAL}

O conceito de comunidade epistêmica tem sua origem nas análises das relações e da cooperação internacional. Para P. Haas, comunidades epistêmicas se destinam a "reduzir a incerteza" num contexto internacional marcado pela diminuição das capacidades de antecipação e de decisão dos atores responsáveis pela gestão internacional. Ao assegurar a coordenação internacional ${ }^{20}$, eles fornecem as informações e os conselhos que os atores políticos necessitam para operar de forma eficaz na cena internacional, o que coloca esses grupos de atores em posições estratégicas: "Ao mesmo tempo em que as demandas [de informações] aumentam, vemos uma proliferação de redes ou de comunidades de especialistas capazes de produzir e fornecer informação. Como os políticos solicitam suas opiniões e lhes delegam suas responsabilidades, os membros da comunidade dominante tornam-se atores fortes a nível nacional como a nível internacional". ${ }^{21}$ Isso cria uma competição de fato entre as diferentes comunidades pelo monopólio das posições de conselheiros dos governantes. Além disso, a dependência da necessidade de informação coloca os responsáveis pela tomada de decisão em relação com as comunidades epistêmicas proporcionando-lhes a oportunidade de institucionalizar sua participação nos processos políticos, e de legitimar sua influência. Assim, diz Haas, "na medida em que uma comunidade epistêmica consolida seu poder sobre governos nacionais e das secretarias internacionais, ela tem a possibilidade de institucionalizar sua influência e de fazer valer suas opiniões na política internacional de forma mais ampla". 22

20 HAAS, Peter M. Introduction: Epistemic Communities and International Policy Coordination, International Organization, v. 49, n. 1, p. 1-35, 1992.

21 HAAS, Peter M. Introduction: Epistemic Communities and International Policy Coordination. International Organization, v. 49, n. 1, 1992. p. 4, NT: «As demands for such information arise, networks or communities of specialists capable of producing and providing the information emerge and proliferate. The members of a prevailing community become strong actors at the national and transnational level as decision makers solicit their information and delegate responsibility to them. A community's advice, though, is informed by its own broader worldviews.

22 HAAS, Peter M. Introduction: Epistemic Communities and International Policy Coordination, International Organization, v. 49, n. 1, 1992. NT: «To the extent to which an epistemic community consolidates bureaucratic power within national administrations and international secretariats, it stands to institutionalize its influence and insinuate its views into broader international politics.» 
Comunidades epistêmicas são reguladores de cooperação internacional. Produzem ideias que sustenta a ação política no jogo internacional, elas organizam e canalizam a mudança dos princípios da gestão internacional. Elas "podem influir nos interesses do Estado, seja por meio da identificação diretamente para as autoridades políticas, aclarando as dimensões importantes de um problema, influenciando, assim, a escolha dos responsáveis pela decisão quanto aos interesses que eles defendem. Os responsáveis políticos pela decisão de um Estado podem, então, incluir sobre os interesses e comportamentos de outros Estados, aumentando, assim, as chances de convergência dos comportamentos dos Estados e a coordenação internacional das políticas." 23

Aplicada à política penal, o conceito de "comunidade epistêmica" se transforma num duplo ponto de vista. Ele permite introduzir no sentido da construção da estratégia penal formal, enfatizando que a definição dos princípios de ação em matéria penal é a necessidade da produção, pelos diversos grupos de atores, das estruturas de pensamento de ação estatal. Contrariamente à aproximação das políticas públicas em termos genéricos de "redes de ação pública"24, o modelo de comunidades epistêmicas parte da configuração do campo penal para analisar os arranjos das redes de profissionais envolvidos na formação das matrizes de ação em matéria penal. O conceito coloca no centro da análise a dimensão cognitiva dos processos, o que o torna menos estática do que a abordagem de rede. Mas o conceito de "comunidade epistêmica" permite, então, concentrar-se sobre a doutrina no seu sentido mais amplo, revendo as atividades, desafios e perfil dos protagonistas da interação doutrinária, à luz das particularidades das atividades que pontuam a construção e renovação dos referenciais da ação política. O campo penal não está mais limitado a um pequeno círculo de atores, teóricos ou práticos, supondo estar distante da política e do fato social, e competindo pela apropriação do monopólio da interpretação dos textos jurídicos. ${ }^{25}$ Ele é estruturado pelo confronto das comunidades epistêmicas contrárias, cujos membros concorrem para definir os princípios que nortearão a escolha dos políticos em matéria penal.

Para a definição das comunidades epistêmicas penais, partimos da definição dada por Haas: "Uma comunidade epistêmica é uma rede de profissionais com reconhecida experiência em um campo particular e que reivindicam com autoridade o seu conhecimento político neste domínio. Mesmo se uma comunidade epistêmica reunir profissionais de disciplinas de origem diversa, eles compartilham 1) a mesma crença em um conjunto de normas e princípios que permitem definir uma base fundamental para a ação social dos membros da comunidade; 2) as mesmas crenças causais que decorrem da observação das práticas responsáveis dos principais problemas que surgem em seu domínio e que permitem esclarecer as múltiplas ligações entre as ações políticas e os resultados desejados; 3) as mesmas noções de validade, ou seja, de critérios intersubjetivos e definidos internamente para medir o peso e a validade de um conhecimento em sua área de competência; e 4) uma mesma iniciativa política, ou seja, um conjunto de práticas comuns associadas com um conjunto de problemas para os quais a sua competência profissional é dirigida, sem que provavelmente haja a convicção de que o bem-estar humano será melhorado.”26 As comunidades epistêmicas criminais indi-

23 HAAS, Peter M. Introduction: Epistemic Communities and International Policy Coordination, International Organization, v. 49, n. 1, 1992. NT: «Members of transnational epistemic communities can influence state interests either by directly identifying them for decision makers or by illuminating the salient dimensions of an issue from which the decision makers may then deduce their interests. The decision makers in one state may, in turn, influence the interests and behavior of other states, thereby increasing the likelihood of convergent state behavior and international policy coordination, informed by the causal beliefs and policy preferences of the epistemic community.»

24 Ver, por exemplo, os estudos reunidos em B. Marin: MARIN, Bernd; MAYNTZ, $\square$ Renate (Ed.). Policy Networks: empirical evidence and theoretical consideration. Frankfurt/Main: Campus, 1991.

25 Ver BOURDIEU, Pierre. La force du droit: éléments pour une sociologie du champ juridique, Actes de la recherche en sciences sociales, n. 64, p. 3-19, 1986.

26 HAAS, Peter op. cit., p. 3, NT: "An epistemic community is a network of professionals with recognized expertise and competence in a particular domain and an authoritative claim to policy-relevant knowledge within that domain or issue-area. 4 Although an epistemic community may consist of professionals from a variety of disciplines and backgrounds, they have (1) a shared set of normative and principled beliefs, which provide a value-based rationale for the social action of community members; (2) shared causal beliefs, which are derived from their analysis of practices leading or contributing to a central set of problems in their domain and which then serve as the basis for elucidating the multiple linkages between possible policy actions and desired outcomes; (3) 
cam as redes de conhecimento e de ação caracterizadas pela adesão comum dos seus membros a um mesmo paradigma ${ }^{27}$ isto é, a uma mesma explicação causal dos problemas criminais (nível cognitivo) ou o mesmo sistema de valores estabelecidos como referências normativas para a estratégia penal (nível normativo) e para a adoção do mesmo tipo de representações de ação para fazer face à criminalidade (nível instrumental). Estes são grupos muitas vezes informais, em que os membros estão unidos pela participação comum no mesmo sistema de referências conceituais e normativas que inspiram as soluções que eles preconizam a problemas criminais. $^{28}$

Embora queiramos nos distanciar da abordagem de redes ${ }^{29}$, a utilização da palavra "rede" para designar as comunidades epistêmicas penais pode atrapalhar. Especificamos que o termo "rede" será usado neste artigo num sentido similar ao de "grupo". Reagrupamentos de atores estruturados entre os quais existem relações estáveis, as comunidades epistêmicas penais atuam pela transcrição na lei penal de um paradigma específico. A pesquisa, portanto, pode mover-se em duas direções opostas, mas que não são exclusivas: formação de comunidades; a diferenciação dos paradigmas e os princípios de identificação das comunidades.

\subsection{A formação das comunidades epistêmicas penais}

A própria comunidade epistêmica penal é de ser descrita como estável, e de reivindicar uma capacidade de ação sobre a política. Mas a constituição desses grupos de atores em comunidades é, muitas vezes, um processo longo, que condiciona a legibilidade do paradigma suportado pela rede, e sua institucionalização como doutrina oficial para a ação política. Por isso, é importante estudar a formação dessas redes de atores em comunidades epistêmicas. Isso permite que, em primeiro lugar, se avalie o lugar da comunidade considerada em relação às outras redes do campo penal, e se analisem as atividades organizacionais e simbólicas pelas quais ela se impôs como um grupo relevante no campo penal. Isso, então, permite mostrar que as comunidades epistêmicas penais podem ser concebidas, apenas, em relação a uma certa história que não podemos deixar de ter em conta no estudo da atividade dessas redes.

O modelo proposto por Nicholas C. Mullins, para analisar a estrutura e a institucionalização da biologia molecular, pode ter aqui alguma utilidade. ${ }^{30}$ É de se lembrar que o direito penal não tem a priori nada a ver com a biologia e que qualquer transposição de conceitos de um campo científico para outro deve ser feita com cautela. Para Mullins, um grupo paradigmático evolui em três estágios. Num primeiro momento, está-se na presença de pesquisadores trabalhando independentemente uns dos outros e pensam sobre um novo paradigma, sem fazer dessa atividade uma prioridade: é a "fase paradigmática". Em um segundo momento, os membros do grupo paradigmático iniciam a cooperação que tem lugar em diferentes níveis: formação recíproca (aprendizado), a cooperação em vários projetos de pesquisas comuns (coleguismo), publicação conjunta (co-autoria). Mullins distingue duas etapas nesse segundo momento: a etapa da rede, em que os princípios metodológicos e as técnicas são progressivamente formados; e de grupo ${ }^{31}$ que corresponde à configuração comum de regras, protocolos de pesquisa, de uma linguagem, de um estilo, formas de escrever e citar: é a "fase dogmática". A terceira etapa é a institucionalização do grupo. As hipóteses, as soluções, a metodologia são permanentemente estabilizadas; o recrutamento de pesquisadores e colaboradores é mais

shared notions of validity- that is, intersubjective, internally defined criteria for weighing and validating knowledge in the domain of their expertise; and (4) a common policy enterprise-that is, a set of common practices associated with a set of problems to which their professional competence is directed, presumably out of the conviction that human welfare will be enhanced as a consequence." 27 No sentido que entende Kuhn: KUHN, Thomas S. La structure des révolutions scientifiques. Paris: Flammarion, 1983.

28 Nesse sentido, HECLO, Hugh. Issue Networks and the Executive Establishment. In: KING, Anthony. (Éd.). The New American Political System. Washington D.C.: American Enterprise Institute, 1978. p. 103-104 especialmente.

29 NT. (l'approche par réseaux) refere-se o Autor à abordagem de redes «network approaches», ver p. ex. a Rev. Adm. Pública, Rio de Janeiro, v. 43, n. 5, Sept./Oct. 2009, cuja edição é dedicada ao tema.

30 MULLINS, Nicholas C. The Development of Scientific Speciality: the phage group and the origin of molecular biology, Minerva, n. 10, p. 51-82, 1972.

31 NT. "clustère", de origem inglesa: cluster - grupo, aglomerado, etc. 
importante; cursos universitários são criados; manuais são publicados, revistas editadas, organizam-se colóquios, estabelecem-se retribuições específicas no domínio da pesquisa (diplomas): é a "fase acadêmica". ${ }^{32}$ A densidade da rede é avaliada como a intensidade das atividades que caracterizam a fase acadêmica. Como os grupos paradigmáticos de Mullins, a formação de uma comunidade epistêmica penal é um processo dinâmico: a comunidade se constitui ao mesmo tempo em que cria um consenso em torno do paradigma, e que o grupo se organiza de maneira a apoiar eficazmente a sua própria reprodução.

Uma tal abordagem é operacional para analisar a evolução do grupo de reformadores penais que, em torno de Bérenger ${ }^{33}$ e Haussonville, ${ }^{34}$ constituíram no início da Terceira República ${ }^{35}$ a Sociedade Geral de Prisões, com o objetivo de modernizar a repressão penal e humanizar os regimes penitenciários. ${ }^{36} \mathrm{Em}$ vez de descrever a Sociedade Geral de Prisões como um lugar de sociabilidade com base no qual emerge uma poderosa rede de relacionamentos, o analista se concentra no estudo das atividades de seus membros as quais contribuam para a formação de uma comunidade capaz, por sua influência, de estruturar o campo penal e influenciar os responsáveis pelas decisões políticas. Reconstituir as sucessivas fases do nascimento do grupo revela um encontro de atores movidos pelo desejo de promover um paradigma determinado. Para adquirir o estatuto de rede relevante na área criminal, eles construíram diversas estratégias: publicação de estudos na Revue Pénitentiaire et de Droit Pénal, segundo as linhas editoriais que combinam com o estado da problemática coletiva; organização de simpósios, jornadas de estudos e outros encontros nos quais se trocam pontos de vista sobre a política criminal; desenvolvimento de procedimentos específicos de recrutamento; relação com a universidade, a magistratura, advogados e outros atores coletivos que gravitam em torno da doutrina penal (associações de patronato, sindicatos...) — como entrada para o estudo das condições para o surgimento de comunidade epistêmica que, sob a Terceira República, estará na vanguarda da reforma penal e penitenciária.

A mesma abordagem é pertinente para ver como, em desdobramento da antiga defesa social que F. Gramatica ${ }^{37}$ tentou reformar, a nova defesa social se constituiu em comunidade epistêmica a qual exerceu, entre 1945 e 1975, uma influência determinante sobre a legislação criminal na França: criação de uma Sociedade Internacional de Defesa Social; lançamento da Revue de Science Criminelle et de Droit Pénal Comparé que, desde muito tempo, será o órgão da comunidade; inauguração do ciclos de conferências no Instituto de Direito Comparado de Paris; direção das Jornadas Nacionais de Defesa Social; publicação de estudos diversos; criação em 1975 de um centro de pesquisa sobre as políticas criminais, ${ }^{38}$ diretamente encarregado de defender

32 Ver a análise que Dominique Vinck fez das três etapas, em VINCK, Dominique. Sociologie des sciences. Paris : Armand Colin, 1995. p. $96-98$.

33 NT. René Bérenger (1830-1915) jurista, advogado, Doutor em direito, Deputado (1871-1876), Senador "Sénateur inamovible" (1876-1915), Membro da Academia das ciências morais. Cf. Bibliothèque Nationale de France. Disponível em: <http://data.bnf. fr/10302465/rene_berenger/>

34 NT. Paul-Gabriel Othenin de Cléron, Vicomte d'Haussonville (1843-1924) deputado e membro da aristocracia liberal francesa, responsável pela elaboração da síntese do relatório da Comissão Parlamentar (1871-1872) 'Les établissements pénitentiaires en France et aux colonies", encarregada de estudar o sistema prisional e as instituições penais francesas e de suas colônias, onde evidenciou um estado catastrófico das 428 prisões e cadeias francesas. Tendo originado duas proposições legislativas: para reformar o sistema prisional (Bérenger) tido como responsável pelo crescente aumento da reincidência, e a segunda (Voisin) para a educação e manutenção de jovens reclusos. Cf. École nationale d'administration pénitentiaire-Énap. Disponível em: http://www.enap.justice.fr/ressources/index. php?rubrique $=39$

35 NT. Declarada em 1879, durante a Guerra Franco-Prussiana vigorou até 1940.

36 BADINTER, Robert. La prison républicaine. Paris: Fayard, 1992; KALUSZYNSKI, M. À l’origine des politiques pénales en France sous la IIIe République. Un laboratoire de réflexions: la Société générale des prisons. In: AREPPOS (Éd.). Philanthropies et politiques sociales en Europe XVIII e-XXe siècles. Paris : Anthropos/Économica, 1994. (Coll. Historiques). p. $133-144$.

37 NT. Filippo Gramatica (1901-1979), professor italiano, fundador da escola da Nova Defesa Social, autor da obra Principi di diritto penale soggettivo, que considerava a personalidade do delinquente e seu grau de antisociabilidade como o eixo central de sua teoria; propugnava, entre outras medidas, a reparação do dano produzido à vítima, a responsabilidade por intencionalidade do autor, independentemente da consequência produzida, a abolição da culpa, a preterintencionalidade e a responsabilidade objetiva, além da pena de morte e o fim das previsões das penas mínimas.

38 NT. Trata-se do Centro de Pesquisas de Política Criminal — "Centre de Recherches de Politique Criminelle (C. R. P. C.)" criado na realidade em 1972, tendo o Professor Marc Ancel — magistrado e Teórico do Direito, como presidente, conforme Mireille Delmas-Marty "notícia" — na Revue internationale de droit compare, Année 1975, v. 27, n. 4, p. 915-916 —, o lançamento de uma 
a promoção do paradigma político-criminal; lançamento no mesmo ano dos Archives de Politique Criminelle, ${ }^{39}$ que marcam a autonomia da comunidade; habilitação de diplomas universitários em matéria de política criminal — todos os sinais de formação e institucionalização da comunidade epistêmica liberal, entre a Libération $^{40}$ e os anos 80.

No estudo da formação de uma comunidade epistêmica criminal, devemos também levar em conta como evolui seu tamanho: pode-se analisar o número de seus membros, mas também os grupos profissionais representados na comunidade. Esse último, na verdade, revela intenção de expandir para além da esfera doutrinária. Compostos por acadêmicos, juízes, advogados, sindicalistas, atores que agem dentro da administração central e dos gabinetes ministeriais, cada comunidade epistêmica é o objeto de um recrutamento transsetorial. Somos, assim, levados a proceder a uma verdadeira etnografia do campo penal para expor a lógica dos processos daquele grupo paradigmático, muitas vezes informal, nos primeiros tempos, depois do qual é institucionalizado como comunidade epistêmica.

\section{I.2. A diferenciação dos paradigmas}

É igualmente possível analisar como as comunidades epistêmicas penais diferenciam os modelos de reação penal que elas querem ver traduzidos em lei. A perspectiva que sugerimos é sensivelmente diferente da abordagem em termos de conflito de interpretação de texto jurídico, ${ }^{41}$ já que seu interesse não está nas atividades ao termo das quais o sentido do texto legal se fixa, mas aqueles, numerosos, que visam suscitar a transformação dos marcos de interpretação e de aplicação do texto futuro. É relevante para o estudo do campo penal as controvérsias em que se opõem comunidades epistêmicas penais para a construção de novas matrizes que irão moldar o pensamento e ação em matéria penal. Interessando-se na inovação no domínio penal, estuda a participação das comunidades epistêmicas na criação de novos modelos para a repressão penal.

A abordagem é, em todos os aspectos, compatível com aquelas adotadas por T.S. Kuhn, ${ }^{42}$ M. Callon ${ }^{43}$ e B. Latour, ${ }^{44}$ com base no conceito de "tradução", para refletir a inovação em matéria científica. Inspirando em parte em Wittgenstein que, no seu Investigations (1953), apresentou toda a linguagem como um conjunto de regras de jogos relacionados às situações da vida e de nenhum modo intercambiáveis, se sabe que Kuhn propôs ${ }^{45}$, por meio da noção de paradigma, uma maneira de analisar a produção das verdades científicas: o paradigma elucida o fluxo de interpretações de que é objeto; é no jogo das descrições, das explicações e das clarificações que aquelas dá lugar e que é revelada; mas, ao mesmo tempo, surgem contradições que podem levar à sua contestação. Afirmando o "Princípio da Simetria" Kuhn inovou em relação à Bachelard ${ }^{46} \mathrm{e}$ $\operatorname{Popper}^{47}$ : a validade de um modelo científico não resulta, somente, da objetividade do processo com base

nova publicação, a revista os "Archives de politique criminelle", em 1975. Cf. Disponível em: <http://www.persee.fr/web/revues/ home/prescript/article/ridc_0035-3337_1975_num_27_4_16510>.

39 NT. Publicação anual do "Centre de Recherches de Politique Criminelle (C.R.P.C.)". Na breve apresentação feita por Marc Ancel, no primeiro número, é enfatizado que esta nova publicação deverá «conter os resultados de pesquisas já realizadas e avançadas o suficiente para ser levada à atenção de especialistas interessados nos problemas de política criminal ».

40 NT. Expressão que marca a libertação da França da ocupação alemã na Segunda Guerra.

41 BOURDIEU, Pierre. La force du droit: éléments pour une sociologie du champ juridique», Actes de la recherche en sciences sociales, n. 64, p. 3-19, 1986.; CHEVALLIER, Jacques «Les interprètes du droit. In: POIRMEUR, Yves; BERNARD, Alain. (Ed.). La doctrine juridique. Paris: PUF, 1993. p. 259-281.

42 NT. Thomas Samuel Kuhn (1922-1996) físico, historiador e filósofo da ciência americano. Segundo a Stanford Encyclopedia of Philosophy foi um dos mais influentes filósofos da ciência do Século XX. Seu livro de 1962 "The Structure of Scientific Revolutions" é um dos mais citados trabalhos acadêmicos de todos os tempos. Disponível em: <http://plato.stanford.edu/entries/thomas-kuhn/>. 43 NT. Michel Callon (1945) é Professor de Sociologia na "École des mines de Paris" e membro do "Centre de sociologie de l'innovation". É um influente autor no campo da ciência e tecnologia, é um dos proponentes da "actor-network theory (ANT)" ou "théorie de l'acteur-réseau" com Bruno Latour e Madeleine Akrich.

44 NT. Bruno Latour (1947) é um antropólogo francês, sociólogo e filósofo da ciência.

45 KUHN, Thomas S. La structure des révolutions scientifiques. Paris : Flammarion, 1983. (Kuhn, 1983)

46 NT. Gaston Bachelard (1884-1962) filósofo e poeta francês cujo pensamento está voltado principalmente em questões referentes à filosofia da ciência.

47 NT. Sir Karl Raimund Popper (1902-1994) filósofo e professor na London School of Economics, possui vasta produção intelectual 
no qual ele procede ou da sua contestação e falseabilidade, ele também pode ser avaliado à luz da história do modelo e sua inserção na dinâmica da construção do conhecimento. Consoante Callon e Latour, "o princípio de simetria implica que nós entramos nos conteúdos, não para apresentar a ciência feita, mas para mostrar a história de sua elaboração". ${ }^{48} \mathrm{O}$ que interessava a Kuhn, e depois dele Callon e Latour, é a substância do debate científico, ou seja, as controvérsias. Por sucessivas "traduções", o modelo adquire uma identidade ao mesmo tempo que sua sistematicidade. Na controvérsia, a construção das "verdades científicas" aparece como uma dinâmica contínua de enunciação e reutilização das proposições que têm significado para o debate científico. ${ }^{49}$

A diferenciação dos padrões de reação penal ocorre na controvérsia entre as comunidades epistêmicas dentro do campo penal. Os colóquios e congressos, as publicações de doutrinadores ou sindicalistas são o suporte das controvérsias durante as quais está envolvido o domínio de um modelo teórico sobre os outros e o reconhecimento científico e político dos atores envolvidos na sua promoção. Da controvérsia, os diferentes atores disputam por estabelecer seu modelo, mas também para garantir sua superioridade sobre esquemas alternativos. Indiretamente, eles estão em posição de ser designados como conselheiros daqueles que tomam decisões políticas penais.

Há na França, pelo menos desde 1945, duas grandes comunidades epistêmicas, cujas teses estão fortemente enraizadas no debate penal. A primeira comunidade é de tendência humanista. Contestando as soluções repressivas assim como todo recurso sistemático à prisão, seus membros são próximos da nova defesa social ou da corrente mais contemporânea de defesa dos direitos do homem. Ela considera que a repressão criminal tradicional fracassou, devendo reduzir o domínio das soluções clássicas (repressão com vocação dissuasiva ou neutralizante) e propõe criar novos processos de reação criminal, suscetíveis de contribuir para a reabilitação dos delinquentes. Os participantes dessa leitura denunciam os fracassos da utopia curativa da detenção e tentam «provocar os terapêuticos modernos a completa "ressocialização" dos prisioneiros, ou seja, sua conversão aos valores sócio-culturais, protegidos pela lei penal. $\rangle^{50} \mathrm{O}$ delinquente é considerado como não tendo internalizado, devido à singularidade do seu contexto e sua marginalidade, os padrões da vida em comunidade. Incumbe então à sociedade lhe "responsabilizar". ${ }^{51}$ A solução do fenômeno criminal reside na aplicação de um tratamento individualizado orientado à prevenção. Não será pelo confinamento, tampouco pelo recurso a uma repressão inutilmente brutal, que se concorda em apresentar como criminógeno (criminogène) $)^{52}$. $\mathrm{O}$ desafio é «descobrir, entre as sanções não privativas de liberdade, substitutas, equivalentes da prisão como meio de prevenção individual da delinquência.» ${ }^{53}$

Uma outra comunidade epistêmica preconiza, ao inverso da primeira, um aumento da repressão e a sistematização do recurso à prisão. De inspiração neoclássica, essa comunidade manifesta um grande interesse pelos processos acelerados ("comparecimento imediato" como uma condição da celeridade da repressão) e um compromisso visceral com a prisão, considerada como solução indispensável à proteção da sociedade face à criminalidade. Trata-se, com base em seu ponto de vista, necessário "ousar punir"54 tanto para defender a sociedade, mas também para tratar os comportamentos criminais que demonstram uma vontade deliberada de causar danos e de desfrutar dos benefícios do crime. As escolhas penais mais eficazes são aquelas que se respaldam na dissuasão e na exemplaridade, como condicionante da certeza da aplicação das penas impostas pelos tribunais.

em várias áreas do conhecimento, sobretudo no campo da filosofia da ciência.

48 CALLON, Michel; LATOUR, Bruno. Introduction. In : CALLON, Michel; LATOUR, Bruno. La science telle qu'elle se fait. Paris : La Découverte, 1991. (Coll. Textes à l'appui). p. 7-36.

49 LATOUR, Bruno. La science en action. Paris : La Découverte, 1989. (Coll. Textes à l'appui).

50 MERLE, Roger. Place respective des sanctions privatives et non privatives de liberté, Rapport aux journées franco-roumaines de la Société de législation comparée, 1981.

51 ANCEL, Marc. La défense sociale nowvelle. 3. ed. Paris : Cujas, 1981.

52 No sentido de que possa contribuir para o desenvolvimento da criminologia.

53 MERLE, Roger. Place respective des sanctions privatives et non privatives de liberté, Rapport aux journées franco-roumaines de la Société de législation comparée, 1981.

54 SOYER, Jean-Claude. Il faut oser punir, Le Figaro, 29 mars 1980. 
O debate penal vê a oposição dos membros dessas duas comunidades epistêmicas, que produzem os padrões de reação penal destinado aos tomadores de decisão em matéria penal, e que, ao fazê-lo, diferem-se uns dos outros. A análise da diferenciação dos paradigmas penais pelas comunidades epistêmicas criminais revela como se negociam os modelos penais entre os protagonistas do debate penal. Focando a pesquisa não nas respostas, mas na formalização e sua expressão, se trata, em última análise, de explicar a construção das matrizes teóricas que devem servir de suporte para a definição da estratégia penal formal. Este trabalho de formalização e expressão dos modelos é, no entanto, apenas, um aspecto do potencial disponível para as comunidades epistêmicas para institucionalizar a sua influência.

\section{Modos DE ORGANIZAÇÃO E ESTRATÉGIAS DE INFLUÊNCIA DAS COMUNIDADES EPISTÊMICAS PENAIS}

As comunidades epistêmicas penais desempenham um papel importante para a produção e para a renovação das matrizes teóricas da ação pública em matéria penal. Elas são construídas e lhes são atribuídas a articulação das ideias e a ação no domínio da luta anticrime e é na realização dessa missão que são medidas sua capacidade de influir sobre a política e de orientar suas opções, ou seja, enfim, a institucionalização de sua participação na definição da estratégia penal. No número de recursos ${ }^{55}$ que podem se prevalecer os membros dessa rede, e a sua capacidade de colaborar ou participar do poder político, se junta, também, sua aptidão para estruturar as mobilizações, que se realizam fora do campo político para instigar à decisão política.

\subsection{A colaboração com a política}

A concepção das comunidades epistêmicas tem lugar idealmente no "néopluralisme" ${ }^{56}$ Ultrapassando as análises marxistas e pluralistas clássicas do Estado, os autores "néopluralistas" insistem na capacidade da instância estatal para "autonomisar" os fatores e pressões externas. Esse exemplo não é mais percebido como objeto de apropriação de classes, nem como um lugar de uma concorrência entre os diversos interesses. Ele é, ao contrário, capaz de liberar os afetados e de estruturar eficazmente seu ambiente. Esse deslocamento, que pode ser percebido na abordagem «realista e organizacional» do Estado proposto por T. Scokpol ${ }^{57}$, é apresentado de uma forma mais sistemática e refinada por J. March ${ }^{58}$ e, J. Olsen ${ }^{59}$, em 1989, embora em um domínio diferente (March e Olsen, 1989). Ele abre em todo o caso pistas interessantes para repensar o papel do Estado na condução de políticas públicas. Essa postura envolve algumas premissas que F.-X. Merrien resumiu bem: «1) O Estado não está completamente desligado (coupé) da sociedade civil, e existe múltiplas interacõoes entre os círculos do Estado e as redes externas; 2) é nestes círculos de sociabilidade e mais particularmente nestes verdadeiros laboratórios de ideias que são associações, clubes politicos, "clubes de pensamento", redes formadas em torno de revistas, etc. que formam os

55 MARSH, David. Théorie de l'État et modèle de réseaux d'action publique. In : LE GALÈS, Patrick ; TATCHER, Mark (Dir.). Les réseaux de politique publique. Débat autour des policy networks. Paris : L’Harmattan, 1995. (Coll. Logiques politiques). p. 143.

56 NT: "Neopluralism is one of a class of research findings or social science models—such as elitism, pluralism, and corporatism—that refer to the structure of power and policy making in some domain of public policy. Originating from Robert Dabl's pluralism model in Who Governs? (1961), neopluralism evolved in the study of American politics through discarding or modifying some of Dabl's ideas, while adding new concerns about agenda building, the logic of collective action, special-interest subgovernments, social movements, advocacy coalitions, and the theory of political processes. Neopluralism is normally a finding of complex action in policy systems, but neopluralism does not assume that complexity implies fairness of representation, nor does it assume interest group elimination of autonomous action by governmental agencies. Neopluralism Annual Review of Political Science Vol. 10: 45-66 (Volume publication date June 2007).” Disponível em: <http://www.annualreviews.org/doi/abs/ 10.1146/annurev.polisci.10.072005.1 52119?journalCode=polisci>.

57 NT. Theda Scokpol, socióloga e cientista política americana da Universidade de Harvard. SCOKPOL, Theda. États et révolutions sociales. La révolution en France, en Russie, en Chine. Paris : Fayard, 1979. (Coll. L'espace du politique). p. 51 a 54 especialmente.

58 NT. James Gardner March, professor emeritus na Stanford University e Stanford Graduate School of Education, tem atuado na pesquisa em organizações e processos de decisão organizacionais.

59 NT. Johan P. Olsen, cientista político norueguês, foi professor da Universidade de Bergen, Noruega. 
novos paradigmas em matéria de ação política [...];5) Certamente, os homens no topo do Estado, ou perto dos cumes do Estado, desempenham um papel importante na elaboração das novas soluções, mas a partir de ideias que se originam em círculos mais amplos que o próprio Estado [...]. $\rangle^{60} \mathrm{Na}$ verdade, se as comunidades epistêmicas se compõe de atores capazes de influenciar a política por meio de sua oferta de modelos de resposta penal, os atores estatais, também, participam desses círculos em que se constrói a mudança: diretores da administração central do Ministério da Justiça, membros dos gabinetes ministeriais e dos corpos de inspeção, "altos" magistrados, membros das comissões parlamentares cooperam com revistas e são membros de sociedades científicas e outros círculos que trabalham na elaboração de paradigmas que serão então consagrados pelo legislador penal.

Somos, portanto, levados a concentrar a pesquisa na colaboração que se estabelece entre os produtores de paradigmas e política. Colaboração em rede, ela observa o interior do sistema político-administrativo do qual faz parte os membros das comunidades epistêmicas. Elas têm em suas fileiras não apenas teóricos e profissionais do direito penal, mas também atores que colocam suas funções próximo ao coração dos centros de decisão política. A hipótese é a de que em matéria penal a ciência e a política se encontram no campo do debate doutrinário e é construída a legitimação da repressão penal, mas também na administração central, nos gabinetes ministeriais, nas comissões parlamentares os modelos teóricos são convertidos em projetos concretos. A colaboração das comunidades epistêmicas com a política se observa também nas comissões de estudo para assistir o Chanceler na preparação de uma lei ou na realização de uma reforma. As comissões do Ministério da Justiça são, de acordo com a "cor política" da maioria, compostas de atores de uma das grandes comunidades epistêmicas penais, as quais dispõem de oportunidades de introduzir nas reformas que são "comandadas" os esquemas que elas mesmas formaram.

A Nova Defesa Social constitui um exemplo emblemático de comunidade epistêmica do campo penal. Idealizada por seus fundadores como um "paradigma", mas também um "movimento", a nova defesa social, inspirou o pensamento e a ação sobre a política penal entre 1945 e 1975. O novo Código Penal é largamente inspirado nas teses dessa comunidade. ${ }^{61}$

Após o fim da guerra, a França empreendeu uma reforma de seu sistema penitenciário, o ambiente da política criminal foi, então, em grande parte, povoado pelos proponentes da Nova Defesa Social que já começava a constituir uma comunidade, apesar de uma visibilidade científica ainda limitada. ${ }^{62}$ É instituída uma comissão para definir as bases do novo sistema penitenciário. Sua presidência é confiada a Paul Amor, ${ }^{63}$ mas também compreende MM. Cannat ${ }^{64}$ e Pinatel, ${ }^{65}$ ambos próximos da Sociedade Geral de Prisões e da parte francesa da Defesa Social, que se dissociara mais claramente da "família italiana", em 1954. ${ }^{66}$ A presença da Defesa Social já está clara em 1952: uma Comissão de estudos penais legislativos é instituída, ligada ao Ministro da Justiça, que retoma os projetos desenvolvidos anteriormente sob a autoridade do Procurador-Geral Matter ${ }^{67}$ e do professor Donnedieu de Vabres. ${ }^{68}$ Regularmente alterada até 1954, a Comissão condu-

60 MERRIEN, François-Xavier. État et politiques sociales: contribution à une théorie "néo-institutionnaliste", Sociologie du travail, v. 32, n. 3, 1990, p. 293; POLLET, Gilles. Analyse des politiques publiques et perspectives théoriques. Essai de modélisation à travers l'exemple des politiques de retraite dans une perspective historique. In : FAURE, Alain, et al. La construction du sens dans les politiques publiques. Débat autour de la notion de référentiel. Paris : L'Harmattan, 1995. p. 25-40. (Coll. Logiques politiques).

61 NT. O "Novo Código Penal francês" foi aprovado em 1992 e entrou em vigor em 1 de março de 1994, revogando o antigo Código Penal de 1810.

62 FAUGERON, Claude; LEBOULAIRE, Jean-Michel. La création du service social des prisons et l'évolution de la réforme pénitentiaire en France de 1945 à 1958, Déviance et société, n. 4, p. 317-359, 1988.

63 NT. Paul Amor (1901-1984) magistrado francês, primeiro diretor da Administração Penitenciária francesa. Participou, em 1945, na grande reforma penitenciaria (chamada “reforma Amor”) cujo objetivo era colocar a correção e a reinserção social do condenado no centro da pena privativa de liberdade.

64 NT. Magistrado, professor e pesquisador de Direito Penal e Penitenciário francês, controlador-geral dos serviços penitenciários franceses

65 NT. Jean Pinatel (1913-1999) criminólogo francês.

66 PERREAU, L. La réforme Amor, Mémoire de l'École nationale d'administration pénitentiaire, 1991.

67 NT. Paul Matter (1865-1938) foi magistrado e historiador francês.

68 NT. Henri Donnedieu de Vabres (1880-1952) jurista francês (foi um dos autores do projeto de reforma do processo penal de 
ziu os aspectos penais da reforma judiciária, em colaboração com o Gabinete, às vezes atualizando o projeto que o Parlamento tinha votado em 1957, mas que jamais entrou em vigor. O Procurador-Geral Besson ${ }^{69}$ logo assumiu a sua presidência e sucedeu nesse posto ao Professor Donnedieu de Vabres, cujo projeto foi rejeitado, alguns anos antes, pela doutrina e pelos tribunais. Essa Comissão foi composta por altos magistrados que gravitam em torno da administração central do Ministério da Justiça, dos tribunais superiores e dos círculos doutrinários. A Comissão, que tem toda a liberdade para ouvir as pessoas que julga útil consultar, tem por membros Louis Hugueney, MM. Ledoux e Patin (Conselheiros da Corte de Cassação), M. Lebègue (Advogado-geral no Tribunal de Cassação), M. Martin (presidente da Câmara do Tribunal de Paris), M. Ribet (antigo bâtonnier de Paris), ${ }^{70} \mathrm{M}$. Toulouse (advogado), MM. Arpaillange e Aubin (magistrados). Um decreto de 5 de março de 1953 completou a composição da Comissão, incorporando M. Boucheron (substituto na Corte de apelação de Paris), M. de Segogne (presidente da Ordem dos Advogados no Conselho de Estado e na Corte de Cassação), M. Andriot (bâtonnier de Lyon). Em junho de 1954, os novos membros são nomeados pelo Guarda dos Selos (Ministro da Justiça): MM. Brouchot, Damour, Ancel ${ }^{71}$ (conselheiros da Corte de cassação), M. Meiss (presidente da Câmara da Corte de Paris), M. Combaldieu (substituto na Corte de Apelação de Paris), M. Gollety (juiz de instrução no Tribunal de Seine), M. Vouin (Professor de Direito), M. Celice (presidente da Ordem dos Advogados e conselheiro de Estado na Corte de Cassação), M. Charles Claude Duval (advogado). No momento da conclusão da elaboração do Código de Processo Penal, a Comissão está totalmente sob o controle da nova defesa social. Seus membros, magistrados, advogados ou professores de direito, participam, assim, dos trabalhos da Sociedade Geral das Prisões e da Seção de Ciência Criminal do Instituto de Direito Comparado de Paris. É nesse contexto que, na virada dos anos cinquenta, elaboraram-se os modelos teóricos usados pelos tomadores de decisão em matéria penal. E são fortemente marcados pelo discurso da escola da nova defesa social. Essa comunidade epistêmica também tem ramificações internacionais, o que contribui para o seu sucesso. Essa capacidade de investir no cenário internacional (seção de defesa social das ONU e logo instâncias de pesquisa no Conselho da Europa, Associações Internacionais de Direito Penal, Criminologia...) condiciona, também, o mimetismo institucional em matéria penal: padrões de reação criminal elaborada em um país são importados pelos membros da comunidade epistêmica para o seu próprio sistema nacional; as organizações internacionais fazem a amplificação do discurso da comunidade epistêmica, que eles se servem para alimentar a sua agenda.

A influência da nova defesa social é, ainda, mais pronunciada em tonro dos anos setenta. Após a passagem de Jean Foyer ${ }^{72}$ pela Praça Vendôme, ${ }^{73}$ que se comprometeu a "condenar à morte" a nova defesa social, um vasto movimento de reforma penal será realizado. Pierre Arpaillange (magistrado e antigo ministro francês) jogando o seu apoio a Elysee ${ }^{74}$ e dispondo de recursos que lhe permitem contornar o Ministro da Justiça, iniciou uma modernização voluntária da Justiça Penal. Em breve, ele criou um Comitê de coordenação da investigação forense cuja presidência é confiada a Paul Amor, um defensor da defesa social. Também estabelece o Conselho de Legislação Penal, sob o controle do trio Aydalot — Touffait — Battestini, três figuras da alta magistratura. O Conselho tem em suas fileiras os professores Vouin e Léauté, bem como M. Touren cuja longevidade na direção dos processos criminais é igualada apenas por P. Arpaillange e B. Cotte. Esta "elite penal" baseia-se amplamente nas teses da nova defesa social. A Comissão para a revisão do Código Penal é colocada também, desde a sua criação, sob o controle da nova defesa social. A. Peyrefitte, segundo os neoclás-

1949), foi também juiz nos julgamentos de Nuremberg.

69 NT. Antonin Besson (1895-1985) Procurador-Geral junto à Corte de Cassação (1951-62).

70 Bâtonnier - advogado eleito presidente do conselho da ordem. A origem do termo está ligada ao costume do advogado mais velho que conduzia nas procissões a barra — barreau — da bandeira da Confraria de São Nicolas a qual pertencia os advogados. Cf. Dictionnaire du droit privé de Serge Braudo. Disponível em: < http://www. dictionnaire-juridique.com/definition/batonnier.php>. 71 NT. Marc Ancel (1902-1990) magistrado e teórico do Direito, defensor da política criminal associada à "Nova Defesa Social", na qual tencionava repensar o sistema penal sob a perspectiva da defesa dos direitos do homem e não mais na prevalência da defesa da sociedade.

72 NT. Jean Foyer (1921-2008) político e jurista francês.

73 NT. Por metonímia, onde se localiza o Ministério da Justiça.

74 NT. Pela mesma figura de linguagem, o palácio residencial do Presidente da França. 
sicos, o mais duro do círculo da Universidade, «enterrará» o projeto de Código Penal de 1978. Mas é sob a influência direta dos participantes da defesa social que a versão final do projeto de 1983 e o projeto de 1986 são adotados. No novo Conselho de Revisão agora presidido por Robert Badinter, ${ }^{75}$ há, entre outros, o professor Léauté (Jacques), Mireille Delmas-Marty, M. Braunschweig, que assume por algum tempo a direção do gabinete do Ministro da Justiça, ${ }^{76}$ P. Arpaillange. Esses atores também se encontram em uma segunda comissão, encarregada de reformar o processo penal e é presidida pelo Professor Léauté.

Essa colaboração é a oportunidade de transações sutis entre as comunidades epistêmicas e os tomadores de decisões políticas. Estes encontram recursos na ação das comunidades os apoios que podem invocar no jogo político: invocando os trabalhos de uma comissão, o político manifesta, no curso da competição política, que ele está agindo com a garantia da elite científica. A política criminal recomendada aparece como sendo inspirada por especialistas, cuja competência é comprovada. Por outro lado, a comunidade epistêmica eleita é distinta das outras. Devido à colaboração que ocorre entre a rede de especialistas e os tomadores de decisões políticas, uma hierarquia é criada entre as comunidades epistêmicas. De um lado, aqueles cujo discurso é autoritário é ouvido pela política — que prevalece na sua atividade — tem o seu prestigio e sua visibilidade social reforçada. Do outro, aqueles que, para serem ouvidos, são reduzidos à denúncia da estratégia penal formal, à margem do campo penal, vê os seus modelos privados de toda legitimidade. Essa colaboração das comunidades epistêmicas com a política é particularmente visível na Quinta República. ${ }^{77}$ As mudanças políticas são geralmente acompanhadas de reorientações na política penal, concebidas por professores de direito, juízes, advogados ou sindicalistas "próximos" da comunidade que, do mesmo modo que as «novas autoridades», estavam anteriormente na «oposição».

\subsection{A estruturação das mobilizações e dos confrontos políticos em torno de questões criminais}

É em torno de esquemas teóricos construídos pelas comunidades epistêmicas penais que se formam alianças transversais, nos momentos particulares, para incitar a política para mudar as orientações da política criminal. Temos aqui, por meio do conceito de comunidades epistêmicas, um instrumento particularmente adequado para a análise da construção da agenda política em matéria penal. A ocorrência, em diferentes momentos da ação pública, de situações críticas ou de eventos escandalosos permite várias coalizões de atores para garantir a promoção de "causas" susceptíveis de serem apoiadas pela política, com base em modelos desenvolvidos pelas comunidades epistêmicas. ${ }^{78}$ As comunidades epistêmicas criminais produzem, em outras palavras, os quadros de análise por meio dos quais grupos mobilizados em um contexto crítico por uma determinada questão "mediatize" a leitura do problema e habilite suas reivindicações. Os membros das comunidades epistêmicas penais também são, por vezes, parte dessas coalizões heterogêneas, mas constituídas sob uma base idêntica. De acordo com Sabatier, nesses grupos mobilizados «podem ser agregadas várias coalizôes de defesa, composta de pessoas provenientes de diversas organizaçooes, que partilham de um conjunto de crenças normativas e causais e muitas vezes atuando em concerto». ${ }^{79}$ Isso pode ser muito bem visto em 1980, antes da aprovação da lei «segurança-liberdade», enquanto as mobilizações em torno «do projeto Peyrefitte»" ${ }^{80}$ ganhavam intensidade.

75 NT. Foi presidente do Conselho Constitucional de 1986 a1995, conhecido por sua luta incansável pela reabilitação de presos e principalmente contra a pena de morte. Foi a partir de projeto por ele apresentado, como Ministro da Justiça do governo Mitterrand, que o parlamento francês aboliu essa pena, em 1981, além de ter uma participação decisiva na elaboração do novo Código Penal francês de 1992.

76 "cabinet du garde".

77 Em vigor desde 4/10/1958, é a quinta e atual constituição republicana da França.

78 Nesse sentido, SABATIER, Paul. An Advocacy Coalition. Framework of Policy Change and the Role- Oriented Learning Therein, Policy Sciences, 21, 1988, p. 128- 168.

79 Ibid., p. 133.

80 NT. Refere-se a Alain Peyrefitte, político, escritor e diplomata, que apresentou, quando Ministro da Justiça da França (19771981), o projeto «sécurité-liberté», cujo objetivo era "reforçar a segurança e proteger a liberdade das pessoas". Dois anos após a eleição de François Mitterrand à presidência da França e baseado no relatório da "Comissão Léauté", algumas das disposições foram 
Entre as coalisões dos atores mobilizados, incluem aqueles de setores da vida social muito diversa: sindicatos, estudantes, religiosos ao lado de juristas que desejam orientar o texto de uma forma que tenha sua preferência. E entre estes, há os membros das comunidades epistêmicas que se opõem regularmente na cena penal. Na ocasião de reativação da rede de atores próximos da nova defesa social, as VIIIa Jornadas de Estudos do Instituto de Criminologia de Paris permitiram que a comunidade de juristas progressistas expressassem publicamente a hostilidade de todos os juristas ao texto do Ministro da Justiça, ${ }^{81}$ ao mesmo tempo em que, aproveitando o amplo espaço de expressão que lhes deixa o Le Figaro, os juristas próximos ou membros da comunidade epistêmica neoclássica saudou a iniciativa do Ministro da Justiça que eles apoiam. As comunidades epistêmicas desempenham assim um papel importante na formação do discurso dos profissionais da política que eles tendem a influenciar.

Os atores políticos se posicionam na mobilização das oposições de paradigmas, o que não significa que as divisões políticas são necessariamente baseadas em divisões doutrinárias. ${ }^{82}$ As concepções da repressão penal defendidas pelos atores políticos são idênticas àquelas encontradas na oposição entre as comunidades epistêmicas. A estrutura dos discursos dos políticos recupera, largamente, o discurso das comunidades epistêmicas penais. Os atores políticos favoráveis às políticas penais repressivas e securitárias analisam o fenômeno criminal nos mesmos termos que os proponentes da comunidade epistêmica penal neoclássica. Para uns e para outros, a sociedade não pode ser responsável pelos atos cometidos pelos delinquentes. Trata-se de indivíduos livres e responsáveis que uma disposição natural para prejudicar e abusar de sua liberdade conduz à transgressão da lei penal. Qualquer análise da criminalidade que valorize excessivamente determinantes pessoais e sociais conduz a um enfraquecimento das forças da repressão penal e a um questionamento da responsabilidade individual, que é o suporte teórico da repressão. Já que ele (delinquente) sabe o que faz e por isso tem consciência do risco da transgressão à lei, a ele deve ser retribuída (a pena) em consequência. Sem ser feroz, a resposta penal deve ser rápida, incluir um mínimo de inconvenientes para o ofensor, ser certa e dissuasiva. Parlamentares repressivos e penalistas neoclássicos preconizam, assim, uma política penal que, ignorando fatores estruturais da delinquência, consiste em estratégias de prevenção geral: defesa da sociedade e neutralização dos delinquentes pelo uso de penas longas e certas, que permitem reduzir a reincidência, generalizando os processos acelerados de julgamento das infrações. Qualquer coisa que ajude a fazer justiça criminal rápida e severa, e a pena dissuasiva e exemplar, é valorizada por esses atores.

Geralmente pertencentes à esquerda, os defensores da prevenção têm, inversamente, um discurso próximo das teses da nova defesa social e da corrente dos direitos humanos: compreender os infratores de crimes para melhor integrá-los na sociedade, os consideram como homens capazes de redenção e dignos de compaixão, faz da estratégia penal um elemento de uma política social mais ampla de combate aos fatores de exclusão social e de marginalidade, tais são as prioridades que os atores políticos favoráveis à prevenção defendem, mobilizando, assim, o jogo político as teses de uma comunidade epistêmica penal dos que lhes estão próximos. Como os defensores da Nova Defesa Social, eles descrevem, sempre, o homem atrás do culpado. A pena deve servir à ressocialização do delinquente, para os valores da sociedade que ele não internalizou ou contra os quais se levantou por causa de alguma frustração particular. As autoridades encarregadas da repressão penal devem, em todos os casos, respeitar as regras destinadas a garantir os direitos fundamentais do culpado, que o seu desvio não lhe fez perder.

revogadas pela Lei de 10 de junho de 1983.

81 Ver CHEVALLIER, Jacques. Les juristes et le projet "sécurité - liberté", Léviathan, n. 6-7, p. 1981. p. 44 e seg.

82 Encontramos uma certa postura "homóloga", embora em um domínio muito diferente, nos trabalhos de C. Charle, sobre a autonomia relativa da política em comparação com o campo literário no caso Dreuyfus. Ver, por exemplo, CHARLE, Christophe. Champ littéraire et champ du pouvoir: les écrivains et l'affaire Dreyfus, Les Annales ESC, n. 2, p. 240-264, 1977. 


\section{Considerações finais}

A ideia de comunidade epistêmica penal evoca a existência de grupos de atores, organizados em redes informais na cena doutrinária e entretém relações com base na existência de preferências axiológicas, cognitivas e instrumentais idênticas. Organizados em diferentes pontos do campo doutrinário e do campo político-administrativo, os membros de uma comunidade epistêmica operam, além disso, segundo uma lógica diferente daquela que preside o funcionamento de uma organização: a especialização de tarefas e a diferenciação de papéis que singularizam esta última, as redes de atores substituem um princípio de versatilidade e "intercambialidade". A tendência à formalização de regras de ação coletiva e à objetivação dos dispositivos jurídicos fixados que caracterizam a organização diferem do "informal" e do "oficial" aqueles que obedecem a ação das redes de atores penais. Essa característica, também, permite que os membros da comunidade epistêmica se movam em diferentes lugares do sistema político-administrativo, em princípio fechados à inovação. A redundância das relações (muitas vezes muito pessoais) entre os membros dessas comunidades facilita, assim, a circulação de informação e a construção de linhas de ação coerentes, dentro de um prazo bastante curto, que nem sempre permite a existência de dispositivos formais de regulação de sua cooperação. O campo penal não é um "mundo fechado", no qual os atores, de perfil homogêneo, ficam isolados das dinâmicas sociais e políticas. Esse setor se analisa, ao contrário, como um lugar de intercâmbio entre doutrinadores, sindicatos, mas também funcionários públicos e políticos, pertencentes a comunidades epistêmicas penais que rivalizam na forma das matrizes conceituais fundantes da ação pública em matéria penal.

\section{O Autor}

Atua no ensino e pesquisa em Ciência Política na Faculdade de Direito e Política e Ciências Sociais da Universidade da Picardie Jules Verne. Suas publicações mais recentes incluem:

- «Contribution à un schéma d'analyse de l'élaboration de La décision de politique pénale, thèse pour le doctorat en science politique, juin $1997 »$;

- «L'institution de la perpétuité réelle. Contribution à l'étude des processus décisionnels pénaux », Revue de science criminelle et de droit pénal comparé, $\mathrm{n}^{\circ}$ 1, 1997;

- «La sûreté de l'État dans Le débat politique. Analyse thématique de deux discours parlementaires », dans CURAPP (éd.), La politique ailleurs, Paris, PUF, 1998;

- «Comment les idées passent dans l'action. Le changement du discours public en matière économique au Cameroun », Polis, Revue camerounaise de science politique, vol. 3, n 1, 1998.

\section{Para saber Mals ${ }^{83}$}

ARON, Henry J. Cox. Politics and the professors: the great society in perspective. Washington D.C.: Brookings, 1978 .

MAZUR, Allan. The Dynamics of Technical Controversy. Washington D.C.: Communications Press, 1981.

NELSON, Barbara J. Making an Issue of Child Abuse: political agenda setting for social problems. Chicago: University of Chicago Press, 1984.

RADAELLI, Claudio M. Knowledge Utilization and Policy Making, Journal of European Public Policy, v. 2, n. 2, p. 159-183, 1995.

83 Indicação de Stéphane Enguéléguélé. 
SABATIER, Paul A.; JENKINSSMITH Hank C. (Ed.). Policy Change and Learning. An Advocacy Coalition Approach. San Francisco, Oxford: Westview Press, Boulder, 1993.

\section{EM PORTUGUÊs ${ }^{84}$}

ADLER, Emanuel. O papel das elites políticas e intelectuais e das instituições no desenvolvimento da informática e da energia nuclear na Argentina e no Brasil. Revista de Ciências Sociais, Rio de Janeiro, v. 31, n. 3, p. 373-403, 1988.

ALVES, Reinaldo Rossano. Punir e perdoar: análise da política pública na edição dos Decretos de indulto. Rio de Janeiro: Lumen Juris. 2016.

ANDRADE, Rodrigo de. Rede de Atores Pastorais e sua influência nas Políticas Públicas de Juventude: constituição de uma Comunidade Epistêmica. Revista Juventude e Políticas Públicas, 2014 - revistasnj.ibict.br. Disponível em: <http://revistasnj.ibict.br/ojs_snj/index.php/snj/article/view/RODRIGO\%20DE\%20 ANDRADE $>$.

CERVO, Amado Luiz. Sob o signo neoliberal: as relações internacionais da América Latina. Rev. Bras. Polit. Int., Brasília, v. 43, n. 2, p. 5-27, July/Dec. 2000.

MAFFRA, Lourrene de C. Alexandre. Comunidades Epistêmicas: estudo sobre a regulação do uso de células-tronco no Brasil. OBSERVARE Universidade Autónoma de Lisboa, v. 4, n. 1, p. 79-90, maio/out. 2013.

OLIVEIRA, Maria Clara. Comunidades epistêmicas e transferências condicionadas de renda. Preparado para o II Seminário Discente da Pós-Graduação em Ciência Política da USP. Disponível em <http://web. fflch.usp.br/centrodametropole/antigo/static/uploads/>. semináriodiscentedcp_maio_2012_maria_Clara_Oliveira.pdf>.

PATTI, Carlo. O programa nuclear brasileiro entre passado e futuro. Boletim Meridiano 47, v. 14, n. 140, p. 49-55, nov./dez. 2013.

\section{REFERÊNCIAS}

ANCEL, Marc. La défense sociale nouvelle. 3. ed. Paris: Cujas, 1981.

ASSIER-ANDRIEU, Louis. La norme pénale comme enjeu culturel, Les cabiers de la sécurité intérieure, n. 18, p. 39-49, 1994.

BADINTER, Robert. Naissance d'une justice . In: ID. (Dir.). Une autre justice 1789-1799. Paris : Fayard, 1989. p. 9-25. (Coll. Histoire de la justice).

BADINTER, Robert. La prison républicaine. Paris : Fayard, 1992.

BERNAT DE CELIS, Jacqueline. Fallait-il créer un délit d'usage illicite de stupéfiant? Une étude de sociologie législative. Paris : CESDIP, 1992. (Coll. Déviance et contrôle social).

BOURDIEU, Pierre. La force du droit: éléments pour une sociologie du champ juridique, Actes de la recherche en sciences sociales, n. 64, p. 3-19, 1986.

CALLON, Michel ; LATOUR, Bruno. Introduction. In: CALLON, Michel ; LATOUR, Bruno. La science telle qu'elle se fait. Paris : La Découverte, 1991. p. 7-36. (Coll. Textes à l’appui).

84 Indicações do tradutor. 
CHARLE, Christophe. Champ littéraire et champ du pouvoir: les écrivains et l'affaire Dreyfus, Les Annales ESC, n. 2, p. 240-264, 1977.

CHEVALLIER, Jacques. Les interprètes du droit. In : POIRMEUR, Yves ; BERNARD, Alain. (Ed.). La doctrine juridique. Paris: PUF, 1993. p. 259-281.

CHEVALLIER, Jacques. Les juristes et le projet "sécurité liberté", Léviathan, n. 6-7, p. 44, 1981.

FAUGERON, Claude; LEBOULAIRE, Jean-Michel. La création du service social des prisons et l'évolution de la réforme pénitentiaire en France de 1945 à 1958, Déviance et société, n. 4, p. 317-359, 1988.

FAUGERON, Claude. Du pénal à la discipline: l'ordre et le contrôle pénal en France. Bilan de la recherche en France depuis 1980. In: ROBERT, Philippe ; VAN OUTRIVE, Lode. (Ed.). Crime et justice en Europe. Paris: L'Harmattan, 1993. p. 115-167. (Coll. Logiques sociales ).

HAAS, Peter M. Introduction: epistemic communities and international policy coordination, International Organization, v. 49, n. 1, p. 1-35, 1992.

HECLO, Hugh. Issue Networks and the Executive Establishment. In: KING, Anthony. (Éd.). The New American Political System. Washington D.C.: American Enterprise Institute, 1978. p. 103-104 especialmente.

HOPKINS, Andrew. Crime, Law and Business: the Sociological Sources of Australian Monopoly Law. Canberra: Australian Institute of Criminology, 1978.

KALUSZYNSKI, M. À l’origine des politiques pénales en France sous la IIIe République. Un laboratoire de réflexions: la Société générale des prisons. In : AREPPOS (Éd.). Philanthropies et politiques sociales en Europe XVIII e-XXe siècle. Paris : Anthropos/Économica, 1994. p. 133- 144. (Coll. Historiques).

KALUSZYNSKI, Martine. Production de la loi et genèse des politiques pénales. La Société générale des prisons 1897-1900, Rapport terminal. Grenoble: CERAT, 1996.

KUHN, Thomas. S. La structure des révolutions scientifiques. Paris : Flammarion, 1983.

LASCOUMES, Pierre; PONCELA, Pierrette ; LENOËL, Pierre. Au nom de l'ordre. Une histoire du Code pénal. Paris : Hachette, 1989.

LASCOUMES, Pierre. Pluralité d'acteurs, pluralité d'actions dans la création contemporaine des lois. In: . Études en hommage à Christian Debuyst, Liège. Bruxelles: Mardaga, 1990. p. 145-163.

LASCOUMES, Pierre ; SERVERIN, Évelyne. Le droit comme activité sociale: pour une approche wébérienne des activités juridiques. Droit et Société, n. 9, p. 165-187, 1988.

LASCOUMES, Pierre ; ROTH, R. ; SANSONNETI, R. L'incrimination en matière économique. Genève : CETEL, Université de Genève, 1989.

LATOUR, Bruno. La science en action. Paris : La Découverte, 1989. (Coll. Textes à l'appui).

LÉVY, René ; ROUSSEAUX, Xavier. États, justice pénale et histoire: bilan et perspectives, Droit et Société, n. 20-21, p. 249-279, 1992.

MARCH, James G.; OLSEN, Johan P. Rediscovering Institutions: The Organizational Basis of Politics. New York: Free Press, 1989.

MARIN, Bernd; MAYNTZ, $\square$ Renate (Ed.). Policy Networks: empirical evidence and theoretical consideration. Frankfurt/Main: Campus, 1991.

MARSH, David. Théorie de l'État et modèle de réseaux d'action publique. In : LE GALÈS, Patrick ; TATCHER,Mark (Dir.). Les réseaux de politique publique. Débat autour des policy networks. Paris : L'Harmattan, 1995. (Coll. Logiques politiques). p. 143 e seguintes. 
MERLE, Roger. Place respective des sanctions privatives et non privatives de liberté, Rapport aux journées franco-roumaines de la Société de législation comparée, 1981.

MERRIEN, François-Xavier. État et politiques sociales: contribution à une théorie "néo-institutionnaliste", Sociologie du travail, v. 32, n. 3, p. 267-294, 1990.

MULLINS, Nicholas C. The Development of Scientific Speciality: The Phage Group and the Origin of Molecular Biology, Minerva, n. 10, p. 51-82, 1972.

PERREAU, L. La réforme Amor, Mémoire de l'École nationale d'administration pénitentiaire. 1991.

POLLET, Gilles. Analyse des politiques publiques et perspectives théoriques. Essai de modélisation à travers l'exemple des politiques de retraite dans une perspective historique. In : FAURE, Alain, et al. La construction du sens dans les politiques publiques. Débat autour de la notion de référentiel. Paris : L'Harmattan, 1995. p. 25-40. (Coll. Logiques politiques).

PORRET, Michel. Les réquisitoires des procureurs généraux de Genève au XVIIIe siècle, Genèses, n. 19, 1995.

ROBERT, Philippe. De la "criminologie de la réaction pénale" à une "sociologie pénale", L'année sociologique, v. 31, 1981.

ROBERT, Philippe. (Éd.). Entre l'ordre et la liberté, la détention provisoire: deux siècles de débats. Paris: L'Harmattan, 1992. (Coll. Logiques juridiques).

ROBERT, Philippe. (Éd.). La création de la loi et ses acteurs. L'exemple du droit pénal. Oñati: IISL, 1991. (Coll. Oñati Proceedings).

ROUSSEAUX, Xavier. La répression de l'homicide en Europe occidentale (Moyen Âge-Temps modernes), Genèses, n. 19, p. 122-147, 1995.

SABATIER, Paul. An Advocacy Coalition. Framework of Policy Change and the Role- Oriented Learning Therein, Policy Sciences, v. 21, p. 128- 168, 1988.

SAVELSBERG, Joachim J. The making of criminal law norms in Welfare States. Law and Society Review, v. 21, n. 4, p. 529, 1987.

SAVELSBERG, Joachim J. Rationalities and experts in the making of criminal law against economic crime, Law and Policy, n. 2-3, 1988.

SCHATTSCHEINDER, Elmer E. The Semi-Sovereign People. New York: Holt, 1960.

SCOKPOL, Theda. États et révolutions sociales. La révolution en France, en Russie, en Chine. Paris : Fayard, 1979. (Coll. L'espace du politique).

SOYER, Jean-Claude. Il faut oser punir. Le Figaro, 29 mars 1980.

STRYKER, Robin. Government Regulation. In: BORGATTA, Edgard F.; BORGATTA, Marie L. (Ed.). Encyclopedia of Sociology. New York: Mac Millan, 1992.

STRYKER, Robin. Rules, Resources, and Legitimacy Process: Some Implications for Social Conflict, Order, and Change », American Journal of Sociology, v. 99, n. 4, p. 847, 1994.

VINCK, Dominique. Sociologie des sciences. Paris: Armand Colin, 1995. 


\section{Delinquência juvenil: relações entre desenvolvimento, funções executivas e comportamento social na adolescência*}

\author{
Juvenile delinquency: relationships between \\ development, executive functions, and social \\ behavior in adolescence
}

\author{
André Vilela Komatsu** \\ Rafaelle CS Costa*** \\ Marina Rezende Bazon****
}

* Recebido em 29/05/2018

Aprovado em 09/07/2018

** Doutorando em Psicologia pela Universidade de São Paulo (USP) e pesquisador visitante da Universitat de Barcelona. Membro do Grupo de Estudos e Pesquisa em Desenvolvimento e Intervenção Psicossocial (GEPDIP). Possui graduação e mestrado em Psicologia pela Universidade de São Paulo. E-mail: avk@ usp.br

*** Educadora Social do Programa de Fortalecimento de Vínculos da Organização Comunitária Santo Antônio Maria de Claret e mestranda em Psicologia pela USP. Membro do Grupo de Estudos e Pesquisa em Desenvolvimento e Intervenção Psicossocial. Possui graduação em Psicologia pela USP. E-mail: rafaellecscosta@ gmail.com

**** Docente do Departamento de Psicologia da Universidade de São Paulo (USP) e coordenadora do Grupo de Estudos e Pesquisa em Desenvolvimento e Intervenção Psicossocial. Possui graduação em Psicologia pela USP, Mestrado en Science - Psychoéducation pela Université de Montreal e Doutorado em Psicologia pela USP. E-mail: mbazon@fffclrp.usp.br

\section{Resumo}

Funções Executivas (FEs) consistem em processos mentais de ordem superior, necessários para o controle emocional, cognitivo e comportamental. A adolescência é uma etapa crucial para o desenvolvimento das FEs. Defasagens/Déficits nas funções dificultam/impossibilitam comportamentos sociais adequados e aumentam o risco para problemas de comportamento (dentre os quais a prática de delitos). O objetivo deste artigo é apresentar os resultados de uma revisão integrativa do conhecimento científico produzido em torno das relações entre FEs e comportamento delituoso na adolescência e discutir as implicações desse corpo de conhecimento reunido para programas de prevenção e tratamento/acompanhamento socioeducativo. A literatura aponta que as FEs podem se relacionar com o comportamento delituoso de forma indireta e direta. Indiretamente, disfunções executivas contribuem para a existência de dificuldades de ajustamento ao meio acadêmico e laboral, aumentando as chances de o adolescente se afastar dessas instituições sociais, de regulação da conduta, e se envolver com práticas divergentes. Diretamente, disfunções executivas, especialmente no plano do controle de impulsos, contribuem para a emissão de delitos específicos e para a violência. A literatura indica que as FEs podem ser estimuladas e desenvolvidas. Ações preventivas podem ser implementadas desde os primeiros meses de vida até à adolescência, no âmbito da família e da escola. Ações de tratamento devem focalizar as FEs mais diretamente relacionadas aos problemas manifestos e levar em consideração fatores contraproducentes ao desenvolvimento das FEs, como o estresse, o isolamento social/emocional e a saúde como um todo. Salienta-se que é necessário integrar esses conhecimentos às legislações e políticas públicas brasileiras.

Palavras-chave: Comportamento pró-social. Comportamento antissocial. Delinquência juvenil. Funções executivas. Psicologia do adolescente. 
Executive Functions (FEs) are higher order mental processes required for emotional, cognitive and behavioral control. Adolescence is a crucial stage in the development of FEs. Delays/deficits in these functions makes it impossible or more difficult to emit appropriate social behaviors and increase the risk for behavioral problems (including offenses). The objective of this study is to present the results of an integrative review of the scientific knowledge produced around the relationships between EFs and criminal behavior during adolescence and to discuss its implications for programs of prevention and treatment in socioeducative context. The literature points out that EFs relate to criminal behavior indirectly and directly. Indirectly, executive dysfunctions contribute to increase difficulties in adjusting to the academic and work environment, increasing the chances of the teenager moving away from these social institutions, which regulates the behavior, and engaging in antisocial practices. Directly, executive dysfunctions, especially regarding impulse control, contribute to the emerging of specific offenses and to violence. The literature indicates that EFs can be stimulated and developed. Preventive actions can be implemented from the first months of life through adolescence, in the family and school contexts. Treatment actions should focus on EFs specifically related to behavior problems exhibited and take into account factors counterproductive to the development of EFs, such as stress, social and emotional isolation and health as a whole. It should be noted that it is necessary to integrate this knowledge into Brazilian public policies and legislation.

Key-words: Adolescent psychology. Antisocial behavior. Executive functions. Juvenile delinquency. Prosocial behavior.

\section{INTRODUÇão}

O desenvolvimento do cérebro humano inicia-se a partir da terceira semana gestacional e continua ao longo da vida por meio de processos dinâmicos e adaptativos que promovem o surgimento e/ou a diferenciação de novas estruturas e funções — a chamada (neuroplasticidade) ${ }^{1}$. Embora essas transformações ocorram de forma contínua, alguns períodos são marcados por evidentes saltos quantitativos e qualitativos em termos de aquisições. A adolescência, estágio de transição da infância à vida adulta, é notadamente um desses períodos. Os processos neuropsicológicos que ocorrem nessa fase fazem com que a adolescência seja considerada um momento crítico para as trajetórias desenvolvimentais nos campos da cognição, das interações sociais, da personalidade e, por conseguinte, da adaptabilidade ${ }^{2}$, o que deve fomentar especial sensibilidade para com essa etapa da vida, no tocante às formas de responder às suas demandas e de lidar com as suas dificuldades, ou seja, no tocante às condições propiciadas para o crescimento e o desenvolvimento saudável dos adolescentes ${ }^{3}$, à semelhança daquela que se deve ter para com as crianças na primeira etapa da infância.

1 Os processos pelos quais o cérebro desenvolve suas estruturas e funções com base nas experiências são amplamente descritos na literatura e podem ser encontrados em: GREENWOOD, Pamela. Functional plasticity in cognitive aging: Review and hypothesis. Neuropsychology, v. 21, n. 6, p. 657-673, 2007; PAUS, Tomás; KESHAVAN, Matcheri; GIEDD, Jay. Why do many psychiatric disorders emerge during adolescence? Nature Reviews Neuroscience, v. 9, n. 12, p. 947-957, 2008; STILES, Joan; JERNIGAN, Terry. The Basics of Brain Development. Neuropsychology Review, v. 20, n. 4, p. 327-348, 2010.

2 Devido a condições peculiares do desenvolvimento do cérebro durante a adolescência, as experiências vividas nessa fase produzem efeitos mais duradouros que experiências vividas posteriormente, conforme indicam os estudos: ARAIN, Mariam et al. Maturation of the adolescent brain. Neuropsycbiatric Disease and Treatment, v. 9, p. 449-461, 2013; PAUS, Tomás; KESHAVAN, Matcheri; GIEDD, Jay. Why do many psychiatric disorders emerge during adolescence? Nature Reviews Neuroscience, v. 9, n. 12, p. 947-957, 2008. 3 A criança e o adolescente, por serem indivíduos em desenvolvimento, necessitam de proteção e de cuidado especial, devendo ser amparados pela família, sociedade e Estado com o objetivo de se propiciar um ambiente favorável ao desenvolvimento integral e harmônico de sua personalidade: LIMA, Renata Mantovani de; POLI, Leonardo Macedo; JOSÉ, Fernanda São. A Evolução Histórica dos Direitos da Criança e do Adolescente: da insignificância jurídica e social ao reconhecimento de direitos e garantias fundamentais. Rev. Bras. Polít. Públicas, Brasília, v. 7, n. 2, p. 313-329, 2017. 
As diversas oscilações emocionais e comportamentais observadas na adolescência podem ser atribuídas, ao menos em parte, a um descompasso natural no estágio desenvolvimental entre diferentes áreas cerebrais e, consequentemente, suas respectivas funções. Por exemplo, os circuitos neuronais ligados ao sistema de recompensas se estabelecem mais rapidamente que os circuitos ligados ao controle comportamental e emocional e ao de planejamento de longo prazo, o que tornam os jovens mais propensos a buscarem atividades de risco, e menos inclinados a planejarem seu futuro ${ }^{45}$. Essa condição, somada a determinadas condições sociais e culturais, algumas específicas à adolescência, fazem com que essa fase seja a de maior incidência de diferentes problemas de comportamento — internalizantes e externalizantes —, bem como de muitos transtornos mentais ${ }^{678}$.

Embora todos os adolescentes passem pelos mesmos processos maturacionais, o tempo em que eles ocorrem variam de indivíduo para indivíduo, e são influenciados por diversos fatores como: genética; níveis dos hormônios sexuais estrógeno, progesterona e testosterona; qualidade nutricional; padrões de sono; estresse físico ou psicológico; abuso de drogas e outros estímulos ambientais ${ }^{9}$. Esses determinantes do desenvolvimento neural fazem com que cada indivíduo possua padrões singulares de ligações estruturais e funcionais, denominados conectoma (termo que pode ser compreendido como uma espécie de impressão digital neural). $\mathrm{O}$ conectoma indica a aptidão de cada indivíduo para desenvolver competências relacionadas às funções executivas $(\mathrm{FEs})^{10}{ }^{11}$.

Função Executiva - FE (também conhecida como controle executivo ou controle cognitivo) é um amplo construto que remete a processos cognitivos de ordem superior que governam comportamentos guiados por objetivos e respostas adaptativas a situações novas, complexas ou ambíguas ${ }^{12}$. Em relação às FEs, há consenso geral de que existem três núcleos básicos: Controle Inibitório; Memória de Trabalho; Flexibilidade Cognitiva. Desses núcleos derivam uma série de subfunções necessárias à autorregulação emocional e comportamental apropriada à execução de tarefas cotidianas ${ }^{13}$. Diferenças individuais na performance dessas funções são preditores e moderadores relevantes para uma série de resultados na vida, como sucesso acadêmico, laboral e relacional ${ }^{14} 15$.

O Controle Inibitório refere-se à capacidade de o indivíduo controlar a própria atenção, emoção, pensamento e comportamento, o que lhe permite escolher ou mudar como reagir ou comportar-se frente aos estímulos ambientais ou aos impulsos/às predisposições internas ${ }^{16}$. As funções relacionadas a esse núcleo podem ser divididas em controle de interferência (atenção seletiva e inibição cognitiva) e autocontrole (ini-

4 ARAIN, Mariam et al. Maturation of the adolescent brain. Neuropsycbiatric Disease and Treatment, v. 9, p. 449-461, 2013.

5 KONRAD, Kerstin; FIRK, Christine; UHLHAAS, Peter. Brain Development During Adolescence: Neuroscientific Insights Into This Developmental Period. Deutsches Ärzteblatt International, v. 110, n. 25, p. 425-431, 2013.

6 LEE, Francis et al. Adolescent mental health-Opportunity and obligation: Emerging neuroscience offers hope for treatments. Science, New York, v. 346, n. 6209, p. 547-549, 2014.

7 MOFFITT, Terrie. Male antisocial behaviour in adolescence and beyond. Nature Human Behaviour, v. 2, n. 3, p. 177-186, 2018.

8 PAUS, Tomás; KESHAVAN, Matcheri; GIEDD, Jay. Why do many psychiatric disorders emerge during adolescence? Nature Reviews Neuroscience, v. 9, n. 12, p. 947-957, 2008.

9 Alguns estudos revisaram os principais determinantes do desenvolvimento neural e como eles afetam à saúde física e mental do indivíduo: ARAIN, Mariam et al. Maturation of the adolescent brain. Neuropsychiatric Disease and Treatment, v. 9, p. 449-461, 2013; e GALVÁN, Adriana. Adolescence, brain maturation and mental health. Nature Neuroscience, v. 20, n. 4, p. 503-504, 2017.

10 FINN, Emily et al. Functional connectome fingerprinting: Identifying individuals using patterns of brain connectivity. Nature Neuroscience, v. 18, n. 11, p. 1664-1671, 2015.

11 KAUFMANN, Tobias et al. Delayed stabilization and individualization in connectome development are related to psychiatric disorders. Nature Neuroscience, v. 20, n. 4, p. 513-515, 2017.

12 HUGHES, Claire; GRAHAM, Andrew; GRAYSON, Andrew. Executive function in childhood: Development and disorder. In: OATES, John. (Ed.). Cognitive Development. Oxford: Open University Press, 2005. p. 205-230.

13 DIAMOND, Adele. Executive functions. Annual Review of Psychology, v. 64, p. 135-168, 2013.

14 DIAMOND, Adele. Executive functions. Annual Review of Psychology, v. 64, p. 135-168, 2013.

15 ROMERO, María. Executive control enhancement and cognitive training. 2017. Tese (Doutorado), Universidad de Granada, Granada, 2017.

16 DIAMOND, Adele. Executive functions. Annual Review of Psychology, v. 64, p. 135-168, 2013. 
bição comportamental e emocional). No tocante ao controle de interferência, a atenção seletiva capacita o indivíduo a focar estímulos de seu interesse e suprimir a atenção dos demais estímulos ${ }^{17}$. A inibição cognitiva permite a supressão de representações mentais como pensamentos ou memórias indesejáveis ou irrelevantes para determinada situação, o que tem grande influência sobre a memória de trabalho ${ }^{18}$. Essas duas classes de habilidades são fundamentais para o aprendizado e o sucesso acadêmico.

A segunda dimensão do controle inibitório, o autocontrole, envolve a capacidade de exercer controle sobre as próprias emoções e comportamentos, resistindo a vontades ou a prazeres imediatos em detrimento de metas de longo prazo, mais significativas ${ }^{19}{ }^{20}$. Vale ressaltar que, embora para vários autores o conceito de autocontrole seja mais amplo ${ }^{21} 22$, abrangendo quase todos os aspectos dos três núcleos de FEs mencionados anteriormente, na classificação de Diamond ${ }^{24}$, embasada em investigações relacionados a substratos neurais, o termo autocontrole se restringe às dimensões emocional e comportamental.

Memória de Trabalho, outro núcleo das FEs, compreende a capacidade de manter, temporariamente, e de manipular informações na mente com o objetivo de executar tarefas cognitivas simples e complexas como compreensão de linguagem, aprendizado e raciocínio ${ }^{25}$. Entre outras funções, a memória de trabalho é responsável por incorporar novas informações ao pensamento, transformar instruções em planos de ação, considerar outros pontos de vista, relacionar ideias semelhantes e separar ideias distintas ${ }^{26}$. Essas habilidades são fundamentais para uma série de tarefas do dia a dia.

Com relação ao terceiro núcleo básico das FEs, a Flexibilidade Cognitiva, nesse as funções se desenvolvem como desdobramento do desenvolvimento das funções nos dois núcleos anteriores; elas remetem à capacidade de ajustar apropriadamente o próprio comportamento frente às mudanças ambientais ${ }^{27}$. A flexibilidade cognitiva nos permite mudar nosso foco de atenção de um estímulo para outro; atualizar nossas crenças com base em novas informações; considerar múltiplos elementos simultaneamente; "quebrar" pensamentos complexos em unidades mais simples; considerar perspectivas diferentes em um mesmo cenário ${ }^{28}$ ${ }^{29}{ }^{30}$. Essas habilidades também são fundamentais para uma série de tarefas do dia a dia.

As evidências científicas revelam que todas essas funções, relacionadas a estruturas neurais, estão em franco desenvolvimento durante a adolescência e que, mesmo indivíduos da mesma idade, podem diferir bastante em relação ao seu ritmo maturacional. Um atraso desenvolvimental na aquisição dessas funções pode ter origem em fatores biológicos e/ou ambientais e impossibilita ou eleva o custo de respostas apropriadas/esperadas em determinados contextos. Assim, levando em consideração que pressões e exigências sociais se impõem aos indivíduos tendo, de forma geral, como parâmetro, sua idade cronológica, muitos

17 DIAMOND, Adele. Executive functions. Annual Review of Psychology, v. 64, p. 135-168, 2013.

18 NOREEN, Saima; MACLEOD, Malcolm. What Do We Really Know about Cognitive Inhibition? Task Demands and Inhibitory Effects across a Range of Memory and Behavioural Tasks. PLoS ONE, v. 10, n. 8, 2015.

19 DELISI, Matt. Low Self-Control Is a Brain-Based Disorder. In: BEAVER, Kevin; BARNES, JC; BOUTWELL, Brian. The nurture versus biosocial debate in criminology: on the origins of criminal behavior and criminality. Thousand Oaks: Sage Publication Inc., 2014.

20 DIAMOND, Adele. Executive functions. Annual Review of Psychology, v. 64, p. 135-168, 2013.

21 DUCKWORTH, Angela; KERN, Margaret. A meta-analysis of the convergent validity of self-control measures. Journal of Research in Personality, v. 45, n. 3, p. 259-268, 2011.

22 FUJITA, Kentaro. On conceptualizing self-control as more than the effortful inhibition of impulses. Personality and Social Psychology Review, v. 15, n. 4, p. 352-366, 2011

23 GOTTFREDSON, Michael; HIRSCHI, Travis. A general theory of crime. Stanford, CA: Stanford University Press, 1990.

24 DIAMOND, Adele. Executive functions. Annual Review of Psychology, v. 64, p. 135-168, 2013.

25 BADDELEY, Alan. Working memory. Science, v. 255, n. 5044, p. 556-9, 1992.

26 DIAMOND, Adele. Executive functions. Annual Review of Psychology, v. 64, p. 135-168, 2013.

27 DIAMOND, Adele. Executive functions. Annual Review of Psychology, v. 64, p. 135-168, 2013.

28 DAJANI, Dina; UDDIN, Lucina. Demystifying cognitive flexibility: Implications for clinical and developmental neuroscience. Trends in Neurosciences, v. 38, n. 9, p. 571-578, 2015.

29 DIAMOND, Adele. Executive functions. Annual Review of Psychology, v. 64, p. 135-168, 2013.

30 HAUSER, Tobias et al. Cognitive flexibility in adolescence: Neural and behavioral mechanisms of reward prediction error processing in adaptive decision making during development. Neuroimage, v. 104, p. 347-354, 2015. 
adolescentes se encontram em situações em que não são capazes de responder conforme as expectativas sociais, independentemente de suas vontades ou esforços. O problema é que, por essa razão, muitos são submetidos a respostas ambientais também inadequadas/rígidas, que tendem a reiterar as dificuldades desses adolescentes, no plano das aquisições relacionadas às FEs.

A manifestação de comportamentos de risco, incluindo práticas desviantes, passíveis de serem tipificadas como atos infracionais, na adolescência, pode ser compreendida nessa perspectiva. Sabe-se que comportamentos delituosos, nessa etapa da vida, são comuns e, certamente, se atrelam aos processos desenvolvimentais em curso ${ }^{31}$. Na perspectiva da Criminologia Desenvolvimental, a grande questão é entender por que, para a maioria dos adolescentes, esses comportamentos tendem a ser manifestações pontuais, ao passo que, para um subgrupo, se tornam repetitivos, denotando um padrão de funcionamento (a)típico, que risca contaminar, negativamente, a trajetória desenvolvimental do indivíduo. Nessa corrente, investigações foram realizadas e, em relação às variáveis pessoais relacionadas, reiteradamente identificadas, compreendem-se as FEs como preditoras ou como moderadoras.

No âmbito do Controle Inibitório, defasagens/déficits nas funções inerentes ao controle de interferência (atenção seletiva e inibição cognitiva) e ao autocontrole (inibição comportamental e emocional), predizem delinquência juvenil, pois estas remetem a habilidades fundamentais para o aprendizado e o sucesso acadêmico ${ }^{32}$. Déficits/defasagens no autocontrole relacionam-se, ainda, com a delinquência juvenil de outras formas. Primeiramente, de modo indireto, tem-se que baixo autocontrole contribui para uma série de resultados negativos na vida, devido à propensão para falhar em engajar-se em planos de vida de mais longo prazo, como estudos, emprego e relacionamentos, o que favorece a adoção de um estilo de vida desviante ${ }^{33}$ 34 35. De modo direto, baixo autocontrole, enquanto indicador de impulsividade e desregulação emocional, concorre para a busca por satisfação imediata às próprias e/ou para reações violentas mediante frustrações, o que aumenta a suscetibilidade para ações criminosas ${ }^{36}{ }^{37}$.

No tocante à Memória de Trabalho, considerando-se o fato de as funções inerentes serem fundamentais na avaliação do risco envolvido em determinadas atividades, tem-se que defasagens/déficits nessas, de modo direto, aumentam a probabilidade de uso abusivo de $\operatorname{drogas}^{38}$ e de envolvimento em atividades delituosas ${ }^{39}$. Ademais, as defasagens / os déficits afetam o processamento de informações sociais, recurso cognitivo responsável por decodificar a intenção atribuída aos outros (hostil versus não hostil, por exemplo), na interação social, o que, também, contribui para a emissão de comportamentos violentos ${ }^{40}{ }^{41}$.

31 MOFFITT, Terrie. Male antisocial behaviour in adolescence and beyond. Nature Human Behaviour, v. 2, n. 3, p. 177-186, 2018.

32 BAZON, Marina; SILVA, Jorge; FERRARI, Renata. Trajetórias escolares de adolescents em conflito com a lei. Educação em Revista, Belo Horizonte, v. 29, n. 02, p. 175-199, 2013.

33 DELISI, Matt. Low Self-Control Is a Brain-Based Disorder. In: BEAVER, Kevin; BARNES, JC; BOUTWELL, Brian. The nurture versus biosocial debate in criminology: on the origins of criminal behavior and criminality. Thousand Oaks: Sage Publication Inc., 2014.

34 FARRINGTON, David et al. Criminal Careers Up to Age 50 and Life Success Up to Age 48: New Findings from the Cambridge Study in Delinquent Development. PsycEXTRA Dataset, 2006.

35 KOMATSU, André Vilela; BAZON, Marina Rezende. Adolescentes em conflito com a lei: justiça juvenil pela perspectiva da criminologia desenvolvimental. In: NOJIRI, S. (Org.). Direito, Psicologia e Neurociência. Ribeirão preto: IELD, 2016. 186p.

36 KOMATSU, André Vilela; BAZON, Marina Rezende. Personal Differences among Brazilian Adolescents with Distinct Levels of Engagement in Delinquency. International Journal of Criminology and Sociology, v. 6, p. 65-74, 2017.

37 WALTERS, Glenn. Low Self-Control, Peer Rejection, Reactive Criminal Thinking, and Delinquent Peer Associations: Connecting the Pieces of the Crime Puzzle. Journal of Developmental and Life-Course Criminology, v. 2, n. 2, p. 209-231, 2016.

38 PANWAR, Karni et al. Differential associations between impulsivity and risk-taking and brain activations underlying working memory in adolescents. Addictive Behaviors, v. 39, n. 11, p. 1606-1621, 2014.

39 NORDVALL, Olov; JONSSON, Bert; NEELY, Anna. Self-reported and performance-based measures of executive functions in interned youth. Psychology, Crime \& Law, v. 23, n. 3, p. 240-253, 2016.

40 FRANCO, Mariana; BAZON, Marina. Social Information Processing and Aggravation of Conduct in Young Offenders. International Annals of Criminology, v. 55, n. 01, p. 114-131, 2017.

41 MEIJERS, Jesse et al. Differences in executive functioning between violent and non-violent offenders. Psychological Medicine, v. 47, n. 10, p. 1784-1793, 2017. 
Com relação à Flexibilidade Cognitiva, defasagens/déficits predizem comportamentos delituosos e/ou violentos ${ }^{42}{ }^{43}$ porque, segundo alguns autores ${ }^{44}{ }^{45}$, estas/estes remetem a dificuldades em incorporar ideias morais e éticas abstratas nos raciocínios que subsidiam as ações sociais. Assim, indivíduos com atraso em funções de flexibilidade cognitivas acabam ajustando seus comportamentos às suas próprias demandas, especialmente sob condições estressantes, porque têm dificuldade em considerar outras perspectivas ou em captar sinais sociais, o que pode contribuir para ações ou reações inadequadas, criminais e violentas ${ }^{46}$.

Visando entender melhor como as defasagens / os déficits neurodesenvolvimentais se produzem e se relacionam com a delinquência juvenil, com vistas à consideração dessas informações na construção e na implementação de políticas públicas para a juventude, especificamente na área da Justiça Juvenil, o objetivo deste artigo é apresentar os resultados de uma revisão integrativa do conhecimento científico produzido em torno das funções executivas no que respeita ao comportamento delituoso na adolescência e discutir as implicações desse conhecimento em termos de intervenção de prevenção e de tratamento/acompanhamento socioeducativo.

\section{Método}

Há um crescente interesse em estudar a relação entre FEs e comportamento delituoso, principalmente com o advento de novos métodos e instrumentos nos campos da neurociência e da avaliação neuropsicológica. A título de exemplo, o cruzamento dos termos "executive function" com os termos "delinquen*", "offen*" ou "crime*" na base de dados Web of Science resulta em quatro produções até o ano 1999; 37 produções de 2000 a 2010; e 99 produções de 2011 até maio de 2018. Esse montante de pesquisas, embora não possa, ainda, ser considerado volumoso, já produziu um conhecimento significativo na área. Esse é, em parte, apresentado neste artigo, de forma integrada, com vistas a sumarizar os estudos levantados e estabelecer uma conclusão sobre o tema investigado. Para isso, os artigos mais recentes do indexador Web of Science (literatura internacional) e da biblioteca eletrônica Scielo Brasil (literatura nacional), dos últimos 10 anos, foram selecionados com base nos descritores supramencionados, privilegiando aqueles com métodos — instrumentos e amostras - distintos entre si, visando ilustrar as diversas formas pelas quais o objeto de investigação foi abordado e fornecer um panorama mais atual e completo possível, sem ser repetitivo. Todos os artigos selecionados têm amostra composta por adolescentes em conflito com a lei. Para melhor controlar o efeito de variáveis intervenientes, foram excluídos estudos que se propuseram a investigar adolescentes em situação de vulnerabilidade social (sem histórico de cometimento de delitos), com diagnóstico de desordem psiquiátrica e/ou com comorbidades relacionadas.

\section{Funções Executivas e Comportamentos Delituosos}

Destaca-se, primeiramente, que a grande maioria dos estudos recuperados lançou mão de testes neuropsicológicos, de base psicométrica, para avaliar diferentes aspectos das FEs. Alguns autores sublinham que os testes não devem ser considerados a medida padrão ouro das FEs e que, portanto, devem ser utilizados

42 PIHET, Sandrine et al. Cognitive and Emotional Deficits Associated with Minor and Serious Delinquency in High-Risk Adolescents. Psychiatry, Psychology and Law, v. 19, n. 3, p. 427-438, 2012.

43 VILÂ-BALLÓ, Adrià et al. Neurophysiological correlates of cognitive flexibility and feedback processing in violent juvenile offenders. Brain Research, v. 1610, p. 98-109, 2015.

44 JEVTIC, Bisera. Moral Judgement of Delinquents. Procedia: Social and Behavioral Sciences, v. 149, p. 449-455, 2014.

45 PONTIUS, Anneliese. Neurological aspects in some type of delinquency, especially among juveniles. Toward a neurological model of ethical action. Adolescence, v. 7, p. 289-308, 1972.

46 MILLER, Laurence. Neuropsychological perspectives on delinquency. Behavioral Sciences \& the Law, v. 6, p. 409-428, 1988. 
em conjunto com outras formas de coleta de dados, principalmente as observações e os crivos/as escalas de pontuação, em contextos naturais da vida do indivíduo ${ }^{47}$. Afirmam, contudo, que o método de testagem tem valor por ser rápido, econômico e não invasivo, o que viabiliza ou facilita muitas atividades, tanto de pesquisa, quanto das instituições e dos profissionais que prestam serviço de avaliação neuropsicológica. Nesses casos, defasagens em FEs podem ser detectadas com base na medida do desempenho com relação aos seguintes aspectos: tempo para a iniciação da tarefa; qualidade do planejamento e do organização do comportamento; capacidade para inibir impulsos e/ou alterar o foco da atenção e/ou em reter informações relevantes para a execução da tarefa; capacidade para corrigir os próprios erros ou usar feedbacks para mudar estratégias que não funcionam ${ }^{48}$. Assim, serão descritos e discutidos estudos que tiveram como objetivo investigar a relação entre o desempenho em FEs e o comportamento delituoso, e o fizeram por meio de testes neuropsicológicos.

Interessantemente, num dos primeiros estudos identificados, os autores Enns, Reddon, Das e Boudreau ${ }^{49}$ investigaram a existência de déficits executivos em adolescentes infratoras do sexo feminino $(\mathrm{n}=$ 100), por meio do instrumento Cognitive Assessment System (CAS), composto por um conjunto de 12 subtestes que avaliam planejamento, atenção, processamento simultâneo e processamento sucessivo. As adolescentes obtiveram desempenhos inferiores à média da população em todas as tarefas. Foi verificado maior tamanho de efeito entre o processamento sucessivo das adolescentes infratoras e não infratoras, seguidos de tamanhos de efeito médios em planejamento e na pontuação geral do CAS. Enns e colegas ${ }^{50}$ sugerem, assim, que alguns déficits neuropsicológicos específicos podem diferenciar grupos de adolescentes infratoras de não infratoras, a exemplo do que outros estudos verificariam em meio a adolescentes do sexo masculino.

No estudo de Syngelaki, Moore, Savage, Fairchild e Van Goozen ${ }^{51}$, por exemplo, diversos domínios de FEs foram investigados em adolescentes infratores do sexo masculino ( $\mathrm{n}=103$ ), comparando-os com um grupo controle $(\mathrm{n}=84)$, por meio da aplicação dos seguintes instrumentos: Wisconsin Card Sorting Test $\left(\right.$ WCST $^{52}$ - um dos testes mais usados para avaliar FEs, em específico a Habilidade de Atenção Alternada; Cambridge Neuropsychological Test Automated Battery (CANTAB), uma bateria de testes computadorizada que avalia Memória de Trabalho Espacial, Atenção Alternada e Aprendizagem Reversa, e Habilidade de Planejamento Espacial; Decision-making task (versão modificada do The Risky Choice Task - RCT) ${ }^{53}$, teste computadorizado que avalia o comportamento de tomada de risco por meio de um jogo de apostas com recompensas diferenciais. Os resultados obtidos pelo WCST indicaram maior número de erros perseverativos (que denotam insistência em um padrão de resposta, mesmo quando ele não é mais recompensado) no grupo dos adolescentes infratores, sugerindo dificuldade em alterar o próprio comportamento. A partir dos testes do CANTAB, verificou-se que os infratores cometeram mais erros nas tarefas de memória de trabalho espacial e apresentaram menos habilidades de planejamento de tarefas e para mudar o próprio comportamento.

47 BARKLEY, Russell. Executive Functions: What they are, How they work, and Why they evolve. New York: The Guilford Press, 2012.

48 STRAUSS, Esther; SHERMAN, Elisabeth; SPREEN, Otfried. A compendium of neuropsychological tests: administration, norms, and commentary. 3. ed. New York: Oxford University Press, 2016.

49 ENNS, Richard; REDDON, John; DAS, JP; BOUDREAU, Allison. Measuring executive functions in female delinquents using the Cognitive assessment system. Journal of Offender Rehabilitation, v. 47, n. 1/2, p. 3-23, 2008.

50 ENNS, Richard; REDDON, John; DAS, JP; BOUDREAU, Allison. Measuring executive functions in female delinquents using the Cognitive assessment system. Journal of Offender Rehabilitation, v. 47, n. 1/2, p. 3-23, 2008.

51 SYNGELAKI, Eva et al. Executive Functioning and risky decision making in Young male offenders. Criminal Justice and Behavior, v. 36, n. 11, p. 1213-1227. 2009.

52 O WCST é composto por cartões com diferentes formas geométricas (estrela, triângulo, círculo), em diferentes cores e quantidades. O participante deve escolher um critério para associar um cartão a outro e, após isso, ele recebe um feedback (o aplicador informa ao participante se a associação está correta ou não). Após completar uma sequência correta, a regra do teste muda (os cartões passam a ser associados de outra forma) e o feedback do aplicador ao participante também muda. Assim, o participante deve se adaptar cognitivamente a essas mudanças.

53 No RCT, o participante é apresentado a duas rodas da fortuna na tela do computador e deve escolher qual das duas proporcionará maior chance de acerto. Sem que o participante saiba, as rodas proporcionam probabilidades diferentes de ganho de pontos, assim como recompensas diferentes. 
Referente à capacidade de tomar decisões aferida pelo RCT, verificou-se maior propensão dos infratores para apostas e escolhas mais arriscadas, sobretudo depois de receber uma recompensa pequena. Observou-se, contudo, que frente a recompensas muito grandes ou muito pequenas os adolescentes infratores e não infratores se comportaram de modo semelhante.

Os autores argumentam que dificuldades em relação à aprendizagem reversa e à modulação do próprio comportamento (quando alterada a dinâmica de recompensa) e os prejuízos de memória de trabalho são consistentes com a literatura da área. A regulação do próprio comportamento e a aprendizagem reversa — com base em alterações nas demandas do ambiente — são fundamentais para o processo de controle inibitório que, por sua vez, tem importância para a capacidade de abdicar à prática de delitos, frente a oportunidades; a memória de trabalho, em seu turno, relacionar-se-ia mais com a possibilidade do adolescente ter sucesso em atividades pró-sociais, que demandam habilidades dessa natureza.

Syngelaki e colegas ${ }^{54}$, todavia, declaram que esperavam que os adolescentes do estudo formassem uma amostra heterogênea em termos de dificuldades emocionais e comportamentais, visto que, na amostra, provavelmente, havia adolescentes com padrões diferenciados de comportamento delituoso. $\mathrm{O}$ início da prática de delitos tardio (na segunda metade da adolescência) prediz um padrão que, em tese, remete a uma trajetória de implicação em delitos menos grave, geralmente menos associada a defasagens psicossociais, se comparada a trajetórias cuja prática de delitos tem início precoce (no final da infância/no início da adolescência), as quais, em geral, remetem a uma implicação em delitos mais grave, persistente ${ }^{55}$.

Levando-se em consideração esses aspectos, Muscatello e colegas ${ }^{56}$ se propuseram a estudar as FEs especificamente em adolescentes infratores $(n=147)$ de início tardio. Para tanto, utilizaram os seguintes instrumentos: WCST; Teste de Fluência Verbal ${ }^{57}$, um teste de produção verbal que avalia controle inibitório, memória de trabalho, velocidade de processamento e habilidade de planejamento; Teste de Stroop ${ }^{58}$, que contém estímulos visuais e verbais conflitantes e avalia controle inibitório e flexibilidade cognitiva. Além disso, utilizaram o Teste de Matrizes Progressivas de Raven ${ }^{59}$, que proporciona medida de funcionamento intelectual global (QI). Os infratores do estudo apresentaram desempenhos de produção na faixa clínica aquém do normativo - na tarefa de Fluência Verbal e baixa performance no WCST, ambos sinalizando prejuízo em flexibilidade cognitiva. Ademais, necessitarem de mais tempo que o esperado para responder à fase de interferência de atenção no Teste de Stroop, o que denota dificuldades no processo de controle inibitório. Ainda, identificou-se QI inferior à média.

Déficits dessa ordem não eram esperados em adolescentes cujo comportamento delituoso teria tido início na segunda metade da adolescência, remetendo a episódios mais circunscritos. Esses dados em aparente contradição com a literatura levam a pensar sobre a importância de se considerar sob quais condições os déficits executivos representam um fator implicado na manifestação do comportamento delituoso. Os

54 SYNGELAKI, Eva et al. Executive Functioning and risky decision making in Young male offenders. Criminal Justice and Behavior, v. 36, n. 11, p. 1213-1227. 2009.

55 FARRINGTON, David et al. Criminal Careers Up to Age 50 and Life Success Up to Age 48: New Findings from the Cambridge Study in Delinquent Development. PsycEXTRA Dataset, 2006.

56 MUSCATELLO, Maria et al. Executive functions and basic symptoms in adolescent antisocial behavior: A cross-sectional study on an Italian sample of late-onset offenders. Comprehensive Psychiatry, v. 55, p. 631-638, 2014.

57 No Teste de Fluência Verbal, o participante é convidado a falar, em um minuto, todas as palavras que se recorda com a letra F; depois, com a letra A e, em seguida, com a letra S. Por fim, também em um minuto, deve falar todos os nomes de animais que se recordar.

58 O Teste de Stroop é composto por três cartões de fundo branco; o Cartão A contém retângulos de diferentes cores, frente aos quais o participante deve verbalizar as cores correspondentes; o Cartão B contém palavras neutras escritas nas mesmas cores dos retângulos do Cartão A, e neste cartão o participante deve dizer os nomes das cores das palavras; O último, o Cartão C, é composto por palavras que nomeiam cores, impressas em cores diferentes, conflitantes (exemplo: a palavra "verde" escrita na cor azul), diante das quais o participante é orientado a responder da mesma forma como fez no cartão anterior, verificando as cores das palavras. $\mathrm{O}$ participante é avaliado pelo número de erros e pelo tempo de latência para completar a tarefa do Cartão C.

59 O teste é composto por 12 conjuntos de itens, dos quais o participante deve escolher uma figura entre as possíveis para completar um padrão para cada item. 
autores postularam que os déficits denotados nas FEs nesses adolescentes representariam um fator de risco para a continuidade do comportamento delituoso.

Nesse sentido Borrani, Frías, Ortiz, Garcia e Valdez ${ }^{60}$ conduziram uma investigação com objetivo semelhante aos das já descritas, lançando mão do Teste de Stroop como ferramenta de avaliação. Considerando o fato de a maior parte dos infratores apresentarem defasagem escolar, os pesquisadores, contudo, formaram grupos de adolescentes não infratores, para comparação, tendo por critério a apresentação ou não defasagem escolar. Assim, trabalharam com um grupo de adolescentes não infratores com defasagem escolar ( $\mathrm{n}=$ 27) e com outro sem defasagem escolar $(n=27)$, e com um de adolescentes infratores $(n=27)$. A justificativa refere-se ao fato de que a escolaridade tende a gerar melhores desempenhos.

Os resultados revelaram que, para o domínio de inibição comportamental, os grupos de adolescentes com defasagem escolar (infratores e não infratores) apresentram performance semelhante entre si e pior que os adolescentes não infratores com escolaridade compatível à idade, sugerindo que a baixa performance pode estar mais associada à escolaridade que ao comportamento delituoso. Para o domínio de flexibilidade cognitiva, o desempenho dos três grupos foi semelhante. Os domínios investigados não diferenciaram, portanto, adolescentes infratores de não infratores com baixa escolarização.

Os resultados de Borrani e colegas ${ }^{61}$ são interessantes à medida em que convidam à consideração de outros fatores - não discutidos/investigados — que podem proteger um grupo de se tornar infrator ou aumentar o risco para que outro grupo se torne. Contudo, ele não permite conclusões definitivas. Estas dependem de avaliações mais completas, que apreendam o funcionamento das funções neuropsicológicas em toda a sua complexidade. Neste estudo, utilizou-se, apenas, um teste. Conforme indica a revisão de Moffitt e Caspi ${ }^{6}$, nem todos os adolescentes com déficits executivos cometerão delitos porque há outras variáveis mediadoras, que podem influenciar esse comportamento. Por isso, as avaliações nesse campo devem ser realizadas e interpretadas com parcimônia, considerando-se tantos fatores quanto possível, de forma a não fomentar conclusões indevidas ${ }^{63}$.

Focalizando estudos mais específicos, atinentes à relação entre FEs e delitos de natureza específica, Miyaguchi e Shirataki ${ }^{64}$ compararam grupos de adolescentes infratores com históricos de delitos sexuais ( $\mathrm{n}$ = 55) e sem histórico de delitos sexuais $(\mathrm{n}=155)$ por meio dos seguintes instrumentos: Behavioural Assessment of the Dysexecutive Syndrome - BADS, uma bateria de seis testes que avalia déficits executivos; Wechsler Adult Intelligence Scale - Third Edition (WAIS-III; Wechsler, 1997); Wechsler Intelligence Scale for Children - Third Edition (WISC-III; Wechsler, 1991), que remete a escalas compostas por 14 subtestes que aferem o funcionamento intelectual global do adolescente e resultam em quocientes de inteligência (QI) Geral, Verbal e de Execução. Os autores controlaram a variável QI, que sabidamente é um fator que pode interferir nos resultados, identificando infratores sexuais com baixo QI $(\mathrm{n}=27)$ e com QI normativo $(\mathrm{n}=28)$, e infratores não sexuais com baixo QI $(n=105)$ e com QI normativo $(n=50)$. A partir da comparação entre os grupos de baixo QI, observou-se que os escores dos adolescentes com histórico de delitos sexuais foi significativamente menor que os dos adolescentes sem histórico de delitos sexuais no escore geral da BADS e em dois de seus subtestes: Rule Shift Cards Test (que avalia atenção alternada) e Modified Six Elements (que avalia memória prospectiva, que pode ser concebida como lembrar-se de fazer uma ação no futuro, que é um aspecto da

60 BORRANI, Jorge et al. Analysis of Cognitive inhibition and flexibility in juvenile delinquentes. The Journal of Forensic Psychiatry \& Psychology, v. 26, n. 1, p. 60-77, 2015.

61 BORRANI, Jorge et al. Analysis of Cognitive inhibition and flexibility in juvenile delinquentes. The Journal of Forensic Psychiatry \& Psychology, v. 26, n. 1, p. 60-77, 2015.

62 MOFFITT, Terrie; CASPI, Avshalom. Evidence from Behavioral Genetics for Environmental Contributions to Antisocial Conduct. In: WIKSTROM, Per-Olof; SAMPSON, Robert. Handbook of socialization: Theory and research. New York, NY, US: Guilford Press, 2007. p. 96-123.

63 URBINA, Susana. Fundamentos da testagem psicológica. Porto Alegre: Artmed, 2006.

64 MIYAGUCHI, Koji; SHIRATAKI, Sadaaki. Executive functioning problems of juveline sex offenders with low leves of measured intelligence. Journal of Intellectual \& Developmental Disability, v. 39, n. 3, p. 253-260, 2014. 
memória de trabalho). Nos subtestes das escalas Weschler, o grupo de adolescentes com histórico de delitos sexuais também teve desempenho inferior nos subtestes que avaliam Memória de Trabalho e Velocidade de Processamento. Destaca-se que não foram identificadas diferenças de desempenho entre os adolescentes de QI normativo - com e sem histórico de delitos sexuais. Essas evidências corroboram as obtidas no estudo de Muscatello e colegas ${ }^{65}$, no qual também se verificou uma relação entre déficits executivos e funcionamento intelectual global prejudicado.

Miyaguchi e Shirataki ${ }^{66}$ apontam que é provável que os adolescentes com histórico de delitos sexuais e baixo QI tenham mais defasagens desenvolvimentais que os adolescentes com histórico de delitos sexuais e QI normativo, ou que esse último grupo tenha o impacto das defasagens diminuído em função do QI mais alto. Dado que as evidências desta pesquisa se centraram, especialmente, nos déficits em habilidades de controle de interferência e em memória de trabalho, construtos que têm relação indireta com as manifestações comportamentais da delinquência, depreende-se que esses déficits, associados ao baixo QI, atuem mais no sentido de compor um quadro de desvantagens psicossociais que dificultam que o adolescente desenvolva comportamentos pró-sociais.

Burton, Demuynck e Yoder ${ }^{67}$ também investigaram a relação entre o funcionamento executivo e o cometimento de delitos sexuais. Uma amostra de adolescentes infratores $(\mathrm{n}=165)$ apreendidos pelo cometimento de delitos sexuais foi avaliada ${ }^{68}$ pelo Behavior Rating Inventory of Executive Function - Self Report (BRIEF-SR), versão autoaplicável do questionário que avalia os prejuízos decorrentes dos déficits executivos; pelo Self Report Delinquency (SRD), questionário que investiga os delitos que a pessoa já cometeu ao longo da vida; e pelo Self Report Sexual Aggression Scale (SERSAS), um inventário que investiga os comportamentos sexuais agressivos/violentos cometidos ao longo da vida. Não foram encontradas correlações entre as escalas do BRIEF e os delitos não sexuais cometidos. No entanto, foram encontradas correlações moderadas e pequenas entre os domínios de Inibição Comportamental e de Habilidades de Solução de Problemas da BRIEF e os delitos de natureza sexual. A falta de inibição comportamental/autocontrole pode ter influência direta e/ou indireta no desenvolvimento de condutas delituosas, conforme já apontado. O déficit em habilidades de solução de problemas, por seu turno, especialmente em relação ao domínio de flexibilidade cognitiva, ao dificultar o desenvolvimento de estilos pró-sociais efetivos, para resolver as demandas pessoais e relacionais, aumenta o risco de o adolescente adotar estilos antissociais, o que lhe torna vulnerável ao envolvimento em práticas ilegais — violentas e criminalizadas.

Por fim, destaca-se o estudo de Vilà-Balló, Hdez-Lafuente, Rostan, Cunillera e Rodriguez-Fornells ${ }^{69}$, no qual se empregou uma metodologia diferente daquela utilizada nas outras investigações para a aferição das FEs apresentadas neste artigo. Os autores estudaram a atividade eletrofisiológica correspondente aos déficits das FEs em adolescentes infratores, por meio da aferição de potenciais elétricos esperados frente a situações em que se processa um feedback negativo ou se verifica a necessidade de inibir o próprio comportamento. Com isso, verificaram que os adolescentes violentos tiveram mais dificuldade nas tarefas que exigiam detecção de erros e inibição do próprio comportamento, comparados a adolescentes infratores não violentos. Esses resultados corroboram a tese de que dificuldades na captação de sinais sociais e na inibição comportamental aumentam as chances de se comportar de forma violenta em determinados contextos.

65 MUSCATELLO, Maria et al. Executive functions and basic symptoms in adolescent antisocial behavior: A cross-sectional study on an Italian sample of late-onset offenders. Comprehensive Psycbiatry, v. 55, p. 631-638, 2014.

66 MIYAGUCHI, Koji et al. Cognitive training for delinquents within a residential service in Japan. Children and Youth Services Review, v. 34, n. 9, p. 1762-1768, 2012.

67 BURTON, David; DEMUYNCK, Sophia; YODER, Jamie. Executive Dysfunction predicts delinquency but not characteristic of sexual agression among adolescent sexual offenders. Sexual Abuse: A Journal of Research and Treatment, v. 28, n. 8, p. 707-721, 2016.

68 Os instrumentos utilizados neste estudo são de autorrelato; contém perguntas referentes a comportamentos passados, frente as quais o respondente deve declarar sua ocorrência e/ou frequência.

69 VILÀ-BALLÓ, Adrià et al. Neurophysiological correlates of cognitive flexibility and feedback processing in violent juvenile offenders. Brain Research, v. 1610, p. 98-109, 2015. 
Em suma, o conjunto dos resultados das investigações relativas às FEs indica que elas, embora possam não ser a causa do delito, explicam algumas variações no comportamento individual. Assim, as investigações nesse campo são relevantes - em especial as que ponderam sobre as condições em que as FEs contam para o desenvolvimento do comportamento social. As evidências mais consistentes, advindas de estudos empregando diferentes metodologias/instrumentos, revelam que o domínio mais vezes associado ao comportamento delituoso é o da autorregulação / do autocontrole. Ao lado das outras funções cognitivas, a autorregulação / o autocontrole é uma das variáveis pessoais, talvez a de maior peso, relacionadas à resiliência mediante a exposição dos indivíduos a fatores de risco ambientais específicos para a delinquência ${ }^{70}$. Dessa forma, indivíduos com capacidades elevadas de autorregulação são menos suscetíveis às influências exercidas pelos pares de idade e menos propensos a agirem de forma impulsiva, conseguindo exercer maior controle sobre as contingências contextuais. Além disso, conseguem mais facilmente engajarem-se em atividades pró-sociais e serem bem-sucedidos nelas, o que gera experiências positivas que reforçam a opção por um estilo de vida pró-social, o que suscita um ciclo positivo de comportamentos socialmente ajustados e vivências reforçadoras. Ademais, embora os estudos não sejam homogêneos quanto aos déficits encontrados nas FEs, em infratores, os dados levam a crer que a dificuldade de regular o comportamento em função da sensibilidade diferencial à recompensa e à punição é muito relevante no desenvolvimento do comportamento delituoso ${ }^{71}$.

Tais constatações podem ter importantes implicações em intervenções com adolescentes em conflito com a lei. Com o objetivo de explorar as possibilidades já aventadas nesse campo, expõem-se a seguir, brevemente, as abordagens e as técnicas atinentes às FEs, usualmente empregadas em programas de prevenção e de tratamento concernentes ao envolvimento de adolescentes com prática de delitos.

\section{IMPLICAÇÕES DO CONHECIMENTO SOBRE AS FES EM INTERVENÇÕES EM DELINQUÊNCIA JUVENIL}

A neuroplasticidade na adolescência atinge níveis que não se repetirão nas fases posteriores da vida ${ }^{72}$, o que torna os adolescentes potencialmente capazes de se adaptarem às mais diversas situações. $\mathrm{O}$ sentido do termo "adaptação", utilizado nesta seção deste artigo, não necessariamente representa "a forma ideal de enfrentar um determinado problema"; trata-se mais propriamente do processo de ajuste do indivíduo ao meio em que está inserido e dos resultados que decorrem, podendo ser um ajuste pró-social e/ou saudável ou antissocial e/ou patológico. Em outras palavras, a adolescência, por ser um período de alta suscetibilidade aos estímulos ambientais, é, em si mesmo, um momento de vulnerabilidade para o surgimento de problemas de comportamento e até mesmo de transtornos mentais, em face à adaptação que se processa a ambientes precários, violentos, hostis e/ou criminalizados.

Os estudos estimam que um em cada cinco adolescentes tem algum transtorno mental que persistirá na vida adulta, como transtornos de humor, de controle de impulsos, de uso de substâncias e de conduta ${ }^{73}$

\footnotetext{
70 MOFFITT, Terrie et al. A gradient of childhood self-control predicts health, wealth, and public safety. Proceedings of the National Academy of Sciences, v. 108, n. 7, p. 2693-2698, 2011.

71 SYNGELAKI, Eva et al. Executive Functioning and risky decision making in Young male offenders. Criminal Justice and Behavior, v. 36, n. 11, p. 1213-1227, 2009.

72 LEE, Francis et al. Adolescent mental health-Opportunity and obligation: Emerging neuroscience offers hope for treatments. Science, New York, v. 346, n. 6209, p. 547-549, 2014.

73 KAUFMANN, Tobias et al. Delayed stabilization and individualization in connectome development are related to psychiatric disorders. Nature Neuroscience, v. 20, n. 4, p. 513-515, 2017.
} 
74 75. Um relatório da Organização Mundial de Saúde ${ }^{76}$ revela que os gastos relacionados ao tratamento de transtornos mentais que surgem antes da vida adulta são cerca de 10 vezes maiores que os relacionados a transtornos que surgem durante a vida adulta. Assim, em uma primeira instância, é de suma importância evitar o surgimento dessas condições ou detectá-las precocemente de modo a aumentar as chances de sucesso da intervenção ${ }^{77}{ }^{78}$.

Com esse intuito, descrevem-se modalidades de ações, baseadas em evidências, que têm como objetivo promover o desenvolvimento das FEs e, assim, contribuir para a proteção da população infanto-juvenil contra uma série de problemáticas de ordem afetiva, cognitiva e comportamental. Essas ações implicam modificações ambientais e podem ser categorizadas em dois eixos: 1. Prevenção em âmbito familiar e escolar; 2. Tratamento em contextos específicos. A primeira ação é de cunho preventivo e prevê atuações nos contextos em que as crianças e os adolescentes passam a maior parte de seu tempo: em casa e na escola. É consenso entre os pesquisadores que políticas de prevenção são as medidas de melhor custo-benefício para a problemática da delinquência juvenil. ${ }^{79} \mathrm{~A}$ segunda é de caráter interventivo, e se faz necessária quando a prevenção falhou e os problemas decorrentes das defasagens/dos déficits desenvolvimentais aparecem; estas são, porém, mais custosas e requerem a atuação de profissionais mais especializados.

A prevenção em âmbito familiar deve ocorrer, primariamente, por meio dos adultos responsáveis pela socialização da criança. O Centro da Criança em Desenvolvimento da Universidade de Harvard ${ }^{80}$ disponibiliza na internet um guia gratuito de atividades que estimulam as FEs em crianças e adolescentes que podem ser incorporados às práticas parentais. Essas atividades foram desenvolvidas com base em estudos científicos, cujos detalhes são especificados em cada um dos guias disponíveis em sua página na internet. As atividades variam de estimulações sensoriais em bebês a jogos de imaginação, interpretação e de contar histórias na infância e a jogos de cartas e de tabuleiros que envolvem raciocínios lógicos e abstratos para adolescentes. Complementarmente, Galisnky ${ }^{81}$, em seu livro, aborda sete habilidades de vida essenciais a toda criança: foco e autocontrole; pensamento em perspectiva; comunicação; construir conexões; pensamento crítico; enfrentamento de problemas; aprendizado autônomo e engajado. O livro possui linguagem simples e serve como um guia instrutivo para pais/responsáveis que desejam estimular essas habilidades em seus filhos.

Um ponto crítico da ação preventiva com foco nas FEs refere-se ao fato de que não se tem a situação ideal em que todos os pais/responsáveis buscam por livre e espontânea vontade se informar e se formar a respeito dessas práticas estimuladoras e protetivas para o desenvolvimento da criança e do adolescente. Nesse sentido, uma medida conveniente seria estimular seu interesse pela temática por meio da confecção e do compartilhamento de cartilhas e de vídeos informativos, mostrando o que são, qual a importância e como é possível estimular as FEs. Uma segunda medida seria preparar profissionais da educação e da saúde, como os dos programas de Saúde da Família, para instruírem e incentivarem os cuidadores — pais/responsáveis — a respeito das FEs e das práticas educativas que podem adotar para estimulá-las ${ }^{82}$.

74 LEE, Francis et al. Adolescent mental health-Opportunity and obligation: Emerging neuroscience offers hope for treatments. Science, New York, v. 346, n. 6209, p. 547-549, 2014.

75 PAUS, Tomás; KESHAVAN, Matcheri; GIEDD, Jay. Why do many psychiatric disorders emerge during adolescence? Nature Reviews Neuroscience, v. 9, n. 12, p. 947-957, 2008.

76 ORGANIZAÇÃO MUNDIAL DA SAÚDE (OMS). Economic Aspects of Mental Health in Children and Adolescents. Geneva: WHO, 2007.

77 BEECHAM, Jennifer. Annual Research Review: Child and adolescent mental health interventions: A review of progress in economic studies across different disorders. Journal of Child Psychology and Psychiatry, v. 55, n. 6, p. 714-732, 2014.

78 LOEBER, Rolf; FARRINGTON, David; WASCHBUSCH, Daniel. Serious and Violent Offenders. In: LOEBER, Ralf; FARRINGTON, Davis. (Ed.) Serious and violent juvenile offenders: risk factors and successful interventions. Thousand Oaks, CA: Sage, 1998. 79 LOEBER, Rolf; FARRINGTON, David; WASCHBUSCH, Daniel. Serious and Violent Offenders. In: LOEBER, Ralf; FARRINGTON, Davis. (Ed.) Serious and violent juvenile offenders: risk factors and successful interventions. Thousand Oaks, CA: Sage, 1998. 80 CENTER ON THE DEVELOPING CHILD AT HARVARD UNIVERSITY. Enhancing and practicing executive function skills with children from infancy to adolescence. 2014.

81 GALINSKY, Ellen. Mind in the making: the seven essential life skills every child needs. Harper Collins E-books, 2010.

82 MEUWISSEN, Alyssa; ENGLUND, Michelle. Executive function in at-risck children: importance of father-figure support 
Outro espaço estratégico para promover práticas preventivas é diretamente na escola. Segundo Meltzer e Basho ${ }^{83}$, é possível criar ambientes escolares em que os processos das FEs sejam focalizados e possam ser sistematicamente estimulados, compondo, assim, um tema transversal nos currículos. Com base em resultados do Instituto de Pesquisa para Aprendizagem e Desenvolvimento e revisões metanalíticas da literatura, as autoras descrevem um programa para instrumentalizar os profissionais da educação que desejem implantar esse tipo de "cultura" em sala de aula ou na escola. A ideia é que os profissionais consigam adaptar os princípios gerais da implementação da estimulação das FEs em ambiente escolar ao contexto de suas próprias escolas, começando pela avaliação das capacidades executivas de cada aluno. Sugerem que, a partir disso, se pode estabelecer uma estratégia de desenvolvimento de FEs essenciais ao aprendizado e ao sucesso acadêmico como o estabelecimento, o planejamento e a priorização de tarefas ${ }^{84}$; a manipulação mental de informações ${ }^{85}$; a flexibilidade cognitiva para solução de problemas $^{86}$; o automonitoramento e a autorregulação emocional ${ }^{87}$ ${ }^{88}$. Essas aquisições não apenas protegem o aluno de fracassar e evadir a escola como também podem ser generalizadas a outros contextos, formando indivíduos resilientes a uma série de problemáticas da vida.

A segunda modalidade de atuação remete às intervenções necessárias quando o adolescente já apresenta algum prejuízo socioemocional, que pode ser decorrente de alguma disfunção executiva. Refere-se, assim, a intervenções de prevenção secundária ou de tratamento. Em alguns casos, sem desconsiderar aspectos sociais e contextuais relevantes da vida do indivíduo, a defasagem desenvolvimental pode ter se acumulado de modo a participar como fator relevante à implicação do adolescente com a prática de delitos. Nessa situação, o primeiro procedimento é a realização de uma avaliação fundada em instrumentos confiáveis e a validação ecológica dos resultados por meio da verificação de sua compatibilidade com o que se observa na vida real do adolescente ${ }^{89}$. Substanciado pela avaliação, um plano interventivo deve ser elaborado com o objetivo de suprir as necessidades desenvolvimentais do adolescente, devendo este ser, ao mesmo tempo, compatível com suas capacidades e com o seu contexto de vida.

No caso dos adolescentes em conflito com a lei, tais condições são previstas pelo Estatuto da Criança e do Adolescente ${ }^{90}$ e pelo Sistema Nacional de Atendimento Socioeducativo ${ }^{91}$. Todavia, o Estatuto da Criança e do Adolescente (ECA), no seu artigo 112, prescreve que "A medida aplicada ao adolescente levará em conta a sua capacidade de cumpri-la, as circunstâncias e a gravidade da infração", ante a falta de fundamentação científica apropriada, tem gerado práticas no âmbito de todo o sistema de justiça juvenil que riscam se nortear por critérios totalmente subjetivos (para não dizer discricionários), ou que se assentam quase que exclusivamente na apreciação das "circunstâncias e da gravidade da infração", à luz de critérios jurídicos".

and mother parenting. Journal of Applied Developmental Psychology, v. 44, p. 72-80, 2016.

83 MELTZER, Lynn; BASHO, Surina. Creating a Classroomwide Executive Function Culture That Fosters Strategy Use, Motivation, and Resilience. In: MELTZER, Lynn (Ed.). Promotin executive functions in the classroom. New York: Guildford Press, 2010. p. 28-52.

84 KRISHNAN, Kalyani; FELLER, Melissa; ORKIN, Melissa. Goal Setting, Planning, and Prioritizing: The Foundations of Effective Learning. In: MELTZER, Lynn (Ed.). Promotin executive functions in the classroom. New York: Guildford Press, 2010. p. 57-85. 85 KINCAID, Donna; TRAUTMAN, Nancy. Remembering: Teaching Students How to Retain and Mentally Manipulate Information. In: MELTZER, Lynn (Ed.). Promotin executive functions in the classroom. New York: Guildford Press, 2010. p. 110-139.

86 MELTZER, Lynn; BAGNATO, Jennifer. Shifting and Flexible Problem Solving: The Anchors for Academic Success. In: MELTZER, Lynn (Ed.). Promotin executive functions in the classroom. New York: Guildford Press, 2010. p. 140-159.

87 BAGNATO, Jennifer; MELTZER, Lynn. Self- Monitoring and Self- Checking: The Cornerstones of Independent Learning. In: MELTZER, Lynn (Ed.). Promotin executive functions in the classroom. New York: Guildford Press, 2010. p. 160-173.

88 STEIN, Judith. Emotional Self- Regulation: A Critical Component of Executive Function. In: MELTZER, Lynn (Ed.). Promotin executive functions in the classroom. New York: Guildford Press, 2010. p. 175-201.

89 BARKLEY, Russell. Executive functions: what they are, how they work, and why they evolve. New York: The Guilford Press, 2012.

90 BRASIL. Estatuto da criança e do adolescente. São Paulo: Atlas, 1991.

91 BRASIL. Lei n. 12.594, de 18 de janeiro de 2012. Disponível em: <http://www.planalto.gov.br/ccivil_03/_ato2011-2014/2012/ lei/112594.htm>. Acesso em: 17 abr. 2018.

92 MARUSCHI, Maria Cristina; BAZON, Marina. Justiça Juvenil: a aplicação e a execução das medidas socioeducativas pelos parâmetros do modelo "risco-necessidade-responsividade". Rio de Janeiro: Instituto INNOVARE, 2014. v. 1. p. 42-72. 
Conforme indicam Komatsu e Bazon ${ }^{93}$, no contexto sociocultural brasileiro, ainda, se padece da falta de referenciais teóricos e metodológicos consistentes, e parâmetros confiáveis para a devida interpretação do que seria a "capacidade de cumprir" a medida.

Na perspectiva da neurociência, o estado de funcionamento do próprio indivíduo deveria ser considerado enquanto parte das circunstâncias e da gravidade da infração. Conforme se argumentou anteriormente, muitas crianças e adolescentes não são capazes de atingir um nível de autorregulação comportamental necessário para evitar infringir as regras ou as leis em face às condições ambientais em que estão inseridos. Isto não significa ser complacente com todo e qualquer comportamento dos jovens sob a justificativa de que eles não são ainda capazes de fazer diferente. Ao contrário, implica elaborar e propor respostas jurídicas e socais contingentes e consistentes frente aos comportamentos indesejáveis.

McCloskey, Perkins e Van Diviner ${ }^{94}$ salientam que é muito difícil para algumas figuras de autoridade aceitar que as consequências que devem ser aplicadas aos comportamentos indesejáveis de um jovem sejam outras que a punição. Para os autores, essa dificuldade baseia-se na crença de que não punir comportamentos errados "ensina" os jovens que eles podem fazer o que quiserem; ou que os jovens obedientes se sentiriam injustiçados vendo outros fazerem coisas erradas sem serem punidos. Nesse sentido, uma consequência punitiva suscita um sentimento de justiça no agente da punição ou na sociedade ${ }^{95}$; mas, em muitos casos, ela não é capaz de gerar o comportamento desejável no indivíduo punido ${ }^{96}{ }^{97}$. Nessas situações, a solução seria promover competências no infrator para que ele consiga se comportar de forma apropriada e ter a oportunidade de ser reforçado positivamente por isso. É com base nessa lógica que surge a necessidade de intervenções diferenciadas focalizadas nas necessidades de autoregulação de cada indivíduo.

Para McCloskey, Perkins e Van Diviner ${ }^{98}$, a intervenção em relação às dificuldades executivas tem três premissas básicas: 1. as dificuldades nas funções executivas estão relacionadas a um sub funcionamento do cérebro; 2. as funções cerebrais podem ser alteradas por meio de intervenções; 3. as intervenções podem ativar funções intactas do cérebro. Dessa forma, considera-se que a plasticidade cerebral - capacidade do cérebro em mudar sua organização e seu funcionamento com base em atividades e experiências anteriores - é a base sobre a qual se propõe um treinamento/uma intervenção de prevenção secundária (ou tratamento) $)^{99} 100$.

A ideia básica de uma intervenção dessa natureza é a de que os indivíduos podem melhorar suas performances se experimentarem condições que ativem repetidamente regiões neurais envolvidas na execução de tarefas que requerem a função de interesse, por meio de um treinamento regular, durante um período suficientemente extenso ${ }^{101} 102$. Como consequência, o efeito do treinamento pode se generalizar para outras

93 KOMATSU, André Vilela; BAZON, Marina Rezende. Adolescentes em conflito com a lei: justiça juvenil pela perspectiva da criminologia desenvolvimental. In: NOJIRI, S. (Org.). Direito, Psicologia e Neurociência. Ribeirão preto: IELD, 2016. 186p.

94 MCCLOSKEY, George; PERKINS, Lisa; VAN DIVINER, Bob. Assessment and Intervention for Executive Function Difficulties. New York: Routledge, 2009.

95 Dias e Custódio oferecem uma crítica sobre como o discurso punitivo relacionado a crianças e adolescentes não só está enraizado no ideário popular, como também afeta a agenda política brasileira: DIAS, Felipe da Veiga; CUSTÓDIO, André Viana. O discurso expansivo-punitivo dos meios de comunicação e sua influência na formação da agenda das políticas públicas de combate à criminalidade de crianças e de adolescentes no Brasil. Rev. Bras. Polít. Públicas, Brasília, v. 3, n. 1, p. 91-104, 2013.

96 GERSHOFF, Elizabeth. Corporal punishment by parents and associated child behavior and experiences: A meta-analysis and theoretical review. Psychological Bulletin, v. 128, p. 539-579, 2002.

97 SKINNER, Burrhus Frederic. About Behaviorism. New York: Knopf, 1974.

98 MCCLOSKEY, George; PERKINS, Lisa; VAN DIVINER, Bob. Assessment and Intervention for Executive Function Difficulties. New York: Routledge, 2009.

99 DIAMOND, Adele; LING, Daphne. Conclusions about interventions, programs, and approaches for improving executive functions that appear justified and those that, despite much hype, do not. Developmental Cognitive Neuroscience, v. 18, p. 34-48, 2016.

100 ROMERO, María. Executive control enhancement and cognitive training. 2017. Tese (Doutorado), Universidad de Granada, Granada, 2017.

101 ROMERO, María. Executive control enhancement and cognitive training. 2017. Tese (Doutorado) - Universidad de Granada, Granada, 2017.

102 STOKES, Mark; BUSCHMAN, Timothy; MILLER, Earl. Dynamic Coding for Flexible Cognitive Control. The Wiley Hand- 
tarefas que não foram treinadas, mas que fazem parte do mesmo domínio funcional ${ }^{103}$. A noção do efeito generalizador da estimulação de circuitos neurais foi testada em uma série de intervenções e os resultados mostraram efeitos positivos 104105106107.

De maneira geral, os programas de intervenção indicam exercitar as mesmas áreas que os programas de prevenção; a diferença subjaz na importância de o tratamento focar nas necessidades pessoais específicas, identificadas como defasadas/deficitárias no beneficiário da intervenção. Com base em estudos experimentais, inúmeros programas se mostraram efetivos em melhorar a performance das FEs: jogos computadorizados que exercitam a memória de trabalho (aplicativos com esse tipo de jogo possuem versões gratuitas na internet ${ }^{108}$; jogos de tabuleiros que estimulam o raciocínio lógico ${ }^{109}$; exercícios aeróbicos e a prática esportiva, desde que associados a algum treinamento cognitivo ${ }^{110}{ }^{111}$; prática de Yoga e de Mindfullness ${ }^{112}{ }^{113}$; exercícios cognitivos de papel e caneta ${ }^{114}$; psicoterapia cognitivas e comportamentais ${ }^{115}$.

Contudo, as evidências mostram que a estimulação das FEs não é igualmente efetiva para todas as pessoas, não ficando claro nos estudos por que algumas pessoas se beneficiam mais que outras. Isso tem implicações importantes na eficácia da intervenção individual no mundo real. A esse respeito, Diamond e Ling ${ }^{116}$ argumentam que há, certamente, outros fatores influenciando nesse processo. Os autores indicam que, sendo as FEs reguladas, principalmente, pelo córtex pré-frontal (CPF), a área evolutivamente mais jovem do cérebro, elas são muito vulneráveis a situações de estresse, tristeza, solidão e má condição física. Sabe-se que as tarefas que exigem raciocínio, autocontrole e adaptação à mudança são melhor desempenhadas quando o indivíduo está menos estressado, quando se sente socialmente e emocionalmente acolhido e quando está bem de saúde (incluindo qualidade do sono). Por conseguinte, Diamond e Ling ${ }^{117}$ hipotetizam que as intervenções mais bem-sucedidas são aquelas que estimulam não somente as FEs, diretamente, mas sim as que incluem também estratégias que indiretamente reduzem os fatores que impactam, negativamente, o CPF e promovem os fatores que impactam, positivamente, o CPF. Todos esses fatores deveriam ser levados em consideração na determinação e na execução das medidas socioeducativas aos adolescentes em conflito com a lei.

book of Cognitive Control, p. 221-241, 2017.

103 ROMERO, María. Executive control enhancement and cognitive training. 2017. Tese (Doutorado) - Universidad de Granada, Granada, 2017.

104 DIAMOND, Adele. Executive functions. Annual Review of Psychology, v. 64, p. 135-168, 2013.

105 DIAMOND, Adele; LING, Daphne. Conclusions about interventions, programs, and approaches for improving executive functions that appear justified and those that, despite much hype, do not. Developmental Cognitive Neuroscience, v. 18, p. 34-48, 2016.

106 ENRIQUEZ-GEPPERT, Stefanie; HUSTER, René; HERRMANN, Christoph. Boosting brain functions: Improving executive functions with behavioral training, neurostimulation, and neurofeedback. International Journal of Psychophysiology, v. 88, n. 1, p. 1-16, 2013.

107 MCCLOSKEY, George; PERKINS, Lisa; VAN DIVINER, Bob. Assessment and Intervention for Executive Function Difficulties. New York: Routledge, 2009.

108 DIAMOND, Adele. Executive functions. Annual Review of Psychology, v. 64, p. 135-168, 2013.

109 DIAMOND, Adele; LEE, Kathleen. Interventions shown to Aid Executive Function Development in Children 4-12 Years Old. Science, New York, v. 333, n. 6045, p. 959-964, 2011.

110 DIAMOND, Adele. Executive functions. Annual Review of Psychology, v. 64, p. 135-168, 2013.

111 DIAMOND, Adele; LING, Daphne. Conclusions about interventions, programs, and approaches for improving executive functions that appear justified and those that, despite much hype, do not. Developmental Cognitive Neuroscience, v. 18, p. 34-48, 2016.

112 DIAMOND, Adele; LEE, Kathleen. Interventions shown to Aid Executive Function Development in Children 4-12 Years Old. Science, New York, v. 333, n. 6045, p. 959-964, 2011.

113 DIAMOND, Adele; LING, Daphne. Conclusions about interventions, programs, and approaches for improving executive functions that appear justified and those that, despite much hype, do not. Developmental Cognitive Neuroscience, v. 18, p. 34-48, 2016.

114 MIYAGUCHI, Koji et al. Cognitive training for delinquents within a residential service in Japan. Children and Youth Services Review, v. 34, n. 9, p. 1762-1768, 2012.

115 MCCLOSKEY, George; PERKINS, Lisa; VAN DIVINER, Bob. Assessment and Intervention for Executive Function Difficulties. New York: Routledge, 2009.

116 DIAMOND, Adele; LING, Daphne. Conclusions about interventions, programs, and approaches for improving executive functions that appear justified and those that, despite much hype, do not. Developmental Cognitive Neuroscience, v. 18, p. 34-48, 2016. 117 DIAMOND, Adele; LING, Daphne. Conclusions about interventions, programs, and approaches for improving executive functions that appear justified and those that, despite much hype, do not. Developmental Cognitive Neuroscience, v. 18, p. 34-48, 2016. 


\section{Considerações Finais}

A adolescência é um período de grandes transformações neurodesenvolvimentais. Pela plasticidade que lhe é inerente, representa, ao mesmo tempo, um recurso e uma vulnerabilidade. As transformações em curso apresentam-se como um "período sensível", ou seja, um período em que a aprendizagem de habilidades ou desenvolvimento de aptidões e competências se faz de modo intenso e mais fácil. Assim, de um lado, se os estímulos ambientais existem e são adequados, o adolescente faz aquisições que lhe permitirá lidar de modo cada vez mais competente com as complexas demandas psicossociais. De outro lado, se os estímulos ambientais não existem ou são inadequados, haverá defasagens/déficits que perpassarão sua adaptação psicossocial, concorrendo para a emergência de inúmeros problemas de comportamento e, até mesmo, transtornos mentais. Sem a estimulação adequada, o desenvolvimento dos circuitos neurais pode sofrer um atraso, limitando as capacidades executivas do adolescente e aumentando sua dificuldade em responder apropriadamente às demandas sociais.

Em relação a essa perspectiva, no presente artigo buscou-se integrar os conhecimentos científicos acerca das principais FEs relacionadas ao comportamento delituoso, no escopo do desenvolvimento do adolescente. As FEs são importantes para o funcionamento adaptativo em praticamente todas as esferas da vida. Defasagens/déficits nas FEs podem se relacionar com a prática delituosa de forma indireta e direta. $\mathrm{Na}$ forma indireta, disfunções executivas contribuem para a existência de dificuldades de ajustamento ao meio acadêmico e também ao laboral, que aumentam as chances de o adolescente se afastar dessas instituições sociais, de regulação da conduta e, assim, se envolver com práticas divergentes e/ou delituosas. $\mathrm{Na}$ forma direta, disfunções executivas, especialmente no plano do controle de impulsos, contribuem para a emissão de delitos específicos e para a violência.

A literatura sugere que as FEs podem ser estimuladas e desenvolvidas. Assim, buscou-se igualmente pontuar ações específicas para diminuir os fatores de risco e promover os fatores de proteção em relação ao desenvolvimento pleno das FEs. As ações preventivas podem ser aplicadas desde os primeiros meses de vida até à adolescência e possuem como foco os contextos familiar e escolar, em que as crianças passam a maior parte de seu tempo. As ações de tratamento (ou de prevenção secundária) devem ser mais específicas, no sentido de focalizar as FEs mais diretamente relacionadas aos problemas manifestos, e mais duradouras, além de levar em consideração fatores contraproducentes ao desenvolvimento das FEs, como o estresse, o isolamento social/emocional e a saúde como um todo.

Por último, é preciso destacar que, a despeito da velocidade com a qual as ciências relacionadas ao desenvolvimento humano estão progredindo, com o advento de novas tecnologias e métodos de investigação, oferecendo muito conhecimento útil, pouco ou quase nada foi incorporado às legislações e às políticas públicas brasileiras. Assim, o desafio imediato consiste em envidar esforços para que haja maior difusão e integração desse tipo de conhecimento.

\section{REFERÊNCIAS}

ARAIN, Mariam et al. Maturation of the adolescent brain. Neuropsychiatric Disease and Treatment, v. 9, p. 449461, 2013.

BADDELEY, Alan. Working memory. Science, v. 255, n. 5044, p. 556-9, 1992.

BAGNATO, Jennifer; MELTZER, Lynn. Self- Monitoring and Self- Checking: The Cornerstones of Independent Learning. In: MELTZER, Lynn (Ed.). Promotin executive functions in the classroom. New York: Guildford Press, 2010. p. 160-173. 
BARKLEY, Russell. Executive functions: what they are, how they work, and why they evolve. New York: The Guilford Press, 2012.

BAZON, Marina; SILVA, Jorge; FERRARI, Renata. Trajetórias escolares de adolescents em conflito com a lei. Educação em Revista, Belo Horizonte, v. 29, n. 02, p. 175-199. 2013.

BEECHAM, Jennifer. Annual research review: child and adolescent mental health interventions: a review of progress in economic studies across different disorders. Journal of Child Psychology and Psychiatry, v. 55, n. 6, p. 714-732, 2014.

BORRANI, Jorge et al. Analysis of Cognitive inhibition and flexibility in juvenile delinquentes. The Journal of Forensic Psychiatry \& Psychology, v. 26, n. 1, p. 60-77, 2015.

BRASIL. Estatuto da criança e do adolescente. São Paulo: Atlas, 1991.

BRASIL. Lei n. 12.594, de 18 de janeiro de 2012. Disponível em: <http://www.planalto.gov.br/ccivil_03/_ ato2011-2014/2012/lei/112594.htm>. Acesso em: 17 abr. 2018.

BURTON, David; DEMUYNCK, Sophia; YODER, Jamie. Executive Dysfunction predicts delinquency but not characteristic of sexual agression among adolescent sexual offenders. Sexual Abuse: A Journal of Research and Treatment, v. 28, n. 8, p. 707-721, 2016

CENTER ON THE DEVELOPING CHILD AT HARVARD UNIVERSITY. Enhancing and practicing executive function skills with children from infancy to adolescence. 2014. Disponível em: <https://children.wi.gov/Documents/Harvard\%20Parenting\%20Resource.pdf>. Acesso em: 18 abr. 2018.

DAJANI, Dina; UDDIN, Lucina. Demystifying cognitive flexibility: Implications for clinical and developmental neuroscience. Trends in Neurosciences, v. 38, n. 9, p. 571-578, 2015.

DELISI, Matt. Low Self-Control Is a Brain-Based Disorder. In: BEAVER, Kevin; BARNES, JC; BOUTWELL, Brian. The nurture versus biosocial debate in criminology: on the origins of criminal behavior and criminality. Thousand Oaks: Sage Publication Inc., 2014. p. 172-183.

DIAMOND, Adele. Executive functions. Annual Review of Psychology, v. 64, p. 135-168, 2013.

DIAMOND, Adele; LEE, Kathleen. Interventions shown to aid executive function development in children 4-12 years old. Science, New York, v. 333, n. 6045, p. 959-964, 2011.

DIAMOND, Adele; LING, Daphne. Conclusions about interventions, programs, and approaches for improving executive functions that appear justified and those that, despite much hype, do not. Developmental Cognitive Neuroscience, v. 18, p. 34-48, 2016.

DIAS, Felipe da Veiga; CUSTÓDIO, André Viana. O discurso expansivo-punitivo dos meios de comunicação e sua influência na formação da agenda das políticas públicas de combate à criminalidade de crianças e de adolescentes no Brasil. Rev. Bras. Polít. Públicas, Brasília, v. 3, n. 1, p. 91-104, 2013.

DUCKWORTH, Angela; KERN, Margaret. A meta-analysis of the convergent validity of self-control measures. Journal of Research in Personality, v. 45, n. 3, p. 259-268, 2011.

ENNS, Richard et al. Measuring executive functions in female delinquents using the Cognitive assessment system. Journal of Offender Rehabilitation, v. 47, n. 1/2, p. 3-23, 2008.

ENRIQUEZ-GEPPERT, Stefanie; HUSTER, René; HERRMANN, Christoph. Boosting brain functions: Improving executive functions with behavioral training, neurostimulation, and neurofeedback. International Journal of Psychophysiology, v. 88, n. 1, p. 1-16, 2013.

FARRINGTON, David et al. Criminal careers up to age 50 and life success up to age 48: new findings from the cambridge study in delinquent development. PsycEXTRA Dataset, 2006. 
FINN, Emily et al. Functional connectome fingerprinting: identifying individuals using patterns of brain connectivity. Nature Neuroscience, v. 18, n. 11, p. 1664-1671, 2015.

FRANCO, Mariana; BAZON, Marina. Social information processing and aggravation of conduct in young offenders. International Annals of Criminology, v. 55, n. 01, p. 114-131, 2017.

FUJITA, Kentaro. On conceptualizing self-control as more than the effortful inhibition of impulses. Personality and Social Psychology Review, v. 15, n. 4, p. 352-366, 2011.

GALINSKY, Ellen. Mind in the making: the seven essential life skills every child needs. Harper Collins Ebooks, 2010.

GALVÁN, Adriana. Adolescence, brain maturation and mental health. Nature Neuroscience, v. 20, n. 4, p. 503-504, 2017.

GERSHOFF, Elizabeth. Corporal punishment by parents and associated child behavior and experiences: a meta-analysis and theoretical review. Psychological Bulletin, v. 128, p. 539-579, 2002.

GOTTFREDSON, Michael; HIRSCHI, Travis. A general theory of crime. Stanford, CA: Stanford University Press, 1990.

GREENWOOD, Pamela. Functional plasticity in cognitive aging: review and hypothesis. Neuropsychology, v. 21, n. 6, p. 657-673, 2007.

HAUSER, Tobias et al. Cognitive flexibility in adolescence: Neural and behavioral mechanisms of reward prediction error processing in adaptive decision making during development. Neuroimage, v. 104, p. 347-354, 2015.

HUGHES, Claire; GRAHAM, Andrew; GRAYSON, Andrew. Executive function in childhood: Development and disorder. In: OATES, John. (Ed.). Cognitive Development. Oxford: Open University Press, p. 2005. 205-230.

JEVTIC, Bisera. Moral Judgement of Delinquents. Procedia: Social and Behavioral Sciences, v. 149, p. 449455, 2014.

JOYAL, Christian; BEAULIEU-PLANTE, Jolyane; CHANTÉRAC, Antoine. The neuropsychology of sex offenders: a meta analysis. Sexual Abuse: A Jornal of Research and Treatment, v. 20, n. 10, p. 1-29, 2013.

KAUFMANN, Tobias et al. Delayed stabilization and individualization in connectome development are related to psychiatric disorders. Nature Neuroscience, v. 20, n. 4, p. 513-515, 2017.

KINCAID, Donna; TRAUTMAN, Nancy. Remembering: Teaching Students How to Retain and Mentally Manipulate Information. In: MELTZER, Lynn (Ed.). Promotin executive functions in the classroom. New York: Guildford Press, 2010. p. 110-139.

KOMATSU, André Vilela; BAZON, Marina Rezende. Adolescentes em conflito com a lei: justiça juvenil pela perspectiva da criminologia desenvolvimental. In: NOJIRI, S. (Org.). Direito, Psicologia e Neurociência. Ribeirão preto: IELD, 2016. 186p.

KOMATSU, André Vilela; BAZON, Marina Rezende. Personal differences among brazilian adolescents with distinct levels of engagement in delinquency. International Journal of Criminology and Sociology, v. 6, p. 6574, 2017.

KONRAD, Kerstin; FIRK, Christine; UHLHAAS, Peter. Brain development during adolescence: neuroscientific insights into this developmental period. Deutsches Ärateblatt International, v. 110, n. 25, p. 425-431, 2013.

KRISHNAN, Kalyani; FELLER, Melissa; ORKIN, Melissa. Goal setting, planning, and prioritizing: the foundations of effective learning. In: MELTZER, Lynn (Ed.). Promotin executive functions in the classroom. New 
York: Guildford Press, 2010. p. 57-85.

LEE, Francis et al. Adolescent mental health: opportunity and obligation: Emerging neuroscience offers hope for treatments. Science, New York, v. 346, n. 6209, p. 547-549, 2014.

LIMA, Renata Mantovani de; POLI, Leonardo Macedo; JOSÉ, Fernanda São. A evolução histórica dos direitos da criança e do adolescente: da insignificância jurídica e social ao reconhecimento de direitos e garantias fundamentais. Rev. Bras. Polít. Públicas, Brasília, v. 7, n. 2, p. 313-329, 2017.

LOEBER, Rolf; FARRINGTON, David; WASCHBUSCH, Daniel. Serious and violent offenders. In: LOEBER, Ralf; FARRINGTON, Davis. (Ed.) Serious and violent juvenile offenders: risk factors and successful interventions. Thousand Oaks, CA: Sage, 1998. p.13-29.

MARUSCHI, Maria Cristina; BAZON, Marina. Justiça Juvenil: a aplicação e a execução das medidas socioeducativas pelos parâmetros do modelo "risco-necessidade-responsividade". Rio de Janeiro: Instituto INNOVARE, 2014. v. 1. p. 42-72.

MCCLOSKEY, George; PERKINS, Lisa; VAN DIVINER, Bob. Assessment and intervention for executive function difficulties. New York: Routledge, 2009.

MEIJERS, Jesse et al. Differences in executive functioning between violent and non-violent offenders. Psychological Medicine, v. 47, n. 10, p. 1784-1793, 2017.

MELTZER, Lynn; BAGNATO, Jennifer. Shifting and Flexible Problem Solving: The Anchors for Academic Success. In: MELTZER, Lynn (Ed.). Promotin executive functions in the classroom. New York: Guildford Press, 2010. p. 140-159.

MELTZER, Lynn; BASHO, Surina. Creating a classroomwide executive function culture that fosters strategy use, motivation, and resilience. In: MELTZER, Lynn (Ed.). Promotin executive functions in the classroom. New York: Guildford Press, 2010. p. 28-52.

MEUWISSEN, Alyssa; ENGLUND, Michelle. Executive function in at-risck children: importance of father-figure support and mother parenting. Journal of Applied Developmental Psychology, v. 44, p. 72-80, 2016.

MILLER, Laurence. Neuropsychological perspectives on delinquency. Behavioral Sciences \& the Law, v. 6, p. 409-428, 1988.

MIYAGUCHI, Koji et al. Cognitive training for delinquents within a residential service in Japan. Children and Youth Services Review, v. 34, n. 9, p. 1762-1768, 2012.

MIYAGUCHI, Koji; SHIRATAKI, Sadaaki. Executive functioning problems of juveline sex offenders with low leves of measured intelligence. Journal of Intellectual \& Developmental Disability, v. 39, n. 3, p. 253-260, 2014.

MOFFITT, Terrie et al. A gradient of childhood self-control predicts health, wealth, and public safety. Proceedings of the National Academy of Sciences, v. 108, n. 7, p. 2693-2698, 2011.

MOFFITT, Terrie. Male antisocial behaviour in adolescence and beyond. Nature Human Behaviour, v. 2, n. 3 , p. 177-186, 2018.

MOFFITT, Terrie; CASPI, Avshalom. Evidence from Behavioral Genetics for Environmental Contributions to Antisocial Conduct. In: WIKSTROM, Per-Olof; SAMPSON, Robert. Handbook of socialization: Theory and research. New York, NY, US: Guilford Press, 2007. p. 96-123.

MUSCATELLO, Maria et al. Executive functions and basic symptoms in adolescent antisocial behavior: a cross-sectional study on an Italian sample of late-onset offenders. Comprehensive Psychiatry, v. 55, p. 631-638, 2014.

NORDVALL, Olov; JONSSON, Bert; NEELY, Anna. Self-reported and performance-based measures of executive functions in interned youth. Psychology, Crime \& Law, v. 23, n. 3, p. 240-253, 2016. 
NOREEN, Saima; MACLEOD, Malcolm. What do we really know about cognitive inhibition? task demands and inhibitory effects across a range of memory and behavioural tasks. PLOS ONE, v. 10, n. 8, 2015.

ORGANIZAÇÃO MUNDIAL DA SAÚDE. Economic Aspects of Mental Health in Children and Adolescents. Geneva: WHO, 2007.

PANWAR, Karni et al. Differential associations between impulsivity and risk-taking and brain activations underlying working memory in adolescents. Addictive Behaviors, v. 39, n. 11, p. 1606-1621, 2014.

PAUS, Tomás; KESHAVAN, Matcheri; GIEDD, Jay. Why do many psychiatric disorders emerge during adolescence? Nature Reviews Neuroscience, v. 9, n. 12, p. 947-957, 2008.

PIHET, Sandrine et al. Cognitive and emotional deficits associated with minor and serious delinquency in high-risk adolescents. Psychiatry, Psychology and Law, v. 19, n. 3, p. 427-438, 2012.

PONTIUS, Anneliese. Neurological aspects in some type of delinquency, especially among juveniles: toward a neurological model of ethical action. Adolescence, v. 7, p. 289-308, 1972.

ROMERO, María. Executive control enhancement and cognitive training. 2017. Tese (Doutorado), Universidad de Granada, Granada, 2017.

SKINNER, Burrhus Frederic. About Behaviorism. New York: Knopf, 1974.

STEIN, Judith. Emotional Self- Regulation: A Critical Component of Executive Function. In: MELTZER, Lynn (Ed.). Promotin executive functions in the classroom. New York: Guildford Press, 2010. p. 175-201.

STILES, Joan; JERNIGAN, Terry. The Basics of Brain Development. Neuropsychology Review, v. 20, n. 4, p. 327-348, 2010.

STOKES, Mark; BUSCHMAN, Timothy; MILLER, Earl. Dynamic Coding for Flexible Cognitive Control. The Wiley Handbook of Cognitive Control, p. 221-241, 2017.

STRAUSS, Esther; SHERMAN, Elisabeth; SPREEN, Otfried. A compendium of neuropsychological tests: administration, norms, and commentary. 3. ed. New York: Oxford University Press, 2016.

SYNGELAKI, Eva et al. Executive functioning and risky decision making in young male offenders. Criminal Justice and Behavior, v. 36, n. 11, p. 1213-1227, 2009.

URBINA, Susana. Fundamentos da testagem psicológica. Porto Alegre: Artmed, 2006.

VILÀ-BALLÓ, Adrià et al. Neurophysiological correlates of cognitive flexibility and feedback processing in violent juvenile offenders. Brain Research, v. 1610, p. 98-109, 2015.

VILÀ-BALLÓ, Adrià. Neuropshysiological correlates of error monitoring and inhibitory processing in juvenile violent offenders. Biological Psychology, v. 102, p. 141-152, 2014.

WALTERS, Glenn. Low self-control, peer rejection, reactive criminal thinking, and delinquent peer associations: connecting the pieces of the crime puzzle. Journal of Developmental and Life-Course Criminology, v. 2, n. 2, p. 209-231, 2016. 


\title{
Límites temporales a las penas privativas de libertad atendiendo al desarrollo psicosocial*
}

\author{
Time limits on custodial sentences in the \\ light of psychosocial development
}

Silvio Cuneo**

\section{Resumen}

Este artículo analiza la posible compatibilidad de las penas privativas de libertad perpetuas o muy extensas con las diversas teorías sobre el fin de la pena. En las conclusiones se descarta que desde las teorías absolutas o retributivas se pueda justificar la cadena perpetua o una pena muy extensa por dos motivos: Primero porque reprochar un comportamiento humano supone el reconocimiento de la categoría de persona del condenado, por ende, deben rechazarse todas las condenas que traten al condenado como no-persona, entendiendo que el reconocimiento de la dignidad humana y el respeto por los derechos fundamentales no puede restringirse a una categoría de seres humanos. En segundo lugar, porque la retribución mira al Yo, a la identidad personal del sujeto, la que con el tiempo cambia. En este punto -central para esta investigación- se le dará especial importancia, a la hora de justificar y limitar la aplicación de las penas, a las etapas del desarrollo psicosocial de la persona humana.

Palabras clave: Penas privativas de la libertad. Cadena perpetua. Prevención general. Prevención especial. Retribución. Etapas del desarrollo psicosocial.

\section{Abstract}

This article analyses the possible compatibility between life or very long terms imprisonment sentence and the various theories regarding the end of the sentence.

In the conclusion it will be excluded the possibility of justifying life im-

* Recebido em 24/06/2018 Aprovado em 12/07/2018

** Coordinador del Centro de Investigaciones Criminológicas de la Justicia Penal de la UniversidadCentral de Chile. Doctoren Derecho por la Universitat Pompeu Fabra y por la Universitá degli Studi di Trento. Autor de libros: 'Cárceles y Pobreza. Distorsiones del populismo penal' (2018), 'El Encarcelamiento Masivo' (2017), 'La cárcel moderna. Una crítica necesaria' (2017), 'Cine y Derecho penal (2010). Email: silviocuneo@hotmail.com prisonment or a very long sentence on the basis of absolute or retributive theory on two grounds: firstly, because reproaching human behaviour implies the knowledge of the type of person of the convicted, therefore, all convictions that treat the persecuted as a non-person must be rejected, on the understanding that recognition of human dignity and respect for fundamental rights cannot be restricted to a category of human beings. Secondly, because retribution looks at the "Self", at the personal identity of the subject, which changes with time. At this point - key to this research - special importance will be given to the stages of the psycho-social development of the human person when justifying and limiting the application of sentences. 
Keywords: Prison sentences. Life sentence. General prevention. Special prevention. Retribution. Stages of psycho-social development.

\section{INTRODUCCIÓN}

Este artículo busca responder a la pregunta de si se pueden justificar, siguiendo criterios de justicia y utilidad, penas privativas de libertad perpetuas o muy extensas - de más de 10 años, por ejemplo- o si, por el contrario, las penas privativas de la libertad deben tener un límite temporal, y en caso de tenerlo, cuál debiera ser dicho límite.

Para responder a la interrogante planteada, argumentaré sobre cuáles debieran ser los fundamentos y los límites de las penas en un Estado democrático de derecho respetuoso de la dignidad humana.

Partiendo de la base de que ni la pena capital ni la tortura son compatibles con el respeto por la dignidad humana, tampoco debieran la cadena perpetua (que es tortura y pena de muerte) y otras penas extensas, imponerse sin vulnerar la dignidad del condenado. La posibilidad de concebir no-personas a las que es dable aplicar un Derecho penal de enemigos es incompatible con una concepción liberal, de ultima ratio, del Derecho penal.

Tras preguntarme por la compatibilidad de las teorías sobre el fin de la pena con la cadena perpetua, y otras penas privativas de libertad extensas, este trabajo concluye que desde algunas teorías relativas o utilitarias la justificación vendrá dada por datos fácticos que verifiquen el cumplimiento de los fines esperados. Con las teorías absolutas o de la justicia, en cambio, la cadena perpetua y las penas excesivamente extensas, no resultan compatibles. Esto principalmente por dos razones: Por una parte, porque las teorías absolutas conciben a los delincuentes como personas responsables de sus actos y, en consecuencia, deben tratarlos como tales a la hora de juzgarlos, condenarlos y en todo momento en el que cumplan la pena, por lo que resultan incompatibles penas que deshumanicen al condenado. Por otra parte la retribución a la hora de sancionar mira al Yo, a la identidad del sujeto, la que con el tiempo cambia, lo que necesariamente supone que en un momento dado ya no sea posible retribuirle la culpa a un sujeto por un delito perpetrado después de tanto tiempo. Para poder explicar los cambios de la identidad del sujeto, y sus posibles efectos limitantes de una sanción retributiva, se analizarán estudios sobre las etapas del desarrollo psicosocial de la persona humana.

Antes de pasar a revisar el asunto central de este trabajo conviene recordar que si es que el estudio del Derecho penal cumple alguna función importante, ésta no puede ser otra que la contención del poder punitivo, o al menos un desenmascaramiento del funcionalismo con que opera. Sólo en cumplimiento de su función contenedora es posible hablar de Derecho penal en lugar de puro poder punitivo o, expresado con otras palabras, el Derecho penal se humaniza cuando limita el poder punitivo, y la humanización del Derecho penal se traduce en la concepción de ciudadanos, y no de súbditos, a los que protege de las garras del poder punitivo.

En esto, el discurso debe ser consecuente erga omnes, y debe ser cuidadoso en no dejar la válvula abierta al poder punitivo (que debe ser siempre limitado). De lo contrario, esta válvula permanecerá abierta y terminará centrándose y persiguiendo, como siempre, a los más desposeídos.

A continuación, en la segunda parte de este trabajo, se realizarán algunas interrogantes, las que se irán desarrollando en la tercera parte, para luego plantear las conclusiones. 


\section{INTERROGANTES EN TORNO A LA CADENA PERPETUA Y A LA EXTENSIÓN DE LAS PENAS PRIVATIVAS DE LA LIBERTAD}

La cadena perpetua y las penas privativas de libertad de extensa duración son cuestionables tanto por los devastadores efectos que generan en los penados ${ }^{1}$ como por los elevados costos que significa su mantención en las sociedades actuales. Al respecto surgen diversas interrogantes sobre las que espero dar luces para una mejor comprensión:

¿Cabe en una sociedad democrática una pena que suprime al penado? ¿Es la cadena perpetua un residuo de sociedades bárbaras? ¿Son menos democráticos los Estados que la contemplan como sanción? ¿Se puede justificar la cadena perpetua a la luz de alguna teoría sobre el fin de la pena? ¿Satisface el presidio perpetuo los requerimientos utilitarios de la prevención general y especial? ¿Puede justificarse desde una perspectiva retribucionista? ¿Es compatible con el reconocimiento de la dignidad humana?

No existen estudios empíricos que demuestren que las cárceles puedan disminuir delitos; antes bien, se ha demostrado que o los dejan inalterados o los aumentan, ${ }^{2}$ por lo mismo, es dable preguntarse cómo puede compatibilizarse la cadena perpetua con la idea de reeducación.

Por otra parte, si no resulta posible condenar a nadie a perpetuidad, ¿qué hacemos con aquellos delincuentes que no pueden reinsertarse? ¿Es, en la realidad penitenciaria, distinta la pena que la medida de seguridad?

Además, si las teorías del tratamiento reeducador han fracasado e incluso se ha demostrado que la cárcel es criminógena, impulsa la reincidencia y genera un estigma social etiquetando al delincuente, ${ }^{3}$ ¿influirán estos estudios empíricos en cómo debemos justificar las penas?

\section{Compatibilidad entre la cadena perpetua (U otras penas privativas de libertad EXCESIVAMENTE LARGAS) Y LAS TEORÍAS SOBRE EL FIN DE LA PENA}

A continuación intentaré responder a la pregunta de si la cadena perpetua puede justificarse según las diversas teorías sobre el fin de la pena. Partiré analizando las teorías relativas o preventivas (la pena útil) y luego las absolutas o retributivas (la pena justa). No examinaré las teorías mixtas, las que creo no pasan de ser una yuxtaposición de doctrinas absolutas y relativas. Para éstas, la justificación de la cadena perpetua puede ser mucho más estricta, porque requiere que se justifique desde una perspectiva absoluta y relativa, como lo

1 Sobre los efectos de las penas privativas de libertad, los estudios de campo se remontan a los años cuarenta del pasado Siglo. Sobre esto véanse: CLEMMER, D. The prision community, Nueva York: Holt, Rinehart and Winston, 1958. (Originalmente publicado en 1940). GOFFMAN, Erving. Internados: ensayos sobre la situación social de los enfermos mentales. Traducción de María Oyuela. Buenos Aires: Talleres Gráficos Color Efe, 1992. (Originalmente publicado en 1961). Para estudios más recientes, véanse: GOZZANO, M. Compendio di psichiatria clinica e criminológica. Turín: Rosenberg \& Sellier, 1971. p. 240-246; LIEBLING, A.; MARUNA, S. (Ed.). The effects of imprissonment. Londres: Willan Publishing, 2005. p. 3.

2 Sobre el particular, véase: Cid Moliné, J., ¿Es la prisión criminógena?: un análisis comparativo de reincidencia entre la pena de prisión y la suspensión de la pena, en Jueces penales y penas en España, Valencia: Tirant lo Blanch, 2002.

3 Sobre la teoría del etiquetamiento o Labeling Approach puede consultarse LARRAURI, E. ¿Para qué sirve la criminología?. Cuadernos de Derecho Judicial - CJPG, Madrid, Política Criminal, 1999. p. 8.

Esta teoría, basada en el inteaccionismo simbólico, significó un cambio de paradigma en el estudio de la desviación, alejándose íntegramente de la sociología que la precedía, que entendía el control social como una respuesta a la desviación (véase: LARRAURI, E. La herencia de la criminología crítica. 2. ed. México: Siglo XXI,1992. p. 28). El Labeling Approach plantea una idea diametralmente opuesta a las que la precedían, al entender que la desviación es una respuesta al control social. Bajo la vieja idea de que la persona deviene en lo que se dice que es, la teoría del etiquetamiento colegirá que quien es tratado (etiquetado) de delincuente será más propenso a delinquir que quién no ha sido etiquetado como tal (véase, TANNENBAUM, F. Crime and the community. New: Nueva York, 1938. p.19). 
hace Roxin, ${ }^{4}$ o bien puede consistir en la combinación de criterios de fundamentación absolutos y relativos. Tampoco me detendré en las teorías negativas de la pena, puesto que como ellas niegan que la pena tenga legitimación, claramente no justifican la cadena perpetua.

Si bien autores como Rafael Alcácer ${ }^{5}$ distinguen para justificar las penas criterios empíricos o instrumentales de aquéllos valorativos o ético-políticos, para mí esta diferenciación no tendría gran importancia, porque respecto de las teorías relativas o preventivas, que buscan generar algún efecto en el futuro y no suponen una desvaloración de un acto pasado, bastaría la comprobación empírica de eficacia de la pena para justificar o no una sanción. Por ejemplo, si un drástico aumento de penas para el delito de manejo en estado de ebriedad logra demostrar empíricamente que éste se reduce, se podría decir que, desde una perspectiva preventivo-general -y quizá también especial-, dicha sanción encuentra justificación. Por otro lado, si tras un estudio empírico es posible concluir que la pena de muerte no logró disminuir los delitos de violación u homicidio, dicha sanción, desde criterios preventivo-generales, no podría justificarse, pero sí desde criterios de prevención especial negativa, ya que el condenado a muerte no podrá seguir perpetrando delitos. En conclusión, respecto de la prevención, como ésta no supone un desvalor de una conducta del pasado, sino sólo un instrumento tendiente a la evitación de delitos futuros, o como su nombre lo indica, a prevenir delitos, carece de sentido preguntarnos por alguna legitimación o justificación que diga relación con valores. Por otro lado, en el caso de la retribución, consistiendo ésta en una desaprobación, en una desvaloración pública que se concreta en la pena, sí tiene sentido hablar de justificación valorativa o ético-política, puesto que la retribución se mueve en el mundo de los valores.

\subsection{Las teorías relativas}

\section{a) La prevención general}

Para la prevención general (positiva y negativa) la cadena perpetua se puede justificar sólo si se comprueba empíricamente que ésta previene delitos. Esta formulación choca con dos problemas prácticos. Por una parte, parece difícil dicha compatibilización porque la experiencia demuestra que crímenes castigados durante largos períodos de tiempo con penas severas se siguen cometiendo, lo que hace difícil conciliar cualquier pena con la prevención general. Y, por otro lado, resulta difícil saber si es la pena la que genera el efecto preventivo o si, más bien, la mayoría de las personas no suelen cometer delitos no por temor a una pena, sino por otro tipo de consideraciones de carácter ético. Si bien la prevención general no parece encontrar impedimentos axiológicos para justificar y defender la cadena perpetua, sí parece difícil demostrar que esta sanción consiga los efectos esperados.

Ya desde Beccaria se viene diciendo que la prevención de los delitos se consigue más por la certeza de la pena que por su severidad. Entonces, si el marqués lombardo tiene razón, parece complejo otorgarle legitimidad a la cadena perpetua, al menos desde la prevención general. ${ }^{6}$ En este mismo sentido, para Silva Sánchez

mientras los incrementos en la severidad de las penas no tienen efectos preventivos comprobados, éstos si resultan del reforzamiento de los factores que inciden en una mayor certeza de la sanción (...) si el aumento de la certeza de las sanciones penales (y por tanto, en general, el aumento de la certeza de que el sistema penal funcionará satisfactoriamente) supone incrementos verificables en la eficacia

4 ROXIN, C. Derecho penal parte general: fundamentos: la estructura de la teoría del delito. Traducción de la $2^{\mathrm{a}}$ edición alemana y notas por D. M. Luzón Peña, M. Díaz y García Conlledo y J. de Vicente Remesal. Madrid: Civitas, 1997. t. 1.

5 ALCÁCER GUIRAO, R. Los fines del Derecho penal: una aproximación desde la filosofía política. Anuario de Derecho penal y Ciencias penales (LI). Disponible em: < http://vlex.com/vid/fines-aproximacion-filosofia-politica-383186>. 1998. p. 378.

6 La afirmación de que el Derecho penal no intimida ha sido sostenida por varios autores. Para Muñoz Conde, "[e]n ningún caso se puede aceptar [...] que las leyes penales cooperan productivamente en el aumento o en la disminución de la criminalidad" en: MUÑOZ CONDE, F. Derecho penal y control social. Santa Fe de Bogotá: Editorial Temis, 1999. p. 125; para Bustos y Hormazábal, los efectos preventivo-generales no serían comprobables empíricamente, en: BUSTOS, J.; HORMAZÁBAL, H. Lecciones de derecho penal. Madrid: Editorial Trotta, 1997. v. 1 
preventiva de las normas, ello es indicativo de que el Derecho penal en su conjunto intimida más de lo que intimidaría su ausencia. ${ }^{78}$

El principal problema de la justificación empírica de la cadena perpetua radica en que dicha pena sólo se ha aplicado respecto de delitos de gran gravedad, y precisamente los autores de estos delitos son normalmente difíciles de amedrentar; por ende, la amenaza intimidatoria difícilmente producirá los efectos buscados por esta pena. Paradójicamente sería posible concluir que la cadena perpetua sería justificable, desde la prevención general, si se castigara con esta pena el manejo en estado de ebriedad o algún delito de cuello blanco. En cambio, parece difícil justificarla respecto de violaciones y asesinatos.

Tampoco me atrevo a afirmar que con esta pena se aseguren los fines de paz social buscados o queridos por la prevención general positiva, aunque podría argumentarse que esto sí se produce basado en antecedentes concretos. $\mathrm{Al}$ respecto desconozco estudios empíricos que puedan acreditar esta eficacia preventivo general positiva y no me imagino cómo podrían elaborarse. En conclusión, creo que la cadena perpetua no podría justificarse en base a criterios de prevención general negativa y no tengo una respuesta categórica respecto a su modalidad positiva.

b) La prevención especial

En principio, la prevención especial negativa sí podría justificarse la cadena perpetua, porque el sujeto encarcelado no podrá perpetrar delitos contra la comunidad libre. Sin embargo, como se habrá advertido de la afirmación anterior, esto supone desconocer la dignidad de las personas privadas de libertad, ya que su seguridad valdría nada o menos que la de quienes se encuentran en libertad. Lo único que se puede esperar de una pena privativa de libertad, de corta o de larga duración, es que los internos no puedan perpetrar delitos en la comunidad libre, pues, como observa Hentig,

[n]umerosos delitos se producen en las cárceles, desde los comunes atentados contra la propiedad, hasta falsificaciones documentales y de moneda, extorsiones, tráfico ilegal de alcohol y estupefacientes, violaciones, riñas y, desde luego, homicidios. ${ }^{9}$

Hoy, además, se cometen múltiples delitos desde dentro de las cárceles hacia la comunidad libre, por ejemplo, estafas telefónicas, falsificación de moneda, tráfico de drogas, etc. Asimismo, grupos de crimen organizado, mafias y narcotraficantes, suelen reclutar a sus soldados en las prisiones, los que, una vez libres, y por falta de otras oportunidades, entran rápidamente a las filas de estos grupos organizados. En estas circunstancias parece quimérico afirmar que la privación de libertad significa que el interno no cometerá delitos.

Las cárceles distan mucho de ser un lugar donde se cumple una pena sólo privativa de libertad en la que sus presos conviven sin perpetrar crímenes preparándose para la tan anhelada reinserción social. Antes bien, todo lo contrario: los niveles de violencia y la constante comisión de delitos en la mayoría de las cárceles son muy superiores que en la comunidad libre. Sin embargo, es claro que al menos respecto de la sociedad libre las posibilidades de perpetrar delitos desde la cárcel son muy inferiores en relación con las que tiene un

7 SILVA SÁNCHEZ, J. Aproximación al derecho penal contemporâneo. 2. ed. ampliada y actualizada. Buenos Aires: B de F, 2010. p. 252. 8 Diversos estudios han demostrado que más importante que la gravedad de la sanción lo es su probabilidad. Sobre el particular: LIEBERMAN, David. Learning, behavior, and cognition: Wadsworth. Belmont: Publishing, 1993; AZRAN, N.; HOLZ, W. C.; HAKE, D. F. Fixed ratio punishment. Experimental Analysis of Behavior, 6. 1963. Disponible en: <http://www.ncbi.nlm.nih.gov/pmc/articles/PMC1404287/pdf/jeabehav00187-0003.pdf.>.; LANDE, S. An irresponsive time analysis of variable-ratio punishment. Journal of Experimental Analysis of Behavior, 35, 1981; entre otros. Otro factor importante disuasivo lo constituye la dilación, en el sentido que una sanción próxima a la perpetración de un delito puede ser más disuasiva que una más grave si es más inmediata. Al respecto: Solomon, R., TURNER, L. H. Y; LESSAC, M. S. Some effects of delay of punishment on resistence to temptation in dos. Journal of Personality and Social Psychology, 8, 1968 y LOEWENSTEIN, G., Out of control: visceral influences of behavior. Organizational Behavior and Human Decision Processes, 65, 1996. Sobre el estudio de Solomon, Turner y Lessac, hay que ser sumamente cautos puesto que no nos parece que puedan ser comparables las reacciones de los animales sancionados con las de personas sancionadas. Resulta difícil, si no imposible, que un perro entienda perfectamente el porqué de una sanción por algo que hizo hace una semana. En cambio, creemos que un hombre puede entender el porqué de una sanción aplicada meses e incluso años después de la perpetración de su delito. 9 HENTIG, H. La pena. Traducción castellana y notas por José María Rodríguez Devesa. Madrid: Editorial Espasa Calpe, 1967. p. 376-381. t. 2 
sujeto en libertad. Por ende, si esta teoría es capaz de desconocer la dignidad o la calidad de personas de los presos, bien podría justificarse para éstas la cadena perpetua. ${ }^{10}$

Para la prevención especial positiva, la cadena perpetua podría justificarse sólo si consideramos que existen sujetos cuya resocialización es imposible. Es decir, esta teoría justificaría la cadena perpetua sólo respecto de los delincuentes incorregibles, ${ }^{11}$ utilizando la denominación de Von Liszt y de Ferri. Es decir, para que esta teoría, que profesa la resocialización, pueda justificar la pena perpetua (o una pena privativa de libertad muy extensa), es necesario que crea en la existencia de seres inferiores a los que es necesario separar de la convivencia social.

Un último problema práctico para la prevención especial (tanto negativa como positiva) se genera porque en las sociedades modernas la privación de libertad es la pena más grave que se puede aplicar. Entonces, un condenado a ésta ya no podría recibir más pena. Por ende, sus posteriores delitos no podrían ser sancionados, lo que significa que podrá perpetrarlos con completa impunidad.

\subsection{La retribución}

Para la retribución la cadena perpetua no puede justificarse, y esto por dos motivos vinculados entre sí. En primer lugar, porque si la retribución, como desvaloración, concibe a los delincuentes como personas responsables de sus actos, debe seguir tratándolas como tales a la hora de condenarlas y en todo momento en el que cumplan la pena. Es decir, para la retribución los delincuentes son personas porque responden de sus actos y al momento de responder, esto es, al cumplir la pena, siguen siendo personas, por lo que quedan fuera penas que deshumanicen al condenado. El segundo motivo por el que pensamos que la retribución no puede justificar la cadena perpetua es porque la retribución a la hora de sancionar mira al Yo, a la identidad del sujeto, la que, con el tiempo, cambia, lo que necesariamente supone que en un momento ya no podremos retribuirle la culpa a un sujeto por un delito perpetrado hace tanto tiempo. Partiremos analizando el primero de los motivos y reservaremos para el final la argumentación acerca del cambio de la identidad del sujeto por el paso del tiempo.

a) La retribución necesariamente lleva a una concepción de un Derecho penal antropológicamente fundado, un Derecho penal de hombre y para hombres, ${ }^{12}$ en el que no puede dejar de verse en el condenado

10 La reserva de la categoría de persona sólo para algunos seres humanos ha sido defendida por diversos autores que, de una u otra manera, han legitimado un poder punitivo de carácter totalitario o con incrustaciones de corte autoritario. Por ejemplo, Carl Schmitt como jurista del nacionalsocialismo y defensor del Estado absoluto participó en la creación de leyes tendientes a purificar al III Reich de la contaminación judía; o Günther Jakobs, para quien "un individuo que no admite ser obligado a entrar en un estado de ciudadanía no puede disfrutar de los beneficios del concepto de persona”, en JAKOBS, G. Derecho penal del enemigo. Traducción de Manuel Cancio Meliá. Madrid: Civitas, 2003. p. 40. Tales concepciones, aunque se autodenominen "meramente descriptivas" y que ostenten asepsia científica abundan en la historia del Derecho penal y han contribuido a " $[\mathrm{t}]$ omar con naturalidad y hasta considerar revolucionarias la esterilización y la castración como medidas de policía preventiva, la profusión de penas de muerte, la ejecución de adolescentes, considerar delito la relación sexual con judíos o negros, los campos de concentración incluso para quienes no cometieron ningún delito", etc., en ZAFFARONI, R. Introducción al libro: Grispigni, Filippo y Mezger, Edmund la reforma penal nacionalsocialista. Buenos Aires: Ediar, 2009. p. 10. En el mismo sentido, observa MUNOZZ CONDE que: "Grispigni describe la decidida aceptación en los textos jurídico-penales nacionalsocialistas de sanciones tales como la esterilización de enfermos con enfermedades hereditarias, asociales, alcohólicos, etc.; la castración de delincuentes sexuales peligrosos; y la aplicación a menores de edad peligrosos de penas previstas para delincuentes adultos, incluso la pena de muerte. Y describe y entiende esas reformas como la consecuencia de una concepción del derecho penal basado en la idea de peligrosidad y que no tiene otra misión que la defensa social”, en: MUNOZ CONDE, F. Apéndice al libro: Grispigni, Filippo y Mezger, Edmund la reforma penal nacional-socialista. Buenos Aires: Ediar, 2009. p. 102 y 103. El mismo Grispigni no formula ninguna expresión, ni expresa ni tácita, "contra el hecho mismo de la esterilización o castración de delincuentes o asociales como sanción criminal” en MUNOZ CONDE, F. Apéndice al libro: Grispigni, Filippo y Mezger, Edmund la reforma penal nacional-socialista. Buenos Aires: Ediar, 2009. p. 106.

11 Bien podría tratarse de sujetos indisciplinables.

12 La denominación la tomo de Rivacoba, M. Introducción al estudio de los principios cardinales de derecho penal. Direito e Ciudadania n. 6, p. 57-62, 1999. Este artículo estaba destinado a ser la introducción de un libro que se titularía Los principios cardinales del derecho penal, proyecto que quedó inconcluso tras la muerte de Rivacoba. Varias de las ideas que se plantean en esta parte del trabajo formarían parte de dicho libro, pero no llegaron a ser escritas por el autor. Las utilizo sin señalar cita, puesto que la fuente era el 
a un semejante. Por eso las penas perpetuas o extremadamente largas son inadmisibles, por su radical inhumanidad, al paso que en el concepto de retribución está inscrita la persona como fin, no como medio. Esta concepción se opone tanto a quienes proponen, justifican o legitiman planteamientos que conciban la existencia de seres humanos que no sean personas como a un pretendido Derecho penal del enemigo. ${ }^{13}$

Esta primera limitación se funda en un principio de bumanidad que concurre en toda retribución bien entendida. ${ }^{14}$ Sobre la base de la seguridad y a través de ella se llega a la humanidad, a la comunidad pura, a la convivencia, que no es sólo coexistencia. El principio de humanidad supone también un sentido solidario, individualista, que no es egoísta, y que lleva a realizar la humanidad tanto en lo colectivo como en lo individual. No se trata de una humanidad entendida como buenos sentimientos, sentimentalismo, ternura del corazón ni del lenguaje de las lágrimas, sino que de la humanidad del Derecho penal concebida en sentido objetivo. Esta humanidad, si bien tiene un sentido colectivo, culmina en un sentido individual, porque concibe al hombre como sujeto de dignidad, titular de un destino personal e intransferible, con capacidad de soñar y desplegar su actuar con una serie de posibilidades implícitas para hacer posible esa comunidad, esa convivencia.

Esto hace que lo que dé sentido al Derecho penal sea precisamente este principio de humanidad. Por esto, el Derecho penal para esta concepción liberal tiene que ser mínimo, de ultima ratio y tiene que llevar a un sentido reductivo, minimizador, que no necesariamente es abolicionista, porque efectivamente el individuo debe responder de sus actos cuando éstos ofendan de manera insoportable bienes jurídicos de valoración colectiva, pero porque debe primar el interés individual al colectivo, a la hora de penar, debe emplearse la mínima aflicción, sólo aquélla que sea indispensable.

Un Derecho penal liberal, humanizado, que se aplique a una comunidad de seres libres, librevolentes como autofines, tiene necesariamente que ser un Derecho penal reducido y fragmentario. Un Derecho penal autoritario, en cambio, no es fragmentario.

Lo menos que se puede hacer, en virtud del principio de humanidad, es rebajar las penas, descriminalizar, despenalizar, desjudicializar conductas. Hay que sacar cosas del Derecho penal y propiciar modelos de resolución de conflictos.

Sin perjuicio de lo señalado precedentemente, se debe tener presente que el proceso reductivo tiene una contrapartida, cual es la necesidad de crear nuevos delitos y nuevas penas. Sin embargo, a la hora de crear nuevos delitos, hay también que crear nuevas condenas que estén en sintonía con el principio de humanidad, penas humanas, de hombres y para hombres. Así como el abolicionismo revolucionario cuestionó la pena de muerte, hoy se debe discutir, además de la pena capital, las de privación de libertad, especialmente las de larga duración, y todas las penas que excluyan al penado.

En virtud del principio de humanidad se deben descartar penas que traten al delincuente como no-hombre, que lo excluyan, como la pena de muerte o la reclusión, que en períodos más o menos prolongados rompe con la convivencia y anula la personalidad. Una reclusión prolongada más allá de ciertos límites -15 años, por ejemplo- causa graves daños irreversibles en la personalidad. Penas de veinte o más años son, en los hechos, perpetuas, pues, aunque se vuelva a la libertad, se vuelve aniquilado.

Si bien nadie niega de plano el principio de humanidad, éste se deforma por las distintas maneras que adoptan los diversos ordenamientos. Las doctrinas preventivistas no concuerdan con este principio, pues

propio Rivacoba quien me las transmitió en clases y en amenas conversaciones.

13 Para Zaffaroni " [t] odo discurso penal que acepta o legitima la existencia de enemigos no sólo arrastra un elemento de estado absoluto, sino que implica una semilla de genocidio, y si ningún accidente detiene el curso que desencadena, su resultado final es la masacre", em ZAFFARONI, R. Introducción al libro: Grispigni, Filippo y Mezger, Edmund la reforma penal nacional-socialista. Buenos Aires: Ediar, 2009. p. 25.

14 MAYER, M. Se ocupa de la idea de bumanidad como la idea del derecho, en filosofía del derecho. Traducción de la segunda edición original por Luis Legaz Lacambra. Madrid: Editorial Labor, 1931. 
rebajan la humanidad y la dignidad del hombre, transformándolo en un mero instrumentos para fines fijados por otros. En la retribución, en cambio, se concreta la desvaloración en la pena, pero no se excluye al penado de la convivencia.

Hay que tener presente las palabras de Goethe, en el sentido de que tanto si se ha de castigar, como si se ha de tratar con dulzura debe mirarse a los hombres bumanamente, en una comunidad de seres libres y fines en sí mismos. Y ser fin en sí es ser sujeto de dignidad. El reconocimiento de la dignidad es la base para designar la igualdad, puesto que en dignidad no hay nadie más digno, somos todos igualmente dignos. En dignidad se excluyen las jerarquías. El Derecho penal que no es liberal es sólo un fenómeno de poder, es puro poder punitivo y no Derecho.

Respecto a los límites máximos que debe tener una pena privativa de libertad (necesarios para una bien entendida retribución), algunos autores se han aventurado a fijar un tiempo determinado. Así, si para Guzmán Dalbora "la exclusión irreversible y total de un sujeto de la libre relación jurídica, contradice el concepto de la pena por la culpabilidad, que se orienta a restituir esa relación", ${ }^{15}$ la pena debe limitarse y [c]omo se estima que la degradación física y psíquica ya no tiene remedio después de diez o quince años, estos son también los límites máximos recomendados para las sanciones" privativas de la libertad. ${ }^{16}$

Para Von Hirsch, que plantea una teoría del merecimiento aplicada en forma benigna, la prisión

debe estar limitada para delitos graves (fundamentalmente para delitos violentos y para los casos más graves de criminalidad de cuello blanco), y la duración de la privación de libertad para estos delitos debería ser de hasta 3 años -excepto para el homicidio, donde cinco años sería el límite normal. ${ }^{17}$

Por su parte, Kleinig, basándose no tanto en una teoría del merecimiento como en la idea de trato humano y decente a los seres humanos, propone como límite máximo una pena de 25 años. ${ }^{18}$

b) La retribución mira al Yo, a la identidad personal del sujeto, la que con el tiempo cambia. Dado lo anterior, parece pertinente una pregunta ulterior sobre la identidad personal del Yo en busca de elementos que permitan fijar límites temporales a una pena fundada en el reproche personal.

Afortunadamente,

[e]n el Derecho penal de nuestros días no se suele discutir la vigencia de un principio llamado de personalidad de las penas, según el cual la pena debe ser impuesta al sujeto considerado responsable del delito, que es quien tiene que soportarla. ${ }^{19}$

Este principio junto al de responsabilidad por el hecho propio integran el principio de culpabilidad en sentido amplio ${ }^{20}$ en base al cual sólo se puede penar al mismo sujeto que cometió el delito y que se consideró responsable tras un juicio penal. Al contrario, cuando la pena recae en un sujeto distinto al que perpetró el delito se vulnera el principio de culpabilidad. La exigencia de identidad del sujeto equipara identidad individual a identidad corporal. ${ }^{21} \mathrm{Al}$ parecer, lo que hay tras la exigencia de identidadpersonal y del principio de culpabilidad es la idea de merecimiento, esencial a toda retribución. ${ }^{22}$ Pero ¿qué es identidad personal?

15 GUZMÁN DALBORA, J. La pena y la extinción de la responsabilidad penal: primera parte. Santiago de Chile: Legal Publishing, 2008. p. 200.

16 GUZMÁN DALBORA, J. La pena y la extinción de la responsabilidad penal: primera parte. Santiago de Chile: Legal Publishing, 2008. p. 204.

17 VON HIRSCH, A. Censurar y castigar. Traducción de Elena Larrauri. Madrid: Trotta, 1998. p. 80.

18 Citado en VON HIRSCH, A. Censurar y castigar. Traducción de Elena Larrauri. Madrid: Trotta, 1998. p. 74.

19 SILVA SÁNCHEZ, J. Identidad en el tiempo y responsabilidad penal. el juicio jurisdiccional de imputación de responsabilidad y la identidad entre agente y acusado: estudios penales en homenaje a Enrique Gimbernat. Madrid: Edisofer, 2008. t. 2. p. 662.

20 SILVA SÁNCHEZ, J. Identidad en el tiempo y responsabilidad penal: el juicio jurisdiccional de imputación de responsabilidad y la identidad entre agente y acusado: estudios penales en homenaje a Enrique Gimbernat. Madrid: Edisofer, 2008. t. 2. p. 662.

21 SILVA SÁNCHEZ, J. Identidad en el tiempo y responsabilidad penal: el juicio jurisdiccional de imputación de responsabilidad y la identidad entre agente y acusado: estudios penales en homenaje a Enrique Gimbernat. Madrid: Edisofer, 2008. t. 2. p. 662.

22 En cambio las tesis preventivas bien pueden prescindir de la noción de merecimiento para conseguir los fines preventivos anhelados. 
Para contestar a esta pregunta habría que analizar, al menos, dos corrientes filosóficas. Por una parte, los empiristas o reduccionistas, quienes en base a los cambios físicos y psíquicos que experimenta el sujeto con el paso del tiempo, niegan la identidad personal de éste en distintos momentos. ${ }^{23}$ Para ellos, no pudiendo afirmarse la existencia de una identidad personal, a lo sumo podría hablarse de "mera comunidad de estados mentales sucesivos, fases o etapas personales". ${ }^{24}$ A partir de esta concepción procedería plantearse si podemos responsabilizar penalmente a un sujeto en un tiempo posterior a la comisión de un delito (en tiempo 2), entendiéndolo sucesor de ese aparentemente mismo sujeto por un delito cometido en un tiempo anterior (en tiempo 1). Como parece difícil sostener que no habría que responsabilizarlo, la pregunta más pertinente, a mi juicio, sería si a partir de algún cambio (paso de un determinado lapso de tiempo o de un hecho traumático) podríamos, o no, reducir o anular dicha imputación.

Para la otra corriente, la metafísica, sí existiría identidad personal en el sujeto en diversos momentos. Habría "una identidad personal sustancial basada en la permanencia de los componentes corporal y espiritual del sujeto $[. .$.$] se trata de una permanencia esencial". { }^{25}$ Como se comprenderá, para esta tesis ni el paso del tiempo ni hechos trascendentes cambiarían la esencia individual. Por ende, no habría ningún problema en atribuir responsabilidad por un delito pasado, aunque hayan transcurrido varios decenios, puesto que se trataría del idéntico mismo sujeto. Normalmente, para los distintos ordenamientos jurídico-penales "la identidad personal se imputa". ${ }^{26}$ Sin embargo, parece necesario limitar dicho concepto normativista, por motivos prácticos y de justicia. La doctrina penal pasa por alto que el sujeto muta y asume que el sujeto siempre es el mismo (así se imputa); los límites temporales que se establecen por el Derecho penal están más relacionados con criterios prácticos que con una supuesta mutación del yo.

Según Merkel, a los requisitos tácitos de la imputación penal pertenece la suposición de que los sujetos de actuaciones penales significativas permanecen, en el curso del tiempo, idénticos a sí mismos como personas. ${ }^{27}$ Sin embargo, para este autor en determinadas situaciones esta afirmación resulta falsa o implausible. Para tratar el problema de la identidad en el tiempo -el que según Merkel no ha sido suficientemente desarrollado por las ciencias penales- se remonta al mito griego, recogido por Plutarco, del barco de Teseo, que volvía desde Creta y al que retiraban una a una las tablas estropeadas, reemplazándolas por otras nuevas, hasta el punto que ya no conservaba ninguna de las originales. De esto surge la interrogante sobre si se trataría entonces del mismo barco después de que le han cambiado todas las tablas. Luego Merkel agrega una variante al ejemplo: un marinero recoge todas las piezas que desechan para reemplazarlas por nuevas, y construye un barco exactamente igual al de Teseo. ¿Cuál de los dos sería entonces el barco original? Para Merkel cabrían tres respuestas posibles: el primero, el segundo o ninguno, ya que no podrían ser los dos al mismo tiempo. El trasfondo de la cuestión reside en el dilema de si una vez que van cambiando las partes que componen un todo permanece la identidad.

Si trasladamos el ejemplo a los seres humanos, podemos decir que, al menos en el plano físico-biológico, las personas no conservamos ni una célula durante toda nuestra vida, pues todas están en permanente renovación. ¿Somos entonces las mismas personas después de un cierto período de tiempo o de una cierta cantidad de modificaciones? ${ }^{28}$

23 Entre los sostenedores de esta postura se encuentran Locke y Hume. Para el primero, "quienes han olvidado su delito no merecen castigo", en SILVA SÁNCHEZ, J. Identidad en el tiempo y responsabilidad penal: el juicio jurisdiccional de imputación de responsabilidad y la identidad entre agente y acusado: estudios penales en homenaje a Enrique Gimbernat. Madrid: Edisofer, 2008. t. 2. p. 666 y 680. Esta afirmación se debe a la concepción de Locke que desecha el criterio de la identidad corporal asumiendo el de la conciencia que se basa en los recuerdos. En: MERKEL, R. Personale identität und die Grenzen Strafrechtlicher Zurechnung. Juristen Zeitung n. 10, p. 505-506, 1999.

24 SILVA SÁNCHEZ, J. Identidad en el tiempo y responsabilidad penal: el juicio jurisdiccional de imputación de responsabilidad y la identidad entre agente y acusado: estudios penales en homenaje a Enrique Gimbernat. Madrid: Edisofer, 2008. t. 2. p. 666.

25 SILVA SÁNCHEZ, J. Identidad en el tiempo y responsabilidad penal: el juicio jurisdiccional de imputación de responsabilidad y la identidad entre agente y acusado: estudios penales en homenaje a Enrique Gimbernat. Madrid: Edisofer, 2008. t. 2. p. 667.

26 SILVA SÁNCHEZ, J. Identidad en el tiempo y responsabilidad penal: el juicio jurisdiccional de imputación de responsabilidad y la identidad entre agente y acusado: Estudios penales en homenaje a Enrique Gimbernat. Madrid: Edisofer, 2008. t. 2. p. 670.

27 MERKEL, R. Personale identität und die Grenzen Strafrechtlicher Zurechnung. Juristen Zeitung, n. 10, 1999 . p. 502.

28 MERKEL nos ilustra mediante la referencia a dos casos de ciencia ficción. En primer lugar, plantea el problema de la teletrans- 
Más aún, ¿qué pasa con los cambios que vamos sufriendo a nivel psicológico? ¿Alteran éstos también nuestra identidad del yo? Sobre el particular, Merkel analiza los casos de Alzheimer y los de pérdida total de la memoria. ¿Sigue siendo el mismo aquél que ha perdido toda autonomía o toda vinculación con su pasado? Y, enlazándolo con nuestra investigación, ¿`se puede sancionar a alguien que no recuerde nada de su delito? Para nosotros cobra importancia esta pregunta, además, en la fase de cumplimiento. Si el condenado pierde la memoria, ¿puede seguir cumpliendo la condena por algo que no recuerda? ¿Podemos afirmar que seguimos retribuyéndole la culpabilidad a un sujeto que no sabe por qué está cumpliendo una pena?29 30

Si entendemos que con el paso del tiempo el merecimiento, el juicio de reproche y la necesidad de pena disminuyen, procede preguntarse entonces a partir de cuándo o a partir de qué circunstancia la culpabilidad del sujeto en tiempo pasado se desvanece a tal punto que la pena no parece ser justa. ${ }^{31}$

Tanto las teorías metafísicas como las empiristas, por moverse en niveles de total abstracción, parecen no satisfacer problemas jurídico-penales del mundo real, como la aflicción del preso que sufre de soledad en su celda. Sin embargo, es posible adscribir a una teoría ecléctica entendiendo que no habría problemas para imputarle a un sujeto sus actos anteriores con ciertos límites temporales o circunstanciales; ${ }^{32}$ es decir, concebir, desde la retribución, que el sujeto debe responder por sus actos pasados, pero no de manera indefinida y perpetua.

De lo que se trata es de pensar la culpabilidad de manera dinámica, considerando que el paso del tiempo hace que la culpabilidad del sujeto deje de ser la misma culpabilidad a la que se le retribuía en el momento de la sentencia y que lo condenaba para así compensar el hecho constitutivo de delito. Se trata de una limitación de carácter estructural que entiende que carece de sentido que a alguien se le sancione por el resto de su vida o por períodos demasiado extensos.

Si bien es posible saber -o acaso sólo intuir- que el sujeto va cambiando con el tiempo, no se puede tener la certeza de si es posible afirmar que en algún momento ese sujeto ya no sea el mismo que cometió el delito. Algo podría hacernos pensar que, después de veinte años de condena, ya no se trata del mismo sujeto que perpetró el delito. Claramente no concuerdan con esta tesis ni las legislaciones norteamericanas, ni muchos tribunales de los Estados Unidos de América que condenan reiteradamente a cadena perpetua a menores de edad de entre trece y diecisiete años sin posibilidad de acceder a la libertad condicional.

portación. Una máquina almacena la información de todas nuestras células en un punto A, y la reproduce en un punto B. ¿Es la persona del punto B la misma que la que estaba en A? El segundo ejemplo responde a un caso de la vida real, llevado por el BGH en 1983 con el nombre de Sirius-Fall. Un hombre convence a una joven que ha sido elegida para transmutarse en un ser superior una vez que abandone su cuerpo actual. Si el cambio se hubiera producido, ¿`eguiría siendo la joven la misma persona que antes? MERKEL, R. Personale identität und die Grenzen Strafrechtlicher Zurechnung. Juristen Zeitung, n. 10, p. 53-505, 1999.

29 MERKEL se refiere al caso de un hombre que, luego de tener un accidente en bicicleta, sufrió una pérdida total de la memoria y comenzó a pedalear mecánicamente sin rumbo fijo, bebiendo de baños abiertos, durmiendo al descampado y sin comer. Tras una semana de incesante camino se preguntó qué estaba haciendo y no supo responderse. Merkel se pregunta: si este hombre hubiera cometido antes del accidente un delito, ¿podríamos condenarlo por él, aunque no lo recuerde? MERKEL, R. Personale identität und die Grenzen Strafrechtlicher Zurechnung. Juristen Zeitung, n. 10, p. 53-505, 1999. p. 509.

30 Si bien se trata de una situación distinta, en la que no hay pérdida de memoria, resulta interesante el caso chileno conocido como El chacal de Nabueltoro. En 1960, en la localidad de Nahueltoro (Chile), un alcohólico en estado casi de salvajismo mató a una mujer y a sus cinco hijos. Tras treinta y dos meses de cárcel, en los que el autor experimentó sorprendentes cambios de conducta, puesto que era la primera vez en su vida que convivía con más personas, aprendió el oficio de hacer guitarras, se transformó al catolicismo y se arrepintió de sus crímenes. Pese a la intervención de Eloy Parra, el sacerdote que vivió de cerca esta transformación, pidiendo reiteradamente el indulto presidencial, éste no fue otorgado por el entonces Presidente de la República Jorge Alessandri, y el chacal fue ejecutado. Esta historia fue llevada al cine por Miguel Littin con el título "El chacal de Nahueltoro" y constituye una pieza indispensable del séptimo arte latinoamericano.

31 Podría argumentarse que es el hecho el que con el paso del tiempo merece menor reproche. Sin embargo, no entraremos en esta cuestión para centrarnos especialmente en la disminución de culpabilidad del sujeto por el paso del tiempo o por el acaecimiento de circunstancias especiales.

32 Para el objeto de estudio de este artículo me centraré en los límites temporales. Circunstanciales podrían ser, por ejemplo, un contexto de guerra, una grave crisis económica o una catástrofe natural. Estas circunstancias podrían despertar en el sujeto instintos primitivos prevaleciendo los de auto conservación. 
Un estudio realizado por Amnesty International y Human Rights Watch publicado en 2005 muestra que hay, en Estados Unidos, al menos 2.225 personas cumpliendo cadena perpetua sin libertad provisional por delitos cometidos cuando eran menores de dieciocho años, la mayoría de los cuales cumple dicha pena por su primer delito. El $16 \%$ de los condenados habría perpetrado su delito cuando tenía entre trece y quince años. ${ }^{33}$

La dramática situación descrita por el informe de Amnesty International y Human Rights Watch parece difícilmente defendible desde criterios preventivos, pero en relación a lo que ahora quisiera enfatizar, esta situación resulta inaceptable para una concepción retribucionista y no sólo por la evidente inhumanidad de dichas penas, puesto que si la condena se funda en la retribución, debemos entender que seguimos retribuyéndole la culpa a lo largo de las fases del cumplimiento de la pena privativa de libertad. Sobre esto se basa la idea de que habría entonces, en algún momento, una retribución no merecida porque la culpabilidad, vinculada a la identidad personal, ha ido disminuyendo con el paso del tiempo y con el cambio de identidad del sujeto, llegando en un momento a ser tan mínima como para no poder justificar ya la pena.

Puede que tras veinte o cuarenta años quede aún un núcleo de identidad en el sujeto, pero parece que ese núcleo de identidad no es suficiente para soportar la lógica de la responsabilidad, la lógica del merecimiento, la lógica de la retribución, porque no se daría una identidad lo bastantemente fuerte entre el sujeto que cometió el delito y el que está cumpliendo la pena en un momento muy posterior. Si afirmamos que el sujeto cambia, llegando a mutar su identidad personal, llegaría un momento en que ya no es posible continuar compensando la culpabilidad porque la persona ha pasado a tener una identidad distinta

La idea aquí planteada entiende que no se puede hacer responsable a ese sujeto tras un extenso espacio de tiempo, porque ya no sería el mismo. Una condena perpetua o muy prolongada supondría un exceso de pena que no podría ser compensable con la culpabilidad, porque la culpabilidad, entendida como aquella parte del sí mismo, determinada por su propia voluntad, por su Yo que en un momento determinado ha decidido cometer un hecho delictuoso, ya no es la misma. Si esto podemos comprobarlo, habría aquí un límite a la pena privativa de libertad desde una concepción retributiva.

Aunque esta teoría parece ser sólo una intuición, ya que resulta imposible saber empíricamente si y cuándo una persona pasa a tener una identidad distinta, es posible intentar dotar a estos postulados de un carácter científico vinculándolos a estudios sobre las fases del desarrollo biológico y psicológico. ${ }^{34}$

Erik Erikson, un psicoanalista alemán (1902-1994), elaboró en Estados Unidos una teoría del desarrollo de la personalidad en la que describe ocho etapas del desarrollo psicosocial del ser humano. ${ }^{35}$ Para Erikson una persona psicológicamente sana debe pasar por cada una de esas etapas y sufrir lo propio de cada etapa y disfrutar de sus beneficios.

Las primeras cuatro etapas se relacionan con crisis y conflictos en el desarrollo de la vida hasta los trece años. Ellas son: 1.- Confianza frente a desconfianza, etapa que transcurre desde el nacimiento hasta los dieciocho meses de vida aproximadamente; 2.- Autonomía frente a vergüenza y duda, etapa que transcurre desde los dieciocho meses hasta los tres años; 3.- Iniciativa frente a sentimiento de culpa, etapa que transcurre desde los tres a los cinco años, y; 4.- Laboriosidad frente a inferioridad, etapa que va desde los cinco hasta los trece años aproximadamente.

Las cuatro etapas finales son las que más nos importan a objeto de entender una limitación de responsabilidad de carácter jurídico-penal, entendiendo que antes de los trece años carece de todo sentido atribuir algún tipo de responsabilidad penal. Esto podría responder a la admisión de que "hasta la adolescencia, el individuo no puede desarrollar los requisitos de desarrollo fisiológico, maduración mental y responsabilidad

33 Puede consultarse el informe en: <http://www.amnestyusa.org/>.

34 El Derecho penal debe escuchar a las ciencias para limitar sus efectos. La inimputabilidad de los niños o de los dementes responde a concepciones que provienen del mundo de las disciplinas causales explicativas.

35 ERIKSON, E. Identidad, juventud y crisis. Traducción de Alfredo Guéra. Madrid: Taurus Ediciones, 1980. p. 80. 
social para experimentar y atravesar la crisis de identidad". ${ }^{36}$ Pasemos a analizar las etapas que incluirían la vida desde la adolescencia hasta la senectud.

La quinta etapa o adolescencia, se caracterizaría por la existencia de un conflicto de Identidad frente a confusión de identidad. Abarcaría un período que iría aproximadamente entre los trece y los veintiún años. En esta etapa el joven busca definir una identidad propia, se trata de

un modo de vida entre la infancia y la edad adulta. Así, en los últimos años de escolaridad, los jóvenes, acosados por la revolución fisiológica de su maduración genital y ante la incertidumbre de sus roles adultos, parecen muy ocupados con caprichosas tentativas por establecer una subcultura adolescente mediante lo que tiene el aspecto de una identidad final. ${ }^{37} 38$

En la sexta etapa, el joven adulto, vive un conflicto de relación intima frente al aislamiento. Esta comprendería el período que va desde los veintiún hasta los cuarenta años aproximadamente y se caracteriza por una mayor seguridad, puesto que al parecer este joven adulto ya no necesitaría, como antes, mostrarse algo a sí mismo.

La séptima etapa, de adultez, se caracteriza por un conflicto de generatividad frente a estancamiento, e iría desde los cuarenta a los sesenta años. Esta etapa suele relacionarse con la crianza de hijos y se caracteriza por una constante preocupación por el futuro (de los hijos, de las futuras generaciones, etc.)

Por último, en la octava etapa, de senectud o madurez, surge un conflicto de integridad frente a desesperanza. Esta etapa abarcaría el período comprendido desde los sesenta años en adelante, y se caracteriza por un deterioro físico, la presencia de enfermedades, un debilitamiento muscular y la preocupación cierta por la muerte propia o de pares.

Si filosóficamente puede defenderse la idea de que el sujeto va cambiando en el tiempo, que eso afecta a la culpabilidad y que además psicosocialmente existen esas etapas que se encuentran analizadas y han sido estudiadas por la psicología, entonces parece que lo que sólo era una intuición tiene un apoyo científico que permitiría acotar la pena desde la retribución, límite que rondaría, según los estudios de Erikson, en 20 años o menos, es decir, la duración de cada etapa. ${ }^{39}$ Esto se desprende de la necesidad de que el individuo pueda vivir en libertad en cada una de las etapas, para así poder aspirar un pleno desarrollo.

Desde el punto de vista retributivo parece coherente que el mal de la pena se prolongue sólo respecto de una de las cuatro etapas: que el delito cometido en una etapa de la vida se le retribuya en la misma fase en que cometió el delito. Excepcionalmente, si el delito se comete a fines de una de las etapas, a los diecinueve años por ejemplo, podría pasar la pena a la etapa siguiente teniendo que asumir el marco de la fase sucesora. Sin embargo, parece prudente limitar la pena y que en ningún caso supere la mitad de la etapa siguiente, dejando así libre la mitad de dicho ciclo para que el sujeto pueda desarrollarse en esa nueva fase.

\section{Conclusiones}

El Derecho, en general, y especialmente el Derecho penal, deben nutrirse de diversas disciplinas para así poder aplicar sus preceptos normativos. Este trabajo, que desarrolla un cuestionamiento a las penas privati-

36 ERIKSON, E. Identidad, juventud y crisis. Traducción de Alfredo Guéra. Madrid: Taurus Ediciones, 1980. p. 78.

37 ERIKSON, E. Identidad, juventud y crisis. Traducción de Alfredo Guéra. Madrid: Taurus Ediciones, 1980. p. 110.

38 Lo planteado precedentemente (en nota 3) sobre la teoría del etiquetamiento o Labeling Approach es aún más sensible tratándose de adolescentes, quienes son más propensos a devenir en lo que se dice que son, asumiendo las etiquetas de delincuente juvenil y adecuando su comportamiento a las expectativas de la etiqueta. Véanse: LARRAURI, E. La herencia de la criminología crítica. 2 . ed. México: Siglo XXI, 1992. TANNENBAUM, F. Crime and the community. New: Nueva York, 1938.

39 Un factor distorsionador que debemos considerar, a propósito de las penas privativas de la libertad, se encontraría en los efectos psicológicos y fisiológicos que produce el encierro en el condenado. La reclusión y la rutina mutan la percepción del tiempo, haciendo que el condenado perciba que éste pasa con más lentitud, lo que, creemos, afecta y desfigura las fases o épocas que son naturales al hombre. 
vas de la libertad perpetuas o muy extensas, dedica especial importancia a las etapas del desarrollo psicosocial como fundamento limitativo de la aplicación de las penas según concepciones de justicia o retributivas.

A la hora de verificar si es dable justificar las penas perpetuas o muy extensas, es necesario diferenciar el tipo de teoría sobre el fin de la pena que busque justificar su imposición. Así, a las teorías relativas, que defienden funciones preventivas -más que fines-, les resultan preferidos los argumentos de corte empírico. Por ende, no parece que estos planteamientos puedan ser teorías sobre el fin de la pena, ya que a éstas les es propia una connotación valorativa que no se puede encontrar en las observaciones de tipo únicamente utilitario. Por eso no nos resulta viable dar una respuesta categórica acerca de si la prevención puede o no justificar la cadena perpetua, ya que esta posible justificación dependerá de datos fácticos en los que podrá verificarse si se cumplen o no los fines esperados. Así, por ejemplo, la cadena perpetua podrá justificarse desde la prevención general negativa, si se comprueba que ésta intimida; o desde la prevención especial negativa, si se verifica que con ésta se saca de circulación al penado, etc.

Por otra parte, sostener que la retribución se mueve en el mundo de los valores no equivale a decir que ésta deba despreciar desdeñosamente los datos de la realidad, ya que la naturaleza y la medida abstracta de la pena dependen de consideraciones históricas. La retribución, desvinculada enteramente de los efectos reales de la pena en el penado y en la sociedad, degenera en la retribución propia del idealismo hegeliano, en el sentido de que llevaría a penar porque hay que penar y punto.

De acuerdo con esta concepción de retribución, atenta a la realidad social y especialmente a los efectos que la pena produce en el penado, se descarta toda posible justificación de la cadena perpetua y de las penas de muy larga duración, por los dos motivos que fueron desarrollados precedentemente.

Quisiera ahora, para concluir estas reflexiones, esbozar mi propia propuesta de límites temporales a las penas privativas de la libertad. Ante todo, creo que se debe reservar la pena de prisión únicamente para delitos de especial gravedad, sea contra bienes individuales (asesinato, violación y otros), sea contra bienes jurídicos colectivos cuya ofensa delictuosa afecta gravemente a una multitud de personas (delitos contra el orden público y económico, principalmente). Y, para los delitos de baja y mediana gravedad, propongo el establecimiento de penas distintas a la prisión, que no se presenten en la ley como penas alternativas a la privativa de libertad, sino como pena inmediata y única de esos delitos. Si bien este asunto ha preocupado bastante a la doctrina, parece que la ciencia penal no ha desarrollado todo su poder de imaginación en la búsqueda de penas distintas de la prisión. Ante esta situación parece necesario hacer un uso más amplio y diversificado de la restricción de la libertad ambulatoria, de la inhabilitación para el ejercicio de ciertos derechos, de las penas pecuniarias y de otras formas de sanción que, respetando la dignidad del condenado, lo afecten en bienes que el hombre del siglo XXI considera importantes, pero distintos de las penas privativas de libertad.

Respecto a las penas privativas de libertad, y en atención a los daños irreversibles que produce en el condenado un encierro de más de quince años, propongo que éste sea el límite máximo de la pena privativa de libertad. Me gustaría, si pienso en genocidas o en tiranos, poder proponer un límite superior -40 años, por ejemplo. Sin embargo, no debe perderse de vista que el genocida es también persona, ya que para una teoría liberal de Derecho penal antropológicamente fundado, la sociedad se compone de personas (no de enemigos o no-personas) y se sanciona a personas (por monstruosos que puedan parecer) y, en consecuencia, no debe dejarse de ver en el penado a un semejante, quien, a la hora de ser sancionado, debe seguir siendo reconocido como sujeto de dignidad.

En relación a los estudios de Erikson citados en la tercera parte y entendiendo que de las cuatro etapas que importan para la imputación penal de responsabilidad hay una de menor duración temporal -en concreto, la adolescencia o quinta etapa, la que para Erikson comprende un período que va desde los trece a los veintiún años-, proponemos un límite de ocho años como máxima pena privativa de libertad para los delitos perpetrados por adolescentes, esto es, por personas que, a la hora de cometer el delito, tenían entre 
dieciocho ${ }^{40}$ y veintiún años.

En resumen, y para concluir lo planteado en este trabajo, creo que desde criterios retributivos o de justicia la pena no debe exceder de 15 años tratándose de autores mayores de 21 años, y una pena que no supere los 8 años para los menores de 21 años.

\section{REFERENCIAS}

ALCÁCER GUIRAO, R. Los fines del Derecho penal: una aproximación desde la filosofía política. Anuario de Derecho penal y Ciencias penales (LI). Disponible em: < http://vlex.com/vid/fines-aproximacion-filosofiapolitica-383186>. 1998.

AZRAN, N.; HOLZ, W. C.; HAKE, D. F. Fixed ratio punishment. Experimental Analysis of Behavior, 6. 1963. Disponible en: <http://www.ncbi.nlm.nih.gov/pmc/articles/PMC1404287/pdf/jeabehav00187-0003. pdf.>.

BUSTOS, J.; HORMAZÁBAL, H. Lecciones de derecho penal. Madrid: Editorial Trotta, 1997. v. 1

Cid Moliné, J., ¿Es la prisión criminógena?: un análisis comparativo de reincidencia entre la pena de prisión y la suspensión de la pena, en Jueces penales y penas en España, Valencia: Tirant lo Blanch, 2002.

CLEMMER, D. The prision community, Nueva York: Holt, Rinehart and Winston, 1958. (Originalmente publicado en 1940).

CROFTS, N. at al. Spread of bloodborne viruses among Australian prison entrants. British Medical Journal, v. 310, n. 6975, 1995.

ERIKSON, E. Identidad, juventudy crisis. Traducción de Alfredo Guéra. Madrid: Taurus Ediciones, 1980.

GOFFMAN, Erving. Internados: ensayos sobre la situación social de los enfermos mentales. Traducción de María Oyuela. Buenos Aires: Talleres Gráficos Color Efe, 1992. (Originalmente publicado en 1961).

GOZZANO, M. Compendio di psichiatria clinica e criminológica. Turín: Rosenberg \& Sellier, 1971. p. 240-246.

GUZMÁN DALBORA, J. La pena y la extinción de la responsabilidad penal: primera parte. Santiago de Chile: Legal Publishing, 2008.

HENTIG, H. La pena. Traducción castellana y notas por José María Rodríguez Devesa. Madrid: Editorial Espasa Calpe, 1967. t. 2

JAKOBS, G. Individuo y persona: sobre la imputación jurídico-penal y los resultados de la moderna investigación neurológica. En: CANCIO, Melia; FEIJOO, Sánchez (Coord.). Teoría funcional de la pena y de la culpabilidade. Madrid, 2008.

JAKOBS, G. Derecho penal del enemigo. Traducción de Manuel Cancio Meliá. Madrid: Civitas, 2003.

LANDE, S. An irresponsive time analysis of variable-ratio punishment. Journal of Experimental Analysis of Behavior, 35, 1981.

LARRAURI, E. ¿Para qué sirve la criminología?. Cuadernos de Derecho Judicial - CJPG, Madrid, Política Criminal, 1999.

LARRAURI, E. La herencia de la criminología crítica. 2. ed. México: Siglo XXI, 1992.

LIEBERMAN, David. Learning, behavior, and cognition: Wadsworth. Belmont Publishing, 1993.

40 Esto considerando que bajo los dieciséis años no debe haber imputación penal y, asimismo, entre los dieciséis y los dieciocho un régimen especial de Derecho penal con trato más suave para los menores de edad. 
LIEBLING, A.; MARUNA, S. (Ed.). The effects of imprissonment. Londres: Willan Publishing, 2005.

LOEWENSTEIN, G., Out of control: visceral influences of behavior. Organizational Behavior and Human Decision Processes, 65, 1996.

MAYER, M. Filosofía del derecho. Traducción de la segunda edición original por Luis Legaz Lacambra. Madrid: Editorial Labor, 1931.

MAYER, M. Se ocupa de la idea de bumanidad como la idea del derecho, en filosofía del derecho. Traducción de la segunda edición original por Luis Legaz Lacambra. Madrid: Editorial Labor, 1931.

MERKEL, R. Personale identität und die Grenzen Strafrechtlicher Zurechnung. Juristen Zeitung n. 10, p. 505-506, 1999.

MOLINA FERNÁNDEZ, F. ¿Culpabilidad sin libertad?. En: CANCIO, Melia; FEIJOO, Sánchez (Coord.). Teoría funcional de la pena y de la culpabilidad. Madrid, 2008.

MUÑOZ CONDE, F. Apéndice al libro: Grispigni, Filippo y Mezger, Edmund la reforma penal nacionalsocialista. Buenos Aires: Ediar, 2009.

MUÑOZ CONDE, F. Derecho penal y control social. Santa Fe de Bogotá: Editorial Temis, 1999.

RIVACOBA, M. Función y aplicación de la pena. Buenos Aires: Editorial Depalma, 1993.

Rivacoba, M. Introducción al estudio de los principios cardinales de derecho penal. Direito e Ciudadania n. 6, p. 57-62, 1999.

ROXIN, C. Derecho penal parte general: fundamentos: la estructura de la teoría del delito. Traducción de la $2^{a}$ edición alemana y notas por D. M. Luzón Peña, M. Díaz y García Conlledo y J. de Vicente Remesal. Madrid: Civitas, 1997. t. 1.

SILVA SÁNCHEZ, J. Del derecho abstracto al derecho real. Indret, n. 4, 2006 Disponible em: <http://www. indret.com/pdf/377_es.pdf>.

SILVA SÁNCHEZ, J. Aproximación al derecho penal contemporâneo. 2. ed. ampliada y actualizada. Buenos Aires: B de F, 2010.

SILVA SÁNCHEZ, J. Identidad en el tiempo y responsabilidad penal: el juicio jurisdiccional de imputación de responsabilidad y la identidad entre agente y acusado: estudios penales en homenaje a Enrique Gimbernat. Madrid: Edisofer, 2008. t. 2.

Solomon, R., TURNER, L. H. Y; LESSAC, M. S. Some effects of delay of punishment on resistence to temptation in dos. Journal of Personality and Social Psychology, 8, 1968.

TANNENBAUM, F. Crime and the community. New: Nueva York, 1938.

VON HIRSCH, A. Censurary castigar. Traducción de Elena Larrauri. Madrid: Trotta, 1998.

ZAFFARONI, R. Derecho penal parte general. Buenos Aires: Ediar, 2000.

ZAFFARONI, R. El enemigo en el derecho penal. Buenos Aires: Ediar, 2007.

ZAFFARONI, R. Introducción al libro: Grispigni, Filippo y Mezger, Edmund la reforma penal nacional-socialista. Buenos Aires: Ediar, 2009. 


\section{Neurolaw e as perspectivas para uma análise objetiva do comportamento sugestionado: repercussão das falsas memórias na esfera penal*}

\author{
Neurolaw and the perspectives for an \\ objetive analysis on the suggestioned \\ behavior: repercussion of false memories for \\ the criminal case
}

* Recebido em 25/05/2018

Aprovado em 09/07/2018

** Doutora em Ciência Política pela Universidade Federal de Pernambuco. Mestre em Direito Constitucional pela Universidade de Fortaleza - UNIFOR. Formação em Leadership and Conflict Management pela Stanford University. Formação em Metodologia Quantitativa pela UERJ. Especialista em Direito Processual Civil pela UNIFOR. Professora dos Cursos de Graduação e Pós-Graduação lato sensu em Direito e Processo Constitucionais na Universidade de Fortaleza. Pesquisadora do Grupo Epistemologia e Método na Ciência Política Comparada (Cnpq/UFPE). Pesquisadora do Grupo de Pesquisa Laboratório de Ciências Criminais - LACRIM (Cnpq/ UNIFOR). Coordenadora do Projeto de Pesquisa Processo Civil e Proteção da Pessoa nas Relações Privadas. Advogada. E-mail: mariana.dionisio@ unifor.br

*** Doutora em Direito Constitucional pela Universidade de Fortaleza - UNIFOR. Mestre em Direito Constitucional pela Universidade de Fortaleza - UNIFOR. Professora das disciplinas Direito Constitucional e Direito Internacional no Curso de Graduação em Direito da Universidade de Fortaleza. Assessora Pedagógica do Curso de graduação em Direito - UNIFOR. E-mail: mcartaxo@gmail.com

**** Doutor em Direito Constitucional pela Universidade de Fortaleza - UNIFOR. Mestre em Direito Constitucional pela Universidade de Fortaleza - UNIFOR. Professor Auxiliar da Universidade de Fortaleza. Professor Assistente da Faculdade Ari de Sá (Fortaleza/CE). Assessor de Desembargador no Tribunal de Justiça do Estado do Ceará. E-mail: rafaelgmota@yahoo.com.br

\author{
Mariana Dionísio de Andrade** \\ Marina Andrade Cartaxo*** \\ Rafael Gonçalves Mota****
}

\section{Resumo}

O presente artigo possui como objetivo geral a análise sobre o seguinte problema de pesquisa: há mecanismos objetivos de identificação da implantação de falsas memórias que comprometem o testemunho no processo penal? Como objetivos específicos, o artigo busca esclarecer a relação entre neurociência e direito, e as implicações dessa interação para a resolução de problemas concretos na esfera jurídica, considerando que a coleta de depoimentos das testemunhas consiste em um dos meios de prova mais utilizados no processo penal brasileiro. Como elemento complementar, será realizada a análise do julgamento do caso Escola de Educação Infantil Base, em São Paulo, como exemplo paradigmático da presença de falsas memórias como elemento definidor da decisão judicial. A abordagem é qualitativa, com suporte em revisão de literatura e análise descritiva dos fenômenos pesquisados, além de se apoiar em análise quantitativa, com base em informações baseadas em padrões numéricos e disponibilizadas pelo STJ, em relação à periodização compreendida entre 2012 e 2018. A contribuição é original e inédita. Conclui-se que há uma grave lacuna quanto à definição de elementos objetivos para a identificação de falsas memórias e seu discernimento em relação ao crime de falso testemunho. Entretanto, é necessário enfrentar o fato de que o reconhecimento do comportamento sugestionado exige aprofundamento e interdisciplinaridade, e que a identificação sobre a incidência de falsas memórias pode evitar enormes prejuízos para o direito processual penal.

Palavras-chave: Neurolaw. Falsas memórias. Comportamento sugestionado. Psicologia do testemunho. 


\section{Abstract}

This article intends to analyze the following research problem: are there objective mechanisms to identify the implementation of false memories that compromise testimony in criminal proceedings? As specific objectives, the article seeks to clarify the relationship between neuroscience and law, and the implications of this interaction for solving concrete problems in the legal sphere, considering that the collection of witness testimonies consists of one of the most used means of proof in the Brazilian criminal proceedings. As a complementary element, an analysis of the judgment of the case of the School of Early Childhood Education Base, in São Paulo, will be carried out as a paradigmatic example of the presence of false memories as a defining element of the judicial decision. The study have a qualitative approach, with support in literature review and descriptive analysis of the phenomena researched, in addition to supporting the quantitative analysis, based on information based on numerical standards and made available by the Superior Court of Justice, during the period between 2012 and 2018. The contribution is original and unpublished. It is concluded that there is a serious gap regarding the definition of objective elements for the identification of false memories and their discernment in relation to the crime of false witness. However, it is necessary to face the fact that the recognition of the suggested behavior requires deepening and interdisciplinarity, and that identification on the incidence of false memories can avoid enormous damages to the criminal procedural law.

Keywords: Neurolaw. False memories. Suggestioned behavior. Psychology of the witness.

\section{INTRODUÇÃO}

O artigo propõe uma análise sobre o seguinte problema de pesquisa: há mecanismos objetivos de identificação da implantação de falsas memórias que comprometem o testemunho no processo penal brasileiro? Trata-se de um tema relevante na medida em que o direito processual penal brasileiro depende das provas orais e da coleta de depoimento testemunhal como mecanismo de prova; o que aduz, inequivocamente, à ideia de que, se há comprometimento no depoimento, pode haver prejuízo na produção de provas, incidindo negativamente sobre a idoneidade de todo o processo.

Apesar da importância do conhecimento conceitual para a cognição humana, os cientistas sabem pouco sobre os mecanismos e estruturas neurais subjacentes. Para as ciências jurídicas, há uma carência no estudo dos mecanismos explicativos quanto à participação e utilização de lembranças individuais durante o processo, que ocorre por meio de testemunhas que, não raro, podem se confundir ou relatar eventos distorcidos, prejudicando o processo, a acusação e a defesa.

O entendimento sobre os limites do reconhecimento e identificação por testemunhas é elemento de grande relevância para o direito, não apenas porque o uso de depoimentos baseados em afirmações testemunhais é recorrente em diversas áreas do direito, mas principalmente porque é necessário garantir aos envolvidos alguma segurança durante a coleta de provas orais.

$\mathrm{O}$ artigo se divide em cinco tópicos. O primeiro, aborda a relação entre neurociência e direito, e as implicações dessa interação para a resolução de problemas concretos na esfera jurídica. O segundo tópico enfoca a presença da empatia como mecanismo que tende a gerar influência sobre o comportamento da testemunha, o que não pode ser olvidado em relação à coleta de provas orais e depoimentos no âmbito do direito processual penal e civil.

O terceiro tópico discute a presença de falsas memórias e mecanismos de reconhecimento dessa característica, relacionando o conceito à perspectiva do uso de um depoimento emanado por testemunhas sugestionáveis e os riscos de prejuízo para o bom curso do processo. 
O quarto tópico faz uma abordagem sobre a relação entre a implementação de falsas memórias, bases neurais e fragilidades possíveis no depoimento, e o caso da Escola de Educação Infantil Base, em 1994, no Estado de São Paulo.

O quinto tópico se propõe a fazer uma abordagem empírica com base em padrões numéricos de mensuração, oriundos da análise de dados para identificar os efeitos decorrentes da implantação de falsas memórias sobre as decisões monocráticas no âmbito do Superior Tribunal de Justiça, com periodização entre 2012 a 2018.

A escolha da pesquisa qualitativa como metodologia de investigação se sustenta na necessidade em avaliar teorias polissêmicas e definições cruciais para o tema em desenvolvimento, conferindo suporte teórico, documental e doutrinário para as proposições. Permitiu ainda a construção de inferências válidas com base na análise acurada de textos com balizamento científico, propiciando um importante caminho para o acesso às informações desejadas e consequente fortalecimento do conhecimento acadêmico.

A pesquisa também é exploratória, uma vez que utiliza levantamento bibliográfico de diversas fontes, exemplos que estimulam a compreensão e que atingem a finalidade elementar da pesquisa, que consiste na demonstração da pluralidade de ideias que circundam o tema em estudo.

A análise também possui contribuição complementar da abordagem quantitativa, uma vez que se propõe a examinar o fenômeno com base na coleta e tratamento de informações relativas a padrões numéricos de mensuração, para verificar a correlação entre a teoria estudada e a realidade fática dos acontecimentos.

A pesquisa possui base em uma abordagem teórica múltipla, considerando que o estudo fenomenológico não é dedutivo, mas sim, construído pela análise de diferentes bases de conhecimento e interpretação da realidade.

O artigo é relevante porque propõe uma abordagem sobre a problemática das falsas memórias e suas implicações na esfera jurídica, inclusive no que se refere às consequências para o processo. Ainda, oferece uma valiosa contribuição para os estudos da neurociência aplicada ao direito.

O texto trata de tema importante na aplicação do direito, uma vez que o sistema jurídico brasileiro não comporta hierarquia entre provas. Assim, as provas testemunhais, geralmente desprovidas de respaldo técnico-científico podem ser influenciadas por diversos fatores, inclusive pela implantação de falsas memórias.

\section{NeUROLAW: RELAÇÃo ENTRE NEUROCIÊNCIA E A PSICOLOGIA DO TESTEMUNHO}

O conceito consiste em uma ideia ou uma construção mental que representa um fenômeno do mundo real. Alguns conceitos são complicados, mas constituem elemento fundamental no debate e na pesquisa científica. Considerando-se que um dos objetivos primários da pesquisa consiste em descrever conceitos e analisar a relação entre eles, é fundamental compreender a ideia da relação entre neurociência e direito, denominada neste artigo de neurolaw.

Uma questão conceitual é expressa em ideias, mas é difícil de responder empiricamente. Uma questão concreta, por outro lado, é expressa por meio de propriedades tangíveis, que podem ser respondidas empiricamente. O desafio é descobrir como transformar conceitos em termos concretos, expressar ideias vagas no que possa ser descrito e analisado.

Neurolaw é um campo de pesquisas interdisciplinares, ainda em desenvolvimento, que compreende a relevância das neurociências para aspectos jurídicos de determinadas questões, especialmente na aplicação do direito penal e útil na esfera da psiquiatria forense.

Entretanto, há poucos estudos voltados à aplicação da neurociência durante o reconhecimento e escolha 
de testemunhas e a influência de suas memórias na descrição do fato, que é de fundamental importância para o devido processo legal, produção de provas subsequentes e persecução da verdade real.

Ainda, a ideia de neurolaw consiste em levantar questões complexas sobre a natureza da culpa, livre arbítrio e culpabilidade. Trata-se de uma interseção do direito e da ciência, que envolve o uso de imagens cerebrais e outras técnicas neurocientíficas para determinar as causas biológicas que interferem no julgamento e tomada de decisão.

A neurolaw é predominantemente usada para mitigar as sentenças criminais, mas tem potencial para melhorar a efetividade da reabilitação e encarceramento.

Para todas as possíveis aplicações sob a perspectiva do direito, é necessário conhecer as potencialidades e os riscos, especialmente no que diz respeito ao campo de acesso às memórias, para que não haja distorções ou interpretações equivocadas sobre fatos e eventos jurídicos que são objeto de julgamento.

O direito e a neurociência parecem estranhos à primeira vista, mas se correlacionam fortemente. Portanto, o engajamento da lei com evidências neurocientíficas é um caminho inevitável. Por um lado, a eficácia dos sistemas legais na regulação do comportamento e a resolução da justiça muitas vezes depende da evidência de pesagem sobre como e por que uma pessoa se comportou como ele ou ela fez.

Por outro lado, os advogados são eticamente obrigados a defender os interesses de seus clientes, permanecendo alertas para informações novas, relevantes ou potencialmente persuasivas (campo em que os conhecimentos da neurociência podem oferecer explicações relevantes), que poderia ajudar a explicar ou contextualizar o comportamento de seus clientes.

É claro que a relevância da neurociência para o direito depende intimamente da questão jurídica específica e do contexto. E a evidência neurocientífica é apenas um tipo de evidência, a ser ponderada ao lado de outros tipos de provas.

Cumpre destacar que evidências neurocientíficas podem ajudar o processo em pelo menos sete formas, que podem se apresentar conjuntamente ${ }^{1}$ : (1) a partir do reforço, quando a confiança do jurado em uma conclusão é aumentada diante de outras evidências não-neurocientíficas (como a existência de doença incapacitante, por exemplo); (2) a partir do desafio, questionando ou contradizendo qualquer outra evidência em um caso ou uma suposição legal relevante; (3) com base na detecção ou identificação sobre a existência de fatos legalmente relevantes (como lesões, mentiras ou conduta dolosa do agente); (4) com base na classificação das pessoas em categorias (pessoas com ou sem filhos, por exemplo, no julgamento de um crime de parricídio); (5) com base na intervenção, fornecendo novos métodos para atingir os objetivos legais; (6) com base na explicação, esclarecendo o processo de tomada de decisão com informações que podem levar a decisões mais informadas e menos tendenciosas; e (7) com base na previsão, melhorando a capacidade da lei de estimar probabilidades de comportamento futuro (como um padrão de reincidência no cometimento de condutas típicas de violência doméstica).

A neurociência também pode fazer importantes contribuições em relação a jurados e juízes. Para que um sistema legal seja considerado justo, deve se basear no julgamento sólido desses terceiros imparciais, na medida em que decidem a culpa dos arguidos e atribuem punições adequadas.

Para o presente artigo, o cerne das preocupações está na capacidade de retenção de informações conexas pela memória da testemunha, cujo depoimento será de fundamental relevância para a solução de um caso, o que demanda conhecimento sobre aspectos comportamentais, biológicos e muitas vezes emocionais dos envolvidos.

Ressalte-se que a neurociência permanece limitada na sua capacidade de impactar processos legais devido à dificuldade que surge quando se tenta traduzir uma ciência mecânica para aspectos psicológicos.

1 JONES, Owen D. et al. Law and Neuroscience. Journal of Neuroscience, v. 33, n. 45, p. 236-280, 2013. 
Não que a neurolaw tenha a capacidade de mudar fundamentalmente o sistema legal, porque há um universo de informações ainda desconhecido sobre o funcionamento do cérebro humano e suas conexões com a realidade.

A complexidade do comportamento humano é extremamente profunda e dificilmente seria possível definir um rol taxativo e autoexauriente de possibilidades das conexões que podem ser feitas, por exemplo, durante a atividade de testemunhar.

O comportamento dos indivíduos depende de muitas variáveis que levam a padrões gerais, e a eficiência da tradução de uma postura ainda exige repetições para a coleta de evidências comportamentais. Mas conhecer a neurociência pode ser útil para fazer contribuições à doutrina jurídica, sem o apelo de causar uma revolução.

Os argumentos que procuram explicar o comportamento baseado na atividade cerebral interessam ao estudo das relações jurídicas, tanto em contextos civis como criminais, e são úteis para uma variedade de propósitos.

\section{O PROBLEMA DA EMPATIA SOBRE O COMPORTAMENTO DA TESTEMUNHA}

O objetivo da lei é proteger os interesses da sociedade e promover a justiça, e hoje a integração do direito e da neurociência está na vanguarda de admissibilidade legal. A neurociência cognitiva tem potencial para contribuir em grande medida para a atuação jurídica, mas a questão é saber se a neurociência está preparada para fazer essas contribuições objetivas e de maneira imediata, mesmo com a enorme complexidade do comportamento humano.

O cognitivo moderno, das neurociências, representa uma visão global da natureza humana, causando, assim, um forte impacto sobre os fundamentos da arquitetura conceitual do conhecimento jurídico, o que permite um profundo repensar do que é absolutamente necessário. Só não se tem ainda os resultados dessa reconsideração, mas certamente será inevitável.

Os problemas do ser humano são sempre os mesmos sob certos aspectos, porque o corpo e especialmente o cérebro se adaptam muito lentamente a mudanças culturais e geográficas, que ocorrem no mundo em que vivem e trabalham.

O conceito de "mente estendida" é um elemento essencial a ser usado numa introdução à análise das possíveis alterações a serem feitas no clássico conceito de relação jurídica, e talvez seja mais importante que a descoberta dos neurônios-espelho. De acordo com essa doutrina, de fato, o cérebro também incorpora os sujeitos e não apenas os objetos com os quais interage socialmente em sua representação da realidade.

Se o efeito emulativo produzido pela liberação operada pelos neurônios-espelho é na base do fenômeno genericamente descrito como "empatia", a extensão "mente" tende a incorporar características pertencentes às outras pessoas, como os antigos casais bem sabem, a tal ponto que distinguir um do outro muitas vezes se torna muito difícil.

Em outras palavras, se a empatia está na base do conceito de harmonia, a mente estendida é responsável por um processo, ainda a ser bem descrito, em que uma permeação ocorre entre dois seres humanos. É por isso que o processo de estudar e definir a parceria em termos inovadores é tão difícil do ponto de vista jurídico, em ambos os casos de uma parceria público-privada².

2 PICOZZA, Eugenio. Public Law and Private Law Issues. In: PICOZZA, Eugenio (Ed). Neurolaw: an introduction. Nova York: Springer, 2016. p.119-166. 


\section{QUANDO O DEPOIMENTO PODE PREJUDICAR O PROCESSO: TESTEMUNHA SUGESTIONÁVEL}

Conferir credibilidade apenas à memória nem sempre pode ser uma resposta razoável, uma vez que nem sempre os indivíduos guardam com precisão todas as informações, especialmente porque a atenção aos fatos e às circunstâncias se dividem por interesse. As memórias humanas são maleáveis, abertas a sugestões e, não raro, involuntariamente falsas. Nem sempre a totalidade dos eventos cotidianos são percebidos da mesma maneira, o que pode influenciar a dimensão das memórias de acordo com as vivências próprias de cada pessoa ${ }^{3}$.

As lembranças são seletivas, porque correspondem ao impacto que certas circunstâncias representam para cada um. Confiar na exatidão da memória pode ser um caminho arriscado na busca da verdade real.

Uma falsa memória é uma lembrança fabricada ou distorcida de um evento. As pessoas costumam pensar na memória como qualquer coisa parecida com um gravador de vídeo, documentando e armazenando com precisão tudo o que acontece com clareza perfeita.

Na realidade, a memória é muito propensa à falácia ou à manipulação. Indivíduos, com diferentes conceitos, valores e formação, podem se sentir completamente confiantes de que sua memória é precisa, mas essa confiança não é garantia de que uma determinada memória esteja correta.

Trata-se de uma maneira pela qual as experiências passadas são acessadas e mescladas com impressões do presente, com base em mecanismos dinâmicos associados à retenção e recuperação da informação, o que pode gerar graves distorções ${ }^{4}$.

É possível definir a falsa memória não como uma falha de lembrança, mas como algo mais complexo, que envolve a incorporação de recordações que se referem a acontecimentos que não necessariamente aconteceram, ou relatos emocionais equivocados de experiências vividas. Tais memórias representam uma lembrança distinta de algo que não aconteceu, e podem ser implantadas por terceiros. Não se trata de esquecer ou misturar detalhes de coisas que foram vivenciadas, mas sim, lembrar de coisas que nunca foram experimentadas. ${ }^{5}$

Fatores externos e/ou psicológicos podem influenciar a implantação de falsas memórias, incluindo informações incorretas e atribuição inadequada da fonte original da informação. O conhecimento existente e outras lembranças também podem interferir na formação de uma nova memória, fazendo com que a recordação de um evento seja confundida ou sugestionada, incorporando novas informações ou experiências. ${ }^{6}$

O paradigma da falsa memória atrai as pessoas a lembrar falsamente itens que nunca foram apresentados. Assim, é possível que indivíduos possam orientar explicitamente como processam a informação, o que aduz à possibilidade que indícios afetivos também possam orientar o processamento de informações?

Memórias falsas também podem ser surpreendentemente persistentes. Inclusive, podem se manifestar a partir do uso de técnicas de recuperação de memória, como terapias e entrevistas, que involuntariamente são susceptíveis de gerar memórias falsas; memórias aparentes para eventos que nunca ocorreram. No sistema de justiça criminal, no processo trabalhista ou em demandas civis, por exemplo, a existência de falsas memórias pode gerar graves consequências.

Por exemplo, antes de atingir a idade de três anos, o cérebro humano não está fisiologicamente apto para formar memórias que duram até a idade adulta, o que significa que as lembranças reivindicadas desse pe-

3 MARSCH, Elizabeth J.; FAZIO, Lisa K. Correcting False Memories. Psychological Science, v. 21, n. 6, p. 801-803, 2010.

4 STERNBERG, R. J. Psicologia cognitiva. Porto Alegre: Artes Médicas Sul, 2000.

5 BRAINERD, Charles J.; REYNA, Valerie F. The Science of False Memory. New York: Oxford University Press, 2005.

6 LOFTUS, Elizabeth F.; PICKRELL, John E. The Formation of False Memories. Psychiatric Annals, n. 25, p. 720-725, 1995.

7 CLORE, Gerald L.; STORBECK, Justin. Affect Influences False Memories at Encoding: Evidence from Recognition Data. Emotion, Emotion. v. 11, n. 4, p. 981-989, 2011. 
ríodo são suspeitas, mas podem influenciar a formação de memórias futuras, enviesando o raciocínio sobre determinados temas, apontando para memórias reprimidas. Há estudos que revelam que as formas sutis de uma questão podem afetar o que uma testemunha relata, justamente pela correlação que internamente pode fazer com suas memórias reprimidas.

Em última análise, os métodos de interrogação também devem ser verificados, porque, se inadequados, podem levar a relatos de testemunhas oculares equivocadas, acusações sem fundamento e até a falsas confissões, baseadas em percepções distorcidas da realidade.

O que torna as memórias humanas tão suscetíveis se resume ao modo como o cérebro armazena informações. Isso é encapsulado por um conceito chamado de Teoria dos Rótulos Difusos, descrito pela primeira vez nos anos 90 pelos psicólogos norte-americanos Charles Brainerd e Valerie Reyna. A teoria sugere que os cérebros depositam memórias em duas formas: rótulos de memória genérica e memória?

Os rótulos de memória genética são habilidades complexas e saberes refinados inatos, herdados natural e inexplicavelmente, de forma ancestral. A memória reflete um conjunto de vivências cuja lembrança se consolidou no cérebro, e que perduram ao longo do tempo, envolvendo o pensamento consciente ${ }^{10}$.

As distorções de memória surgem porque o cérebro armazena e relembra esses tipos de informação de forma independente, de acordo com a teoria. Uma vez que as memórias genéricas também são mais duradouras e mais confiáveis ao longo do tempo, isso leva a uma conversa cruzada de memória.

A ideia de implantar recordações imperfeitas se relaciona com as associações que cérebro humano é capaz de construir. Um estudo sobre as possíveis associações desenvolvidas com base em sugestões, considerou uma amostra composta por 426 estudantes universitários de diferentes instituições de ensino (Estados escolhidos para a consulta: São Paulo, Rio Grande do Sul e Paraná); 283 mulheres e 143 homens, com idade média entre 23 a 27 anos. Com base em um cálculo estatístico que aferiu a relação entre o grau de associação semântica individual e a força das palavras no experimento, verificou-se, em um teste de recordação livre, a forte presença de associações baseadas em sugestões ${ }^{11}$.

Em mais um estudo sobre falsas memórias, verificou-se a relação entre a implantação de recordações e o depoimento de testemunhas oculares, acrescentando ao teste falsas memórias em adultos por meio da técnica misinformation effects, na qual fatos verdadeiros são contados e mesclados com eventos que não aconteceram, mas que são coerentes com os fatos reais. Os resultados evidenciaram aumento dos indicadores de reconhecimento falso e redução consequente de reconhecimento dos eventos verdadeiros ${ }^{12}$.

A manipulação de memórias pela introdução de recordações imperfeitas também possui repercussões na esfera imagética. É possível realizar associações não apenas semânticas para estimular a memória, mas também visuais, o que indica sugestões pela introdução de histórias e imagens, com base na criatividade do introdutor e adaptação associativa do receptor ${ }^{13}$.

Entretanto, é necessário diferenciar as consequências sobre a implantação de falsas memórias do crime de falso testemunho, previsto pelo art. 342 do Código Penal brasileiro como o ato de "fazer afirmação falsa, ou negar ou calar a verdade como testemunha, perito, contador, tradutor ou intérprete em processo judicial,

8 STERN, Peter. Encoding false memories. Science, v. 354, n. 6309, p. 193-194, oct. 2016.

9 MARSCH, Elizabeth J.; MULLET, Hillary G. Correcting False Memories: Errors Must Be Noticed and Replaced. Memory \& Cognition, v. 44, n. 3, p. 403-412, 2016.

10 LOMBroso, Paul. Aprendizado e memória. Revista Brasileira de Psiquiatria, v. 26, n. 3, p. 207-210, 2004.

11 STEIN, Lilian Milnitsky; FEIX, Leandro da Fonte; ROHENKOHL, Gustavo. Avanços metodológicos no estudo das falsas memórias: construção e normatização do procedimento de palavras associadas. Psicologia Reflexão e Crítica, v. 19, n. 2, p. 166-176, 2006.

12 LOFTUS, Elizabeth F.; PALMER, J. C. Reconstruction of automobile destruction: An example of the interaction between language and memory. Journal of Verbal Learning and Verbal Behavior, n. 13, p. 585-589, 1974.

13 TURNEY, Indira C.; DENNIS, Nancy A. Elucidating the neural correlates of related false memories using a systematic measure of perceptual relatedness. NeuroImage, v. 146, n. 1, p. 940-950, feb. 2017. 
ou administrativo, inquérito policial, ou em juízo arbitral”, punível com reclusão de 2 (dois) a 4 (quatro) anos, e multa em razão da gravidade dos prejuízos decorrentes das falsas afirmações para o comprometimento do processo como um todo.

Enquanto a implantação de falsas memórias atinge a esfera psicológica do depoente, que efetivamente acredita no que expressa como verdade (muito embora o depoimento possa fazer parte de um histórico desconectado com a realidade dos fatos), o crime de falso testemunho possui a condicionante da plena ciência quanto às inverdades relatadas, o que é feito com o objetivo principal de manipular a realidade e as impressões do julgador acerca dos eventos.

Ainda, o crime de falso testemunho possui natureza formal e pode ser caracterizado independentemente da produção do resultado material efetivamente desejado pelo agente, visto que a consumação se dá no momento da simples prestação do depoimento falso ${ }^{14}$, pela simples potencialidade de dano para a administração da justiça.

O processo penal possui ritos que dependem da memória da testemunha, o que implica uma ritualística arriscada, na medida em que memórias são manipuláveis, frágeis e moldáveis pelas circunstâncias pessoais de percepção de cada indivíduo.

Nem sempre é possível armazenar um volume grande de informações visuais com precisão, especialmente porque a velocidade dos fatos nem sempre é compatível com os padrões valorativos do indivíduo que retém a informação.

O falso testemunho, contrariamente às falsas memórias, consiste em ato consciente e manifesto para causar prejuízo ao processo com base em informações enganosas. A repercussão do falso depoimento no processo evidencia uma possível fragilidade quanto aos mecanismos de detecção das contradições.

Não raro, juízes intuitivamente captam as contradições e detectam o falso testemunho, com base em técnicas psicológicas ou mesmo experiência profissional. Porém, não se trata de um meio infalível, uma vez que a decisão judicial, que põe termo ao processo principal, não pode ser pautada na intuição do julgador.

É necessário criar procedimentos que auxiliem a uma produção de provas adequada, evitando que percepções equivocadas danifiquem as provas adjacentes e o próprio processo.

Sobre o tema, a Resolução no 75, de 12 de maio de 2009, do Conselho Nacional de Justiça (CNJ), que dispõe sobre os concursos públicos para o ingresso na carreira da magistratura em todos os ramos do Poder Judiciário nacional, determina em seu Anexo IV que o curso de formação deve conter noções gerais de direito e formação humanística, que inclui o aprofundamento sobre o processo psicológico e a obtenção da verdade judicial, além da avaliação sobre o comportamento de partes e testemunhas.

\section{Repercussões das falsas memórias PARA A ESFERA PENAL: O CASO dA ESCOLA DE EDUCAÇÃO INFANTIL BASE}

A memória é moldável e é necessário compreender seus mecanismos de formação. Tanto a formação quanto a evocação de memórias de curta e longa duração são fortemente moduladas por meios relacionados à vida emocional, e que a hiperatividade da amígdala causado pelo estresse pode produzir os blank spaces familiares ${ }^{15}$.

14 BRASIL. HC 73.976-SP. Ministro Relator Carlos Velloso. Supremo Tribunal Federal. Disponível em: < https://stf.jusbrasil. com.br/jurisprudencia/14816214/habeas-corpus-hc-81381-sp-stf>.

15 BALMAKUND, Zurizadai. The Realities of Neurolaw: a composition of data \& research. In: University of St. Thomas Journal of Law and Public Policy, v. 9, n. 2, p. 234-258, 2015. 
Estudos sobre o conjunto e a formação de memórias são muito importantes de soluções de casos. Em muitos julgamentos brasileiros, os blank spaces ou a modificação nas memórias causada por estresse ou situações muito emocionais consistem na chave para a decisão entre considerar ou não a utilização de um depoimento testemunhal.

As memórias se relacionam com bases neurais do altruísmo humano, neurogenética e neurociência cognitiva da psicopatia e bases psicológicas e neurais de pertencimento. Substratos neurais de emoções básicas e morais, ressaltam a importância de sentido moral das pessoas para o funcionamento dos sistemas legais.

As pesquisas que discutem os substratos físicos da moral e a descoberta de que mudanças nos substratos físicos podem modificar o senso moral de alguém, conduzem à seguinte reflexão: o livre arbítrio realmente existe? As implicações para a lei são óbvias: se não há livre-arbítrio, todo o direito civil, baseado na ideia de autonomia, e toda a lei criminal, fundada na noção de culpa (responsabilidade pessoal), deve ser repensado ${ }^{16}$.

Em algumas áreas, os tribunais limitam o interesse de um especialista no testemunho do fenômeno geral. Tratam-se de microssistemas penais especializados ${ }^{17}$. No Brasil, a busca por um eficientismo persecutório pode não deter plena atenção aos falsos sentidos ou implantação de falsas memórias, o que é preocupante em um contexto de relevante uso da prova testemunhal ${ }^{18}$.

O tratamento dado pelos tribunais ao testemunho de especialistas, por exemplo, pode diminuir a precisão das identificações de testemunhas oculares. Tribunais americanos geralmente permitem que testemunhas oculares testemunhem sobre fatores, como identificações cruzadas ou estresse, que podem afetar negativamente a precisão.

Eles não permitem testemunho, o que impede a verificação se uma determinada identificação foi precisa ou não. No caso Estados Unidos vs. Smith, por exemplo, o tribunal explicou que o valor desse testemunho geral foi educativo. Educar o júri sobre essa pesquisa seria um passo importante ao longo do caminho para o uso de conhecimento científico melhorado para criar procedimentos legais mais precisos e justos.

O testemunho não consistiu um diagnóstico, enfatizou a corte de Smith, pois a aplicação desta pesquisa aos fatos do caso não exclui a competência do júri. No entanto, em uma série de outros casos, os tribunais, ou exigem, ou permitem que especialistas ofereçam diagnósticos para identificar se o caso em questão é uma instância de algum fenômeno legalmente relevante.

Outro exemplo, um autor deve introduzir perícia sobre o fenômeno geral e a questão individualizada. Um demandante alegando que a exposição ao benzeno causou sua leucemia, por exemplo, teria que introduzir tanto evidência científica de que o benzeno causa leucemia e evidências de diagnóstico científico de que a exposição ao benzeno causou especificamente sua leucemia.

Nos casos que envolvem identificação forense - variando de impressões digitais a armas de fogo - os tribunais geralmente permitem que especialistas testifiquem das duas formas. Assim, um perito em armas de fogo tipicamente atesta que certas marcas em casos de cartuchos estão associadas a um grupo de armas de fogo e, adicionalmente, que as marcas no cartucho caso encontrado na cena do crime foram feitas por uma arma específica.

Três decisões da Suprema Corte dos Estados Unidos ilustram o quão longe se chegou e quão distante ainda se está no entendimento das limitações de inferência científica. Todos os três casos envolveram pesquisa comportamental e neurocientífica que demonstrou que o cérebro, com a sua concomitante capacidade

16 PRATA, Henrique Moraes; FREITAS, Márcia Araújo Sabino de. Brainzil Imaging: Challenges for the Largest Latin American Country. In: SPRANGER, Tade Matthias. Internacional Neurolaw: A comparative analysis. Nova York: Springer, 2012. p. 67-88.

17 ARAÚJO, Felipe Dantas de. Criminologia crítica e política criminal antilavagem de dinheiro e contrafinanciamento do terrorismo: barreira epistêmica e agenda de diálogo. Revista Brasileira de Políticas Públicas, Brasília, v. 2, n. 2, p. 01-27, 2012.

18 LIMA, José Wilson Ferreira; SUXBERGER, Antonio Henrique Graciano. O processo penal e a engenharia de controle da política criminal. Revista Brasileira de Politicas Públicas, Brasília, v. 7, n. 1, p. 286-306, 2017. 
de desenvolvimento, não amadurece totalmente até o início dos 20 anos.

No caso Roper vs. Simmons (2005), o Tribunal considerou que a Oitava Emenda não permitia impor a pena de morte para réu que tinha matado antes dos 18 anos. No caso Graham vs. Florida (2009), o Tribunal alargou esse raciocínio para outro conjunto de delinquentes juvenis, aqueles enfrentando a prisão perpétua por outros crimes a não ser o de homicídio. A decisão, como a de Roper, foi categórica, aplicando-se a todos os indivíduos abaixo da idade de 18 no momento em que o crime foi cometido.

Finalmente, no caso Miller vs. Alabama (2013), o Tribunal concluiu que a Oitava Emenda também pró́be prisão perpétua para jovens condenados de homicídio. Citando tanto Roper e Graham, uma vez novamente a decisão do Tribunal referenciou descobertas científicas que diminuíram a culpabilidade moral de uma criança e reforçou a perspectiva de que, com o passar dos anos, e desenvolvimento neurológico essas “deficiências" podem ser corrigidas ${ }^{19}$.

No entanto, em Miller, a Corte se recusou a impedir capacidade do sentenciador para fazer essa distinção. Ao contrário de Roper e Graham, o precedente Miller deu aos tribunais a opção de sentenciar infratores jovens à prisão perpétua, no caso a caso, apesar do fato de que não há pesquisa neurocientífica disponível para ajudar tal determinação. Não haveria uma assinatura neural para a maturidade, nenhum teste psicológico que revele quão bem desenvolvido é um indivíduo.

O Tribunal constatou que o estado da ciência indicou diferenças relevantes de maturidade entre adolescentes e adultos, que apoiaram a decisão de que era inconstitucional sentenciar homicídio de adolescentes infratores à vida obrigatória na prisão. A ciência em adolescentes como um grupo, assim, ajudou a estabelecer a regra constitucional. Mas, na prática, os tribunais devem agora condenar adolescentes individualmente.

Quase certamente, na sentença, as partes procuram apresentar o testemunho "científico" de especialistas que tendem a demonstrar apoio às suas perspectivas. No Brasil, há uma tendência ${ }^{20}$ ao posicionamento favorável pela aplicação de diagnósticos neurocientíficos para corroborar seus entendimentos.

Sobre o tema, é importante considerar um caso brasileiro emblemático, cujos depoimentos com base em falsas memórias e falso testemunho foram determinantes para uma série consequente de prejuízos, tanto processuais, quanto relativos à violação de direitos fundamentais.

No início da década de 1990, o casal Icushiro e Maria Aparecida Shimada decidiu adquirir estabelecimento de ensino básico em decadência, situado no bairro da Aclimação, Estado de São Paulo, juntamente com outro casal que seria responsável pela área administrativa. A Escola de Educação Infantil Base, comprada pelo casal, foi reestruturada para atender crianças do bairro e seguia com suas funções adequadamente.

Até em 1994, duas mães de alunos se dirigiram à $6^{a}$ Delegacia de Polícia, na zona sul de São Paulo para registrar Boletim de Ocorrência contra os casais que trabalhavam na escola, atribuindo a estes o comportamento lascivo e pornográfico, com base no relato de seus filhos menores. ${ }^{21}$

A denúncia sobre o envolvimento dos donos da Escola Base na realização de orgias sexuais com crianças, conforme compreensão dos pais a partir do relato dos filhos e com ampla cobertura da imprensa nacional, deu início a um processo desgastante e midiático quanto à conduta dos donos do estabelecimento.

O delegado responsável, à época, chegou a obter um mandado determinando a busca e apreensão de quaisquer indícios da existência do crime, tanto na casa dos donos da Escola base, como no interior do estabelecimento, entretanto, nada foi localizado.

19 MARSCH, Elizabeth J.; MULLET, Hillary G. Correcting False Memories: Errors Must Be Noticed and Replaced. Memory \& Cognition, v. 44, n. 3, p. 403-412, 2016.

20 Como exemplo, tem-se o Tribunal de Justiça do Estado de São Paulo, com voto proferido pelo Desembargador Figueiredo

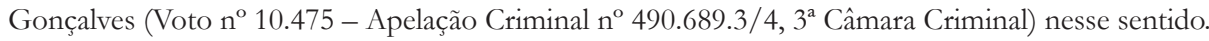

21 RIBEIRO, Alex. Caso Escola Base: os abusos da imprensa. São Paulo: Ática, 2003. 
O Instituto Médico Legal emitiu resultados do exame de corpo de delito, identificando que a presença de assaduras evidenciava a prática de atos libidinosos contra as crianças examinadas, em período semelhante ao da denúncia.

A partir desse resultado, divulgado nacionalmente, a Escola Base foi depredada e havia comoção geral em prol do linchamento dos proprietários. O caso em si apresentou diversos erros processuais e procedimentais (oitiva dos menores sem a presença de psicólogos, realização de exames inconclusivos etc.), que chegaram a comprometer o curso da ação penal.

Até o presente, nunca foram localizadas evidências robustas sobre o cometimento dos abusos sexuais e demais crimes relatados, especialmente quanto à violência física e psicológica sofrida pelos menores.

Restou comprovado apenas o sofrimento vivenciado pelos acusados, que tiveram suas vidas absolutamente devassadas e diversos direitos fundamentais violados em razão das denúncias sem fundamento ou baseadas em falsas memórias implantadas nas crianças.

Os direitos fundamentais dos indivíduos devem ser considerados em papel de destaque, porque evidenciam a guarda sobre a honra, idoneidade moral e física ${ }^{22}$. Essa fundamentalidade impõe o cuidado com o teor das denúncias, justamente para evitar um julgamento moral antecipado, que pode nublar a verdade dos fatos, afastar a possibilidade de defesa real e prejudicar jurisdicionados e o próprio processo.

No caso da Escola Base, o imaginário popular constituiu terreno fértil para a condenação precipitada dos donos do estabelecimento, uma vez que até o laudo emitido pelo Instituto Médico Legal era pouco preciso e poderia sugerir tanto uma possível agressão quanto assaduras infantis por micose ou higiene inadequada.

Some-se à denunciação falaciosa a irresponsabilidade da imprensa na cobertura e divulgação dos fatos, a possibilidade de implantação de falsas memórias nas crianças, os inúmeros erros de condução processual e a sede de punição de pessoas que se identificavam emocionalmente com os relatos: configura-se uma tempestade perfeita para a destruição definitiva da imagem dos proprietários da Escola Base.

A prova testemunhal, no caso em apreço, foi fundamental para a condução da investigação e do processo; o que não significa dizer que tenha sido o único meio de prova coletado, mas, sem dúvidas, o de maior relevância. Assim, como estabelecer critérios objetivos ou minimamente fiáveis para garantir que a principal peça do processo não possui vícios?

Ainda, até que ponto seria possível identificar que se tratavam de denúncias infundadas, considerando-se que partiram de crianças? A gravidade da utilização de provas que podem estar contaminadas por falsas memórias exige uma análise ampla do contexto em que os relatos são produzidos, para que seja possível identificar fatores que possam gerar prejuízo ou danos decorrentes do depoimento (v.g. falso reconhecimento, identificação equivocada deum sujeito ou de uma circunstância fora do contexto).

A situação evidencia o fundamental papel da realização de um processo penal adequado, conduzido por procedimentos como a perícia psicológica em casos que envolvem suspeita de abuso sexual infanto-juvenil ${ }^{23}$, que, por vezes, podem ser caracterizados pela presença de falsas memórias ou mesmo por laudos inconclusos ${ }^{24}$.

Ainda, dada a importância da declaração realizada pelas partes na coleta de depoimentos orais, é essencial que haja elementos capazes de identificar a eventual presença de falsas memórias, prevenindo riscos à continuidade ordenada do processo ${ }^{25}$.

22 ADAMY, Pedro. Direitos fundamentais e as relações especiais de sujeição. Revista Brasileira de Políticas Públicas, Brasília, v. 8, n. 1, p. 360-376, 2018.

23 SCHAEFER, Luiziana Souto; ROSSETTO, Silvana; HAAG KRISTENSEN, Christian. Perícia psicológica no abuso sexual de crianças e adolescentes. Psicologia: Teoria e Pesquisa, v. 28, n. 2, p. 227-250, apr./jun. 2012.

24 OLIVEIRA, Denise Cabral Carlos de. Abuso sexual infantil em laudos psicológicos: as "duas psicologias". Physis, v. 27, n. 3, p. $579-604,2017$.

25 MARTÍN DE AGAR, José Tomás. El valor de la declaración de las partes en el proceso de nulidad. Ius Canonicum, v. 57, n. 


\section{ANÁLISE DE DADOS: IDENTIFICANDO A IMPLANTAÇÃO DE FALSAS MEMÓRIAS EM DECISÕES MONOCRÁTICAS NO ÂMBITO DO SUPERIOR TRIBUNAL DE JUSTIÇA}

O tema é relevante e exige profundas discussões porque envolve a extensão do poder punitivo do Estado e a possibilidade de condenação pautada em falsas memórias, o que evidentemente afeta o gozo de direitos como a liberdade, a idoneidade moral e física, a dignidade, incidindo negativamente sobre todo o sistema constitucional democrático.

Elementos como traumas, falhas de memória, distorção da percepção pela falta de maturidade, sugestão, lapsos e influência da vontade subconsciente; podem se tornar fatores que propiciam a incidência de falsas memórias. Estas, são lembranças de um evento que pode ter ocorrido de outra forma, ou mesmo que pode sequer ter acontecido ${ }^{26}$.

Apenas uma fração das informações que o cérebro humano tem acesso é devidamente registrada, mas sofre influência oriunda de valores e emoções pessoais, conceitos pré-estabelecidos, impressões íntimas, interação com outras memórias e variados elementos psíquicos e externos ${ }^{27}$. Ou seja, a memória é um espaço de recordações que podem ser difusas, e que podem não refletir a inteireza das circunstâncias visualizadas.

Para compreender o efeito das falsas memórias sobre as ações penais, foram coletadas 50 decisões monocráticas no âmbito do Superior Tribunal de Justiça, com periodização entre 2012 a 2018, cujos marcos final e inicial foram definidos pela disponibilidade dos dados. Foram excluídos casos em que foi verificada a eventual repetição de registro, assim como os casos de falso testemunho, considerando-se, apenas, a identificação de falsas memórias.

A consulta foi gerada com base na ocorrência do termo "falsas memórias", que ocorreram em Acórdãos referentes a pedidos de habeas corpus, Revisão Criminal e Recurso Especial. A ideia consiste em verificar se há identificação de falsas memórias implantadas em testemunhas e aferir se houve prejuízo para o depoimento.

Tabela 1. Presença de falsas memórias como fator determinante para a decisão nas ações penais no âmbito de Superior Tribunal de Justiça.

\begin{tabular}{|l|l|l|l|l|l|}
\hline \multicolumn{2}{|l|}{ Tipo } & Data & Efeito da Falsa Memória & Matéria & Tipo de Ação \\
\hline 01 & HC 438768 & $\begin{array}{l}\text { DJe } \\
04 / 05 / 2018\end{array}$ & Contaminação da prova & Penal & Crime Patrimonial \\
\hline 02 & $\begin{array}{l}\text { AREsp } \\
1192667\end{array}$ & $\begin{array}{l}\text { DJe } \\
22 / 03 / 2018\end{array}$ & Contaminação da prova & Penal & Crime Patrimonial \\
\hline 03 & $\begin{array}{l}\text { REsp } \\
1622861\end{array}$ & $\begin{array}{l}\text { DJe } \\
22 / 03 / 2018\end{array}$ & Desqualificação da parte & Família & Alienação Parental \\
\hline 04 & RvCr 004254 & $\begin{array}{l}\text { DJe } \\
16 / 03 / 2018\end{array}$ & Contaminação da prova & Penal & Crime Patrimonial \\
\hline 05 & $\begin{array}{l}\text { REsp } \\
1708648\end{array}$ & $\begin{array}{l}\text { DJe } \\
09 / 02 / 2018\end{array}$ & $\begin{array}{l}\text { Contaminação da prova } \\
\text { DJe } \\
07 / 02 / 2018\end{array}$ & Penal & Crime Sexual \\
\hline 06 & HC 418229 & Contaminação da prova & Penal & Crime Sexual \\
\hline
\end{tabular}

114, p. 663-706, 2017.

26 ÁVILA, Gustavo Noronha de; BALDASSO, Flaviane. A Repercussão do Fenômeno das Falsas Memórias na Prova Testemunhal: uma análise a partir dos Julgados do Tribunal de Justiça do Rio Grande do Sul. Revista Brasileira de Direito Processual Penal, v. 4, n. 1, p. 371-409, 2018.

27 IZQUIERDO, Iván. Memória. Porto Alegre: Artmed, 2006. 


\begin{tabular}{|c|c|c|c|c|c|}
\hline \multicolumn{2}{|c|}{ Tipo } & \multirow{2}{*}{$\begin{array}{l}\text { Data } \\
\text { DJe } \\
13 / 12 / 2017 \\
\end{array}$} & \multirow{2}{*}{$\begin{array}{l}\text { Efeito da Falsa Memória } \\
\text { Desqualificação da parte }\end{array}$} & \multirow{2}{*}{$\begin{array}{l}\text { Matéria } \\
\text { Família }\end{array}$} & \multirow{2}{*}{$\begin{array}{l}\text { Tipo de Ação } \\
\text { Modificação de Guar- } \\
\text { da }\end{array}$} \\
\hline 07 & $\begin{array}{l}\text { AREsp } \\
875573\end{array}$ & & & & \\
\hline 08 & HC 414762 & $\begin{array}{l}\text { DJe } \\
04 / 12 / 2017\end{array}$ & Contaminação da prova & Penal & Crime contra a Vida \\
\hline 09 & $\begin{array}{l}\text { AREsp } \\
1179882\end{array}$ & $\begin{array}{l}\text { DJe } \\
27 / 11 / 2017\end{array}$ & Contaminação da prova & Penal & Crime Patrimonial \\
\hline 10 & $\begin{array}{l}\text { AREsp } \\
1138046\end{array}$ & $\begin{array}{l}\text { DJe } \\
04 / 09 / 2017\end{array}$ & Contaminação da prova & Penal & Crime contra a Vida \\
\hline 11 & $\begin{array}{l}\text { AREsp } \\
611138\end{array}$ & $\begin{array}{l}\text { DJe } \\
07 / 08 / 2017\end{array}$ & Desqualificação da parte & Família & Alienação Parental \\
\hline 12 & $\begin{array}{l}\text { AREsp } \\
812592\end{array}$ & $\begin{array}{l}\text { DJe } \\
04 / 08 / 2017\end{array}$ & Desqualificação da parte & Família & Alienação Parental \\
\hline 13 & $\begin{array}{l}\text { AREsp } \\
695464\end{array}$ & $\begin{array}{l}\text { DJe } \\
13 / 08 / 2017\end{array}$ & Desqualificação da parte & Família & Alienação Parental \\
\hline 14 & $\begin{array}{l}\text { REsp } \\
1659274\end{array}$ & $\begin{array}{l}\text { DJe } \\
01 / 08 / 2017\end{array}$ & Contaminação da prova & Penal & Crime Sexual \\
\hline 15 & RHC 071469 & $\begin{array}{l}\text { DJe } \\
07 / 06 / 2017\end{array}$ & Contaminação da prova & Penal & Crime Patrimonial \\
\hline 16 & $\begin{array}{l}\text { REsp } \\
1410187\end{array}$ & $\begin{array}{l}\text { DJe } \\
02 / 06 / 2017\end{array}$ & Contaminação da prova & Penal & Crime Sexual \\
\hline 17 & $\begin{array}{l}\text { AREsp } \\
1081469\end{array}$ & $\begin{array}{l}\text { DJe } \\
29 / 05 / 2017\end{array}$ & Contaminação da prova & Penal & Crime Sexual \\
\hline 18 & HC 367243 & $\begin{array}{l}\text { DJe } \\
17 / 05 / 2017\end{array}$ & Contaminação da prova & Penal & Crime Sexual \\
\hline 19 & $\begin{array}{l}\text { AREsp } \\
976156\end{array}$ & $\begin{array}{l}\text { DJe } \\
18 / 04 / 2017\end{array}$ & Desqualificação da parte & Família & Alienação Parental \\
\hline 20 & $\begin{array}{l}\text { REsp } \\
1654311\end{array}$ & $\begin{array}{l}\text { DJe } \\
21 / 03 / 2017\end{array}$ & Contaminação da prova & Penal & Crime Sexual \\
\hline 21 & HC 391270 & $\begin{array}{l}\text { DJe } \\
16 / 03 / 2017\end{array}$ & Contaminação da prova & Penal & Crime contra a Vida \\
\hline 22 & $\begin{array}{l}\text { AREsp } \\
995639\end{array}$ & $\begin{array}{l}\text { DJe } \\
24 / 11 / 2016\end{array}$ & Contaminação da prova & Penal & Crime contra a Vida \\
\hline 23 & HC 367015 & $\begin{array}{l}\text { DJe } \\
07 / 11 / 2016\end{array}$ & Contaminação da prova & Penal & Crime contra a Vida \\
\hline 24 & RHC 031332 & $\begin{array}{l}\text { DJe } \\
17 / 10 / 2016\end{array}$ & Contaminação da prova & Penal & Crime contra a Vida \\
\hline 25 & $\begin{array}{l}\text { REsp } \\
1460206\end{array}$ & $\begin{array}{l}\text { DJe } \\
06 / 10 / 2016\end{array}$ & Contaminação da prova & Penal & $\begin{array}{l}\text { Mandado de Segu- } \\
\text { rança }\end{array}$ \\
\hline 26 & HC 372969 & $\begin{array}{l}\text { DJe } \\
27 / 09 / 2016\end{array}$ & Contaminação da prova & Penal & Crime Sexual \\
\hline
\end{tabular}




\begin{tabular}{|c|c|c|c|c|c|}
\hline \multicolumn{2}{|c|}{ Tipo } & \multirow{2}{*}{$\begin{array}{l}\text { Data } \\
\text { DJe } \\
06 / 09 / 2016 \\
\end{array}$} & \multirow{2}{*}{$\begin{array}{l}\text { Efeito da Falsa Memória } \\
\text { Desqualificação da parte }\end{array}$} & \multirow{2}{*}{$\begin{array}{l}\text { Matéria } \\
\text { Família }\end{array}$} & \multirow{2}{*}{$\begin{array}{l}\text { Tipo de Ação } \\
\text { Modificação de Guar- } \\
\text { da }\end{array}$} \\
\hline 27 & $\begin{array}{l}\text { AREsp } \\
963512\end{array}$ & & & & \\
\hline 28 & HC 367243 & $\begin{array}{l}\text { DJe } \\
15 / 08 / 2016\end{array}$ & Contaminação da prova & Penal & Crime Sexual \\
\hline 29 & $\begin{array}{l}\text { AREsp } \\
680625\end{array}$ & $\begin{array}{l}\text { DJe } \\
01 / 08 / 2016\end{array}$ & Desqualificação da parte & Família & Alienação Parental \\
\hline 30 & HC 221294 & $\begin{array}{l}\text { DJe } \\
20 / 05 / 2016\end{array}$ & Contaminação da prova & Penal & Crime Patrimonial \\
\hline 31 & RHC 071469 & $\begin{array}{l}\text { DJe } \\
19 / 05 / 2016\end{array}$ & Contaminação da prova & Penal & $\begin{array}{l}\text { Mandado de Segu- } \\
\text { rança }\end{array}$ \\
\hline 32 & $\begin{array}{l}\text { AREsp } \\
753835\end{array}$ & $\begin{array}{l}\text { DJe } \\
06 / 05 / 2016\end{array}$ & Contaminação da prova & Penal & Crime Sexual \\
\hline 33 & HC 117338 & $\begin{array}{l}\text { DJe } \\
04 / 04 / 2016\end{array}$ & Contaminação da prova & Penal & Crime contra a Vida \\
\hline 34 & HC 205946 & $\begin{array}{l}\text { DJe } \\
31 / 03 / 2016\end{array}$ & Contaminação da prova & Penal & Tráfico de Drogas \\
\hline 35 & $\begin{array}{l}\text { RE nos EDcl } \\
\text { no AgRg no } \\
\text { HC } 300170\end{array}$ & $\begin{array}{l}\text { DJe } \\
31 / 03 / 2016\end{array}$ & Contaminação da prova & Penal & Crime contra a Vida \\
\hline 36 & RHC 062780 & $\begin{array}{l}\text { DJe } \\
07 / 12 / 2015\end{array}$ & Contaminação da prova & Penal & Crime Sexual \\
\hline 37 & RHC 051664 & $\begin{array}{l}\text { DJe } \\
31 / 08 / 2015\end{array}$ & Contaminação da prova & Penal & Crime contra a Vida \\
\hline 38 & HC 234113 & $\begin{array}{l}\text { DJe } \\
05 / 08 / 2015\end{array}$ & Contaminação da prova & Penal & Crime contra a Vida \\
\hline 39 & RHC 033946 & $\begin{array}{l}\text { DJe } \\
05 / 08 / 2015\end{array}$ & Contaminação da prova & Penal & Crime contra a Vida \\
\hline 40 & RHC 030438 & $\begin{array}{l}\text { DJe } \\
05 / 08 / 2015\end{array}$ & Contaminação da prova & Penal & Crime contra a Vida \\
\hline 41 & $\begin{array}{l}\text { PET no HC } \\
322956\end{array}$ & $\begin{array}{l}\text { DJe } \\
27 / 05 / 2015\end{array}$ & Contaminação da prova & Penal & Tráfico de Drogas \\
\hline 42 & HC 222156 & $\begin{array}{l}\text { DJe } \\
23 / 03 / 2015\end{array}$ & Contaminação da prova & Penal & Crime contra a Vida \\
\hline 43 & HC 300170 & $\begin{array}{l}\text { DJe } \\
18 / 03 / 2015\end{array}$ & Contaminação da prova & Penal & Crime contra a Vida \\
\hline 44 & $\begin{array}{l}\text { AREsp } \\
614950\end{array}$ & $\begin{array}{l}\text { DJe } \\
17 / 03 / 2015\end{array}$ & Contaminação da prova & Penal & Crime Sexual \\
\hline 45 & RHC 043202 & $\begin{array}{l}\text { DJe } \\
10 / 02 / 2015\end{array}$ & Contaminação da prova & Penal & Crime Sexual \\
\hline 46 & $\begin{array}{l}\text { REsp } \\
1366560\end{array}$ & $\begin{array}{l}\text { DJe } \\
11 / 12 / 2014\end{array}$ & Desqualificação da parte & Família & Alienação Parental \\
\hline
\end{tabular}




\begin{tabular}{|c|l|l|l|l|l|}
\hline \multicolumn{2}{|l|}{ Tipo } & Data & Efeito da Falsa Memória & Matéria & Tipo de Ação \\
\hline 47 & $\begin{array}{l}\text { AREsp } \\
486008\end{array}$ & $\begin{array}{l}\text { DJe } \\
02 / 05 / 2014\end{array}$ & Desqualificação da parte & Família & Alienação Parental \\
\hline 48 & MC 019921 & $\begin{array}{l}\text { DJe } \\
30 / 10 / 2012\end{array}$ & Desqualificação da parte & Família & $\begin{array}{l}\text { Modificação de Guar- } \\
\text { da }\end{array}$ \\
\hline 49 & HC 249833 & $\begin{array}{l}\text { DJe } \\
06 / 08 / 2012\end{array}$ & Desqualificação da parte & Família & Alienação Parental \\
\hline 50 & $\begin{array}{l}\text { PETDOC no } \\
\text { HC 239318 }\end{array}$ & $\begin{array}{l}\text { DJe } \\
25 / 06 / 2012\end{array}$ & Desqualificação da parte & Família & Alienação Parental \\
\hline
\end{tabular}

Fonte: Elaboração própria com base nos dados disponibilizados pela consulta de jurisprudência do STJ (2018, on line).

Considerando-se o delito relacionado ao julgamento que traz o termo "falsas memórias", segundo a classificação "Assunto CNJ”, o estudo evidenciou diversos tipos penais. Os casos verificados envolvem matéria penal e direito de família, e os mais frequentes são: ações que envolvem crime contra o patrimônio, alienação parental e modificação de guarda, tráfico ilícito de entorpecentes, crime contra a vida e crime contra a dignidade sexual (estupro, atentado violento ao pudor e estupro de vulnerável).

Cumpre destacar que a análise sobre as decisões jurisprudenciais é utilizada na presente pesquisa justamente para evidenciar a relevância e atualidade do tema, com base na demonstração dos efeitos da apresentação de falsas memórias sobre a dinâmica processual.

A Figura 1 evidencia o percentual de prejuízo quanto à implementação de falsas memórias e contaminação do testemunho para o processo, conforme segue:

Figura 1. Natureza das ações cujas provas testemunhais foram prejudicadas em razão da implantação de falsas memórias (em termos percentuais):

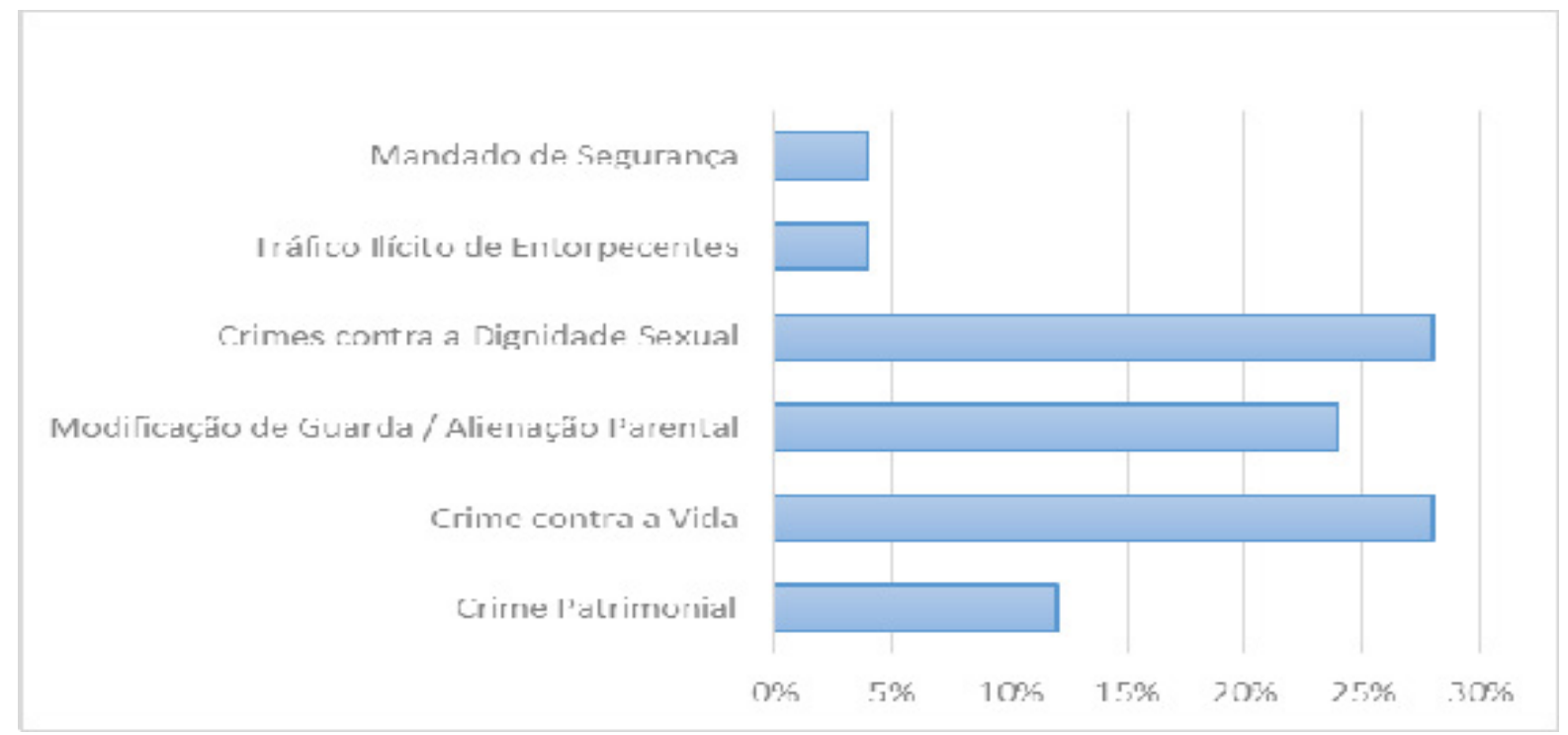

Fonte: Elaboração própria com base nos dados disponibilizados pela consulta de jurisprudência do STJ (2018, on line).

Ainda, foi identificado o percentual das ações cujas provas testemunhais foram de alguma forma comprometidas pela implantação de falsas memórias, evidenciando diferenças significativas nos assuntos tratados. Nas decisões monocráticas avaliadas no âmbito do Superior Tribunal de Justiça, $12 \%$ correspondiam aos crimes contra o patrimônio, $28 \%$ correspondiam aos crimes contra a vida, $28 \%$ identificavam a presença 
de falsas memórias nas ações cujo teor era crimes contra a dignidade sexual (abuso de menores, estupro de vulnerável e estupro), 24\% correspondiam às ações envolvendo direito de visitas, modificação de guarda e alienação parental, $4 \%$ correspondiam às ações que envolviam tráfico ilícito de entorpecentes e, em igual medida, 4\% correspondiam aos mandados de segurança.

A figura evidencia uma forte tendência à predominância de falsas memórias nas causas que envolvem crimes contra a vida e crimes sexuais, o que sugere a gravidade e consequências sobre a vida dos jurisdicionados e da sociedade como um todo. Nos referidos casos, as falsas memórias foram identificadas, o que não impõe afirmar que tal identificação ocorra na integralidade das ações.

\section{Considerações finais}

É possível verificar que, para a amostra coletada no período analisado, há forte presença de falsas memórias relatadas durante os depoimentos e coleta de prova testemunhal, o que inequivocamente gera prejuízo para o processo e pode influenciar o teor da decisão judicial, condenando inocentes e gerando insegurança jurídica.

Seja em razão das tentativas de desqualificação intencional de uma das partes, como verificado nas ações de modificação de guarda e alienação parental, ou o possível esquecimento dos fatos pelos depoentes durante o período em que o processo permaneceu sobrestado, ou mesmo pela introdução de recordações sobre fatos que nunca existiram; a implantação de falsas memórias surte efeitos sobre o curso dos processos.

Há, ainda, um padrão decisório que aduz a uma forte tendência da mente humana para guardar somente a emoção do acontecimento, deixando no esquecimento justamente o que seria mais importante a ser relatado no processo, ou seja, a memória cognitiva, provida de detalhes técnicos e despida de contaminação. Portanto, a identificação das falsas memórias pelos votos não se resume à correlação com o crime de falso testemunho, mas sim, há uma clara distinção sobre a profundidade do fenômeno.

Compreender a dimensão das associações que cérebro humano pode fazer é fundamental para determinar a extensão dos danos que podem advir como consequência da implantação de falsas memórias, quando recordações equivocadas sobre determinados eventos prejudicam o discernimento e obscurecer o entendimento sobre a verdade real dos acontecimentos.

A ausência de mecanismos objetivos de reconhecimento dos desdobramentos da mente pelo magistrado exige a presença de outros profissionais habilitados para identificar a presença de lembranças confusas durante a captação dos depoimentos, uma vez que as falsas memórias podem gerar prejuízos irreversíveis para o curso do processo, para o acusado e, principalmente, para a sociedade.

\section{REFERÊNCIAS}

ADAMY, Pedro. Direitos fundamentais e as relações especiais de sujeição. Revista Brasileira de Políticas Públicas, Brasília, v. 8, n. 1, p. 360-376, 2018.

ARAÚJO, Felipe Dantas de. Criminologia crítica e política criminal antilavagem de dinheiro e contrafinanciamento do terrorismo: barreira epistêmica e agenda de diálogo. Revista Brasileira de Políticas Públicas, Brasília, v. 2, n. 2, p. 01-27, 2012.

ÁVILA, Gustavo Noronha de; BALDASSO, Flaviane. A repercussão do fenômeno das falsas memórias na prova testemunhal: uma análise a partir dos julgados do tribunal de justiça do Rio Grande do Sul. Revista Brasileira de Direito Processual Penal, v. 4, n. 1, p. 371-409, 2018. 
BALMAKUND, Zurizadai. The realities of neurolaw: a composition of data \& research. In: University of St. Thomas Journal of Law and Public Policy, v. 9, n. 2, p. 234-258, 2015.

BRAINERD, Charles J.; REYNA, Valerie F. The science of false memory. New York: Oxford University Press, 2005.

BRASIL. Decreto-lei no 2.848, de 7 de dezembro de 1940. Código Penal Brasileiro de 1940. Brasília: Senado Federal, 1940.

BRASIL. HC 73.976-SP. Ministro Relator Carlos Velloso. Supremo Tribunal Federal. Disponível em: <https://stf.jusbrasil.com.br/jurisprudencia/14816214/habeas-corpus-hc-81381-sp-stf>.

BRASIL. Superior Tribunal de Justiça. Jurisprudência do STJ. Decisões monocráticas. Disponível em: $<$ http://www.sti.jus.br/SCON/decisoes/toc.jsp?livre=falsas + mem\%F3rias\&\&tipo_visualizacao $=$ RESU MO\&b=DTXT\&thesaurus $=J U R I D I C O \& p=$ true $>$.

CLORE, Gerald L.; STORBECK, Justin. Affect Influences false memories at encoding: evidence from recognition data. Emotion, Emotion. v. 11, n. 4, p. 981-989, 2011.

CONSELHO NACIONAL DE JUSTIÇA. Resolução no 75 de 12 de maio de 2009. Disponível em: < http:/ / www.cnj.jus.br/images/stories/docs_cnj/resolucao/rescnj_75b.pdf>. 2018.

IZQUIERDO, Iván. Memória. Porto Alegre: Artmed, 2006.

JONES, Owen D. et al. Law and neuroscience. Journal of Neuroscience, v. 33, n. 45, p. 17624-17630, 2013.

LIMA, José Wilson Ferreira; SUXBERGER, Antonio Henrique Graciano. O processo penal e a engenharia de controle da política criminal. Revista Brasileira de Políticas Públicas, Brasília, v. 7, n. 1, p. 286-306, 2017.

LOFTUS, Elizabeth F.; PALMER, J. C. Reconstruction of automobile destruction: an example of the interaction between language and memory. Journal of Verbal Learning and Verbal Behavior, n. 13, p. 585-589, 1974.

LOFTUS, Elizabeth F; PICKRELL, John E. The formation of false memories. Psychiatric Annals, n. 25, p. 720-725, 1995.

LOMBROSO, Paul. Aprendizado e memória. Revista Brasileira de Psiquiatria, v. 26, n. 3, p. 207-210, 2004.

MARSCH, Elizabeth J.; FAZIO, Lisa K. Correcting false memories. Psychological Science, v. 21, n. 6, p. 801-803, 2010.

MARSCH, Elizabeth J.; MULLET, Hillary G. Correcting false memories: errors must be noticed and replaced. Memory \& Cognition, v. 44, n. 3, p. 403-412, 2016.

MARTÍN DE AGAR, José Tomás. El valor de la declaración de las partes en el proceso de nulidad. Ius Canonicum, v.57, n. 114, p. 663-706, 2017.

OLIVEIRA, Denise Cabral Carlos de. Abuso sexual infantil em laudos psicológicos: as “duas psicologias". Physis, v. 27, n. 3, p. 579-604, 2017.

PICOZZA, Eugenio. Public law and private law issues. In: PICOZZA, Eugenio (Ed). Neurolaw: an introduction. Nova York: Springer, 2016. p.119-166.

PRATA, Henrique Moraes; FREITAS, Márcia Araújo Sabino de. Brainzil imaging: challenges for the largest Latin American country. In: SPRANGER, Tade Matthias. Internacional Neurolaw: a comparative analysis. Nova York: Springer, 2012. p. 67-88.

RIBEIRO, Alex. Caso escola base: os abusos da imprensa. São Paulo: Ática, 2003.

SCHAEFER, Luiziana Souto; ROSSETTTO, Silvana; HAAG KRISTENSEN, Christian. Perícia psicológica 
no abuso sexual de crianças e adolescentes. Psicologia: Teoria e Pesquisa, v. 28, n. 2, p. 227-250, abr./jun. 2012.

STEIN, Lilian Milnitsky; FEIX, Leandro da Fonte; ROHENKOHL, Gustavo. Avanços metodológicos no estudo das falsas memórias: construção e normatização do procedimento de palavras associadas. Psicologia Reflexão e Crítica, v. 19, n. 2, p. 166-176, 2006.

STERN, Peter. Encoding false memories. Science, v. 354, n. 6309, p. 193-194, oct. 2016.

STERNBERG, R. J. Psicologia cognitiva. Porto Alegre: Artes Médicas Sul, 2000.

STORBECK, Justin; CLORE, Gerald L.; PHELPS, Elizabeth A. Affect influences false memories at encoding: evidence from recognition data. Emotion, v. 11, n. 4, p. 981-989, 2011.

TREFFERT, Darold. Memória genética: como sabemos o que não aprendemos. Disponível em: <http:// www2.uol.com.br/vivermente/noticias/memoria_genetica_como_sabemos_coisas_que_nunca_aprendemos.html>.

TURNEY, Indira C.; DENNIS, Nancy A. Elucidating the neural correlates of related false memories using a systematic measure of perceptual relatedness. NeuroImage, v. 146, n. 1, p. 940-950, feb. 2017. 


\section{REVISTA BRASILEIRA DE POLÍTICAS PÚBLICAS BRAZILIAN JOURNAL OF PUBLIC POLICY}

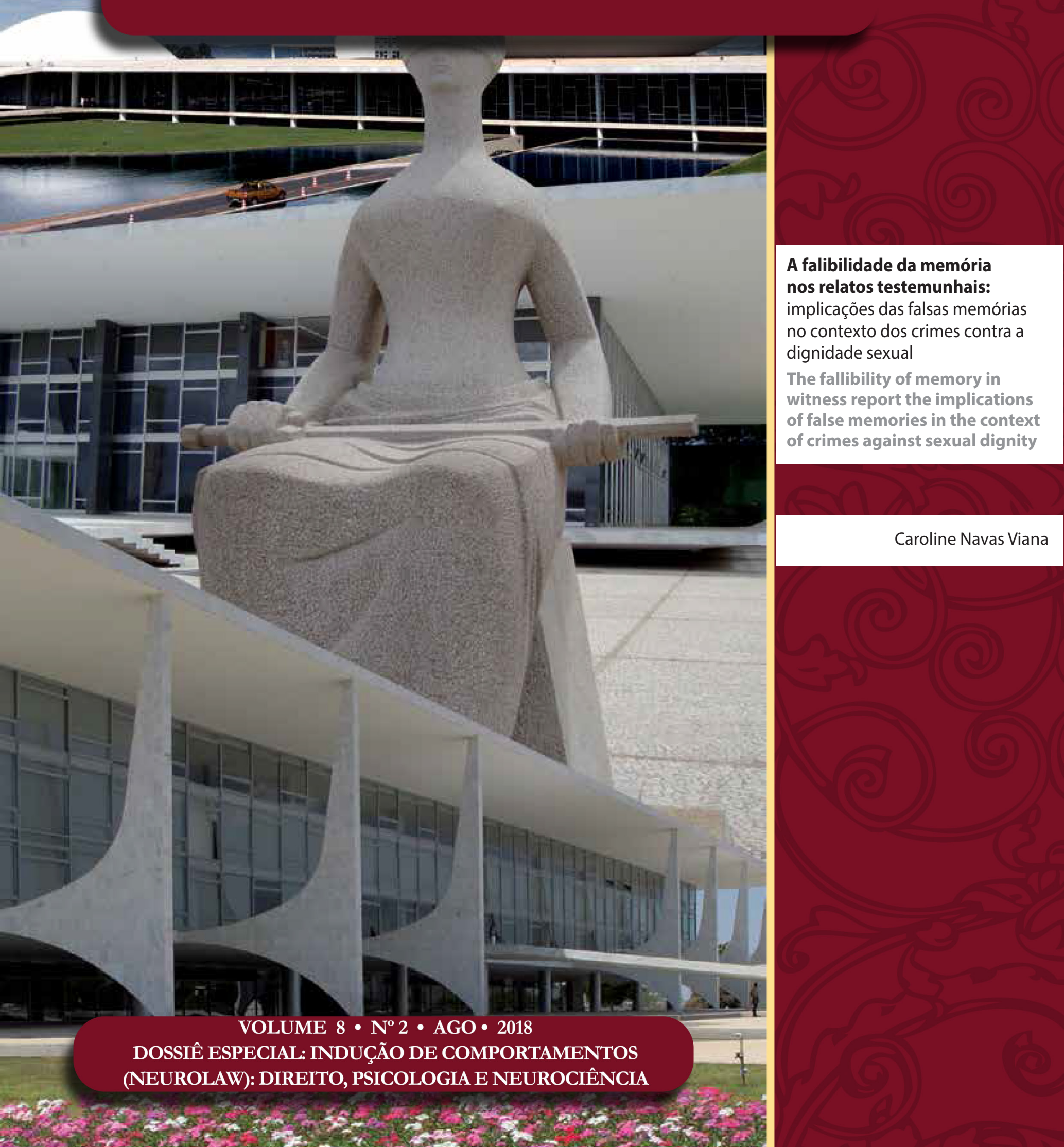




\title{
A falibilidade da memória nos relatos testemunhais: implicações das falsas memórias no contexto dos crimes contra a dignidade sexual*
}

\author{
The fallibility of memory in witness report \\ the implications of false memories in the \\ context of crimes against sexual dignity
}

Caroline Navas Viana**

\section{Resumo}

Este artigo busca desvendar, pela perspectiva dos estudos sobre Falsas Memórias, a falibilidade dos relatos testemunhais no Processo Penal, em especial nos casos em que a prova oral é aceita como exclusivo meio probatório para a resolução do litígio. Sob o entendimento que a memória humana é falha, estando sujeita ao esquecimento e contaminações, percebeu-se que o relato testemunhal, bem como o reconhecimento de pessoas pela vítima, nem sempre será preciso e fidedigno, estando esses processos sujeitos a erros que podem culminar em desastrosas consequências no Processo; em especial quando se estudam os crimes contra a dignidade sexual, os quais dependem, em grande medida, da prova testemunhal para sua solução. $O$ estudo das Falsas Memórias no Direito se faz indispensável, na medida em que, ao entender o melhor funcionamento do fenômeno, podem ser tomadas atitudes que facilitam a identificação da problemática, bem como medidas que visem à redução dos danos, tornando a prova testemunhal um meio probatório mais seguro. Por essa razão, neste trabalho, por meio de uma pesquisa descritiva e qualitativa do tema, realizou-se um estudo sobre a prova testemunhal, sobre o funcionamento da memória humana e sobre os diversos aspectos que circundam o fenômeno das Falsas Memórias. Tendo constatado a fragilidade do testemunho, sob a ótica da falibilidade da memória, este trabalho se mostra valoroso, sobretudo, enquanto aponta o quão defasado está o tratamento dado a prova testemunhal e quão grave são suas consequências.

Palavras-chave: Falsas memórias. Falibilidade. Prova testemunhal. Crimes contra a dignidade sexual. Testemunha ocular.

* Recebido em 31/05/2018 Aprovado em 10/07/2018

** Advogada graduada em Direito pela Universidade de São Paulo, Campus de Ribeirão Preto, pesquisadora na área de Neurociência aplicada ao Direito, com enfoque em falsas memórias; tendo atuado durante a graduação na Defensoria Pública e na Justiça Estadual de Ribeirão Preto. Email: carol48sjc@hotmail.com

\section{Abstract}

This article seeks to unveil, from the perspective of the studies on False Memories, the fallibility of witness reports in the criminal procedure, especially in cases in which the oral test is accepted as exclusive means of proof for the resolution of the litigation. Under the understanding that human 
memory is flawed, subject to forgetfulness and contamination, it has been realized that the testimonial testimony, as well as the recognition of persons by the victims will not be always accurate and reliable, also these processes are subject to errors that can culminate in disastrous consequences in the procedure; especially when we study crimes against sexual dignity, which rely heavily on testimonial evidence for its solution. The research of the False Memories in the law studies become indispensable, because understanding how does the phenomenon works makes it possible to take measures that facilitate the identification of the problematic, as well as actions focused on the reduction of the damages, making the testimonial evidence as a probative mean more secure. Therefore, in this work, through a descriptive and qualitative research of the subject, a study is carried out on the subjects of testimonial evidence, the functioning of human memory and on the various aspects that surround the phenomenon of False Memories. Having found the fragility of the testimony from the point of view of the fallibility of memory, this work shows its value as it points out how outdated the treatment of the testimonial evidence is and how serious its consequences are.

Keywords: False memories. Fallibility. Testimonial evidence. Crimes against sexual dignity. Eyewitness testimony.

\section{INTRODUÇÃo}

O presente artigo tem como objeto o estudo das implicações das Falsas Memórias no Processo Penal, com enfoque nos impactos desse fenômeno na palavra da testemunha e da vítima em situações nas quais a prova oral é tida como instrumento isolado de prova.

Nesse sentido, a pesquisa proposta neste artigo será voltada à análise das falsas memórias no contexto dos crimes contra a dignidade sexual, uma vez que essa modalidade, em regra, não apresenta materialidade, podendo ocorrer sem a presença de outras testemunhas, a não ser a vítima. Nessa vertente, vislumbra-se um cenário jurídico no qual, para o Processo Penal Brasileiro, a palavra da testemunha é aceita como prova isolada para a confirmação do crime sexual; assim como, na presença de outras provas, a palavra da vítima costuma ter alto valor probatório diante do livre convencimento do Juiz. Em ambos os casos, a prova testemunhal tem o poder de sozinha convencer o Magistrado a se posicionar favorável à condenação.

Todavia, em contramão ao pensamento jurídico consolidado, a prova testemunhal é um meio probatório extremamente complexo e que demanda uma série de cuidados para não ser eivado. Ao depender da narrativa da testemunha sobre o fato ocorrido ou pelo reconhecimento do suspeito, deposita-se toda segurança jurídica na capacidade de memorização e interpretação da vítima sobre o ocorrido. Ocorre, entretanto, que a memória não é infalível. Ao contrário, ela pode apresentar erros e distorções, comprometendo a fidedignidade das lembranças e, consequentemente, colocando em dúvida a credibilidade da prova testemunhal e do resultado do processo sob uma ótica pouco questionada no Processo Penal.

Nesse sentido, este trabalho procurará, de forma não exaustiva, apontar e esclarecer o que são Falsas Memórias, como elas funcionam, e, principalmente, como influenciam testemunhas e vítimas de maneira a comprometerem o resultado justo do Processo.

\section{Da PROVA teStemunhal COMO MEIO DE PROVA}

Antes de iniciar propriamente a análise sobre as implicações das Falsas Memórias, é imprescindível alguns apontamentos sobre o funcionamento da prova testemunhal no Processo Penal Brasileiro.

A começar pela definição: entende-se por meio de prova todo elemento que pode servir, direta ou indi- 
retamente, à demonstração da verdade que se busca no processo. ${ }^{1}$ Nesse sentido, a palavra da testemunha já é uma figura consolidada no meio jurídico probatório, tanto pela sua importância histórica quanto por ser um dos instrumentos de prova mais requisitados.

Como o próprio nome propõe, esse meio probatório centra-se na figura da testemunha que consiste, por sua vez, na pessoa que depõe em juízo sobre fato criminoso, por ela presenciado, e suas circunstâncias, como também informa sobre a personalidade do agente criminoso, ${ }^{2}$ sempre sob palavra de honra de dizer a verdade do que souber e do que lhe for perguntado.

De acordo com a sistemática processual penal, o testemunho é regido, primordialmente, por três princípios: a oralidade, a retrospectividade e a objetividade.

O princípio da oralidade é extraído, diretamente, dos artigos 204, 217, 221 e 223 do Código de Processo Penal $^{3}$, pelo qual se entende que o depoimento deverá ser prestado mediante narrativa verbal, ou seja, oralmente, quando, em contato direto com juiz, com as partes e com seus representantes, excetuados os casos expressamente previstos em lei. Acredita-se que a oralidade do testemunho atribui legitimidade ao discurso, auxiliando o convencimento social que, quando se harmoniza com o convencimento do juiz julgador, constitui sua força, prestígio e eficácia moralizadora. ${ }^{4}$

A retrospectividade, por sua vez, determina que a testemunha seja chamada em juízo para reproduzir fatos passados conhecidos, e não para aventurar-se em fazer previsões futurísticas. Com base nos registros que ficam memorizados em sua mente, a testemunha realiza esses relatos retrospectivos, cabendo ao magistrado o exercício da atividade recognitiva. ${ }^{5}$

Por fim, a objetividade centra-se na ideia de que a testemunha não poderá manifestar no relato dos fatos suas opiniões pessoais, se não em circunstâncias em que tais perspectivas forem inseparáveis, conforme artigo 213 do Código de Processo Penal ${ }^{6}$. Não cabe, portanto, a esta emitir seu juízo de valor sobre o ocorrido, devendo atrelar seu discurso somente aos fatos percebidos por seus sentidos e pertinentes ao objeto da demanda.

Em consonância com esses termos, entende-se por testemunha a pessoa comprometida a dizer a verdade, frente a conhecimento de fato juridicamente relevante, de forma a corroborar a constituição da verdade, agindo sob o compromisso de estar sendo imparcial e dizendo a verdade. ${ }^{7}$

Ocorre, entretanto, que a objetividade da testemunha e a finalidade do relato testemunhal não está isenta de severas críticas. Quando outras áreas do saber são consideradas, percebe-se que o testemunho é uma prova altamente dependente da recordação de fatos, vinculados à capacidade de memorização de quem os narra. Muito se exige da habilidade de recordação da testemunha, a qual tem que descrever com clareza e detalhes um momento que provavelmente foi vivenciado sob forte emoção e de maneira extraordinária; não se levando em consideração a possibilidade da falibilidade do testemunho. Alerta o qual se intensifica quando se verifica que não existe nenhuma regra processual capaz de determinar até onde as testemunhas merecem crédito para terem sua memória e palavras levadas em consideração como instrumento probatório.

1 ISHIDA, Válter Kenji. Processo penal: de acordo com a reforma processual penal. São Paulo: Atlas, 2009. Disponível em: <https://www.passeidireto.com/arquivo/18046231/valter-kenji-ishida---processo-penal---1-edicao---ano-2009>. Acesso em: 10 jul. 2017. p. 113.

2 ISHIDA, Válter Kenji. Processo penal: de acordo com a reforma processual penal. São Paulo: Atlas, 2009. Disponível em: <https://www.passeidireto.com/arquivo/18046231/valter-kenji-ishida---processo-penal---1-edicao---ano-2009>. Acesso em: 10 jul. 2017. p. 131-132.

3 CÉSPEDES, Lívia; ROCHA, Fabiana da (Org.) Vade mecum. São Paulo: Saraiva, 2017. p. 614-615.

4 MALATESTA, Nicola Framarino Dei. A lógica das provas em matéria criminal. Trad.: Paolo Capitanio. Campinas: Bookseller, 2004. p. 326.

5 FLECH, Larissa Civardi. Falsas memórias no processo penal. Disponível em: <https://www.lume.ufrgs.br/bitstream/handle/10183/67291/000872494.pdf?sequence=1>. Acesso em: 20 jul. 2017.

6 CÉSPEDES, Lívia; ROCHA, Fabiana da (Org.) Vade mecum. São Paulo: Saraiva, 2017. p. 614.

7 NUCCI, Guilherme de Souza. Código de Processo Penal Comentado. 8. ed. São Paulo: Revista dos Tribunais, 2008, p. 449. 
Mesmo assim, a prova testemunhal é tida como um dos meios probatórios mais antigos ainda em uso, bem como uma das mais fáceis a ser produzidas comparativamente com outros instrumentos de prova. No Processo Penal, sua utilização é comum, tendo importância considerável no meio, mesmo, pois, não raro, serve como única base para acusações, na ausência de outros meios comprovatórios. ${ }^{8} \mathrm{Caso}$ este muito comum nos chamados crimes contra a dignidade sexual.

\section{DOS CRIMES CONTRA A DIGNIDADE SEXUAL: SUA MATERIALIDADE E COMPROVAÇÃO}

O título VI da parte especial do Código Penal regula os crimes contra a dignidade sexual. Em suma, esse título busca tutelar a liberdade sexual, frisando que é de motivação própria as escolhas das pessoas no tocante ao sexo e ao consentimento de sua prática, em consideração à maturidade da vítima. ${ }^{9}$ Inclusive, a doutrina moderna entende que, no que envolve esses crimes, não há discussão de qualquer aspecto de conotação moral, mas, somente, a preocupação com a proteção com a liberdade sexual da vítima. ${ }^{10} \mathrm{~A}$ intenção, pois, não é o controle da atividade sexual do ser humano, mas, sim, a proteção contra ações que atuem contra a liberdade de exercê-la. ${ }^{11}$

A grande problemática, entretanto, encontra-se na comprovação da ocorrência desse tipo criminal. Uma vez que essa modalidade nem sempre apresenta resquícios materiais para serem utilizados como meio de prova, é admitido que o ato criminoso seja comprovado com base no relato da vítima. Em outras palavras, é permitido que a palavra da testemunha seja utilizada como instrumento isolado de prova nesses processos.

Na prática, a doutrina entende que, nesses tipos de crime, a autoridade e a materialidade são confirmadas pela palavra da pessoa ofendida, cabendo ao juiz analisar a credibilidade da palavra da vítima. ${ }^{12}$ Nos crimes de estupro, por exemplo, entende-se que o testemunho se apresente como viga mestre das provas, devendo a vítima mostrar suas imputações de forma firme, segura e em lógica com os outros fatos comprovatórios do processo para conseguir sustentar a condenação do agressor. ${ }^{13}$

Quando a materialidade está presente, é indispensável a realização de exame de corpo de delito, conforme previsto no artigo 158 do Código de Processo Penal ${ }^{14}$. Mesmo assim, por força normativa do artigo 182 do mesmo código ${ }^{15}$, o juiz possui discricionariedade para ao tomar sua decisão, não ficando adstrito ao laudo desse exame, podendo, inclusive, rejeitá-lo em todo ou em parte, haja vista que ele possui liberdade para valorar as provas ao realizar seu julgamento, sempre motivando seu entendimento.

Ocorre, também, que nem sempre os crimes contra dignidade sexual deixam vestígios ${ }^{16}$, ou, mesmo que deixem, nem sempre são constatados ou coletados. Problema este agravado quando se percebe que o estupro, assim como os outros delitos sexuais, com frequência, é praticado às escuras, geralmente, em locais desabitados ou de difícil acesso, sem a presença de outras testemunhas a não ser a vítima e o real autor. Por esse motivo os crimes contra a dignidade sexual também são chamados de crimes clandestinos, visto que são praticados às escondidas, ao não alcance de testemunhas, com cuidados oportunos à consumação, para não serem desvendados e não deixarem vestígios. ${ }^{17}$ Nessas condições, a palavra da vítima constitui a única fonte

8 ARANHA, Adalberto José Q. T. de Camargo. Da prova no processo penal. 7. ed. São Paulo: Saraiva, 2006. p. 156-157.

9 ISHIDA, Válter Kenji. Curso de direito penal. 2. ed. São Paulo: Atlas, 2009.p. 411-412.

10 GRECO, Alessandra Orcesi Pedro; RASSI, João Daniel. Crimes Contra a Dignidade Sexual. São Paulo: Atlas, 2010 , p. 53.

11 TELES, Ney Moura. Direito Penal: parte especial: arts. 213 a 359-H. 2. ed. São Paulo: Atlas, 2006. p. 3.

12 ISHIDA, Válter Kenji. Curso de direito penal. 2. ed. São Paulo: Atlas, 2009. p. 414.

13 DELMANTO, Celso. Código Penal comentado: acompanhamento de comentários, jurisprudência, súmula em matéria penal e legislação complementar. 8. ed. São Paulo: Saraiva, 2010. p. 695.

14 CÉSPEDES, Lívia; ROCHA, Fabiana da (Org.) Vade mecum. São Paulo: Saraiva, 2017. p. 610.

15 CÉSPEDES, Lívia; ROCHA, Fabiana da (Org.) Vade mecum. São Paulo: Saraiva, 2017. p. 612.

16 CAPEZ, Fernando. Curso de direito penal. 9. ed. São Paulo: Saraiva, 2011. v. 3. p. 38.

17 MUCCIO, Hidejalma. Curso de processo penal. 2. ed. Rio de Janeiro: Método, 2011. p. 913-914. 
que corrobora a acusação do ato, ocorrendo um nítido confronto entre seu discurso, ao se dizer violentada, e o do condenado, que se diz inocente, sem haver consenso para o que realmente aconteceu.

O que hoje muitos magistrados e doutrinadores adotam como um posicionamento frente a casos como este é o dever do magistrado em ter a sensibilidade para apurar se os fatos relatados pela vítima realmente ocorreram, analisando a verossimilhança da narrativa contada, uma vez que se contrapõe com o discurso negativo do acusado. ${ }^{18}$

Acredita-se que a palavra da vítima, coerente e firme, pode basear uma condenação, em especial nesses crimes realizados sem a presença de outros meios probabilísticos comprovados. Sendo tamanha sua relevância, a ponto de poder mudar o destino de um processo criminal. ${ }^{19}$

Para tais análises, os magistrados levam em conta as características da personalidade da pessoa ofendida, seus hábitos e sua ligação com o opressor, dentre outros elementos, sempre sob a maior cautela possível. ${ }^{20}$ Afinal, são necessárias ressalvas na forma como é vista a narrativa acusatória da vítima, cujo conteúdo está carregado de sentimentos humanos como ódio, raiva e paixão, os quais podem distorcer os fatos concretos. Ademais, em relação a esse tipo de depoimento, o ofendido não realiza o juramento de dizer a verdade, podendo, inclusive, mentir em juízo. ${ }^{21}$ Por isso, o julgador aceita tal depoimento com atenção, devendo usar métodos comparativos com outras provas quando possível, posto que a pessoa ofendida se trata de uma parte imparcial cujo interesse está voltado para o desfecho do processo em seu favor. ${ }^{22}$

A verdade é que, na carência de outras comprovações e com o intuito de avaliar a veracidade do relato, o Magistrado, muitas vezes, acaba se valendo de artifícios de valoração que nem sempre atingem o bem desejado, qual seja de perceber o nível de credibilidade do testemunho. Muitas vezes, baseiam-se, simplesmente, na personalidade da vítima e do acusado, bem como em suas aparências sociais. A moça recatada, mais introduzida em valores morais e culturais, tende a ter seu depoimento valorizado com mais estima, principalmente, se comparada a uma moça de má fama, com comportamento sexual fora dos padrões convencionais em que se acredita que, para escapar de mais pressões sobre sua conturbada vida sexual, poderia invocar um estupro como razão para uma gravidez indesejada, por exemplo. ${ }^{23} \mathrm{Ou}$ seja, mesmo demandando o bom senso do juiz, e na análise única de cada caso concreto, muitas vezes tais decisões acabam recaindo em visões estereotipadas do comportamento das pessoas, não revelando o real teor das intenções da vítima.

Assim, em relação a esses tipos criminais, a certeza sobre os fatos é atingida de maneira diferenciada. Quando a materialidade desses crimes não é passível de ser constatada pelo exame de corpo delito ou não sendo realizada tal verificação, a autoria e materialidade são confirmadas nas afirmações do ofendido, pois, de outro modo, seriam condutas criminosas passiveis de impunidade. A certeza, portanto, recai, completa e unicamente, sobre a credibilidade do que é dito e não dito pela vítima a favor da condenação do acusado. Ou, em outras palavras, recai sobre a memória deste a respeito dos fatos ocorridos.

Mas, afinal, será a memória humana tão confiável e infalível a ponto de ser seguro depositar o destino criminal de pessoas na credibilidade do que é lembrado pela testemunha? Para essa e tantas outras dúvidas, o estudo do funcionamento da memória se faz indispensável.

18 GRECO FILHO, Rogério Greco. Curso de direito penal: parte especial. 10. ed. Rio de Janeiro: Impetus, 2013. v. 3. p. 486.

19 GOULART, Valéria Diez Scarance Fernandes. Tortura e prova no processo penal. São Paulo: Atlas, 2002. p. 96.

20 NUCCI, Guilherme de Souza. Código de Processo Penal comentado. 8. ed. São Paulo: Revista dos Tribunais, 2008. p. 952.

21 LOPES JUNIOR, Aury. Direito processual penal e sua conformidade constitucional. 4. ed. Rio de Janeiro: Lúmen Júris, 2009. v. 1. p. 639.

22 TOURINHO FILHO, Fernando da Costa. Processo penal. 30. ed. São Paulo: Saraiva, 2008. v. 3. p. 296.

23 NUCCI, Guilherme de Souza. Código de Processo Penal comentado. 13. ed. Rio de Janeiro: Forense, 2014. Disponível em: <http:// sta.pro.br/livros/19\%20-\%20NUCCI_Guilherme_de_Souza_C\%C3\%B3digo_de_Processo_Penal_Comentado_2014.pdf>. Acesso em: 10 jul. 2017. 


\section{Desmistificando o FUnCIONAMENTO DA MEMÓRIA}

Muito ainda há a se desvendar a respeito do funcionamento da memória e suas dimensões. Entretanto, o estudo da mente vem caminhando em constante evolução e revolucionando a forma como o ser humano se compreende. Nesse sentido, as pesquisas na área vem demonstrando o quanto foram criados mitos desfundados sobre os limites da mente; alguns a subestimando, como outros a superestimando. Nesse sentido, este tópico em diante é, pois, um "grande divisor de caminhos", em que o leitor tem de se preparar para que muitas crenças sejam quebradas a respeito do funcionamento da mente; e aberto a entender a memória e suas dimensões sob uma nova ótica, a qual trabalha com as falhas da mente e busca compreendê-las.

Como um primeiro ponto a ser abordado, diferentemente do que se acredita, a memória não é essencialmente estática. As imagens não conseguem ser armazenadas e evocadas, nos momentos desejados, com tanta perfeição como se imagina.

Sabe-se que a memória se trata de um conjunto de mecanismos psíquicos responsáveis pelo armazenamento de informações e experiências vividas, permitindo sua fixação, retenção e posterior evocação. É a faculdade de reter ideias, impressões e conhecimentos adquiridos. ${ }^{24}$

Em outras palavras, a memória é o meio pelo qual os sujeitos humanos recorrem às suas experiências passadas a fim de utilizar essas informações no presente. Trata-se de um processo de mecanismos dinâmicos associados à retenção e à recuperação da informação. ${ }^{25} \mathrm{~A}$ memória é composta, portanto, pelo registro e gravação de informações, mas também pela lembrança destas, de forma que, no momento de evocação das memórias, o evento recordado não será lembrado com todos os detalhes.

Em consonância com essa visão, a evocação de memórias se assemelha muito mais à ideia de "representação aproximativa", do que a uma reconstrução exata do fato lembrado. ${ }^{26}$ Nas ilustres palavras de Antônio Damásio:

As imagens não são armazenadas sob forma fac-similares de coisas, de acontecimentos, de palavras ou frases. O cérebro não arquiva fotografias Polaroid de pessoas, objetos, paisagens; não armazena fitas magnéticas com música e fala; não armazena filmes com cenas de nossa vida; nem retém cartões com "deixas" ou mensagens de teleprompter do tipo daquelas que ajudam os políticos a ganhar a vida. [...] Se o cérebro fosse uma biblioteca esgotaríamos suas prateleiras à semelhança do que acontece nas bibliotecas. ${ }^{27}$

Quando um fato, um momento, um objeto ou uma pessoa é recordada, o resultado obtido dessa evocação não é uma reprodução idêntica. Trata-se de uma interpretação, oriunda da versão original.

Autores como Altavilla explicam que, no complexo processo de sistematização de uma percepção, é posto em uso o processo associativo, configurando-se com frequência em causas de deformações, acentuadas pelas imperfeições do processo mnemônico. A dinamicidade da memória funda-se na ideia de que a percepção não se fixa em uma imóvel chapa fotográfica, mas, sim, adentra em um órgão primordialmente dinâmico, o qual está sujeito a influências das percepções anteriores, sofrendo um ininterrupto trabalho de deformação que culminam em novas aquisições psíquicas. ${ }^{28}$

Nesse viés, faz-se o primeiro alerta ignorado pelos processualistas: a forma como a testemunha se re-

24 FLECH, Larissa Civardi. Falsas memórias no processo penal. Disponível em: <https://www.lume.ufrgs.br/bitstream/handle/10183/67291/000872494.pdf?sequence=1>. Acesso em: 20 jul. 2017.

25 STERnBerg, R. J. Psicologia cognitiva. Porto Alegre: Artes Médicas Sul, 2000. p. 204.

26 DAMÁSIO, Antônio. O erro de Descartes: emoção, razão e o cérebro humano. Trad. Dora Vicente e Georgina Segurado. 8. ed. São Paulo: Companhia das Letras, 2001. p. 128-129.

27 DAMÁSIO, Antônio. O erro de Descartes: emoção, razão e o cérebro humano. Trad. Dora Vicente e Georgina Segurado. 8. ed. São Paulo: Companhia das Letras, 2001. p. 128.

28 AltaVilla, Enrico. Psicologia judiciária. Tradução de Fernando de Miranda. 2. ed. São Paulo: Livraria Acadêmica Saraiva Editores, 1945. v. 1. p. 34-35. 
corda acerca do fato delituoso não é capaz de ser reconstruída da mesma maneira como o evento ocorreu na realidade. A percepção, seja por um viés filosófico, antropológico ou psicológico, justifica, por si só, a tese da impossibilidade da reconstrução do "todo" como seria o ideal na "busca da verdade" no processo. A existência do processo de tradução ${ }^{29}$ que ocorre entre a realidade das experiências e a formação da memória e, entre esta e posteriormente a evocação, culmina na constante transformação e reconstrução das informações, não transpondo em exatidão a realidade fática tão primordial para um testemunho fidedigno.

Ademais, como uma complementação à dinamicidade da memória, cabe acrescentar que se descobriu que a atividade sensorial e a forma como os fatos são interpretados estão totalmente ligados pela potencialidade na percepção dos estímulos. Em outras palavras, a realidade exterior é compreendida da maneira como os órgãos de sentido a conseguem captar; de modo que, a percepção varia tanto de indivíduo para indivíduo, como também para o mesmo sujeito a depender do momento de sua vida. Nesse sentido a forma como o mundo externo é captado mostra-se, pois, completamente relativa, tendo a percepção do meio maior ou menor potencialidade a variar com as circunstâncias fisiológicas do ambiente, como, por exemplo, enxerga-se melhor de dia e após estar descansado e ouve-se mais precisão à noite. ${ }^{30}$

Também, vincula-se a essa ideia outro aspecto importantíssimo da memória: o processo de esquecimento. Ao contrário do que, durante muito tempo se acreditou, a imensa maioria de tudo aquilo que se aprende ou se vivencia, ou seja, as inúmeras memórias que os indivíduos formam ao decorrer da vida acabam sendo perdidas ou esquecidas. ${ }^{31}$ A memória ao contrário do senso comum não funciona como um gravador ou uma câmera em que qualquer momento é possível recuperar uma lembrança da forma exata como ela ocorreu. ${ }^{32}$ As recordações estão em constante transformação e, com frequência, os fatos vivenciados são esquecidos, mesmo que tenham ocorrido poucos minutos atrás. Esse fenômeno de esquecimento é fisiológico, sendo, sobretudo, uma função adaptativa, na medida em que permite o bloqueio de excesso de informação inútil e a não recordação contínua de momentos dolorosos, humilhantes ou aterrorizantes. ${ }^{33}$

Virgílio trata muito bem dessa relação: ${ }^{34}$

[...] o conteúdo da memória é função da velocidade do esquecimento. Isso quer dizer que a memória é o que resta quando nós esquecemos, e que não há memória sem esquecimento. Porém, a rapidez do esquecimento é mais importante, porque se esquecemos muito rápido, caímos na amnésia, mas se nós não esquecemos ficamos loucos!

Assim, se, por um lado, a memória revela seu teor positivo em evitar que os homens se sintam "aprisionados" em suas lembranças e sentimentos que dela decorrem ${ }^{35}$, por outro, no campo jurídico processual, demonstra a necessidade da coleta de prova em tempo hábil, a fim de que a testemunha não tenha suas lembranças extintas ou viciadas.

29 DI GESU, Cristina. Prova penal e falsas memórias. 2. ed. Porto Alegre: Livraria do Advogado, 2014. p. 108-109.

30 AltaVilla, Enrico. Psicologia judiciária. 2. ed. Tradução de Fernando de Miranda. São Paulo: Livraria Acadêmica Saraiva Editores, 1945. v. 1. p.16-17.

31 IZQUIERDO, Iván. Memória. 2. ed. Porto Alegre: Artmed, 2011. Disponível em: <https://books.google.com.br/books?id=

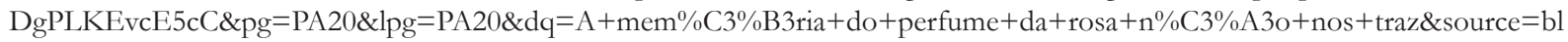
\&ots=-7zWKcMeAf\&sig=1RsAEb4JgImA7aag5RGeLR4wxbI\&hl=pt-BR\&sa=X\&ved=0ahUKEwiTs5Sbz5rVAhWJgZAKHQo 0BFcQ6AEIJzAA\# $=$ =snippet\&q=trabalho\&f=false >. Acesso em: 23 jul. 2017.

32 STEIN, Lilian M. Avanços Científicos em Psicologia do Testemunho Aplicados ao Reconhecimento Pessoal e aos Depoimentos Forenses. Série Pensando o Direito, Brasília, n. 59, 2015.

33 IZQUIERDO, I. $A$ arte de esquecer. 2. ed. Rio de Janeiro: Vieira \& Lent, 2009. v. 1. p.125.

34 VIRILIO, Paul. "O paradoxo da memória do presente na era cibernética". Entrevista com Paul Virilio concedida a Frederico Casalegno. In: Memória cotidiana: comunidades e comunicaşão na era das redes. Entrevista com Paul Virilio concedida a Frederico Casalegno. CASAlEGNO, Frederico. Memória cotidiana: comunidades e comunicação na era das redes. Trad. de Adriana Amaral, Francisco Rüdger e Sandra Montardo. Porto Alegre: Sulina, 2006.

35 IZQUIERDO, Iván. Memória. 2. ed. Porto Alegre: Artmed, 2011. Disponível em: <https://books.google.com.br/books?id= DgPLKEvcE5cC\&pg=PA20\&lpg=PA20\&dq $=\mathrm{A}+\mathrm{mem} \% \mathrm{C} 3 \% \mathrm{~B} 3 \mathrm{ria}+\mathrm{do}+$ perfume $+\mathrm{da}+\mathrm{rosa}+\mathrm{n} \% \mathrm{C} 3 \% \mathrm{~A} 3 \mathrm{o}+$ nos + traz\&source $=\mathrm{bl}$ \&ots=-7zWKcMeAf\&sig=1RsAEb4JgImA7aag5RGeLR4wxbI\&hl=pt-BR\&sa=X\&ved=0ahUKEwiTs5Sbz5rVAhWJgZAKHQo 0 BFcQ6AEIJzAA\# $_{\mathrm{v}}=$ snippet\&q=trabalho\&f=false $>$. Acesso em: 23 jul. 2017. p. 30. 


\section{A EMOÇÃO E O ESQUECIMENTO}

Outro ponto interessantíssimo que, por sua vez, também revela outra problemática para os relatos testemunhais encontra-se na relação da emoção com o esquecimento. É de fé pública que existe uma tendência de os eventos mais marcantes e emocionantes persistirem com mais intensidade e detalhamento na memória. Inclusive, por meio dessa crença, o processo penal se vale, com tanta credibilidade, dos relatos testemunhais das vítimas que passaram por eventos traumáticos; acredita-se que estas, por passarem por momentos de emoção intensa, teriam uma capacidade superior no armazenamento do fato ocorrido, lembrando com melhor qualidade e quantidade de detalhes do que vítimas e testemunhas que não passaram por situações com a mesma carga de sentimentos.

É certo que, logo após o ocorrido, esses acontecimentos marcantes são lembrados com muita riqueza de detalhes. Contudo, a capacidade de o cérebro recordar, por anos ou décadas, um evento com precisão, mesmo em se tratando de um evento marcante com alto teor emocional, trata-se de uma verdadeira crença popular.

O que ocorre, na realidade, é que, realmente, o processo de recordação é facilitado pela emoção. ${ }^{36}$ Contudo, recentes pesquisas apontam que, se, por um lado, existe a tendência de esses eventos emocionais serem recordados com mais facilidade, apresentando um maior índice de memória verdadeira, por outro, existe um aumento proporcional na lembrança de falsas memórias desses eventos. ${ }^{37}$ Em outras palavras, a emoção, realmente, auxilia o processo de recordação, sem entretanto, imunizar esse tipo de lembrança de todos processos de distorções a que a memória está sujeita.

Pesquisas também apontam para os efeitos em níveis extremos de emoção. Embora níveis moderados de emoção potencializam o processo de codificação e, subsequentemente, a performance da memória, percebeu-se que, em níveis extremos, restam prejudicados esses processos de codificação. ${ }^{38} \mathrm{~A}$ forte emoção afeta os processos de cognição e comportamento da pessoa envolvida, em consequência comprometendo a facilidade da recepção e registro de informações. Tanto a falta de atenção como a dificuldade de concentração nesses casos são fatores que afetam, negativamente, o desempenho da memória e, consequentemente, como esses eventos são lembrados.

Os efeitos da emoção na memória não podem ser compreendidos, pois, como uma relação linear, mas sim, curvilínea. Se os níveis de estresse contribuem para a melhoria da memória até certo patamar, acima deste, os efeitos negativos se intensificam, provocando uma piora nas lembranças. ${ }^{39}$

Para piorar o cenário, o cérebro tende a apagar primeiro os detalhes não emocionais. ${ }^{40}$ Ao evocarmos uma lembrança intensa, os detalhes emocionais são constantemente rememorados, enquanto os detalhes periféricos a essas sensações vão se extinguindo, os quais são, justamente, os elementos mais relevantes ao testemunho.

Não existe, nesse viés, uma memória emocional não suscetível a distorções. Tanto as memórias de conotação emocional extremamente negativas como as lembranças de um crime de abuso sexual, até de fatos positivos, de muita felicidade, acabam sucumbindo a esses processos de esquecimento e distorções. ${ }^{41}$

36 STEIN, Lilian M. et al. “Memória, humor e emoção”. Revista de Psiquiatria, Rio Grande do Sul, v. 28, n. 1, p. 66-68, 2006. Disponível em: <http://www.scielo.br/scielo.php?script=sci_arttext\&pid=S0101-81082006000100008>. Acesso em: 8 set. 2017.

37 BRAINERD, C. J. et al. How does negative emotion induce false memories? Psychological science, v. 19, n. 9, p. 919-925, 2008.

38 DI GESU, Cristina. Prova penal e falsas memórias. 2. ed. Porto Alegre: Livraria do Advogado, 2014. p. 113.

39 STEIN, Lilian M. et al. “ Memória, humor e emoção”. Revista de Psiquiatria, Rio Grande do Sul, v. 28, n. 1, p. 66-68, 2006. Disponível em: <http://www.scielo.br/scielo.php?script=sci_arttext\&pid=S0101-81082006000100008>. Acesso em: 8 set. 2017. 40 IZQUIERDO, Ivan. A memória. Entrevisyta com Ivan Izquierdo concedida à RAN - Revista Argentina de Neurociência, por Ignacio Brusco, MD; Diego Golombeck, Phd e Sérgio Strejilevich, MD. Trad. Renato M. E. Sabbatini. Disponivel em: < http:// www.cerebromente.org.br/n04/opiniao/izquierdo.htm >. Acesso em: 23 jul. 2017. p. 5.

41 KENSINGER, E. A., \& SHACTER, D. L. When the red sox shocked the yankees: comparing negative and positive memories. 
Trazendo esses fatos para a seara criminal, avista-se uma grande problemática. Seja moderado ou intenso, o crime, sem dúvida, gera um nível de emoção para aquele que é testemunha ou aquele que é vítima. De forma que, a tendência da memória é de guardar a emoção do acontecimento, a sensação que o evento produziu, em compromisso do que seria mais importante a ser relatado no processo, ou seja, a memória cognitiva, provida de detalhes técnicos e despida de contaminação (emoção, distorção, esquecimento, subjetivismo e juízo de valor. $)^{42}$

\section{Da FORMAÇÃo dAS FALSAS MEMÓRIAS}

Conforme o que já foi explicado, pode-se afirmar que a memória advém tanto das informações armazenadas quanto dos novos elementos que vão se agregando a essas informações ao decorrer do tempo. Nesse sentido, numa analogia, a memória não funciona como ler um livro; mais sim, como escrever um livro com base em anotações fragmentadas. ${ }^{43}$ Ao serem evocadas, as lembranças estão sujeitas a processos de interpretação, de integração ou de supressão de $\operatorname{dados}^{44}$, fato que torna cada experiência lembrada, única.

Diante desses aspectos e de tantos outros que atuam no processo mnemônico, não raras vezes, essas lembranças vão ganhando traços distorcidos, culminando numa falsificação da lembrança, ou, o que hoje se conhece por Falsas Memórias.

De forma sucinta, as Falsas Memórias ocorrem como resultado das distorções externas ou endógenas, ou seja, por indução de terceiros ou por recriação do próprio indivíduo, os mecanismos de aquisição, retenção ou recuperação falham, trazendo o sujeito ao erro. ${ }^{45}$ Em outras palavras, as Falsas Memórias caracterizam-se por serem lembranças de fatos, lugares, pessoas, e eventos que nunca ocorreram ou que ocorrem de forma diversa, em decorrência das transformações naturais que a memória humana sofre nesses processos mnemônicos.

Os estudos das Falsas Memórias são importantíssimos, nesse sentido, uma vez que o fenômeno faz parte do dia a dia das pessoas, decorrente do funcionamento saudável da mente, não se tratando de uma patologia ou distúrbio. ${ }^{46}$ Como um fenômeno que ocorre diariamente, muitas vezes passa despercebido, não trazendo consequências severas para o cotidiano das pessoas. Em contrapartida, em áreas como a jurídica, o não reconhecimento da problemática traz consequências drásticas.

Impera salientar que as Falsas Memória não se confundem com a mentira ou com fantasias criadas pelas pessoas. As Falsas Memória são extremamente semelhantes a memórias verdadeiras, tanto em sua base cognitiva quanto neurobiológica, se diferenciando, somente, pela sua composição, formada no todo ou em parte, por lembranças de informações ou de eventos que não ocorreram na realidade. ${ }^{47}$ Até mesmo o usuário de falsas lembranças não consegue diferenciá-las de um discurso mentiroso, pois, apesar da a mentira ser um ato consciente, em que a pessoa tem noção do seu espaço de criação e manipulação, nas Falsas Memórias, o agente crê sinceramente na verdade que está relatando, não se dando conta de que o que fala é tão falso

Psychonomic Bulletin \& Review, v. 13, n. 5, p. 757-763, 2006.

42 DI GESU, Cristina. Prova penal e falsas memórias. 2. ed. Porto Alegre: Livraria do Advogado, 2014. p. 114.

43 KIHLSTROM, J. F. Exbumed memory. New York: Guilford, 1998. p. 33.

44 LOPES JÚNIOR, Aury. Direito processual penal e sua conformidade constitucional. 8. ed. Porto Alegre: Lumen Juris, 2011. v.1. p. 665.

45 FLECH, Larissa Civardi. Falsas memórias no processo penal. Disponível em: <https://www.lume.ufrgs.br/bitstream/handle/10183/67291/000872494.pdf? sequence=1>. Acesso em: 20 jul. 2017.

46 NEUFELD, Carmem Beatriz; BRUST, Priscila Goergen; STEIN, Lilian Milnitsky. Compreendendo o Fenômeno das Falsas Memórias. In: STEIN, Lilian Milnitsky et. al. Falsas memórias: fundamentos científicos e suas aplicações clínicas e jurídicas. Porto Alegre: Artmed, 2010. p. 37.

47 NEUFELD, Carmem Beatriz; BRUST, Priscila Goergen; STEIN, Lilian Milnitsky. Compreendendo o Fenômeno das Falsas Memórias. In: STEIN, Lilian Milnitsky et. al. Falsas memórias: fundamentos científicos e suas aplicações clínicas e jurídicas. Porto Alegre: Artmed, 2010. p. 36. 
como se uma mentira fosse. ${ }^{48}$

Uma das grandes problemáticas enfrentadas trata-se de os juristas se limitarem a reconhecer o erro voluntário ou mentira como o único mal dos testemunhos, inclusive, tipificando e castigando a conduta, conhecida como falso testemunho, por lei. ${ }^{49}$ Apesar de ambos serem perigosos para a credibilidade da prova testemunhal, as Falsas Memórias são mais graves, na medida em que a testemunha ou vítima desliza no imaginário sem se dar conta disso, fato que dificulta sua identificação no processo. ${ }^{50}$

\section{Os eXPerimentos de Elizabeth Loftus}

No caminho para a compreensão das Falsas Memórias, é praticamente impossível não se deparar com as contribuições feitas pela pesquisadora Elizabeth Loftus. Ao decorrer das mais de quatro décadas de pesquisas, Elizabeth Loftus conseguiu se consolidar como a maior autoridade no cenário dos estudos das Falsas Memórias, estabelecendo o que se entende hoje pelo fenômeno.

A autora conduziu pesquisas e experimentos com mais de 20 mil pessoas, a fim de constatar a ocorrência do fenômeno quando os indivíduos entram em contato com dados não verdadeiros. Como resultado de seus estudos apresentou o entendimento de que as lembranças podem ser altamente manipuladas com base em informações errôneas sobre momentos nunca vividos ${ }^{51}$, bem como podem distorcer os acontecimentos realmente vivenciados.

Constatou, também em suas pesquisas, que a desinformação é um fator modificativo em potencial das lembranças, alterando-as, seja de maneira previsível até mesmo espetacular, nas situações mais cotidianas ${ }^{52}$. Ou seja, as pessoas estão sujeitas a terem informações erradas se imiscuindo em suas lembranças a todo instante, seja em uma conversa com outra pessoa, em um processo interrogativo realizado de forma sugestiva, em uma leitura de jornal e até mesmo quando se assiste a uma reportagem na televisão. ${ }^{53}$

Loftus destaca o quanto essas falsas memórias tomam a dimensão de verdade na cabeça do indivíduo. Tratam-se de memórias embelezadas de detalhes, que se assemelham em todos os pontos com uma memória verdadeira ${ }^{54}$.

Nesse sentido, vale citar de forma exemplificativa, o clássico teste de Loftus e Palmer, o qual comprovou que somente pela troca de uma palavra específica em uma pergunta feita aos participantes, pode-se culminar no surgimento de falsas lembranças, corroborando a tese do poder de sugestão no relato testemunhal. Nesse experimento, os pesquisadores recrutaram voluntários para assistirem a um curto vídeo de um acidente de trânsito envolvendo cinco carros. A seguir, os participantes foram divididos em grupos para responderem a uma pergunta relativa a cena que tinham visto. A pergunta consistia em determinar a velocidade dos carros no acidente, com a diferença que para cada grupo modificou-se uma palavra na pergunta direcionada aos pesquisados. Para uma turma questionou-se à que velocidade circulavam os carros quando estes "se encontraram"; para outro, quando "toparam"; no seguinte, quando "bateram"; e no último, quando "se estraçalharam". Por fim perguntaram se havia a presença de sangue e vidros quebrados. Surpreendentemente todos os entrevistados terem assistido ao mesmo vídeo do acidente e serem questionados após a mesma

48 LOPES JÚNIOR, Aury. Direito processual penal e sua conformidade constitucional. 8. ed. Porto Alegre: Lumen Juris, 2011. v. 1. p. 658. 49 DI GESU, Cristina. Prova penal e falsas memórias. 2. ed. Porto Alegre: Livraria do Advogado, 2014. p. 130-131.

50 LOPES JÚNIOR, Aury. Direito processual penal e sua conformidade constitucional. 8. ed. Porto Alegre: Lumen Juris, 2011. v. 1. p. 658.

51 LOFTUS, Elizabeth. "As falsas lembranças". Revista Viver Mente \& Cérebro, p. 90-93, 2005. p. 90.

52 DI GESU, Cristina. Prova penal e falsas memórias. 2. ed. Porto Alegre: Livraria do Advogado, 2014. p. 133.

53 LOFTUS, Elizabeth. “As falsas lembranças”. Revista Viver Mente \& Cérebro, p. 90-93, 2005.p. 90

54 NEWS, CBN. Exclusive: The bunny effect. Youtube, 8 mar. 2009. Disponível em: <https://www.youtube.com/ watch?v=eZIPzSeUDDw>. Acesso em: 29 jul. 2017. 
quantidade de tempo transcorrido, as respostas foram extremamente diversificadas a depender do tipo de perguntas que lhes foram direcionadas. Quando questionados acerca da velocidade em que os carros estavam no momento em que "se encontraram" a velocidade média obtida das respostas foi de $35 \mathrm{~km}$ por hora, e que não havia vidros quebrados, nem sangue na cena. Para aqueles em que foi perguntada a velocidade dos carros no momento em que "toparam", foram apontadas velocidades mais altas, vidro quebrado, e ausência de sangue. Aqueles que receberam a palavra "bateram" relataram que os carros estavam em velocidade alta, possivelmente entre 60 e $85 \mathrm{~km}$ por hora, com a presença de vidros quebrados e, em alguns casos, sangue. O último grupo, quando questionado sobre a maneira como os carros se "estraçalharam", indicaram velocidades altíssimas, vidros quebrados, sangue, e até pessoas mortas. ${ }^{55}$

Em que pese parecer surreal, não há, neste artigo, o intuito em se desacreditar a prova testemunhal, ante sim, apontar todo o cuidado e ressalvas que devem ser feitos a esse instrumento probatório. O Processo Penal está intimamente ligado com essa problemática, principalmente quando a declaração da vítima e da testemunha forem a única prova acusatória existente. O ponto essencial é perceber que, embora haja o desejo de se desvendar o que realmente aconteceu, a fim de se solucionar o litígio, é necessária uma análise minuciosa quanto à declaração da testemunha, em especial nos casos em que ela figurar como elemento probatório isolado. O induzimento realizado pelos parentes, amigos, policiais, entrevistadores, julgadores, até mesmo pela mídia, em casos notórios, compromete a forma como o crime é lembrado e como ele será relatado. Diante disso, é preciso perceber que, além da deficiência na coleta de provas materiais, constata-se um despreparo pelos profissionais jurídicos para saber identificar e lidar com as falsas memórias, inclusive, no sentido de entenderem que, a depender do grau de contaminação, a palavra da vítima não é suficiente para derrubar a presunção de inocência do acusado. ${ }^{56}$

\section{A PROVA TESTEMUNHAL COMO MEIO ISOLADO DE PROVA}

Infelizmente, no âmbito da Justiça Estadual a prova pericial e os demais instrumentos probatórios são muito pobres, devido à falta de recursos disponíveis para as investigações do caso, tornando-a despida de recursos que lhe confeririam uma melhor qualidade técnica. Esses fatos tornam a prova testemunhal, reconhecida por ser de baixo custo financeiro e de rápido acesso, a prova mais fácil e mais utilizada para a resolução de litígios, nesses tipos de caso. ${ }^{57}$

Daí a necessidade, da prova oral ser colhida e utilizada com a maior cautela possível, uma vez que, se tamanha responsabilidade é depositada nesse tipo probatório, não podem ser negligenciados os cuidados que devem ser tomados frente a todas as problemáticas envolvidas nesse meio. A preocupação do Direito em averiguar e punir os depoimentos mentirosos, enquadrados como falsos testemunho, demonstra o quão ciente e alerta o sistema processual está quanto às consequências gravíssimas frente a um relato não verdadeiro; porém, por outro lado, revela o quanto o Direito está defasado por acreditar que a mentira consciente trata-se do maior desafio a ser superado na prova oral, não sabendo lidar com o falso testemunho sob outras perspectivas, inclusive no que concerne a testemunhas vítimas de falsas memórias.

Nos Estados Unidos, segundo estimativas feitas ao final da década de 1980, a cada ano, mais de 75 mil julgamentos de crimes são decididos embasados na prova testemunhal. Em estudo recente, no qual utilizou-se a análise do DNA para comprovar a inocência de condenados injustamente, percebeu-se que, dentre 40 dos acusados analisados, 36 deles, ou seja, 90\% do total, tinham sido presos pela identificação errada realizada pelas testemunhas no ato de reconhecimento. ${ }^{58}$

55 IZQUIERDO, I. A arte de esquecer. 2. ed. Rio de Janeiro: Vieira \& Lent, 2009. v. 1. p. 140.

56 DI GESU, Cristina. Prova penal e falsas memórias. 2. ed. Porto Alegre: Livraria do Advogado, 2014. p. 135.

57 DI GESU, Cristina. Prova penal e falsas memórias. 2. ed. Porto Alegre: Livraria do Advogado, 2014. p. 161.

58 SCHACTER, Daniel. Os sete pecados da memória: como a mente esquece e lembra. Rio de Janeiro: Rocco, 2003. p. 118. 
Infelizmente, por mais que tenham sido desenvolvidas outras técnicas, dados mais atuais demonstram que o uso do relato testemunhal como prova única ou principal para a condenação continuam a produzir em massa incriminações injustas, principalmente quando se analisam os julgamentos de crimes contra a dignidade sexual. Nesse sentido, dados fornecidos pelo Innocence Project, um projeto no qual, por meio de trabalho pro bonu, elaboram recursos contra decisões de tribunais e fazem pedidos de reabertura de casos onde exista a possibilidade de inocência de pessoas condenadas, demonstram que de 195 casos em que foi conseguida a exoneração, 148 deles tratavam-se de crimes sexuais, e, por sua vez, dos 148, em 103 deles foram comprovados a ocorrência de falso reconhecimento como causa principal da condenação. Isto representa um porcentual de erro de mais de $69 \% .{ }^{59}$

Dados como estes alertam o quanto as Falsas Memórias e os outros erros e distorções a que a mente está sujeita são fontes de influência para o processo penal, tornando-se inestimável as consequências para as partes quando o estudo desses impactos e possíveis soluções são renegadas no meio jurídico.

\section{Do RECONHECIMENTO PESSOAL CONDUZIDO SEM A OBSERVÂNCIA DAS FORMALIDADES LEGAIS}

Em que pese o processo penal tente regular o ato de reconhecimento, existem muitas lacunas e falhas no modo como é conduzido pelas autoridades na prática; de forma que são, na grande maioria dos casos, desconsideradas variáveis, como as próprias falsas memórias, ainda que estejam a todo instante interferindo nesses processos.

Sabendo-se que, no processo de reconhecimento, a testemunha é levada a perceber alguma coisa, imagem esta que acaba sendo comparada com o que havia realmente percebido no contexto do litigio, ${ }^{60}$ nota-se que a percepção humana é o fator-chave ao se reconhecer o agressor.

Como a percepção humana se aprimora por meio da repetição, tornando-se mais precisa e complexa; uma imagem consegue ser evocada com mais detalhes e distinguida entre seus pares, quando já se tem um conhecimento prévio e consolidado acerca do objeto ou da pessoa lembrada. ${ }^{61} \mathrm{Em}$ outras palavras, uma imagem se torna mais nítida proporcionalmente ao número de vezes que é rememorada em um certo período de tempo. Portanto, no processo de reconhecimento, é imprescindível o cuidado para que a imagem do suspeito fornecida pelas autoridades não seja "metralhada" à vítima de forma a se sobrepor a imagem do real agressor.

É esse um ponto crucial, que passa muitas vezes despercebido nos tribunais: a certeza da testemunha sobre quem está reconhecendo não necessariamente está ligada com a verdade, ante sim, está relacionada com a percepção que foi se tornando mais precisa pelas evocações continuas da imagem do possível suspeito. Suspeito que não necessariamente é o autor do crime, tratando-se, muitas vezes, de um inocente que, em decorrência de alguma sugestão no processo de reconhecimento, fez com que a testemunha imiscuísse sua imagem com a do verdadeiro criminoso, e passasse a recorda-la no lugar deste, até se tornar uma certeza.

Um caso desse tipo foi apontado por Stein e Neufeld ${ }^{62}$ :

Chamado para fazer uma corrida, um taxista foi vítima de um assalto, no qual sofreu ferimentos e foi levado ao hospital. O investigador do caso mostrou ao taxista, que ainda estava em fase de recuperação,

59 INNOCENCE Project. Disponíveis em: <https://www.innocenceproject.org/all-cases/\#involved-yes, exonerated-bydna,sex-crimes >. Acesso em: 31 maio. 2018.

60 CORDERO, Franco. Procedimiento penal. Trad.: Jorge Guerrero. Santa Fé de Bogotá- Colômbia: Editorial Temis, 2000. v. 2. p. 106.

61 DI GESU, Cristina. Prova penal e falsas memórias. 2. ed. Porto Alegre: Livraria do Advogado, 2014. p. 162.

62 NEUFELD, Carmem Beatriz; BRUST, Priscila Goergen; STEIN, Lilian Milnitsky. Compreendendo o Fenômeno das Falsas Memórias. In: STEIN, Lilian Milnitsky et. al. Falsas memórias: fundamentos científicos e suas aplicações clínicas e jurídicas. Porto Alegre: Artmed, 2010. p. 22. 
duas fotografias de suspeitos. O taxista não reconheceu os homens apresentados nas fotos como sendo algum dos assaltantes. Passados alguns dias, quando foi à delegacia para realizar o reconhecimento dos suspeitos, ele identificou dois deles como sendo os autores do assalto. Os homens identificados possivelmente eram aqueles mesmos das fotos mostradas no hospital. Os suspeitos foram presos e acusados pelo assalto. Ao ser questionado em juízo sobre seu grau de certeza de que os acusados eram mesmo os assaltantes, o taxista declarou: 'eu tenho mais certeza que foram eles, do que meus filhos são meus filhos!' Todavia, alguns meses depois, dois rapazes foram presos por assalto em uma cidade vizinha, quando interrogados, confessaram diversos delitos, incluindo o assalto ao taxista.

Percebe-se, com base no caso exposto, que a recordação do taxista sofreu distorções por conta de seu contato com as fotos, fazendo com que a imagem do rosto dos rapazes das fotografias substituísse a lembrança dos verdadeiros autores, fato que culminou na incriminação de dois inocentes.

Na fase pré-processual, é normal a apresentação de fotografias dos supostos suspeitos à vítima, como um ato preparatório de reconhecimento, inclusive, com o intuito de se dar maior legitimidade e credibilidade à identificação. ${ }^{63}$ Ato este que acaba em alguns casos influenciando a vítima a qual crê que a polícia, na posição de figura de autoridade e experiente na solução de casos, somente realizaria um ato de reconhecimento se já tivesse um suspeito de peso. ${ }^{64}$ Dessa maneira, mesmo na dúvida, o crédito na polícia e a vontade de se fazer justiça acabam contribuindo para a indução a uma falsa lembrança.

Ocorre que o reconhecedor trabalha sobre uma matéria alógica, rodeada de sensações. Na lembrança de um rosto, não existem os mesmos caminhos racionais por meio dos quais se constroem as narrativas de fatos ou eventos passados. A recordação de uma face está muito mais ligada a impressões visuais, que se perdem facilmente na memória, do que a lembranças historicamente elaboradas ${ }^{65}$ Em outras palavras, para uma pessoa de capacidade cognitiva normal, é muito mais difícil a memorização de um rosto que foi visualizado somente uma vez, e, possivelmente, em um curto período, do que rememorar a face de uma pessoa conhecida ou de lembrar uma história, cuja lógica dos fatos contribuem para ser mais facilmente recordada. A evocação da imagem de um rosto depende, sobretudo, da lembrança de detalhes, que, como já demonstrado, são extremamente expostos ao esquecimento e à distorção.

Não bastasse a dificuldade natural, muitas vezes as regras do ato de reconhecimento processual não são obedecidas, podendo surgir contaminações em decorrência desses erros procedimentais. Como determina o artigo 226 do Código de Processo Penal ${ }^{66}$, cabe a pessoa que faz o reconhecimento descrever a pessoa a ser identificada, para, a partir desses dados, serem selecionados possíveis suspeitos que tenham as mesmas características físicas a fim de que a vítima aponte, caso esteja no grupo, o autor do crime.

Todavia as regras sejam claras, nem sempre os suspeitos apresentados, seja no reconhecimento fotográfico como no pessoal, são semelhantes fisicamente, induzindo a vítima a reconhecer a figura do autor naquele único suspeito mostrado que coincida com a descrição feita. Bem como, acontece de a vítima não ser bem instruída no sentido de não se sentir pressionada a reconhecer o criminoso dentre os suspeitos trazidos, haja vista que nem sempre dentre os sujeitos mostrados encontra-se o autor do fato. ${ }^{67}$

A não obrigatoriedade da aplicação dos procedimentos determinados pelo artigo 226, somado à falta de sanções em caso de descumprimento das regras, bem como à falta de maiores instruções para um procedimento mais seguro, como a determinação do número de participantes que enquadrarão o rol de suspeitos mostrados, tornam ainda mais precário o esquema procedimental. ${ }^{68}$ Isto sem considerar o fato extremamente prejudicial da impossibilidade de, em juízo, se reiterar o ato de reconhecimento na presença das mesmas

63 DI GESU, Cristina. Prova penal e falsas memórias. 2. ed. Porto Alegre: Livraria do Advogado, 2014. p. 164.

64 DI GESU, Cristina. Prova penal e falsas memórias. 2. ed. Porto Alegre: Livraria do Advogado, 2014. p. 165.

65 CORDERO, Franco. Procedimiento Penal. Trad.: Jorge Guerrero. Bogotá: Temis, 2000. v. 2. p. 111.

66 CÉSPEDES, Lívia; ROCHA, Fabiana da (Org.) Vade mecum. São Paulo: Saraiva, 2017. p. 615-616.

67 GIACOMOLLI, Nereu josé. A fase pre-liminar no processo penal: crises, misérias e novas metodologias investigativas. Rio de Janeiro, Lumen Juris, 2011. p. 157-158.

68 DI GESU, Cristina. Prova penal e falsas memórias. 2. ed. Porto Alegre: Livraria do Advogado, 2014. p. 167. 
pessoas apresentadas na fase preliminar, à maneira que somente o acusado será a presença repetida em ambos os casos, contribuindo para o induzimento da vítima ao reconhecê-lo. ${ }^{69}$

Frente a todas essas problemáticas, seria prudente a justiça brasileira parar de se valer do processo de reconhecimento por meio de fotografias discricionárias, atentando-se mais ao livre relato das características do imputado, principalmente quando essas condenações, baseadas em reconhecimento fotográfico ou pessoal, são feitas sem a devida atenção às regras procedimentais. ${ }^{70}$ Os atos formais, apontados em lei, devem ser vistos como obrigatórios e, portanto, respeitados, na medida que como regras já estabelecidas visam a um procedimento de maior qualidade e ajudam a evitar distorções. Afinal, a questão crucial é criar um cenário cujo nível de indução seja o menor possível, em que a polícia tenha o cuidado de não confundir a vítima apresentando-a fotos de suspeitos de forma discricionária, bem como, no reconhecimento pessoal, construir a roda de testemunhas em número e semelhanças suficientes, a fim de que a testemunha identifique por si o suspeito, em vez de ser guiada a ele por erros técnicos, comprometendo todo o propósito do ato de reconhecimento, qual seja conhecer o real agressor. ${ }^{71}$

\section{TEMPO DE COLHEITA DA PROVA TESTEMUNHAL: DO TRANSCURSO DO TEMPO}

Outro ponto de primordial entendimento quando se estudam falsas memórias no contexto jurídico diz respeito ao tempo do processo. A razoável duração do processo, garantida constitucionalmente no artigo $5^{\circ}$, LXXVIII, determina que: "a todos no âmbito judicial e administrativo, são assegurados a razoável duração do processo e os meios que garantam a celeridade de sua tramitação" "72. Essa garantia deve ser entendida sob duas óticas, a primeira a qual se refere a preocupação quanto à demora jurisdicional e a todos os problemas decorrentes da falta de rapidez na tramitação; e a segunda perspectiva, que visa à proteção dos direitos e das garantias das partes, que poderia ser mitigada em decorrência de um processo muito célere. ${ }^{73}$

Em outras palavras, o processo, ao mesmo tempo que não pode ser julgado imediatamente, sem que haja a maturação do ato de julgar e a observância das garantias fundamentais do contraditório, da ampla defesa, da presunção de inocência, da motivação das decisões judiciais, dentre outras mais; ${ }^{74}$ não pode se prolongar, indefinidamente, a ponto de se tornar ineficiente em seu propósito, uma vez que, pelo transcurso prolongado do tempo, podem ocorrer o perecimento das pretensões, danos econômicos e psicológicos às partes e profissionais do Direito, incentivos à composições desvantajosas, e, consequentemente, o descrédito da força Judiciária e do Estado. ${ }^{75}$

O tempo do processo é resultado de regras processuais e da matéria litigiosa, a qual determina o ritmo dos procedimentos. ${ }^{76} \mathrm{Na}$ prática, o tempo de duração do processo aumentou, tendo em vista que a sociedade e as relações que a regem estão evoluindo e se tornando mais complexas, da mesma maneira que o mecanismo estatal está sobrecarregado. O maior acesso ao Judiciário, refletindo em um constante aumento no volume de processos, está gerando seu congestionamento, de forma que a estrutura estatal não está sendo capaz de acompanhar esse aumento na demanda. ${ }^{77}$

69 LOPES JUNIOR, Aury. Direito processual penal e sua conformidade constitucional. 2. ed. Rio de Janeiro: Lúmen Júris, 2007. v. 1. p. 632.

70 DI GESU, Cristina. Prova penal e falsas memórias. 2. ed. Porto Alegre: Livraria do Advogado, 2014. p. 169.

71 LOPES JÚNIOR, Aury. Direito processual penal e sua conformidade constitucional. 8. ed. Porto Alegre: Lumen Juris, 2011. v. 1. p. 674.

72 CÉSPEDES, Lívia; ROCHA, Fabiana da (Org.) Vade mecum. São Paulo: Saraiva, 2017. p. 9.

73 DI GESU, Cristina. Prova penal e falsas memórias. 2. ed. Porto Alegre: Livraria do Advogado, 2014. p. 172.

74 DI GESU, Cristina. Prova penal e falsas memórias. 2. ed. Porto Alegre: Livraria do Advogado, 2014. p. 172-173

75 TUCCI, José Rogério Cruz e. Tempo e processo: uma análise empírica das repercussões do tempo na fenomenologia processual (civil e penal). São Paulo: Revista dos Tribunais, 1997.

76 SPENGLER, Fabiana Marion. Da jurisdição à mediação: por uma outra cultura no tratamento de conflitos. Ijuí: Ed. Unijuí, 2010. p. 212.

77 TUCCI, José Rogério Cruz e. Tempo e processo: uma análise empírica das repercussões do tempo na fenomenologia processual 
A questão do tempo de duração do processo é de grande importância, na medida em que o Estado se caracteriza, principalmente, pela sua função social, tendo como função primordial assegurar o bem comum e realizar a justiça social. ${ }^{78}$ Nesse sentido, não há justiça social quando o Estado, por meio do Poder Judiciário, não sabe lidar em tempo hábil e de forma efetiva com as demandas que lhe são apresentadas. ${ }^{79}$

A prova testemunhal relaciona-se nesse contexto, à medida que a duração do processo afeta, diretamente, a qualidade técnica desse meio probatório. Quando se pensa na prova testemunhal, não se pode esquecer de que o fator temporal afeta, diretamente, a forma como os eventos, pessoas e coisas são lembradas. A memória não funciona como um "HD" de computador, em que os arquivos são abertos e resgatados a um clique. A memória é falha. E o tempo atua o sentido de impulsionar a ocorrência desses erros.

Por isso o transcurso do tempo constitui um fator extremamente prejudicial à acurácia desse tipo probatório, de maneira que será maior a sua confiabilidade se feita dentre de um prazo razoável. Uma vez que a prova testemunhal se baseia na memória das pessoas, não pode ser negligenciado o fator da passagem do tempo na mente; afinal, existe uma tendência ao esquecimento, em que os detalhes dos acontecimentos se desvanecem, bem como tornam-se mais sujeitos a distorções e a sugestões. ${ }^{80}$

Assim como ensinou Gauer, os acontecimentos não são retidos na memória; posto que as imagens não se fixam, acabam escapando pela fluidez da velocidade. ${ }^{81}$ Em outras palavras, a mente não fixa, eternamente, as memórias com exatidão. De quanta credibilidade e valor tem, portanto, uma prova testemunhal feita meses ou anos depois do ocorrido, quando essas lembranças já passaram por inimagináveis processos de distorção?

Ao estudar falsas memórias, entende-se o perigo da situação, muitas vezes despercebido pelo nosso sistema processual atual. Somando isto às supracitadas problemáticas no ato de reconhecimento, temos um cenário jurídico extremamente despreparado para lidar com a problemática. E, mesmo assim, ainda se julgam casos, principalmente os crimes contra dignidade sexual, baseando-se somente no que é dito pela vítima. Vítima que, em regra, passou por processos de entrevista e reconhecimento que não estão devidamente atentos quanto a fatores de contaminação da memória, e que, muitas vezes, teve sua palavra ouvida meses, ou mesmo anos depois do ocorrido, decorrente da longa duração do processo.

Assim, ao se pensar na pretensão do Estado em solucionar o litígio visando aos seus ideais de justiça social, a colheita da prova testemunhal deve ser feita em tempo certo, a fim de que o tempo transcorrido entre delito ao reconhecimento ou ao relato testemunhal não seja extenso o bastante para contaminar a forma como o evento é lembrado, comprometendo o resultado justo do processo. Dessa maneira, o processo não pode se prolongar a ponto de, quando chamada em juízo, a vítima já não se lembre com precisão do ocorrido, vendo-se forçada a lembrar imprecisamente do agressor e dos fatos para a solução do litígio.

(civil e penal). São Paulo: Revista dos Tribunais, 1997.

78 SILVA, Queli Cristiane Schiefelbein da; SPENGLER, Fabiana Marion. Memória e Tempo: a razoável Duração do Processo Pós-Emenda Constitucional no 45/2004. Direito em Debate: Revista do Departamento de Ciências Jurídicas e Sociais da Unijuí, Rio Grande do Sul, v. 12, n. 39, p. 99-121, 2013.

79 RODRIGUES, Horácio Wanderlei. Acesso à Justiça e prazo razoável na prestação jurisdicional. In: WAMBIER, Teresa Arruda Alvin (Org.). Reforma do Judiciário: primeiras reflexões sobre a emenda constitucional n. 45/2004. São Paulo: Revista dos Tribunais, 2005. p. 285.

80 DI GESU, Cristina. Prova penal e falsas memórias. 2. ed. Porto Alegre: Livraria do Advogado, 2014. p. 173.

81 GAUER, Ruth. “Falar em tempo, viver o tempo!”. In. GAUER, Ruth M. Chittó; LINHARES, Mozard (Org). Tempo: história. Curitiba: Juruá, 1999. p. 26. 


\section{RepetiçÃo dAs ENTREVISTAS: DA PROVA TESTEMUNHAL COMO ELEMENTO PROBATÓRIO IRREPETÍVEL}

Apesar do transcurso do tempo agir, normalmente, de forma negativa na memória, favorecendo o esquecimento e a perca gradual de nitidez e detalhes, bem como o aumento de chances do desenvolvimento de falsas memórias, a passagem do tempo não significa, necessariamente, que o processo de esquecimento sempre acontecerá. Isto, porque existem fatores que atuam no sentido de melhorarem a retenção da lembrança, sendo um desses elementos o número de vezes que a pessoa ficou recuperando o evento em sua mente, ou seja, quanta vezes ela relembrou-se do ocorrido ao decorrer do tempo. ${ }^{82}$

Nesse sentido, o processo de recuperação ocorre quando o sujeito pensa ou fala sobre algum evento, forçando a evocação de uma lembrança. Ao evocar uma memória repetidas vezes, existe a tendência de consolidar seu armazenamento. ${ }^{83}$ Por isso, à primeira vista, a repetição de entrevistas aparenta ser benéfica a fidedignidade do que for relatado pela testemunha, uma vez que, ao constantemente relatar o ocorrido, os detalhes serão mais facilmente armazenados e não se sujeitaram ao esquecimento.

Todavia, isto se comprovaria caso se tratasse de um cenário ideal sem interferências. Na realidade, cada vez que uma memória é recuperada, existe o risco de ela ser modificada por sugestões internas e externas, ${ }^{84}$ fazendo com que pela repetição constante da lembrança contaminada, ela seja armazenada com erros e distorções.

A repetição de entrevistas, em virtude desse fator, muitas vezes acaba propagando efeitos danosos à memória. O longo transcurso de tempo entre as entrevistas, somado às induções internas e externas que a testemunha sofre dentro e fora desses processos, oportuniza a contaminação daquilo que a testemunha ou vítima realmente viu ou ouviu, de forma que o contato com outras pessoas e com entrevistadores confunde aquele entrevistado a ponto de não saber identificar aquilo que sabe daquilo que lhe foi falado posteriormente. ${ }^{85}$ Dito isto, percebe-se um fator importantíssimo negligenciado pela justiça brasileira: a prova testemunhal não é repetível.

Ocorre que o sistema atual não atua considerando esses entendimentos, inclusive, é frequente, na maioria dos casos, a repetição de entrevistas com as testemunhas, independentemente do tempo transcorrido e de possíveis contaminações nas lembranças. Assim, mesmo que por força do artigo 155 do Código de Processo Penal $^{86}$, o qual determina que o juiz não pode formar sua convicção somente em informações colhidas na fase da investigação, a não ser que se tratem de provas irrepetíveis; a vítima, mesmo que seja ouvida em data próxima à ocorrência do delito, quando suas memórias ainda estão melhor preservadas, dificilmente terá suas declarações usadas como prova, pois se acredita que, como a entrevista pode ser refeita com a mesma qualidade e fidedignidade nas respostas a qualquer momento, o uso dessa prova produzida em fase pré-processual torna-se inviável.

Essa visão opõe-se totalmente ao que se sabe atualmente sobre o funcionamento da mente e seus limites. O que os estudos têm revelado promovem a ideia da prova testemunhal como uma prova irrepetível, ou seja, impossível de ser novamente realizada, seja pelo fator temporal, que culmina no esquecimento e em distorções das lembranças, seja pelo simples fato de um testemunho não ser igual ao outro. ${ }^{87}$

82 STEIN, Lilian M. Avanços Científicos em Psicologia do Testemunho Aplicados ao Reconhecimento Pessoal e aos Depoimentos Forenses. Série Pensando o Direito, Brasília, n. 59, p. 21-22, 2015.

83 ROEDIGER, Henry L.; KARPICKE, Jeffrey D. Test-enhanced learning taking memory tests improves long-term retention. Psychological Science, v. 17, n. 3, p. 249-255, 2006.

84 CHAN, Jason C. K.; THOMAS, Ayanna K.; BULEVICH, John B. Recalling a witnessed event increases eyewitness suggestibility the reversed testing effect. Psychological Science, v. 20, n. 1, p. 66-73. 2009.

85 DI GESU, Cristina. Prova penal e falsas memórias. 2. ed. Porto Alegre: Livraria do Advogado, 2014. p. 182.

86 CÉSPEDES, Lívia; ROCHA, Fabiana da (Org.) Vade mecum. São Paulo: Saraiva, 2017. p. 609.

87 STEIN, Lilian M. Avanços Científicos em Psicologia do Testemunho Aplicados ao Reconhecimento Pessoal e aos Depoimen- 
Nesse sentido, o grande erro hoje constatado quanto à repetição de entrevistas concentra-se em dois fatos, portanto: na crença de que a prova testemunhal se trata de uma prova que pode ser repetida, inclusive, com a mesma qualidade, independentemente do tempo ou dos métodos empregados na entrevista que for realizada, e que a repetição de entrevistas não é danosa à preservação da prova oral. Dois fatos que poderiam ser superados, com o material de estudo e pesquisa já existentes sobre o tema.

\section{SUBJETIVISMO DO JULGADOR: A IMPARCIALIDADE E NEUTRALIDADE DO JULGADOR}

Para finalizar esse breve estudo sobre o grande campo de pesquisa que engloba as Falsas Memórias e suas implicações, deve ser feita uma última análise a uma figura central e controversa no processo penal: o Juiz e sua subjetividade.

Como é sabido, o Juiz na posição de autoridade máxima do processo, tem como dever se manter imparcial frente às partes. O julgador deve postar-se entre as partes e acima delas, como condição de sua função, ${ }^{88}$ adotando condutas que não demonstrem favorecimentos a uma determinada parte em detrimento da outra. Por isso, o Princípio da Imparcialidade é de essencial importância e relevância no Direito, uma vez que controla discriminações e atitudes arbitrárias dos Juízes quanto ao tratamento diferenciado das partes no processo.

A imparcialidade dos Juízes, entretanto, não deve ser tamanha a ponto de cegar os julgadores quanto às desigualdades, dilemas e anseios ocorrentes, da mesma maneira que não deve ser compreendida como a legitimação da total abstenção judicial, a ponto da produção de um resultado injusto no processo. Por isto, discute-se a neutralidade do Juiz, uma vez que um julgador imparcial não necessariamente será um julgador neutro.

Sendo o Julgador um ser humano, é impossível que sejam excluídas no seu ato de julgar suas motivações, suas questões existenciais, suas emoções, sua visão de mundo, bem como seus preconceitos. Por mais distanciado e focado que esteja dos seus instintos, por mais que esteja em postura profissional, o Juiz, no ato de julgar, ainda carrega consigo, projetando no processo, seu eu particular. É o agente social que fala, na posição do profissional; de maneira que seus valores, tradições e costumes, ou seja, toda a sua singularidade que dita os rumos da sentença. ${ }^{89}$

Sabendo que o Julgador carrega e usa seu subjetivismo ao julgar, a avaliação das provas também está sujeita a passar por essa análise interna do Magistrado. Ainda que toda prova usada no processo, ao ser avaliada, deva observar o Princípio do Livre Convencimento Motivado, mitigando a discricionariedade do Juiz ao fazê-la, não há como controlar que esta avaliação seja feita de forma meramente racional, sem ser contaminada pelas vivências, posturas ideológicas, influências e modo de pensar do Julgador, ou seja, pela sua subjetividade.

Posto isto, o subjetivismo do Julgador, também, tem que ser visto como um fator de contaminação da prova testemunhal. ${ }^{90}$ Uma vez que a forma como o Juiz interpreta o caso não é neutra, todo o tipo de informação que venha a ser conhecida por este, seja falsa ou verdadeira, processual ou extraprocessual, que diga algo a respeito do caso julgado, tem potencial de influenciar o modo como decidirá a questão.

tos Forenses. Série Pensando o Direito, Brasília, n. 59, p. 32, 2015.

88 CINTRA, A. C. de A.; DINAMARCO, C. R.; GRINOVER, A. P. Teoria geral do processo. 18. ed. São Paulo: Malheiros, 2002. p. 51-52.

89 GIACOMOLLI, José Nereu; DUARTE, Lisa Bastos. "O mito da neutralidade na motivação das decisões judiciais: aspectos epistemológicos". Revista da AJURIS, v. 33, n. 102, jun. 2006. Disponível em: < http://livepublish.iob.com.br/ntzajuris/lpext.dll/In fobase $/ 1722 \mathrm{f} / 17289 / 17 \mathrm{c} 5 \mathrm{e}$ ?f=templates\&fn=document-frame.htm\&2.0>. Acesso em: 5 set. 2017.

90 DI GESU, Cristina. Prova penal e falsas memórias. 2. ed. Porto Alegre: Livraria do Advogado, 2014. p. 187. 
Por isso, sabendo que vivemos em uma sociedade com altos índices de criminalidade, em que, diariamente, os Julgadores têm de lidar com os mais variados tipos de suspeitos e criminosos, é imprescindível que os Magistrados não se deixem levar pelas aparências, preconceitos e estereótipos ligados a certos tipos de pessoas e certos tipos de crime. Cada caso é único, e assim deve ser visto. Rótulos e apelo social por justiça ocorrem a todo momento e devem ser evitados; bem como a pressão da mídia, em denegrir e ver incriminados determinados suspeitos, não pode ser tomada como formadora de opinião por aqueles que julgaram os casos. Infelizmente, esse cenário não consegue ser totalmente controlado. O Juiz é um ser humano, e não uma "máquina" desprovida de razão e emoção, que consegue se distanciar de todas essas influências. O Juiz, como qualquer Homem, também sente, pensa e se emociona, mas também discrimina e faz pré-julgamentos. Diante disto, na ciência que os crimes contra a dignidade sexual estão dentre os crimes vistos com mais negatividade dentro do nosso meio social, é primordial que o Julgador tenha responsabilidade ao tomar seu posicionamento, não se deixando levar por pressões externas e preconceitos próprios, tentando-se abstrair ao máximo possível dessas influências e avaliando as provas e formando sua decisão com o maior cuidado e calma que conseguir.

Afinal, conforme ao acima exposto, é indispensável que esses mesmos julgadores comecem a rever a forma como o relato testemunhal é avaliado. A ciência da existência das Falsas Memórias e suas implicações por parte do Magistrado faz toda a diferença para a formação de uma sentença mais justa e acurada. Se abster de visões estereotipadas e pré-julgadas para o processo significa muito mais do que ser um ser humano melhor, é se tornar um profissional melhor. Profissional este que tem em seu poder decidir pela verdade e não somente ser levado pela testemunha a um julgamento errôneo.

\section{Considerações finais}

Diante de todo exposto, importa salientar algumas conclusões. Retomando a análise dos crimes contra a dignidade sexual, impera notar que esse tipo criminal, diante da natureza dos delitos que engloba, está suscetível de não ser facilmente comprovado. Os crimes contra a dignidade sexual têm em comum o alto risco de serem consumados sem que deixem rastros materiais, e, mesmo em situações que apresentem vestígios, em regra, esse vestígio se não colhido em tempo hábil perde sua função como prova. Nesse contexto, é senso comum na Justiça casos envolvendo esse tipo de crime serem solucionado com base na palavra testemunhal, a qual em regra trata-se da vítima, uma vez que é frequente esta ser a única presente no momento da agressão sexual.

A palavra da vítima, nesse sentido, adquire importante posição como meio de prova nos crimes contra a dignidade sexual, podendo o Magistrado, por livre escolha, avaliar o peso probatório dela frente às outras provas colhidas para a solução do litígio. O que se percebe é que os Juízes muitas vezes superestimam o relato da vítima em comprometimento de outras evidências trazidas em juízo, haja vista que existe toda uma crença de que uma testemunha de boa reputação, comprometida com a verdade e a justiça e que se mostre firme em seu discurso, não cometeria erros ao descrever os fatos e ao reconhecer os suspeitos.

Essa visão dos fatos não resta verdadeira. A fidedignidade de um relato não depende da intenção do sujeito, de sua personalidade, das suas condutas de vida, tampouco da sua certeza com suas lembranças. A fidedignidade de uma lembrança está muito mais ligada à capacidade de memorização daquele indivíduo, do nível de exposição que esse sujeito teve a sugestões e induções, bem como à quantidade de distorções e falsas lembranças que foram produzidas nesse meio tempo.

O fato de a Justiça se mostrar muitas vezes despreparada para lidar com problemáticas envolvendo a preservação da memória da testemunha é de inestimável peso negativo. As consequências não são simples, tampouco irrelevantes. Os erros relativos a falhas na memória podem culminar em graves acontecimentos: 
não raro a testemunha lembra, distorcidamente, dos fatos ou realiza um falso reconhecimento, o que culmina na prisão de pessoas inocentes e na impunidade dos reais culpados. O problema se intensifica quando se foca no fato de a prova testemunhal ser utilizada como instrumento probatório isolado nos crimes contra a dignidade sexual, e, mesmo assim, devido à falta de conhecimento e cuidado das autoridades jurídicas e policiais, as testemunhas se contaminam e apresentam erros em suas lembranças, comprometendo toda a segurança e justiça do processo.

Por meio dos estudos das falsas memórias descobriu-se muito mais sobre o funcionamento da capacidade de recordação, inclusive, entendendo alguns fatores que levam a distorções e alterações na forma como um evento é recordado. Percebeu-se que as induções podem ser tão fortes a ponto de a pessoa lembrar com alto grau de certeza fatos ou eventos que nunca ocorreram ou que não ocorrem com exatidão daquela maneira, bem como reconhecer erroneamente pessoas, objetos e coisas. Esses estudos demonstraram que diversas condutas realizadas nas entrevistas policiais e judiciais com as vítimas estavam levando estas a criarem falsas memórias. Mais especificamente, a entrevista que era o método utilizado com o propósito de descobrir a verdade, muitas vezes, implicava na destruição de toda a credibilidade e acurácia da prova oral, a qual, em certos casos, é a única prova válida para a solução do litígio.

Com estudo das Falsas Memórias, também, é possível buscar soluções, que, apesar de não solucionarem por completo a problemática, reduzem, expressamente, o nível de danos. Alguns métodos buscam tornar o procedimento realizado nas entrevistas menos intrusivo, dando mais liberdade à testemunha a lembrar-se sozinha dos fatos, sem ser guiada pelo entrevistador e, consequentemente, induzir-se pelas atitudes deste. Além de tantas outras metodologias que buscam contornar os diversos meios de contaminação.

Por isto, no Direito, é fundamental o estudo das Falsas Memórias, com o intuito de se compreender o melhor funcionamento da capacidade de recordação do ser humano, assim como as possíveis falhas e as melhores soluções, a fim de construir um meio jurídico preparado para lidar, adequadamente, com a testemunha e, consequentemente, com a melhor preservação das memórias desta, culminando em resultados mais justos e comprometidos com a verdade..

\section{REFERÊNCIAS}

ALTAVILlA, Enrico. Psicologia judiciária. Tradução de Fernando de Miranda. 2. ed. São Paulo: Livraria Acadêmica Saraiva Editores, 1945. v. 1.

ARANHA, Adalberto José Q. T. de Camargo. Da prova no processo penal. 7. ed. São Paulo: Saraiva, 2006.

BRAINERD, C. J. et al. How does negative emotion induce false memories? Psychological science, v. 19, n. 9, p. 919-925, 2008.

CAPEZ, Fernando. Curso de direito penal. 9. ed. São Paulo: Saraiva, 2011. v. 3.

CÉSPEDES, Lívia; ROCHA, Fabiana da (Org.) Vade mecum. São Paulo: Saraiva, 2017.

CHAN, Jason C. K.; THOMAS, Ayanna K.; BULEVICH, John B. Recalling a witnessed event increases eyewitness suggestibility the reversed testing effect. Psychological Science, v. 20, n. 1, p. 66-73, 2009.

CINTRA, A. C. de A.; DINAMARCO, C. R.; GRINOVER, A. P. Teoria geral do processo. 18. ed. São Paulo: Malheiros, 2002.

CORDERO, Franco. Procedimiento penal. Trad.: Jorge Guerrero. Santa Fé de Bogotá- Colômbia: Editorial Temis, 2000. v. 2.

DAMÁSIO, Antônio. O erro de Descartes: emoção, razão e o cérebro humano. Trad. Dora Vicente e Georgina Segurado. 8. ed. São Paulo: Companhia das Letras, 2001. 
DELMANTO, Celso. Código Penal comentado: acompanhamento de comentários, jurisprudência, súmula em matéria penal e legislação complementar. 8. ed. São Paulo: Saraiva, 2010.

DI GESU, Cristina. Prova penal e falsas memórias. 2. ed. Porto Alegre: Livraria do Advogado, 2014.

FLECH, Larissa Civardi. Falsas memórias no processo penal. Disponível em: <https://www.lume.ufrgs.br/ bitstream/handle/10183/67291/000872494.pdf?sequence=1>. Acesso em: 20 jul. 2017.

GAUER, Ruth. “Falar em tempo, viver o tempo!”. In. GAUER, Ruth M. Chittó; LINHARES, Mozard. (Org). Tempo: história. Curitiba: Juruá, 1999.

GIACOMOLLI, José Nereu; DUARTE, Lisa Bastos. “ O mito da neutralidade na motivação das decisões judiciais: aspectos epistemológicos”. Revista da AJURIS, v. 33, n. 102, jun. 2006. Disponível em: < http:// livepublish.iob.com.br/ntzajuris/lpext.dll/Infobase/1722f/17289/17c5e?f=templates\&fn=document-frame.htm\&2.0>. Acesso em: 5 set. 2017.

GIACOMOLLI, Nereu josé. A fase pre-liminar no processo penal: crises, misérias e novas metodologias investigativas. Rio de Janeiro: Lumen Juris, 2011.

GOULART, Valéria Diez Scarance Fernandes. Tortura e prova no processo penal. São Paulo: Atlas, 2002.

GRECO FILHO, Rogério Greco. Curso de direito penal: parte especial. 10. ed. Rio de Janeiro: Impetus, 2013. v. 3.

INNOCENCE Project. Disponíveis em: <https://www.innocenceproject.org/all-cases/\#involvedyes,exonerated-by-dna,sex-crimes $>$. Acesso em: 31 maio. 2018.

ISHIDA, Válter Kenji. Curso de direito penal. 2. ed. São Paulo: Atlas, 2009.

ISHIDA, Válter Kenji. Processo penal: de acordo com a reforma processual penal. São Paulo: Atlas, 2009. Disponível em: <https://www.passeidireto.com/arquivo/18046231/valter-kenji-ishida---processo-penal--1-edicao---ano-2009>. Acesso em: 10 jul. 2017. p. 113.

IZQUIERDO, I. $A$ arte de esquecer. 2. ed. Rio de Janeiro: Vieira \& Lent, 2009. v. 1.

IZQUIERDO, Ivan. A memória. Entrevisyta com Ivan Izquierdo concedida à RAN - Revista Argentina de Neurociência, por Ignacio Brusco, MD; Diego Golombeck, Phd e Sérgio Strejilevich, MD. Trad. Renato M. E. Sabbatini. Disponível em: <http://www.cerebromente.org.br/n04/opiniao/izquierdo.htm>. Acesso em: 23 jul. 2017.

IZQUIERDO, Iván. Memória. 2. ed. Porto Alegre: Artmed, 2011. Disponível em: <https://books.google.com.br $/$ books?id $=$ DgPLKEvcE5cC\&pg $=$ PA20\&lpg $=$ PA20\&dq $=\mathrm{A}+$ mem $\% \mathrm{C} 3 \% \mathrm{~B} 3 \mathrm{ria}+\mathrm{do}+$ perfume $+\mathrm{da}+$ rosa $+\mathrm{n} \% \mathrm{C} 3 \% \mathrm{~A} 3 \mathrm{o}+$ nos + traz\&source $=$ bl\&ots $=-7 \mathrm{zWKcMeAf \& sig}=1 \mathrm{RsAEb} 4 J \mathrm{JImA}$ 7aag5RGeLR4wxbI\&hl=pt-BR\&sa $=$ X\&ved=0ahUKEwiTs5Sbz5rVAhWJgZAKHQo0BFcQ6AEIJzAA\#v=snippet\&q $=$ trabalho\&f=false $>$. Acesso em: 23 jul. 2017.

IZQUIERDO, Iván. Memória. Porto Alegre: Artmed, Reimpressão, 2006.

KENSINGER, E. A., \& SHACTER, D. L. When the red sox shocked the yankees: comparing negative and positive memories. Psychonomic Bulletin \& Review, v. 13, n. 5, p. 757-763, 2006.

KIHLSTROM, J. F. Exhumed memory. New York: Guilford, 1998.

LOFTUS, Elizabeth. “As falsas lembranças”. Revista Viver Mente \& Cérebro, p. 90-93, 2005.

LOPES JUNIOR, Aury. Direito processual penal e sua conformidade constitucional. 4. ed. Rio de Janeiro: Lúmen Júris, 2009. v. 1.

LOPES JÚNIOR, Aury. Direito processual penal e sua conformidade constitucional. 8. ed. Porto Alegre: Lumen Juris, 2011. v.1. 
MALATESTA, Nicola Framarino Dei. A lógica das provas em matéria criminal. Trad.: Paolo Capitanio. Campinas: Bookseller, 2004.

MUCCIO, Hidejalma. Curso de processo penal. 2. ed. Rio de Janeiro: Método, 2011.

NEUFELD, Carmem Beatriz; BRUST, Priscila Goergen; STEIN, Lilian Milnitsky. Compreendendo o Fenômeno das Falsas Memórias. In: STEIN, Lilian Milnitsky; et. al. Falsas memórias: fundamentos científicos e suas aplicações clínicas e jurídicas. Porto Alegre: Artmed, 2010. p. 21-41.

NEWS, CBN. Exclusive: The bunny effect. Youtube, 8 mar. 2009. Disponível em: $<$ https://www.youtube. com/watch?v=eZlPzSeUDDw>. Acesso em: 29 jul. 2017.

NUCCI, Guilherme de Souza. Código de Processo Penal comentado. 13. ed. Rio de Janeiro: Forense, 2014. Disponível em: <http://sta.pro.br/livros/19\%20-\%20NUCCI_Guilherme_de_Souza_C\%C3\%B3digo_de_ Processo_Penal_Comentado_2014.pdf>. Acesso em: 10 jul. 2017.

NUCCI, Guilherme de Souza. Código de Processo Penal comentado. 8. ed. São Paulo: Revista dos Tribunais, 2008.

RODRIGUES, Horácio Wanderlei. Acesso à Justiça e prazo razoável na prestação jurisdicional. In: WAMBIER, Teresa Arruda Alvin (Org.). Reforma do Judiciário: primeiras reflexões sobre a emenda constitucional n. 45/2004. São Paulo: Revista dos Tribunais, 2005.

ROEDIGER, Henry L.; KARPICKE, Jeffrey D. Test-enhanced learning taking memory tests improves long-term retention. Psychological Science, v. 17, n. 3, p. 249-255, 2006.

SCHACTER, Daniel. Os sete pecados da memória: como a mente esquece e lembra. Rio de Janeiro: Rocco, 2003.

SILVA, Queli Cristiane Schiefelbein da; SPENGLER, Fabiana Marion. Memória e Tempo: a razoável Duração do Processo Pós-Emenda Constitucional no 45/2004. Direito em Debate: Revista do Departamento de Ciências Jurídicas e Sociais da Unijuí, Rio Grande do Sul, v. 12, n. 39, p. 99-121, 2013.

SPENGLER, Fabiana Marion. Da jurisdição à mediação: por uma outra cultura no tratamento de conflitos. Ijuí: Unijuí, 2010.

STEIN, Lilian M. Avanços Científicos em Psicologia do Testemunho Aplicados ao Reconhecimento Pessoal e aos Depoimentos Forenses. Série Pensando o Direito, Brasília, n. 59, 2015.

STEIN, Lilian M. et al. "Memória, humor e emoção”. Revista de Psiquiatria, Rio Grande do Sul, v. 28, n. 1, p. 66-68, 2006. Disponível em: <http://www.scielo.br/scielo.php?script=sci_arttext\&pid =S0101-81082006000100008>. Acesso em: 8 set. 2017.

STERNBERG, R. J. Psicologia cognitiva. Porto Alegre: Artes Médicas Sul, 2000.

TOURINHO FILHO, Fernando da Costa. Processo penal. 30. ed. São Paulo: Saraiva, 2008. v. 3.

TUCCI, José Rogério Cruz e. Tempo e processo: uma análise empírica das repercussões do tempo na fenomenologia processual (civil e penal). São Paulo: Revista dos Tribunais, 1997.

VIRILIO, Paul. "O paradoxo da memória do presente na era cibernética”. Entrevista com Paul Virilio concedida a Frederico Casalegno. In: Memória cotidiana: comunidades e comunicação na era das redes. Entrevista com Paul Virilio concedida a Frederico Casalegno. CASALEGNO, Frederico. Memória cotidiana: comunidades e comunicação na era das redes. Trad. de Adriana Amaral, Francisco Rüdger e Sandra Montardo. Porto Alegre: Sulina, 2006. 


\title{
A (ir)repetibilidade da prova penal dependente da memória: uma discussão com base na psicologia do testemunho*
}

\author{
The (un)repeatability of memory-dependent \\ criminal evidence: a discussion from the \\ psychology of witness
}

\author{
William Weber Cecconello** \\ Gustavo Noronha de Avila*** \\ Lilian Milnitsky Stein****
}

* Recebido em 31/05/2018

Aprovado em 13/07/2018

** Doutorando e Mestre em Psicologia pela PUCRS. E-mail: william.cecconello@gmail. com

*** Doutor (2012) e Mestre em Ciências Criminais (2006) pela Pontifícia Universidade Católica do Rio Grande do Sul (PUCRS). Professor do Mestrado em Ciência Jurídica e da Faculdade de Direito do Centro de Ensino Superior de Maringá/PR (Unicesumar). Professor da Especialização em Ciências Criminais do Uniceuma/MA, OAB/PA, Uniritter, Unisinos, ABDConst e Instituto Paranaense de Educação. Foi Pesquisador do Ministério da Justiça (2014/2015) e participou das Audiências Públicas sobre o Novo Código de Processo Penal (2016). E-mail: gusnavila@gmail.com

**** Professora titular do Programa de Pós-Graduação em Psicologia da Pontifícia Universidade Católica do Rio Grande do Sul, com Posdoutorado na Universidad de Barcelona, Espanha (2011) e Doutorado em Cognitive Psychology - University of Arizona, EUA (1998).E-mail: stein.lilian@gmail.com

\section{Resumo}

Provas dependentes da memória de uma testemunha podem ser as únicas evidências de que um crime ocorreu. Entretanto, os procedimentos utilizados em oitivas de testemunhas ou reconhecimentos de suspeitos podem alterar a memória original do fato. Tais riscos são, ainda, maiores dados que no Brasil provas dependentes da memória humana são consideradas provas repetíveis. A repetibilidade dessa prova não leva em conta o possível esquecimento de informações, ou a inserção de informações posteriores ao evento, que modificam a memória original. Este artigo visa apresentar as capacidades e limitações das provas dependentes da memória humana, comparando como a legislação e procedimentos utilizados para produção dessas provas por atores de justiça. Ao final, são discutidas políticas públicas que podem auxiliar a diminuir a distância entre conhecimento científico e práticas adotadas no nosso país. Se por um lado não é possível mudar o funcionamento da memória humana, é imprescindível pensar em mudanças no sistema de justiça que ajudem a preservar essa prova que deveria ser considerada irrepetível.

Palavras-chave: Prova penal. Provas repetíveis. Entrevista cognitiva. Psicologia do testemunho. Falsas memórias.

\section{Abstract}

Eyewitness memory may by the only evidence of a crime. However, the procedures used to obtain eyewitness testimony or suspect identification may change permanently the original memory. This risk is even higher in Brasil, because memory-dependent evidence is considered repeatable. The repeatability of this evidence does not account the possibility of forgetting or post-event information that may change the original memory. This paper aims to present the capacity and limitation of human-memory-dependent evidence, comparing to how justice system laws and procedures are used to obtain this evidence. In the end, we discuss public policies that may help to 
decrease the distance between scientific knowledge and the practices used in our country. On one hand we cannot chance how human memory works, it is indispensable to think about chances in justice system that help to preserve this evidence, that should be considered unrepeatable.

Keywords: Witness evidence. Criminal policies. Suggestibility. False memories. Public Policies.

\section{INTRODUÇÃO}

A prova advinda da memória humana é uma das mais utilizadas no meio jurídico, sendo muitas vezes a única evidência disponível para a elucidação de um crime ${ }^{1}$. Atualmente, no Brasil, a prova penal dependente da memória humana é considerada repetível, o que significa que pode ser coletada múltiplas vezes sem que, em tese, houvesse algum prejuízo. É esperado que a repetibilidade auxilie o processo de coleta de prova mais fidedigna dependente da memória, pois uma testemunha que diz a verdade estará segura e não haverá contradição em relação aos relatos desta. Porém, a repetibilidade do testemunho ou reconhecimento não é uma garantia de que as informações recordadas são verdadeiras, ou que a testemunha reconheceu, corretamente, o responsável pelo crime.

O problema associado à repetibilidade da prova advinda da memória humana pode ser observada no caso de John Jerome White, em 1979, nos EUA, acusado de assalto decorrido de estupro². A vítima, uma senhora de 74 anos, realizou o reconhecimento fotográfico na delegacia, indicando, sem muita certeza, ter sido Jerome o responsável pelo crime. Visando a uma evidência mais fidedigna, a polícia solicitou um novo reconhecimento fotográfico, apresentando uma nova foto de Jerome, na qual ele aparecia alinhado juntamente com outros cinco homens. Nesse segundo reconhecimento, novamente a vítima identificou Jerome, agora com maior confiança. Jerome foi a julgamento, e, quando solicitada para reconhecer o responsável em juízo, a vítima, novamente, o reconheceu, dessa vez sem hesitação. Jerome, que sempre alegou não ser o estuprador, foi mantido em cárcere durante 22 anos até um teste de DNA provar sua inocência. Por meio dessa amostra de DNA, a polícia conseguiu chegar até o real perpetrador, revelando um aspecto emblemático desse caso: o perpetrador era um dos quatro homens alinhados à Jerome, na foto apresentada à vítima no segundo reconhecimento.

Diversos casos, assim como o de Jerome, já demonstraram que inocentes podem ser condenados devido a provas dependentes da memória ${ }^{3}$. As variáveis envolvidas nesse tipo de prova têm sido estudadas nas últimas décadas, visando entender como o esquecimento de informações e a sugestionabilidade afetam a memória humana. Mais especificamente a Psicologia do Testemunho tem estudado os erros decorrentes de processos cognitivos de testemunhas, e como os procedimentos realizados por atores de justiça podem aumentar ou diminuir a fidedignidade da prova advinda da memória da testemunha. Este artigo inicia explorando as implicações da repetibilidade da prova testemunhal no Brasil, à luz do estado da arte da Psicologia do Testemunho, em um primeiro momento. A seguir, será analisado como a prova testemunhal é entendida no meio jurídico, para, então, explicar como a lacuna entre o sistema de justiça e o conhecimento científico podem levar a erros de justiça ao repetir a prova testemunhal. Ao final, são discutidas políticas públicas necessárias para a construção de um processo penal democrático, com atenuação significativa de injustiças decorrentes da prova dependente da memória.

1 STEIN, L. M.; ÁVILA, G. N. Avanços científicos em psicologia do testemunho aplicados ao reconhecimento pessoal e aos depoimentos forenses. Brasília: Secretaria de Assuntos Legislativos, Ministério da Justiça (Série Pensando Direito, No. 59), 2015, p. 42. Disponível em: < http://pensando.mj.gov.br/wp-content/uploads/2016/02/PoD_59_Lilian_web-1.pdf>. Acesso em: 22 maio 2018.

2 INNOCENCE PROJECT. John Jerome White. Disponível em: < https://www.innocenceproject.org/cases/john-jeromewhite/> . Acesso em: 22 maio 2018.

3 WEST, Emily; METERKO, Vanessa. Innocence project: DNA exonerations, 1989-2014: review of data and findings from the first 25 years. Alb. L. Rev., v. 79, p. 717, 2015. 


\section{Capacidades e limites da memória humana}

A recordação e o reconhecimento de uma testemunha são subjacentes acerca de como o cérebro humano codifica, armazena, e recupera informações ${ }^{4}$. A memória humana possui capacidades de reter informações por muito tempo, como uma vítima que recorda, detalhadamente, de um abuso sexual presenciado na infância. Entretanto, a memória humana, também, possui limitações como recordar de informações que não ocorreram ou reconhecer um inocente como sendo o criminoso ${ }^{5}$. Nesta seção apresentaremos, de forma breve, como a memória humana funciona, para explicar os riscos decorrentes da repetibilidade da coleta dessa prova.

A primeira etapa para a formação de uma memória é a codificação: durante o fato, tudo o que a vítima ou testemunha é capaz de ver, ouvir, sentir, etc., é interpretado pelo cérebro, e podem vir a se tornar parte da memória para o evento ${ }^{6}$. A capacidade atencional de seres humanos é limitada, e, consequentemente, é impossível codificar todos os estímulos que ocorrem no ambiente ${ }^{7}$. Se, durante o crime, o perpetrador porta uma arma, por exemplo, esse estímulo que representa uma ameaça atrai a atenção da vítima. Há diferenças na codificação do fato quando existe a presença de arma. Quando isto ocorrer, a tendência será o prejuízo da codificação do rosto do criminoso ${ }^{8}$. Há diversas outras condições do evento que podem ter impacto na codificação de um evento, como estresse ${ }^{9}$, distância do local do fato ${ }^{10}$ e idade da testemunha ${ }^{11}$. As variáveis envolvidas durante a codificação do evento não estão sobre o controle do sistema de justiça, mas podem impactar a qualidade da memória para o fato.

Independentemente de como os estímulos são experienciados e codificados durante o fato, uma memória do evento e da face do criminoso são formadas, dando início à etapa de armazenamento. Uma vez armazenadas, as informações do evento podem ser esquecidas. Há mais de um século pesquisas científicas têm demonstrado que a memória pode se deteriorar com o decorrer do tempo ${ }^{12}$. Assim, no intervalo de tempo entre o fato de interesse da justiça criminal até o depoimento, que invariavelmente demora mais do que um ano, muitas informações são esquecidas ${ }^{13}$. O esquecimento ocorre para que a memória seja armazenada em

4 LOFTUS, Elizabeth F. Planting misinformation in the human mind: a 30-year investigation of the malleability of memory. Learning \& Memory, v. 12, n. 4, p. 361-366, 2005. Disponível em: <http://learnmem.cshlp.org/content/12/4/361.abstract>. Acesso em: 22 maio 2018.; SCHACTER, Daniel L.; LOFTUS, Elizabeth F. Memory and law: what can cognitive neuroscience contribute? Nat Neurosci, v. 16, n. 2, p. 119-123, 2013. Disponível em: <http://dx.doi.org/10.1038/nn.3294>.

5 CLARK, Steven E.; GODFREY, Ryan D. Eyewitness identification evidence and innocence risk. Psychonomic Bulletin $\{\&\}$ Review, v. 16, n. 1, p. 22-42, 2009; LOFTUS, Elizabeth F. Planting misinformation in the human mind: a 30-year investigation of the malleability of memory. Learning \& Memory, v. 12, n. 4, p. 361-366, 2005. Disponível em: < http://learnmem.cshlp.org/content/12/4/361.abstract>. Acesso em: 22 maio 2018.

6 IZQUIERDO, Ivan. Questões sobre memória. São Leopoldo: Unisinos, 2006. p. 21.

7 THOMA, Volker; LAVIE, Nilli. Perceptual load effects on processing distractor faces indicate face-specific capacity limits. Visual Cognition, v. 21, n. 8, p. 1053-1076, 2013.

8 FAWCETT, Jonathan M. et al. Of guns and geese: a meta-analytic review of the "weapon focus" literature. Psychology, Crime \& Law, v. 19, n. 1, p. 35-66, 2013. Disponível em: <http://dx.doi.org/10.1080/1068316X.2011.599325>. Acesso em: 22 maio 2018.

9 DEFFENBACHER, Kenneth A. et al. A meta-analytic review of the effects of high stress on eyewitness memory. v. 28, n. 6, 2004. Disponível em: $<$ https://digitalcommons.unomaha.edu/cgi/viewcontent.cgi?referer=https://www.google.com.br/\&httpsredir=1\&ar ticle $=1000 \&$ context $=$ psychfacpub $>$. Acesso em: 22 maio 2018 .

10 LAMPINEN, James Michael et al. Effects of distance on face recognition: implications for eyewitness identification. Psychonomic Bulletin \& Review, p. 1489-1494, 2014.

11 ERICKSON, William Blake; LAMPINEN, James Michael; MOORE, Kara N. Eyewitness identifications by older and younger adults: a meta-analysis and discussion. Journal of Police and Criminal Psychology, v. 31, n. 2, p. 108-121, 2016.

12 EBBINGHAUS, Hermann. Memory (HA Ruger \& CE Bussenius, Trans.). New York: Teachers College., 1913; FLIN, Rhona et al. The effect of a five-month delay on children's and adults' eyewitness memory. British Journal of Psychology, v. 83, n. 3, p. 323336, 1992. Disponível em: <http://dx.doi.org/10.1111/j.2044-8295.1992.tb02444.x>. Acesso em: 22 maio 2018. LOFTUS, Elizabeth F. Planting misinformation in the human mind: a 30-year investigation of the malleability of memory. Learning \& Memory, v. 12, n. 4, p. 361-366, 2005. Disponível em: <http://learnmem.cshlp.org/content/12/4/361.abstract>. Acesso em: 22 maio 2018. SCHACTER, Daniel L. Os sete pecados da memória: como a mente esquece e lembra. São Paulo: Rocco, 2003.

13 STEIN, L. M.; ÁVILA, G. N. Avanços cientificos em psicologia do testemunbo aplicados ao reconhecimento pessoal e aos depoimentos forenses. Brasília: Secretaria de Assuntos Legislativos, Ministério da Justiça (Série Pensando Direito, No. 59)., 2015, p. 47. Disponível em: 
meio a conexões de diversos neurônios, em vez de em um local específico no cérebro, como uma fotografia ou filmagem ${ }^{14}$. As conexões sinápticas entre os neurônios que sustentam a memória se degradam com o decorrer do tempo. A maioria das memórias que juntamos se perdem por falta de reforço ${ }^{15}$.

A memória de um fato, assim como nossos músculos, enfraquece na medida em que os neurônios por ela responsáveis não são exercitados. Assim como um músculo, é preciso atenção para qual o procedimento utilizado na recuperação da memória, e não somente para quantas vezes foi repetido. Um exercício realizado repetidamente, de maneira correta, pode tornar os neurônios mais fortes, enquanto exercícios incorretos ou a repetição excessiva de procedimentos podem deteriorar tais neurônios. Importante notar uma limitação crucial que difere essa metáfora da realidade: ao contrário de um músculo, uma memória não possui formato específico, e os procedimentos utilizados para acessar essa memória podem alterá-la de maneira permanente.

$\mathrm{O}$ ato de evocar a memória, como recordar o evento ou reconhecer o perpetrador, se refere à etapa de recuperação. Em vez de uma recordação de informações estáticas, a memória humana é maleável, e, durante a recuperação, além de reforçadas novas informações, podem ser agregadas à recordação original do fato ${ }^{16}$. Por exemplo, é comum que testemunhas conversem entre si acerca do crime presenciado, e, durante essa conversa, uma testemunha pode recordar informações que a outra não havia codificado ${ }^{17}$. Essas informações são armazenadas juntamente à memória original do fato, sem que haja um registro de quais informações foram inseridas durante ou após o evento ${ }^{18}$.

A maleabilidade da memória humana impõe um custo: a exposição a informações incorretas pode levar a uma recordação ou ao reconhecimento falso. Um exemplo é o experimento conduzido por EISEN et al. ${ }^{19}$, em que os participantes assistiram a um vídeo de um carro sendo roubado por um homem careca e sem tatuagens, e conversavam sobre o crime com outras testemunhas. Uma das testemunhas era um "falso participante" (i.e., confederado) treinado pelos pesquisadores para dizer aos demais que o assaltante tinha uma tatuagem no pescoço. Após uma semana os participantes deveriam reconhecer o perpetrador em um alinhamento de oito faces de homens carecas. Apenas 34\% dos participantes reconheceram o verdadeiro perpetrador enquanto $43,8 \%$ dos participantes reconheceram um suspeito inocente que possuía tatuagem no pescoço. Ou seja, para quase metade dos participantes, a informação incorreta obtida após o evento (tatuagem no pescoço), foi armazenada juntamente à memória do fato (rosto do perpetrador), levando a um reconhecimento falso.

As etapas de armazenamento e recordação acontecem num continum: uma vez que a memória é evocada, ela encontra-se em um estado transiente em que novas informações podem ser inseridas e armazenadas jun-

<http://pensando.mj.gov.br/wp-content/uploads/2016/02/PoD_59_Lilian_web-1.pdf>. Acesso em: 22 maio 2018.

14 DUDAI, Yadin; EDELSON, Micah G. Personal memory: is it personal, is it memory? Memory Studies, v. 9, n. 3, p. 275-283, 2016. Disponível em: <http://mss.sagepub.com/content/9/3/275.abstract>.; SCHACTER, Daniel L.; LOFTUS, Elizabeth F. Memory and law: what can cognitive neuroscience contribute? Nat Neurosci, v. 16, n. 2, p. 119-123, 2013. Disponível em: <http:// dx.doi.org/10.1038/nn.3294>. Acesso em: 22 maio 2018. WERNER, Nicole-Simone; KÜHNEL, Sina; MARKOWITSCH, Hans J. The neuroscience of face processing and identification in eyewitnesses and offenders. Frontiers in Behavioral Neuroscience, v. 7, p. 1-12, dec. 2013. Disponível em: <http://journal.frontiersin.org/article/10.3389/fnbeh.2013.00189/abstract>. Acesso em: 22 maio 2018. 15 BADDELEY, Alan. Essentials of human memory (classic edition). [s.l.]: Psychology Press, 2013, p. 29.

16 SCOBORIA, Alan et al. A mega-analysis of memory reports from eight peer-reviewed false memory implantation studies. Memory, v. 25, n. 2, p. 146-163, 2017.

17 PATERSON, Helen M.; KEMP, Richard I. Co-witnesses talk: a survey of eyewitness discussion. Psychology, Crime \& Law, v. 12, n. 2, p. 181-191, 2006. Disponível em: <http://dx.doi.org/10.1080/10683160512331316334>.; SKAGERBERG, Elin M.; WRIGHT, Daniel B. The prevalence of co-witnesses and co-witness discussions in real eyewitnesses. Psychology, Crime \& Law, v. 14, n. 6, p. 513-521, 2008. Disponível em: <http://dx.doi.org/10.1080/10683160801948980>.

18 DUDAI, Yadin; EDELSON, Micah G. Personal memory: is it personal, is it memory? Memory Studies, v. 9, n. 3, p. 275-283, 2016. Disponível em: <http://mss.sagepub.com/content/9/3/275.abstract>.; HIRST, William; ECHTERHOFF, Gerald. Remembering in conversations: the social sharing and reshaping of memories. Annual Review of Psychology, v. 63, n. 1, p. 55-79, 2012. Disponível em: <http://dx.doi.org/10.1146/annurev-psych-120710-100340>.

19 EISEN, Mitchell L. et al. "I think he had a tattoo on his neck": how co-witness discussions about a perpetrator's description can affect eyewitness identification decisions. Journal of Applied Research in Memory and Cognition, v. 6, n. 3, p. 274-282, 2017. 
tamente com a memória original ${ }^{20}$. Entretanto, não permanece registrado no cérebro se as informações que compõem a memória foram armazenadas durante ou após o fato ${ }^{21}$. A memória que uma testemunha tem do fato é resultado da codificação original somada às recuperações subsequentes, como conversas com outras testemunhas sobre o ocorrido, entrevistas com policiais, ou reconhecimento de suspeitos. Nesse sentido, a repetibilidade da prova dependente da memória pode apresentar um risco de deteriorar essa evidência, ao invés de preservá-la.

Durante uma oitiva, a testemunha acessa o conteúdo armazenado acerca do fato e deve transformá-lo em palavras. Nesse processo cada pergunta feita pelo entrevistador implica a possibilidade de interferir não apenas no relato, mas também na memória original do fato ${ }^{22}$. Um exemplo é o estudo clássico de Loftus e Palmer ${ }^{23}$, que expuseram participantes a um vídeo de um acidente automobilístico. Ao questionar os participantes, os resultados demonstraram que a alteração de uma única palavra foi suficiente para modificar a memória das testemunhas. Participantes questionados "a que velocidade os carros estavam quando se encostaram?" responderam, em média, " $50 \mathrm{~km} / \mathrm{h}$ ", enquanto participantes questionados "A que velocidade os carros estavam quando se esmagaram?" responderam, em média, "65 km/h". Após esse experimento, diversos outros estudos verificaram que a forma como uma pergunta é feita pode levar uma testemunha a contradizer uma informação verdadeira relatada, induzir seu relato, e até mesmo criar uma falsa memória ${ }^{24}$. Ou seja, apenas uma pergunta mal elaborada pode ser o suficiente para que a memória original da testemunha seja alterada de forma permanente.

A maleabilidade da memória da testemunha não significa a realização ou repetição de procedimentos, que são inerentemente prejudiciais à memória do fato. Repetidas entrevistas permitem trazer mais informações da testemunha. Entretanto, o benefício na repetição de oitivas de testemunhas e vítimas ocorre apenas quando se utiliza um protocolo com validade científica, aplicado por um profissional com capacitação adequada à utilização deste ${ }^{25}$. A respeito desses dois aspectos (quem realiza e como realiza) reside a impossibilidade de repetir o testemunho na conjuntura brasileira atual.

20 DUDAI, Yadin; EDELSON, Micah G. Personal memory: is it personal, is it memory? Memory Studies, v. 9, n. 3, p. 275-283, 2016. Disponível em: <http://mss.sagepub.com/content/9/3/275.abstract>.; NEWMAN, Eryn J.; FRENDA, Steven J.; LOFTUS, Elizabeth F. False memories. In: BRUINSMA, Gerben; WEISBURD, David (Ed.). Encyclopedia of criminology and criminal justice. New York, NY: Springer New York, 2014. p. 1555-1563.

21 SCHACTER, Daniel L.; LOFTUS, Elizabeth F. Memory and law: what can cognitive neuroscience contribute? Nat Neurosci, v. 16, n. 2, p. 119-123, 2013. Disponível em: <http://dx.doi.org/10.1038/nn.3294>. Acesso em: 22 maio 2018.

22 BOWLES, Peter V.; SHARMAN, Stefanie J. A review of the impact of different types of leading interview questions on child and adult witnesses with intellectual disabilities. Psychiatry, Psychology and Law, v. 21, n. 2, p. 205-217, 2014. Disponível em: <http://dx.doi.org/10.1080/13218719.2013.803276>. Acesso em: 22 maio 2018. PETERSON, Carole; DOWDEN, Craig; TOBIN, Jennifer. Interviewing preschoolers: comparisons of yes/no and wh-questions. Law and Human Behavior, v. 23, n. 5, p. 539, 1999; e ROEBERS, Claudia M.; SCHNEIDER, Wolfgang. The impact of misleading questions on eyewitness memory in children and adults. Applied Cognitive Psychology, v. 14, n. 6, p. 509-526, 2000. Disponível em: <http://dx.doi.org/10.1002/10990720(200011/12)14:6\%3C509::AID-ACP668\%3E3.0.CO;2-W>. Acesso em: 22 maio 2018.

23 LOFTUS, Elizabeth F.; PALMER, John C. Reconstruction of automobile destruction: an example of the interaction between language and memory. Journal of Verbal Learning and Verbal Behavior, v. 13, n. 5, p. 585-589, 1974. Disponível em: <http://www. demenzemedicinagenerale.net/images/mens-sana/AutomobileDestruction.pdf>. Acesso em: 25 maio 2018.

24 BOWLES, Peter V.; SHARMAN, Stefanie J. A review of the impact of different types of leading interview questions on child and adult witnesses with intellectual disabilities. Psychiatry, Psychology and Law, v. 21, n. 2, p. 205-217, 2014. Disponível em: <http:// dx.doi.org/10.1080/13218719.2013.803276>. Acesso em: 22 maio 2018. FRITZLEY, H. V.; LINDSAY, Rod C. L.; LEE, Kang. Young children's response tendencies toward yes-no questions concerning actions. Child Development, v. 84, n. 2, p. 711-725, 2013; PETERSON, Carole; DOWDEN, Craig; TOBIN, Jennifer. Interviewing preschoolers: comparisons of yes/no and wh-questions. Law and Human Behavior, v. 23, n. 5, p. 539, 1999; ROEBERS, Claudia M.; SCHNEIDER, Wolfgang. The impact of misleading questions on eyewitness memory in children and adults. Applied Cognitive Psychology, v. 14, n. 6, p. 509-526, 2000. Disponível em: <http:// dx.doi.org/10.1002/1099-0720(200011/12)14:6\%3C509::AID-ACP668\%3E3.0.CO;2-W>. Acesso em: 22 maio 2018.

25 KRIX, Alana C. et al. Consistency across repeated eyewitness interviews: contrasting police detectives' beliefs with actual eyewitness performance. PLOS ONE, v. 10, n. 2, p. e0118641, 2015. Disponível em: < https://doi.org/10.1371/journal.pone.0118641>. Acesso em: 22 maio 2018. ODINOT, Geralda et al. Are two interviews better than one? eyewitness memory across repeated cognitive interviews. PLOS ONE, v. 8, n. 10, p. e76305, 2013. Disponível em: <https://doi.org/10.1371/journal.pone.0076305>. Acesso em: 22 maio 2018. 
Atualmente, atores do direito não possuem capacitação científica para realizar entrevistas com testemunhas e, consequentemente, oitivas são conduzidas com base na própria experiência. Este não é um indicador da qualidade de entrevistas realizadas ${ }^{26}$. Soma-se a isto o longo tempo transcorrido entre o fato e a recuperação deste, pois, como citado anteriormente, à medida em que o tempo transcorre desde o acontecido, a qualidade da memória do fato diminui. Quanto pior a qualidade do traço de memória original, maior a possibilidade que as informações pós evento tenham um impacto na prova testemunhal ${ }^{27}$. Ao aumentar as vezes em que uma testemunha é repetidamente entrevistada, após um longo tempo transcorrido desde o fato, sem a utilização de procedimentos adequados, aumenta-se a probabilidade de que a memória original seja modificada de forma permanente, com perda e possíveis distorções das informações.

O reconhecimento de um suspeito é uma prova irrepetível, pois é em si um processo sujeito a alterar memória original ${ }^{28}$. Quando a testemunha realiza um reconhecimento, o cérebro tenta verificar a similaridade entre o rosto observado (suspeito), e a memória do fato (rosto do perpetrador). Se a vítima identifica o suspeito como perpetrador do ato, esse rosto torna-se atrelado à memória do evento. Assim, a repetição do reconhecimento de um suspeito não resulta em nenhum benefício: uma vez que um suspeito é reconhecido (seja ele inocente ou não), há maior probabilidade que esse mesmo rosto seja identificado em um novo reconhecimento subsequente ${ }^{29}$. Além disto, o procedimento de repetição do reconhecimento de um suspeito pode ter o efeito indesejado de gerar uma maior familiaridade com esse rosto, levando a testemunha a ter, ainda, maior convicção de que está diante do real perpetrador, mesmo que ele não seja ${ }^{30}$. Após múltiplos reconhecimentos, a confiança da testemunha não é resultante da memória original do fato, mas sim da repetição à exposição do rosto do suspeito, o que pode levar um suspeito inocente a ser reconhecido com alto grau de certeza.

A impossibilidade de repetir um reconhecimento pode ser ilustrado pelo caso de Jerome apresentado no início deste artigo: no segundo reconhecimento, a vítima reconheceu novamente Jerome, ao invés de identificar o real perpetrador do crime. Enquanto o rosto do real perpetrador havia sido observado durante o estupro, situação que dificultava sua codificação (i.e., situação estressante, pouca iluminação), o rosto de Jerome foi reconhecido incialmente em uma delegacia, em que as condições de observação eram melhores à do próprio fato. Esse primeiro reconhecimento atrelou a face de Jerome à face do perpetrador do crime, distorcendo a memória original. Quando a vítima realizou o segundo reconhecimento, a memória da face do primeiro reconhecimento (Jerome) já estava mais nítida do que a do próprio perpetrador. Consequentemente, a vítima estava mais propensa a identificar falsamente a Jerome como o abusador do que realizar um reconhecimento verdadeiro.

Em suma, a repetibilidade da prova testemunhal pode ter um efeito indesejado: enquanto o detalhamento da memória original diminui as informações obtidas após o evento tem maior possibilidade de alterá-la.

26 MILNE, R.; SHAW, Gary; BULL, Ray. Investigative interviewing: the role of research. Applying Psychology to Criminal Justice, p. 65-80, 2007; STEIN, L. M.; ÁVILA, G. N. Avanços científicos em psicologia do testemunho aplicados ao reconbecimento pessoal e aos depoimentos forenses. Brasília: Secretaria de Assuntos Legislativos, Ministério da Justiça (Série Pensando Direito, No. 59)., 2015, p. 51. Disponível em: <http://pensando.mj.gov.br/wp-content/uploads/2016/02/PoD_59_Lilian_web-1.pdf>.

27 FLIN, Rhona et al. The effect of a five-month delay on children's and adults' eyewitness memory. British Journal of Psychology, v. 83, n. 3, p. 323-336, 1992. Disponível em: <http://dx.doi.org/10.1111/j.2044-8295.1992.tb02444.x >. Acesso em: 22 maio 2018. SCHWARTZ, Shari L.; WRIGHT, Daniel B. Memory conformity for new and old items with immediate and delayed testing. Applied Cognitive Psychology, v. 26, n. 4, p. 508-515, 2012. Disponível em: <http://dx.doi.org/10.1002/acp.2820>. Acesso em: 22 maio 2018. 28 CLARK, Steven E.; GODFREY, Ryan D. Eyewitness identification evidence and innocence risk. Psychonomic Bulletin \{\&\} Review, v. 16, n. 1, p. 22-42, 2009; WIXTED, John T.; WELLS, Gary L. The relationship between eyewitness confidence and identification accuracy: a new synthesis. Psychological Science in the Public Interest, v. 18, n. 1, p. 10-65, 2017. Disponível em: < http://dx.doi. org/10.1177/1529100616686966>. Acesso em: 22 maio 2018.

29 STEBLAY, Nancy K.; DYSART, Jennifer E. Repeated eyewitness identification procedures with the same suspect. Journal of Applied Research in Memory and Cognition, v. 5, n. 3, p. 284-289, 2016; STEBLAY, N. K.; TIX, R. W.; BENSON, S. L. Double exposure: the effects of repeated identification lineups on eyewitness accuracy. Applied Cognitive Psychology, n. 27, p. 644-654, 2013.

30 STEBLAY, Nancy K.; DYSART, Jennifer E. Repeated eyewitness identification procedures with the same suspect. Journal of Applied Research in Memory and Cognition, v. 5, n. 3, p. 284-289, 2016. 
Tais informações não são novas para a literatura da Psicologia do Testemunho, que já conta com um consolidado arcabouço científico, baseado em centenas de pesquisas empíricas ao redor do mundo. Entretanto, o escasso diálogo entre essa ciência e a prática compromete a efetividade do sistema de justiça brasileiro. Frente a isto, quais seriam as possibilidades? Seria irresponsável passar a desconsiderar quaisquer casos em que a única prova seja a memória da vítima e da testemunha. Entretanto, também é ineficaz ignorar esse problema e continuar a basear-se, apenas, em procedimentos que são derivados da própria experiência de quem o realiza, ou baseados em leis redigidas muito antes de descobertas científicas acerca de como a memória humana funciona. Por um lado, é impossível repetir o reconhecimento de uma vítima, por outro lado, novas entrevistas podem resultar em um maior número de informações úteis para o caso em julgado. Essas possibilidades devem ser exploradas com base na revisão do entendimento jurídico da prova advinda da memória, somado à realização de políticas públicas que busquem diminuir a lacuna entre conhecimento científico e atuação do sistema de justiça.

\section{RePETIBILIDADE DA PROVA PENAL DEPENDENTE DA MEMÓRIA}

O tema da memória não é novo nas discussões jurídicas. Em que pese os estudos da Psicologia Experimental terem surgido com mais força no último século, é possível dizer que uma certa intuição sobre a confiabilidade das testemunhas já existia desde muito, como na obra de 1516 de Farinacci $^{31}$.

Apesar de essa desconfiança ser bastante antiga, recentes estudos empíricos demonstraram que as práticas dos juristas são incompatíveis com as seculares preocupações doutrinárias ${ }^{32}$. Atores da justiça criminal consideram que o testemunho e o reconhecimento têm grande valor no conjunto probatório de um caso ${ }^{33}$. Porém, para esse impacto ser positivo, é preciso entender como a memória humana funciona e de que maneira os procedimentos realizados podem comprometer a qualidade dessa prova.

Segundo Perfecto Ibañez ${ }^{34}$, no que diz respeito à avaliação de credibilidade da testemunha, normalmente se trabalha com a noção de que essa pessoa sempre trabalha com a intuição, uma função do sexto sentido que permite captar aquilo que a técnica não alcança. Portanto, fundamental a antecipação da prova penal dependente da memória. Isto se justifica em função de "fatores previsíveis de risco de indisponibilidade de prova justificarem sua produção antecipada, mas em contraditório de partes e perante um juiz.”35.

Nosso sistema jurídico classifica as provas penais em três espécies: antecipadas, cautelares e repetíveis ou reproduzíveis. Costuma-se elencar as provas penais dependentes da memória naquela última espécie ${ }^{36}$. Uma das justificativas para essa organização é a estrutura bifásica existente no processo penal brasileiro, constituída pela investigação preliminar e pelo processo judicial em si, conduzido perante o Poder Judiciário. A primeira, por suas características essenciais, não exige a presença de todas as garantias constitucionais. Já na segunda, em que a prova é produzida perante o juiz, há acesso, em tese, amplo e irrestrito às garantias. Inclusive, o conceito de prova adotado por nosso Código de Processo Penal (CPP) está atrelado à presença

31 FARINACCI, Prosperi. Tractatus Integer de Testibus (1617). Disponível em: <http://reader.digitale-sammlungen.de/en/fs1/ object/display/bsb10625696_00001.html>. Acesso em: 15 nov. 2017.

32 STEIN, L. M.; ÁVILA, G. N. Avanços cientificos em psicologia do testemunbo aplicados ao reconbecimento pessoal e aos depoimentos forenses. Brasília: Secretaria de Assuntos Legislativos, Ministério da Justiça (Série Pensando Direito, No. 59). 2015. Disponível em: <http:// pensando.mj.gov.br/wp-content/uploads/2016/02/PoD_59_Lilian_web-1.pdf>. Acesso em: 22 maio 2018.

33 STEIN, L. M.; ÁVILA, G. N. Avanços cientificos em psicologia do testemunbo aplicados ao reconbecimento pessoal e aos depoimentos forenses. Brasília: Secretaria de Assuntos Legislativos, Ministério da Justiça (Série Pensando Direito, No. 59). 2015. Disponível em: <http:// pensando.mj.gov.br/wp-content/uploads/2016/02/PoD_59_Lilian_web-1.pdf>. Acesso em: 22 maio 2018.

34 PERFECTO IBAÑEZ, Andrés. Prueba y convicción judicial en al proceso penal. Buenos Aires: Hammurabi, 2009. p. 55.

35 BADARÓ, Gustavo. Processo penal. 5. ed. São Paulo: Revista dos Tribunais, 2017. p. 431; LOPES Jr., Aury. Direito processual penal. 9. ed. São Paulo: Saraiva, 2012. p. 608.

36 POLASTRI, Marcellus. Manual de processo penal. 4. ed. Rio de Janeiro: Lumen Juris, 2009. p. 83; LOPES Jr., Aury. Direito processual penal. 9. ed. São Paulo: Saraiva, 2012. p. 608. 
da garantia do contraditório constitucional.

Badaró $^{37}$ realiza a diferenciação entre provas cautelares, repetíveis e antecipadas (Art. 155, CPP). De acordo com o autor, a prova irrepetível não é produzida, tampouco submetida ao contraditório. A prova cautelar é produzida sem a observância do contraditório, normalmente na investigação preliminar, com posterior submissão ao contraditório judicial. Por fim, as provas antecipadas são aquelas produzidas em juízo, com a antecipação do contraditório, mesmo que a questão criminal, ainda, esteja sendo objeto de inquérito policial.

Portanto, o conceito jurídico de prova irrepetível difere do conhecimento científico atual sobre como a memória humana funciona. O problema diz respeito às indefinidas vezes em que será acessada a memória da testemunha/vítima, de acordo com os ritos processuais adotados. Uma testemunha, por exemplo, em caso de crime doloso contra a vida, de competência do Tribunal do Júri, pode vir a ser ouvida três vezes pelos autores de sistema de justiça criminal: na fase do inquérito, na de pronúncia e na do plenário.

A forma como os juristas costumam tratar do fator tempo e seus reflexos na coleta da prova penal dependente da memória está bem representada na Súmula N. 455 do Superior Tribunal de Justiça. Esse verbete traz a seguinte proposição: "A decisão que determina a produção antecipada deve ser concretamente fundamentada, não a justificando unicamente o mero decurso do tempo." (grifo nosso). Como explanado na seção anterior, além do esquecimento, há o risco de distorção da memória original, quando há longo decurso de tempo entre a data do fato e as entrevistas forenses.

Nesse sentido, é preciso considerar a concreta possibilidade de a informação contida na memória não estar mais disponível não apenas por ter sido esquecida, mas por ter sido modificada devido a interações com outras pessoas, realização de entrevistas repetidas, entre outros. Assim, atualmente há um "risco previsível", que para ser evitado exigirá a antecipação da produção da prova penal dependente da memória, somado à utilização de técnicas adequadas para sua coleta.

Por outro lado, é preciso ressaltar a decisão tomada no Recurso em Habeas Corpus N. 30438/PA, de relatoria do Ministro Rogério Schietti Cruz. Mesmo contrariando entendimento majoritário de seu órgão colegiado, o julgador considerou que o transcurso de tempo considerável desde a data dos fatos autoriza a produção antecipada da prova testemunhal. Da decisão, lê-se: "o transcurso de longo tempo desde a data do crime produz prejuízo à sua reconstrução histórica, dada a natural incapacidade da memória humana de conservar seus registros eternamente".

Conforme vimos, a possibilidade de constitucionalizar a prova penal dependente da memória, está diretamente vinculada à variável tempo. Pergunta-se: qual é a qualidade do contraditório estabelecido judicialmente quando a memória da testemunha/vítima foi distorcida pelas más práticas adotadas e pelo longo decurso de tempo? Uma possível soluções para esses problemas pode ser buscada por meio de novas políticas públicas que visem suprir as lacunas observadas na coleta e análise de provas dependentes da memória humana.

\section{Políticas públicas para uma prova antecipada}

Uma vez definidos os problemas resultantes da repetibilidade da prova dependente da memória, é preciso buscar soluções. Nesse sentido, políticas públicas devem levar em conta um problema bastante claro: a memória humana não é uma fotografia, e os procedimentos utilizados no Brasil, em regra inadequados, têm grande potencial de sugestionar a testemunha/vítima. É preciso que esse tipo de prova seja coletada em um momento oportuno, por meio dos procedimentos corretos, por profissionais capacitados, utilizando as

37 BADARÓ, Gustavo. Processo penal. 5. ed. São Paulo: Revista dos Tribunais, 2017. p. 431. 
ferramentas disponíveis em acordo com o estado da arte da Psicologia do Testemunho.

Políticas públicas podem ser entendidas como a coordenação dos meios à disposição do Estado para a realização de objetivos socialmente relevantes e politicamente determinados ${ }^{38}$. Mas, para além de uma perspectiva estritamente estatal, as políticas públicas podem ser entendidas como um conjunto de decisões inter-relacionadas, que selecionam objetivos e meios necessários para alcançá-los, dentro de uma situação específica em que o alvo dessas decisões se encontra ${ }^{39}$. As políticas publicas devem ser implementadas por meio de atores, instituições e ideias, sendo o papel do governo bastante importante devido a sua "capacidade

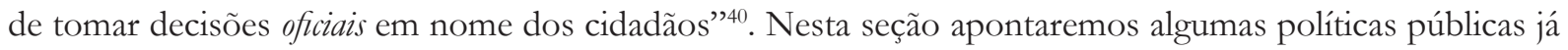
implementadas em outros países que podem ser adaptadas à realidade brasileira, visando uma maior eficiência de nosso sistema de justiça.

Para encaminhar um problema, é preciso conhecê-lo. Nesse sentido, o esforço conjunto da Secretaria de Assuntos Legislativos (SAL) com o Instituto de Pesquisas Econômicas Aplicadas (IPEA) resultou em um relatório acerca das práticas de entrevistas com testemunhas/vítimas e reconhecimento realizados no país ${ }^{41}$. Esse importante movimento em direção à mudanças normativas acerca do tratamento da prova penal dependente da memória foi paralisado, devido à instabilidade política vivida pelo país desde 2015. Entretanto, o relatório indicou problemas que vão desde à legislação até às práticas realizadas nesses procedimentos, os quais serão brevemente explanados ao decorrer desta seção.

Um importante aspecto observado no país é que os artigos que versam sobre a prova testemunhal (Art. 204, Art. 209, Art. 210, Art. 212, Art. 215, Art. 217) encontram-se destoantes dos achados científicos realizados nos últimos 50 anos, resultando em práticas pouco eficazes no sistema de justiça criminal. Assim, a policy-making segue urgente para evitar a condenação de inocentes e a não identificação de responsáveis por delitos. São necessárias, portanto, reformulações na legislação, de forma que tópicos abordados ao longo deste artigo sejam considerados, e procedimentos revistos e padronizados.

Ainda que no Brasil a prova penal dependente da memória seja de grande relevância no conjunto probatório, não há padronização de procedimentos de coleta e análise $e^{42}$. Inexistem salas específicas para a realização de oitivas e interrogatórios, bem como para o reconhecimento de suspeitos. Em alguns casos, as testemunhas de acusação e defesa permanecem no mesmo local enquanto prestam depoimento, o que pode inibir a testemunha a relatar informações, e contaminar a própria memória ao ser exposto ao relato de outra pessoa. Nesse sentido, são necessárias salas devidamente preparadas para esse fim, de forma que testemunhas e suspeitos sejam mantidos de forma segura. Uma sala de entrevistas é um ambiente que, além de visar à segurança e ao conforto da testemunha, possibilita o controle acerca de estímulos que possam interferir, como os relativos ao ambiente ou exposição ao relato de outras testemunhas.

A forma como essas provas são coletadas deve, também, evitar a contaminação da memória. Nesse sentido, têm sido desenvolvidos protocolos para a entrevistas de vítimas e testemunhas, como a Entrevista Cognitiva, a entrevista autoaplicada ${ }^{43}$ (SAI- Self-Administered Interview) e o NICHD para crianças e adoles-

38 BUCCI, Maria Paula Dallari. Políticas públicas e direito administrativo. Revista de Informação Legislativa, n. 133, p. 91, jan./mar. 1997.

39 JENKINS, William. Policy analysis: a political and organizational perspective. Londres: M. Robertson, 1978. p. 80.

40 HOWLETT, M.; RAMESH, M.; PERL, A. Política pública: seus ciclos e subsistemas: uma análise de políticas públicas a partir das relações Estado e sociedade. Rio de Janeiro: Elsevier, 2013. p. 4.

41 STEIN, L. M.; ÁVILA, G. N. Avanços científicos em psicologia do testemunho aplicados ao reconbecimento pessoal e aos depoimentos forenses. Brasília: Secretaria de Assuntos Legislativos, Ministério da Justiça (Série Pensando Direito, No. 59), 2015. Disponível em: < http:// pensando.mj.gov.br/wp-content/uploads/2016/02/PoD_59_Lilian_web-1.pdf>. Acesso em: 22 maio 2018.

42 STEIN, L. M.; ÁVILA, G. N. Avanços cientificos em psicologia do testemunho aplicados ao reconbecimento pessoal e aos depoimentos forenses. Brasília: Secretaria de Assuntos Legislativos, Ministério da Justiça (Série Pensando Direito, No. 59). 2015. Disponível em: < http:// pensando.mj.gov.br/wp-content/uploads/2016/02/PoD_59_Lilian_web-1.pdf>. Acesso em: 22 maio 2018.

43 PINTO, Luciano Haussen; STEIN, Lilian Milnitsky. Nova ferramenta de entrevista investigativa na coleta de testemunhos: a versão brasileira da Self-Administered InterviewC - Fórum Brasileiro de Segurança Pública. Rev. Bras. Segur. Pública, v. 11, n. 1, p. 110-128, 2017. Disponível em: <http://www.forumseguranca.org.br/publicacoes/nova-ferramenta-de-entrevista-investigativa-na- 
centes vítimas de abuso sexual ${ }^{44}$. Os protocolos supracitados já estão adaptados para uso no Brasil, e tem sido demonstrado, por meio de diversos experimentos, que possibilitam um relato de um maior número de informações, com a menor interferência possível ${ }^{45}$.

No que diz respeito ao reconhecimento, a única diretriz específica refere-se à fase processual. Entretanto, mesmo essa etapa a vítima já realizou outras identificações durante a fase investigativa. Nesse sentido, a literatura científica tem verificado de forma consistente que apenas a primeira tentativa de identificação é váli$\mathrm{da}^{46}$. Portanto, políticas públicas acerca do reconhecimento devem visar garantir que a primeira tentativa seja realizada da forma menos indutiva possível. Nesse sentido, é preciso abolir a prática de show-up (apresentar apenas o rosto de um suspeito para a testemunha, perguntando sobre se é ou não o responsável pelo delito), visto que esse procedimento tem grande potencial de induzir um falso reconhecimento no âmbito forense $\mathrm{e}^{47}$. O suspeito deve ser apresentado alinhado a outras faces similares, atentando para quem é o profissional que realiza o procedimento, e quais as instruções dadas à testemunha ${ }^{48}$.

Apenas a padronização de procedimentos de coleta de prova dependente da memória não é suficiente, pois será necessária, também, a capacitação de profissionais. Atualmente, não são contemplados na formação de atores do direito treinamentos regulares acerca de como conduzir oitivas com vítimas e testemunhas para outros crimes, o que prejudica a qualidade da prova obtida ${ }^{49}$. A inexistência desses treinamentos tem impacto não apenas para testemunhas, mas também em entrevistas com suspeitos que podem diminuir a possibilidade de obter informações úteis para o processo investigativo ${ }^{50}$. Nesse sentido é necessário capacitar e supervisionar profissionais acerca de seus procedimentos de entrevista e reconhecimento de suspeitos, de forma em que possam verificar quais pontos estão sendo implementados corretamente, e quais ainda necessitam ser aprimorados ${ }^{51}$.

coleta-de-testemunhos-a-versao-brasileira-da-self-administered-interview/>. Acesso em: 22 maio 2018.

44 PAULO, Rui; ALBUQUERQUE, Pedro B.; BULL, Ray. A entrevista cognitiva melhorada: pressupostos teóricos, investigação e aplicação. Psicologia, v. 28, n. 2, p. 21-30, 2014. Disponível em: < http://revista.appsicologia.org/index.php/rpsicologia/article/ view/639>. Acesso em: 22 maio 2018. BENIA, L. et al. The NICHD investigative interview protocol: a meta-analytic review. Journal of Children Sexual Abuse, v. 24, p. 259-279, 2015; WILLIAMS, Cavalcanti de Albuquerque et al. Investigação de suspeita de abuso sexual infantojuvenil: o protocolo NICHD. Temas em Psicologia, v. 22, p. 415-432, 2014. Disponível em: <http://pepsic.bvsalud.org/ scielo.php?script=sci_arttext\&pid=S1413-389X2014000200013\&nrm=iso >. Acesso em: 22 maio 2018.

45 GABBERT, Fiona; HOPE, Lorraine; FISHER, Ronald P. Protecting eyewitness evidence: examining the efficacy of a selfadministered interview tool. Law and Human Behavior, v. 33, n. 4, p. 298-307, 2009; LAMB, Michael E. et al. A structured forensic interview protocol improves the quality and informativeness of investigative interviews with children: a review of research using the NICHD investigative interview protocol. Child Abuse \& Neglect, v. 31, n. 11, p. 1201-1231, 2007; MEMON, Amina; MEISSNER, Christian A.; FRASER, Joanne. The cognitive interview: a meta-analytic review and study space analysis of the past 25 years. Psychology, Public Policy, and Law, v. 16, n. 4, p. 340-372, 2010. Disponível em: <http://doi.apa.org/getdoi.cfm?doi=10.1037/a0020518>. Acesso em: 22 maio 2018.

46 STEBLAY, Nancy K.; DYSART, Jennifer E. Repeated eyewitness identification procedures with the same suspect. Journal of Applied Research in Memory and Cognition, v. 5, n. 3, p. 284-289, 2016.

47 CLARK, S. E. Costs and benefits of eyewitness identification reform: psychological science and public policy. Perspectives on Psychological Science, v. 7, n. 3, p. 238-259, 2012.

48 CLARK, Steven E.; GODFREY, Ryan D. Eyewitness identification evidence and innocence risk. Psychonomic Bulletin \{ \& $\}$ Review, v. 16, n. 1, p. 22-42, 2009; WELLS, Gary L.; SEELAU, Eric P. Eyewitness identification: psychological research and legal policy on lineups. Psychology, Public Policy, and Law, v. 1, n. 4, p. 765, 1995.

49 STEIN, L. M.; ÁVILA, G. N. Avancos científicos em psicologia do testemunho aplicados ao reconbecimento pessoal e aos depoimentos forenses. Brasília: Secretaria de Assuntos Legislativos, Ministério da Justiça (Série Pensando Direito, No. 59). 2015. Disponível em: < http:// pensando.mj.gov.br/wp-content/uploads/2016/02/PoD_59_Lilian_web-1.pdf>. Acesso em: 22 maio 2018.

50 FISHER, Ronald P.; GEISELMAN, R. Edward. The cognitive interview method of conducting police interviews: eliciting extensive information and promoting therapeutic jurisprudence. International Journal of Law and Psychiatry, v. 33, n. 5, p. 321-328, 2010. Disponível em: <http://www.sciencedirect.com/science/article/pii/S0160252710000762>. Acesso em: 22 maio 2018.

51 MACDONALD, Sarah; SNOOK, Brent; MILNE, Rebecca. Witness interview training: a field evaluation. Journal of Police and Criminal Psychology, v. 32, n. 1, p. 77-84, 2017. Disponível em: <https://doi.org/10.1007/s11896-016-9197-6>. Acesso em: 22 maio 2018. MEMON, Amina et al. Towards understanding the effects of interviewer training in evaluating the cognitive interview. Applied Cognitive Psychology, v. 8, n. 7, p. 641-659, 1994. Disponível em: <http://dx.doi.org/10.1002/acp.2350080704>. Acesso em: 22 maio 2018. MYKLEBUST, Trond; BJØRKLUND, Roald A. The effect of long-term training on police officers' use of open and closed questions in field investigative interviews of children (FIIC). Journal of Investigative Psychology and Offender Profiling, v. 3, n. 3, p. 165-181, 2006. Disponível em: <http://dx.doi.org/10.1002/jip.52>. Acesso em: 22 maio 2018. 
Uma vez realizados, o único registro que se mantém acerca dos procedimentos de entrevista e reconhecimento são relatórios assinados pelas testemunhas. Entretanto, esse procedimento implica dois problemas. O primeiro refere-se ao fato de que isto impõe uma alta carga cognitiva, visto que os profissionais devem transcrever e questionar ao mesmo tempo, ou manter toda a informação na memória para então transcre$v \mathrm{r}^{52}$. O segundo, ao fato de que não são preservados os relatos originais, apenas sua transcrição, o que faz com que muitas informações se percam ${ }^{53}$. É preciso manter um registro não apenas a respeito do que é dito pela testemunha, mas também do que foi perguntado. Por esse motivo, é de extrema importância que tais procedimentos sejam gravados, em áudio e vídeo, de forma que preservem a prova original.

Apesar do quadro dramático das práticas relativas à prova penal dependente da memória, em nosso país, situação semelhante ocorria em países onde mudanças legislativas estruturais alteraram, substancialmente, as antigas práticas ${ }^{54}$. Nesse sentido, além das políticas públicas relativas à normatização, será necessário observar mudanças que possam, culturalmente, sustentar as reformas legislativas. Políticas públicas educacionais, então, podem ser determinantes nesse processo. Exemplo de ação a ser realizada seria a introdução da disciplina "Psicologia do Testemunho" nos currículos das Faculdades de Direito, em conjunto com os treinamentos dos atores jurídicos que já operam no sistema de justiça criminal. Por meio da educação, inclusive, pontos sensíveis, como a investigação preliminar, poderiam avançar significativamente, pois não possuem regramento específico para a realização de entrevistas com testemunhas, vítimas e suspeitos, por exemplo.

Em países em que essas políticas públicas foram adotadas além de resultar em uma melhor coleta e análise da prova testemunhal, observou-se que a rotina diária de diferentes atores do sistema de justiça é otimiza$\mathrm{d} \mathrm{a}^{55}$. Profissionais envolvidos na etapa investigativa podem coletar provas com maior eficiência, ao conhecer o funcionamento da memória humana e as melhores práticas para a obtenção de provas provenientes da memória ${ }^{56}$. De forma semelhante, profissionais envolvidos na etapa processual podem compreender aspectos envolvidos na prova testemunhal, e avaliar com maior propriedade qual a qualidade de tal prova ${ }^{57}$.

Há diversas particularidades que permeiam o processo de coleta de testemunho e reconhecimento. Como não é possível mudar a forma como a memória de testemunhas funciona, é preciso rever quais os procedimentos utilizados, visando garantir a validade dessa prova. A implementação de políticas públicas pode resultar em um maior prestígio do sistema de justiça criminal, no sentido de sua legitimação. Somente a partir de da implementação de políticas públicas que versem acerca de como, quando e quem realiza os procedimentos, é possível considerar a possibilidade de repetibilidade da prova dependente da memória humana.

52 MILNE, R.; SHAW, Gary; BULL, Ray. Investigative interviewing: the role of research. Applying Psychology to Criminal Justice, p. 65-80, 2007.

53 WESTERA, N.; KEBBELL, M.; MILNE, Becky. Losing two thirds of the story: a comparison of the video-recorded police interview and live evidence of rape complainants. Criminal Law Review, n. 4, p. 290-308, 2013.

54 BULL, Ray. Seminário Internacional Avanços Científicos e Desafios Práticos na Coleta de Depoimento Forense e Reconhecimento de Pessoas. Disponível em: <http://imagem.camara.gov.br/internet/audio/exibeaudio.asp?codGravacao $=51042 \&$ hrInicio $=2014,11,13,11,50$, $32 \&$ hrFim $=2014,11,13,11,50,32 \&$ descEvento $=$ Semin $\%$ C3 $\%$ A 1 rio $\% 20$ Internacional $\% 20$ Avan $\%$ C $3 \%$ A 7 os $\% 20$ Cient $\%$ C $3 \%$ ADfi$\cos \% 20 \mathrm{e}^{0} \% 20$ Desa...\&diffDataFinal=34\&ultimoElemento=false >. [áudio]. Acesso em: 12 maio 2018.

55 VALENTINE, Tim; FITZGERALD, Ryan J. Identifying the culprit: an international perspective on the National Academy of Sciences report on eyewitness identification evidence. Applied Cognitive Psychology, v. 30, n. 1, p. 135-138, 2016. Disponível em: <http://doi.wiley.com/10.1002/acp.3164>. Acesso em: 22 maio 2018.

56 MYKLEBUST, Trond; BJØRKLUND, Roald A. The effect of long-term training on police officers' use of open and closed questions in field investigative interviews of children (FIIC). Journal of Investigative Psychology and Offender Profiling, v. 3, n. 3, p. 165181, 2006. Disponível em: <http://dx.doi.org/10.1002/jip.52>. Acesso em: 22 maio 2018. STEBLAY, N. K.; WELLS, G. L.; DOUGLASS, A. B. Memory distortion in eyewitnesses: a meta-analysis of the post-identification feedback effect. Applied Cognitive Psychology, v. 20, n. 7, p. 859-869, 2014.

57 HOWE, Mark L. Memory lessons from the courtroom: reflections on being a memory expert on the witness stand. Memory, v. 21 , n. 5 , p. $576-583,2013$. 


\section{Considerações finais}

Provas dependentes da memória humana são repetíveis? Dado o contexto brasileiro acerca de como tais provas são coletadas e analisadas, com práticas contrariando frontalmente décadas de pesquisa da psicologia experimental, a resposta é não. Questões feitas durante uma entrevista por um policial, advogado ou juiz, bem como o reconhecimento de um suspeito podem alterar a memória de uma testemunha. Como argumentado, uma recuperação ocorrida, após um ano, não é apenas a recordação de um evento, mas a soma de todas as sugestões às quais a testemunha foi exposta após o evento (relatos de outras testemunhas, perguntas indutivas, e reconhecimentos fotográficos). Assim, o principal risco de tratar a prova penal dependente da memória como repetível está na possibilidade de ela ser alterada de forma permanente quando recuperada.

Quanto maior o tempo decorrido desde o evento, maior a probabilidade que a recordação original já esteja modificada. Entretanto, há algumas possibilidades que podem ser exploradas desde que sejam elaboradas políticas públicas que levem em conta as capacidades e limitações de memória humana. Nesse sentido, devem ser instauradas políticas públicas que visem à implementação de práticas baseadas em evidências, bem como de políticas legislativas e educacionais, tanto na formação geral do ator jurídico (graduação) quanto específica (treinamentos). Se a memória é uma importante evidência de um fato, é importante que esta seja coletada e analisada como tal. Somente considerando as capacidades e limitações da memória humana é possível tornar procedimentos mais eficazes e alcançar uma efetividade em preservar dos direitos fundamentais de acusados e vítimas.

\section{REFERÊNCIAS}

BADARÓ, Gustavo. Processo penal. 5. ed. São Paulo: Revista dos Tribunais, 2017.

BADDELEY, Alan. Essentials of human memory (classic edition). [s.1.]: Psychology Press, 2013.

BENIA, L. et al. The NICHD investigative interview protocol: a meta-analytic review. Journal of Children Sexual Abuse, v. 24, p. 259-279, 2015.

BOWLES, Peter V.; SHARMAN, Stefanie J. A review of the impact of different types of leading interview questions on child and adult witnesses with intellectual disabilities. Psychiatry, Psychology and Law, v. 21, n. 2, p. 205-217, 2014. Disponível em: < http://dx.doi.org/10.1080/13218719.2013.803276>. Acesso em: 22 maio 2018.

BUCCI, Maria Paula Dallari. Políticas públicas e direito administrativo. Revista de Informação Legislativa, n. 133, p. 88-98, jan./mar. 1997.

BULL, Ray. Seminário Internacional Avanços Científicos e Desafios Práticos na Coleta de Depoimento Forense e Reconhecimento de Pessoas. Disponível em: < http://imagem.camara.gov.br/internet/audio/exibeaudio.asp?codGrav acao $=51042 \&$ hrInicio $=2014,11,13,11,50,32 \& \mathrm{hrFim}=2014,11,13,11,50,32 \&$ descEvento $=$ Semin $\% \mathrm{C} 3 \% \mathrm{~A} 1 \mathrm{r}$ io $\% 20$ Internacional $\% 20$ Avan $\%$ C $3 \%$ A 7 os $\% 20$ Cient $\%$ C $3 \%$ AD ficos $\% 20 \mathrm{e} \% 20$ Desa...\&diffDataFinal $=34 \&$ ultimoElemento=false $>$. [áudio] Acesso em: 12 maio 2018.

CLARK, S. E. Costs and benefits of eyewitness identification reform: psychological science and public policy. Perspectives on Psychological Science, v. 7, n. 3, p. 238-259, 2012.

CLARK, Steven E.; GODFREY, Ryan D. Eyewitness identification evidence and innocence risk. Psychonomic Bulletin $\{\ll\}$ Review, v. 16, n. 1, p. 22-42, 2009.

DEFFENBACHER, Kenneth A. et al. A meta-analytic review of the effects of high stress on eyewitness memory, v. 28, n. 6, 2004. Disponível em: <https://digitalcommons.unomaha.edu/cgi/viewcontent.cgi?referer=https:// 
www.google.com.br $/ \&$ httpsredir=1\&article $=1000 \&$ context $=$ psychfacpub $>$. Acesso em: 22 maio 2018 .

DUDAI, Yadin; EDELSON, Micah G. Personal memory: is it personal, is it memory? Memory Studies, v. 9, n. 3, p. 275-283, 2016. Disponível em: <http://mss.sagepub.com/content/9/3/275.abstract $>$. Acesso em: 22 maio 2018.

EBBINGHAUS, Hermann. Memory (HA Ruger \& CE Bussenius, Trans.). New York: Teachers College, 1913.

EISEN, Mitchell L. et al. "I think he had a tattoo on his neck": how co-witness discussions about a perpetrator's description can affect eyewitness identification decisions. Journal of Applied Research in Memory and Cognition, v. 6, n. 3, p. 274-282, 2017.

ERICKSON, William Blake; LAMPINEN, James Michael; MOORE, Kara N. Eyewitness identifications by older and younger adults: a meta-analysis and discussion. Journal of Police and Criminal Psychology, v. 31, n. 2, p. 108-121, 2016.

FARINACCI, Prosperi. Tractatus Integer de Testibus (1617). Disponível em: < http:/ / reader.digitale-sammlungen.de/en/fs1/object/display/bsb10625696_00001.html>. Acesso em: 15 nov. 2017.

FAWCETT, Jonathan M. et al. Of guns and geese: a meta-analytic review of the "weapon focus" literature. Psychology, Crime \& Law, v. 19, n. 1, p. 35-66, 2013. Disponível em: <http://dx.doi.org/10.1080/106831 6X.2011.599325>. Acesso em: 22 maio 2018.

FISHER, Ronald P.; GEISELMAN, R. Edward. The cognitive interview method of conducting police interviews: eliciting extensive information and promoting therapeutic jurisprudence. International Journal of Law and Psychiatry, v. 33, n. 5, p. 321-328, 2010. Disponível em: <http://www.sciencedirect.com/science/ article/pii/S0160252710000762>. Acesso em: 22 maio 2018.

FLIN, Rhona et al. The effect of a five-month delay on children's and adults' eyewitness memory. British Journal of Psychology, v. 83, n. 3, p. 323-336, 1992. Disponível em: <http://dx.doi.org/10.1111/j.2044-8295.1992. tb02444.x>. Acesso em: 22 maio 2018.

FRITZLEY, H. V.; LINDSAY, Rod C. L.; LEE, Kang. Young children's response tendencies toward yes-no questions concerning actions. Child Development, v. 84, n. 2, p. 711-725, 2013.

GABBERT, Fiona; HOPE, Lorraine; FISHER, Ronald P. Protecting eyewitness evidence: examining the efficacy of a self-administered interview tool. Law and Human Behavior, v. 33, n. 4, p. 298-307, 2009.

HIRST, William; ECHTERHOFF, Gerald. Remembering in conversations: the social sharing and reshaping of memories. Annual Review of Psychology, v. 63, n. 1, p. 55-79, 2012. Disponível em: < http://dx.doi. org/10.1146/annurev-psych-120710-100340>. Acesso em: 22 maio 2018.

HOWE, Mark L. Memory lessons from the courtroom: reflections on being a memory expert on the witness stand. Memory, v. 21, n. 5, p. 576-583, 2013.

HOWLETT, M.; RAMESH, M.; PERL, A. Politica pública: seus ciclos e subsistemas: uma análise de políticas públicas a partir das relações Estado e sociedade. Rio de Janeiro: Elsevier, 2013.

INNOCENCE PROJECT. John Jerome White. [s.d.]. Disponível em: < https://www.innocenceproject.org/ cases/john-jerome-white/>. Acesso em: 22 maio 2018.

IZQUIERDO, Ivan. Questões sobre memória. São Leopoldo: Unisinos, 2006.

JENKINS, William. Policy analysis: a political and organizational perspective. Londres: Martin Robertson, 1978.

KRIX, Alana C. et al. Consistency across repeated eyewitness interviews: contrasting police detectives' beliefs with actual eyewitness performance. PLOS ONE, v. 10, n. 2, p. e0118641, 2015. Disponível em: 
<https://doi.org/10.1371/journal.pone.0118641>. Acesso em: 22 maio 2018.

LAMB, Michael E. et al. A structured forensic interview protocol improves the quality and informativeness of investigative interviews with children: a review of research using the NICHD investigative interview protocol. Child Abuse \& Neglect, v. 31, n. 11, p. 1201-1231, 2007.

LAMPINEN, James Michael et al. Effects of distance on face recognition: implications for eyewitness identification. Psychonomic Bulletin \& Review, p. 1489-1494, 2014.

LOFTUS, Elizabeth F. Planting misinformation in the human mind: a 30-year investigation of the malleability of memory. Learning \& Memory, v. 12, n. 4, p. 361-366, 2005. Disponível em: <http://learnmem.cshlp. org/content/12/4/361.abstract>. Acesso em: 22 maio 2018.

LOFTUS, Elizabeth F.; PALMER, John C. Reconstruction of automobile destruction: an example of the interaction between language and memory. Journal of Verbal Learning and Verbal Behavior, v. 13, n. 5, p. 585589, 1974. Disponível em: <http://www.demenzemedicinagenerale.net/images/mens-sana/AutomobileDestruction.pdf>. Acesso em: 25 maio 2018.

LOPES JÚNIOR, Aury. Direito processual penal. 9. ed. São Paulo: Saraiva, 2012.

MACDONALD, Sarah; SNOOK, Brent; MILNE, Rebecca. Witness interview training: a field evaluation. Journal of Police and Criminal Psychology, v. 32, n. 1, p. 77-84, 2017. Disponível em: <https://doi.org/10.1007/ s11896-016-9197-6>. Acesso em: 22 maio 2018.

MEMON, Amina et al. Towards understanding the effects of interviewer training in evaluating the cognitive interview. Applied Cognitive Psychology, v. 8, n. 7, p. 641-659, 1994. Disponível em: <http://dx.doi. org/10.1002/acp.2350080704>. Acesso em: 22 maio 2018.

MEMON, Amina; MEISSNER, Christian A.; FRASER, Joanne. The cognitive interview: a meta-analytic review and study space analysis of the past 25 years. Psychology, Public Policy, and Law, v. 16, n. 4, p. 340-372, 2010. Disponível em: <http://doi.apa.org/getdoi.cfm?doi=10.1037/a0020518>. Acesso em: 22 maio 2018.

MILNE, R.; SHAW, Gary; BULL, Ray. Investigative interviewing: the role of research. Applying Psychology to Criminal Justice, p. 65-80, 2007.

MYKLEBUST, Trond; BJØRKLUND, Roald A. The effect of long-term training on police officers' use of open and closed questions in field investigative interviews of children (FIIC). Journal of Investigative Psychology and Offender Profiling, v. 3, n. 3, p. 165-181, 2006. Disponível em: <http://dx.doi.org/10.1002/jip.52>. Acesso em: 22 maio 2018.

NEWMAN, Eryn J.; FRENDA, Steven J.; LOFTUS, Elizabeth F. False memories. In: BRUINSMA, Gerben; WEISBURD, David (Ed.). Encyclopedia of Criminology and Criminal Justice. New York, NY: Springer New York, 2014. p. 1555-1563.

ODINOT, Geralda et al. Are two interviews better than one? eyewitness memory across repeated cognitive interviews. PLOS ONE, v. 8, n. 10, p. e76305, 2013. Disponível em: <https://doi.org/10.1371/journal. pone.0076305>. Acesso em: 22 maio 2018.

PATERSON, Helen M.; KEMP, Richard I. Co-witnesses talk: a survey of eyewitness discussion. Psychology, Crime \& Law, v. 12, n. 2, p. 181-191, 2006. Disponível em: <http://dx.doi.org/10.1080/106831605123313 16334>. Acesso em: 22 maio 2018.

PAULO, Rui; ALBUQUERQUE, Pedro B.; BULL, Ray. A entrevista cognitiva melhorada: pressupostos teóricos, investigação e aplicação. Psicologia, v. 28, n. 2, p. 21-30, 2014. Disponível em: < http://revista.appsicologia.org/index.php/rpsicologia/article/view/639>. Acesso em: 22 maio 2018.

PERFECTO IBAÑEZ, Andrés. Pruebay convicción judicial en al proceso penal. Buenos Aires: Hammurabi, 2009. 
PETERSON, Carole; DOWDEN, Craig; TOBIN, Jennifer. Interviewing preschoolers: comparisons of yes/no and wh-questions. Law and Human Behavior, v. 23, n. 5, p. 539, 1999.

PINTO, Luciano Haussen; STEIN, Lilian Milnitsky. Nova ferramenta de entrevista investigativa na coleta de testemunhos: a versão brasileira da Self-Administered InterviewC - Fórum Brasileiro de Segurança Pública. Rev. Bras. Segur. Pública, v. 11, n. 1, p. 110-128, 2017. Disponível em: <http://www.forumseguranca.org. $\mathrm{br} /$ publicacoes/nova-ferramenta-de-entrevista-investigativa-na-coleta-de-testemunhos-a-versao-brasileirada-self-administered-interview/>. Acesso em: 22 maio 2018.

POLASTRI, Marcellus. Manual de processo penal. 4. ed. Rio de Janeiro: Lumen Juris, 2009.

ROEBERS, Claudia M.; SCHNEIDER, Wolfgang. The impact of misleading questions on eyewitness memory in children and adults. Applied Cognitive Psychology, v. 14, n. 6, p. 509-526, 2000. Disponível em: < http:/ / dx.doi.org/10.1002/1099-0720(200011/12)14:6\%3C509::AID-ACP668\%3E3.0.CO;2-W>. Acesso em: 22 maio 2018.

SCHACTER, Daniel L. Os sete pecados da memória: como a mente esquece e lembra. São Paulo: Rocco, 2003.

SCHACTER, Daniel L.; LOFTUS, Elizabeth F. Memory and law: what can cognitive neuroscience contribute? Nat Neurosci, v. 16, n. 2, p. 119-123, 2013. Disponível em: <http://dx.doi.org/10.1038/nn.3294>. Acesso em: 22 maio 2018.

SCHWARTZ, Shari L.; WRIGHT, Daniel B. Memory conformity for new and old items with immediate and delayed testing. Applied Cognitive Psychology, v. 26, n. 4, p. 508-515, 2012. Disponível em: <http://dx.doi. org/10.1002/acp.2820>. Acesso em: 22 maio 2018.

SCOBORIA, Alan et al. A mega-analysis of memory reports from eight peer-reviewed false memory implantation studies. Memory, v. 25, n. 2, p. 146-163, 2017.

SKAGERBERG, Elin M.; WRIGHT, Daniel B. The prevalence of co-witnesses and co-witness discussions in real eyewitnesses. Psychology, Crime \& Law, v. 14, n. 6, p. 513-521, 2008. Disponível em: <http://dx.doi. org/10.1080/10683160801948980>. Acesso em: 22 maio 2018.

STEBLAY, Nancy K.; DYSART, Jennifer E. Repeated eyewitness identification procedures with the same suspect. Journal of Applied Research in Memory and Cognition, v. 5, n. 3, p. 284-289, 2016.

STEBLAY, N. K.; TIX, R. W.; BENSON, S. L. Double exposure: the effects of repeated identification lineups on eyewitness accuracy. Applied Cognitive Psychology, n. 27, p. 644-654, 2013.

STEBLAY, N. K.; WELLS, G. L.; DOUGLASS, A. B. Memory distortion in eyewitnesses: a meta-analysis of the post-identification feedback effect. Applied Cognitive Psychology, v. 20, n. 7, p. 859-869, 2014.

STEIN, L. M.; ÁVILA, G. N. Avanços científicos em psicologia do testemunho aplicados ao reconhecimento pessoal e aos depoimentos forenses. Brasília: Secretaria de Assuntos Legislativos, Ministério da Justiça (Série Pensando Direito, No. 59)., 2015. Disponível em: <http://pensando.mj.gov.br/wp-content/uploads/2016/02/PoD_59_Lilian_web-1.pdf>. Acesso em: 22 maio 2018.

THOMA, Volker; LAVIE, Nilli. Perceptual load effects on processing distractor faces indicate face-specific capacity limits. Visual Cognition, v. 21, n. 8, p. 1053-1076, 2013.

VALENTINE, Tim; FITZGERALD, Ryan J. Identifying the culprit: an international perspective on the National Academy of Sciences report on eyewitness identification evidence. Applied Cognitive Psychology, v. 30, n. 1, p. 135-138, 2016. Disponível em: <http://doi.wiley.com/10.1002/acp.3164>. Acesso em: 22 maio 2018.

WELLS, Gary L.; SEELAU, Eric P. Eyewitness identification: psychological research and legal policy on lineups. Psychology, Public Policy, and Law, v. 1, n. 4, p. 765, 1995. 
WERNER, Nicole-Simone; KÜHNEL, Sina; MARKOWITSCH, Hans J. The neuroscience of face processing and identification in eyewitnesses and offenders. Frontiers in Bebavioral Neuroscience, v. 7, p. 1-12, dec. 2013. Disponível em: <http://journal.frontiersin.org/article/10.3389/fnbeh.2013.00189/abstract>. Acesso em: 22 maio 2018.

WEST, Emily; METERKO, Vanessa. Innocence project: DNA exonerations, 1989-2014: review of data and findings from the first 25 years. Alb. L. Rev., v. 79, p. 717, 2015.

WESTERA, N.; KEBBELL, M.; MILNE, Becky. Losing two thirds of the story: a comparison of the video-recorded police interview and live evidence of rape complainants. Criminal Law Review, n. 4, p. 290308, 2013.

WILLIAMS, Cavalcanti de Albuquerque et al. Investigação de suspeita de abuso sexual infantojuvenil: o protocolo NICHD. Temas em Psicologia, v. 22, p. 415-432, 2014. Disponível em: < http:/ / pepsic.bvsalud.org/ scielo.php?script=sci_arttext\&pid=S1413-389X2014000200013\&nrm=iso >. Acesso em: 22 maio 2018.

WIXTED, John T.; WELLS, Gary L. The relationship between eyewitness confidence and identification accuracy: a new synthesis. Psychological Science in the Public Interest, v. 18, n. 1, p. 10-65, 2017. Disponível em: <http://dx.doi.org/10.1177/1529100616686966>. Acesso em: 22 maio 2018. 


\section{Normas Editoriais}

1. Serão aceitas colaborações inéditas e a publicação de um artigo está condicionada à sua adequação às normas editoriais, e seu simples recebimento desobriga a sua publicação. A revista Prismas: Direito, Políticas Públicas e Mundialização classificará as colaborações de acordo com as seguintes seções:

1.1 Artigos: compreende textos que contenham relatos completos de estudos ou pesquisas concluídas, matérias de caráter opinativo, revisões da literatura e colaborações assemelhadas.

1.2 Resenhas: compreende análises críticas de livros, de periódicos recentemente publicados, dissertações e teses.

2. Excepcionalmente, a equipe editorial poderá aceitar a submissão de trabalhos que já tenham sido publicados e caso isso ocorra, serão submetidos ao mesmo processo de avaliação pelos pares que aqueles inéditos. $\mathrm{O}$ autor deverá apresentar autorização por escrito do editor da revista na qual seu trabalho tenha sido originalmente publicado, acompanhado de cópia do mesmo.

3. O processo de avaliação dos artigos e resenhas compreende duas fases: a primeira destinada à análise da adequação do trabalho à linha editorial da revista (Equipe Editorial) e a segunda referente à avaliação do conteúdo e qualidade dos trabalhos. Esta segunda fase é realizada mediante o processo de avaliação pelos pares, ou seja, os artigos serão submetidos à aprovação de no mínimo 2 pareceristas adhoc.

4. Os trabalhos serão enviados para a avaliação sem a identificação de autoria

5. Os trabalhos devem ser enviados no seguinte padrão:

$1^{a}$ Página: Começar com o título do título do trabalho, seguido do texto. Não inseriro nome dos autores ou outros elementos queidentifiquem a autoria. A autoria do artigo e a qualificação dos autores são inseridas nos campos específicos do formulário eletrônico. O objetivo aqui é garantir uma avaliação cega por pares. Os textos deverão ser digitados em Arial 12, espaço 1,5 margem de 2,5 $\mathrm{cm}$, numeração arábica das páginas no ângulo superior direito, em programa compatível com o Word para Windows.

Título do trabalho: o título deve ser breve e suficientemente específico e descritivo para representar o conteúdo do texto e deverá ter a sua tradução para o inglês.

Resumo: em todos os artigos submetidos deve ser incluído um resumo informativo com o máximo de 250 palavras e espaço entre linhas simples. O resumo deve ser estruturado com as seguintes informações:

Objetivo do artigo (obrigatório);

Metodologia (obrigatório);

Conclusões (obrigatório);

Limitações da pesquisa e suas implicações (se aplicável);

Limitações práticas (se aplicável)

Originalidade ou valor (obrigatório); 
A evolução da comunicação científica e da transmissão de conhecimentos possibilitou ao UniCEUB a criação de meios para o intercâmbio de idéias entre pares e a disseminação de informações.

As novas tecnologias da informação produzem sensíveis alterações nos processos de comunicação científica. Atualmente, a editoração das publicações acadêmicas do UniCEUB é informatizada em todas as suas etapas, com a utilização da plataforma SEER, Sistema de Editoração Eletrônico de Revistas. A aplicação do SEER permitiu acrescentar, no processo editorial, a avaliação dos pareceristas ad hoc e deu aos membros dos comitês editoriais e aos editores condições para consolidar a produção científica no UniCEUB e difundi-la por meio dos periódicos acadêmicos em mídia impressa e eletrônica.

Todas as edições das publicações científicas do UniCEUB estão disponíveis no site www.publicacoesacademicas.uniceub.br, com infraestrutura para acesso livre.

O UniCEUB publica as seguintes revistas:

- Revista Brasileira de Políticas Públicas

- Revista de Direito Internacional

- Universitas Arquitetura e Comunicação Social

- Universitas Ciências da Saúde

- Universitas Gestão e TI

- Universitas Humanas

- Universitas JUS

- Universitas Relações Internacionais

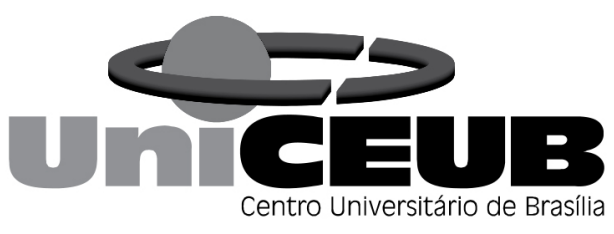


Destacar no mínimo três e no máximo seis palavraschave que representem o conteúdo do texto. O resumo e as palavras-chave deverão ter a sua tradução para o inglês.

Agradecimentos: agradecimentos a auxílios recebidos para a elaboração do trabalho deverão ser mencionados no final do artigo.

Notas: notas referentes ao corpo do artigo deverão vir no rodapé do texto.

Apêndices: apêndices podem ser empregados no caso de listagens extensivas, estatísticas e outros elementos de suporte.

Materiais gráficos: fotografias nítidas e gráficos (estritamente indispensáveis à clareza do texto) poderão ser aceitos e cada fotografia ou gráfico deverá vir no texto e além disso cada um deverá ser enviado em arquivo separado. Se as ilustrações enviadas já tiverem sido publicadas, mencionar a fonte e a permissão para reprodução.

Quadros: os quadros deverão ser acompanhados de cabeçalho que permita compreender o significado dos dados reunidos, sem necessidade de referência ao texto. Assinalar, no texto, pelo seu número de ordem, os locais onde os quadros devem ser intercalados.

Referências: as referências redigidas segundo a norma NBR 6023/2002 da Associação Brasileira de Normas Técnicas (ABNT), deverão ser apresentadas por ordem alfabética e constituir uma lista única no final do artigo. A exatidão e adequação das referências a trabalhos que tenham sido consultados e mencionados no texto do artigo são da responsabilidade do autor. Informações procedentes de comunicação pessoal, de trabalhos em andamento ou não publicados não devem ser incluídas na lista de referências, mas indicada em nota de rodapé. Não utilizar o sistema Autor data para citações. O formato utilizado pela revista é o sistema numérico, onde a citação é indicada por número sobrescrito e a referência mencionada em nota de rodapé.

Recomendações: recomenda-se que se observem as normas da ABNT referentes à apresentação de artigos em publicações periódicas (NBR 6022/2002), apresentação de citações em documentos (NBR 10520/2002), apresentação de originais (NBR 12256), norma para datar (NBR 892), numeração progressiva das seções de um documento (NBR 6024/2003) e resumos (NBR $6028 / 2003)$.

A revista se reserva o direito de efetuar nos originais alterações de ordem normativa, ortográfica e gramatical, com vistas a manter o padrão culto da língua, respeitando, porém, o estilo dos autores.

A partir de 2009, consideramos útil formular algumas sugestões (não obrigatórias) aos autores, com base nos principais motivos por recusa de artigos nos anos anteriores.

8. Responsabilidades e conflitos de interesse: A responsabilidade pelas informações e opiniões indicadas nos artigos é exclusiva dos autores. Eventuais conflitos de interesse serão de responsabilidade dos próprios autores e não do periódico.

\section{Envio dos trabalhos:}

1. Os trabalhos deverão ser enviados para a equipe editorial da revista no endereço eletrônico www.rdi.uniceub.br

2. Cada autor deve enviar declaração de responsabilidade nos termos abaixo:

“Eu XXXX certifico que participei da concepção do trabalho tornar pública minha responsabilidade pelo seu conteúdo, que não omiti quaisquer ligações ou acordos de financiamento entre os autores e companhias que possam ter interesse na publicação deste artigo."

3. Para as colaborações inéditas, cada autor deve enviar a transferência de direitos autorais nos termos abaixo:

"Eu XXXX declaro que em caso de aceitação do artigo inédito, a revista Revista Brasileira de Políticas Públicas passa a ter os direitos autorais a ele referentes. 
V. $8, n^{\circ} 2$

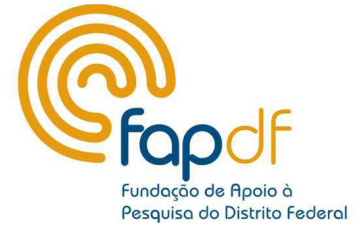

Pesquisa do Distrito federal

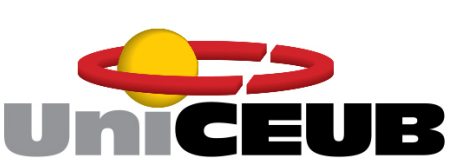

